In cooperation with the Texas Commission on Environmental Quality

\title{
Summary of Annual Mean, Maximum, Minimum, and L-scale Statistics of Daily Mean Streamflow for 712 U.S. Geological Survey Streamflow- Gaging Stations in Texas Through 2003
}

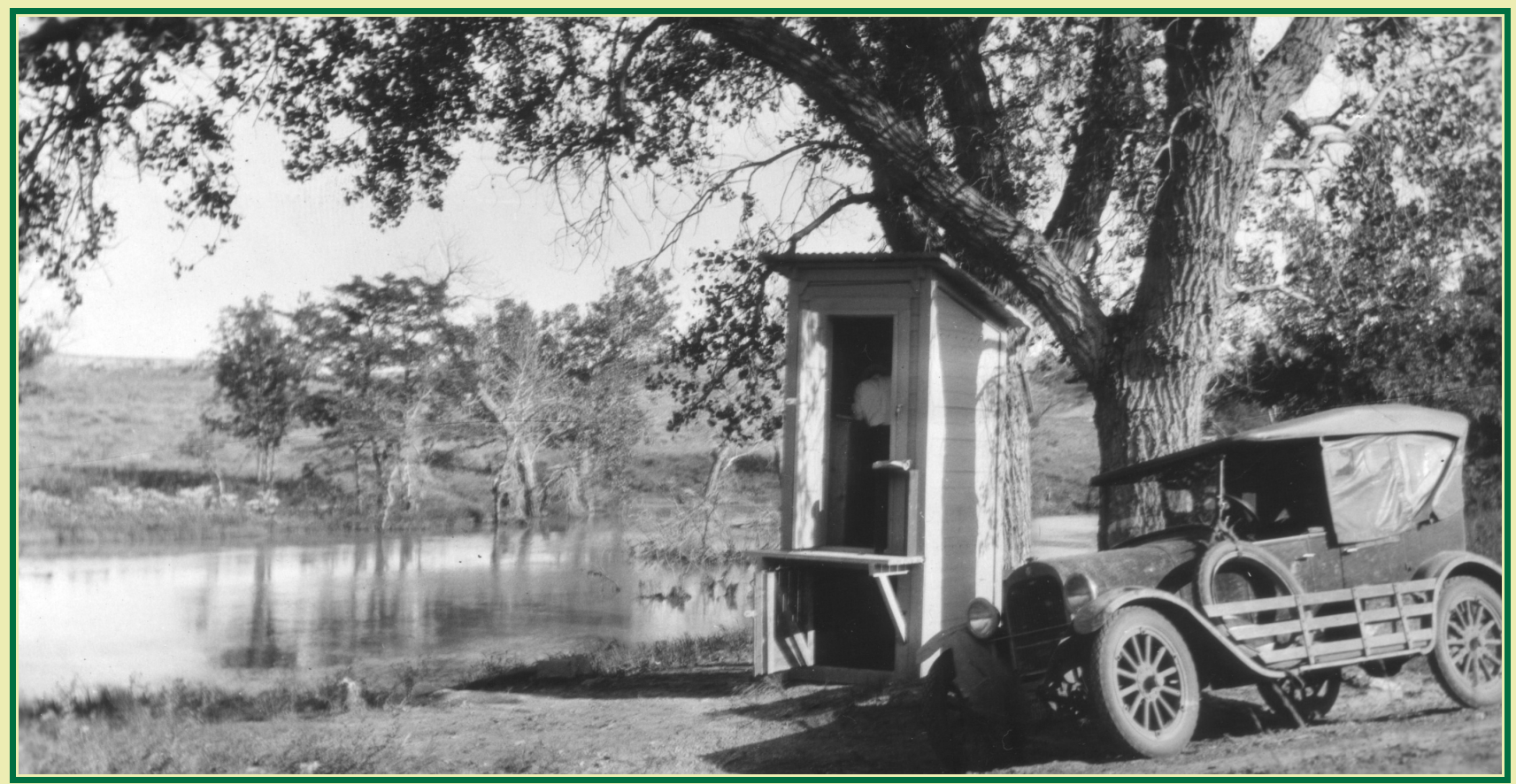

Data Series 248

U.S. Department of the Interior U.S. Geological Survey 
Cover. Photo of station 07297500 Prairie Dog Town Fork Red River near Canyon, Texas, in August 1925 (see page 14 


\section{Summary of Annual Mean, Maximum, Minimum, and L-scale Statistics of Daily Mean Streamflow for 712 U.S. Geological Survey Streamflow- Gaging Stations in Texas Through 2003}

By William H. Asquith, Joseph Vrabel, and Meghan C. Roussel

In cooperation with the Texas Commission on Environmental Quality

Data Series 248

U.S. Department of the Interior

U.S. Geological Survey 


\section{U.S. Department of the Interior DIRK KEMPTHORNE, Secretary}

\section{U.S. Geological Survey \\ Mark D. Myers, Director}

U.S. Geological Survey, Reston, Virginia: 2007

For more information about the USGS and its products:

Telephone: 1-888-ASK-USGS

World Wide Web: http://www.usgs.gov/

Any use of trade, product, or firm names in this publication is for descriptive purposes only and does not imply endorsement by the U.S. Government.

Although this report is in the public domain, permission must be secured from the individual copyright owners to reproduce any copyrighted materials contained within this report.

Suggested citation:

Asquith, W.H., Vrabel, Joseph, and Roussel, M.C., 2007, Summary of annual mean, maximum, minimum, and L-scale statistics of daily mean streamflow for 712 U.S. Geological Survey streamflow-gaging stations in Texas through 2003: U.S. Geological Survey Data Series 248, 721 p.

Also available at:

http://pubs.usgs.gov/ds/2007/248/ 


\section{Contents}

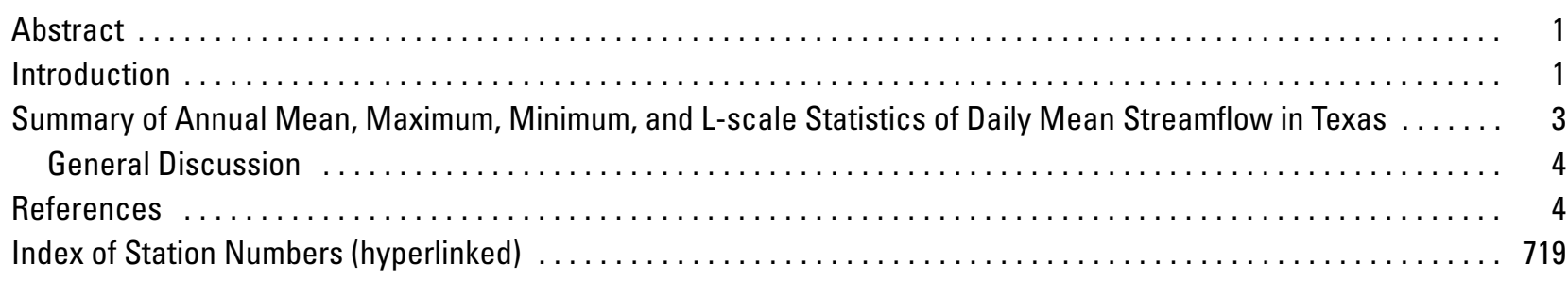

\section{Figures}

1. Map showing locations of U.S. Geological Survey streamflow-gaging stations in Texas with at least

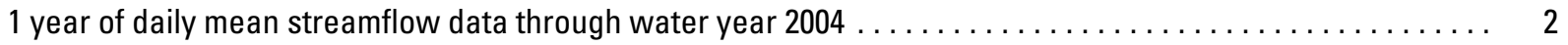

22713 Graphs showing:

2. Analysis of annual mean, maximum, minimum, and L-scale statistics of daily mean streamflow for U.S. Geological Survey streamflow-gaging station 07227470 Canadian River at lascosa, lexas $\ldots \ldots \ldots$ b

3. Analysis of annual mean, maximum, minimum, and L-scale statistics of daily mean streamflow for U.S. Geological Survey streamflow-gaging station 07227500 Canadian River near Amarillo, lexas $\ldots \ldots \ldots$,

4. Analysis of annual mean, maximum, minimum, and L-scale statistics of daily mean streamflow for U.S. Geological Survey streamflow-gaging station 07227920 Dixon Creek near Borger, Texas $\ldots \ldots \ldots \ldots$. 8

5. Analysis of annual mean, maximum, minimum, and L-scale statistics of daily mean streamflow for U.S. Geological Survey streamflow-gaging station 07228000 Canadian River near Canadian, Texas $\ldots \ldots$...

6. Analysis of annual mean, maximum, minimum, and L-scale statistics of daily mean streamflow for U.S. Geological Survey streamflow-gaging station 07233500 Palo Duro Creek near Spearman, lexas $\ldots \ldots$ 10

7. Analysis of annual mean, maximum, minimum, and L-scale statistics of daily mean streamflow for U.S. Geological Survey streamflow-gaging station 07235000 Wolf Creek at Lipscomb, lexas $\ldots \ldots \ldots \ldots$ i1

8. Analysis of annual mean, maximum, minimum, and L-scale statistics of daily mean streamflow for U.S. Geological Survey streamflow-gaging station 07295500 lierra Blanca Creek above Buffalo Lake

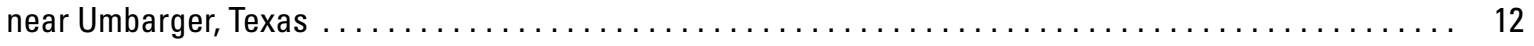

9. Analysis of annual mean, maximum, minimum, and L-scale statistics of daily mean streamflow for U.S. Geological Survey streamflow-gaging station 07296100 Tierra Blanca Creek below Buffalo Lake near Umbarger, Texas $\ldots \ldots \ldots \ldots \ldots \ldots \ldots \ldots \ldots \ldots \ldots \ldots \ldots \ldots \ldots \ldots \ldots \ldots \ldots \ldots, 13$

10. Analysis of annual mean, maximum, minimum, and L-scale statistics of daily mean streamflow for U.S. Geological Survey streamflow-gaging station 07297500 Prairie Dog lown Fork Red River near

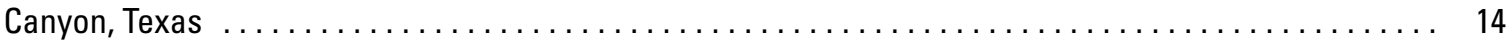

11. Analysis of annual mean, maximum, minimum, and L-scale statistics of daily mean streamflow for U.S. Geological Survey streamflow-gaging station 07297910 Prairie Dog Town Fork Red River near

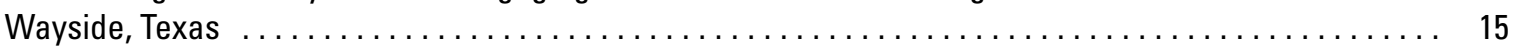

12. Analysis of annual mean, maximum, minimum, and L-scale statistics of daily mean streamflow for U.S. Geological Survey streamflow-gaging station 07298000 North lule Draw at Reservoir near

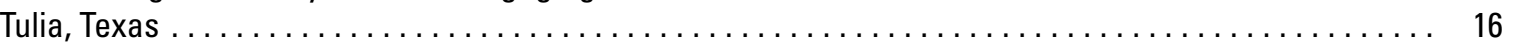

13. Analysis of annual mean, maximum, minimum, and L-scale statistics of daily mean streamflow for U.S. Geological Survey streamflow-gaging station 07298200 Tule Creek near Silverton, Texas $\ldots \ldots \ldots \ldots$ 17

14. Analysis of annual mean, maximum, minimum, and L-scale statistics of daily mean streamflow for U.S. Geological Survey streamflow-gaging station 07298500 Prairie Dog Town Fork Red River near

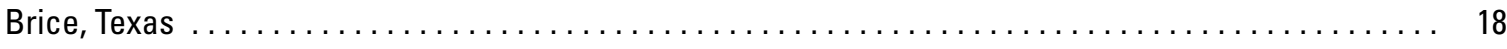

15. Analysis of annual mean, maximum, minimum, and L-scale statistics of daily mean streamflow for U.S. Geological Survey streamflow-gaging station 07299000 Mulberry Creek near Brice, lexas $\ldots \ldots \ldots$ 19 
16. Analysis of annual mean, maximum, minimum, and L-scale statistics of daily mean streamflow for U.S. Geological Survey streamflow-gaging station 07299200 Prairie Dog lown Fork Red River near

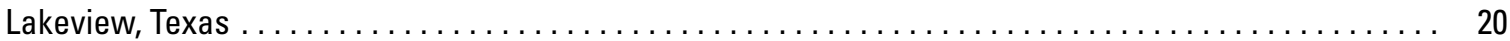

17. Analysis of annual mean, maximum, minimum, and L-scale statistics of daily mean streamflow for U.S. Geological Survey streamflow-gaging station 07299300 Little Red River near Turkey, Texas $\ldots \ldots \ldots 21$

18. Analysis of annual mean, maximum, minimum, and L-scale statistics of daily mean streamflow for U.S. Geological Survey streamflow-gaging station 07299500 Prairie Dog Town Fork Red River near

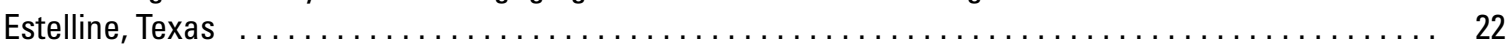

19. Analysis of annual mean, maximum, minimum, and L-scale statistics of daily mean streamflow for U.S. Geological Survey streamflow-gaging station 07299512 Jonah Creek at Weir near Estelline,

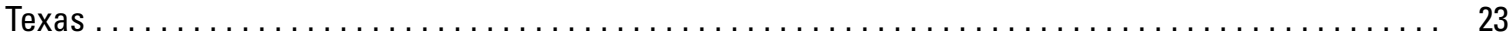

20. Analysis of annual mean, maximum, minimum, and L-scale statistics of daily mean streamflow for U.S. Geological Survey streamflow-gaging station 07299514 Jonah Creek below Weir near

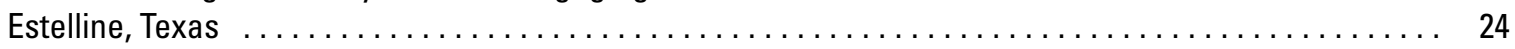

21. Analysis of annual mean, maximum, minimum, and L-scale statistics of daily mean streamflow for U.S. Geological Survey streamflow-gaging station 07299530 Salt Creek near Estelline, Texas $\ldots \ldots \ldots \ldots$

22. Analysis of annual mean, maximum, minimum, and L-scale statistics of daily mean streamflow for U.S. Geological Survey streamflow-gaging station 07299540 Prairie Dog Town Fork Red River near

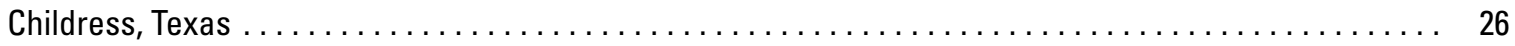

23. Analysis of annual mean, maximum, minimum, and L-scale statistics of daily mean streamflow for U.S. Geological Survey streamflow-gaging station 07299570 Red River near Quanah, Texas $\ldots \ldots \ldots$

24. Analysis of annual mean, maximum, minimum, and L-scale statistics of daily mean streamflow for U.S. Geological Survey streamflow-gaging station 07299670 Groesbeck Creek at State Highway 6

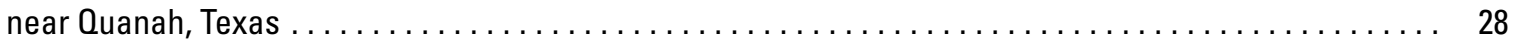

25. Analysis of annual mean, maximum, minimum, and L-scale statistics of daily mean streamflow for U.S. Geological Survey streamflow-gaging station 07299850 Salt Fork Red River near Clarendon,

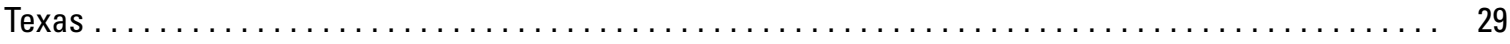

26. Analysis of annual mean, maximum, minimum, and L-scale statistics of daily mean streamflow for U.S. Geological Survey streamflow-gaging station 07299890 Lelia Lake Creek below Bell Creek

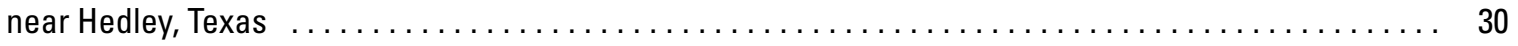

27. Analysis of annual mean, maximum, minimum, and L-scale statistics of daily mean streamflow for U.S. Geological Survey streamflow-gaging station 07300000 Salt Fork Red River near Wellington,

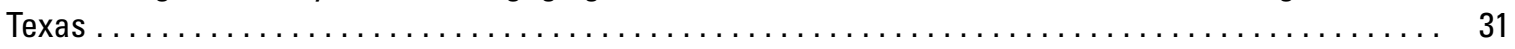

28. Analysis of annual mean, maximum, minimum, and L-scale statistics of daily mean streamflow for U.S. Geological Survey streamflow-gaging station 07301200 McClellan Creek near McLean, Texas $\ldots \ldots .32$

29. Analysis of annual mean, maximum, minimum, and L-scale statistics of daily mean streamflow for U.S. Geological Survey streamtlow-gaging station 07301300 North Fork Red River near Shamrock,

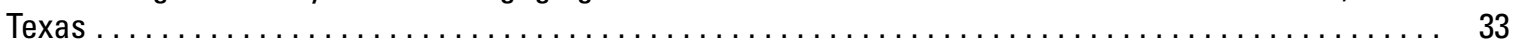

30. Analysis of annual mean, maximum, minimum, and L-scale statistics of daily mean streamflow for U.S. Geological Survey streamflow-gaging station 07301410 Sweetwater Creek near Kelton, Texas . . . . 34

31. Analysis of annual mean, maximum, minimum, and L-scale statistics of daily mean streamflow for U.S. Geological Survey streamflow-gaging station 07307500 Quitaque Creek near Quitaque, Texas ...... 35

32. Analysis of annual mean, maximum, minimum, and L-scale statistics of daily mean streamflow for U.S. Geological Survey streamflow-gaging station 07307600 North Pease River near Childress,

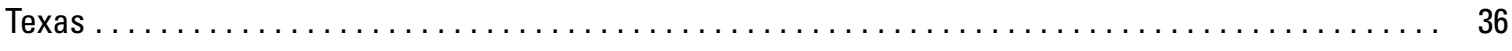

33. Analysis of annual mean, maximum, minimum, and L-scale statistics of daily mean streamflow for U.S. Geological Survey streamflow-gaging station 07307750 Middle Pease River at U. S. Highways

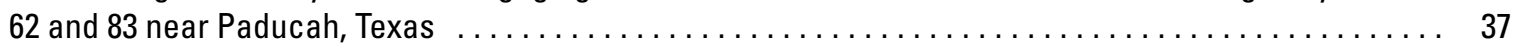


34. Analysis of annual mean, maximum, minimum, and L-scale statistics of daily mean streamflow for U.S. Geological Survey streamflow-gaging station 07307760 Mliddle Pease River near Paducah,

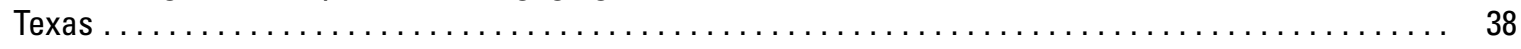

35. Analysis of annual mean, maximum, minimum, and L-scale statistics of daily mean streamflow for U.S. Geological Survey streamflow-gaging station 07307800 Pease River near Childress, Texas $\ldots \ldots \ldots 39$

36. Analysis of annual mean, maximum, minimum, and L-scale statistics of daily mean streamflow for U.S. Geological Survey streamflow-gaging station 07308000 Pease River near Crowell, Texas $\ldots \ldots \ldots$

37. Analysis of annual mean, maximum, minimum, and L-scale statistics of daily mean streamflow for U.S. Geological Survey streamflow-gaging station 07308200 Pease River near Vernon, Texas $\ldots \ldots \ldots \ldots$. $\ldots 1$

38. Analysis of annual mean, maximum, minimum, and L-scale statistics of daily mean streamflow for U.S. Geological Survey streamflow-gaging station 07308500 Red River near Burkburnett, Texas $\ldots \ldots \ldots 42$

39. Analysis of annual mean, maximum, minimum, and L-scale statistics of daily mean streamflow for U.S. Geological Survey streamflow-gaging station 07311600 North Wichita River near Paducah,

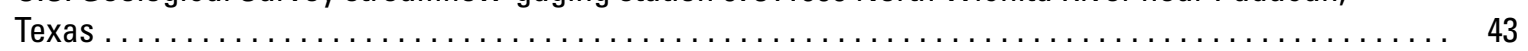

40. Analysis of annual mean, maximum, minimum, and L-scale statistics of daily mean streamflow for U.S. Geological Survey streamflow-gaging station 07311622 North Wichita River near Crowell,

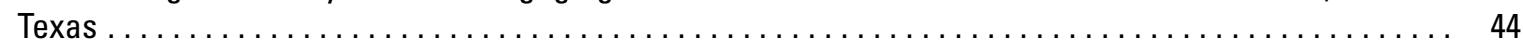

41. Analysis of annual mean, maximum, minimum, and L-scale statistics of daily mean streamflow for U.S. Geological Survey streamflow-gaging station 07311630 Middle Wichita River near Guthrie,

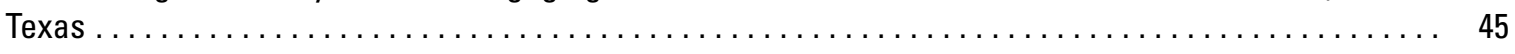

42. Analysis of annual mean, maximum, minimum, and L-scale statistics of daily mean streamflow for U.S. Geological Survey streamflow-gaging station 07311648 Middle Wichita River near Truscott,

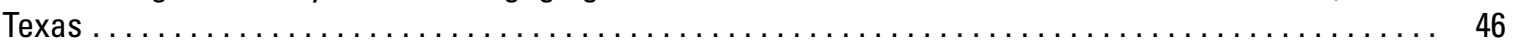

43. Analysis of annual mean, maximum, minimum, and L-scale statistics of daily mean streamflow for U.S. Geological Survey streamflow-gaging station 07311700 North Wichita River near Truscott,

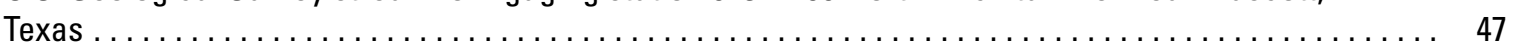

44. Analysis of annual mean, maximum, minimum, and L-scale statistics of daily mean streamflow for U.S. Geological Survey streamflow-gaging station 07311780 South Wichita River near Guthrie,

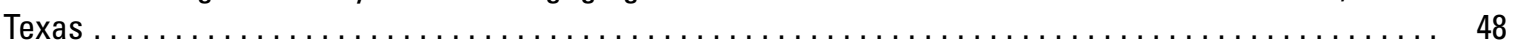

45. Analysis of annual mean, maximum, minimum, and L-scale statistics of daily mean streamflow for U.S. Geological Survey streamflow-gaging station 07311782 South Wichita River at Low How Dam

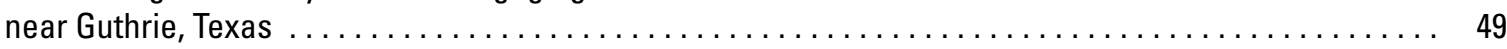

46. Analysis of annual mean, maximum, minimum, and L-scale statistics of daily mean streamflow for U.S. Geological Survey streamflow-gaging station 07311783 South Wichita River below Low How

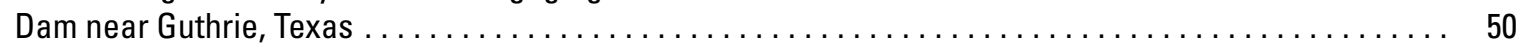

47. Analysis of annual mean, maximum, minimum, and L-scale statistics of daily mean streamflow for U.S. Geological Survey streamflow-gaging station 07311790 South Wichita River at Ross Ranch

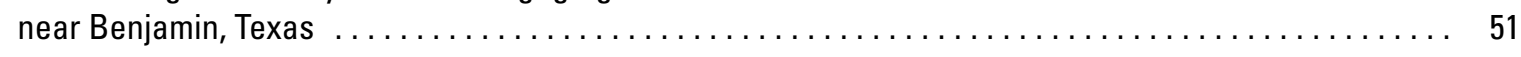

48. Analysis of annual mean, maximum, minimum, and L-scale statistics of daily mean streamflow for U.S. Geological Survey streamflow-gaging station 073T1800 South Wichita River near Benjamin,

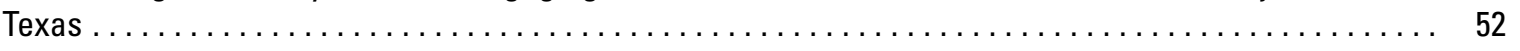

49. Analysis of annual mean, maximum, minimum, and L-scale statistics of daily mean streamflow for U.S. Geological Survey streamflow-gaging station 07311900 Wichita River near Seymour, Texas $\ldots \ldots \ldots$. . 53

50. Analysis of annual mean, maximum, minimum, and L-scale statistics of daily mean streamflow for U.S. Geological Survey streamflow-gaging station 07312100 Wichita River near Mabelle, Texas $\ldots \ldots \ldots$.... 54

51. Analysis of annual mean, maximum, minimum, and L-scale statistics of daily mean streamflow for U.S. Geological Survey streamflow-gaging station 07312130Wichita River at State Highway 25

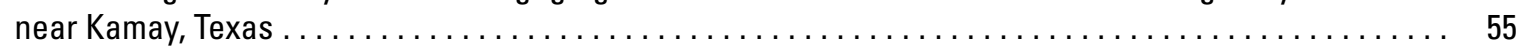

52. Analysis of annual mean, maximum, minimum, and L-scale statistics of daily mean streamflow for U.S. Geological Survey streamflow-gaging station 07312200 Beaver Creek near Electra, Texas $\ldots \ldots \ldots$ 
53. Analysis of annual mean, maximum, minimum, and L-scale statistics of daily mean streamflow for U.S. Geological Survey streamflow-gaging station 07312500 Wichita River at Wichita Falls, lexas $\ldots \ldots$. 51

54. Analysis of annual mean, maximum, minimum, and L-scale statistics of daily mean streamflow for U.S. Geological Survey streamflow-gaging station 07312700 Wichita River near Charlie, Texas $\ldots \ldots \ldots$. 58

55. Analysis of annual mean, maximum, minimum, and L-scale statistics of daily mean streamflow for U.S. Geological Survey streamflow-gaging station 07314500 Little Wichita River near Archer City,

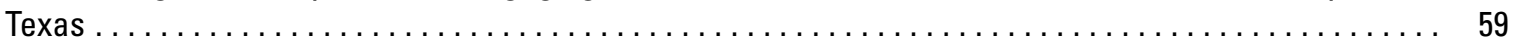

56. Analysis of annual mean, maximum, minimum, and L-scale statistics of daily mean streamflow for U.S. Geological Survey streamflow-gaging station 07314900 Little Wichita River above Henrietta,

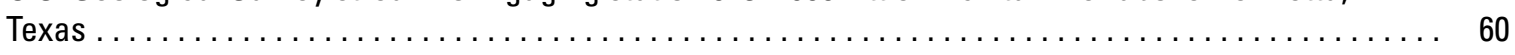

57. Analysis of annual mean, maximum, minimum, and L-scale statistics of daily mean streamflow for U.S. Geological Survey streamflow-gaging station 07315200 East Fork Little Wichita River near

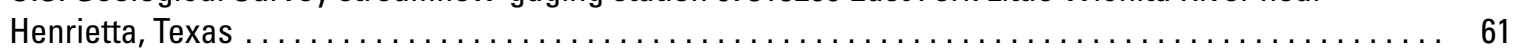

58. Analysis of annual mean, maximum, minimum, and L-scale statistics of daily mean streamflow for U.S. Geological Survey streamflow-gaging station 07315400 Little Wichita River near Ringgold,

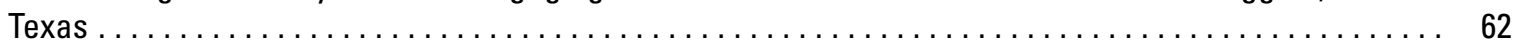

59. Analysis of annual mean, maximum, minimum, and L-scale statistics of daily mean streamflow for U.S. Geological Survey streamflow-gaging station 07316200 MineralCreek near Sadler, Texas $\ldots \ldots \ldots$. $\ldots 3$

60. Analysis of annual mean, maximum, minimum, and L-scale statistics of daily mean streamflow for U.S. Geological Survey streamflow-gaging station 07332600 Bois d'Arc Creek near Randolph, lexas $\ldots .64$

61. Analysis of annual mean, maximum, minimum, and L-scale statistics of daily mean streamflow for U.S. Geological Survey streamflow-gaging station 07335400 Sanders Creek near Chicota, lexas $\ldots \ldots$. 65

62. Analysis of annual mean, maximum, minimum, and L-scale statistics of daily mean streamflow for U.S. Geological Survey streamflow-gaging station 07336750 Little Pine Creek near Kanawha, lexas $\ldots .66$

63. Analysis of annual mean, maximum, minimum, and L-scale statistics of daily mean streamflow for $\begin{array}{lll}\text { U.S. Geological Survey streamflow-gaging station 07336800 Pecan Bayou near Clarksville, Texas } & \ldots \ldots & 67\end{array}$

64. Analysis of annual mean, maximum, minimum, and L-scale statistics of daily mean streamflow for U.S. Geological Survey streamflow-gaging station 07336820 Red River near De Kalb, Texas $\ldots \ldots \ldots \ldots$ 68

65. Analysis of annual mean, maximum, minimum, and L-scale statistics of daily mean streamflow for U.S. Geological Survey streamflow-gaging station 07342465 South Sulphur River at Commerce,

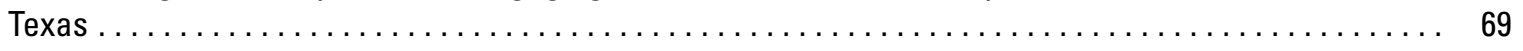

66. Analysis of annual mean, maximum, minimum, and L-scale statistics of daily mean streamflow for U.S. Geological Survey streamflow-gaging station 07342470 South Sulphur River near Commerce,

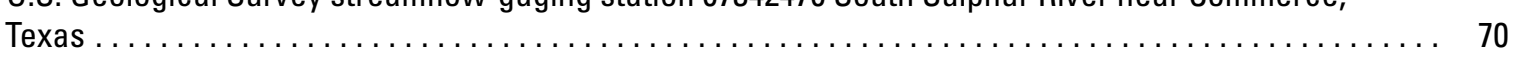

67. Analysis of annual mean, maximum, minimum, and L-scale statistics of daily mean streamflow for U.S. Geological Survey streamflow-gaging station 07342480 Middle Sulphur River at Commerce,

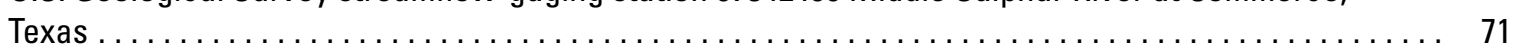

68. Analysis of annual mean, maximum, minimum, and L-scale statistics of daily mean streamflow for U.S. Geological Survey streamflow-gaging station 07342500 South Sulphur River near Cooper, Texas $\ldots \ldots \ldots \ldots \ldots \ldots \ldots \ldots \ldots \ldots \ldots \ldots \ldots \ldots \ldots \ldots \ldots \ldots \ldots \ldots \ldots \ldots \ldots \ldots, 72$

69. Analysis of annual mean, maximum, minimum, and L-scale statistics of daily mean streamflow for U.S. Geological Survey streamflow-gaging station 07343000 North Sulphur River near Cooper,

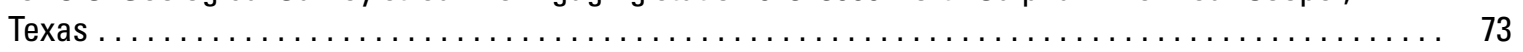

70. Analysis of annual mean, maximum, minimum, and L-scale statistics of daily mean streamflow for \begin{tabular}{|l|l|l|l|}
\hline U.S. Geological Survey streamflow-gaging station 07343200 Sulphur River near Talco, Texas & $\ldots \ldots \ldots \ldots$ & 74
\end{tabular}

71. Analysis of annual mean, maximum, minimum, and L-scale statistics of daily mean streamflow for U.S. Geological Survey streamflow-gaging station 07343300 Cuthand Creek near Bogata, Texas ....... 75

\begin{tabular}{l|l|l|l|l|} 
72. & Analysis of annual mean, maximum, minimum, and L-scale statistics of daily mean streamflow for & \\
\hline
\end{tabular} 
73. Analysis of annual mean, maximum, minimum, and L-scale statistics of daily mean streamflow for U.S. Geological Survey streamflow-gaging station 07344000 Sulphur River near Darden, Texas $\ldots \ldots \ldots \ldots$

74. Analysis of annual mean, maximum, minimum, and L-scale statistics of daily mean streamflow for U.S. Geological Survey streamflow-gaging station 07344482 Big Cypress Creek near Winnsboro,

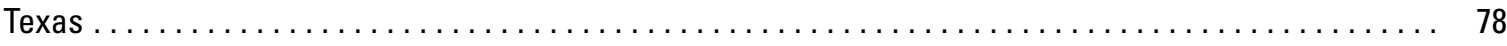

75. Analysis of annual mean, maximum, minimum, and L-scale statistics of daily mean streamflow for U.S. Geological Survey streamflow-gaging station 07344486 Brushy Creek at Scroggins, Texas . . . . . 79

76. Analysis of annual mean, maximum, minimum, and L-scale statistics of daily mean streamflow for U.S. Geological Survey streamflow-gaging station 07344500 Big Cypress Creek near Pittsburg,

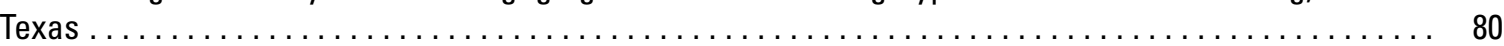

77. Analysis of annual mean, maximum, minimum, and L-scale statistics of daily mean streamflow for

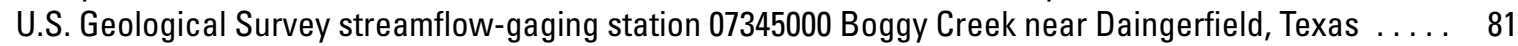

78. Analysis of annual mean, maximum, minimum, and L-scale statistics of daily mean streamflow for U.S. Geological Survey streamflow-gaging station 07346000 Big Cypress Creek near Jefferson,

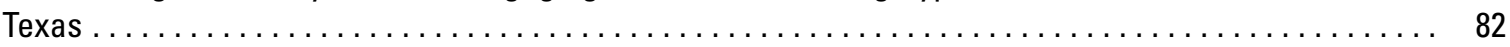

79. Analysis of annual mean, maximum, minimum, and L-scale statistics of daily mean streamflow for U.S. Geological Survey streamflow-gaging station 07346045 Black Cypress Bayou at Jefferson,

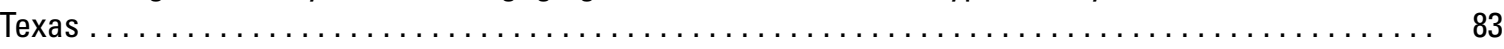

80. Analysis of annual mean, maximum, minimum, and L-scale statistics of daily mean streamflow for U.S. Geological Survey streamflow-gaging station 07346050 Little Cypress Creek near Ore City,

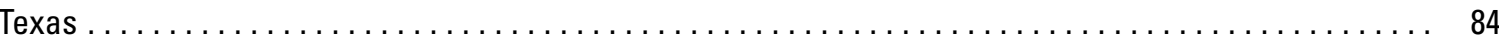

81. Analysis of annual mean, maximum, minimum, and L-scale statistics of daily mean streamflow for U.S. Geological Survey streamflow-gaging station 07346070 Little Cypress Creek near Jefferson,

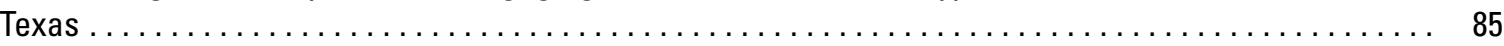

82. Analysis of annual mean, maximum, minimum, and L-scale statistics of daily mean streamflow for U.S. Geological Survey streamflow-gaging station 07346140 Frazier Creek near Linden, Texas $\ldots \ldots \ldots$

83. Analysis of annual mean, maximum, minimum, and L-scale statistics of daily mean streamflow for U.S. Geological Survey streamflow-gaging station 08017200 Cowleech Fork Sabine River at

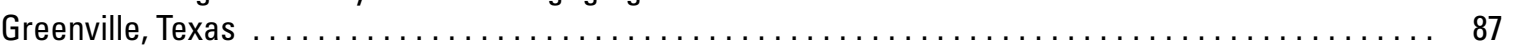

84. Analysis of annual mean, maximum, minimum, and L-scale statistics of daily mean streamflow for U.S. Geological Survey streamflow-gaging station 08017300 South Fork Sabine River near Quinlan,

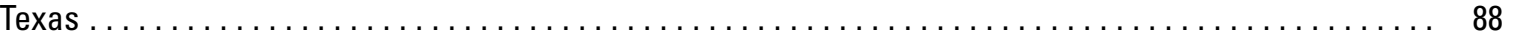

85. Analysis of annual mean, maximum, minimum, and L-scale statistics of daily mean streamflow for U.S. Geological Survey streamflow-gaging station 08017410 Sabine River near Wills Point, Texas $\ldots$. . . 89

86. Analysis of annual mean, maximum, minimum, and L-scale statistics of daily mean streamflow for U.S. Geological Survey streamflow-gaging station 08017500 Sabine River near Emory, Texas $\ldots \ldots \ldots$

87. Analysis of annual mean, maximum, minimum, and L-scale statistics of daily mean streamflow for U.S. Geological Survey streamflow-gaging station 08018500 Sabine River near Mineola, Texas . . . . ... 91

88. Analysis of annual mean, maximum, minimum, and L-scale statistics of daily mean streamflow for U.S. Geological Survey streamflow-gaging station 08018730 Burke Creek near Yantis, Texas $\ldots \ldots \ldots \ldots$

89. Analysis of annual mean, maximum, minimum, and L-scale statistics of daily mean streamflow for U.S. Geological Survey streamflow-gaging station 08019000 Lake Fork Creek near Quitman, Texas . . . . . 93

90. Analysis of annual mean, maximum, minimum, and L-scale statistics of daily mean streamflow for U.S. Geological Survey streamflow-gaging station 08019200 Sabine River near Hawkins, Texas $\ldots \ldots \ldots .94$

91. Analysis of annual mean, maximum, minimum, and L-scale statistics of daily mean streamflow for U.S. Geological Survey streamflow-gaging station 08019500 Big Sandy Creek near Big Sandy,

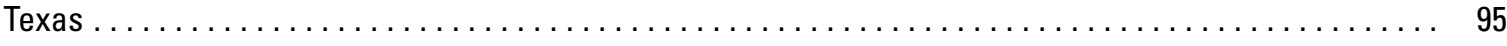

92. Analysis of annual mean, maximum, minimum, and L-scale statistics of daily mean streamflow for U.S. Geological Survey streamflow-gaging station 08020000 Sabine River near Gladewater, Texas $\ldots \ldots .96$ 
93. Analysis of annual mean, maximum, minimum, and L-scale statistics of daily mean streamflow for

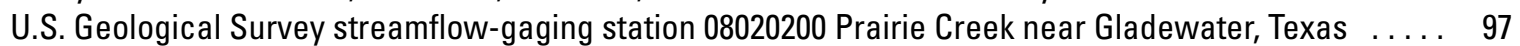

94. Analysis of annual mean, maximum, minimum, and L-scale statistics of daily mean streamflow for

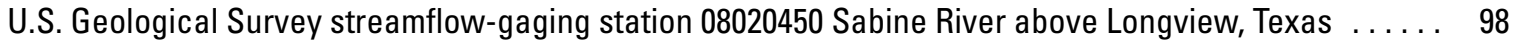

95. Analysis of annual mean, maximum, minimum, and L-scale statistics of daily mean streamflow for U.S. Geological Survey streamflow-gaging station 08020500 Sabine River near Longview, Texas . . . . . . 99

96. Analysis of annual mean, maximum, minimum, and L-scale statistics of daily mean streamflow for U.S. Geological Survey streamflow-gaging station 08020700 Rabbit Creek at Kilgore, Texas $\ldots \ldots \ldots \ldots$

\begin{tabular}{l|l|l|l|} 
97. & Analysis of annual mean, maximum, minimum, and L-scale statistics of daily mean streamflow for \\
\hline U.S. Geological Survey streamflow-gaging station 08020900 Sabine River below Longview, Texas & $\ldots \ldots$ & . . \\
\hline
\end{tabular}

98. Analysis of annual mean, maximum, minimum, and L-scale statistics of daily mean streamflow for U.S. Geological Survey streamflow-gaging station 08020960 Mill Creek near Henderson, lexas $\ldots \ldots \ldots 102$

99. Analysis of annual mean, maximum, minimum, and L-scale statistics of daily mean streamflow for U.S. Geological Survey streamflow-gaging station 08020980 Mill Creek near Longview, Texas $\ldots \ldots \ldots \ldots$

100. Analysis of annual mean, maximum, minimum, and L-scale statistics of daily mean streamflow for $\begin{array}{lll}\text { U.S. Geological Survey streamflow-gaging station 08020990 Tiawichi Creek near Longview, Texas } & \ldots . . . & 104\end{array}$

101. Analysis of annual mean, maximum, minimum, and L-scale statistics of daily mean streamflow for U.S. Geological Survey streamflow-gaging station 08021000 Cherokee Bayou near Elderville,

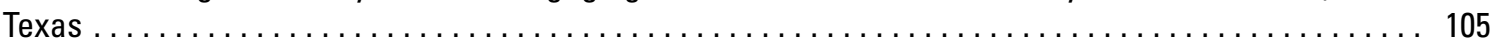

102. Analysis of annual mean, maximum, minimum, and L-scale statistics of daily mean streamflow for U.S. Geological Survey streamflow-gaging station 08022040 Sabine River near Beckville, Texas $\ldots \ldots . .106$

103. Analysis of annual mean, maximum, minimum, and L-scale statistics of daily mean streamflow for U.S. Geological Survey streamflow-gaging station 08022070 Martin Creek near Tatum, Texas $\ldots \ldots \ldots 107$

104. Analysis of annual mean, maximum, minimum, and L-scale statistics of daily mean streamflow for U.S. Geological Survey streamflow-gaging station 08022300 Murvaul Bayou near Gary, Texas $\quad \ldots \ldots \ldots 108$

\begin{tabular}{l|l|l|} 
105. Analysis of annual mean, maximum, minimum, and L-scale statistics of daily mean streamflow for \\
\hline
\end{tabular}

106. Analysis of annual mean, maximum, minimum, and L-scale statistics of daily mean streamflow for

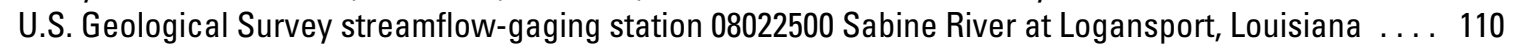

107. Analysis of annual mean, maximum, minimum, and L-scale statistics of daily mean streamflow for U.S. Geological Survey streamflow-gaging station 08023200 Tenaha Creek near Shelbyville, Texas ..... 111

108. Analysis of annual mean, maximum, minimum, and L-scale statistics of daily mean streamflow for U.S. Geological Survey streamflow-gaging station 08024400 Sabine River near Milam, Texas $\ldots \ldots \ldots \ldots 112$

109. Analysis of annual mean, maximum, minimum, and L-scale statistics of daily mean streamflow for U.S. Geological Survey streamflow-gaging station 08024500 Palo Gaucho Bayou near Hemphill,

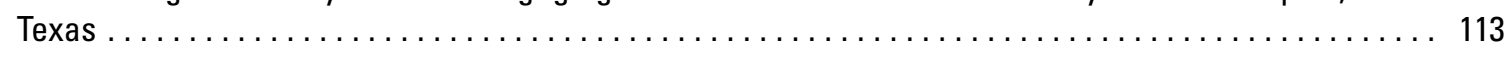

110. Analysis of annual mean, maximum, minimum, and L-scale statistics of daily mean streamflow for U.S. Geological Survey streamflow-gaging station 08025307 Mill Creek near Burkeville, Texas $\ldots \ldots \ldots 114$

111. Analysis of annual mean, maximum, minimum, and L-scale statistics of daily mean streamflow for U.S. Geological Survey streamflow-gaging station 08025360 Sabine River at Toledo Bend

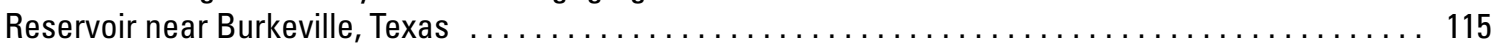

112. Analysis of annual mean, maximum, minimum, and L-scale statistics of daily mean streamflow for U.S. Geological Survey streamflow-gaging station 08026000 Sabine River near Burkeville, Texas $\ldots \ldots . .116$

\begin{tabular}{l|l|l|l|} 
113. Analysis of annual mean, maximum, minimum, and L-scale statistics of daily mean streamflow for \\
\hline
\end{tabular}

114. Analysis of annual mean, maximum, minimum, and L-scale statistics of daily mean streamflow for $\begin{array}{ll}\text { U.S. Geological Survey streamflow-gaging station } 08029500 \text { Big Cow Creek near Newton, Texas } & \ldots \ldots . .118\end{array}$

115. Analysis of annual mean, maximum, minimum, and L-scale statistics of daily mean streamflow for U.S. Geological Survey streamflow-gaging station 08030000 Cypress Creek near Buna, Texas $\ldots \ldots \ldots 19$ 
116. Analysis of annual mean, maximum, minimum, and L-scale statistics of daily mean streamflow for U.S. Geological Survey streamflow-gaging station 08030500 Sabine River near Ruliff, Texas $\ldots \ldots \ldots$ 120

117. Analysis of annual mean, maximum, minimum, and L-scale statistics of daily mean streamflow for U.S. Geological Survey streamflow-gaging station 08031000 Cow Bayou near Mauriceville, Texas $\ldots \ldots$... 121

118. Analysis of annual mean, maximum, minimum, and L-scale statistics of daily mean streamflow for U.S. Geological Survey streamflow-gaging station 08031200 Kickapoo Creek near Brownsboro,

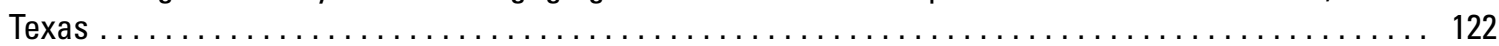

119. Analysis of annual mean, maximum, minimum, and L-scale statistics of daily mean streamflow for U.S. Geological Survey streamflow-gaging station 08031500 Neches River near Reese, Texas $\ldots \ldots \ldots 123$

120. Analysis of annual mean, maximum, minimum, and L-scale statistics of daily mean streamflow for U.S. Geological Survey streamflow-gaging station 08032000 Neches River near Neches, Texas $\ldots \ldots \ldots 124$

121. Analysis of annual mean, maximum, minimum, and L-scale statistics of daily mean streamflow for U.S. Geological Survey streamflow-gaging station 08032500 Neches River near Alto, Texas $\ldots \ldots \ldots \ldots 125$

122. Analysis of annual mean, maximum, minimum, and L-scale statistics of daily mean streamflow for U.S. Geological Survey streamflow-gaging station 08033000 Neches River near Diboll, Texas $\ldots \ldots \ldots 126$

123. Analysis of annual mean, maximum, minimum, and L-scale statistics of daily mean streamflow for U.S. Geological Survey streamflow-gaging station 08033300 Piney Creek near Groveton, Texas $\ldots \ldots \ldots 127$

124. Analysis of annual mean, maximum, minimum, and L-scale statistics of daily mean streamflow for U.S. Geological Survey streamflow-gaging station 08033500 Neches River near Rockland, Texas $\ldots \ldots \ldots 128$

125. Analysis of annual mean, maximum, minimum, and L-scale statistics of daily mean streamflow for U.S. Geological Survey streamflow-gaging station 08033700 Striker Creek near Summerfield,

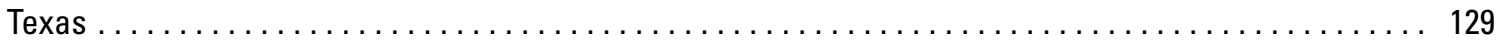

126. Analysis of annual mean, maximum, minimum, and L-scale statistics of daily mean streamflow for U.S. Geological Survey streamflow-gaging station 08033900 East Fork Angelina River near

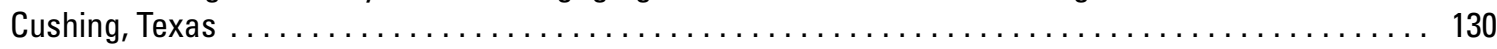

127. Analysis of annual mean, maximum, minimum, and L-scale statistics of daily mean streamflow for U.S. Geological Survey streamflow-gaging station 08034500 Mud Creek near Jacksonville, Texas $\ldots \ldots$.... 131

128. Analysis of annual mean, maximum, minimum, and L-scale statistics of daily mean streamflow for U.S. Geological Survey streamflow-gaging station 08035000 Mud Creek at Ponta, Texas $\ldots \ldots \ldots \ldots 132$

129. Analysis of annual mean, maximum, minimum, and L-scale statistics of daily mean streamflow for U.S. Geological Survey streamflow-gaging station 08036500 Angelina River near Alto, Texas $\ldots \ldots \ldots 133$

130. Analysis of annual mean, maximum, minimum, and L-scale statistics of daily mean streamflow for U.S. Geological Survey streamflow-gaging station 08037000 Angelina River near Lutkin, Texas $\ldots \ldots \ldots 134$

131. Analysis of annual mean, maximum, minimum, and L-scale statistics of daily mean streamflow for U.S. Geological Survey streamflow-gaging station 08037050 Bayou Lanana at Nacogdoches,

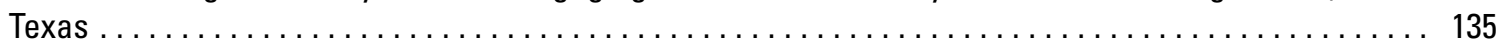

132. Analysis of annual mean, maximum, minimum, and L-scale statistics of daily mean streamflow for U.S. Geological Survey streamflow-gaging station 08037500 Arenoso Creek near San Augustine,

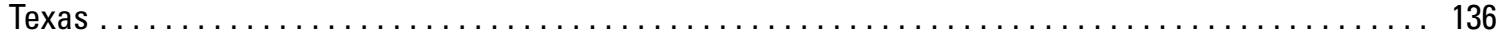

133. Analysis of annual mean, maximum, minimum, and L-scale statistics of daily mean streamflow for U.S. Geological Survey streamflow-gaging station 08038000 Attoyac Bayou near Chireno, Texas $\ldots \ldots \ldots 137$

134. Analysis of annual mean, maximum, minimum, and L-scale statistics of daily mean streamflow for U.S. Geological Survey streamflow-gaging station 08038500 Angelina River near Zavalla, Texas $\ldots \ldots \ldots 138$

135. Analysis of annual mean, maximum, minimum, and L-scale statistics of daily mean streamflow for U.S. Geological Survey streamflow-gaging station 08039100 Ayish Bayou near San Augustine,

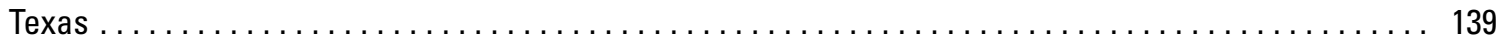

136. Analysis of annual mean, maximum, minimum, and L-scale statistics of daily mean streamflow for $\begin{array}{llllll}\text { U.S. Geological Survey streamflow-gaging station 08039500 Angelina River near Ebenezer, Texas } & \ldots & \ldots & 140\end{array}$ 
137. Analysis of annual mean, maximum, minimum, and L-scale statistics of daily mean streamflow for

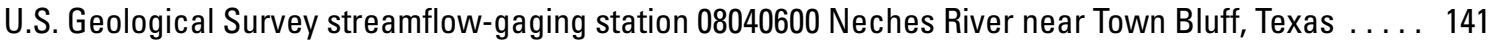

138. Analysis of annual mean, maximum, minimum, and L-scale statistics of daily mean streamflow for U.S. Geological Survey streamflow-gaging station 08041000 Neches River at Evadale, Texas $\ldots \ldots \ldots .142$

139. Analysis of annual mean, maximum, minimum, and L-scale statistics of daily mean streamflow for U.S. Geological Survey streamflow-gaging station 08041500 Village Creek near Kountze, Texas $\ldots \ldots \ldots 143$

140. Analysis of annual mean, maximum, minimum, and L-scale statistics of daily mean streamflow for U.S. Geological Survey streamflow-gaging station 08041700 Pine lsland Bayou near Sour Lake,

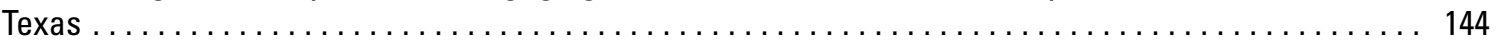

141. Analysis of annual mean, maximum, minimum, and L-scale statistics of daily mean streamflow for U.S. Geological Survey streamflow-gaging station 08042000 Taylor Bayou near LaBelle, Texas $\ldots \ldots \ldots 145$

142. Analysis of annual mean, maximum, minimum, and L-scale statistics of daily mean streamflow for U.S. Geological Survey streamflow-gaging station 08042500 Hillebrandt Bayou near Lovell Lake,

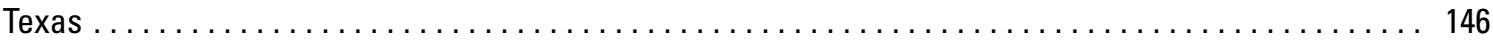

143. Analysis of annual mean, maximum, minimum, and L-scale statistics of daily mean streamflow for U.S. Geological Survey streamflow-gaging station 08042700 North Creek near Jacksboro, Texas $\ldots \ldots \ldots 147$

144. Analysis of annual mean, maximum, minimum, and L-scale statistics of daily mean streamflow for U.S. Geological Survey streamflow-gaging station 08042800 West Fork Trinity River near

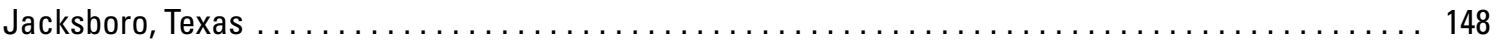

145. Analysis of annual mean, maximum, minimum, and L-scale statistics of daily mean streamflow for U.S. Geological Survey streamflow-gaging station 08042900 Beans Creek at Wizard Wells, Texas $\ldots . . .149$

146. Analysis of annual mean, maximum, minimum, and L-scale statistics of daily mean streamflow for U.S. Geological Survey streamflow-gaging station 08043500 West Fork Trinity River at Bridgeport,

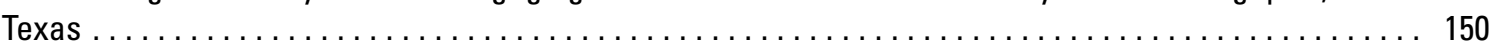

147. Analysis of annual mean, maximum, minimum, and L-scale statistics of daily mean streamflow for

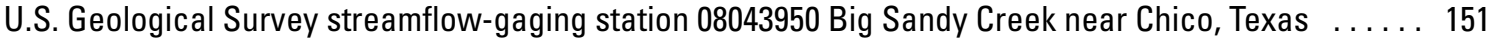

148. Analysis of annual mean, maximum, minimum, and L-scale statistics of daily mean streamflow for U.S. Geological Survey streamflow-gaging station 08044000 Big Sandy Creek near Bridgeport,

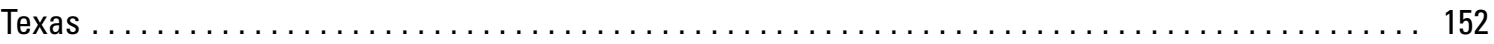

149. Analysis of annual mean, maximum, minimum, and L-scale statistics of daily mean streamflow for

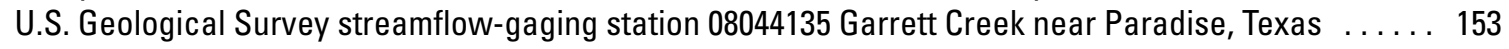

150. Analysis of annual mean, maximum, minimum, and L-scale statistics of daily mean streamflow for U.S. Geological Survey streamflow-gaging station 08044140 Salt Creek near Paradise, Texas $\ldots \ldots \ldots .154$

151. Analysis of annual mean, maximum, minimum, and L-scale statistics of daily mean streamflow for U.S. Geological Survey streamflow-gaging station 08044500 West Fork Trinity River near Boyd,

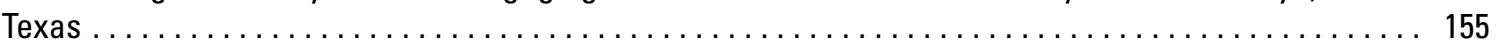

152. Analysis of annual mean, maximum, minimum, and L-scale statistics of daily mean streamflow for U.S. Geological Survey streamflow-gaging station 08044800 Walnut Creek at Reno, Texas $\ldots \ldots \ldots \ldots \ldots$

153. Analysis of annual mean, maximum, minimum, and L-scale statistics of daily mean streamflow for U.S. Geological Survey streamflow-gaging station 08045500 West Fork Trinity River at Lake Worth Dam above Fort Worth, Texas $\ldots \ldots \ldots \ldots \ldots \ldots \ldots \ldots \ldots \ldots \ldots \ldots \ldots \ldots \ldots \ldots \ldots \ldots \ldots$

154. Analysis of annual mean, maximum, minimum, and L-scale statistics of daily mean streamflow for U.S. Geological Survey streamflow-gaging station 08045850 Clear Fork Trinity River near

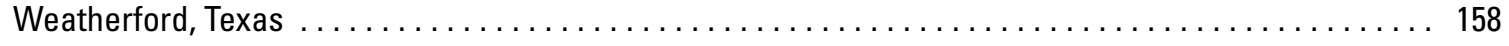

155. Analysis of annual mean, maximum, minimum, and L-scale statistics of daily mean streamflow for U.S. Geological Survey streamflow-gaging station 08046000 Clear Fork Trinity River near Aledo,

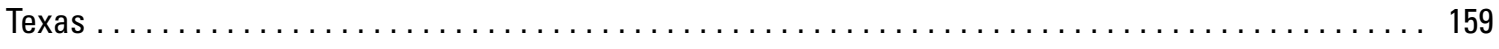

156. Analysis of annual mean, maximum, minimum, and L-scale statistics of daily mean streamflow for U.S. Geological Survey streamflow-gaging station 08047000 Clear Fork Trinity River near

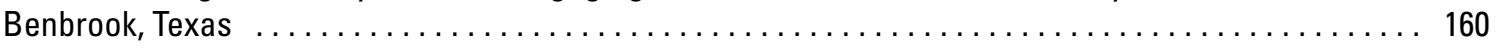


157. Analysis of annual mean, maximum, minimum, and L-scale statistics of daily mean streamflow for U.S. Geological Survey streamflow-gaging station 08047050 Marys Creek at Benbrook, Texas $\ldots . . . .161$

158. Analysis of annual mean, maximum, minimum, and L-scale statistics of daily mean streamflow for U.S. Geological Survey streamflow-gaging station 08047500 Clear Fork Trinity River at Fort Worth,

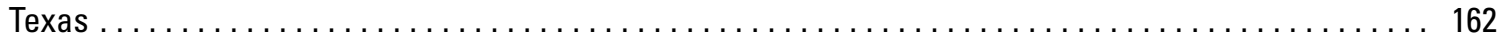

159. Analysis of annual mean, maximum, minimum, and L-scale statistics of daily mean streamflow for U.S. Geological Survey streamflow-gaging station 08048000 West Fork Trinity River at Fort Worth,

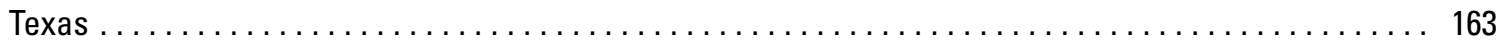

160. Analysis of annual mean, maximum, minimum, and L-scale statistics of daily mean streamflow for U.S. Geological Survey streamflow-gaging station 08048520 Sycamore Creek at Interstate

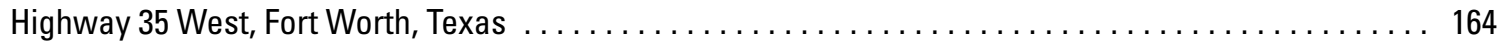

161. Analysis of annual mean, maximum, minimum, and L-scale statistics of daily mean streamflow for U.S. Geological Survey streamflow-gaging station 08048530 Sycamore Creek Tributary above Semenary South Shopping Center, Fort Worth, Texas $\ldots \ldots \ldots \ldots \ldots \ldots \ldots \ldots \ldots \ldots \ldots \ldots \ldots \ldots$

162. Analysis of annual mean, maximum, minimum, and L-scale statistics of daily mean streamflow for U.S. Geological Survey streamflow-gaging station 08048540 Sycamore Creek Tributary at Interstate Highway 35 West, Fort Worth, Texas $\ldots \ldots \ldots \ldots \ldots \ldots \ldots \ldots \ldots \ldots \ldots \ldots \ldots \ldots$

163. Analysis of annual mean, maximum, minimum, and L-scale statistics of daily mean streamflow for U.S. Geological Survey streamflow-gaging station 08048543West Fork Trinity River at Beach Street, Fort Worth, Texas

164. Analysis of annual mean, maximum, minimum, and L-scale statistics of daily mean streamflow for U.S. Geological Survey streamflow-gaging station 08048600 Dry Branch at Fain Street, Fort Worth,

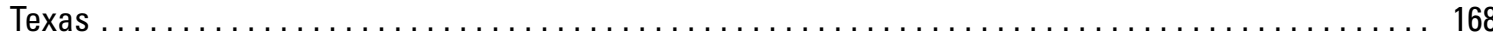

165. Analysis of annual mean, maximum, minimum, and L-scale statistics of daily mean streamflow for

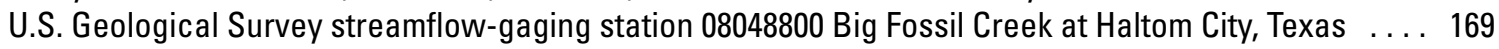

166. Analysis of annual mean, maximum, minimum, and L-scale statistics of daily mean streamflow for U.S. Geological Survey streamflow-gaging station 08048850 Little Fossil Creek at Mlesquite Street,

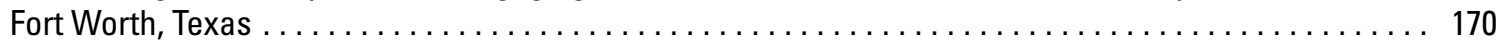

167. Analysis of annual mean, maximum, minimum, and L-scale statistics of daily mean streamflow for U.S. Geological Survey streamflow-gaging station 08048970 Village Creek at Everman, Texas $\ldots \ldots \ldots 171$

168. Analysis of annual mean, maximum, minimum, and L-scale statistics of daily mean streamflow for U.S. Geological Survey streamflow-gaging station 08048980 Village Creek at Kennedale, Texas $\ldots \ldots \ldots 172$

169. Analysis of annual mean, maximum, minimum, and L-scale statistics of daily mean streamflow for U.S. Geological Survey streamflow-gaging station 08049000 Village Creek near Handley, Texas $\ldots \ldots \ldots 173$

170. Analysis of annual mean, maximum, minimum, and L-scale statistics of daily mean streamflow for U.S. Geological Survey streamflow-gaging station 08049500 West Fork Trinity River at Grand

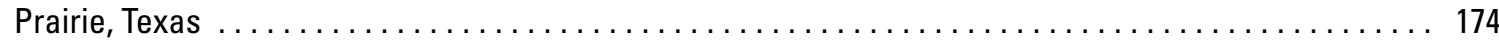

171. Analysis of annual mean, maximum, minimum, and L-scale statistics of daily mean streamflow for U.S. Geological Survey streamflow-gaging station 08049550 Big Bear Creek near Grapevine,

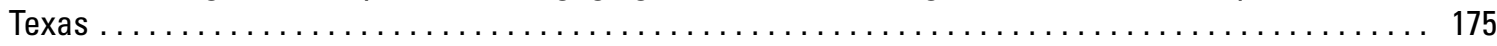

172. Analysis of annual mean, maximum, minimum, and L-scale statistics of daily mean streamflow for U.S. Geological Survey streamflow-gaging station 08049553 Big Bear Creek at Euless/Grapevine

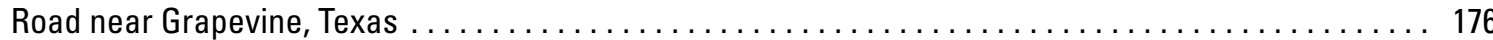

173. Analysis of annual mean, maximum, minimum, and L-scale statistics of daily mean streamflow for U.S. Geological Survey streamflow-gaging station 08049556 Unnamed Tributary Big Bear Creek (Outflow 19) near Euless, Texas $\ldots \ldots \ldots \ldots \ldots \ldots \ldots \ldots \ldots \ldots \ldots \ldots \ldots \ldots \ldots \ldots \ldots \ldots \ldots$

174. Analysis of annual mean, maximum, minimum, and L-scale statistics of daily mean streamflow for U.S. Geological Survey streamflow-gaging station 08049565 Trigg Branch at DFW Airport near

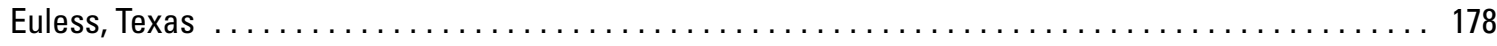


175. Analysis of annual mean, maximum, minimum, and L-scale statistics of daily mean streamflow for U.S. Geological Survey streamflow-gaging station 08049569 Big Bear Creek at State Highway 183

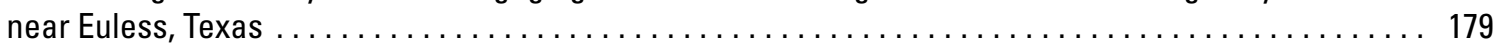

176. Analysis of annual mean, maximum, minimum, and L-scale statistics of daily mean streamflow for U.S. Geological Survey streamflow-gaging station 08049580 Mountain Creek near Venus, Texas $\ldots \ldots \ldots 180$

177. Analysis of annual mean, maximum, minimum, and L-scale statistics of daily mean streamflow for U.S. Geological Survey streamflow-gaging station 08049600 Mountain Creek near Cedar Hill,

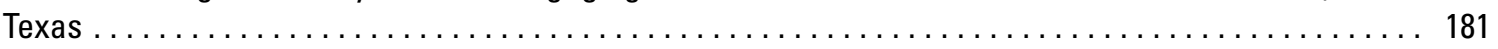

178. Analysis of annual mean, maximum, minimum, and L-scale statistics of daily mean streamflow for

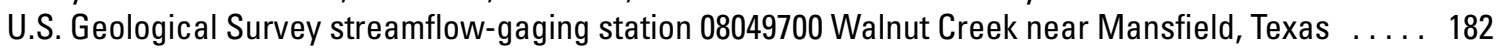

179. Analysis of annual mean, maximum, minimum, and L-scale statistics of daily mean streamflow for U.S. Geological Survey streamflow-gaging station 08050000 Mlountain Creek near Grand Prairie,

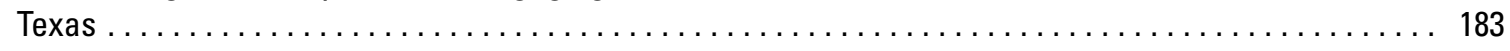

180. Analysis of annual mean, maximum, minimum, and L-scale statistics of daily mean streamflow for U.S. Geological Survey streamflow-gaging station 08050100 Mlountain Creek at Grand Prairie,

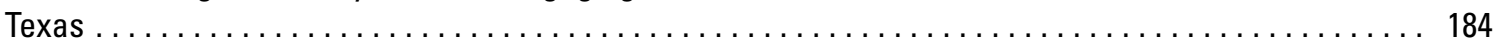

181. Analysis of annual mean, maximum, minimum, and L-scale statistics of daily mean streamflow for U.S. Geological Survey streamflow-gaging station 08050300 Elm Fork Trinity River near Muenster,

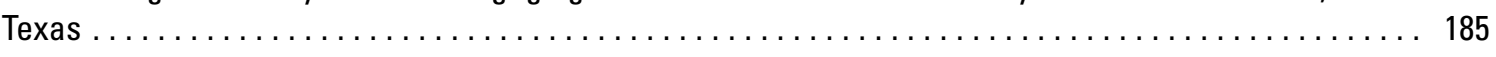

182. Analysis of annual mean, maximum, minimum, and L-scale statistics of daily mean streamflow for U.S. Geological Survey streamflow-gaging station 08050400 Elm Fork Trinity River at Gainesville,

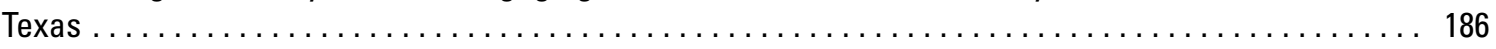

183. Analysis of annual mean, maximum, minimum, and L-scale statistics of daily mean streamflow for U.S. Geological Survey streamflow-gaging station 08050500 Elm Fork Trinity River near Sanger,

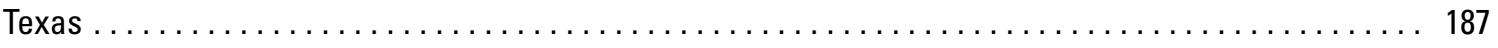

184. Analysis of annual mean, maximum, minimum, and L-scale statistics of daily mean streamflow for

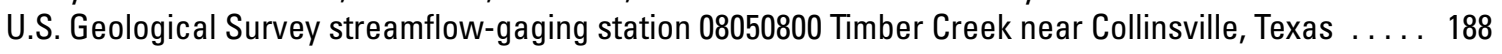

185. Analysis of annual mean, maximum, minimum, and L-scale statistics of daily mean streamflow for

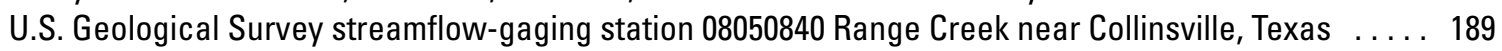

186. Analysis of annual mean, maximum, minimum, and L-scale statistics of daily mean streamflow for U.S. Geological Survey streamflow-gaging station 08051000 lsle du Bois Creek near Pilot Point,

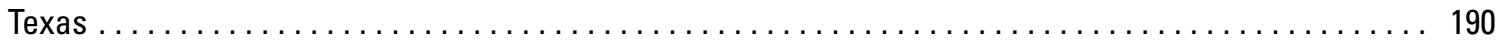

187. Analysis of annual mean, maximum, minimum, and L-scale statistics of daily mean streamflow for U.S. Geological Survey streamflow-gaging station 08051130 Elm Fork Trinity River near Plot Point,

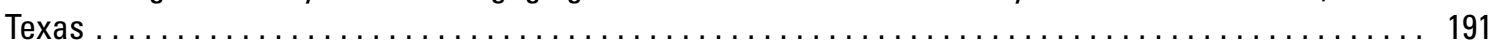

188. Analysis of annual mean, maximum, minimum, and L-scale statistics of daily mean streamflow for U.S. Geological Survey streamflow-gaging station 08051500 Clear Creek near Sanger, Texas $\ldots \ldots \ldots .192$

189. Analysis of annual mean, maximum, minimum, and L-scale statistics of daily mean streamflow for U.S. Geological Survey streamflow-gaging station 08052000 Elm Fork Trinity River near Denton,

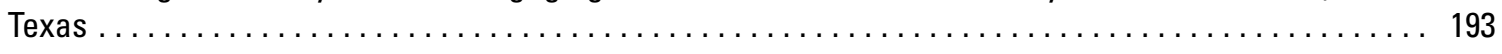

190. Analysis of annual mean, maximum, minimum, and L-scale statistics of daily mean streamflow for $\begin{array}{lll}\text { U.S. Geological Survey streamflow-gaging station 08052650 Little Elm Creek near Celina, Texas } & \ldots \ldots \ldots & \ldots\end{array}$

191. Analysis of annual mean, maximum, minimum, and L-scale statistics of daily mean streamflow for U.S. Geological Survey streamflow-gaging station 08052700 Little Elm Creek near Aubrey, Texas $\ldots . . . .195$

192. Analysis of annual mean, maximum, minimum, and L-scale statistics of daily mean streamflow for U.S. Geological Survey streamflow-gaging station 08052780 Hickory Creek at Denton, Texas . . . . . . 196

193. Analysis of annual mean, maximum, minimum, and L-scale statistics of daily mean streamflow for U.S. Geological Survey streamflow-gaging station 08053000 Elm Fork Trinity River near Lewisville,

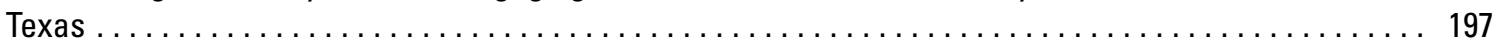


194. Analysis of annual mean, maximum, minimum, and L-scale statistics of daily mean streamflow for U.S. Geological Survey streamflow-gaging station 08053500 Denton Creek near Justin, Texas $\ldots \ldots \ldots 198$

195. Analysis of annual mean, maximum, minimum, and L-scale statistics of daily mean streamflow for U.S. Geological Survey streamflow-gaging station 08054000 Denton Creek near Roanoke, Texas $\ldots \ldots \ldots 199$

196. Analysis of annual mean, maximum, minimum, and L-scale statistics of daily mean streamflow for U.S. Geological Survey streamflow-gaging station 08055000 Denton Creek near Grapevine, Texas $\ldots . . .200$

197. Analysis of annual mean, maximum, minimum, and L-scale statistics of daily mean streamflow for U.S. Geological Survey streamflow-gaging station 08055500 Elm Fork Trinity River near Carrollton,

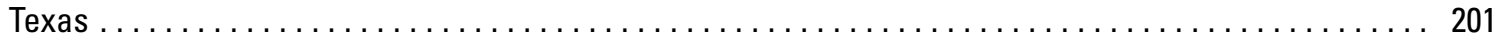

198. Analysis of annual mean, maximum, minimum, and L-scale statistics of daily mean streamflow for U.S. Geological Survey streamflow-gaging station 08055700 Bachman Branch at Dallas, Texas $\ldots \ldots .202$

199. Analysis of annual mean, maximum, minimum, and L-scale statistics of daily mean streamflow for U.S. Geological Survey streamflow-gaging station 08056500 Turtle Creek at Dallas, Texas $\ldots \ldots \ldots \ldots 203$

200. Analysis of annual mean, maximum, minimum, and L-scale statistics of daily mean streamflow for U.S. Geological Survey streamflow-gaging station 08057000 Trinity River at Dallas, Texas $\ldots \ldots \ldots 204$

201. Analysis of annual mean, maximum, minimum, and L-scale statistics of daily mean streamflow for U.S. Geological Survey streamflow-gaging station 08057100 White Rock Creek at Keller Springs

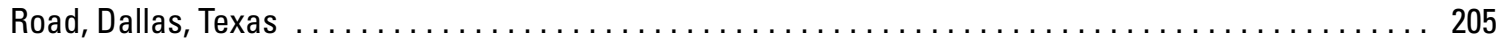

202. Analysis of annual mean, maximum, minimum, and L-scale statistics of daily mean streamflow for U.S. Geological Survey streamflow-gaging station 08057200White Rock Creek at Greenville

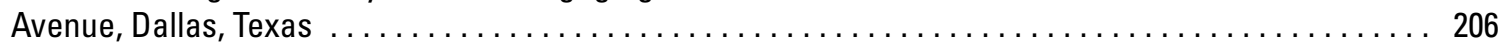

203. Analysis of annual mean, maximum, minimum, and L-scale statistics of daily mean streamflow for U.S. Geological Survey streamflow-gaging station 08057300 White Rock Creek at White Rock

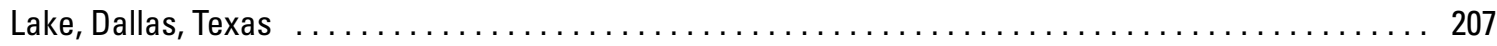

204. Analysis of annual mean, maximum, minimum, and L-scale statistics of daily mean streamflow for U.S. Geological Survey streamflow-gaging station 08057410 Trinity River below Dallas, Texas $\ldots \ldots \ldots 208$

205. Analysis of annual mean, maximum, minimum, and L-scale statistics of daily mean streamflow for U.S. Geological Survey streamflow-gaging station 08057445 Prairie Creek at U. S. Highway 175,

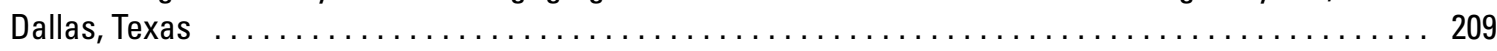

206. Analysis of annual mean, maximum, minimum, and L-scale statistics of daily mean streamflow for U.S. Geological Survey streamflow-gaging station 08057448 Trinity River near Wilmer, Texas $\ldots \ldots \ldots 210$

207. Analysis of annual mean, maximum, minimum, and L-scale statistics of daily mean streamflow for U.S. Geological Survey streamflow-gaging station 08057450 Tenmile Creek at State Highway 342,

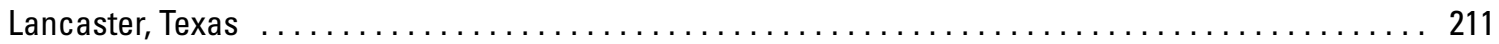

208. Analysis of annual mean, maximum, minimum, and L-scale statistics of daily mean streamflow for U.S. Geological Survey streamflow-gaging station 08058500 Honey Creek near McKinney, Texas . . . . 212

209. Analysis of annual mean, maximum, minimum, and L-scale statistics of daily mean streamflow for U.S. Geological Survey streamflow-gaging station 08058900 East Fork Trinity River at McKinney,

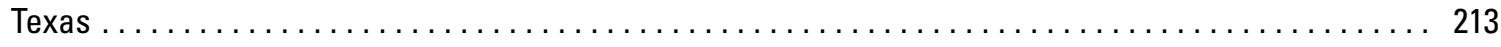

210. Analysis of annual mean, maximum, minimum, and L-scale statistics of daily mean streamflow for U.S. Geological Survey streamflow-gaging station 08059000 East Fork Trinity River near McKinney,

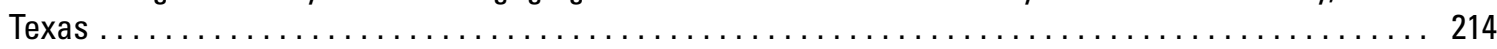

211. Analysis of annual mean, maximum, minimum, and L-scale statistics of daily mean streamflow for U.S. Geological Survey streamflow-gaging station 08059400 Sister Grove Creek near Blue Ridge,

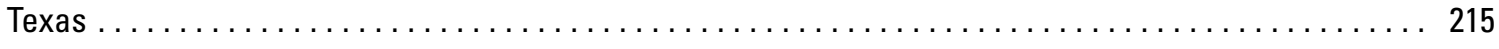

212. Analysis of annual mean, maximum, minimum, and L-scale statistics of daily mean streamflow for U.S. Geological Survey streamflow-gaging station 08059500 Sister Grove Creek near Princeton,

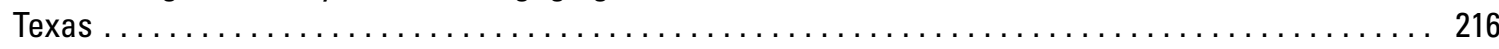


213. Analysis of annual mean, maximum, minimum, and L-scale statistics of daily mean streamflow for U.S. Geological Survey streamflow-gaging station 08060000 East Fork Trinity River above Plot

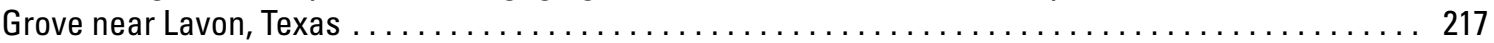

214. Analysis of annual mean, maximum, minimum, and L-scale statistics of daily mean streamflow for U.S. Geological Survey streamflow-gaging station 08061000 East Fork Trinity River near Lavon,

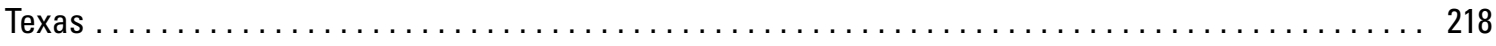

215. Analysis of annual mean, maximum, minimum, and L-scale statistics of daily mean streamflow for U.S. Geological Survey streamflow-gaging station 08061500 East Fork Trinity River near Rockwall,

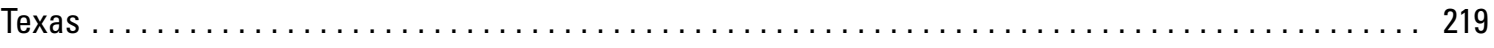

216. Analysis of annual mean, maximum, minimum, and L-scale statistics of daily mean streamflow for U.S. Geological Survey streamflow-gaging station 08061540 Rowlett Creek near Sachse, Texas $\ldots \ldots . .220$

217. Analysis of annual mean, maximum, minimum, and L-scale statistics of daily mean streamflow for U.S. Geological Survey streamflow-gaging station 08061700 Duck Creek near Garland, Texas $\ldots \ldots \ldots 221$

218. Analysis of annual mean, maximum, minimum, and L-scale statistics of daily mean streamflow for U.S. Geological Survey streamflow-gaging station 08061750 East Fork Trinity River near Forney,

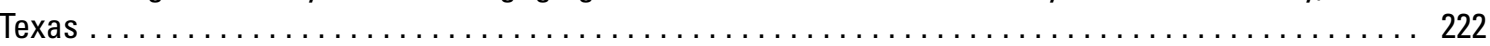

219. Analysis of annual mean, maximum, minimum, and L-scale statistics of daily mean streamflow for U.S. Geological Survey streamflow-gaging station 08061950 South Mesquite Creek at Mercury

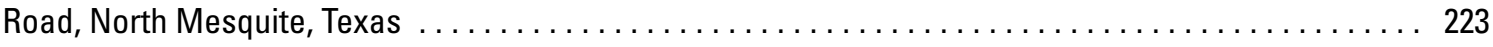

220. Analysis of annual mean, maximum, minimum, and L-scale statistics of daily mean streamflow for U.S. Geological Survey streamflow-gaging station 08062000 East Fork Trinity River near Crandall,

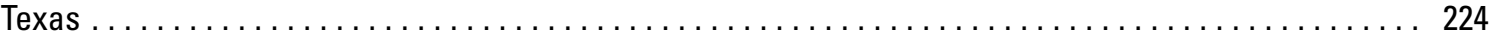

221. Analysis of annual mean, maximum, minimum, and L-scale statistics of daily mean streamflow for U.S. Geological Survey streamflow-gaging station 08062500 Trinity River near Rosser, Texas $\ldots \ldots \ldots 225$

222. Analysis of annual mean, maximum, minimum, and L-scale statistics of daily mean streamflow for U.S. Geological Survey streamflow-gaging station 08062650 Cedar Creek Reservoir Spillway

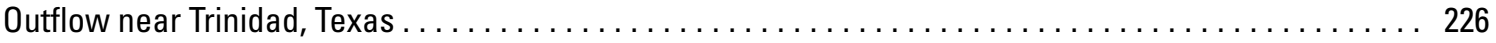

223. Analysis of annual mean, maximum, minimum, and L-scale statistics of daily mean streamflow for U.S. Geological Survey streamflow-gaging station 08062700 Trinity River at Trinidad, Texas $\ldots \ldots \ldots 227$

224. Analysis of annual mean, maximum, minimum, and L-scale statistics of daily mean streamflow for U.S. Geological Survey streamflow-gaging station 08062800 Cedar Creek near Kemp, Texas $\ldots \ldots \ldots 228$

225. Analysis of annual mean, maximum, minimum, and L-scale statistics of daily mean streamflow for U.S. Geological Survey streamflow-gaging station 08062900 Kings Creek near Kaufman, Texas $\ldots \ldots \ldots 229$

226. Analysis of annual mean, maximum, minimum, and L-scale statistics of daily mean streamflow for U.S. Geological Survey streamflow-gaging station 08062980 Lacey Fork near Mabank, Texas $\ldots \ldots \ldots 230$

227. Analysis of annual mean, maximum, minimum, and L-scale statistics of daily mean streamflow for U.S. Geological Survey streamflow-gaging station 08063000 Cedar Creek near Mabank, Texas $\ldots \ldots \ldots 231$

228. Analysis of annual mean, maximum, minimum, and L-scale statistics of daily mean streamflow for U.S. Geological Survey streamflow-gaging station 08063003 South Twin Creek near Eustace,

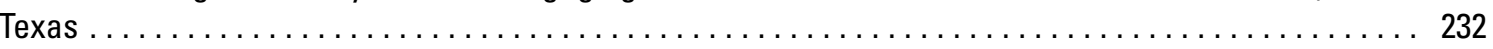

229. Analysis of annual mean, maximum, minimum, and L-scale statistics of daily mean streamflow for U.S. Geological Survey streamflow-gaging station 08063020 Cedar Creek at Trinidad, Texas $\ldots \ldots \ldots 233$

230. Analysis of annual mean, maximum, minimum, and L-scale statistics of daily mean streamflow for U.S. Geological Survey streamflow-gaging station 08063100 Richland Creek near Dawson, Texas ...... 234

231. Analysis of annual mean, maximum, minimum, and L-scale statistics of daily mean streamflow for U.S. Geological Survey streamflow-gaging station 08063200 Pin Oak Creek near Hubbard, Texas $\ldots \ldots .235$

232. Analysis of annual mean, maximum, minimum, and L-scale statistics of daily mean streamflow for U.S. Geological Survey streamflow-gaging station 08063500 RichlandCreek near Richland, Texas $\ldots \ldots .236$ 
233. Analysis of annual mean, maximum, minimum, and L-scale statistics of daily mean streamflow for U.S. Geological Survey streamflow-gaging station 08063800 Waxahachie Creek near Bardwell,

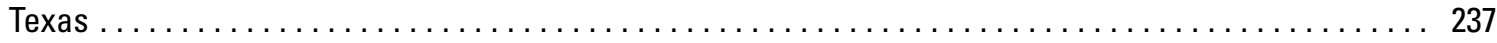

234. Analysis of annual mean, maximum, minimum, and L-scale statistics of daily mean streamflow for U.S. Geological Survey streamflow-gaging station 08064100 Chambers Creek near Rice, Texas . . . . . . 238

235. Analysis of annual mean, maximum, minimum, and L-scale statistics of daily mean streamflow for U.S. Geological Survey streamflow-gaging station 08064500 Chambers Creek near Corsicana,

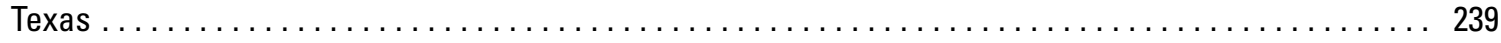

236. $\quad$ Analysis of annual mean, maximum, minimum, and L-scale statistics of daily mean streamflow for U.S. Geological Survey streamflow-gaging station 08064700 Tehuacana Creek near Streetman,

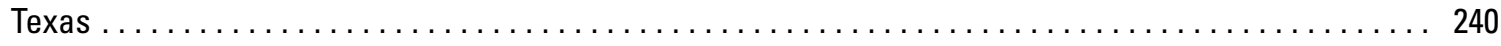

237. Analysis of annual mean, maximum, minimum, and L-scale statistics of daily mean streamflow for U.S. Geological Survey streamflow-gaging station 08064800 Catfish Creek near Tennessee Colony,

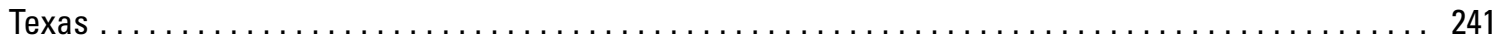

238. Analysis of annual mean, maximum, minimum, and L-scale statistics of daily mean streamflow for U.S. Geological Survey streamflow-gaging station 08065000 Trinity River near Oakw0od, Texas $\ldots \ldots \ldots 242$

239. Analysis of annual mean, maximum, minimum, and L-scale statistics of daily mean streamflow for U.S. Geological Survey streamflow-gaging station 08065200 Upper Keechi Creek near Oakwood,

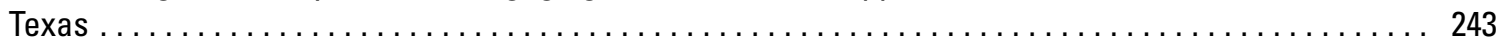

240. Analysis of annual mean, maximum, minimum, and L-scale statistics of daily mean streamflow for U.S. Geological Survey streamflow-gaging station 08065350 Trinity River near Crockett, Texas $\ldots \ldots \ldots 244$

241. Analysis of annual mean, maximum, minimum, and L-scale statistics of daily mean streamflow for U.S. Geological Survey streamflow-gaging station 08065500 Trinity River near Midway, Texas $\ldots \ldots \ldots 245$

242. Analysis of annual mean, maximum, minimum, and L-scale statistics of daily mean streamflow for U.S. Geological Survey streamflow-gaging station 08065700 Caney Creek near Madisonville,

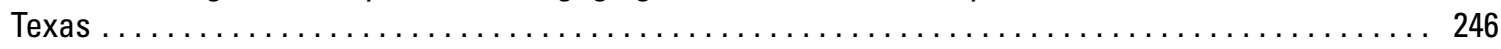

243. Analysis of annual mean, maximum, minimum, and L-scale statistics of daily mean streamflow for U.S. Geological Survey streamflow-gaging station 08065800 Bedias Creek near Madisonville,

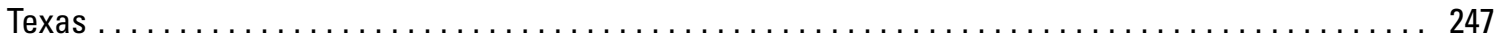

244. Analysis of annual mean, maximum, minimum, and L-scale statistics of daily mean streamflow for U.S. Geological Survey streamflow-gaging station 08066000 Trinity River at Riverside, Texas $\ldots \ldots \ldots 248$

245. Analysis of annual mean, maximum, minimum, and L-scale statistics of daily mean streamflow for U.S. Geological Survey streamflow-gaging station 08066100 White Rock Creek near Trinity, Texas $\ldots . . .249$

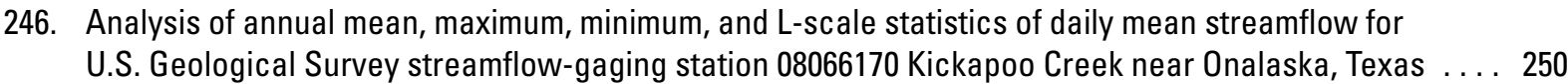

247. Analysis of annual mean, maximum, minimum, and L-scale statistics of daily mean streamflow for U.S. Geological Survey streamflow-gaging station 08066191 Livingston Reservoir Outtlow Weir

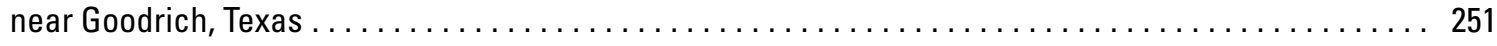

248. Analysis of annual mean, maximum, minimum, and L-scale statistics of daily mean streamflow for $\begin{array}{llllll}\text { U.S. Geological Survey streamflow-gaging station 08066200 Long King Creek at Livingston, Texas } & \ldots \ldots & 252\end{array}$

249. Analysis of annual mean, maximum, minimum, and L-scale statistics of daily mean streamflow for U.S. Geological Survey streamflow-gaging station 08066250 Trinity River near Goodrich, Texas $\ldots \ldots \ldots 253$

250. Analysis of annual mean, maximum, minimum, and L-scale statistics of daily mean streamflow for U.S. Geological Survey streamflow-gaging station 08066300 Menard Creek near Rye, Texas $\ldots \ldots \ldots 254$

251. Analysis of annual mean, maximum, minimum, and L-scale statistics of daily mean streamflow for U.S. Geological Survey streamflow-gaging station 08066500 Trinity River at Romayor, Texas $\ldots \ldots \ldots 25$

252. Analysis of annual mean, maximum, minimum, and L-scale statistics of daily mean streamflow for U.S. Geological Survey streamflow-gaging station 08067000 Trinity River at Liberty, Texas $\ldots \ldots \ldots \ldots 256$

253. Analysis of annual mean, maximum, minimum, and L-scale statistics of daily mean streamflow for U.S. Geological Survey streamflow-gaging station 08067500 Cedar Bayou near Crosby, Texas . . . . . . 257 
254. Analysis of annual mean, maximum, minimum, and L-scale statistics of daily mean streamflow for U.S. Geological Survey streamflow-gaging station 08067525Goose Creek at Baytown, Texas $\ldots \ldots \ldots 258$

255. Analysis of annual mean, maximum, minimum, and L-scale statistics of daily mean streamflow for U.S. Geological Survey streamflow-gaging station 08067610 Lake Conroe Outflow Weir near

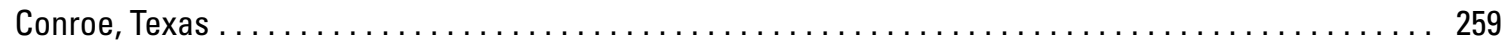

256. Analysis of annual mean, maximum, minimum, and L-scale statistics of daily mean streamflow for U.S. Geological Survey streamflow-gaging station 08067650West Fork San Jacinto River below

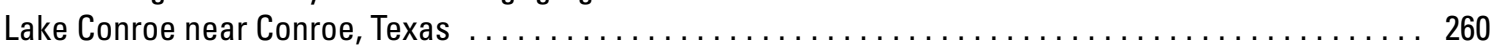

257. Analysis of annual mean, maximum, minimum, and L-scale statistics of daily mean streamflow for U.S. Geological Survey streamflow-gaging station 08067700 Caney Creek near Dobbin, Texas . ...... 261

258. Analysis of annual mean, maximum, minimum, and L-scale statistics of daily mean streamflow for U.S. Geological Survey streamflow-gaging station 08067900 Lake Creek near Conroe, Texas $\ldots \ldots \ldots 262$

259. Analysis of annual mean, maximum, minimum, and L-scale statistics of daily mean streamflow for U.S. Geological Survey streamflow-gaging station 08068000West Fork San Jacinto River near

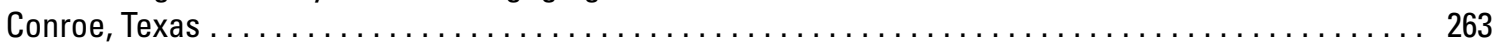

260. Analysis of annual mean, maximum, minimum, and L-scale statistics of daily mean streamflow for U.S. Geological Survey streamflow-gaging station 08068090West Fork San Jacinto River above

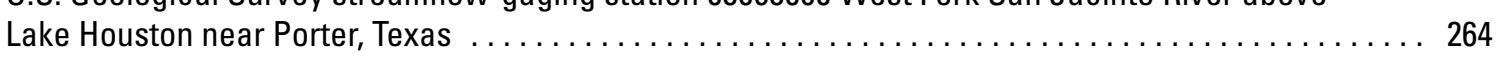

261. Analysis of annual mean, maximum, minimum, and L-scale statistics of daily mean streamflow for U.S. Geological Survey streamflow-gaging station 08068275 Spring Creek near Tomball, Texas $\ldots \ldots \ldots 265$

262. Analysis of annual mean, maximum, minimum, and L-scale statistics of daily mean streamflow for U.S. Geological Survey streamflow-gaging station 08068325 Willow Creek near Tomball, Texas $\ldots \ldots \ldots 266$

263. Analysis of annual mean, maximum, minimum, and L-scale statistics of daily mean streamflow for U.S. Geological Survey streamflow-gaging station 08068390 Bear Branch at Research Boulevard,

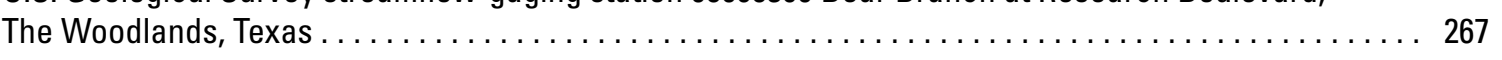

264. Analysis of annual mean, maximum, minimum, and L-scale statistics of daily mean streamflow for U.S. Geological Survey streamflow-gaging station 08068400 Panther Branch at Gosling Road, the

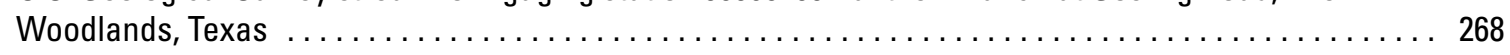

265. Analysis of annual mean, maximum, minimum, and L-scale statistics of daily mean streamflow for
U.S. Geological Survey streamflow-gaging station 08068450 Panther Branch near Spring, Texas $\ldots . \ldots 269$

266. Analysis of annual mean, maximum, minimum, and L-scale statistics of daily mean streamflow for U.S. Geological Survey streamflow-gaging station 08068500 Spring Creek near Spring, Texas $\ldots \ldots \ldots 270$

267.
Analysis of annual mean, maximum, minimum, and L-scale statistics of daily mean streamflow for
U.S. Geological Survey streamflow-gaging station 08068520 Spring Creek at Spring, Texas $\ldots \ldots \ldots \ldots 271$

268. Analysis of annual mean, maximum, minimum, and L-scale statistics of daily mean streamflow for U.S. Geological Survey streamflow-gaging station 08068720 Cypress Creek at Katy-Hockley Road

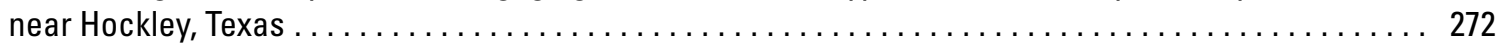

269. Analysis of annual mean, maximum, minimum, and L-scale statistics of daily mean streamflow for U.S. Geological Survey streamflow-gaging station 08068740 Cypress Creek at House-Hahl Road

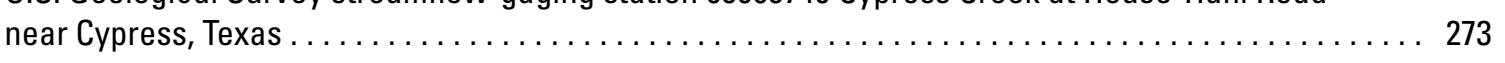

270. Analysis of annual mean, maximum, minimum, and L-scale statistics of daily mean streamflow for U.S. Geological Survey streamflow-gaging station 08068780 Little Cypress Creek near Cypress,

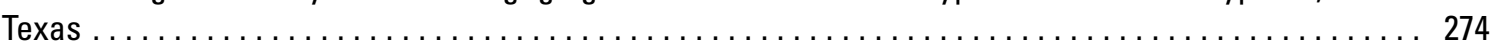

271. Analysis of annual mean, maximum, minimum, and L-scale statistics of daily mean streamflow for U.S. Geological Survey streamflow-gaging station 08068800 Cypress Creek at Grant Road near

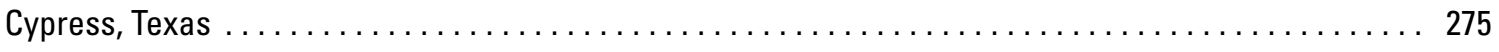

272. Analysis of annual mean, maximum, minimum, and L-scale statistics of daily mean streamflow for U.S. Geological Survey streamflow-gaging station 08068900 Cypress Creek at Stuebner-Airline

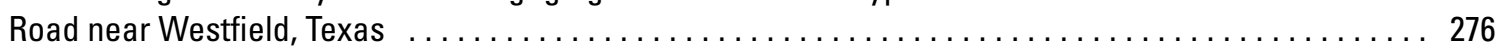


273. Analysis of annual mean, maximum, minimum, and L-scale statistics of daily mean streamflow for U.S. Geological Survey streamflow-gaging station 08069000 Cypress Creek near Westfield, Texas $\quad \ldots \ldots 277$

274. Analysis of annual mean, maximum, minimum, and L-scale statistics of daily mean streamflow for U.S. Geological Survey streamflow-gaging station 08069500 West Fork San Jacinto River near

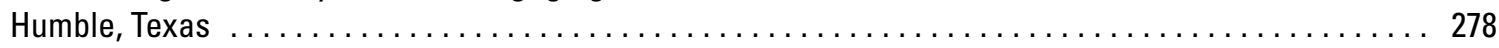

275. Analysis of annual mean, maximum, minimum, and L-scale statistics of daily mean streamflow for U.S. Geological Survey streamflow-gaging station 08070000 East Fork San Jacinto River near

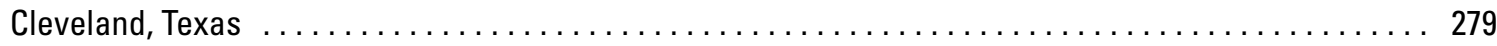

276. $\quad$ Analysis of annual mean, maximum, minimum, and L-scale statistics of daily mean streamflow for U.S. Geological Survey streamflow-gaging station 08070200 East Fork San Jacinto River near New

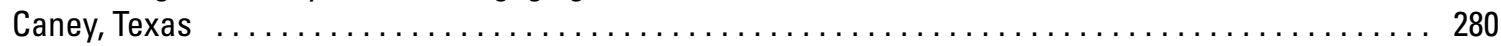

277. Analysis of annual mean, maximum, minimum, and L-scale statistics of daily mean streamflow for U.S. Geological Survey streamflow-gaging station 08070500 Caney Creek near Splendora, Texas $\ldots \ldots \ldots 281$

278. Analysis of annual mean, maximum, minimum, and L-scale statistics of daily mean streamflow for U.S. Geological Survey streamflow-gaging station 08071000 Peach Creek at Splendora, Texas $\ldots \ldots \ldots 282$

279. Analysis of annual mean, maximum, minimum, and L-scale statistics of daily mean streamflow for U.S. Geological Survey streamflow-gaging station 08071280 Luce Bayou above Lake Houston near

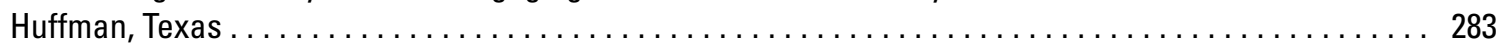

280. Analysis of annual mean, maximum, minimum, and L-scale statistics of daily mean streamflow for U.S. Geological Survey streamflow-gaging station 08071500 San Jacinto River near Huffman,

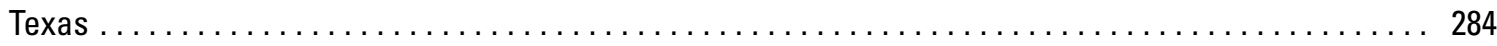

281. Analysis of annual mean, maximum, minimum, and L-scale statistics of daily mean streamflow for U.S. Geological Survey streamflow-gaging station 08072300 Buffalo Bayou near Katy, Texas $\ldots \ldots \ldots 285$

282. Analysis of annual mean, maximum, minimum, and L-scale statistics of daily mean streamflow for U.S. Geological Survey streamflow-gaging station 08072730 Bear Creek near Barker, Texas $\ldots \ldots \ldots 286$

283. Analysis of annual mean, maximum, minimum, and L-scale statistics of daily mean streamflow for U.S. Geological Survey streamflow-gaging station 08072760 Langham Creek at West Little York

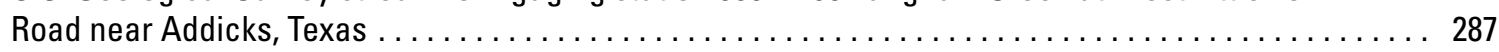

284. Analysis of annual mean, maximum, minimum, and L-scale statistics of daily mean streamflow for U.S. Geological Survey streamflow-gaging station 08073500 Buffalo Bayou near Addicks, Texas . . . . . 288

285. Analysis of annual mean, maximum, minimum, and L-scale statistics of daily mean streamflow for U.S. Geological Survey streamflow-gaging station 08073600 Buffalo Bayou at West Belt Drive,

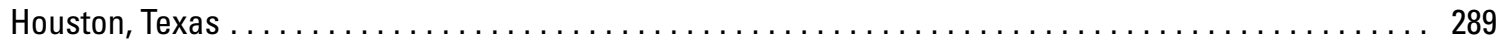

286. Analysis of annual mean, maximum, minimum, and L-scale statistics of daily mean streamflow for U.S. Geological Survey streamflow-gaging station 08073700 Buffalo Bayou at Piney Point, Texas $\ldots \ldots \ldots 290$

287. Analysis of annual mean, maximum, minimum, and L-scale statistics of daily mean streamflow for U.S. Geological Survey streamflow-gaging station 08074000 Buffalo Bayou at Houston, Texas ........ 291

288. Analysis of annual mean, maximum, minimum, and L-scale statistics of daily mean streamflow for U.S. Geological Survey streamflow-gaging station 08074020 Whiteoak Bayou at Alabonson Road,

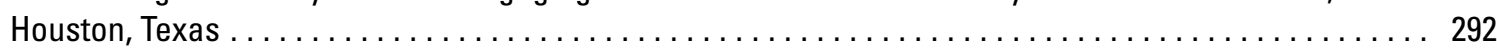

289. $\quad$ Analysis of annual mean, maximum, minimum, and L-scale statistics of daily mean streamflow for U.S. Geological Survey streamflow-gaging station 08074150 Cole Creek at Deihl Road, Houston,

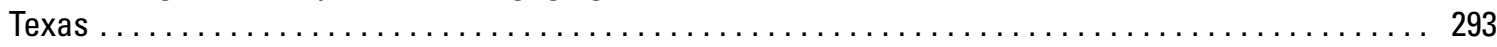

290. Analysis of annual mean, maximum, minimum, and L-scale statistics of daily mean streamflow for U.S. Geological Survey streamflow-gaging station 08074250 Brickhouse Gully at Costa Rica Street,

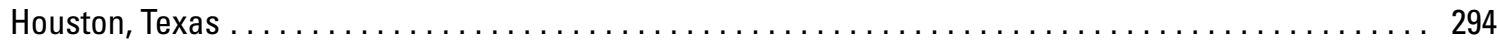

291. Analysis of annual mean, maximum, minimum, and L-scale statistics of daily mean streamflow for U.S. Geological Survey streamflow-gaging station 08074500 Whiteoak Bayou at Houston, Texas $\ldots \ldots \ldots 29$

292. Analysis of annual mean, maximum, minimum, and L-scale statistics of daily mean streamflow for U.S. Geological Survey streamflow-gaging station 08074760 Brays Bayou at Alief, Texas $\ldots \ldots \ldots \ldots 296$ 
293. Analysis of annual mean, maximum, minimum, and L-scale statistics of daily mean streamflow for U.S. Geological Survey streamflow-gaging station 08074780 Keegans Bayou at Keegan Road near Houston, Texas $\ldots \ldots \ldots \ldots \ldots \ldots \ldots \ldots \ldots \ldots \ldots \ldots \ldots \ldots \ldots \ldots \ldots \ldots \ldots \ldots \ldots \ldots \ldots \ldots$

294. Analysis of annual mean, maximum, minimum, and L-scale statistics of daily mean streamflow for U.S. Geological Survey streamflow-gaging station 08074800 Keegans Bayou at Roark Road near

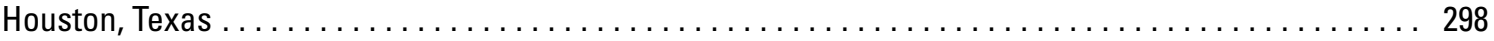

295. Analysis of annual mean, maximum, minimum, and L-scale statistics of daily mean streamflow for U.S. Geological Survey streamflow-gaging station 08074810 Brays Bayou at Gessner Drive,

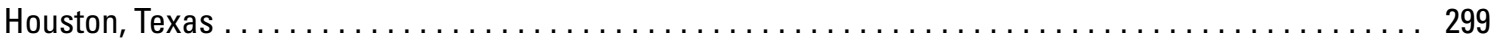

296. Analysis of annual mean, maximum, minimum, and L-scale statistics of daily mean streamflow for U.S. Geological Survey streamflow-gaging station 08075000 Brays Bayou at Houston, Texas $\ldots \ldots \ldots 300$

297. Analysis of annual mean, maximum, minimum, and L-scale statistics of daily mean streamflow for U.S. Geological Survey streamflow-gaging station 08075400 Sims Bayou at Hiram Clarke Street,

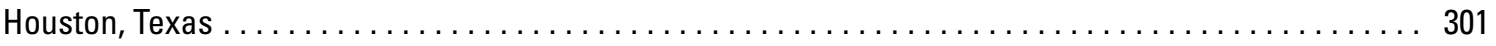

298. Analysis of annual mean, maximum, minimum, and L-scale statistics of daily mean streamflow for U.S. Geological Survey streamflow-gaging station 08075500 Sims Bayou at Houston, Texas $\ldots \ldots \ldots \ldots 302$

299. Analysis of annual mean, maximum, minimum, and L-scale statistics of daily mean streamflow for U.S. Geological Survey streamflow-gaging station 08075650 Berry Bayou at Forest Oaks Street,

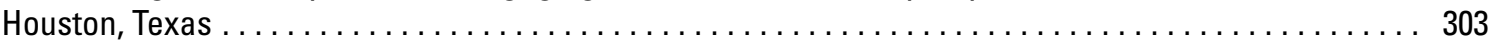

300. Analysis of annual mean, maximum, minimum, and L-scale statistics of daily mean streamflow for U.S. Geological Survey streamflow-gaging station 08075730 Vince Bayou at Pasadena, Texas $\ldots \ldots \ldots 4$

301. Analysis of annual mean, maximum, minimum, and L-scale statistics of daily mean streamflow for U.S. Geological Survey streamflow-gaging station 08075770 Hunting Bayou at Interstate Highway

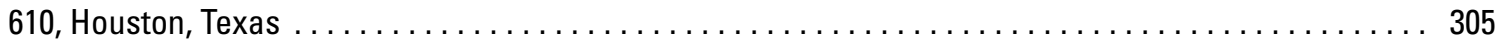

302. Analysis of annual mean, maximum, minimum, and L-scale statistics of daily mean streamflow for U.S. Geological Survey streamflow-gaging station 08075780 Greens Bayou at Cutten Road near

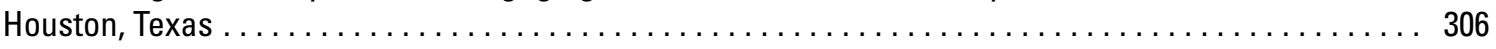

303. Analysis of annual mean, maximum, minimum, and L-scale statistics of daily mean streamflow for U.S. Geological Survey streamflow-gaging station 08075900 Greens Bayou near U. S. Highway 75

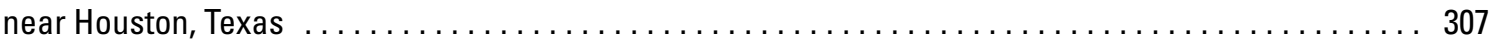

$304 . \quad$ Analysis of annual mean, maximum, minimum, and L-scale statistics of daily mean streamflow for

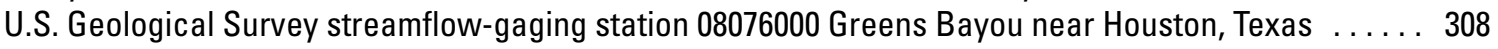

\begin{tabular}{l|ll}
305. & Analysis of annual mean, maximum, minimum, and L-scale statistics of daily mean streamflow for \\
\hline & U.S. Geological Survey streamflow-gaging station 08076180 Garners Bayou near Humble, Texas $\ldots \ldots$.... 309
\end{tabular}

306. Analysis of annual mean, maximum, minimum, and L-scale statistics of daily mean streamflow for U.S. Geological Survey streamflow-gaging station 08076500 Halls Bayou at Houston, Texas $\ldots \ldots \ldots 310$

307. Analysis of annual mean, maximum, minimum, and L-scale statistics of daily mean streamflow for U.S. Geological Survey streamflow-gaging station 08076700 Greens Bayou at Ley Road, Houston,

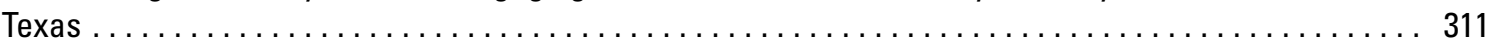

308. Analysis of annual mean, maximum, minimum, and L-scale statistics of daily mean streamflow for U.S. Geological Survey streamflow-gaging station 08077000 Clear Creek near Pearland, Texas $\ldots \ldots \ldots 312$

309. Analysis of annual mean, maximum, minimum, and L-scale statistics of daily mean streamflow for U.S. Geological Survey streamflow-gaging station 08077540 Clear Creek at Friendswood, Texas $\ldots \ldots \ldots 313$

310. Analysis of annual mean, maximum, minimum, and L-scale statistics of daily mean streamflow for U.S. Geological Survey streamflow-gaging station 08078000 Chocolate Bayou near Alvin, Texas $\ldots \ldots . .314$

311. Analysis of annual mean, maximum, minimum, and L-scale statistics of daily mean streamflow for U.S. Geological Survey streamflow-gaging station 08079000 0yster Creek near Angleton, Texas $\ldots . \ldots . .315$

312. Analysis of annual mean, maximum, minimum, and L-scale statistics of daily mean streamflow for U.S. Geological Survey streamflow-gaging station 08079500 North Fork Double Mountain Fork

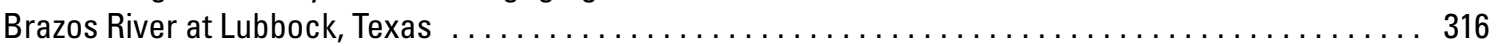


313. Analysis of annual mean, maximum, minimum, and L-scale statistics of daily mean streamflow for U.S. Geological Survey streamflow-gaging station 08079575 North Fork Double Mountain Fork Brazos River near Post, Texas $\ldots \ldots \ldots \ldots \ldots \ldots \ldots \ldots \ldots \ldots \ldots \ldots \ldots \ldots \ldots \ldots \ldots \ldots$

314. Analysis of annual mean, maximum, minimum, and L-scale statistics of daily mean streamflow for U.S. Geological Survey streamflow-gaging station 08079600 Double Mountain Fork Brazos River at

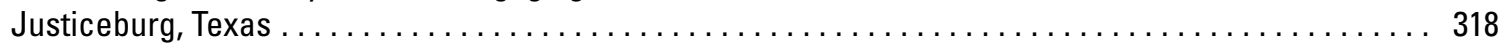

315. Analysis of annual mean, maximum, minimum, and L-scale statistics of daily mean streamflow for U.S. Geological Survey streamflow-gaging station 08080000 Double Mountain Fork Brazos River

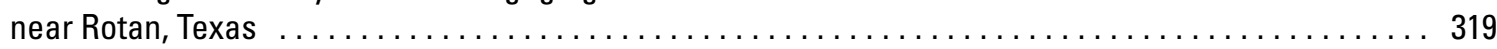

316. Analysis of annual mean, maximum, minimum, and L-scale statistics of daily mean streamflow for U.S. Geological Survey streamflow-gaging station 08080500 Double Mountain Fork Brazos River

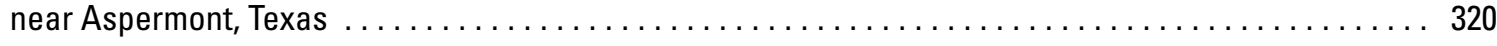

317. Analysis of annual mean, maximum, minimum, and L-scale statistics of daily mean streamflow for U.S. Geological Survey streamflow-gaging station 08080540 McDonald Creek near Post, Texas $\ldots \ldots . .321$

318. Analysis of annual mean, maximum, minimum, and L-scale statistics of daily mean streamflow for U.S. Geological Survey streamflow-gaging station 08080700 Running Water Draw at Plainview,

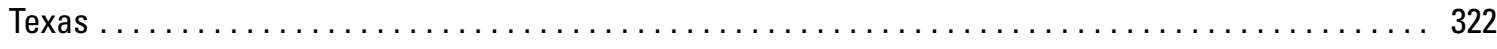

319. Analysis of annual mean, maximum, minimum, and L-scale statistics of daily mean streamflow for U.S. Geological Survey streamflow-gaging station 08080950 Duck Creek near Girard, Texas $\ldots \ldots \ldots 323$

320. Analysis of annual mean, maximum, minimum, and L-scale statistics of daily mean streamflow for U.S. Geological Survey streamflow-gaging station 08081000 Salt Fork Brazos River near Peacock,

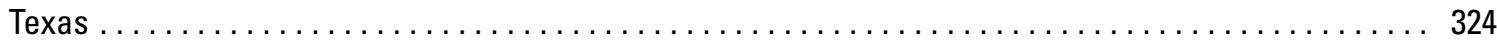

321. Analysis of annual mean, maximum, minimum, and L-scale statistics of daily mean streamflow for U.S. Geological Survey streamflow-gaging station 08081200 Croton Creek near Jayton, Texas $\ldots \ldots \ldots 325$

322. Analysis of annual mean, maximum, minimum, and L-scale statistics of daily mean streamflow for U.S. Geological Survey streamflow-gaging station 08081500 Salt Croton Creek near Aspermont,

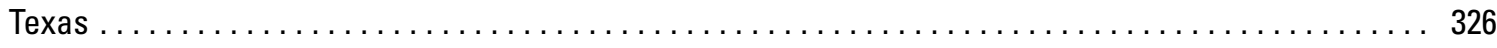

323. Analysis of annual mean, maximum, minimum, and L-scale statistics of daily mean streamflow for U.S. Geological Survey streamflow-gaging station 08082000 Salt Fork Brazos River near

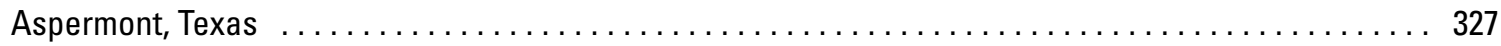

324. Analysis of annual mean, maximum, minimum, and L-scale statistics of daily mean streamflow for U.S. Geological Survey streamflow-gaging station 08082100 Stinking Creek near Aspermont,

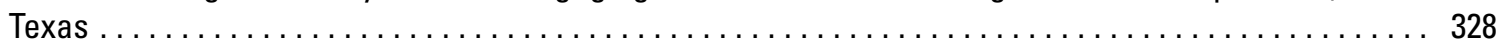

325. Analysis of annual mean, maximum, minimum, and L-scale statistics of daily mean streamflow for U.S. Geological Survey streamflow-gaging station 08082180 North Croton Creek near Knox City,

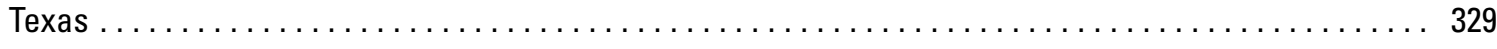

326. Analysis of annual mean, maximum, minimum, and L-scale statistics of daily mean streamflow for U.S. Geological Survey streamflow-gaging station 08082500 Brazos River at Seymour, Texas $\ldots \ldots \ldots 330$

327. Analysis of annual mean, maximum, minimum, and L-scale statistics of daily mean streamflow for U.S. Geological Survey streamflow-gaging station 08082700 Millers Creek near Munday, Texas $\ldots \ldots \ldots 331$

328. Analysis of annual mean, maximum, minimum, and L-scale statistics of daily mean streamflow for U.S. Geological Survey streamflow-gaging station 08083000 Brazos River near Graham, Texas $\ldots \ldots \ldots 332$

329. Analysis of annual mean, maximum, minimum, and L-scale statistics of daily mean streamflow for U.S. Geological Survey streamflow-gaging station 08083100 Clear Fork Brazos River near Roby,

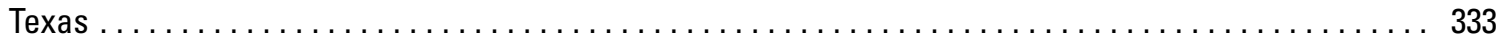

330. Analysis of annual mean, maximum, minimum, and L-scale statistics of daily mean streamflow for U.S. Geological Survey streamflow-gaging station 08083230 Clear Fork Brazos River near Noodle,

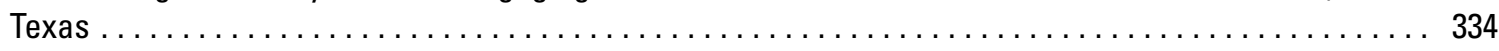


331. Analysis of annual mean, maximum, minimum, and L-scale statistics of daily mean streamflow for U.S. Geological Survey streamflow-gaging station 08083240 Clear Fork Brazos River at Hawley,

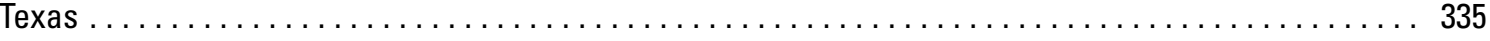

332. Analysis of annual mean, maximum, minimum, and L-scale statistics of daily mean streamflow for U.S. Geological Survey streamflow-gaging station 08083245 Mulberry Creek near Hawley, Texas $\ldots \ldots . .336$

333. Analysis of annual mean, maximum, minimum, and L-scale statistics of daily mean streamflow for U.S. Geological Survey streamflow-gaging station 08083300 Elm Creek near Abilene, Texas $\ldots \ldots \ldots .337$

334. Analysis of annual mean, maximum, minimum, and L-scale statistics of daily mean streamflow for U.S. Geological Survey streamflow-gaging station 08083400 Little Elm Creek near Abilene, Texas $\ldots \ldots . . .338$

335. Analysis of annual mean, maximum, minimum, and L-scale statistics of daily mean streamflow for U.S. Geological Survey streamflow-gaging station 08083420 Cat Claw Creek at Abilene, Texas $\ldots \ldots \ldots 339$

336. Analysis of annual mean, maximum, minimum, and L-scale statistics of daily mean streamflow for U.S. Geological Survey streamflow-gaging station 08083430 Elm Creek at Abilene, Texas . . . . . . . . . 340

337. $\frac{\text { Analysis of annual mean, maximum, minimum, and L-scale statistics of daily mean streamflow for }}{\text { U.S. Geological Survey streamflow-gaging station 08083470 Cedar Creek at Abilene, Texas } \ldots \ldots \ldots \ldots 34}$

338. $\quad$ Analysis of annual mean, maximum, minimum, and L-scale statistics of daily mean streamflow for U.S. Geological Survey streamflow-gaging station 08083480 Cedar Creek at Interstate Highway 20,

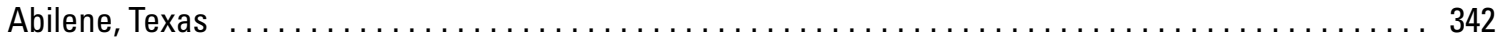

339. Analysis of annual mean, maximum, minimum, and L-scale statistics of daily mean streamflow for U.S. Geological Survey streamflow-gaging station 08084000 Clear Fork Brazos River at Nugent,

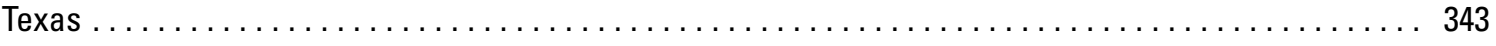

340. $\quad$ Analysis of annual mean, maximum, minimum, and L-scale statistics of daily mean streamflow for U.S. Geological Survey streamflow-gaging station 08084800 California Creek near Stamford, Texas $\ldots . . .344$

341. Analysis of annual mean, maximum, minimum, and L-scale statistics of daily mean streamflow for U.S. Geological Survey streamflow-gaging station 08085000 Paint Creek near Haskell, Texas $\ldots \ldots \ldots 345$

342. $\quad$ Analysis of annual mean, maximum, minimum, and L-scale statistics of daily mean streamflow for U.S. Geological Survey streamflow-gaging station 08085500 Clear Fork Brazos River at Fort Griffin,

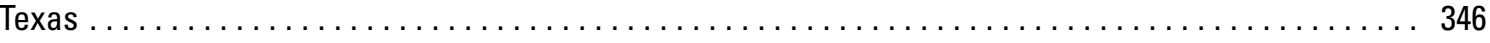

343. Analysis of annual mean, maximum, minimum, and L-scale statistics of daily mean streamflow for U.S. Geological Survey streamflow-gaging station 08086000 Clear Fork Brazos River at Crystal

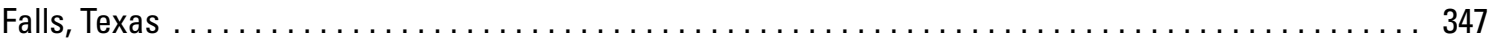

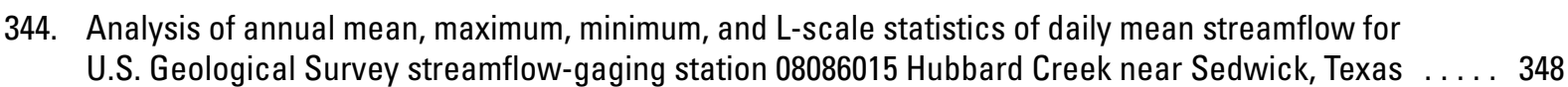

345. Analysis of annual mean, maximum, minimum, and L-scale statistics of daily mean streamflow for U.S. Geological Survey streamflow-gaging station 08086050 Deep Creek at Mloran, Texas $\ldots \ldots \ldots \ldots$

346. Analysis of annual mean, maximum, minimum, and L-scale statistics of daily mean streamflow for U.S. Geological Survey streamflow-gaging station 08086100 Hubbard Creek near Albany, Texas $\ldots . . . . .350$

347. Analysis of annual mean, maximum, minimum, and L-scale statistics of daily mean streamflow for U.S. Geological Survey streamflow-gaging station 08086120 Salt Prong Hubbard Creek at

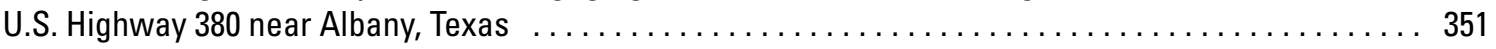

348. Analysis of annual mean, maximum, minimum, and L-scale statistics of daily mean streamflow for U.S. Geological Survey streamflow-gaging station 08086150 North Fork Hubbard Creek near

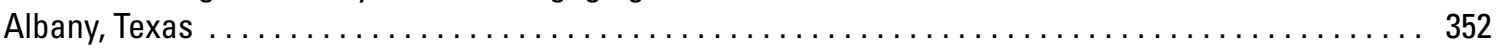

349. Analysis of annual mean, maximum, minimum, and L-scale statistics of daily mean streamflow for U.S. Geological Survey streamflow-gaging station 08086200 Salt Prong Hubbard Creek near

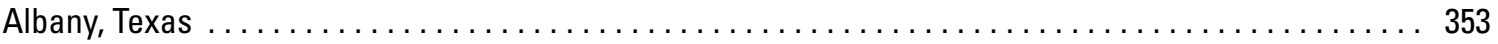

350. Analysis of annual mean, maximum, minimum, and L-scale statistics of daily mean streamflow for U.S. Geological Survey streamflow-gaging station 08086210 Snailum Creek near Albany, Texas $\ldots \ldots \ldots 354$

351. Analysis of annual mean, maximum, minimum, and L-scale statistics of daily mean streamflow for U.S. Geological Survey streamflow-gaging station 08086212 Hubbard Creek below Albany, Texas . . . . . 355 
352. Analysis of annual mean, maximum, minimum, and L-scale statistics of daily mean streamflow for U.S. Geological Survey streamflow-gaging station 08086235 Battle Creek near Moran, Texas $\ldots \ldots \ldots 356$

353. Analysis of annual mean, maximum, minimum, and L-scale statistics of daily mean streamflow for U.S. Geological Survey streamflow-gaging station 08086260 Pecan Creek near Eolian, Texas $\ldots \ldots \ldots 35$

354. Analysis of annual mean, maximum, minimum, and L-scale statistics of daily mean streamflow for U.S. Geological Survey streamflow-gaging station 08086290 Big Sandy Creek above Breckenridge,

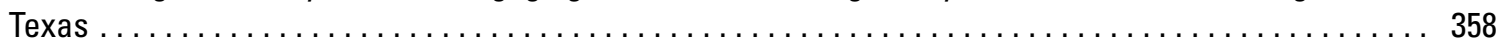

355. Analysis of annual mean, maximum, minimum, and L-scale statistics of daily mean streamflow for U.S. Geological Survey streamflow-gaging station 08086500 Hubbard Creek near Breckenridge,

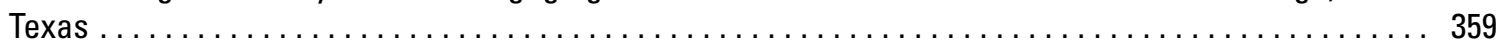

356. Analysis of annual mean, maximum, minimum, and L-scale statistics of daily mean streamflow for U.S. Geological Survey streamflow-gaging station 08087300 Clear Fork Brazos River at Eliasville,

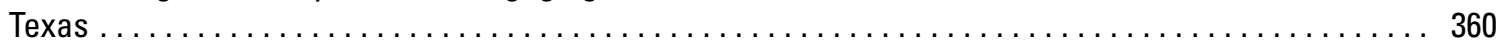

357. Analysis of annual mean, maximum, minimum, and L-scale statistics of daily mean streamflow for U.S. Geological Survey streamflow-gaging station 08088000 Brazos River near South Bend, Texas . . . . . 361

358. Analysis of annual mean, maximum, minimum, and L-scale statistics of daily mean streamflow for U.S. Geological Survey streamflow-gaging station 08088100 Salt Creek at Olney, Texas $\ldots \ldots \ldots \ldots \ldots$

359. Analysis of annual mean, maximum, minimum, and L-scale statistics of daily mean streamflow for U.S. Geological Survey streamflow-gaging station 08088200 Salt Creek near Newcastle, Texas $\ldots \ldots \ldots 363$

360. Analysis of annual mean, maximum, minimum, and L-scale statistics of daily mean streamflow for U.S. Geological Survey streamflow-gaging station 08088300 Briar Creek near Graham, Texas $\ldots \ldots \ldots .364$

361. Analysis of annual mean, maximum, minimum, and L-scale statistics of daily mean streamflow for U.S. Geological Survey streamflow-gaging station 08088450 Big Cedar Creek near Ivan, Texas $\ldots \ldots \ldots 365$

362. Analysis of annual mean, maximum, minimum, and L-scale statistics of daily mean streamflow for U.S. Geological Survey streamflow-gaging station 08088600 Brazos River at Morris Sheppard Dam

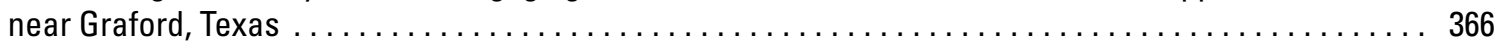

363. Analysis of annual mean, maximum, minimum, and L-scale statistics of daily mean streamflow for U.S. Geological Survey streamflow-gaging station 08088610 Brazos River near Graford, Texas $\ldots \ldots \ldots . . . .367$

364. Analysis of annual mean, maximum, minimum, and L-scale statistics of daily mean streamflow for U.S. Geological Survey streamflow-gaging station 08089000 Brazos River near Palo Pinto, Texas $\ldots \ldots . .368$

365. Analysis of annual mean, maximum, minimum, and L-scale statistics of daily mean streamflow for U.S. Geological Survey streamflow-gaging station 08090500 Palo Pinto Creek near Santo, Texas $\ldots \ldots .369$

366. Analysis of annual mean, maximum, minimum, and L-scale statistics of daily mean streamflow for U.S. Geological Survey streamflow-gaging station 08090800 Brazos River near Dennis, Texas $\ldots \ldots \ldots .370$

367. Analysis of annual mean, maximum, minimum, and L-scale statistics of daily mean streamflow for U.S. Geological Survey streamflow-gaging station 08091000 Brazos River near Glen Rose, Texas . . . . . 371

368. Analysis of annual mean, maximum, minimum, and L-scale statistics of daily mean streamflow for U.S. Geological Survey streamflow-gaging station 08091500 Paluxy River at Glen Rose, Texas . . . . . . 372

369. Analysis of annual mean, maximum, minimum, and L-scale statistics of daily mean streamflow for

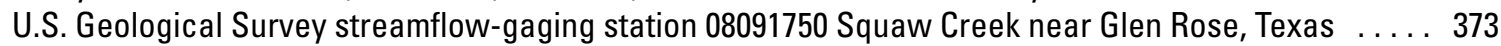

370. Analysis of annual mean, maximum, minimum, and L-scale statistics of daily mean streamflow for U.S. Geological Survey streamflow-gaging station 08092000 Nolan River at Blum, Texas $\ldots \ldots \ldots \ldots 374$

371. Analysis of annual mean, maximum, minimum, and L-scale statistics of daily mean streamflow for U.S. Geological Survey streamflow-gaging station 08092600 Brazos River at Whitney Dam near

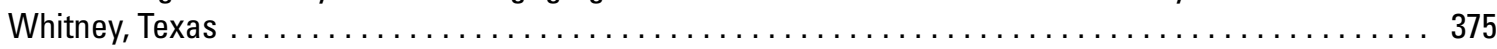

372. Analysis of annual mean, maximum, minimum, and L-scale statistics of daily mean streamflow for U.S. Geological Survey streamflow-gaging station 08093100 Brazos River near Aquilla, Texas $\ldots \ldots \ldots 376$

373. Analysis of annual mean, maximum, minimum, and L-scale statistics of daily mean streamflow for U.S. Geological Survey streamflow-gaging station 08093250 Hackberry Creek at Hillsboro, Texas $\ldots \ldots .377$ 
374. Analysis of annual mean, maximum, minimum, and L-scale statistics of daily mean streamflow for U.S. Geological Survey streamflow-gaging station 08093360 Aquilla Creek above Aquilla, Texas $\ldots \ldots \ldots 378$

375. Analysis of annual mean, maximum, minimum, and L-scale statistics of daily mean streamflow for U.S. Geological Survey streamflow-gaging station 08093400 Cobb Creek near Abbott, Texas $\ldots \ldots \ldots .379$

376. Analysis of annual mean, maximum, minimum, and L-scale statistics of daily mean streamflow for U.S. Geological Survey streamflow-gaging station 08093500 Aquilla Creek near Aquilla, Texas $\ldots \ldots \ldots 380$

377. Analysis of annual mean, maximum, minimum, and L-scale statistics of daily mean streamflow for U.S. Geological Survey streamflow-gaging station 08093700 North Bosque River at Stephenville,

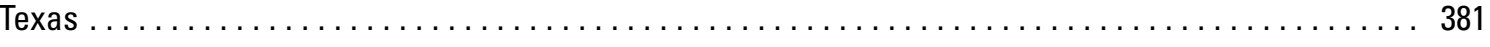

378. Analysis of annual mean, maximum, minimum, and L-scale statistics of daily mean streamflow for U.S. Geological Survey streamflow-gaging station 08094800 North Bosque River at Hico, Texas $\ldots \ldots \ldots 382$

379. Analysis of annual mean, maximum, minimum, and L-scale statistics of daily mean streamflow for U.S. Geological Survey streamflow-gaging station 08095000 North Bosque River near Clifton,

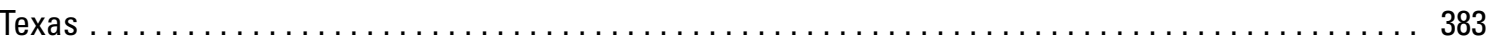

380. Analysis of annual mean, maximum, minimum, and L-scale statistics of daily mean streamflow for U.S. Geological Survey streamflow-gaging station 08095200 North Bosque River at Valley Mills,

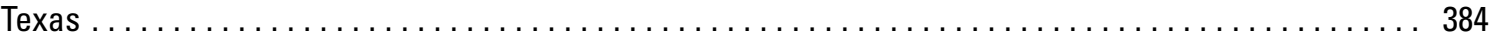

381. Analysis of annual mean, maximum, minimum, and L-scale statistics of daily mean streamflow for U.S. Geological Survey streamflow-gaging station 08095300 Middle Bosque River near VIcGregor,

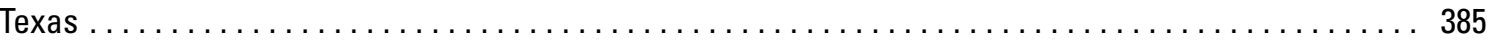

382. Analysis of annual mean, maximum, minimum, and L-scale statistics of daily mean streamflow for U.S. Geological Survey streamflow-gaging station 08095400 Hog Creek near Crawtord, Texas $\ldots \ldots \ldots 386$

383. Analysis of annual mean, maximum, minimum, and L-scale statistics of daily mean streamflow for U.S. Geological Survey streamflow-gaging station 08095500 South Bosque River near

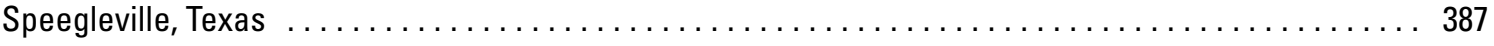

384. Analysis of annual mean, maximum, minimum, and L-scale statistics of daily mean streamflow for U.S. Geological Survey streamflow-gaging station 08095600 Bosque River near Waco, Texas $\ldots \ldots \ldots 38$

385. Analysis of annual mean, maximum, minimum, and L-scale statistics of daily mean streamflow for U.S. Geological Survey streamflow-gaging station 08096500 Brazos River at Waco, Texas $\ldots \ldots \ldots \ldots 389$

386. Analysis of annual mean, maximum, minimum, and L-scale statistics of daily mean streamflow for U.S. Geological Survey streamflow-gaging station 08097500 Brazos River near Marlin, Texas $\ldots \ldots \ldots .390$

387. Analysis of annual mean, maximum, minimum, and L-scale statistics of daily mean streamflow for U.S. Geological Survey streamflow-gaging station 08098000 Deer Creek at Chilton, Texas $\ldots \ldots \ldots \ldots$. . . .

388. Analysis of annual mean, maximum, minimum, and L-scale statistics of daily mean streamflow for U.S. Geological Survey streamflow-gaging station 08098290 Brazos River near Highbank, Texas . . . . . 392

389. Analysis of annual mean, maximum, minimum, and L-scale statistics of daily mean streamflow for U.S. Geological Survey streamflow-gaging station 08098300 Little Pond Creek near Burlington,

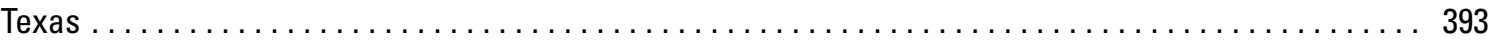

390. Analysis of annual mean, maximum, minimum, and L-scale statistics of daily mean streamflow for U.S. Geological Survey streamflow-gaging station 08099100 Leon River near De Leon, Texas $\ldots \ldots \ldots 394$

391. Analysis of annual mean, maximum, minimum, and L-scale statistics of daily mean streamflow for U.S. Geological Survey streamflow-gaging station 08099300 Sabana River near De Leon, Texas $\ldots \ldots \ldots 395$

392. Analysis of annual mean, maximum, minimum, and L-scale statistics of daily mean streamflow for U.S. Geological Survey streamflow-gaging station 08099500 Leon River near Hasse, Texas $\ldots \ldots \ldots . . .396$

393. Analysis of annual mean, maximum, minimum, and L-scale statistics of daily mean streamflow for U.S. Geological Survey streamflow-gaging station 08100000 Leon River near Hamilton, Texas $\ldots \ldots \ldots .397$

394. Analysis of annual mean, maximum, minimum, and L-scale statistics of daily mean streamflow for U.S. Geological Survey streamflow-gaging station 08100500 Leon River at Gatesville, Texas $\ldots \ldots \ldots$ 
395. Analysis of annual mean, maximum, minimum, and L-scale statistics of daily mean streamflow for U.S. Geological Survey streamflow-gaging station 08101000 Cowhouse Creek at Pidcoke, Texas $\ldots . . .399$

396. Analysis of annual mean, maximum, minimum, and L-scale statistics of daily mean streamflow for U.S. Geological Survey streamflow-gaging station 08101500 Cowhouse Creek near Killeen, Texas . ... 400

397. Analysis of annual mean, maximum, minimum, and L-scale statistics of daily mean streamflow for U.S. Geological Survey streamflow-gaging station 08102500 Leon River near Belton, Texas $\ldots \ldots \ldots .401$

398. Analysis of annual mean, maximum, minimum, and L-scale statistics of daily mean streamflow for U.S. Geological Survey streamflow-gaging station 08102600 Nolan Creek at Belton, Texas $\ldots \ldots \ldots \ldots 402$

399. Analysis of annual mean, maximum, minimum, and L-scale statistics of daily mean streamflow for

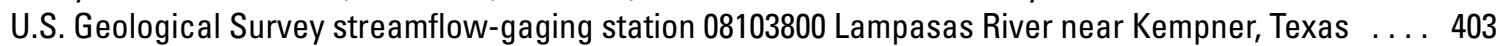

400. Analysis of annual mean, maximum, minimum, and L-scale statistics of daily mean streamflow for U.S. Geological Survey streamflow-gaging station 08103900 South Fork Rocky Creek near Briggs,

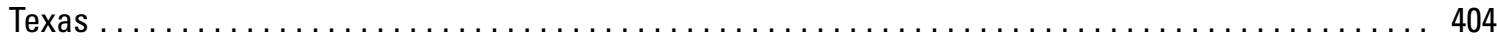

401. Analysis of annual mean, maximum, minimum, and L-scale statistics of daily mean streamflow for U.S. Geological Survey streamflow-gaging station 08104000 Lampasas River at Youngsport, Texas $\ldots . . .405$

402. Analysis of annual mean, maximum, minimum, and L-scale statistics of daily mean streamflow for U.S. Geological Survey streamflow-gaging station 08104100 Lampasas River near Belton, Texas $\ldots \ldots .406$

403. Analysis of annual mean, maximum, minimum, and L-scale statistics of daily mean streamflow for U.S. Geological Survey streamflow-gaging station 08104310 Salado Creek below Salado Springs

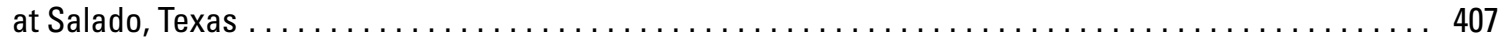

404. Analysis of annual mean, maximum, minimum, and L-scale statistics of daily mean streamflow for U.S. Geological Survey streamflow-gaging station 08104500 Little River near Little River, Texas . . . . . . 408

405. Analysis of annual mean, maximum, minimum, and L-scale statistics of daily mean streamflow for U.S. Geological Survey streamflow-gaging station 08104700 North Fork San Gabriel River near

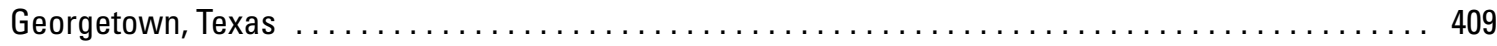

406. Analysis of annual mean, maximum, minimum, and L-scale statistics of daily mean streamflow for U.S. Geological Survey streamflow-gaging station 08104900 South Fork San Gabriel River at

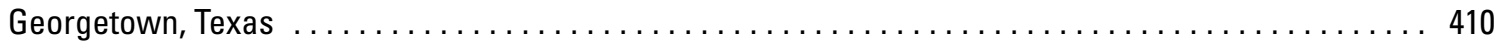

407. Analysis of annual mean, maximum, minimum, and L-scale statistics of daily mean streamflow for U.S. Geological Survey streamflow-gaging station 08105000 San Gabriel River at Georgetown,

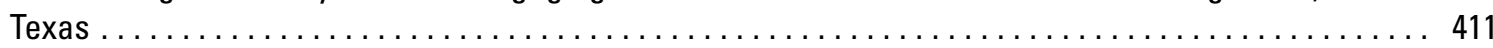

408. Analysis of annual mean, maximum, minimum, and L-scale statistics of daily mean streamflow for U.S. Geological Survey streamflow-gaging station 08105095 Berry Creek at Airport Road near

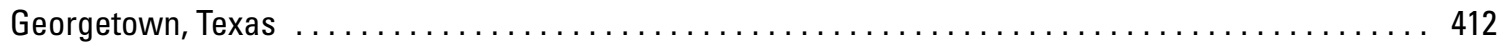

409. Analysis of annual mean, maximum, minimum, and L-scale statistics of daily mean streamflow for U.S. Geological Survey streamflow-gaging station 08105100 Berry Creek near Georgetown, Texas . . .. 413

410. Analysis of annual mean, maximum, minimum, and L-scale statistics of daily mean streamflow for U.S. Geological Survey streamflow-gaging station 08105200 Berry Creek at State Highway 971

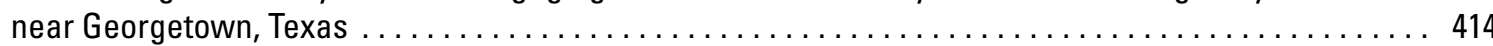

411. Analysis of annual mean, maximum, minimum, and L-scale statistics of daily mean streamflow for U.S. Geological Survey streamflow-gaging station 08105300 San Gabriel River near Weir, Texas $\ldots \ldots . .415$

412. Analysis of annual mean, maximum, minimum, and L-scale statistics of daily mean streamflow for U.S. Geological Survey streamflow-gaging station 08105400 San Gabriel River near Circleville,

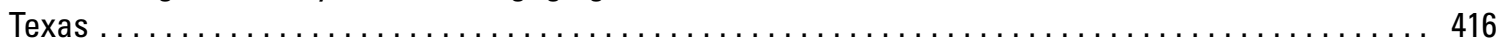

413. Analysis of annual mean, maximum, minimum, and L-scale statistics of daily mean streamflow for

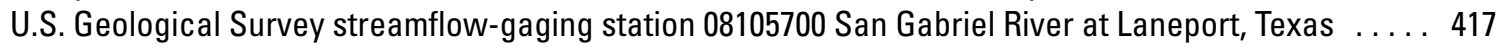

414. Analysis of annual mean, maximum, minimum, and L-scale statistics of daily mean streamflow for U.S. Geological Survey streamflow-gaging station 08106300 Brushy Creek near Rockdale, Texas $\ldots . . .418$ 
415. Analysis of annual mean, maximum, minimum, and L-scale statistics of daily mean streamflow for U.S. Geological Survey streamflow-gaging station 08106310 San Gabriel River near Rockdale,

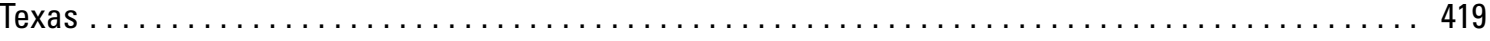

416. Analysis of annual mean, maximum, minimum, and L-scale statistics of daily mean streamflow for U.S. Geological Survey streamflow-gaging station 08106350 Little River near Rockdale, Texas $\ldots \ldots \ldots 420$

417. Analysis of annual mean, maximum, minimum, and L-scale statistics of daily mean streamflow for U.S. Geological Survey streamflow-gaging station 08106500 Little River at Cameron, Texas $\ldots \ldots \ldots \ldots$ 421

418. Analysis of annual mean, maximum, minimum, and L-scale statistics of daily mean streamflow for U.S. Geological Survey streamflow-gaging station 08107000 Big Elm Creek near Temple, Texas $\ldots \ldots \ldots 422$

419. Analysis of annual mean, maximum, minimum, and L-scale statistics of daily mean streamflow for U.S. Geological Survey streamflow-gaging station 08107500 Big Elm Creek near Buckholts, Texas $\ldots . \ldots 423$

420. Analysis of annual mean, maximum, minimum, and L-scale statistics of daily mean streamflow for U.S. Geological Survey streamflow-gaging station 08108000 North Elm Creek near Ben Arnold,

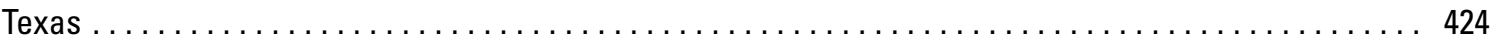

421. Analysis of annual mean, maximum, minimum, and L-scale statistics of daily mean streamflow for U.S. Geological Survey streamflow-gaging station 08108200 North Elm Creek near Cameron,

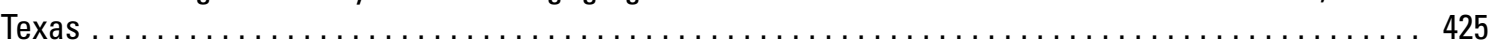

422. Analysis of annual mean, maximum, minimum, and L-scale statistics of daily mean streamflow for U.S. Geological Survey streamflow-gaging station 08108700 Brazos River at State Highway 21

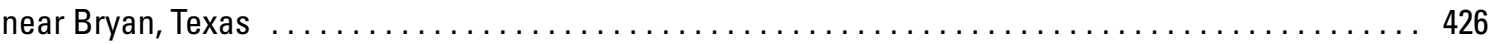

423. Analysis of annual mean, maximum, minimum, and L-scale statistics of daily mean streamflow for U.S. Geological Survey streamflow-gaging station 08109000 Brazos River near Bryan, Texas $\ldots \ldots \ldots .427$

424. Analysis of annual mean, maximum, minimum, and L-scale statistics of daily mean streamflow for U.S. Geological Survey streamflow-gaging station 08109700 Middle Yegua Creek near Dime Box,

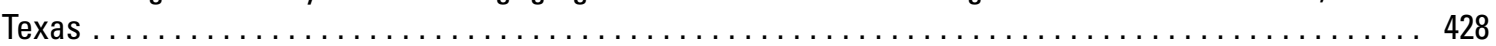

425. Analysis of annual mean, maximum, minimum, and L-scale statistics of daily mean streamflow for U.S. Geological Survey streamflow-gaging station 08109800 East Yegua Creek near Dime Box,

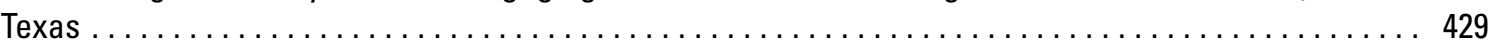

426. Analysis of annual mean, maximum, minimum, and L-scale statistics of daily mean streamflow for \begin{tabular}{l|l|lll} 
U.S. Geological Survey streamflow-gaging station 08110000 Yegua Creek near Somerville, Texas & $\ldots . . . .4$ & 430
\end{tabular}

427. Analysis of annual mean, maximum, minimum, and L-scale statistics of daily mean streamflow for U.S. Geological Survey streamflow-gaging station 08110100 Davidson Creek near Lyons, Texas $\quad \ldots \ldots .431$

428. Analysis of annual mean, maximum, minimum, and L-scale statistics of daily mean streamflow for U.S. Geological Survey streamflow-gaging station 08110200 Brazos River at Washington, Texas $\ldots \ldots .432$

429. Analysis of annual mean, maximum, minimum, and L-scale statistics of daily mean streamflow for U.S. Geological Survey streamflow-gaging station 08110325 Navasota River above Groesbeck,

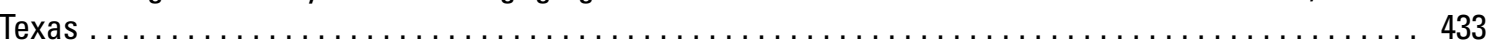

430. Analysis of annual mean, maximum, minimum, and L-scale statistics of daily mean streamflow for U.S. Geological Survey streamflow-gaging station 08110400 Navasota River near Groesbeck,

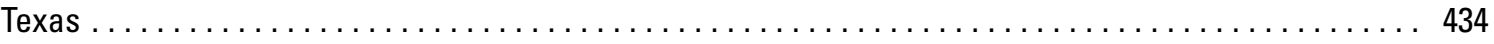

431. Analysis of annual mean, maximum, minimum, and L-scale statistics of daily mean streamflow for U.S. Geological Survey streamflow-gaging station 08110430 Big Creek near Freestone, Texas . . . . . . 435

432. Analysis of annual mean, maximum, minimum, and L-scale statistics of daily mean streamflow for U.S. Geological Survey streamflow-gaging station 08110500 Navasota River near Easterly, Texas . ..... 436

433. Analysis of annual mean, maximum, minimum, and L-scale statistics of daily mean streamflow for U.S. Geological Survey streamflow-gaging station 08110800 Navasota River at 0ld Spanish Road

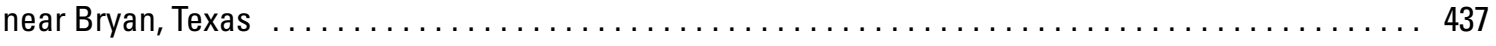

434. Analysis of annual mean, maximum, minimum, and L-scale statistics of daily mean streamflow for U.S. Geological Survey streamflow-gaging station 08111000 Navasota River near Bryan, Texas $\ldots . . . .438$ 
435. Analysis of annual mean, maximum, minimum, and L-scale statistics of daily mean streamflow for U.S. Geological Survey streamflow-gaging station 08111010Navasota River near College Station,

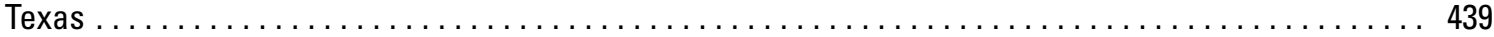

436. Analysis of annual mean, maximum, minimum, and L-scale statistics of daily mean streamflow for U.S. Geological Survey streamflow-gaging station 08111025 Burton Creek at Villa Mlaria Road,

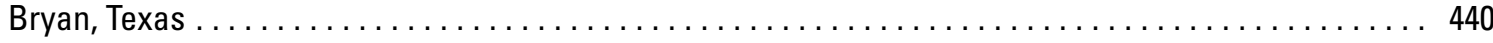

437. Analysis of annual mean, maximum, minimum, and L-scale statistics of daily mean streamflow for U.S. Geological Survey streamflow-gaging station 08111050 Hudson Creek near Bryan, Texas $\ldots \ldots . . .441$

438. Analysis of annual mean, maximum, minimum, and L-scale statistics of daily mean streamflow for $\begin{array}{lll}\text { U.S. Geological Survey streamflow-gaging station } 08111500 \text { Brazos River near Hempstead, Texas } & \ldots \ldots & 442\end{array}$

439. Analysis of annual mean, maximum, minimum, and L-scale statistics of daily mean streamflow for U.S. Geological Survey streamflow-gaging station 08111700 Mill Creek near Bellville, Texas $\ldots \ldots \ldots 443$

440. Analysis of annual mean, maximum, minimum, and L-scale statistics of daily mean streamflow for U.S. Geological Survey streamflow-gaging station 08114000 Brazos River at Richmond, Texas $\ldots \ldots \ldots 444$

441. Analysis of annual mean, maximum, minimum, and L-scale statistics of daily mean streamflow for U.S. Geological Survey streamflow-gaging station 08114500 Brazos River near Juliff, Texas $\ldots \ldots \ldots 445$

442. Analysis of annual mean, maximum, minimum, and L-scale statistics of daily mean streamflow for U.S. Geological Survey streamflow-gaging station 08115000 Big Creek near Needville, Texas $\ldots \ldots \ldots 446$

443. Analysis of annual mean, maximum, minimum, and L-scale statistics of daily mean streamflow for U.S. Geological Survey streamflow-gaging station 08115500 Fairchild Creek near Needville, Texas . . . . 447

444. Analysis of annual mean, maximum, minimum, and L-scale statistics of daily mean streamflow for U.S. Geological Survey streamflow-gaging station 08116000 Big Creek near Guy, Texas $\ldots \ldots \ldots \ldots .448$

445. Analysis of annual mean, maximum, minimum, and L-scale statistics of daily mean streamflow for U.S. Geological Survey streamflow-gaging station 08116400 Dry Creek near Rosenberg, Texas $\ldots \ldots$. . . 449

446. Analysis of annual mean, maximum, minimum, and L-scale statistics of daily mean streamflow for U.S. Geological Survey streamflow-gaging station 08116500 Dry Creek near Richmond, Texas $\ldots \ldots \ldots 450$

447. Analysis of annual mean, maximum, minimum, and L-scale statistics of daily mean streamflow for U.S. Geological Survey streamflow-gaging station 08116650 Brazos River near Rosharon, Texas . . . . . 451

448. Analysis of annual mean, maximum, minimum, and L-scale statistics of daily mean streamflow for $\begin{array}{llllll}\text { U.S. Geological Survey streamflow-gaging station 08117500 San Bernard River near Boling, Texas } & \ldots & 452\end{array}$

449. Analysis of annual mean, maximum, minimum, and L-scale statistics of daily mean streamflow for U.S. Geological Survey streamflow-gaging station 08117900 Big Boggy Creek near Wadsworth,

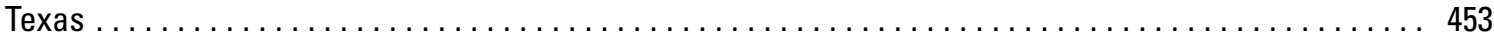

450. Analysis of annual mean, maximum, minimum, and L-scale statistics of daily mean streamflow for U.S. Geological Survey streamflow-gaging station 08117995 Colorado River near Gail, Texas . . . . . . . 454

451. Analysis of annual mean, maximum, minimum, and L-scale statistics of daily mean streamflow for U.S. Geological Survey streamflow-gaging station 08118500 Bull Creek near Ira, Texas $\ldots \ldots \ldots \ldots \ldots 45$

452. Analysis of annual mean, maximum, minimum, and L-scale statistics of daily mean streamflow for U.S. Geological Survey streamflow-gaging station 08119000 Bluff Creek near Ira, Texas $\ldots \ldots \ldots \ldots .456$

453. Analysis of annual mean, maximum, minimum, and L-scale statistics of daily mean streamflow for U.S. Geological Survey streamflow-gaging station 08119500 Colorado River near Ira, Texas $\ldots \ldots \ldots \ldots 45$

454. Analysis of annual mean, maximum, minimum, and L-scale statistics of daily mean streamflow for U.S. Geological Survey streamflow-gaging station 08120500 Deep Creek near Dunn, Texas $\ldots \ldots \ldots \ldots 458$

455. Analysis of annual mean, maximum, minimum, and L-scale statistics of daily mean streamflow for U.S. Geological Survey streamflow-gaging station 08120700 Colorado River near Cuthbert, Texas . . . . . 459

456. Analysis of annual mean, maximum, minimum, and L-scale statistics of daily mean streamflow for U.S. Geological Survey streamflow-gaging station 08121000 Colorado River at Colorado City,

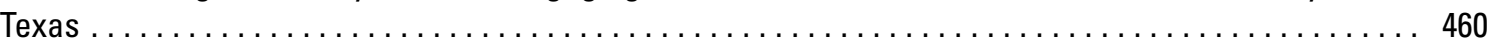


457. Analysis of annual mean, maximum, minimum, and L-scale statistics of daily mean streamflow for U.S. Geological Survey streamflow-gaging station 08121500 Morgan Creek near Westbrook, Texas .... 461

458. Analysis of annual mean, maximum, minimum, and L-scale statistics of daily mean streamflow for U.S. Geological Survey streamflow-gaging station 08122000 Graze Creek near Westbrook, Texas $\ldots \ldots .462$

459. Analysis of annual mean, maximum, minimum, and L-scale statistics of daily mean streamflow for U.S. Geological Survey streamflow-gaging station 08122500 Morgan Creek near Colorado City,

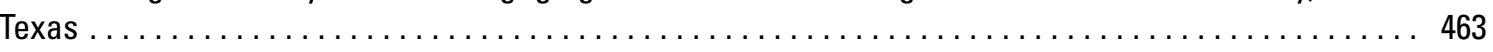

460. Analysis of annual mean, maximum, minimum, and L-scale statistics of daily mean streamflow for U.S. Geological Survey streamflow-gaging station 08123500 Champion Creek near Colorado City,

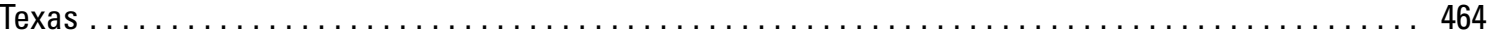

461. Analysis of annual mean, maximum, minimum, and L-scale statistics of daily mean streamflow for U.S. Geological Survey streamflow-gaging station 08123650 Beals Creek above Big Spring, Texas . . ... 465

462. Analysis of annual mean, maximum, minimum, and L-scale statistics of daily mean streamflow for U.S. Geological Survey streamflow-gaging station 08123700 Beals Creek at Big Spring, Texas . . . . . 466

463. Analysis of annual mean, maximum, minimum, and L-scale statistics of daily mean streamflow for U.S. Geological Survey streamflow-gaging station 08123720 Beals Creek near Coahoma, Texas $\ldots . . . .467$

464. Analysis of annual mean, maximum, minimum, and L-scale statistics of daily mean streamflow for U.S. Geological Survey streamflow-gaging station 08123800 Beals Creek near Westbrook, Texas $\ldots \ldots .468$

465. Analysis of annual mean, maximum, minimum, and L-scale statistics of daily mean streamflow for U.S. Geological Survey streamflow-gaging station 08123850 Colorado River above Silver, Texas $\ldots \ldots . . .469$

466. Analysis of annual mean, maximum, minimum, and L-scale statistics of daily mean streamflow for U.S. Geological Survey streamflow-gaging station 08123900 Colorado River near Silver, Texas $\ldots \ldots \ldots 470$

467. Analysis of annual mean, maximum, minimum, and L-scale statistics of daily mean streamflow for U.S. Geological Survey streamflow-gaging station 08124000 Colorado River at Robert Lee, Texas $\ldots . . .471$

468. Analysis of annual mean, maximum, minimum, and L-scale statistics of daily mean streamflow for U.S. Geological Survey streamflow-gaging station 08126380 Colorado River near Ballinger, Texas $\ldots . .472$

469. Analysis of annual mean, maximum, minimum, and L-scale statistics of daily mean streamflow for U.S. Geological Survey streamflow-gaging station 08126500 Colorado River at Ballinger, Texas $\ldots \ldots \ldots 473$

470. Analysis of annual mean, maximum, minimum, and L-scale statistics of daily mean streamflow for U.S. Geological Survey streamflow-gaging station 08127000 Elm Creek at Ballinger, Texas $\ldots \ldots \ldots \ldots 44$

471. Analysis of annual mean, maximum, minimum, and L-scale statistics of daily mean streamflow for U.S. Geological Survey streamflow-gaging station 08128000 South Concho River at Christoval,

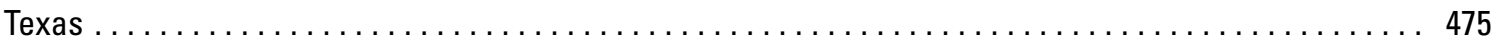

472. Analysis of annual mean, maximum, minimum, and L-scale statistics of daily mean streamflow for U.S. Geological Survey streamflow-gaging station 08128400 Middle Concho River above

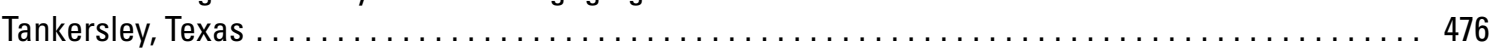

473. Analysis of annual mean, maximum, minimum, and L-scale statistics of daily mean streamflow for U.S. Geological Survey streamflow-gaging station 08128500 Middle Concho River near Tankersley,

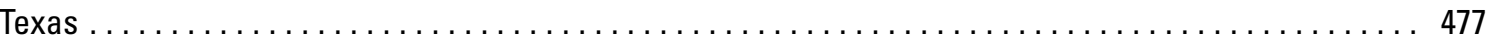

474. Analysis of annual mean, maximum, minimum, and L-scale statistics of daily mean streamflow for U.S. Geological Survey streamflow-gaging station 08129300 Spring Creek above Tankersley, Texas $\quad \ldots .478$

475. Analysis of annual mean, maximum, minimum, and L-scale statistics of daily mean streamflow for U.S. Geological Survey streamflow-gaging station 08130500 Dove Creek at Knickerbocker, Texas . ..... 479

476. Analysis of annual mean, maximum, minimum, and L-scale statistics of daily mean streamflow for U.S. Geological Survey streamflow-gaging station 08130700 Spring Creek above Twin Buttes

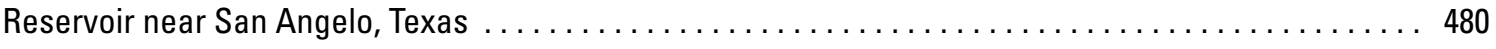

477. Analysis of annual mean, maximum, minimum, and L-scale statistics of daily mean streamflow for U.S. Geological Survey streamflow-gaging station 08131000 Spring Creek near Tankersley, Texas $\ldots . . .481$ 
478. Analysis of annual mean, maximum, minimum, and L-scale statistics of daily mean streamflow for U.S. Geological Survey streamflow-gaging station 08131400 Pecan Creek near San Angelo, Texas $\ldots . . .482$

479. Analysis of annual mean, maximum, minimum, and L-scale statistics of daily mean streamflow for U.S. Geological Survey streamflow-gaging station 08132500 South Concho River at San Angelo,

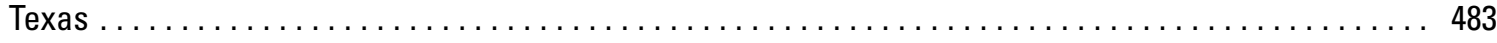

480. Analysis of annual mean, maximum, minimum, and L-scale statistics of daily mean streamflow for U.S. Geological Survey streamflow-gaging station 08133250 North Concho River above Sterling City, Texas.

481. Analysis of annual mean, maximum, minimum, and L-scale statistics of daily mean streamflow for U.S. Geological Survey streamflow-gaging station 08133500 North Concho River at Sterling City,

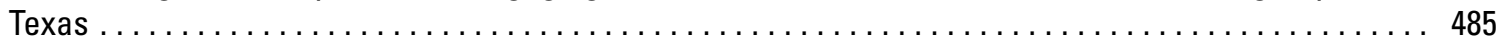

482. Analysis of annual mean, maximum, minimum, and L-scale statistics of daily mean streamflow for U.S. Geological Survey streamflow-gaging station 08133900 Chalk Creek near Water Valley, Texas $\ldots . .486$

483. Analysis of annual mean, maximum, minimum, and L-scale statistics of daily mean streamflow for U.S. Geological Survey streamflow-gaging station 08134000 North Concho River near Carlsbad,

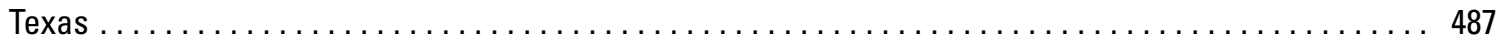

484. Analysis of annual mean, maximum, minimum, and L-scale statistics of daily mean streamflow for U.S. Geological Survey streamflow-gaging station 08134230 Grape Creek near Grape Creek, Texas $\ldots . . .488$

485. Analysis of annual mean, maximum, minimum, and L-scale statistics of daily mean streamflow for U.S. Geological Survey streamflow-gaging station 08134250 North Concho River near Grape

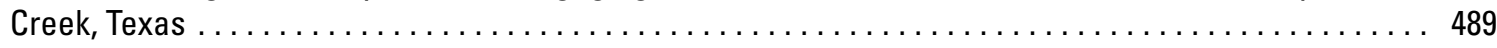

486. Analysis of annual mean, maximum, minimum, and L-scale statistics of daily mean streamflow for U.S. Geological Survey streamflow-gaging station 08135000 North Concho River at San Angelo,

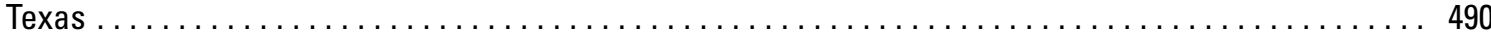

487. Analysis of annual mean, maximum, minimum, and L-scale statistics of daily mean streamflow for U.S. Geological Survey streamflow-gaging station 08136000 Concho River at San Angelo, Texas $\ldots \ldots .491$

488. Analysis of annual mean, maximum, minimum, and L-scale statistics of daily mean streamflow for U.S. Geological Survey streamflow-gaging station 08136500 Concho River at Paint Rock, Texas $\ldots \ldots \ldots 49$

489. Analysis of annual mean, maximum, minimum, and L-scale statistics of daily mean streamflow for U.S. Geological Survey streamflow-gaging station 08136700 Colorado River near Stacy, Texas $\ldots \ldots \ldots 493$

490. Analysis of annual mean, maximum, minimum, and L-scale statistics of daily mean streamflow for U.S. Geological Survey streamflow-gaging station 08138000 Colorado River at Winchell, Texas $\ldots \ldots \ldots 494$

491. Analysis of annual mean, maximum, minimum, and L-scale statistics of daily mean streamflow for U.S. Geological Survey streamflow-gaging station 08139500 Deep Creek near Mercury, Texas $\quad \ldots \ldots \ldots 495$

492. Analysis of annual mean, maximum, minimum, and L-scale statistics of daily mean streamflow for U.S. Geological Survey streamflow-gaging station 08140500 Dry Prong Deep Creek near Mercury,

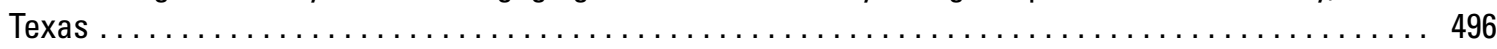

493. Analysis of annual mean, maximum, minimum, and L-scale statistics of daily mean streamflow for $\begin{array}{lll}\text { U.S. Geological Survey streamflow-gaging station } 08140700 \text { Pecan Bayou near Cross Cut, Texas } & \ldots \ldots & \ldots 97\end{array}$

494. Analysis of annual mean, maximum, minimum, and L-scale statistics of daily mean streamflow for U.S. Geological Survey streamflow-gaging station 08140800 Jim Ned Creek near Coleman, Texas $\ldots \ldots .498$

495. Analysis of annual mean, maximum, minimum, and L-scale statistics of daily mean streamflow for U.S. Geological Survey streamflow-gaging station 08141500 Hords Creek near Valera, Texas $\ldots \ldots \ldots$

496. Analysis of annual mean, maximum, minimum, and L-scale statistics of daily mean streamflow for U.S. Geological Survey streamflow-gaging station 08142000 Hords Creek near Coleman, Texas $\ldots \ldots \ldots 00$

497. Analysis of annual mean, maximum, minimum, and L-scale statistics of daily mean streamflow for U.S. Geological Survey streamflow-gaging station 08143500 Pecan Bayou at Brownwood, Texas $\ldots \ldots .501$

498. Analysis of annual mean, maximum, minimum, and L-scale statistics of daily mean streamflow for U.S. Geological Survey streamflow-gaging station 08143600 Pecan Bayou near Mullin, Texas . . . . .. 502 
499. Analysis of annual mean, maximum, minimum, and L-scale statistics of daily mean streamflow for U.S. Geological Survey streamflow-gaging station 08144500 San Saba River at Menard, Texas $\ldots \ldots \ldots 503$

500. Analysis of annual mean, maximum, minimum, and L-scale statistics of daily mean streamflow for U.S. Geological Survey streamflow-gaging station 08144600 San Saba River near Brady, Texas $\quad \ldots . . .504$

501. Analysis of annual mean, maximum, minimum, and L-scale statistics of daily mean streamflow for U.S. Geological Survey streamflow-gaging station 08144800 Brady Creek near Eden, Texas $\ldots \ldots \ldots \ldots 50$

502. Analysis of annual mean, maximum, minimum, and L-scale statistics of daily mean streamflow for U.S. Geological Survey streamflow-gaging station 08145000 Brady Creek at Brady, Texas $\ldots . . \ldots \ldots 506$

503. Analysis of annual mean, maximum, minimum, and L-scale statistics of daily mean streamflow for

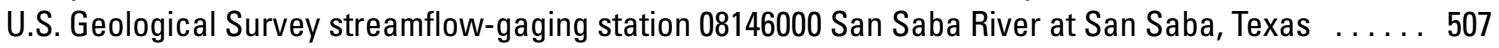

504. Analysis of annual mean, maximum, minimum, and L-scale statistics of daily mean streamflow for $\begin{array}{lllll}\text { U.S. Geological Survey streamflow-gaging station } 08147000 \text { Colorado River near San Saba, Texas } & \ldots . . .508\end{array}$

505. Analysis of annual mean, maximum, minimum, and L-scale statistics of daily mean streamflow for U.S. Geological Survey streamflow-gaging station 08148500 North Llano River near Junction,

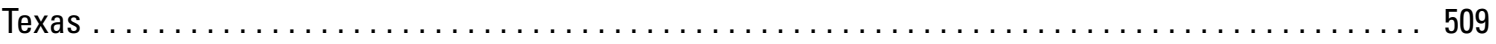

506. Analysis of annual mean, maximum, minimum, and L-scale statistics of daily mean streamflow for U.S. Geological Survey streamflow-gaging station 08150000 Llano River near Junction, Texas . . . . . . 510

507. Analysis of annual mean, maximum, minimum, and L-scale statistics of daily mean streamflow for U.S. Geological Survey streamflow-gaging station 08150700 Llano River near Mason, Texas $\ldots . . . \ldots .511$

508. Analysis of annual mean, maximum, minimum, and L-scale statistics of daily mean streamflow for U.S. Geological Survey streamflow-gaging station 08150800 Beaver Creek near Mason, Texas $\ldots \ldots \ldots .512$

509. Analysis of annual mean, maximum, minimum, and L-scale statistics of daily mean streamflow for U.S. Geological Survey streamflow-gaging station 08151000 Llano River near Castell, Texas $\ldots \ldots \ldots \ldots$

510. Analysis of annual mean, maximum, minimum, and L-scale statistics of daily mean streamflow for U.S. Geological Survey streamflow-gaging station 08151500 Llano River at Llano, Texas $\ldots \ldots \ldots \ldots \ldots .514$

511. Analysis of annual mean, maximum, minimum, and L-scale statistics of daily mean streamflow for U.S. Geological Survey streamflow-gaging station 08152000 Sandy Creek near Kingsland, Texas $\quad \ldots \ldots .515$

512. Analysis of annual mean, maximum, minimum, and L-scale statistics of daily mean streamflow for U.S. Geological Survey streamflow-gaging station 08152900 Pedernales River near

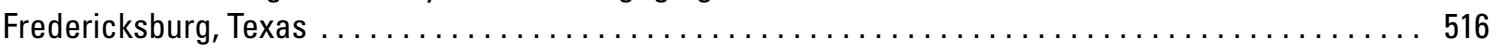

513. Analysis of annual mean, maximum, minimum, and L-scale statistics of daily mean streamflow for U.S. Geological Survey streamflow-gaging station 08153000 Pedernales River at Stonewall, Texas $\ldots . . .517$

514. Analysis of annual mean, maximum, minimum, and L-scale statistics of daily mean streamflow for U.S. Geological Survey streamflow-gaging station 08153500 Pedernales River near Johnson City,

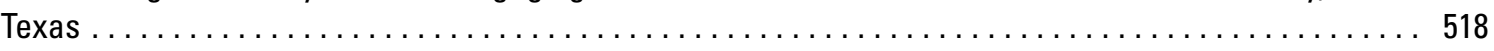

515. $\quad$ Analysis of annual mean, maximum, minimum, and L-scale statistics of daily mean streamflow for U.S. Geological Survey streamflow-gaging station 08154000 Pedernales River near Spicewood,

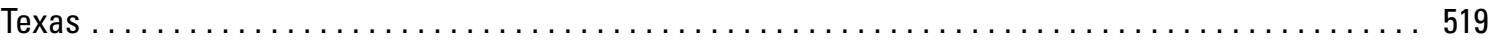

516. Analysis of annual mean, maximum, minimum, and L-scale statistics of daily mean streamflow for U.S. Geological Survey streamflow-gaging station 08154510 Colorado River below Mansfield Dam,

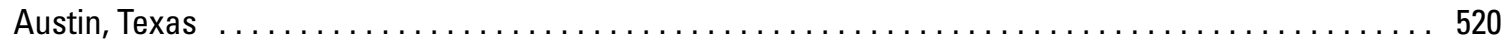

517. Analysis of annual mean, maximum, minimum, and L-scale statistics of daily mean streamflow for U.S. Geological Survey streamflow-gaging station 08154700 Bull Creek at Loop 360 near Austin,

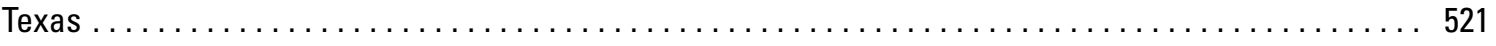

518. $\quad$ Analysis of annual mean, maximum, minimum, and L-scale statistics of daily mean streamflow for U.S. Geological Survey streamflow-gaging station 08155200 Barton Creek at State Highway 71

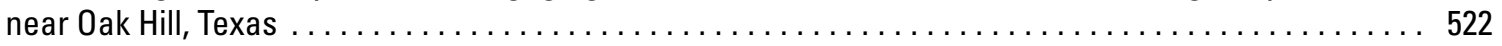

519. Analysis of annual mean, maximum, minimum, and L-scale statistics of daily mean streamflow for U.S. Geological Survey streamflow-gaging station 08155240 Barton Creek at Lost Creek Boulevard

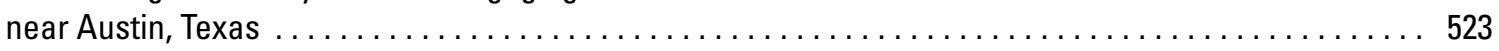


520. Analysis of annual mean, maximum, minimum, and L-scale statistics of daily mean streamflow for U.S. Geological Survey streamflow-gaging station 08155260 Barton Creek near Camp Craft Road

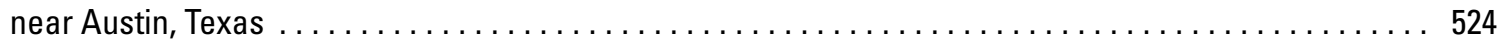

521. Analysis of annual mean, maximum, minimum, and L-scale statistics of daily mean streamflow for U.S. Geological Survey streamflow-gaging station 08155300 Barton Creek at Loop 360, Austin,

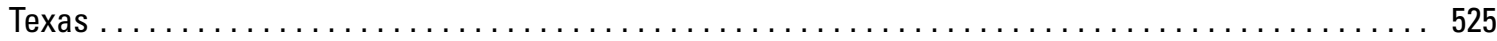

522. Analysis of annual mean, maximum, minimum, and L-scale statistics of daily mean streamflow for U.S. Geological Survey streamflow-gaging station 08155400 Barton Creek above Barton Springs

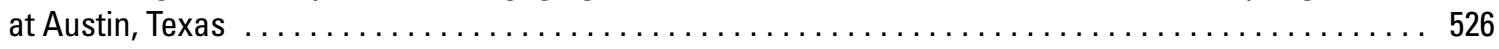

523. Analysis of annual mean, maximum, minimum, and L-scale statistics of daily mean streamflow for U.S. Geological Survey streamflow-gaging station 08156700 Shoal Creek at Northwest Park at

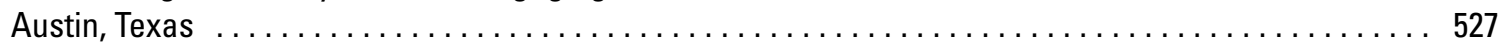

524. Analysis of annual mean, maximum, minimum, and L-scale statistics of daily mean streamflow for U.S. Geological Survey streamflow-gaging station 08156800 Shoalcreek at West 12th Street,

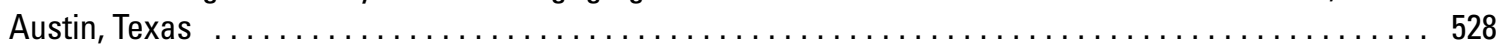

525. Analysis of annual mean, maximum, minimum, and L-scale statistics of daily mean streamflow for U.S. Geological Survey streamflow-gaging station 08157000Waller Creek at 38th Street, Austin,

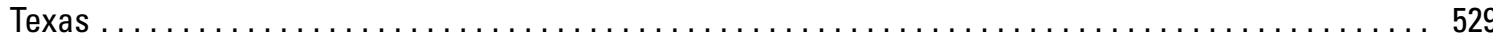

526. Analysis of annual mean, maximum, minimum, and L-scale statistics of daily mean streamflow for U.S. Geological Survey streamflow-gaging station 08157500Waller Creek at 23rd Street, Austin,

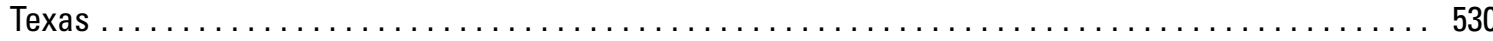

527. Analysis of annual mean, maximum, minimum, and L-scale statistics of daily mean streamflow for U.S. Geological Survey streamflow-gaging station 08157600 East Bouldin Creek at South 1st

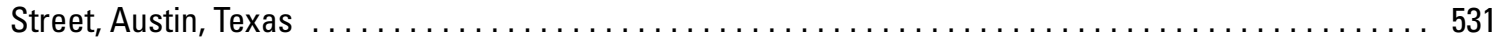

528. Analysis of annual mean, maximum, minimum, and L-scale statistics of daily mean streamflow for U.S. Geological Survey streamflow-gaging station 08157700 Blunn Creek near Little Stacy Park,

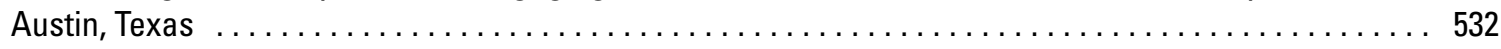

529. Analysis of annual mean, maximum, minimum, and L-scale statistics of daily mean streamflow for U.S. Geological Survey streamflow-gaging station 08158000 Colorado River at Austin, Texas . . . . . . . 533

530. Analysis of annual mean, maximum, minimum, and L-scale statistics of daily mean streamflow for U.S. Geological Survey streamflow-gaging station 08158050 Boggy Creek at U. S. Highway 183,

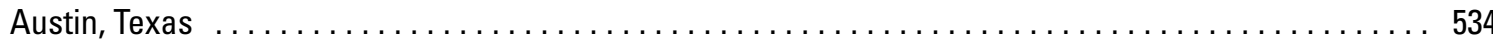

531. Analysis of annual mean, maximum, minimum, and L-scale statistics of daily mean streamflow for U.S. Geological Survey streamflow-gaging station 08158600 Walnut Creek at Webberville Road,

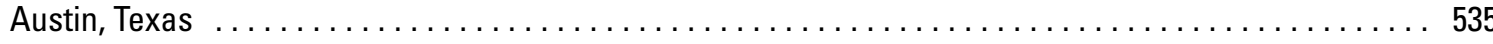

532. Analysis of annual mean, maximum, minimum, and L-scale statistics of daily mean streamflow for U.S. Geological Survey streamflow-gaging station 08158700 Onion Creek near Driftwood, Texas . . . . . 536

533. Analysis of annual mean, maximum, minimum, and L-scale statistics of daily mean streamflow for U.S. Geological Survey streamflow-gaging station 08158800 Onion Creek at Buda, Texas $\ldots \ldots \ldots \ldots .537$

534. Analysis of annual mean, maximum, minimum, and L-scale statistics of daily mean streamflow for U.S. Geological Survey streamflow-gaging station 08158810 Bear Creek below Farm to Market

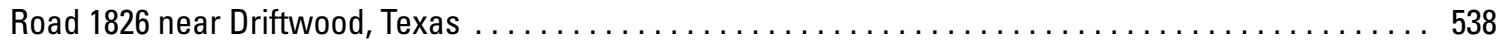

535. Analysis of annual mean, maximum, minimum, and L-scale statistics of daily mean streamflow for U.S. Geological Survey streamflow-gaging station 08158840 Slaughter Creek at Farm to Market

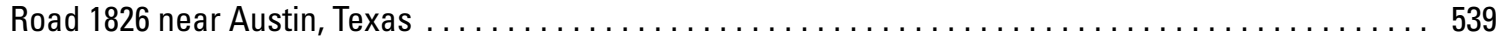

536. Analysis of annual mean, maximum, minimum, and L-scale statistics of daily mean streamflow for U.S. Geological Survey streamflow-gaging station 08158920 Williamson Creek at 0ak Hill, Texas $\ldots \ldots .540$

537. Analysis of annual mean, maximum, minimum, and L-scale statistics of daily mean streamflow for U.S. Geological Survey streamflow-gaging station 08158922 Williamson Creek at Brush Country

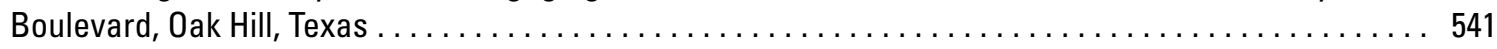


538. Analysis of annual mean, maximum, minimum, and L-scale statistics of daily mean streamflow for U.S. Geological Survey streamflow-gaging station 08158930 Williamson Creek at Manchaca Road,

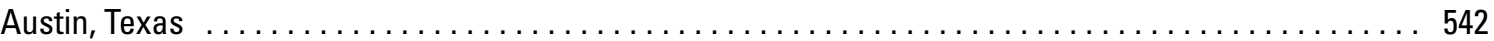

539. Analysis of annual mean, maximum, minimum, and L-scale statistics of daily mean streamflow for U.S. Geological Survey streamflow-gaging station 08158970 Williamson Creek at Jimmy Clay

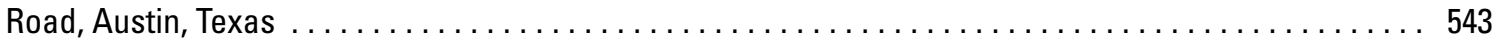

540. Analysis of annual mean, maximum, minimum, and L-scale statistics of daily mean streamflow for U.S. Geological Survey streamflow-gaging station 08159000 Onion Creek at U. S. Highway 183

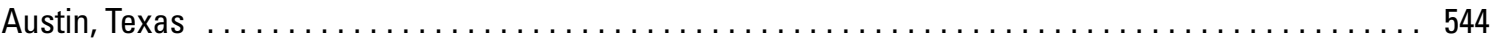

541. Analysis of annual mean, maximum, minimum, and L-scale statistics of daily mean streamflow for U.S. Geological Survey streamflow-gaging station 08159150Wilbarger Creek near Pflugerville,

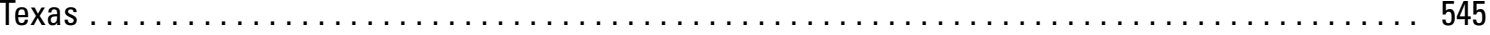

542. Analysis of annual mean, maximum, minimum, and L-scale statistics of daily mean streamflow for U.S. Geological Survey streamflow-gaging station 08159165 Big Sandy Creek near McDade, Texas $\ldots . . .546$

543. Analysis of annual mean, maximum, minimum, and L-scale statistics of daily mean streamflow for U.S. Geological Survey streamflow-gaging station 08159170 Big Sandy Creek near Elgin, Texas $\ldots \ldots \ldots 547$

544. Analysis of annual mean, maximum, minimum, and L-scale statistics of daily mean streamflow for U.S. Geological Survey streamflow-gaging station 08159200 Colorado River at Bastrop, Texas $\ldots \ldots \ldots 548$

545. Analysis of annual mean, maximum, minimum, and L-scale statistics of daily mean streamflow for U.S. Geological Survey streamflow-gaging station 08159500 Colorado River at Smithville, Texas $\ldots . . . .549$

546. Analysis of annual mean, maximum, minimum, and L-scale statistics of daily mean streamflow for U.S. Geological Survey streamflow-gaging station 08160400 Colorado River above La Grange,

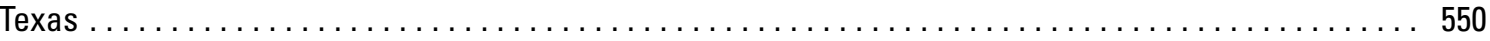

547. Analysis of annual mean, maximum, minimum, and L-scale statistics of daily mean streamflow for U.S. Geological Survey streamflow-gaging station 08160500 Colorado River at La Grange, Texas $\ldots . . .551$

548. Analysis of annual mean, maximum, minimum, and L-scale statistics of daily mean streamflow for U.S. Geological Survey streamflow-gaging station 08160700 Colorado River above Columbus,

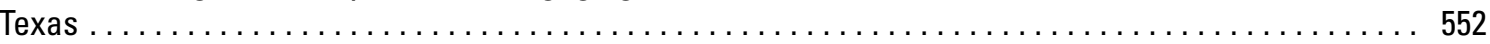

549. Analysis of annual mean, maximum, minimum, and L-scale statistics of daily mean streamflow for U.S. Geological Survey streamflow-gaging station 08160800 Redgate Creek near Columbus, Texas $\quad \ldots . .553$

550. Analysis of annual mean, maximum, minimum, and L-scale statistics of daily mean streamflow for U.S. Geological Survey streamflow-gaging station 08161000 Colorado River at Columbus, Texas $\ldots \ldots \ldots 54$

551. Analysis of annual mean, maximum, minimum, and L-scale statistics of daily mean streamflow for U.S. Geological Survey streamflow-gaging station 08162000 Colorado River at Wharton, Texas $\ldots \ldots \ldots 555$

552. Analysis of annual mean, maximum, minimum, and L-scale statistics of daily mean streamflow for U.S. Geological Survey streamflow-gaging station 08162500 Colorado River near Bay City, Texas . . ... 556

553. Analysis of annual mean, maximum, minimum, and L-scale statistics of daily mean streamflow for U.S. Geological Survey streamflow-gaging station 08162600 Tres Palacios River near Midfield,

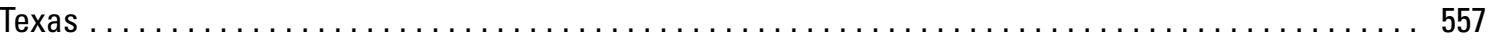

554. Analysis of annual mean, maximum, minimum, and L-scale statistics of daily mean streamflow for U.S. Geological Survey streamflow-gaging station 08164000 Lavaca River near Edna, Texas $\ldots \ldots \ldots .558$

555. Analysis of annual mean, maximum, minimum, and L-scale statistics of daily mean streamflow for U.S. Geological Survey streamflow-gaging station 08164300 Navidad River near Hallettsville,

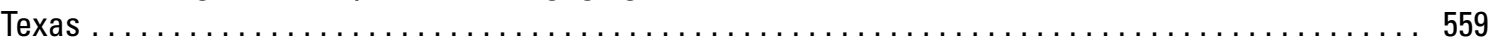

556. Analysis of annual mean, maximum, minimum, and L-scale statistics of daily mean streamflow for U.S. Geological Survey streamflow-gaging station 08164350 Navidad River near Speaks, Texas $\ldots \ldots \ldots 560$

557. Analysis of annual mean, maximum, minimum, and L-scale statistics of daily mean streamflow for U.S. Geological Survey streamflow-gaging station 08164370 Navidad River at Morales, Texas $\ldots . . . \ldots 561$ 
558. Analysis of annual mean, maximum, minimum, and L-scale statistics of daily mean streamflow for U.S. Geological Survey streamflow-gaging station 08164390 Navidad River at Strane Park near

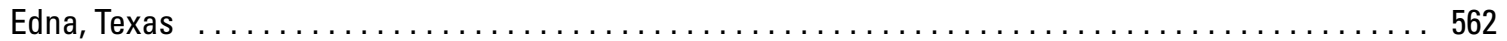

559. Analysis of annual mean, maximum, minimum, and L-scale statistics of daily mean streamflow for U.S. Geological Survey streamflow-gaging station 08164450 Sandy Creek near Ganado, Texas $\ldots \ldots \ldots 563$

560. Analysis of annual mean, maximum, minimum, and L-scale statistics of daily mean streamflow for U.S. Geological Survey streamflow-gaging station 08164500 Navidad River near Ganado, Texas $\ldots \ldots \ldots 564$

561. Analysis of annual mean, maximum, minimum, and L-scale statistics of daily mean streamflow for U.S. Geological Survey streamflow-gaging station 08164503 West Mustang Creek near Ganado,

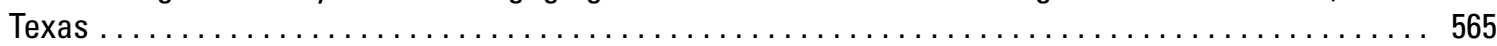

562. Analysis of annual mean, maximum, minimum, and L-scale statistics of daily mean streamflow for U.S. Geological Survey streamflow-gaging station 08164504 East Mustang Creek near Louise,

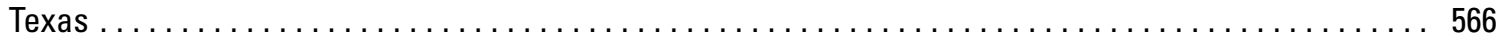

563. Analysis of annual mean, maximum, minimum, and L-scale statistics of daily mean streamflow for U.S. Geological Survey streamflow-gaging station 08164600 Garcitas Creek near Inez, Texas $\ldots \ldots \ldots .567$

564. Analysis of annual mean, maximum, minimum, and L-scale statistics of daily mean streamflow for U.S. Geological Survey streamflow-gaging station 08164800 Placedo Creek near Placedo, Texas $\ldots \ldots .568$

565. Analysis of annual mean, maximum, minimum, and L-scale statistics of daily mean streamflow for U.S. Geological Survey streamflow-gaging station 08165300 North Fork Guadalupe River near

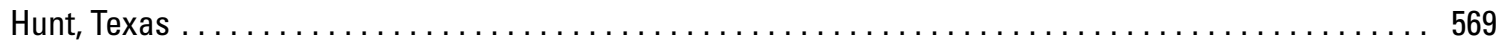

566. Analysis of annual mean, maximum, minimum, and L-scale statistics of daily mean streamflow for U.S. Geological Survey streamflow-gaging station 08165500 Guadalupe River at Hunt, Texas . . . . . . 570

567. Analysis of annual mean, maximum, minimum, and L-scale statistics of daily mean streamflow for U.S. Geological Survey streamflow-gaging station 08166000 Johnson Creek near Ingram, Texas . . . . . 571

568. Analysis of annual mean, maximum, minimum, and L-scale statistics of daily mean streamflow for U.S. Geological Survey streamflow-gaging station 08166140 Guadalupe River above Bear Creek at

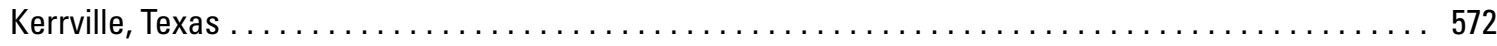

569. Analysis of annual mean, maximum, minimum, and L-scale statistics of daily mean streamflow for U.S. Geological Survey streamflow-gaging station 08166200 Guadalupe River at Kerrville, Texas . . . . . 573

570. Analysis of annual mean, maximum, minimum, and L-scale statistics of daily mean streamflow for U.S. Geological Survey streamflow-gaging station 08166500 Guadalupe River near Comfort, Texas $\ldots . . .574$

571. Analysis of annual mean, maximum, minimum, and L-scale statistics of daily mean streamflow for U.S. Geological Survey streamflow-gaging station 08167000 Guadalupe River at Comfort, Texas $\ldots \ldots \ldots 575$

572. Analysis of annual mean, maximum, minimum, and L-scale statistics of daily mean streamflow for U.S. Geological Survey streamflow-gaging station 08167500 Guadalupe River near Spring Branch,

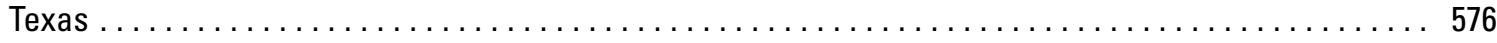

573. Analysis of annual mean, maximum, minimum, and L-scale statistics of daily mean streamflow for U.S. Geological Survey streamflow-gaging station 08167600 Rebecca Creek near Spring Branch,

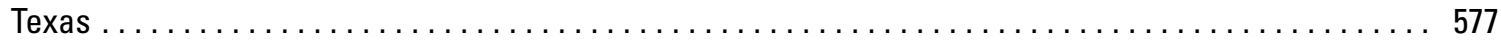

574. Analysis of annual mean, maximum, minimum, and L-scale statistics of daily mean streamflow for U.S. Geological Survey streamflow-gaging station 08167800 Guadalupe River at Sattler, Texas $\ldots \ldots \ldots 578$

575. Analysis of annual mean, maximum, minimum, and L-scale statistics of daily mean streamflow for U.S. Geological Survey streamflow-gaging station 08168500 Guadalupe River above Comal River

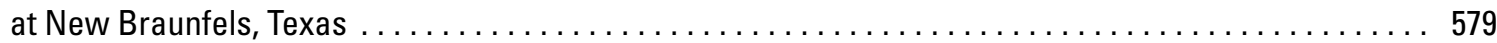

576. Analysis of annual mean, maximum, minimum, and L-scale statistics of daily mean streamflow for U.S. Geological Survey streamflow-gaging station 08169000 Comal River at New Braunfels, Texas $\ldots . . .580$

577. Analysis of annual mean, maximum, minimum, and L-scale statistics of daily mean streamflow for U.S. Geological Survey streamflow-gaging station 08169500 Guadalupe River at New Braunfels,

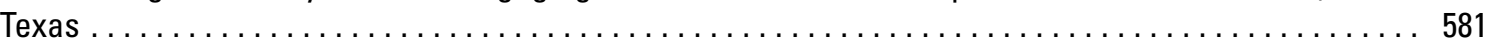


578. Analysis of annual mean, maximum, minimum, and L-scale statistics of daily mean streamflow for U.S. Geological Survey streamflow-gaging station 08170500 San Marcos River at San Marcos,

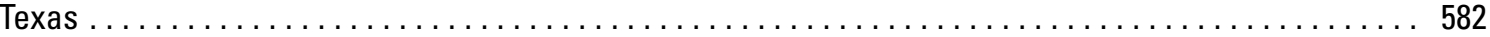

579. Analysis of annual mean, maximum, minimum, and L-scale statistics of daily mean streamflow for U.S. Geological Survey streamflow-gaging station 08171000 Blanco River at Wimberley, Texas . . . . . . 583

580. Analysis of annual mean, maximum, minimum, and L-scale statistics of daily mean streamflow for U.S. Geological Survey streamflow-gaging station 08171300 Blanco River near Kyle, Texas $\ldots \ldots \ldots \ldots .584$

581. Analysis of annual mean, maximum, minimum, and L-scale statistics of daily mean streamflow for U.S. Geological Survey streamflow-gaging station 08172000 San Mlarcos River at Luling, Texas $\ldots \ldots \ldots 58$

582. Analysis of annual mean, maximum, minimum, and L-scale statistics of daily mean streamflow for U.S. Geological Survey streamflow-gaging station 08172400 Plum Creek at Lockhart, Texas $\ldots \ldots \ldots \ldots 56$

583. Analysis of annual mean, maximum, minimum, and L-scale statistics of daily mean streamflow for U.S. Geological Survey streamflow-gaging station 08172500 Plum Creek near Lockhart, Texas $\ldots \ldots \ldots .587$

584. Analysis of annual mean, maximum, minimum, and L-scale statistics of daily mean streamflow for U.S. Geological Survey streamflow-gaging station 08173000 Plum Creek near Luling, Texas $\ldots \ldots \ldots \ldots 58$

585. Analysis of annual mean, maximum, minimum, and L-scale statistics of daily mean streamflow for U.S. Geological Survey streamflow-gaging station 08173500 San Marcos River at Ottine, lexas $\ldots \ldots \ldots$. . . 589

586. Analysis of annual mean, maximum, minimum, and L-scale statistics of daily mean streamflow for U.S. Geological Survey streamflow-gaging station 08173900 Guadalupe River at Gonzales, Texas . . . . . 590

587. Analysis of annual mean, maximum, minimum, and L-scale statistics of daily mean streamflow for U.S. Geological Survey streamflow-gaging station 08174600 Peach Creek below Dilworth, Texas $\ldots \ldots . .591$

588. Analysis of annual mean, maximum, minimum, and L-scale statistics of daily mean streamflow for $\begin{array}{lll}\text { U.S. Geological Survey streamflow-gaging station } 08175000 \text { Sandies Creek near Westhoff, Texas } & \ldots \ldots & 592\end{array}$

589. Analysis of annual mean, maximum, minimum, and L-scale statistics of daily mean streamflow for U.S. Geological Survey streamflow-gaging station 08175800 Guadalupe River at Cuero, Texas $\ldots \ldots \ldots .593$

590. Analysis of annual mean, maximum, minimum, and L-scale statistics of daily mean streamflow for $\begin{array}{lll}\text { U.S. Geological Survey streamflow-gaging station } 08176000 \text { Guadalupe River below Cuero, Texas } & \ldots \ldots & 594\end{array}$

591. Analysis of annual mean, maximum, minimum, and L-scale statistics of daily mean streamflow for U.S. Geological Survey streamflow-gaging station 08176500 Guadalupe River at Victoria, Texas $\ldots . . . .595$

592. Analysis of annual mean, maximum, minimum, and L-scale statistics of daily mean streamflow for U.S. Geological Survey streamflow-gaging station 08176550 Fifteenmile Creek near Weser, Texas $\ldots . . .596$

593. Analysis of annual mean, maximum, minimum, and L-scale statistics of daily mean streamflow for U.S. Geological Survey streamflow-gaging station 08176900 Coleto Creek at Arnold Road near

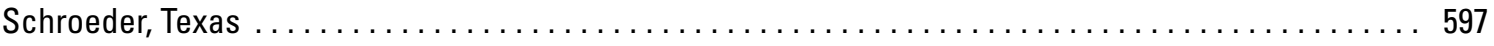

594. Analysis of annual mean, maximum, minimum, and L-scale statistics of daily mean streamflow for U.S. Geological Survey streamflow-gaging station 08176990 Coleto Creek Reservoir Inflow (Guadalupe Diversion) near Schroeder, Texas $\ldots \ldots \ldots \ldots \ldots \ldots \ldots \ldots \ldots \ldots \ldots \ldots \ldots \ldots$

595. Analysis of annual mean, maximum, minimum, and L-scale statistics of daily mean streamflow for U.S. Geological Survey streamflow-gaging station 08177000 Coleto Creek near Schroeder, Texas $\ldots . . . .599$

596. Analysis of annual mean, maximum, minimum, and L-scale statistics of daily mean streamflow for U.S. Geological Survey streamflow-gaging station 08177300 Perdido Creek at Farm to Mlarket

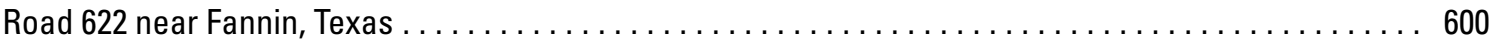

597. Analysis of annual mean, maximum, minimum, and L-scale statistics of daily mean streamflow for U.S. Geological Survey streamflow-gaging station 08177500 Coleto Creek near Victoria, Texas $\ldots \ldots \ldots 601$

598. Analysis of annual mean, maximum, minimum, and L-scale statistics of daily mean streamflow for U.S. Geological Survey streamflow-gaging station 081777000 lmos Creek at Dresden Drive, San

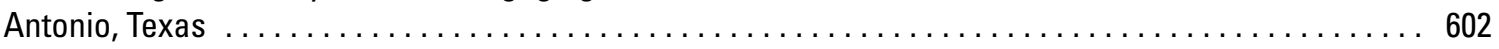


599. Analysis of annual mean, maximum, minimum, and L-scale statistics of daily mean streamflow for U.S. Geological Survey streamflow-gaging station 08177860 San Antonio River at Woodlawn

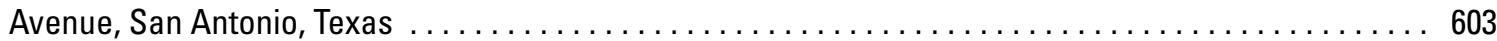

600. Analysis of annual mean, maximum, minimum, and L-scale statistics of daily mean streamflow for U.S. Geological Survey streamflow-gaging station 08178000 San Antonio River at San Antonio,

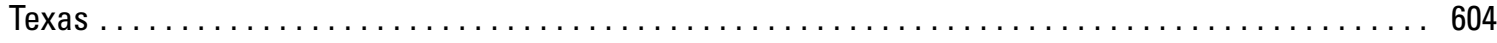

601. Analysis of annual mean, maximum, minimum, and L-scale statistics of daily mean streamflow for U.S. Geological Survey streamflow-gaging station 08178050 San Antonio River at Mlitchell Street,

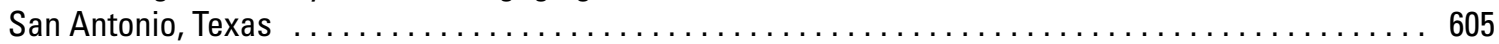

602. Analysis of annual mean, maximum, minimum, and L-scale statistics of daily mean streamflow for U.S. Geological Survey streamflow-gaging station 08178500 San Pedro Creek at Furnish Street,

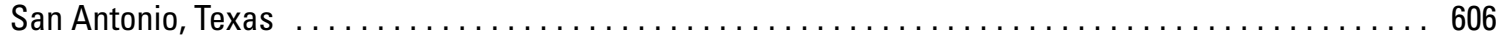

603. Analysis of annual mean, maximum, minimum, and L-scale statistics of daily mean streamflow for U.S. Geological Survey streamflow-gaging station 08178565 San Antonio River at Loop 410, San

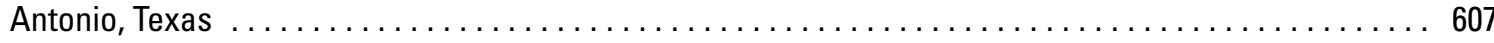

604. Analysis of annual mean, maximum, minimum, and L-scale statistics of daily mean streamflow for U.S. Geological Survey streamflow-gaging station 08178585 Salado Creek at Wilderness Road,

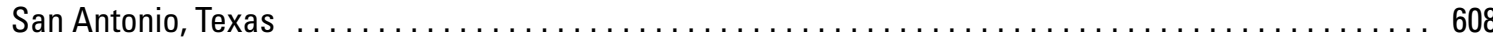

605. Analysis of annual mean, maximum, minimum, and L-scale statistics of daily mean streamflow for U.S. Geological Survey streamflow-gaging station 08178700 Salado Creek at Loop 410, San

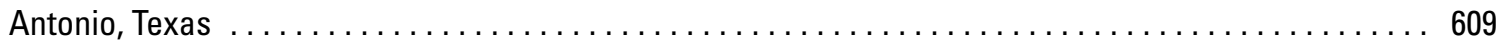

606. Analysis of annual mean, maximum, minimum, and L-scale statistics of daily mean streamflow for U.S. Geological Survey streamflow-gaging station 08178800 Salado Creek at Loop 13, San Antonio,

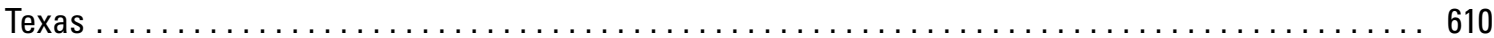

607. Analysis of annual mean, maximum, minimum, and L-scale statistics of daily mean streamflow for U.S. Geological Survey streamflow-gaging station 08178880 Medina River at Bandera, Texas $\ldots \ldots \ldots 611$

608. Analysis of annual mean, maximum, minimum, and L-scale statistics of daily mean streamflow for U.S. Geological Survey streamflow-gaging station 08179000 Medina River near Pipe Creek, Texas $\ldots . \ldots 612$

609. Analysis of annual mean, maximum, minimum, and L-scale statistics of daily mean streamflow for U.S. Geological Survey streamflow-gaging station 08179100 Red BluffCreek near Pipe Creek,

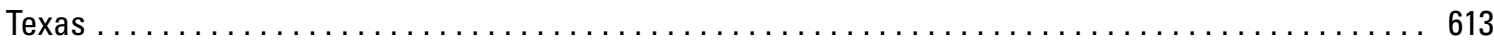

610. Analysis of annual mean, maximum, minimum, and L-scale statistics of daily mean streamflow for U.S. Geological Survey streamflow-gaging station 08179520 Medina River below Medina Lake

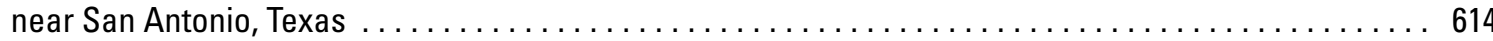

611. Analysis of annual mean, maximum, minimum, and L-scale statistics of daily mean streamflow for

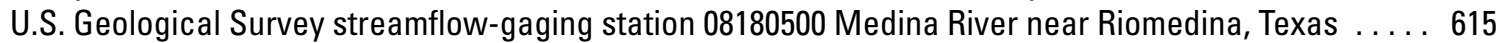

612. Analysis of annual mean, maximum, minimum, and L-scale statistics of daily mean streamflow for U.S. Geological Survey streamflow-gaging station 08180640 Medina River at La Coste, Texas $\ldots \ldots \ldots 616$

613. Analysis of annual mean, maximum, minimum, and L-scale statistics of daily mean streamflow for U.S. Geological Survey streamflow-gaging station 08180700 Medina River near Macdona, Texas . . . . . 617

614. Analysis of annual mean, maximum, minimum, and L-scale statistics of daily mean streamflow for U.S. Geological Survey streamflow-gaging station 08180750 Vledio Creek at Pearsall Road, San

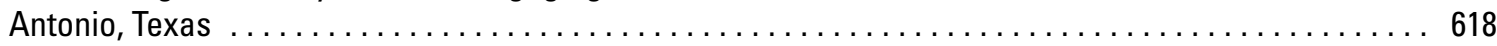

615. Analysis of annual mean, maximum, minimum, and L-scale statistics of daily mean streamflow for U.S. Geological Survey streamflow-gaging station 08180800 Medina River near Somerset, Texas $\ldots \ldots .619$

616. Analysis of annual mean, maximum, minimum, and L-scale statistics of daily mean streamflow for U.S. Geological Survey streamflow-gaging station 08181400 Helotes Creek at Helotes, Texas $\ldots \ldots \ldots 620$

617. Analysis of annual mean, maximum, minimum, and L-scale statistics of daily mean streamflow for U.S. Geological Survey streamflow-gaging station 08181410 Ranch Creek near Helotes, Texas $\ldots . . .6621$ 
618. Analysis of annual mean, maximum, minimum, and L-scale statistics of daily mean streamflow for U.S. Geological Survey streamflow-gaging station 08181450 Leon Creek Tributary at Kelly Air Force Base, Texas $\ldots \ldots \ldots \ldots \ldots \ldots \ldots \ldots \ldots \ldots \ldots \ldots \ldots \ldots \ldots \ldots \ldots \ldots \ldots \ldots \ldots 22$

619. Analysis of annual mean, maximum, minimum, and L-scale statistics of daily mean streamflow for U.S. Geological Survey streamflow-gaging station 08181480 Leon Creek at Interstate Highway 35,

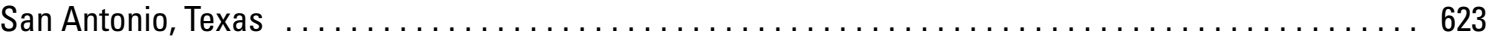

620. Analysis of annual mean, maximum, minimum, and L-scale statistics of daily mean streamflow for $\begin{array}{llllll}\text { U.S. Geological Survey streamflow-gaging station } 08181500 \text { Medina River at San Antonio, Texas } & \ldots \ldots & \ldots & 624\end{array}$

621. Analysis of annual mean, maximum, minimum, and L-scale statistics of daily mean streamflow for U.S. Geological Survey streamflow-gaging station 08181800 San Antonio River near Elmendorf,

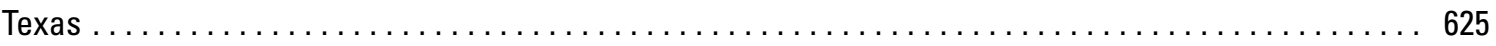

622. Analysis of annual mean, maximum, minimum, and L-scale statistics of daily mean streamflow for U.S. Geological Survey streamflow-gaging station 08182500 Calaveras Creek near Elemendorf,

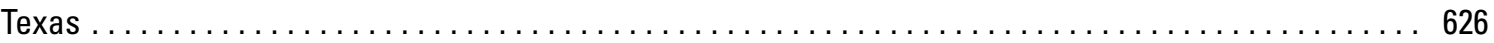

623. Analysis of annual mean, maximum, minimum, and L-scale statistics of daily mean streamflow for U.S. Geological Survey streamflow-gaging station 08183000 San Antonio River at Calaveras,

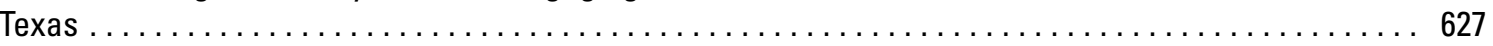

624. Analysis of annual mean, maximum, minimum, and L-scale statistics of daily mean streamflow for U.S. Geological Survey streamflow-gaging station 08183500 San Antonio River near Falls City,

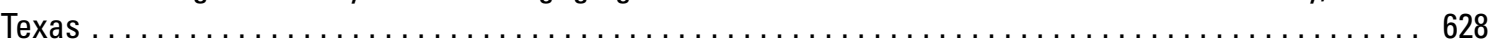

625. Analysis of annual mean, maximum, minimum, and L-scale statistics of daily mean streamflow for U.S. Geological Survey streamflow-gaging station 08183850 Cibolo Creek at Interstate Highway 10

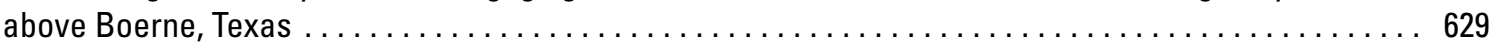

626. Analysis of annual mean, maximum, minimum, and L-scale statistics of daily mean streamflow for

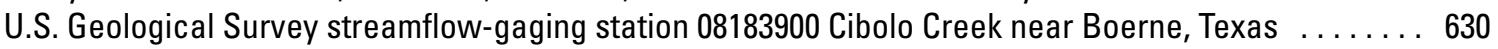

627. Analysis of annual mean, maximum, minimum, and L-scale statistics of daily mean streamflow for U.S. Geological Survey streamflow-gaging station 08184000 Cibolo Creek near Bulverde, Texas $\ldots . . . .6631$

628. Analysis of annual mean, maximum, minimum, and L-scale statistics of daily mean streamflow for U.S. Geological Survey streamflow-gaging station 08184500 Cibolo Creek above Bracken, Texas $\quad \ldots \ldots .632$

629. Analysis of annual mean, maximum, minimum, and L-scale statistics of daily mean streamflow for U.S. Geological Survey streamflow-gaging station 08185000 Cibolo Creek at Selma, Texas $\ldots \ldots \ldots \ldots 633$

630. Analysis of annual mean, maximum, minimum, and L-scale statistics of daily mean streamflow for U.S. Geological Survey streamflow-gaging station 08185500 Cibolo Creek at Sutherland Springs,

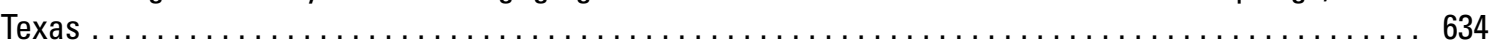

631. Analysis of annual mean, maximum, minimum, and L-scale statistics of daily mean streamflow for U.S. Geological Survey streamflow-gaging station 08186000 Cibolo Creek near Falls City, Texas $\ldots \ldots \ldots 635$

632. Analysis of annual mean, maximum, minimum, and L-scale statistics of daily mean streamflow for U.S. Geological Survey streamflow-gaging station 08186500 Ecleto Creek near Runge, Texas $\ldots \ldots \ldots 636$

633. Analysis of annual mean, maximum, minimum, and L-scale statistics of daily mean streamflow for U.S. Geological Survey streamflow-gaging station 08187500 Escondido Creek at Kenedy, Texas $\ldots . . . .637$

634. Analysis of annual mean, maximum, minimum, and L-scale statistics of daily mean streamflow for U.S. Geological Survey streamflow-gaging station 08188500 San Antonio River at Goliad, Texas $\ldots . . . .6638$

635. Analysis of annual mean, maximum, minimum, and L-scale statistics of daily mean streamflow for U.S. Geological Survey streamflow-gaging station 08189200 Copano Creek near Refugio, Texas $\ldots . . . .6639$

636. $\quad$ Analysis of annual mean, maximum, minimum, and L-scale statistics of daily mean streamflow for U.S. Geological Survey streamflow-gaging station 08189300 Medio Creek near Beeville, Texas $\ldots \ldots \ldots 640$

637. Analysis of annual mean, maximum, minimum, and L-scale statistics of daily mean streamflow for U.S. Geological Survey streamflow-gaging station 08189500 Mission River at Refugio, Texas $\ldots \ldots \ldots .641$

638. Analysis of annual mean, maximum, minimum, and L-scale statistics of daily mean streamflow for U.S. Geological Survey streamflow-gaging station 08189700 Aransas River near Skidmore, Texas $\ldots \ldots .642$ 
639. Analysis of annual mean, maximum, minimum, and L-scale statistics of daily mean streamflow for U.S. Geological Survey streamflow-gaging station 08189800 Chiltipin Creek at Sinton, Texas $\ldots \ldots \ldots \ldots 63$

640. Analysis of annual mean, maximum, minimum, and L-scale statistics of daily mean streamflow for U.S. Geological Survey streamflow-gaging station 08190000 Nueces River at Laguna, Texas $\ldots \ldots \ldots .644$

641. Analysis of annual mean, maximum, minimum, and L-scale statistics of daily mean streamflow for U.S. Geological Survey streamflow-gaging station 08190500West Nueces River near Brackettville,

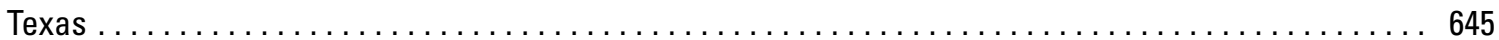

642. Analysis of annual mean, maximum, minimum, and L-scale statistics of daily mean streamflow for U.S. Geological Survey streamflow-gaging station 08191500 Nueces River near Uvalde, Texas $\ldots \ldots \ldots 646$

643. Analysis of annual mean, maximum, minimum, and L-scale statistics of daily mean streamflow for U.S. Geological Survey streamflow-gaging station 08192000 Nueces River below Uvalde, Texas $\ldots \ldots \ldots 647$

644. Analysis of annual mean, maximum, minimum, and L-scale statistics of daily mean streamflow for U.S. Geological Survey streamflow-gaging station 08192500 Nueces River near Cinonia, Texas $\ldots \ldots \ldots 648$

645. Analysis of annual mean, maximum, minimum, and L-scale statistics of daily mean streamflow for U.S. Geological Survey streamflow-gaging station 08193000 Nueces River near Asherton, Texas $\ldots \ldots .649$

646. Analysis of annual mean, maximum, minimum, and L-scale statistics of daily mean streamflow for U.S. Geological Survey streamflow-gaging station 08194000 Nueces River at Cotulla, Texas $\ldots \ldots \ldots .650$

647. Analysis of annual mean, maximum, minimum, and L-scale statistics of daily mean streamflow for

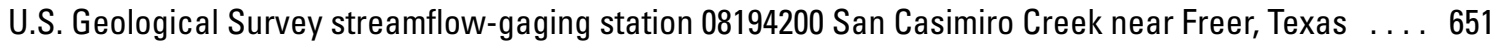

648. Analysis of annual mean, maximum, minimum, and L-scale statistics of daily mean streamflow for U.S. Geological Survey streamflow-gaging station 08194500 Nueces River near Tiden, Texas $\ldots \ldots \ldots 652$

649. Analysis of annual mean, maximum, minimum, and L-scale statistics of daily mean streamflow for U.S. Geological Survey streamflow-gaging station 08194600 Nueces River at Simmons, Texas $\ldots \ldots \ldots 653$

650. Analysis of annual mean, maximum, minimum, and L-scale statistics of daily mean streamflow for U.S. Geological Survey streamflow-gaging station 08195000 Frio River at Concan, Texas $\ldots \ldots \ldots \ldots 654$

651. Analysis of annual mean, maximum, minimum, and L-scale statistics of daily mean streamflow for U.S. Geological Survey streamflow-gaging station 08196000 Dry Frio River near Reagan Wells,

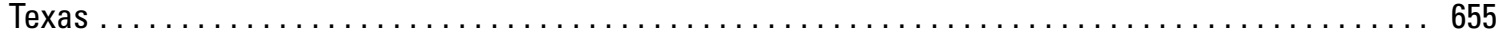

652. Analysis of annual mean, maximum, minimum, and L-scale statistics of daily mean streamflow for U.S. Geological Survey streamflow-gaging station 08196500 Dry Frio River at Knippa, Texas $\ldots \ldots \ldots \ldots 66$

653. Analysis of annual mean, maximum, minimum, and L-scale statistics of daily mean streamflow for U.S. Geological Survey streamflow-gaging station 08197500 Frio River below Dry Frio River near

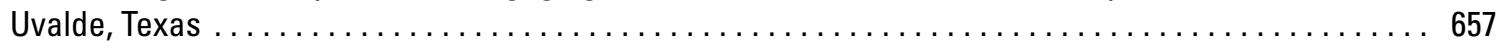

654. Analysis of annual mean, maximum, minimum, and L-scale statistics of daily mean streamflow for U.S. Geological Survey streamflow-gaging station 08198000 Sabinal River near Sabinal, Texas $\ldots \ldots \ldots 658$

655. Analysis of annual mean, maximum, minimum, and L-scale statistics of daily mean streamflow for U.S. Geological Survey streamflow-gaging station 08198500 Sabinal River at Sabinal, Texas $\ldots \ldots \ldots \ldots 65$

656. Analysis of annual mean, maximum, minimum, and L-scale statistics of daily mean streamflow for U.S. Geological Survey streamflow-gaging station 08199700 frio River near Frio Town, Texas $\ldots \ldots \ldots 6$

657. Analysis of annual mean, maximum, minimum, and L-scale statistics of daily mean streamflow for U.S. Geological Survey streamflow-gaging station 08200000 Hondo Creek near Tarpley, Texas $\ldots . \ldots .661$

658. Analysis of annual mean, maximum, minimum, and L-scale statistics of daily mean streamflow for U.S. Geological Survey streamflow-gaging station 08200500 Hondo Creek near Hondo, Texas $\ldots \ldots \ldots 662$

659. Analysis of annual mean, maximum, minimum, and L-scale statistics of daily mean streamflow for U.S. Geological Survey streamflow-gaging station 08200700 Hondo Creek at King Waterhole near

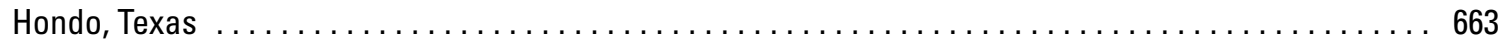

660. Analysis of annual mean, maximum, minimum, and L-scale statistics of daily mean streamflow for U.S. Geological Survey streamflow-gaging station 08201500 Seco Creek at Miller Ranch near

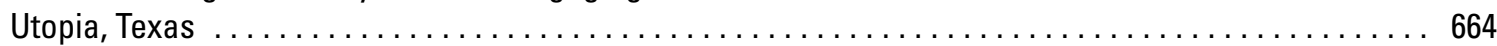


661. Analysis of annual mean, maximum, minimum, and L-scale statistics of daily mean streamflow for U.S. Geological Survey streamflow-gaging station 08202000 Seco Creek near Utopia, Texas $\ldots . . . \ldots .665$

662. Analysis of annual mean, maximum, minimum, and L-scale statistics of daily mean streamflow for U.S. Geological Survey streamflow-gaging station 08202500 Seco Creek near D'Hanis, Texas $\ldots \ldots \ldots 66$

663. Analysis of annual mean, maximum, minimum, and L-scale statistics of daily mean streamflow for U.S. Geological Survey streamflow-gaging station 08202700 Seco Creek at Rowe Ranch near

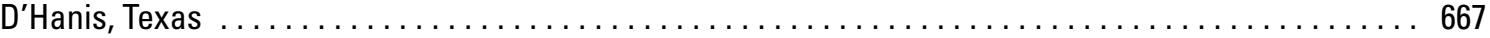

664. Analysis of annual mean, maximum, minimum, and L-scale statistics of daily mean streamflow for U.S. Geological Survey streamflow-gaging station 08204005 Leona River near Uvalde, Texas $\ldots \ldots \ldots 66$

665. Analysis of annual mean, maximum, minimum, and L-scale statistics of daily mean streamflow for U.S. Geological Survey streamflow-gaging station 08204500 Leona River near Divot, Texas $\ldots \ldots \ldots \ldots 6$

666. Analysis of annual mean, maximum, minimum, and L-scale statistics of daily mean streamflow for U.S. Geological Survey streamflow-gaging station 08205500 frio River near Derby, Texas $\ldots \ldots \ldots \ldots 6$

667. Analysis of annual mean, maximum, minimum, and L-scale statistics of daily mean streamflow for U.S. Geological Survey streamflow-gaging station 08206600 frio River at Tilden, Texas $\ldots \ldots \ldots \ldots \ldots$. $\ldots 71$

668. Analysis of annual mean, maximum, minimum, and L-scale statistics of daily mean streamflow for U.S. Geological Survey streamflow-gaging station 08206700 San MiguelCreek near Tiden, Texas $\quad \ldots \ldots 672$

669. Analysis of annual mean, maximum, minimum, and L-scale statistics of daily mean streamflow for U.S. Geological Survey streamflow-gaging station 08206910 Choke Canyon Reservoir (Outlet Works Control) near Three Rivers, Texas $\ldots \ldots \ldots \ldots \ldots \ldots \ldots \ldots \ldots \ldots \ldots \ldots \ldots \ldots$

670. Analysis of annual mean, maximum, minimum, and L-scale statistics of daily mean streamflow for U.S. Geological Survey streamflow-gaging station 08207000 frio River at Calliham, Texas $\ldots \ldots \ldots \ldots 674$

671. Analysis of annual mean, maximum, minimum, and L-scale statistics of daily mean streamflow for U.S. Geological Survey streamflow-gaging station 08207500 Atascosa River near McCoy, Texas $\ldots \ldots \ldots 675$

672. Analysis of annual mean, maximum, minimum, and L-scale statistics of daily mean streamflow for U.S. Geological Survey streamflow-gaging station 08208000 Atascosa River at Whitsett, Texas . . . . . . 676

673. Analysis of annual mean, maximum, minimum, and L-scale statistics of daily mean streamflow for U.S. Geological Survey streamflow-gaging station 08210000 Nueces River near Three Rivers,

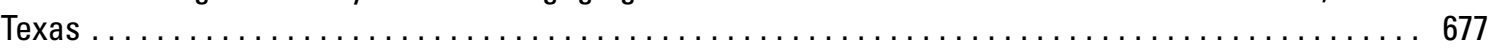

674. Analysis of annual mean, maximum, minimum, and L-scale statistics of daily mean streamflow for U.S. Geological Survey streamflow-gaging station 08210300 Ramirena Creek near George West,

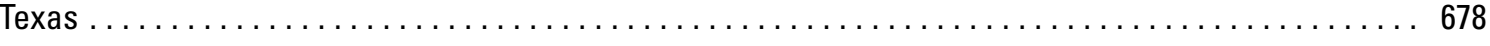

675. Analysis of annual mean, maximum, minimum, and L-scale statistics of daily mean streamflow for U.S. Geological Survey streamflow-gaging station 08210400 Lagarto Creek near George West,

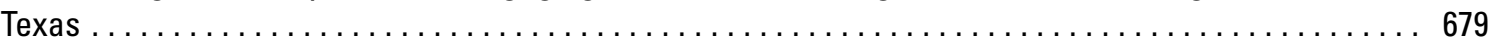

676. Analysis of annual mean, maximum, minimum, and L-scale statistics of daily mean streamflow for U.S. Geological Survey streamflow-gaging station 08211000 Nueces River near Mathis, Texas $\ldots . . .6680$

677. Analysis of annual mean, maximum, minimum, and L-scale statistics of daily mean streamflow for U.S. Geological Survey streamflow-gaging station 08211200 Nueces River at Bluntzer, Texas $\ldots \ldots \ldots$. . . 681

678. Analysis of annual mean, maximum, minimum, and L-scale statistics of daily mean streamflow for U.S. Geological Survey streamflow-gaging station 08211500 Nueces River at Calallen, Texas $\ldots \ldots \ldots 68$

679. Analysis of annual mean, maximum, minimum, and L-scale statistics of daily mean streamflow for U.S. Geological Survey streamflow-gaging station 08211520 0so Creek at Corpus Christi, Texas $\ldots \ldots \ldots 63$

680. Analysis of annual mean, maximum, minimum, and L-scale statistics of daily mean streamflow for U.S. Geological Survey streamflow-gaging station 08211800 San Diego Creek at Alice, Texas $\ldots \ldots \ldots . .684$

681. Analysis of annual mean, maximum, minimum, and L-scale statistics of daily mean streamflow for U.S. Geological Survey streamflow-gaging station 08211900 San Fernando Creek at Alice, Texas $\ldots . . . .685$ 
682. Analysis of annual mean, maximum, minimum, and L-scale statistics of daily mean streamflow for U.S. Geological Survey streamflow-gaging station 08212000 San Fernando Creek near Alice,

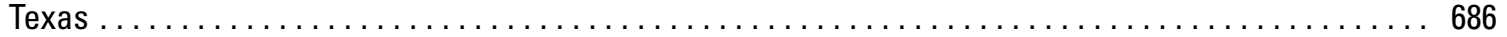

683. Analysis of annual mean, maximum, minimum, and L-scale statistics of daily mean streamflow for U.S. Geological Survey streamflow-gaging station 08212400 Los Olmos Creek near Falfurrias,

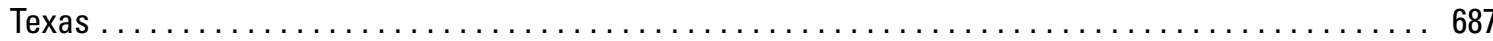

684. Analysis of annual mean, maximum, minimum, and L-scale statistics of daily mean streamflow for

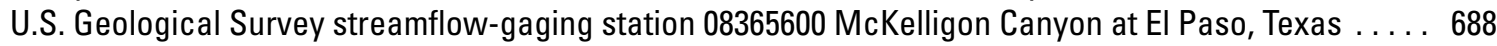

685. Analysis of annual mean, maximum, minimum, and L-scale statistics of daily mean streamflow for U.S. Geological Survey streamflow-gaging station 08365800 Government Ditch at ET Paso, Texas $\ldots \ldots \ldots 68$

686. Analysis of annual mean, maximum, minimum, and L-scale statistics of daily mean streamflow for U.S. Geological Survey streamflow-gaging station 08373200 Cibolo Creek near Presidio, Texas $\ldots \ldots \ldots 690$

687. Analysis of annual mean, maximum, minimum, and L-scale statistics of daily mean streamflow for U.S. Geological Survey streamflow-gaging station 08376300 Sanderson Creek at Sanderson,

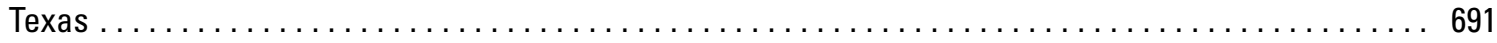

688. Analysis of annual mean, maximum, minimum, and L-scale statistics of daily mean streamflow for U.S. Geological Survey streamflow-gaging station 08411500 Salt Screwbean Draw near Orla,

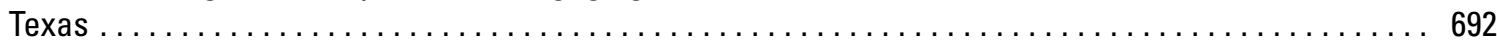

689. Analysis of annual mean, maximum, minimum, and L-scale statistics of daily mean streamflow for U.S. Geological Survey streamflow-gaging station 08412500 Pecos River near Orla, Texas $\ldots \ldots \ldots \ldots 693$

690. Analysis of annual mean, maximum, minimum, and L-scale statistics of daily mean streamflow for U.S. Geological Survey streamflow-gaging station 08414000 Pecos River near Mentone, Texas $\ldots . . . .664$

691. Analysis of annual mean, maximum, minimum, and L-scale statistics of daily mean streamflow for U.S. Geological Survey streamflow-gaging station 08416500 Pecos River above Barstow (Barstow

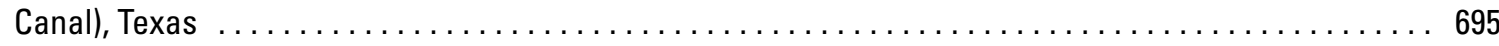

692. Analysis of annual mean, maximum, minimum, and L-scale statistics of daily mean streamflow for U.S. Geological Survey streamflow-gaging station 08420500 Pecos River at Pecos, Texas $\ldots \ldots \ldots \ldots 66$

693. Analysis of annual mean, maximum, minimum, and L-scale statistics of daily mean streamflow for U.S. Geological Survey streamflow-gaging station 08424500 Madera Canyon near Toyahvale, Texas

694. Analysis of annual mean, maximum, minimum, and L-scale statistics of daily mean streamflow for U.S. Geological Survey streamflow-gaging station 08431000 Toyah Creek near Pecos, Texas $\ldots \ldots \ldots 698$

695. Analysis of annual mean, maximum, minimum, and L-scale statistics of daily mean streamflow for U.S. Geological Survey streamflow-gaging station 08431500 Salt Draw near Pecos, Texas $\ldots \ldots \ldots \ldots 69$

696. Analysis of annual mean, maximum, minimum, and L-scale statistics of daily mean streamflow for U.S. Geological Survey streamflow-gaging station 08431700 Limpia Creek above Fort Davis, Texas $\ldots . .700$

697. Analysis of annual mean, maximum, minimum, and L-scale statistics of daily mean streamflow for U.S. Geological Survey streamflow-gaging station 08431800 Limpia Creek below Fort Davis, Texas $\ldots . . .701$

698. Analysis of annual mean, maximum, minimum, and L-scale statistics of daily mean streamflow for U.S. Geological Survey streamflow-gaging station 08432000 Limpia Creek near Fort Davis, Texas $\ldots \ldots \ldots 2$

699. Analysis of annual mean, maximum, minimum, and L-scale statistics of daily mean streamflow for U.S. Geological Survey streamflow-gaging station 08433000 Barrilla Draw near Saragosa, Texas $\ldots \ldots .703$

700. Analysis of annual mean, maximum, minimum, and L-scale statistics of daily mean streamflow for U.S. Geological Survey streamflow-gaging station 08434000 loyah Creek below loyah Lake near

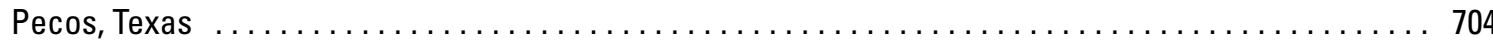

701. Analysis of annual mean, maximum, minimum, and L-scale statistics of daily mean streamflow for U.S. Geological Survey streamflow-gaging station 08435500 Pecos River below Barstow, lexas $\ldots \ldots \ldots 705$

702. Analysis of annual mean, maximum, minimum, and L-scale statistics of daily mean streamflow for U.S. Geological Survey streamflow-gaging station 08435600 Toronto Creek near Alpine, Texas $\ldots \ldots \ldots 706$ 
703. Analysis of annual mean, maximum, minimum, and L-scale statistics of daily mean streamflow for U.S. Geological Survey streamflow-gaging station 08435620 Alpine Creek at Alpine, Texas $\ldots \ldots \ldots 707$

704. Analysis of annual mean, maximum, minimum, and L-scale statistics of daily mean streamflow for U.S. Geological Survey streamflow-gaging station 08435660 Moss Creek near Alpine, Texas $\ldots \ldots \ldots 708$

705. Analysis of annual mean, maximum, minimum, and L-scale statistics of daily mean streamflow for U.S. Geological Survey streamflow-gaging station 08435700 Sunny Glen Canyon near Alpine,

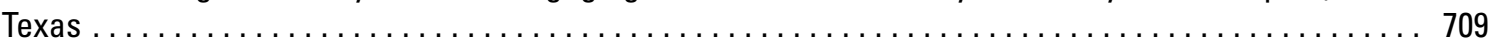

706. Analysis of annual mean, maximum, minimum, and L-scale statistics of daily mean streamflow for U.S. Geological Survey streamflow-gaging station 08435800 Coyanosa Draw near Fort Stockton,

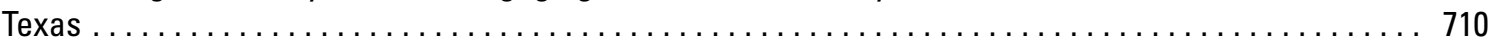

707. Analysis of annual mean, maximum, minimum, and L-scale statistics of daily mean streamflow for U.S. Geological Survey streamflow-gaging station 08438100 Pecos River near Grandfalls, Texas . . . . . 711

708. Analysis of annual mean, maximum, minimum, and L-scale statistics of daily mean streamflow for U.S. Geological Survey streamflow-gaging station 08441500 Pecos River below Grandfalls, Texas $\quad \ldots \ldots l 12$

709. Analysis of annual mean, maximum, minimum, and L-scale statistics of daily mean streamflow for U.S. Geological Survey streamflow-gaging station 08446500 Pecos River near Girvin, Texas $\ldots \ldots \ldots \ldots 713$

710. Analysis of annual mean, maximum, minimum, and L-scale statistics of daily mean streamflow for U.S. Geological Survey streamflow-gaging station 08447000 Pecos River near Sheffield, Texas $\ldots \ldots \ldots 714$

711. Analysis of annual mean, maximum, minimum, and L-scale statistics of daily mean streamflow for U.S. Geological Survey streamflow-gaging station 08447020 Independence Creek near Sheffield,

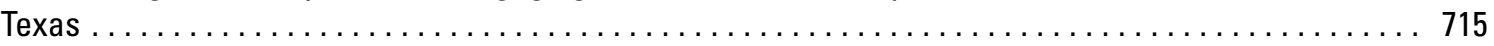

712. $\quad$ Analysis of annual mean, maximum, minimum, and L-scale statistics of daily mean streamflow for U.S. Geological Survey streamflow-gaging station 08449000 Devils River near Juno, Texas $\ldots \ldots \ldots \ldots$

713. Analysis of annual mean, maximum, minimum, and L-scale statistics of daily mean streamflow for U.S. Geological Survey streamflow-gaging station 08455000 Pinto Creek near Del Rio, Texas $\ldots \ldots \ldots .717$

\section{Conversion Factors}

\begin{tabular}{lcl}
\hline Multiply & By & To obtain \\
\hline foot $(\mathrm{ft})$ & 0.3048 & meter $(\mathrm{m})$ \\
cubic feet per second $\left(\mathrm{ft}^{3} / \mathrm{s}\right)$ & .02832 & cubic meters per second $\left(\mathrm{m}^{3} / \mathrm{s}\right)$ \\
\hline
\end{tabular}





\title{
Summary of Annual Mean, Maximum, Minimum, and L-scale Statistics of Daily Mean Streamflow for 712 U.S. Geological Survey Streamflow- Gaging Stations in Texas Through 2003
}

\author{
By William H. Asquith, Joseph Vrabel, and Meghan C. Roussel
}

\begin{abstract}
Analysts and managers of surface-water resources might have interest in selected statistics of daily mean streamflow for U.S. Geological Survey (USGS) streamflow-gaging stations in Texas. The selected statistics are the annual mean, maximum, minimum, and L-scale of daily mean streamflow. Annual L-scale of streamflow is a robust measure of the variability of the daily mean streamflow for a given year. The USGS, in cooperation with the Texas Commission on Environmental Quality, initiated in 2006 a data and reporting process to generate annual statistics for 712 USGS streamflow-gaging stations in Texas. A graphical depiction of the history of the annual statistics for most active and inactive, continuous-record gaging stations in Texas provides valuable information by conveying the historical perspective of streamflow for the watershed. Each figure consists of four time-series plots of the annual statistics of daily mean streamflow for each streamflow-gaging station. Each of the four plots is augmented with horizontal lines that depict the mean and median annual values of the corresponding statistic for the period of record. Monotonic trends for each of the four annual statistics also are identified using Kendall's $\tau$. The history of one or more streamflow-gaging stations could be used in a watershed, river basin, or other regional context by analysts and managers of surface-water resources to guide scientific, regulatory, or other inquiries of streamflow conditions in Texas.
\end{abstract}

\section{Introduction}

Analysts and managers of surface-water resources might have interest in selected statistics of daily mean streamflow for U.S. Geological Survey (USGS) streamflow-gaging stations in Texas. To facilitate information transfer, this report provides graphical and statistical summaries for most of the active and inactive, continuous-record streamflow-gaging stations in Texas. The statistics selected for this report are the annual mean, maximum, minimum, and L-scale. These are collectively referred to as the "annual statistics." Annual L-scale of streamflow is a robust measure of the variability of the daily mean streamflow for a given year.

A graphical depiction of the annual statistics for streamflow-gaging stations in Texas provides valuable information by conveying the historical characteristics of streamflow for the watershed, in particular, and Texas, in general. Therefore, in 2006 the USGS, in cooperation with the Texas Commission on Environmental Quality (TCEQ), initiated a data and reporting process to generate station-specific histories of the annual statistics of daily mean streamflow in Texas. This report includes graphical depictions of the annual statistics for 712 USGS streamflow-gaging stations in Texas with at least 1 year of record through water year 2004 (fig. 11.

Streamflow-gaging stations that monitor spring flow or stage (water level) only were not used. Further, partial-record streamflow-gaging stations were not 


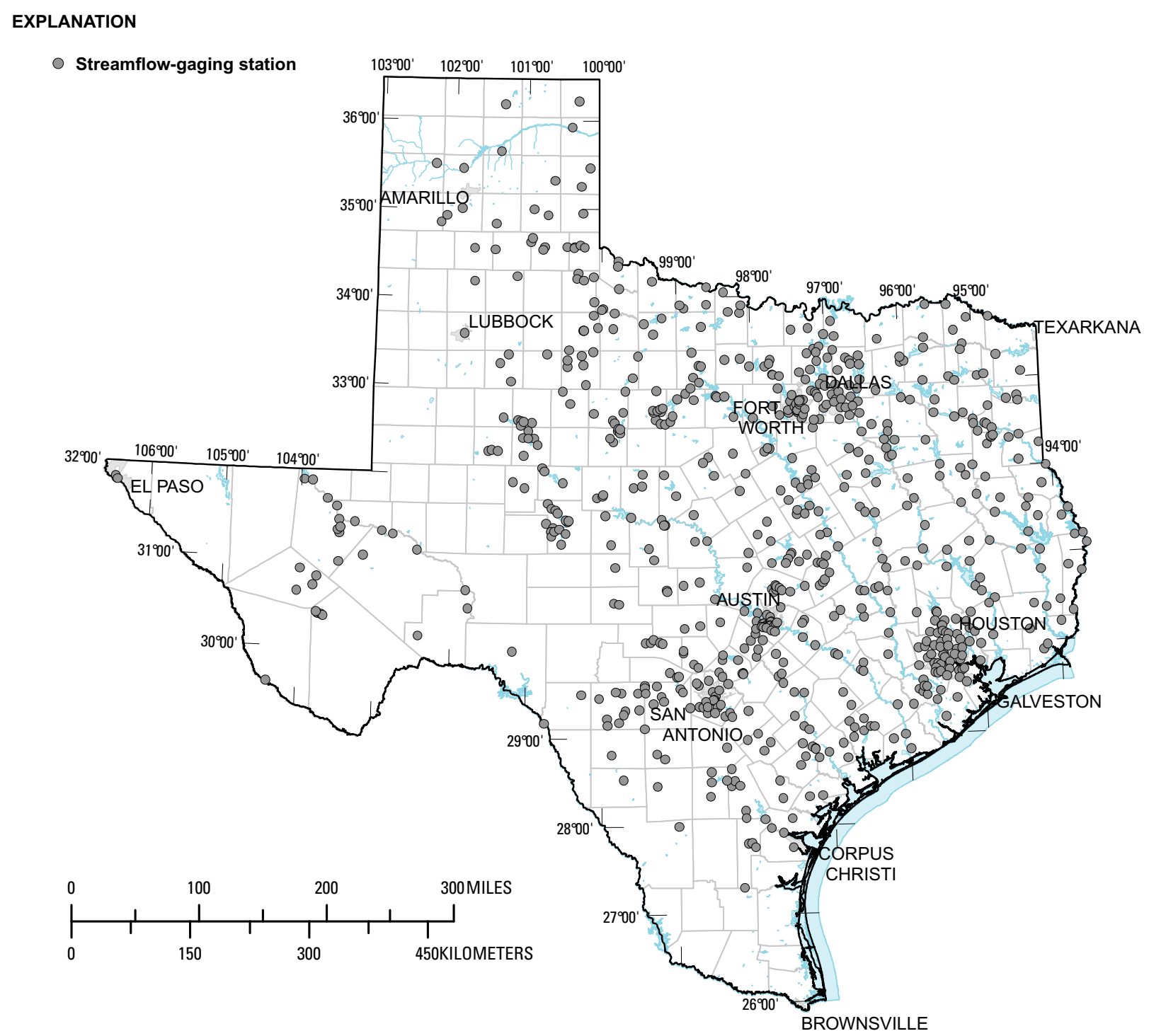

Figure 1. Locations of U.S. Geological Survey streamflow-gaging stations in Texas with at least 1 year of daily mean streamflow data through water year 2004.

used because the full range of streamflow at each station was needed. Partial-record streamflow-gaging stations are sites where discrete measurements of streamflow are obtained over a period of time without continuous data being recorded. These stations intrinsically do not monitor the entire range of streamflow. The 712 stations considered in this report were analyzed in Asquith and others 2006 for an evaluation of the drainage-area ratio method in Texas. A listing of the station numbers, station names, and ancillary information is available in Asquith and others 2006, table 1).
A companion report Asquith and others 2007 considers percentages of zero daily mean streamflow for the same stations and streamflow data.

The data for the 712 stations were obtained from the USGS National Water Information System U.S. Geological Survey, 2005. The stations have at least 1 year of daily mean streamflow record through the 2004 water year. A water year is the 12-month period between October 1 and September 30. The water year is designated by the calendar year in which it ends. Thus, the year ending September 30, 2004, is called 
the "2004 water year." The data were trimmed to the last complete calendar year (2003). The earliest year of streamflow record is 1898 . For the analysis reported here the calendar year context is used for statistical computations. Therefore, the last date of daily mean streamflow is December 31, 2003. The total number of daily values processed is $7,748,449$.

The annual L-scale statistic of daily mean streamflow was computed for each year of record. L-scale is the second L-moment and represents the intra-variation in streamflow. L-scale is analogous, but not equal to, standard deviation; both are similarly interpreted by analysts. L-scale has several well-documented sampling properties such as unbiasedness and efficiency in small samples that make this statistic well suited for streamflow datasets Hosking 1990. Although not an exact equality when computed from samples, the theoretical relation between the standard deviation $(\sigma)$ and L-scale $\left(\lambda_{2}\right)$ is $\sigma=\sqrt{\pi} \lambda_{2}$. Recently, Asquith 2006 summarized the mathematics and theory of L-moments.

Finally, an analysis of monotonic temporal trends in each of the four statistics was done using Kendall's $\tau$. Kendall's $\tau$ measures the strength of the monotonic relation between time and the annual streamflow statistic. Kendall's $\tau$ is nonparametric, meaning that the statistic is based on the ranks of the data and not the actual data values. Positive $\tau$ values indicate that the annual statistic increases with time for the period of record, and negative $\tau$ values indicate that the annual statistic decreases with time for the period of record. Perfect monotonically decreasing relations result in $\tau$ values of exactly -1 ; conversely, perfect monotonically increasing relations result in $\tau$ values of exactly 1 . The $\mathrm{p}$-value is a measure of the strength or statistical significance of the relation; small p-values ( $p$-value $\leq .02$ in this report) indicate a strong relation.

Kendall's $\tau$ is visually augmented by a Theil line when a strong relation is indicated. The Theil line, as discussed by Hollander and Wolfe (1973, p. 205) and Helsel and Hirsch (1992 p. 266), is a robust estimator of the slope of a linear relation between time and the streamflow statistic. The slope is estimated as the median of all unique $(n \times(n-1) / 2)$ slopes between individual data points. The purpose of the Theil line is to provide a visual cue that a statistically significant trend in the annual statistic was detected.

\section{Summary of Annual Mean, Maximum, Minimum, and L-scale Statistics of Daily Mean Streamflow in Texas}

The graphical depiction of the history of daily mean streamflow statistics for each of the 712 stations is provided in figures 2713 (at end of report). Each figure consists of four time-series plots of annual mean, maximum, minimum, and L-scale values of daily mean streamflow. Above the top graph is the text annotation "U.S. Geological Survey streamflow-gaging station \#," where \# is the eight-digit station identification number. This annotation is included to confirm that the pairing of the graphs and the figure caption are correct. Some stations have substantial gaps (measured in years) such as those shown in figure 588 on page 592. No special treatment of the streamflow data was applied for stations with gaps in the period of record.

Each statistic type consists of four components. First, the annual statistics (mean, maximum, minimum, and L-scale) are plotted as $n$ open circles ( $n$ represents the number of data points) in figures 2 713 Each data point was computed using the number of days of observed record for the calendar year. For a full year of record, the number of days for the year was 365 (or 366 for leap years). Incomplete years are plotted for the figures as well with the requisite change in sample size. For the second and third components, the mean and median of the $n$ data points were computed and are illustrated as solid and dashed horizontal lines, respectively. The numeric values of mean and median annual statistics of streamflow are shown in the explanation of each graph. The fourth component is the assessment of a monotonic trend in the data.

For the fourth component, Kendall's $\tau$ was computed using an integrated statistical computing environment The MathWorks, 2006 for the $n$ annual statistics. The p-value for $\tau$ also is shown. Hollander and Wolfe 1973, p. 185-199) and Helsel and Hirsch 1992, p. 212 and 216) provide the background and details of computation. Both $\tau$ and the p-value are shown in figures 2713 to three significant figures, except when there is a perfect decreasing or increasing monotonic relation, in which case the exact $\tau$ value of -1 or 1 , respectively, is given. $\mathrm{P}$-values less than .001 are expressed as $<.001$. 
For stations for which Kendall's $\tau$ has a p-value less than or equal to .02, a Theil trend line is superimposed on a graph as a solid grey line. Thus, the Theil line is not drawn on all graphs of the figures. Also, for some graphs, such as the annual minimum streamflow graph for station 07311783 (fig. 46 on page 50), the Theil line is drawn, but not visible - it is masked by the mean annual minimum streamflow line (solid horizontal line). The masking occurs because the median pairwise slope is precisely zero and is most likely to occur with the annual minimum streamflow because of repeated values of zero streamflow.

In regards to the Theil line, the line could represent an over simplification of the relation between time and the corresponding annual statistic for individual watersheds. The actual temporal changes of the annual statistic for each watershed potentially could indicate curvilinear or even cyclical variations caused by natural or anthropogenic sources.

\section{General Discussion}

The number of stations summarized in this report is too large for effective discussion and commentary of station-specific results. Conceptually, numerous attributes or factors of a watershed influence the annual statistics of daily mean streamflow. Some of these factors could affect one annual statistic and not another. The factors could include climatic setting, land-use changes, and upstream water use or regulations. As a result, specific discussion of the daily mean streamflow history for a given station is beyond the scope of this report. However, some general comments for each of the four annual statistics can be made to guide analysts.

The trend evaluations on the 712 stations can be summarized as follows: The number of stations with a statistically significant positive trend (increase) in the annual mean streamflow is 69 (about 10 percent). The number of stations with a statistically significant negative trend (decrease) in the annual mean streamflow is 34 (about 5 percent). No significant trends were detected for 609 stations (about 85 percent).

The number of stations with a statistically significant positive trend in the annual maximum streamflow is 21 (about 3 percent). The number of stations with a statistically significant negative trend in the annual maximum streamflow is 52 (about 7 percent).
No significant trends were detected for 639 stations (about 90 percent).

The number of stations with a statistically significant positive trend in the annual minimum streamflow is 127 (about 18 percent). The number of stations with a statistically significant negative trend in the annual minimum streamflow is 20 (about 3 percent). No significant trends were detected for 565 stations (about 79 percent).

The number of stations with a statistically significant positive trend in the annual L-scale of streamflow is 47 (about 7 percent). The number of stations with a statistically significant negative trend in the annual L-scale of streamflow is 41 (about 6 percent). No significant trends were detected for 624 stations (about 87 percent).

Finally, each summary provides a compact visual description of the history of selected statistics of daily mean streamflow for the watershed monitored by the USGS streamflow-gaging station. Station-specific interpretations of climatic, hydrologic, anthropogenic, and other processes potentially influencing the magnitude and temporal variations can be made. One or more summaries could be used in a watershed, river basin, or other regional context by analysts and managers of surface-water resources to guide scientific, regulatory, or other inquiries of daily streamflow conditions in Texas.

\section{References}

Asquith, W.H., 2006, L- and TL-moments of the generalized lambda distribution: Computational Statistics and Data Analysis, 13 p., corrected proof available online since August 1, 2006, doi: 10.1016/j.csda.2006.07.016.

Asquith, W.H., Roussel, M.C., and Vrabel, Joseph, 2006, Statewide analysis of the drainage-area ratio method for 34 streamflow percentile ranges in Texas: U.S. Geological Survey Scientific Investigations Report 2006-5286, 34 p., 1 appendix. Available Online

Asquith, W.H., Vrabel, Joseph, and Roussel, M.C., 2007, Summary of percentages of zero daily mean streamflow for 712 U.S. Geological Survey streamflow-gaging stations in Texas through 2003: U.S. Geological Survey Data Series 247, 721 p. Available Online 
Helsel, D.R., and Hirsch, R.M., 1992, Statistical methods in water resources-Studies in environmental science 49: Amsterdam, Elsevier, 529 p.

Hollander, Myles, and Wolfe, D.A., 1973, Nonparametric statistical methods: New York, John Wiley, $503 \mathrm{p}$.

Hosking, J.R.M., 1990, L-moments-Analysis and estimation of distributions using linear combinations of order statistics: Journal Royal Statistical Society B, v. 52, no. 1, p. 105-124.

The MathWorks, 2006, MATLAB version 7.2.0.232 (R2006a): Natick, Mass.

U.S. Geological Survey, 2005, National Water Information System: accessed in July 2005 at http: //nwis.waterdata.usgs.gov/nwis/discharge 

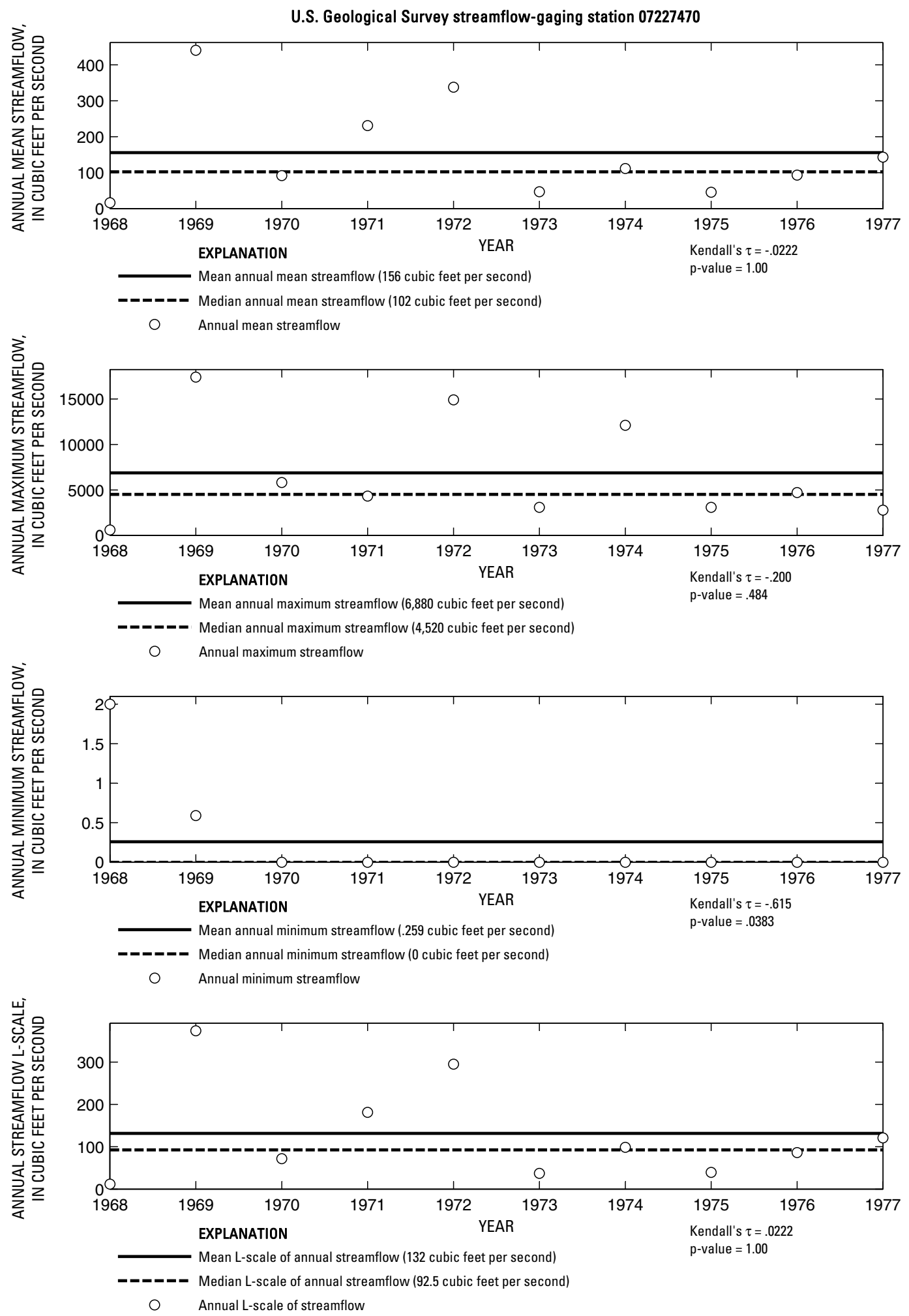

Figure 2. Analysis of annual mean, maximum, minimum, and L-scale statistics of daily mean streamflow for U.S. Geological Survey streamflow-gaging station 07227470 Canadian River at Tascosa, Texas.

Index of Station Numbers 719 

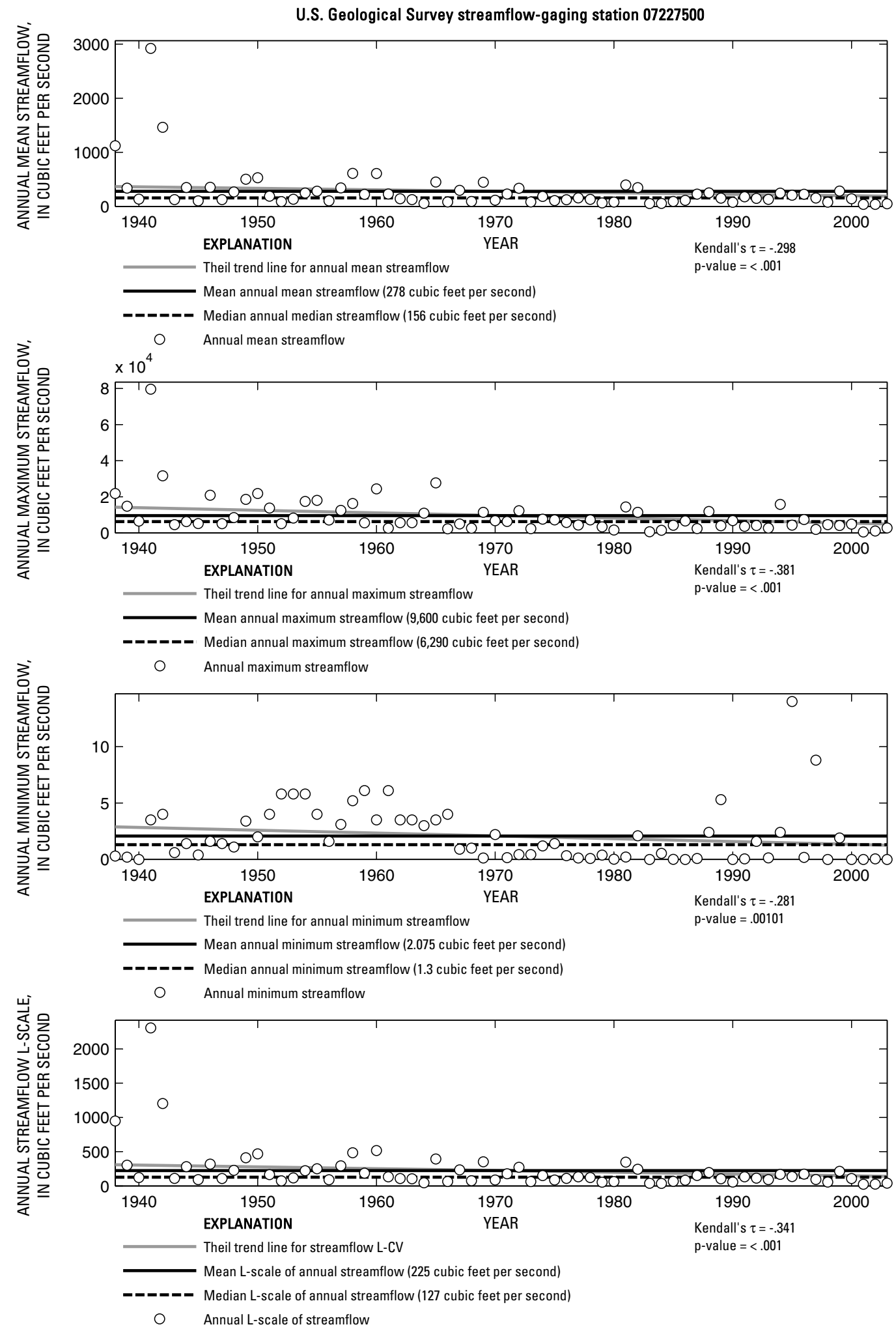

Figure 3. Analysis of annual mean, maximum, minimum, and L-scale statistics of daily mean streamflow for U.S. Geological Survey streamflow-gaging station 07227500 Canadian River near Amarillo, Texas. 


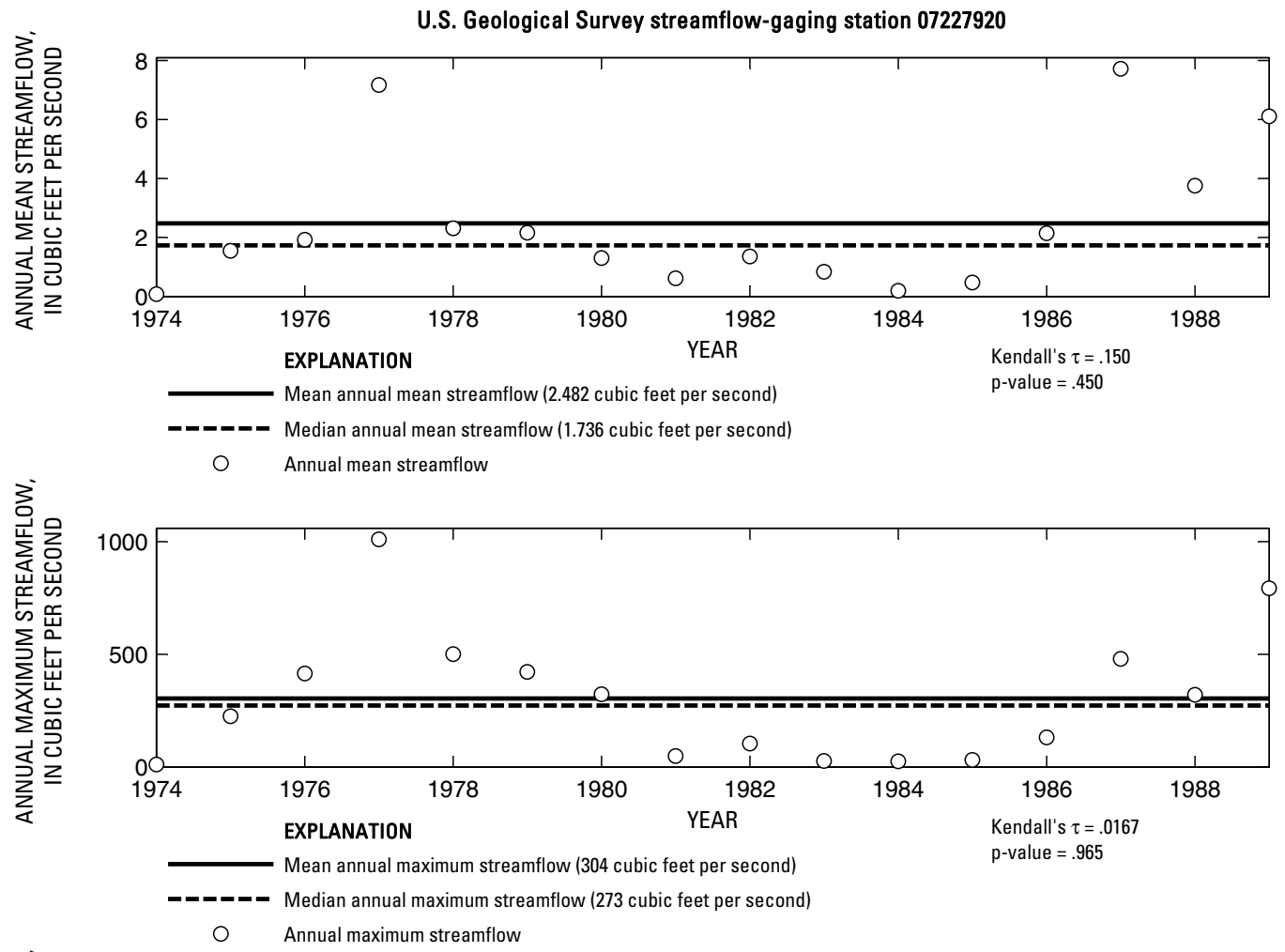

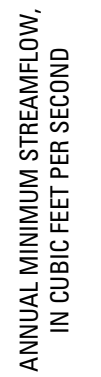

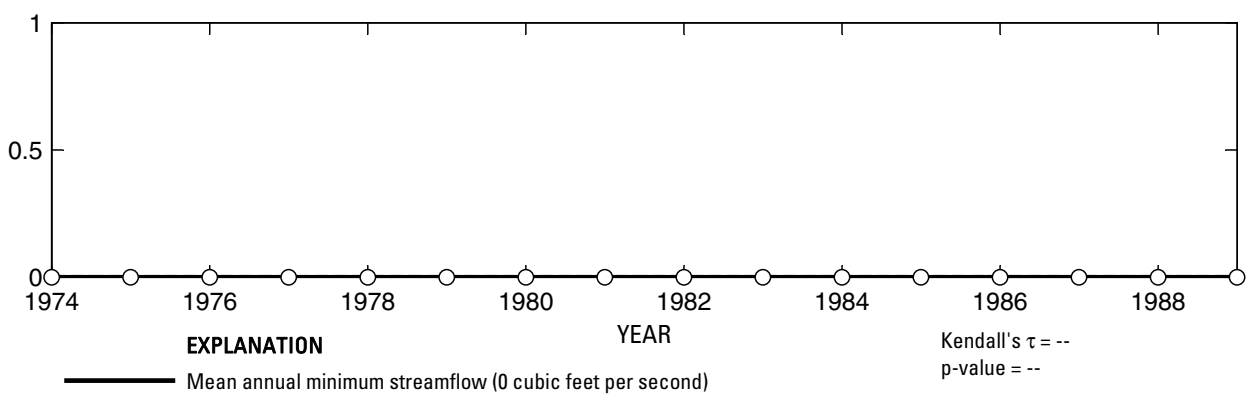

- ב-_ Median annual minimum streamflow (0 cubic feet per second

○ Annual minimum streamflow

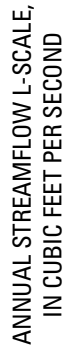

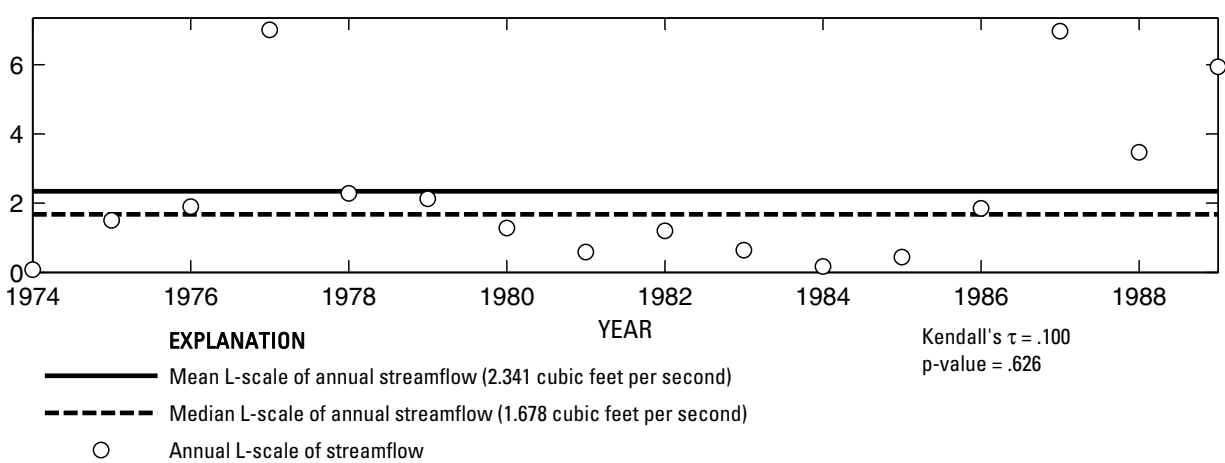

Figure 4. Analysis of annual mean, maximum, minimum, and L-scale statistics of daily mean streamflow for U.S. Geological Survey streamflow-gaging station 07227920 Dixon Creek near Borger, Texas.

Index of Station Numbers 719 


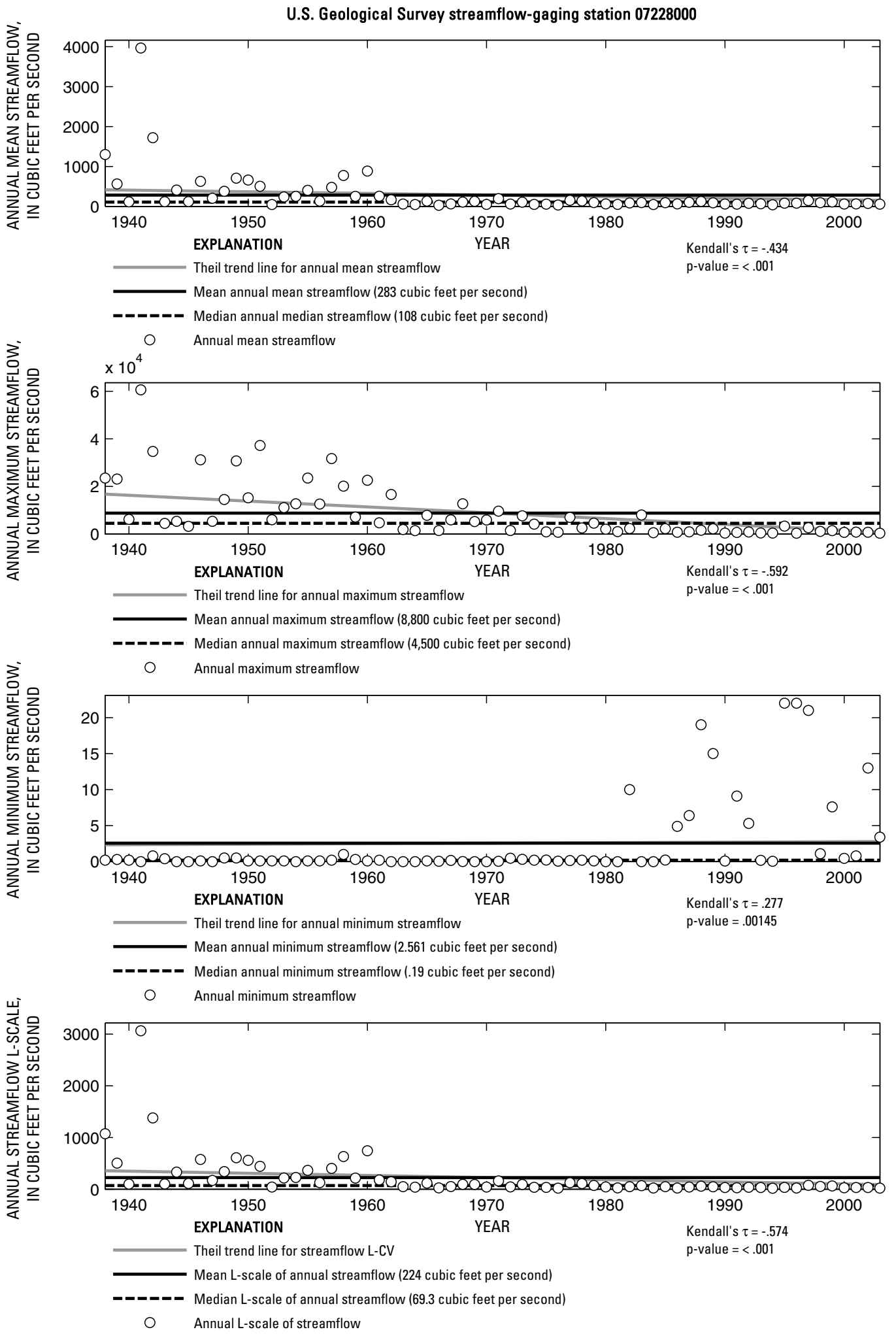

Figure 5. Analysis of annual mean, maximum, minimum, and L-scale statistics of daily mean streamflow for U.S. Geological Survey streamflow-gaging station 07228000 Canadian River near Canadian, Texas. 

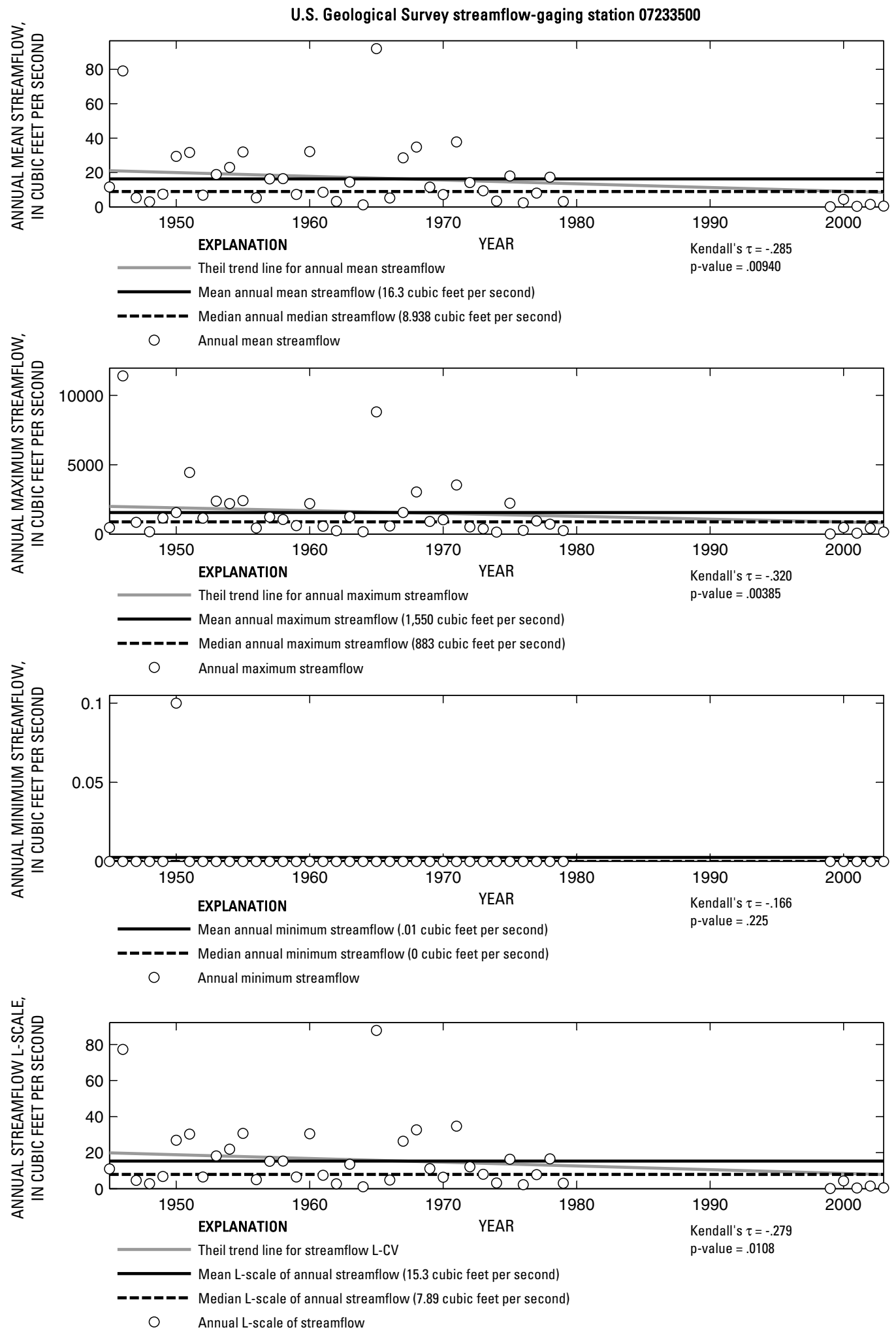

Figure 6. Analysis of annual mean, maximum, minimum, and L-scale statistics of daily mean streamflow for U.S. Geological Survey streamflow-gaging station 07233500 Palo Duro Creek near Spearman, Texas.

Index of Station Numbers 719 


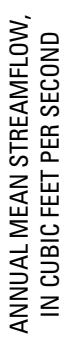

U.S. Geological Survey streamflow-gaging station 07235000

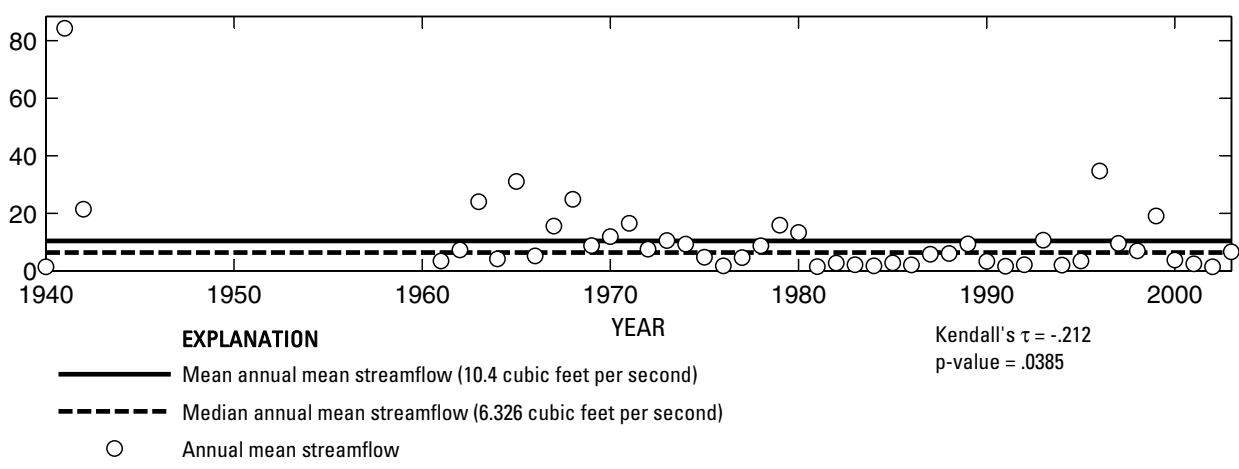

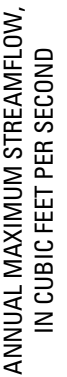

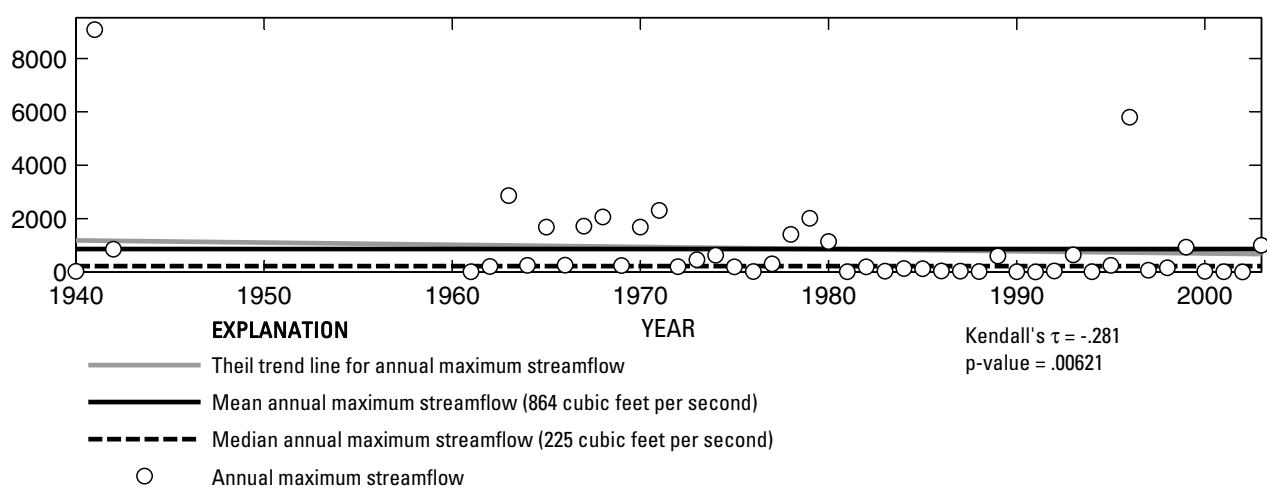

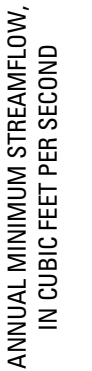

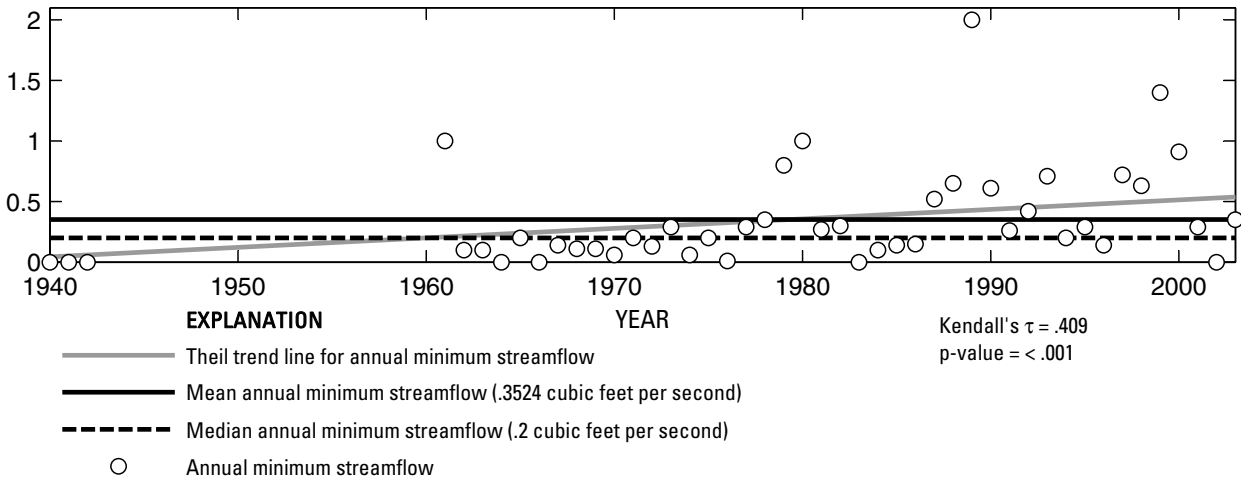

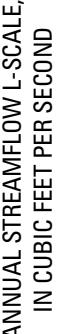

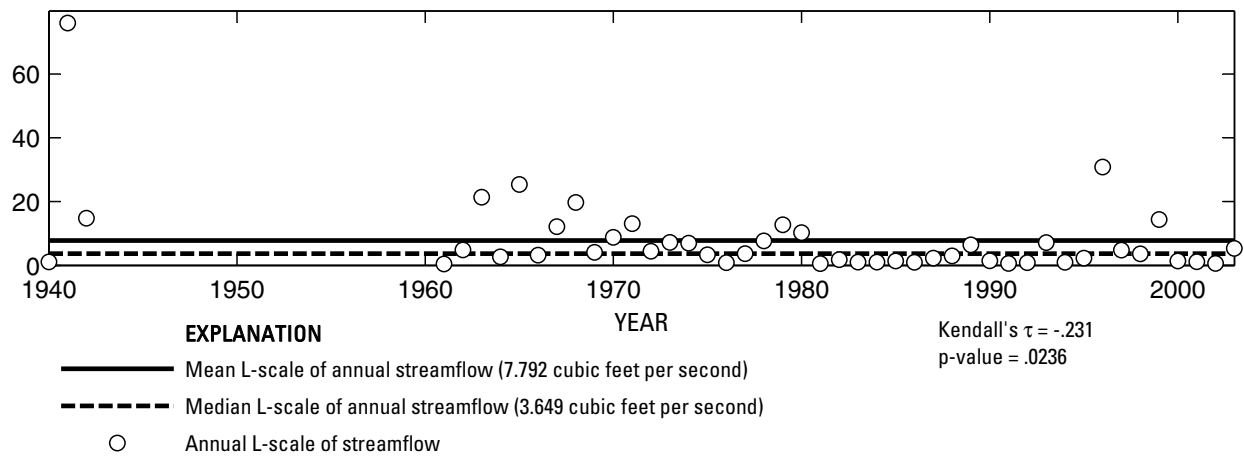

Figure 7. Analysis of annual mean, maximum, minimum, and L-scale statistics of daily mean streamflow for U.S. Geological Survey streamflow-gaging station 07235000 Wolf Creek at Lipscomb, Texas. 

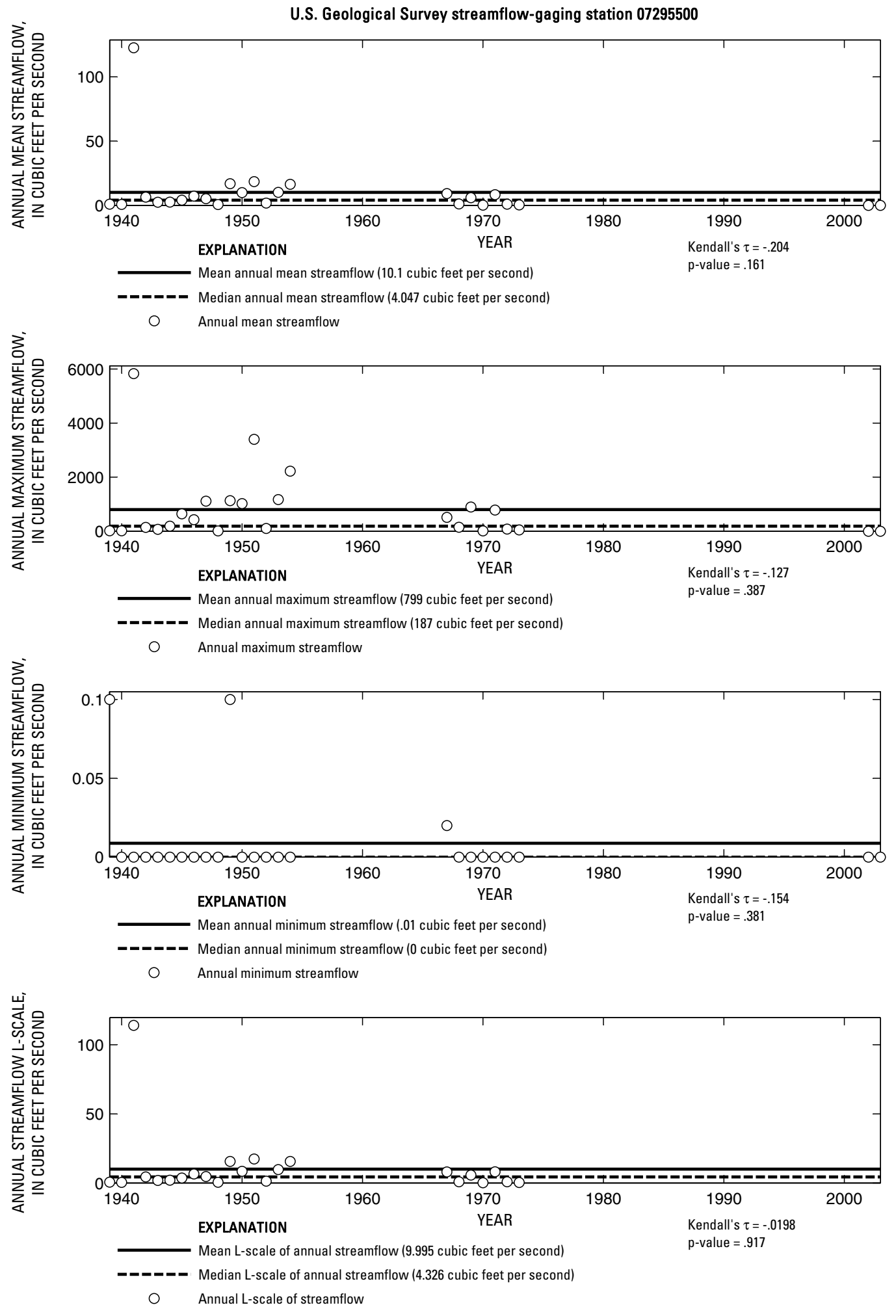

Figure 8. Analysis of annual mean, maximum, minimum, and L-scale statistics of daily mean streamflow for U.S. Geological Survey streamflow-gaging station 07295500 Tierra Blanca Creek above Buffalo Lake near Umbarger, Texas.

Index of Station Numbers 719 

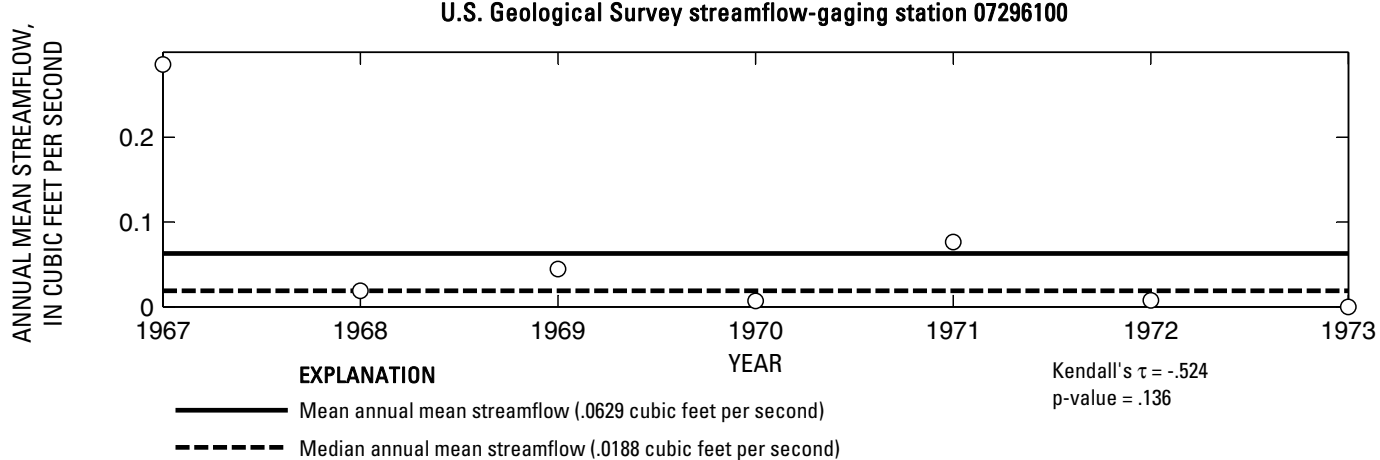

O Annual mean streamflow
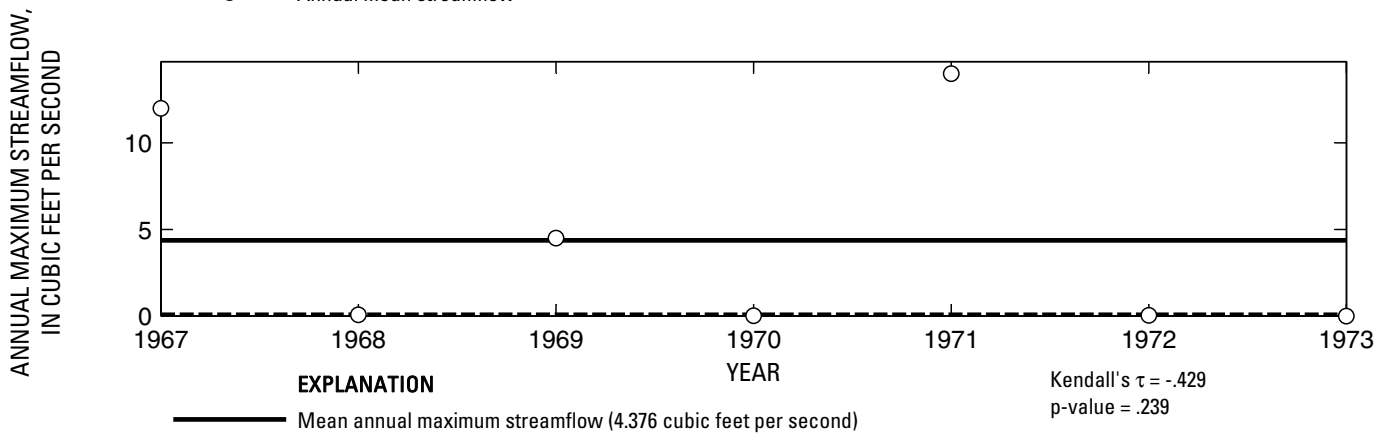

- - Median annual maximum streamflow (.07 cubic feet per second)

Annual maximum streamflow
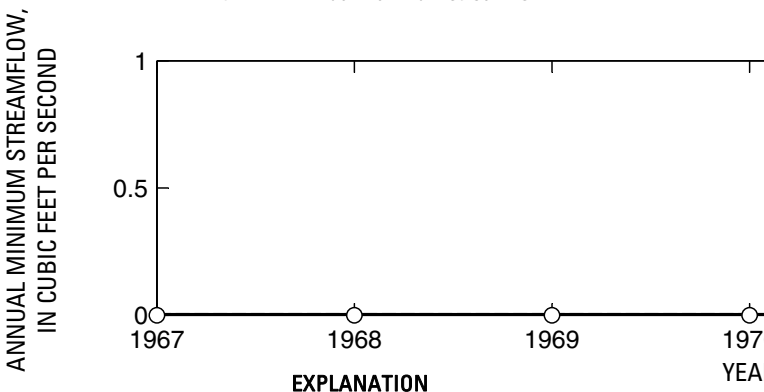

EXPLANATION

Mean annual minimum streamflow ( 0 cubic feet per second)

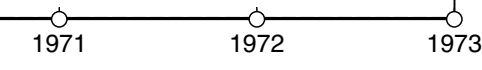

○

Annual minimum streamflow

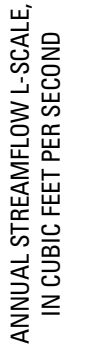

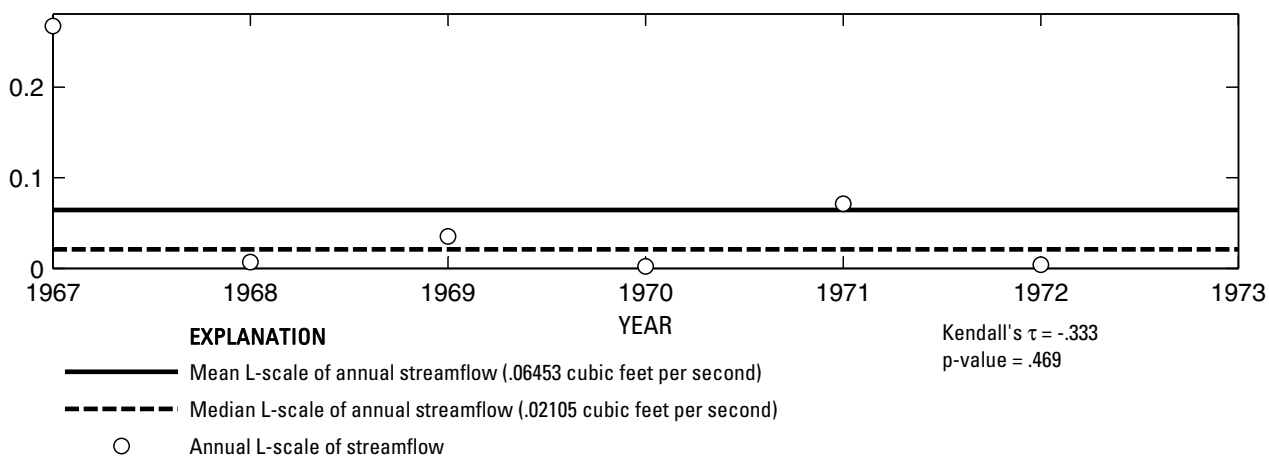

Figure 9. Analysis of annual mean, maximum, minimum, and L-scale statistics of daily mean streamflow for U.S. Geological Survey streamflow-gaging station 07296100 Tierra Blanca Creek below Buffalo Lake near Umbarger, Texas. 

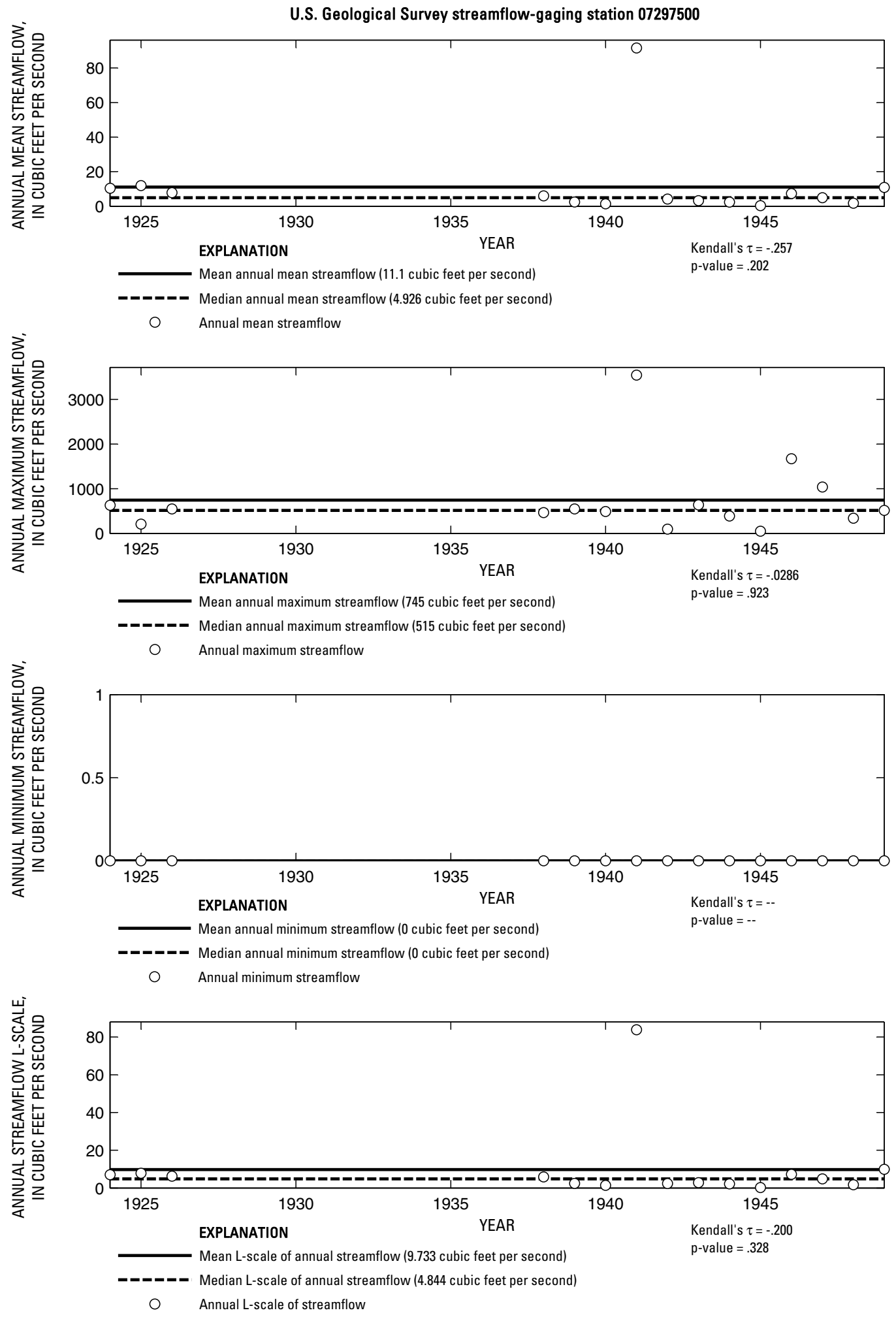

Figure 10. Analysis of annual mean, maximum, minimum, and L-scale statistics of daily mean streamflow for U.S. Geological Survey streamflow-gaging station 07297500 Prairie Dog Town Fork Red River near Canyon, Texas.

Index of Station Numbers 719 

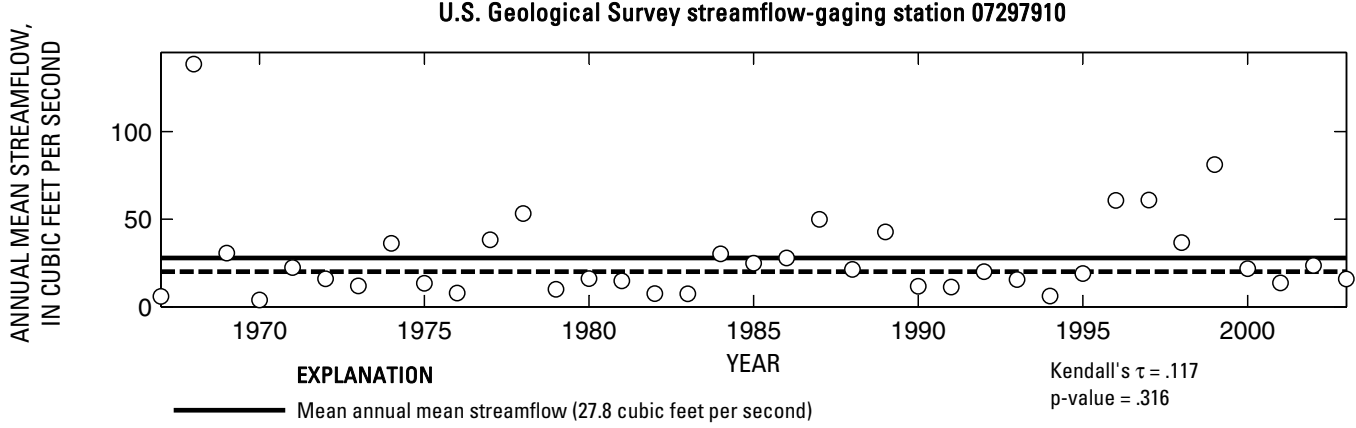

-_-_- Median annual mean streamflow (20 cubic feet per second)

O Annual mean streamflow

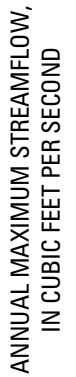

$\times 10^{4}$

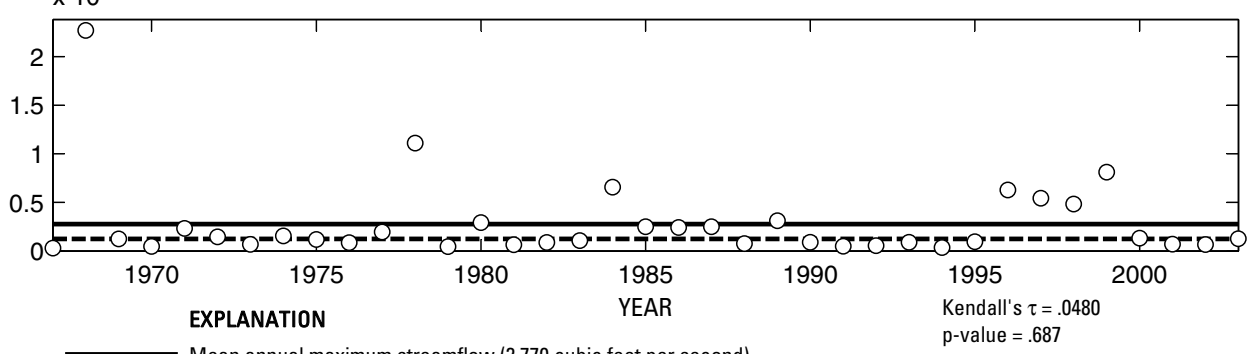

Mean annual maximum streamflow (2,770 cubic feet per second)

- - - - Median annual maximum streamflow (1,250 cubic feet per second)

O Annual maximum streamflow

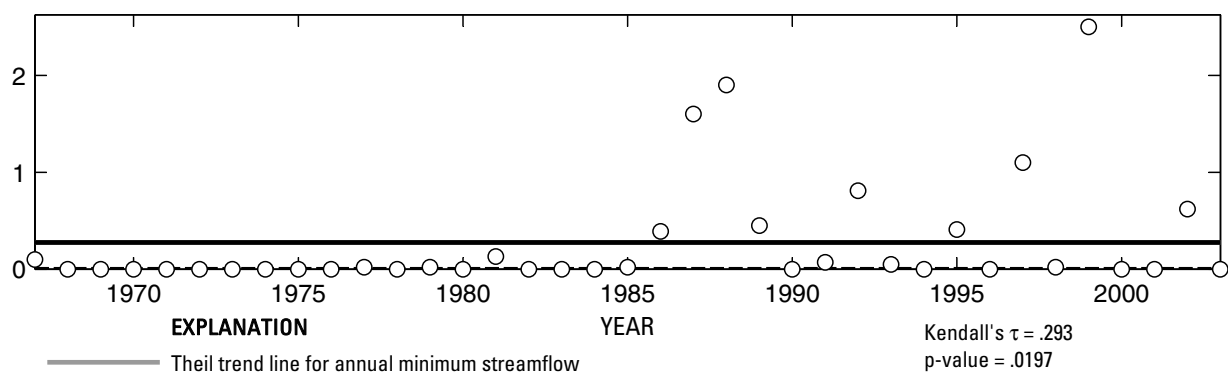

Mean annual minimum streamflow (.2759 cubic feet per second)

- - - Median annual minimum streamflow (0 cubic feet per second)

O Annual minimum streamflow

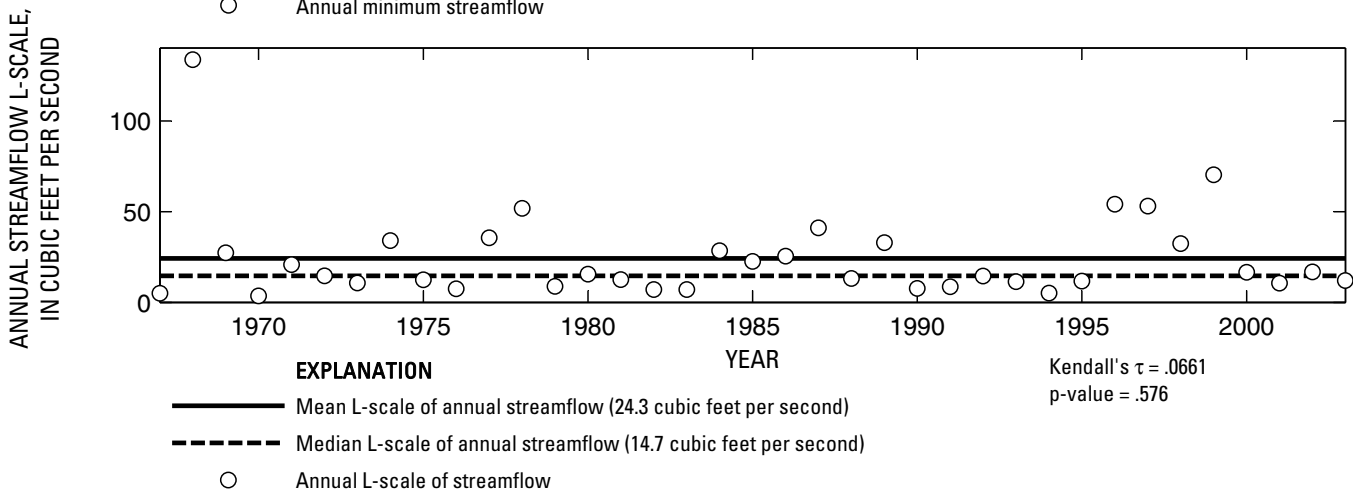

Figure 11. Analysis of annual mean, maximum, minimum, and L-scale statistics of daily mean streamflow for U.S. Geological Survey streamflow-gaging station 07297910 Prairie Dog Town Fork Red River near Wayside, Texas. 

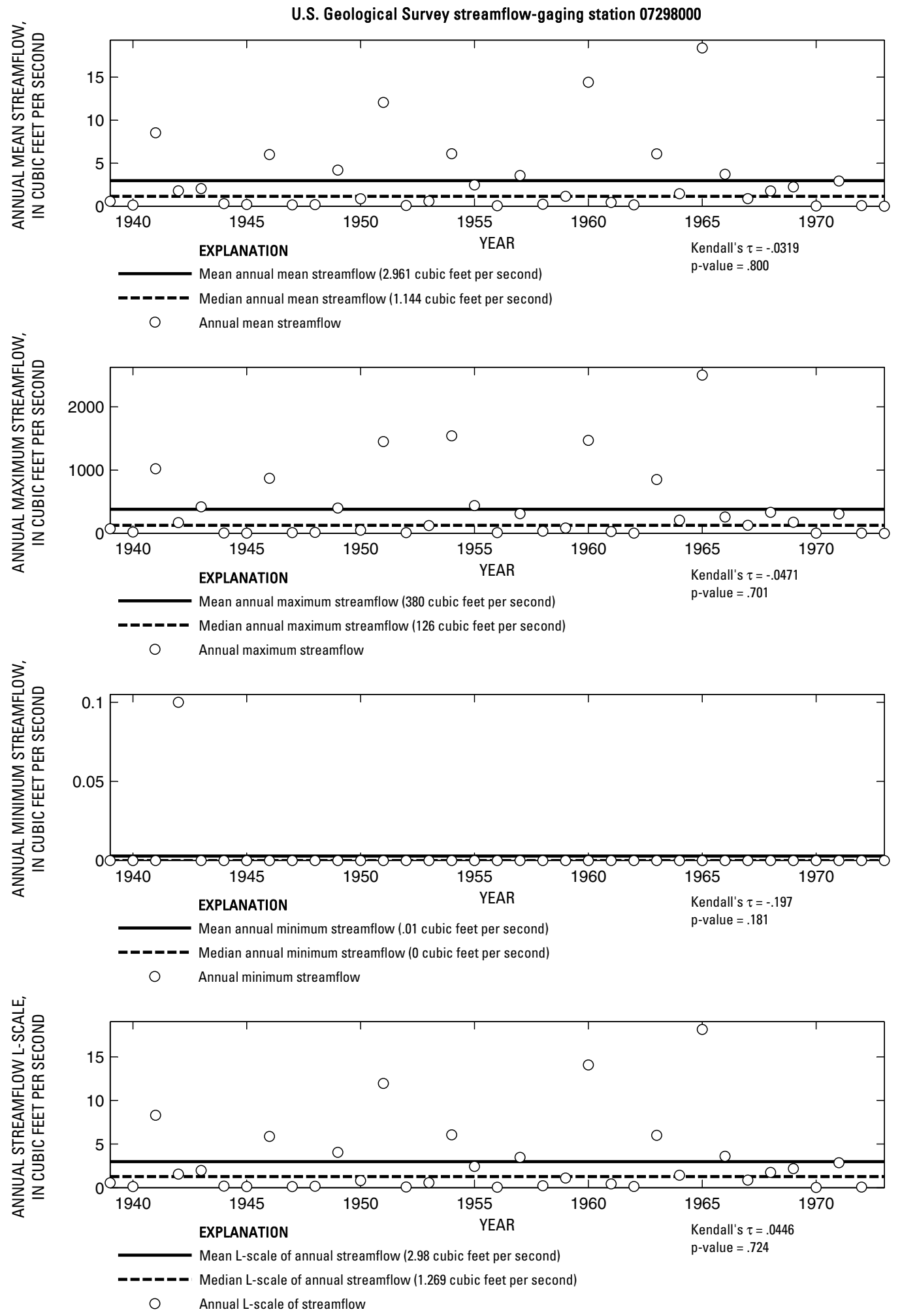

Figure 12. Analysis of annual mean, maximum, minimum, and L-scale statistics of daily mean streamflow for U.S. Geological Survey streamflow-gaging station 07298000 North Tule Draw at Reservoir near Tulia, Texas.

Index of Station Numbers 719 


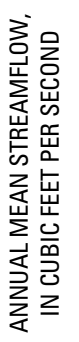

U.S. Geological Survey streamflow-gaging station 07298200

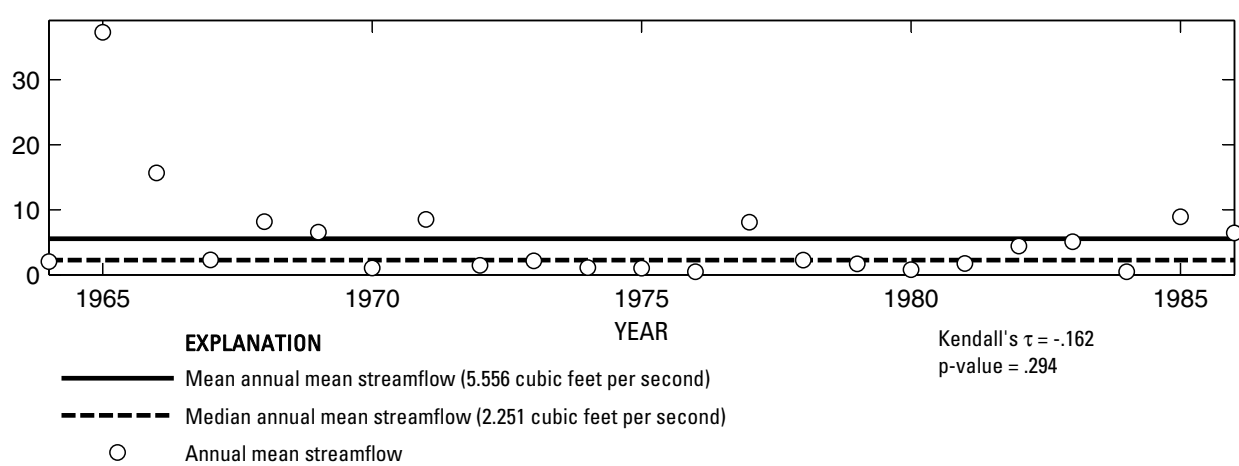

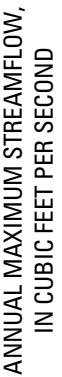

4000
3000
2000
1000

○
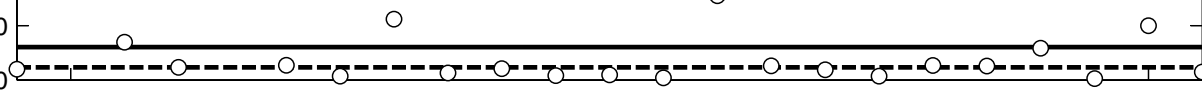

1965

1970

1975

YEAR

1980

Kendall's $\tau=-.178$

EXPLANATION
Mean annual maximum streamflow (607 cubic feet per second)

$\mathrm{p}$-value $=.248$

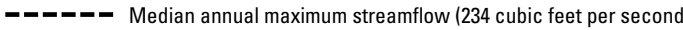

Annual maximum streamflow

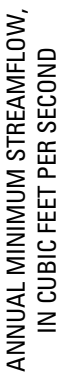

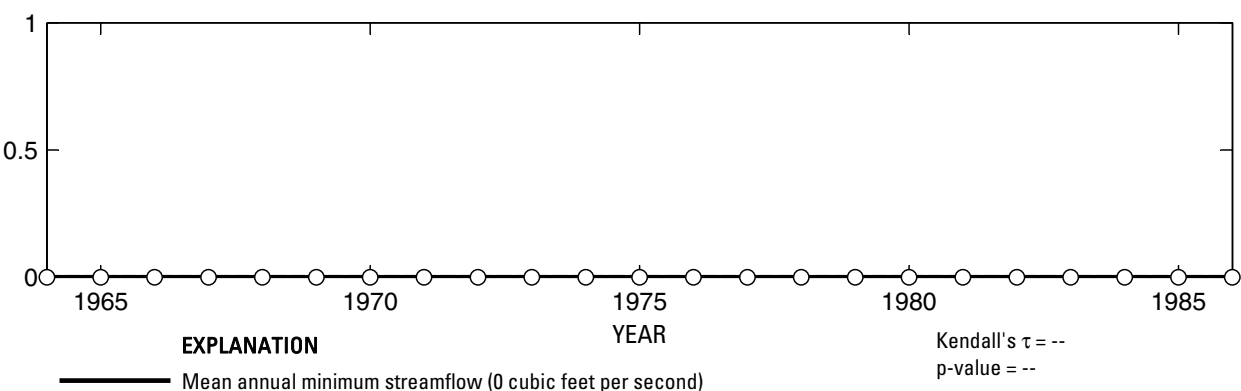

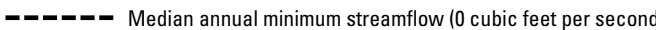

O Annual minimum streamflow
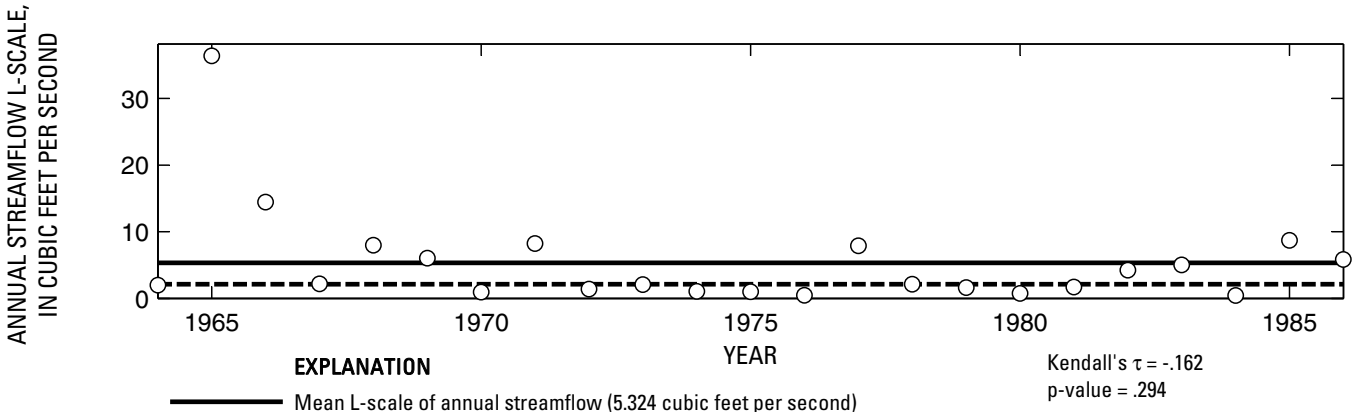

- - - - Median L-scale of annual streamflow (2.135 cubic feet per second)

O Annual L-scale of streamflow

Figure 13. Analysis of annual mean, maximum, minimum, and L-scale statistics of daily mean streamflow for U.S. Geological Survey streamflow-gaging station 07298200 Tule Creek near Silverton, Texas. 

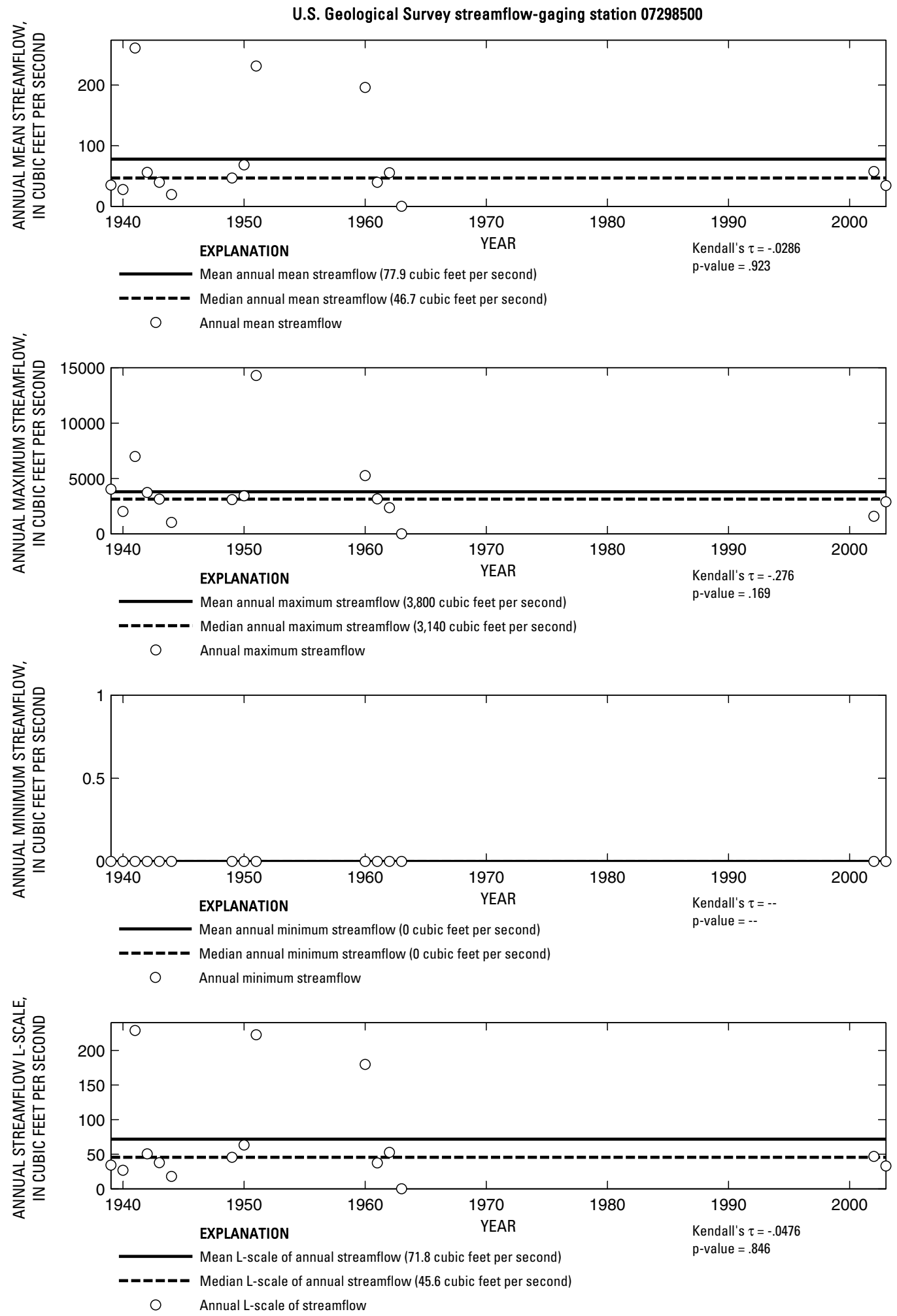

Figure 14. Analysis of annual mean, maximum, minimum, and L-scale statistics of daily mean streamflow for U.S. Geological Survey streamflow-gaging station 07298500 Prairie Dog Town Fork Red River near Brice, Texas.

Index of Station Numbers 719 

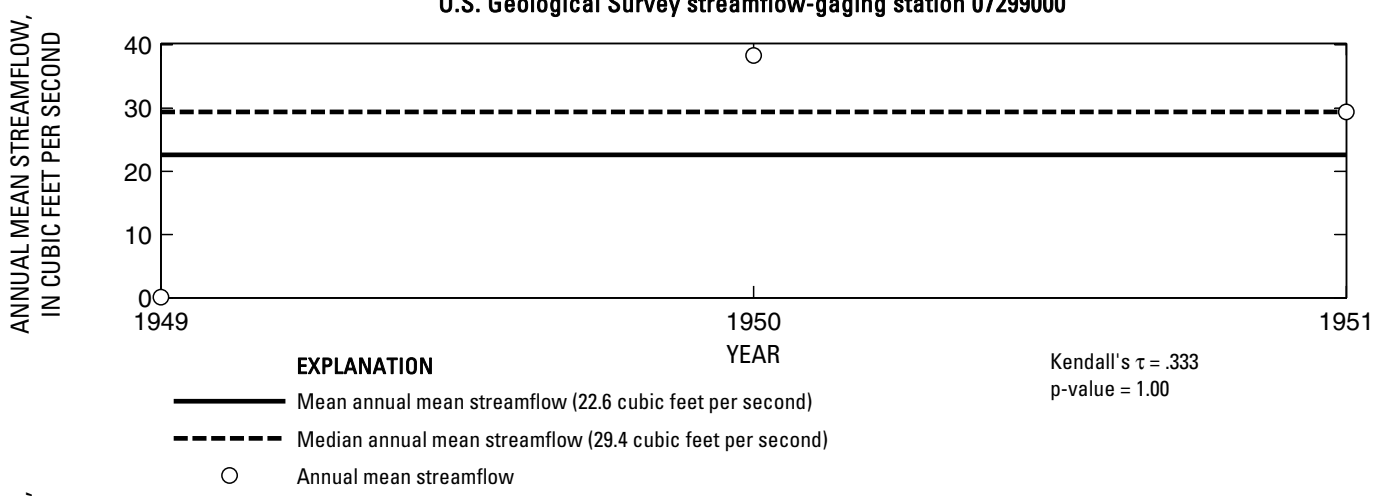

U.S. Geological Survey streamflow-gaging station 07299000

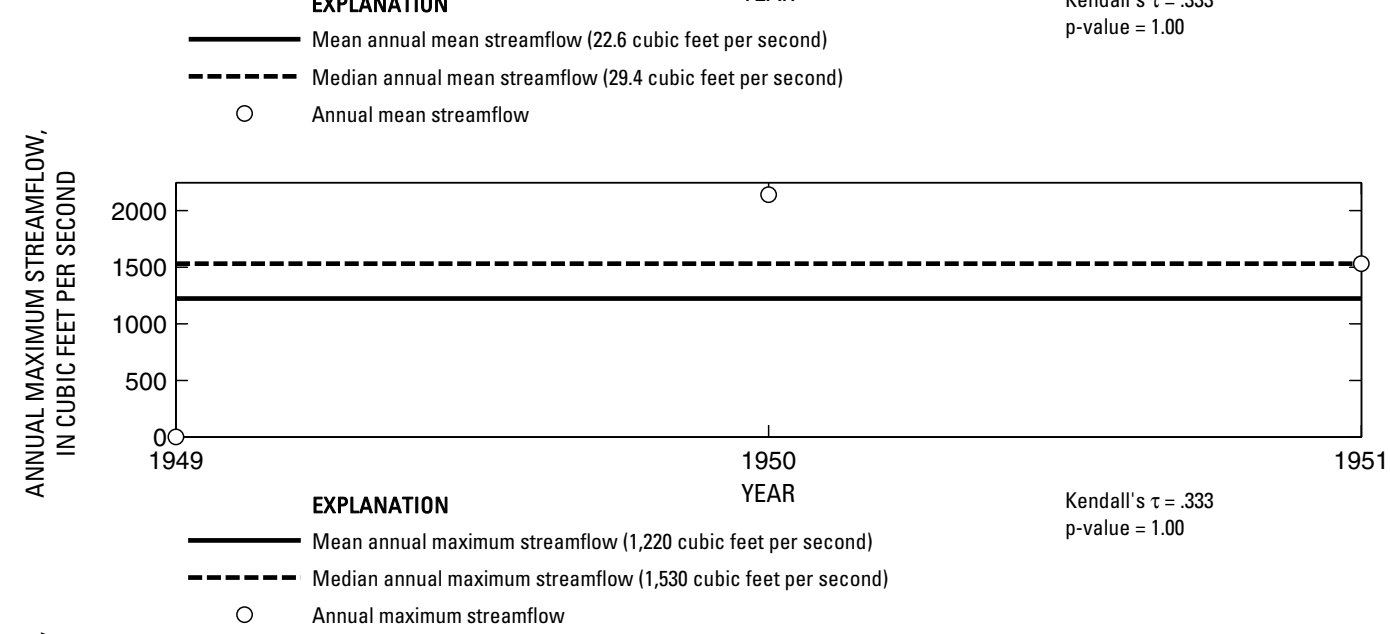

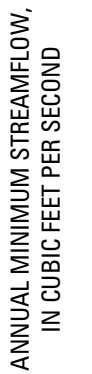

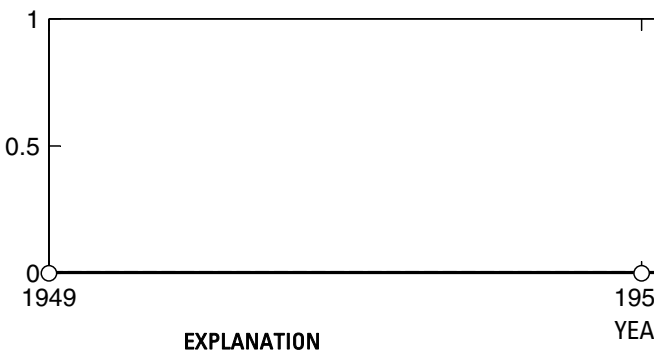

Mean annual minimum streamflow (0 cubic feet per second)

-_-_-_ Median annual minimum streamflow (0 cubic feet per second)

○ Annual minimum streamflow
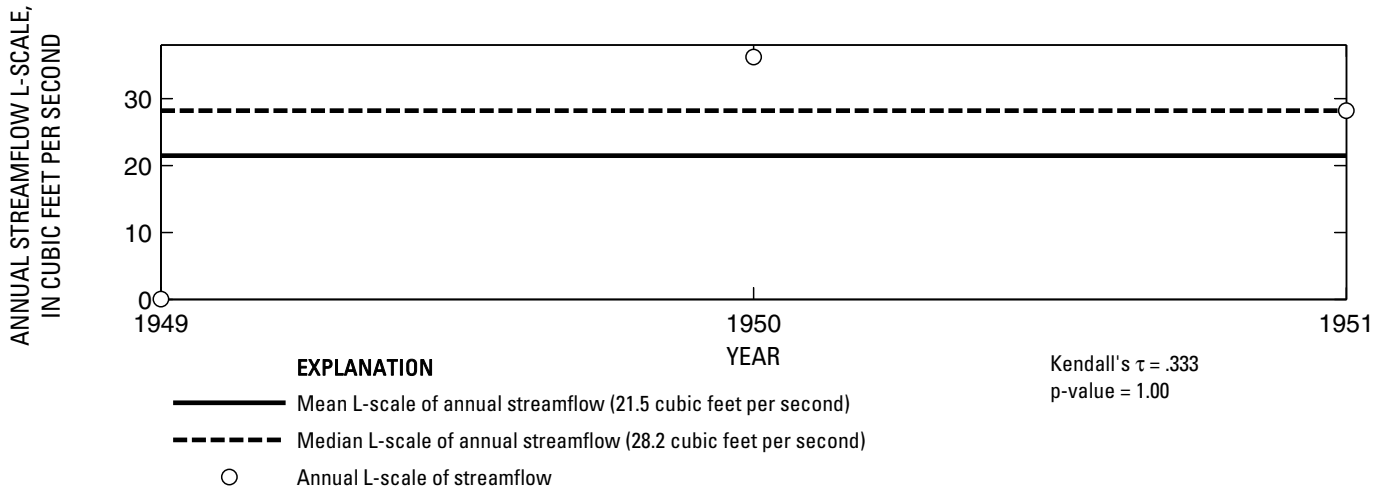

Figure 15. Analysis of annual mean, maximum, minimum, and L-scale statistics of daily mean streamflow for U.S. Geological Survey streamflow-gaging station 07299000 Mulberry Creek near Brice, Texas. 
20 Summary of Annual Mean, Maximum, Minimum, and L-scale Statistics of Daily Mean Streamflow in Texas
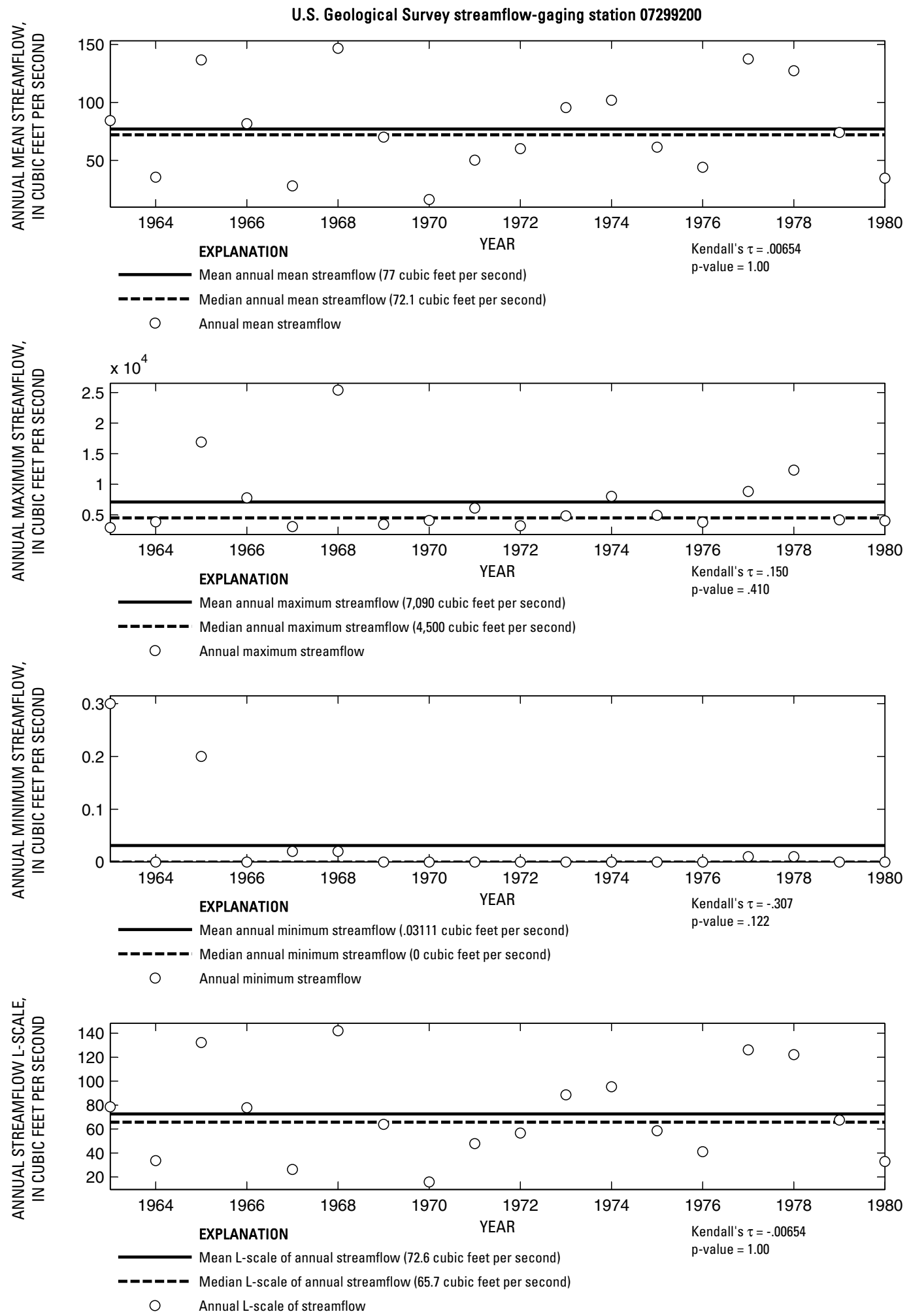

Figure 16. Analysis of annual mean, maximum, minimum, and L-scale statistics of daily mean streamflow for U.S. Geological Survey streamflow-gaging station 07299200 Prairie Dog Town Fork Red River near Lakeview, Texas.

Index of Station Numbers 719 

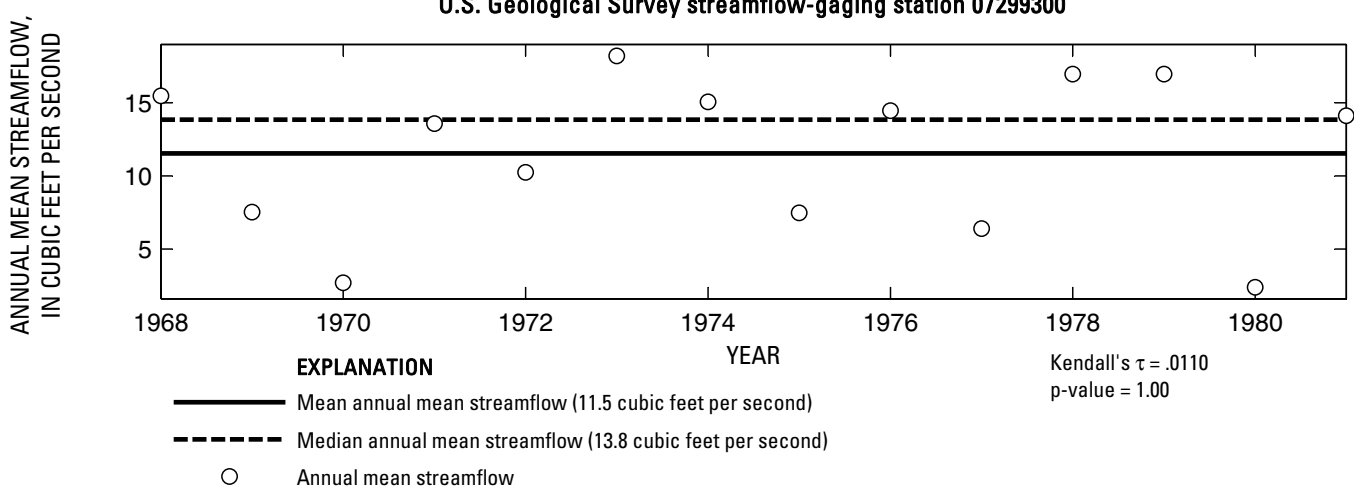

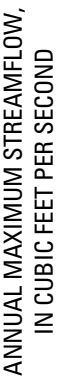

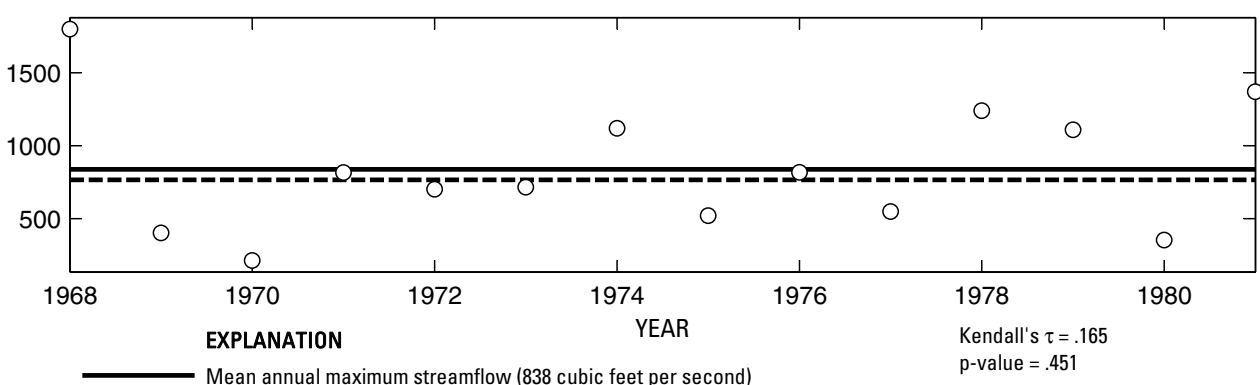

-__-_- Median annual maximum streamflow (766 cubic feet per second)

O Annual maximum streamflow
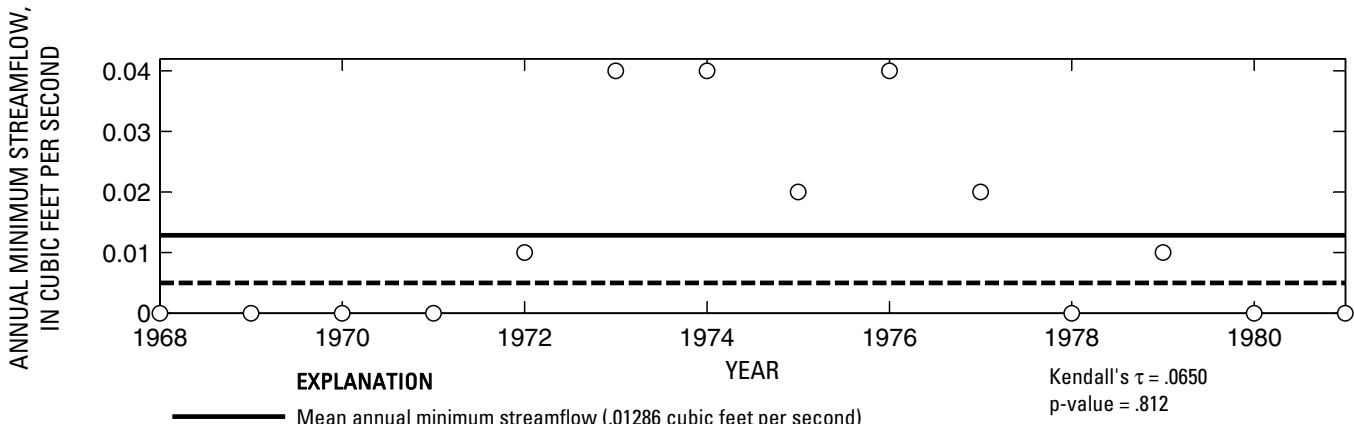

- _- Median annual minimum streamflow (.01 cubic feet per second)

O Annual minimum streamflow

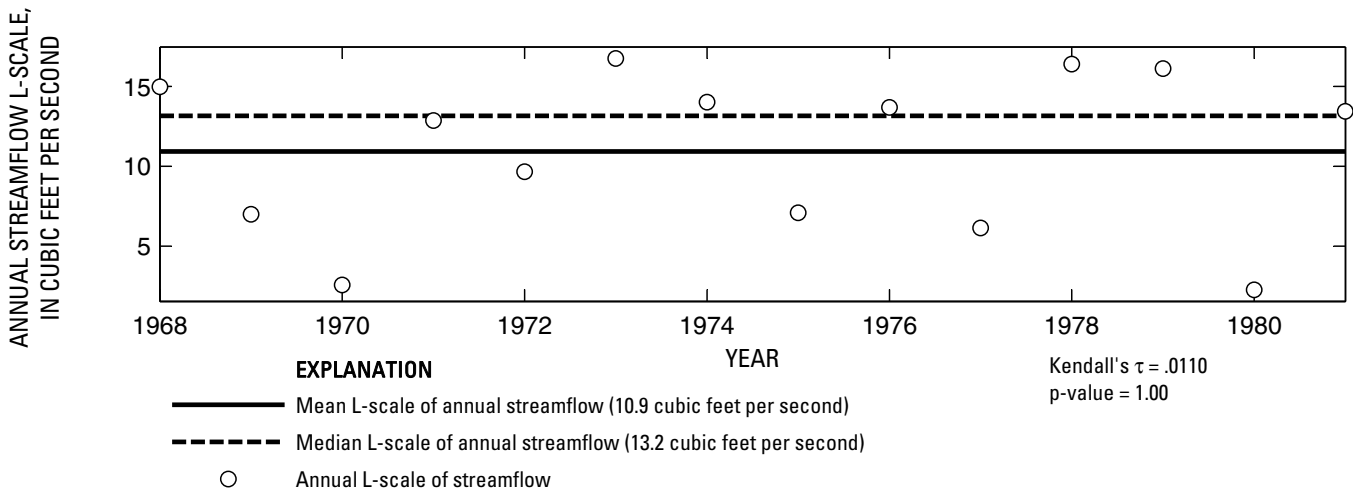

Figure 17. Analysis of annual mean, maximum, minimum, and L-scale statistics of daily mean streamflow for U.S. Geological Survey streamflow-gaging station 07299300 Little Red River near Turkey, Texas. 

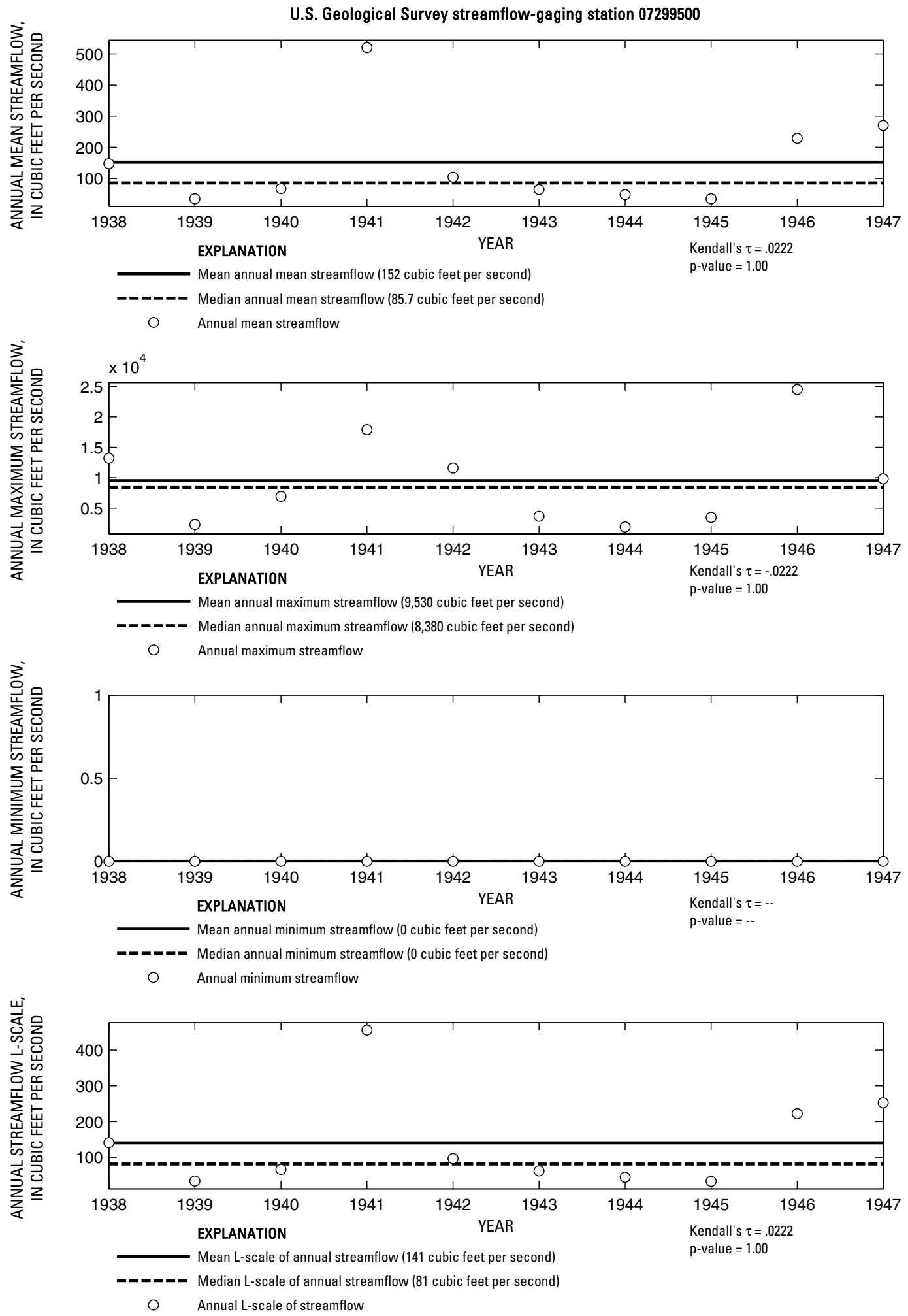

Figure 18. Analysis of annual mean, maximum, minimum, and L-scale statistics of daily mean streamflow for U.S. Geological Survey streamflow-gaging station 07299500 Prairie Dog Town Fork Red River near Estelline, Texas.

Index of Station Numbers 719 


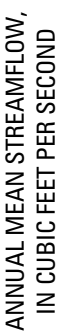

U.S. Geological Survey streamflow-gaging station 07299512

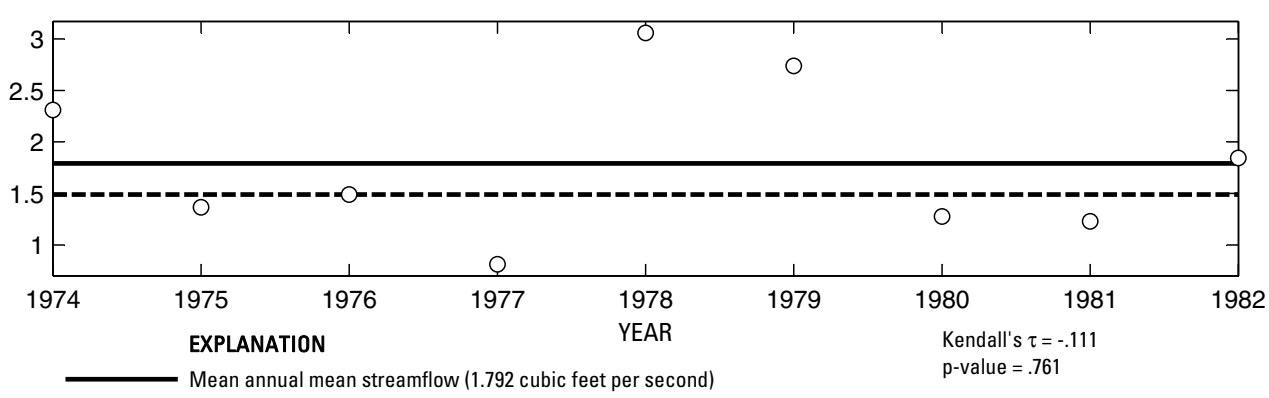

-__-_- Median annual mean streamflow (1.489 cubic feet per second)

O Annual mean streamflow

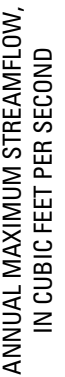

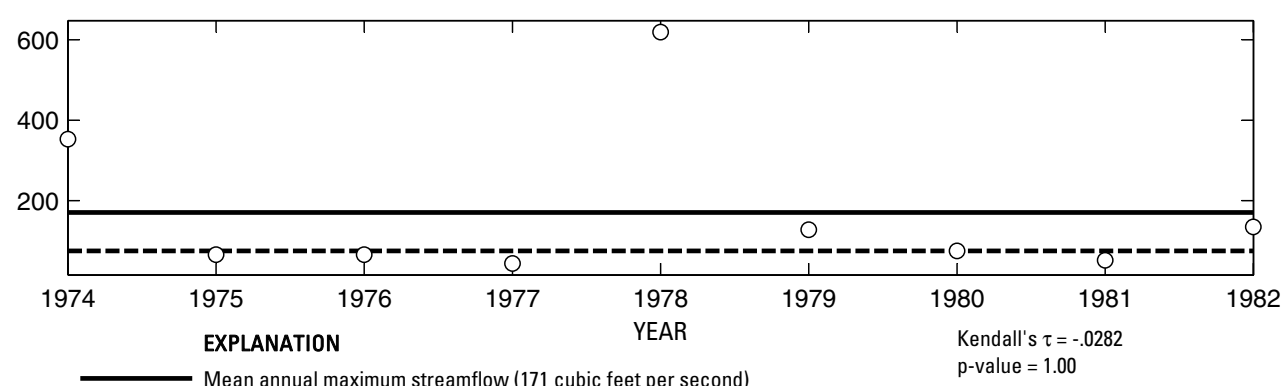

O Annual maximum streamflow

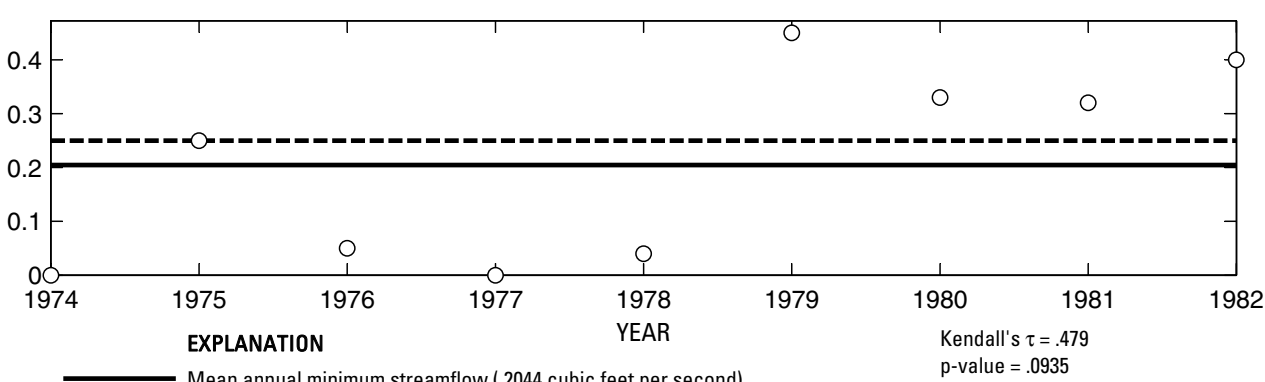

Annual minimum streamflow

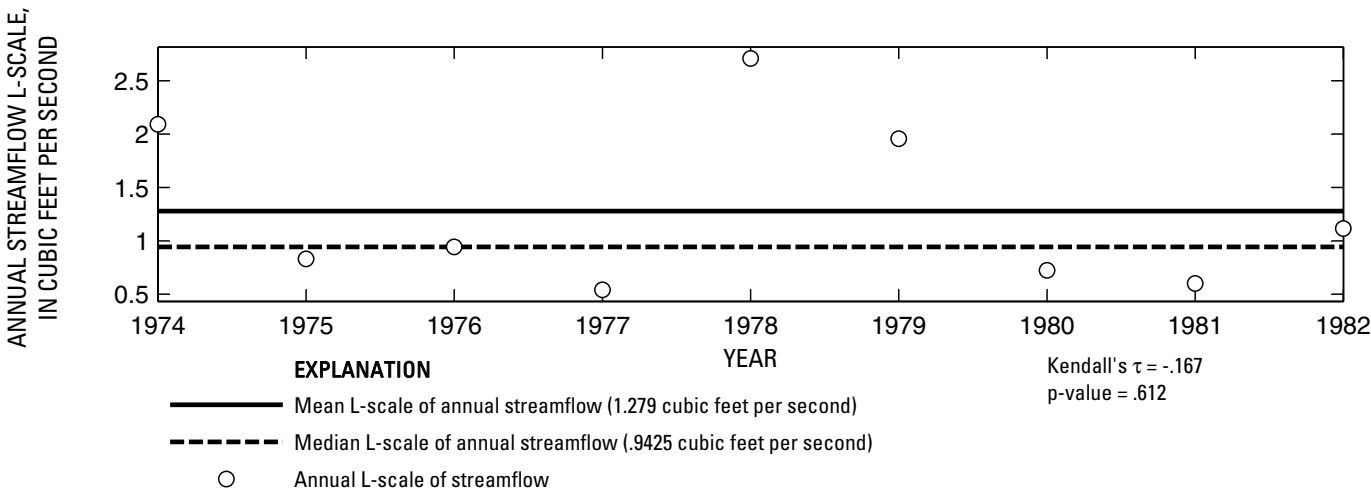

Figure 19. Analysis of annual mean, maximum, minimum, and L-scale statistics of daily mean streamflow for U.S. Geological Survey streamflow-gaging station 07299512 Jonah Creek at Weir near Estelline, Texas. 

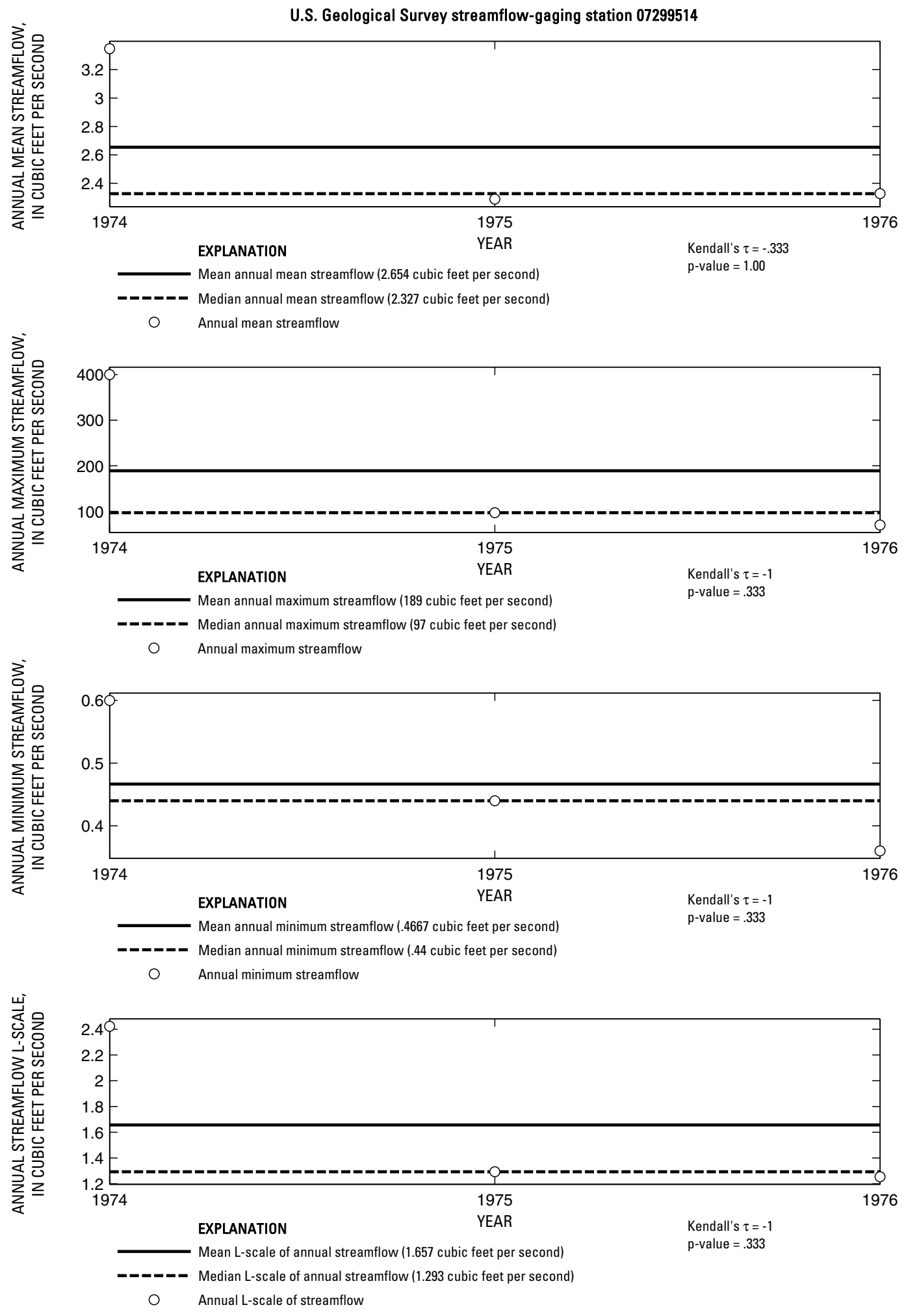

Figure 20. Analysis of annual mean, maximum, minimum, and L-scale statistics of daily mean streamflow for U.S. Geological Survey streamflow-gaging station 07299514 Jonah Creek below Weir near Estelline, Texas.

Index of Station Numbers 719 

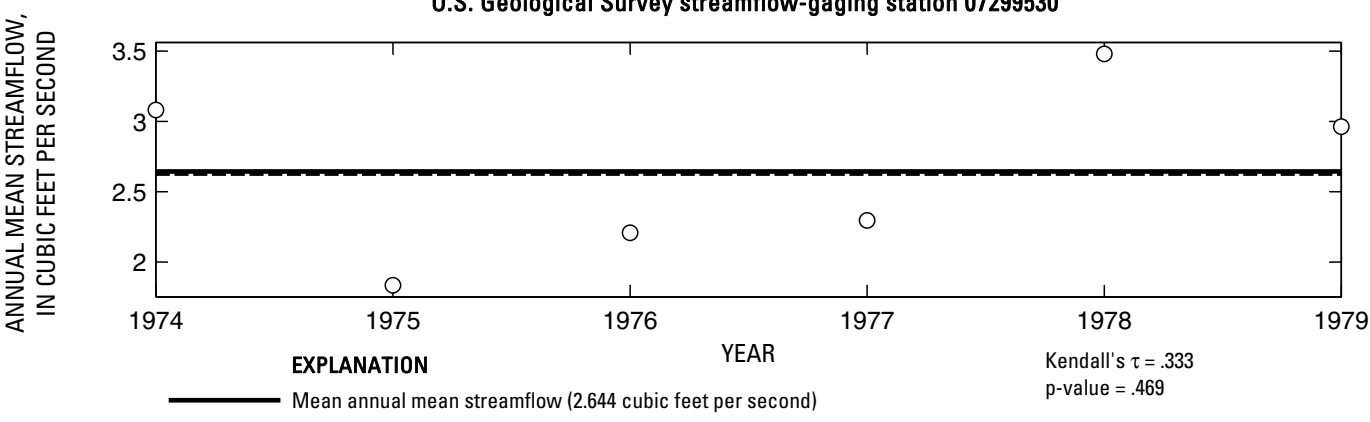

-_-_- Median annual mean streamflow (2.63 cubic feet per second)

O Annual mean streamflow
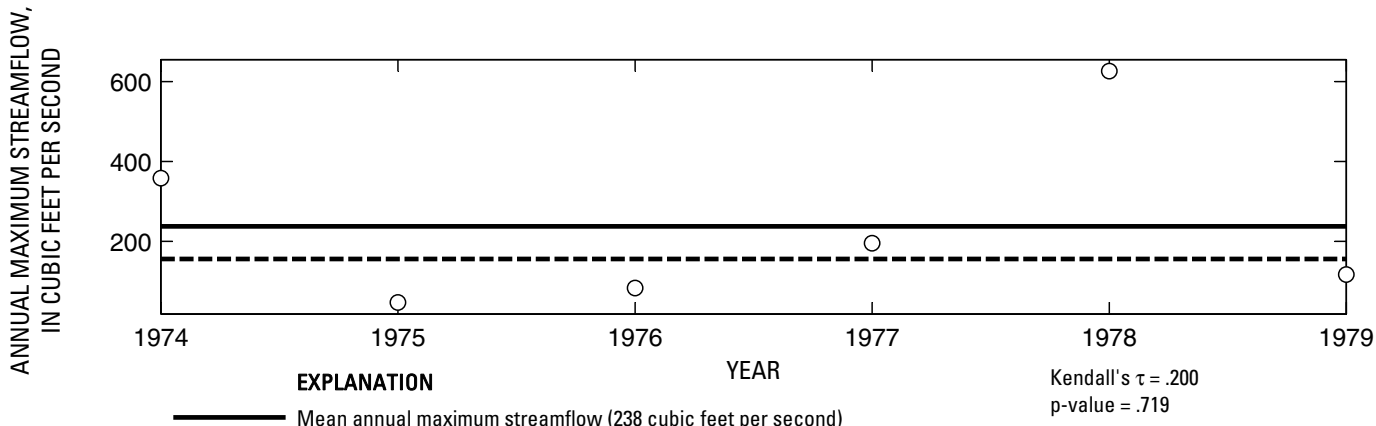

-_-_- Median annual maximum streamflow (156 cubic feet per second)

Annual maximum streamflow
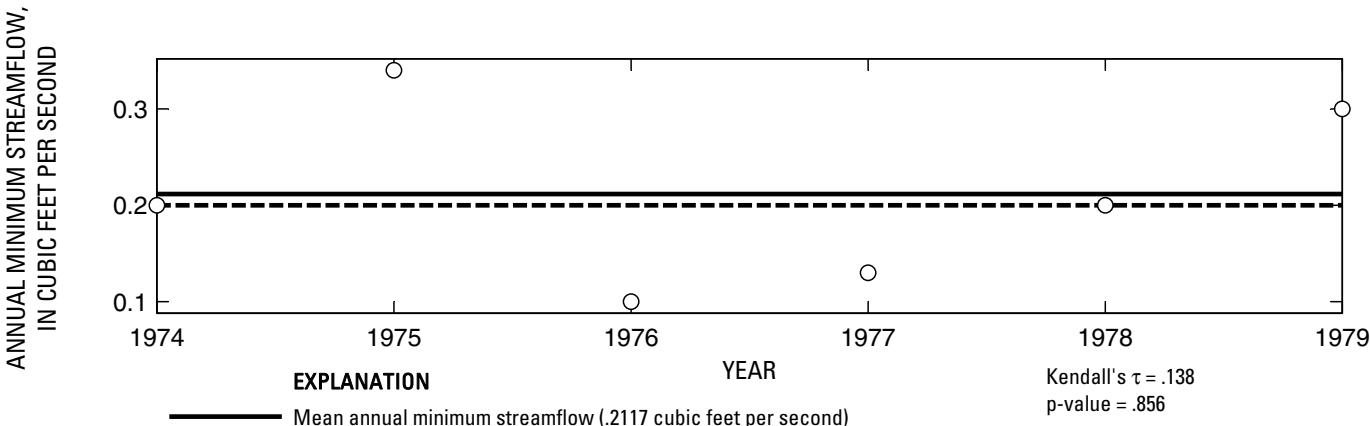

- - - Median annual minimum streamflow (.2 cubic feet per second)

O Annual minimum streamflow

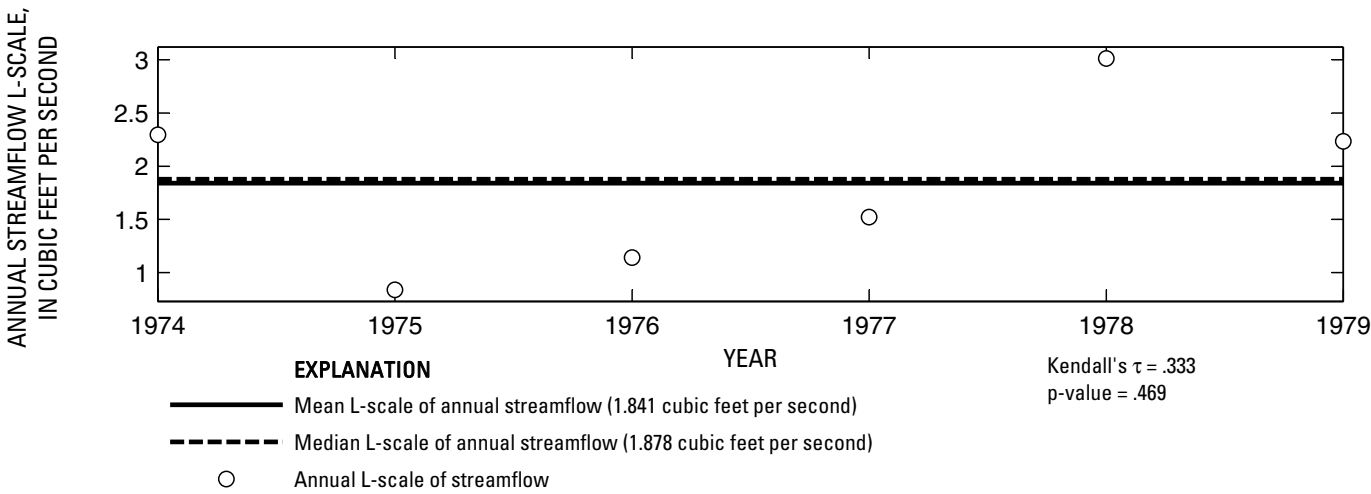

Figure 21. Analysis of annual mean, maximum, minimum, and L-scale statistics of daily mean streamflow for U.S. Geological Survey streamflow-gaging station 07299530 Salt Creek near Estelline, Texas.

Index of Station Numbers 719 


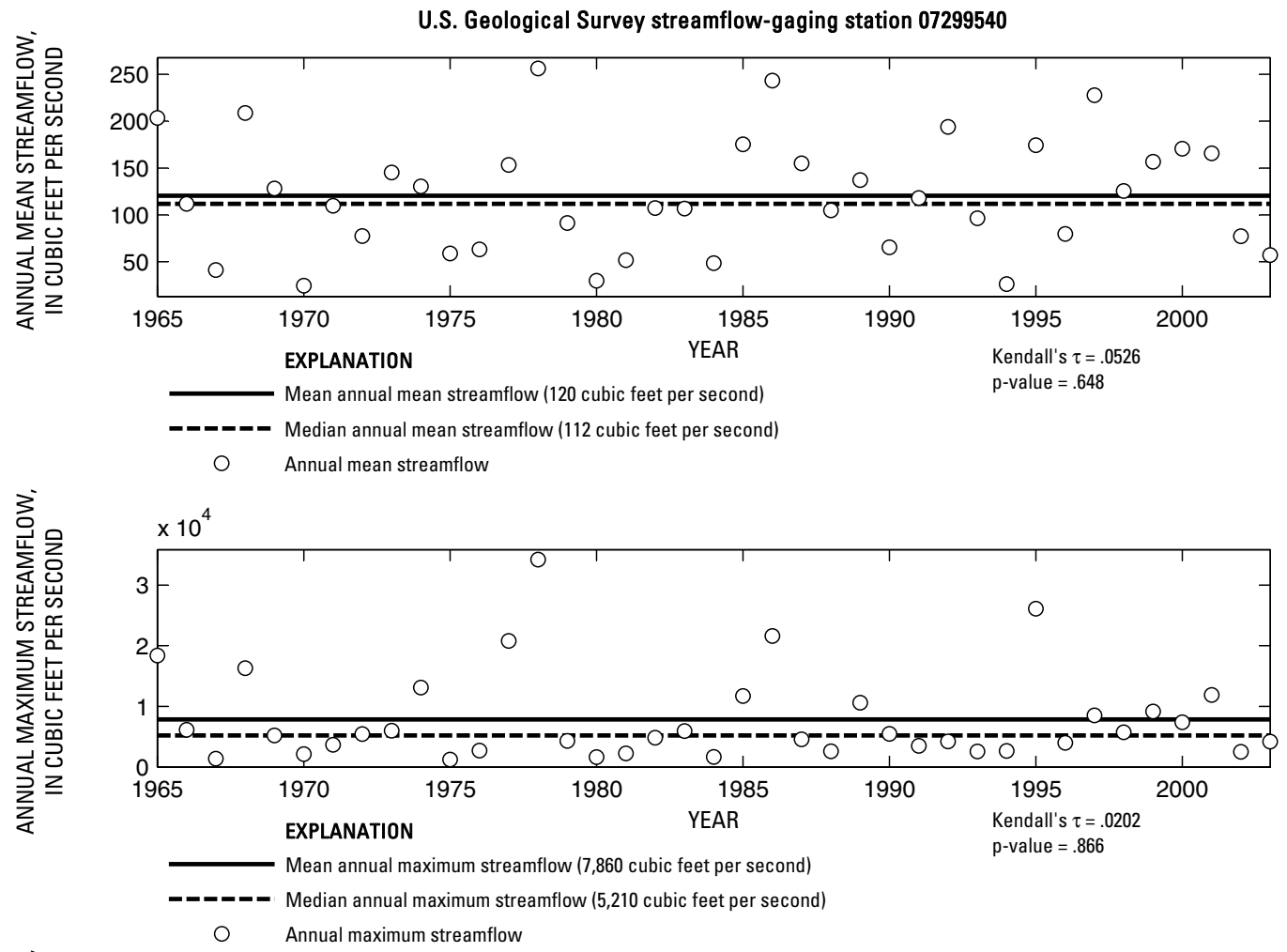

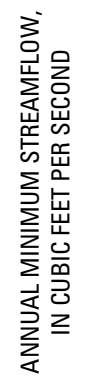

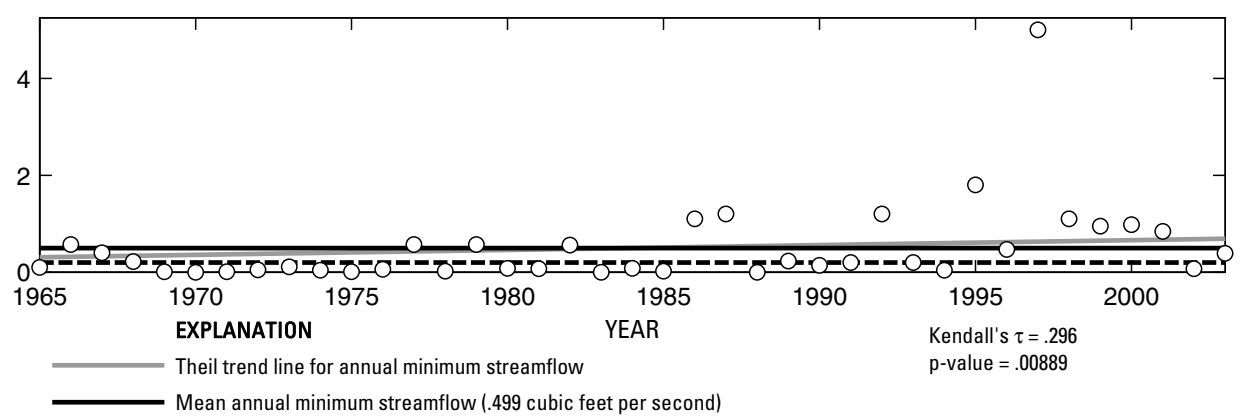

- - - Median annual minimum streamflow (.2 cubic feet per second)

O Annual minimum streamflow

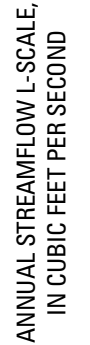

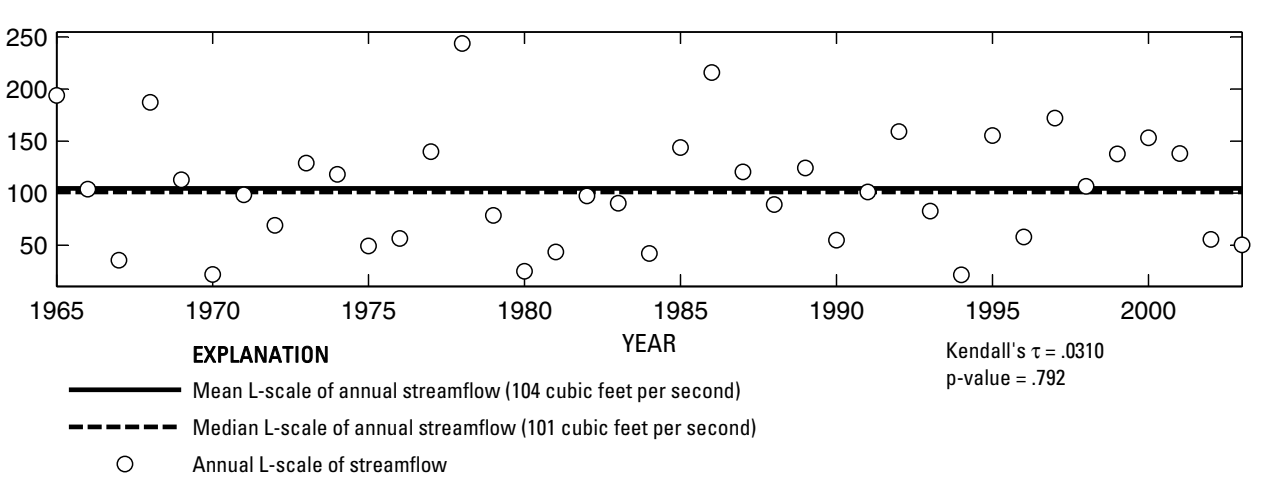

Figure 22. Analysis of annual mean, maximum, minimum, and L-scale statistics of daily mean streamflow for U.S. Geological Survey streamflow-gaging station 07299540 Prairie Dog Town Fork Red River near Childress, Texas.

Index of Station Numbers 719 


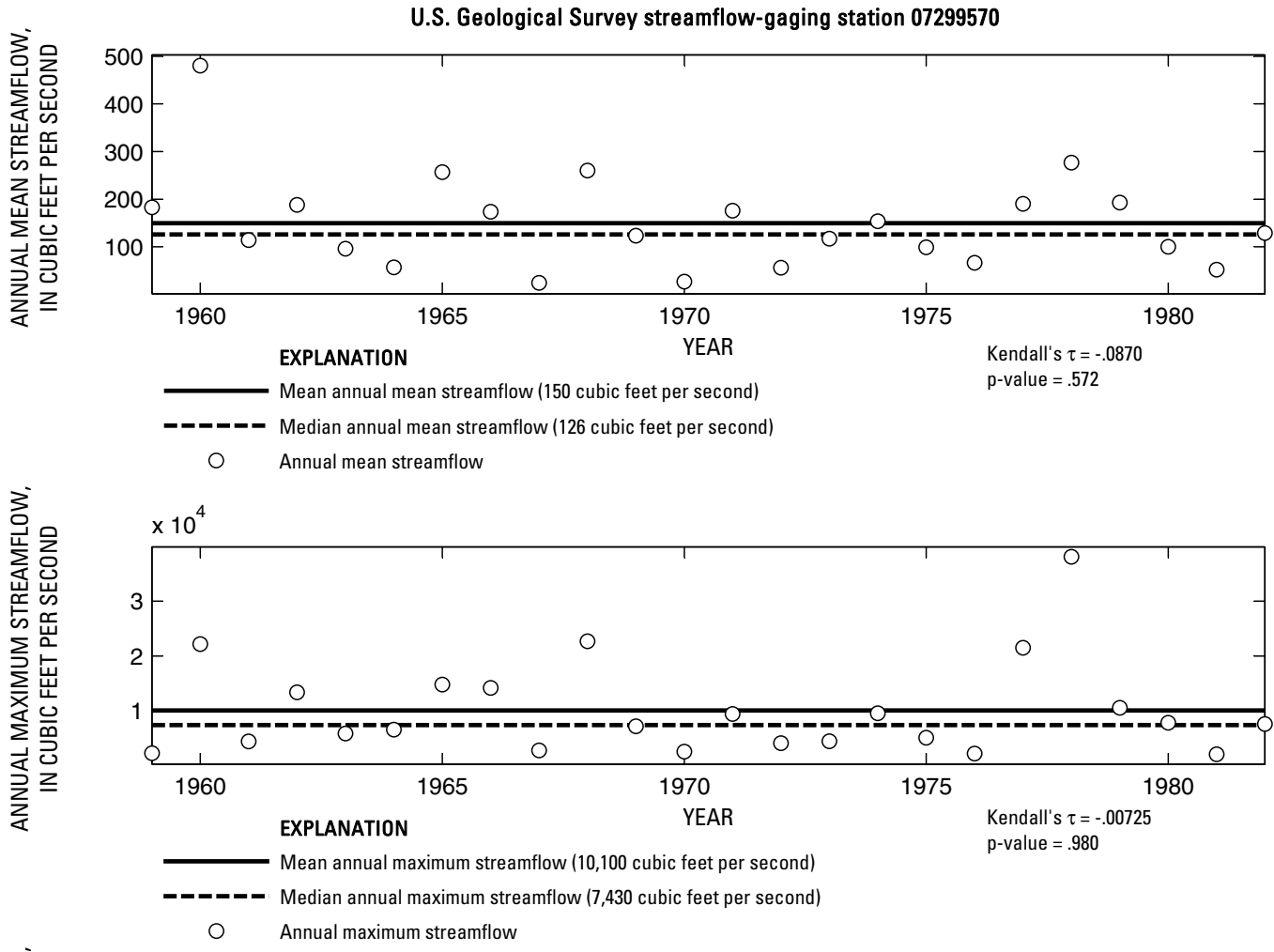

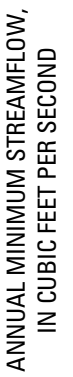

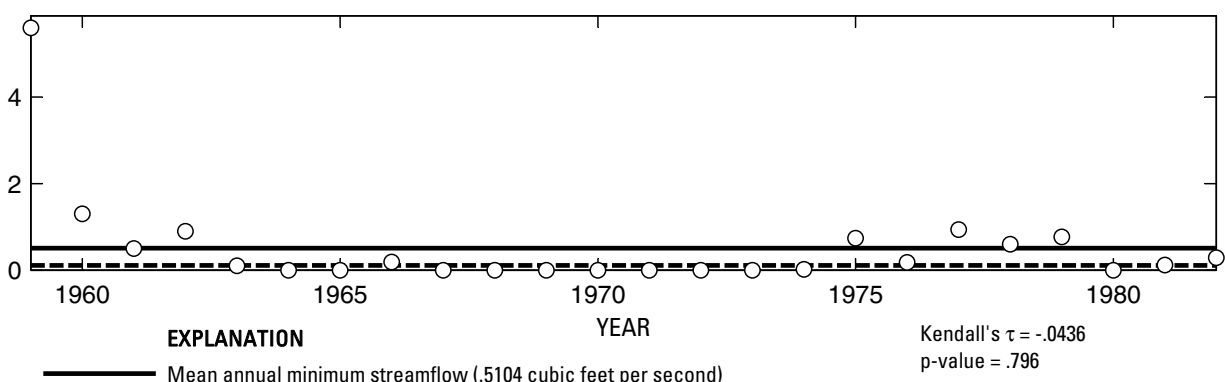

- ב-_- Median annual minimum streamflow (.11 cubic feet per second)

O Annual minimum streamflow

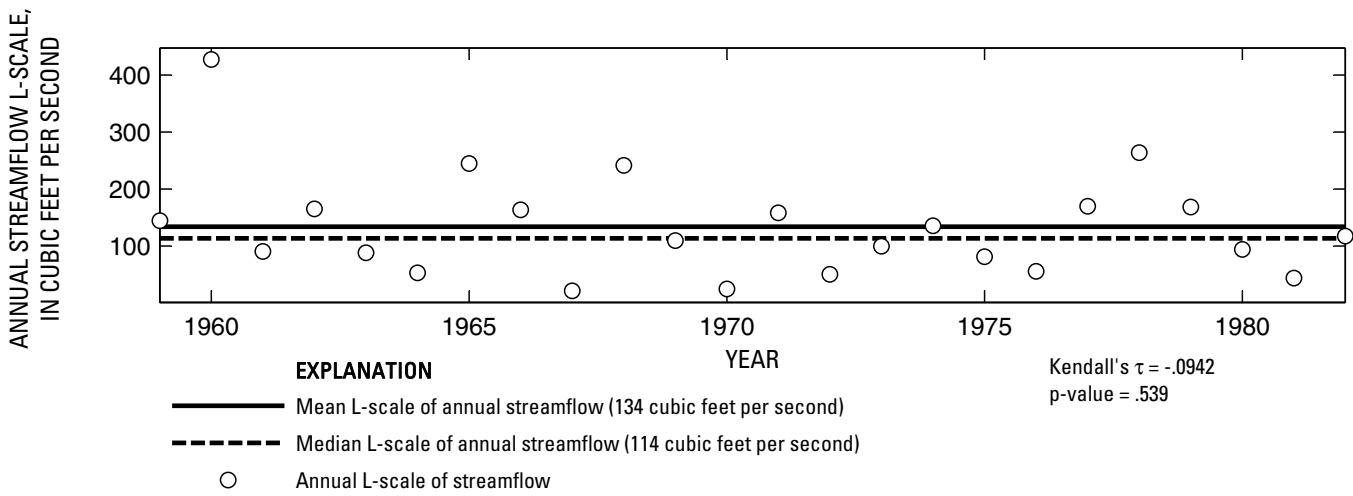

Figure 23. Analysis of annual mean, maximum, minimum, and L-scale statistics of daily mean streamflow for U.S. Geological Survey streamflow-gaging station 07299570 Red River near Quanah, Texas.

Index of Station Numbers 719 


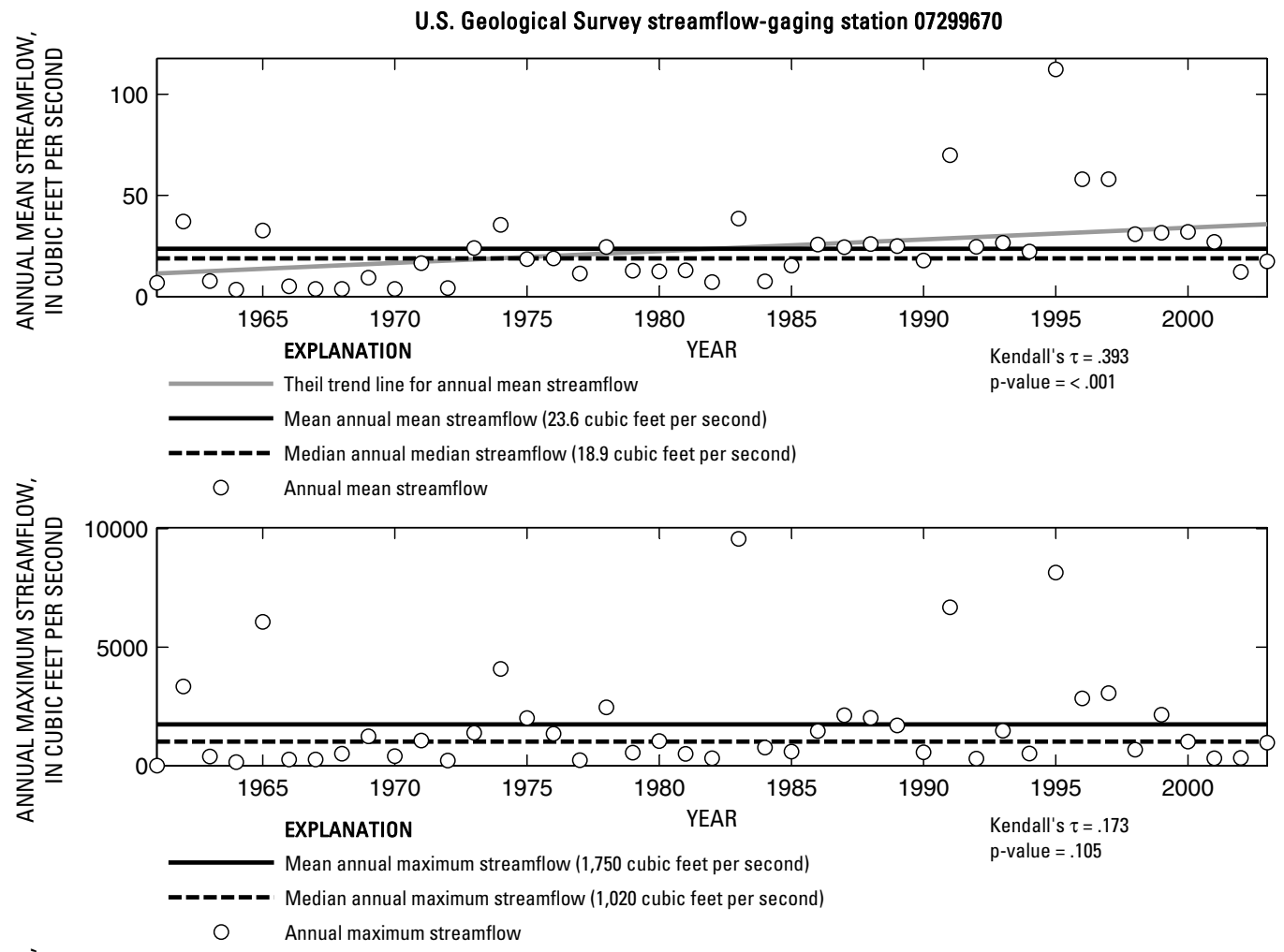

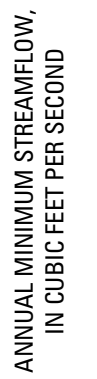

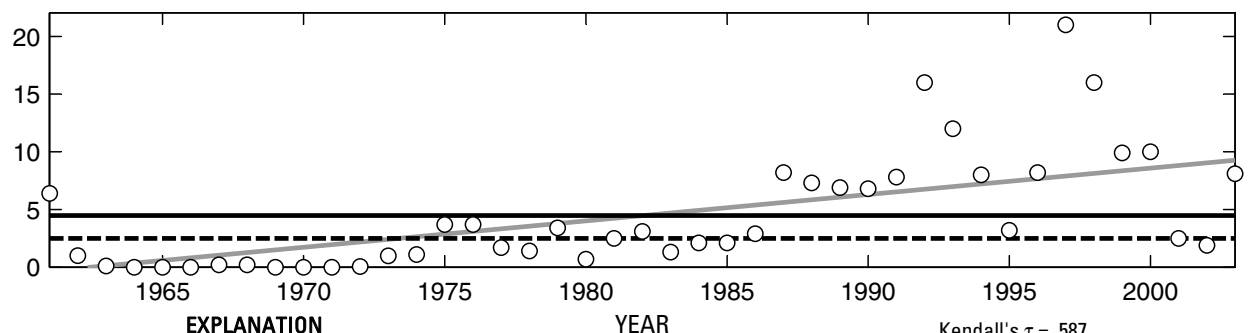

EXPLANATION
Theil trend line for annual minimum streamflow

$\mathrm{p}$-value $=<.001$

Mean annual minimum streamflow (4.476 cubic feet per second)

- - Median annual minimum streamflow (2.5 cubic feet per second)

O Annual minimum streamflow

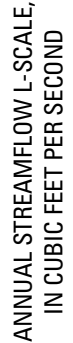

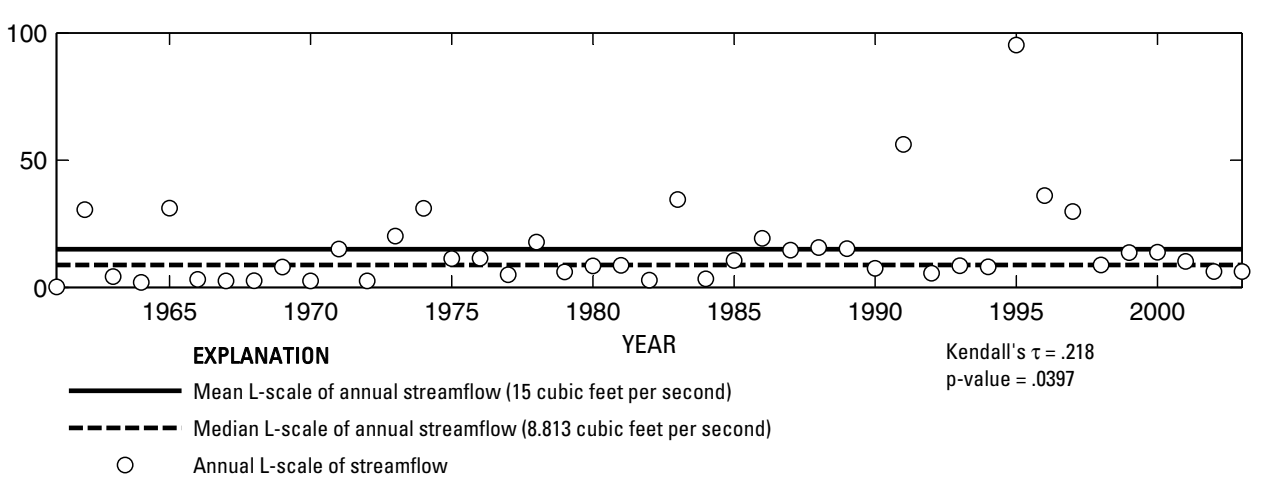

Figure 24. Analysis of annual mean, maximum, minimum, and L-scale statistics of daily mean streamflow for U.S. Geological Survey streamflow-gaging station 07299670 Groesbeck Creek at State Highway 6 near Quanah, Texas.

Index of Station Numbers 719 


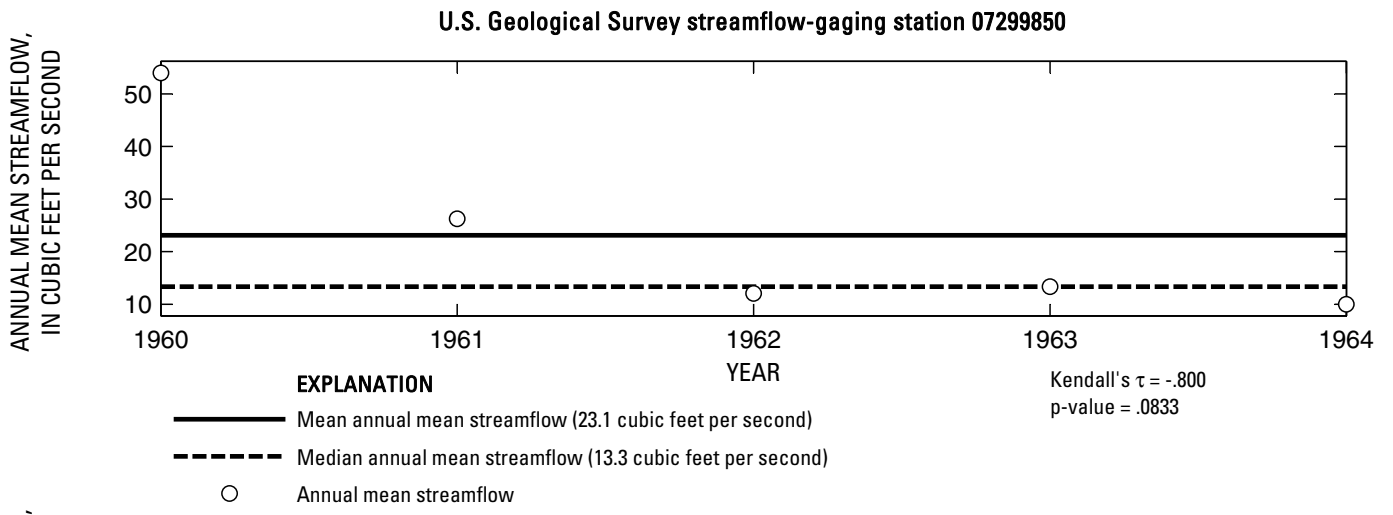

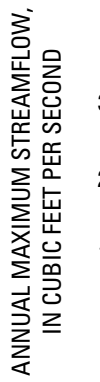

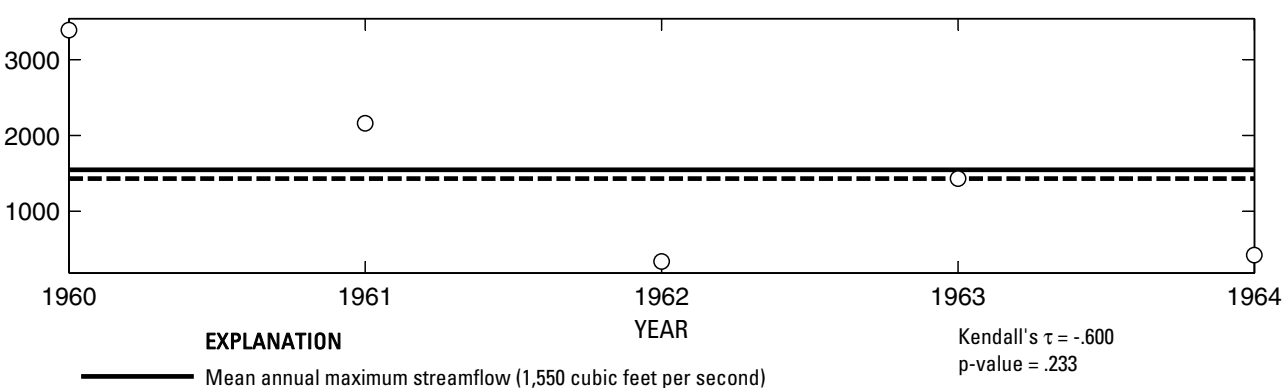

- _- Median annual maximum streamflow (1,430 cubic feet per second)

O Annual maximum streamflow

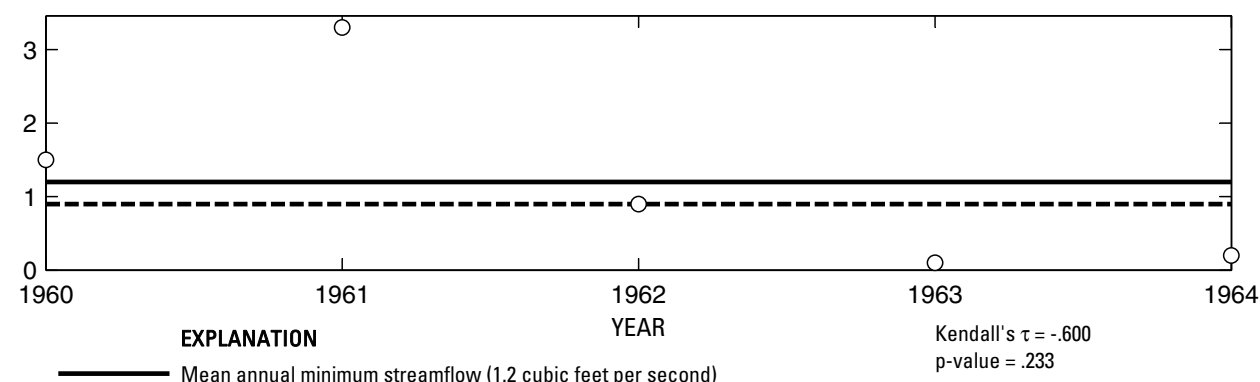

- _- _- Median annual minimum streamflow (.9 cubic feet per second)

O Annual minimum streamflow
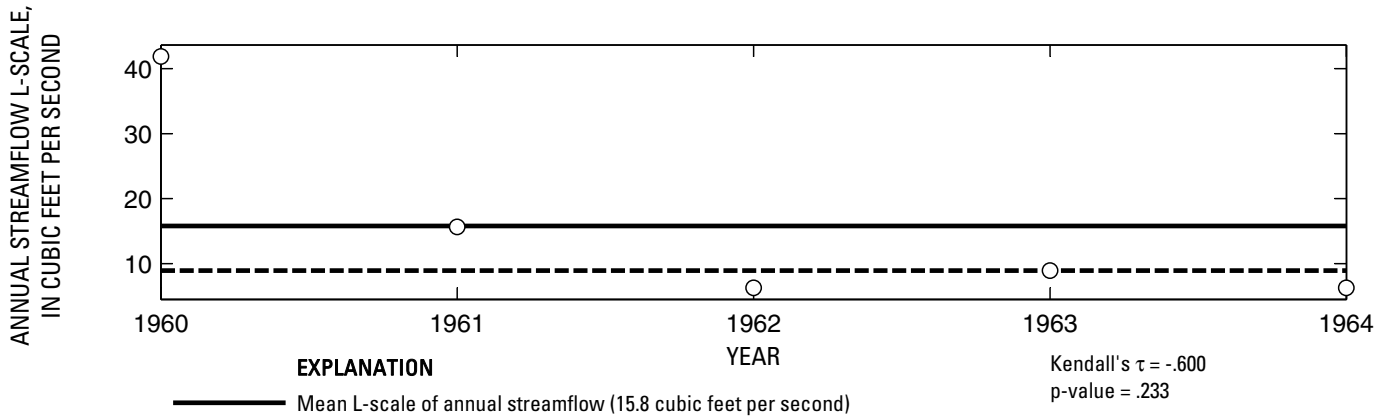

- - - - Median L-scale of annual streamflow (8.95 cubic feet per second)

O Annual L-scale of streamflow

Figure 25. Analysis of annual mean, maximum, minimum, and L-scale statistics of daily mean streamflow for U.S. Geological Survey streamflow-gaging station 07299850 Salt Fork Red River near Clarendon, Texas. 

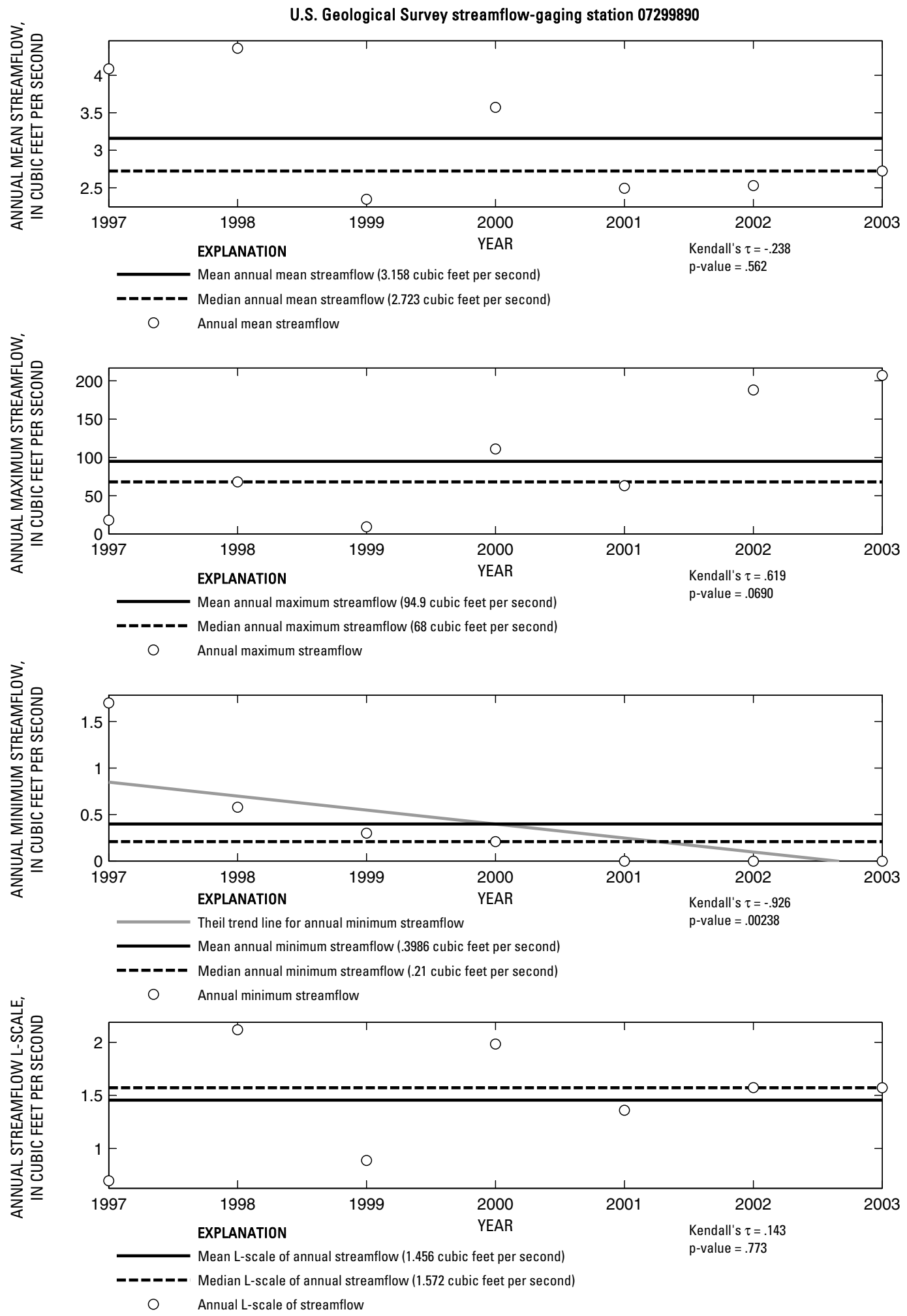

Figure 26. Analysis of annual mean, maximum, minimum, and L-scale statistics of daily mean streamflow for U.S. Geological Survey streamflow-gaging station 07299890 Lelia Lake Creek below Bell Creek near Hedley, Texas.

Index of Station Numbers 719 


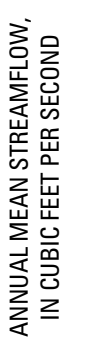

U.S. Geological Survey streamflow-gaging station 07300000

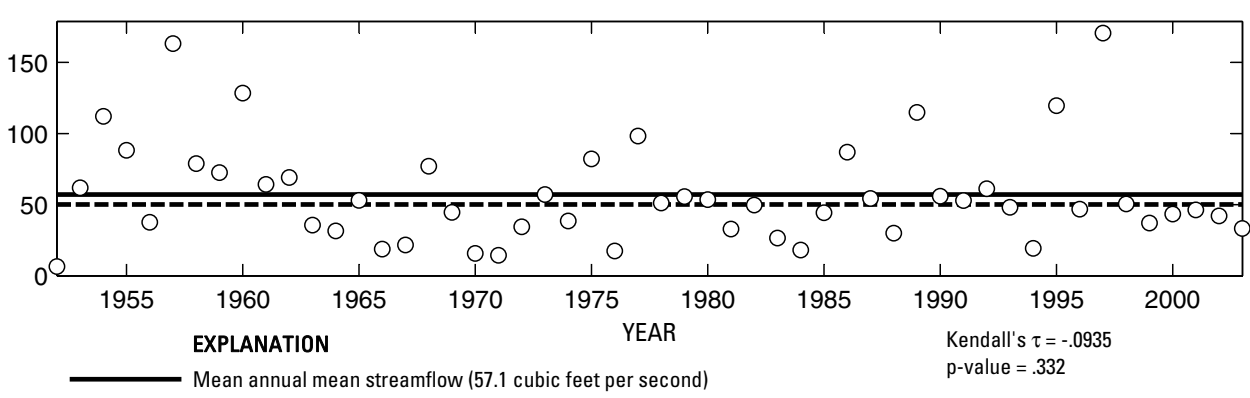

-__-_- Median annual mean streamflow (50.2 cubic feet per second)

O Annual mean streamflow

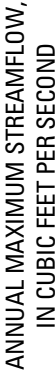

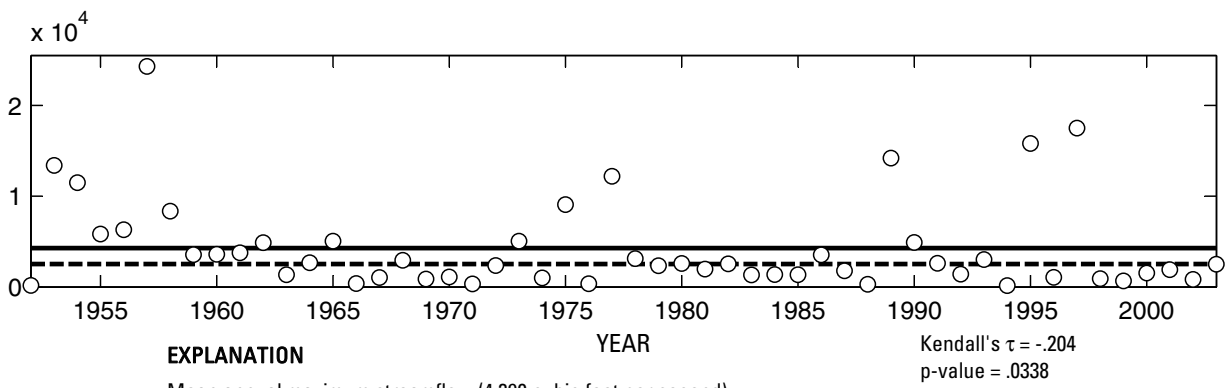

- Mean annual maximum streamflow (4,290 cubic feet per second)

- - Median annual maximum streamflow (2,530 cubic feet per second)

Annual maximum streamflow

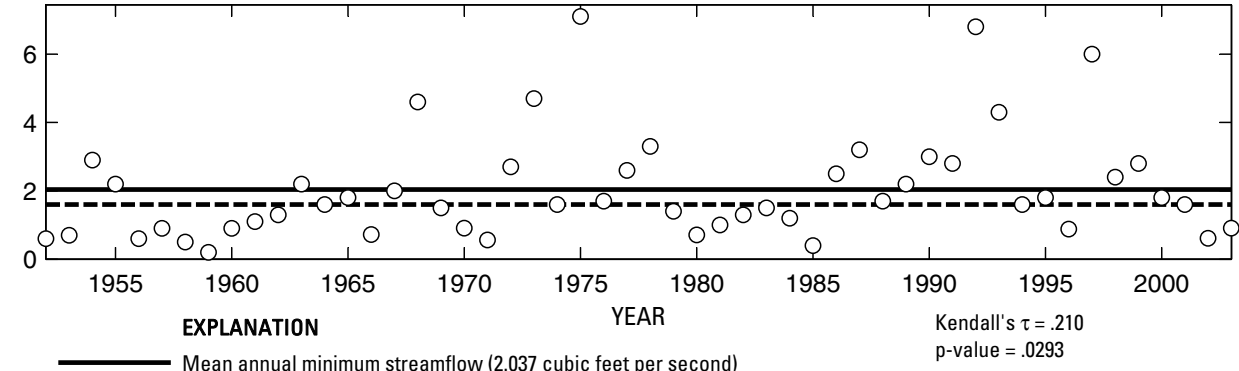

- Median annual minimum streamflow (1.6 cubic feet per second)

O Annual minimum streamflow

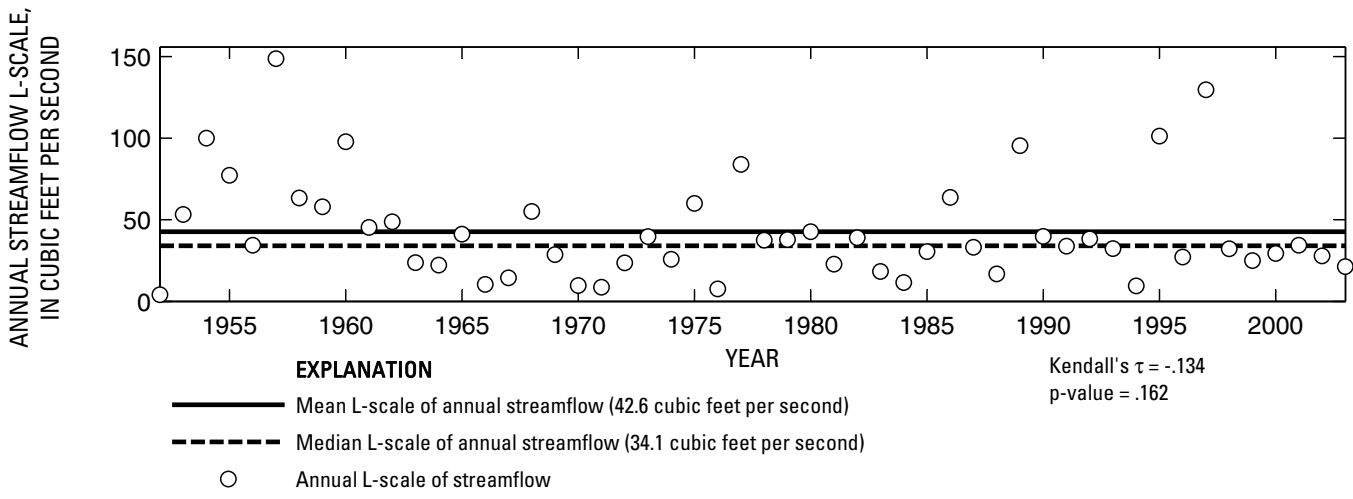

Figure 27. Analysis of annual mean, maximum, minimum, and L-scale statistics of daily mean streamflow for U.S. Geological Survey streamflow-gaging station 07300000 Salt Fork Red River near Wellington, Texas.

Index of Station Numbers 719 

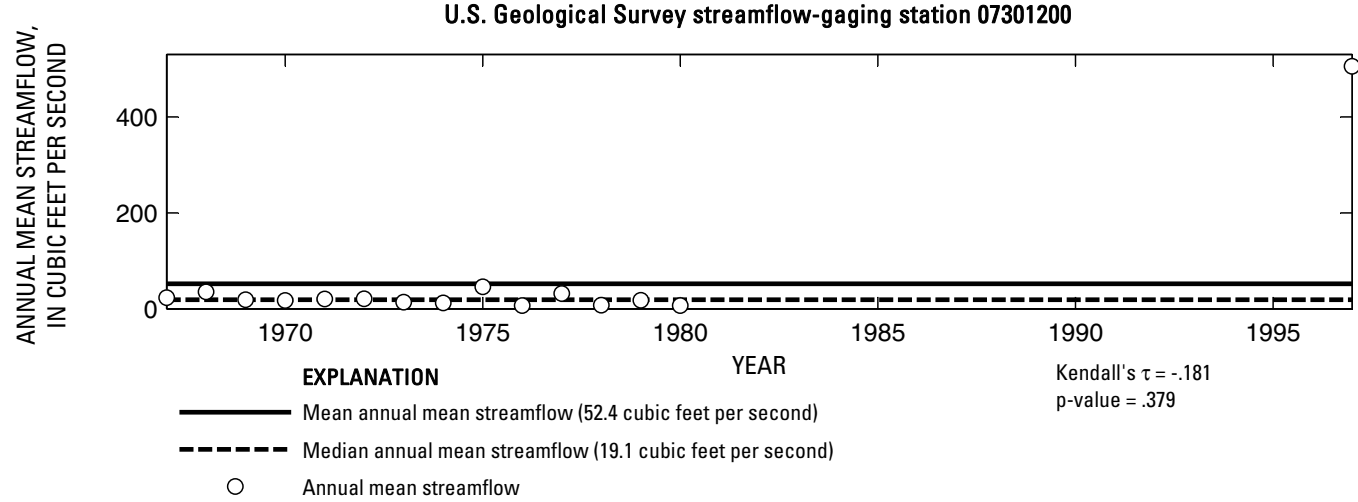

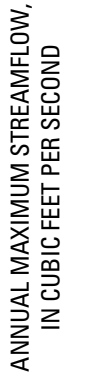

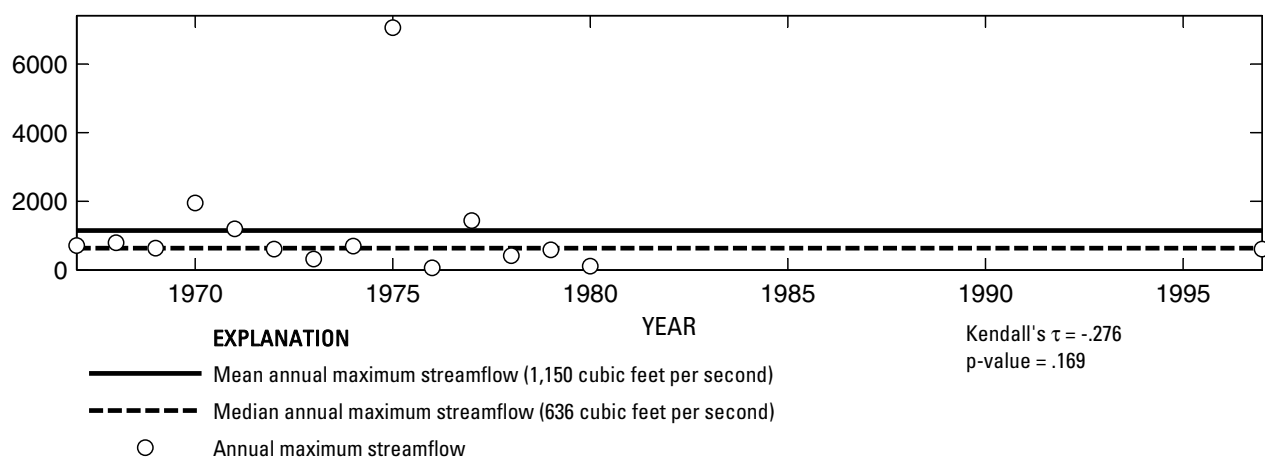

定

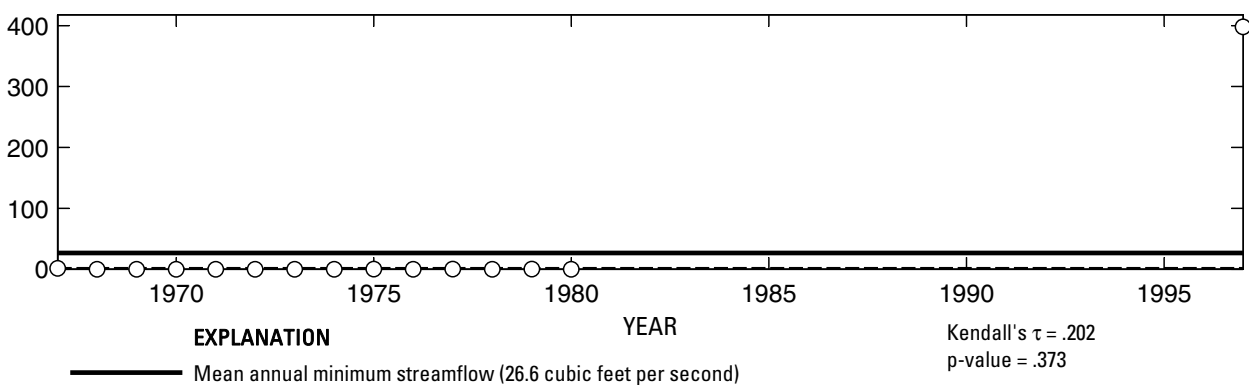

- Median annual minimum streamflow (0 cubic feet per second)

O Annual minimum streamflow
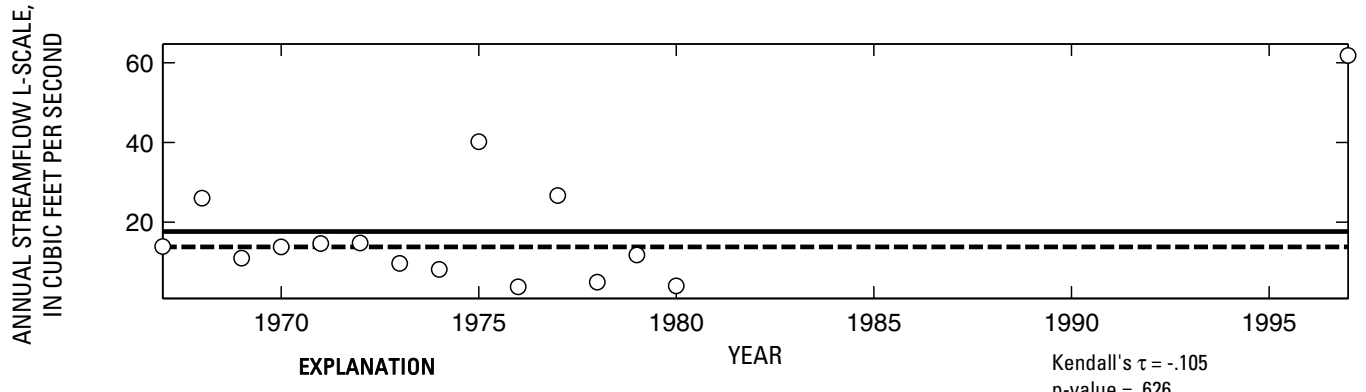

Mean L-scale of annual streamflow (17.7 cubic feet per second)

$\mathrm{p}$-value $=.626$

- - - Median L-scale of annual streamflow (13.8 cubic feet per second)

Annual L-scale of streamflow

Figure 28. Analysis of annual mean, maximum, minimum, and L-scale statistics of daily mean streamflow for U.S. Geological Survey streamflow-gaging station 07301200 McClellan Creek near McLean, Texas.

Index of Station Numbers 719 


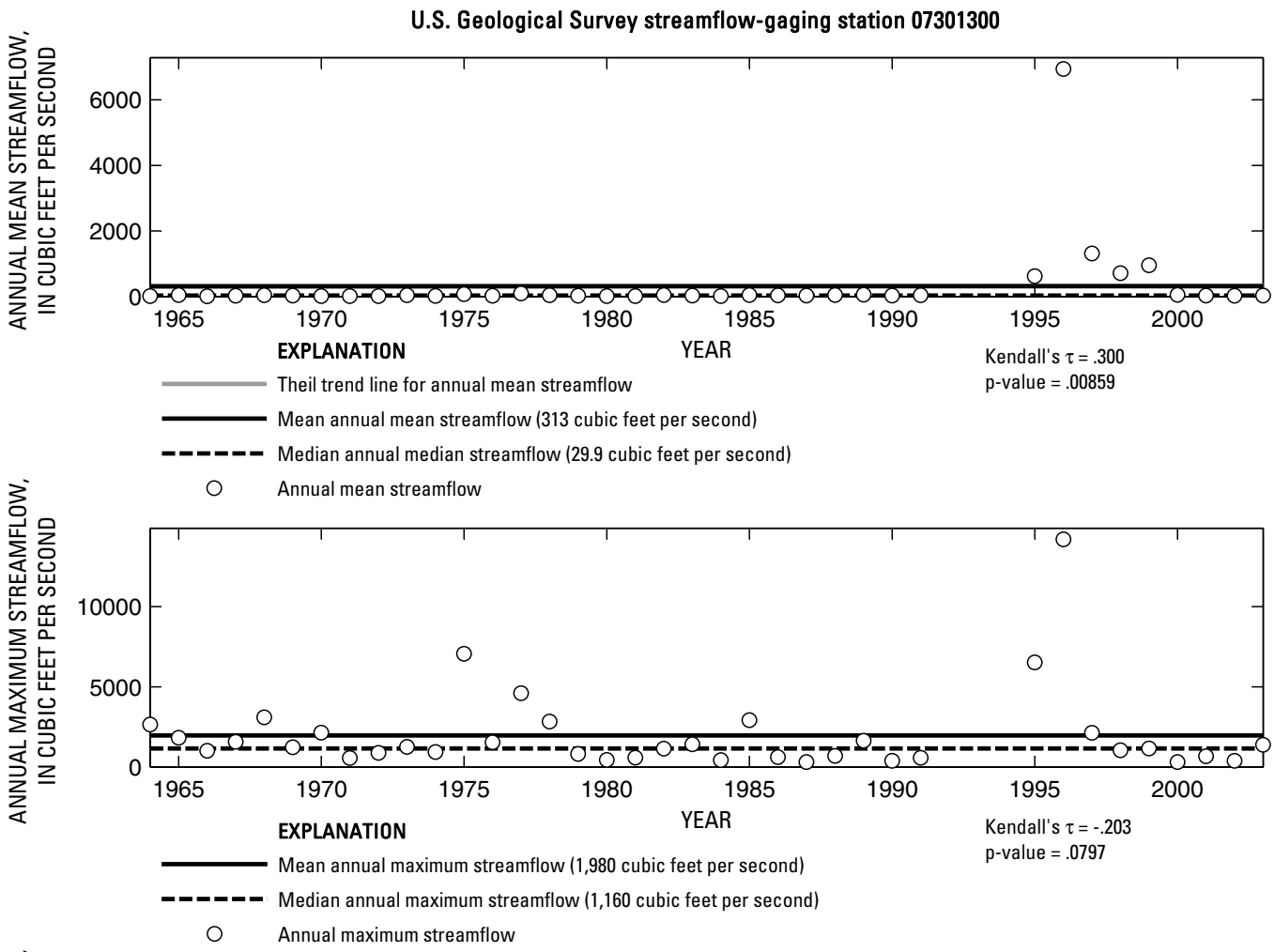

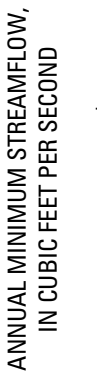

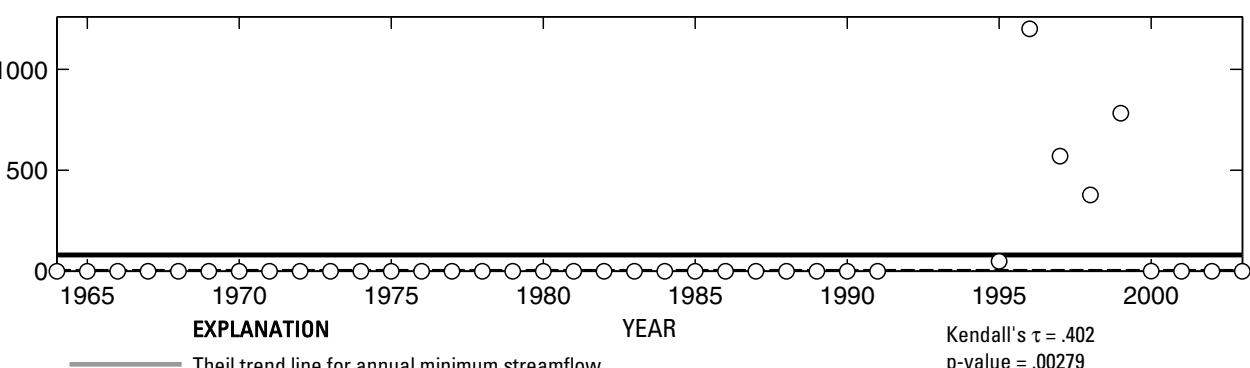

Theil trend line for annual minimum streamflow

- - - Median annual minimum streamflow (0 cubic feet per second)

O Annual minimum streamflow

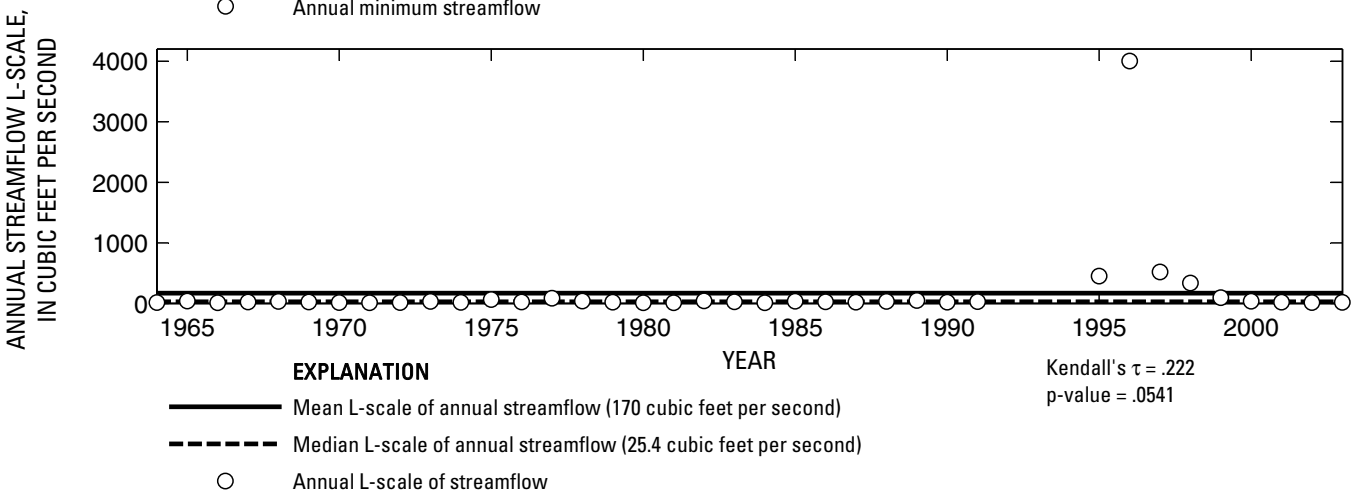

Figure 29. Analysis of annual mean, maximum, minimum, and L-scale statistics of daily mean streamflow for U.S. Geological Survey streamflow-gaging station 07301300 North Fork Red River near Shamrock, Texas. 


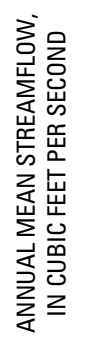

U.S. Geological Survey streamflow-gaging station 07301410

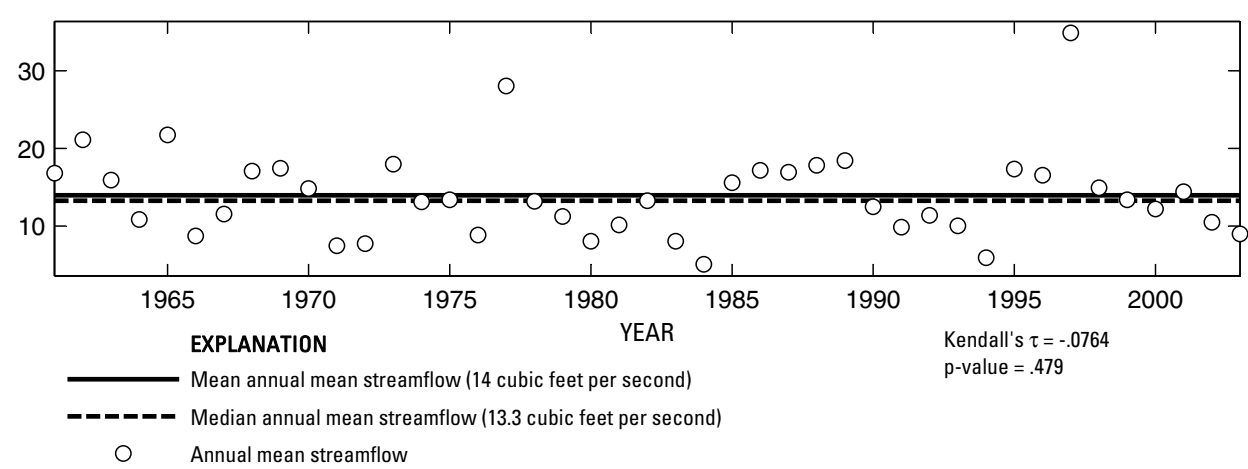

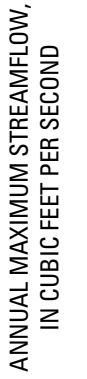

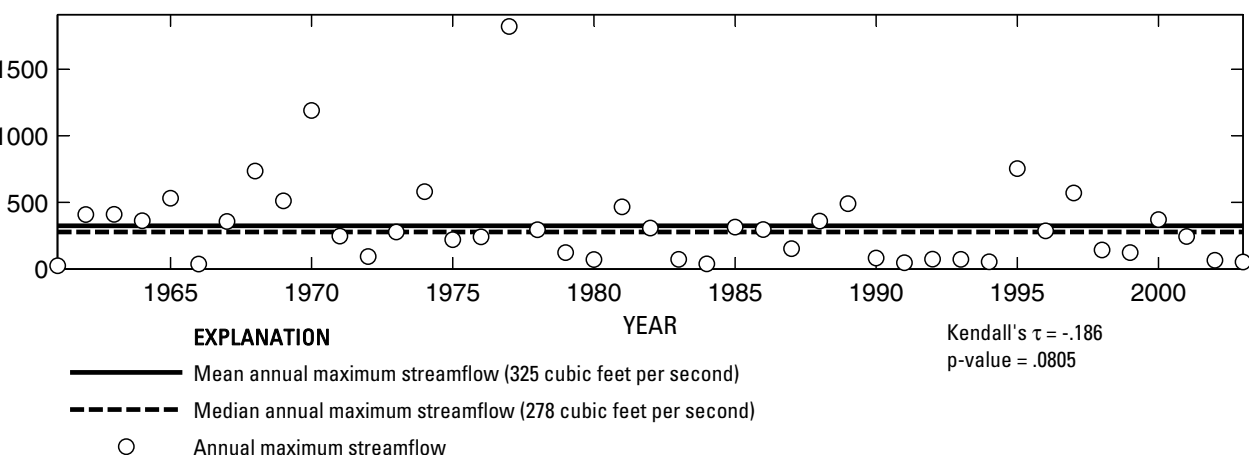

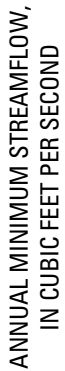

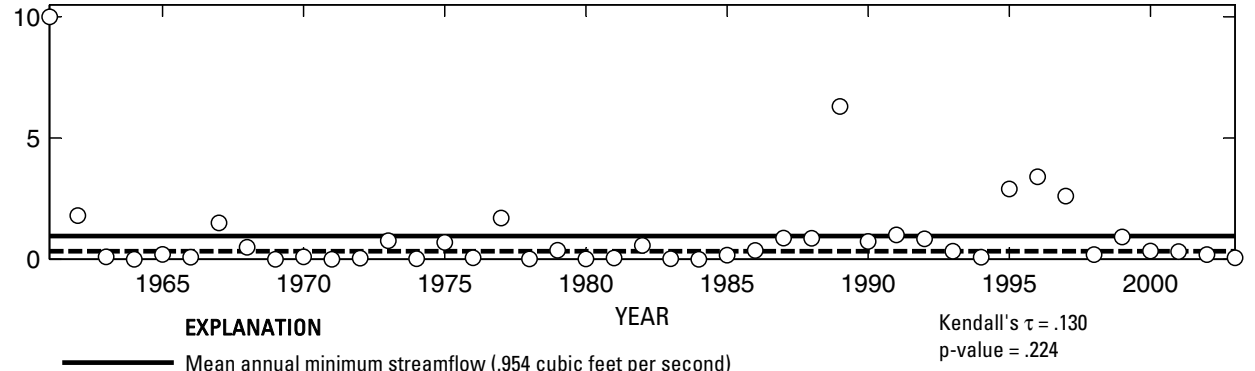

- ב-ב Median annual minimum streamflow (.33 cubic feet per second)

O Annual minimum streamflow

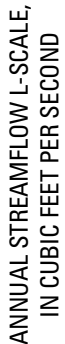

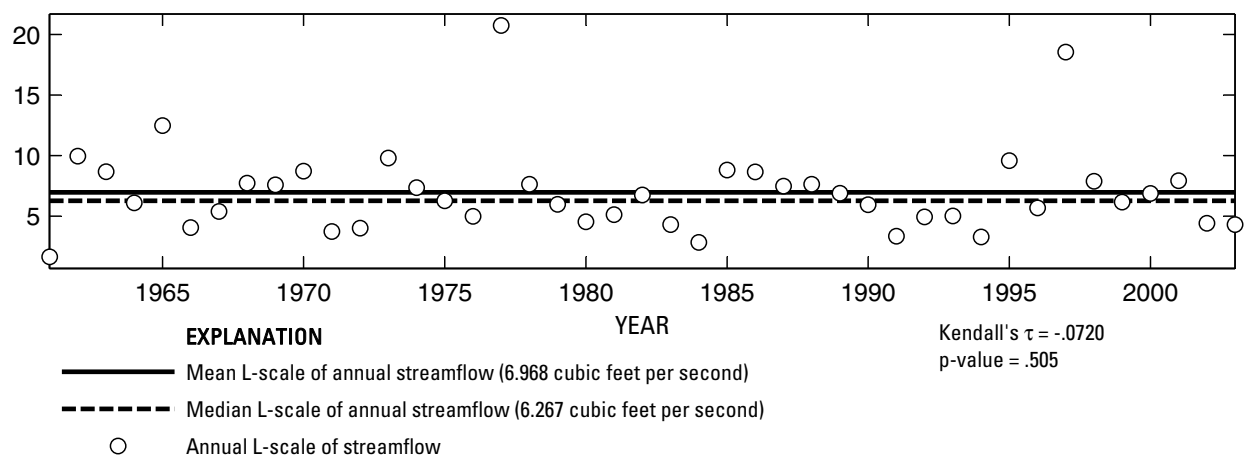

Figure 30. Analysis of annual mean, maximum, minimum, and L-scale statistics of daily mean streamflow for U.S. Geological Survey streamflow-gaging station 07301410 Sweetwater Creek near Kelton, Texas.

Index of Station Numbers 719 


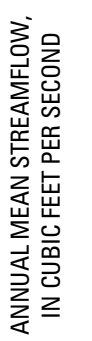

U.S. Geological Survey streamflow-gaging station 07307500

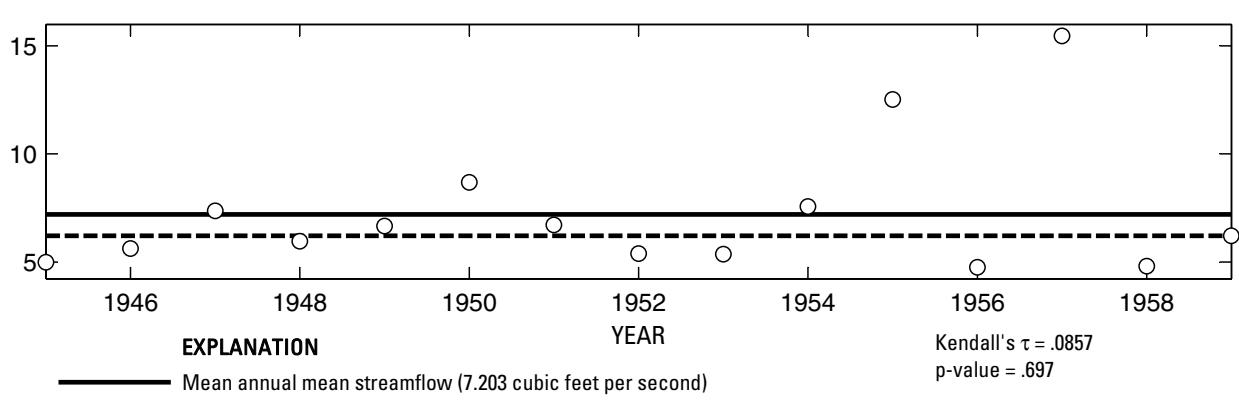

-_-_-_ Median annual mean streamflow (6.213 cubic feet per second)

O Annual mean streamflow

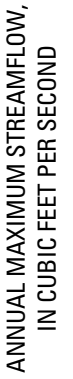

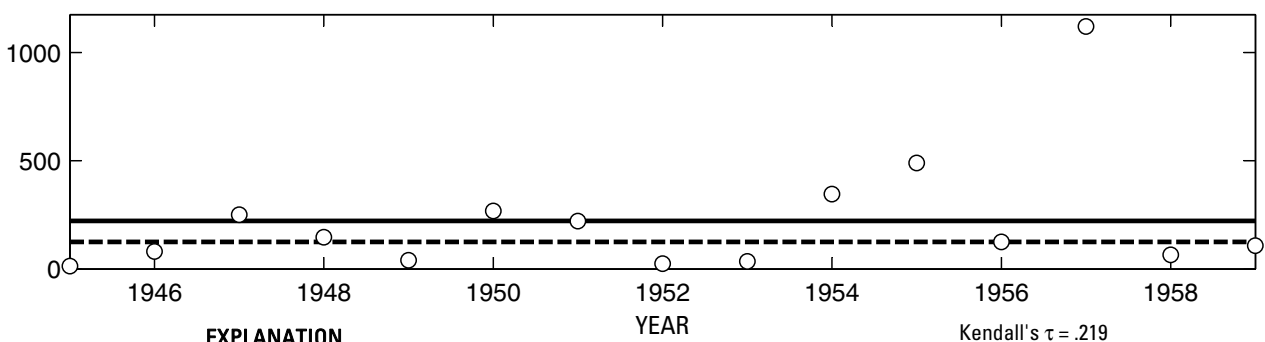

EXPLANATION

Median annual maximum streamflow (125 cubic feet per secon

O Annual maximum streamflow

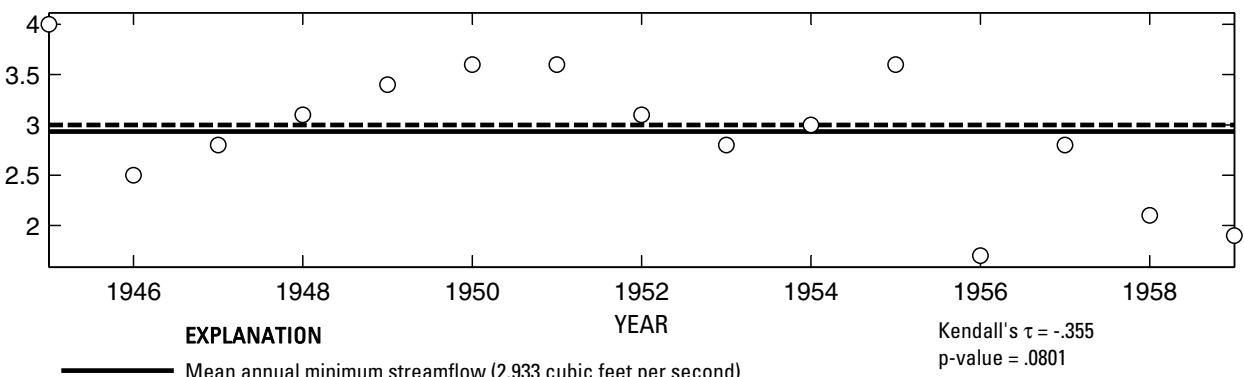

- Median annual minimum streamflow (3 cubic feet per second)

O Annual minimum streamflow
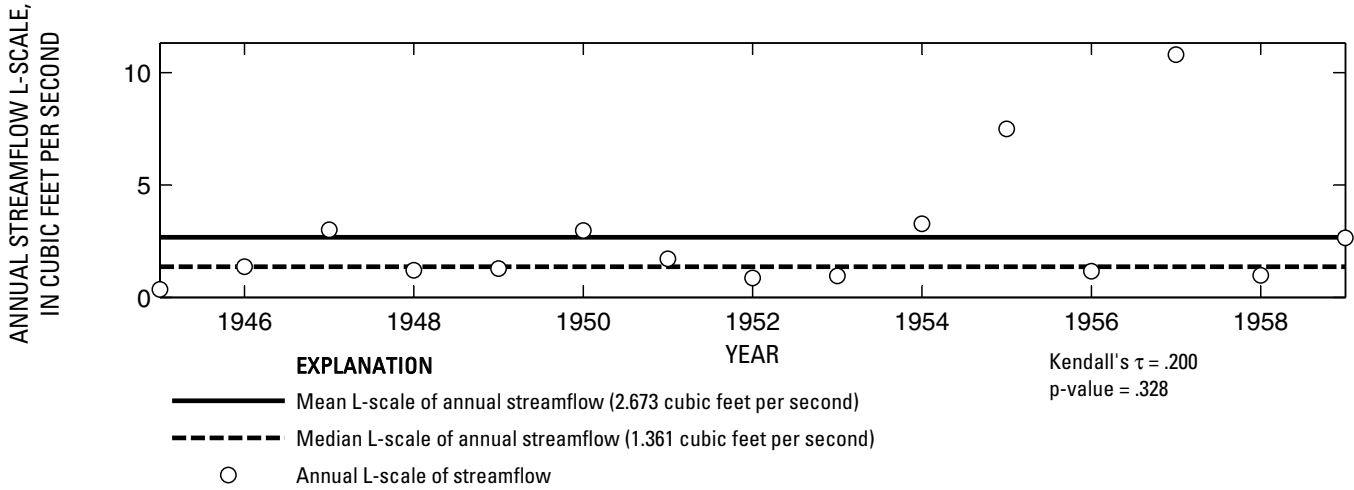

Figure 31. Analysis of annual mean, maximum, minimum, and L-scale statistics of daily mean streamflow for U.S. Geological Survey streamflow-gaging station 07307500 Quitaque Creek near Quitaque, Texas. 

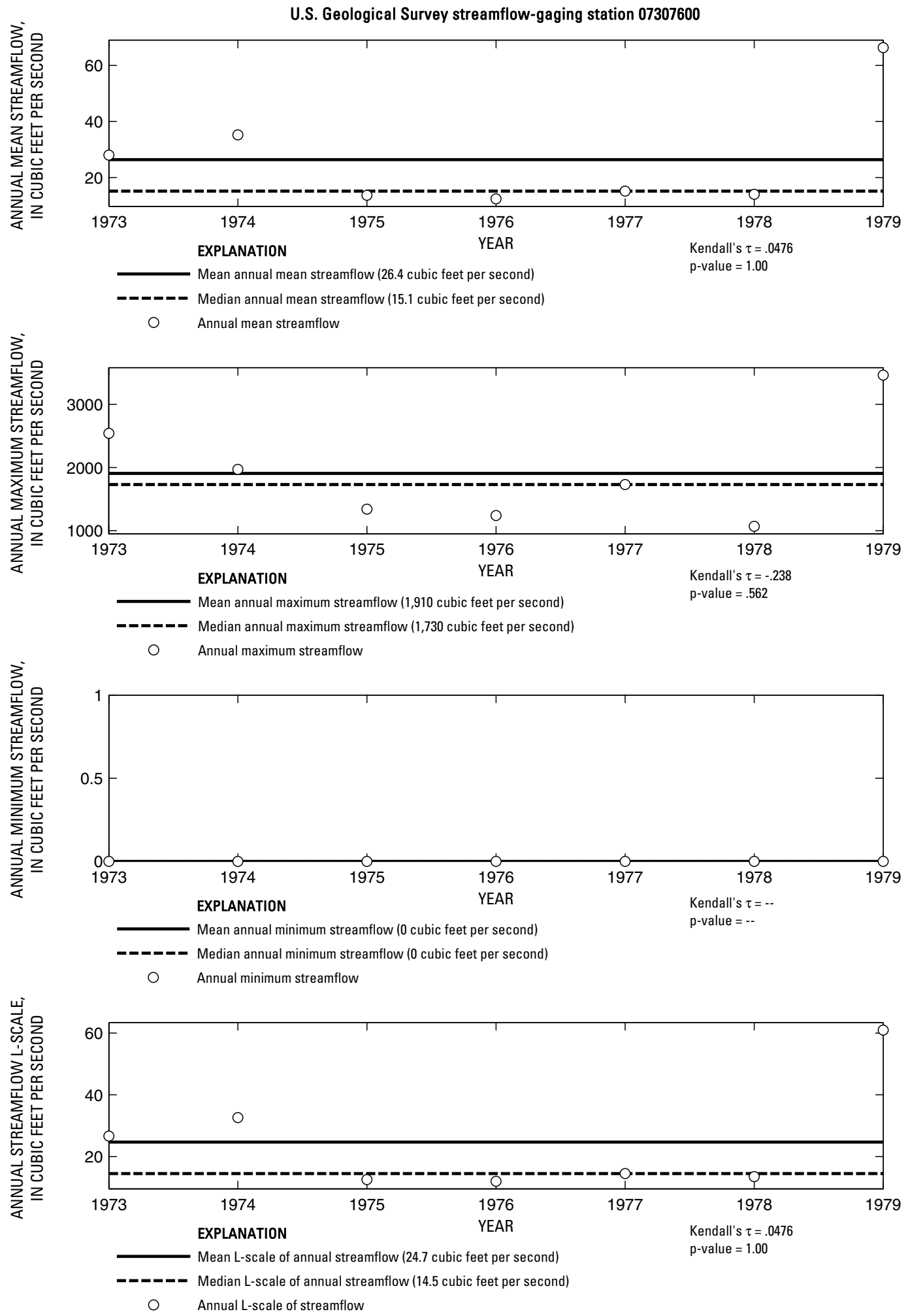

Figure 32. Analysis of annual mean, maximum, minimum, and L-scale statistics of daily mean streamflow for U.S. Geological Survey streamflow-gaging station 07307600 North Pease River near Childress, Texas.

Index of Station Numbers 719 


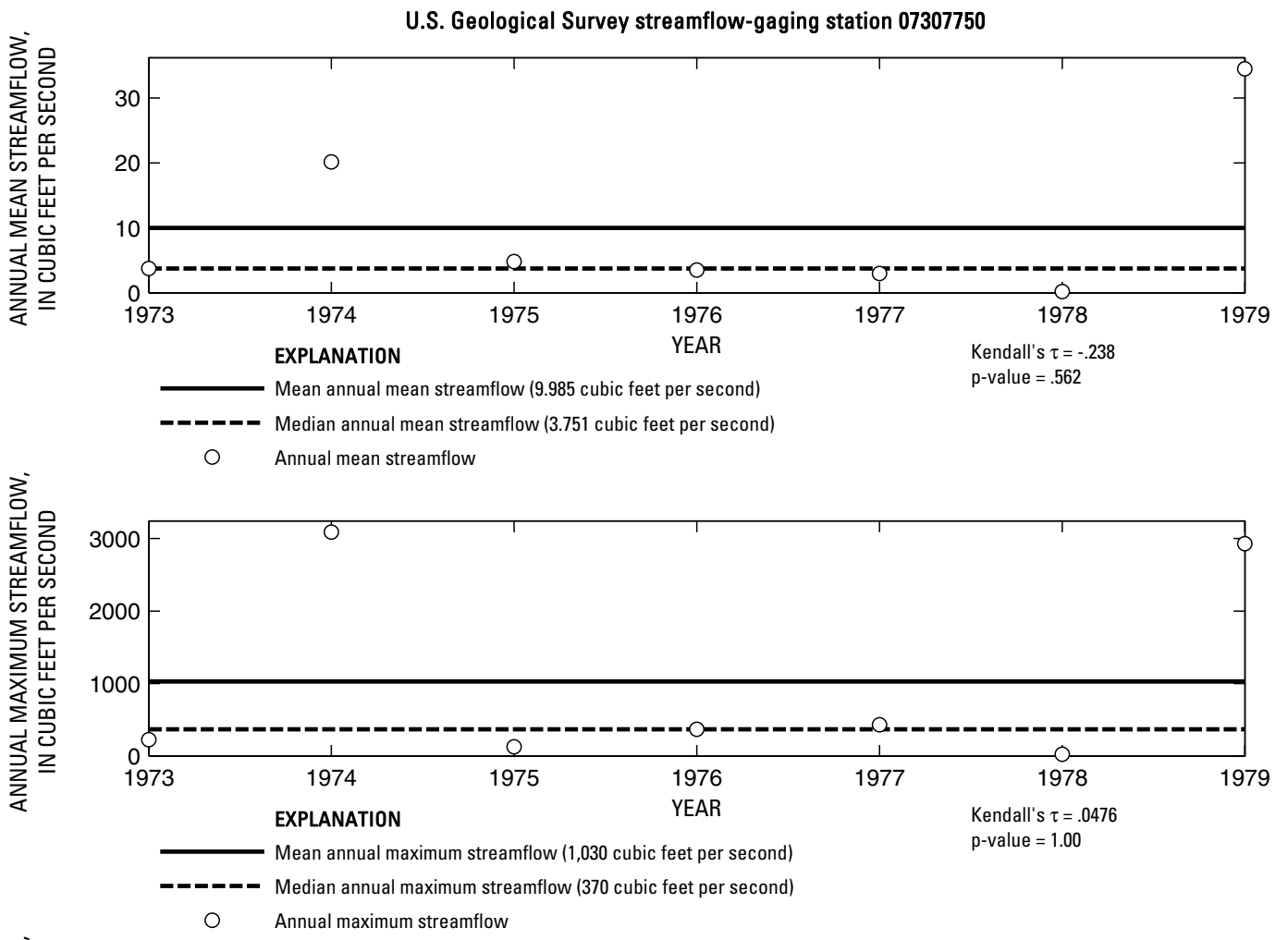

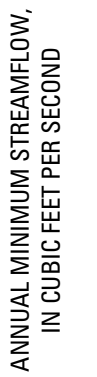

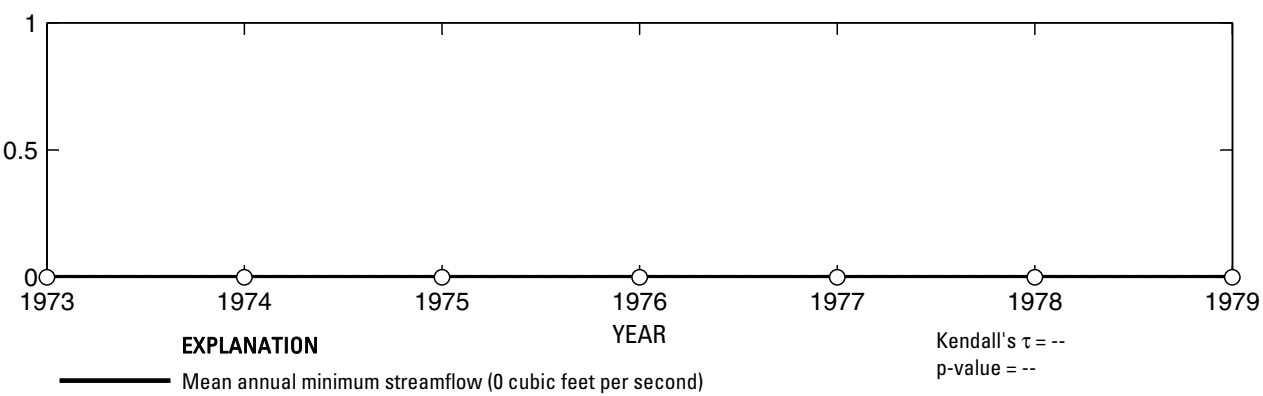

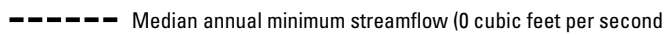

○ Annual minimum streamflow

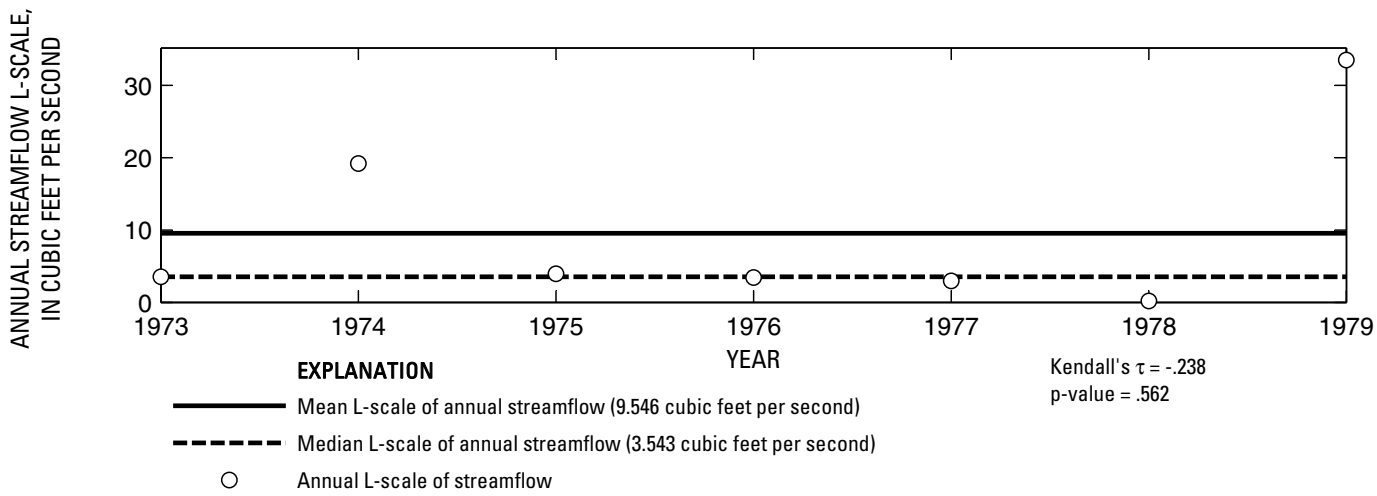

Figure 33. Analysis of annual mean, maximum, minimum, and L-scale statistics of daily mean streamflow for U.S. Geological Survey streamflow-gaging station 07307750 Middle Pease River at U. S. Highways 62 and 83 near Paducah, Texas. 

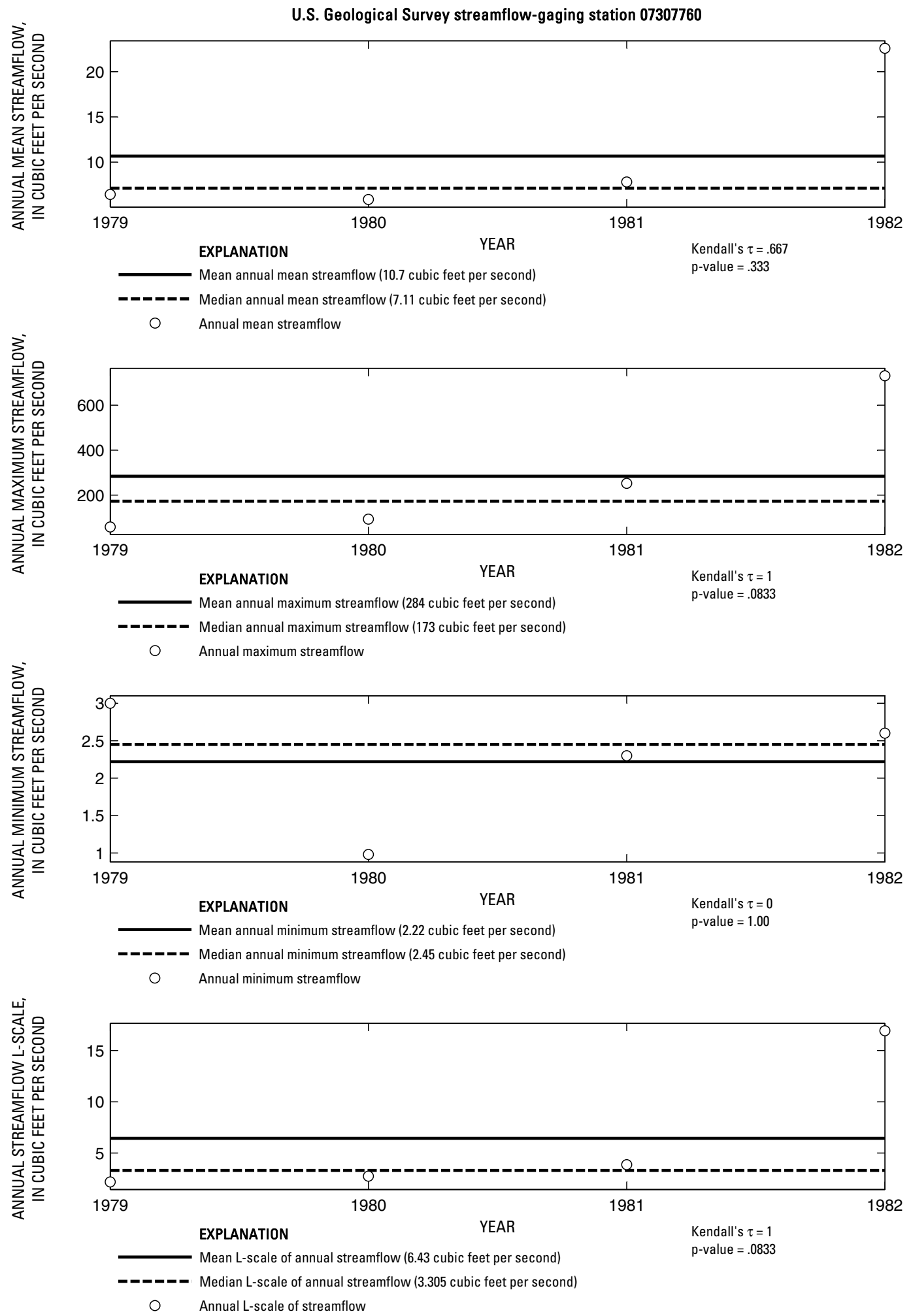

Figure 34. Analysis of annual mean, maximum, minimum, and L-scale statistics of daily mean streamflow for U.S. Geological Survey streamflow-gaging station 07307760 Middle Pease River near Paducah, Texas.

Index of Station Numbers 719 

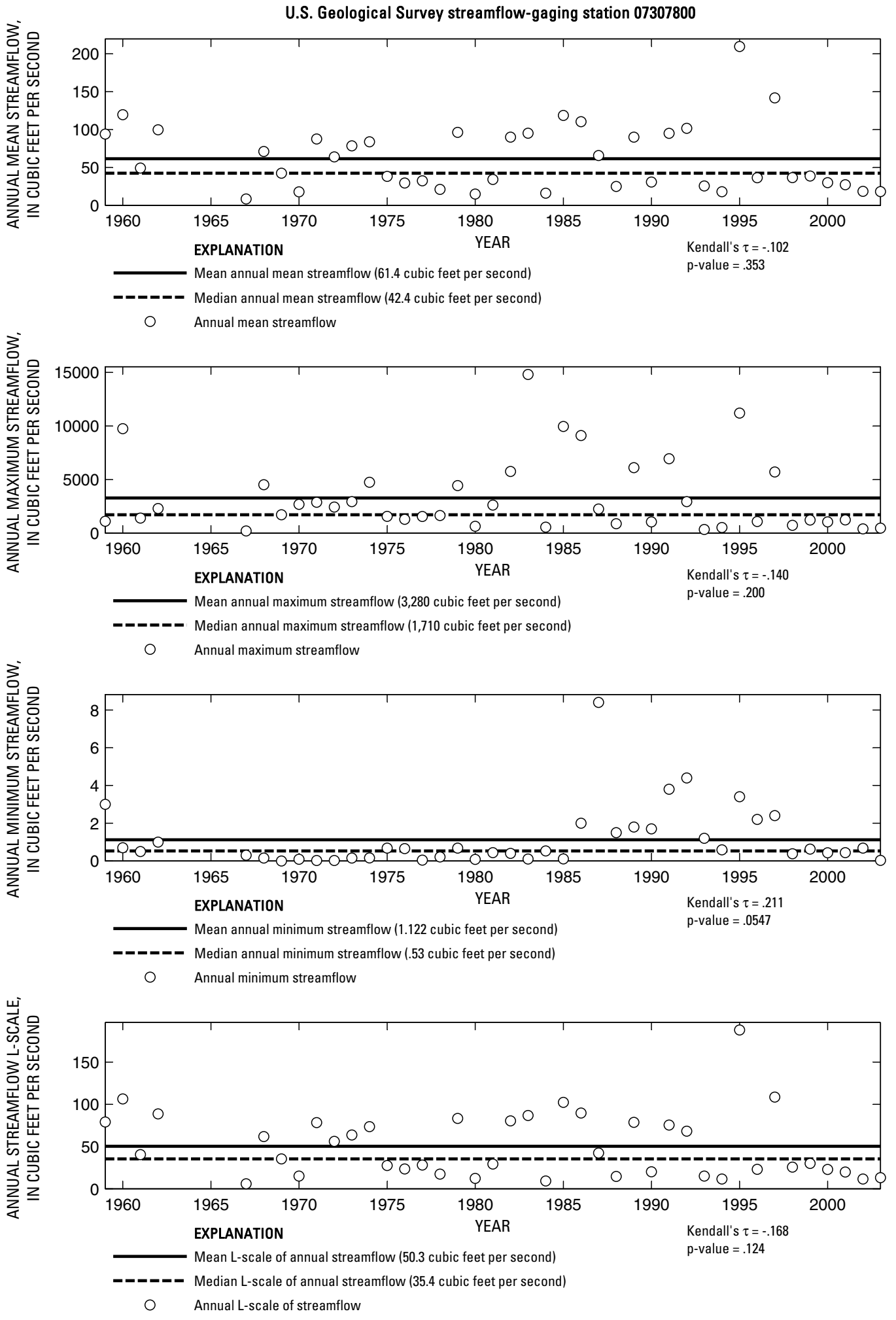

Figure 35. Analysis of annual mean, maximum, minimum, and L-scale statistics of daily mean streamflow for U.S. Geological Survey streamflow-gaging station 07307800 Pease River near Childress, Texas. 


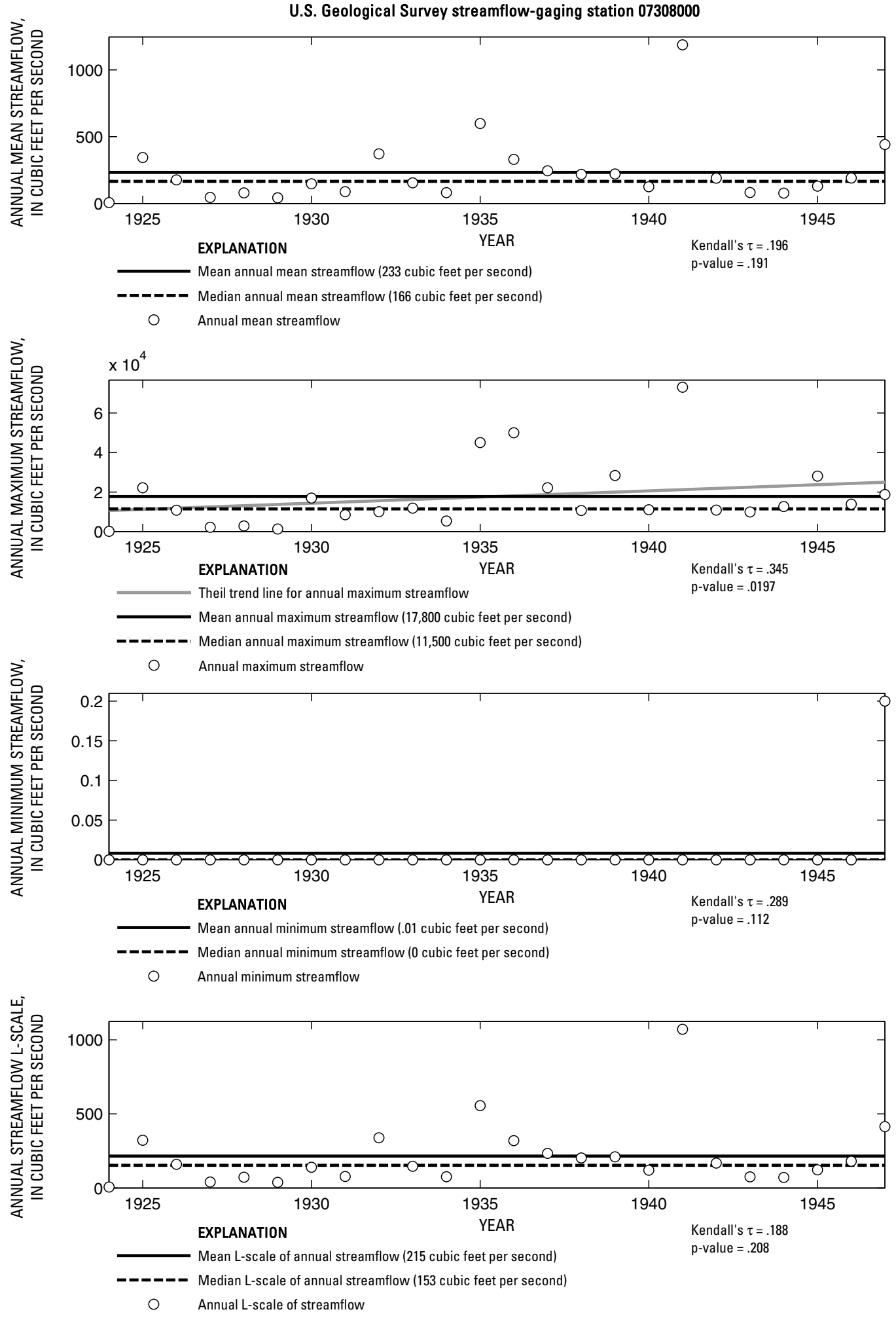

Figure 36. Analysis of annual mean, maximum, minimum, and L-scale statistics of daily mean streamflow for U.S. Geological Survey streamflow-gaging station 07308000 Pease River near Crowell, Texas.

Index of Station Numbers 719 

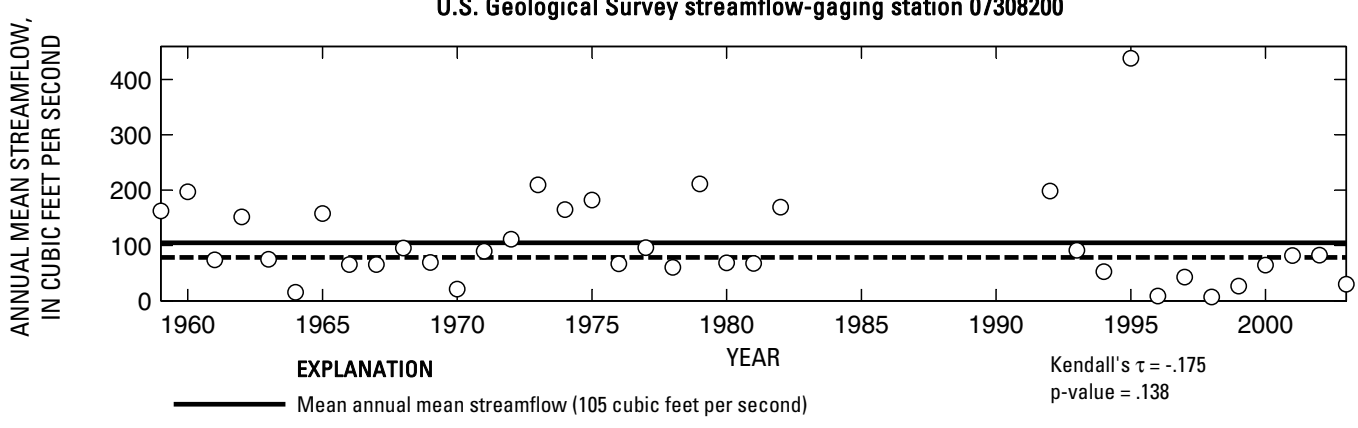

-_-_- Median annual mean streamflow (78.5 cubic feet per second)

O Annual mean streamflow
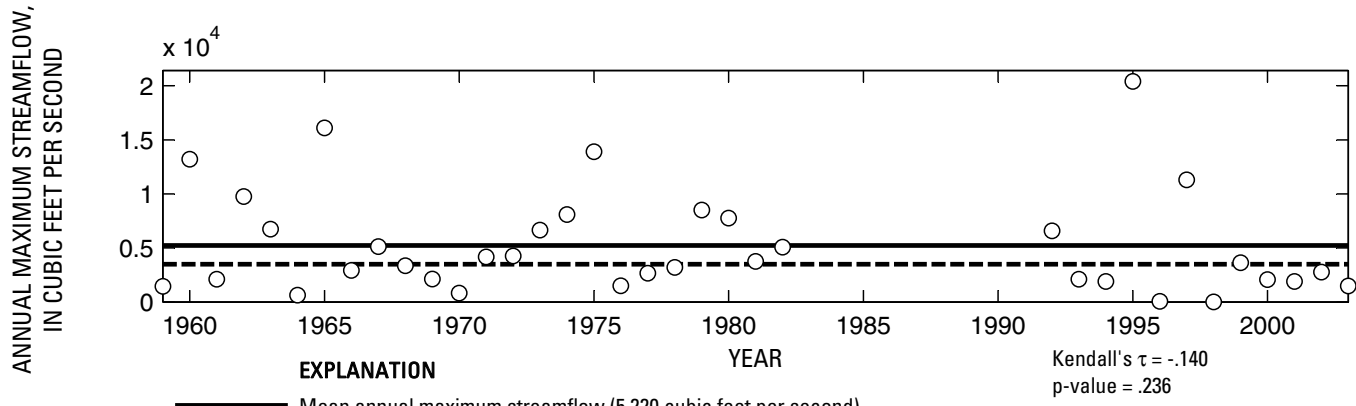

O Annual maximum streamflow

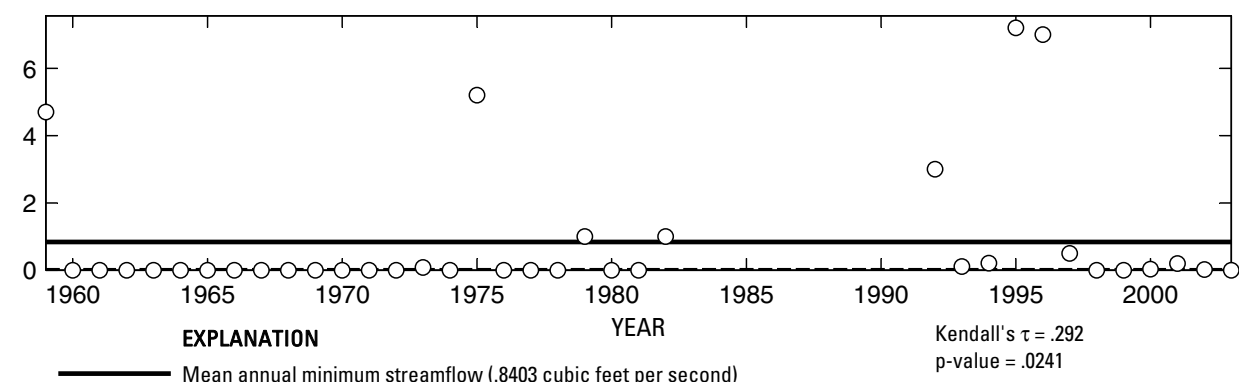

- Median annual minimum streamflow $(0$ cubic feet per second)

O Annual minimum streamflow

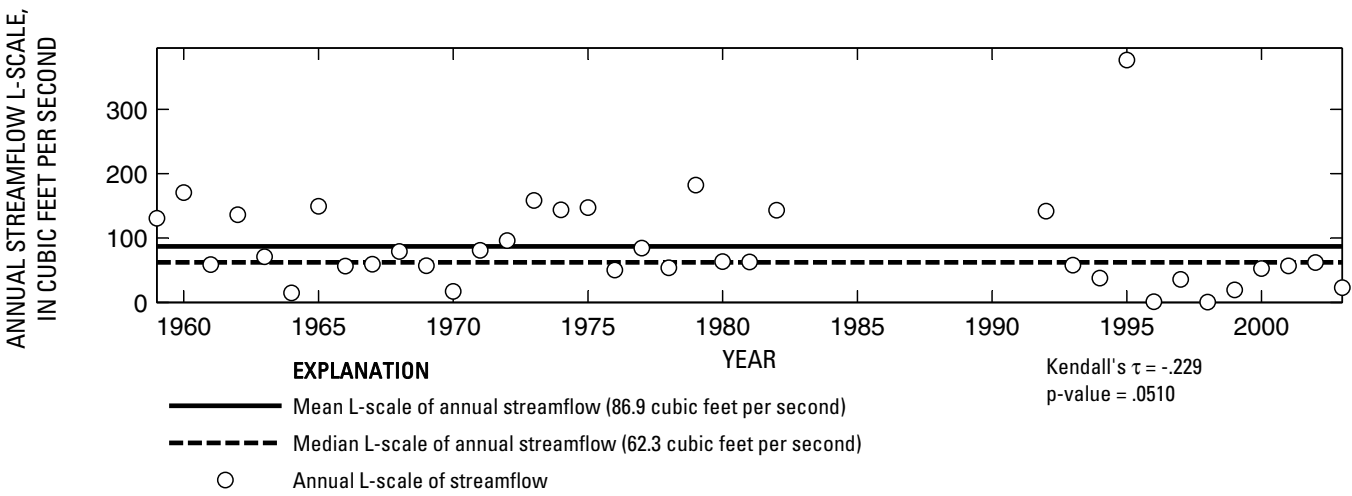

Figure 37. Analysis of annual mean, maximum, minimum, and L-scale statistics of daily mean streamflow for U.S. Geological Survey streamflow-gaging station 07308200 Pease River near Vernon, Texas. 

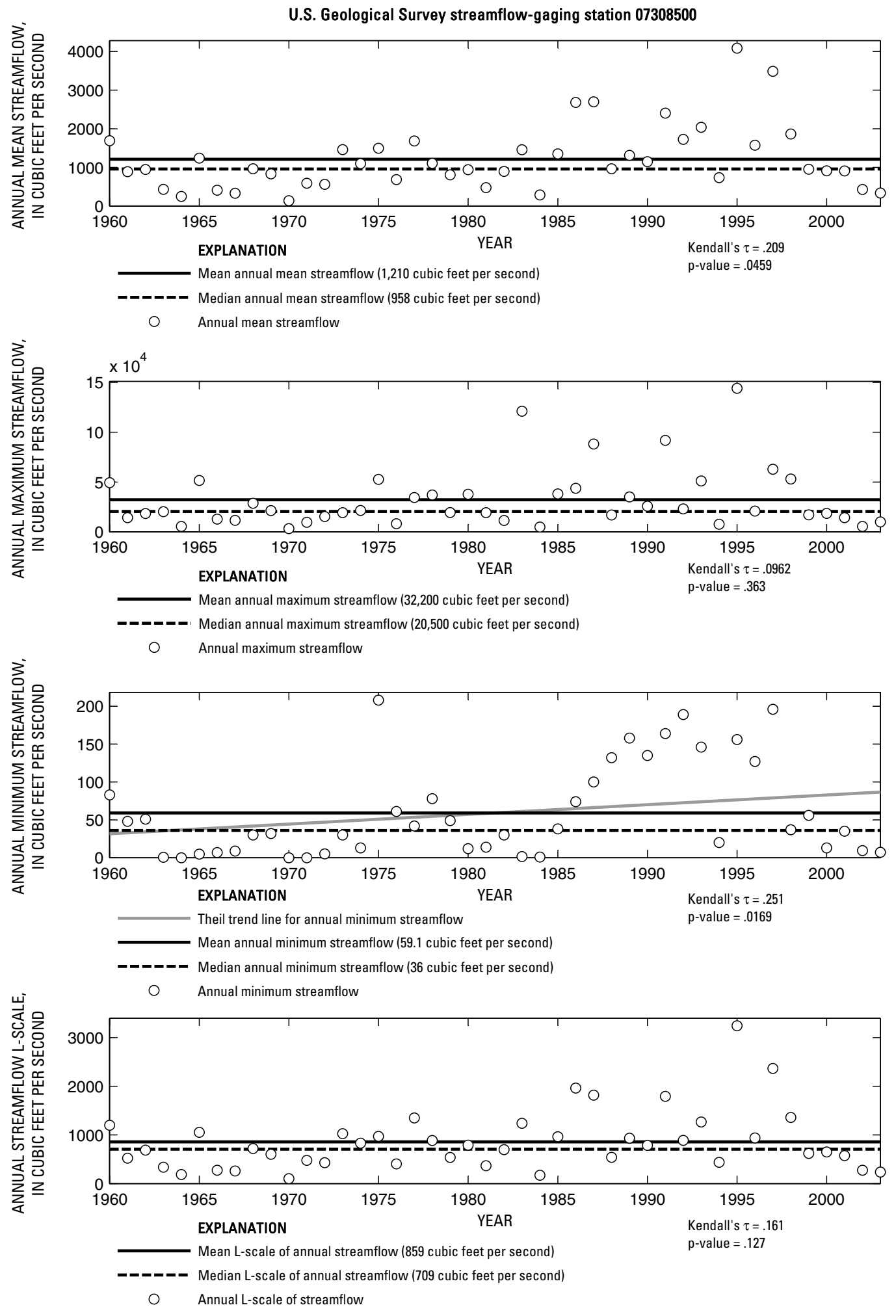

Figure 38. Analysis of annual mean, maximum, minimum, and L-scale statistics of daily mean streamflow for U.S. Geological Survey streamflow-gaging station 07308500 Red River near Burkburnett, Texas.

Index of Station Numbers 719 


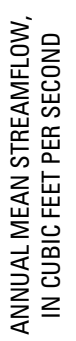

U.S. Geological Survey streamflow-gaging station 07311600

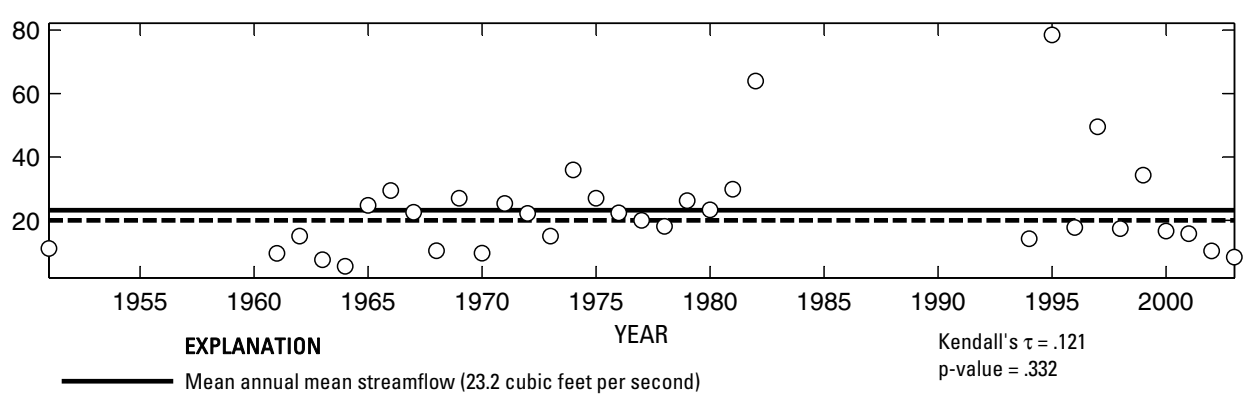

-_-_-_ Median annual mean streamflow (20 cubic feet per second)

O Annual mean streamflow
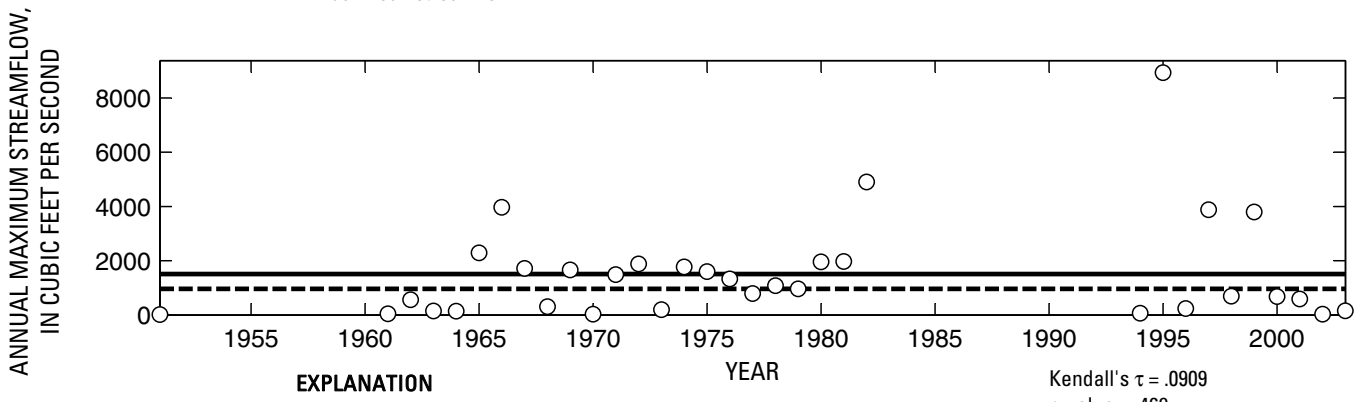

Mean annual maximum streamflow (1,510 cubic feet per second)

$\mathrm{p}$-value $=.469$

- - - Median annual maximum streamflow (961 cubic feet per second)

O Annual maximum streamflow

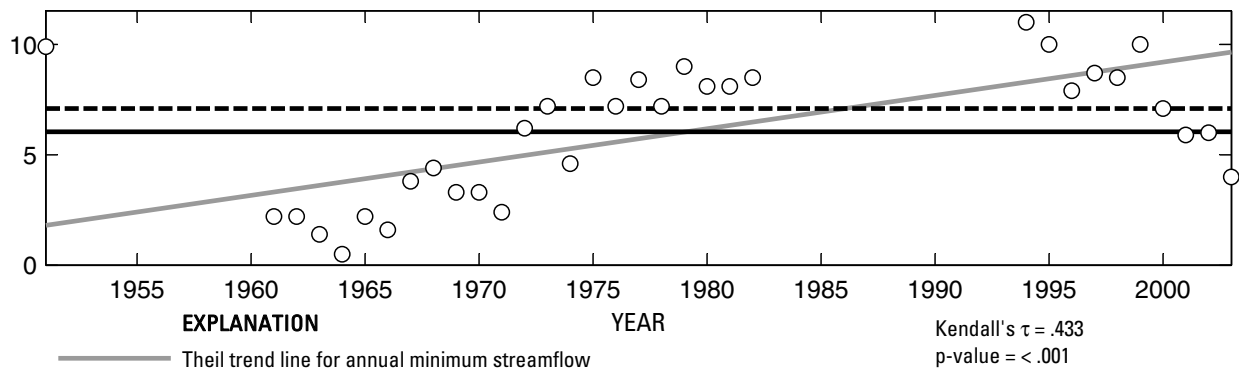

Mean annual minimum streamflow (6.039 cubic feet per second)

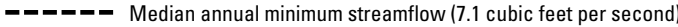

O Annual minimum streamflow

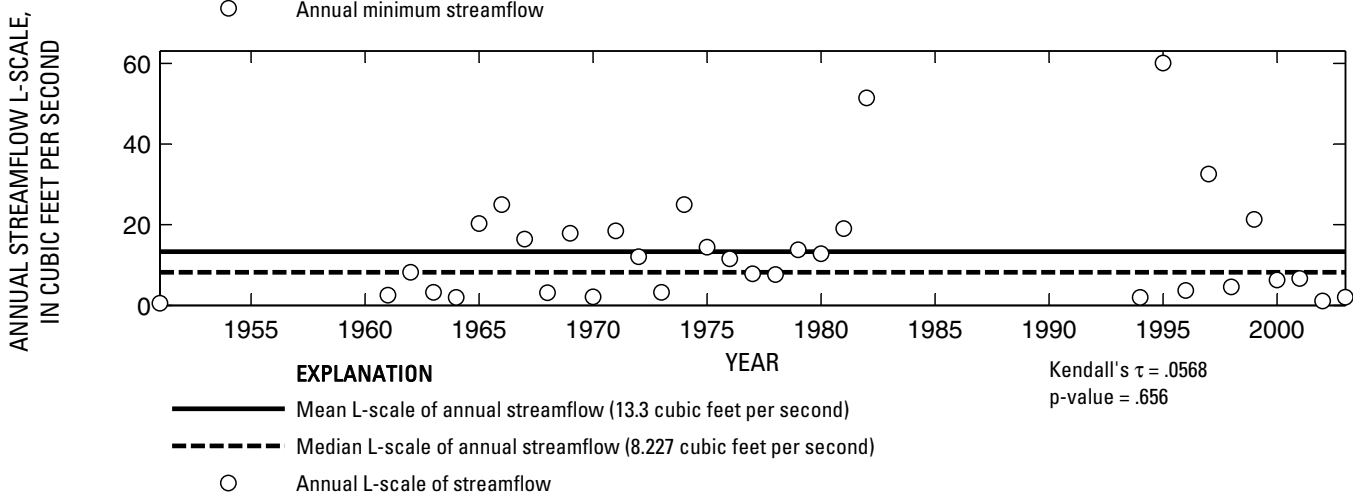

Figure 39. Analysis of annual mean, maximum, minimum, and L-scale statistics of daily mean streamflow for U.S. Geological Survey streamflow-gaging station 07311600 North Wichita River near Paducah, Texas.

Index of Station Numbers 719 

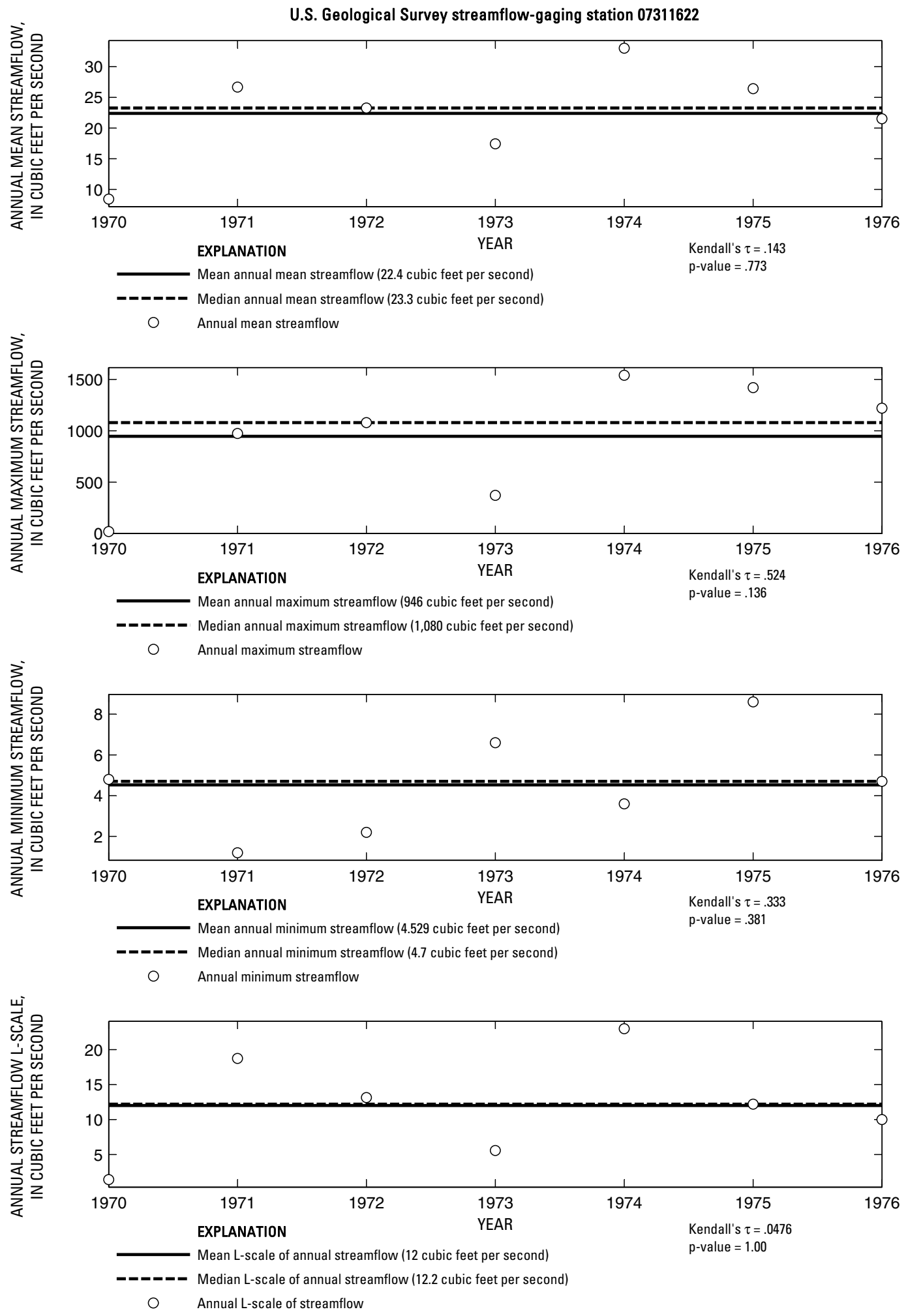

Figure 40. Analysis of annual mean, maximum, minimum, and L-scale statistics of daily mean streamflow for U.S. Geological Survey streamflow-gaging station 07311622 North Wichita River near Crowell, Texas.

Index of Station Numbers 719 


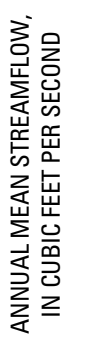

U.S. Geological Survey streamflow-gaging station 07311630

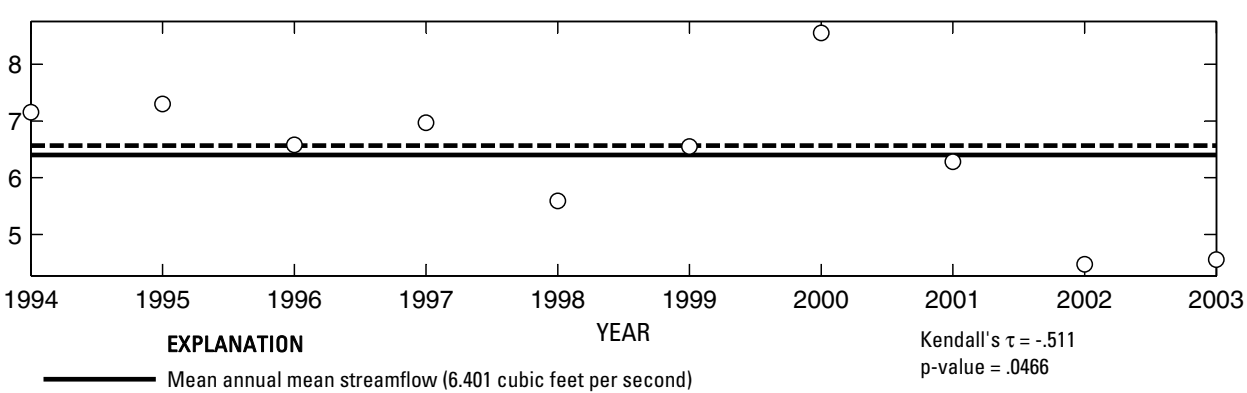

-ーーーー_ Median annual mean streamflow (6.565 cubic feet per second)

O Annual mean streamflow

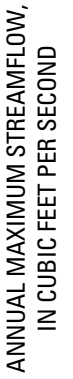

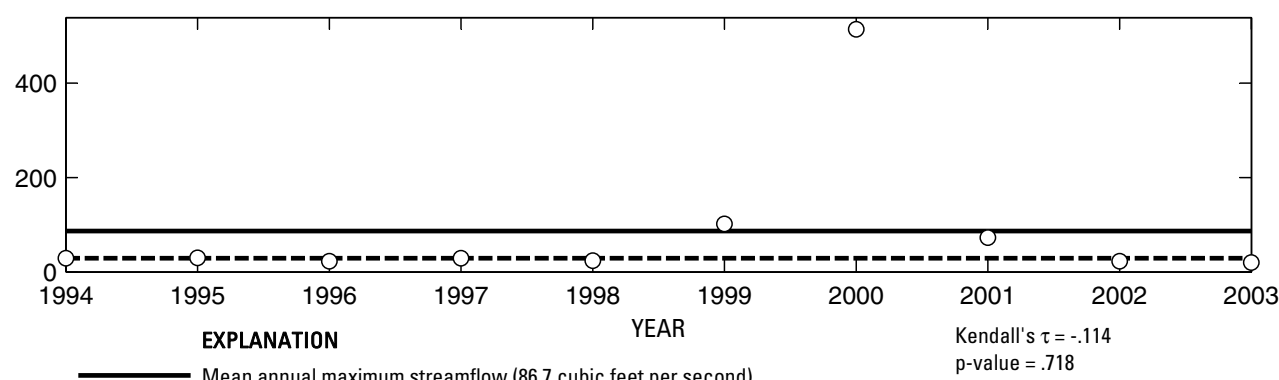

Mean annual maximum streamflow (86.7 cubic feet per second)

p-value $=.718$

Annual maximum streamflow

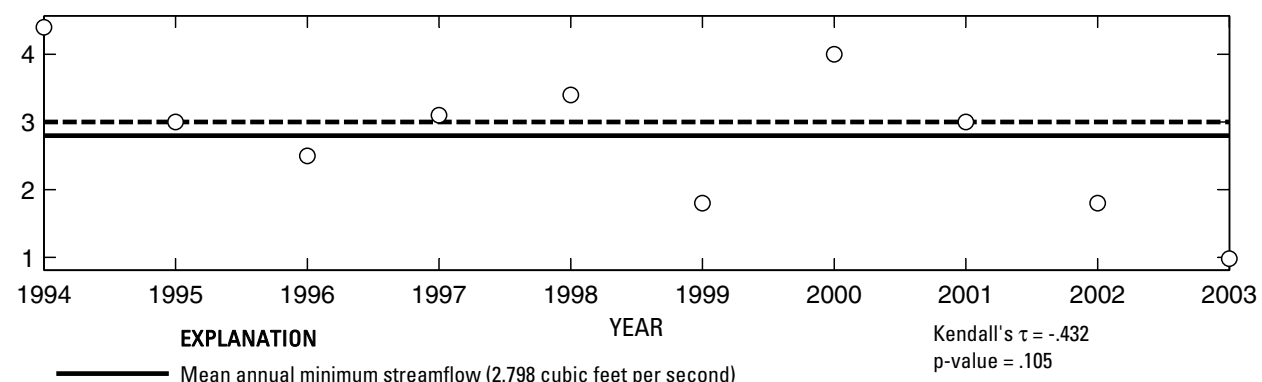

- ב-ב Median annual minimum streamflow (3 cubic feet per second)

O Annual minimum streamflow

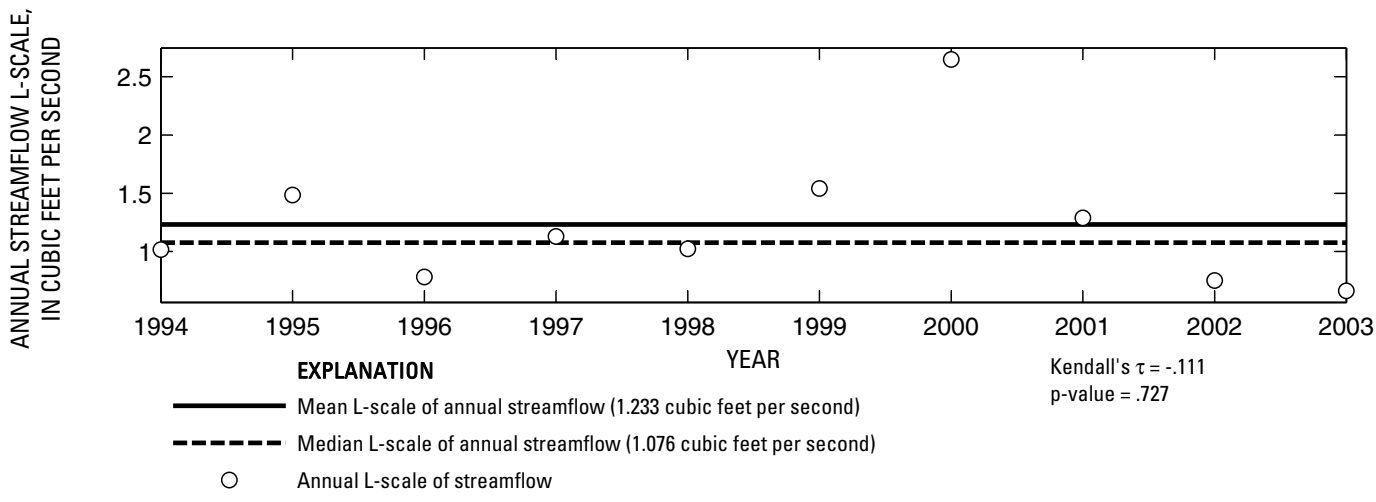

Figure 41. Analysis of annual mean, maximum, minimum, and L-scale statistics of daily mean streamflow for U.S. Geological Survey streamflow-gaging station 07311630 Middle Wichita River near Guthrie, Texas.

Index of Station Numbers 719 
U.S. Geological Survey streamflow-gaging station 07311648

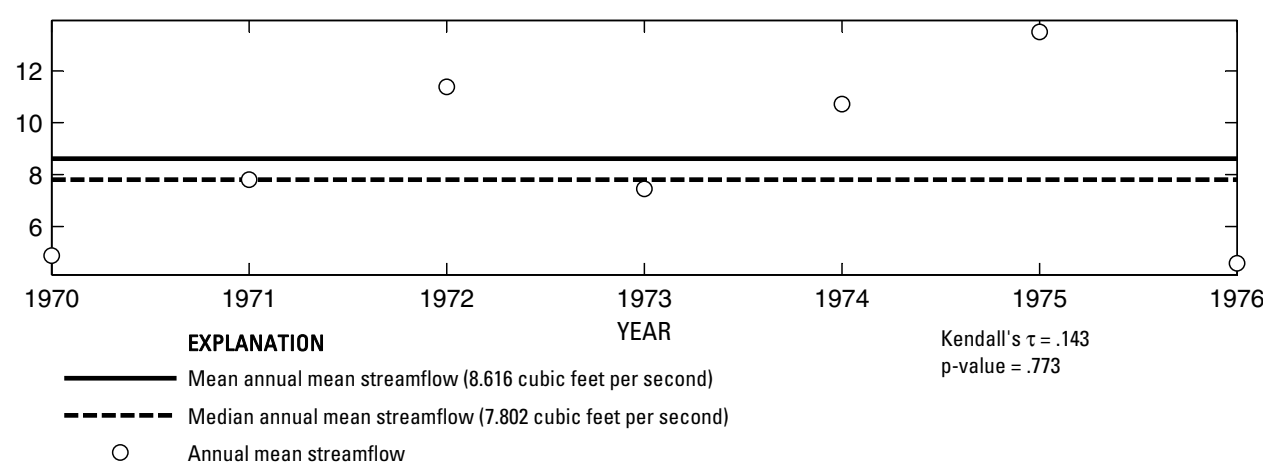

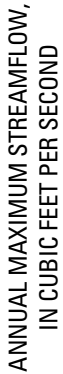

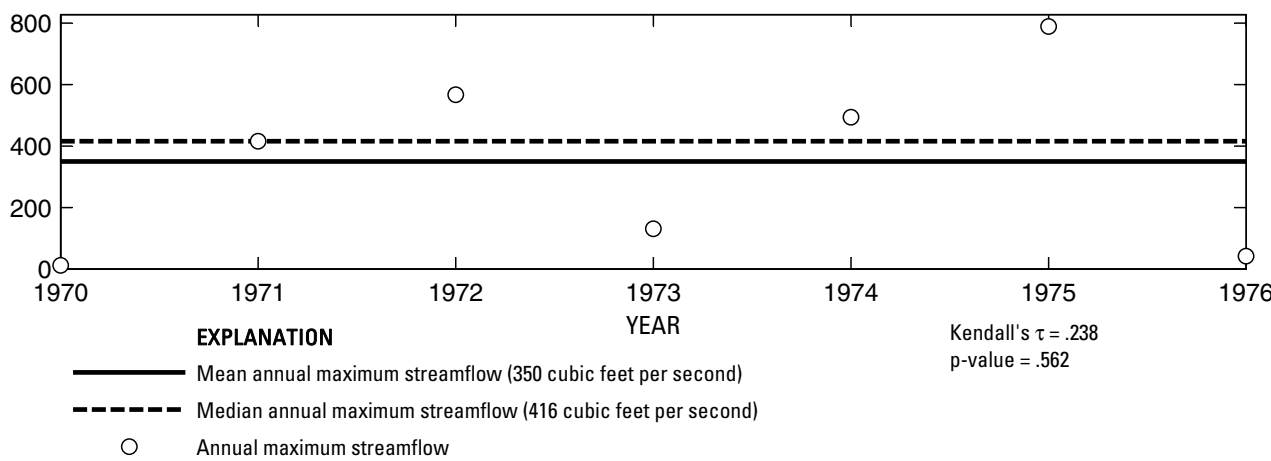

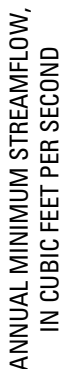

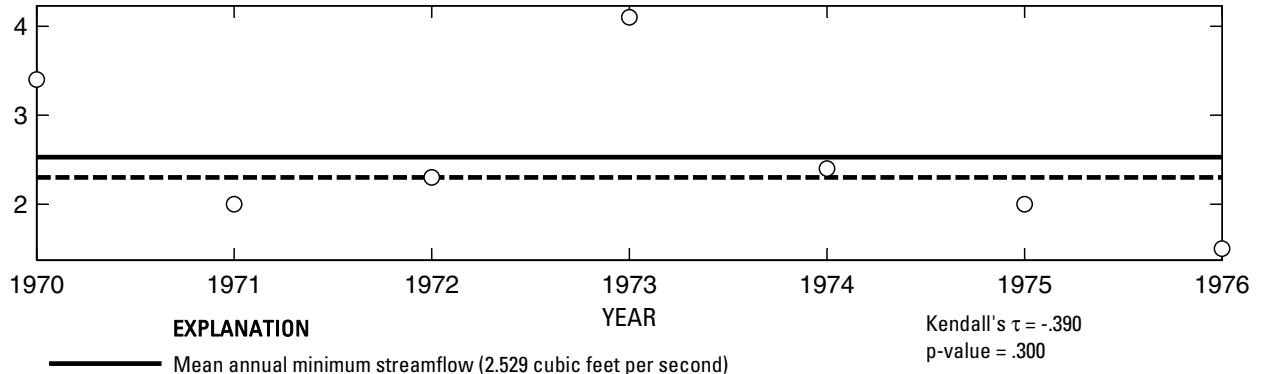

- ב-_- Median annual minimum streamflow (2.3 cubic feet per second)

O Annual minimum streamflow

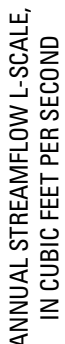

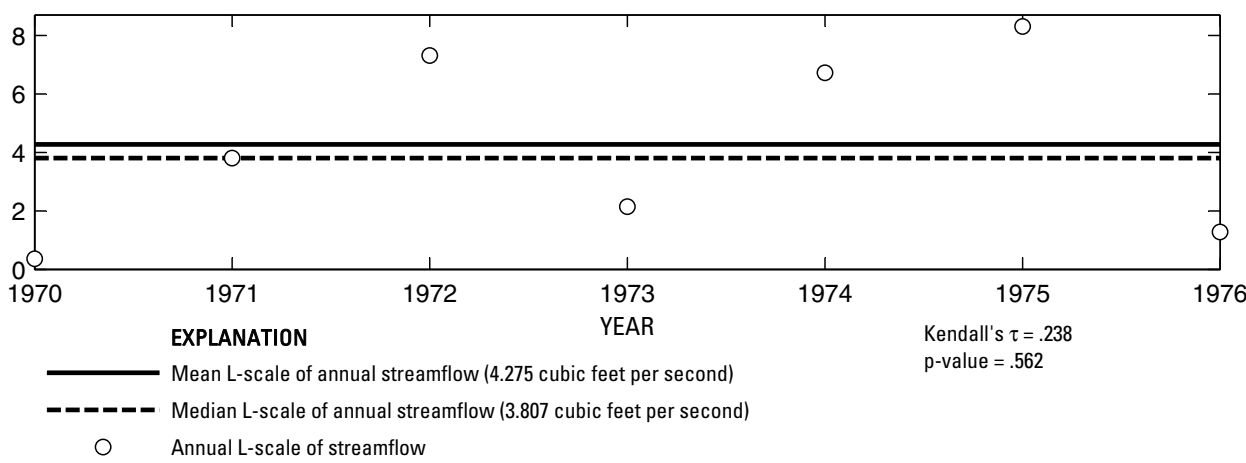

Figure 42. Analysis of annual mean, maximum, minimum, and L-scale statistics of daily mean streamflow for U.S. Geological Survey streamflow-gaging station 07311648 Middle Wichita River near Truscott, Texas.

Index of Station Numbers 719 


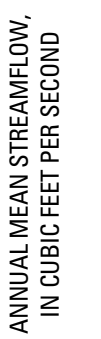

U.S. Geological Survey streamflow-gaging station 07311700

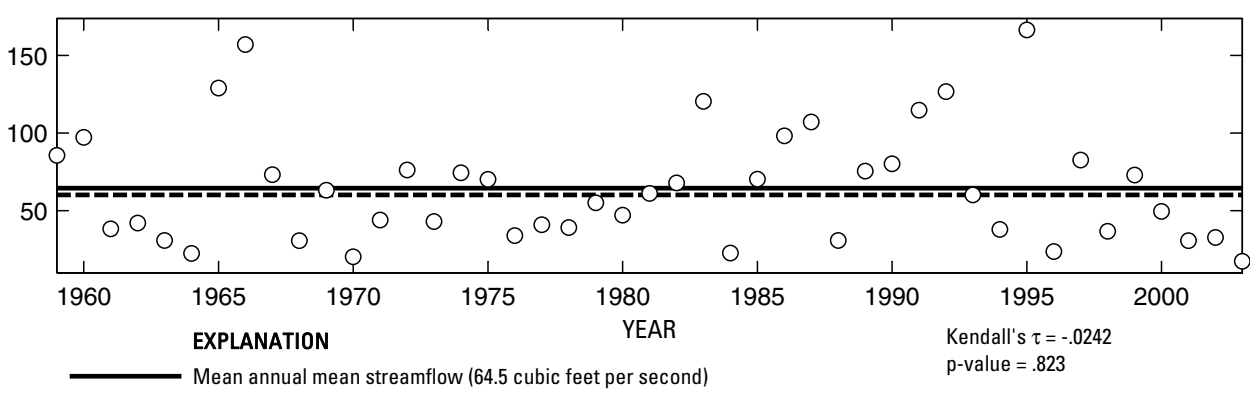

-_-_- Median annual mean streamflow (60.1 cubic feet per second)

Annual mean streamflow

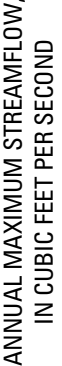

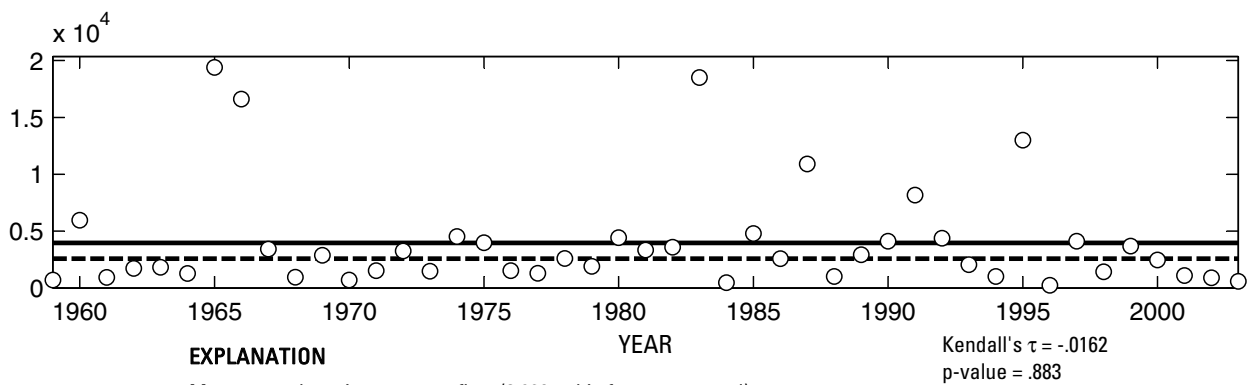

O Annual maximum streamflow

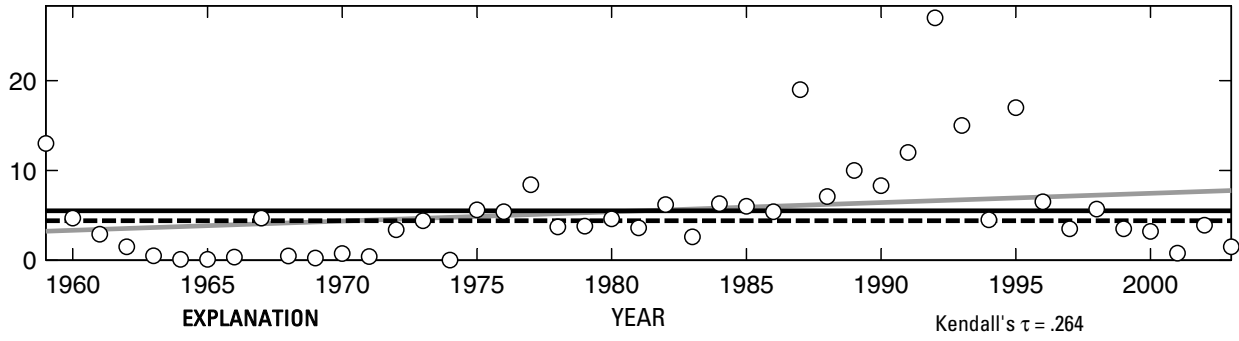

Theil trend line for annual minimum streamflow

$\mathrm{p}$-value $=.0110$

Mean annual minimum streamflow (5.502 cubic feet per second)

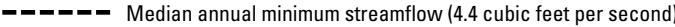

O Annual minimum streamflow
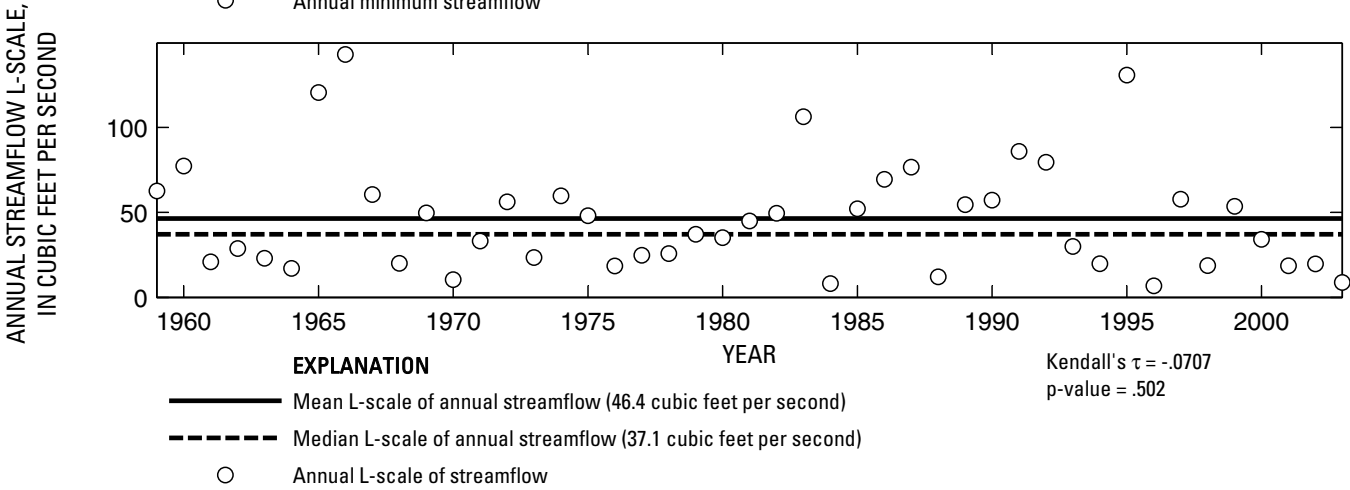

Figure 43. Analysis of annual mean, maximum, minimum, and L-scale statistics of daily mean streamflow for U.S. Geological Survey streamflow-gaging station 07311700 North Wichita River near Truscott, Texas. 

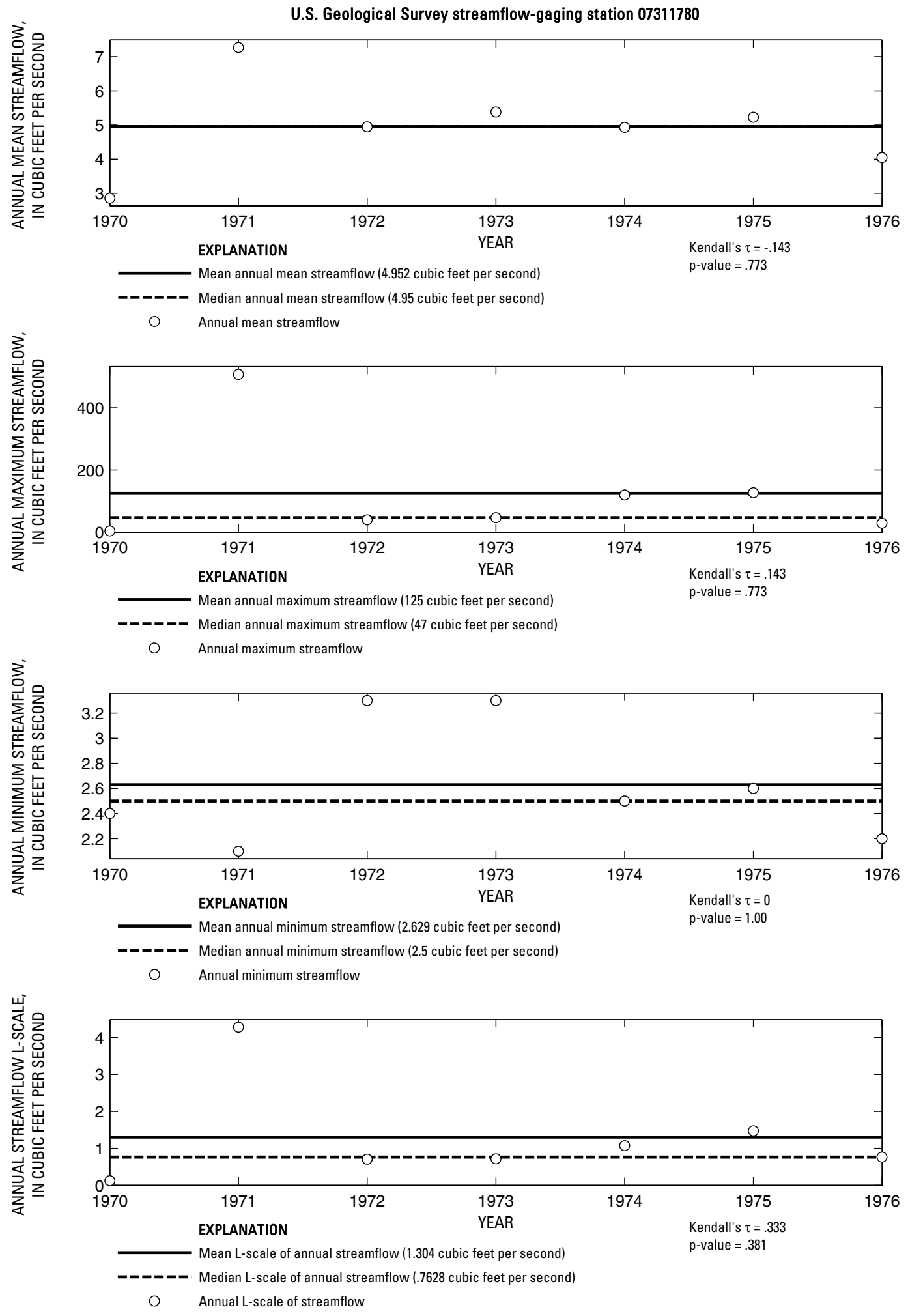

Figure 44. Analysis of annual mean, maximum, minimum, and L-scale statistics of daily mean streamflow for U.S. Geological Survey streamflow-gaging station 07311780 South Wichita River near Guthrie, Texas.

Index of Station Numbers 719 


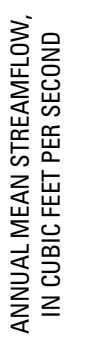

U.S. Geological Survey streamflow-gaging station 07311782

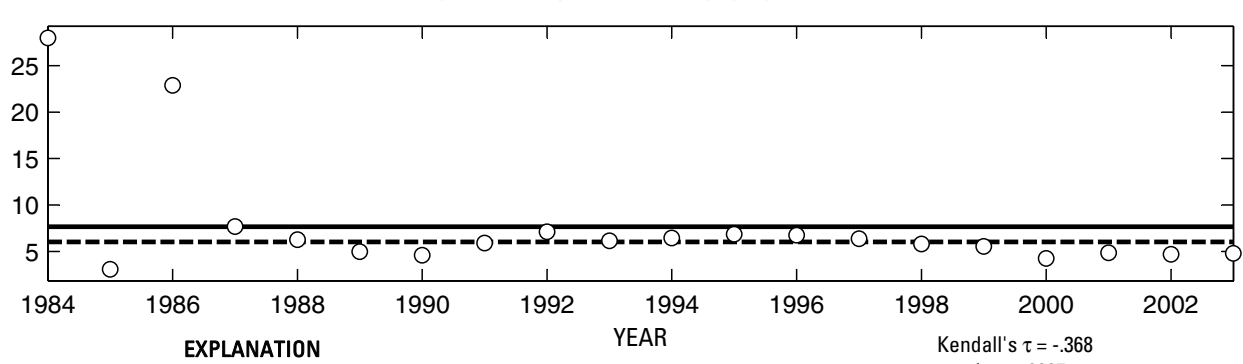

Mean annual mean streamflow (7.649 cubic feet per second)

$\mathrm{p}$-value $=.0237$

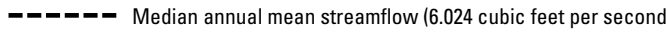

O Annual mean streamflow

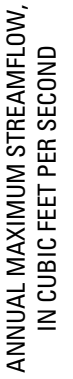

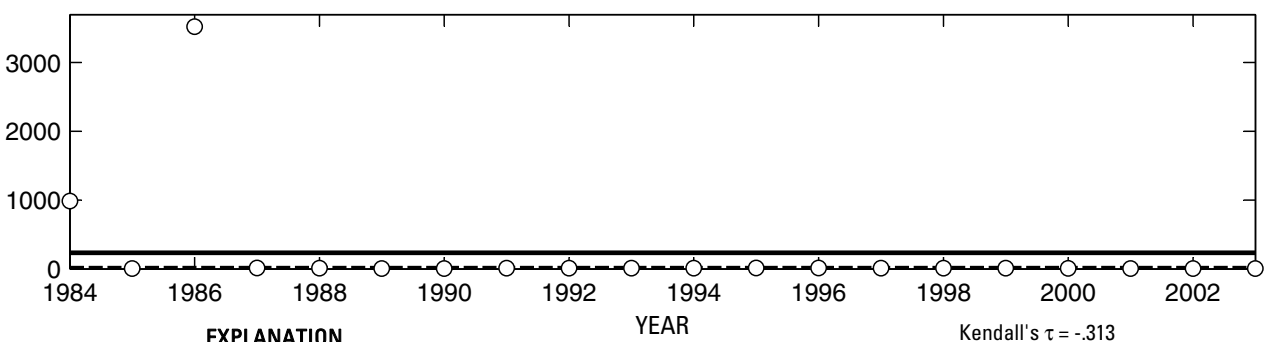

EXPLANATION

p-value $=$

-_-_- Median annual maximum streamflow (11.5 cubic feet per second)

O Annual maximum streamflow

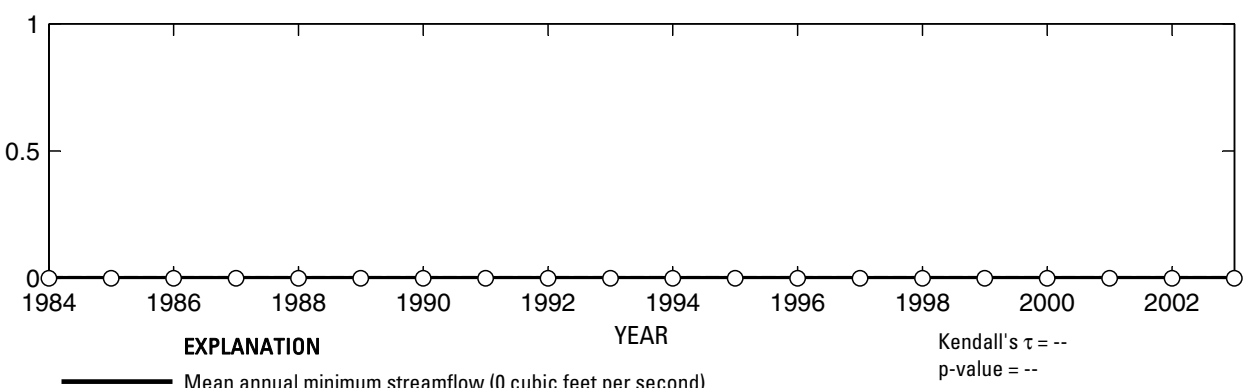

- Median annual minimum streamflow (0 cubic feet per second)

○ Annual minimum streamflow

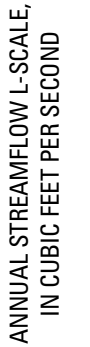

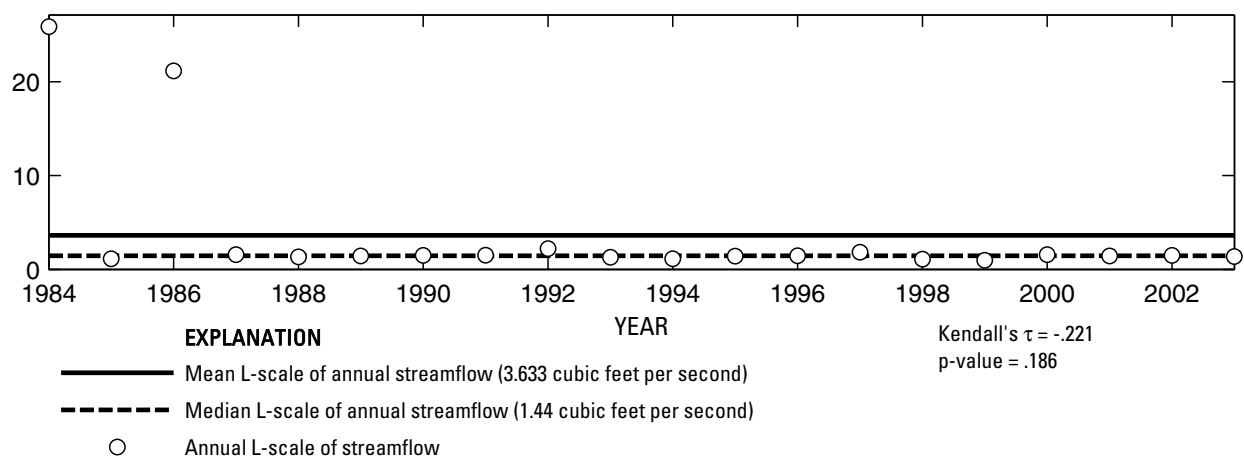

Figure 45. Analysis of annual mean, maximum, minimum, and L-scale statistics of daily mean streamflow for U.S. Geological Survey streamflow-gaging station 07311782 South Wichita River at Low Flow Dam near Guthrie, Texas. 


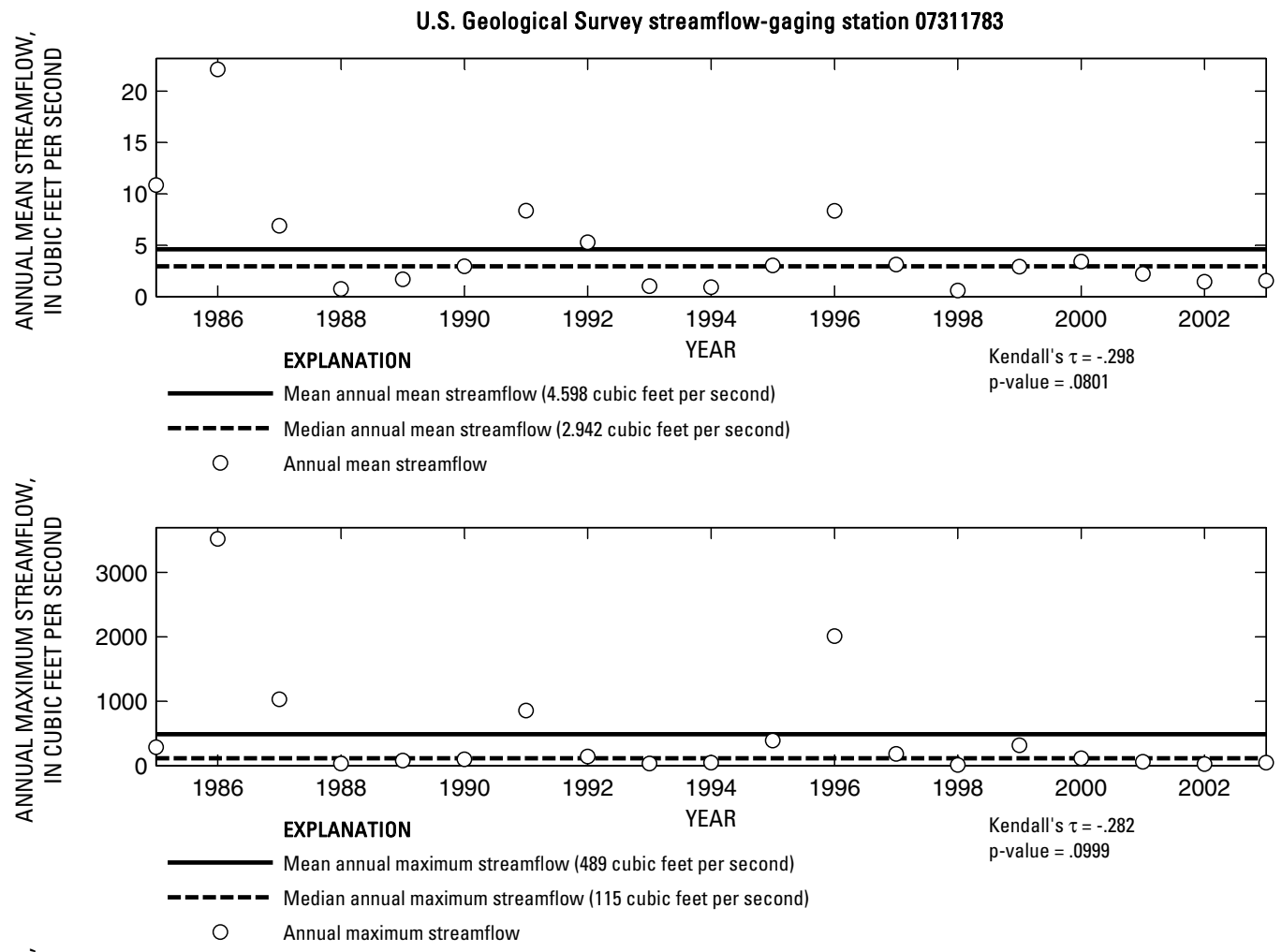

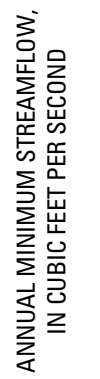

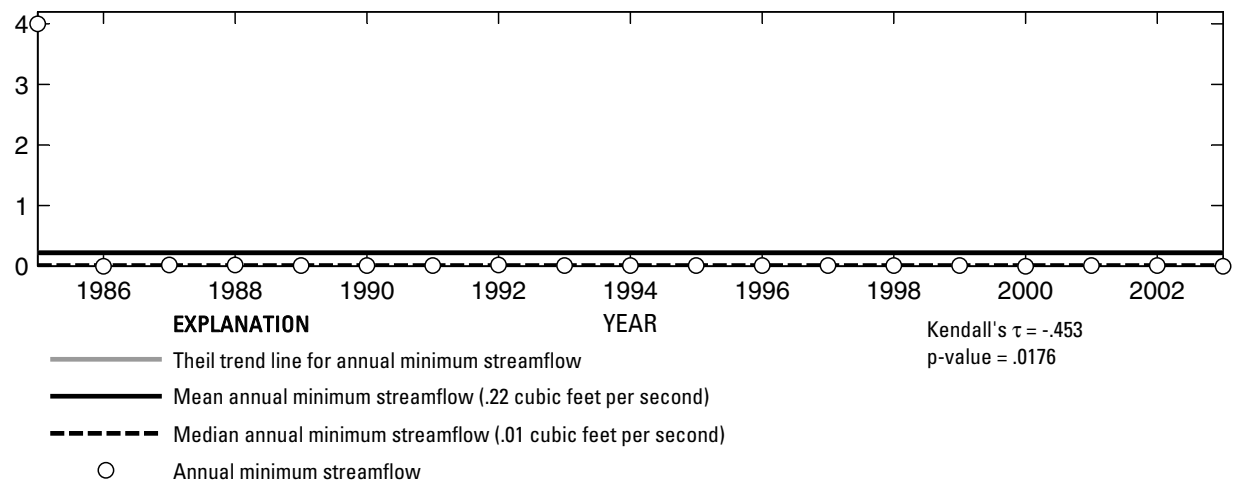

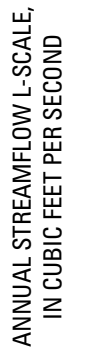

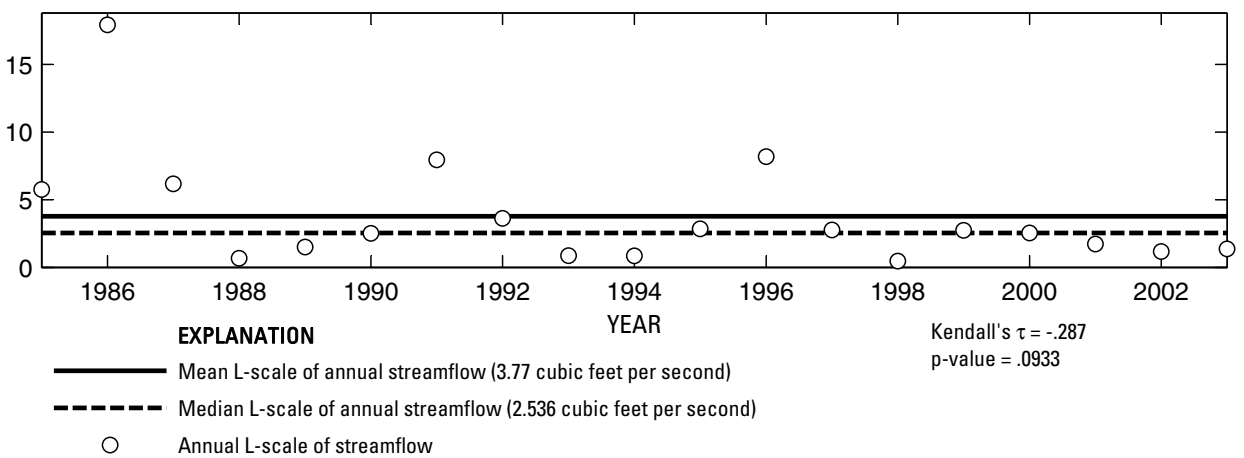

Figure 46. Analysis of annual mean, maximum, minimum, and L-scale statistics of daily mean streamflow for U.S. Geological Survey streamflow-gaging station 07311783 South Wichita River below Low Flow Dam near Guthrie, Texas.

Index of Station Numbers 719 


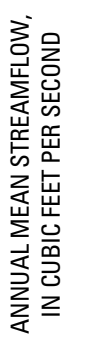

U.S. Geological Survey streamflow-gaging station 07311790

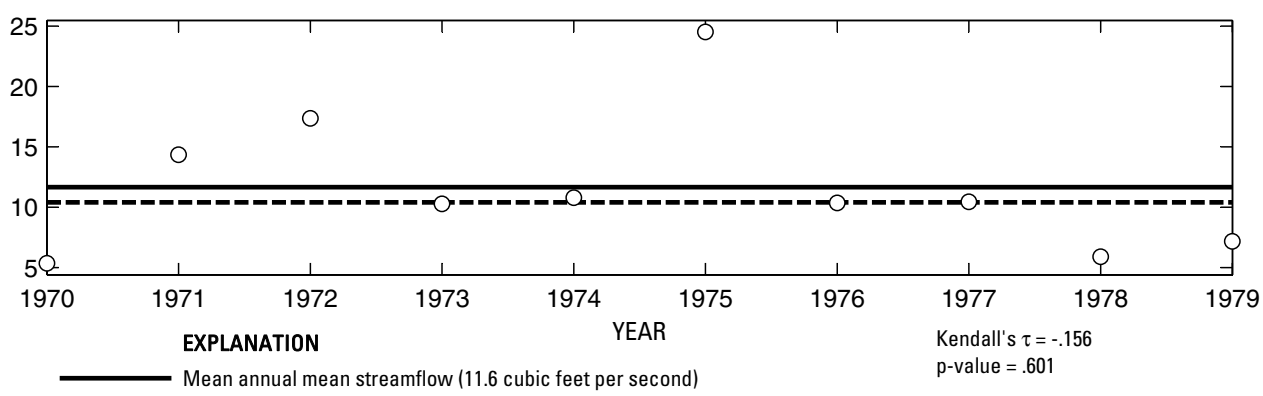

-_-_- Median annual mean streamflow (10.4 cubic feet per second)

O Annual mean streamflow
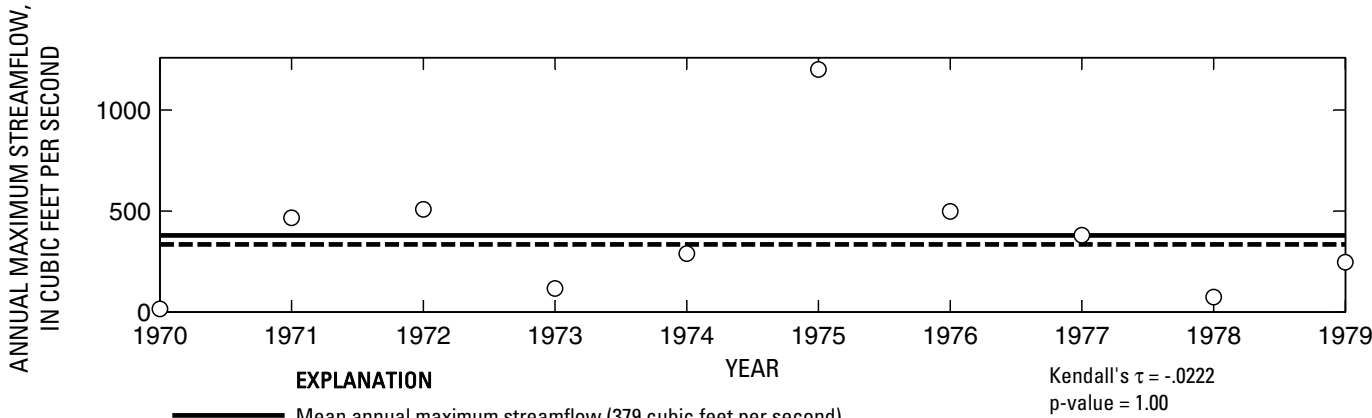

O Annual maximum streamflow

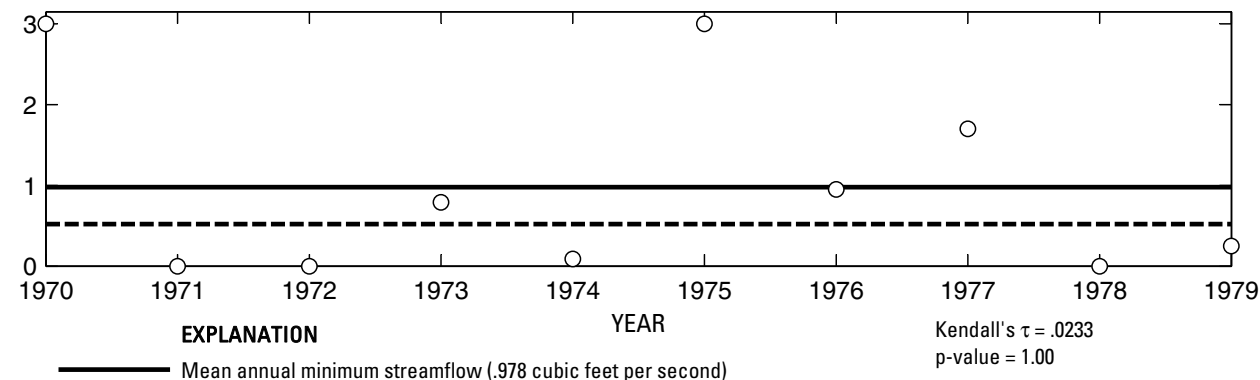

- - - Median annual minimum streamflow (.52 cubic feet per second)

○ Annual minimum streamflow
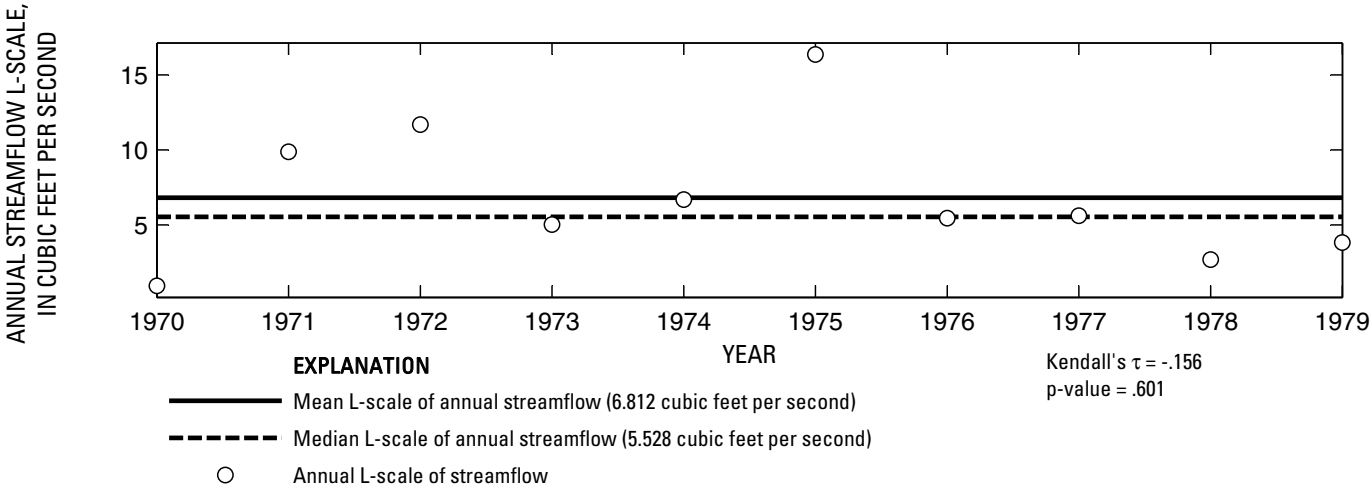

Figure 47. Analysis of annual mean, maximum, minimum, and L-scale statistics of daily mean streamflow for U.S. Geological Survey streamflow-gaging station 07311790 South Wichita River at Ross Ranch near Benjamin, Texas. 


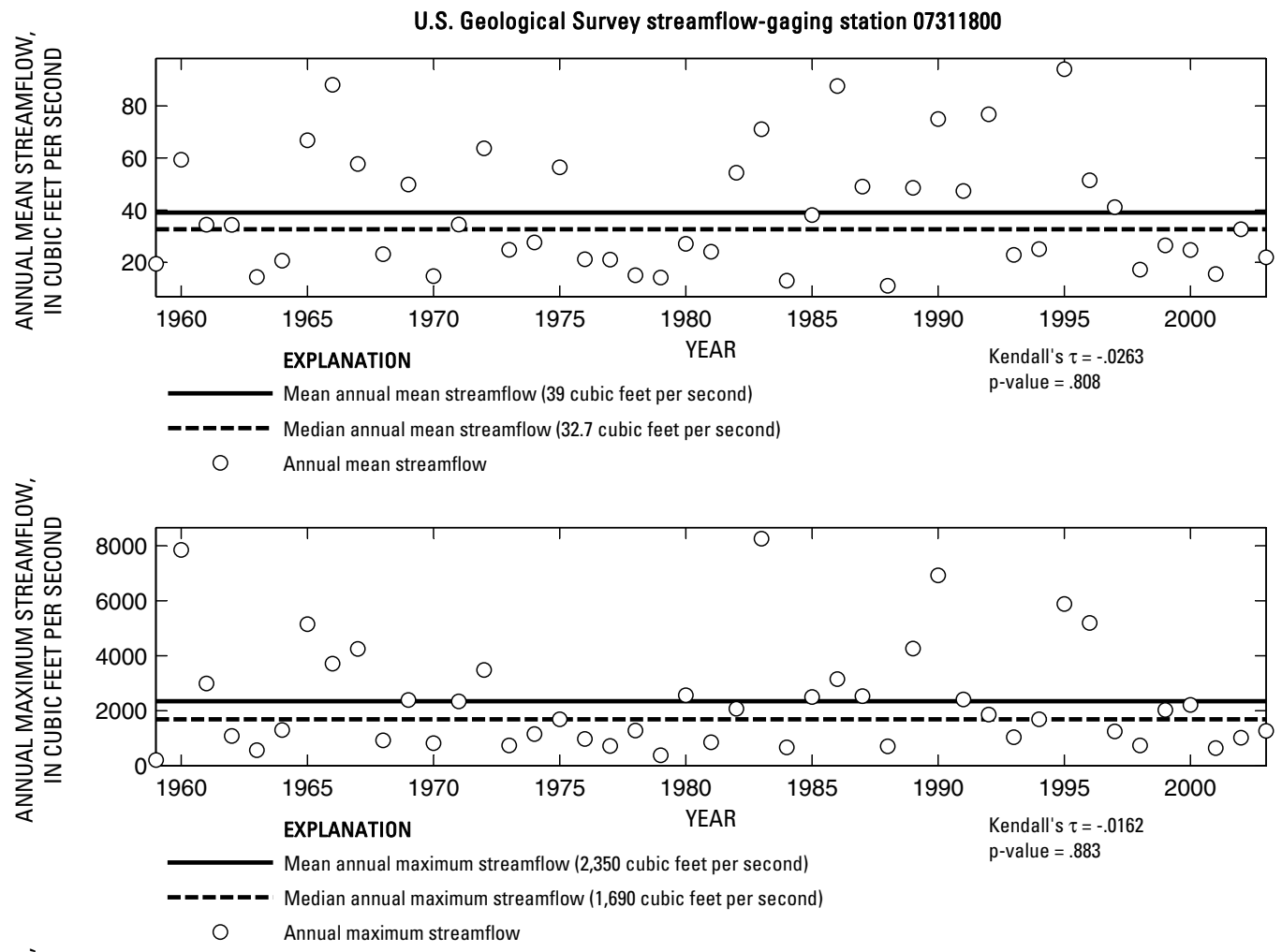

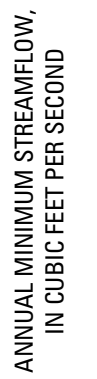

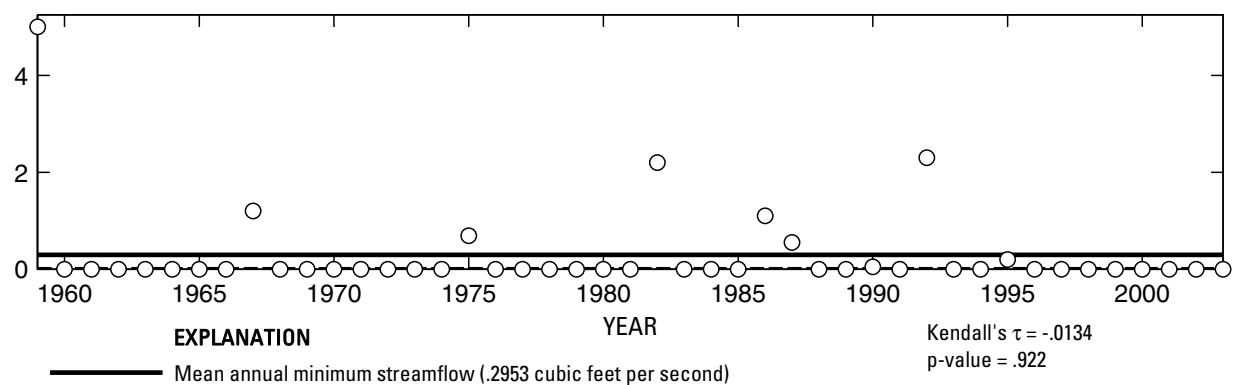

-_a-_ Median annual minimum streamflow (0 cubic feet per second)

O Annual minimum streamflow

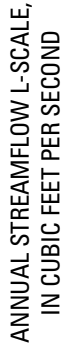

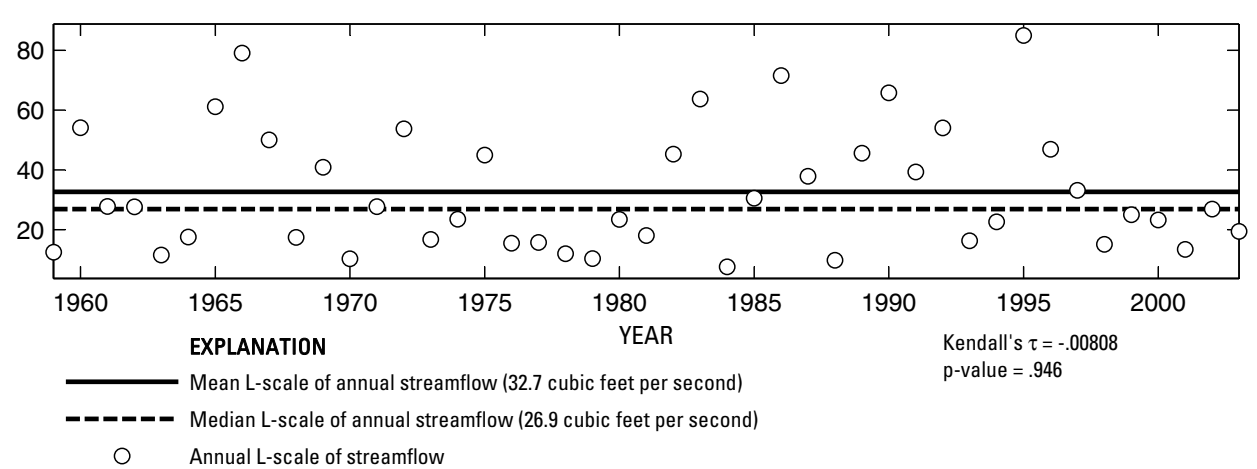

Figure 48. Analysis of annual mean, maximum, minimum, and L-scale statistics of daily mean streamflow for U.S. Geological Survey streamflow-gaging station 07311800 South Wichita River near Benjamin, Texas.

Index of Station Numbers 719 

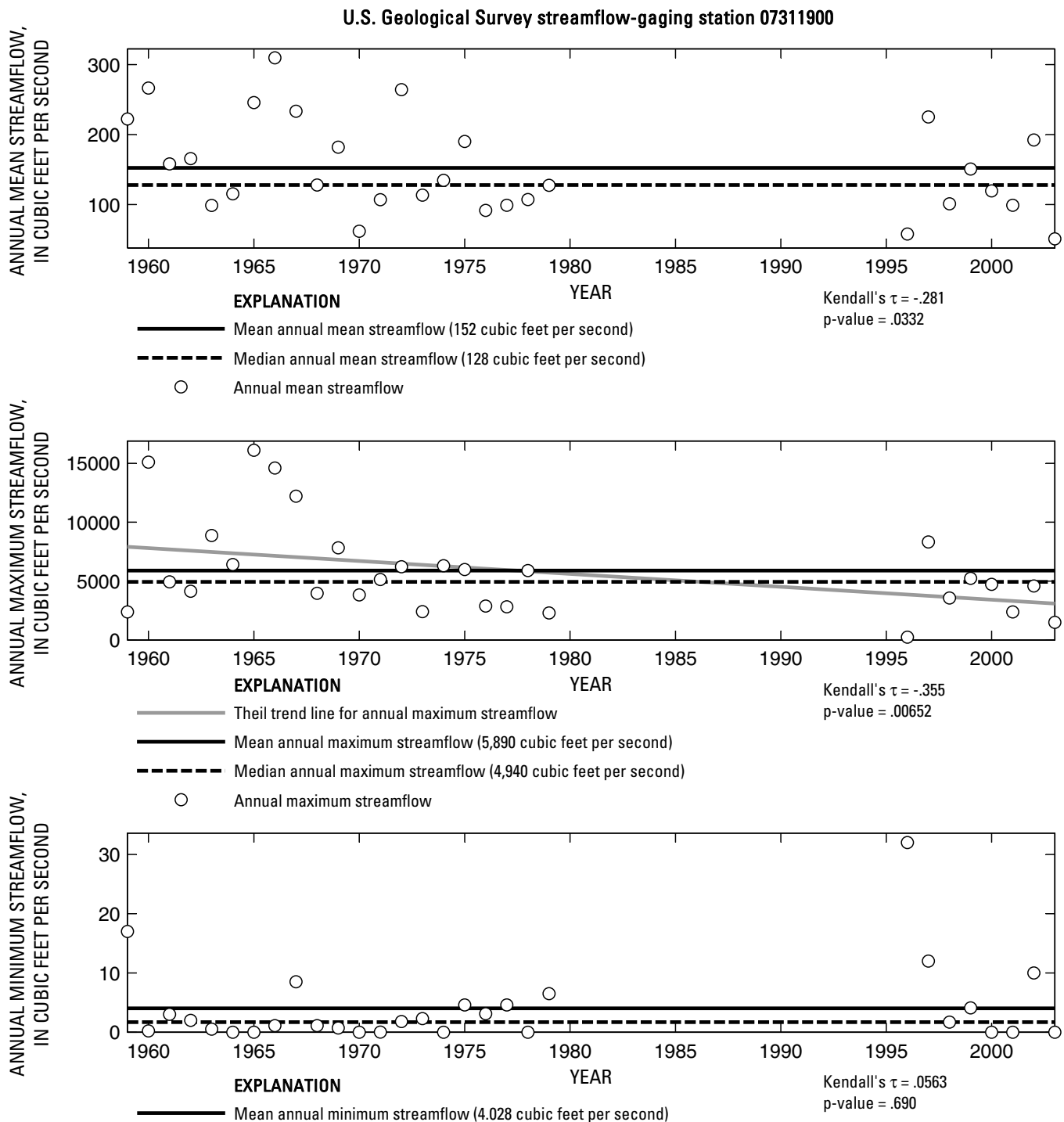

- - - Median annual minimum streamflow (1.7 cubic feet per second)

O Annual minimum streamflow

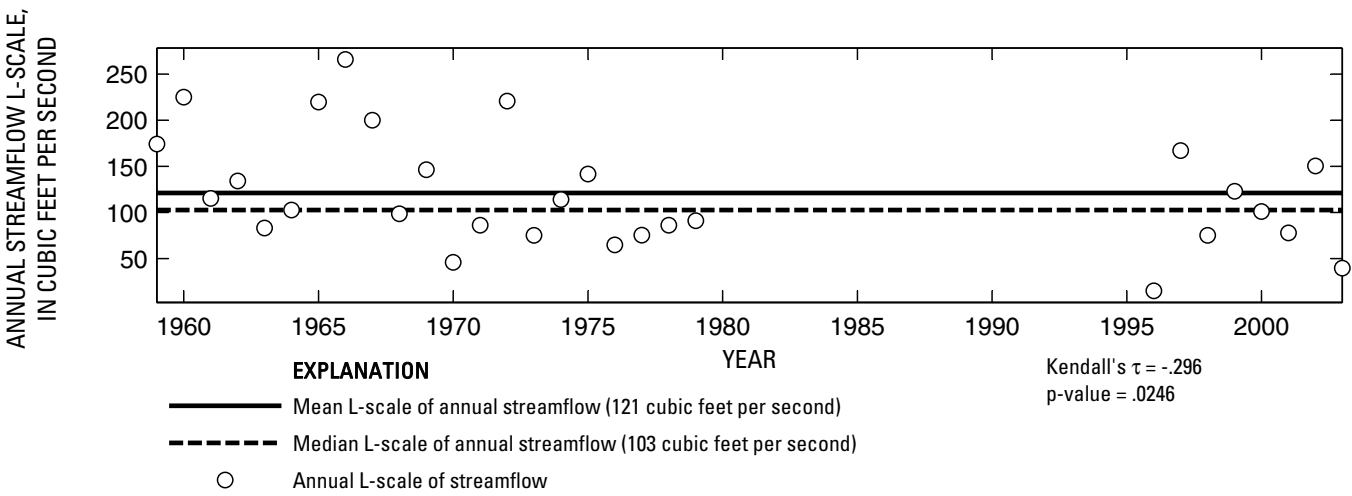

Figure 49. Analysis of annual mean, maximum, minimum, and L-scale statistics of daily mean streamflow for U.S. Geological Survey streamflow-gaging station 07311900 Wichita River near Seymour, Texas. 


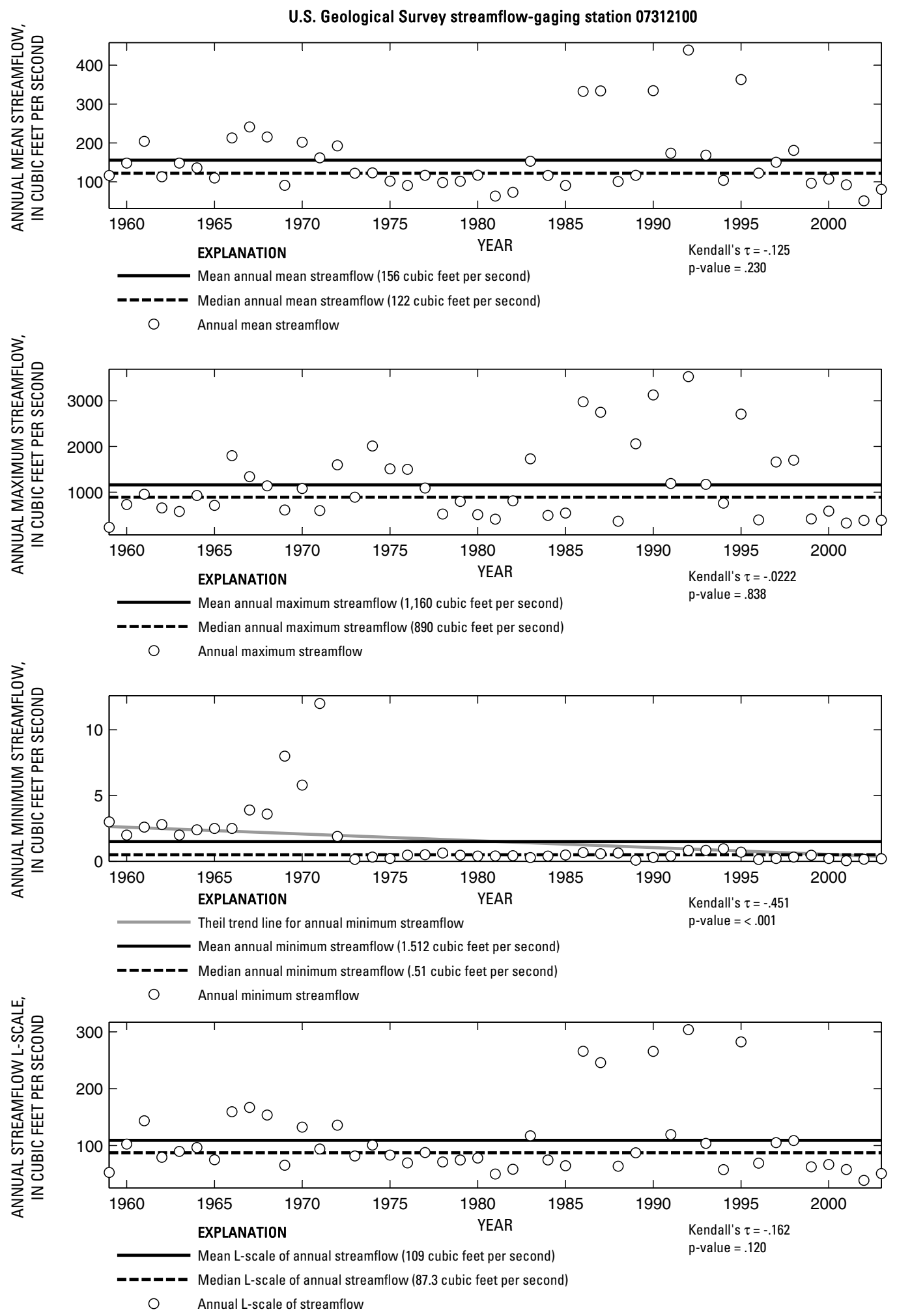

Figure 50. Analysis of annual mean, maximum, minimum, and L-scale statistics of daily mean streamflow for U.S. Geological Survey streamflow-gaging station 07312100 Wichita River near Mabelle, Texas.

Index of Station Numbers 719 

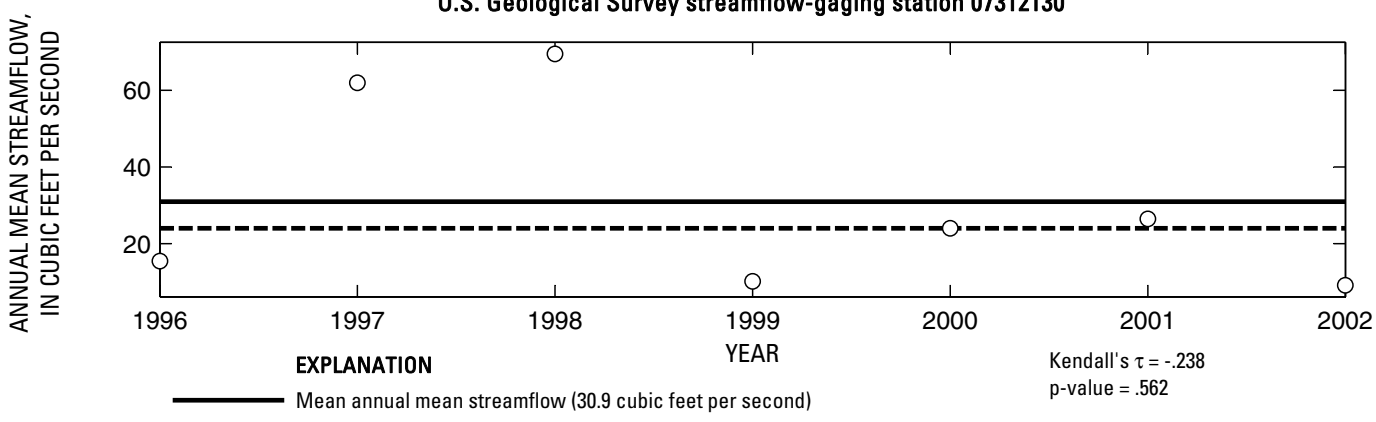

-_-_-_ Median annual mean streamflow (24 cubic feet per second)

O Annual mean streamflow
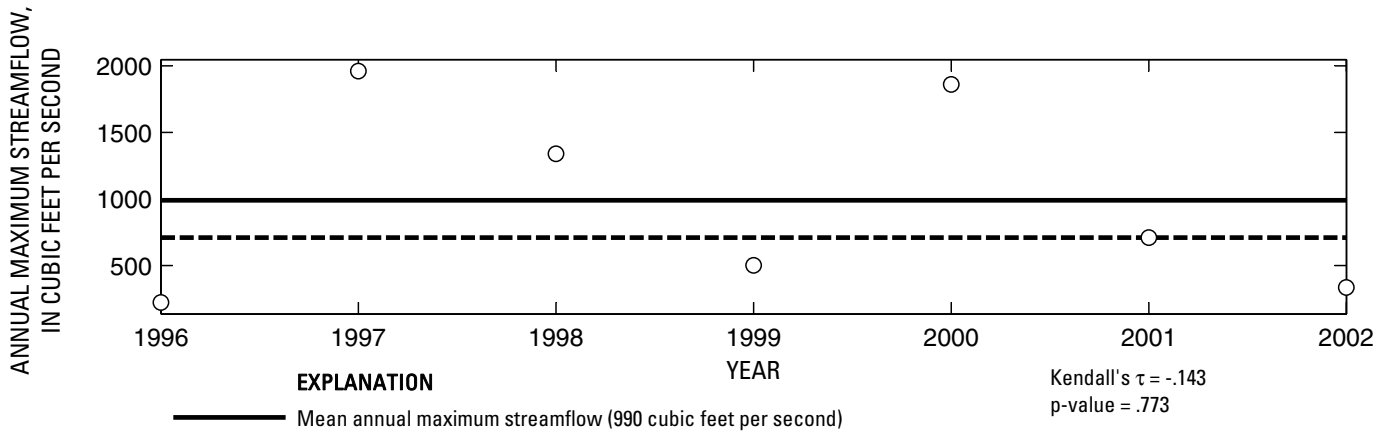

- - _- Median annual maximum streamflow ( 710 cubic feet per second)

Annual maximum streamflow

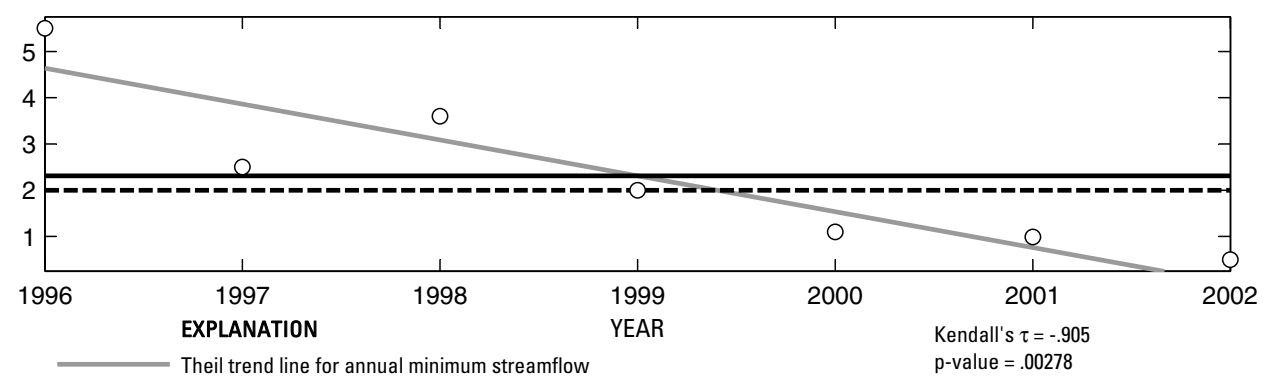

Mean annual minimum streamflow (2.313 cubic feet per second)

-ーーーー Median annual minimum streamflow (2 cubic feet per second)

O Annual minimum streamflow

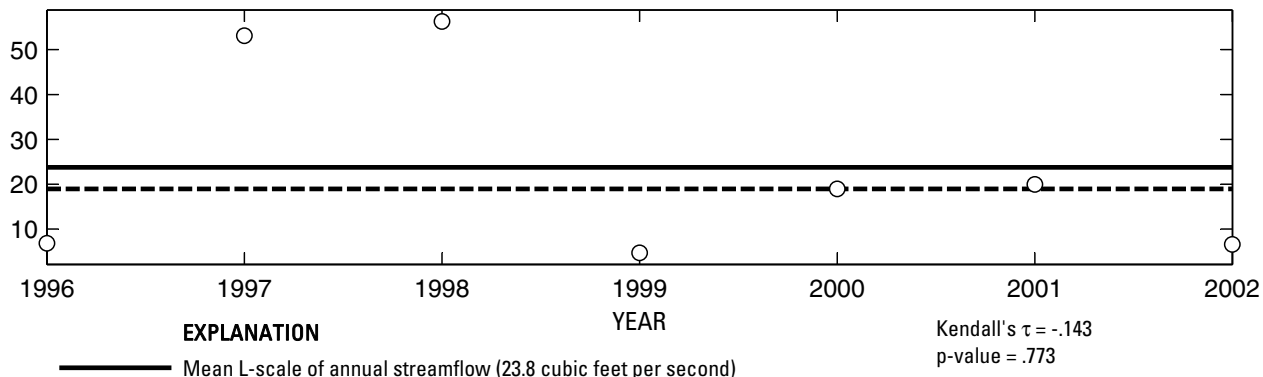

- - - - Median L-scale of annual streamflow (19 cubic feet per second)

Annual L-scale of streamflow

Figure 51. Analysis of annual mean, maximum, minimum, and L-scale statistics of daily mean streamflow for U.S. Geological Survey streamflow-gaging station 07312130 Wichita River at State Highway 25 near Kamay, Texas. 

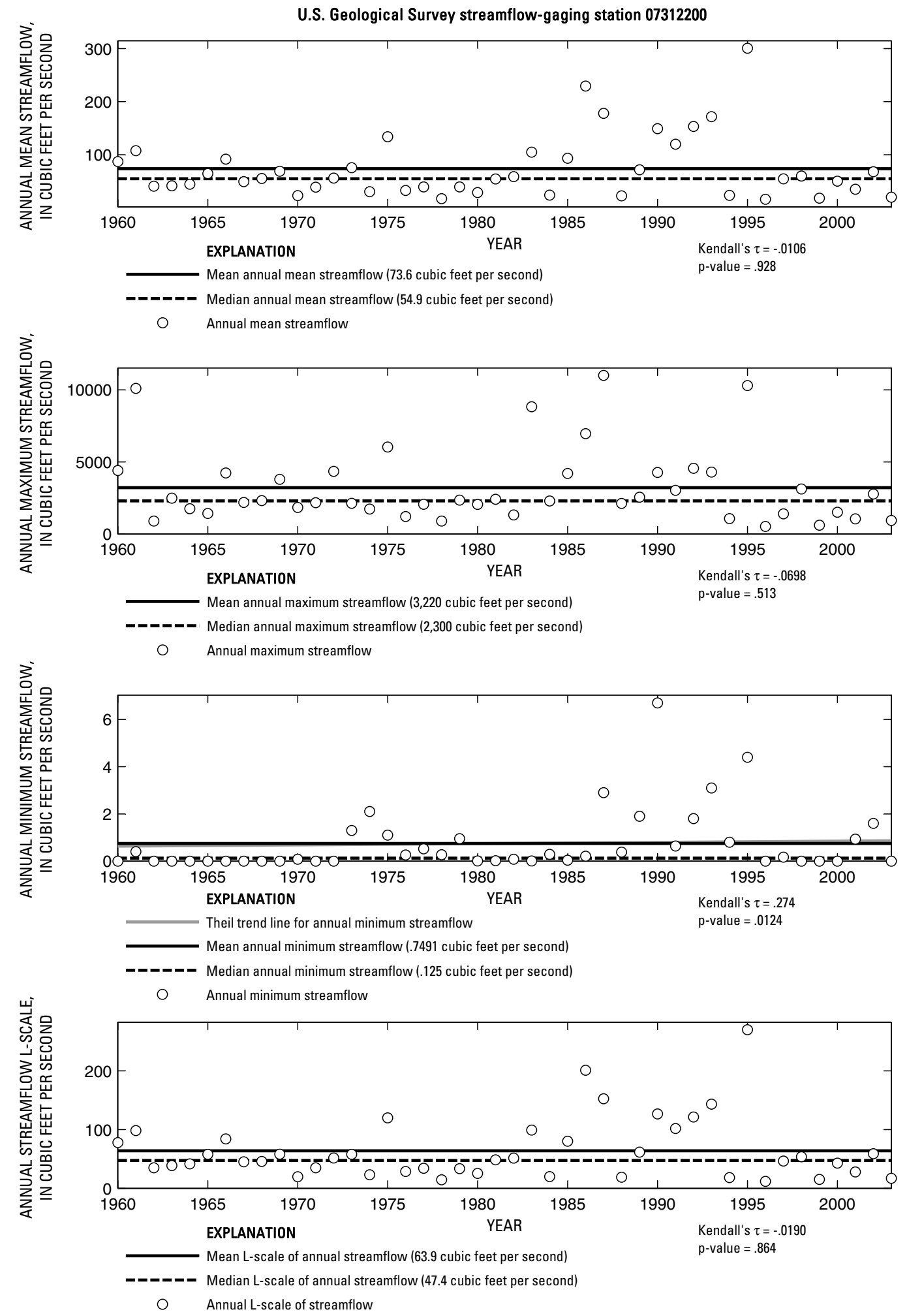

Figure 52. Analysis of annual mean, maximum, minimum, and L-scale statistics of daily mean streamflow for U.S. Geological Survey streamflow-gaging station 07312200 Beaver Creek near Electra, Texas.

Index of Station Numbers 719 

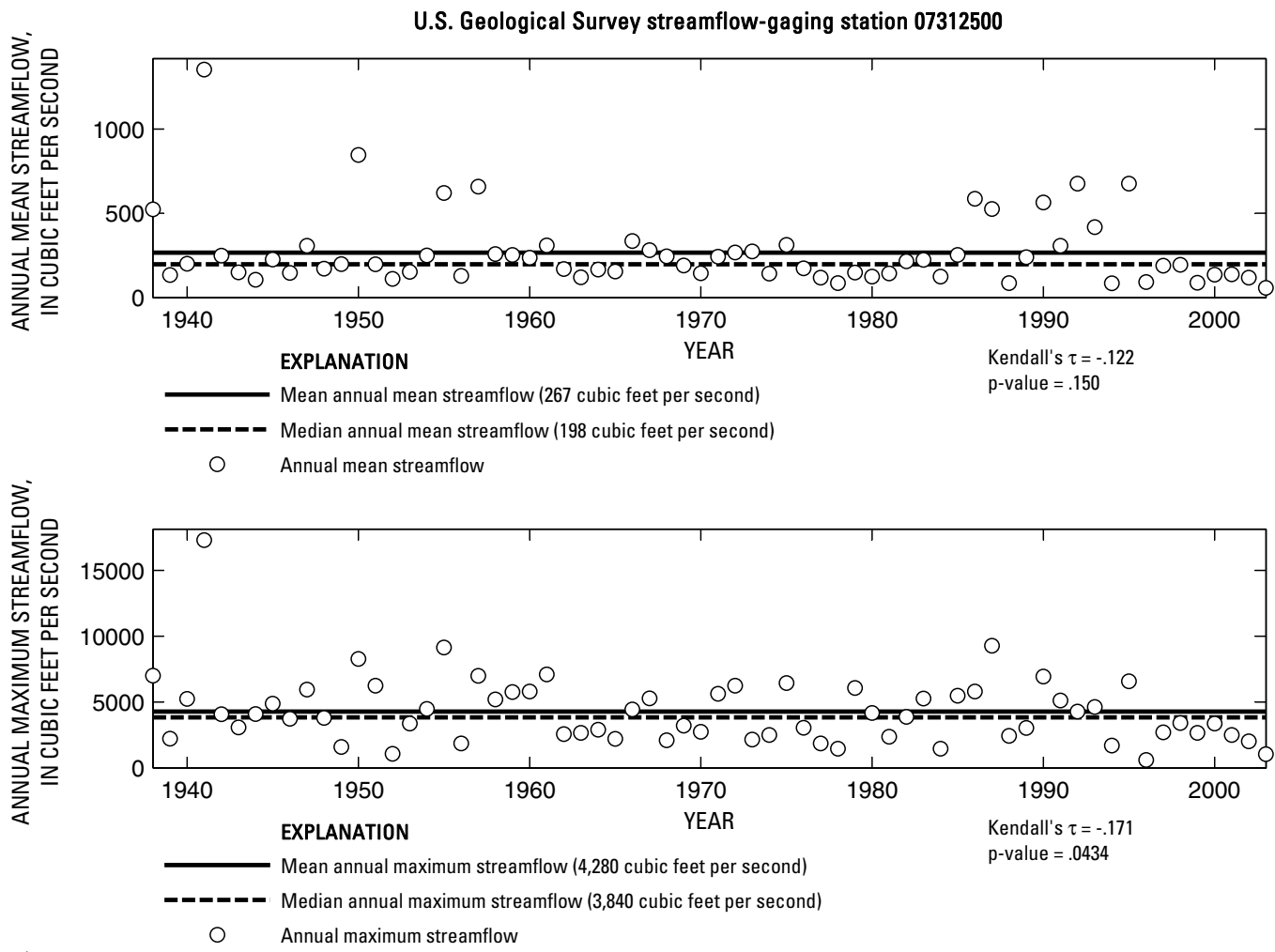

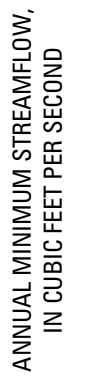

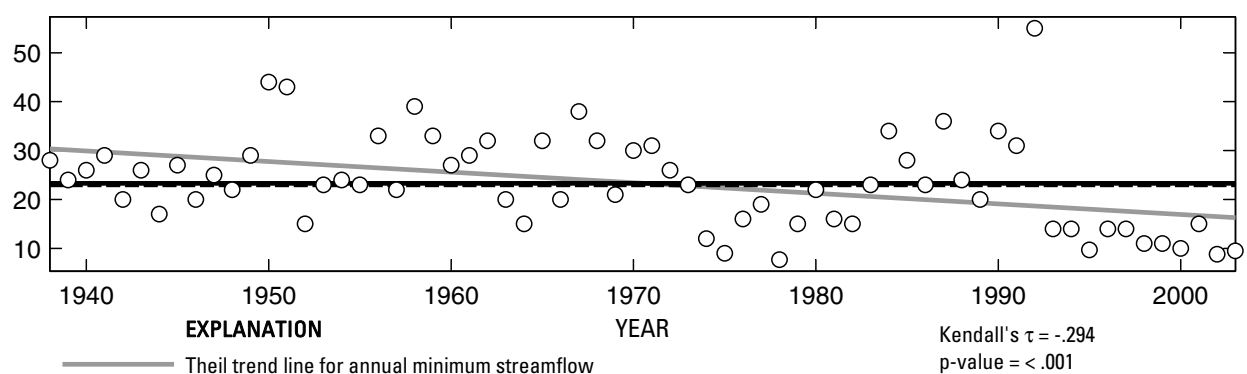

Theil trend line for annual minimum streamflow

p-value $=<.001$

Mean annual minimum streamflow (23.3 cubic feet per second)

Median annual minimum streamflow (23 cubic feet per second)

O Annual minimum streamflow

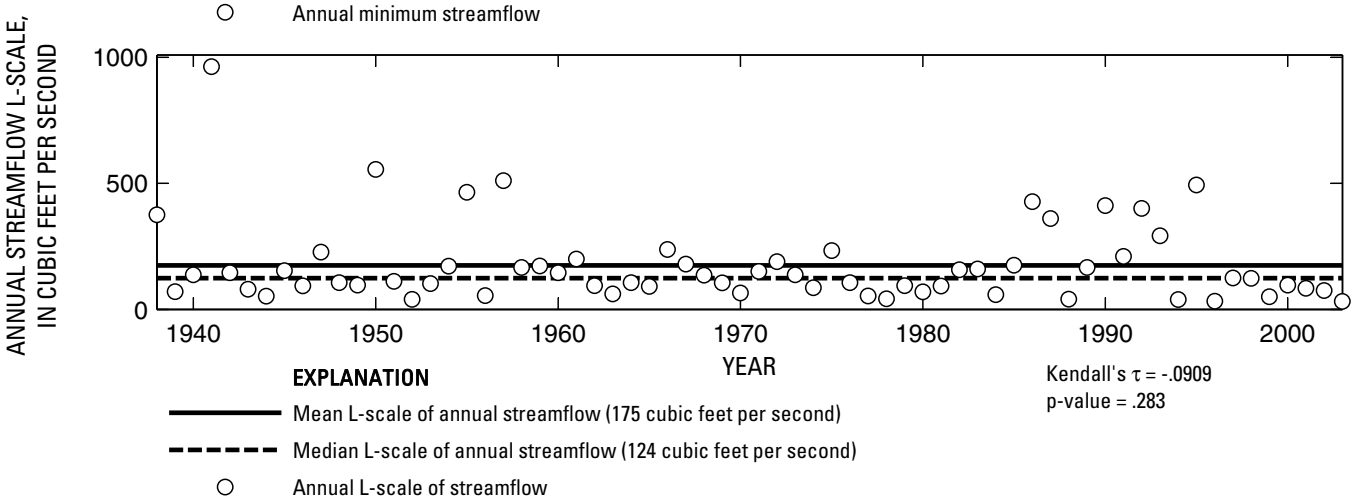

Figure 53. Analysis of annual mean, maximum, minimum, and L-scale statistics of daily mean streamflow for U.S. Geological Survey streamflow-gaging station 07312500 Wichita River at Wichita Falls, Texas. 


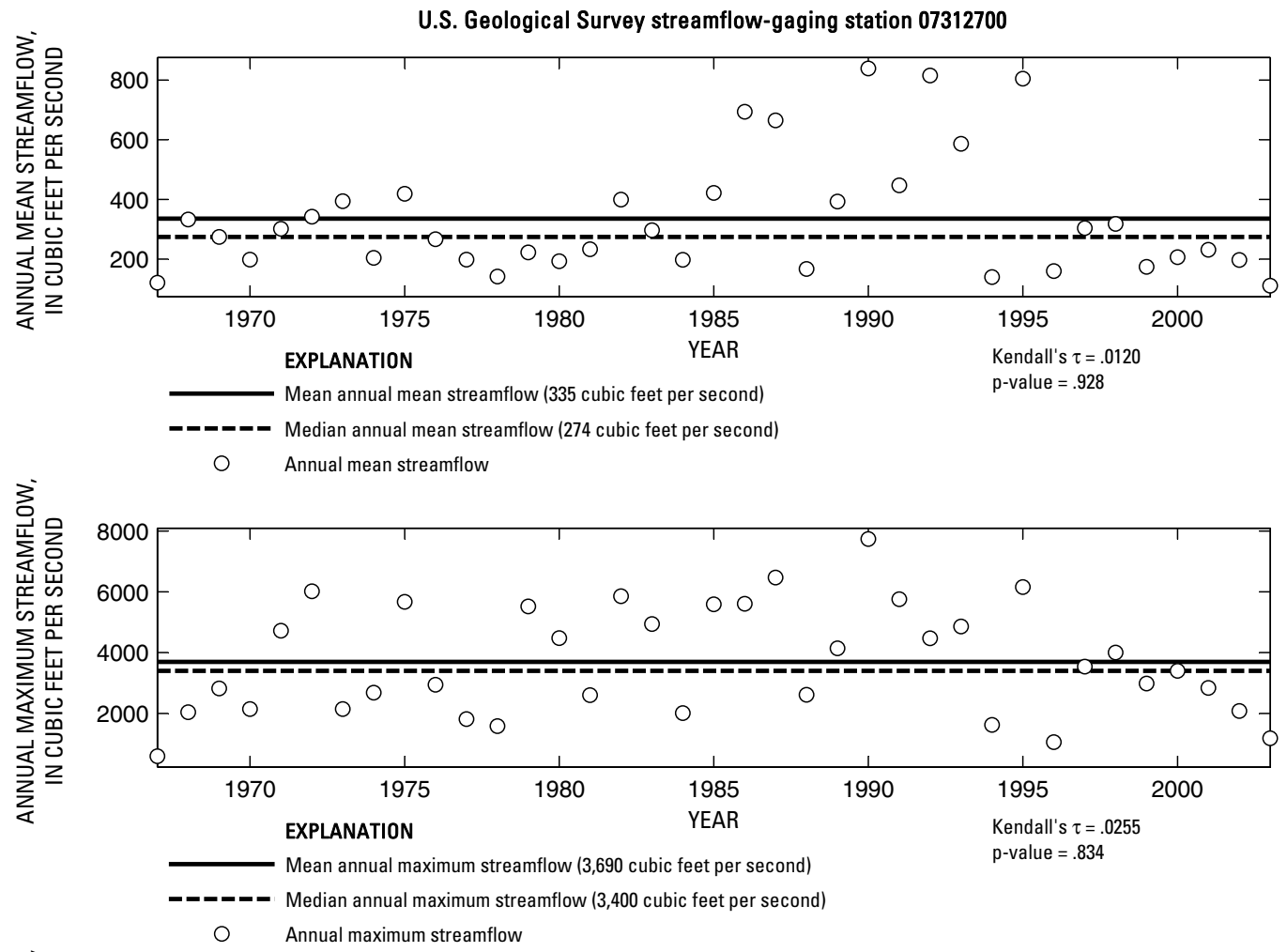

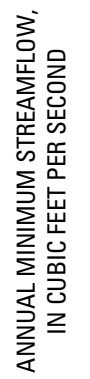

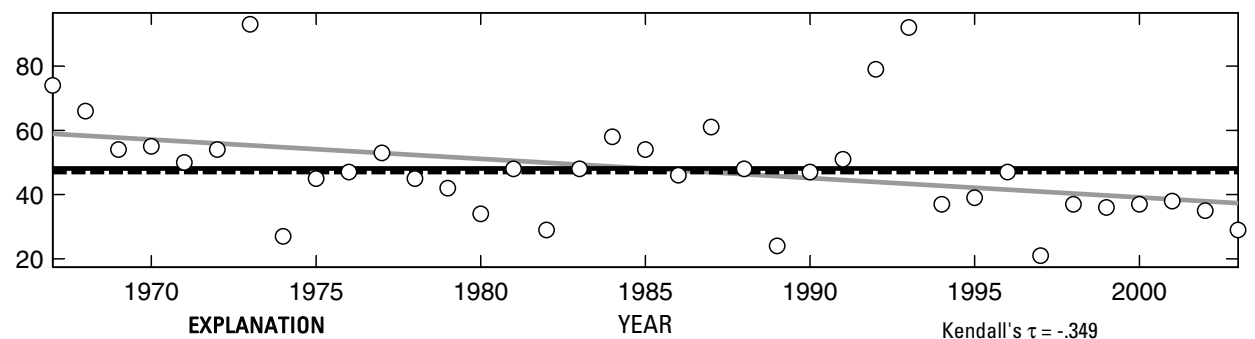

Theil trend line for annual minimum streamflow
Mean annual minimum streamflow (48.1 cubic feet per second)

O Annual minimum streamflow
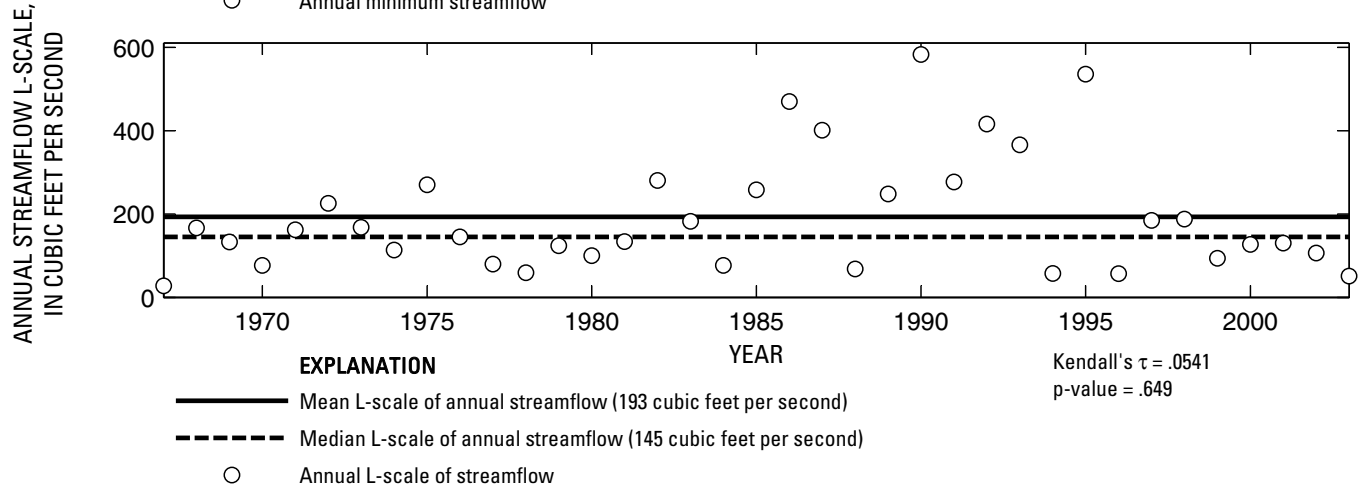

Figure 54. Analysis of annual mean, maximum, minimum, and L-scale statistics of daily mean streamflow for U.S. Geological Survey streamflow-gaging station 07312700 Wichita River near Charlie, Texas.

Index of Station Numbers 719 

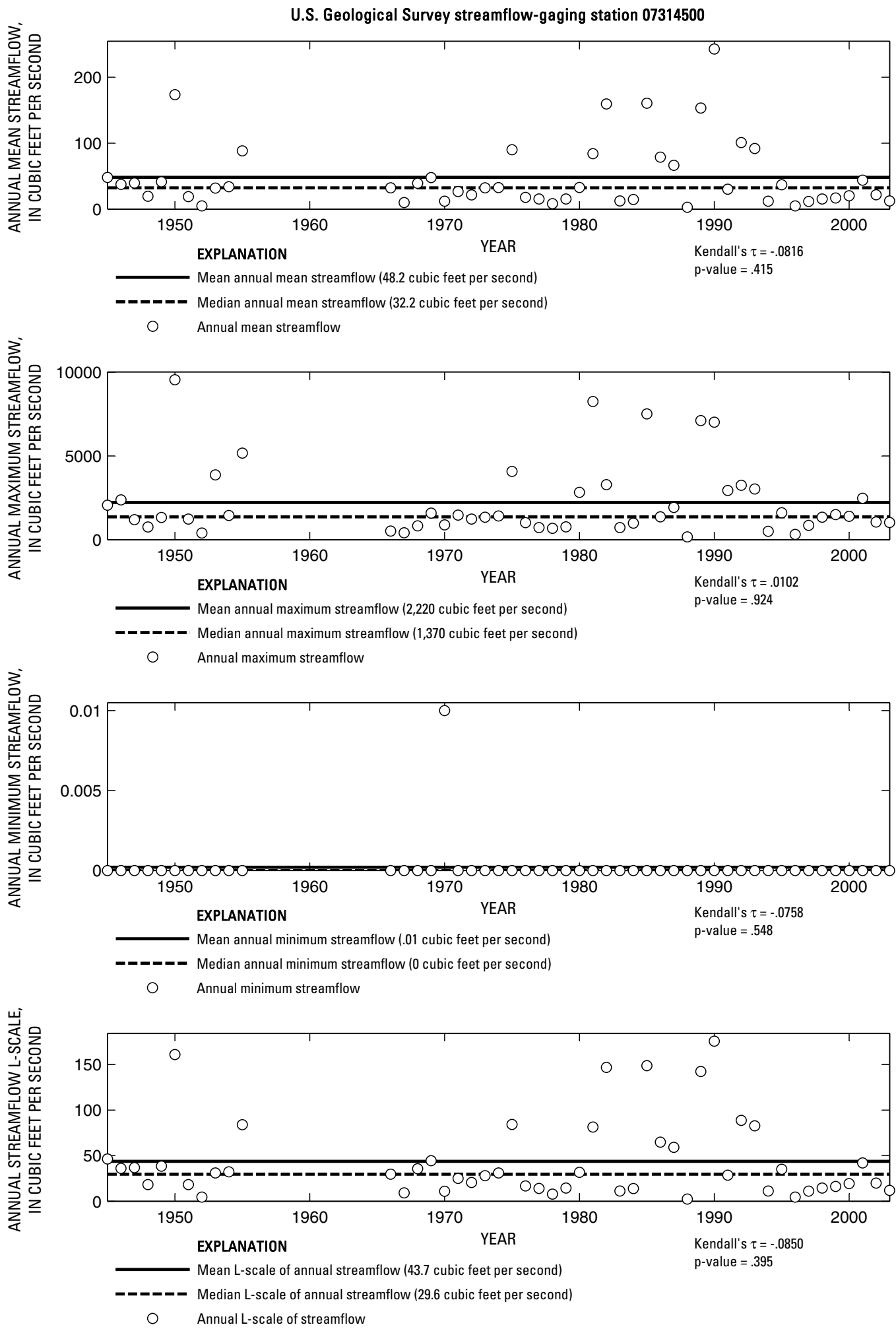

Figure 55. Analysis of annual mean, maximum, minimum, and L-scale statistics of daily mean streamflow for U.S. Geological Survey streamflow-gaging station 07314500 Little Wichita River near Archer City, Texas. 

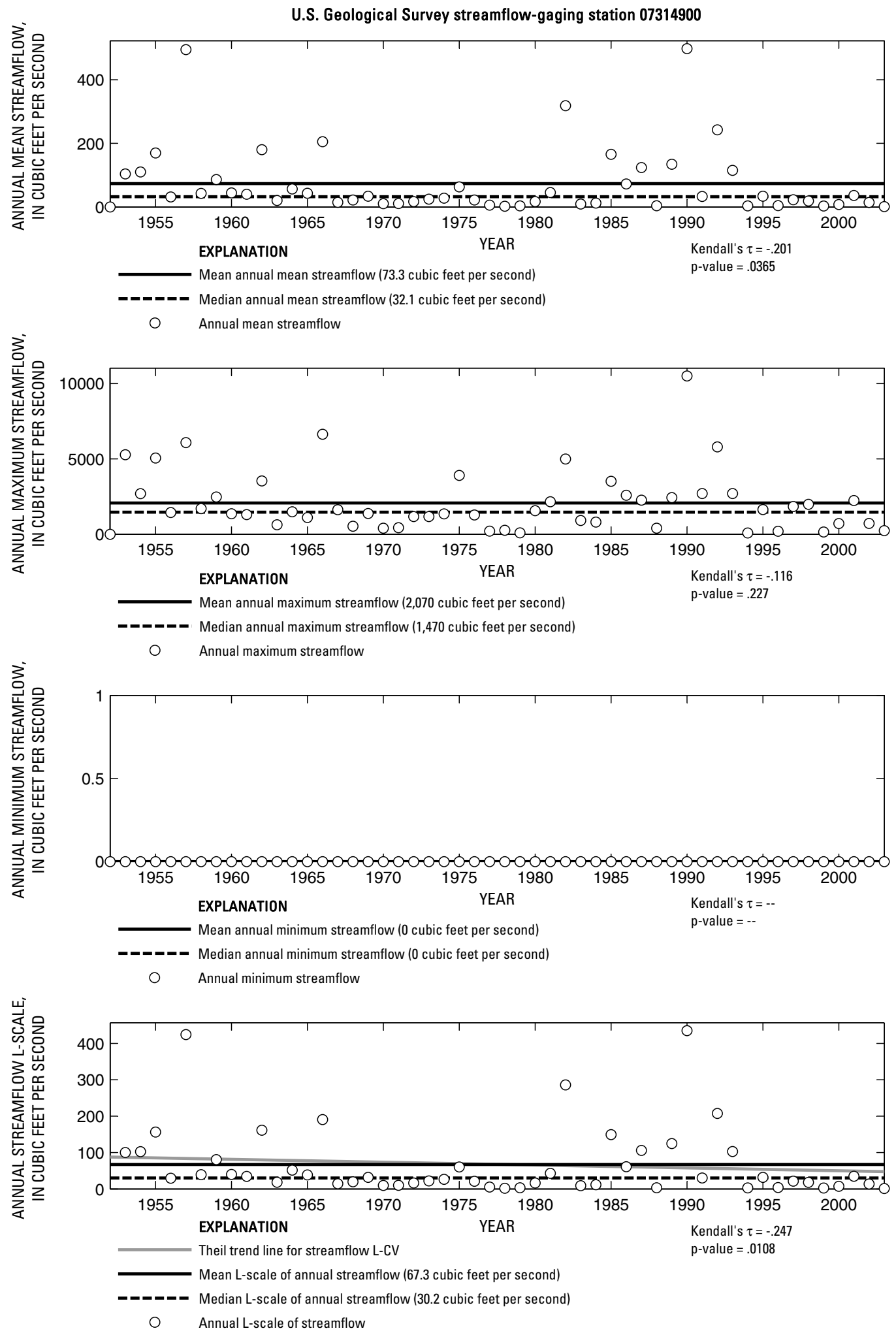

Figure 56. Analysis of annual mean, maximum, minimum, and L-scale statistics of daily mean streamflow for U.S. Geological Survey streamflow-gaging station 07314900 Little Wichita River above Henrietta, Texas.

Index of Station Numbers 719 

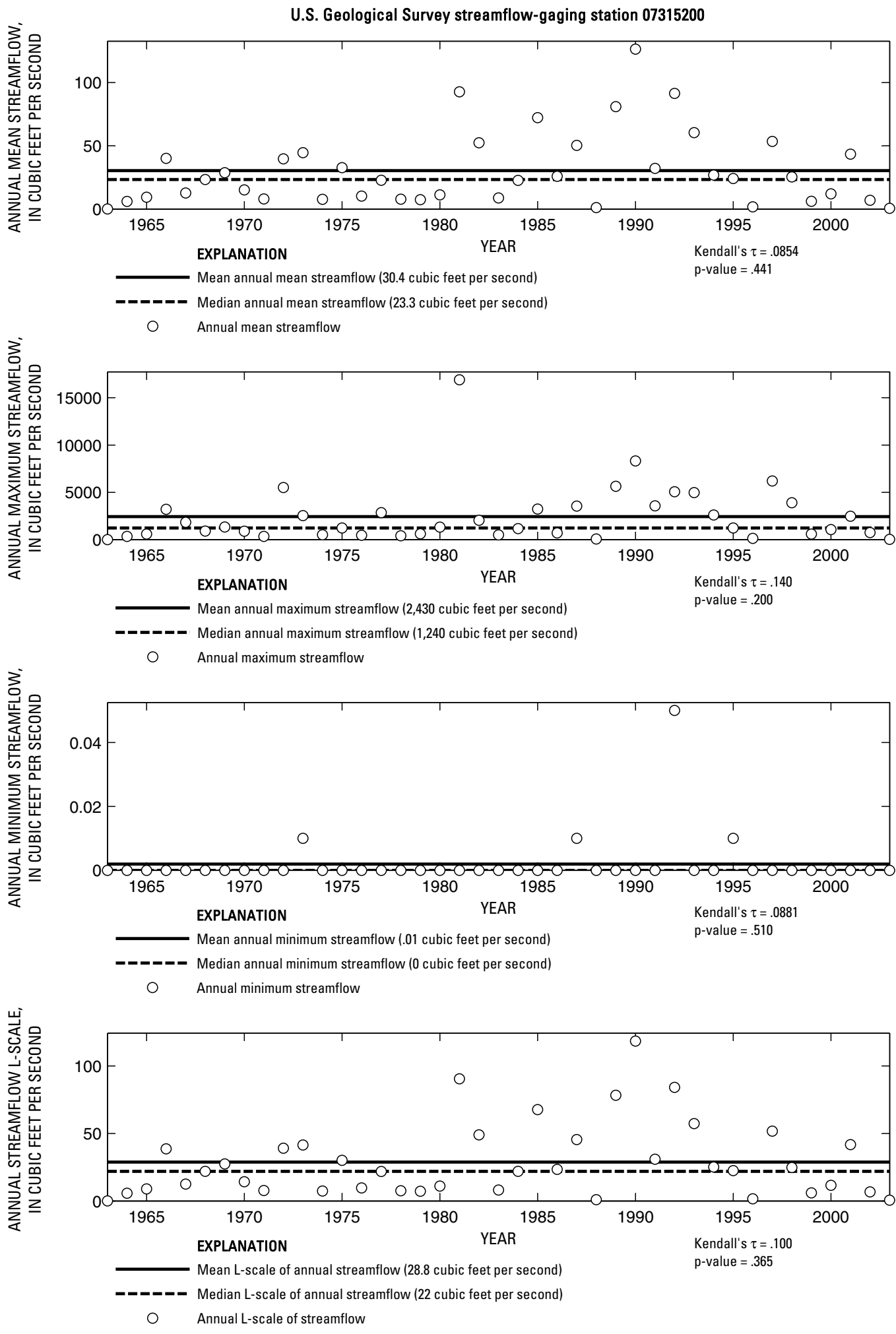

Figure 57. Analysis of annual mean, maximum, minimum, and L-scale statistics of daily mean streamflow for U.S. Geological Survey streamflow-gaging station 07315200 East Fork Little Wichita River near Henrietta, Texas. 

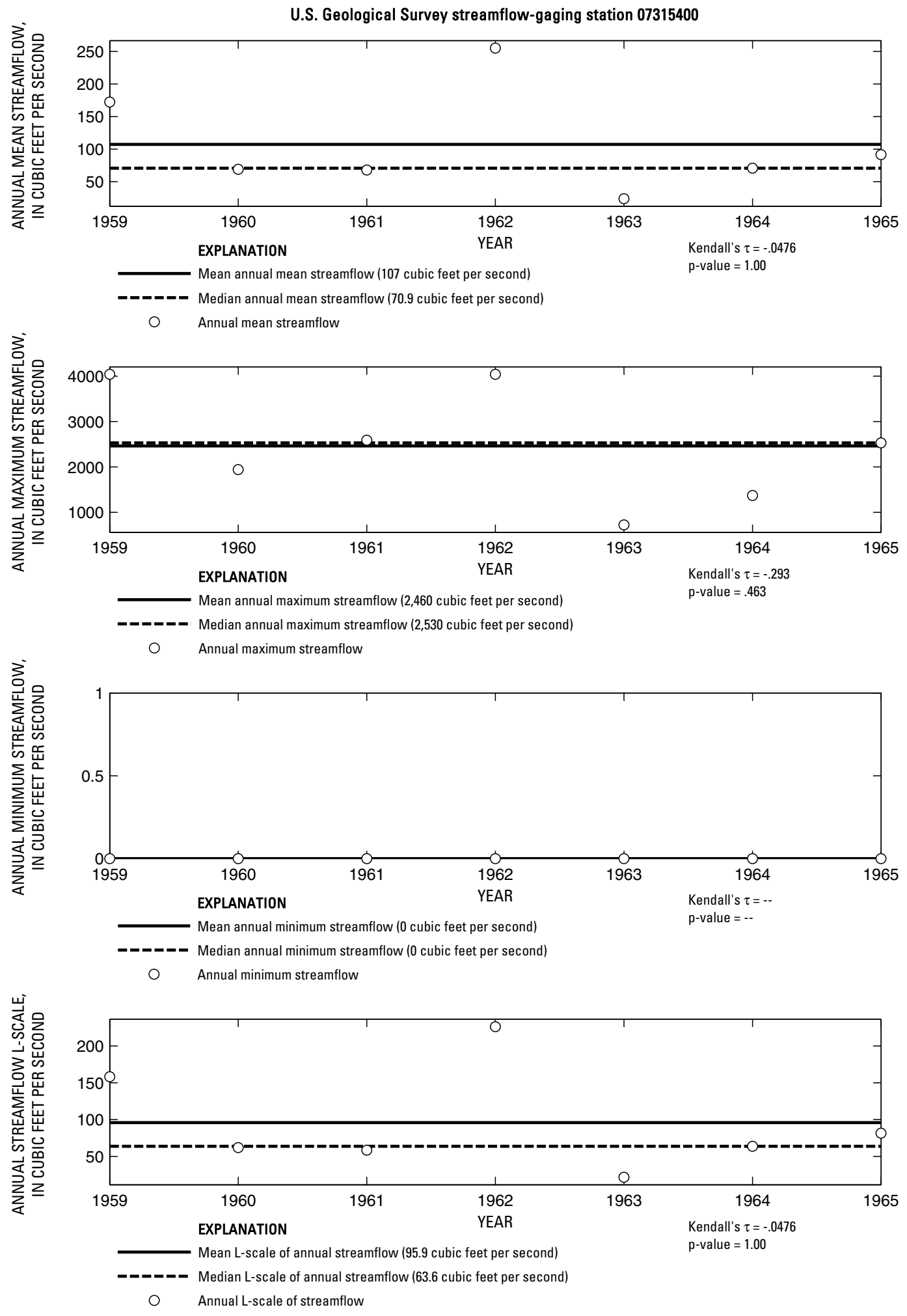

Figure 58. Analysis of annual mean, maximum, minimum, and L-scale statistics of daily mean streamflow for U.S. Geological Survey streamflow-gaging station 07315400 Little Wichita River near Ringgold, Texas.

Index of Station Numbers 719 


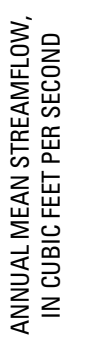

U.S. Geological Survey streamflow-gaging station 07316200

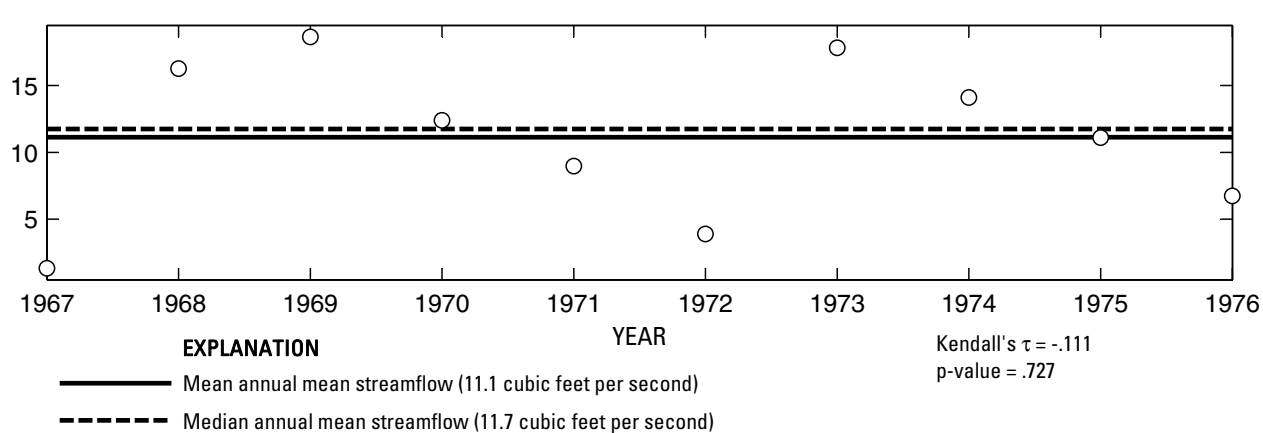

O Annual mean streamflow
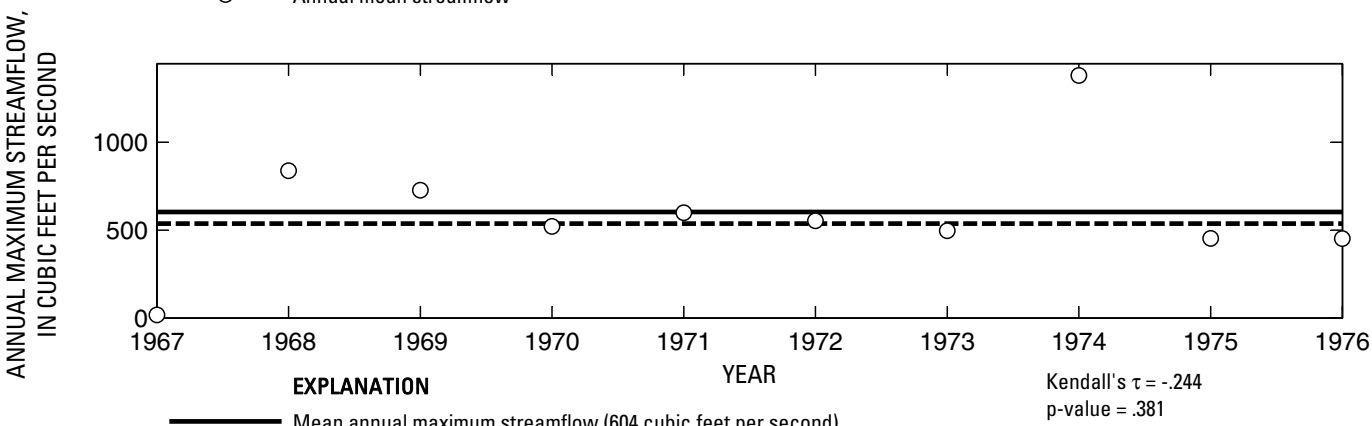

O Annual maximum streamflow
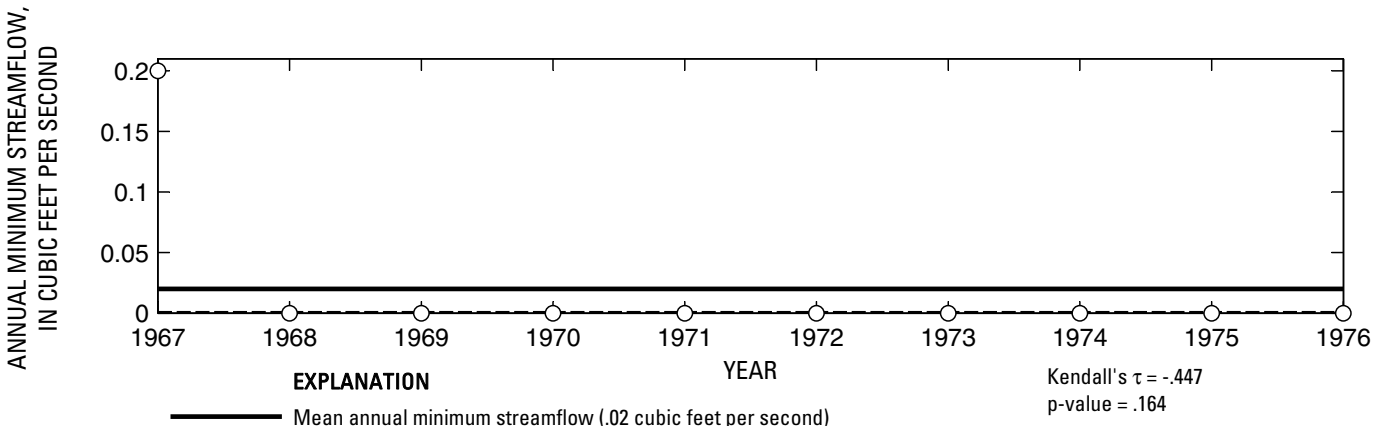

-_-_- Median annual minimum streamflow (0 cubic feet per second)

○ Annual minimum streamflow

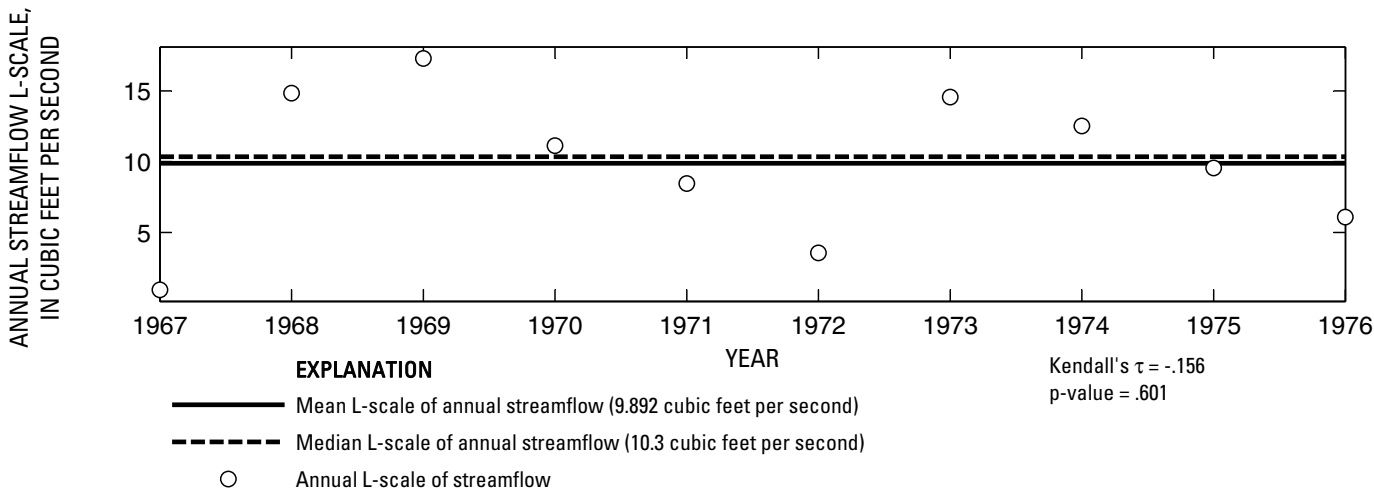

Figure 59. Analysis of annual mean, maximum, minimum, and L-scale statistics of daily mean streamflow for U.S. Geological Survey streamflow-gaging station 07316200 Mineral Creek near Sadler, Texas.

Index of Station Numbers 719 


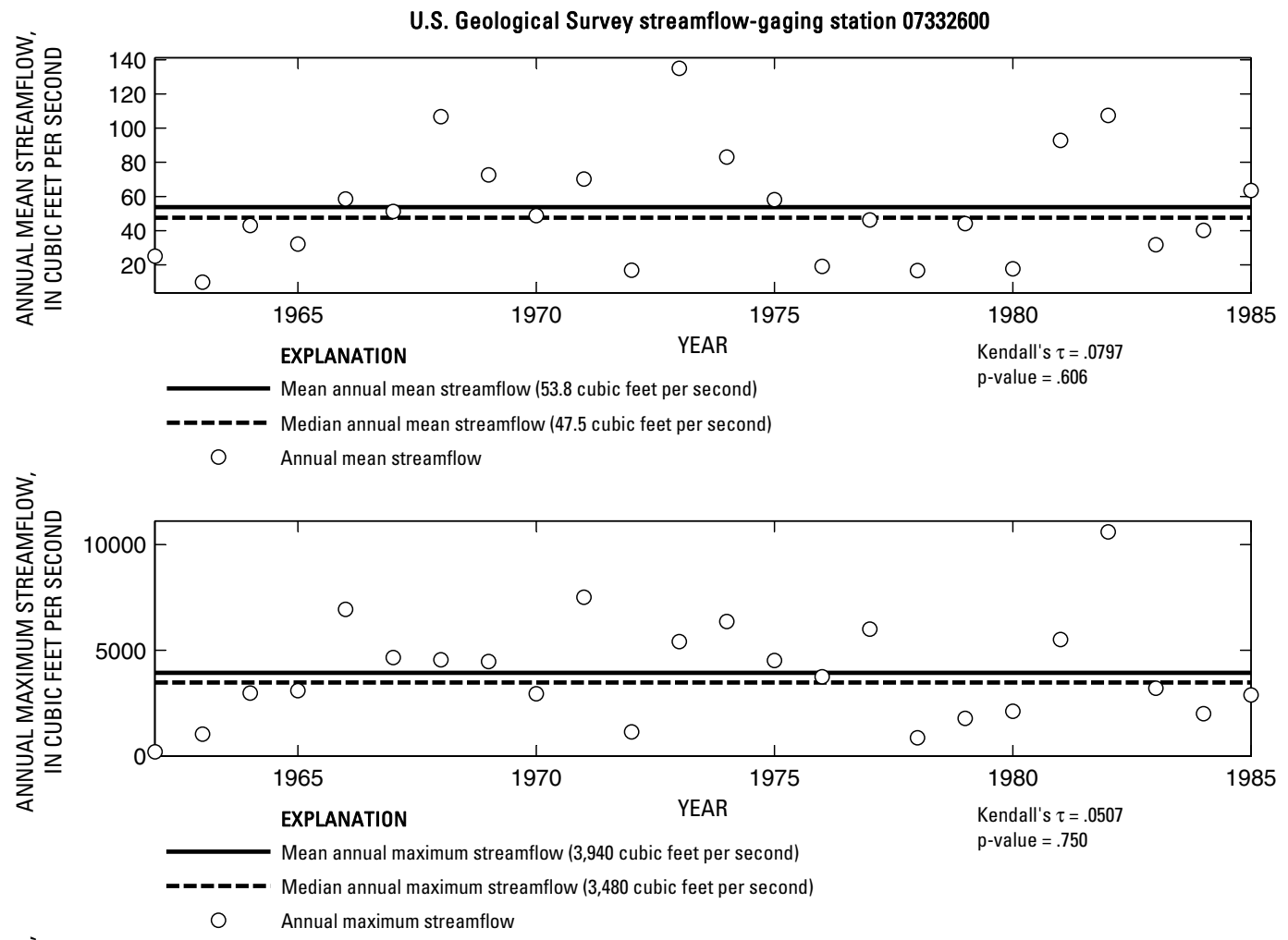

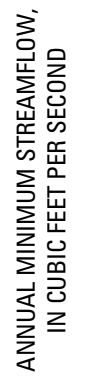

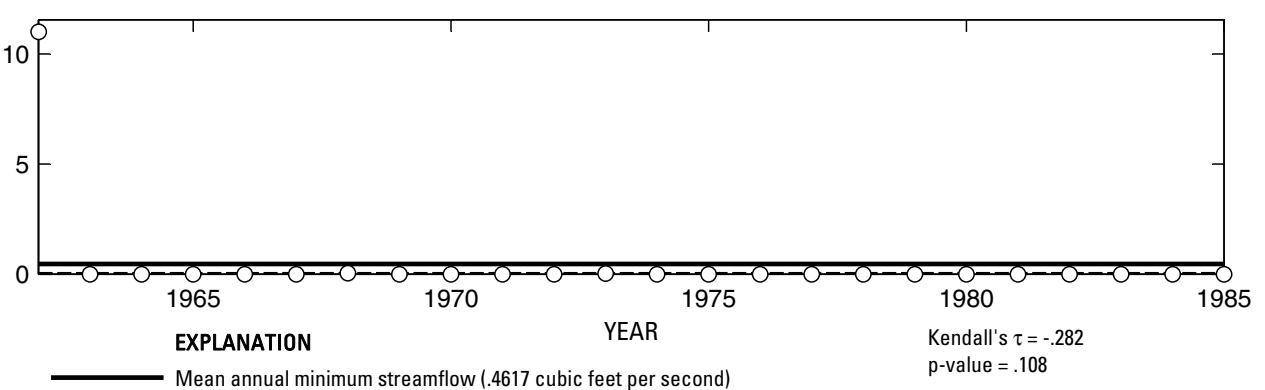

- - - Median annual minimum streamflow (0 cubic feet per second)

O Annual minimum streamflow

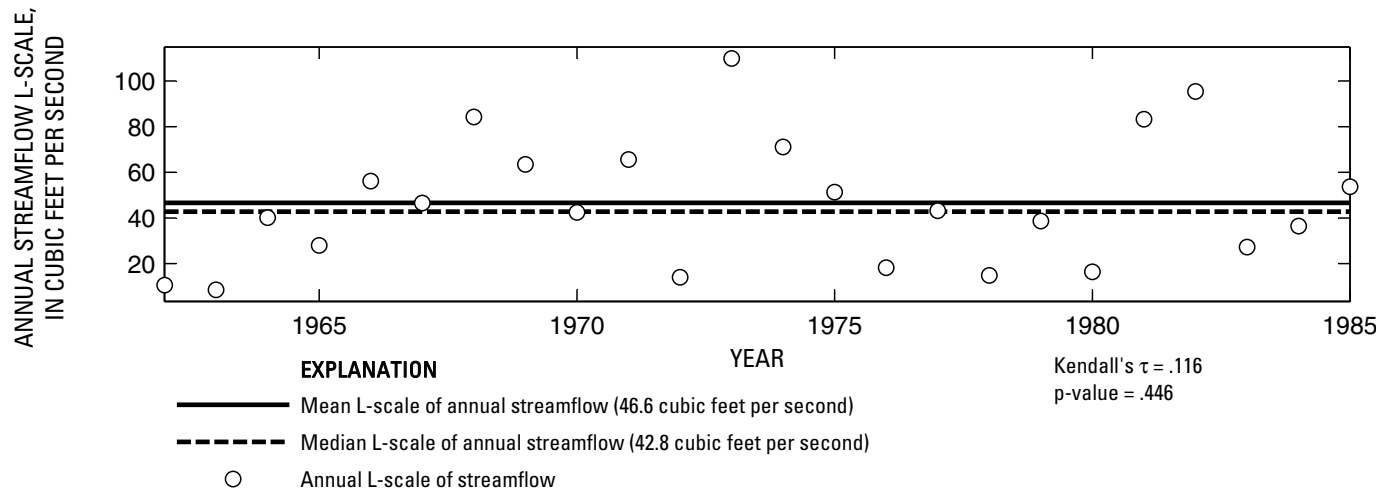

Figure 60. Analysis of annual mean, maximum, minimum, and L-scale statistics of daily mean streamflow for U.S. Geological Survey streamflow-gaging station 07332600 Bois d'Arc Creek near Randolph, Texas.

Index of Station Numbers 719 

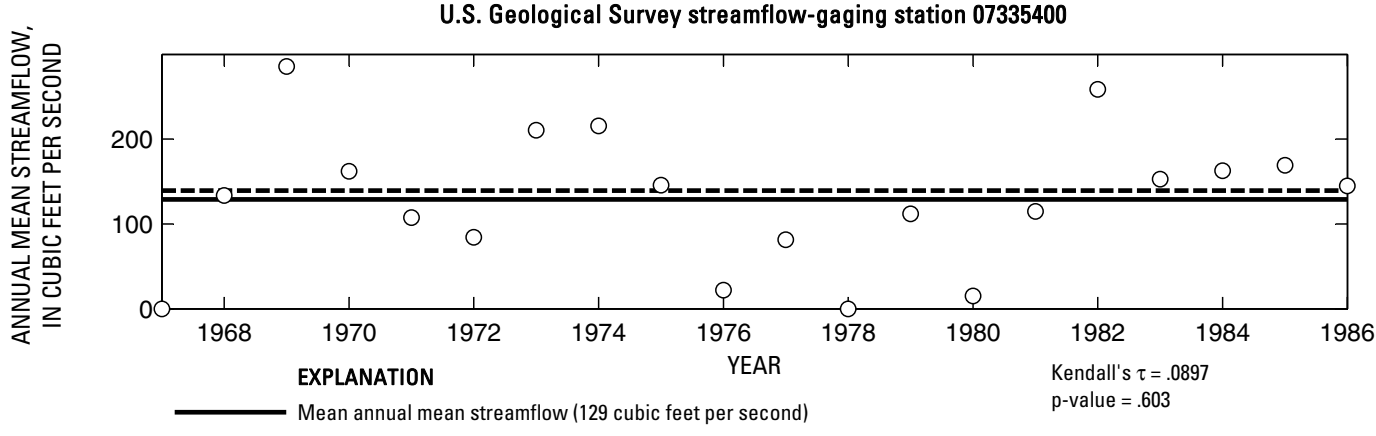

-_-_- Median annual mean streamflow (139 cubic feet per second)

O Annual mean streamflow
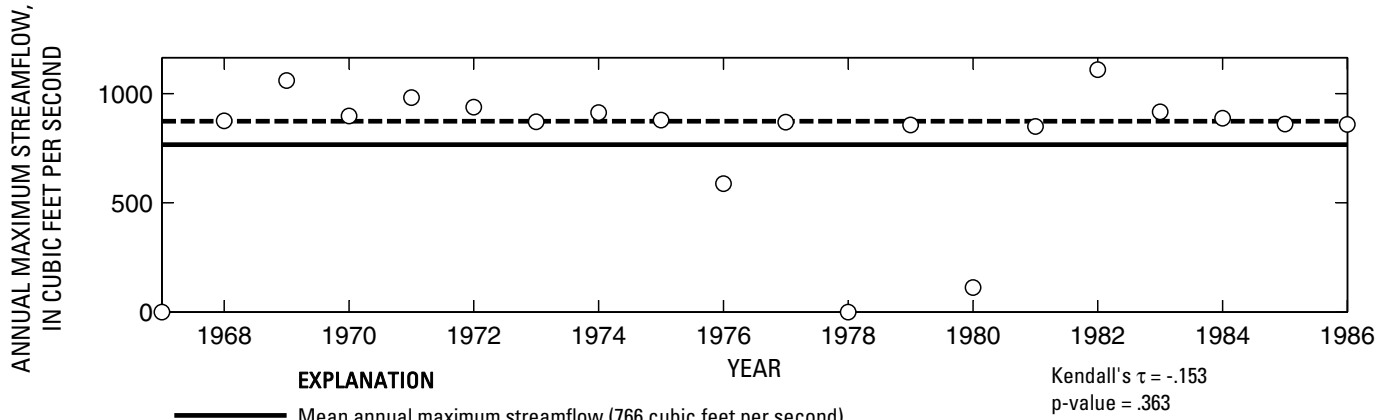

O Annual maximum streamflow

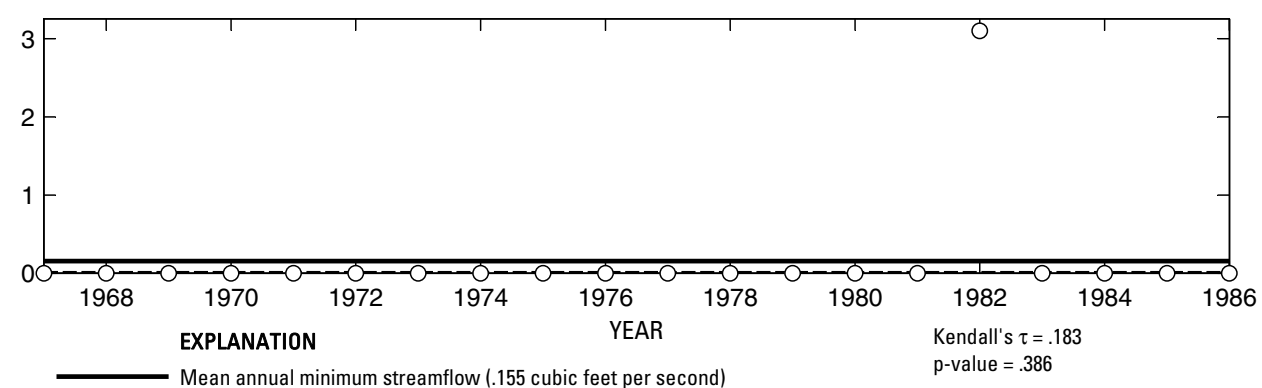

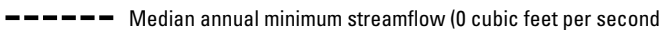

O Annual minimum streamflow

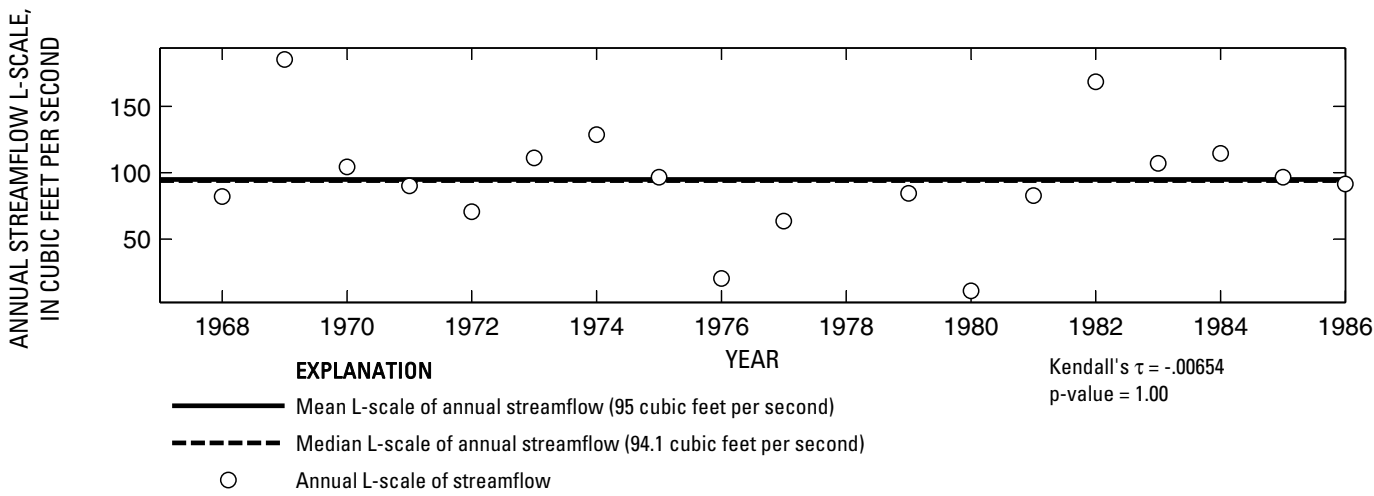

Figure 61. Analysis of annual mean, maximum, minimum, and L-scale statistics of daily mean streamflow for U.S. Geological Survey streamflow-gaging station 07335400 Sanders Creek near Chicota, Texas. 

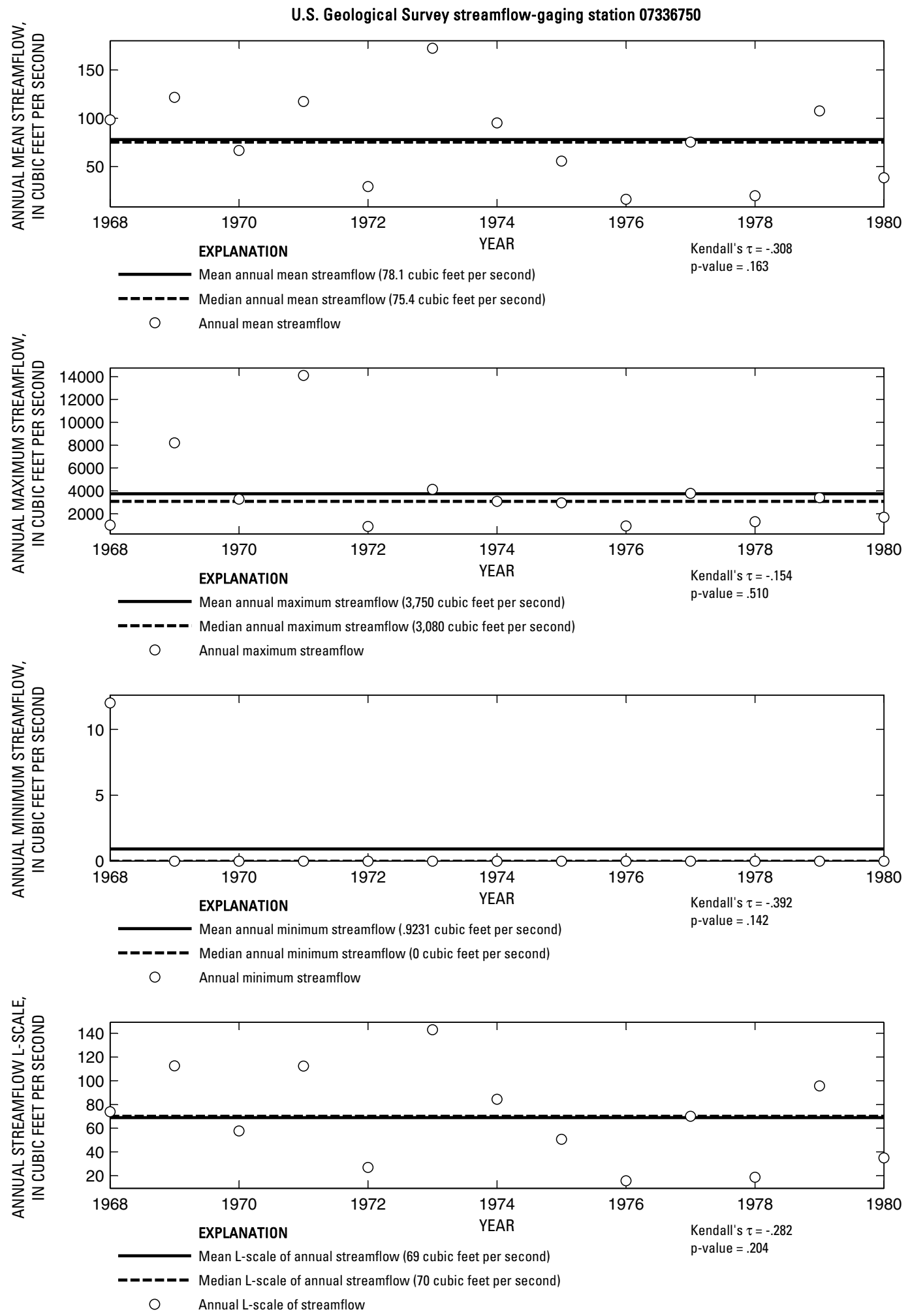

Figure 62. Analysis of annual mean, maximum, minimum, and L-scale statistics of daily mean streamflow for U.S. Geological Survey streamflow-gaging station 07336750 Little Pine Creek near Kanawha, Texas.

Index of Station Numbers 719 


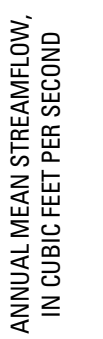

U.S. Geological Survey streamflow-gaging station 07336800

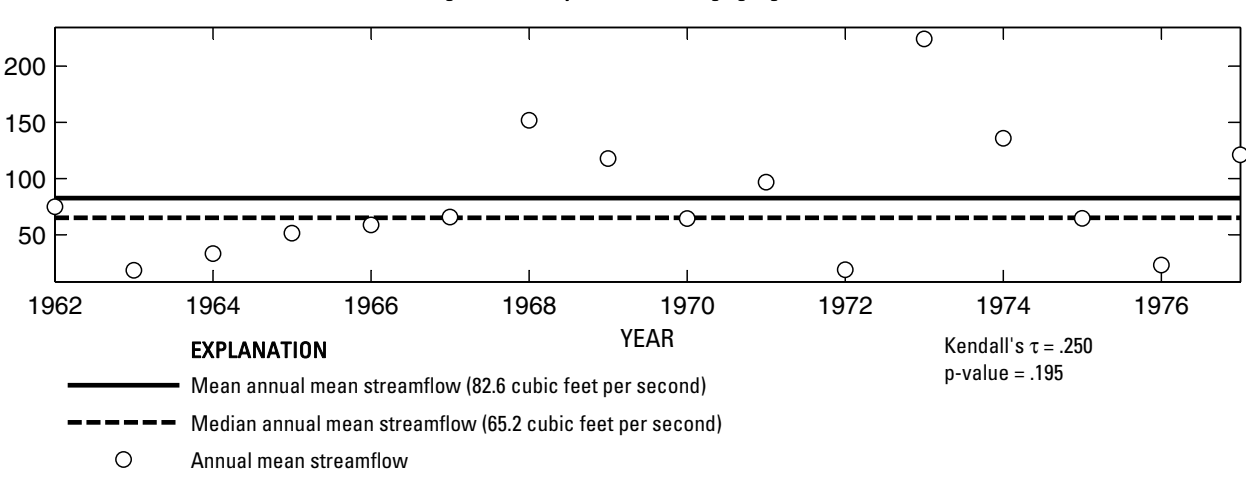

交
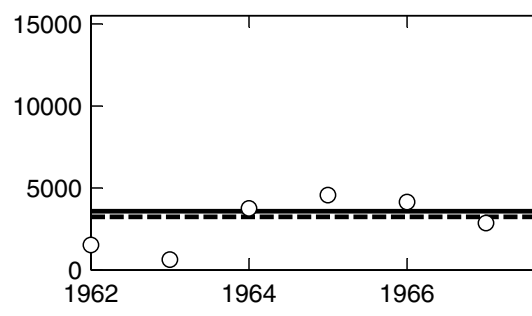

EXPLANATION

Mean annual maximum streamflow (3,580 cubic feet per second)

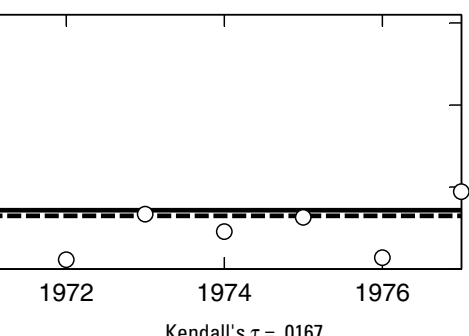

ב-10. Median annual maximum streamflow $(3,250$ cubic feet per second $)$

O Annual maximum streamflow
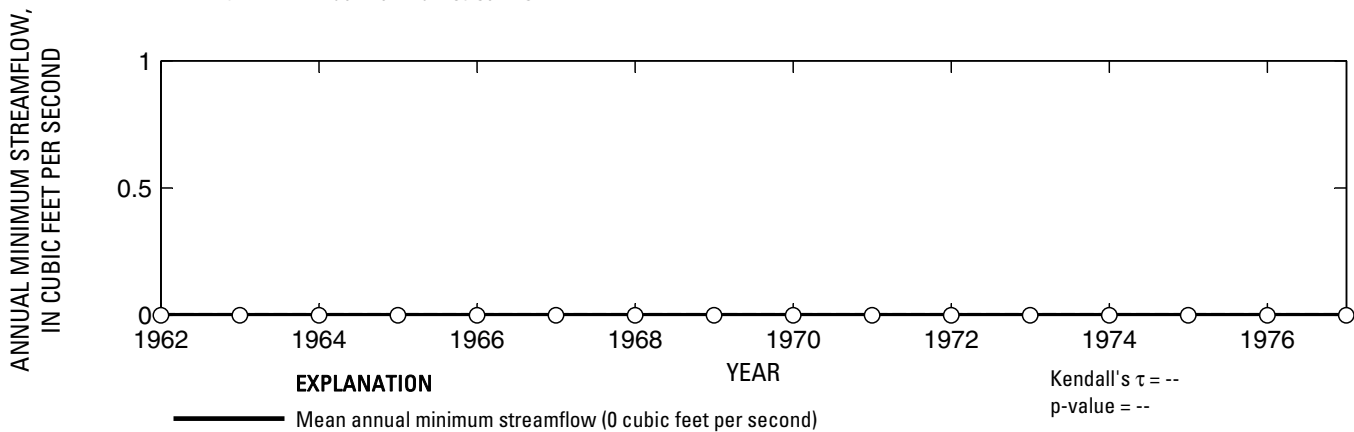

- ב-ב Median annual minimum streamflow (0 cubic feet per second)

○ Annual minimum streamflow

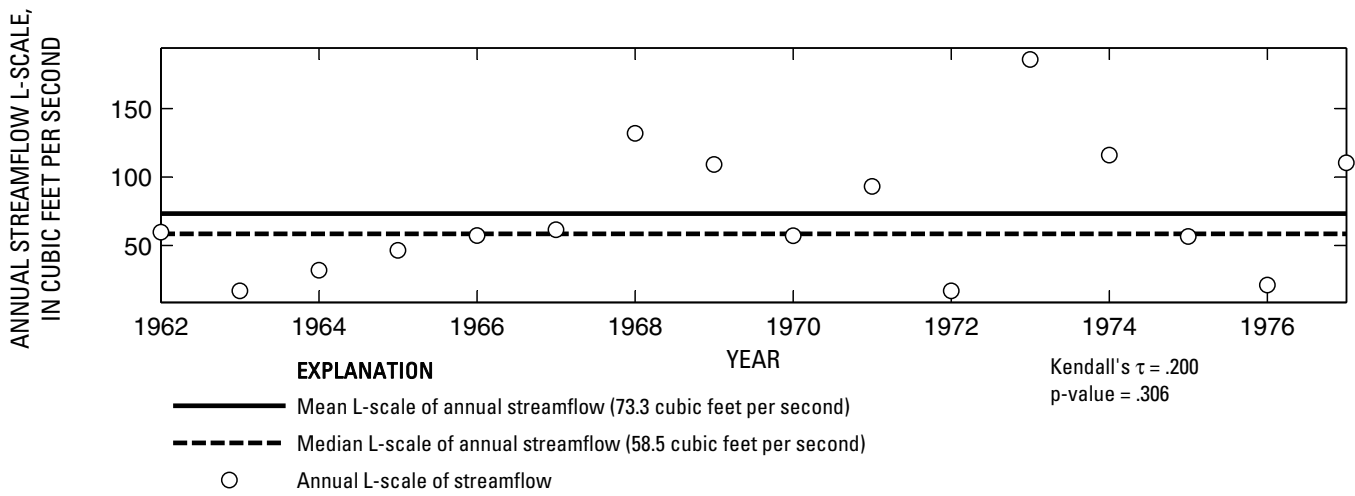

Figure 63. Analysis of annual mean, maximum, minimum, and L-scale statistics of daily mean streamflow for U.S. Geological Survey streamflow-gaging station 07336800 Pecan Bayou near Clarksville, Texas. 

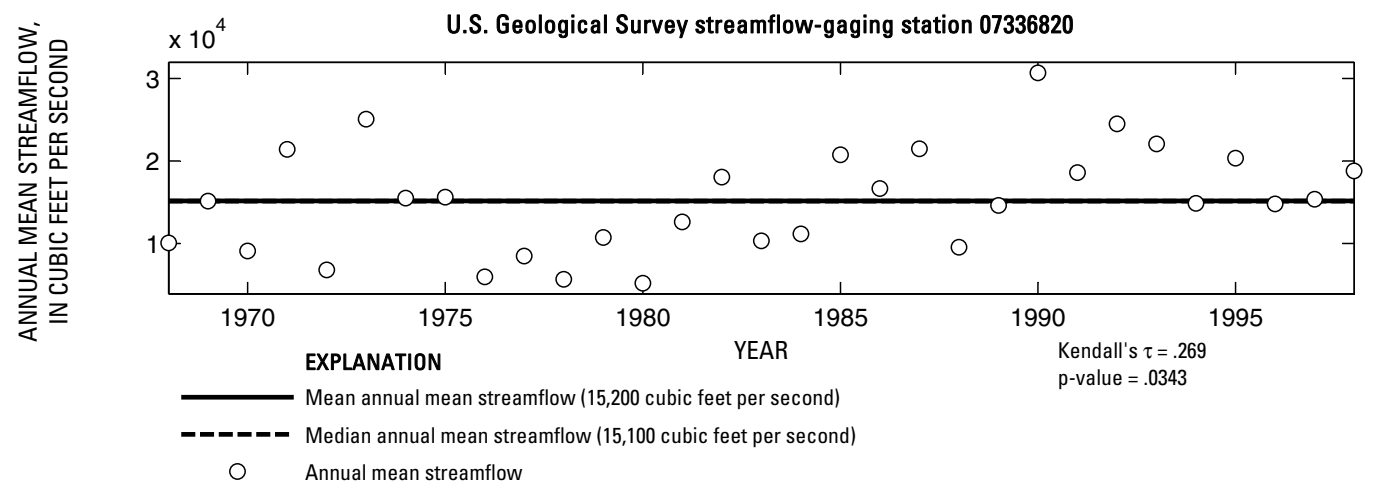

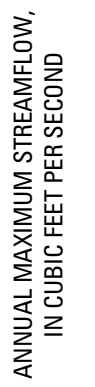

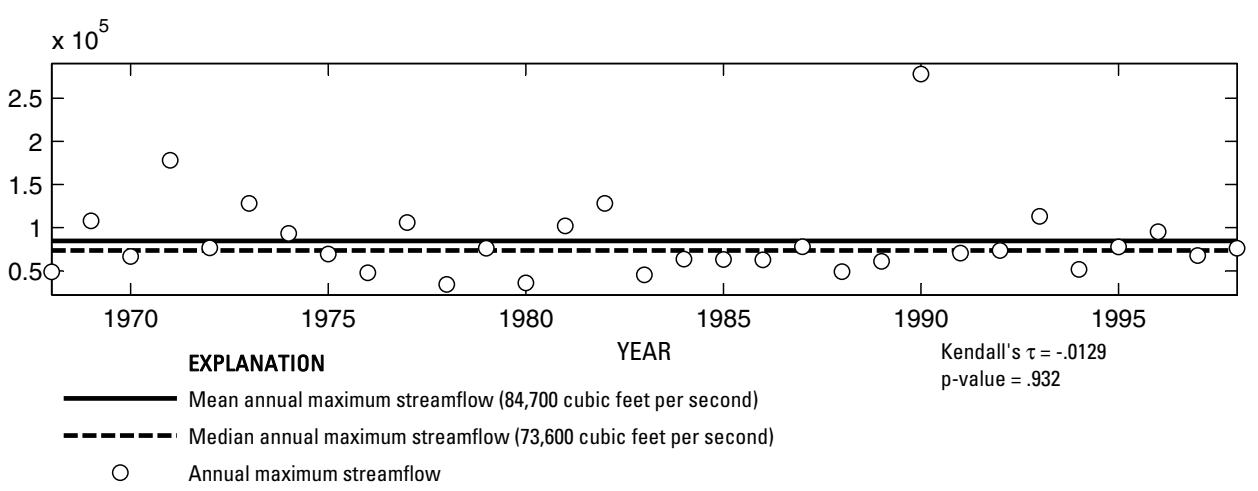

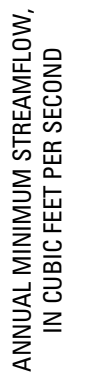

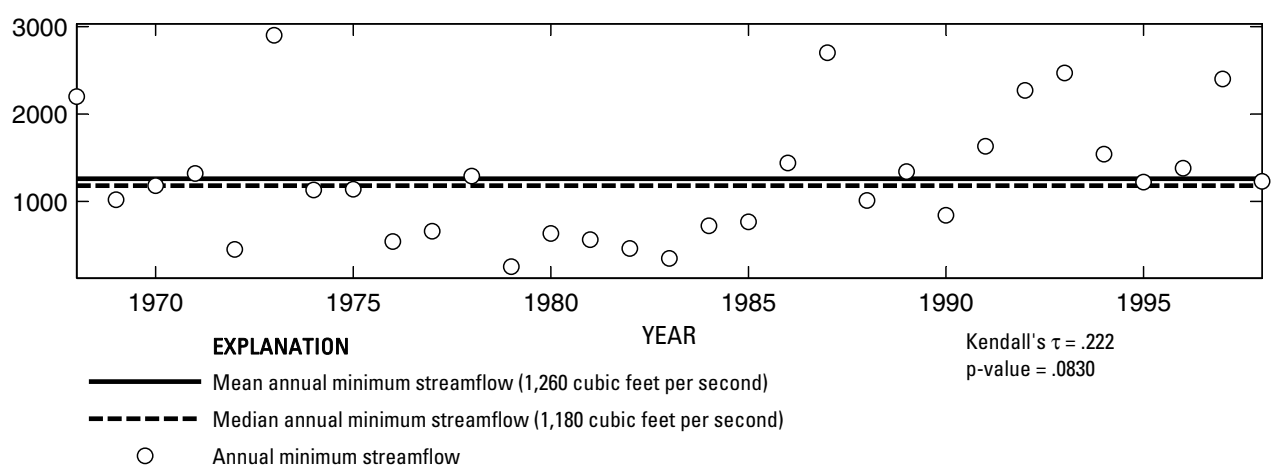

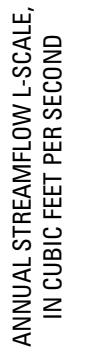

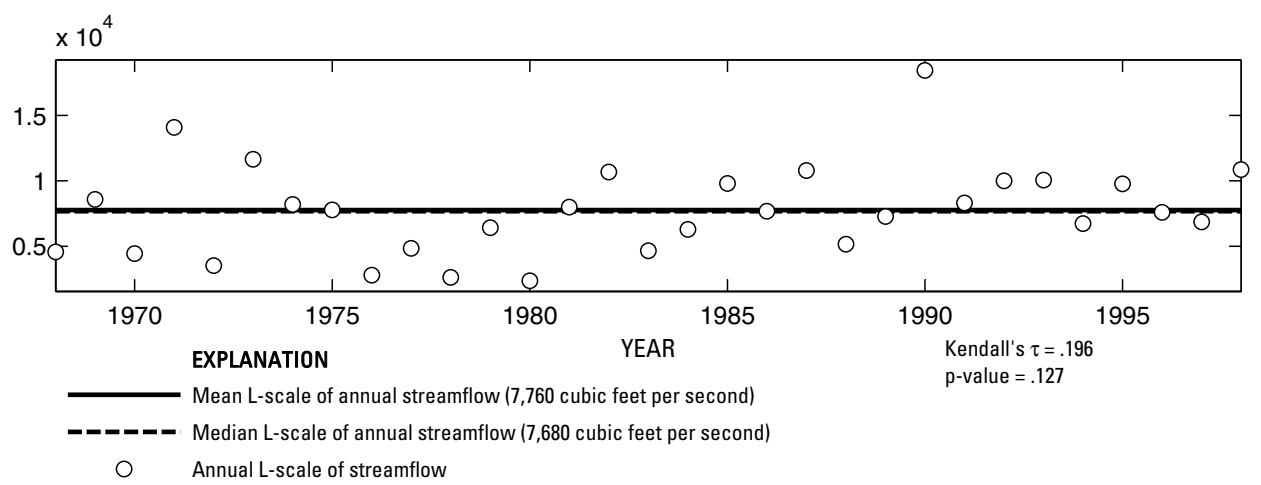

Figure 64. Analysis of annual mean, maximum, minimum, and L-scale statistics of daily mean streamflow for U.S. Geological Survey streamflow-gaging station 07336820 Red River near De Kalb, Texas.

Index of Station Numbers 719 


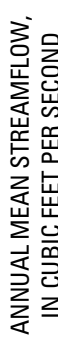

U.S. Geological Survey streamflow-gaging station 07342465

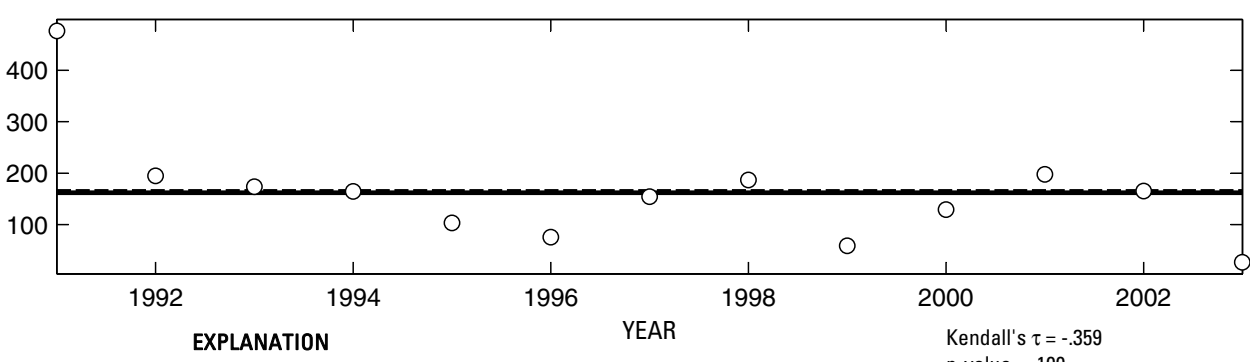

Mean annual mean streamflow (162 cubic feet per second)

$\mathrm{p}$-value $=.100$

-_-_-_ Median annual mean streamflow (164 cubic feet per second)

O Annual mean streamflow

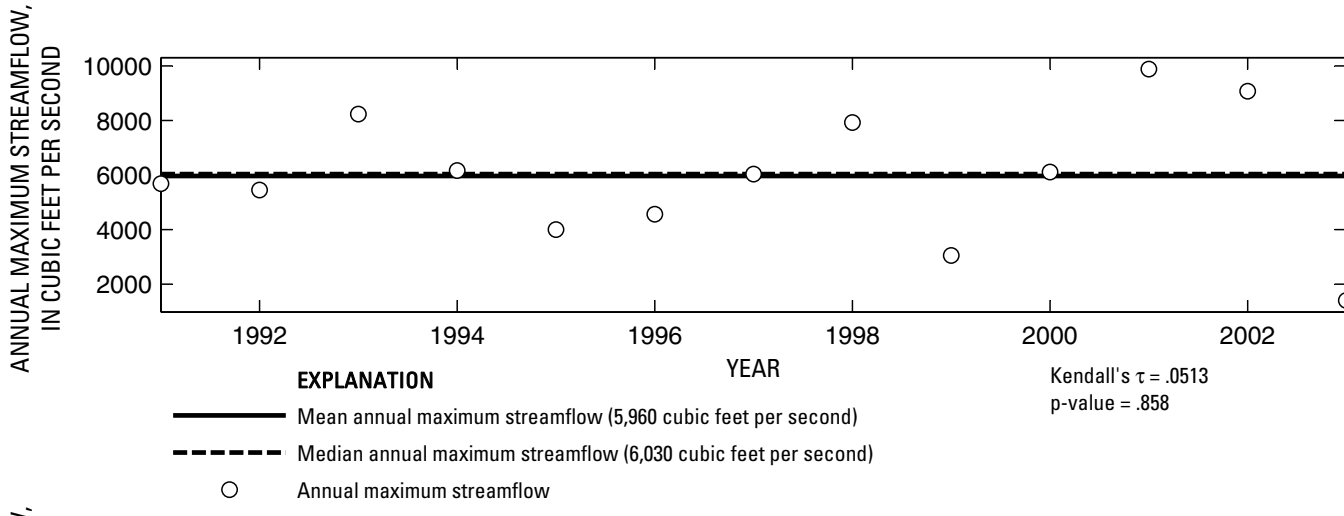

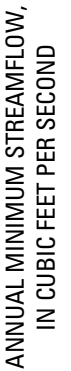

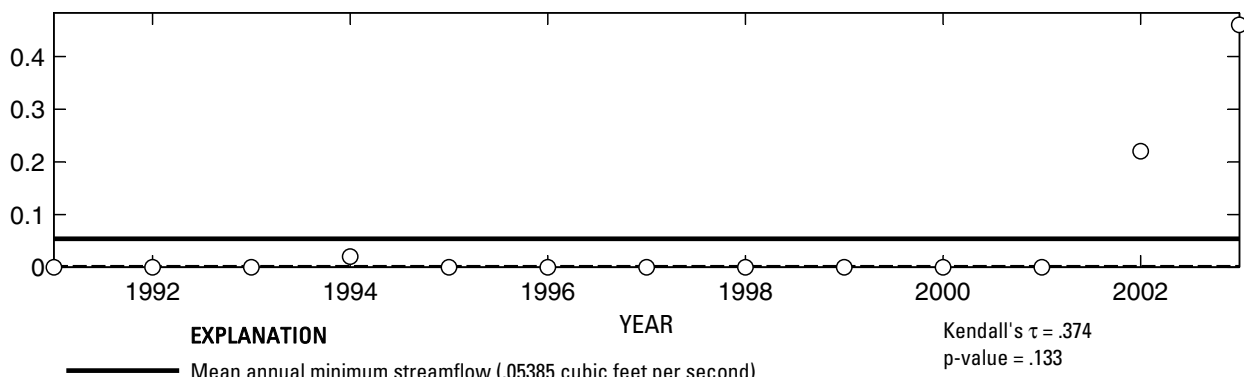

- - Median annual minimum streamflow (0 cubic feet per second)

O Annual minimum streamflow

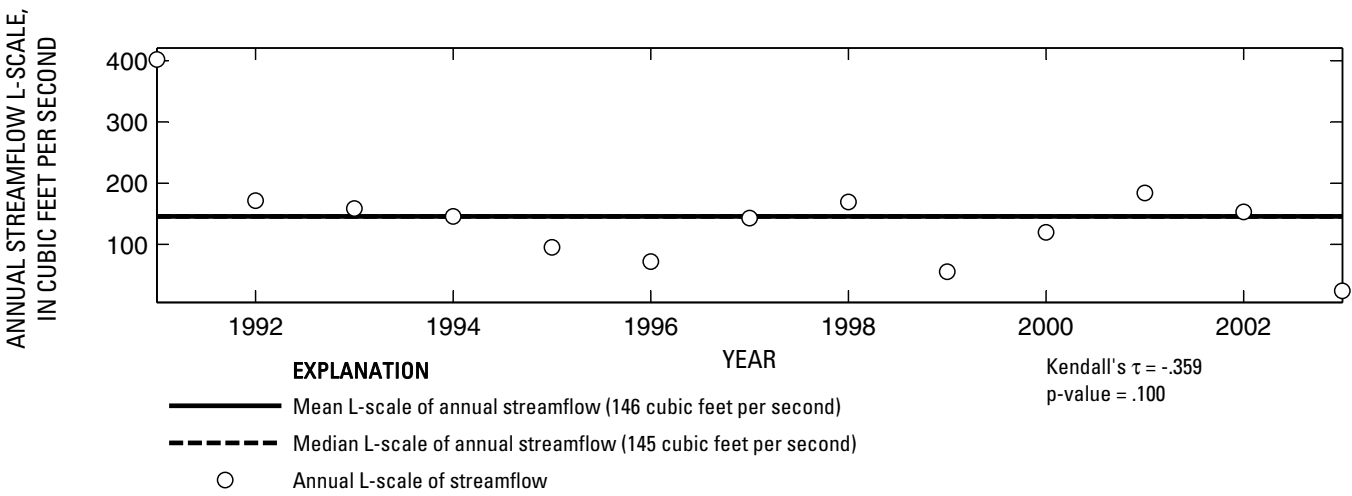

Figure 65. Analysis of annual mean, maximum, minimum, and L-scale statistics of daily mean streamflow for U.S. Geological Survey streamflow-gaging station 07342465 South Sulphur River at Commerce, Texas. 
70 Summary of Annual Mean, Maximum, Minimum, and L-scale Statistics of Daily Mean Streamflow in Texas

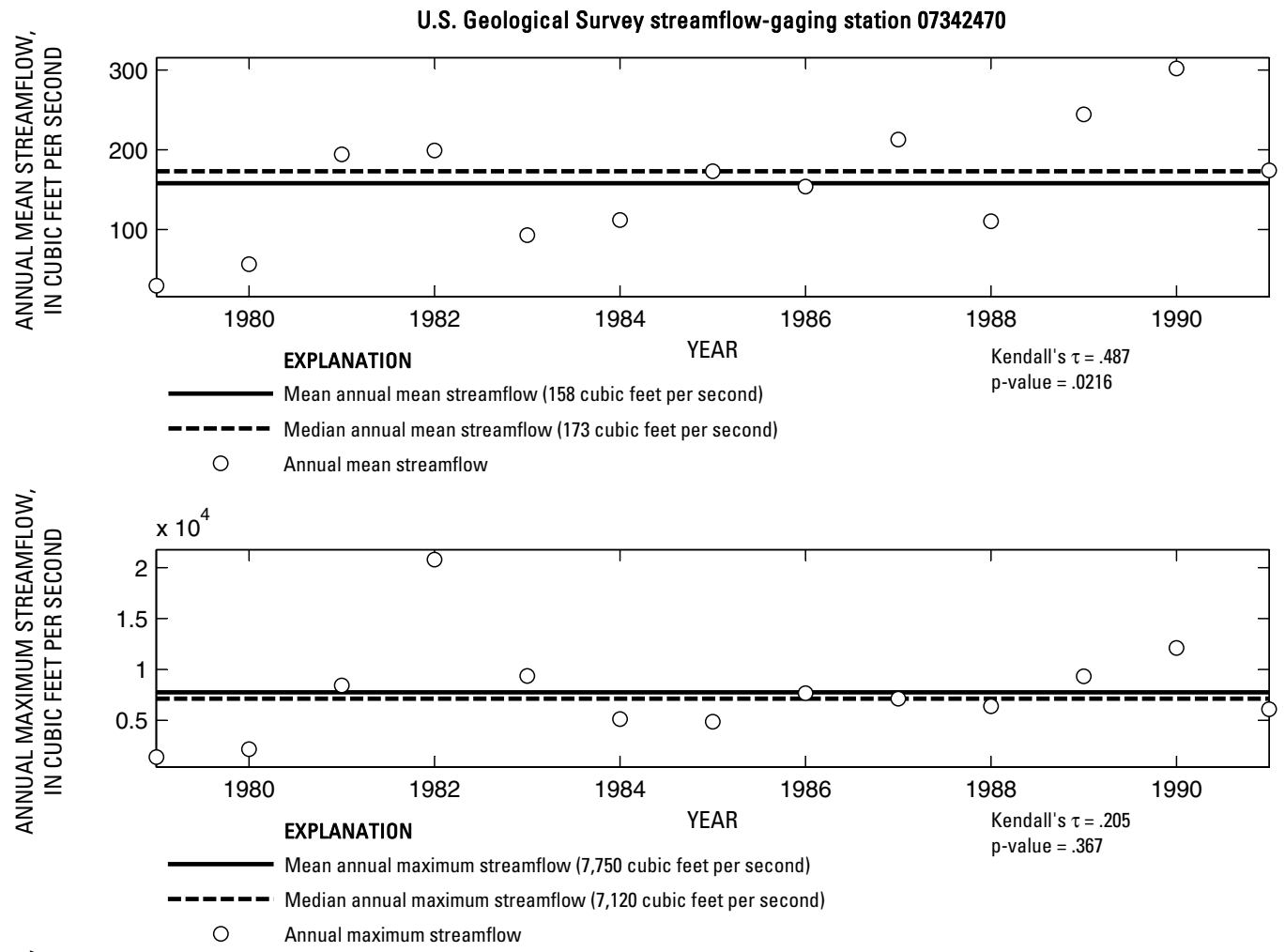

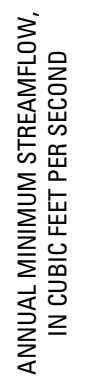

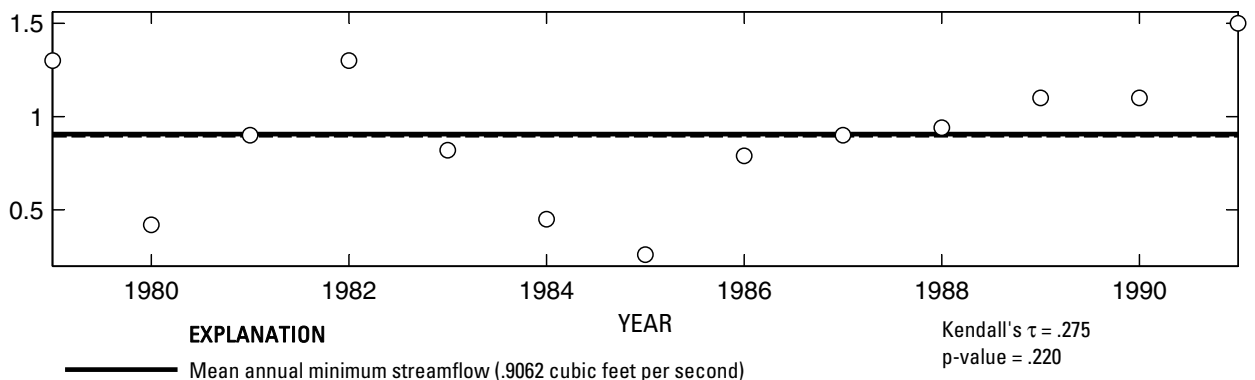

- - - Median annual minimum streamflow (.9 cubic feet per second)

O Annual minimum streamflow

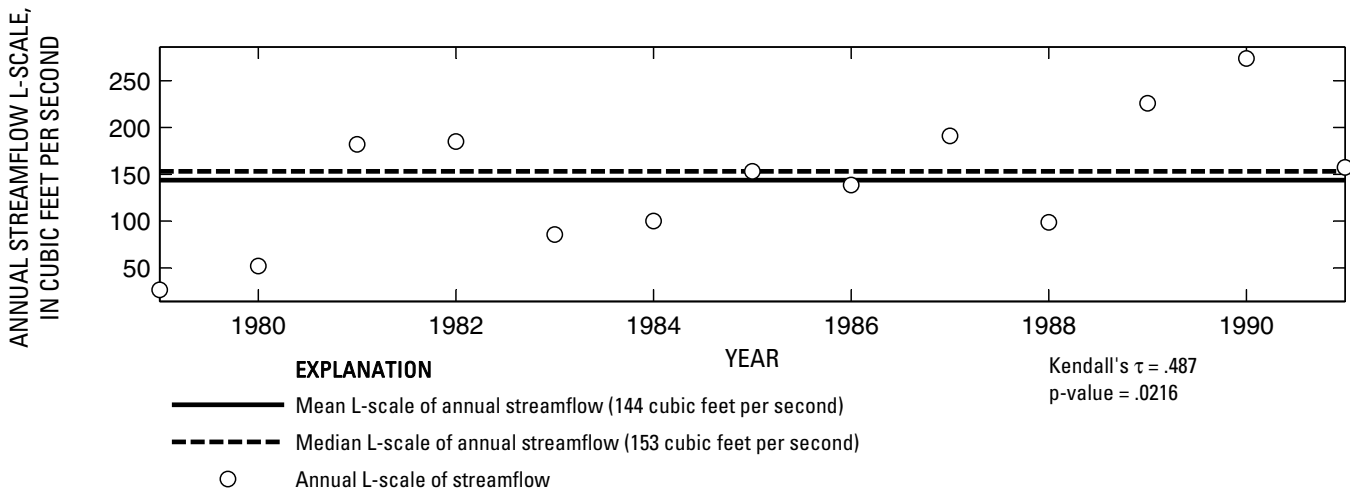

Figure 66. Analysis of annual mean, maximum, minimum, and L-scale statistics of daily mean streamflow for U.S. Geological Survey streamflow-gaging station 07342470 South Sulphur River near Commerce, Texas.

Index of Station Numbers 719 


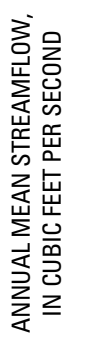

U.S. Geological Survey streamflow-gaging station 07342480

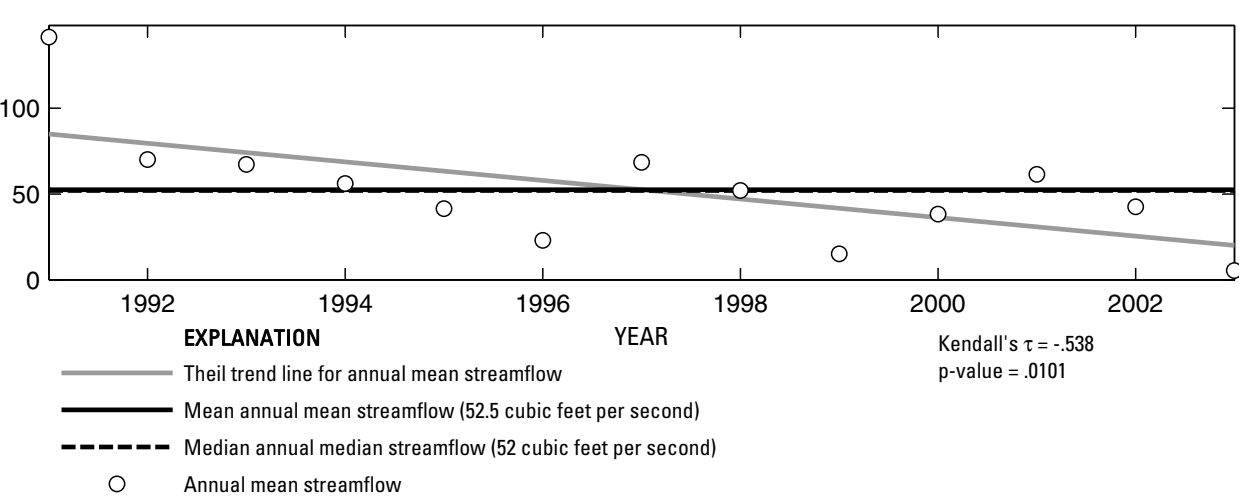

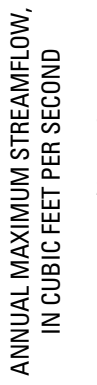

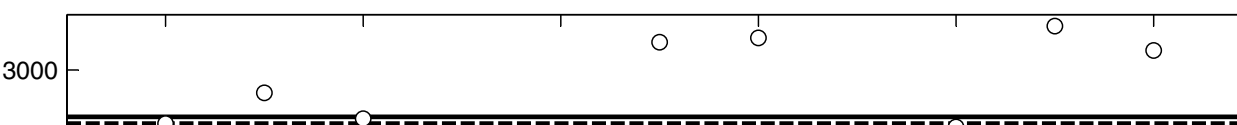

1000
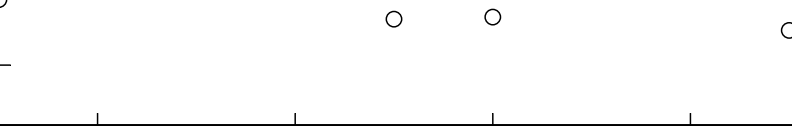

1992
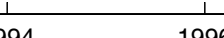

YEAR

998

O

EXPLANATION

Mean annual maximum streamflow (2,330 cubic feet per second)

- Median annual maximum streamflow (2,230 cubic feet per second)

O Annual maximum streamflow
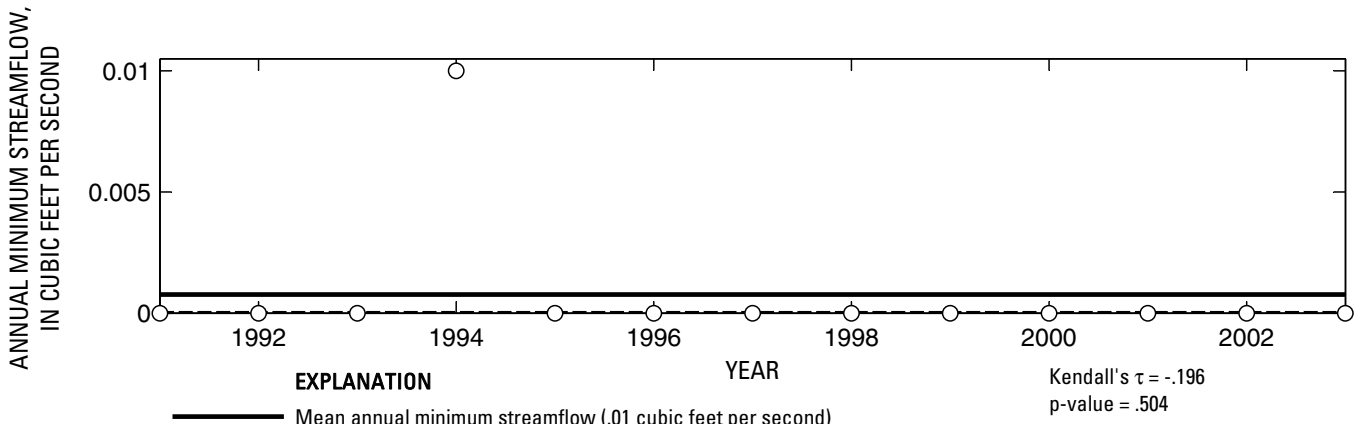

- - - Median annual minimum streamflow (0 cubic feet per second)

O Annual minimum streamflow
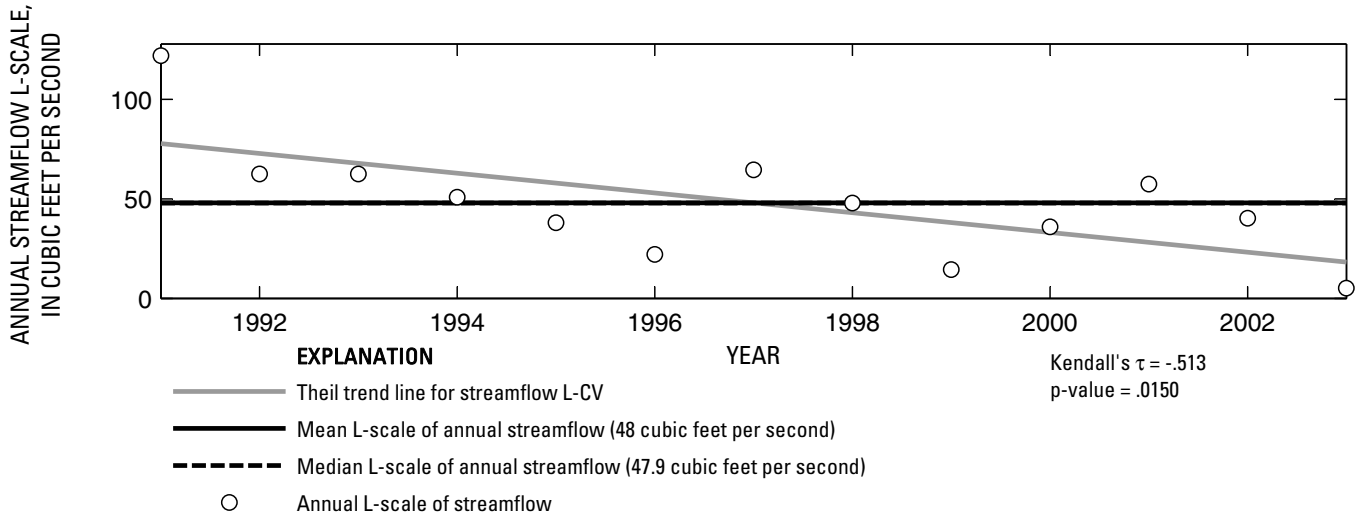

Figure 67. Analysis of annual mean, maximum, minimum, and L-scale statistics of daily mean streamflow for U.S. Geological Survey streamflow-gaging station 07342480 Middle Sulphur River at Commerce, Texas. 

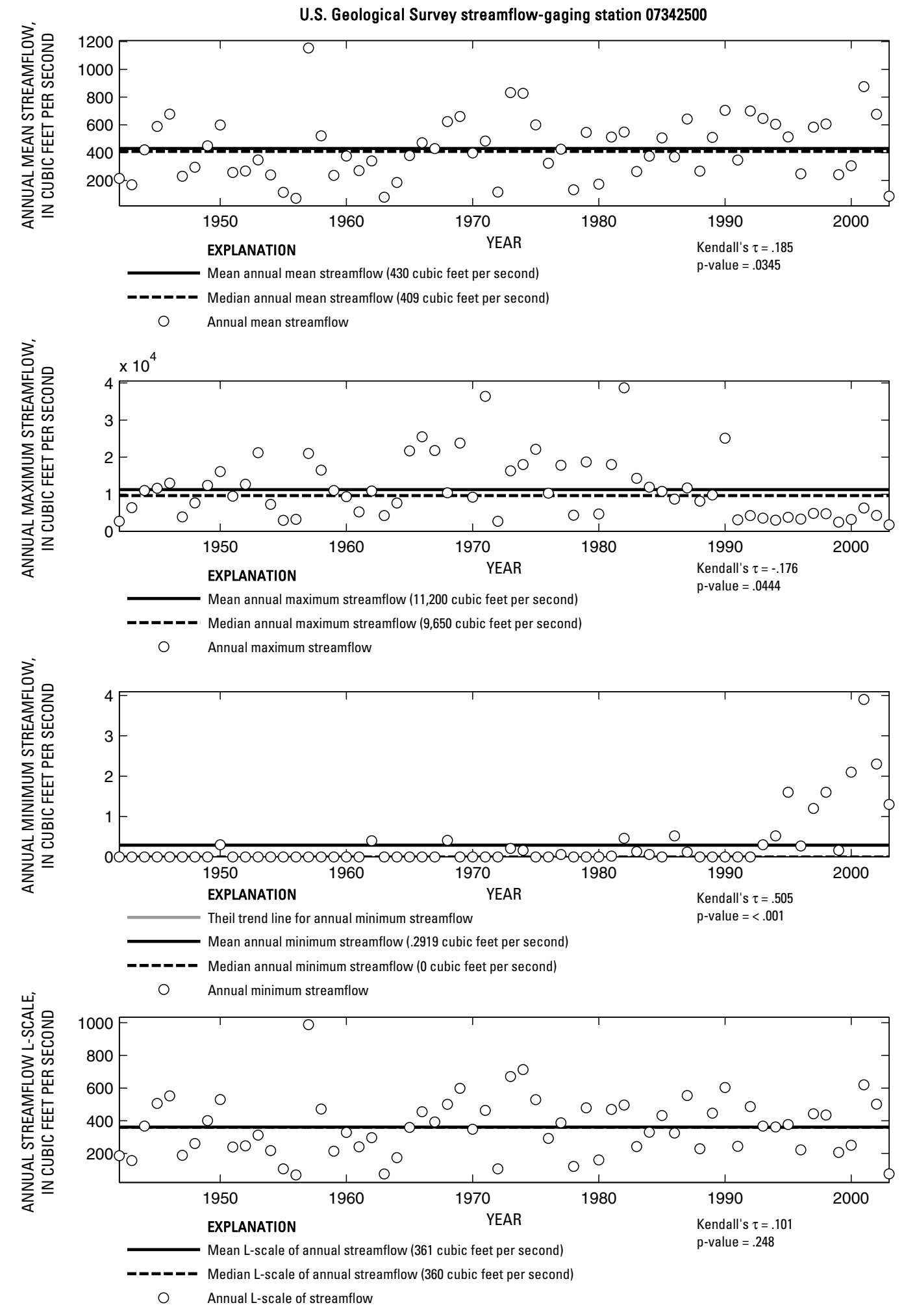

Figure 68. Analysis of annual mean, maximum, minimum, and L-scale statistics of daily mean streamflow for U.S. Geological Survey streamflow-gaging station 07342500 South Sulphur River near Cooper, Texas.

Index of Station Numbers 719 


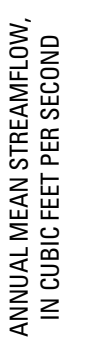

U.S. Geological Survey streamflow-gaging station 07343000

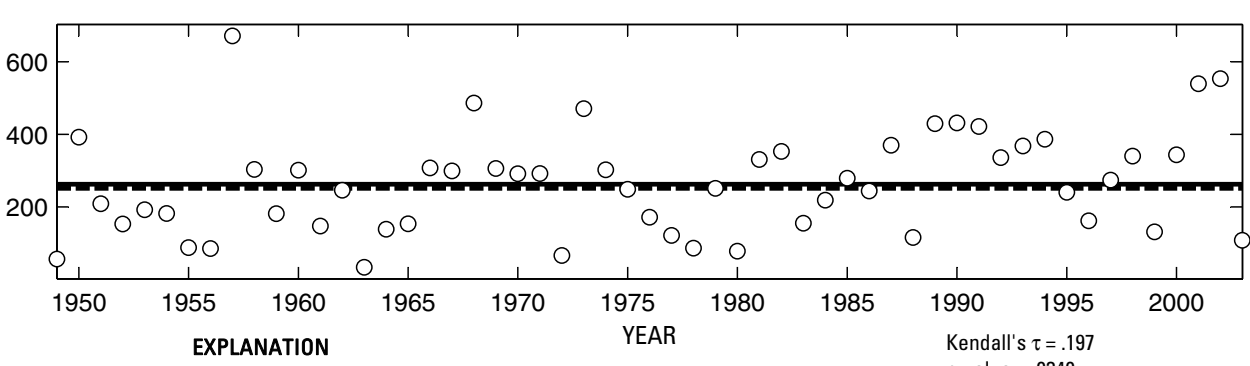

Mean annual mean streamflow (263 cubic feet per second)

p-value $=0340$

-_-_-_ Median annual mean streamflow (251 cubic feet per second)

O Annual mean streamflow

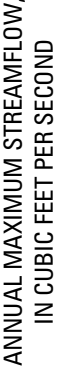

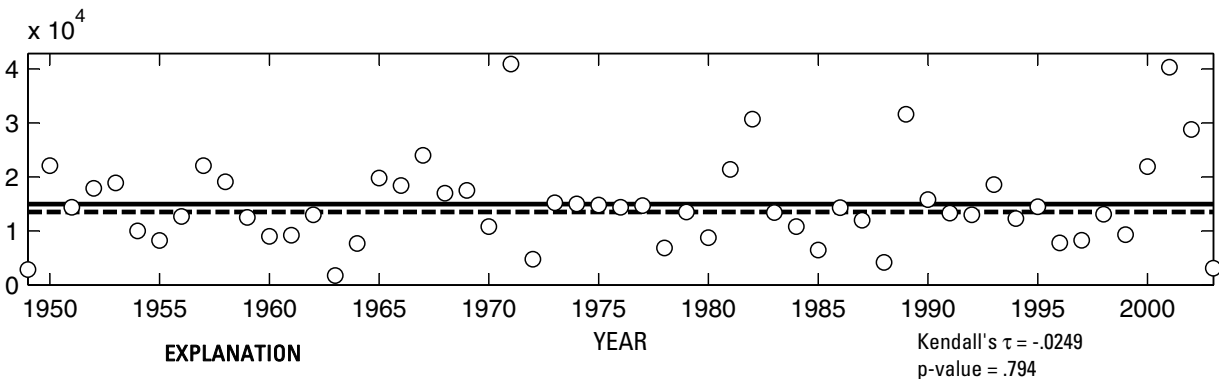

Mean annual maximum streamflow (15,000 cubic feet per second)

- - Median annual maximum streamflow (13,500 cubic feet per second)

Annual maximum streamflow

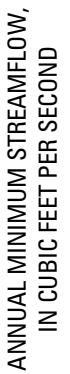

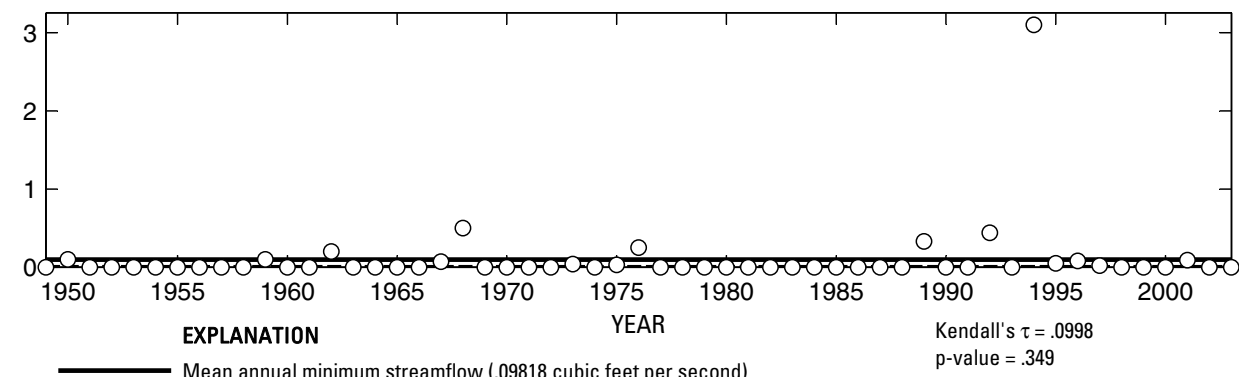

- Median annual minimum streamflow (0 cubic feet per second)

O Annual minimum streamflow

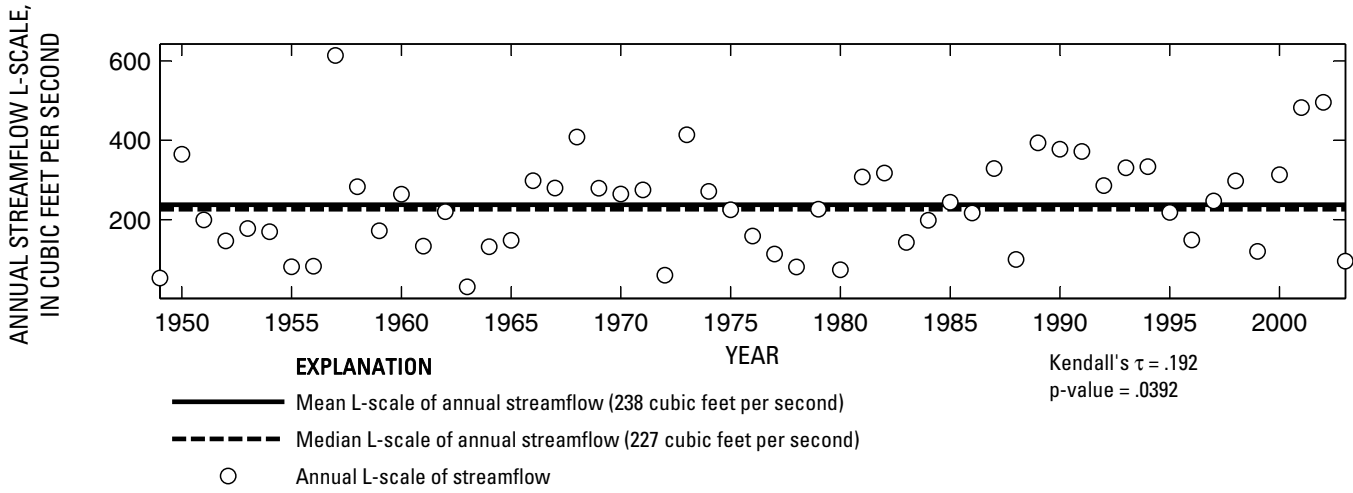

Figure 69. Analysis of annual mean, maximum, minimum, and L-scale statistics of daily mean streamflow for U.S. Geological Survey streamflow-gaging station 07343000 North Sulphur River near Cooper, Texas. 

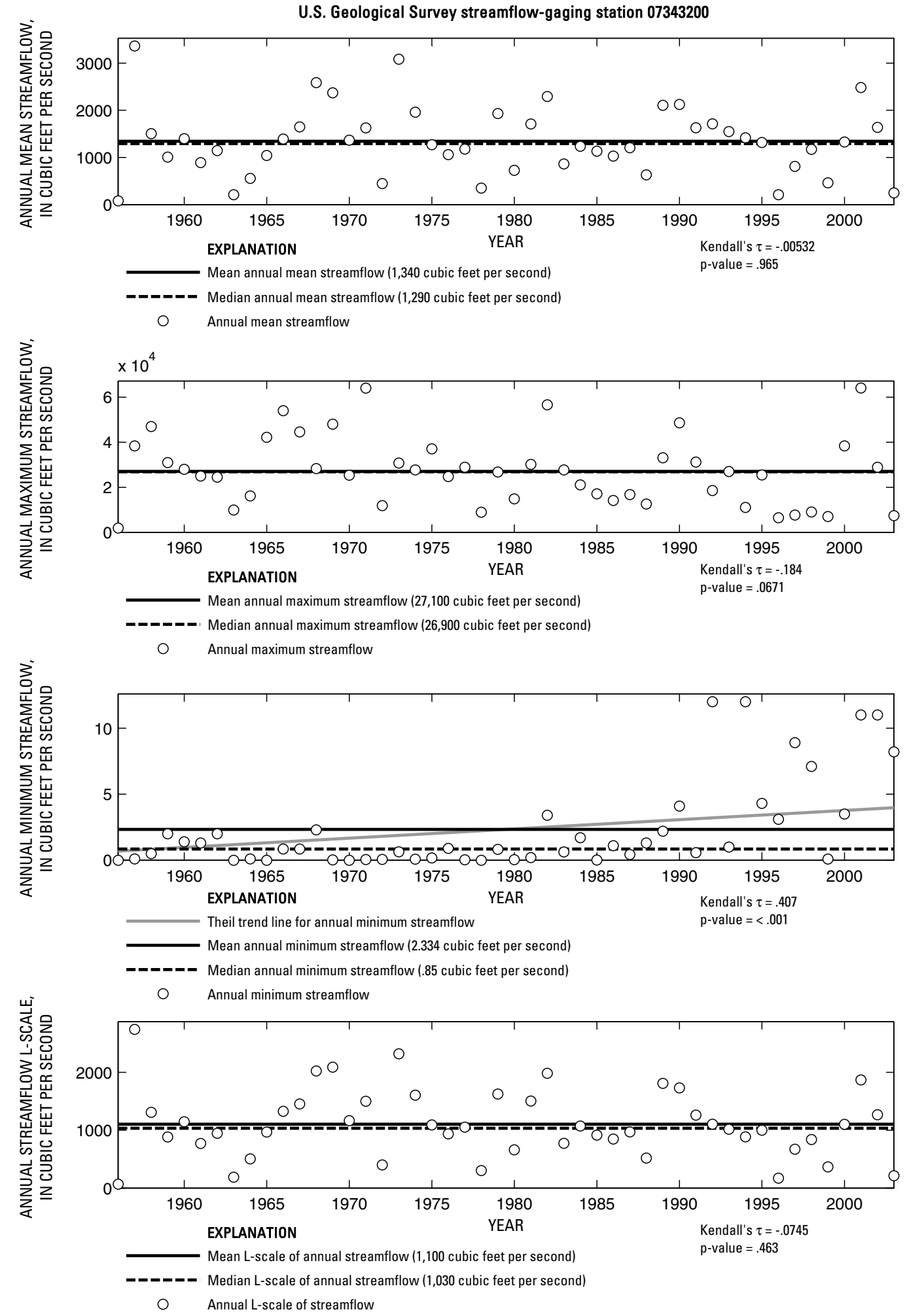

Figure 70. Analysis of annual mean, maximum, minimum, and L-scale statistics of daily mean streamflow for U.S. Geological Survey streamflow-gaging station 07343200 Sulphur River near Talco, Texas.

Index of Station Numbers 719 


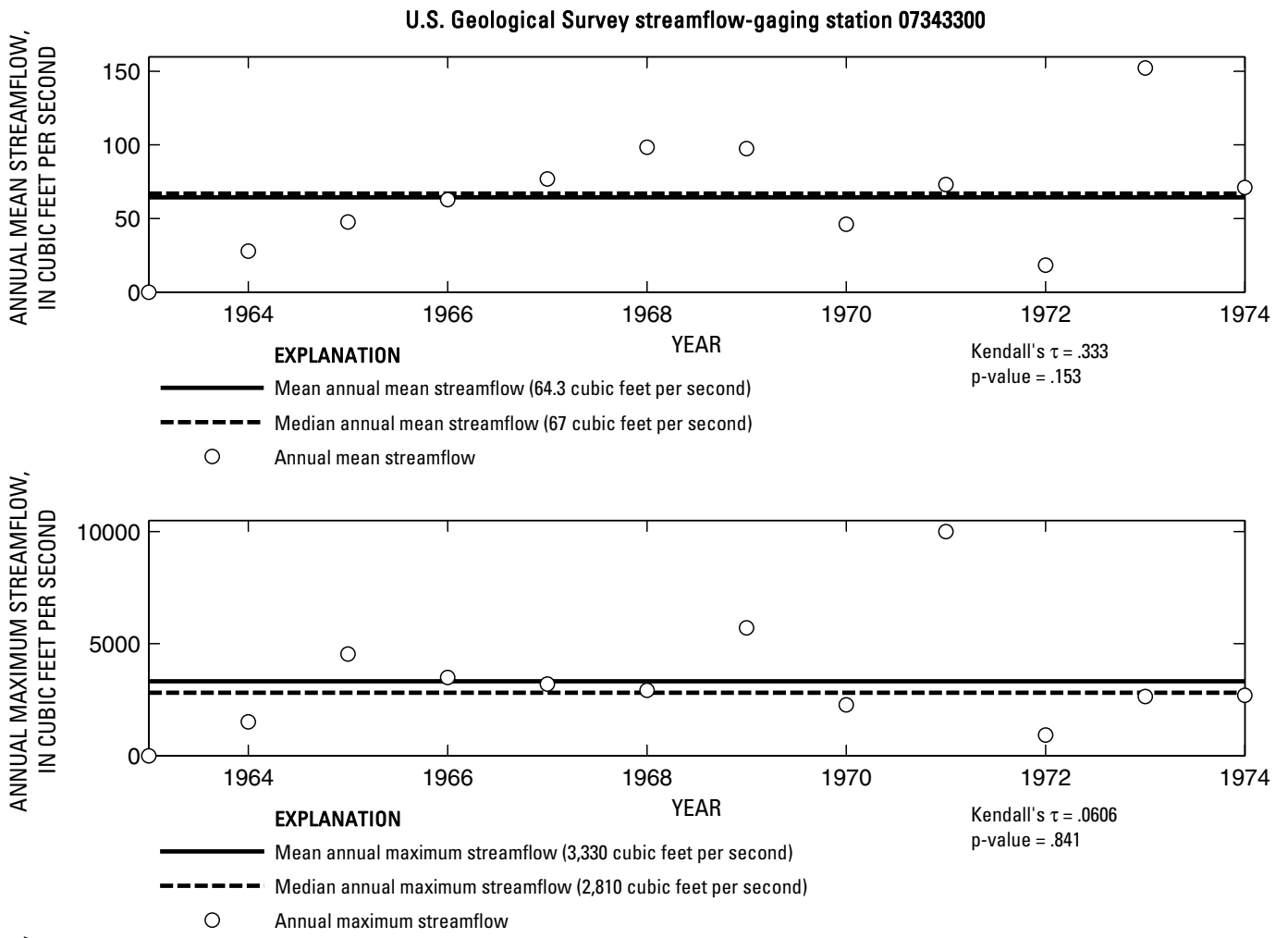

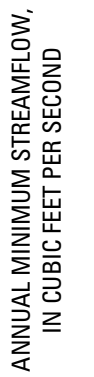

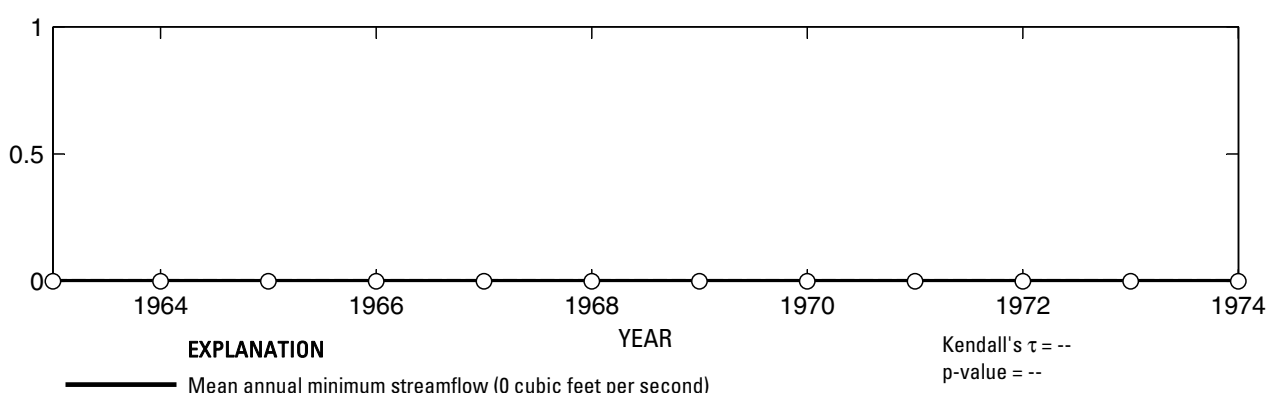

-_-_-_ Median annual minimum streamflow (0 cubic feet per second)

○ Annual minimum streamflow

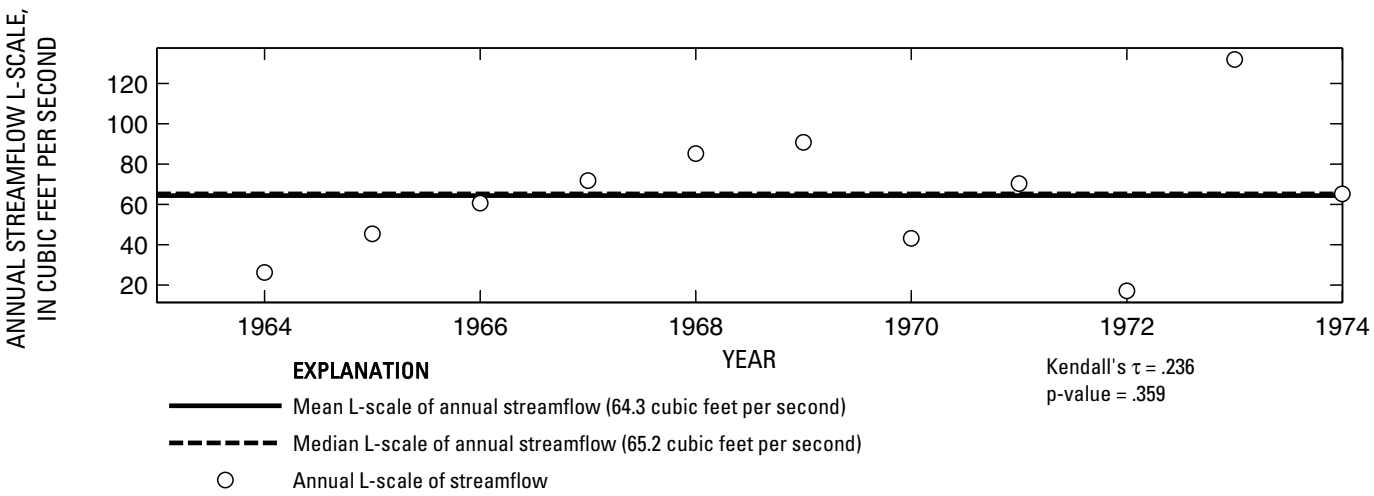

Figure 71. Analysis of annual mean, maximum, minimum, and L-scale statistics of daily mean streamflow for U.S. Geological Survey streamflow-gaging station 07343300 Cuthand Creek near Bogata, Texas. 


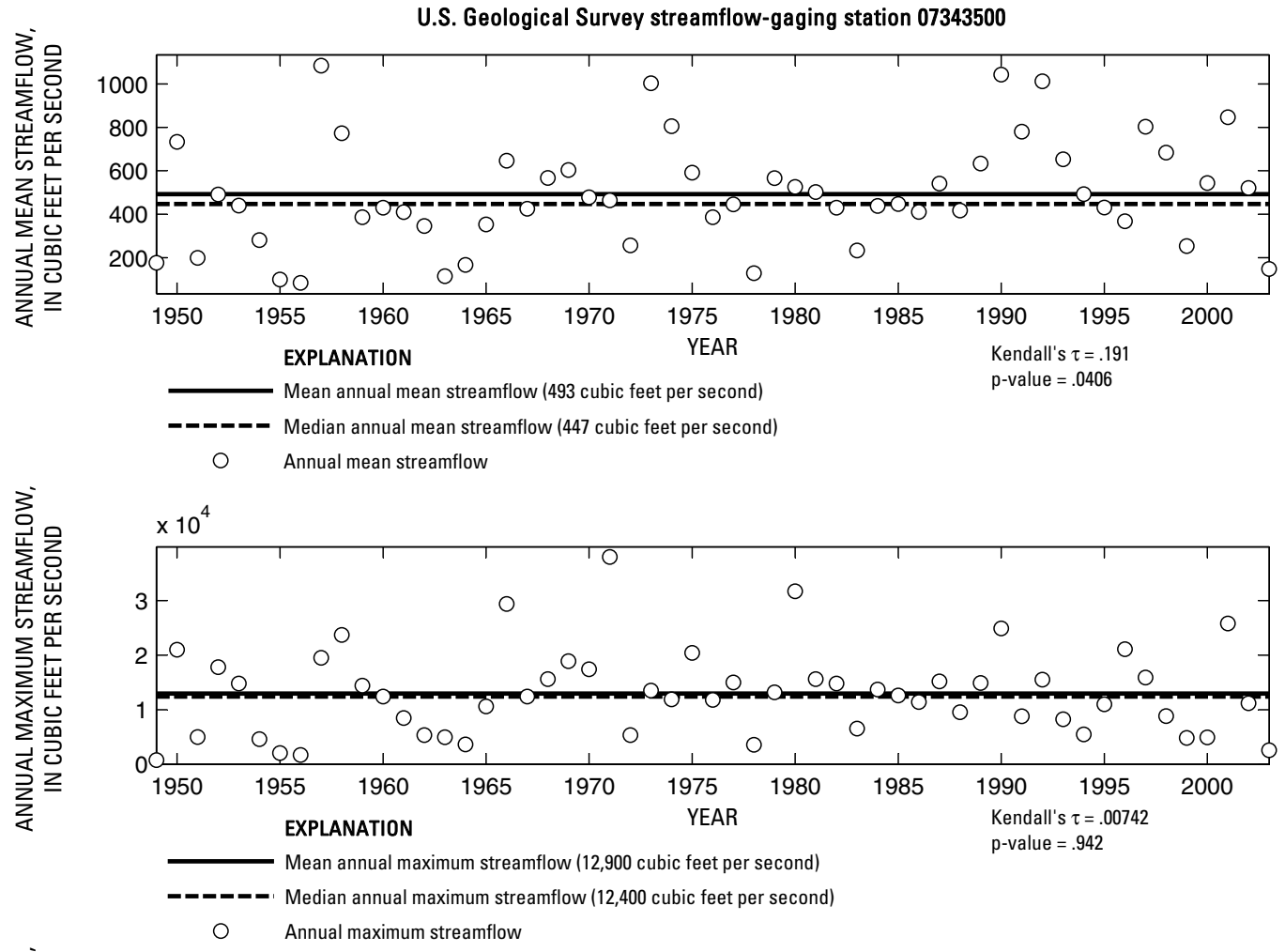

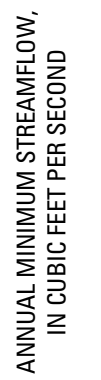

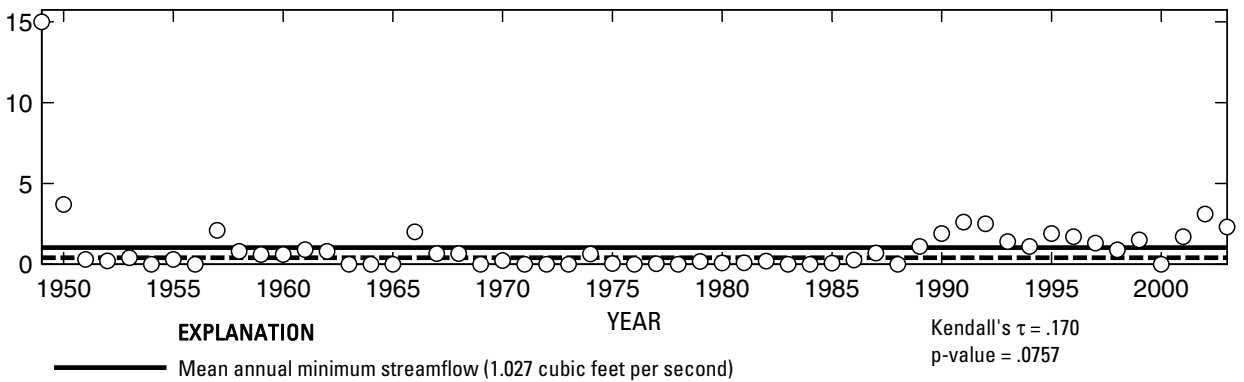

- ב-ב Median annual minimum streamflow (.4 cubic feet per second)

O Annual minimum streamflow

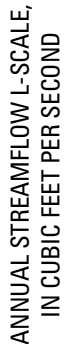

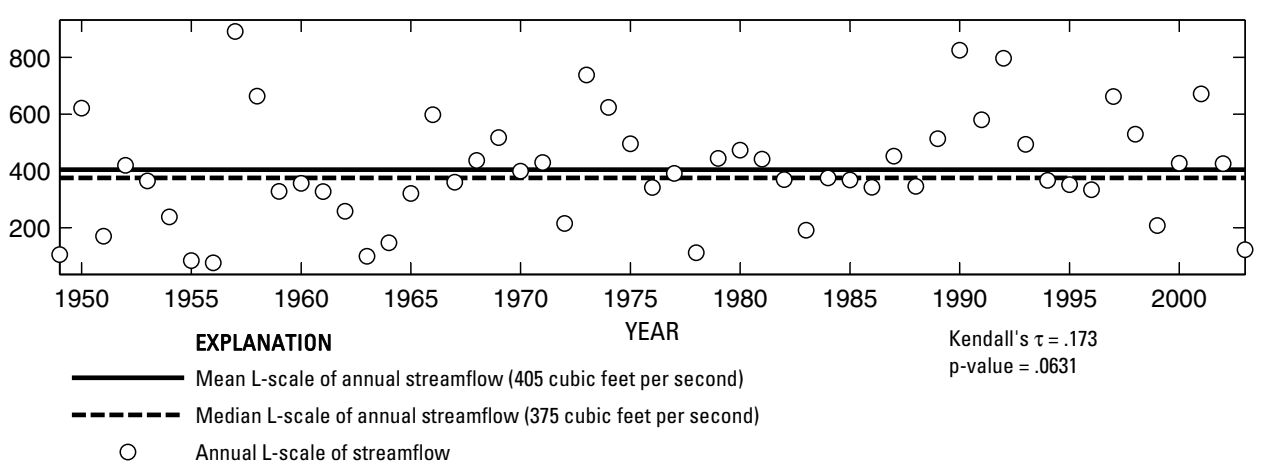

Figure 72. Analysis of annual mean, maximum, minimum, and L-scale statistics of daily mean streamflow for U.S. Geological Survey streamflow-gaging station 07343500 White Oak Creek near Talco, Texas.

Index of Station Numbers 719 


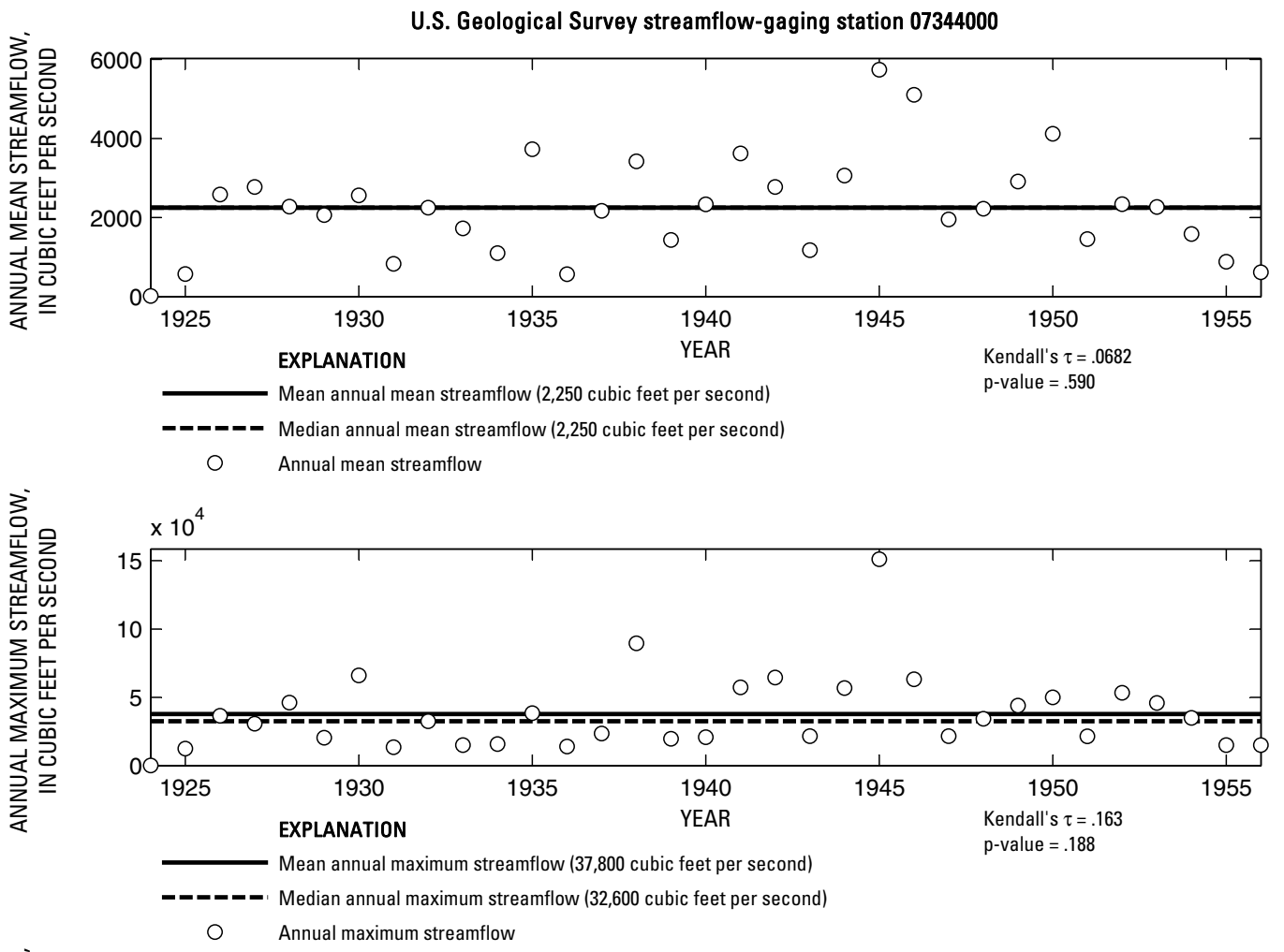

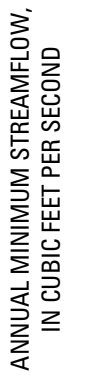

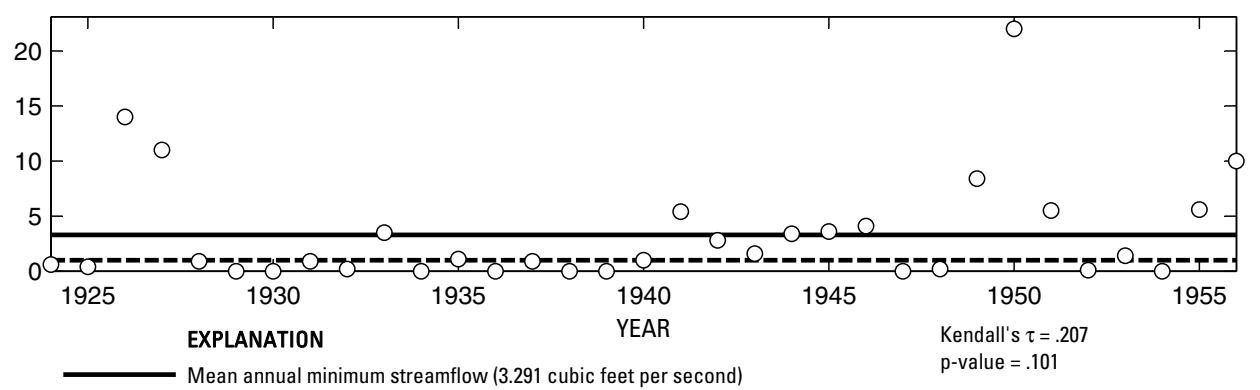

- ב-ב Median annual minimum streamflow (1 cubic feet per second)

O Annual minimum streamflow

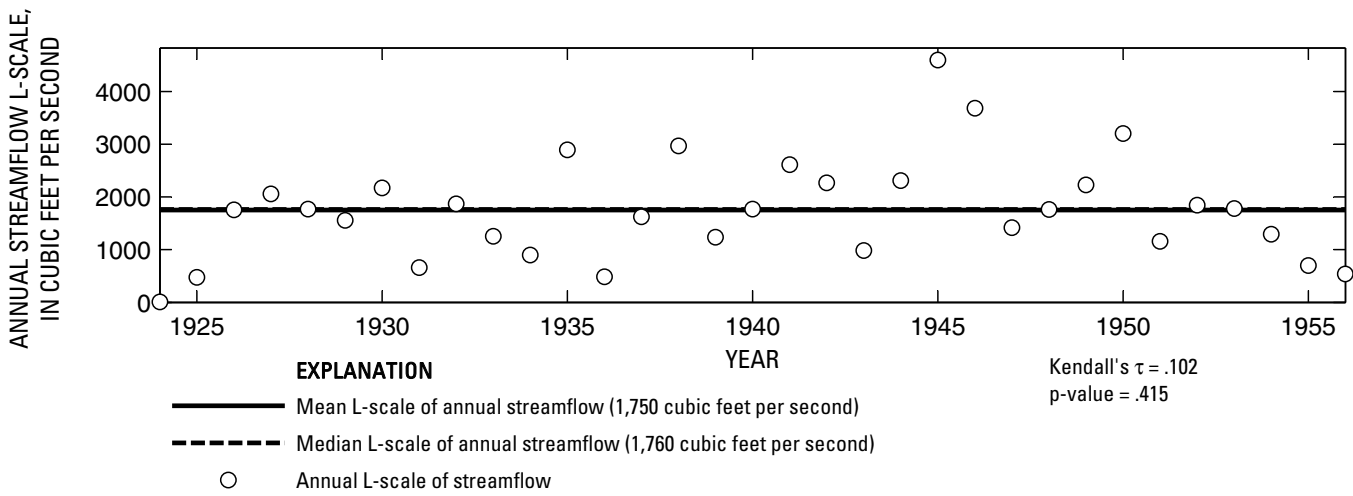

Figure 73. Analysis of annual mean, maximum, minimum, and L-scale statistics of daily mean streamflow for U.S. Geological Survey streamflow-gaging station 07344000 Sulphur River near Darden, Texas. 

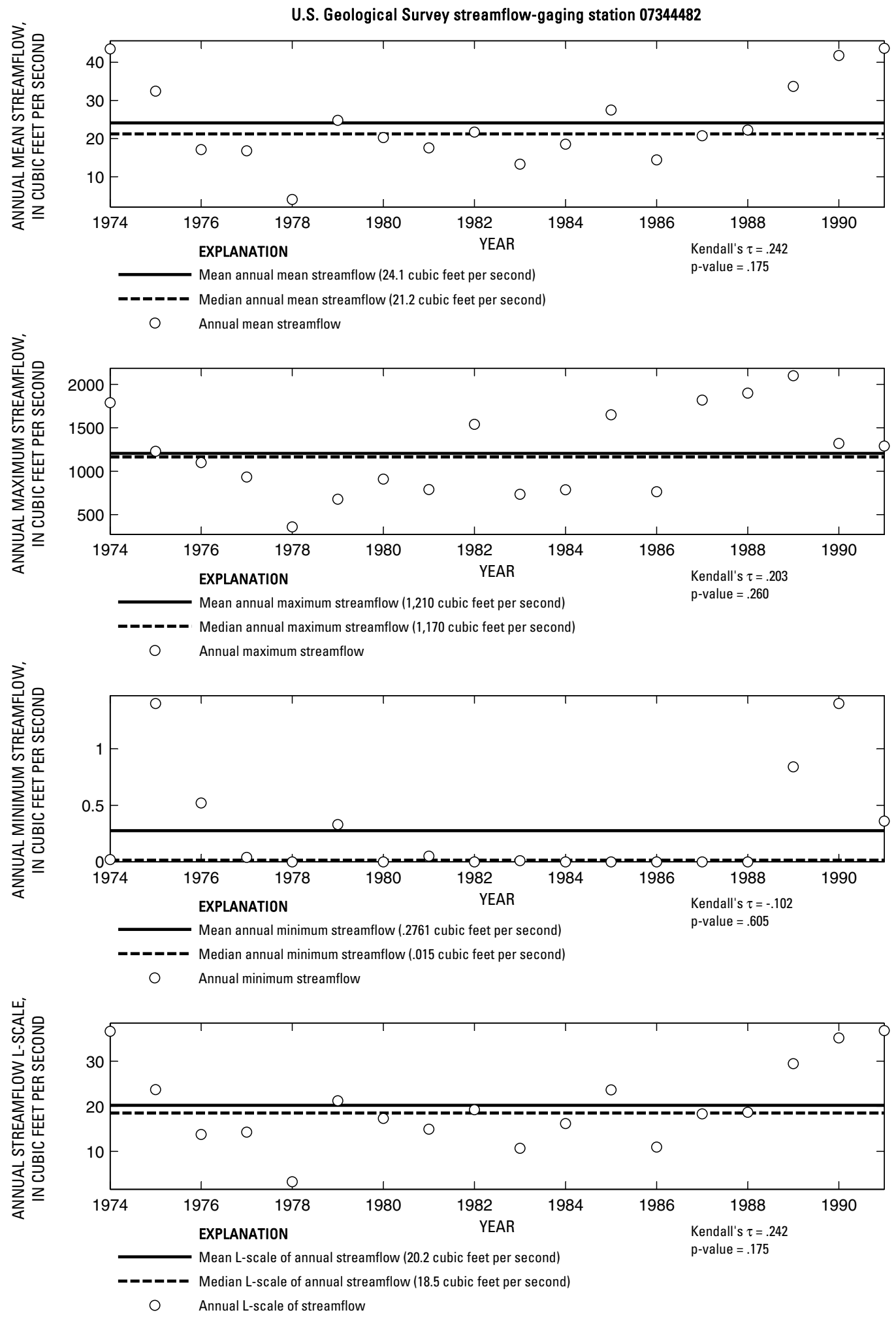

Figure 74. Analysis of annual mean, maximum, minimum, and L-scale statistics of daily mean streamflow for U.S. Geological Survey streamflow-gaging station 07344482 Big Cypress Creek near Winnsboro, Texas.

Index of Station Numbers 719 


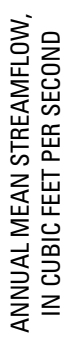

U.S. Geological Survey streamflow-gaging station 07344486

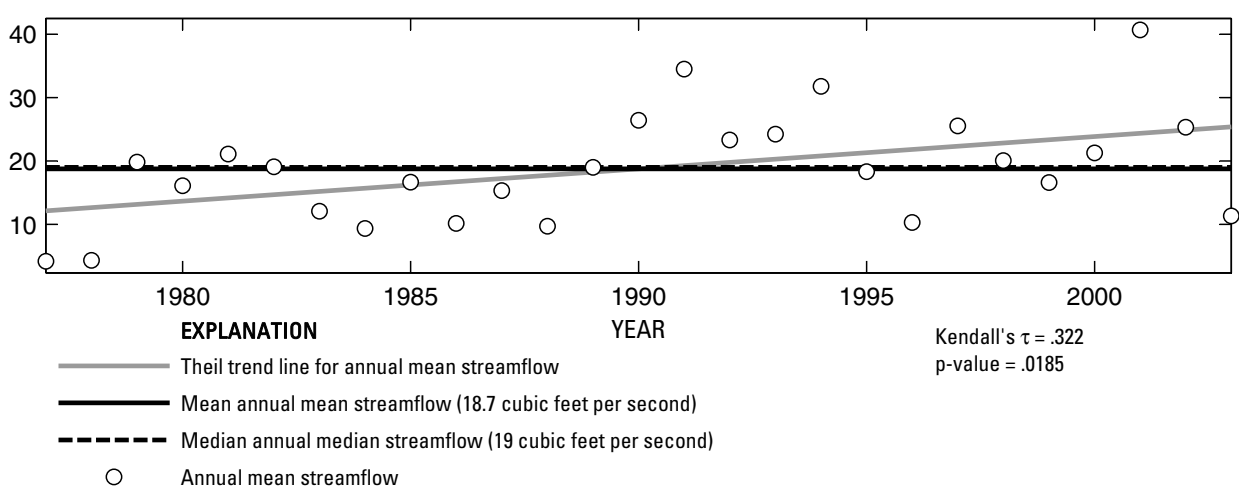

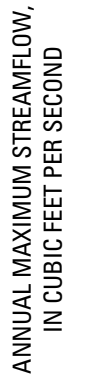

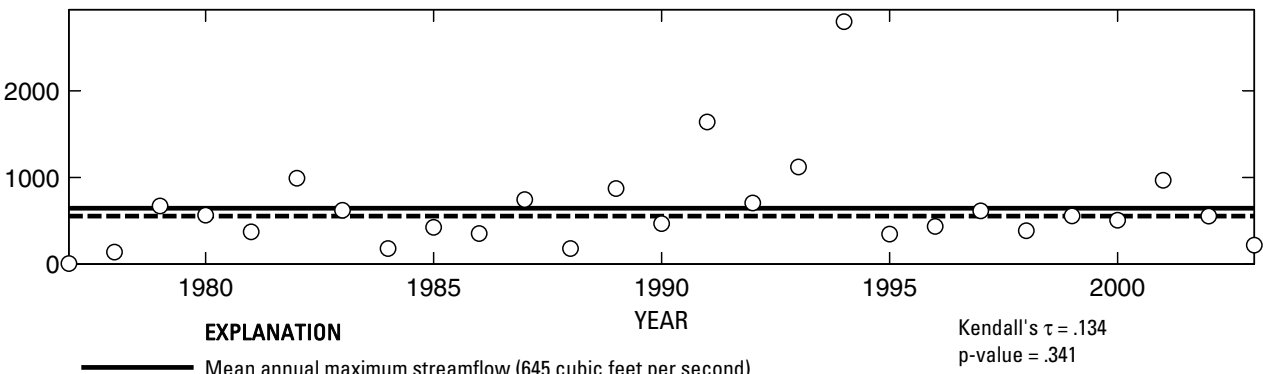

- - - Median annual maximum streamflow (553 cubic feet per second)

Annual maximum streamflow

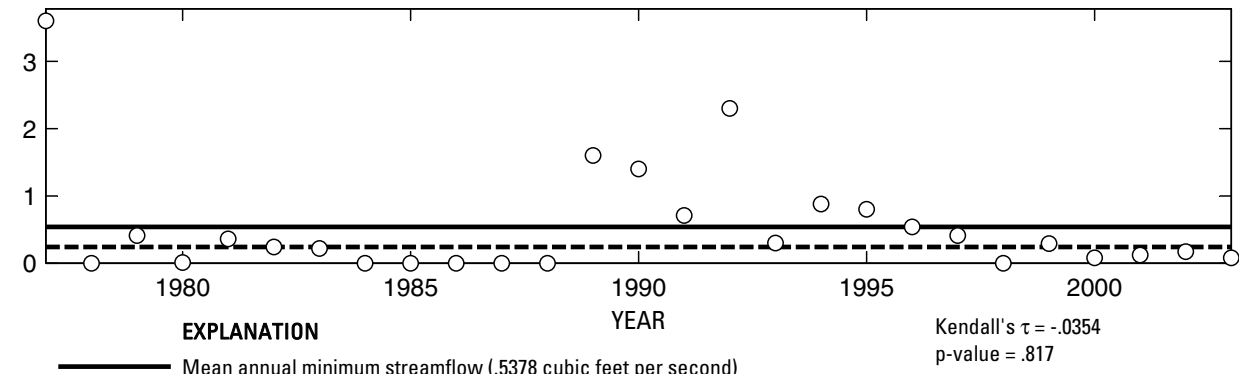

-

O Annual minimum streamflow
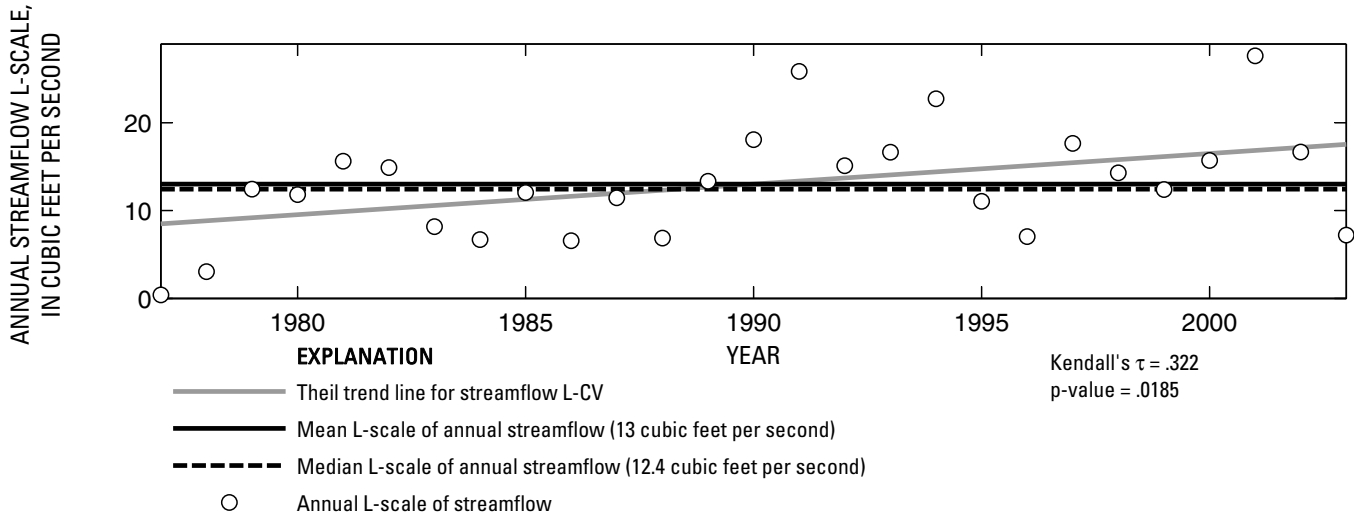

Figure 75. Analysis of annual mean, maximum, minimum, and L-scale statistics of daily mean streamflow for U.S. Geological Survey streamflow-gaging station 07344486 Brushy Creek at Scroggins, Texas. 

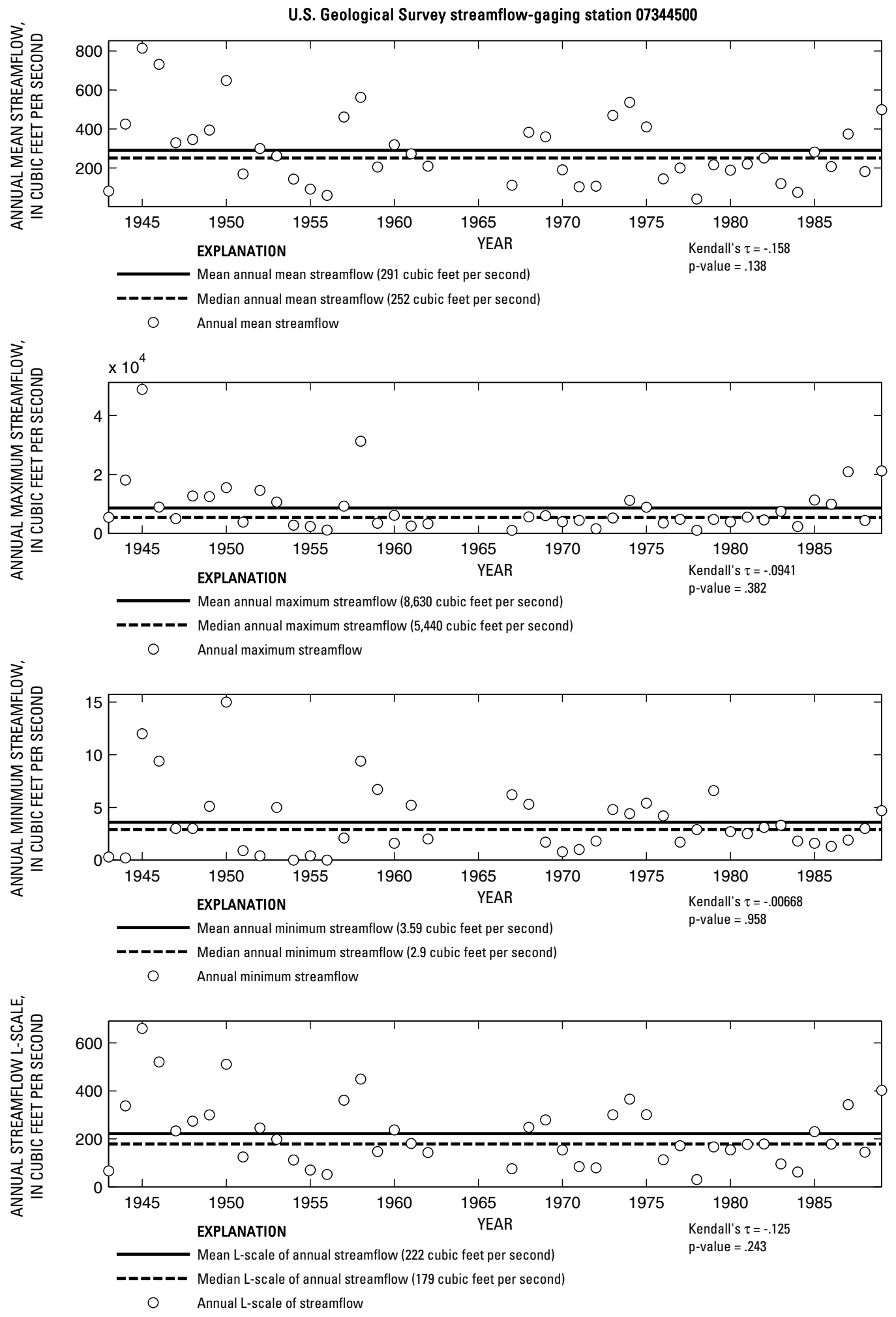

Figure 76. Analysis of annual mean, maximum, minimum, and L-scale statistics of daily mean streamflow for U.S. Geological Survey streamflow-gaging station 07344500 Big Cypress Creek near Pittsburg, Texas.

Index of Station Numbers 719 

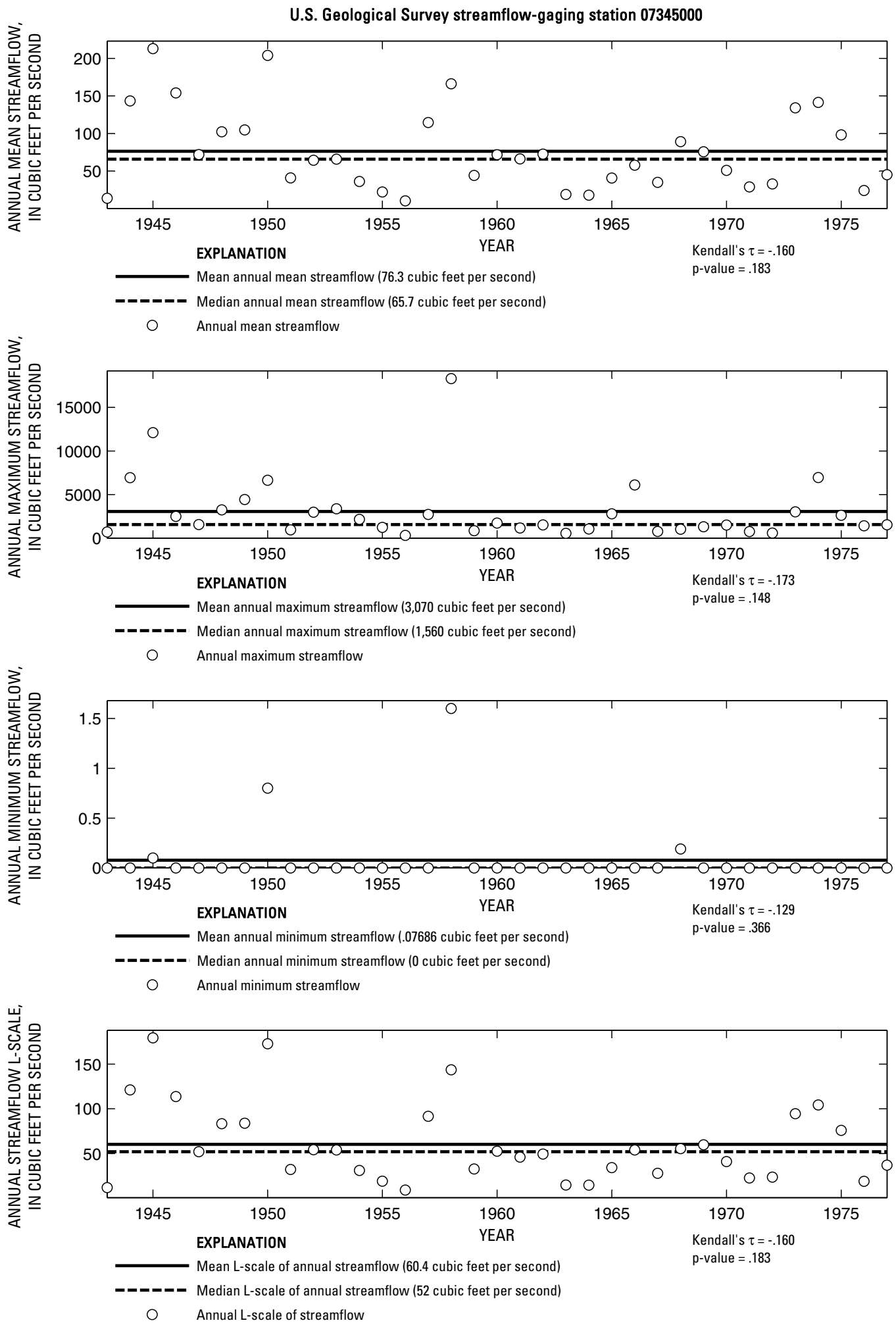

Figure 77. Analysis of annual mean, maximum, minimum, and L-scale statistics of daily mean streamflow for U.S. Geological Survey streamflow-gaging station 07345000 Boggy Creek near Daingerfield, Texas. 


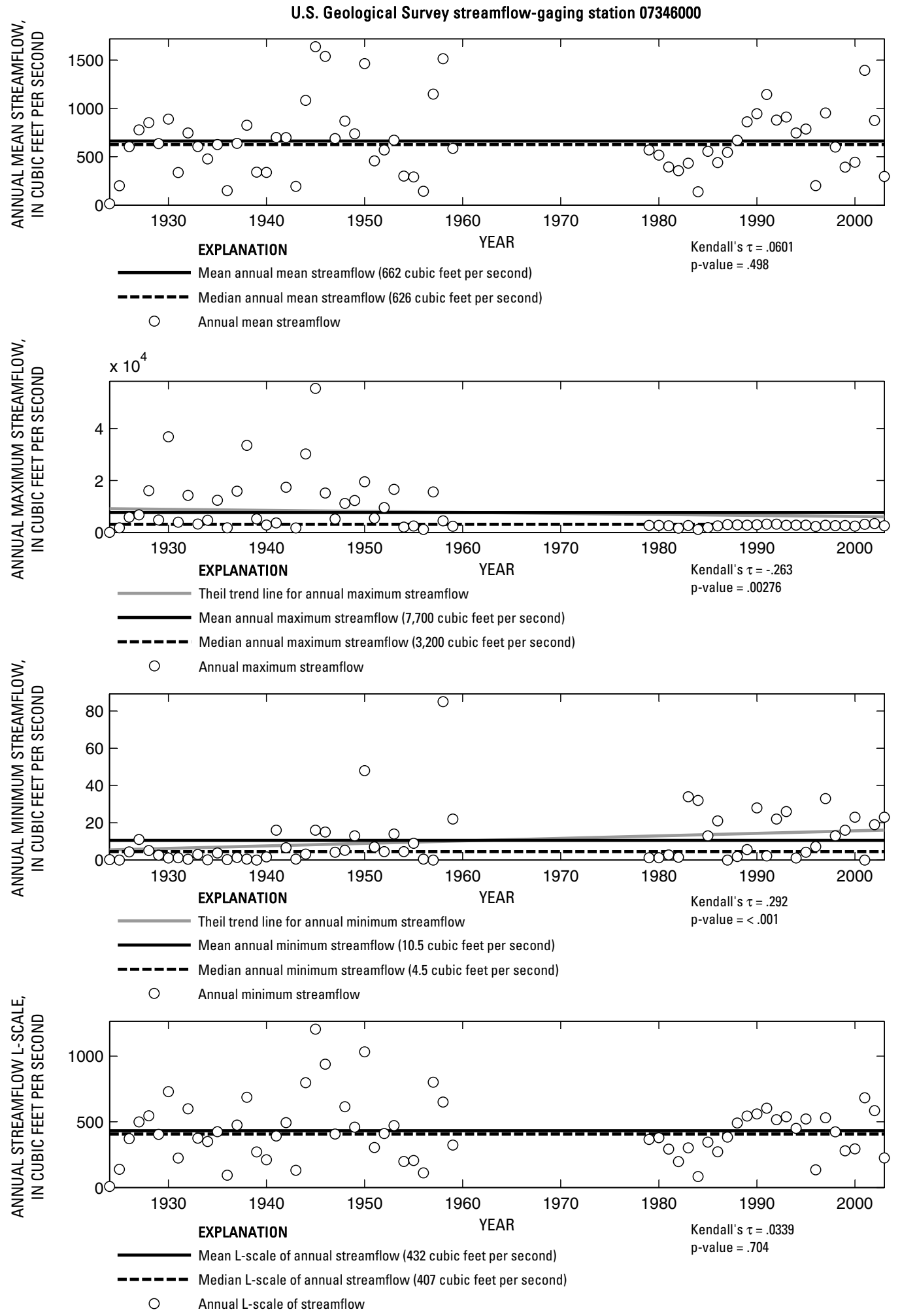

Figure 78. Analysis of annual mean, maximum, minimum, and L-scale statistics of daily mean streamflow for U.S. Geological Survey streamflow-gaging station 07346000 Big Cypress Creek near Jefferson, Texas.

Index of Station Numbers 719 


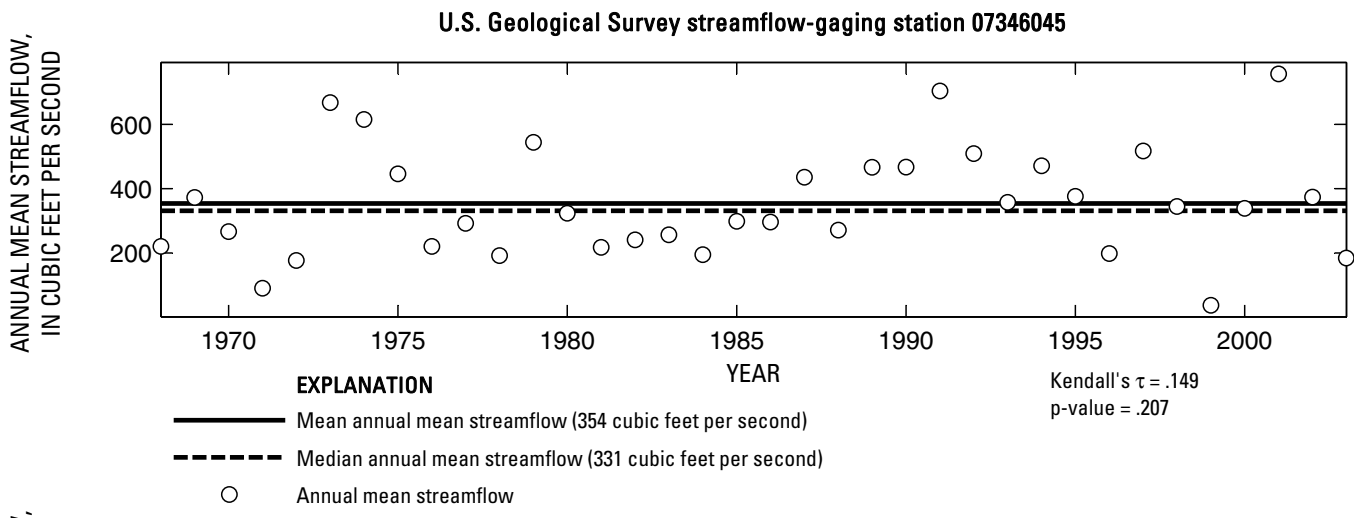

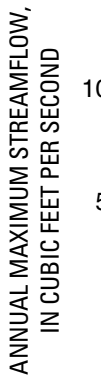

O Annual mean streamflow

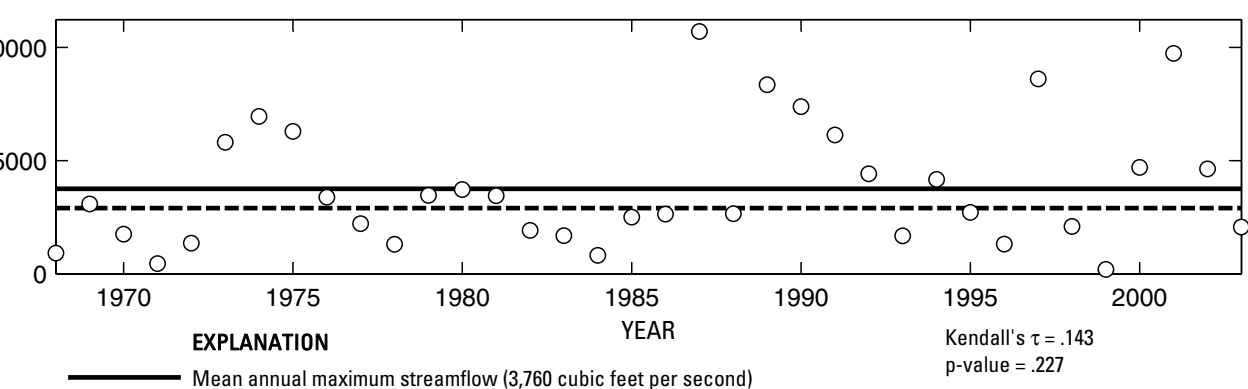

- ב - Median annual maximum streamflow (2,910 cubic feet per second)

- Annual maximum streamflow

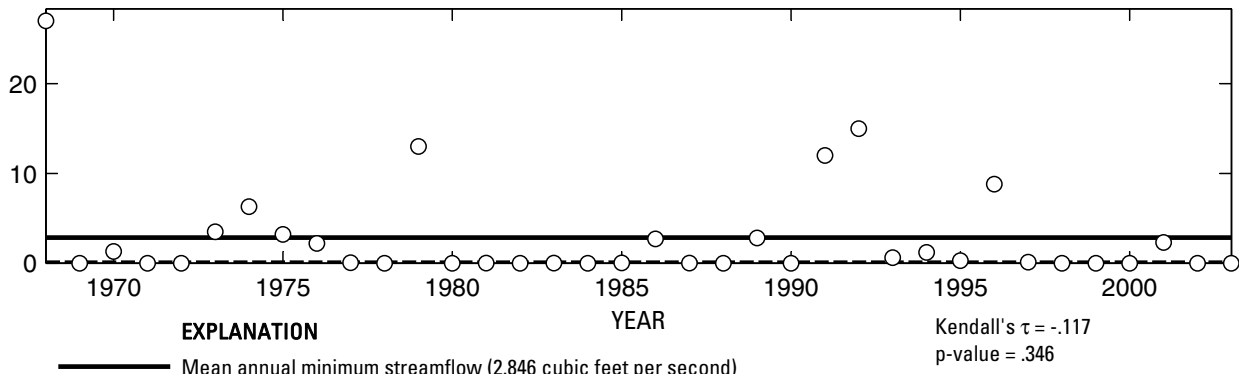

- - - Median annual minimum streamflow (.045 cubic feet per second)

O Annual minimum streamflow

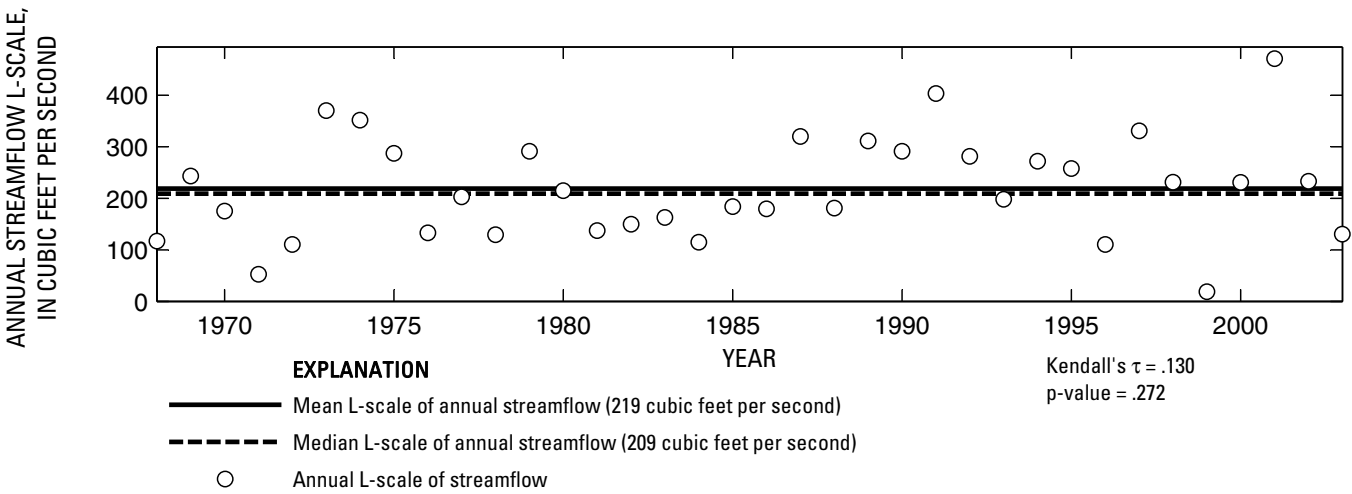

Figure 79. Analysis of annual mean, maximum, minimum, and L-scale statistics of daily mean streamflow for U.S. Geological Survey streamflow-gaging station 07346045 Black Cypress Bayou at Jefferson, Texas. 

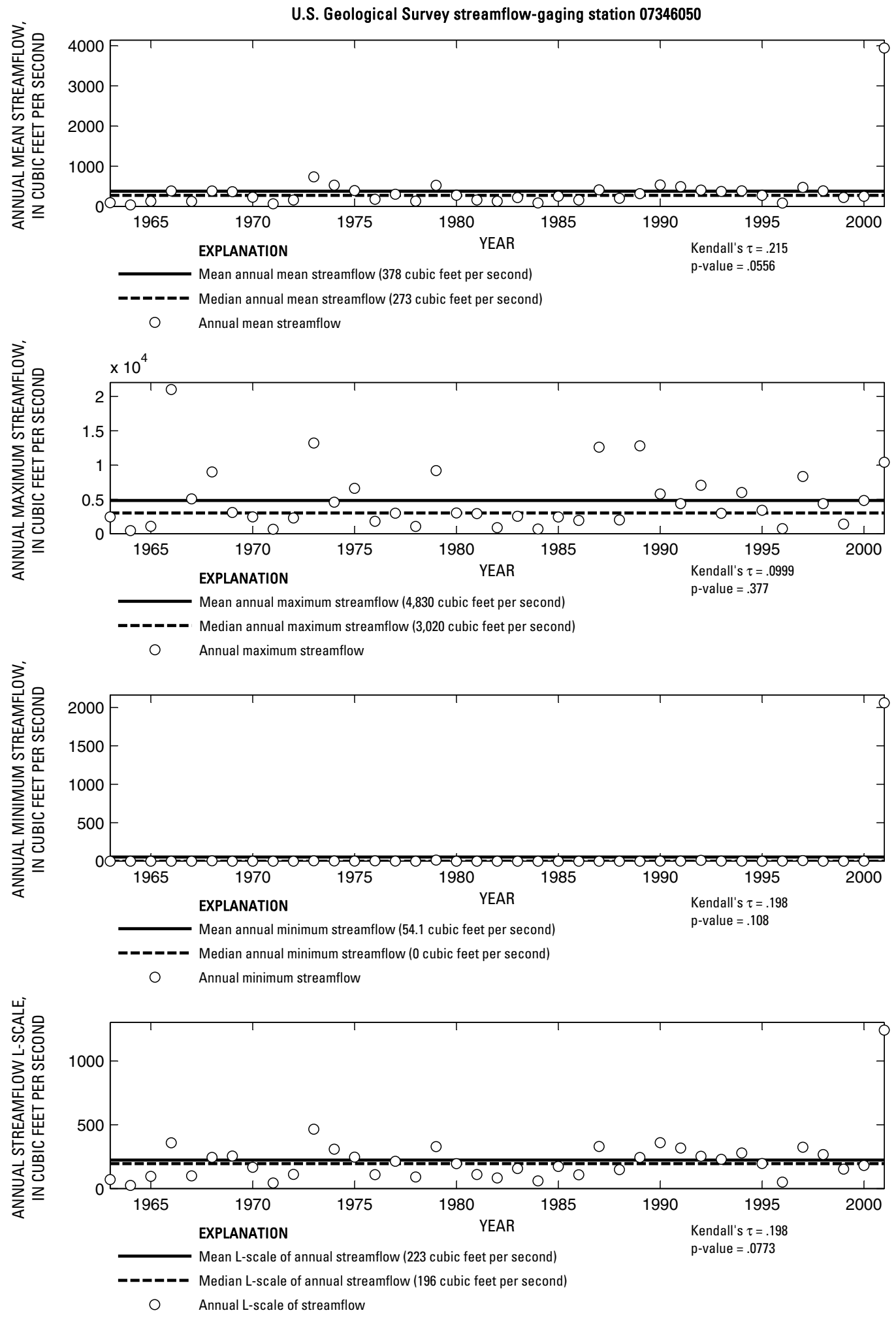

Figure 80. Analysis of annual mean, maximum, minimum, and L-scale statistics of daily mean streamflow for U.S. Geological Survey streamflow-gaging station 07346050 Little Cypress Creek near Ore City, Texas.

Index of Station Numbers 719 


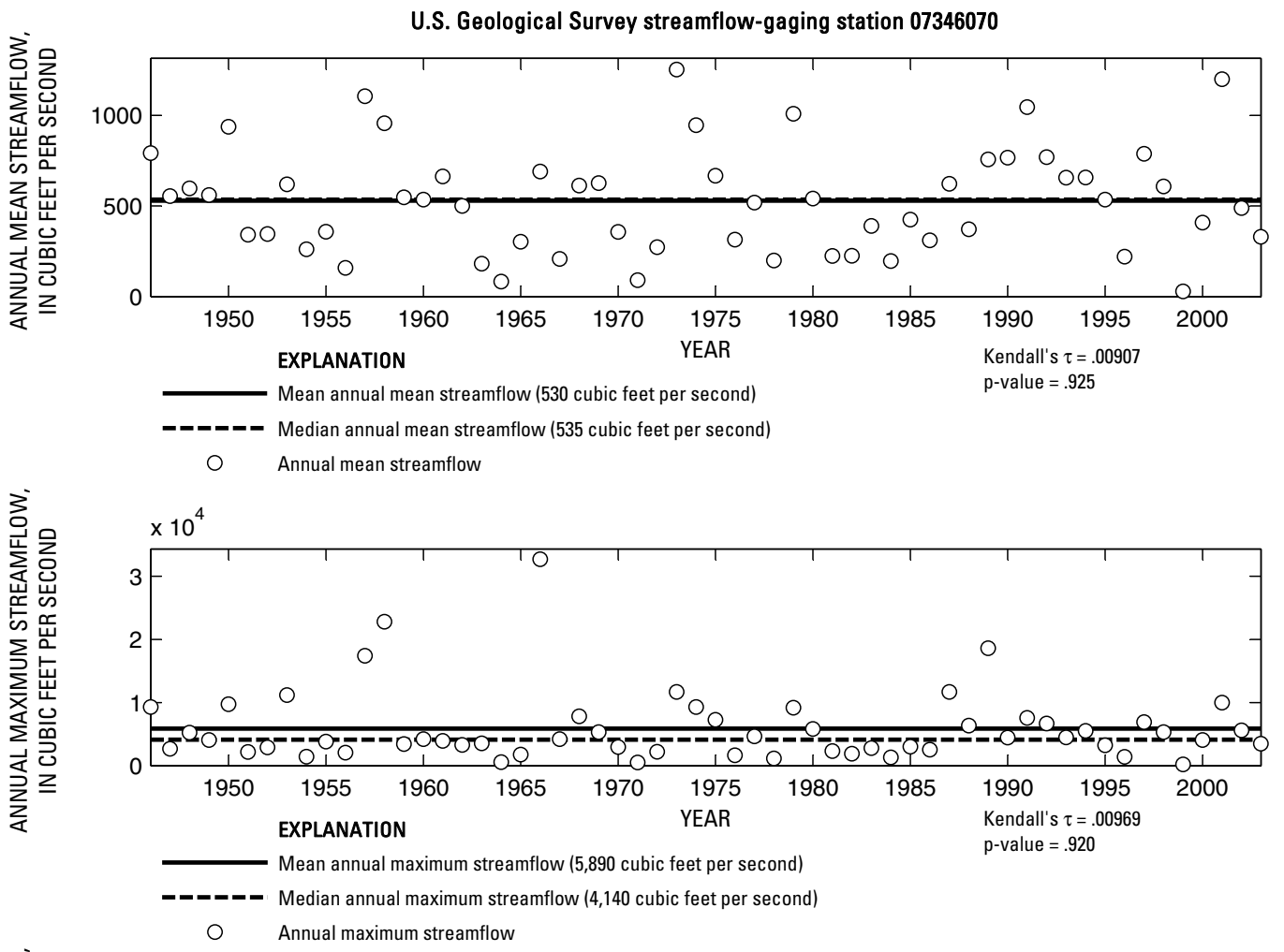

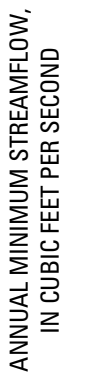

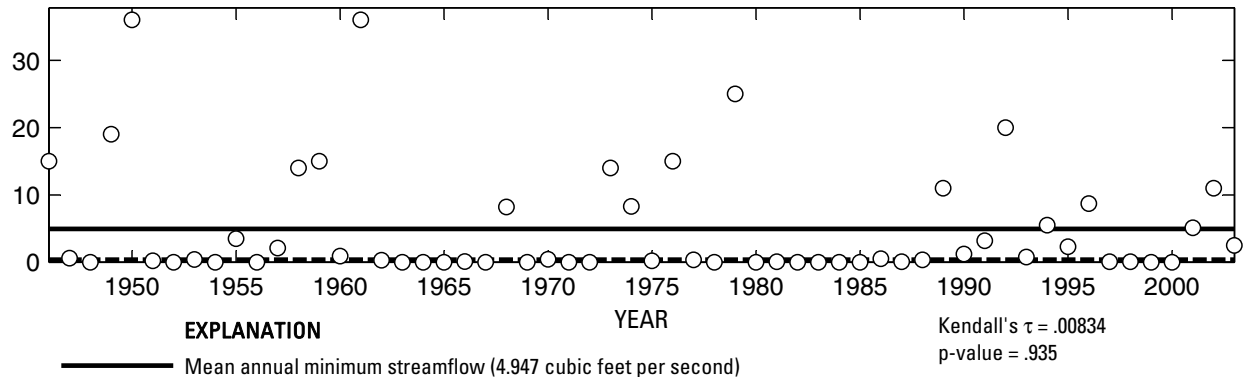

- ב-ב Median annual minimum streamflow (.375 cubic feet per second)

○ Annual minimum streamflow

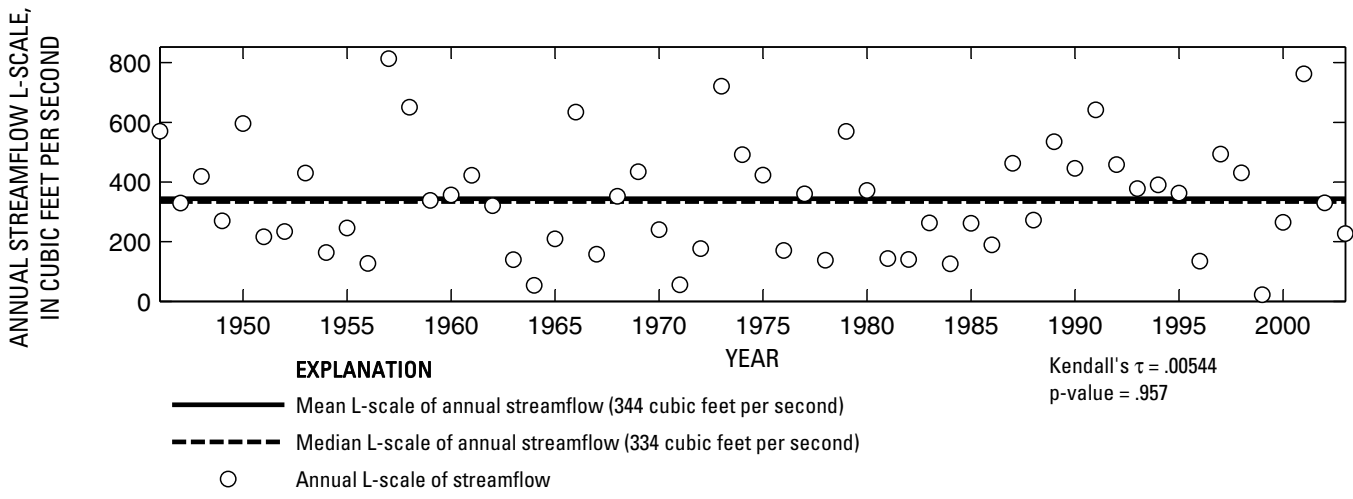

Figure 81. Analysis of annual mean, maximum, minimum, and L-scale statistics of daily mean streamflow for U.S. Geological Survey streamflow-gaging station 07346070 Little Cypress Creek near Jefferson, Texas. 

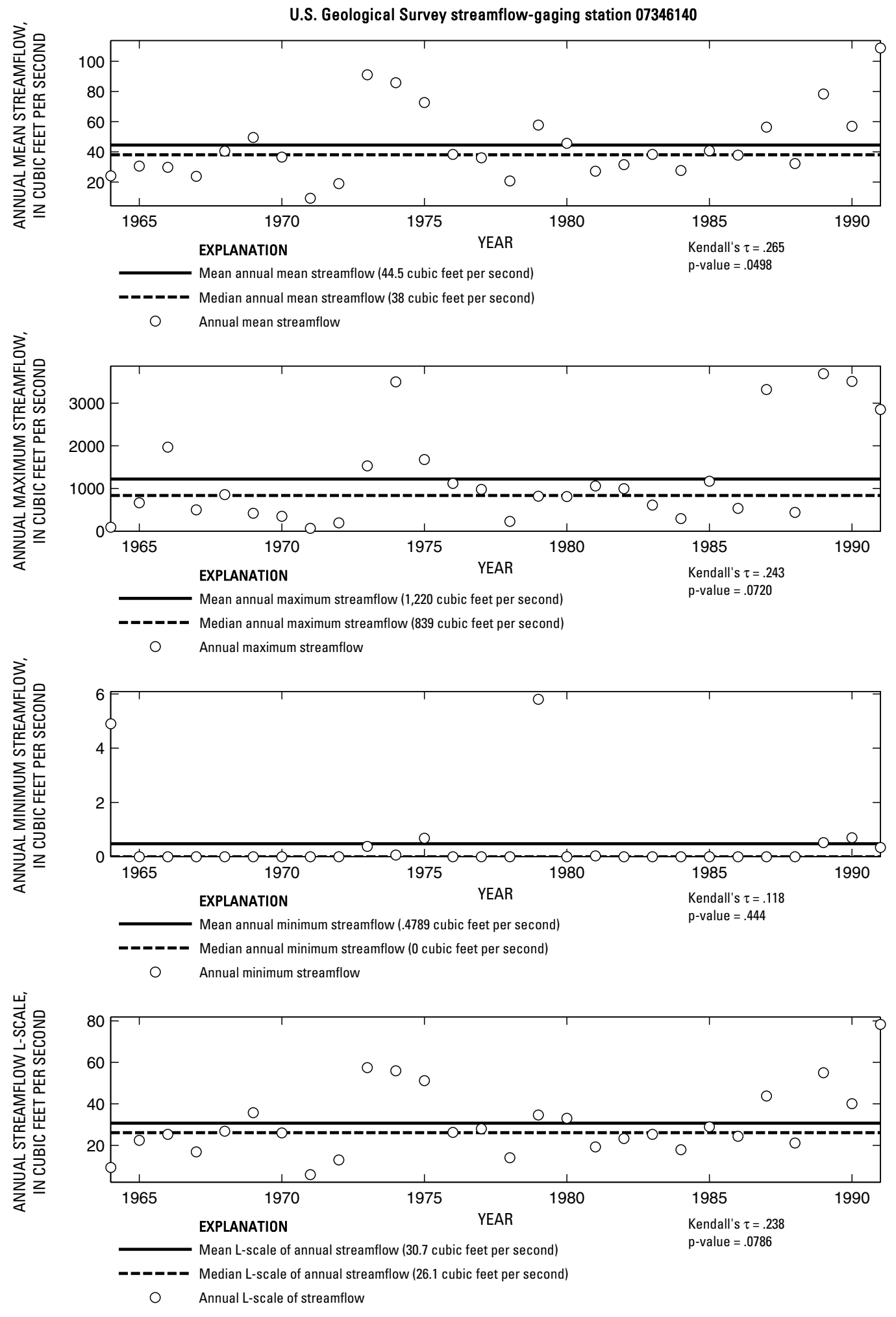

Figure 82. Analysis of annual mean, maximum, minimum, and L-scale statistics of daily mean streamflow for U.S. Geological Survey streamflow-gaging station 07346140 Frazier Creek near Linden, Texas.

Index of Station Numbers 719 


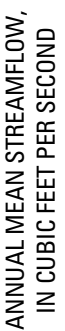

U.S. Geological Survey streamflow-gaging station 08017200

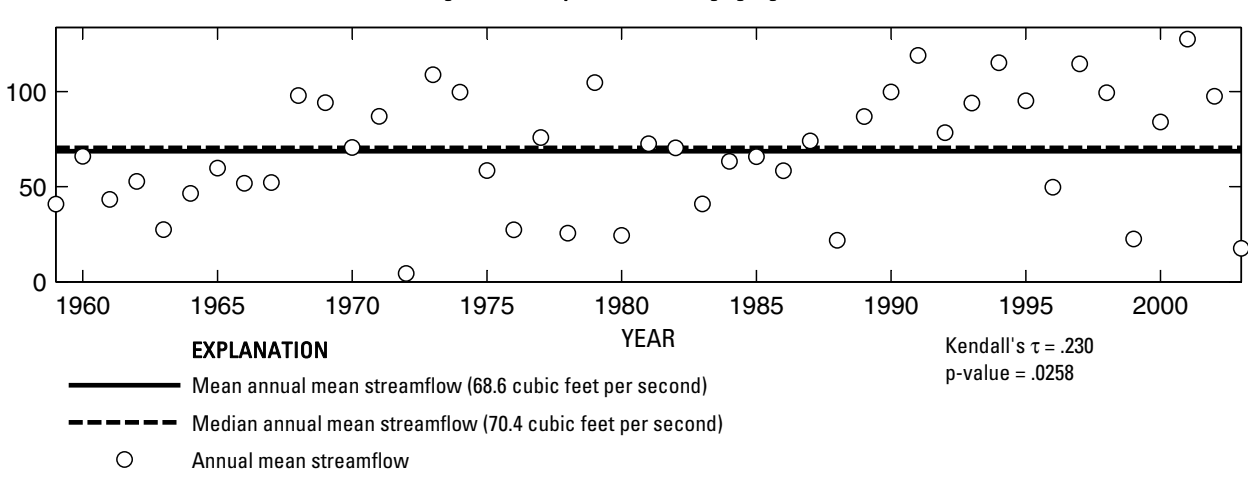

咅

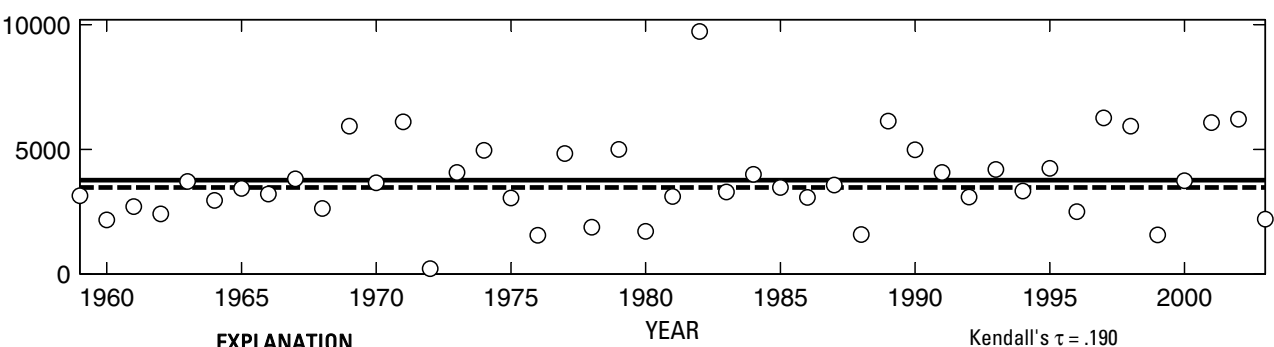

EXPLANATION YEAR Kendall's $\tau=.190$

Mean annual maximum streamflow $(3,770$ cubic feet per second)

$\mathrm{p}$-value $=.0673$

Annual maximum streamflow

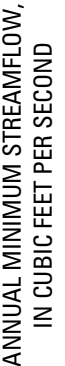

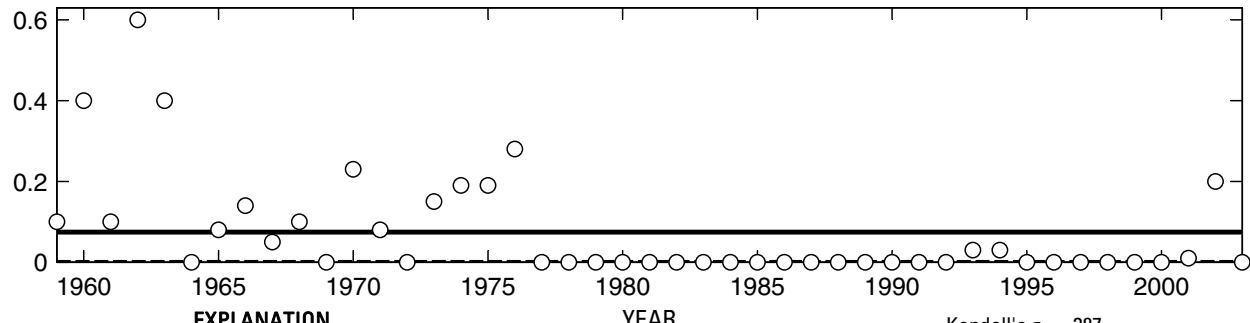

EXPLANATION YEAR Kendall's $\tau=-.387$

Theil trend line for annual minimum streamflow

$\mathrm{p}$-value $=<.001$

Median annual minimum streamflow (0 cubic feet per second)

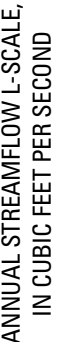

O Annual minimum streamflow

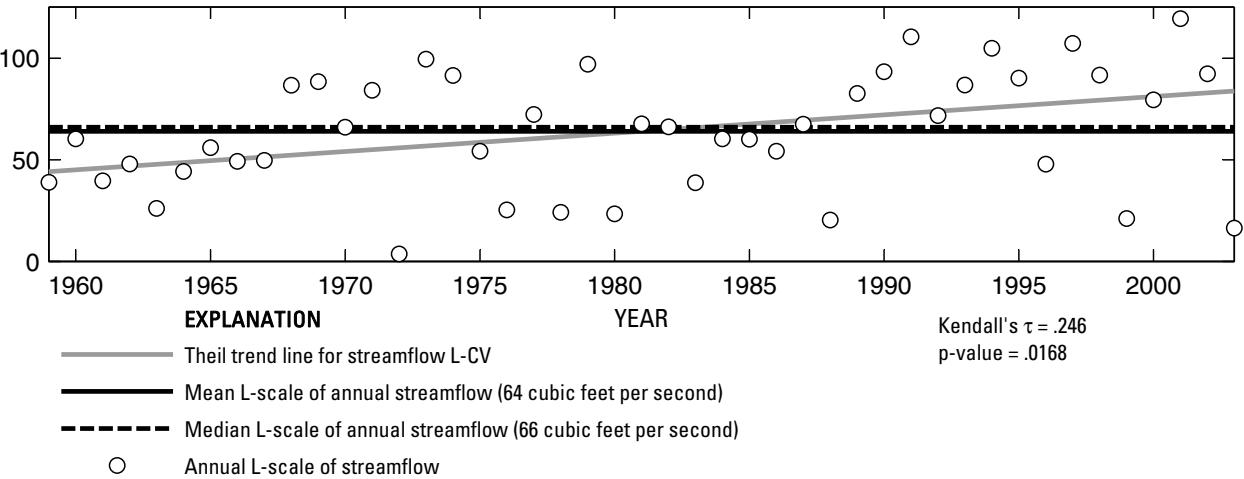

Figure 83. Analysis of annual mean, maximum, minimum, and L-scale statistics of daily mean streamflow for U.S. Geological Survey streamflow-gaging station 08017200 Cowleech Fork Sabine River at Greenville, Texas.

Index of Station Numbers 719 

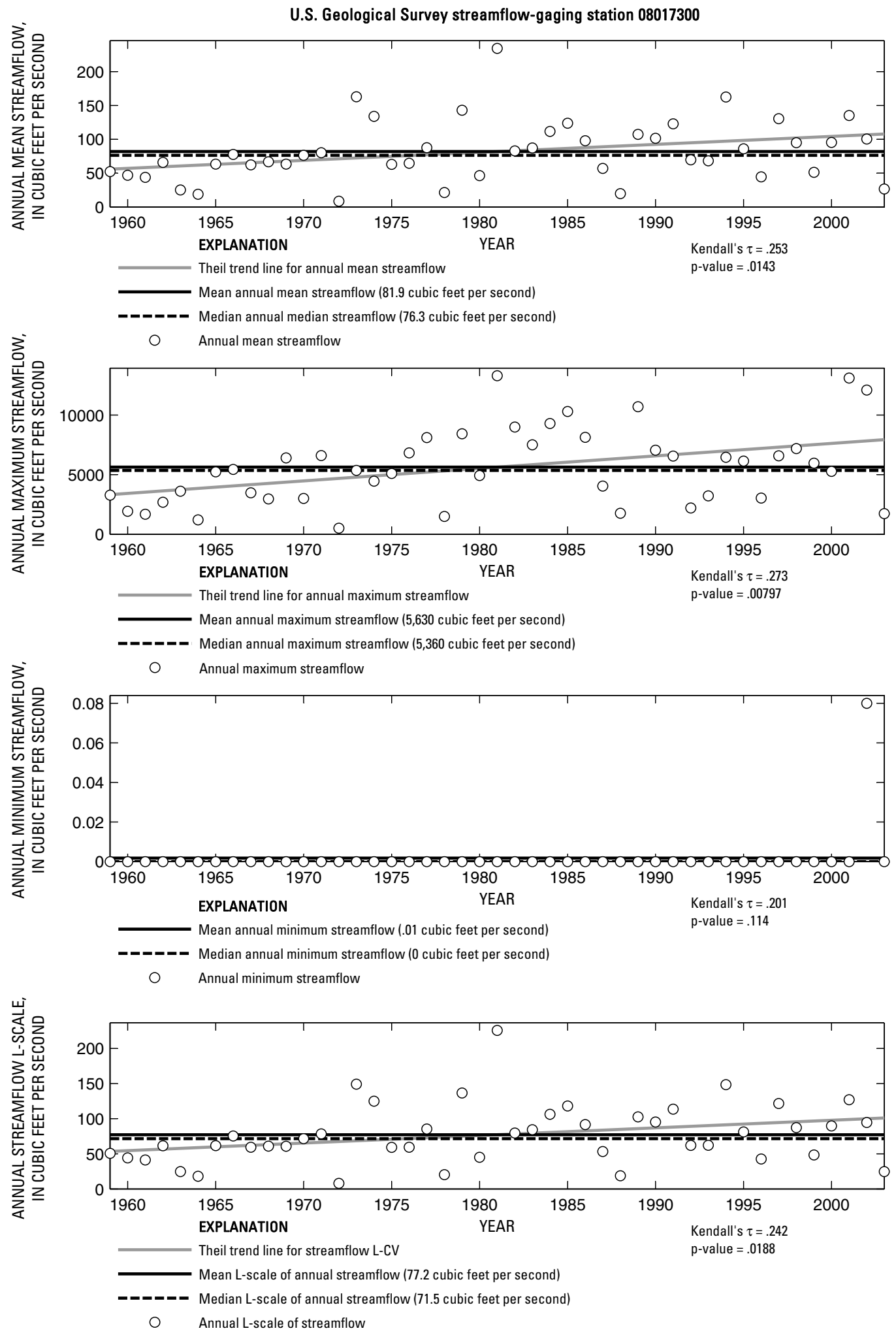

Figure 84. Analysis of annual mean, maximum, minimum, and L-scale statistics of daily mean streamflow for U.S. Geological Survey streamflow-gaging station 08017300 South Fork Sabine River near Quinlan, Texas.

Index of Station Numbers 719 

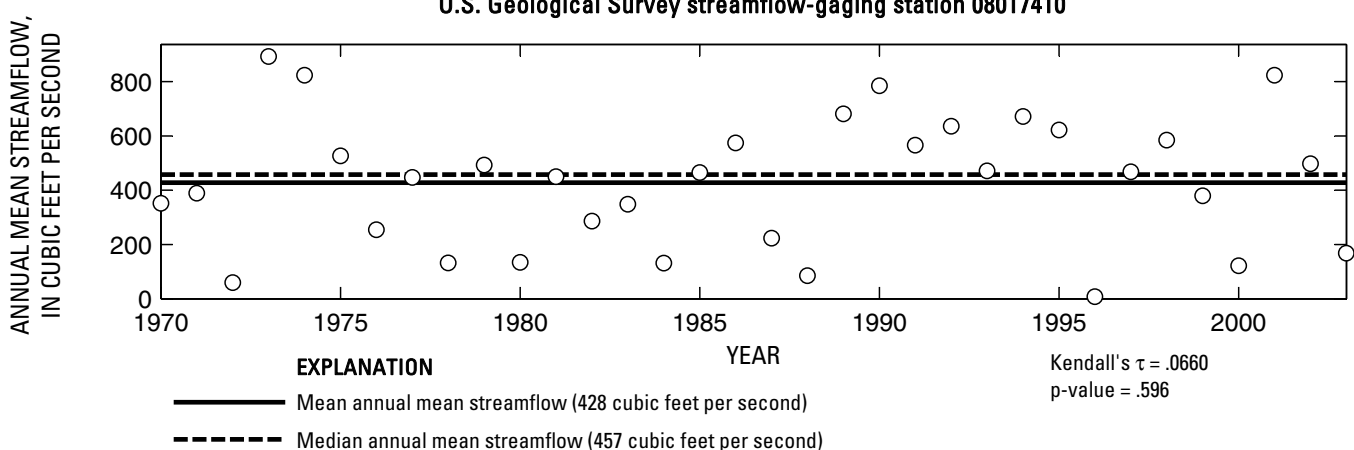

O Annual mean streamflow
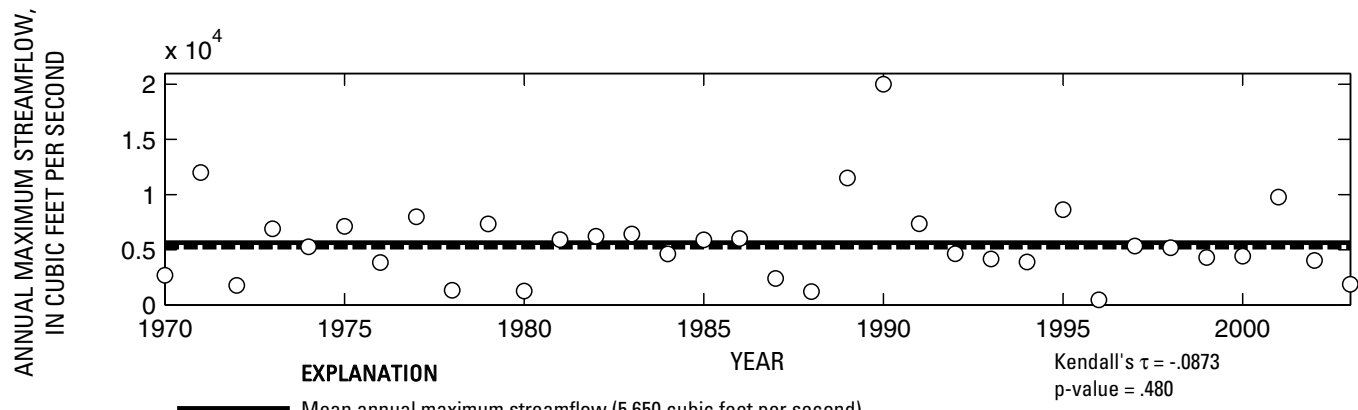

O Annual maximum streamflow
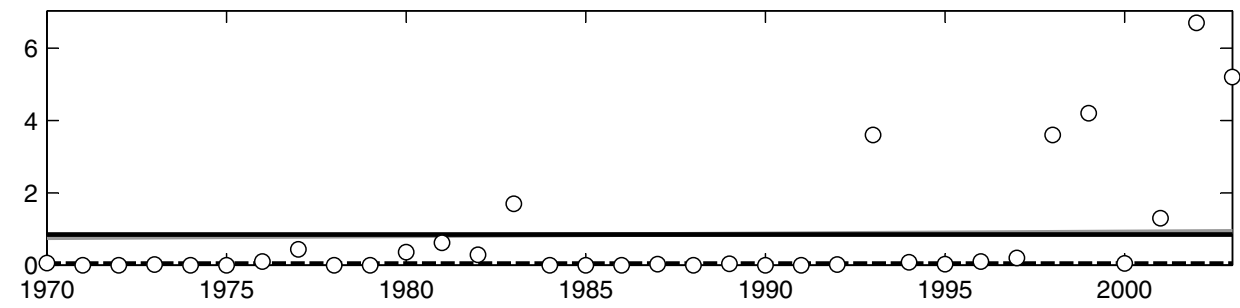

$$
\text { EXPLANATION YEAR Kendall's } \tau=.394
$$

Theil trend line for annual minimum streamflow $\mathrm{p}$-value $=.00175$

O Annual minimum streamflow
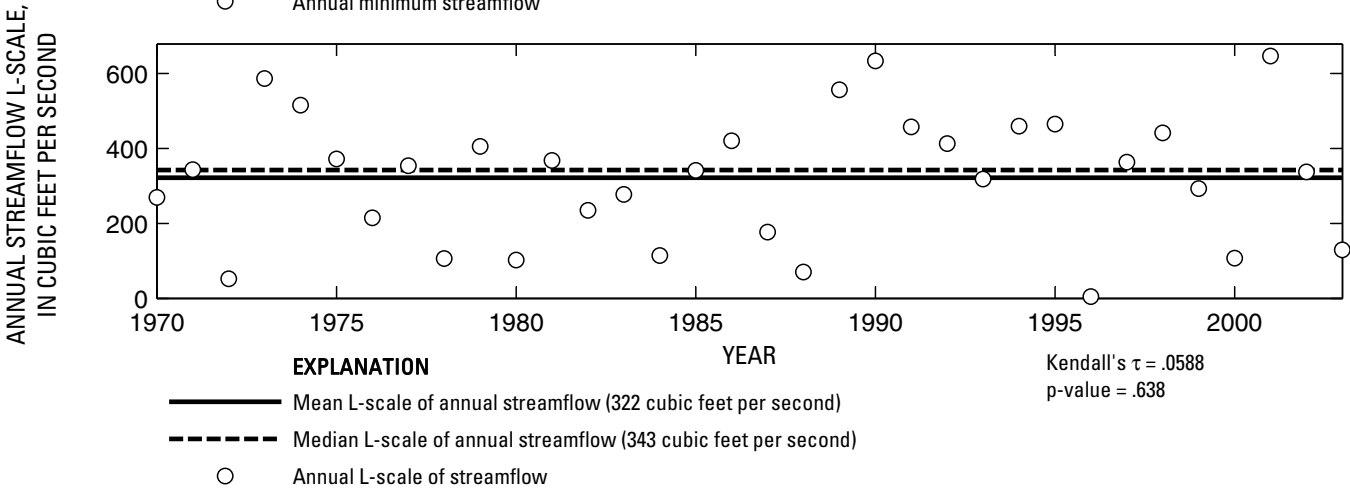

Figure 85. Analysis of annual mean, maximum, minimum, and L-scale statistics of daily mean streamflow for U.S. Geological Survey streamflow-gaging station 08017410 Sabine River near Wills Point, Texas.

Index of Station Numbers 719 

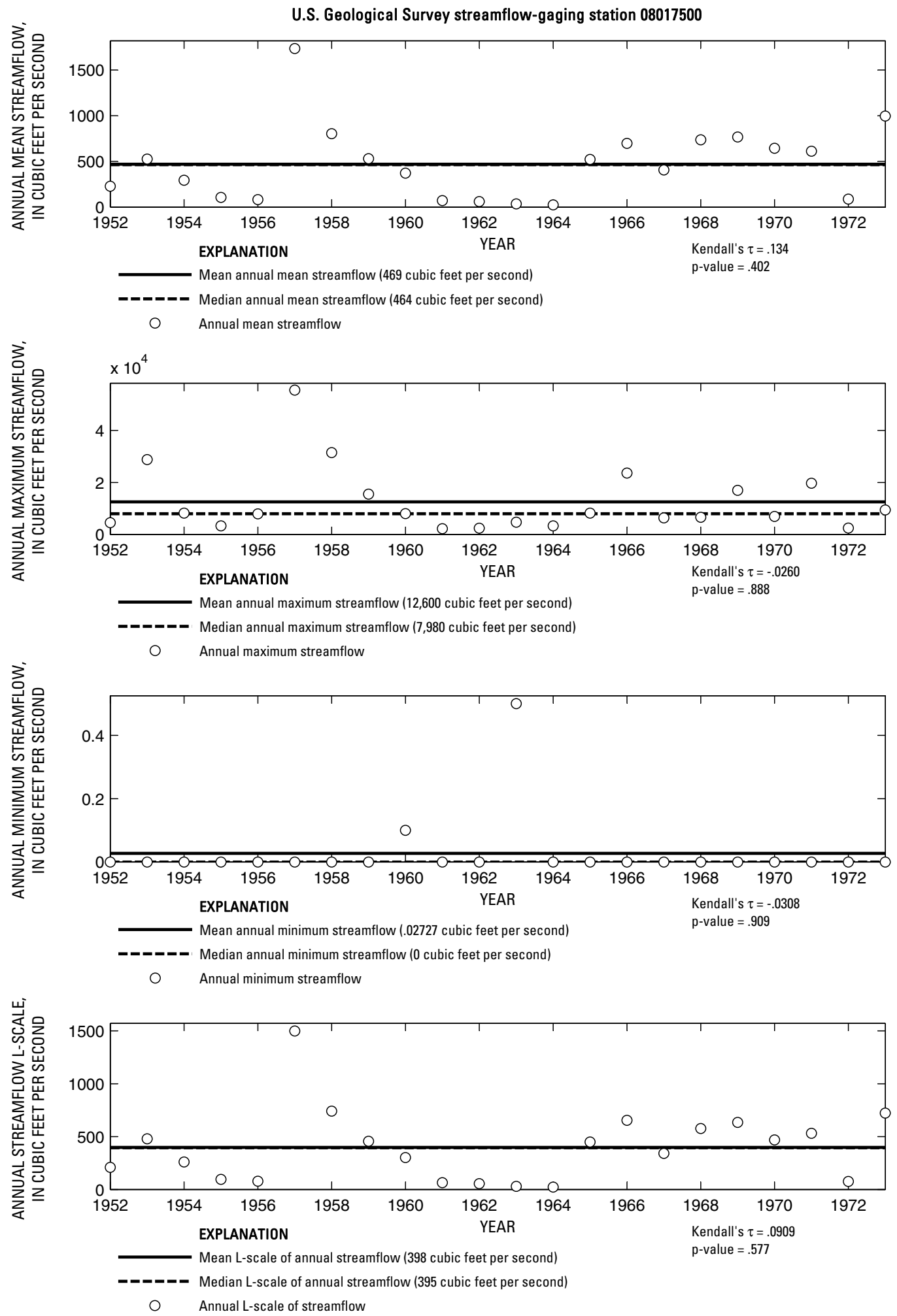

Figure 86. Analysis of annual mean, maximum, minimum, and L-scale statistics of daily mean streamflow for U.S. Geological Survey streamflow-gaging station 08017500 Sabine River near Emory, Texas.

Index of Station Numbers 719 

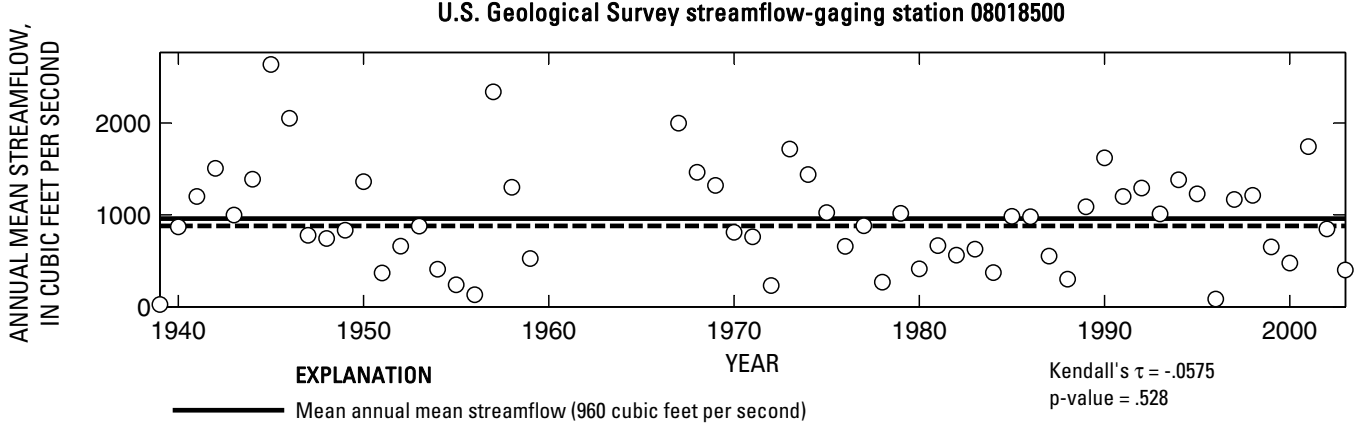

-_-_- Median annual mean streamflow (880 cubic feet per second)

- Annual mean streamflow

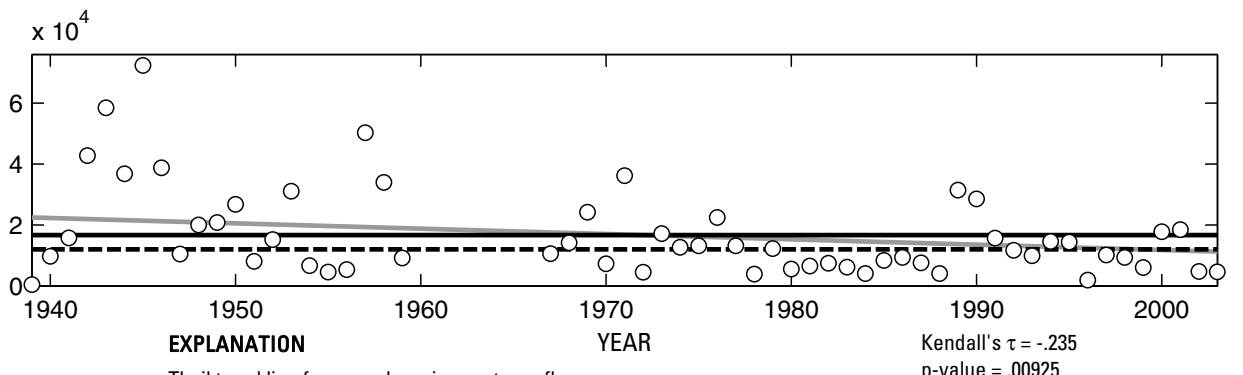

Theil trend line for annual maximum streamflow

p-value $=.00925$

Mean annual maximum streamflow (16,700 cubic feet per second)

-ーーーーー・ Median annual maximum streamflow (12,000 cubic feet per second)

$\bigcirc \quad$ Annual maximum streamflow

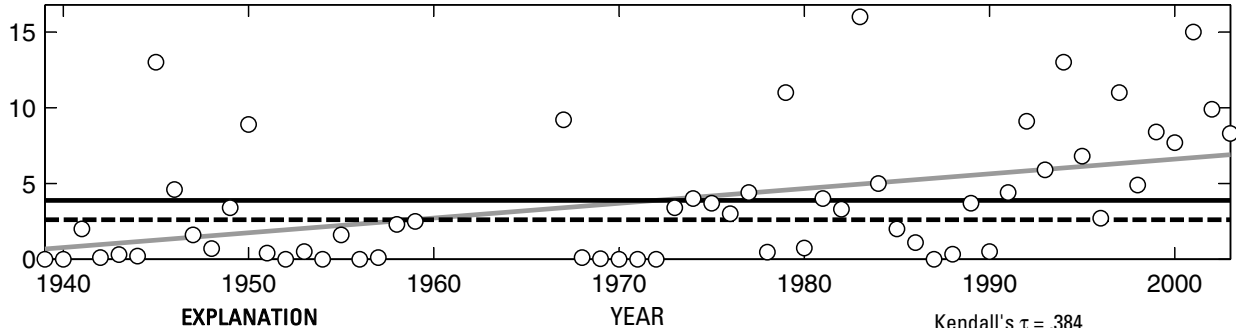

Theil trend line for annual minimum streamflow

Mean annual minimum streamflow (3.884 cubic feet per second)

- - Median annual minimum streamflow (2.6 cubic feet per second)

O Annual minimum streamflow

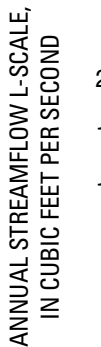

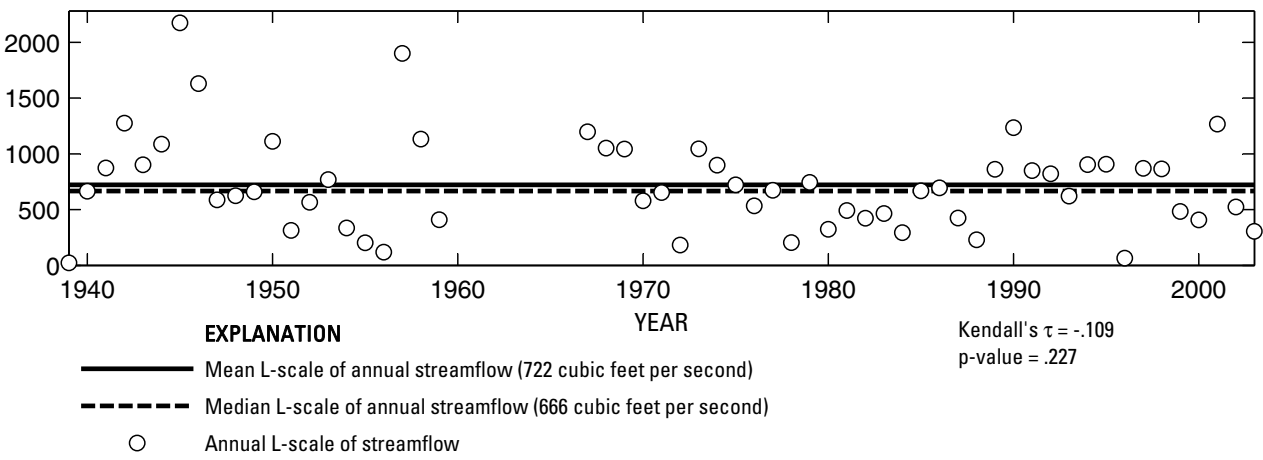

Figure 87. Analysis of annual mean, maximum, minimum, and L-scale statistics of daily mean streamflow for U.S. Geological Survey streamflow-gaging station 08018500 Sabine River near Mineola, Texas. 

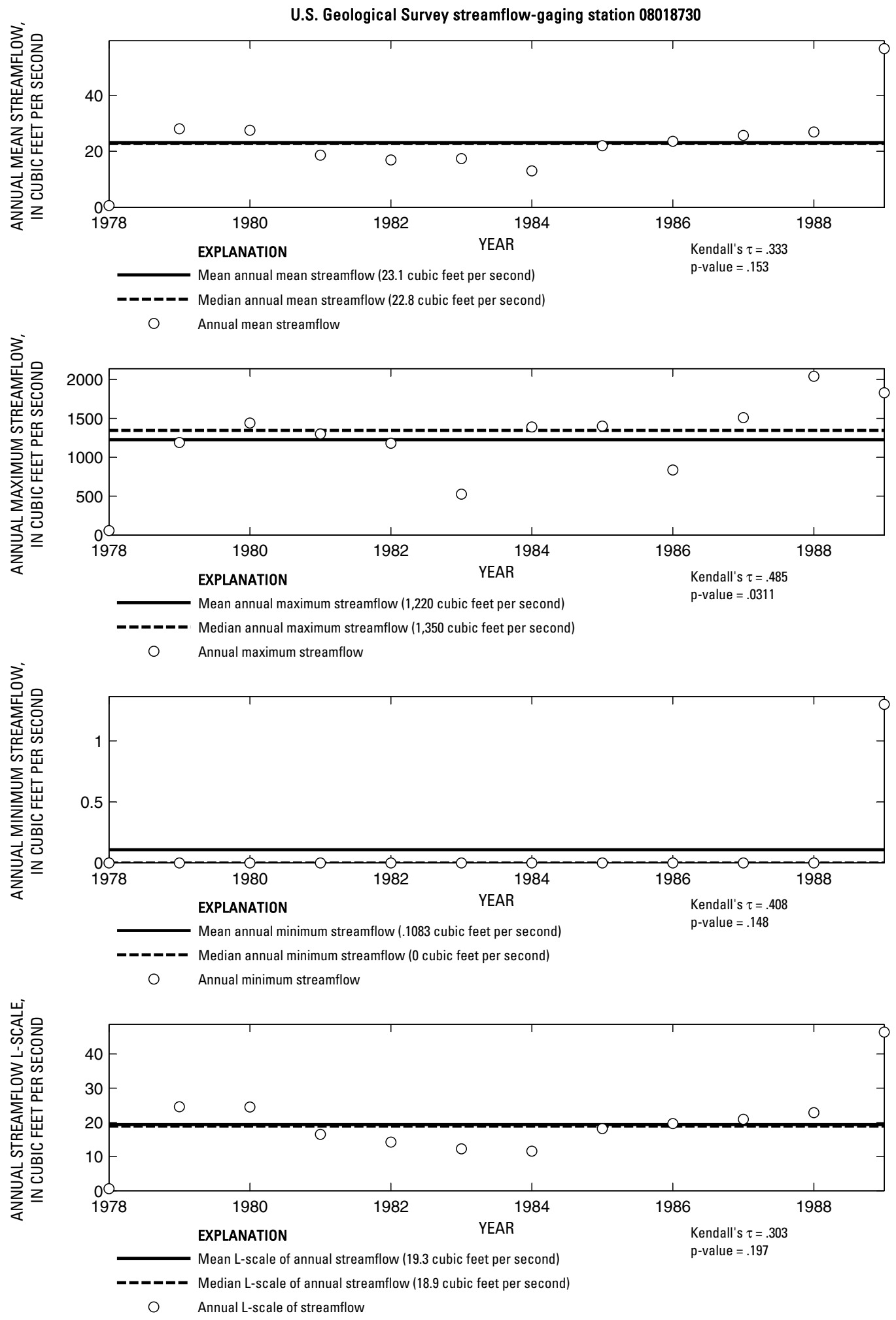

Figure 88. Analysis of annual mean, maximum, minimum, and L-scale statistics of daily mean streamflow for U.S. Geological Survey streamflow-gaging station 08018730 Burke Creek near Yantis, Texas.

Index of Station Numbers 719 


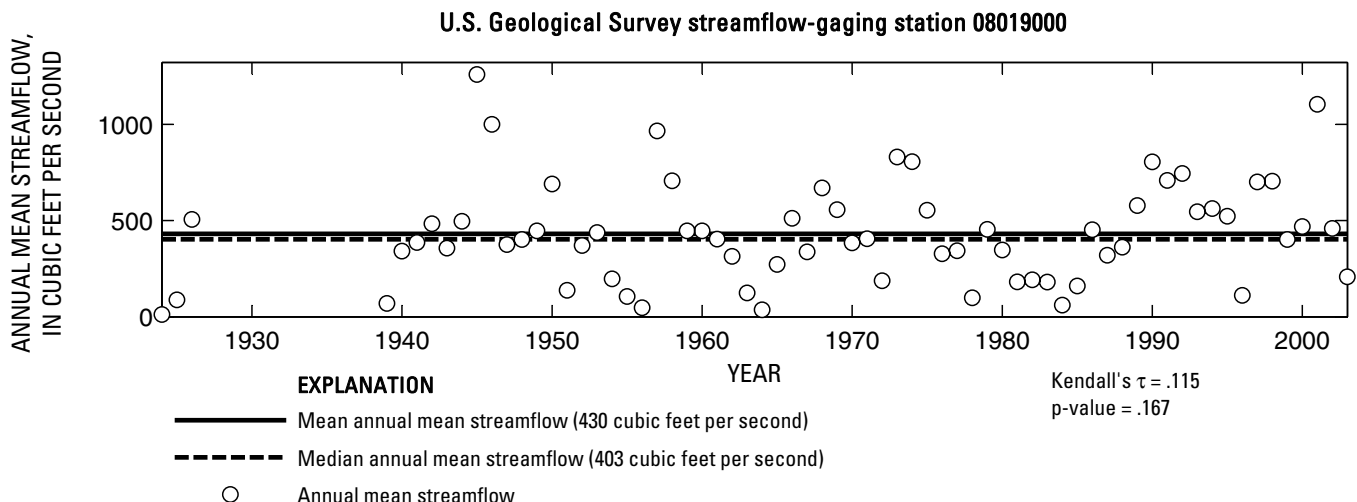

O Annual mean streamflow

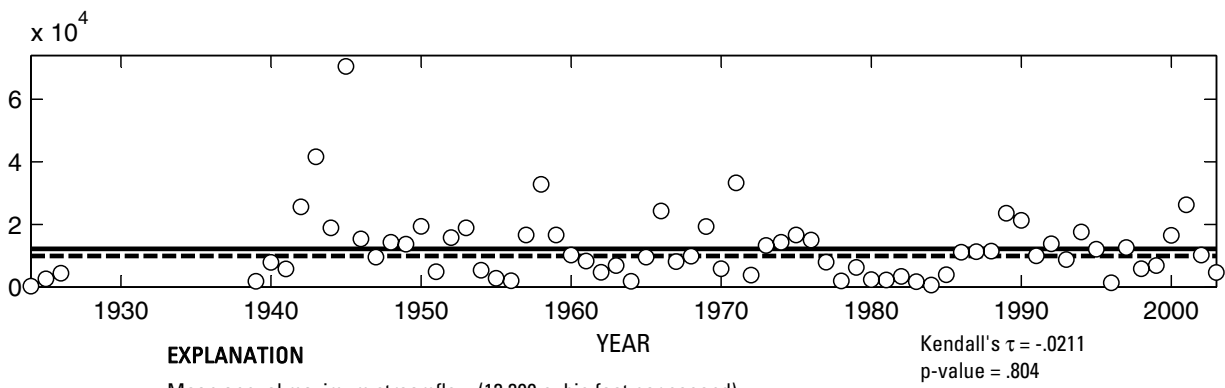

O Annual maximum streamflow

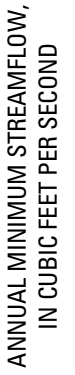

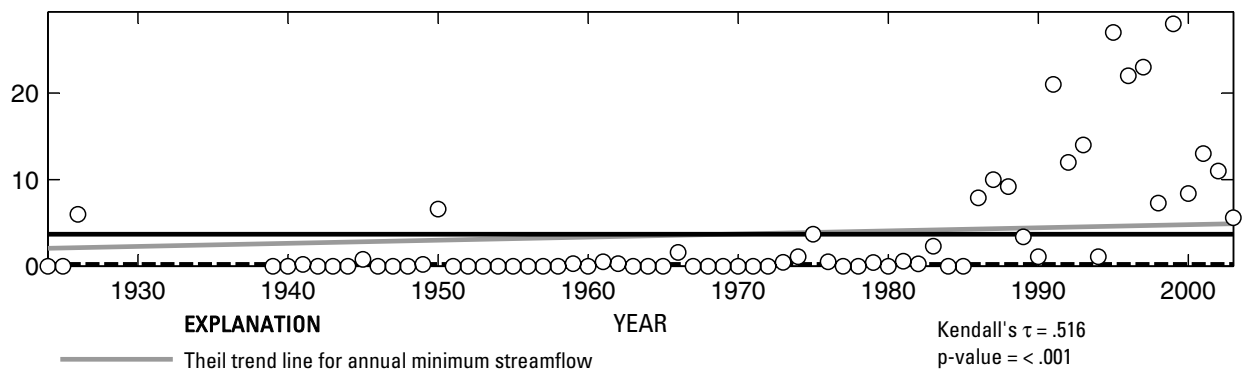

Mean annual minimum streamflow ( 3.689 cubic feet per second)

ーーーーーー Median annual minimum streamflow (.2 cubic feet per second)

O Annual minimum streamflow

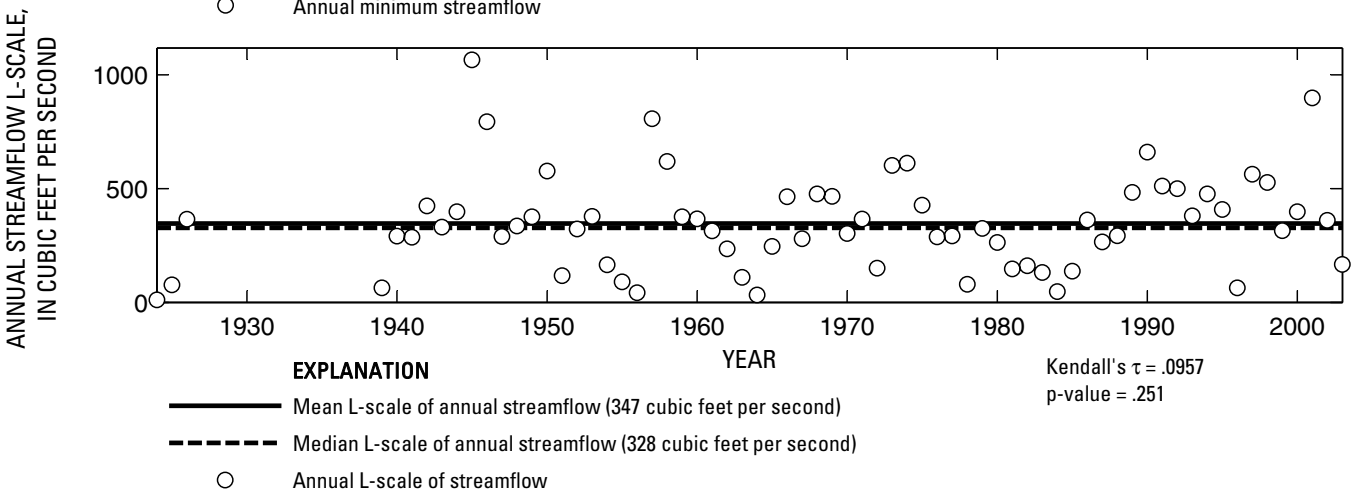

Figure 89. Analysis of annual mean, maximum, minimum, and L-scale statistics of daily mean streamflow for U.S. Geological Survey streamflow-gaging station 08019000 Lake Fork Creek near Quitman, Texas.

Index of Station Numbers 719 

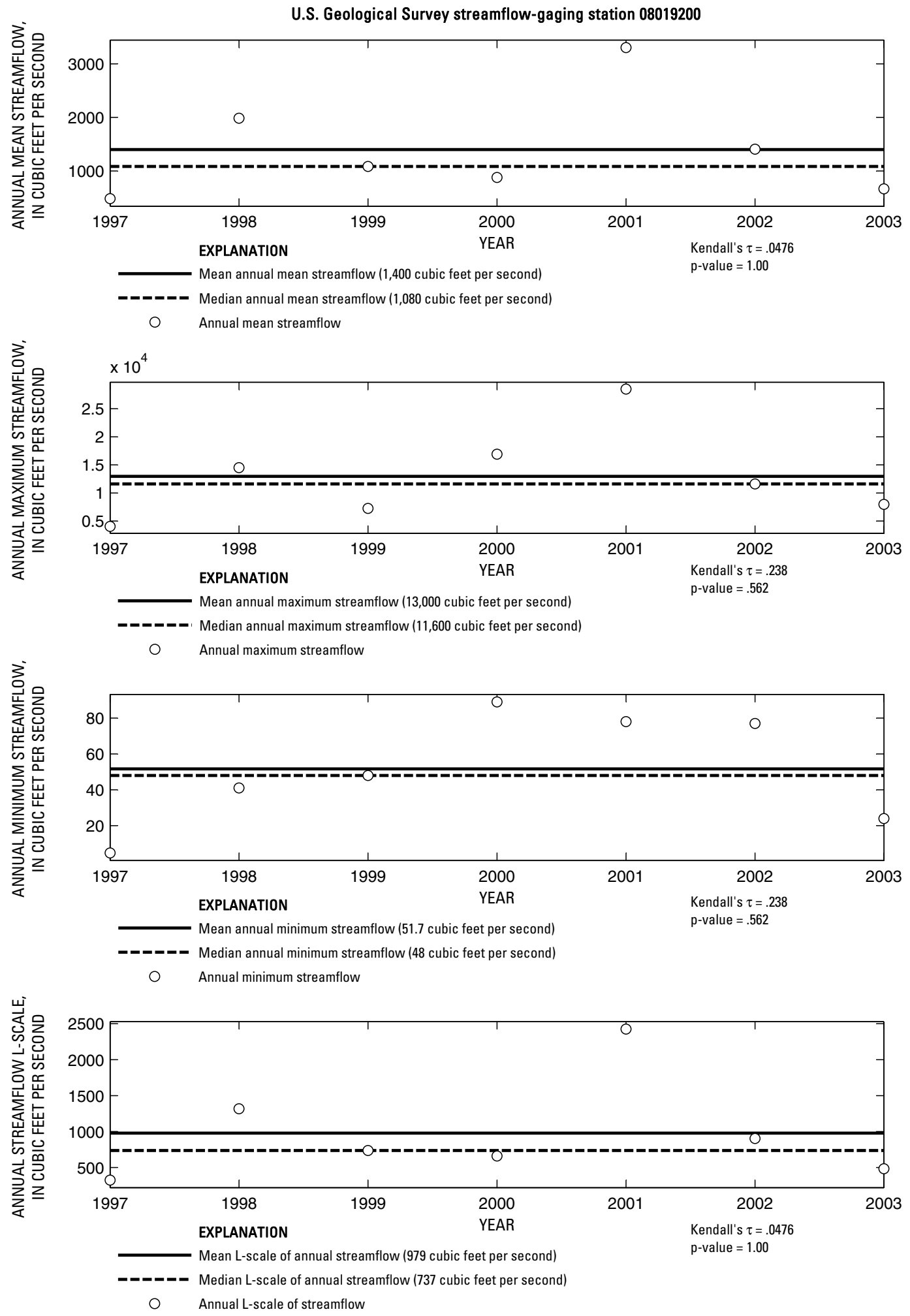

Figure 90. Analysis of annual mean, maximum, minimum, and L-scale statistics of daily mean streamflow for U.S. Geological Survey streamflow-gaging station 08019200 Sabine River near Hawkins, Texas.

Index of Station Numbers 719 

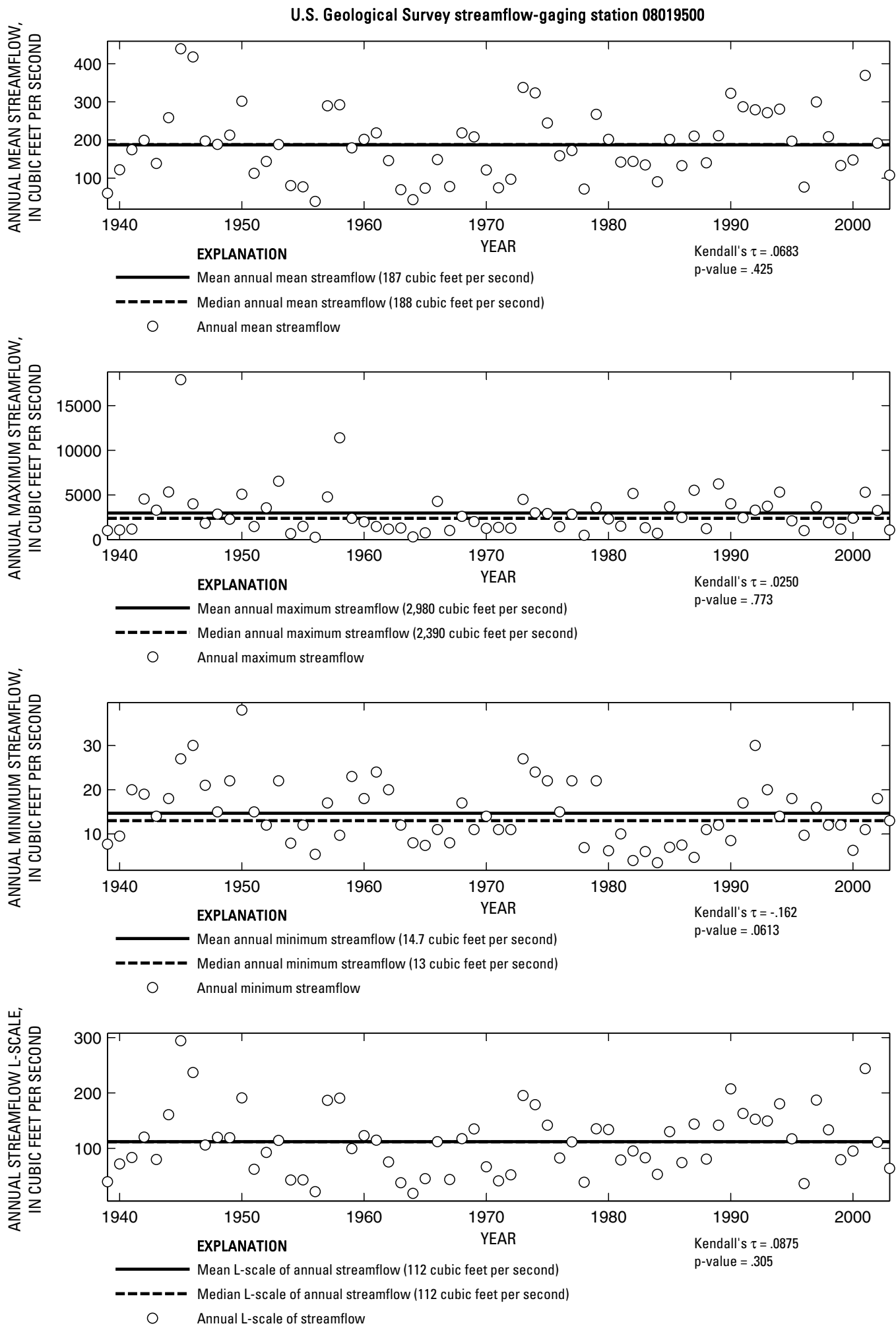

Figure 91. Analysis of annual mean, maximum, minimum, and L-scale statistics of daily mean streamflow for U.S. Geological Survey streamflow-gaging station 08019500 Big Sandy Creek near Big Sandy, Texas. 

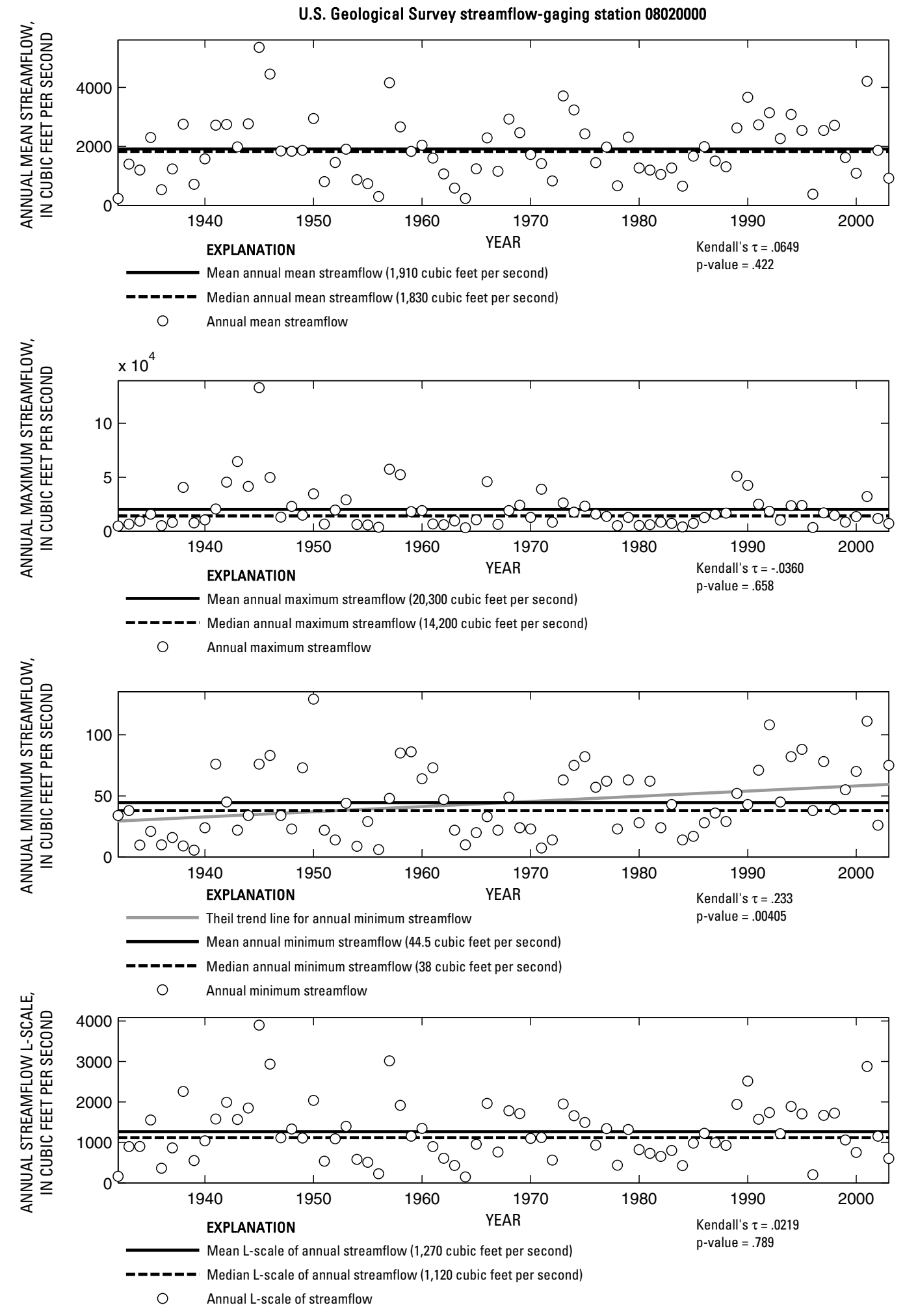

Figure 92. Analysis of annual mean, maximum, minimum, and L-scale statistics of daily mean streamflow for U.S. Geological Survey streamflow-gaging station 08020000 Sabine River near Gladewater, Texas.

Index of Station Numbers 719 

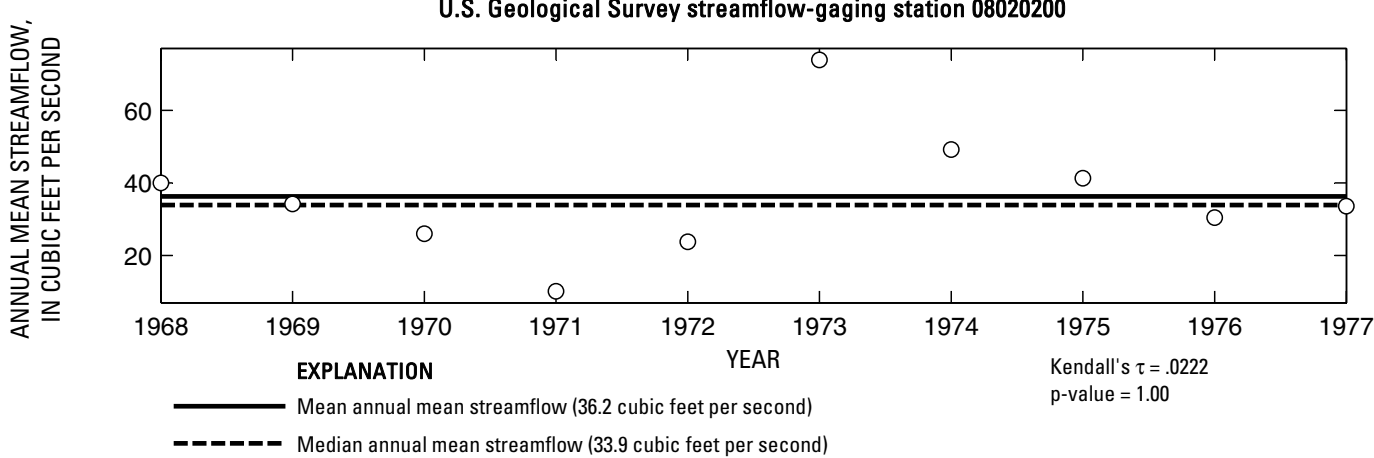

O Annual mean streamflow
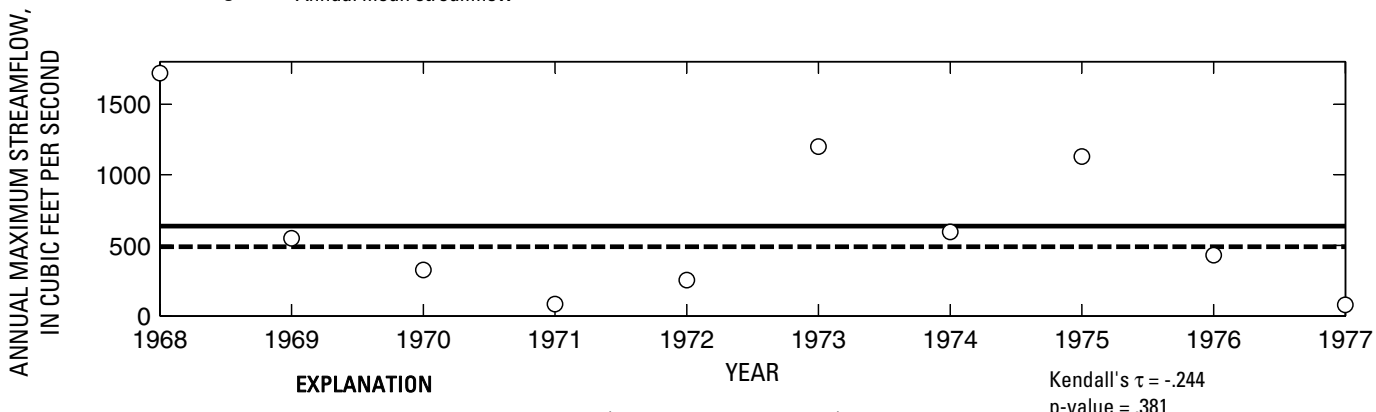

Mean annual maximum streamflow (637 cubic feet per second)

$\mathrm{p}$-value $=.381$

-ーーー- Median annual maximum streamflow (491 cubic feet per second)

- Annual maximum streamflow

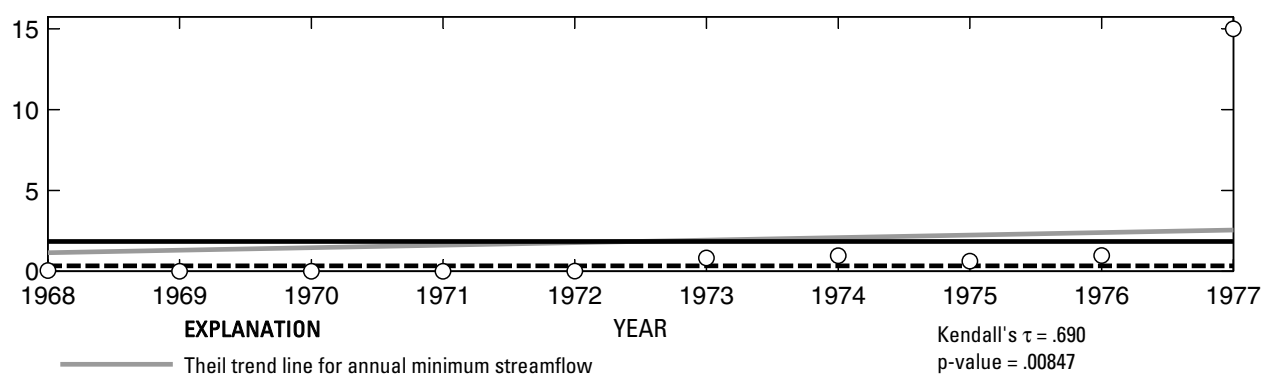

Theil trend line for annual minimum streamflow

$\mathrm{p}$-value $=.00847$

Mean annual minimum streamflow (1.842 cubic feet per second)

- - - Median annual minimum streamflow (.33 cubic feet per second)

O Annual minimum streamflow

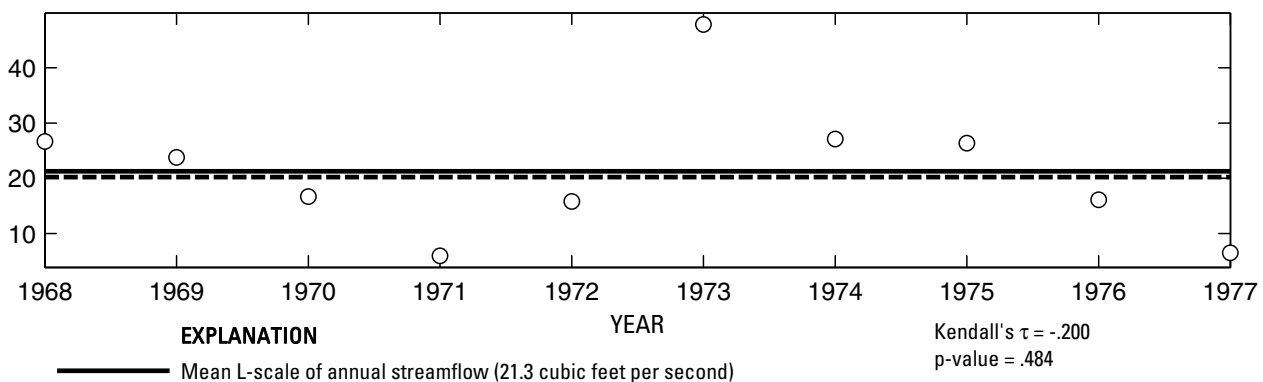

- - - - Median L-scale of annual streamflow (20.2 cubic feet per second)

Annual L-scale of streamflow

Figure 93. Analysis of annual mean, maximum, minimum, and L-scale statistics of daily mean streamflow for U.S. Geological Survey streamflow-gaging station 08020200 Prairie Creek near Gladewater, Texas. 


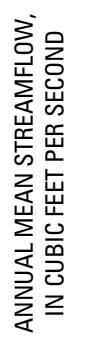

U.S. Geological Survey streamflow-gaging station 08020450

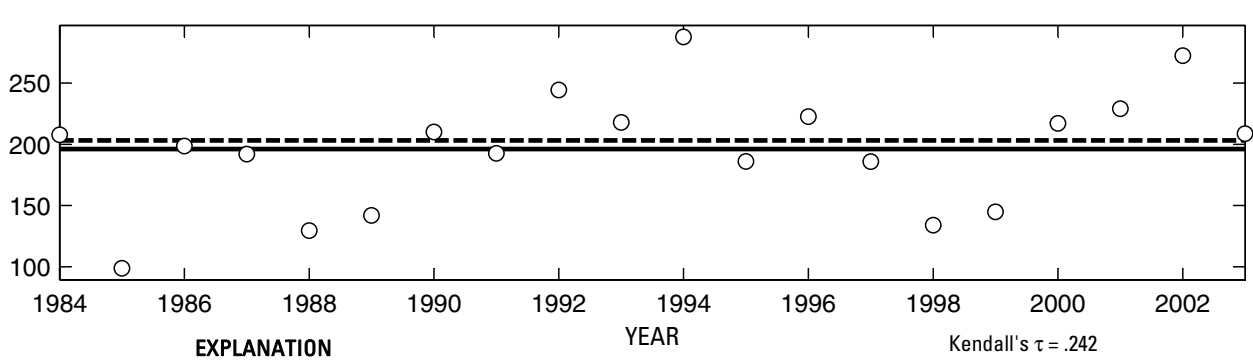

$\mathrm{p}$-value $=.146$

-_-_-_ Median annual mean streamflow (203 cubic feet per second)

O Annual mean streamflow

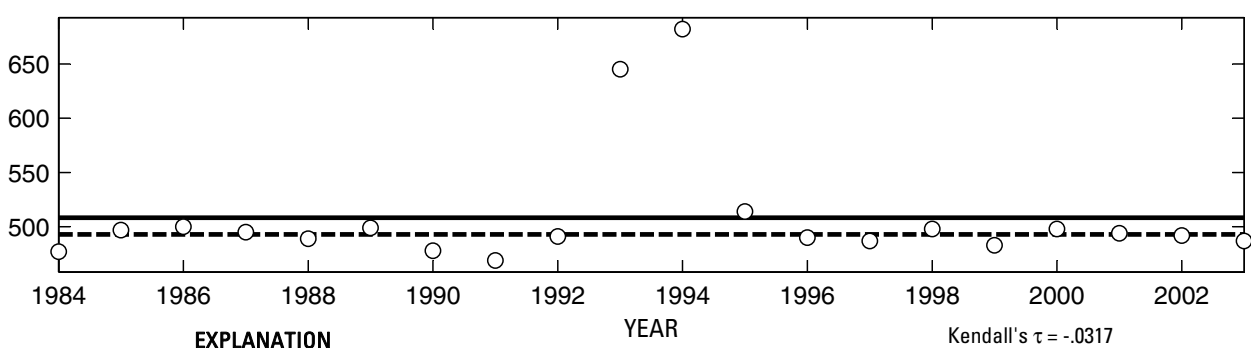

EXPLANATION

Mean annual maximum streamflow (508 cubic feet per second)

$\mathrm{p}$-value $=.871$

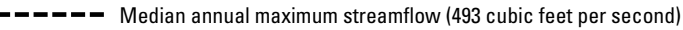

O Annual maximum streamflow

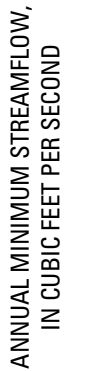

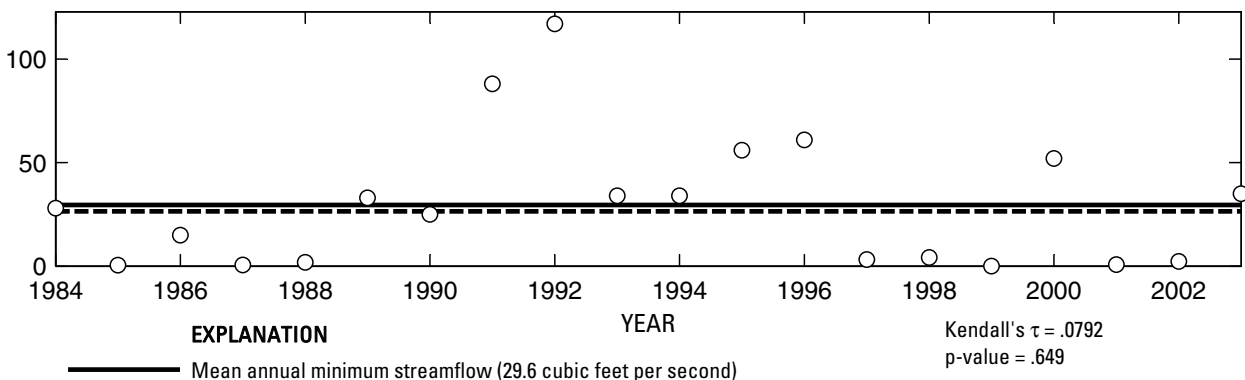

- Median annual minimum streamflow (26.5 cubic feet per second)

○ Annual minimum streamflow

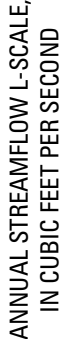

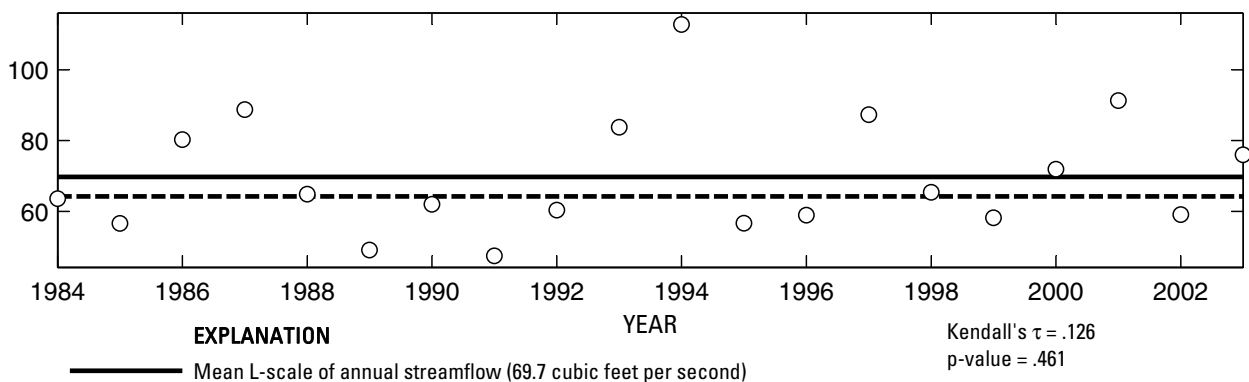

- Median L-scale of annual streamflow (64.2 cubic feet per second)

Annual L-scale of streamflow

Figure 94. Analysis of annual mean, maximum, minimum, and L-scale statistics of daily mean streamflow for U.S. Geological Survey streamflow-gaging station 08020450 Sabine River above Longview, Texas.

Index of Station Numbers 719 


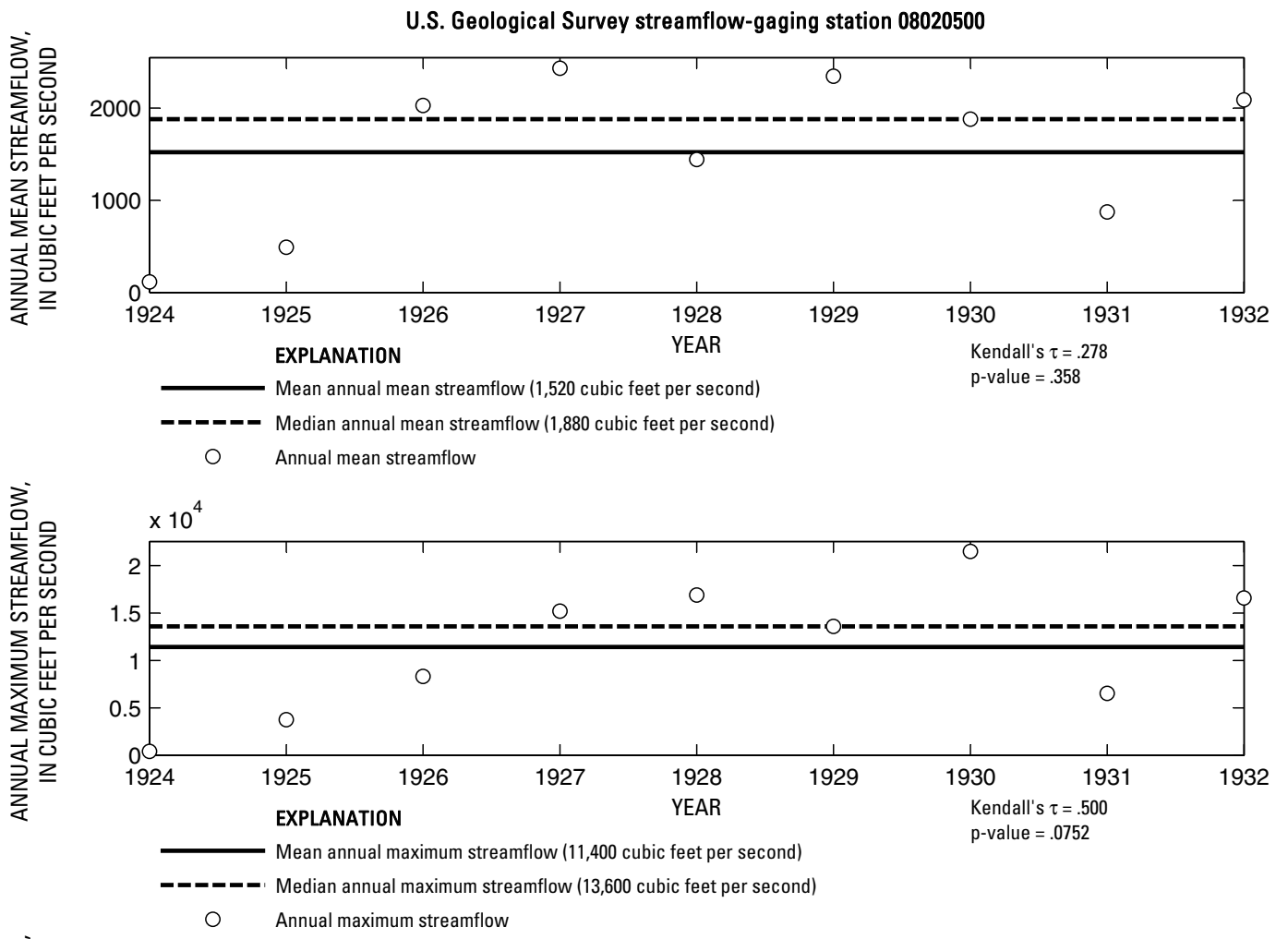

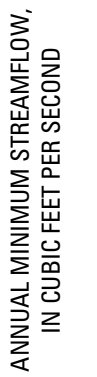

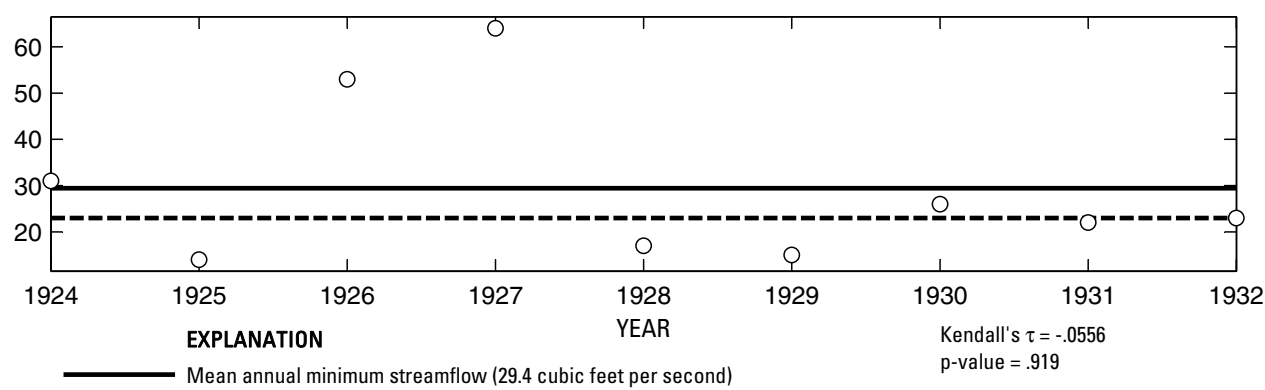

-_-_- Median annual minimum streamflow (23 cubic feet per second)

○ Annual minimum streamflow

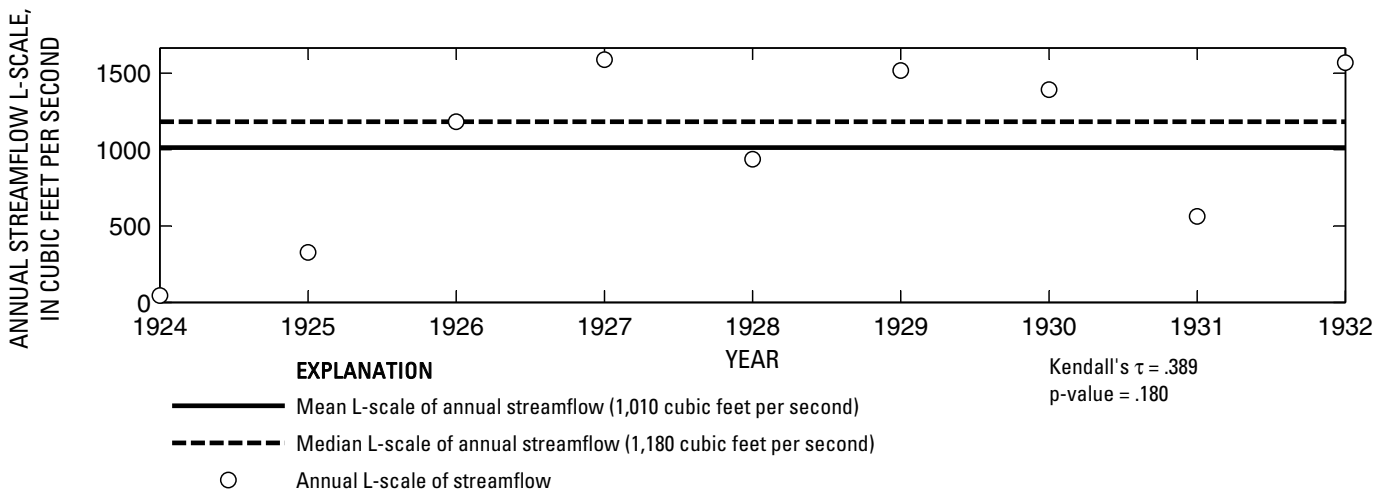

Figure 95. Analysis of annual mean, maximum, minimum, and L-scale statistics of daily mean streamflow for U.S. Geological Survey streamflow-gaging station 08020500 Sabine River near Longview, Texas. 


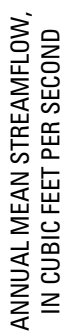

U.S. Geological Survey streamflow-gaging station 08020700

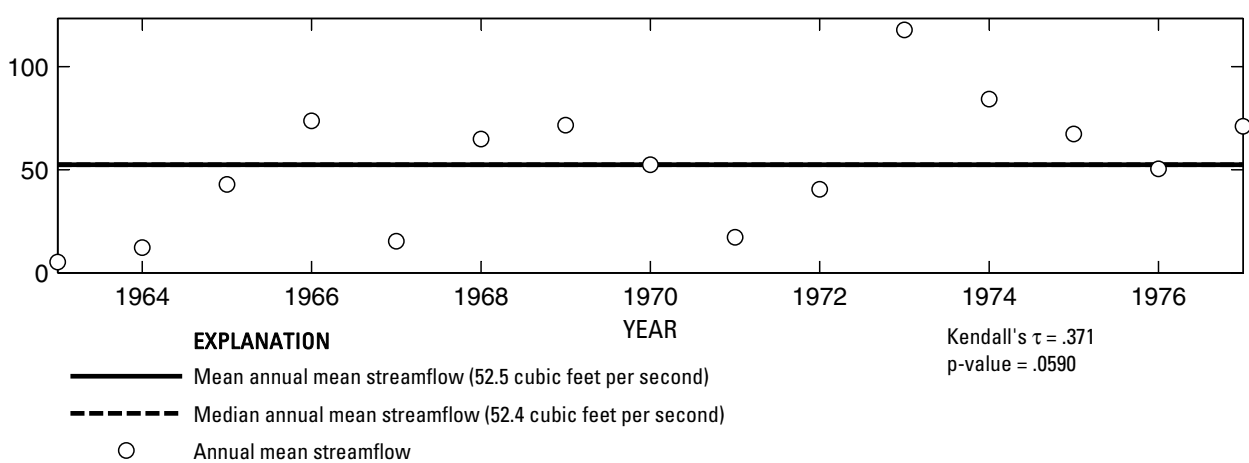

家

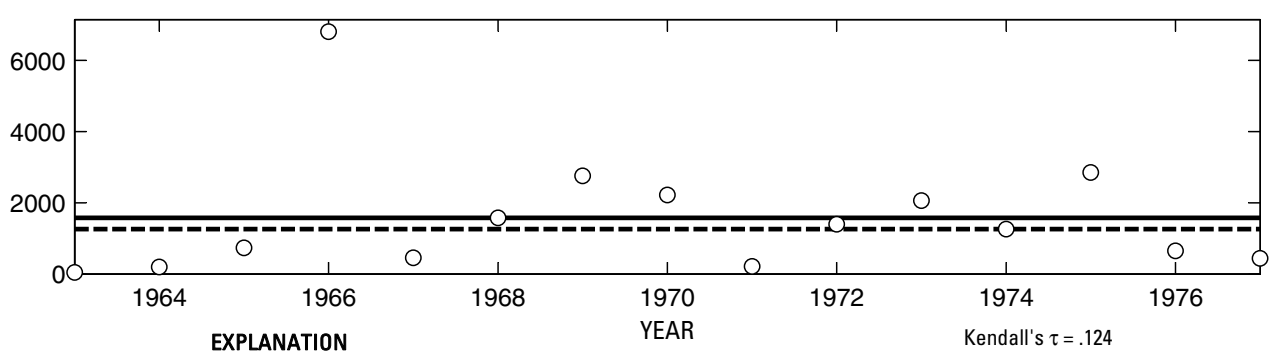

EXPLANATION

Median annual maximum streamflow (1,260 cubic feet per second)

O Annual maximum streamflow

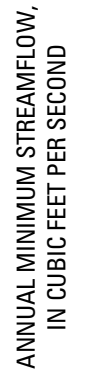

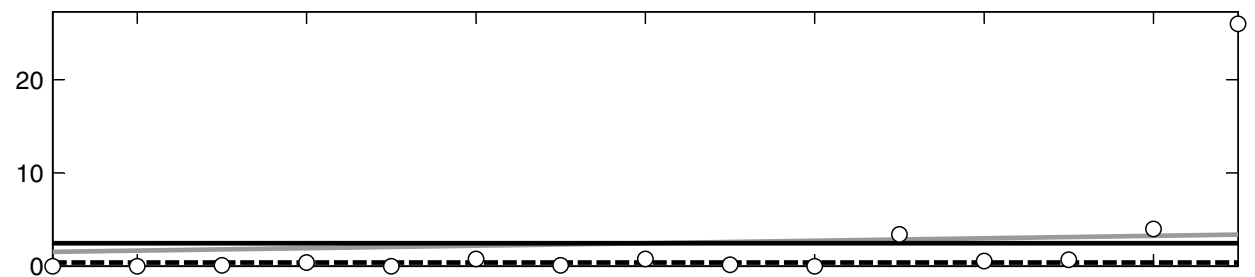

$\begin{array}{lllllll}1964 & 1966 & 1968 & 1970 & 1972 & 1974 & 1976\end{array}$ EXPLANATION YEAR Kendall's $\tau=.572$

Theil trend line for annual minimum streamflow
Mean annual minimum streamflow ( 2.463 cubic feet per second)

$\mathrm{p}$-value $=.00431$

•ーーーーー Median annual minimum streamflow (.4 cubic feet per second)

O Annual minimum streamflow

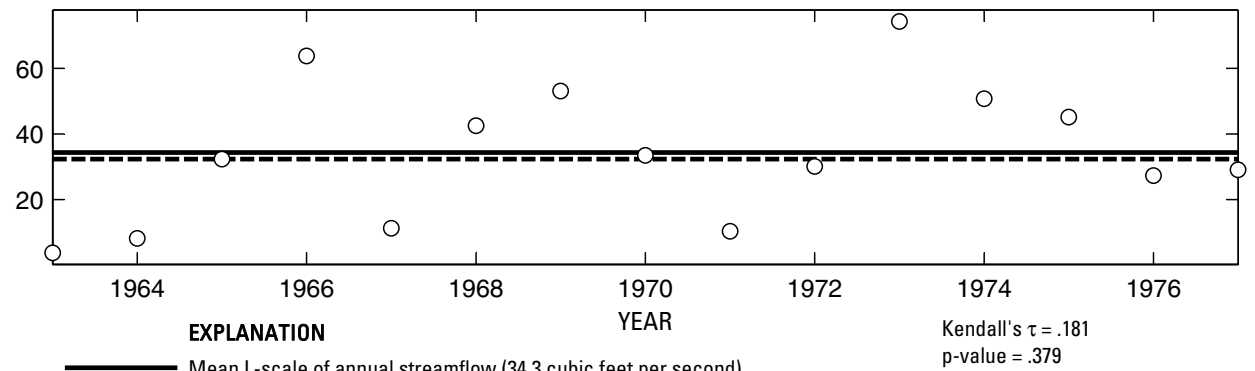

Mean L-scale of annual streamflow (34.3 cubic feet per second)

-ーーーーー Median L-scale of annual streamflow (32.3 cubic feet per second)

O Annual L-scale of streamflow

Figure 96. Analysis of annual mean, maximum, minimum, and L-scale statistics of daily mean streamflow for U.S. Geological Survey streamflow-gaging station 08020700 Rabbit Creek at Kilgore, Texas.

Index of Station Numbers 719 


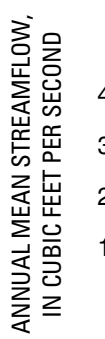

U.S. Geological Survey streamflow-gaging station 08020900

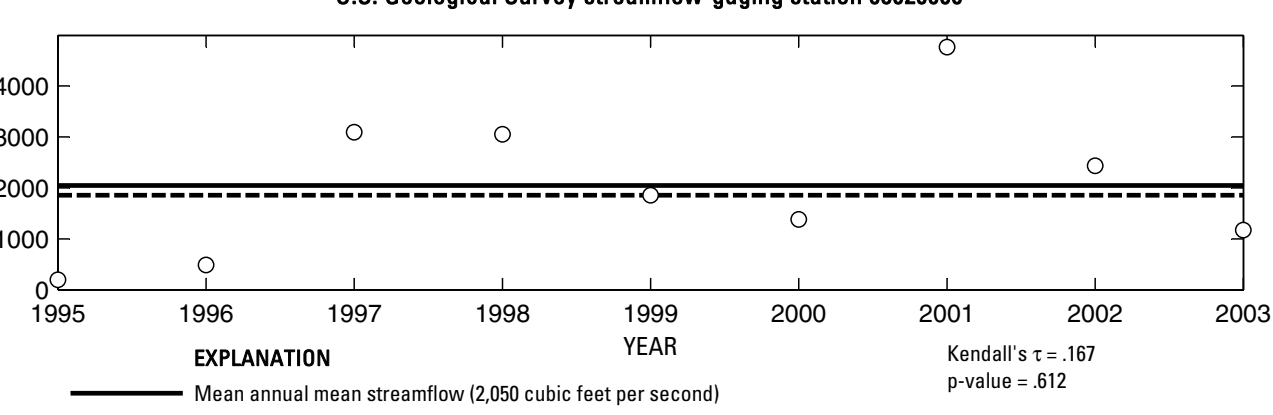

-_o_-_ Median annual mean streamflow (1,860 cubic feet per second)

O Annual mean streamflow

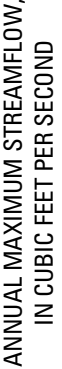
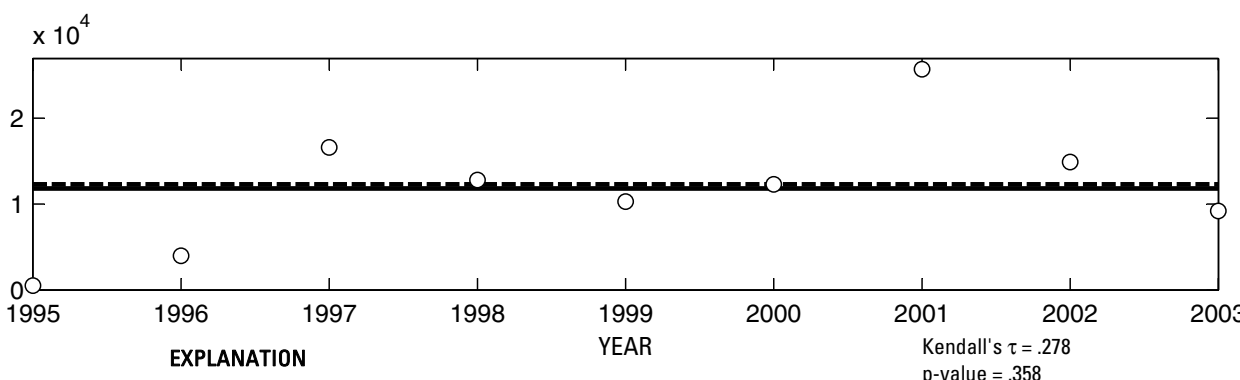

p-value $=358$

Mean annual maximum streamflow $(11,800$ cubic feet per second $)$

- - - Median annual maximum streamflow (12,300 cubic feet per second

O Annual maximum streamflow

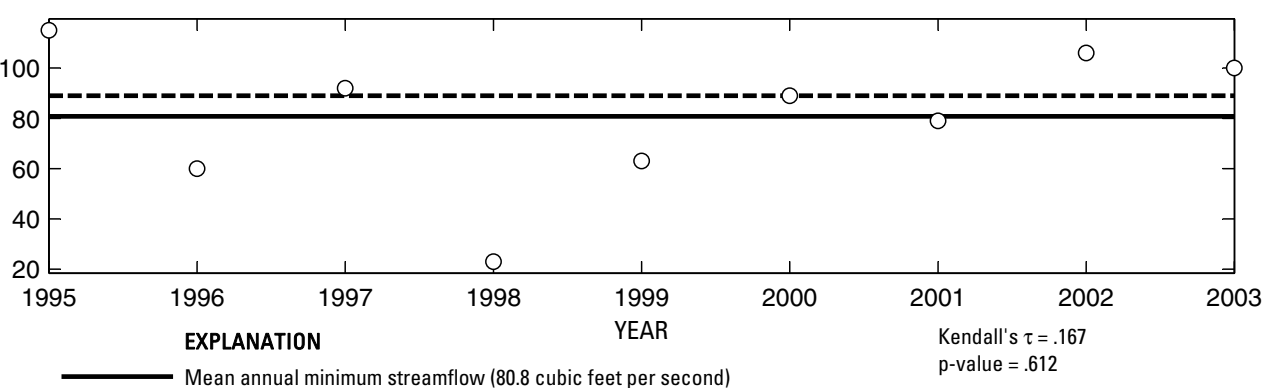

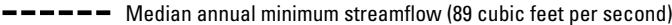

O Annual minimum streamflow

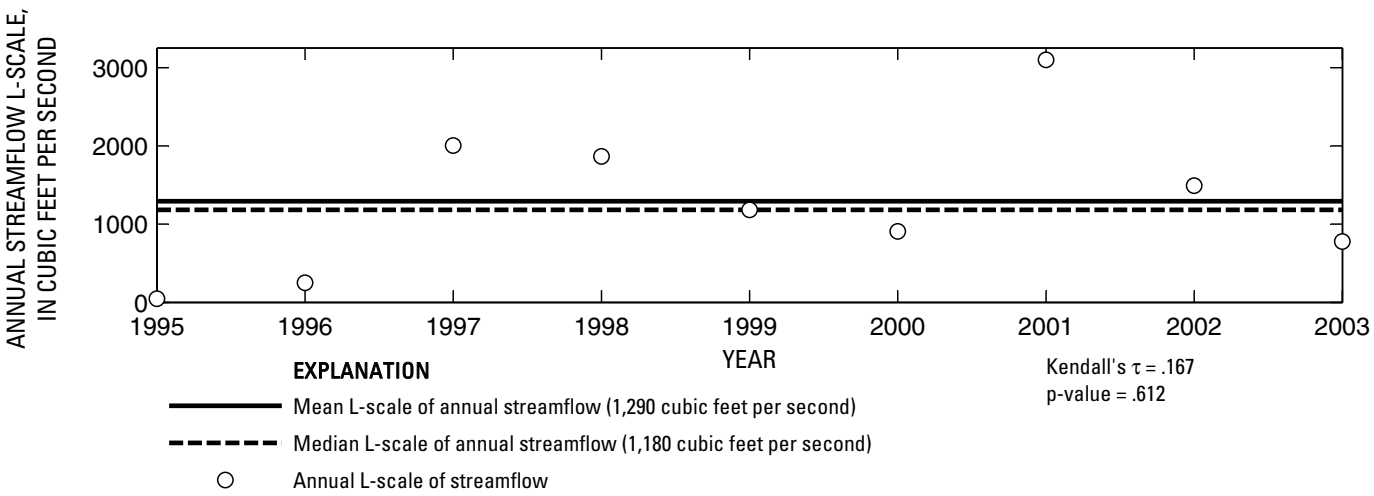

Figure 97. Analysis of annual mean, maximum, minimum, and L-scale statistics of daily mean streamflow for U.S. Geological Survey streamflow-gaging station 08020900 Sabine River below Longview, Texas.

Index of Station Numbers 719 

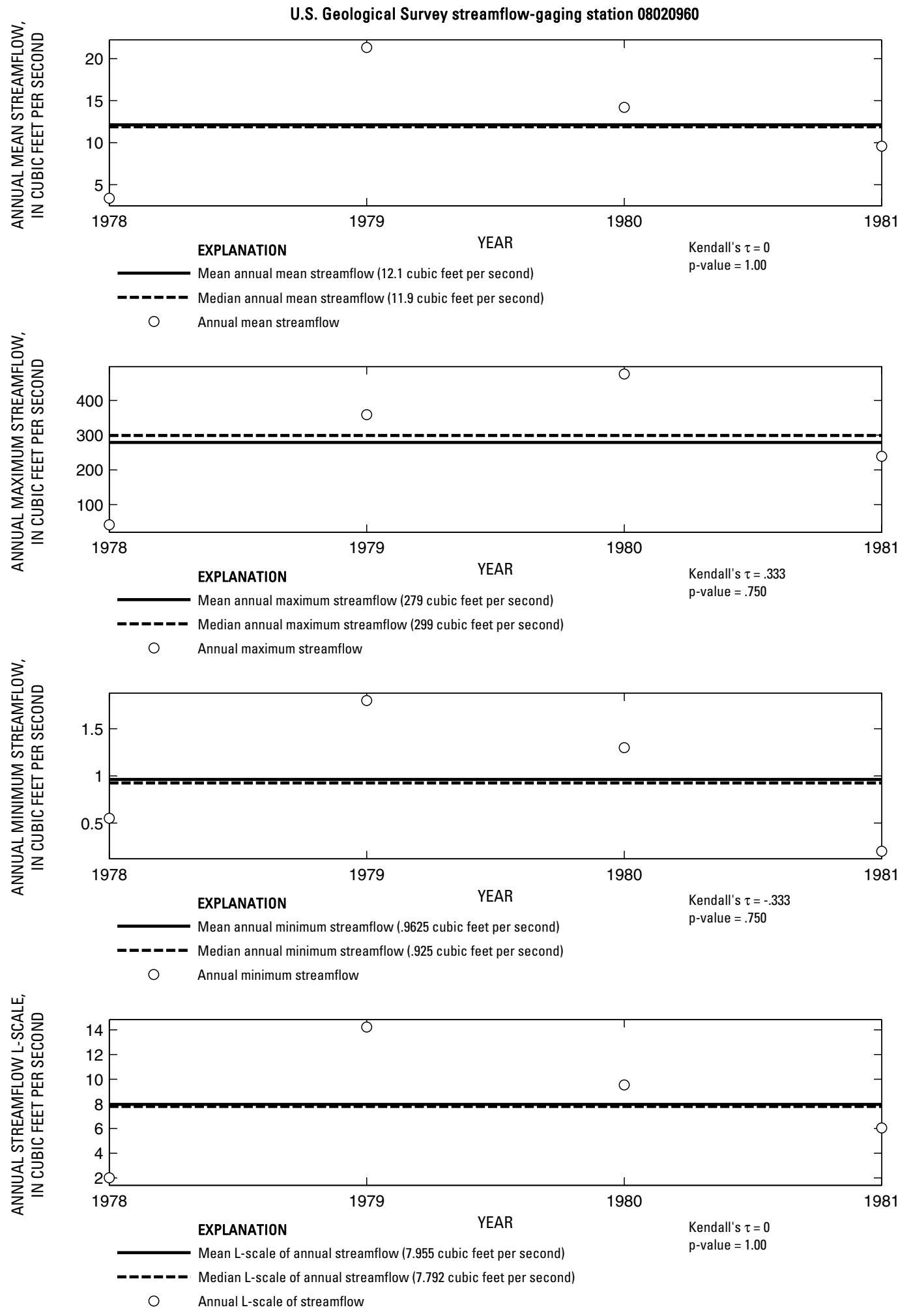

Figure 98. Analysis of annual mean, maximum, minimum, and L-scale statistics of daily mean streamflow for U.S. Geological Survey streamflow-gaging station 08020960 Mill Creek near Henderson, Texas.

|ndex of Station Numbers 719 

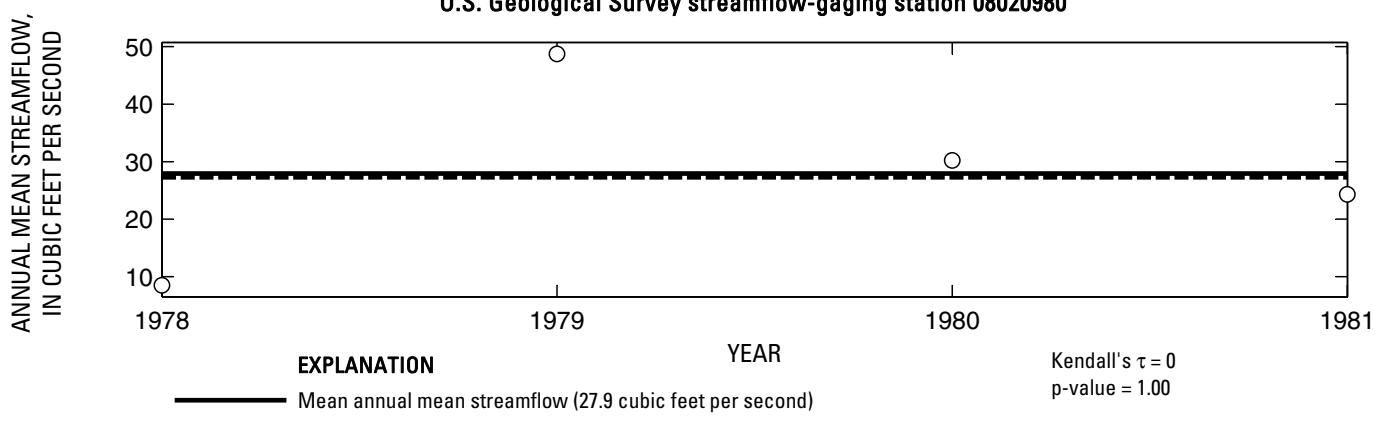

-_-_- Median annual mean streamflow (27.3 cubic feet per second)

O Annual mean streamflow
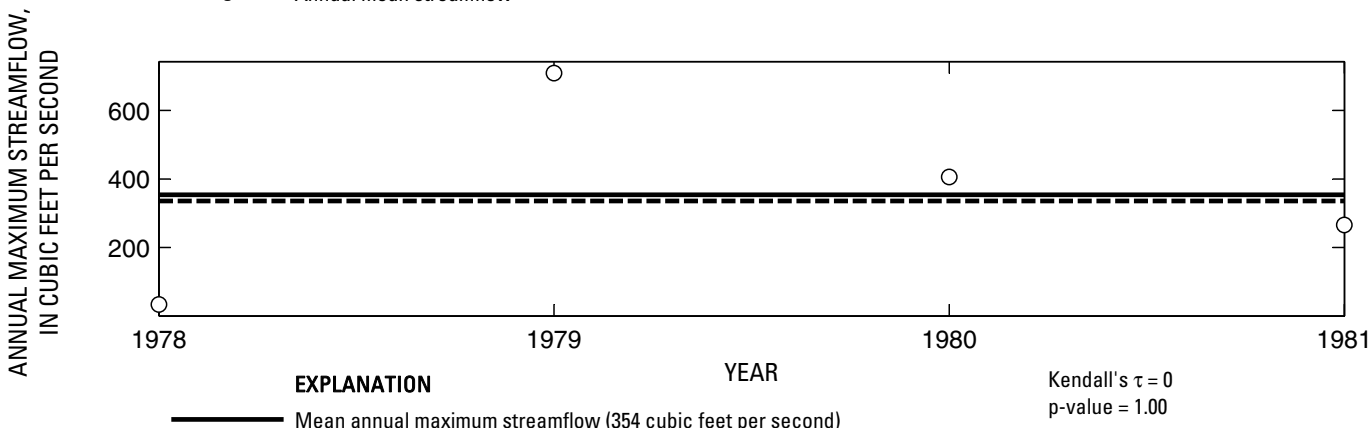

-_-_- Median annual maximum streamflow (336 cubic feet per second)

Annual maximum streamflow

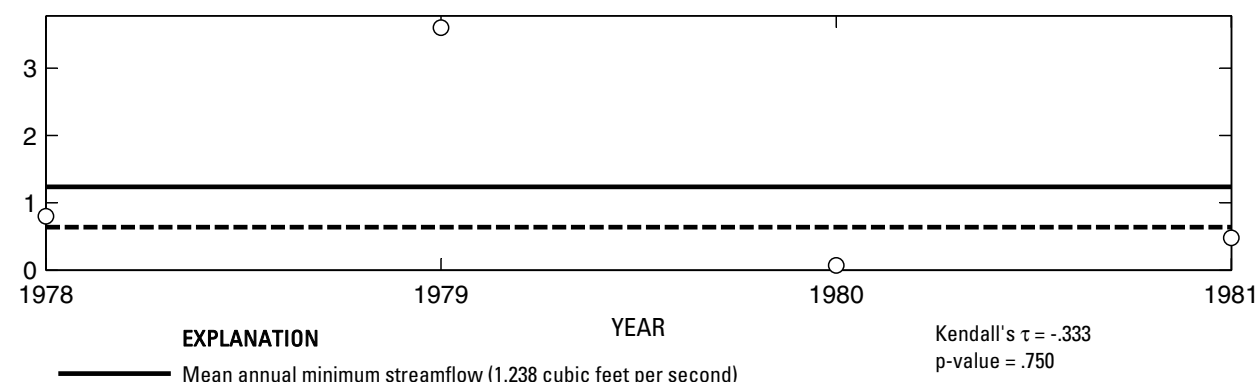

- - - - Median annual minimum streamflow (.64 cubic feet per second)

O Annual minimum streamflow
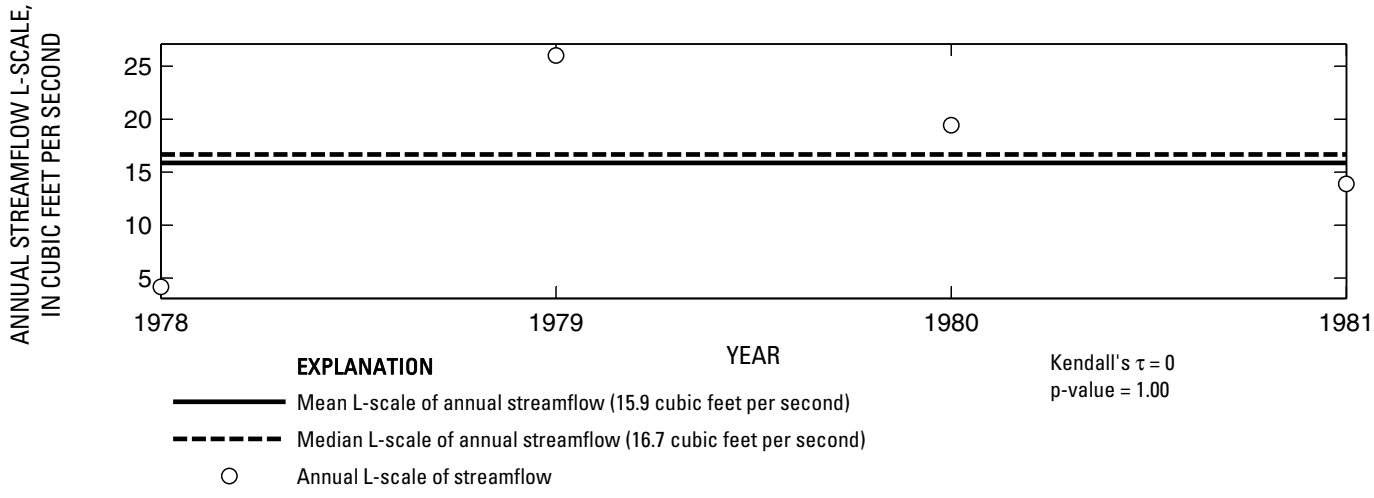

Figure 99. Analysis of annual mean, maximum, minimum, and L-scale statistics of daily mean streamflow for U.S. Geological Survey streamflow-gaging station 08020980 Mill Creek near Longview, Texas. 
U.S. Geological Survey streamflow-gaging station 08020990

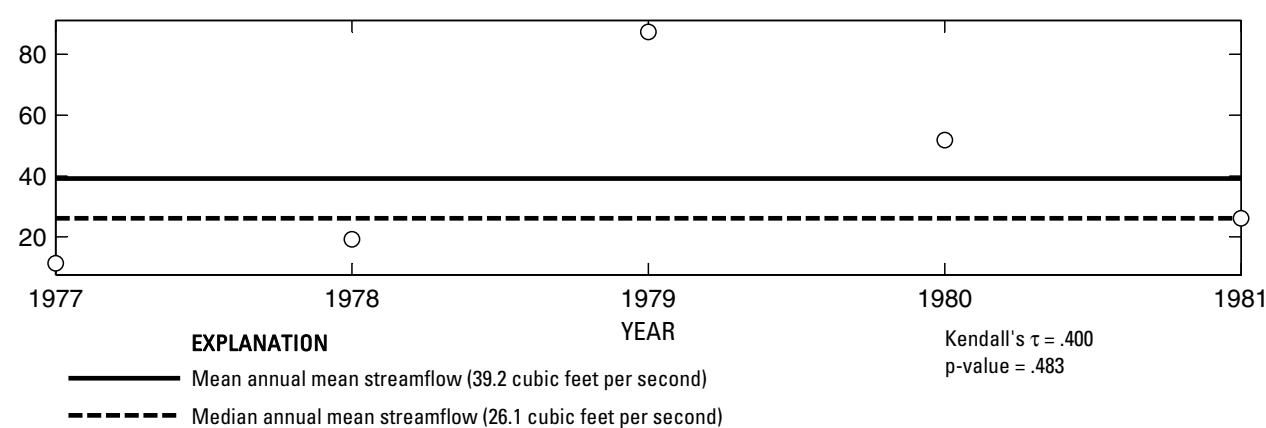

O Annual mean streamflow
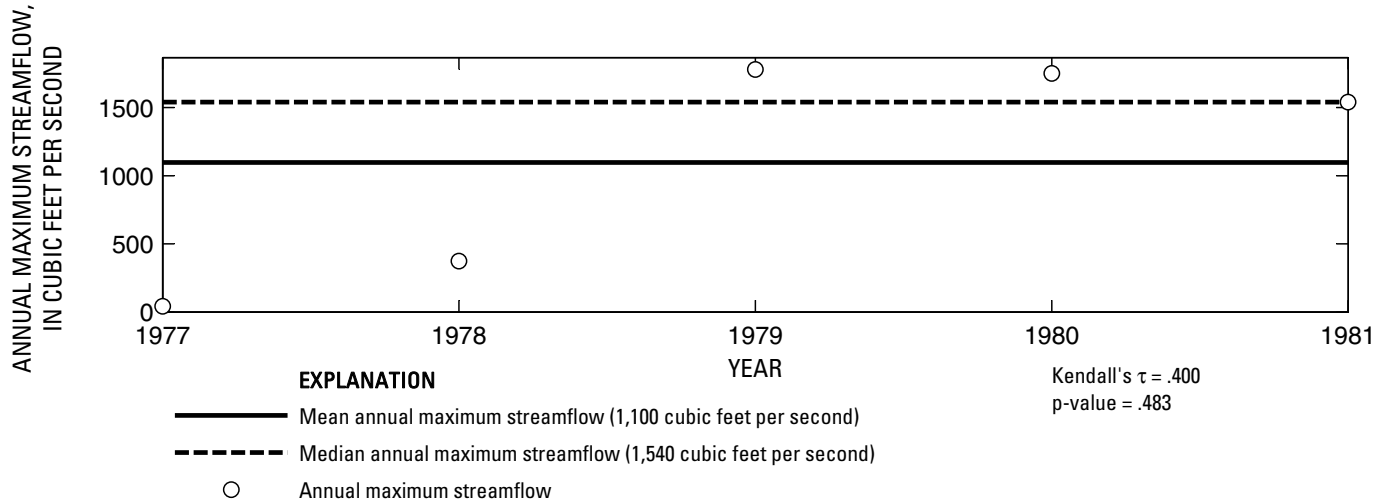

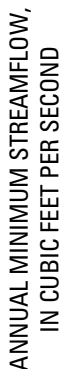

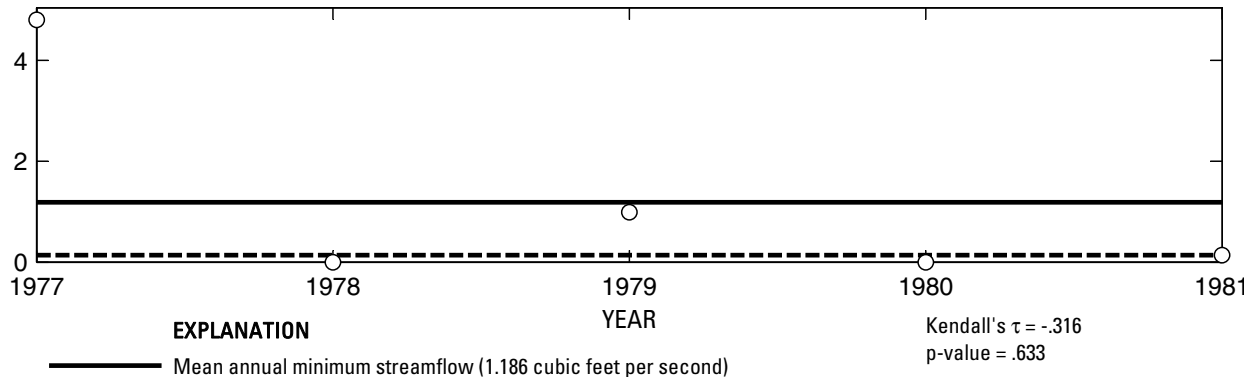

- Median annual minimum streamflow (.14 cubic feet per second)

O Annual minimum streamflow

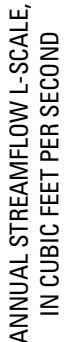

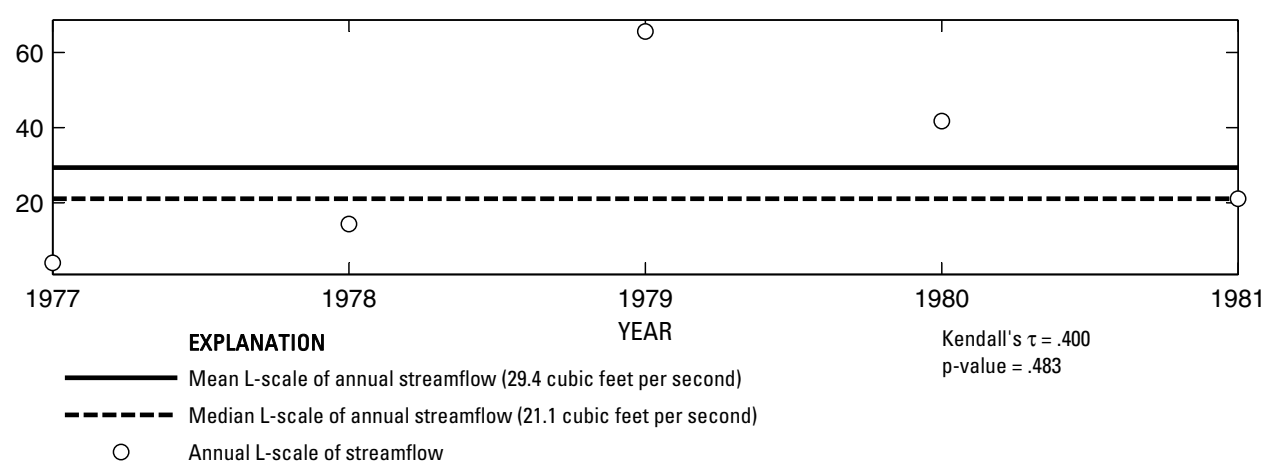

Figure 100. Analysis of annual mean, maximum, minimum, and L-scale statistics of daily mean streamflow for U.S. Geological Survey streamflow-gaging station 08020990 Tiawichi Creek near Longview, Texas.

Index of Station Numbers 719 


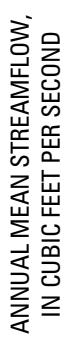

U.S. Geological Survey streamflow-gaging station 08021000

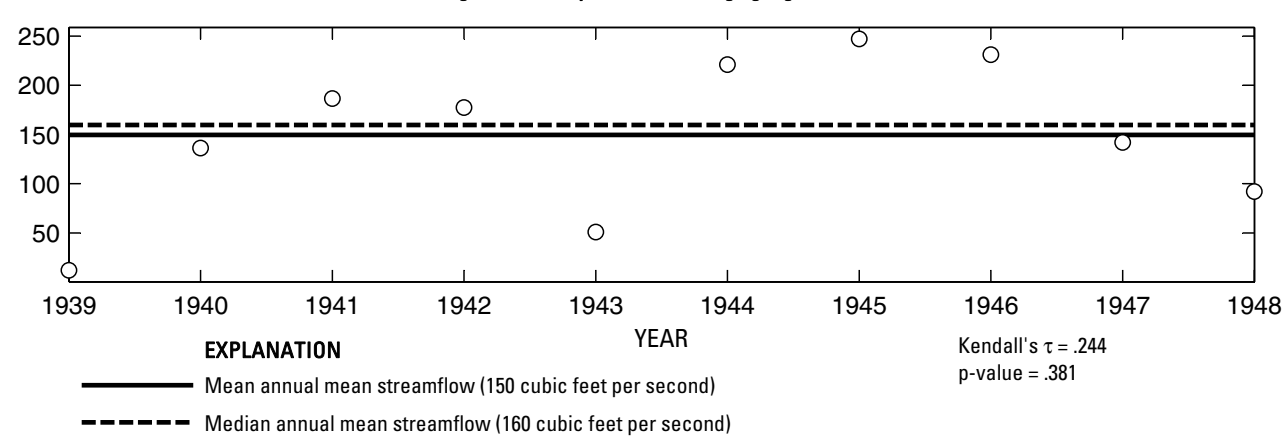

Annual mean streamflow
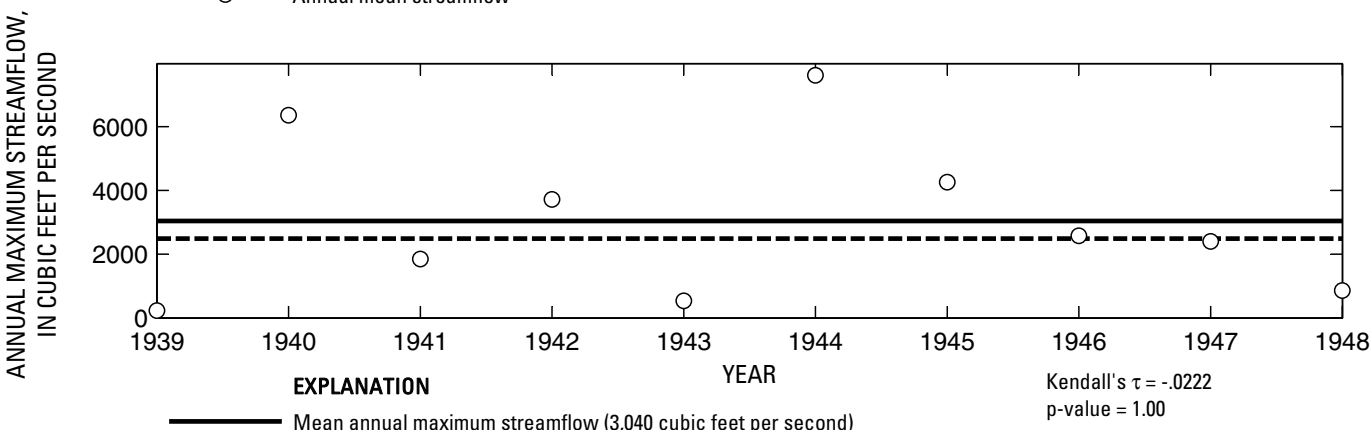

O Annual maximum streamflow

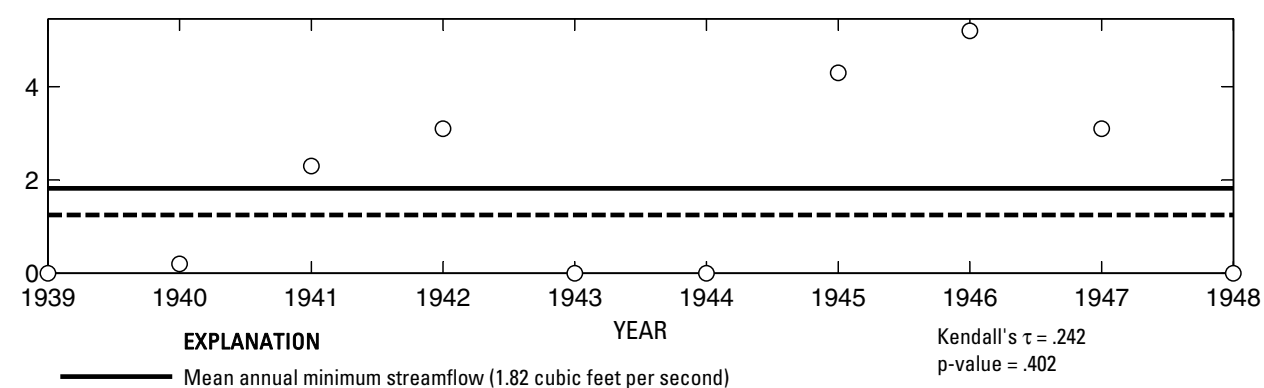

- - - - Median annual minimum streamflow (1.25 cubic feet per second)

O Annual minimum streamflow

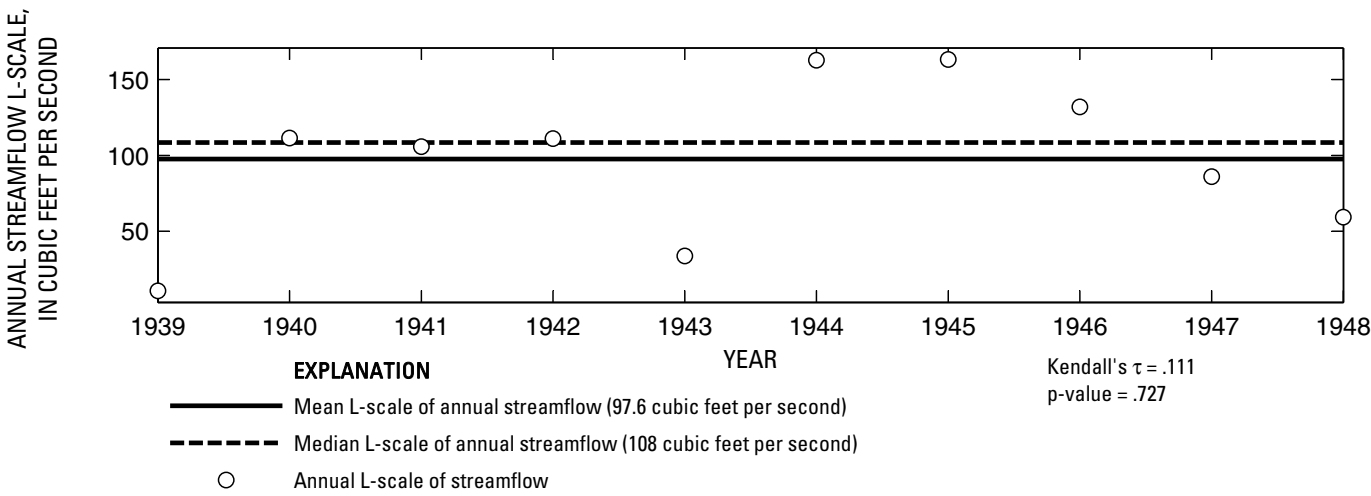

Figure 101. Analysis of annual mean, maximum, minimum, and L-scale statistics of daily mean streamflow for U.S. Geological Survey streamflow-gaging station 08021000 Cherokee Bayou near Elderville, Texas. 


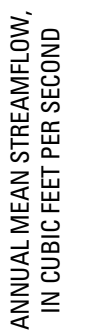

U.S. Geological Survey streamflow-gaging station 08022040

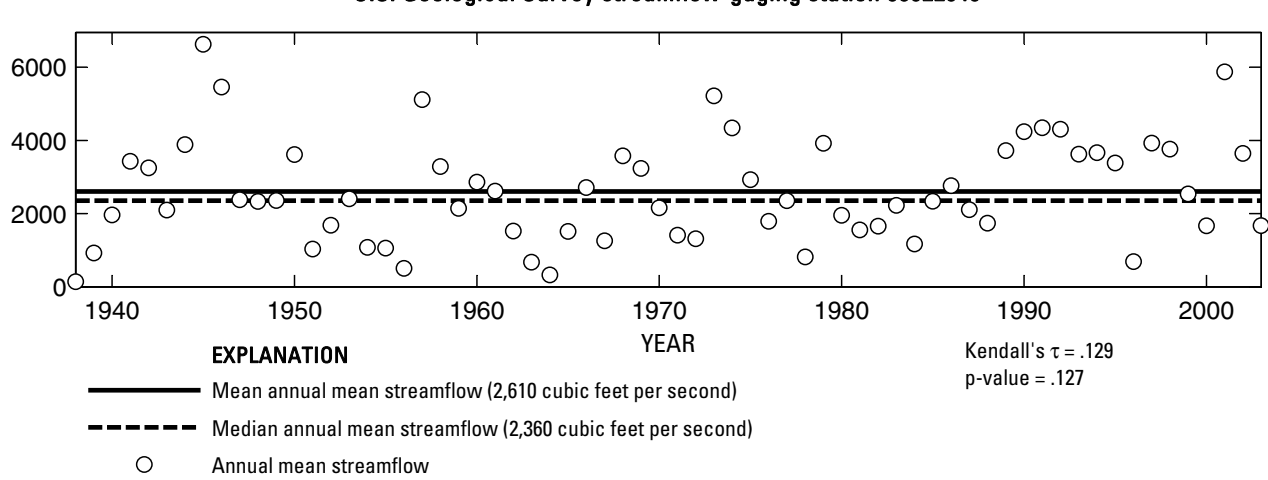

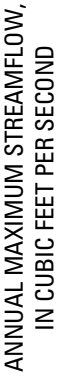
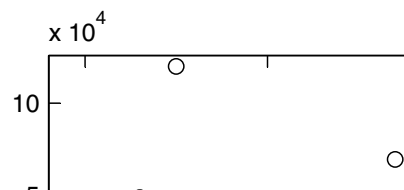

$2-000$

○

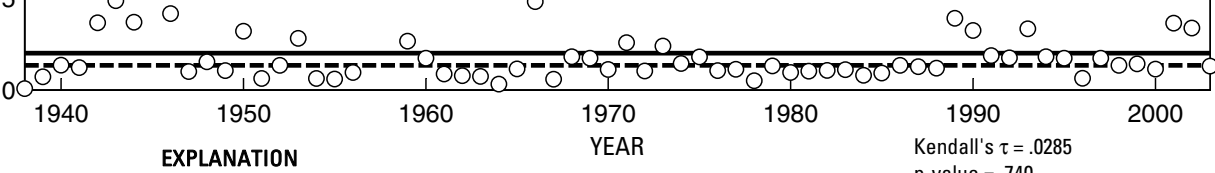

EXPLANATION

$\mathrm{p}$-value $=.740$

-ーーーーー Median annual maximum streamflow (13,400 cubic feet per second)

O Annual maximum streamflow

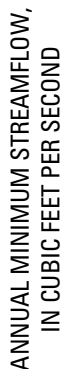

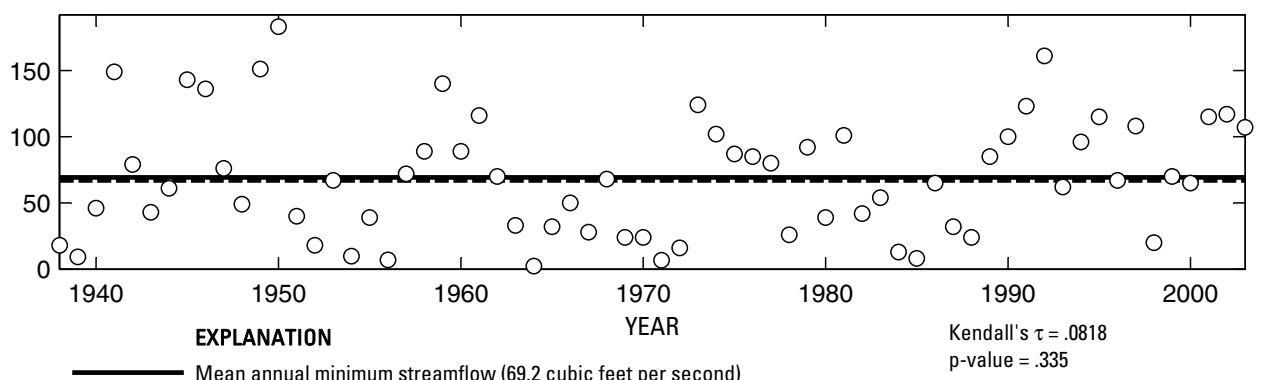

- Median annual minimum streamflow (67 cubic feet per second)

O Annual minimum streamflow

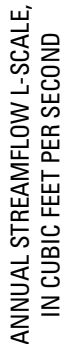

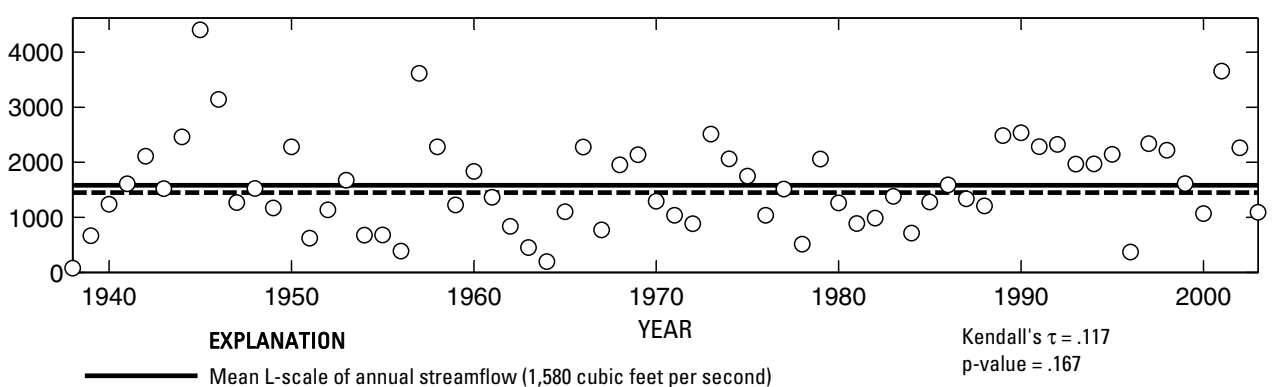

- - - Median L-scale of annual streamflow (1,450 cubic feet per second)

Annual L-scale of streamflow

Figure 102. Analysis of annual mean, maximum, minimum, and L-scale statistics of daily mean streamflow for U.S. Geological Survey streamflow-gaging station 08022040 Sabine River near Beckville, Texas.

Index of Station Numbers 719 


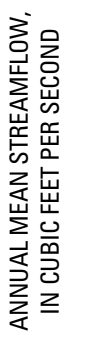

U.S. Geological Survey streamflow-gaging station 08022070

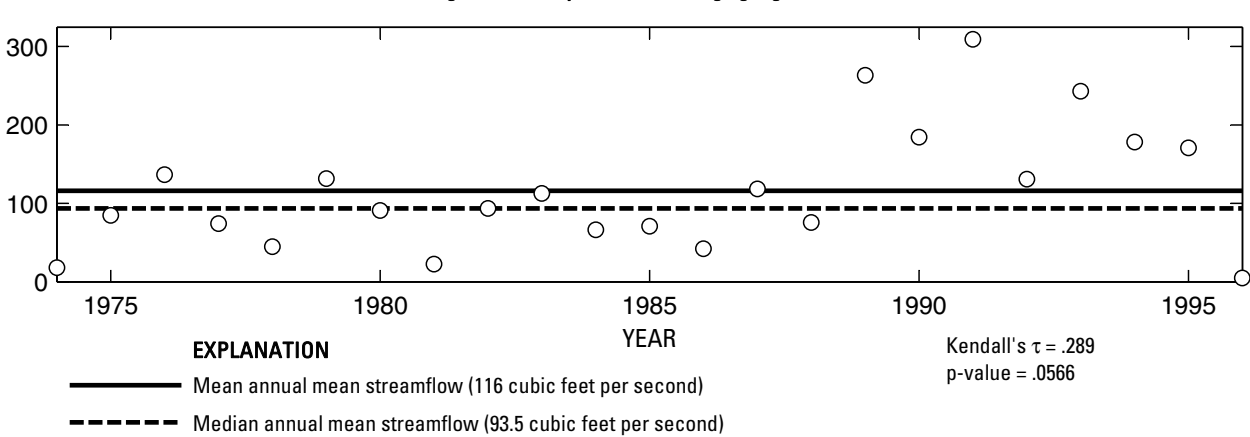

O Annual mean streamflow

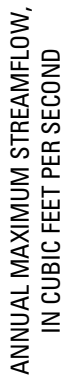

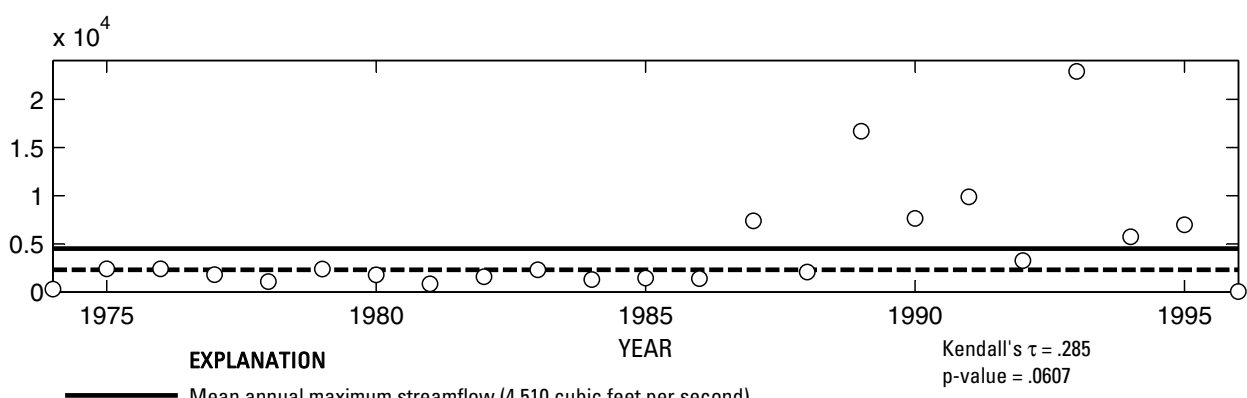

O Annual maximum streamflow

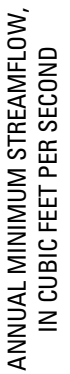

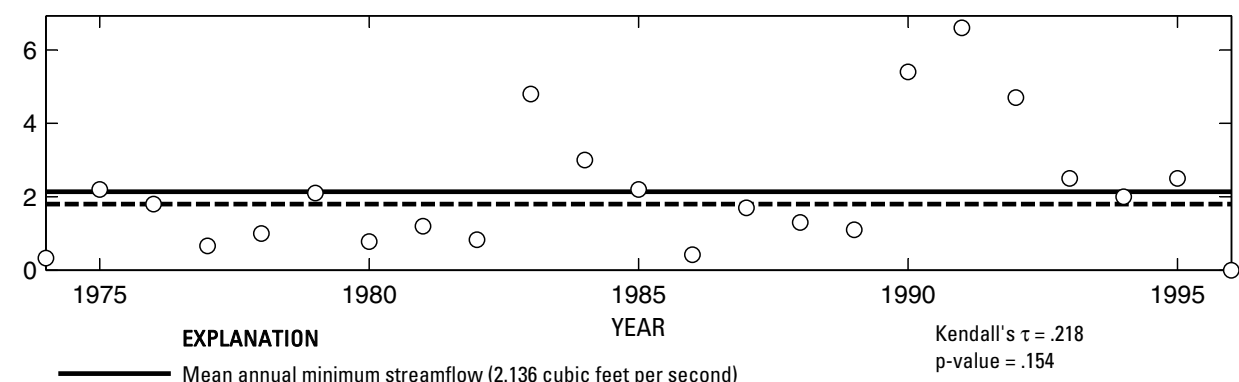

- Median annual minimum streamflow (1.8 cubic feet per second)

O Annual minimum streamflow

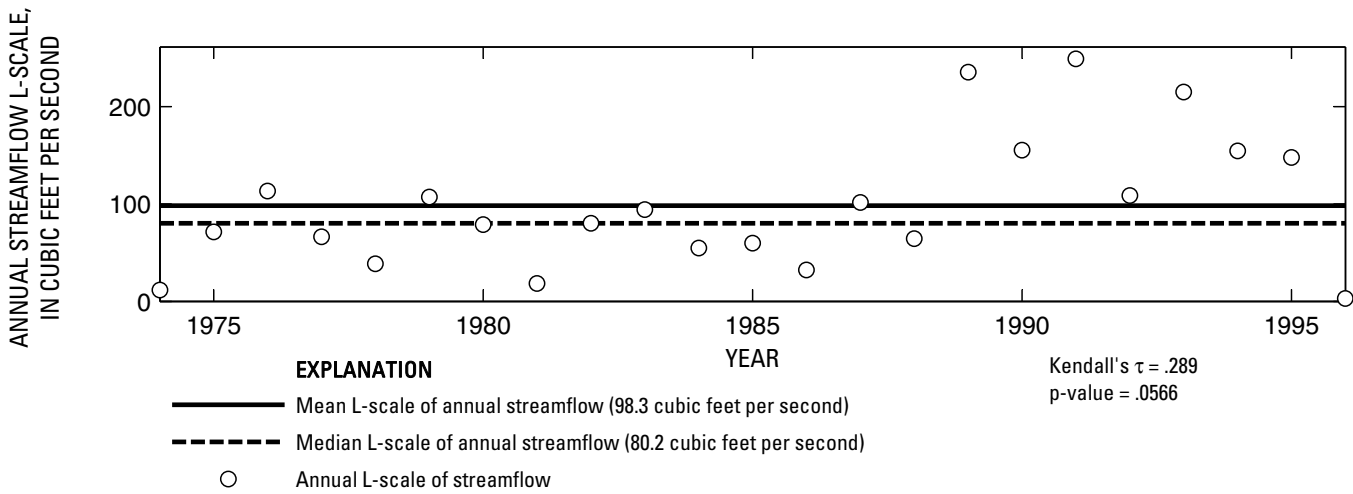

Figure 103. Analysis of annual mean, maximum, minimum, and L-scale statistics of daily mean streamflow for U.S. Geological Survey streamflow-gaging station 08022070 Martin Creek near Tatum, Texas. 


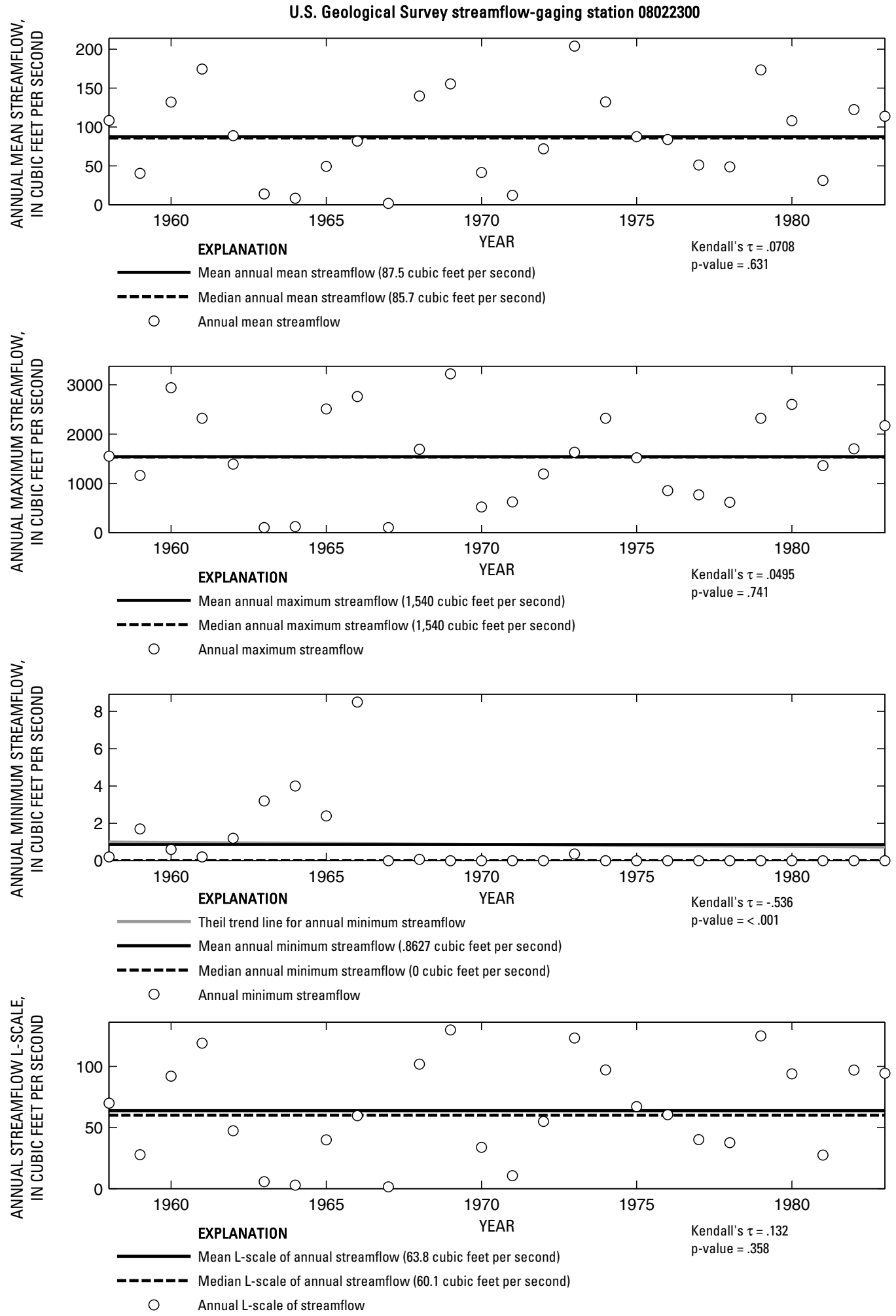

Figure 104. Analysis of annual mean, maximum, minimum, and L-scale statistics of daily mean streamflow for U.S. Geological Survey streamflow-gaging station 08022300 Murvaul Bayou near Gary, Texas.

Index of Station Numbers 719 

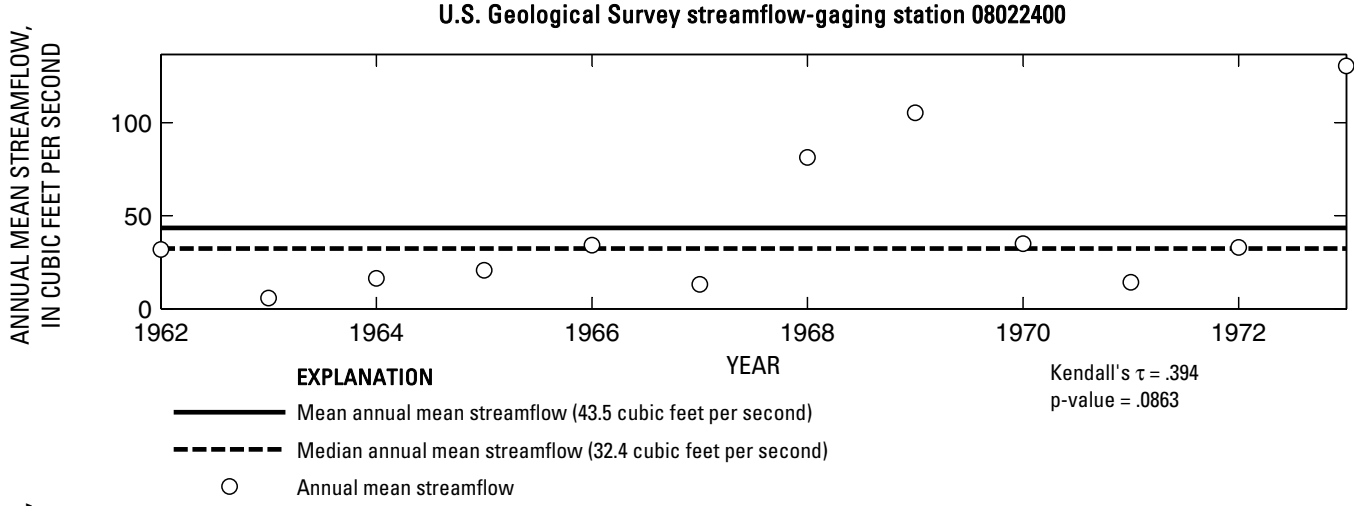

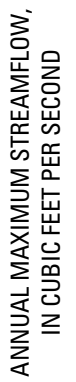

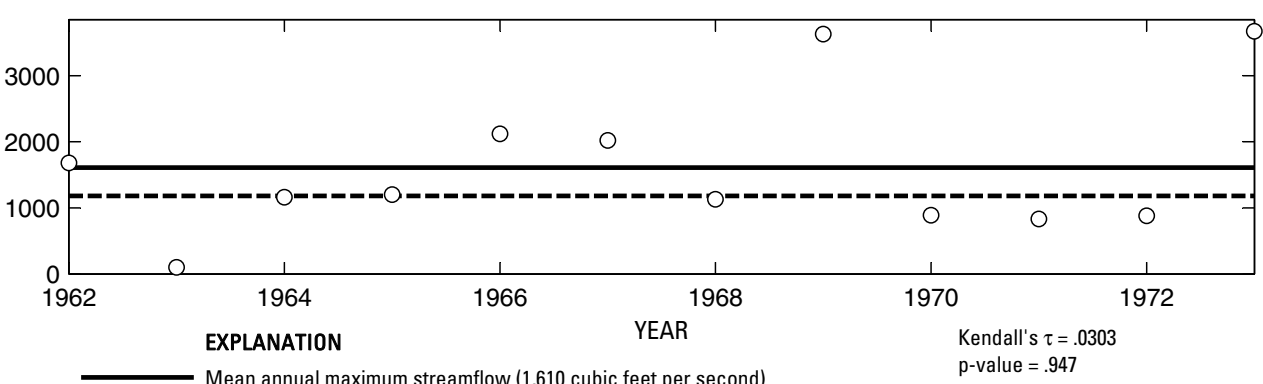

- _ _ _ - Median annual maximum streamflow (1,180 cubic feet per second

O Annual maximum streamflow

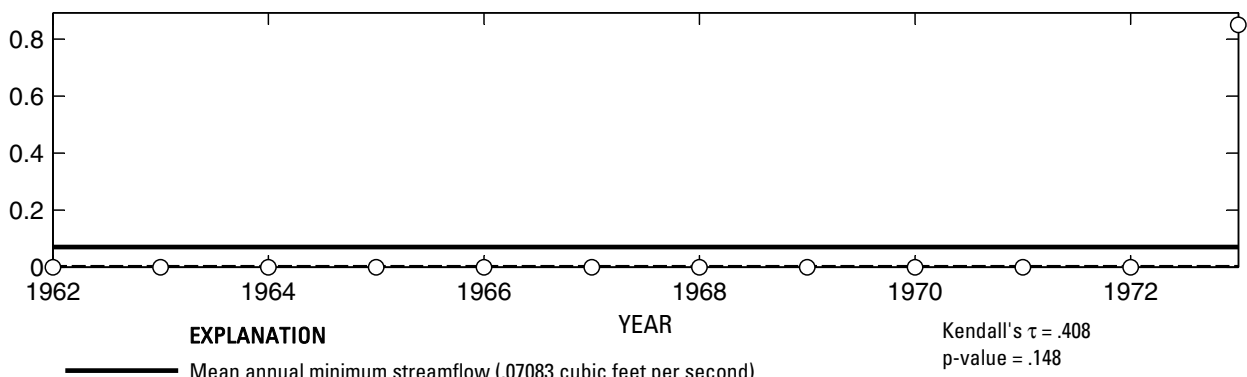

- - - Median annual minimum streamflow (0 cubic feet per second)

O Annual minimum streamflow

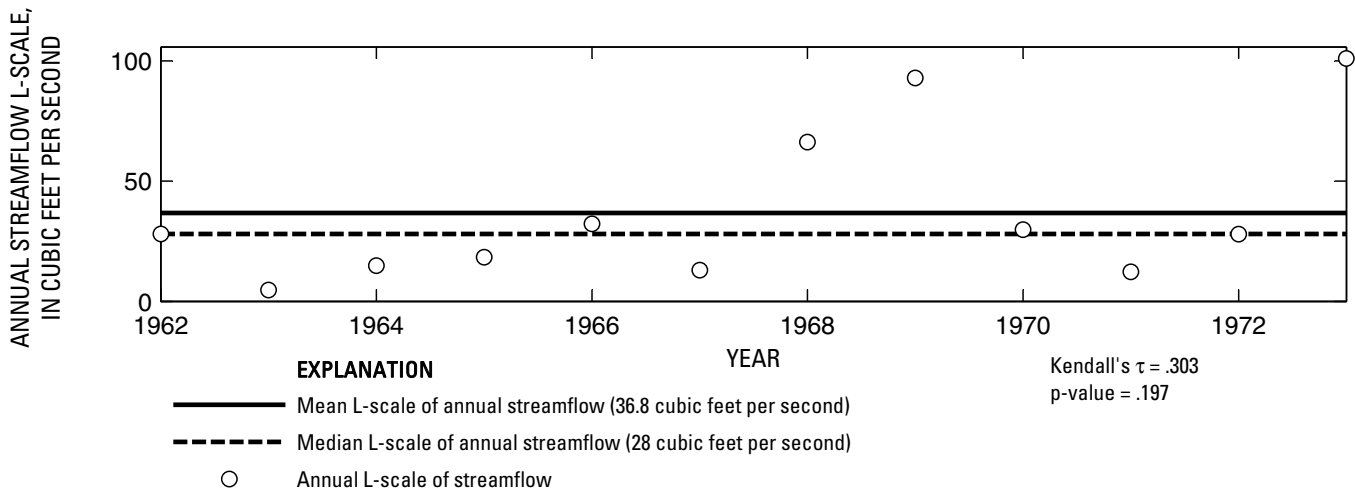

Figure 105. Analysis of annual mean, maximum, minimum, and L-scale statistics of daily mean streamflow for U.S. Geological Survey streamflow-gaging station 08022400 Socagee Creek near Carthage, Texas. 

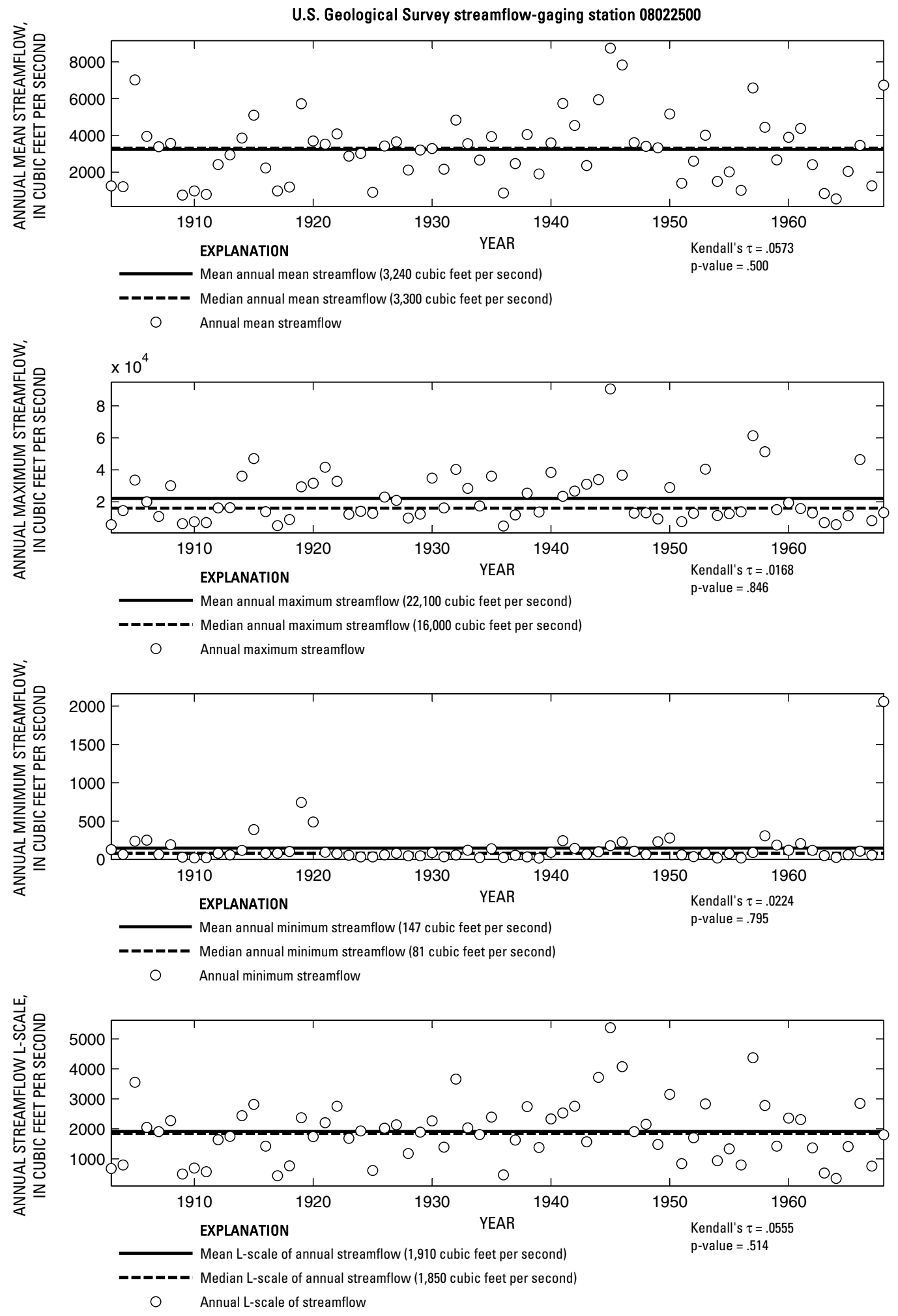

Figure 106. Analysis of annual mean, maximum, minimum, and L-scale statistics of daily mean streamflow for U.S. Geological Survey streamflow-gaging station 08022500 Sabine River at Logansport, Louisiana.

Index of Station Numbers 719 


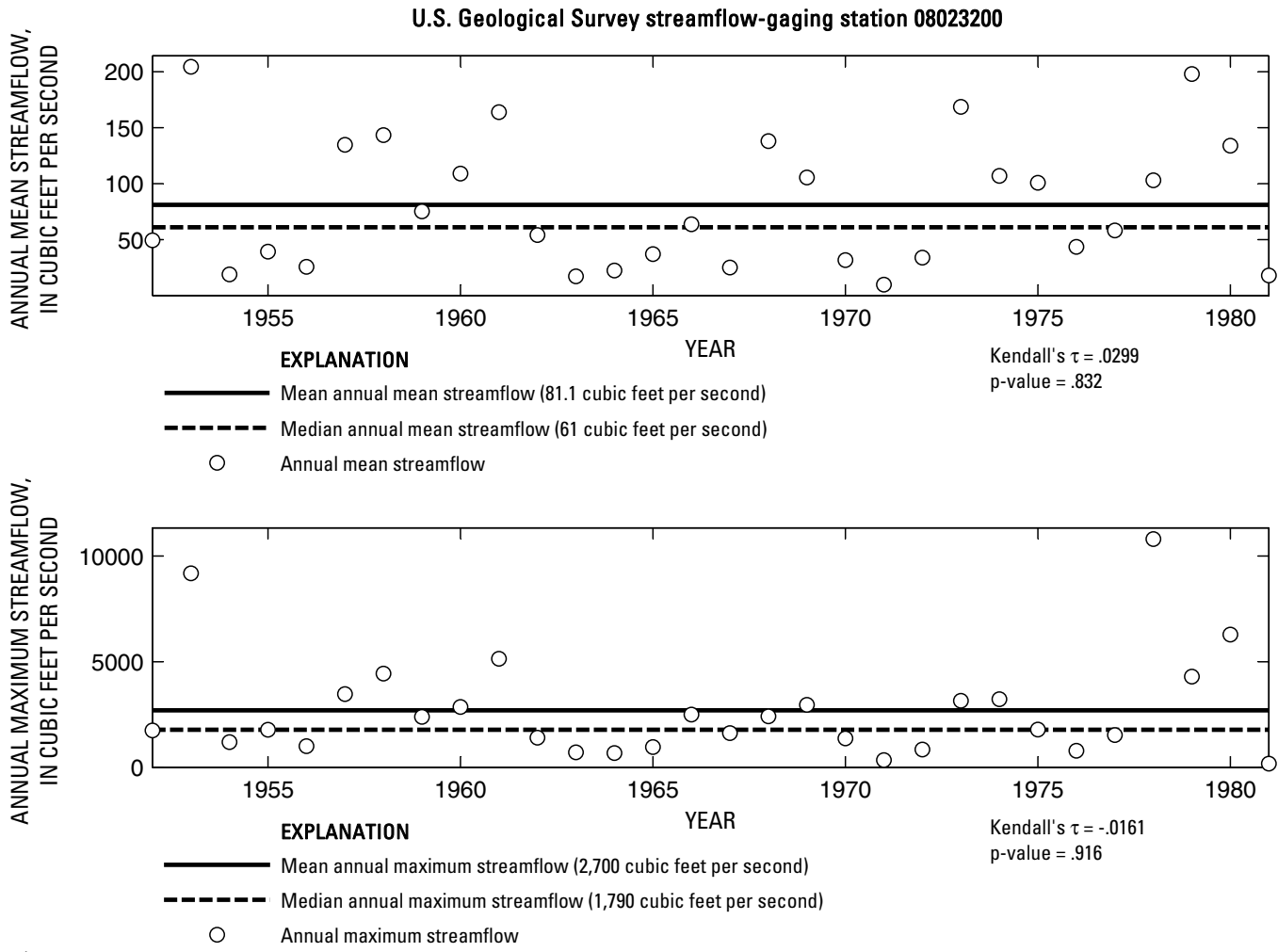

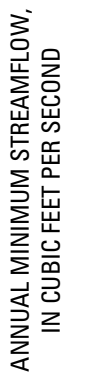

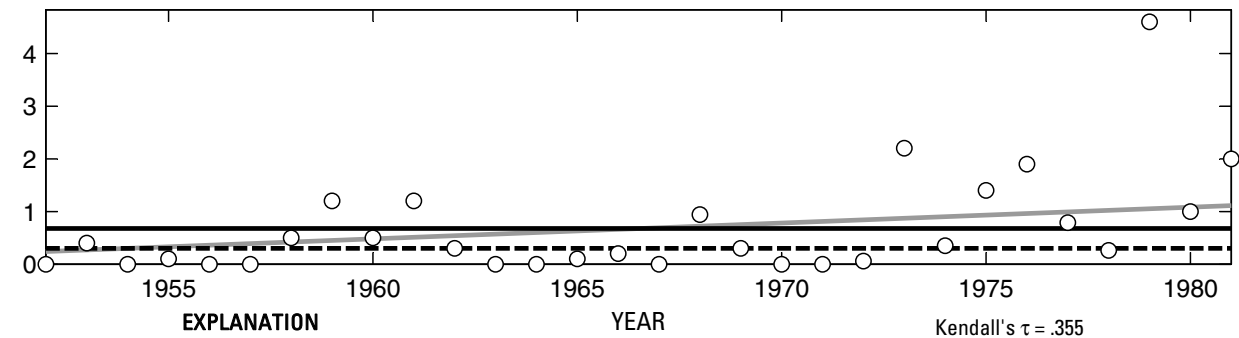

Theil trend line for annual minimum streamflow

Mean annual minimum streamflow (.6767 cubic feet per second)

- ב-ב Median annual minimum streamflow (.3 cubic feet per second)

O Annual minimum streamflow
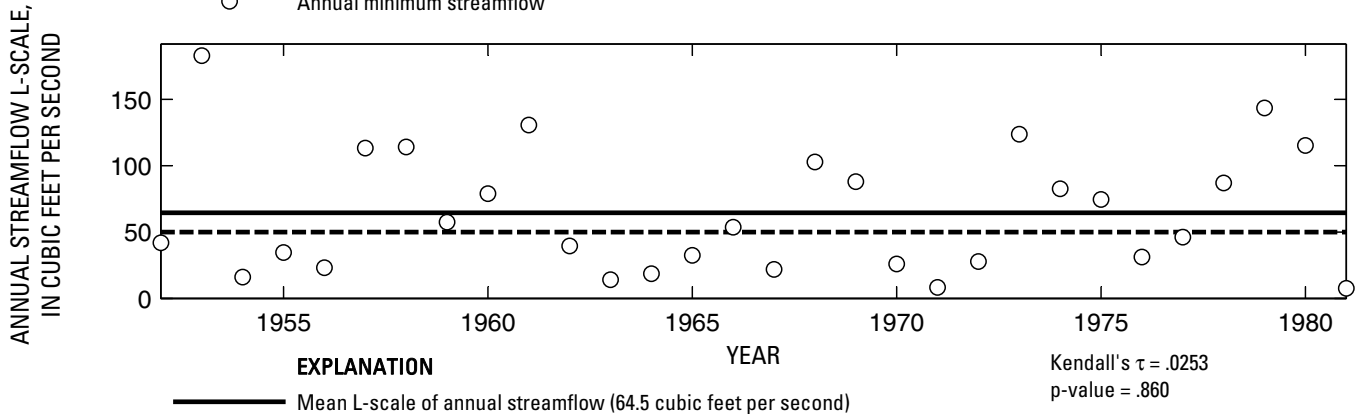

Mean L-scale of annual streamflow (64.5 cubic feet per second)

-ーーーー Median L-scale of annual streamflow (49.9 cubic feet per second)

Annual L-scale of streamflow

Figure 107. Analysis of annual mean, maximum, minimum, and L-scale statistics of daily mean streamflow for U.S. Geological Survey streamflow-gaging station 08023200 Tenaha Creek near Shelbyville, Texas. 
U.S. Geological Survey streamflow-gaging station 08024400
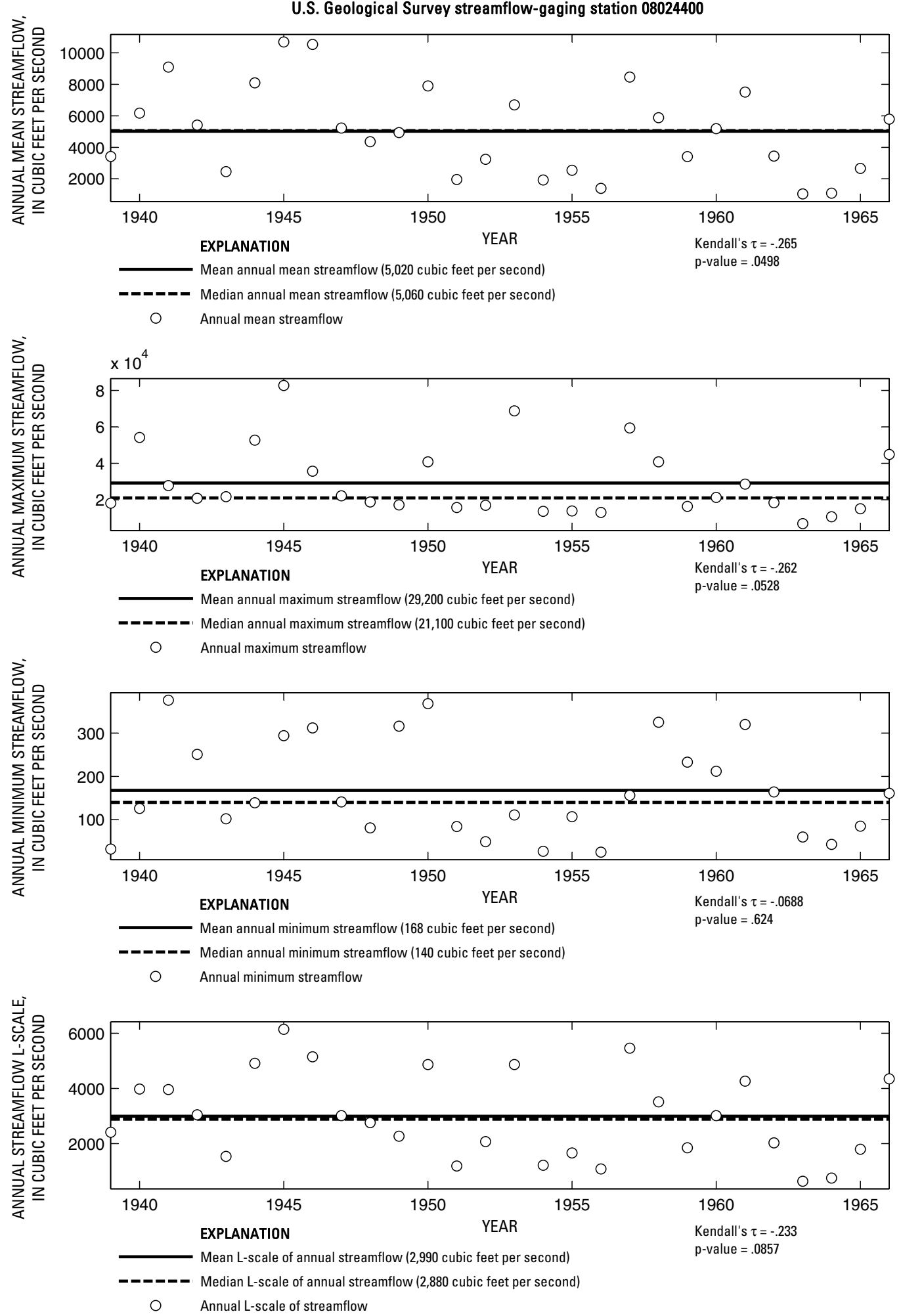

Figure 108. Analysis of annual mean, maximum, minimum, and L-scale statistics of daily mean streamflow for U.S. Geological Survey streamflow-gaging station 08024400 Sabine River near Milam, Texas.

Index of Station Numbers 719 

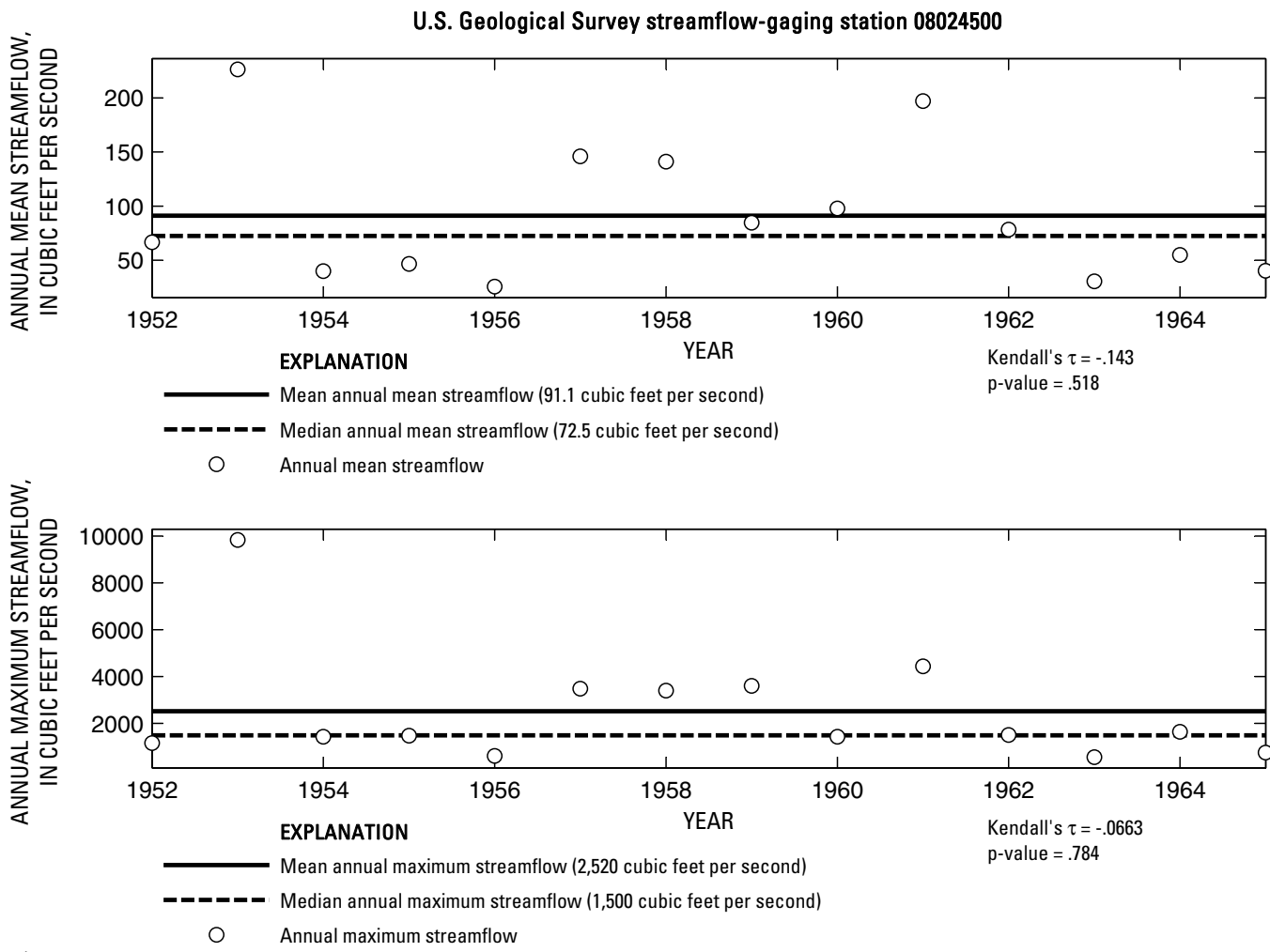

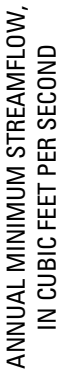

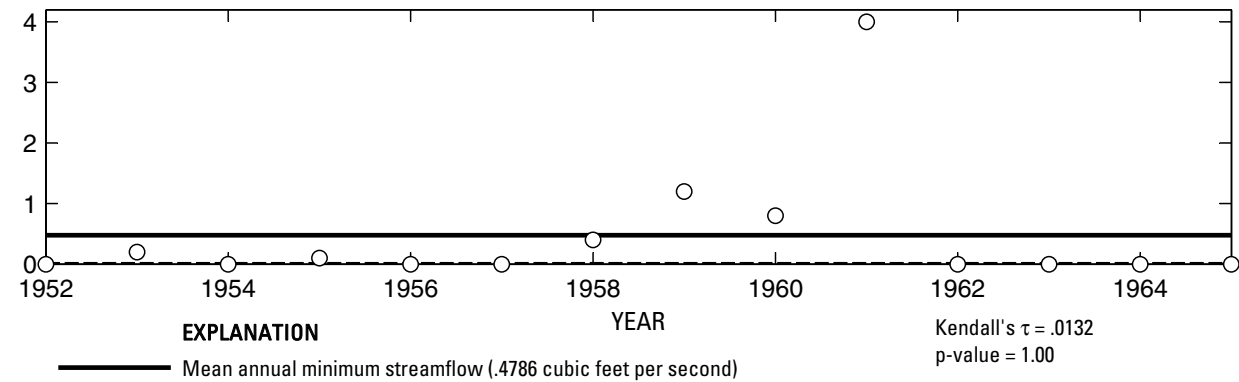

- ב-_ Median annual minimum streamflow (0 cubic feet per second)

O Annual minimum streamflow

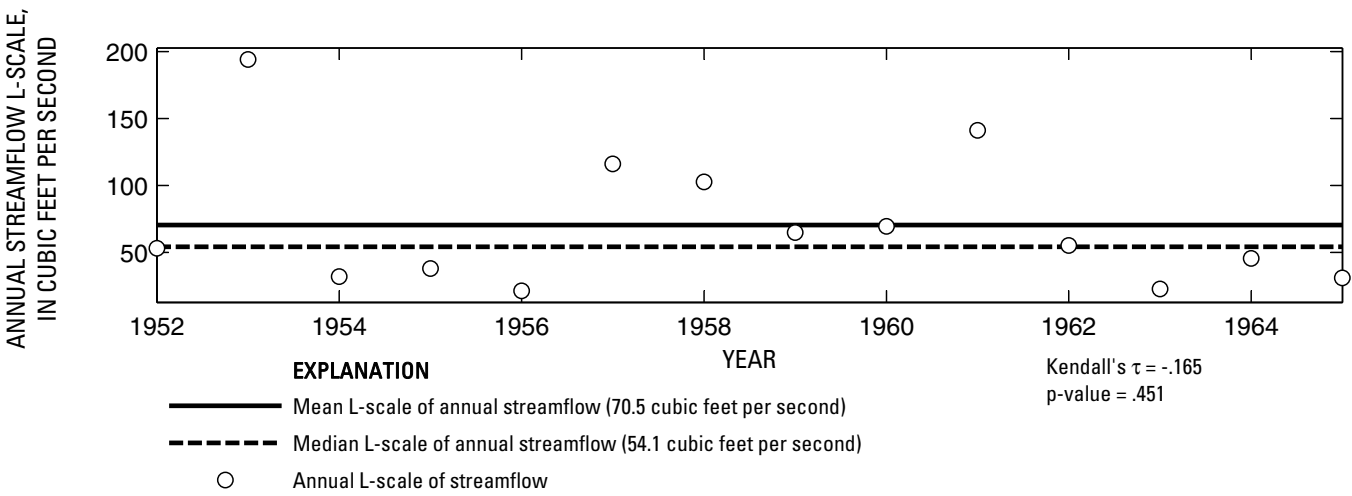

Figure 109. Analysis of annual mean, maximum, minimum, and L-scale statistics of daily mean streamflow for U.S. Geological Survey streamflow-gaging station 08024500 Palo Gaucho Bayou near Hemphill, Texas.

Index of Station Numbers 719 

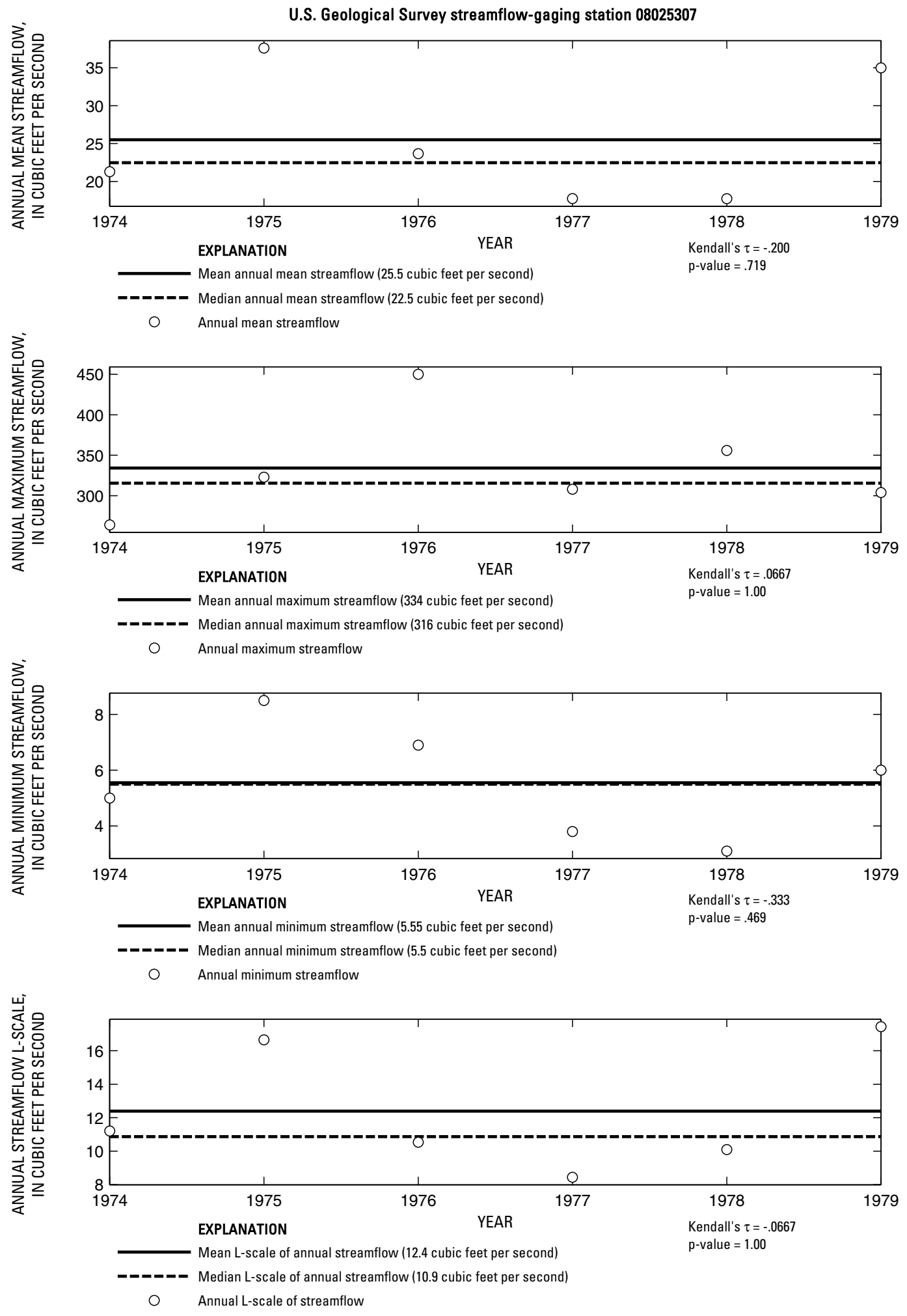

Figure 110. Analysis of annual mean, maximum, minimum, and L-scale statistics of daily mean streamflow for U.S. Geological Survey streamflow-gaging station 08025307 Mill Creek near Burkeville, Texas. 


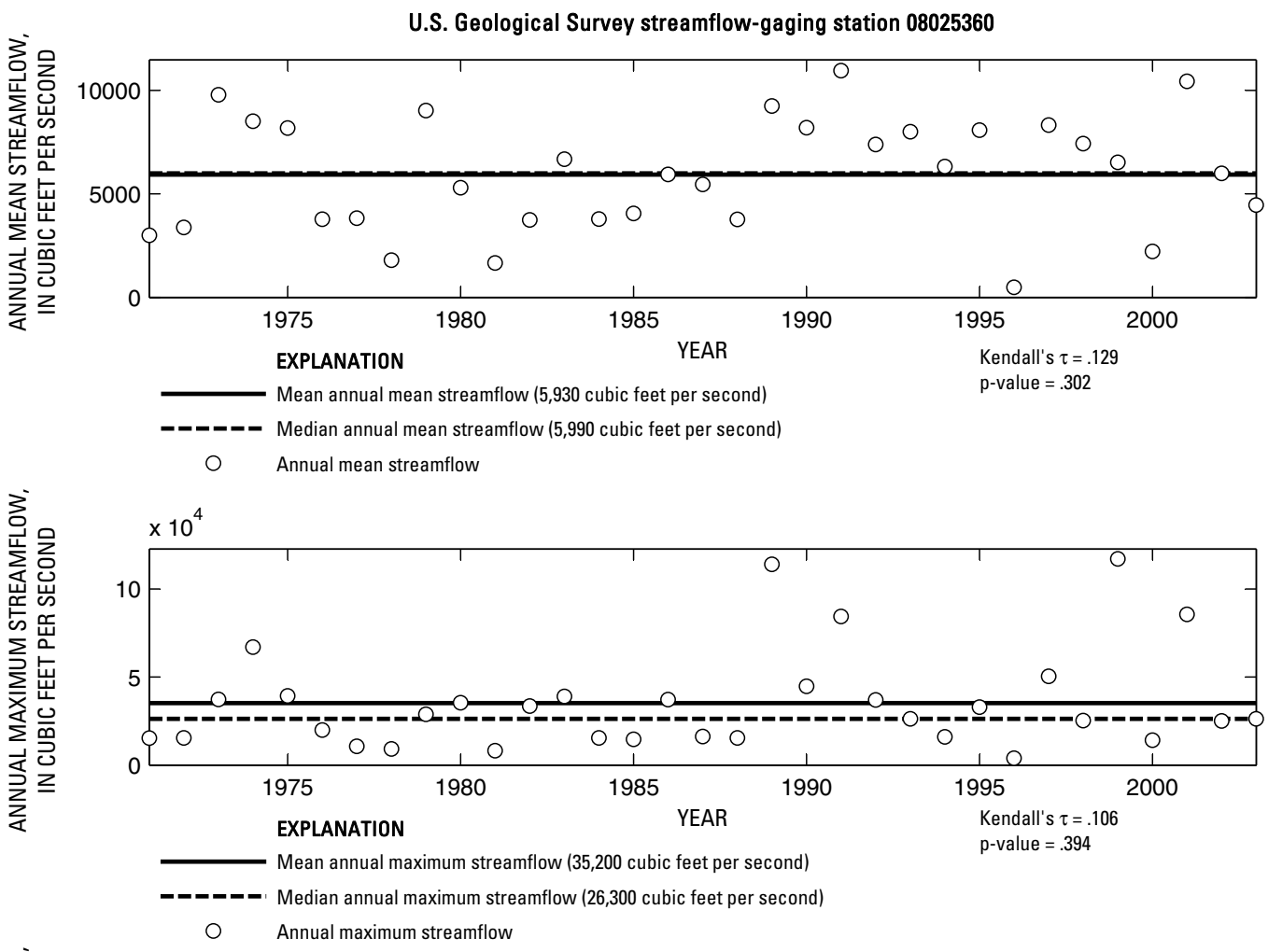

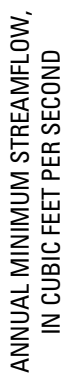

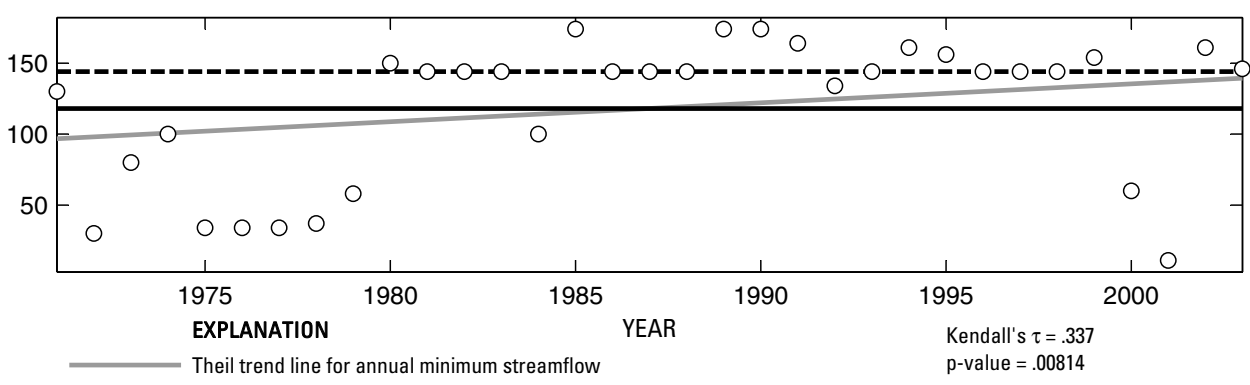

- Mean annual minimum streamflow (118 cubic feet per second)

------ Median annual minimum streamflow (144 cubic feet per second)

O Annual minimum streamflow

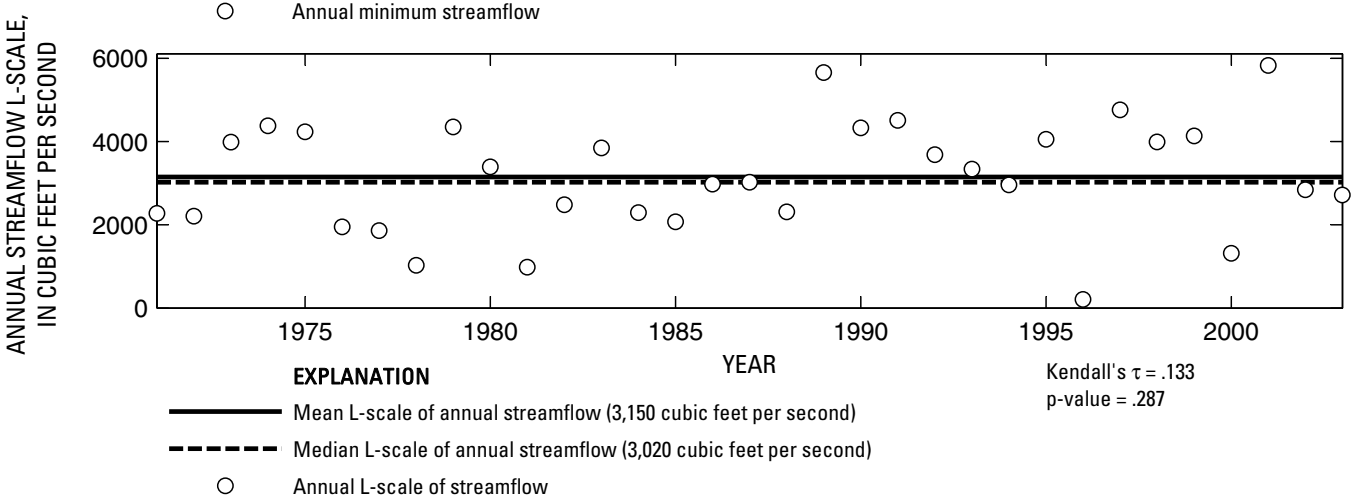

Figure 111. Analysis of annual mean, maximum, minimum, and L-scale statistics of daily mean streamflow for U.S. Geological Survey streamflow-gaging station 08025360 Sabine River at Toledo Bend Reservoir near Burkeville, Texas. 

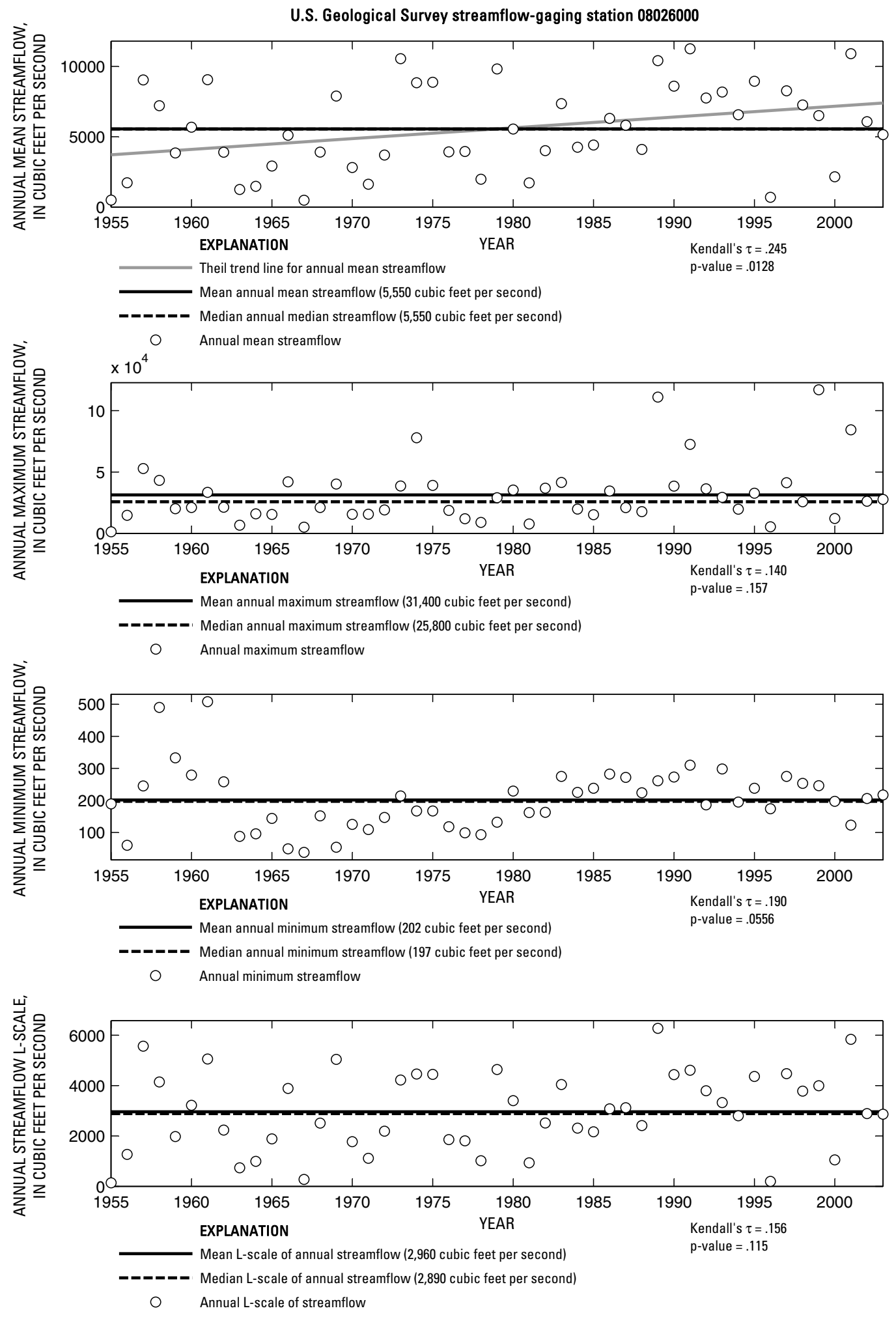

Figure 112. Analysis of annual mean, maximum, minimum, and L-scale statistics of daily mean streamflow for U.S. Geological Survey streamflow-gaging station 08026000 Sabine River near Burkeville, Texas.

Index of Station Numbers 719 


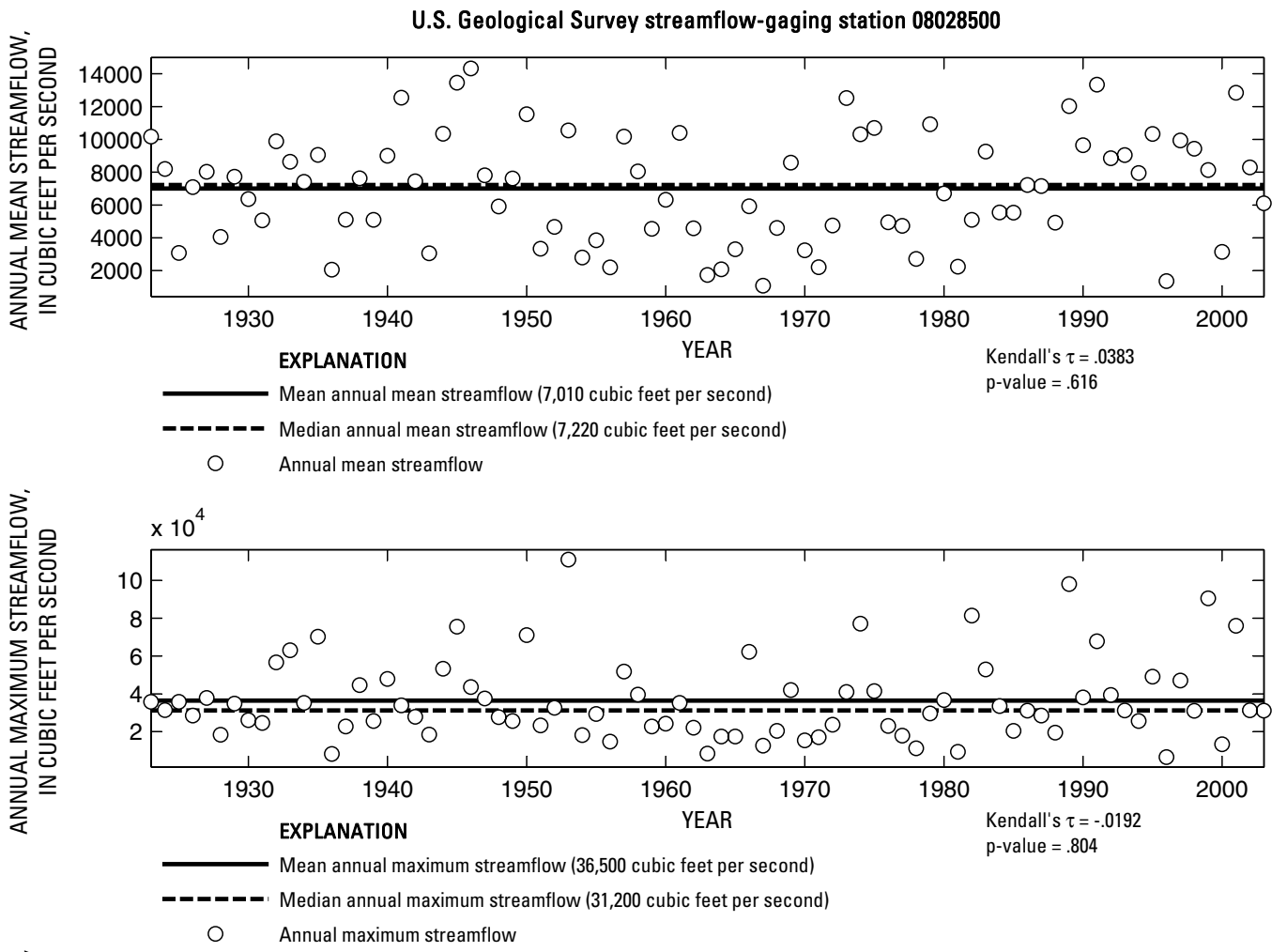

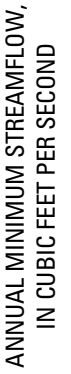

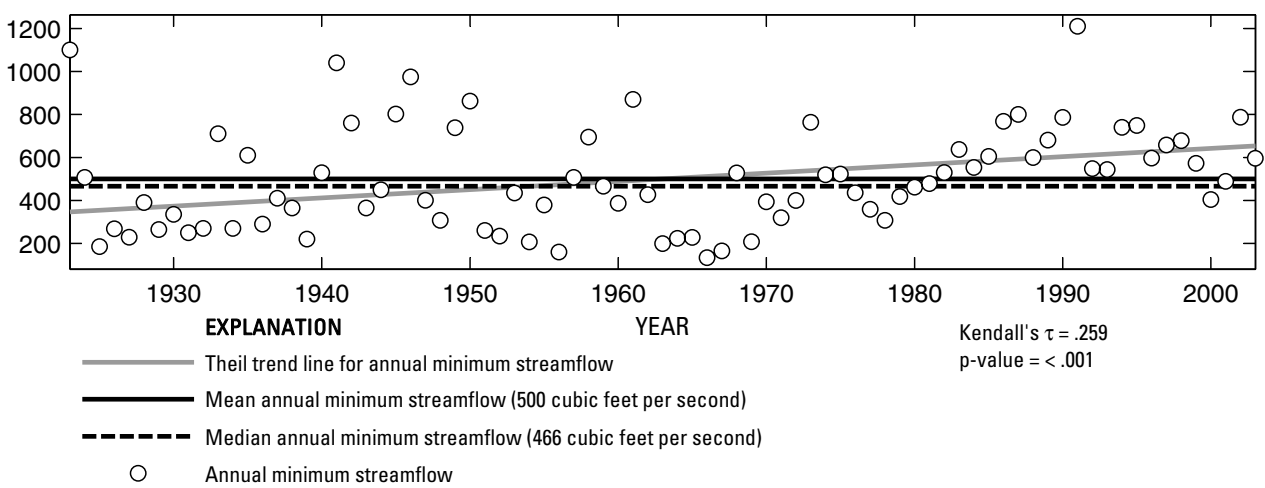

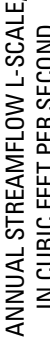

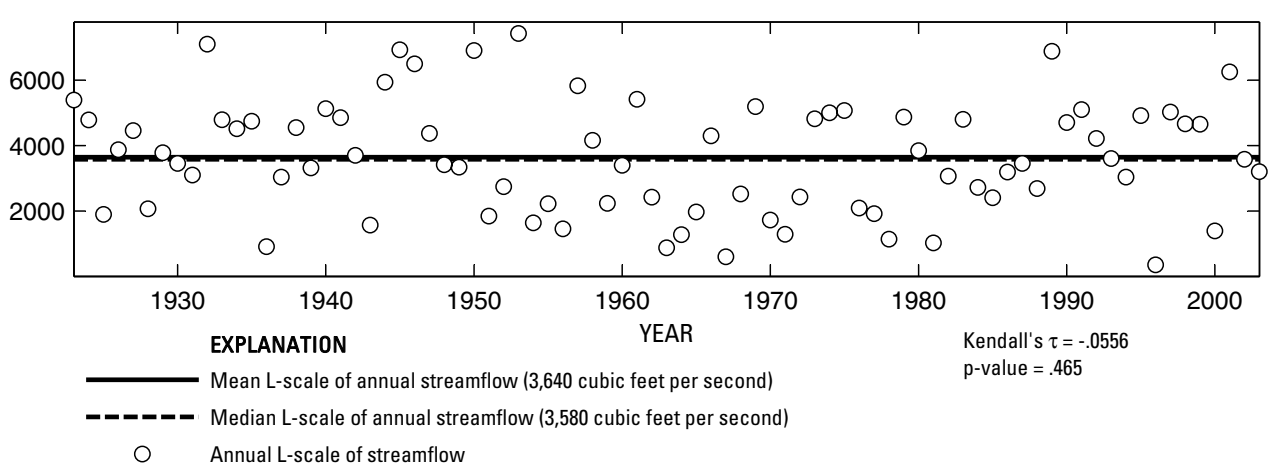

Figure 113. Analysis of annual mean, maximum, minimum, and L-scale statistics of daily mean streamflow for U.S. Geological Survey streamflow-gaging station 08028500 Sabine River near Bon Wier, Texas. 


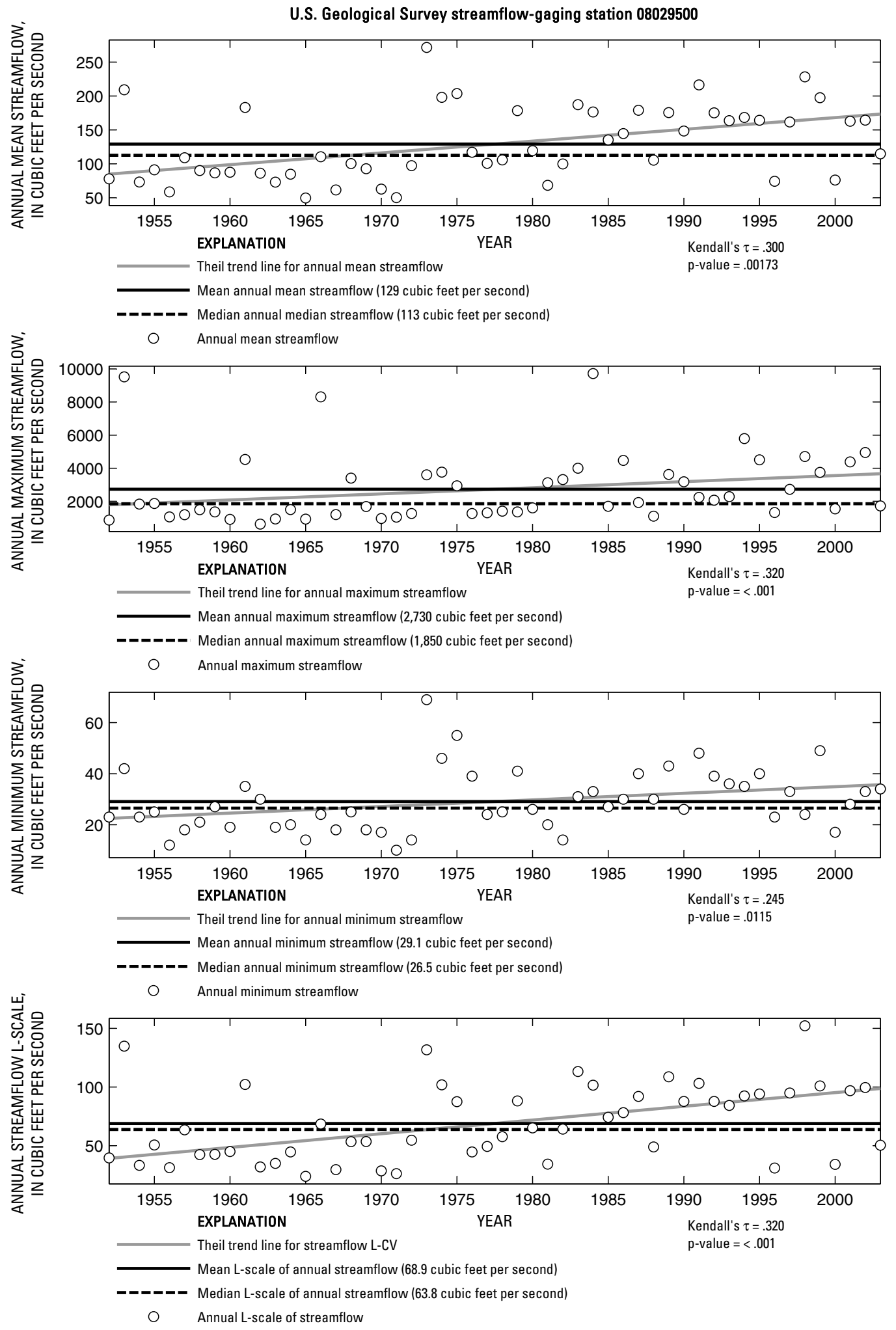

Figure 114. Analysis of annual mean, maximum, minimum, and L-scale statistics of daily mean streamflow for U.S. Geological Survey streamflow-gaging station 08029500 Big Cow Creek near Newton, Texas.

Index of Station Numbers 719 


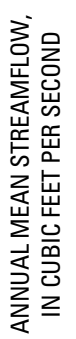

U.S. Geological Survey streamflow-gaging station 08030000

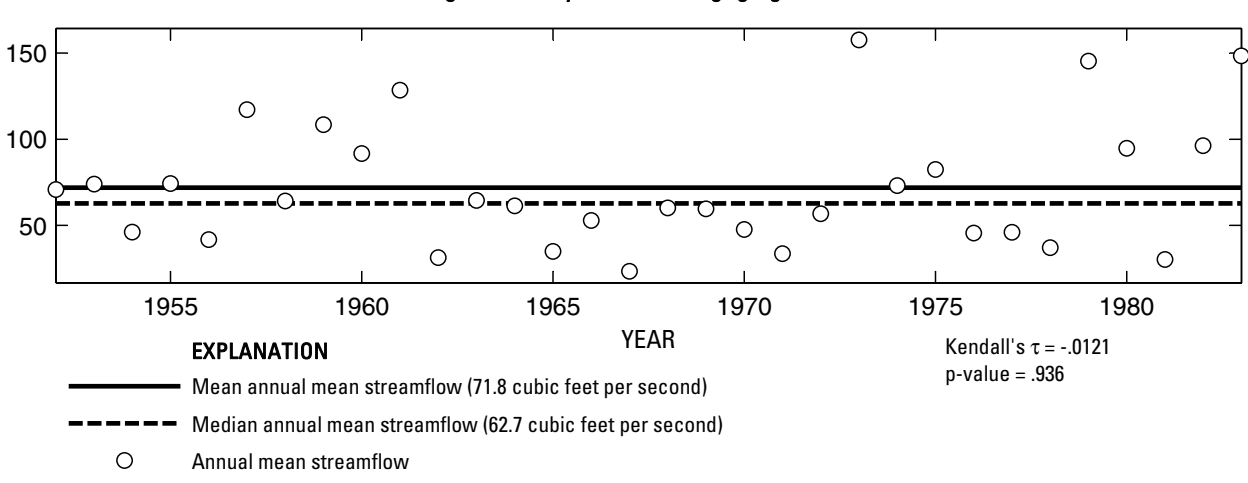

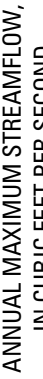

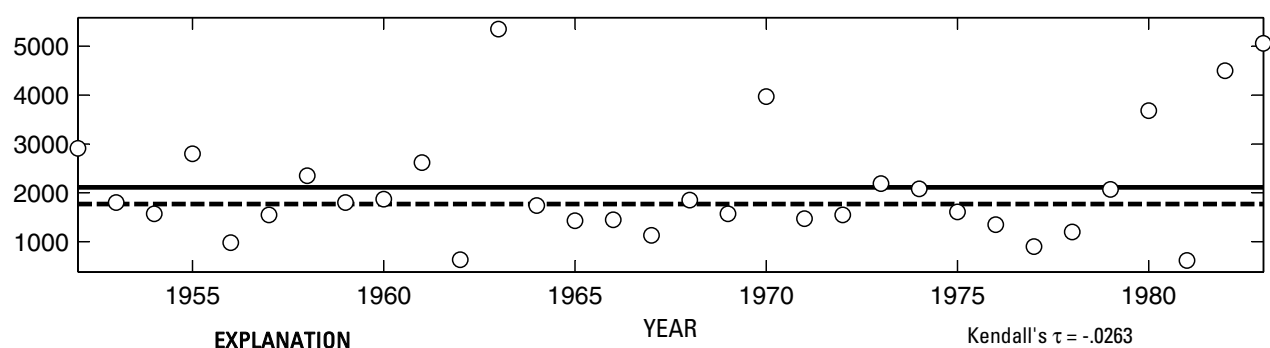

EXPLANATION

feet per second)

$\mathrm{p}$-value $=.846$

- - - - Median annual maximum streamflow (1,770 cubic feet per second)

O Annual maximum streamflow

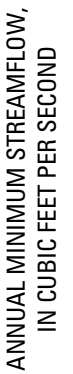

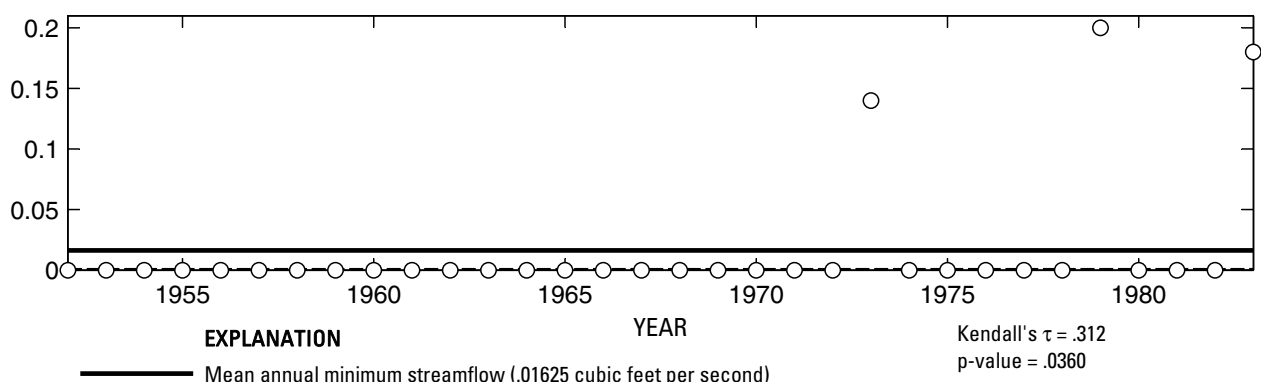

- - - Median annual minimum streamflow (0 cubic feet per second)

○ Annual minimum streamflow

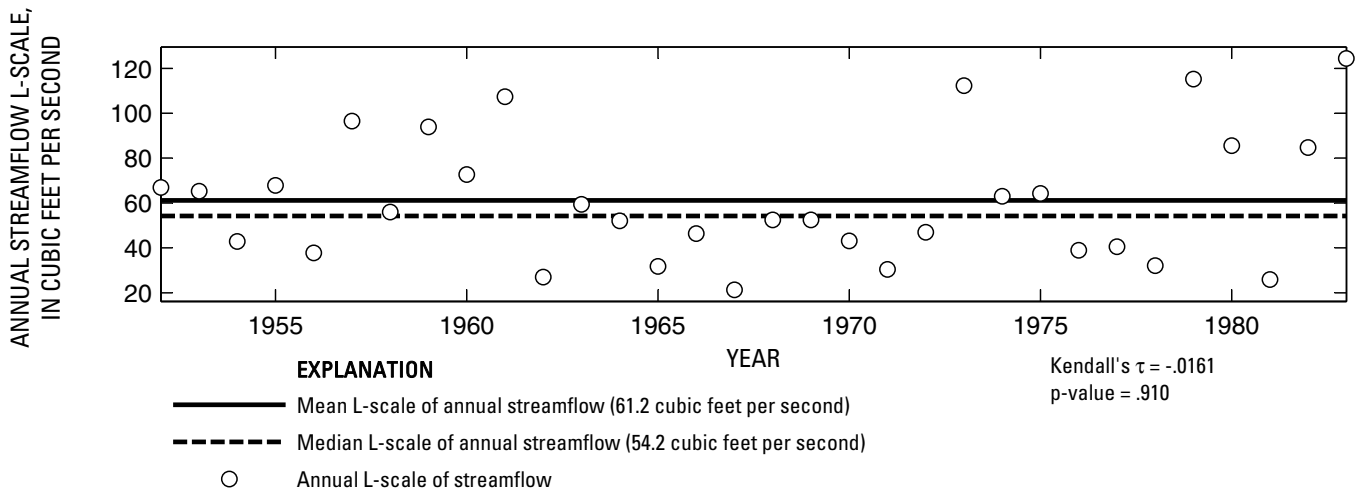

Figure 115. Analysis of annual mean, maximum, minimum, and L-scale statistics of daily mean streamflow for U.S. Geological Survey streamflow-gaging station 08030000 Cypress Creek near Buna, Texas. 

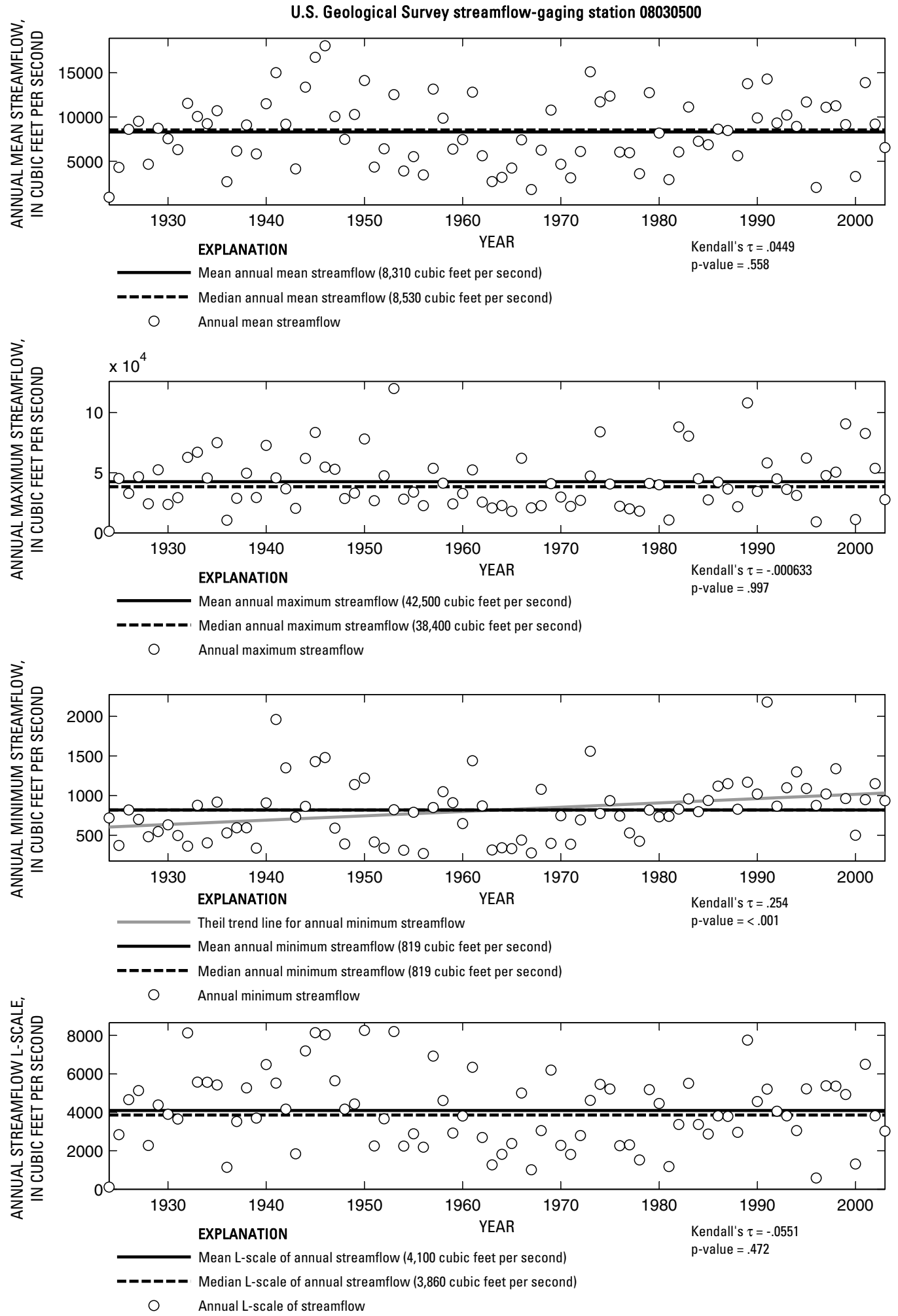

Figure 116. Analysis of annual mean, maximum, minimum, and L-scale statistics of daily mean streamflow for U.S. Geological Survey streamflow-gaging station 08030500 Sabine River near Ruliff, Texas.

Index of Station Numbers 719 

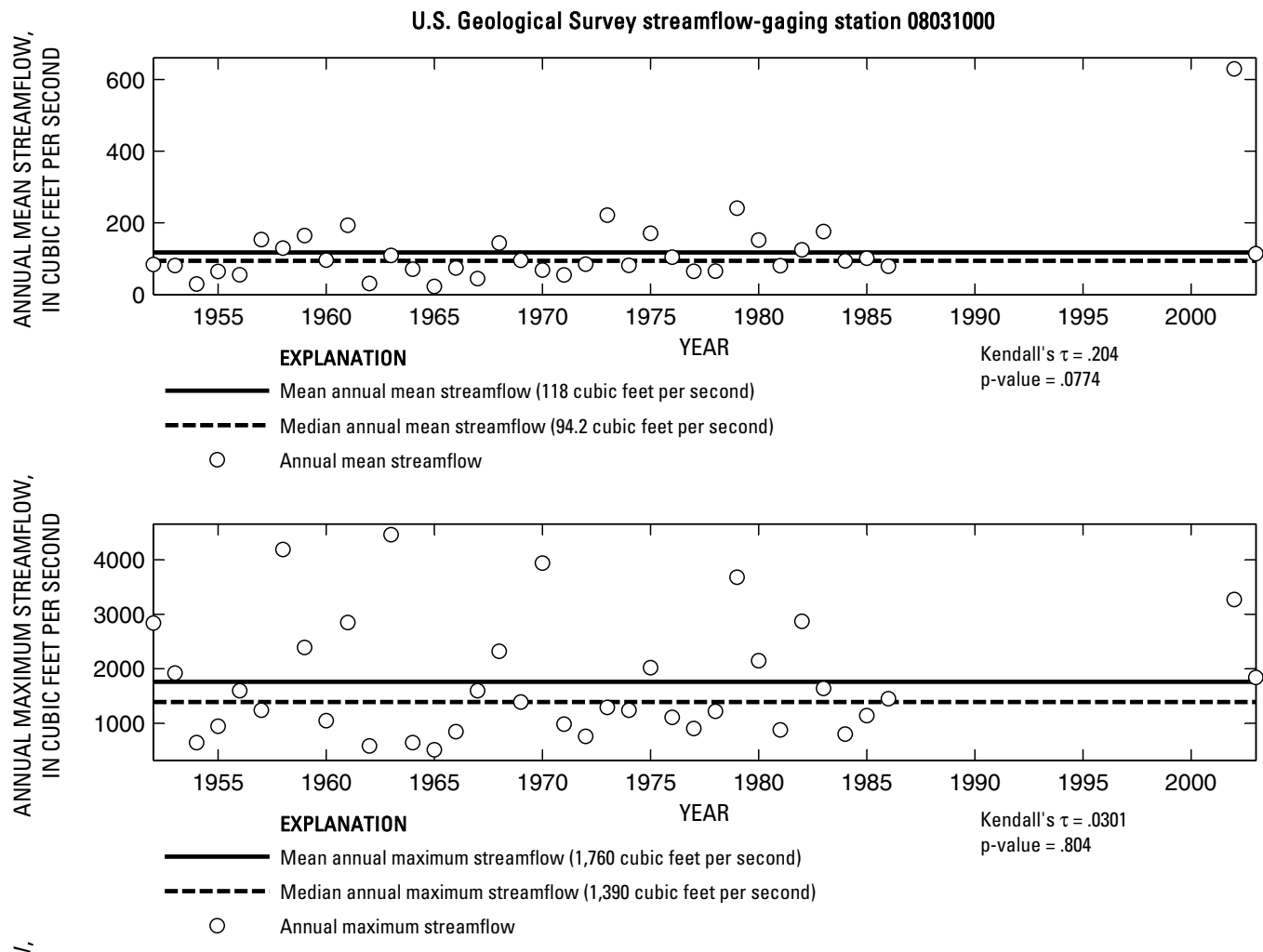

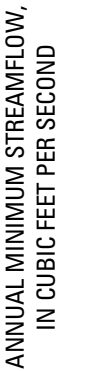

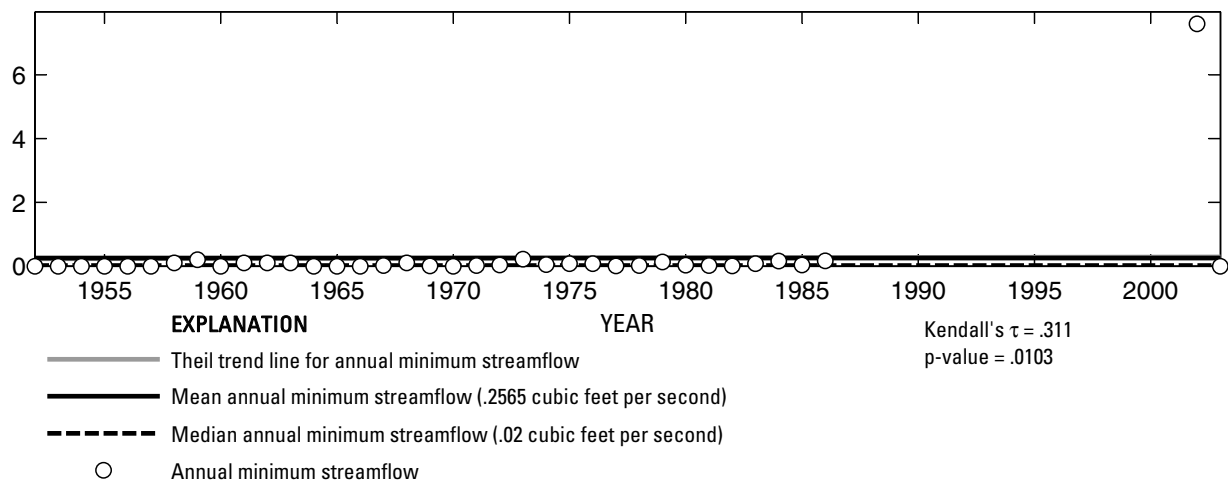

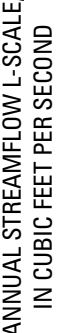

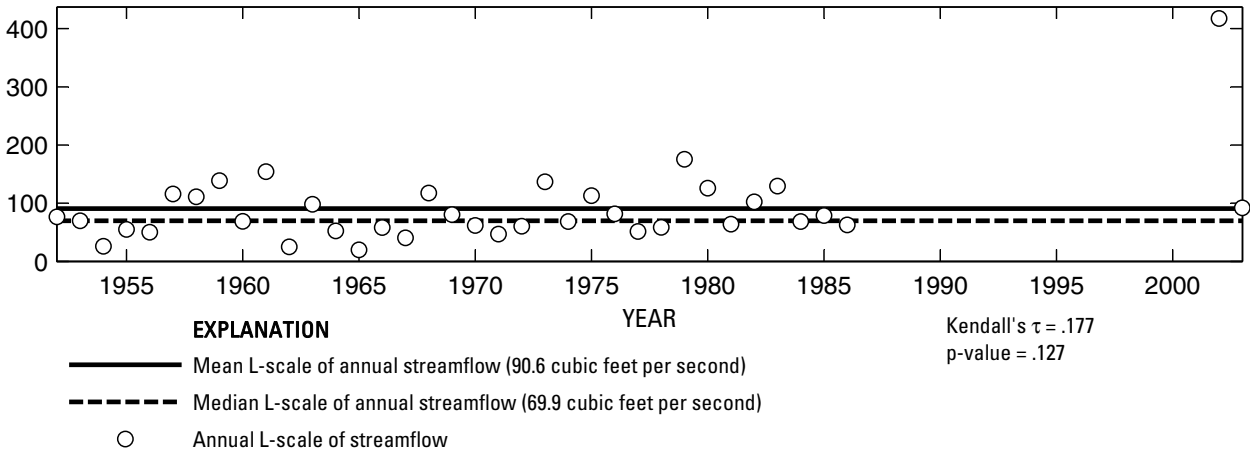

Figure 117. Analysis of annual mean, maximum, minimum, and L-scale statistics of daily mean streamflow for U.S. Geological Survey streamflow-gaging station 08031000 Cow Bayou near Mauriceville, Texas. 
U.S. Geological Survey streamflow-gaging station 08031200

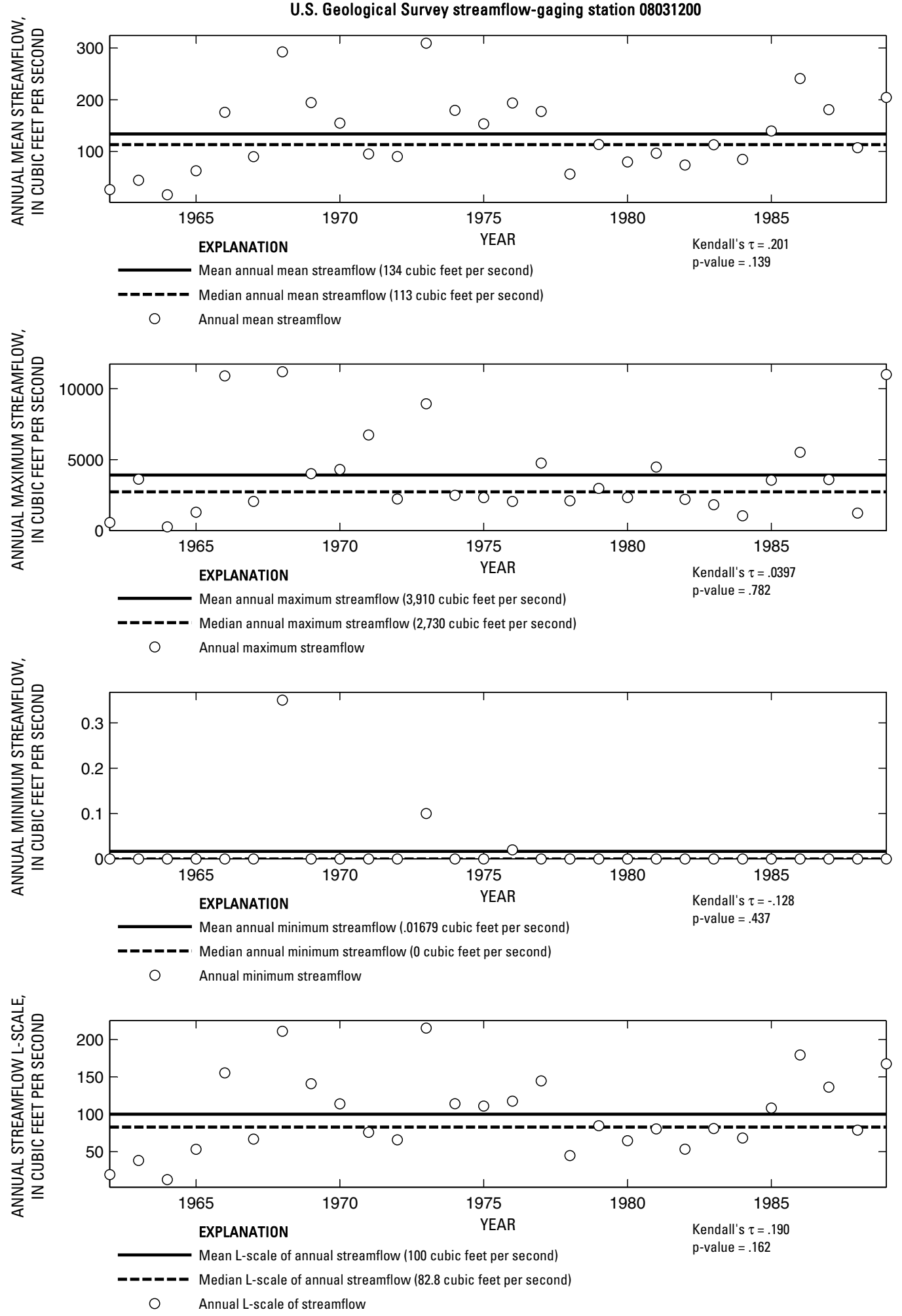

Figure 118. Analysis of annual mean, maximum, minimum, and L-scale statistics of daily mean streamflow for U.S. Geological Survey streamflow-gaging station 08031200 Kickapoo Creek near Brownsboro, Texas.

Index of Station Numbers 719 

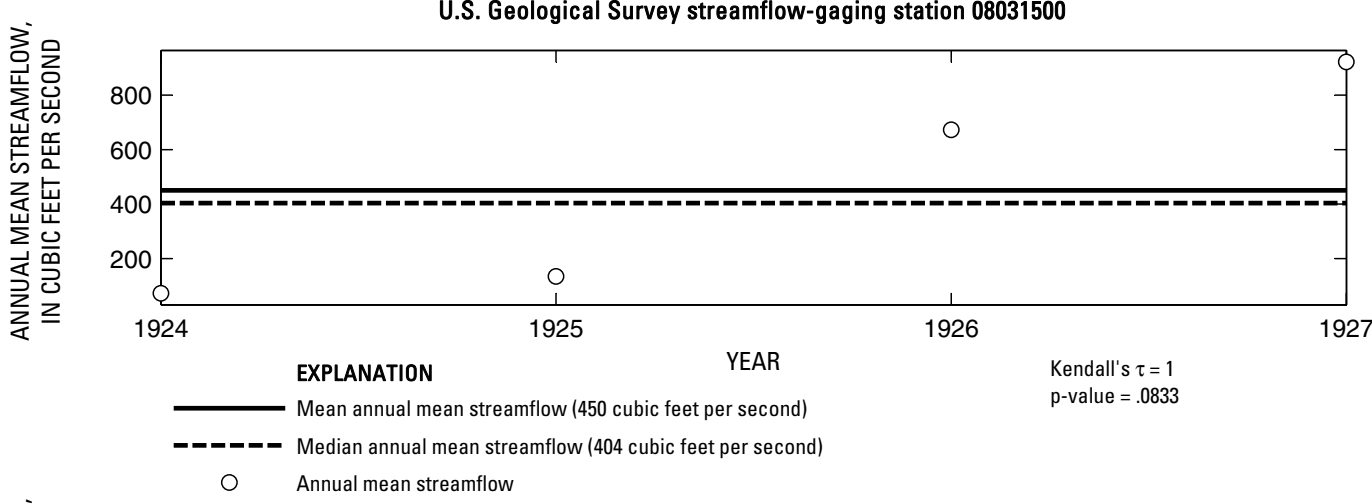

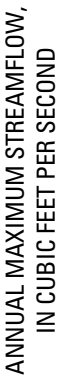

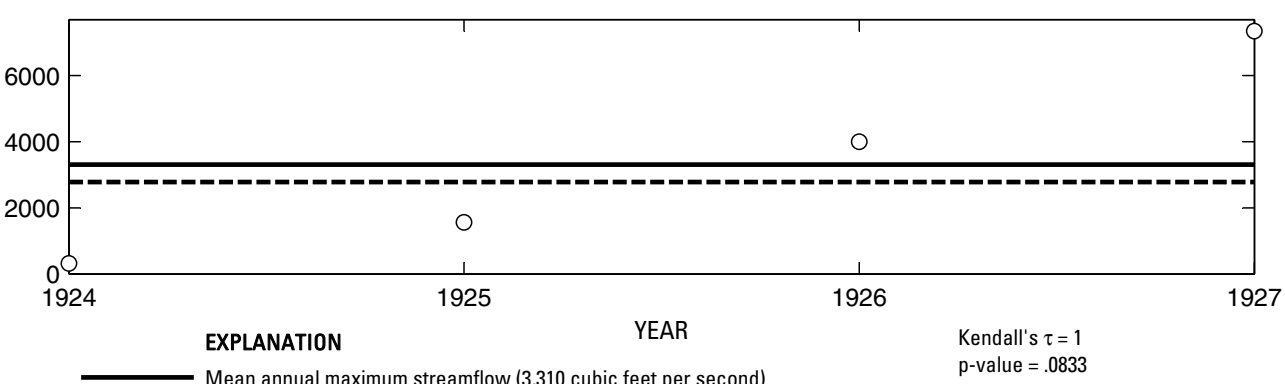

- _ - Median annual maximum streamflow (2,780 cubic feet per second)

Annual maximum streamflow

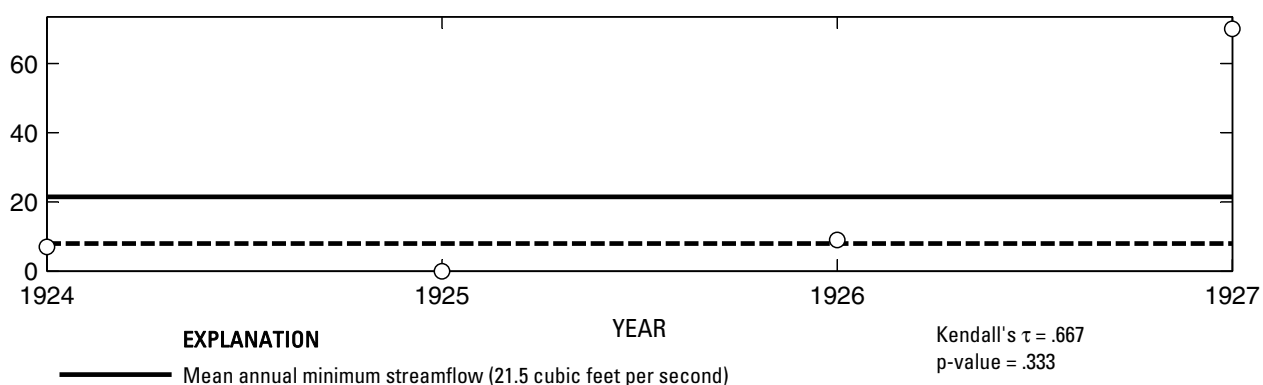

- ב-ב Median annual minimum streamflow (8 cubic feet per second)

O Annual minimum streamflow

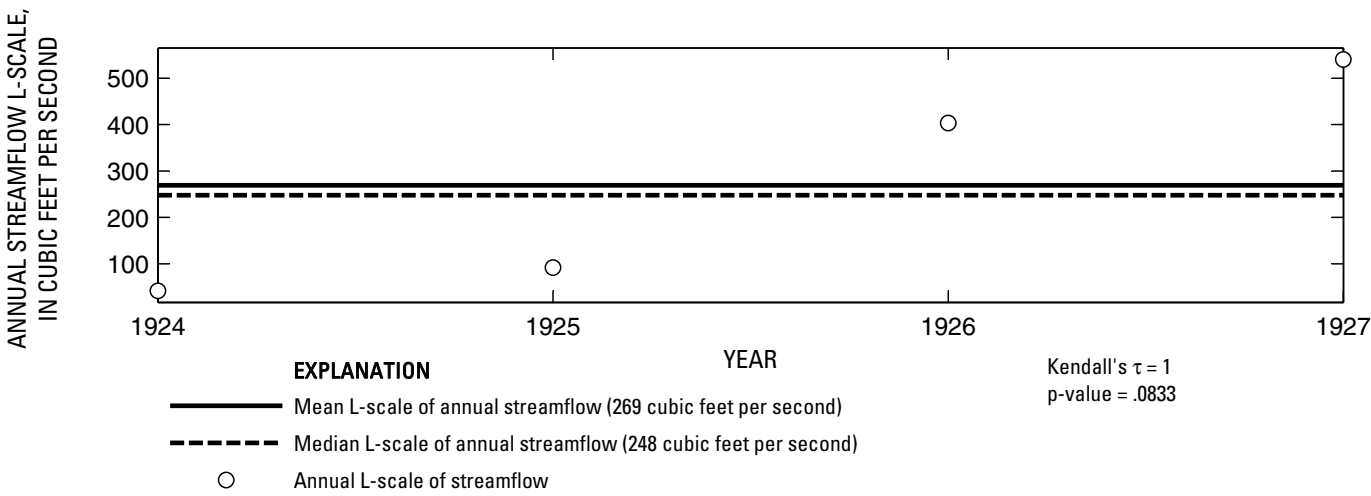

Figure 119. Analysis of annual mean, maximum, minimum, and L-scale statistics of daily mean streamflow for U.S. Geological Survey streamflow-gaging station 08031500 Neches River near Reese, Texas. 
U.S. Geological Survey streamflow-gaging station 08032000

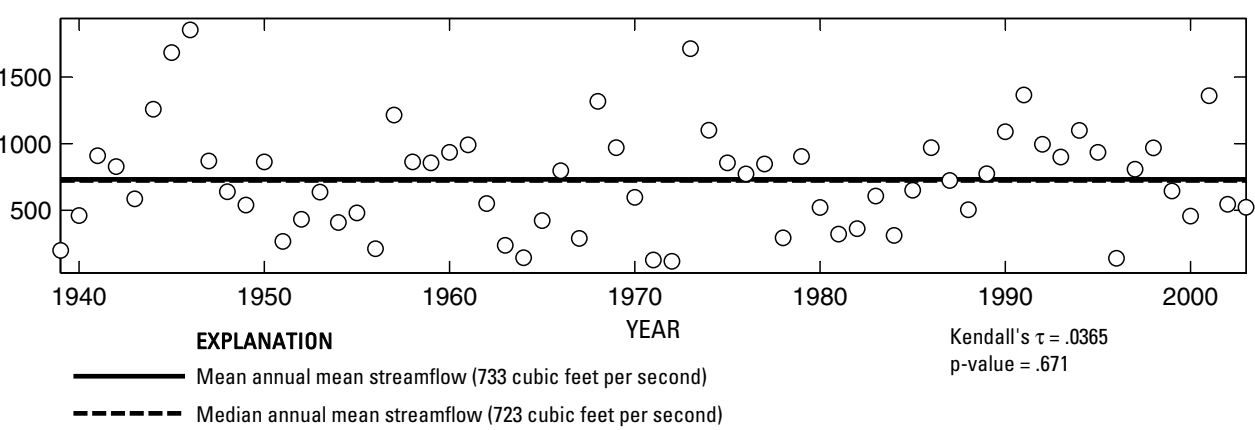

O Annual mean streamflow
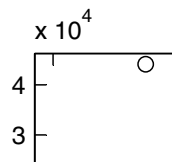

$2-$

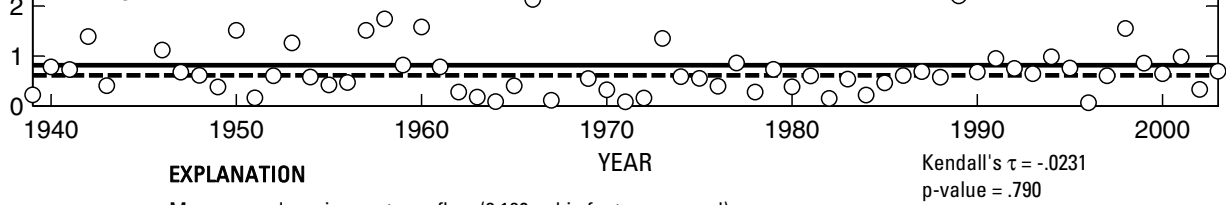

Mean annual maximum streamflow $(8,160$ cubic feet per second)

O Annual maximum streamflow

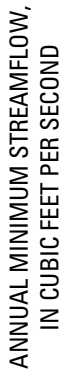

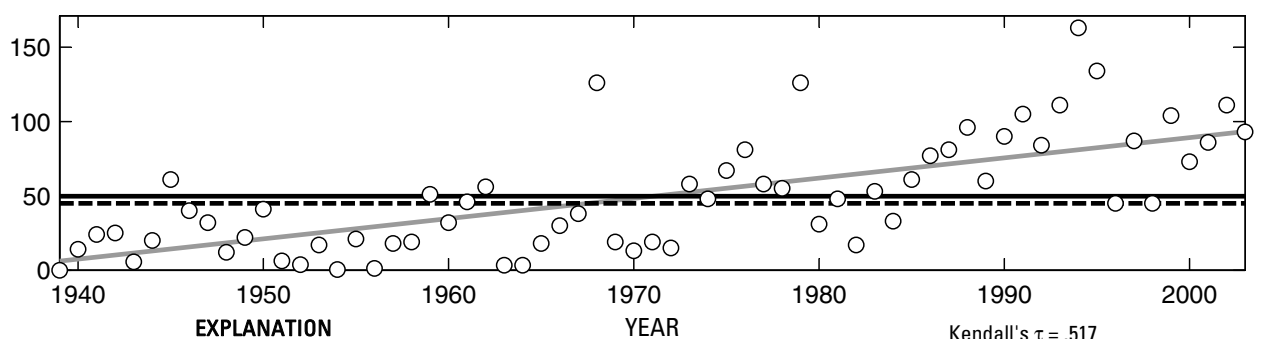

Theil trend line for annual minimum streamflow
Mean annual minimum streamflow (49.8 cubic feet per second)

- Median annual minimum streamflow (45 cubic feet per second)

O Annual minimum streamflow

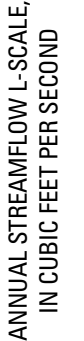

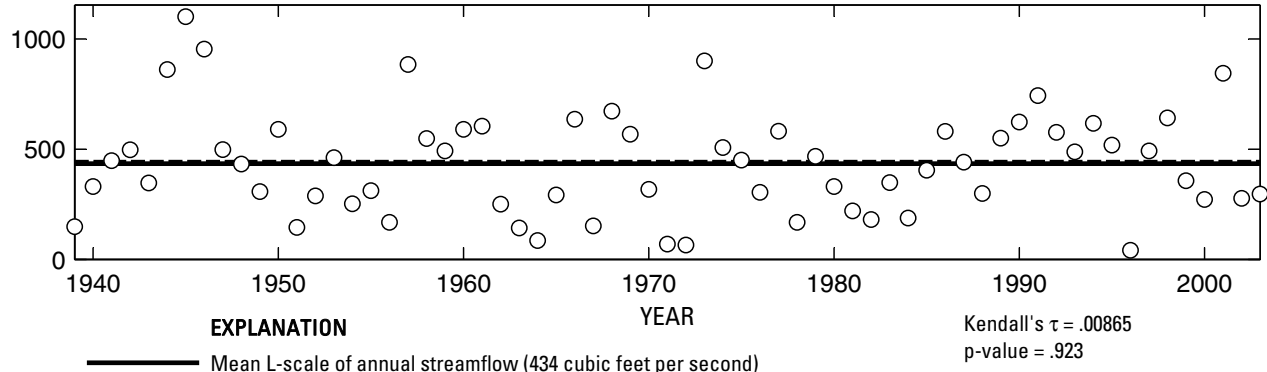

-ーーーーー Median L-scale of annual streamflow (441 cubic feet per second)

Annual L-scale of streamflow

Figure 120. Analysis of annual mean, maximum, minimum, and L-scale statistics of daily mean streamflow for U.S. Geological Survey streamflow-gaging station 08032000 Neches River near Neches, Texas.

Index of Station Numbers 719 

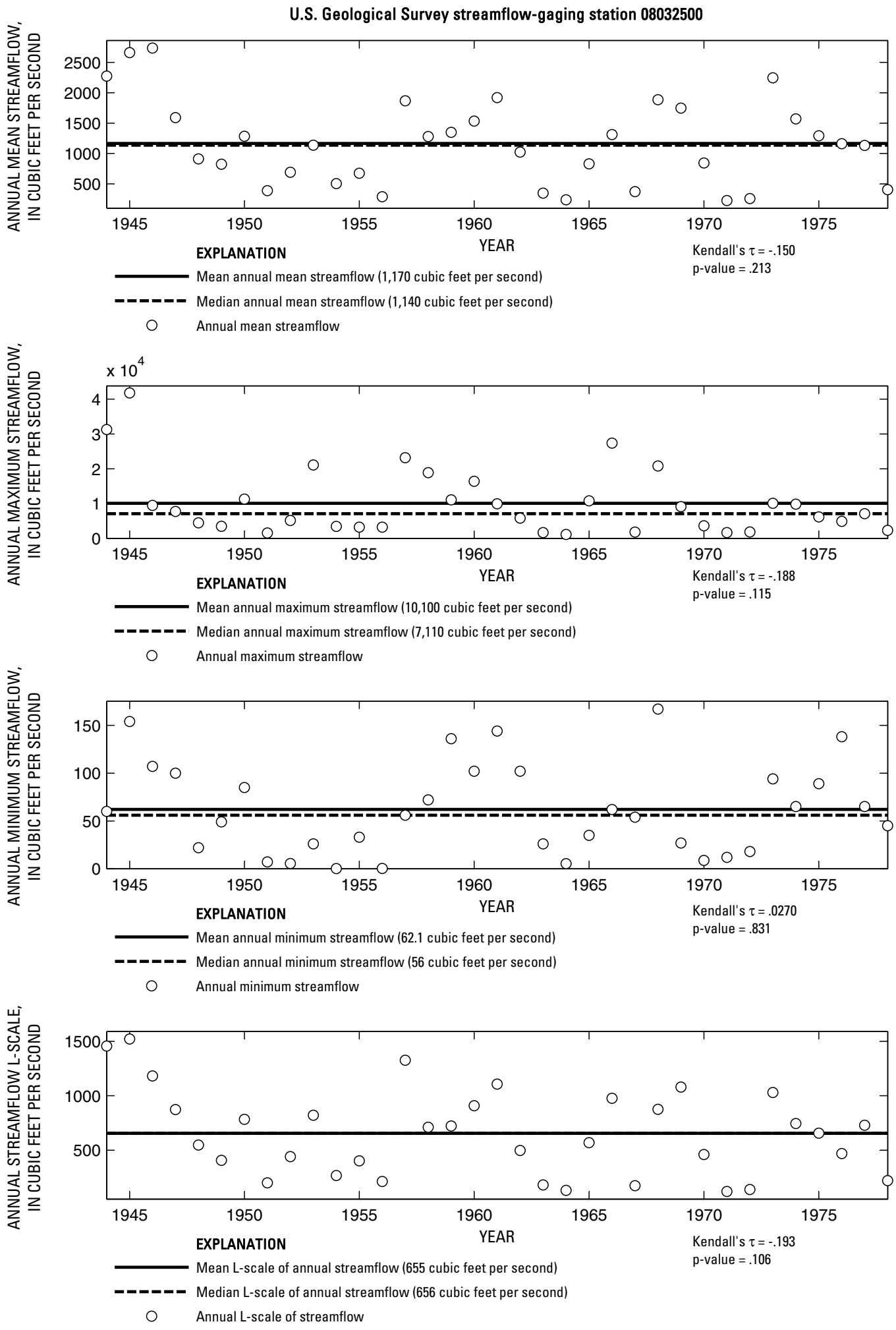

Figure 121. Analysis of annual mean, maximum, minimum, and L-scale statistics of daily mean streamflow for U.S. Geological Survey streamflow-gaging station 08032500 Neches River near Alto, Texas. 

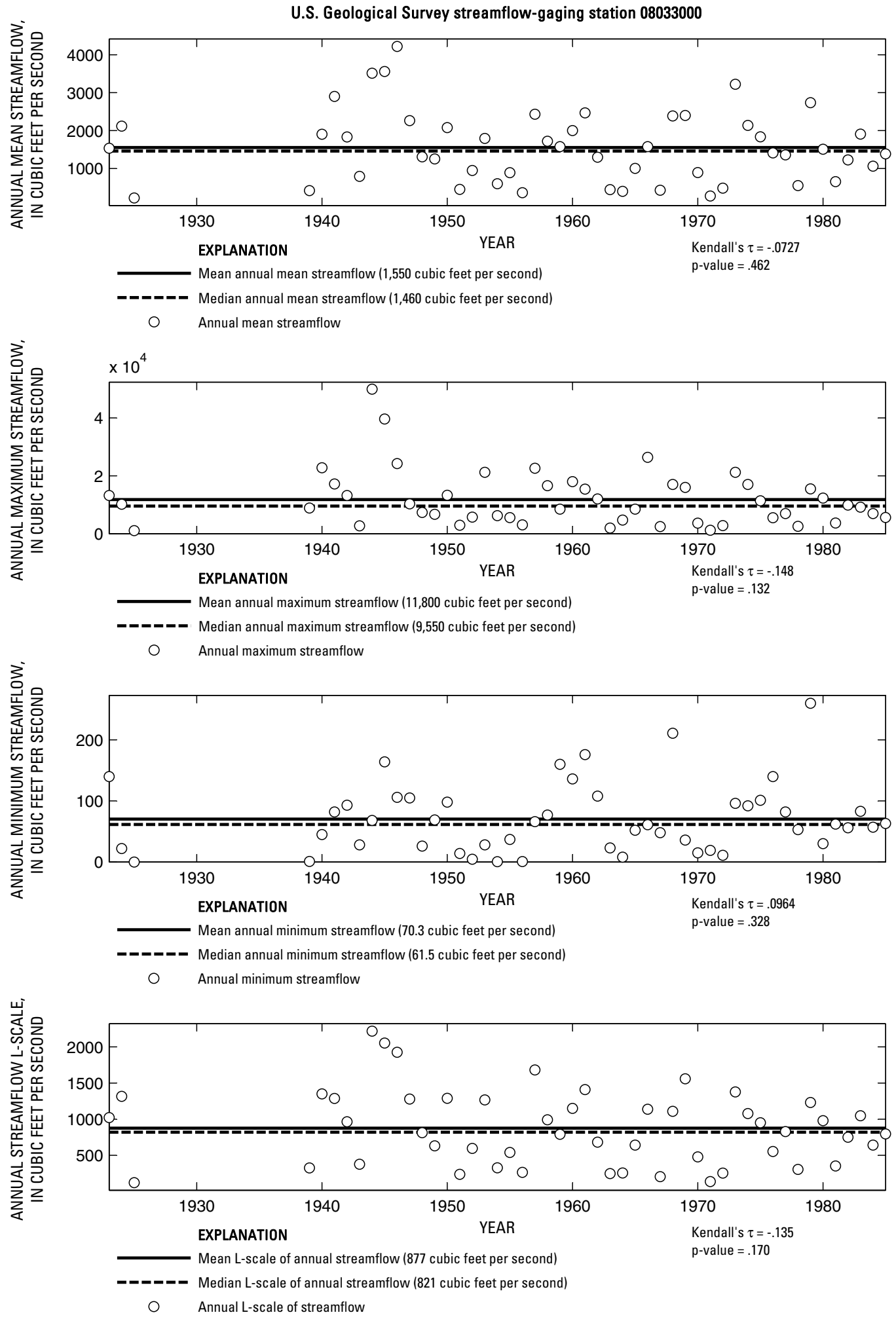

Figure 122. Analysis of annual mean, maximum, minimum, and L-scale statistics of daily mean streamflow for U.S. Geological Survey streamflow-gaging station 08033000 Neches River near Diboll, Texas.

Index of Station Numbers 719 

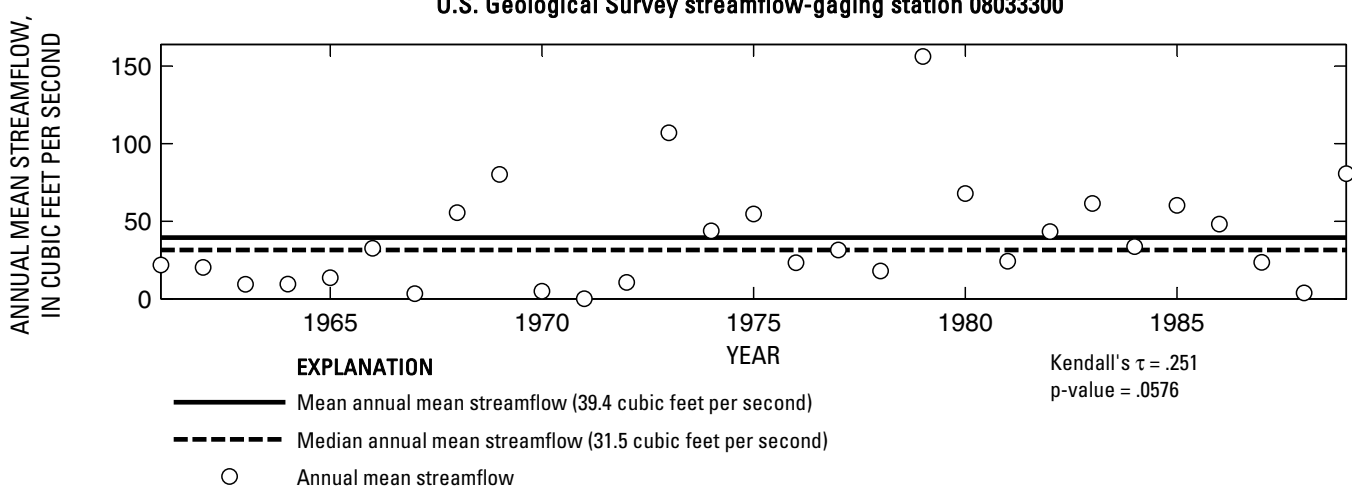

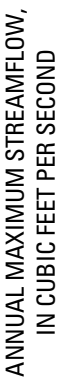

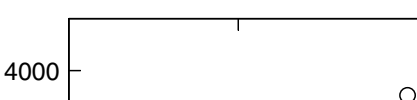

2000

$\circ$

○

○
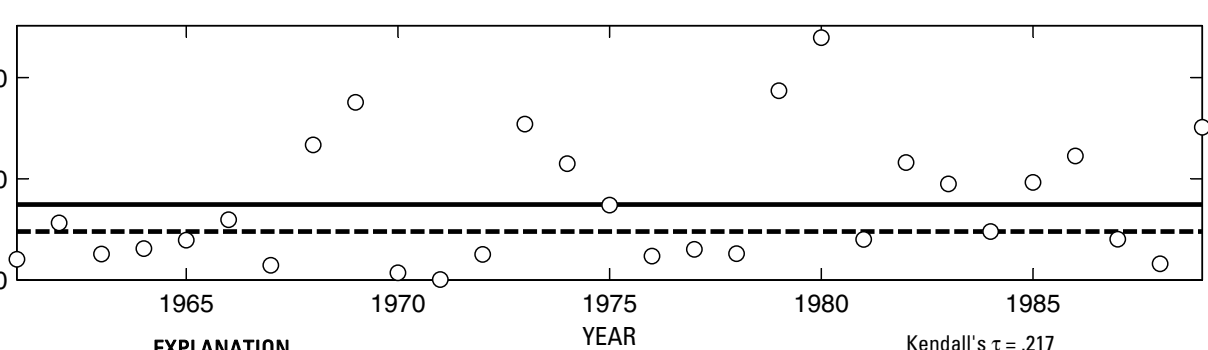

EXPLANATION

YEAR

Kendall's $\tau=.217$

Mean annual maximum streamflow (1,490 cubic feet per second)

$\mathrm{p}$-value $=.103$

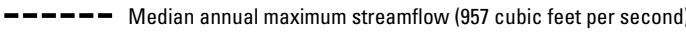

O Annual maximum streamflow
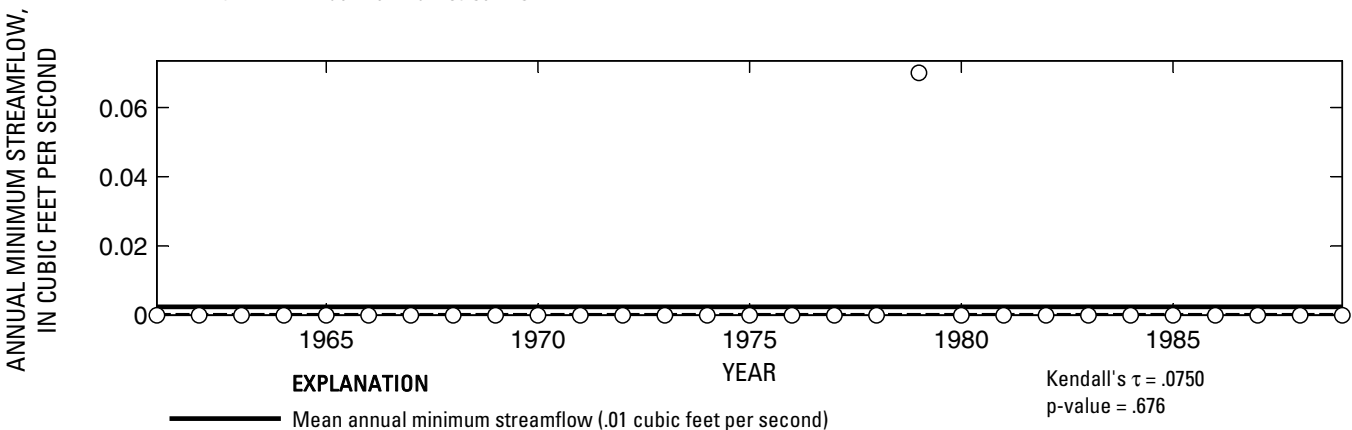

- ב-ב Median annual minimum streamflow (0 cubic feet per second)

○ Annual minimum streamflow
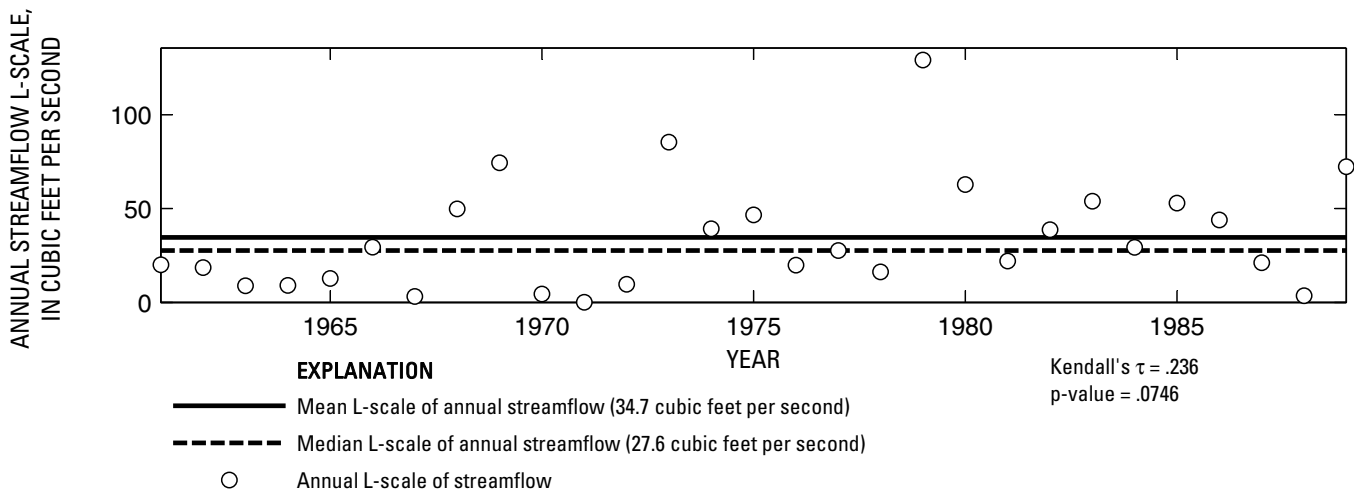

Figure 123. Analysis of annual mean, maximum, minimum, and L-scale statistics of daily mean streamflow for U.S. Geological Survey streamflow-gaging station 08033300 Piney Creek near Groveton, Texas. 
U.S. Geological Survey streamflow-gaging station 08033500
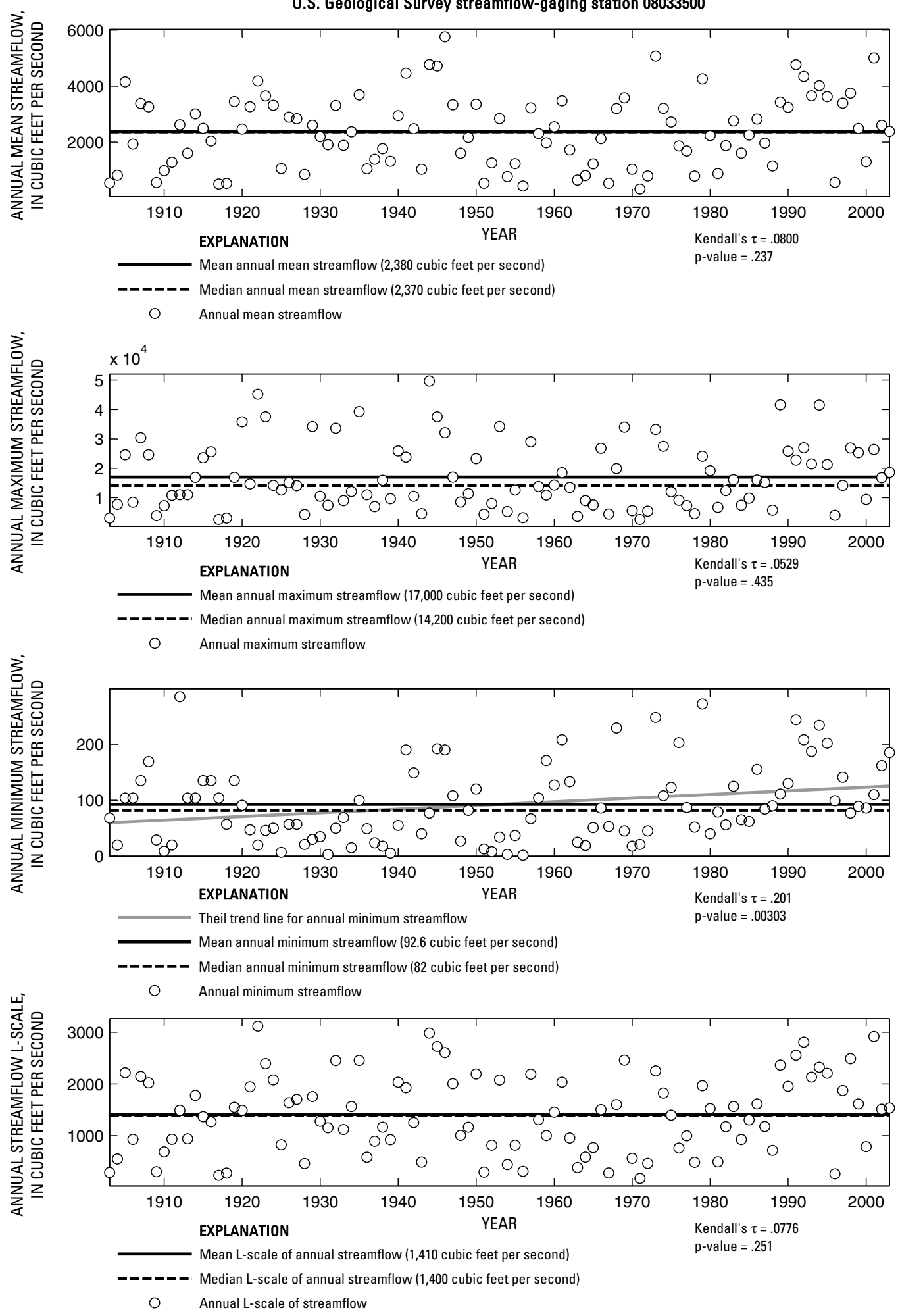

Figure 124. Analysis of annual mean, maximum, minimum, and L-scale statistics of daily mean streamflow for U.S. Geological Survey streamflow-gaging station 08033500 Neches River near Rockland, Texas.

Index of Station Numbers 719 

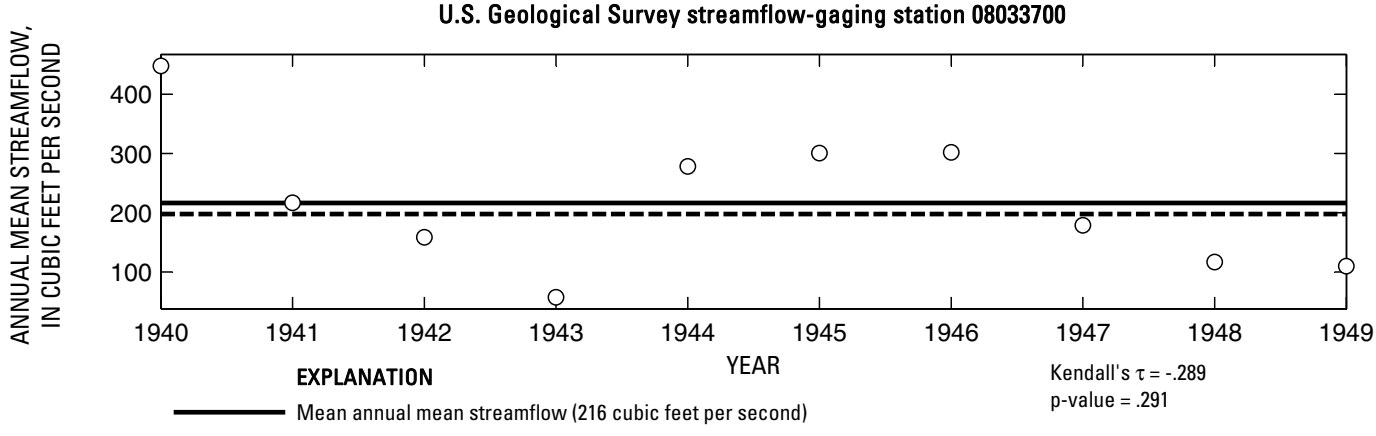

-_-_-_ Median annual mean streamflow (198 cubic feet per second)

O Annual mean streamflow
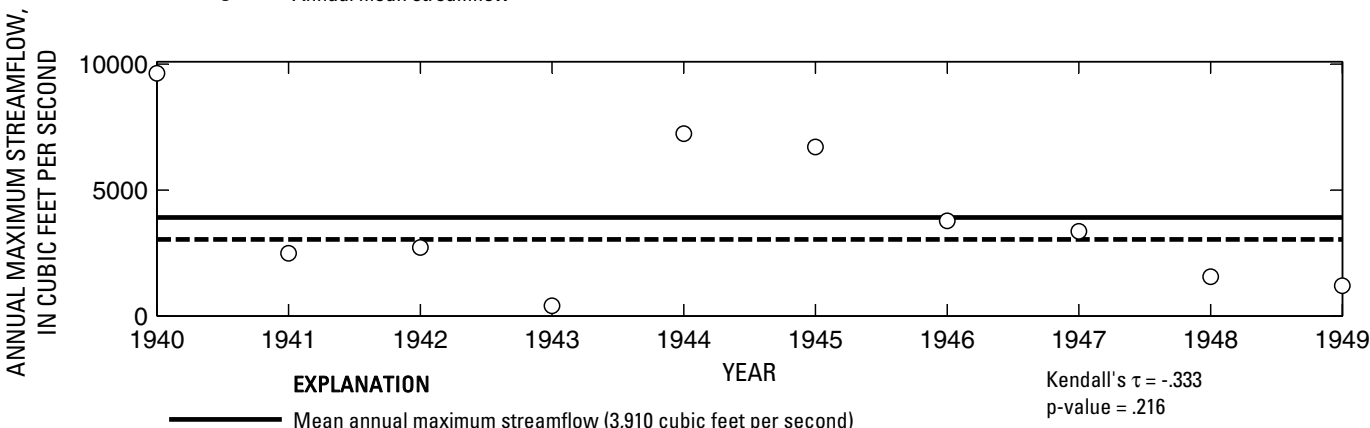

- _ - - Median annual maximum streamflow (3,040 cubic feet per second)

Annual maximum streamflow

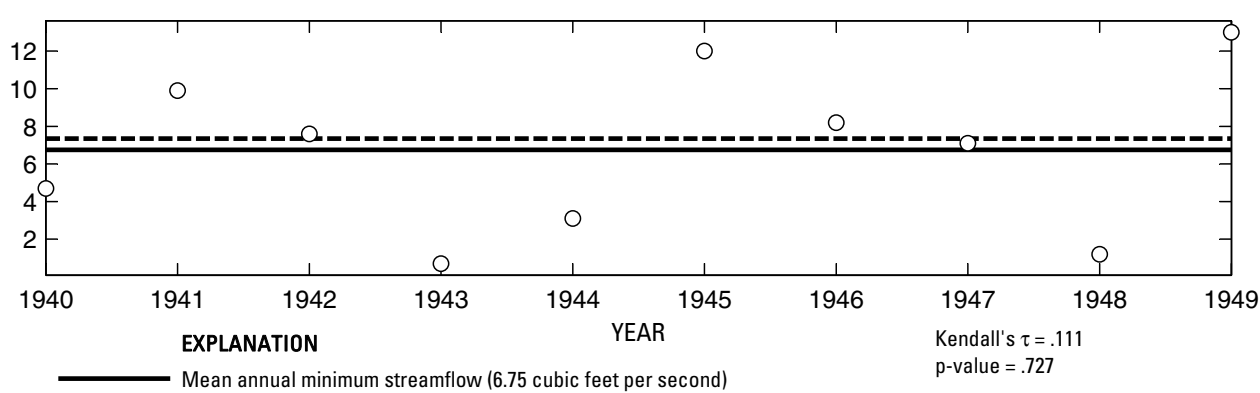

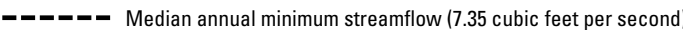

○ Annual minimum streamflow

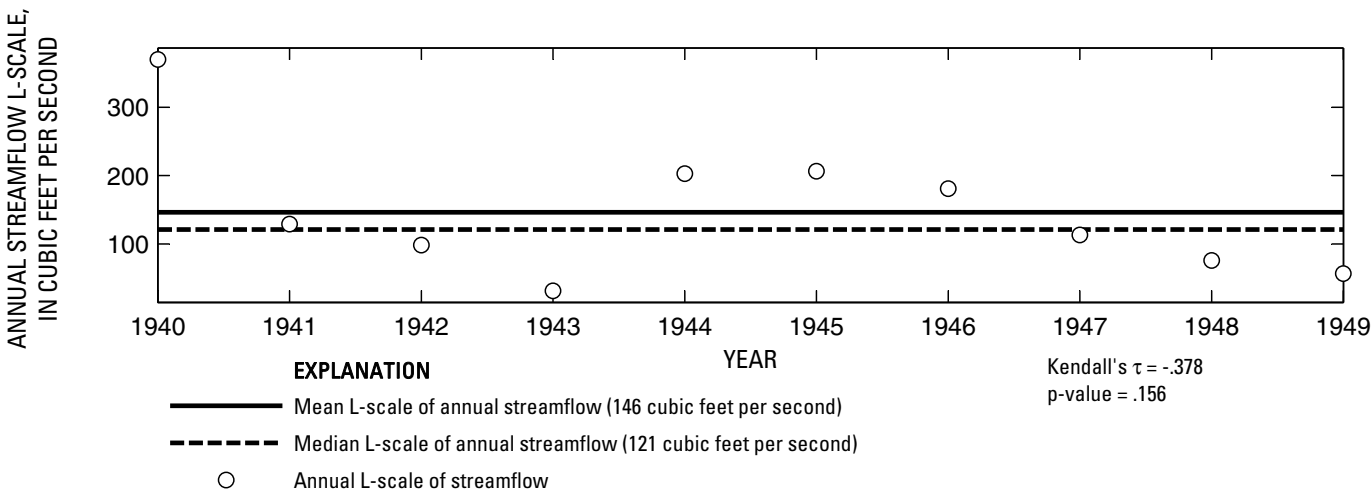

Figure 125. Analysis of annual mean, maximum, minimum, and L-scale statistics of daily mean streamflow for U.S. Geological Survey streamflow-gaging station 08033700 Striker Creek near Summerfield, Texas. 


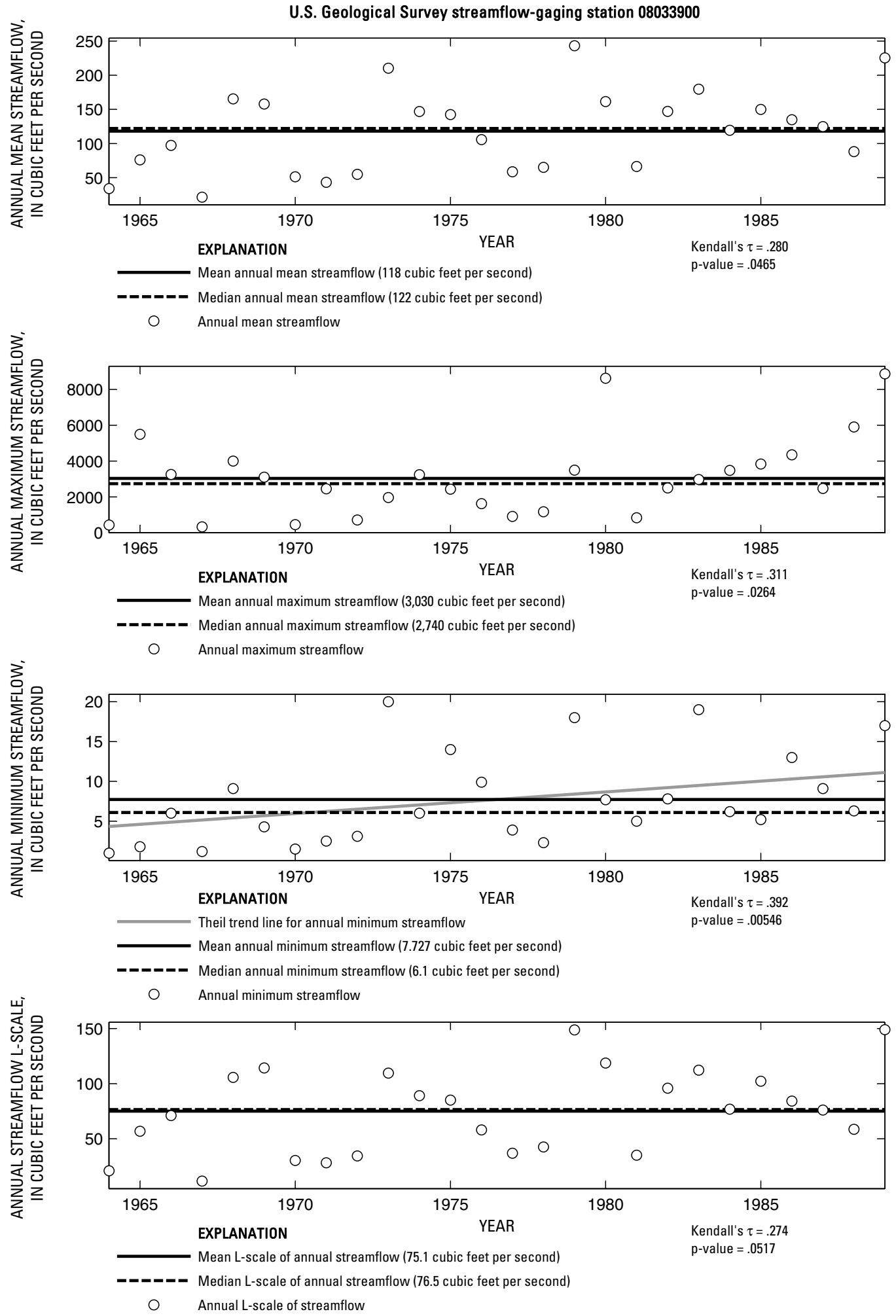

Figure 126. Analysis of annual mean, maximum, minimum, and L-scale statistics of daily mean streamflow for U.S. Geological Survey streamflow-gaging station 08033900 East Fork Angelina River near Cushing, Texas.

Index of Station Numbers 719 


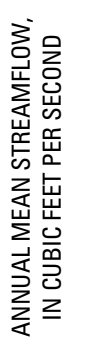

U.S. Geological Survey streamflow-gaging station 08034500

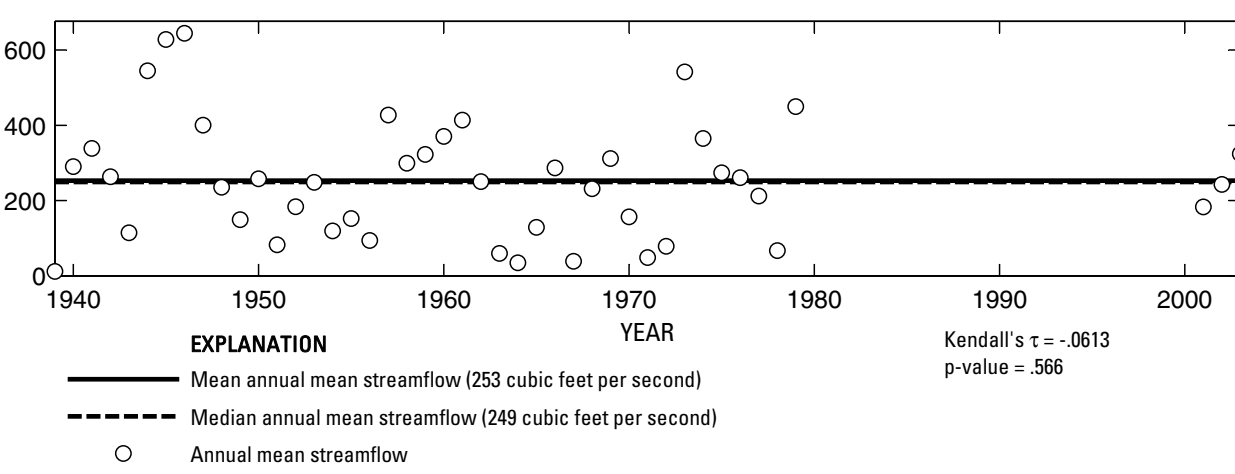

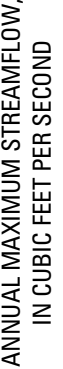

(1.

O
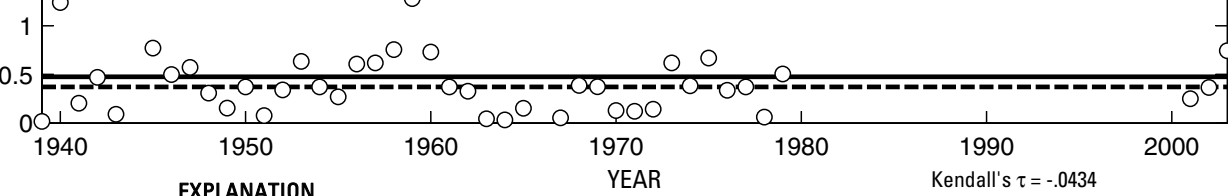

EXPLANATION

p-value $=686$

O Annual maximum streamflow

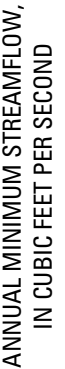

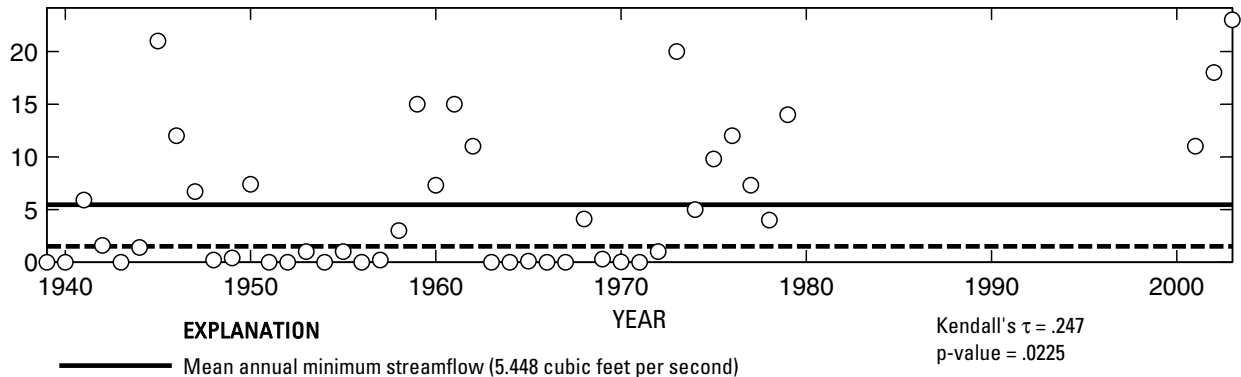

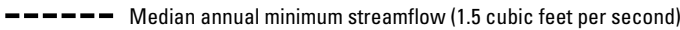

O Annual minimum streamflow
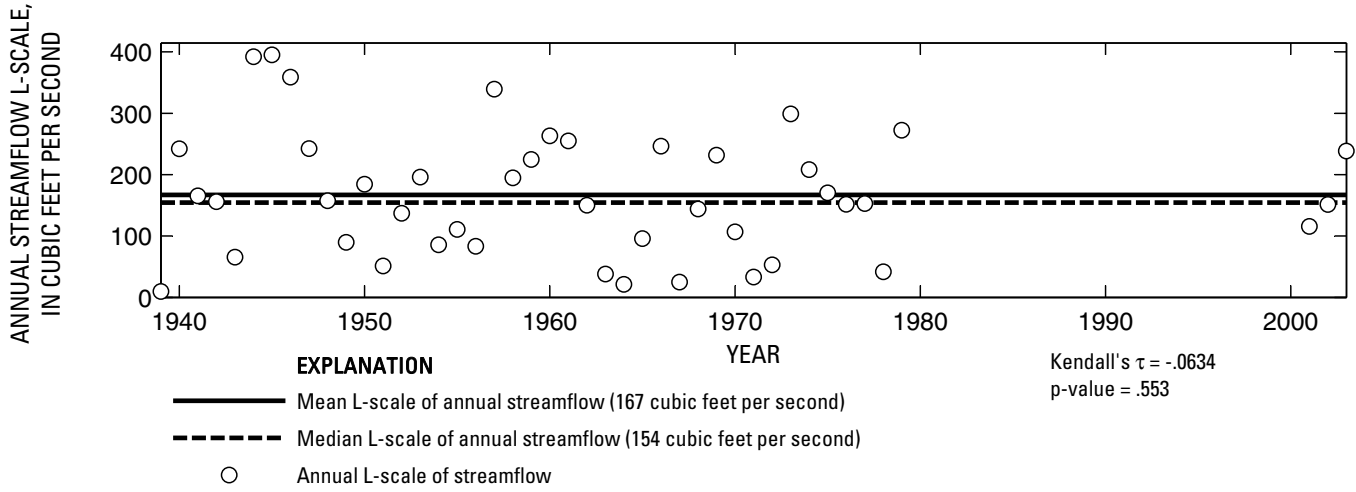

Figure 127. Analysis of annual mean, maximum, minimum, and L-scale statistics of daily mean streamflow for U.S. Geological Survey streamflow-gaging station 08034500 Mud Creek near Jacksonville, Texas. 


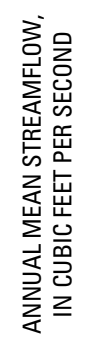

U.S. Geological Survey streamflow-gaging station 08035000

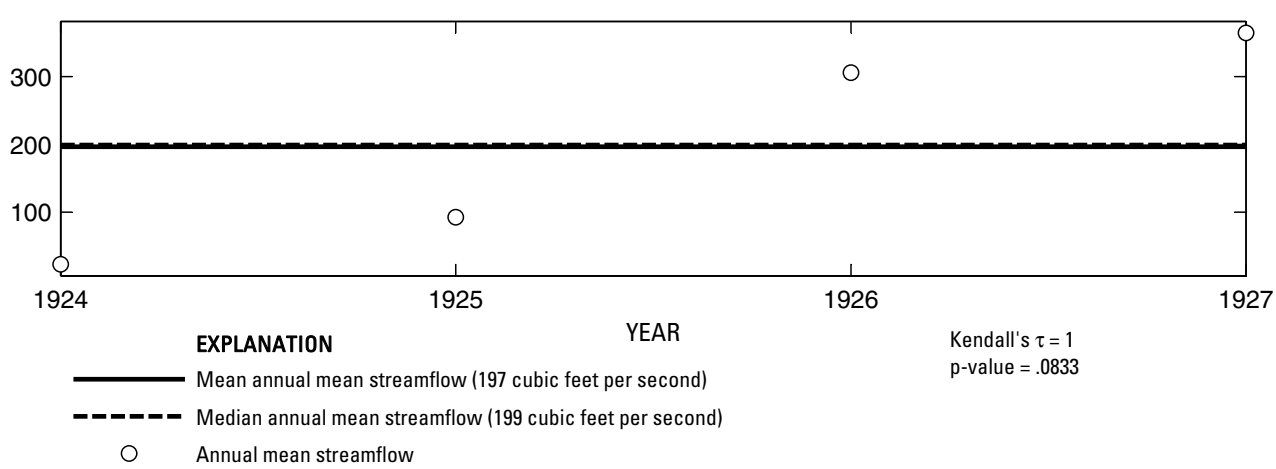

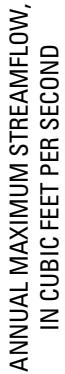

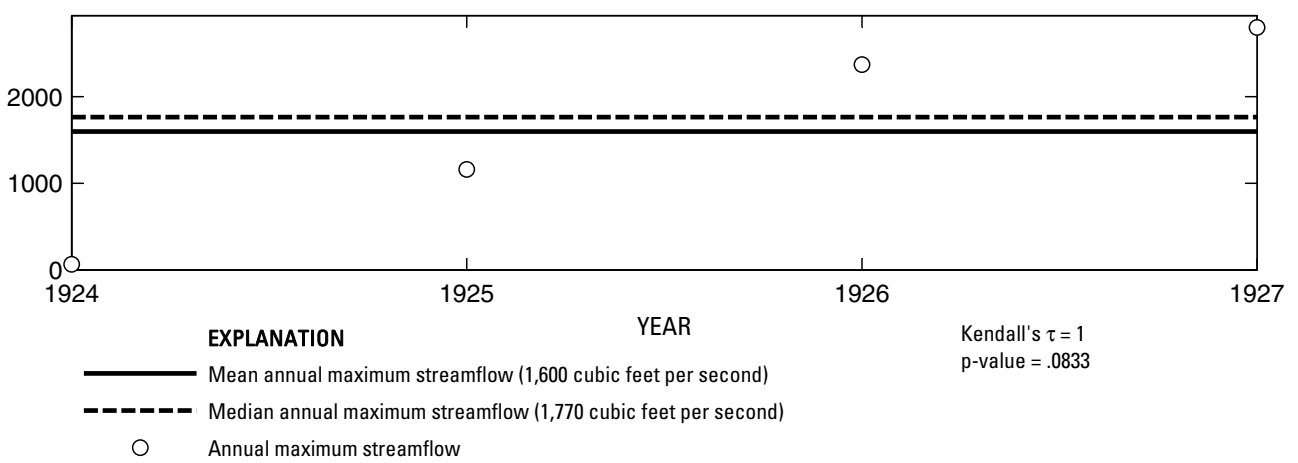

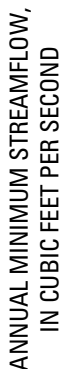

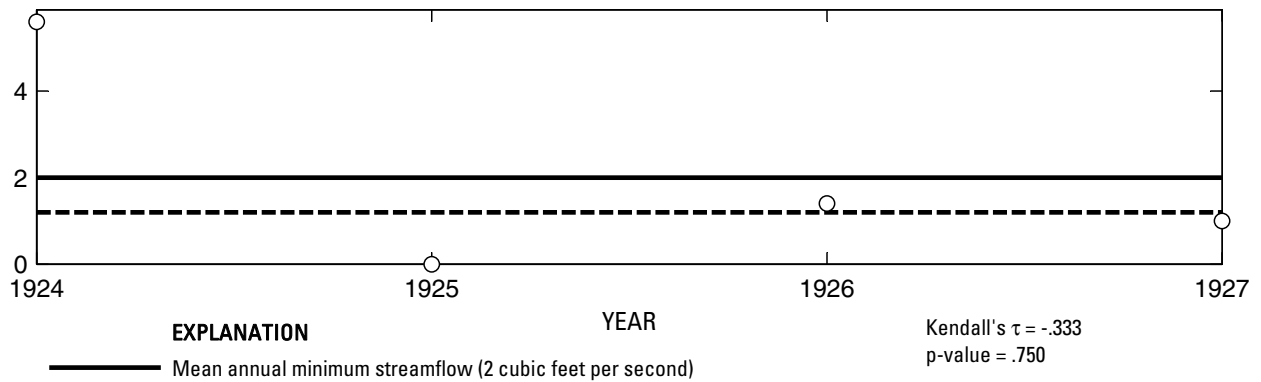

- - - Median annual minimum streamflow (1.2 cubic feet per second)

O Annual minimum streamflow

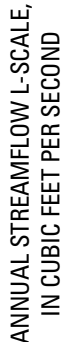

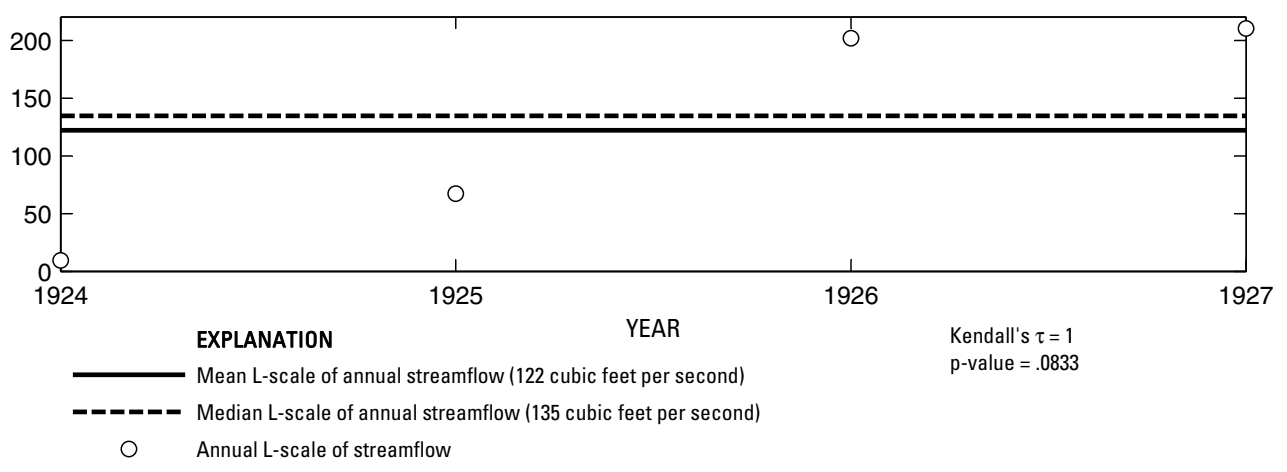

Figure 128. Analysis of annual mean, maximum, minimum, and L-scale statistics of daily mean streamflow for U.S. Geological Survey streamflow-gaging station 08035000 Mud Creek at Ponta, Texas.

Index of Station Numbers 719 

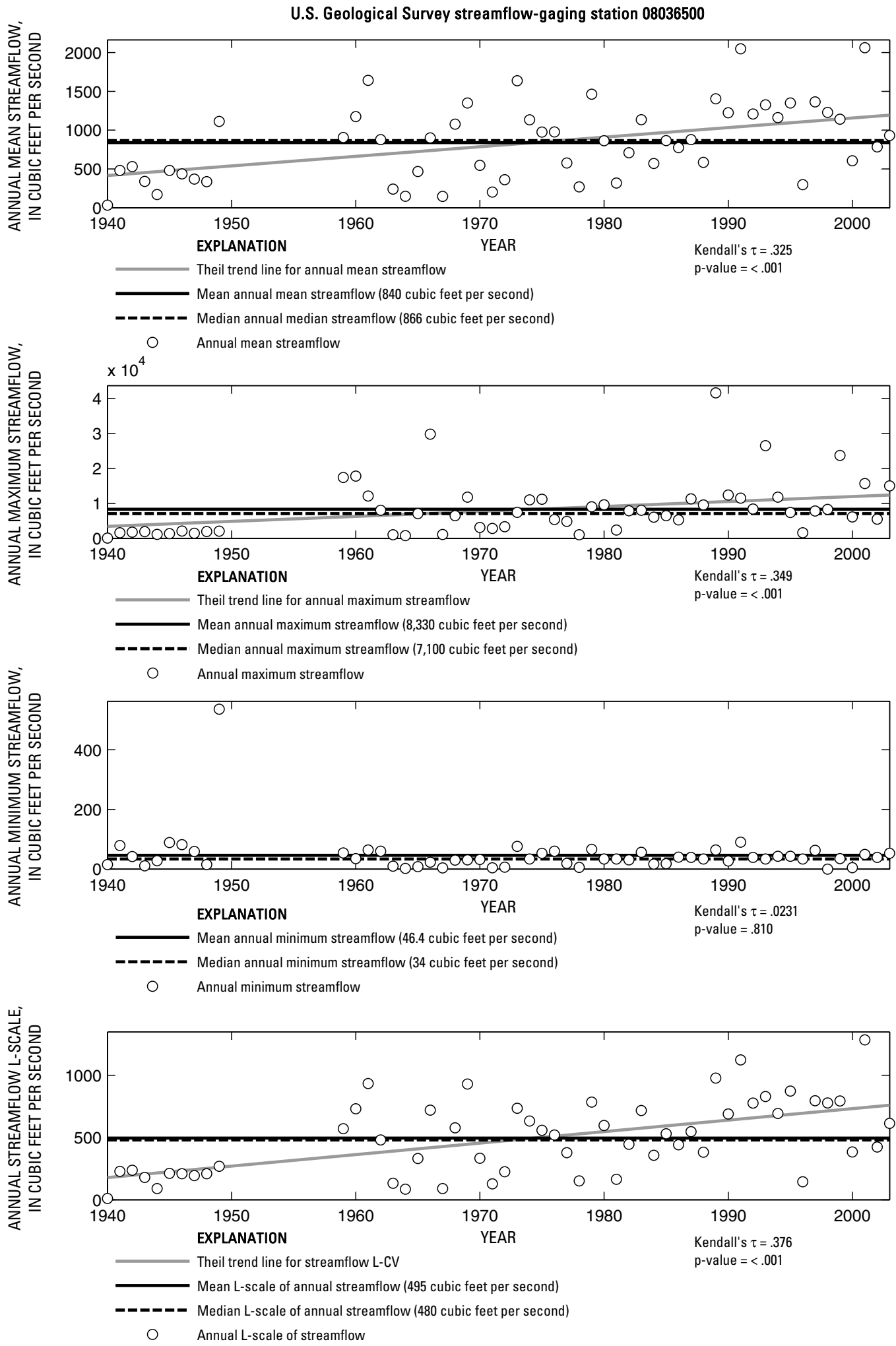

Figure 129. Analysis of annual mean, maximum, minimum, and L-scale statistics of daily mean streamflow for U.S. Geological Survey streamflow-gaging station 08036500 Angelina River near Alto, Texas. 

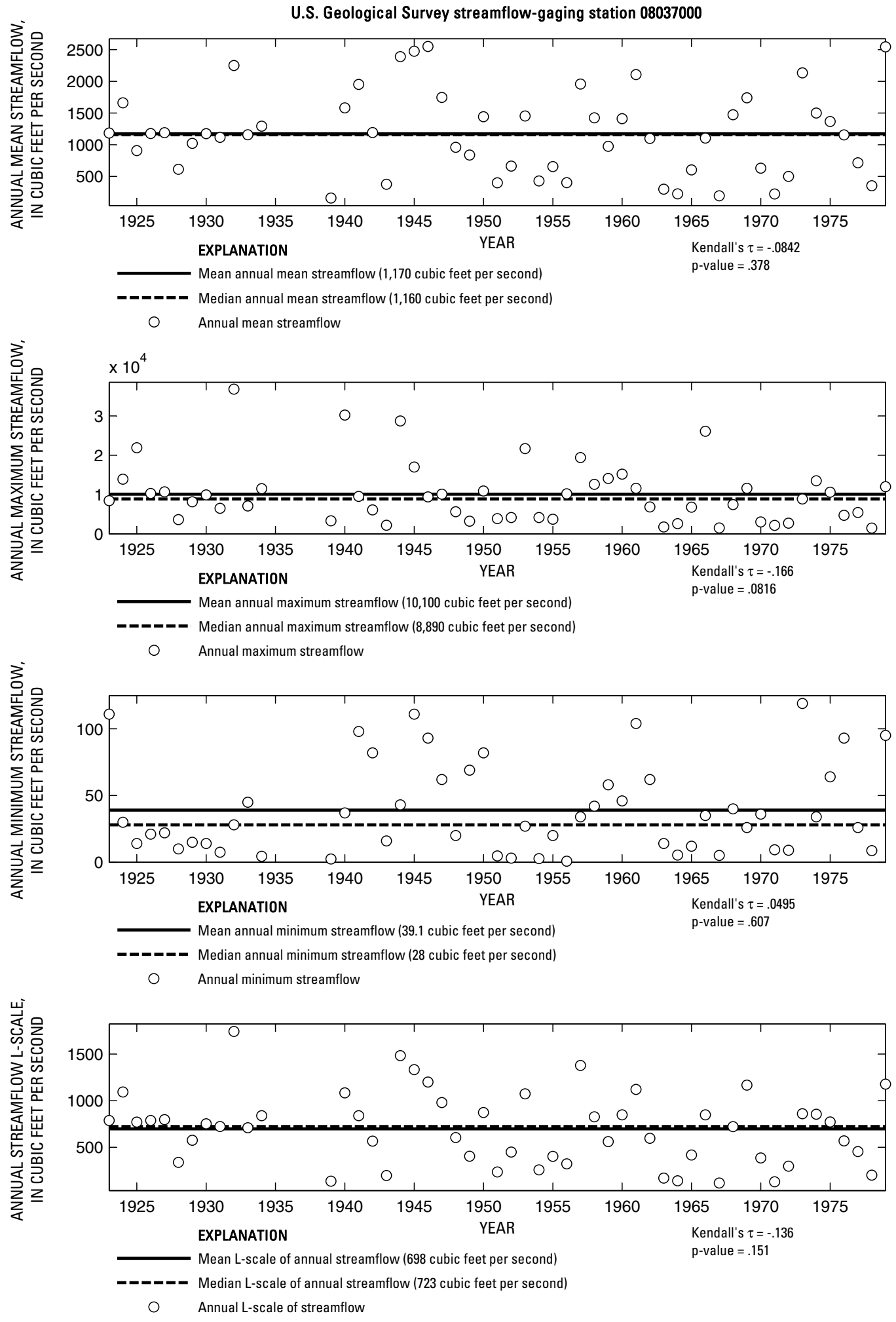

Figure 130. Analysis of annual mean, maximum, minimum, and L-scale statistics of daily mean streamflow for U.S. Geological Survey streamflow-gaging station 08037000 Angelina River near Lufkin, Texas.

Index of Station Numbers 719 


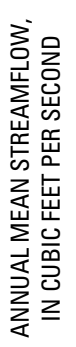

U.S. Geological Survey streamflow-gaging station 08037050

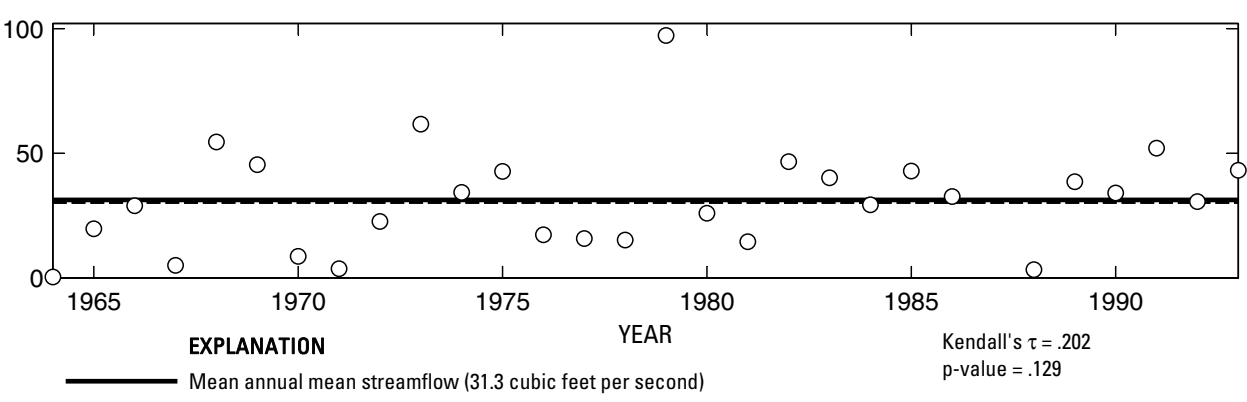

-_-_- Median annual mean streamflow (30.6 cubic feet per second)

O Annual mean streamflow
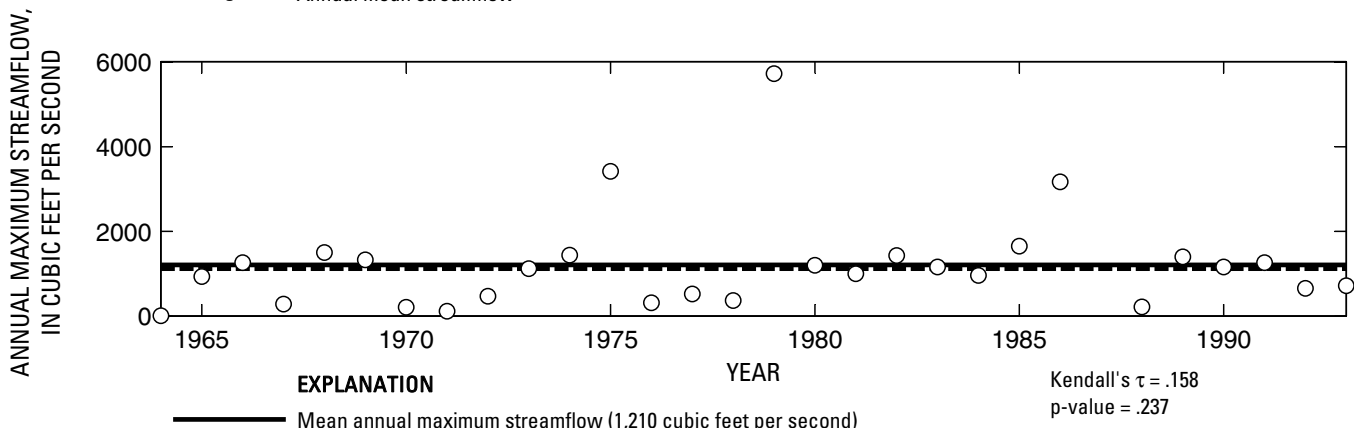

- _ _ - Median annual maximum streamflow (1,120 cubic feet per second

- Annual maximum streamflow

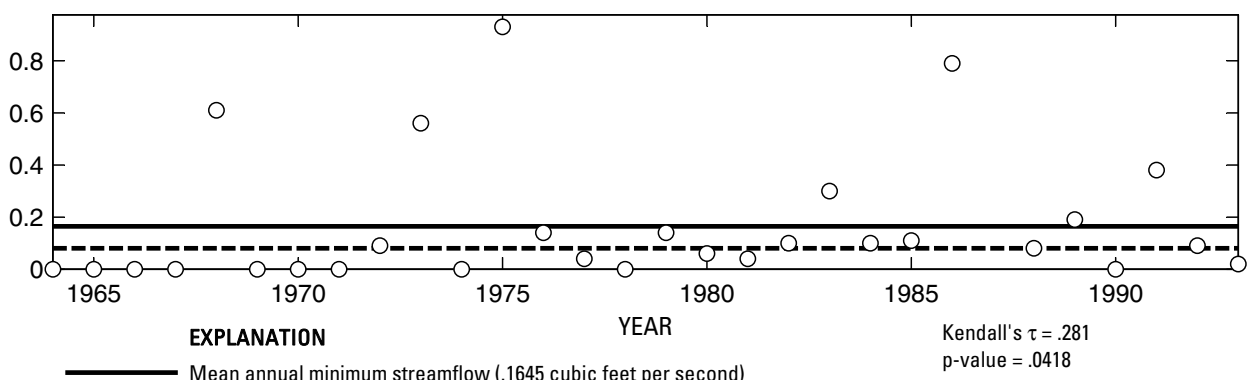

- - Median annual minimum streamflow (.08 cubic feet per second)

O Annual minimum streamflow
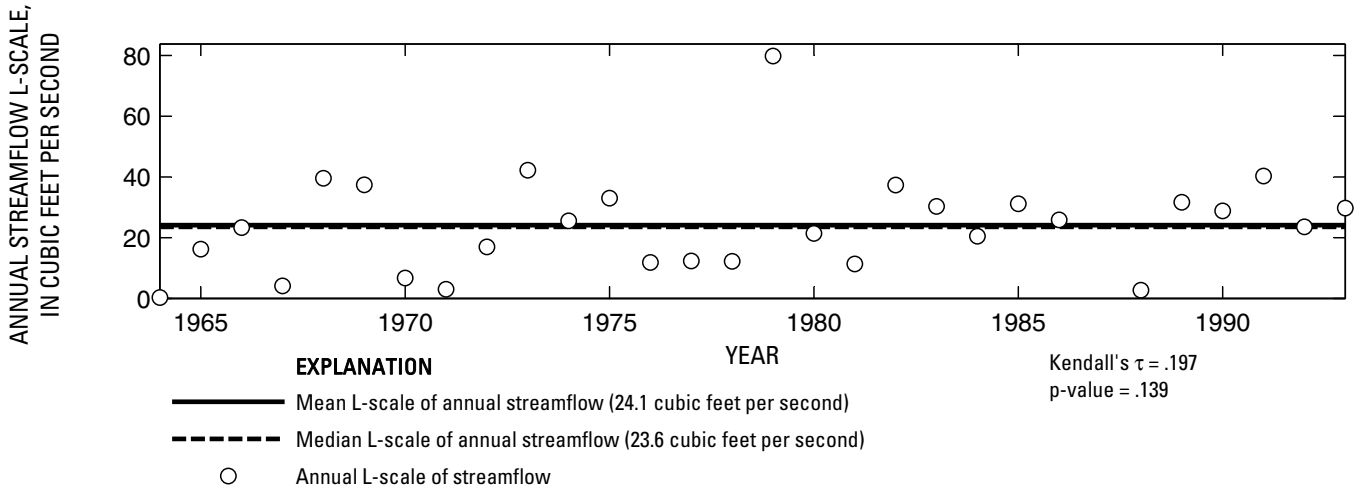

Figure 131. Analysis of annual mean, maximum, minimum, and L-scale statistics of daily mean streamflow for U.S. Geological Survey streamflow-gaging station 08037050 Bayou Lanana at Nacogdoches, Texas. 


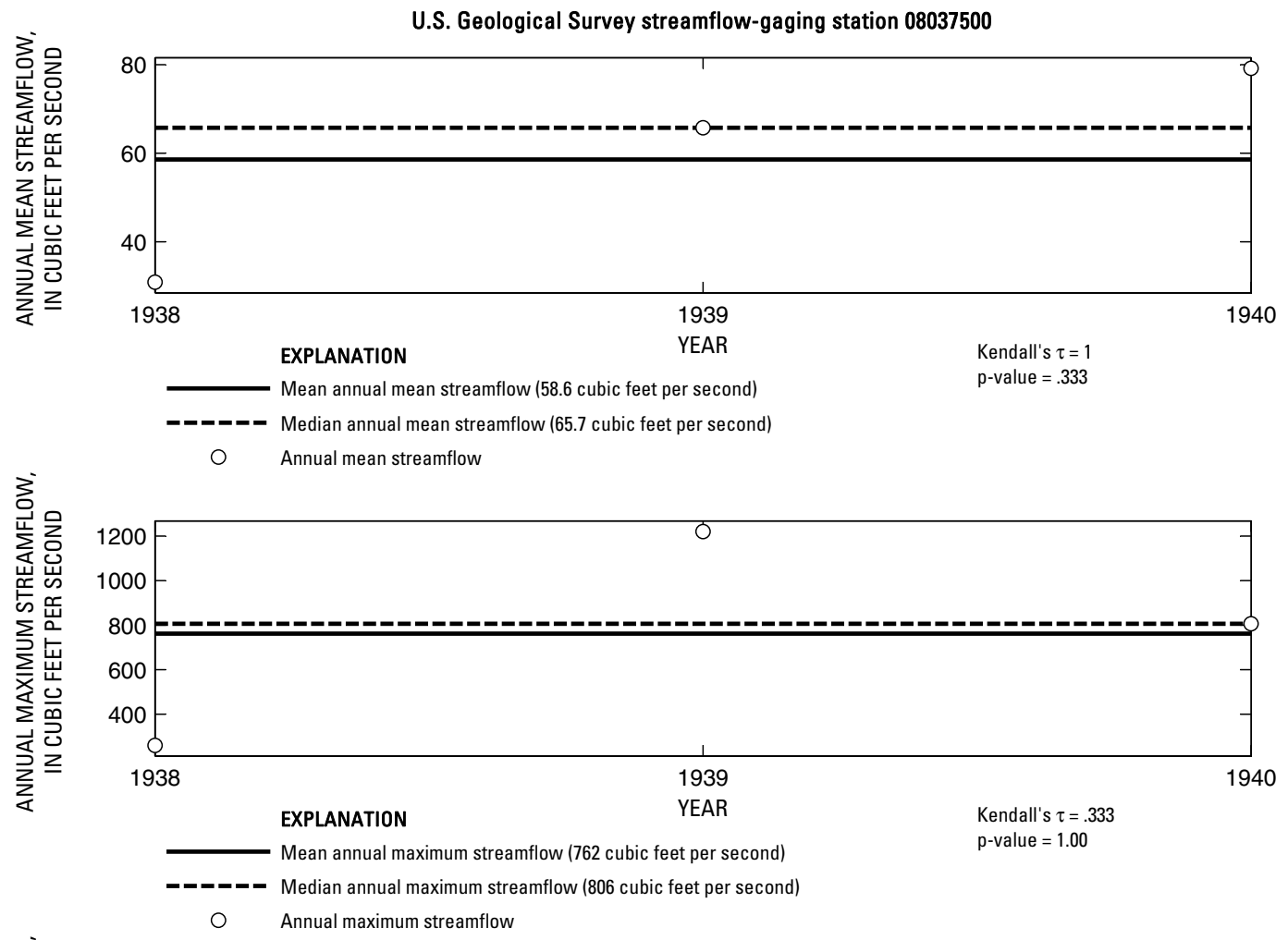

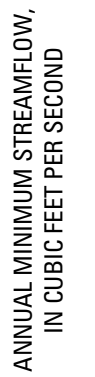

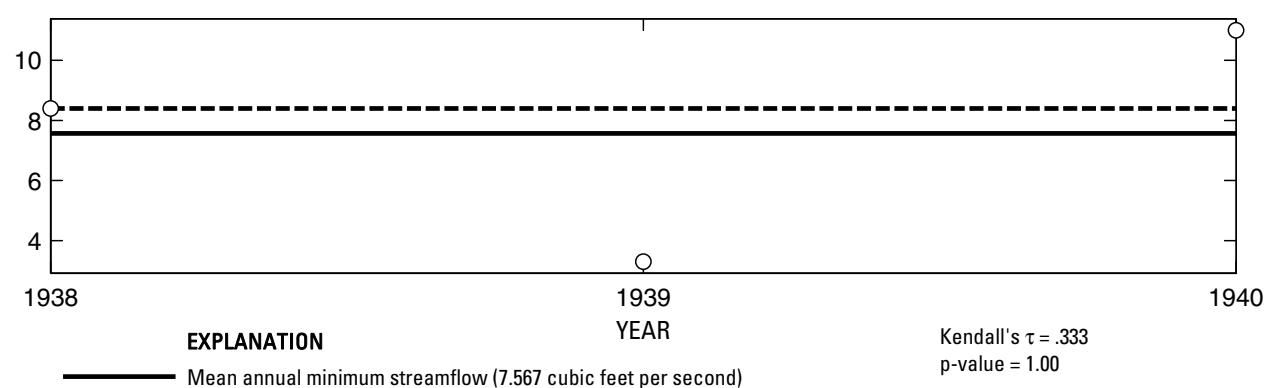

- ב-_- Median annual minimum streamflow (8.4 cubic feet per second)

O Annual minimum streamflow

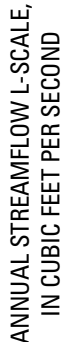

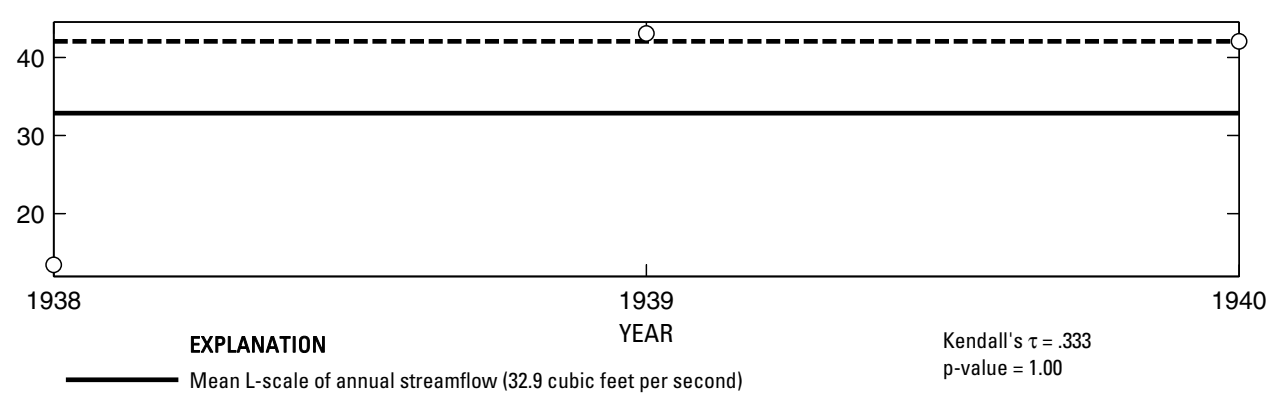

- - - - Median L-scale of annual streamflow (42.1 cubic feet per second)

O Annual L-scale of streamflow

Figure 132. Analysis of annual mean, maximum, minimum, and L-scale statistics of daily mean streamflow for U.S. Geological Survey streamflow-gaging station 08037500 Arenoso Creek near San Augustine, Texas.

Index of Station Numbers 719 


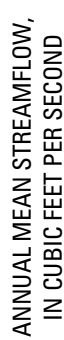

U.S. Geological Survey streamflow-gaging station 08038000

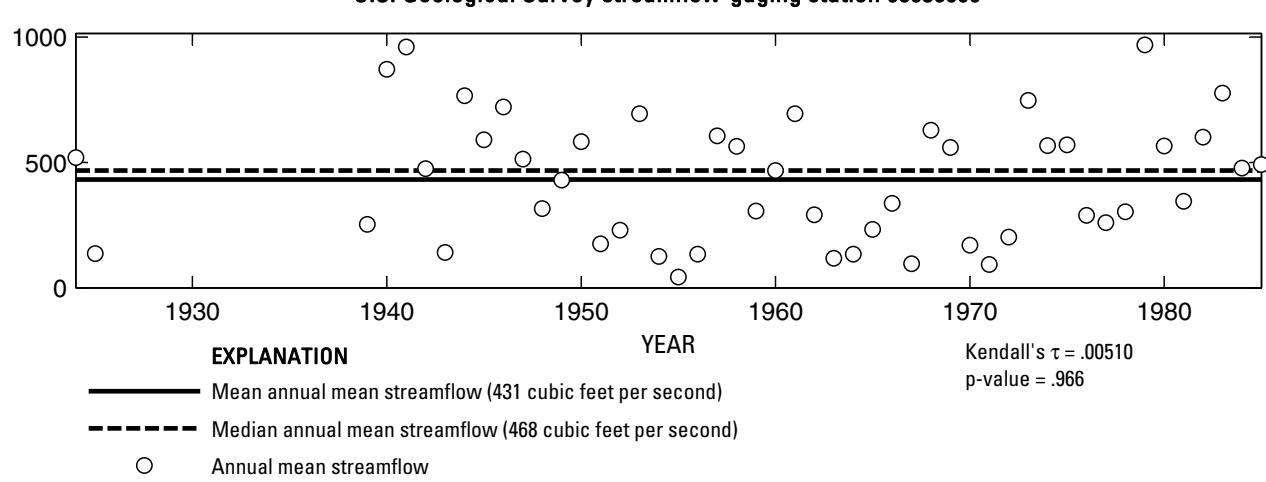

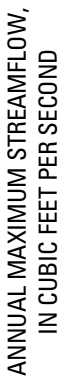
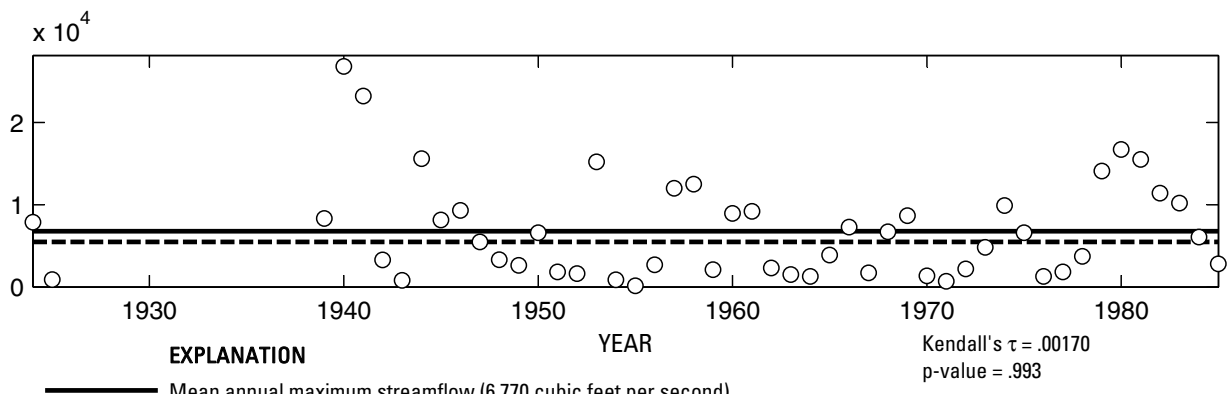

O Annual maximum streamflow

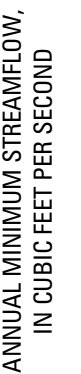

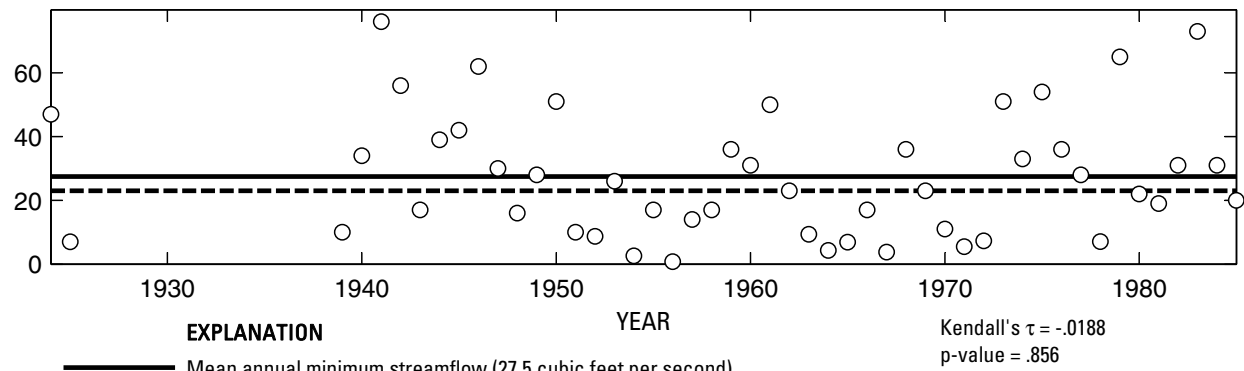

- ב-ב Median annual minimum streamflow (23 cubic feet per second)

O Annual minimum streamflow

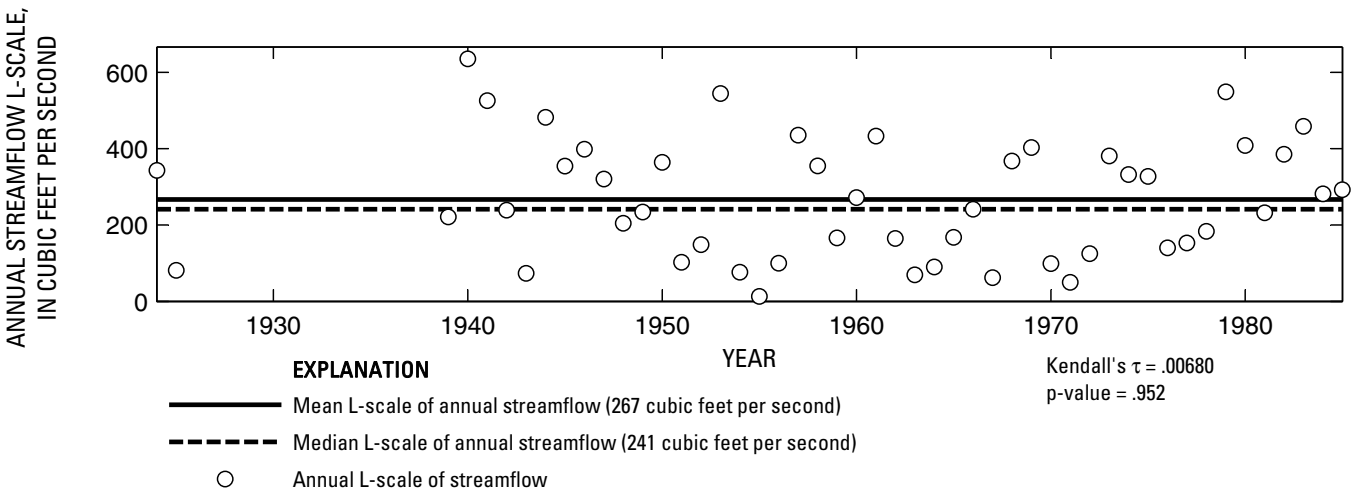

Figure 133. Analysis of annual mean, maximum, minimum, and L-scale statistics of daily mean streamflow for U.S. Geological Survey streamflow-gaging station 08038000 Attoyac Bayou near Chireno, Texas. 


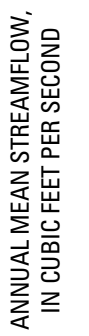

U.S. Geological Survey streamflow-gaging station 08038500

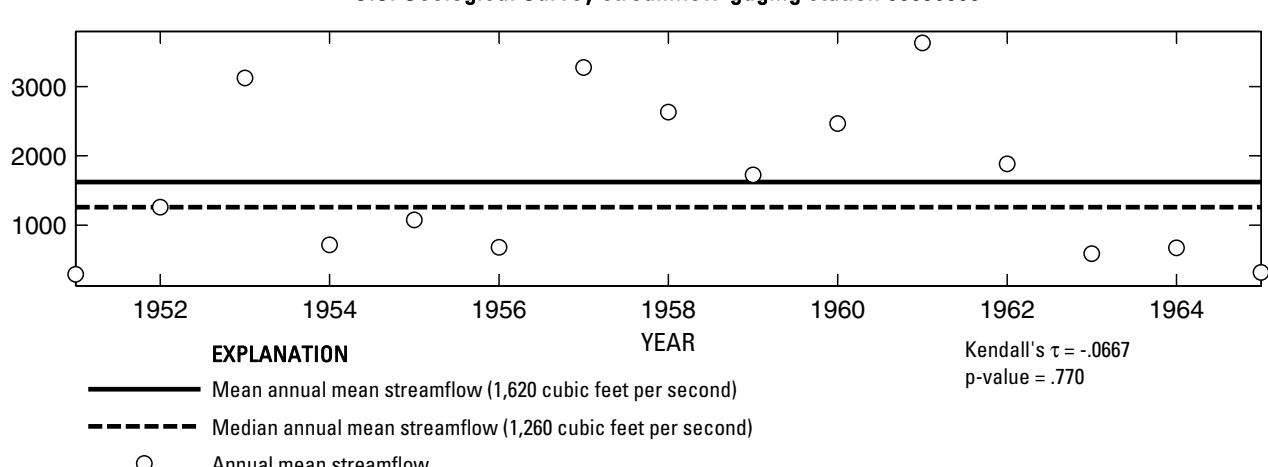

Annual mean streamflow

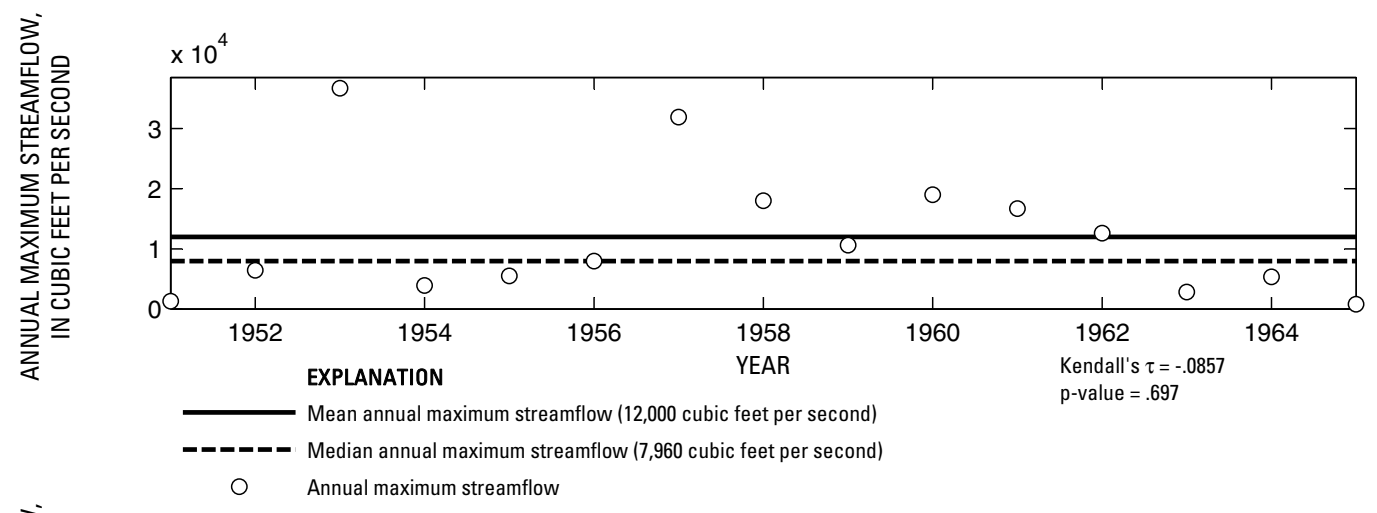

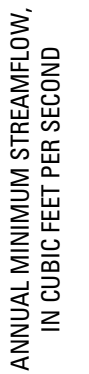

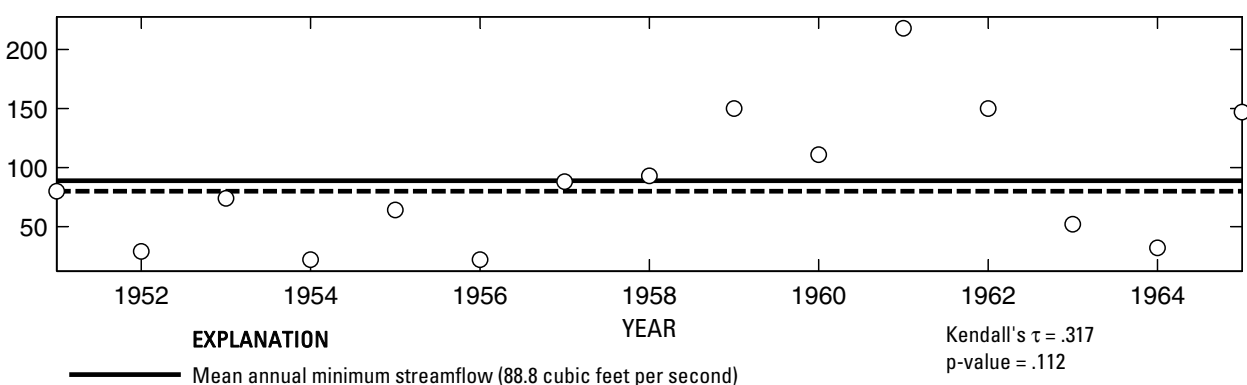

- Median annual minimum streamflow (80 cubic feet per second)

O Annual minimum streamflow

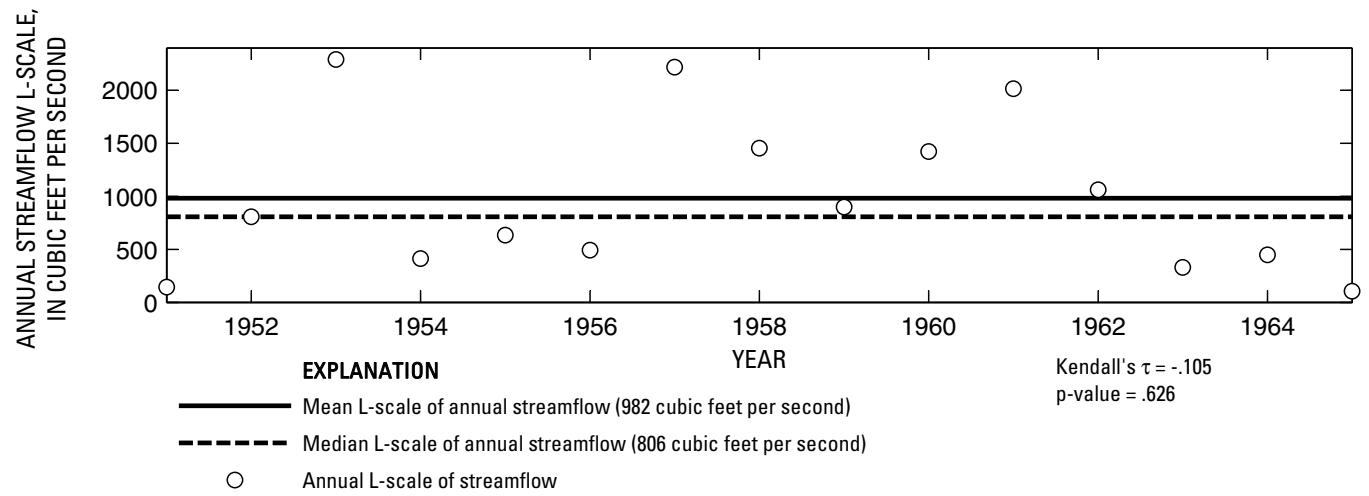

Figure 134. Analysis of annual mean, maximum, minimum, and L-scale statistics of daily mean streamflow for U.S. Geological Survey streamflow-gaging station 08038500 Angelina River near Zavalla, Texas.

Index of Station Numbers 719 

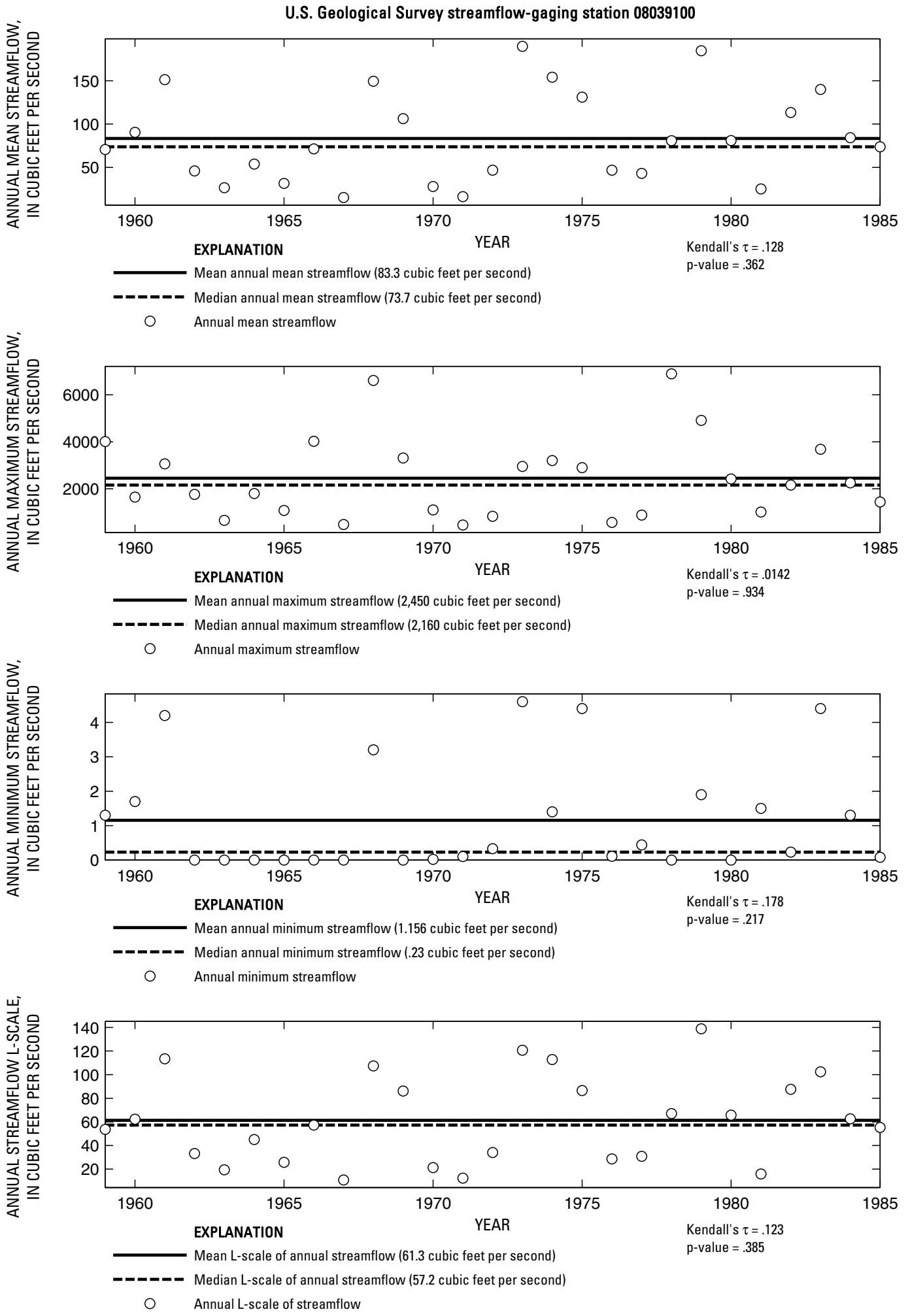

Figure 135. Analysis of annual mean, maximum, minimum, and L-scale statistics of daily mean streamflow for U.S. Geological Survey streamflow-gaging station 08039100 Ayish Bayou near San Augustine, Texas. 
U.S. Geological Survey streamflow-gaging station 08039500
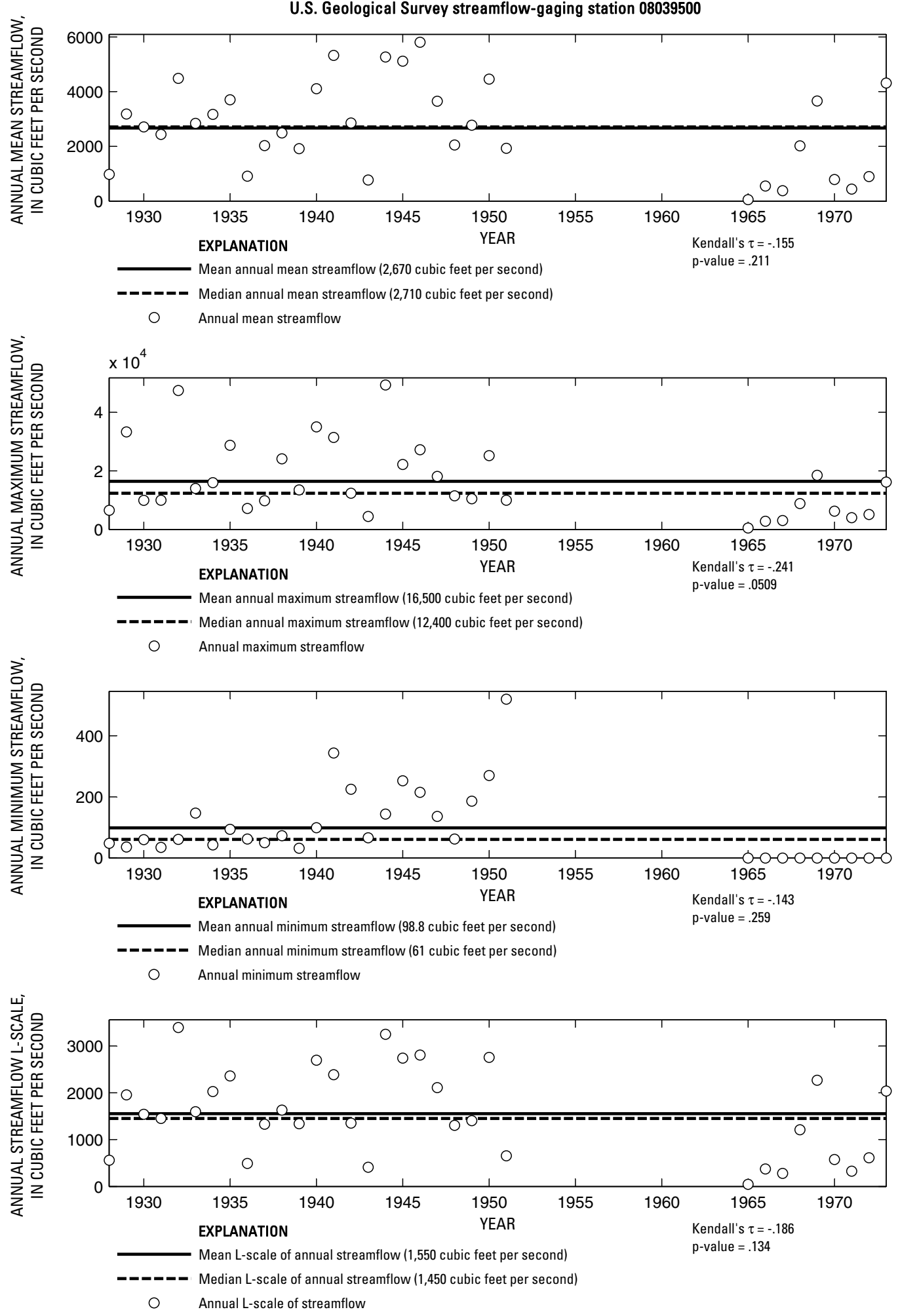

Figure 136. Analysis of annual mean, maximum, minimum, and L-scale statistics of daily mean streamflow for U.S. Geological Survey streamflow-gaging station 08039500 Angelina River near Ebenezer, Texas.

Index of Station Numbers 719 

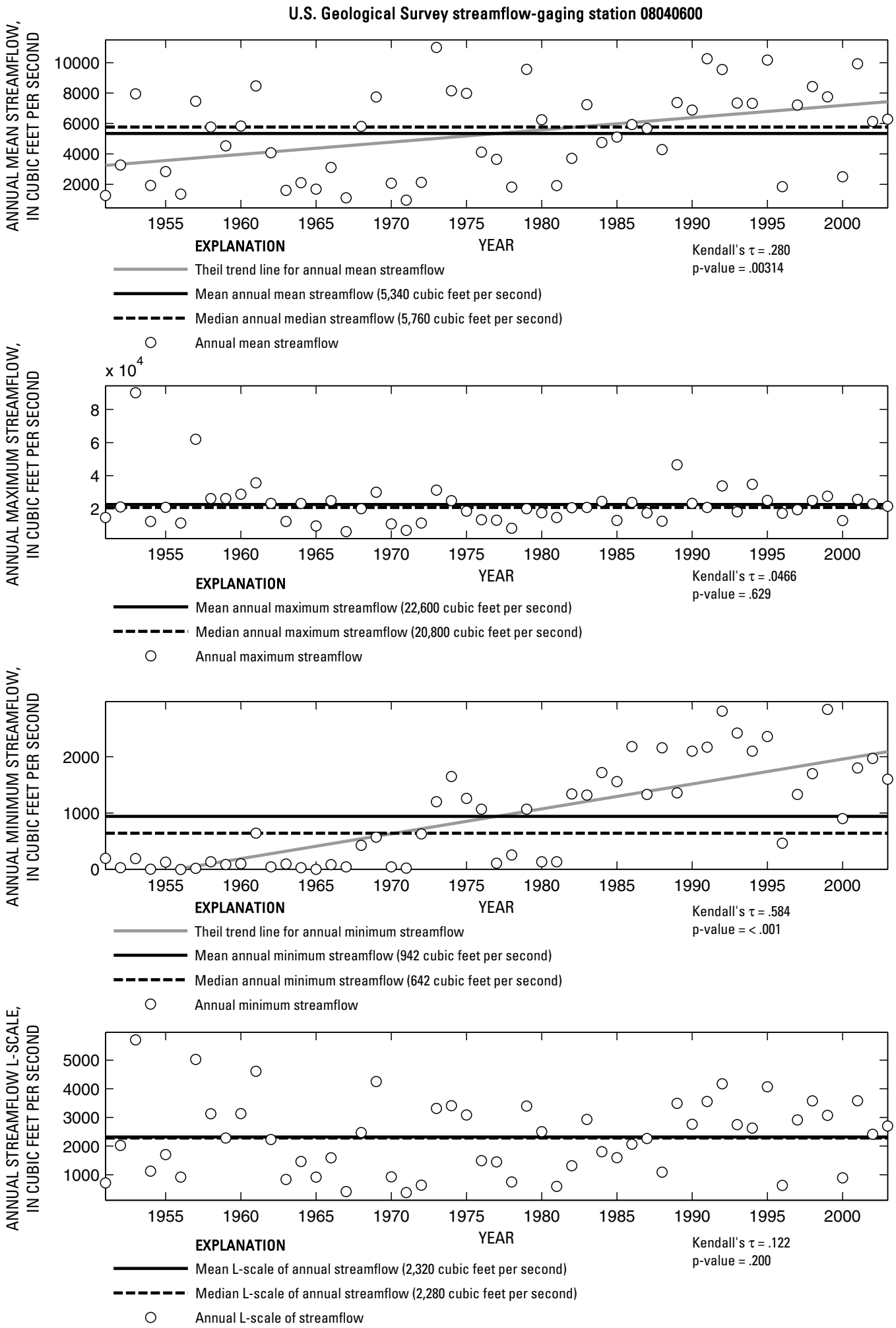

Figure 137. Analysis of annual mean, maximum, minimum, and L-scale statistics of daily mean streamflow for U.S. Geological Survey streamflow-gaging station 08040600 Neches River near Town Bluff, Texas. 

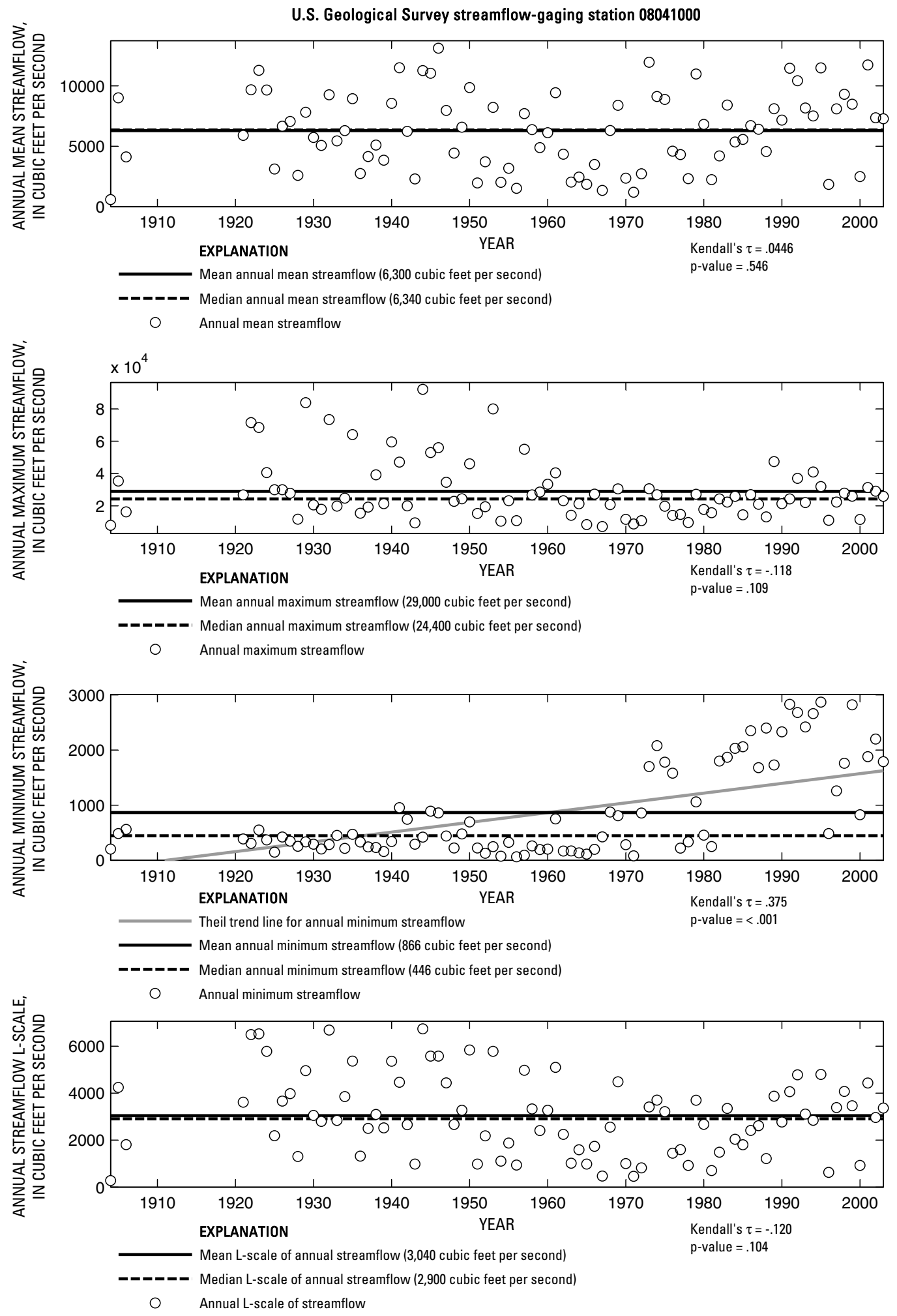

Figure 138. Analysis of annual mean, maximum, minimum, and L-scale statistics of daily mean streamflow for U.S. Geological Survey streamflow-gaging station 08041000 Neches River at Evadale, Texas.

Index of Station Numbers 719 


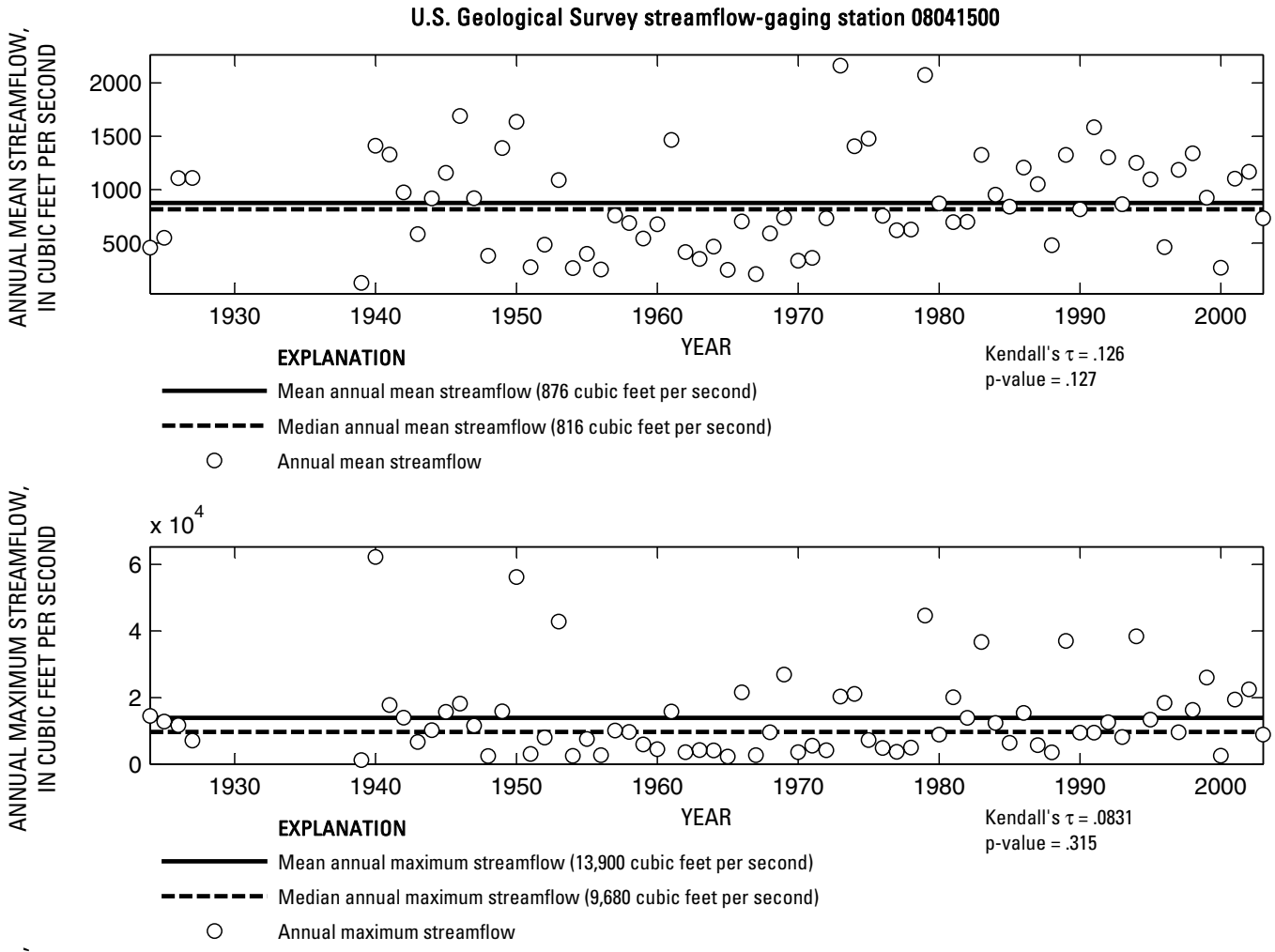

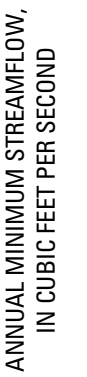

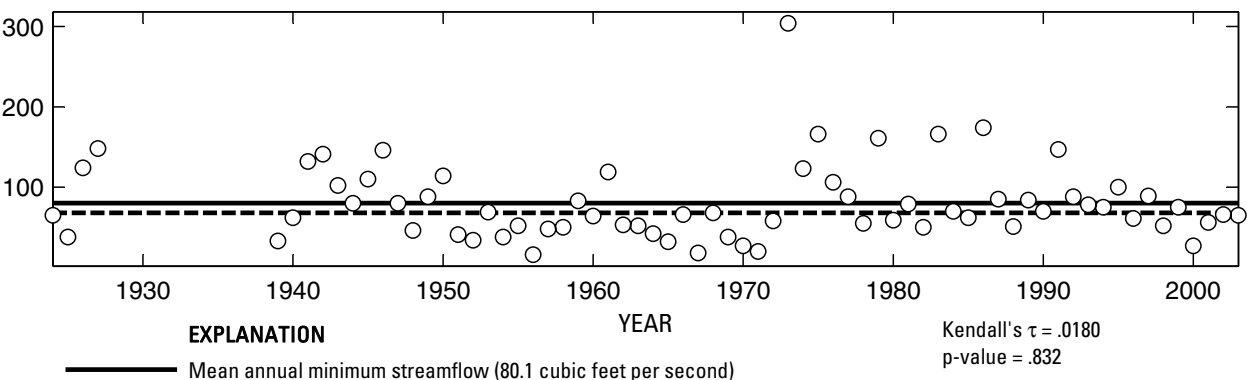

-_-_- Median annual minimum streamflow (68 cubic feet per second)

○ Annual minimum streamflow

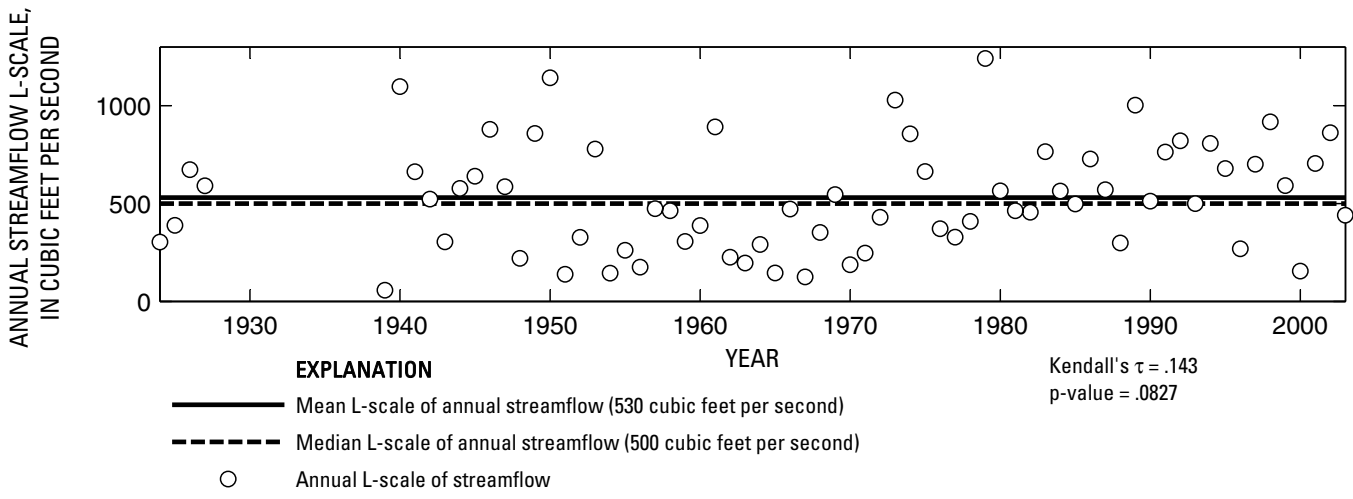

Figure 139. Analysis of annual mean, maximum, minimum, and L-scale statistics of daily mean streamflow for U.S. Geological Survey streamflow-gaging station 08041500 Village Creek near Kountze, Texas. 

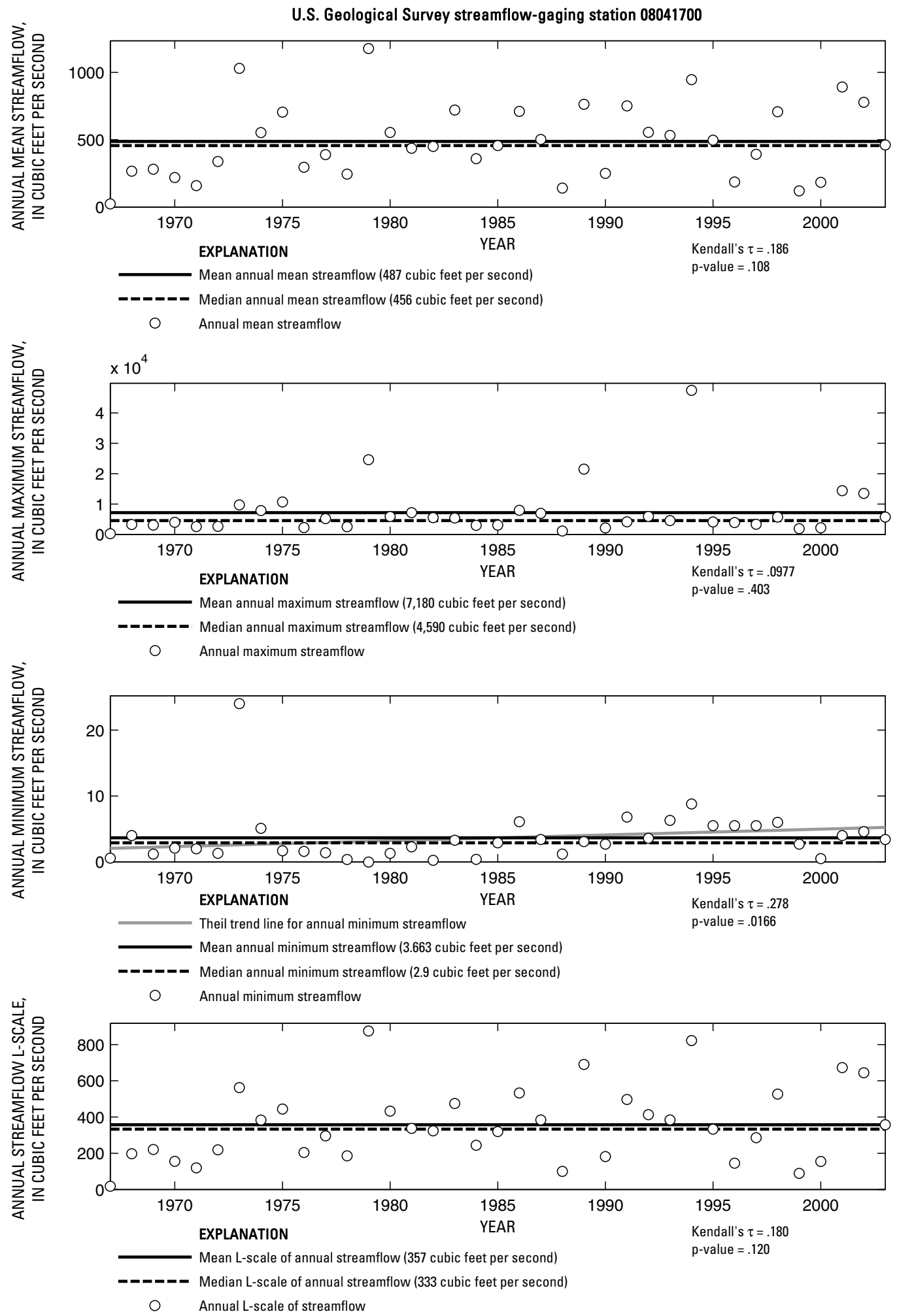

Figure 140. Analysis of annual mean, maximum, minimum, and L-scale statistics of daily mean streamflow for U.S. Geological Survey streamflow-gaging station 08041700 Pine Island Bayou near Sour Lake, Texas.

Index of Station Numbers 719 


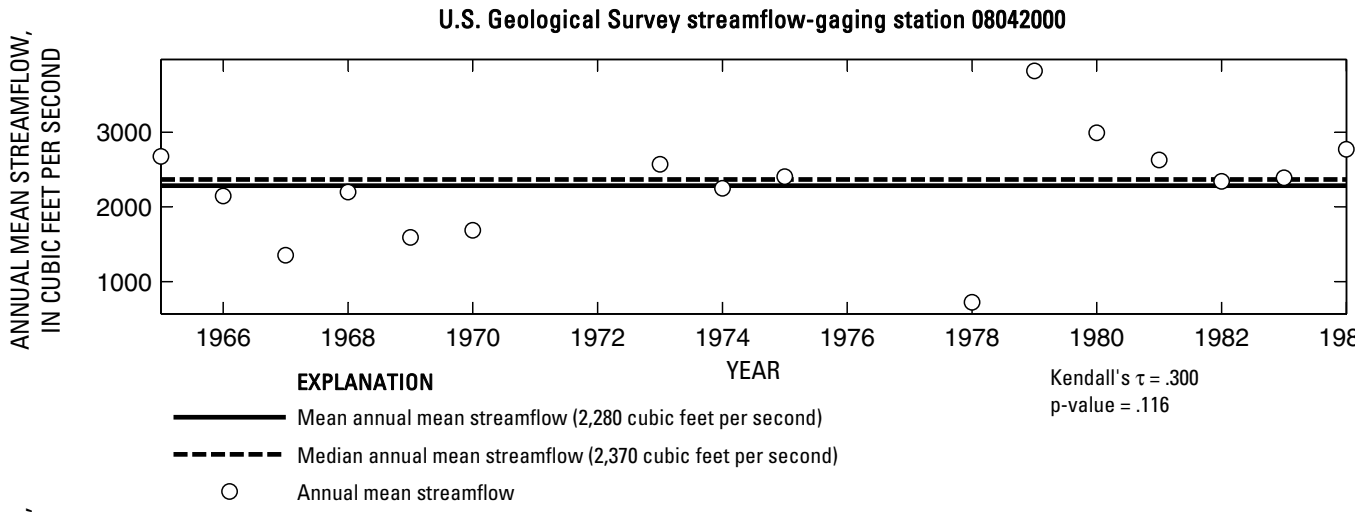

空

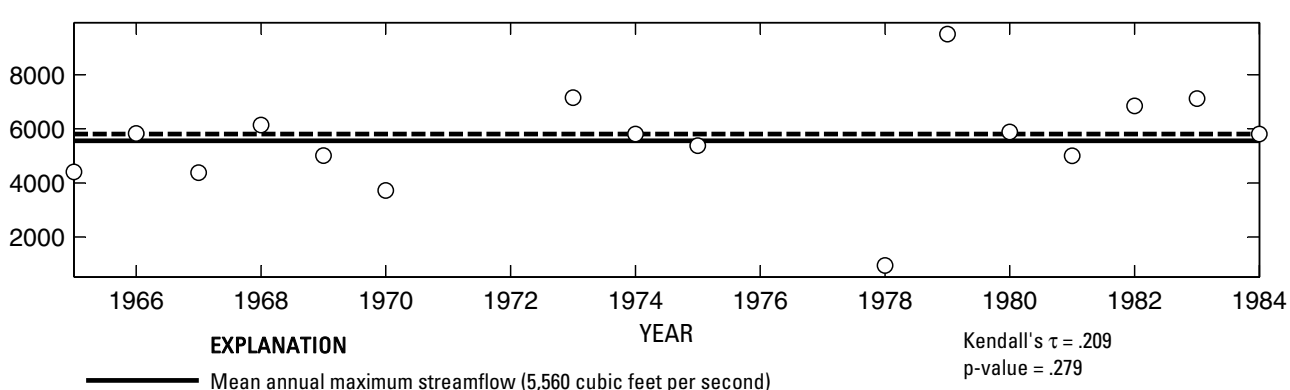

- - Median annual maximum streamflow (5,810 cubic feet per second)

O Annual maximum streamflow

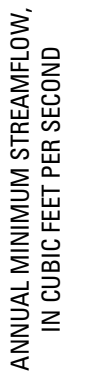

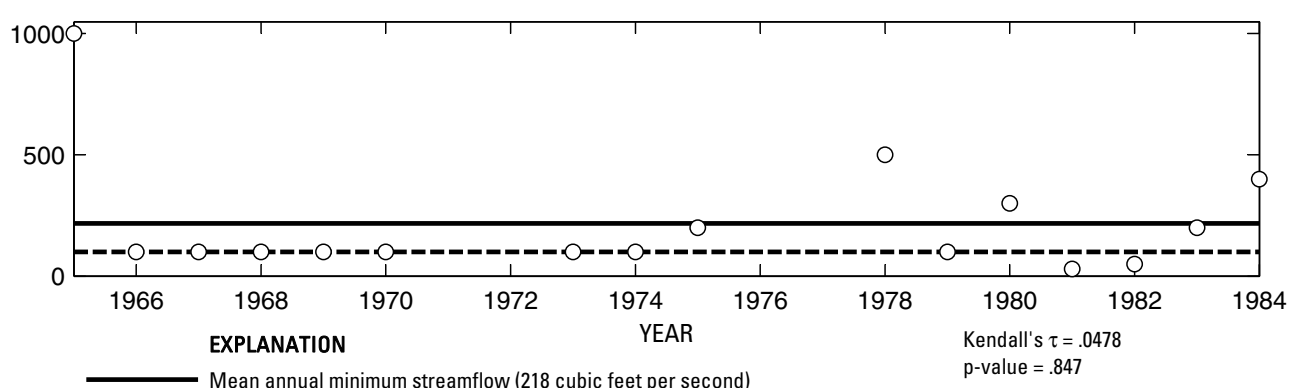

- - - Median annual minimum streamflow (100 cubic feet per second)

O Annual minimum streamflow

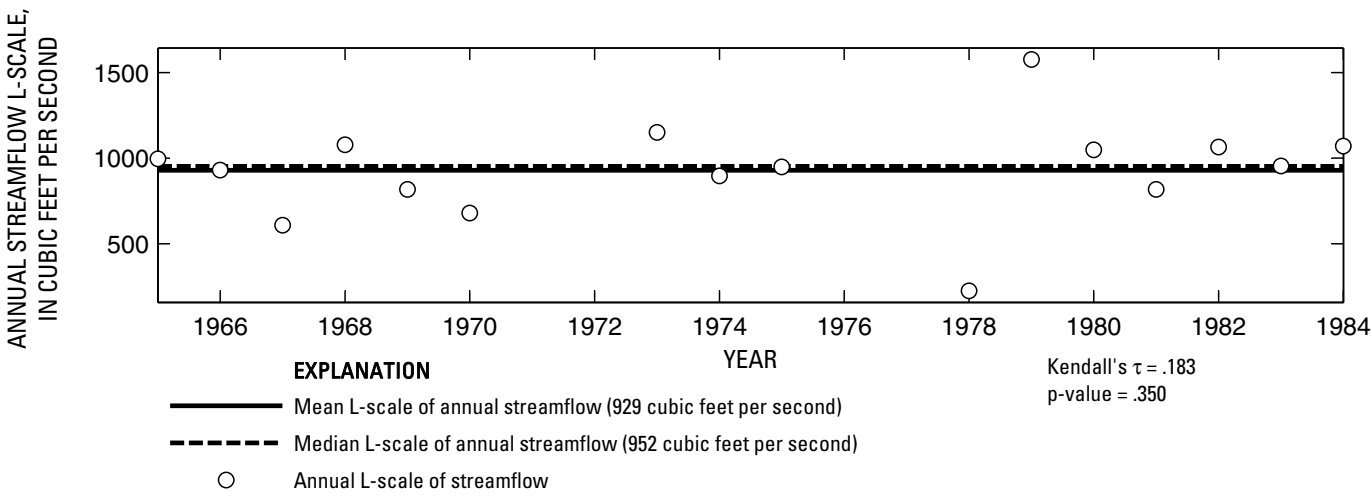

Figure 141. Analysis of annual mean, maximum, minimum, and L-scale statistics of daily mean streamflow for U.S. Geological Survey streamflow-gaging station 08042000 Taylor Bayou near LaBelle, Texas. 
U.S. Geological Survey streamflow-gaging station 08042500
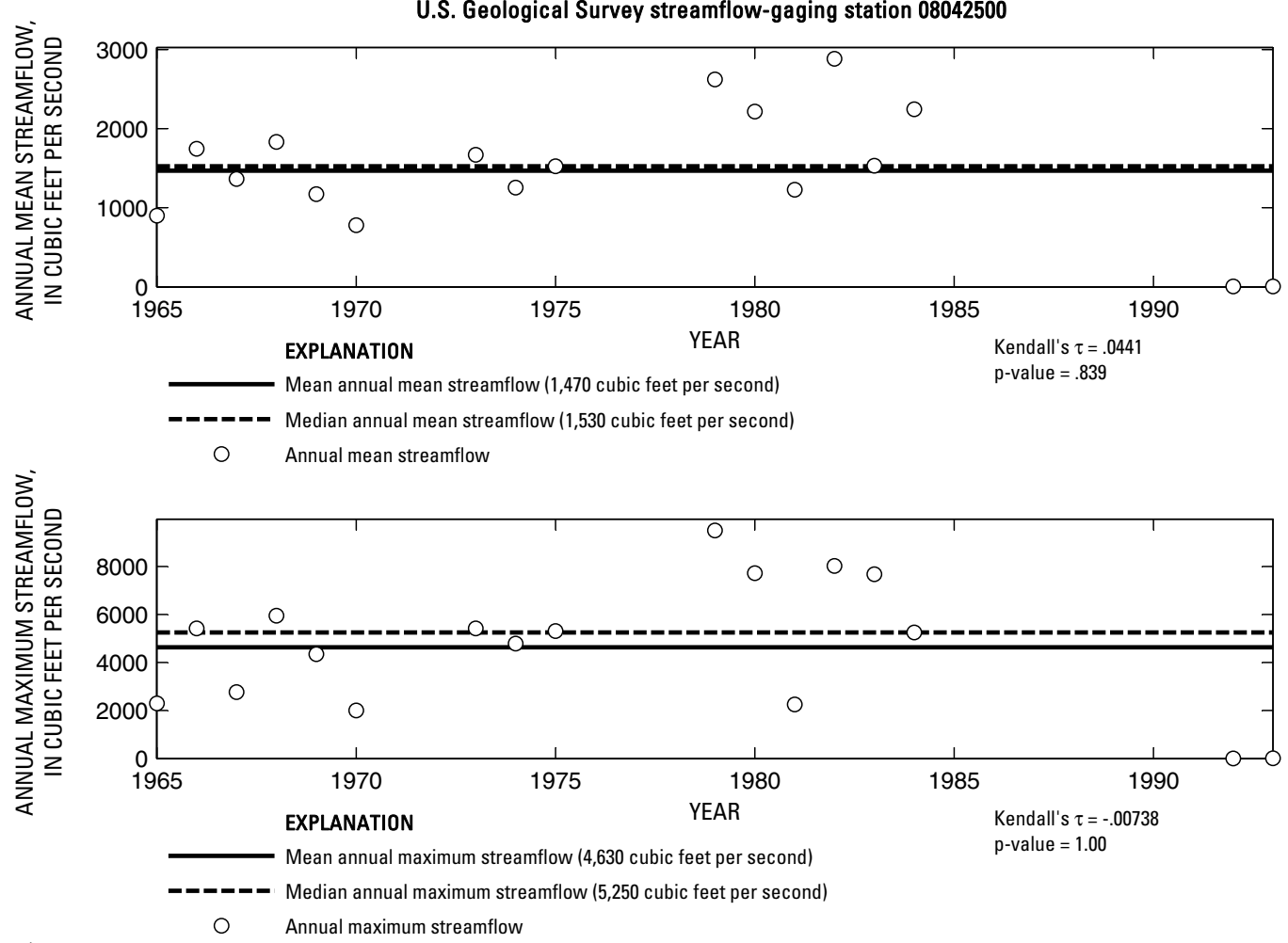

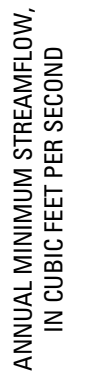
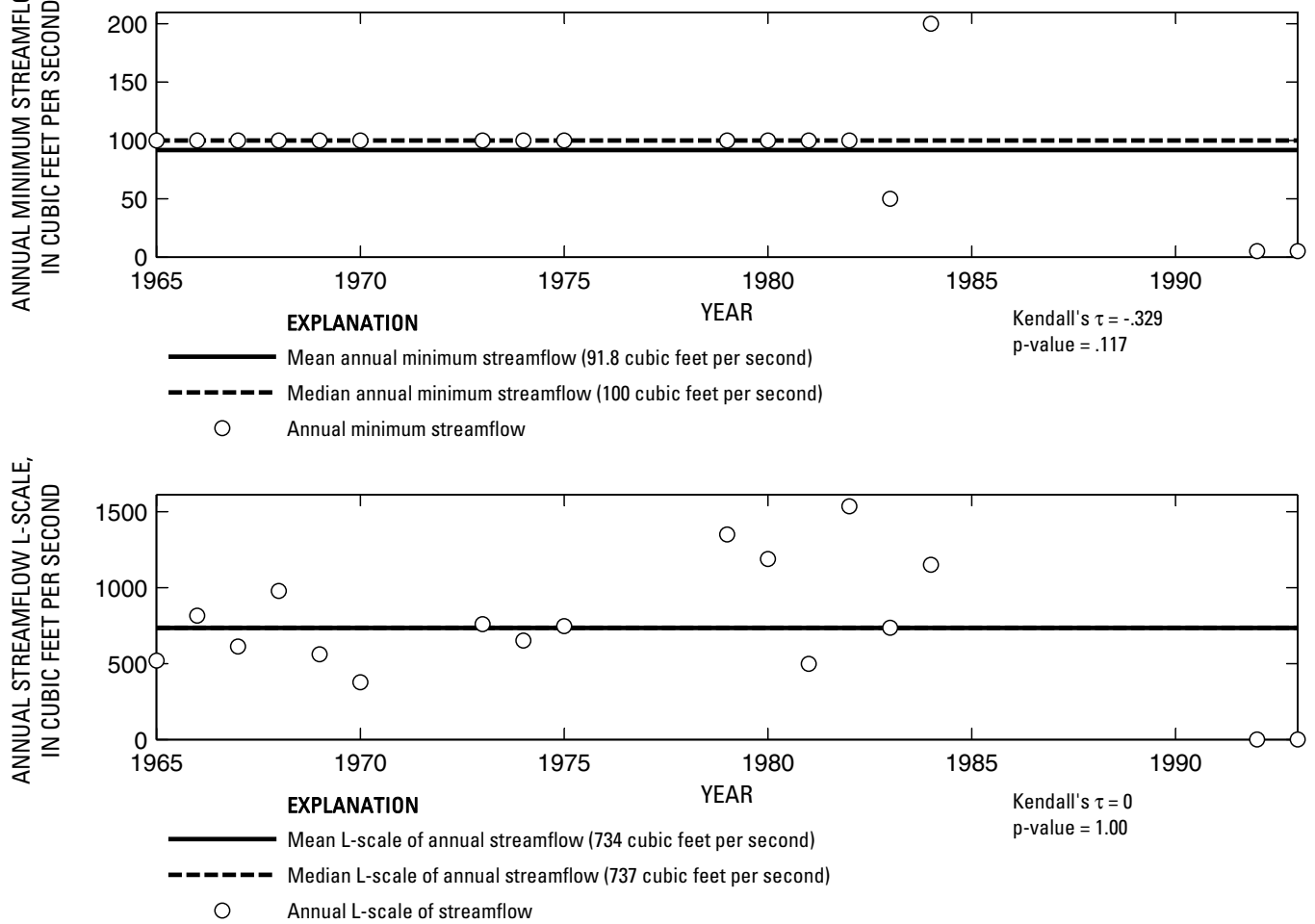

Figure 142. Analysis of annual mean, maximum, minimum, and L-scale statistics of daily mean streamflow for U.S. Geological Survey streamflow-gaging station 08042500 Hillebrandt Bayou near Lovell Lake, Texas.

Index of Station Numbers 719 


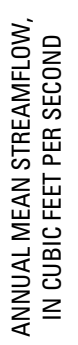

U.S. Geological Survey streamflow-gaging station 08042700

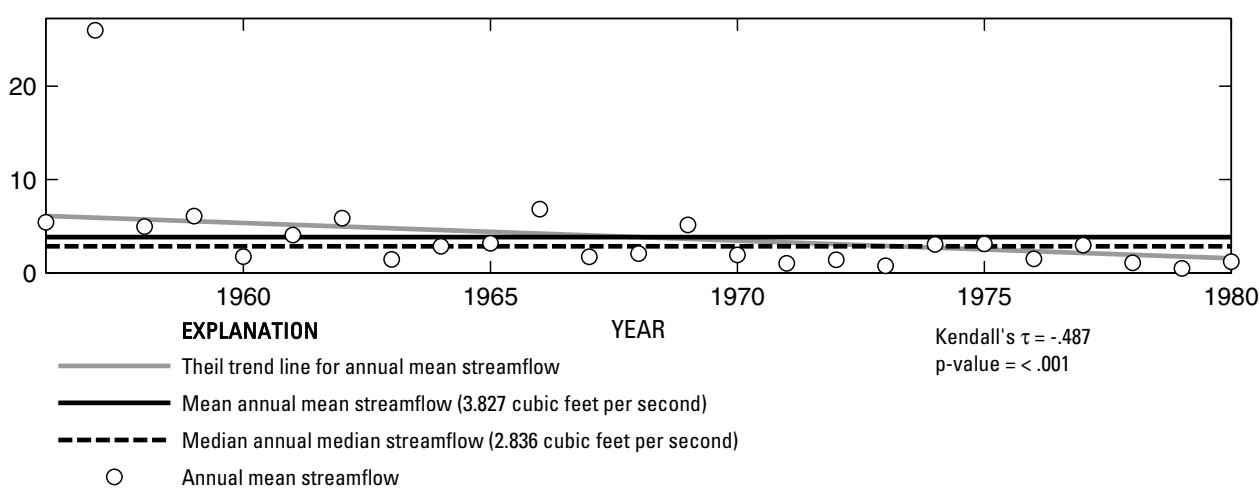

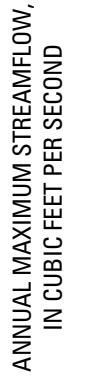

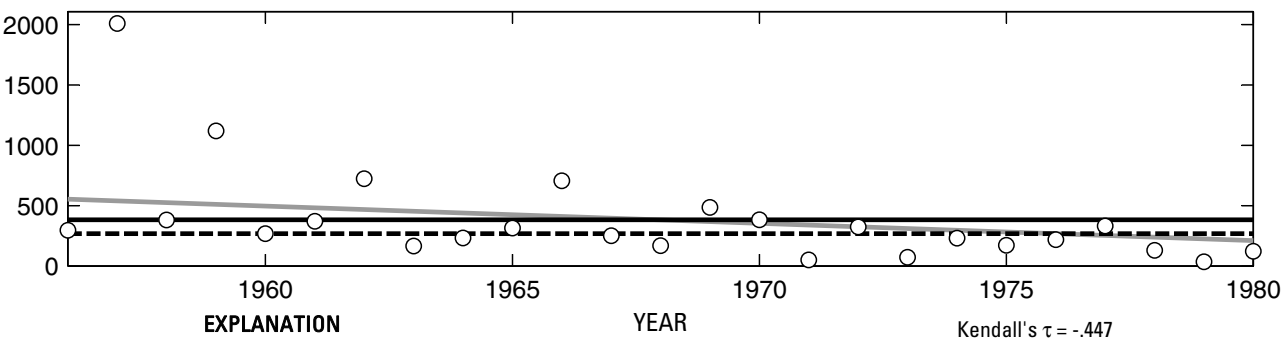

Theil trend line for annual maximum streamflow

Mean annual maximum streamflow (383 cubic feet per second)

ローーーーー Median annual maximum streamflow (268 cubic feet per second)

O Annual maximum streamflow
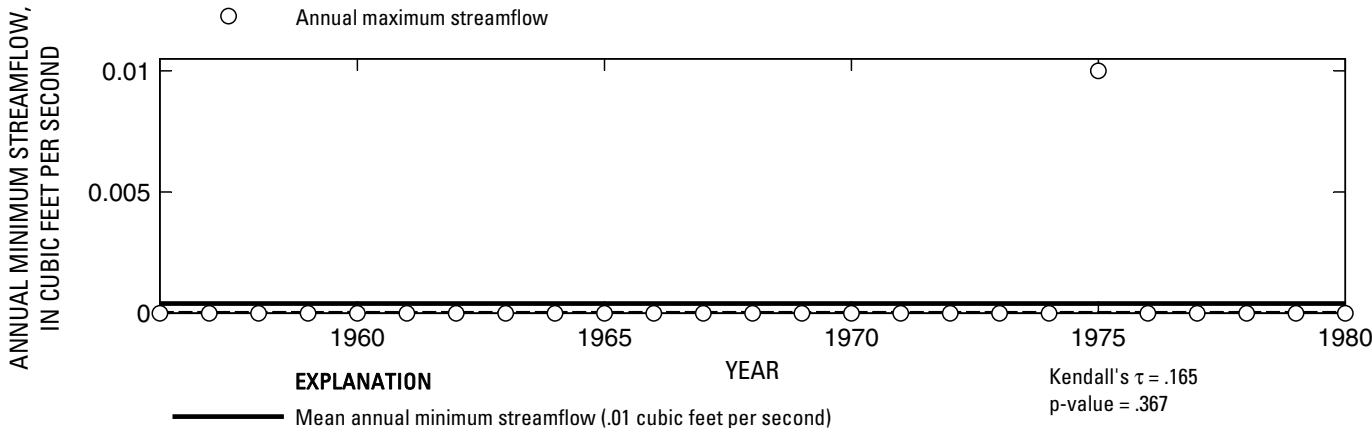

- ב- Median annual minimum streamflow (0 cubic feet per second)

O Annual minimum streamflow

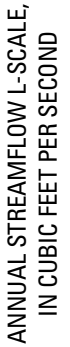

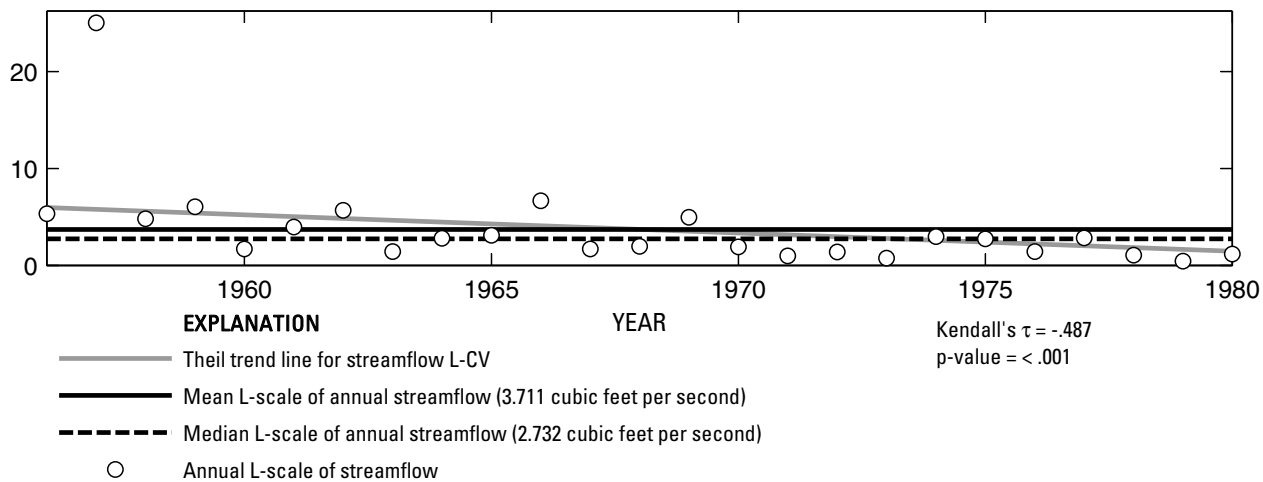

Figure 143. Analysis of annual mean, maximum, minimum, and L-scale statistics of daily mean streamflow for U.S. Geological Survey streamflow-gaging station 08042700 North Creek near Jacksboro, Texas. 
U.S. Geological Survey streamflow-gaging station 08042800
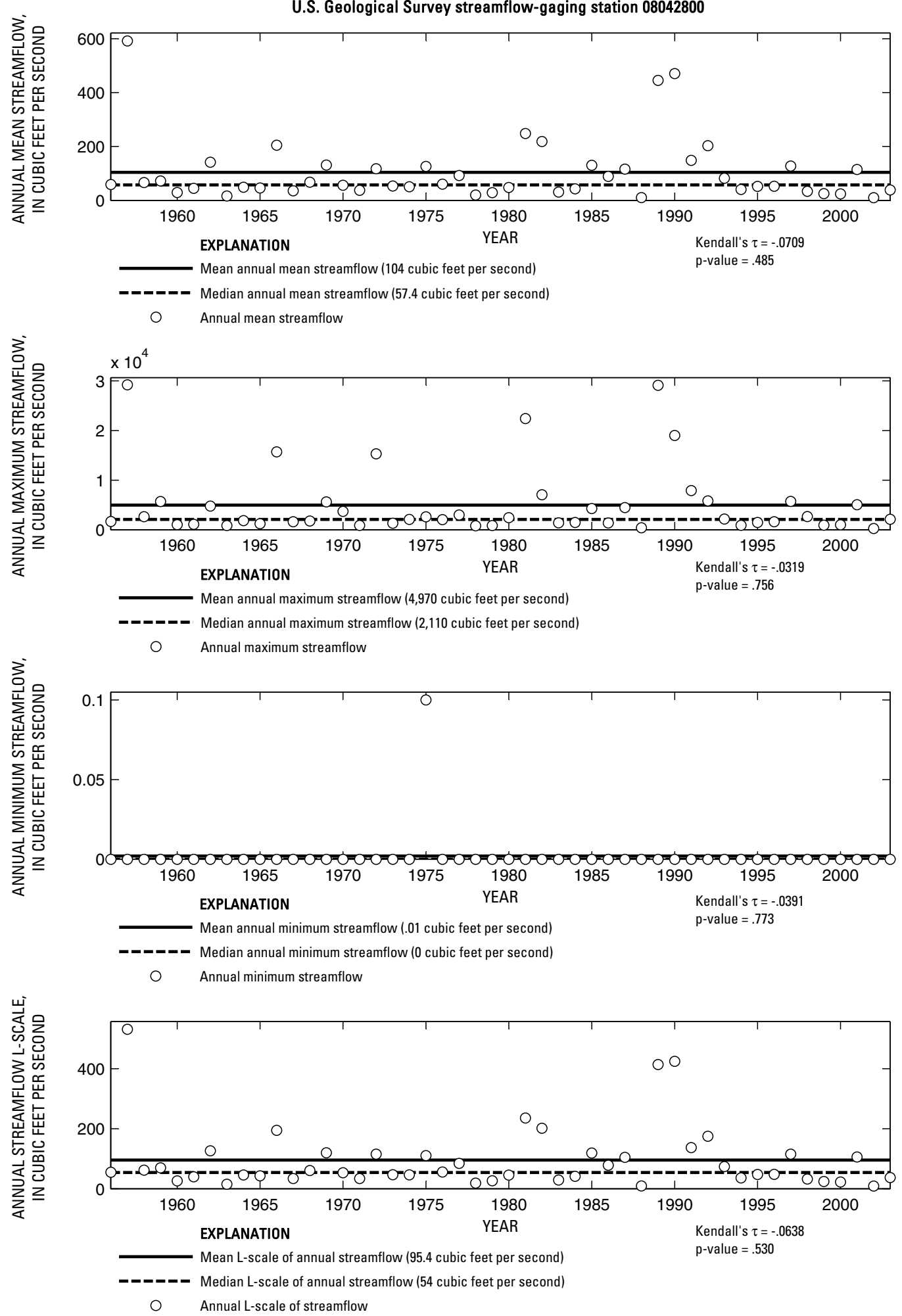

Figure 144. Analysis of annual mean, maximum, minimum, and L-scale statistics of daily mean streamflow for U.S. Geological Survey streamflow-gaging station 08042800 West Fork Trinity River near Jacksboro, Texas.

Index of Station Numbers 719 

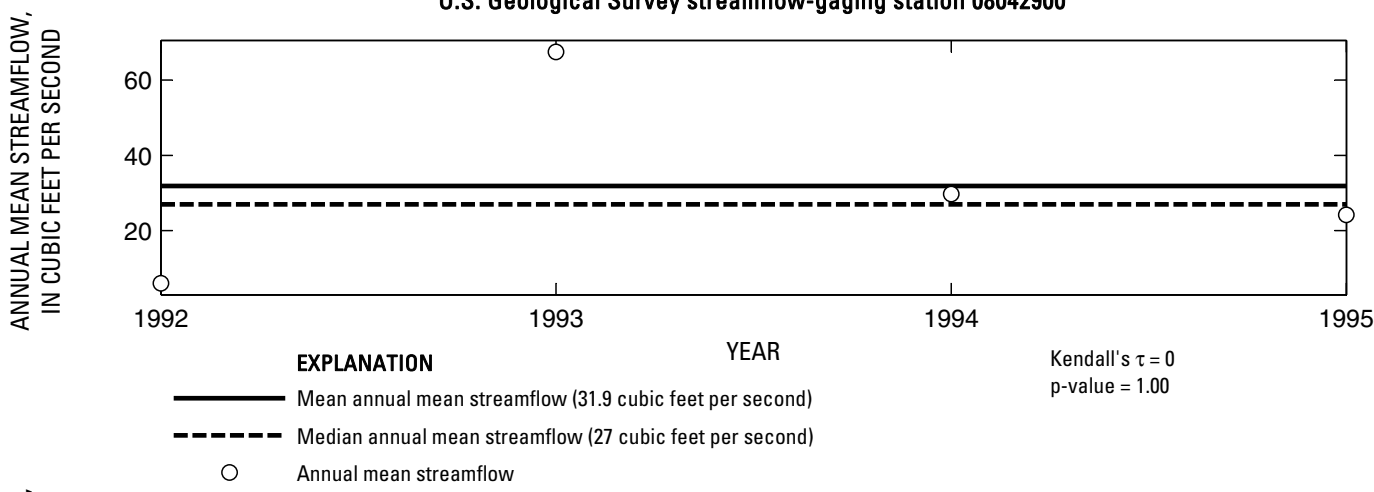

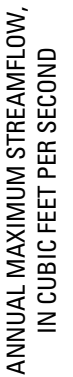
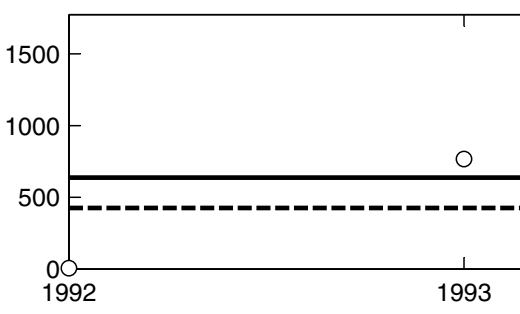

EXPLANATION

YEAR

p-value

- - - Median annual maximum streamflow (426 cubic feet per second)

Annual maximum streamflow
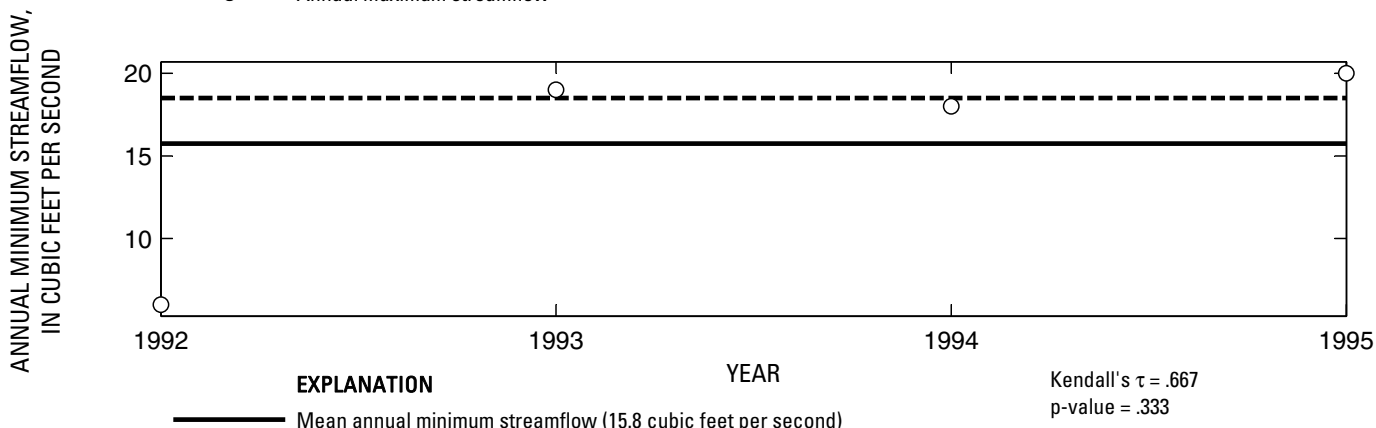

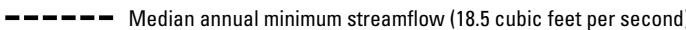

O Annual minimum streamflow
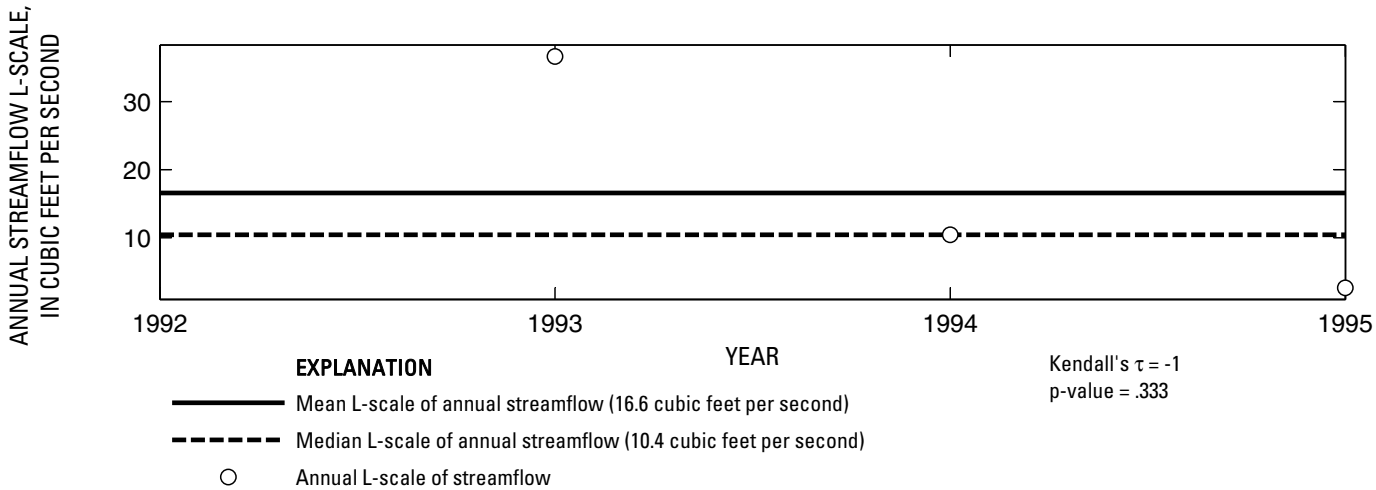

Figure 145. Analysis of annual mean, maximum, minimum, and L-scale statistics of daily mean streamflow for U.S. Geological Survey streamflow-gaging station 08042900 Beans Creek at Wizard Wells, Texas. 
U.S. Geological Survey streamflow-gaging station 08043500

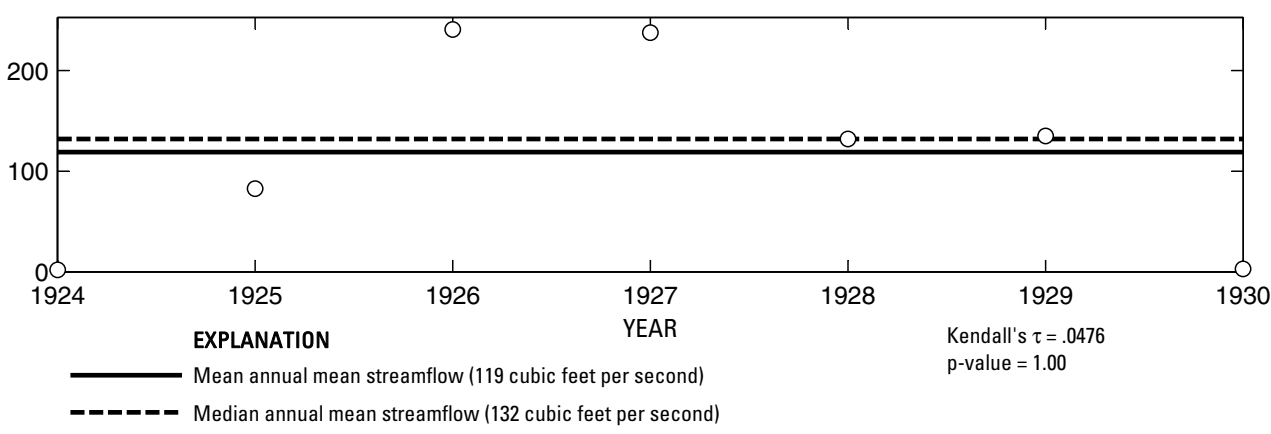

O Annual mean streamflow

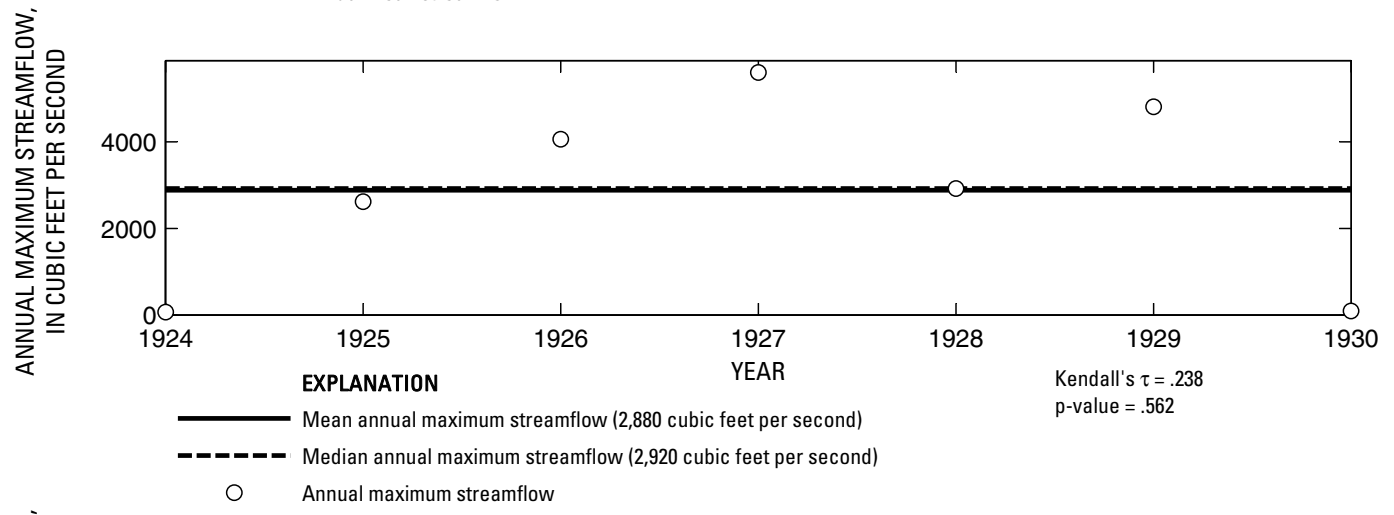

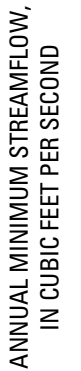

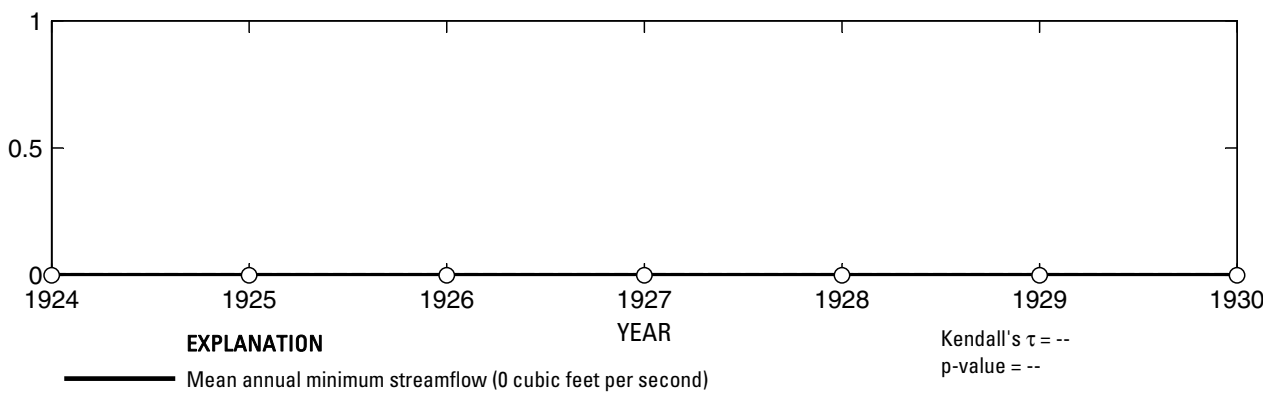

- - - Median annual minimum streamflow (0 cubic feet per second)

Annual minimum streamflow

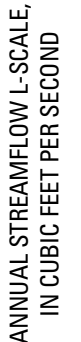

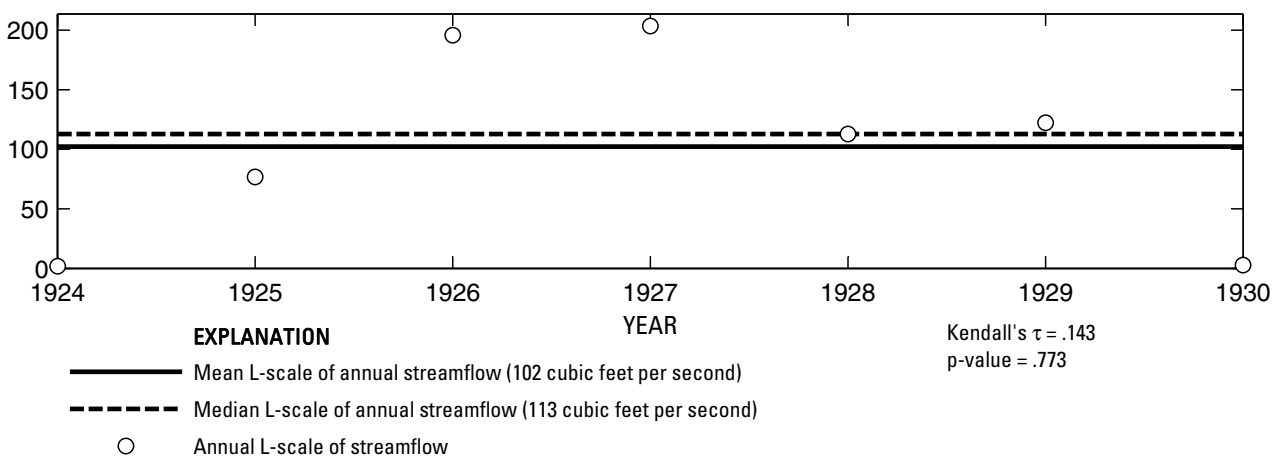

Figure 146. Analysis of annual mean, maximum, minimum, and L-scale statistics of daily mean streamflow for U.S. Geological Survey streamflow-gaging station 08043500 West Fork Trinity River at Bridgeport, Texas.

Index of Station Numbers 719 

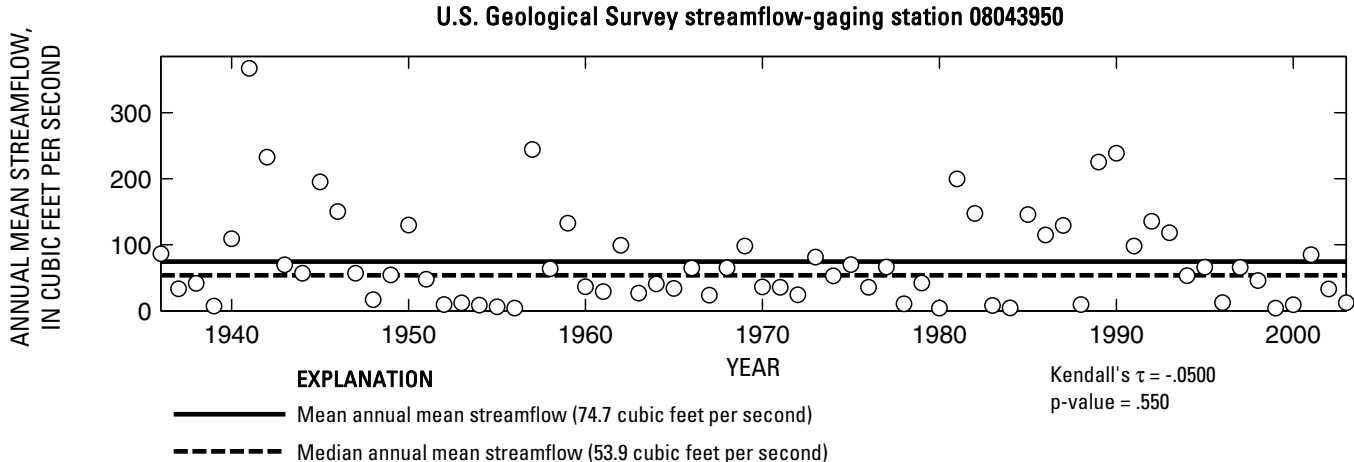

O Annual mean streamflow

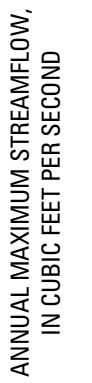

$\times 10^{4}$

○

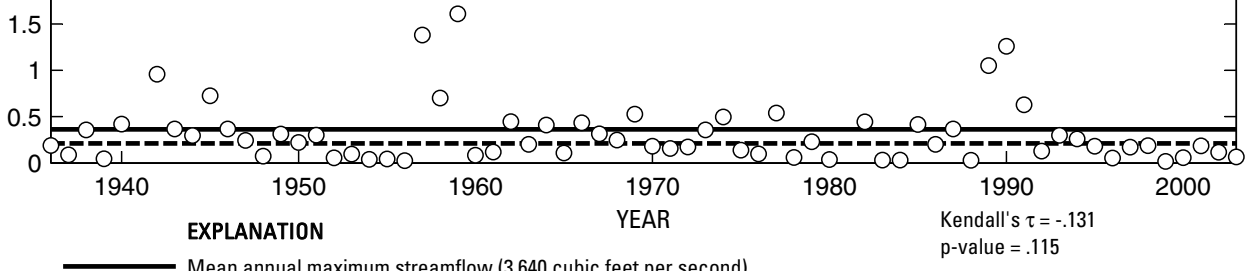

O Annual maximum streamflow

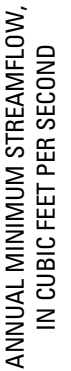

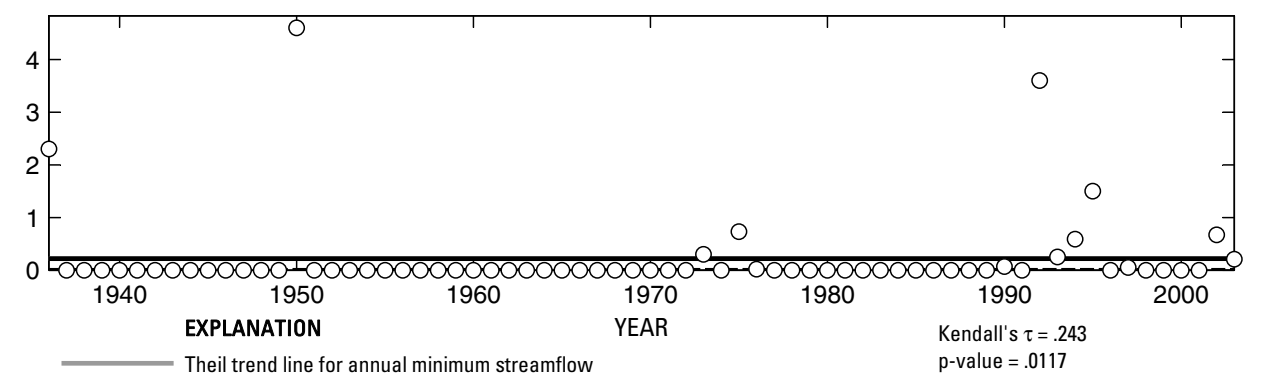

Theil trend line for annual minimum streamflow

$\mathrm{p}$-value $=.0117$

Median annual minimum streamflow (0 cubic feet per second)

Annual minimum streamflow
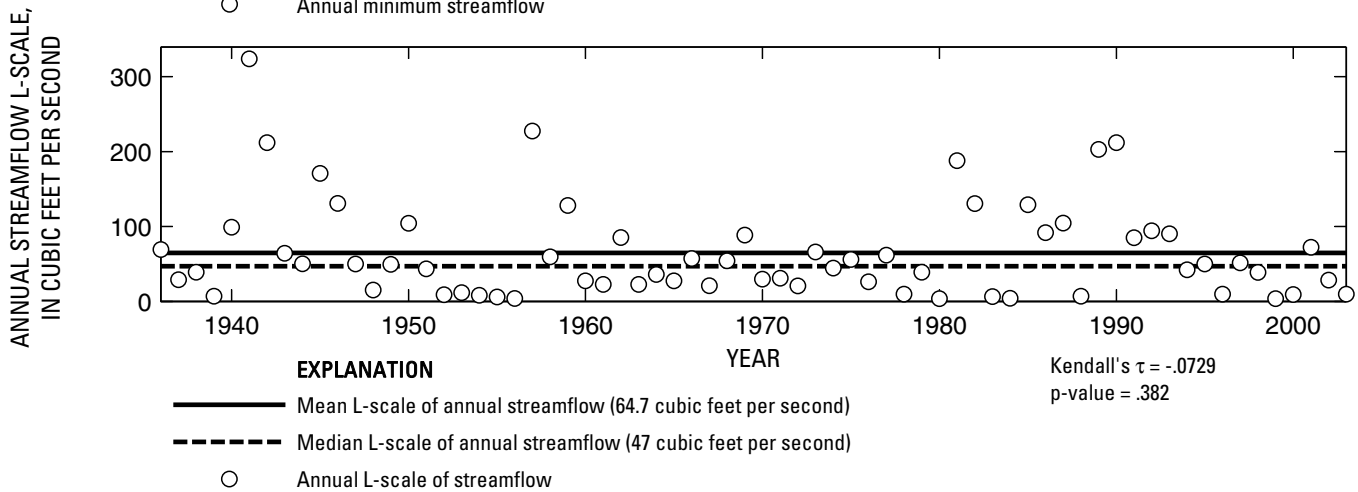

Figure 147. Analysis of annual mean, maximum, minimum, and L-scale statistics of daily mean streamflow for U.S. Geological Survey streamflow-gaging station 08043950 Big Sandy Creek near Chico, Texas. 

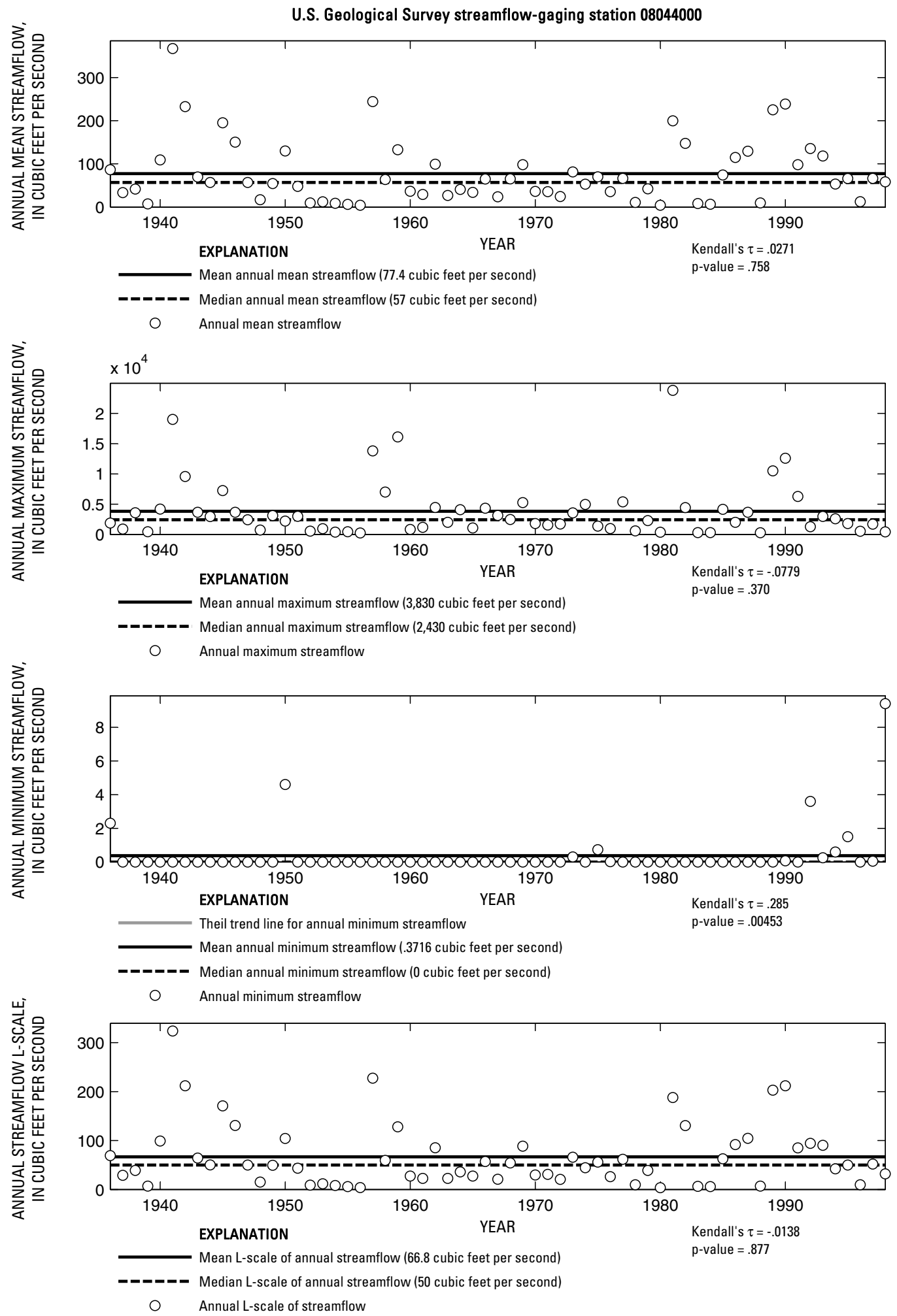

Figure 148. Analysis of annual mean, maximum, minimum, and L-scale statistics of daily mean streamflow for U.S. Geological Survey streamflow-gaging station 08044000 Big Sandy Creek near Bridgeport, Texas.

Index of Station Numbers 719 


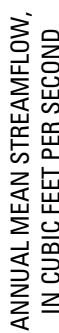

U.S. Geological Survey streamflow-gaging station 08044135

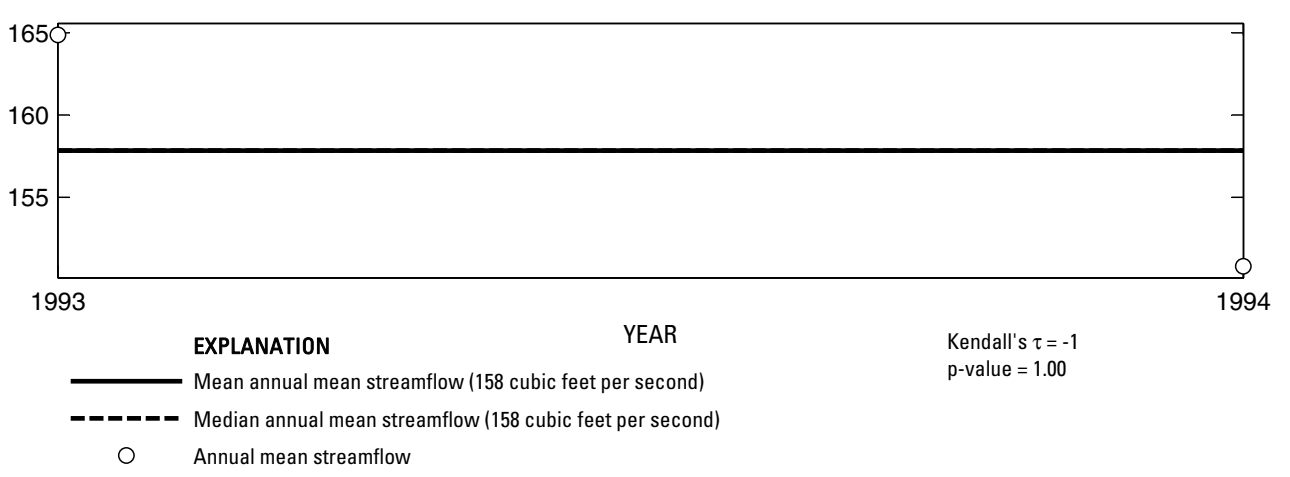

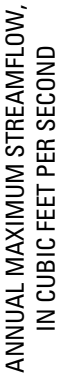

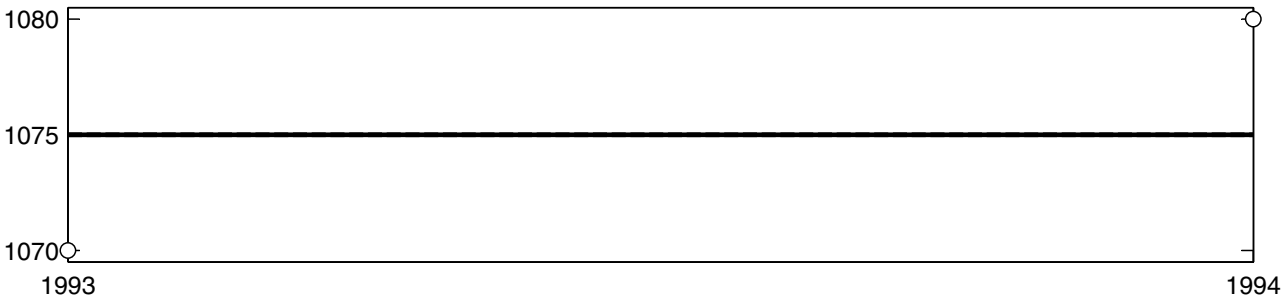

EXPLANATION $\quad$ YEAR Kendall's $\tau=1$

Mean annual maximum streamflow (1,080 cubic feet per second) $\quad$-value $=1.00$

--0-- Median annual maximum streamflow (1,080 cubic feet per second)

O Annual maximum streamflow

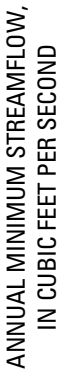

140
130
120
1993

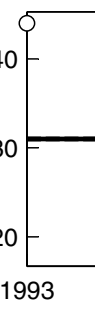

(n)

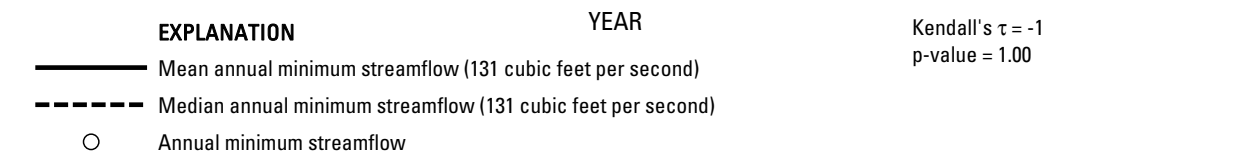

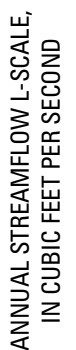

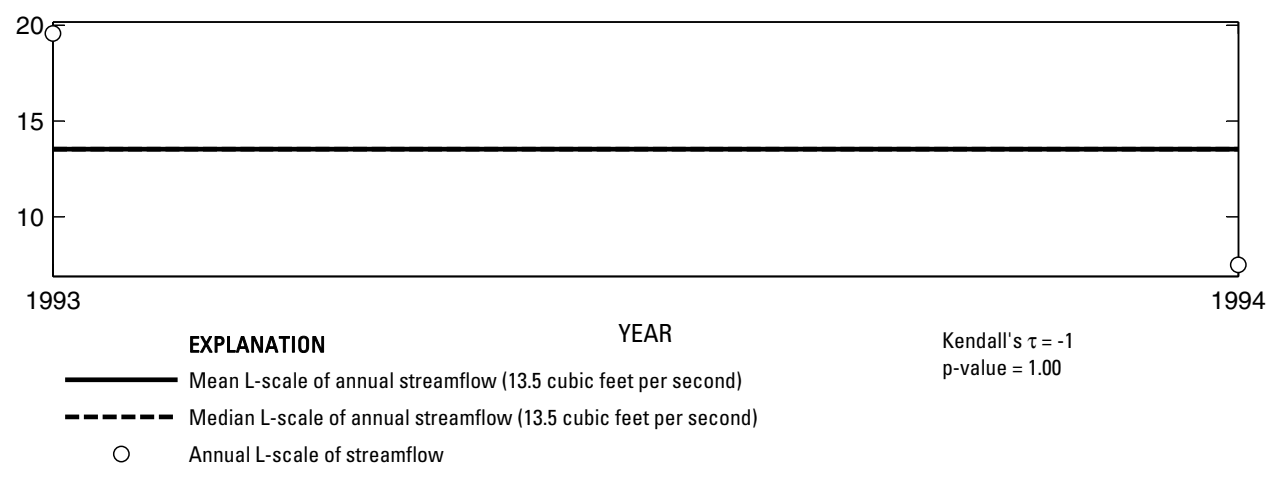

Figure 149. Analysis of annual mean, maximum, minimum, and L-scale statistics of daily mean streamflow for U.S. Geological Survey streamflow-gaging station 08044135 Garrett Creek near Paradise, Texas. 

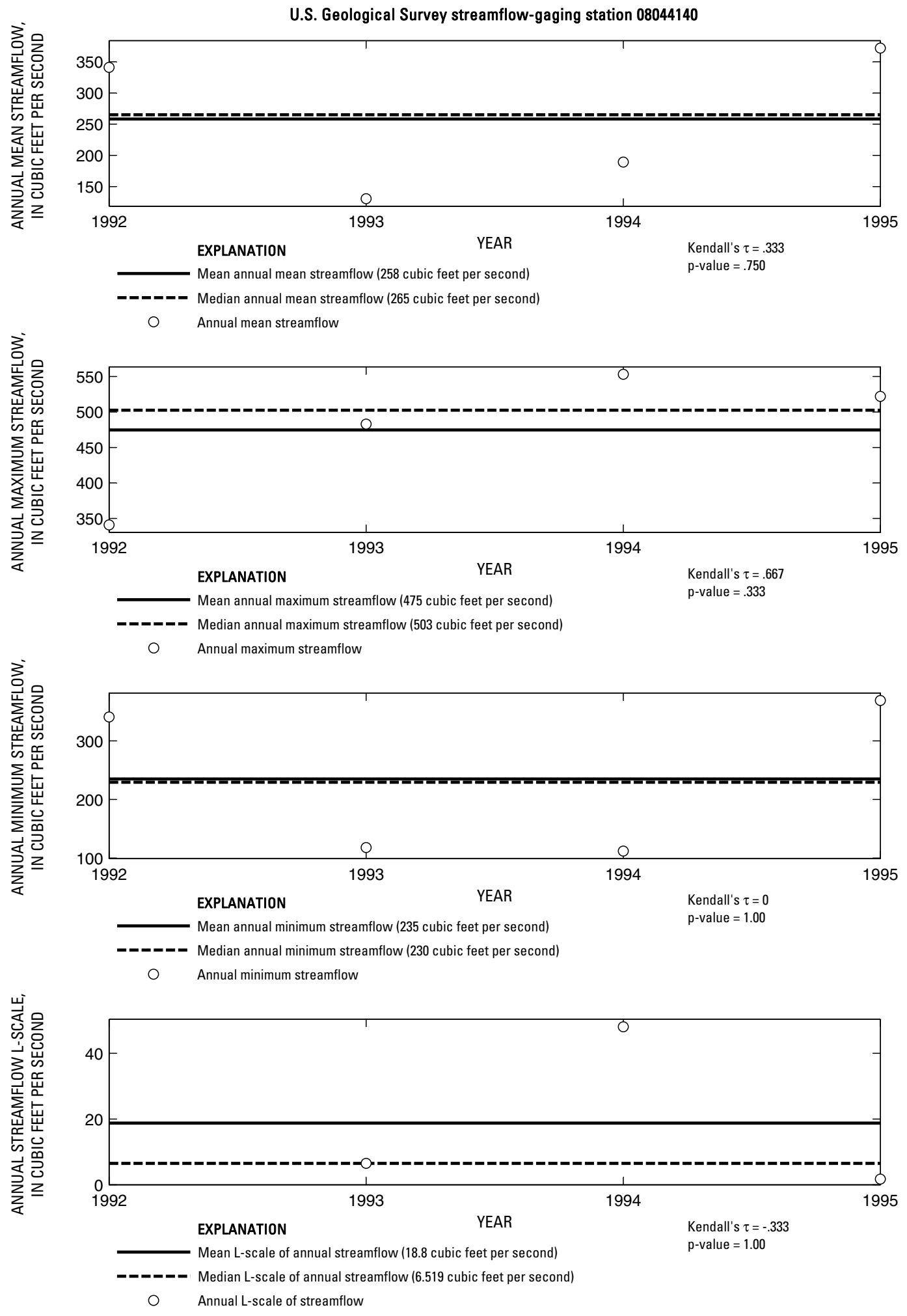

Figure 150. Analysis of annual mean, maximum, minimum, and L-scale statistics of daily mean streamflow for U.S. Geological Survey streamflow-gaging station 08044140 Salt Creek near Paradise, Texas. 


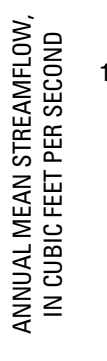

U.S. Geological Survey streamflow-gaging station 08044500

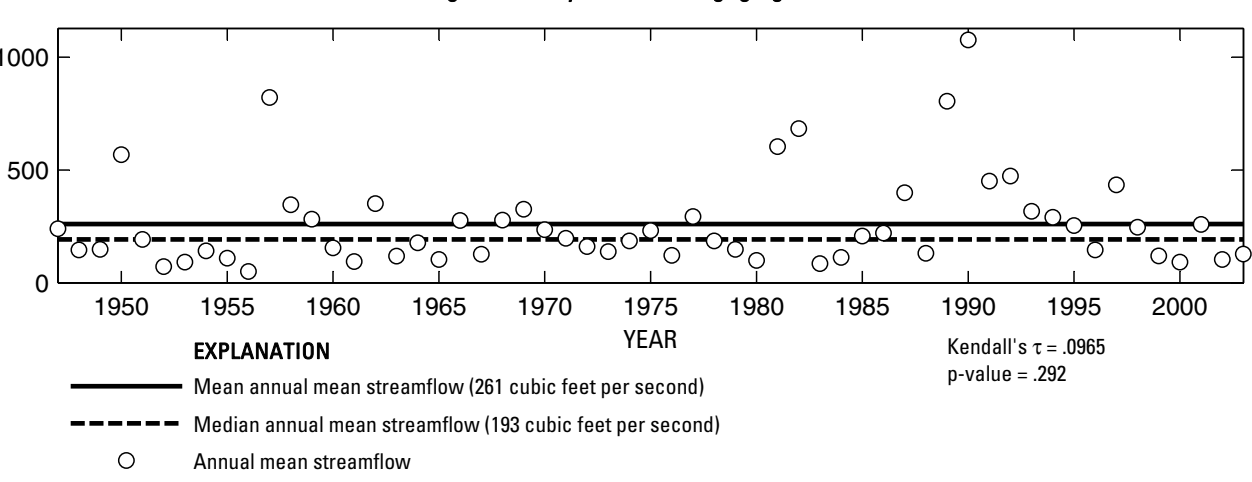

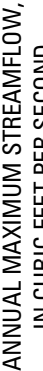

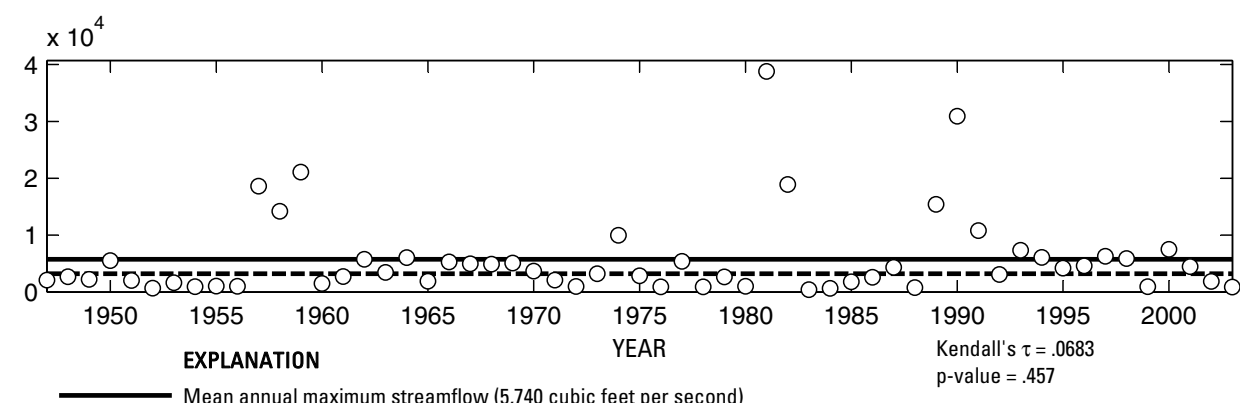

- ב - Median annual maximum streamflow (3,210 cubic feet per second)

O Annual maximum streamflow

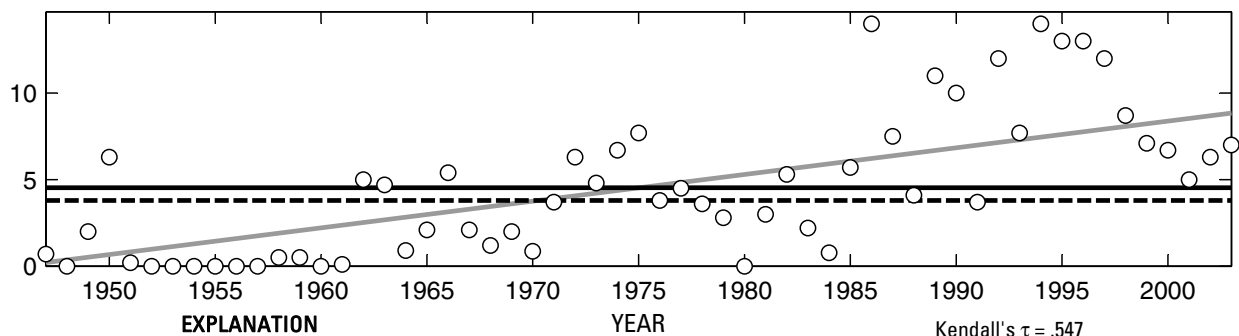

Theil trend line for annual minimum streamflow

Mean annual minimum streamflow (4.53 cubic feet per second)

- - Median annual minimum streamflow (3.8 cubic feet per second)

O Annual minimum streamflow
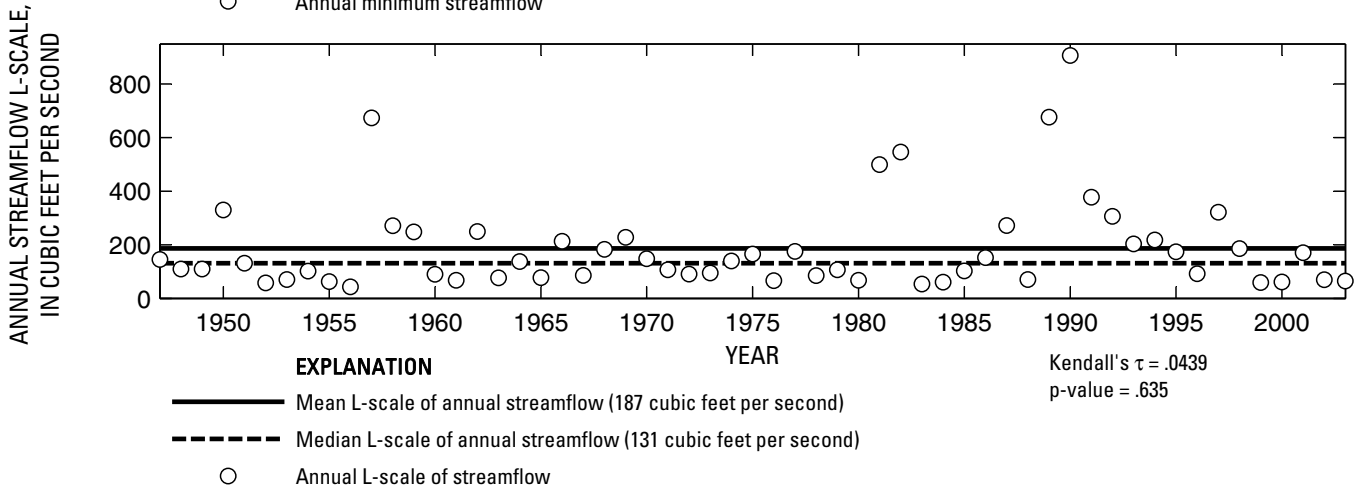

Figure 151. Analysis of annual mean, maximum, minimum, and L-scale statistics of daily mean streamflow for U.S. Geological Survey streamflow-gaging station 08044500 West Fork Trinity River near Boyd, Texas. 

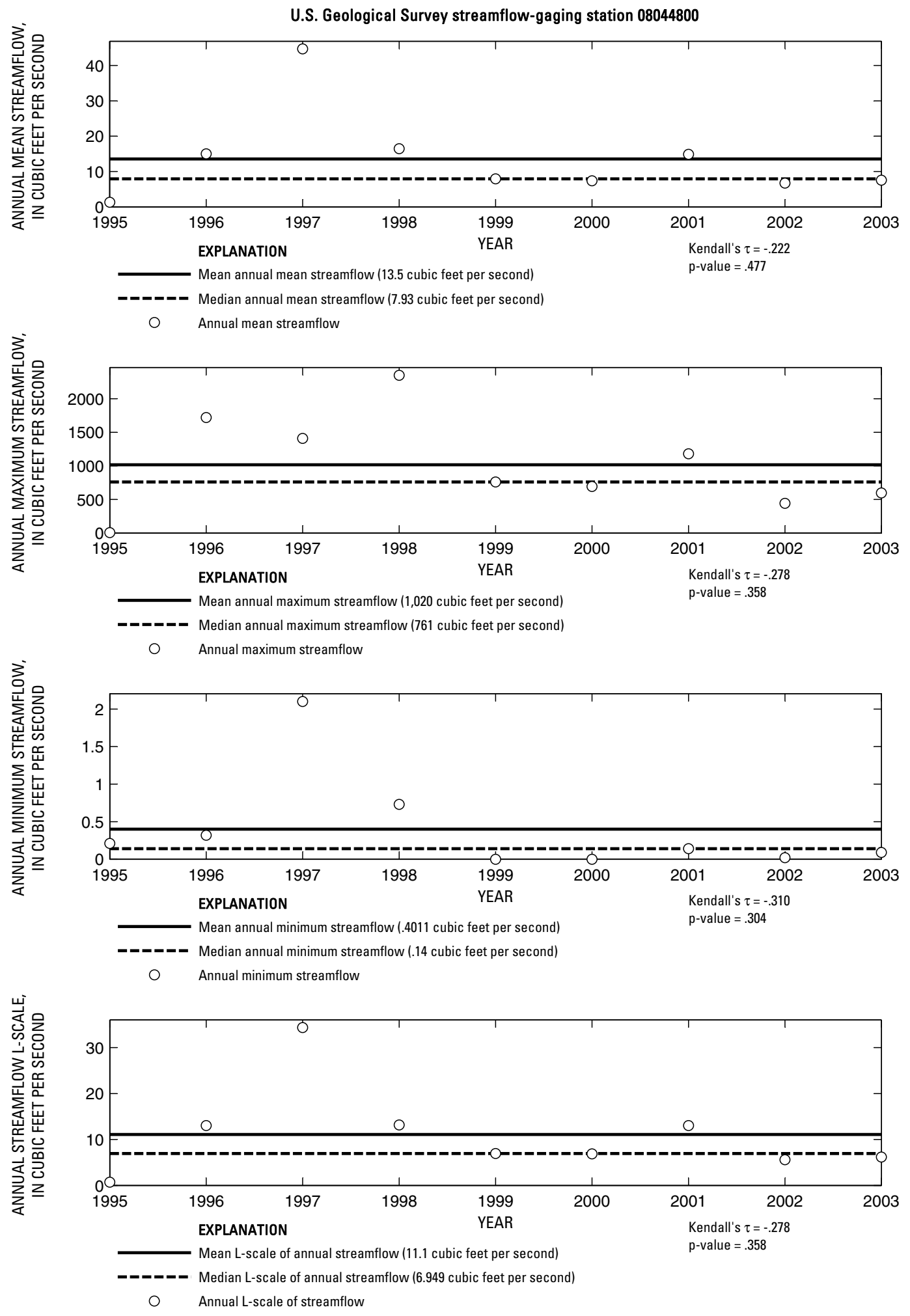

Figure 152. Analysis of annual mean, maximum, minimum, and L-scale statistics of daily mean streamflow for U.S. Geological Survey streamflow-gaging station 08044800 Walnut Creek at Reno, Texas.

Index of Station Numbers 719 


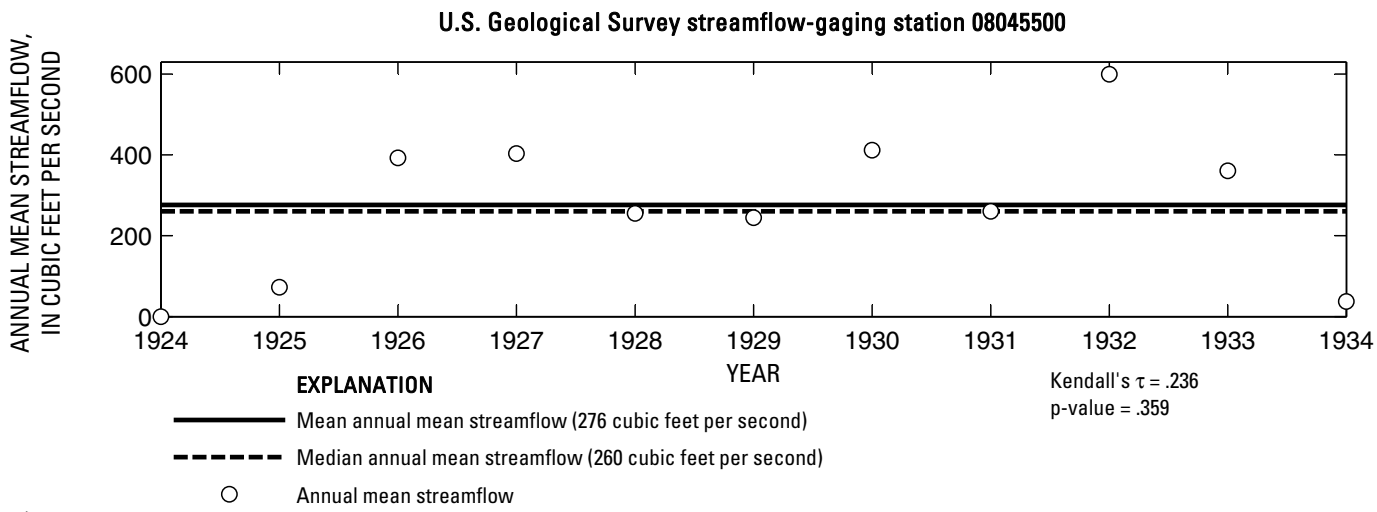

总

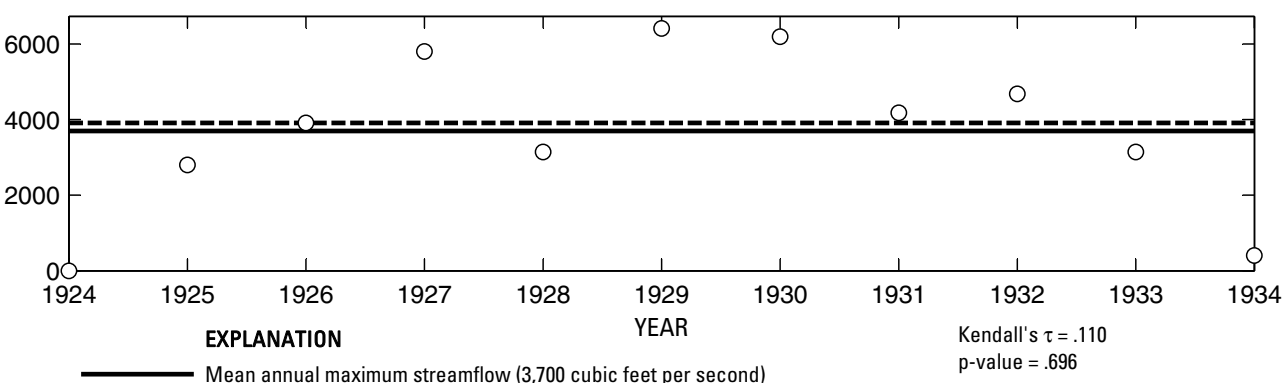

- - Median annual maximum streamflow (3,910 cubic feet per second)

O Annual maximum streamflow

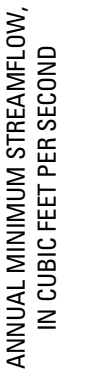

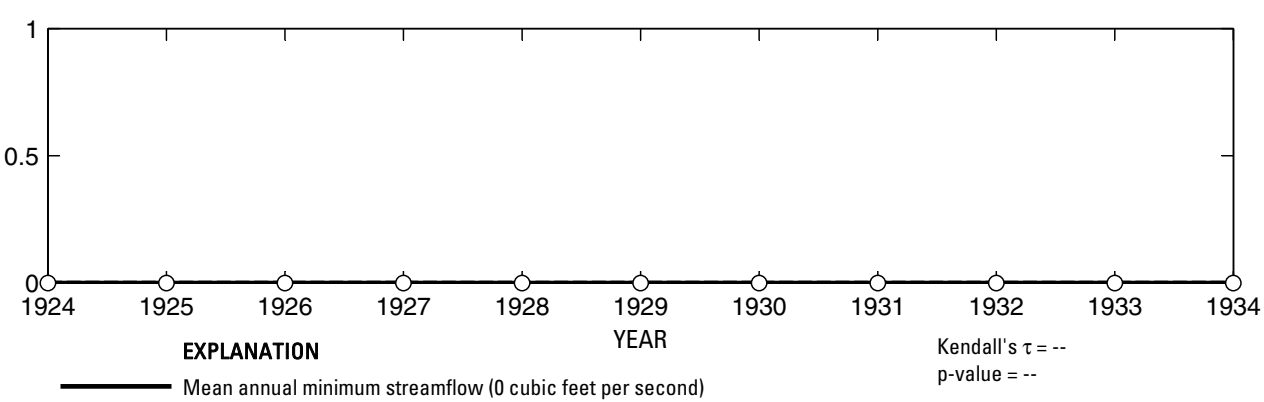

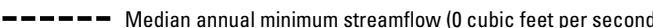

○ Annual minimum streamflow

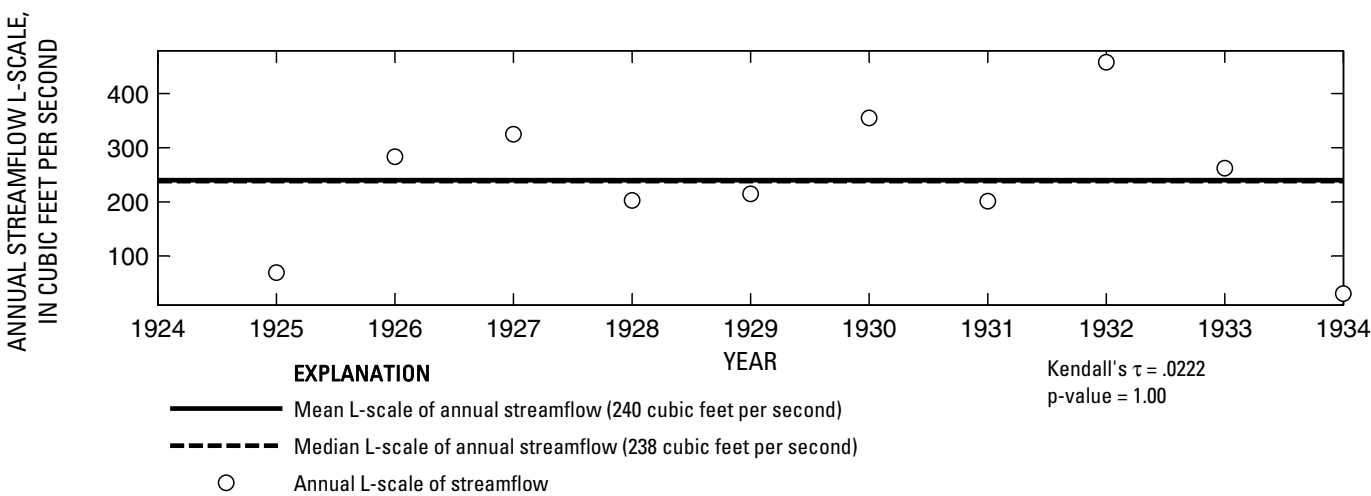

Figure 153. Analysis of annual mean, maximum, minimum, and L-scale statistics of daily mean streamflow for U.S. Geological Survey streamflow-gaging station 08045500 West Fork Trinity River at Lake Worth Dam above Fort Worth, Texas. 
U.S. Geological Survey streamflow-gaging station 08045850

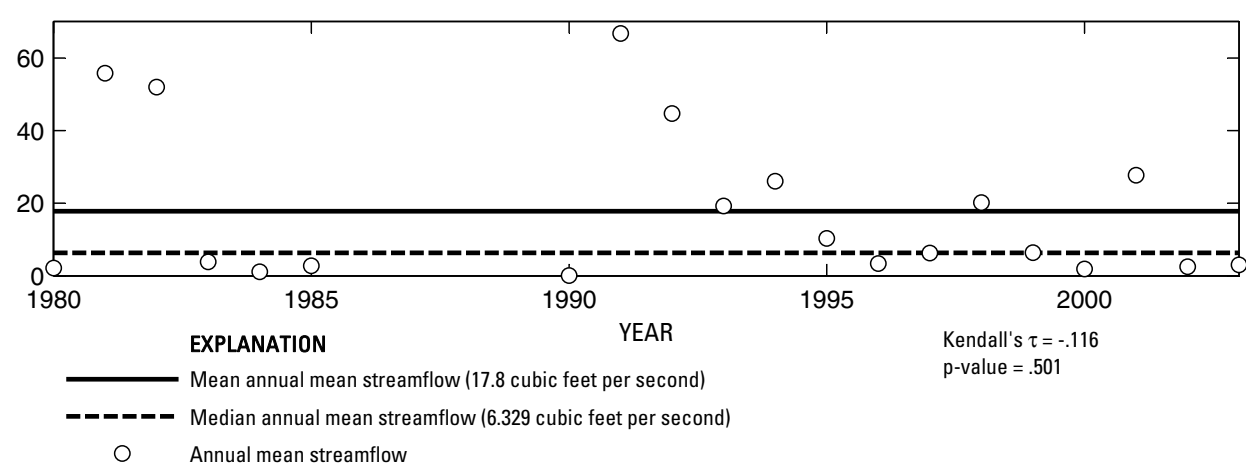

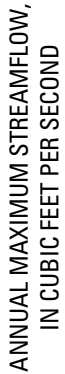

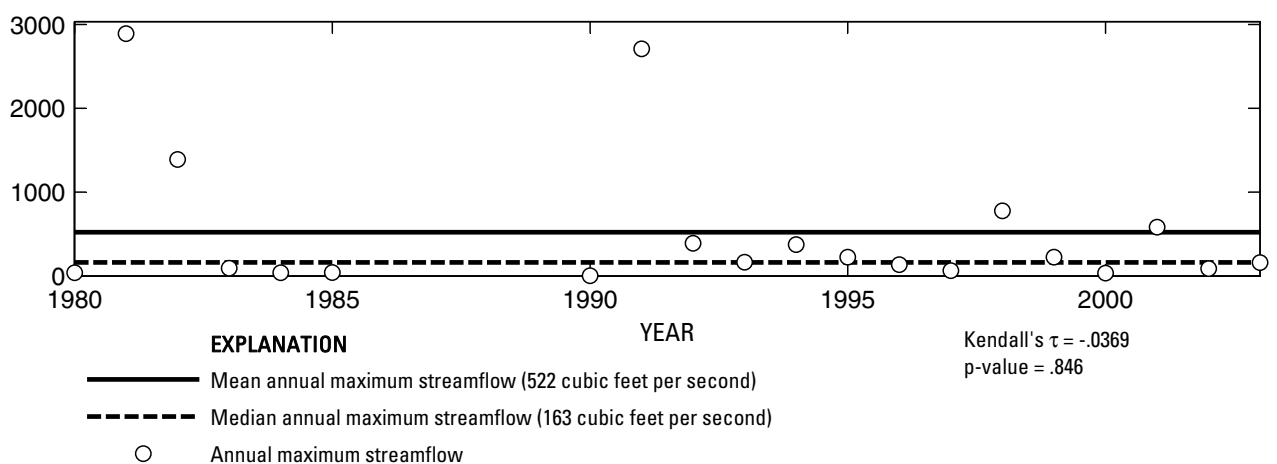

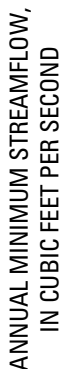

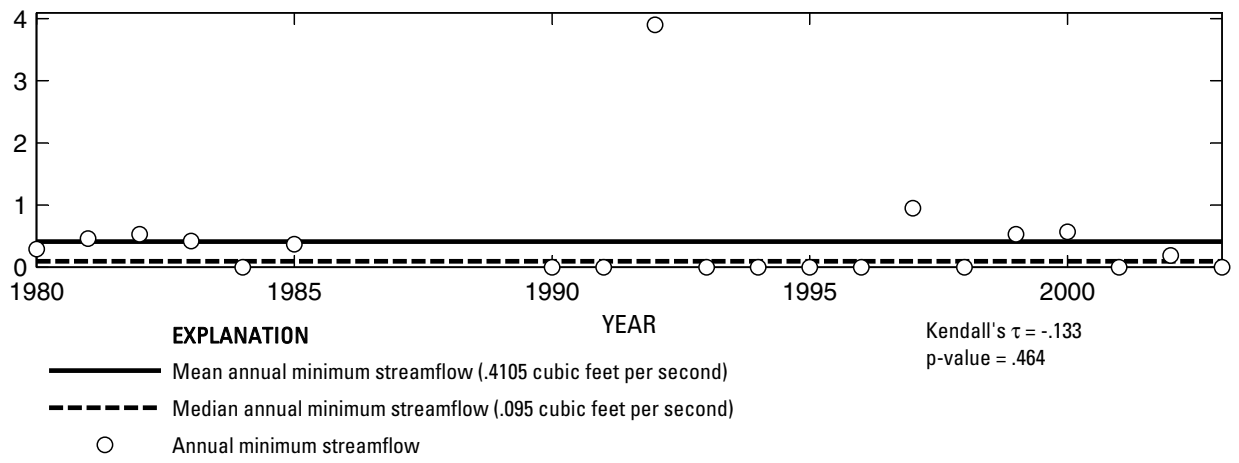

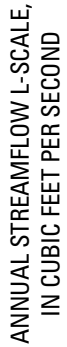

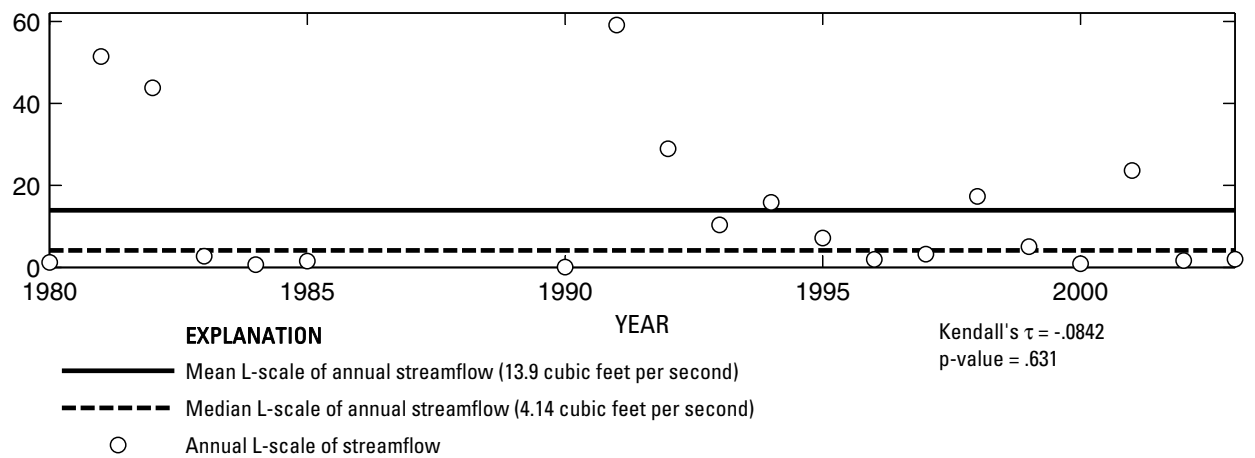

Figure 154. Analysis of annual mean, maximum, minimum, and L-scale statistics of daily mean streamflow for U.S. Geological Survey streamflow-gaging station 08045850 Clear Fork Trinity River near Weatherford, Texas. 

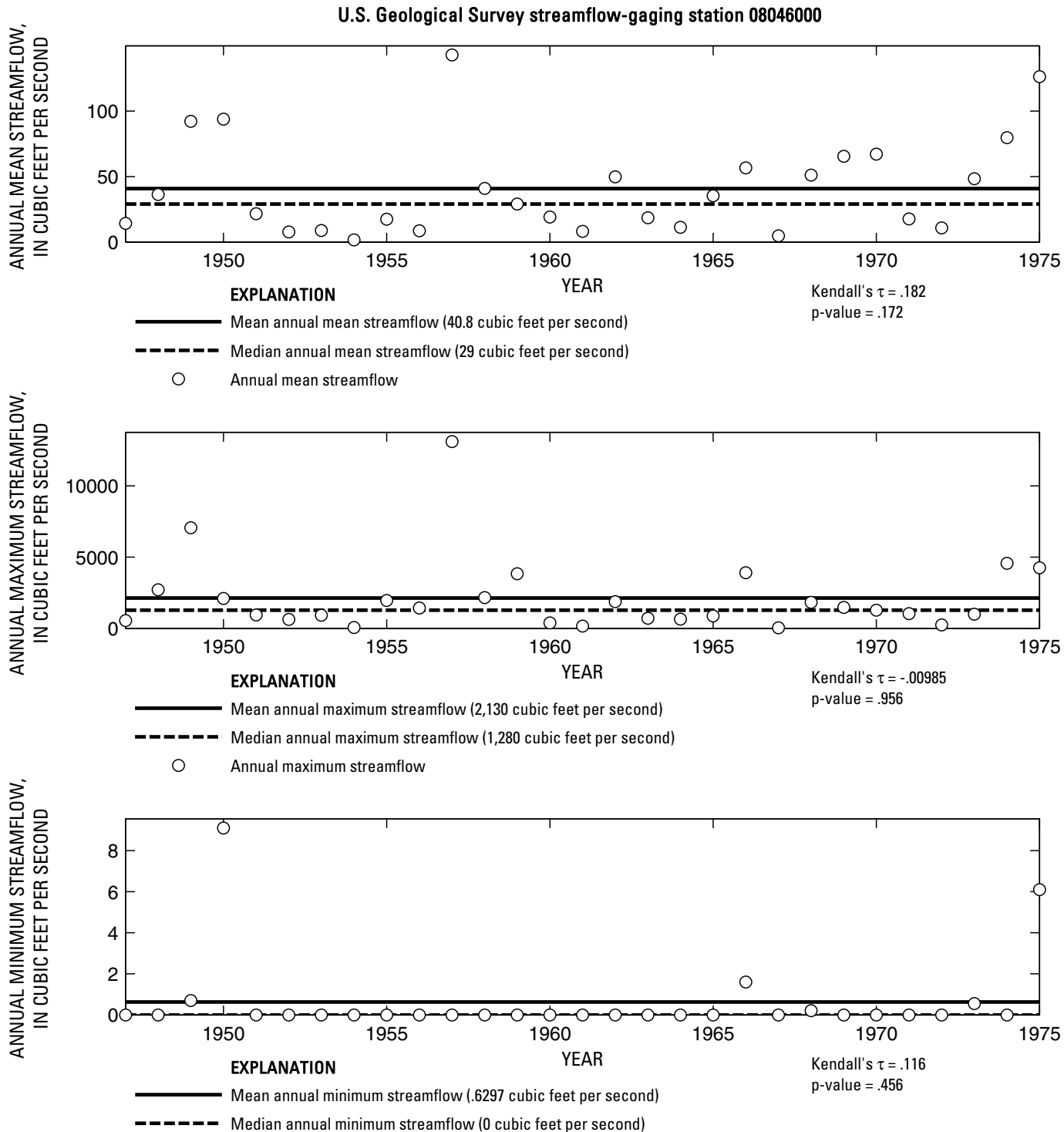

○ Annual minimum streamflow

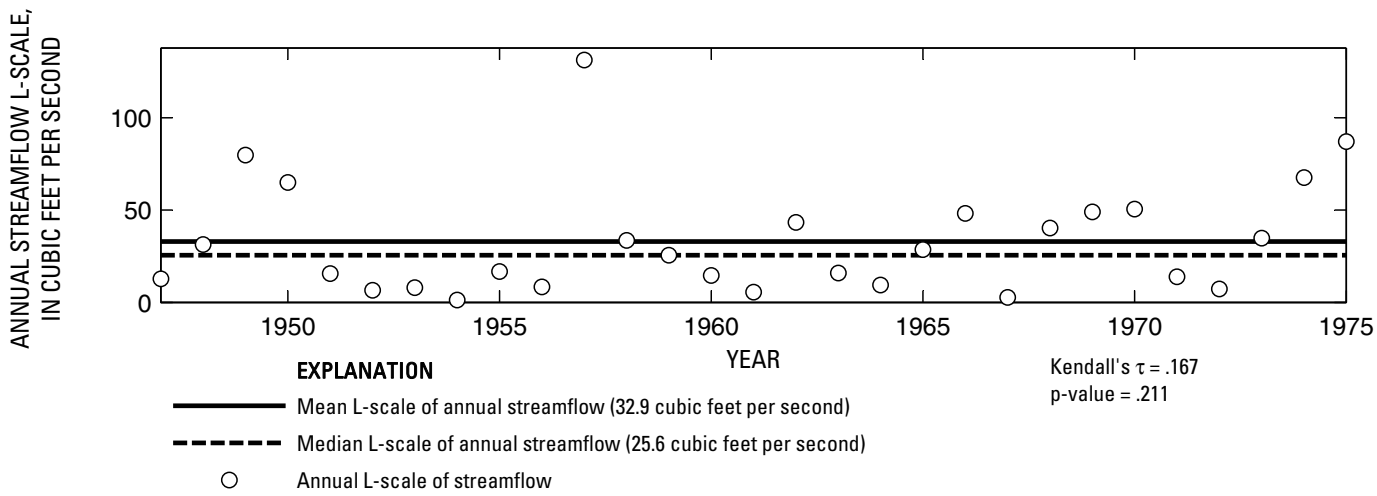

Figure 155. Analysis of annual mean, maximum, minimum, and L-scale statistics of daily mean streamflow for U.S. Geological Survey streamflow-gaging station 08046000 Clear Fork Trinity River near Aledo, Texas. 


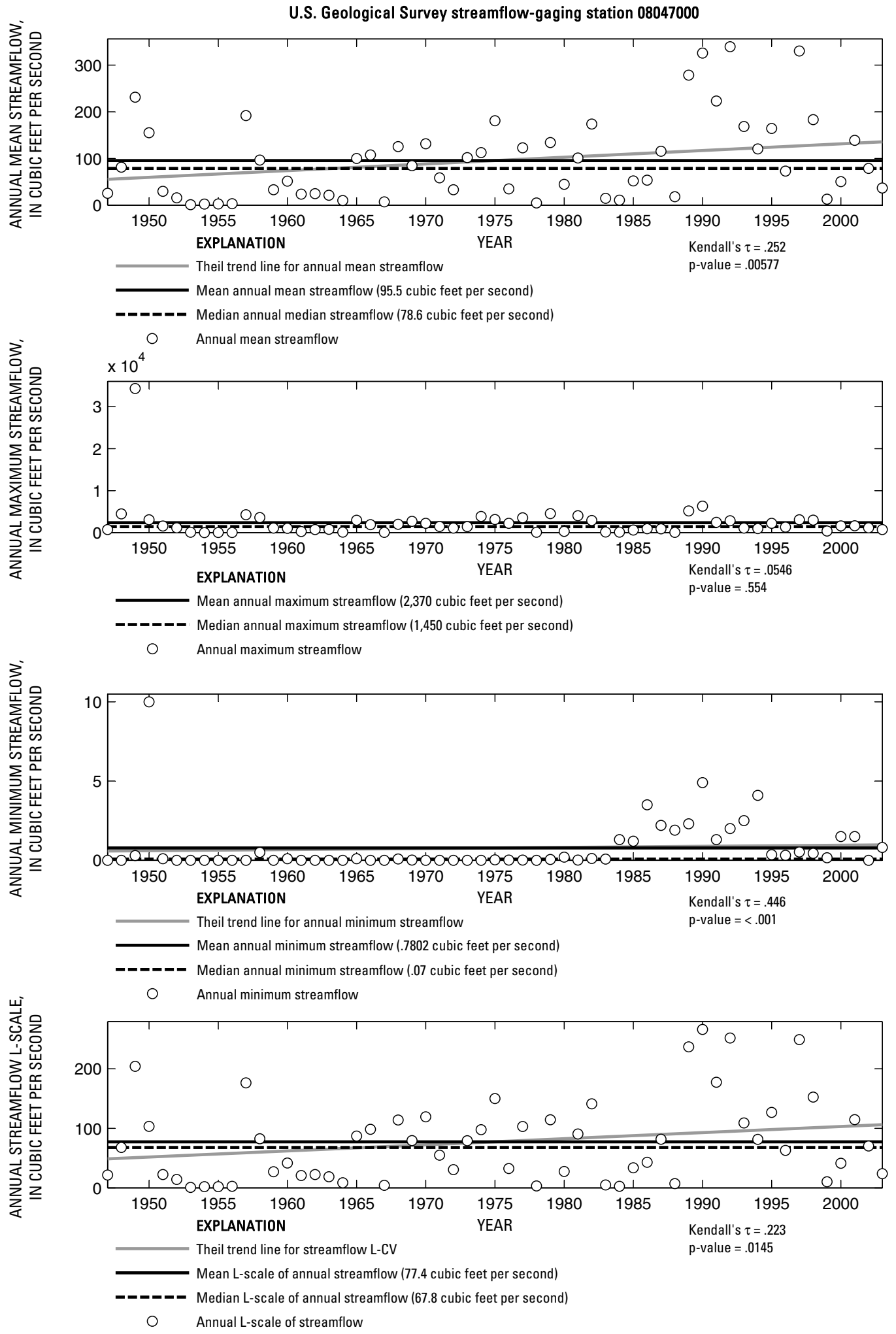

Figure 156. Analysis of annual mean, maximum, minimum, and L-scale statistics of daily mean streamflow for U.S. Geological Survey streamflow-gaging station 08047000 Clear Fork Trinity River near Benbrook, Texas.

Index of Station Numbers 719 

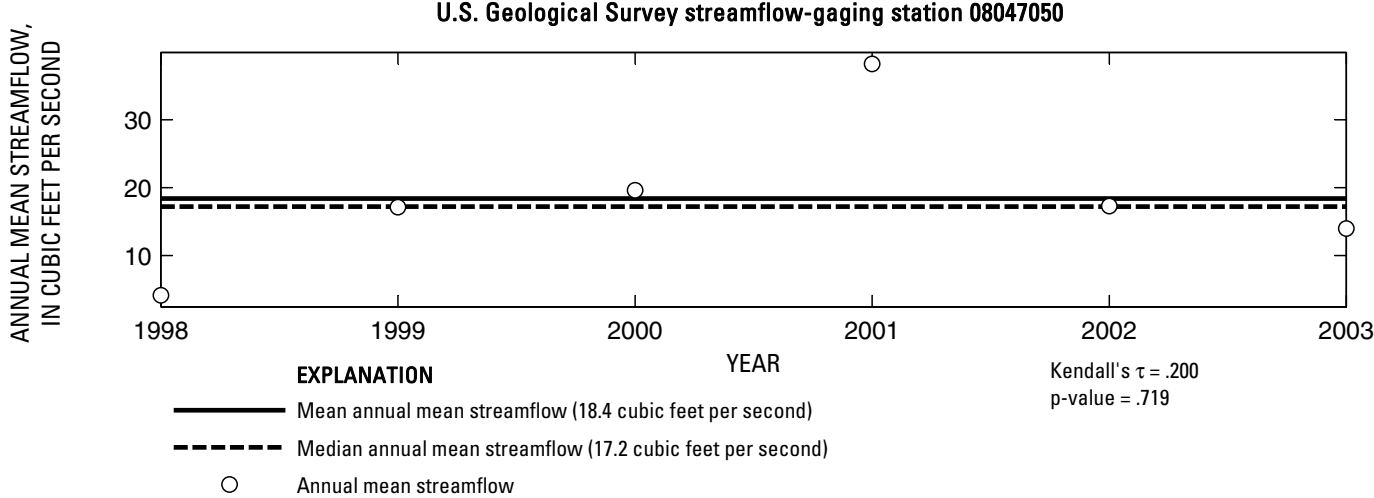

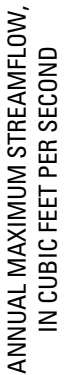

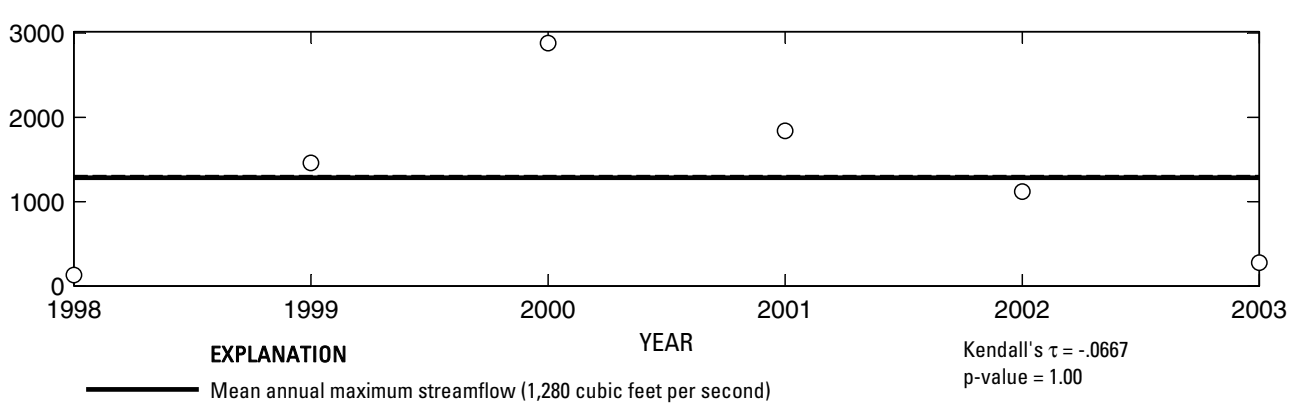

- _ - Median annual maximum streamflow (1,290 cubic feet per second)

O Annual maximum streamflow
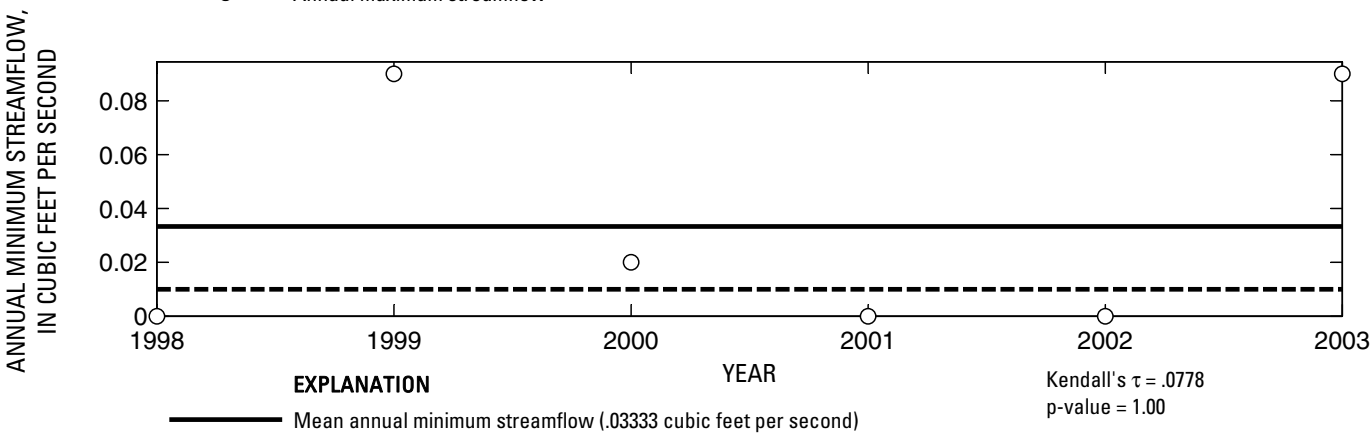

- - ー - - Median annual minimum streamflow (.01 cubic feet per second)

O Annual minimum streamflow

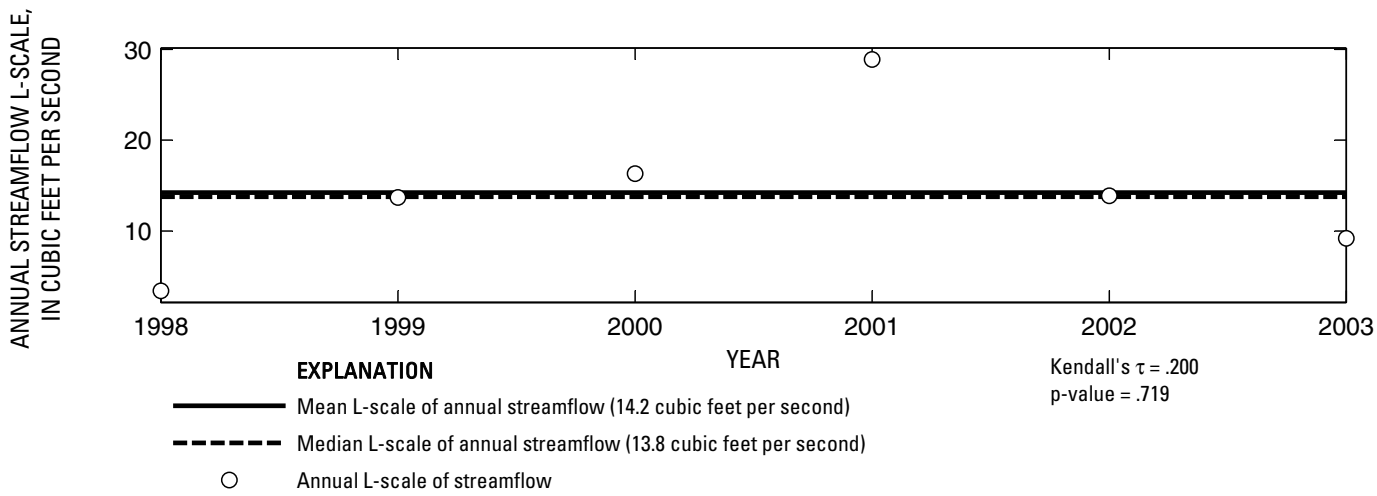

Figure 157. Analysis of annual mean, maximum, minimum, and L-scale statistics of daily mean streamflow for U.S. Geological Survey streamflow-gaging station 08047050 Marys Creek at Benbrook, Texas. 


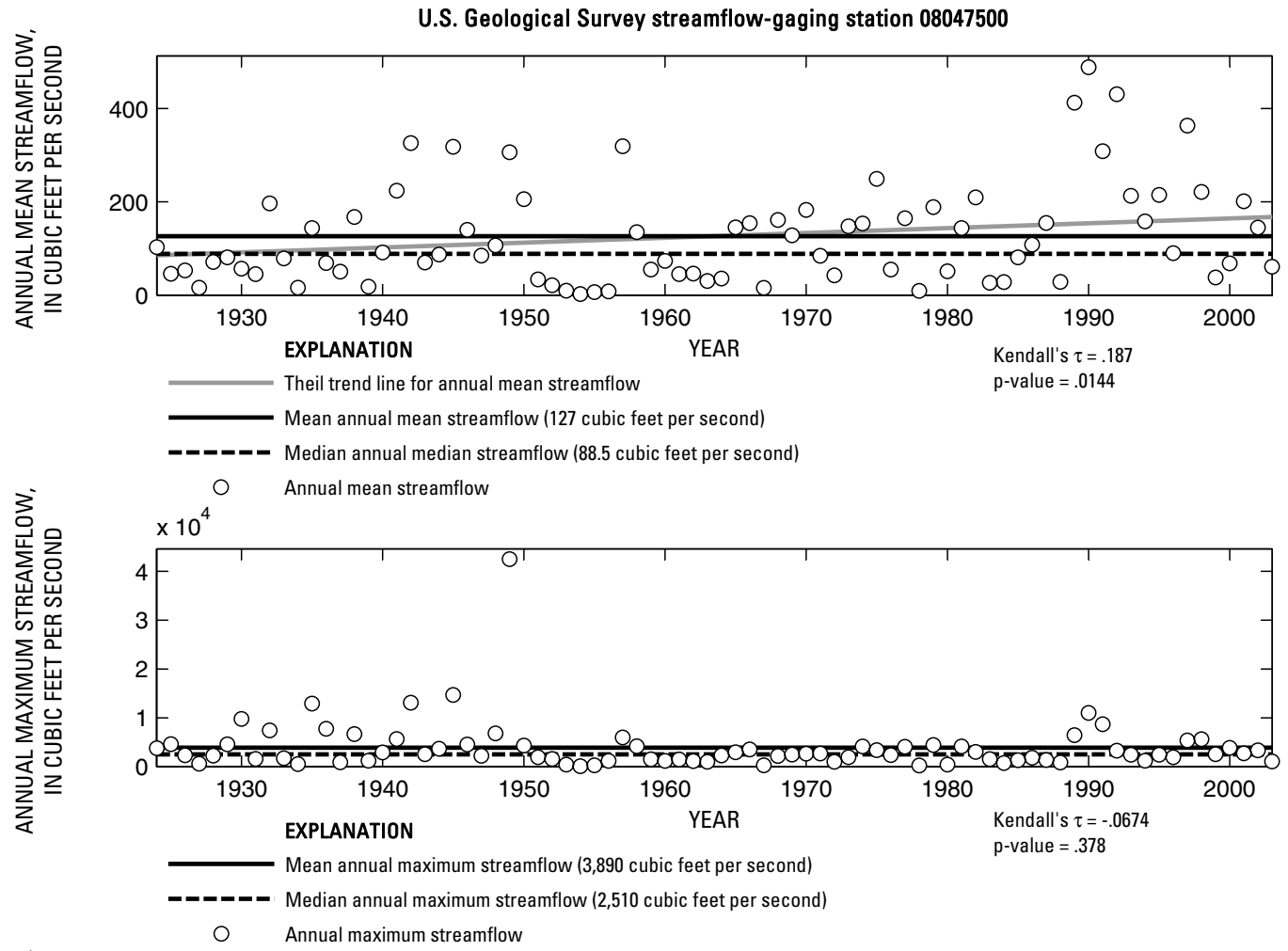

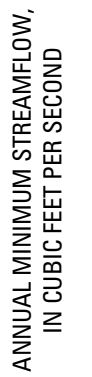

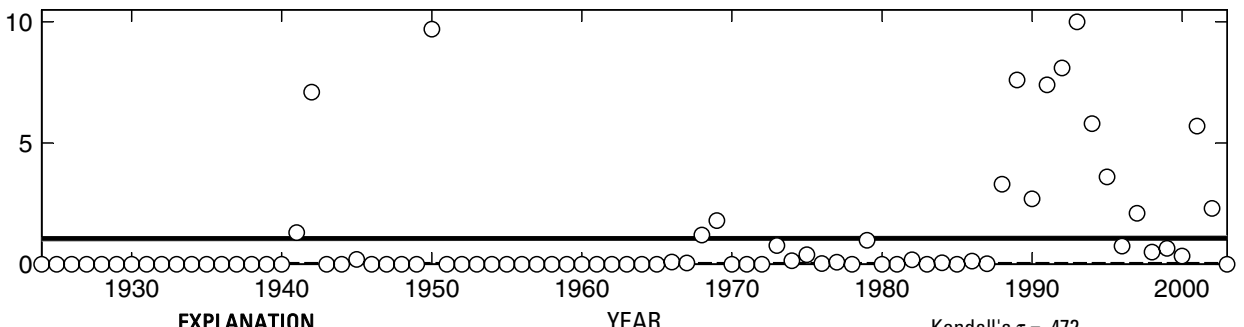

Theil trend line for annual minimum streamflow
Mean annual minimum streamflow (1.063 cubic feet per second)

O Annual minimum streamflow

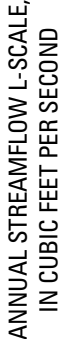

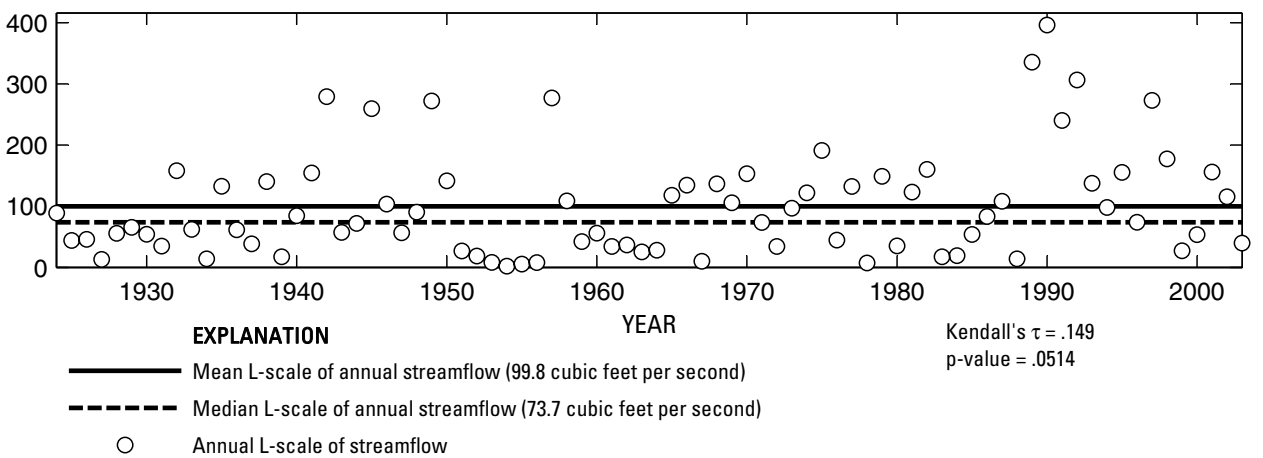

Figure 158. Analysis of annual mean, maximum, minimum, and L-scale statistics of daily mean streamflow for U.S. Geological Survey streamflow-gaging station 08047500 Clear Fork Trinity River at Fort Worth, Texas.

Index of Station Numbers 719 


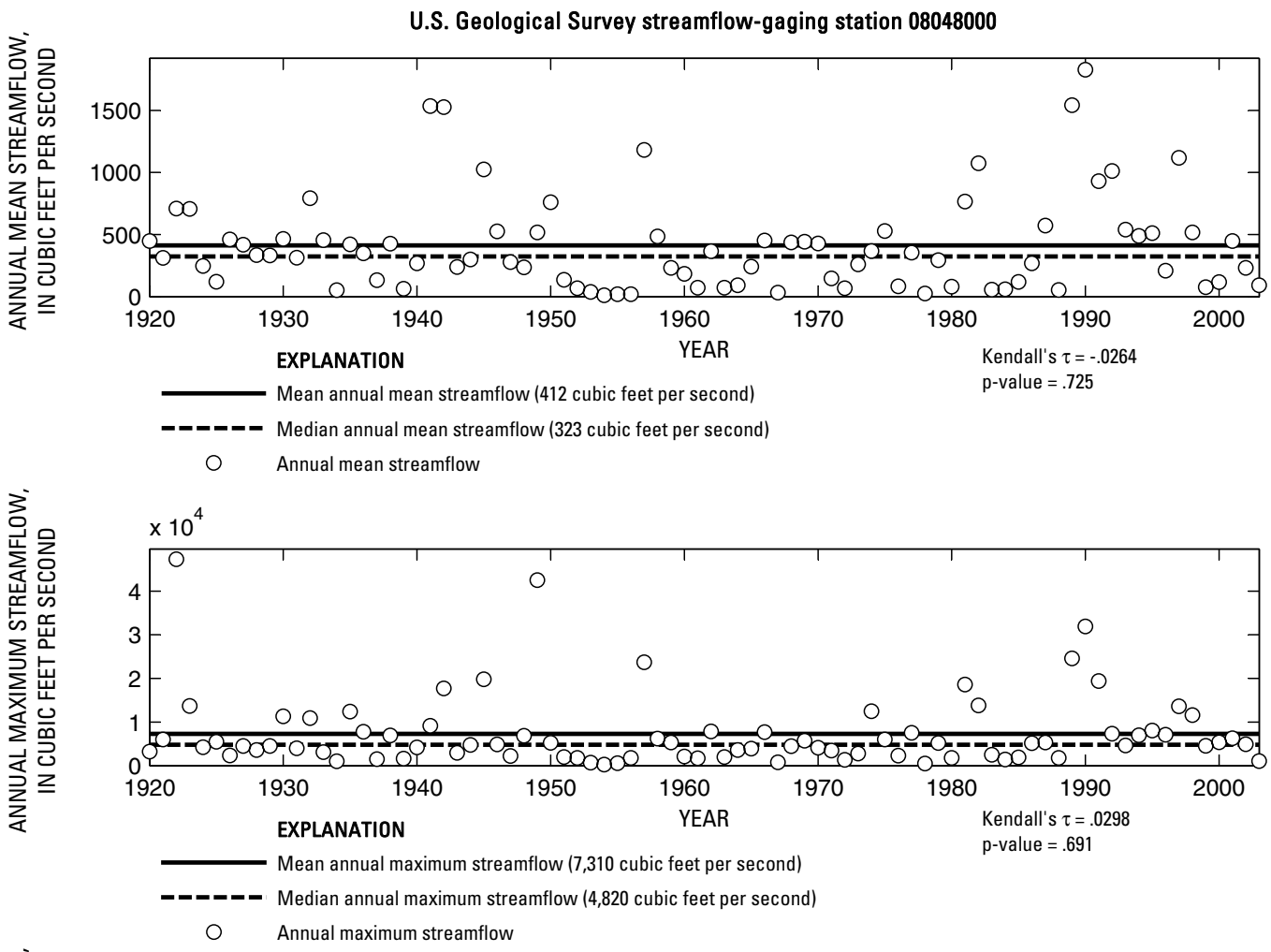

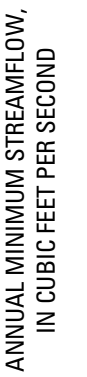
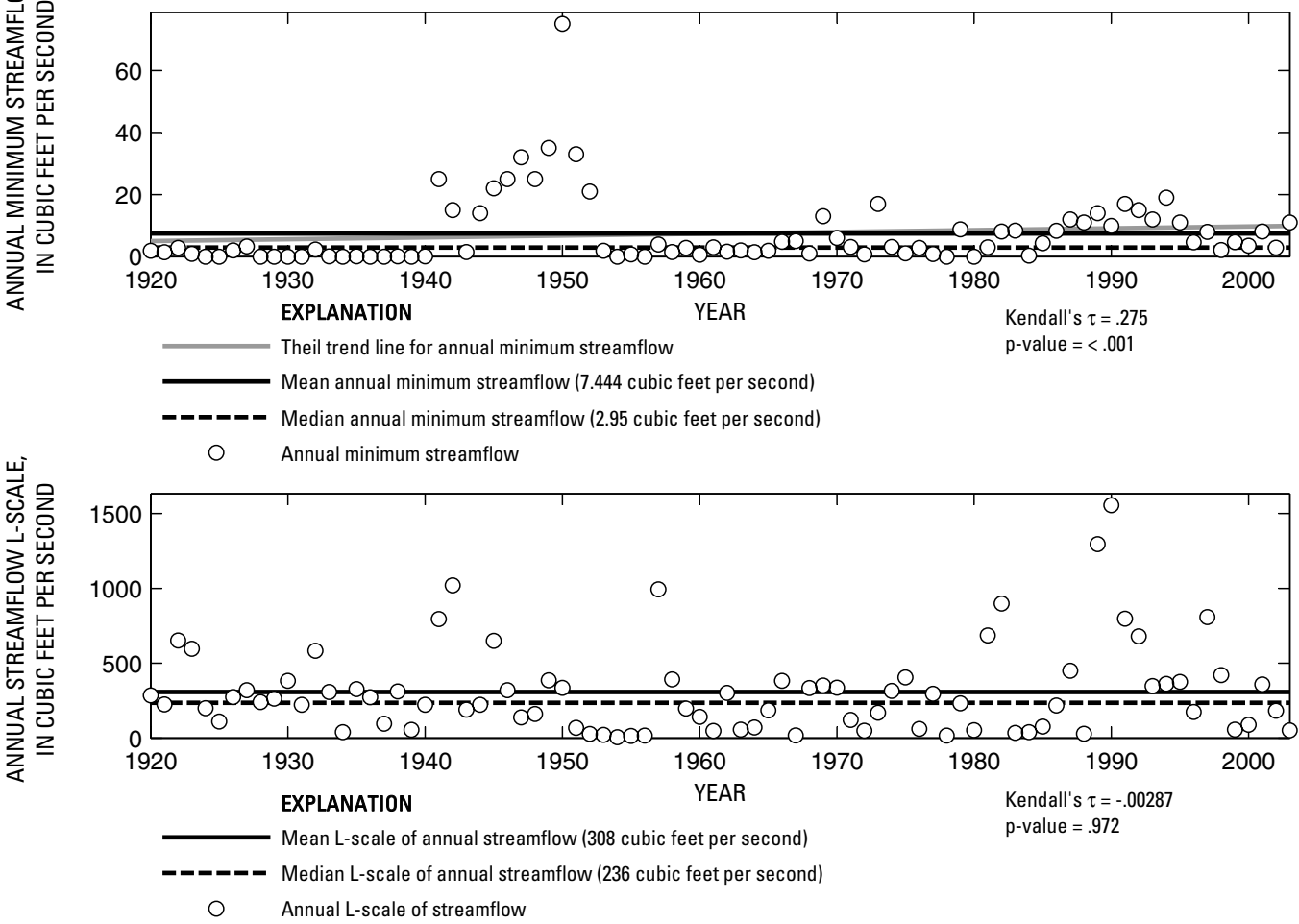

Figure 159. Analysis of annual mean, maximum, minimum, and L-scale statistics of daily mean streamflow for U.S. Geological Survey streamflow-gaging station 08048000 West Fork Trinity River at Fort Worth, Texas. 
U.S. Geological Survey streamflow-gaging station 08048520

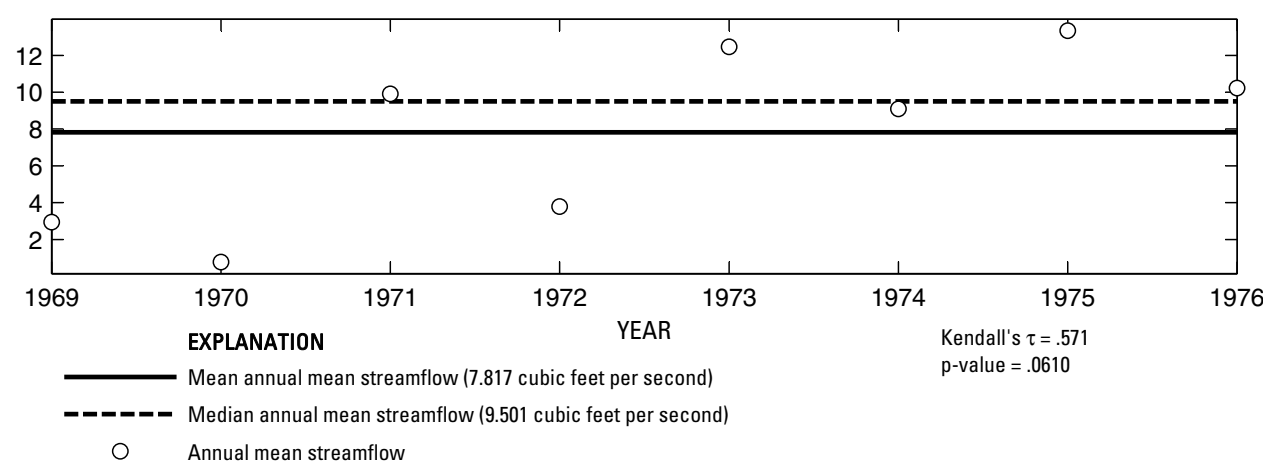

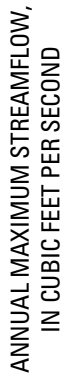

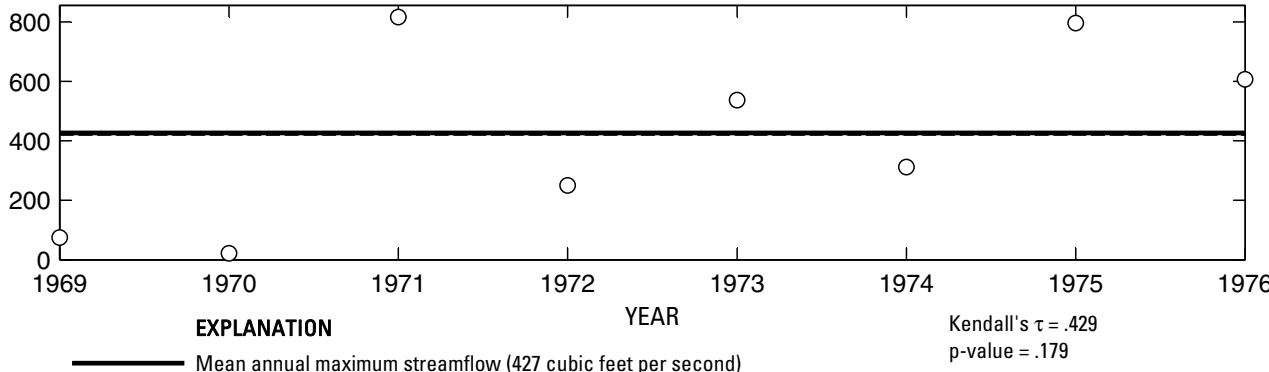

- ב- Median annual maximum streamflow (425 cubic feet per second)

O Annual maximum streamflow

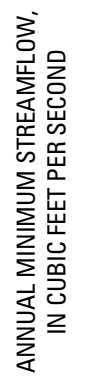

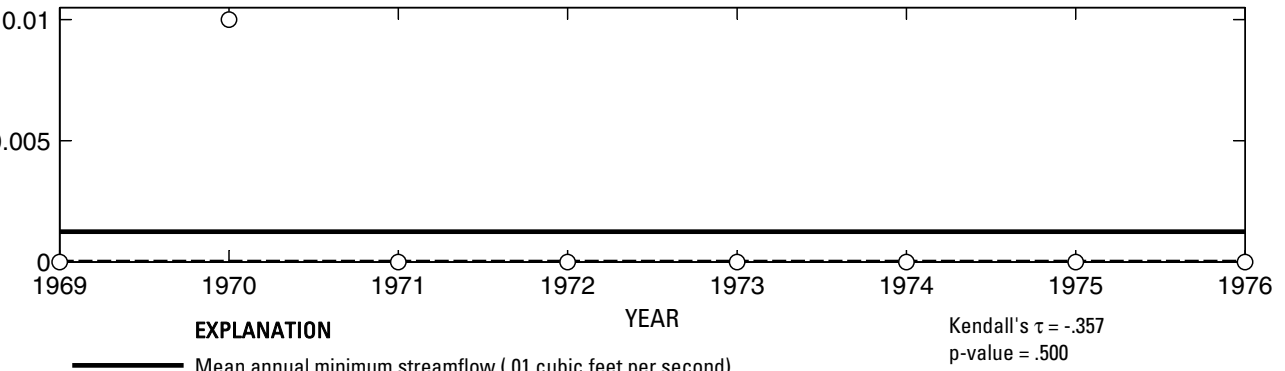

- - Median annual minimum streamflow (0 cubic feet per second)

O Annual minimum streamflow

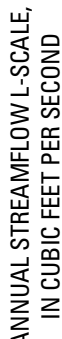

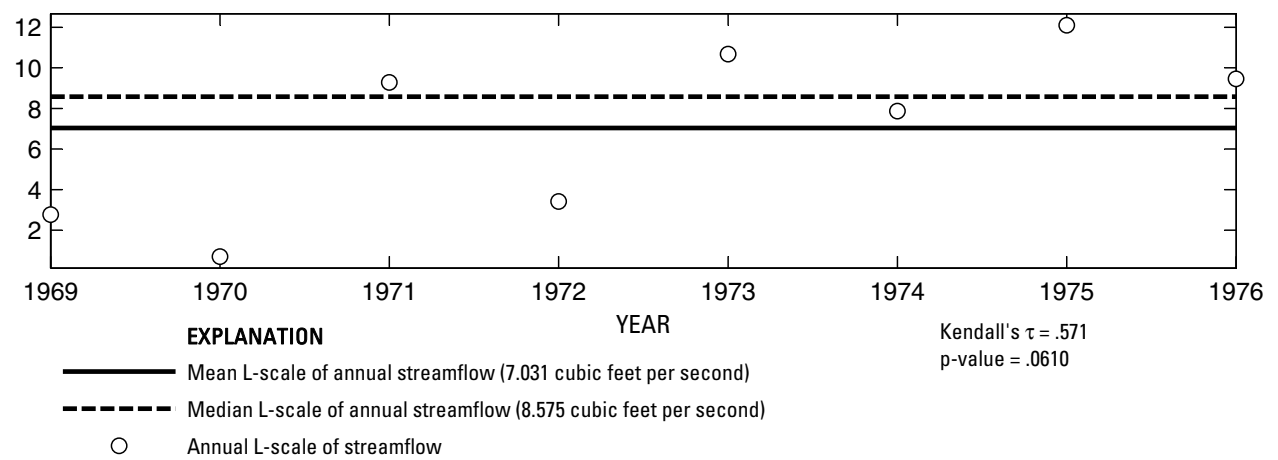

Figure 160. Analysis of annual mean, maximum, minimum, and L-scale statistics of daily mean streamflow for U.S. Geological Survey streamflow-gaging station 08048520 Sycamore Creek at Interstate Highway 35 West, Fort Worth, Texas. 


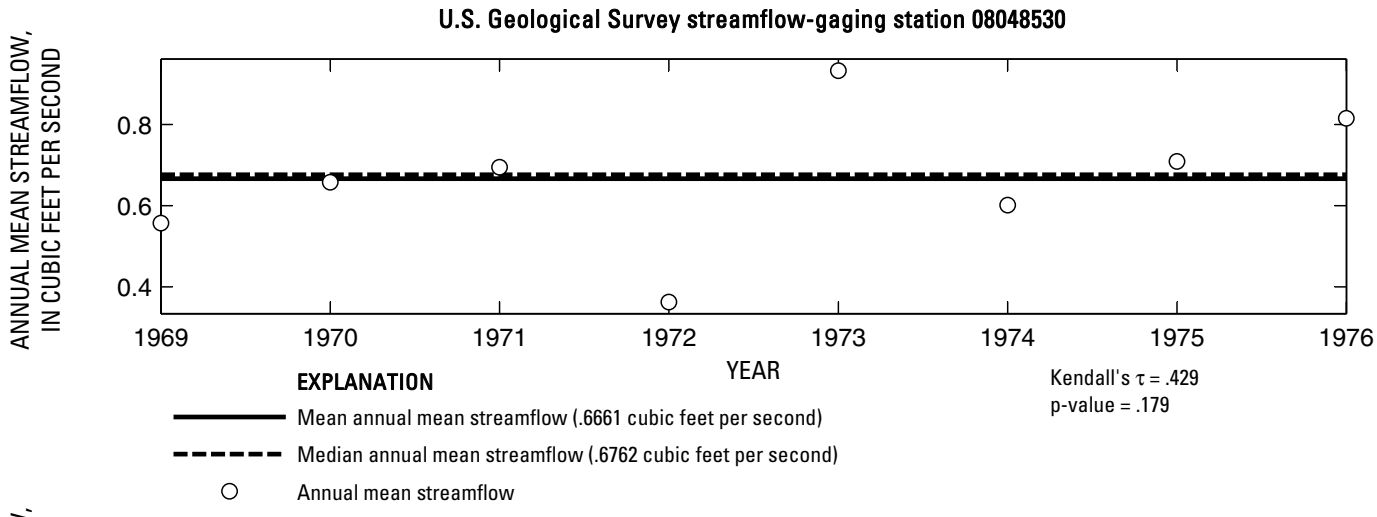

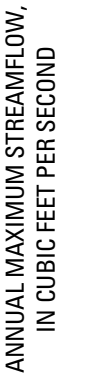

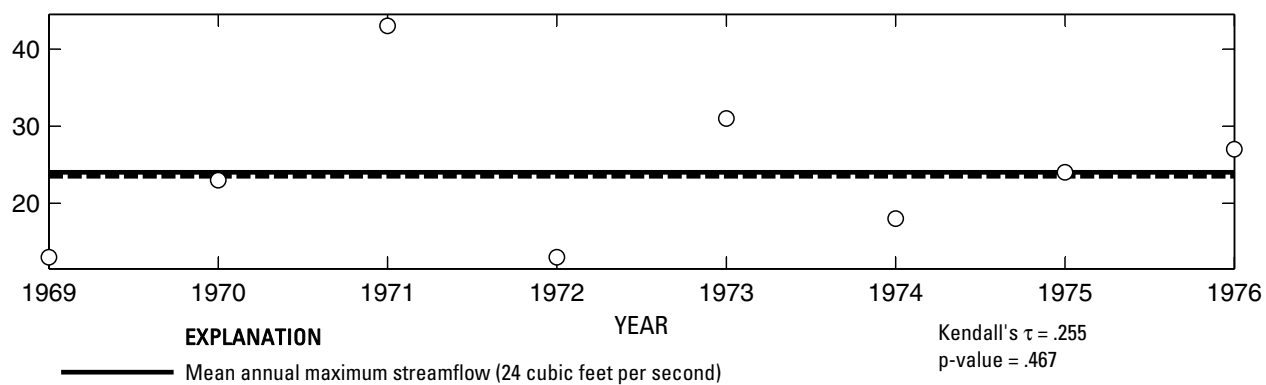

-_o-_- Median annual maximum streamflow (23.5 cubic feet per second)

○ Annual maximum streamflow

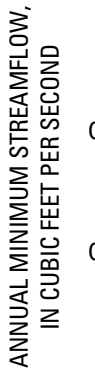

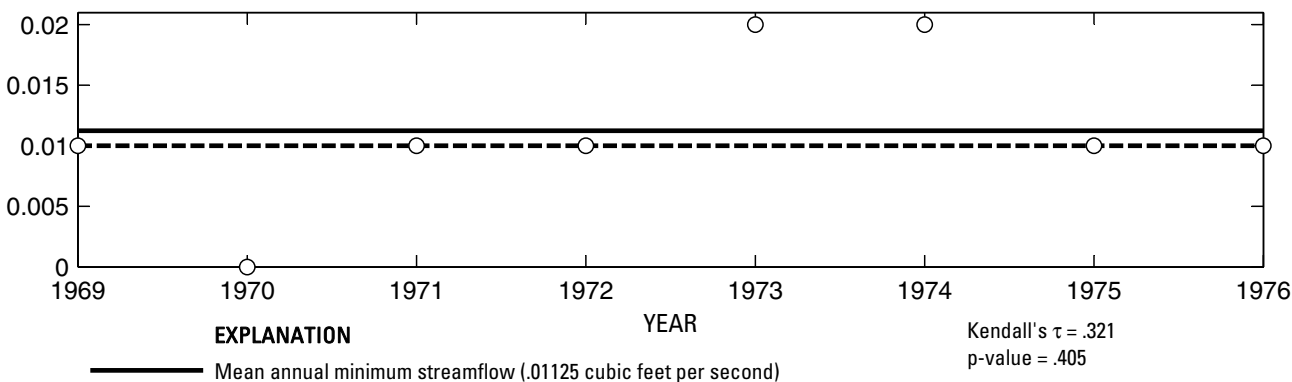

- - Median annual minimum streamflow (.01 cubic feet per second)

O Annual minimum streamflow
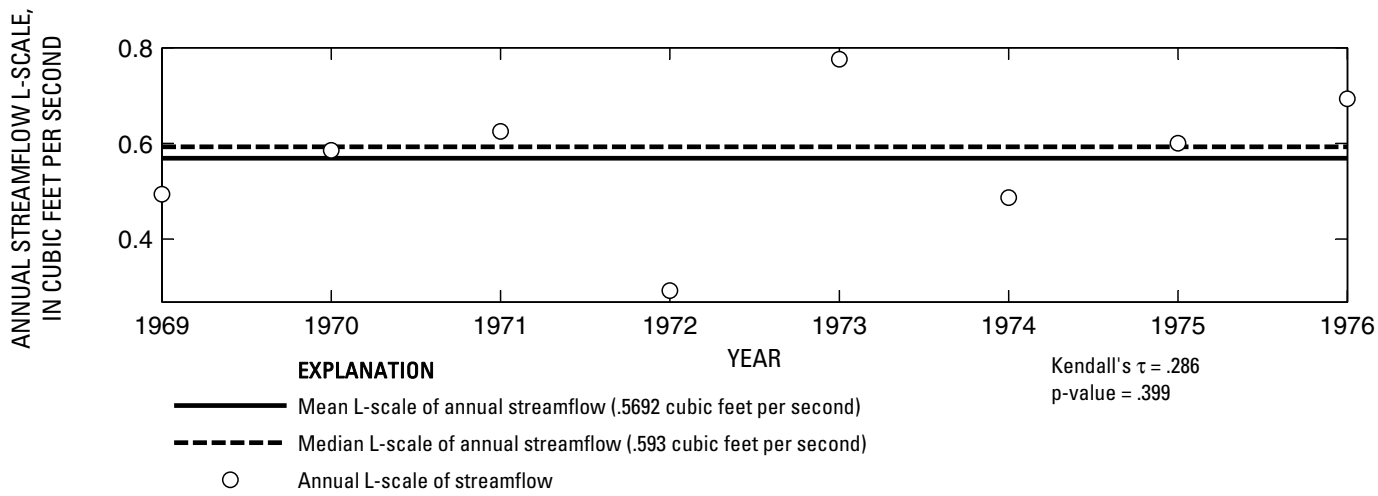

Figure 161. Analysis of annual mean, maximum, minimum, and L-scale statistics of daily mean streamflow for U.S. Geological Survey streamflow-gaging station 08048530 Sycamore Creek Tributary above Semenary South Shopping Center, Fort Worth, Texas. 


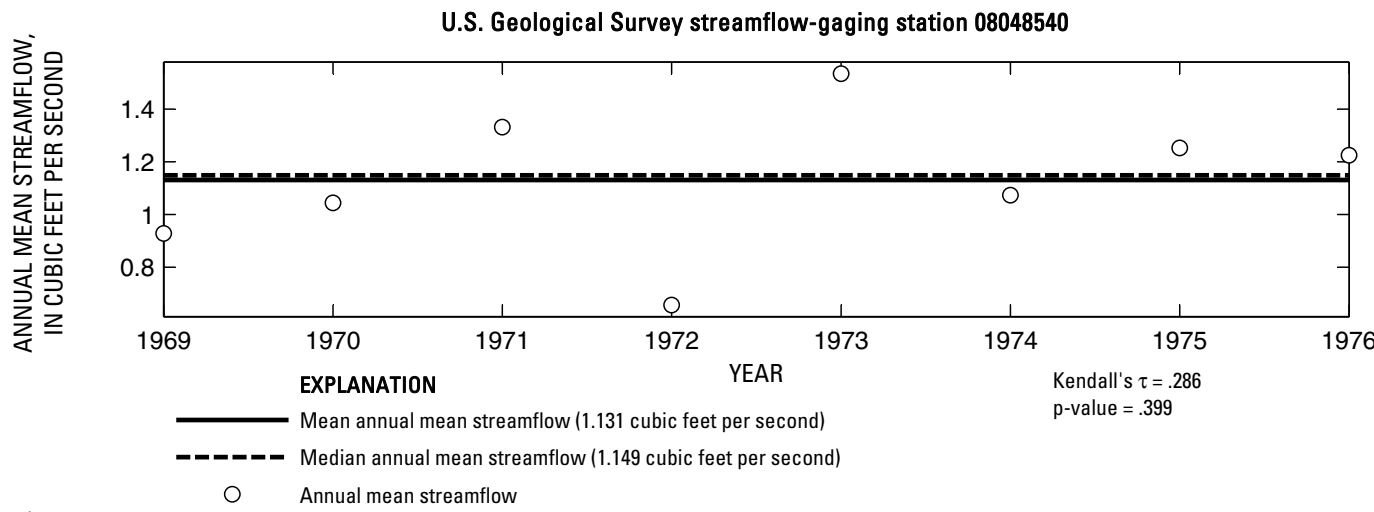

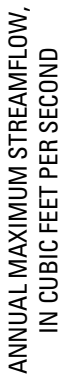

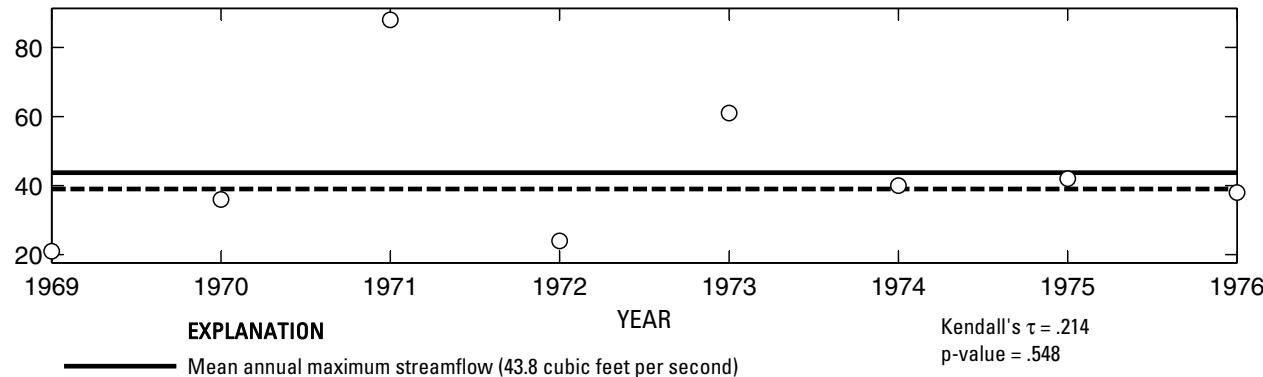

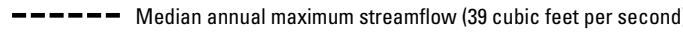

Annual maximum streamflow

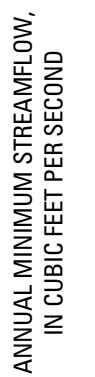

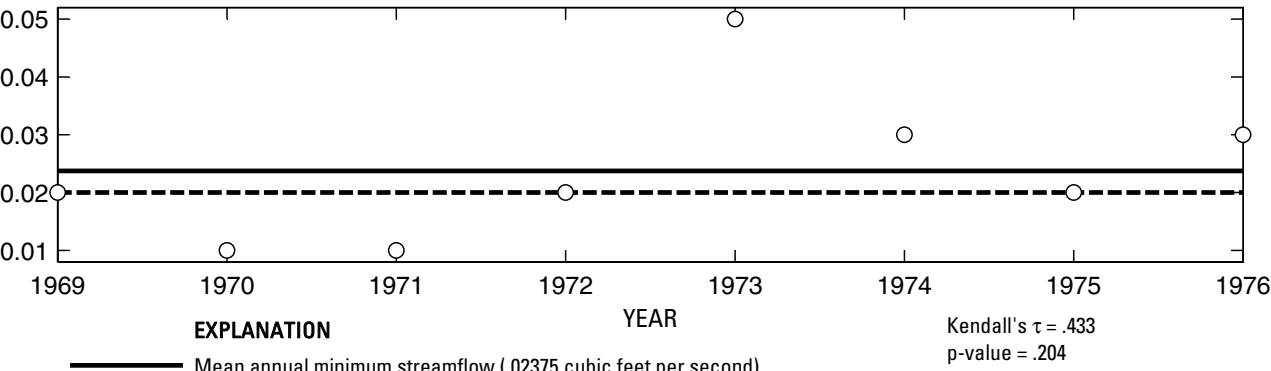

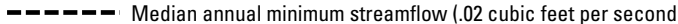

O Annual minimum streamflow

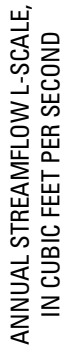

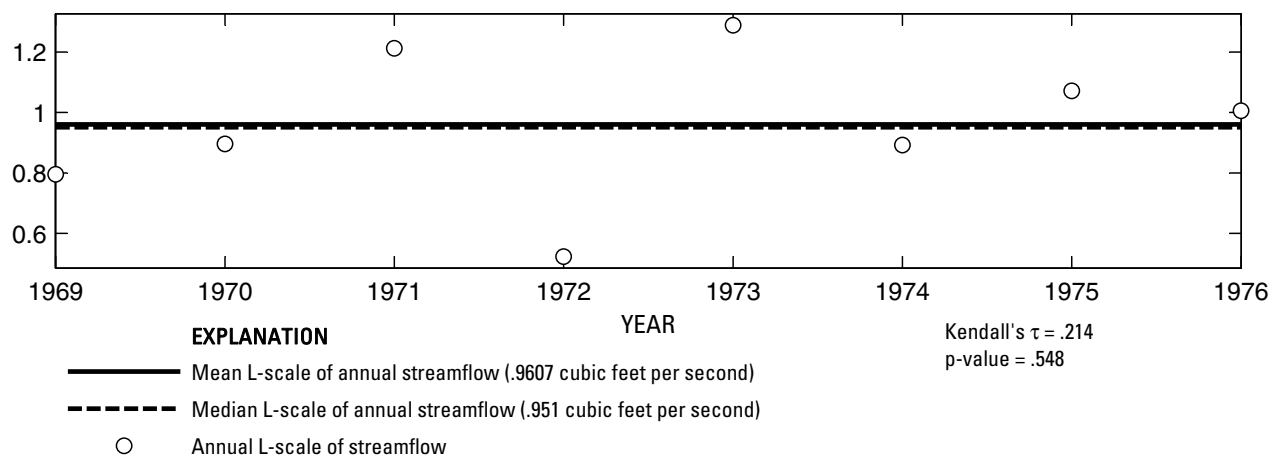

Figure 162. Analysis of annual mean, maximum, minimum, and L-scale statistics of daily mean streamflow for U.S. Geological Survey streamflow-gaging station 08048540 Sycamore Creek Tributary at Interstate Highway 35 West, Fort Worth, Texas. 


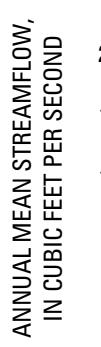

U.S. Geological Survey streamflow-gaging station 08048543

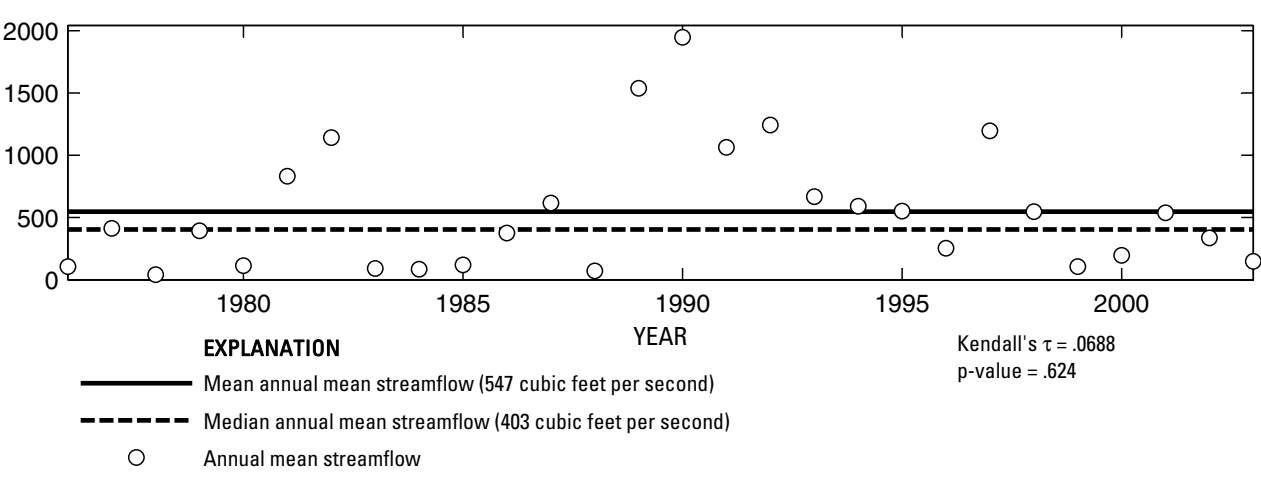

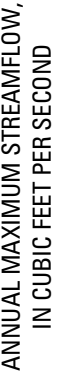
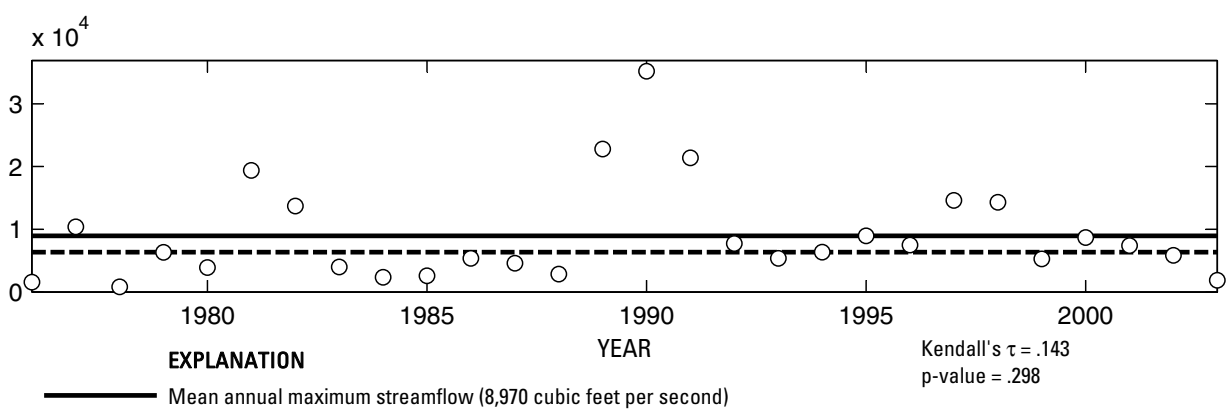

- ב - Median annual maximum streamflow (6,340 cubic feet per second)

O Annual maximum streamflow
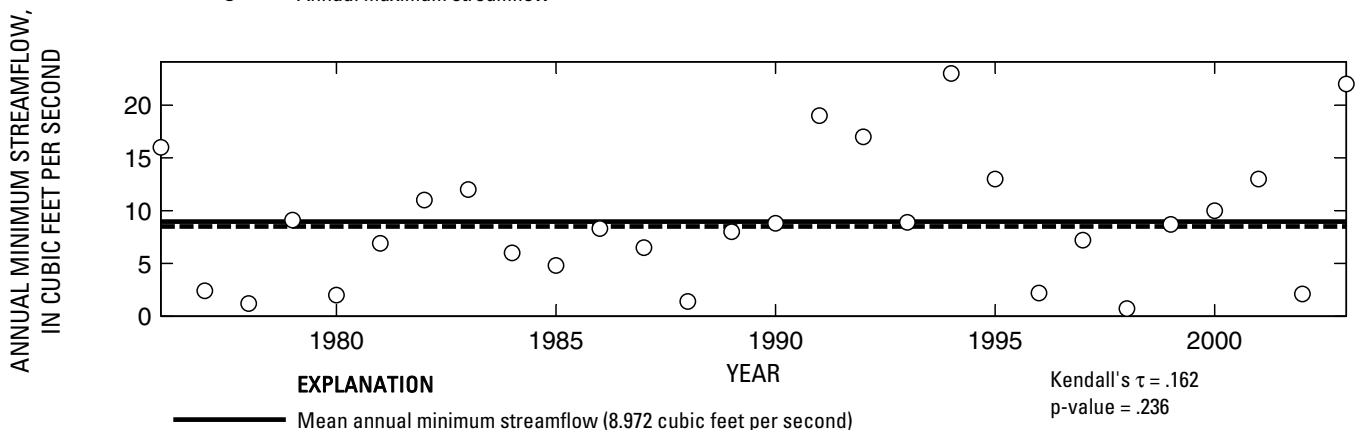

- - ב Median annual minimum streamflow (8.5 cubic feet per second)

O Annual minimum streamflow

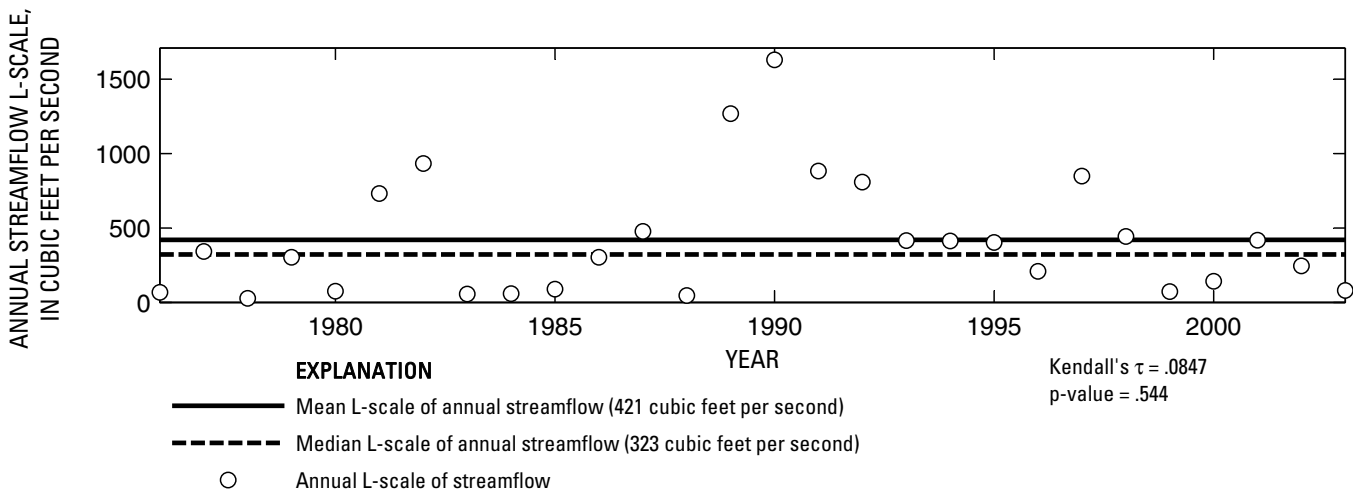

Figure 163. Analysis of annual mean, maximum, minimum, and L-scale statistics of daily mean streamflow for U.S. Geological Survey streamflow-gaging station 08048543 West Fork Trinity River at Beach Street, Fort Worth, Texas. 
U.S. Geological Survey streamflow-gaging station 08048600

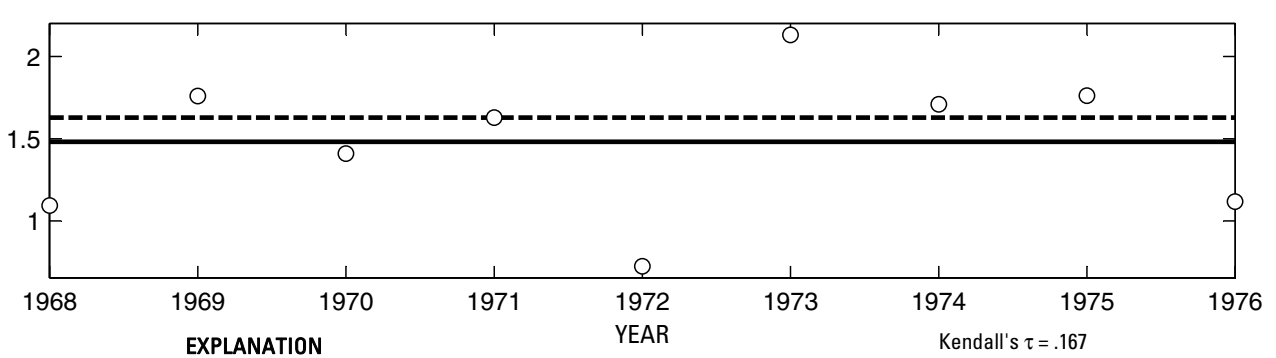

Kendall's $\tau=.167$

Mean annual mean streamflow (1.482 cubic feet per second)

- - - Median annual mean streamflow (1.628 cubic feet per second)

O Annual mean streamflow

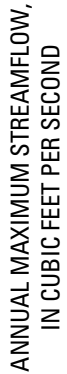

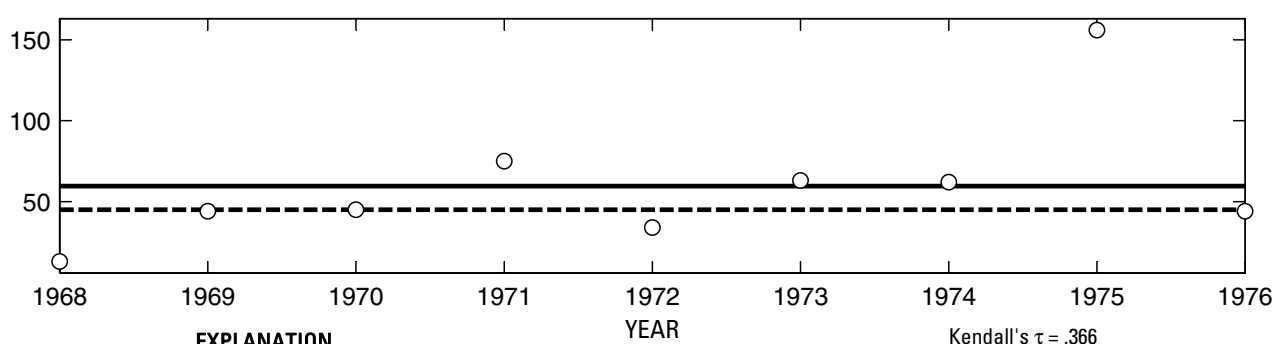

EXPLANATION Kendall's $\tau=36$

Mean annual maximum streamflow (59.6 cubic feet per second)

$\mathrm{p}$-value $=.215$

--_-- Median annual maximum streamflow (45 cubic feet per second)

O Annual maximum streamflow

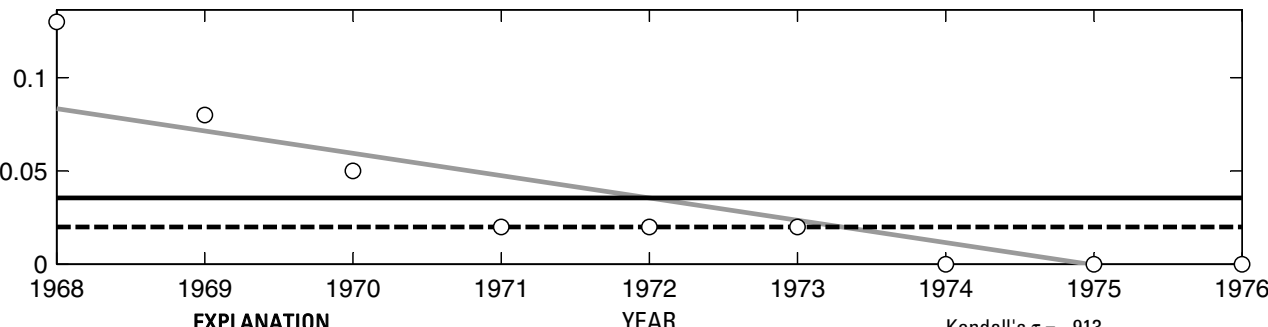

EXPLANATION KEAR Kendall's $\tau=-.913$

Theil trend line for annual minimum streamflow

$\mathrm{p}$-value $=<.001$

O Annual minimum streamflow

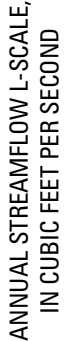

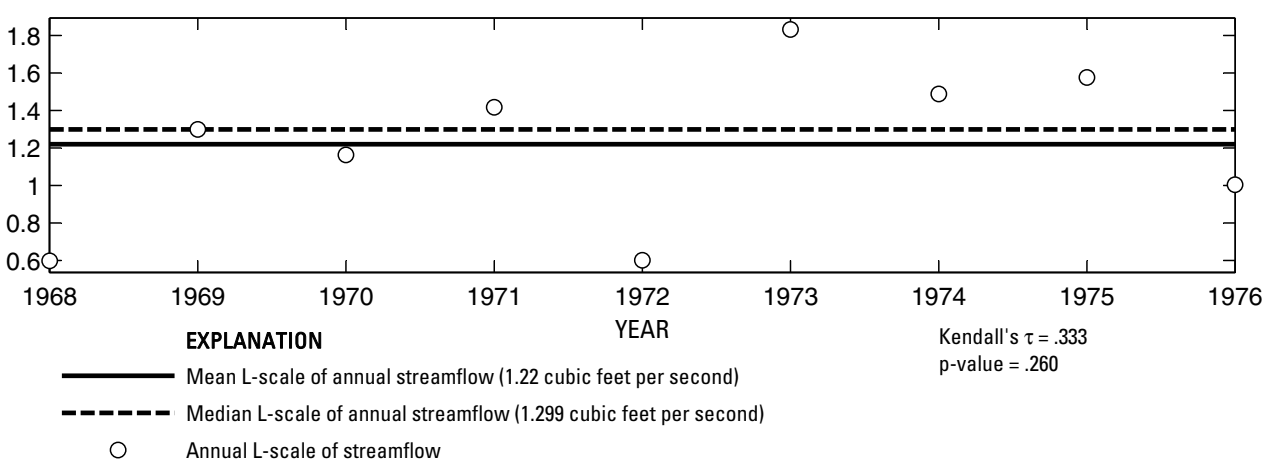

Figure 164. Analysis of annual mean, maximum, minimum, and L-scale statistics of daily mean streamflow for U.S. Geological Survey streamflow-gaging station 08048600 Dry Branch at Fain Street, Fort Worth, Texas.

Index of Station Numbers 719 


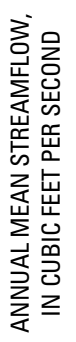

U.S. Geological Survey streamflow-gaging station 08048800

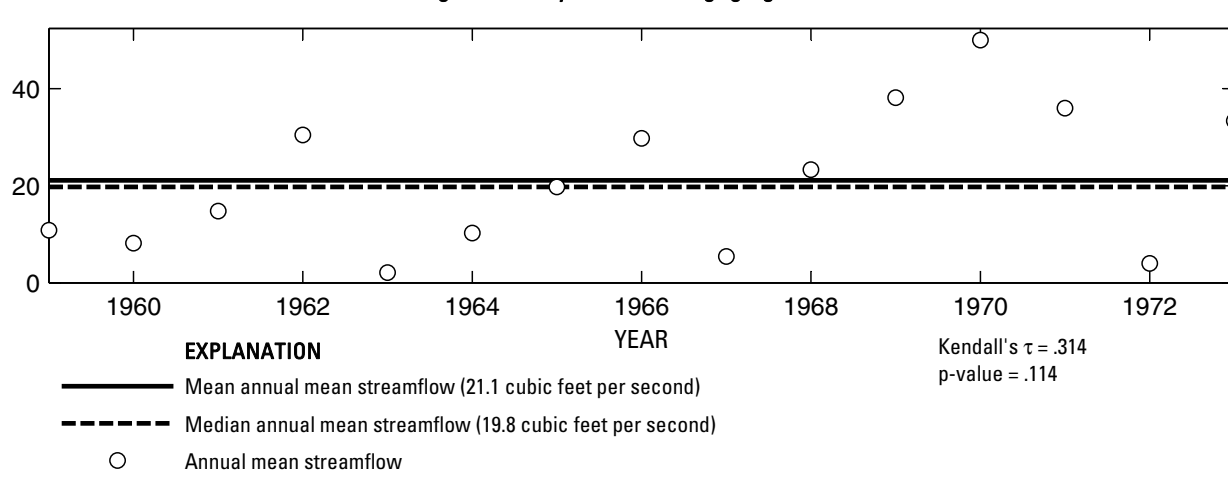

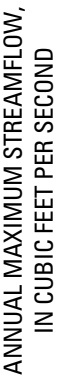

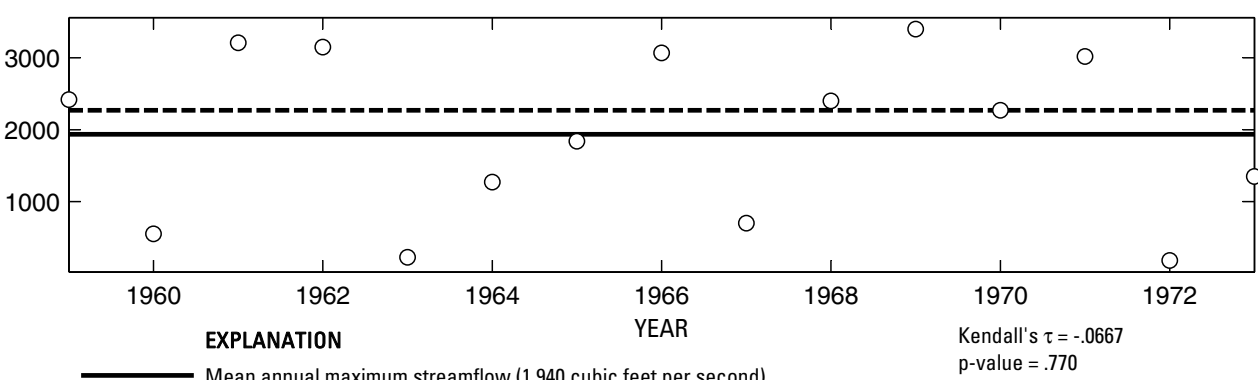

O Annual maximum streamflow

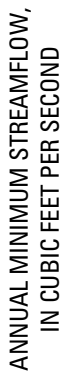

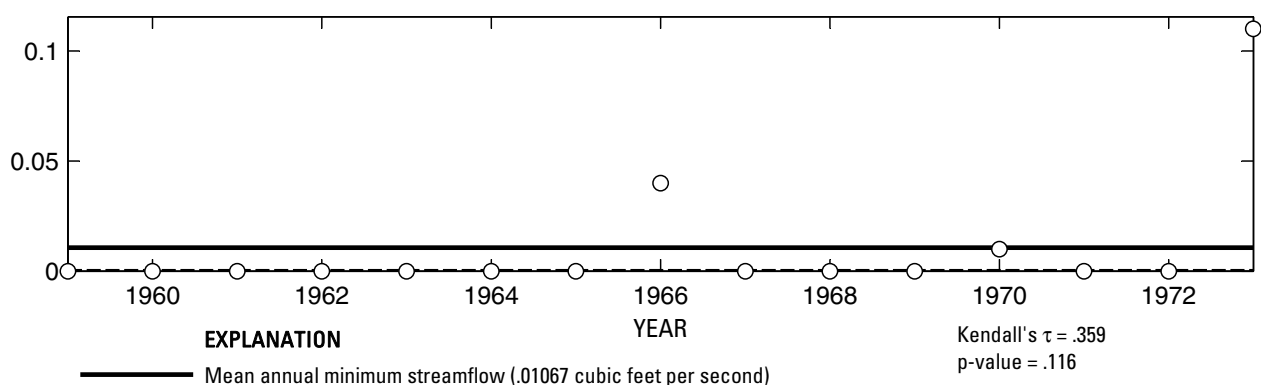

- ב-ב Median annual minimum streamflow (0 cubic feet per second)

O Annual minimum streamflow

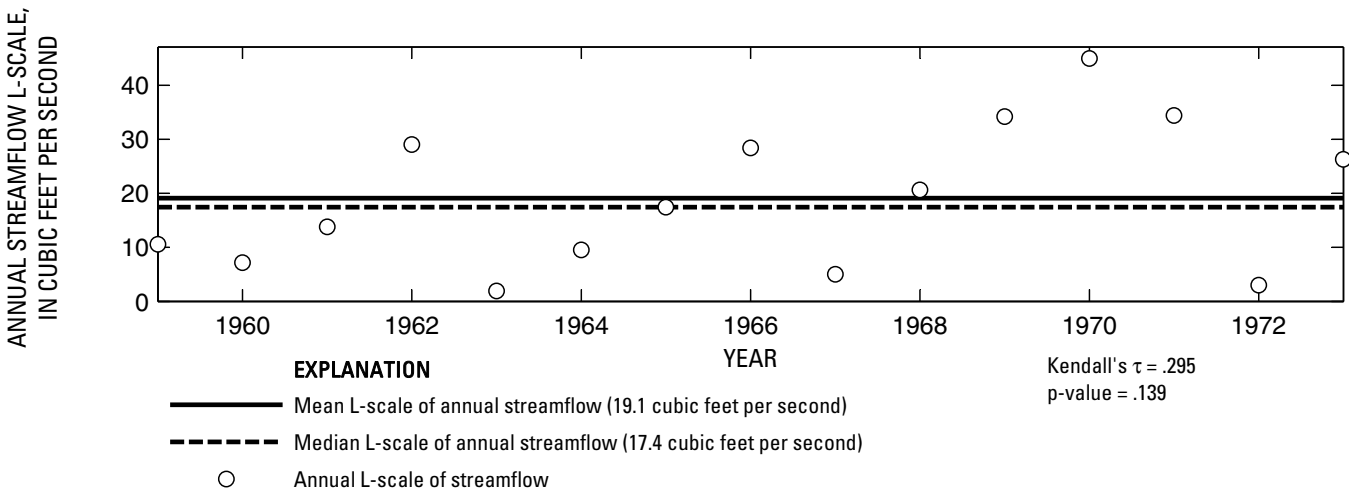

Figure 165. Analysis of annual mean, maximum, minimum, and L-scale statistics of daily mean streamflow for U.S. Geological Survey streamflow-gaging station 08048800 Big Fossil Creek at Haltom City, Texas. 
170 Summary of Annual Mean, Maximum, Minimum, and L-scale Statistics of Daily Mean Streamflow in Texas
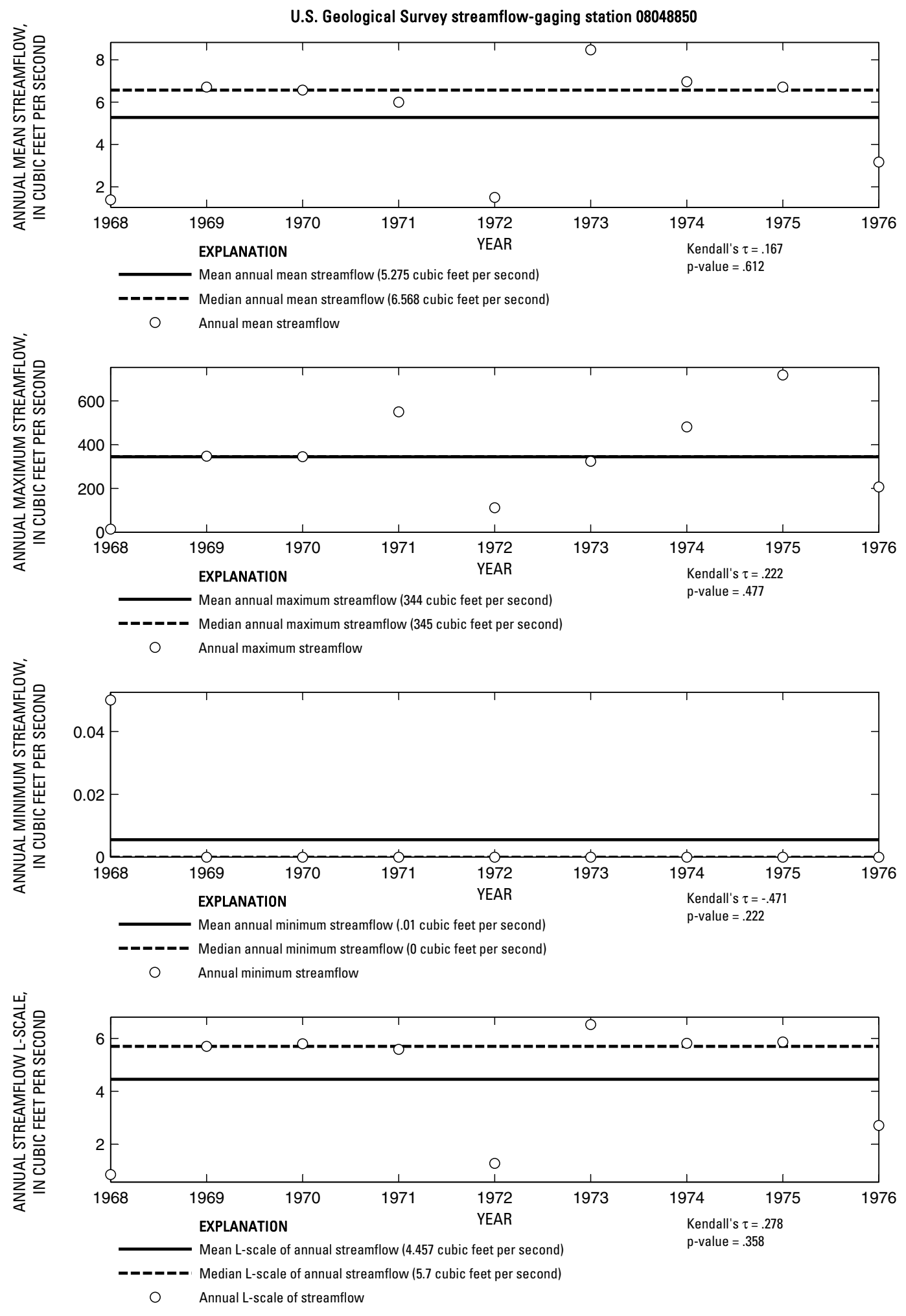

Figure 166. Analysis of annual mean, maximum, minimum, and L-scale statistics of daily mean streamflow for U.S. Geological Survey streamflow-gaging station 08048850 Little Fossil Creek at Mesquite Street, Fort Worth, Texas.

Index of Station Numbers 719 

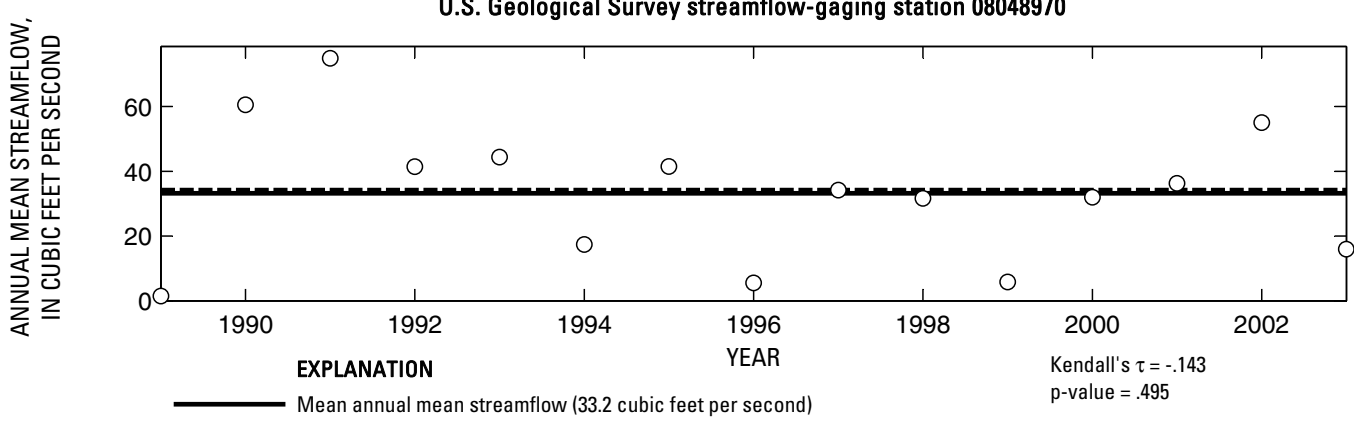

-_-_- Median annual mean streamflow (34.2 cubic feet per second)

O Annual mean streamflow
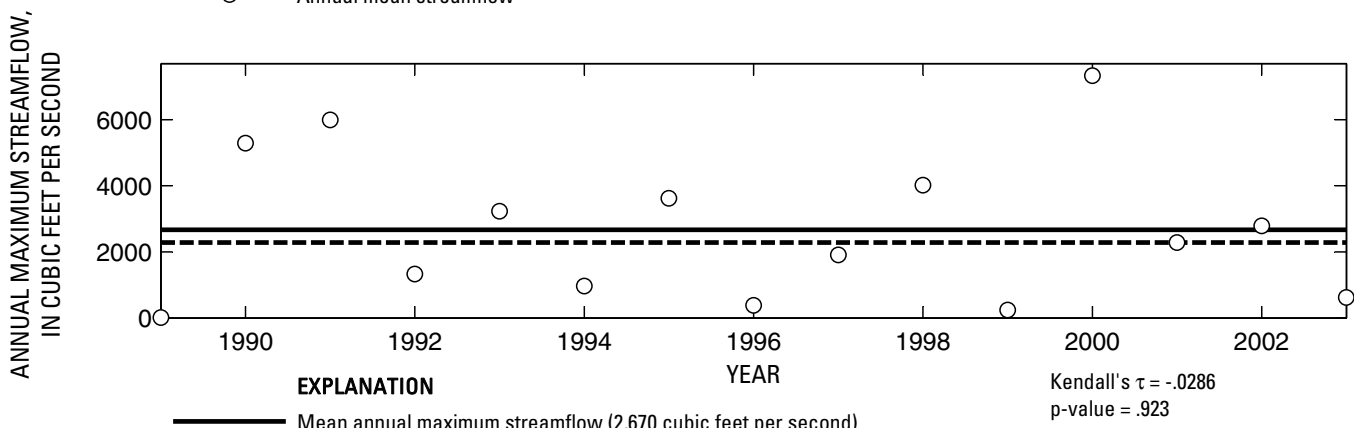

- _ _ Median annual maximum streamflow (2,280 cubic feet per second)

O Annual maximum streamflow
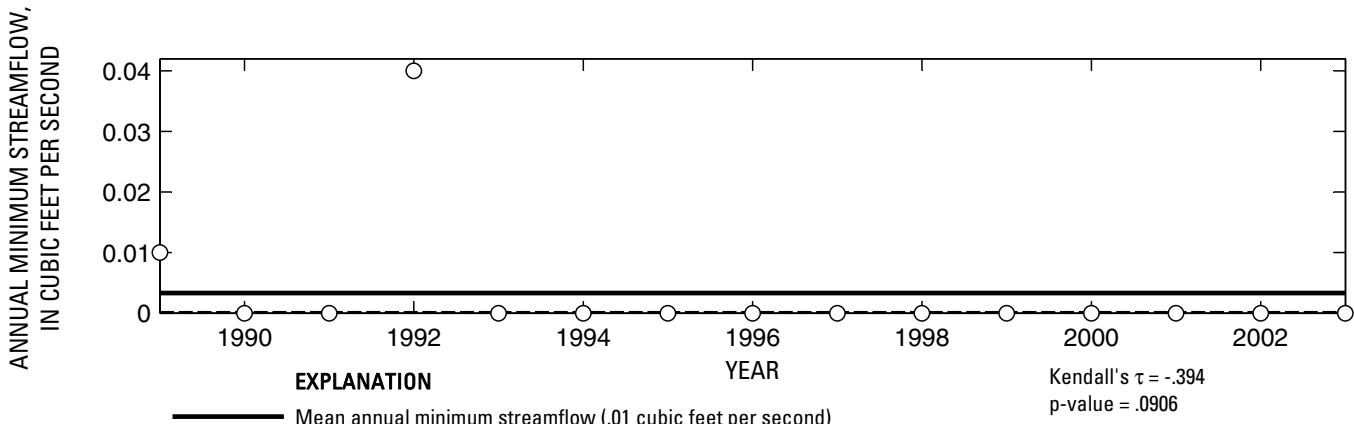

- - - Median annual minimum streamflow (0 cubic feet per second)

○ Annual minimum streamflow
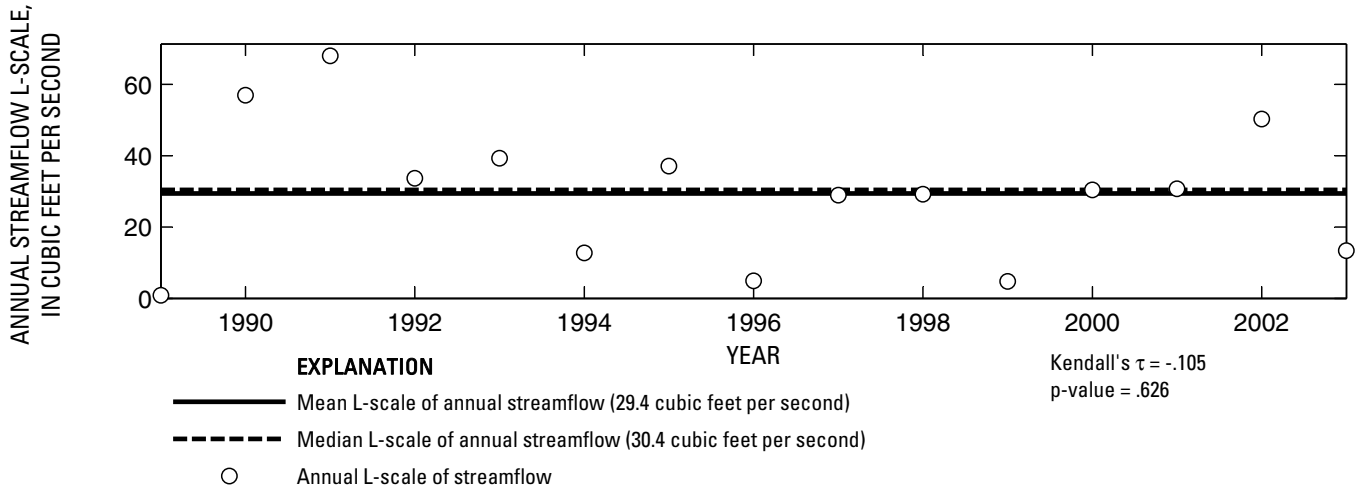

Figure 167. Analysis of annual mean, maximum, minimum, and L-scale statistics of daily mean streamflow for U.S. Geological Survey streamflow-gaging station 08048970 Village Creek at Everman, Texas. 

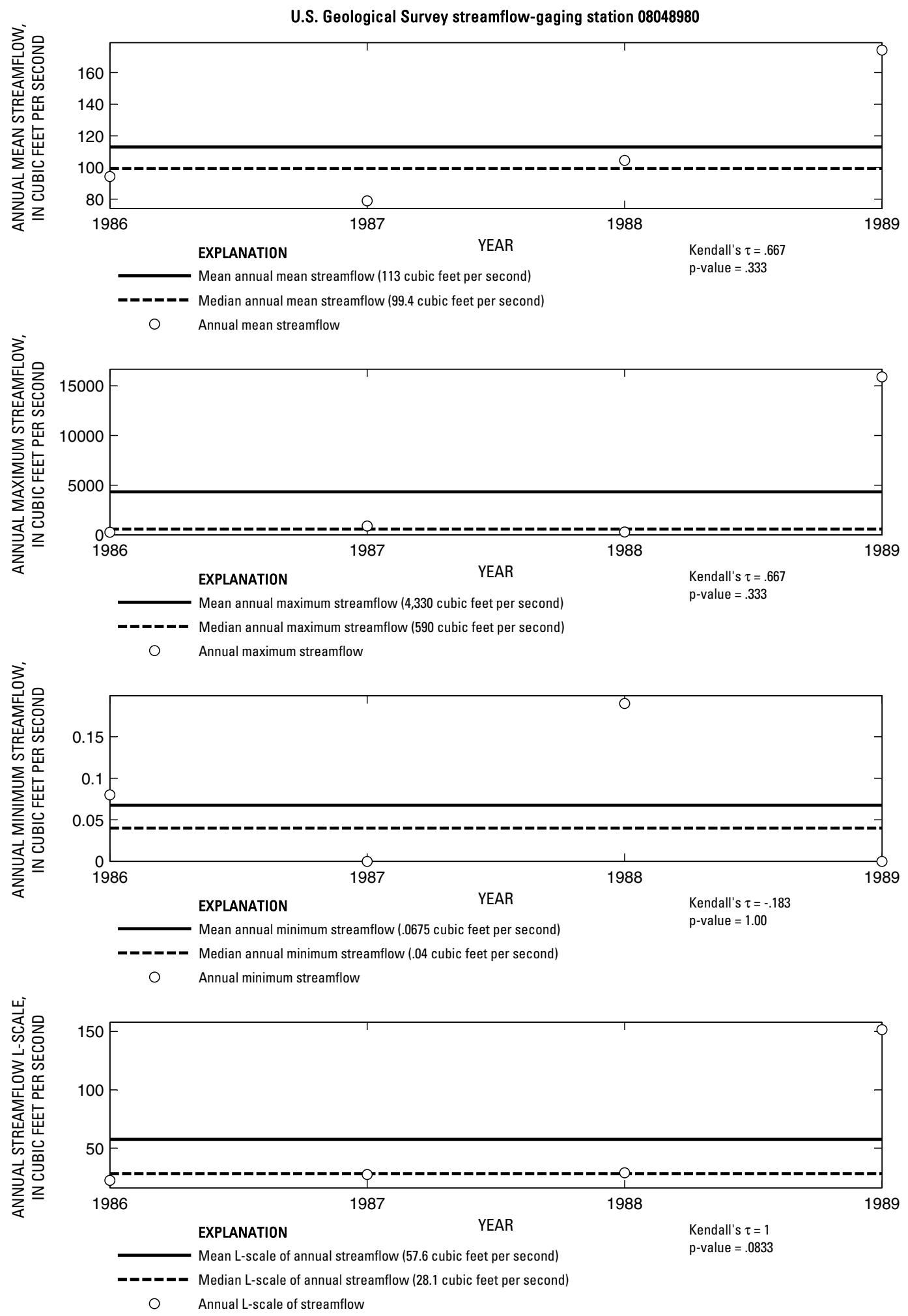

Figure 168. Analysis of annual mean, maximum, minimum, and L-scale statistics of daily mean streamflow for U.S. Geological Survey streamflow-gaging station 08048980 Village Creek at Kennedale, Texas. 


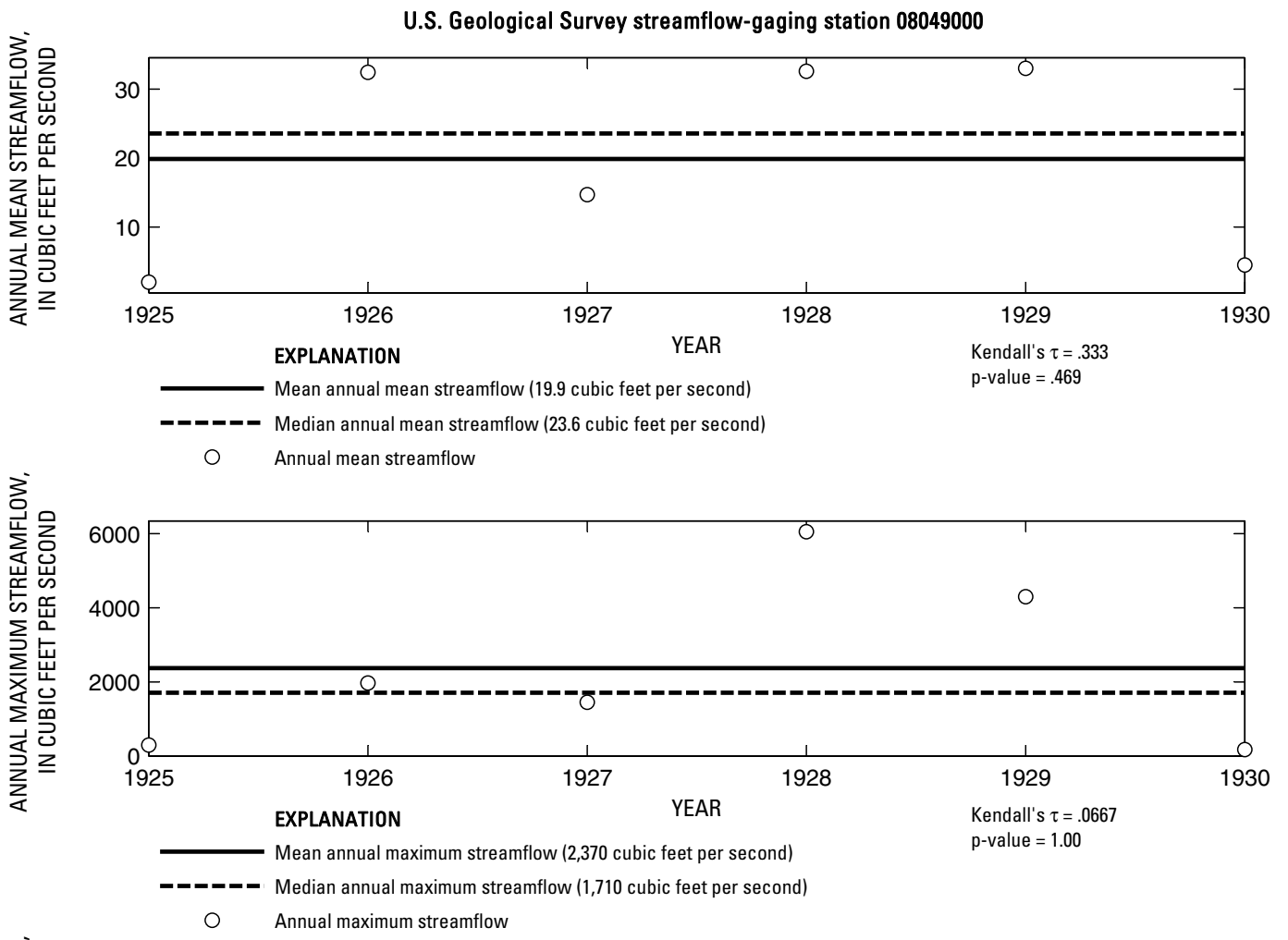

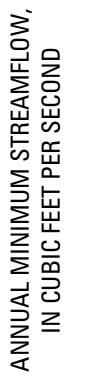

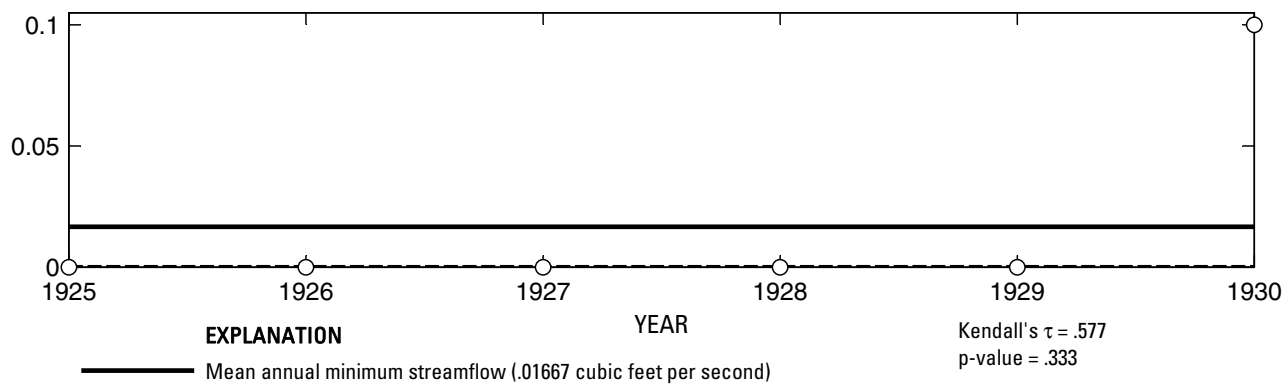

- ב-ב Median annual minimum streamflow (0 cubic feet per second)

O Annual minimum streamflow

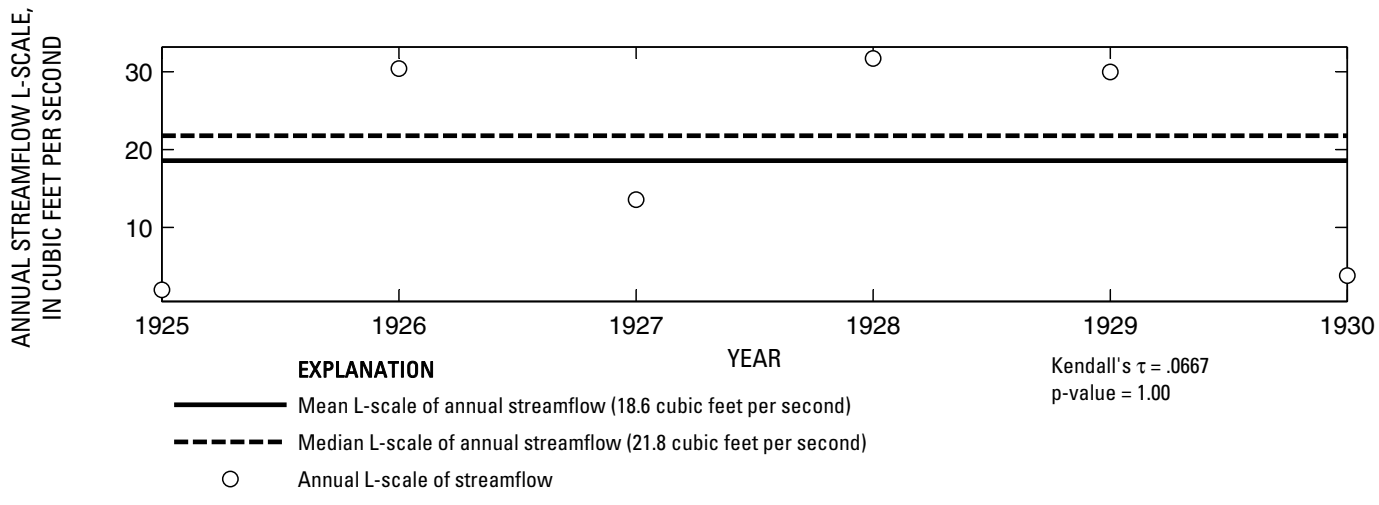

Figure 169. Analysis of annual mean, maximum, minimum, and L-scale statistics of daily mean streamflow for U.S. Geological Survey streamflow-gaging station 08049000 Village Creek near Handley, Texas. 
174 Summary of Annual Mean, Maximum, Minimum, and L-scale Statistics of Daily Mean Streamflow in Texas

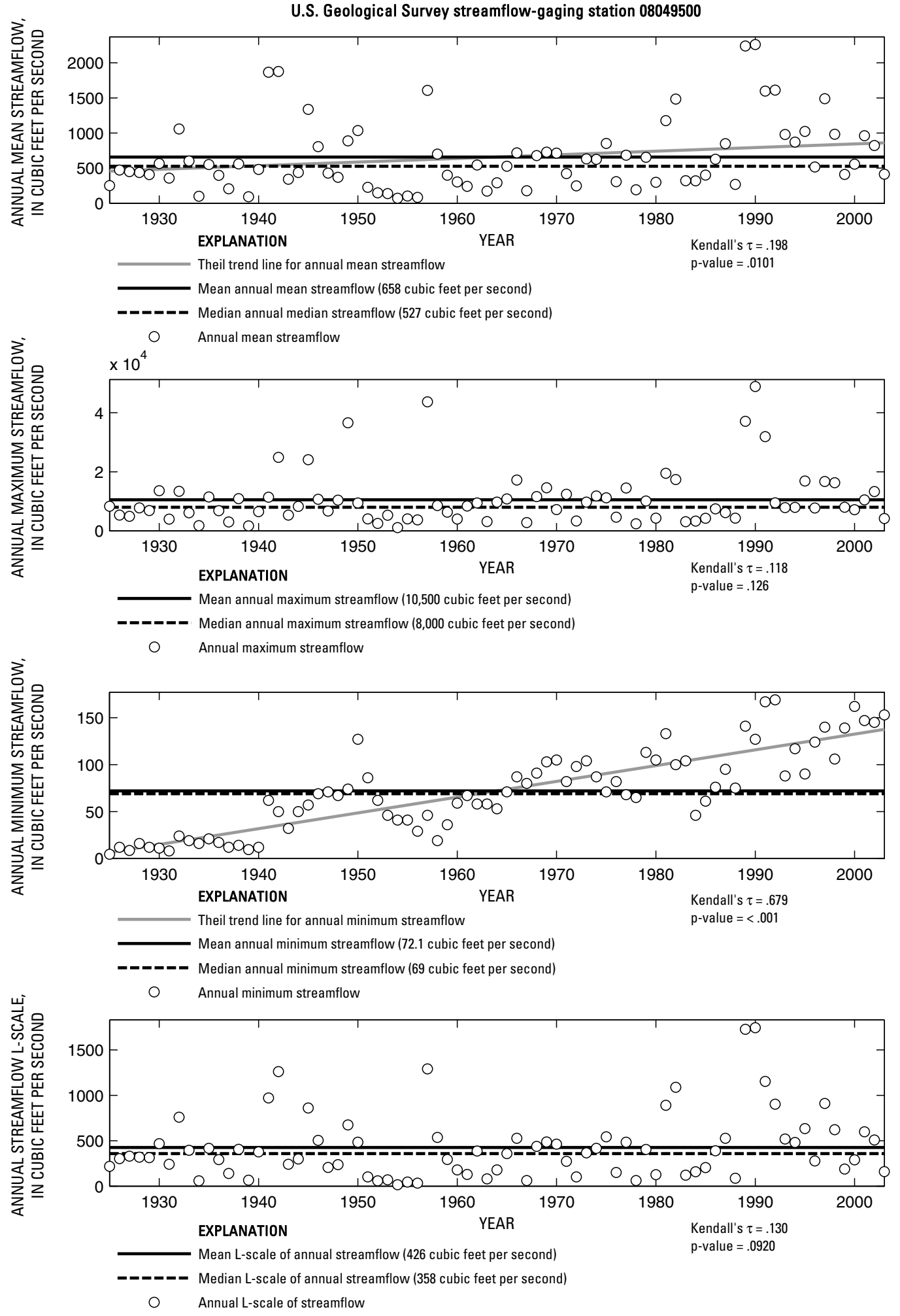

Figure 170. Analysis of annual mean, maximum, minimum, and L-scale statistics of daily mean streamflow for U.S. Geological Survey streamflow-gaging station 08049500 West Fork Trinity River at Grand Prairie, Texas.

Index of Station Numbers 719 


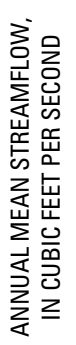

U.S. Geological Survey streamflow-gaging station 08049550

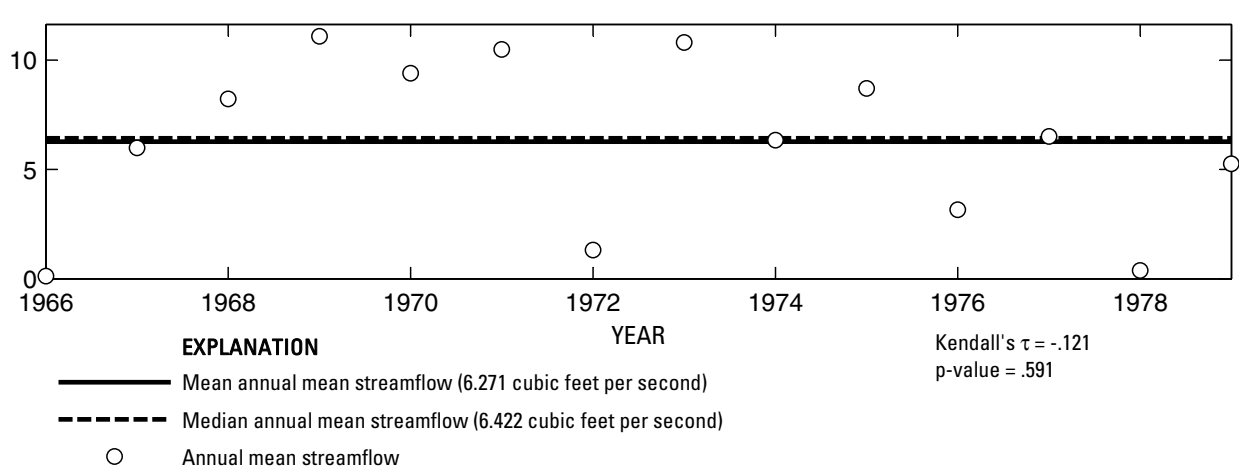

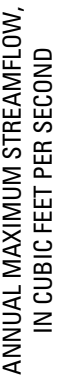

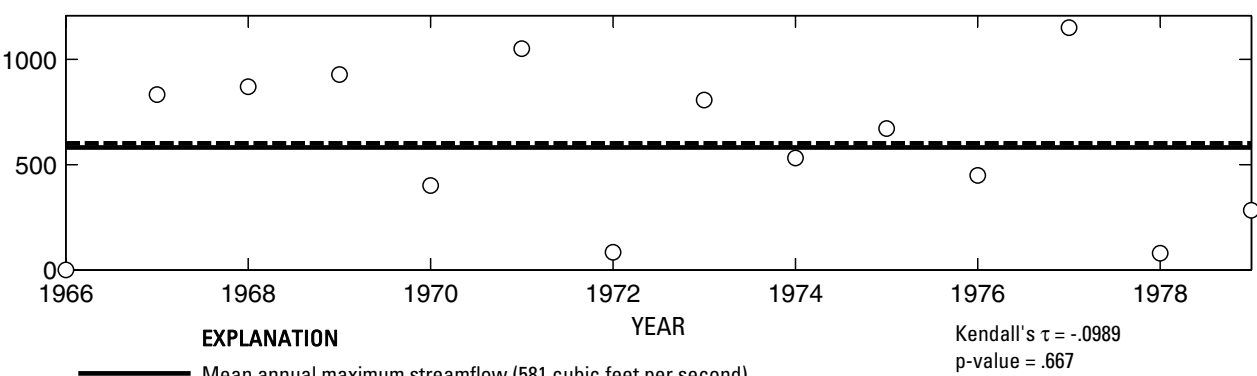

- - - Median annual maximum streamflow (602 cubic feet per second)

Annual maximum streamflow

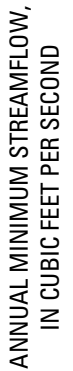

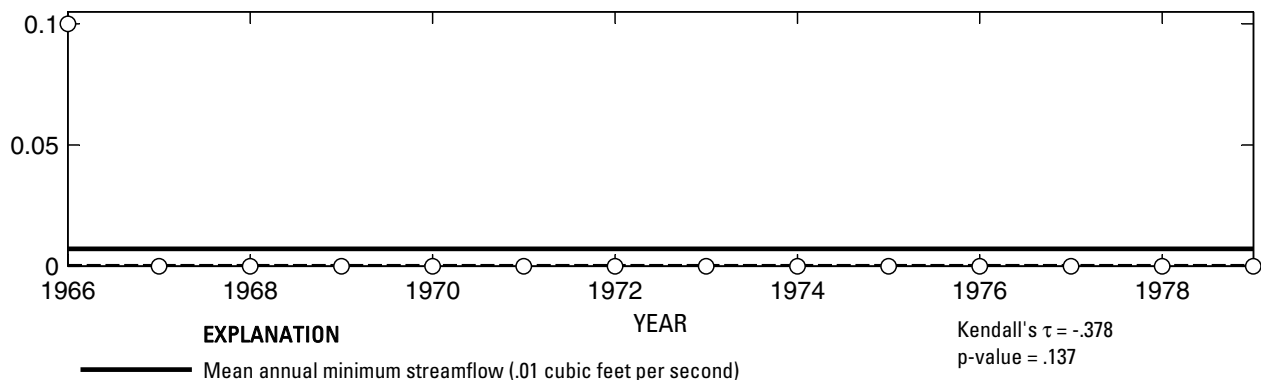

- ב-ב Median annual minimum streamflow (0 cubic feet per second)

○ Annual minimum streamflow

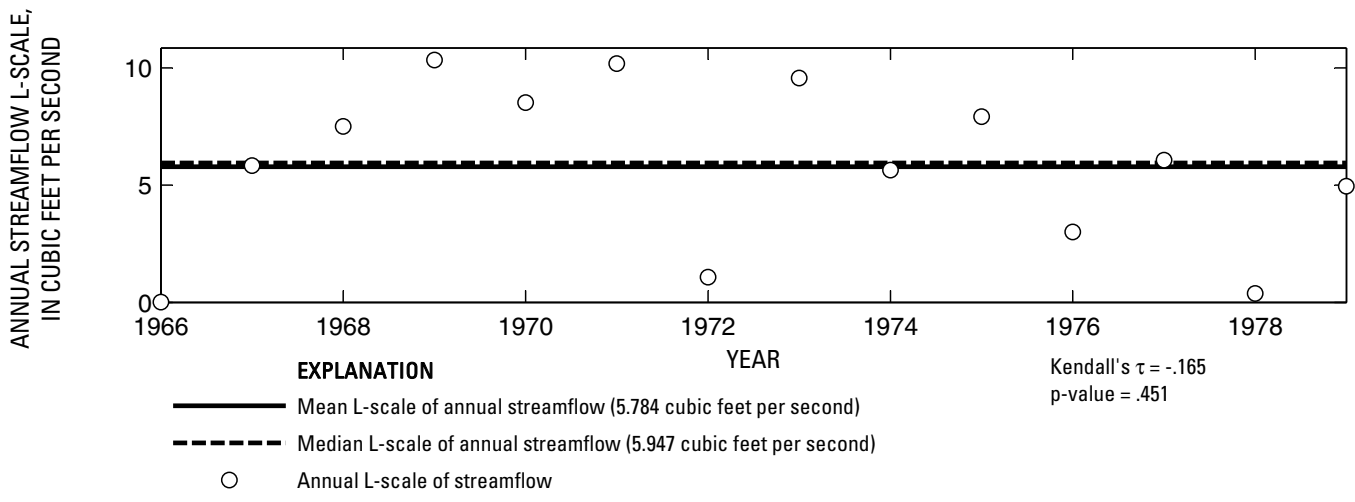

Figure 171. Analysis of annual mean, maximum, minimum, and L-scale statistics of daily mean streamflow for U.S. Geological Survey streamflow-gaging station 08049550 Big Bear Creek near Grapevine, Texas.

Index of Station Numbers 719 


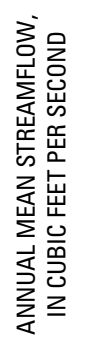

U.S. Geological Survey streamflow-gaging station 08049553

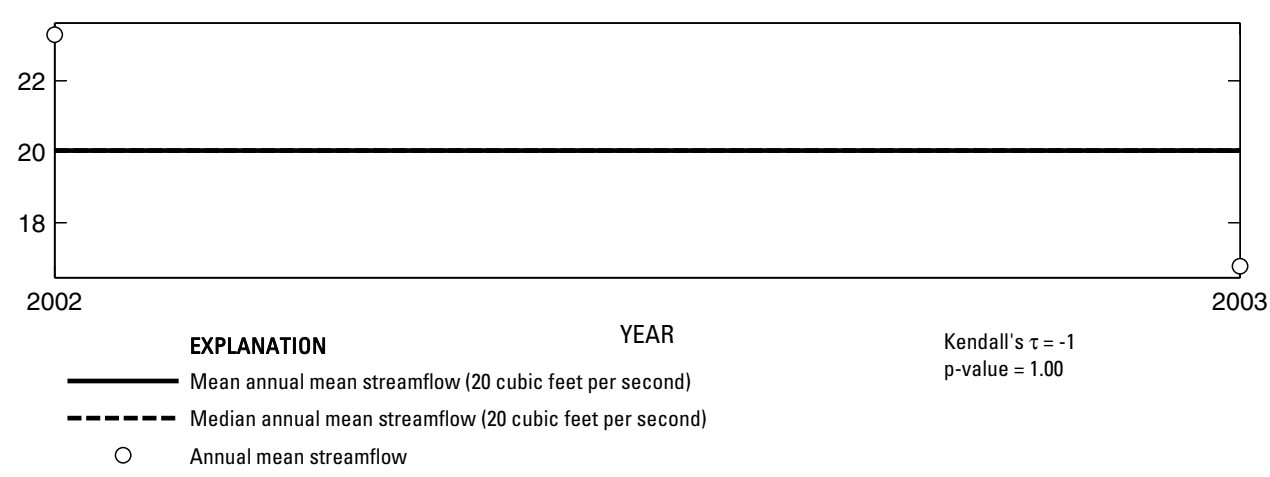

家

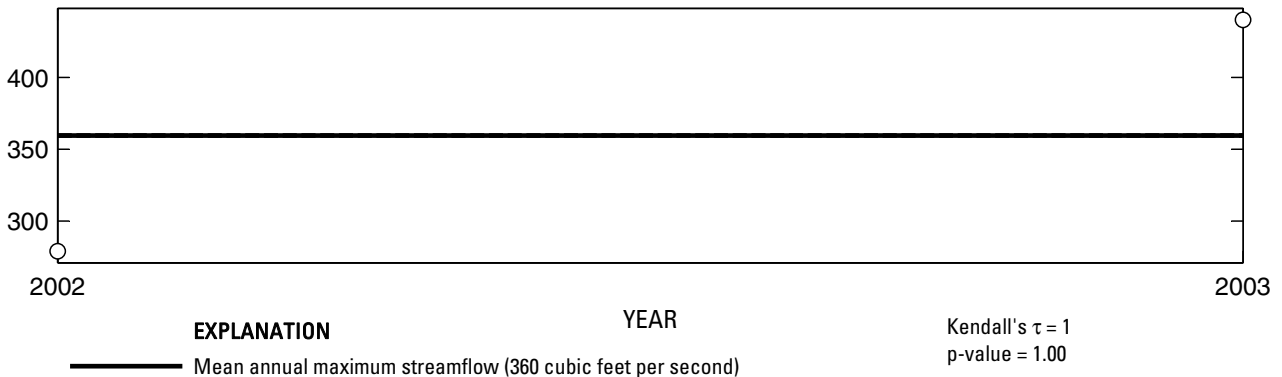

- - - Median annual maximum streamflow (360 cubic feet per second)

O Annual maximum streamflow

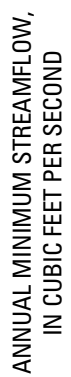

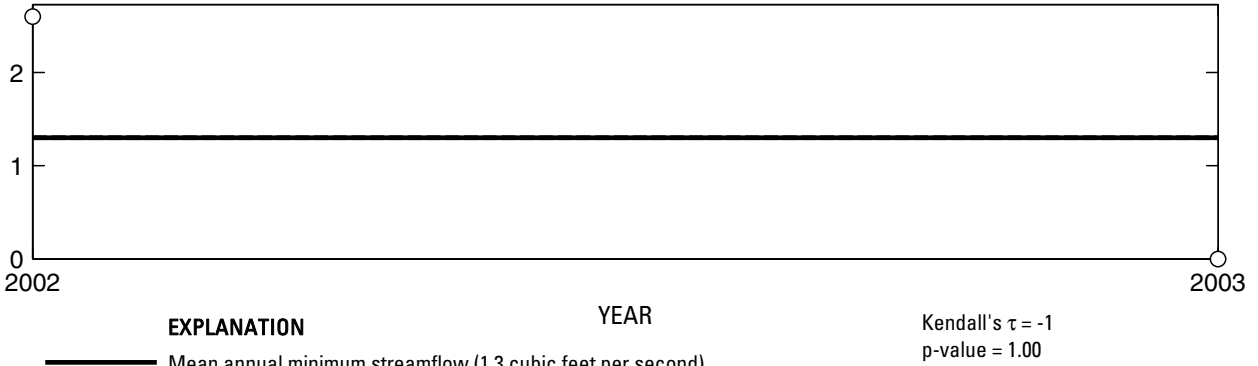

O Annual minimum streamflow

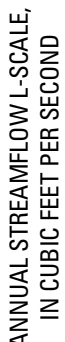

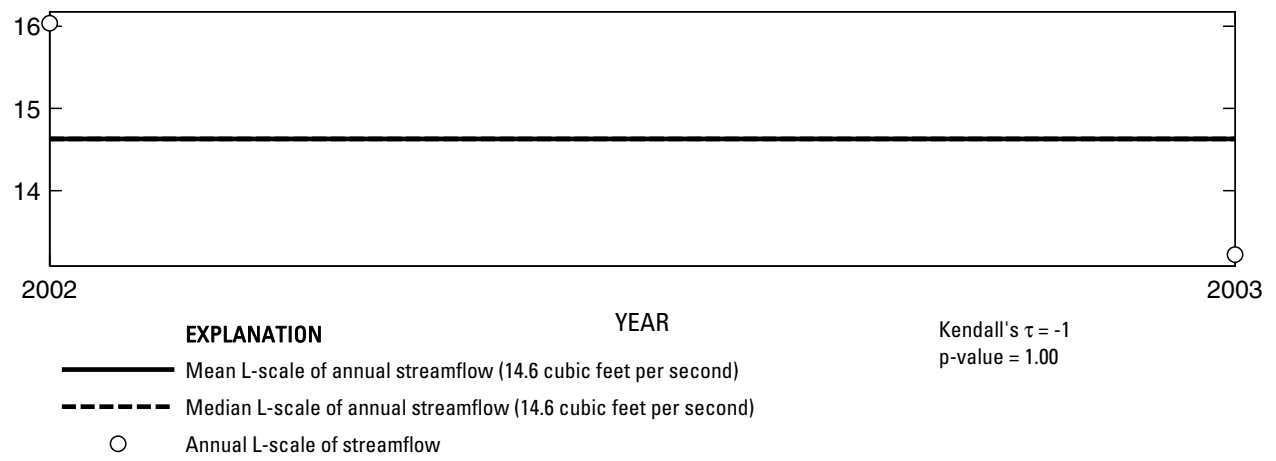

Figure 172. Analysis of annual mean, maximum, minimum, and L-scale statistics of daily mean streamflow for U.S. Geological Survey streamflow-gaging station 08049553 Big Bear Creek at Euless/Grapevine Road near Grapevine, Texas. 


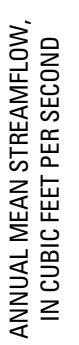

U.S. Geological Survey streamflow-gaging station 08049556

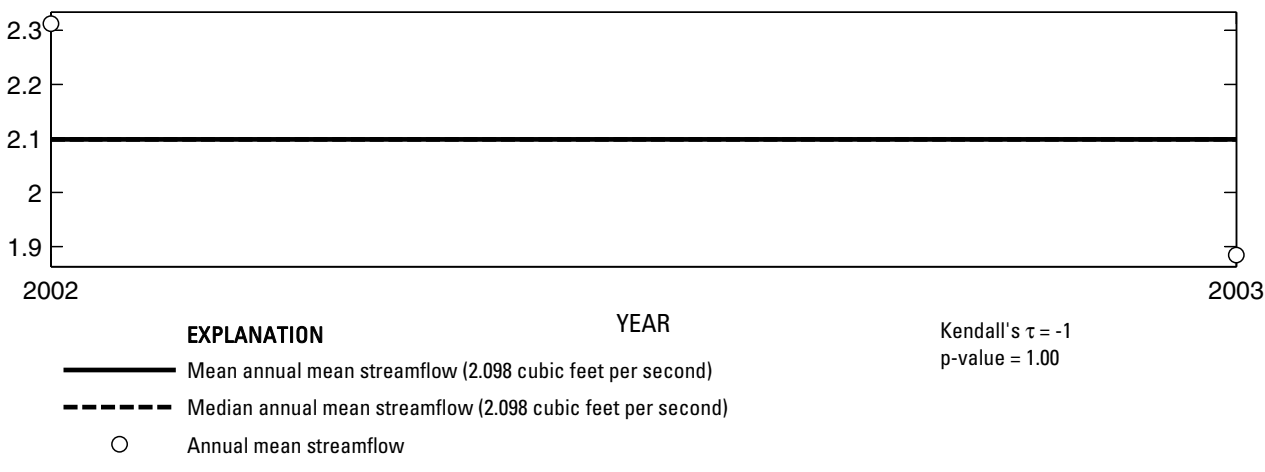

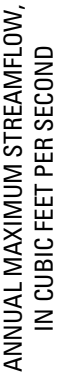

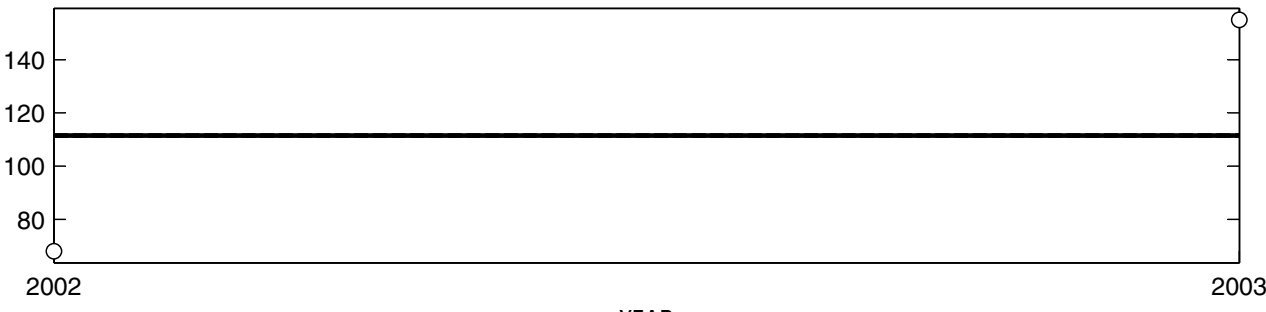

EXPLANATION

YEAR

Kendall's $\tau=1$

Mean annual maximum streamflow (112 cubic feet per second)

$\mathrm{p}$-value $=1.00$

- - - Median annual maximum streamflow (112 cubic feet per second)

○

Annual maximum streamflow

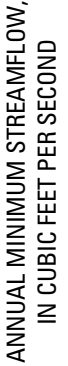

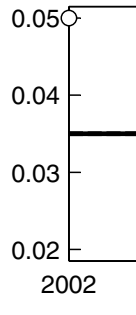

EXPLANATION

Mean annual minimum streamflow ( .035 cubic feet per second)

YEAR

- - - Median annual minimum streamflow ( .035 cubic feet per second)

O

Annual minimum streamflow

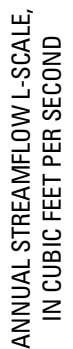

2

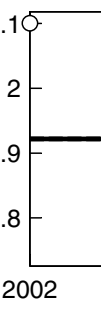

(2) 

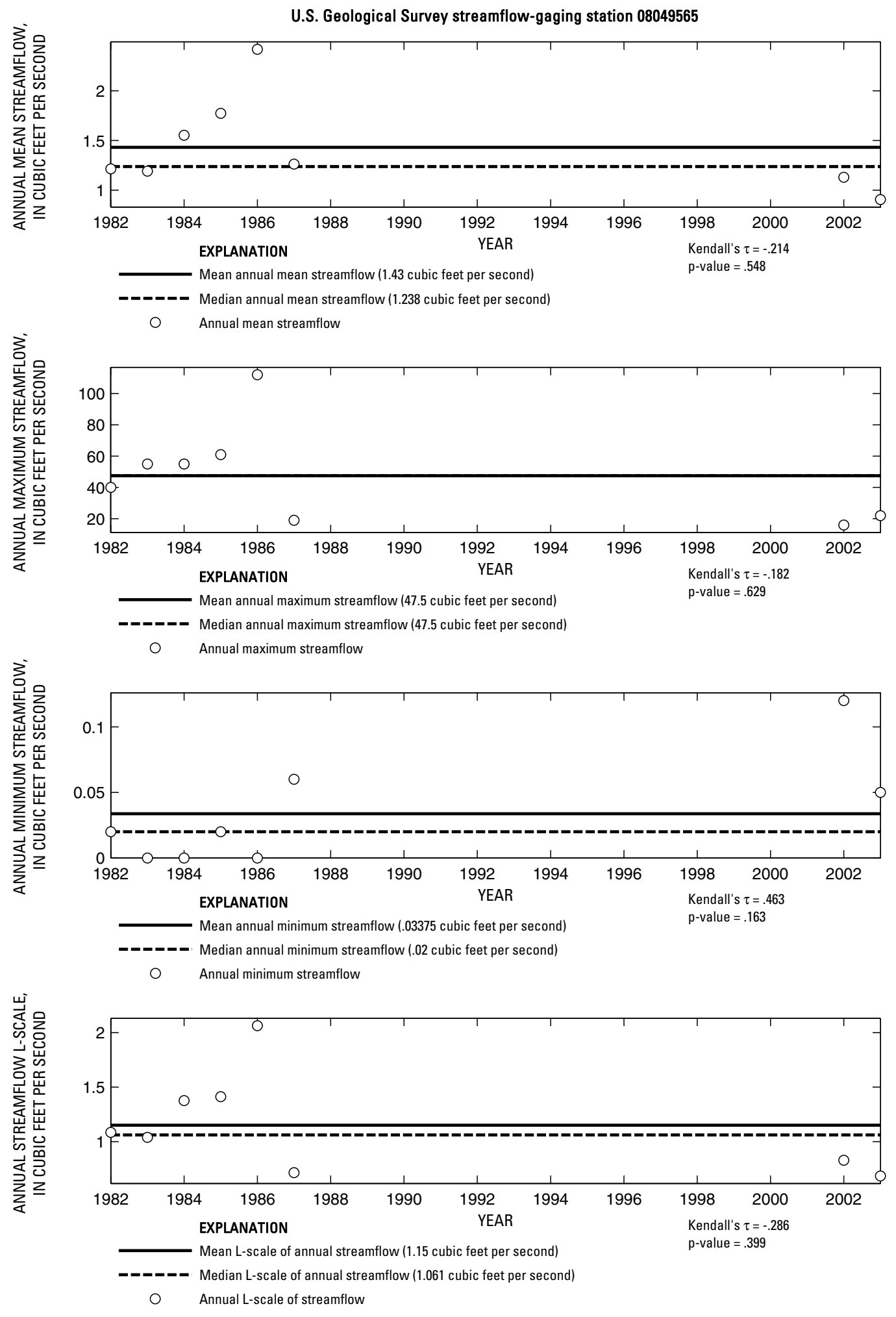

Figure 174. Analysis of annual mean, maximum, minimum, and L-scale statistics of daily mean streamflow for U.S. Geological Survey streamflow-gaging station 08049565 Trigg Branch at DFW Airport near Euless, Texas.

Index of Station Numbers 719 


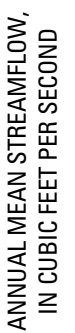

U.S. Geological Survey streamflow-gaging station 08049569

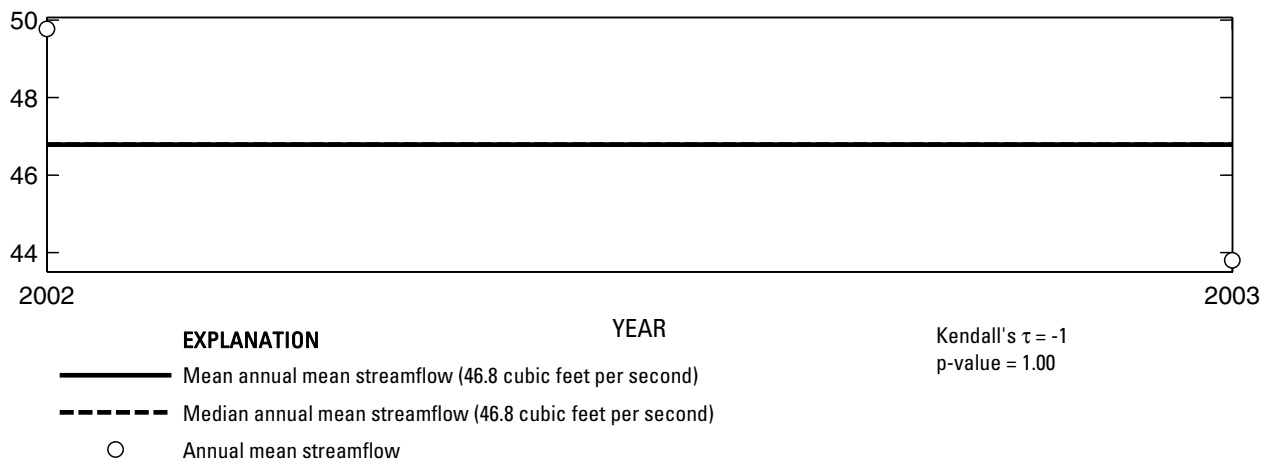

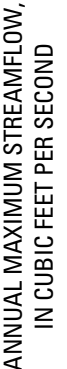

1800
1600
1400
1200
1000
800
20

2002

EXPLANATION

YEAR

2003

Mean annual maximum streamflow $(1,310$ cubic feet per second)

Annual maximum streamflow

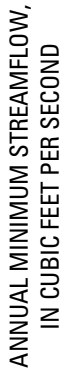
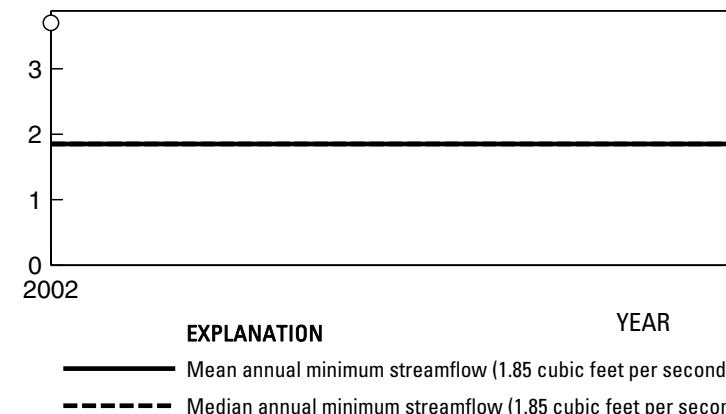

- ב-ב Median annual minimum streamflow (1.85 cubic feet per second)

○

Annual minimum streamflow

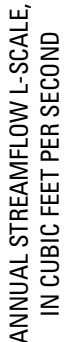

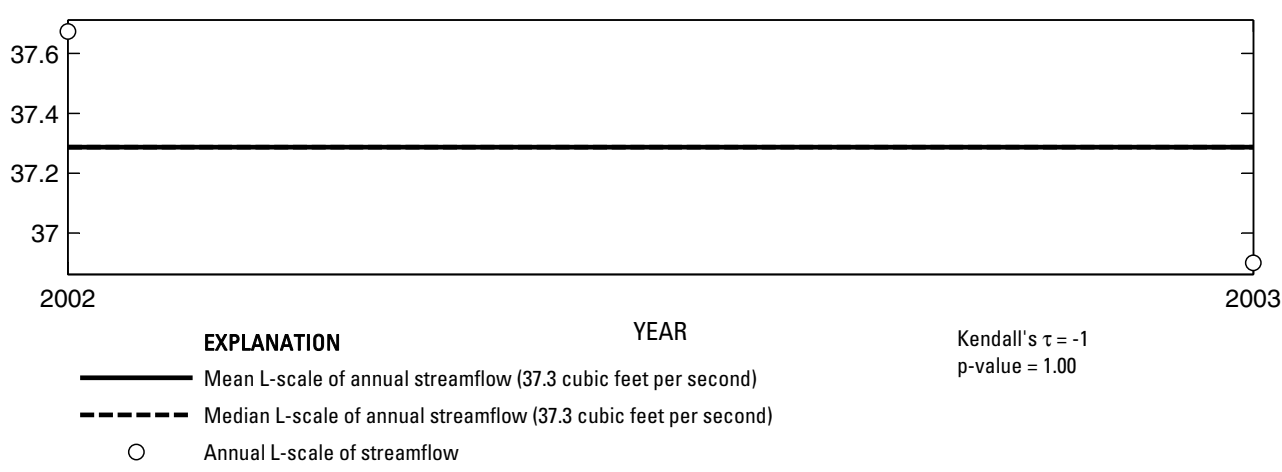

Figure 175. Analysis of annual mean, maximum, minimum, and L-scale statistics of daily mean streamflow for U.S. Geological Survey streamflow-gaging station 08049569 Big Bear Creek at State Highway 183 near Euless, Texas. 
U.S. Geological Survey streamflow-gaging station 08049580
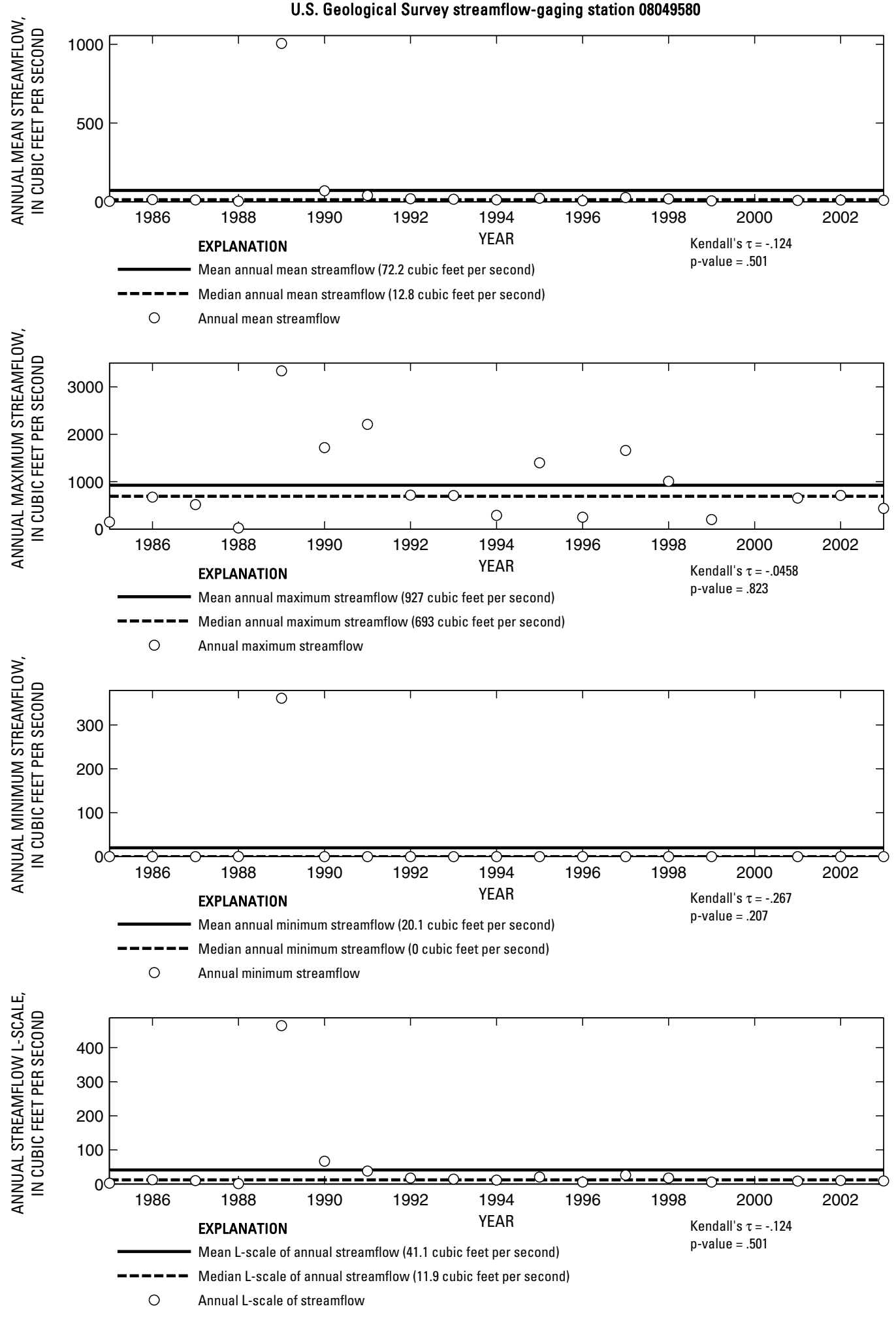

Figure 176. Analysis of annual mean, maximum, minimum, and L-scale statistics of daily mean streamflow for U.S. Geological Survey streamflow-gaging station 08049580 Mountain Creek near Venus, Texas.

Index of Station Numbers 719 

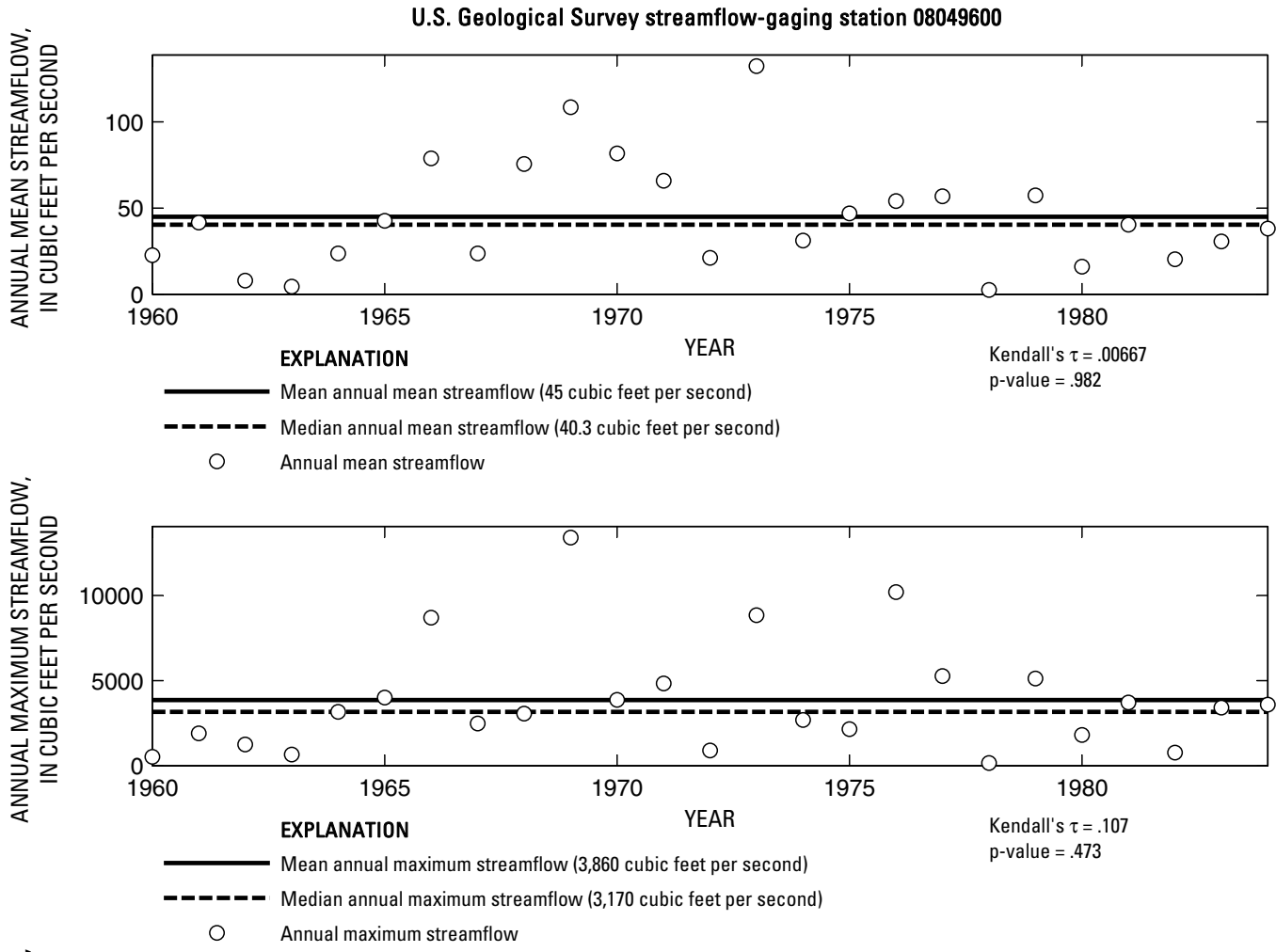

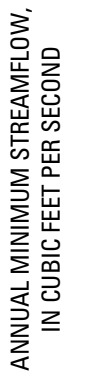

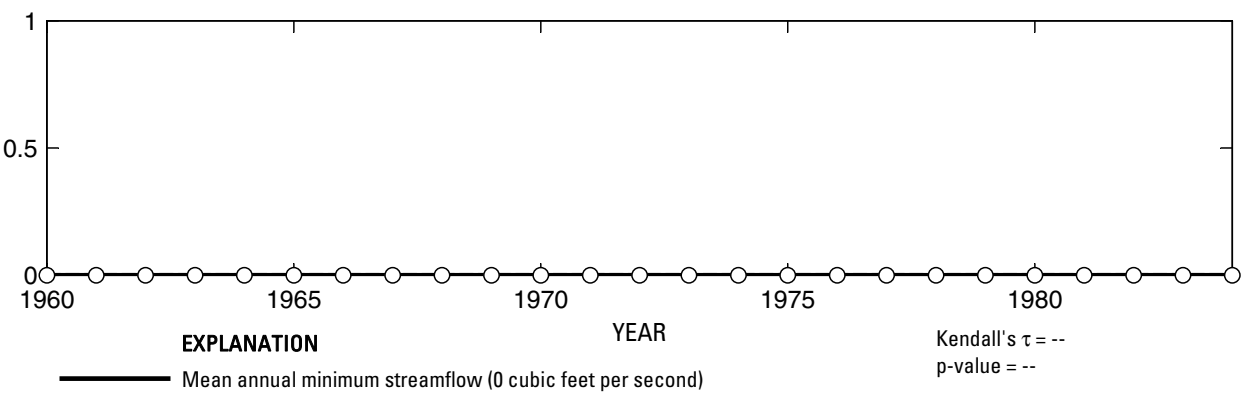

-ביב- Median annual minimum streamflow (0 cubic feet per second)

○ Annual minimum streamflow

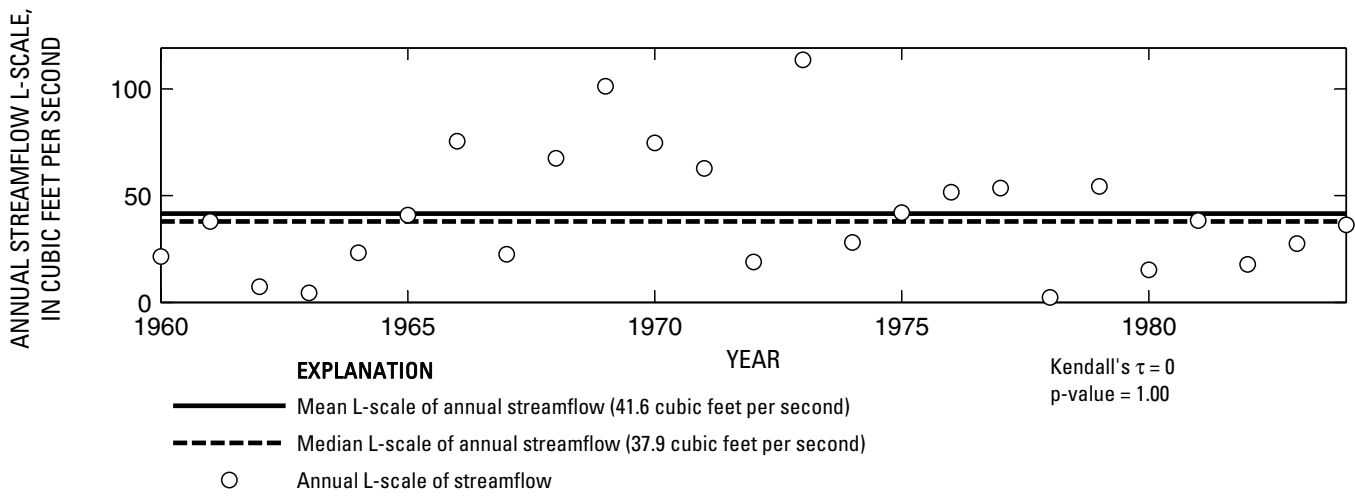

Figure 177. Analysis of annual mean, maximum, minimum, and L-scale statistics of daily mean streamflow for U.S. Geological Survey streamflow-gaging station 08049600 Mountain Creek near Cedar Hill, Texas. 

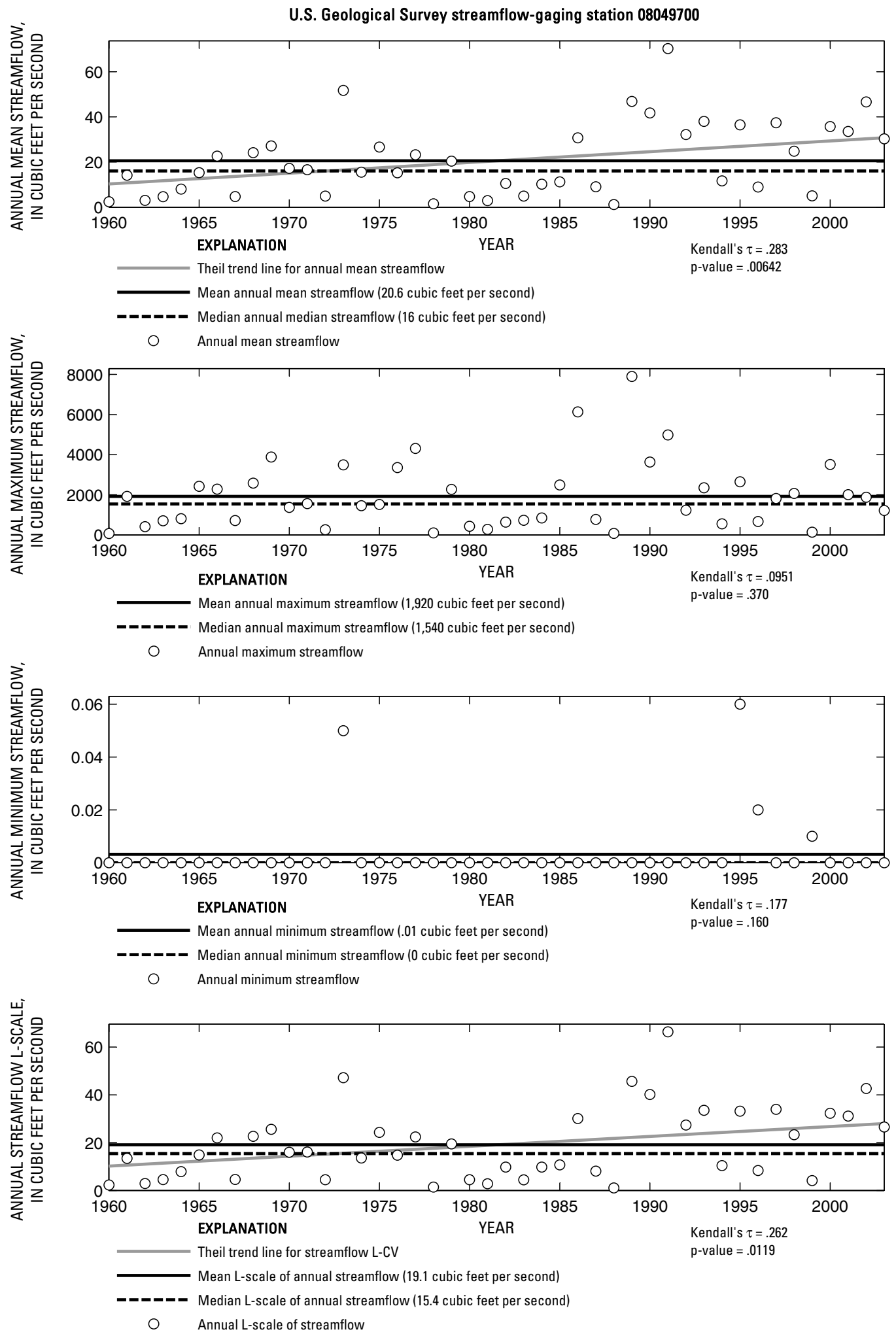

Figure 178. Analysis of annual mean, maximum, minimum, and L-scale statistics of daily mean streamflow for U.S. Geological Survey streamflow-gaging station 08049700 Walnut Creek near Mansfield, Texas.

Index of Station Numbers 719 

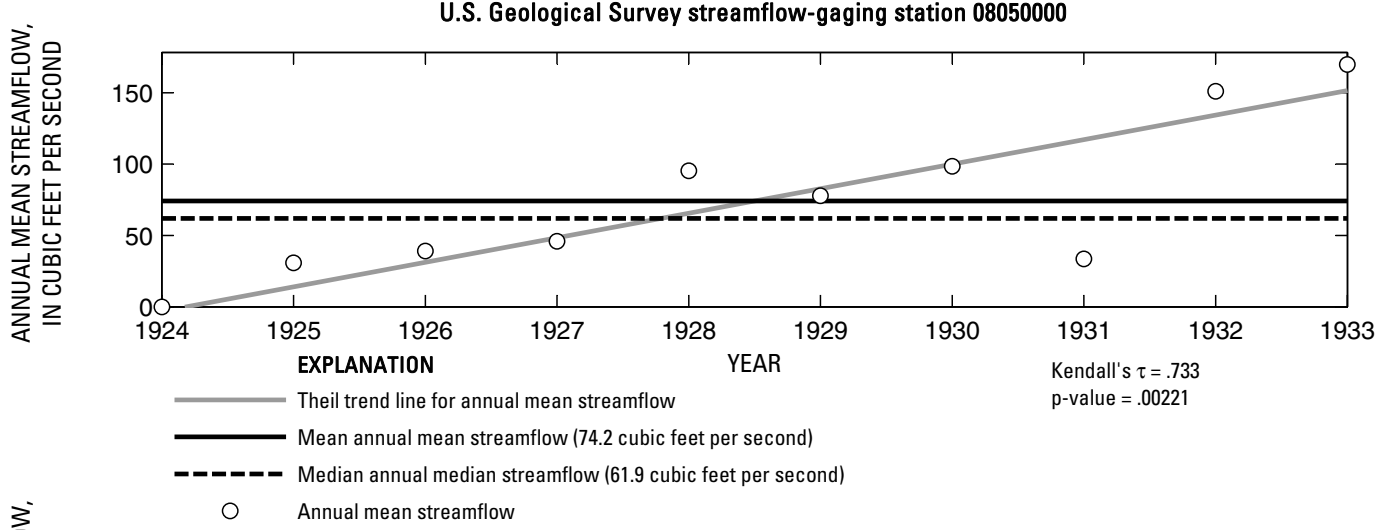

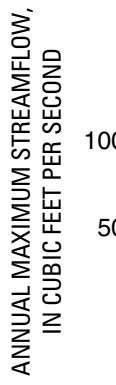

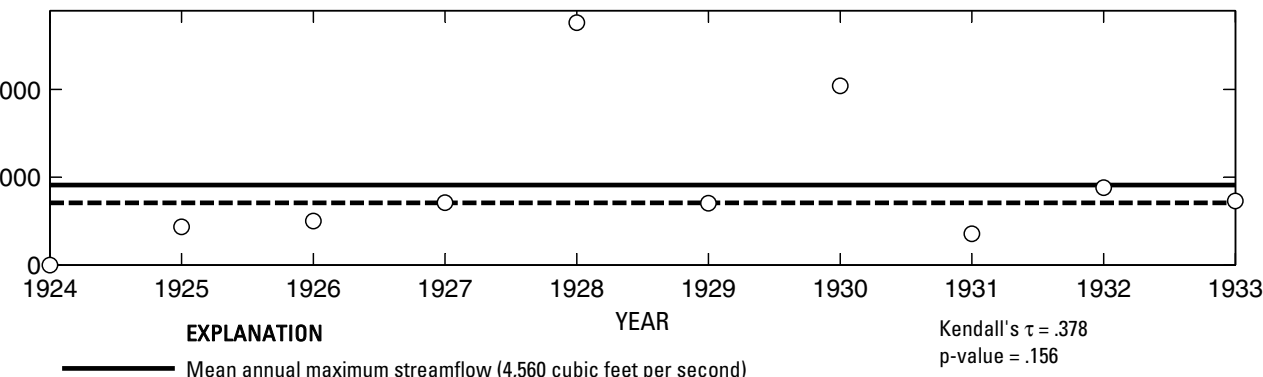

O Annual maximum streamflow

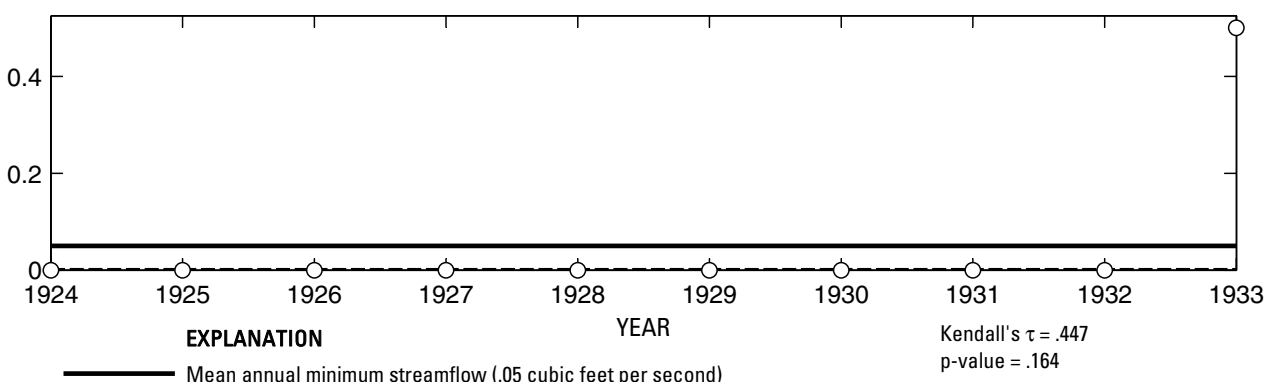

- ב-ב Median annual minimum streamflow (0 cubic feet per second)

O Annual minimum streamflow

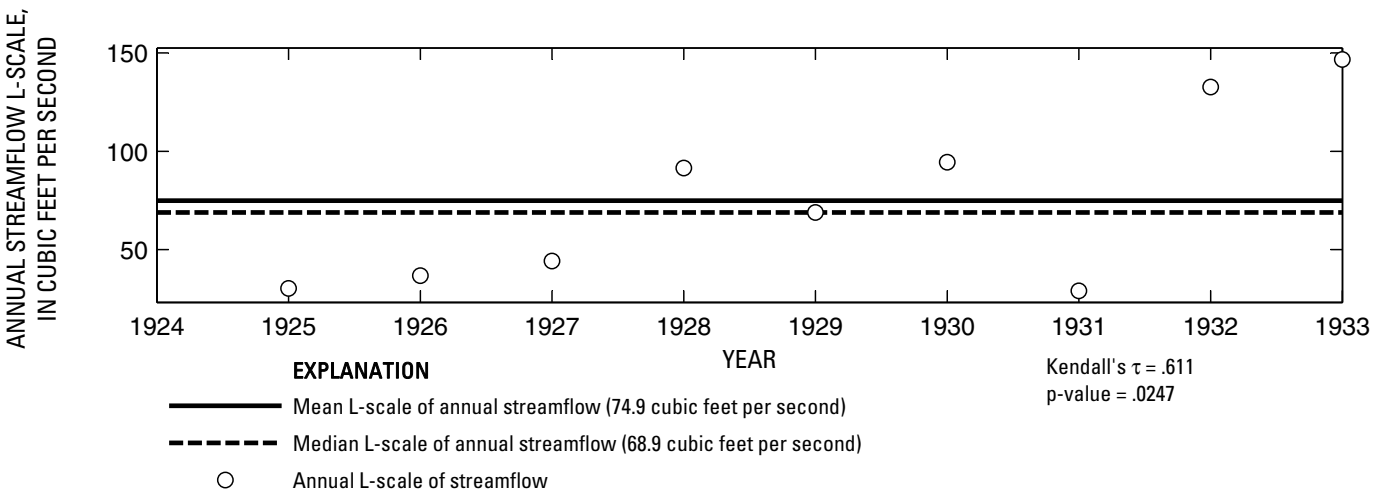

Figure 179. Analysis of annual mean, maximum, minimum, and L-scale statistics of daily mean streamflow for U.S. Geological Survey streamflow-gaging station 08050000 Mountain Creek near Grand Prairie, Texas. 


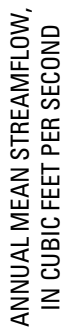

U.S. Geological Survey streamflow-gaging station 08050100

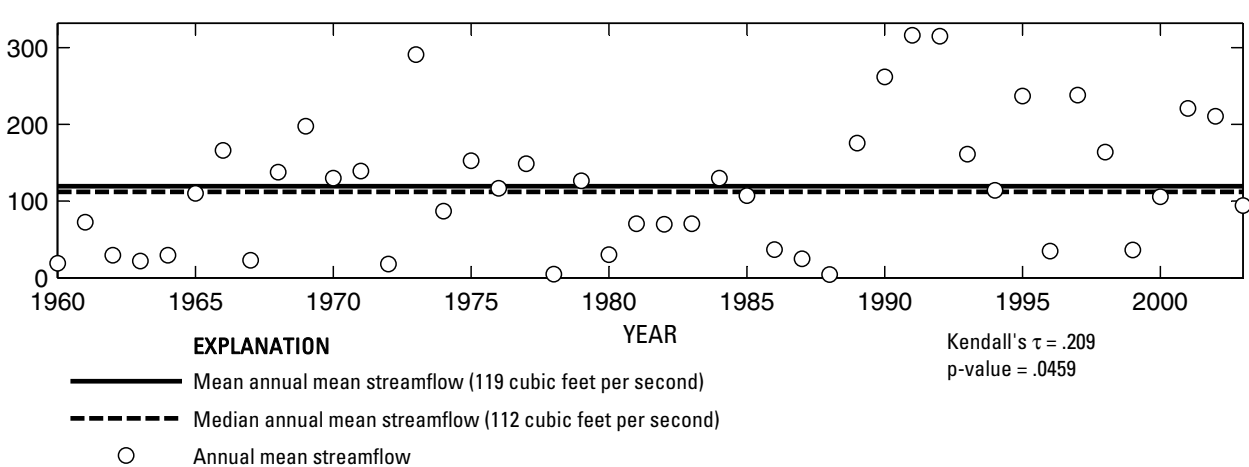

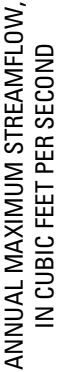

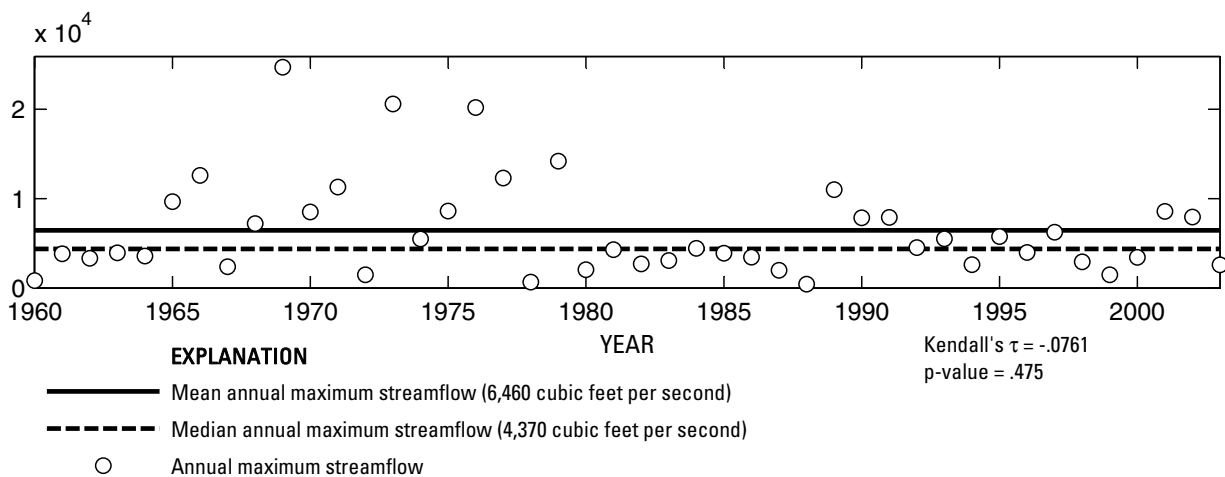

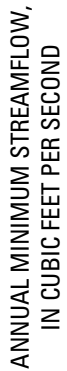

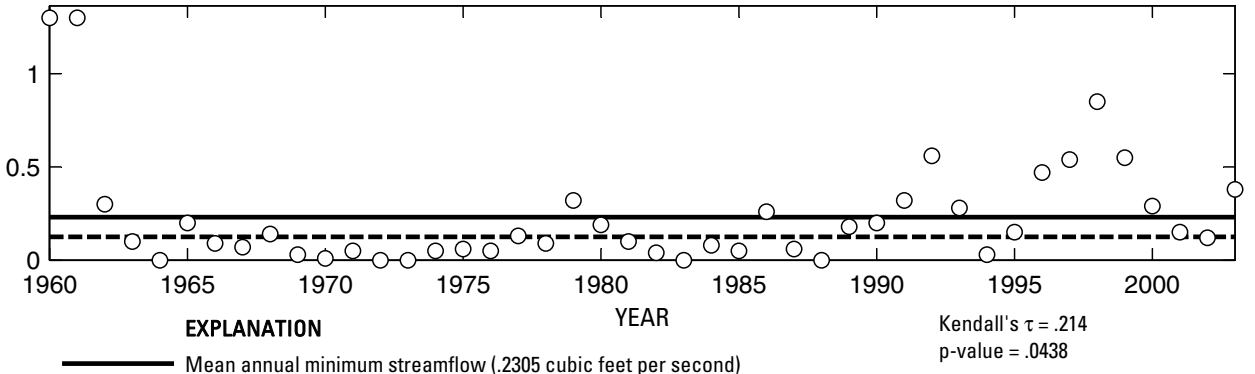

- Median annual minimum streamflow (.125 cubic feet per second)

O Annual minimum streamflow

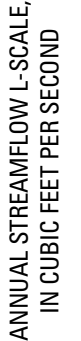

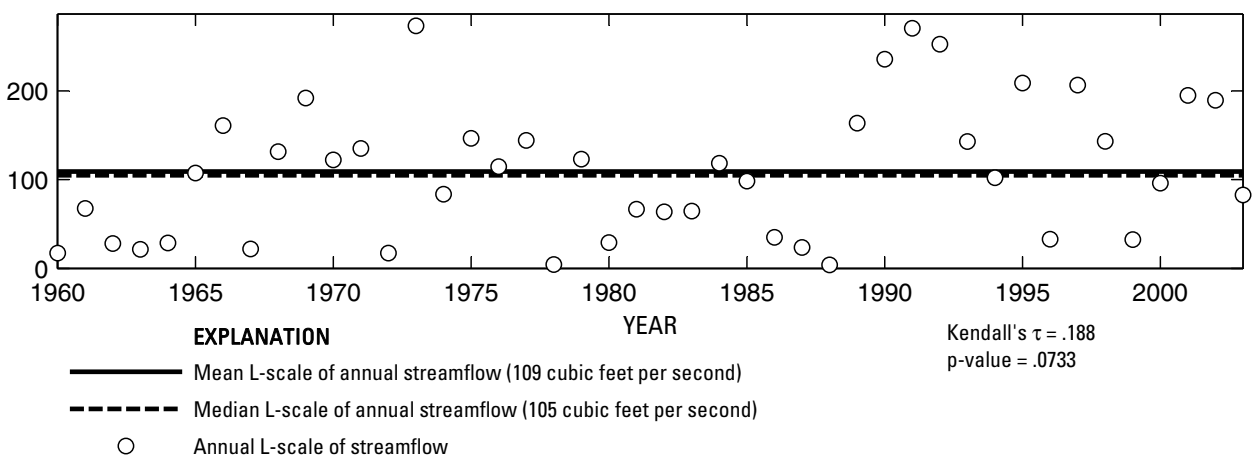

Figure 180. Analysis of annual mean, maximum, minimum, and L-scale statistics of daily mean streamflow for U.S. Geological Survey streamflow-gaging station 08050100 Mountain Creek at Grand Prairie, Texas.

Index of Station Numbers 719 

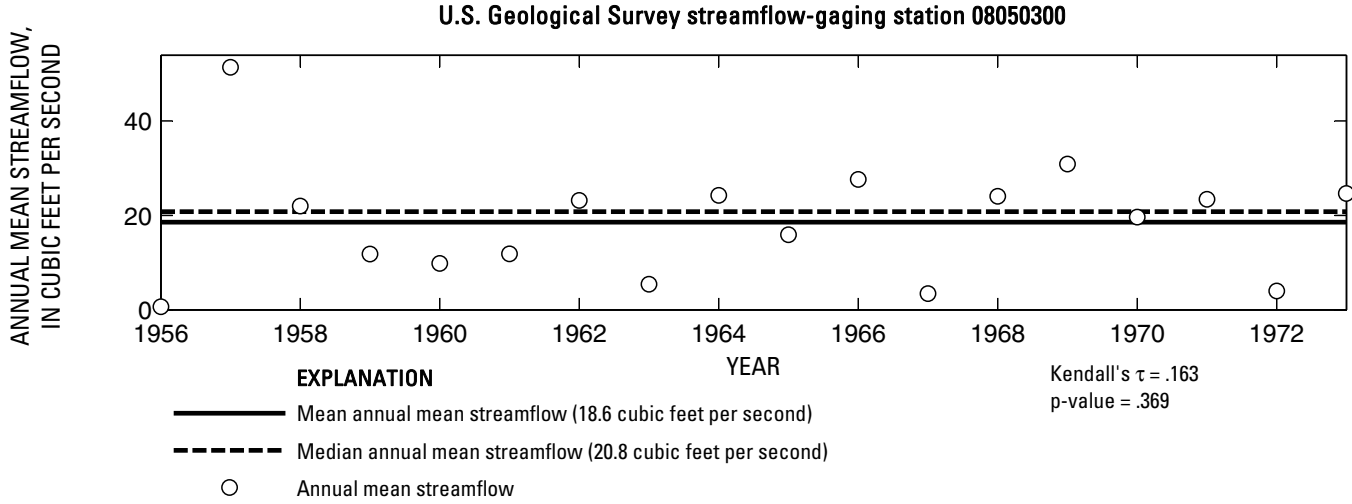

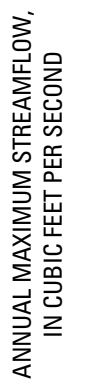

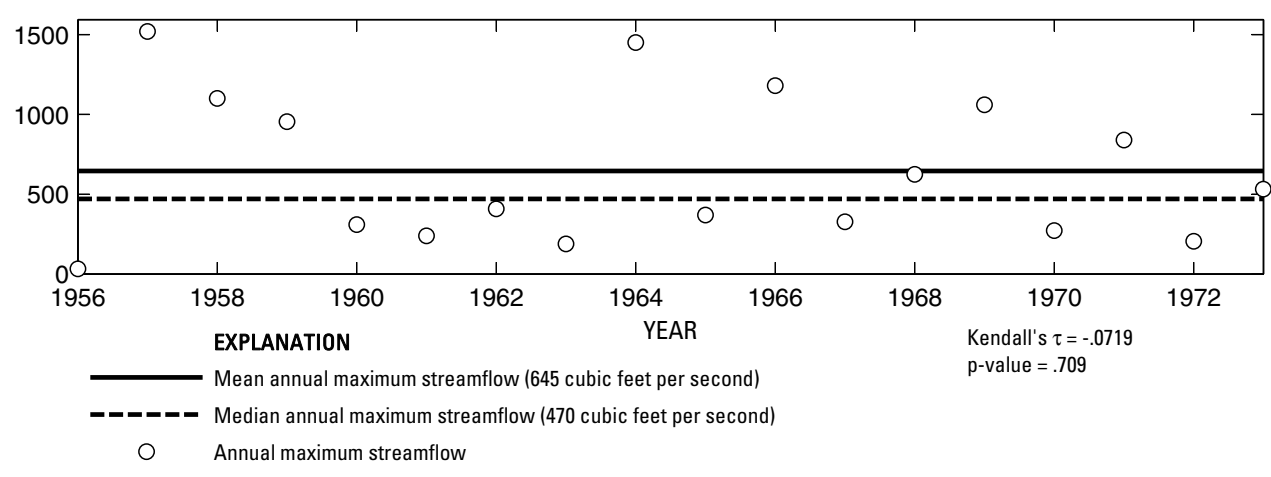

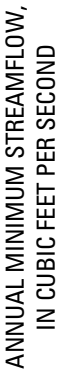

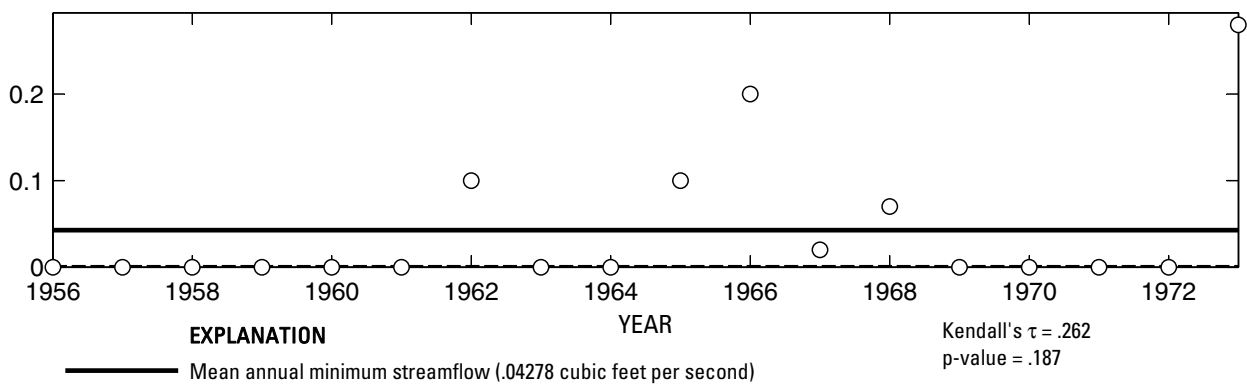

- _ _ - Median annual minimum streamflow (0 cubic feet per second)

O Annual minimum streamflow

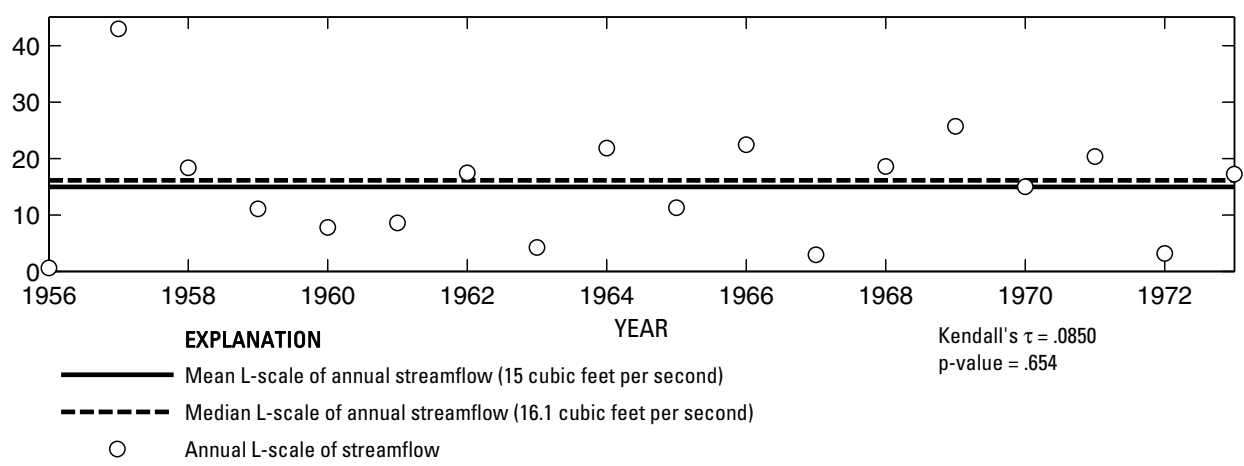

Figure 181. Analysis of annual mean, maximum, minimum, and L-scale statistics of daily mean streamflow for U.S. Geological Survey streamflow-gaging station 08050300 Elm Fork Trinity River near Muenster, Texas. 
U.S. Geological Survey streamflow-gaging station 08050400
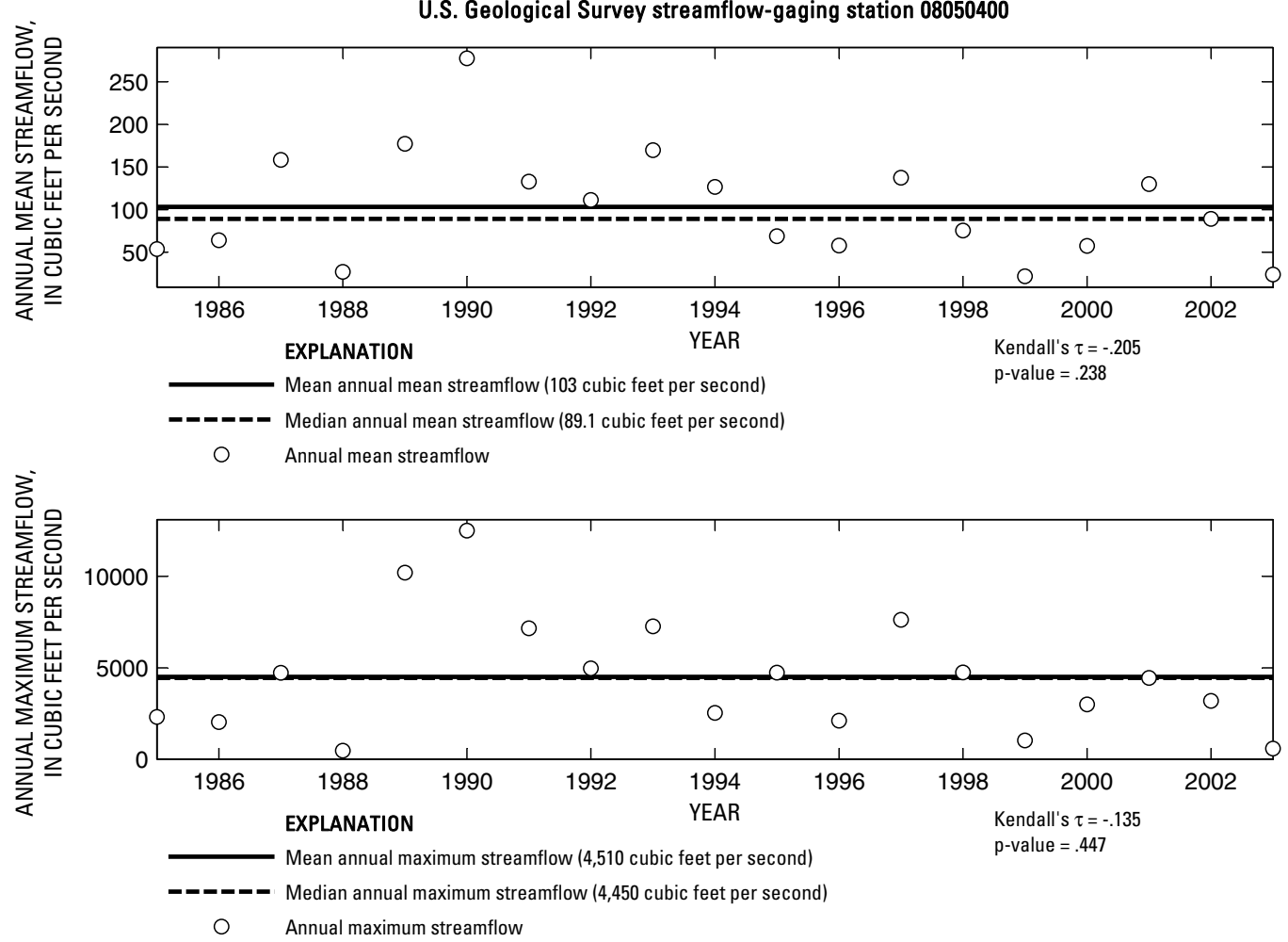

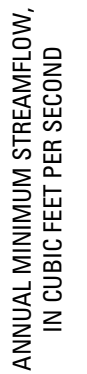

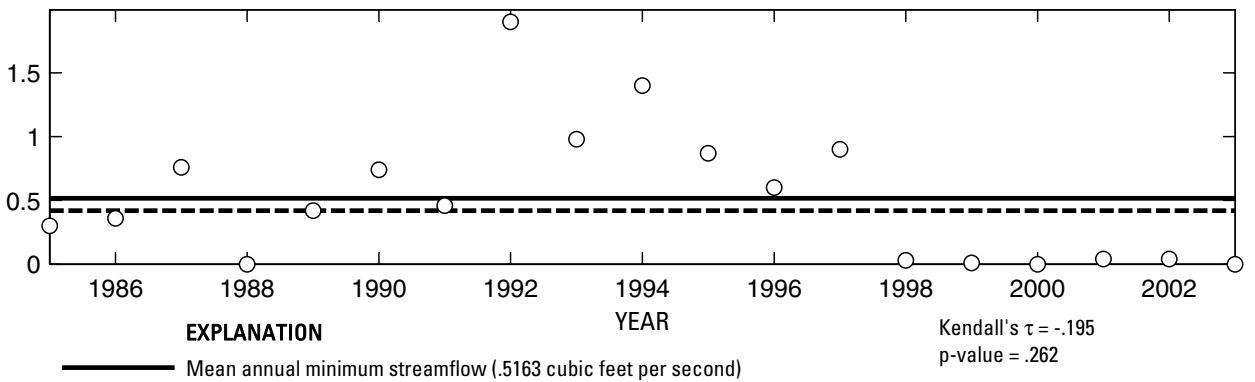

- ב-_- Median annual minimum streamflow (.42 cubic feet per second)

O Annual minimum streamflow

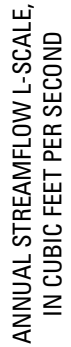

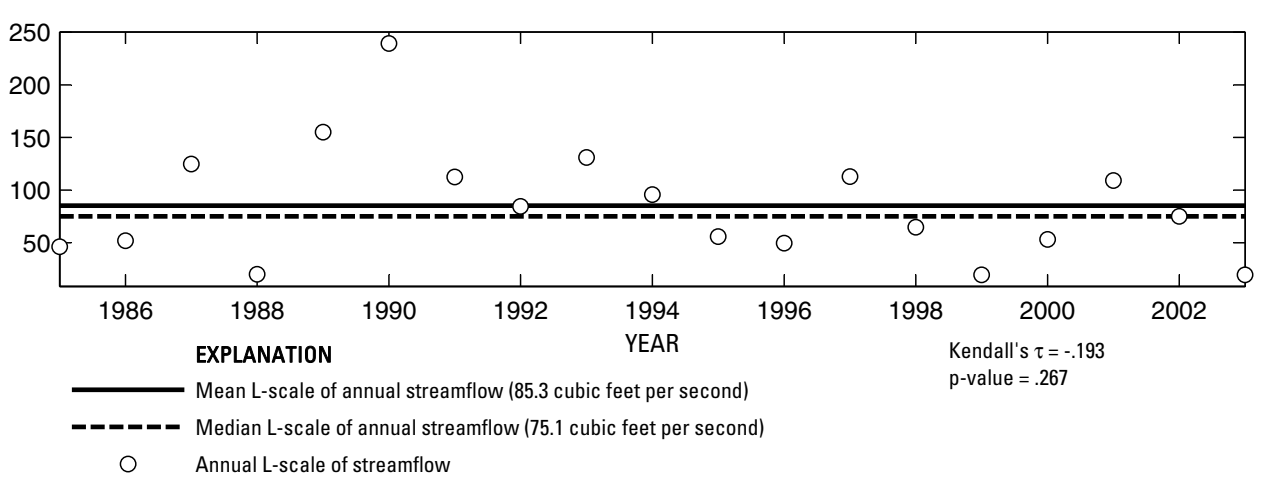

Figure 182. Analysis of annual mean, maximum, minimum, and L-scale statistics of daily mean streamflow for U.S. Geological Survey streamflow-gaging station 08050400 Elm Fork Trinity River at Gainesville, Texas.

Index of Station Numbers 719 

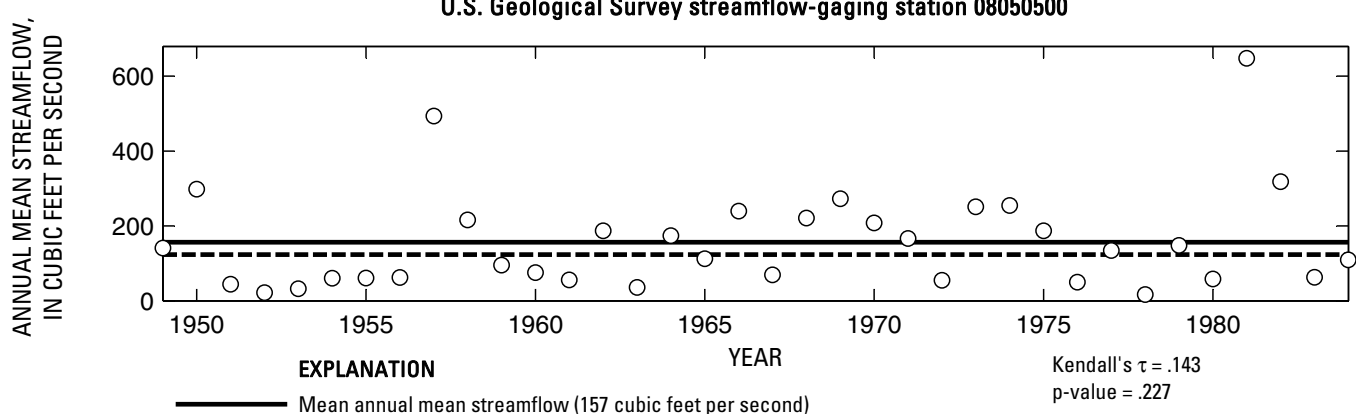

-_-_-_ Median annual mean streamflow (123 cubic feet per second)

O Annual mean streamflow

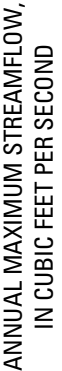

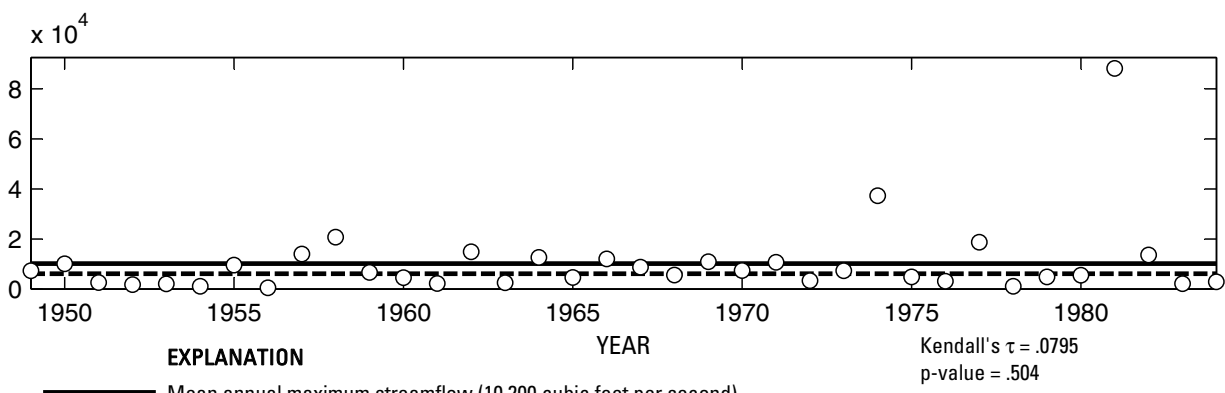

O Annual maximum streamflow

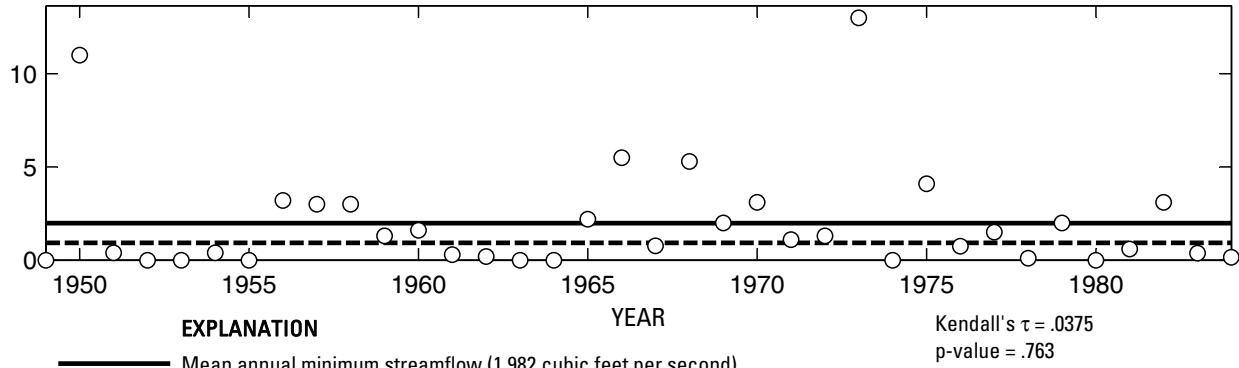

- Median annual minimum streamflow (.935 cubic feet per second)

O Annual minimum streamflow

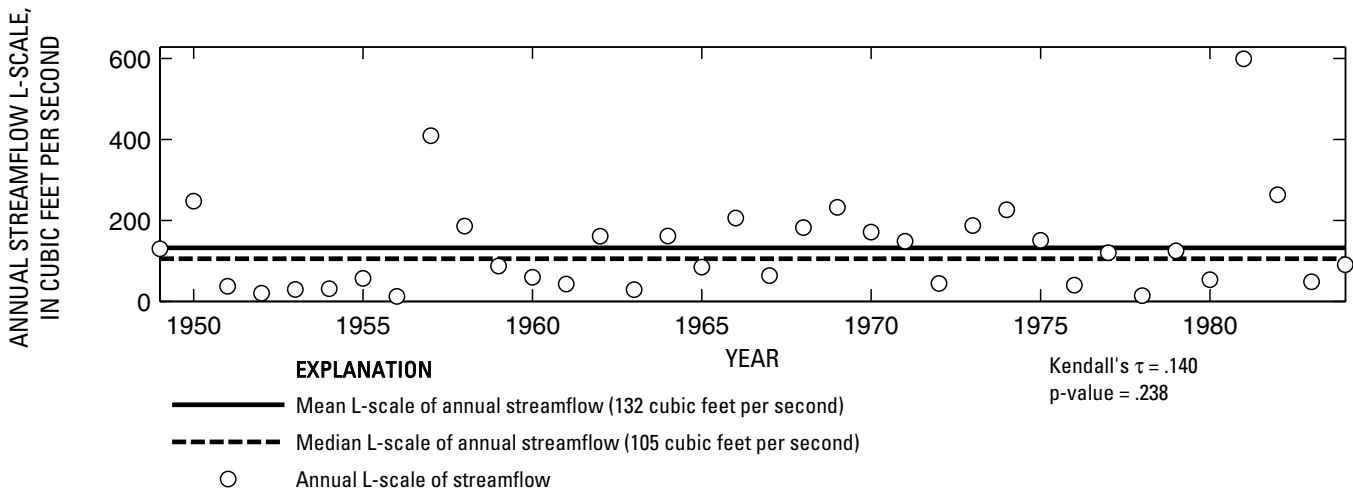

Figure 183. Analysis of annual mean, maximum, minimum, and L-scale statistics of daily mean streamflow for U.S. Geological Survey streamflow-gaging station 08050500 Elm Fork Trinity River near Sanger, Texas. 


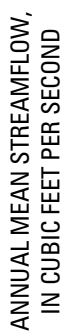

U.S. Geological Survey streamflow-gaging station 08050800

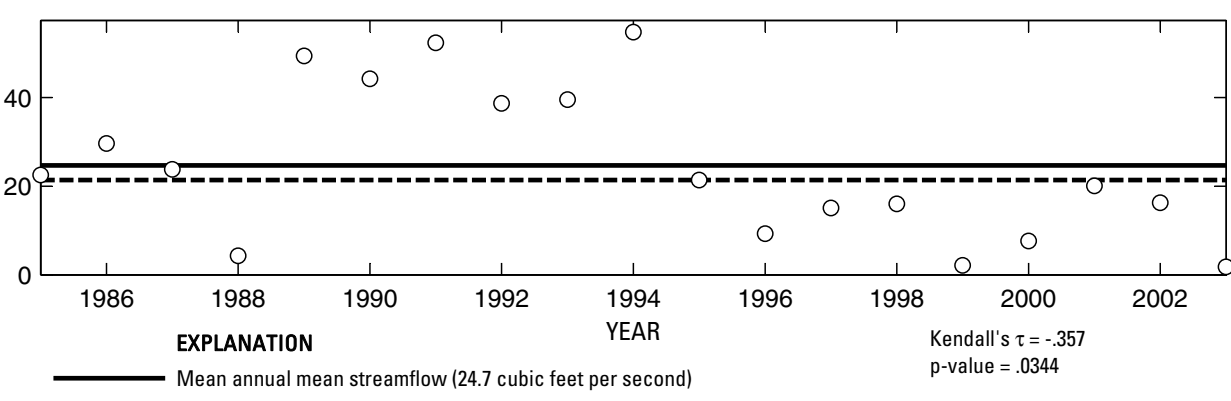

-_-_-_ Median annual mean streamflow (21.4 cubic feet per second)

O Annual mean streamflow

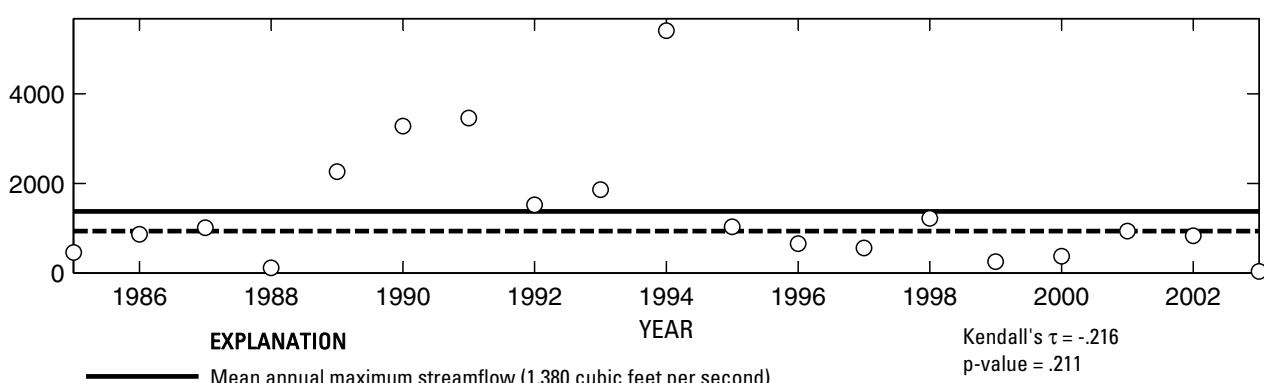

- - Median annual maximum streamflow (937 cubic feet per second)

O Annual maximum streamflow

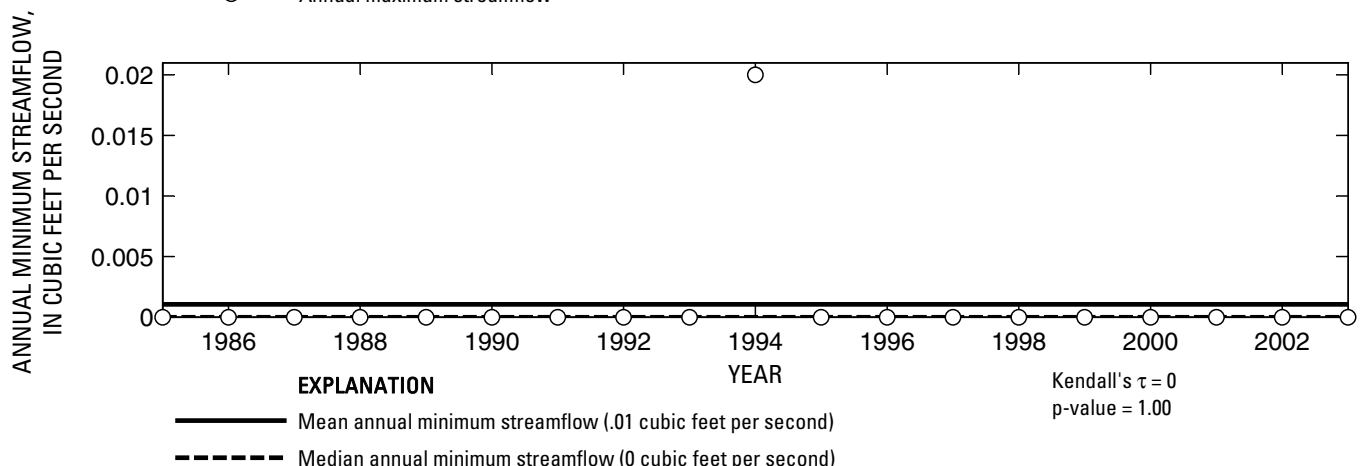

Annual minimum streamflow

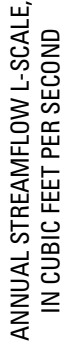

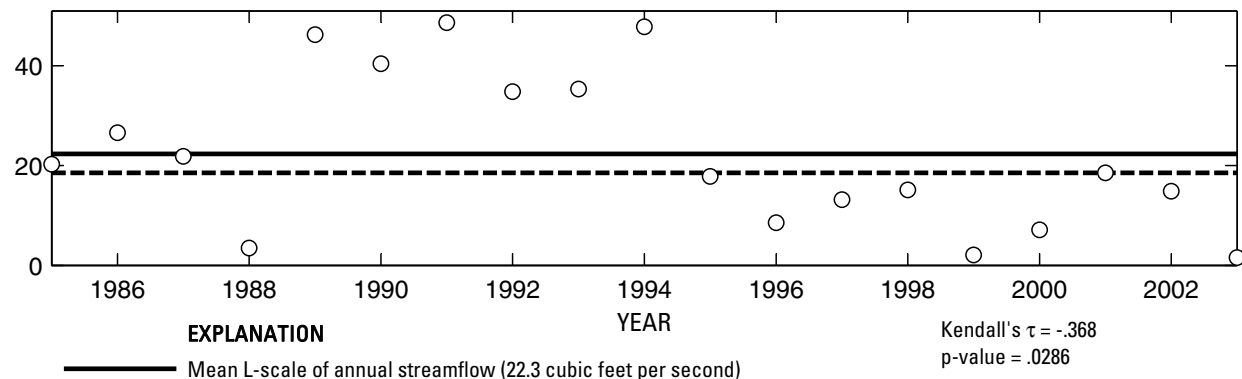

Mean L-scale of annual streamflow (22.3 cubic feet per second)

-ー-ー-ー Median L-scale of annual streamflow (18.5 cubic feet per second)

Annual L-scale of streamflow

Figure 184. Analysis of annual mean, maximum, minimum, and L-scale statistics of daily mean streamflow for U.S. Geological Survey streamflow-gaging station 08050800 Timber Creek near Collinsville, Texas.

Index of Station Numbers 719 


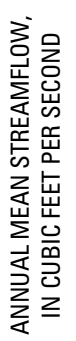

U.S. Geological Survey streamflow-gaging station 08050840

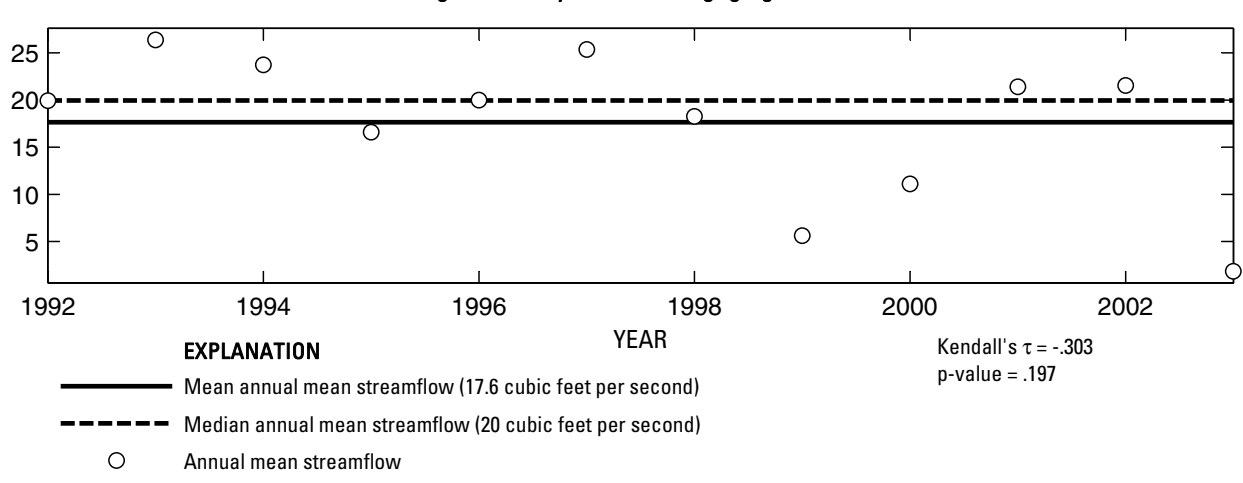

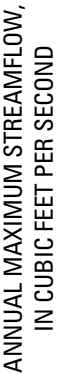

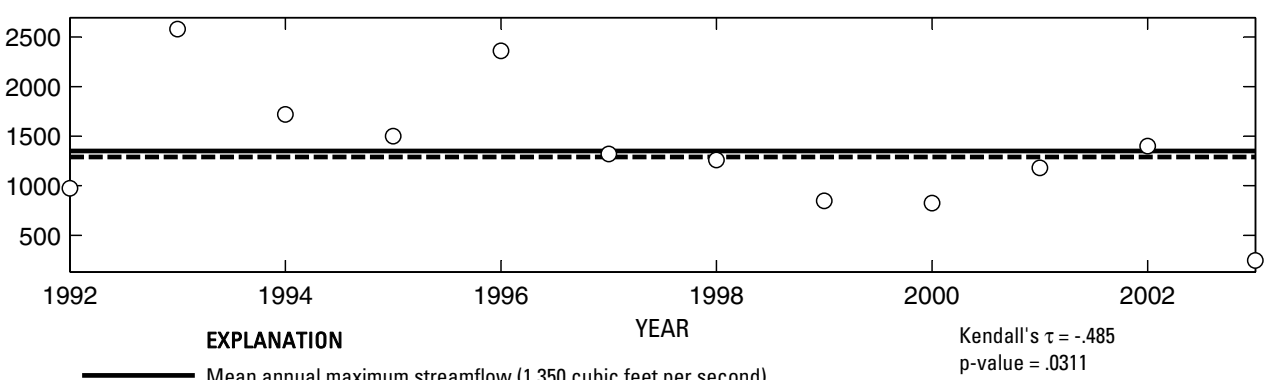

O Annual maximum streamflow
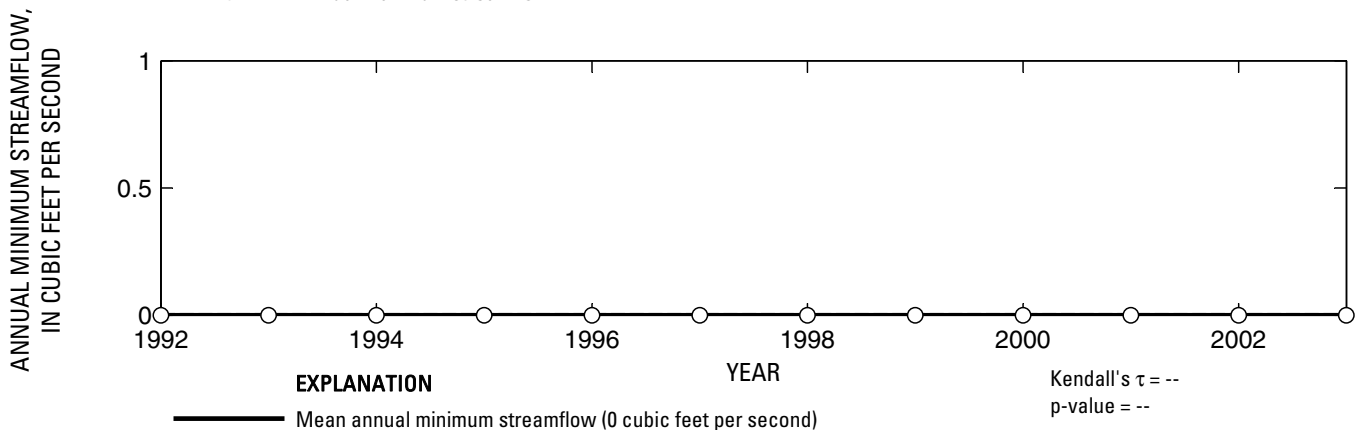

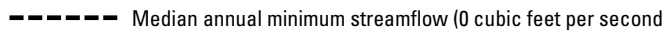

○ Annual minimum streamflow
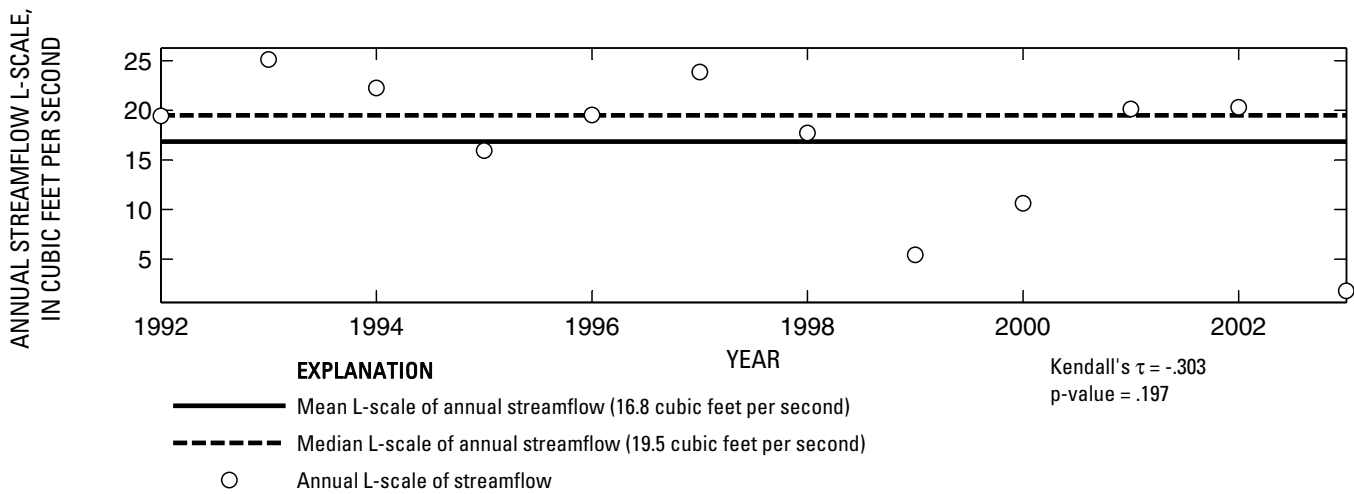

Figure 185. Analysis of annual mean, maximum, minimum, and L-scale statistics of daily mean streamflow for U.S. Geological Survey streamflow-gaging station 08050840 Range Creek near Collinsville, Texas. 


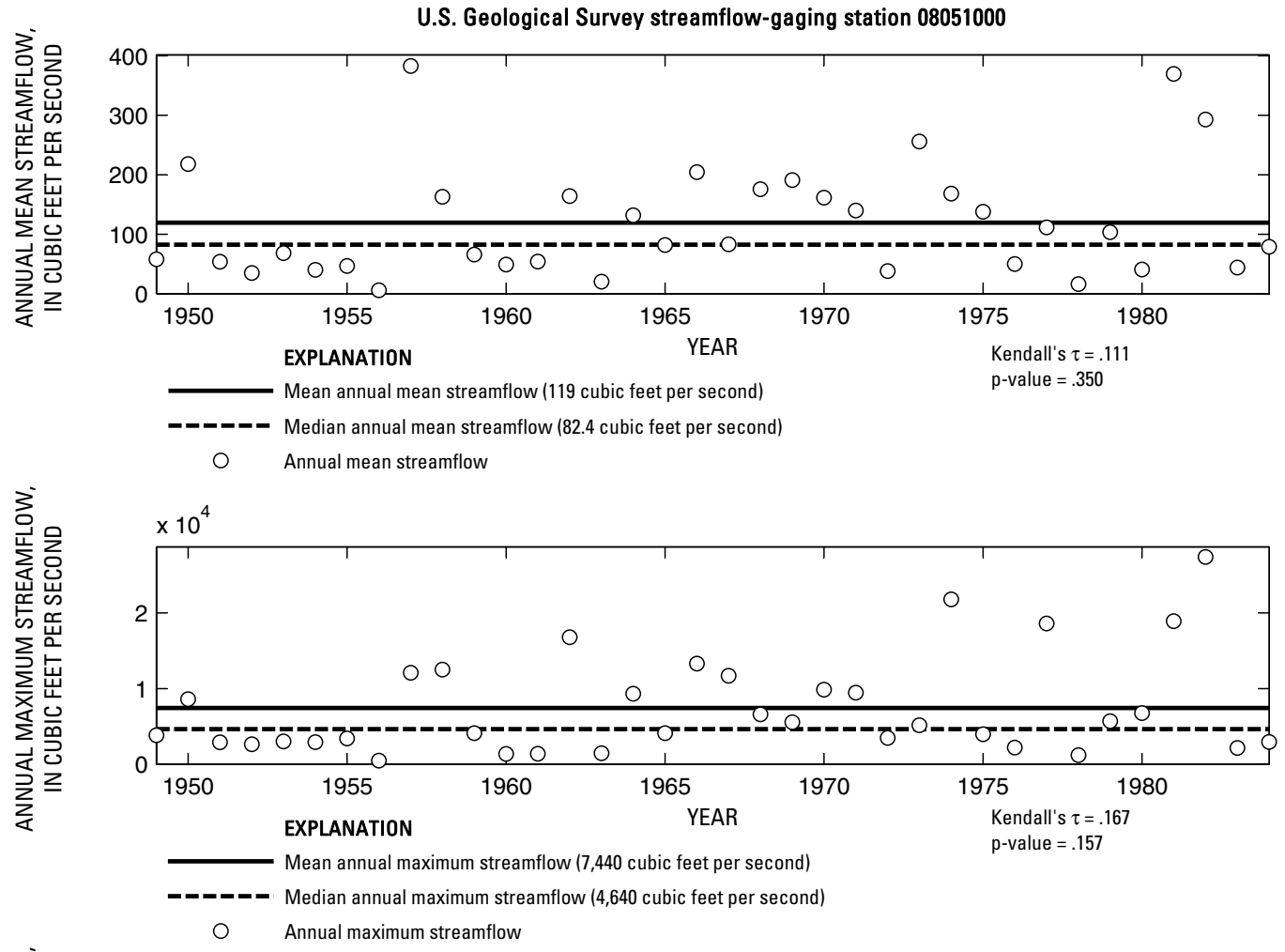

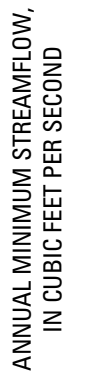

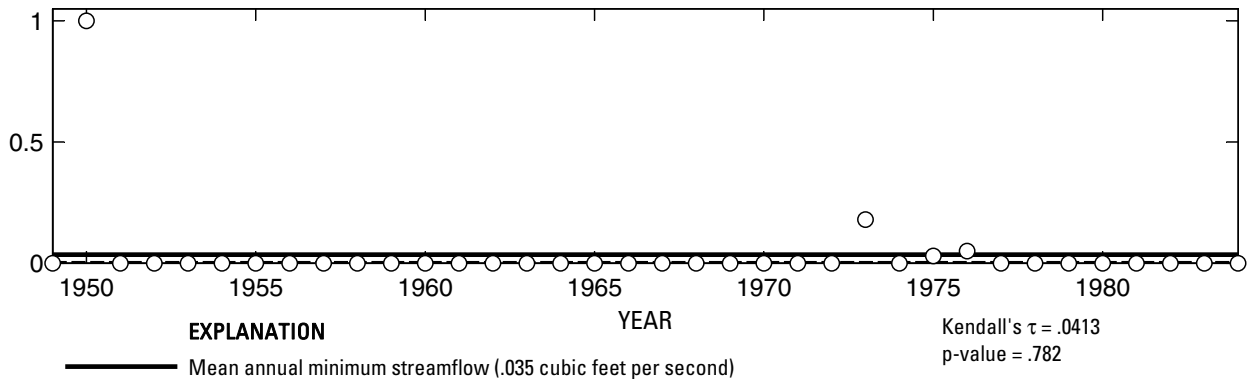

- Median annual minimum streamflow (0 cubic feet per second)

O Annual minimum streamflow

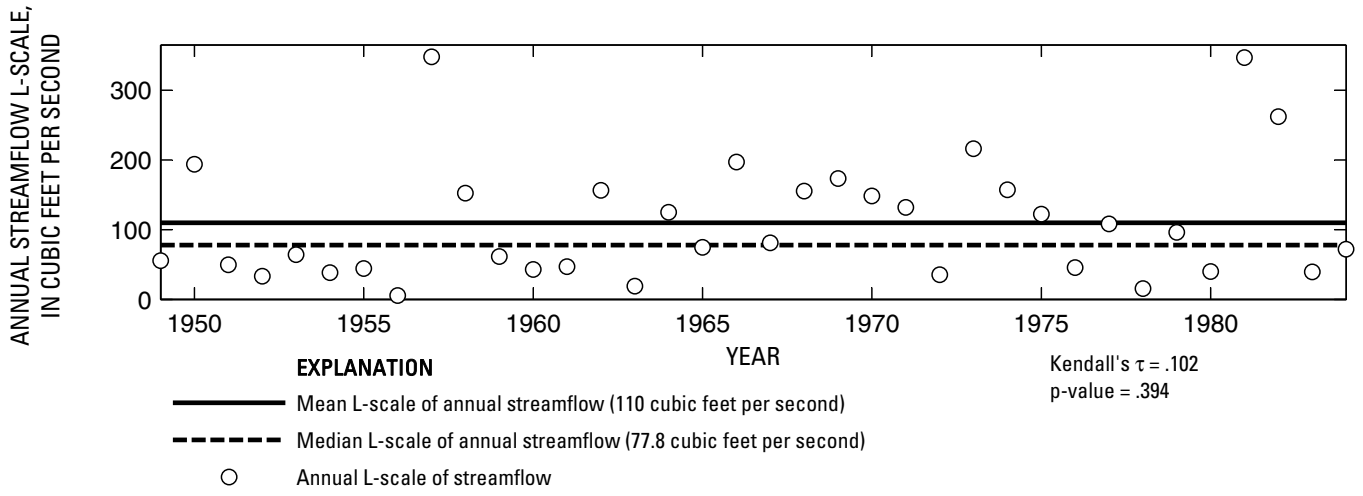

Figure 186. Analysis of annual mean, maximum, minimum, and L-scale statistics of daily mean streamflow for U.S. Geological Survey streamflow-gaging station 08051000 Isle du Bois Creek near Pilot Point, Texas.

Index of Station Numbers 719 


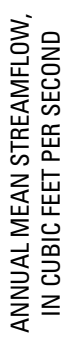

U.S. Geological Survey streamflow-gaging station 08051130

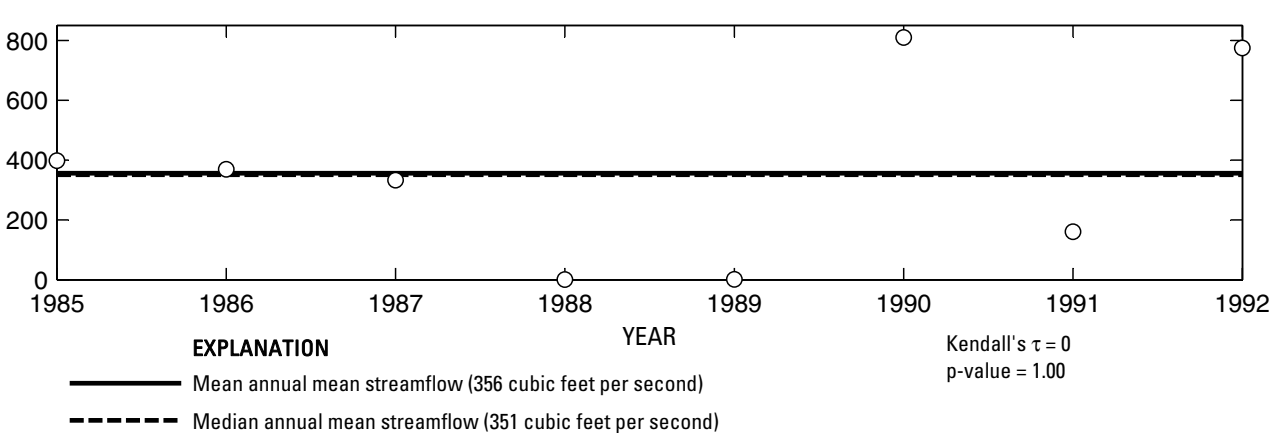

Annual mean streamflow
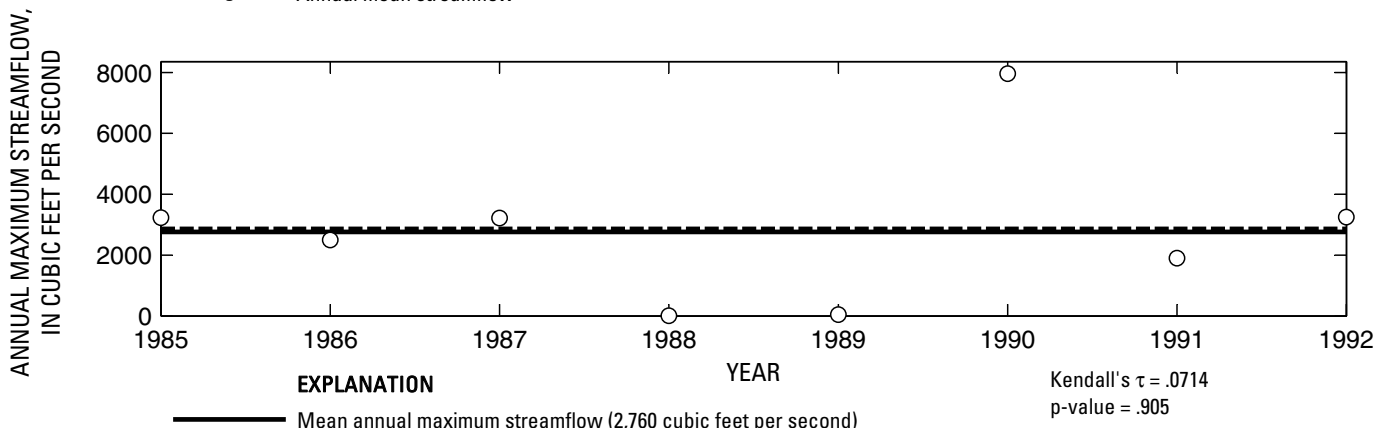

O Annual maximum streamflow

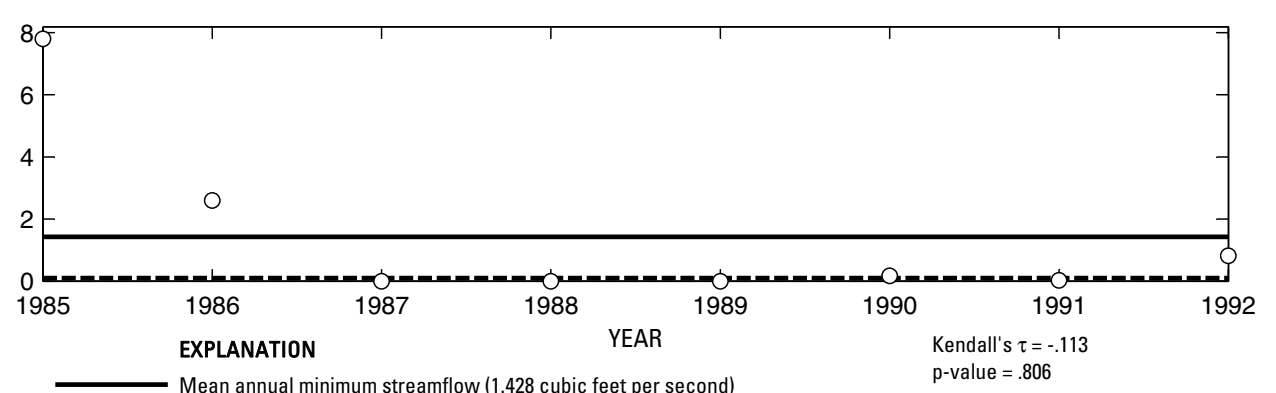

- - Median annual minimum streamflow (.1 cubic feet per second)

O Annual minimum streamflow

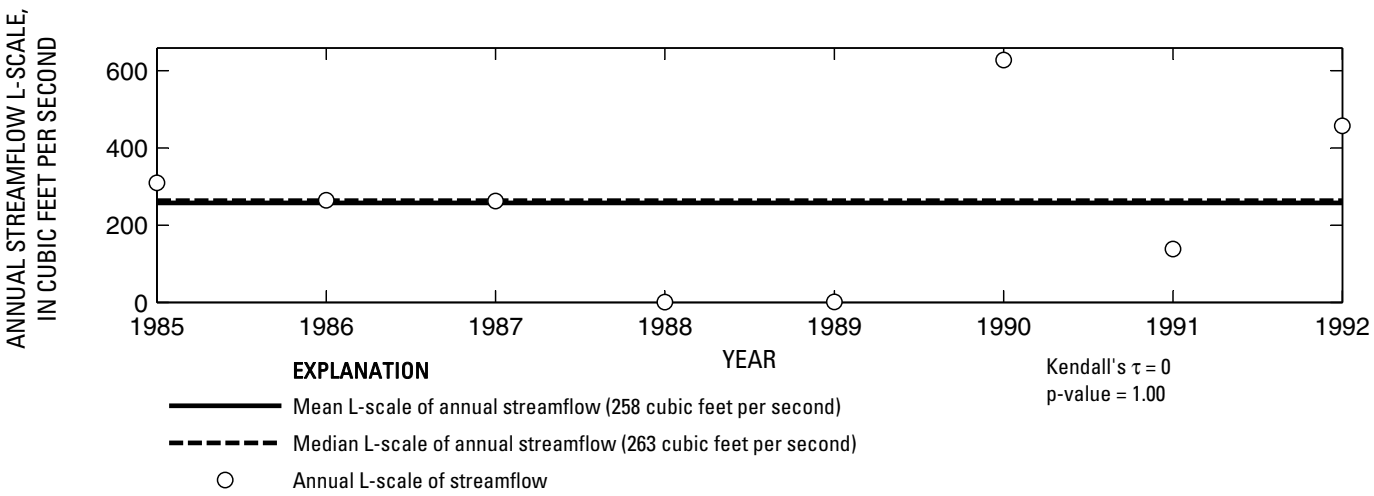

Figure 187. Analysis of annual mean, maximum, minimum, and L-scale statistics of daily mean streamflow for U.S. Geological Survey streamflow-gaging station 08051130 Elm Fork Trinity River near Pilot Point, Texas. 
U.S. Geological Survey streamflow-gaging station 08051500

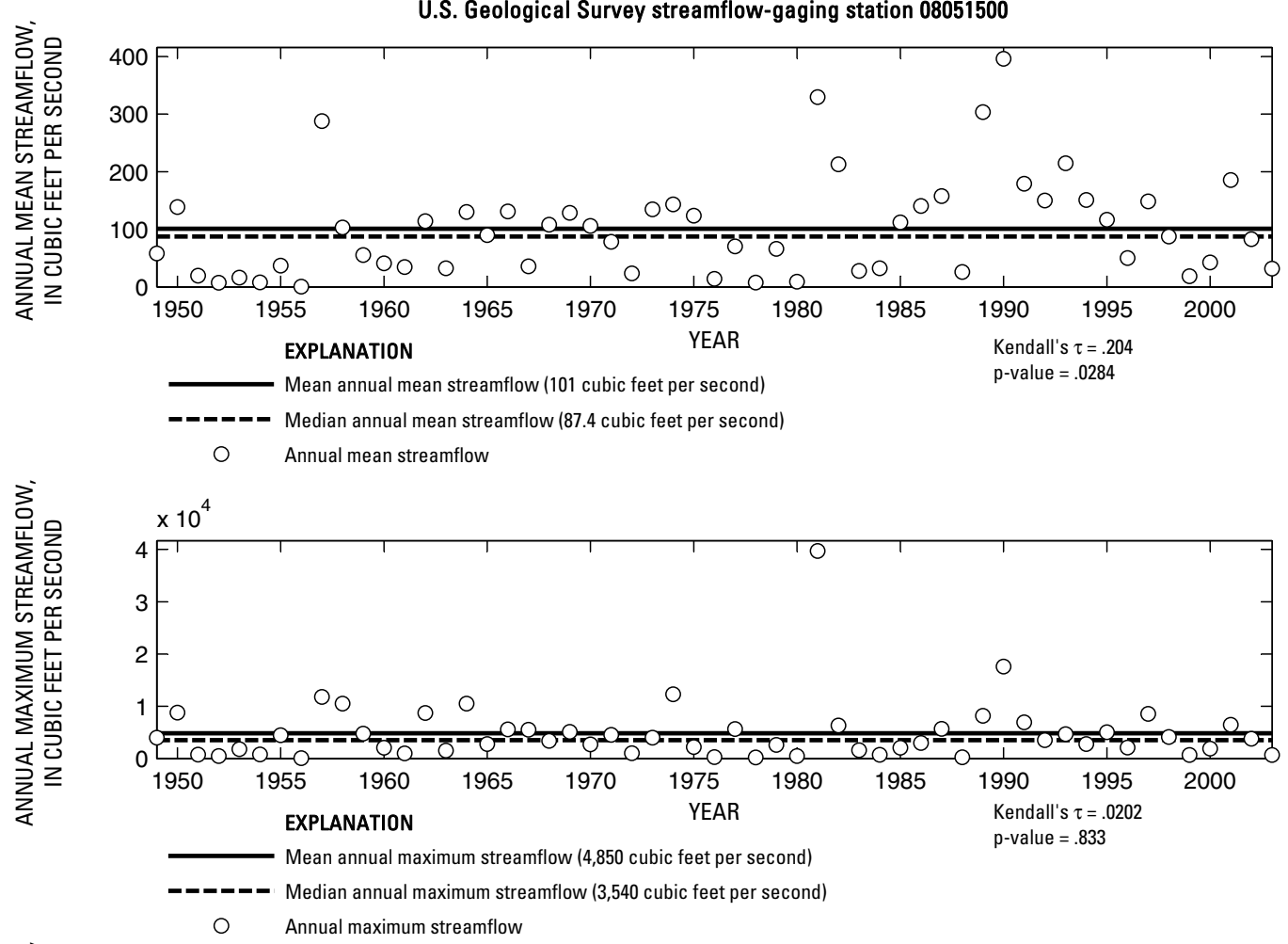

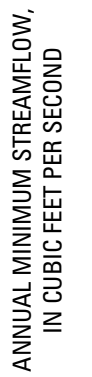

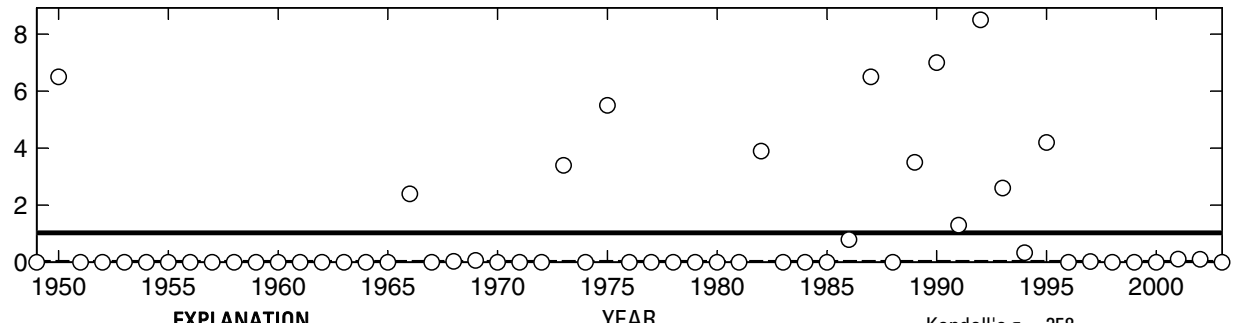

EXPLANATION Kendall's $\tau=.258$

Theil trend line for annual minimum streamflow

- - Median annual minimum streamflow (0 cubic feet per second)

O Annual minimum streamflow

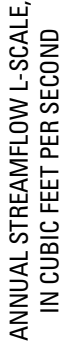

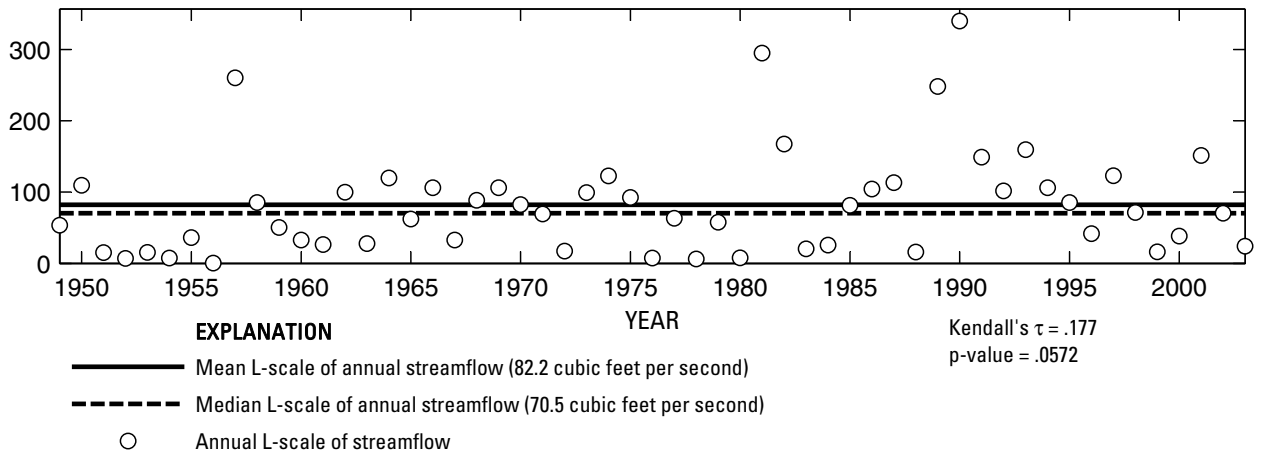

Figure 188. Analysis of annual mean, maximum, minimum, and L-scale statistics of daily mean streamflow for U.S. Geological Survey streamflow-gaging station 08051500 Clear Creek near Sanger, Texas.

Index of Station Numbers 719 


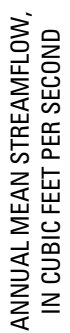

U.S. Geological Survey streamflow-gaging station 08052000

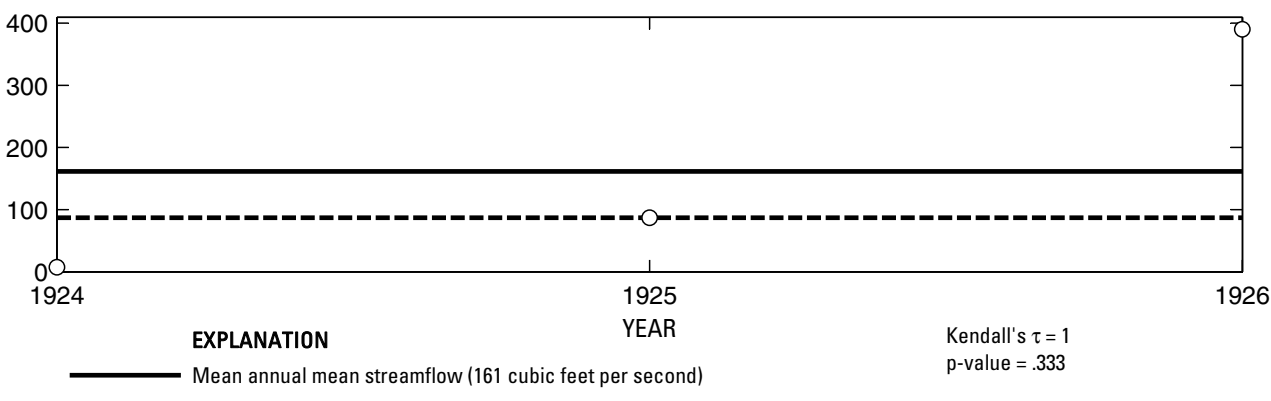

-__-_ Median annual mean streamflow (87 cubic feet per second)

O Annual mean streamflow
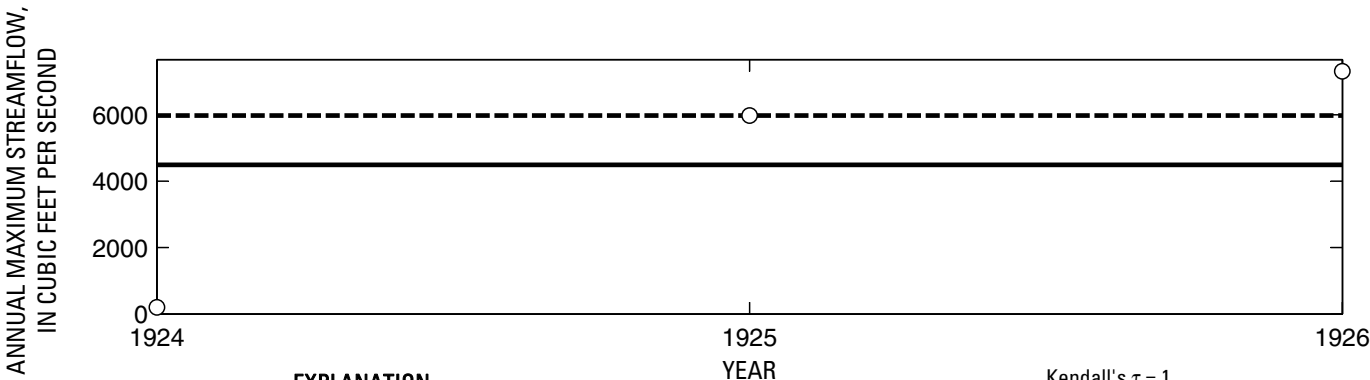

Mean annual maximum streamflow (4,500 cubic feet per second)

- ב-_ Median annual maximum streamflow (5,980 cubic feet per second)

Annual maximum streamflow

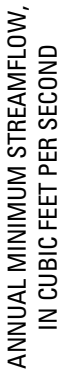

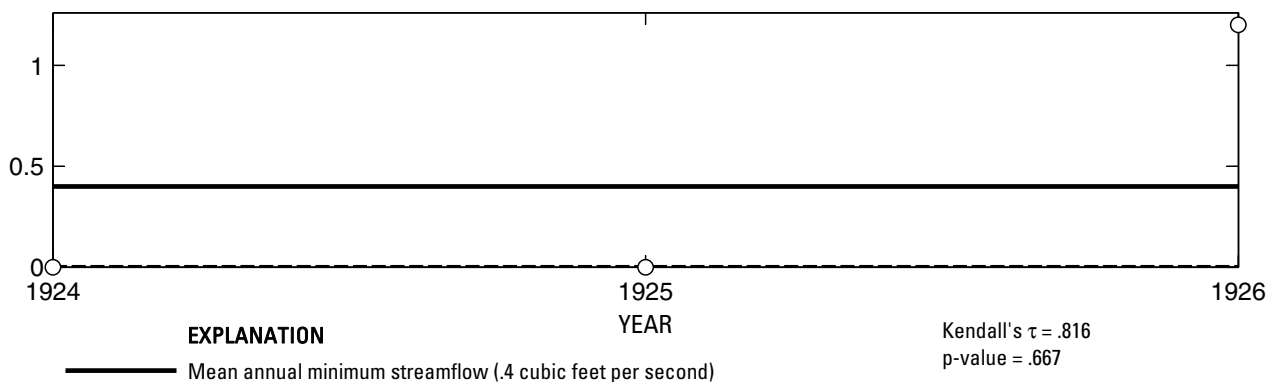

- Median annual minimum streamflow (0 cubic feet per second)

O Annual minimum streamflow
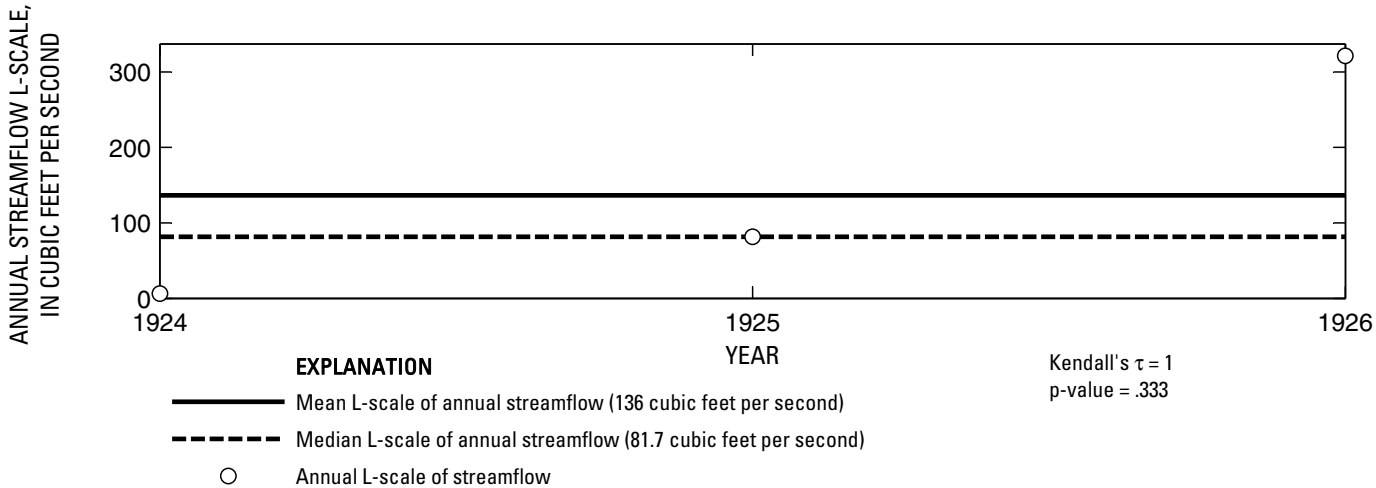

Figure 189. Analysis of annual mean, maximum, minimum, and L-scale statistics of daily mean streamflow for U.S. Geological Survey streamflow-gaging station 08052000 Elm Fork Trinity River near Denton, Texas. 

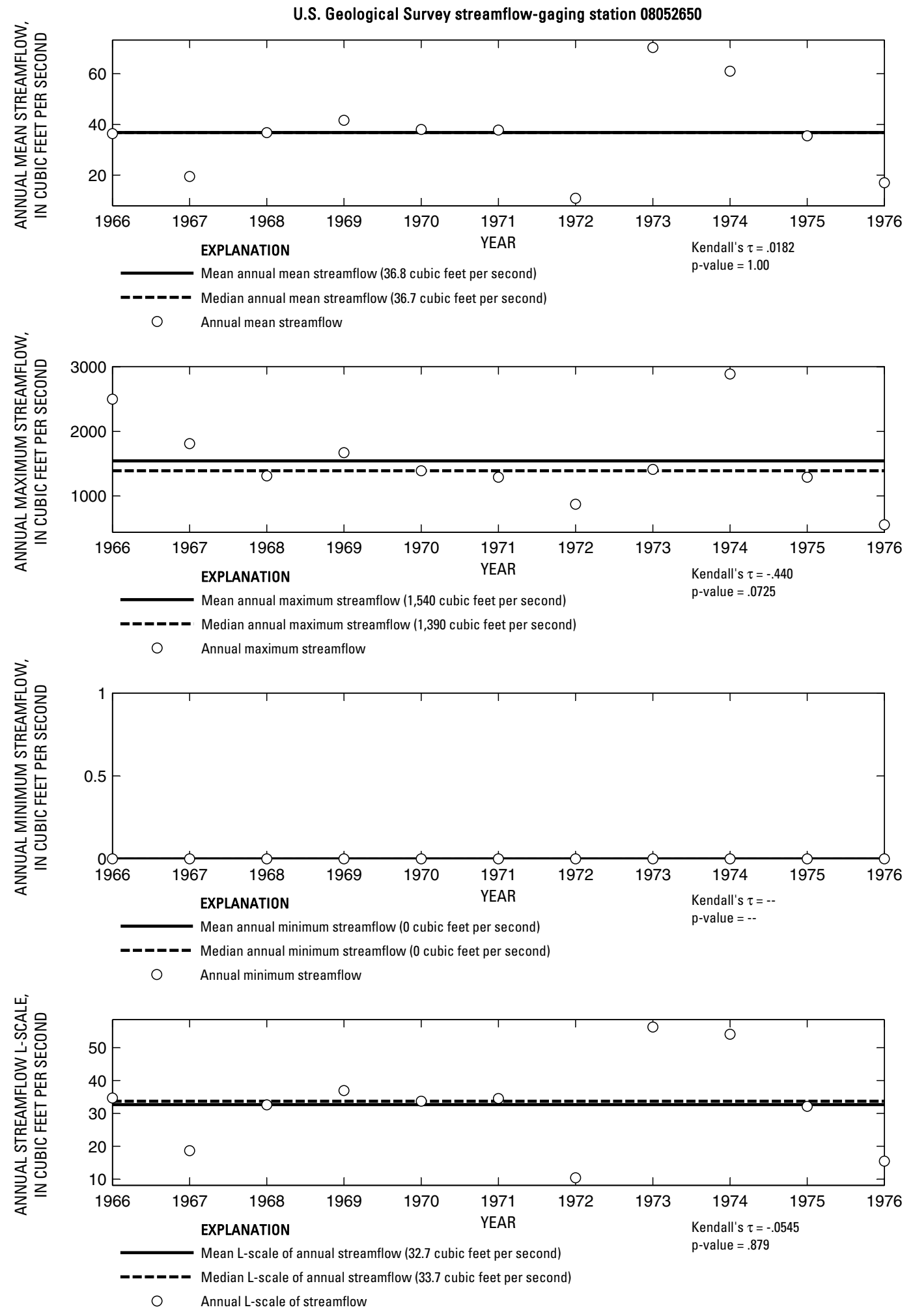

Figure 190. Analysis of annual mean, maximum, minimum, and L-scale statistics of daily mean streamflow for U.S. Geological Survey streamflow-gaging station 08052650 Little Elm Creek near Celina, Texas.

|ndex of Station Numbers 719 

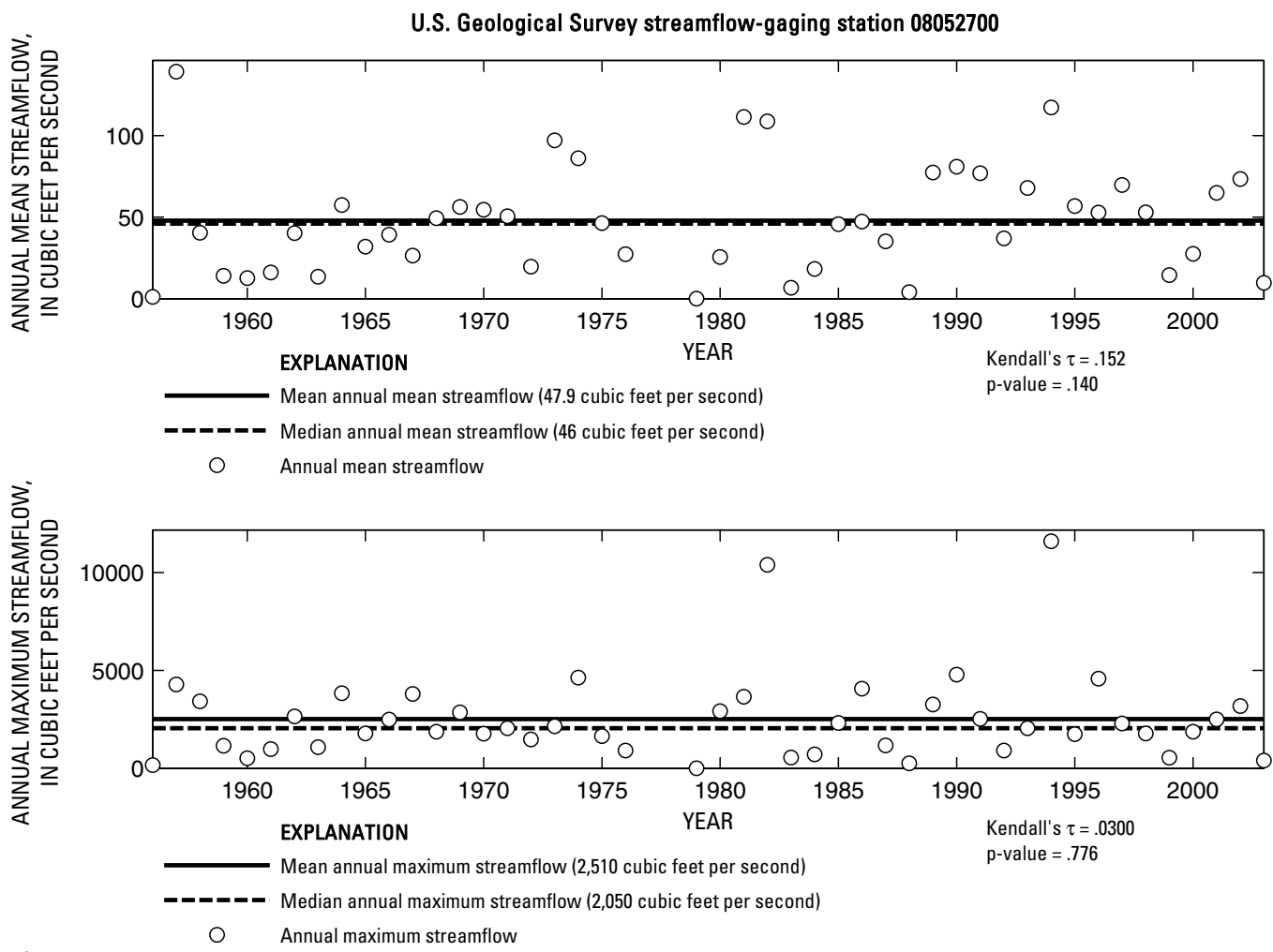

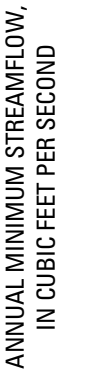

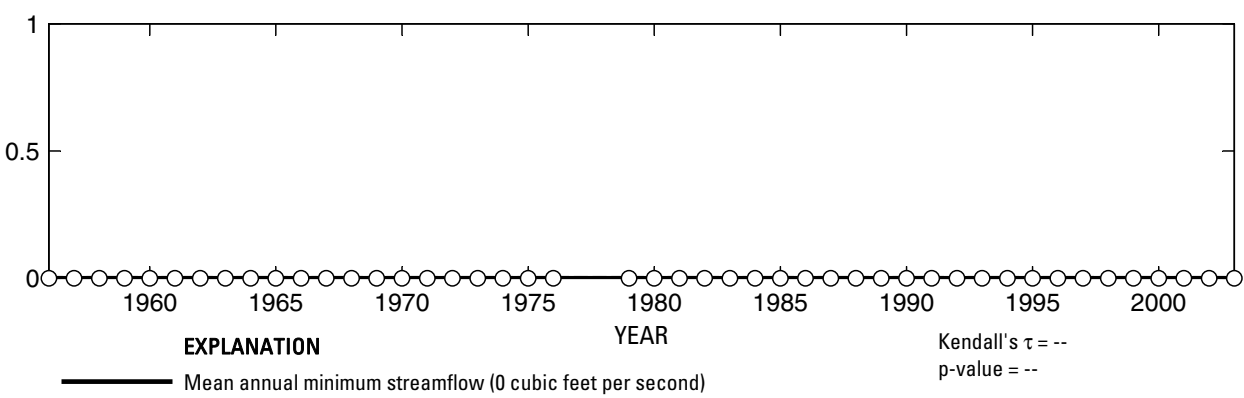

-_-_-_ Median annual minimum streamflow (0 cubic feet per second)

○ Annual minimum streamflow

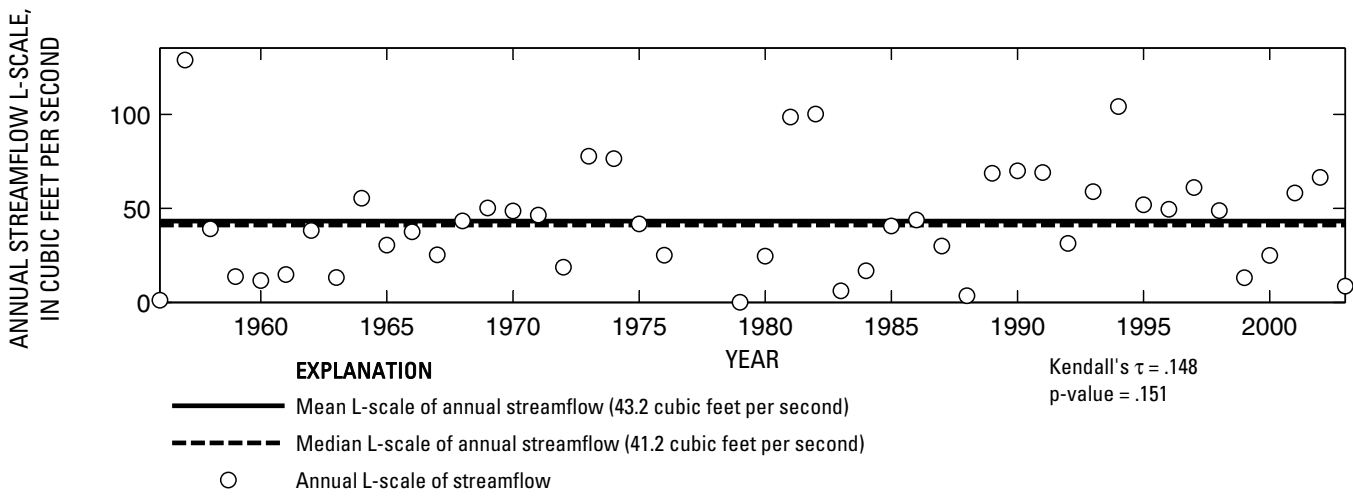

Figure 191. Analysis of annual mean, maximum, minimum, and L-scale statistics of daily mean streamflow for U.S. Geological Survey streamflow-gaging station 08052700 Little Elm Creek near Aubrey, Texas. 


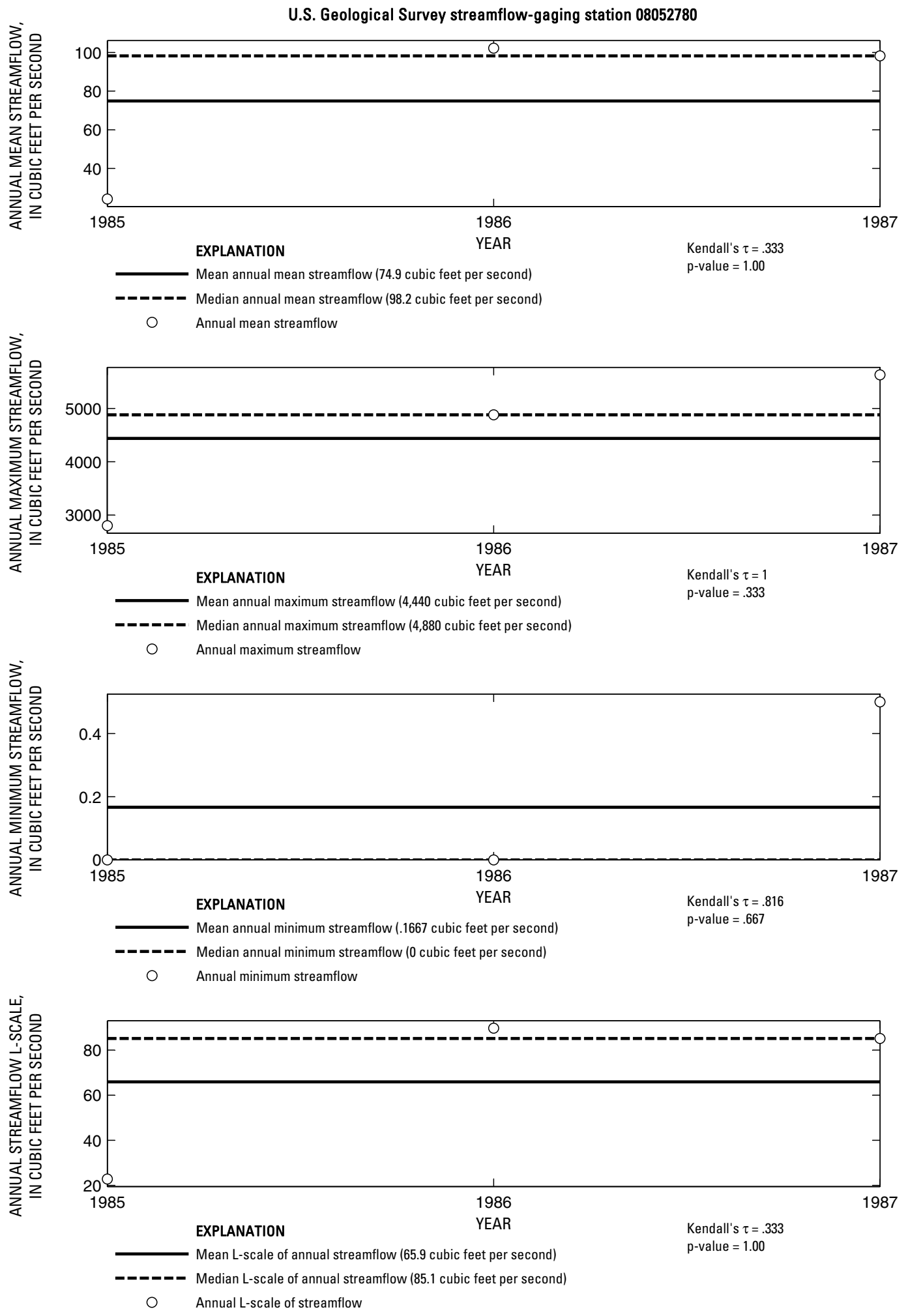

Figure 192. Analysis of annual mean, maximum, minimum, and L-scale statistics of daily mean streamflow for U.S. Geological Survey streamflow-gaging station 08052780 Hickory Creek at Denton, Texas. 


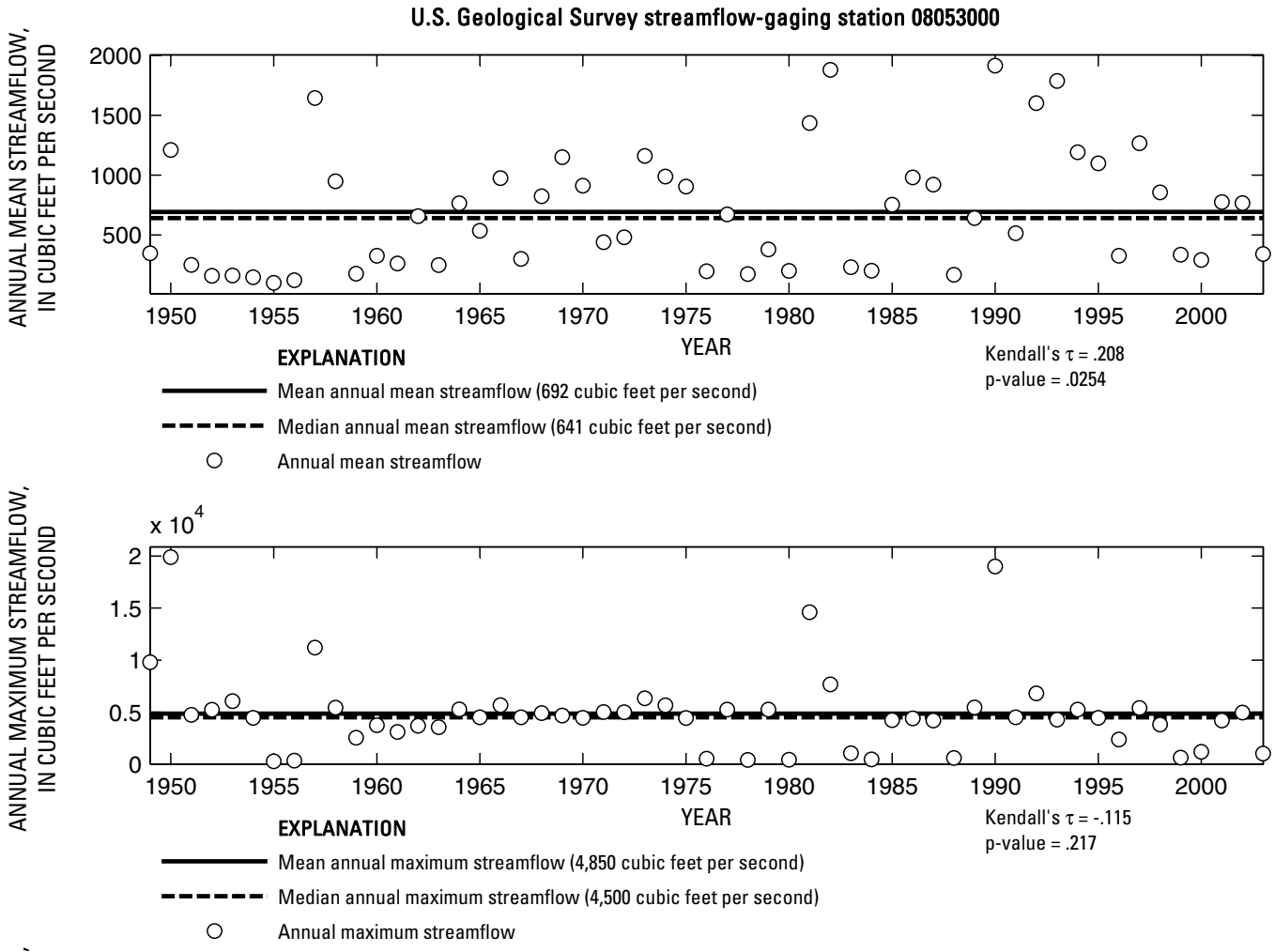

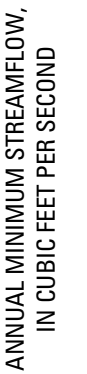

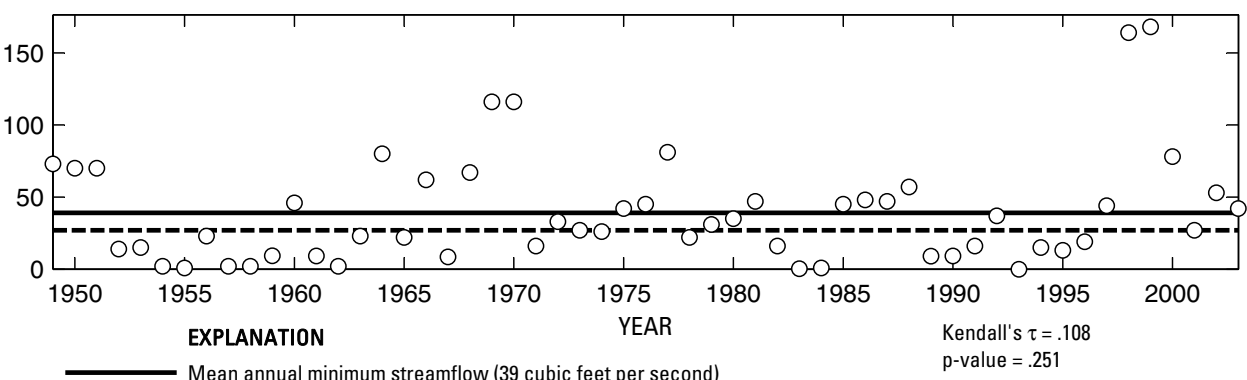

- - - Median annual minimum streamflow (27 cubic feet per second)

O Annual minimum streamflow

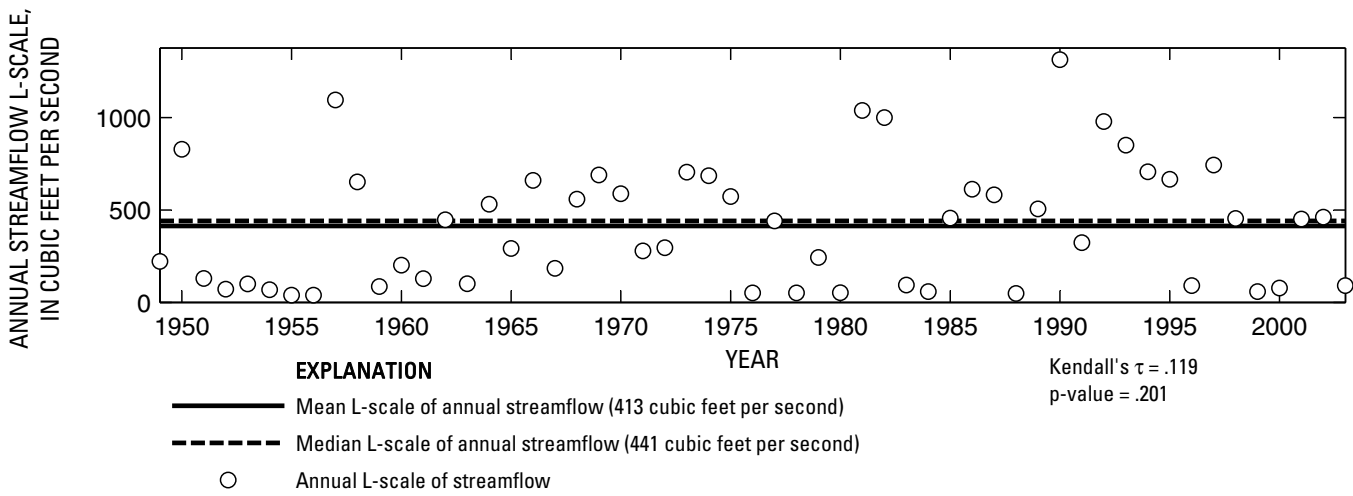

Figure 193. Analysis of annual mean, maximum, minimum, and L-scale statistics of daily mean streamflow for U.S. Geological Survey streamflow-gaging station 08053000 Elm Fork Trinity River near Lewisville, Texas. 

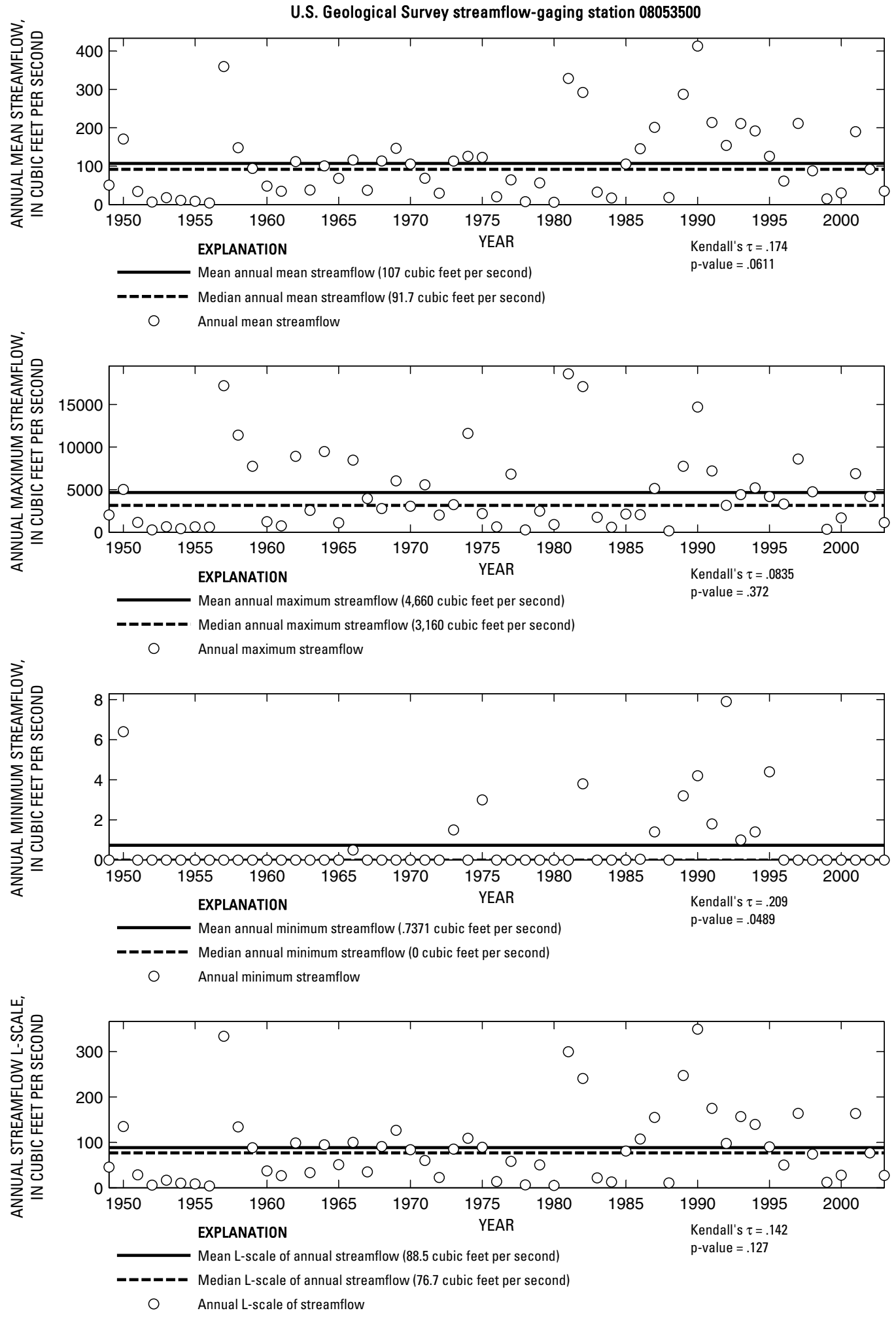

Figure 194. Analysis of annual mean, maximum, minimum, and L-scale statistics of daily mean streamflow for U.S. Geological Survey streamflow-gaging station 08053500 Denton Creek near Justin, Texas.

Index of Station Numbers 719 


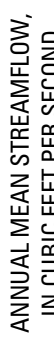

U.S. Geological Survey streamflow-gaging station 08054000

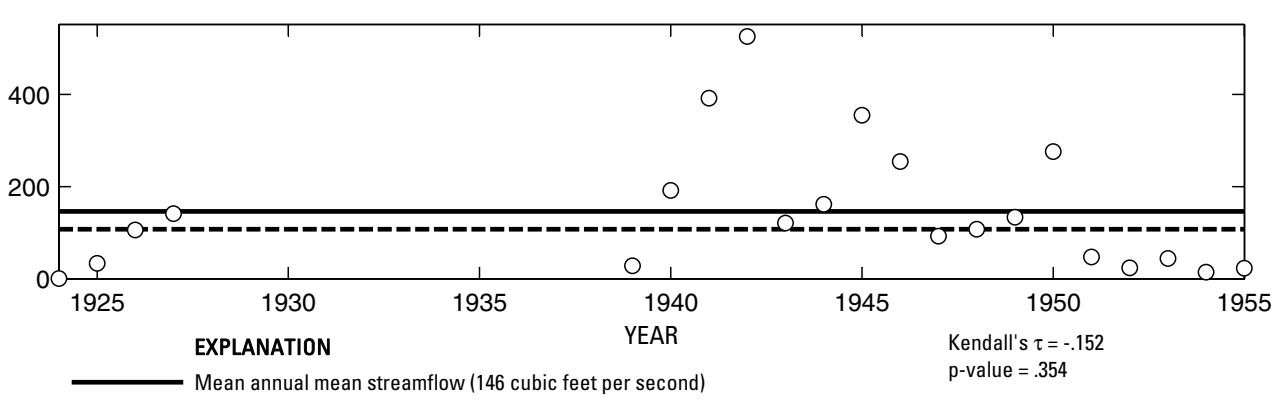

-_-_- Median annual mean streamflow (107 cubic feet per second)

O Annual mean streamflow
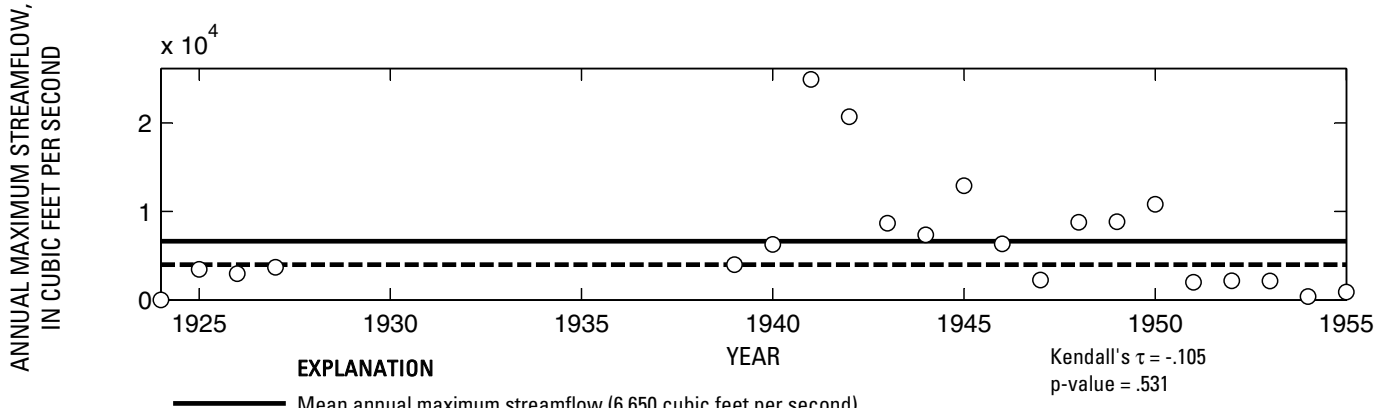

- _ - Median annual maximum streamflow (4,000 cubic feet per second)

O Annual maximum streamflow

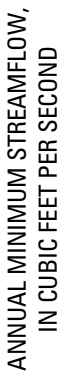

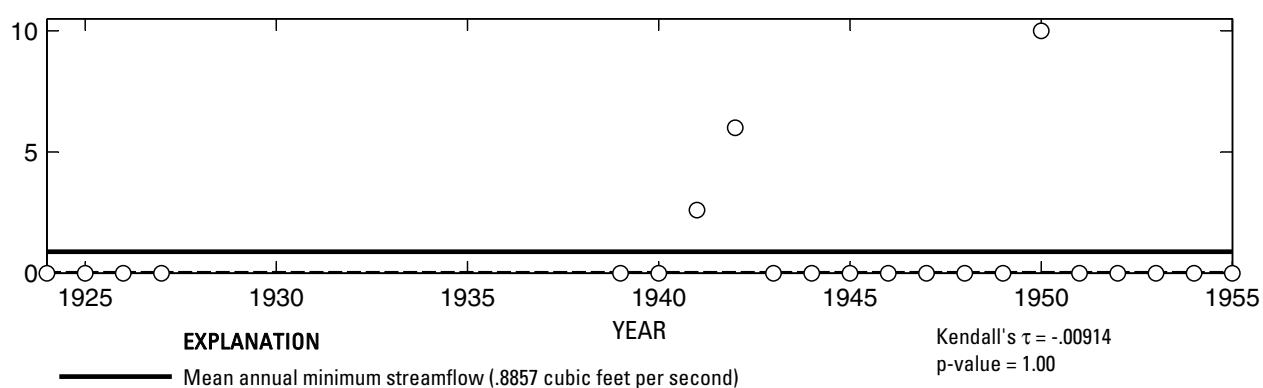

- - Median annual minimum streamflow (0 cubic feet per second)

O Annual minimum streamflow

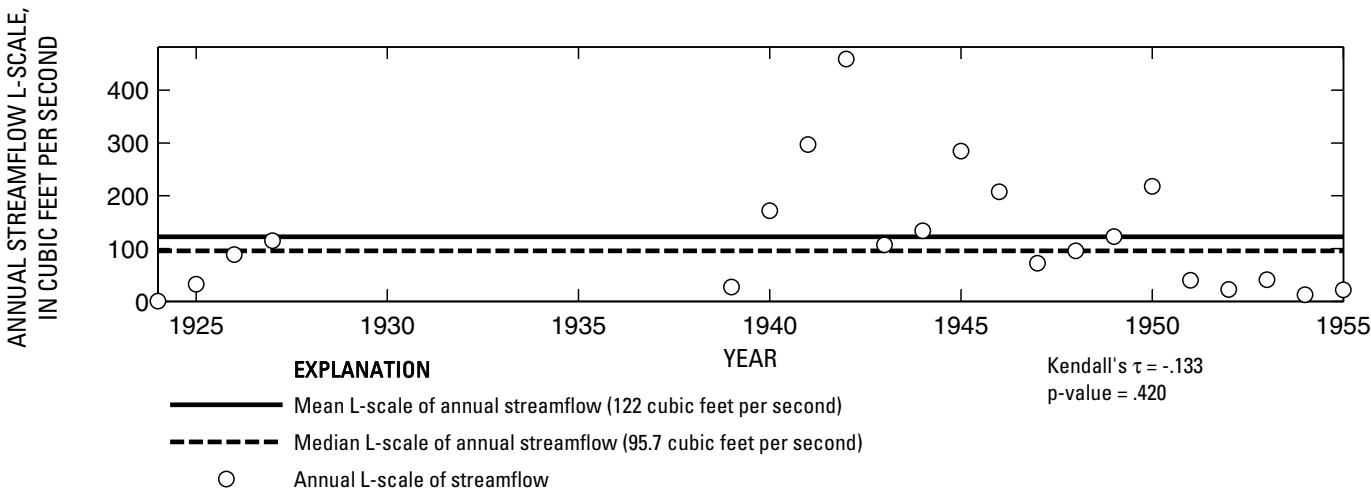

Figure 195. Analysis of annual mean, maximum, minimum, and L-scale statistics of daily mean streamflow for U.S. Geological Survey streamflow-gaging station 08054000 Denton Creek near Roanoke, Texas. 
U.S. Geological Survey streamflow-gaging station 08055000

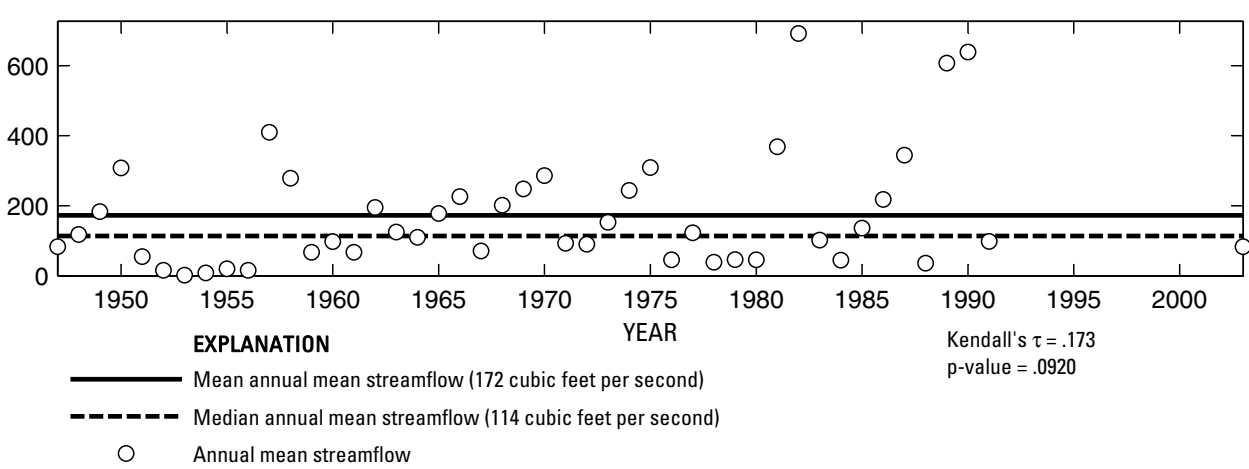

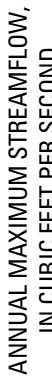

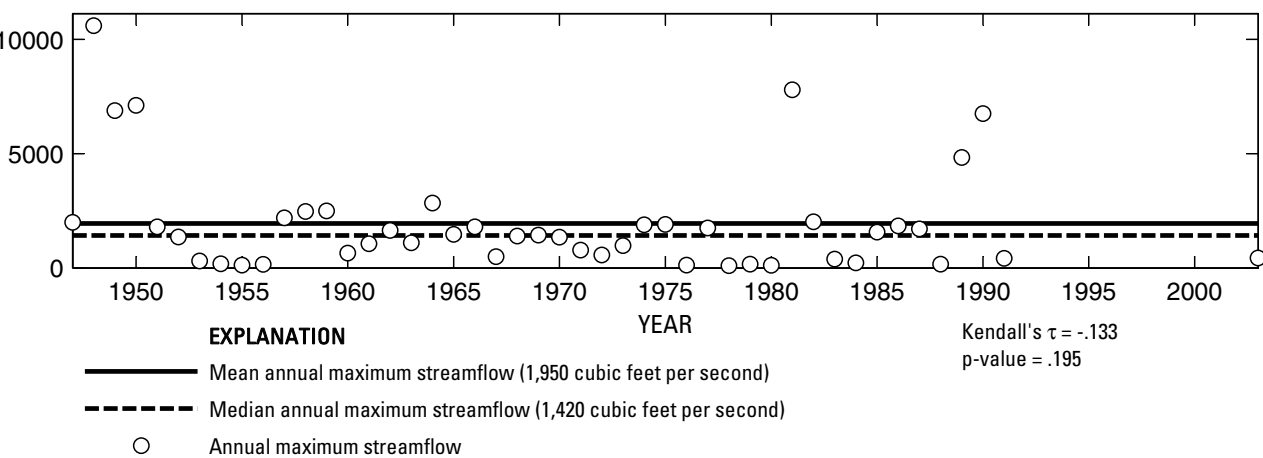

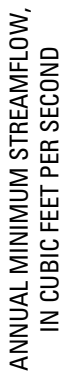

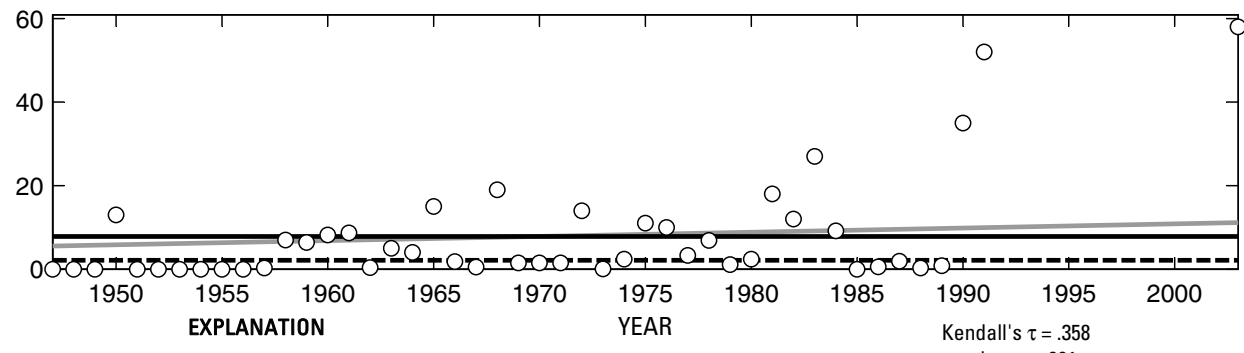

Theil trend line for annual minimum streamflow

$\mathrm{p}$-value $=<.001$

Mean annual minimum streamflow ( 7.82 cubic feet per second)

ーーーー Median annual minimum streamflow (2.15 cubic feet per second)

O Annual minimum streamflow

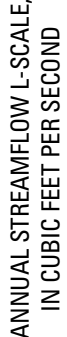

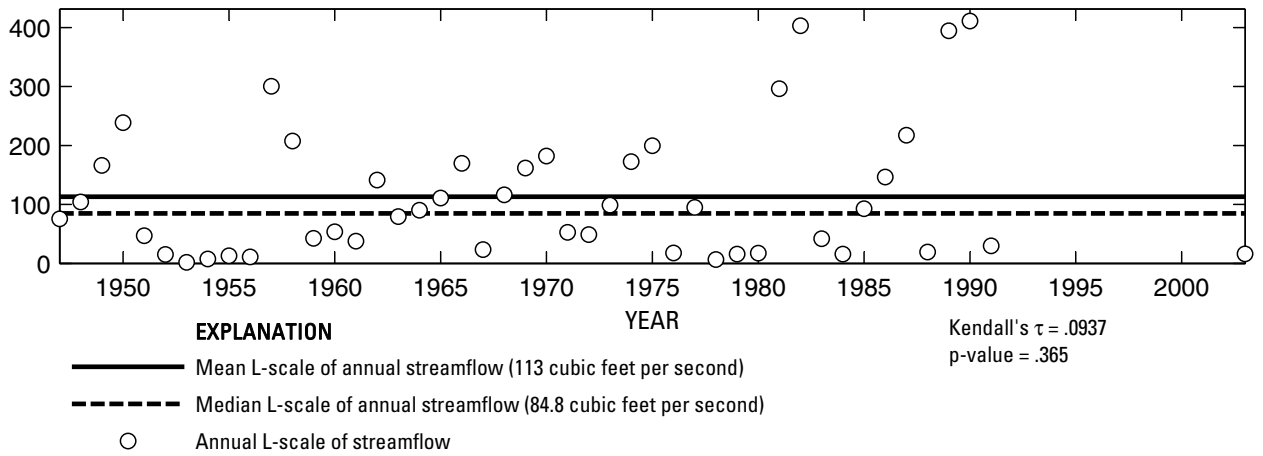

Figure 196. Analysis of annual mean, maximum, minimum, and L-scale statistics of daily mean streamflow for U.S. Geological Survey streamflow-gaging station 08055000 Denton Creek near Grapevine, Texas.

Index of Station Numbers 719 

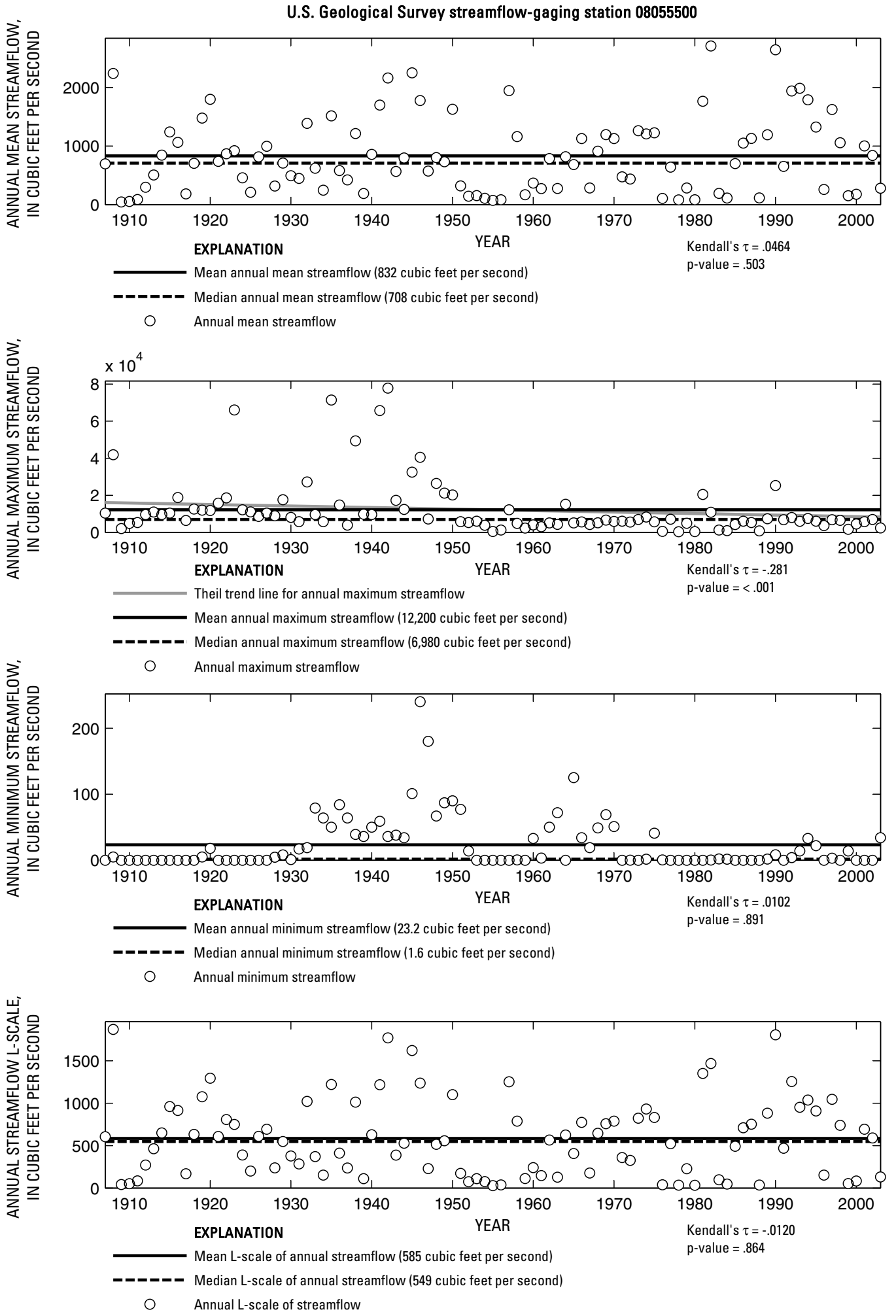

Figure 197. Analysis of annual mean, maximum, minimum, and L-scale statistics of daily mean streamflow for U.S. Geological Survey streamflow-gaging station 08055500 Elm Fork Trinity River near Carrollton, Texas. 


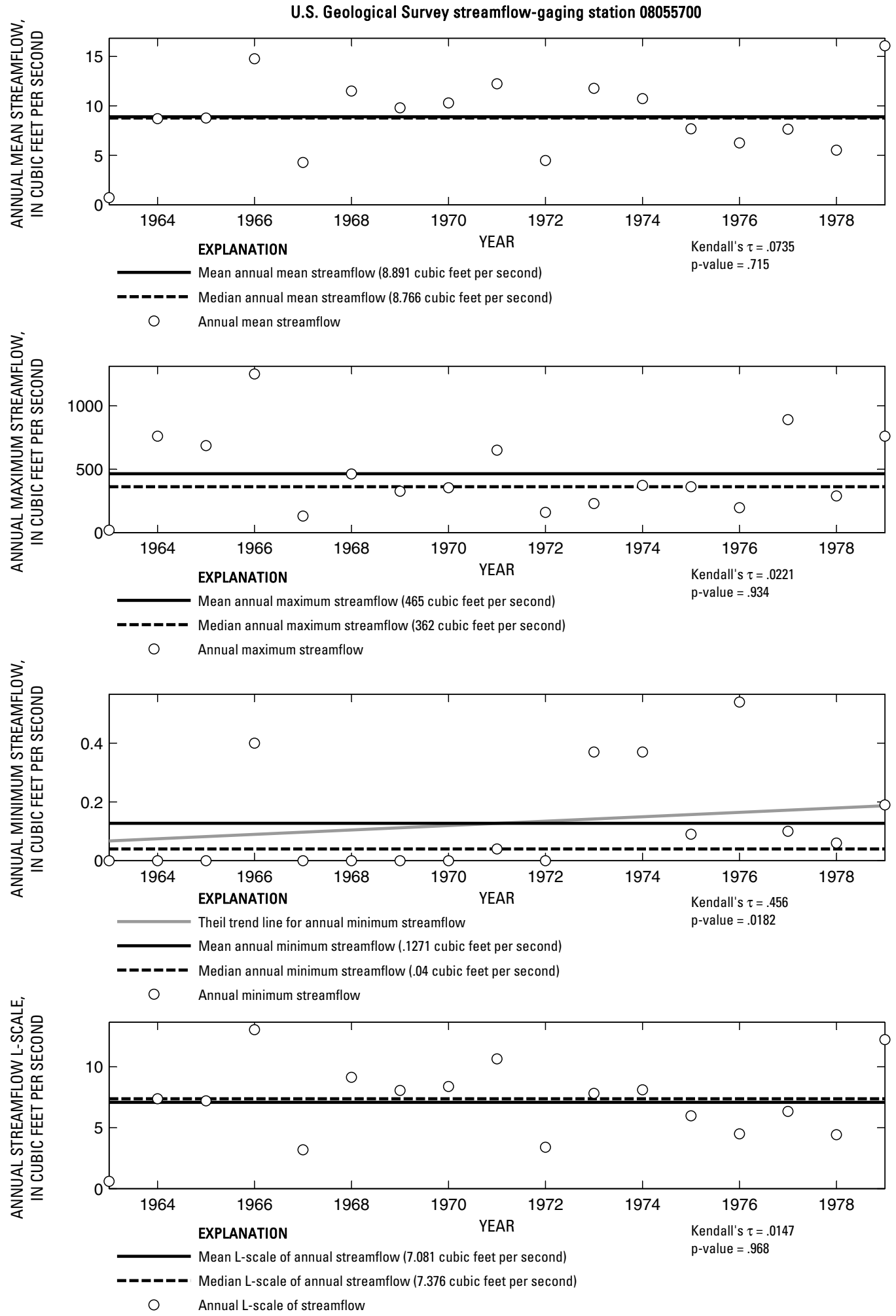

Figure 198. Analysis of annual mean, maximum, minimum, and L-scale statistics of daily mean streamflow for U.S. Geological Survey streamflow-gaging station 08055700 Bachman Branch at Dallas, Texas.

Index of Station Numbers 719 


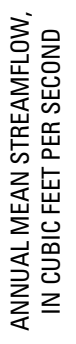

U.S. Geological Survey streamflow-gaging station 08056500

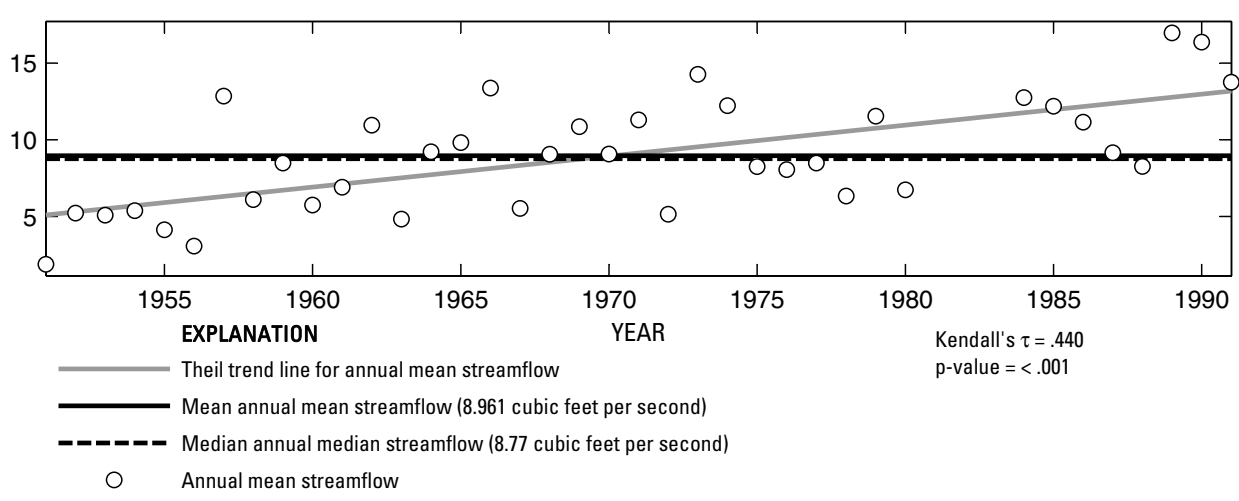

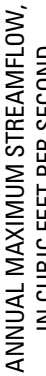

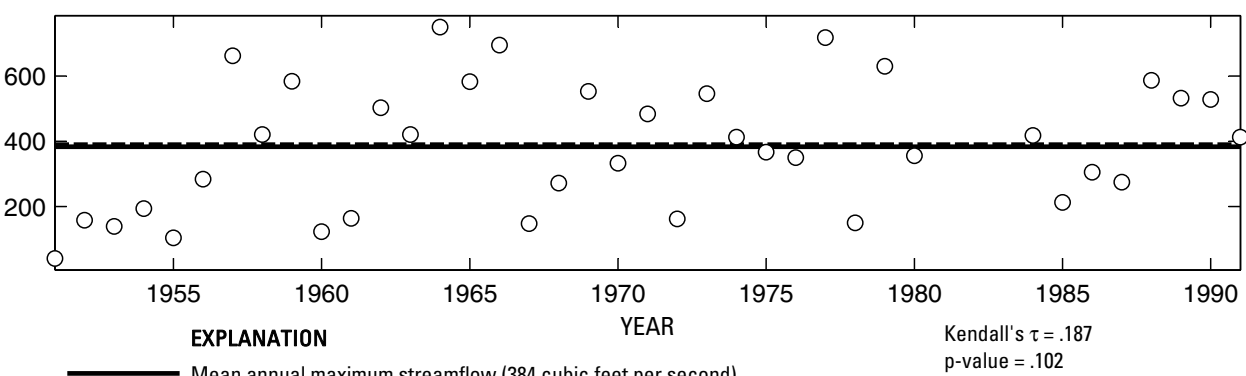

O Annual maximum streamflow

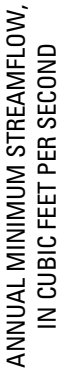

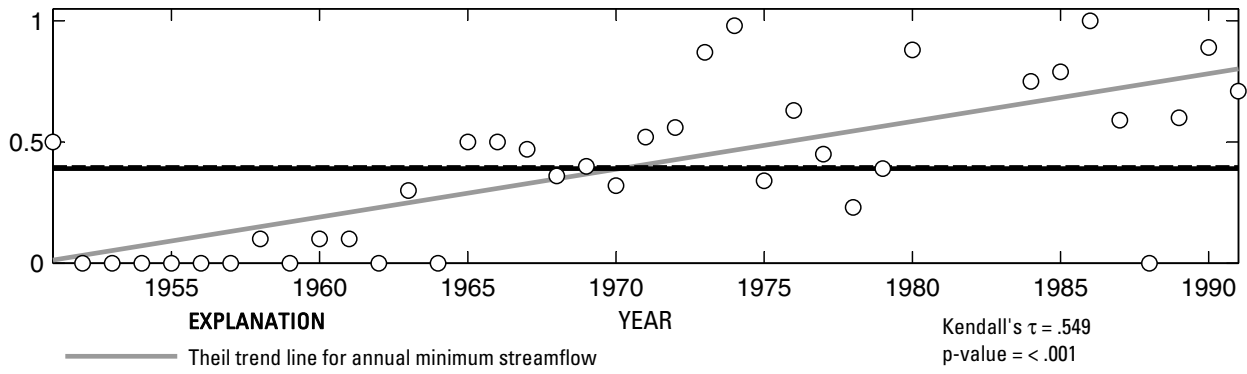

O Annual minimum streamflow
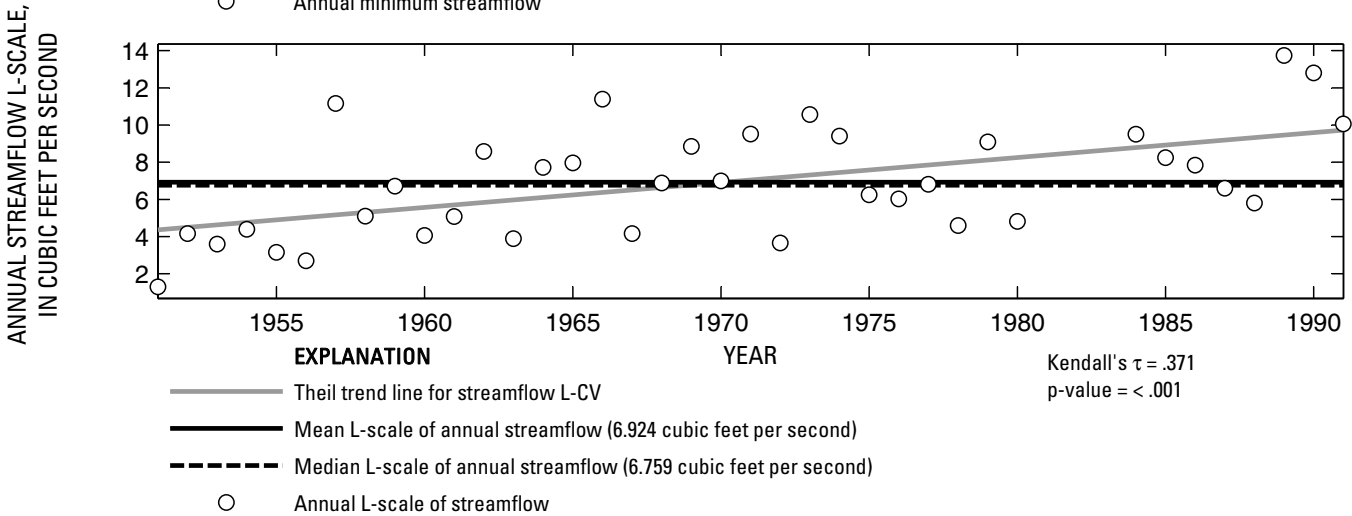

Figure 199. Analysis of annual mean, maximum, minimum, and L-scale statistics of daily mean streamflow for U.S. Geological Survey streamflow-gaging station 08056500 Turtle Creek at Dallas, Texas. 

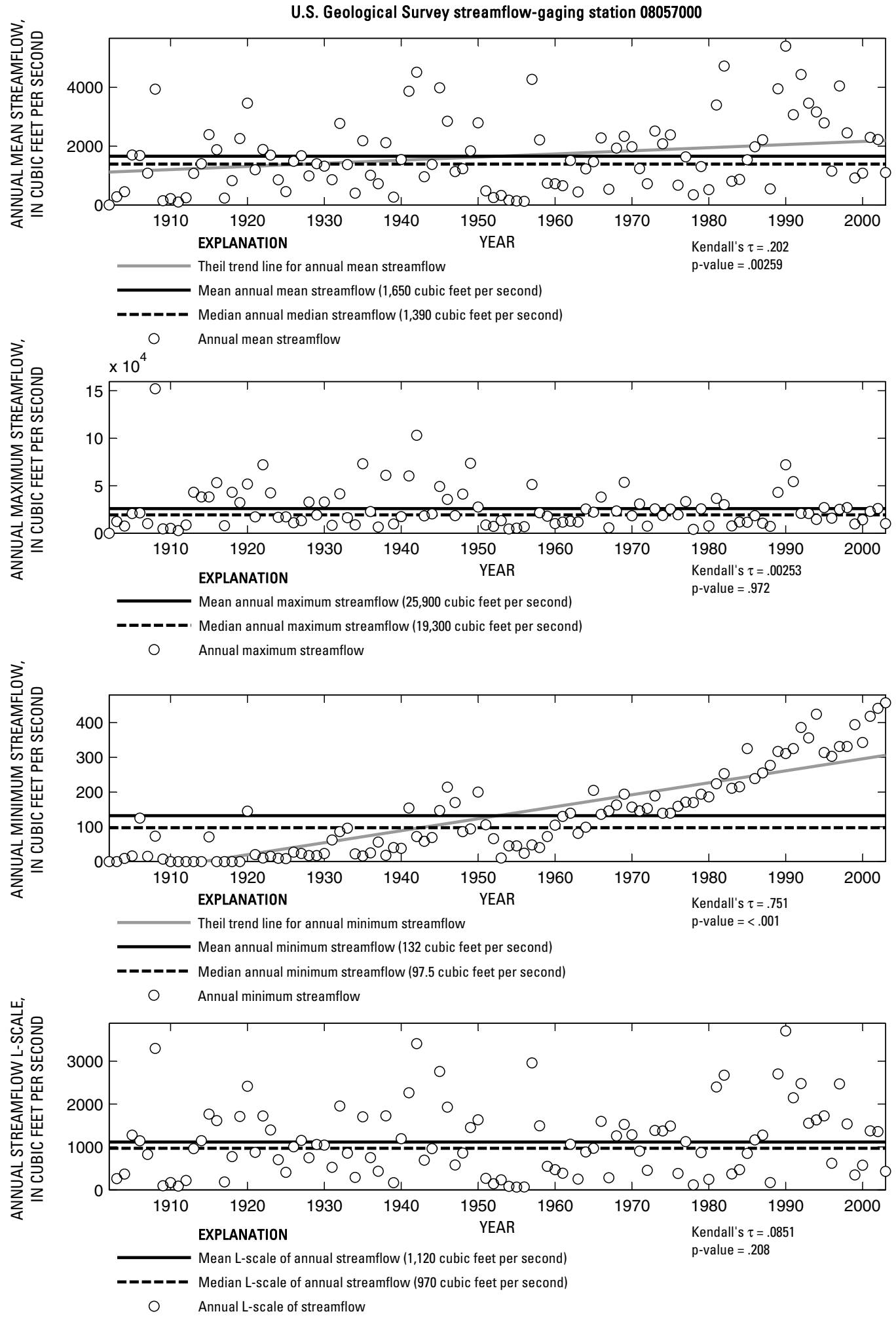

Figure 200. Analysis of annual mean, maximum, minimum, and L-scale statistics of daily mean streamflow for U.S. Geological Survey streamflow-gaging station 08057000 Trinity River at Dallas, Texas.

Index of Station Numbers 719 


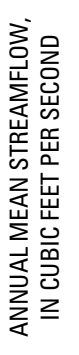

U.S. Geological Survey streamflow-gaging station 08057100

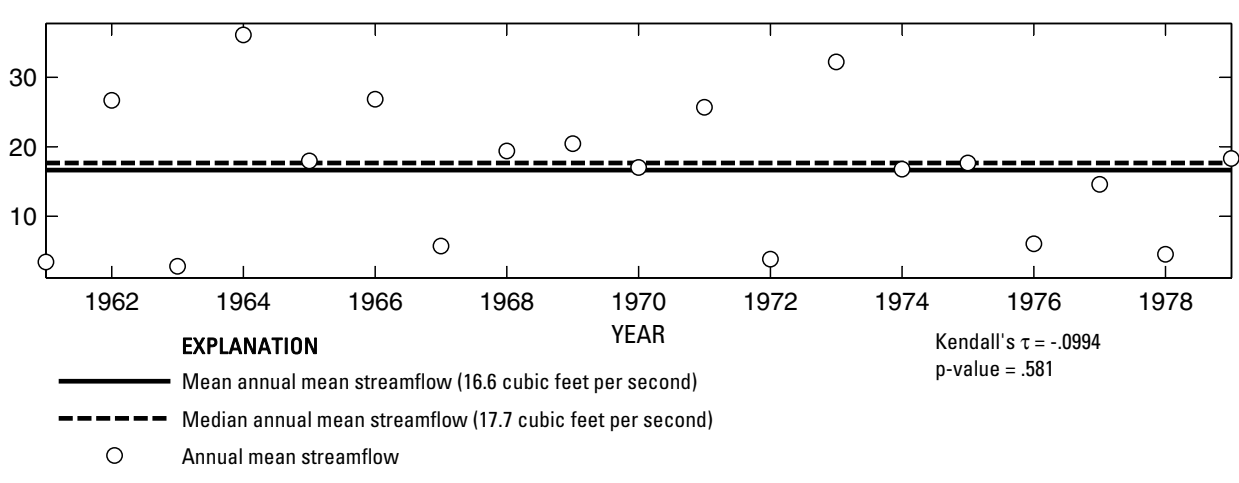

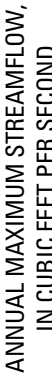

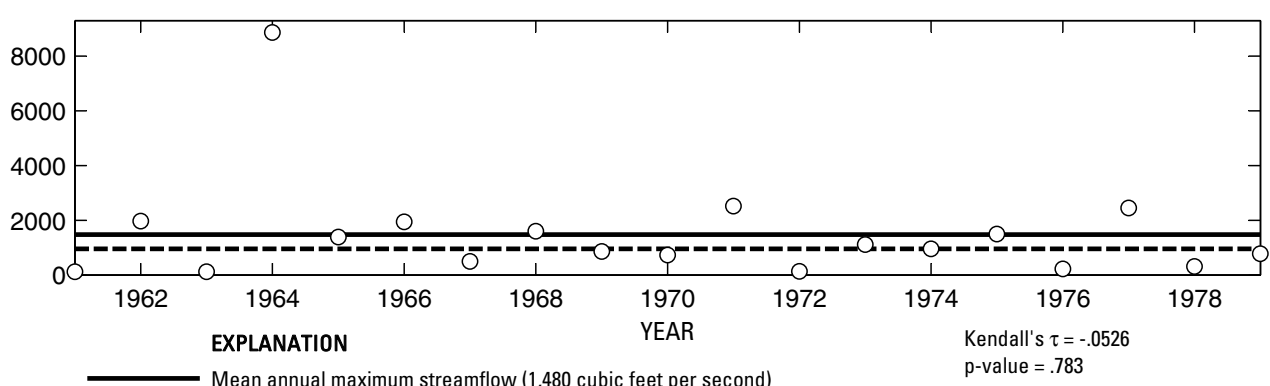

- - - Median annual maximum streamflow (959 cubic feet per second)

O Annual maximum streamflow
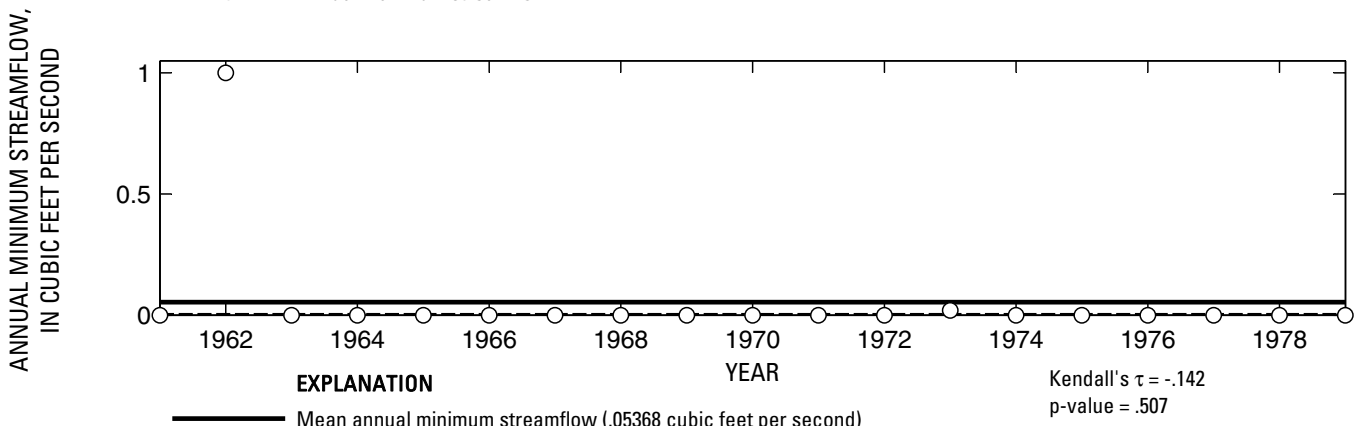

- Median annual minimum streamflow (0 cubic feet per second)

O Annual minimum streamflow

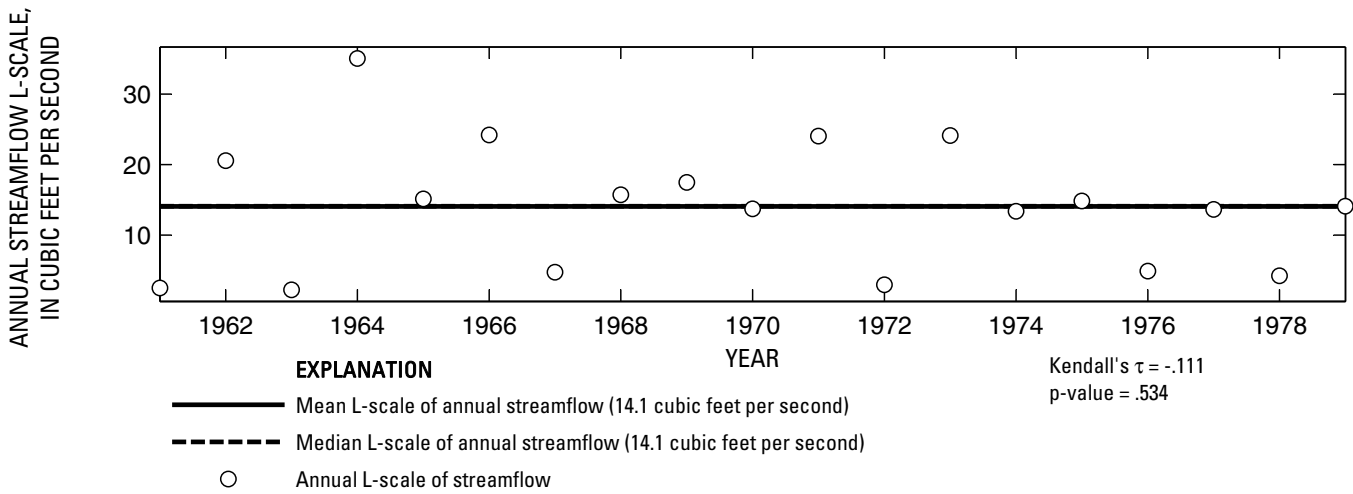

Figure 201. Analysis of annual mean, maximum, minimum, and L-scale statistics of daily mean streamflow for U.S. Geological Survey streamflow-gaging station 08057100 White Rock Creek at Keller Springs Road, Dallas, Texas. 


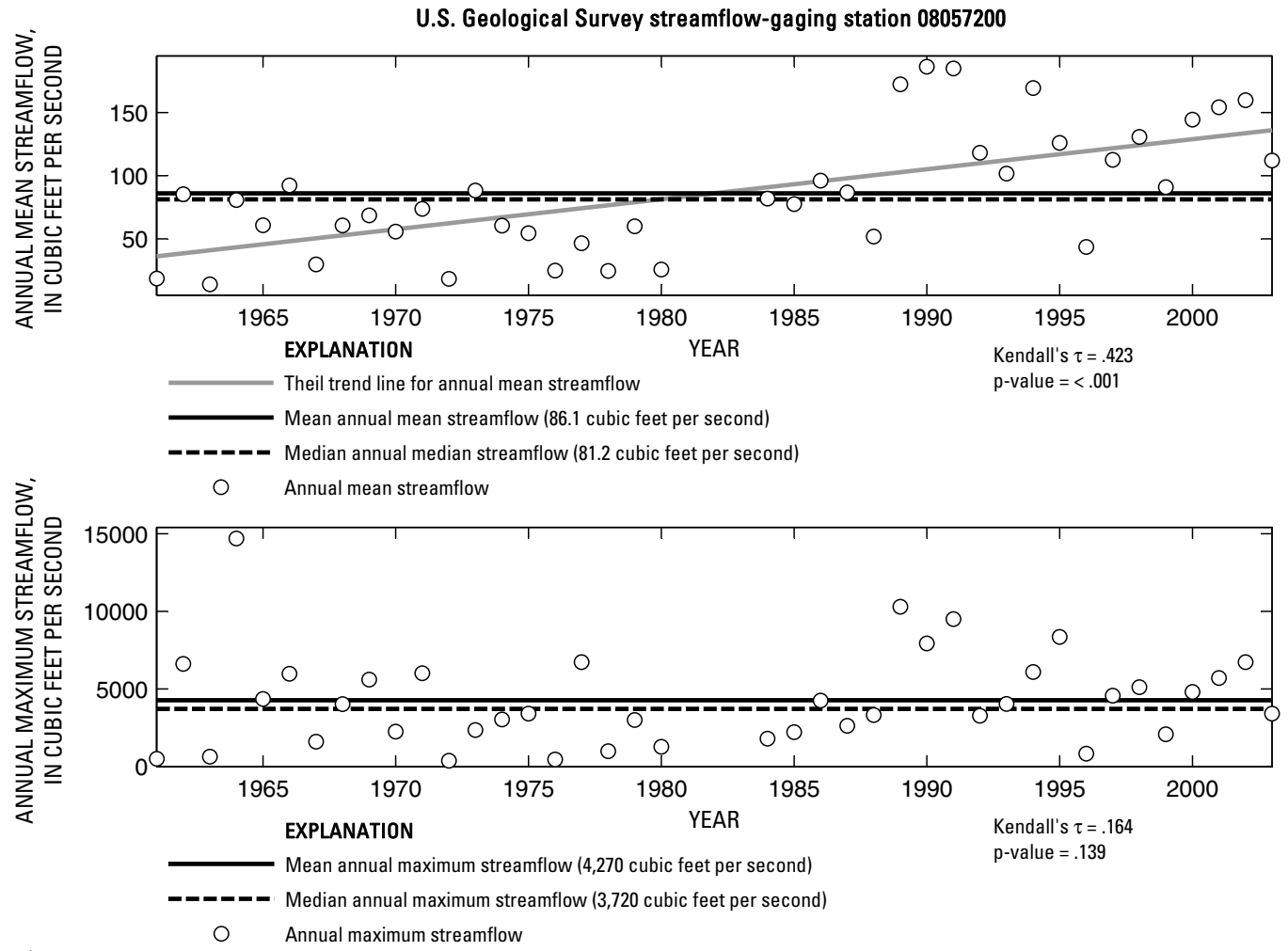

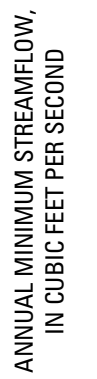

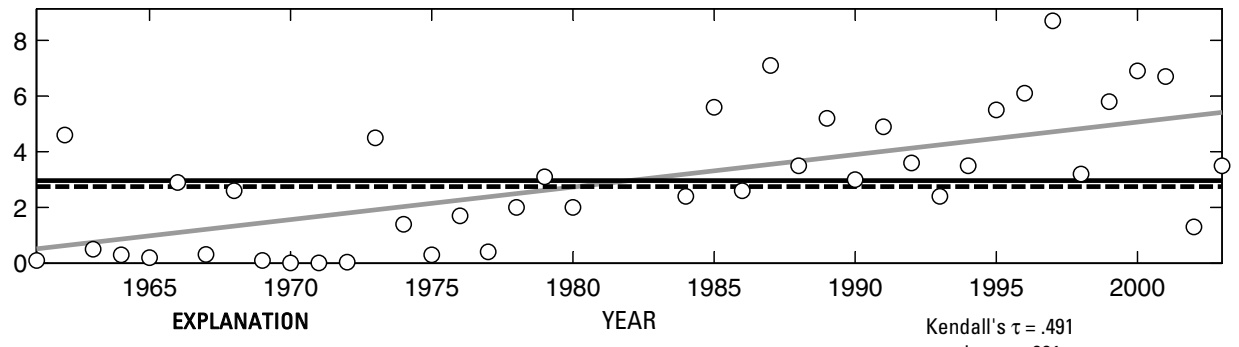

Theil trend line for annual minimum streamflow

$\mathrm{p}$-value $=<.001$

- Mean annual minimum streamflow (2.965 cubic feet per second)

- - Median annual minimum streamflow (2.75 cubic feet per second)

○

Annual minimum streamflow

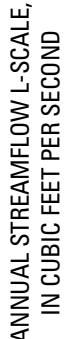

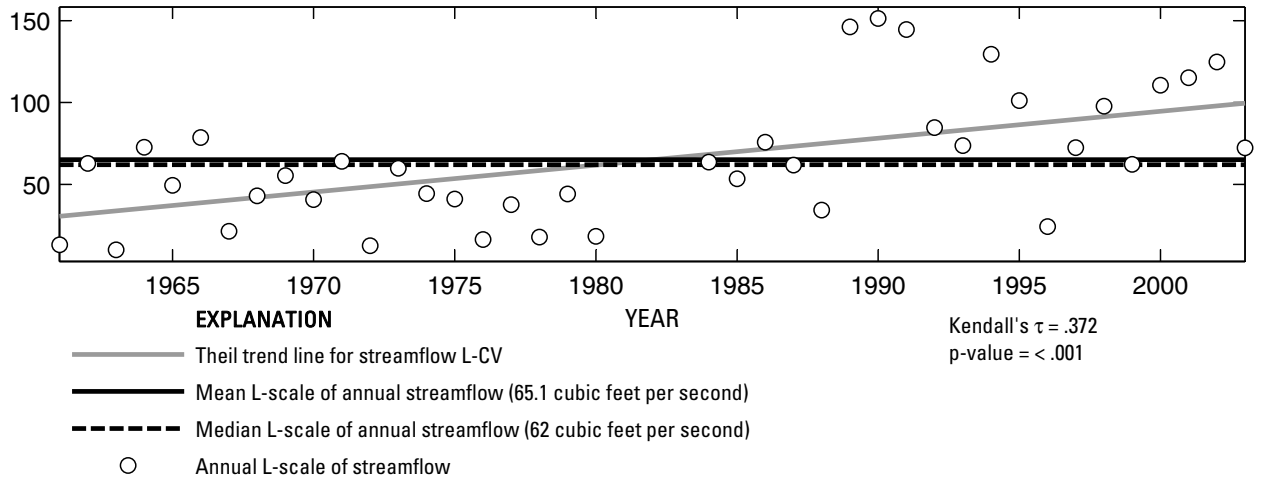

Figure 202. Analysis of annual mean, maximum, minimum, and L-scale statistics of daily mean streamflow for U.S. Geological Survey streamflow-gaging station 08057200 White Rock Creek at Greenville Avenue, Dallas, Texas.

Index of Station Numbers 719 

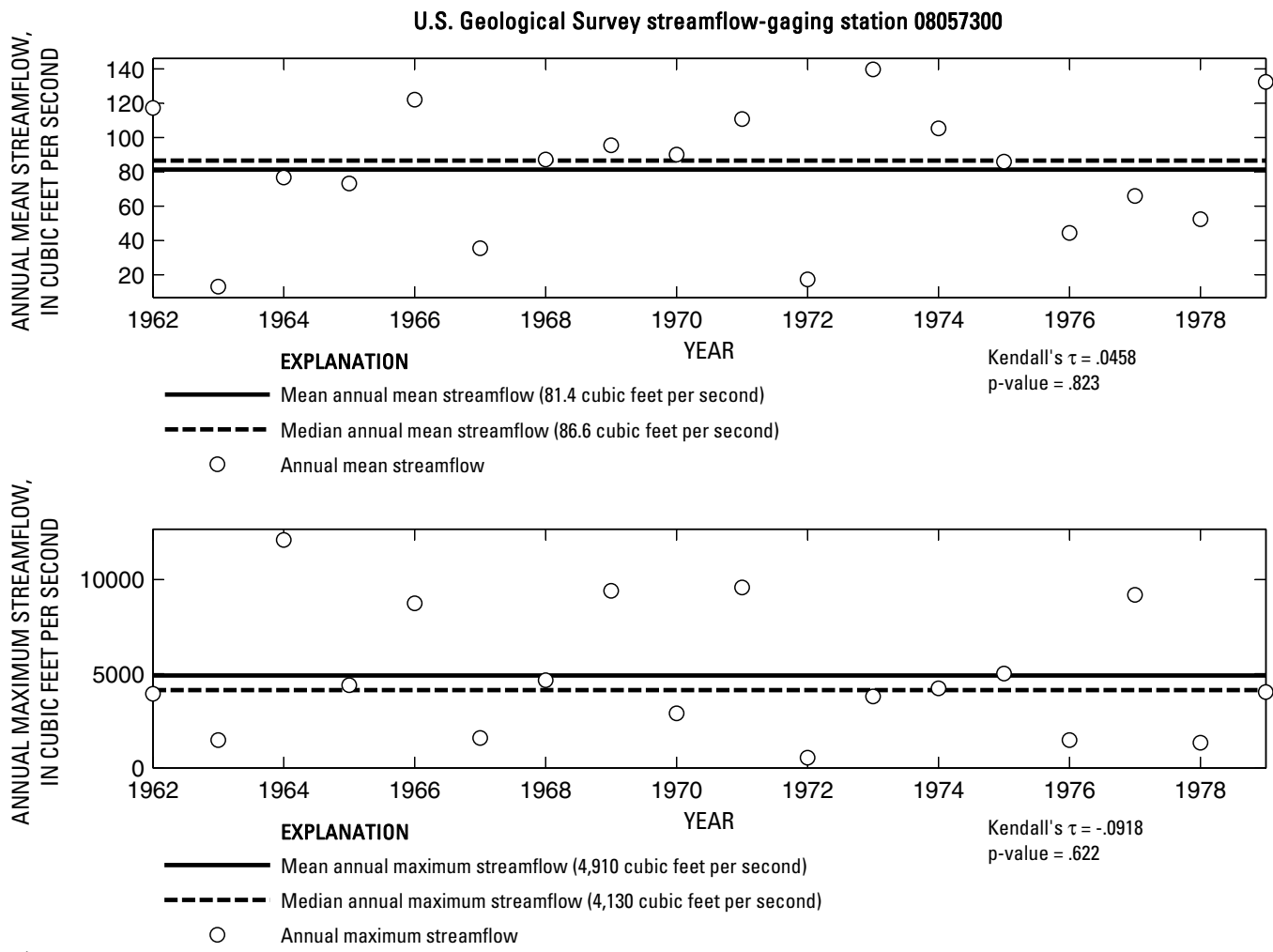

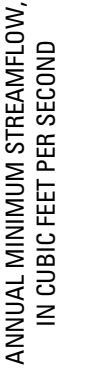

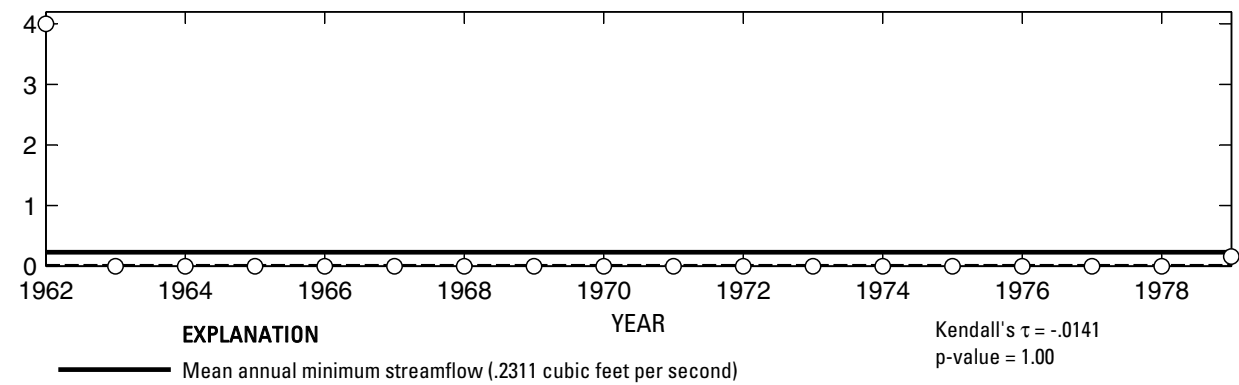

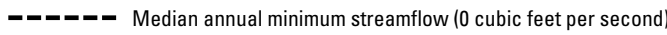

O Annual minimum streamflow

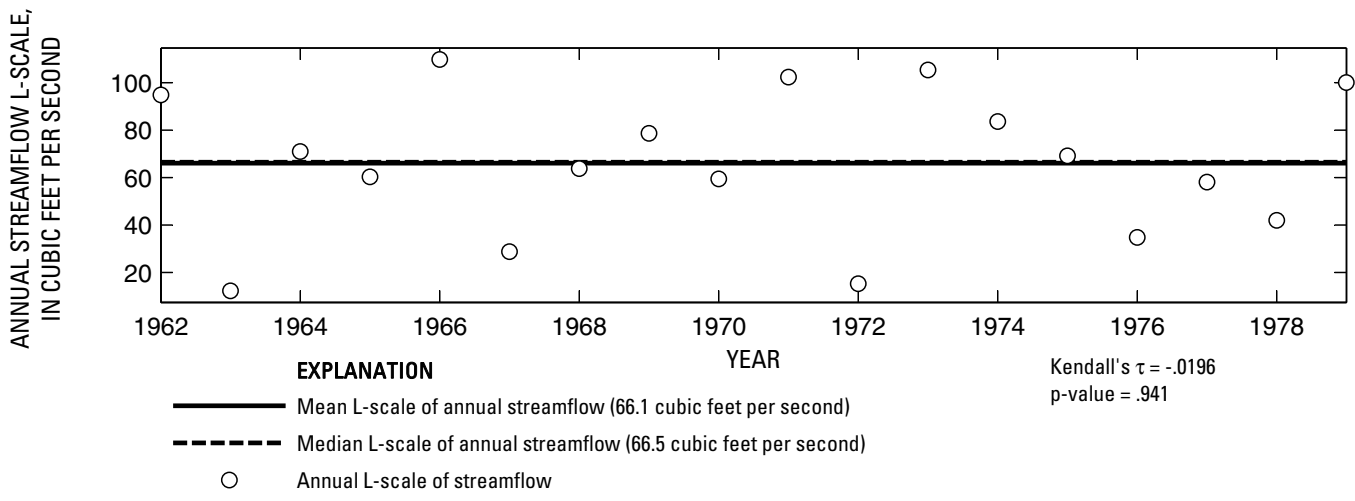

Figure 203. Analysis of annual mean, maximum, minimum, and L-scale statistics of daily mean streamflow for U.S. Geological Survey streamflow-gaging station 08057300 White Rock Creek at White Rock Lake, Dallas, Texas. 
U.S. Geological Survey streamflow-gaging station 08057410

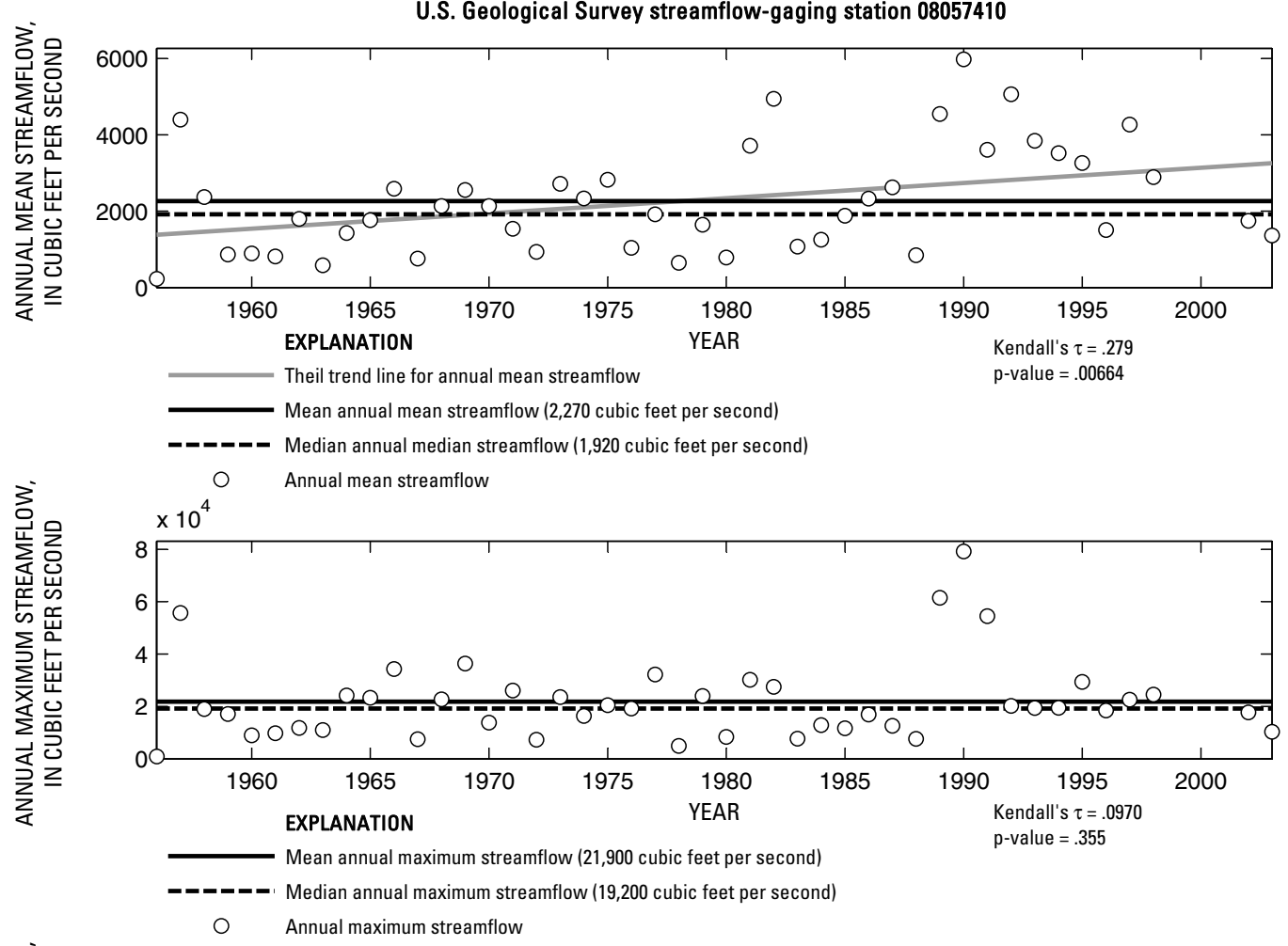

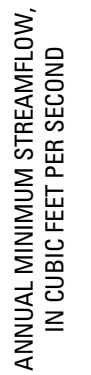

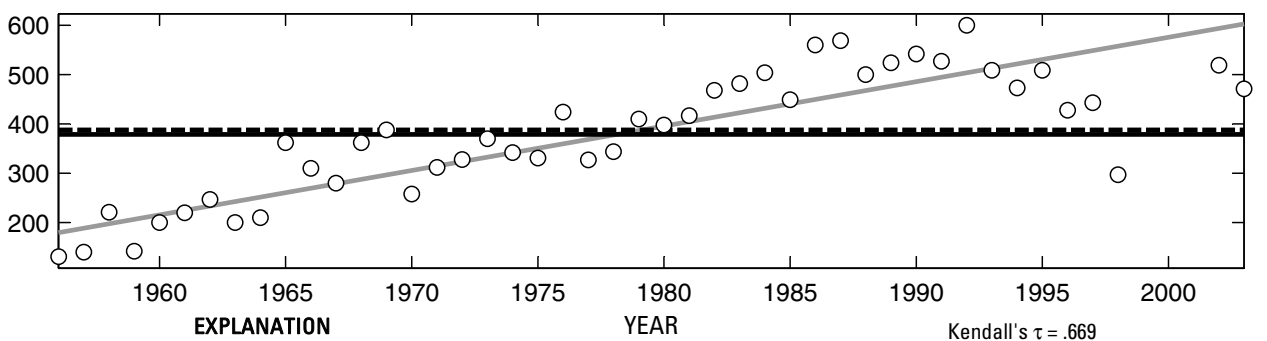

Theil trend line for annual minimum streamflow
Mean annual minimum streamflow ( 379 cubic feet per second)

O Annual minimum streamflow

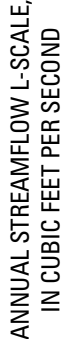

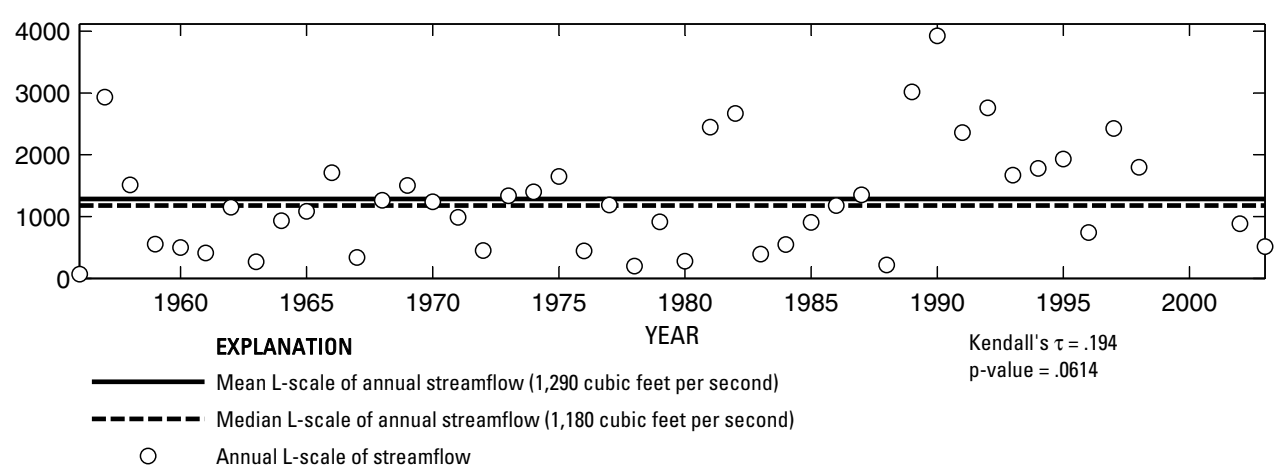

Figure 204. Analysis of annual mean, maximum, minimum, and L-scale statistics of daily mean streamflow for U.S. Geological Survey streamflow-gaging station 08057410 Trinity River below Dallas, Texas.

Index of Station Numbers 719 


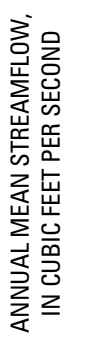

U.S. Geological Survey streamflow-gaging station 08057445

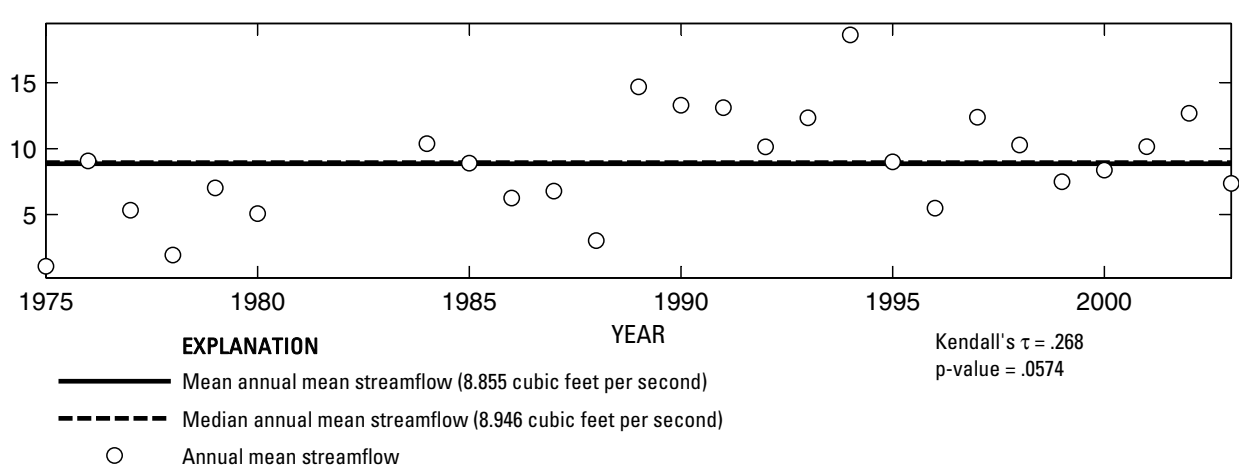

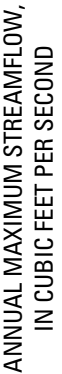

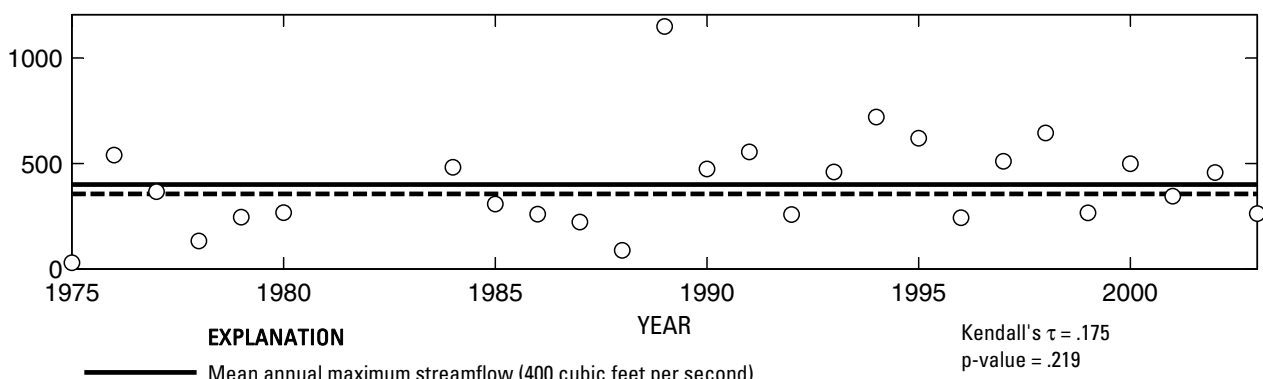

- _-_on Median annual maximum streamflow ( 356 cubic feet per second)

O Annual maximum streamflow
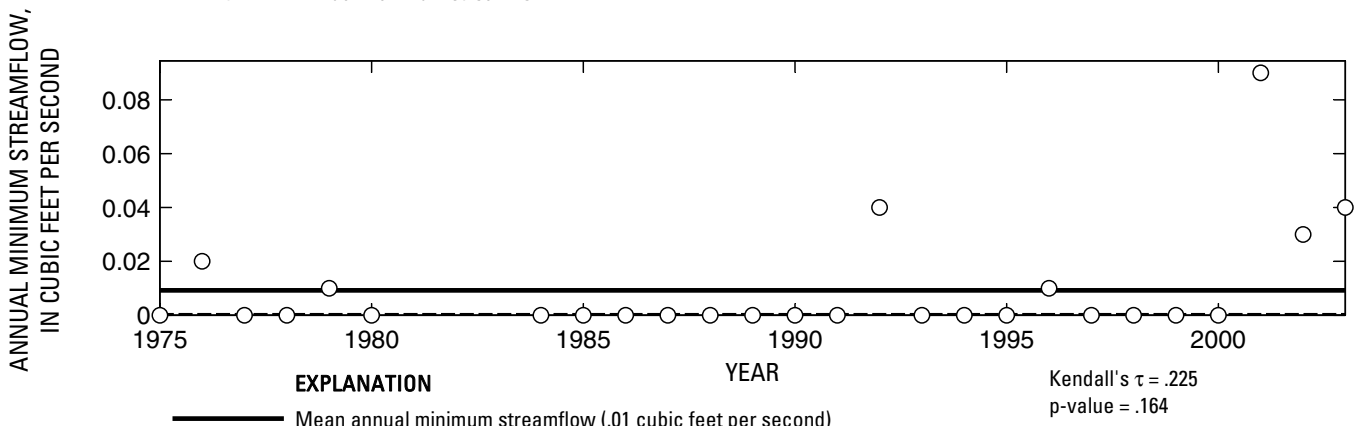

- ב-ב Median annual minimum streamflow (0 cubic feet per second)

O Annual minimum streamflow

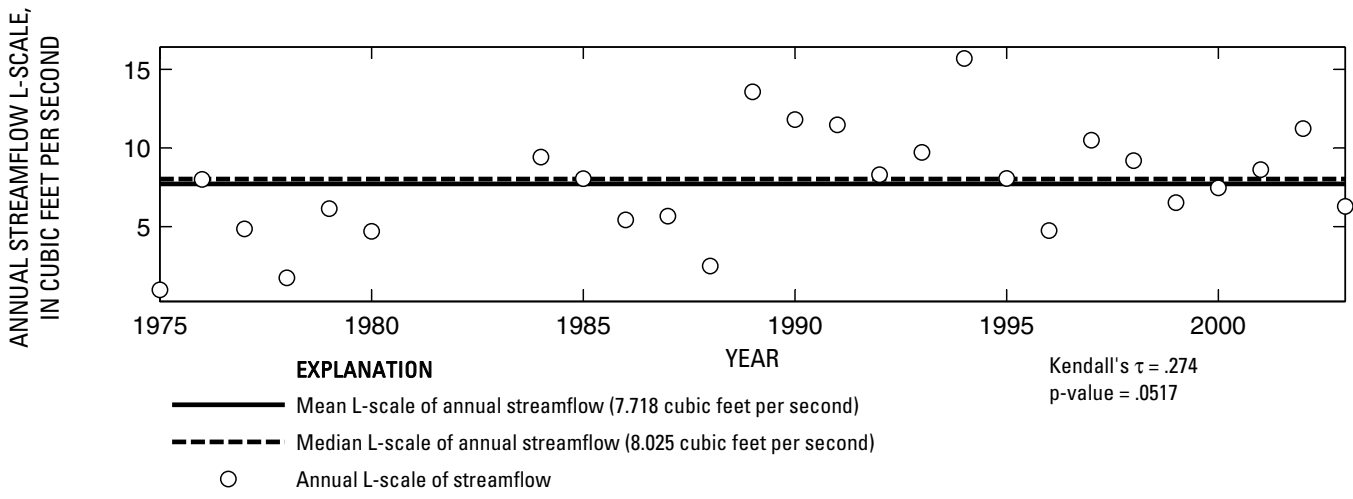

Figure 205. Analysis of annual mean, maximum, minimum, and L-scale statistics of daily mean streamflow for U.S. Geological Survey streamflow-gaging station 08057445 Prairie Creek at U. S. Highway 175, Dallas, Texas. 

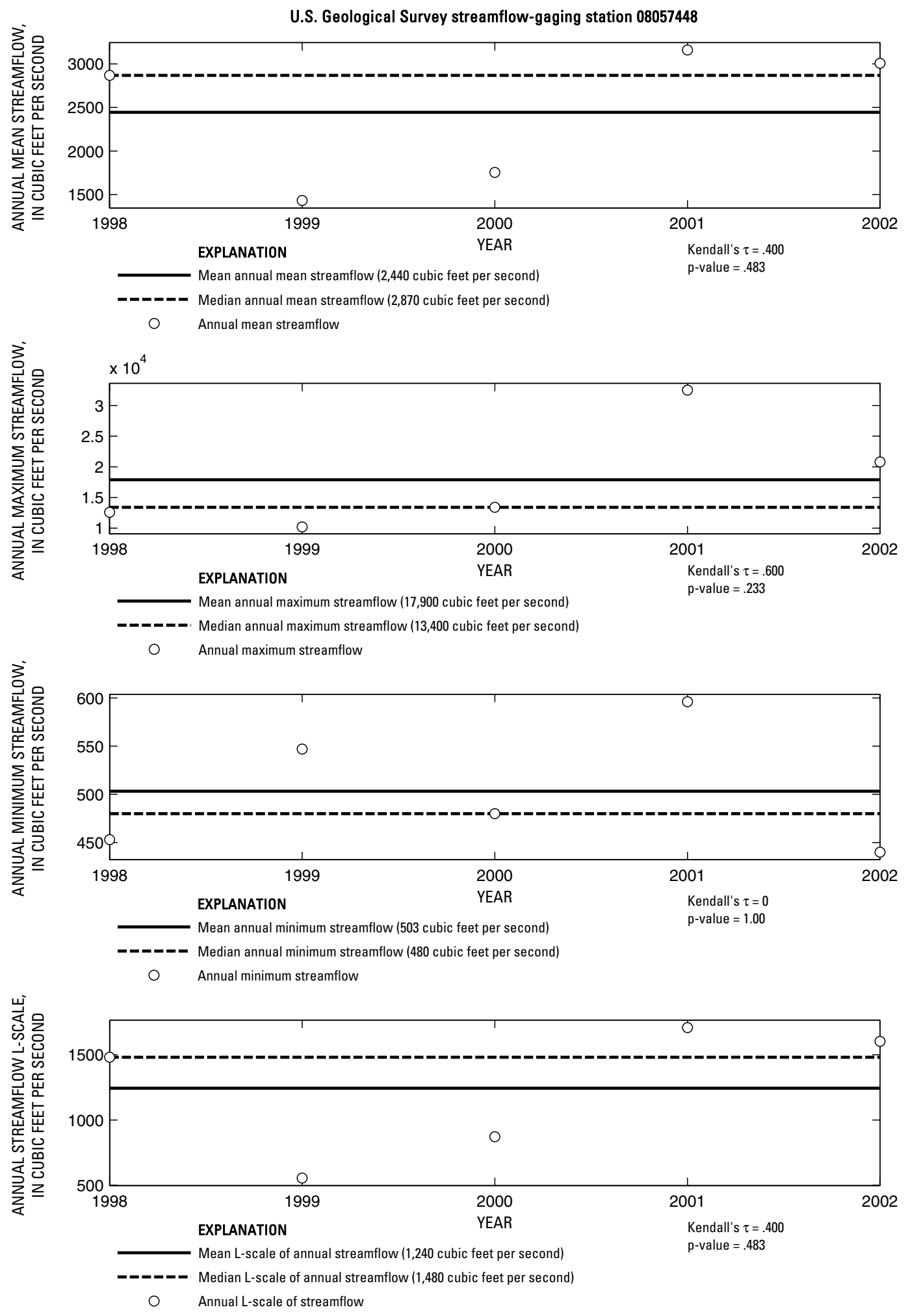

Figure 206. Analysis of annual mean, maximum, minimum, and L-scale statistics of daily mean streamflow for U.S. Geological Survey streamflow-gaging station 08057448 Trinity River near Wilmer, Texas. 


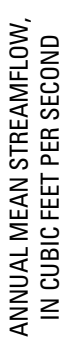

U.S. Geological Survey streamflow-gaging station 08057450

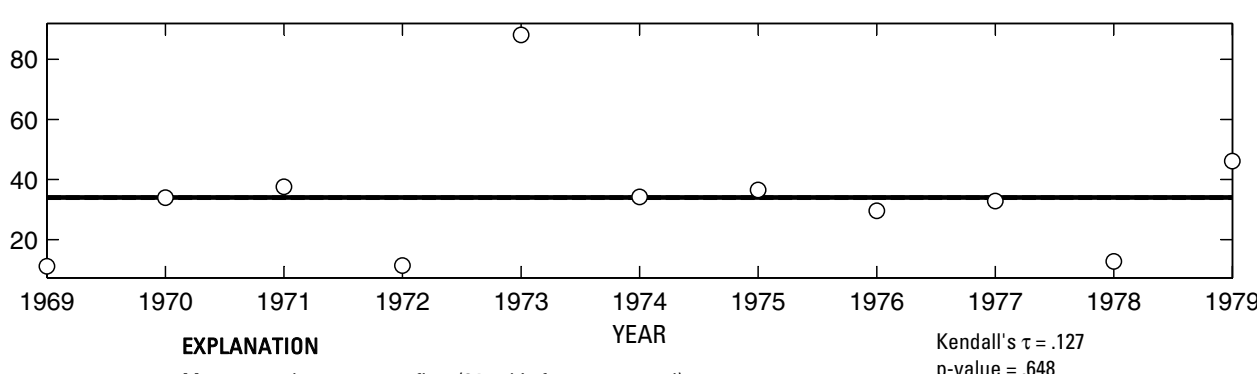

Mean annual mean streamflow (34 cubic feet per second)

p-value $=.648$

-_-_-_ Median annual mean streamflow (34 cubic feet per second)

O Annual mean streamflow
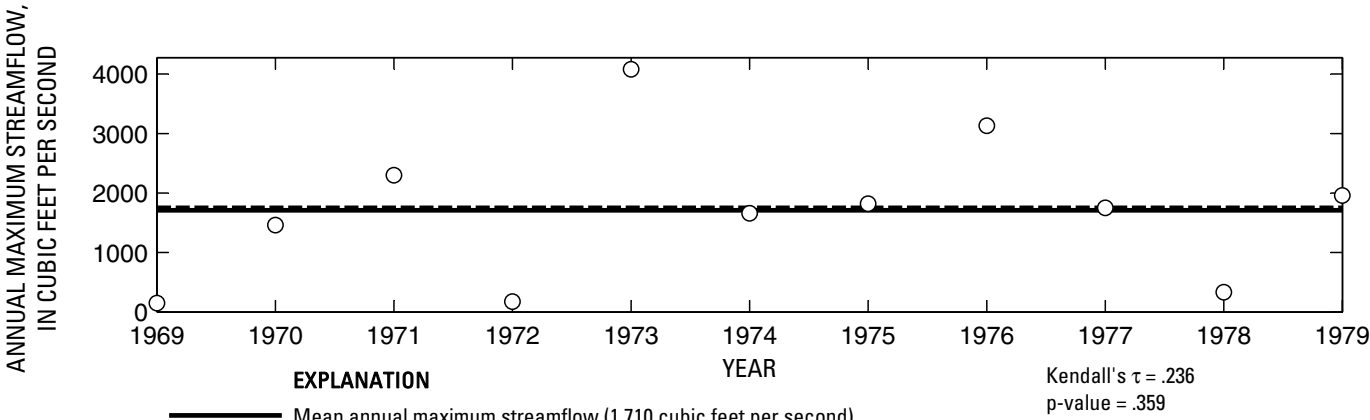

O Annual maximum streamflow

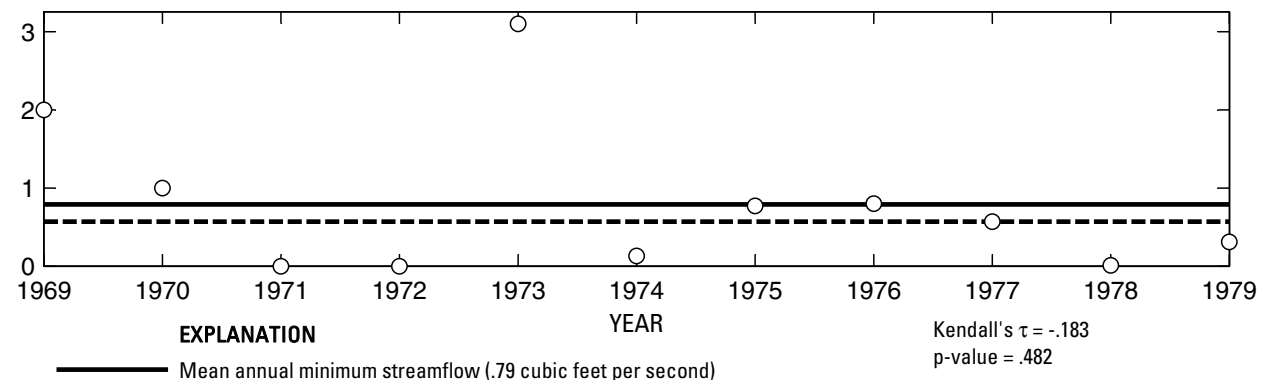

-0-0 Median annual minimum streamflow (.57 cubic feet per second)

○ Annual minimum streamflow
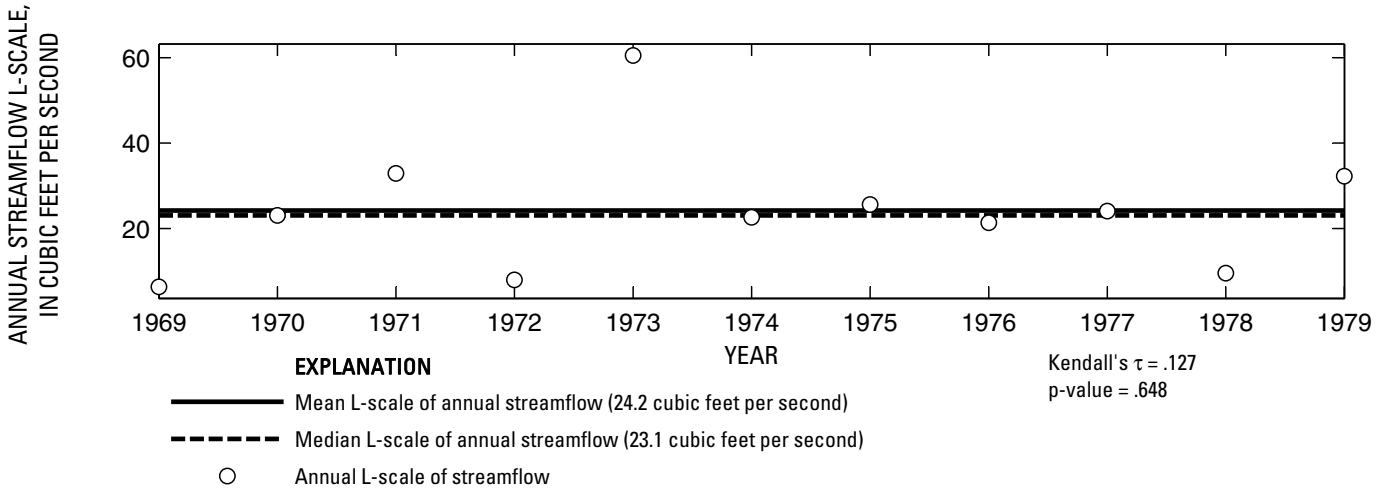

Figure 207. Analysis of annual mean, maximum, minimum, and L-scale statistics of daily mean streamflow for U.S. Geological Survey streamflow-gaging station 08057450 Tenmile Creek at State Highway 342, Lancaster, Texas. 

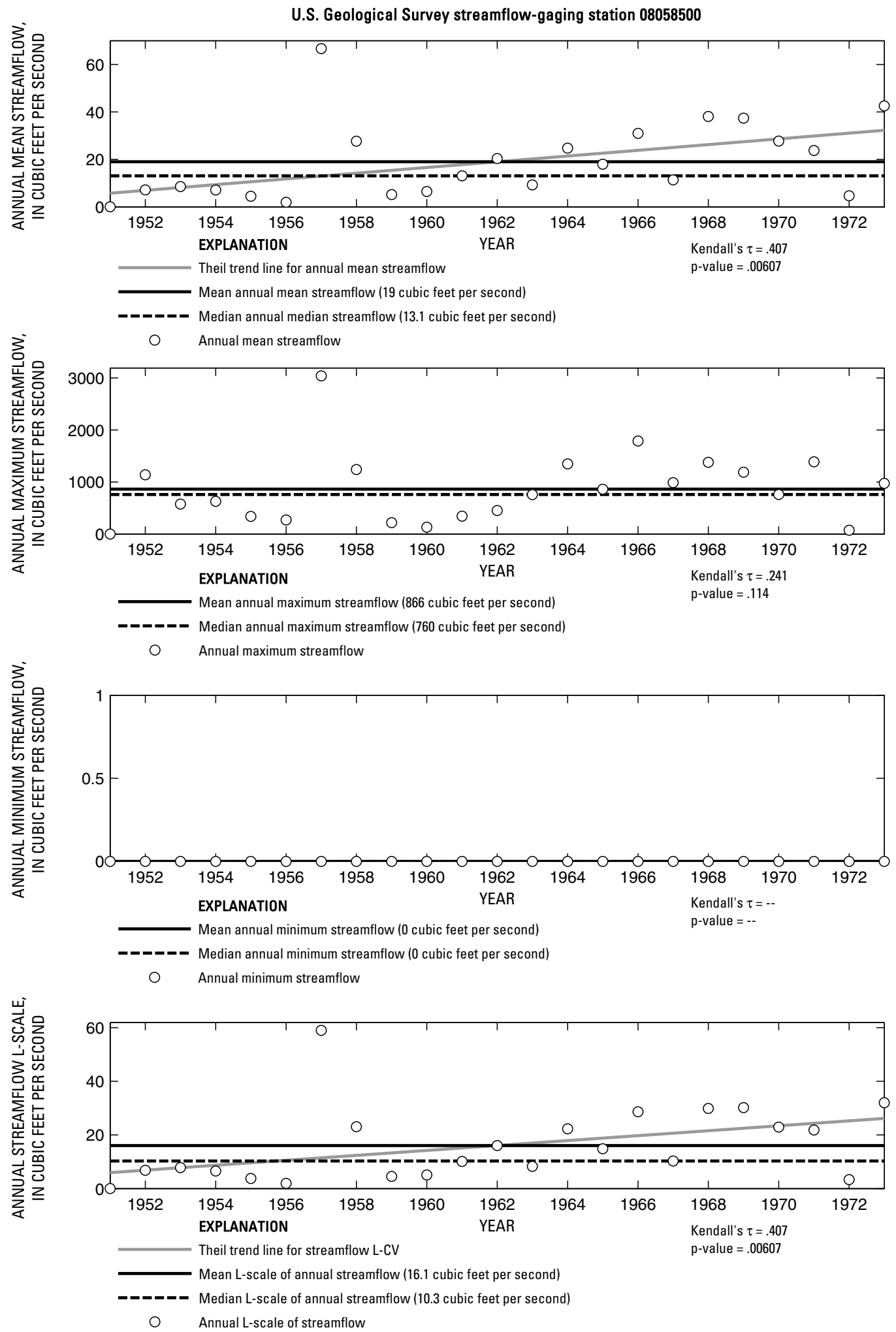

Figure 208. Analysis of annual mean, maximum, minimum, and L-scale statistics of daily mean streamflow for U.S. Geological Survey streamflow-gaging station 08058500 Honey Creek near McKinney, Texas.

Index of Station Numbers 719 

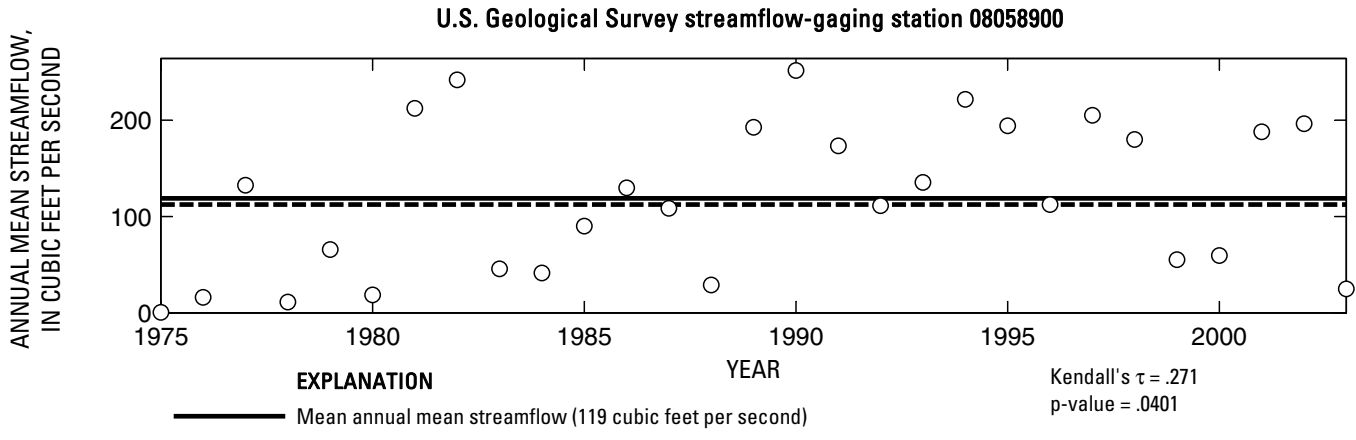

-_-_- Median annual mean streamflow (112 cubic feet per second)

O Annual mean streamflow
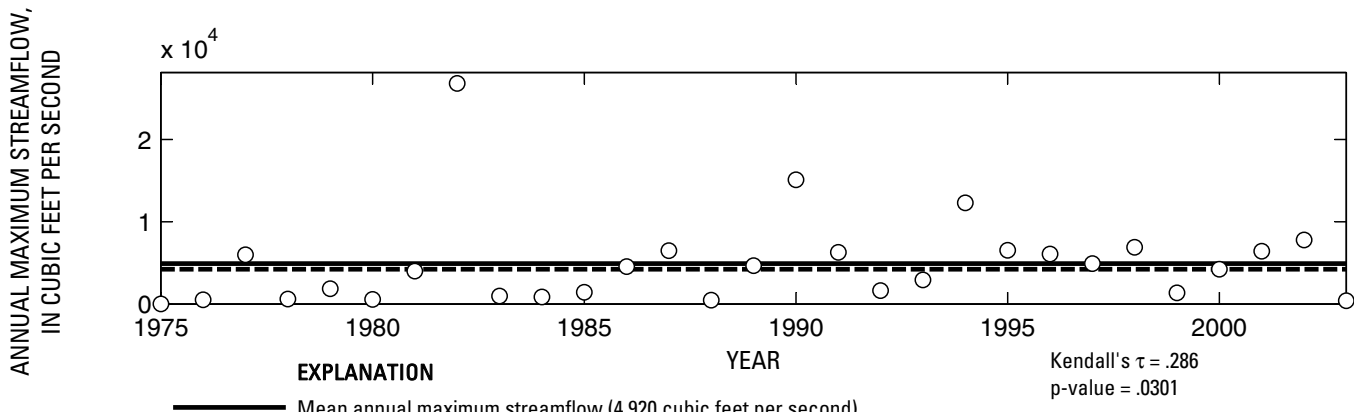

- ב- Median annual maximum streamflow $(4,230$ cubic feet per second)

- Annual maximum streamflow

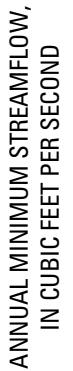

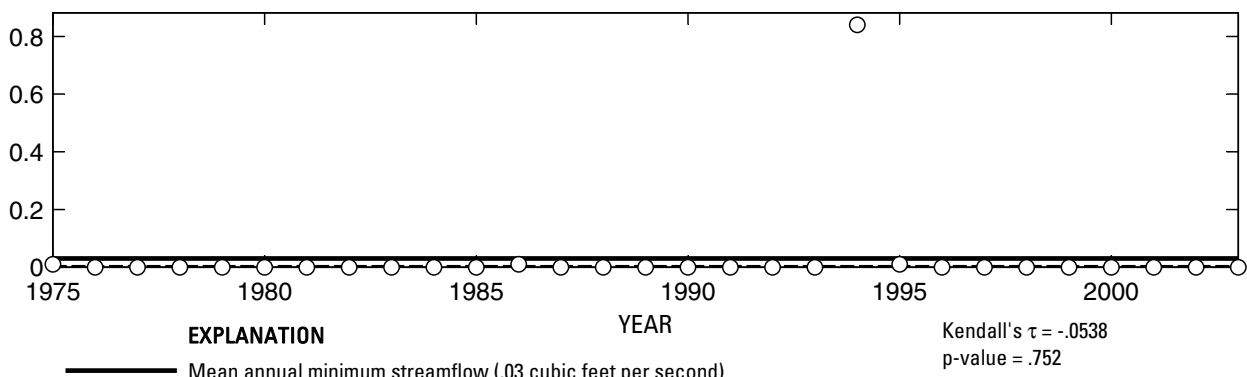

- ב- Median annual minimum streamflow (0 cubic feet per second)

O Annual minimum streamflow

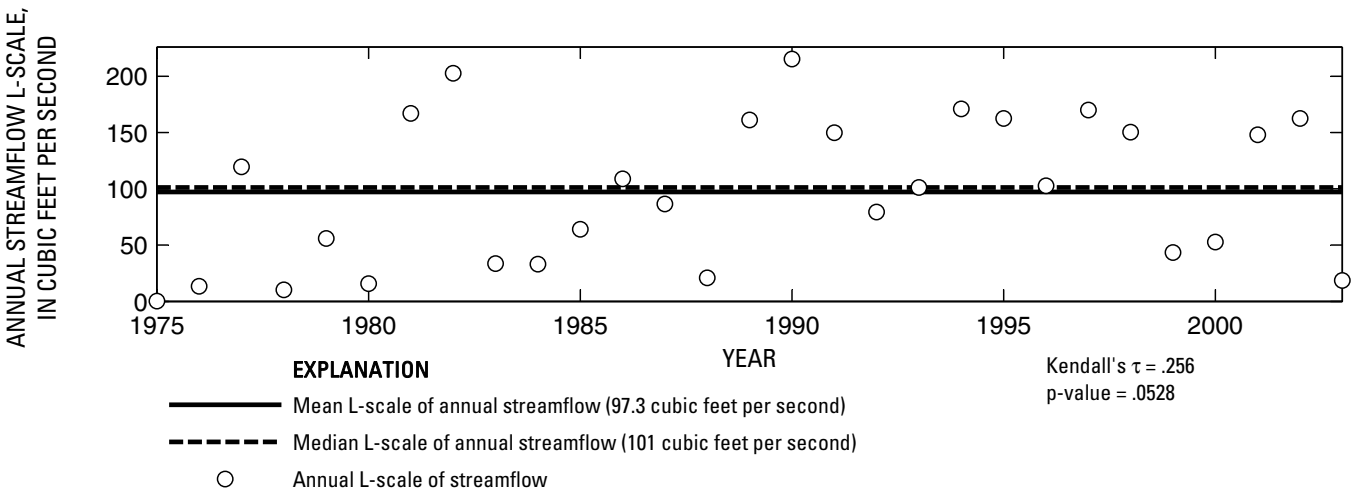

Figure 209. Analysis of annual mean, maximum, minimum, and L-scale statistics of daily mean streamflow for U.S. Geological Survey streamflow-gaging station 08058900 East Fork Trinity River at McKinney, Texas. 


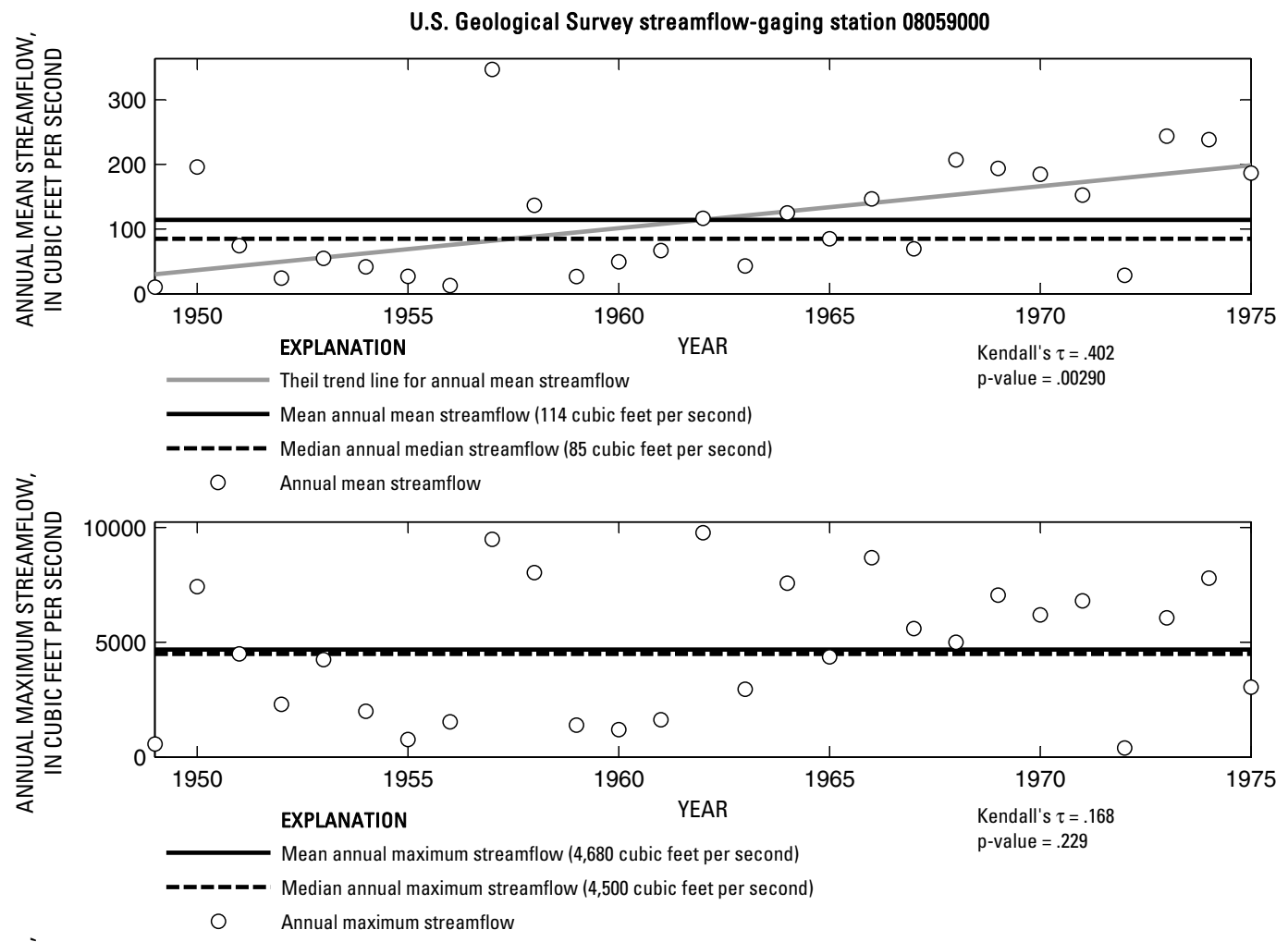

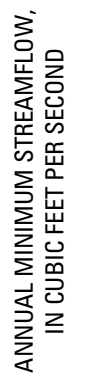

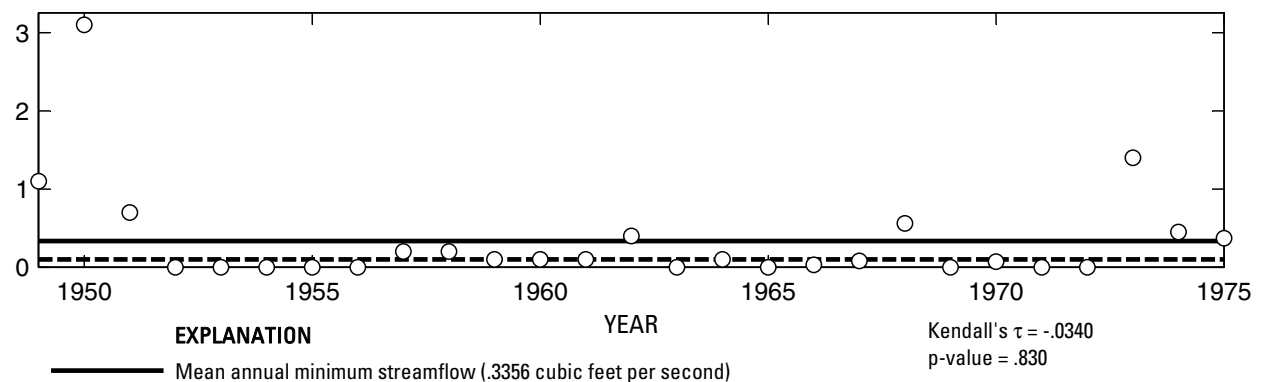

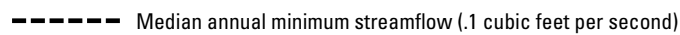

O Annual minimum streamflow

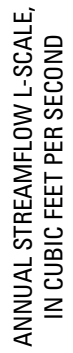

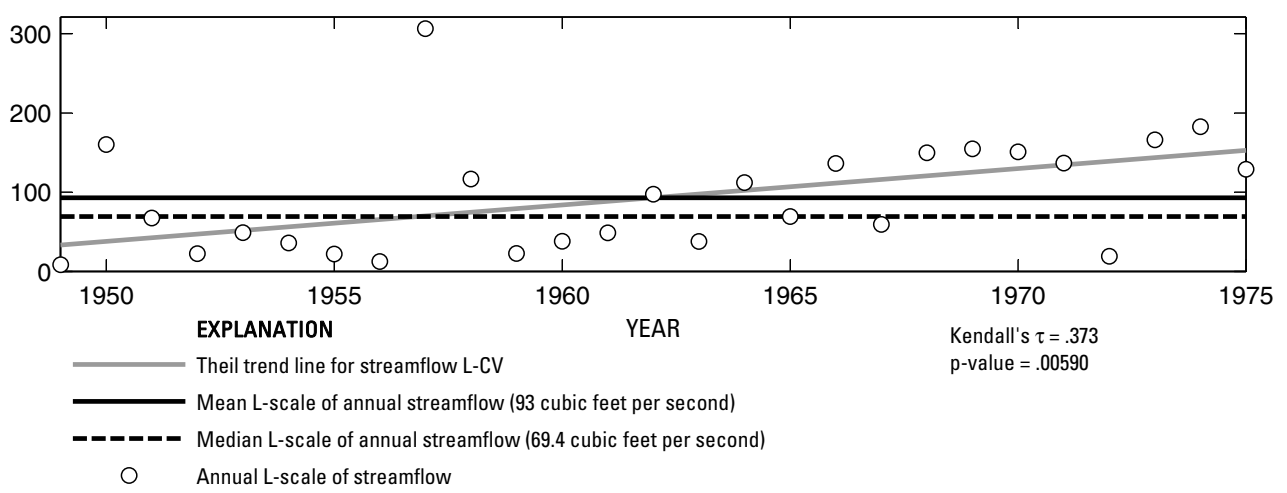

Figure 210. Analysis of annual mean, maximum, minimum, and L-scale statistics of daily mean streamflow for U.S. Geological Survey streamflow-gaging station 08059000 East Fork Trinity River near McKinney, Texas. 

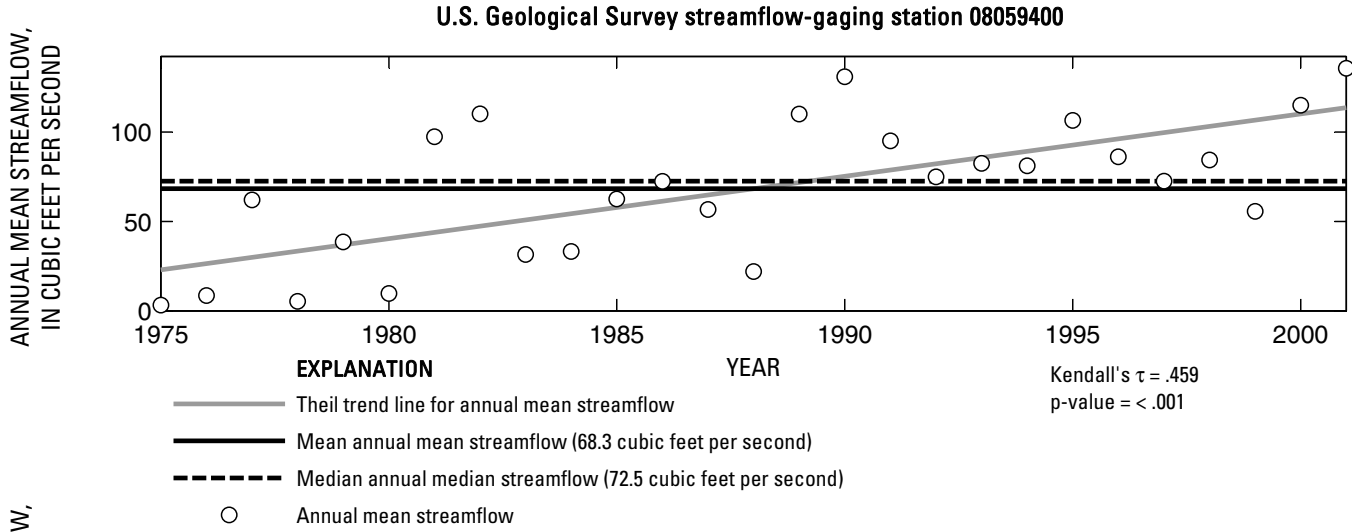

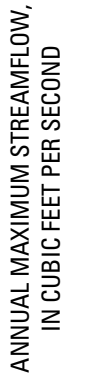
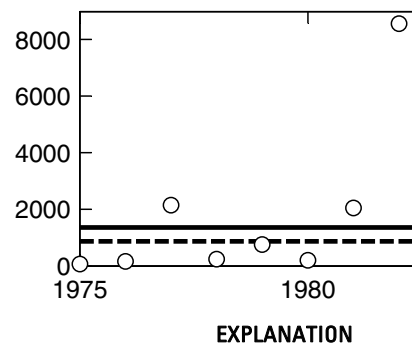

Mean annual maximum streamflow (1,360 cubic feet per second)

O Annual maximum streamflow
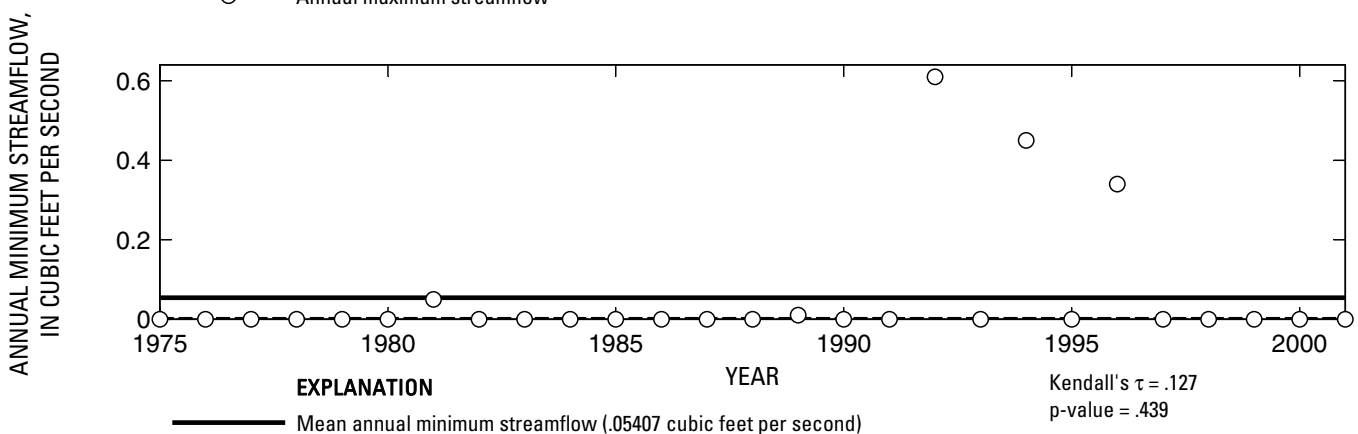

- _- - Median annual minimum streamflow (0 cubic feet per second)

O Annual minimum streamflow
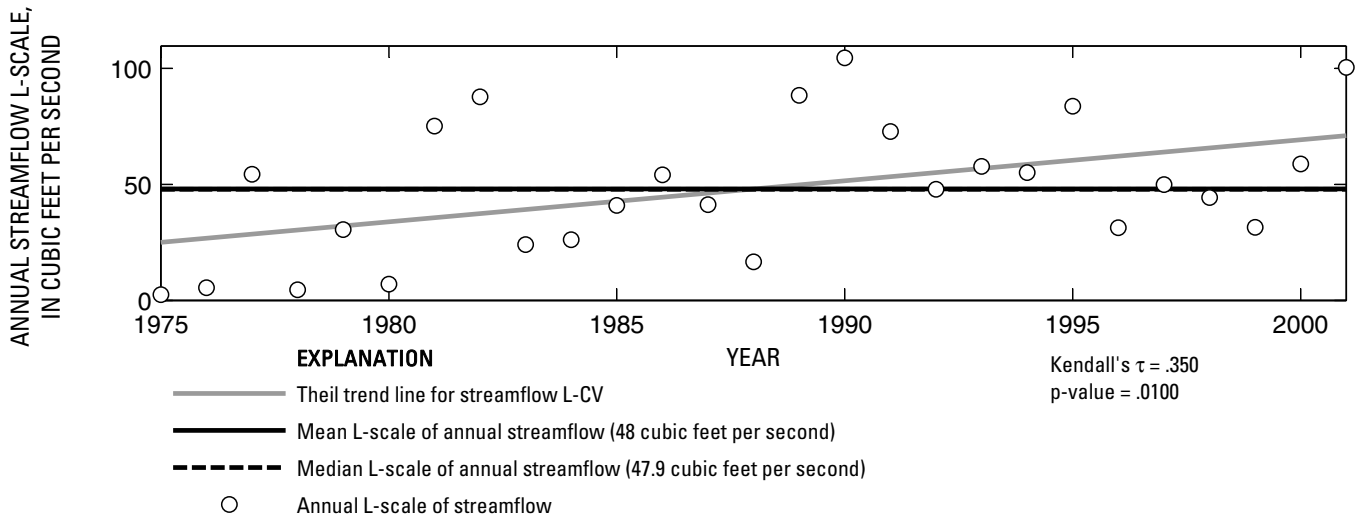

Figure 211. Analysis of annual mean, maximum, minimum, and L-scale statistics of daily mean streamflow for U.S. Geological Survey streamflow-gaging station 08059400 Sister Grove Creek near Blue Ridge, Texas. 


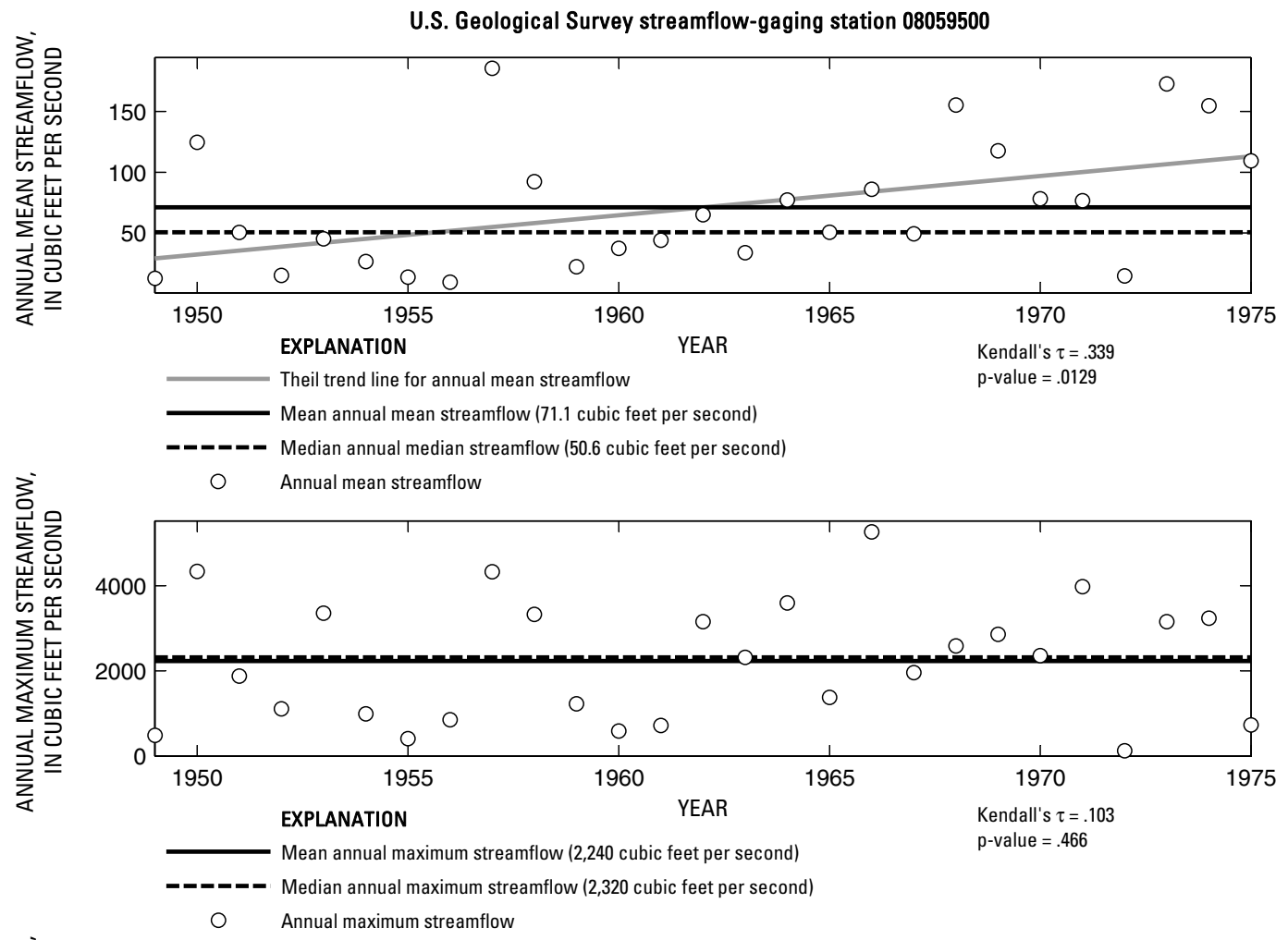

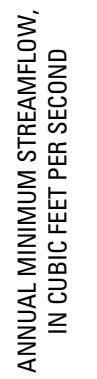

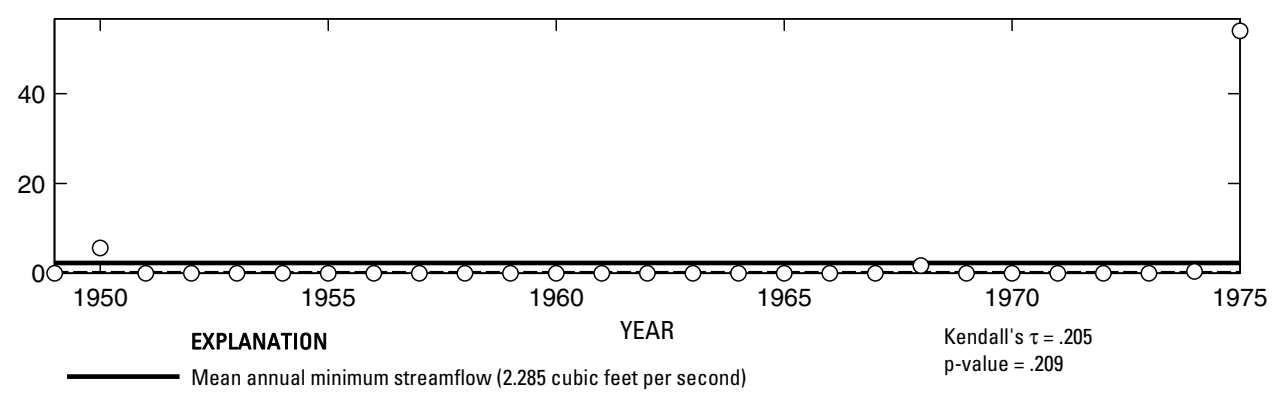

- ב-ב Median annual minimum streamflow (0 cubic feet per second)

O Annual minimum streamflow

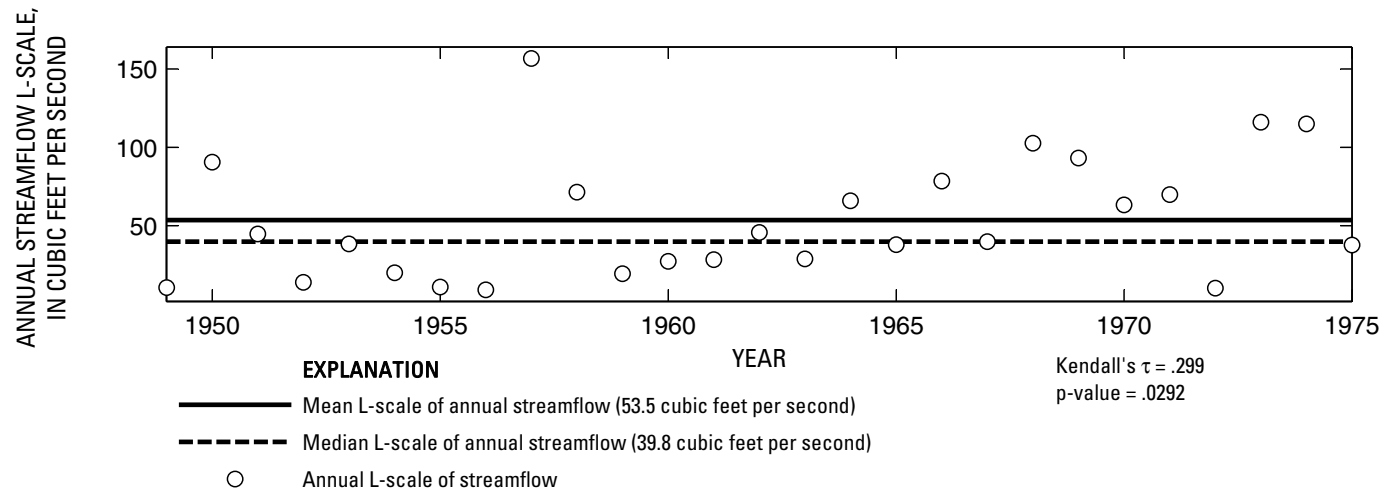

Figure 212. Analysis of annual mean, maximum, minimum, and L-scale statistics of daily mean streamflow for U.S. Geological Survey streamflow-gaging station 08059500 Sister Grove Creek near Princeton, Texas.

Index of Station Numbers 719 


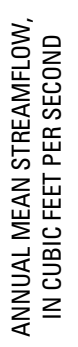

U.S. Geological Survey streamflow-gaging station 08060000

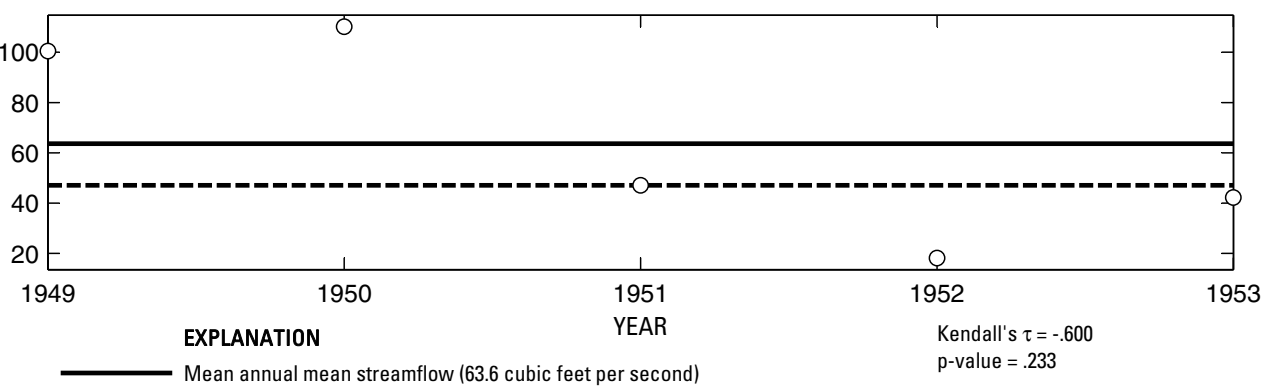

- - - - Median annual mean streamflow (47 cubic feet per second)

O Annual mean streamflow
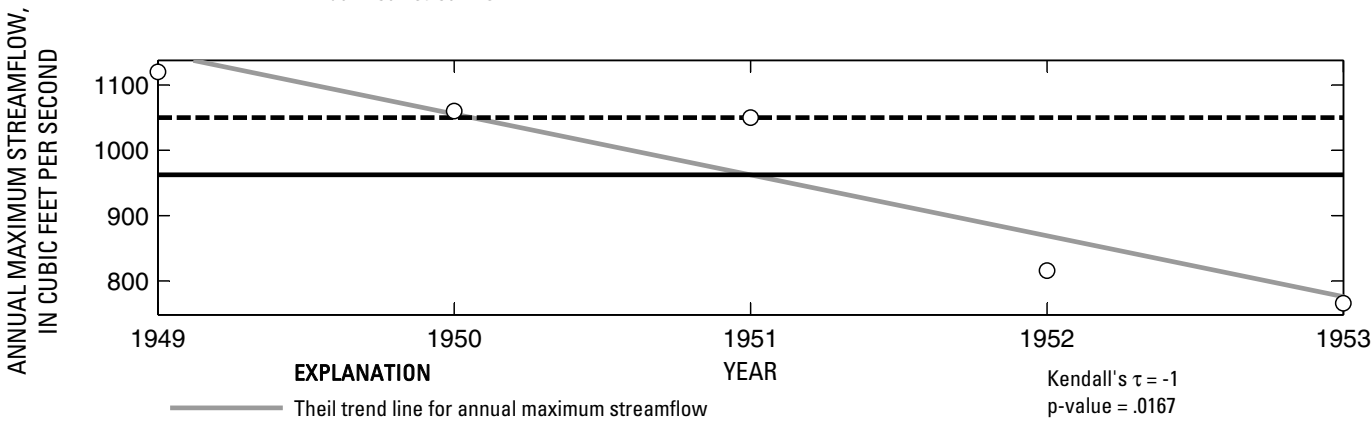

- Mean annual maximum streamflow (962 cubic feet per second)

-ーーーーー Median annual maximum streamflow (1,050 cubic feet per second)

O Annual maximum streamflow

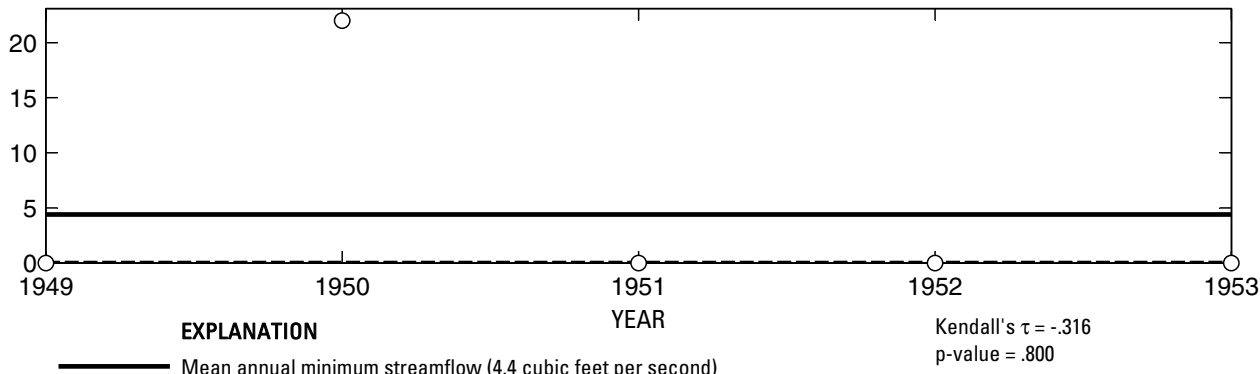

-_-_- Median annual minimum streamflow (0 cubic feet per second)

O Annual minimum streamflow

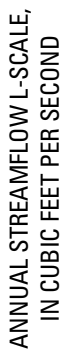

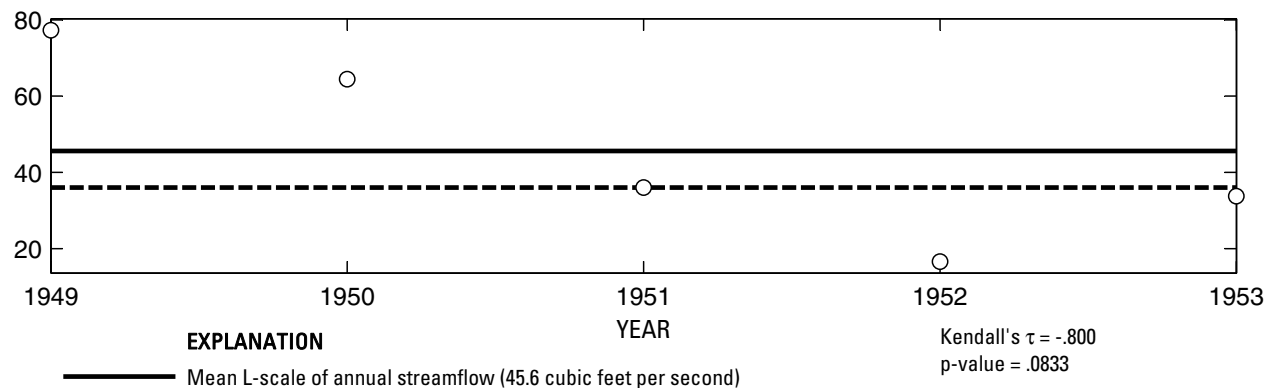

Mean L-scale of annual streamflow (45.6 cubic feet per second)

Kendall's $\tau=-.800$

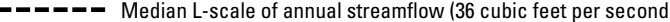

Annual L-scale of streamflow

Figure 213. Analysis of annual mean, maximum, minimum, and L-scale statistics of daily mean streamflow for U.S. Geological Survey streamflow-gaging station 08060000 East Fork Trinity River above Pilot Grove near Lavon, Texas. 

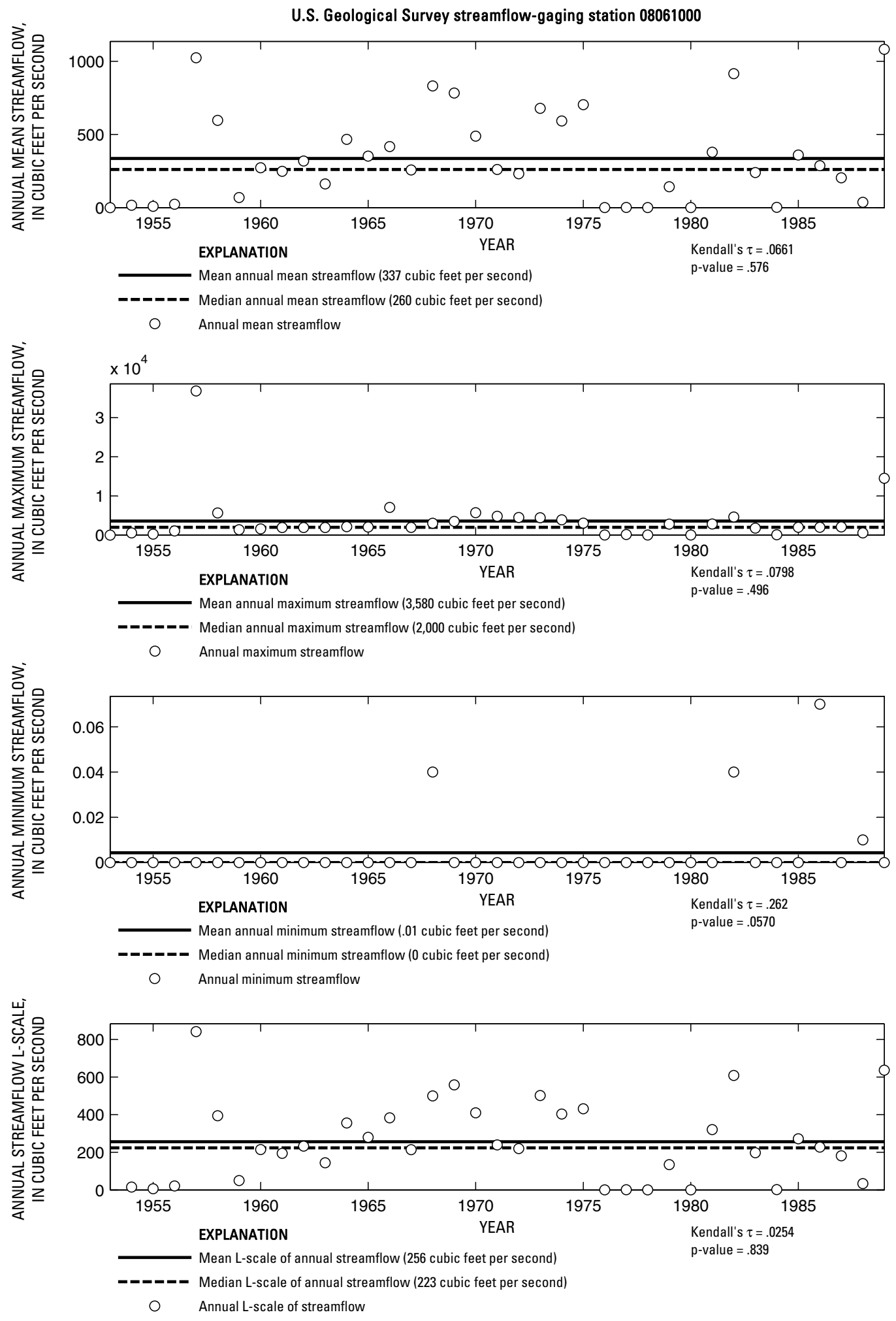

Figure 214. Analysis of annual mean, maximum, minimum, and L-scale statistics of daily mean streamflow for U.S. Geological Survey streamflow-gaging station 08061000 East Fork Trinity River near Lavon, Texas.

Index of Station Numbers 719 

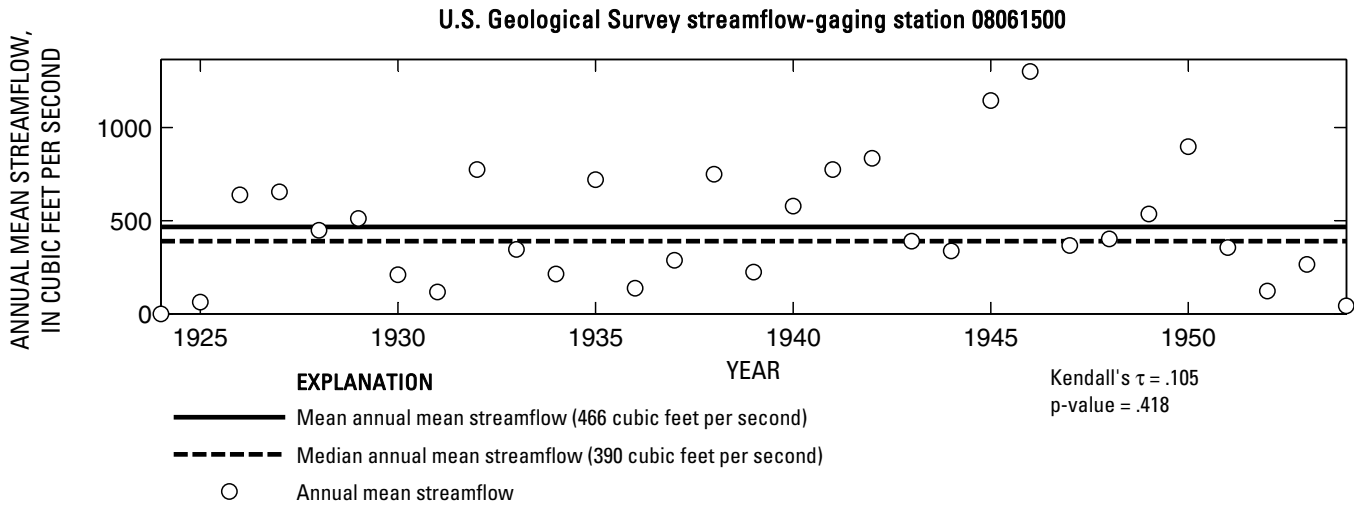

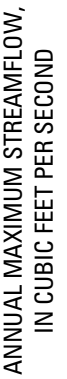
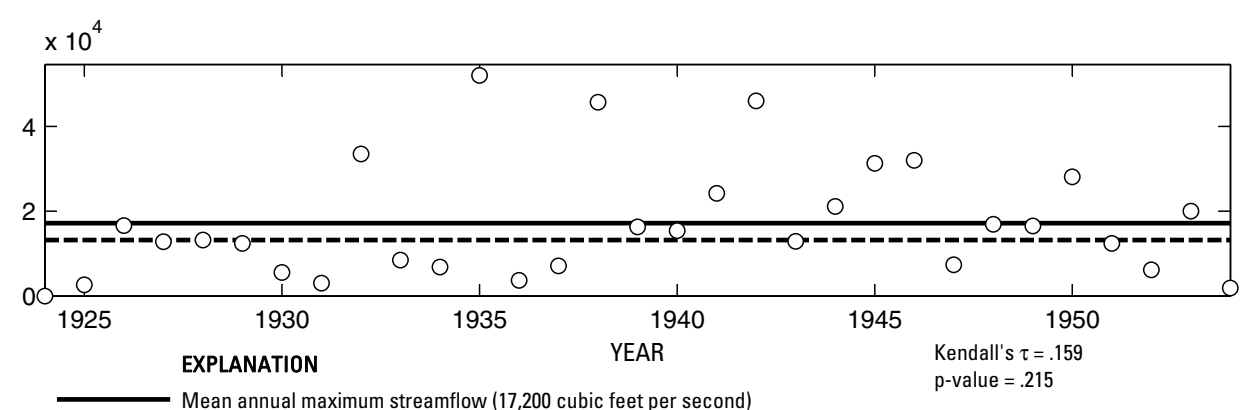

- _- Median annual maximum streamflow (13,200 cubic feet per second)

O Annual maximum streamflow

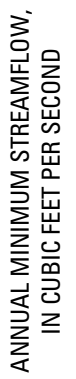

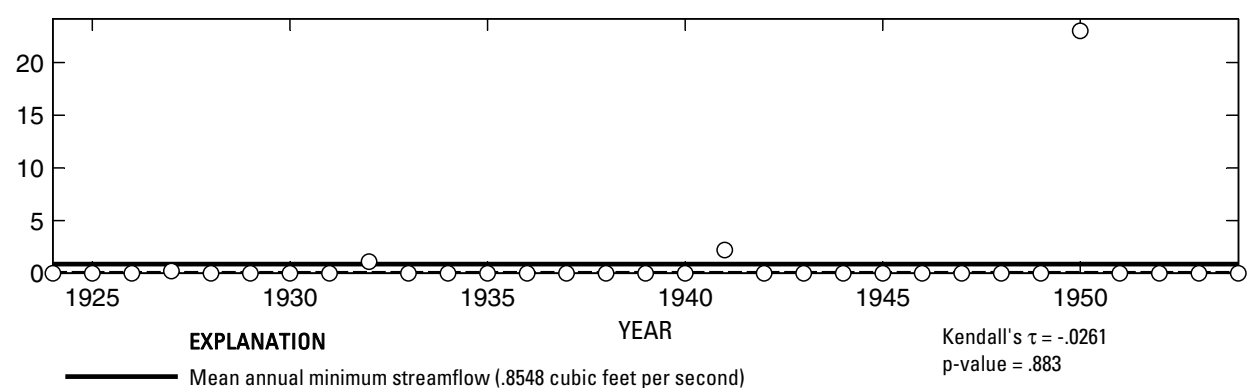

- - Median annual minimum streamflow (0 cubic feet per second)

O Annual minimum streamflow

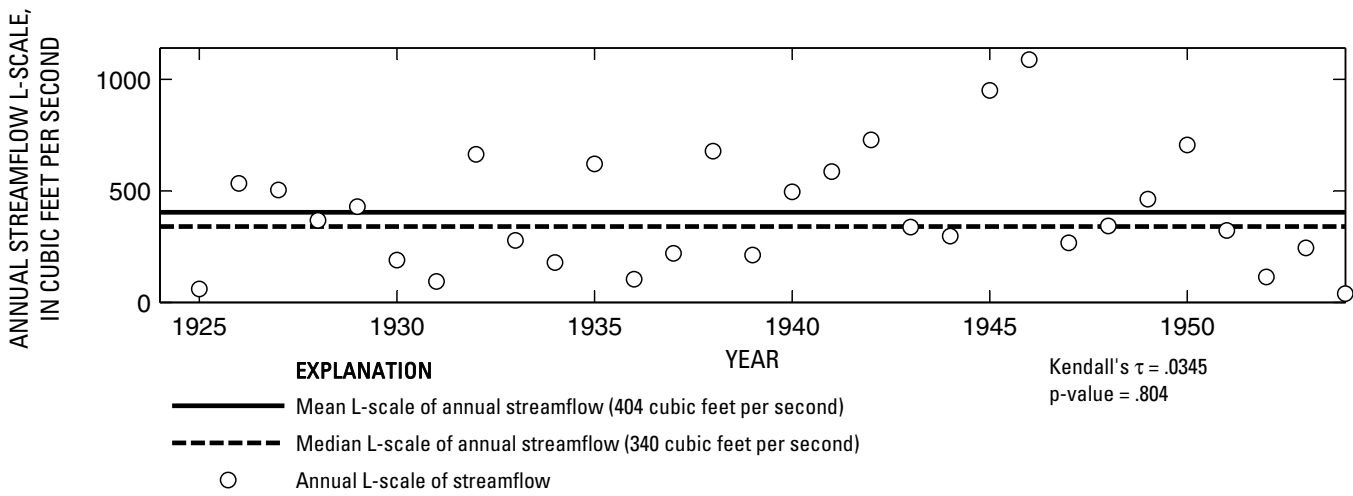

Figure 215. Analysis of annual mean, maximum, minimum, and L-scale statistics of daily mean streamflow for U.S. Geological Survey streamflow-gaging station 08061500 East Fork Trinity River near Rockwall, Texas. 


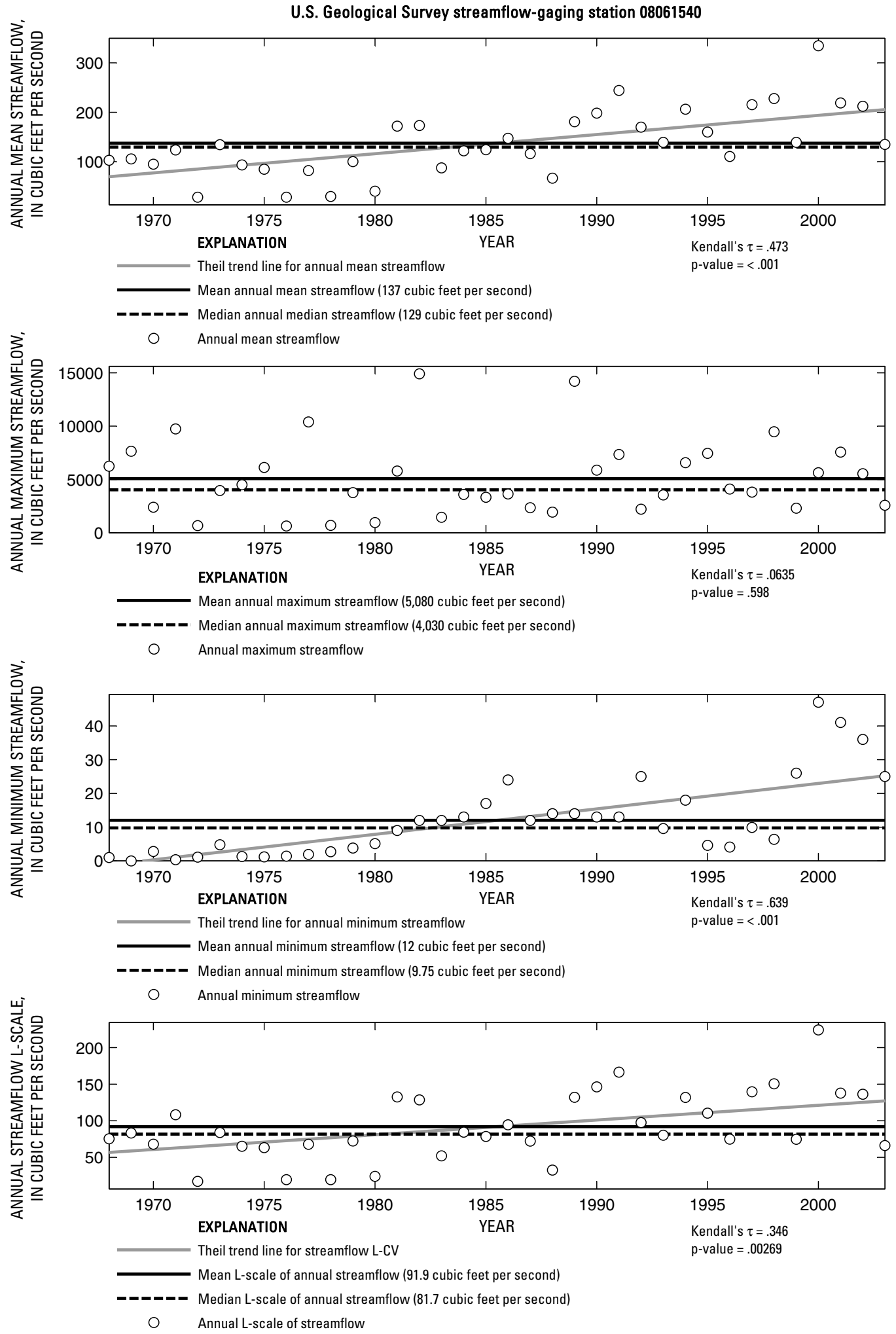

Figure 216. Analysis of annual mean, maximum, minimum, and L-scale statistics of daily mean streamflow for U.S. Geological Survey streamflow-gaging station 08061540 Rowlett Creek near Sachse, Texas.

Index of Station Numbers 719 


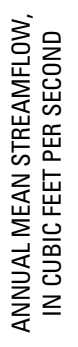

U.S. Geological Survey streamflow-gaging station 08061700

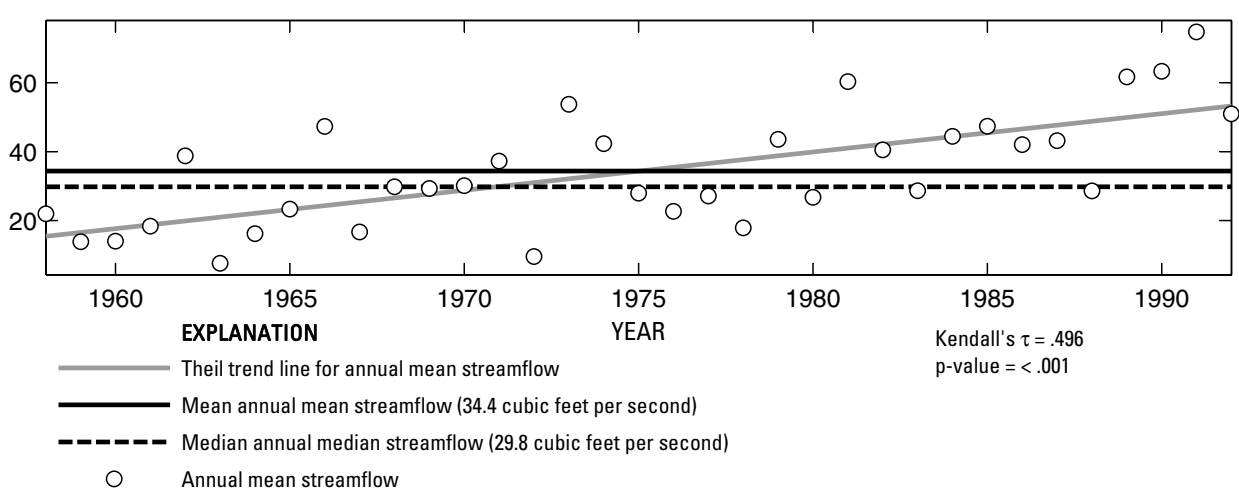

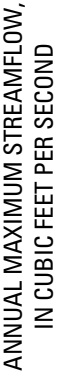

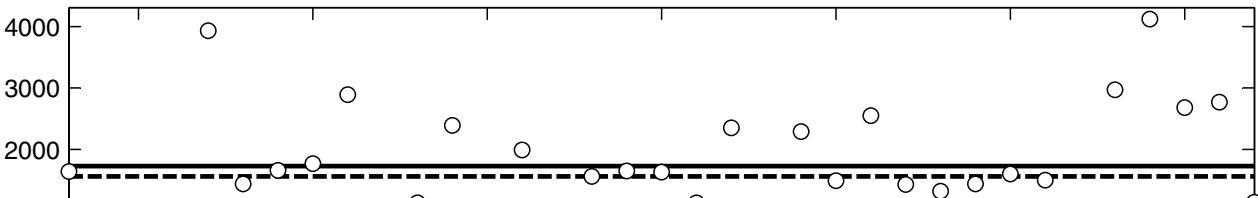

$1000-0$

0 o 0 o 0

1960

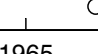

10

O 1975

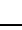

$1980 \quad 1985 \quad 1990$

EXPLANATION

YEAR

Kendall's $\tau=.167$

Mean annual maximum streamflow (1,730 cubic feet per second)

$\mathrm{p}$-value $=.164$

- o- Median annual maximum streamflow (1,560 cubic feet per second)

O Annual maximum streamflow

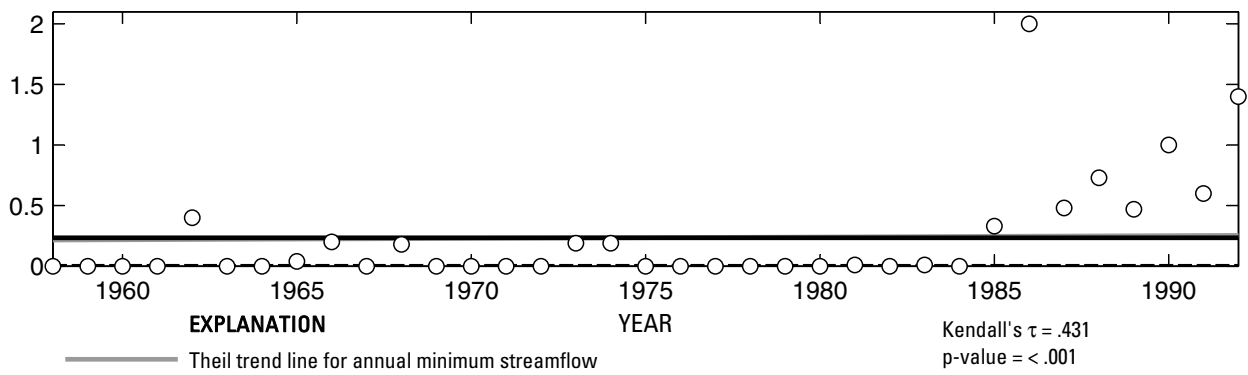

- Median annual minimum streamflow (0 cubic feet per second)

Annual minimum streamflow

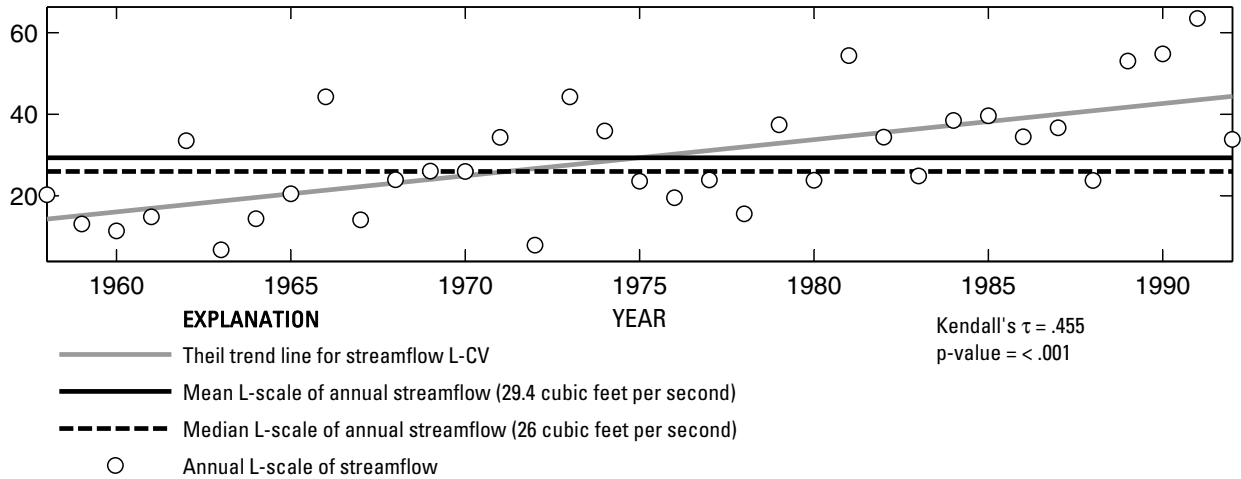

Figure 217. Analysis of annual mean, maximum, minimum, and L-scale statistics of daily mean streamflow for U.S. Geological Survey streamflow-gaging station 08061700 Duck Creek near Garland, Texas. 
U.S. Geological Survey streamflow-gaging station 08061750

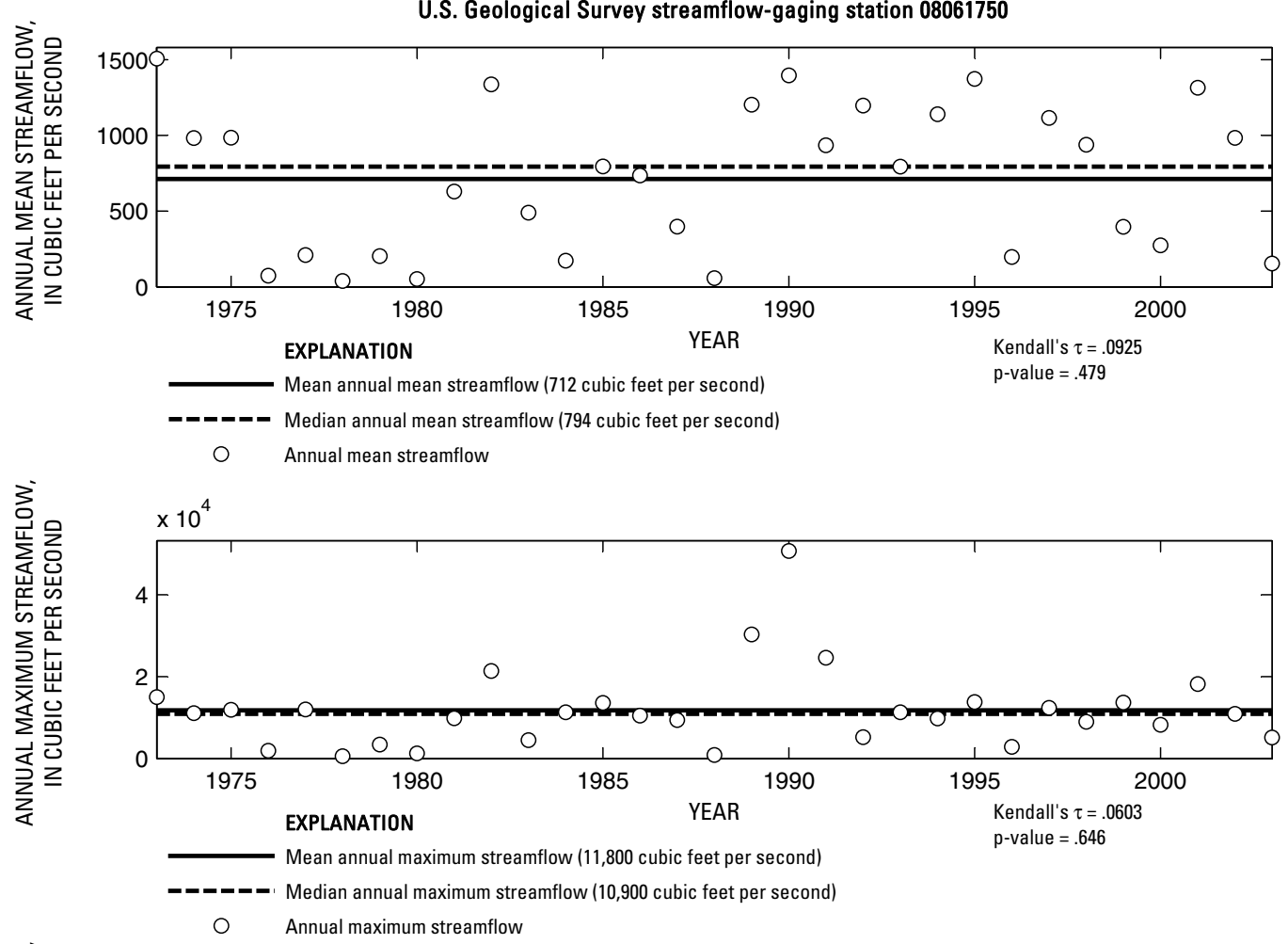

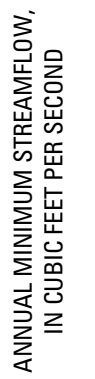

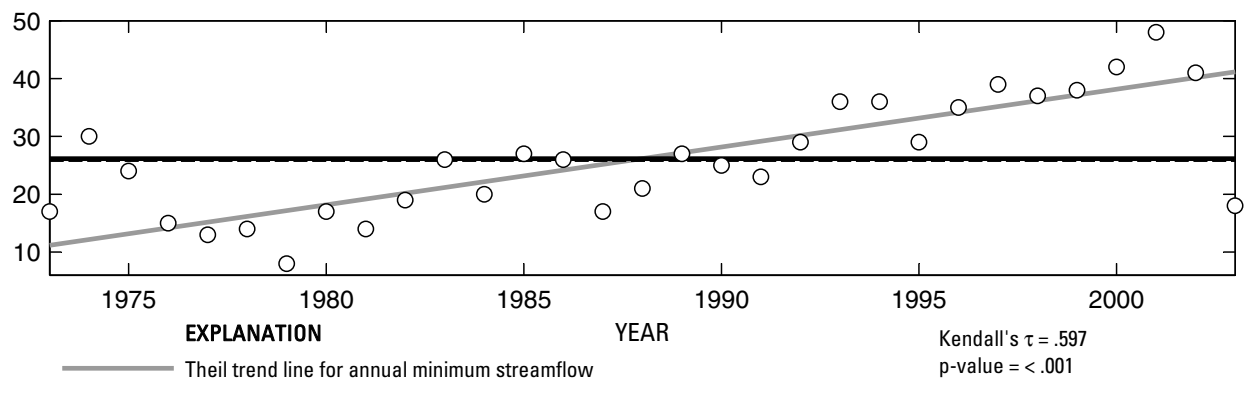

Mean annual minimum streamflow (26.2 cubic feet per second)

- Median annual minimum streamflow ( 26 cubic feet per second)

O Annual minimum streamflow
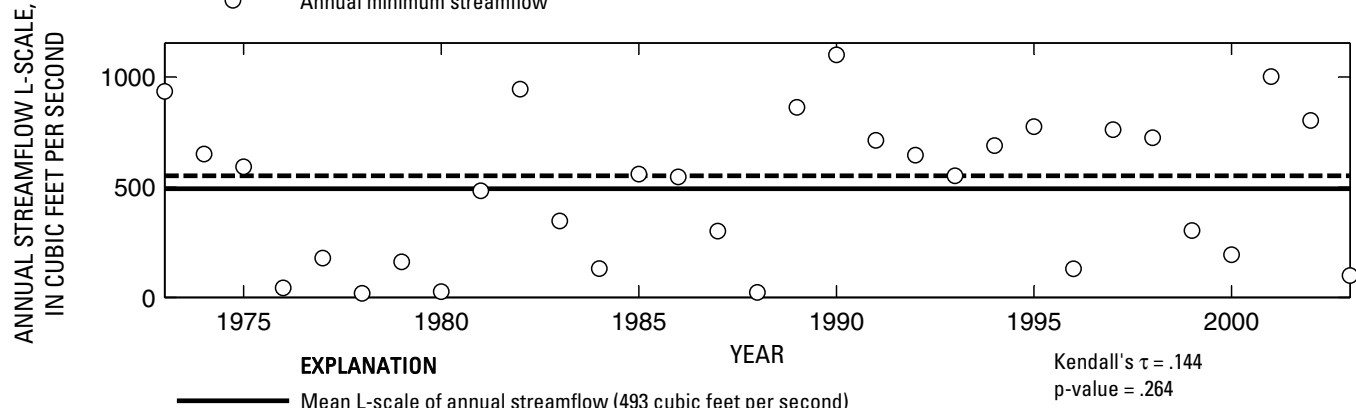

- - - Median L-scale of annual streamflow (552 cubic feet per second)

Annual L-scale of streamflow

Figure 218. Analysis of annual mean, maximum, minimum, and L-scale statistics of daily mean streamflow for U.S. Geological Survey streamflow-gaging station 08061750 East Fork Trinity River near Forney, Texas.

Index of Station Numbers 719 


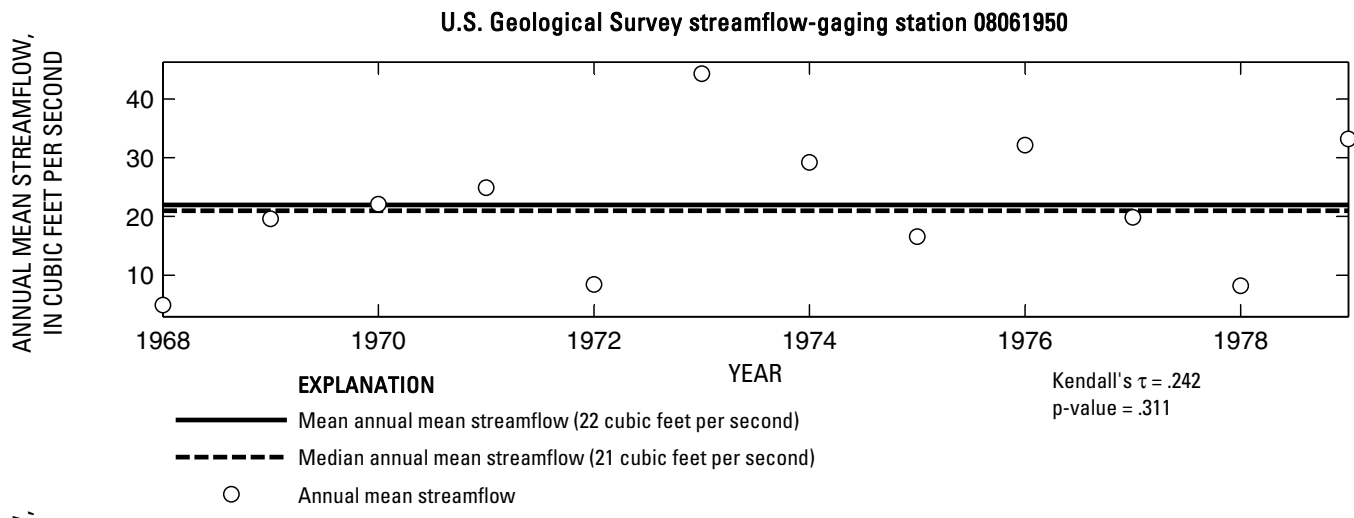

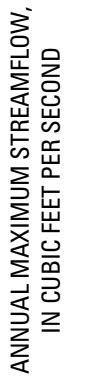

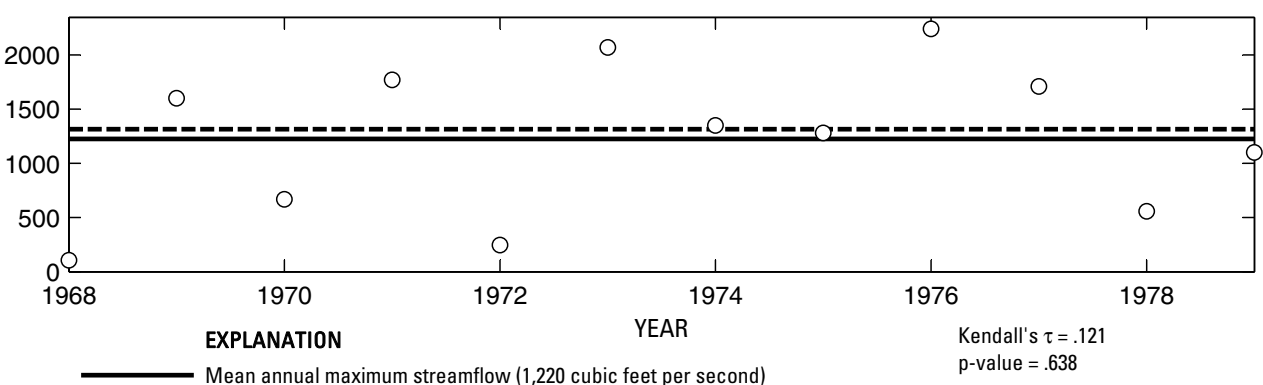

- - - - Median annual maximum streamflow (1,320 cubic feet per second)

O Annual maximum streamflow

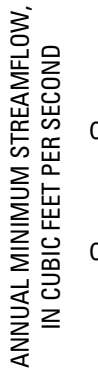

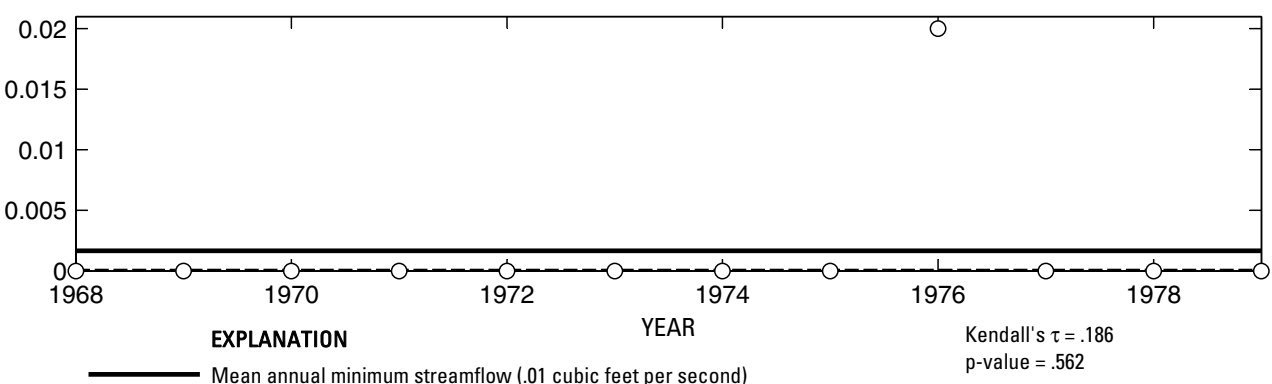

- - Median annual minimum streamflow (0 cubic feet per second)

O Annual minimum streamflow

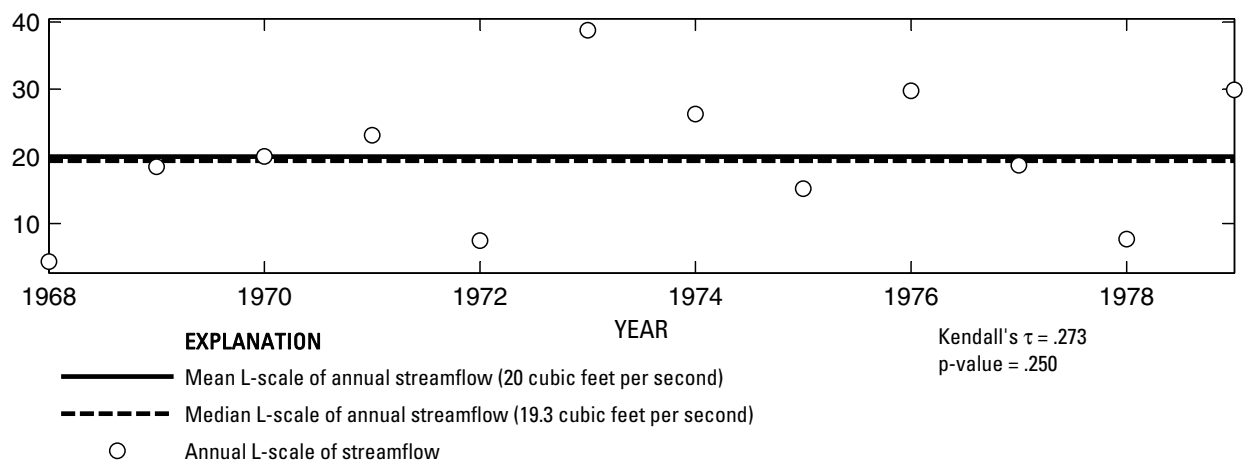

Figure 219. Analysis of annual mean, maximum, minimum, and L-scale statistics of daily mean streamflow for U.S. Geological Survey streamflow-gaging station 08061950 South Mesquite Creek at Mercury Road, North Mesquite, Texas. 


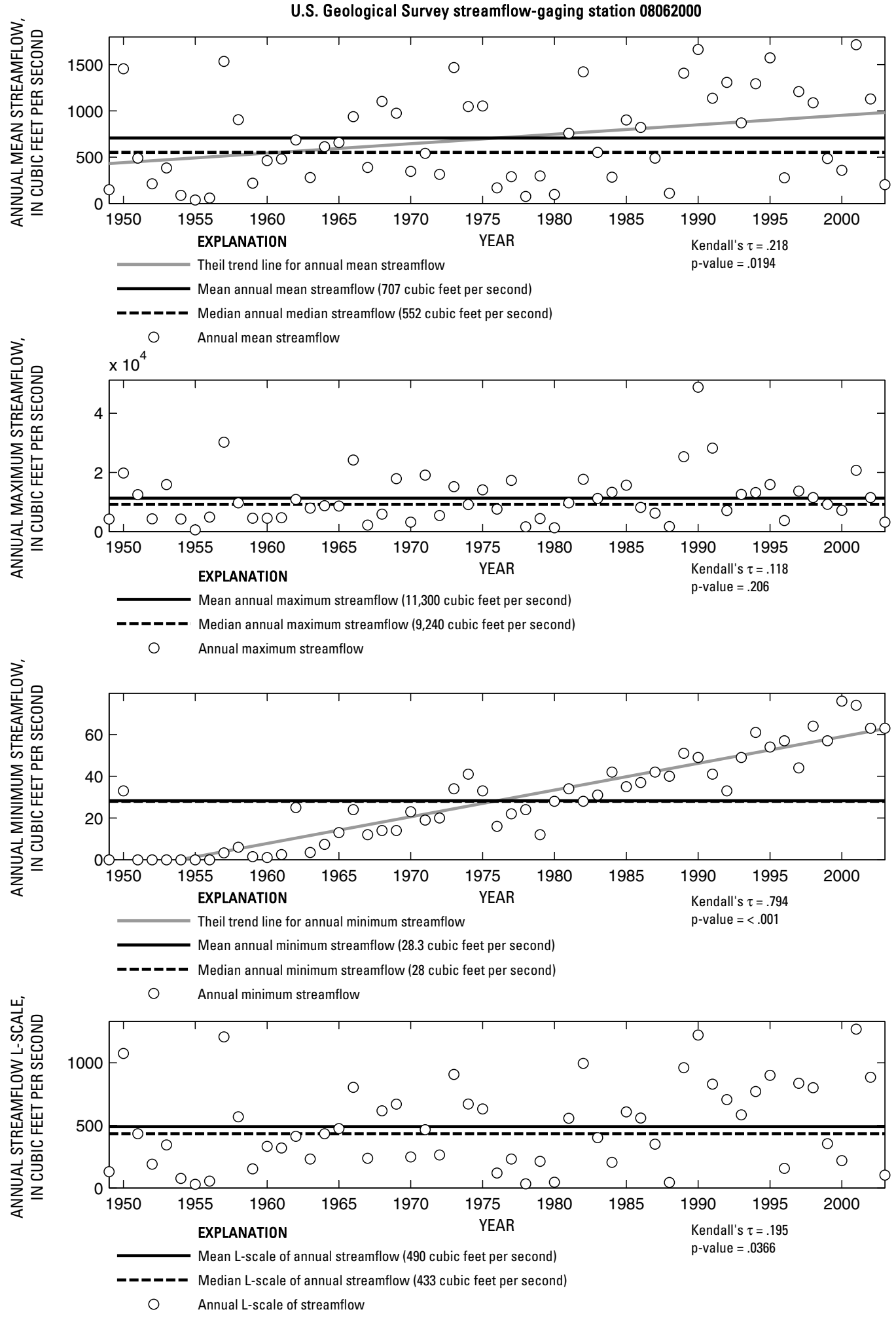

Figure 220. Analysis of annual mean, maximum, minimum, and L-scale statistics of daily mean streamflow for U.S. Geological Survey streamflow-gaging station 08062000 East Fork Trinity River near Crandall, Texas.

Index of Station Numbers 719 


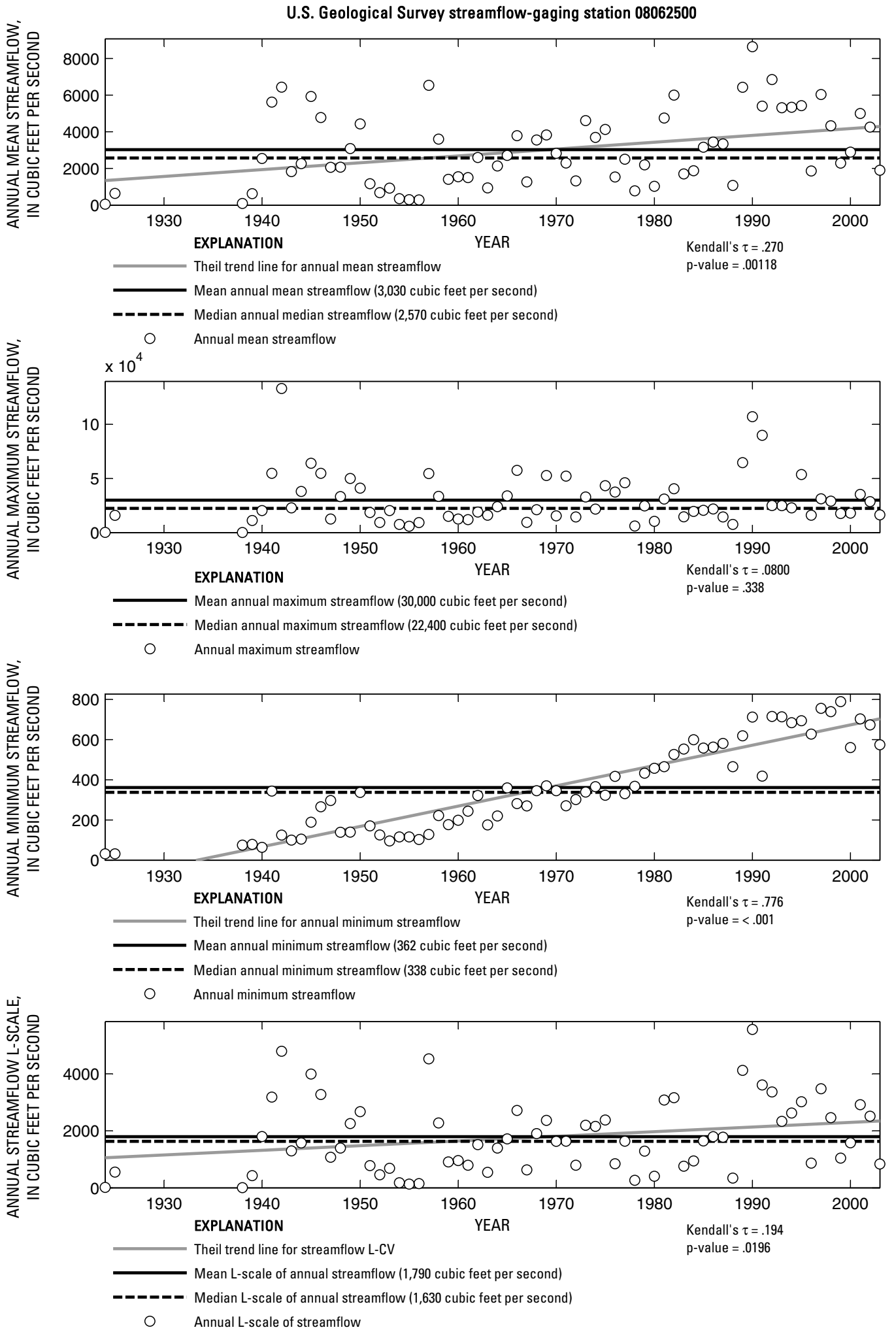

Figure 221. Analysis of annual mean, maximum, minimum, and L-scale statistics of daily mean streamflow for U.S. Geological Survey streamflow-gaging station 08062500 Trinity River near Rosser, Texas. 
U.S. Geological Survey streamflow-gaging station 08062650

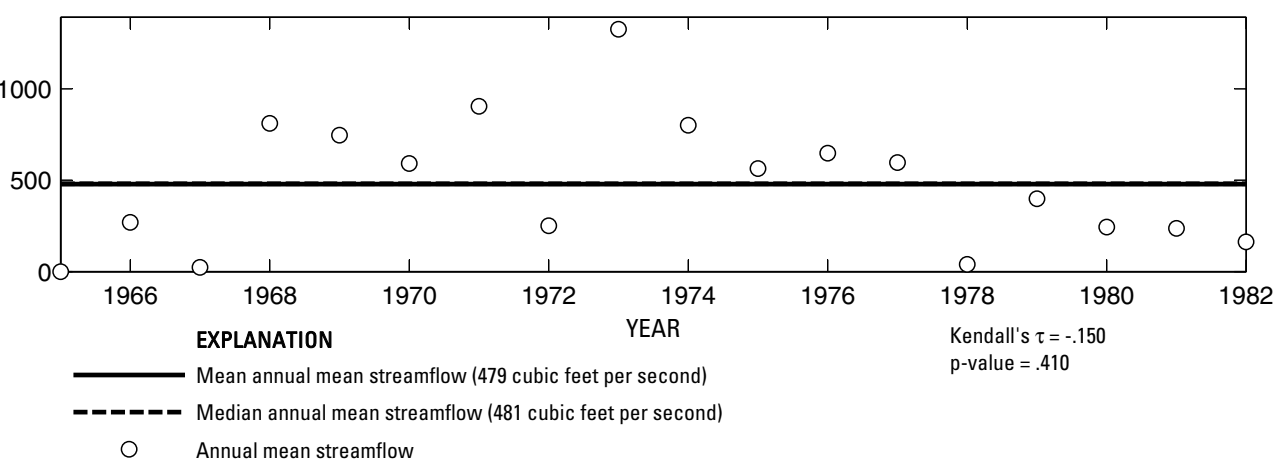

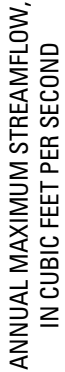

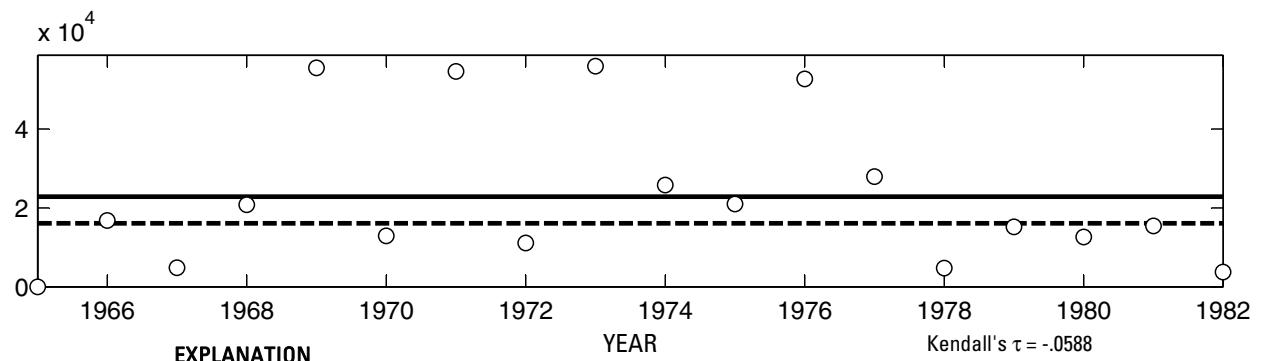

EXPLANATION

Mean annual maximum streamflow (22,900 cubic feet per second)

$\mathrm{p}$-value $=.765$

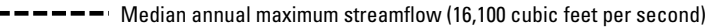

O Annual maximum streamflow

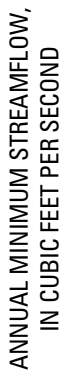

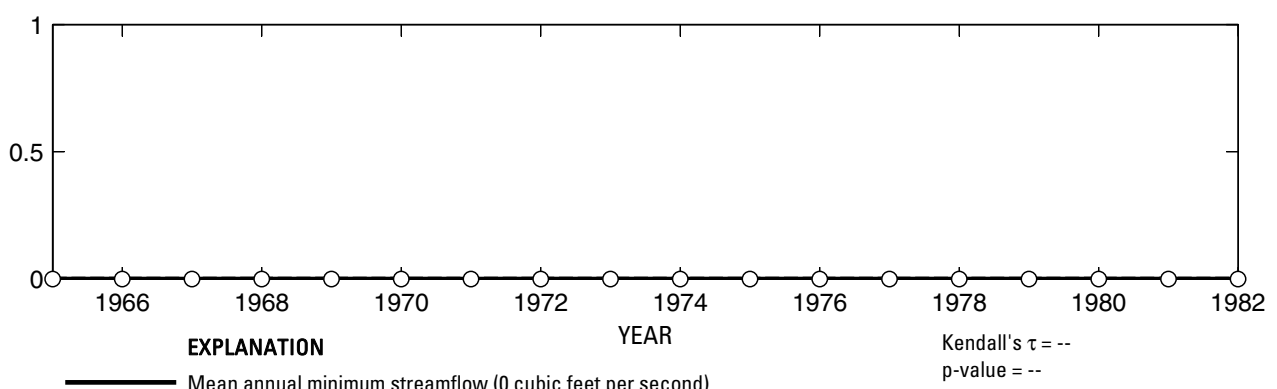

Mean annual minimum streamflow (0 cubic feet per second)

p-value $=--$

- - Median annual minimum streamflow (0 cubic feet per second)

O Annual minimum streamflow

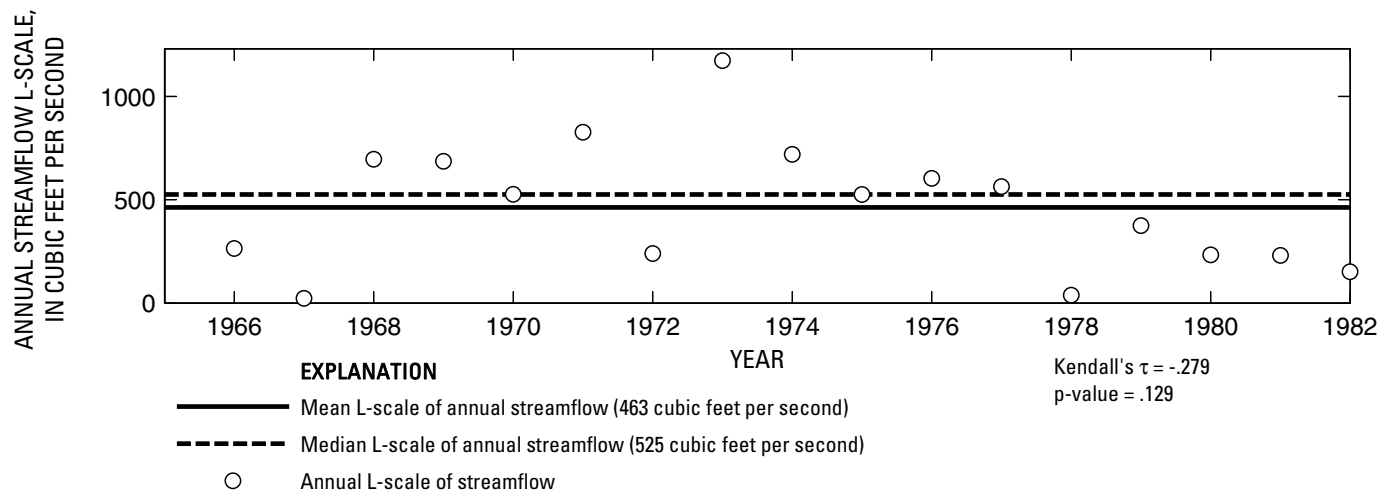

Figure 222. Analysis of annual mean, maximum, minimum, and L-scale statistics of daily mean streamflow for U.S. Geological Survey streamflow-gaging station 08062650 Cedar Creek Reservoir Spillway Outflow near Trinidad, Texas. 


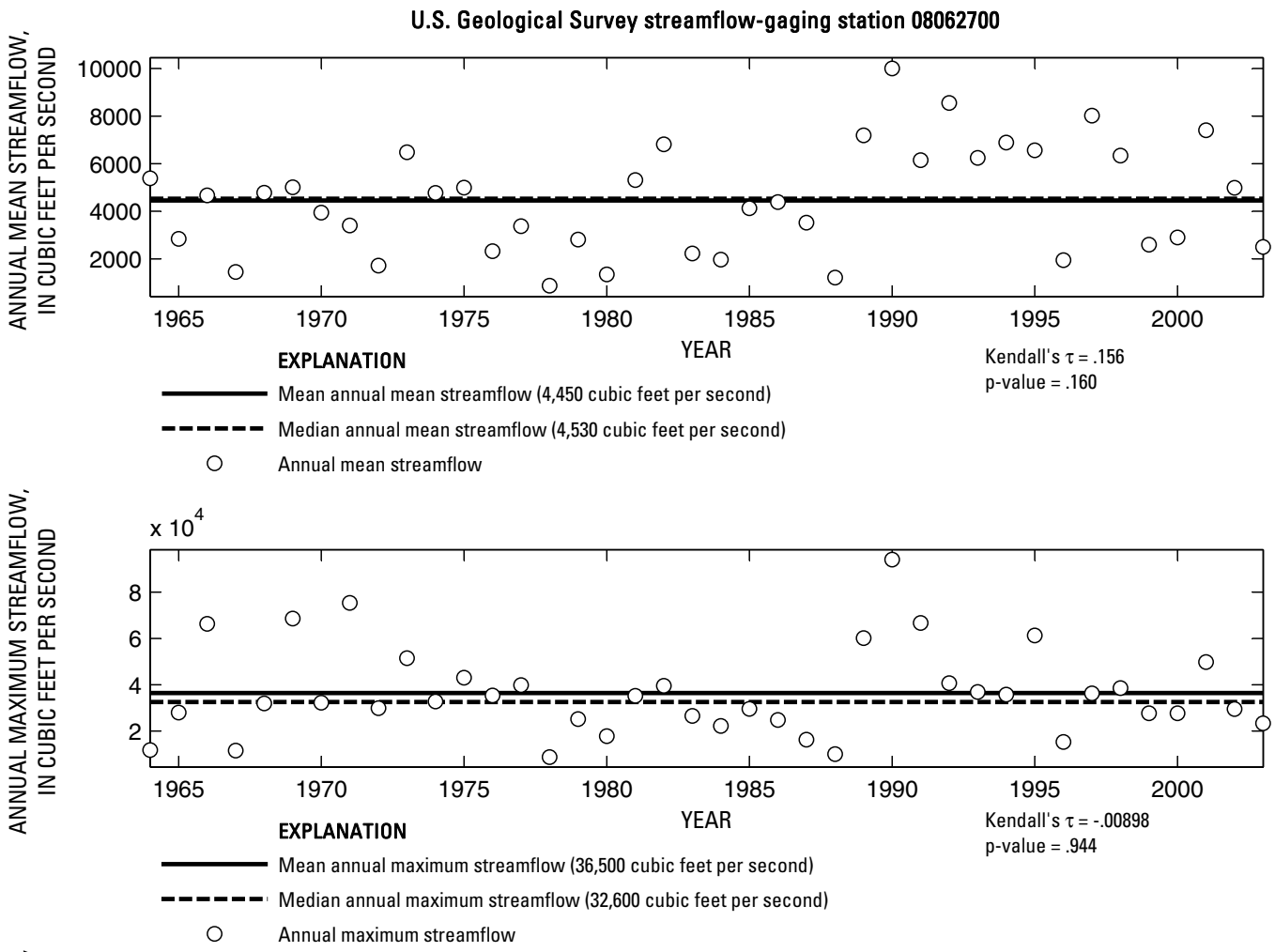

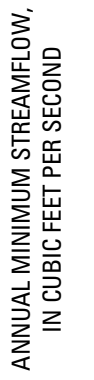
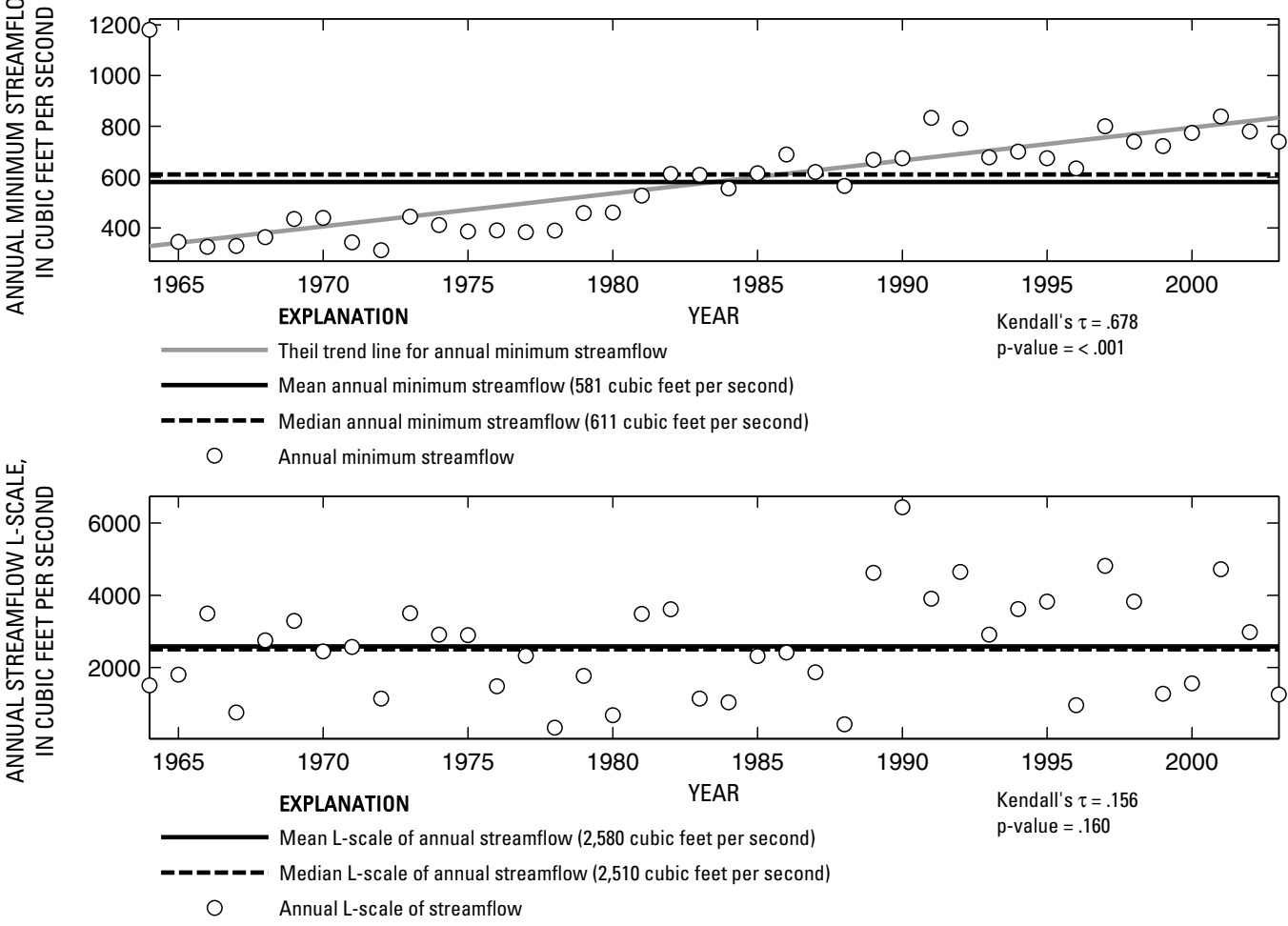

Figure 223. Analysis of annual mean, maximum, minimum, and L-scale statistics of daily mean streamflow for U.S. Geological Survey streamflow-gaging station 08062700 Trinity River at Trinidad, Texas. 

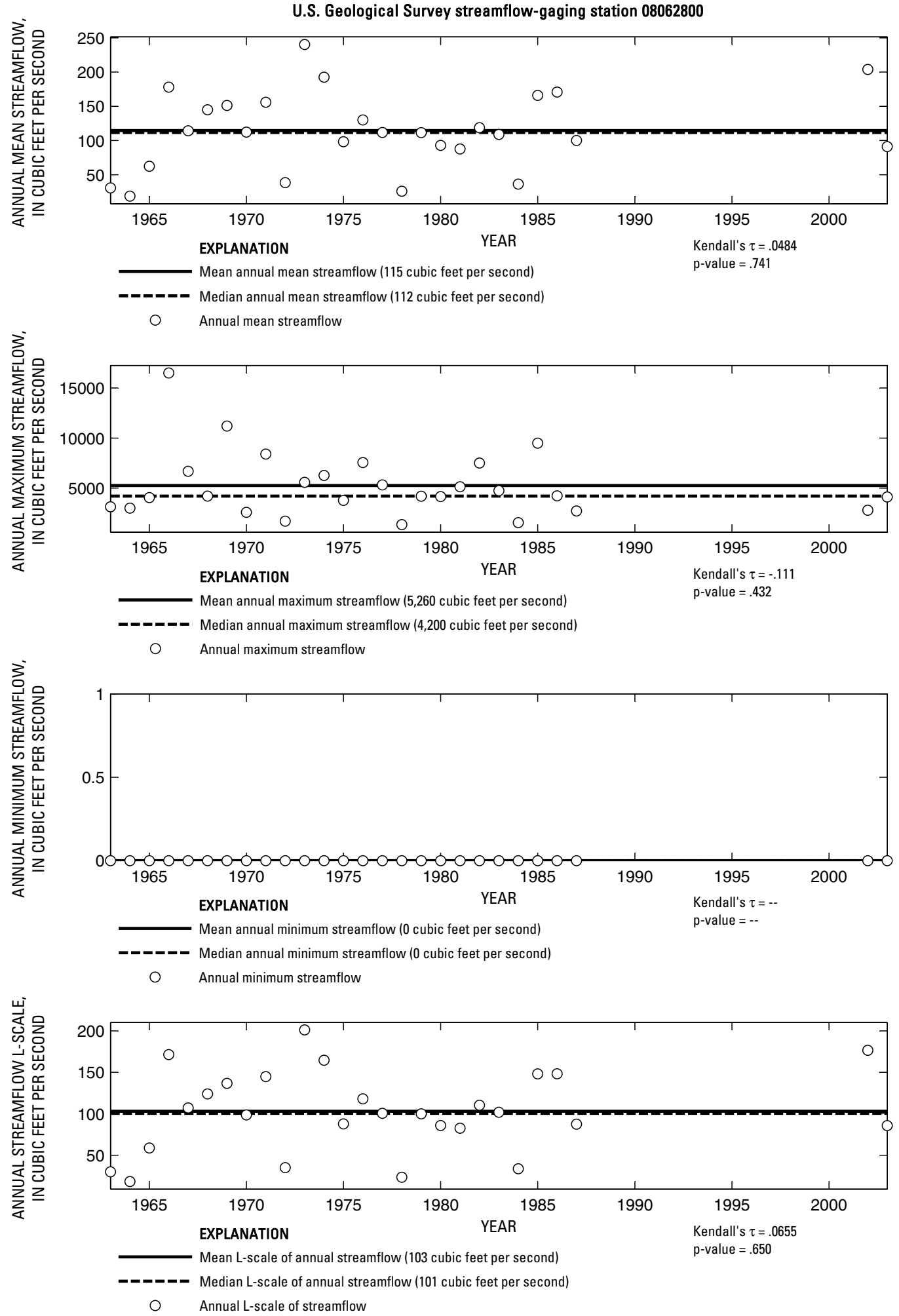

Figure 224. Analysis of annual mean, maximum, minimum, and L-scale statistics of daily mean streamflow for U.S. Geological Survey streamflow-gaging station 08062800 Cedar Creek near Kemp, Texas.

Index of Station Numbers 719 


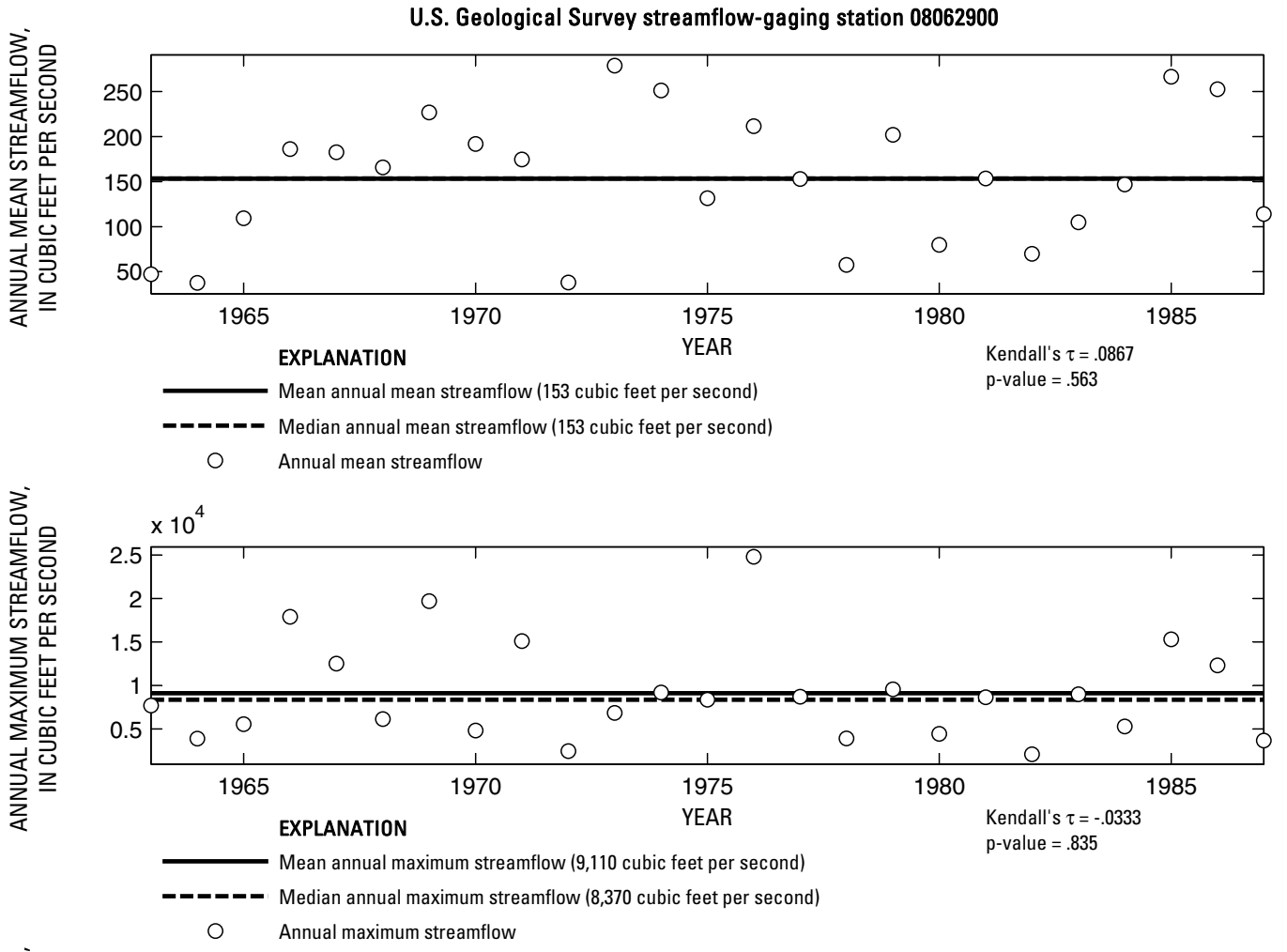

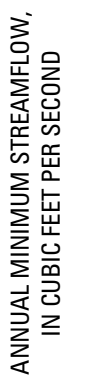

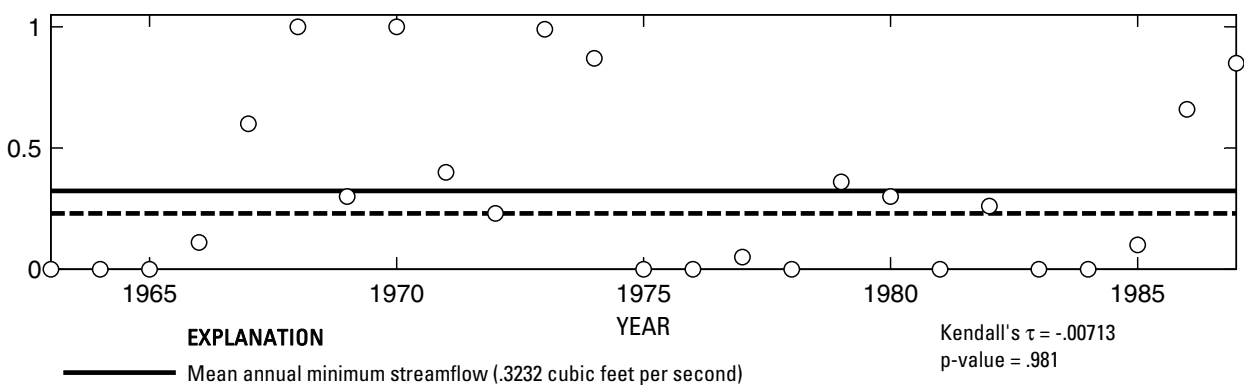

- - - - Median annual minimum streamflow (.23 cubic feet per second)

O Annual minimum streamflow

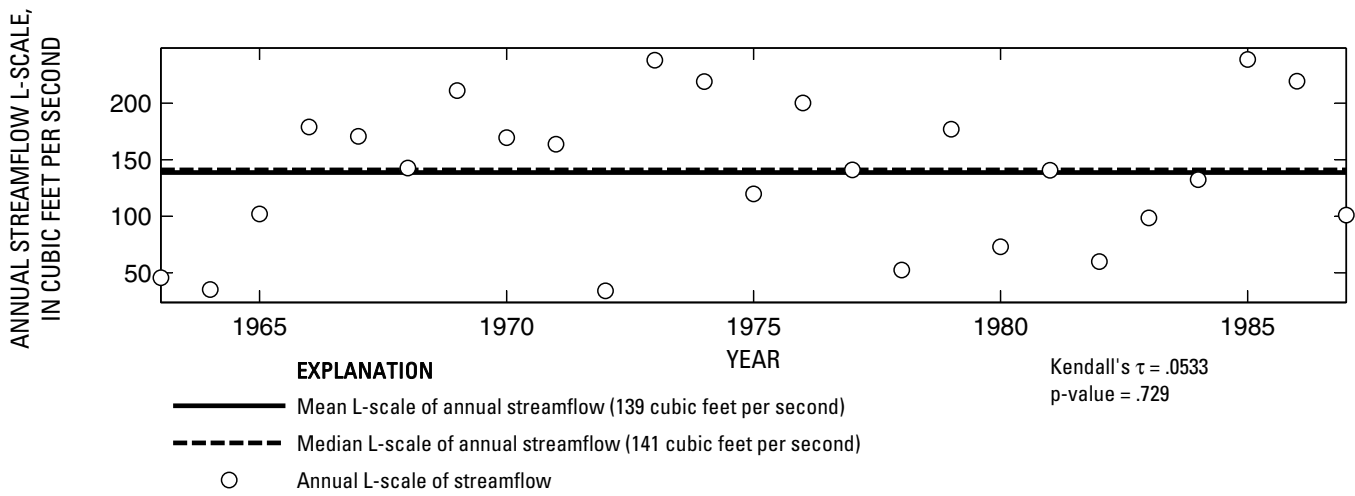

Figure 225. Analysis of annual mean, maximum, minimum, and L-scale statistics of daily mean streamflow for U.S. Geological Survey streamflow-gaging station 08062900 Kings Creek near Kaufman, Texas. 
U.S. Geological Survey streamflow-gaging station 08062980

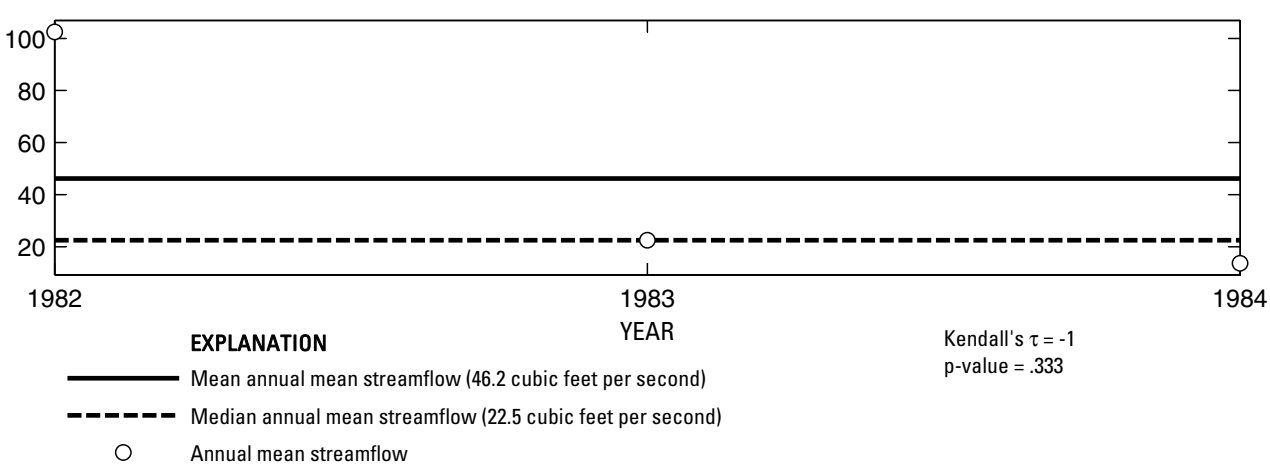

焉

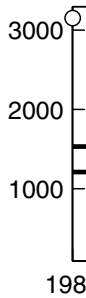

Annual mean streamflow

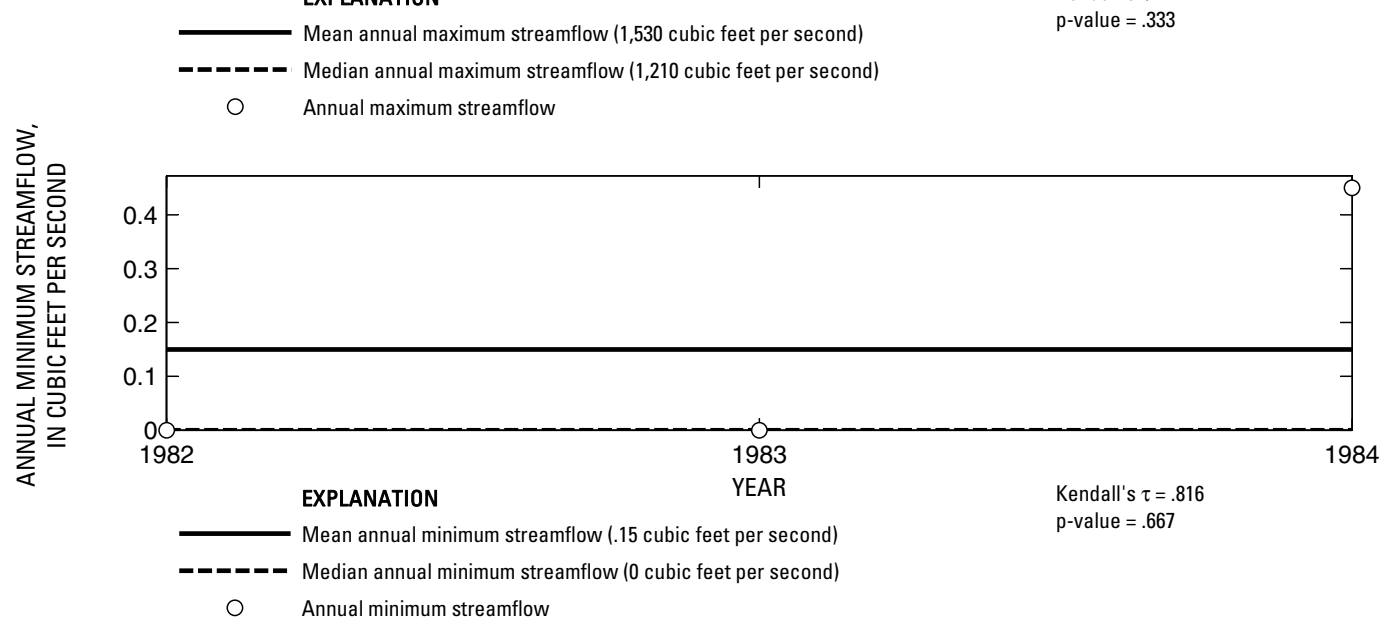

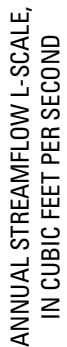

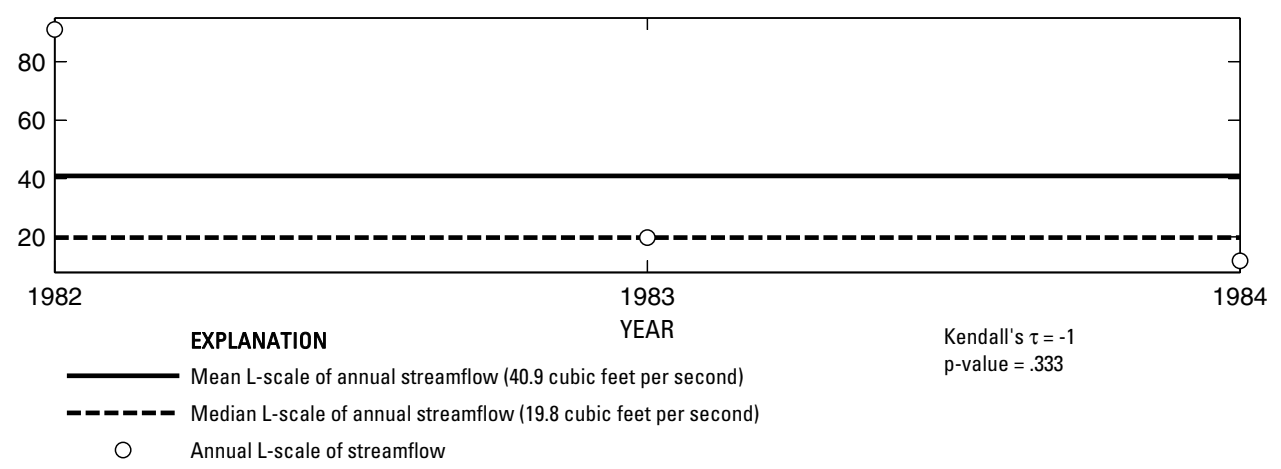

Figure 226. Analysis of annual mean, maximum, minimum, and L-scale statistics of daily mean streamflow for U.S. Geological Survey streamflow-gaging station 08062980 Lacey Fork near Mabank, Texas. 


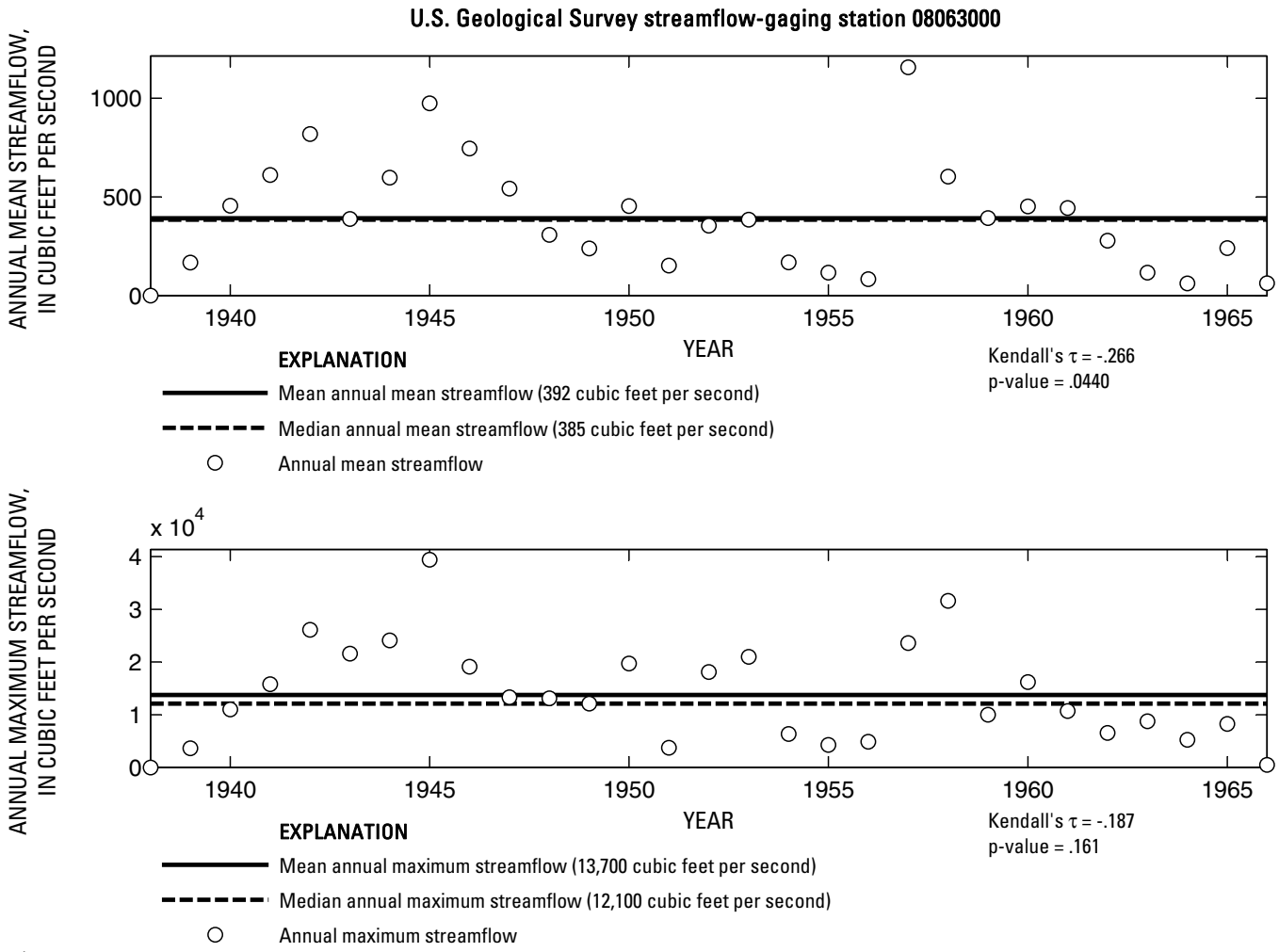

要号

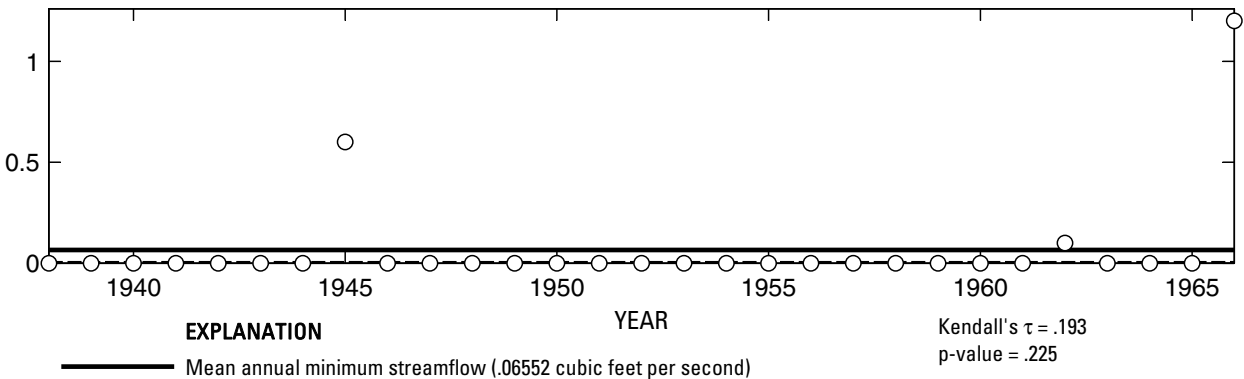

- ב - Median annual minimum streamflow (0 cubic feet per second)

O Annual minimum streamflow

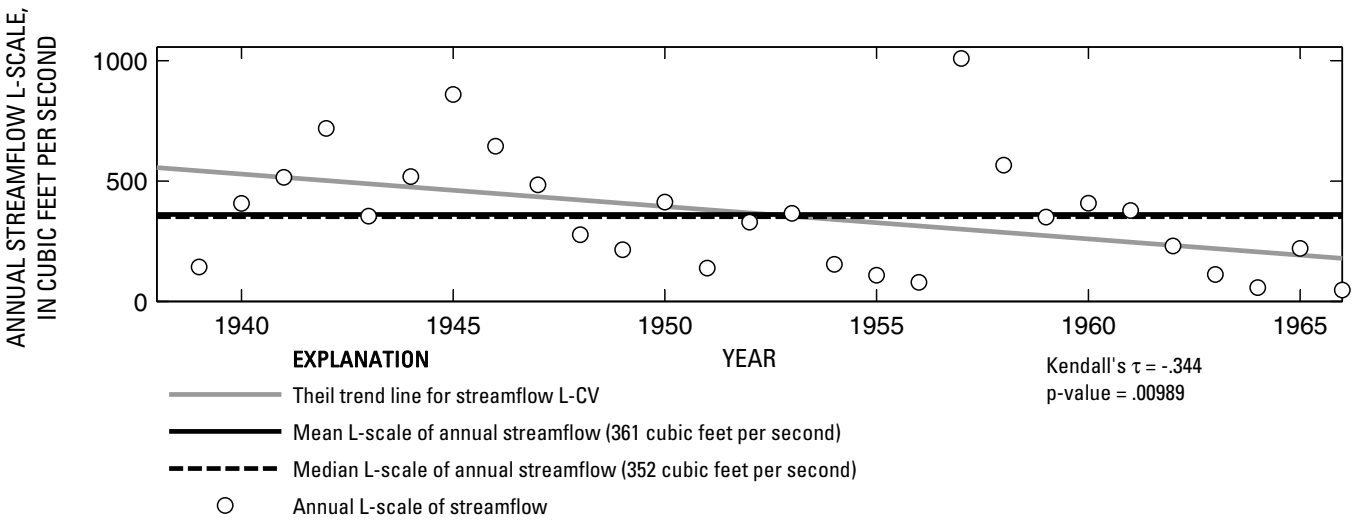

Figure 227. Analysis of annual mean, maximum, minimum, and L-scale statistics of daily mean streamflow for U.S. Geological Survey streamflow-gaging station 08063000 Cedar Creek near Mabank, Texas. 

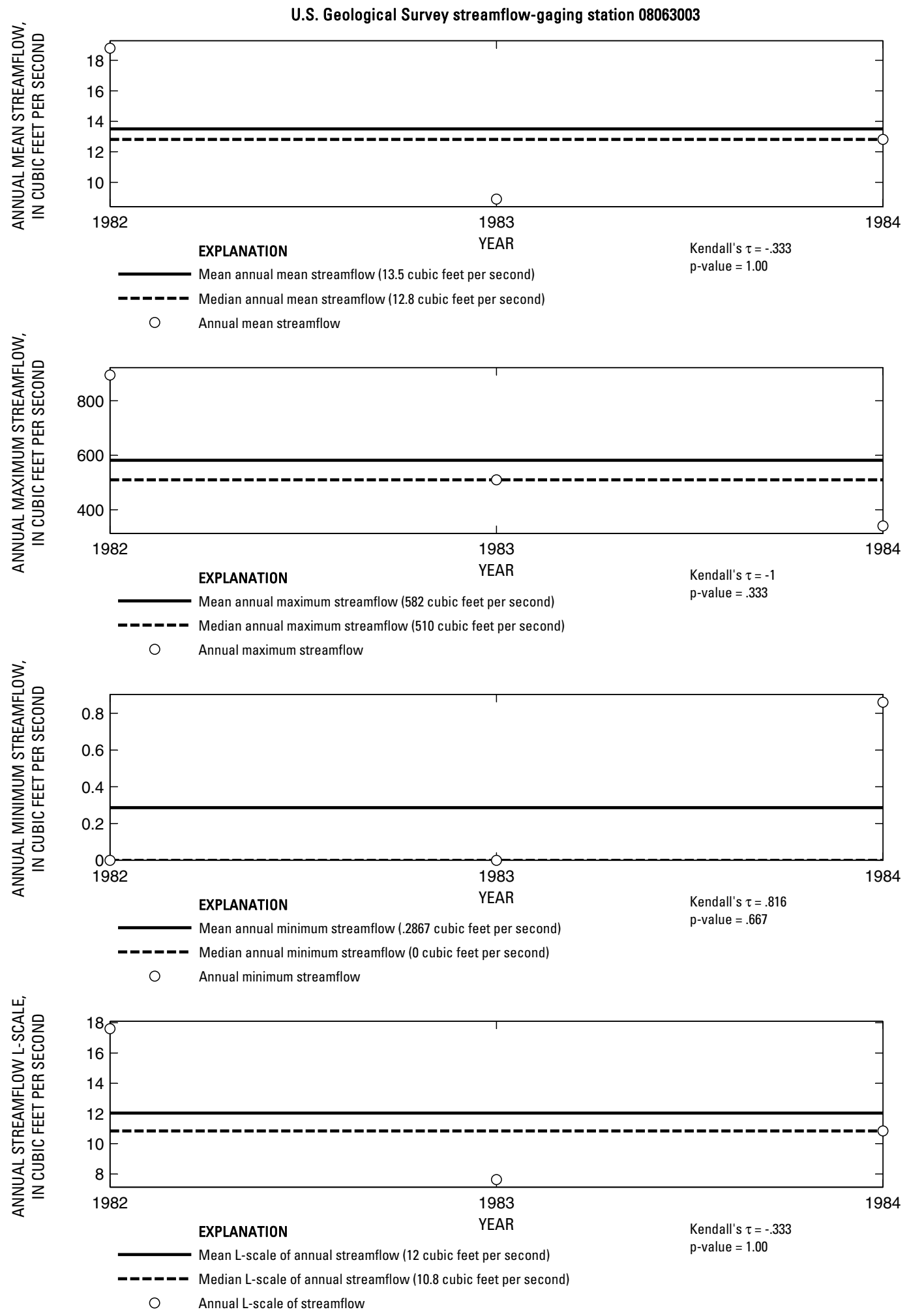

Figure 228. Analysis of annual mean, maximum, minimum, and L-scale statistics of daily mean streamflow for U.S. Geological Survey streamflow-gaging station 08063003 South Twin Creek near Eustace, Texas.

Index of Station Numbers 719 

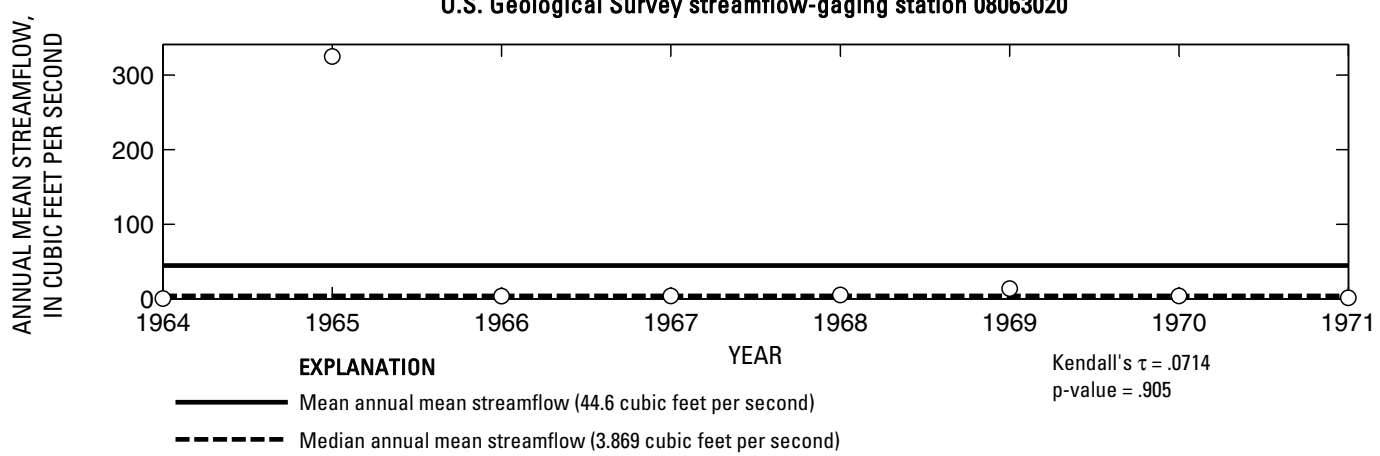

O Annual mean streamflow
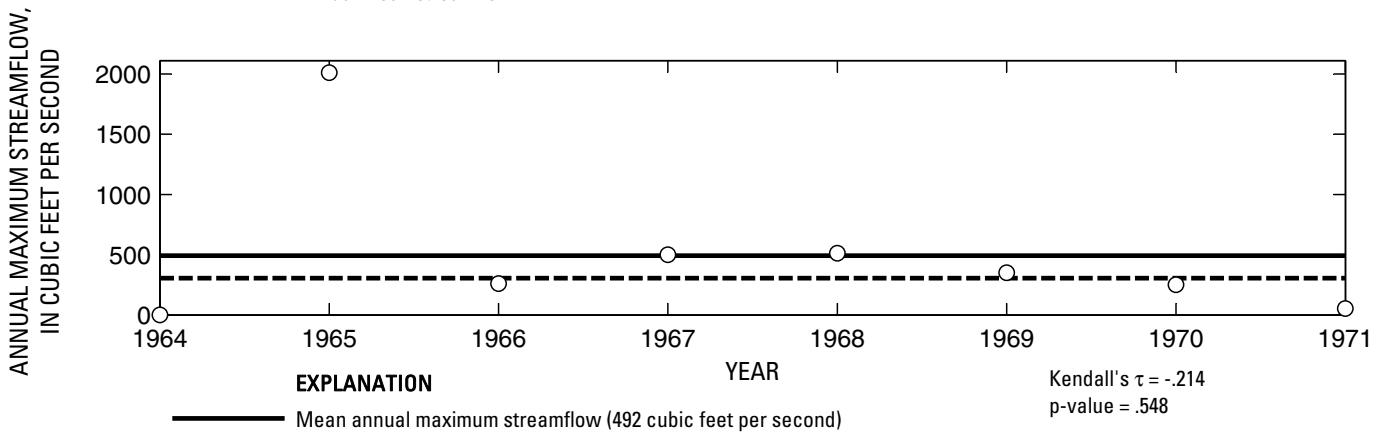

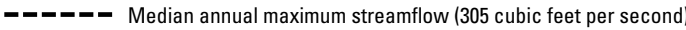

Annual maximum streamflow
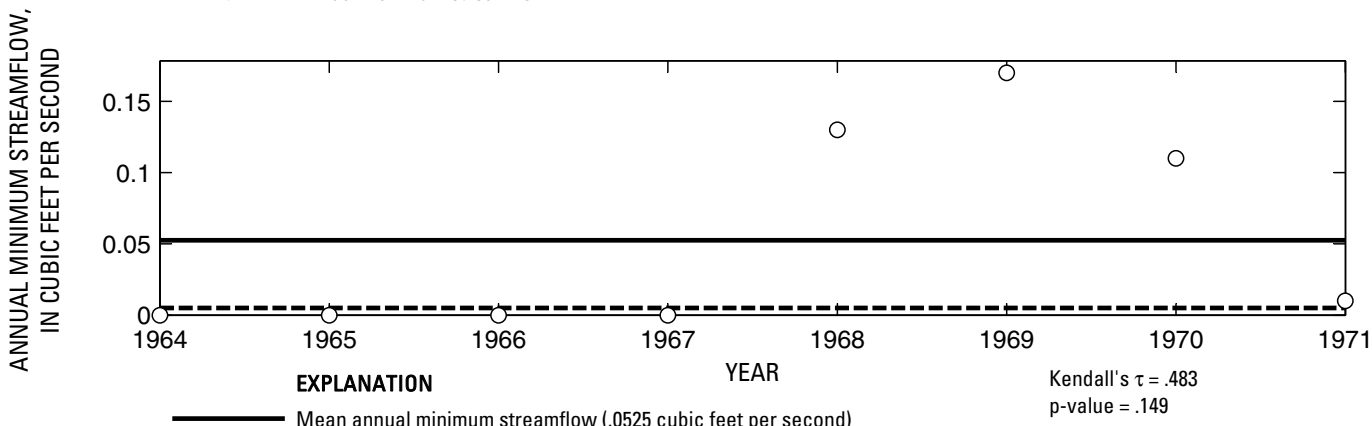

- - - Median annual minimum streamflow (.01 cubic feet per second)

O Annual minimum streamflow

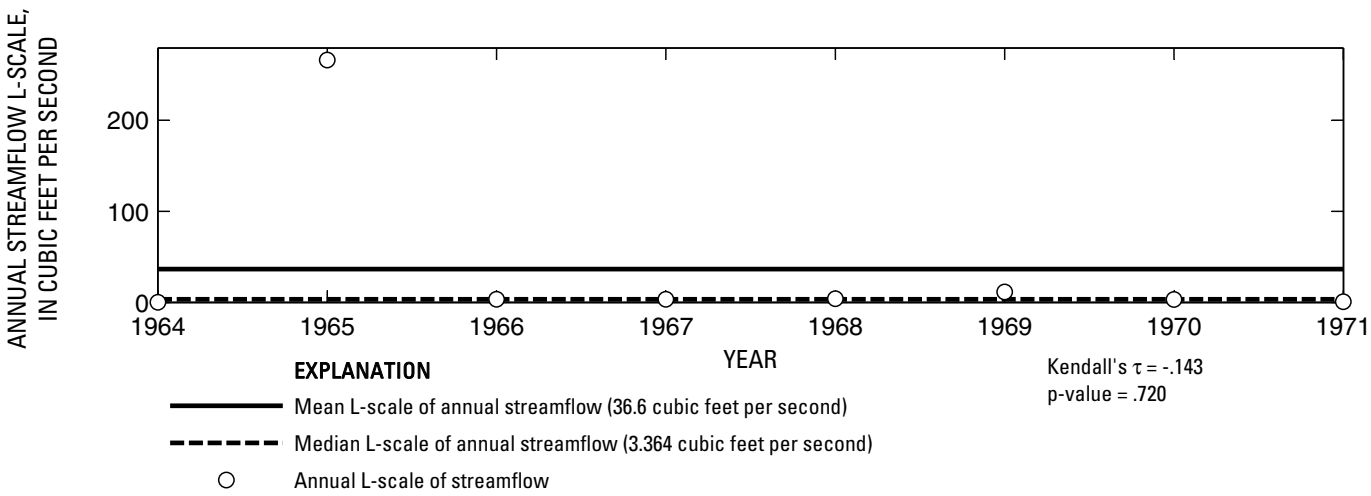

Figure 229. Analysis of annual mean, maximum, minimum, and L-scale statistics of daily mean streamflow for U.S. Geological Survey streamflow-gaging station 08063020 Cedar Creek at Trinidad, Texas. 


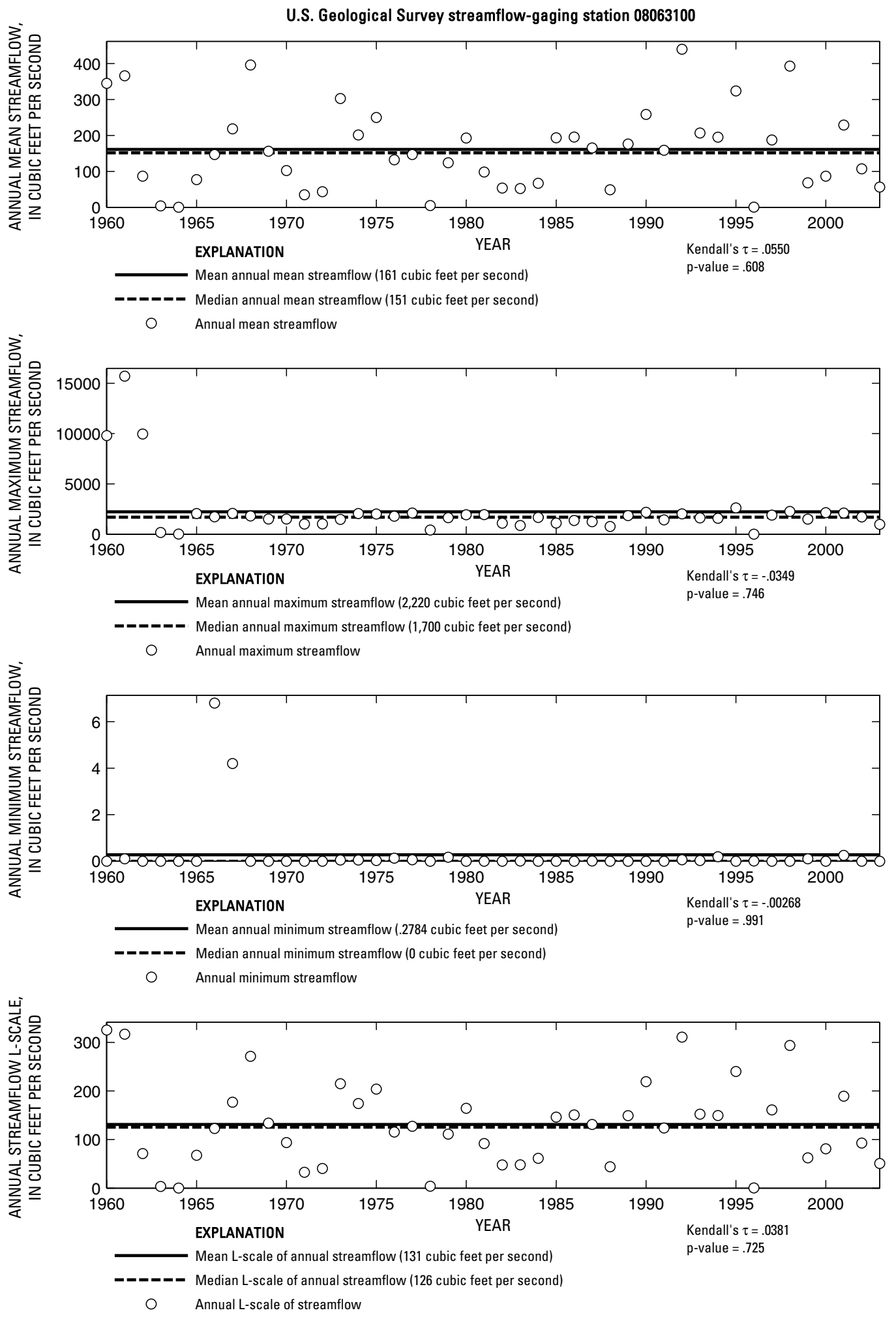

Figure 230. Analysis of annual mean, maximum, minimum, and L-scale statistics of daily mean streamflow for U.S. Geological Survey streamflow-gaging station 08063100 Richland Creek near Dawson, Texas.

Index of Station Numbers 719 


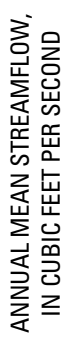

U.S. Geological Survey streamflow-gaging station 08063200

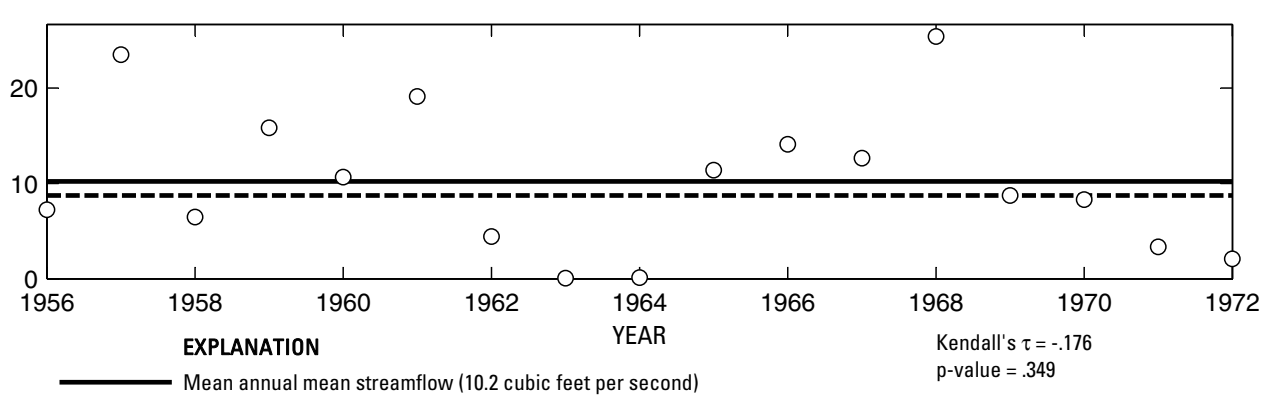

-__-_ Median annual mean streamflow (8.736 cubic feet per second)

O Annual mean streamflow

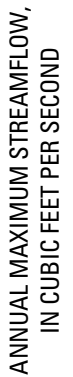

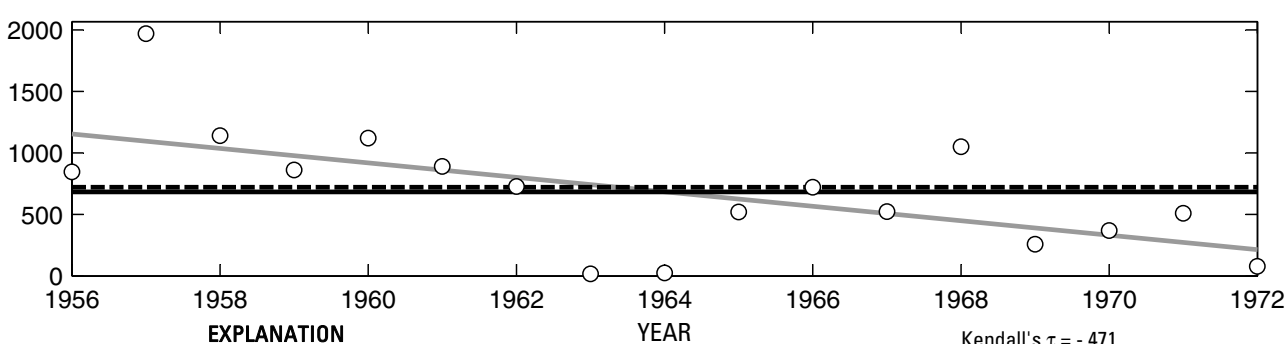

Theil trend line for annual maximum streamflow

Mean annual maximum streamflow (684 cubic feet per second)

-ンーーーー Median annual maximum streamflow (721 cubic feet per second)

O Annual maximum streamflow

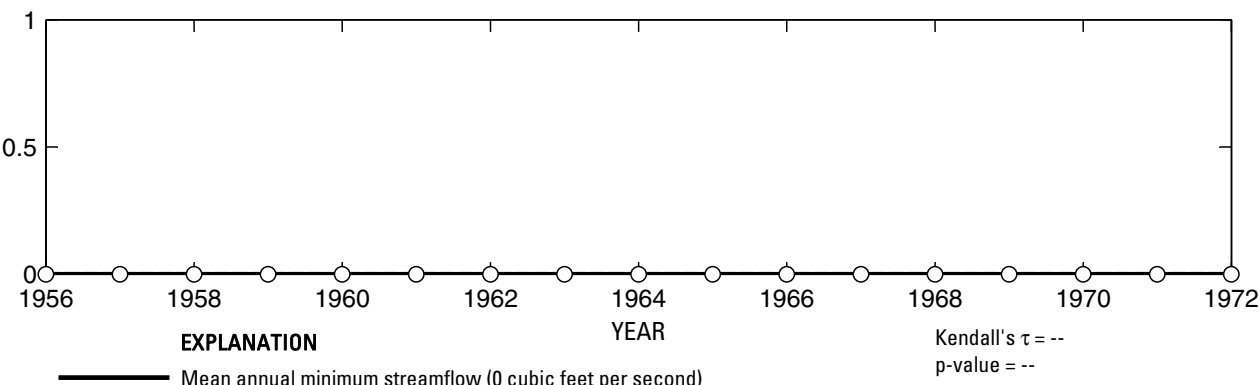

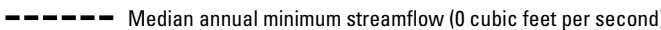

○ Annual minimum streamflow

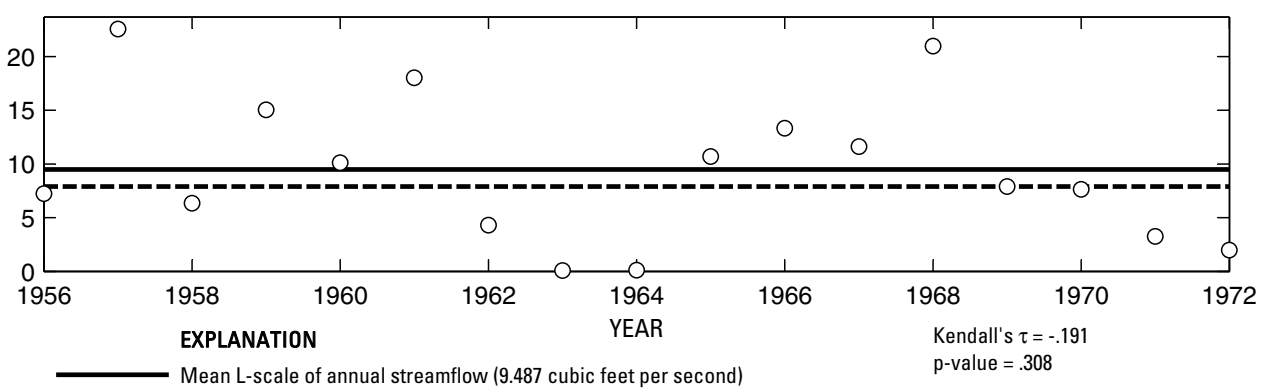

- - - - Median L-scale of annual streamflow (7.904 cubic feet per second)

Annual L-scale of streamflow

Figure 231. Analysis of annual mean, maximum, minimum, and L-scale statistics of daily mean streamflow for U.S. Geological Survey streamflow-gaging station 08063200 Pin Oak Creek near Hubbard, Texas. 


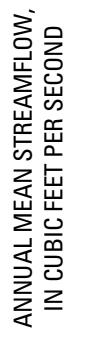

U.S. Geological Survey streamflow-gaging station 08063500

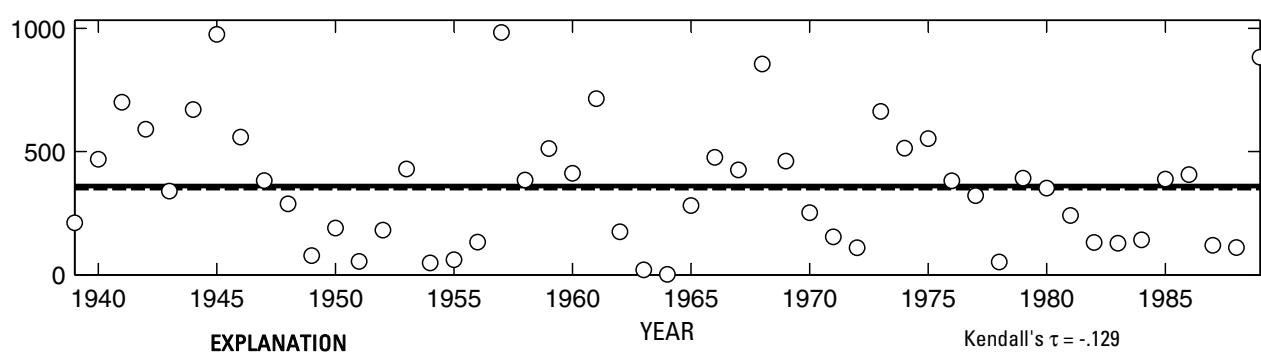

EPLANATION

$\mathrm{p}$-value $=.183$

_- Median annual mean streamflow ( 352 cubic feet per second)

O Annual mean streamflow

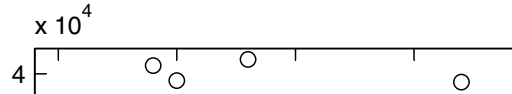

$3-0$
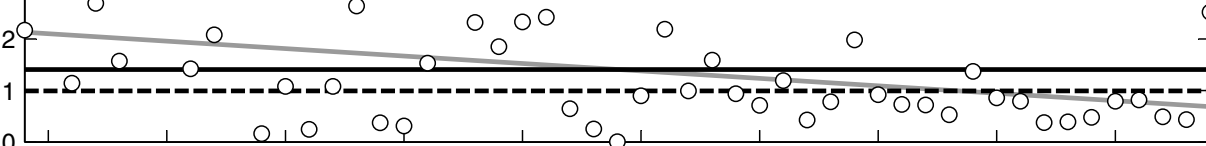

0 L

$1940 \quad 1945 \quad 1950$ EXPLANATION

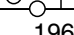

1965

YEAR

$1970 \quad 1975$

1980

Kendall's $\tau=-.312$

Theil trend line for annual maximum streamflow

- Mean annual maximum streamflow (14,100 cubic feet per second)

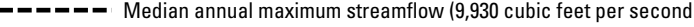

Annual maximum streamflow

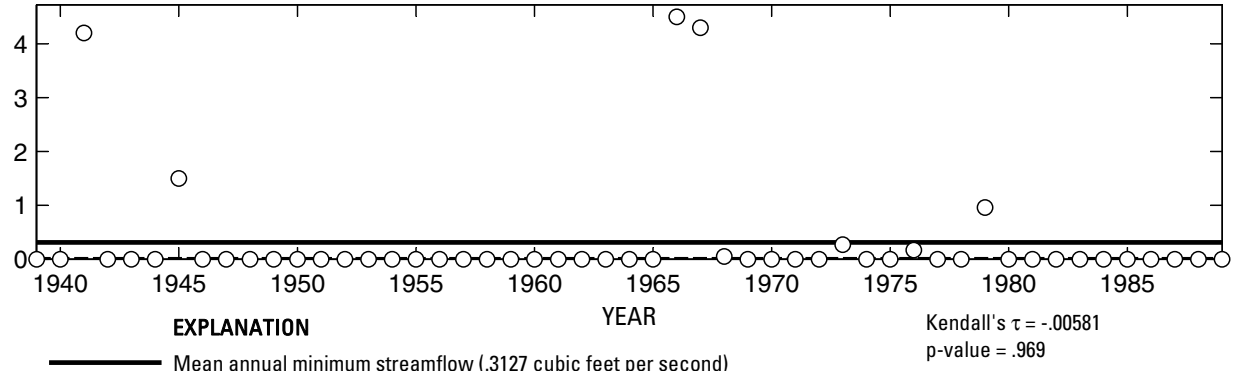

-ーーーーー Median annual minimum streamflow (0 cubic feet per second)

O Annual minimum streamflow

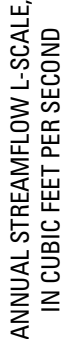

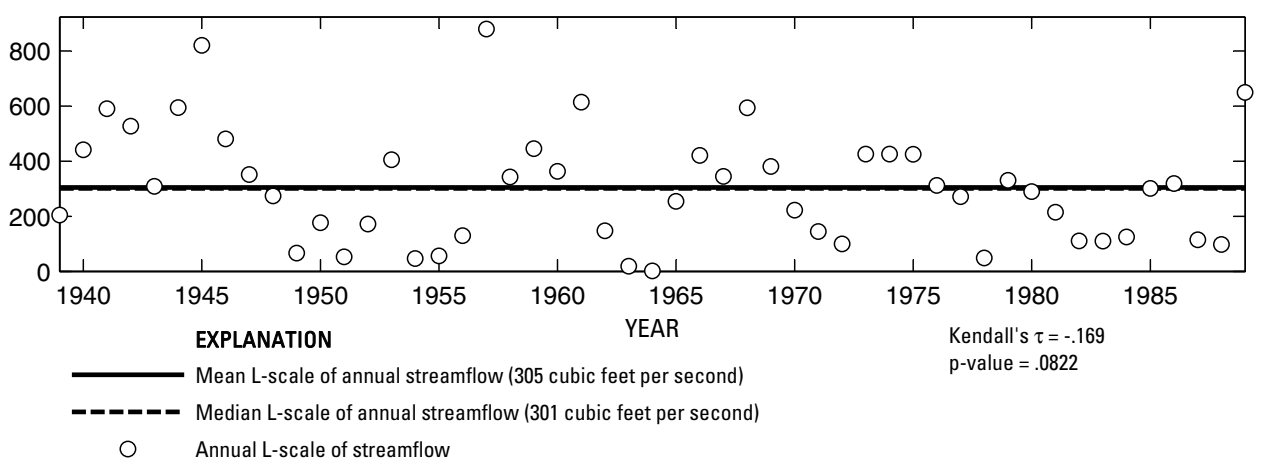

Figure 232. Analysis of annual mean, maximum, minimum, and L-scale statistics of daily mean streamflow for U.S. Geological Survey streamflow-gaging station 08063500 Richland Creek near Richland, Texas.

Index of Station Numbers 719 


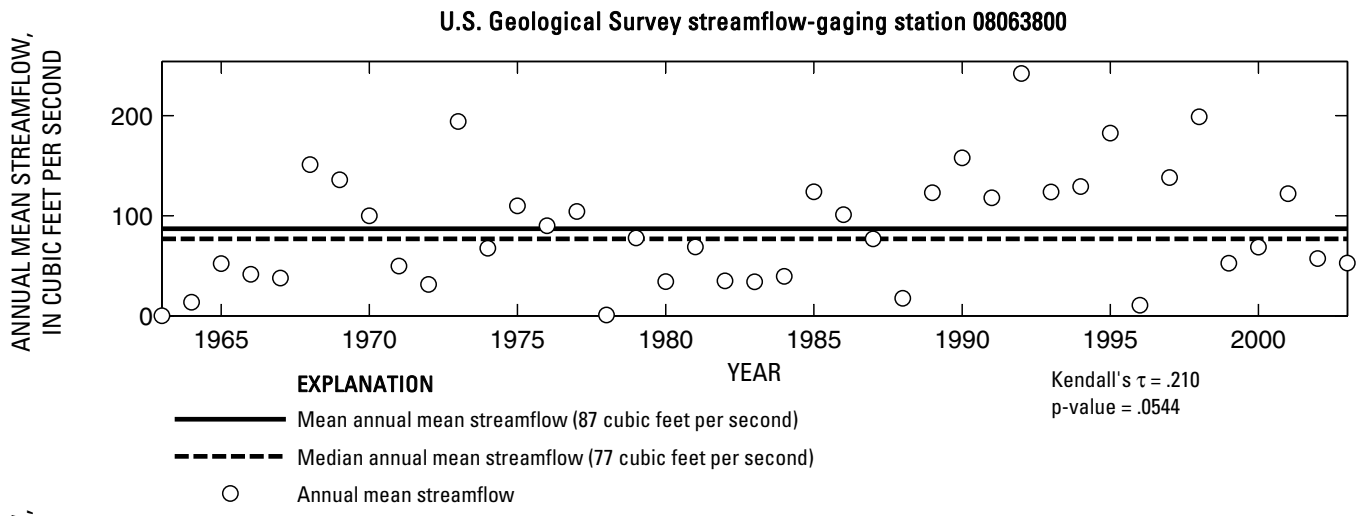

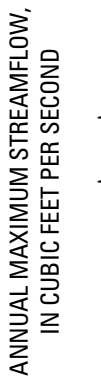

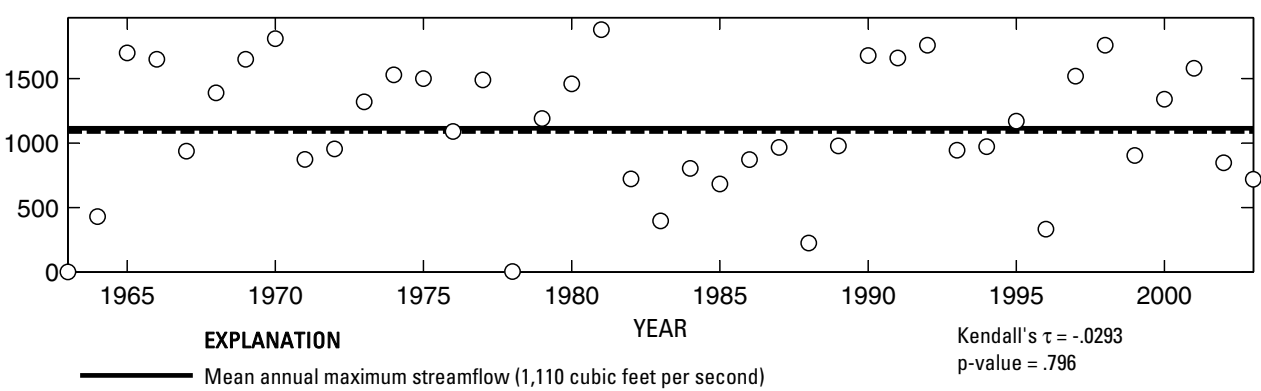

- _ - ב Median annual maximum streamflow (1,090 cubic feet per second

- Annual maximum streamflow

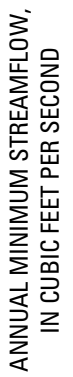

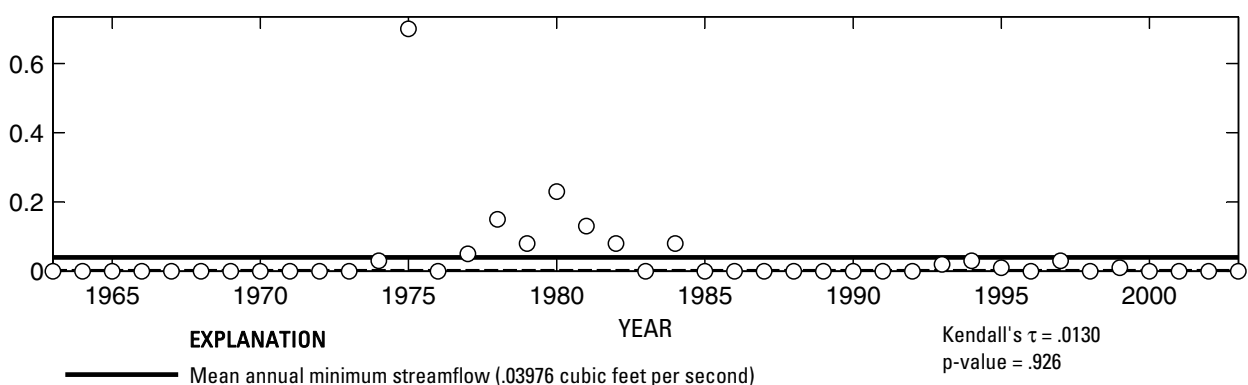

- ב-ב. Median annual minimum streamflow (0 cubic feet per second)

O Annual minimum streamflow

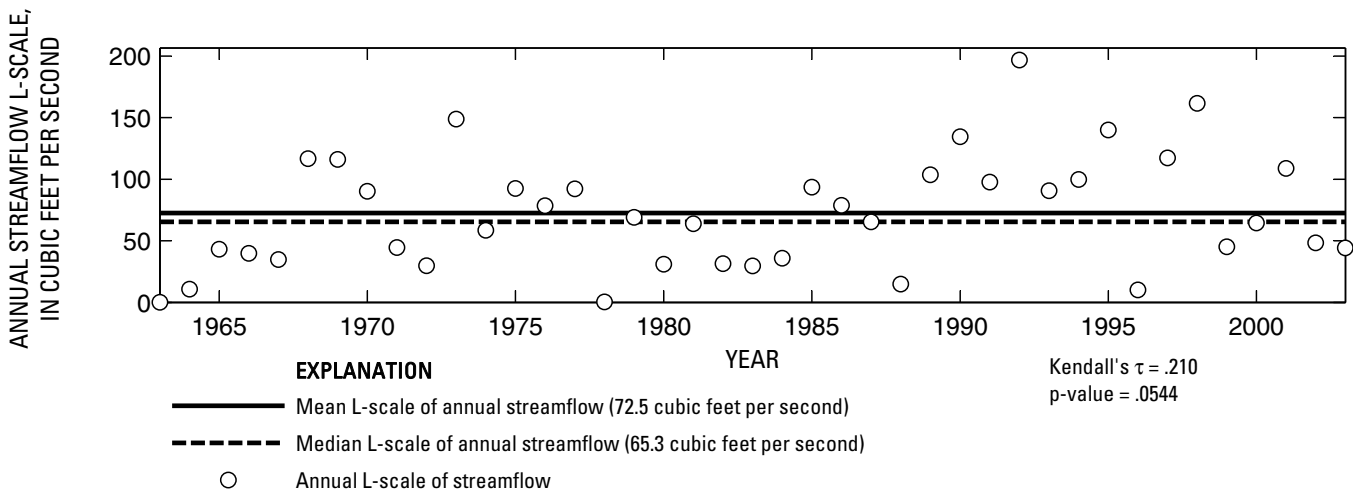

Figure 233. Analysis of annual mean, maximum, minimum, and L-scale statistics of daily mean streamflow for U.S. Geological Survey streamflow-gaging station 08063800 Waxahachie Creek near Bardwell, Texas. 


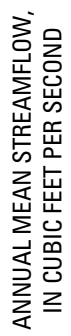

U.S. Geological Survey streamflow-gaging station 08064100

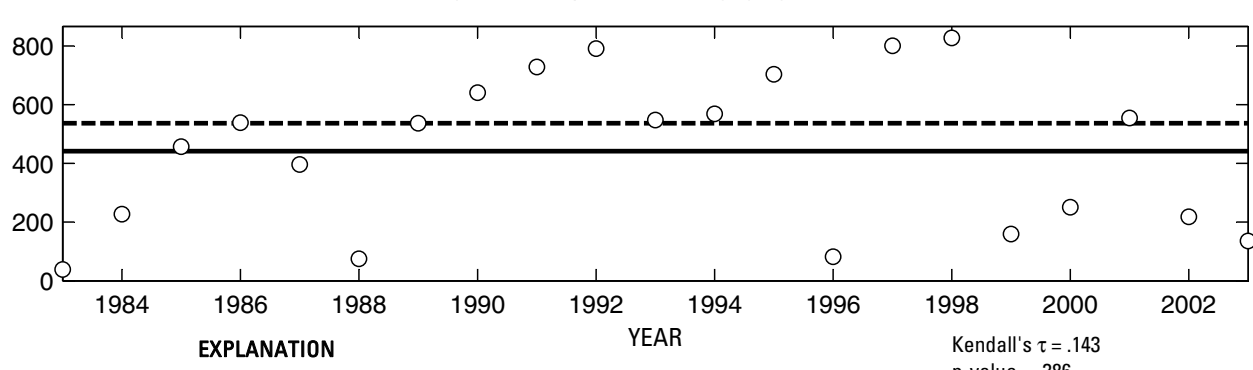

Mean annual mean streamflow (442 cubic feet per second) $\quad$ p-value $=.386$

-ンーーーー Median annual mean streamflow (537 cubic feet per second)

O Annual mean streamflow

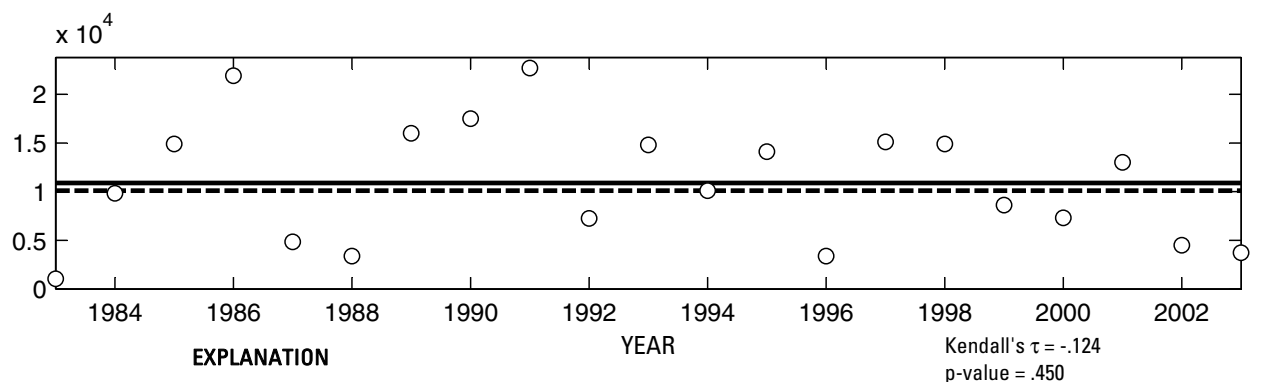

Mean annual maximum streamflow (10,900 cubic feet per second)

$\mathrm{p}$-value $=.450$

-ーーーーー Median annual maximum streamflow (10,100 cubic feet per second)

O Annual maximum streamflow

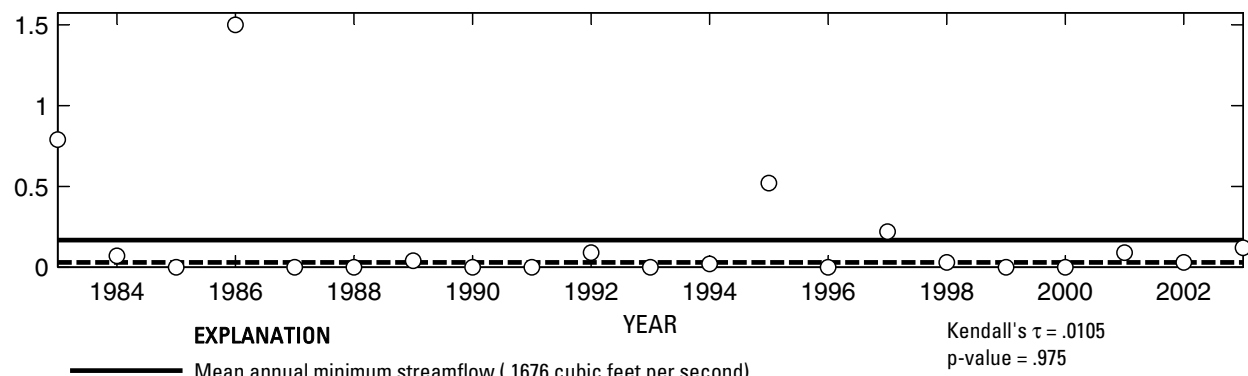

- Median annual minimum streamflow (.03 cubic feet per second)

O Annual minimum streamflow

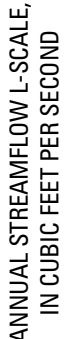

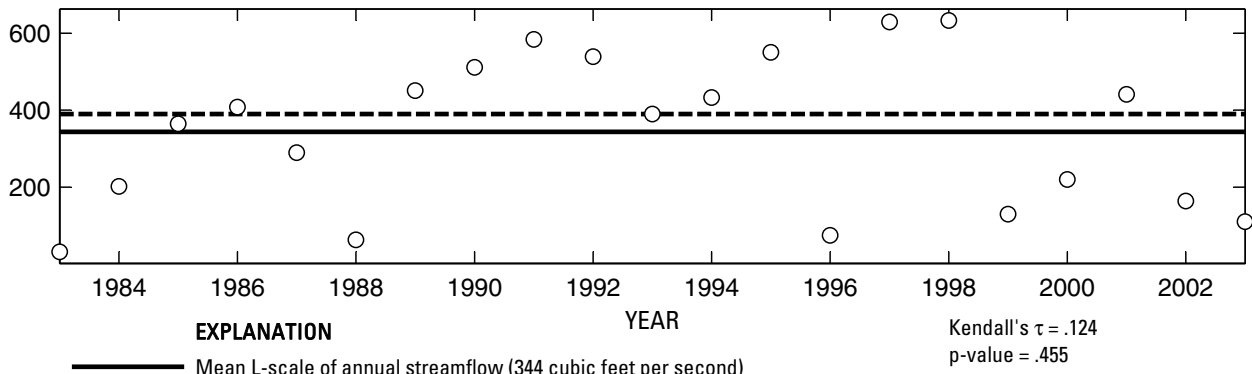

- - - Median L-scale of annual streamflow (390 cubic feet per second)

Annual L-scale of streamflow

Figure 234. Analysis of annual mean, maximum, minimum, and L-scale statistics of daily mean streamflow for U.S. Geological Survey streamflow-gaging station 08064100 Chambers Creek near Rice, Texas.

Index of Station Numbers 719 

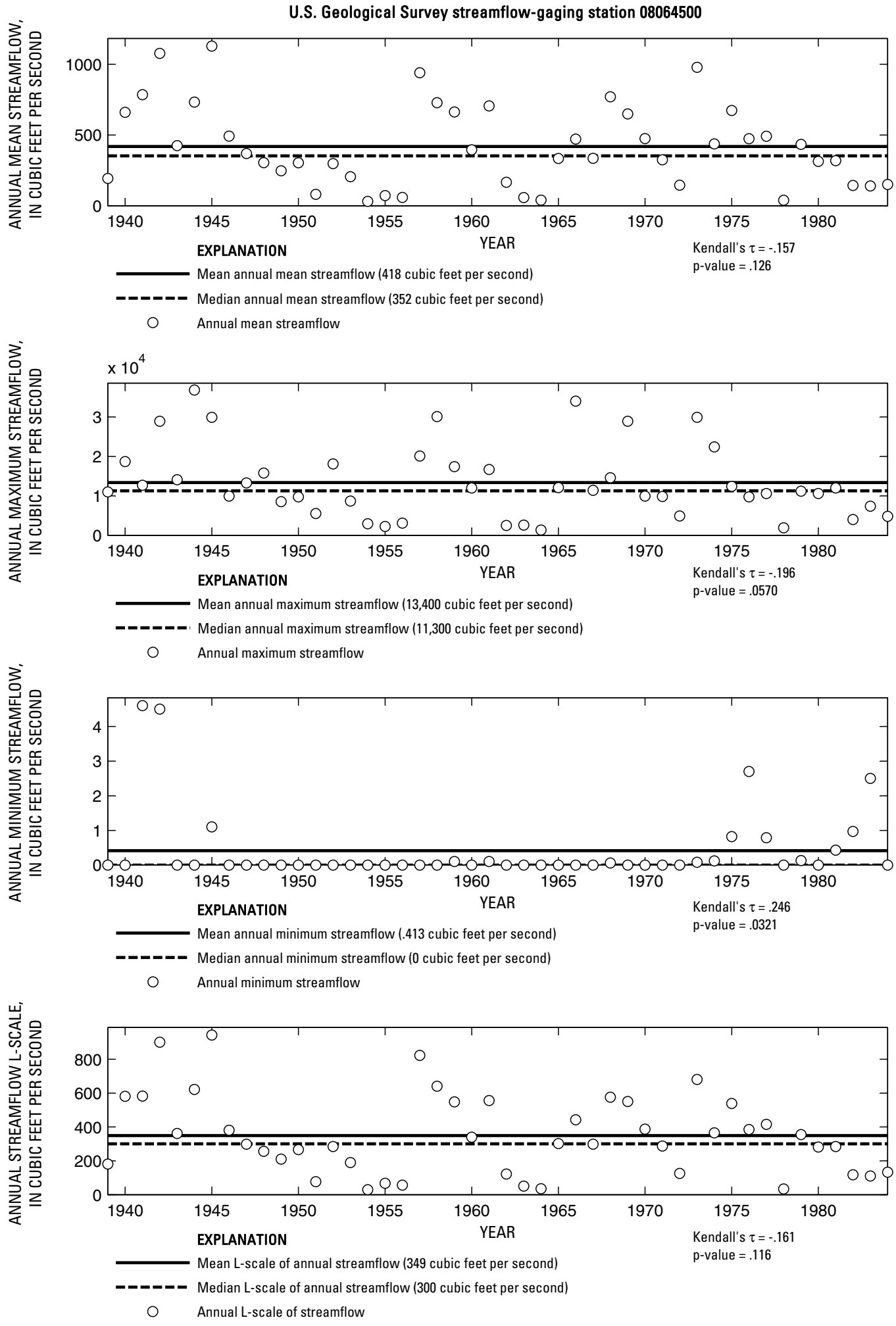

Figure 235. Analysis of annual mean, maximum, minimum, and L-scale statistics of daily mean streamflow for U.S. Geological Survey streamflow-gaging station 08064500 Chambers Creek near Corsicana, Texas. 

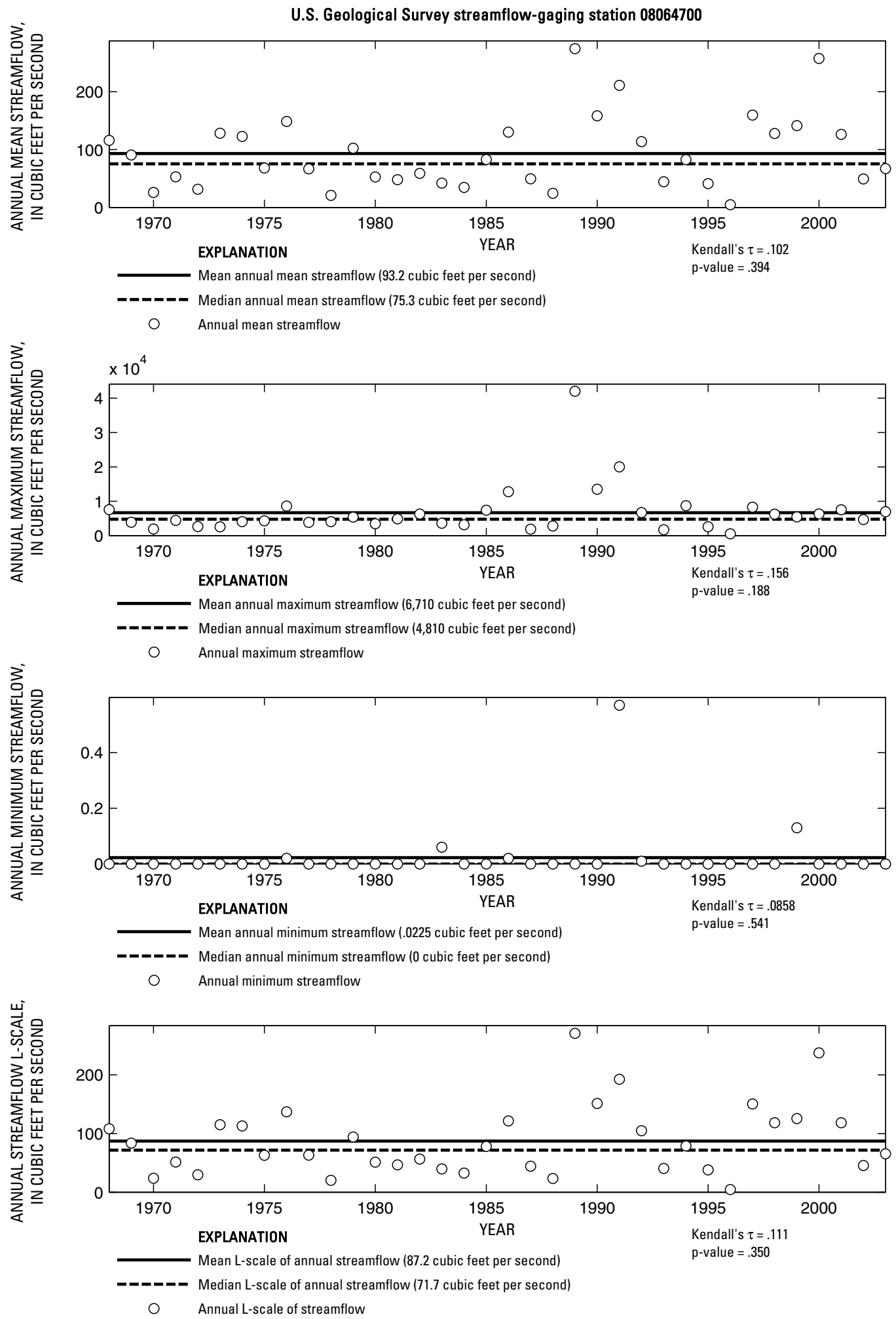

Figure 236. Analysis of annual mean, maximum, minimum, and L-scale statistics of daily mean streamflow for U.S. Geological Survey streamflow-gaging station 08064700 Tehuacana Creek near Streetman, Texas.

Index of Station Numbers 719 

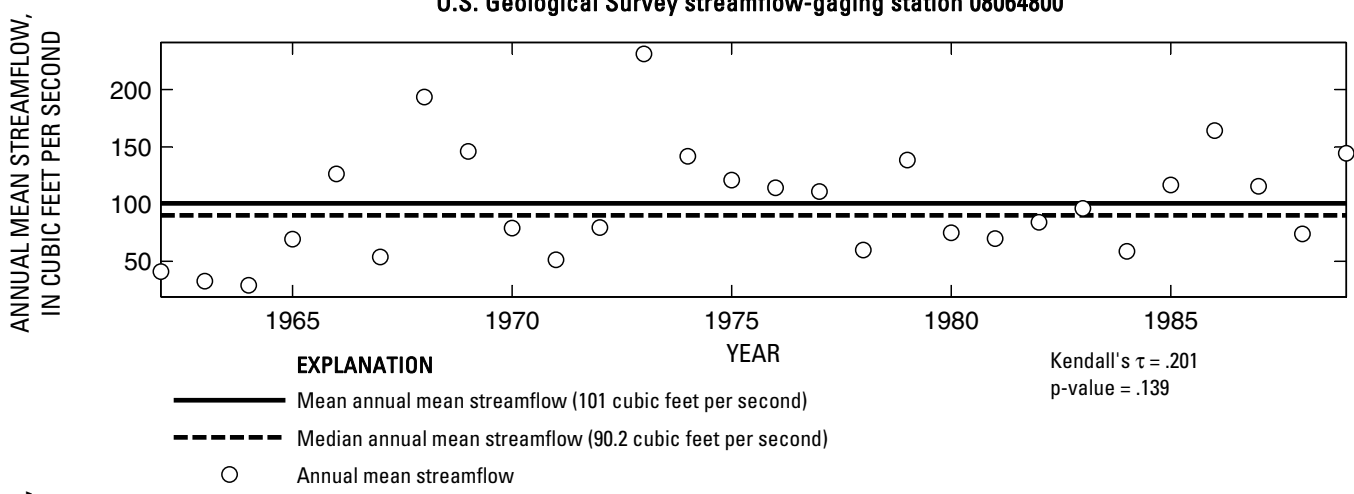

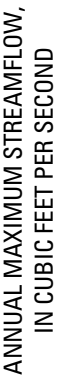

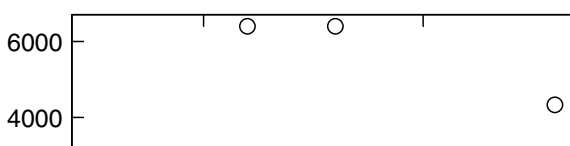

2000 -

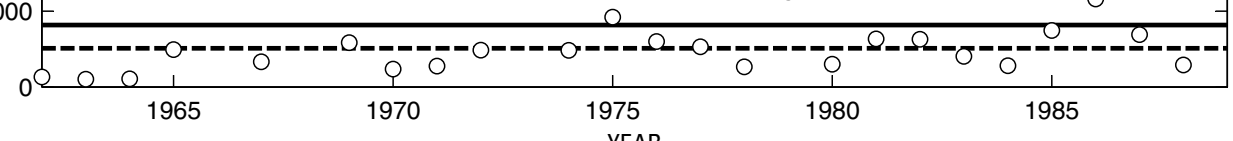

EXPLANATION

Kendall's $\tau=.230$

Mean annual maximum streamflow (1,630 cubic feet per second)

$\mathrm{p}$-value $=.0892$

- - - Median annual maximum streamflow (1,020 cubic feet per second)

O Annual maximum streamflow

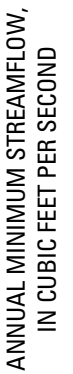

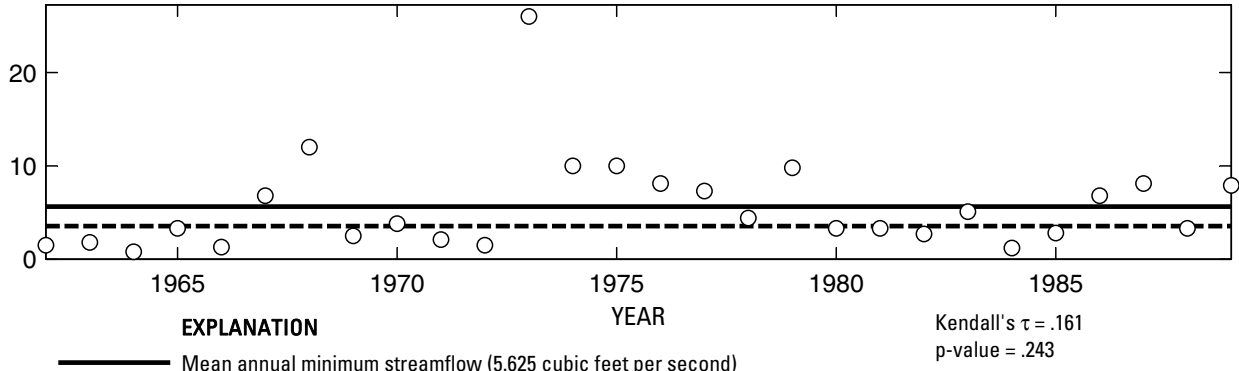

- ב- Median annual minimum streamflow (3.55 cubic feet per second)

O Annual minimum streamflow
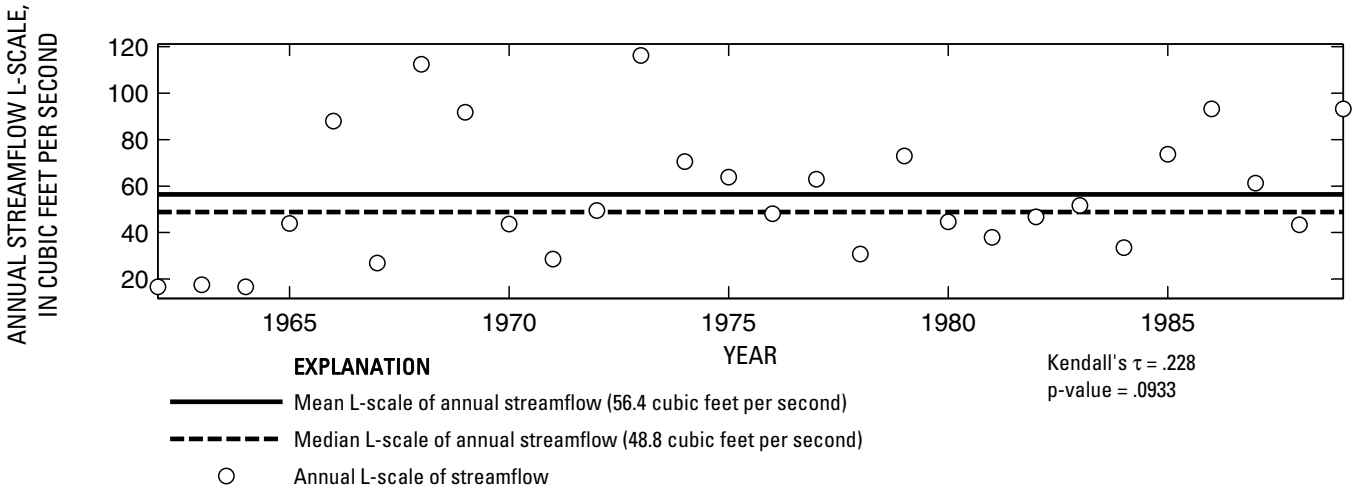

Figure 237. Analysis of annual mean, maximum, minimum, and L-scale statistics of daily mean streamflow for U.S. Geological Survey streamflow-gaging station 08064800 Catfish Creek near Tennessee Colony, Texas. 
U.S. Geological Survey streamflow-gaging station 08065000
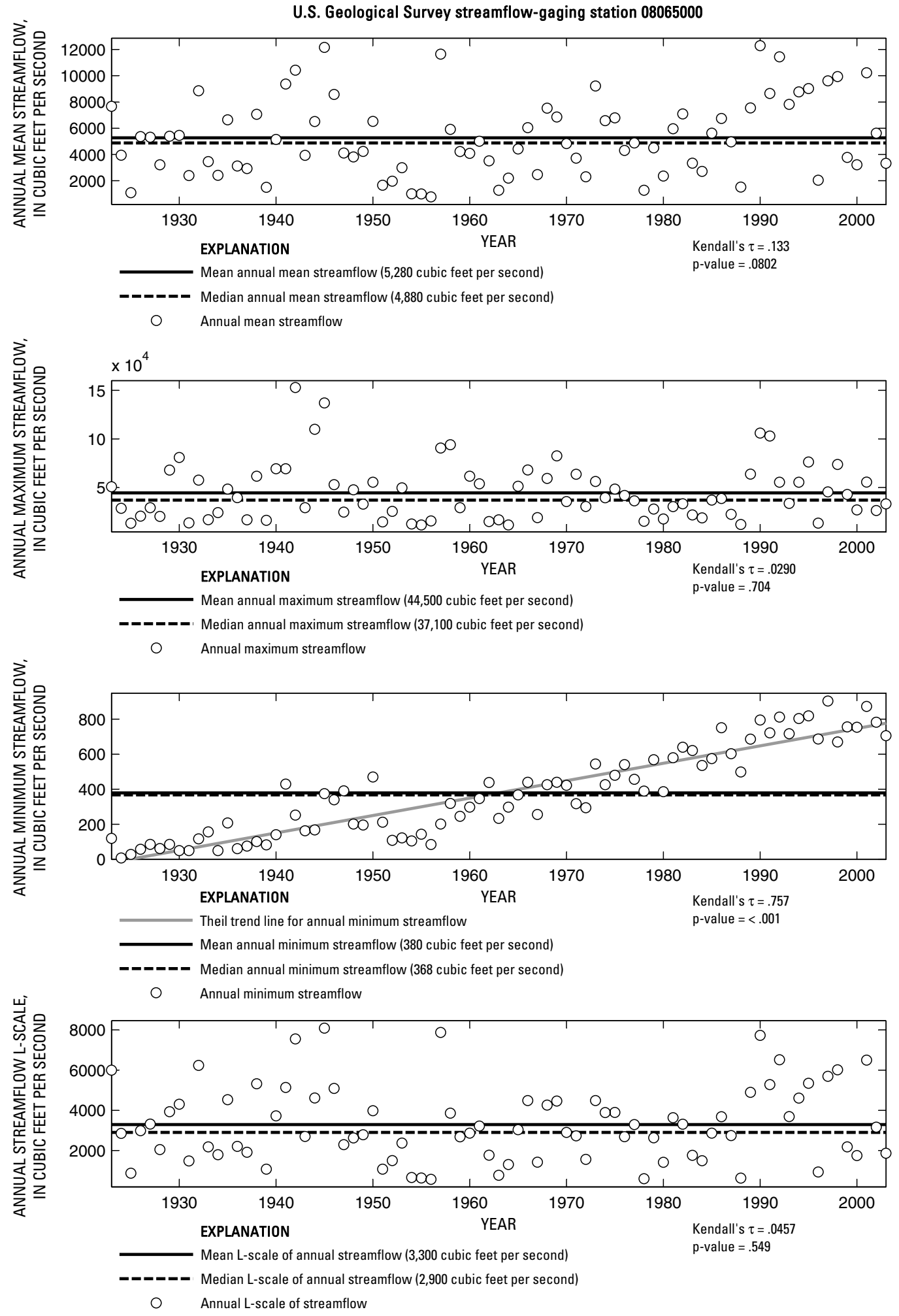

Figure 238. Analysis of annual mean, maximum, minimum, and L-scale statistics of daily mean streamflow for U.S. Geological Survey streamflow-gaging station 08065000 Trinity River near Oakwood, Texas.

Index of Station Numbers 719 

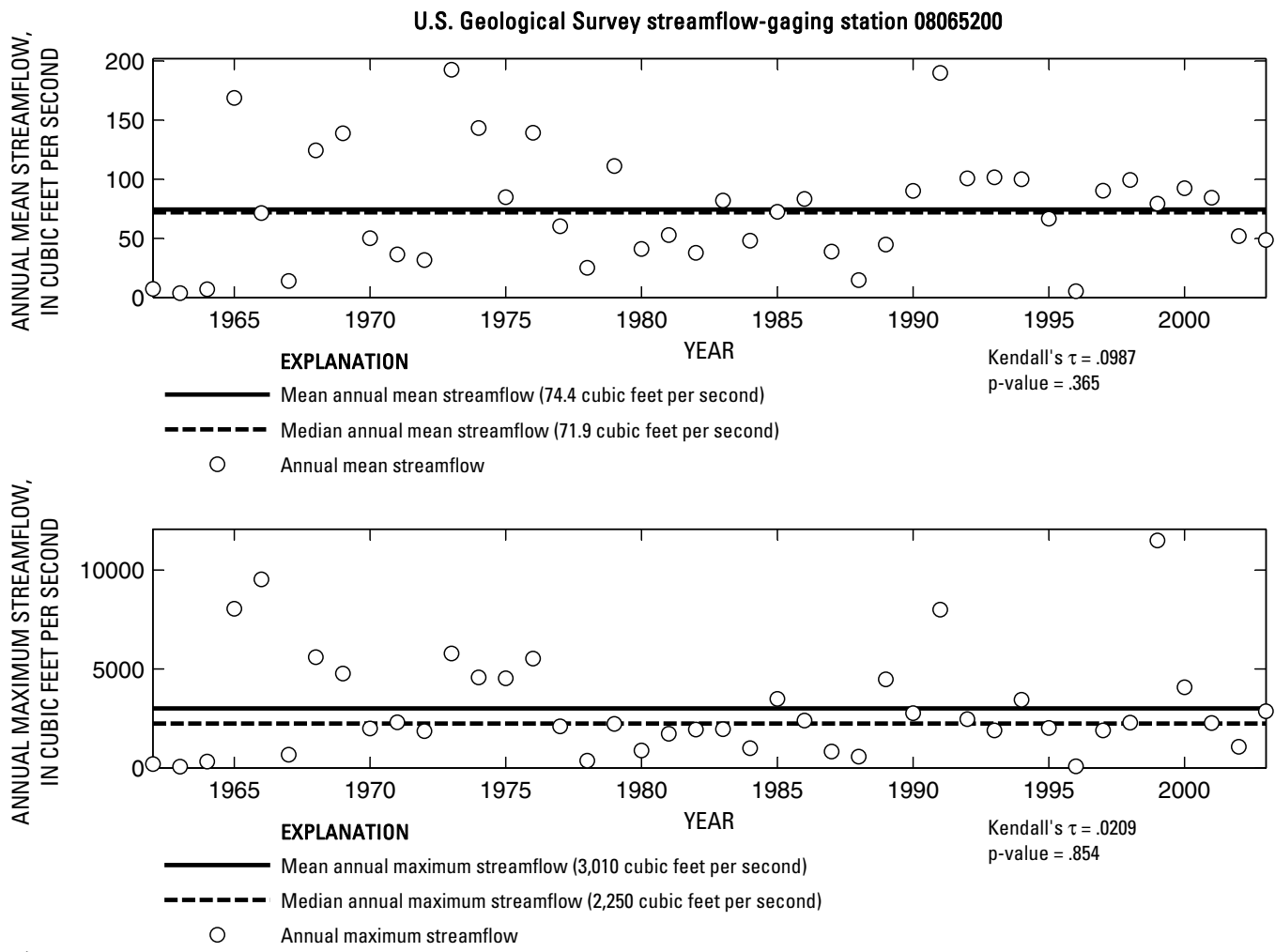

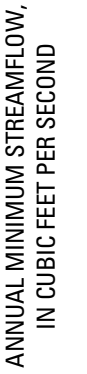

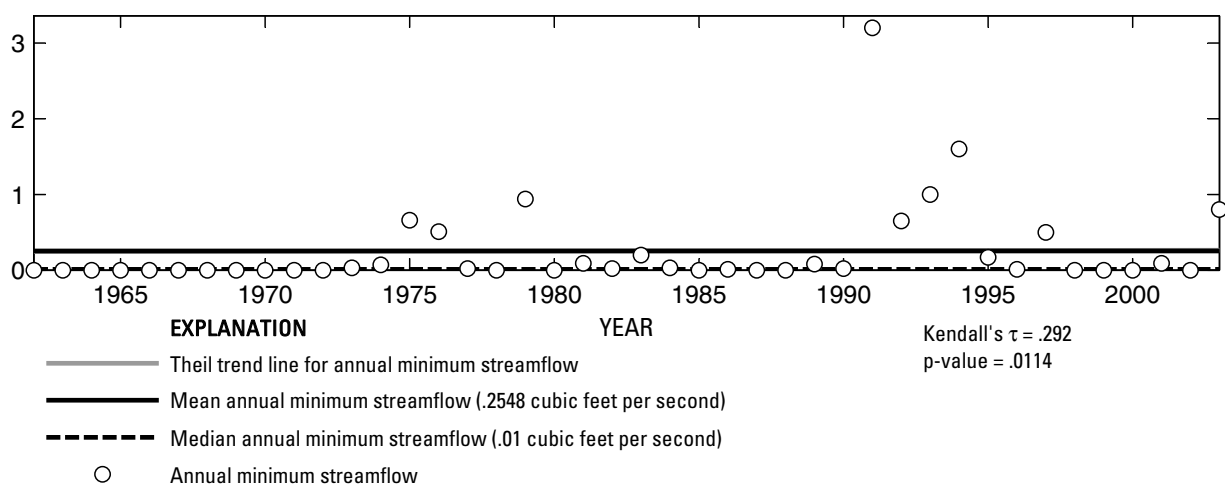

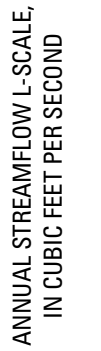

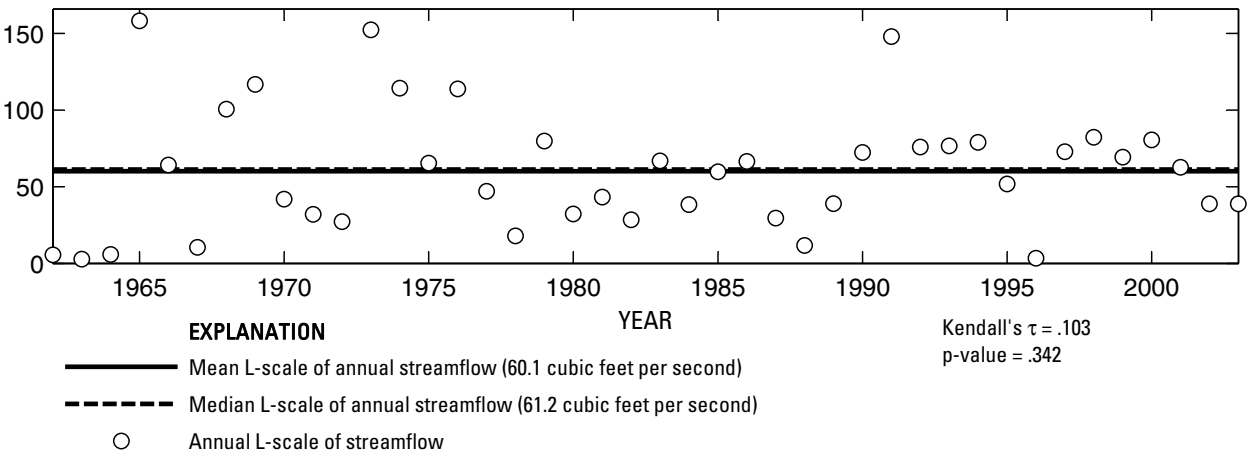

Figure 239. Analysis of annual mean, maximum, minimum, and L-scale statistics of daily mean streamflow for U.S. Geological Survey streamflow-gaging station 08065200 Upper Keechi Creek near Oakwood, Texas. 

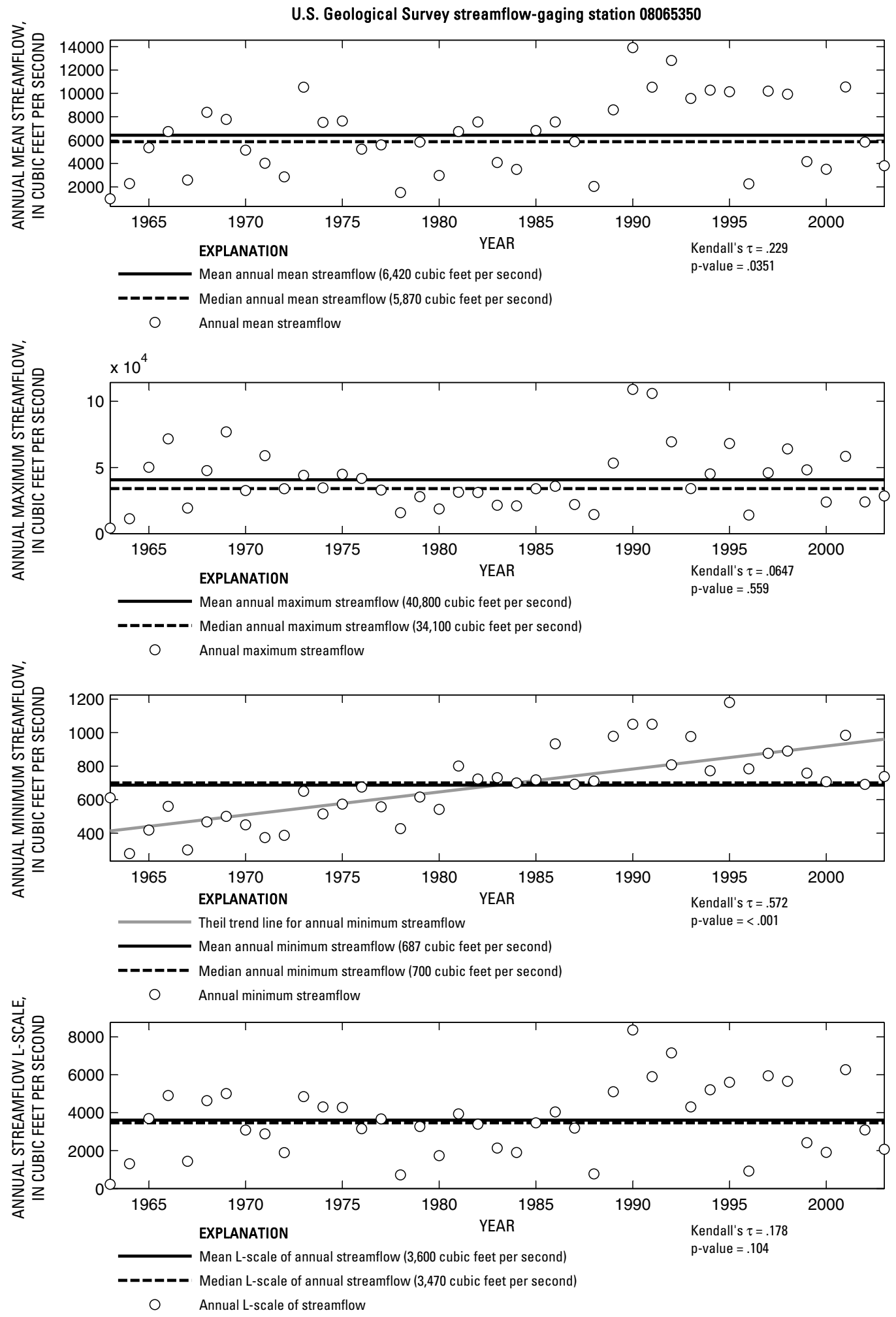

Figure 240. Analysis of annual mean, maximum, minimum, and L-scale statistics of daily mean streamflow for U.S. Geological Survey streamflow-gaging station 08065350 Trinity River near Crockett, Texas.

Index of Station Numbers 719 

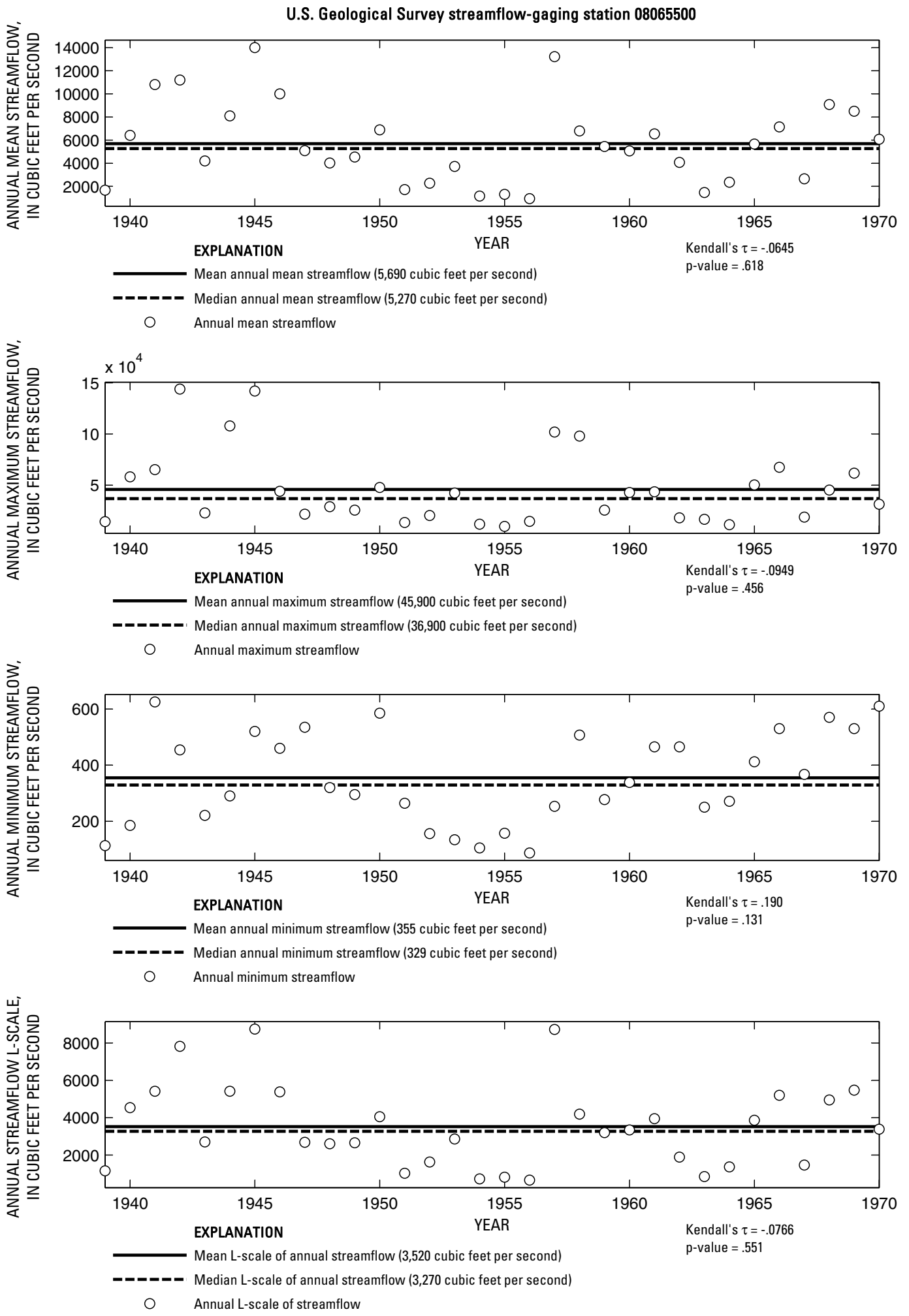

Figure 241. Analysis of annual mean, maximum, minimum, and L-scale statistics of daily mean streamflow for U.S. Geological Survey streamflow-gaging station 08065500 Trinity River near Midway, Texas. 
U.S. Geological Survey streamflow-gaging station 08065700

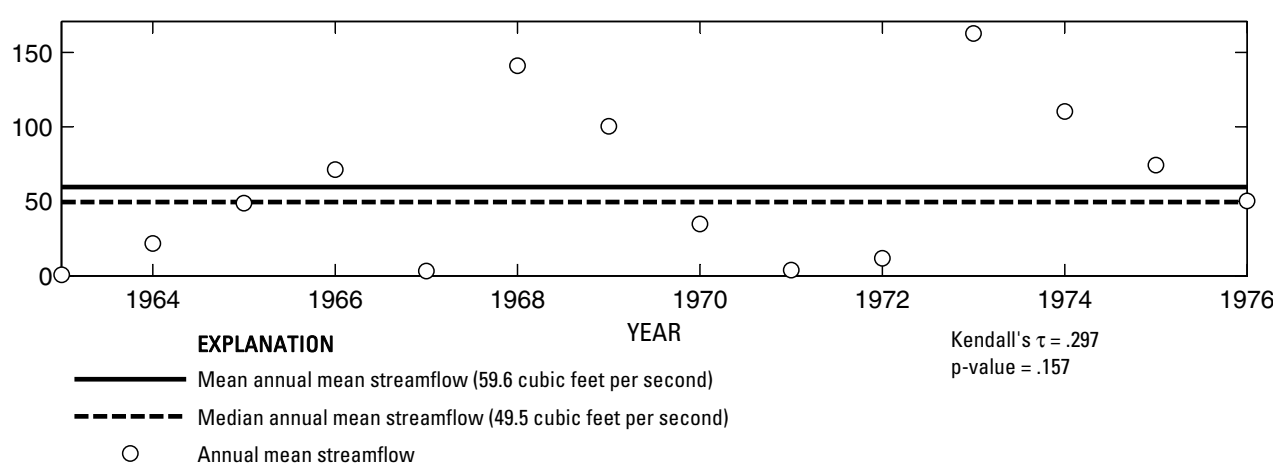

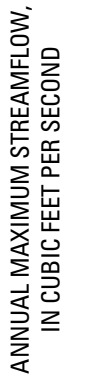

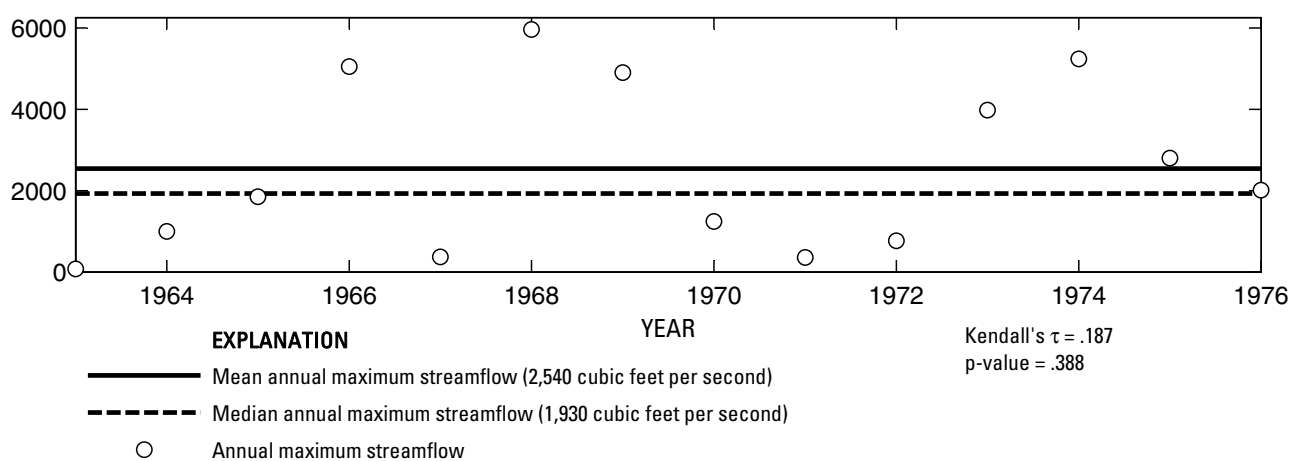

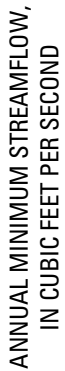

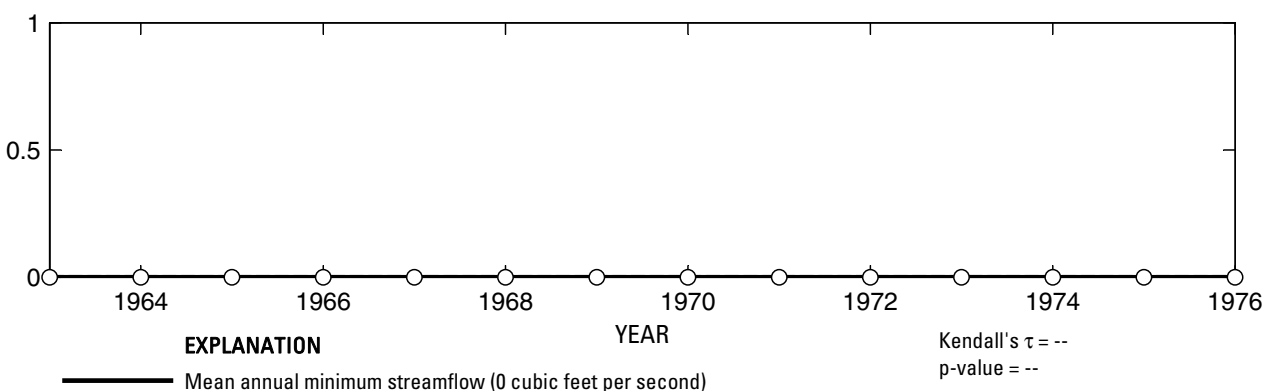

- Median annual minimum streamflow (0 cubic feet per second)

O Annual minimum streamflow

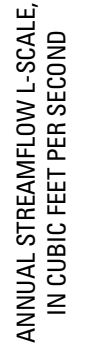

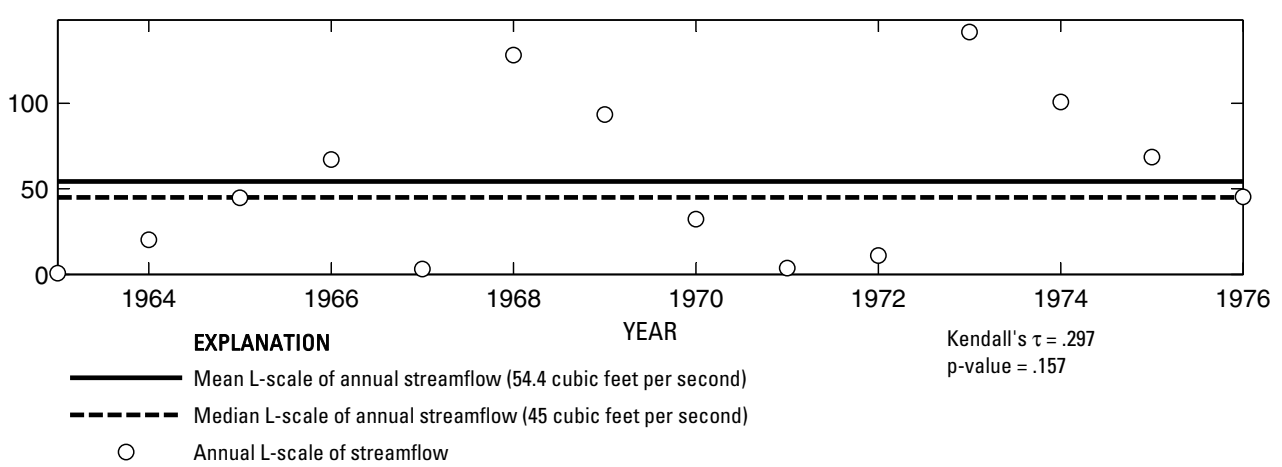

Figure 242. Analysis of annual mean, maximum, minimum, and L-scale statistics of daily mean streamflow for U.S. Geological Survey streamflow-gaging station 08065700 Caney Creek near Madisonville, Texas.

Index of Station Numbers 7719 

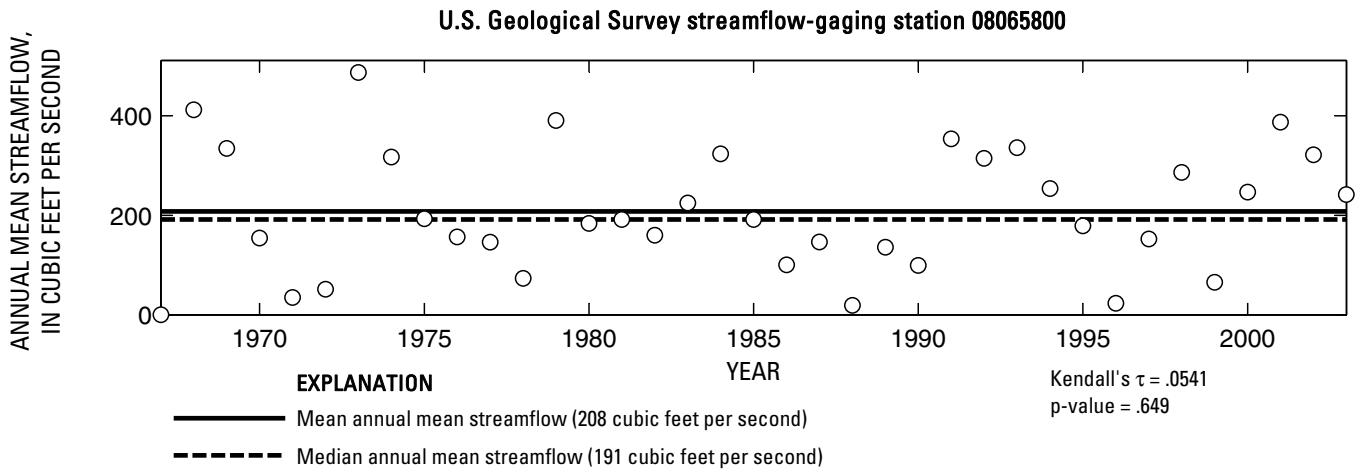

O Annual mean streamflow
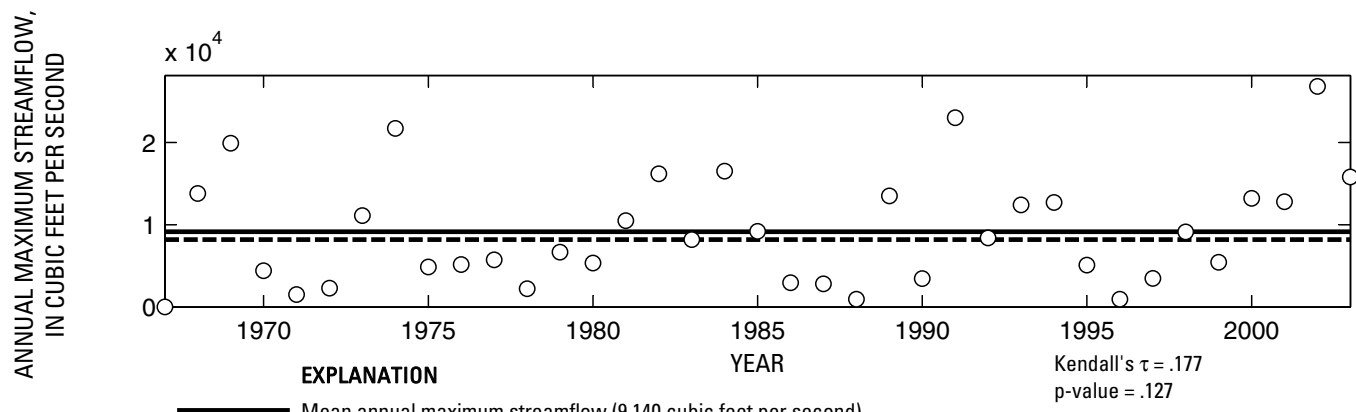

O Annual maximum streamflow
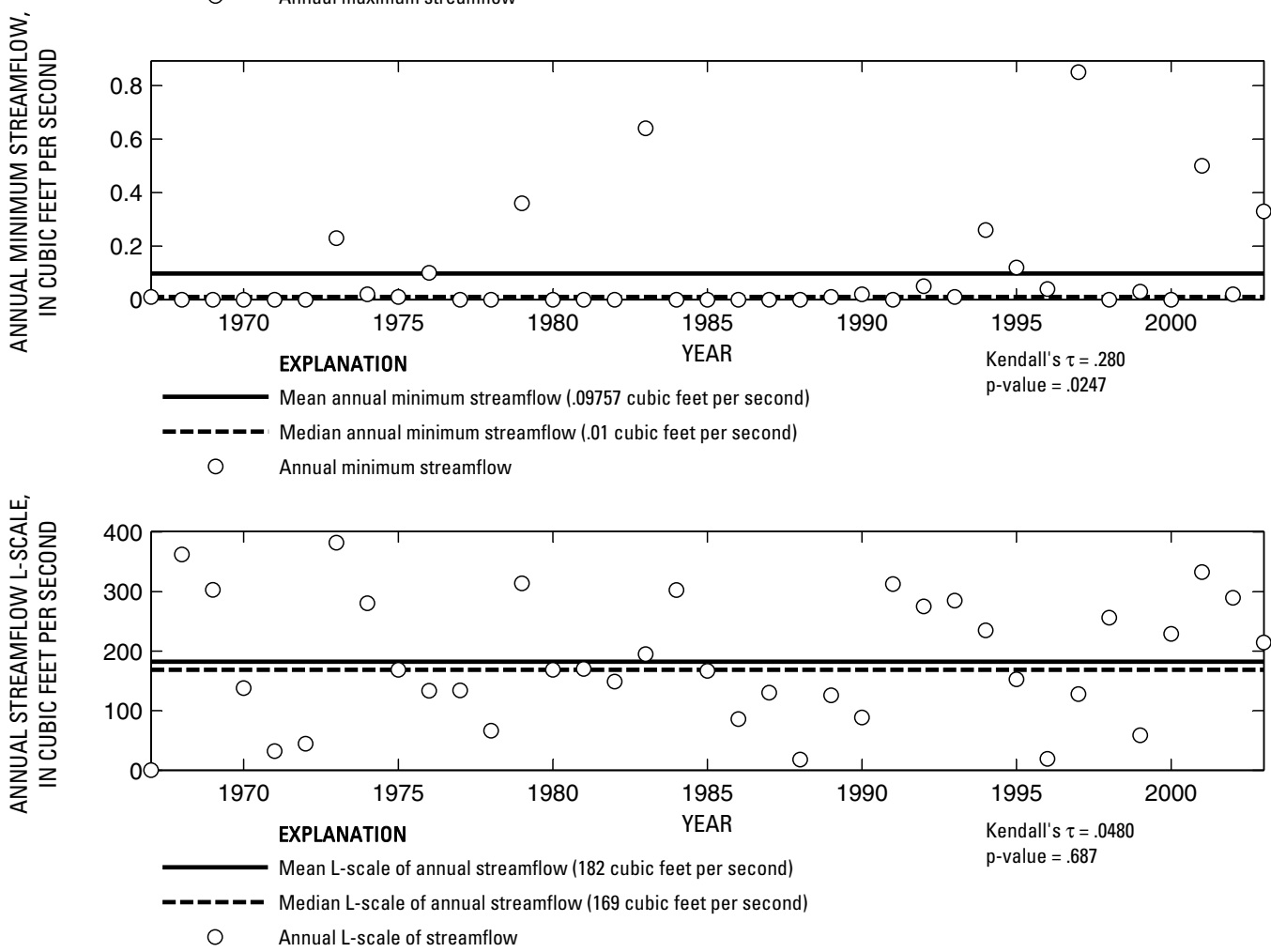

Figure 243. Analysis of annual mean, maximum, minimum, and L-scale statistics of daily mean streamflow for U.S. Geological Survey streamflow-gaging station 08065800 Bedias Creek near Madisonville, Texas.

Index of Station Numbers 779 

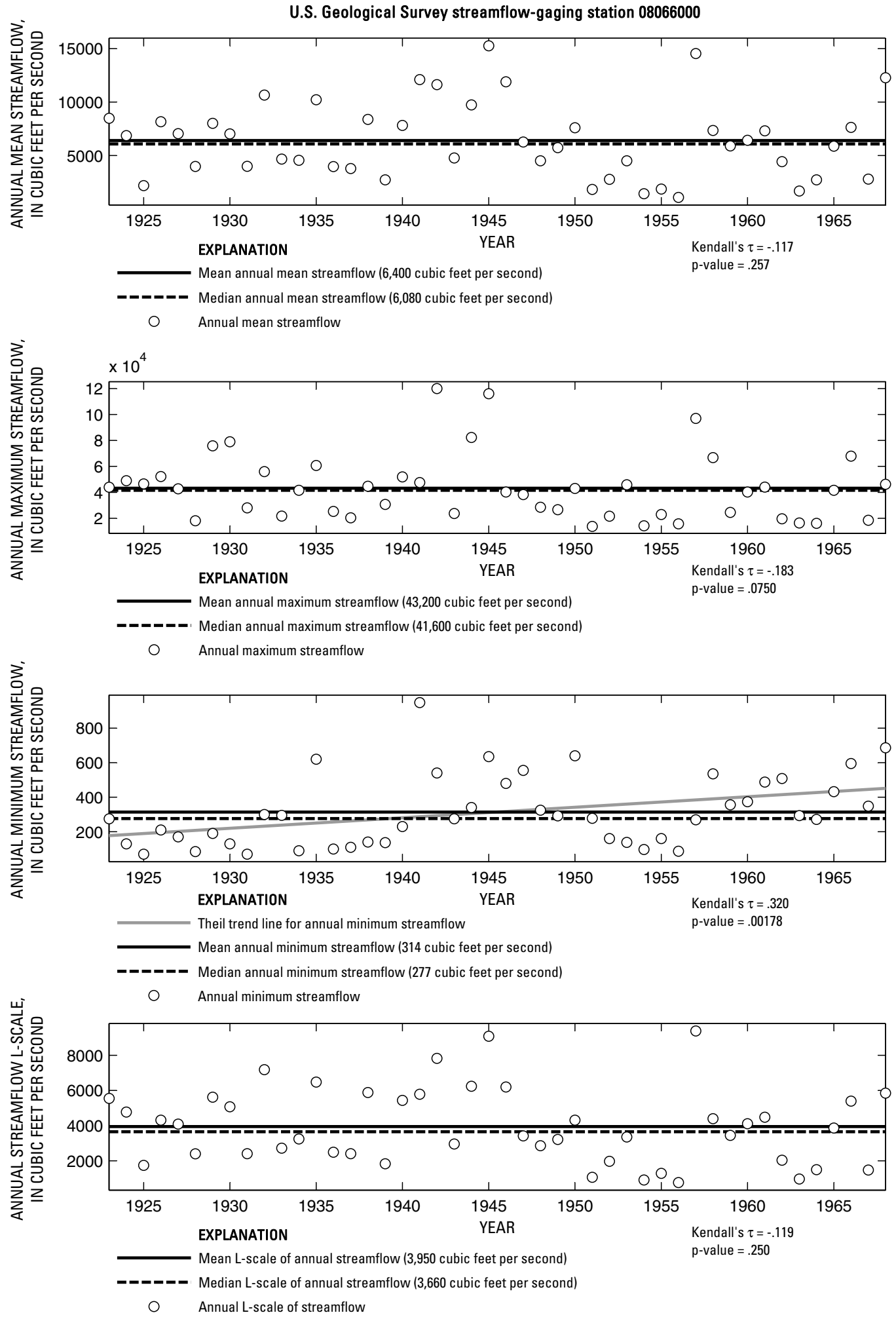

Figure 244. Analysis of annual mean, maximum, minimum, and L-scale statistics of daily mean streamflow for U.S. Geological Survey streamflow-gaging station 08066000 Trinity River at Riverside, Texas.

Index of Station Numbers 719 

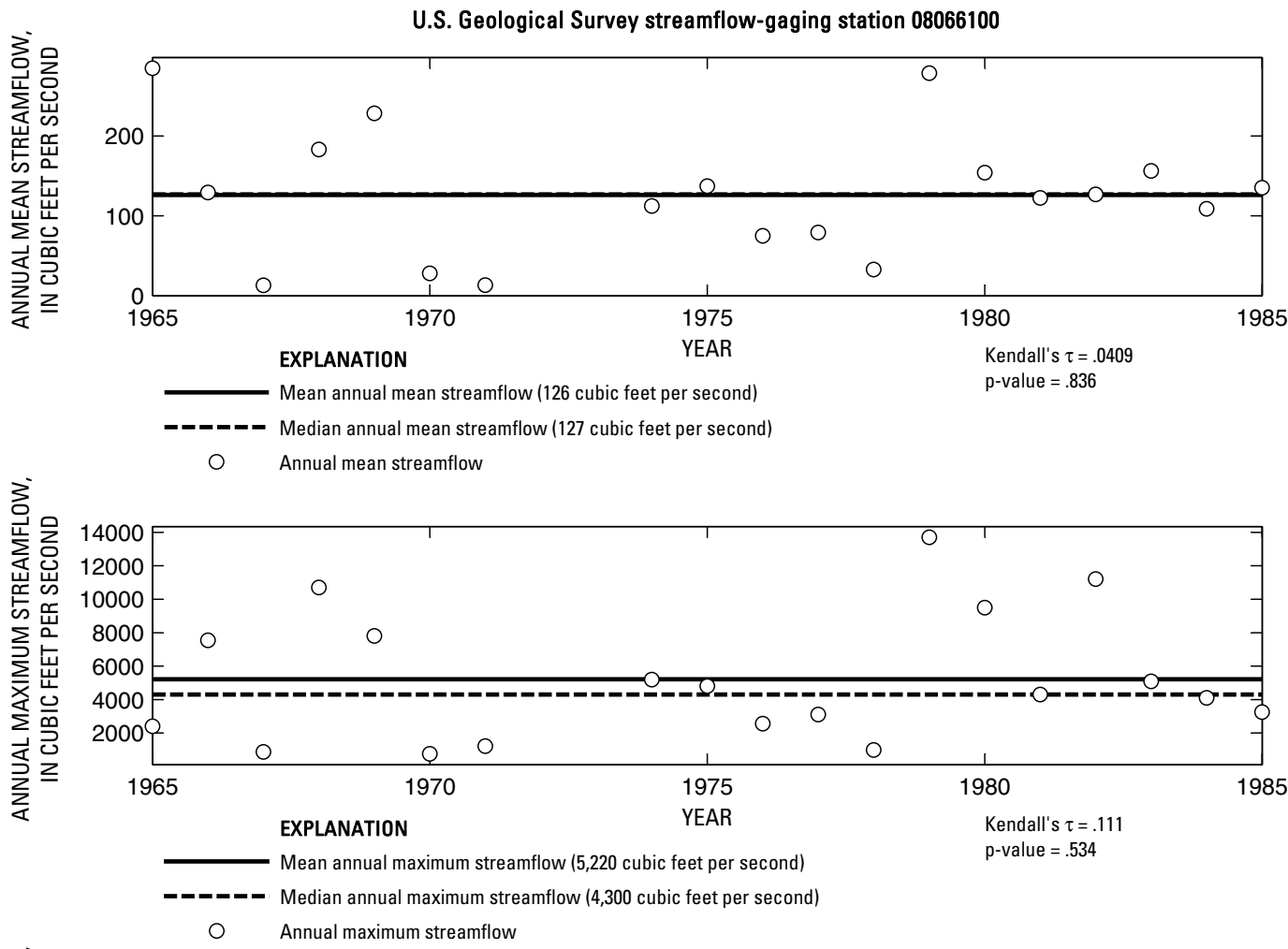

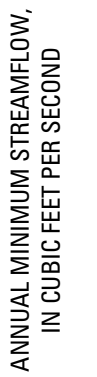

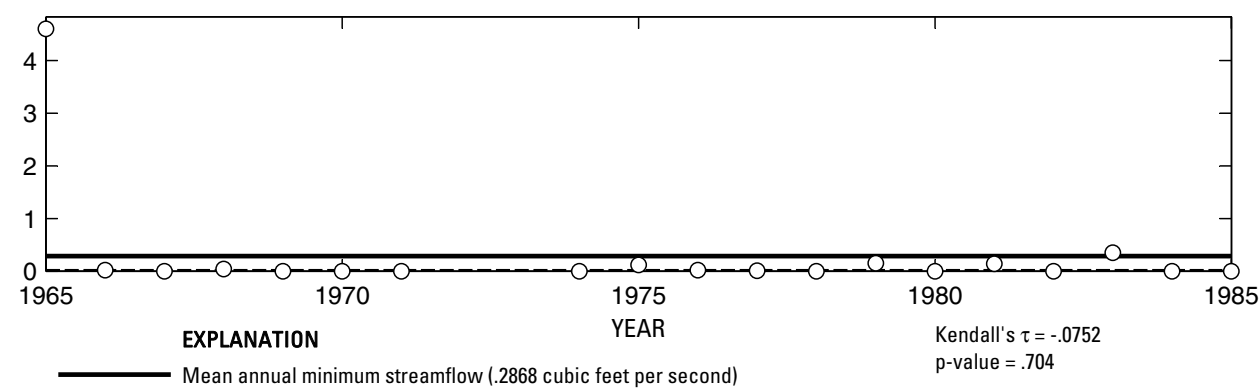

- _- Median annual minimum streamflow (0 cubic feet per second)

O Annual minimum streamflow

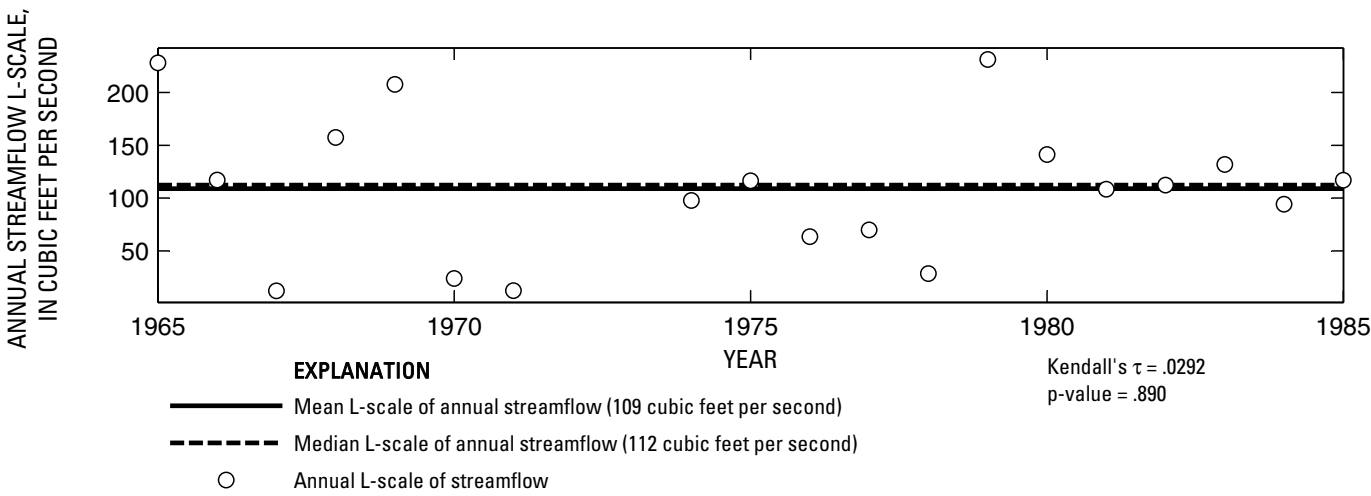

Figure 245. Analysis of annual mean, maximum, minimum, and L-scale statistics of daily mean streamflow for U.S. Geological Survey streamflow-gaging station 08066100 White Rock Creek near Trinity, Texas. 
U.S. Geological Survey streamflow-gaging station 08066170

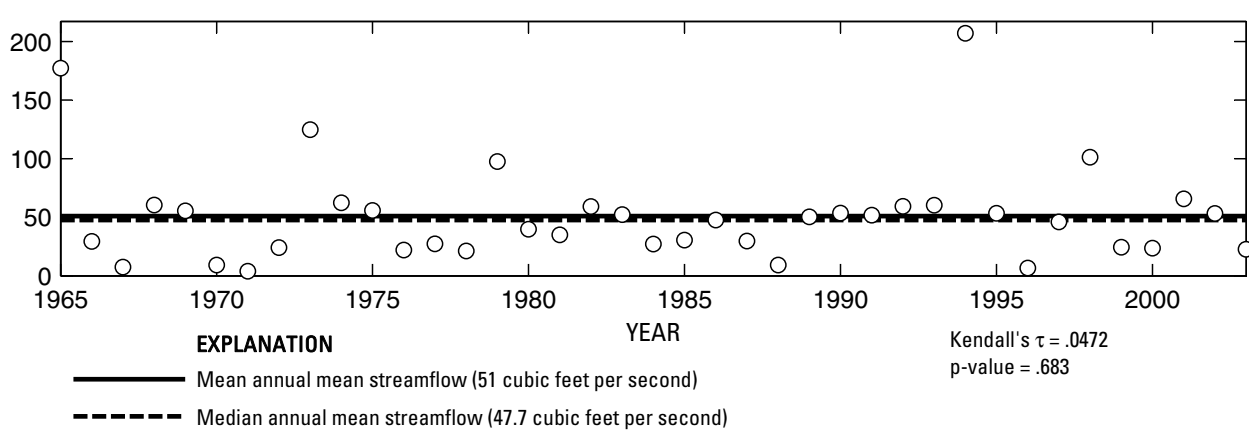

Annual mean streamflow

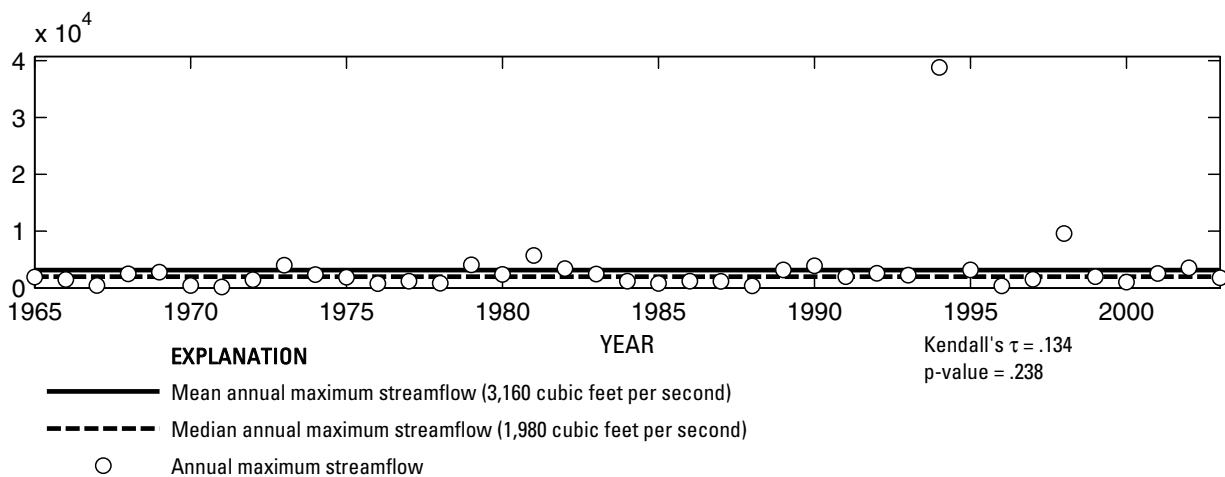

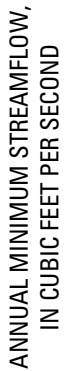

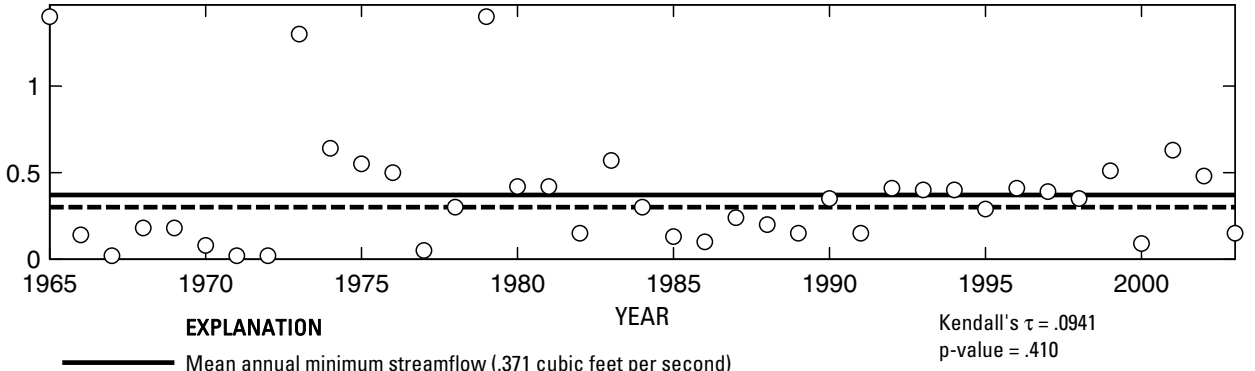

- Median annual minimum streamflow (.3 cubic feet per second)

O Annual minimum streamflow

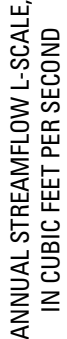

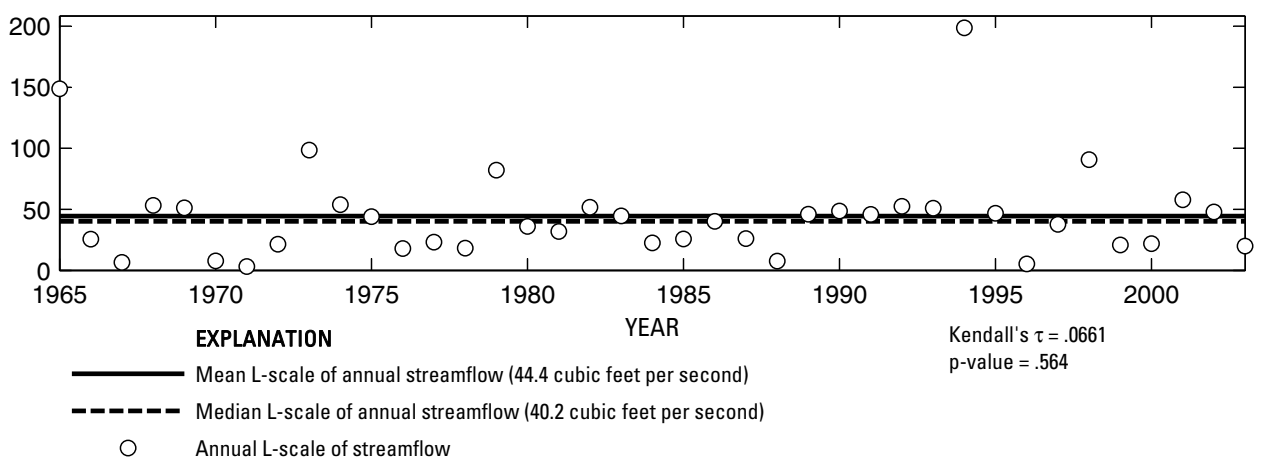

Figure 246. Analysis of annual mean, maximum, minimum, and L-scale statistics of daily mean streamflow for U.S. Geological Survey streamflow-gaging station 08066170 Kickapoo Creek near Onalaska, Texas.

Index of Station Numbers 719 

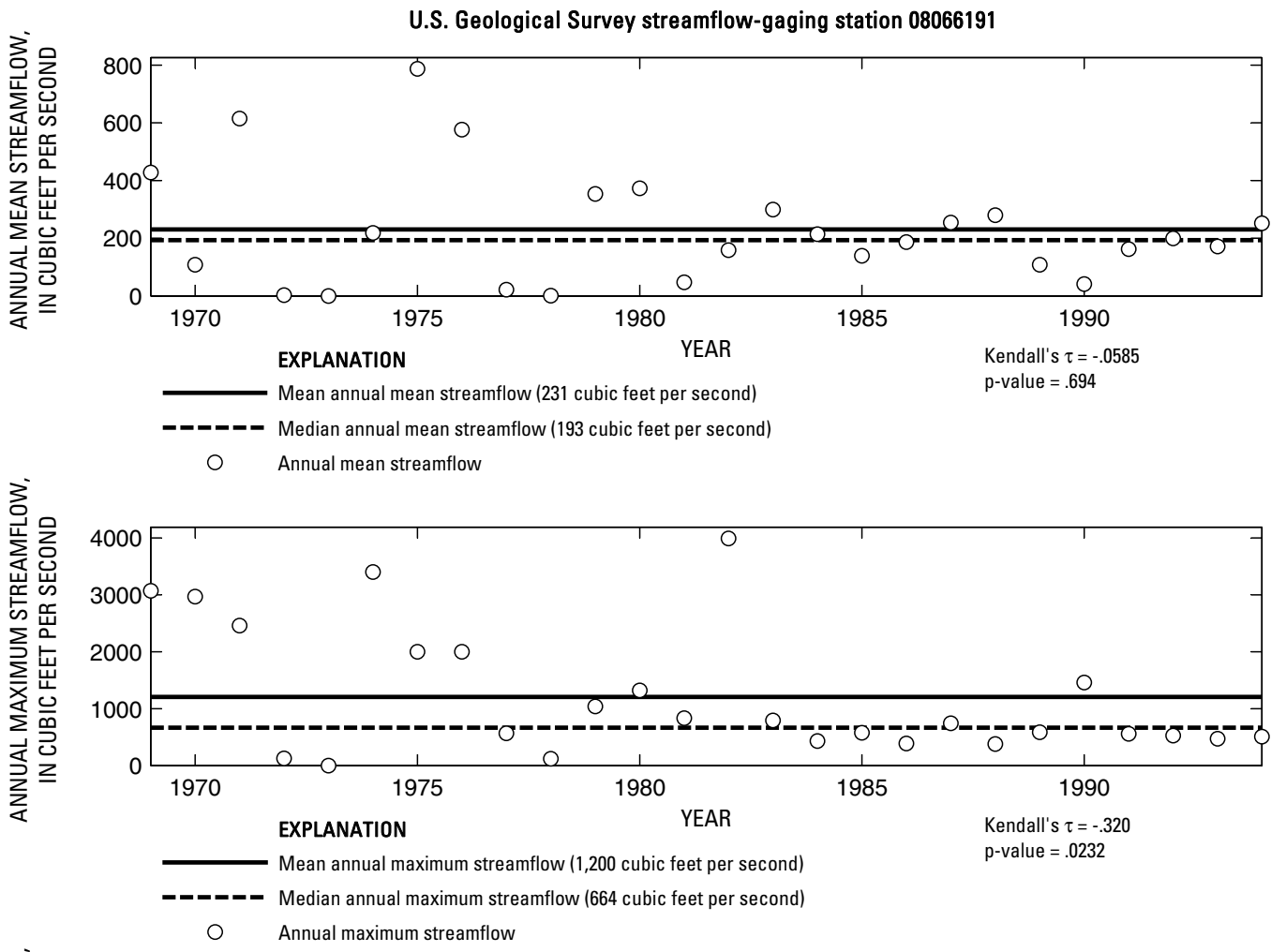

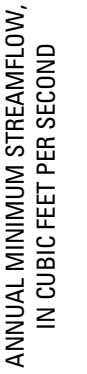

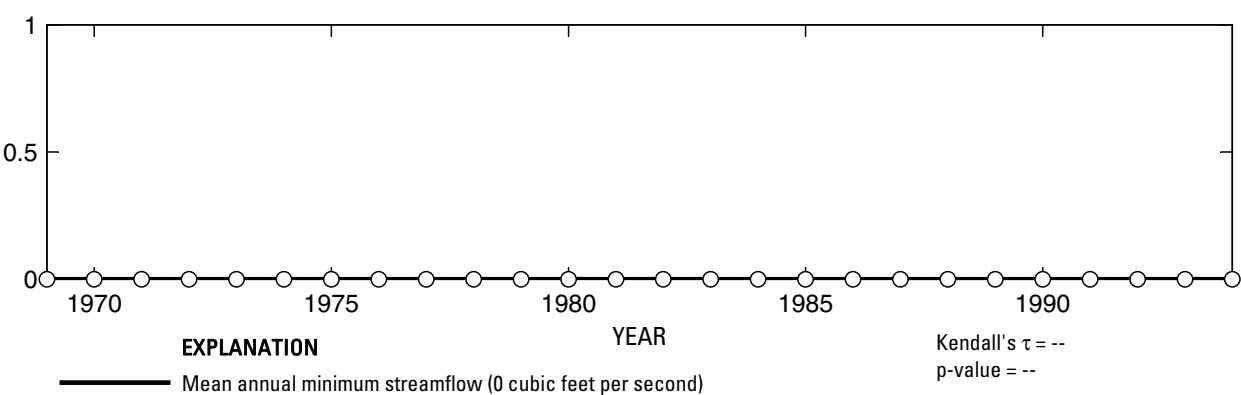

-_-_-_ Median annual minimum streamflow (0 cubic feet per second)

O Annual minimum streamflow

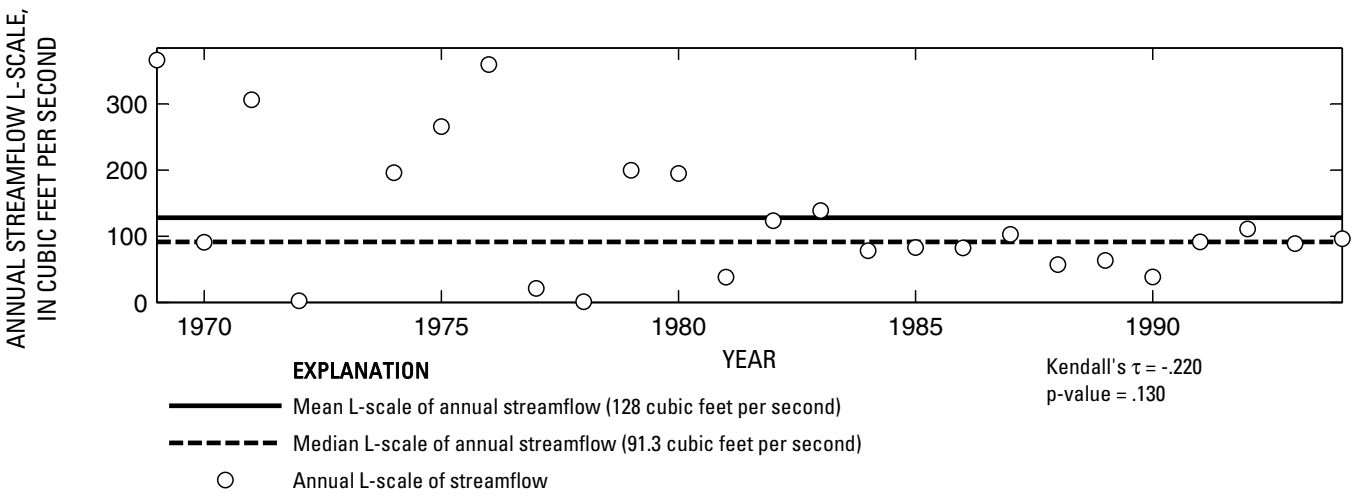

Figure 247. Analysis of annual mean, maximum, minimum, and L-scale statistics of daily mean streamflow for U.S. Geological Survey streamflow-gaging station 08066191 Livingston Reservoir Outflow Weir near Goodrich, Texas. 


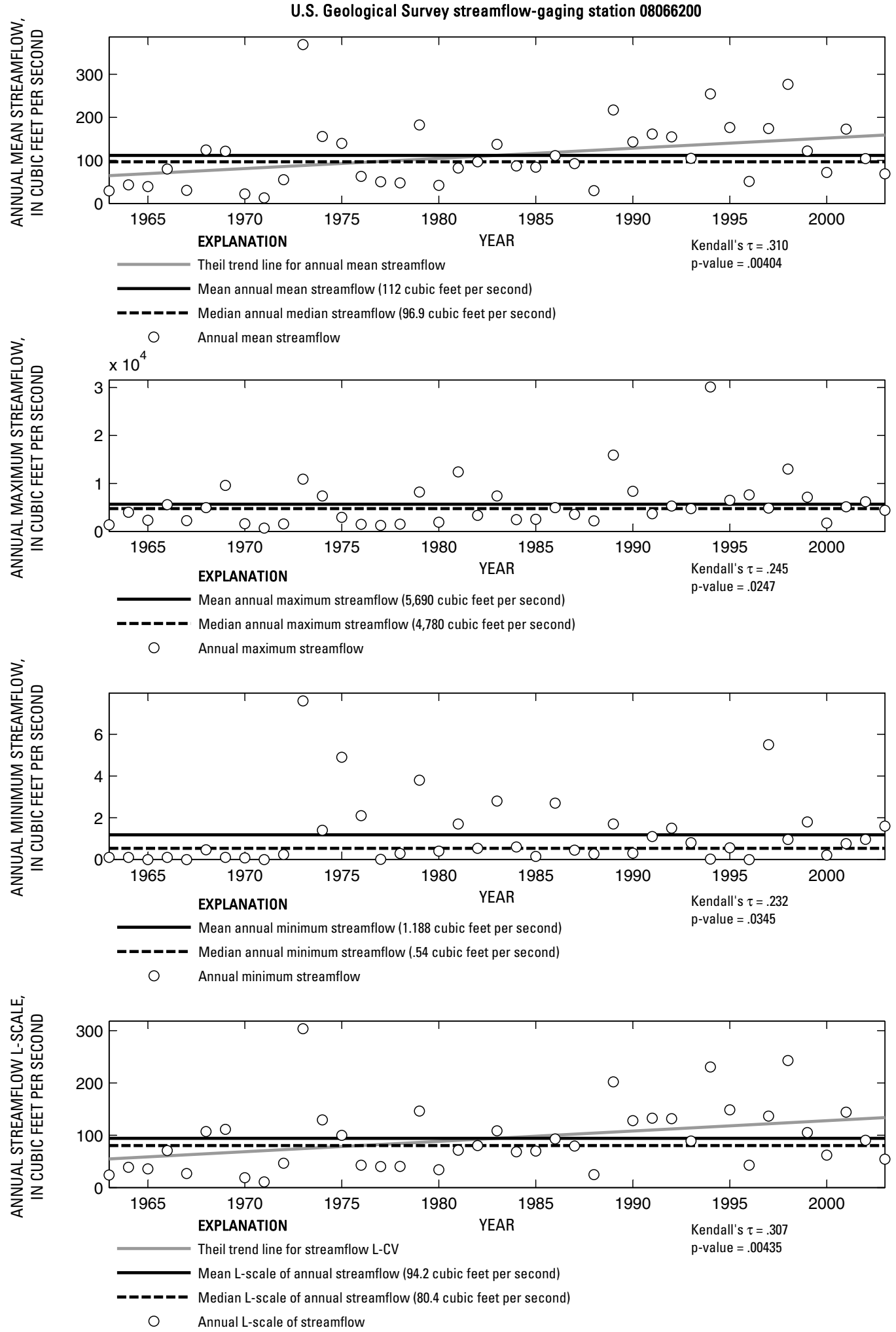

Figure 248. Analysis of annual mean, maximum, minimum, and L-scale statistics of daily mean streamflow for U.S. Geological Survey streamflow-gaging station 08066200 Long King Creek at Livingston, Texas.

Index of Station Numbers 719 


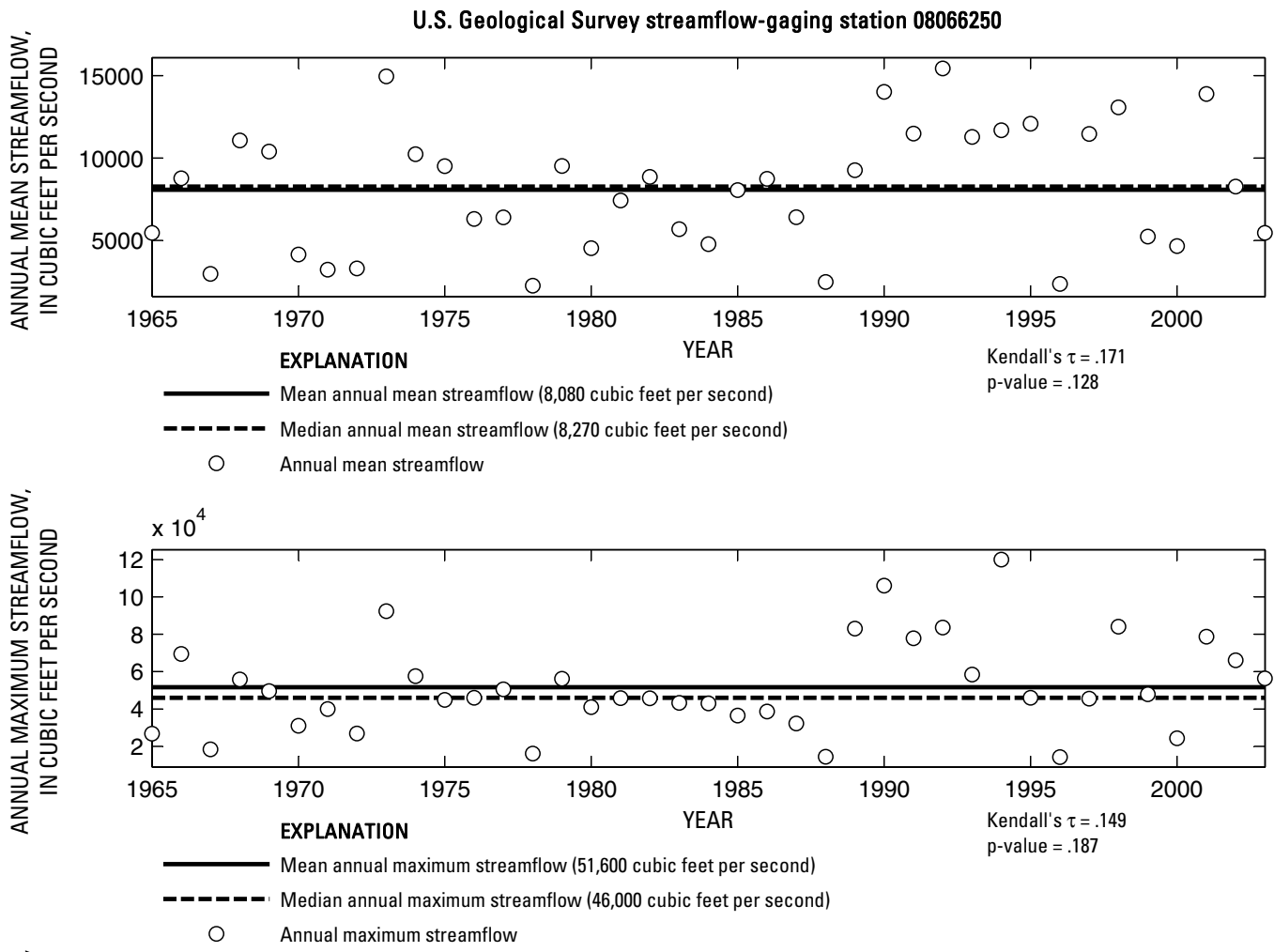

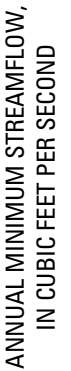

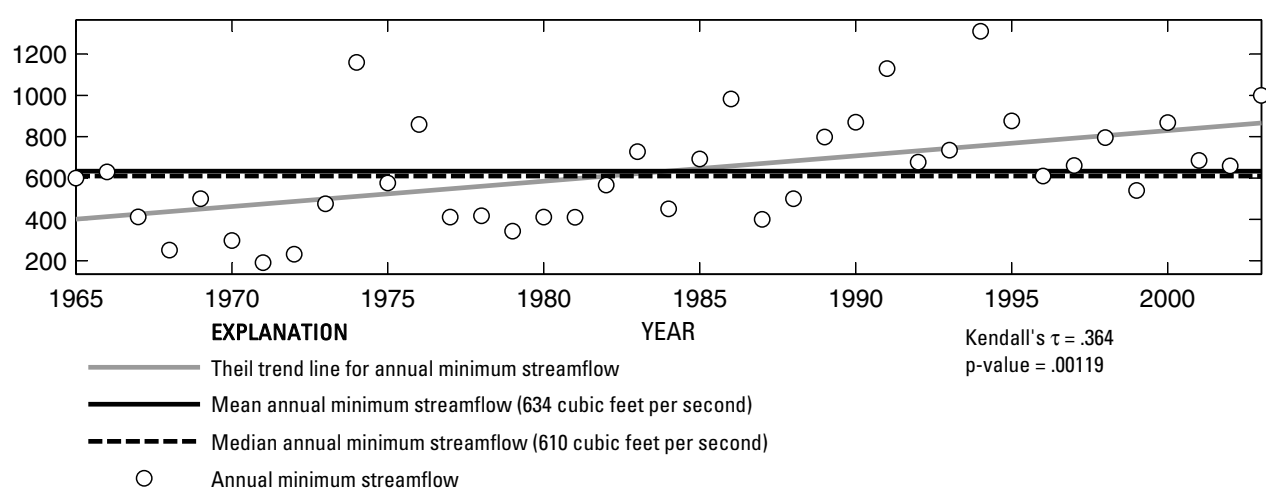

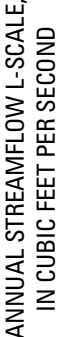

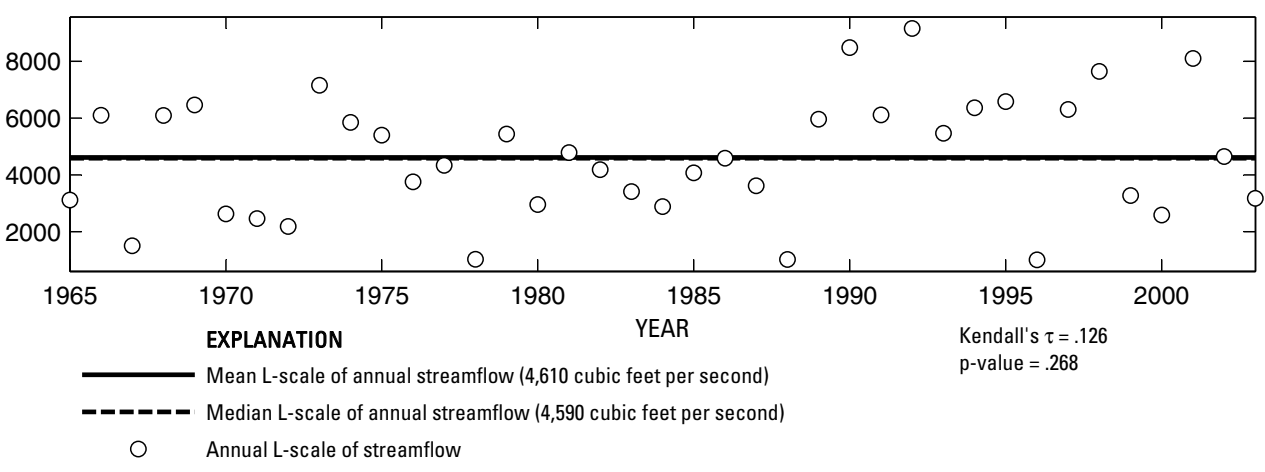

Figure 249. Analysis of annual mean, maximum, minimum, and L-scale statistics of daily mean streamflow for U.S. Geological Survey streamflow-gaging station 08066250 Trinity River near Goodrich, Texas. 
U.S. Geological Survey streamflow-gaging station 08066300

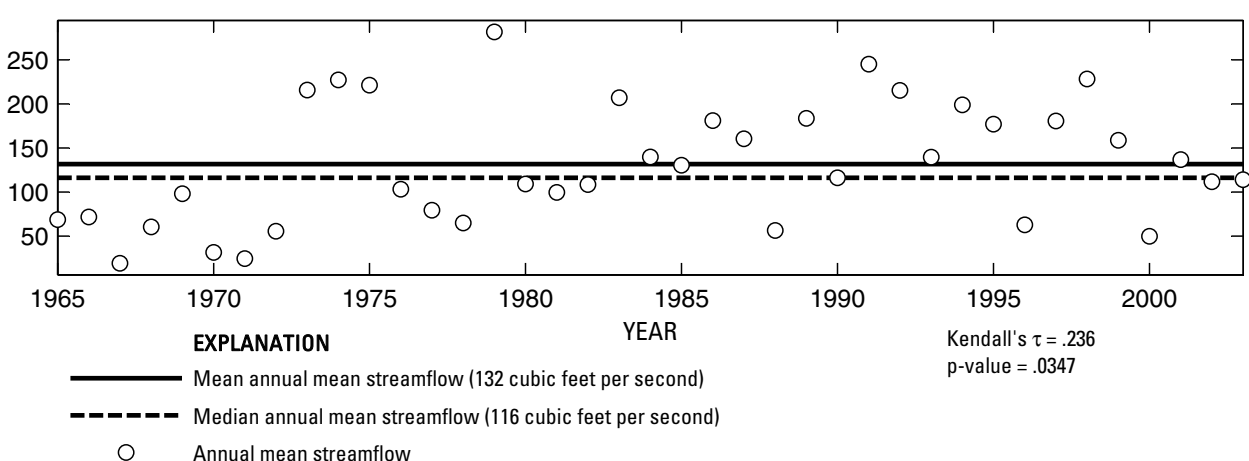

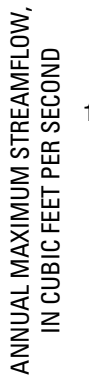

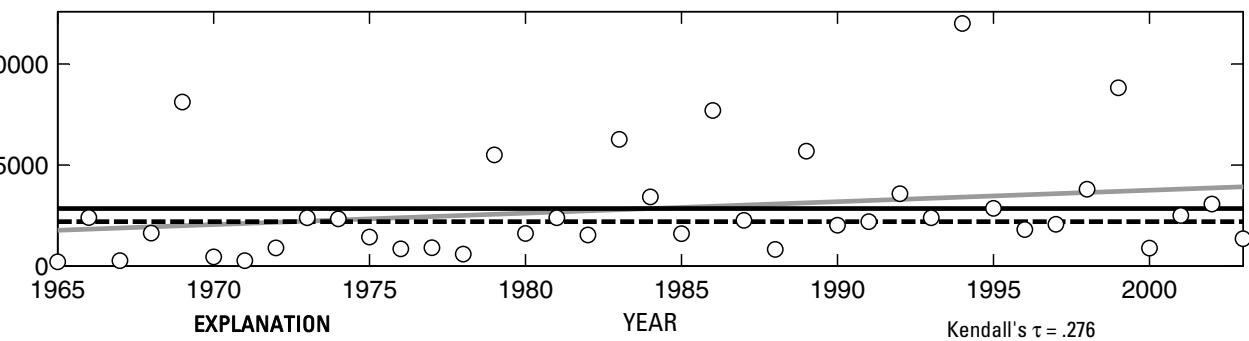

Theil trend line for annual maximum streamflow

p-value $=.01$

Mean annual maximum streamflow (2,840 cubic feet per second)

- ח - Median annual maximum streamflow (2,190 cubic feet per second)

$\bigcirc \quad$ Annual maximum streamflow
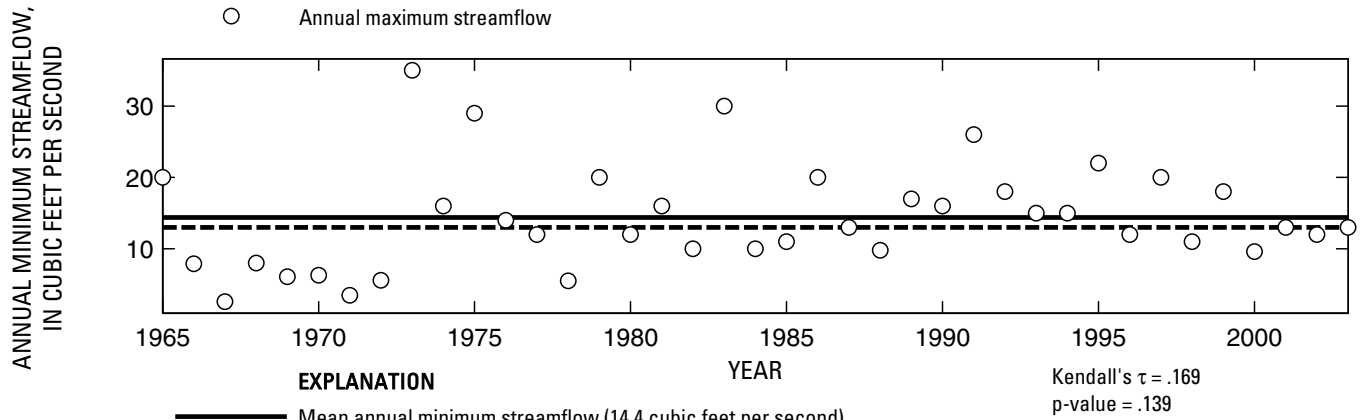

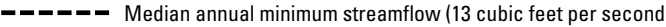

O Annual minimum streamflow

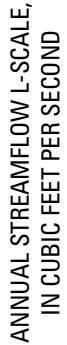

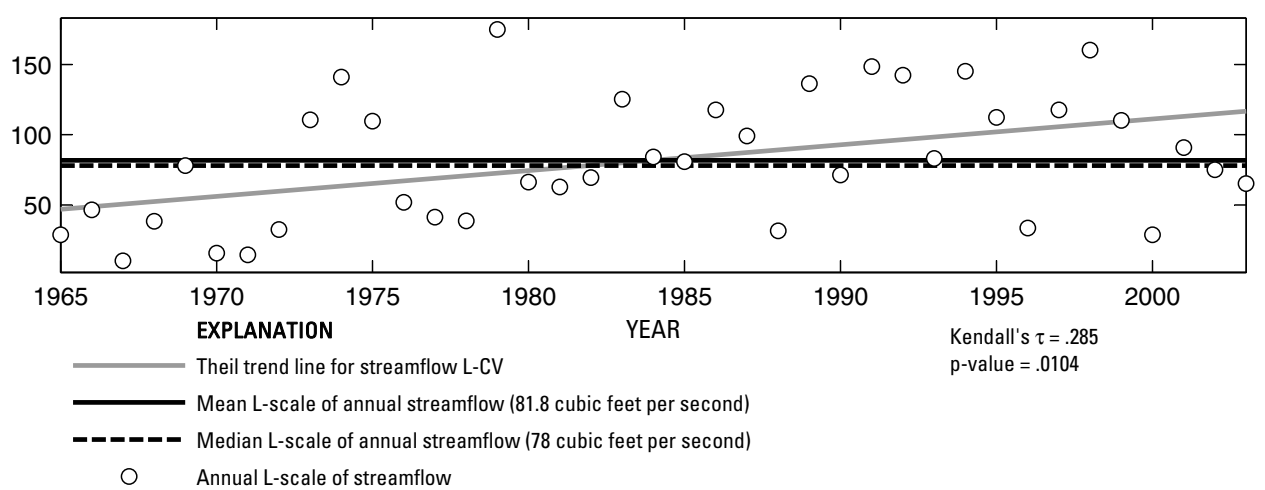

Figure 250. Analysis of annual mean, maximum, minimum, and L-scale statistics of daily mean streamflow for U.S. Geological Survey streamflow-gaging station 08066300 Menard Creek near Rye, Texas.

Index of Station Numbers 719 

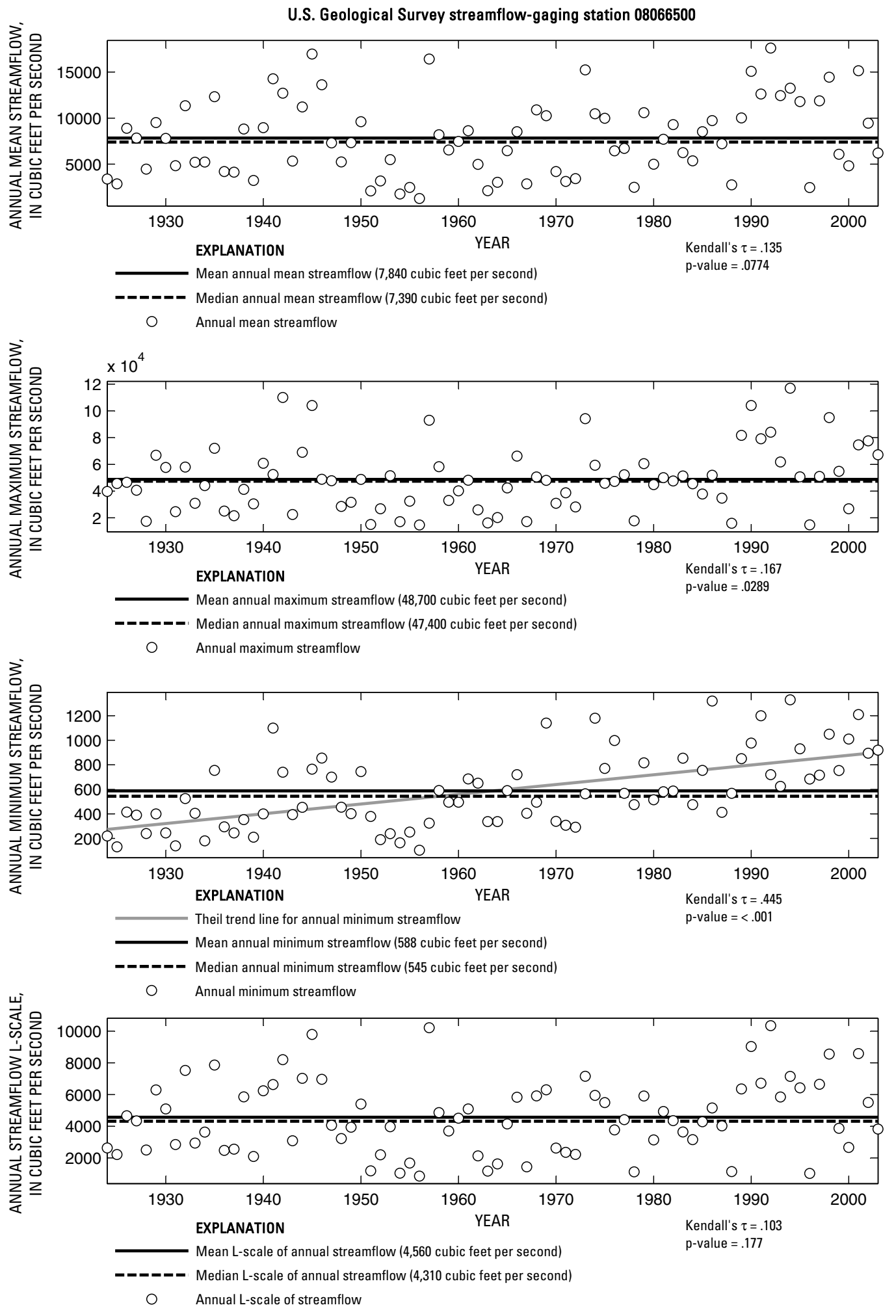

Figure 251. Analysis of annual mean, maximum, minimum, and L-scale statistics of daily mean streamflow for U.S. Geological Survey streamflow-gaging station 08066500 Trinity River at Romayor, Texas. 


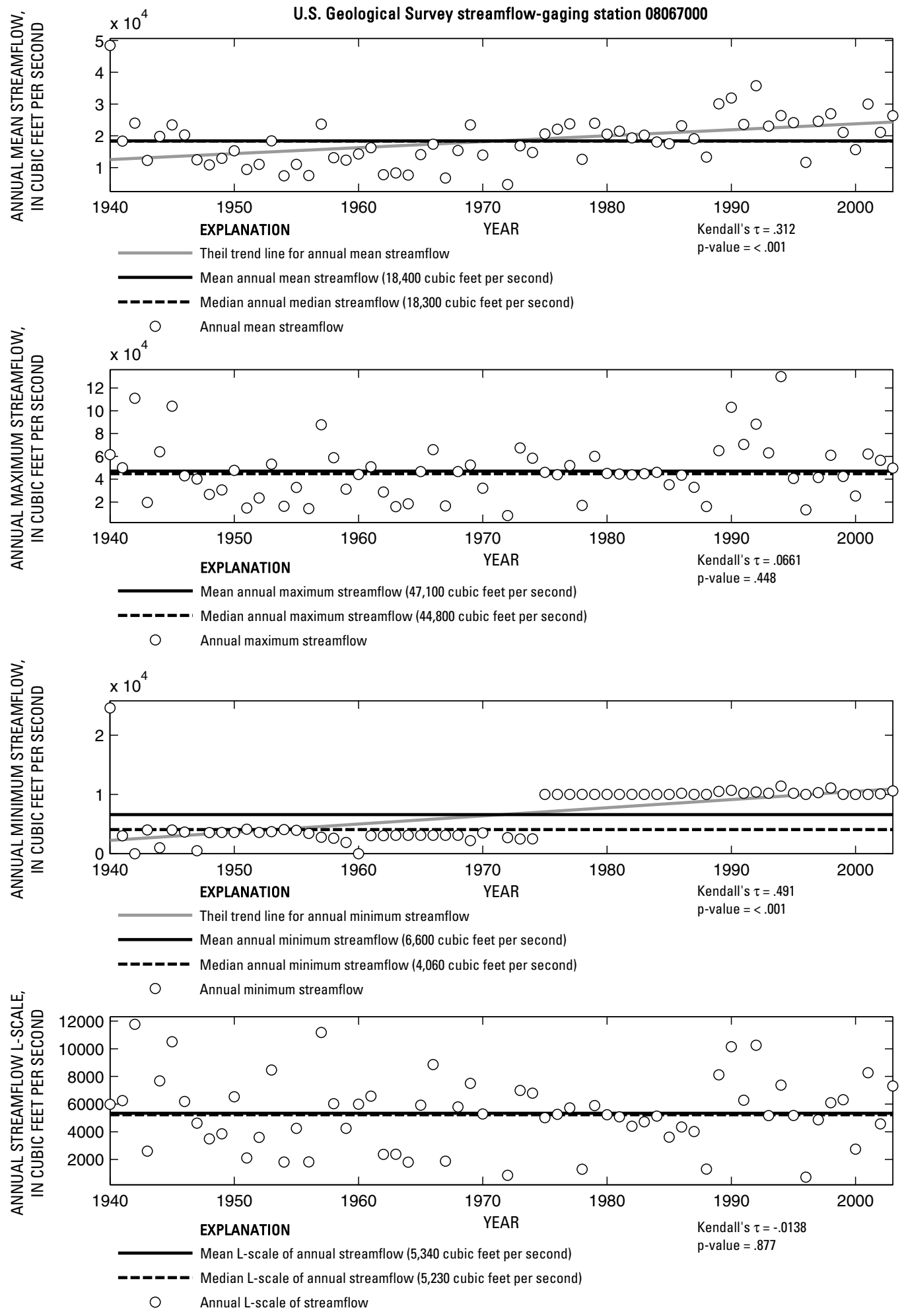

Figure 252. Analysis of annual mean, maximum, minimum, and L-scale statistics of daily mean streamflow for U.S. Geological Survey streamflow-gaging station 08067000 Trinity River at Liberty, Texas.

Index of Station Numbers 719 


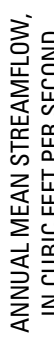

U.S. Geological Survey streamflow-gaging station 08067500

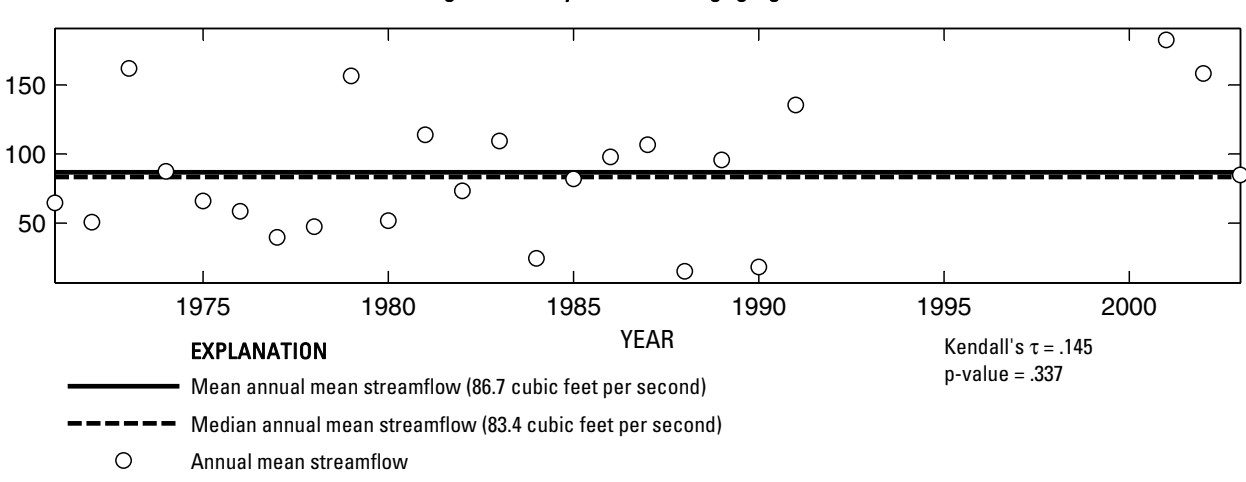

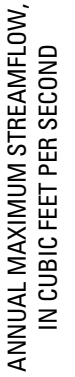

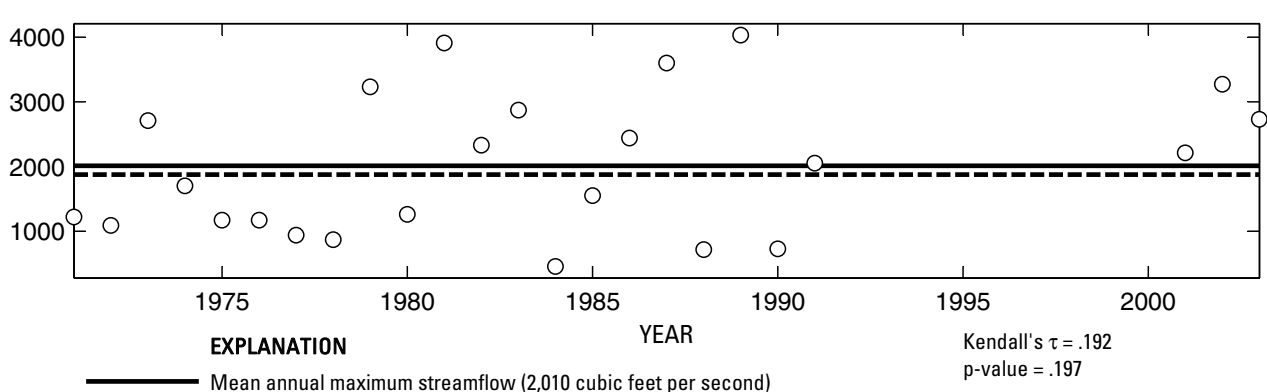

O Annual maximum streamflow

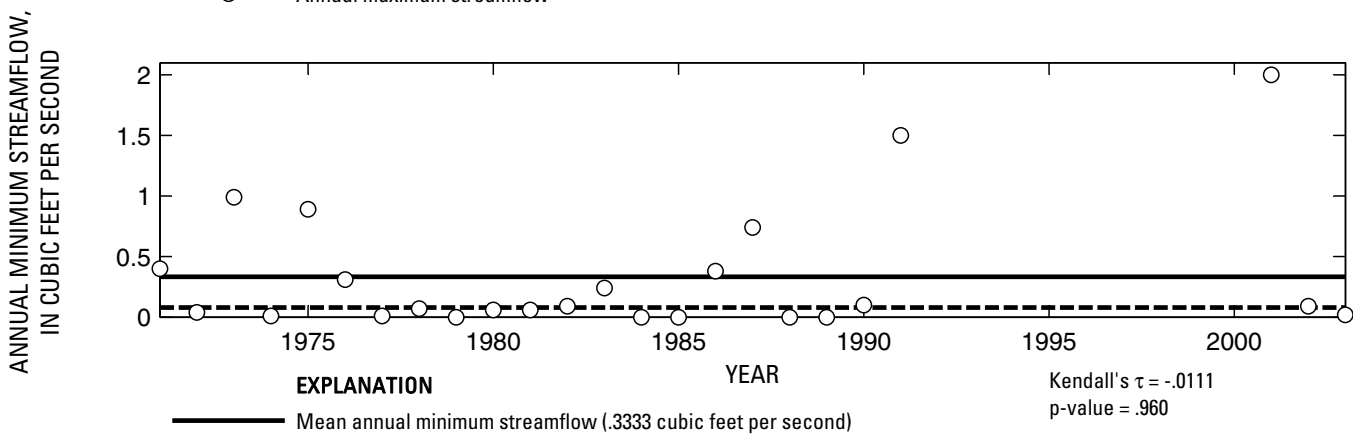

- - - Median annual minimum streamflow (.08 cubic feet per second)

O Annual minimum streamflow

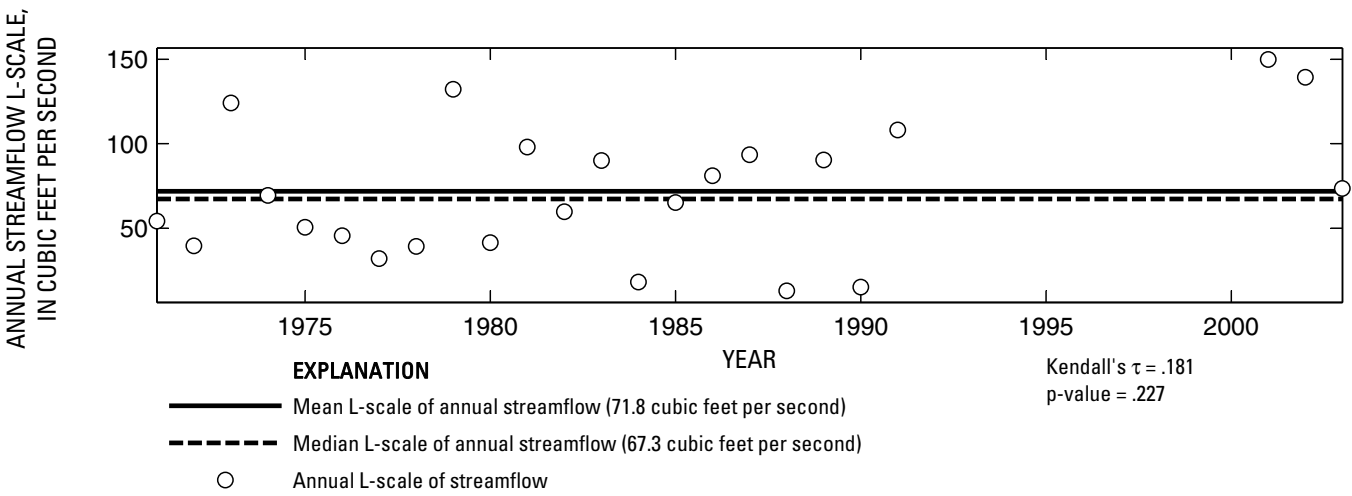

Figure 253. Analysis of annual mean, maximum, minimum, and L-scale statistics of daily mean streamflow for U.S. Geological Survey streamflow-gaging station 08067500 Cedar Bayou near Crosby, Texas. 
U.S. Geological Survey streamflow-gaging station 08067525

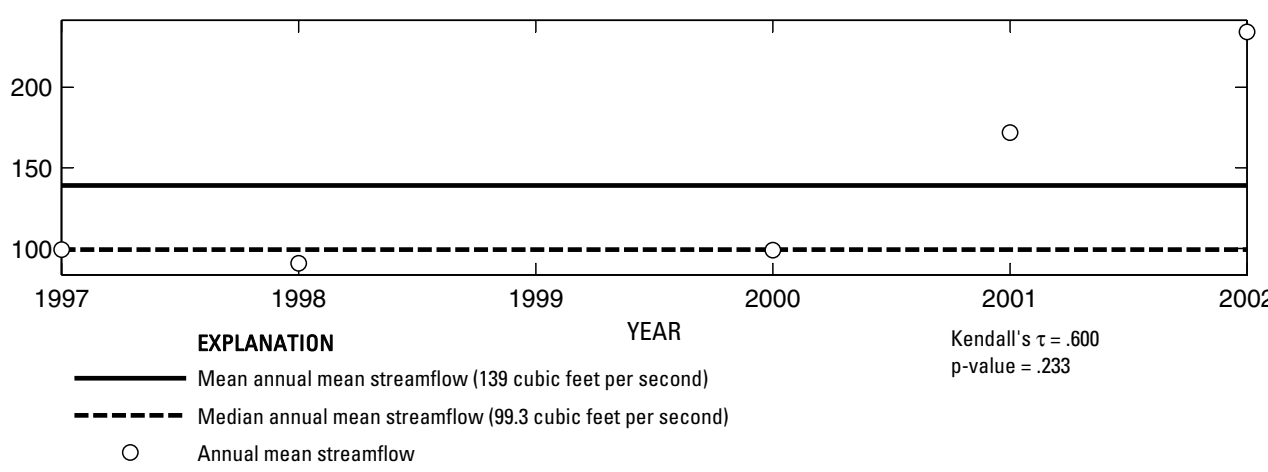

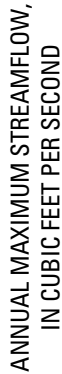

1500
1000
500

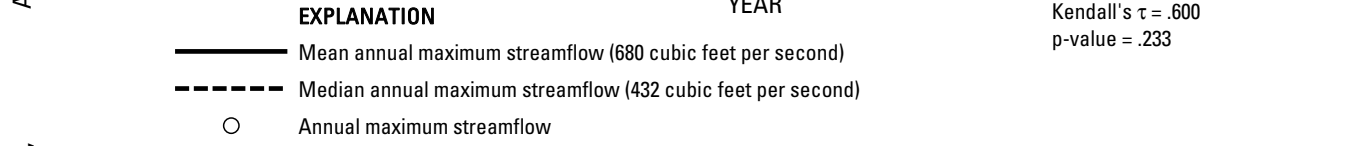

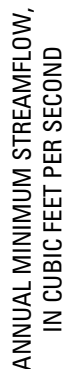

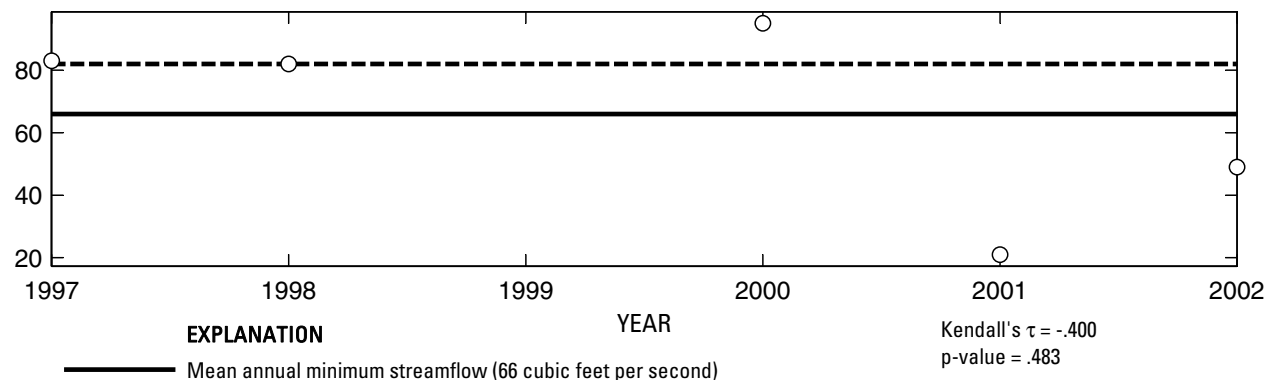

- Median annual minimum streamflow (82 cubic feet per second)

O Annual minimum streamflow

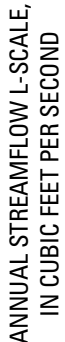

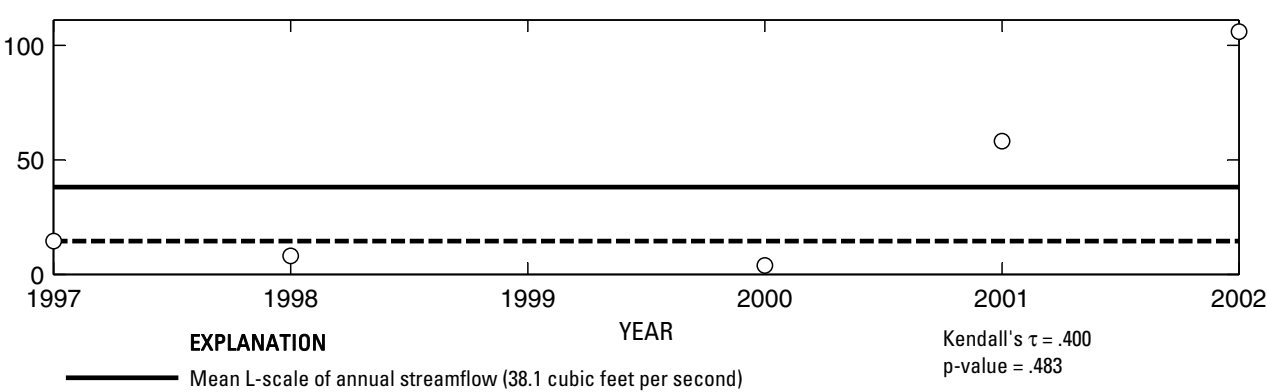

- - - Median L-scale of annual streamflow (14.5 cubic feet per second)

Annual L-scale of streamflow

Figure 254. Analysis of annual mean, maximum, minimum, and L-scale statistics of daily mean streamflow for U.S. Geological Survey streamflow-gaging station 08067525 Goose Creek at Baytown, Texas.

Index of Station Numbers 719 


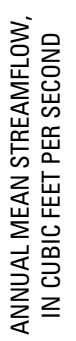

U.S. Geological Survey streamflow-gaging station 08067610

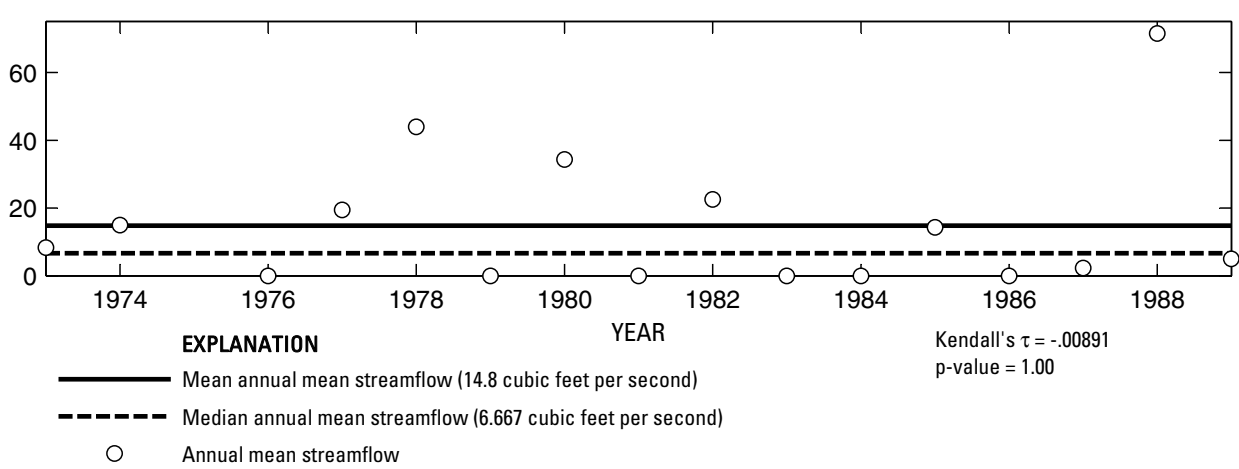

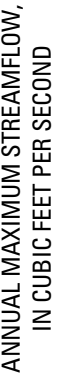

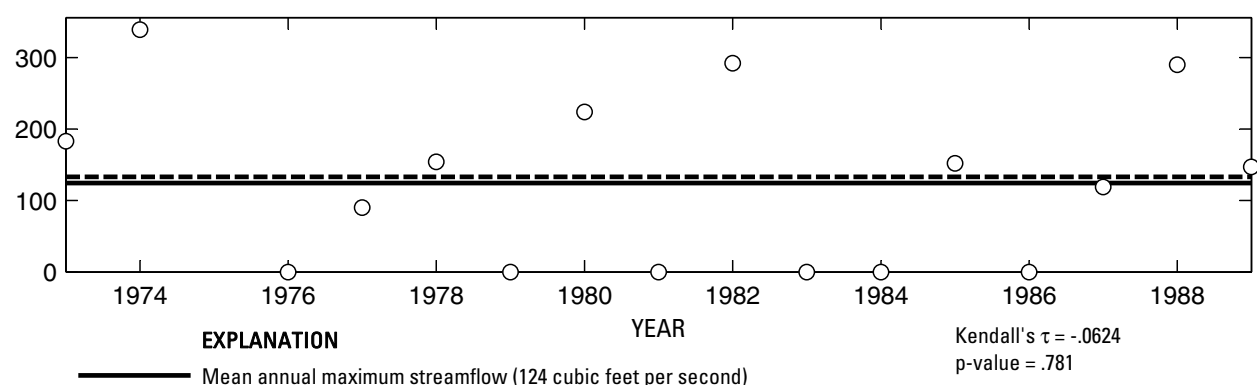

- - ב Median annual maximum streamflow (133 cubic feet per second)

Annual maximum streamflow

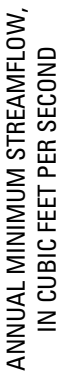

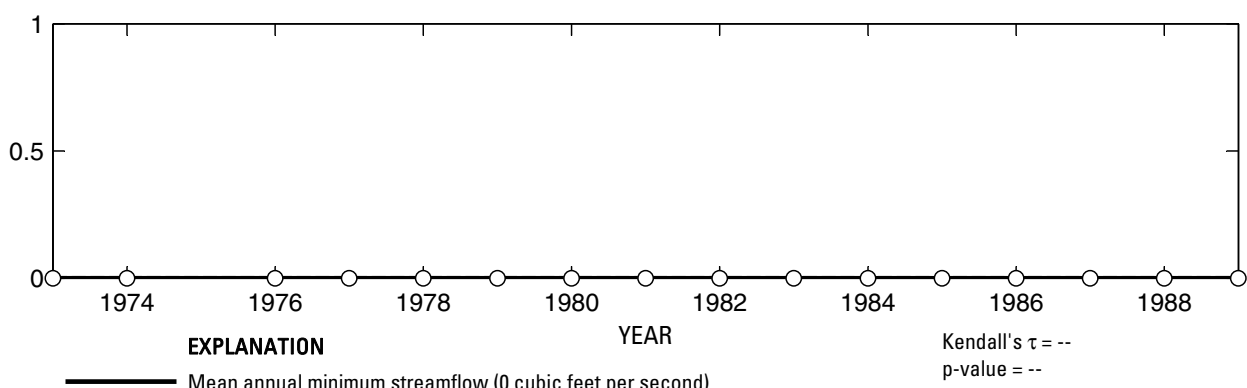

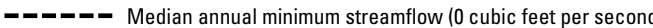

○ Annual minimum streamflow

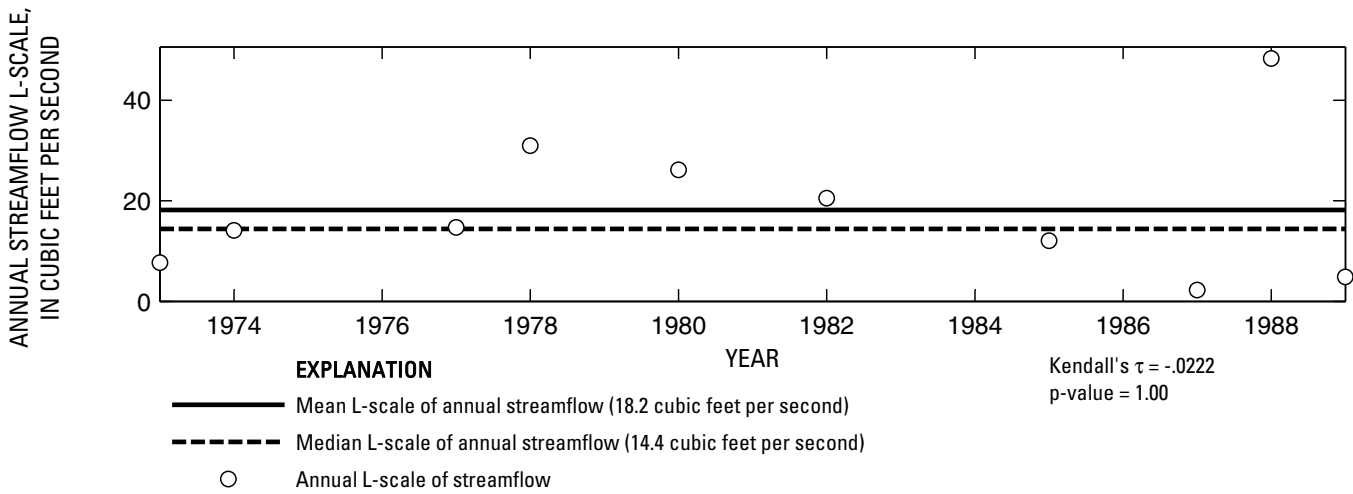

Figure 255. Analysis of annual mean, maximum, minimum, and L-scale statistics of daily mean streamflow for U.S. Geological Survey streamflow-gaging station 08067610 Lake Conroe Outflow Weir near Conroe, Texas.

Index of Station Numbers 719 


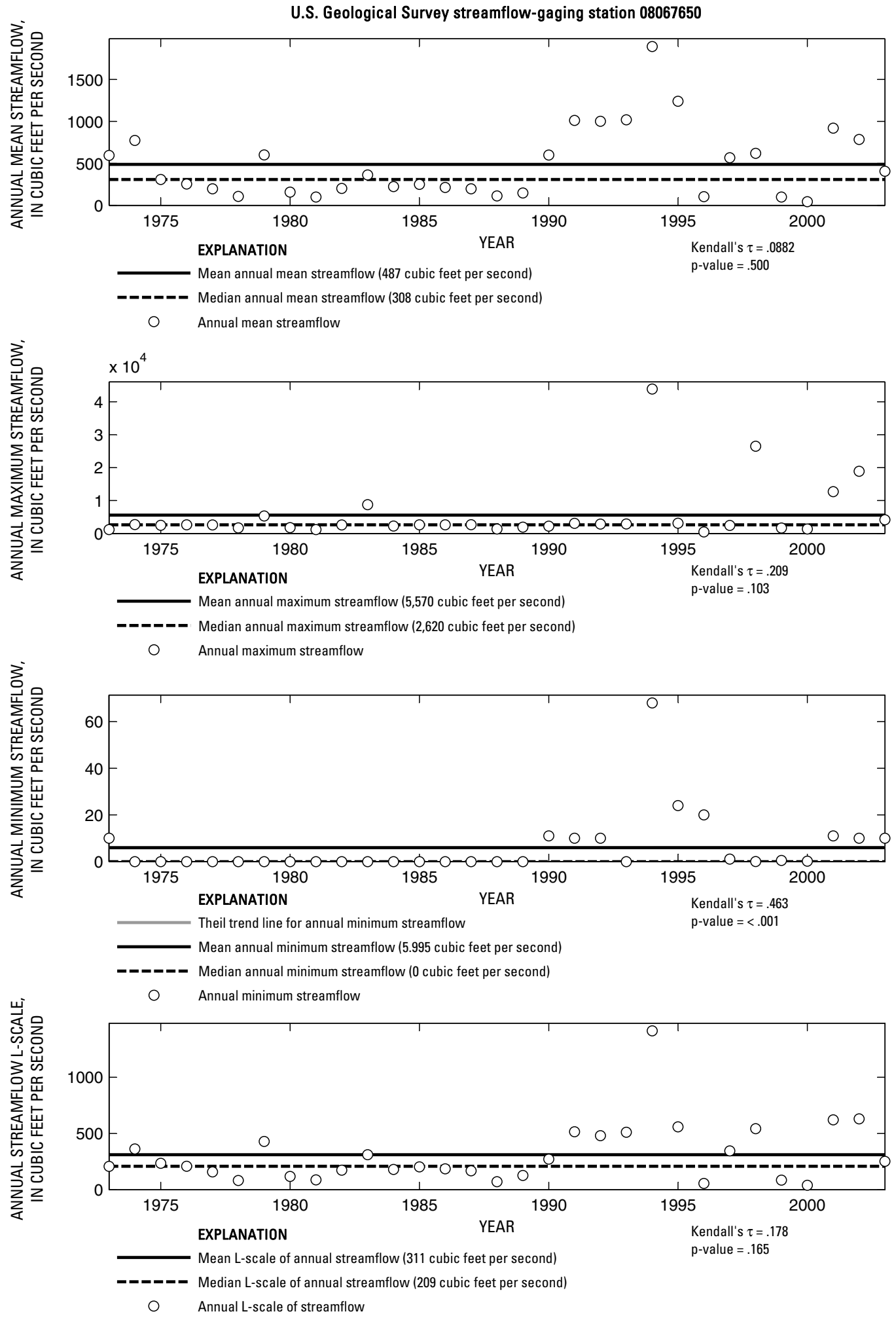

Figure 256. Analysis of annual mean, maximum, minimum, and L-scale statistics of daily mean streamflow for U.S. Geological Survey streamflow-gaging station 08067650 West Fork San Jacinto River below Lake Conroe near Conroe, Texas. 


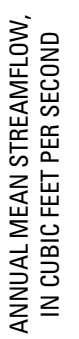

U.S. Geological Survey streamflow-gaging station 08067700

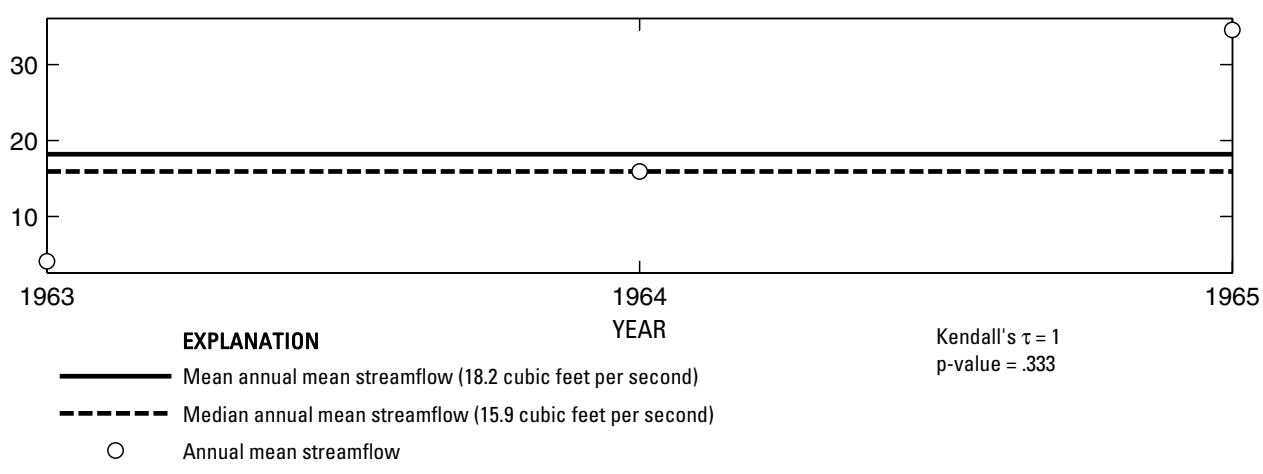

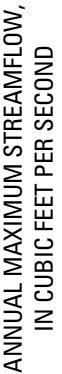

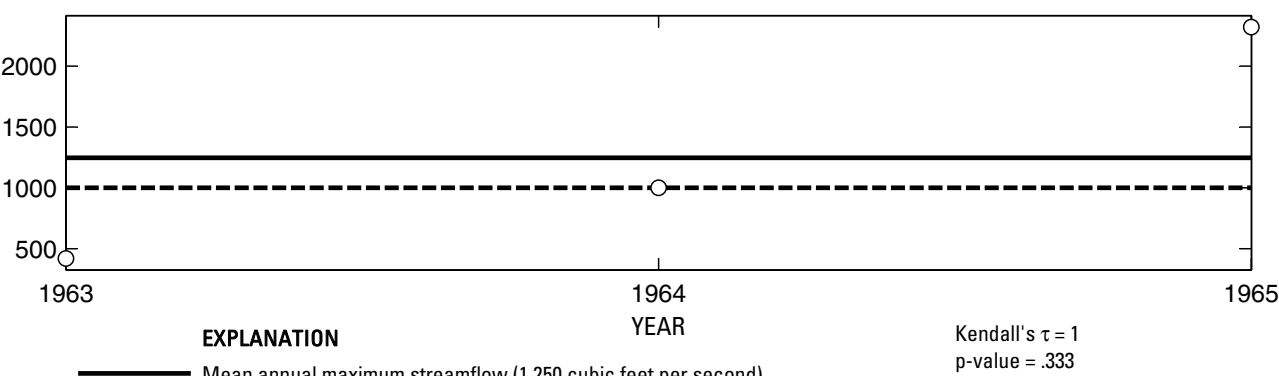

- _ _ _ - Median annual maximum streamflow (1,000 cubic feet per second

Annual maximum streamflow
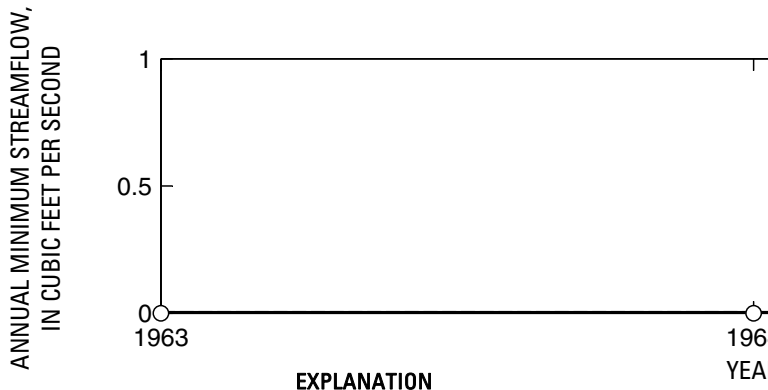

$$
\begin{array}{cl}
\text { Mean annual minimum streamflow ( } 0 \text { cubic feet per second) } \\
\text { Annual minimum streamflow }
\end{array}
$$

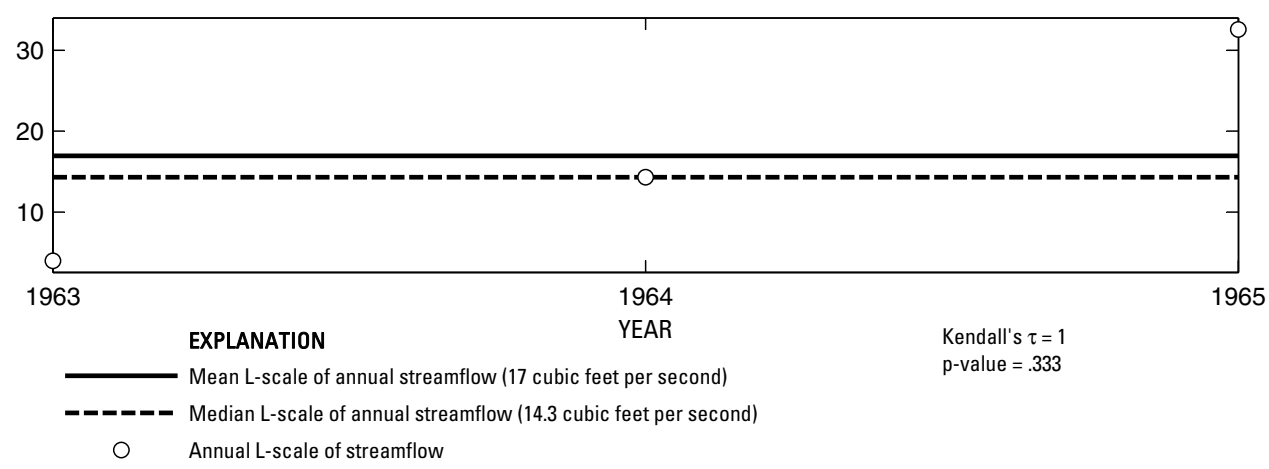

Figure 257. Analysis of annual mean, maximum, minimum, and L-scale statistics of daily mean streamflow for U.S. Geological Survey streamflow-gaging station 08067700 Caney Creek near Dobbin, Texas. 


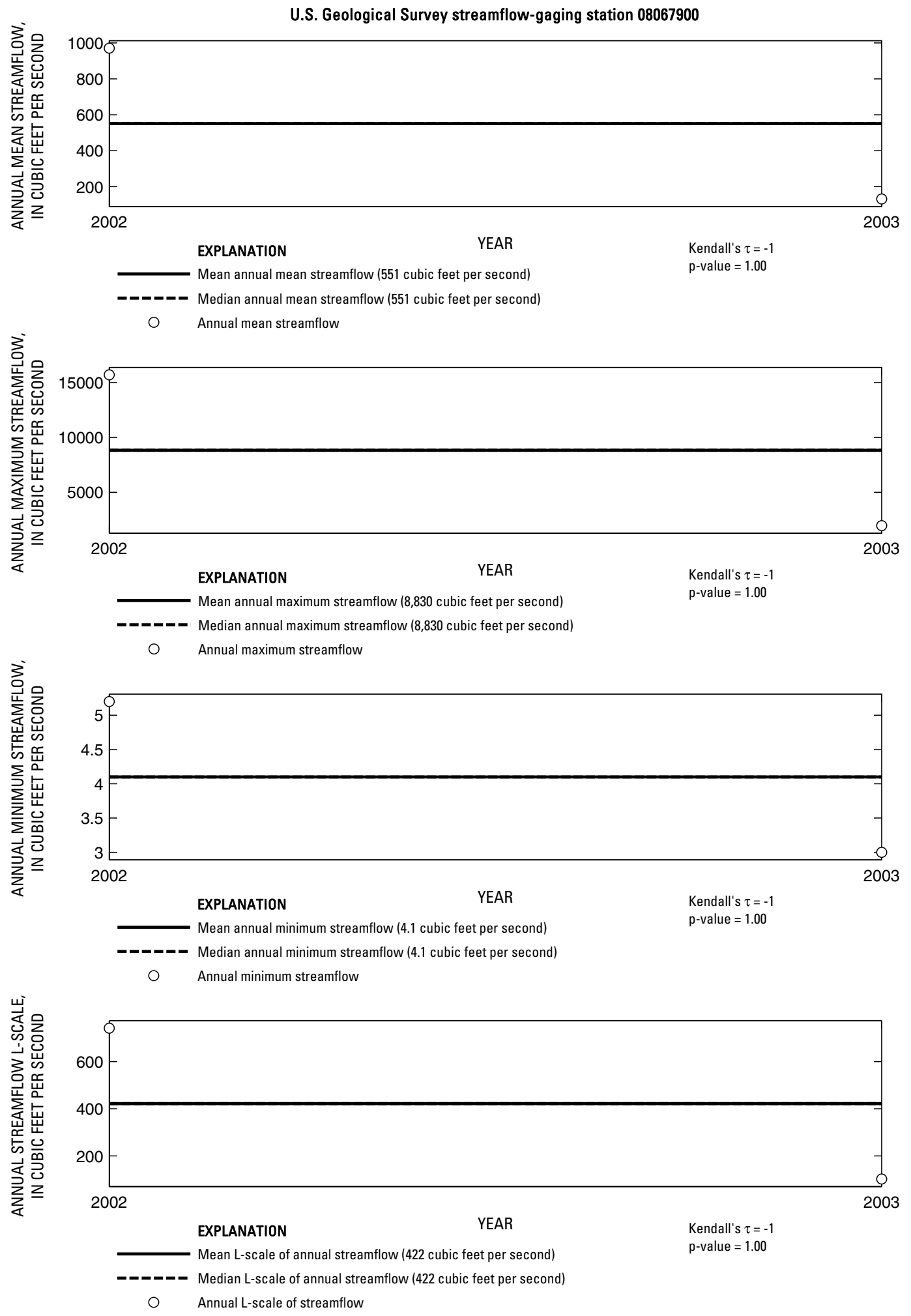

Figure 258. Analysis of annual mean, maximum, minimum, and L-scale statistics of daily mean streamflow for U.S. Geological Survey streamflow-gaging station 08067900 Lake Creek near Conroe, Texas. 

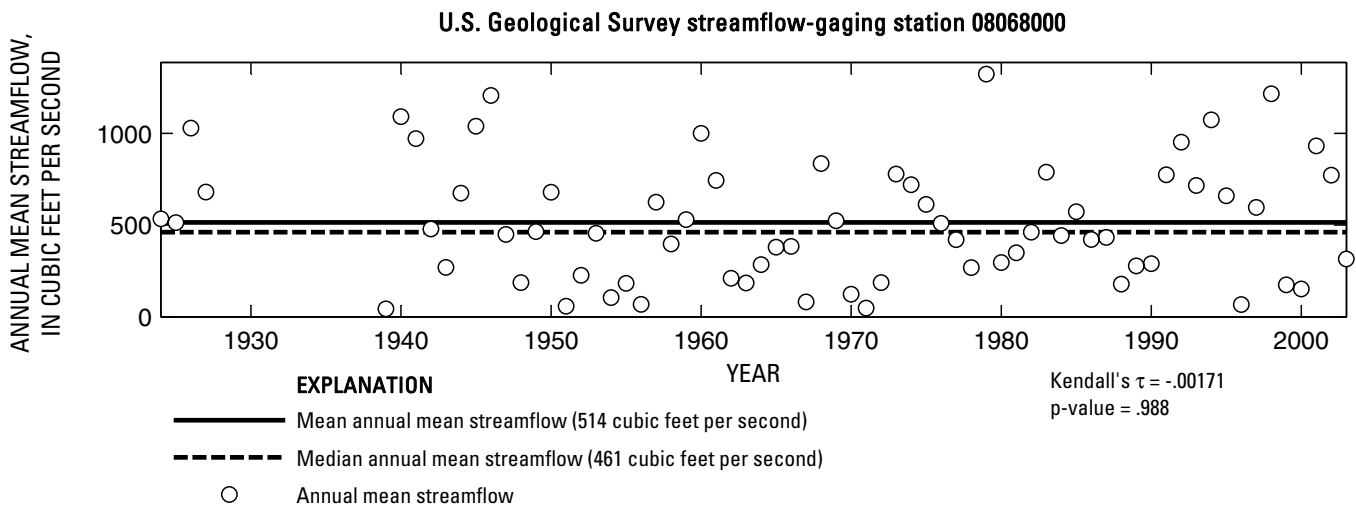

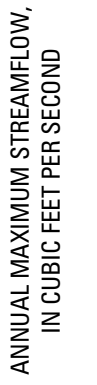

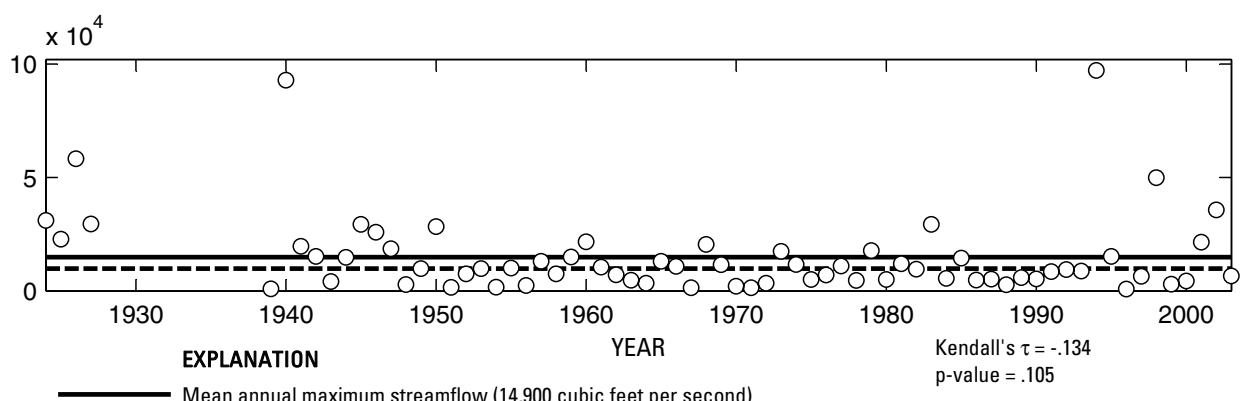

- _ _ - Median annual maximum streamflow (9,900 cubic feet per second

O Annual maximum streamflow
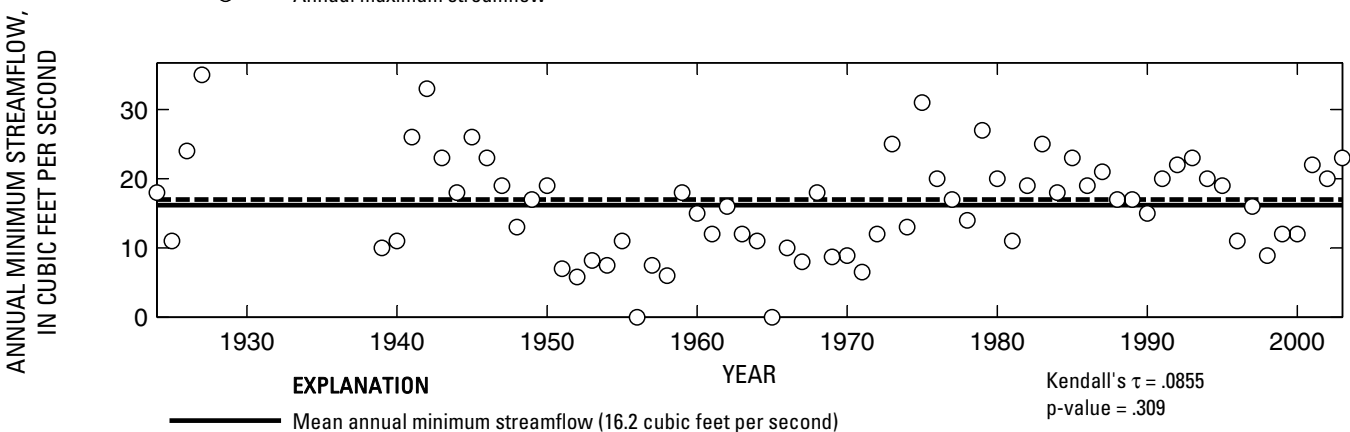

-_-_- Median annual minimum streamflow (17 cubic feet per second)

○ Annual minimum streamflow

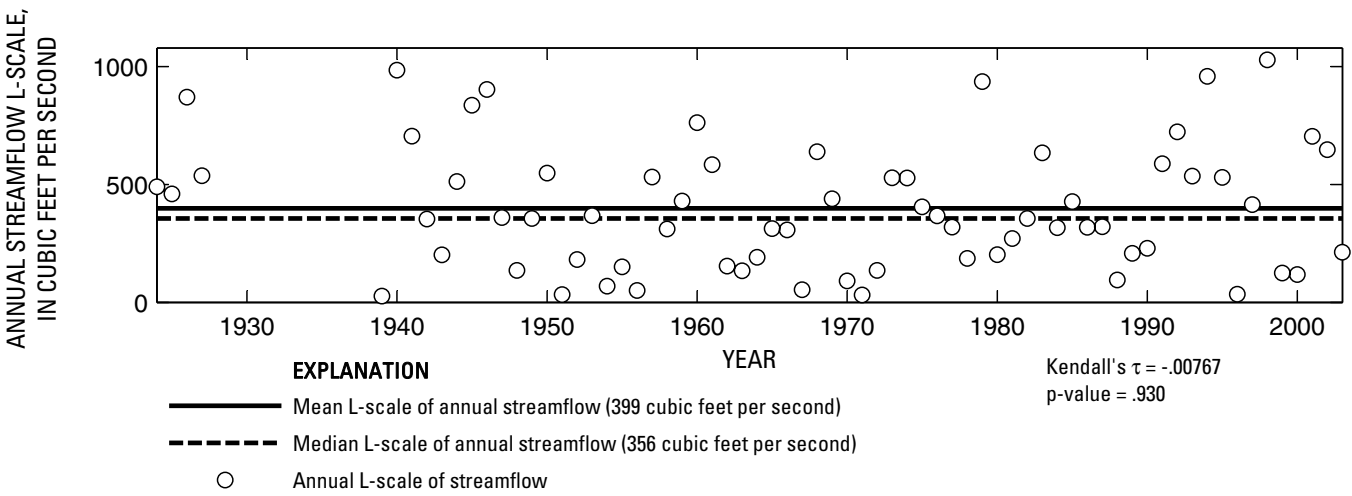

Figure 259. Analysis of annual mean, maximum, minimum, and L-scale statistics of daily mean streamflow for U.S. Geological Survey streamflow-gaging station 08068000 West Fork San Jacinto River near Conroe, Texas. 

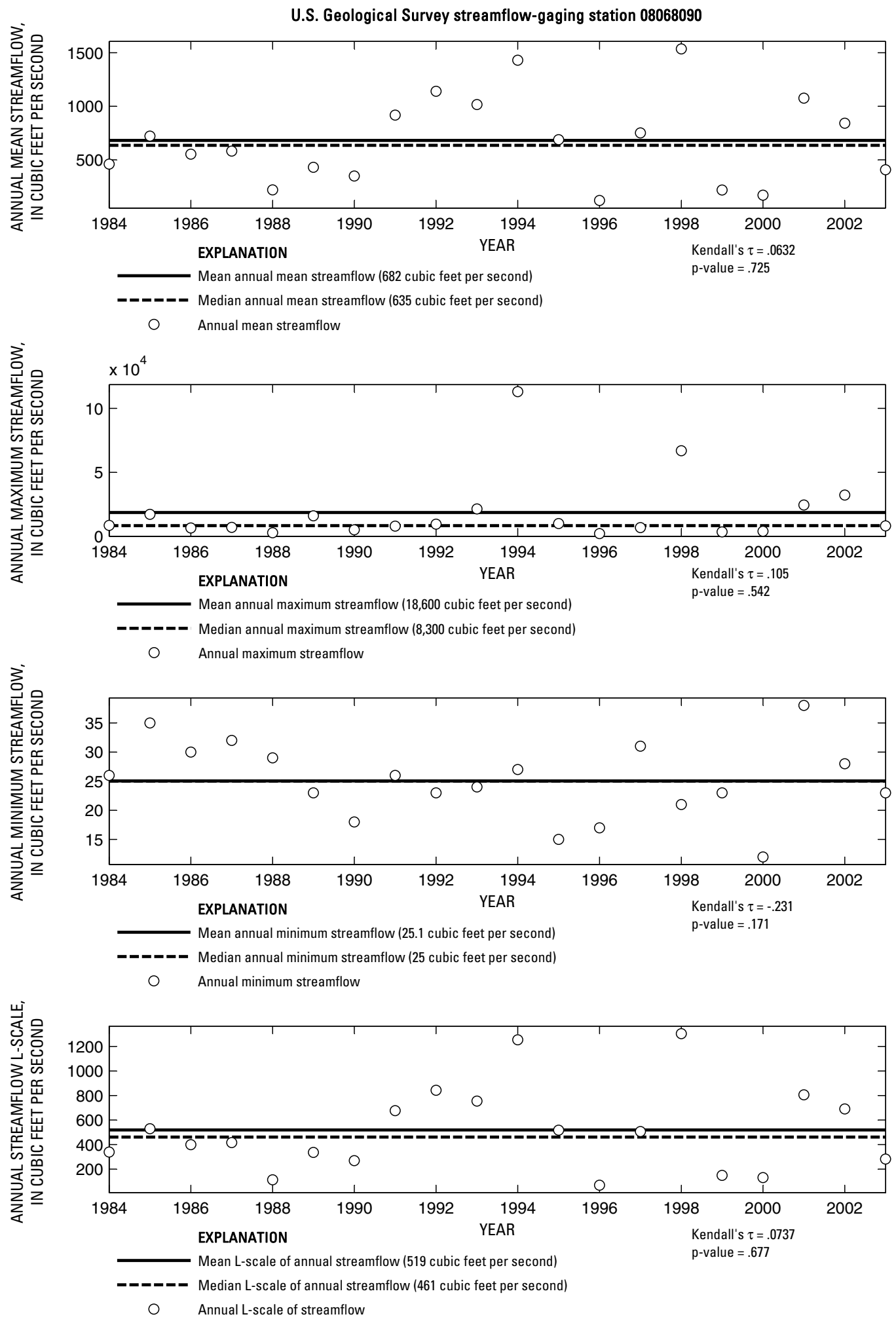

Figure 260. Analysis of annual mean, maximum, minimum, and L-scale statistics of daily mean streamflow for U.S. Geological Survey streamflow-gaging station 08068090 West Fork San Jacinto River above Lake Houston near Porter, Texas. 


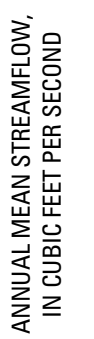

U.S. Geological Survey streamflow-gaging station 08068275

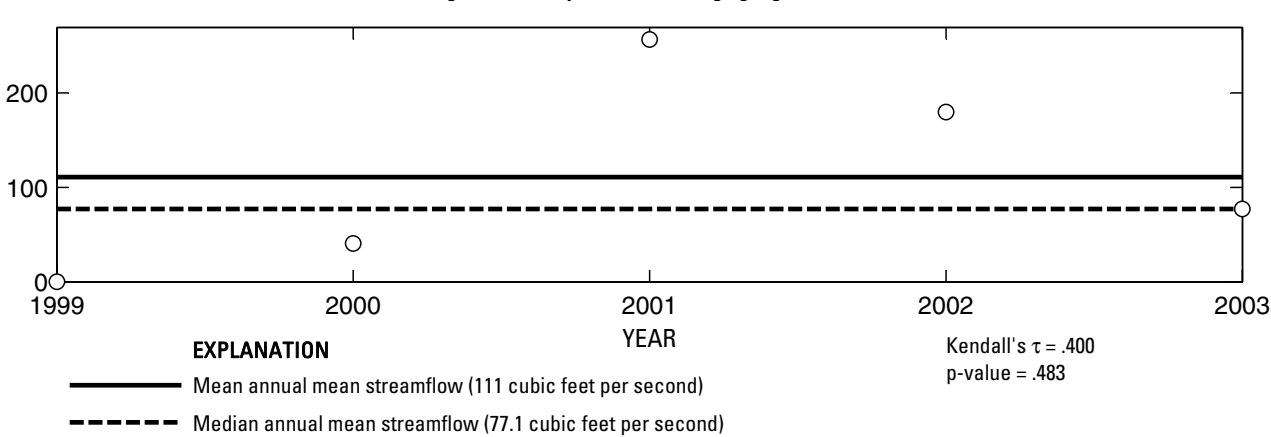

- Annual mean streamflow
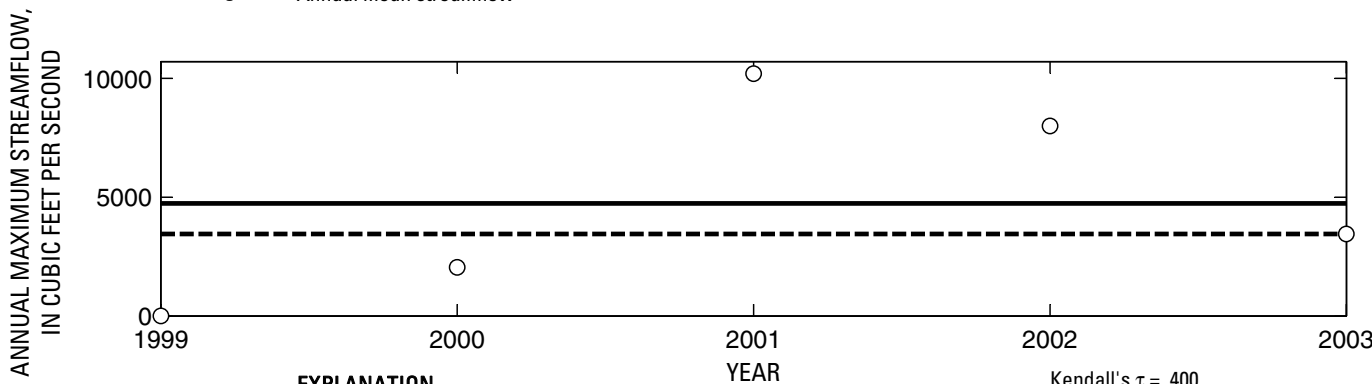

EXPLANATION

$\mathrm{p}$-value $=.483$

- _-__- Median annual maximum streamflow (3,450 cubic feet per second)

Annual maximum streamflow

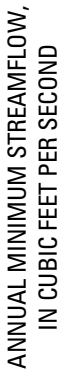

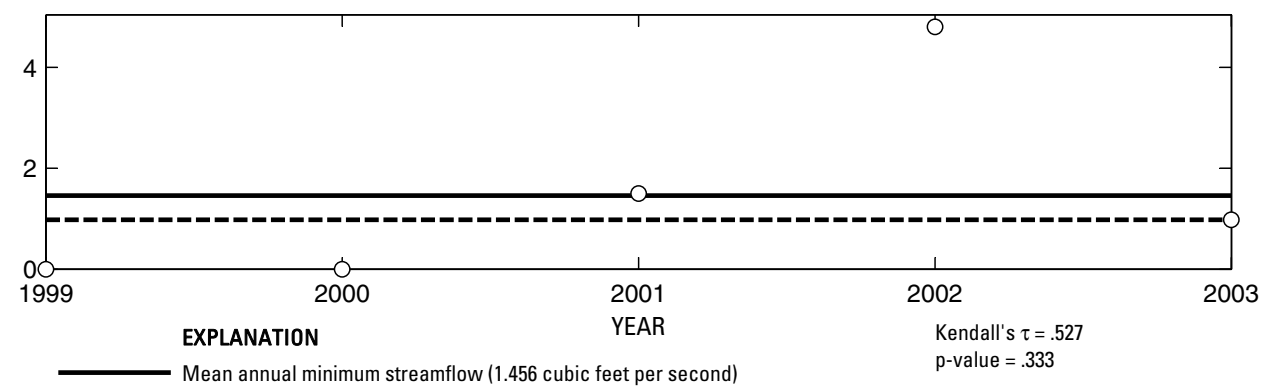

- - - Median annual minimum streamflow (.98 cubic feet per second)

O Annual minimum streamflow
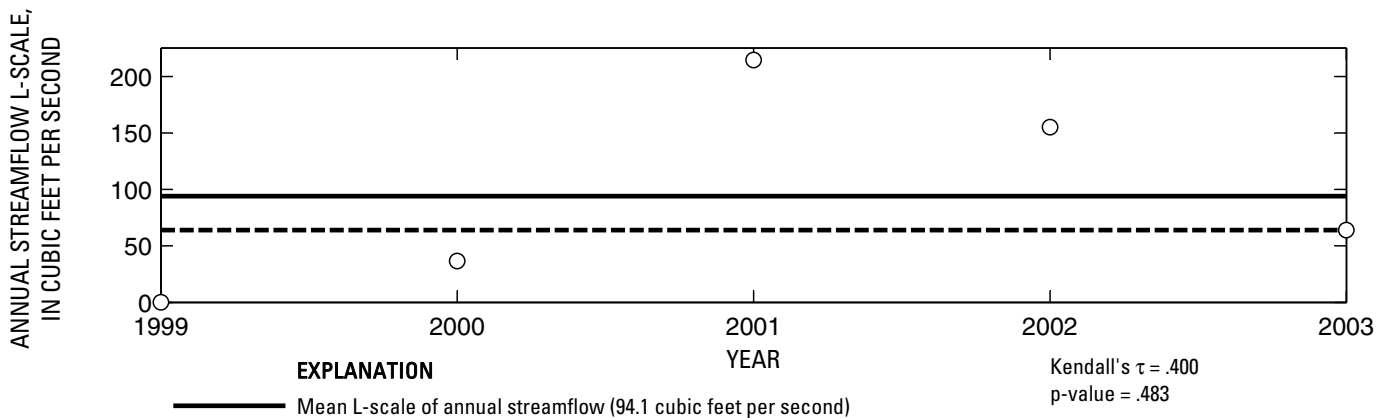

Mean L-scale of annual streamflow (94.1 cubic feet per second)

- - - - Median L-scale of annual streamflow (64 cubic feet per second)

Annual L-scale of streamflow

Figure 261. Analysis of annual mean, maximum, minimum, and L-scale statistics of daily mean streamflow for U.S. Geological Survey streamflow-gaging station 08068275 Spring Creek near Tomball, Texas.

Index of Station Numbers 719 
U.S. Geological Survey streamflow-gaging station 08068325

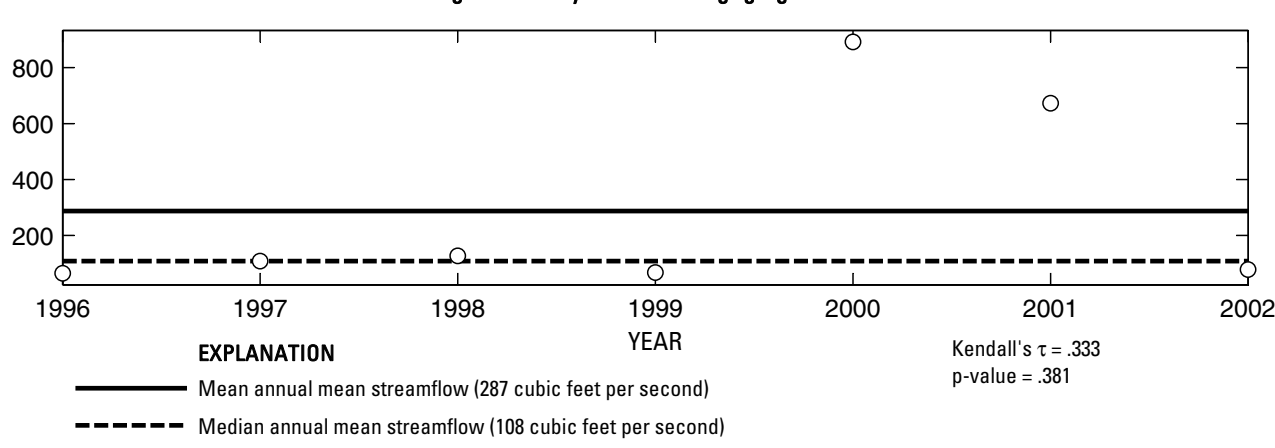

O Annual mean streamflow
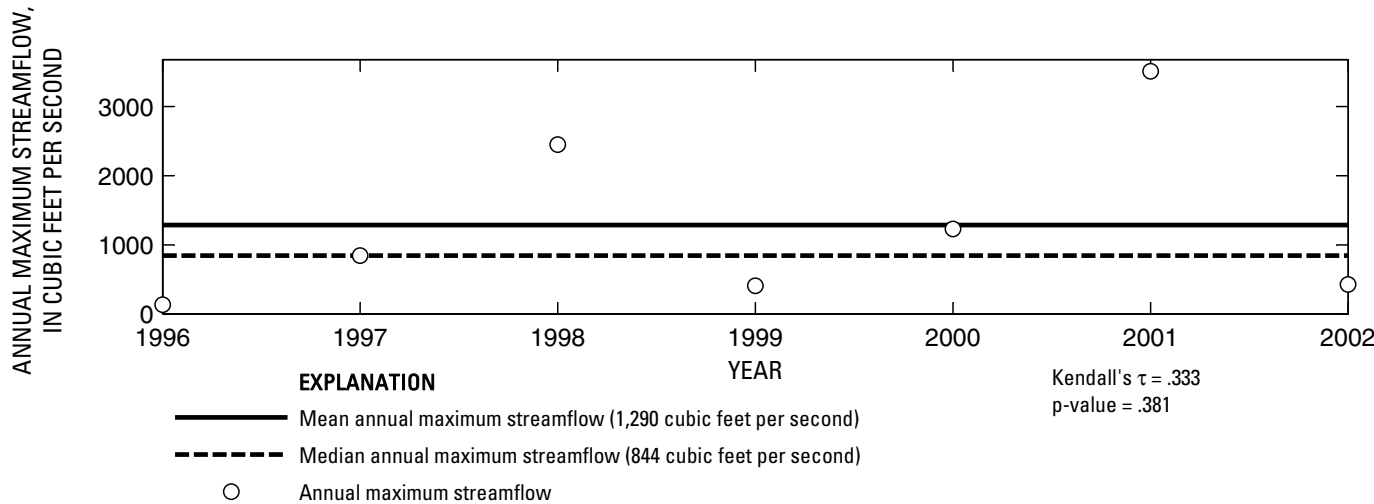

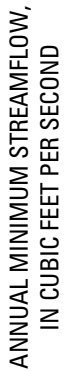

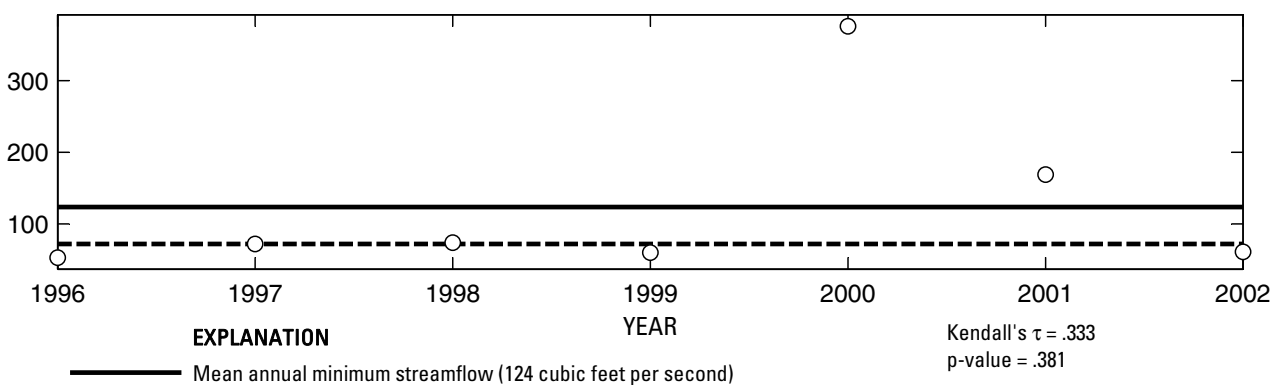

- Median annual minimum streamflow (72 cubic feet per second)

O Annual minimum streamflow

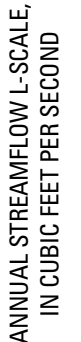

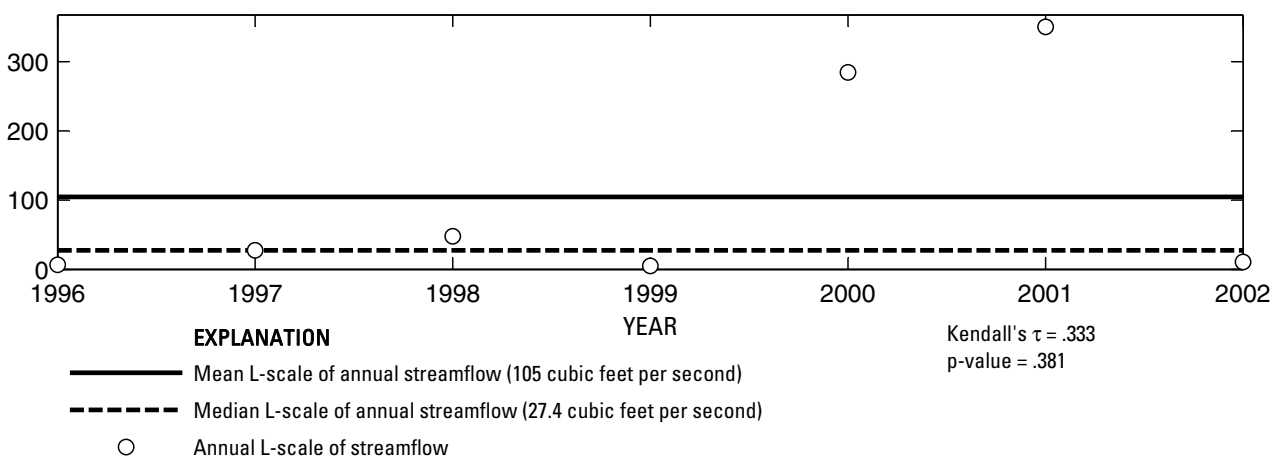

Figure 262. Analysis of annual mean, maximum, minimum, and L-scale statistics of daily mean streamflow for U.S. Geological Survey streamflow-gaging station 08068325 Willow Creek near Tomball, Texas. 


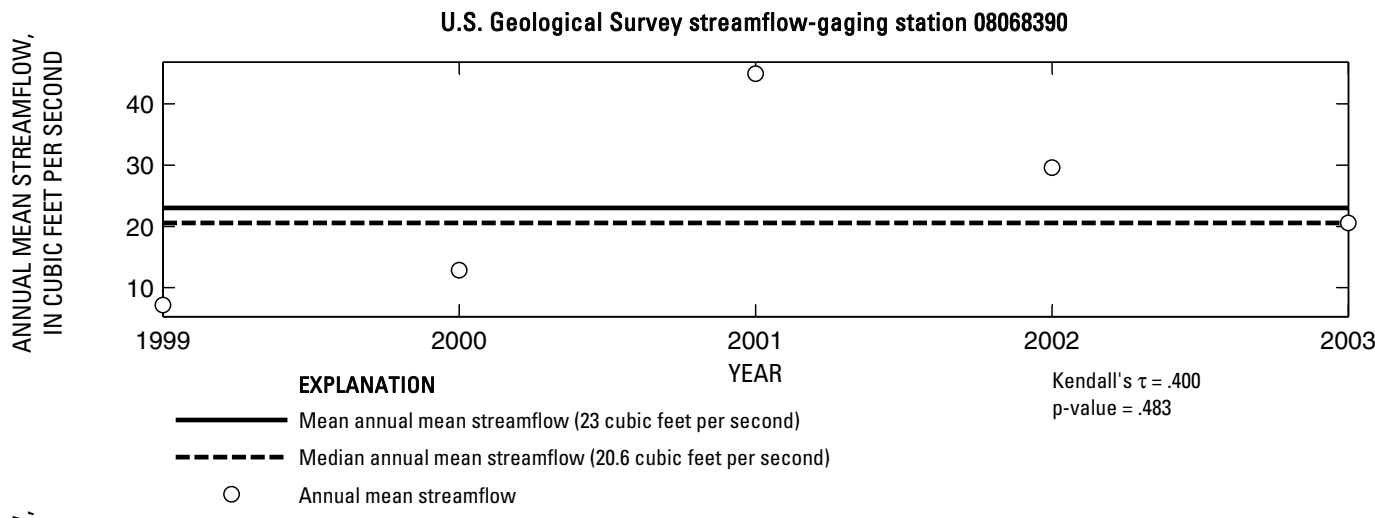

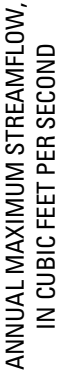

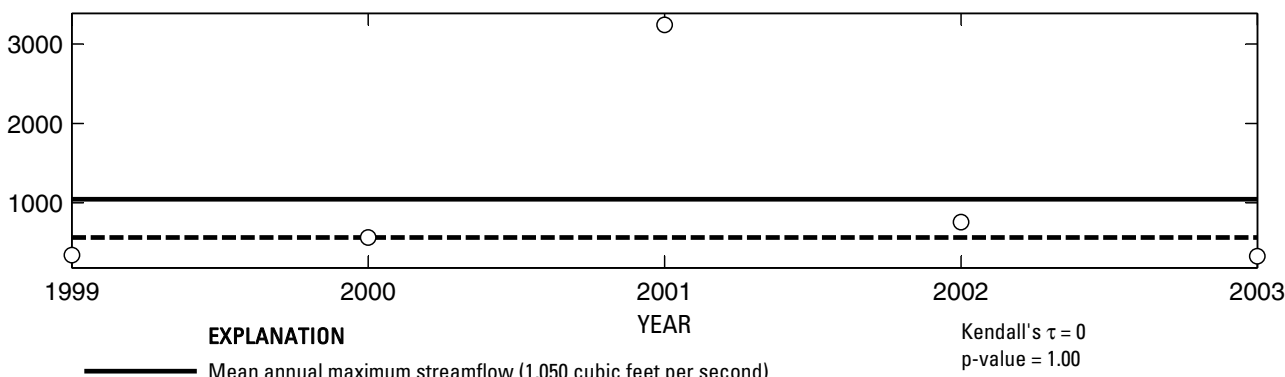

- - - Median annual maximum streamflow ( 565 cubic feet per second)

○ Annual maximum streamflow

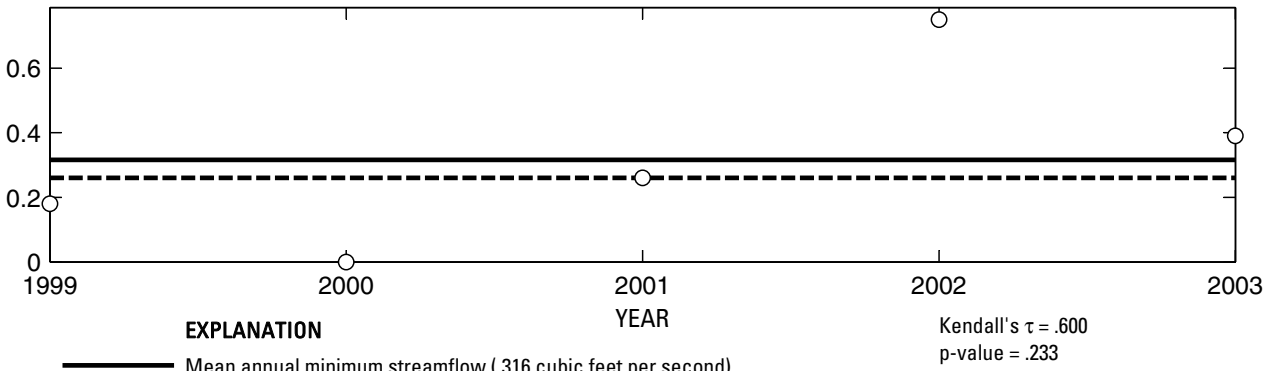

Mean annual minimum streamflow (.316 cubic feet per second)

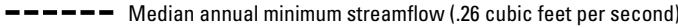

0

Annual minimum streamflow

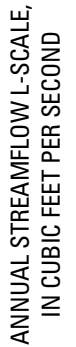

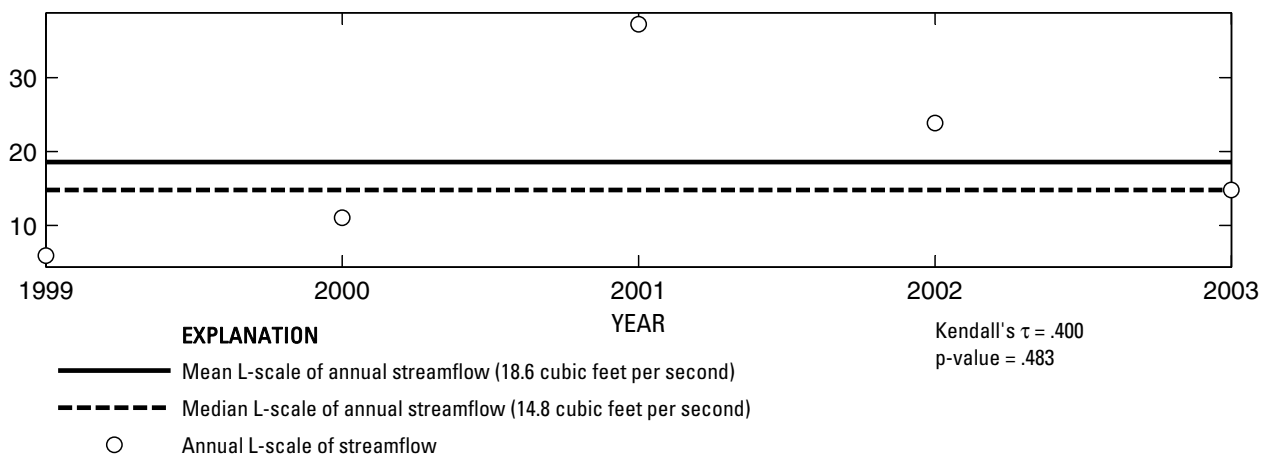

Figure 263. Analysis of annual mean, maximum, minimum, and L-scale statistics of daily mean streamflow for U.S. Geological Survey streamflow-gaging station 08068390 Bear Branch at Research Boulevard, The Woodlands, Texas. 
U.S. Geological Survey streamflow-gaging station 08068400

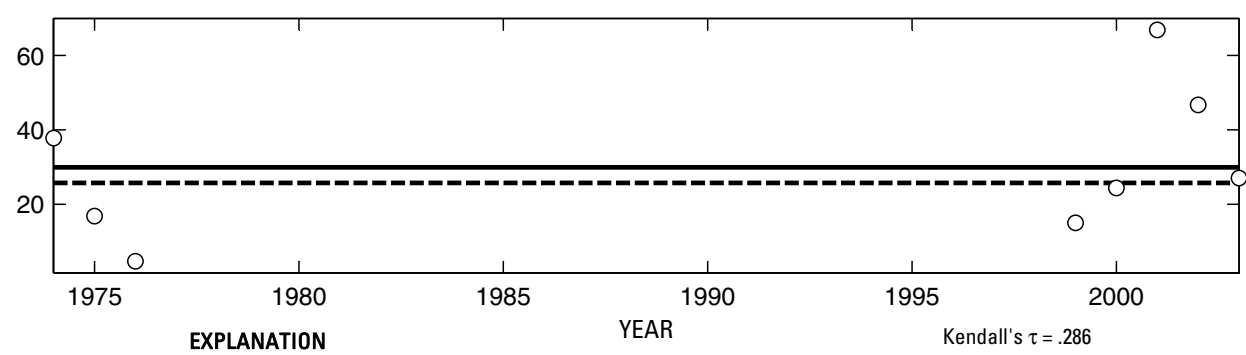

Mean annual mean streamflow (29.9 cubic feet per second)

p-value $=399$

-ンーーーー Median annual mean streamflow (25.7 cubic feet per second)

O Annual mean streamflow

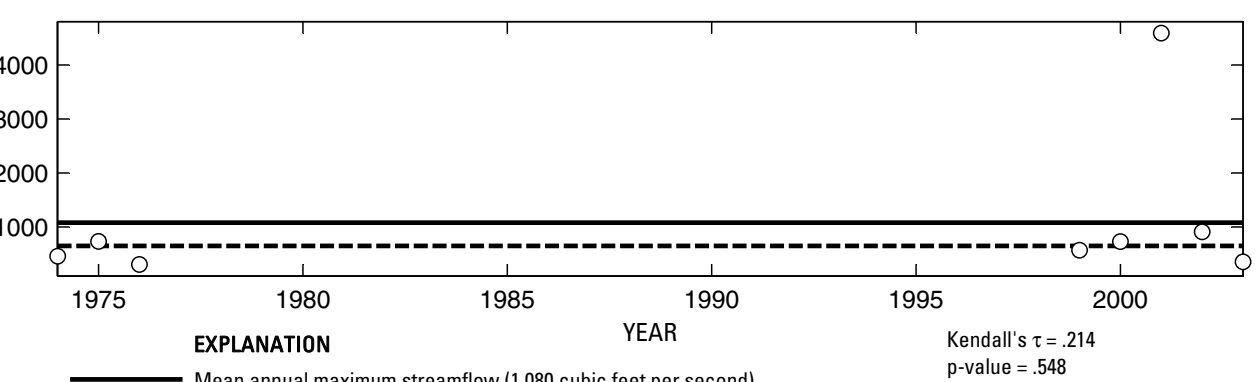

- - - Median annual maximum streamflow (650 cubic feet per second)

O Annual maximum streamflow

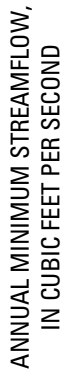

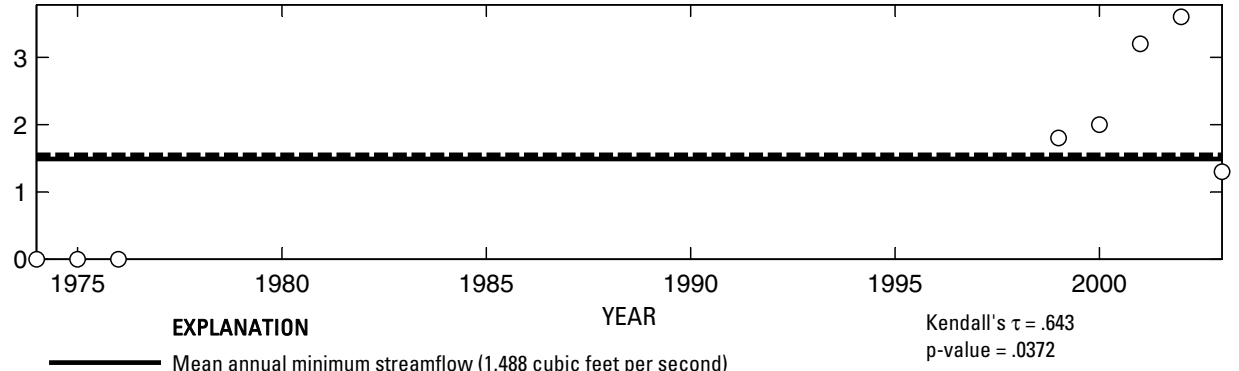

- Median annual minimum streamflow (1.55 cubic feet per second)

O Annual minimum streamflow

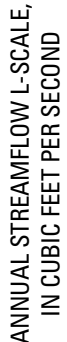

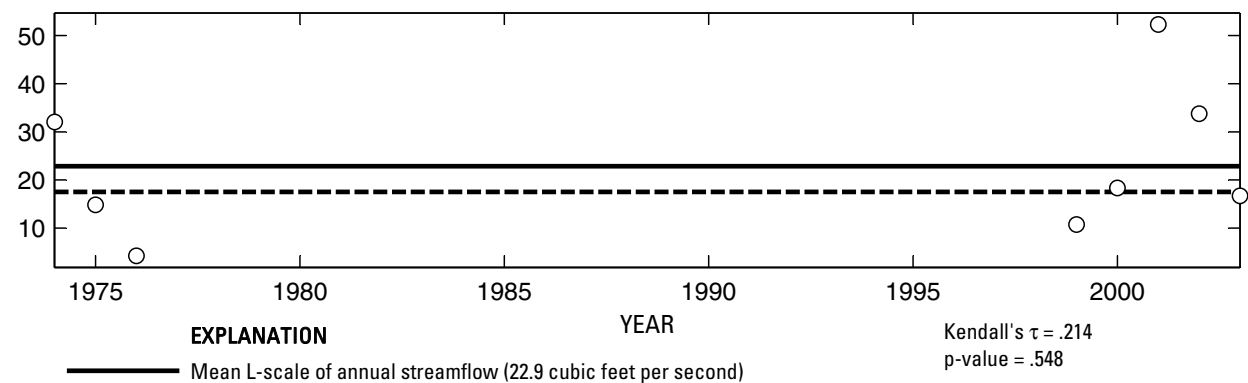

Annual L-scale of streamflow

Figure 264. Analysis of annual mean, maximum, minimum, and L-scale statistics of daily mean streamflow for U.S. Geological Survey streamflow-gaging station 08068400 Panther Branch at Gosling Road, The Woodlands, Texas.

Index of Station Numbers 719 


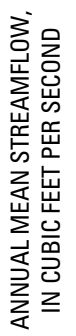

U.S. Geological Survey streamflow-gaging station 08068450

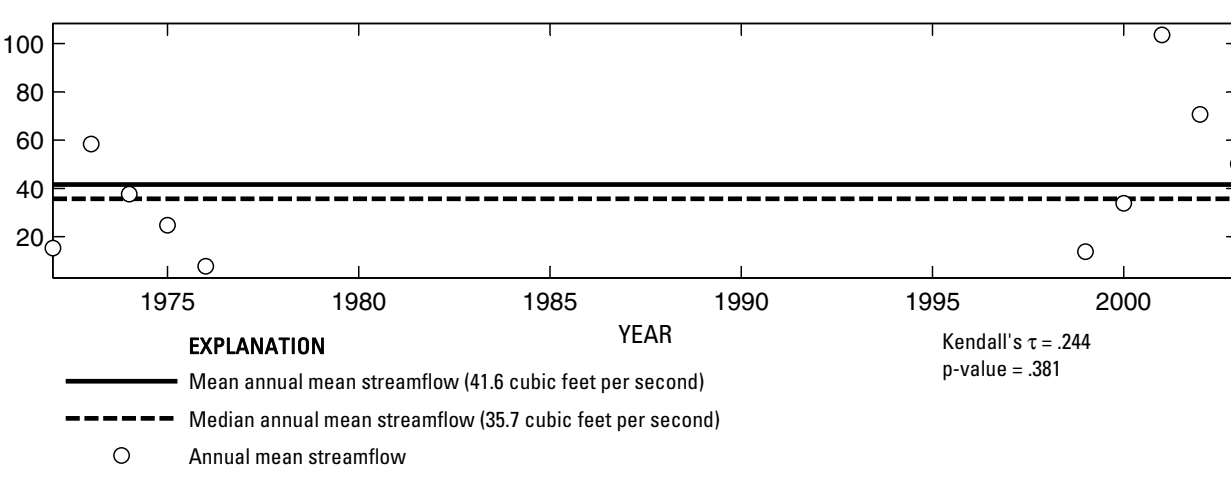

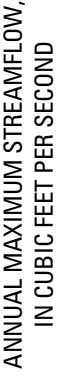
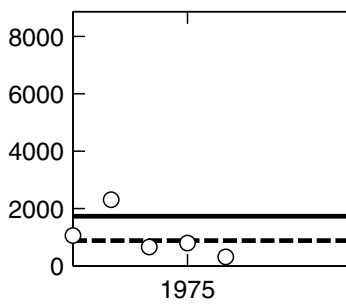
U.S. Geological Survey streamflow-gaging station 08068500

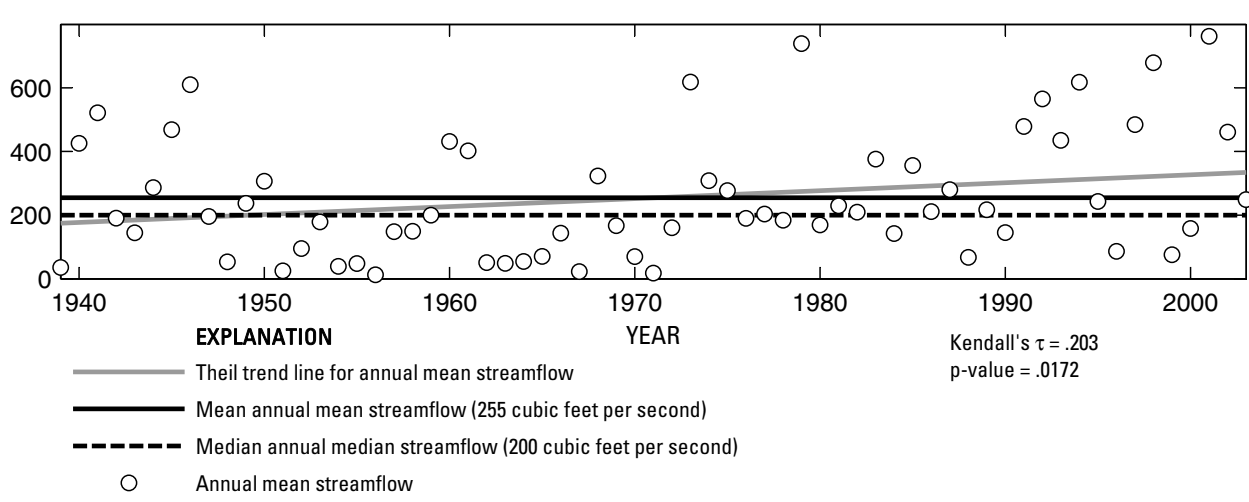

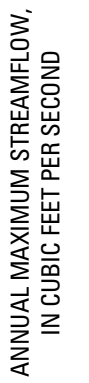

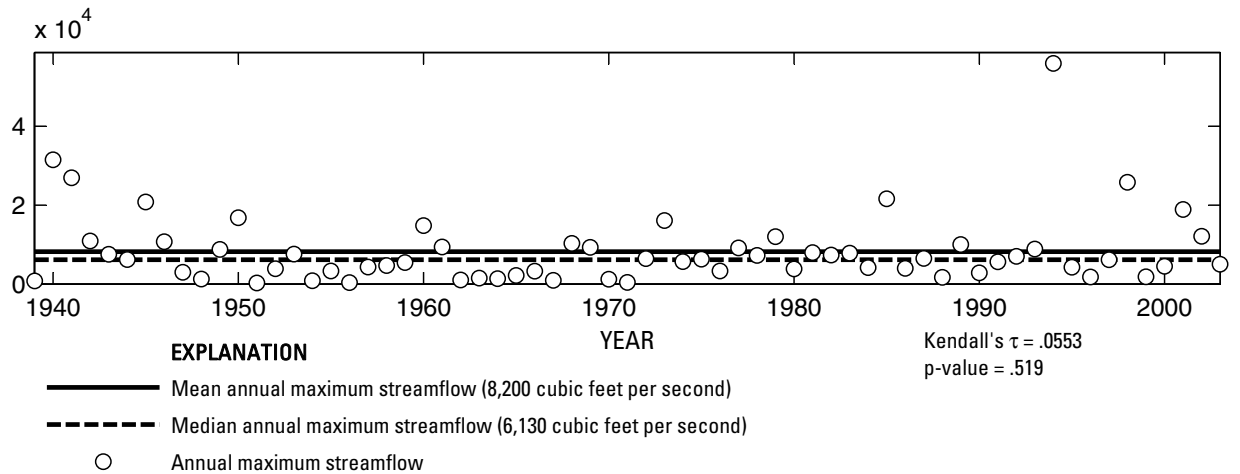

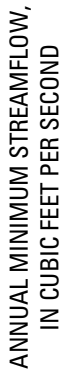

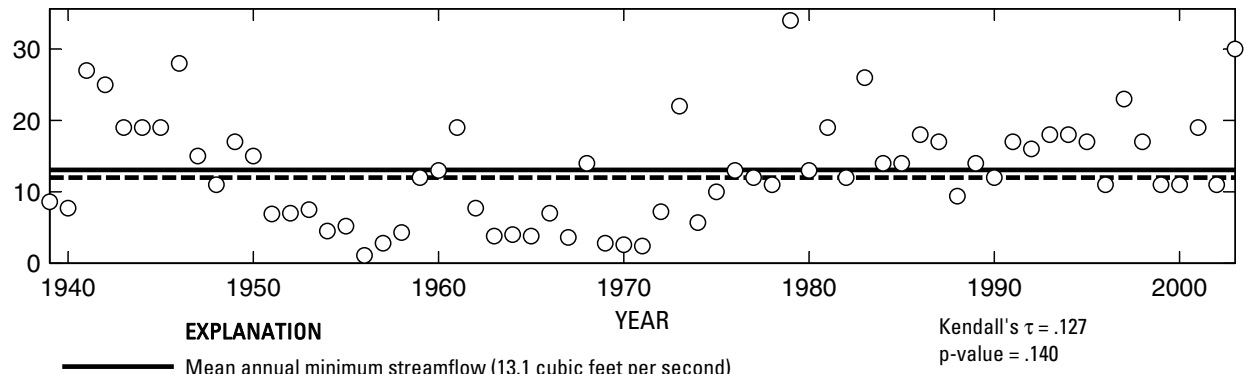

- Median annual minimum streamflow (12 cubic feet per second)

O Annual minimum streamflow

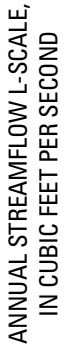

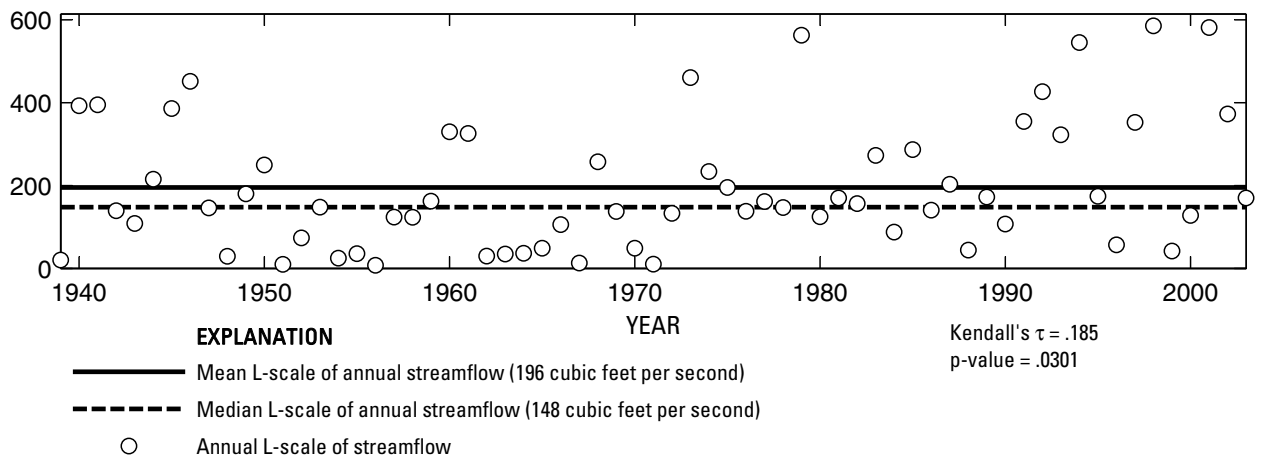

Figure 266. Analysis of annual mean, maximum, minimum, and L-scale statistics of daily mean streamflow for U.S. Geological Survey streamflow-gaging station 08068500 Spring Creek near Spring, Texas.

Index of Station Numbers 719 

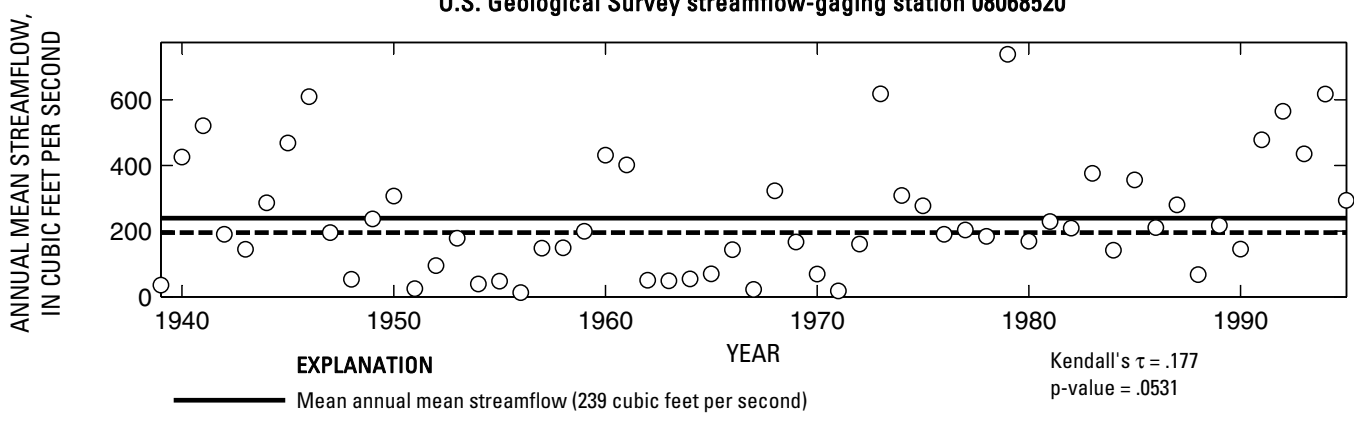

-_-_- Median annual mean streamflow (196 cubic feet per second)

- Annual mean streamflow

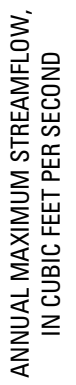

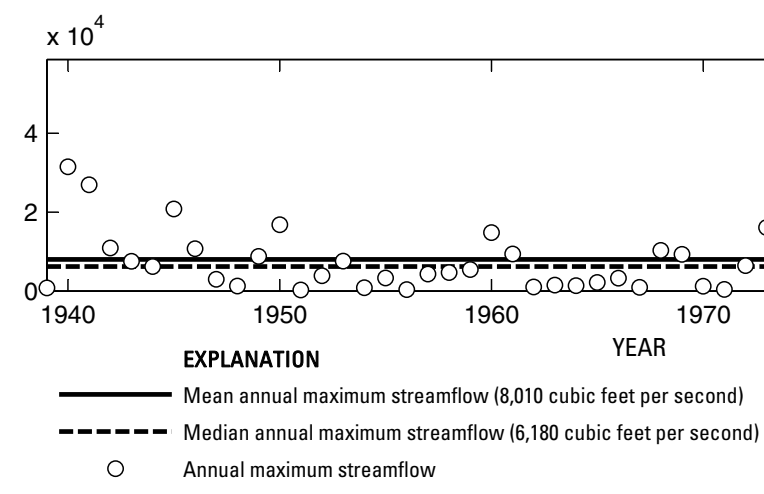

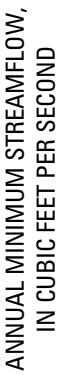

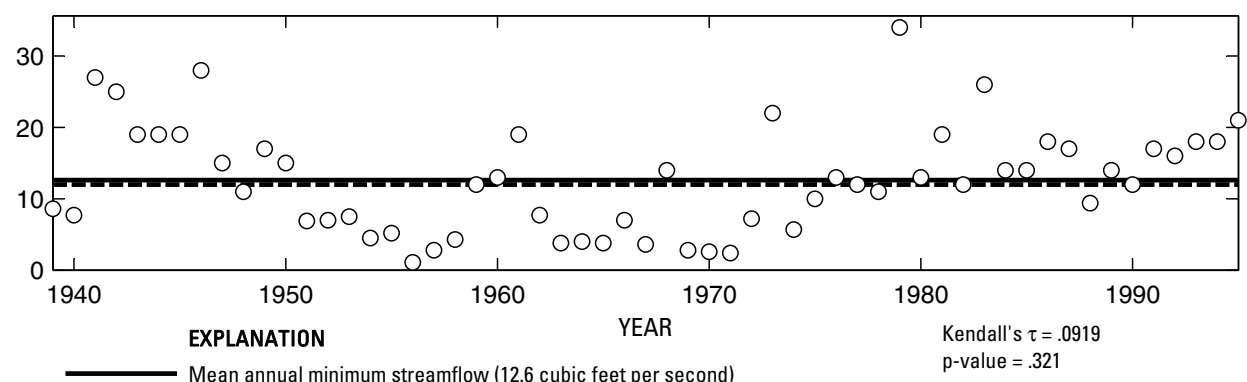

- - - Median annual minimum streamflow (12 cubic feet per second)

O Annual minimum streamflow

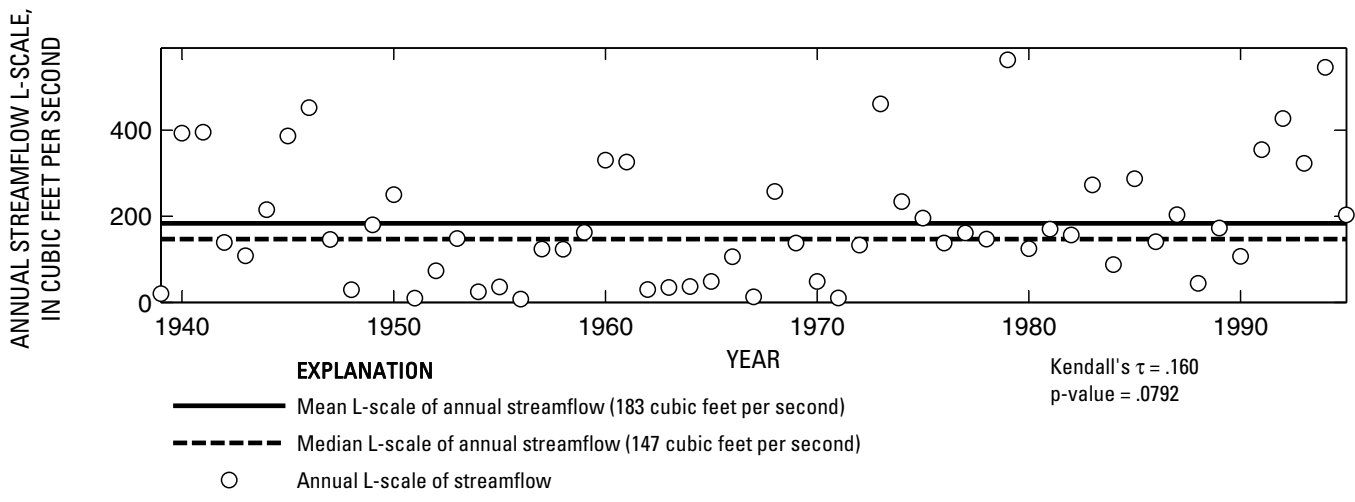

Figure 267. Analysis of annual mean, maximum, minimum, and L-scale statistics of daily mean streamflow for U.S. Geological Survey streamflow-gaging station 08068520 Spring Creek at Spring, Texas. 

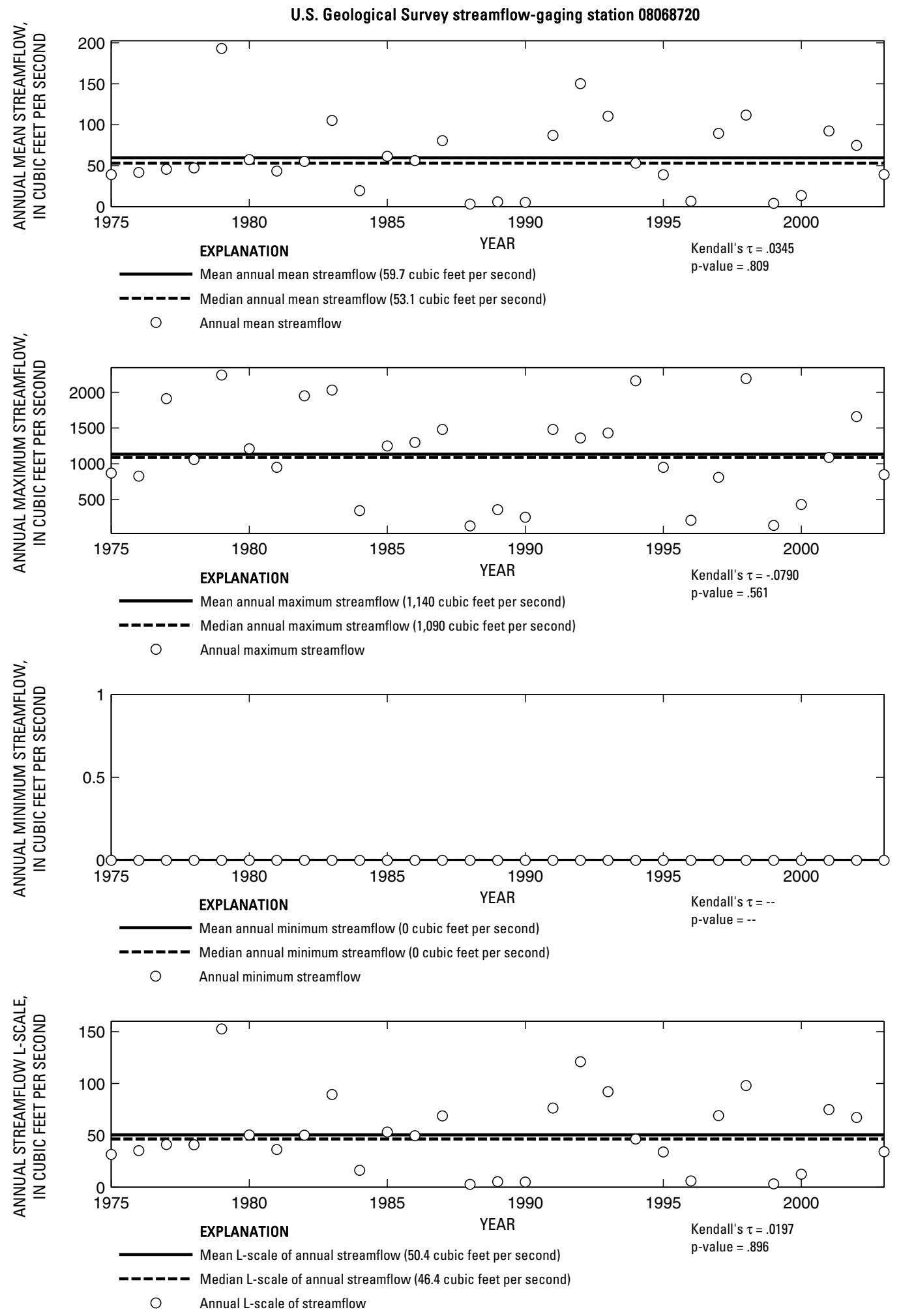

Figure 268. Analysis of annual mean, maximum, minimum, and L-scale statistics of daily mean streamflow for U.S. Geological Survey streamflow-gaging station 08068720 Cypress Creek at Katy-Hockley Road near Hockley, Texas.

Index of Station Numbers 719 

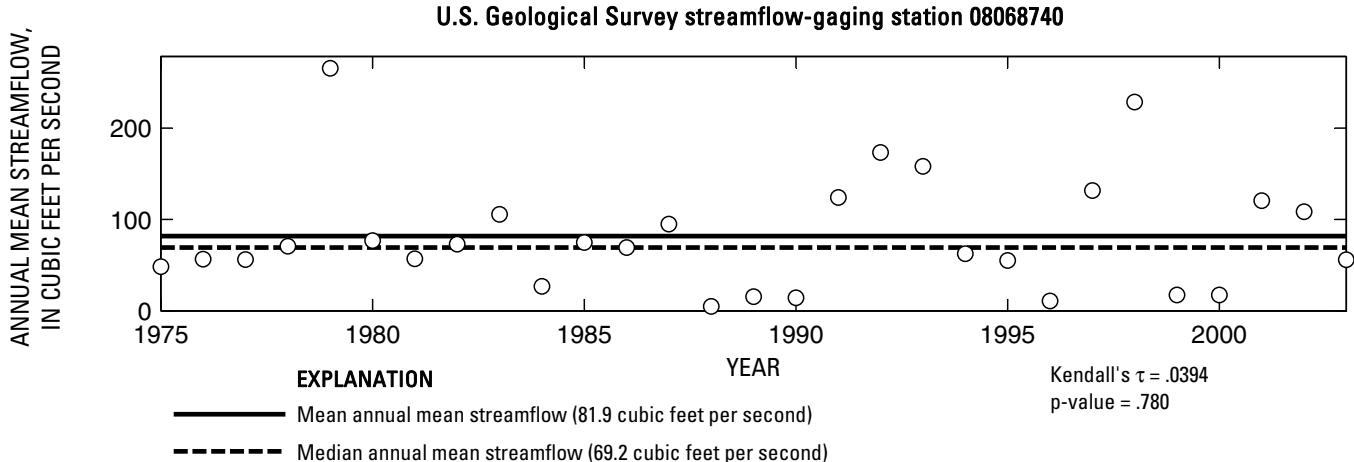

-_-_-_ Median annual mean streamflow (69.2 cubic feet per second)

O Annual mean streamflow
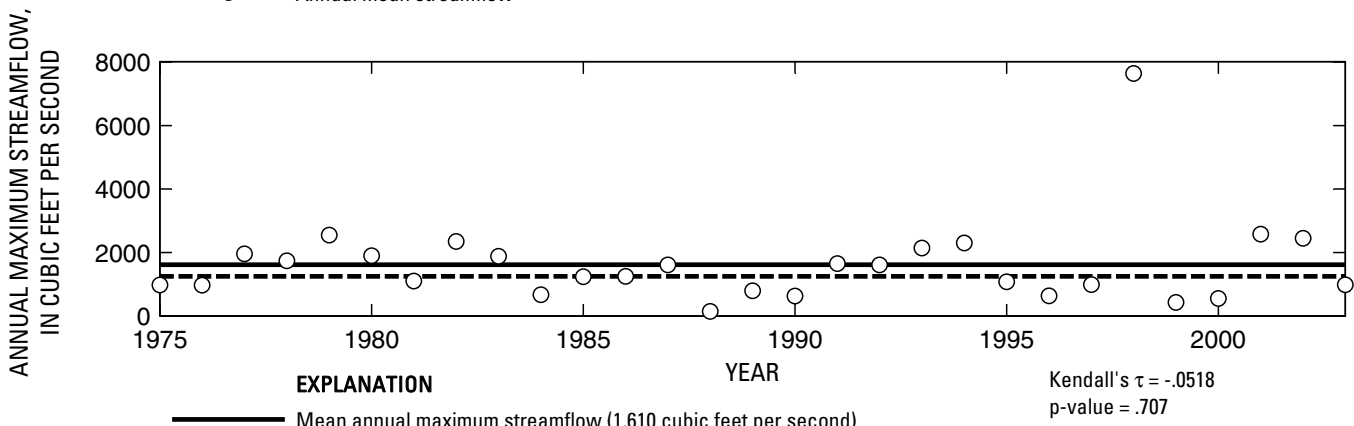

- _ - Median annual maximum streamflow (1,250 cubic feet per second

Annual maximum streamflow

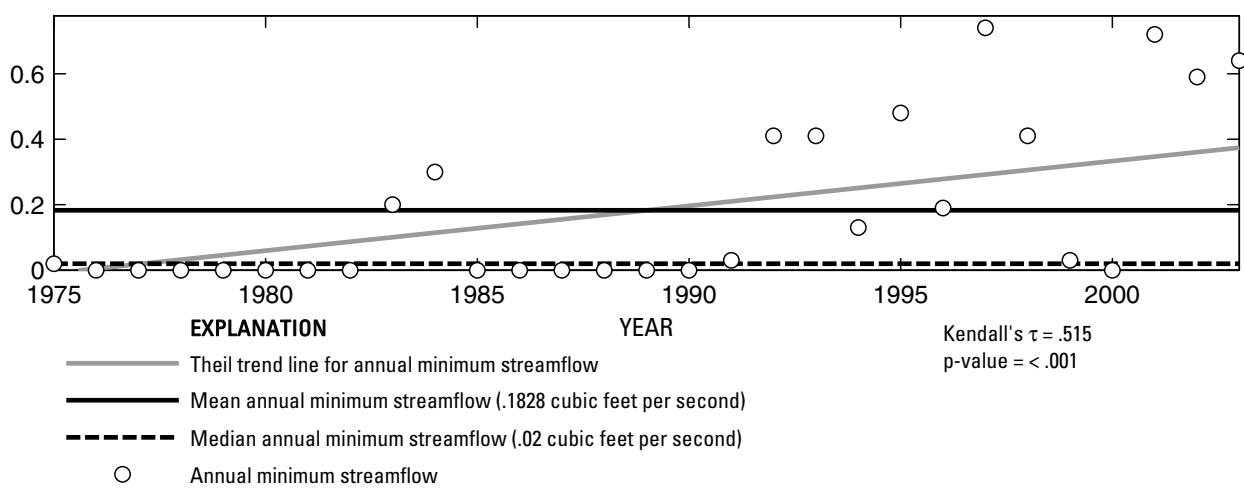

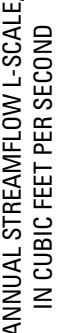

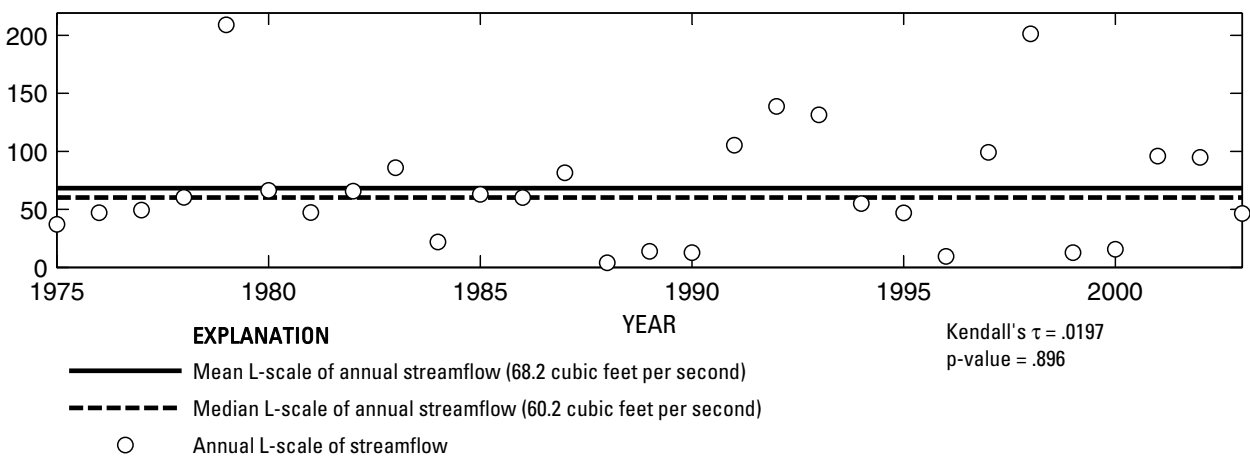

Figure 269. Analysis of annual mean, maximum, minimum, and L-scale statistics of daily mean streamflow for U.S. Geological Survey streamflow-gaging station 08068740 Cypress Creek at House-Hahl Road near Cypress, Texas.

Index of Station Numbers 719 

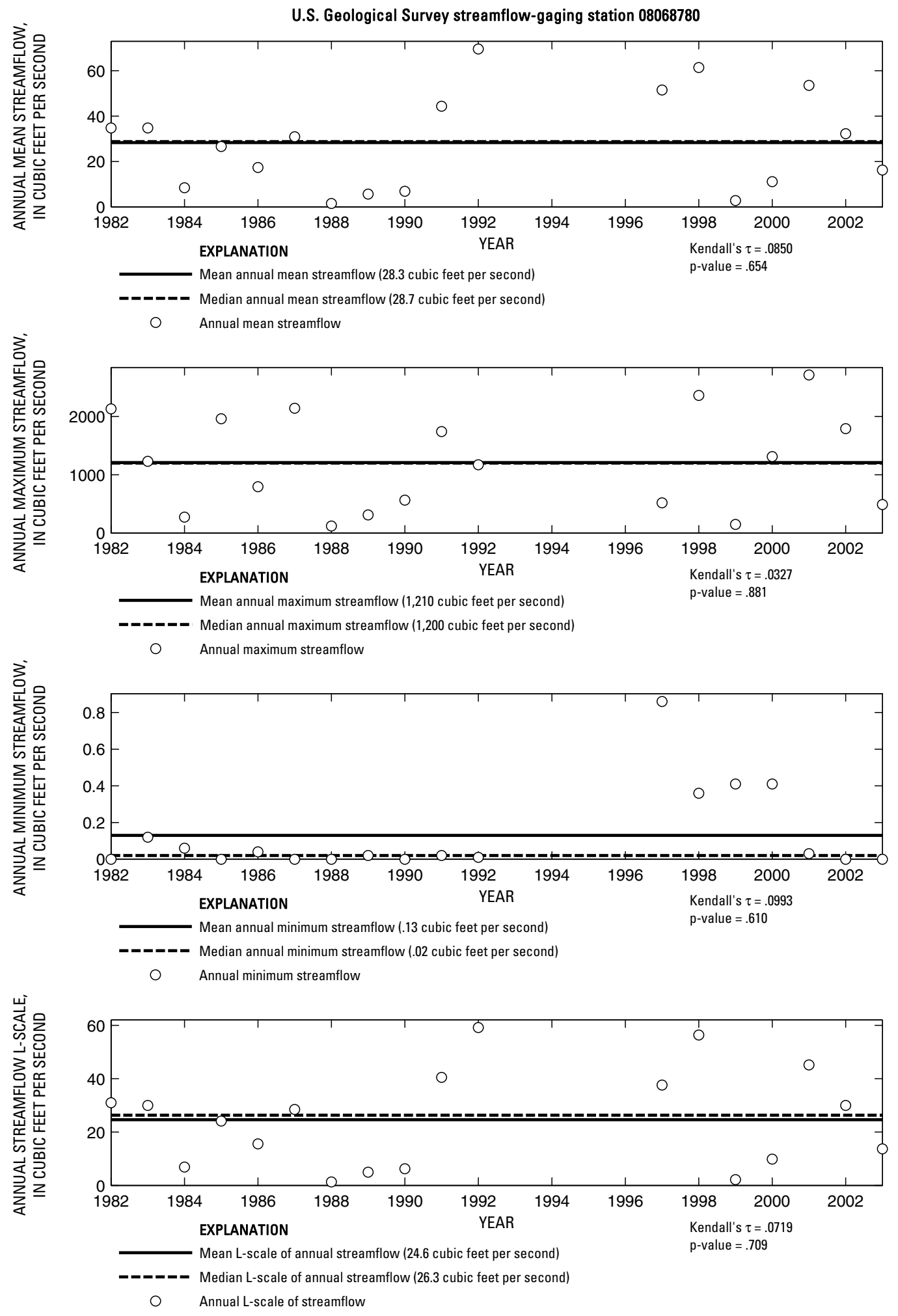

Figure 270. Analysis of annual mean, maximum, minimum, and L-scale statistics of daily mean streamflow for U.S. Geological Survey streamflow-gaging station 08068780 Little Cypress Creek near Cypress, Texas.

Index of Station Numbers 719 


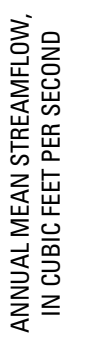

U.S. Geological Survey streamflow-gaging station 08068800

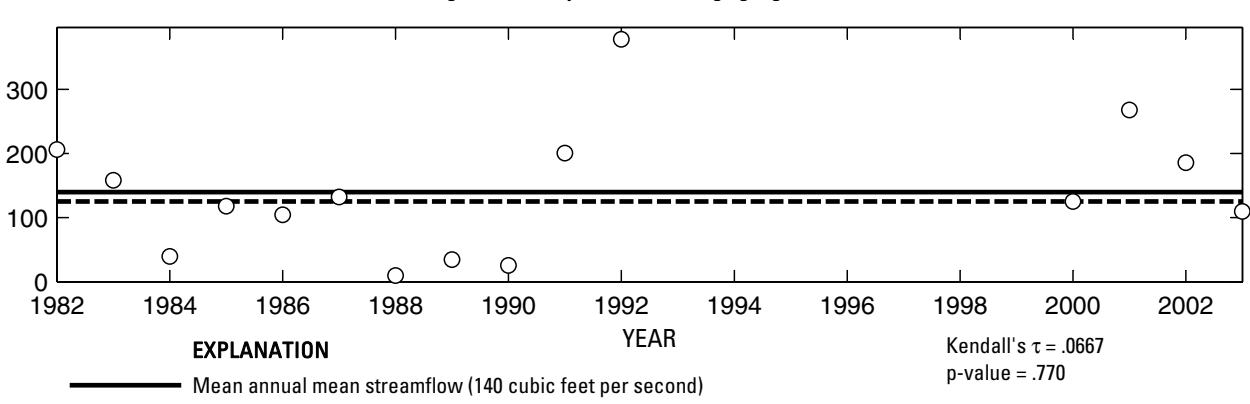

-_-_- Median annual mean streamflow (125 cubic feet per second)

O Annual mean streamflow
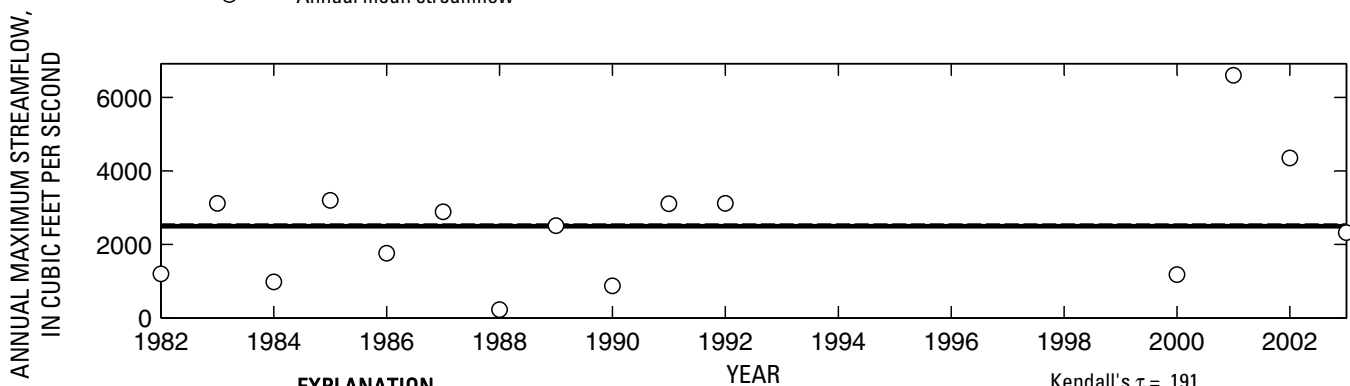

EXPLANATION

p-value $=$

Mean annual maximum streamflow (2,500 cubic feet per second)

O Annual maximum streamflow

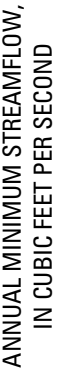

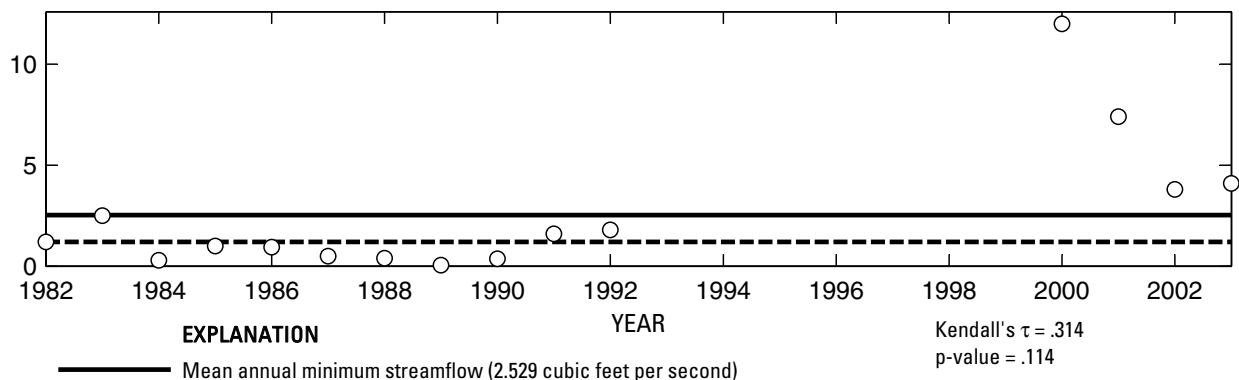

-ーーーー Median annual minimum streamflow (1.2 cubic feet per second)

O Annual minimum streamflow

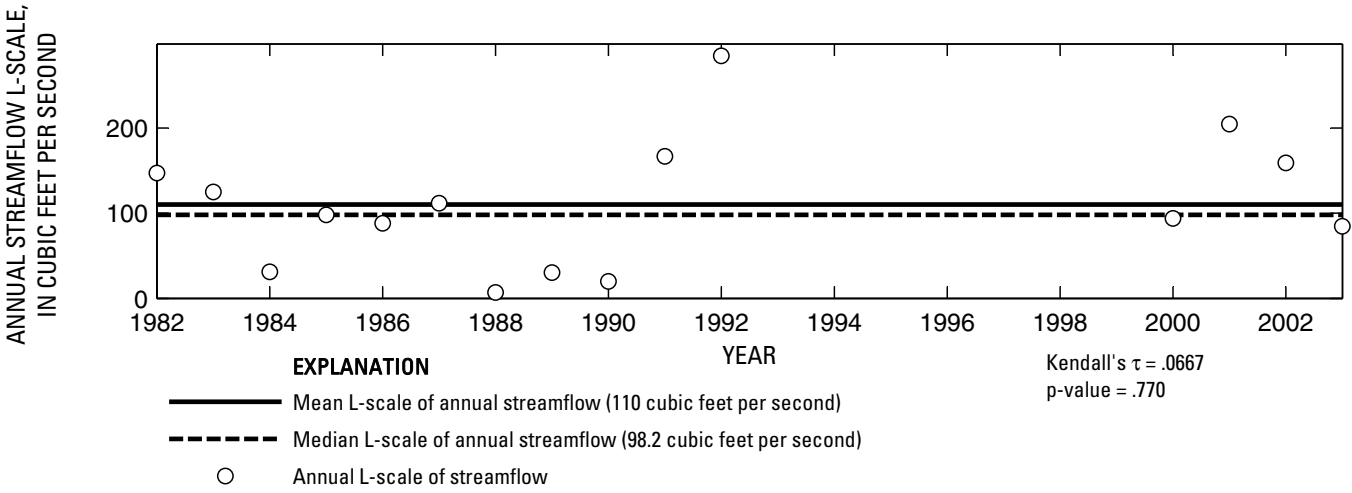

Figure 271. Analysis of annual mean, maximum, minimum, and L-scale statistics of daily mean streamflow for U.S. Geological Survey streamflow-gaging station 08068800 Cypress Creek at Grant Road near Cypress, Texas. 

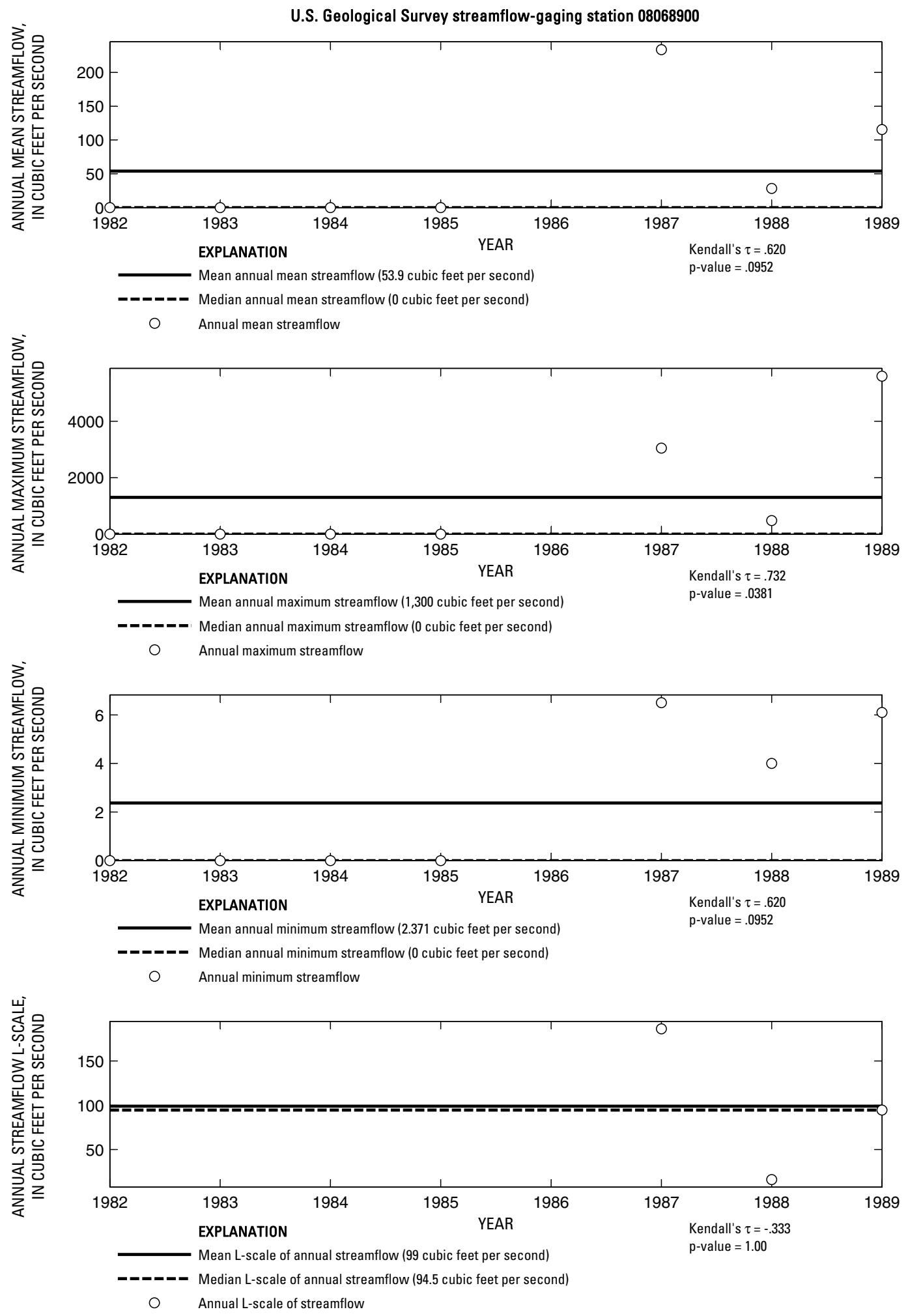

Figure 272. Analysis of annual mean, maximum, minimum, and L-scale statistics of daily mean streamflow for U.S. Geological Survey streamflow-gaging station 08068900 Cypress Creek at Stuebner-Airline Road near Westfield, Texas. 


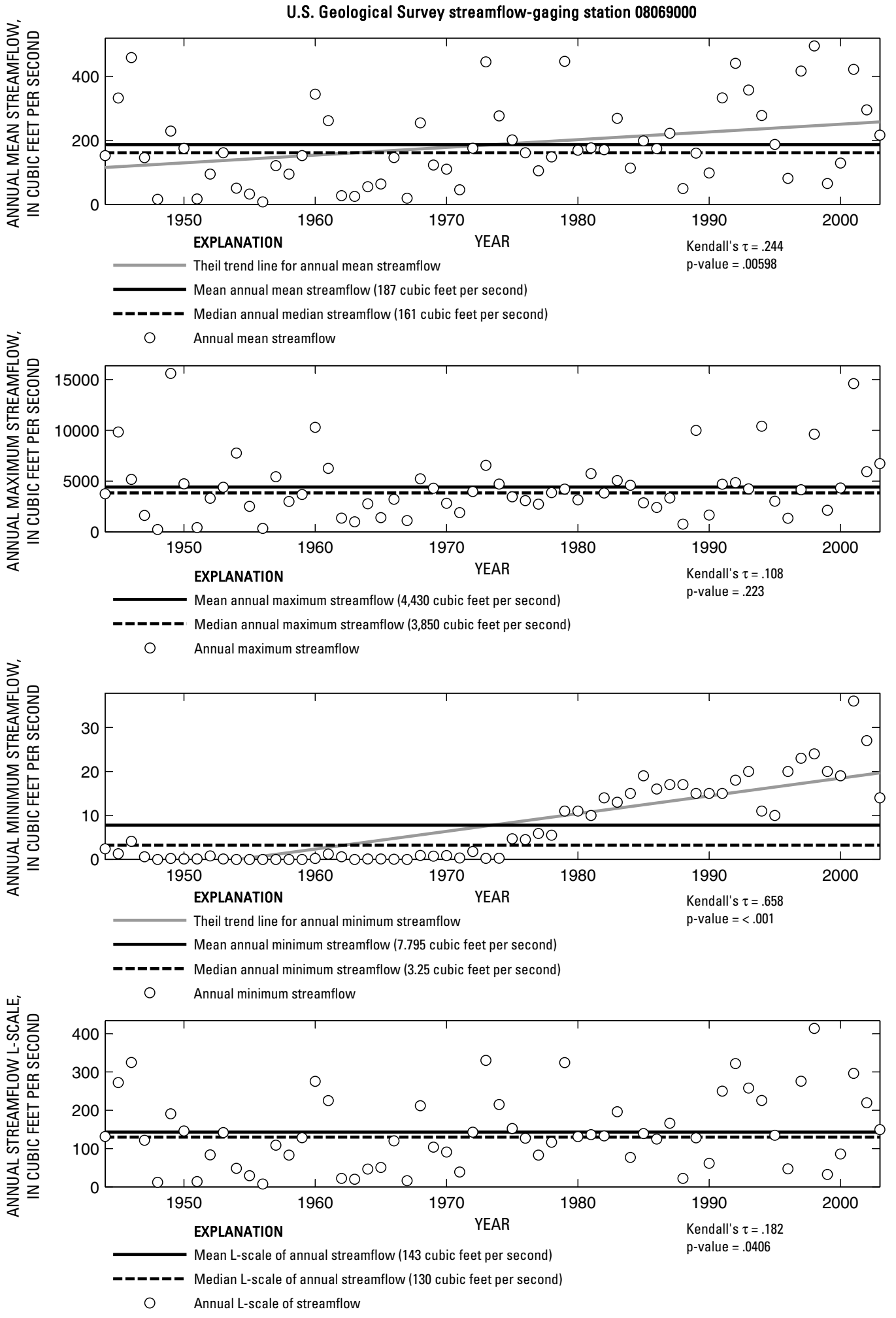

Figure 273. Analysis of annual mean, maximum, minimum, and L-scale statistics of daily mean streamflow for U.S. Geological Survey streamflow-gaging station 08069000 Cypress Creek near Westfield, Texas. 


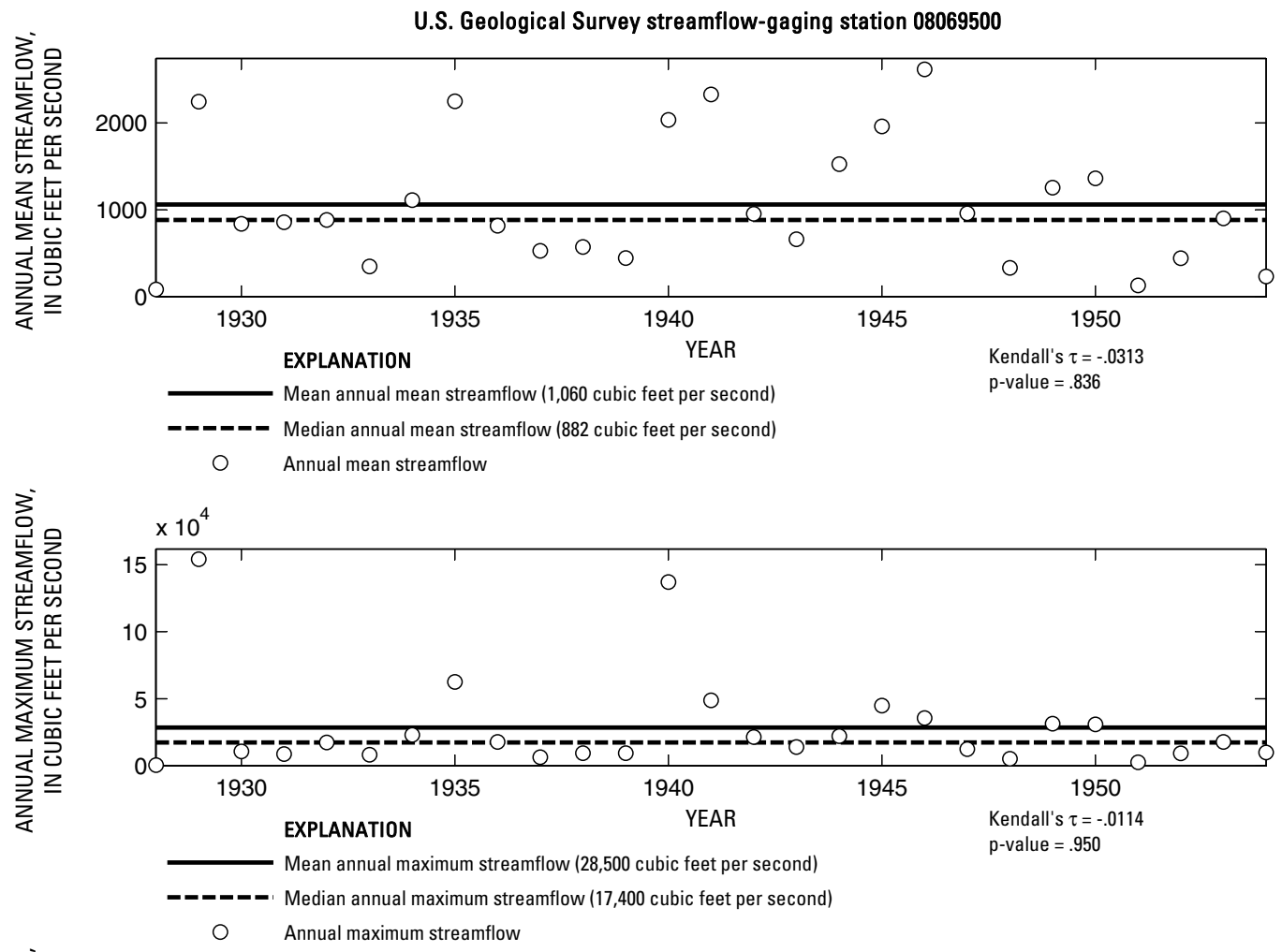

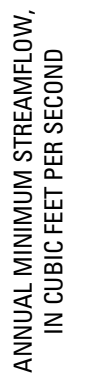

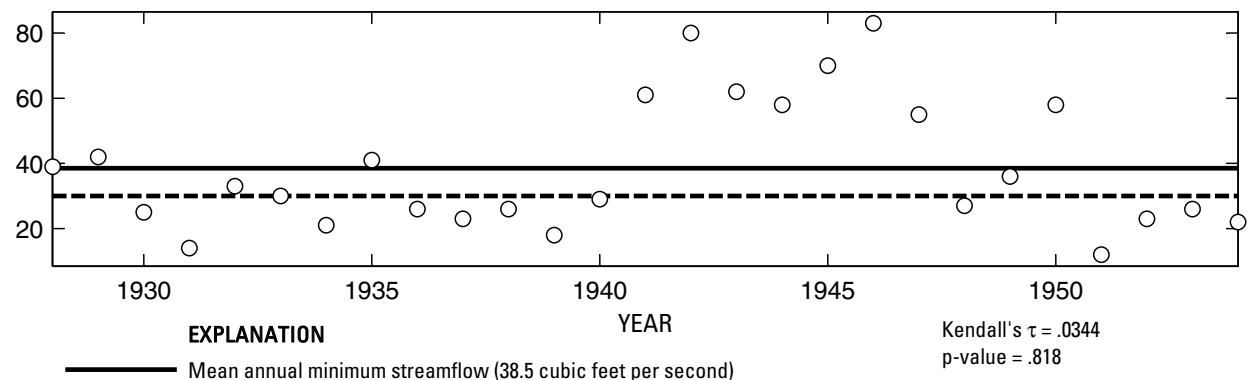

- Median annual minimum streamflow (30 cubic feet per second)

O Annual minimum streamflow

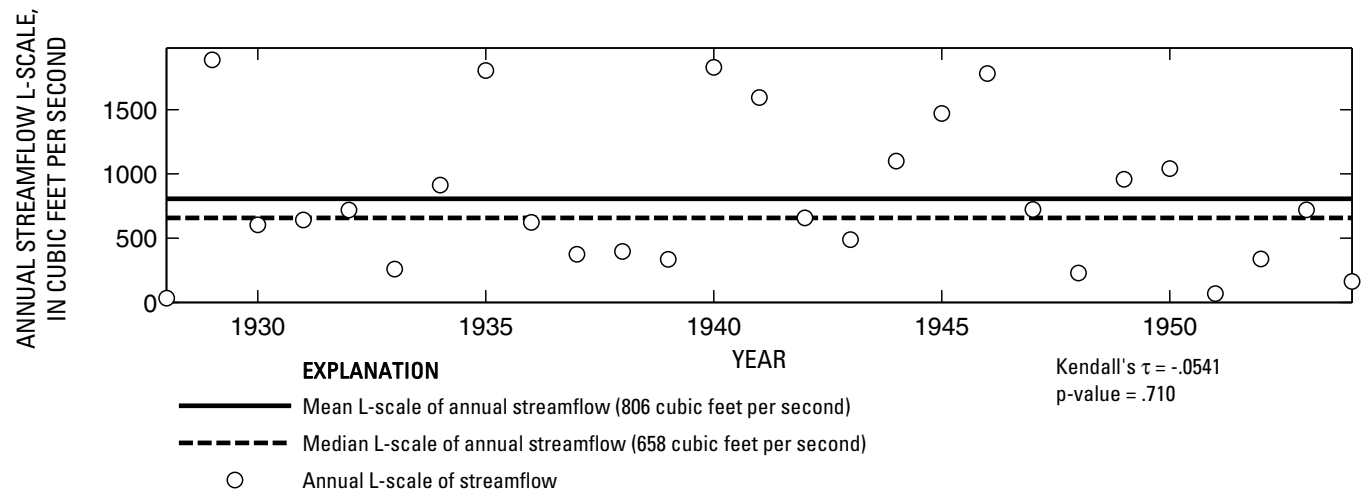

Figure 274. Analysis of annual mean, maximum, minimum, and L-scale statistics of daily mean streamflow for U.S. Geological Survey streamflow-gaging station 08069500 West Fork San Jacinto River near Humble, Texas.

Index of Station Numbers 719 

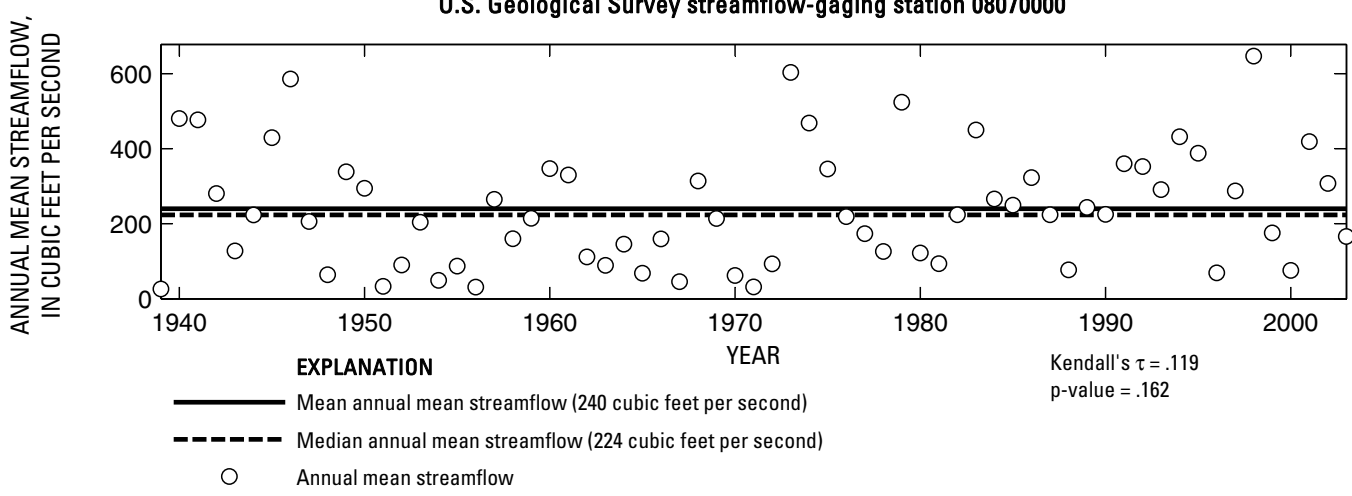

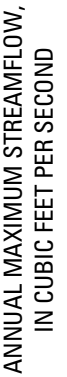
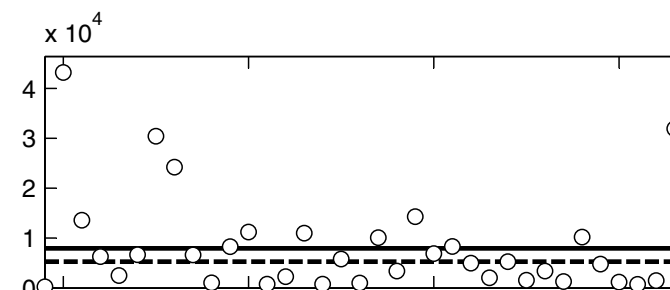

1940
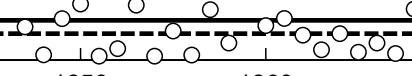

1960

EXPLANATION

Mean annual maximum streamflow $(7,960$ cubic feet per second $)$

- Median annual maximum streamflow (5,270 cubic feet per second)

Annual maximum streamflow

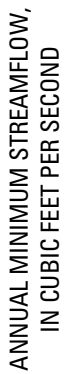

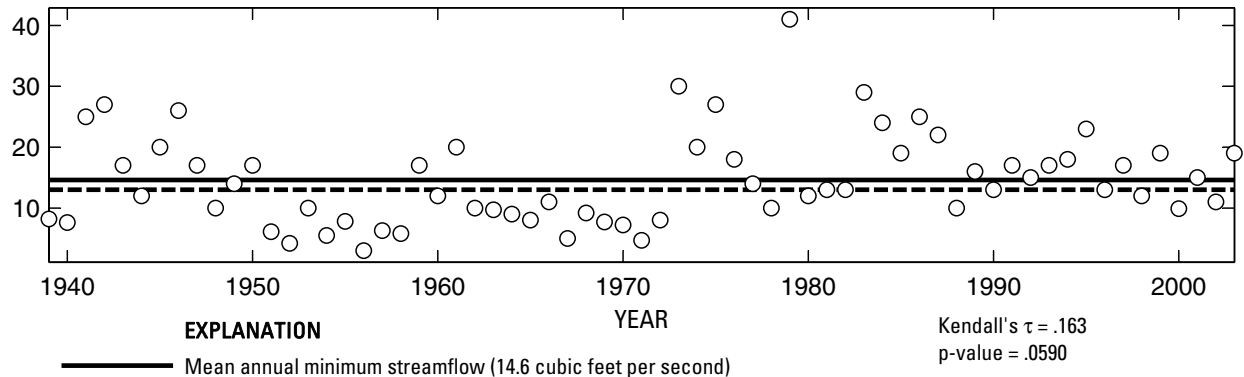

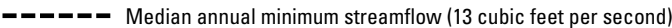

O Annual minimum streamflow
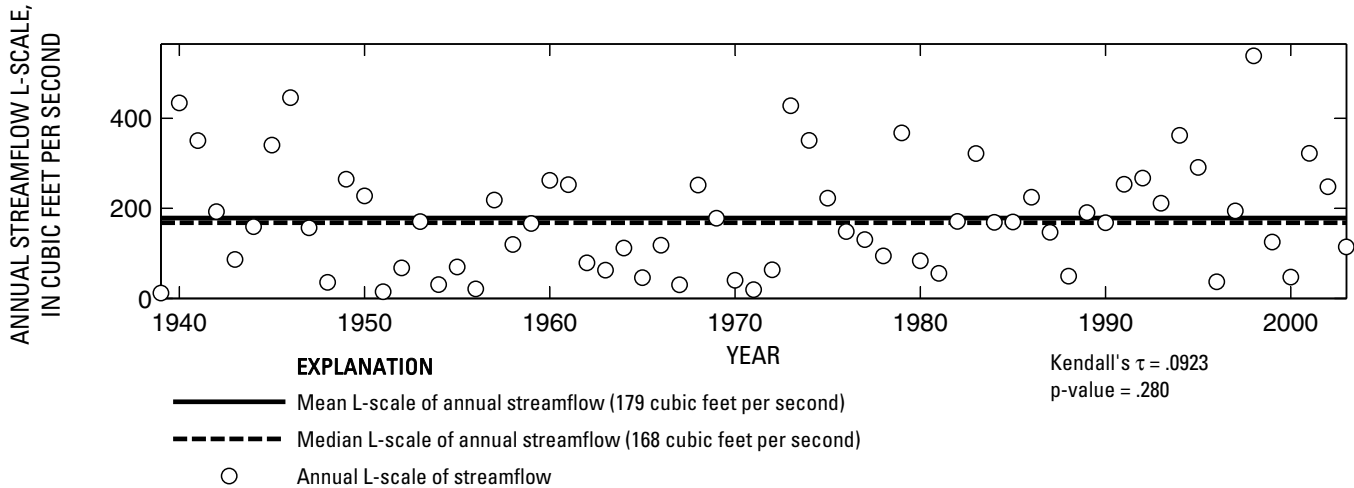

Figure 275. Analysis of annual mean, maximum, minimum, and L-scale statistics of daily mean streamflow for U.S. Geological Survey streamflow-gaging station 08070000 East Fork San Jacinto River near Cleveland, Texas. 


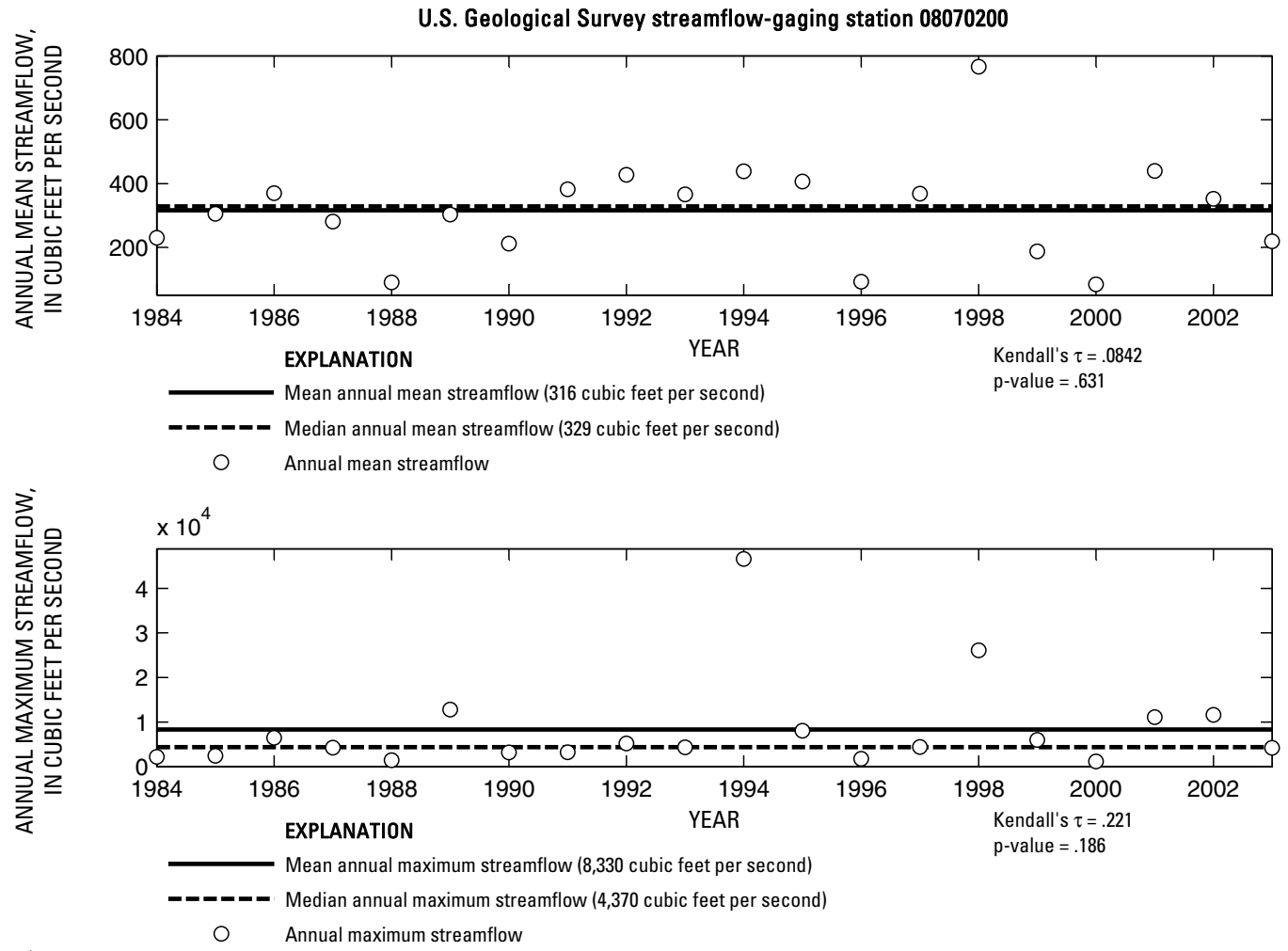

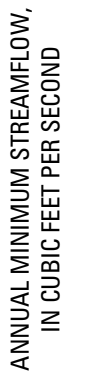

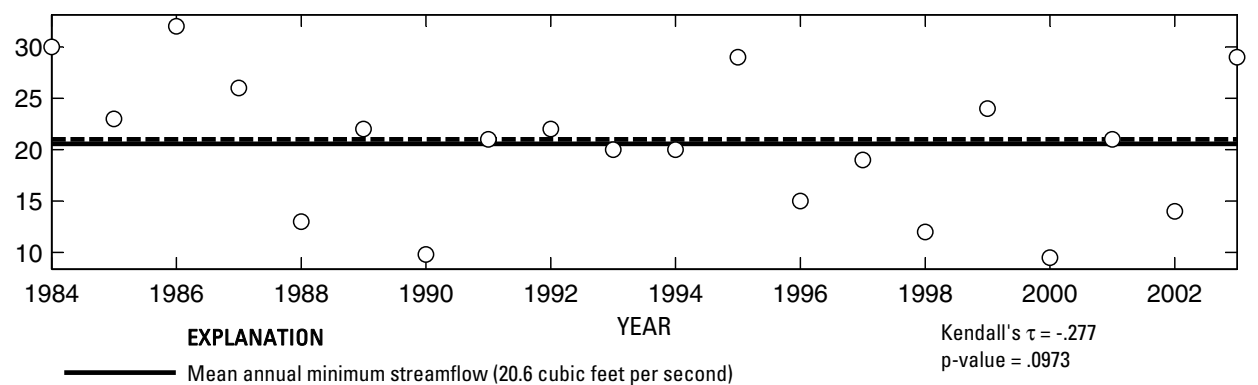

- Median annual minimum streamflow (21 cubic feet per second)

O Annual minimum streamflow

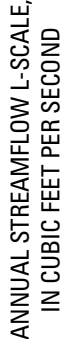

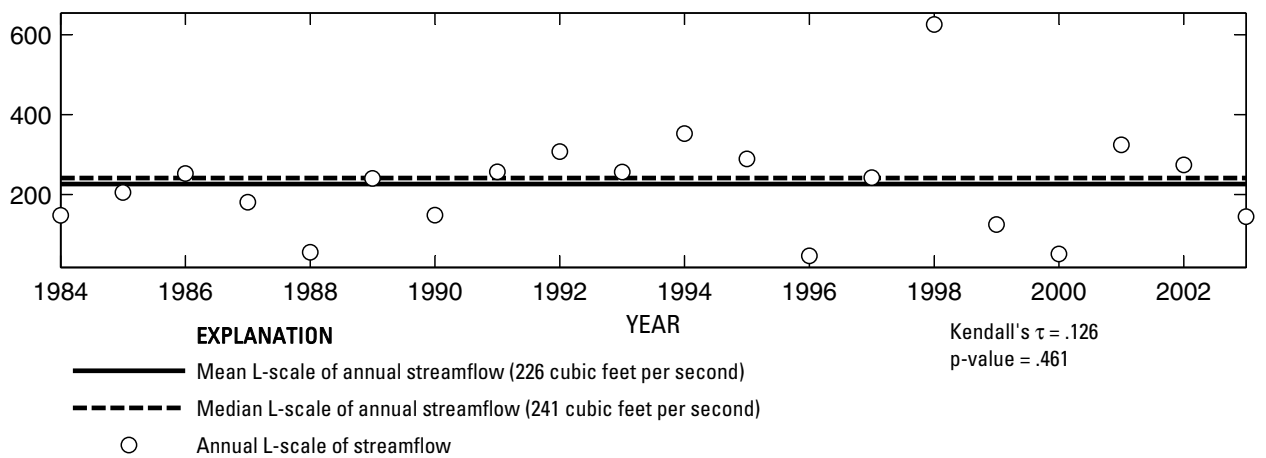

Figure 276. Analysis of annual mean, maximum, minimum, and L-scale statistics of daily mean streamflow for U.S. Geological Survey streamflow-gaging station 08070200 East Fork San Jacinto River near New Caney, Texas.

Index of Station Numbers 719 

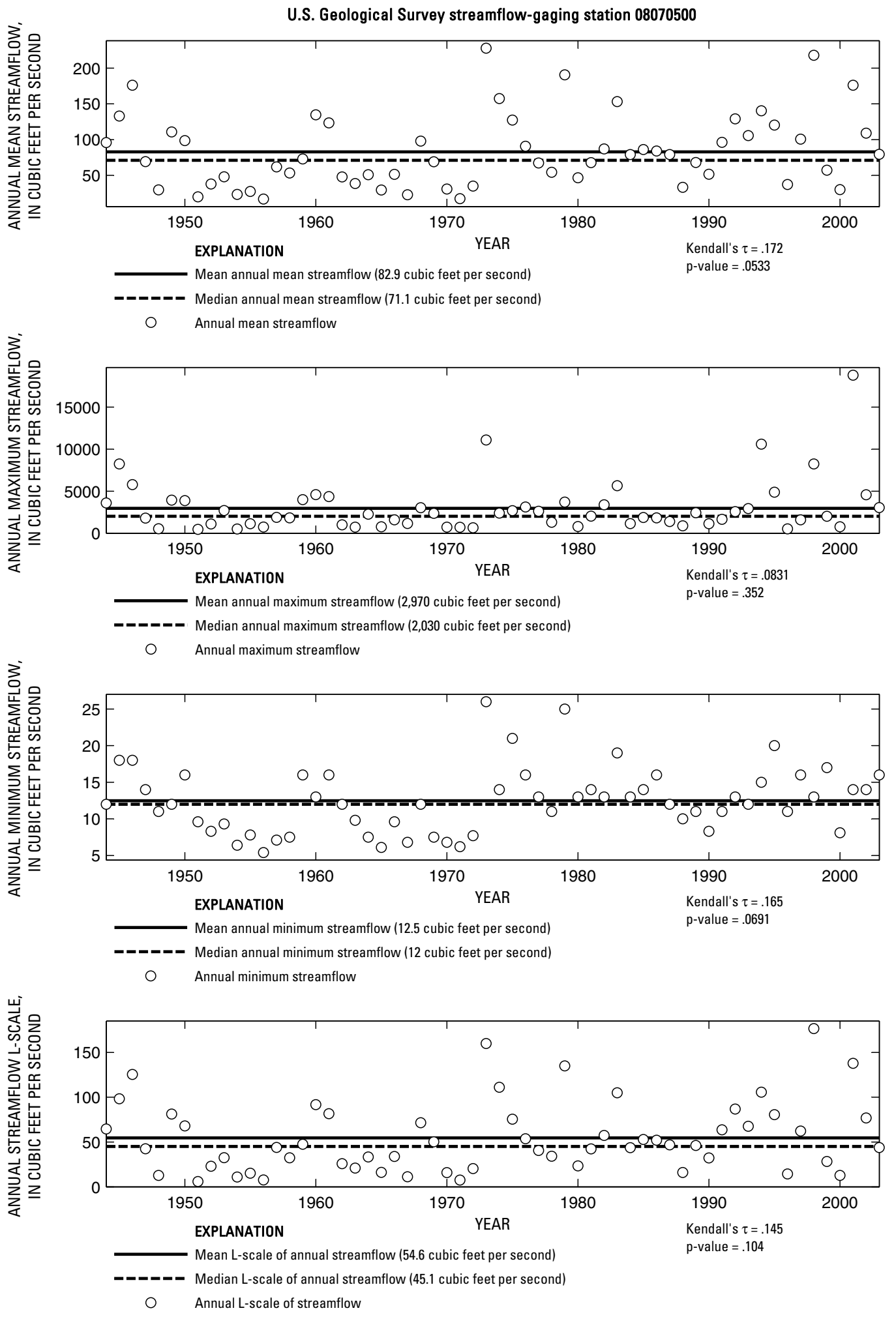

Figure 277. Analysis of annual mean, maximum, minimum, and L-scale statistics of daily mean streamflow for U.S. Geological Survey streamflow-gaging station 08070500 Caney Creek near Splendora, Texas. 


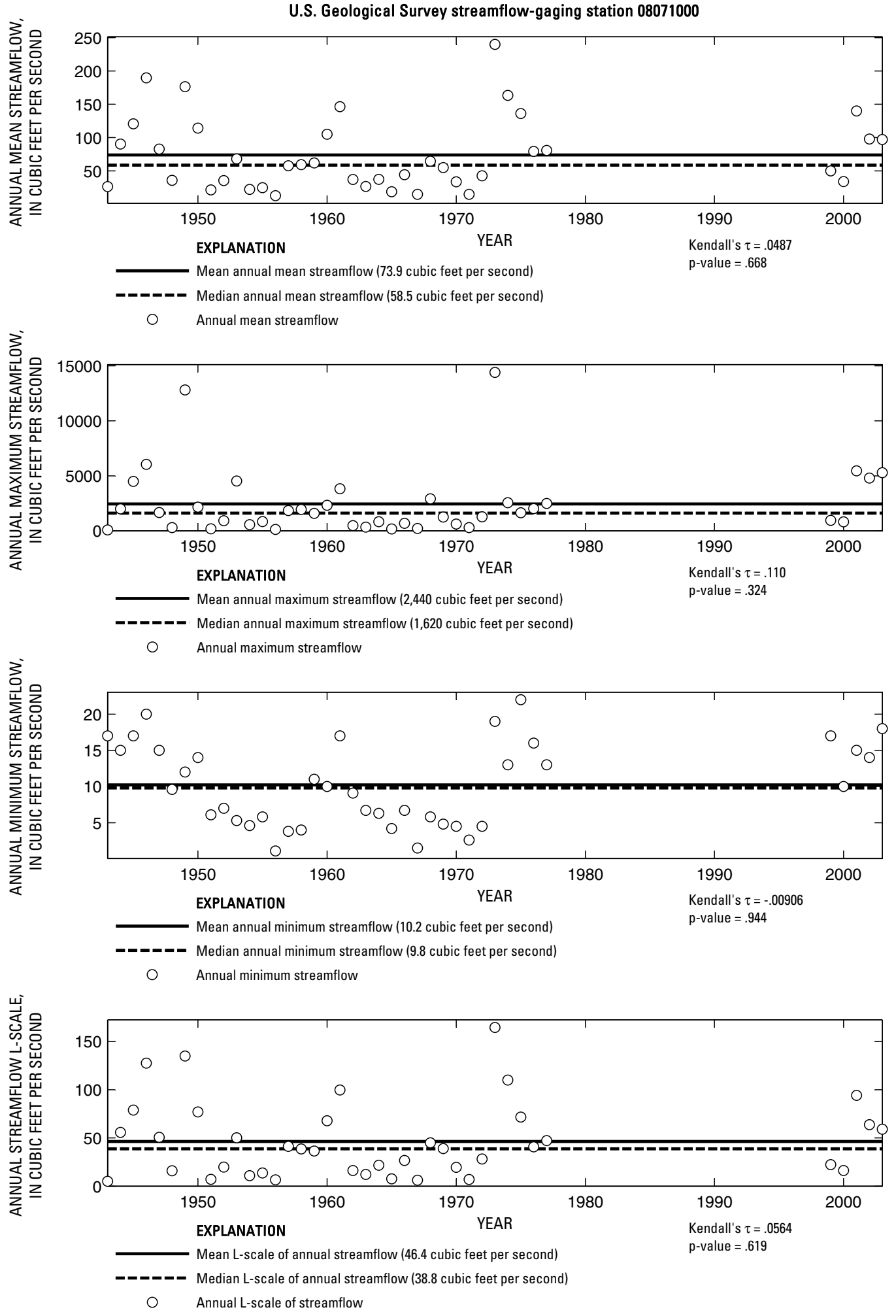

Figure 278. Analysis of annual mean, maximum, minimum, and L-scale statistics of daily mean streamflow for U.S. Geological Survey streamflow-gaging station 08071000 Peach Creek at Splendora, Texas.

Index of Station Numbers 719 


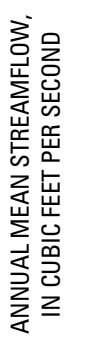

U.S. Geological Survey streamflow-gaging station 08071280

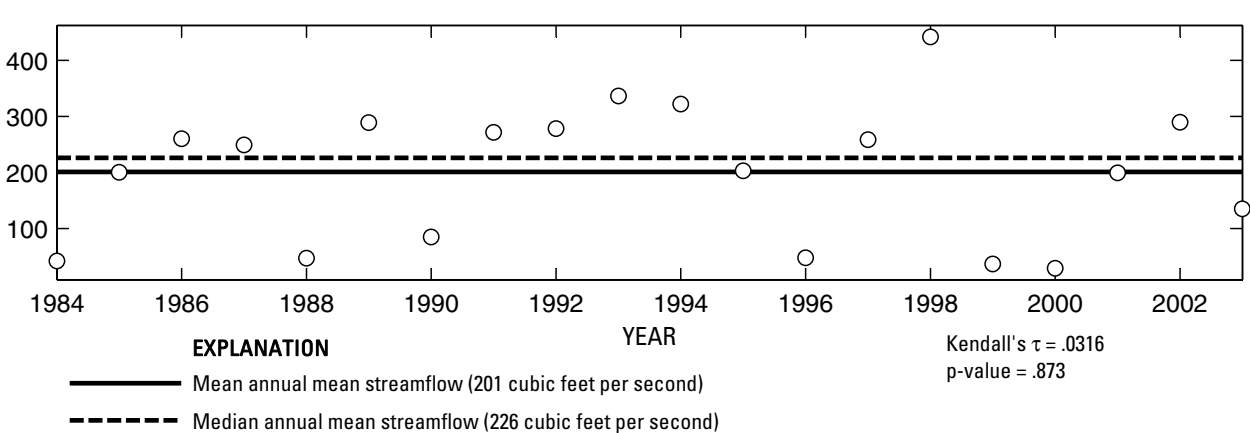

O Annual mean streamflow

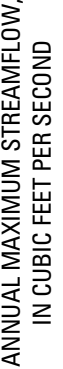

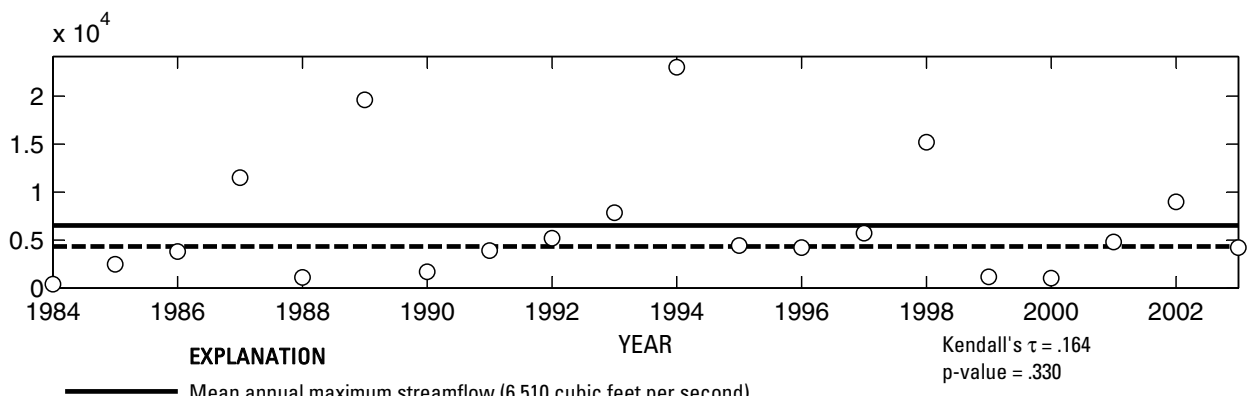

- ב - Median annual maximum streamflow (4,320 cubic feet per second)

O Annual maximum streamflow

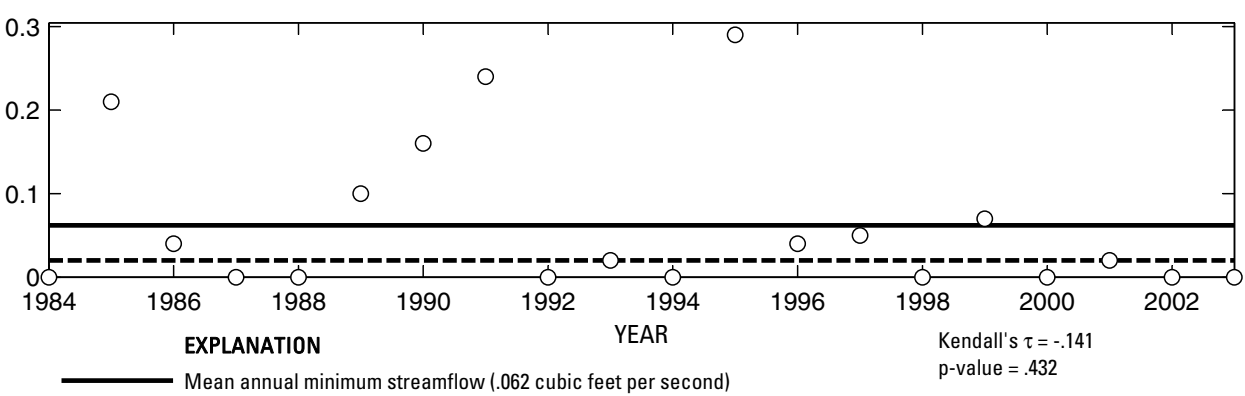

- - - Median annual minimum streamflow (.02 cubic feet per second)

O Annual minimum streamflow
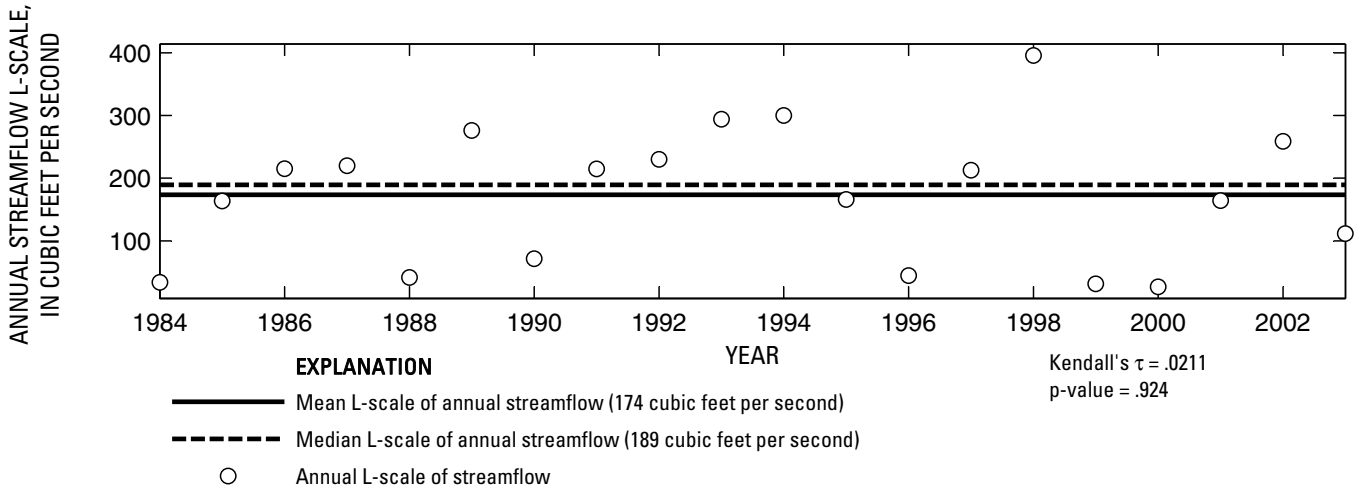

Figure 279. Analysis of annual mean, maximum, minimum, and L-scale statistics of daily mean streamflow for U.S. Geological Survey streamflow-gaging station 08071280 Luce Bayou above Lake Houston near Huffman, Texas.

Index of Station Numbers 719 

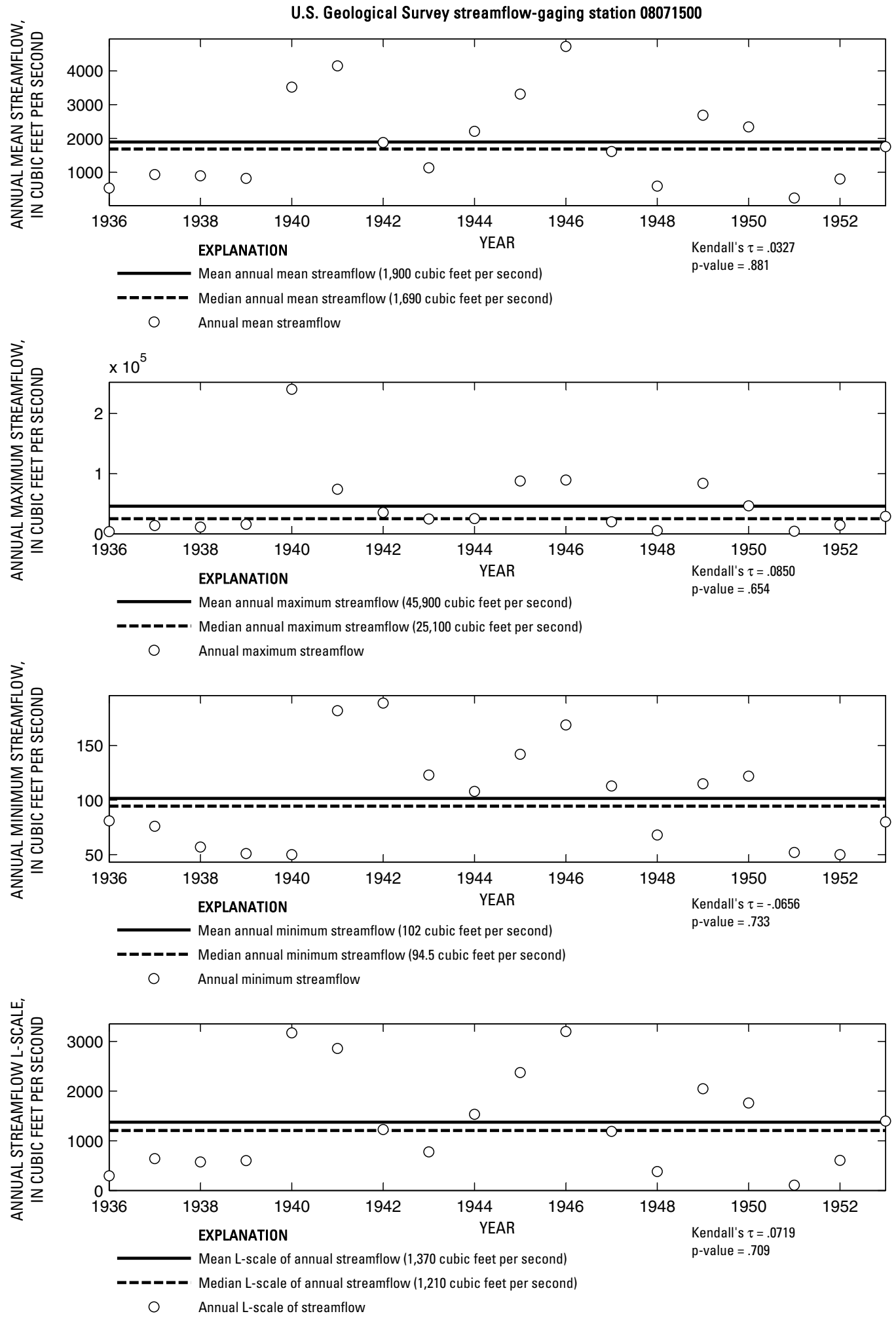

Figure 280. Analysis of annual mean, maximum, minimum, and L-scale statistics of daily mean streamflow for U.S. Geological Survey streamflow-gaging station 08071500 San Jacinto River near Huffman, Texas.

Index of Station Numbers 719 


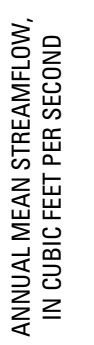

U.S. Geological Survey streamflow-gaging station 08072300

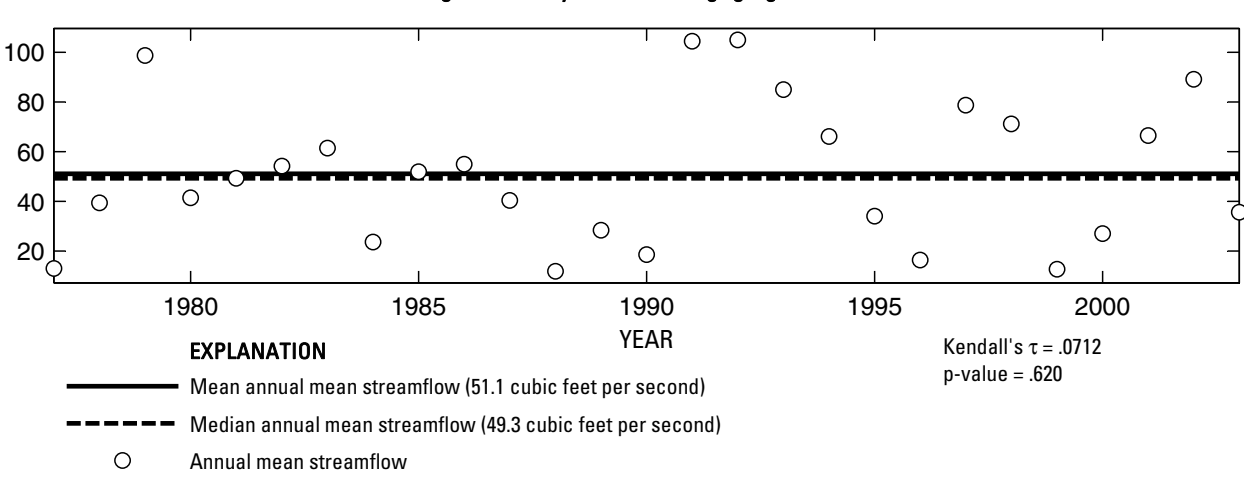

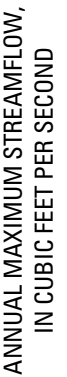

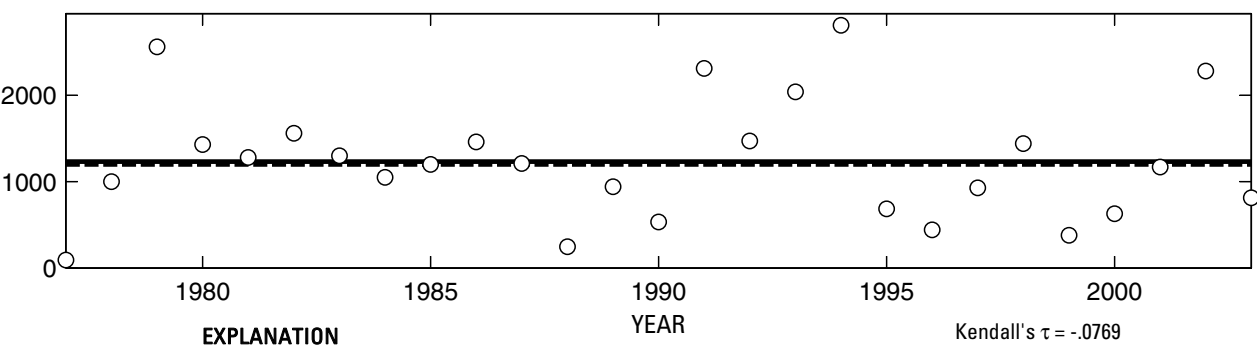

EXPLANATION
Mean annual maximum streamflow $(1,230$ cubic feet per second $)$

p-value $=.591$

- _- Median annual maximum streamflow (1,200 cubic feet per second)

O Annual maximum streamflow
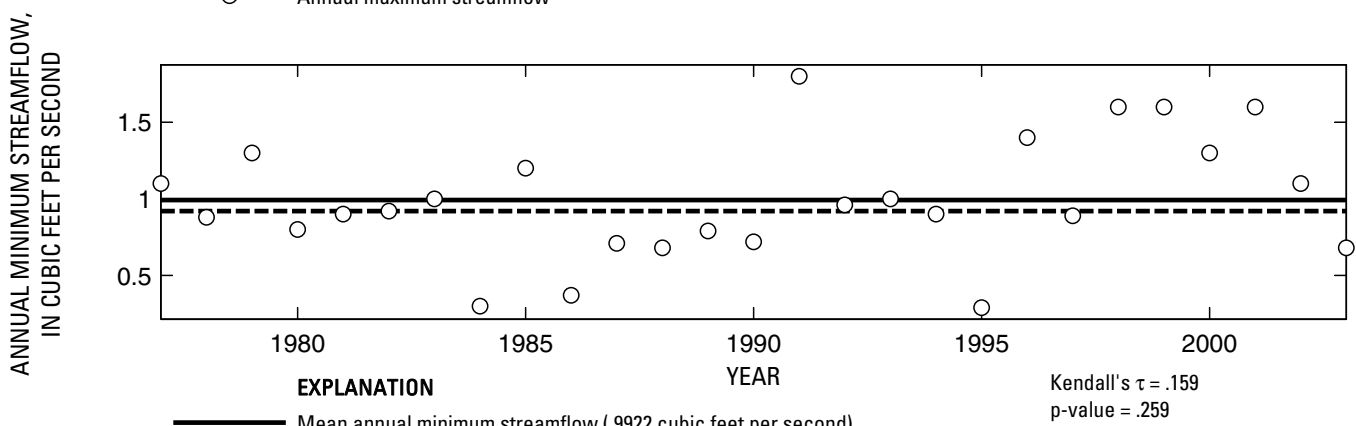

- - - - Median annual minimum streamflow (.92 cubic feet per second)

O Annual minimum streamflow
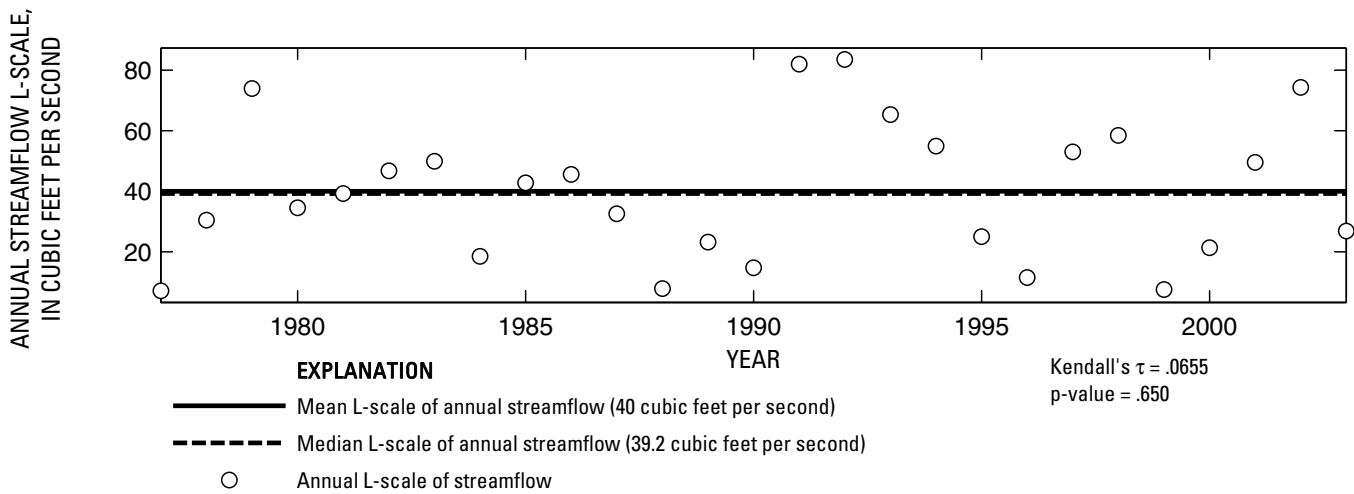

Figure 281. Analysis of annual mean, maximum, minimum, and L-scale statistics of daily mean streamflow for U.S. Geological Survey streamflow-gaging station 08072300 Buffalo Bayou near Katy, Texas.

Index of Station Numbers 719 


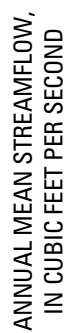

U.S. Geological Survey streamflow-gaging station 08072730

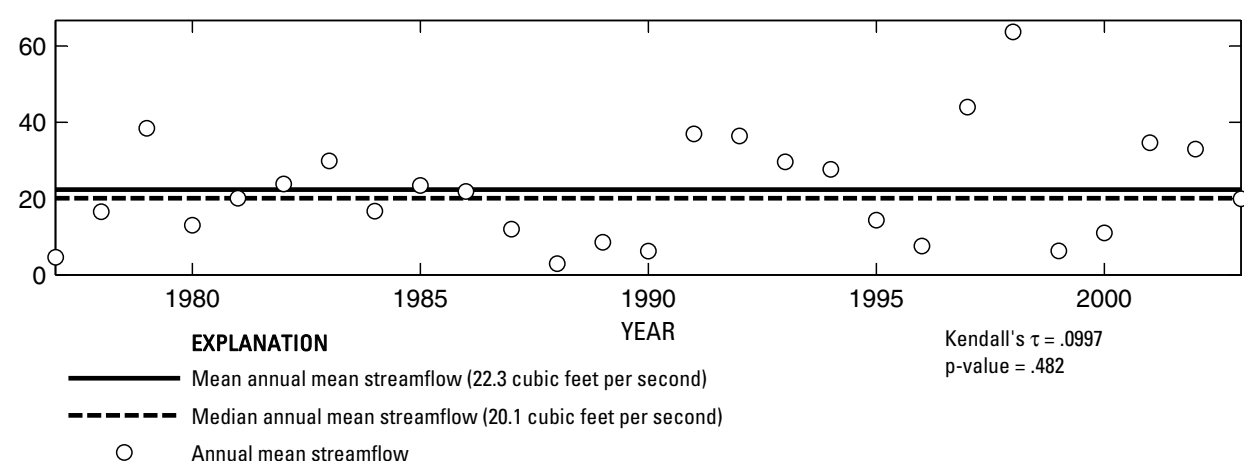

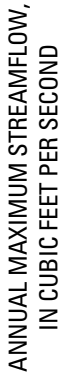

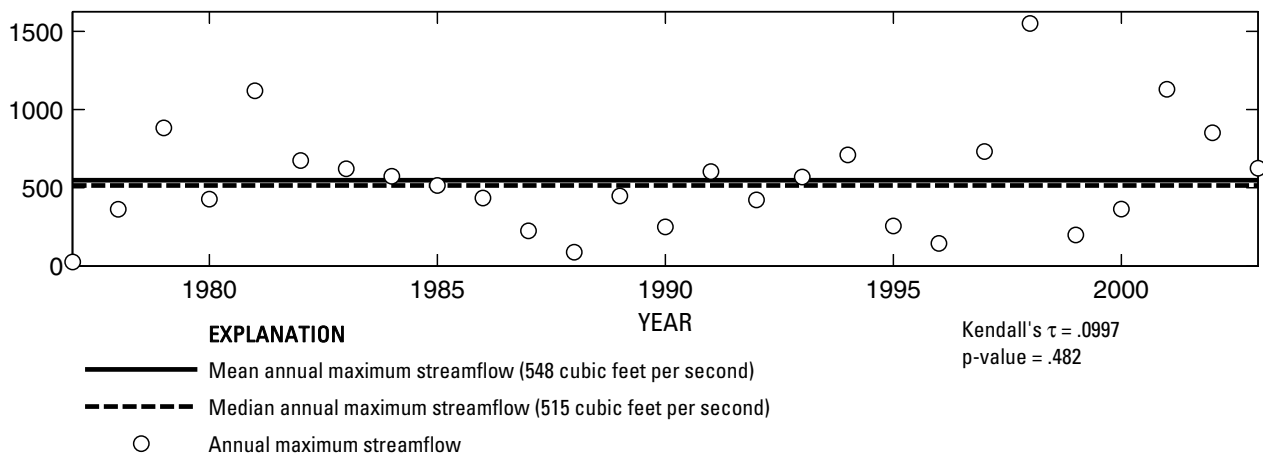

家

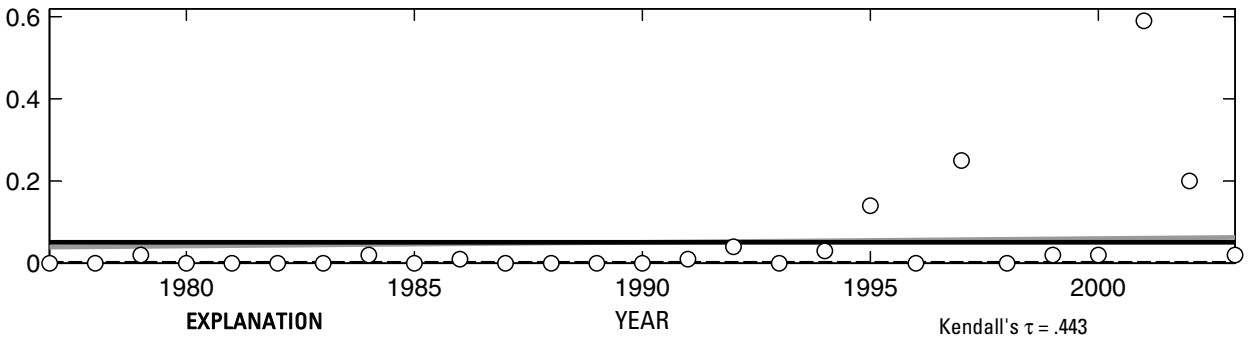

Theil trend line for annual minimum streamflow
Mean annual minimum streamflow (.05074 cubic feet per second)

- - - - Median annual minimum streamflow (0 cubic feet per second)

0

Annual minimum streamflow

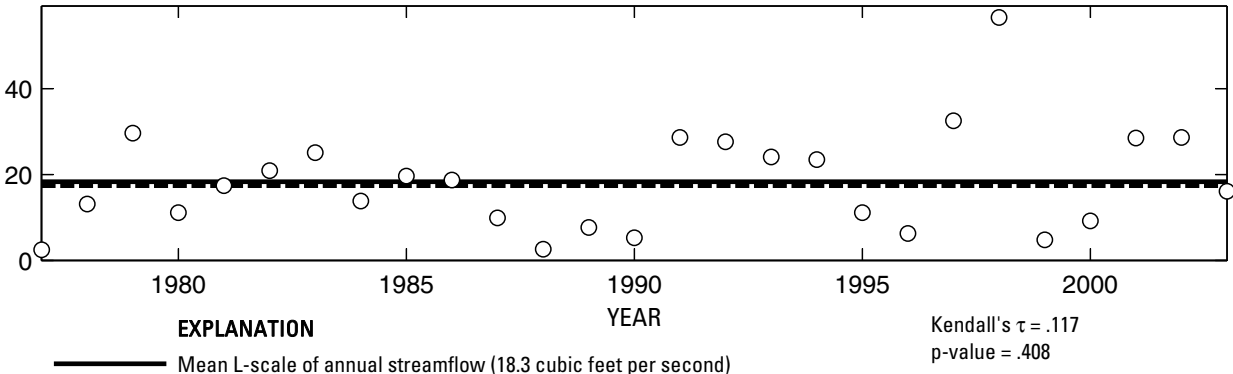

- - - Median L-scale of annual streamflow (17.4 cubic feet per second)

O Annual L-scale of streamflow

Figure 282. Analysis of annual mean, maximum, minimum, and L-scale statistics of daily mean streamflow for U.S. Geological Survey streamflow-gaging station 08072730 Bear Creek near Barker, Texas.

Index of Station Numbers 719 


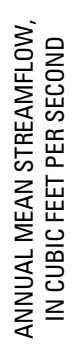

U.S. Geological Survey streamflow-gaging station 08072760

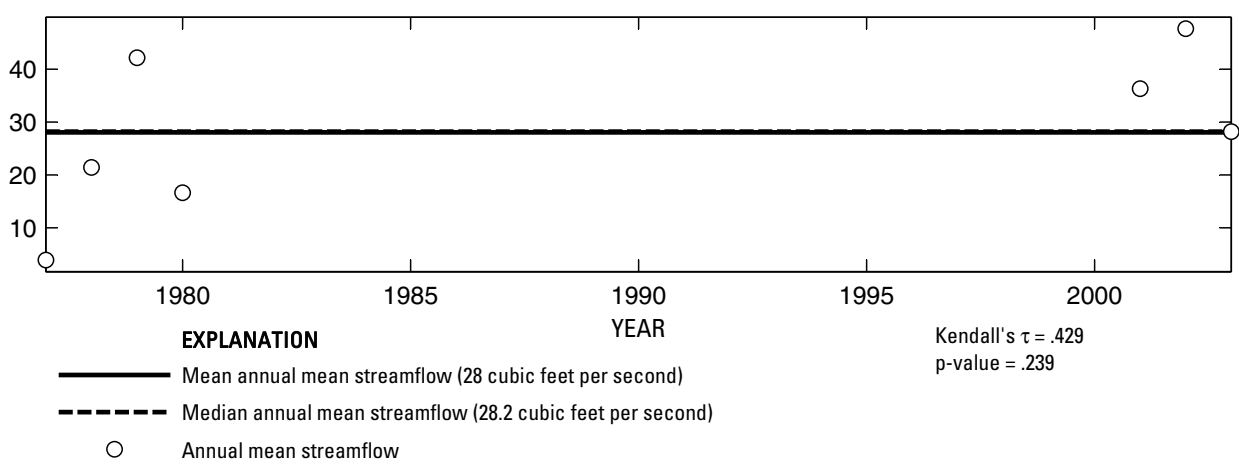

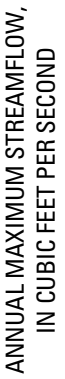

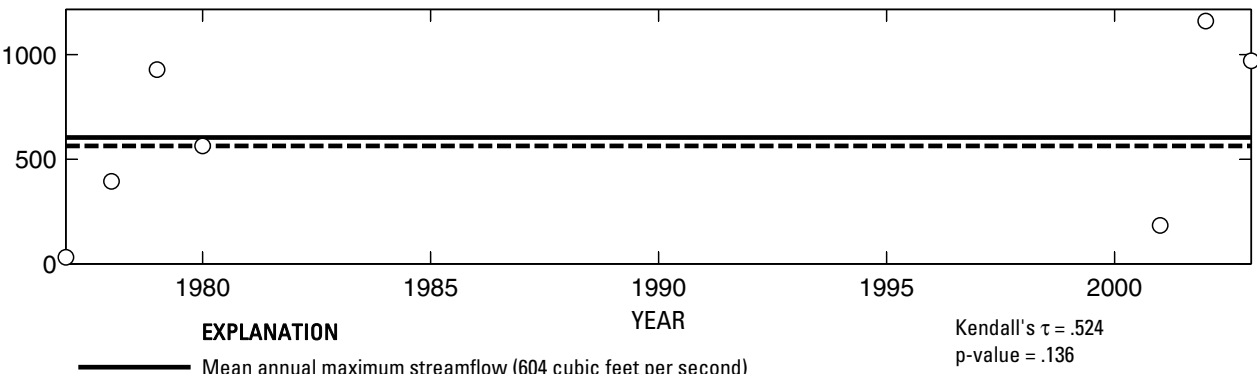

- - - Median annual maximum streamflow (563 cubic feet per second)

○ Annual maximum streamflow

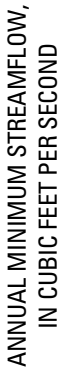

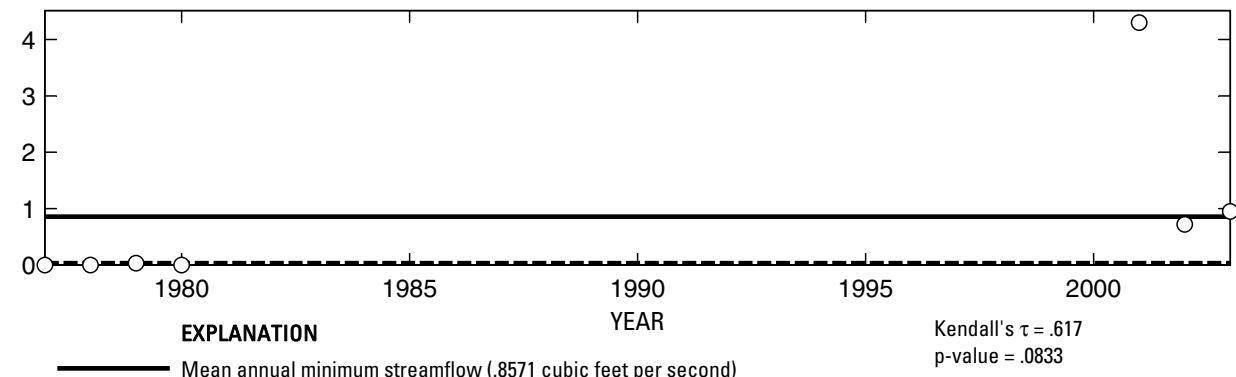

- - - - Median annual minimum streamflow (.03 cubic feet per second)

$\bigcirc \quad$ Annual minimum streamflow

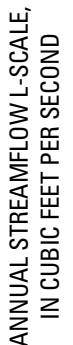

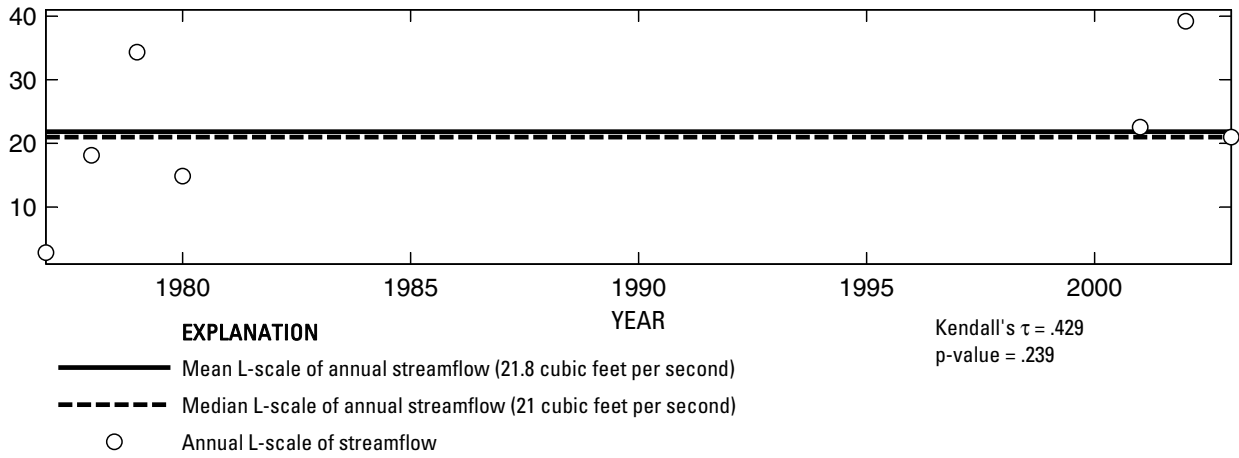

Figure 283. Analysis of annual mean, maximum, minimum, and L-scale statistics of daily mean streamflow for U.S. Geological Survey streamflow-gaging station 08072760 Langham Creek at West Little York Road near Addicks, Texas. 


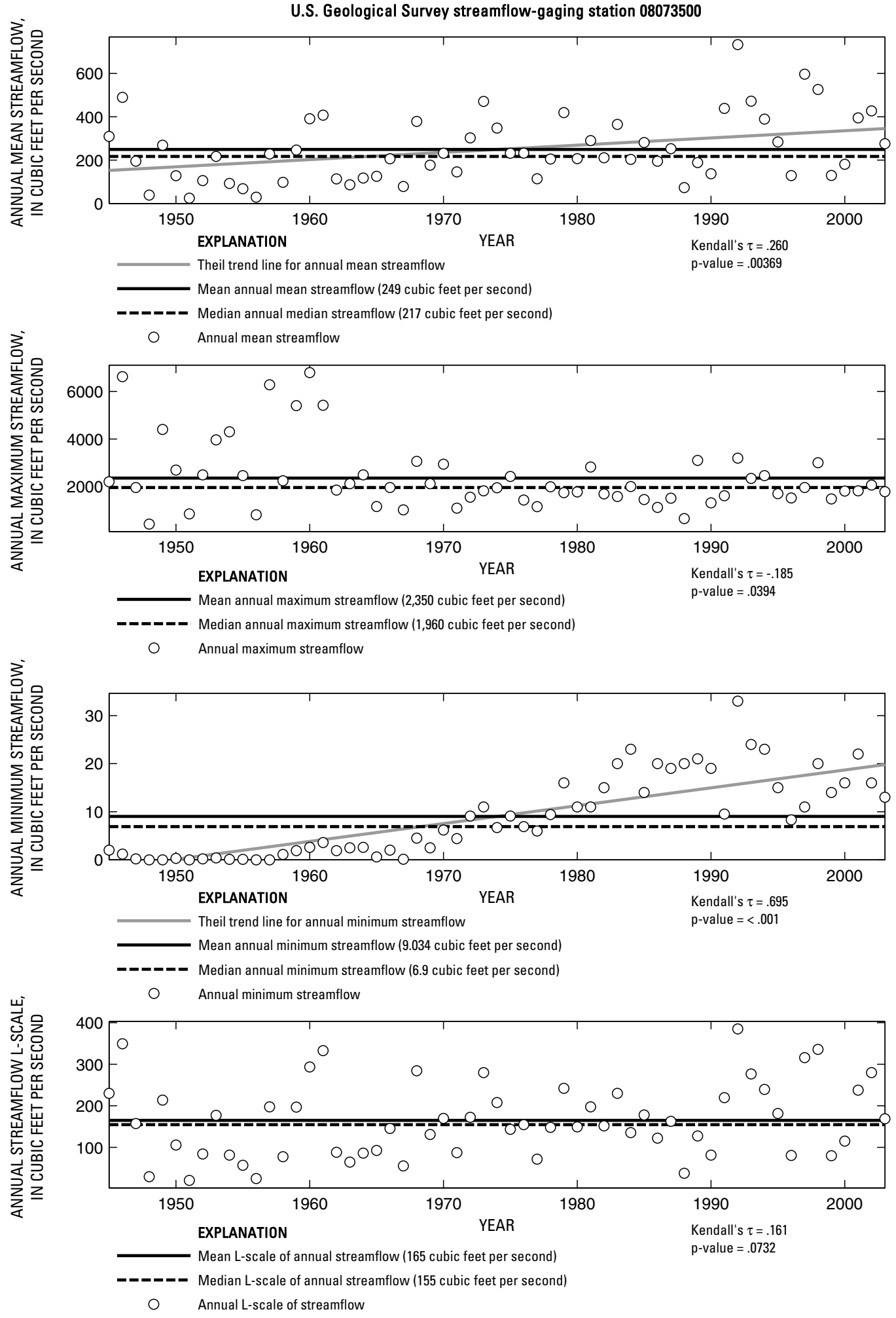

Figure 284. Analysis of annual mean, maximum, minimum, and L-scale statistics of daily mean streamflow for U.S. Geological Survey streamflow-gaging station 08073500 Buffalo Bayou near Addicks, Texas.

Index of Station Numbers 719 

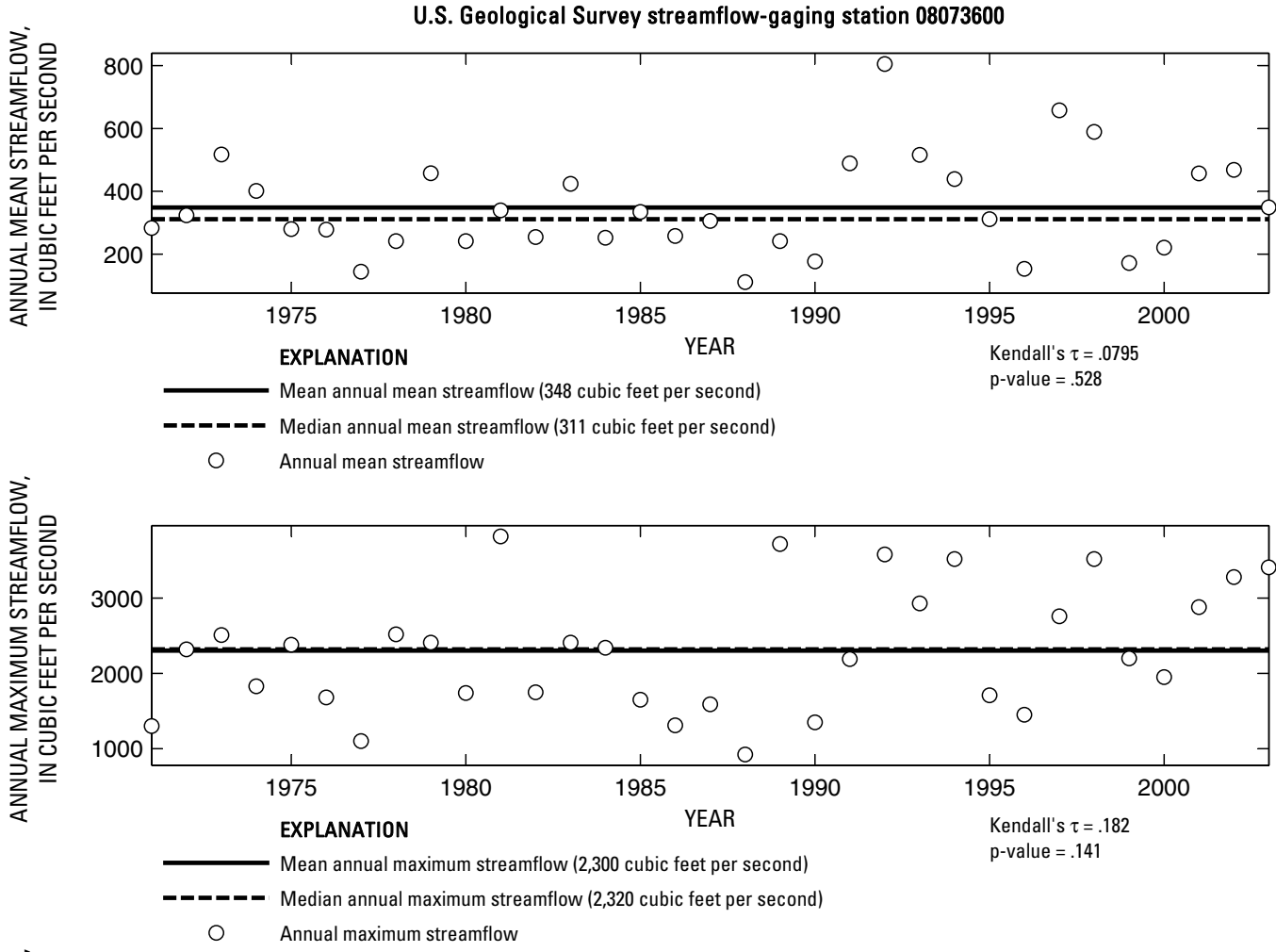

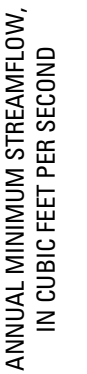

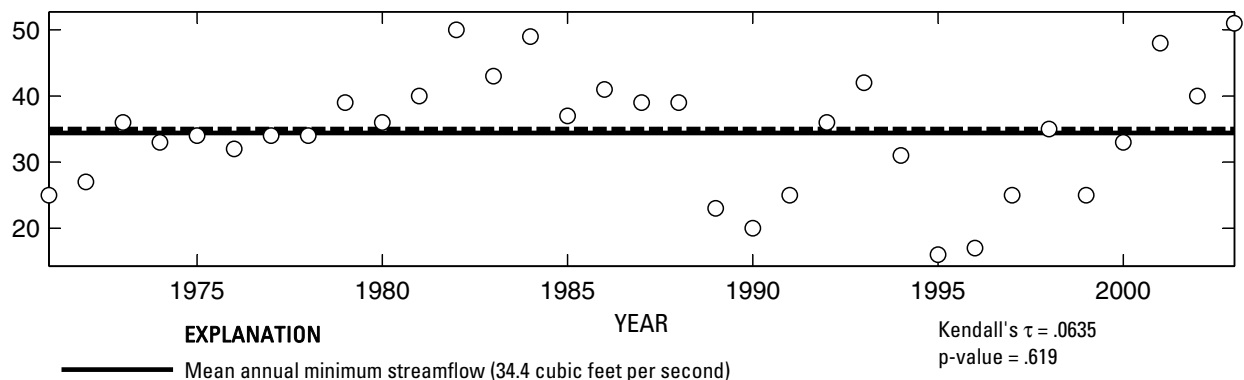

-_-_- Median annual minimum streamflow (35 cubic feet per second)

O Annual minimum streamflow

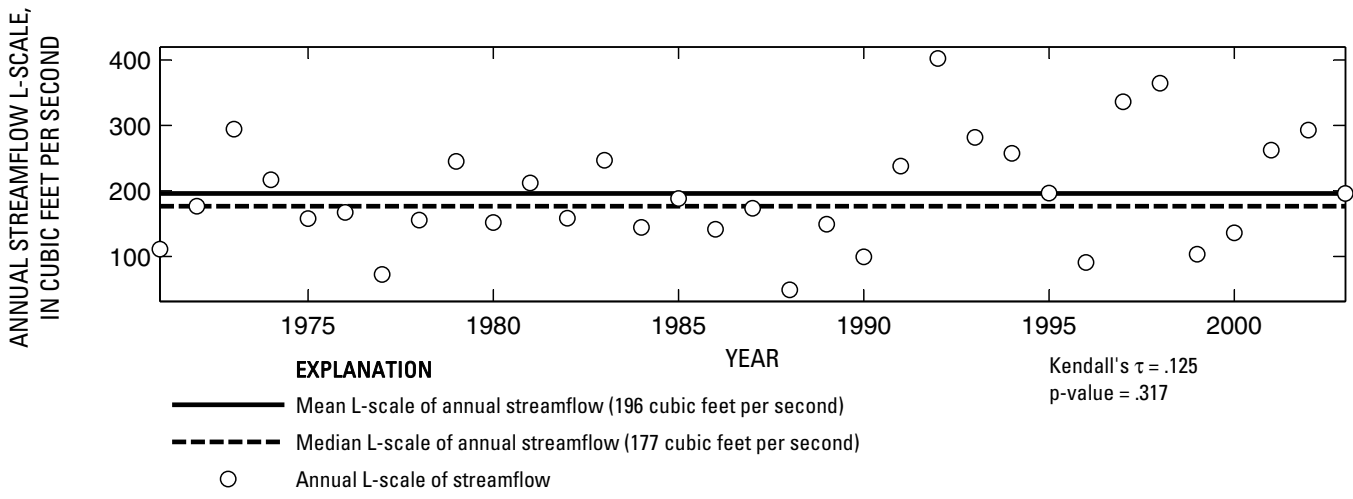

Figure 285. Analysis of annual mean, maximum, minimum, and L-scale statistics of daily mean streamflow for U.S. Geological Survey streamflow-gaging station 08073600 Buffalo Bayou at West Belt Drive, Houston, Texas.

Index of Station Numbers 719 


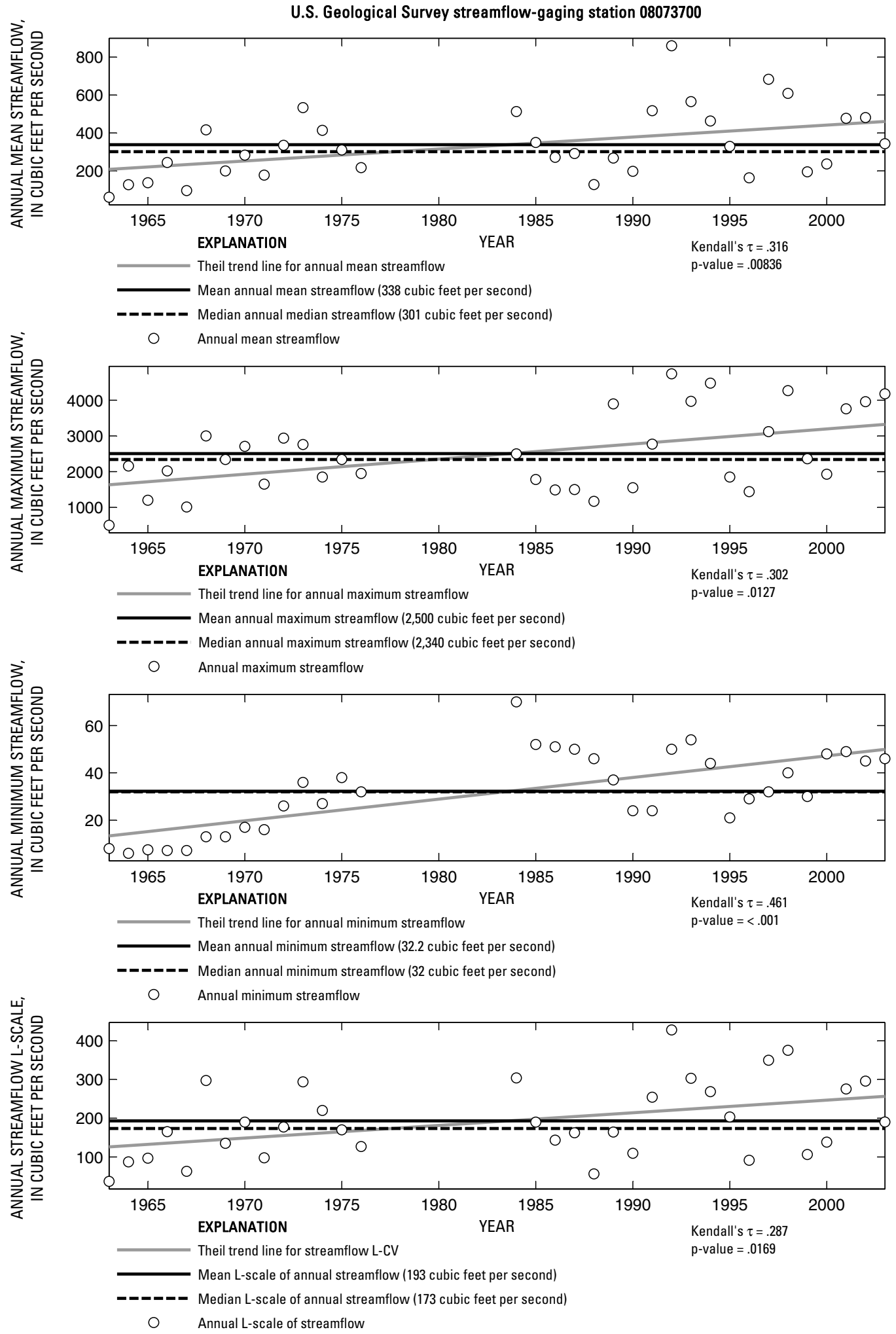

Figure 286. Analysis of annual mean, maximum, minimum, and L-scale statistics of daily mean streamflow for U.S. Geological Survey streamflow-gaging station 08073700 Buffalo Bayou at Piney Point, Texas.

Index of Station Numbers 719 


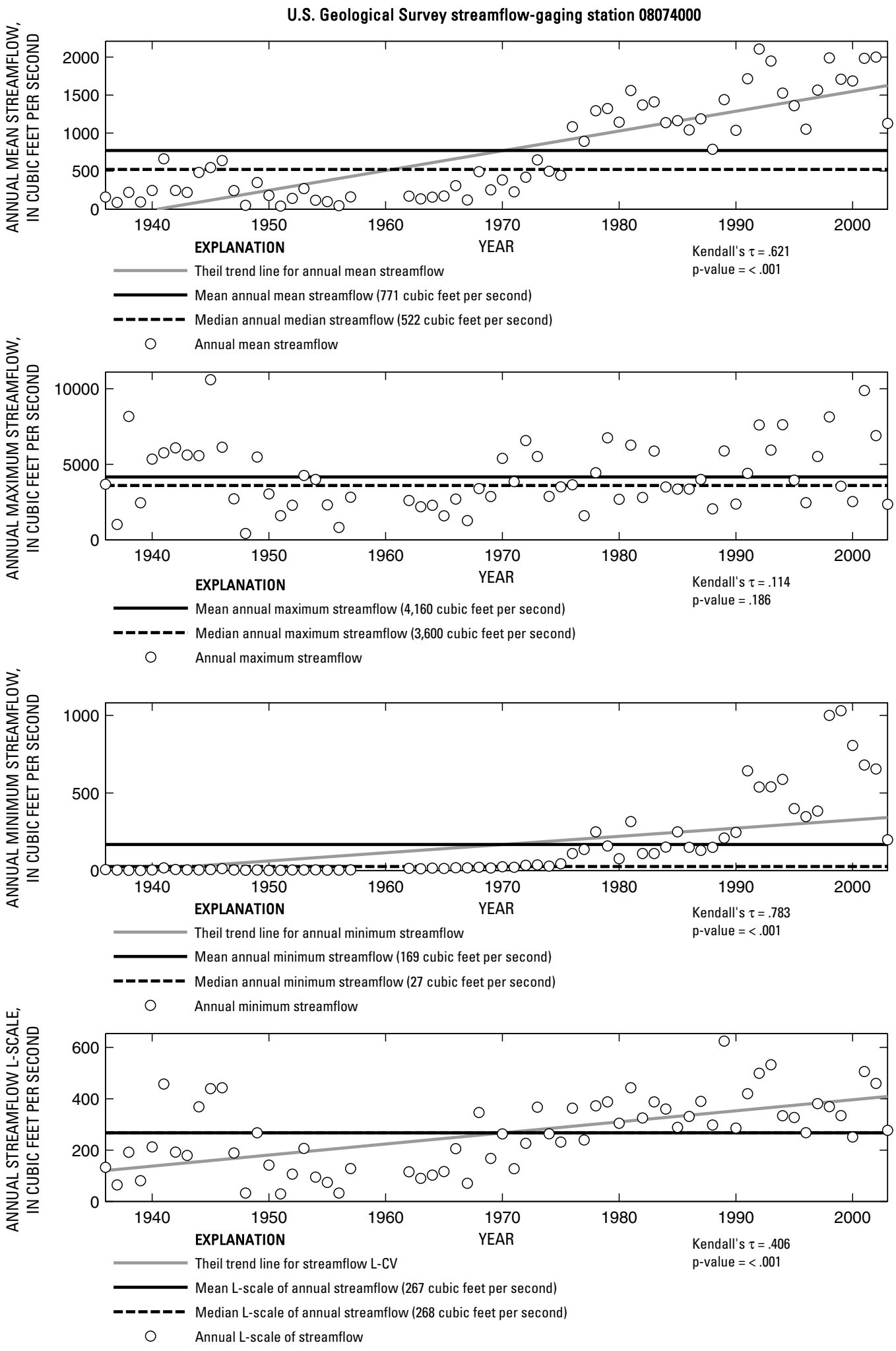

Figure 287. Analysis of annual mean, maximum, minimum, and L-scale statistics of daily mean streamflow for U.S. Geological Survey streamflow-gaging station 08074000 Buffalo Bayou at Houston, Texas. 

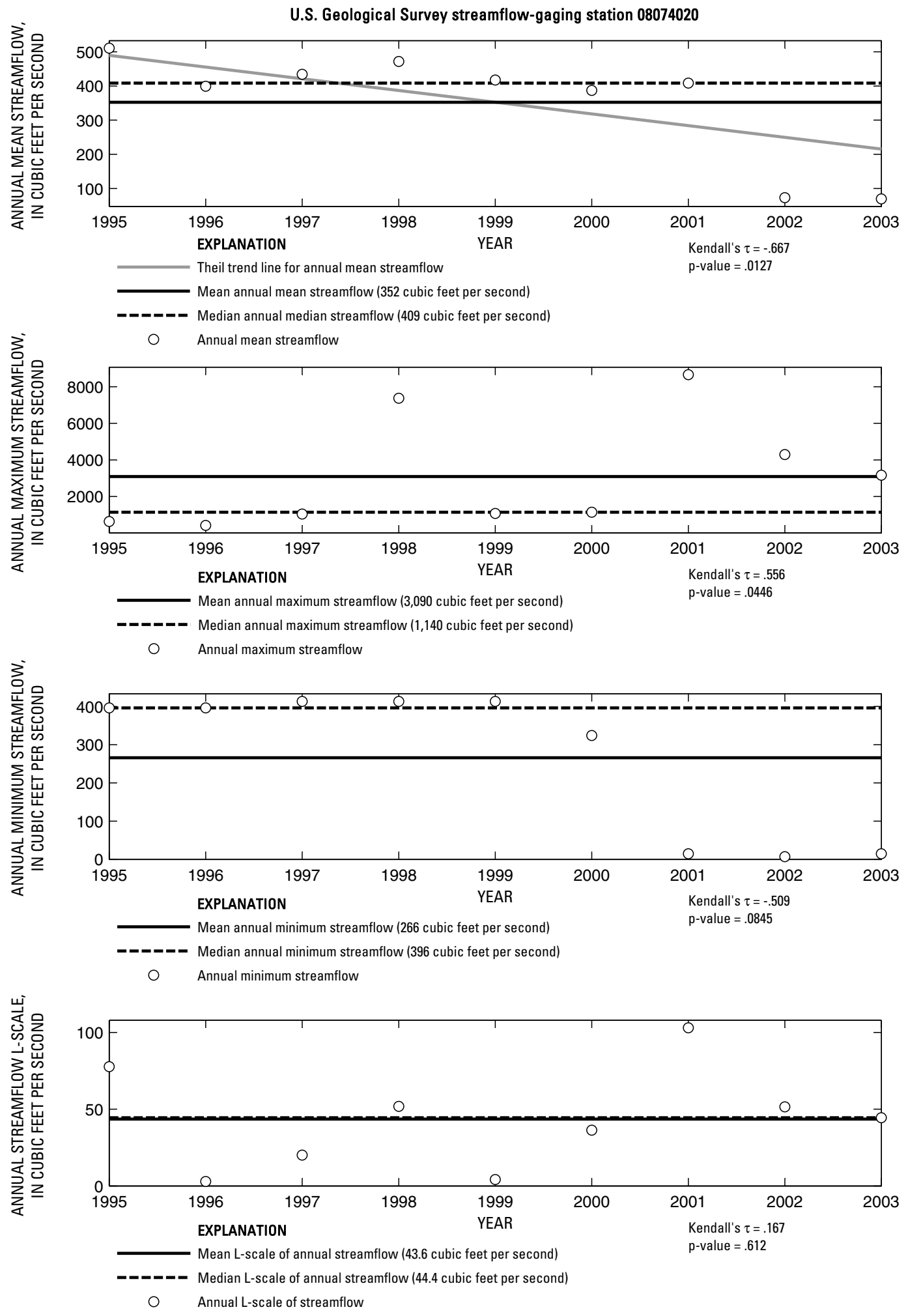

Figure 288. Analysis of annual mean, maximum, minimum, and L-scale statistics of daily mean streamflow for U.S. Geological Survey streamflow-gaging station 08074020 Whiteoak Bayou at Alabonson Road, Houston, Texas.

Index of Station Numbers 719 


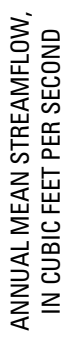

U.S. Geological Survey streamflow-gaging station 08074150

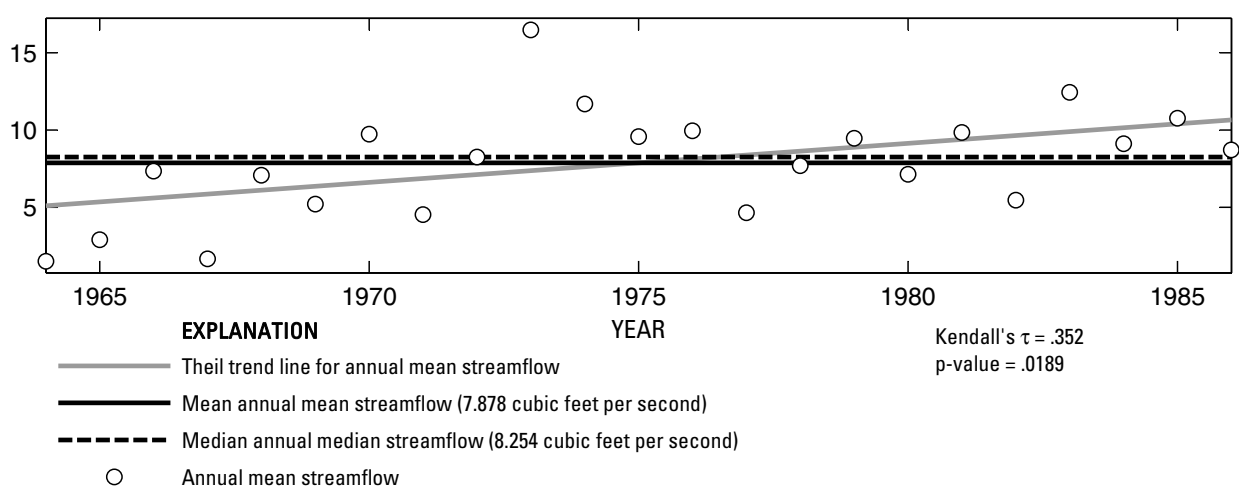

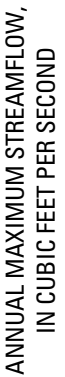

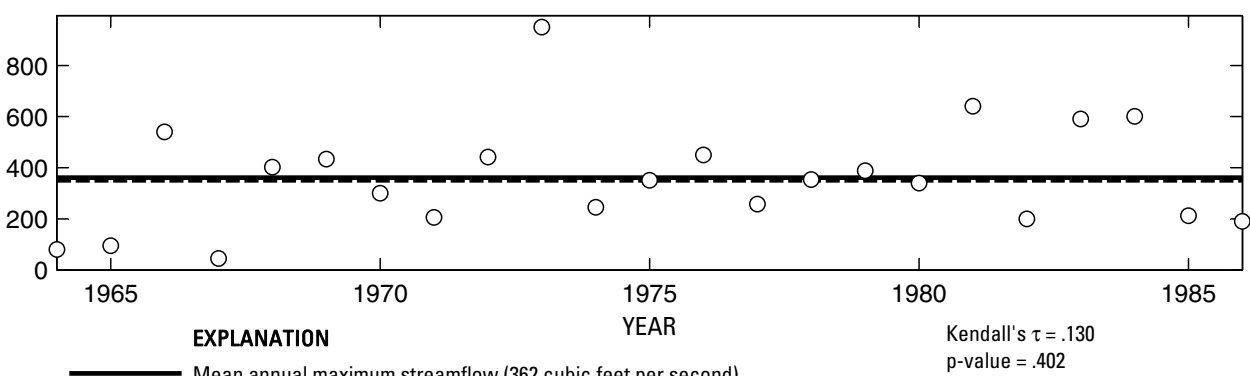

O Annual maximum streamflow

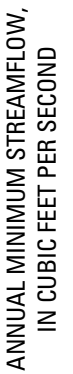

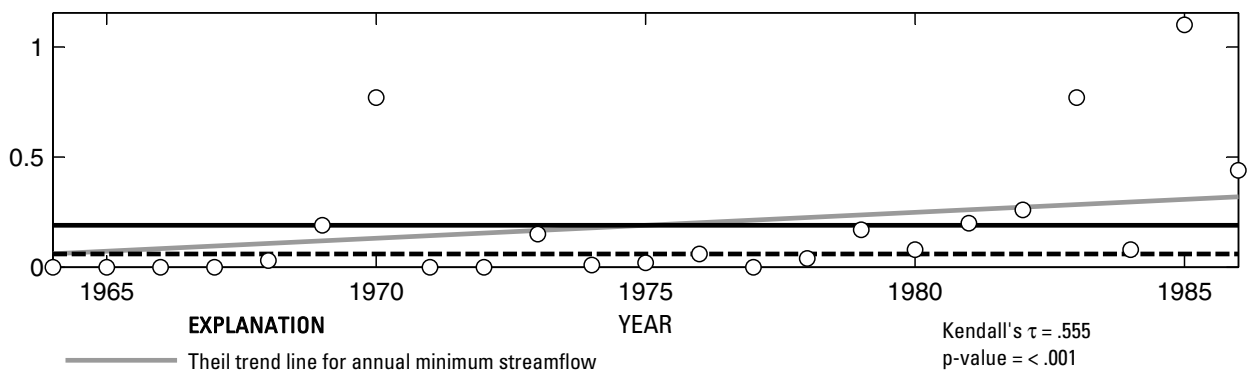

Median annual minimum streamflow (.06 cubic feet per second)

$\bigcirc \quad$ Annual minimum streamflow
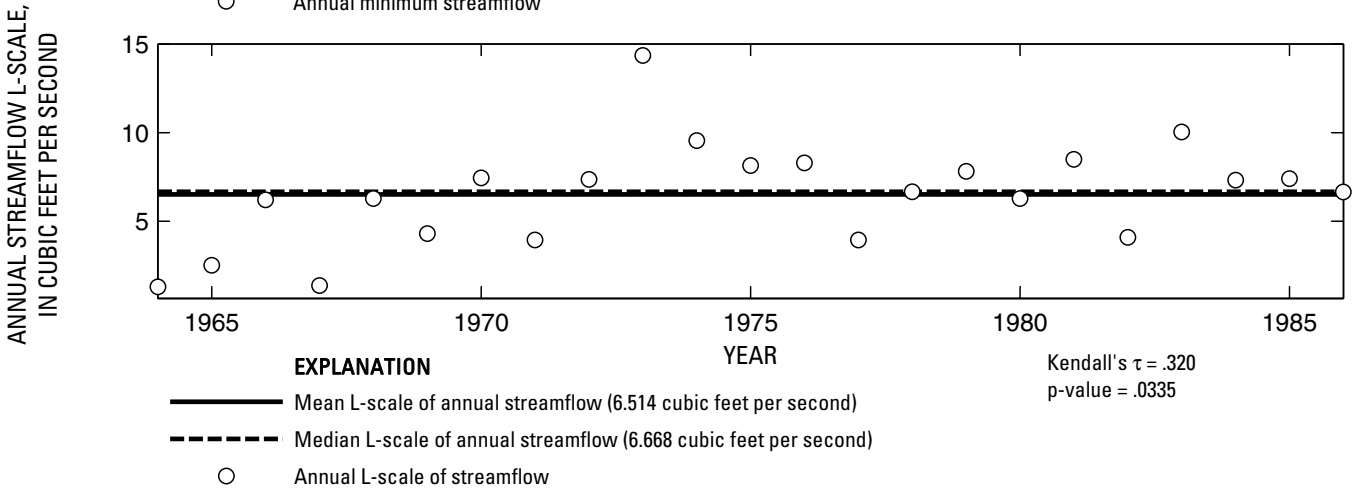

Figure 289. Analysis of annual mean, maximum, minimum, and L-scale statistics of daily mean streamflow for U.S. Geological Survey streamflow-gaging station 08074150 Cole Creek at Deihl Road, Houston, Texas.

Index of Station Numbers 719 
U.S. Geological Survey streamflow-gaging station 08074250

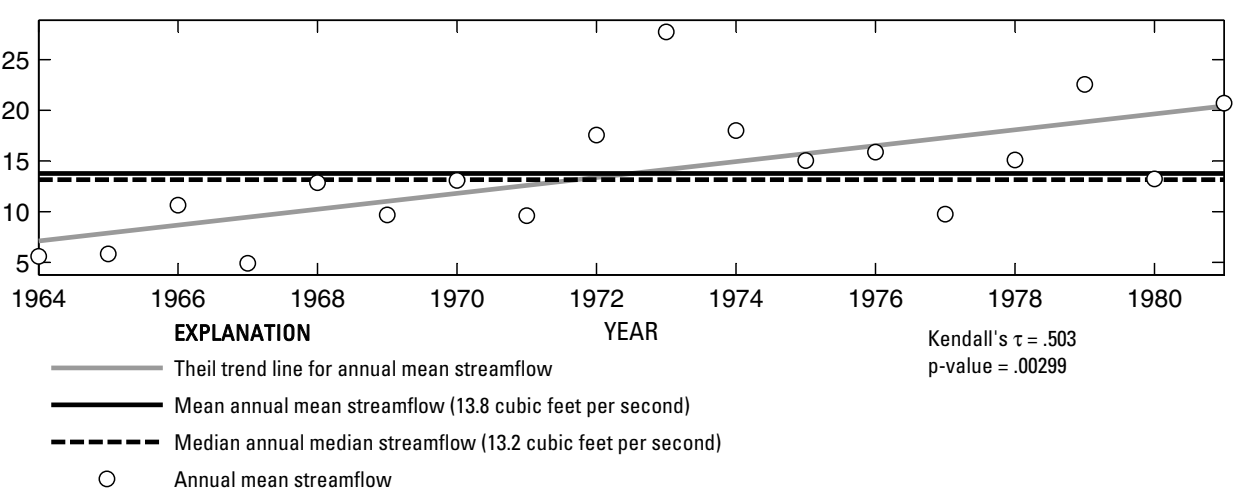

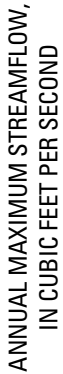

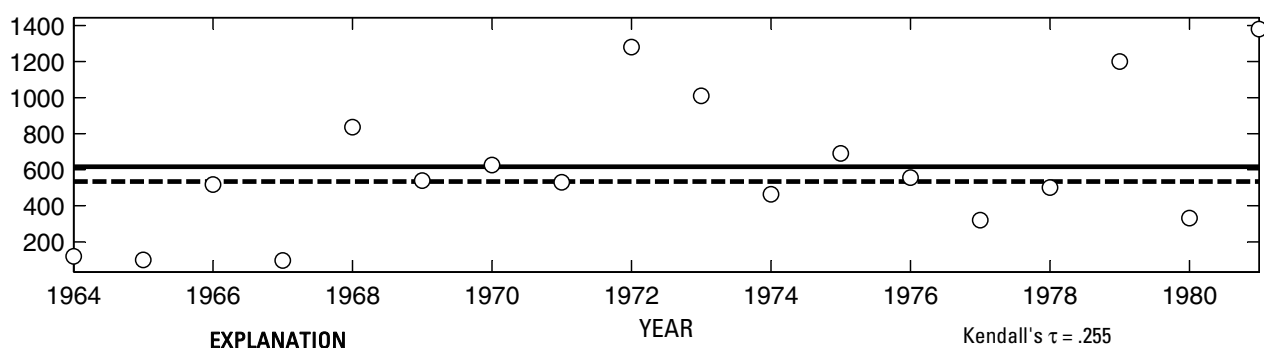

EXPLANATION

p-value $=.152$

- - Median annual maximum streamflow (535 cubic feet per second)

O Annual maximum streamflow

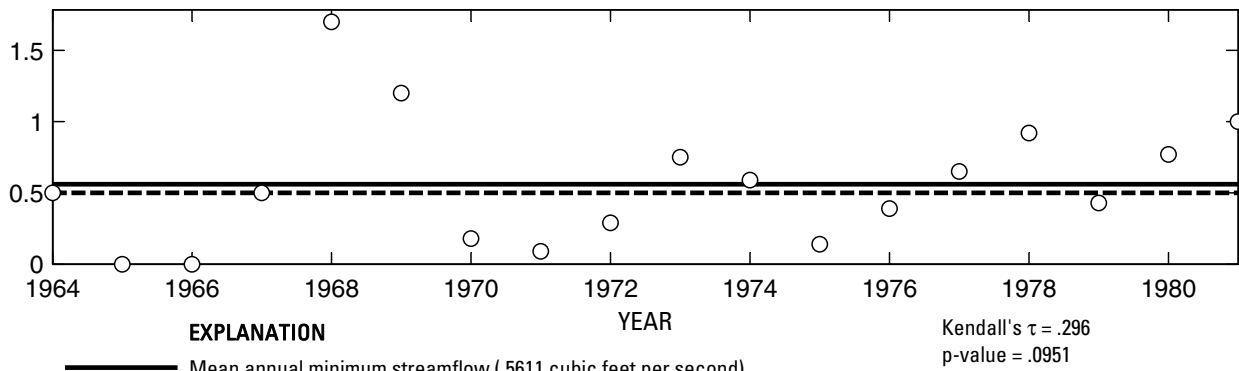

- - Median annual minimum streamflow (.5 cubic feet per second)

O Annual minimum streamflow

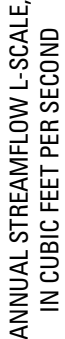

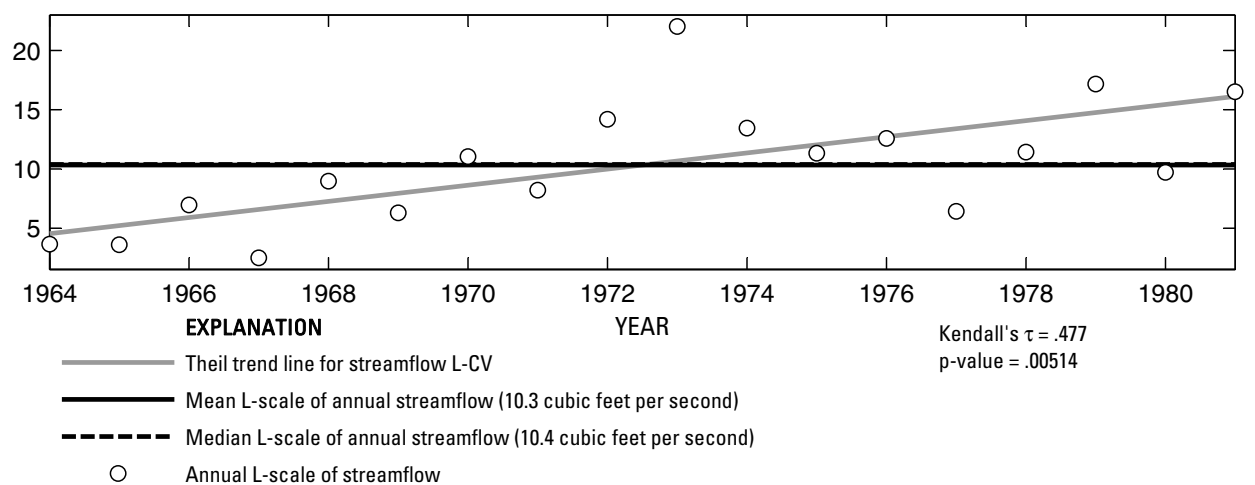

Figure 290. Analysis of annual mean, maximum, minimum, and L-scale statistics of daily mean streamflow for U.S. Geological Survey streamflow-gaging station 08074250 Brickhouse Gully at Costa Rica Street, Houston, Texas.

Index of Station Numbers 719 


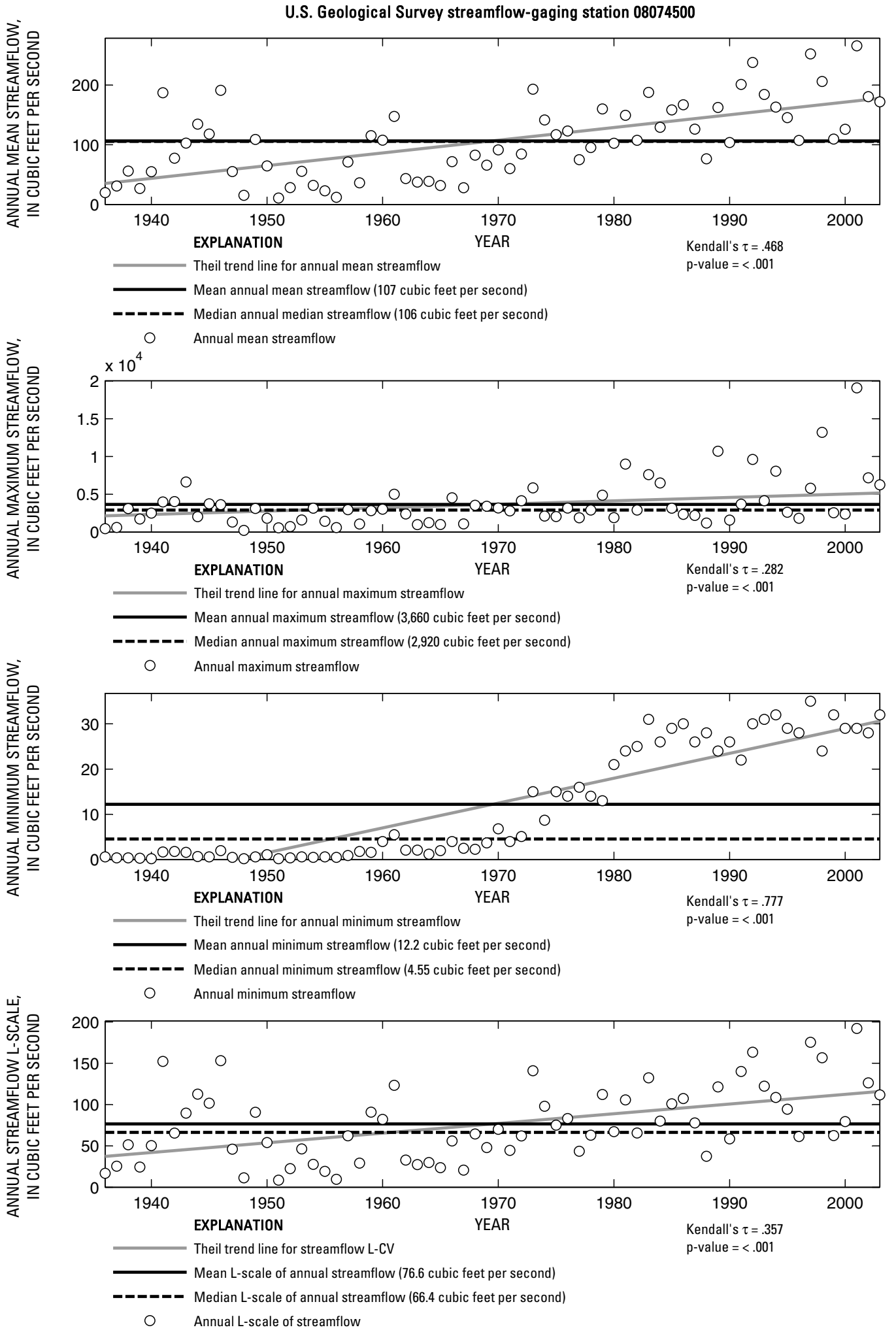

Figure 291. Analysis of annual mean, maximum, minimum, and L-scale statistics of daily mean streamflow for U.S. Geological Survey streamflow-gaging station 08074500 Whiteoak Bayou at Houston, Texas. 
空

U.S. Geological Survey streamflow-gaging station 08074760

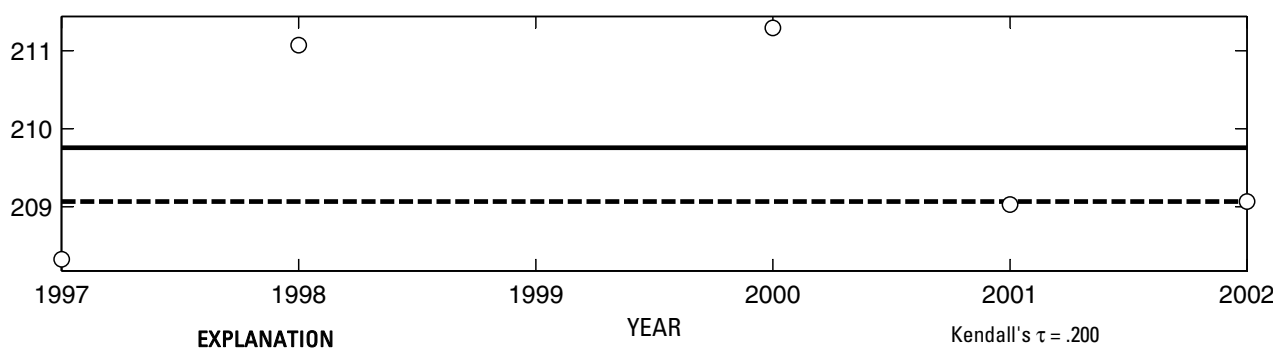

-_-_-_ Median annual mean streamflow (209 cubic feet per second)

O Annual mean streamflow

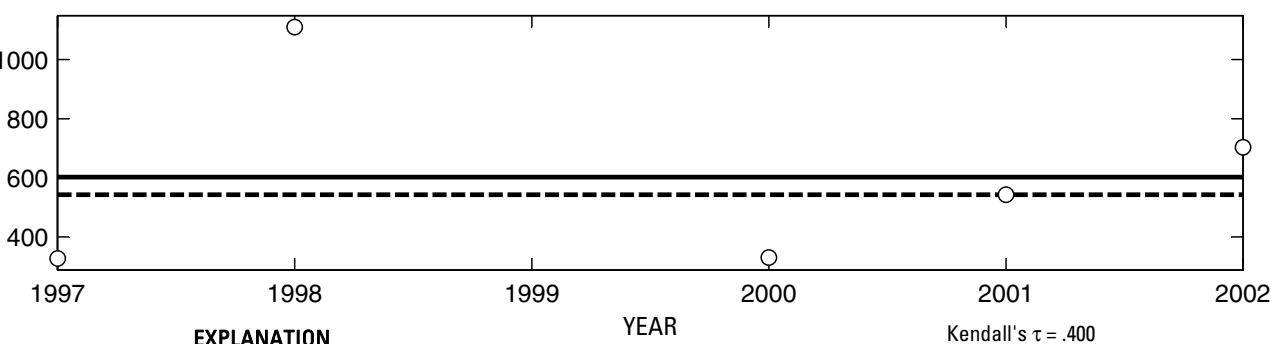

- ב Median annual maximum streamflow (543 cubic feet per second)

Annual maximum streamflow

家

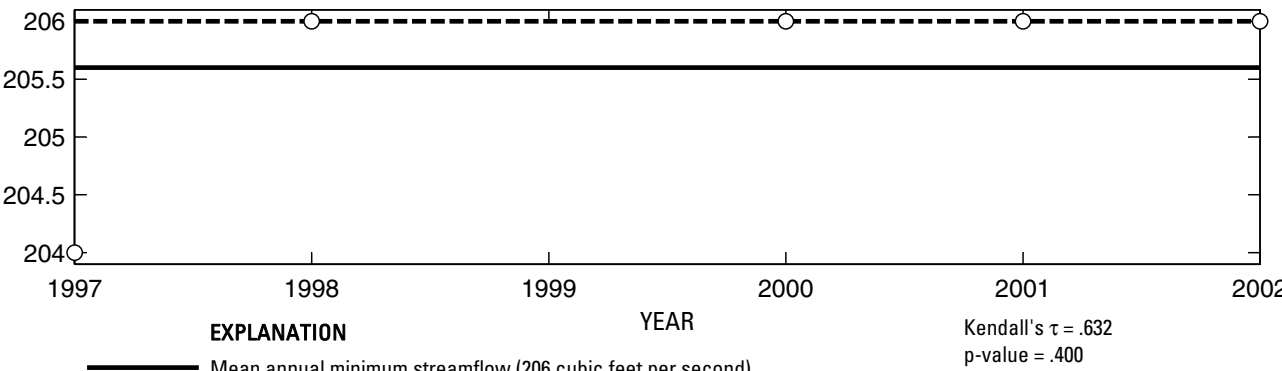

- Median annual minimum streamflow (206 cubic feet per second)

O Annual minimum streamflow

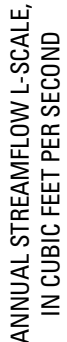

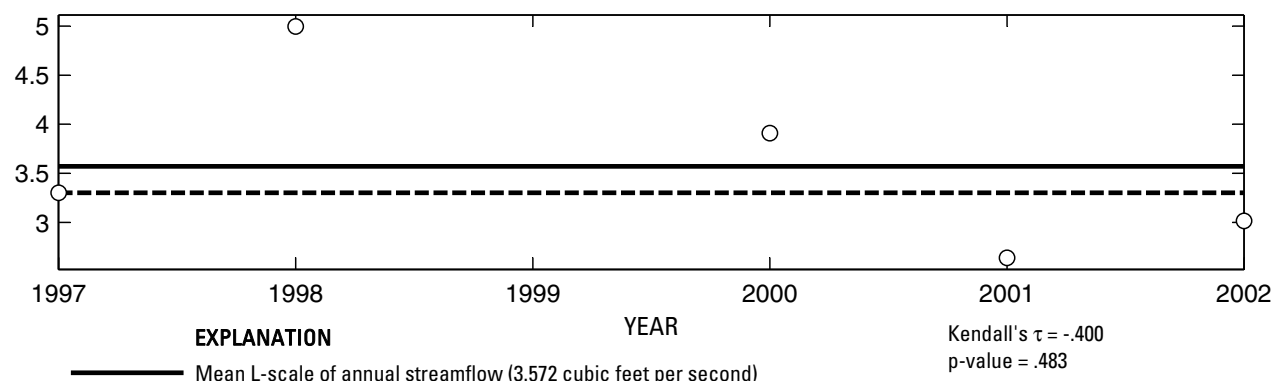

Mean L-scale of annual streamflow (3.572 cubic feet per second)

- - - - Median L-scale of annual streamflow (3.301 cubic feet per second)

Annual L-scale of streamflow

Figure 292. Analysis of annual mean, maximum, minimum, and L-scale statistics of daily mean streamflow for U.S. Geological Survey streamflow-gaging station 08074760 Brays Bayou at Alief, Texas.

Index of Station Numbers 719 

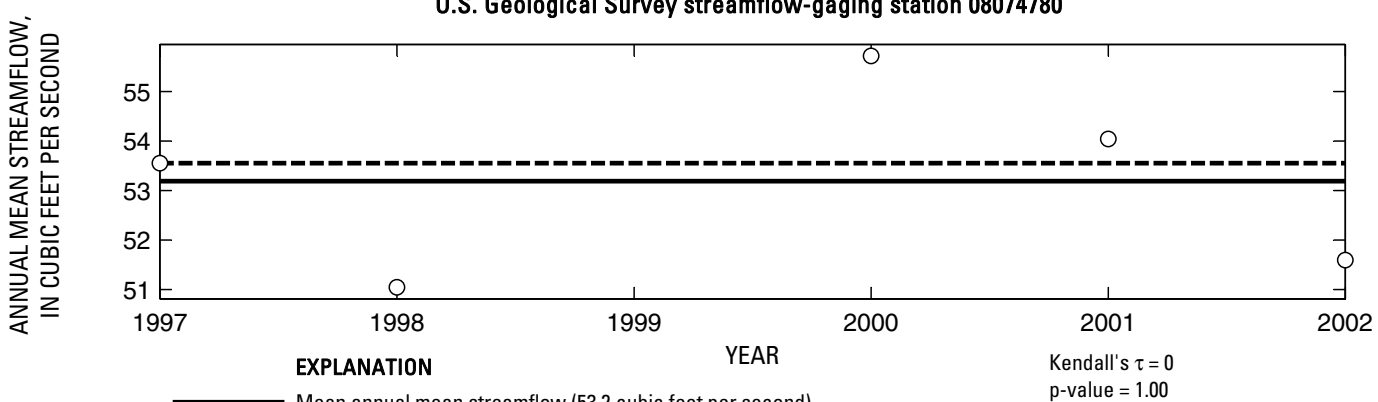

Mean annual mean streamflow (53.2 cubic feet per second)

p-value $=1$

-_-_- Median annual mean streamflow (53.6 cubic feet per second)

O Annual mean streamflow
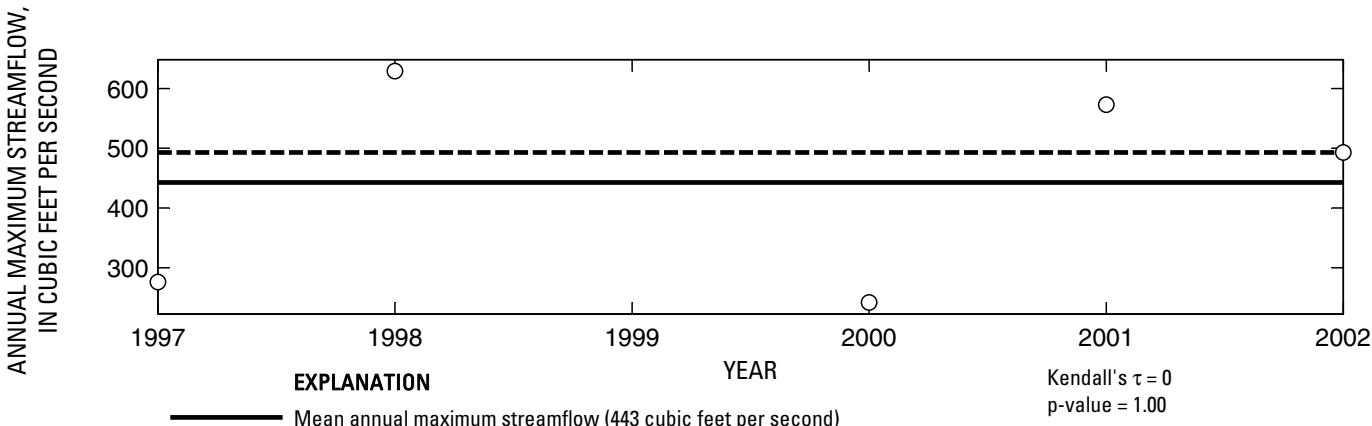

-_a_- Median annual maximum streamflow (493 cubic feet per second)

- Annual maximum streamflow
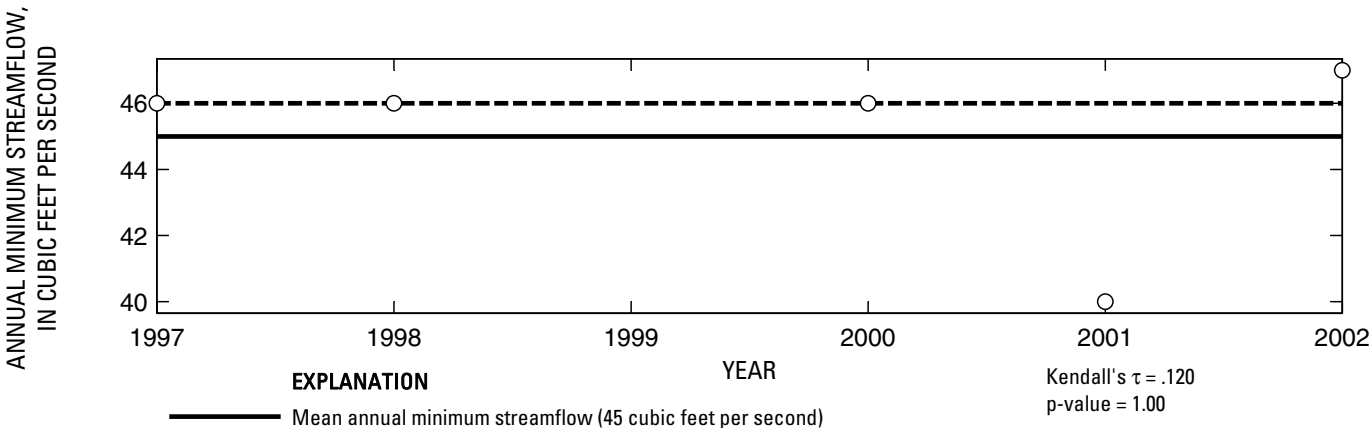

- - Median annual minimum streamflow (46 cubic feet per second)

O Annual minimum streamflow
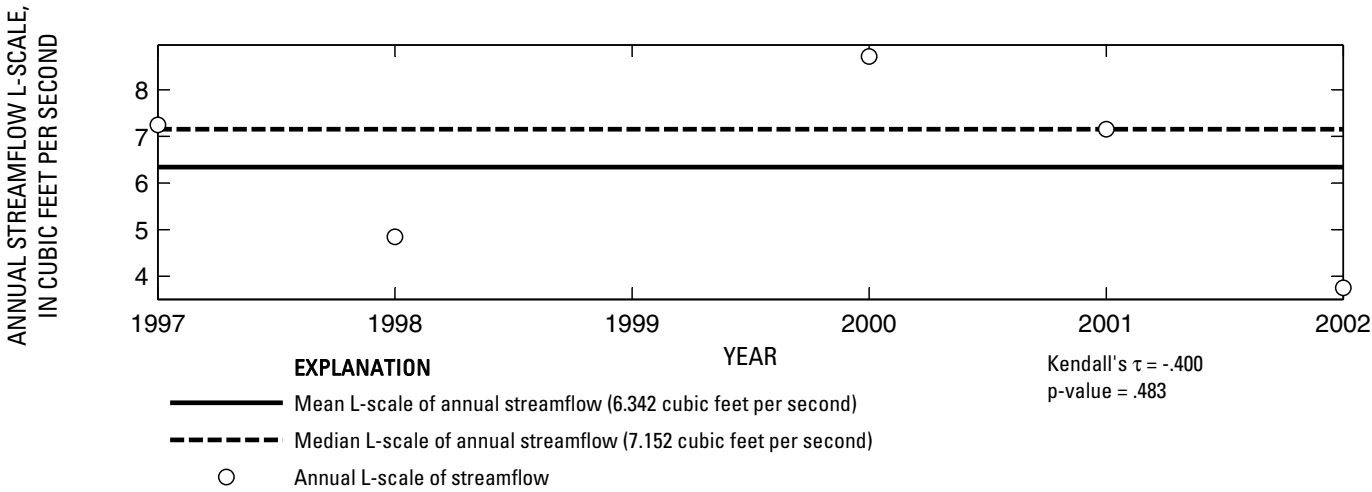

Figure 293. Analysis of annual mean, maximum, minimum, and L-scale statistics of daily mean streamflow for U.S. Geological Survey streamflow-gaging station 08074780 Keegans Bayou at Keegan Road near Houston, Texas.

Index of Station Numbers 719 


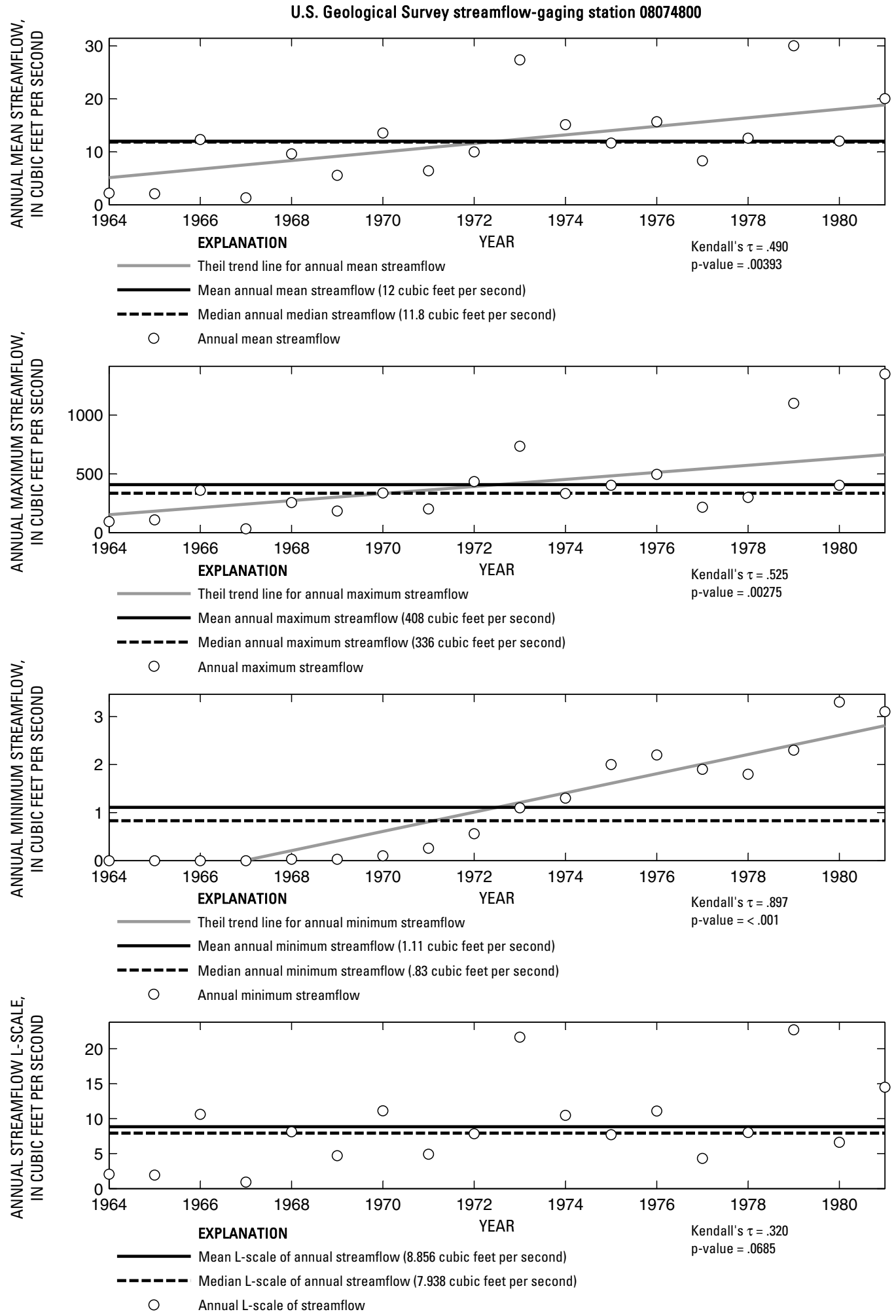

Figure 294. Analysis of annual mean, maximum, minimum, and L-scale statistics of daily mean streamflow for U.S. Geological Survey streamflow-gaging station 08074800 Keegans Bayou at Roark Road near Houston, Texas.

Index of Station Numbers 719 


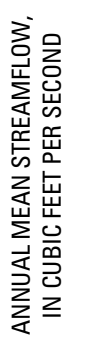

U.S. Geological Survey streamflow-gaging station 08074810

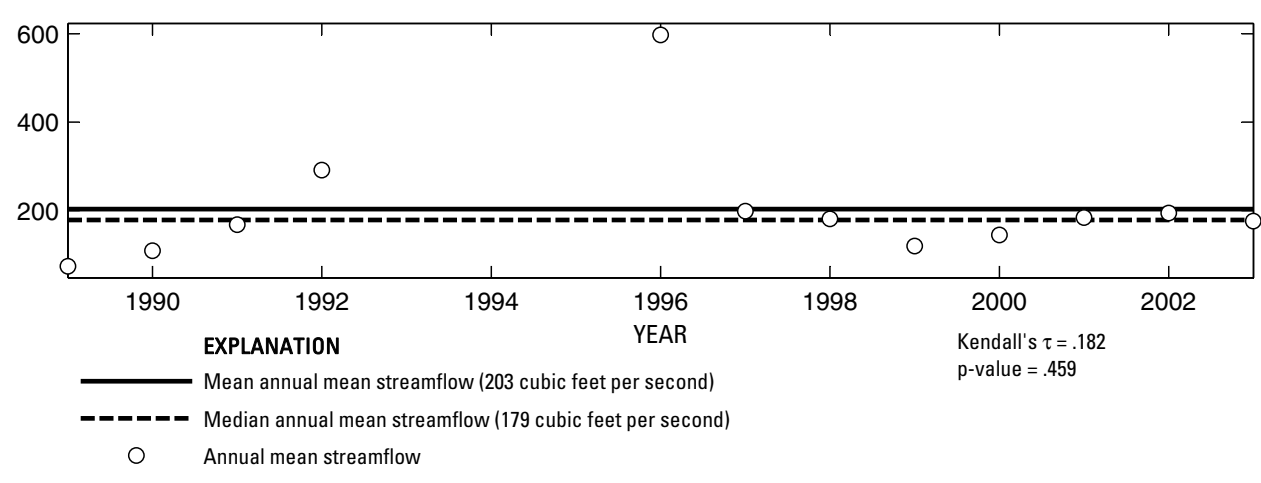

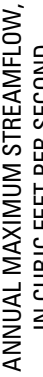

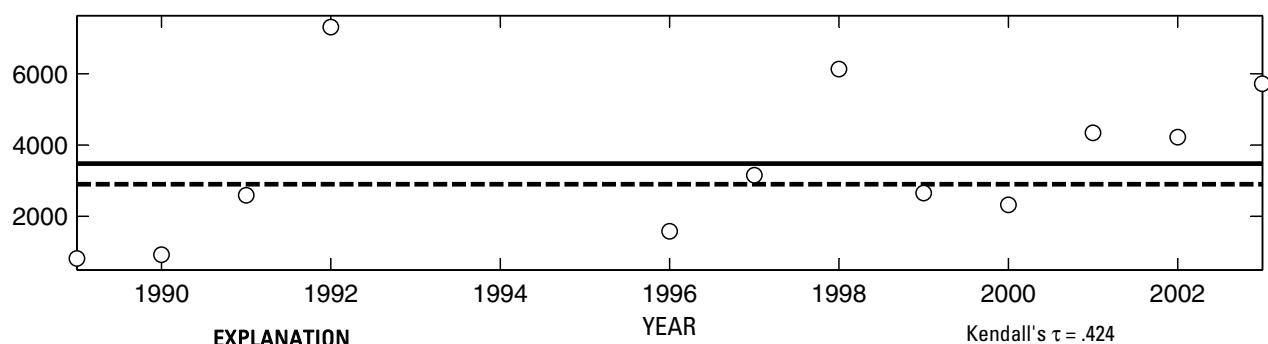

EXPLANATION

p-value $=0.06290$

- _-_- Median annual maximum streamflow (2,900 cubic feet per second)

○ Annual maximum streamflow

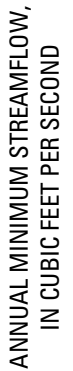

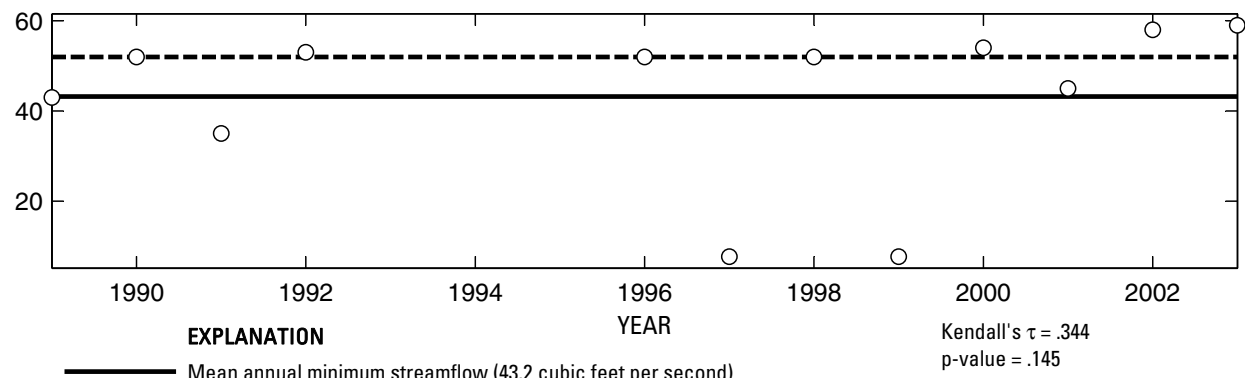

O Annual minimum streamflow

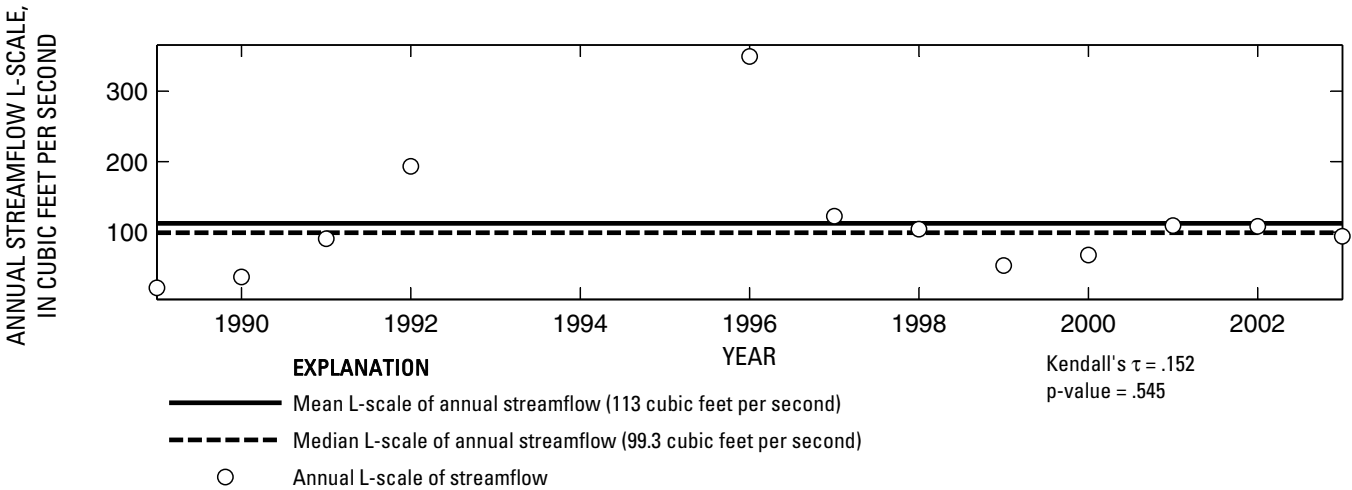

Figure 295. Analysis of annual mean, maximum, minimum, and L-scale statistics of daily mean streamflow for U.S. Geological Survey streamflow-gaging station 08074810 Brays Bayou at Gessner Drive, Houston, Texas.

Index of Station Numbers 719 


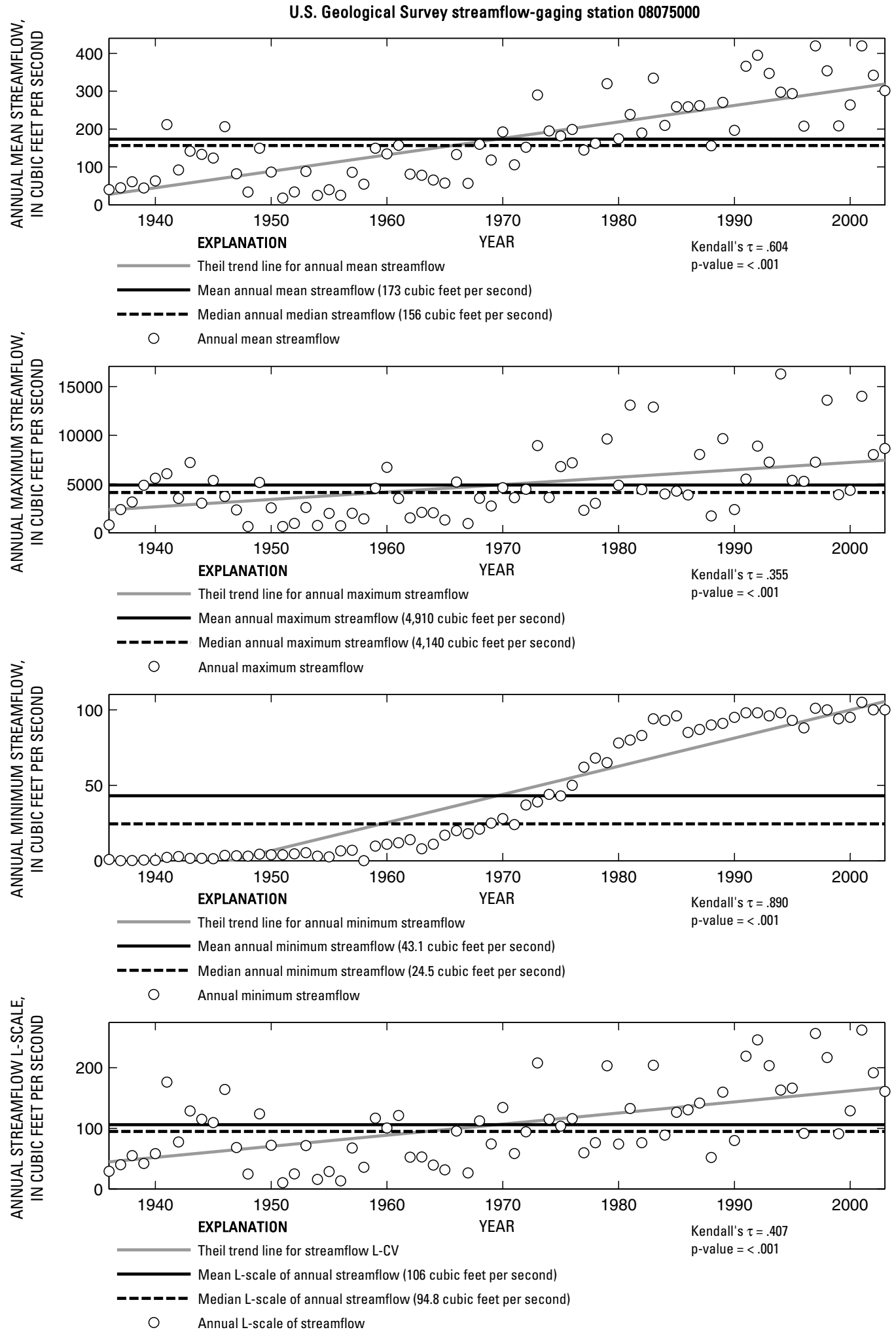

Figure 296. Analysis of annual mean, maximum, minimum, and L-scale statistics of daily mean streamflow for U.S. Geological Survey streamflow-gaging station 08075000 Brays Bayou at Houston, Texas.

Index of Station Numbers 719 


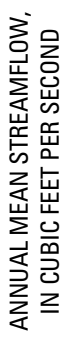

U.S. Geological Survey streamflow-gaging station 08075400

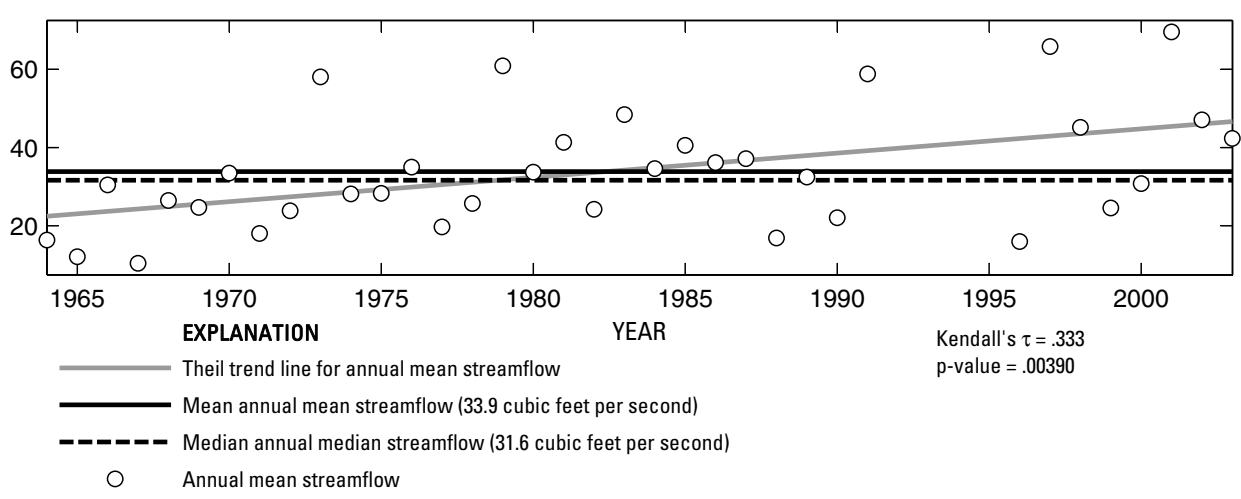

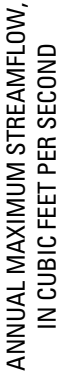

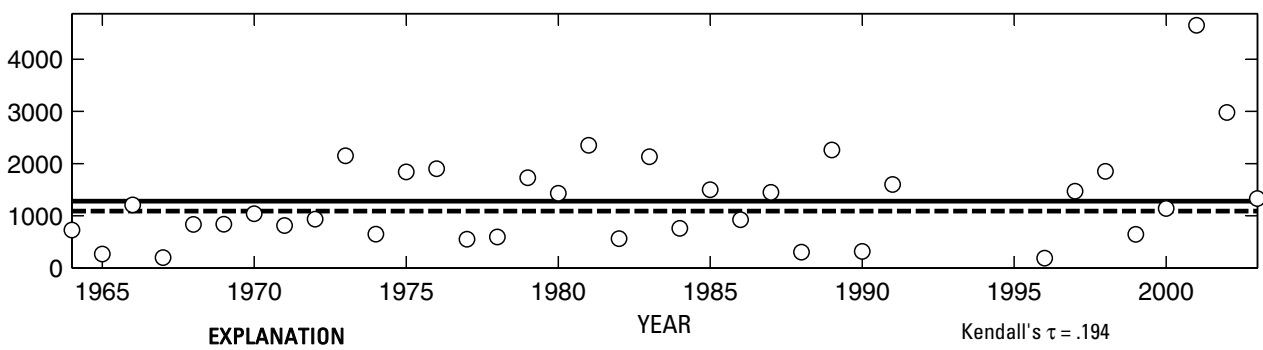

Mean annual maximum streamflow (1,280 cubic feet per second)

p-value $=0$

- - - Median annual maximum streamflow (1,090 cubic feet per second)

Annual maximum streamflow

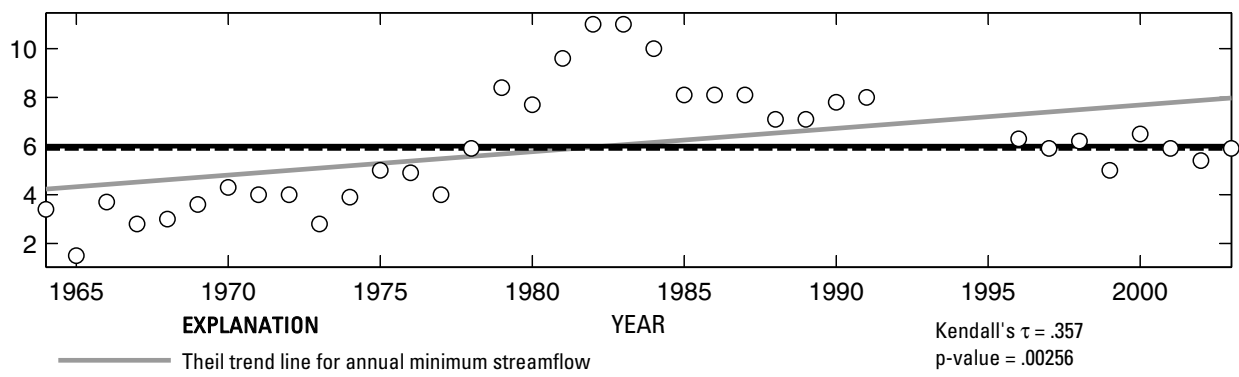

Mean annual minimum streamflow (5.997 cubic feet per second)

ーーーーーーー Median annual minimum streamflow (5.9 cubic feet per second)

O Annual minimum streamflow

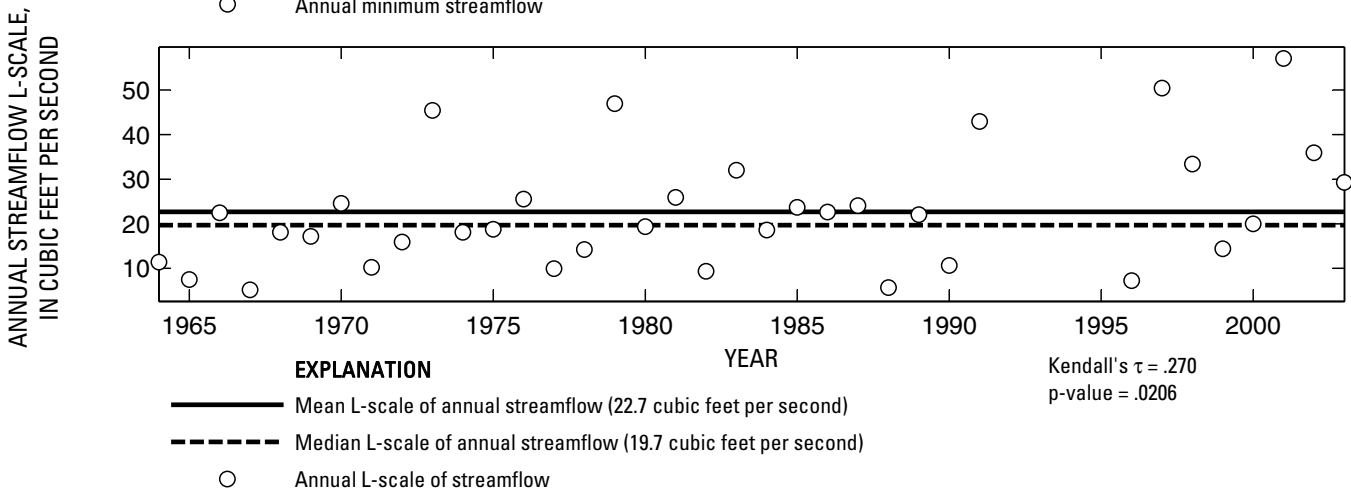

Figure 297. Analysis of annual mean, maximum, minimum, and L-scale statistics of daily mean streamflow for U.S. Geological Survey streamflow-gaging station 08075400 Sims Bayou at Hiram Clarke Street, Houston, Texas. 


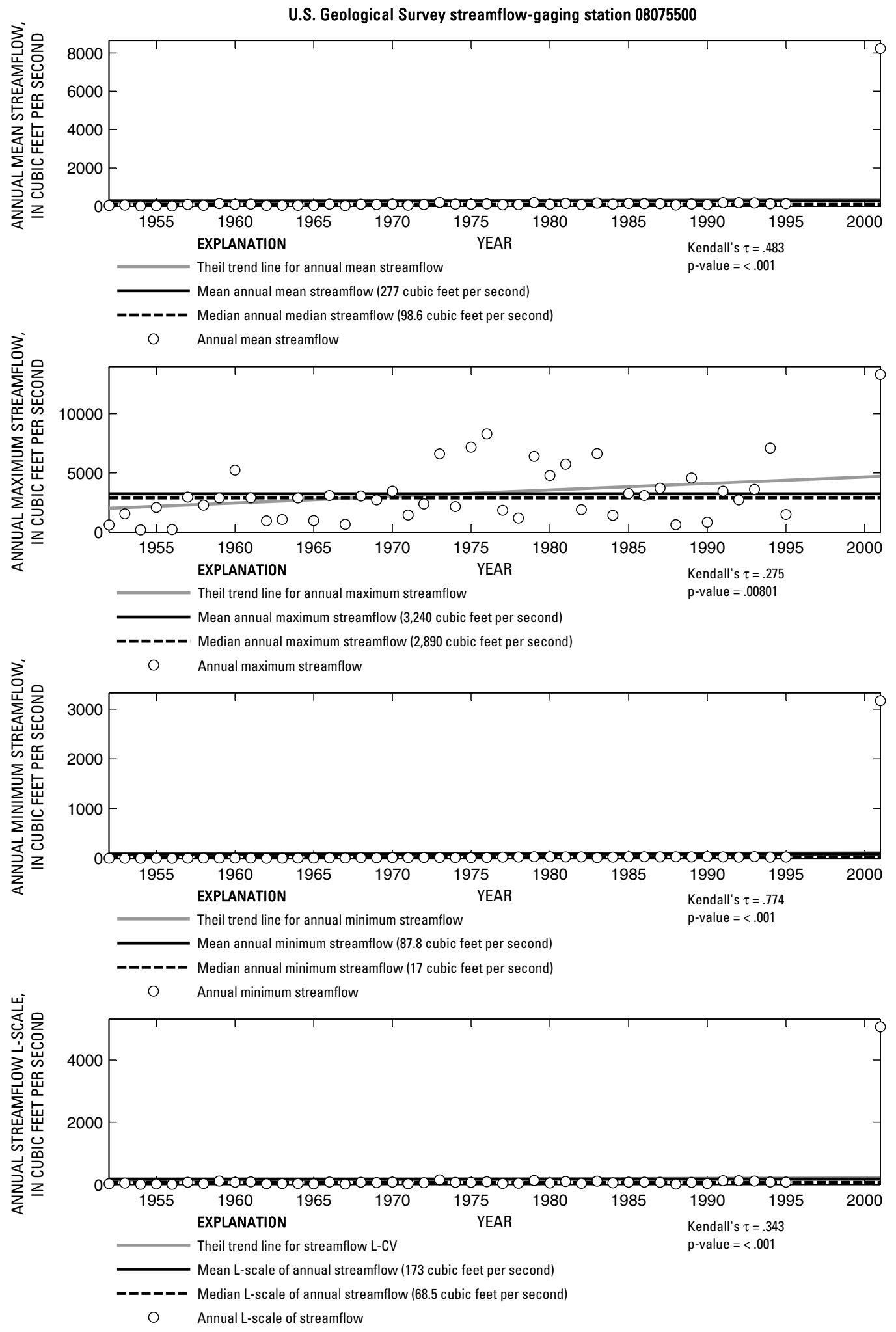

Figure 298. Analysis of annual mean, maximum, minimum, and L-scale statistics of daily mean streamflow for U.S. Geological Survey streamflow-gaging station 08075500 Sims Bayou at Houston, Texas.

Index of Station Numbers 719 

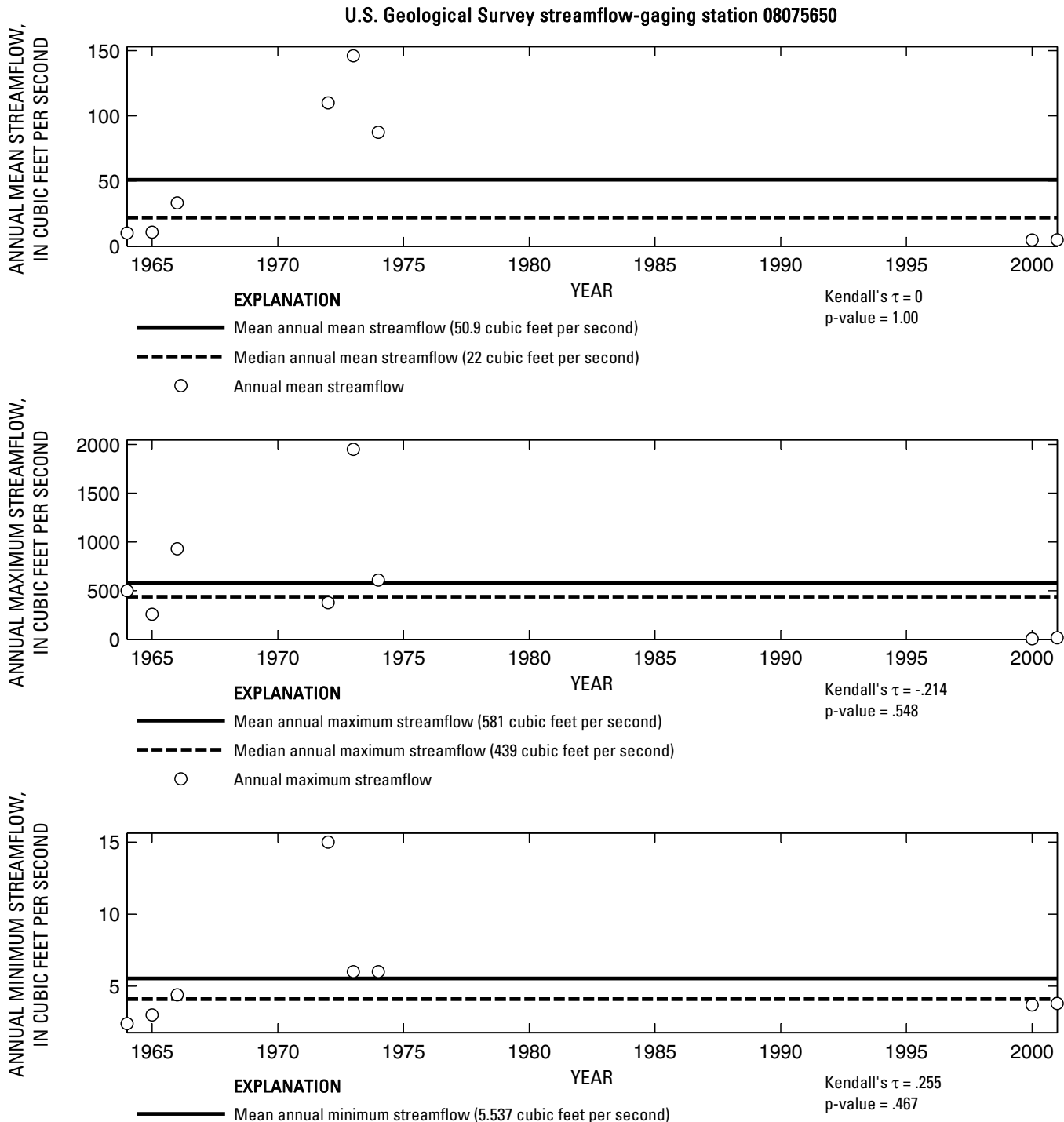

- - - ב Median annual minimum streamflow (4.1 cubic feet per second)

O Annual minimum streamflow

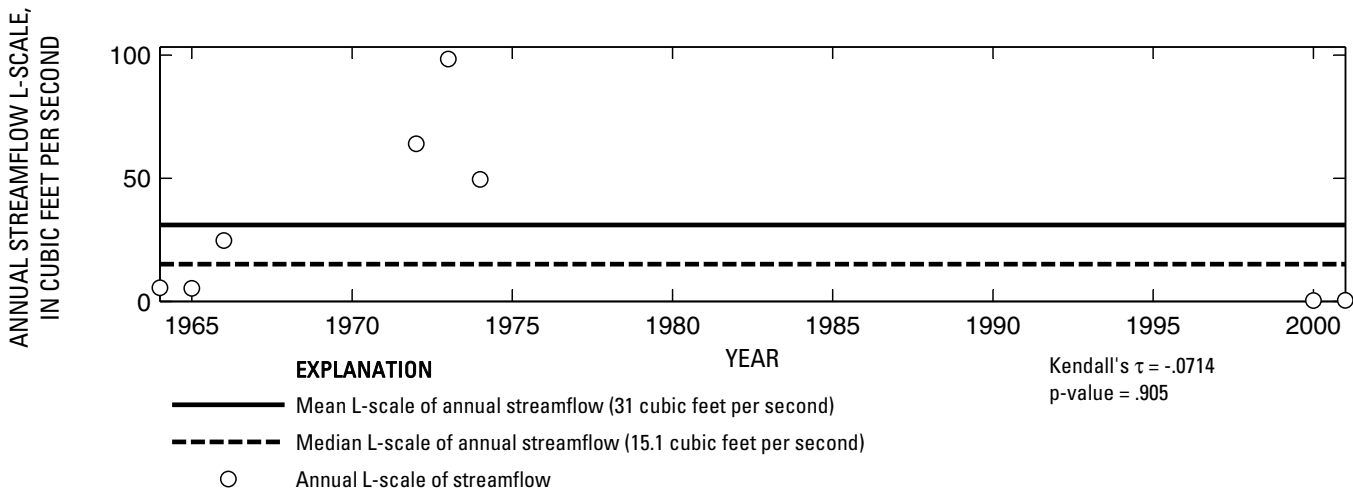

Figure 299. Analysis of annual mean, maximum, minimum, and L-scale statistics of daily mean streamflow for U.S. Geological Survey streamflow-gaging station 08075650 Berry Bayou at Forest Oaks Street, Houston, Texas. 


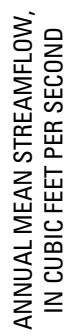

U.S. Geological Survey streamflow-gaging station 08075730

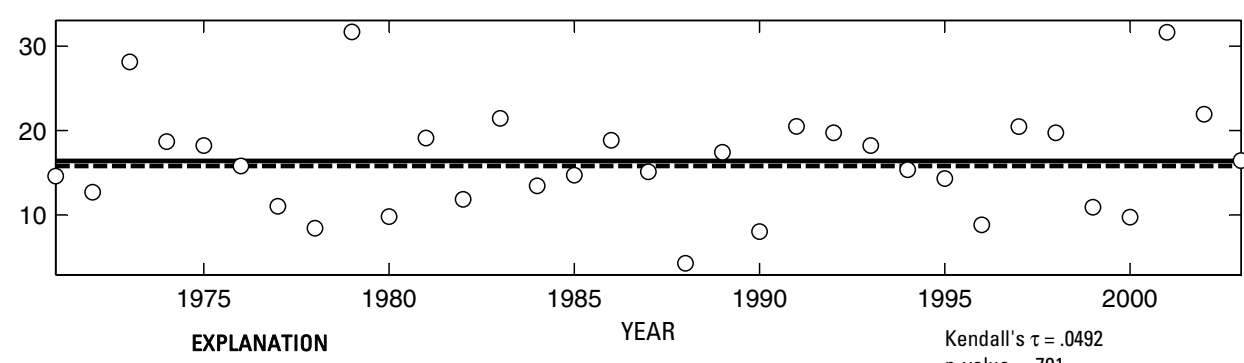

--ン-ー- Median annual mean streamflow (15.8 cubic feet per second)

O Annual mean streamflow

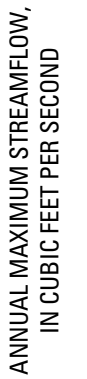

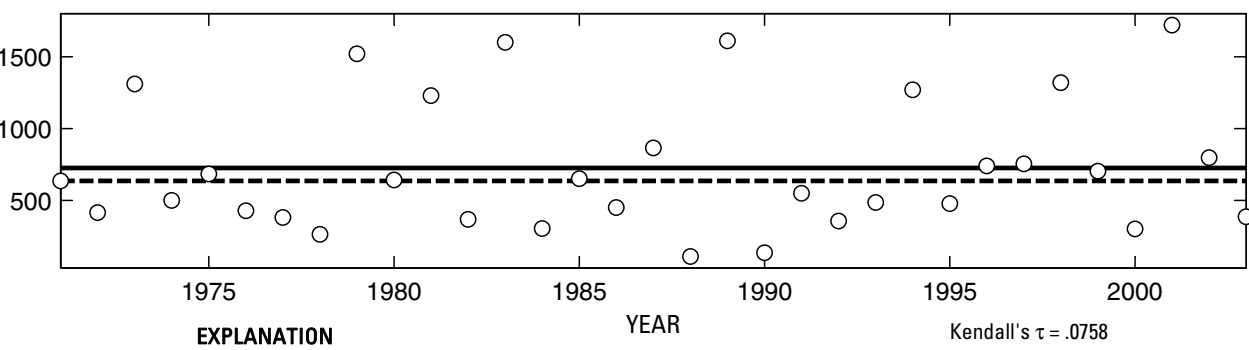

EXPLANATION

Mean annual maximum streamflow (726 cubic feet per second)

$\mathrm{p}$-value $=.549$

-ーーーー Median annual maximum streamflow (636 cubic feet per second)

O Annual maximum streamflow

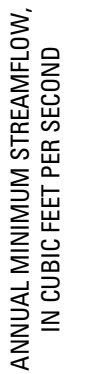

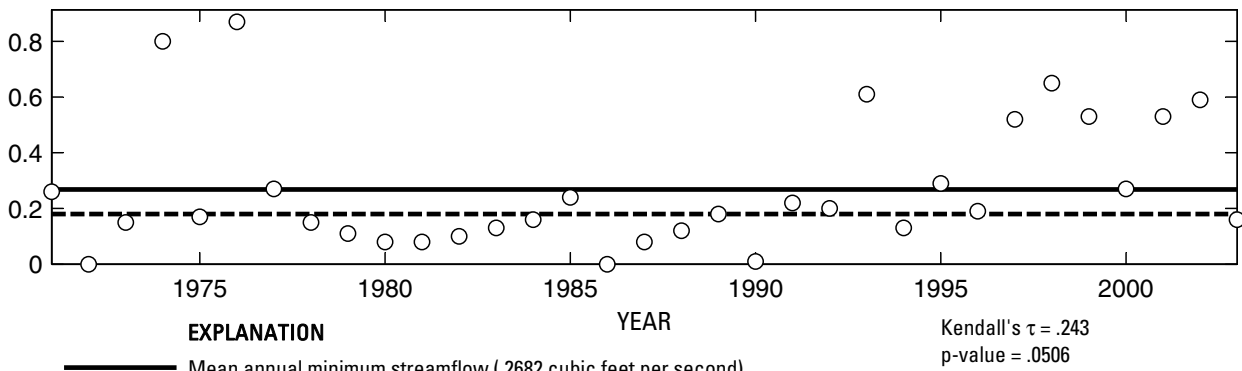

- Median annual minimum streamflow (.18 cubic feet per second)

O Annual minimum streamflow

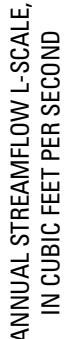

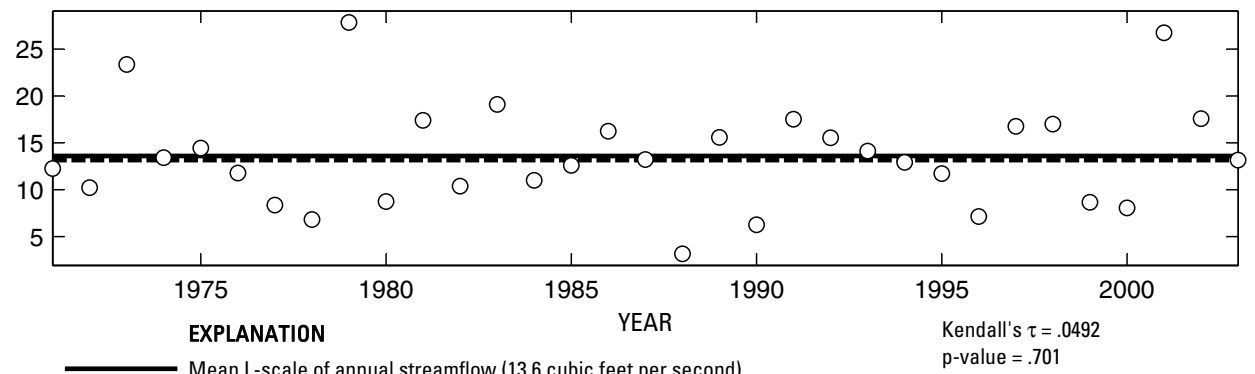

Annual L-scale of streamflow

Figure 300. Analysis of annual mean, maximum, minimum, and L-scale statistics of daily mean streamflow for U.S. Geological Survey streamflow-gaging station 08075730 Vince Bayou at Pasadena, Texas.

Index of Station Numbers 719 


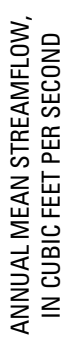

U.S. Geological Survey streamflow-gaging station 08075770
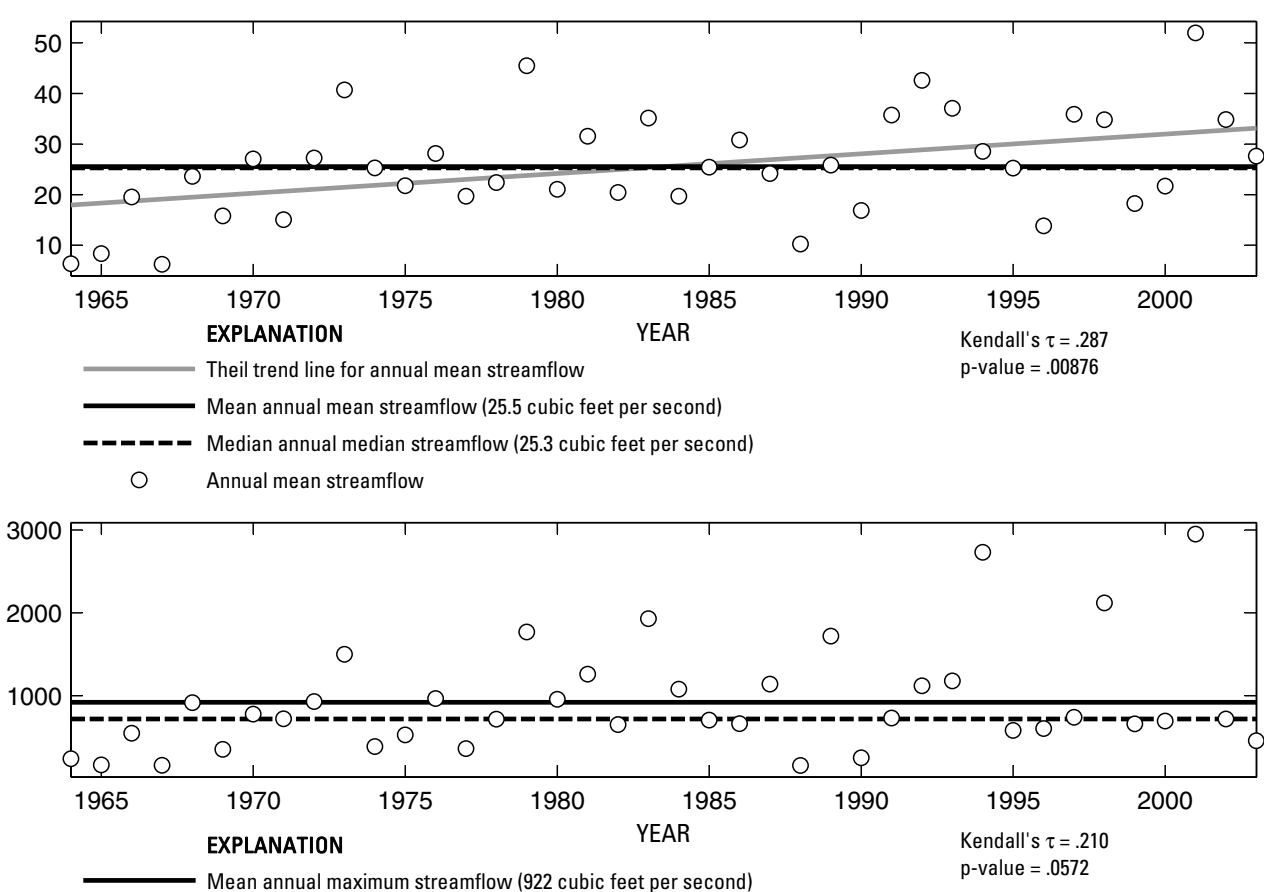

- - - - Median annual maximum streamflow (722 cubic feet per second)

Annual maximum streamflow

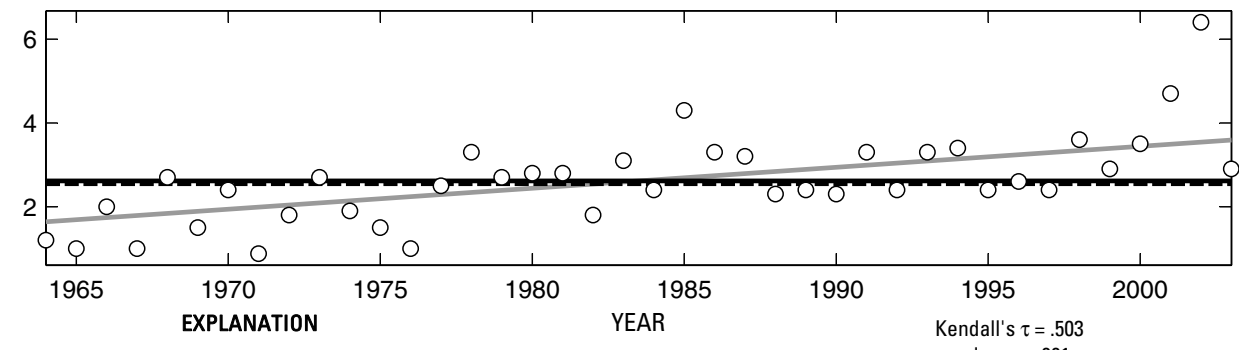

Theil trend line for annual minimum streamflow

$\mathrm{p}$-value $=<.00$

Mean annual minimum streamflow (2.615 cubic feet per second)

- - - Median annual minimum streamflow (2.55 cubic feet per second)

O Annual minimum streamflow
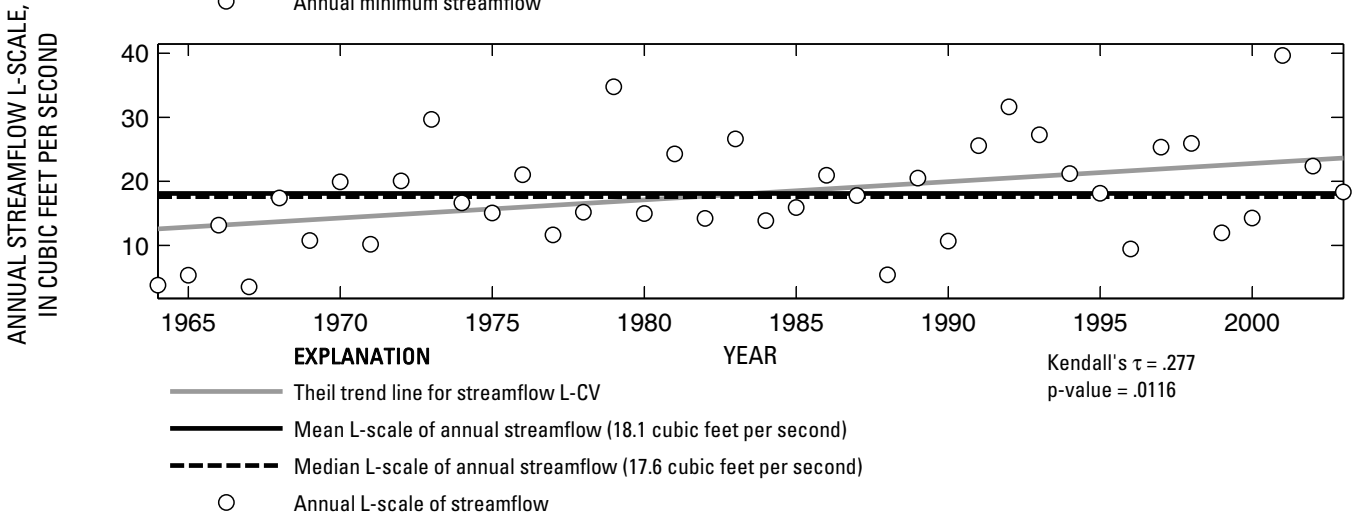

Figure 301. Analysis of annual mean, maximum, minimum, and L-scale statistics of daily mean streamflow for U.S. Geological Survey streamflow-gaging station 08075770 Hunting Bayou at Interstate Highway 610, Houston, Texas. 
U.S. Geological Survey streamflow-gaging station 08075780
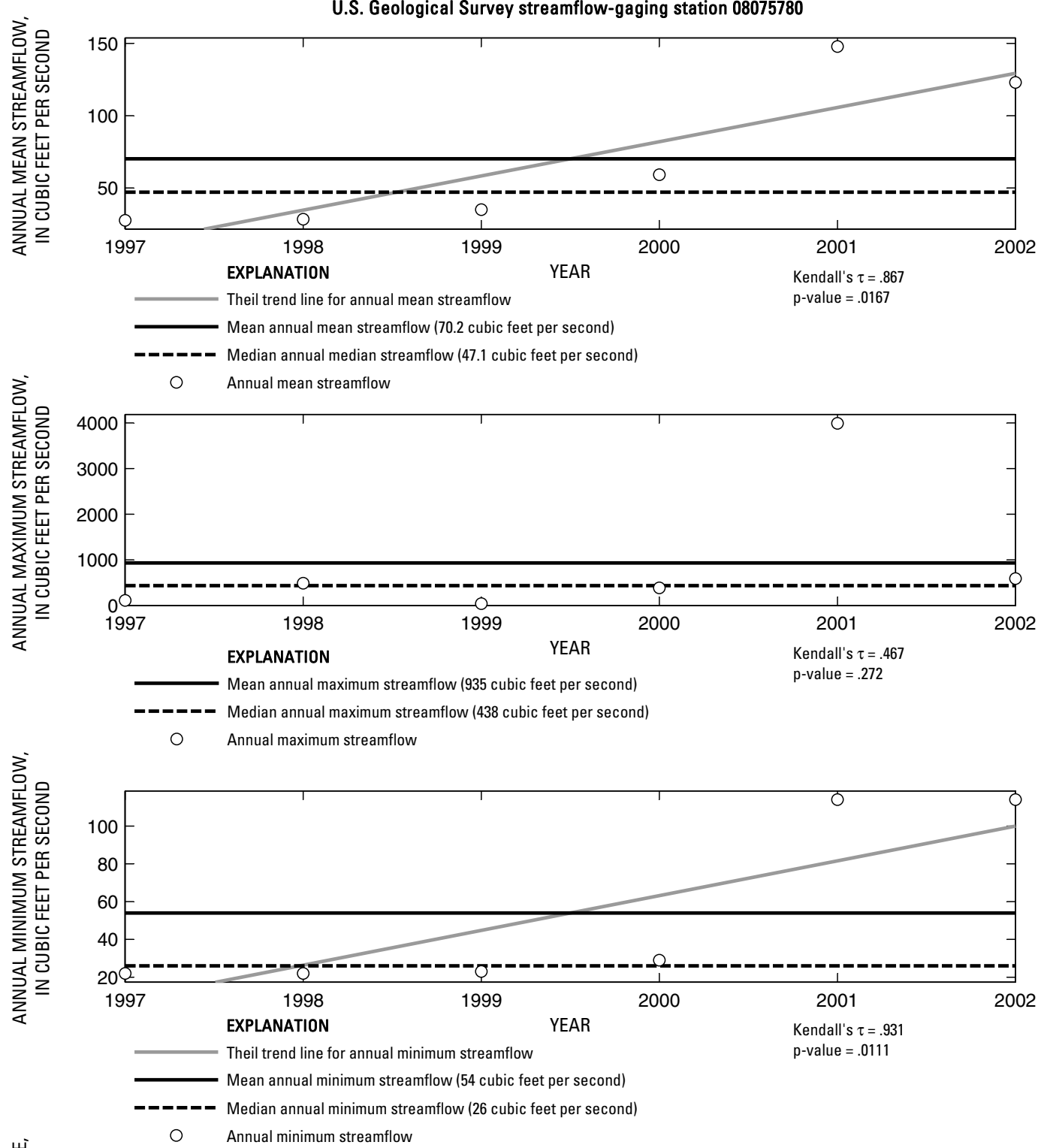

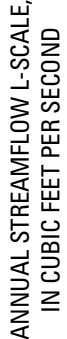

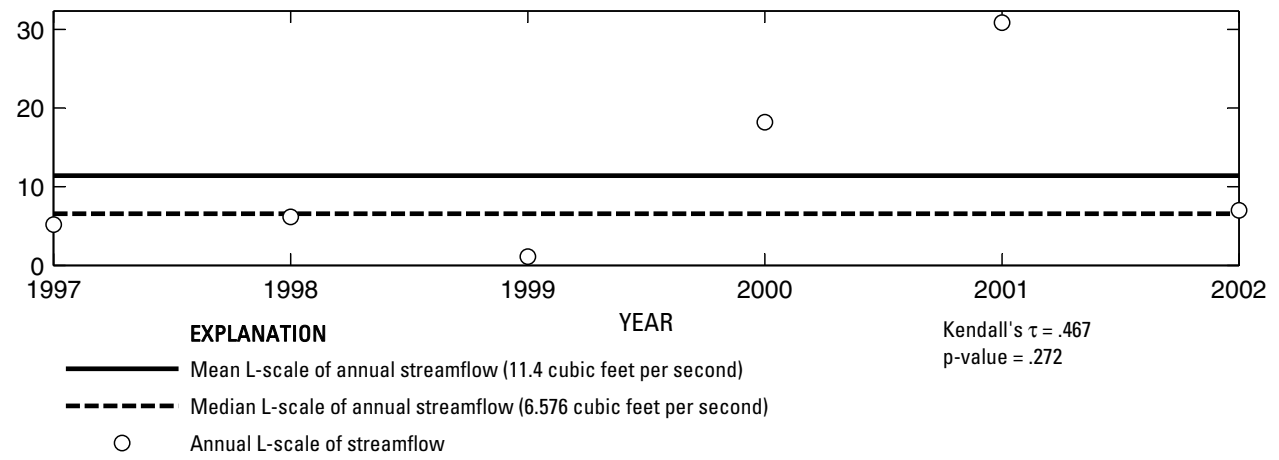

Figure 302. Analysis of annual mean, maximum, minimum, and L-scale statistics of daily mean streamflow for U.S. Geological Survey streamflow-gaging station 08075780 Greens Bayou at Cutten Road near Houston, Texas. 

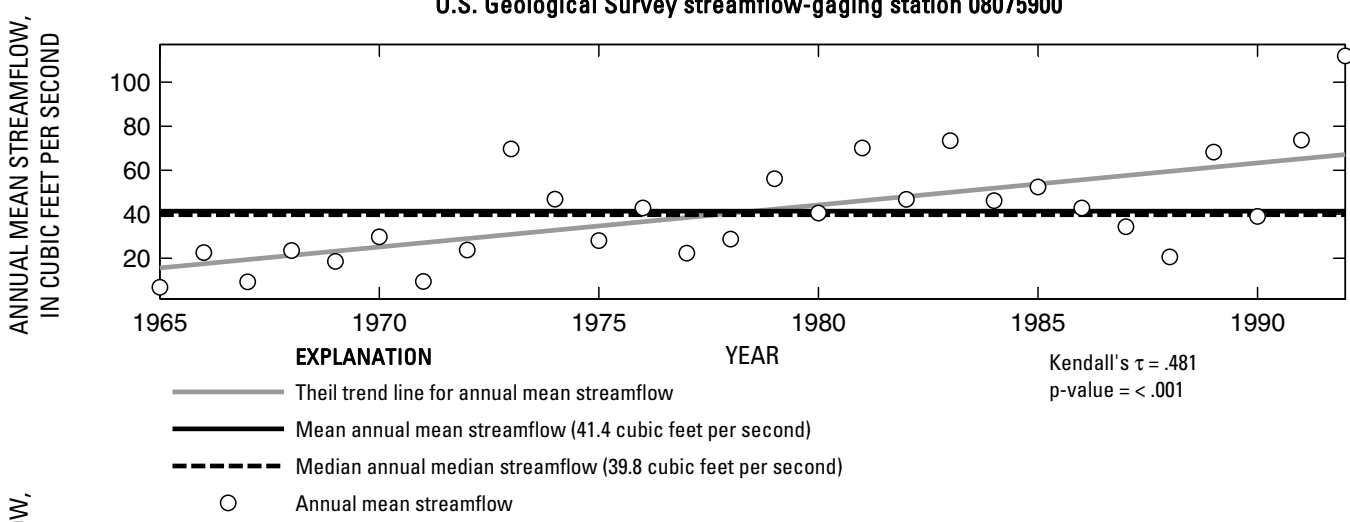

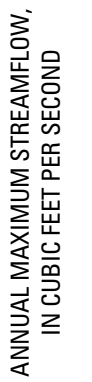

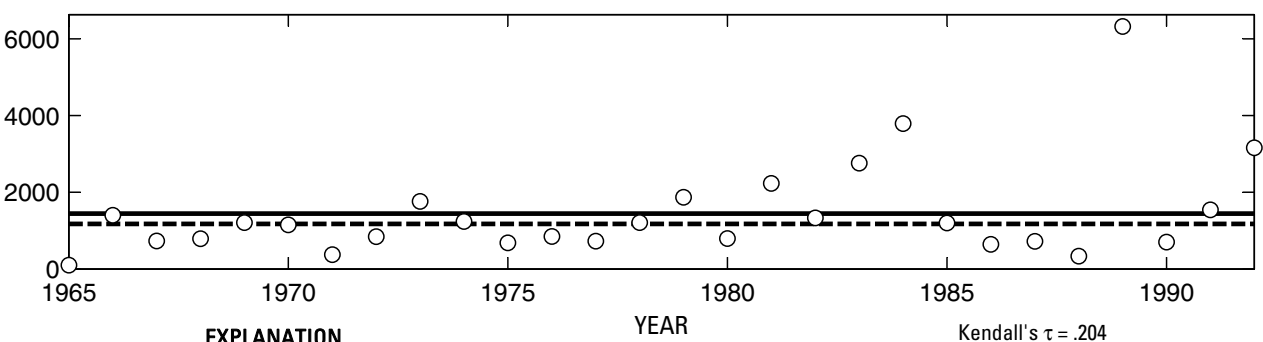

EXPLANATION

$\mathrm{p}$-value $=.133$

- - - Median annual maximum streamflow (1,180 cubic feet per second)

○ Annual maximum streamflow

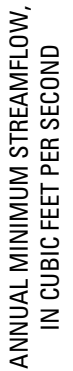

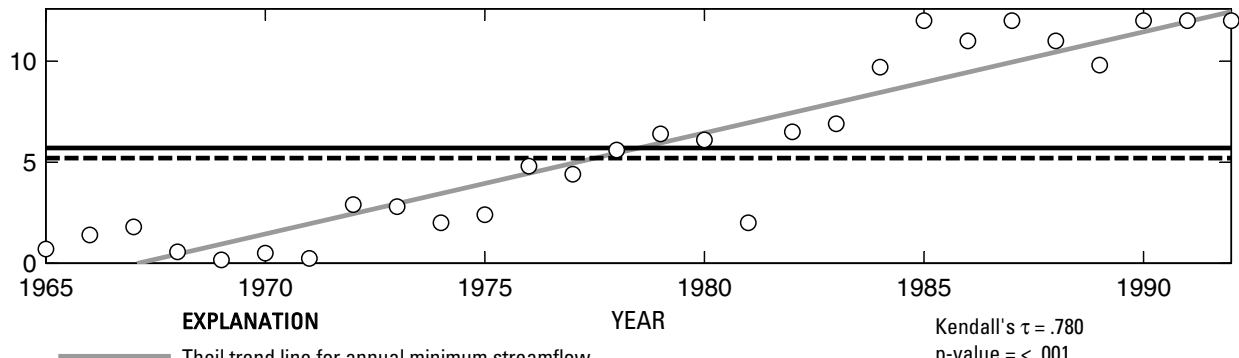

Theil trend line for annual minimum streamflow

$\mathrm{p}$-value $=<.00$

- - - - Median annual minimum streamflow (5.2 cubic feet per second)

O Annual minimum streamflow
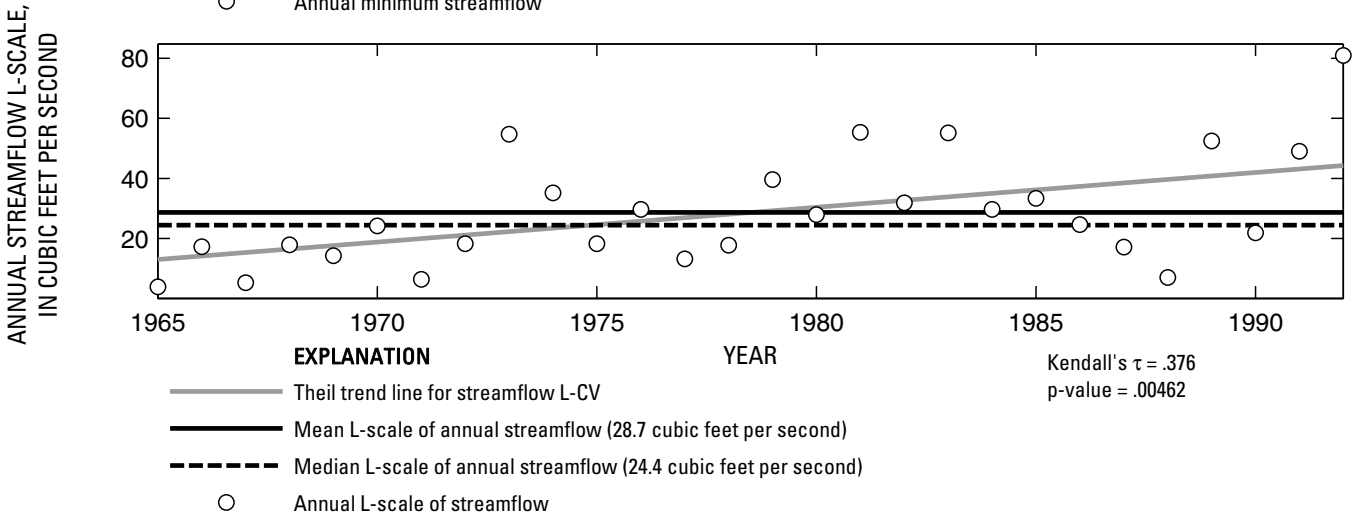

Figure 303. Analysis of annual mean, maximum, minimum, and L-scale statistics of daily mean streamflow for U.S. Geological Survey streamflow-gaging station 08075900 Greens Bayou near U. S. Highway 75 near Houston, Texas.

Index of Station Numbers 719 


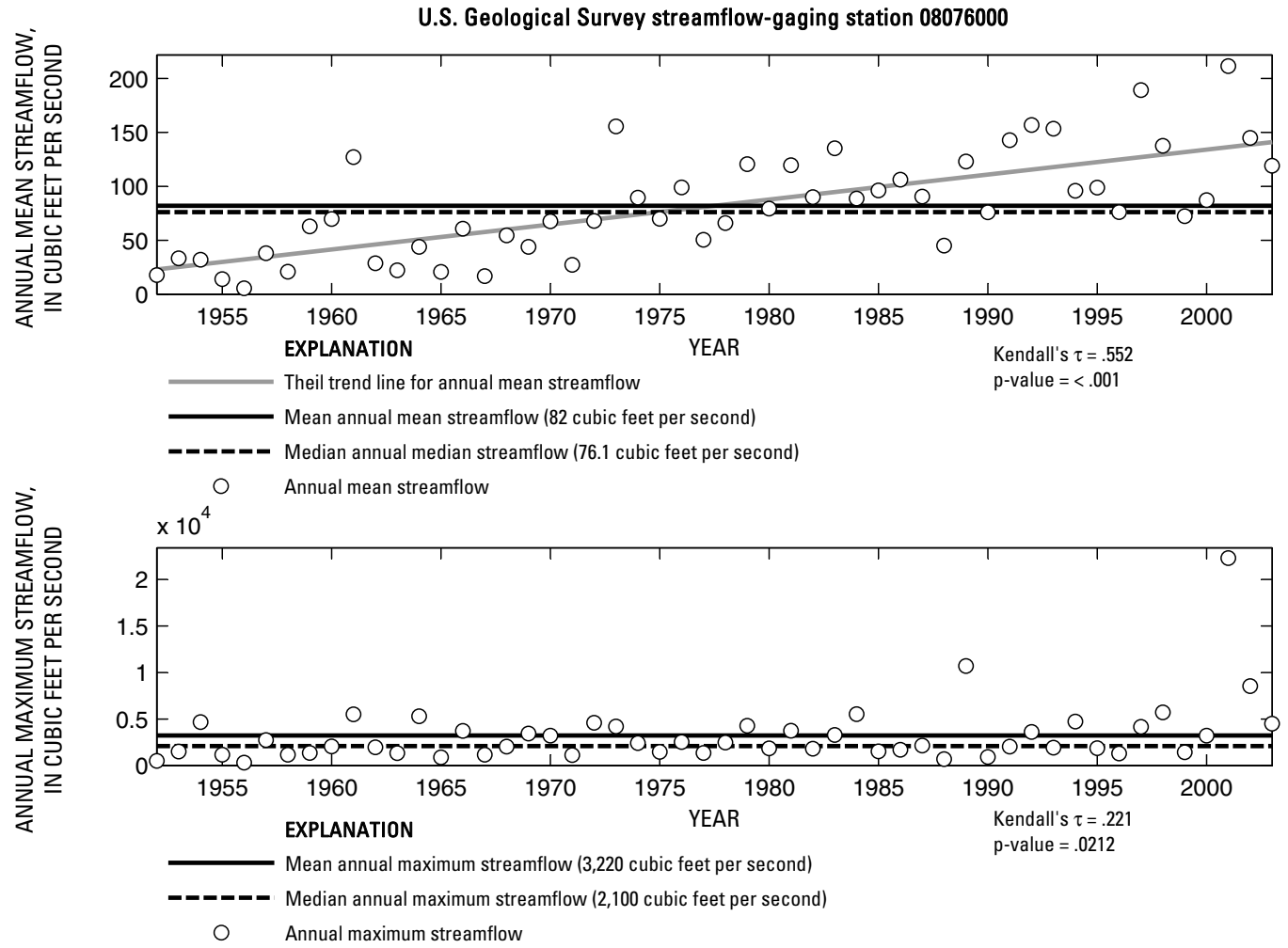

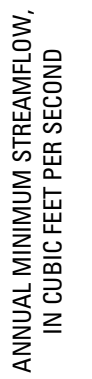

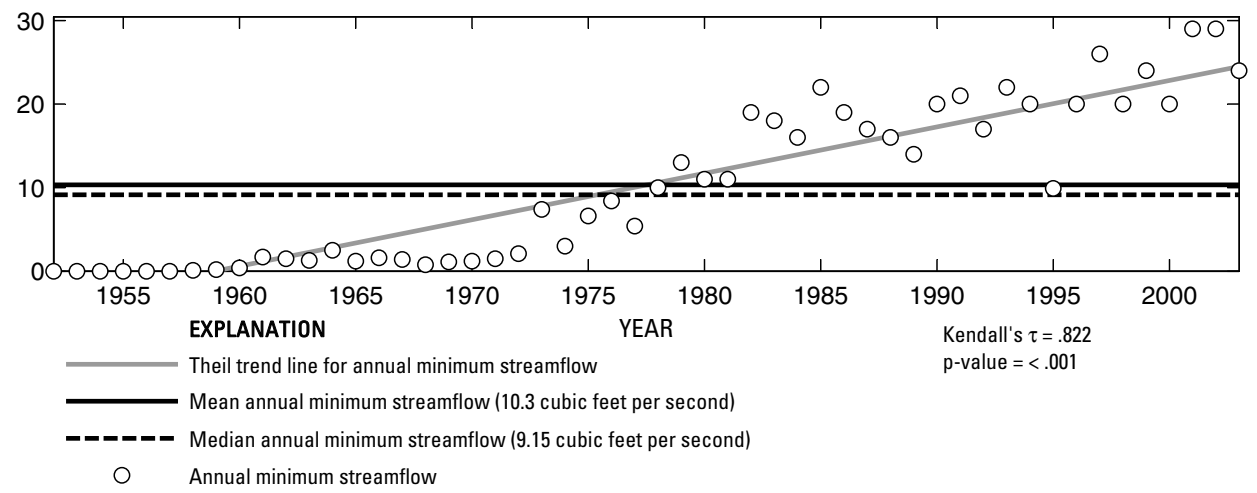

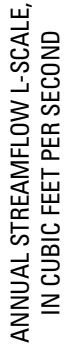

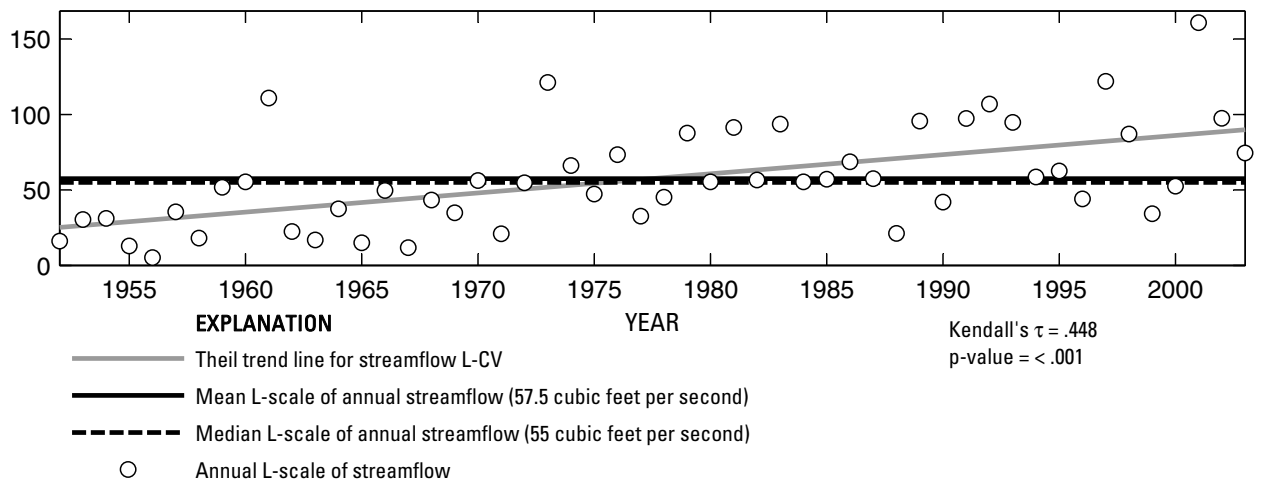

Figure 304. Analysis of annual mean, maximum, minimum, and L-scale statistics of daily mean streamflow for U.S. Geological Survey streamflow-gaging station 08076000 Greens Bayou near Houston, Texas.

Index of Station Numbers 719 
U.S. Geological Survey streamflow-gaging station 08076180

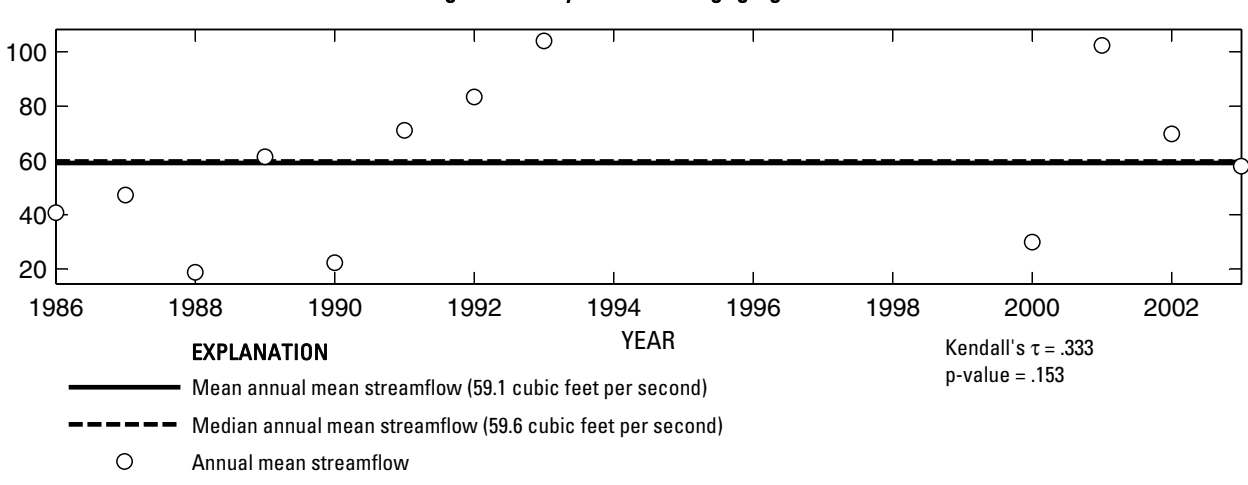

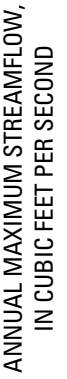

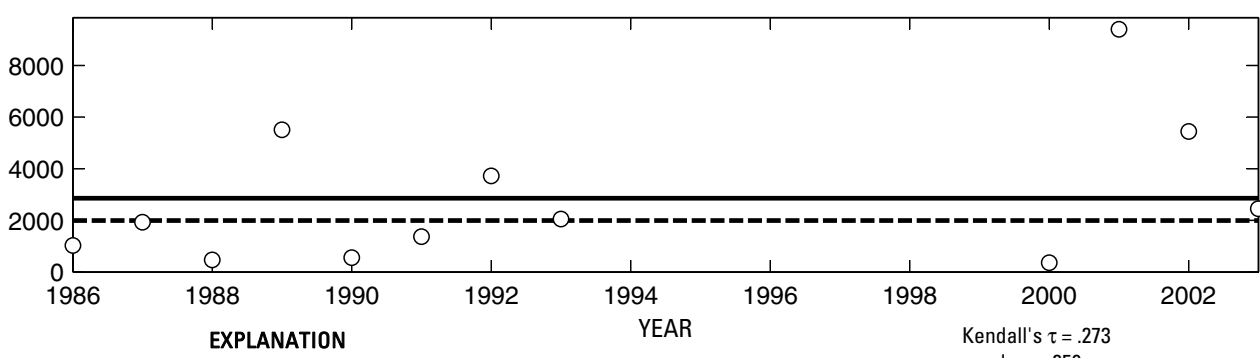

EXPLANATION

$\mathrm{p}$-value $=.250$

- - - Median annual maximum streamflow (1,990 cubic feet per second)

○ Annual maximum streamflow
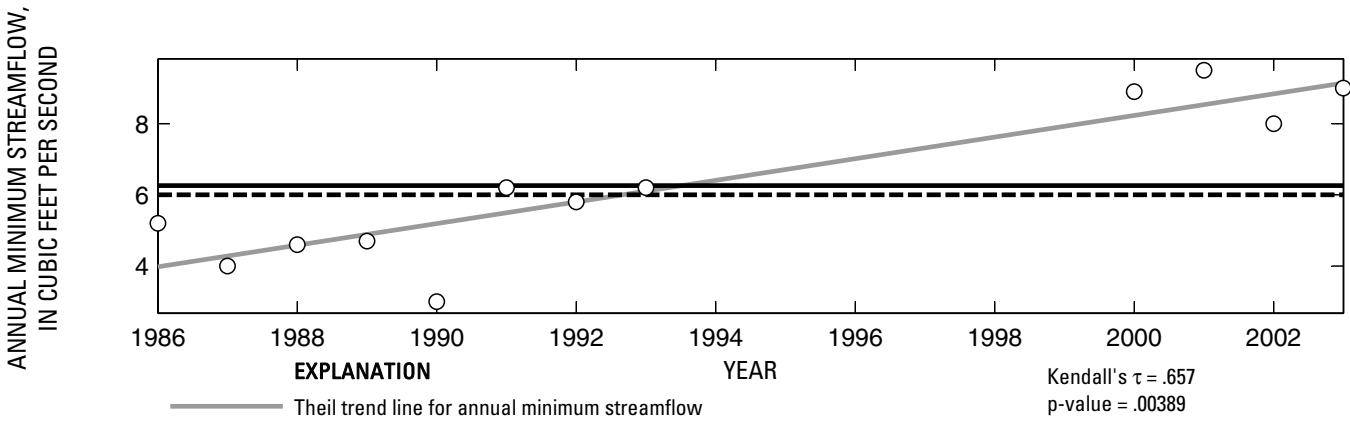

Mean annual minimum streamflow (6.258 cubic feet per second)

- - - Median annual minimum streamflow (6 cubic feet per second)

O Annual minimum streamflow

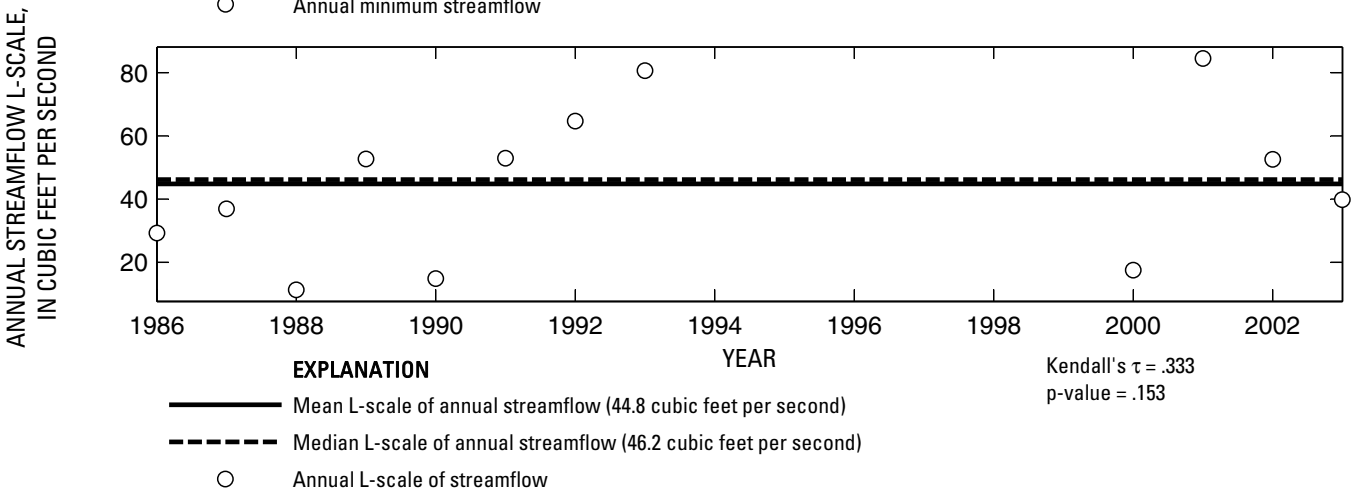

Figure 305. Analysis of annual mean, maximum, minimum, and L-scale statistics of daily mean streamflow for U.S. Geological Survey streamflow-gaging station 08076180 Garners Bayou near Humble, Texas.

Index of Station Numbers 719 


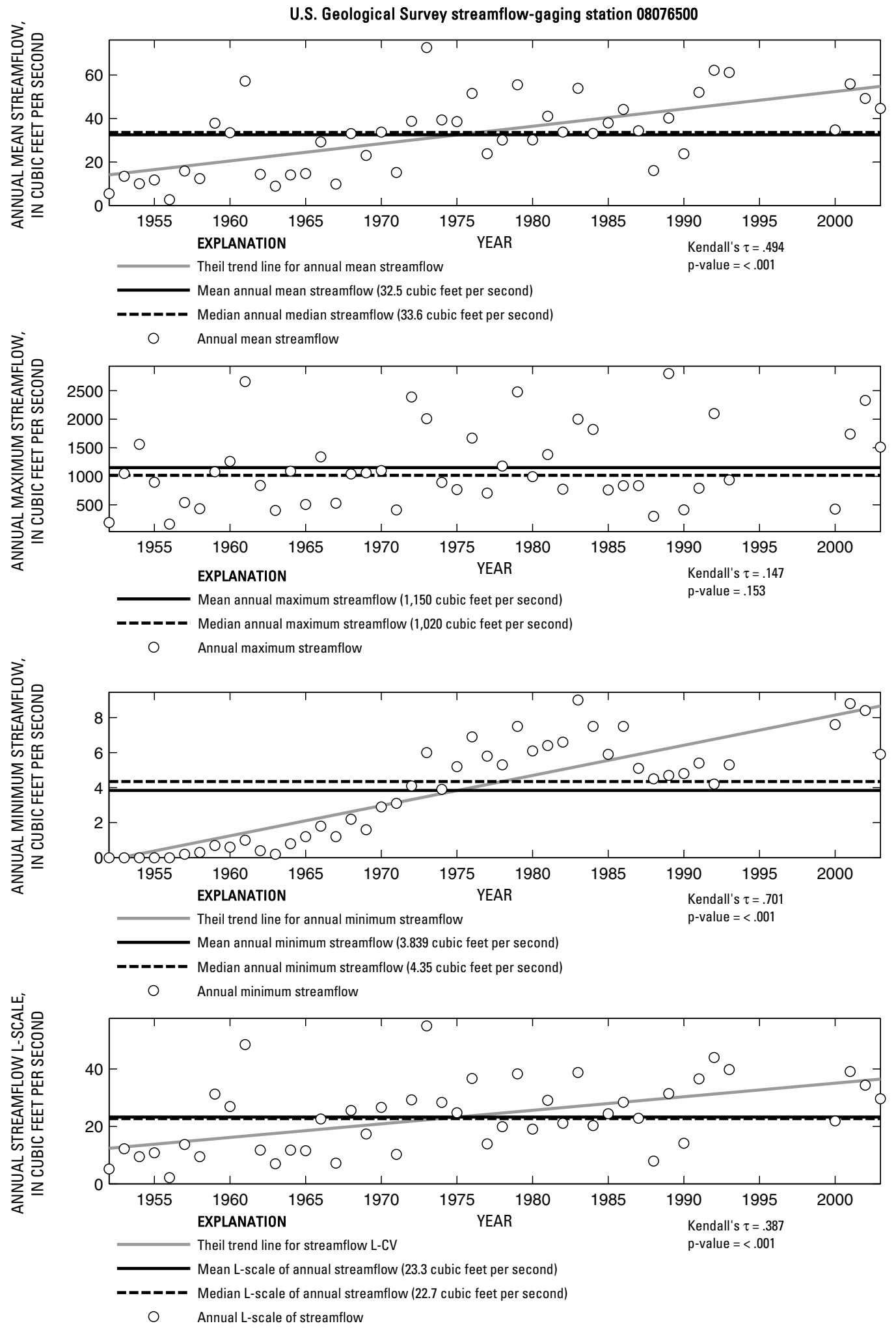

Figure 306. Analysis of annual mean, maximum, minimum, and L-scale statistics of daily mean streamflow for U.S. Geological Survey streamflow-gaging station 08076500 Halls Bayou at Houston, Texas.

Index of Station Numbers 719 


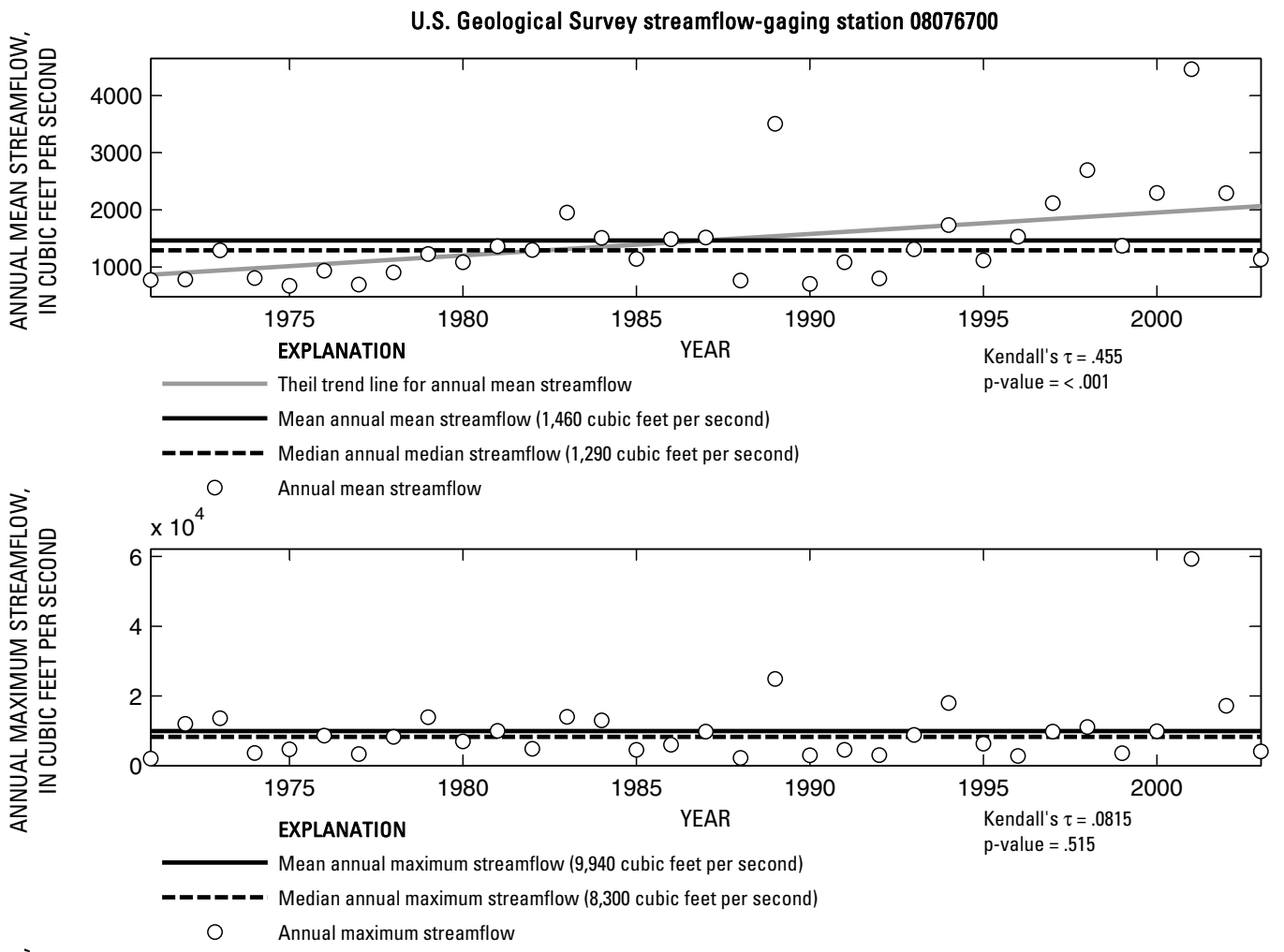

空号

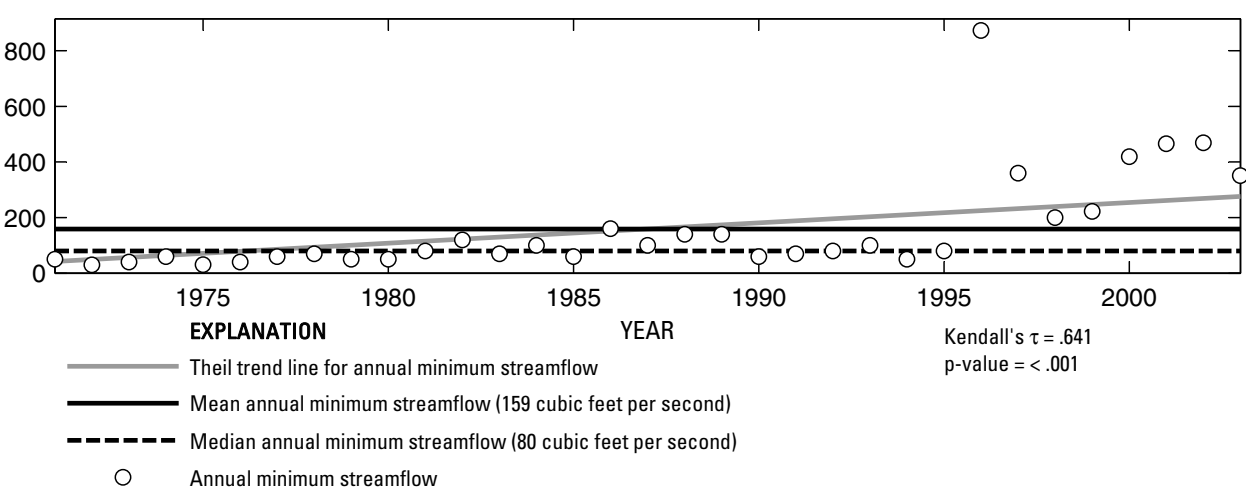

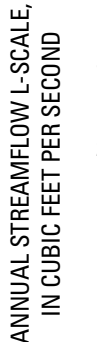

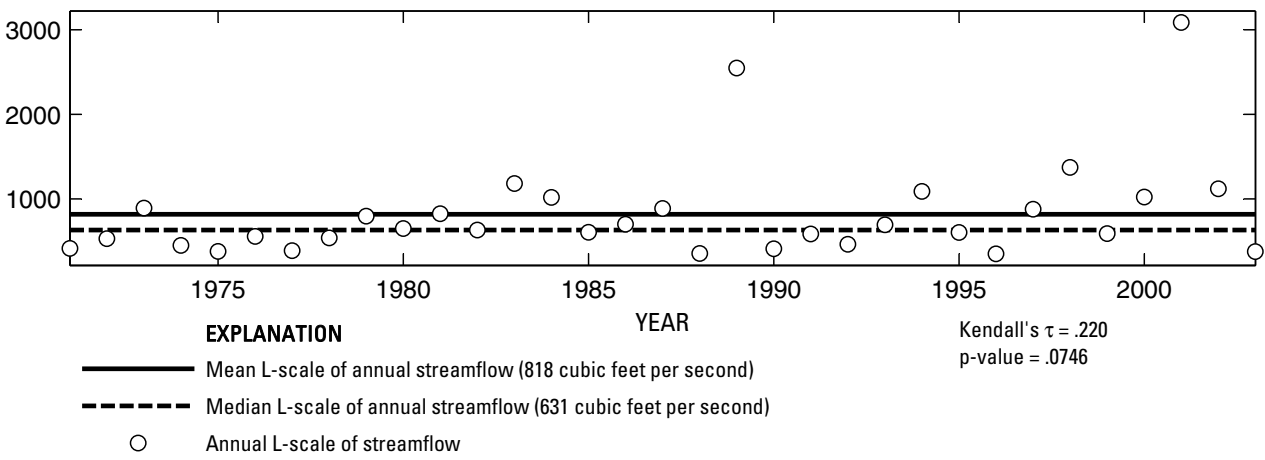

Figure 307. Analysis of annual mean, maximum, minimum, and L-scale statistics of daily mean streamflow for U.S. Geological Survey streamflow-gaging station 08076700 Greens Bayou at Ley Road, Houston, Texas. 

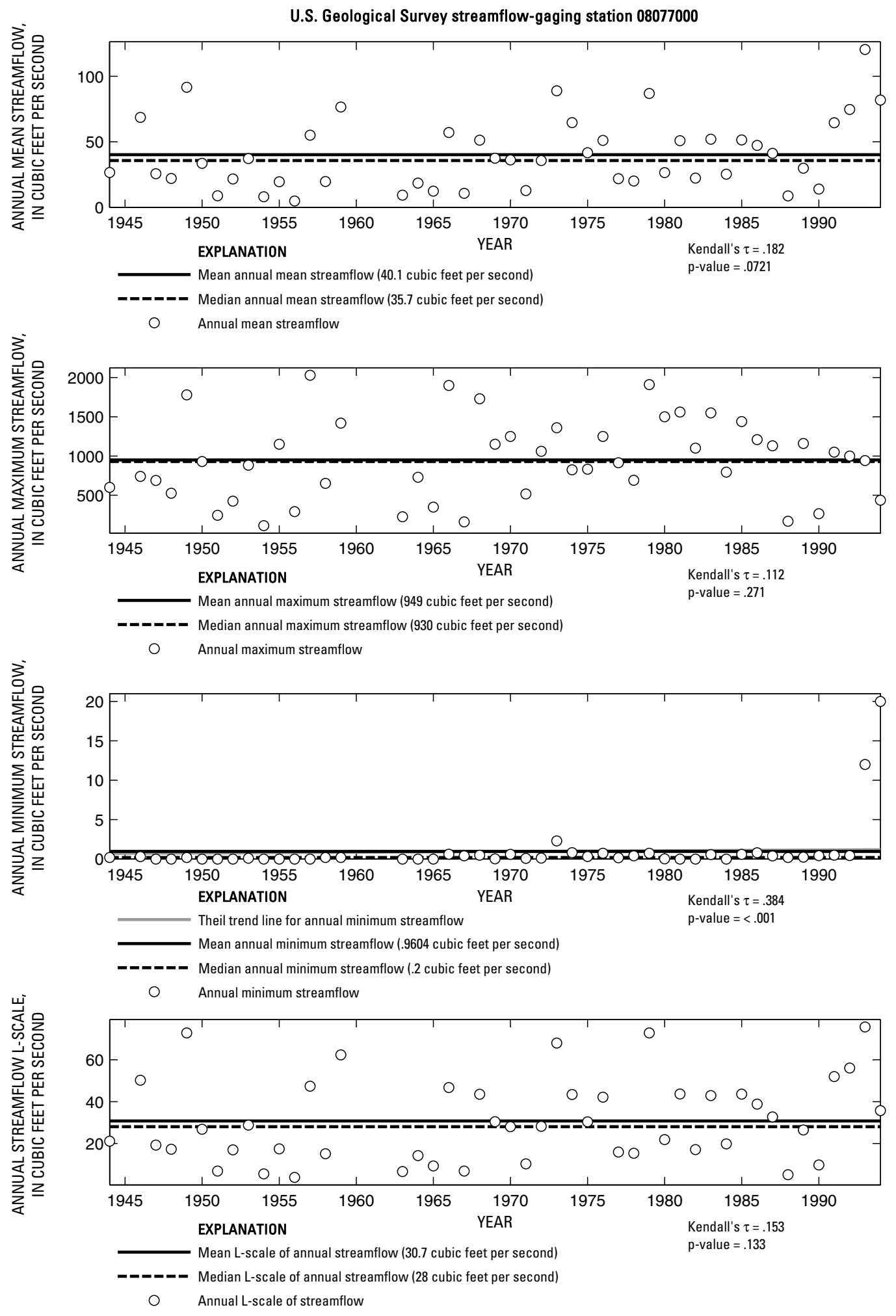

Figure 308. Analysis of annual mean, maximum, minimum, and L-scale statistics of daily mean streamflow for U.S. Geological Survey streamflow-gaging station 08077000 Clear Creek near Pearland, Texas.

Index of Station Numbers 719 


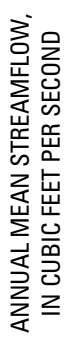

U.S. Geological Survey streamflow-gaging station 08077540

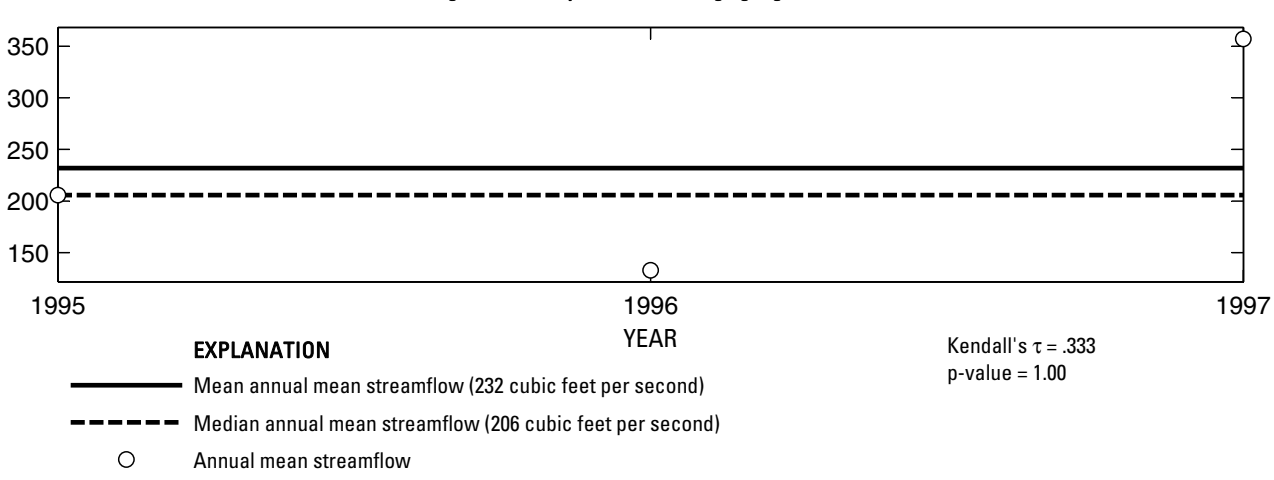

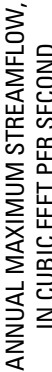
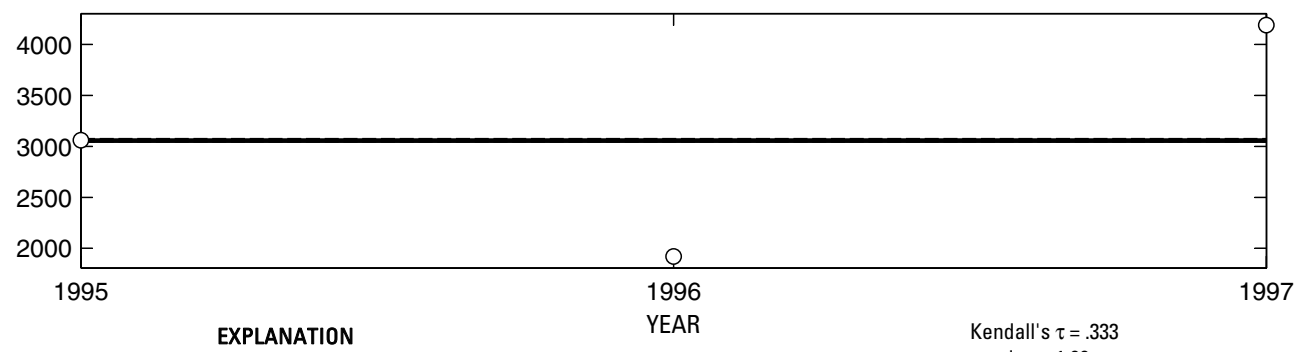

EXPLANATION

p-value $=1$

- _ - - Median annual maximum streamflow (3,060 cubic feet per second)

Annual maximum streamflow
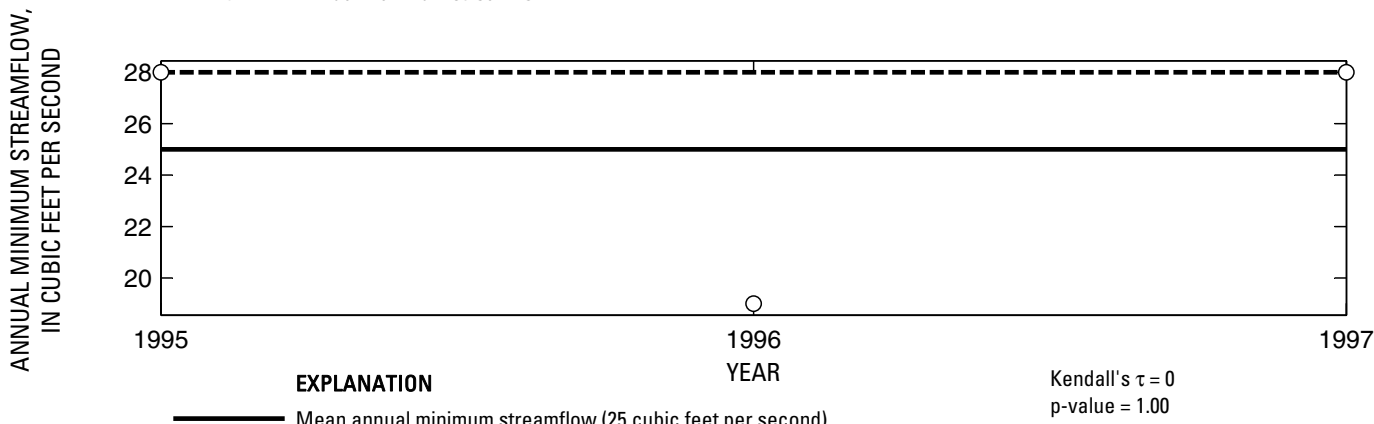

- ב- Median annual minimum streamflow (28 cubic feet per second)

O Annual minimum streamflow

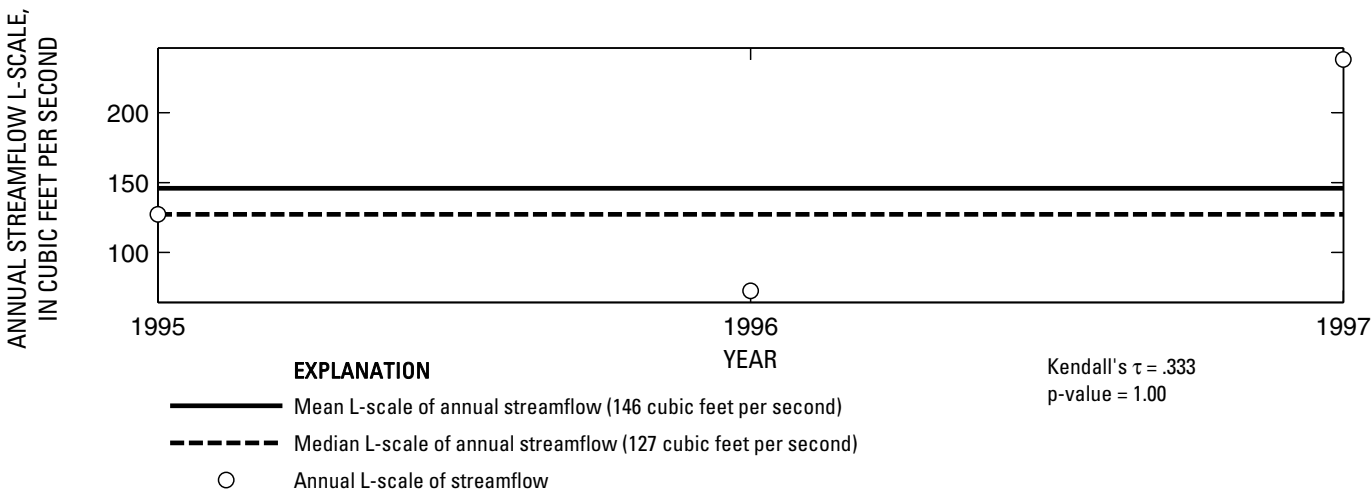

Figure 309. Analysis of annual mean, maximum, minimum, and L-scale statistics of daily mean streamflow for U.S. Geological Survey streamflow-gaging station 08077540 Clear Creek at Friendswood, Texas. 

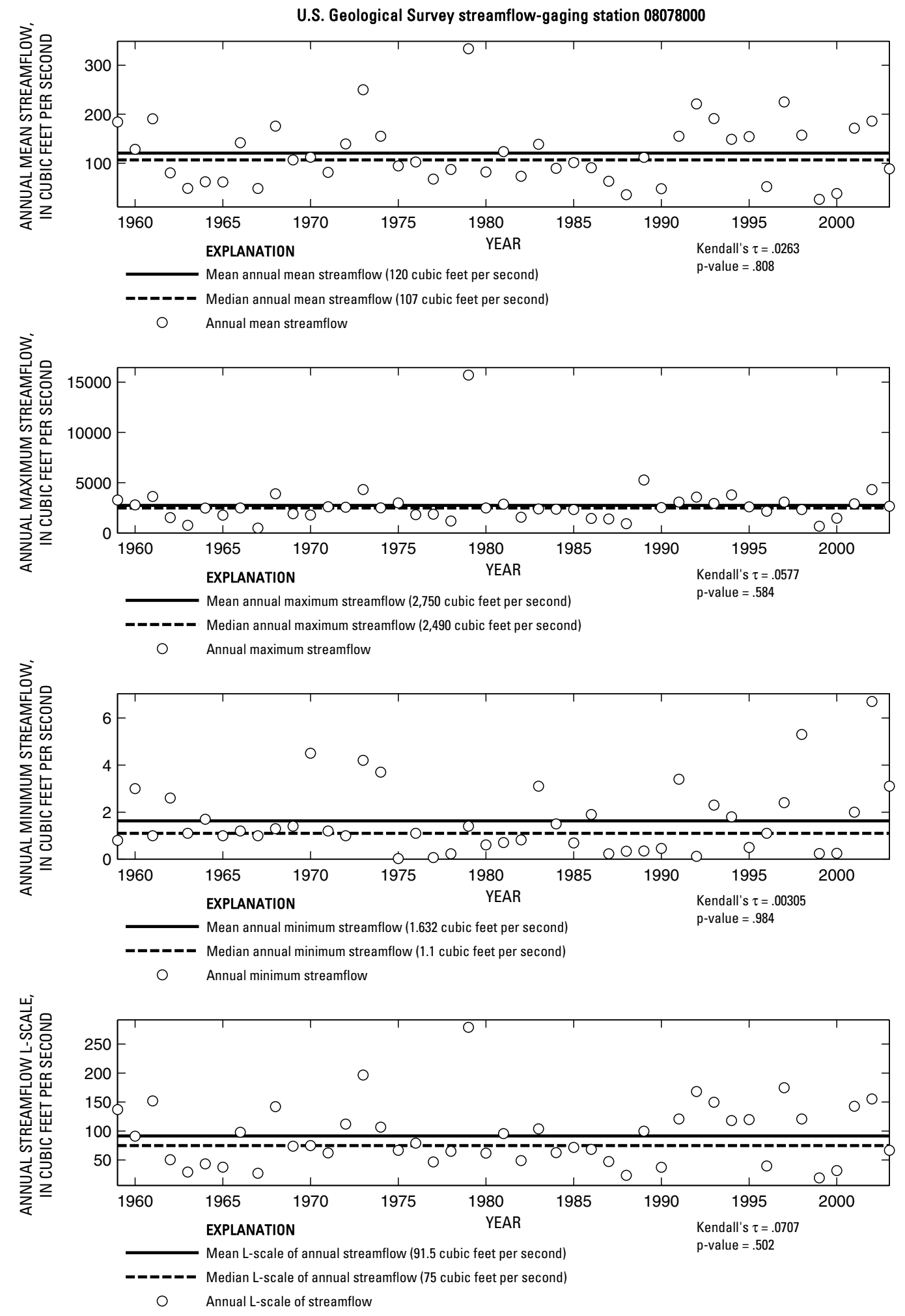

Figure 310. Analysis of annual mean, maximum, minimum, and L-scale statistics of daily mean streamflow for U.S. Geological Survey streamflow-gaging station 08078000 Chocolate Bayou near Alvin, Texas.

Index of Station Numbers 719 


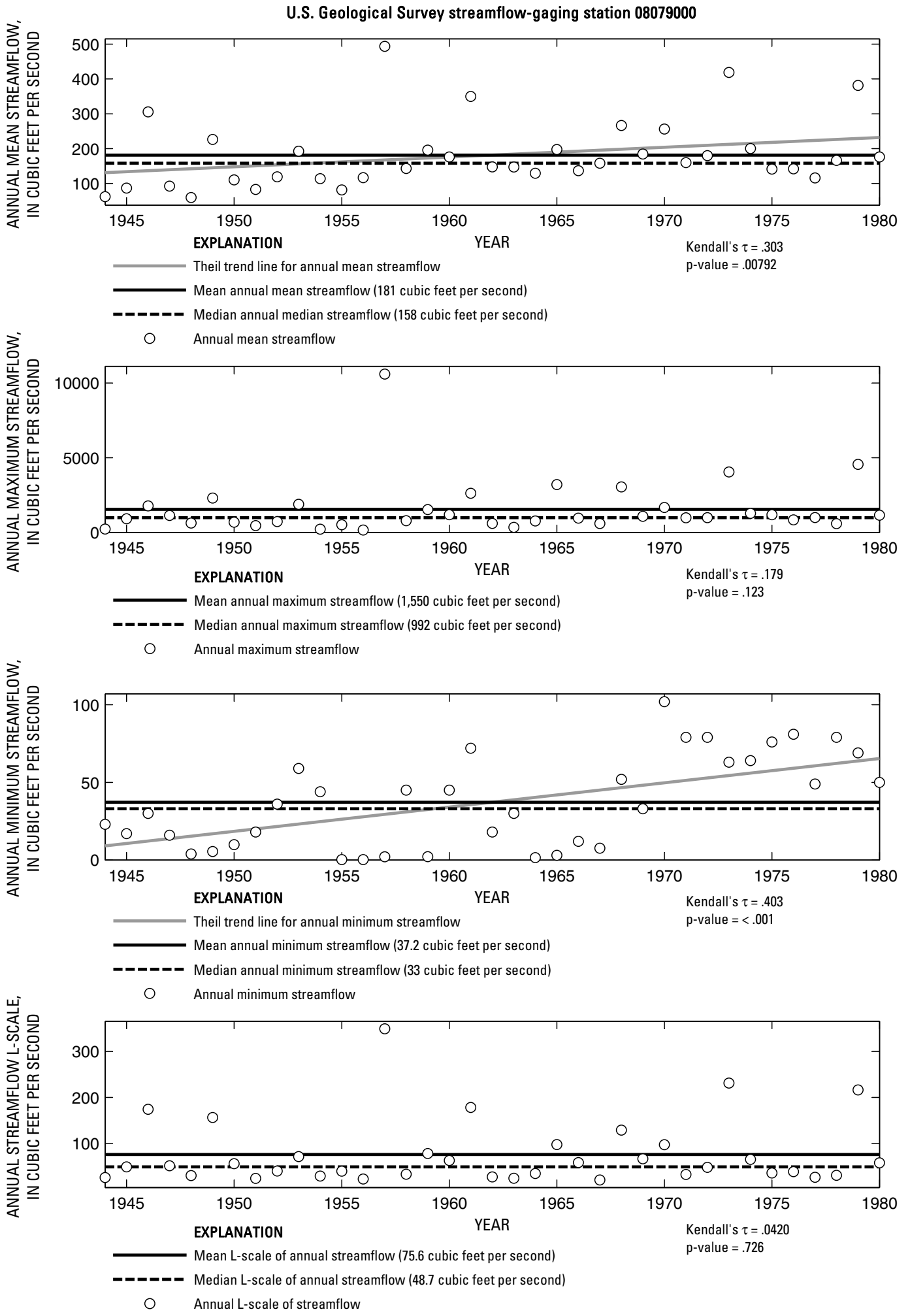

Figure 311. Analysis of annual mean, maximum, minimum, and L-scale statistics of daily mean streamflow for U.S. Geological Survey streamflow-gaging station 08079000 Oyster Creek near Angleton, Texas. 

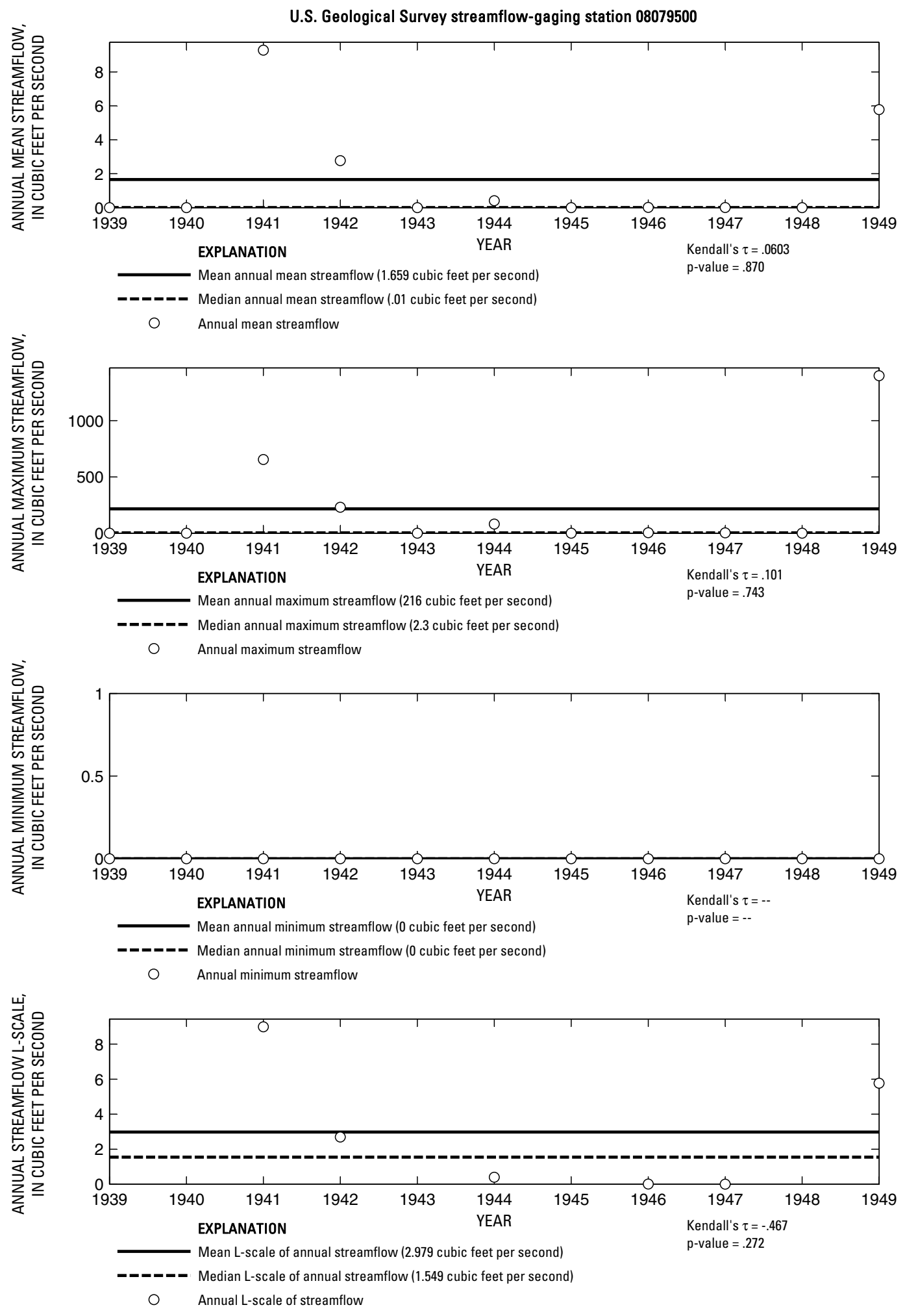

Figure 312. Analysis of annual mean, maximum, minimum, and L-scale statistics of daily mean streamflow for U.S. Geological Survey streamflow-gaging station 08079500 North Fork Double Mountain Fork Brazos River at Lubbock, Texas. 

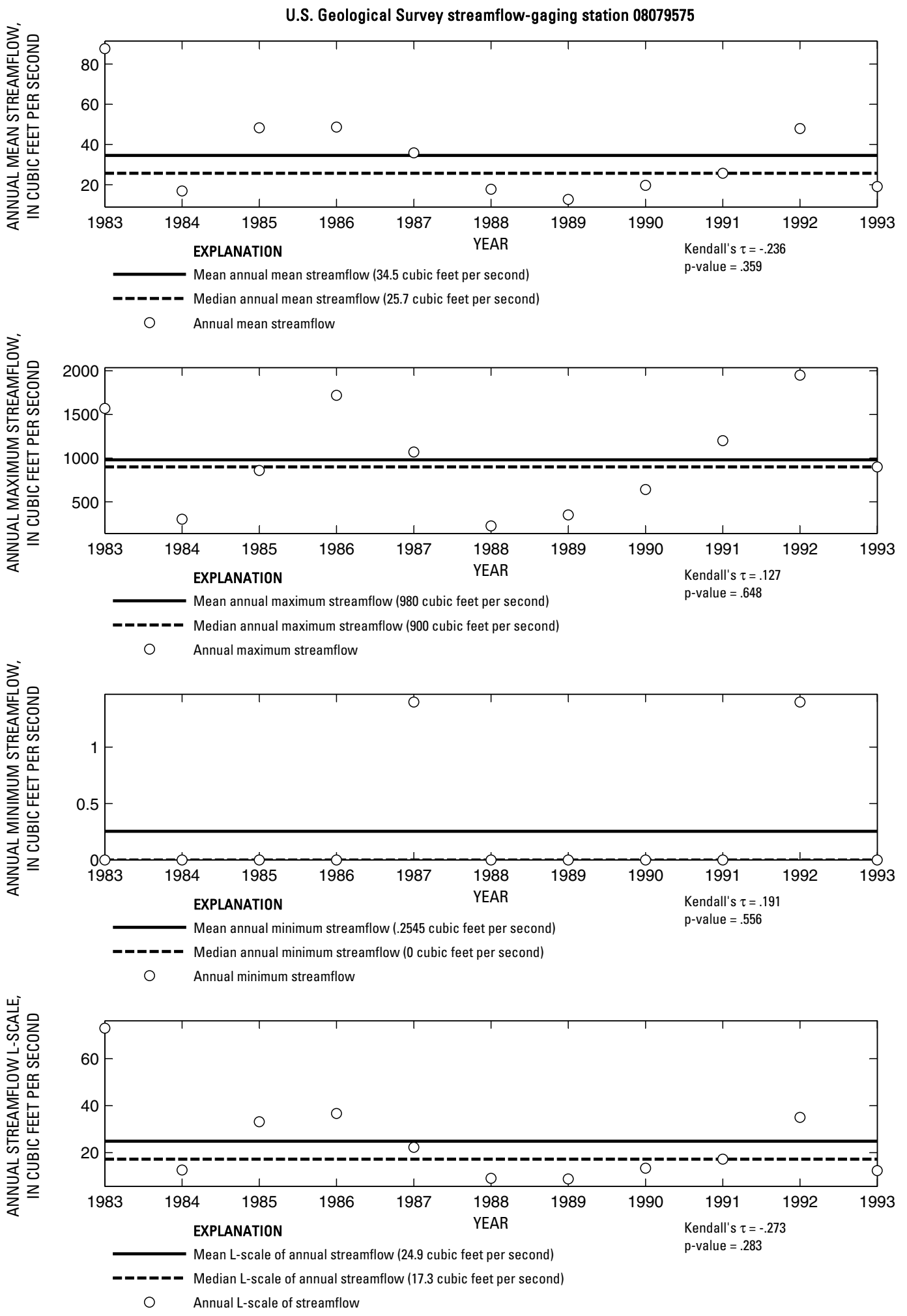

Figure 313. Analysis of annual mean, maximum, minimum, and L-scale statistics of daily mean streamflow for U.S. Geological Survey streamflow-gaging station 08079575 North Fork Double Mountain Fork Brazos River near Post, Texas. 

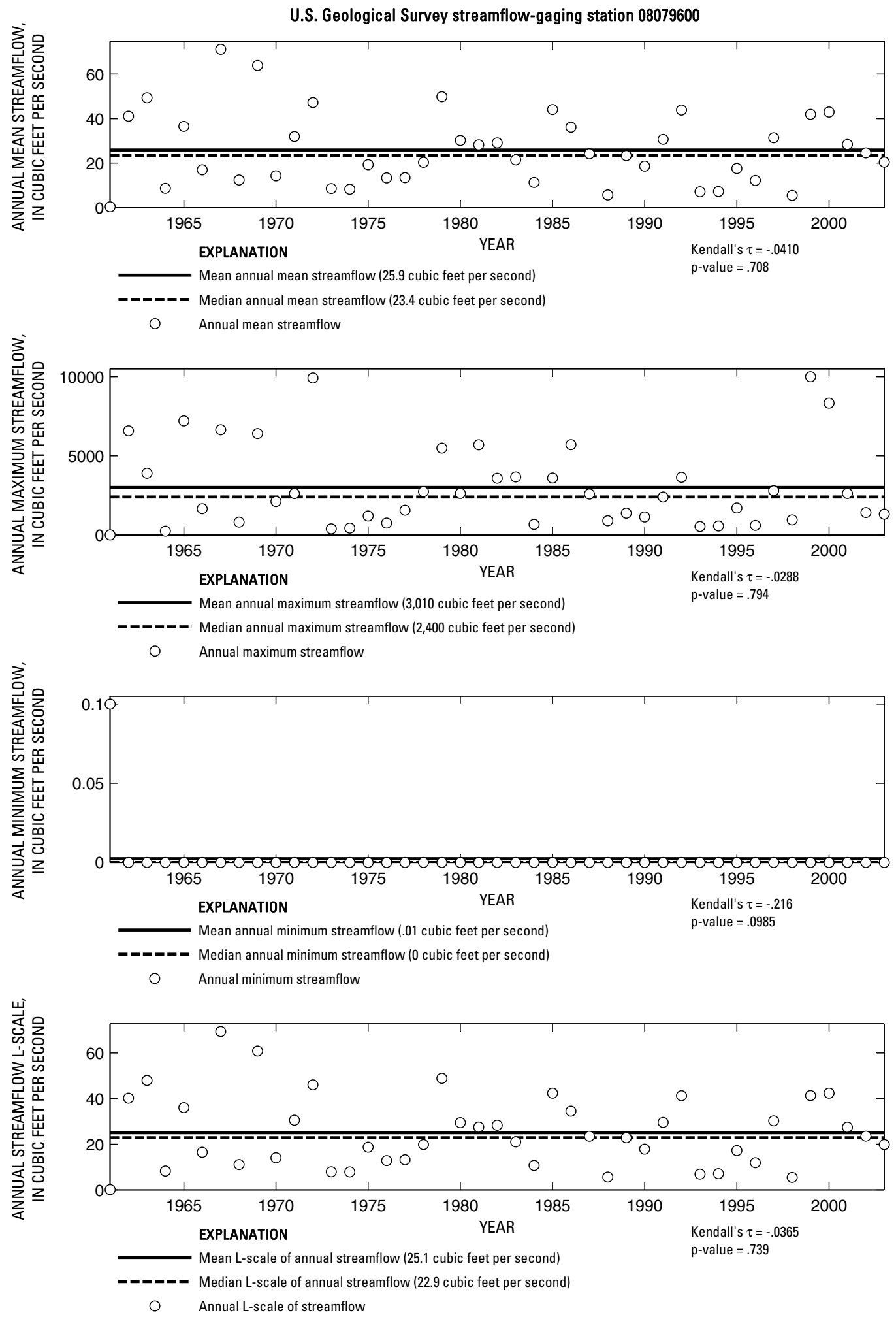

Figure 314. Analysis of annual mean, maximum, minimum, and L-scale statistics of daily mean streamflow for U.S. Geological Survey streamflow-gaging station 08079600 Double Mountain Fork Brazos River at Justiceburg, Texas.

Index of Station Numbers 719 


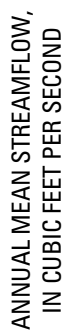

U.S. Geological Survey streamflow-gaging station 08080000

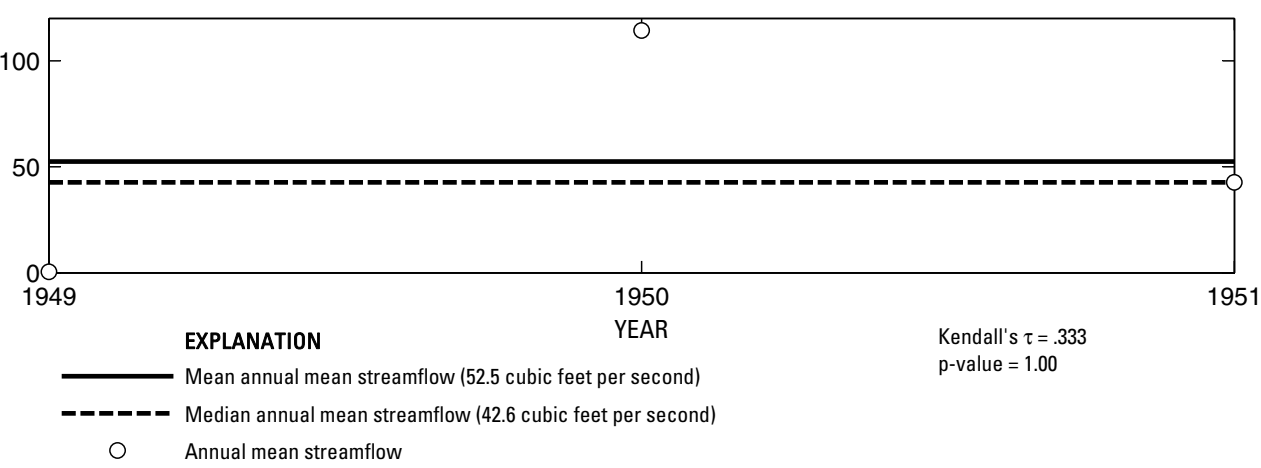

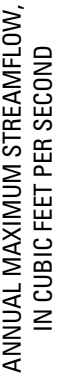

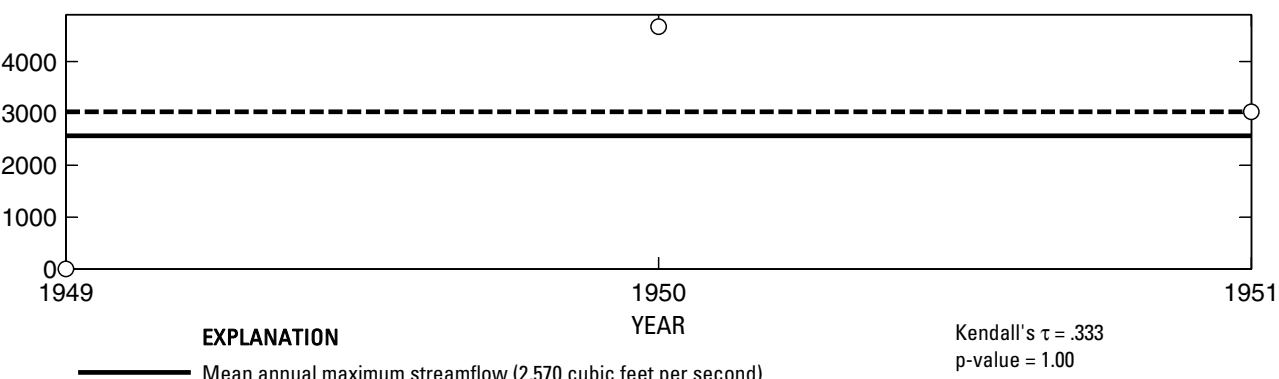

- _ _ - Median annual maximum streamflow (3,030 cubic feet per second)

Annual maximum streamflow
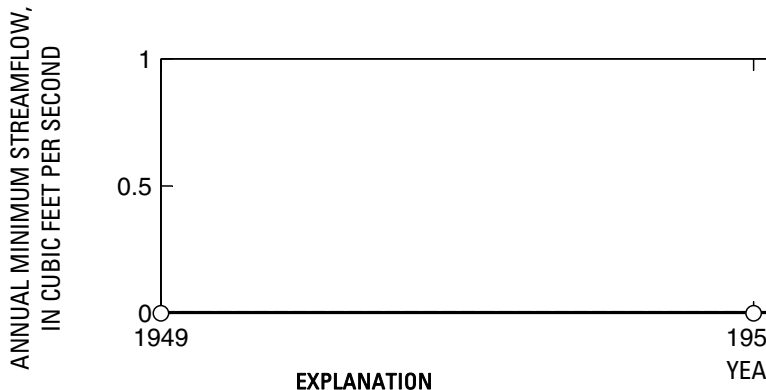

- Mean annual minimum streamflow (0 cubic feet per second)

p-value $=1.00$

O Annual minimum streamflow

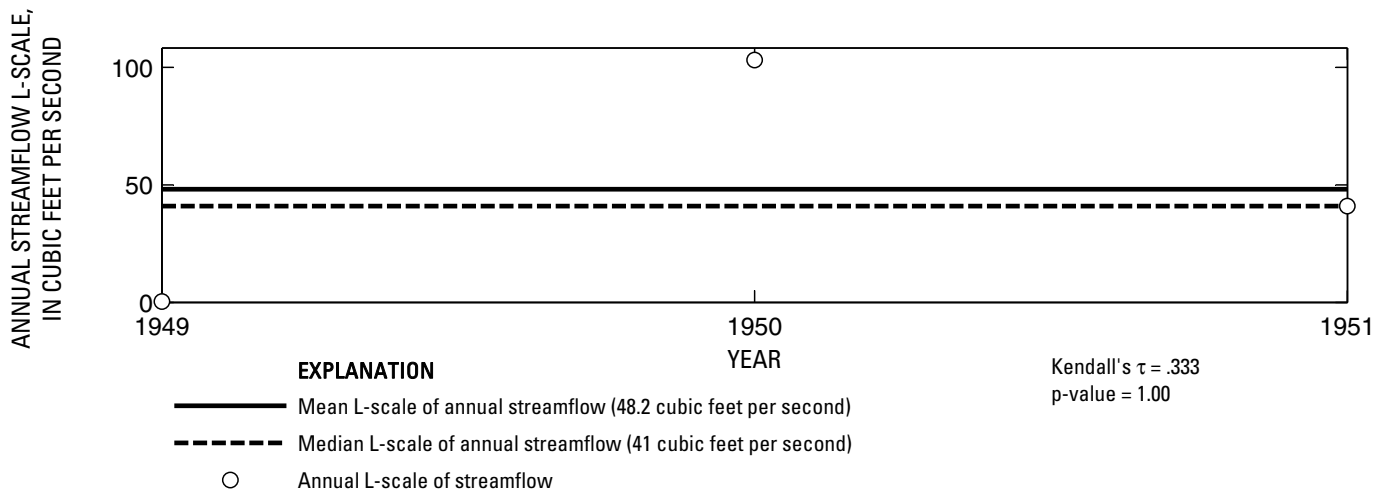

Figure 315. Analysis of annual mean, maximum, minimum, and L-scale statistics of daily mean streamflow for U.S. Geological Survey streamflow-gaging station 08080000 Double Mountain Fork Brazos River near Rotan, Texas. 


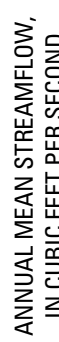

U.S. Geological Survey streamflow-gaging station 08080500

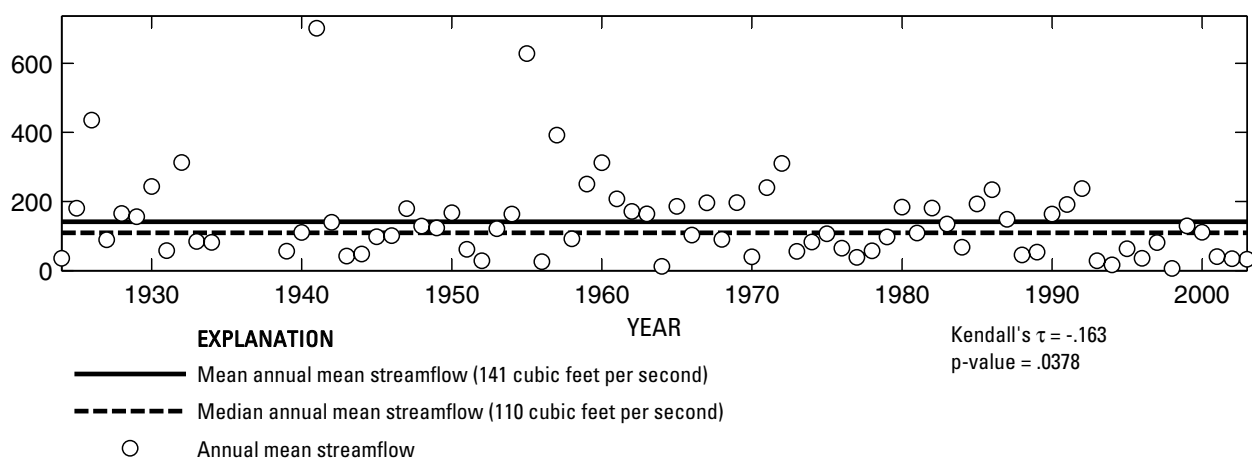

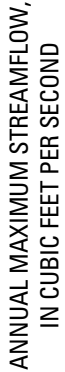
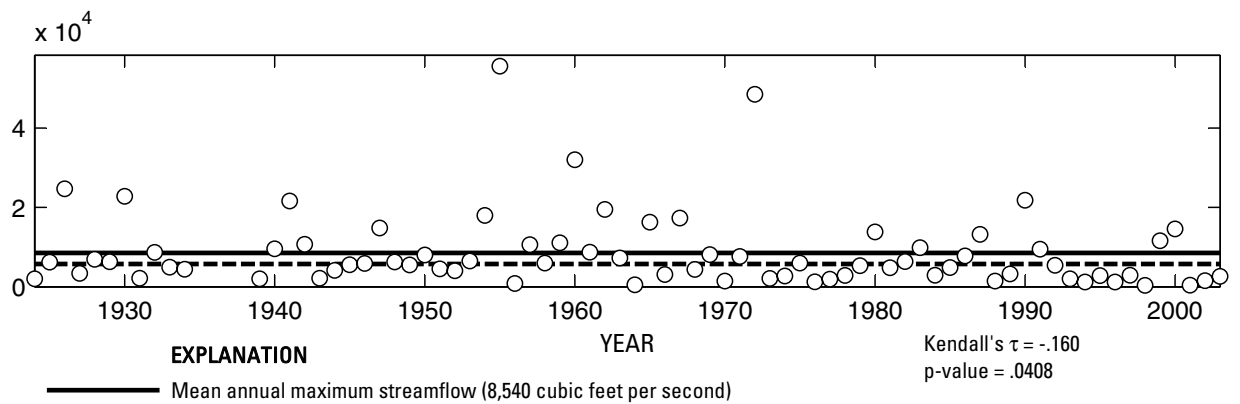

- - - Median annual maximum streamflow (5,720 cubic feet per second)

O Annual maximum streamflow

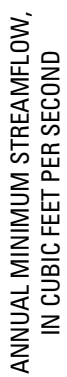

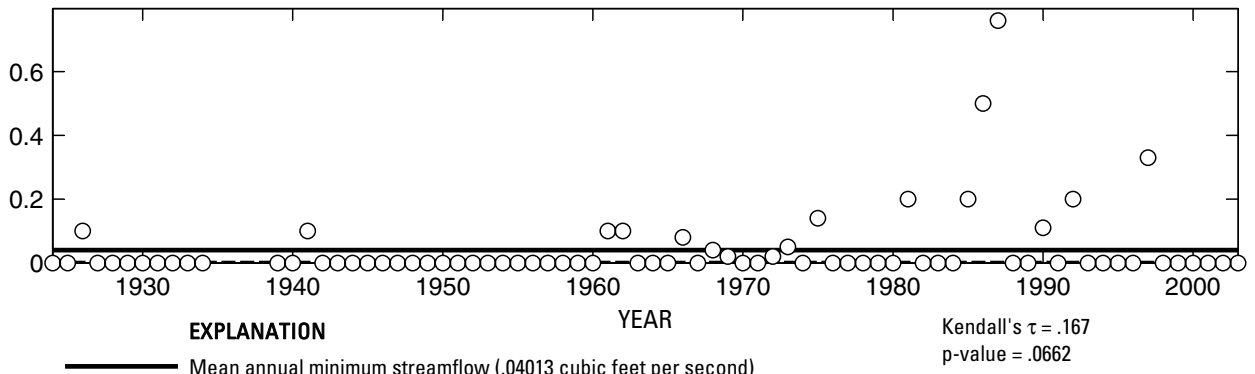

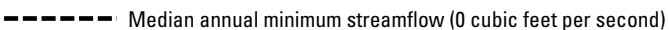

O Annual minimum streamflow

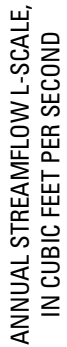

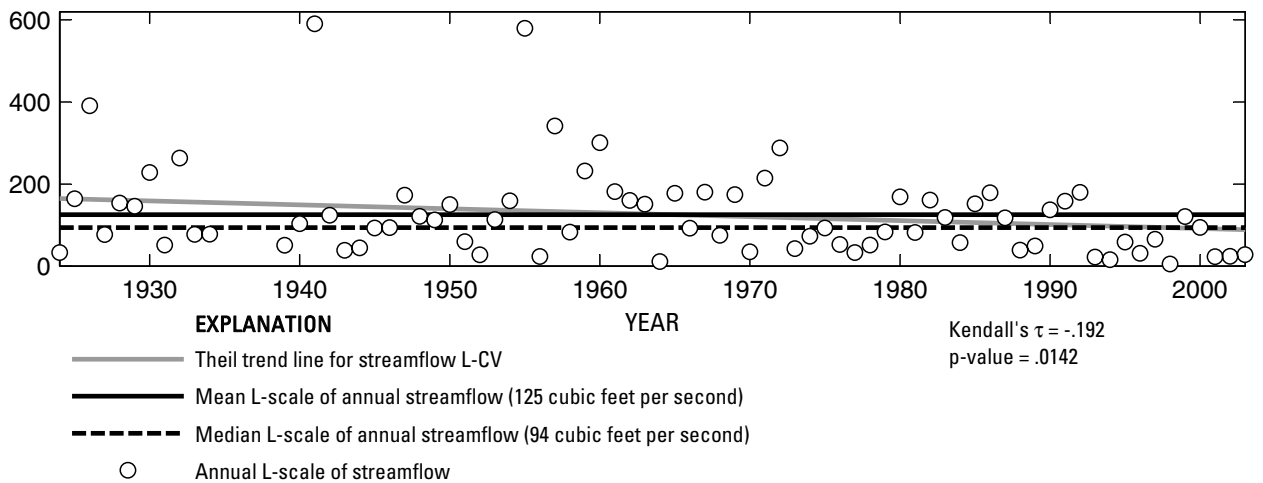

Figure 316. Analysis of annual mean, maximum, minimum, and L-scale statistics of daily mean streamflow for U.S. Geological Survey streamflow-gaging station 08080500 Double Mountain Fork Brazos River near Aspermont, Texas. 


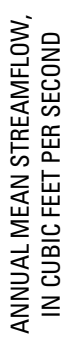

U.S. Geological Survey streamflow-gaging station 08080540

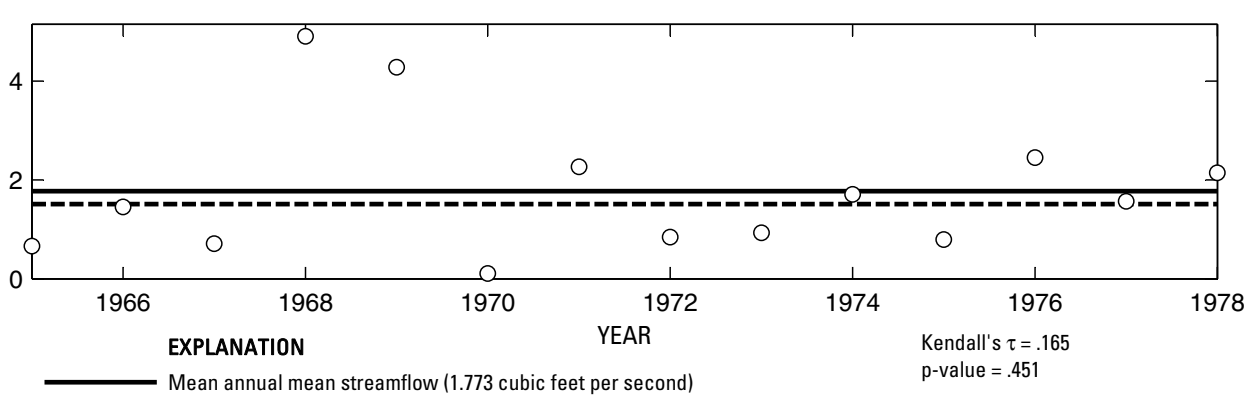

-_o_-_ Median annual mean streamflow (1.512 cubic feet per second)

O Annual mean streamflow
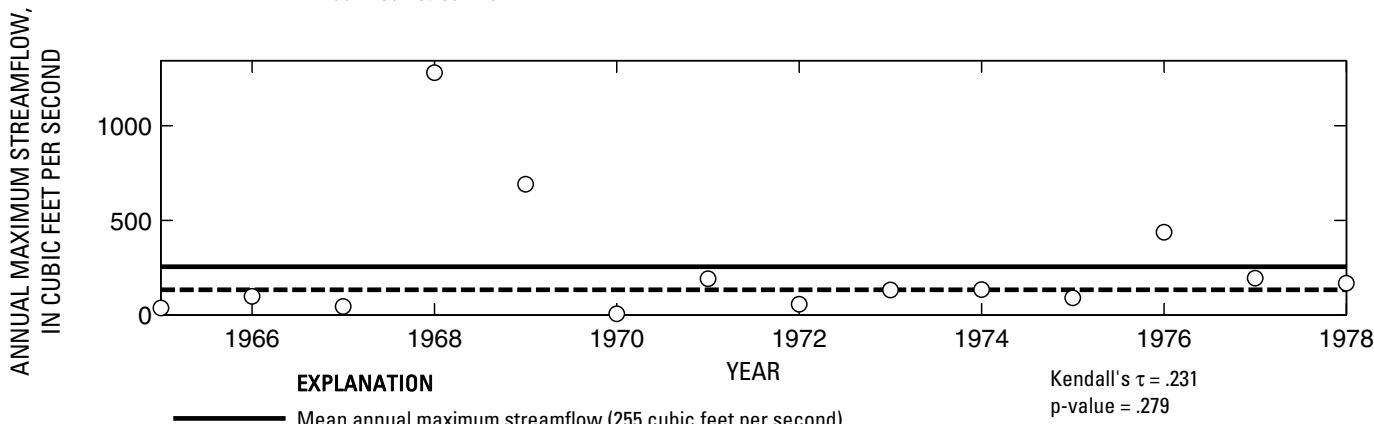

O Annual maximum streamflow

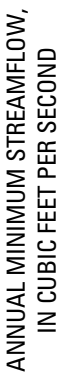

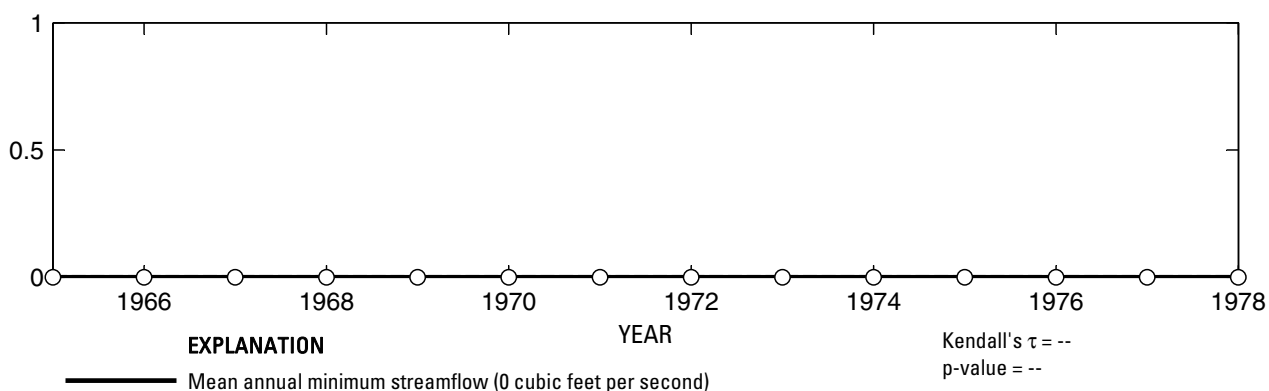

- - ב- Median annual minimum streamflow (0 cubic feet per second)

○ Annual minimum streamflow

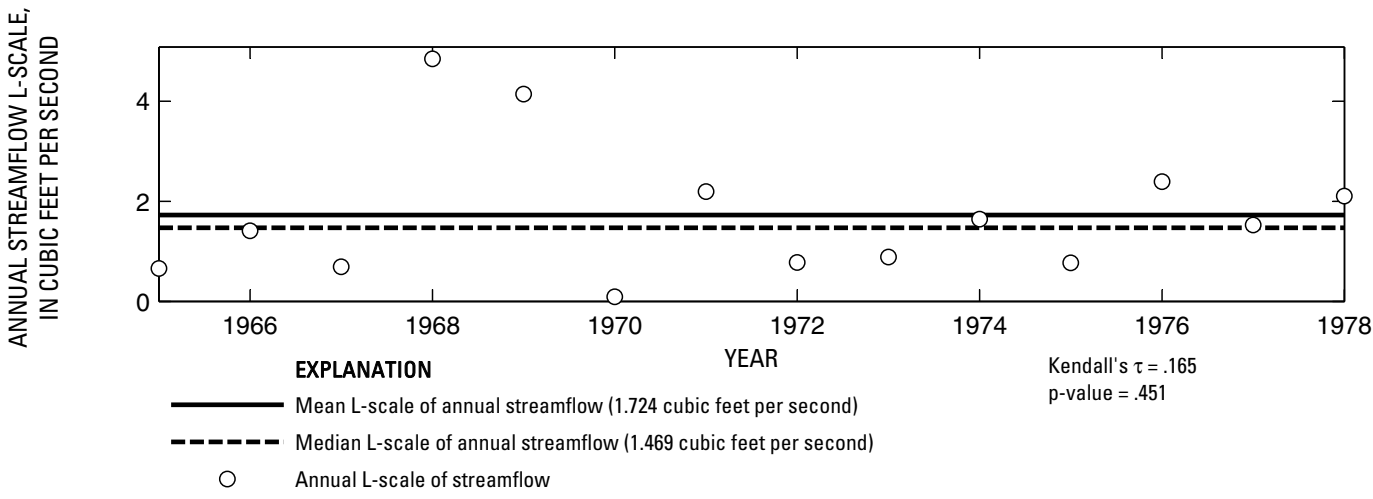

Figure 317. Analysis of annual mean, maximum, minimum, and L-scale statistics of daily mean streamflow for U.S. Geological Survey streamflow-gaging station 08080540 McDonald Creek near Post, Texas. 


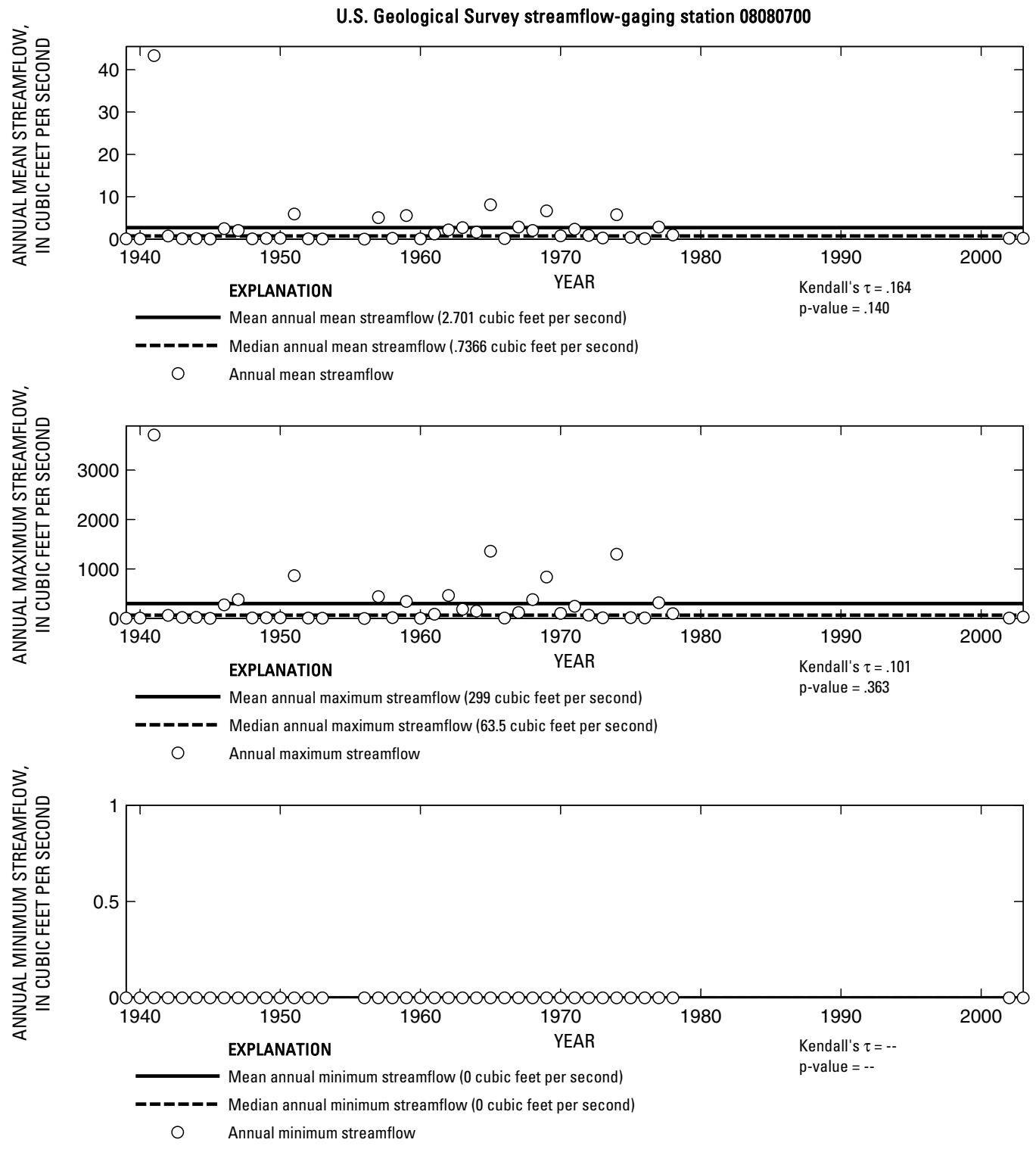

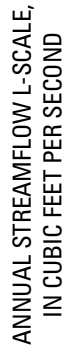

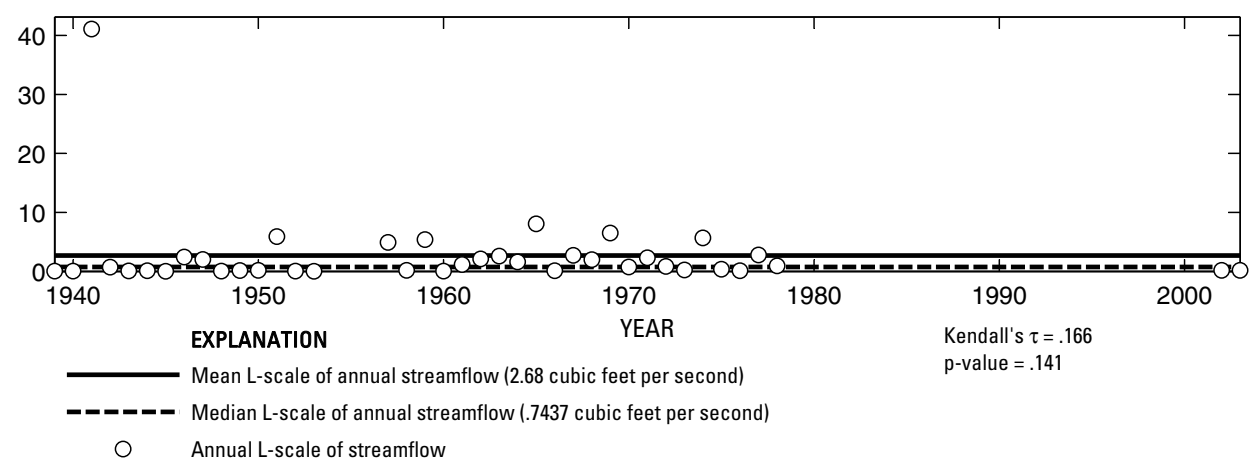

Figure 318. Analysis of annual mean, maximum, minimum, and L-scale statistics of daily mean streamflow for U.S. Geological Survey streamflow-gaging station 08080700 Running Water Draw at Plainview, Texas.

Index of Station Numbers 719 


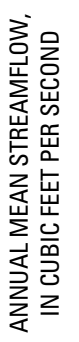

U.S. Geological Survey streamflow-gaging station 08080950

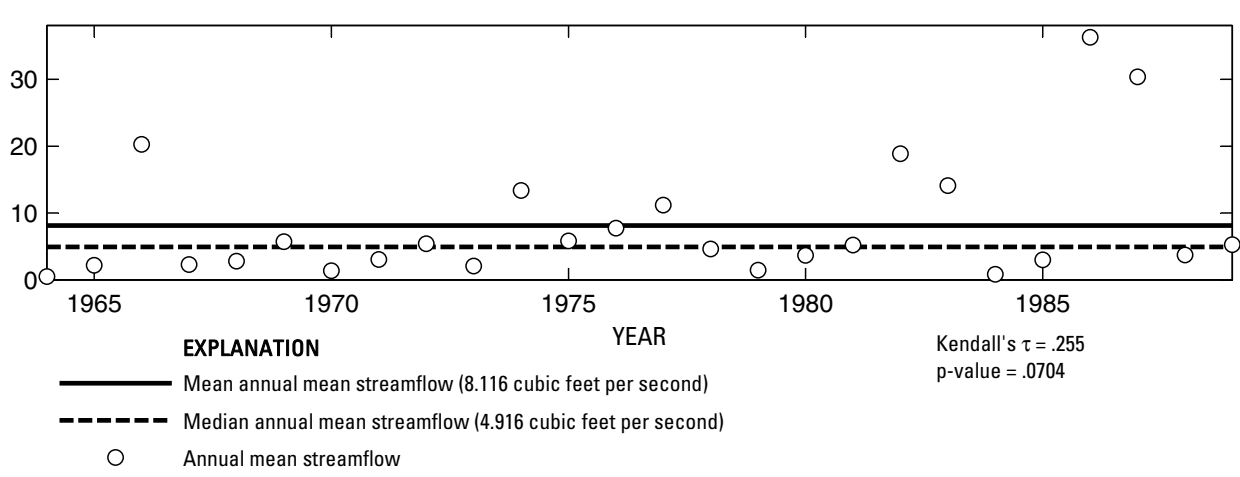

㤩

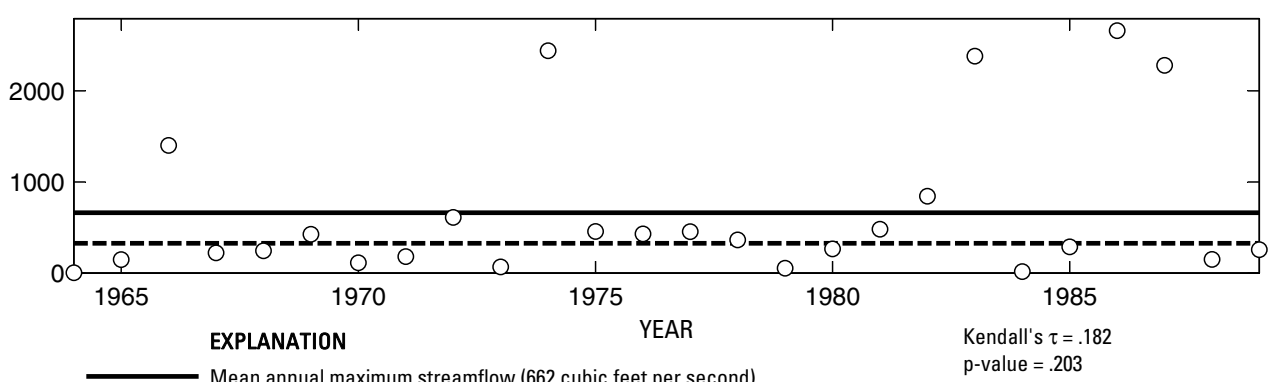

- - - Median annual maximum streamflow (326 cubic feet per second)

Annual maximum streamflow

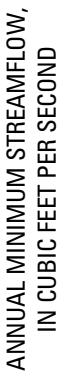

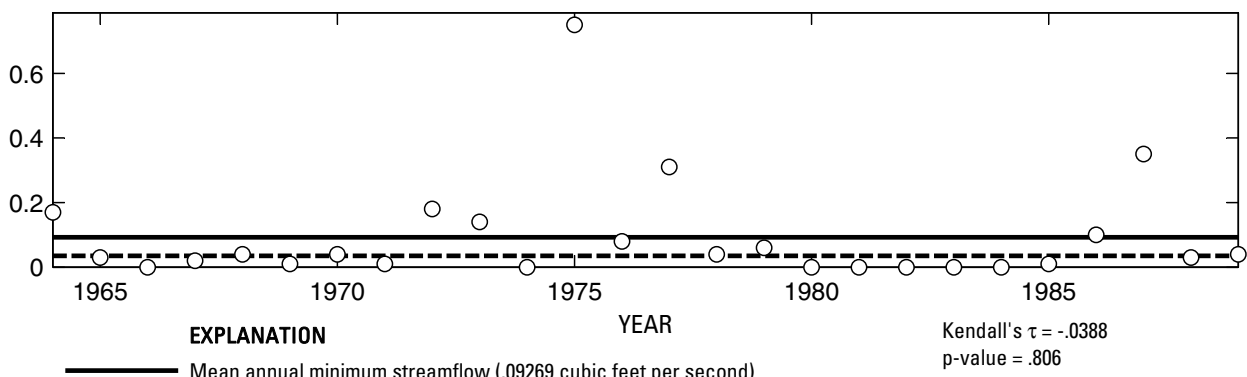

- - - Median annual minimum streamflow (.035 cubic feet per second)

O Annual minimum streamflow

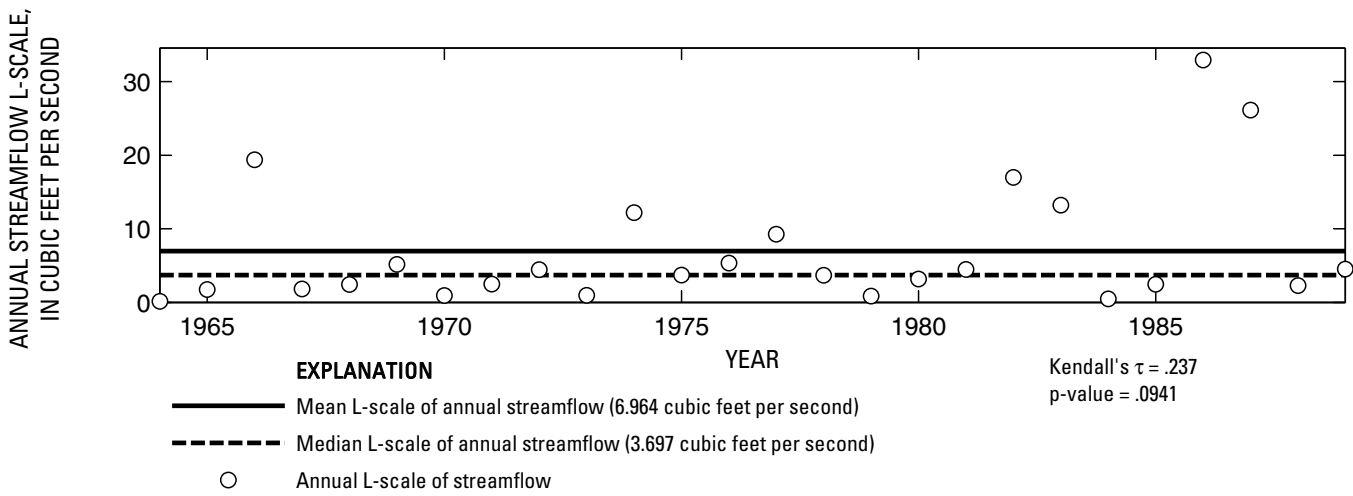

Figure 319. Analysis of annual mean, maximum, minimum, and L-scale statistics of daily mean streamflow for U.S. Geological Survey streamflow-gaging station 08080950 Duck Creek near Girard, Texas. 


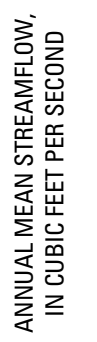

U.S. Geological Survey streamflow-gaging station 08081000

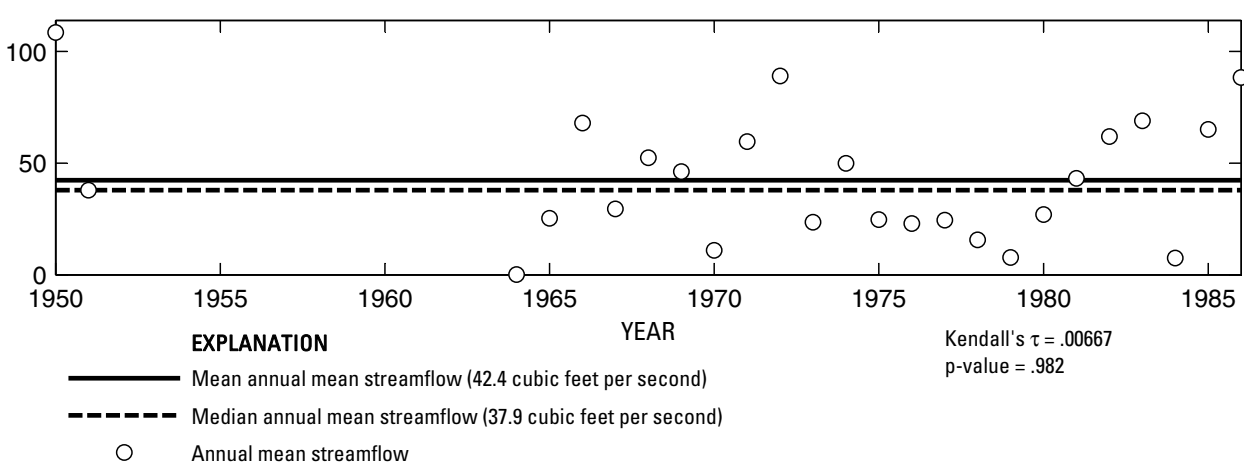

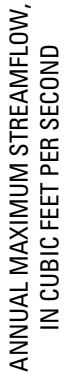

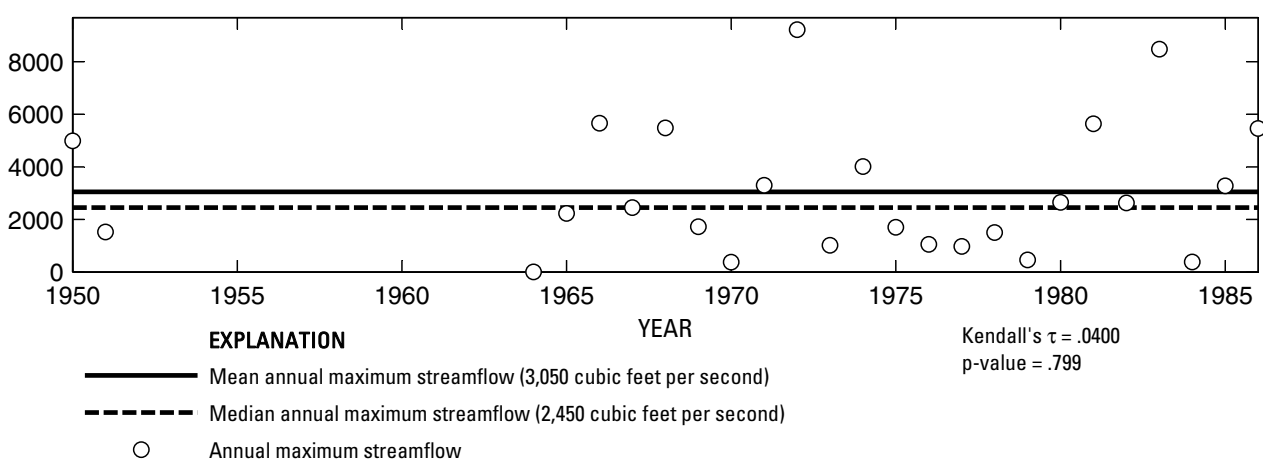

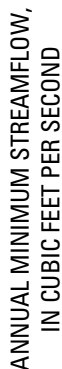

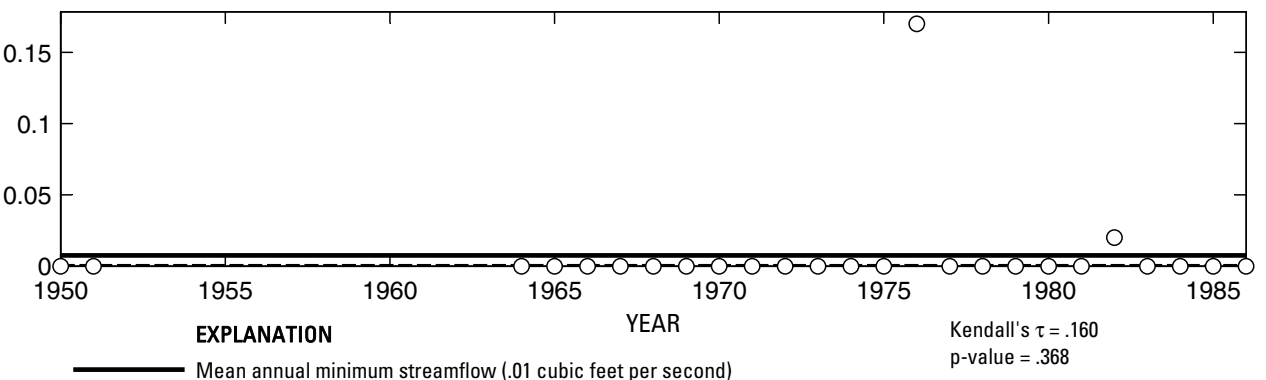

- Median annual minimum streamflow (0 cubic feet per second)

O Annual minimum streamflow

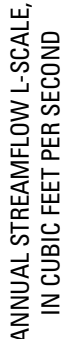

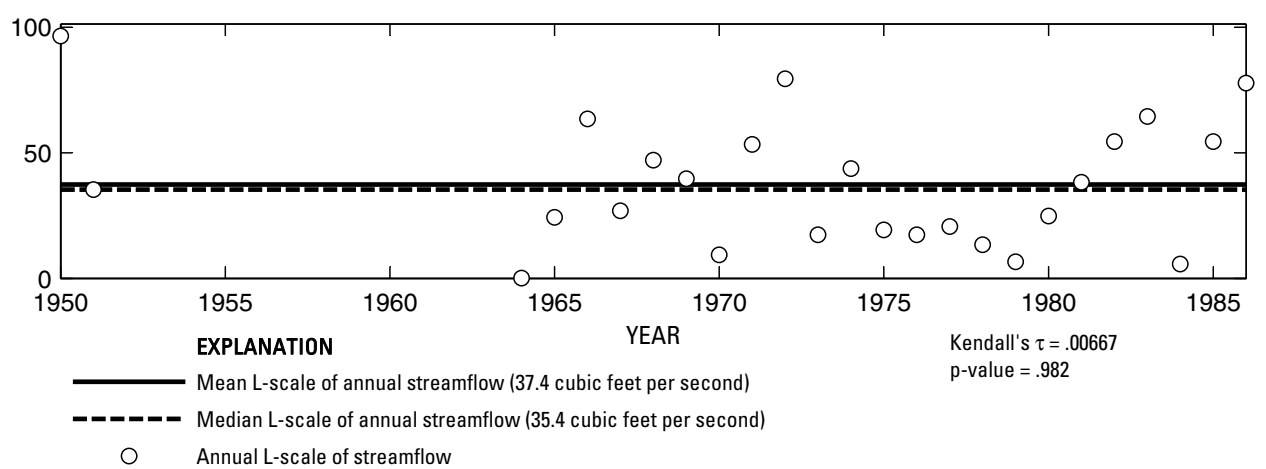

Figure 320. Analysis of annual mean, maximum, minimum, and L-scale statistics of daily mean streamflow for U.S. Geological Survey streamflow-gaging station 08081000 Salt Fork Brazos River near Peacock, Texas.

Index of Station Numbers 719 


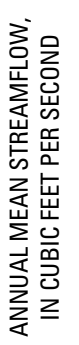

U.S. Geological Survey streamflow-gaging station 08081200

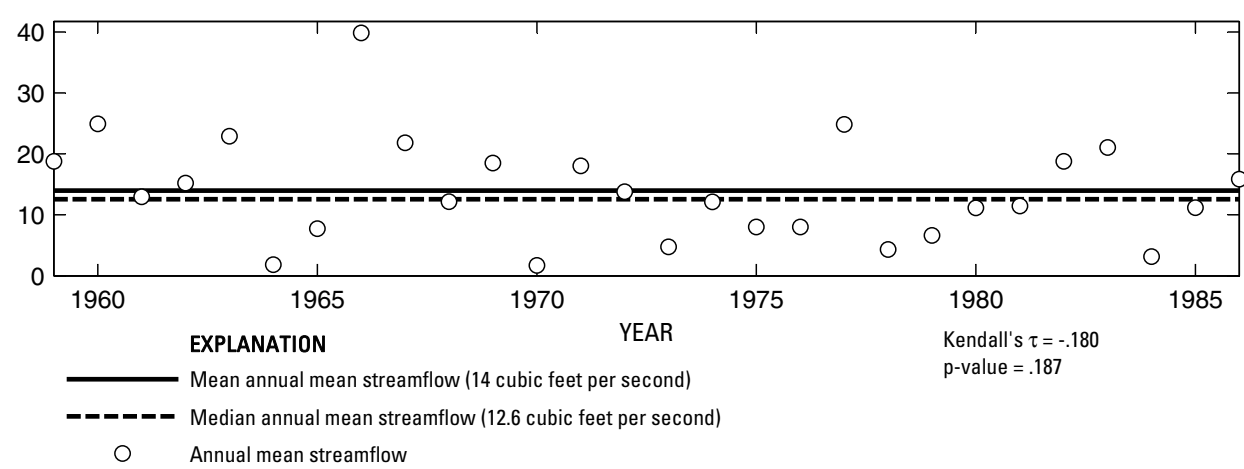

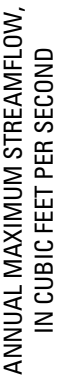

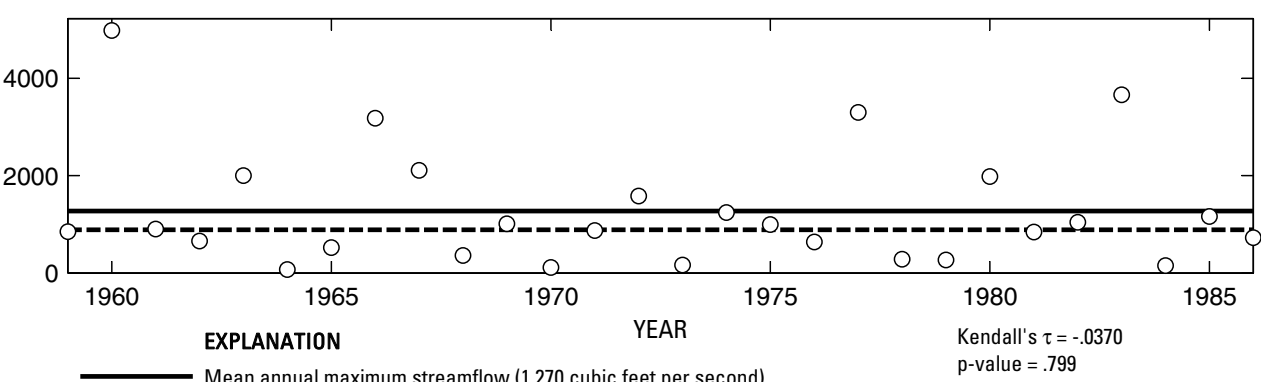

O Annual maximum streamflow

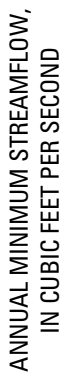

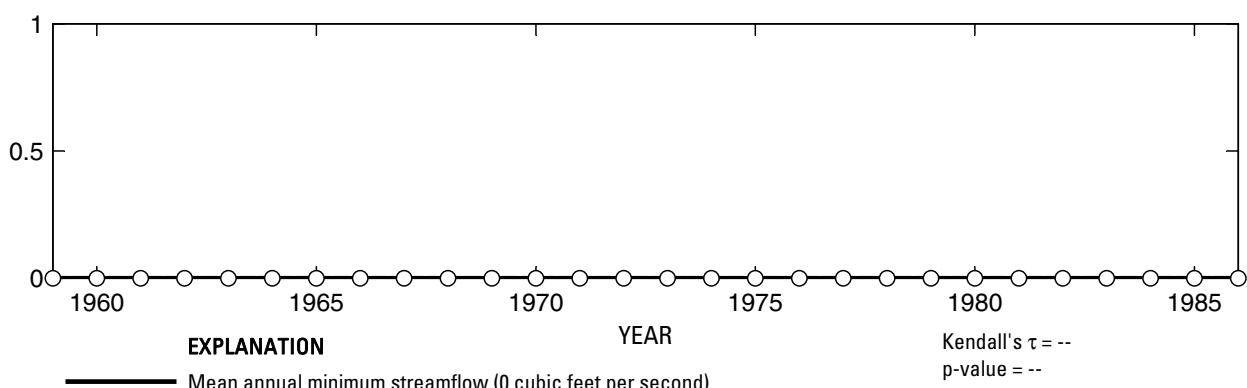

O Annual minimum streamflow

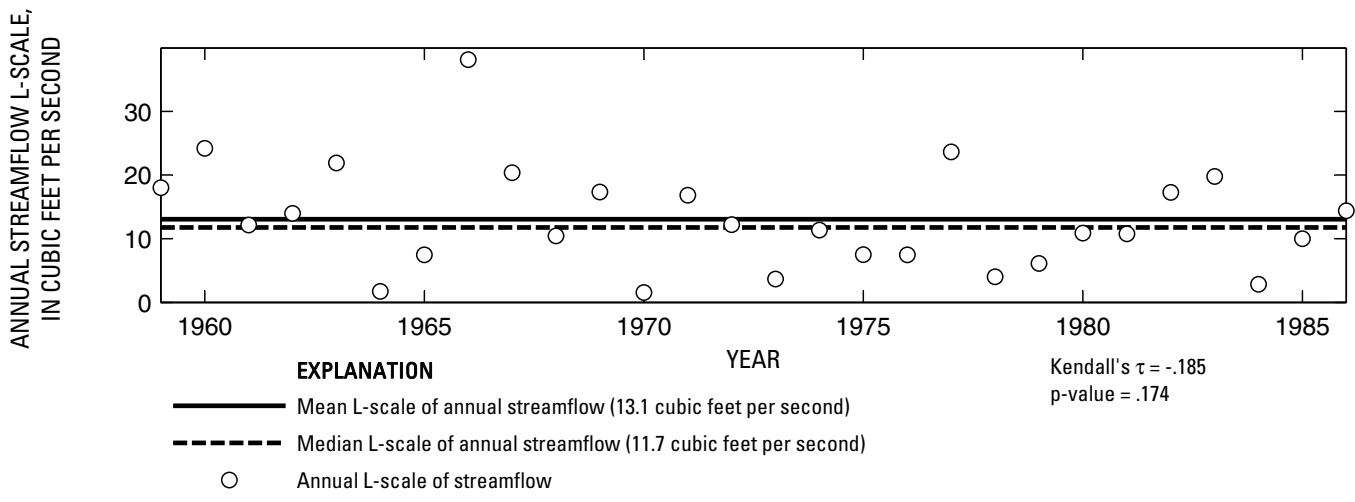

Figure 321. Analysis of annual mean, maximum, minimum, and L-scale statistics of daily mean streamflow for U.S. Geological Survey streamflow-gaging station 08081200 Croton Creek near Jayton, Texas. 
U.S. Geological Survey streamflow-gaging station 08081500

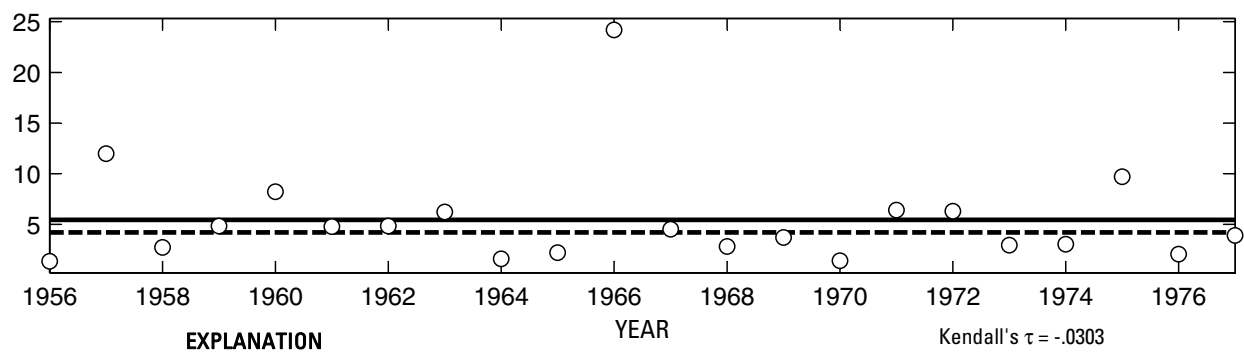

Mean annual mean streamflow (5.441 cubic feet per second)

$\mathrm{p}$-value $=.867$

-__-_- Median annual mean streamflow (4.211 cubic feet per second)

O Annual mean streamflow

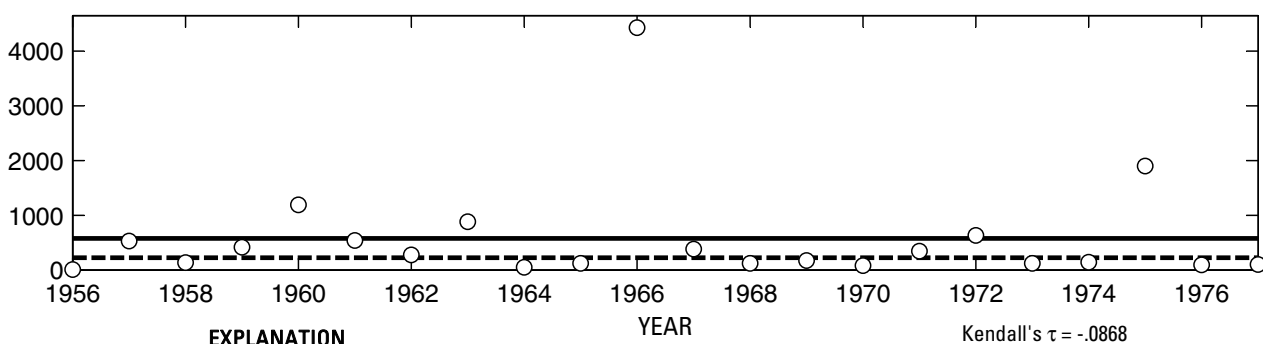

Mean annual maximum streamflow (576 cubic feet per second)

$\mathrm{p}$-value $=.592$

-ーーーーー Median annual maximum streamflow (224 cubic feet per second)

O Annual maximum streamflow

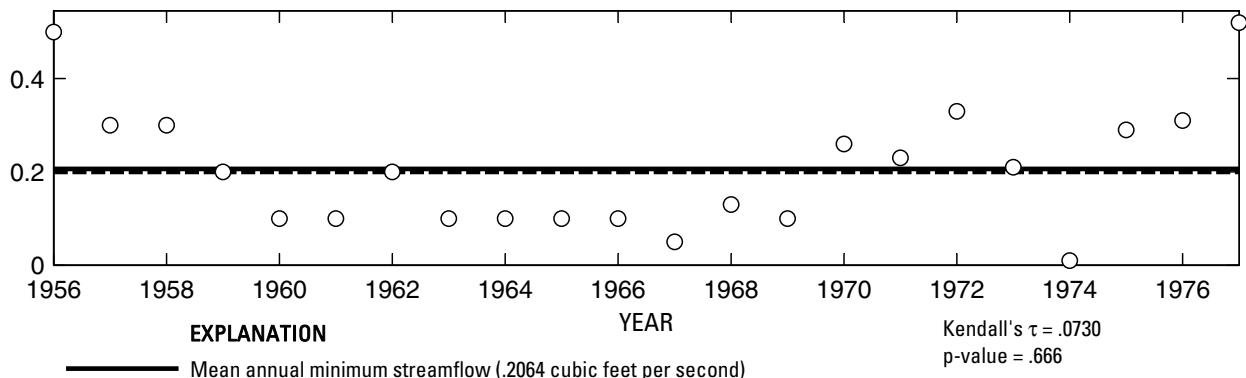

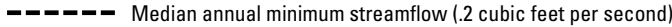

O Annual minimum streamflow

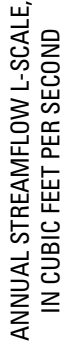

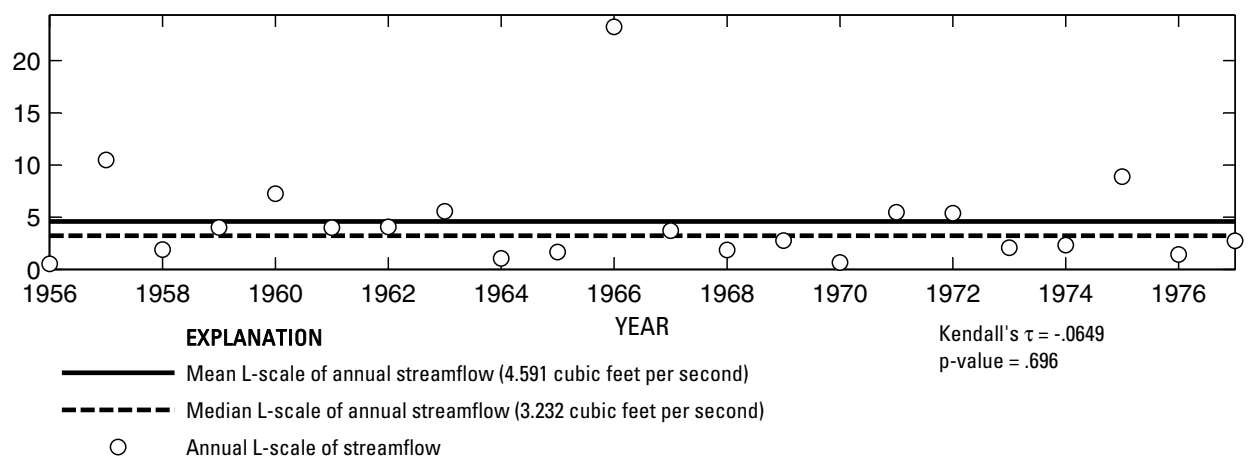

Figure 322. Analysis of annual mean, maximum, minimum, and L-scale statistics of daily mean streamflow for U.S. Geological Survey streamflow-gaging station 08081500 Salt Croton Creek near Aspermont, Texas.

Index of Station Numbers 719 

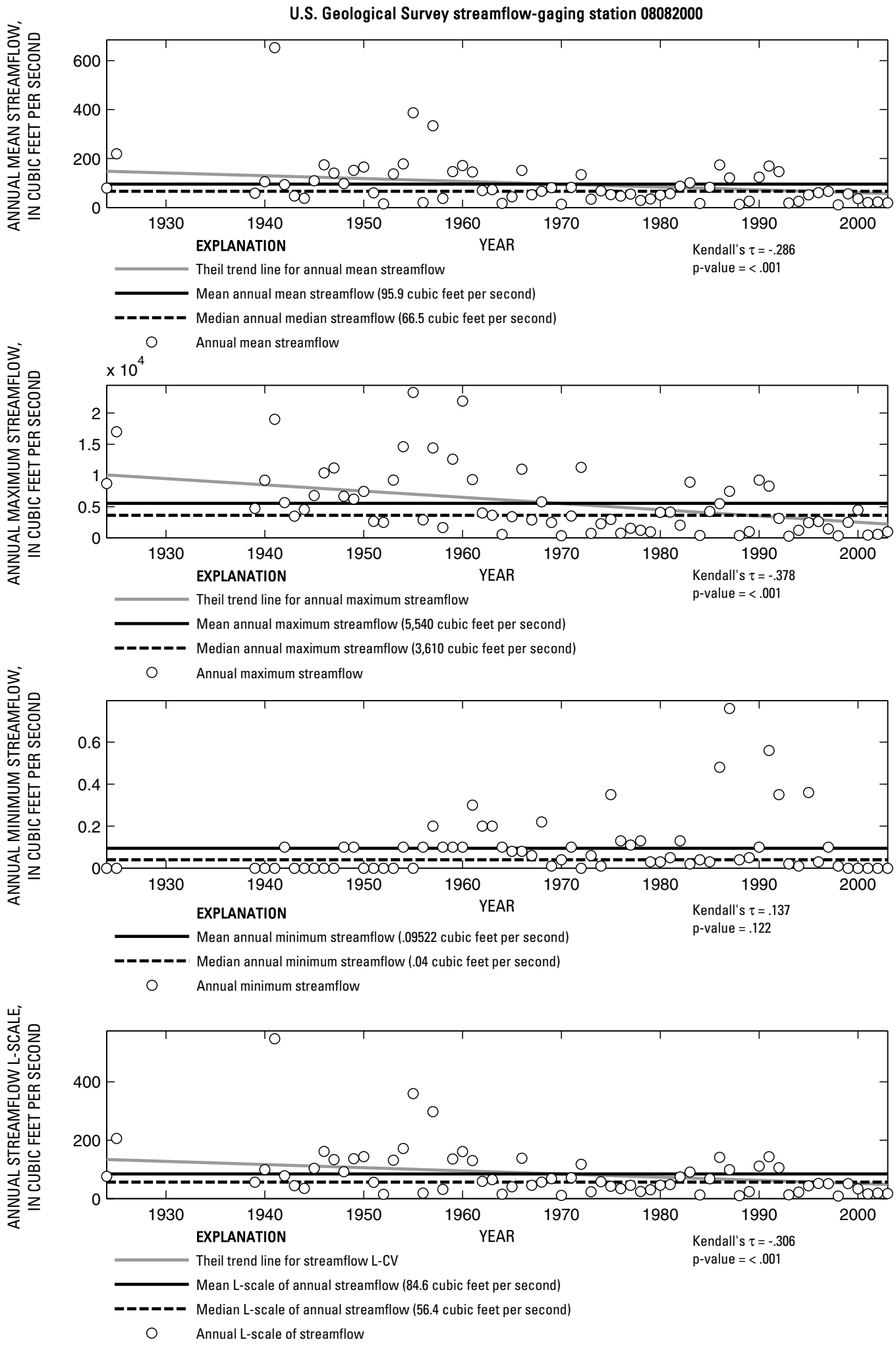

Figure 323. Analysis of annual mean, maximum, minimum, and L-scale statistics of daily mean streamflow for U.S. Geological Survey streamflow-gaging station 08082000 Salt Fork Brazos River near Aspermont, Texas. 


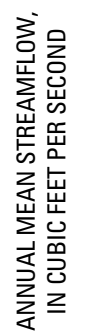

U.S. Geological Survey streamflow-gaging station 08082100

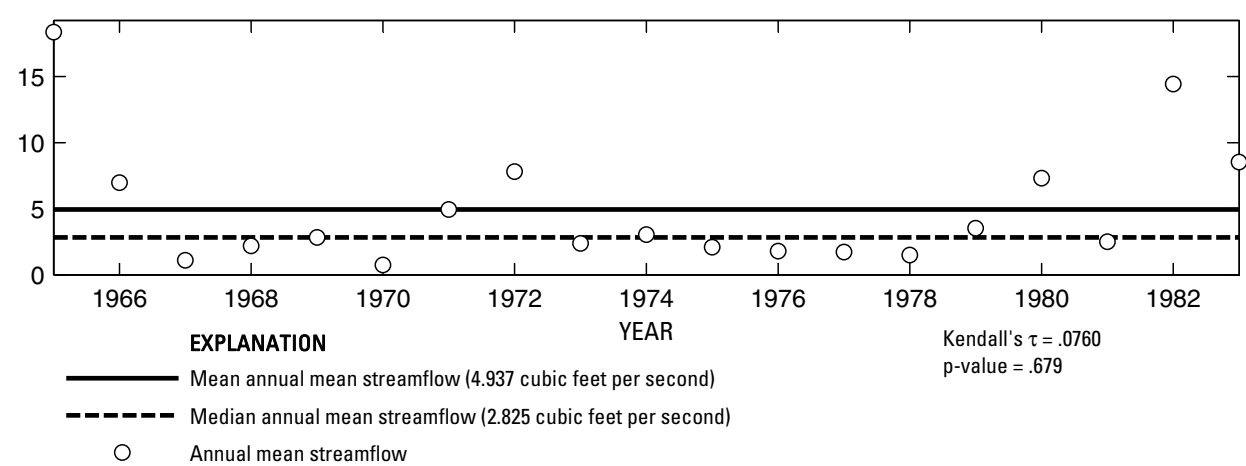

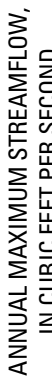

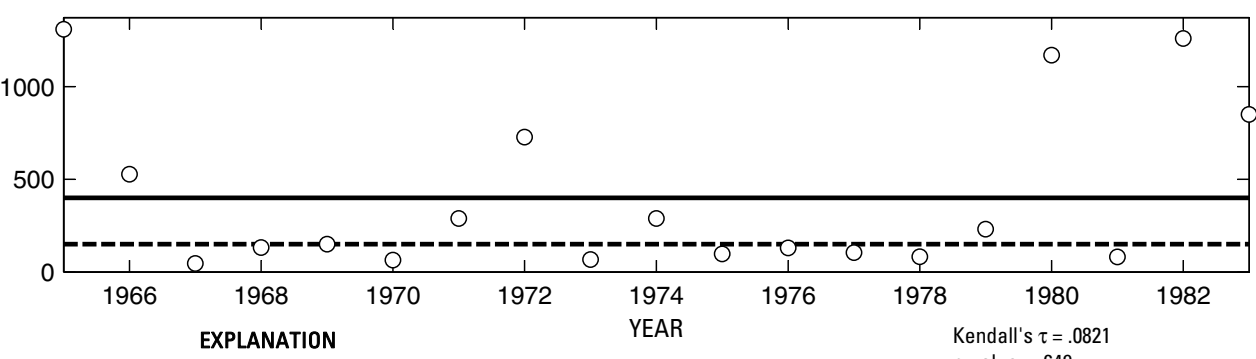

Mean annual maximum streamflow (401 cubic feet per second)

$\mathrm{p}$-value $=.649$

- - - Median annual maximum streamflow (150 cubic feet per second)

O Annual maximum streamflow

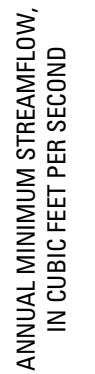

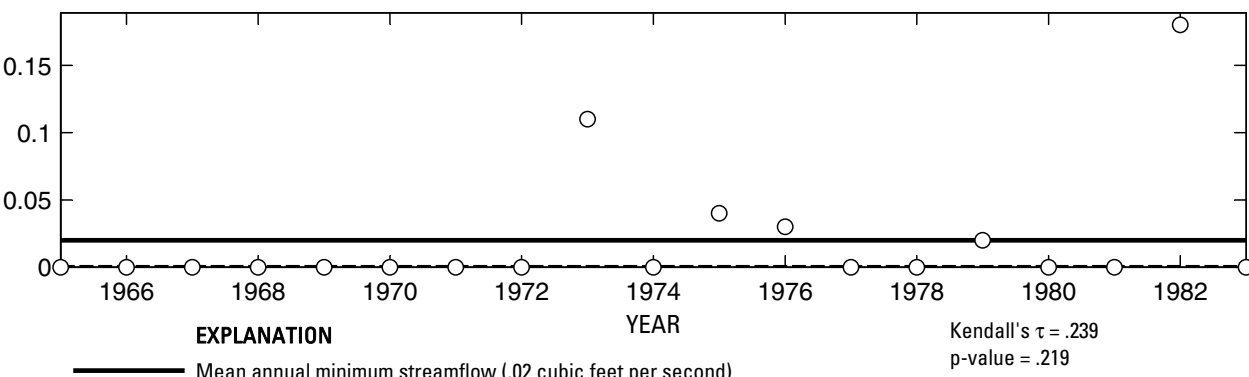

- Median annual minimum streamflow $(0$ cubic feet per second)

O Annual minimum streamflow

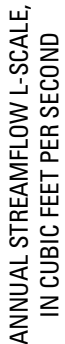

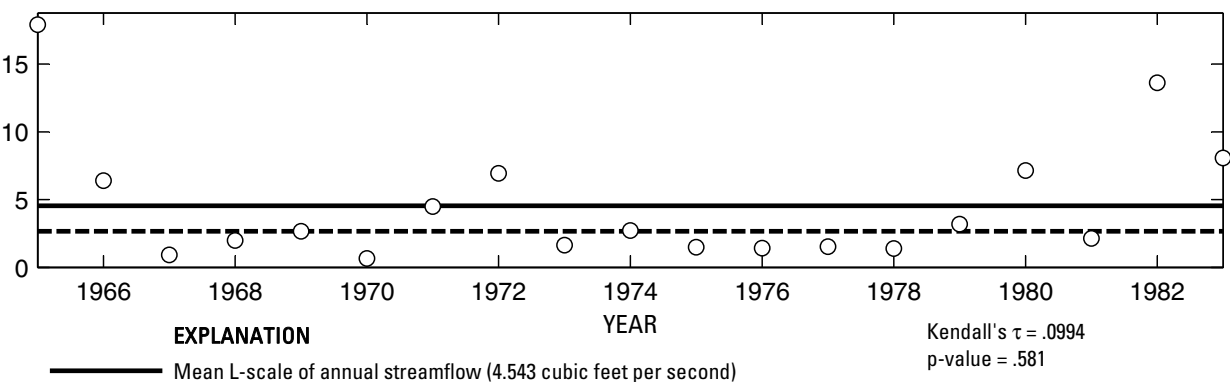

- - - - Median L-scale of annual streamflow (2.66 cubic feet per second)

O Annual L-scale of streamflow

Figure 324. Analysis of annual mean, maximum, minimum, and L-scale statistics of daily mean streamflow for U.S. Geological Survey streamflow-gaging station 08082100 Stinking Creek near Aspermont, Texas.

Index of Station Numbers 719 

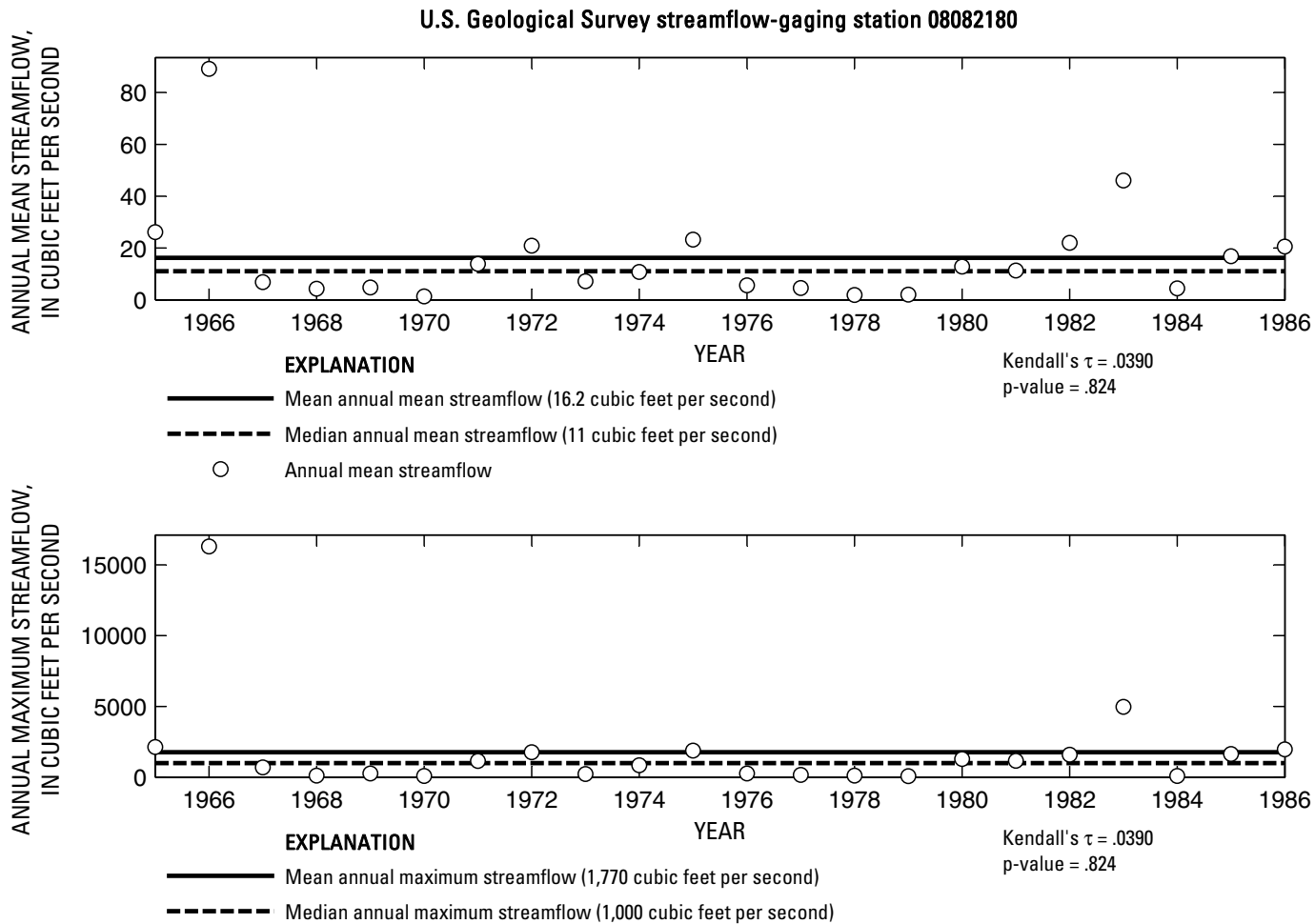

O Annual maximum streamflow

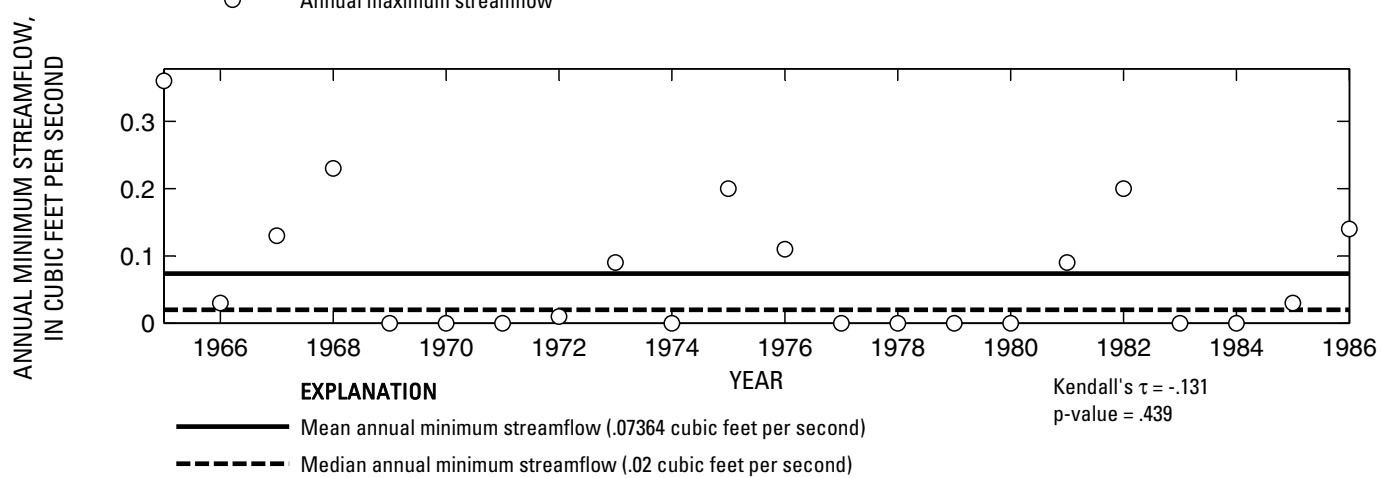

O Annual minimum streamflow

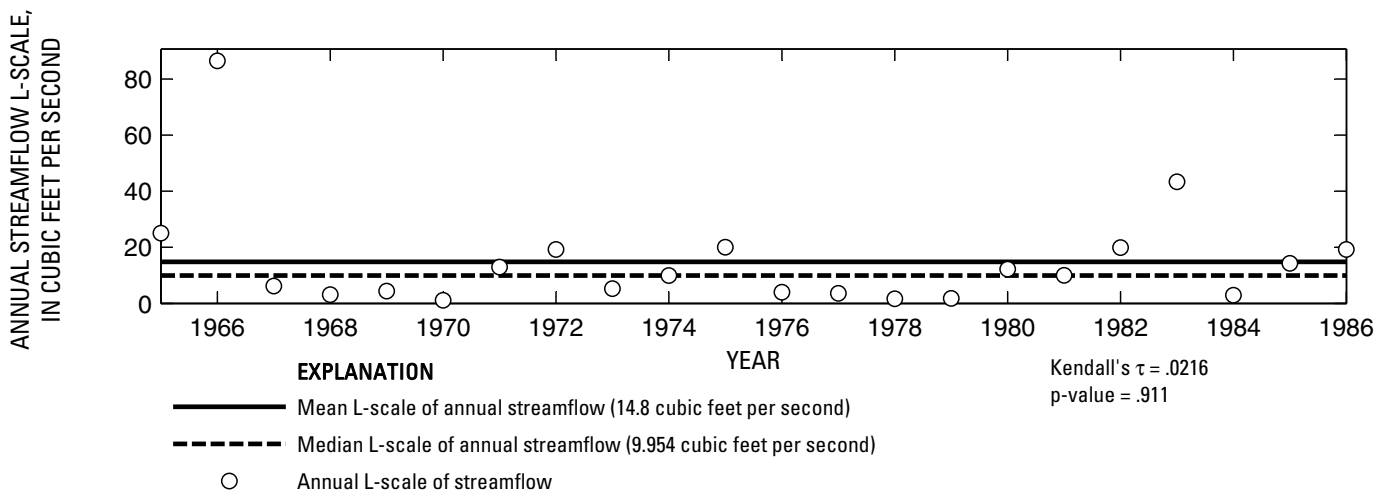

Figure 325. Analysis of annual mean, maximum, minimum, and L-scale statistics of daily mean streamflow for U.S. Geological Survey streamflow-gaging station 08082180 North Croton Creek near Knox City, Texas. 


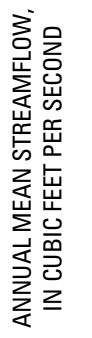

U.S. Geological Survey streamflow-gaging station 08082500

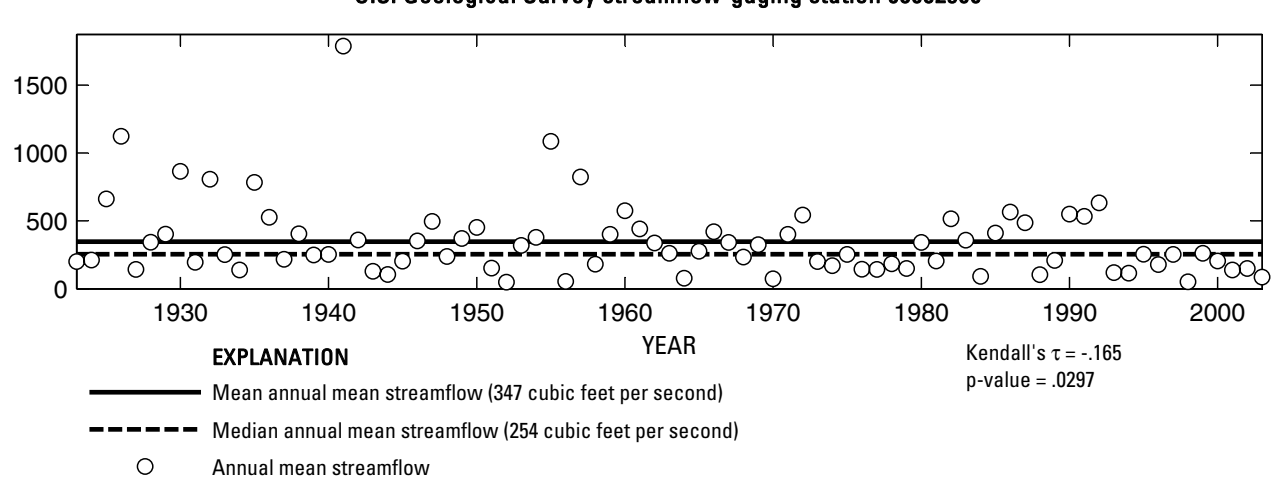

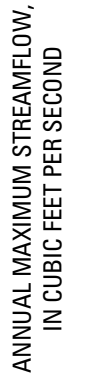

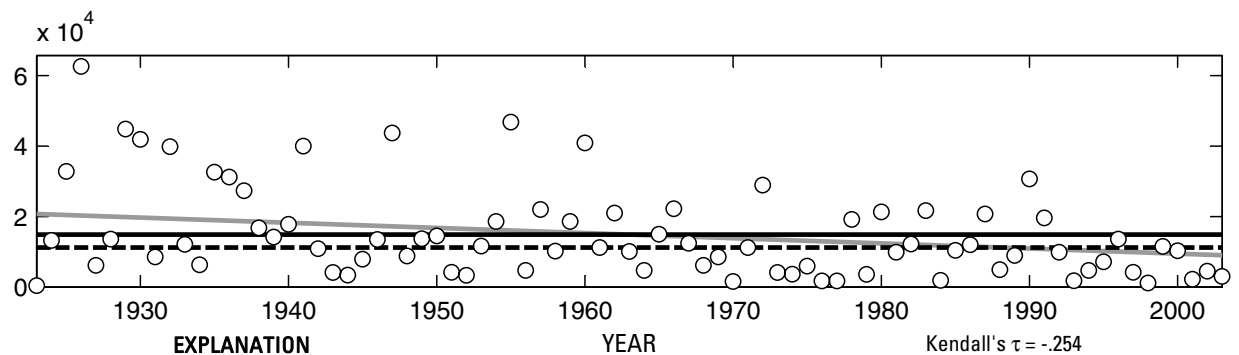

Theil trend line for annual maximum streamflow

Mean annual maximum streamflow (14,900 cubic feet per second)

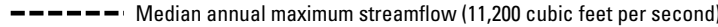

O Annual maximum streamflow

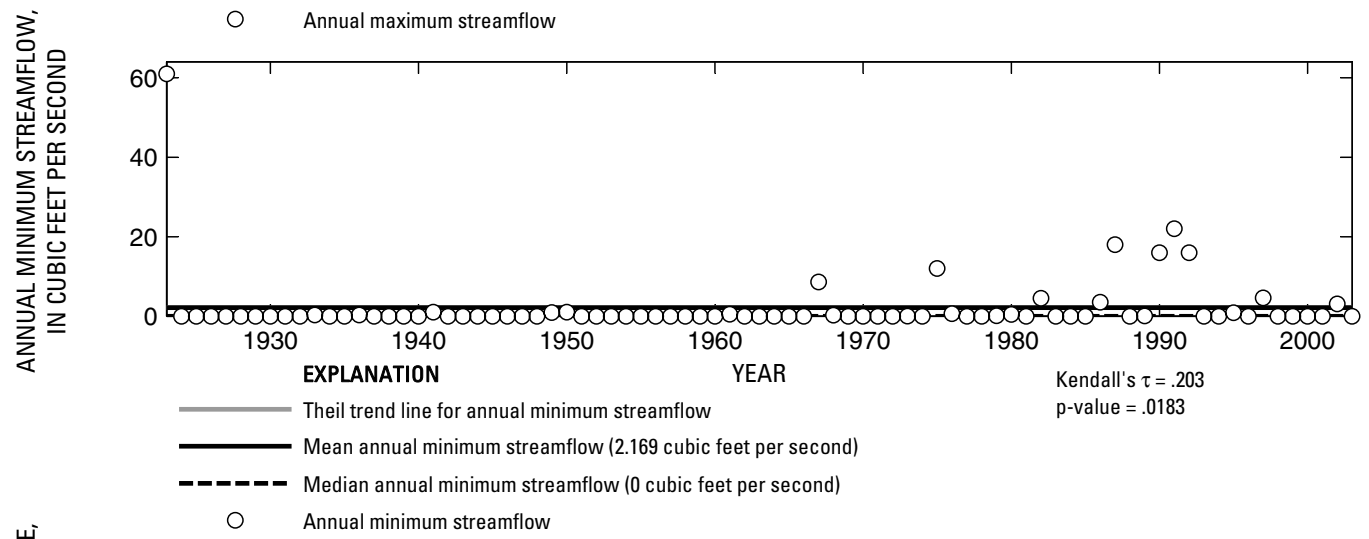

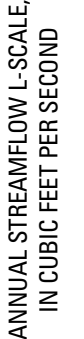

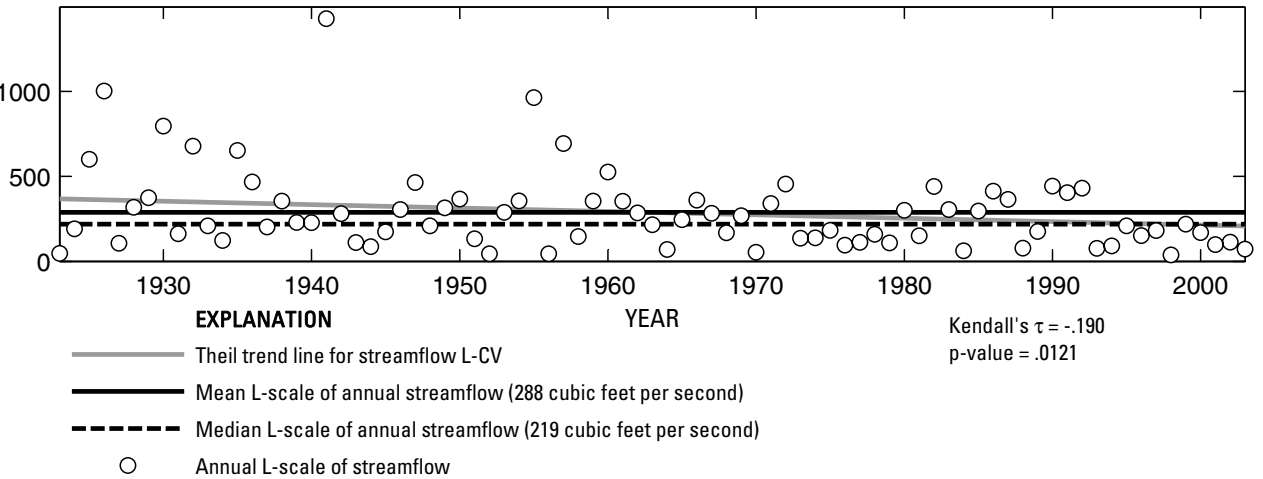

Figure 326. Analysis of annual mean, maximum, minimum, and L-scale statistics of daily mean streamflow for U.S. Geological Survey streamflow-gaging station 08082500 Brazos River at Seymour, Texas.

Index of Station Numbers 719 


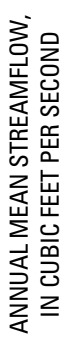

U.S. Geological Survey streamflow-gaging station 08082700

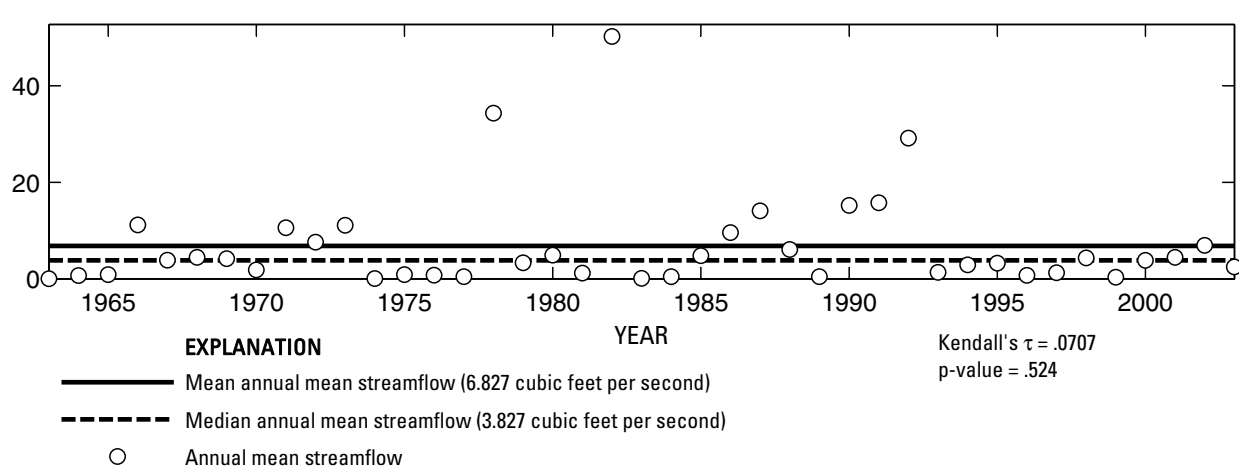

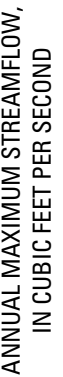

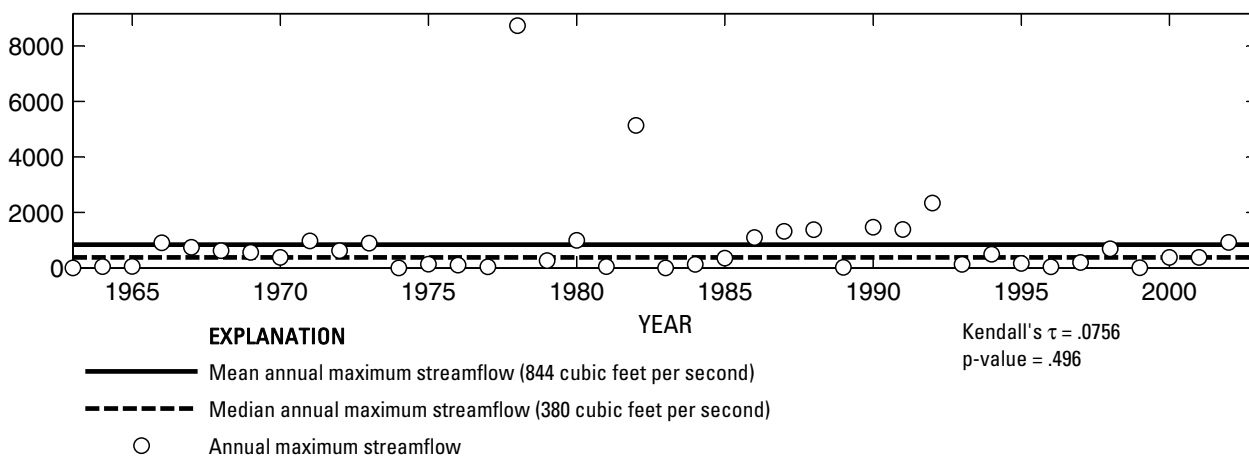

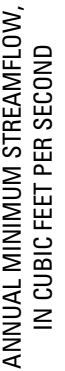

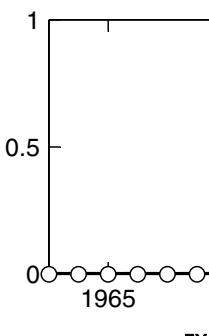

1970
LANATION

Mean annual minimum streamflow (0 cubic feet per second)
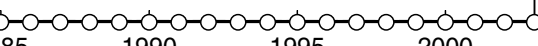

O Annual minimum streamflow

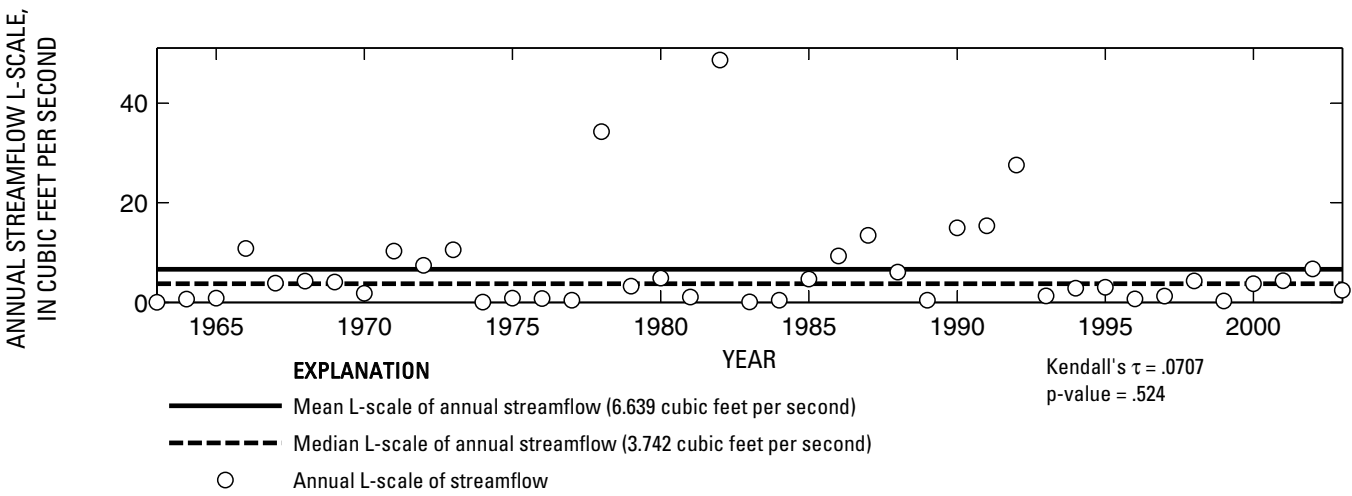

Figure 327. Analysis of annual mean, maximum, minimum, and L-scale statistics of daily mean streamflow for U.S. Geological Survey streamflow-gaging station 08082700 Millers Creek near Munday, Texas. 


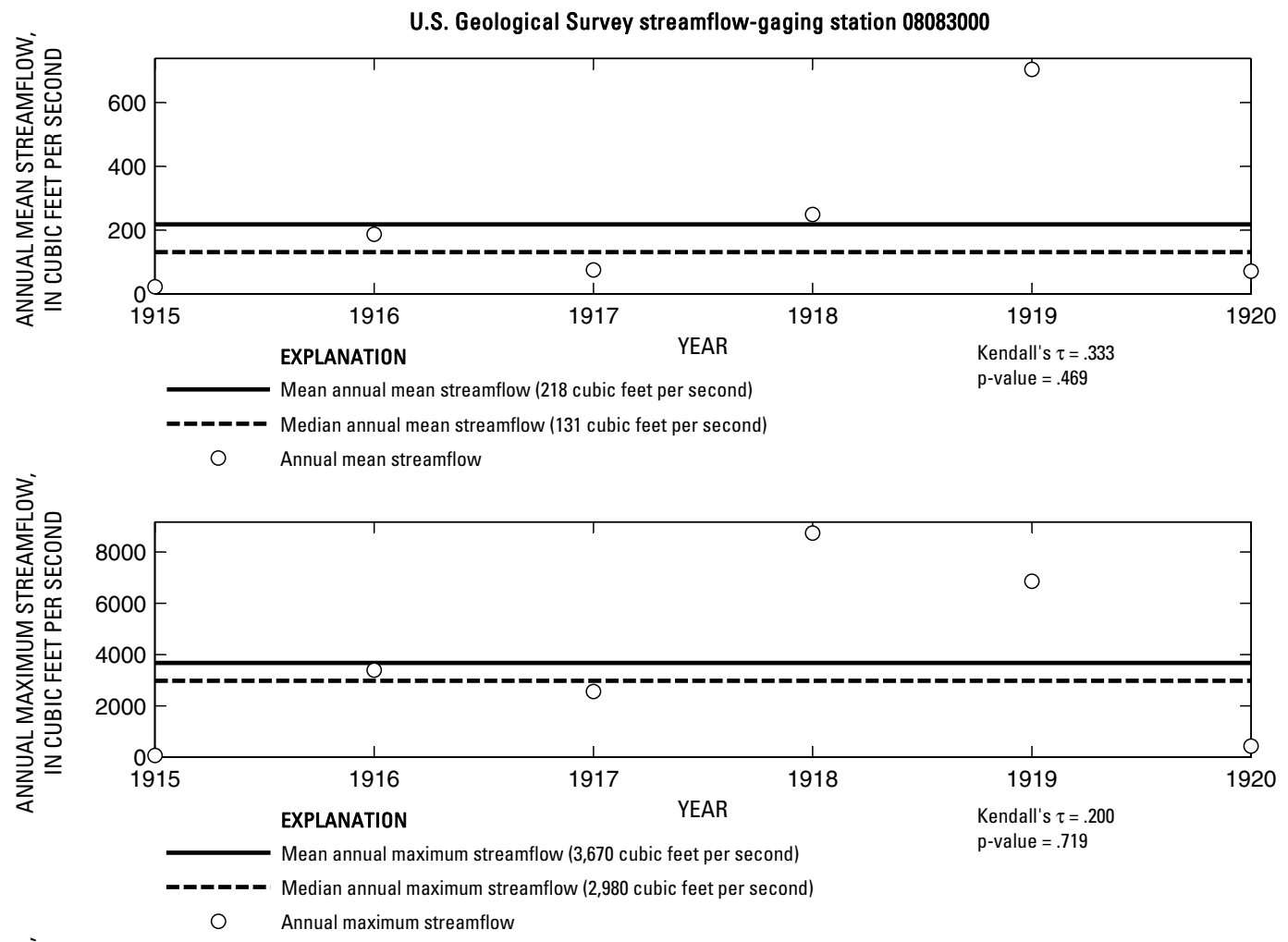

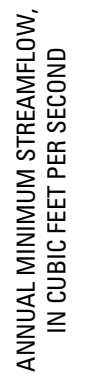

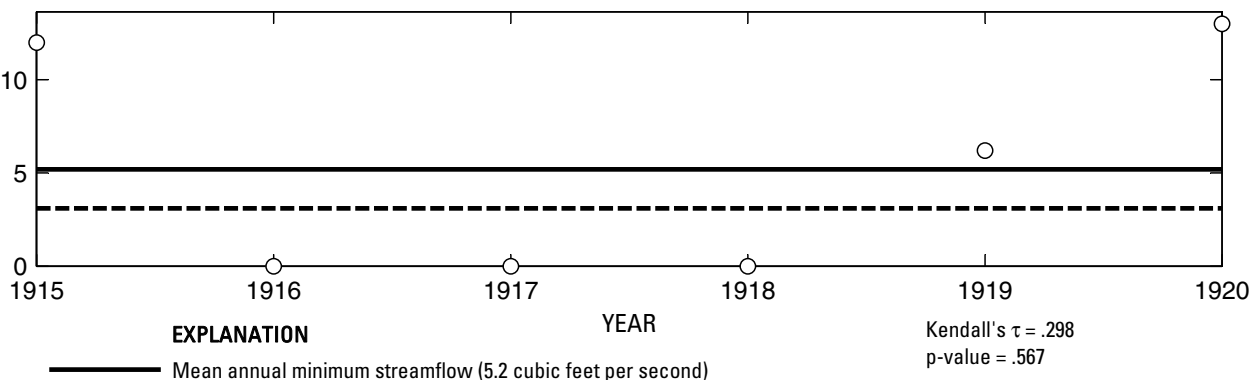

- ב-ב Median annual minimum streamflow (3.1 cubic feet per second)

O Annual minimum streamflow

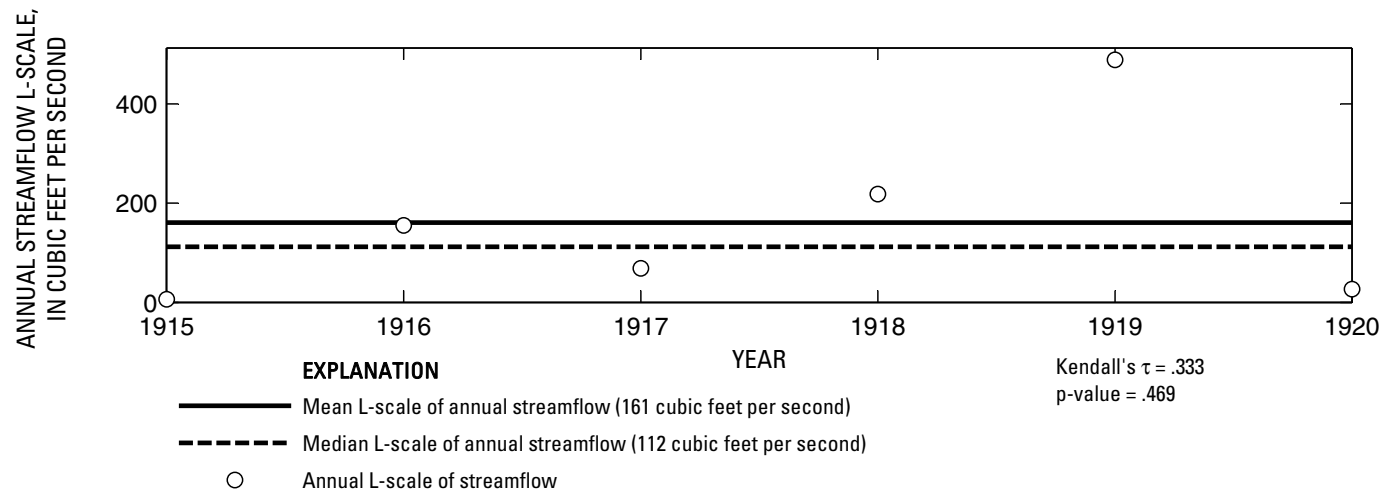

Figure 328. Analysis of annual mean, maximum, minimum, and L-scale statistics of daily mean streamflow for U.S. Geological Survey streamflow-gaging station 08083000 Brazos River near Graham, Texas. 


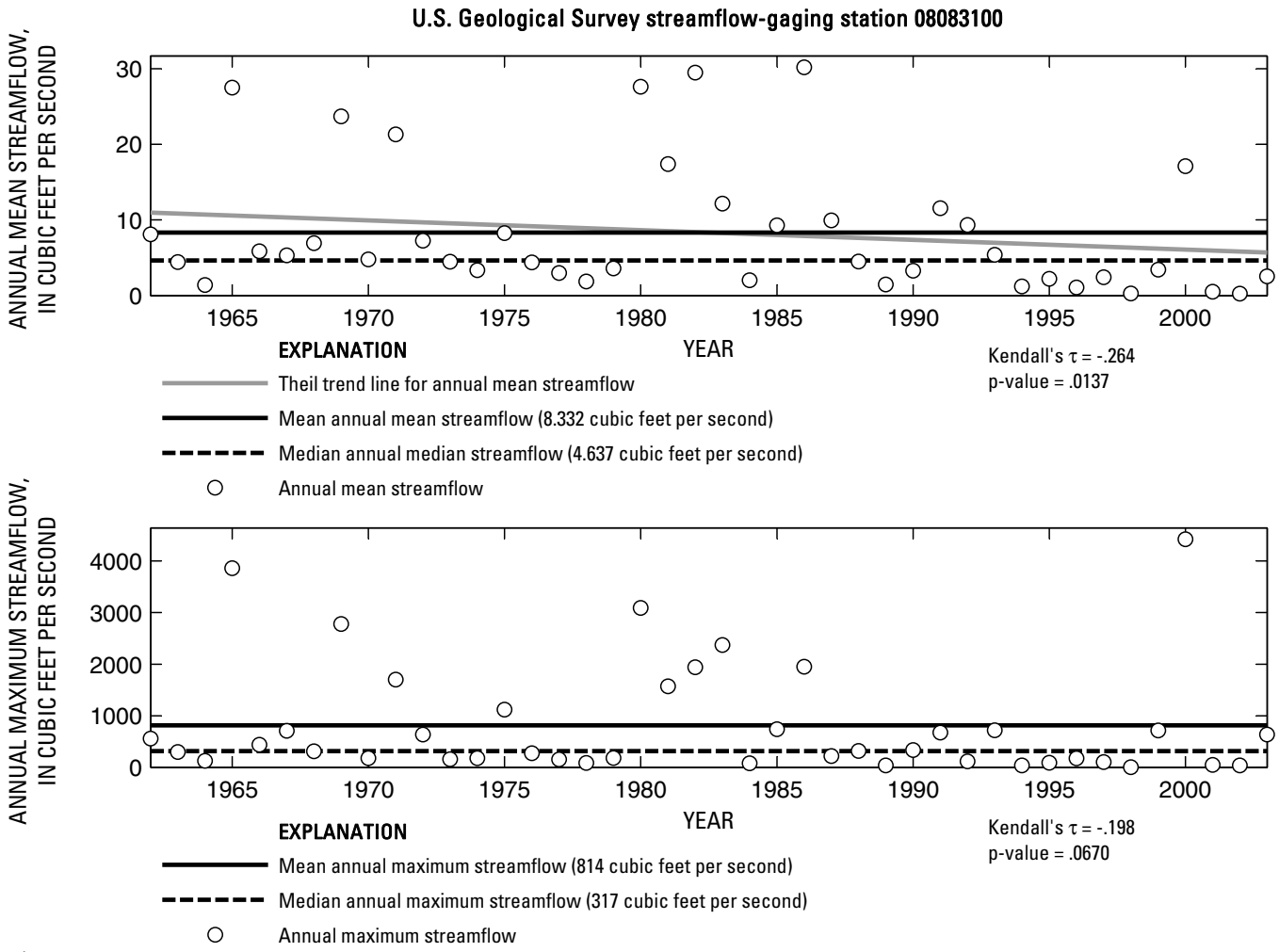

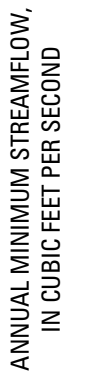

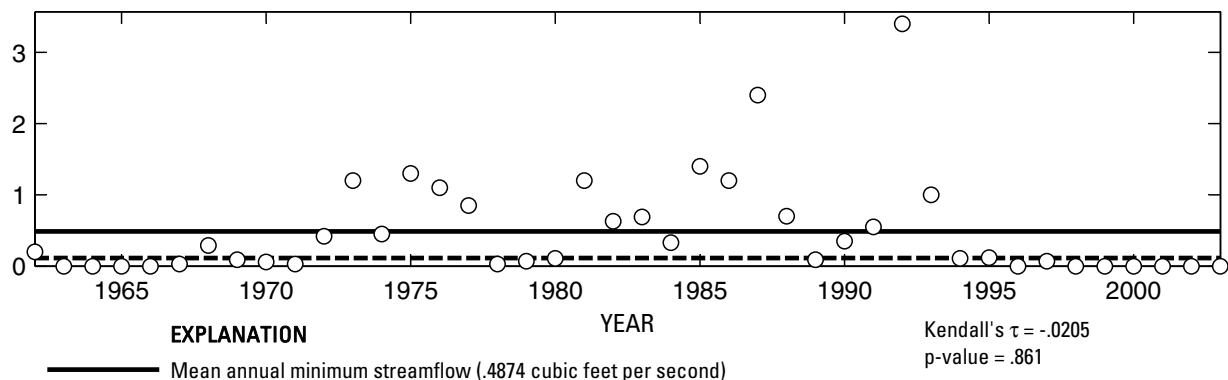

-_ー_-_ Median annual minimum streamflow (.115 cubic feet per second)

O Annual minimum streamflow

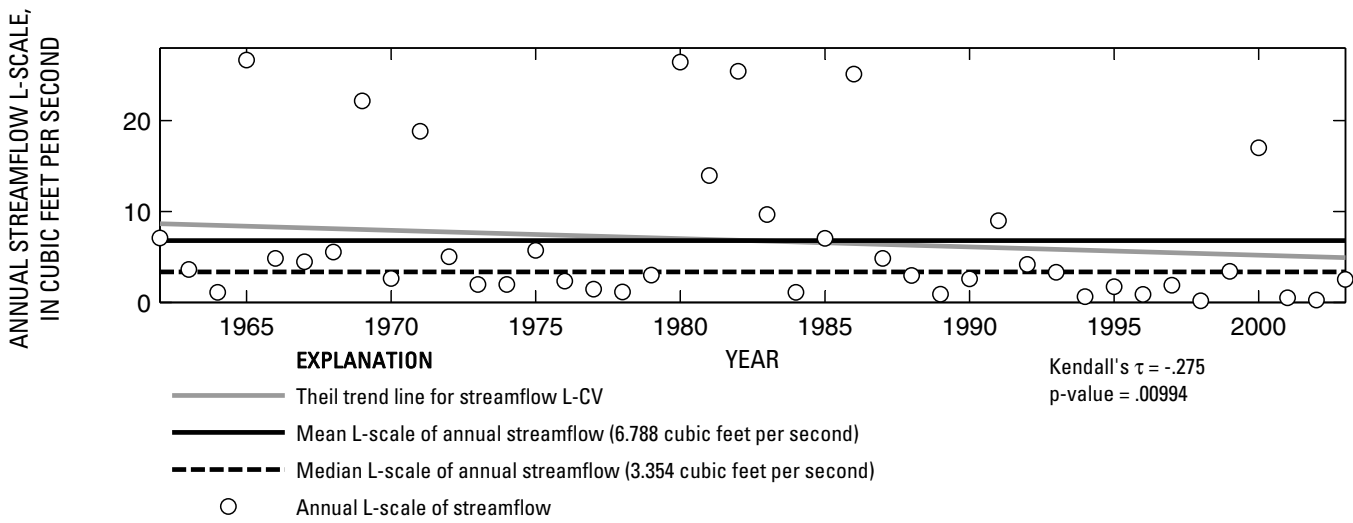

Figure 329. Analysis of annual mean, maximum, minimum, and L-scale statistics of daily mean streamflow for U.S. Geological Survey streamflow-gaging station 08083100 Clear Fork Brazos River near Roby, Texas. 


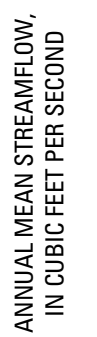

U.S. Geological Survey streamflow-gaging station 08083230

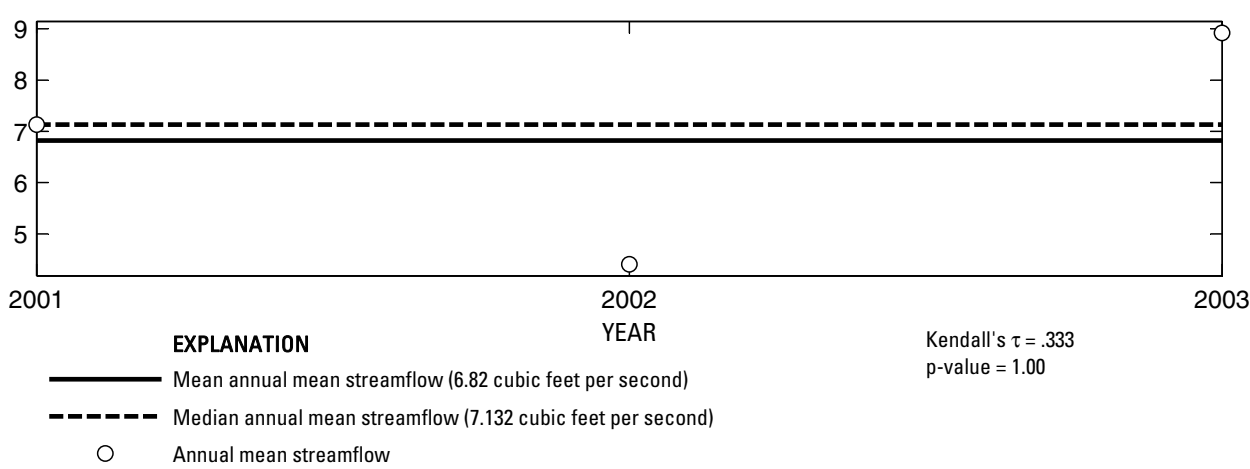

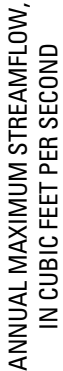

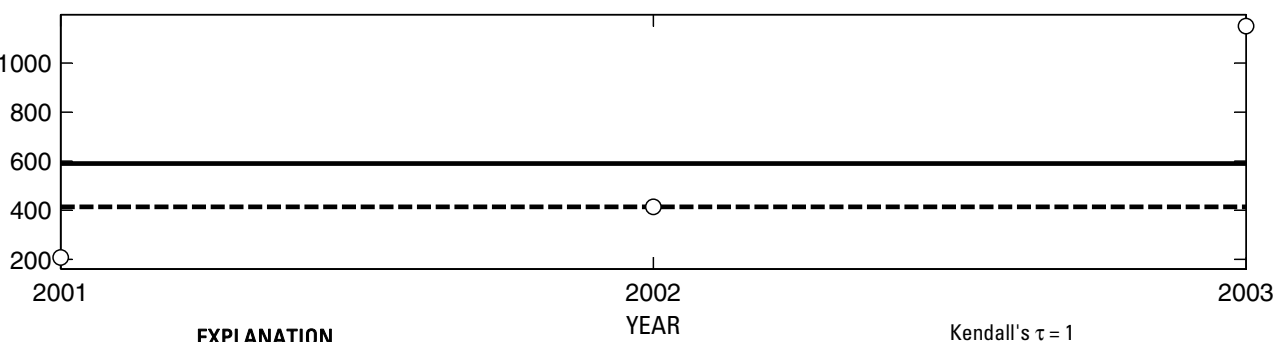

Mean annual maximum streamflow (591 cubic feet per second)

-- - - Median annual maximum streamflow (414 cubic feet per second)

O Annual maximum streamflow

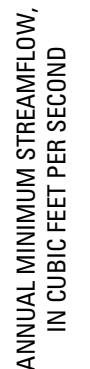

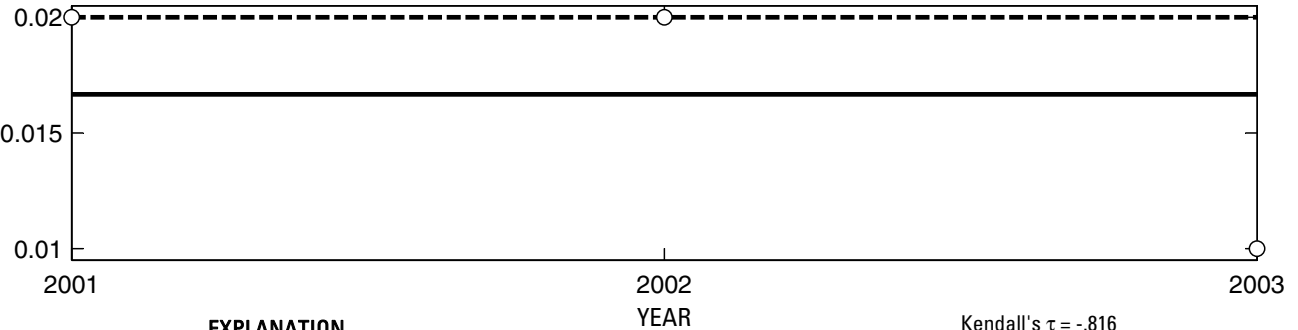

Mean annual minimum streamflow (.01667 cubic feet per second)

$\mathrm{p}$-value $=.667$

- - Median annual minimum streamflow (.02 cubic feet per second)

O Annual minimum streamflow

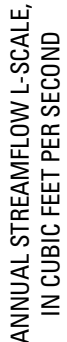

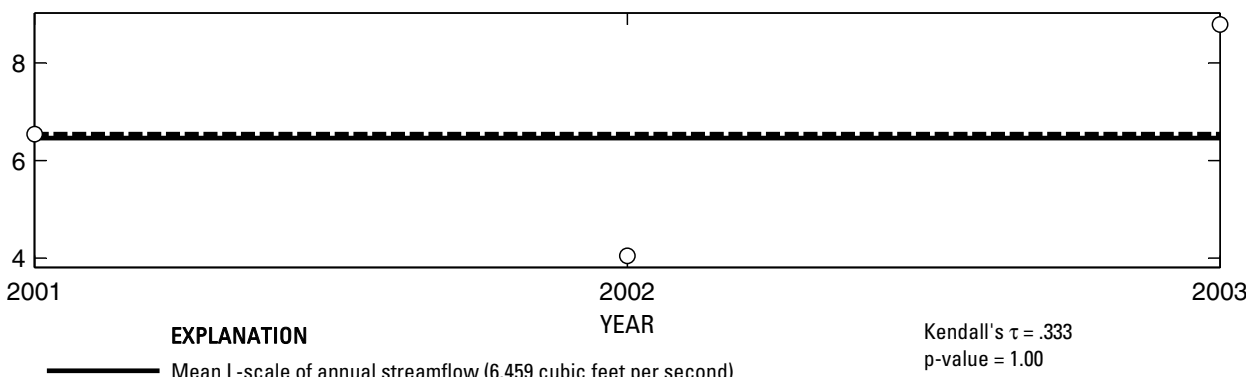

Mean L-scale of annual streamflow (6.459 cubic feet per second)

p-value $=1.00$

------ Median L-scale of annual streamflow (6.542 cubic feet per second)

O Annual L-scale of streamflow

Figure 330. Analysis of annual mean, maximum, minimum, and L-scale statistics of daily mean streamflow for U.S. Geological Survey streamflow-gaging station 08083230 Clear Fork Brazos River near Noodle, Texas.

Index of Station Numbers 719 


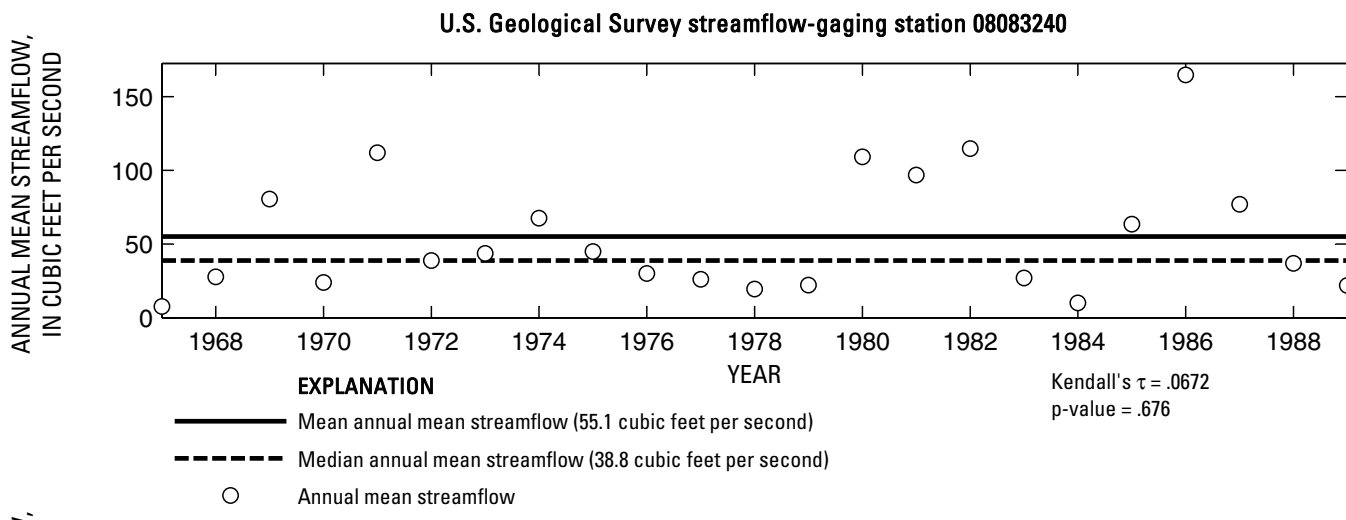

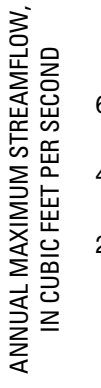

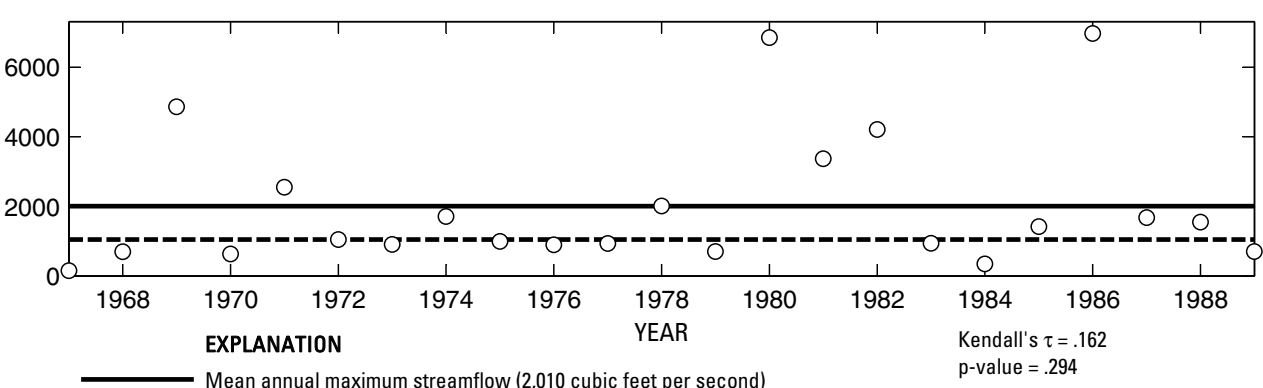

- _ _ _ - Median annual maximum streamflow (1,050 cubic feet per second

○ Annual maximum streamflow

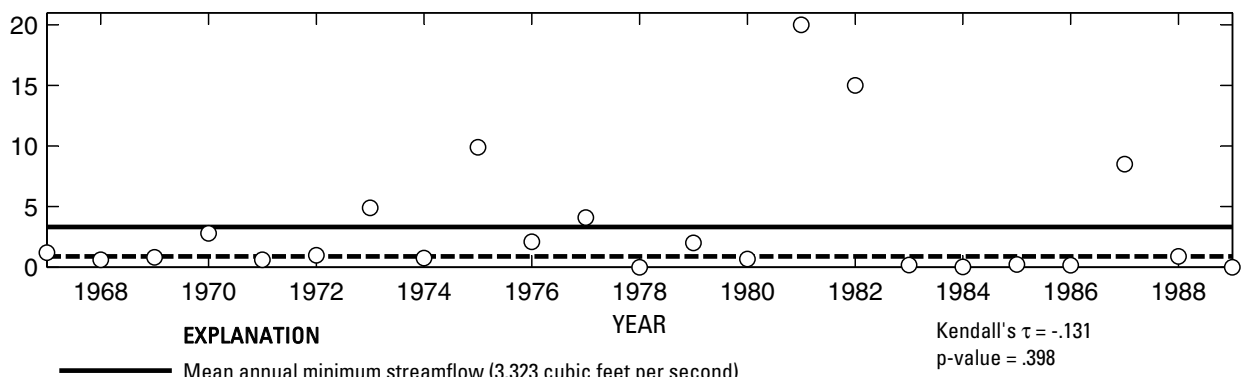

- - - - Median annual minimum streamflow (.89 cubic feet per second)

O Annual minimum streamflow
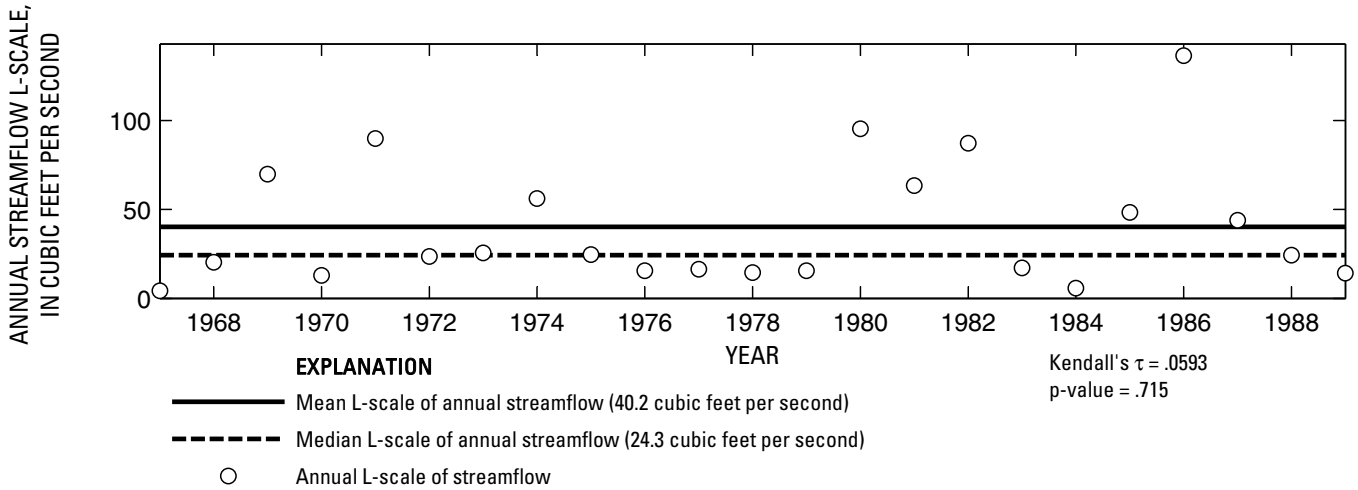

Figure 331. Analysis of annual mean, maximum, minimum, and L-scale statistics of daily mean streamflow for U.S. Geological Survey streamflow-gaging station 08083240 Clear Fork Brazos River at Hawley, Texas. 


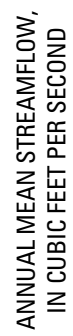

U.S. Geological Survey streamflow-gaging station 08083245

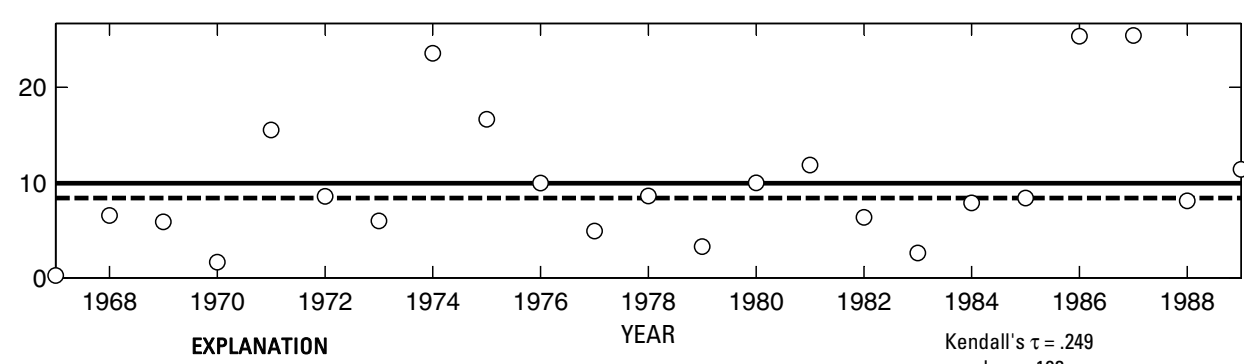

$\mathrm{p}$-value $=.102$

-ーーーーー Median annual mean streamflow ( 8.36 cubic feet per second)

O Annual mean streamflow

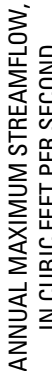

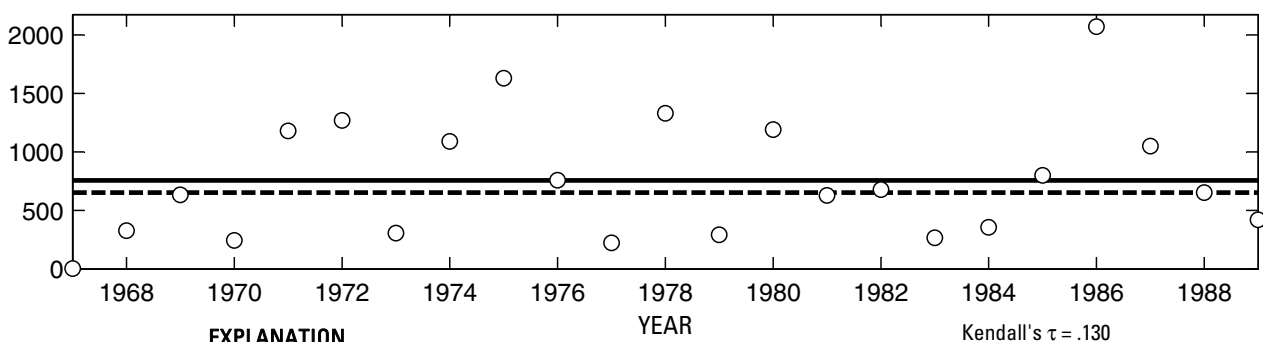

EXPLANATION

-_-_- Median annual maximum streamflow (652 cubic feet per second)

O Annual maximum streamflow

量

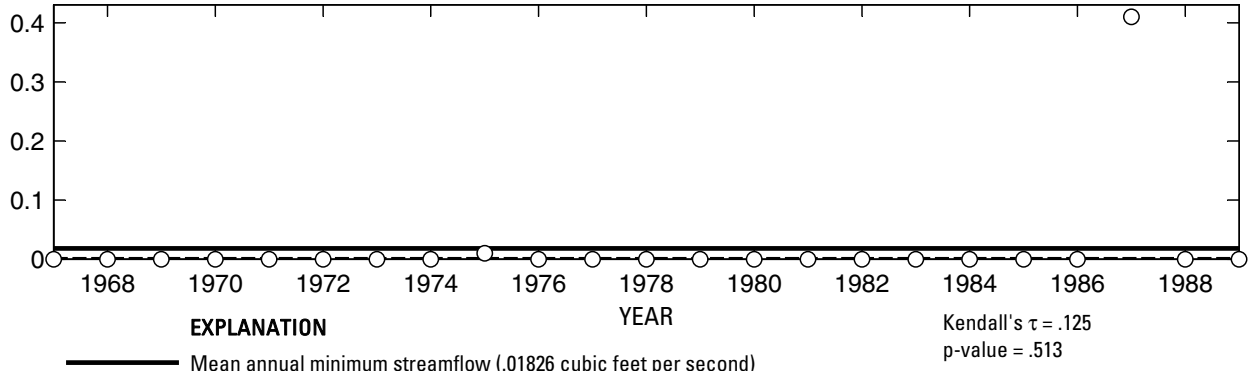

- Median annual minimum streamflow (0 cubic feet per second)

O Annual minimum streamflow

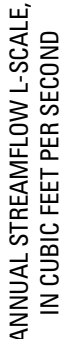

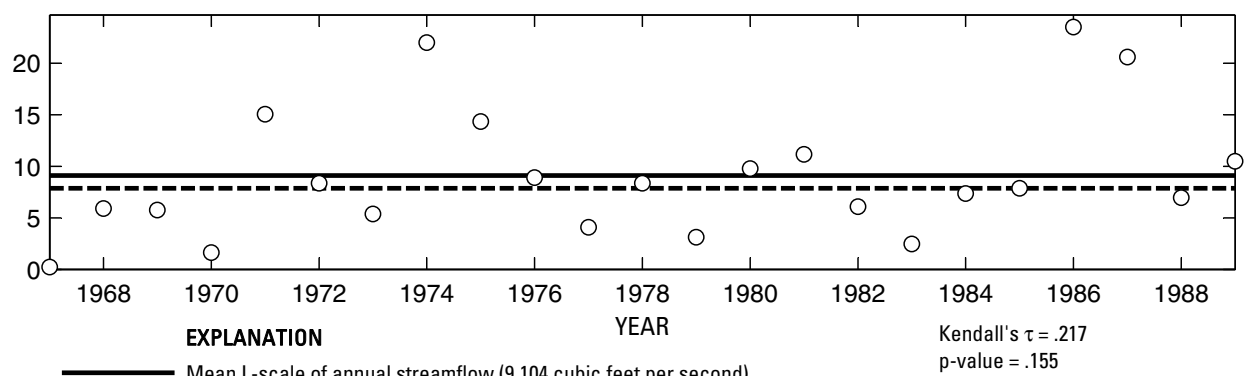

Mean L-scale of annual streamflow (9.104 cubic feet per second)

$\mathrm{p}$-value $=.155$

- - - - Median L-scale of annual streamflow (7.865 cubic feet per second)

Annual L-scale of streamflow

Figure 332. Analysis of annual mean, maximum, minimum, and L-scale statistics of daily mean streamflow for U.S. Geological Survey streamflow-gaging station 08083245 Mulberry Creek near Hawley, Texas.

Index of Station Numbers 719 


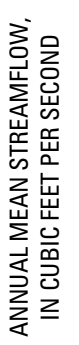

U.S. Geological Survey streamflow-gaging station 08083300

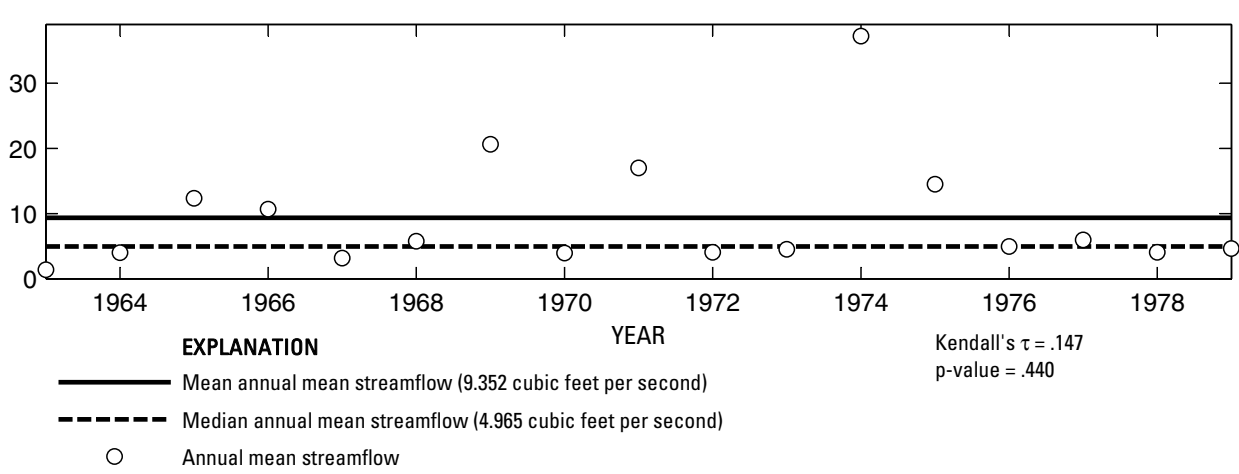

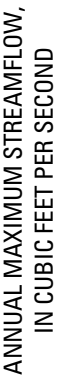

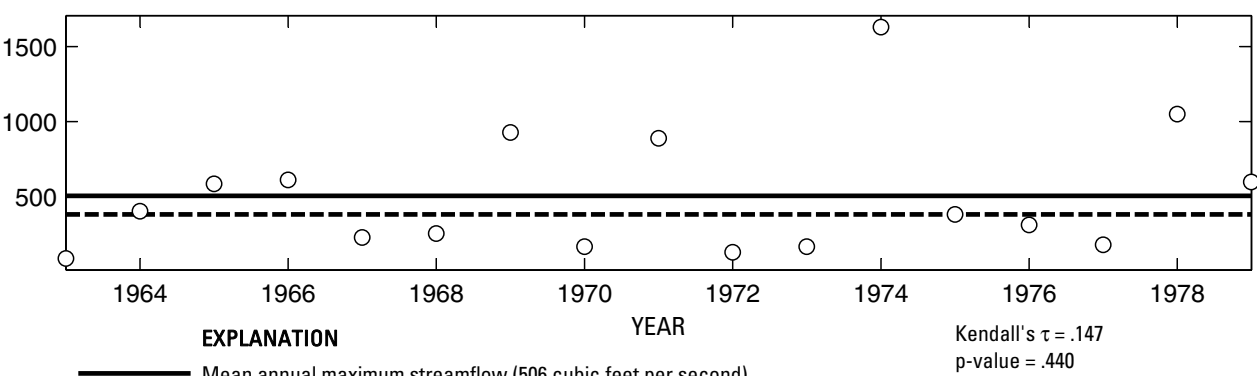

O Annual maximum streamflow

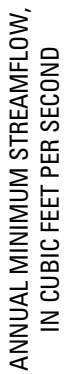

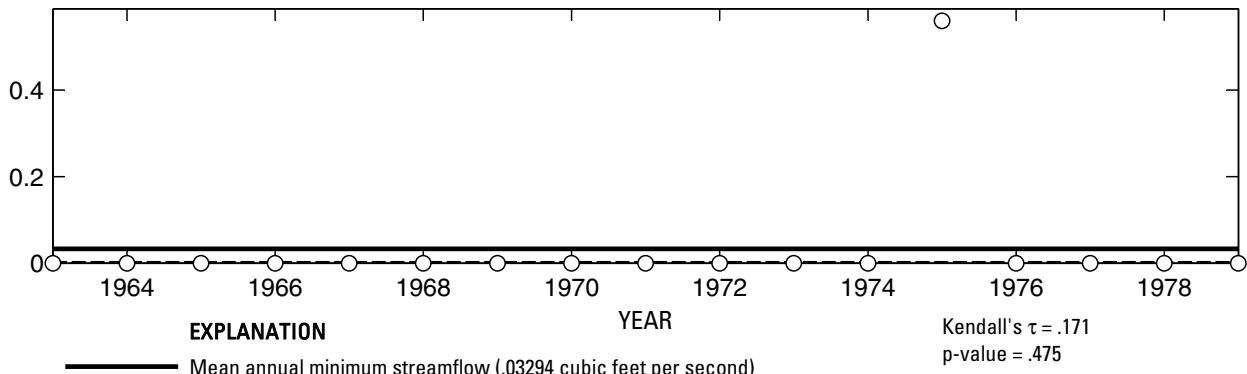

- ב-ב Median annual minimum streamflow (0 cubic feet per second)

O Annual minimum streamflow

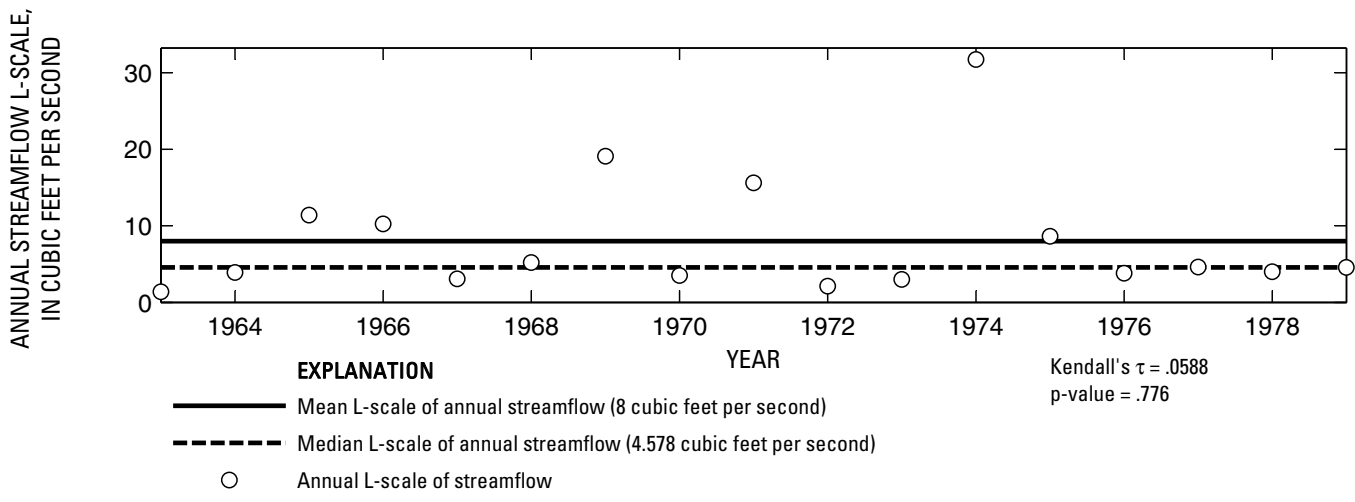

Figure 333. Analysis of annual mean, maximum, minimum, and L-scale statistics of daily mean streamflow for U.S. Geological Survey streamflow-gaging station 08083300 Elm Creek near Abilene, Texas. 
U.S. Geological Survey streamflow-gaging station 08083400

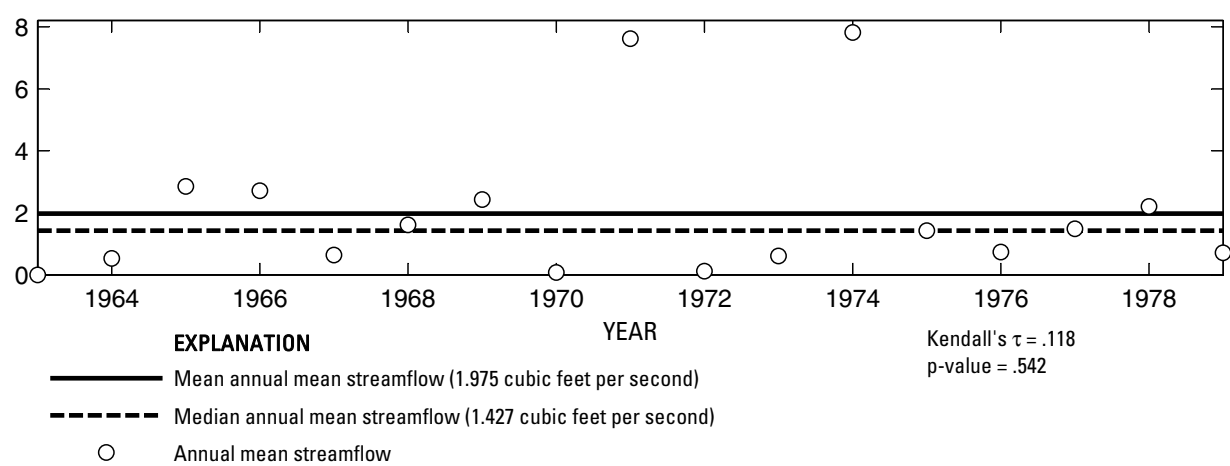

焉

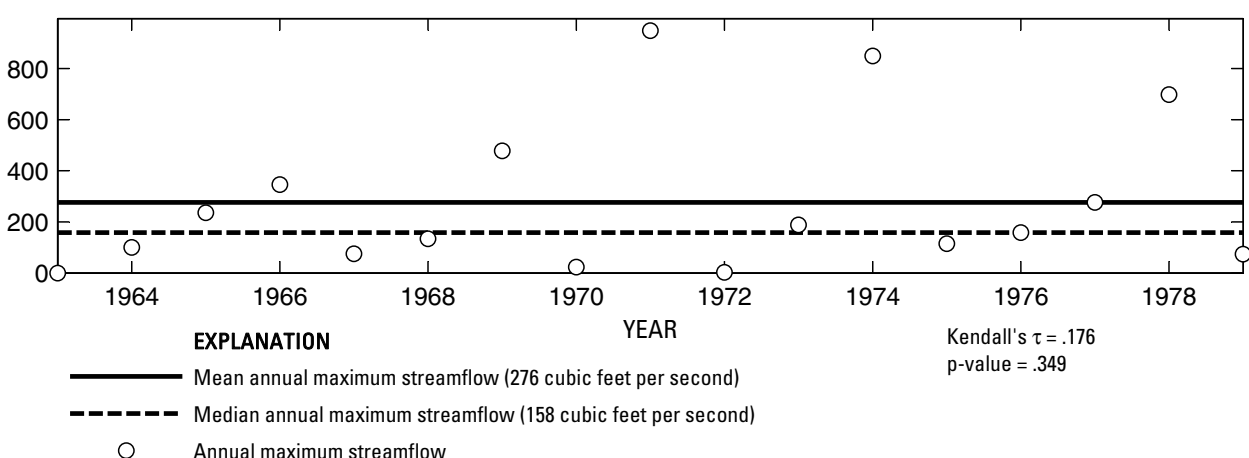

崔

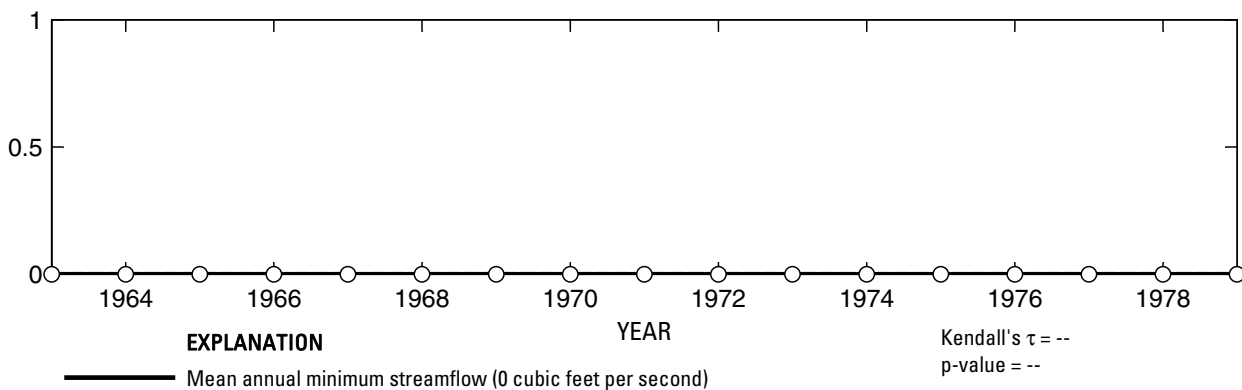

- Median annual minimum streamflow (0 cubic feet per second)

O Annual minimum streamflow

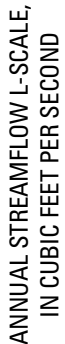

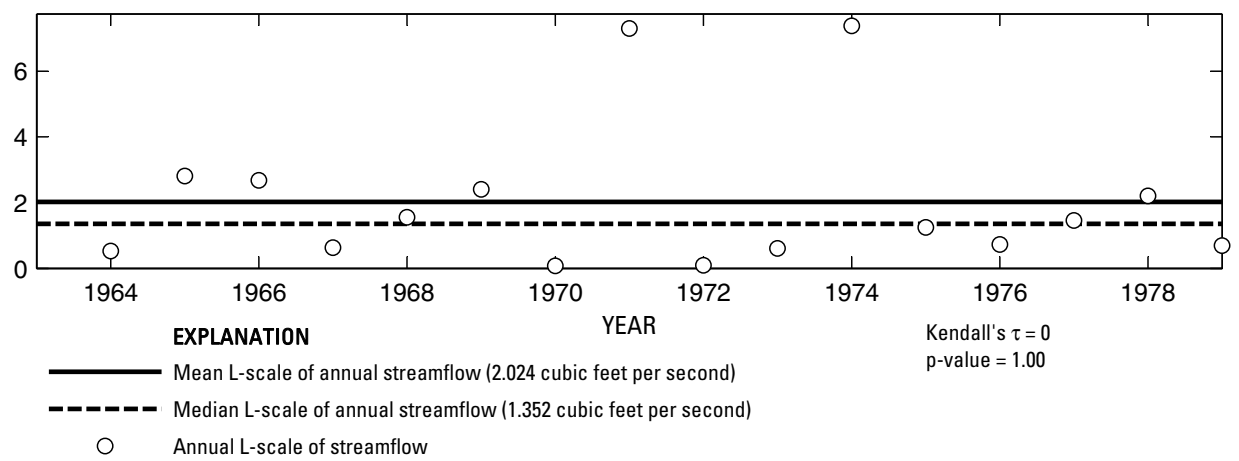

Figure 334. Analysis of annual mean, maximum, minimum, and L-scale statistics of daily mean streamflow for U.S. Geological Survey streamflow-gaging station 08083400 Little Elm Creek near Abilene, Texas.

Index of Station Numbers 719 


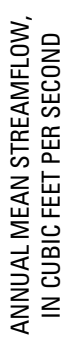

U.S. Geological Survey streamflow-gaging station 08083420

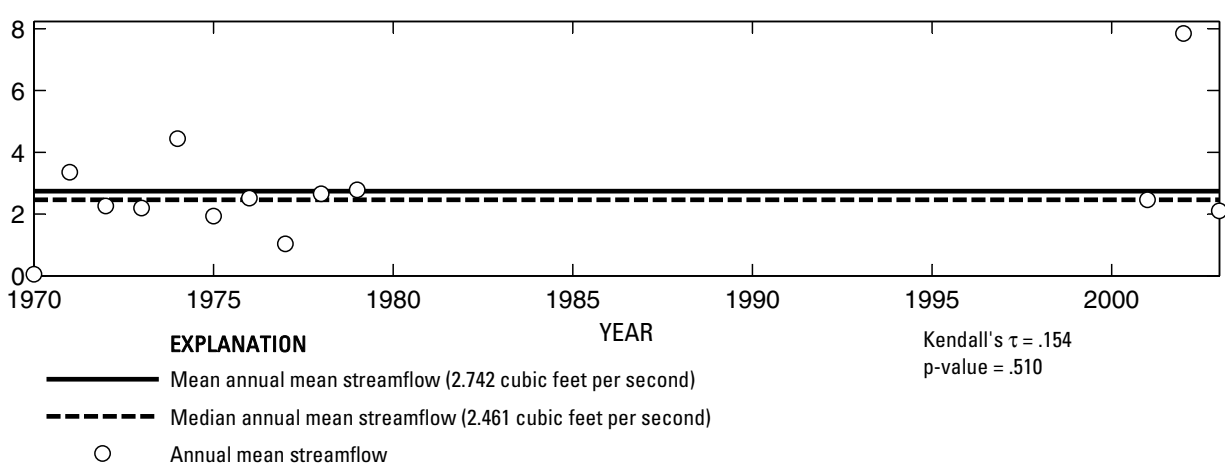

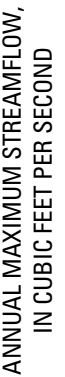

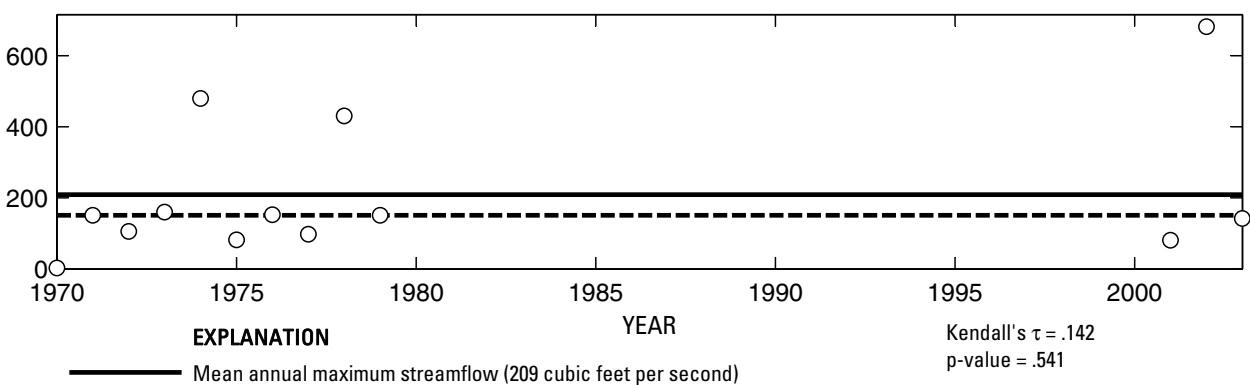

- - - Median annual maximum streamflow (151 cubic feet per second)

Annual maximum streamflow

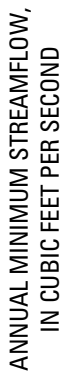

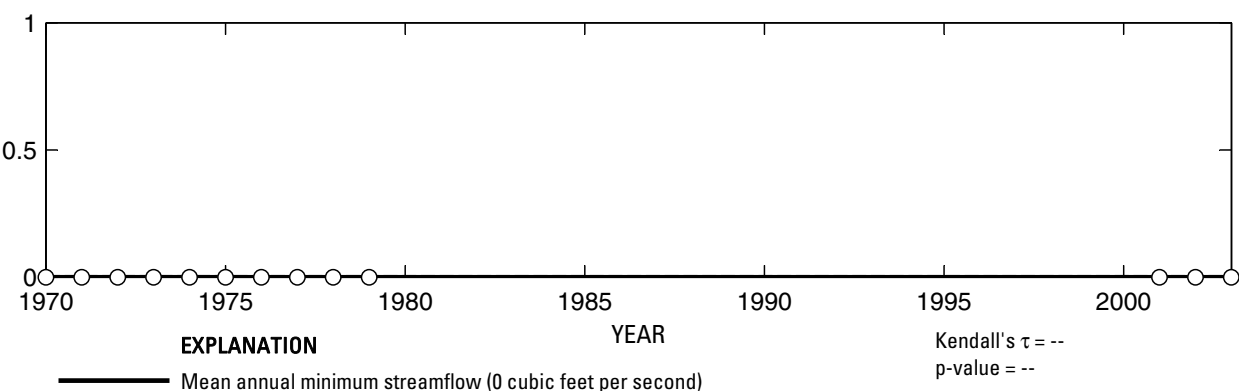

- Median annual minimum streamflow (0 cubic feet per second)

O Annual minimum streamflow
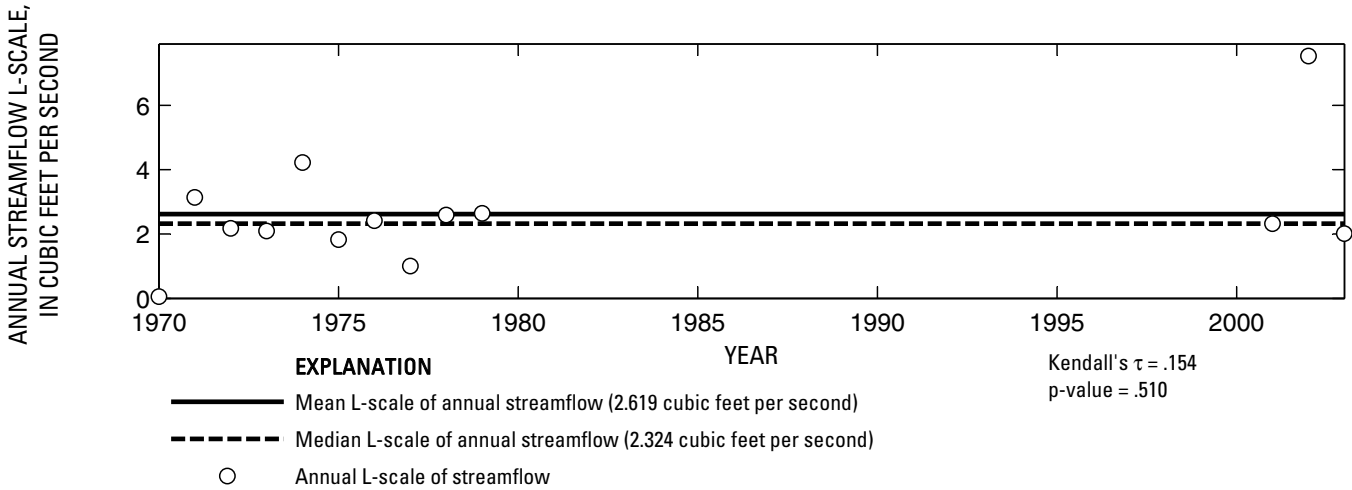

Figure 335. Analysis of annual mean, maximum, minimum, and L-scale statistics of daily mean streamflow for U.S. Geological Survey streamflow-gaging station 08083420 Cat Claw Creek at Abilene, Texas. 
U.S. Geological Survey streamflow-gaging station 08083430

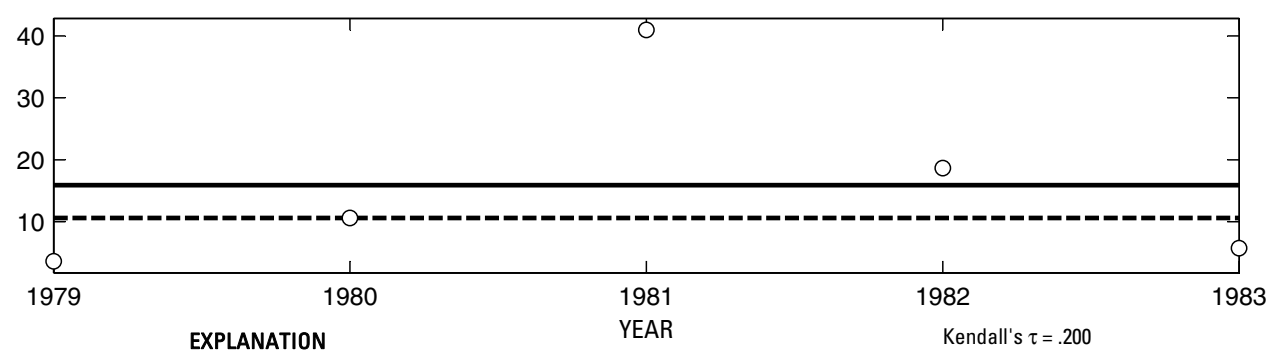

$\mathrm{p}$-value $=817$

-ーーー Median annual mean streamflow (10.6 cubic feet per second)

Annual mean streamflow

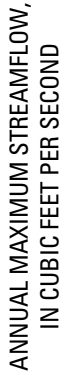

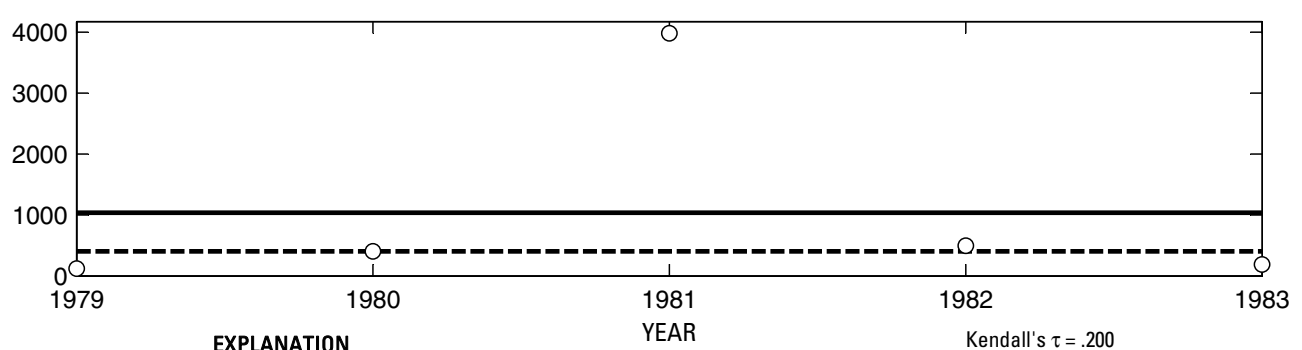

EXPLANATION

Mean annual maximum streamflow (1,040 cubic feet per second)

$\mathrm{p}$-value $=.817$

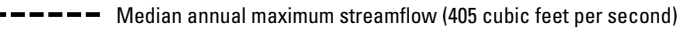

Annual maximum streamflow

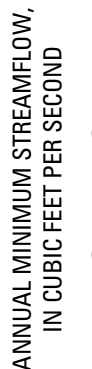

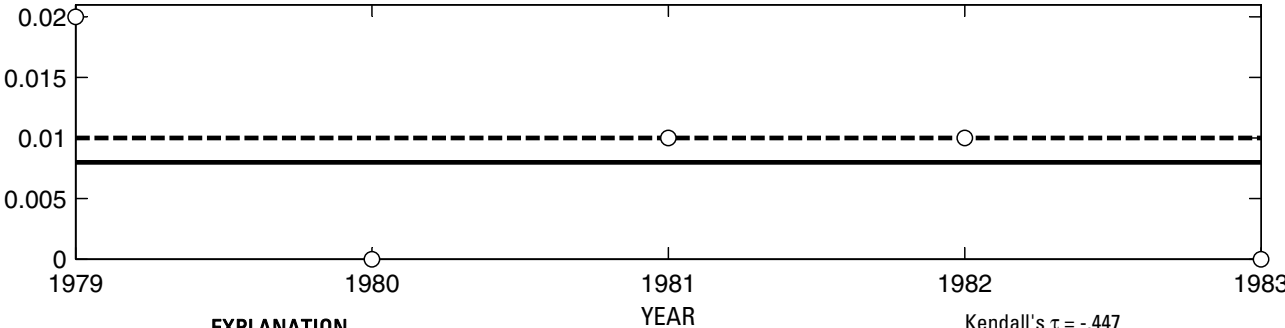

EXPLANATION

Mean annual minimum streamflow (.01 cubic feet per second)

$\mathrm{p}$-value $=.467$

-ンーーー Median annual minimum streamflow (.01 cubic feet per second)

○ Annual minimum streamflow

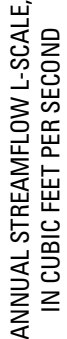

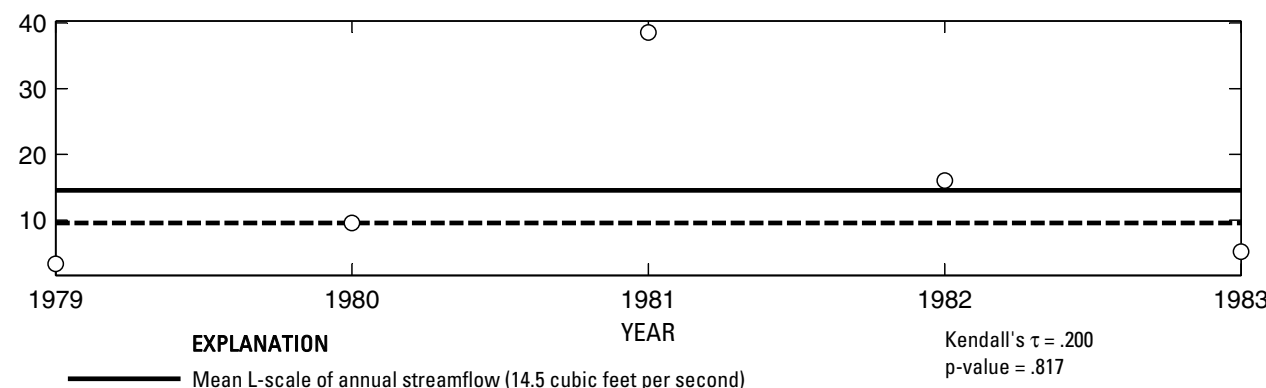

Mean L-scale of annual streamflow (14.5 cubic feet per second)

- - - - Median L-scale of annual streamflow (9.551 cubic feet per second)

Annual L-scale of streamflow

Figure 336. Analysis of annual mean, maximum, minimum, and L-scale statistics of daily mean streamflow for U.S. Geological Survey streamflow-gaging station 08083430 Elm Creek at Abilene, Texas.

Index of Station Numbers 719 


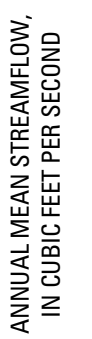

U.S. Geological Survey streamflow-gaging station 08083470

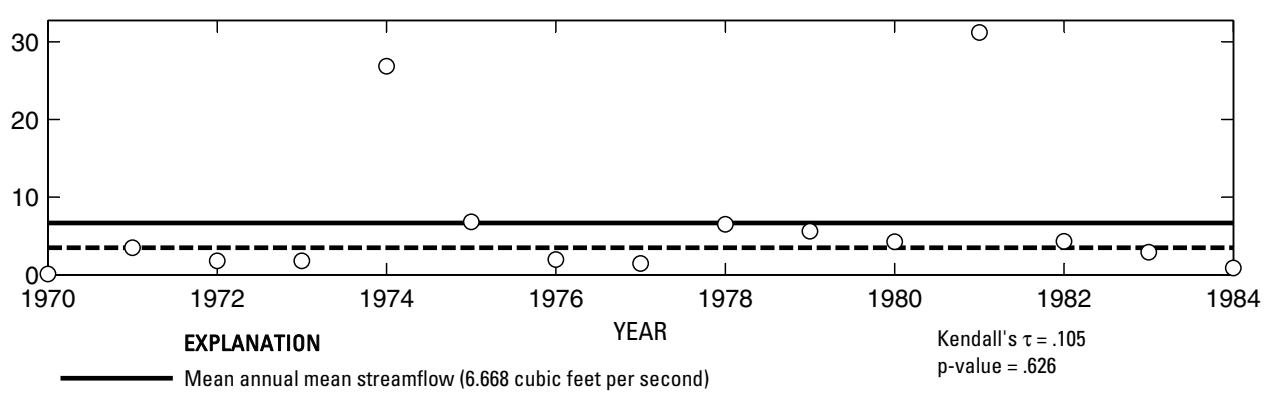

-_ーーー- Median annual mean streamflow (3.484 cubic feet per second)

O Annual mean streamflow

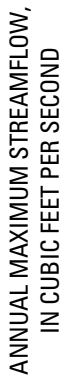

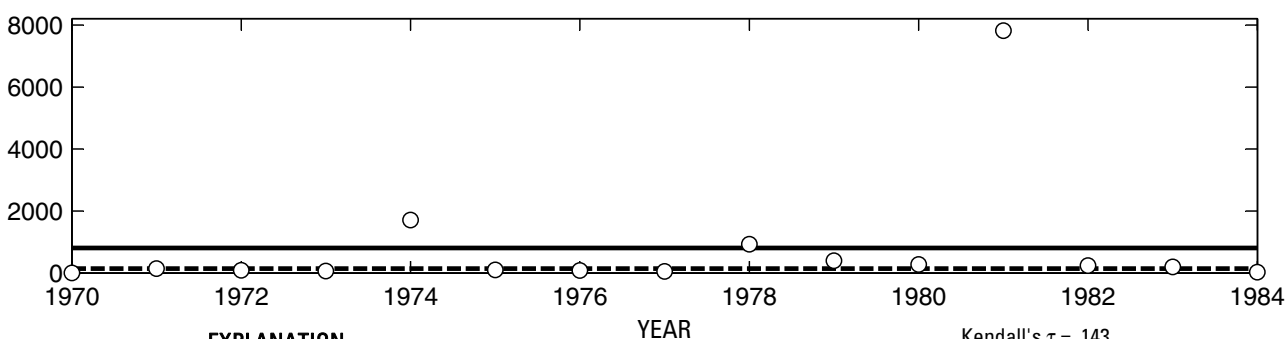

EXPLANATION

p-value $=$

Mean annual maximum streamflow (808 cubic feet per second)

- - - Median annual maximum streamflow (141 cubic feet per second)

Annual maximum streamflow

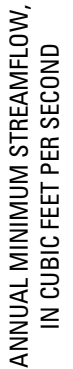

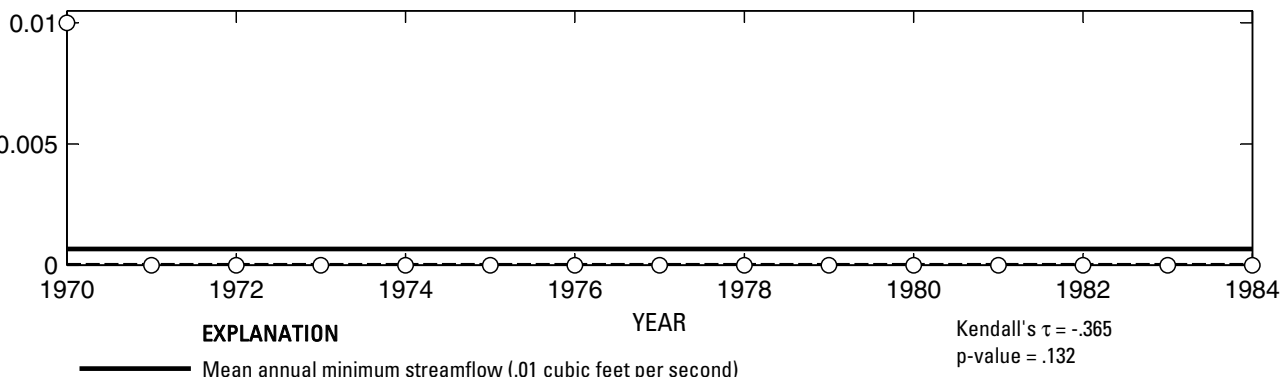

- - Median annual minimum streamflow (0 cubic feet per second)

O Annual minimum streamflow

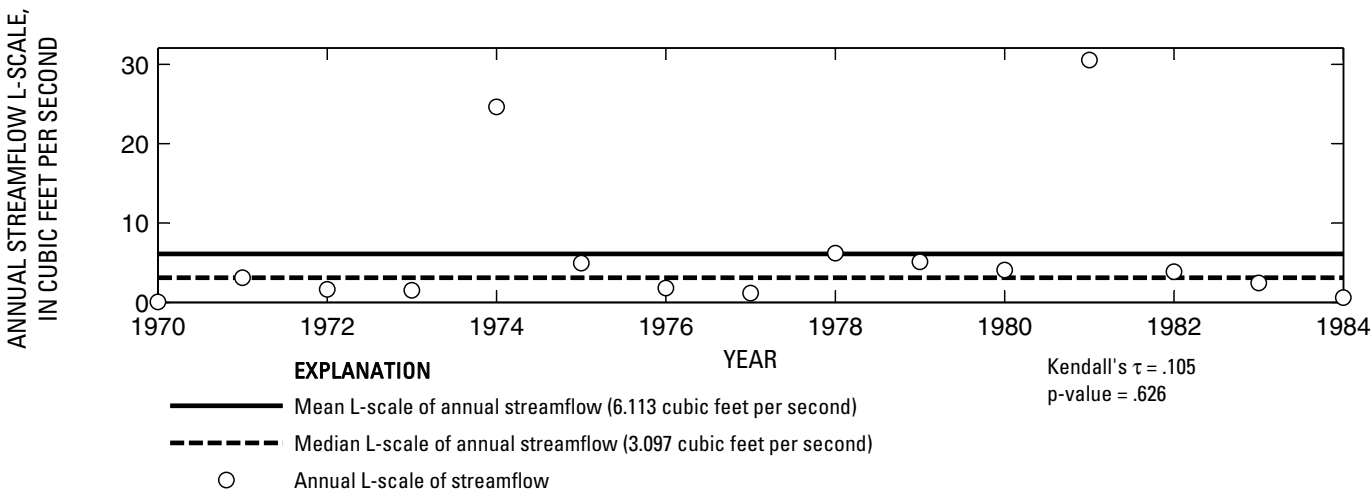

Figure 337. Analysis of annual mean, maximum, minimum, and L-scale statistics of daily mean streamflow for U.S. Geological Survey streamflow-gaging station 08083470 Cedar Creek at Abilene, Texas. 

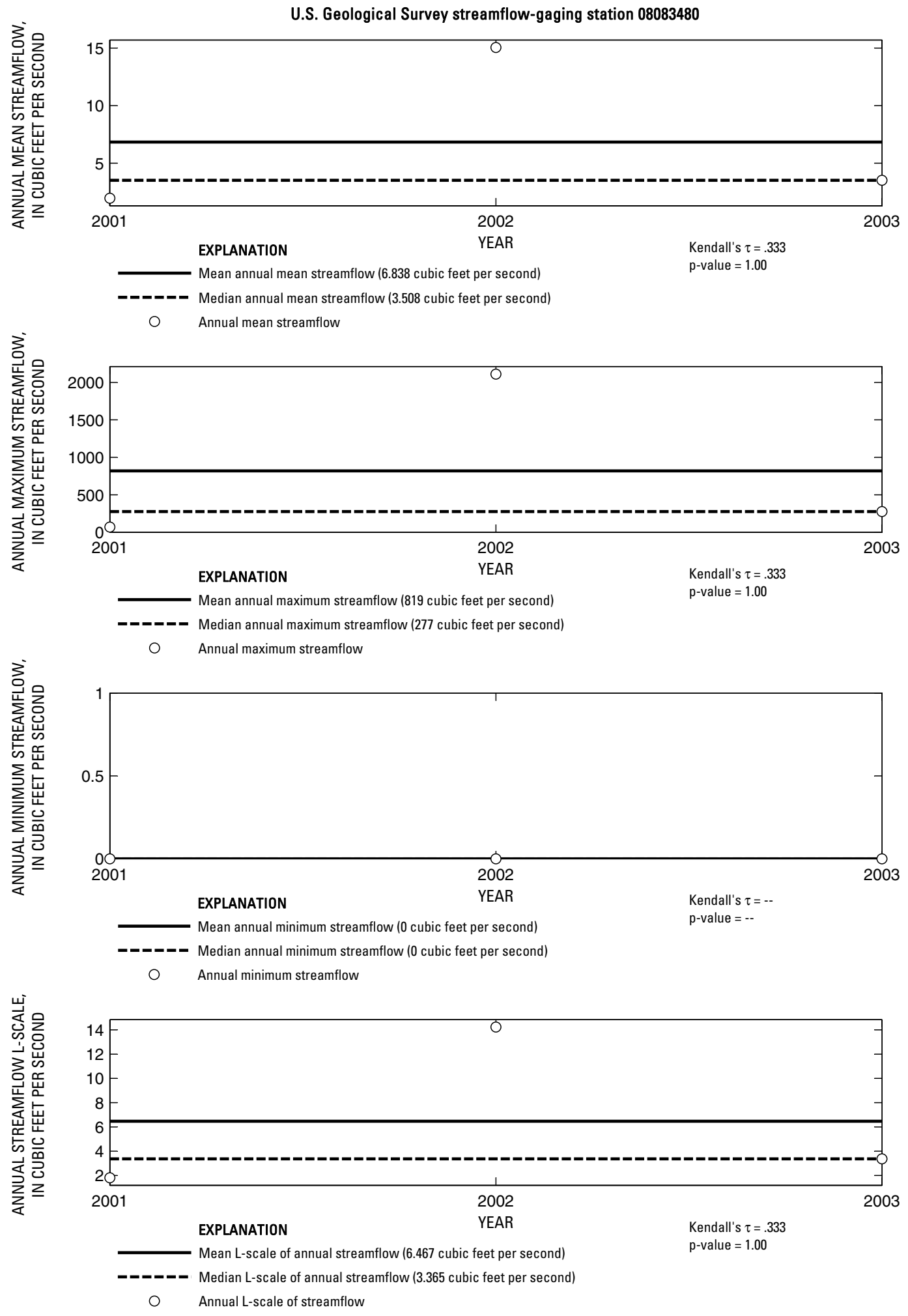

Figure 338. Analysis of annual mean, maximum, minimum, and L-scale statistics of daily mean streamflow for U.S. Geological Survey streamflow-gaging station 08083480 Cedar Creek at Interstate Highway 20, Abilene, Texas. 


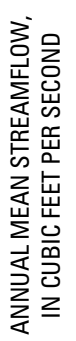

U.S. Geological Survey streamflow-gaging station 08084000
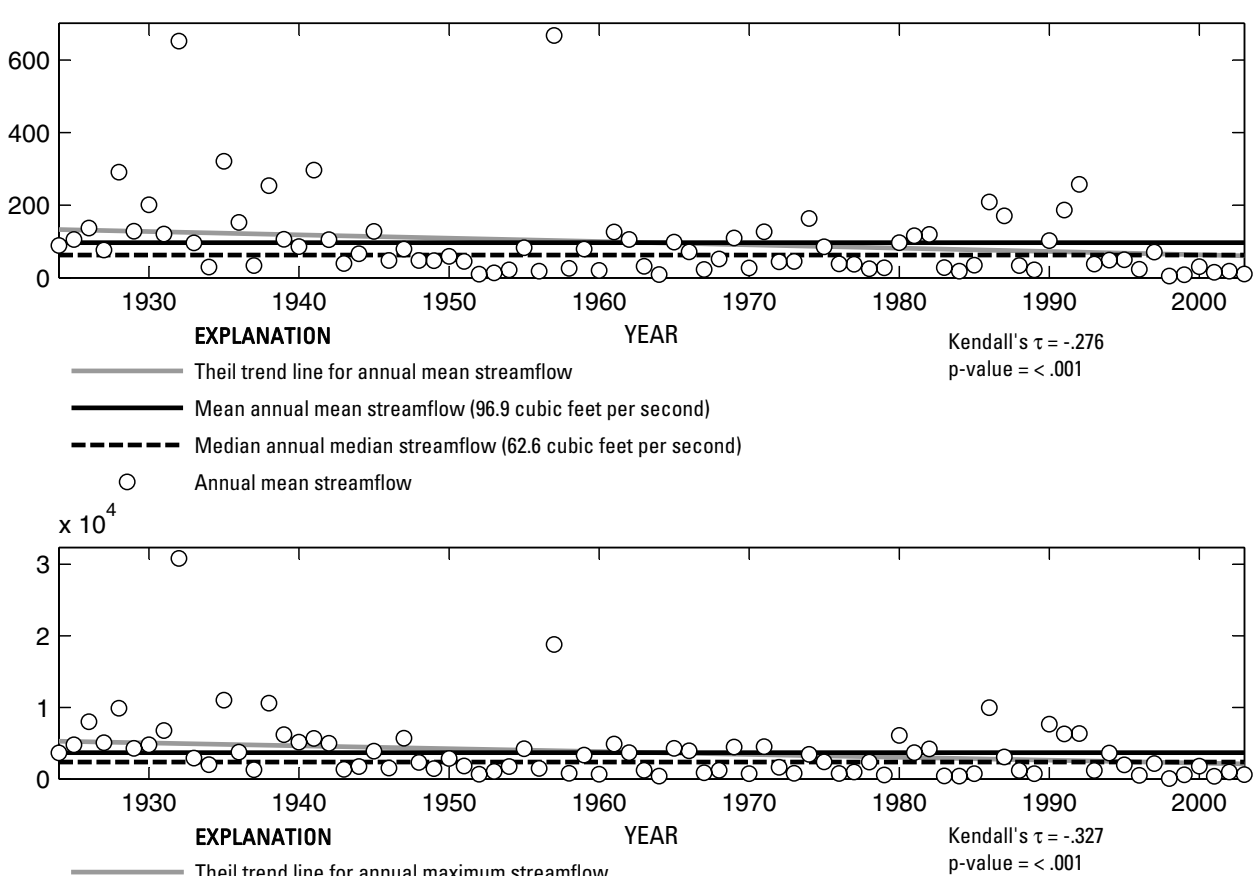

Theil trend line for annual maximum streamflow

Mean annual maximum streamflow (3,690 cubic feet per second)

- Median annual maximum streamflow (2,380 cubic feet per second)

O Annual maximum streamflow

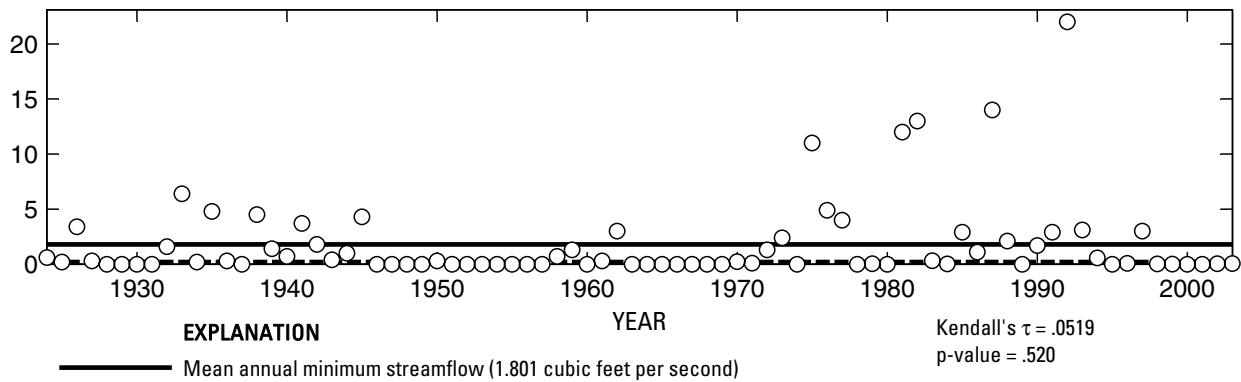

- Median annual minimum streamflow (.2 cubic feet per second

O Annual minimum streamflow

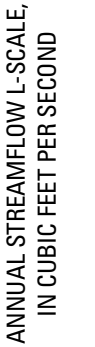

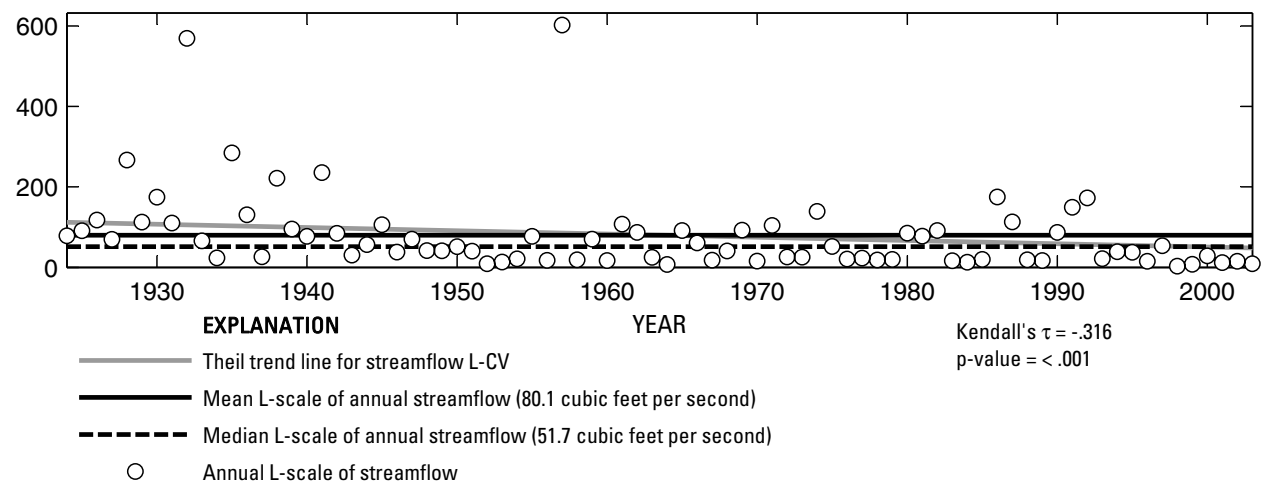

Figure 339. Analysis of annual mean, maximum, minimum, and L-scale statistics of daily mean streamflow for U.S. Geological Survey streamflow-gaging station 08084000 Clear Fork Brazos River at Nugent, Texas. 


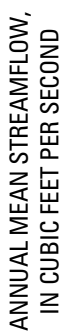

U.S. Geological Survey streamflow-gaging station 08084800

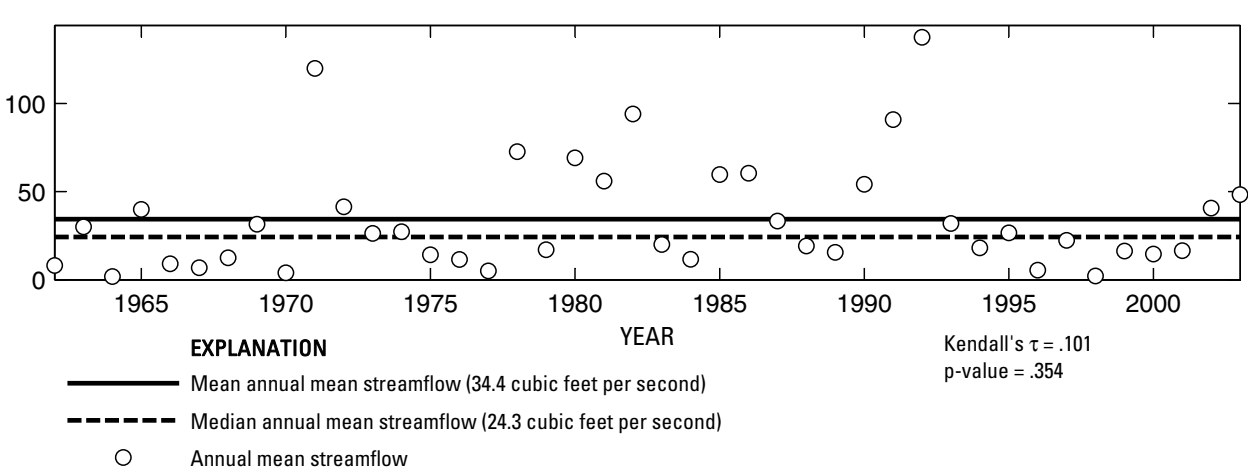

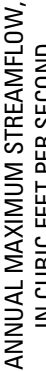
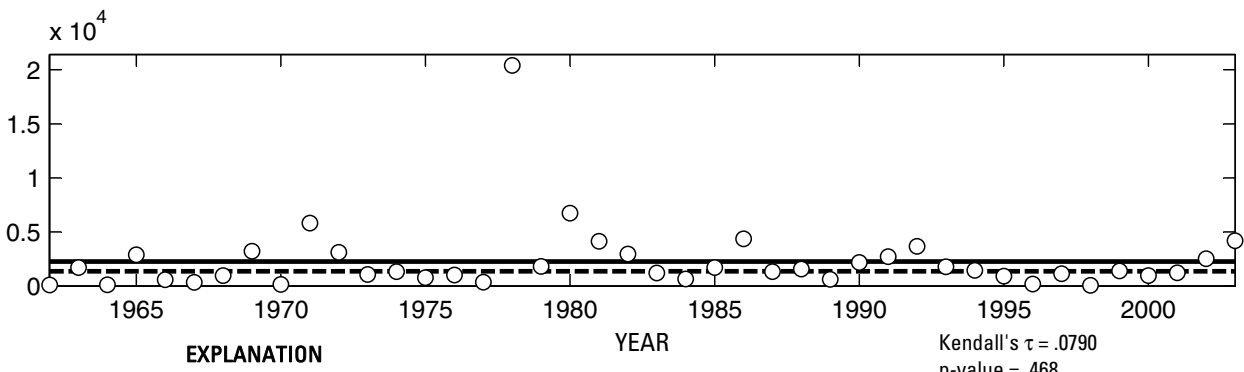

Mean annual maximum streamflow (2,270 cubic feet per second)

-value $=.468$

- Median annual maximum streamflow (1,370 cubic feet per second)

O Annual maximum streamflow

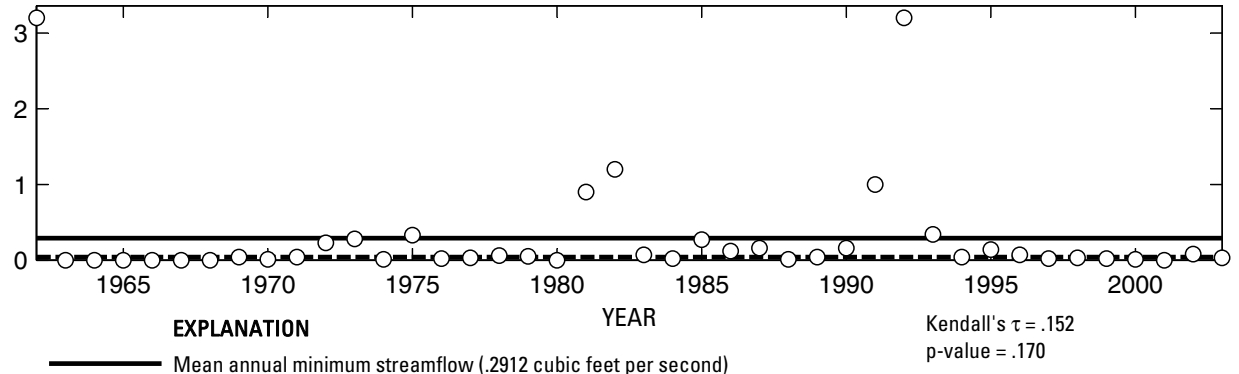

Median annual minimum streamflow (.04 cubic feet per second)

O Annual minimum streamflow

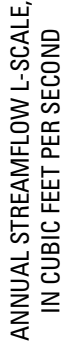

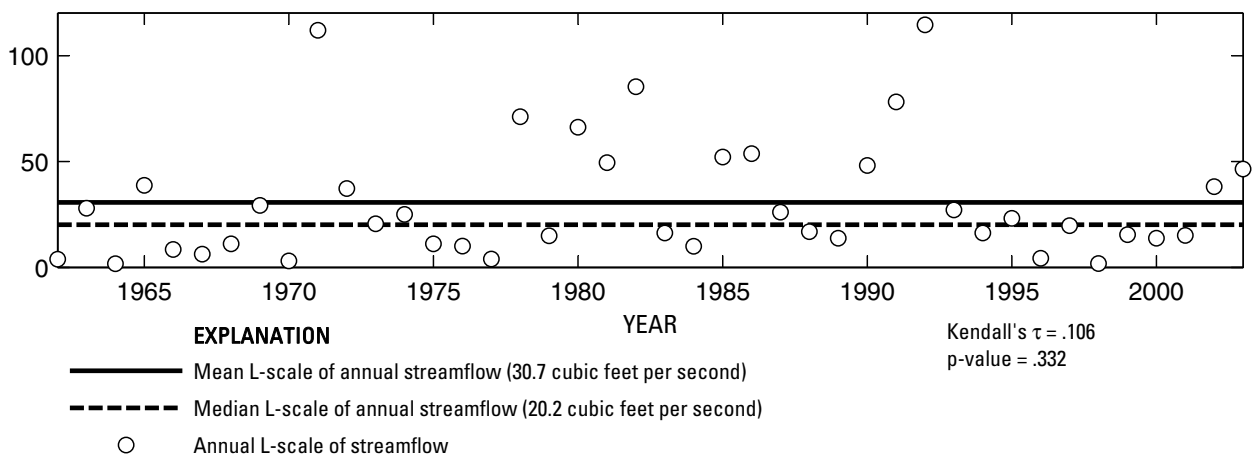

Figure 340. Analysis of annual mean, maximum, minimum, and L-scale statistics of daily mean streamflow for U.S. Geological Survey streamflow-gaging station 08084800 California Creek near Stamford, Texas.

Index of Station Numbers 719 


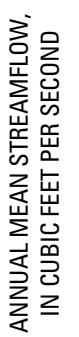

U.S. Geological Survey streamflow-gaging station 08085000

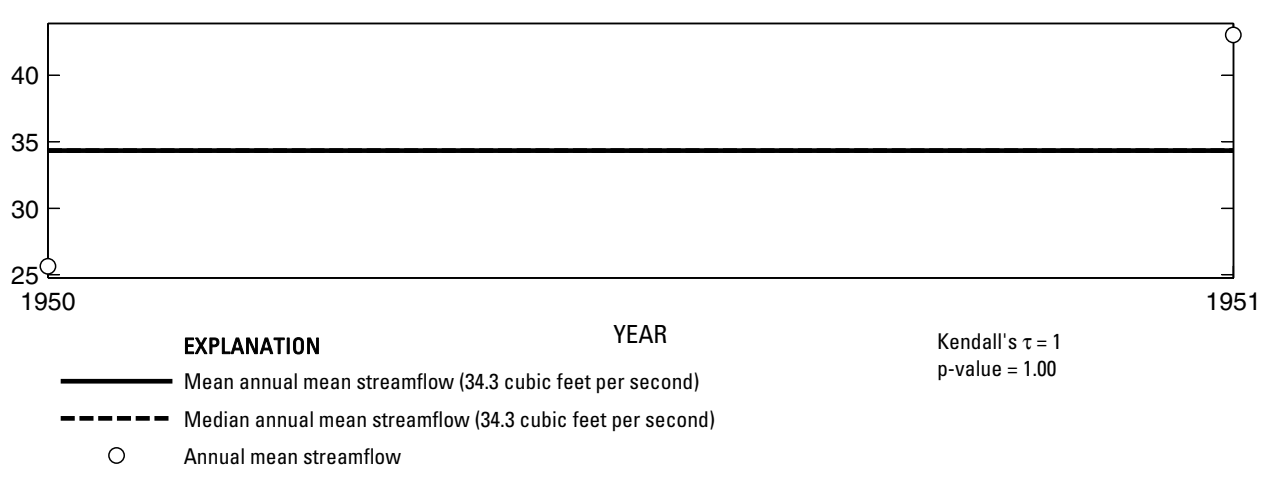

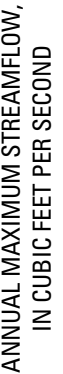
1600
1400
1200
1000

1950

EXPLANATION

YEAR

$\mathrm{p}$-value $=1.00$

Mean annual maximum streamflow (1,310 cubic feet per second)

- - - - - Median annual maximum streamflow (1,310 cubic feet per second

O Annual maximum streamflow

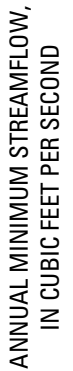

0.5

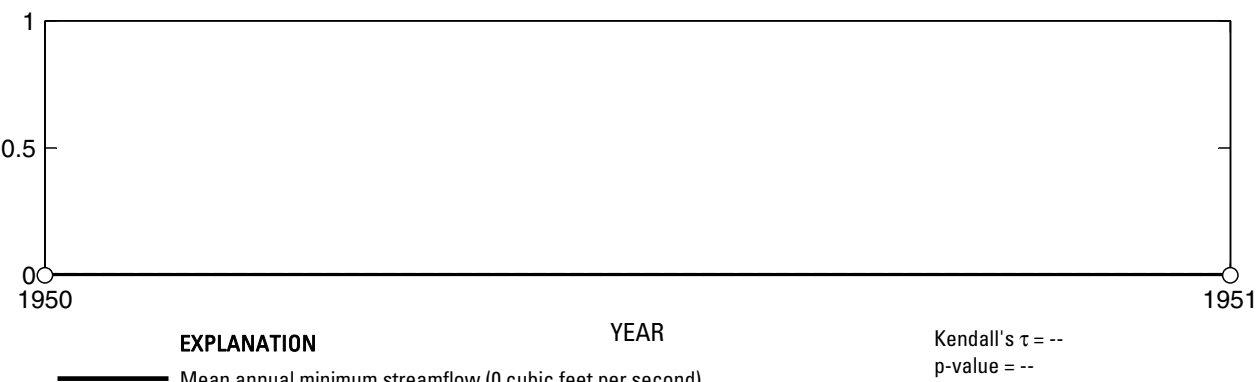

O Annual minimum streamflow

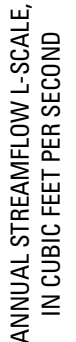

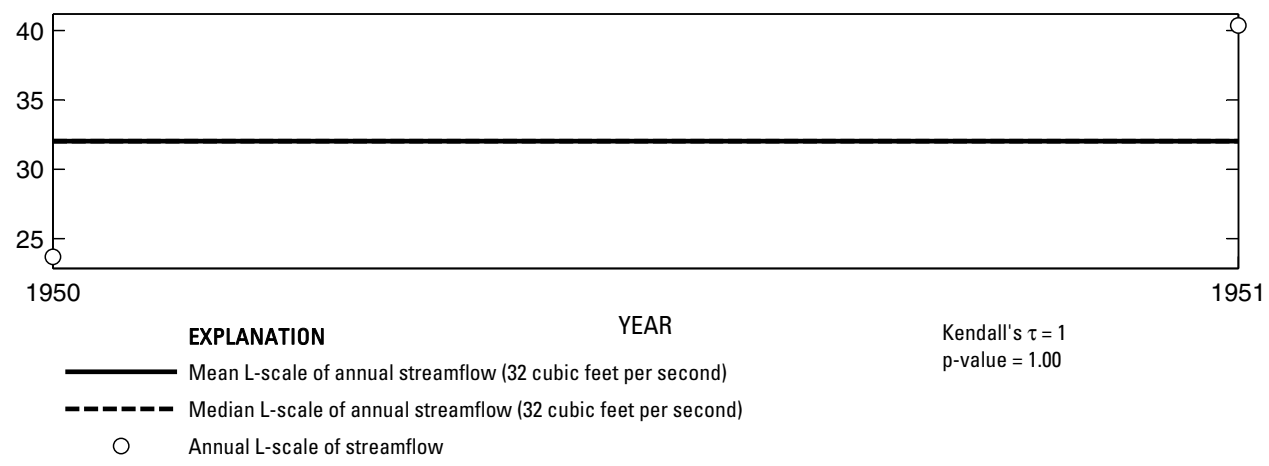

Figure 341. Analysis of annual mean, maximum, minimum, and L-scale statistics of daily mean streamflow for U.S. Geological Survey streamflow-gaging station 08085000 Paint Creek near Haskell, Texas. 


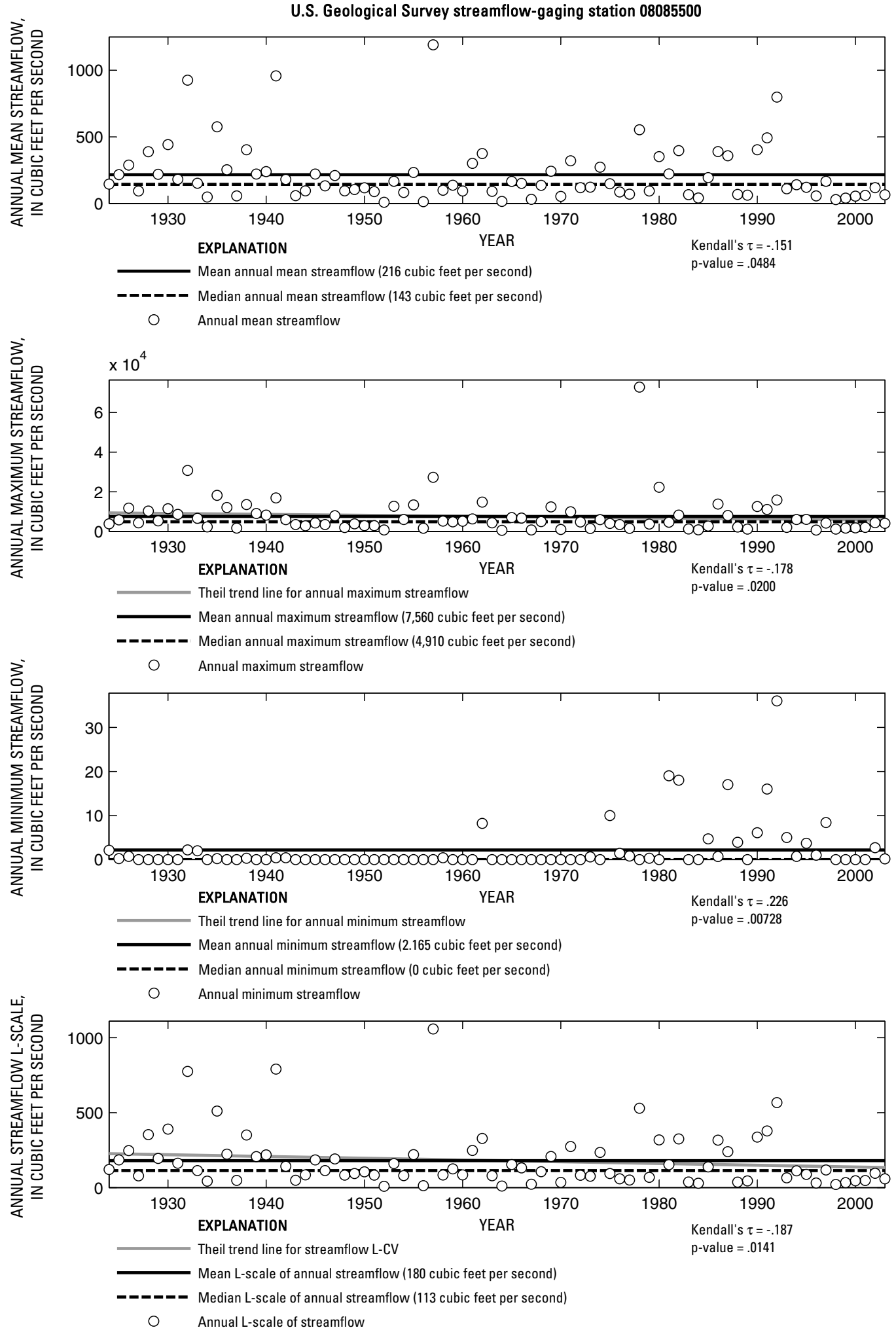

Figure 342. Analysis of annual mean, maximum, minimum, and L-scale statistics of daily mean streamflow for U.S. Geological Survey streamflow-gaging station 08085500 Clear Fork Brazos River at Fort Griffin, Texas.

Index of Station Numbers 719 


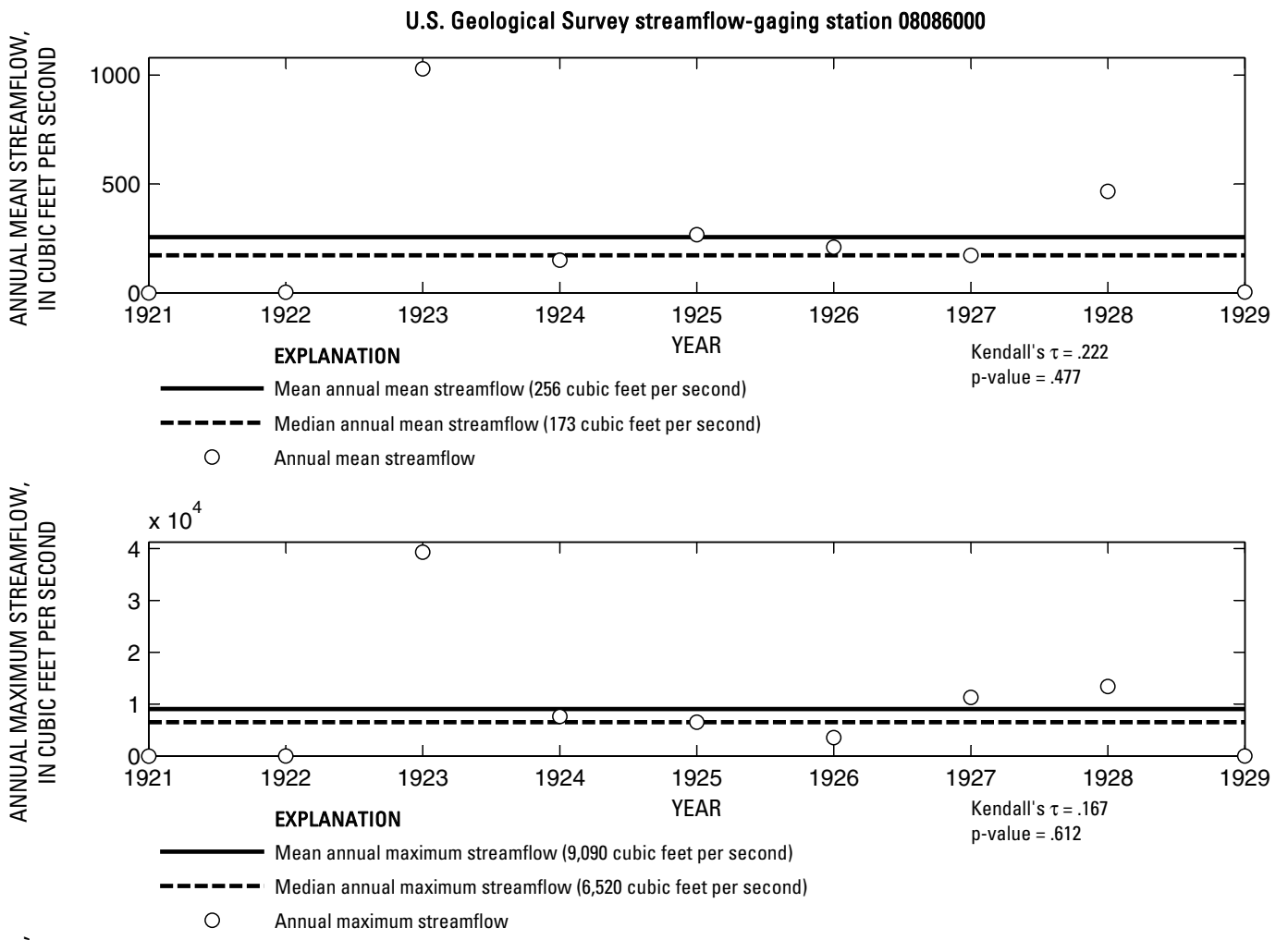

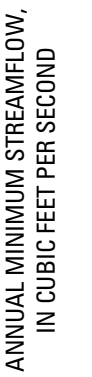

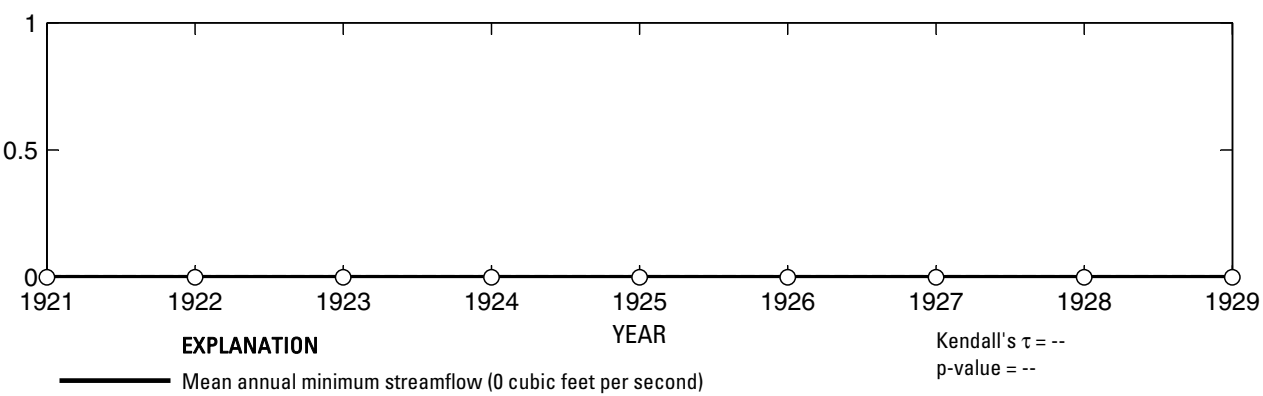

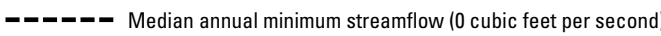

○ Annual minimum streamflow

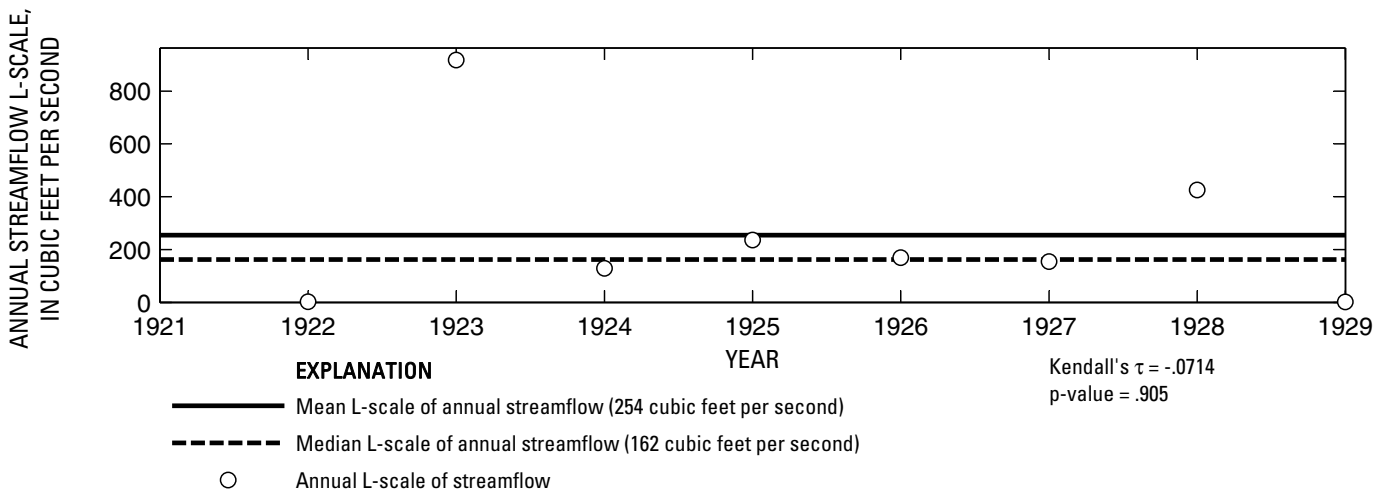

Figure 343. Analysis of annual mean, maximum, minimum, and L-scale statistics of daily mean streamflow for U.S. Geological Survey streamflow-gaging station 08086000 Clear Fork Brazos River at Crystal Falls, Texas. 
U.S. Geological Survey streamflow-gaging station 08086015

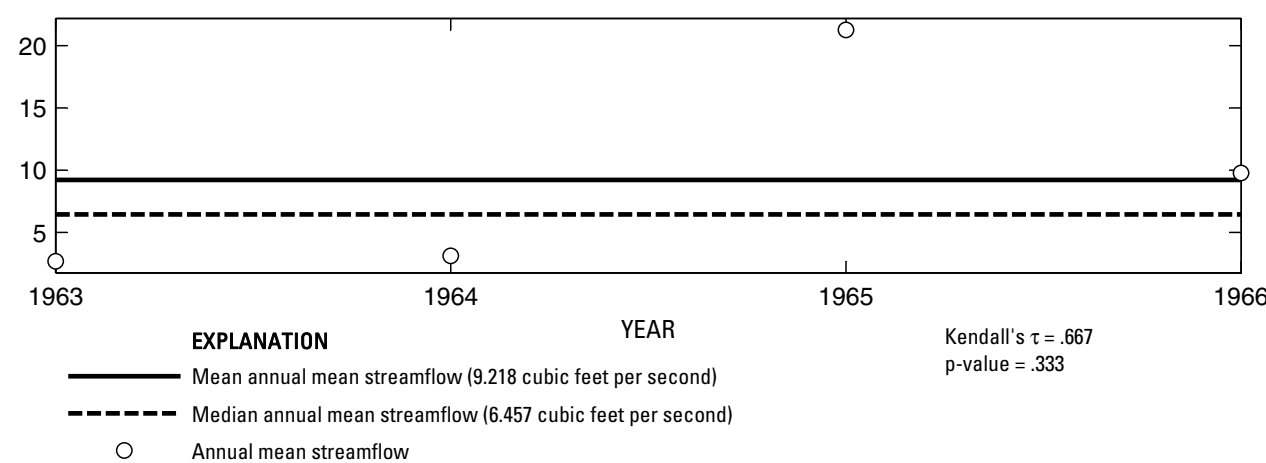

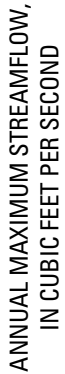

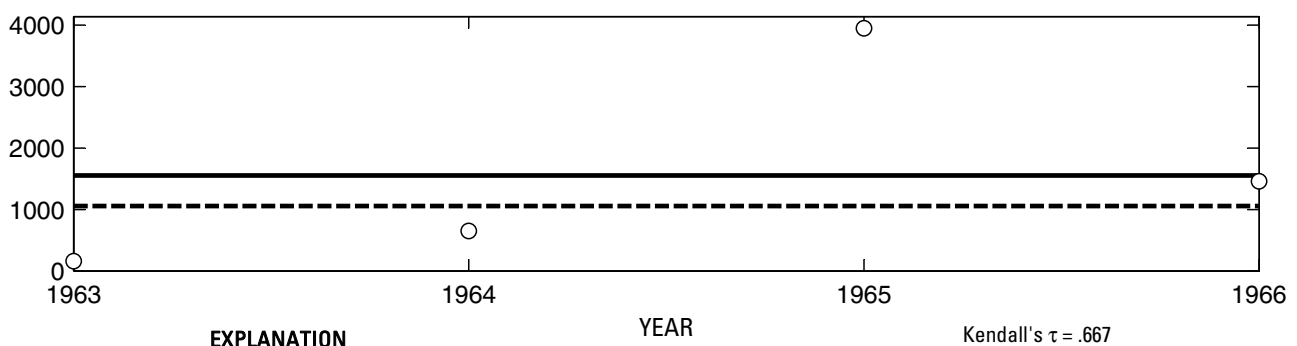

Mean annual maximum streamflow (1,560 cubic feet per second)

$\mathrm{p}$-value $=.333$

- --_- Median annual maximum streamflow (1,060 cubic feet per second)

Annual maximum streamflow

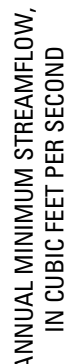

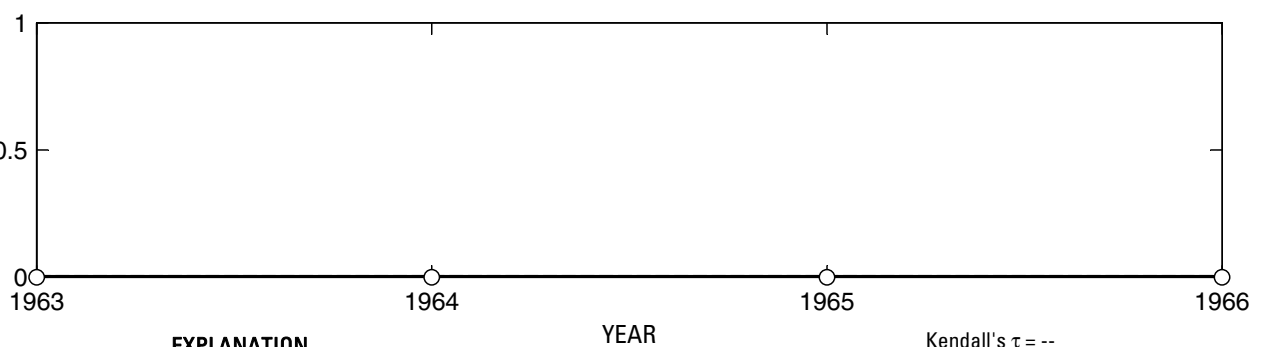

EXPLANATION

p-value $=--$

- Median annual minimum streamflow $(0$ cubic feet per second

○ Annual minimum streamflow

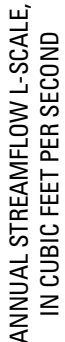

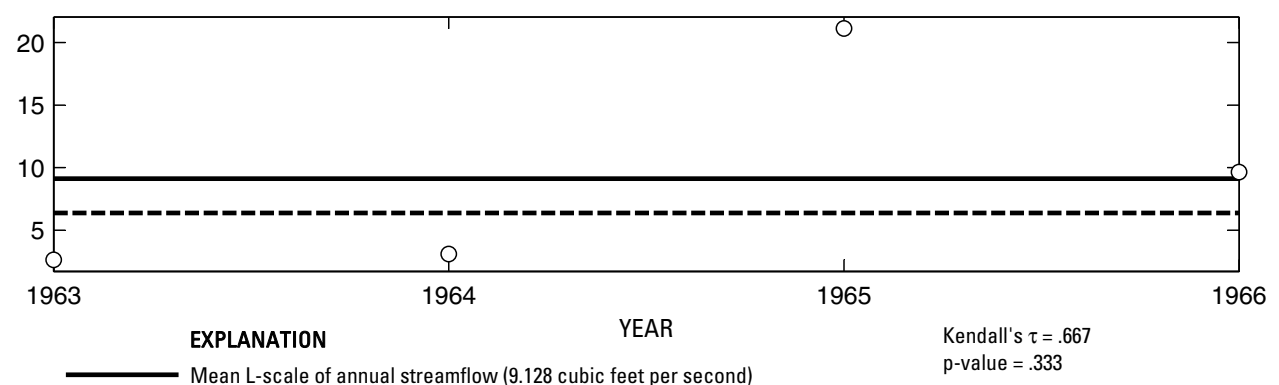

Mean L-scale of annual streamflow (9.128 cubic feet per second)

- --- - Median L-scale of annual streamflow (6.378 cubic feet per second)

O Annual L-scale of streamflow

Figure 344. Analysis of annual mean, maximum, minimum, and L-scale statistics of daily mean streamflow for U.S. Geological Survey streamflow-gaging station 08086015 Hubbard Creek near Sedwick, Texas.

Index of Station Numbers 719 


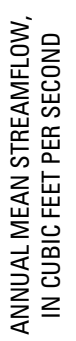

U.S. Geological Survey streamflow-gaging station 08086050

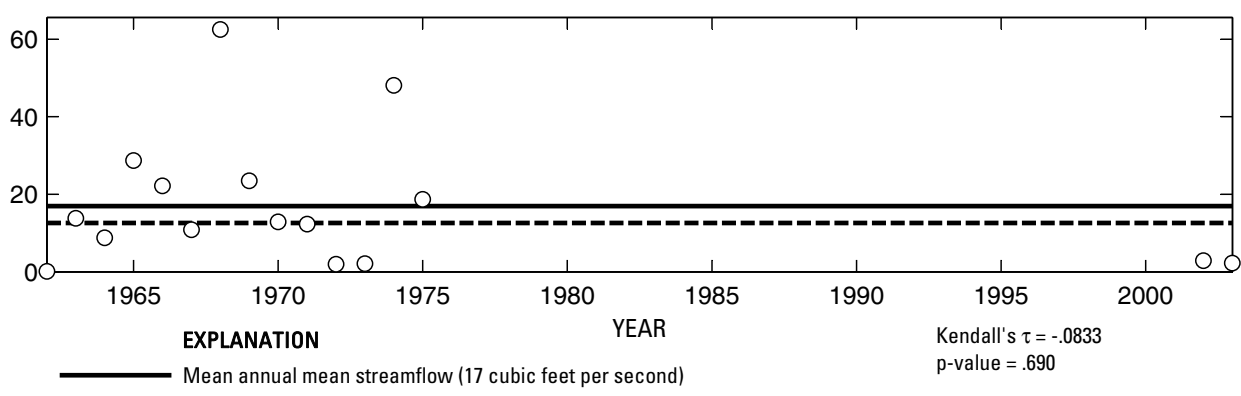

-_-_- Median annual mean streamflow (12.6 cubic feet per second)

O Annual mean streamflow
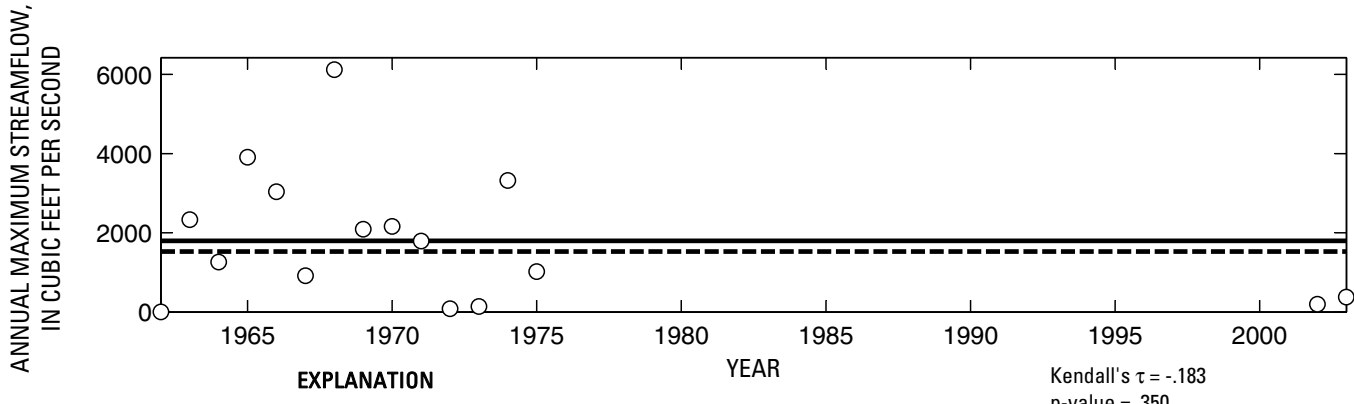

Mean annual maximum streamflow (1,800 cubic feet per second)

-

O Annual maximum streamflow

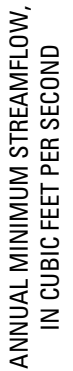

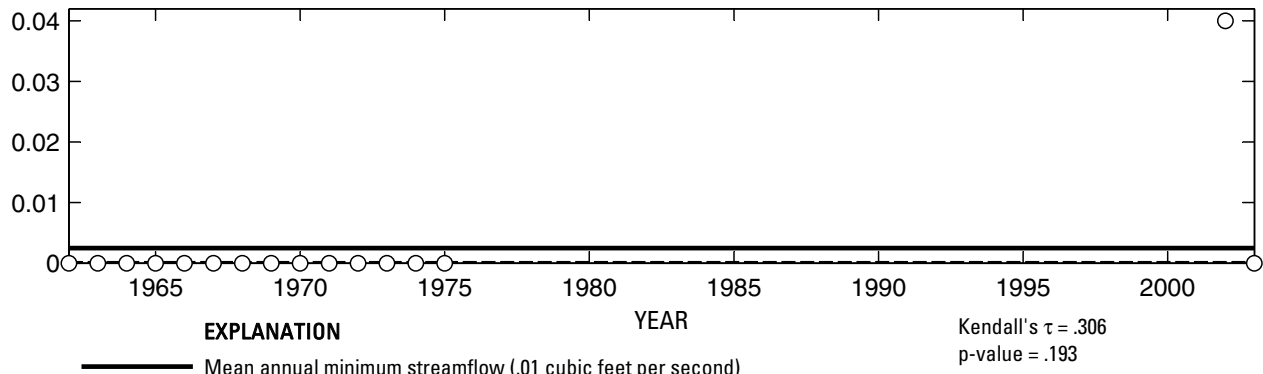

- - - Median annual minimum streamflow (0 cubic feet per second)

O Annual minimum streamflow
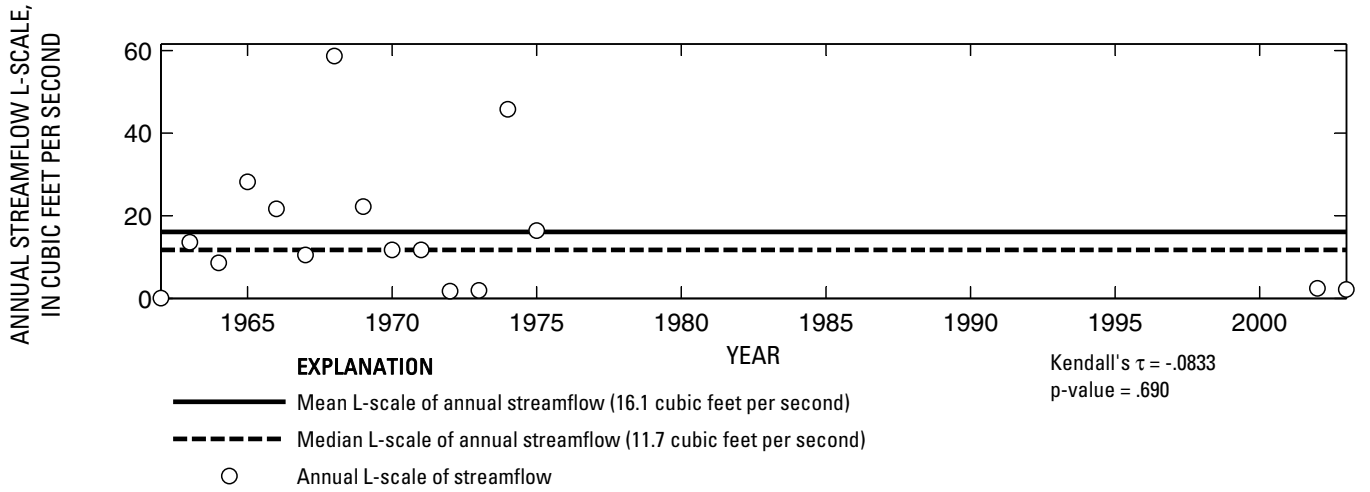

Figure 345. Analysis of annual mean, maximum, minimum, and L-scale statistics of daily mean streamflow for U.S. Geological Survey streamflow-gaging station 08086050 Deep Creek at Moran, Texas. 

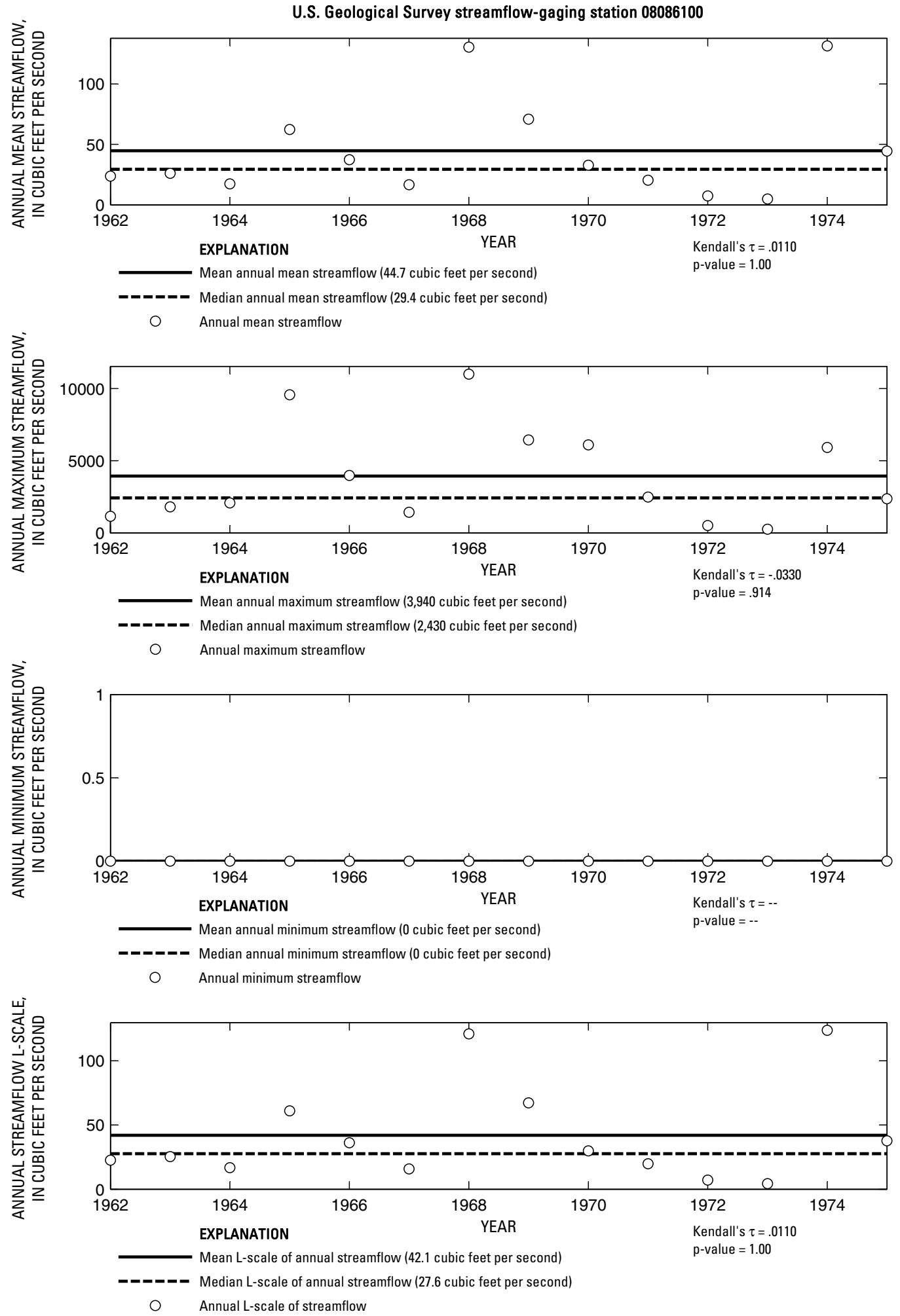

Figure 346. Analysis of annual mean, maximum, minimum, and L-scale statistics of daily mean streamflow for U.S. Geological Survey streamflow-gaging station 08086100 Hubbard Creek near Albany, Texas.

Index of Station Numbers 719 


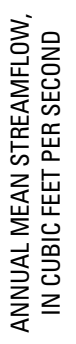

U.S. Geological Survey streamflow-gaging station 08086120

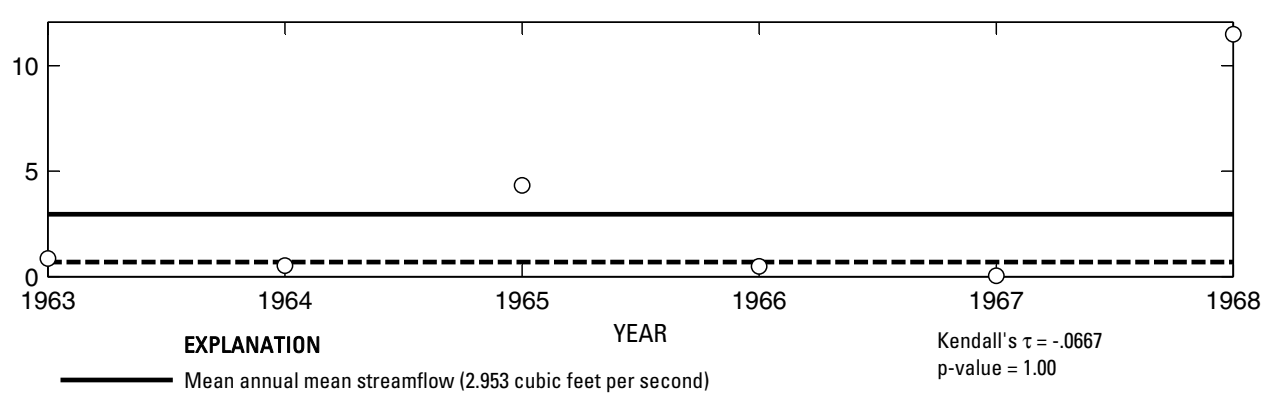

-ーーーーー Median annual mean streamflow (.6889 cubic feet per second)

- Annual mean streamflow

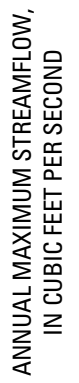

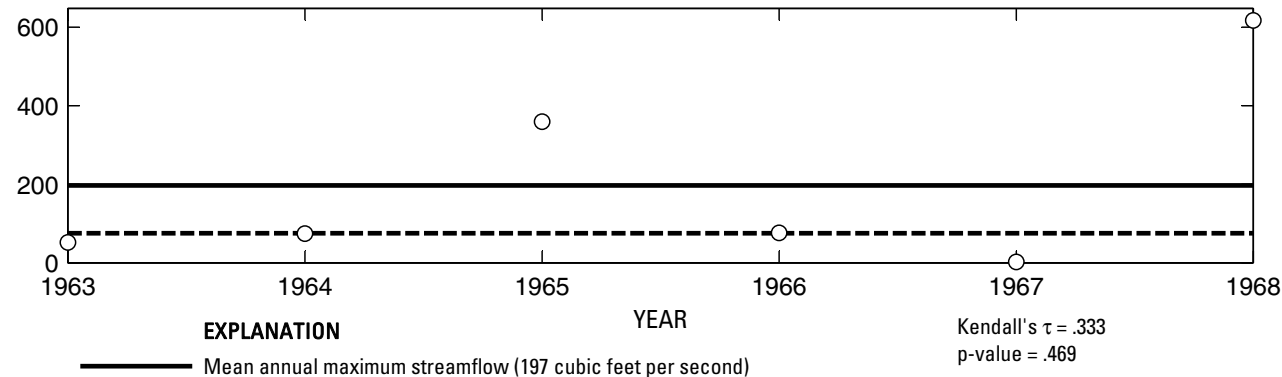

- - Median annual maximum streamflow (75 cubic feet per second)

O Annual maximum streamflow

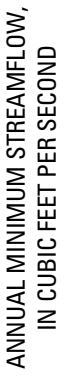

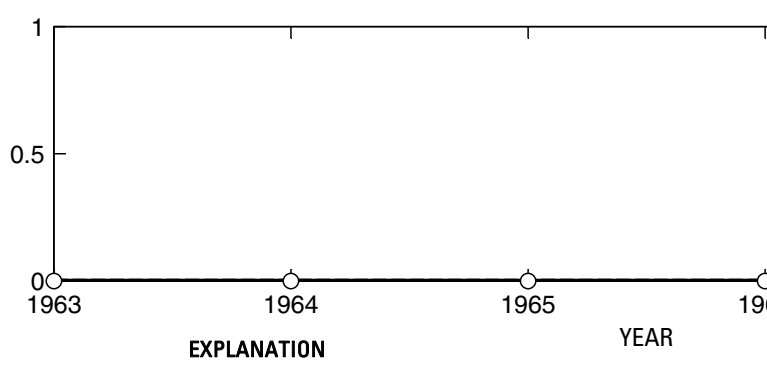

Mean annual minimum streamflow (0 cubic feet per second)

- Median annual minimum streamflow (0 cubic feet per second)

○ Annual minimum streamflow

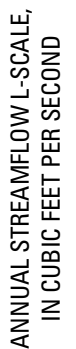

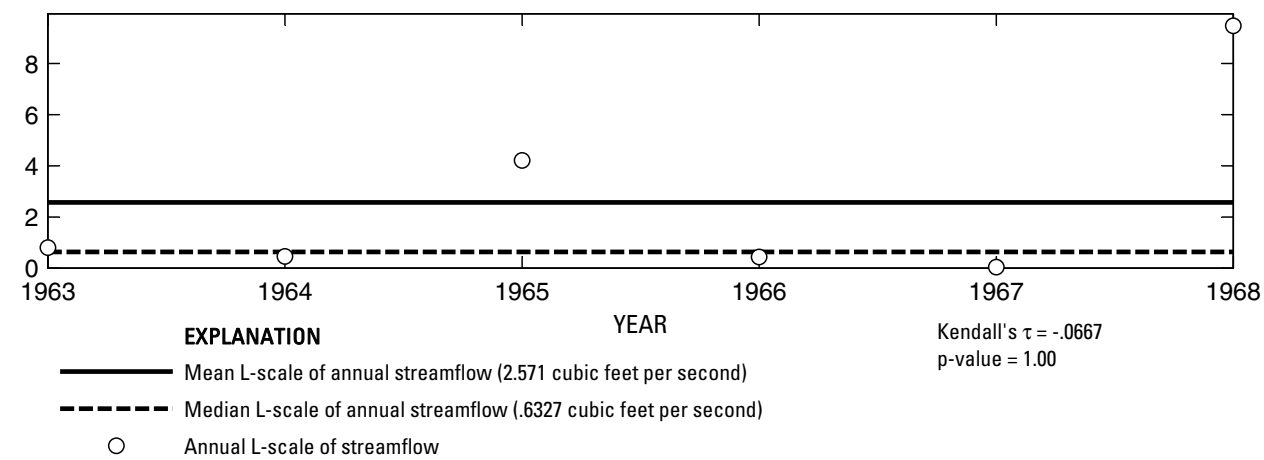

Figure 347. Analysis of annual mean, maximum, minimum, and L-scale statistics of daily mean streamflow for U.S. Geological Survey streamflow-gaging station 08086120 Salt Prong Hubbard Creek at U.S. Highway 380 near Albany, Texas. 


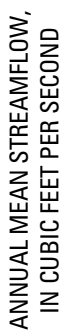

U.S. Geological Survey streamflow-gaging station 08086150

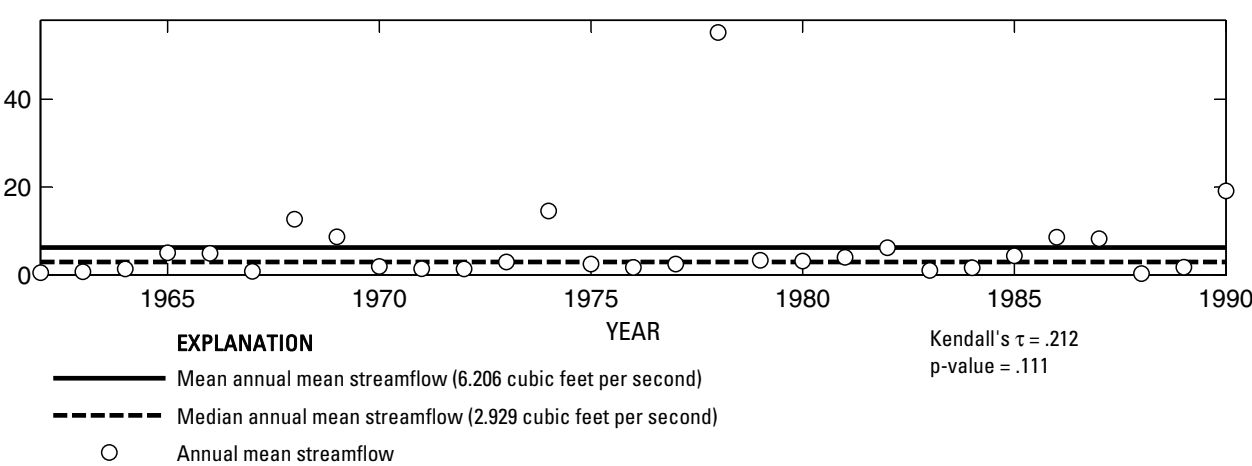

家

10000

5000

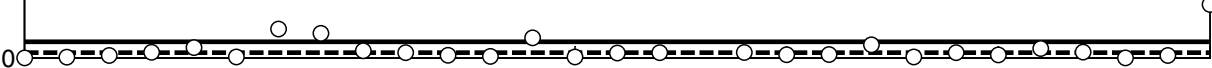

EXPLANATION KEAR Kendall's $\tau=.0863$

Mean annual maximum streamflow (879 cubic feet per second) $\quad$ p-value $=.524$

- Median annual maximum streamflow (289 cubic feet per second)

O Annual maximum streamflow

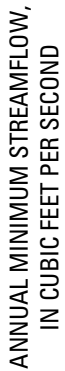

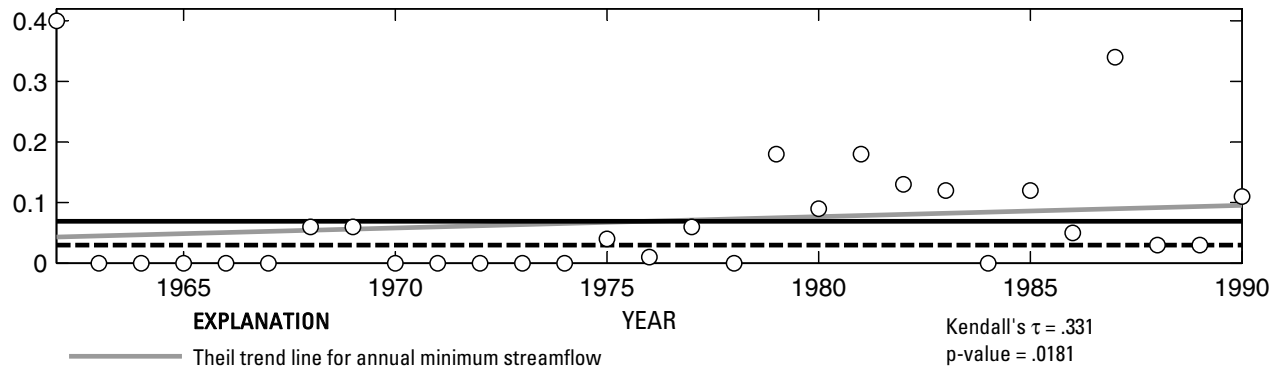

Theil trend line for annual minimum streamflow

$\mathrm{p}$-value $=.018$

Mean annual minimum streamflow (.06931 cubic feet per second)

- Median annual minimum streamflow (.03 cubic feet per second)

O

Annual minimum streamflow

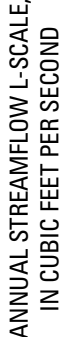

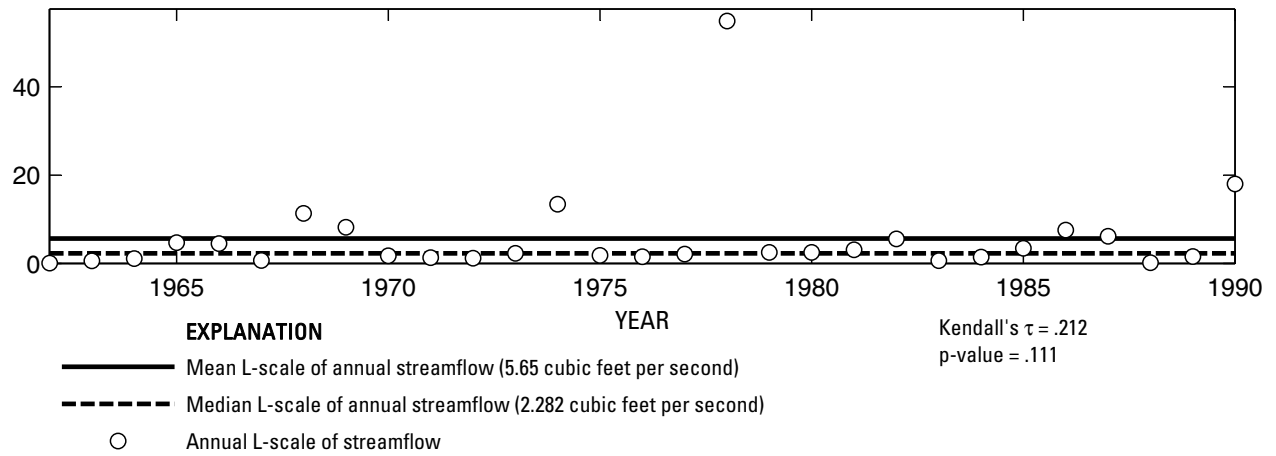

Figure 348. Analysis of annual mean, maximum, minimum, and L-scale statistics of daily mean streamflow for U.S. Geological Survey streamflow-gaging station 08086150 North Fork Hubbard Creek near Albany, Texas.

Index of Station Numbers 719 


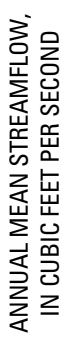

U.S. Geological Survey streamflow-gaging station 08086200

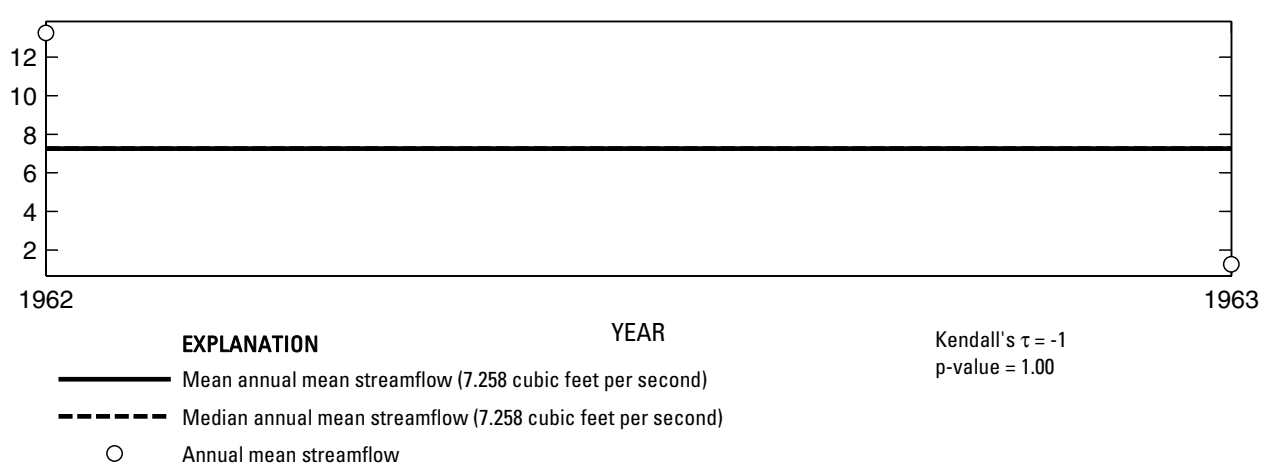

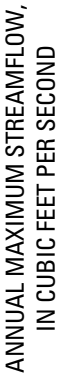

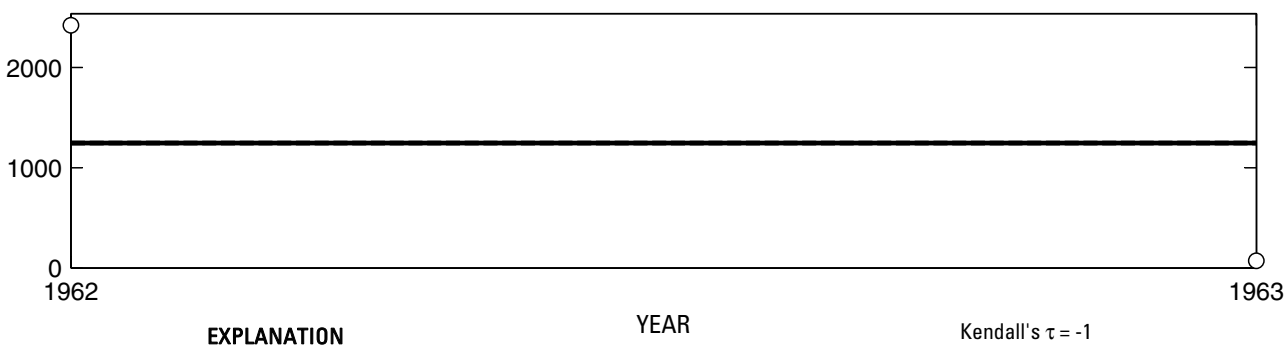

nnual mean streamflow

Mean annual maximum streamflow (1,250 cubic feet per second)

- - - - Median annual maximum streamflow (1,250 cubic feet per second

O Annual maximum streamflow

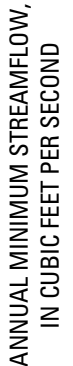
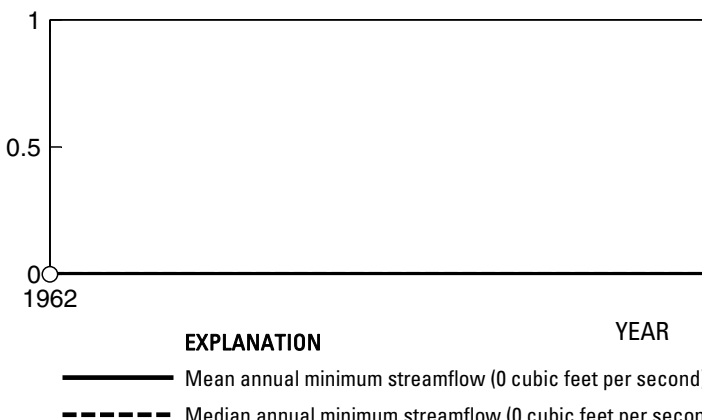

- Median annual minimum streamflow (0 cubic feet per second)

Annual minimum streamflow

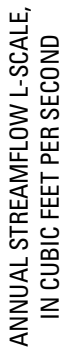

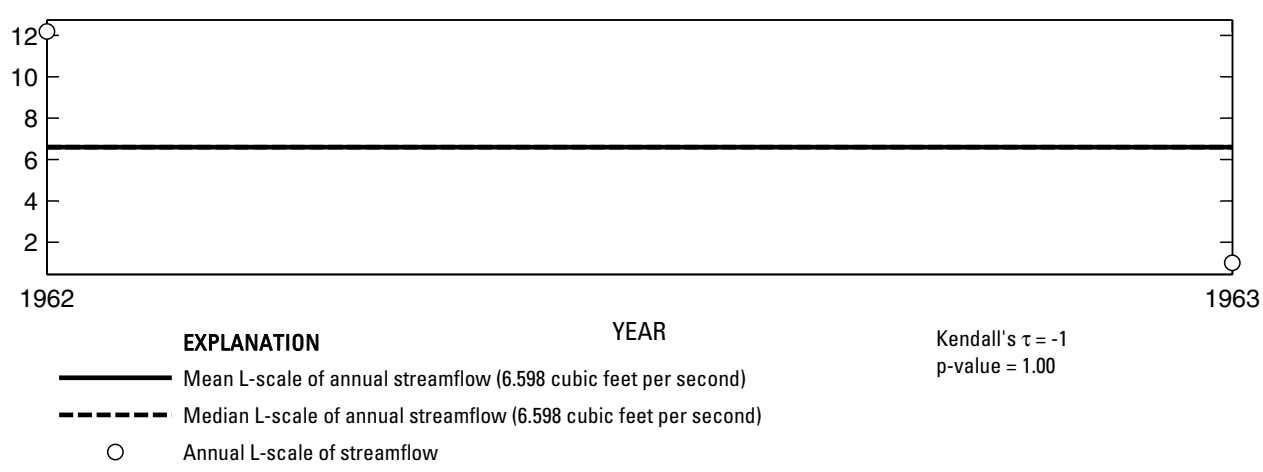

Figure 349. Analysis of annual mean, maximum, minimum, and L-scale statistics of daily mean streamflow for U.S. Geological Survey streamflow-gaging station 08086200 Salt Prong Hubbard Creek near Albany, Texas. 


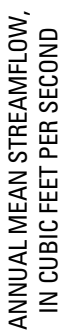

U.S. Geological Survey streamflow-gaging station 08086210

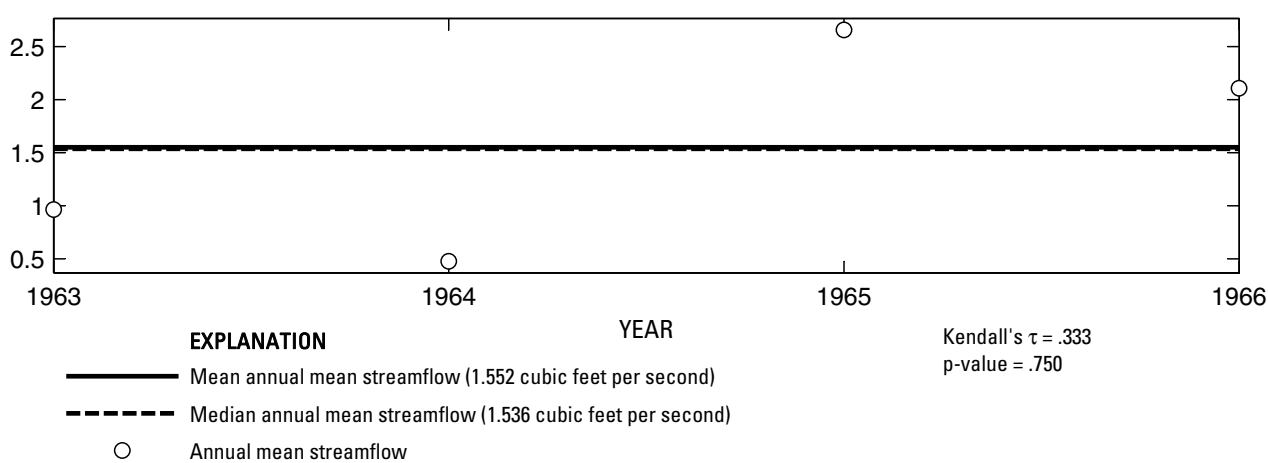

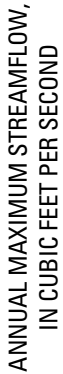

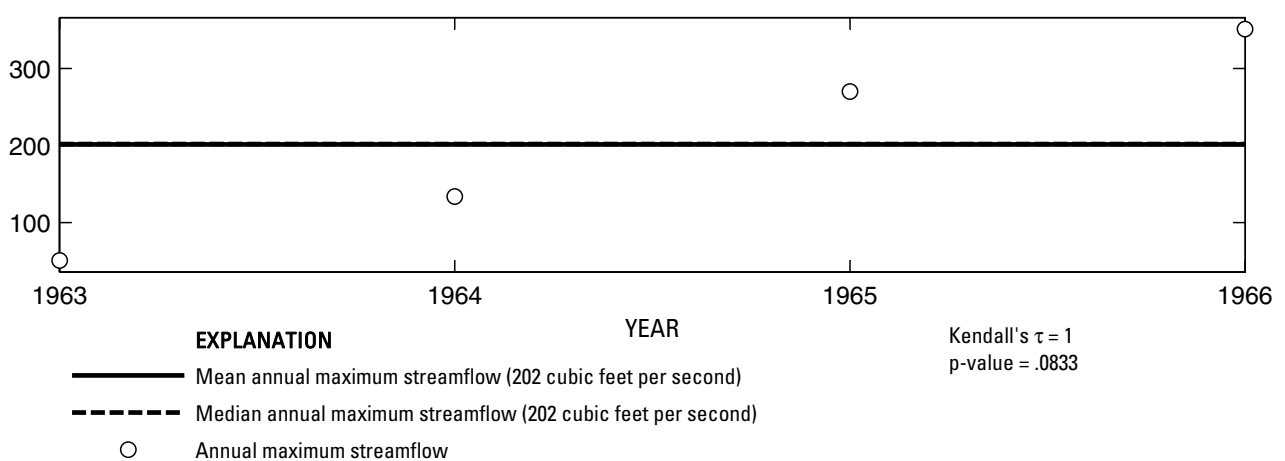

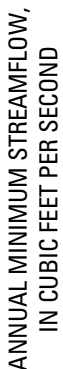

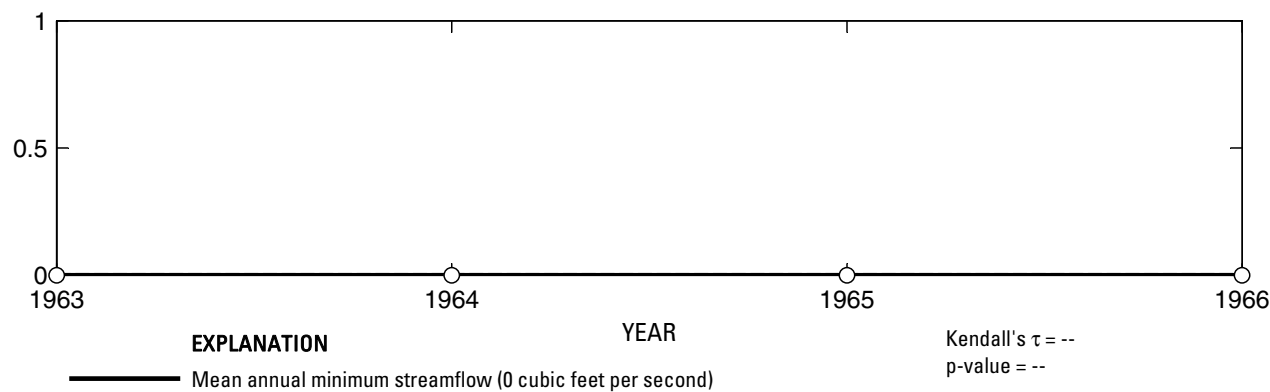

Annual maximum streamflow

- - - Median annual minimum streamflow (0 cubic feet per second)

O Annual minimum streamflow

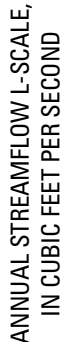

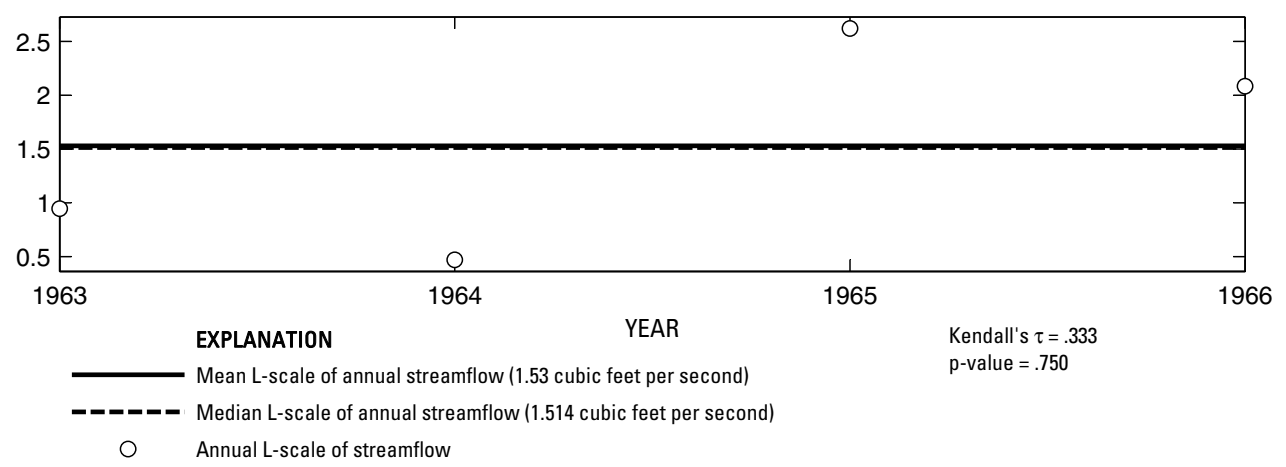

Figure 350. Analysis of annual mean, maximum, minimum, and L-scale statistics of daily mean streamflow for U.S. Geological Survey streamflow-gaging station 08086210 Snailum Creek near Albany, Texas. 


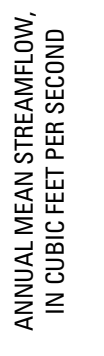

U.S. Geological Survey streamflow-gaging station 08086212

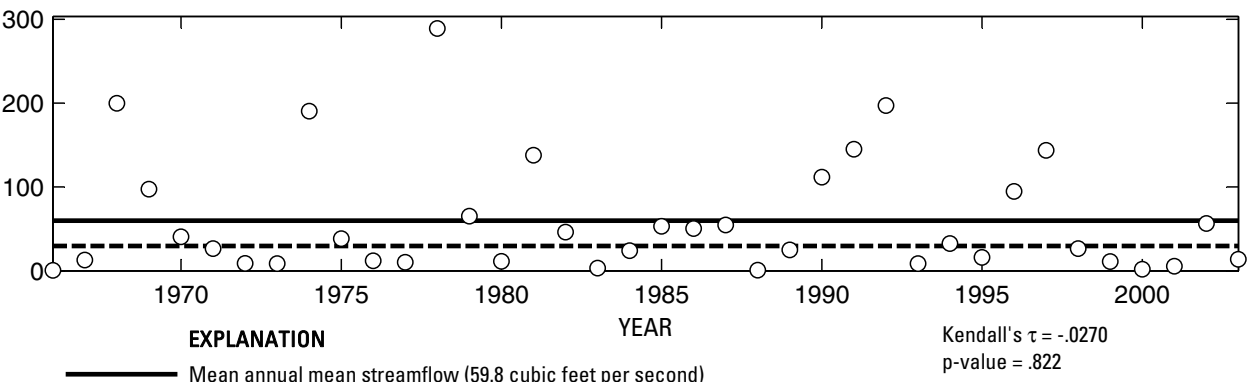

O Annual mean streamflow

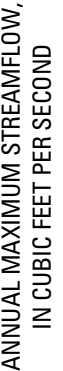
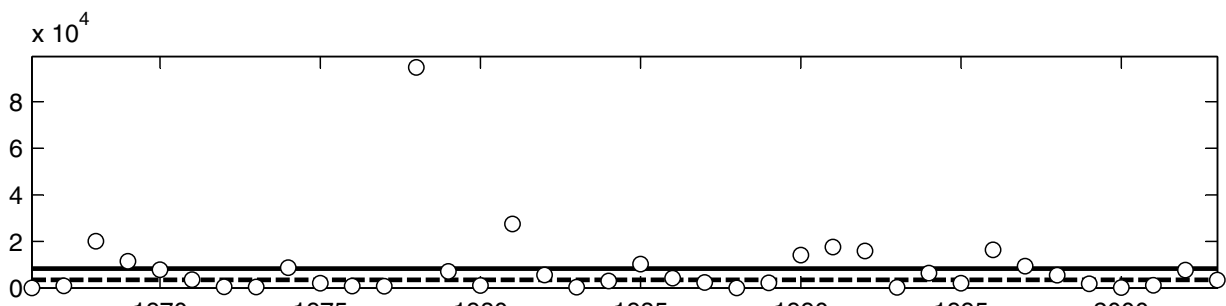

1980

EXPLANATION

1985

1990

1995

Kendall's $\tau=.0156$

Mean annual maximum streamflow (8,360 cubic feet per second)

p-value $=.901$

- o-n - Median annual maximum streamflow (3,510 cubic feet per second)

O Annual maximum streamflow

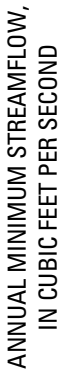

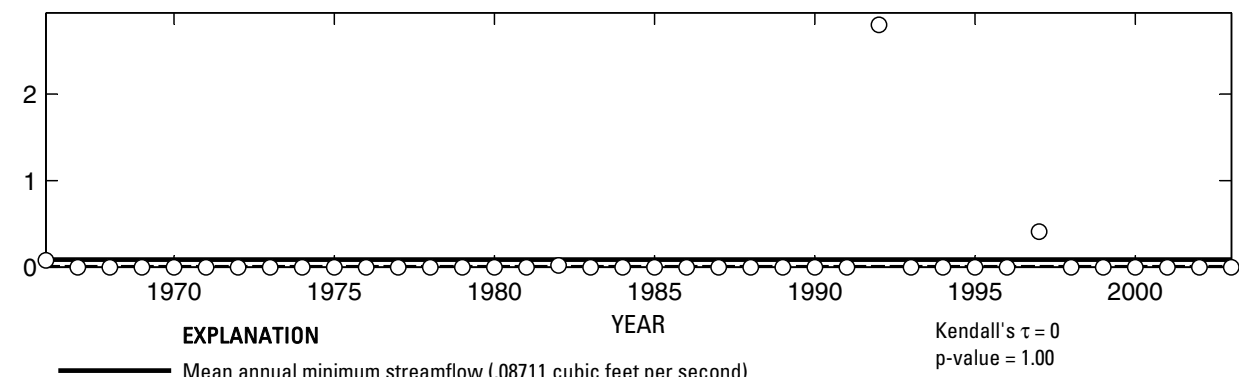

- Median annual minimum streamflow (0 cubic feet per second)

O Annual minimum streamflow

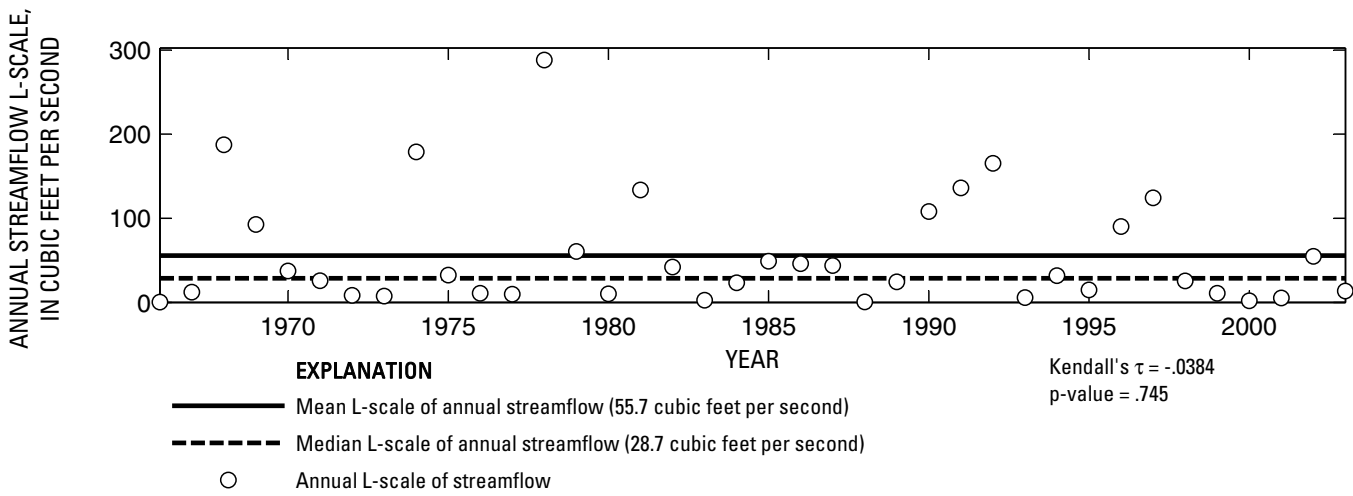

Figure 351. Analysis of annual mean, maximum, minimum, and L-scale statistics of daily mean streamflow for U.S. Geological Survey streamflow-gaging station 08086212 Hubbard Creek below Albany, Texas. 
U.S. Geological Survey streamflow-gaging station 08086235

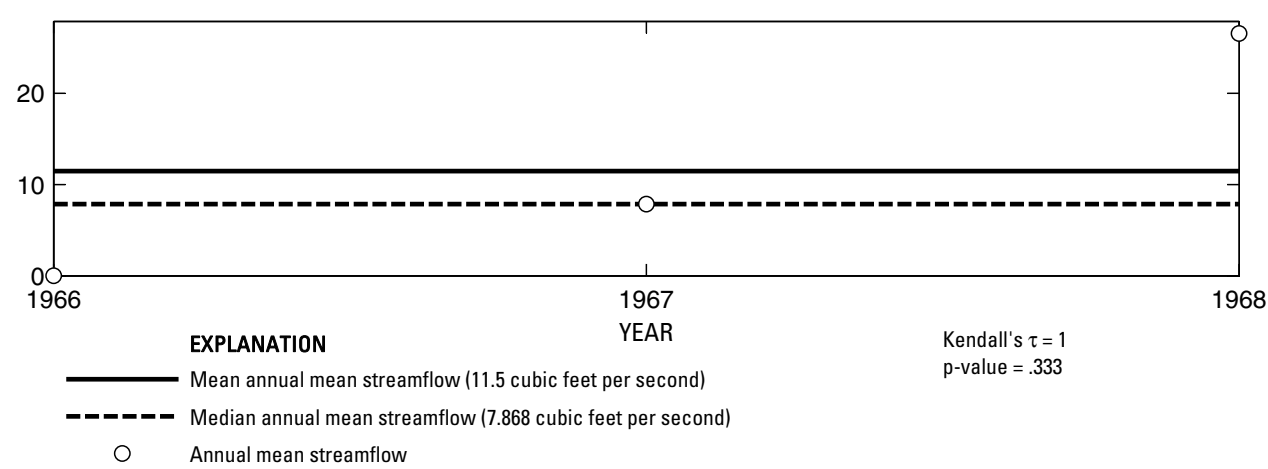

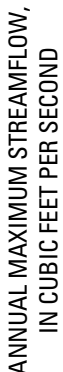

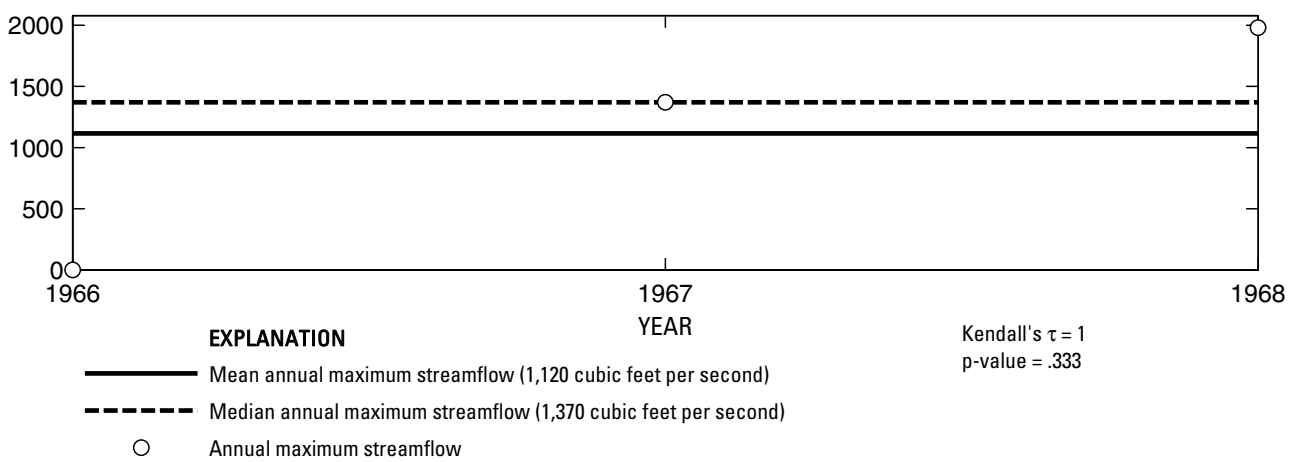

Annual mean streamflow

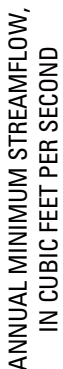

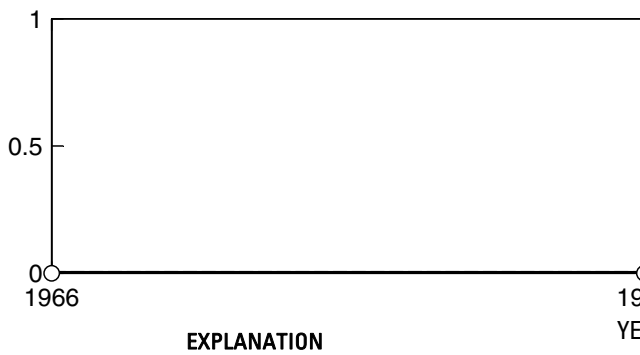

Mean annual minimum streamflow (0 cubic feet per second)

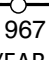

- Median annual minimum streamflow (0 cubic feet per second)

O Annual minimum streamflow

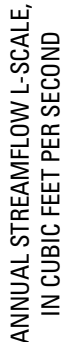

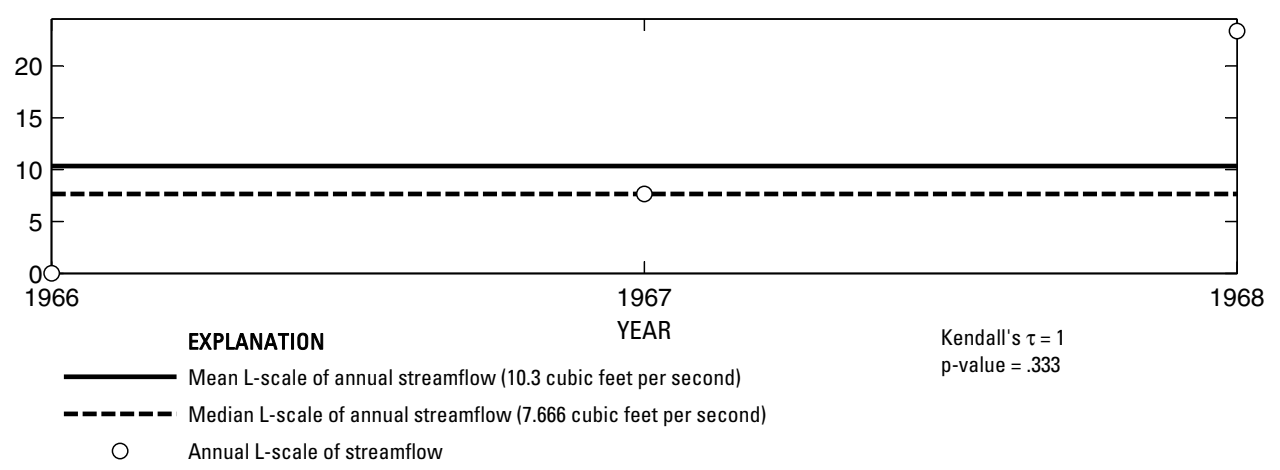

Figure 352. Analysis of annual mean, maximum, minimum, and L-scale statistics of daily mean streamflow for U.S. Geological Survey streamflow-gaging station 08086235 Battle Creek near Moran, Texas. 


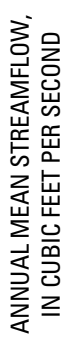

U.S. Geological Survey streamflow-gaging station 08086260

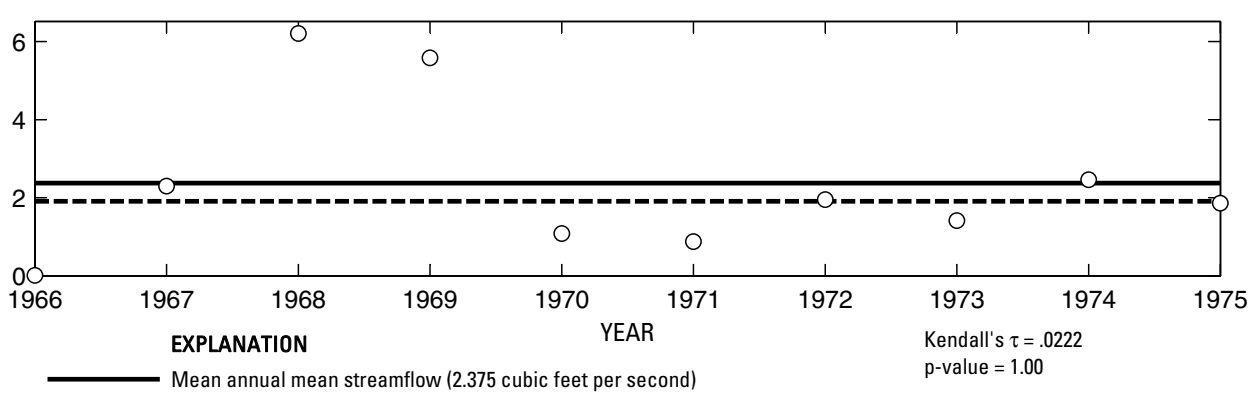

-__-_ Median annual mean streamflow (1.907 cubic feet per second)

O Annual mean streamflow
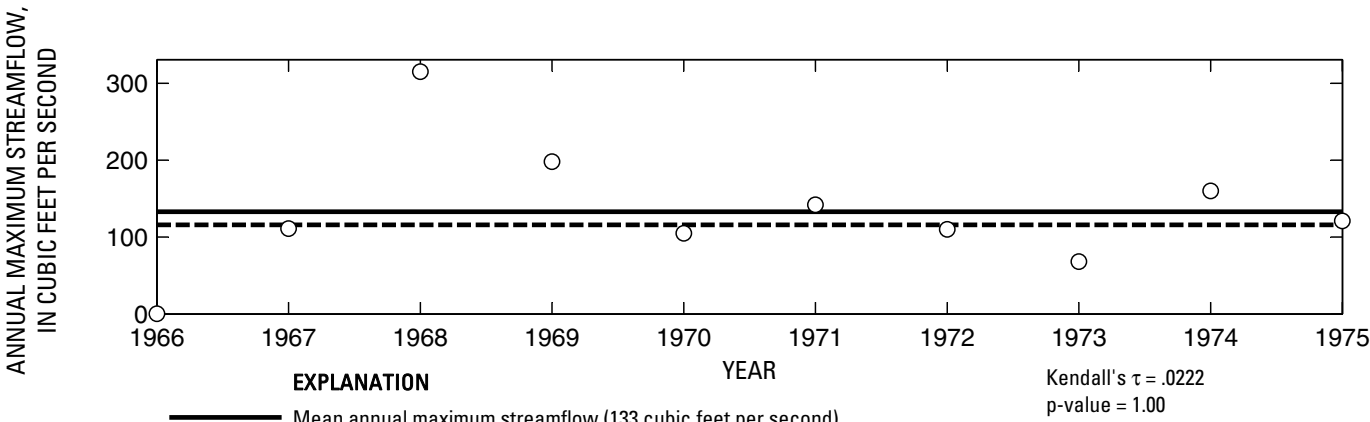

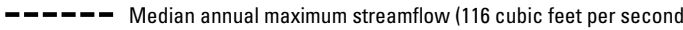

Annual maximum streamflow

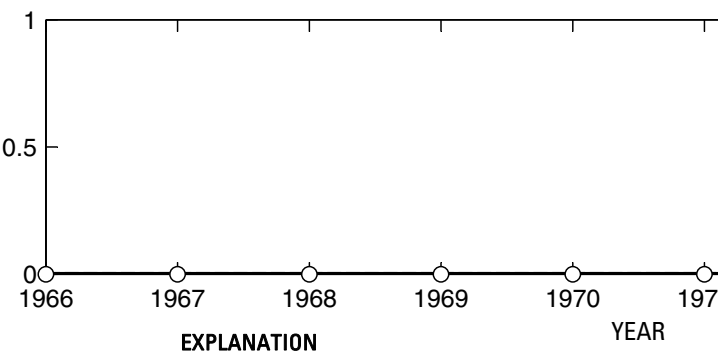

Mean annual minimum streamflow ( 0 cubic feet per second)

$\mathrm{p}$-value $=1.00$

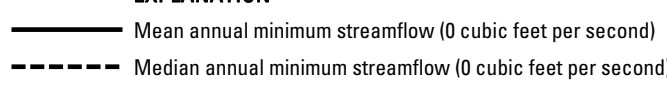

O Annual minimum streamflow

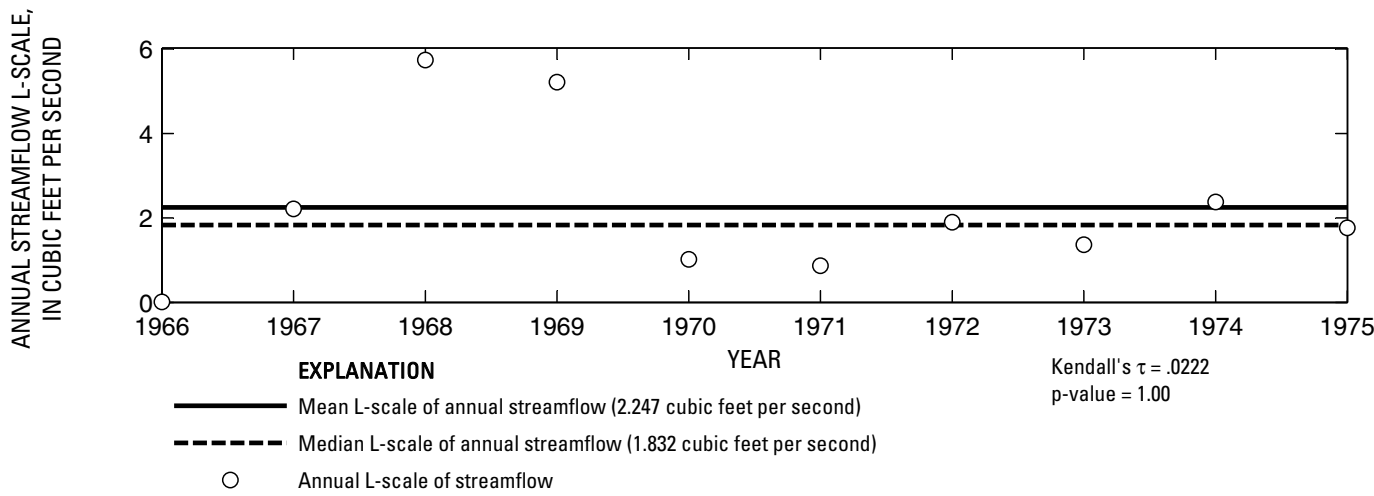

Figure 353. Analysis of annual mean, maximum, minimum, and L-scale statistics of daily mean streamflow for U.S. Geological Survey streamflow-gaging station 08086260 Pecan Creek near Eolian, Texas. 


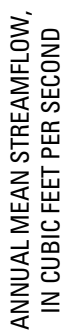

U.S. Geological Survey streamflow-gaging station 08086290

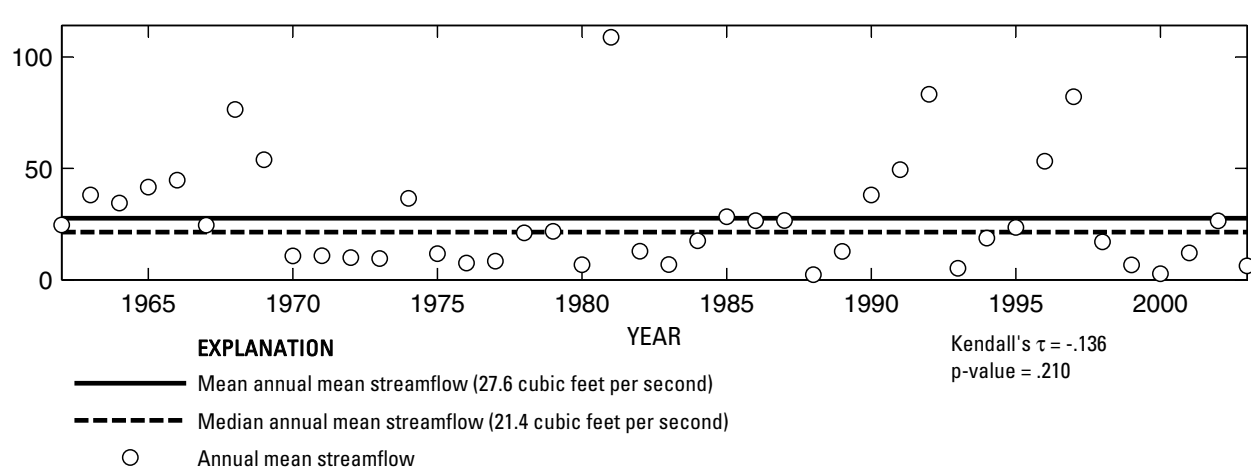

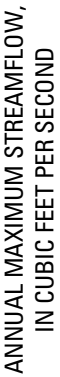
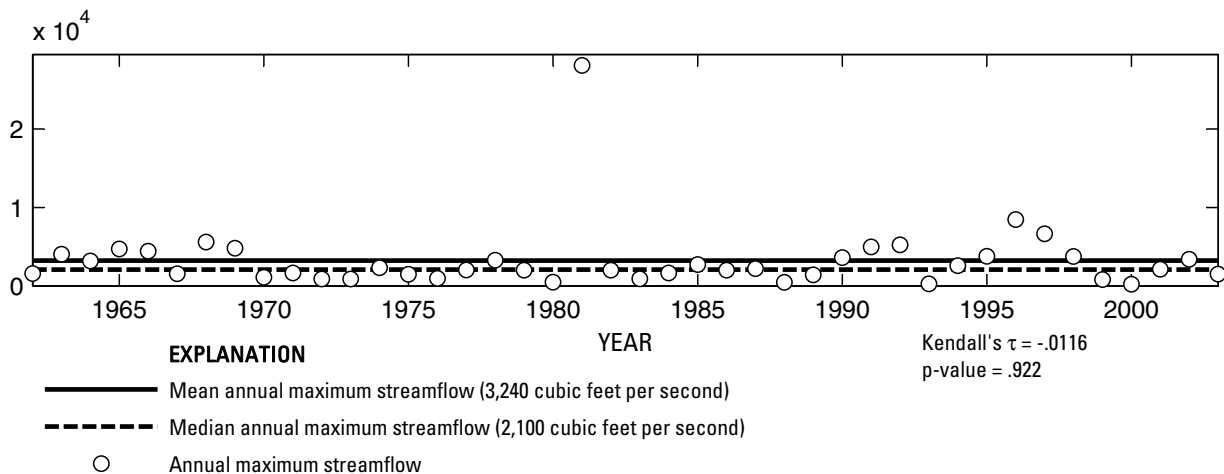

崔

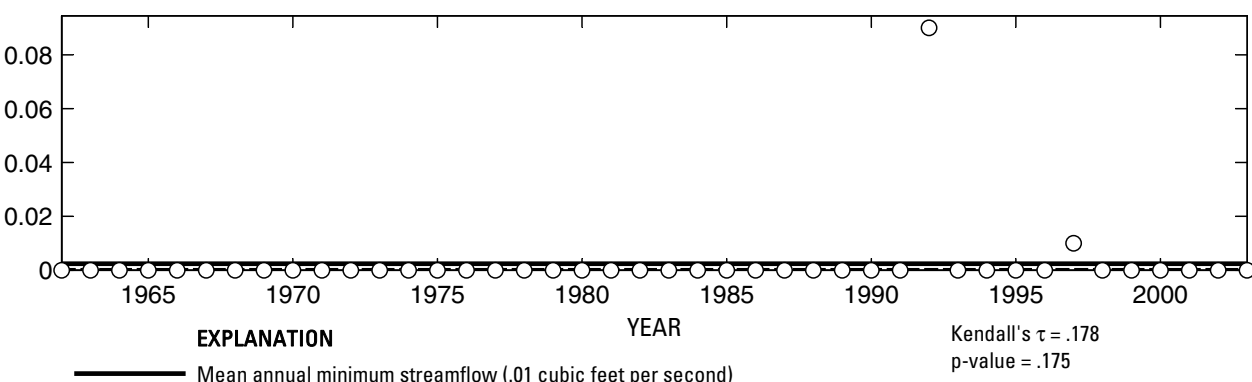

- Median annual minimum streamflow (0 cubic feet per second)

O Annual minimum streamflow

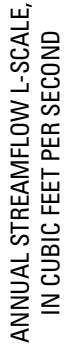

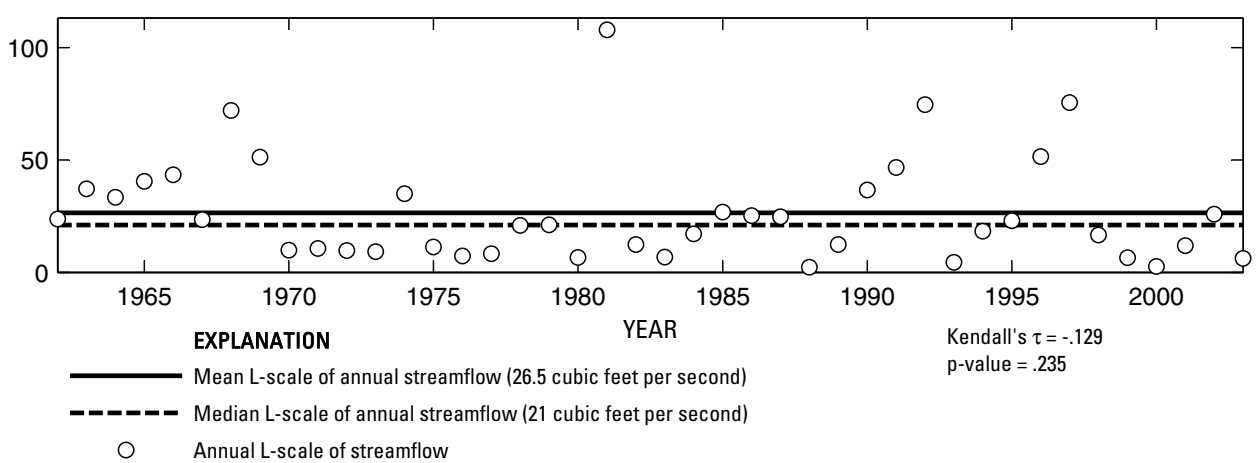

Figure 354. Analysis of annual mean, maximum, minimum, and L-scale statistics of daily mean streamflow for U.S. Geological Survey streamflow-gaging station 08086290 Big Sandy Creek above Breckenridge, Texas.

Index of Station Numbers 719 

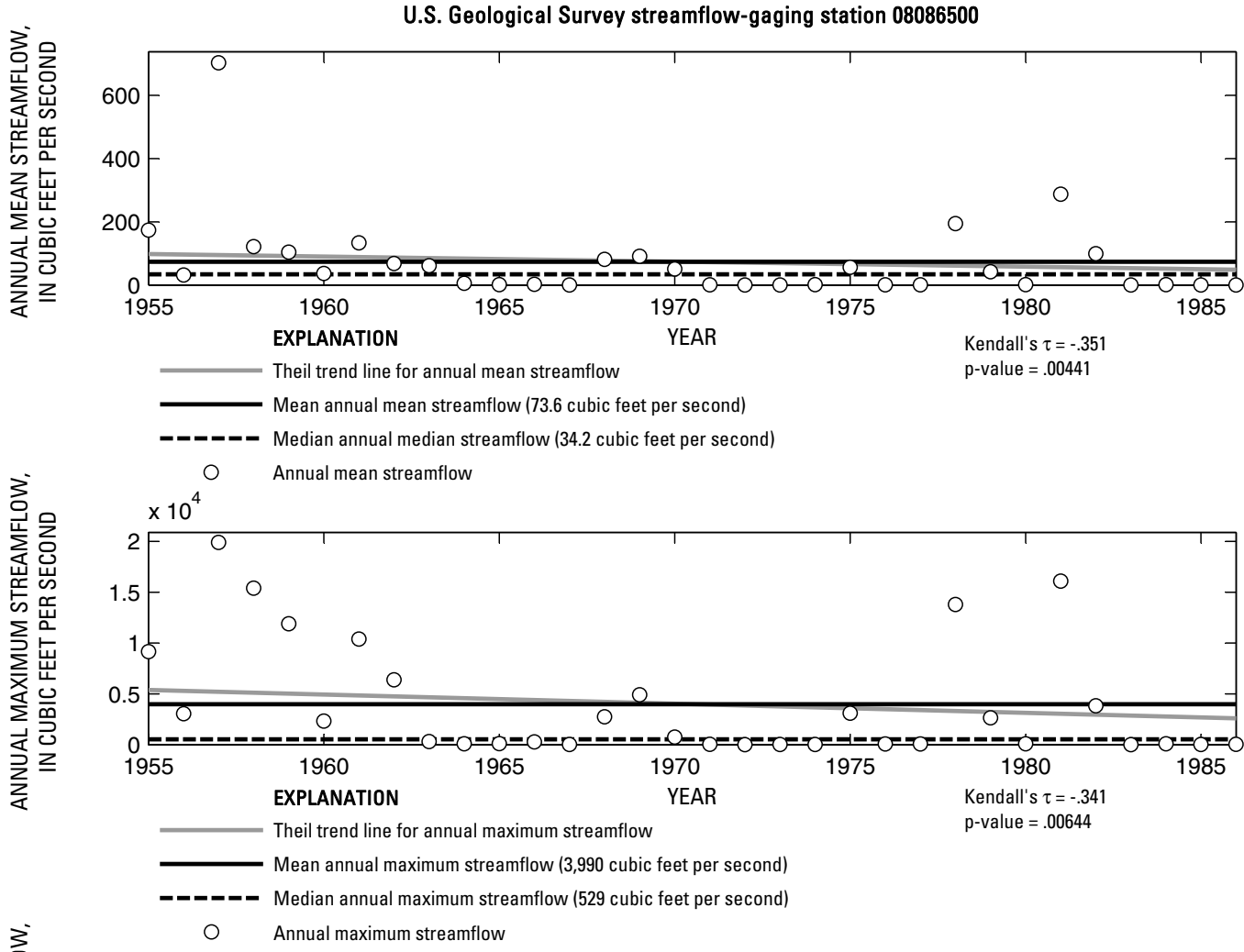

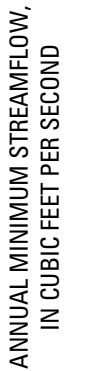

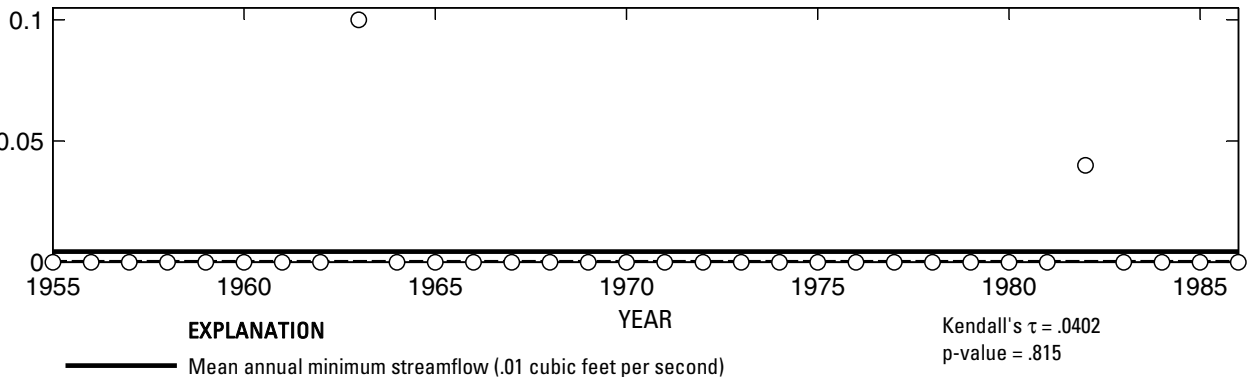

- ב-ב Median annual minimum streamflow (0 cubic feet per second)

O Annual minimum streamflow

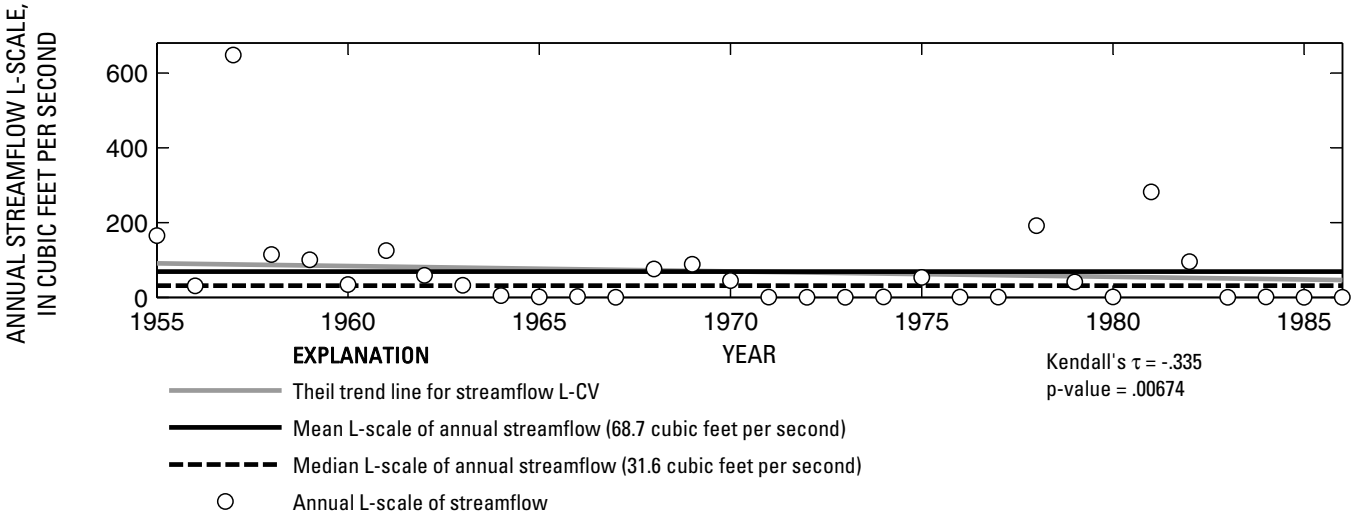

Figure 355. Analysis of annual mean, maximum, minimum, and L-scale statistics of daily mean streamflow for U.S. Geological Survey streamflow-gaging station 08086500 Hubbard Creek near Breckenridge, Texas. 


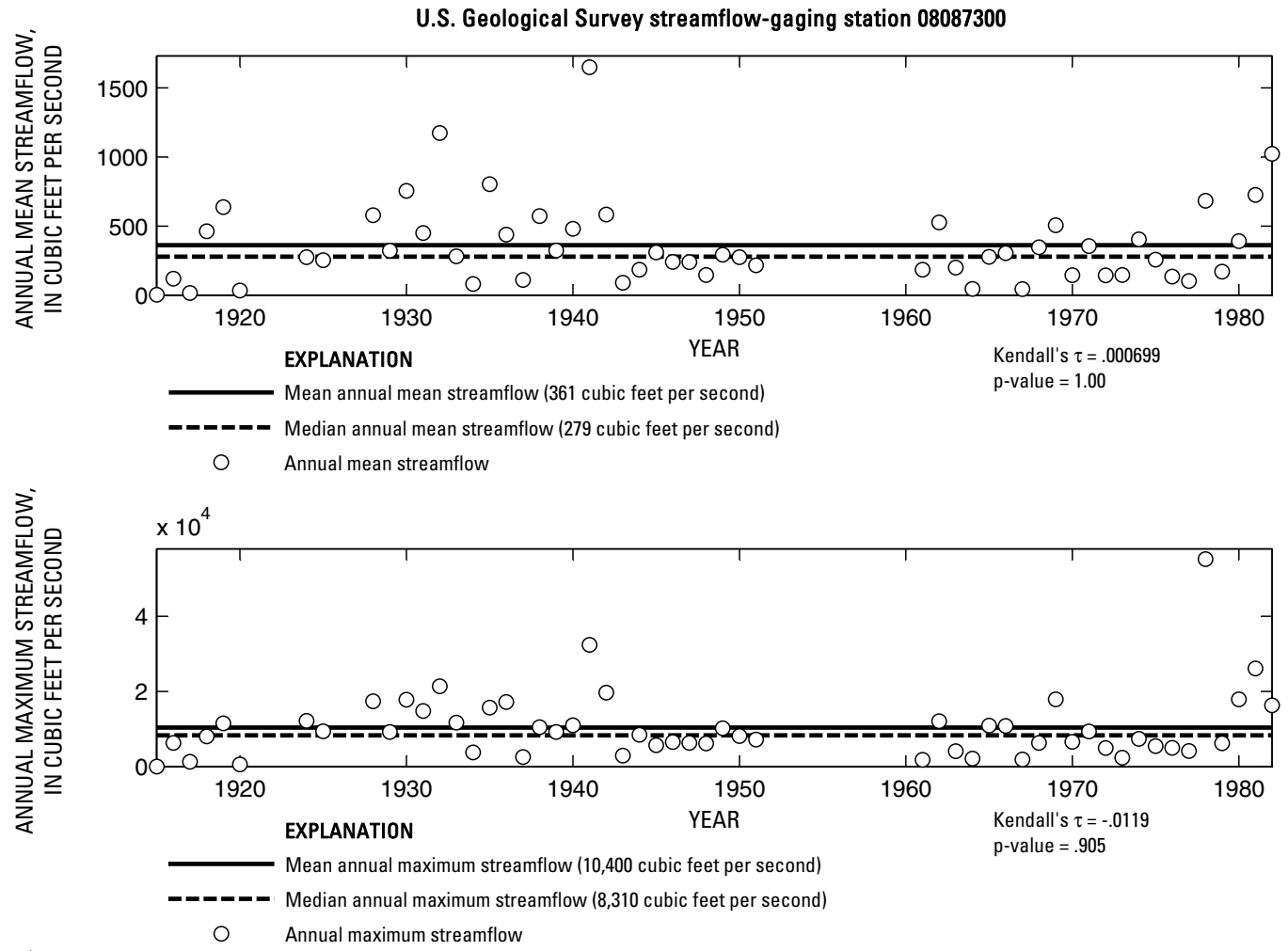

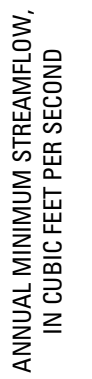
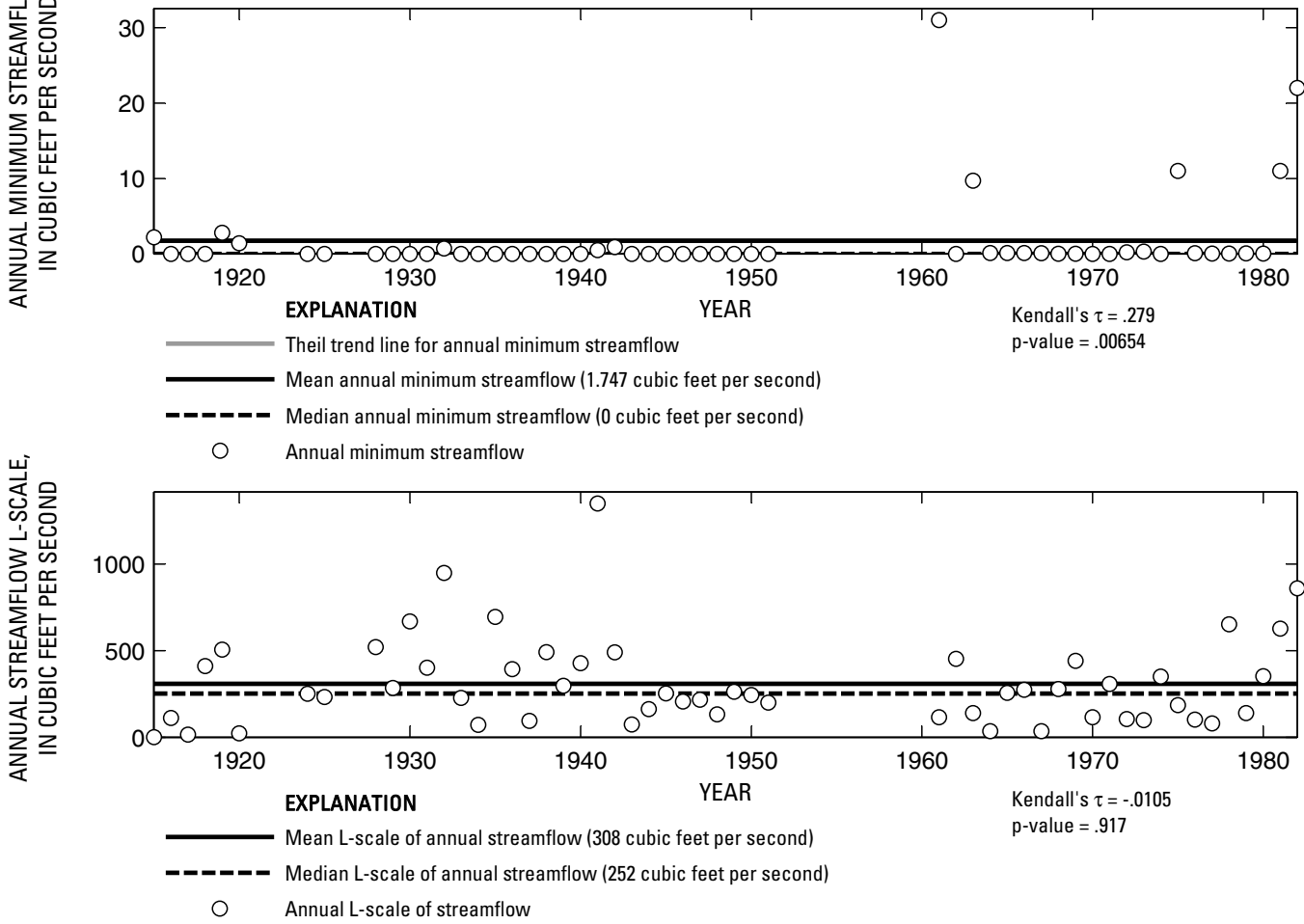

Figure 356. Analysis of annual mean, maximum, minimum, and L-scale statistics of daily mean streamflow for U.S. Geological Survey streamflow-gaging station 08087300 Clear Fork Brazos River at Eliasville, Texas.

Index of Station Numbers 719 

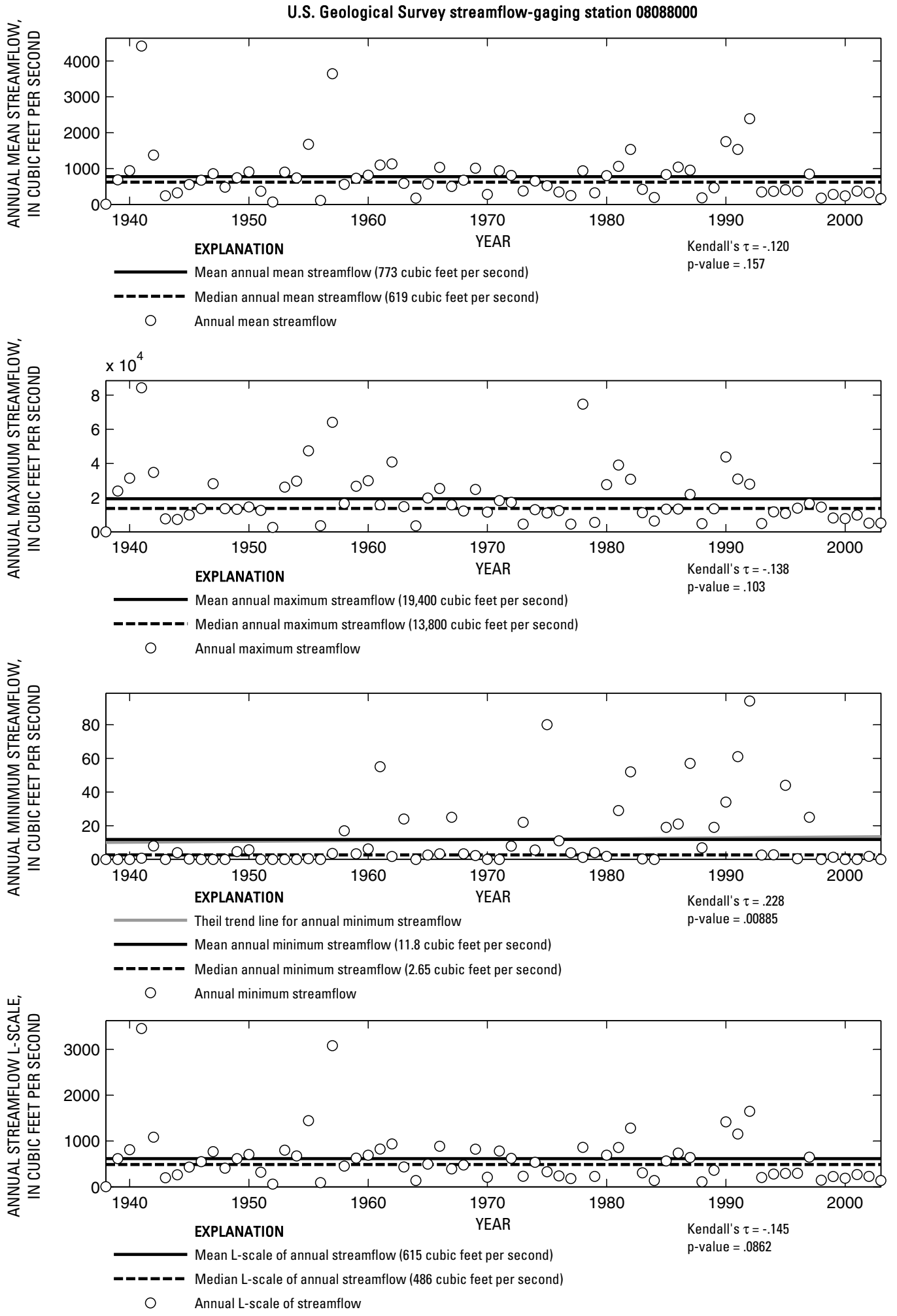

Figure 357. Analysis of annual mean, maximum, minimum, and L-scale statistics of daily mean streamflow for U.S. Geological Survey streamflow-gaging station 08088000 Brazos River near South Bend, Texas. 

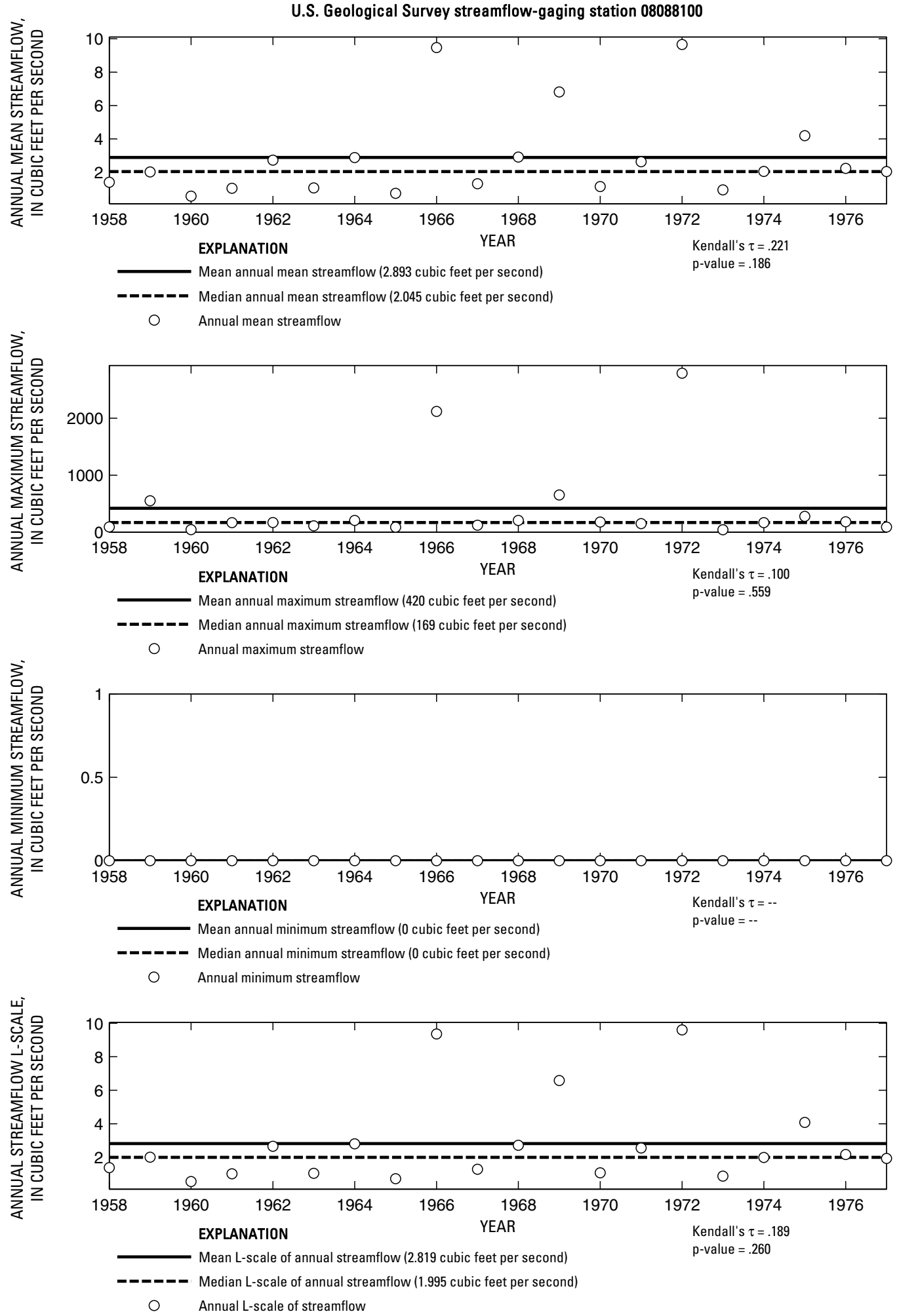

Figure 358. Analysis of annual mean, maximum, minimum, and L-scale statistics of daily mean streamflow for U.S. Geological Survey streamflow-gaging station 08088100 Salt Creek at Olney, Texas.

Index of Station Numbers 719 


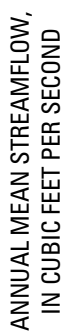

U.S. Geological Survey streamflow-gaging station 08088200

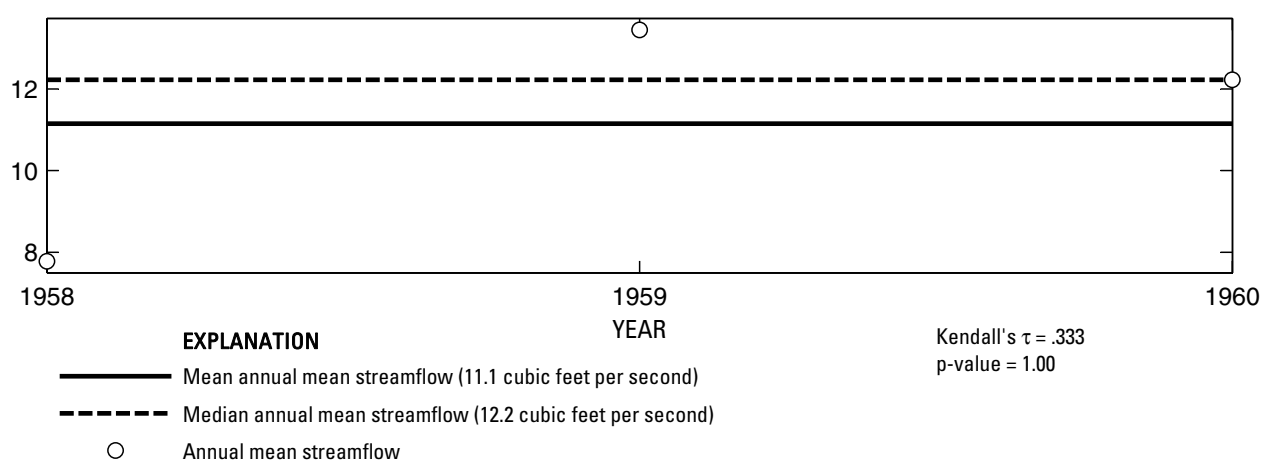

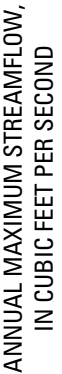

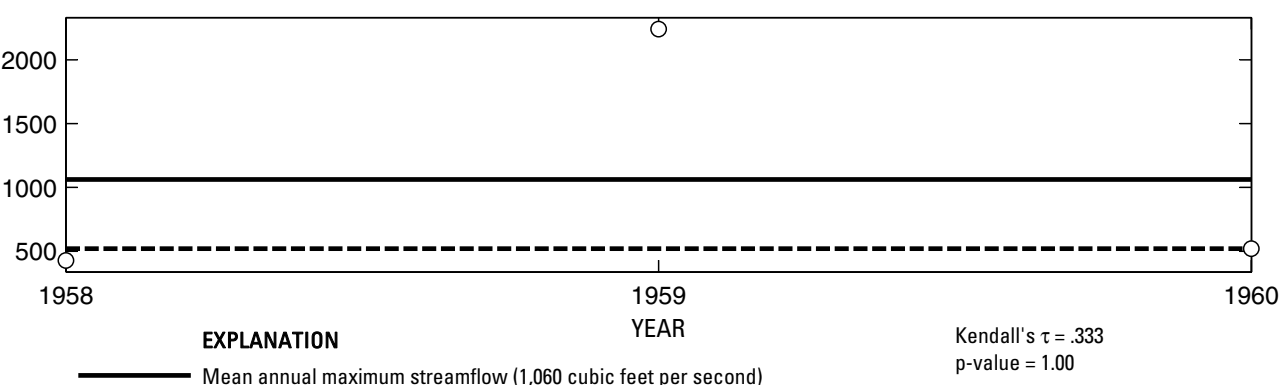

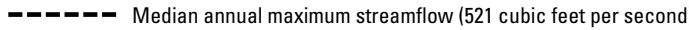

Annual maximum streamflow
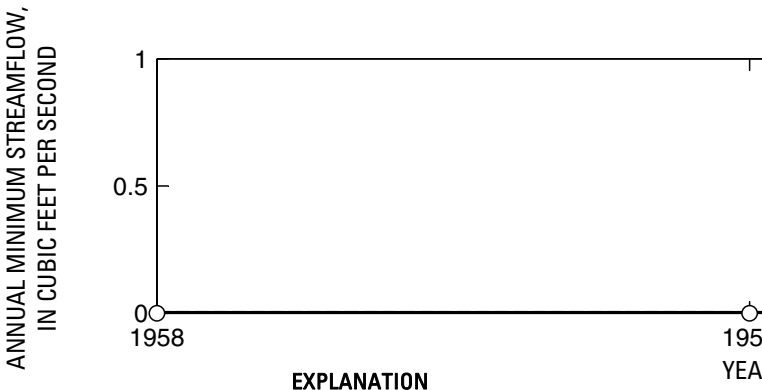

Mean annual minimum streamflow (0 cubic feet per second)

-value $=1.00$

O Annual minimum streamflow
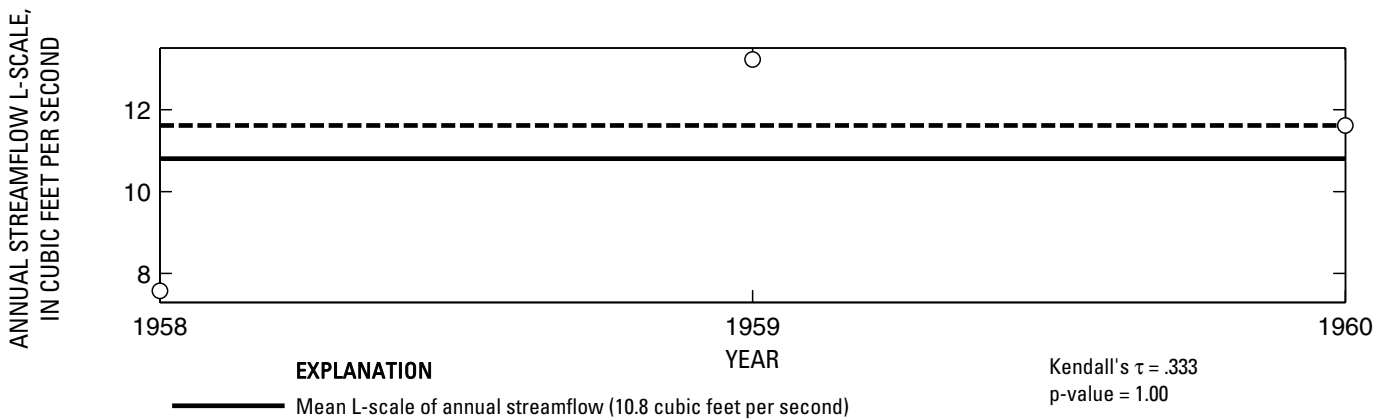

- - - - Median L-scale of annual streamflow (11.6 cubic feet per second)

O Annual L-scale of streamflow

Figure 359. Analysis of annual mean, maximum, minimum, and L-scale statistics of daily mean streamflow for U.S. Geological Survey streamflow-gaging station 08088200 Salt Creek near Newcastle, Texas. 


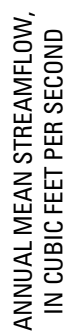

U.S. Geological Survey streamflow-gaging station 08088300

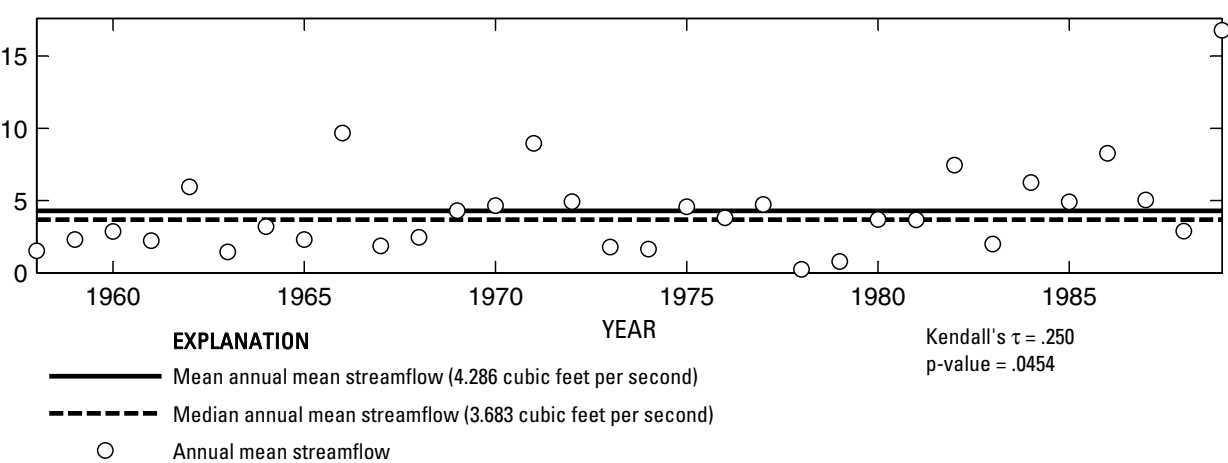

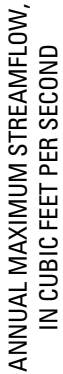

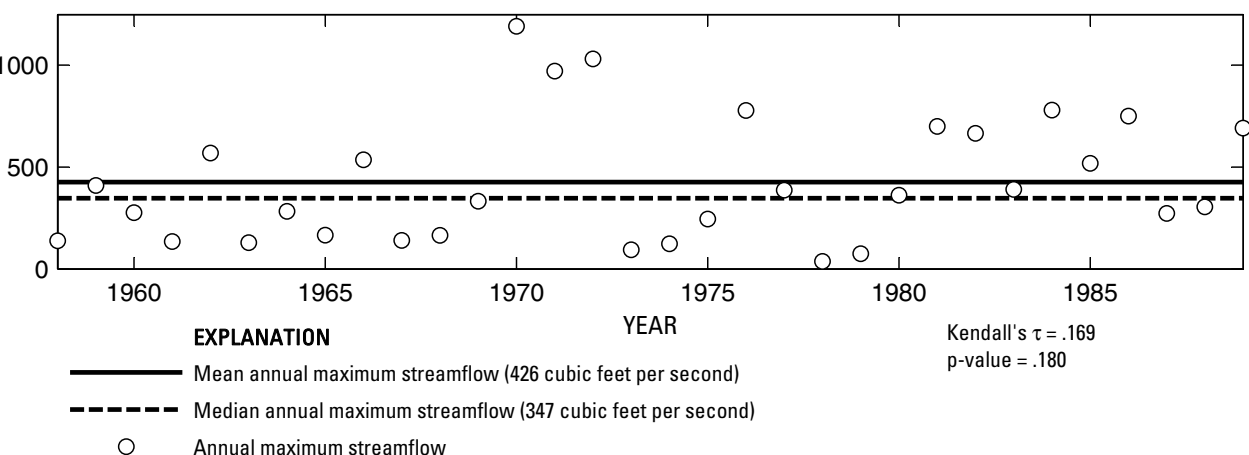

焉

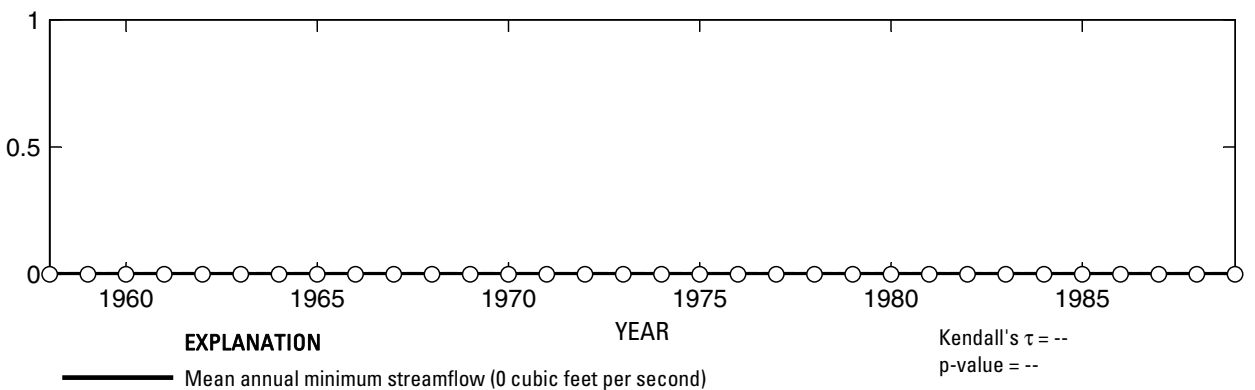

- Median annual minimum streamflow (0 cubic feet per second)

O Annual minimum streamflow

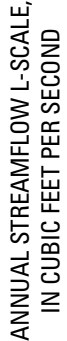

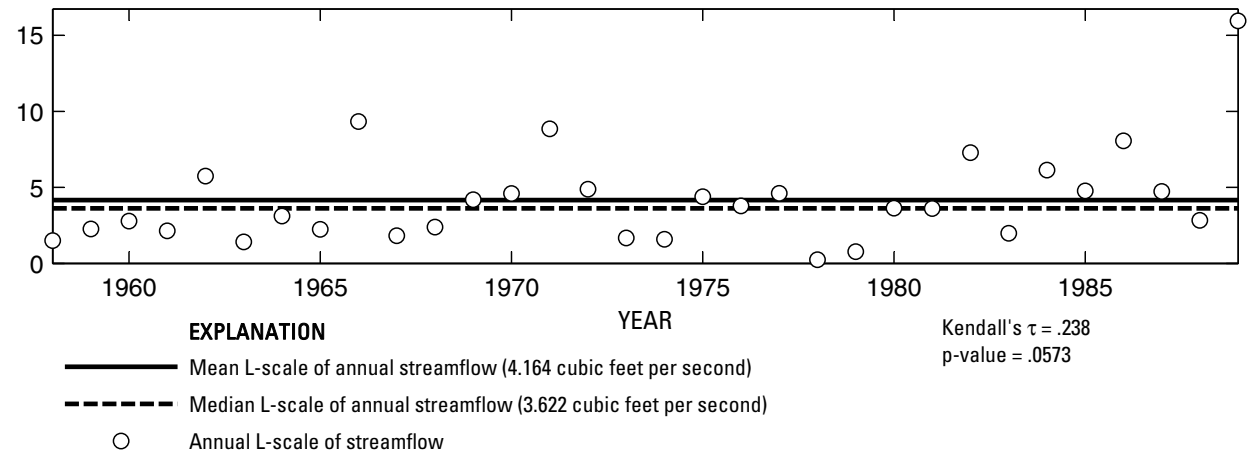

Figure 360. Analysis of annual mean, maximum, minimum, and L-scale statistics of daily mean streamflow for U.S. Geological Survey streamflow-gaging station 08088300 Briar Creek near Graham, Texas.

Index of Station Numbers 719 

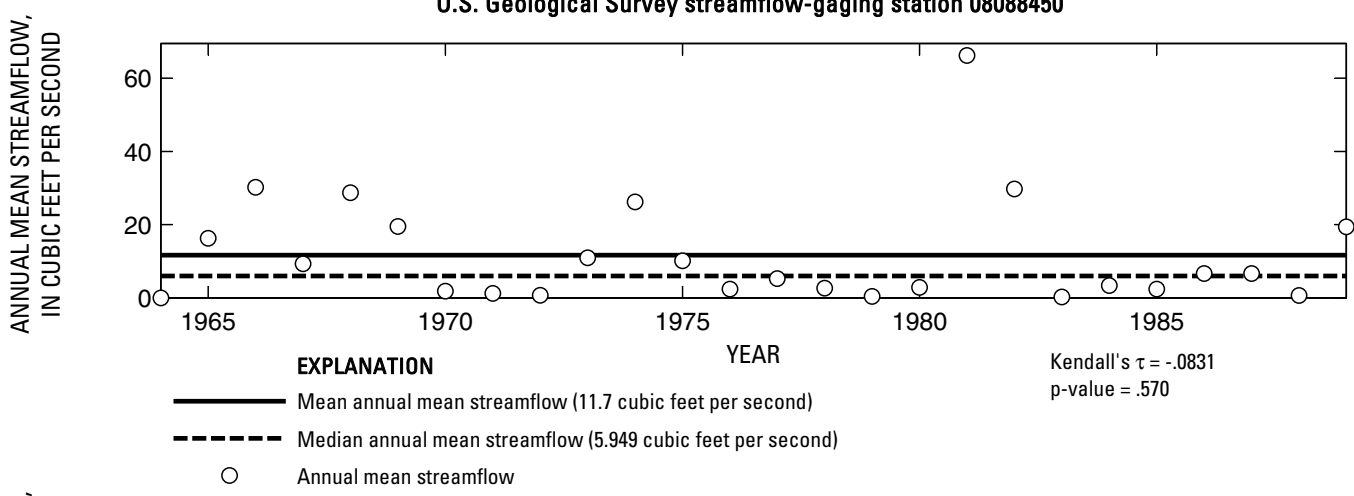

空 15000
10000
5000
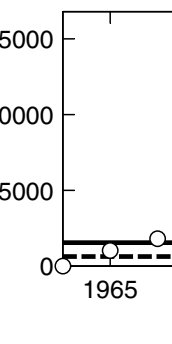


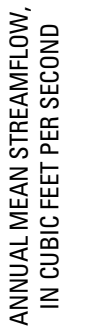

U.S. Geological Survey streamflow-gaging station 08088600

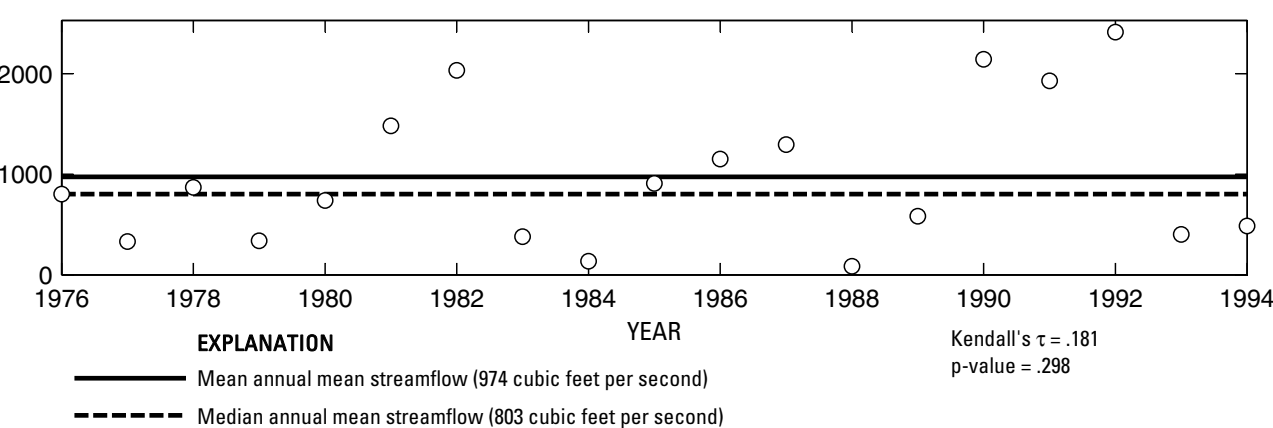

O Annual mean streamflow
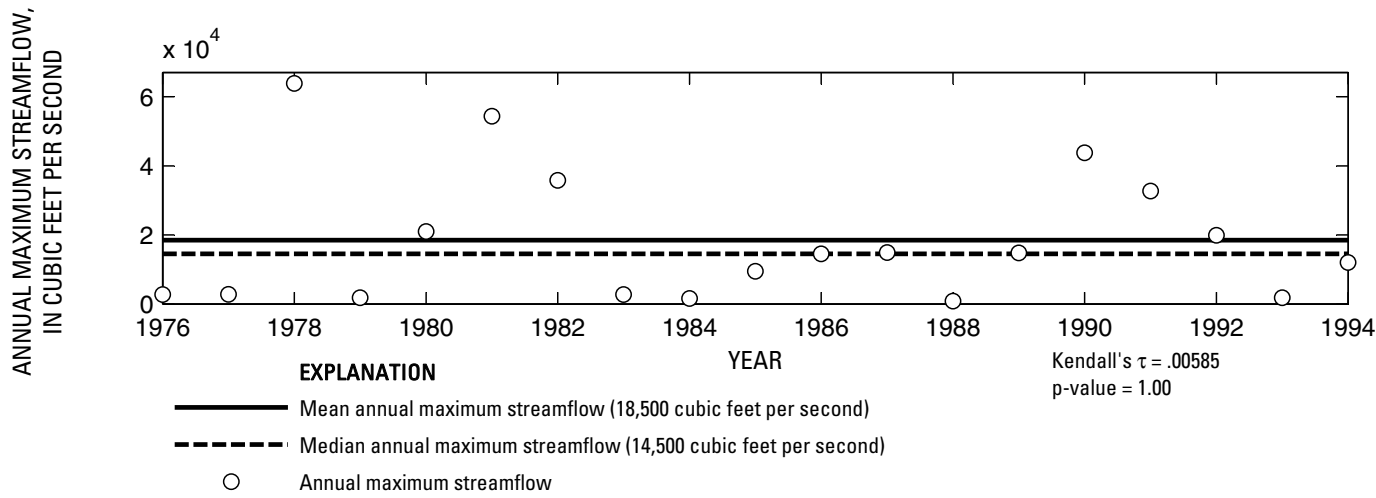

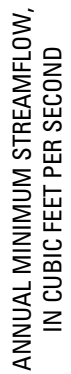

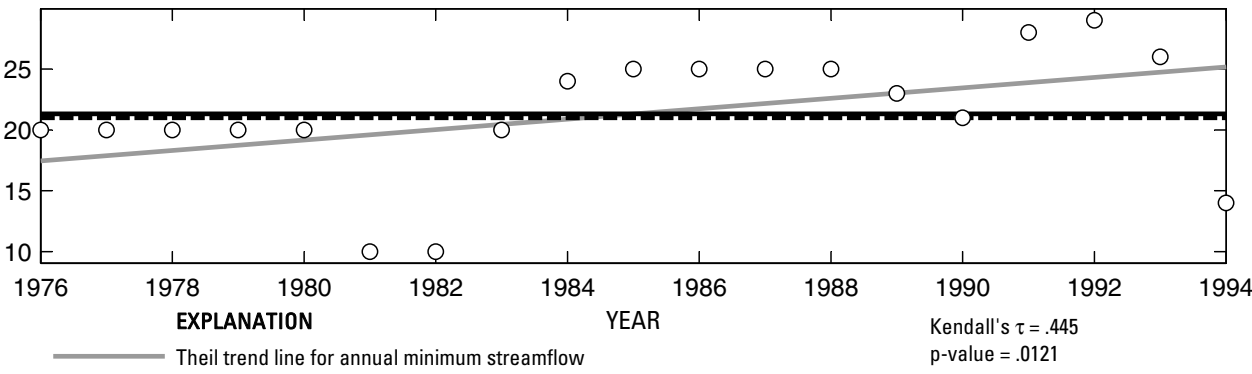

Theil trend line for annual minimum streamflow $\mathrm{p}$-value $=.0121$

Mean annual minimum streamflow (21.3 cubic feet per second)

- Median annual minimum streamflow (21 cubic feet per second)

O Annual minimum streamflow
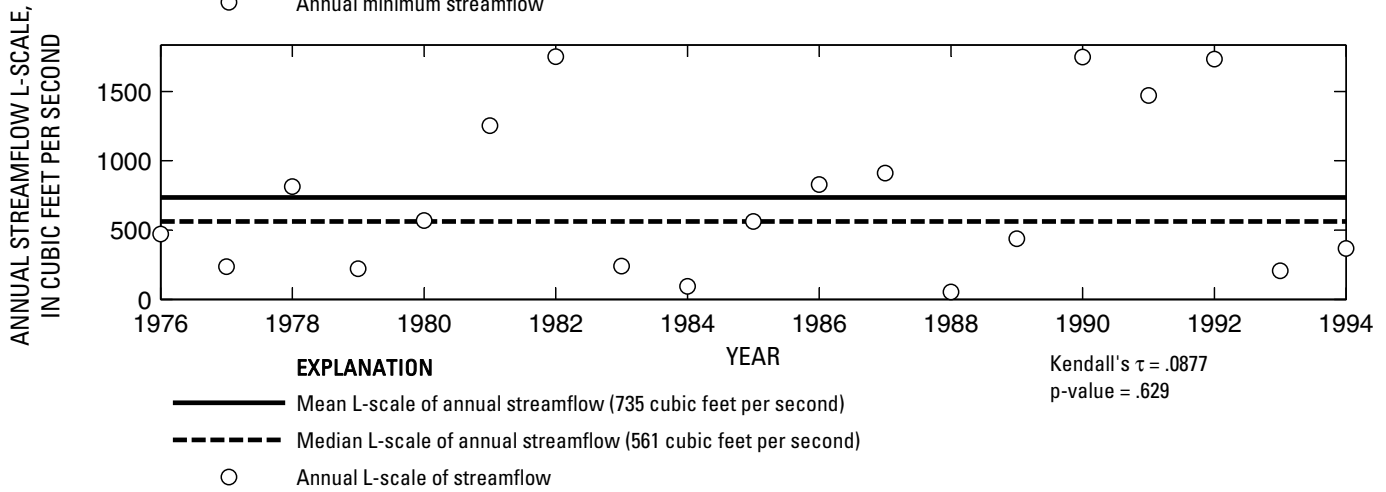

Figure 362. Analysis of annual mean, maximum, minimum, and L-scale statistics of daily mean streamflow for U.S. Geological Survey streamflow-gaging station 08088600 Brazos River at Morris Sheppard Dam near Graford, Texas.

Index of Station Numbers 719 

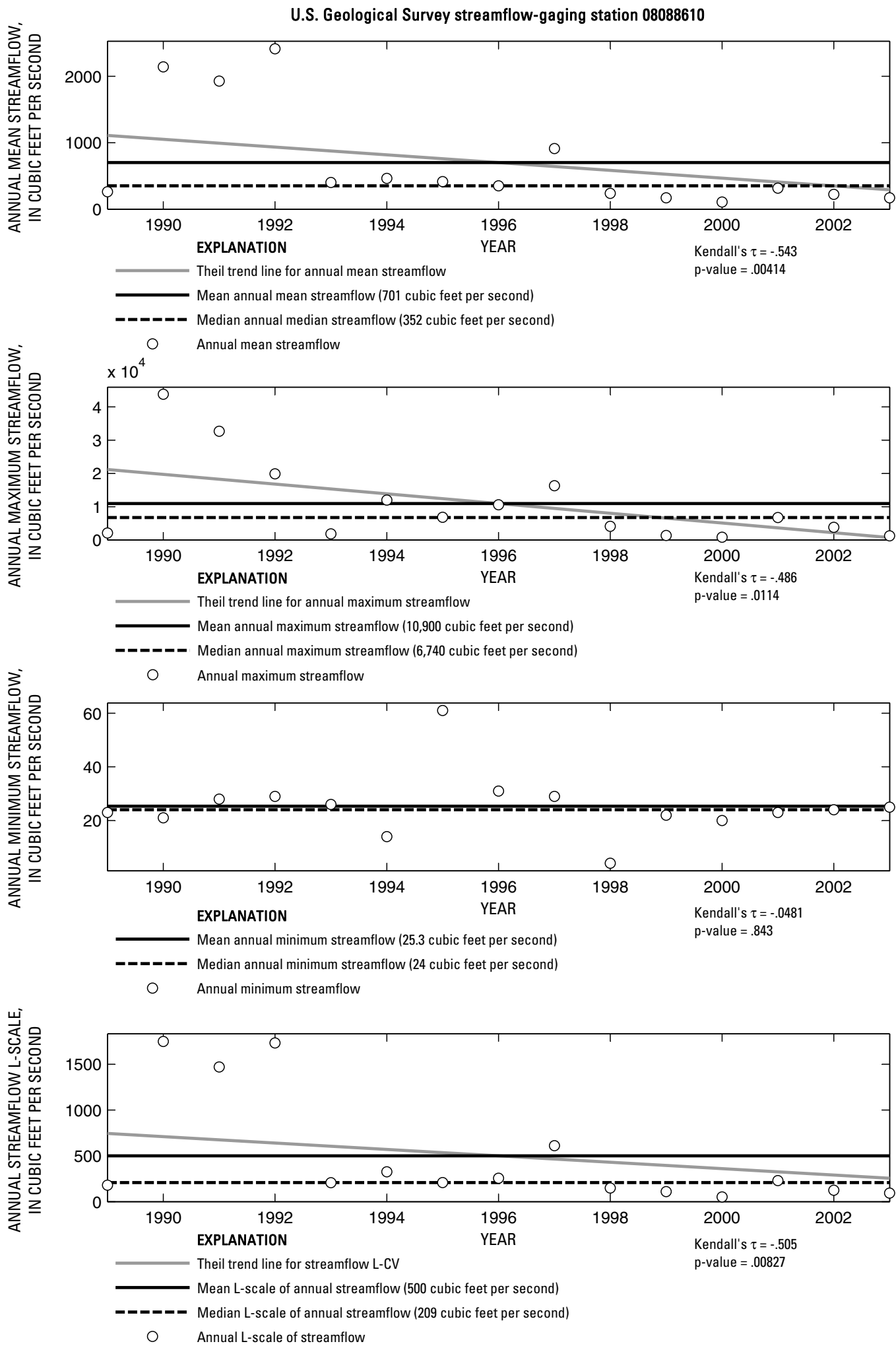

Figure 363. Analysis of annual mean, maximum, minimum, and L-scale statistics of daily mean streamflow for U.S. Geological Survey streamflow-gaging station 08088610 Brazos River near Graford, Texas. 


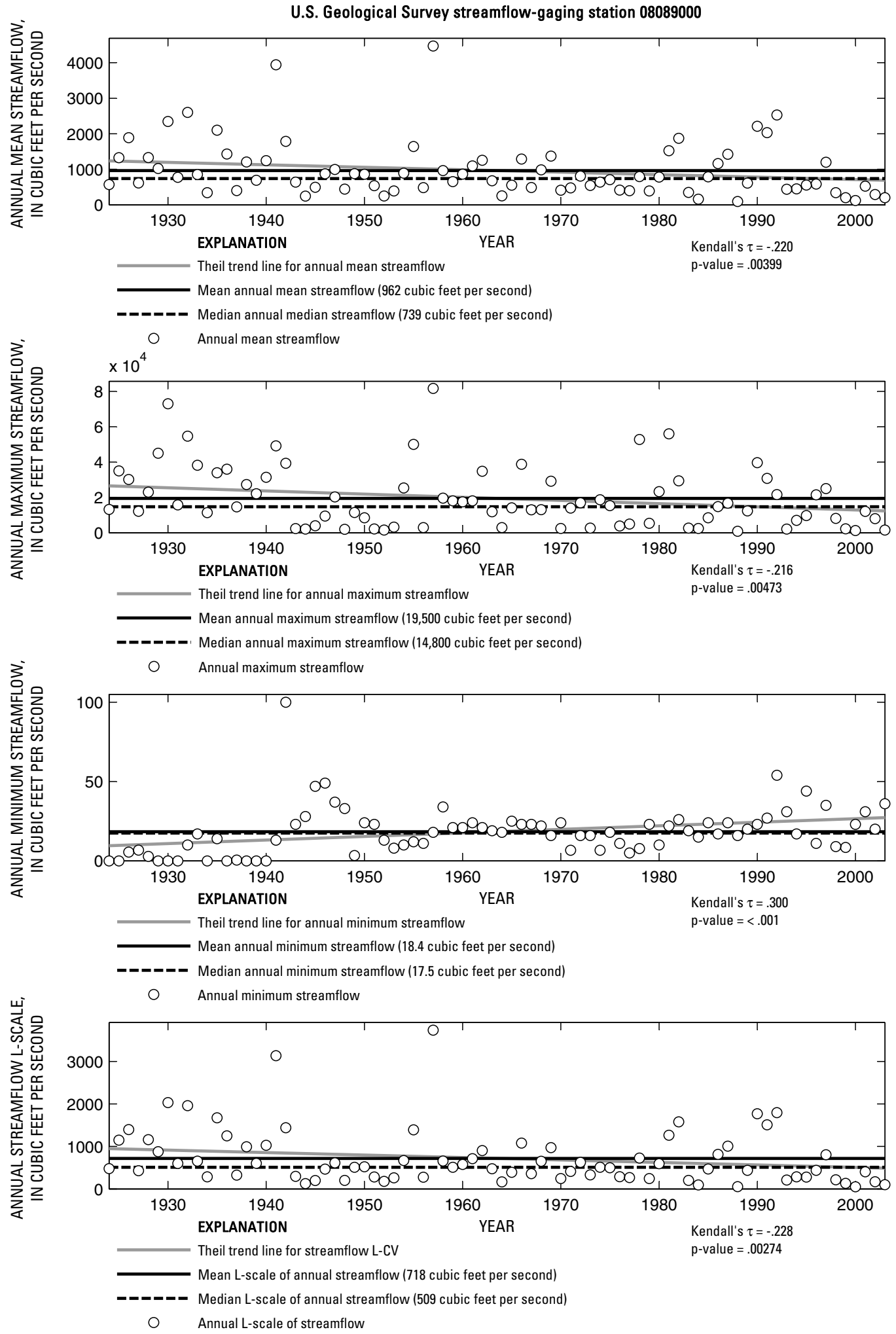

Figure 364. Analysis of annual mean, maximum, minimum, and L-scale statistics of daily mean streamflow for U.S. Geological Survey streamflow-gaging station 08089000 Brazos River near Palo Pinto, Texas.

Index of Station Numbers 719 

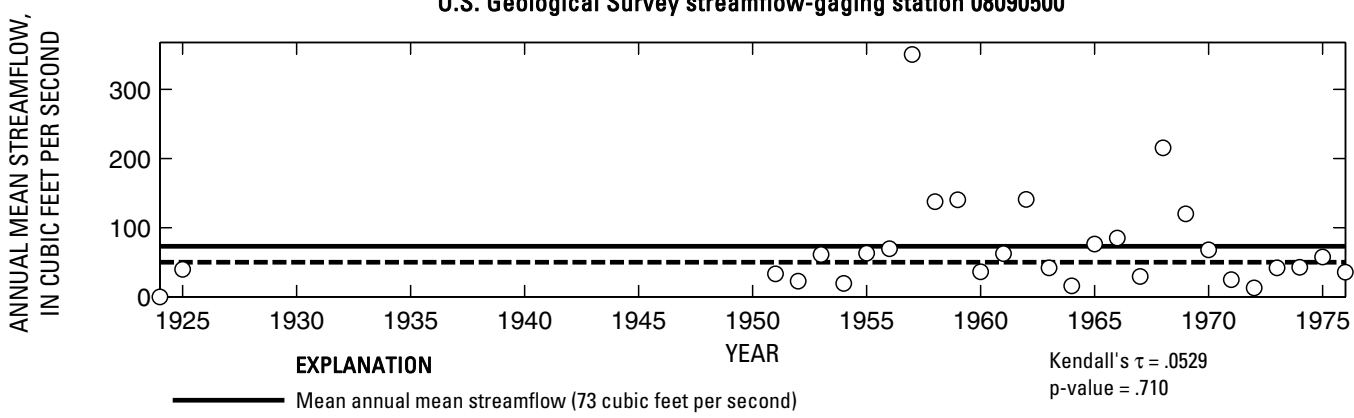

-_-_- Median annual mean streamflow (50.1 cubic feet per second)

O Annual mean streamflow
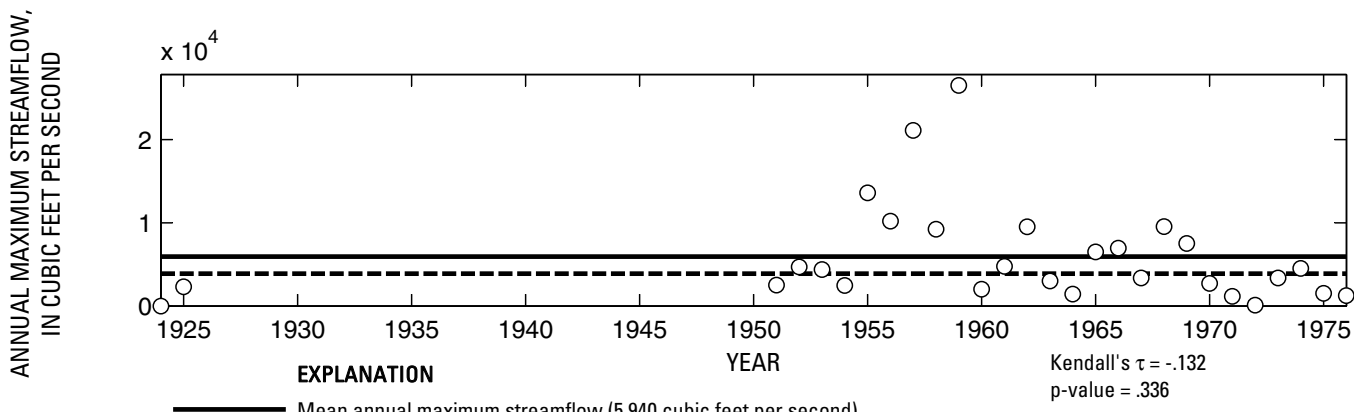

- _ - Median annual maximum streamflow (3,880 cubic feet per second)

O Annual maximum streamflow

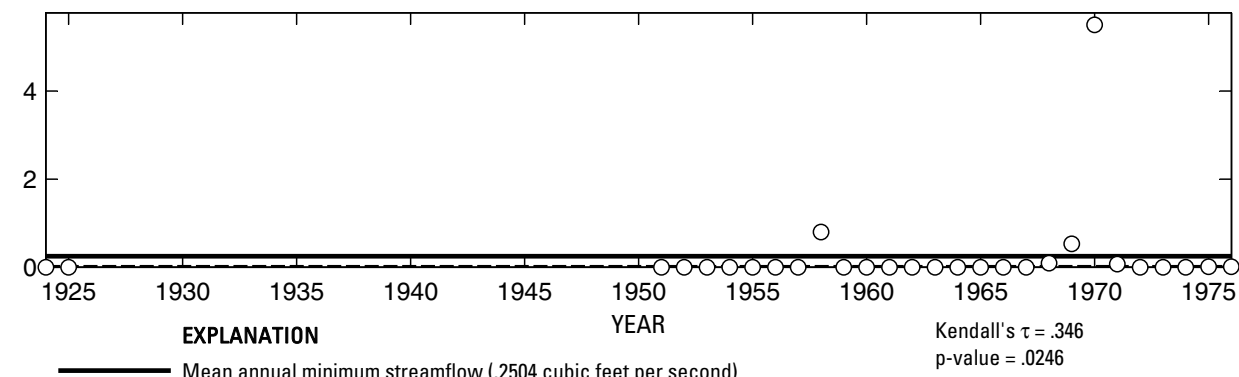

- - Median annual minimum streamflow (0 cubic feet per second)

O Annual minimum streamflow

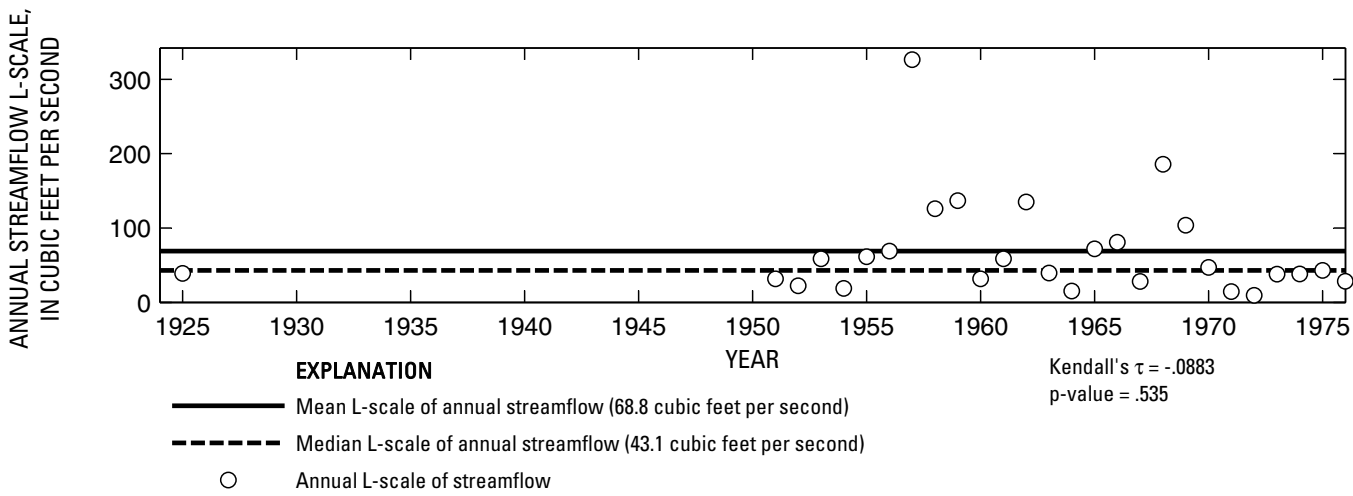

Figure 365. Analysis of annual mean, maximum, minimum, and L-scale statistics of daily mean streamflow for U.S. Geological Survey streamflow-gaging station 08090500 Palo Pinto Creek near Santo, Texas. 

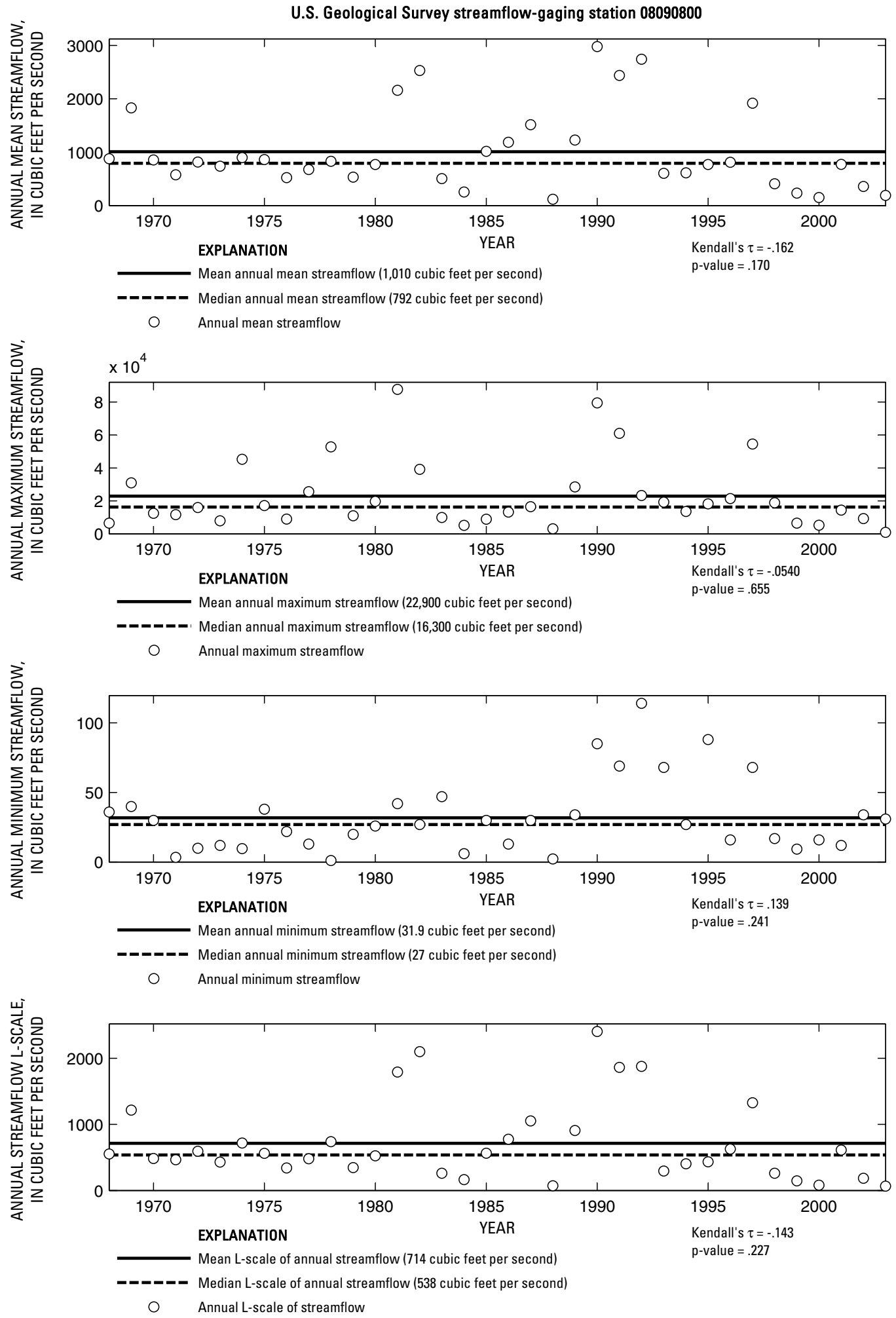

Figure 366. Analysis of annual mean, maximum, minimum, and L-scale statistics of daily mean streamflow for U.S. Geological Survey streamflow-gaging station 08090800 Brazos River near Dennis, Texas.

Index of Station Numbers 719 


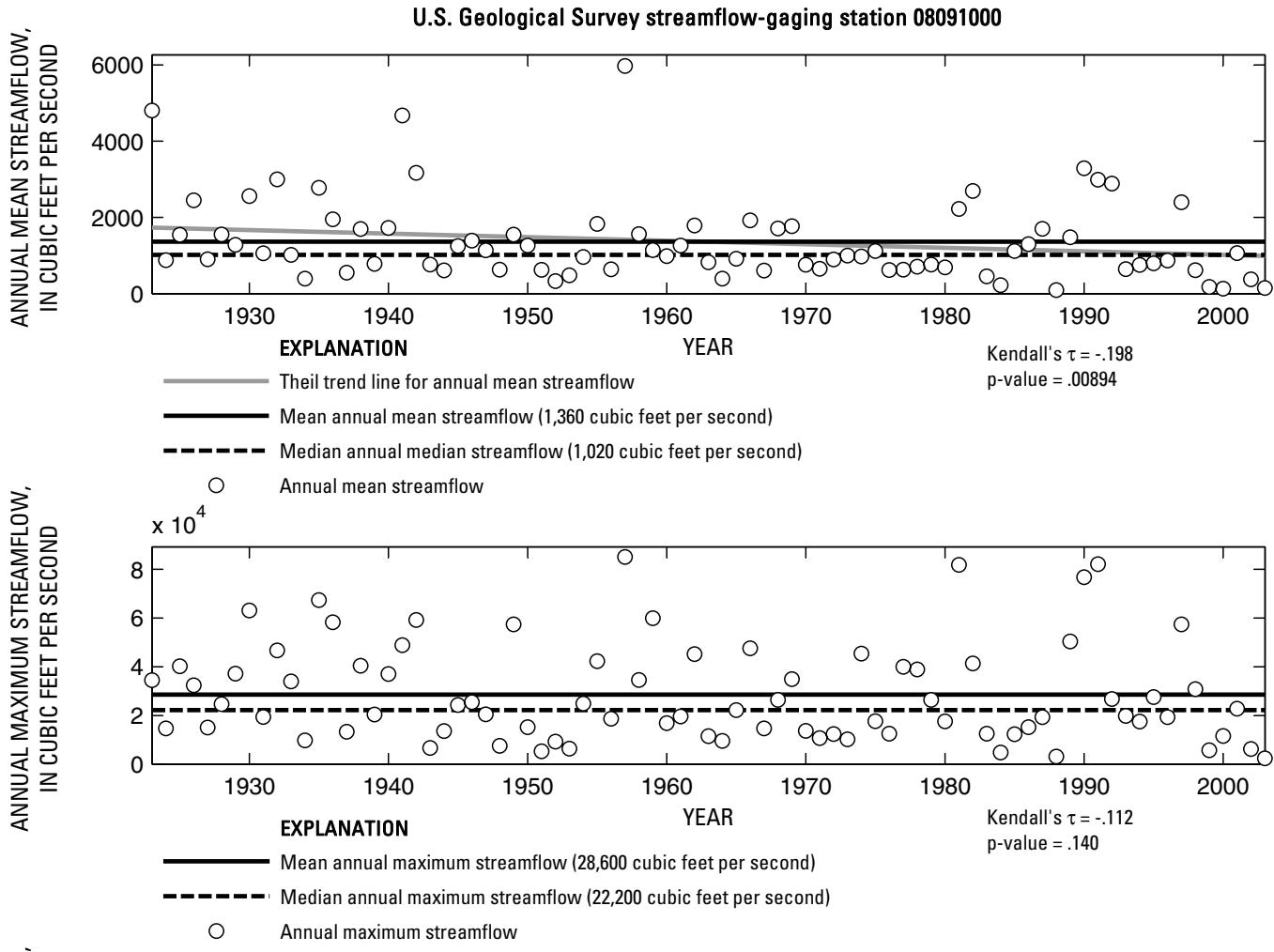

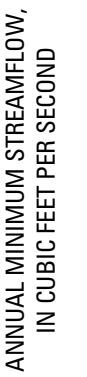

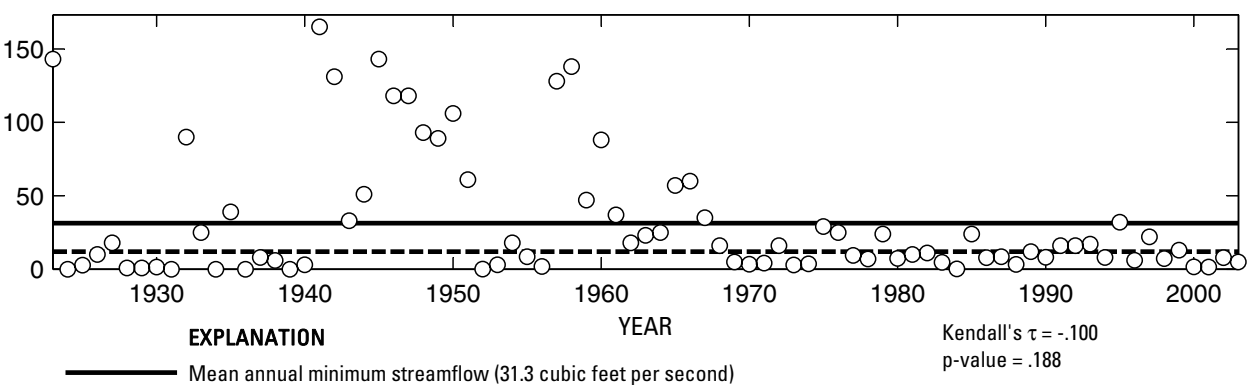

- - - Median annual minimum streamflow (12 cubic feet per second)

○ Annual minimum streamflow

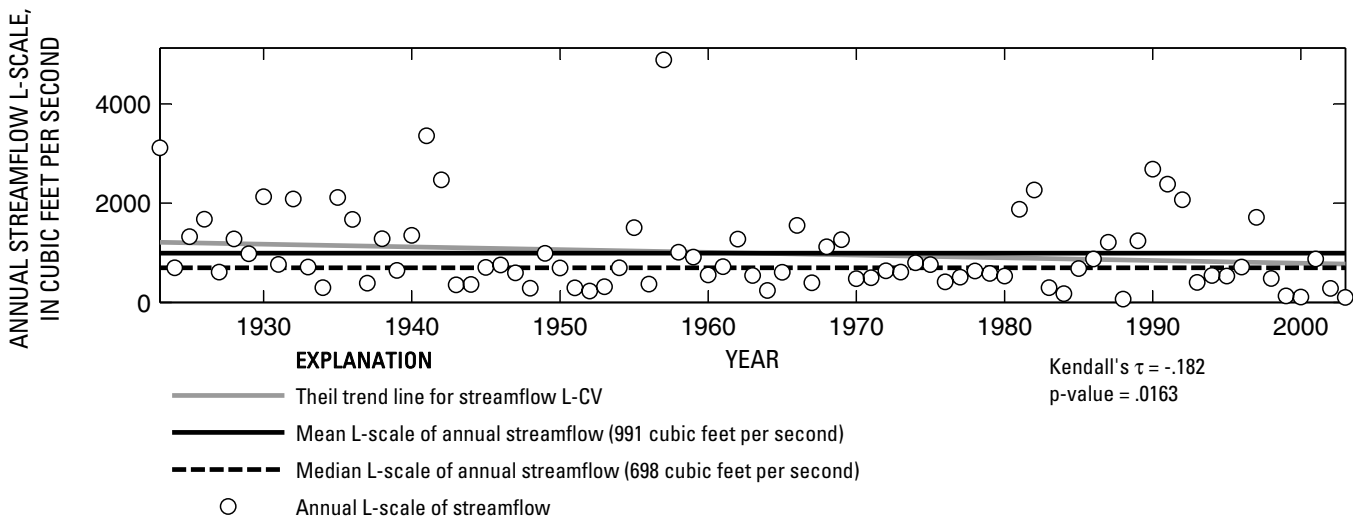

Figure 367. Analysis of annual mean, maximum, minimum, and L-scale statistics of daily mean streamflow for U.S. Geological Survey streamflow-gaging station 08091000 Brazos River near Glen Rose, Texas. 

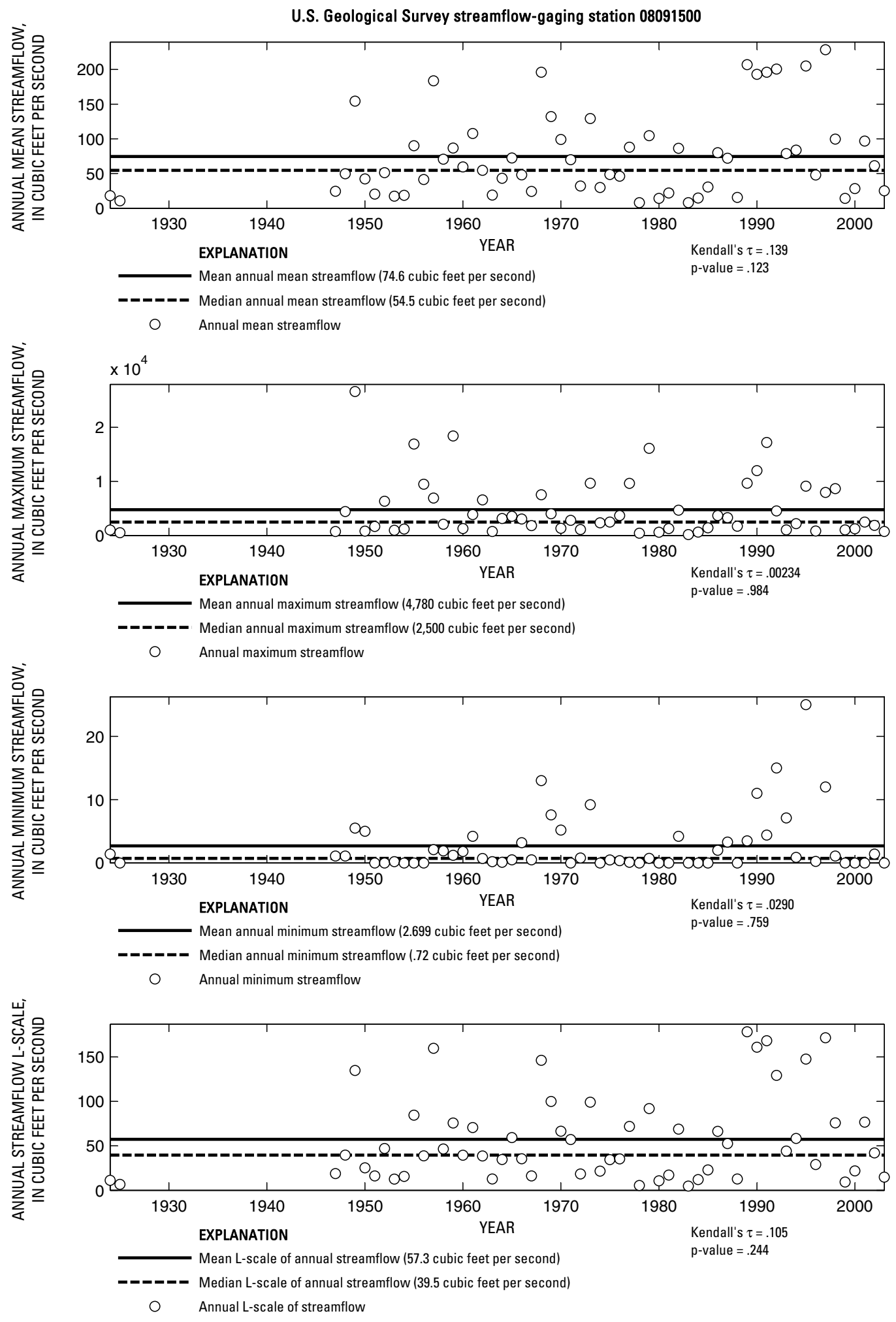

Figure 368. Analysis of annual mean, maximum, minimum, and L-scale statistics of daily mean streamflow for U.S. Geological Survey streamflow-gaging station 08091500 Paluxy River at Glen Rose, Texas. 


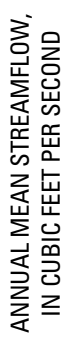

U.S. Geological Survey streamflow-gaging station 08091750

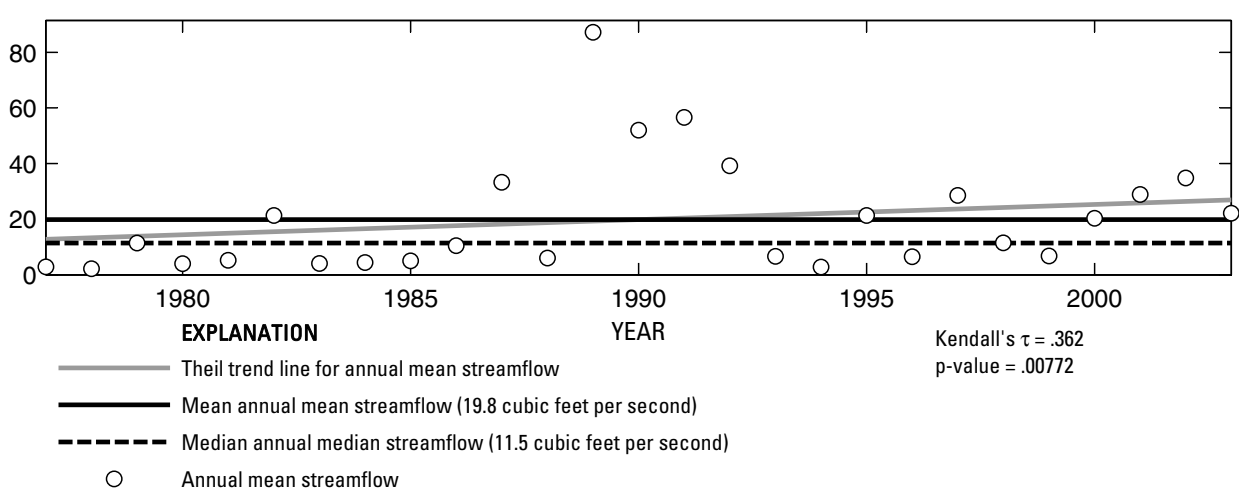

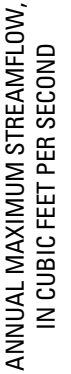
4000
3000
2000
1000
0

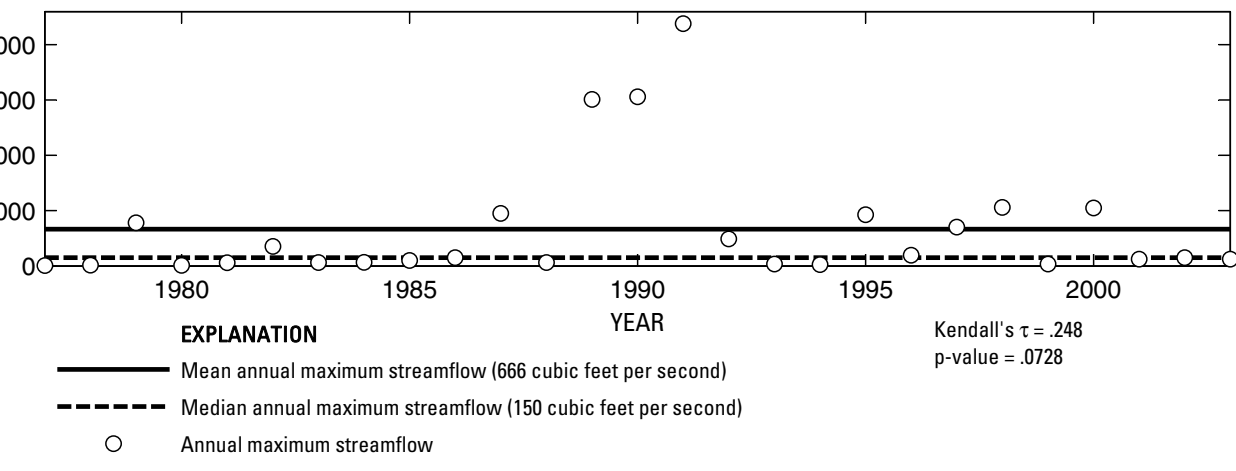

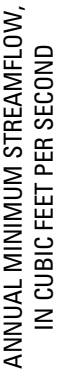

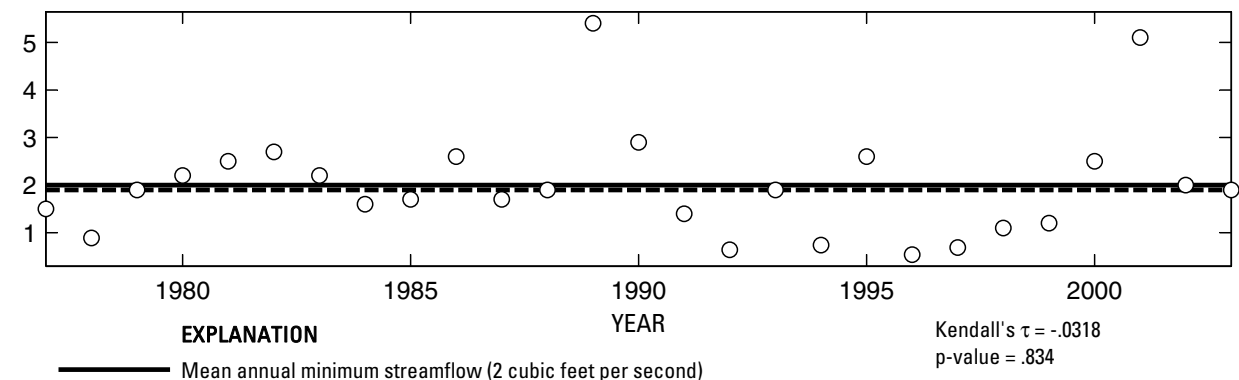

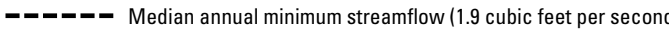

○ Annual minimum streamflow

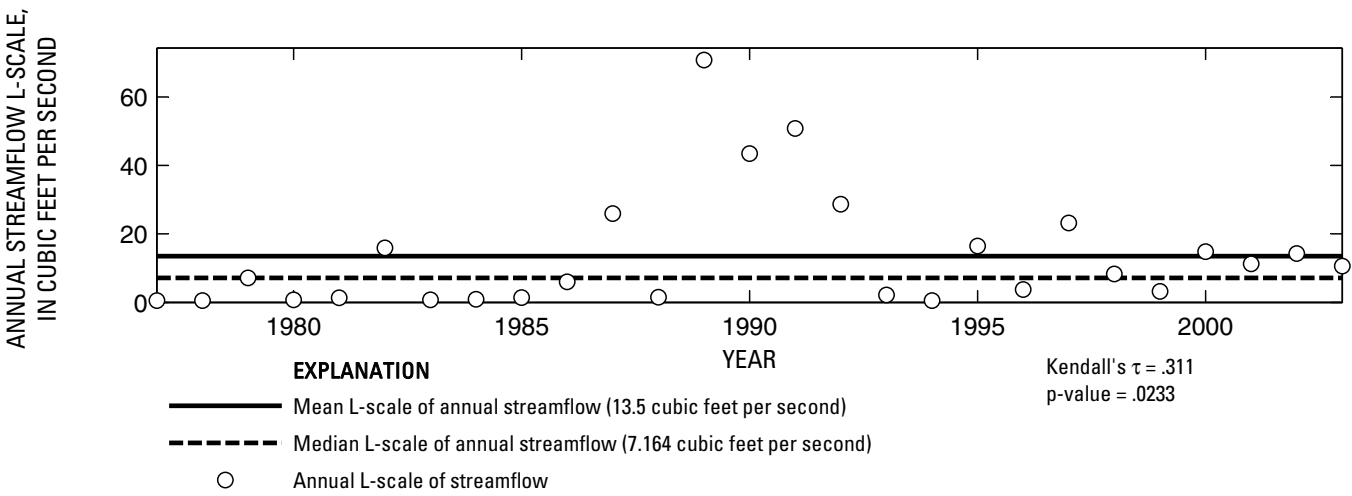

Figure 369. Analysis of annual mean, maximum, minimum, and L-scale statistics of daily mean streamflow for U.S. Geological Survey streamflow-gaging station 08091750 Squaw Creek near Glen Rose, Texas. 

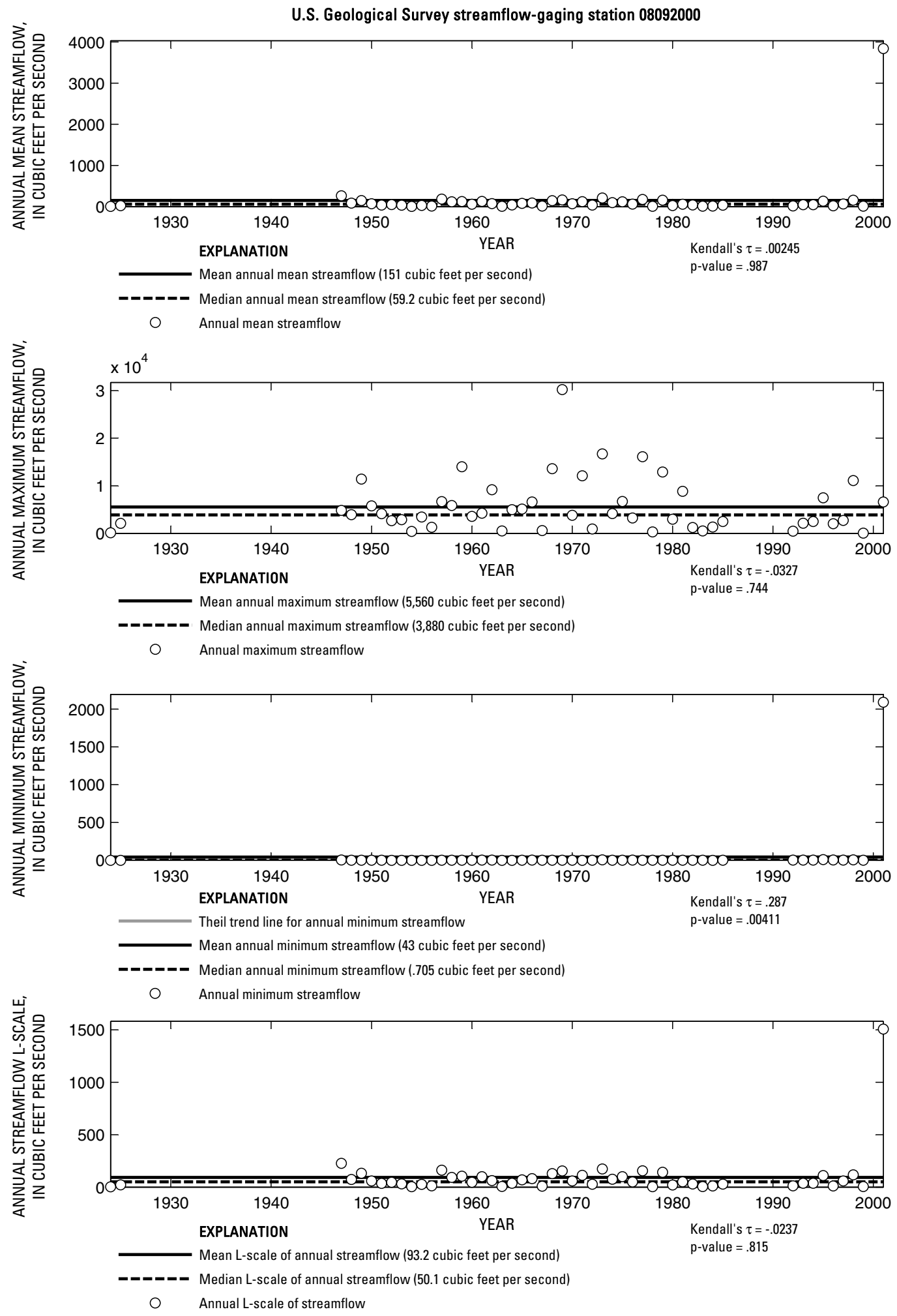

Figure 370. Analysis of annual mean, maximum, minimum, and L-scale statistics of daily mean streamflow for U.S. Geological Survey streamflow-gaging station 08092000 Nolan River at Blum, Texas.

Index of Station Numbers 719 


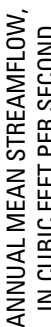

U.S. Geological Survey streamflow-gaging station 08092600

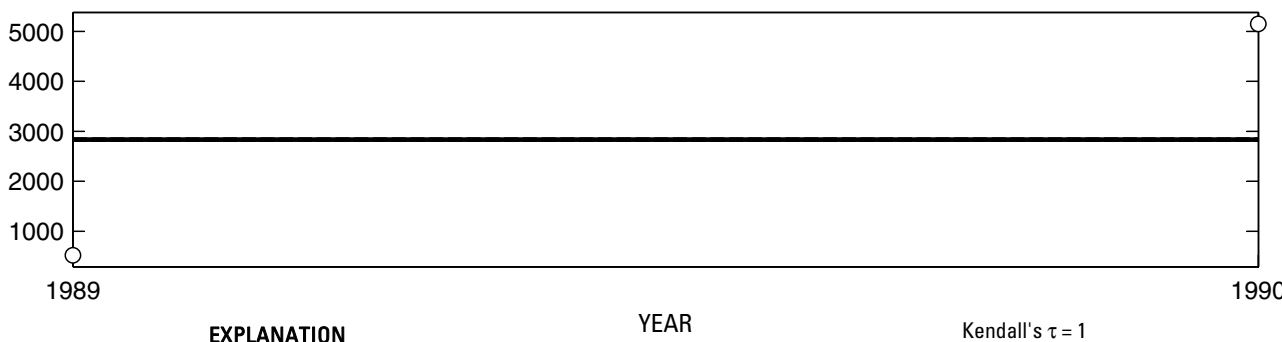

-___ Median annual mean streamflow (2,830 cubic feet per second)

O Annual mean streamflow

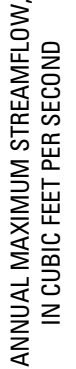
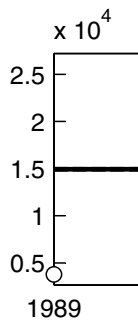

1989

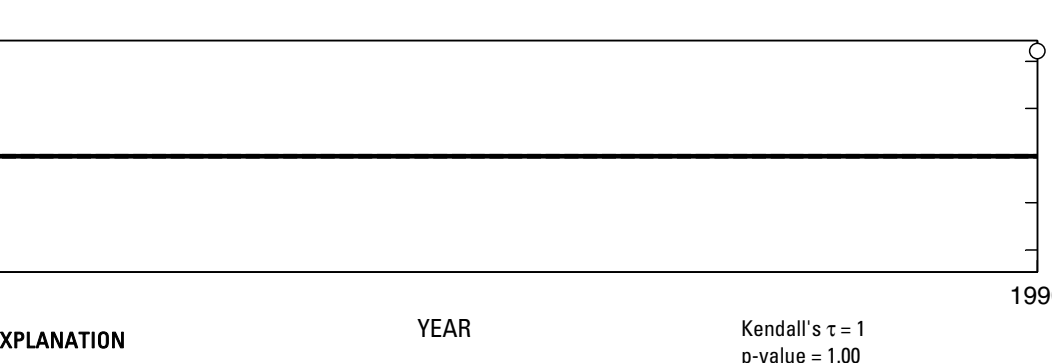

O Annual maximum streamflow

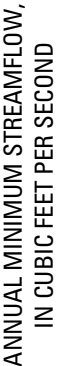

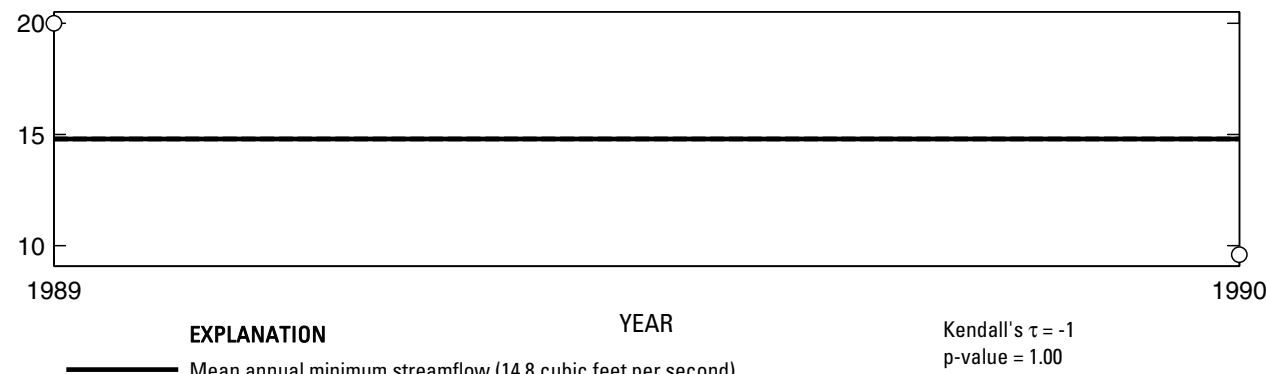

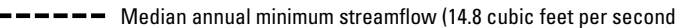

O Annual minimum streamflow

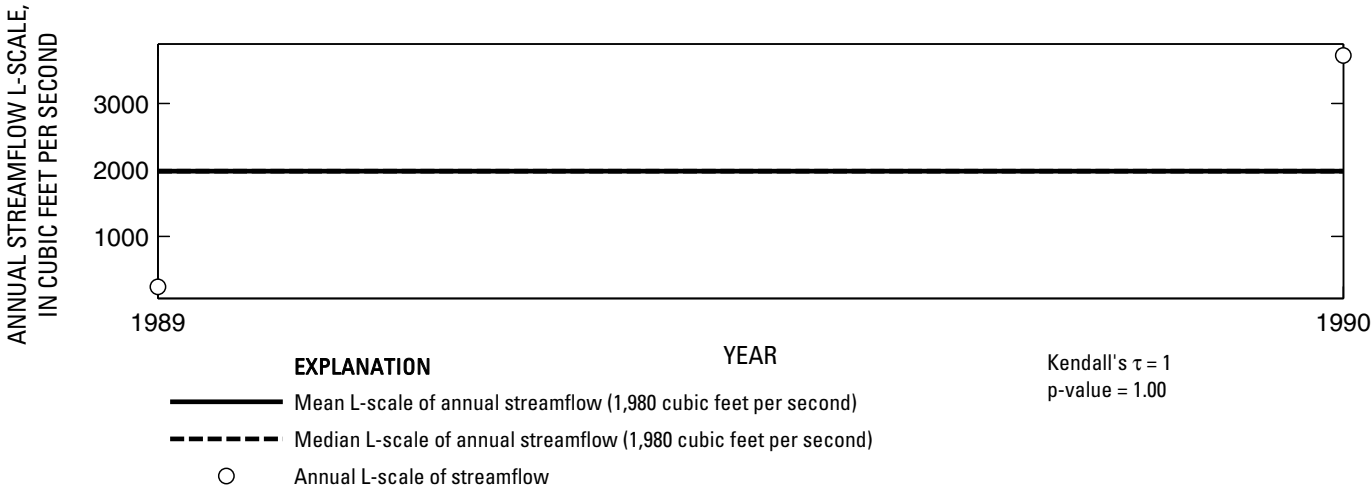

Figure 371. Analysis of annual mean, maximum, minimum, and L-scale statistics of daily mean streamflow for U.S. Geological Survey streamflow-gaging station 08092600 Brazos River at Whitney Dam near Whitney, Texas. 

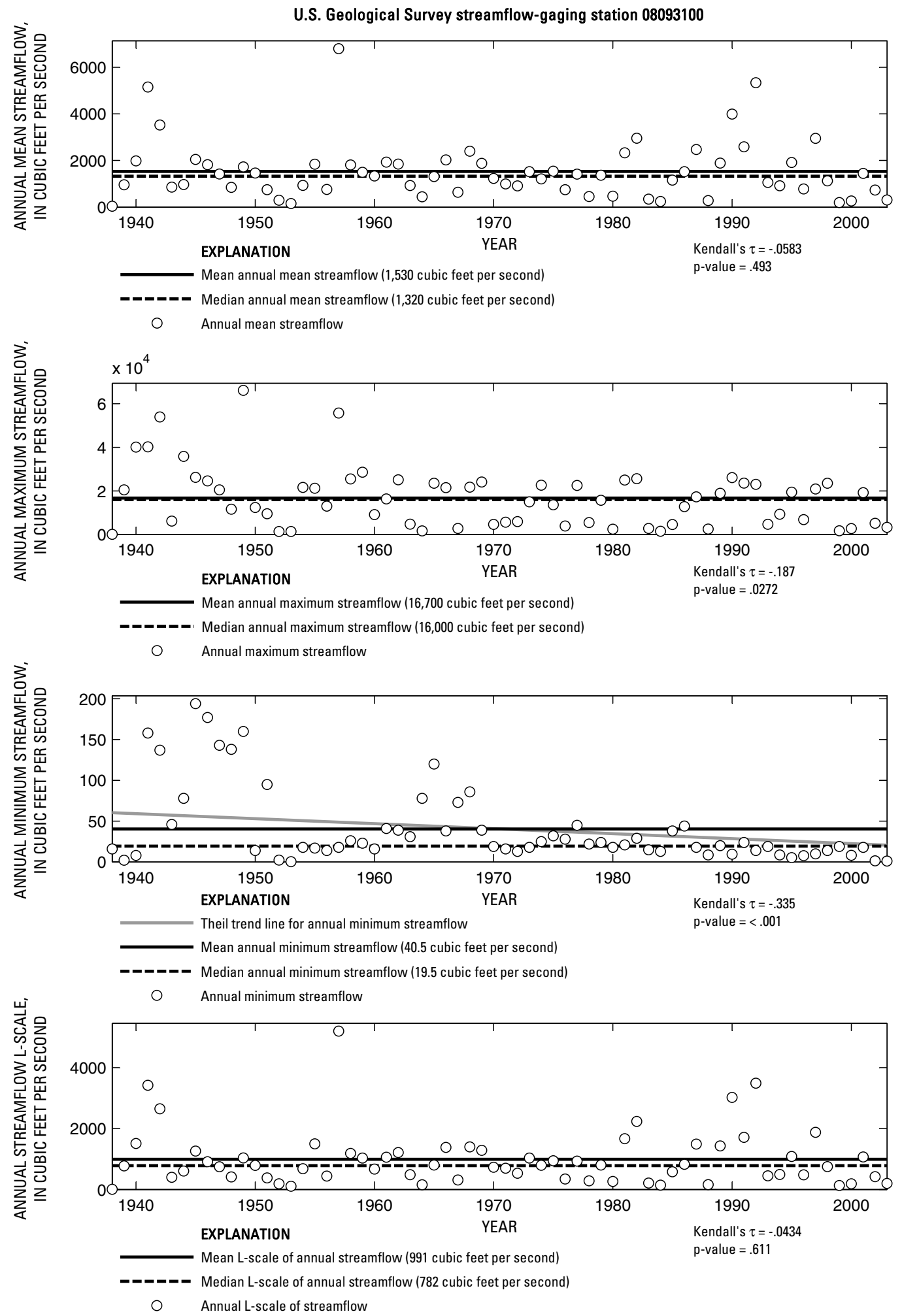

Figure 372. Analysis of annual mean, maximum, minimum, and L-scale statistics of daily mean streamflow for U.S. Geological Survey streamflow-gaging station 08093100 Brazos River near Aquilla, Texas.

Index of Station Numbers 719 


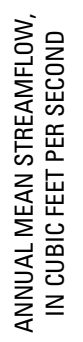

U.S. Geological Survey streamflow-gaging station 08093250

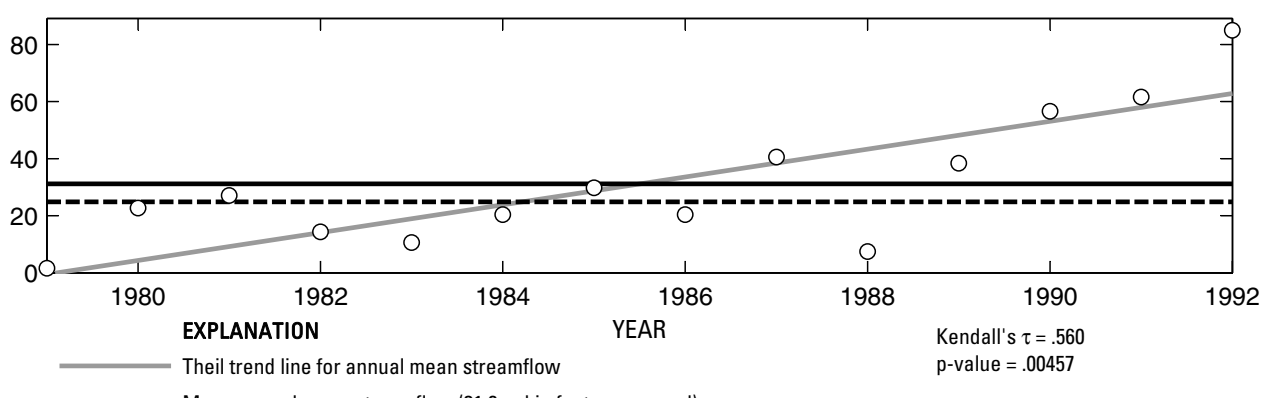

Mean annual mean streamflow (31.2 cubic feet per second)

-ーーーーー Median annual median streamflow (24.9 cubic feet per second)

O Annual mean streamflow
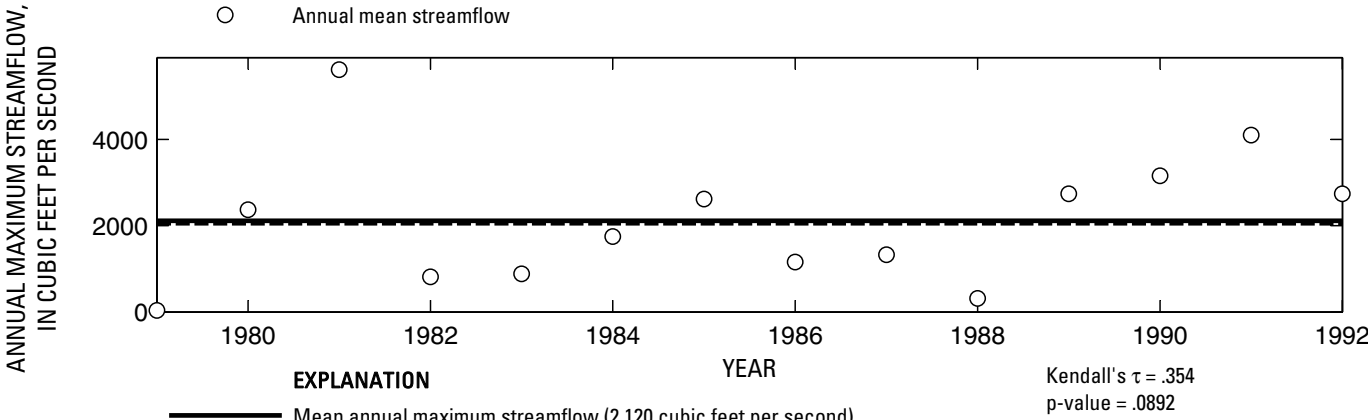

- Median annual maximum streamflow (2,060 cubic feet per second)

O Annual maximum streamflow
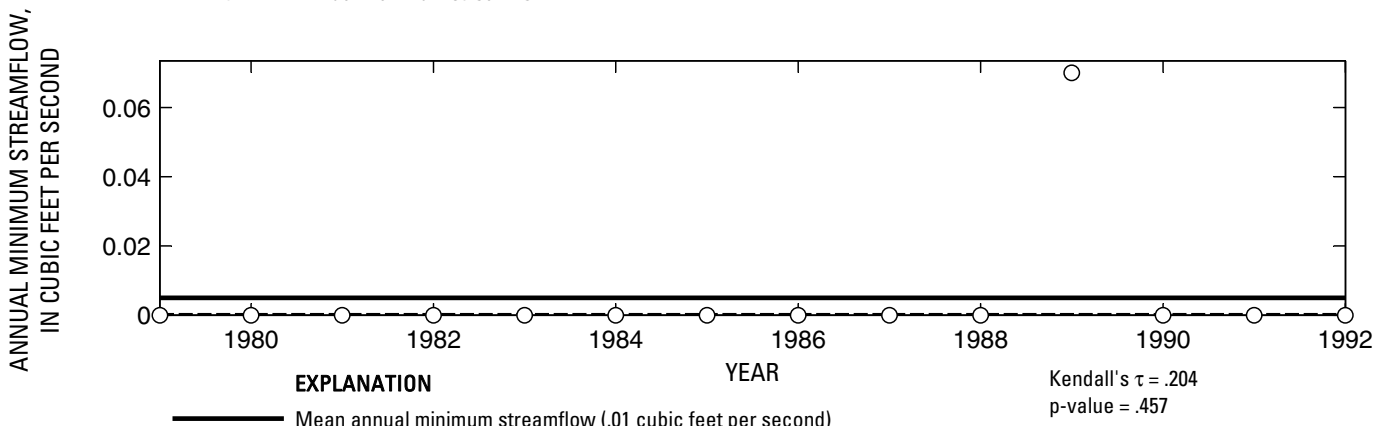

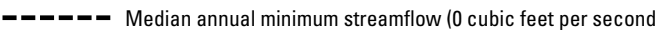

O Annual minimum streamflow
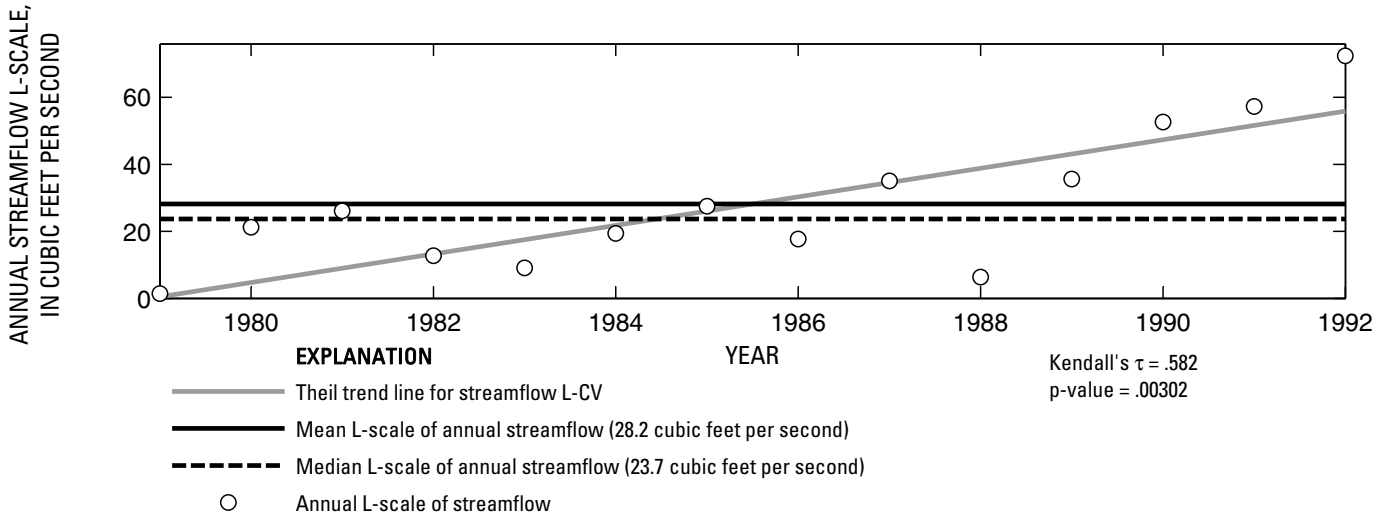

Figure 373. Analysis of annual mean, maximum, minimum, and L-scale statistics of daily mean streamflow for U.S. Geological Survey streamflow-gaging station 08093250 Hackberry Creek at Hillsboro, Texas. 


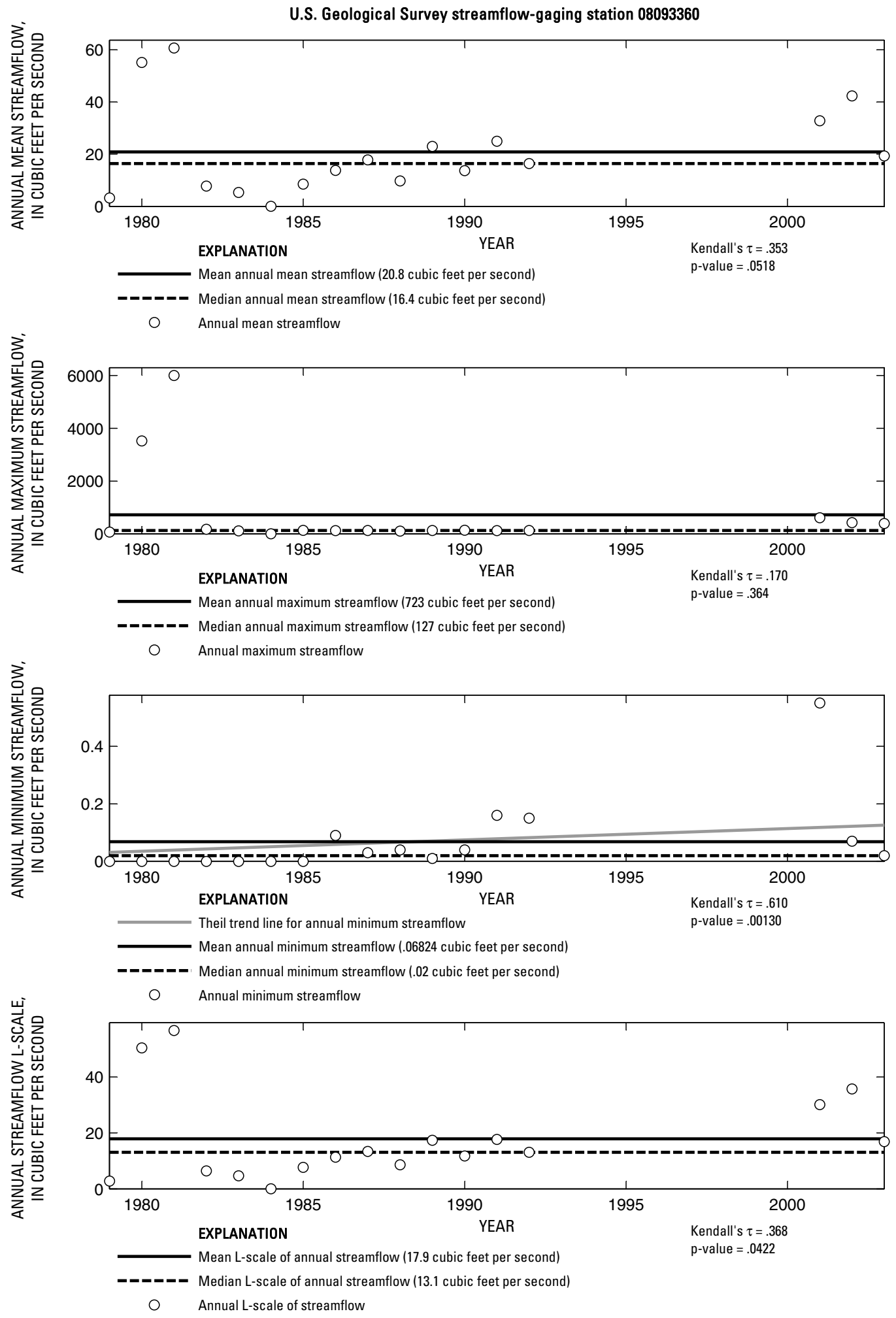

Figure 374. Analysis of annual mean, maximum, minimum, and L-scale statistics of daily mean streamflow for U.S. Geological Survey streamflow-gaging station 08093360 Aquilla Creek above Aquilla, Texas.

Index of Station Numbers 719 

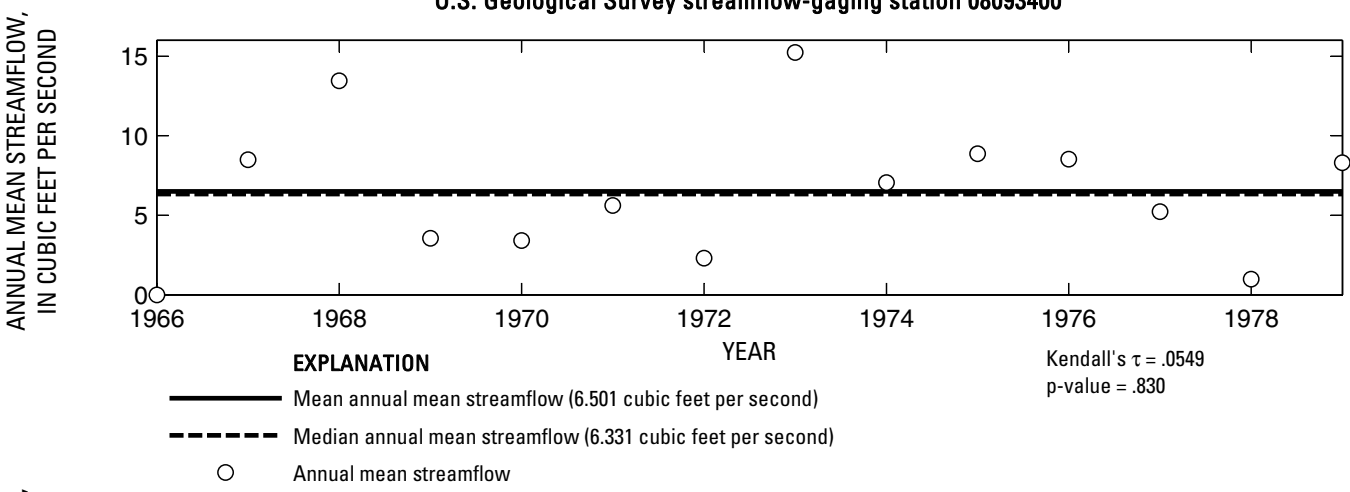

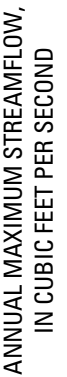

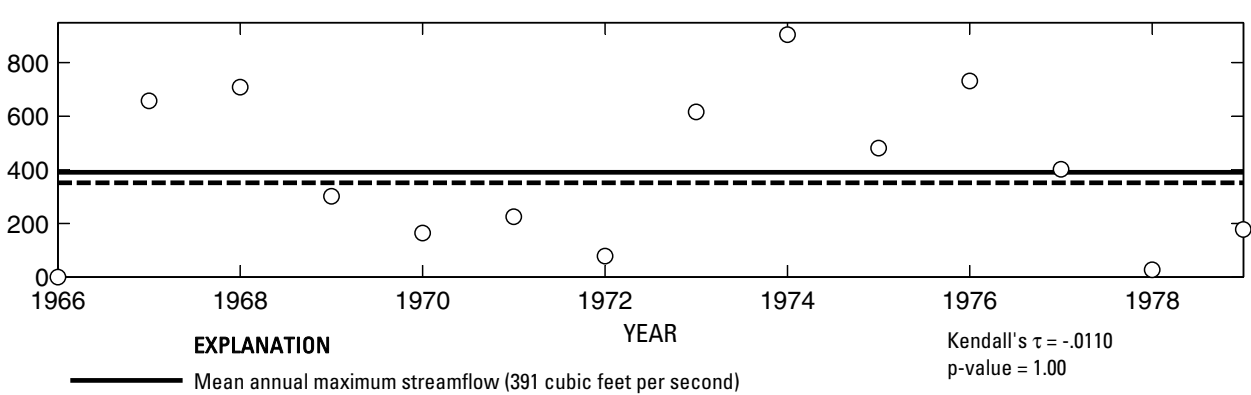

-_-_- Median annual maximum streamflow (352 cubic feet per second)

O Annual maximum streamflow
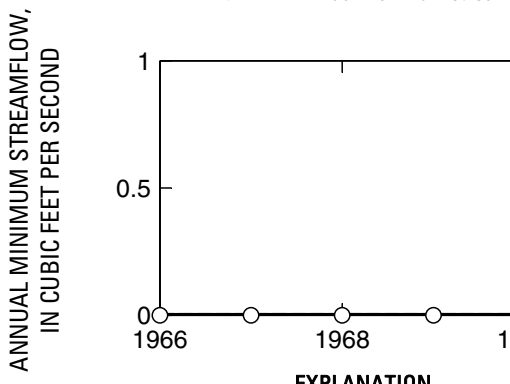
EXPLANATION

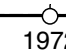

Mean annual minimum streamflow (0 cubic feet per second)

YEAR

-_a-_odian annual minimum streamflow (0 cubic feet per second)

O Annual minimum streamflow
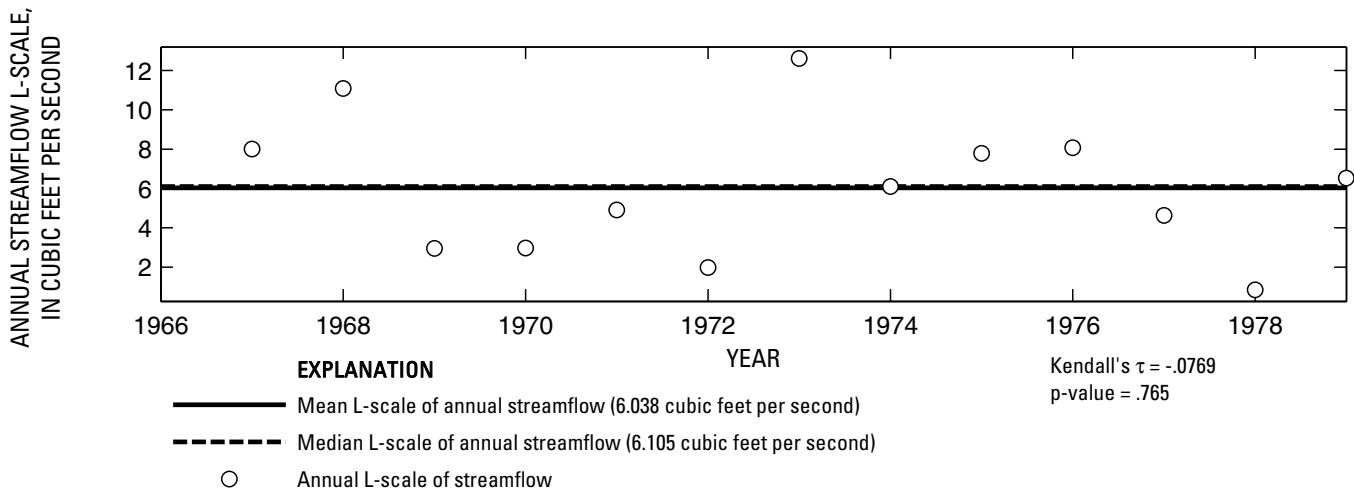

Figure 375. Analysis of annual mean, maximum, minimum, and L-scale statistics of daily mean streamflow for U.S. Geological Survey streamflow-gaging station 08093400 Cobb Creek near Abbott, Texas. 


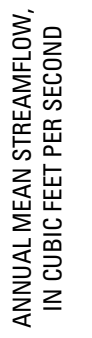

U.S. Geological Survey streamflow-gaging station 08093500

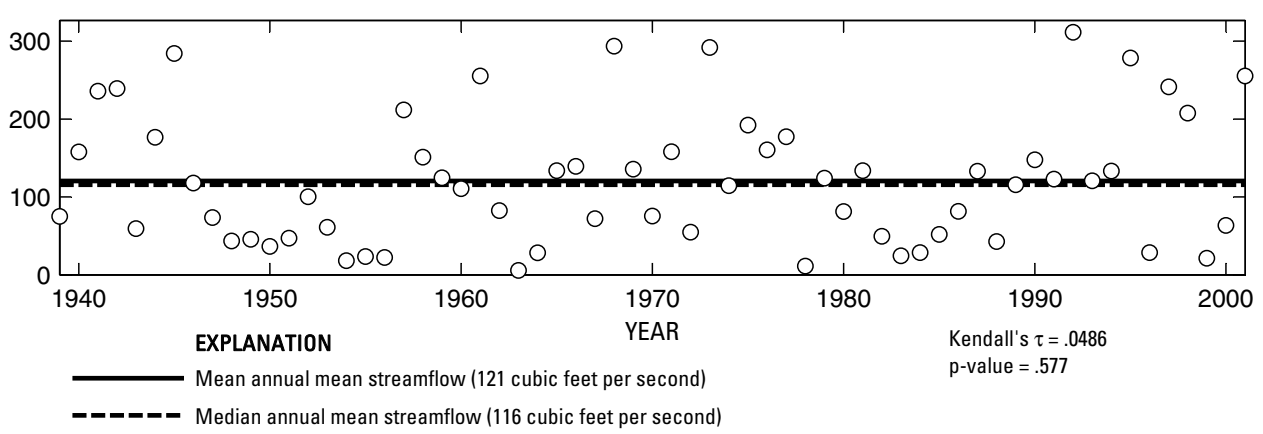

O Annual mean streamflow

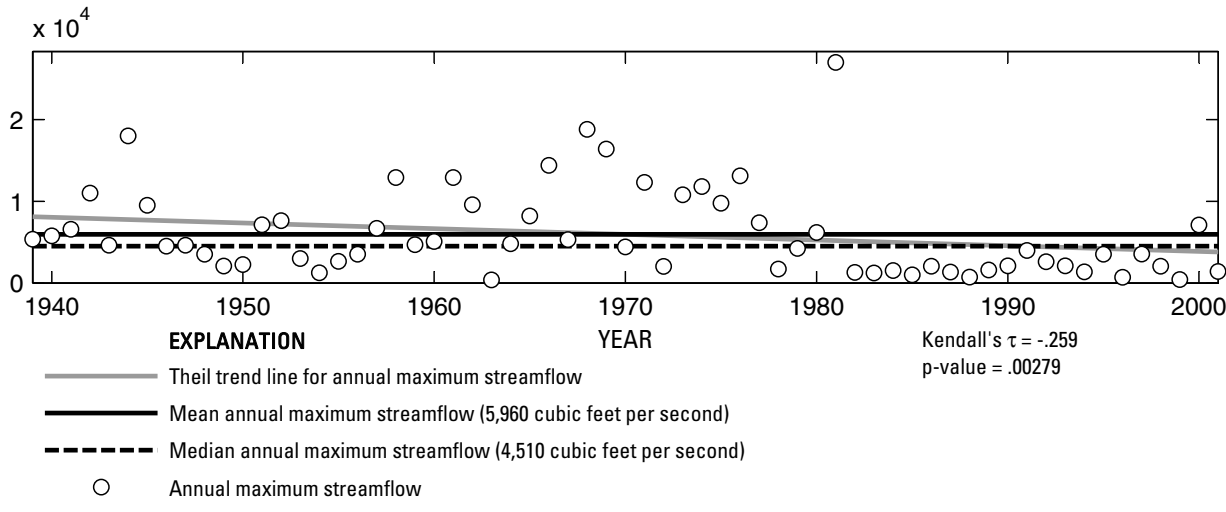

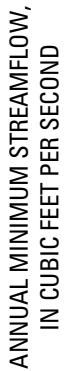

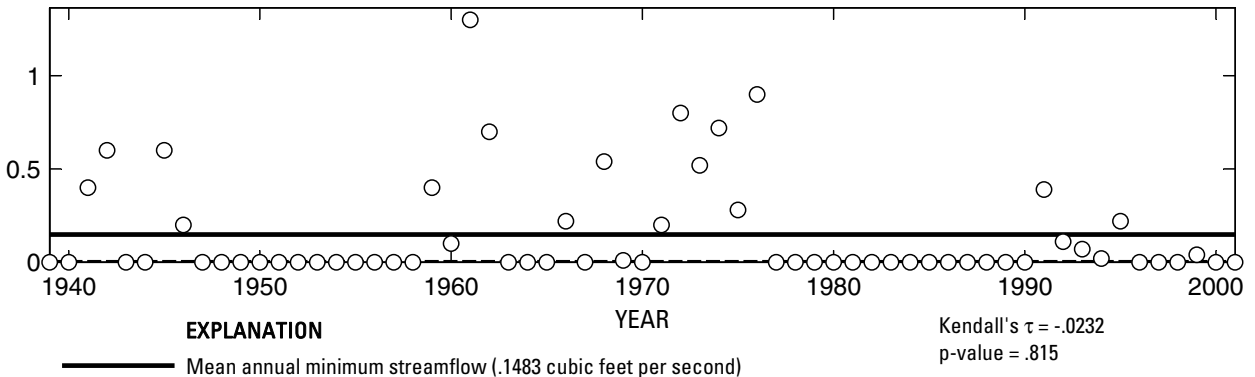

- Median annual minimum streamflow (0 cubic feet per second)

O Annual minimum streamflow

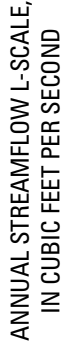

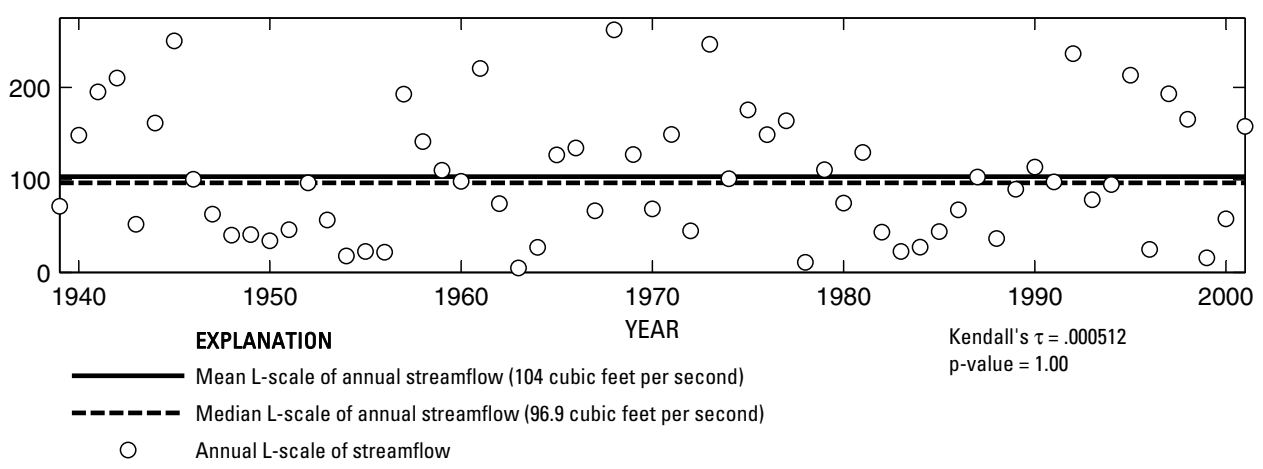

Figure 376. Analysis of annual mean, maximum, minimum, and L-scale statistics of daily mean streamflow for U.S. Geological Survey streamflow-gaging station 08093500 Aquilla Creek near Aquilla, Texas. 


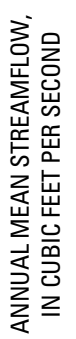

U.S. Geological Survey streamflow-gaging station 08093700

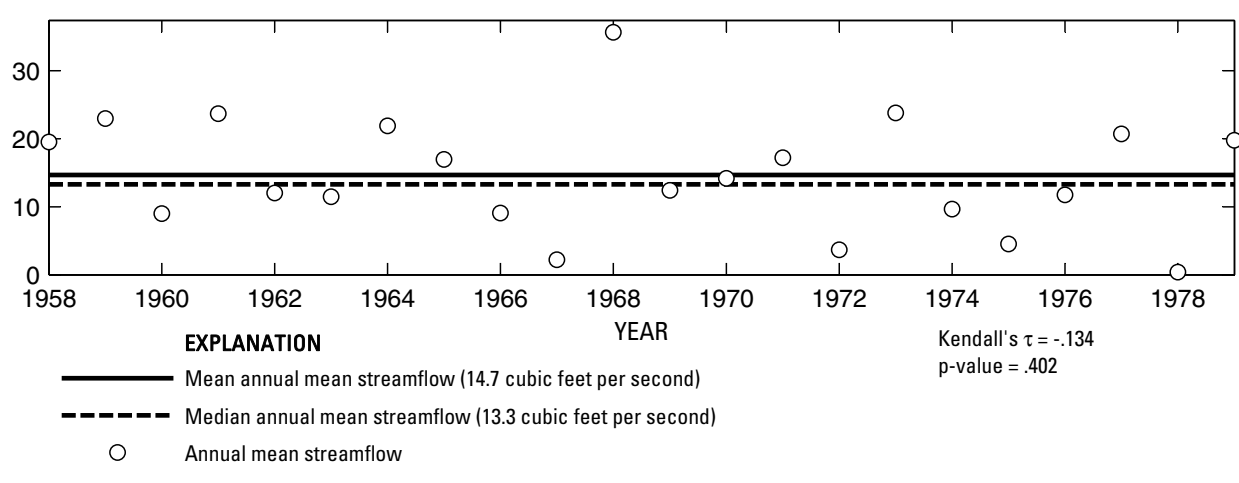

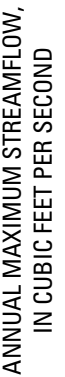

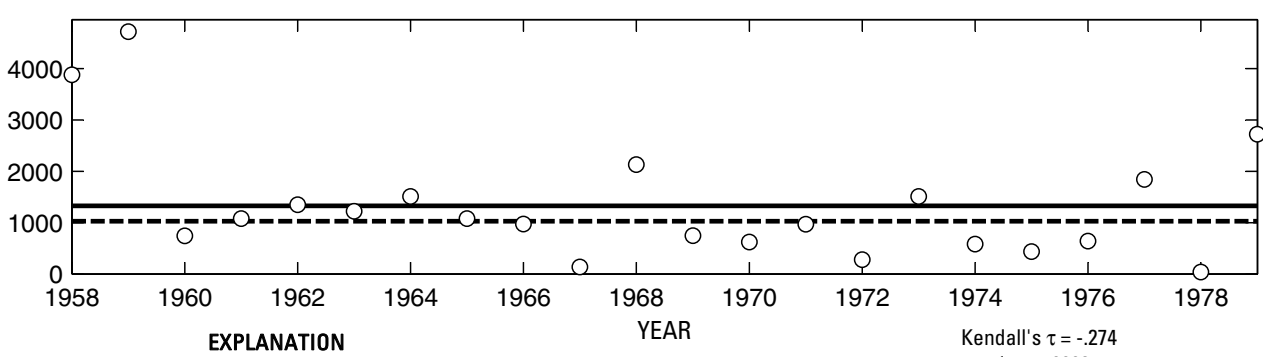

Mean annual maximum streamflow (1,330 cubic feet per second)

- ב- Median annual maximum streamflow $(1,030$ cubic feet per second

O Annual maximum streamflow

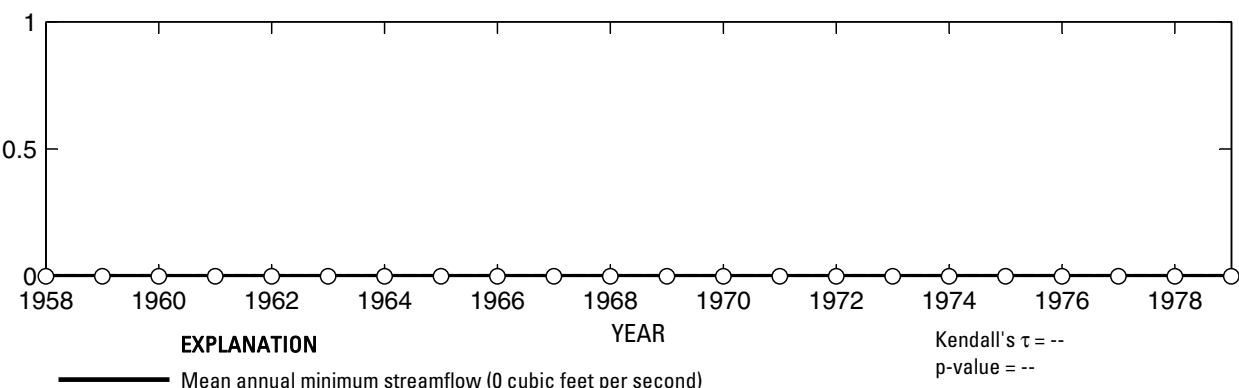

- Median annual minimum streamflow (0 cubic feet per second)

O Annual minimum streamflow

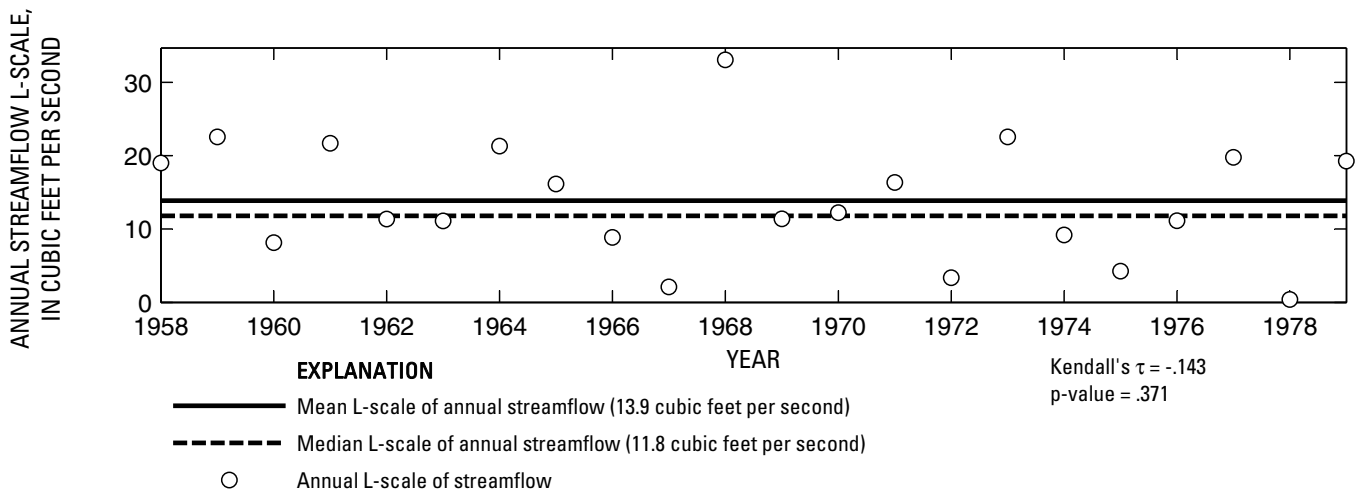

Figure 377. Analysis of annual mean, maximum, minimum, and L-scale statistics of daily mean streamflow for U.S. Geological Survey streamflow-gaging station 08093700 North Bosque River at Stephenville, Texas. 


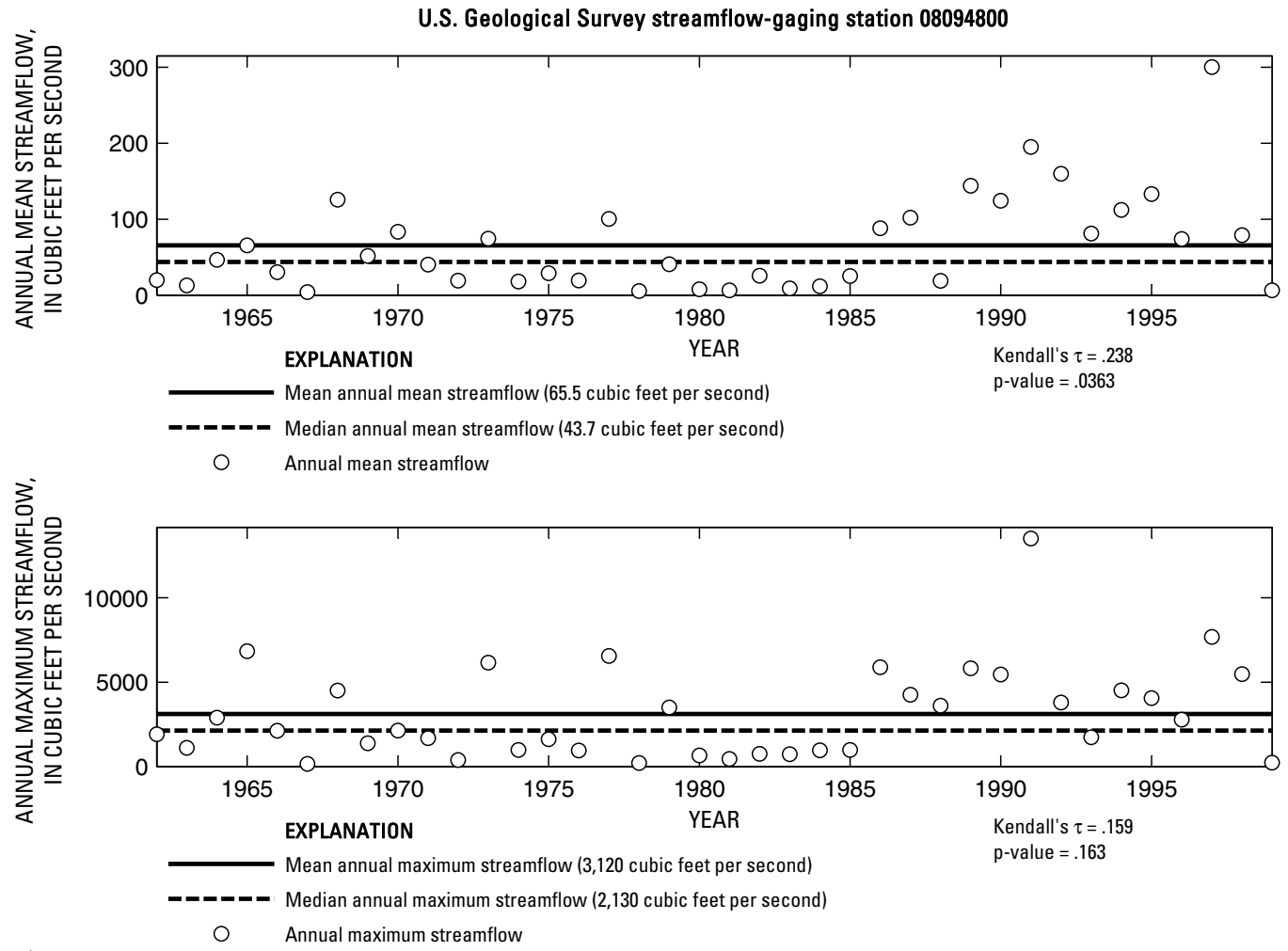

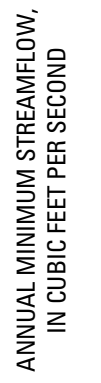

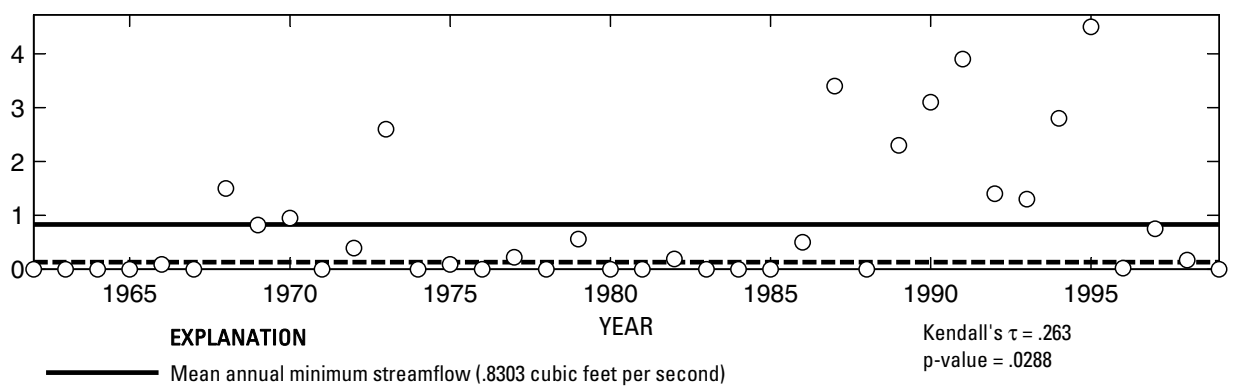

- ב-_ Median annual minimum streamflow (.13 cubic feet per second

O Annual minimum streamflow

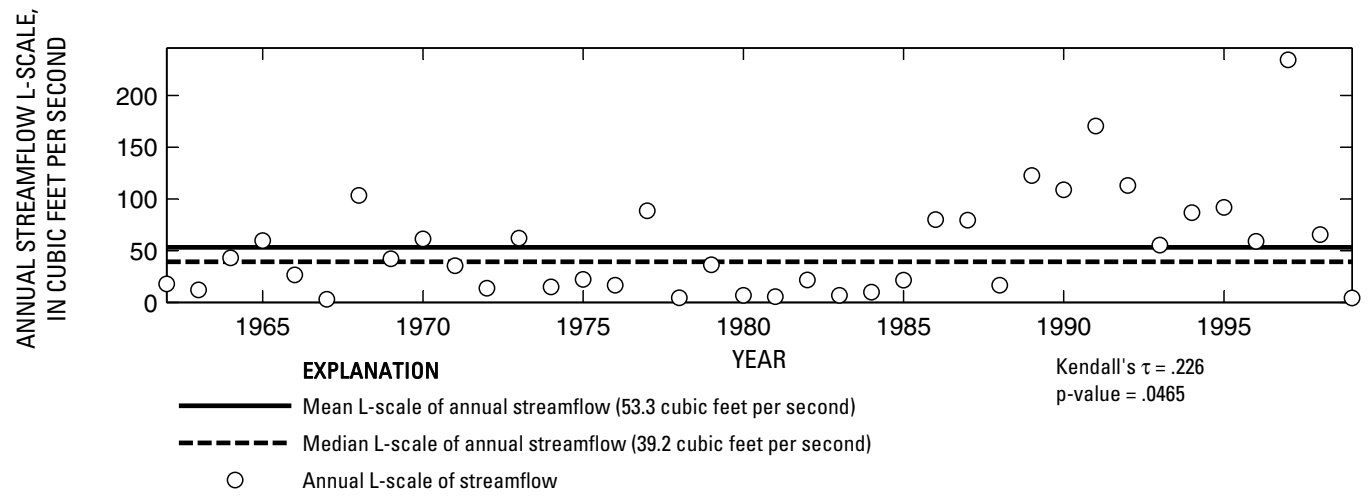

Figure 378. Analysis of annual mean, maximum, minimum, and L-scale statistics of daily mean streamflow for U.S. Geological Survey streamflow-gaging station 08094800 North Bosque River at Hico, Texas. 


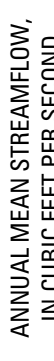

U.S. Geological Survey streamflow-gaging station 08095000

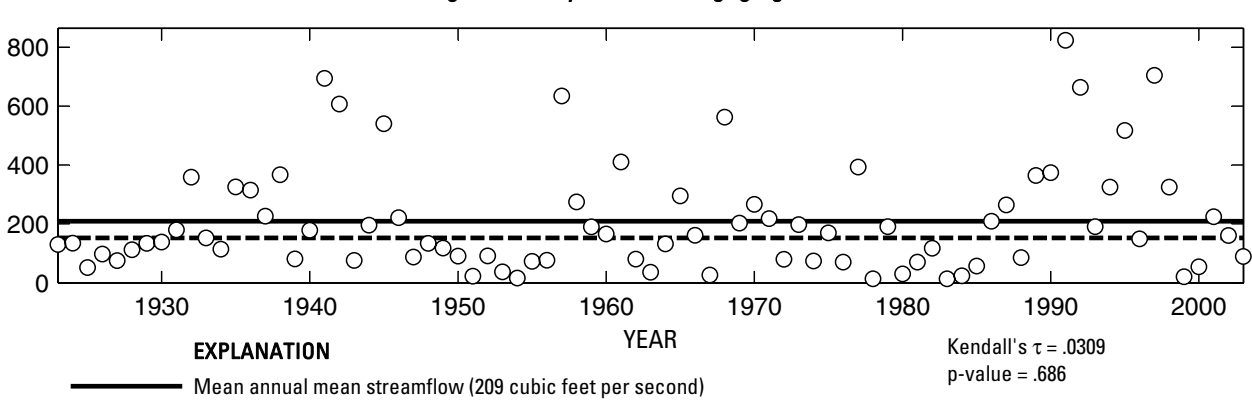

-_-_-_ Median annual mean streamflow (152 cubic feet per second)

O Annual mean streamflow

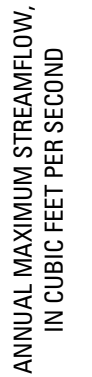

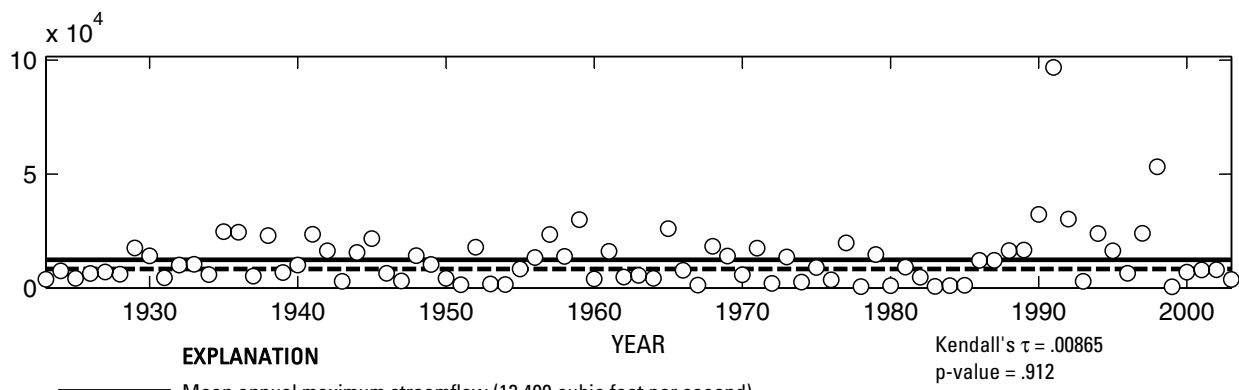

O Annual maximum streamflow

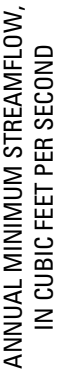

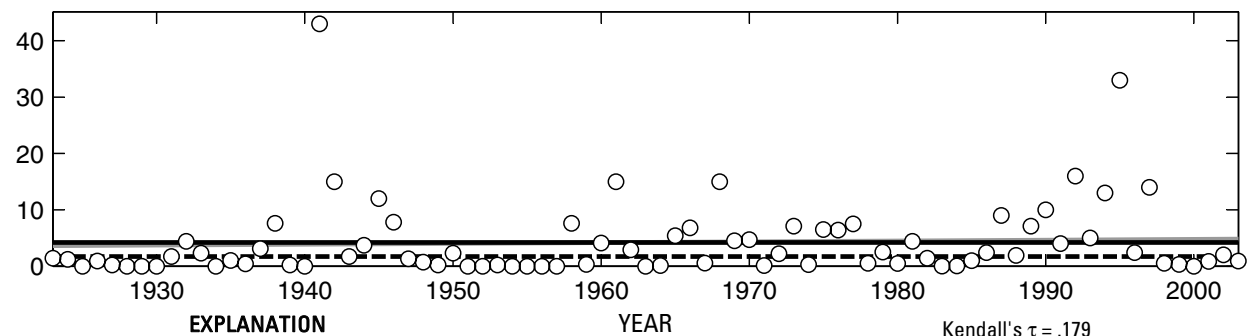

EXPLANATION

YEAP

Theil trend line for annual minimum streamflow

$\mathrm{p}$-value $=.0199$

Mean annual minimum streamflow (4.222 cubic feet per second)

Median annual minimum streamflow (1.7 cubic feet per second)

O Annual minimum streamflow
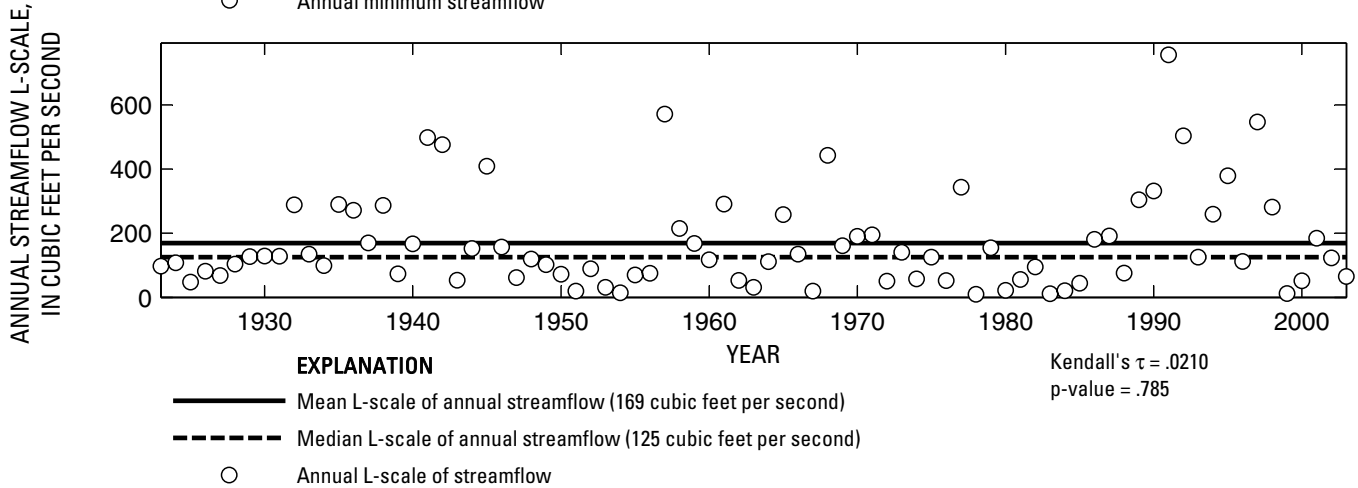

Figure 379. Analysis of annual mean, maximum, minimum, and L-scale statistics of daily mean streamflow for U.S. Geological Survey streamflow-gaging station 08095000 North Bosque River near Clifton, Texas. 


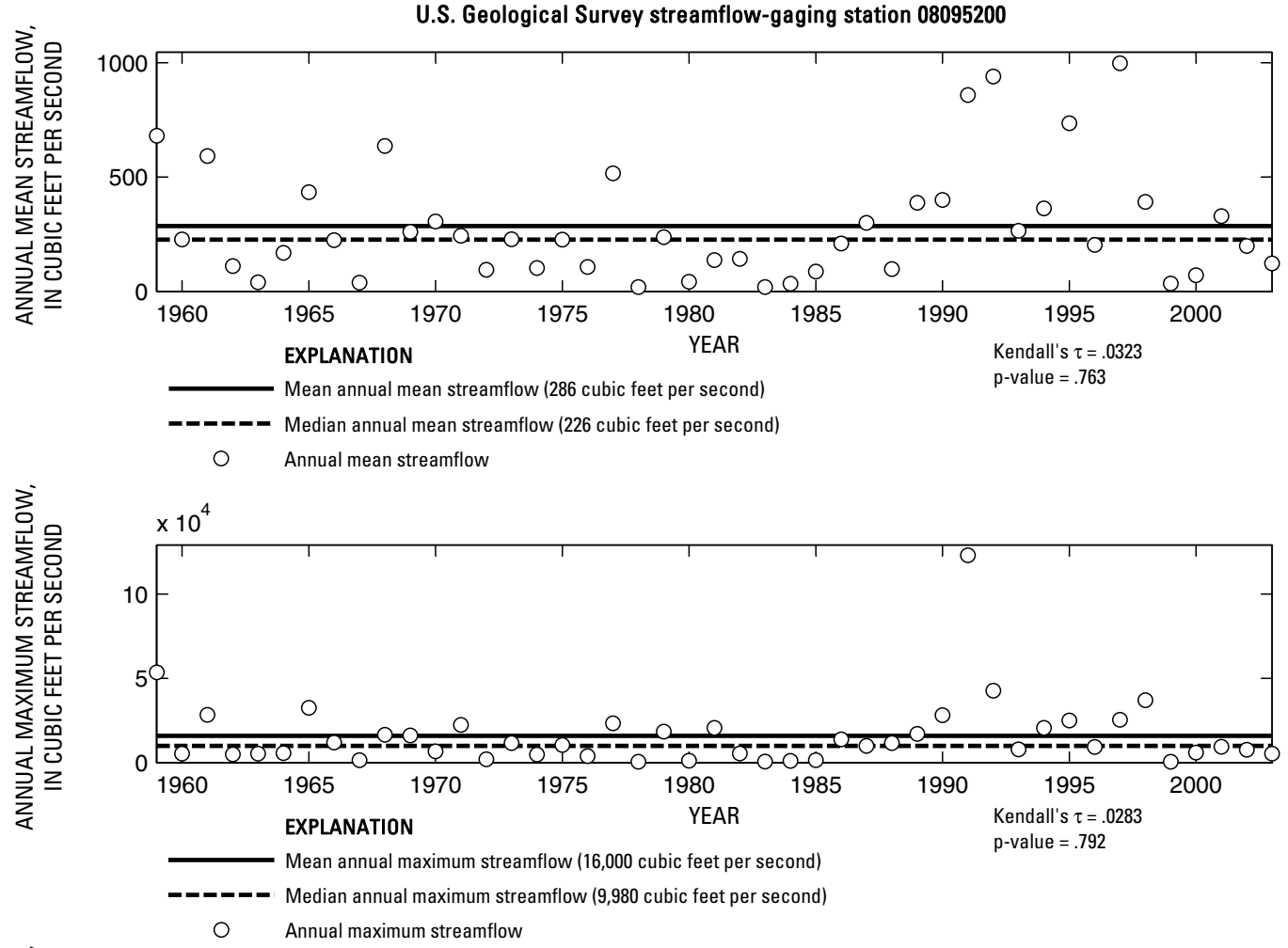

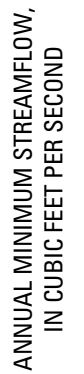

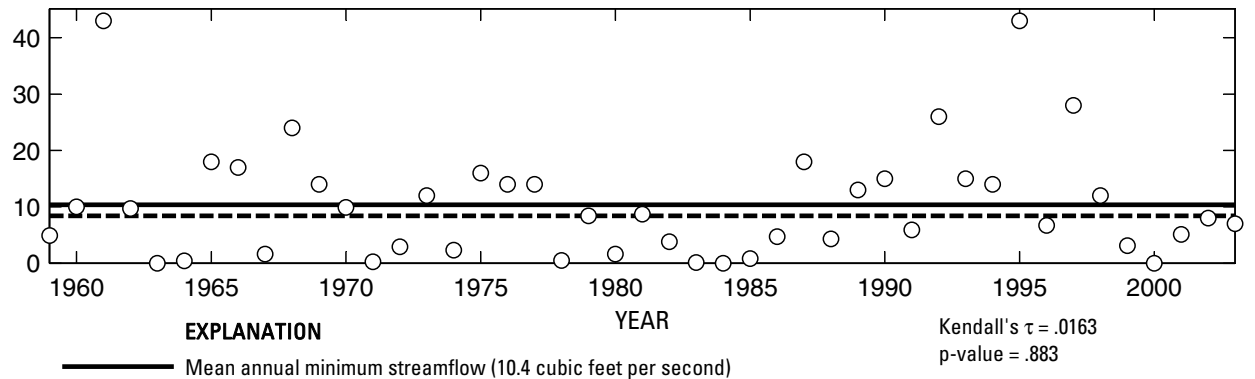

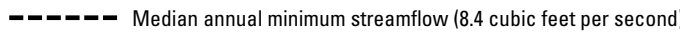

O Annual minimum streamflow

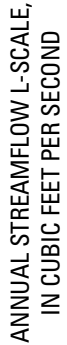

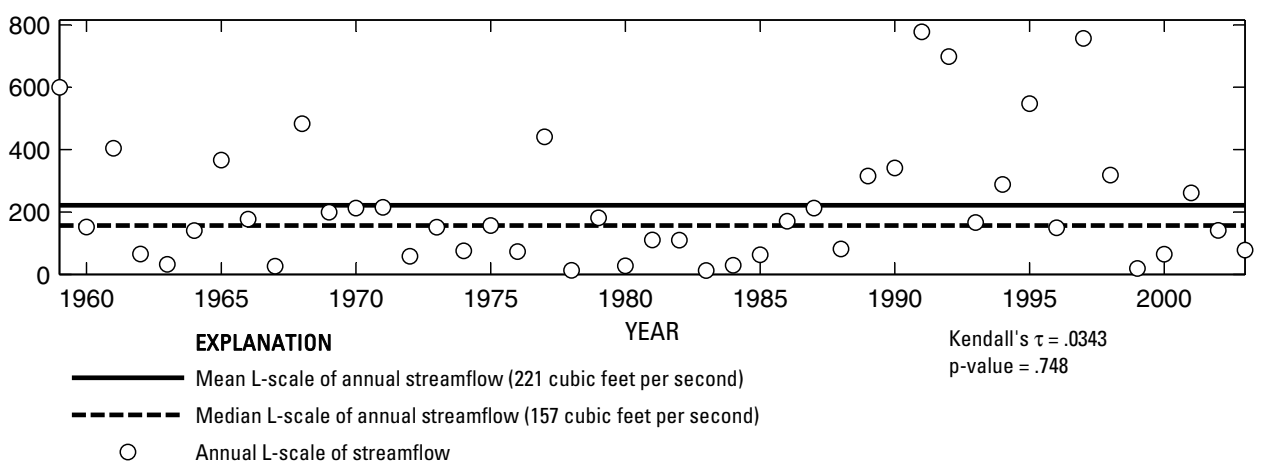

Figure 380. Analysis of annual mean, maximum, minimum, and L-scale statistics of daily mean streamflow for U.S. Geological Survey streamflow-gaging station 08095200 North Bosque River at Valley Mills, Texas.

Index of Station Numbers 719 

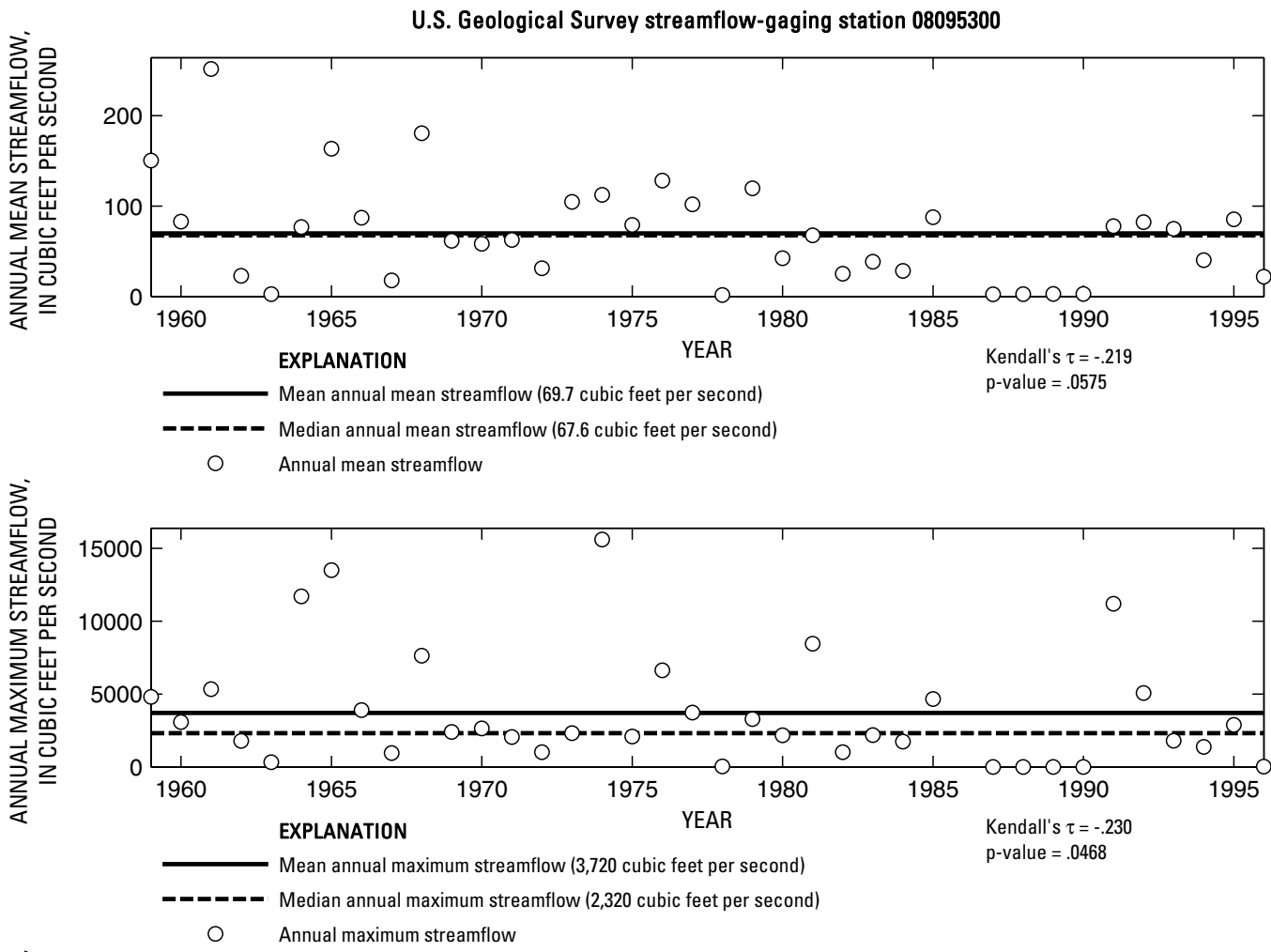

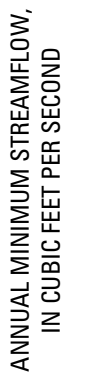

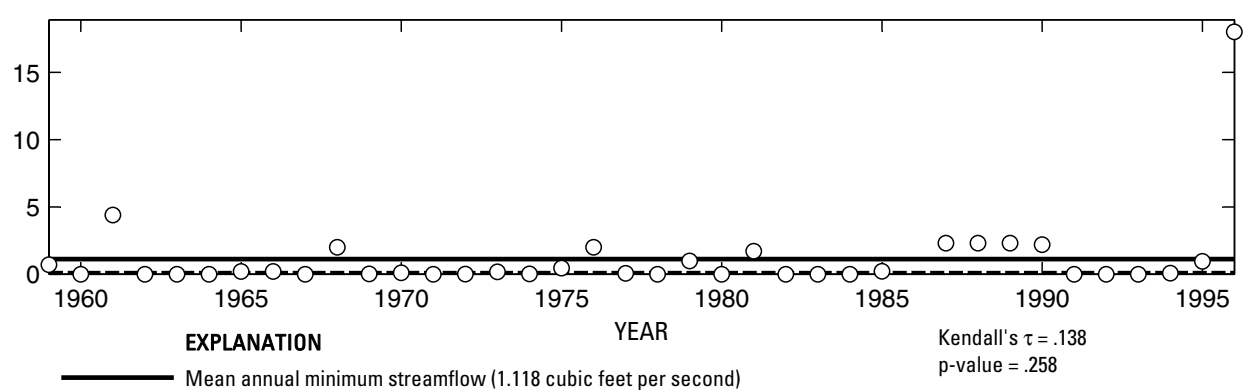

-_-_-_ Median annual minimum streamflow (.07 cubic feet per second)

O Annual minimum streamflow

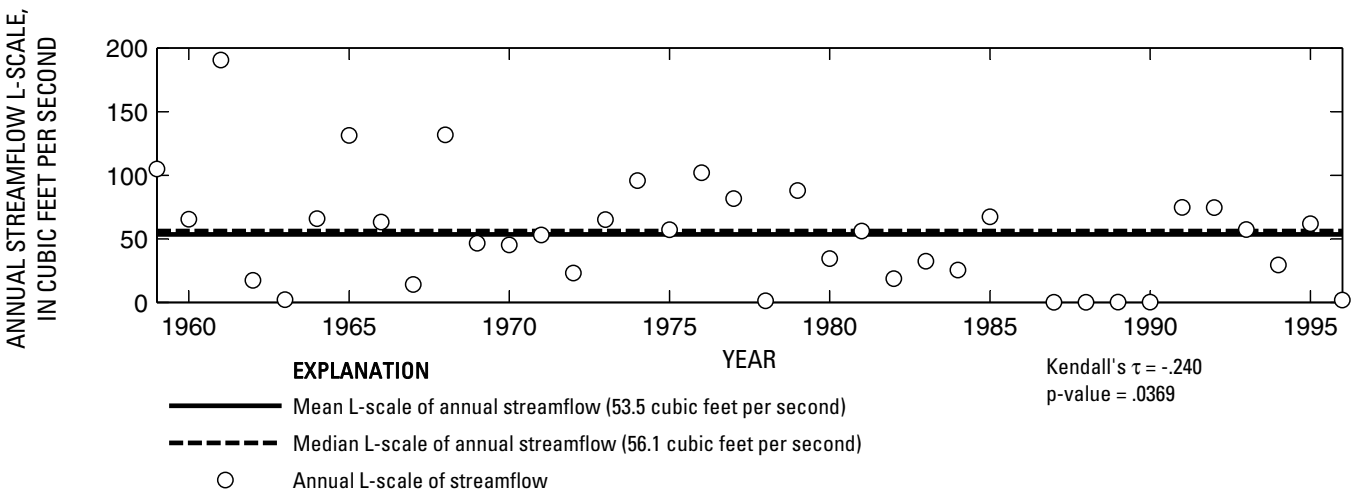

Figure 381. Analysis of annual mean, maximum, minimum, and L-scale statistics of daily mean streamflow for U.S. Geological Survey streamflow-gaging station 08095300 Middle Bosque River near McGregor, Texas. 
U.S. Geological Survey streamflow-gaging station 08095400

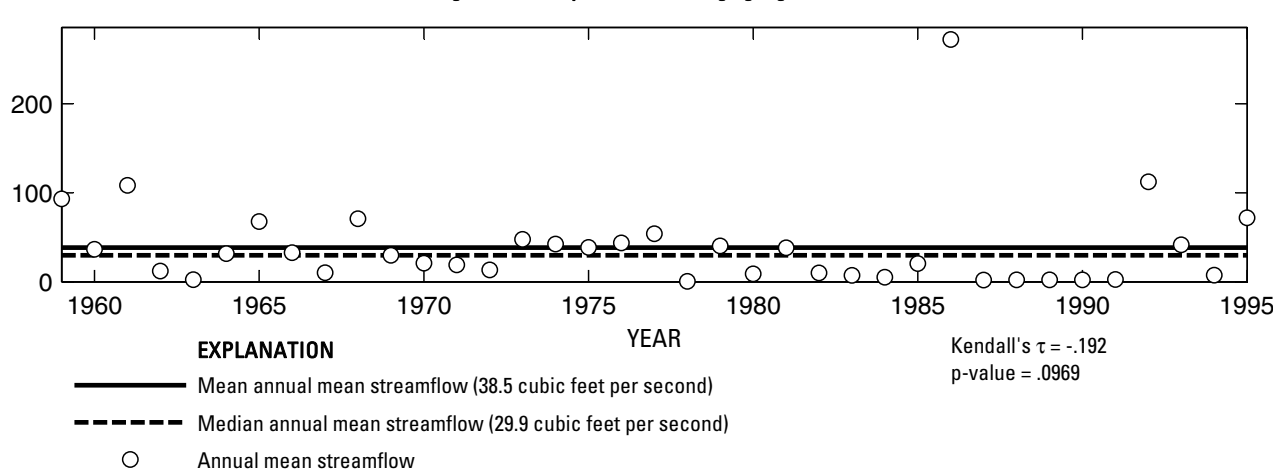

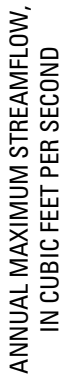

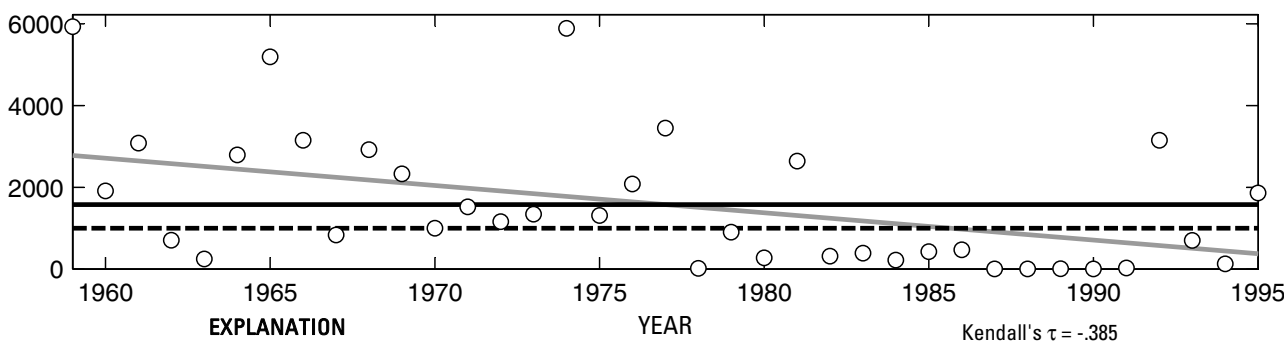

Theil trend line for annual maximum streamflow

p-value $=<$ res

- Mean annual maximum streamflow (1,580 cubic feet per second)

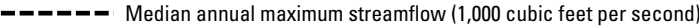

O Annual maximum streamflow

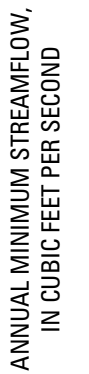

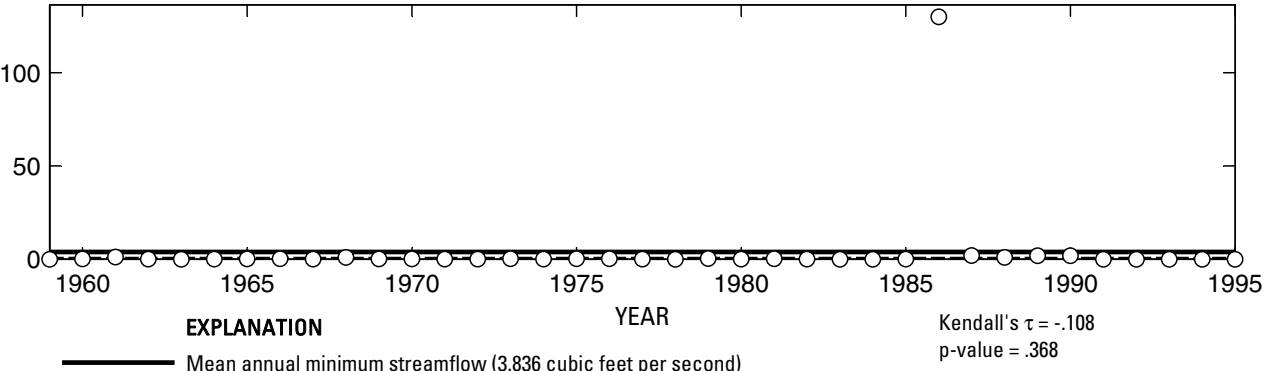

- Median annual minimum streamflow (.1 cubic feet per second)

O Annual minimum streamflow

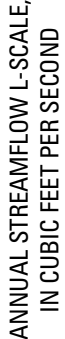

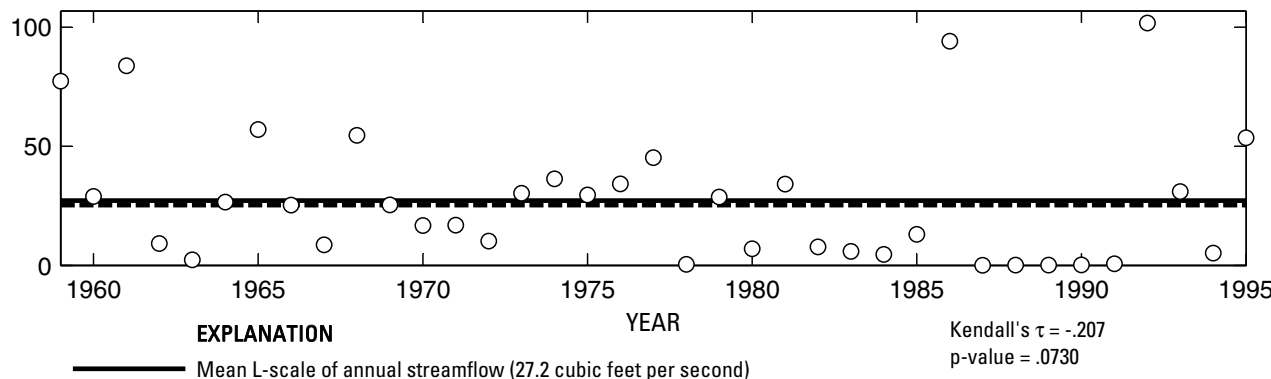

Annual L-scale of streamflow

Figure 382. Analysis of annual mean, maximum, minimum, and L-scale statistics of daily mean streamflow for U.S. Geological Survey streamflow-gaging station 08095400 Hog Creek near Crawford, Texas.

Index of Station Numbers 719 


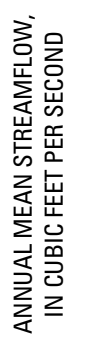

U.S. Geological Survey streamflow-gaging station 08095500

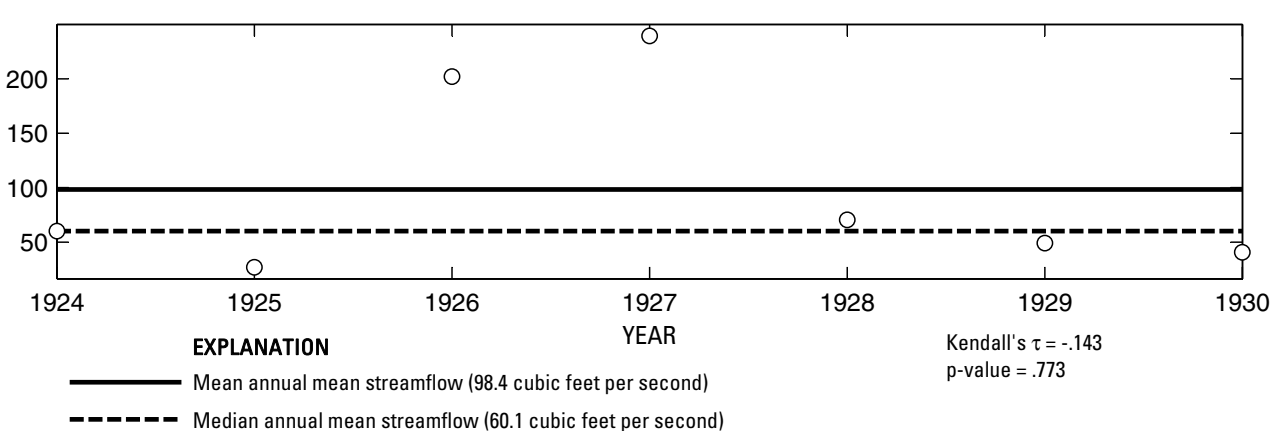

O Annual mean streamflow
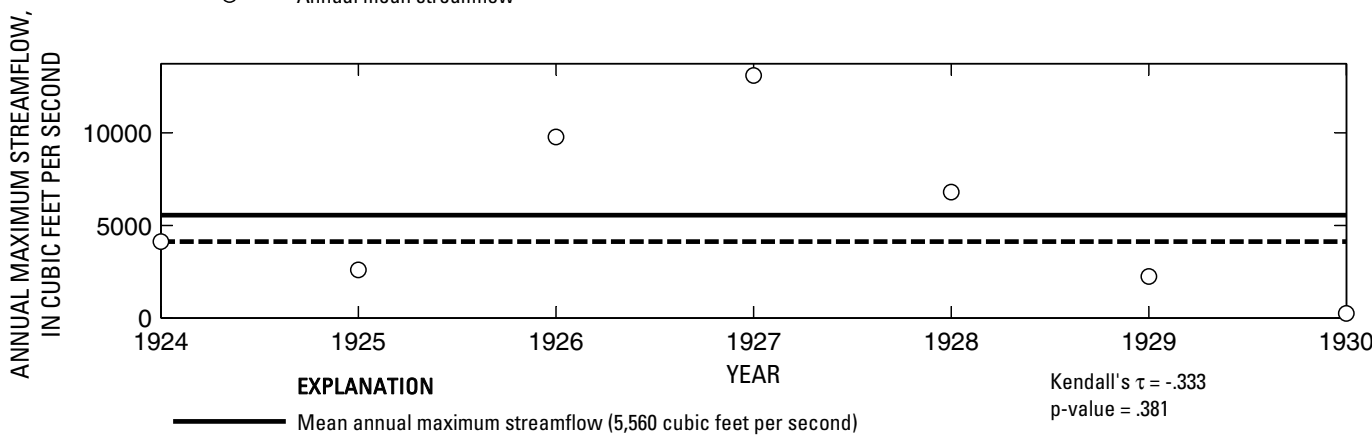

- _ - Median annual maximum streamflow (4,130 cubic feet per second)

O Annual maximum streamflow
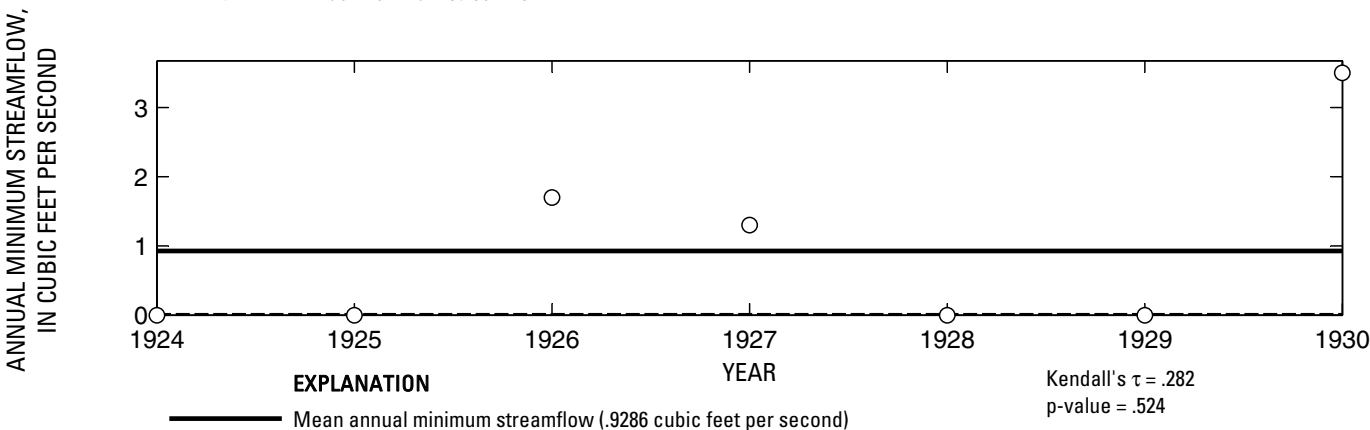

- ב-ב Median annual minimum streamflow $(0$ cubic feet per second

O Annual minimum streamflow

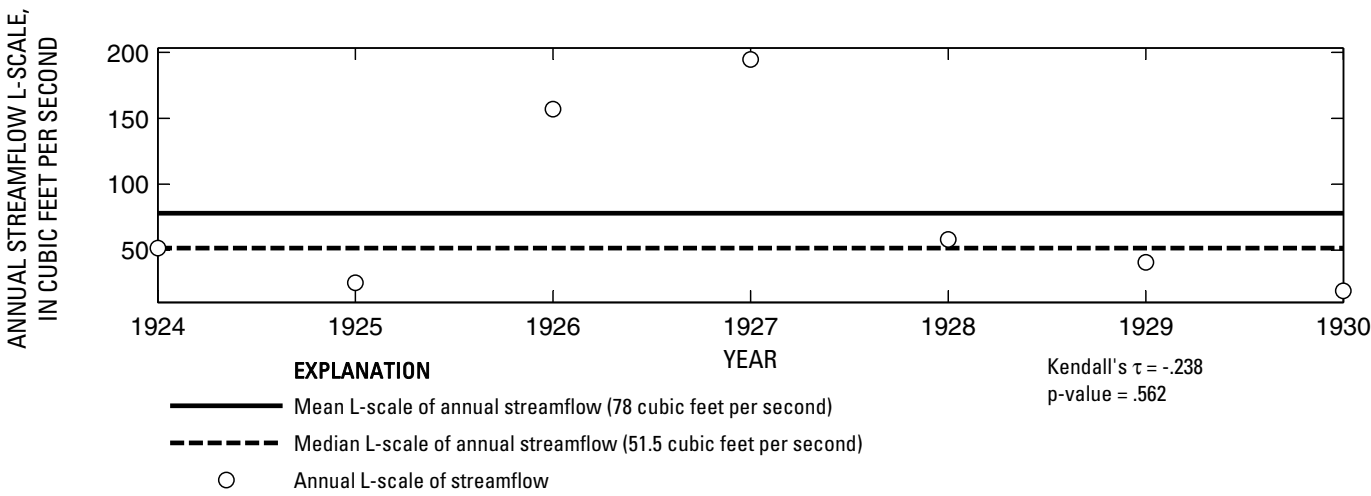

Figure 383. Analysis of annual mean, maximum, minimum, and L-scale statistics of daily mean streamflow for U.S. Geological Survey streamflow-gaging station 08095500 South Bosque River near Speegleville, Texas. 


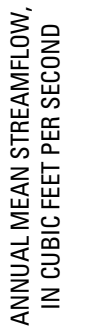

U.S. Geological Survey streamflow-gaging station 08095600

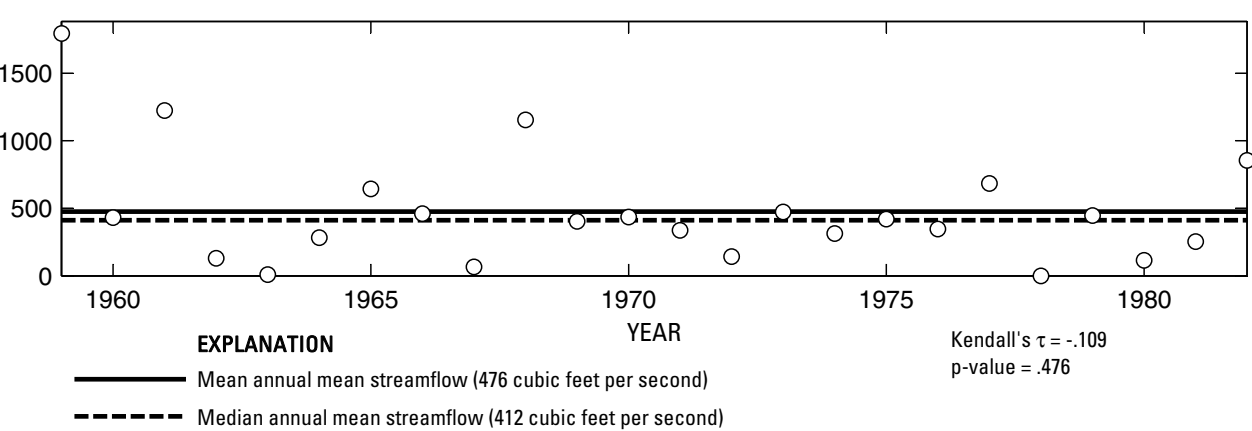

O Annual mean streamflow

$$
\times 10^{4}
$$

4
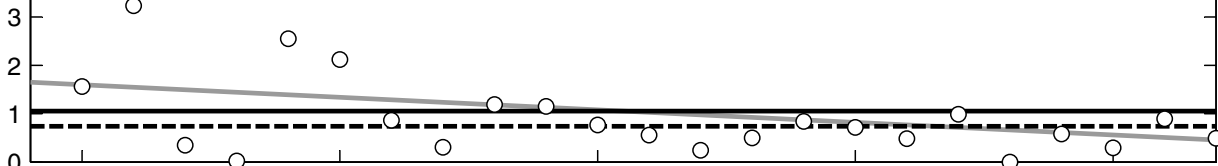

$0 \frac{1}{1960}$

EXPLANATION 1965

Theil trend line for annual maximum streamflow

YEAR Kendall's $\tau=-.355$

Mean annual maximum streamflow (10,500 cubic feet per second)

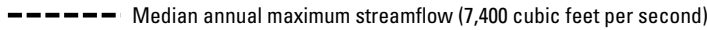

$\bigcirc \quad$ Annual maximum streamflow

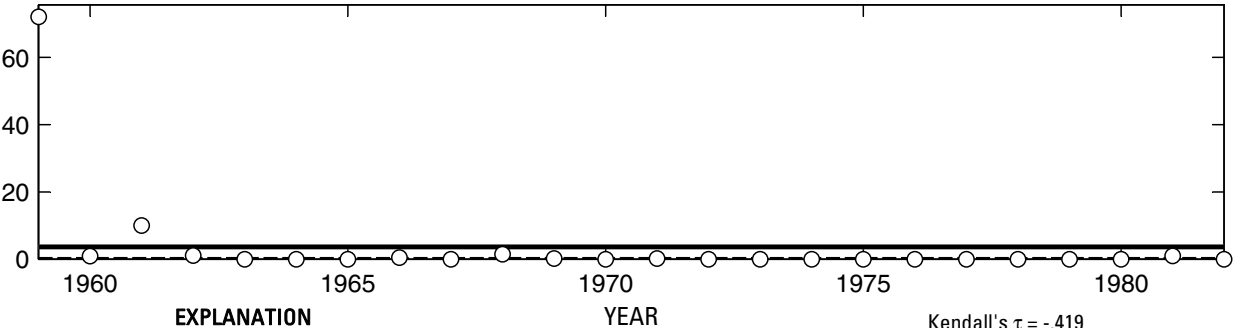

Theil trend line for annual minimum streamflow
Mean annual minimum streamflow ( 3.641 cubic feet per second

$\mathrm{p}$-value $=.00988$

- - - Median annual minimum streamflow (0 cubic feet per second)

O Annual minimum streamflow

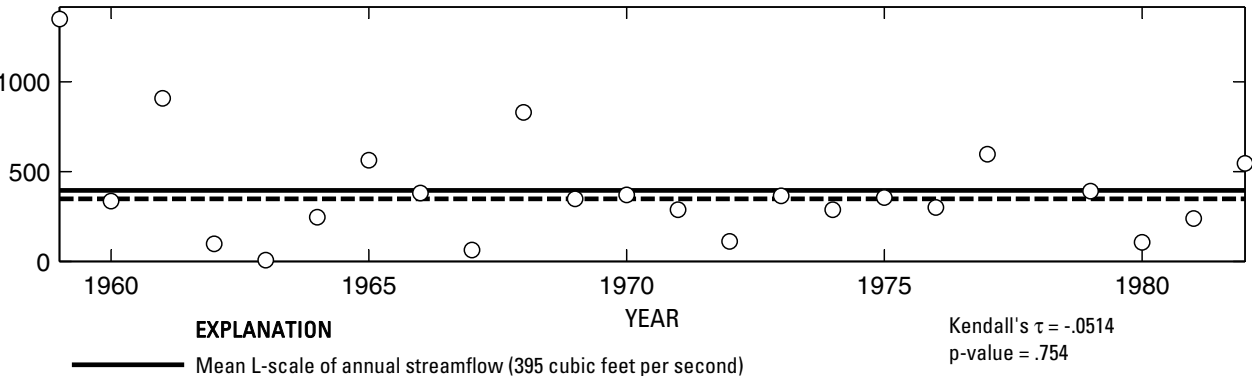

- --ーー- Median L-scale of annual streamflow (348 cubic feet per second)

Annual L-scale of streamflow

Figure 384. Analysis of annual mean, maximum, minimum, and L-scale statistics of daily mean streamflow for U.S. Geological Survey streamflow-gaging station 08095600 Bosque River near Waco, Texas. 


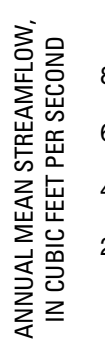

U.S. Geological Survey streamflow-gaging station 08096500

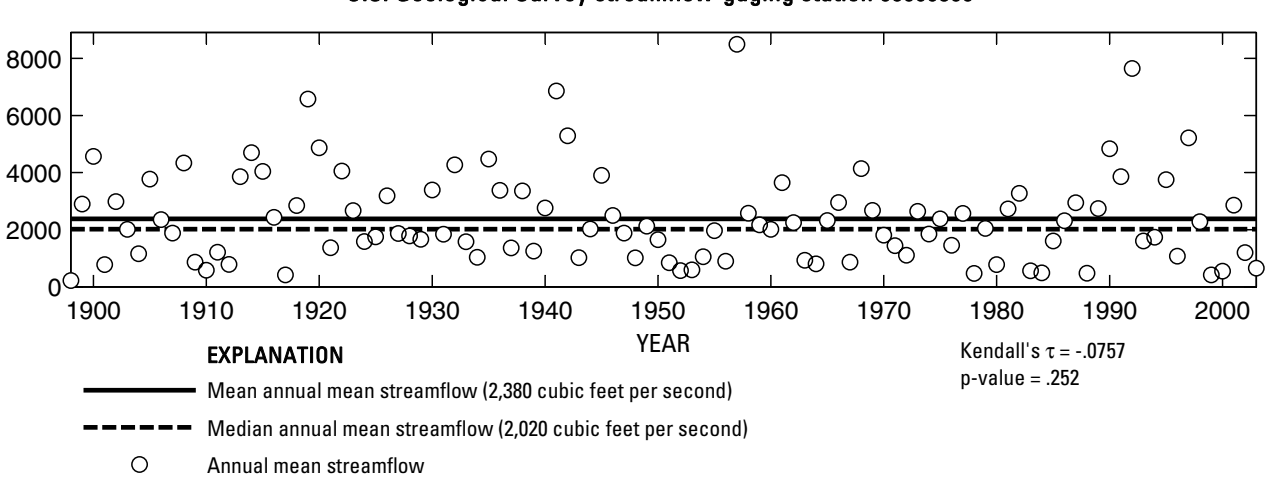

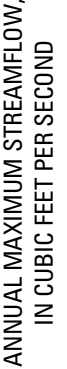
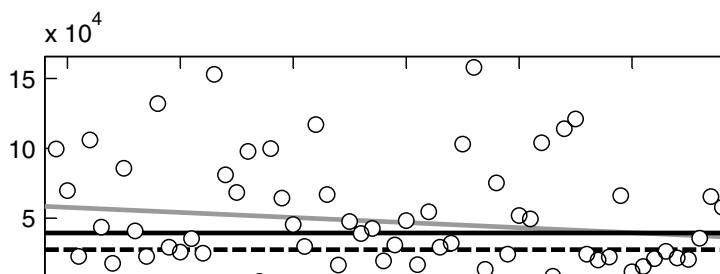
1900 $\begin{array}{ll}1 & 01 \\ 1910 & 1920\end{array}$ 1930

1940
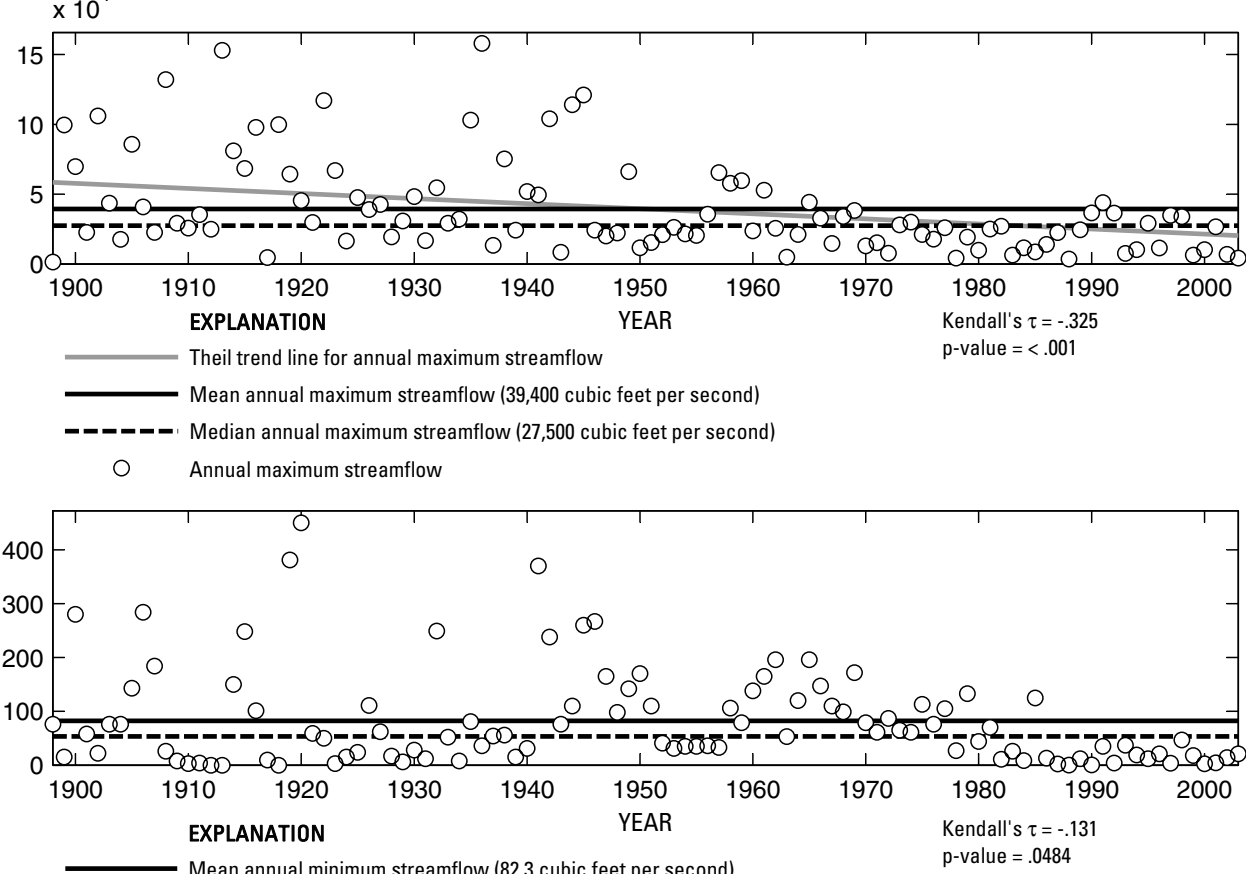

- - ב Median annual minimum streamflow (53.5 cubic feet per second)

O Annual minimum streamflow
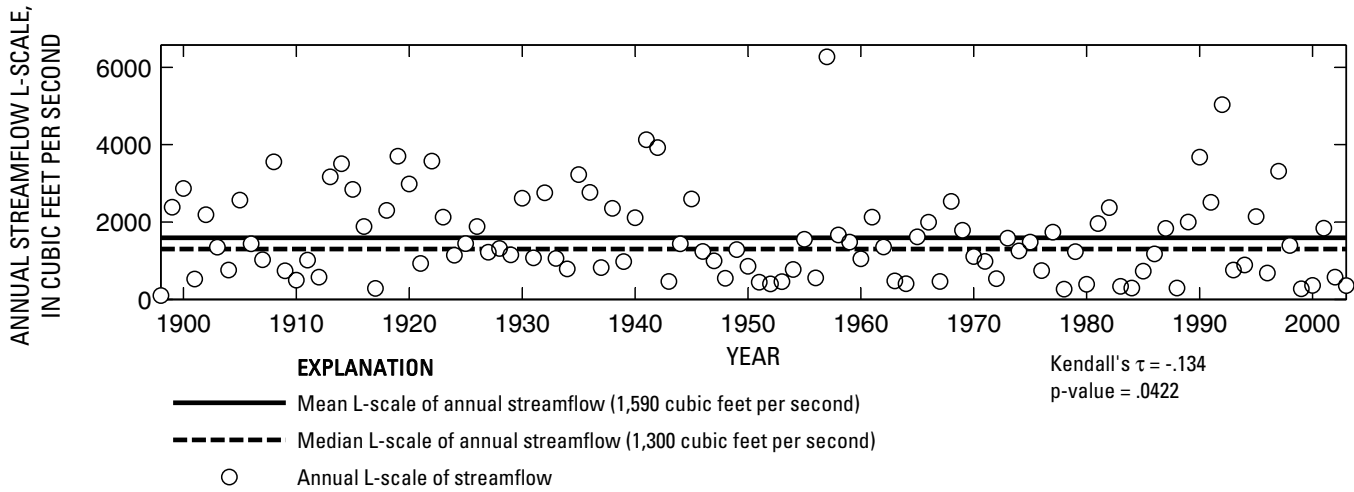

Figure 385. Analysis of annual mean, maximum, minimum, and L-scale statistics of daily mean streamflow for U.S. Geological Survey streamflow-gaging station 08096500 Brazos River at Waco, Texas. 


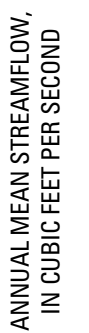

U.S. Geological Survey streamflow-gaging station 08097500

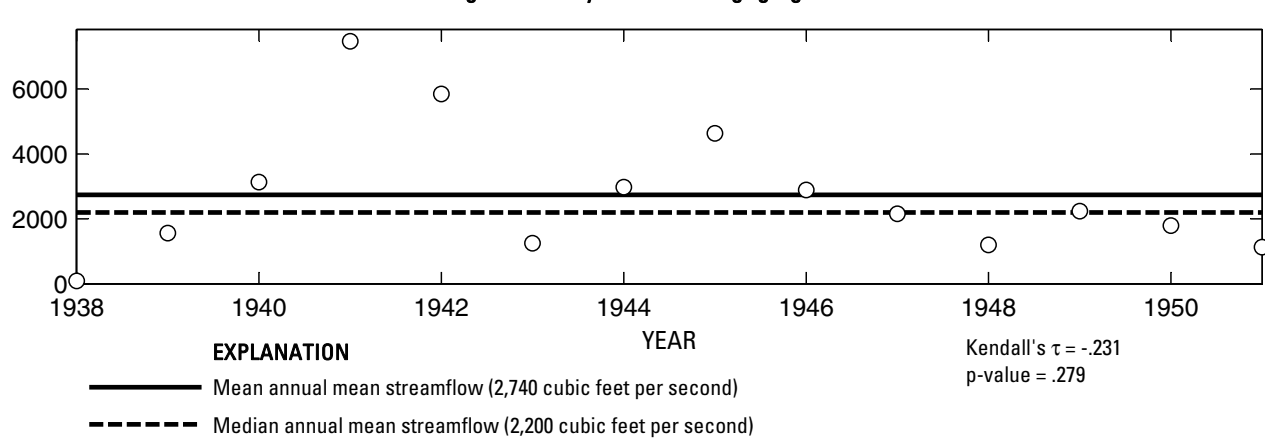

O Annual mean streamflow

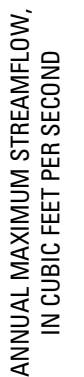

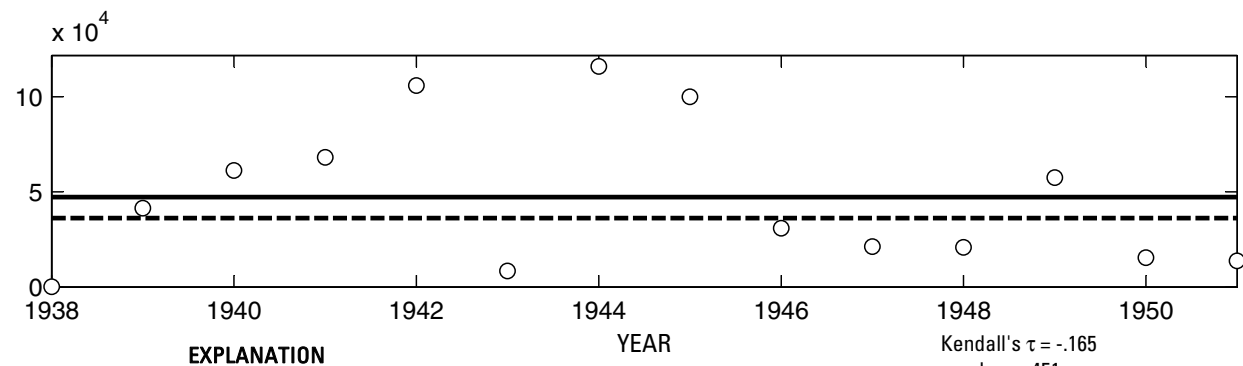

XPLANATION

$\mathrm{p}$-value $=.451$

-_an Median annual maximum streamflow (36,200 cubic feet per second)

O Annual maximum streamflow

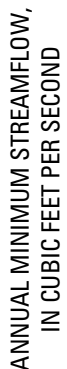

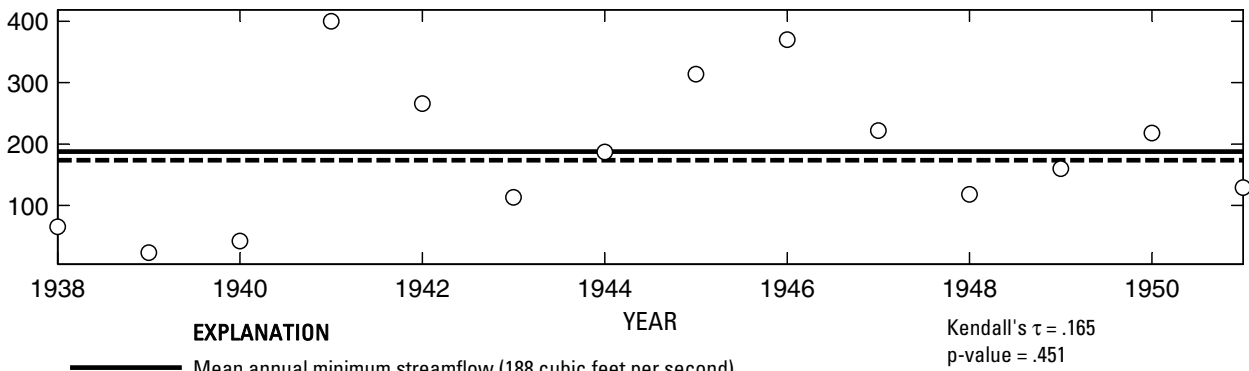

- Median annual minimum streamflow (174 cubic feet per second)

O Annual minimum streamflow

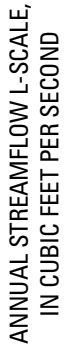

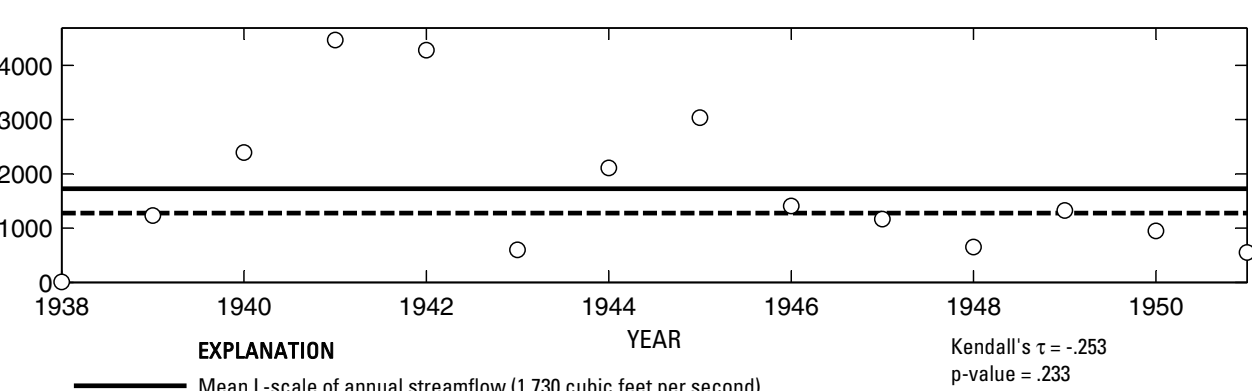

- - - - Median L-scale of annual streamflow (1,280 cubic feet per second)

O Annual L-scale of streamflow

Figure 386. Analysis of annual mean, maximum, minimum, and L-scale statistics of daily mean streamflow for U.S. Geological Survey streamflow-gaging station 08097500 Brazos River near Marlin, Texas.

Index of Station Numbers 719 

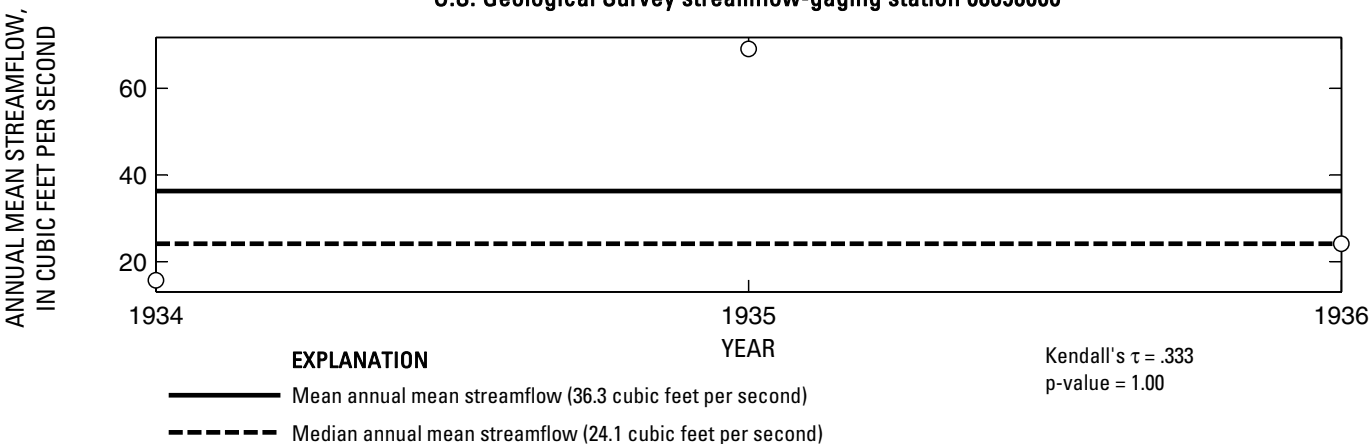

Annual mean streamflow

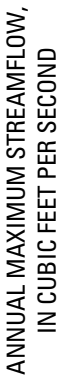

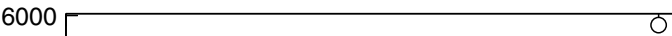

4000

2000

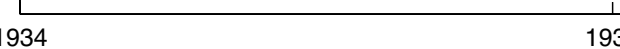

1935

EXPLANATION

YEAR

Mean annual maximum streamflow (2,800 cubic feet per second)

p-value

- - - - Median annual maximum streamflow $(1,410$ cubic feet per second

Annual maximum streamflow

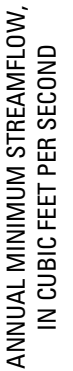

0.5

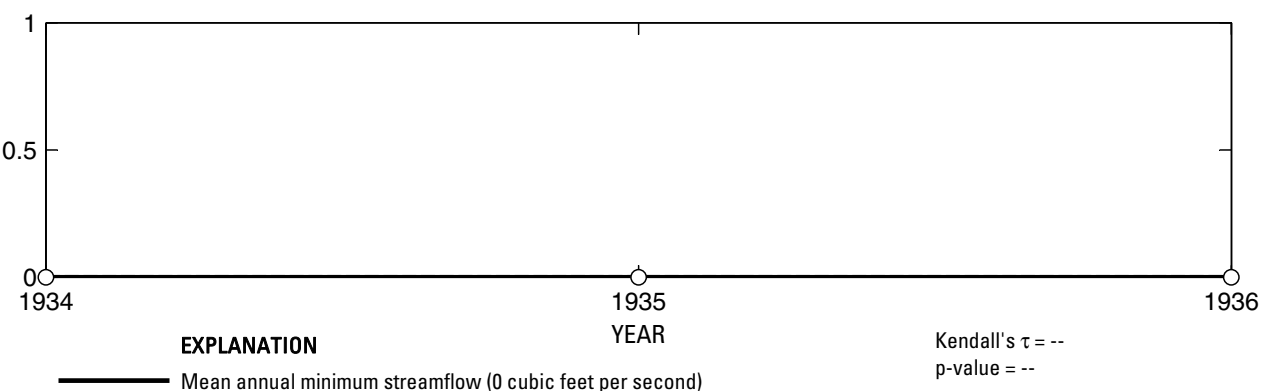

-_o- Median annual minimum streamflow (0 cubic feet per second)

○ Annual minimum streamflow
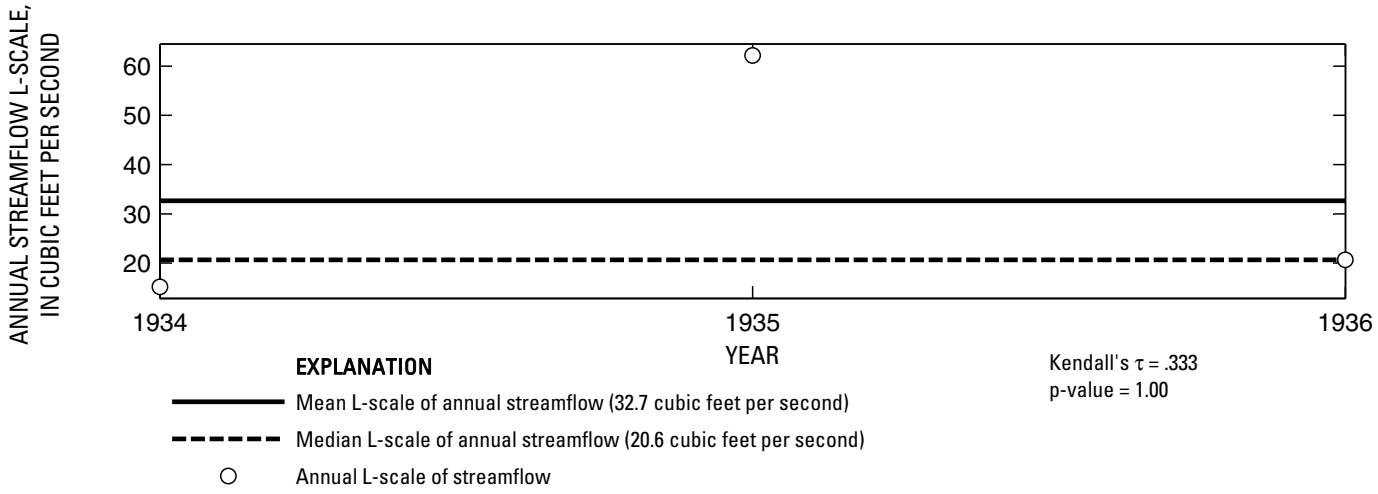

Figure 387. Analysis of annual mean, maximum, minimum, and L-scale statistics of daily mean streamflow for U.S. Geological Survey streamflow-gaging station 08098000 Deer Creek at Chilton, Texas. 


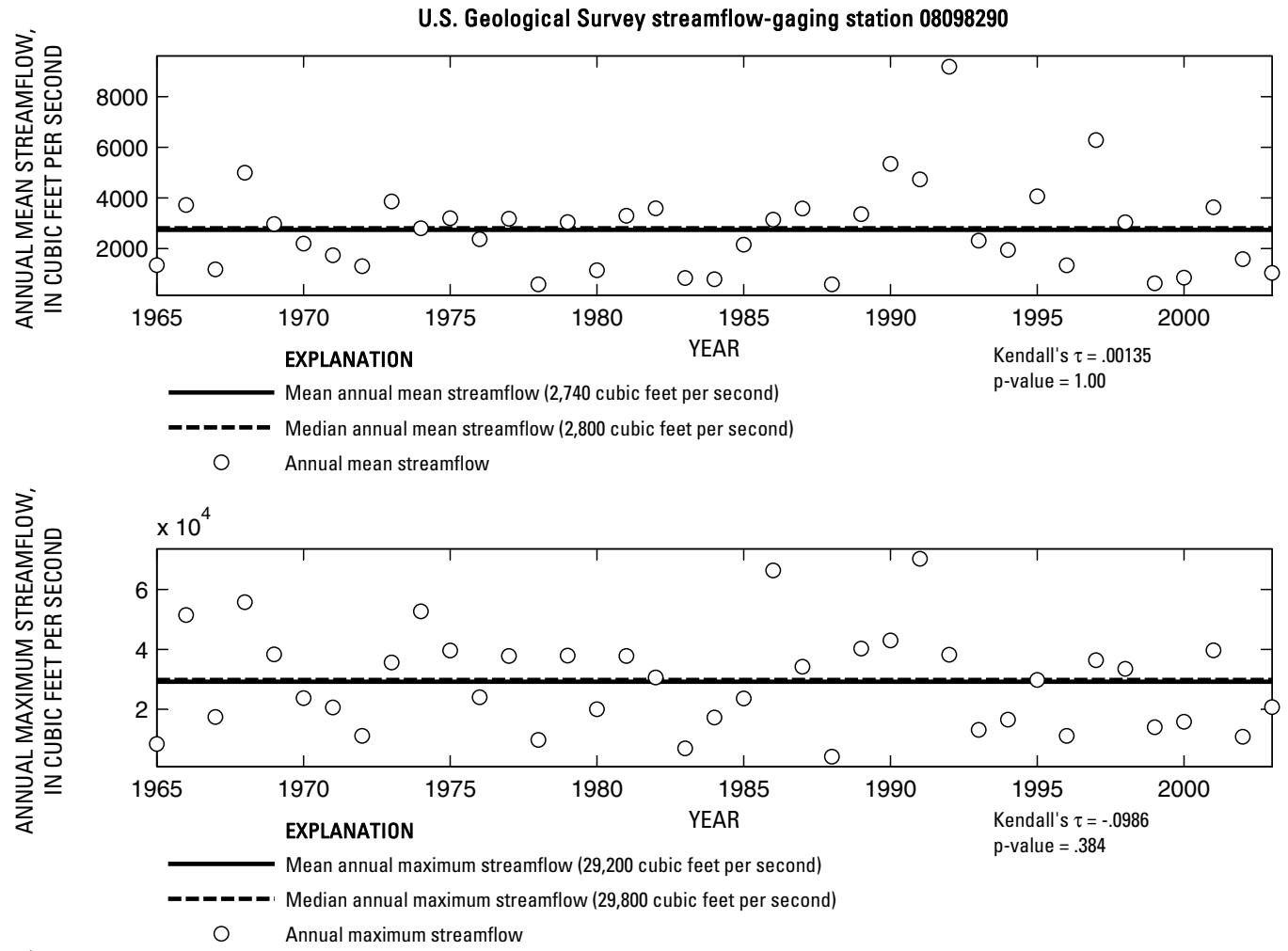

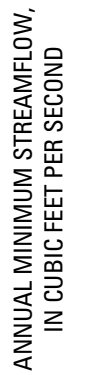

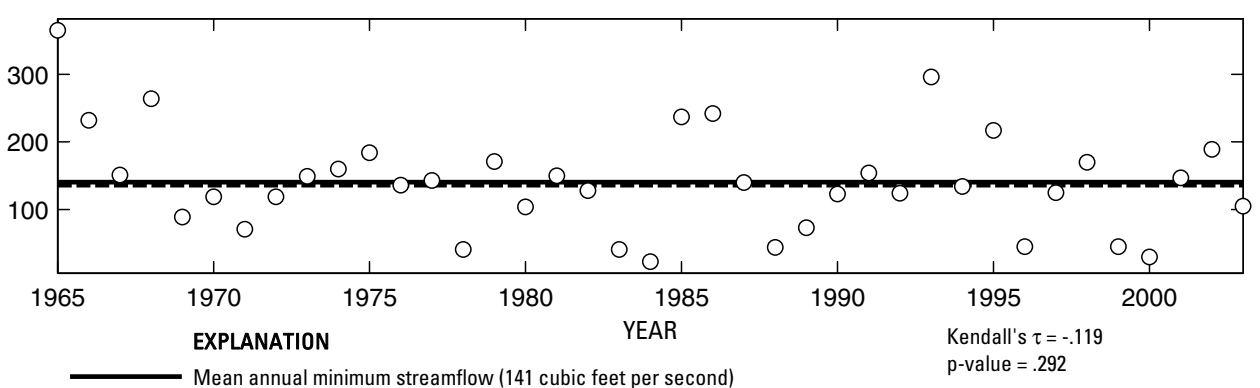

-ーーーーー Median annual minimum streamflow (136 cubic feet per second)

○ Annual minimum streamflow

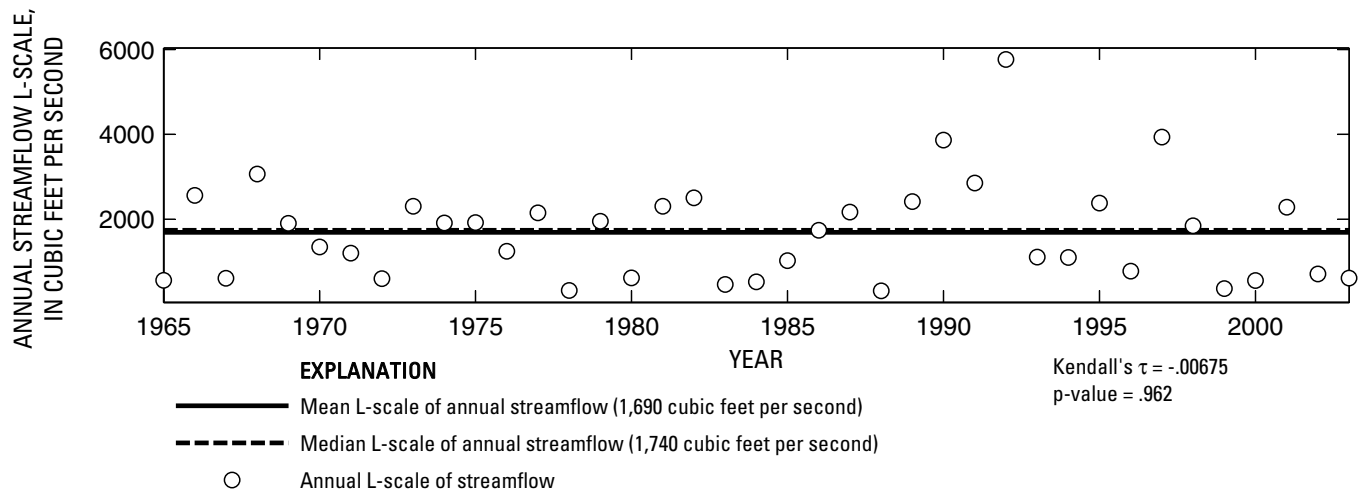

Figure 388. Analysis of annual mean, maximum, minimum, and L-scale statistics of daily mean streamflow for U.S. Geological Survey streamflow-gaging station 08098290 Brazos River near Highbank, Texas.

Index of Station Numbers 719 


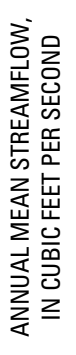

U.S. Geological Survey streamflow-gaging station 08098300

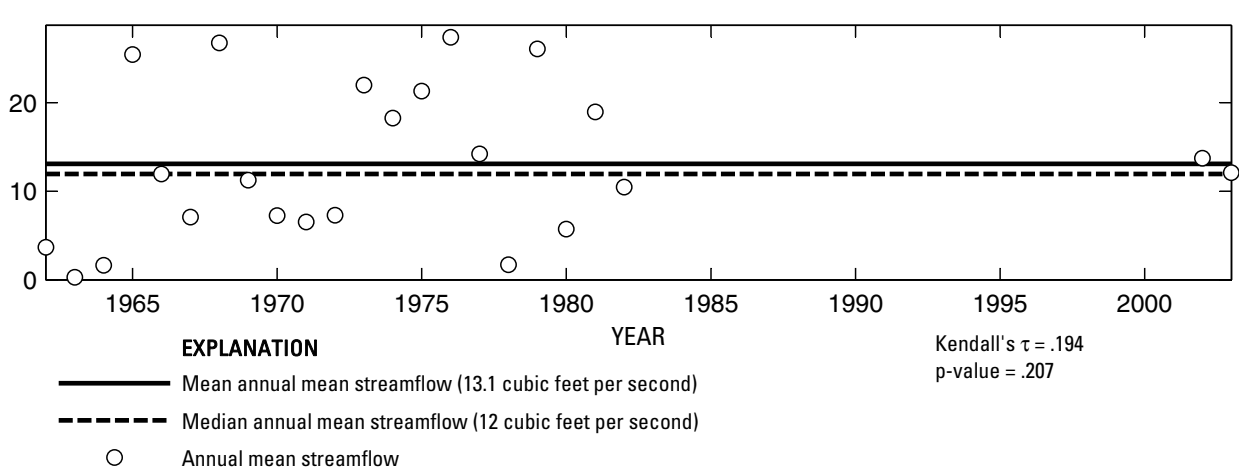

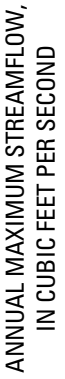

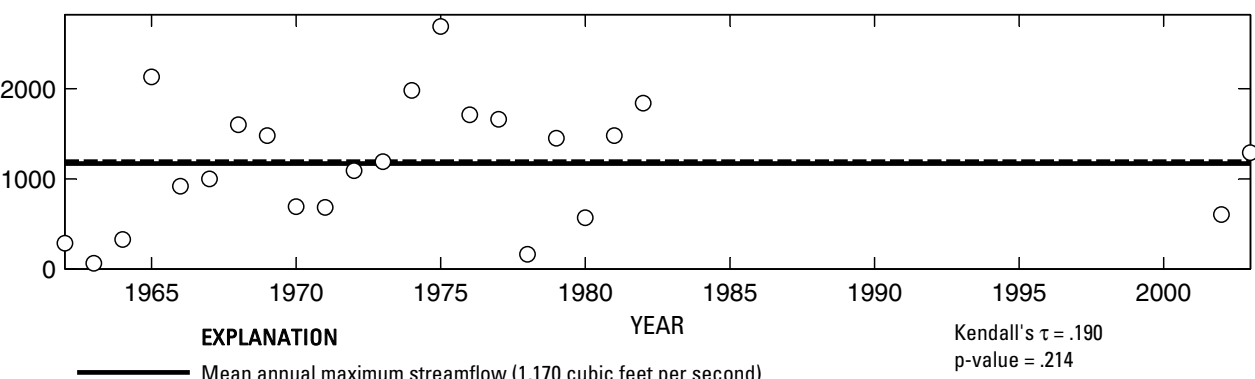

Annual maximum streamflow

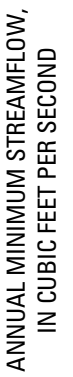

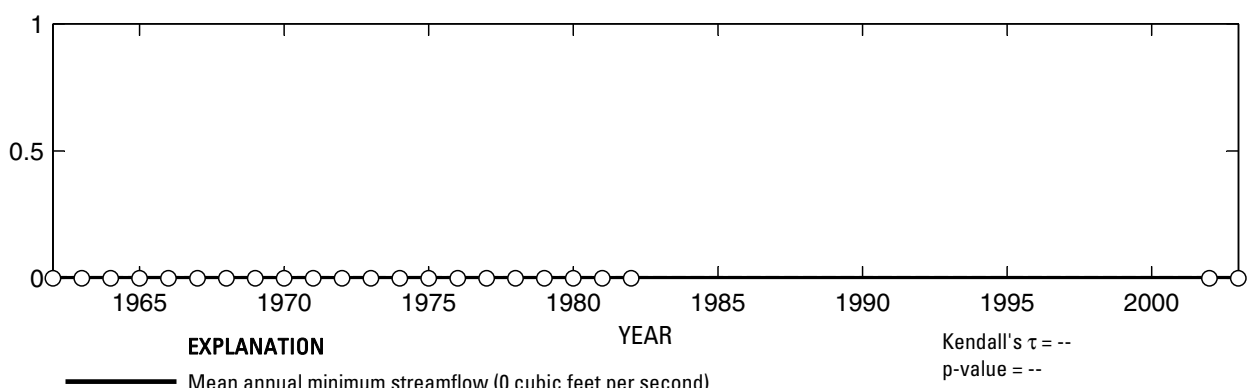

- Median annual minimum streamflow (0 cubic feet per second)

○ Annual minimum streamflow

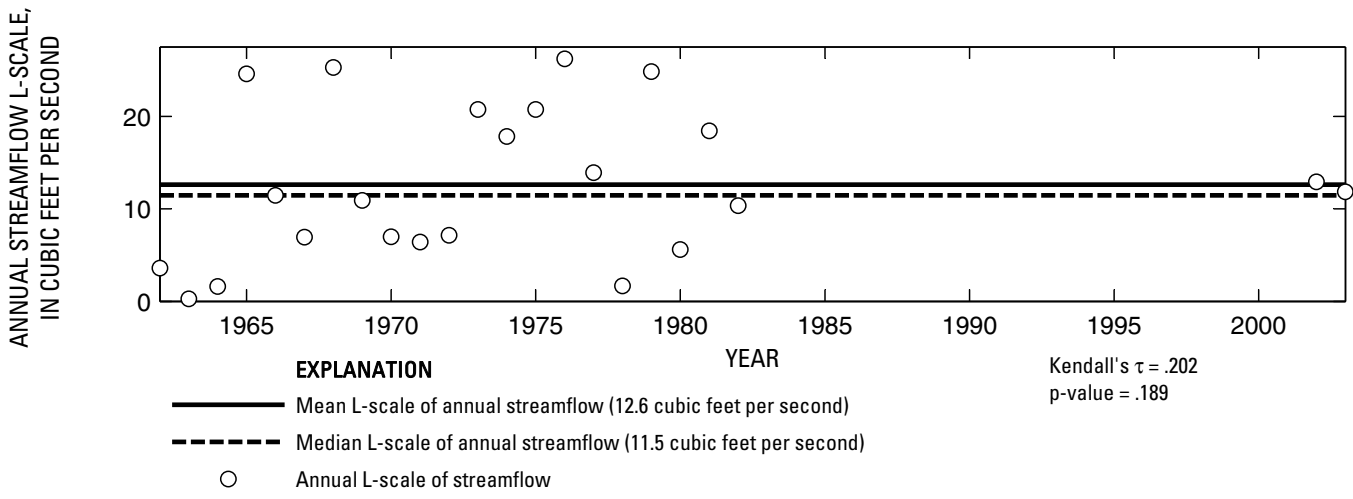

Figure 389. Analysis of annual mean, maximum, minimum, and L-scale statistics of daily mean streamflow for U.S. Geological Survey streamflow-gaging station 08098300 Little Pond Creek near Burlington, Texas. 


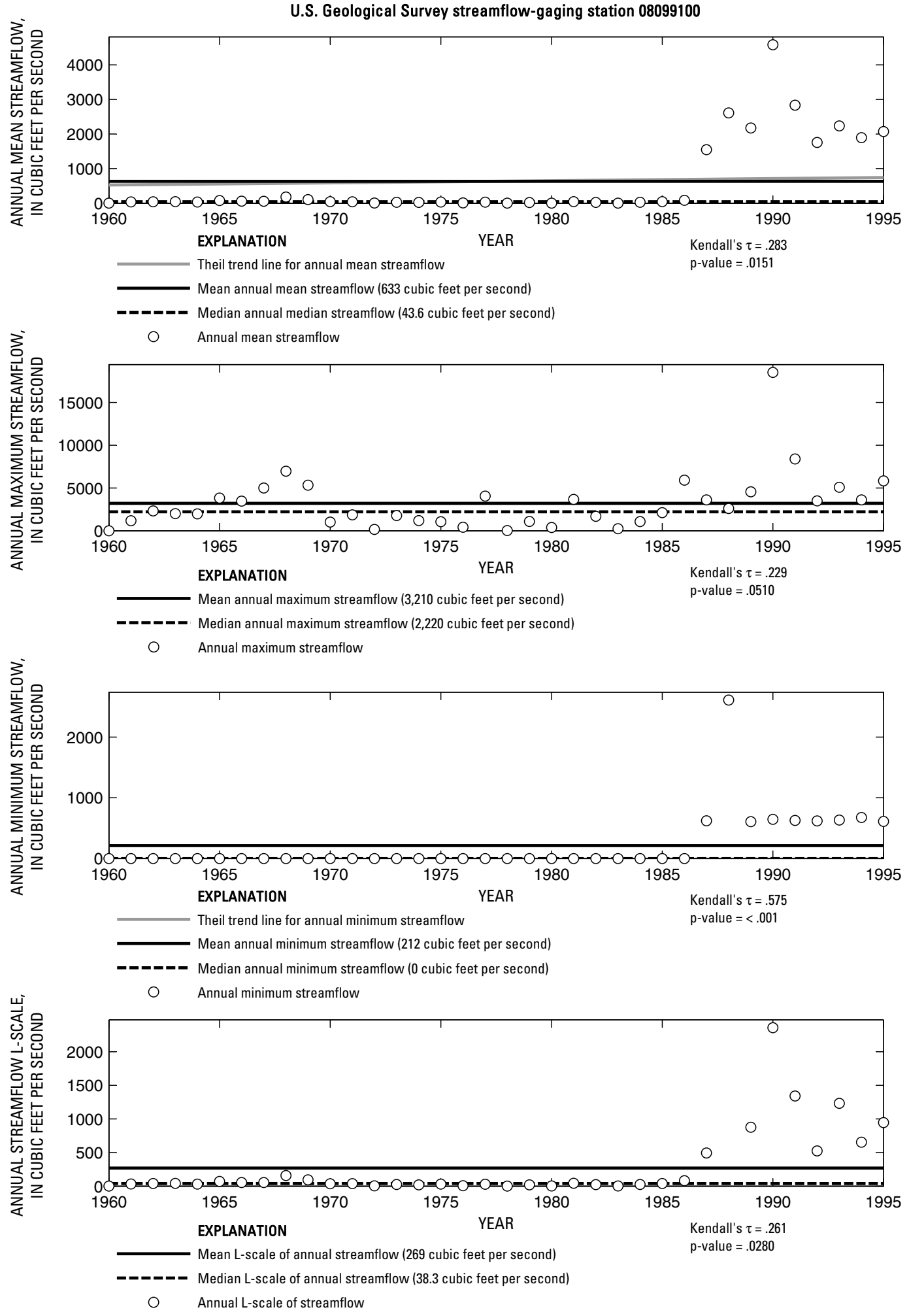

Figure 390. Analysis of annual mean, maximum, minimum, and L-scale statistics of daily mean streamflow for U.S. Geological Survey streamflow-gaging station 08099100 Leon River near De Leon, Texas.

Index of Station Numbers 719 


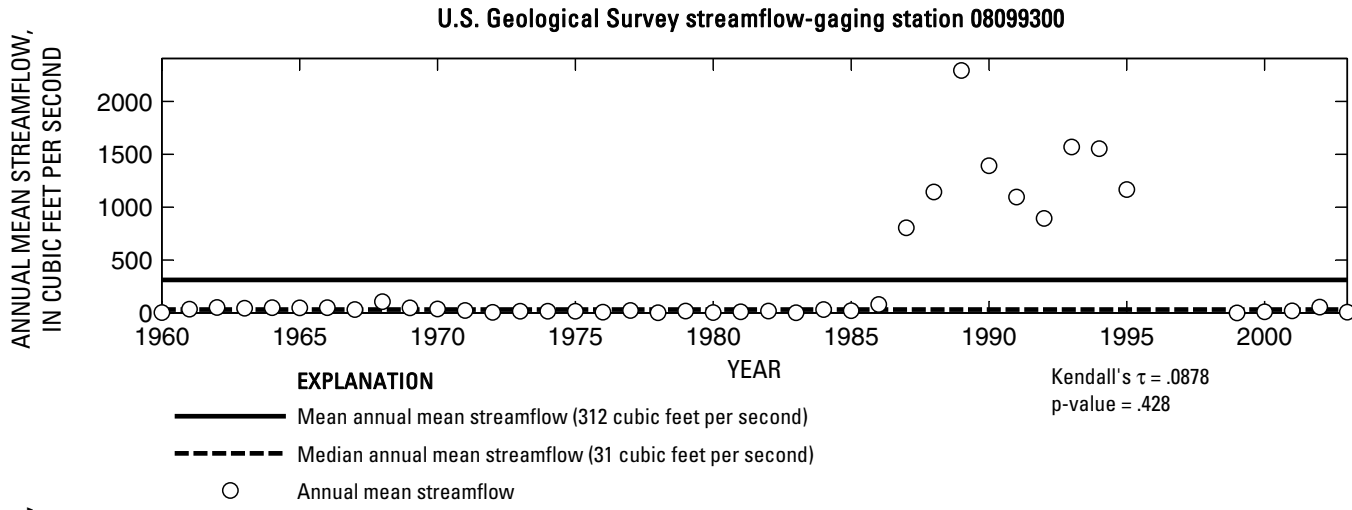

竞号

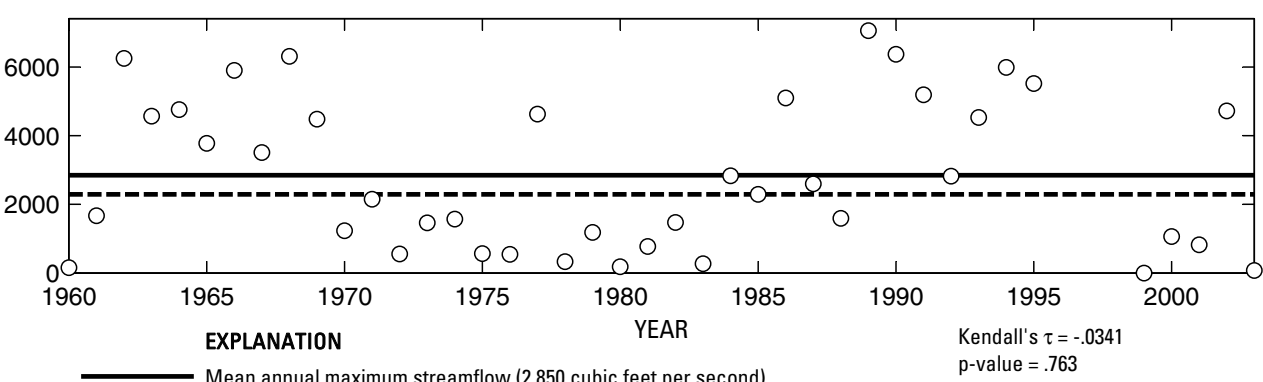

- _ _ - Median annual maximum streamflow (2,290 cubic feet per second)

O Annual maximum streamflow
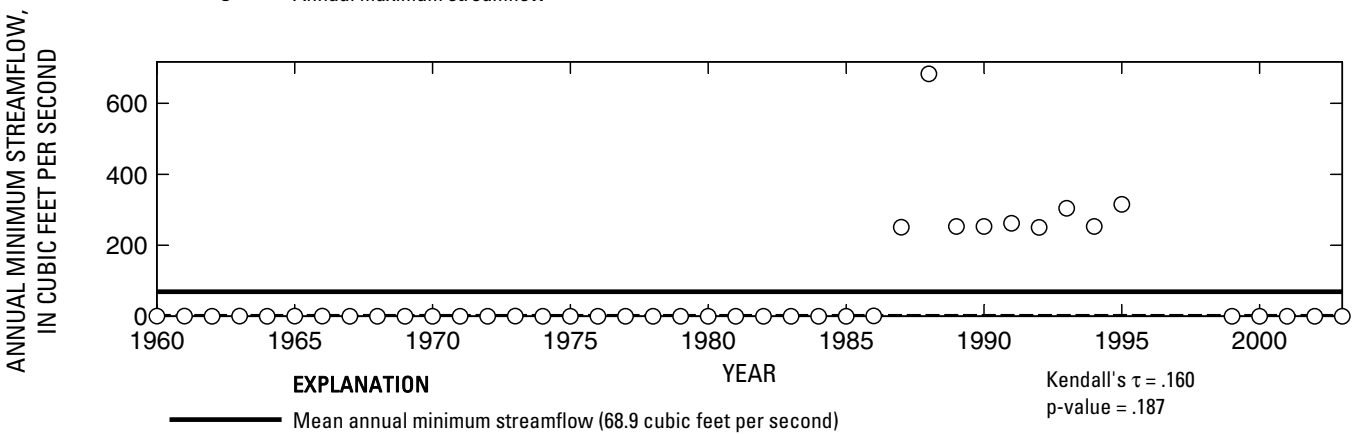

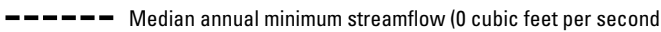

O Annual minimum streamflow

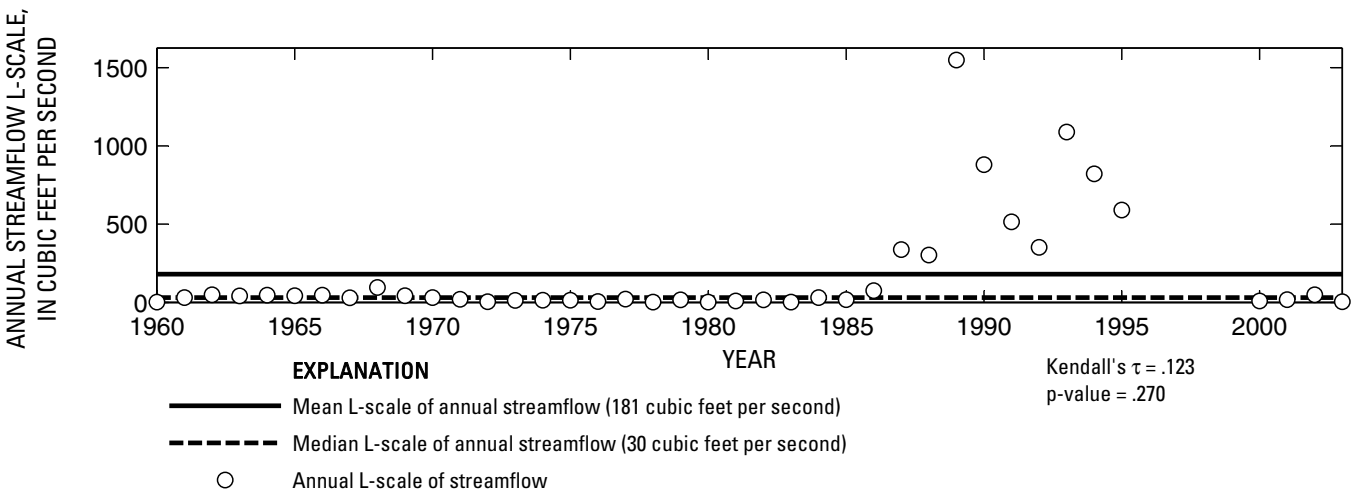

Figure 391. Analysis of annual mean, maximum, minimum, and L-scale statistics of daily mean streamflow for U.S. Geological Survey streamflow-gaging station 08099300 Sabana River near De Leon, Texas. 
U.S. Geological Survey streamflow-gaging station 08099500
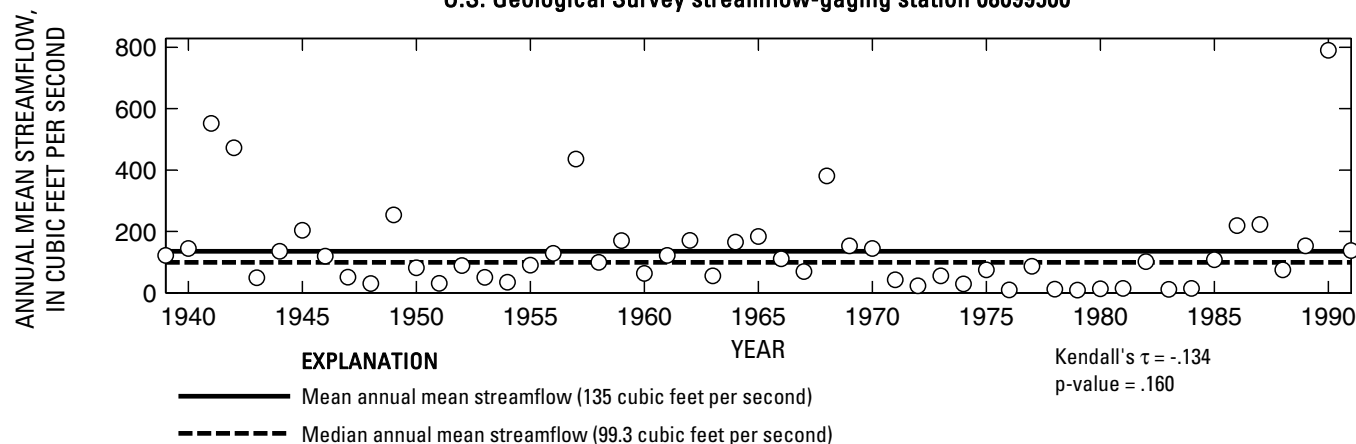

O Annual mean streamflow

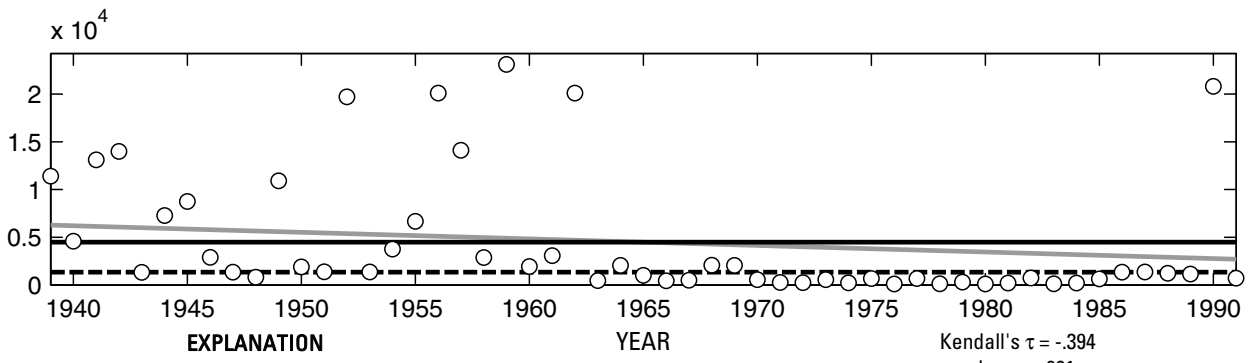

Theil trend line for annual maximum streamflow

p-value $=<.001$

Mean annual maximum streamflow (4,480 cubic feet per second)

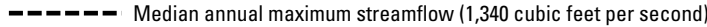

$\bigcirc \quad$ Annual maximum streamflow

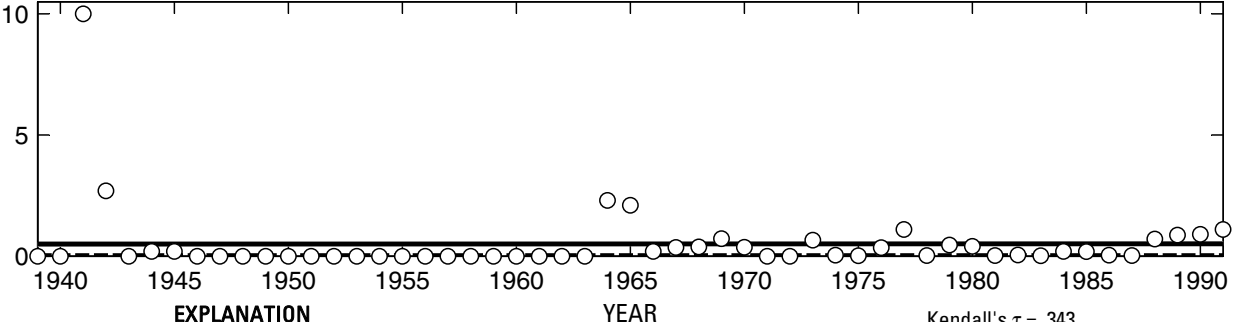
EXPLANATION YEAR Kendall's $\tau=.343$

Theil trend line for annual minimum streamflow $\mathrm{p}$-value $=<.001$

Mean annual minimum streamflow (.5045 cubic feet per second)

- - Median annual minimum streamflow (.03 cubic feet per second)

$\bigcirc$ Annual minimum streamflow

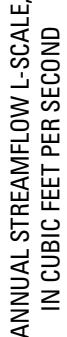

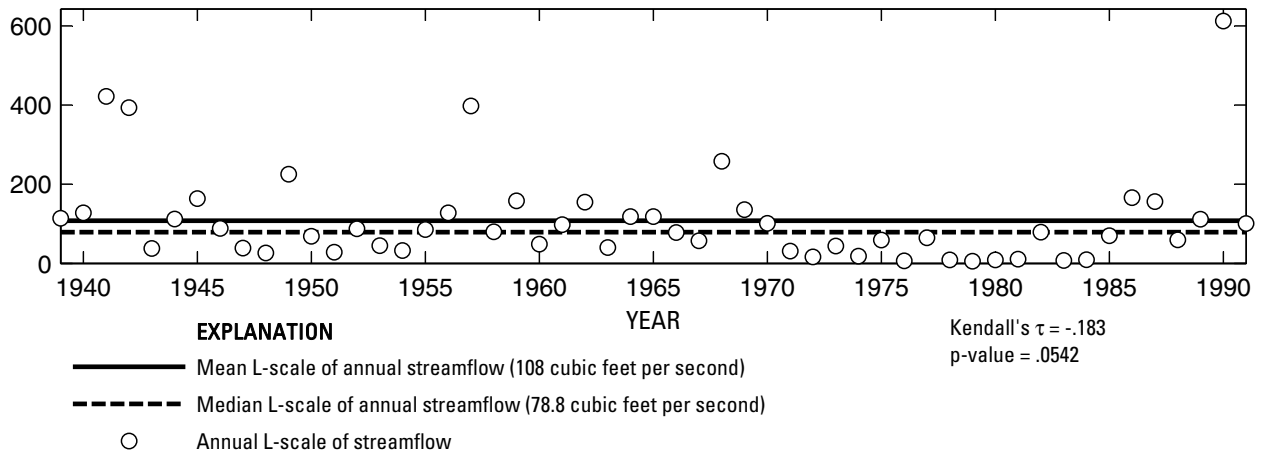

Figure 392. Analysis of annual mean, maximum, minimum, and L-scale statistics of daily mean streamflow for U.S. Geological Survey streamflow-gaging station 08099500 Leon River near Hasse, Texas.

Index of Station Numbers 719 


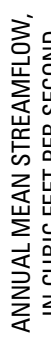

U.S. Geological Survey streamflow-gaging station 08100000

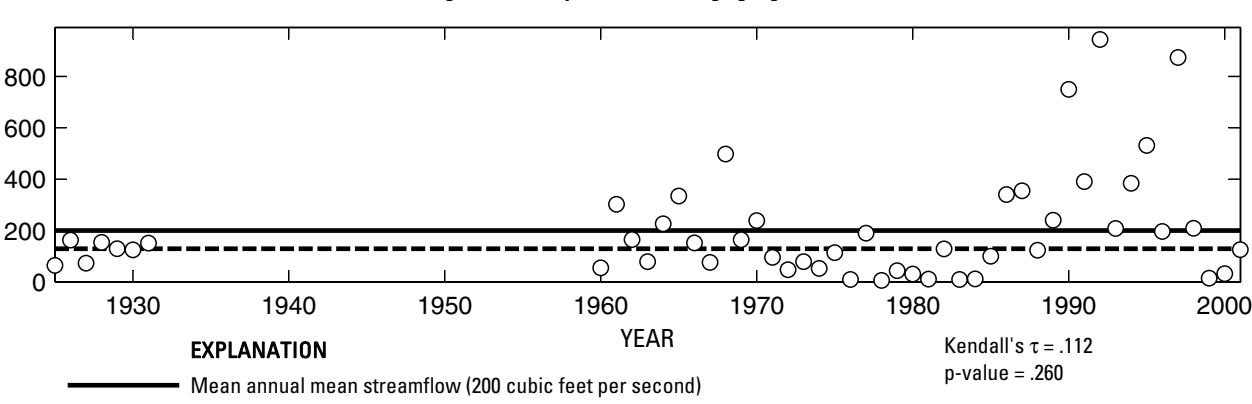

-_-_- Median annual mean streamflow (129 cubic feet per second)

O Annual mean streamflow

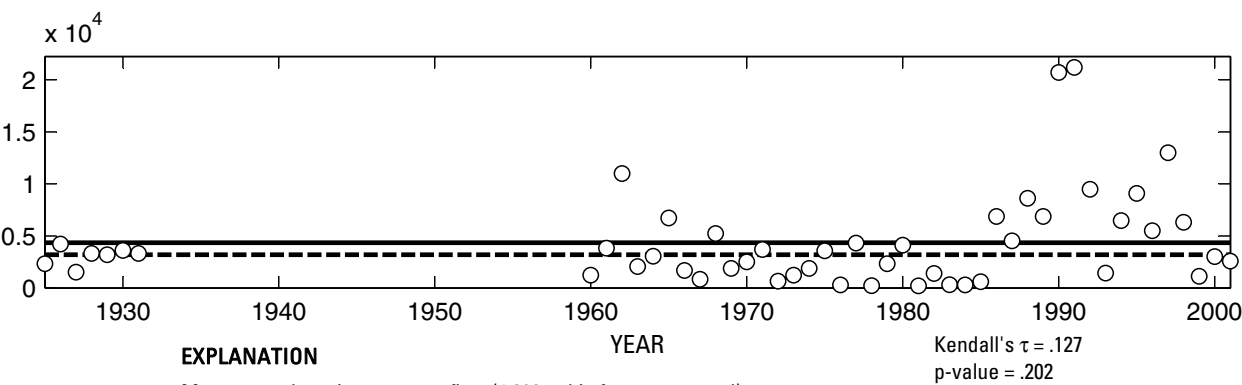

O Annual maximum streamflow

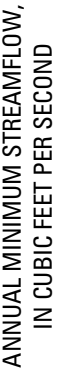

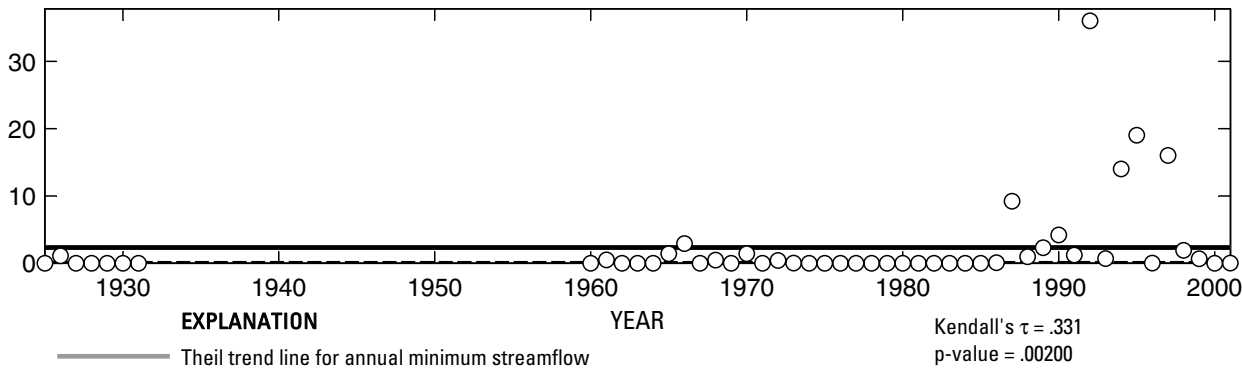

Median annual minimum streamflow $(0$ cubic feet per second)

Annual minimum streamflow

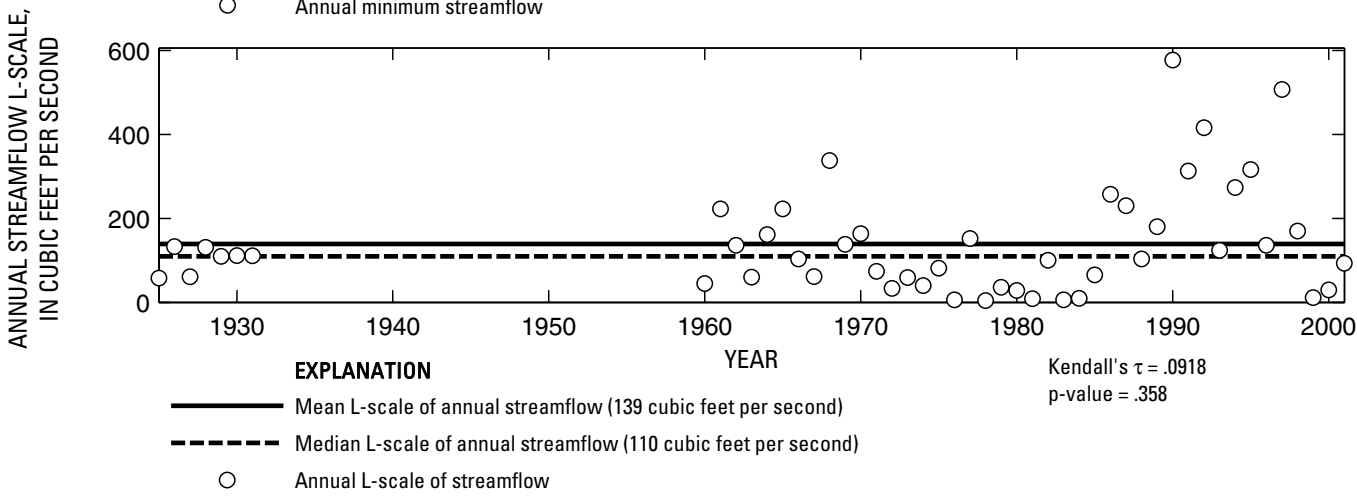

Figure 393. Analysis of annual mean, maximum, minimum, and L-scale statistics of daily mean streamflow for U.S. Geological Survey streamflow-gaging station 08100000 Leon River near Hamilton, Texas. 


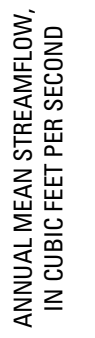

U.S. Geological Survey streamflow-gaging station 08100500

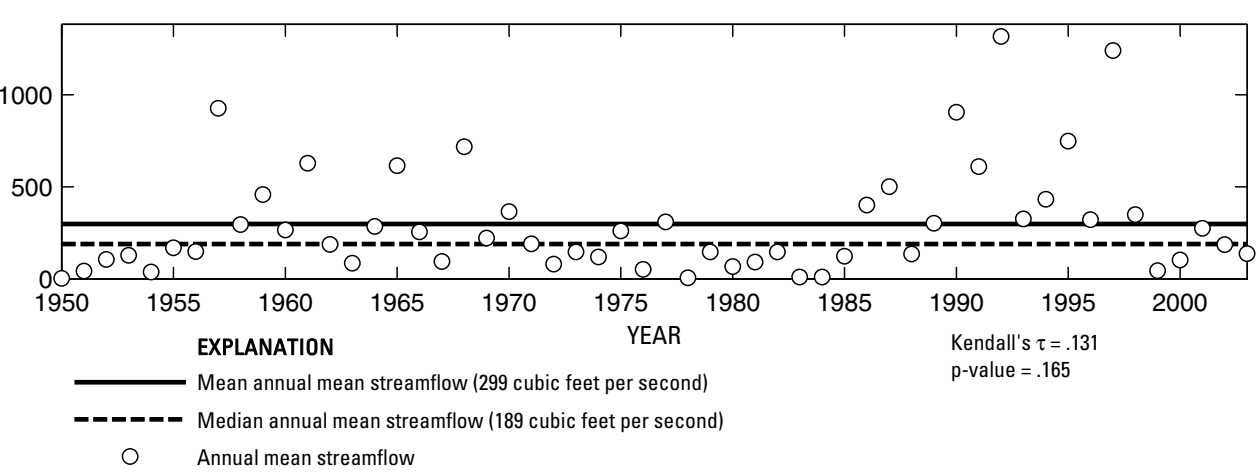

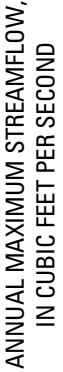

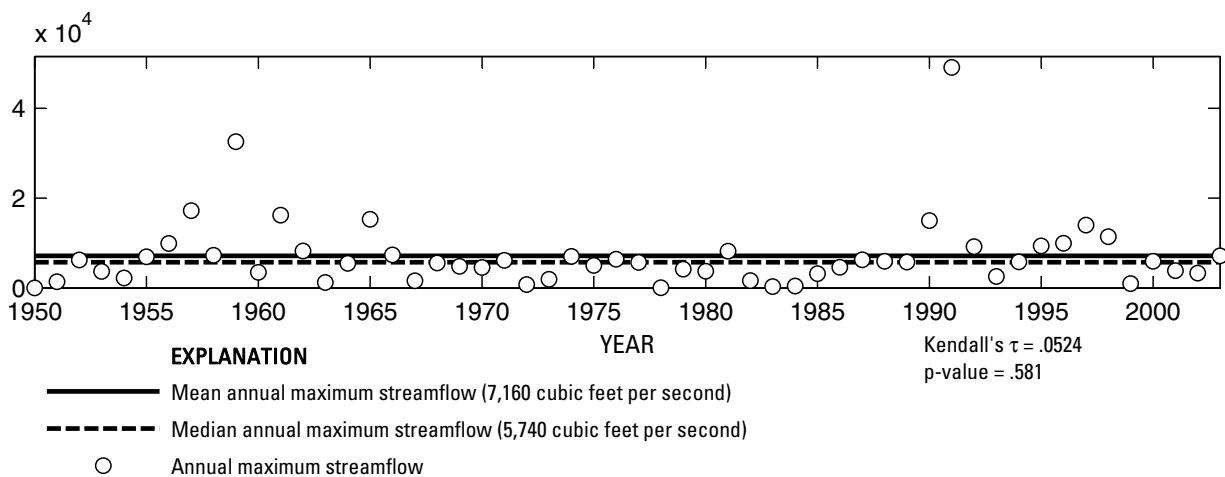

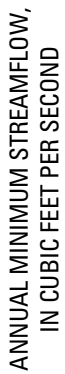

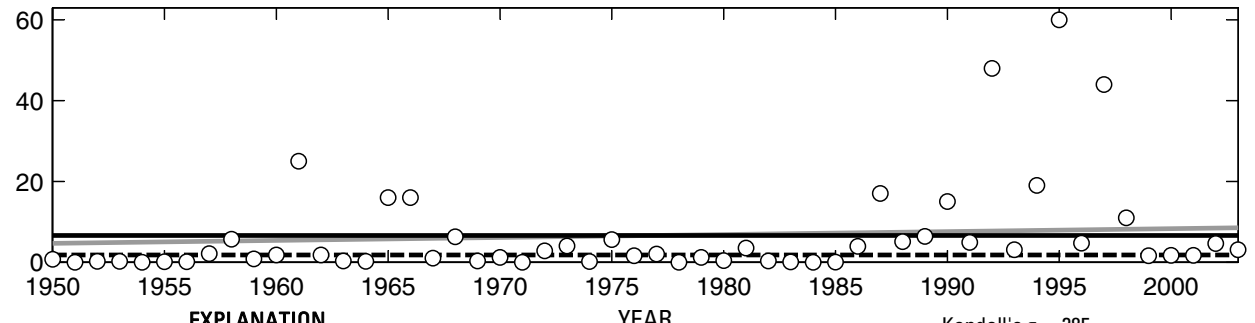

\section{EXPLANATION} YEAR

Kendall's $\tau=.285$ $\mathrm{p}$-value $=.00256$

Theil trend line for annual minimum streamflow

- - - Median annual minimum streamflow (1.8 cubic feet per second)

O Annual minimum streamflow

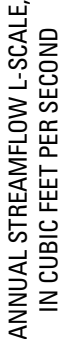

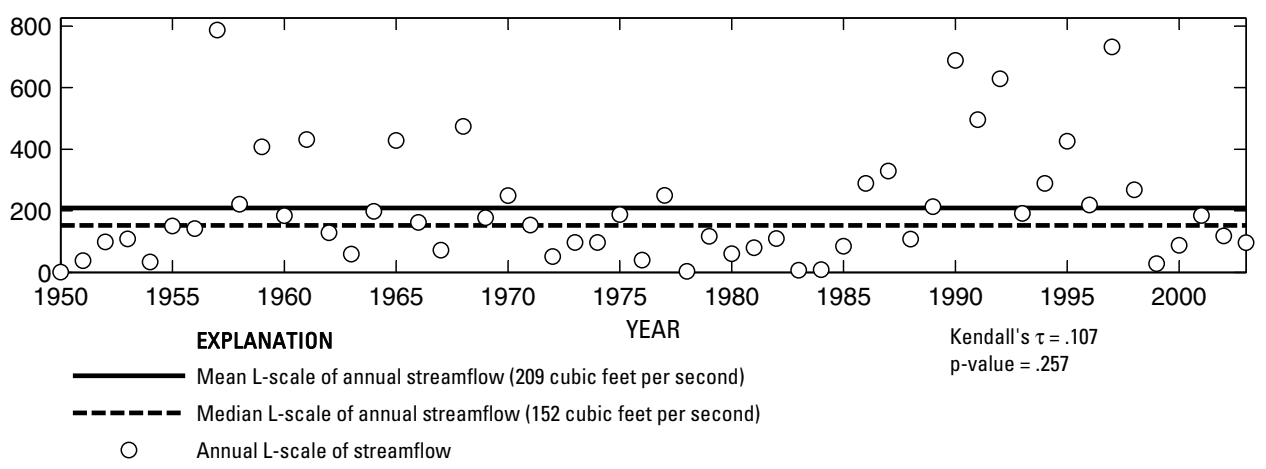

Figure 394. Analysis of annual mean, maximum, minimum, and L-scale statistics of daily mean streamflow for U.S. Geological Survey streamflow-gaging station 08100500 Leon River at Gatesville, Texas.

Index of Station Numbers 719 


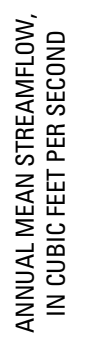

U.S. Geological Survey streamflow-gaging station 08101000

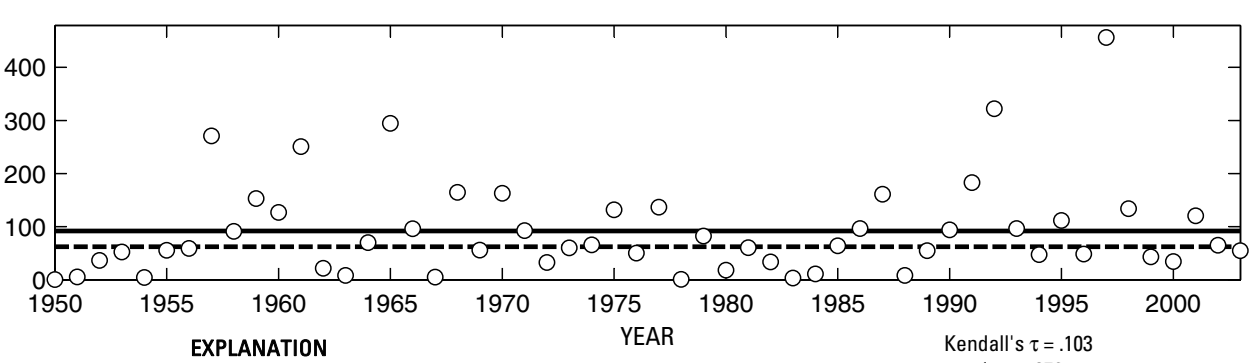

p-value $=.276$

-_-_- Median annual mean streamflow ( 62.3 cubic feet per second)

O Annual mean streamflow

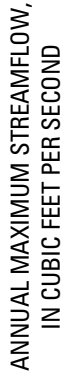

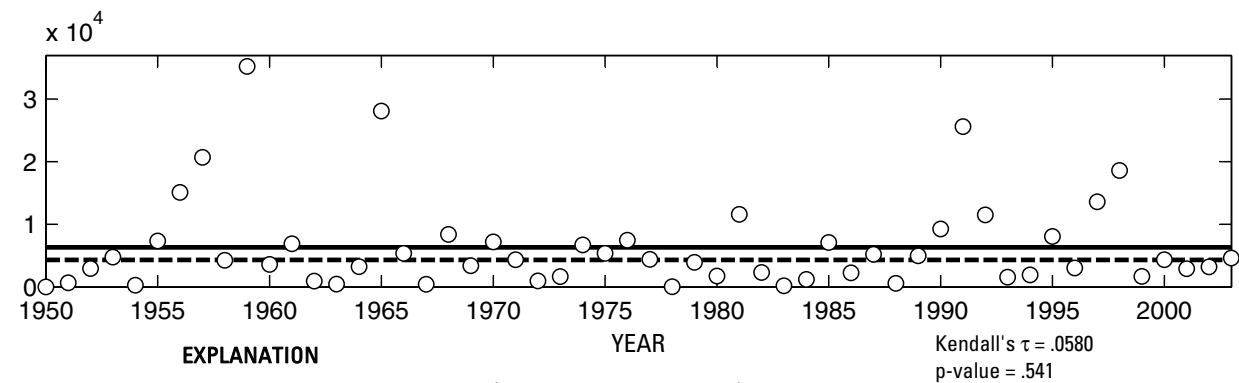

Mean annual maximum streamflow (6,320 cubic feet per second)

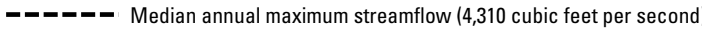

O Annual maximum streamflow

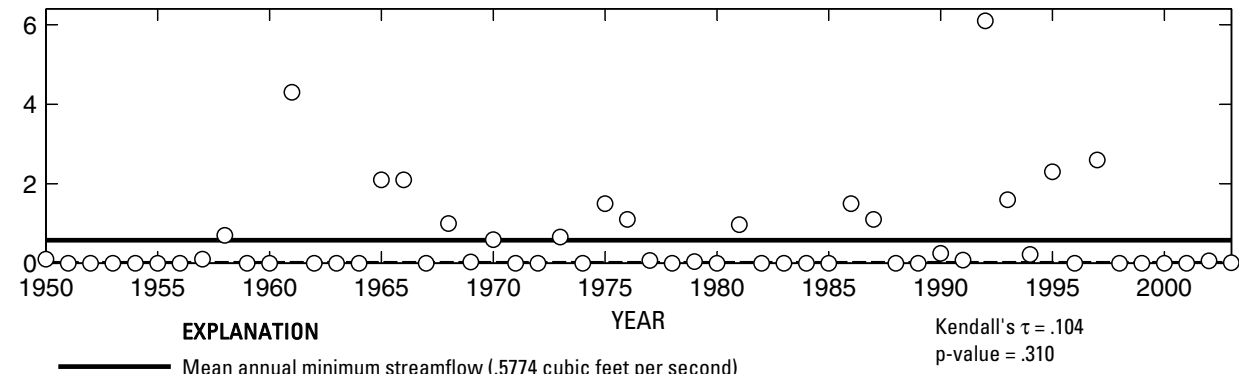

- -ーーー Median annual minimum streamflow (0 cubic feet per second)

O Annual minimum streamflow

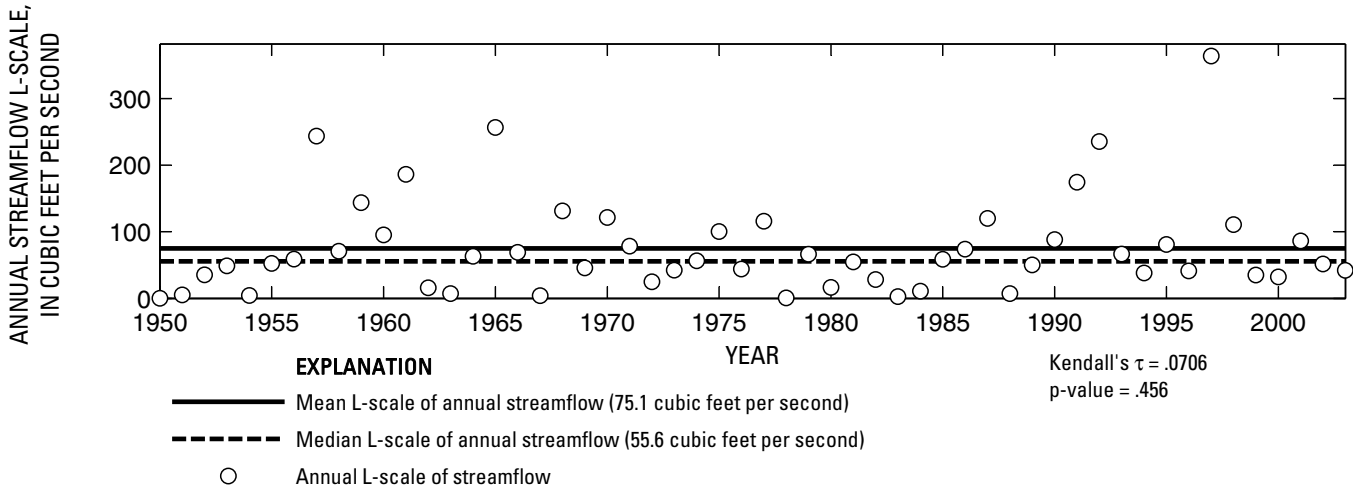

Figure 395. Analysis of annual mean, maximum, minimum, and L-scale statistics of daily mean streamflow for U.S. Geological Survey streamflow-gaging station 08101000 Cowhouse Creek at Pidcoke, Texas. 
U.S. Geological Survey streamflow-gaging station 08101500

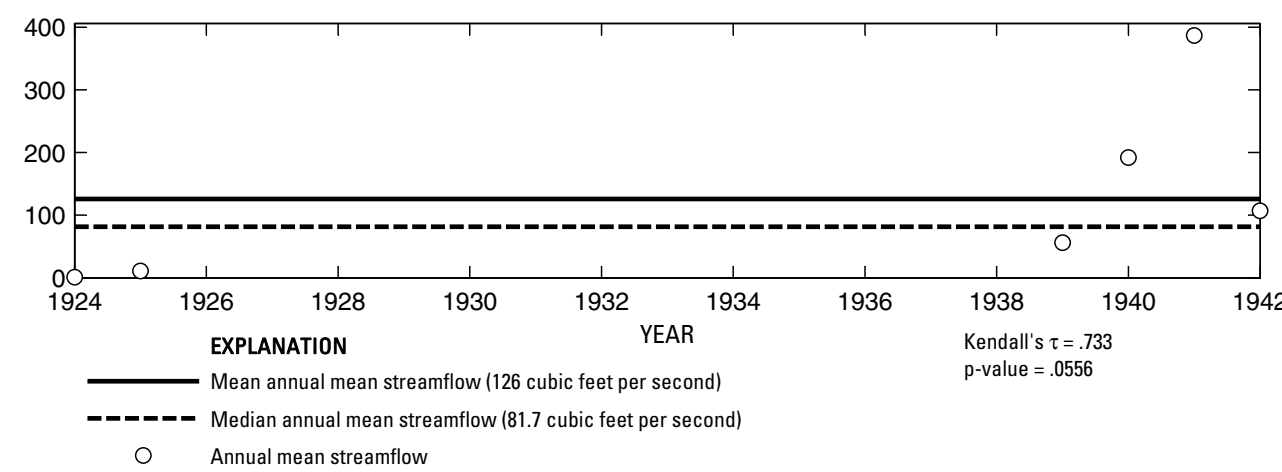

空

10000

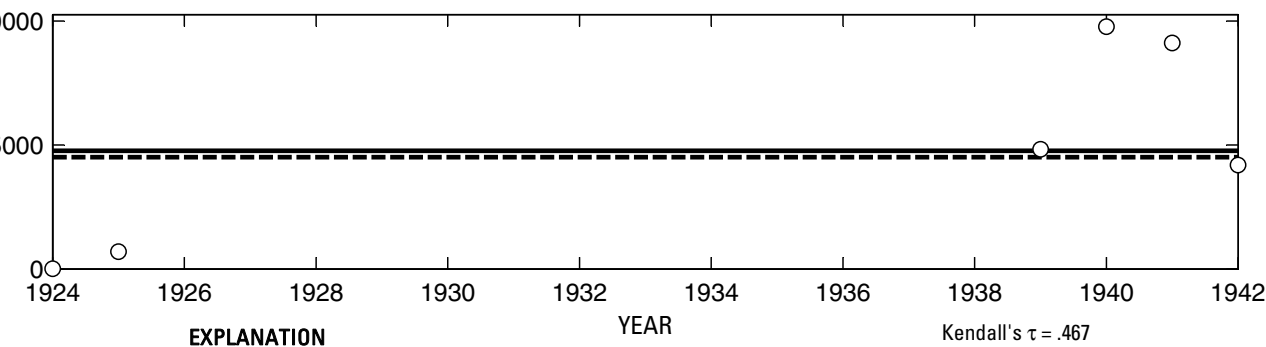

EXPLANATION

- Median annual maximum streamflow (4,510 cubic feet per second)

$\bigcirc \quad$ Annual maximum streamflow

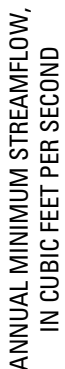

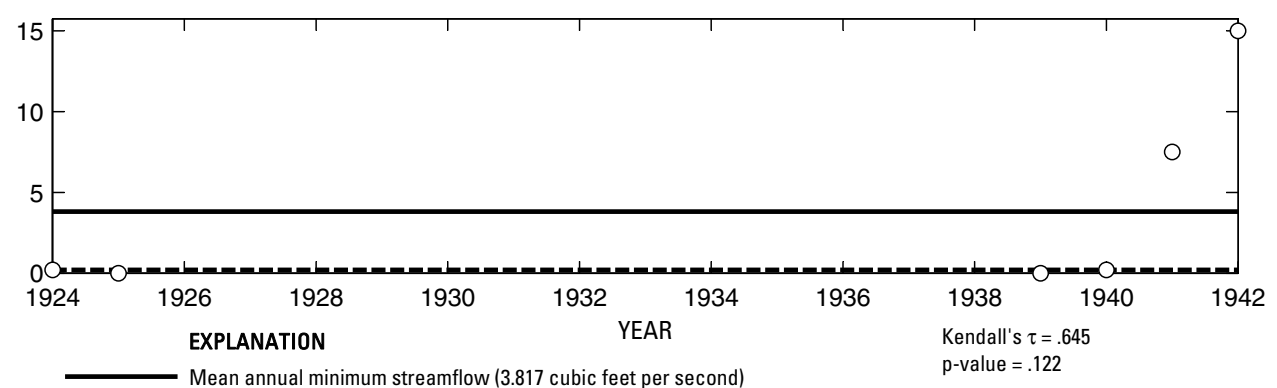

- Median annual minimum streamflow (.2 cubic feet per second)

O Annual minimum streamflow

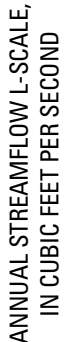

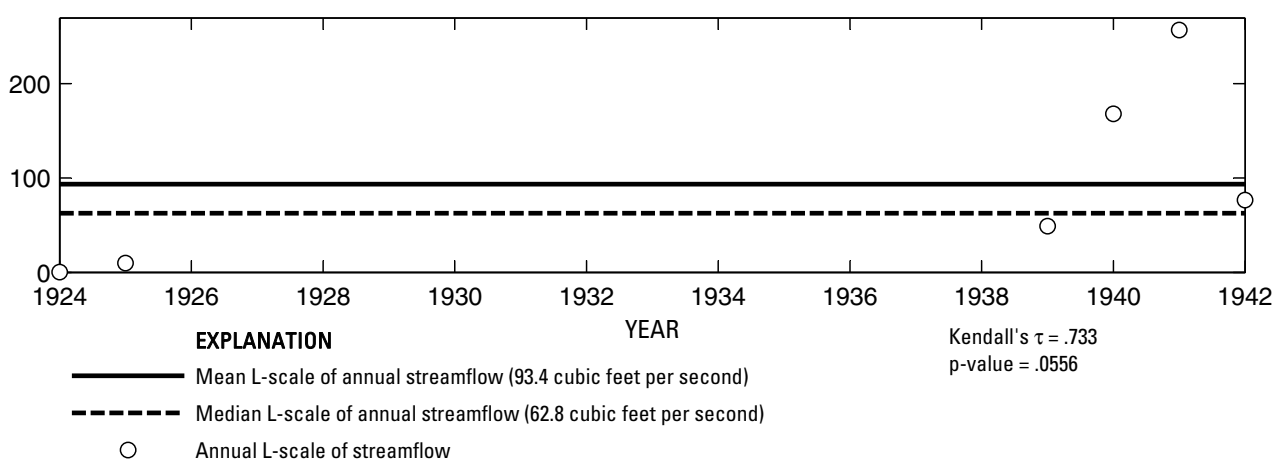

Figure 396. Analysis of annual mean, maximum, minimum, and L-scale statistics of daily mean streamflow for U.S. Geological Survey streamflow-gaging station 08101500 Cowhouse Creek near Killeen, Texas.

Index of Station Numbers 719 

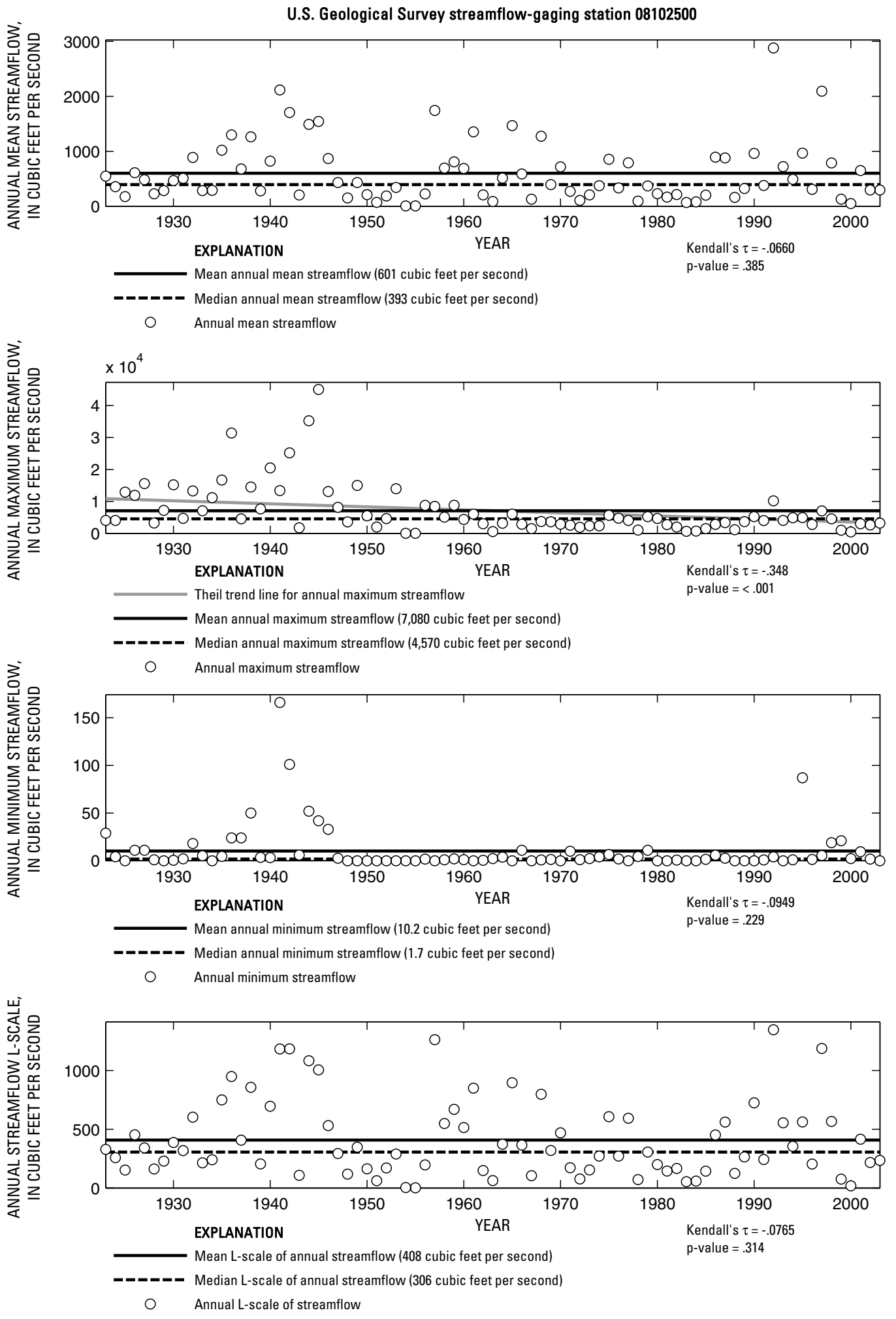

Figure 397. Analysis of annual mean, maximum, minimum, and L-scale statistics of daily mean streamflow for U.S. Geological Survey streamflow-gaging station 08102500 Leon River near Belton, Texas. 
U.S. Geological Survey streamflow-gaging station 08102600

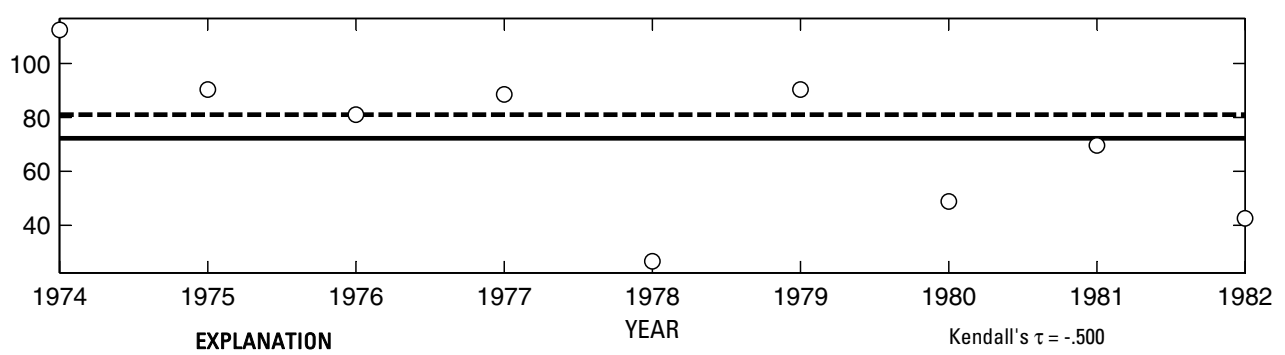

Kendall's $\tau=-.500$

Mean annual mean streamflow (72.3 cubic feet per second)

$\mathrm{p}$-value $=.0752$

-_-_-_ Median annual mean streamflow (81 cubic feet per second)

O Annual mean streamflow

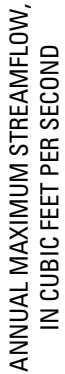

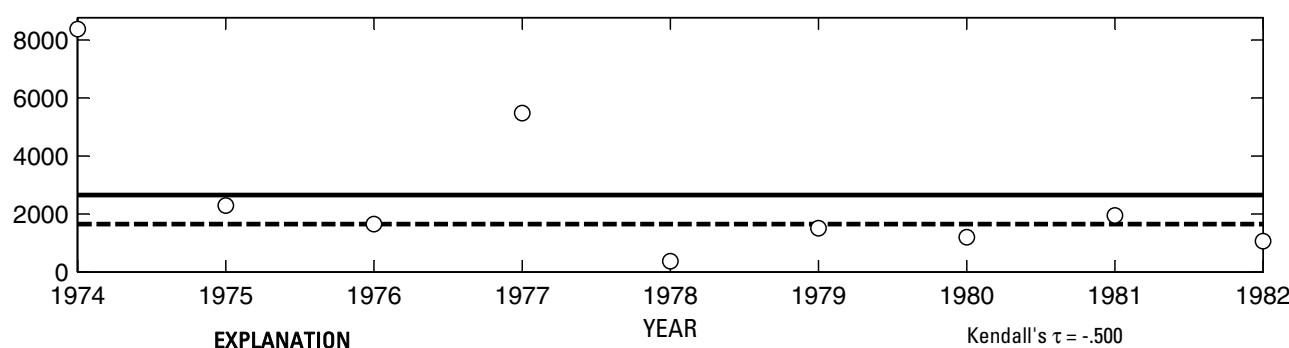

EXPLANATION YEAR Kendall's $\tau=-.500$

Mean annual maximum streamflow (2,650 cubic feet per second)

$\mathrm{p}$-value $=.0752$

- - - Median annual maximum streamflow (1,650 cubic feet per second

O Annual maximum streamflow

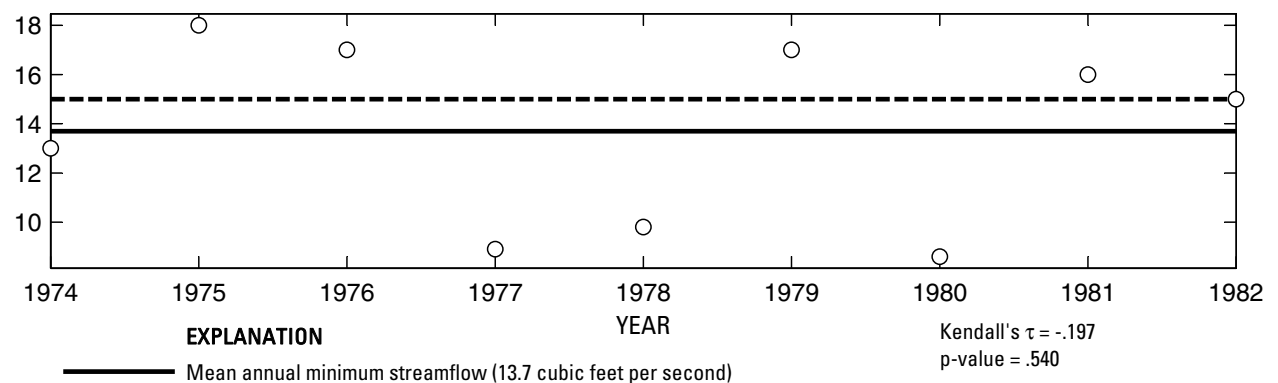

- Median annual minimum streamflow (15 cubic feet per second)

O Annual minimum streamflow

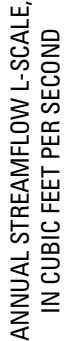

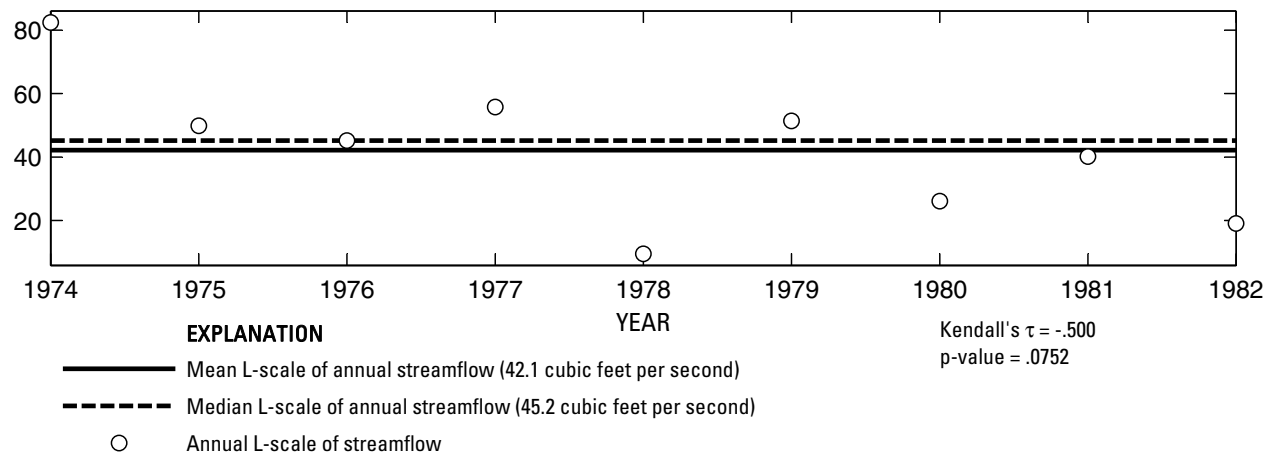

Figure 398. Analysis of annual mean, maximum, minimum, and L-scale statistics of daily mean streamflow for U.S. Geological Survey streamflow-gaging station 08102600 Nolan Creek at Belton, Texas.

|ndex of Station Numbers 719 

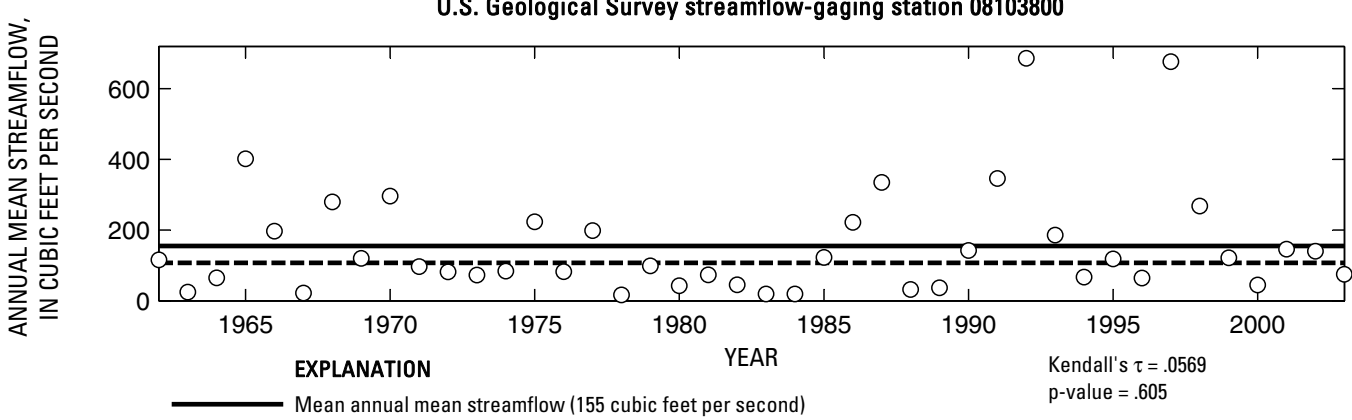

-_-_- Median annual mean streamflow (107 cubic feet per second)

- Annual mean streamflow

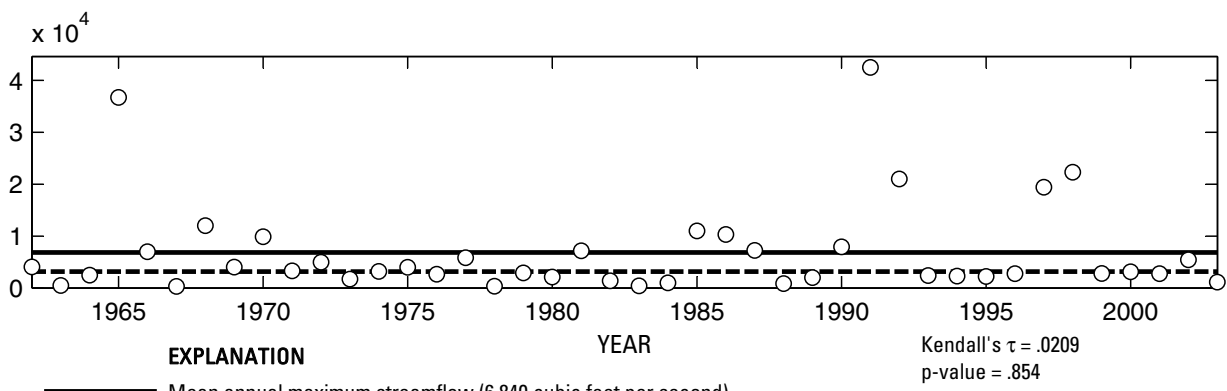

O Annual maximum streamflow

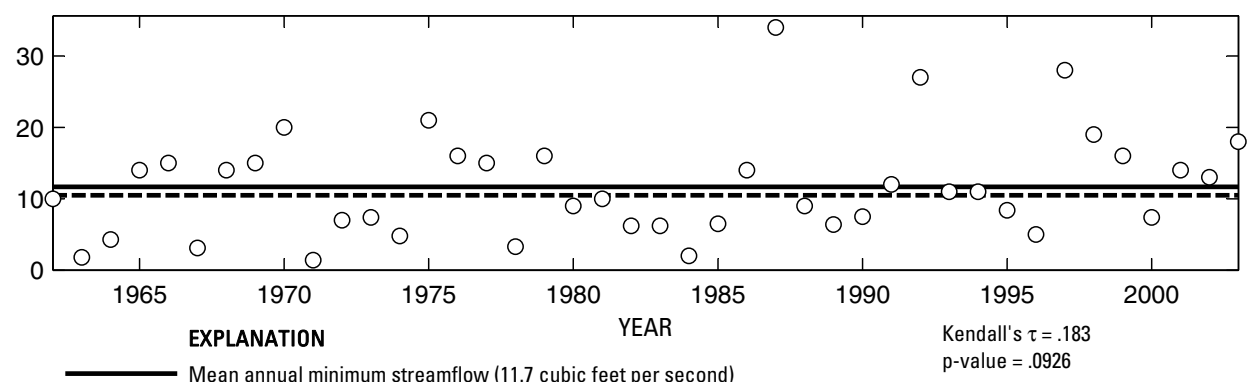

- - ב- Median annual minimum streamflow (10.5 cubic feet per second)

O Annual minimum streamflow
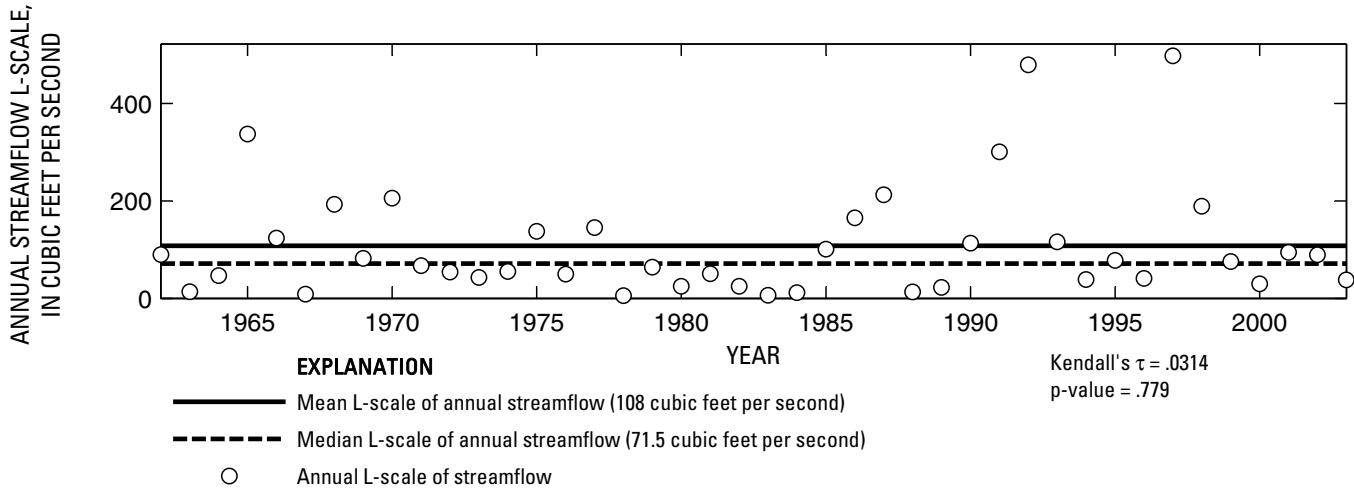

Figure 399. Analysis of annual mean, maximum, minimum, and L-scale statistics of daily mean streamflow for U.S. Geological Survey streamflow-gaging station 08103800 Lampasas River near Kempner, Texas. 
U.S. Geological Survey streamflow-gaging station 08103900

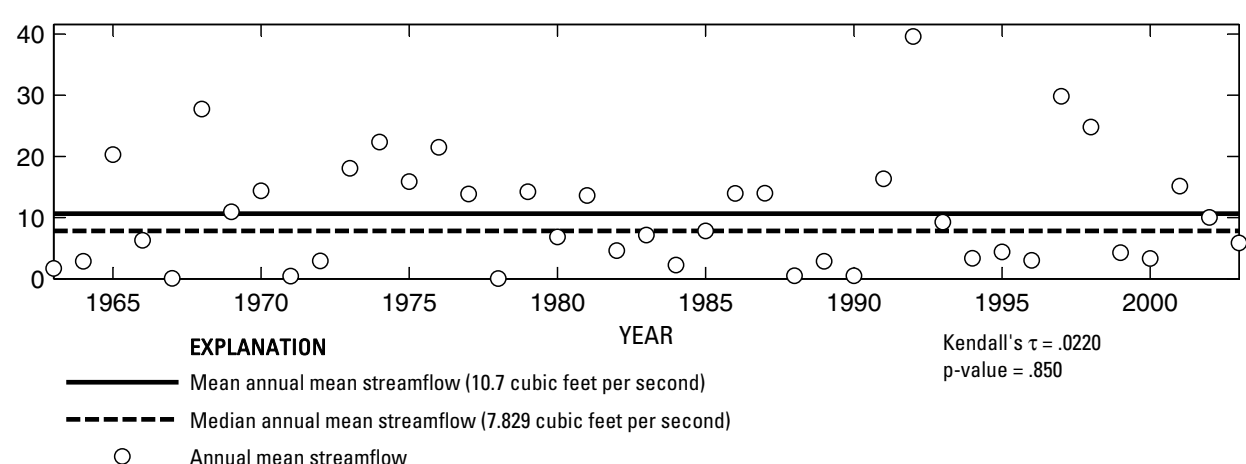

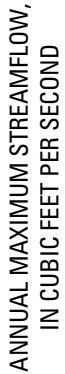

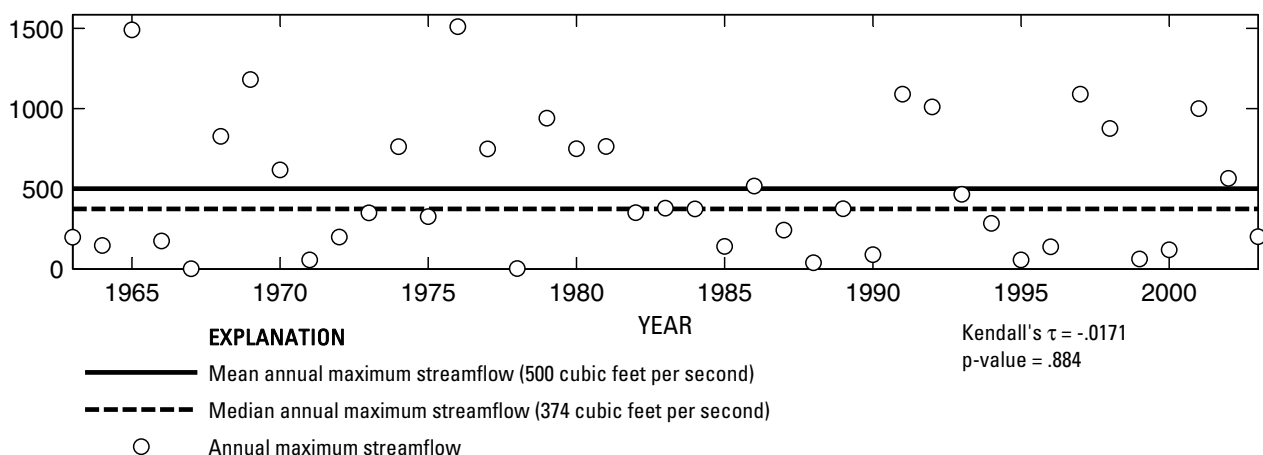

㤩
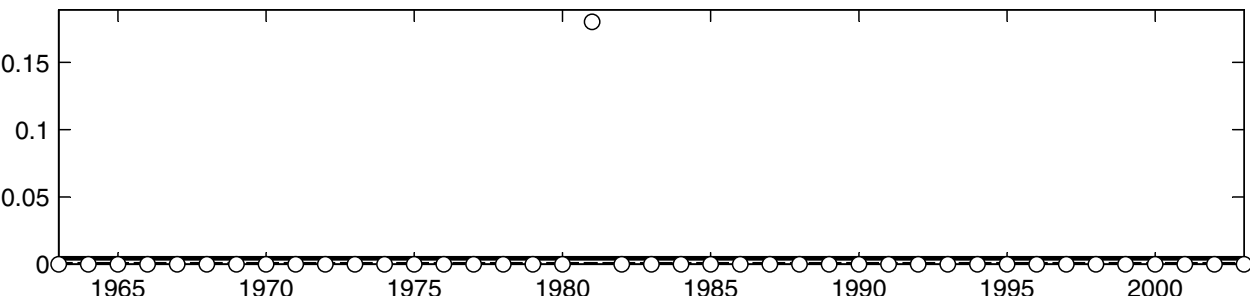
EXPLANATION

Mean annual minimum streamflow (.01 cubic feet per second)

Kendall's $\tau=-.022$

p-value $=.899$

- Median annual minimum streamflow (0 cubic feet per second)

O Annual minimum streamflow

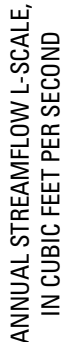

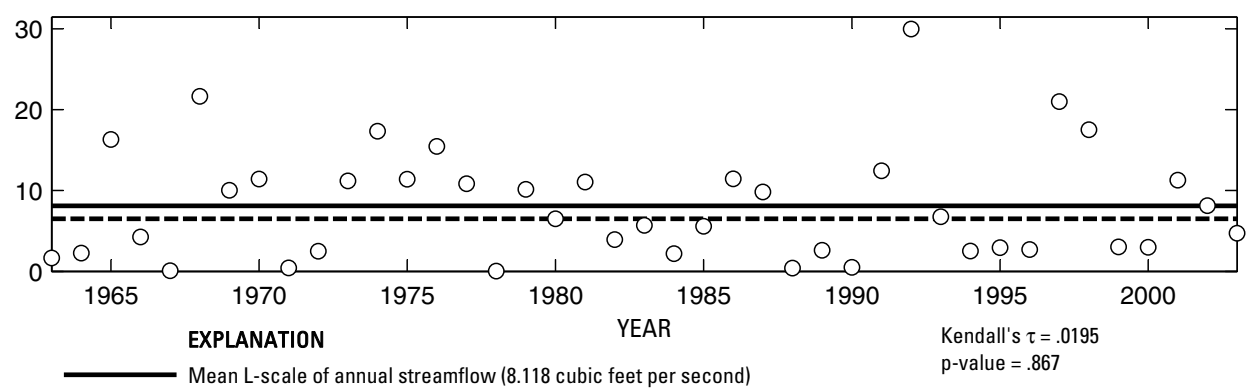

Mean L-scale of annual streamflow (8.118 cubic feet per second)

- - - Median L-scale of annual streamflow (6.502 cubic feet per second)

Annual L-scale of streamflow

Figure 400. Analysis of annual mean, maximum, minimum, and L-scale statistics of daily mean streamflow for U.S. Geological Survey streamflow-gaging station 08103900 South Fork Rocky Creek near Briggs, Texas.

Index of Station Numbers 719 


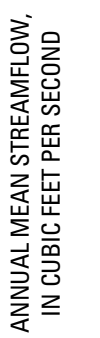

U.S. Geological Survey streamflow-gaging station 08104000

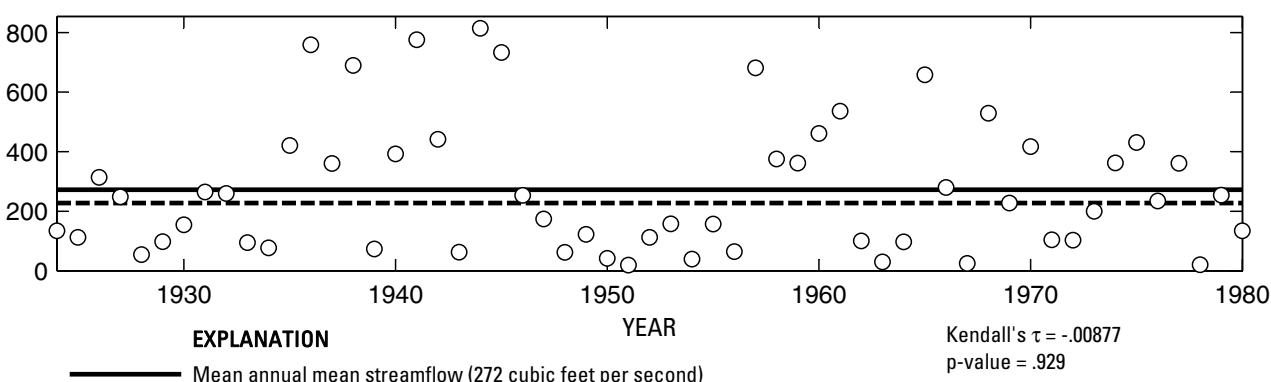

O Annual mean streamflow

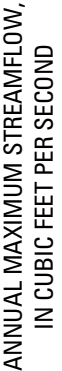
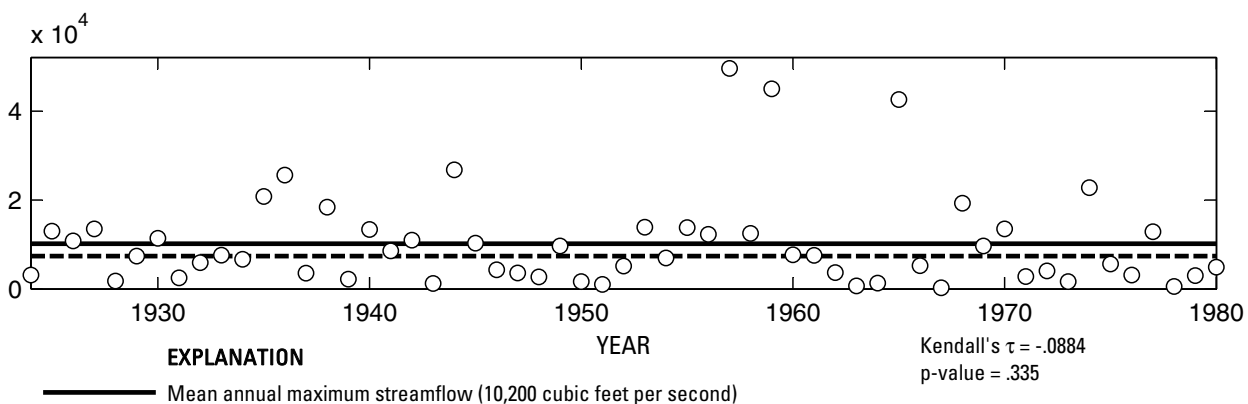

- ב-_- Median annual maximum streamflow (7,410 cubic feet per second)

O Annual maximum streamflow

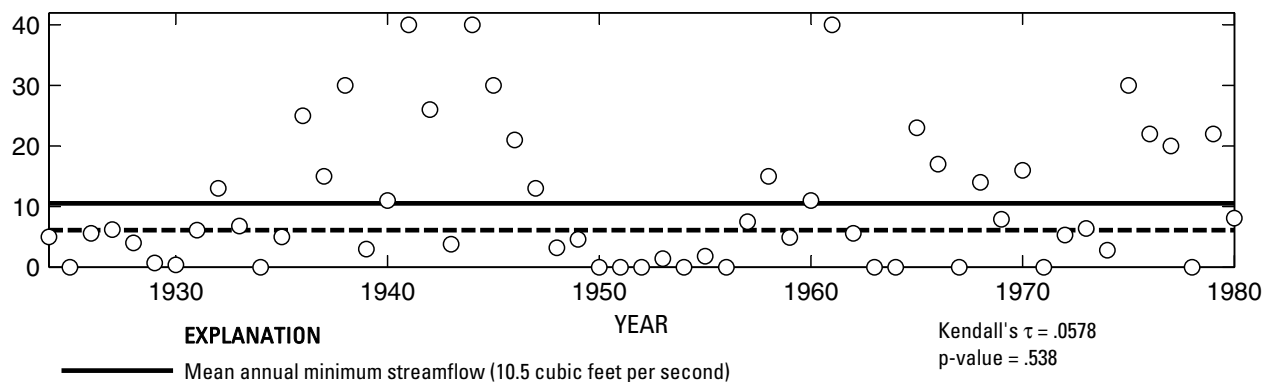

○ Annual minimum streamflow

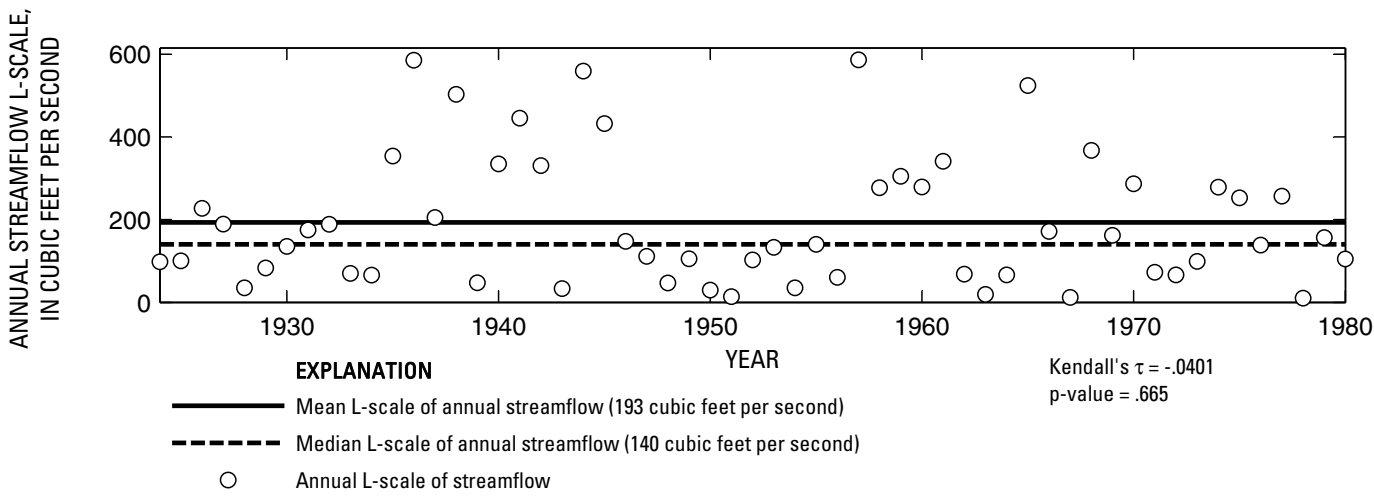

Figure 401. Analysis of annual mean, maximum, minimum, and L-scale statistics of daily mean streamflow for U.S. Geological Survey streamflow-gaging station 08104000 Lampasas River at Youngsport, Texas. 
U.S. Geological Survey streamflow-gaging station 08104100

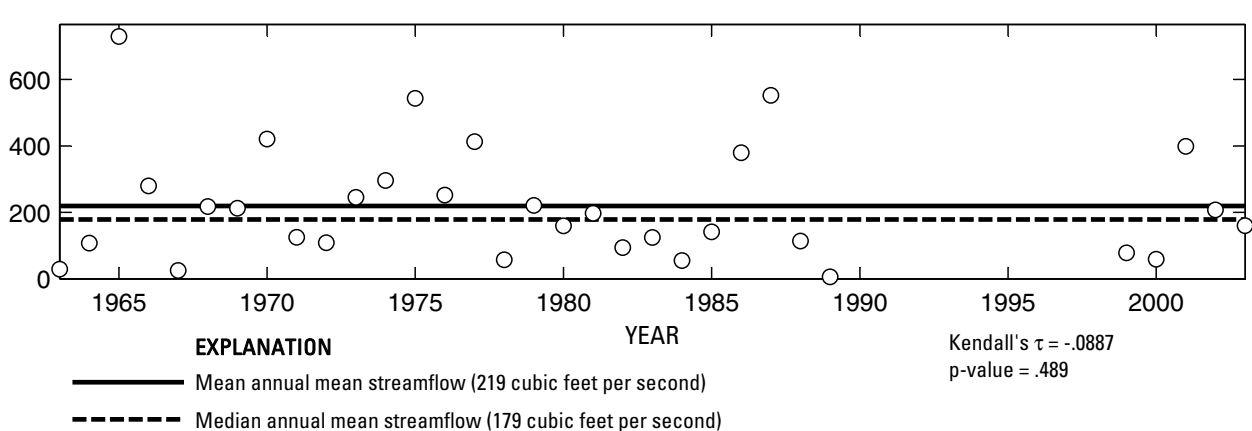

- Annual mean streamflow

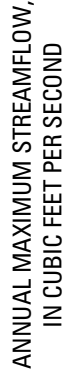

$\times 10^{4}$

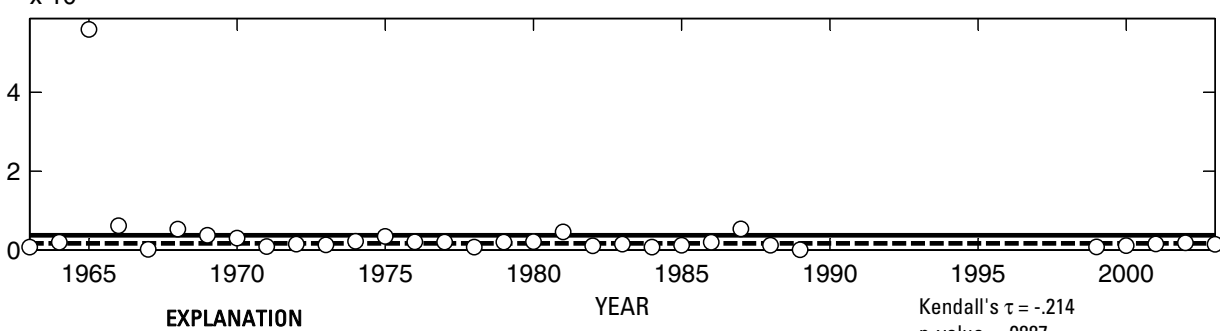

EXPANATION

$\mathrm{p}$-value $=.0887$

- Median annual maximum streamflow (1,680 cubic feet per second)

O Annual maximum streamflow

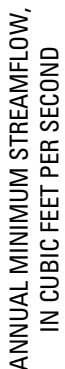

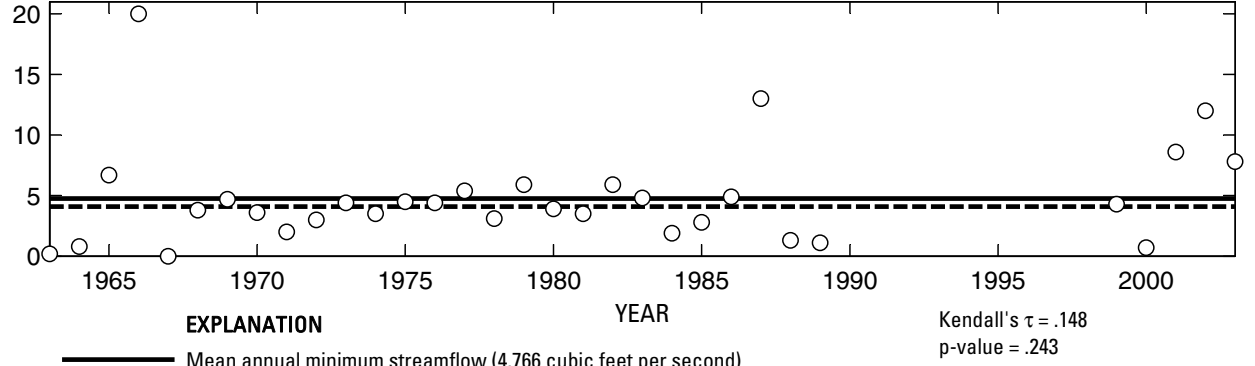

-ーーーー Median annual minimum streamflow (4.1 cubic feet per second)

O Annual minimum streamflow

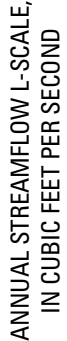

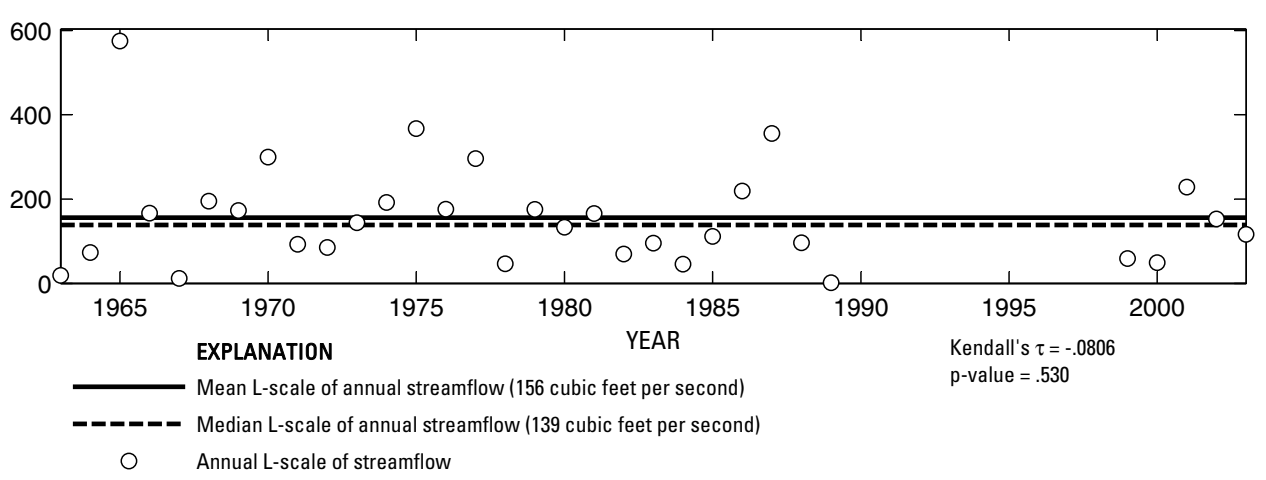

Figure 402. Analysis of annual mean, maximum, minimum, and L-scale statistics of daily mean streamflow for U.S. Geological Survey streamflow-gaging station 08104100 Lampasas River near Belton, Texas.

Index of Station Numbers 719 

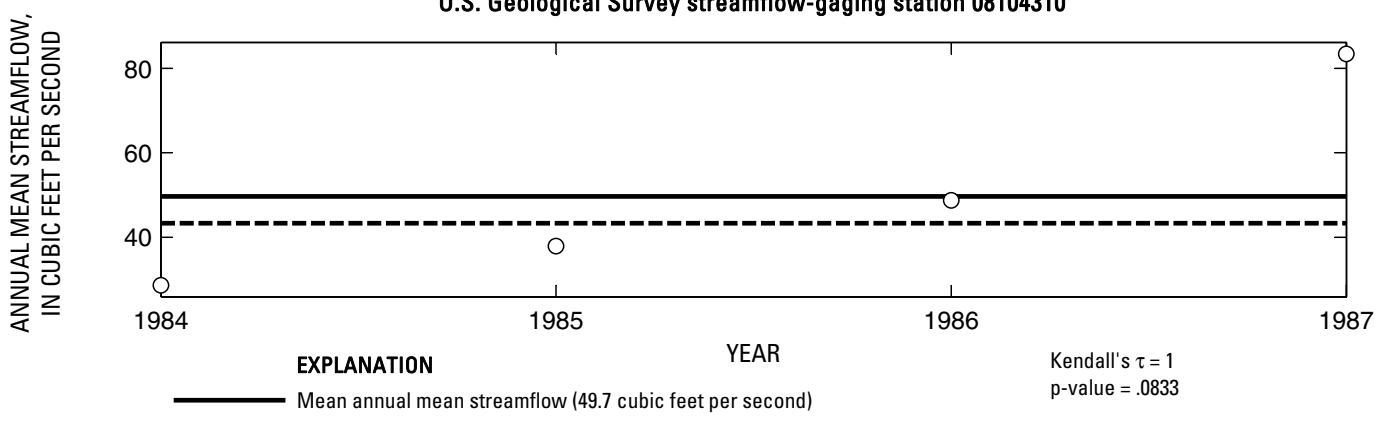

-_-_- Median annual mean streamflow (43.3 cubic feet per second)

O Annual mean streamflow
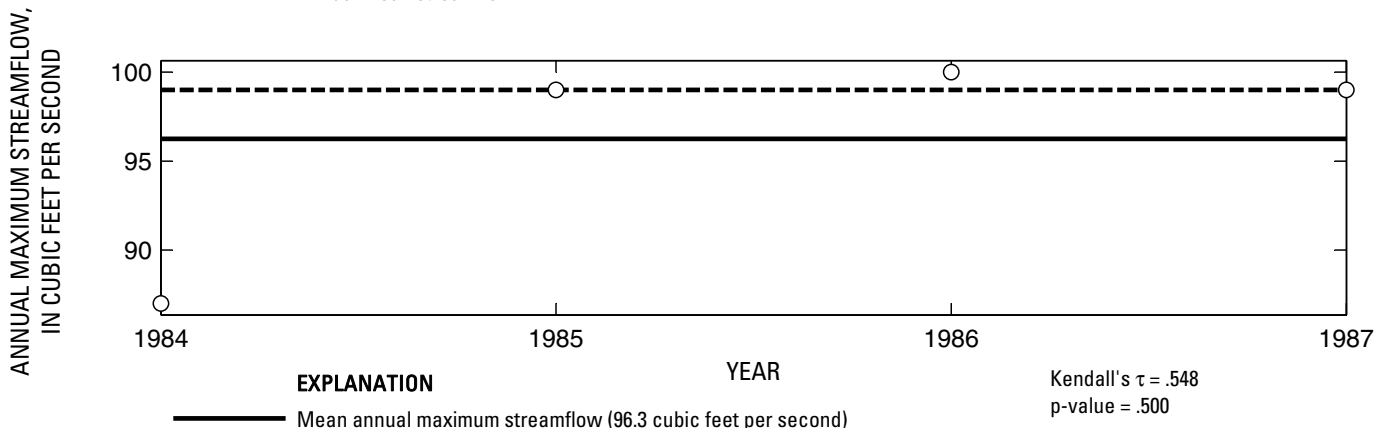

- - ב-_ Median annual maximum streamflow (99 cubic feet per second)

- Annual maximum streamflow
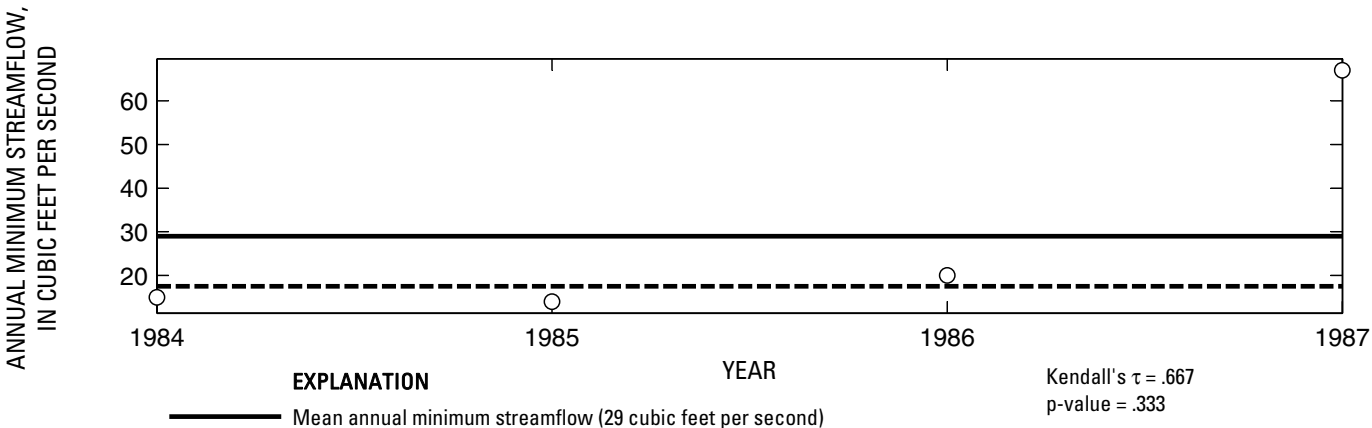

- - Median annual minimum streamflow (17.5 cubic feet per second)

O Annual minimum streamflow
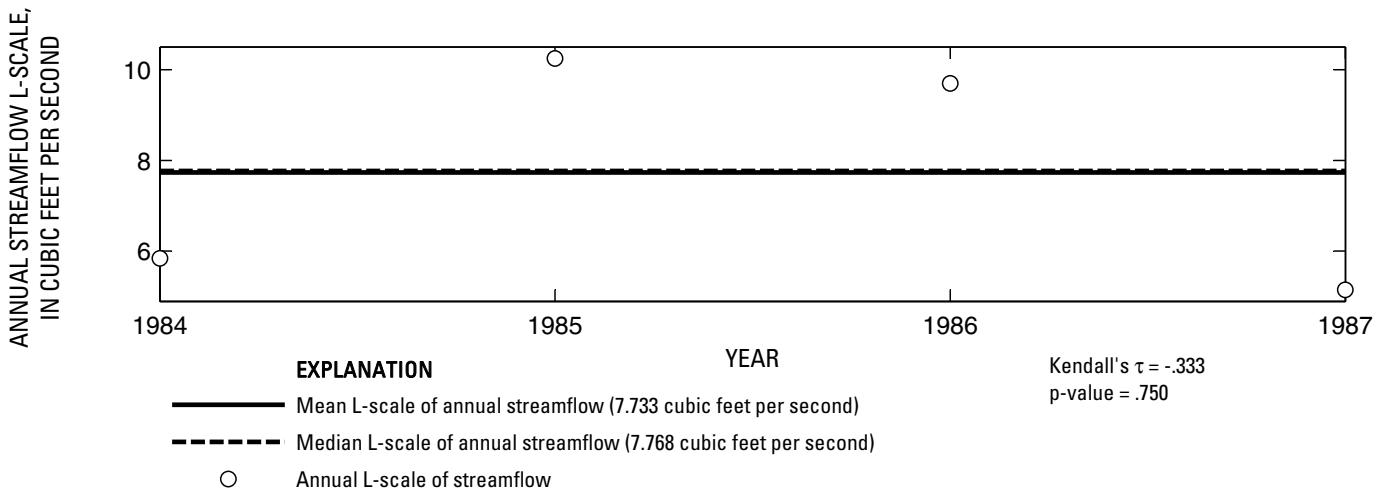

Figure 403. Analysis of annual mean, maximum, minimum, and L-scale statistics of daily mean streamflow for U.S. Geological Survey streamflow-gaging station 08104310 Salado Creek below Salado Springs at Salado, Texas. 

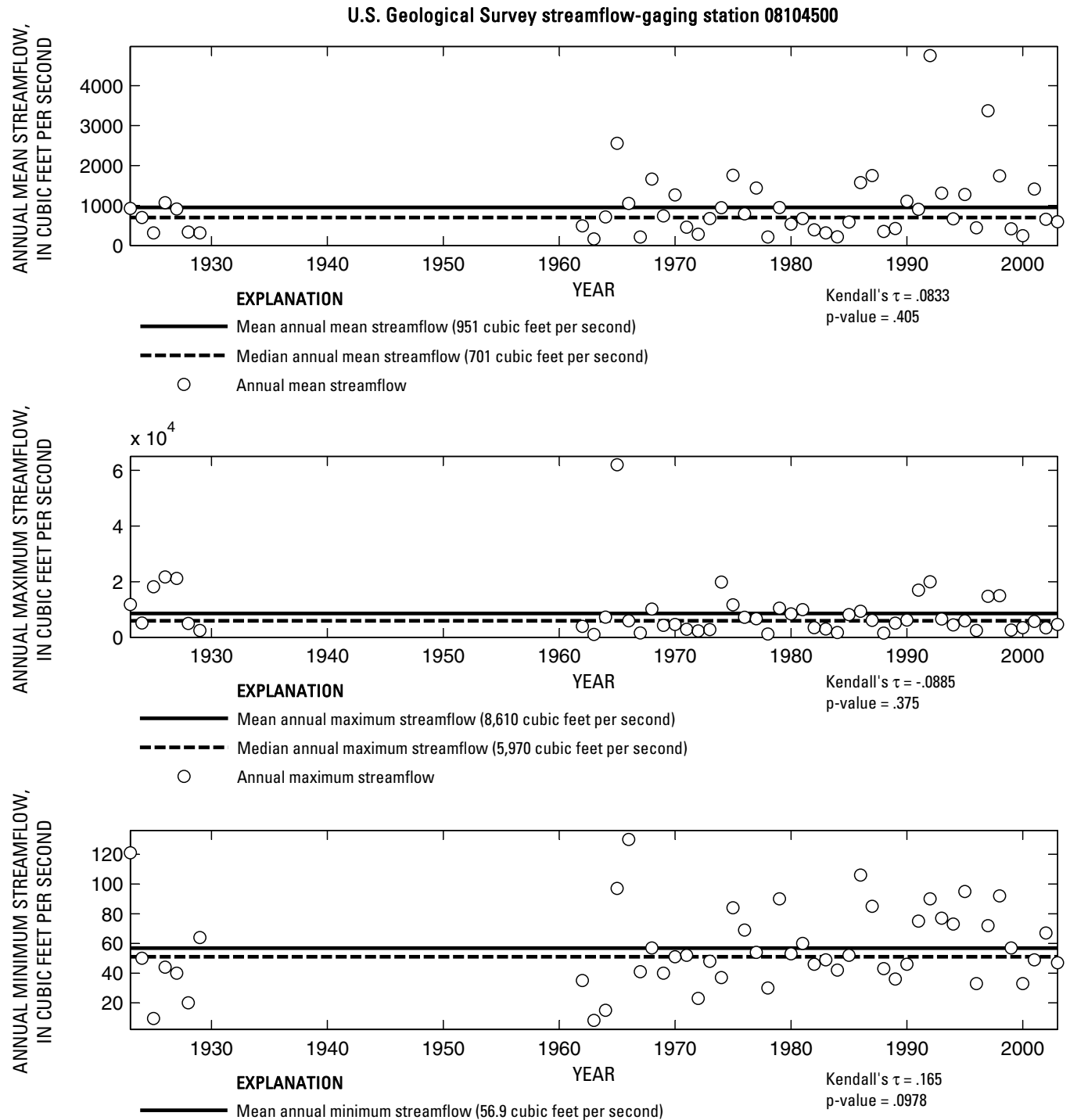

- - Median annual minimum streamflow (51 cubic feet per second)

O Annual minimum streamflow

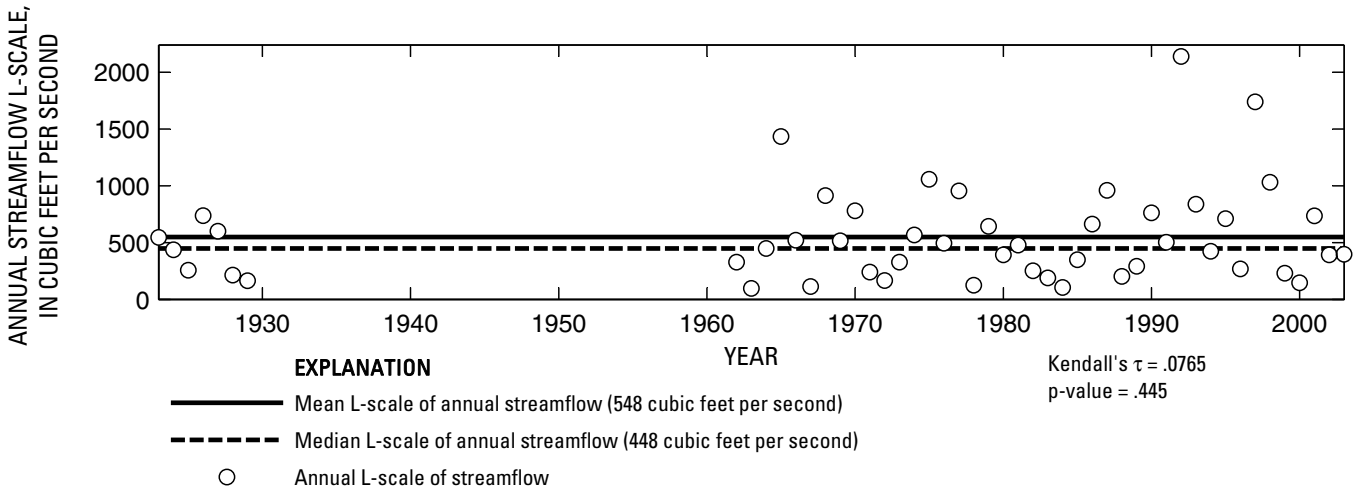

Figure 404. Analysis of annual mean, maximum, minimum, and L-scale statistics of daily mean streamflow for U.S. Geological Survey streamflow-gaging station 08104500 Little River near Little River, Texas.

Index of Station Numbers 719 

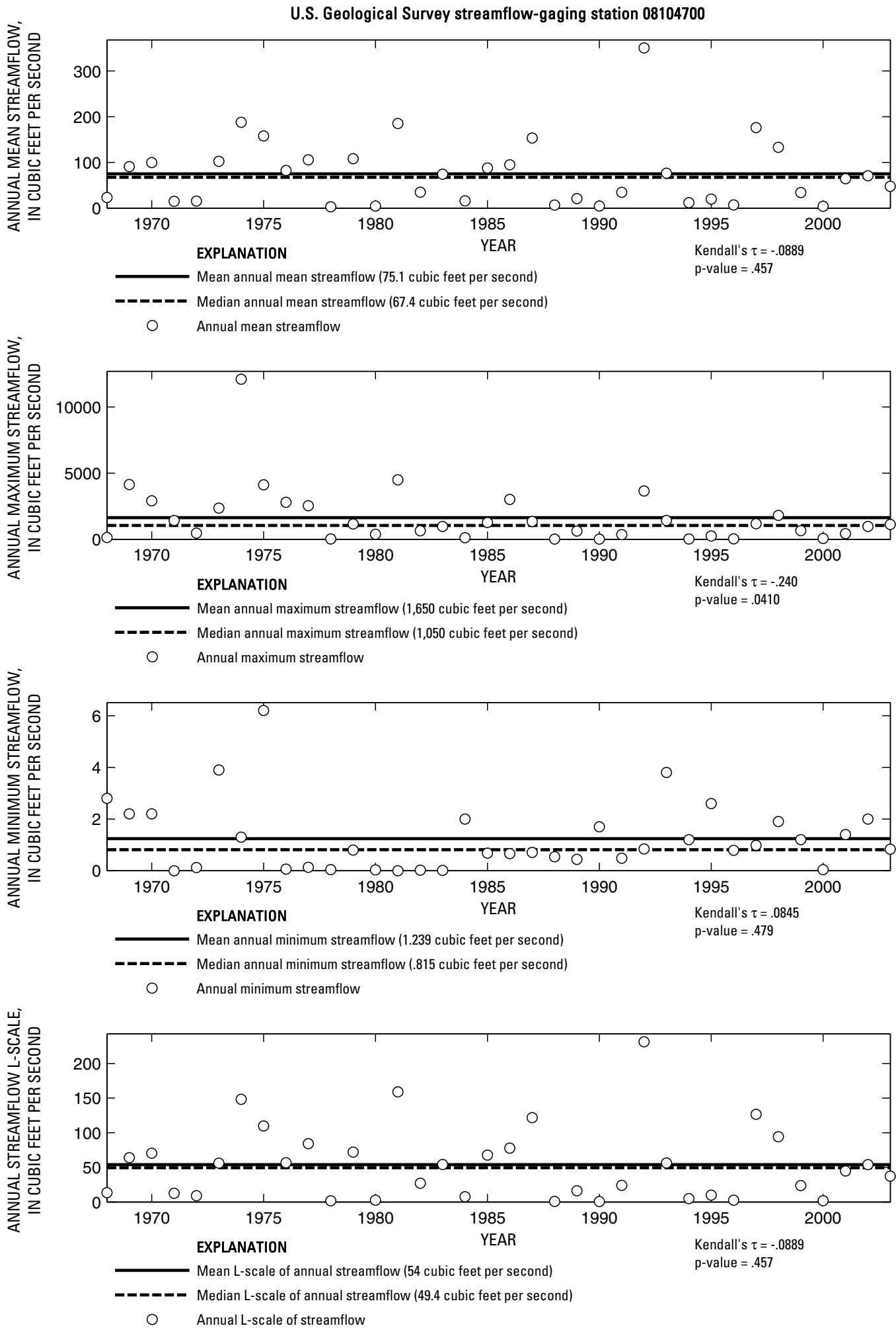

Figure 405. Analysis of annual mean, maximum, minimum, and L-scale statistics of daily mean streamflow for U.S. Geological Survey streamflow-gaging station 08104700 North Fork San Gabriel River near Georgetown, Texas. 

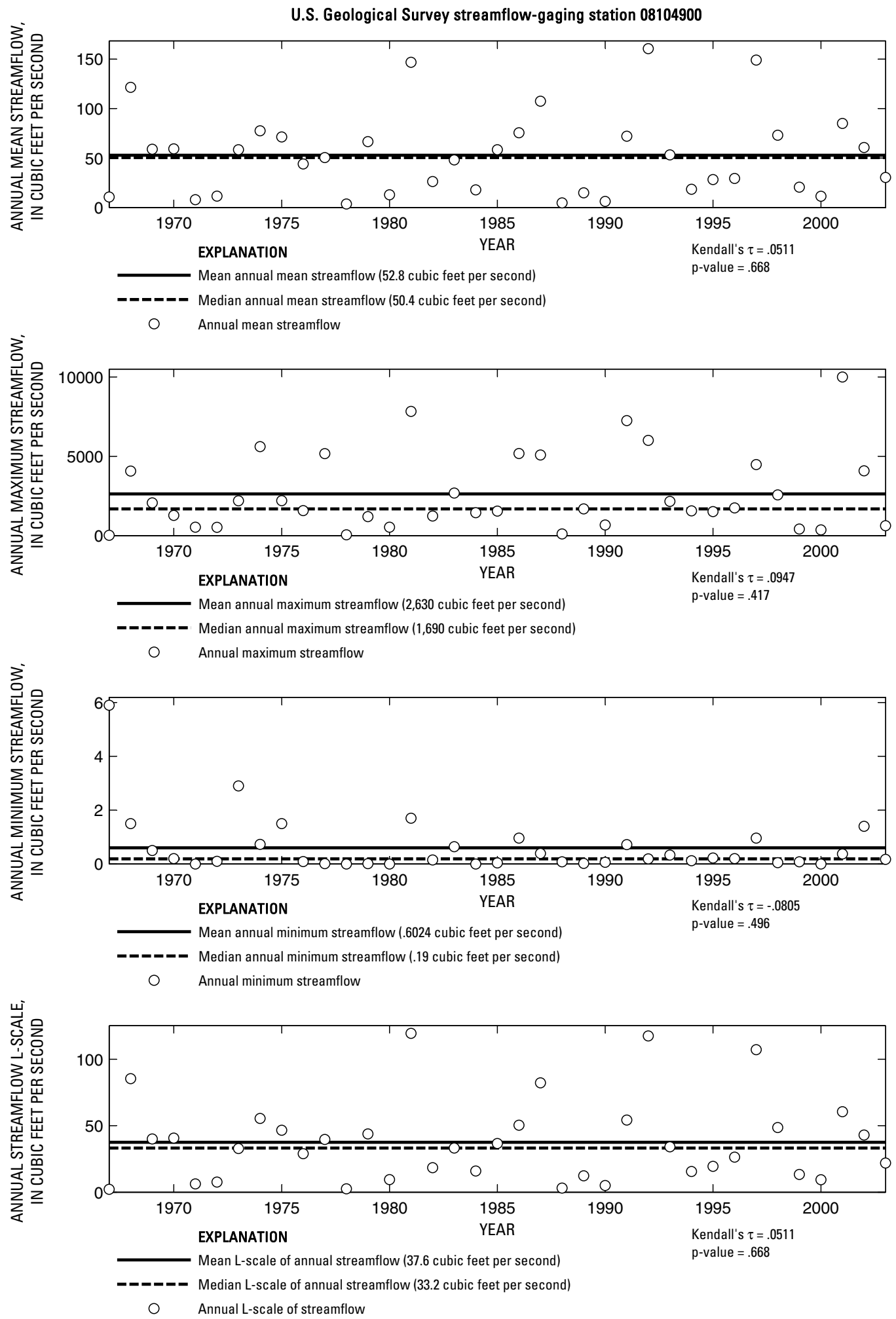

Figure 406. Analysis of annual mean, maximum, minimum, and L-scale statistics of daily mean streamflow for U.S. Geological Survey streamflow-gaging station 08104900 South Fork San Gabriel River at Georgetown, Texas.

Index of Station Numbers 719 


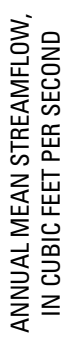

U.S. Geological Survey streamflow-gaging station 08105000

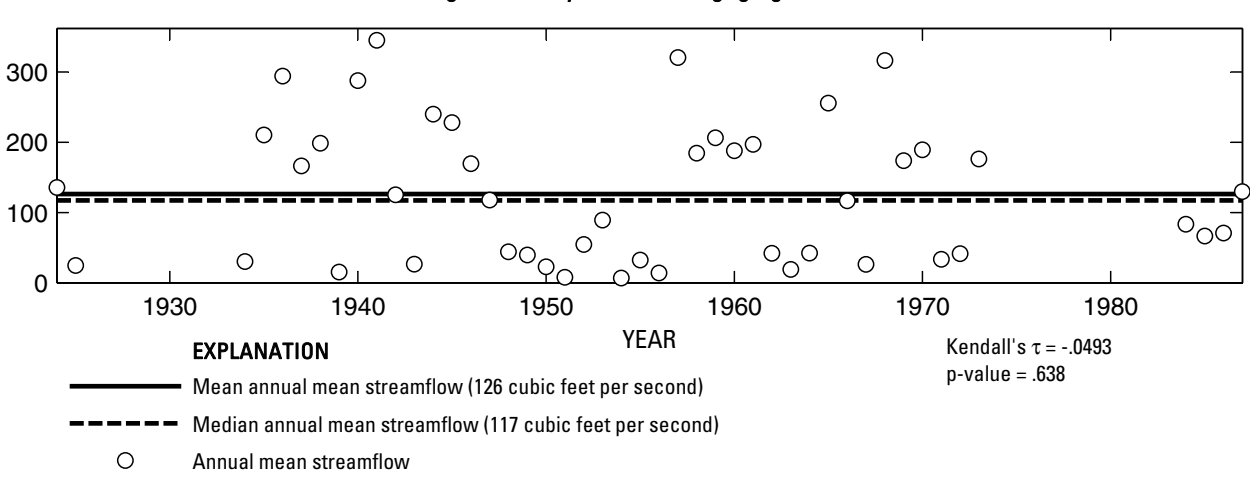

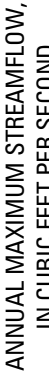

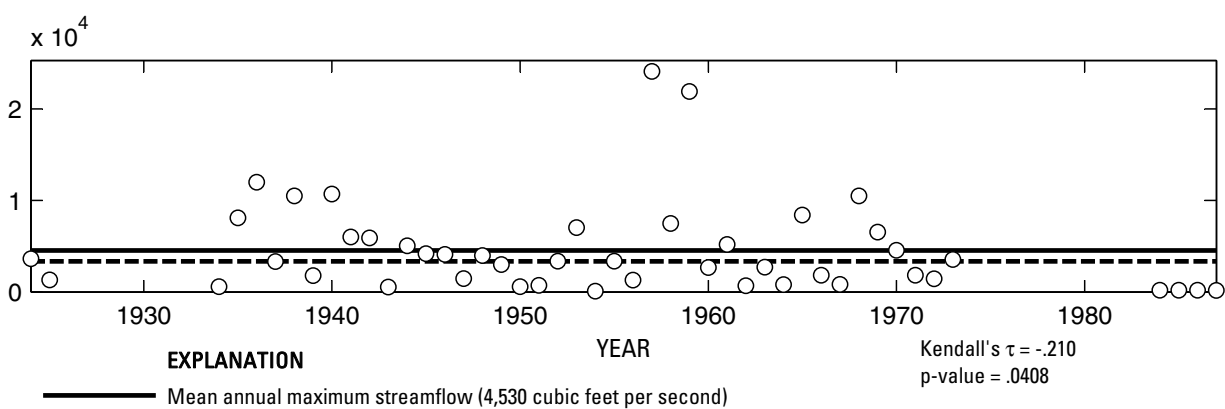

- ב - Median annual maximum streamflow (3,350 cubic feet per second)

O Annual maximum streamflow

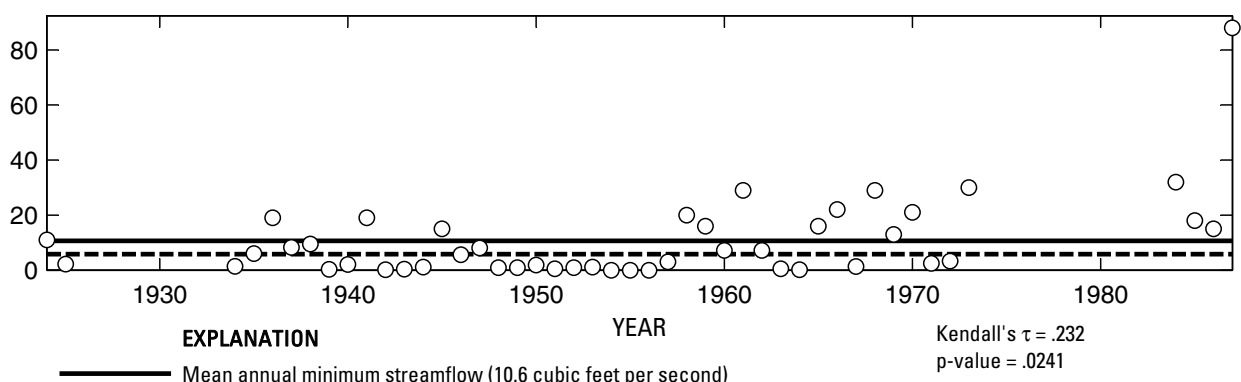

- - - Median annual minimum streamflow (5.8 cubic feet per second)

○ Annual minimum streamflow

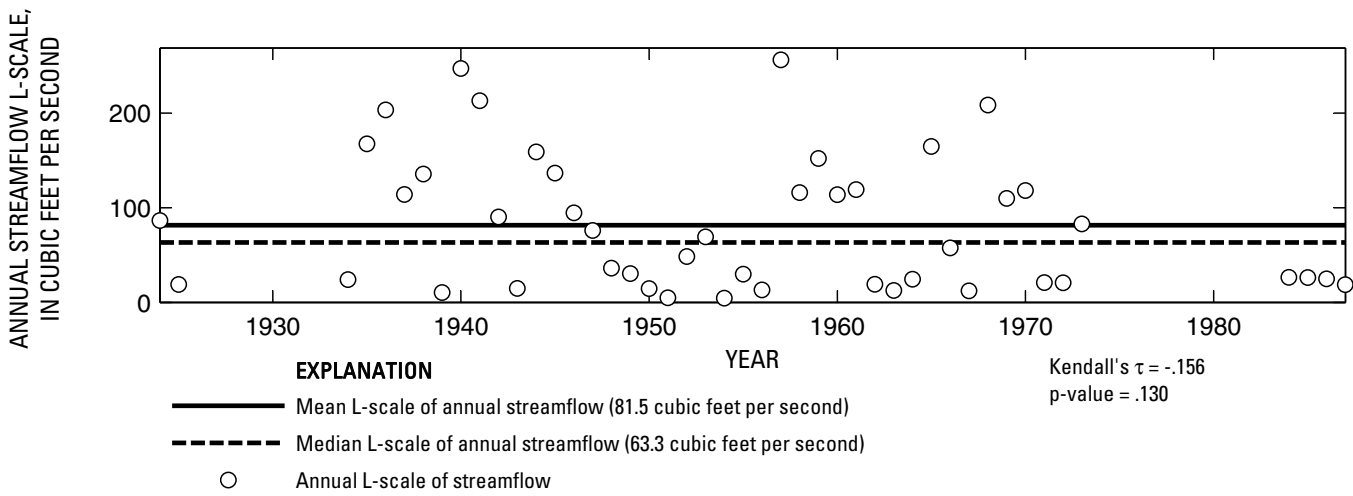

Figure 407. Analysis of annual mean, maximum, minimum, and L-scale statistics of daily mean streamflow for U.S. Geological Survey streamflow-gaging station 08105000 San Gabriel River at Georgetown, Texas. 

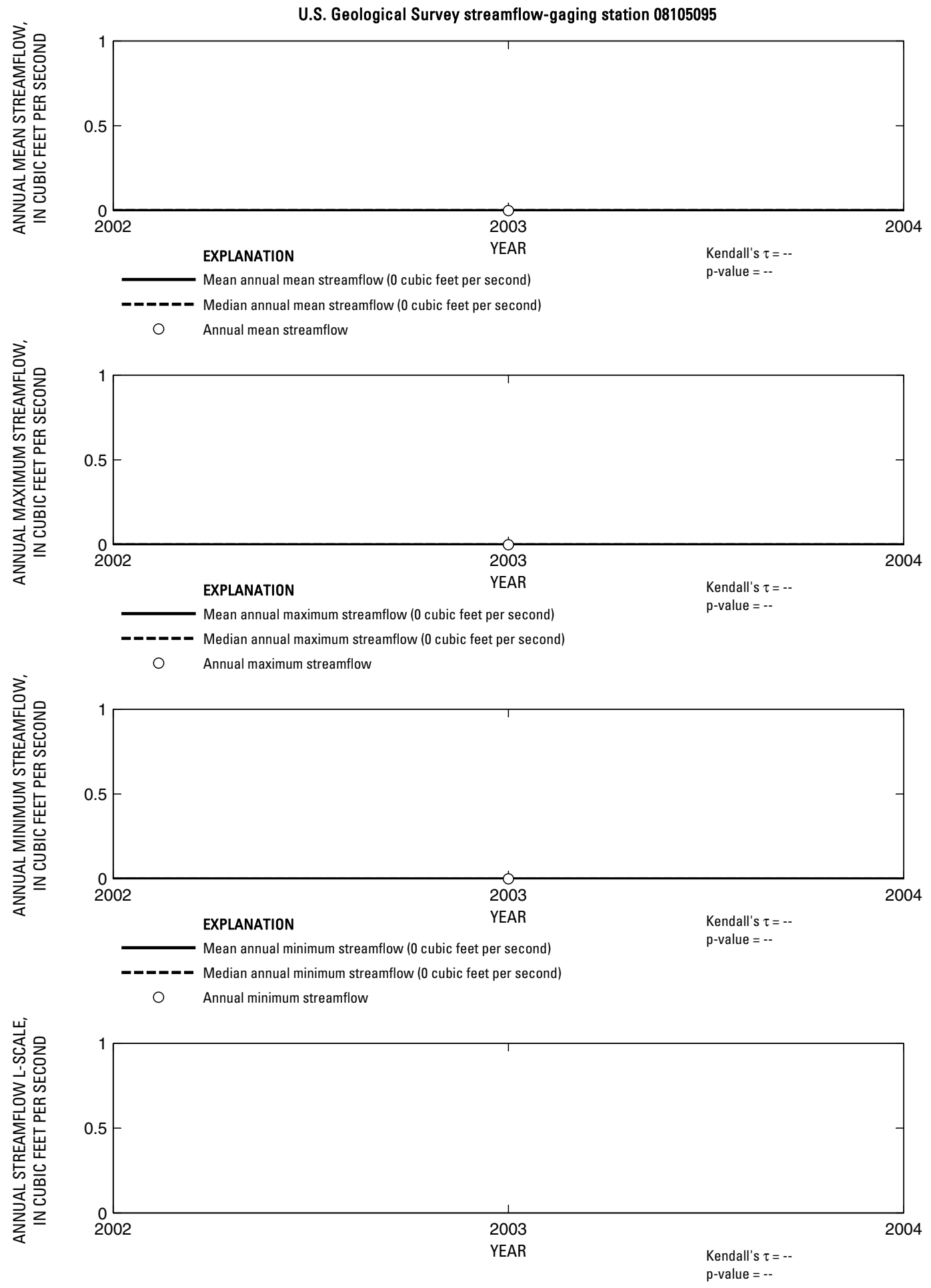

EXPLANATION

Mean L-scale of annual streamflow (NaN cubic feet per second)

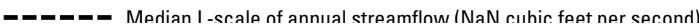

Figure 408. Analysis of annual mean, maximum, minimum, and L-scale statistics of daily mean streamflow for U.S. Geological Survey streamflow-gaging station 08105095 Berry Creek at Airport Road near Georgetown, Texas. 


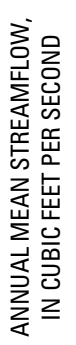

U.S. Geological Survey streamflow-gaging station 08105100

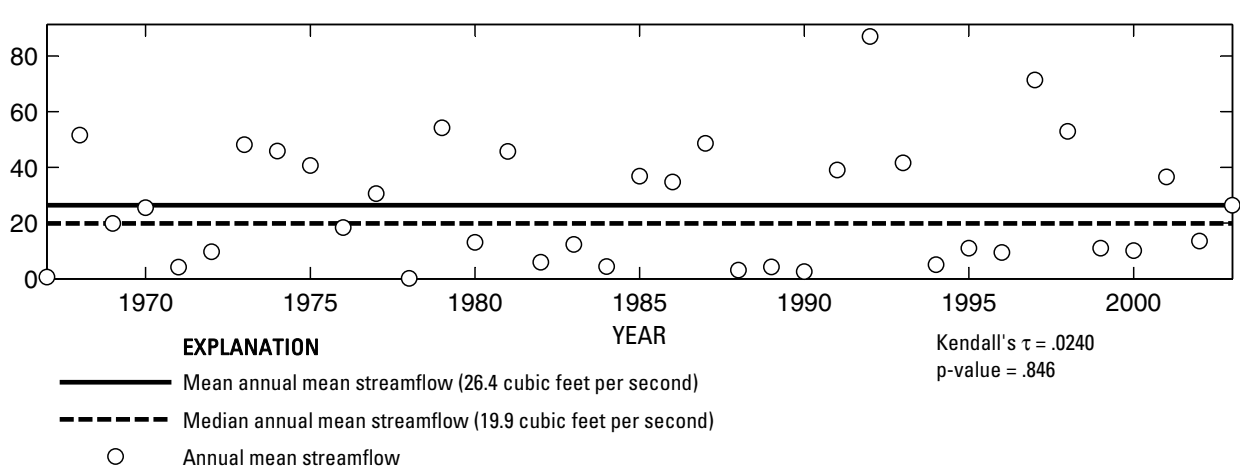

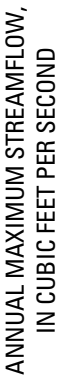

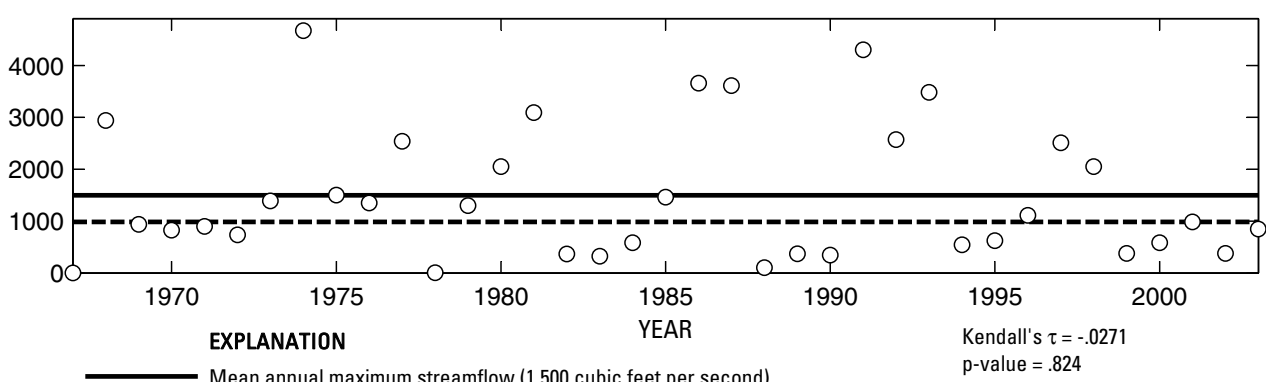

O Annual maximum streamflow

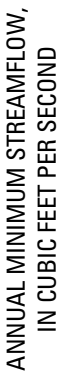

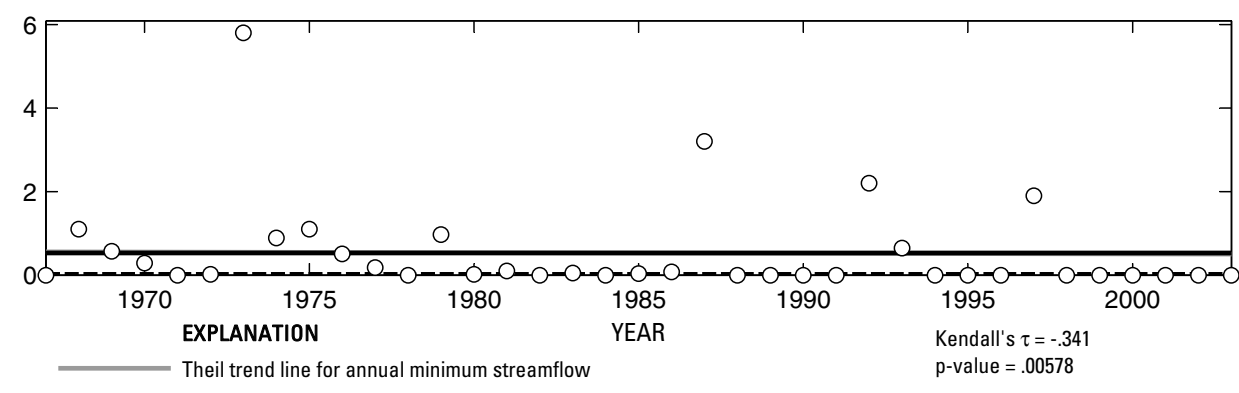

Median annual minimum streamflow (.02 cubic feet per second)

O Annual minimum streamflow
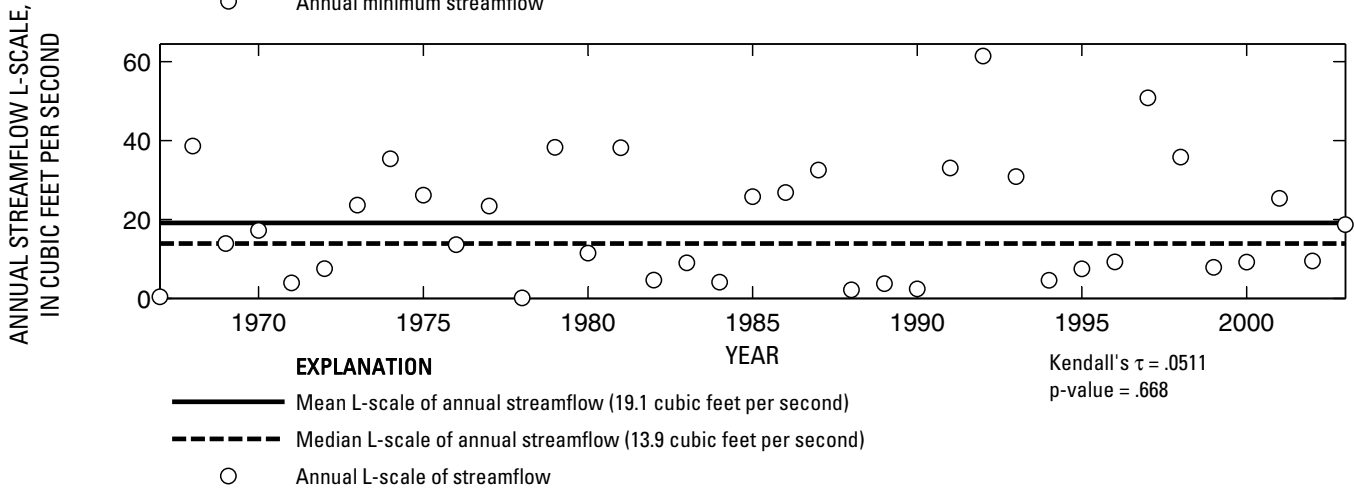

Figure 409. Analysis of annual mean, maximum, minimum, and L-scale statistics of daily mean streamflow for U.S. Geological Survey streamflow-gaging station 08105100 Berry Creek near Georgetown, Texas. 


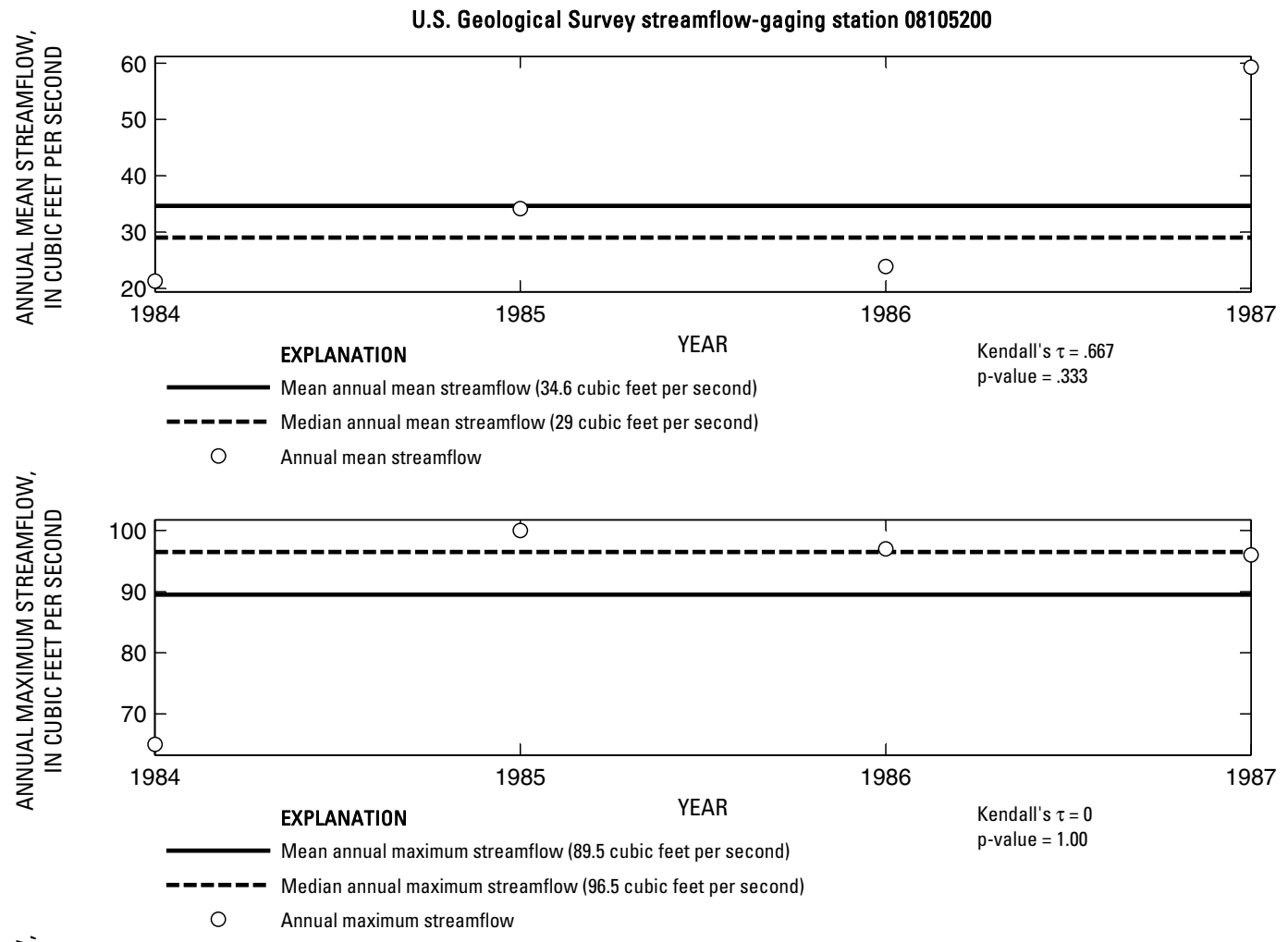

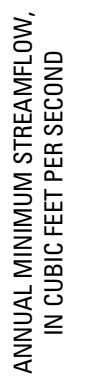

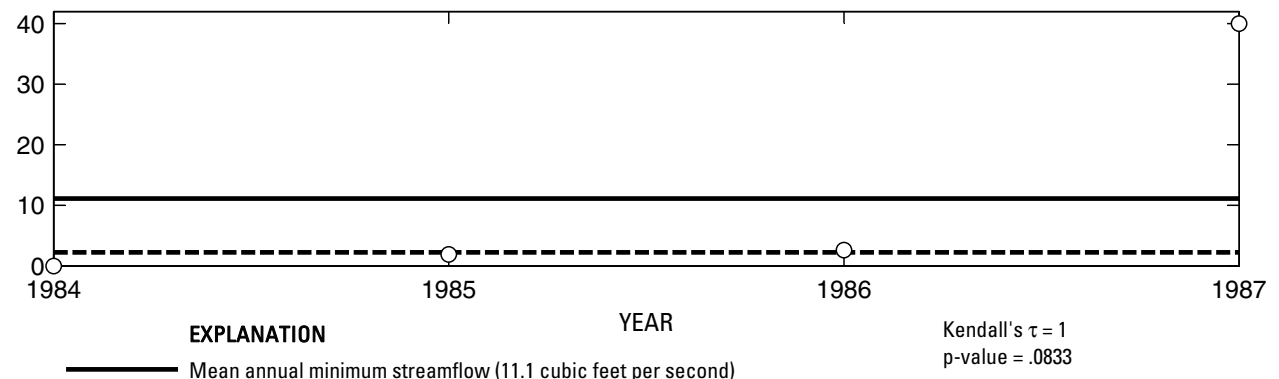

-_-_- Median annual minimum streamflow (2.25 cubic feet per second)

O Annual minimum streamflow

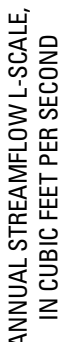

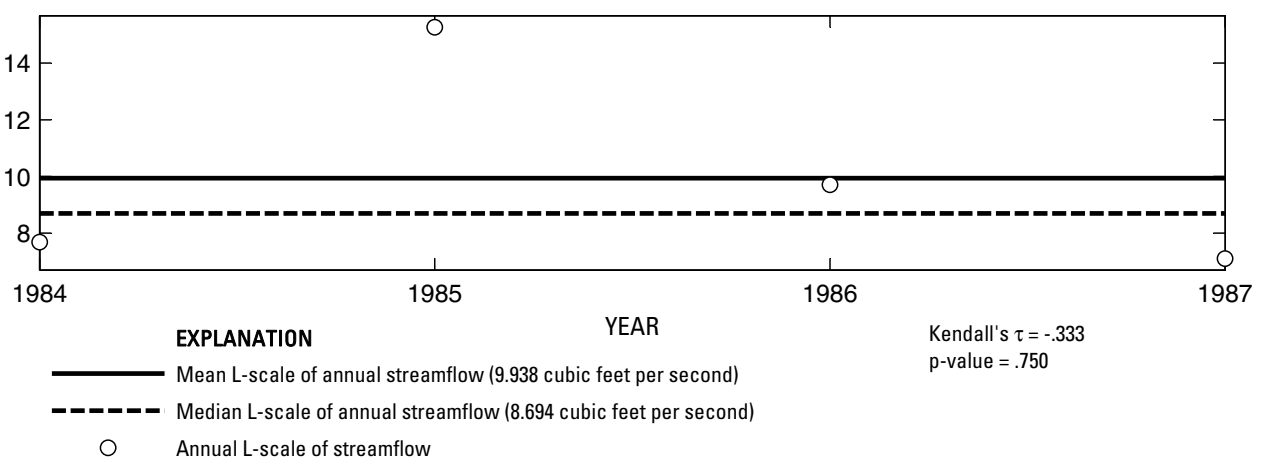

Figure 410. Analysis of annual mean, maximum, minimum, and L-scale statistics of daily mean streamflow for U.S. Geological Survey streamflow-gaging station 08105200 Berry Creek at State Highway 971 near Georgetown, Texas. 

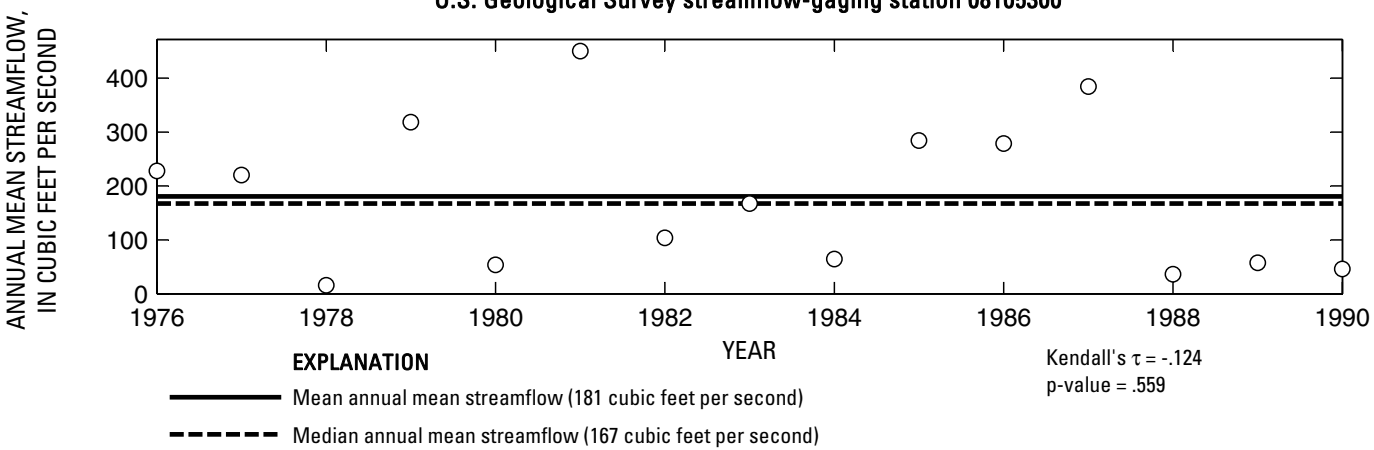

O Annual mean streamflow
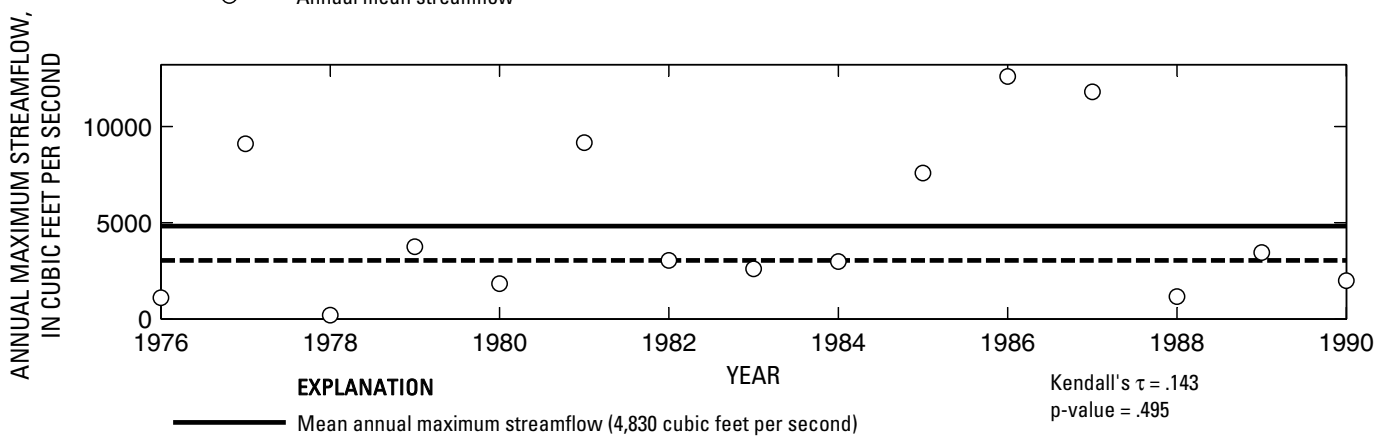

- _-_ - Median annual maximum streamflow (3,040 cubic feet per second)

O Annual maximum streamflow
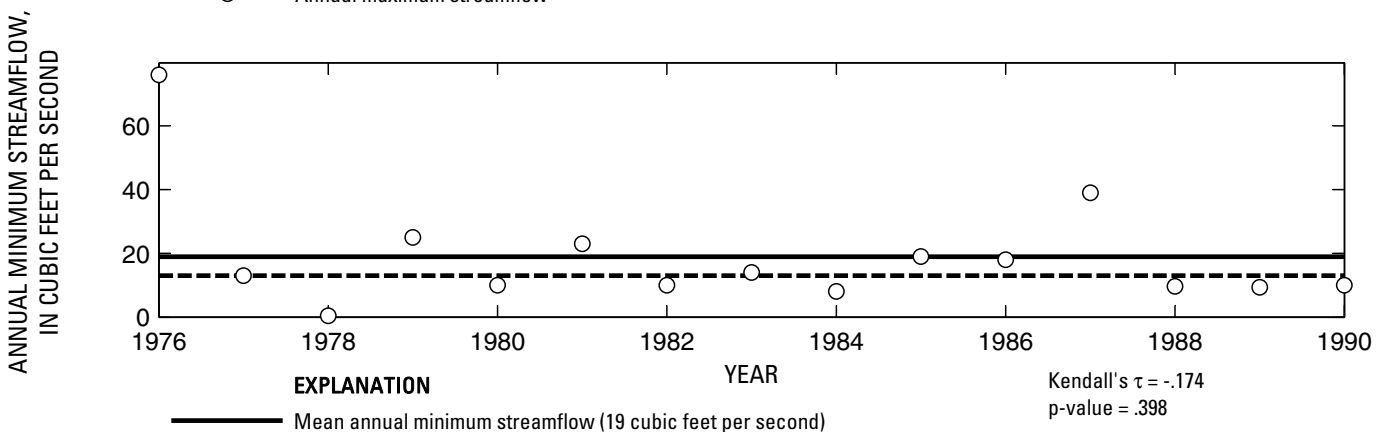

- - _-_- Median annual minimum streamflow (13 cubic feet per second)

O Annual minimum streamflow

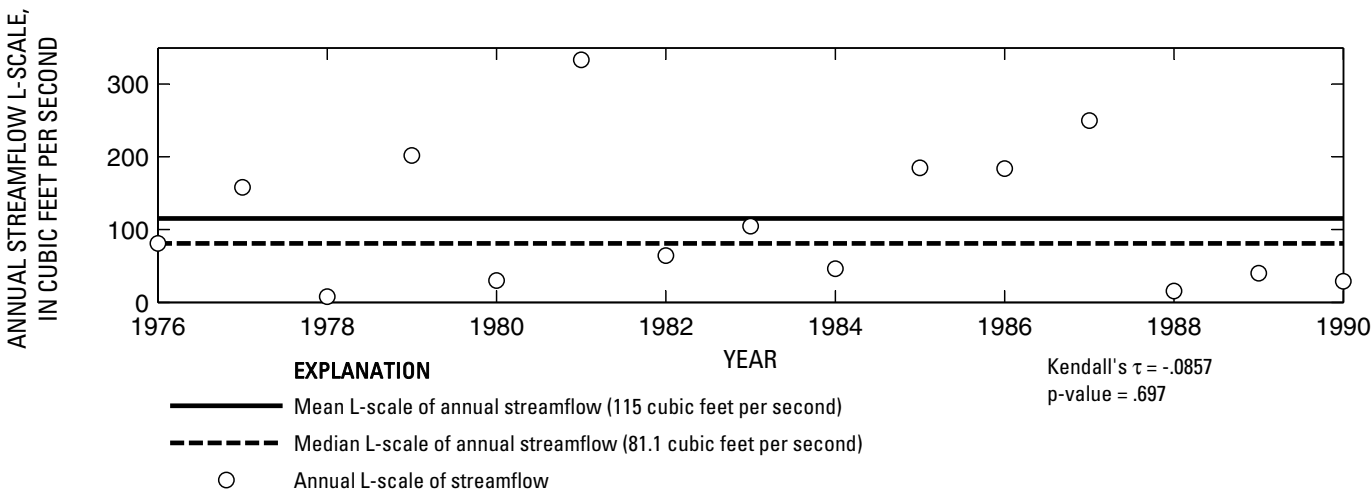

Figure 411. Analysis of annual mean, maximum, minimum, and L-scale statistics of daily mean streamflow for U.S. Geological Survey streamflow-gaging station 08105300 San Gabriel River near Weir, Texas. 
U.S. Geological Survey streamflow-gaging station 08105400

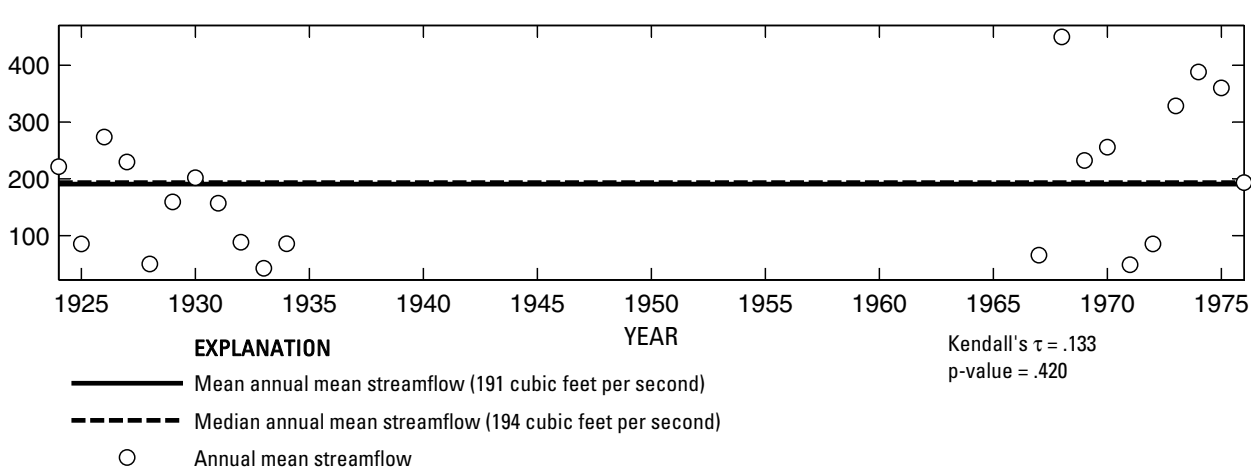

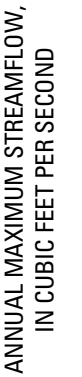

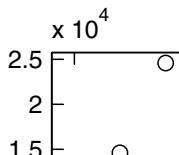

0

1

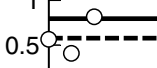

$\frac{1925}{1}$

\begin{tabular}{cc} 
EXPLANATION & YEAR \\
\hline Mean annual maximum streamflow $(7,950$ cubic feet per second)
\end{tabular}

Annual maximum streamflow

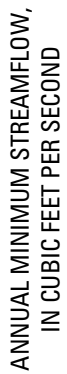

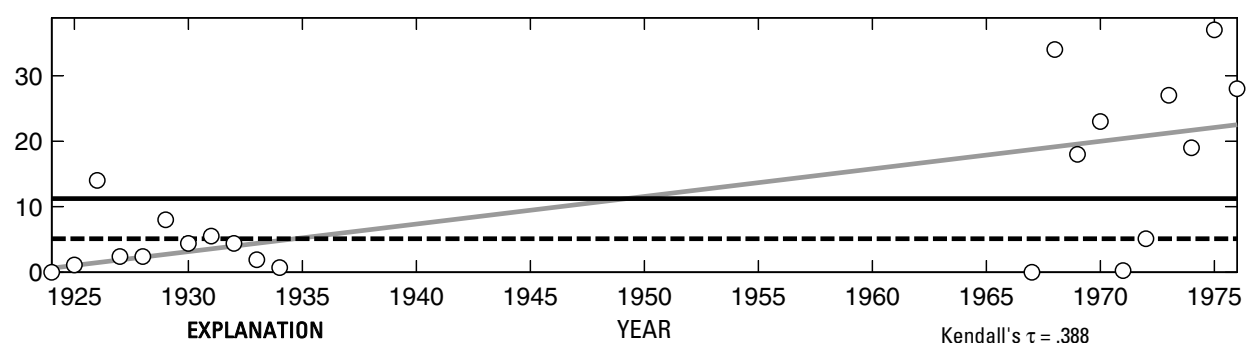
EXPLANATION YEAR Kendall's $\tau=.388$

Theil trend line for annual minimum streamflow $\mathrm{p}$-value $=.0156$

Mean annual minimum streamflow (11.2 cubic feet per second)

- Median annual minimum streamflow (5.1 cubic feet per second) Annual minimum streamflow

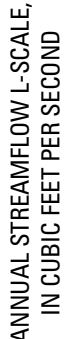

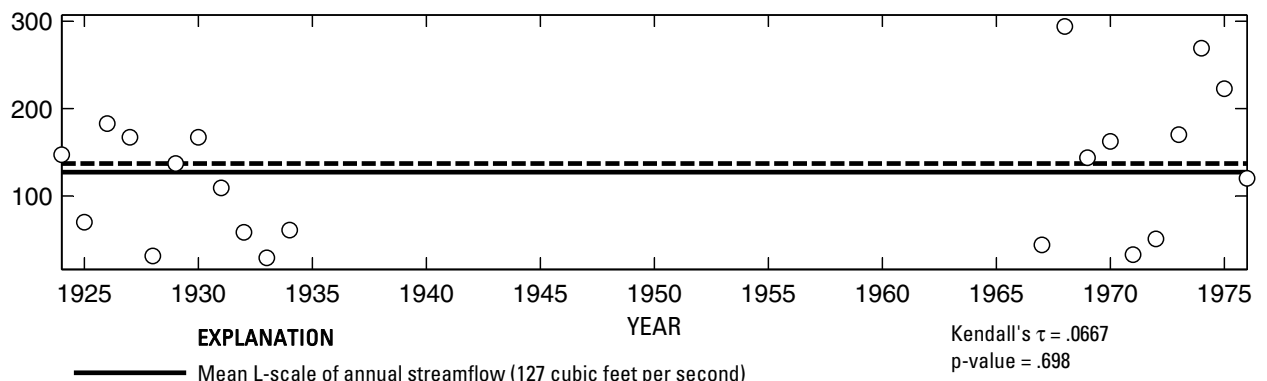

Mean L-scale of annual streamflow (127 cubic feet per second)

$\mathrm{p}$-value $=.698$

- - - - Median L-scale of annual streamflow (137 cubic feet per second)

Annual L-scale of streamflow

Figure 412. Analysis of annual mean, maximum, minimum, and L-scale statistics of daily mean streamflow for U.S. Geological Survey streamflow-gaging station 08105400 San Gabriel River near Circleville, Texas.

Index of Station Numbers 719 

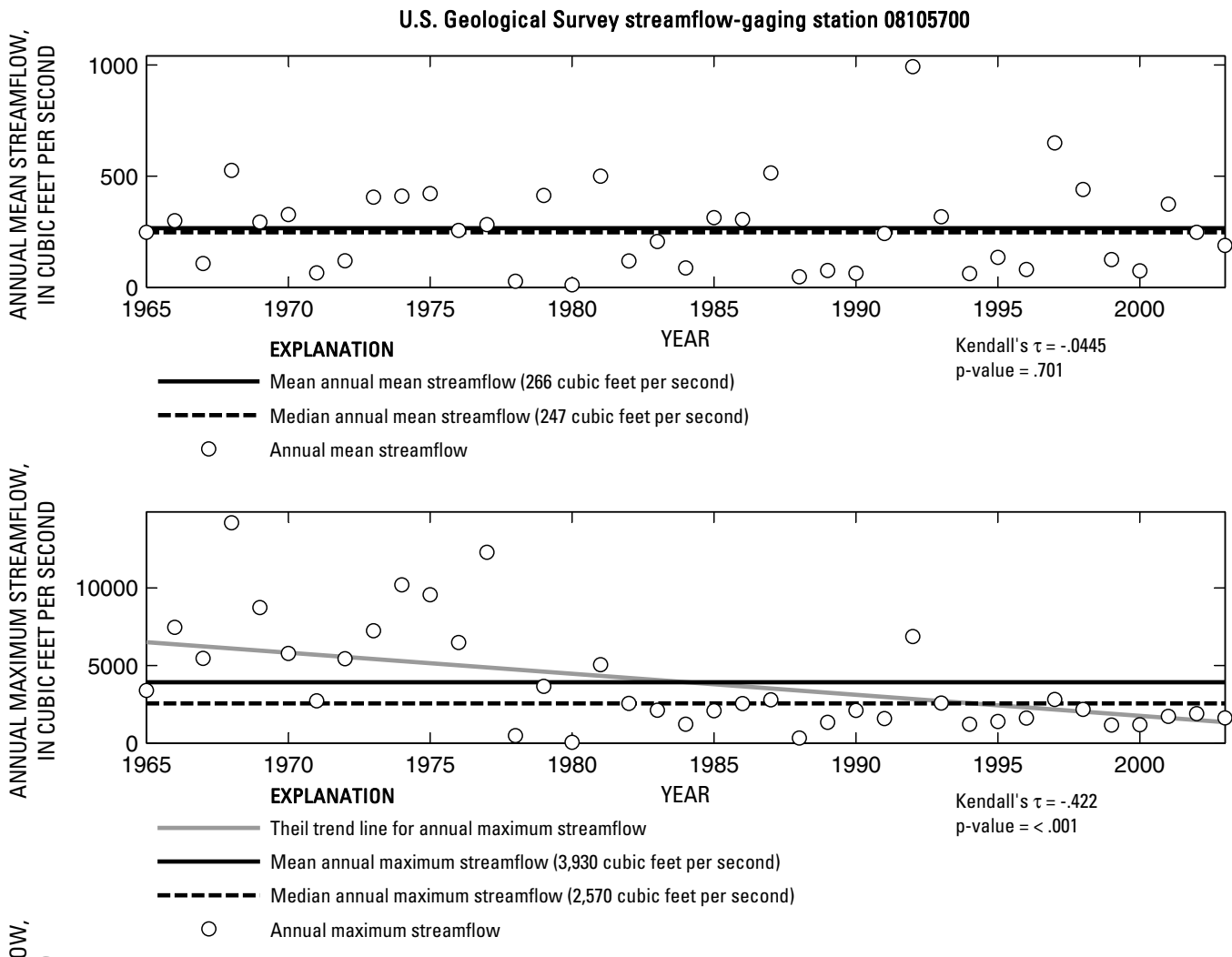

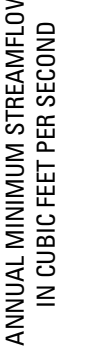

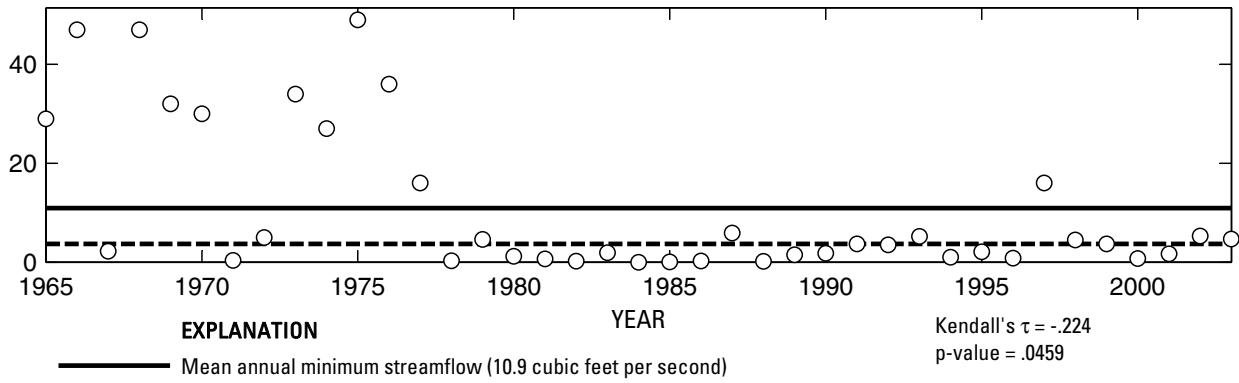

-__-_odian annual minimum streamflow (3.7 cubic feet per second)

O Annual minimum streamflow

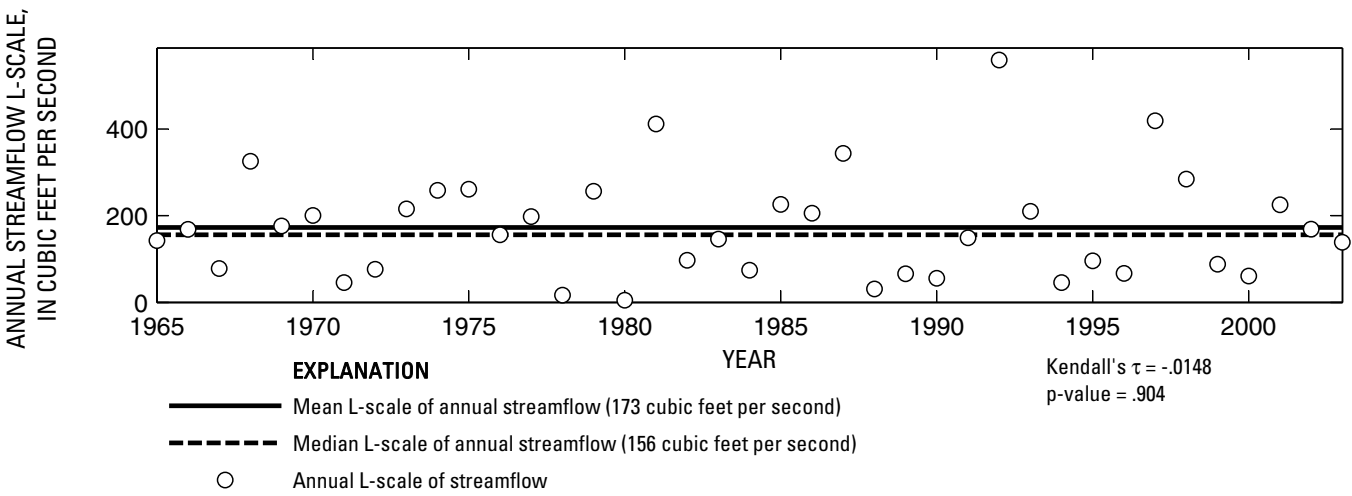

Figure 413. Analysis of annual mean, maximum, minimum, and L-scale statistics of daily mean streamflow for U.S. Geological Survey streamflow-gaging station 08105700 San Gabriel River at Laneport, Texas. 

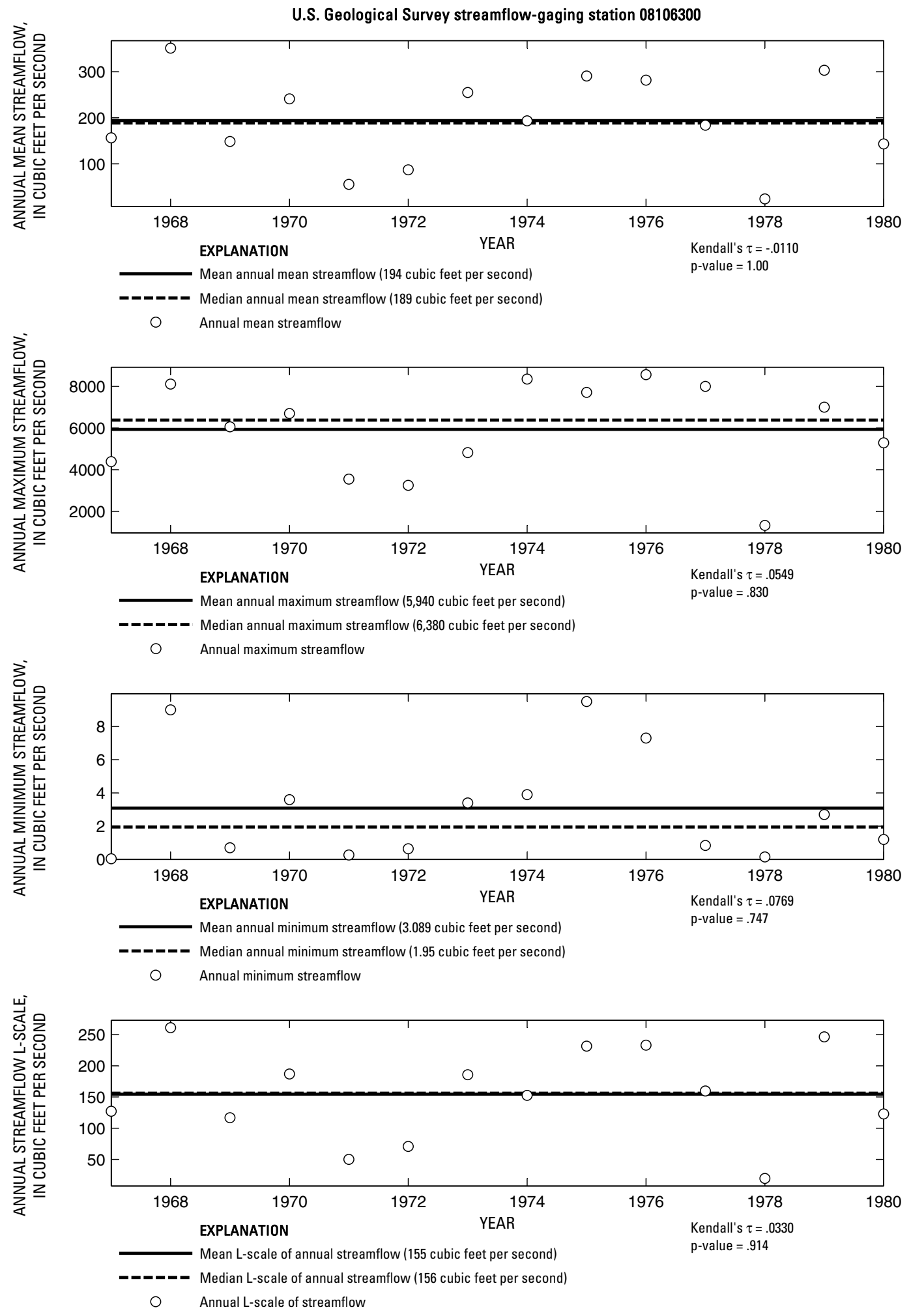

Figure 414. Analysis of annual mean, maximum, minimum, and L-scale statistics of daily mean streamflow for U.S. Geological Survey streamflow-gaging station 08106300 Brushy Creek near Rockdale, Texas. 


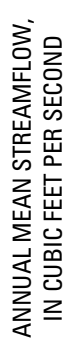

U.S. Geological Survey streamflow-gaging station 08106310

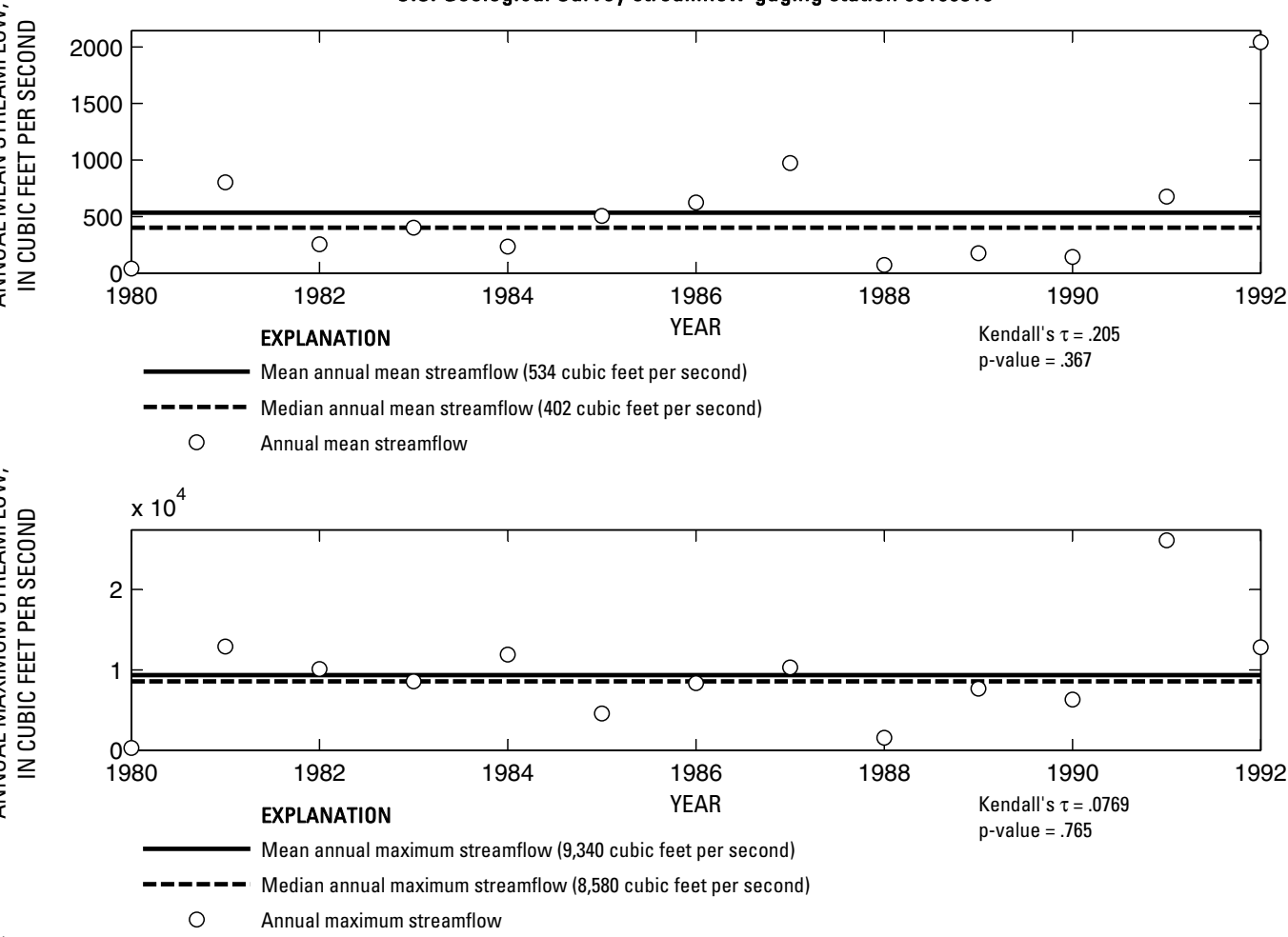

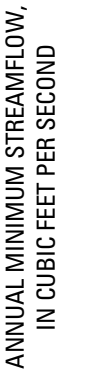

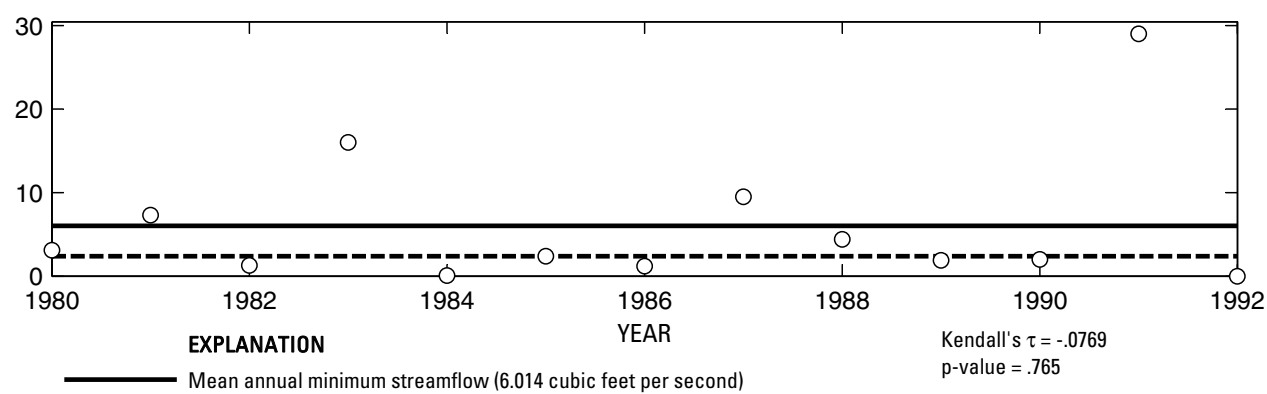

- - - - Median annual minimum streamflow (2.4 cubic feet per second)

O Annual minimum streamflow

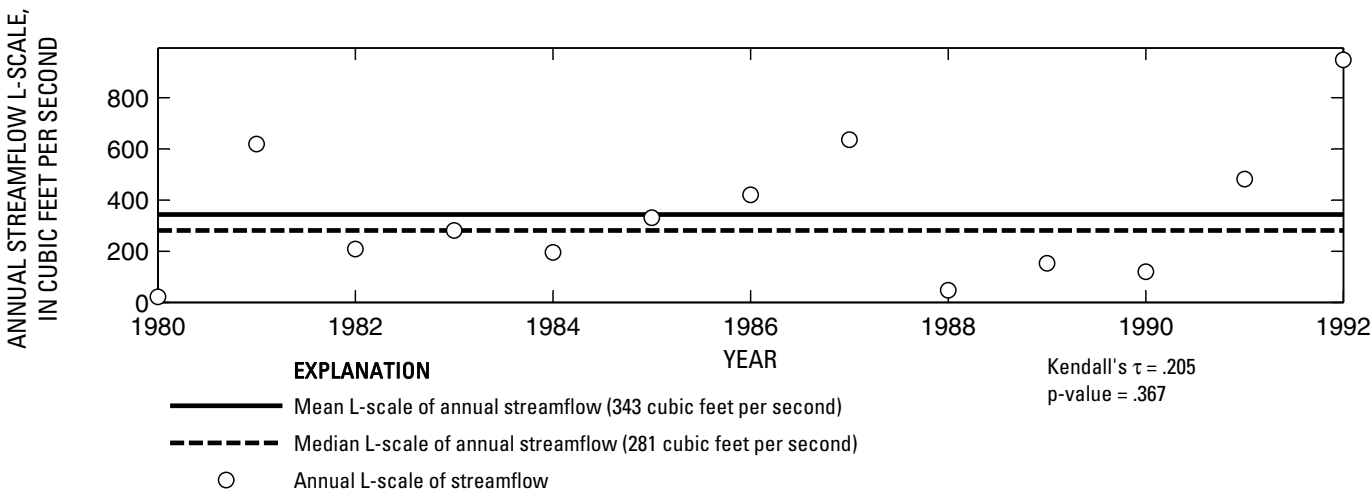

Figure 415. Analysis of annual mean, maximum, minimum, and L-scale statistics of daily mean streamflow for U.S. Geological Survey streamflow-gaging station 08106310 San Gabriel River near Rockdale, Texas. 
U.S. Geological Survey streamflow-gaging station 08106350

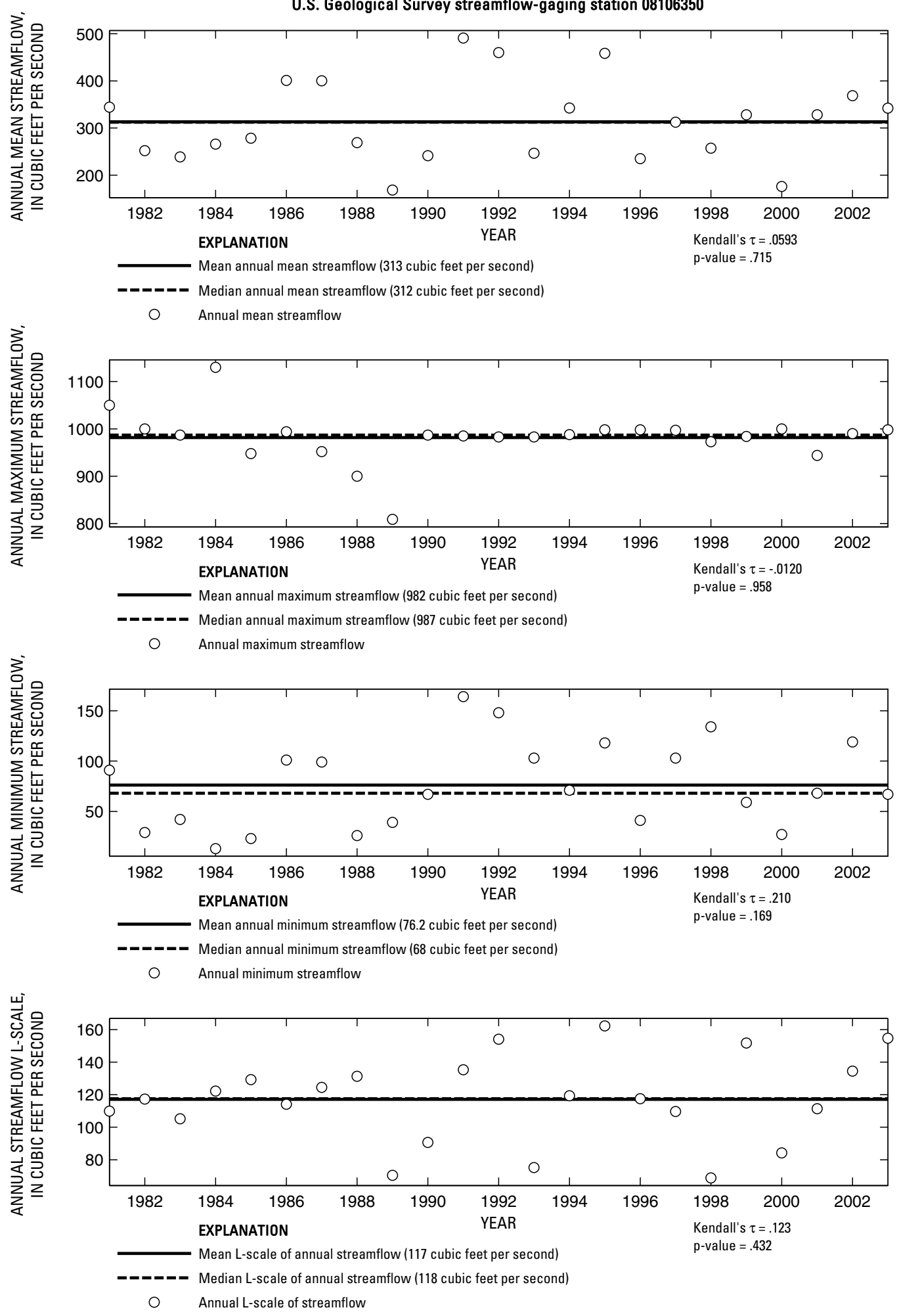

Figure 416. Analysis of annual mean, maximum, minimum, and L-scale statistics of daily mean streamflow for U.S. Geological Survey streamflow-gaging station 08106350 Little River near Rockdale, Texas.

Index of Station Numbers 719 

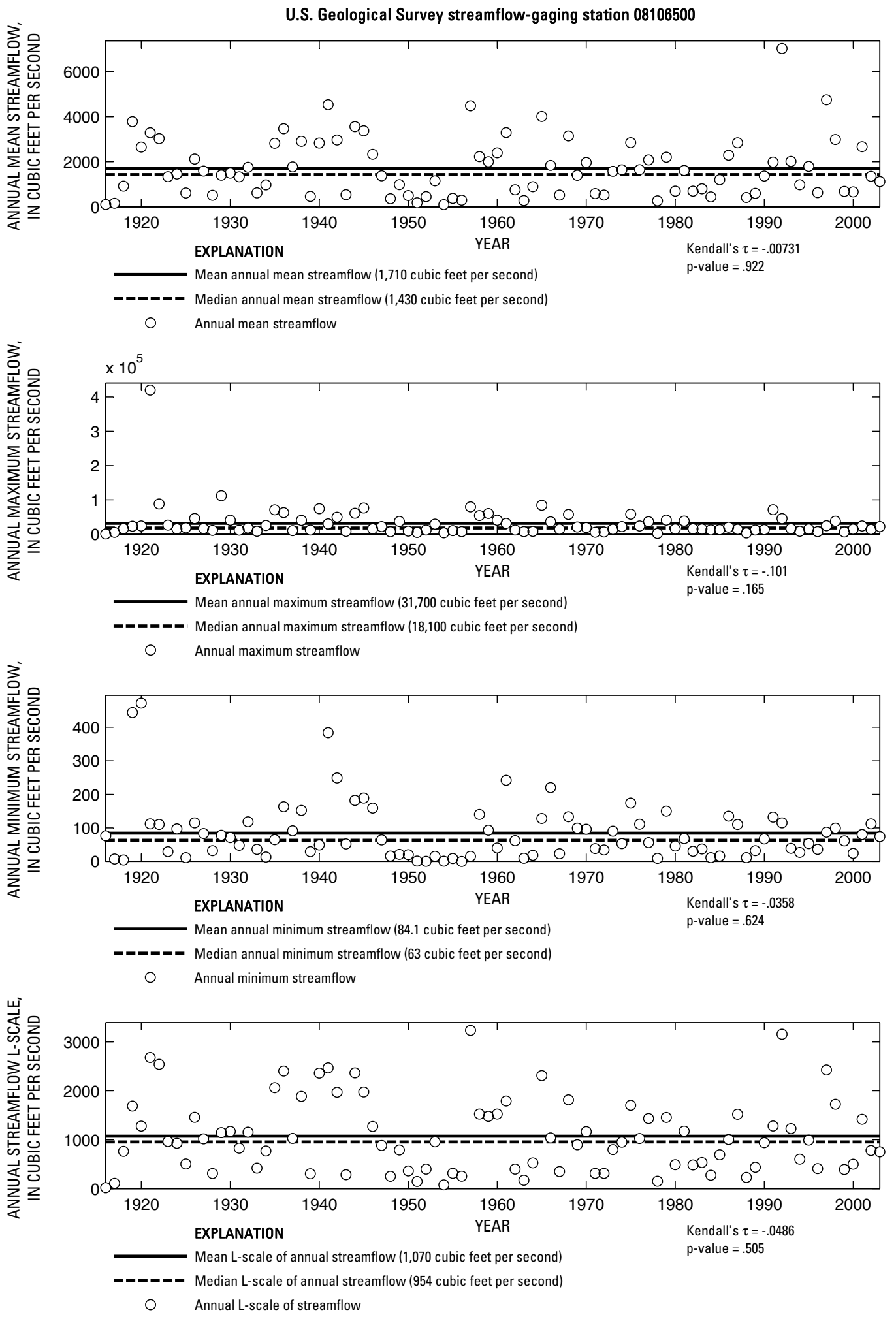

Figure 417. Analysis of annual mean, maximum, minimum, and L-scale statistics of daily mean streamflow for U.S. Geological Survey streamflow-gaging station 08106500 Little River at Cameron, Texas. 
U.S. Geological Survey streamflow-gaging station 08107000

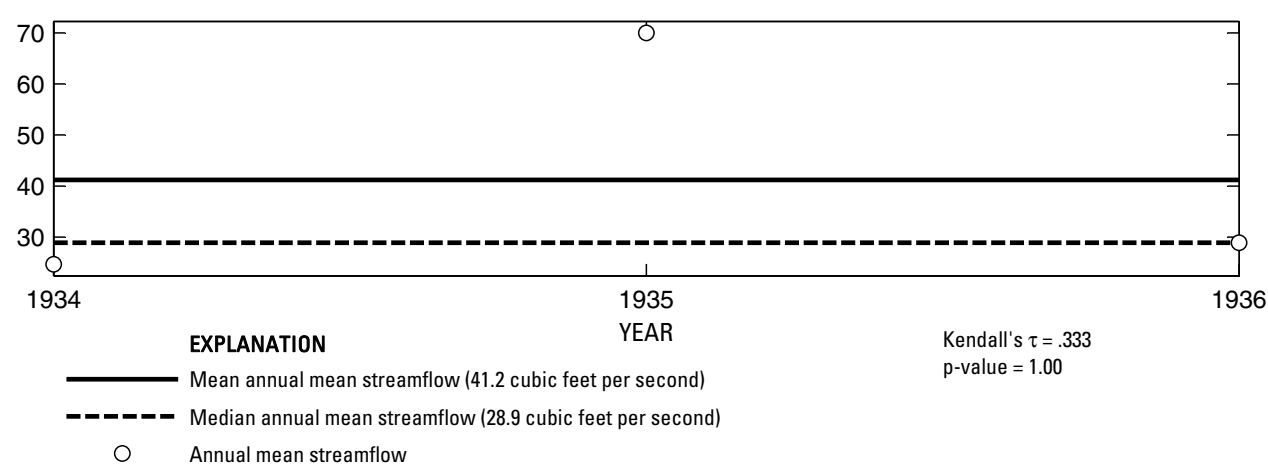

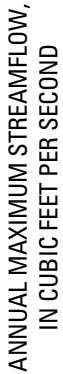

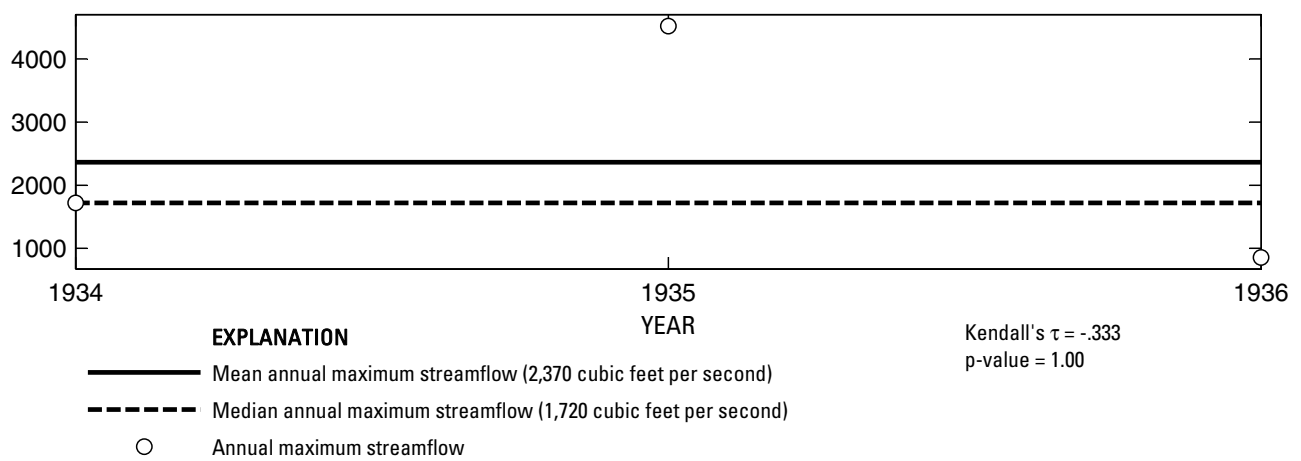

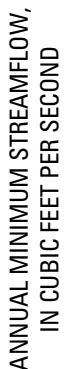

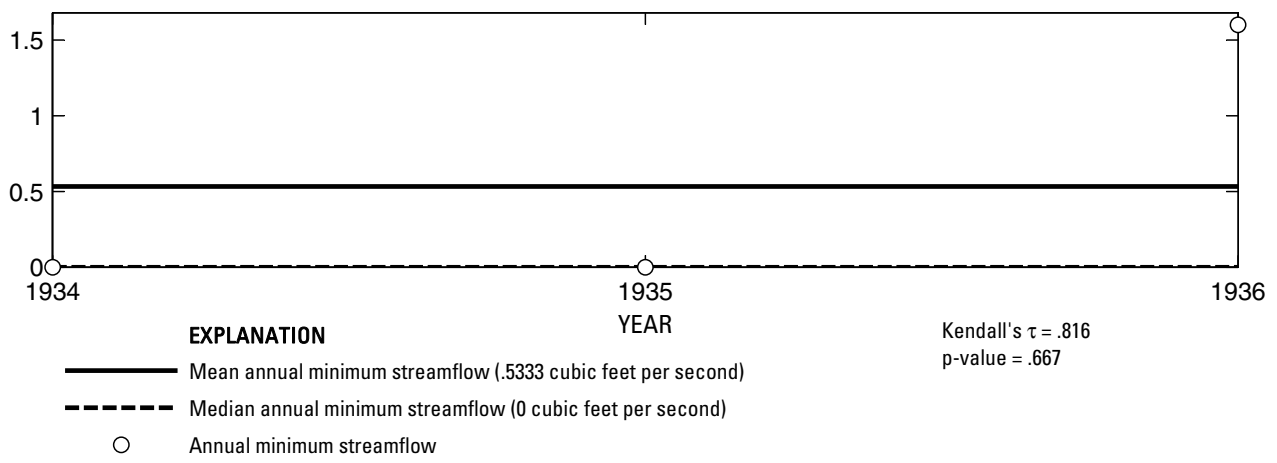

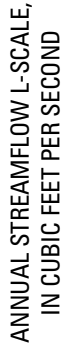

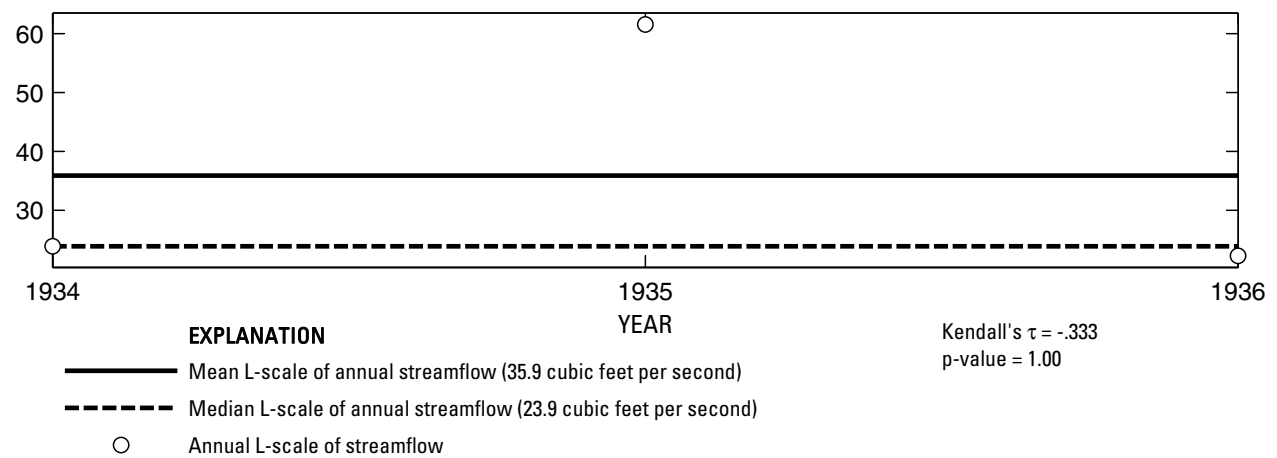

Figure 418. Analysis of annual mean, maximum, minimum, and L-scale statistics of daily mean streamflow for U.S. Geological Survey streamflow-gaging station 08107000 Big Elm Creek near Temple, Texas. 


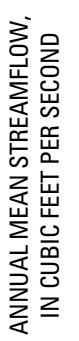

U.S. Geological Survey streamflow-gaging station 08107500

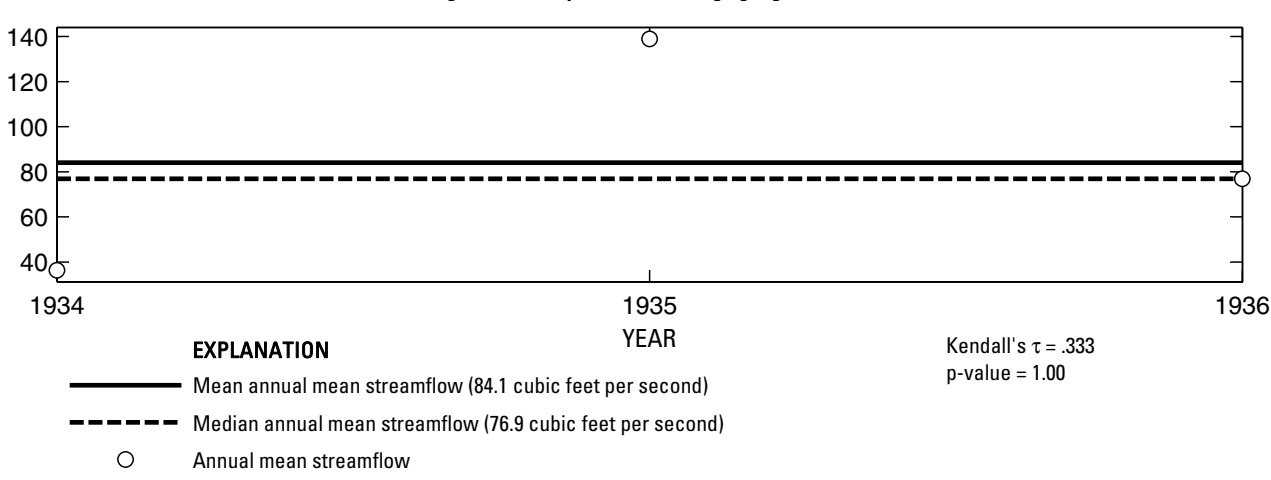

要

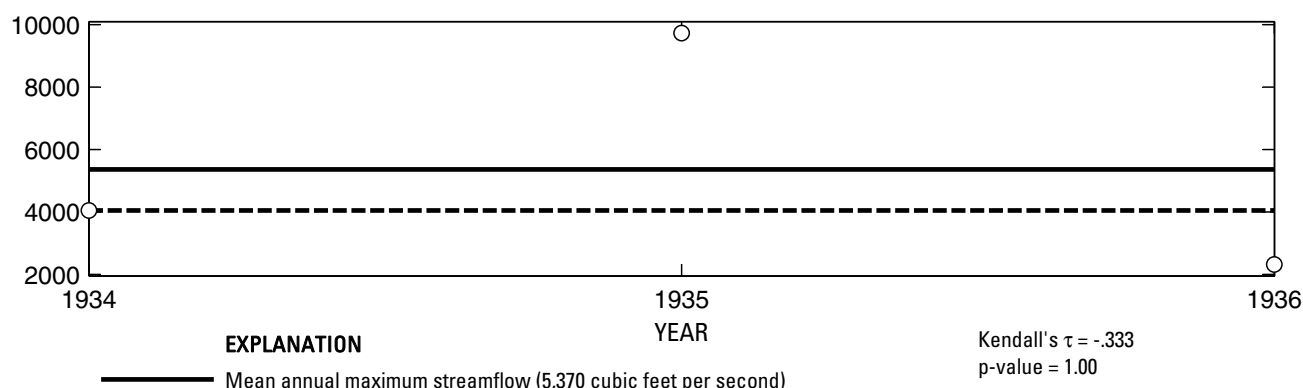

- _ _ _ Median annual maximum streamflow (4,050 cubic feet per second)

- Annual maximum streamflow
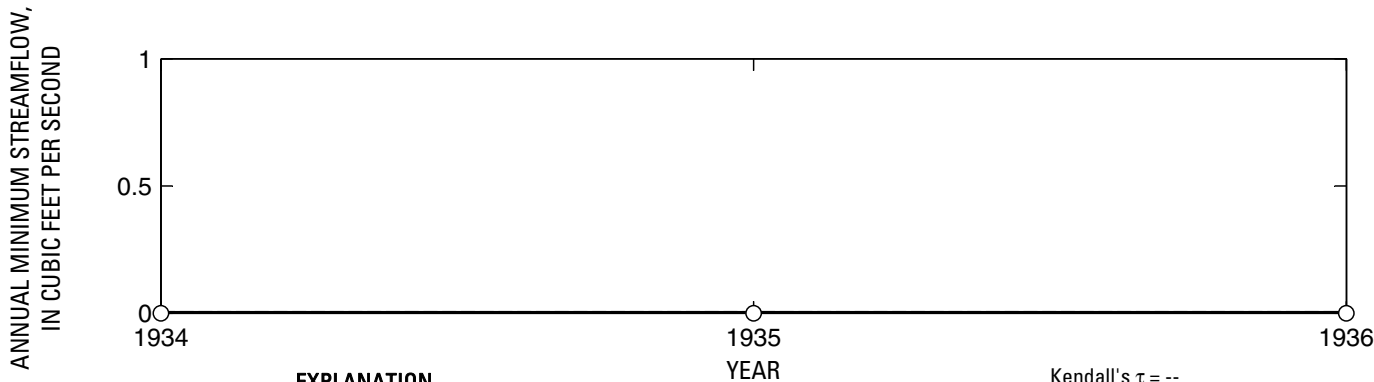

EXPLANATION KEAR Kendall's $\tau=-$

Mean annual minimum streamflow (0 cubic feet per second)

$\mathrm{p}$-value $=--$

- ב-ב Median annual minimum streamflow (0 cubic feet per second)

O Annual minimum streamflow

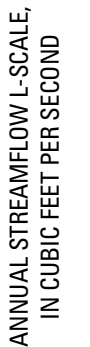

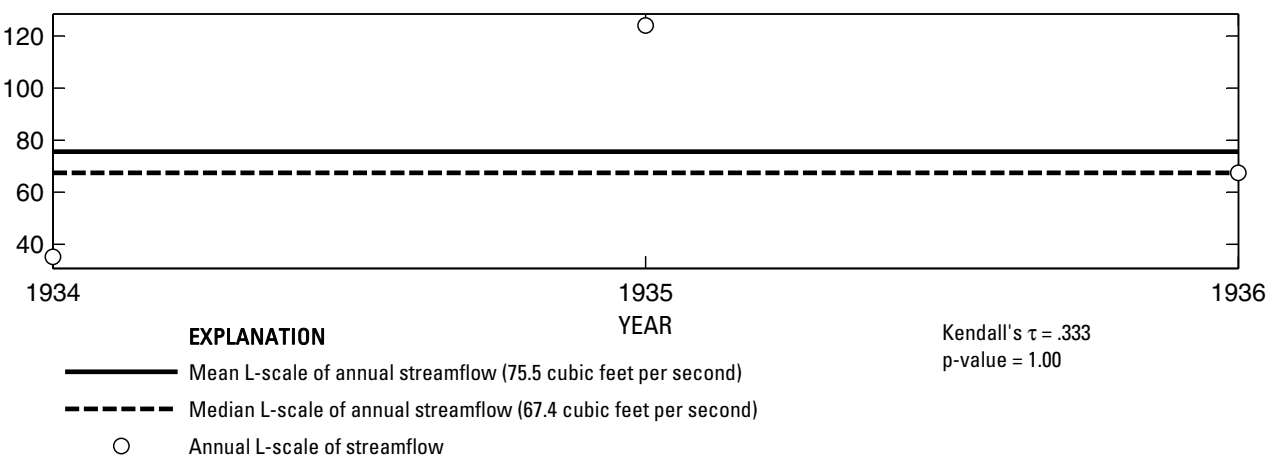

Figure 419. Analysis of annual mean, maximum, minimum, and L-scale statistics of daily mean streamflow for U.S. Geological Survey streamflow-gaging station 08107500 Big Elm Creek near Buckholts, Texas. 
U.S. Geological Survey streamflow-gaging station 08108000

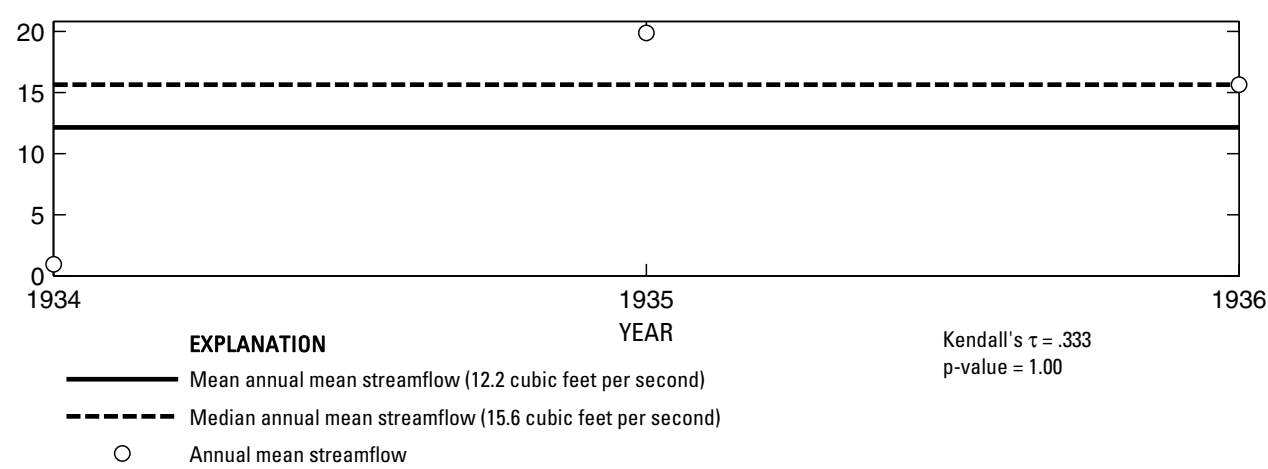

焉

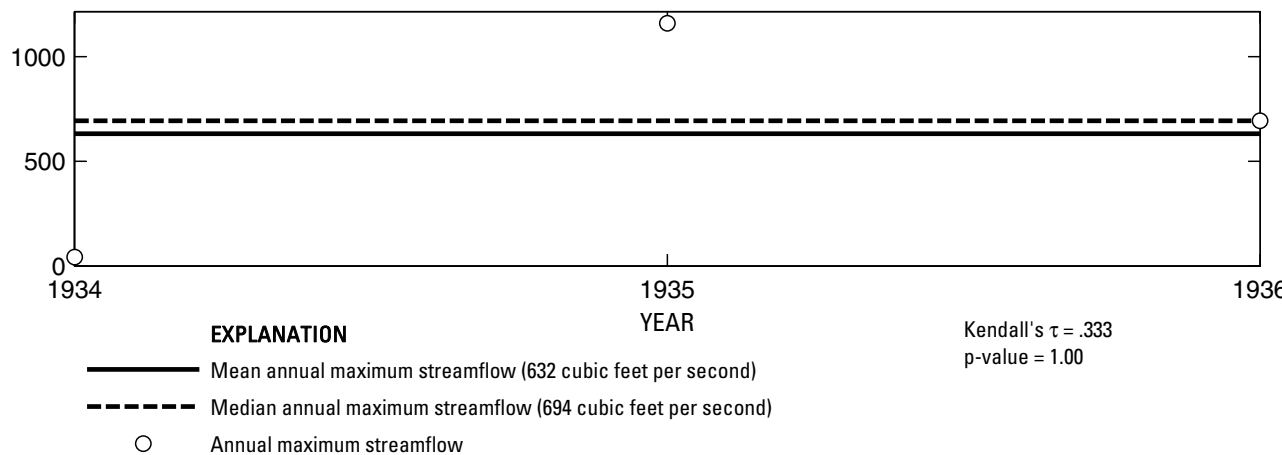

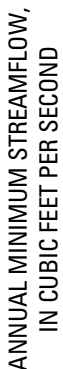

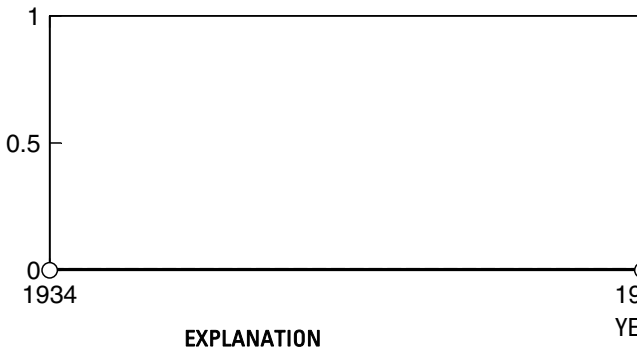

Mean annual minimum streamflow (0 cubic feet per second)

- - - - Median annual minimum streamflow $(0$ cubic feet per second)

O Annual minimum streamflow

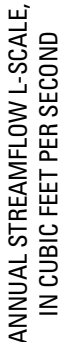

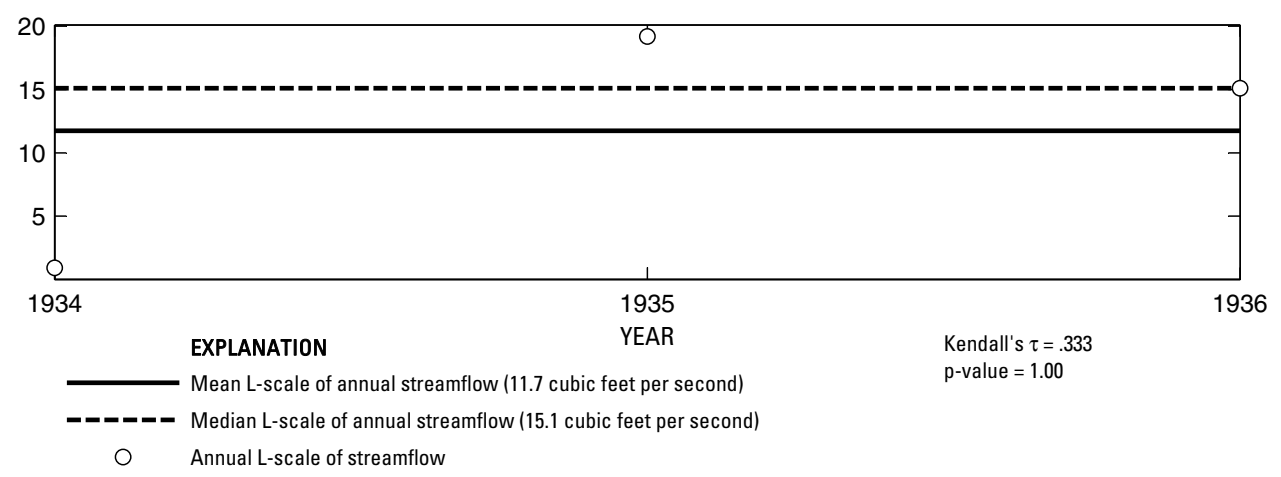

Figure 420. Analysis of annual mean, maximum, minimum, and L-scale statistics of daily mean streamflow for U.S. Geological Survey streamflow-gaging station 08108000 North Elm Creek near Ben Arnold, Texas.

Index of Station Numbers 719 

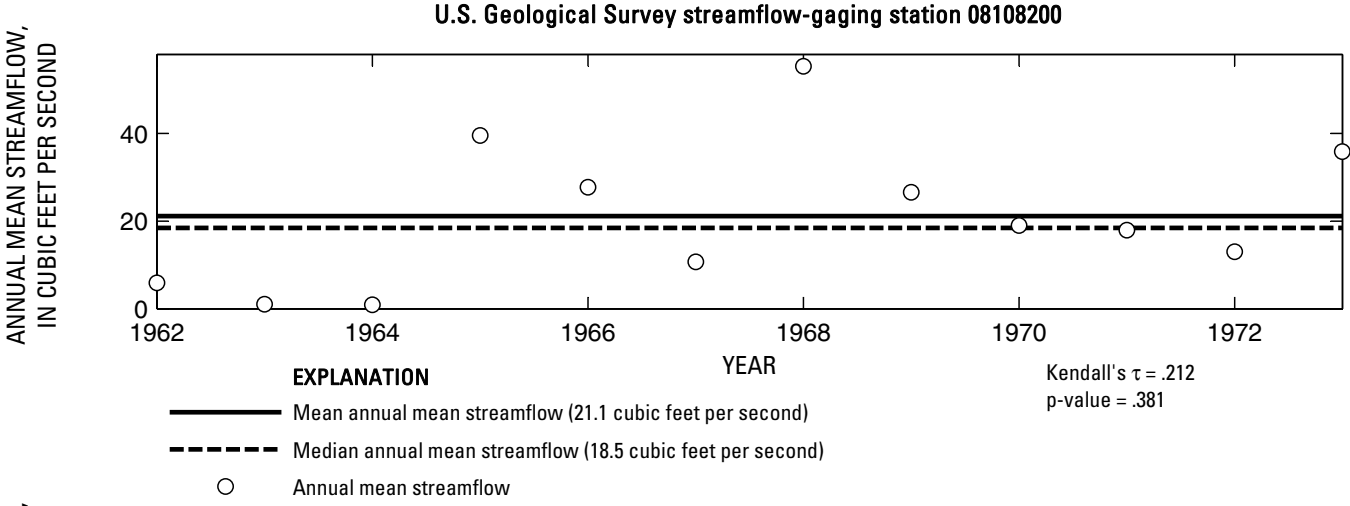

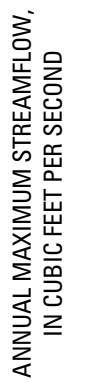

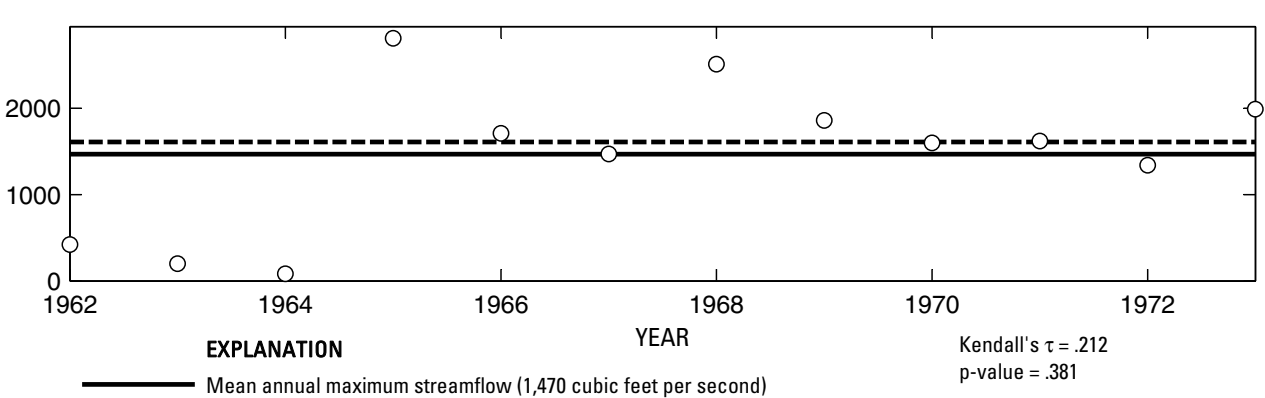

- _-_ _ - Median annual maximum streamflow (1,610 cubic feet per second)

○ Annual maximum streamflow
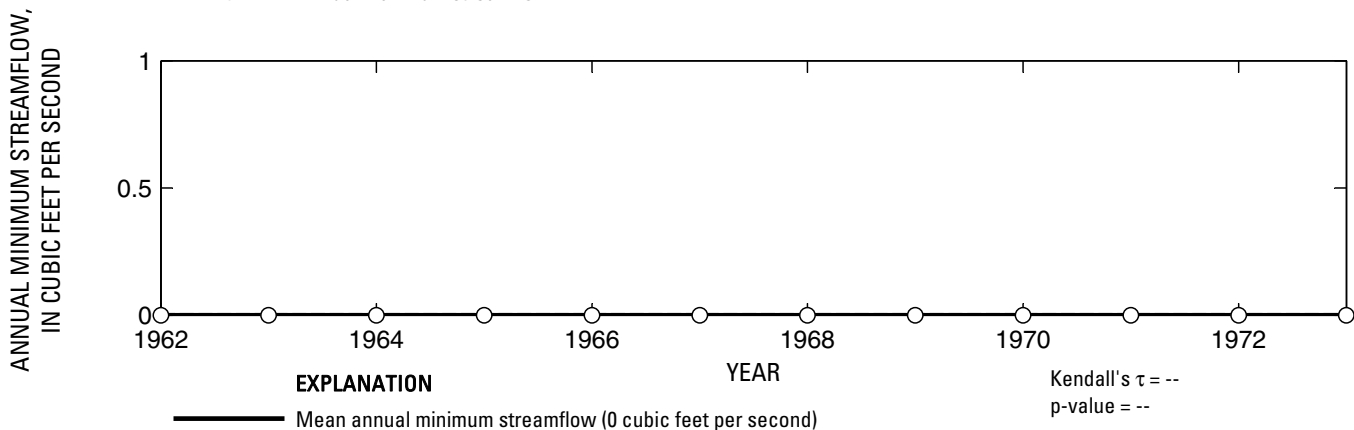

- ב-ב Median annual minimum streamflow (0 cubic feet per second)

○ Annual minimum streamflow

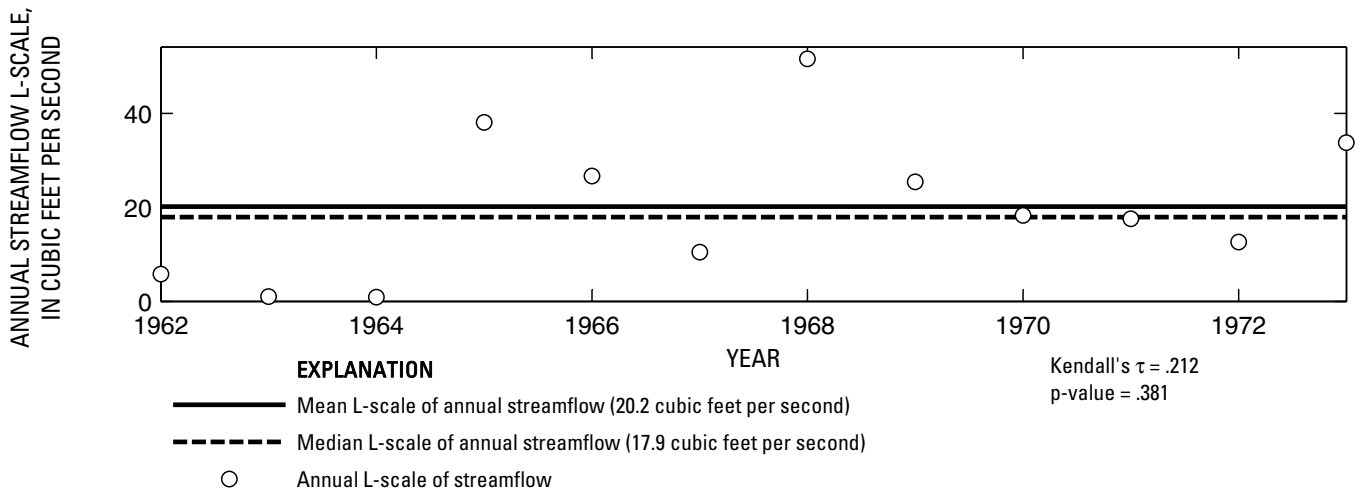

Figure 421. Analysis of annual mean, maximum, minimum, and L-scale statistics of daily mean streamflow for U.S. Geological Survey streamflow-gaging station 08108200 North Elm Creek near Cameron, Texas. 
U.S. Geological Survey streamflow-gaging station 08108700
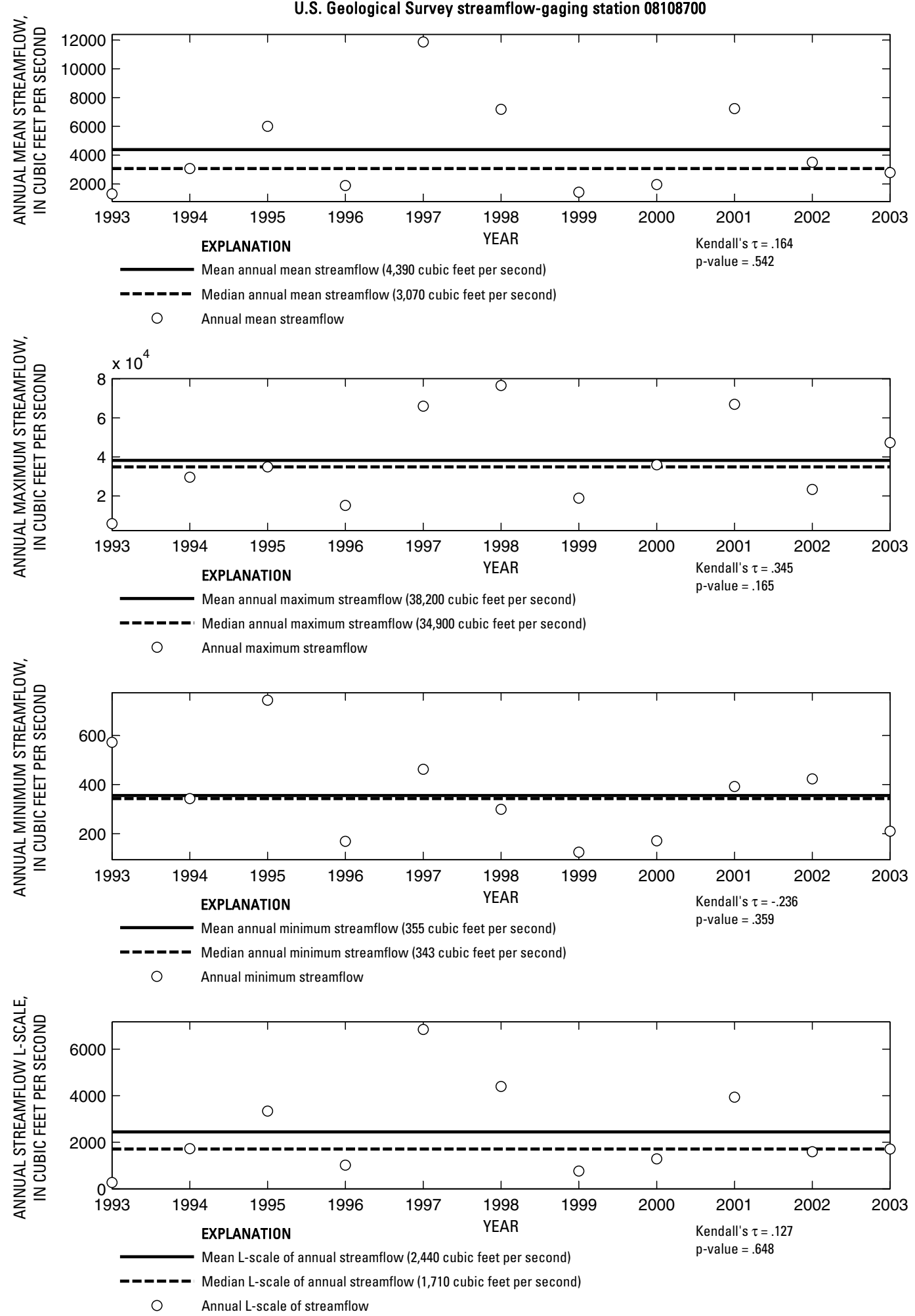

Figure 422. Analysis of annual mean, maximum, minimum, and L-scale statistics of daily mean streamflow for U.S. Geological Survey streamflow-gaging station 08108700 Brazos River at State Highway 21 near Bryan, Texas.

|ndex of Station Numbers 719 

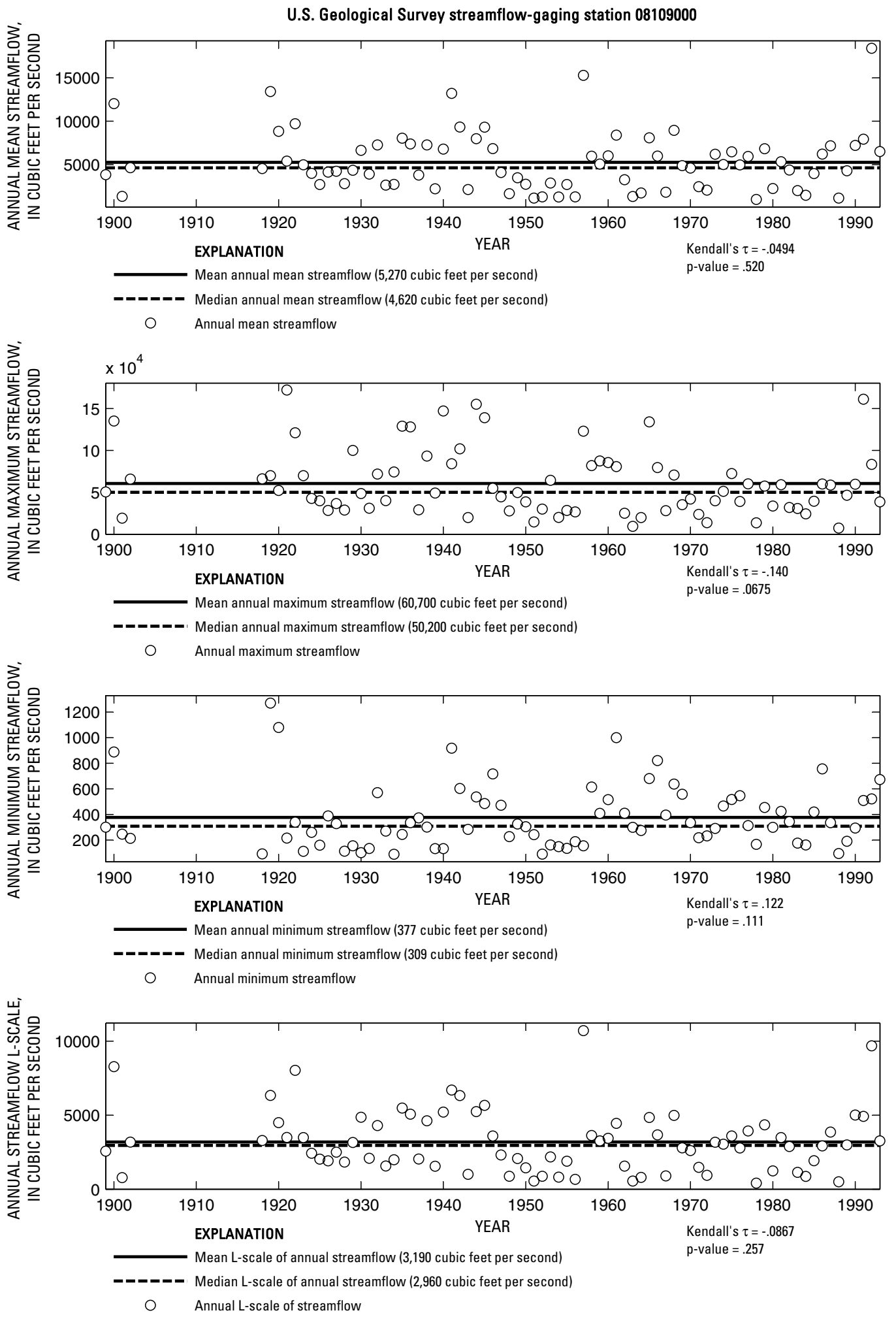

Figure 423. Analysis of annual mean, maximum, minimum, and L-scale statistics of daily mean streamflow for U.S. Geological Survey streamflow-gaging station 08109000 Brazos River near Bryan, Texas. 
U.S. Geological Survey streamflow-gaging station 08109700

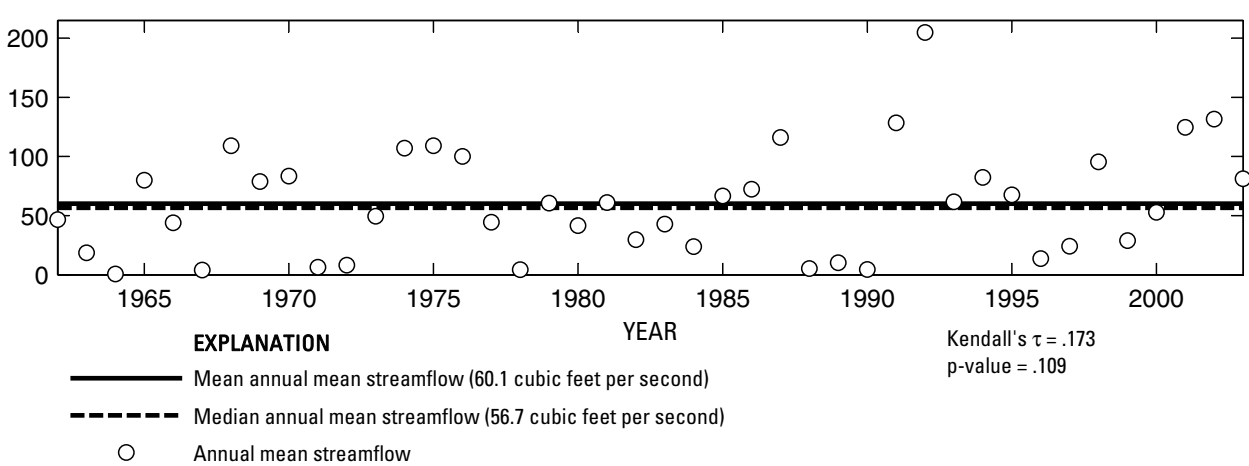

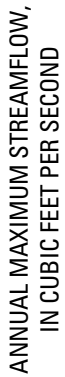

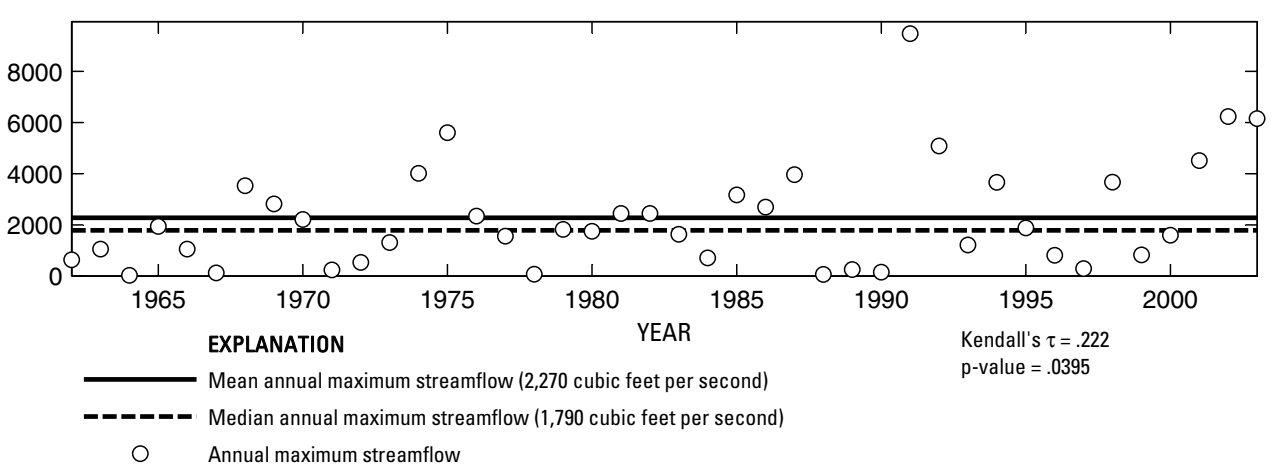

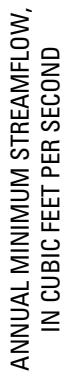

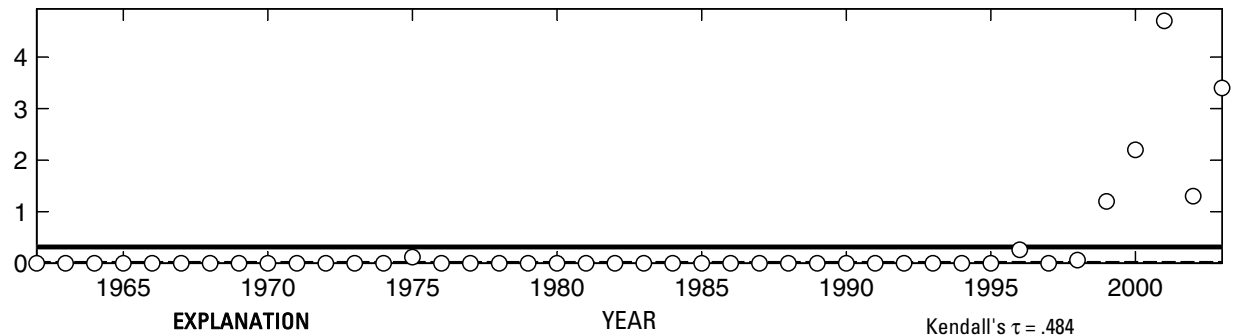

Theil trend line for annual minimum streamflow
Mean annual minimum streamflow (.3152 cubic feet per second

- Median annual minimum streamflow (0 cubic feet per second)

O Annual minimum streamflow

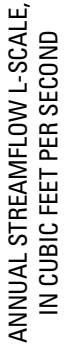

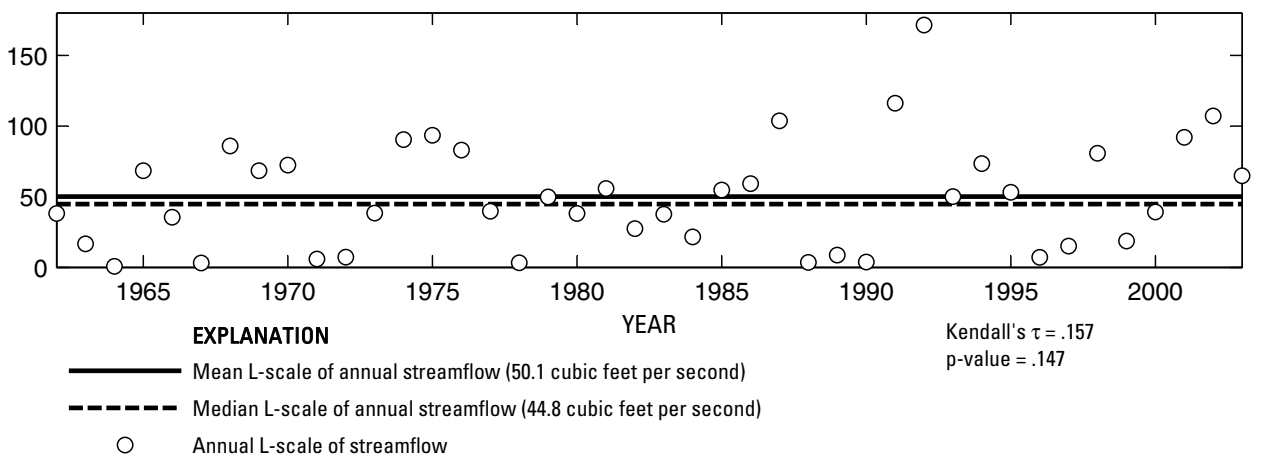

Figure 424. Analysis of annual mean, maximum, minimum, and L-scale statistics of daily mean streamflow for U.S. Geological Survey streamflow-gaging station 08109700 Middle Yegua Creek near Dime Box, Texas.

|ndex of Station Numbers 719 


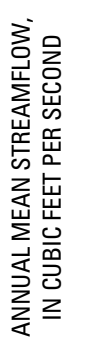

U.S. Geological Survey streamflow-gaging station 08109800

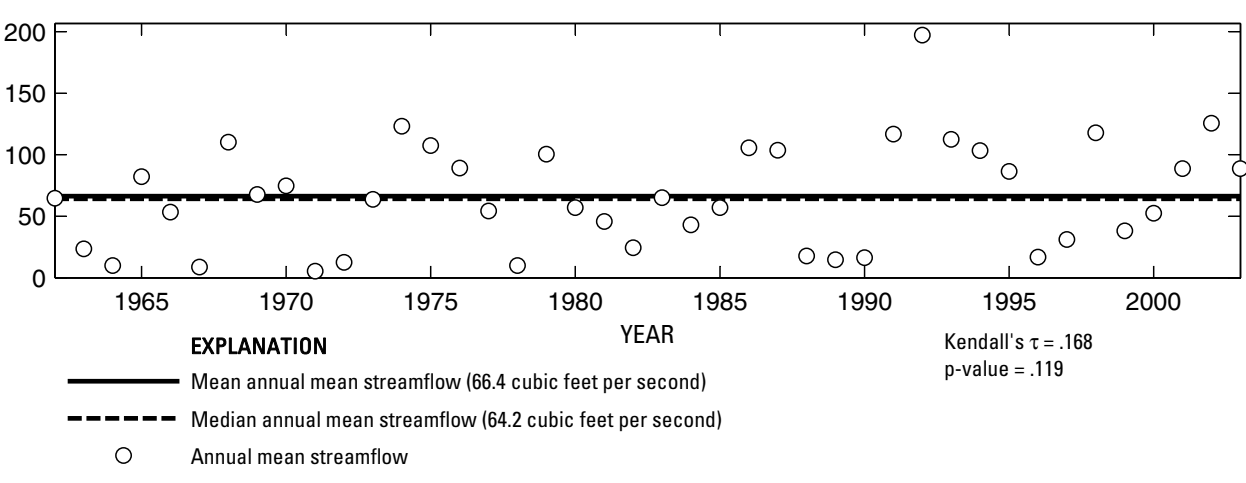

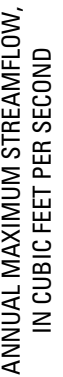

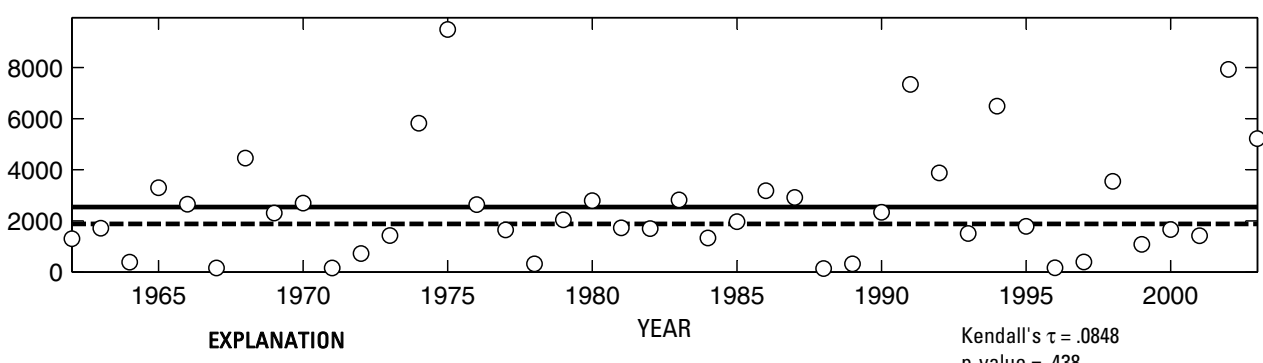

Mean annual maximum streamflow (2,550 cubic feet per second)

p-value $=.438$

- ב- Median annual maximum streamflow (1,880 cubic feet per second)

O Annual maximum streamflow

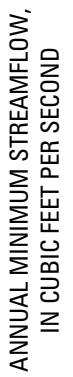

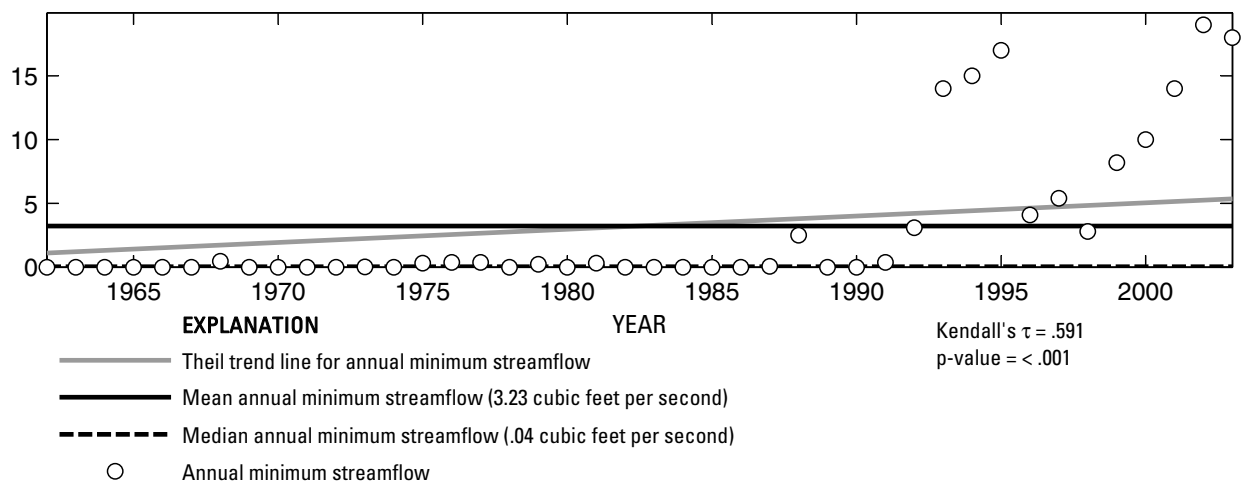

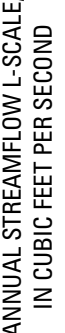

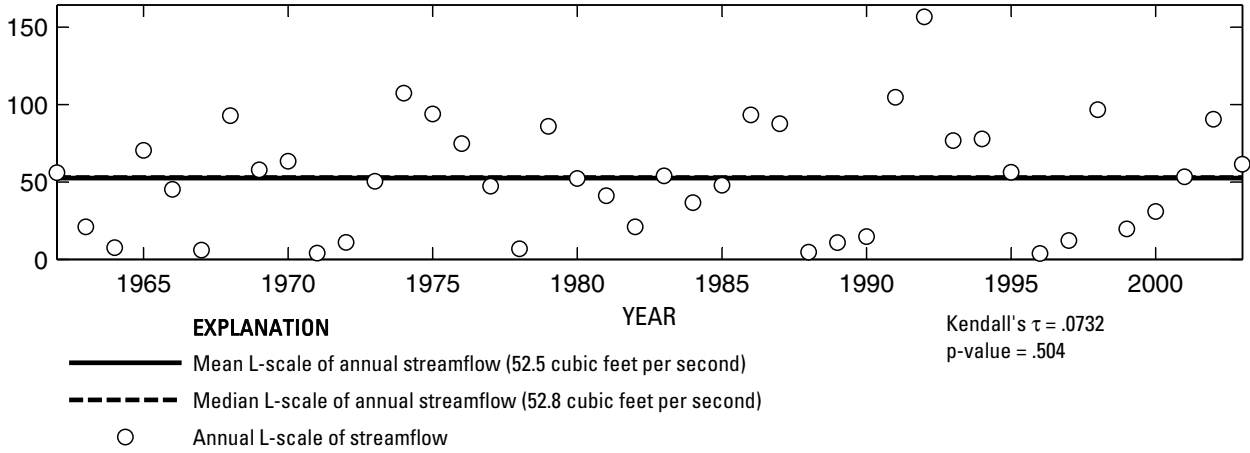

Figure 425. Analysis of annual mean, maximum, minimum, and L-scale statistics of daily mean streamflow for U.S. Geological Survey streamflow-gaging station 08109800 East Yegua Creek near Dime Box, Texas.

Index of Station Numbers 719 
U.S. Geological Survey streamflow-gaging station 08110000

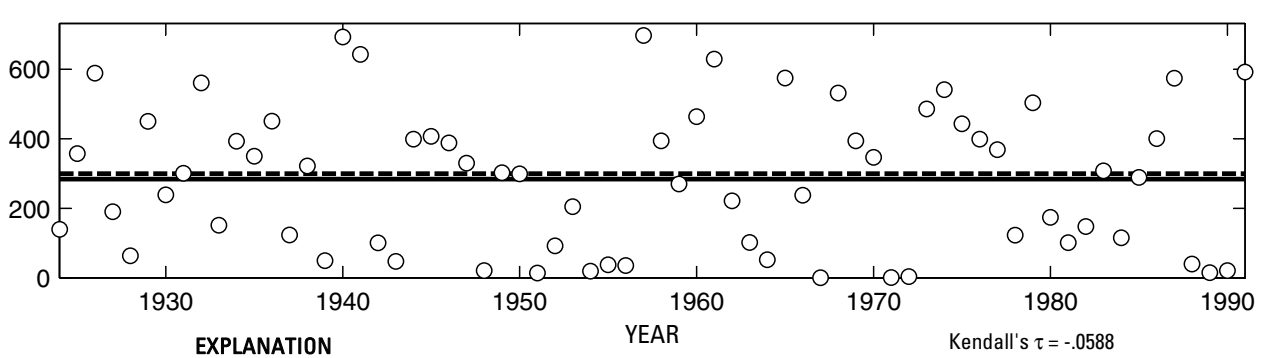

EXPLANATION

r second)

$\mathrm{p}$-value $=.481$

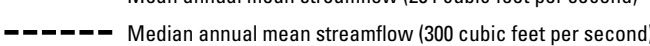

O Annual mean streamflow

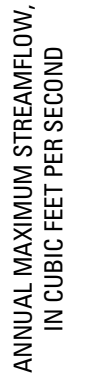

$\times 10^{4}$

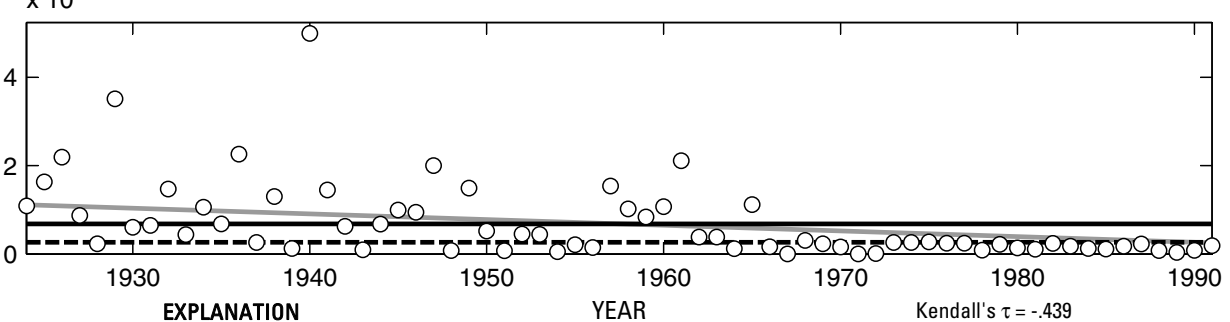

Theil trend line for annual maximum streamflow

Mean annual maximum streamflow (6,820 cubic feet per second)

-ーーーーー・ Median annual maximum streamflow (2,670 cubic feet per second)

Annual maximum streamflow

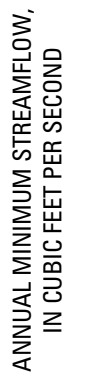

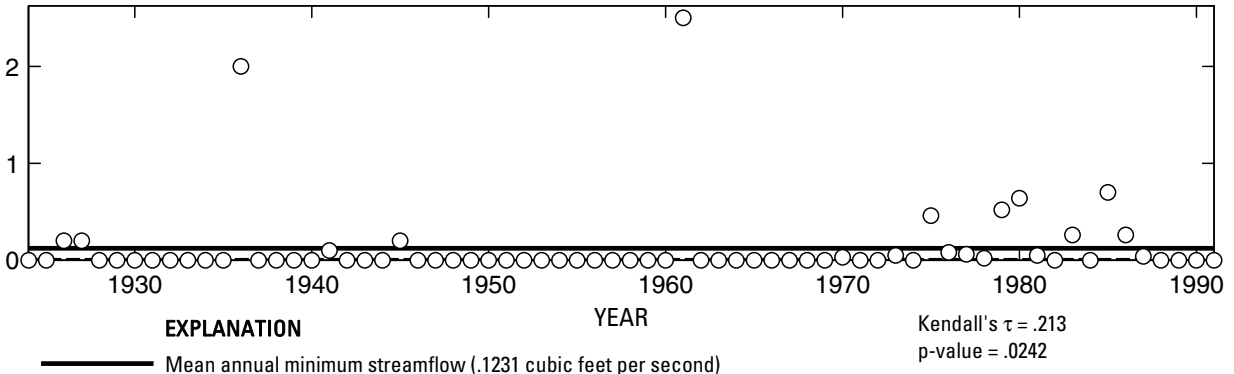

- ב Median annual minimum streamflow (0 cubic feet per second)

O Annual minimum streamflow

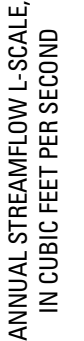

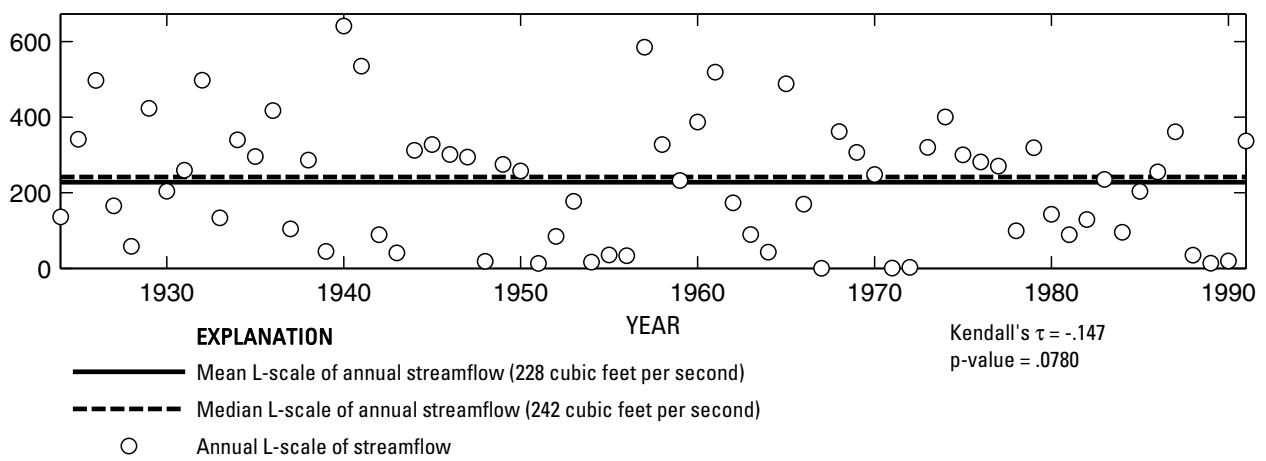

Figure 426. Analysis of annual mean, maximum, minimum, and L-scale statistics of daily mean streamflow for U.S. Geological Survey streamflow-gaging station 08110000 Yegua Creek near Somerville, Texas.

Index of Station Numbers 719 

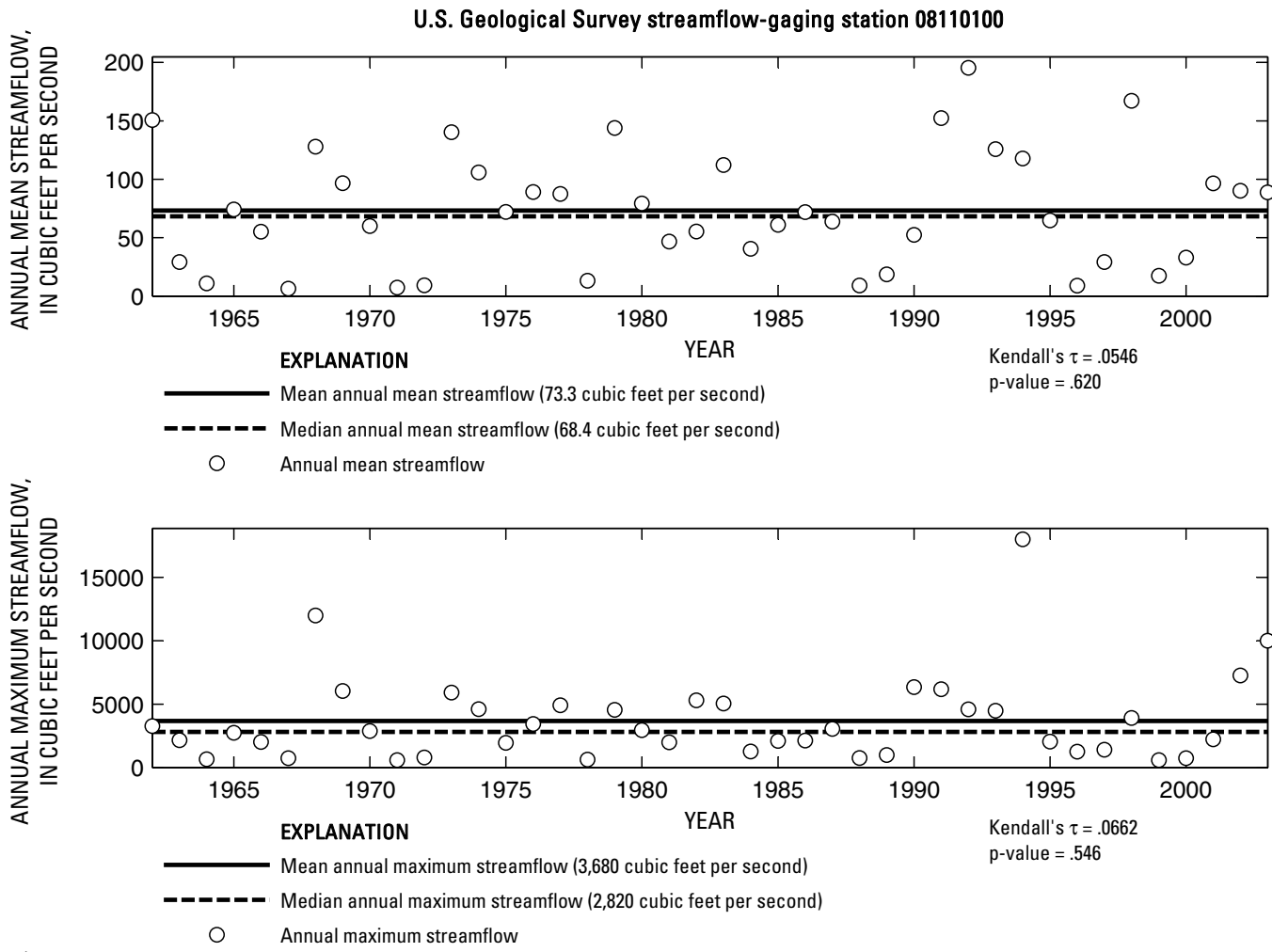

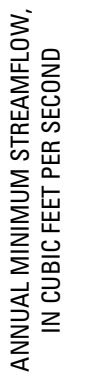

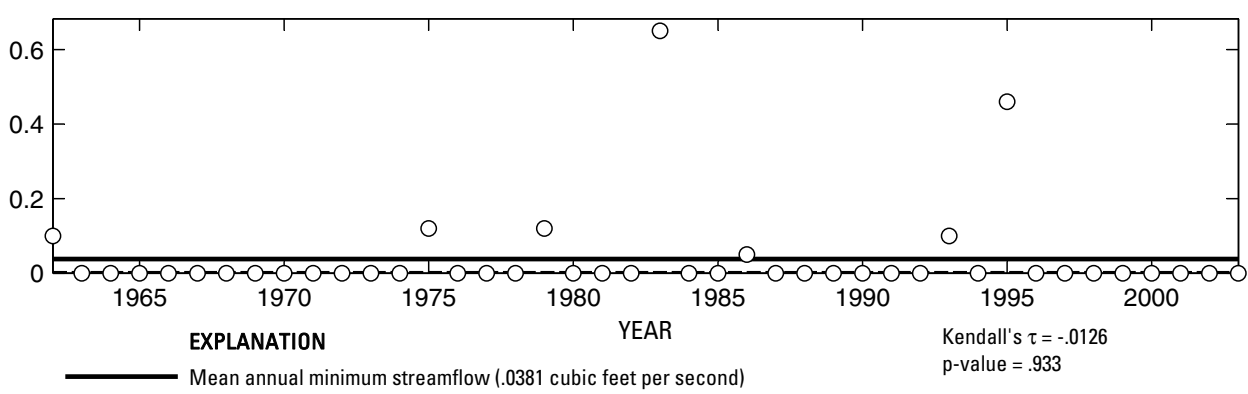

- _- Median annual minimum streamflow (0 cubic feet per second)

O Annual minimum streamflow

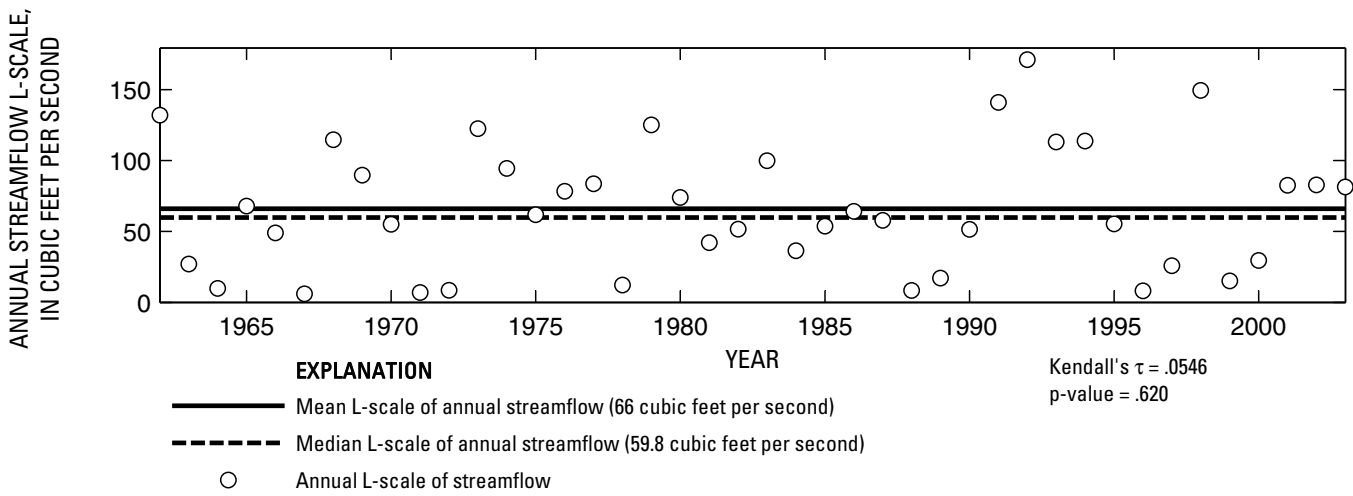

Figure 427. Analysis of annual mean, maximum, minimum, and L-scale statistics of daily mean streamflow for U.S. Geological Survey streamflow-gaging station 08110100 Davidson Creek near Lyons, Texas. 

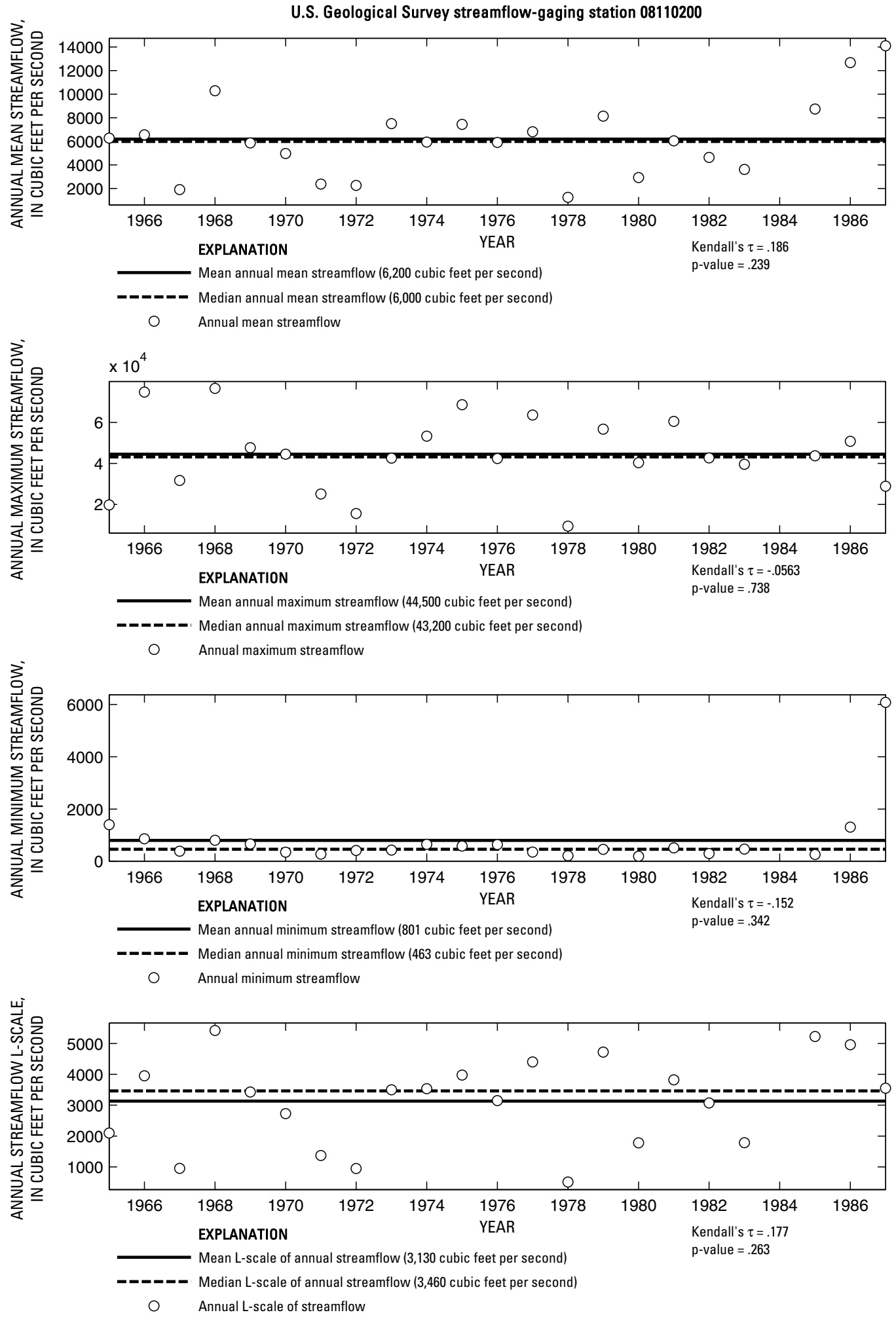

Figure 428. Analysis of annual mean, maximum, minimum, and L-scale statistics of daily mean streamflow for U.S. Geological Survey streamflow-gaging station 08110200 Brazos River at Washington, Texas.

Index of Station Numbers 719 

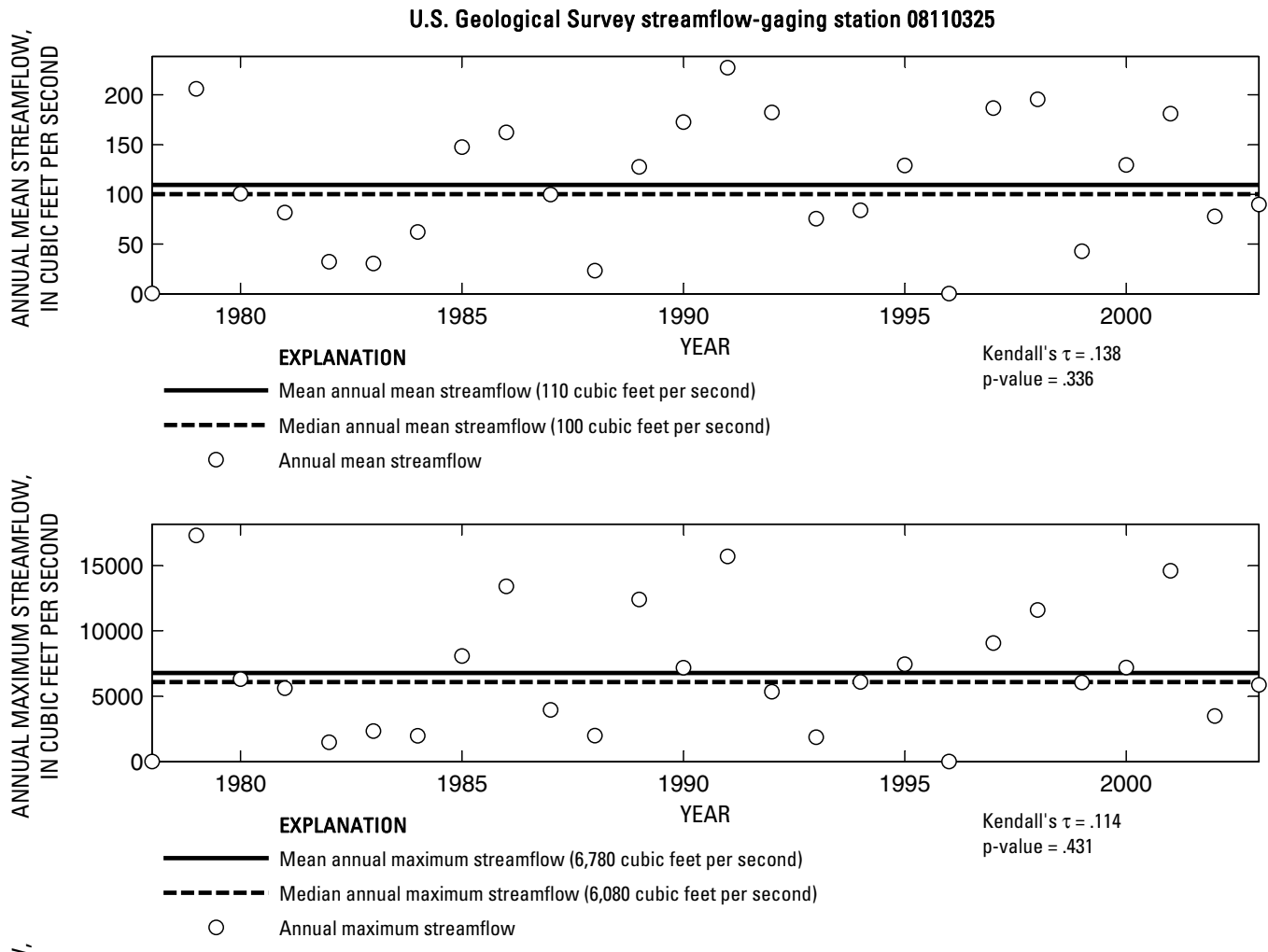

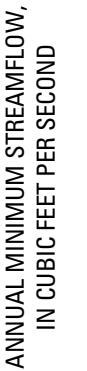

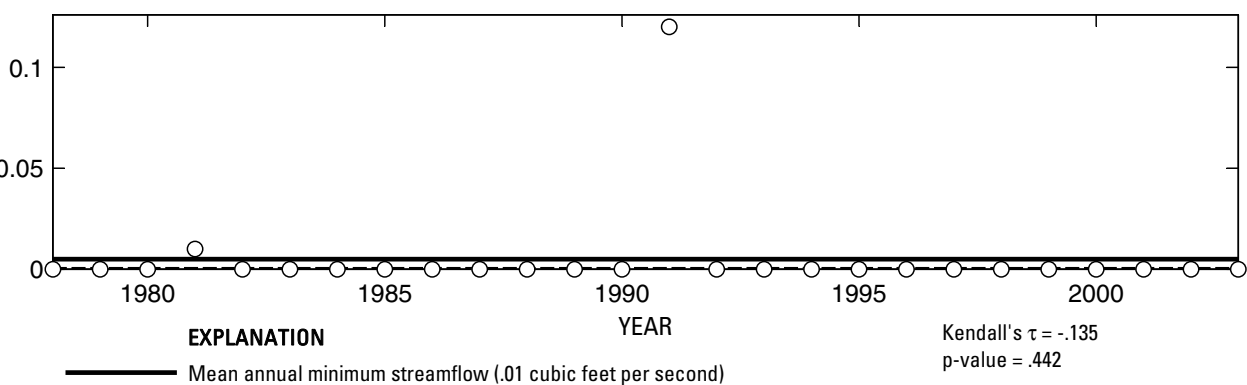

- - Median annual minimum streamflow (0 cubic feet per second)

O Annual minimum streamflow

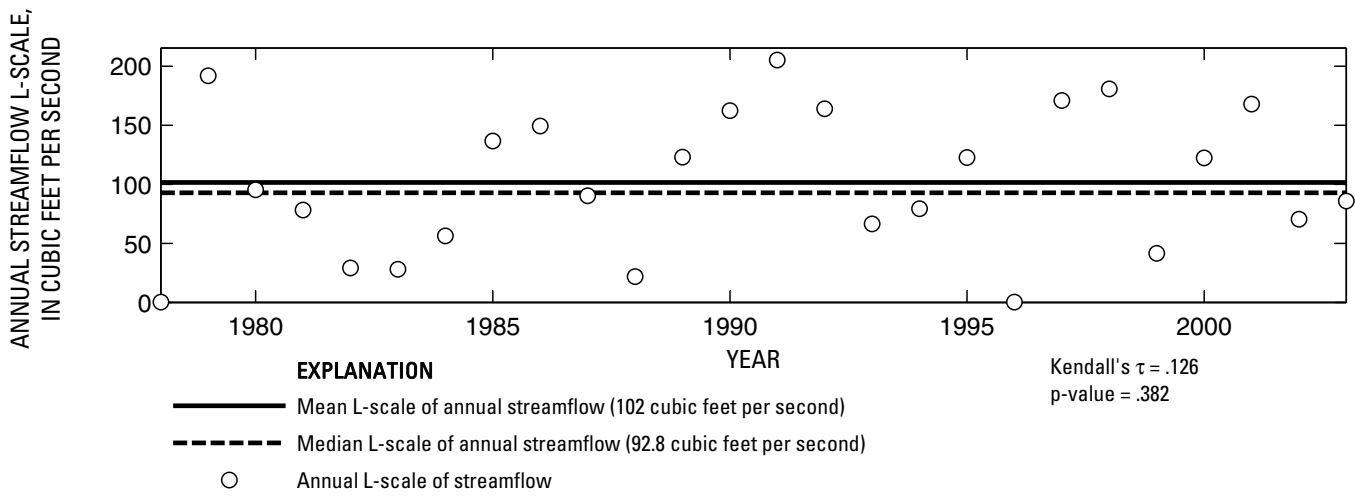

Figure 429. Analysis of annual mean, maximum, minimum, and L-scale statistics of daily mean streamflow for U.S. Geological Survey streamflow-gaging station 08110325 Navasota River above Groesbeck, Texas. 
U.S. Geological Survey streamflow-gaging station 08110400

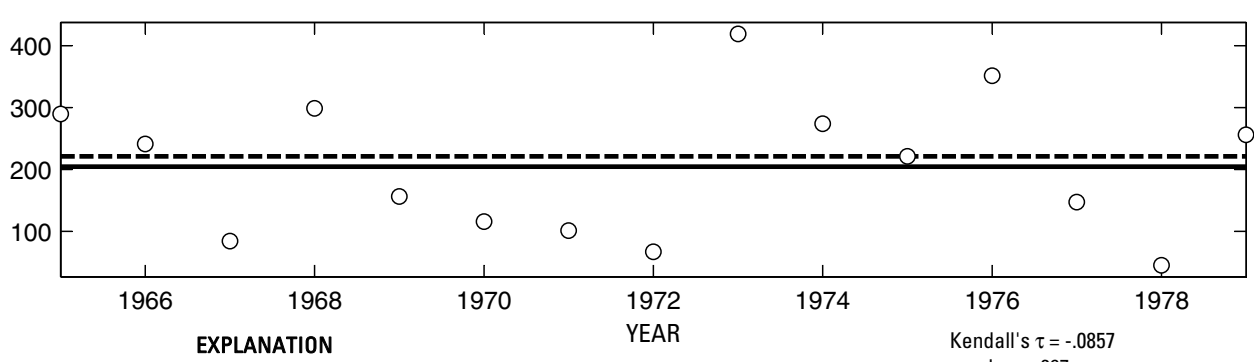

EXPLANATION

$\mathrm{p}$-value $=.697$

-ב-ー- Median annual mean streamflow (221 cubic feet per second)

O Annual mean streamflow
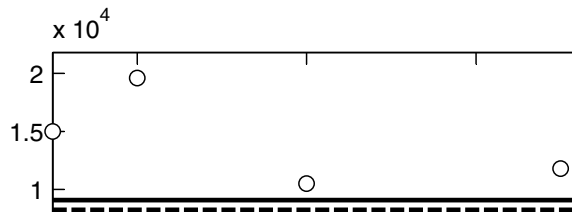

0.5
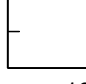

0

$\frac{0}{1970}$

1970

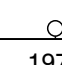

1972

YEAR

Mean annual maximum streamflow (9,090 cubic feet per second)

- ב-_- Median annual maximum streamflow (8,240 cubic feet per second)

O Annual maximum streamflow

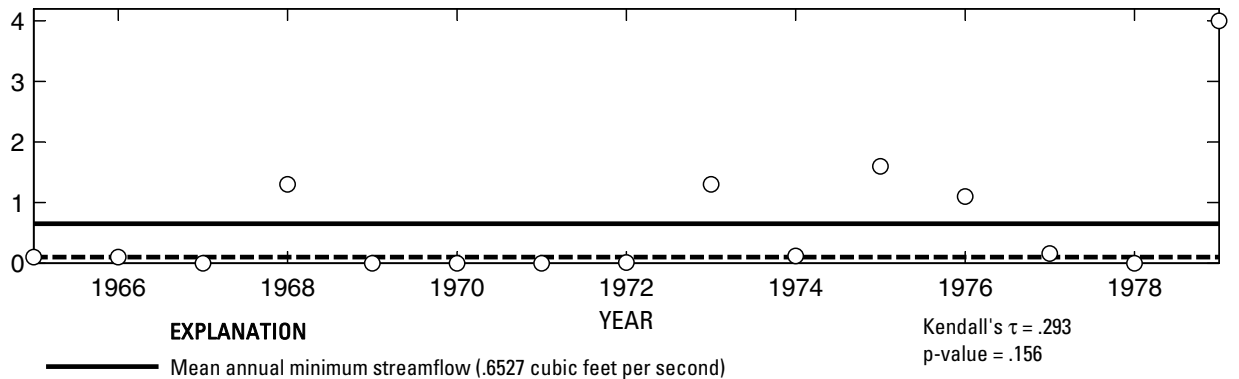

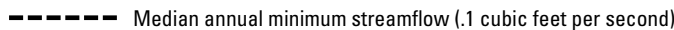

O Annual minimum streamflow

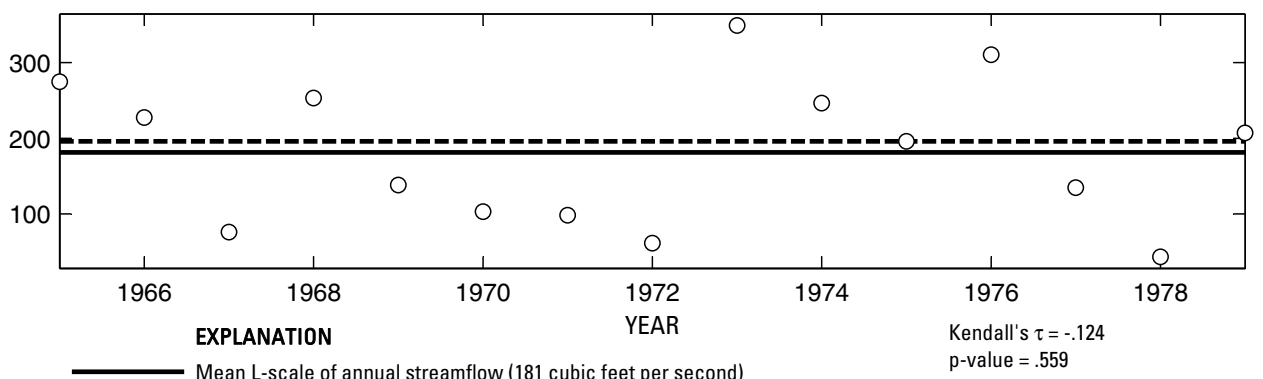

Mean L-scale of annual streamflow (181 cubic feet per second)

- - - Median L-scale of annual streamflow (196 cubic feet per second)

Annual L-scale of streamflow

Figure 430. Analysis of annual mean, maximum, minimum, and L-scale statistics of daily mean streamflow for U.S. Geological Survey streamflow-gaging station 08110400 Navasota River near Groesbeck, Texas.

|ndex of Station Numbers 719 

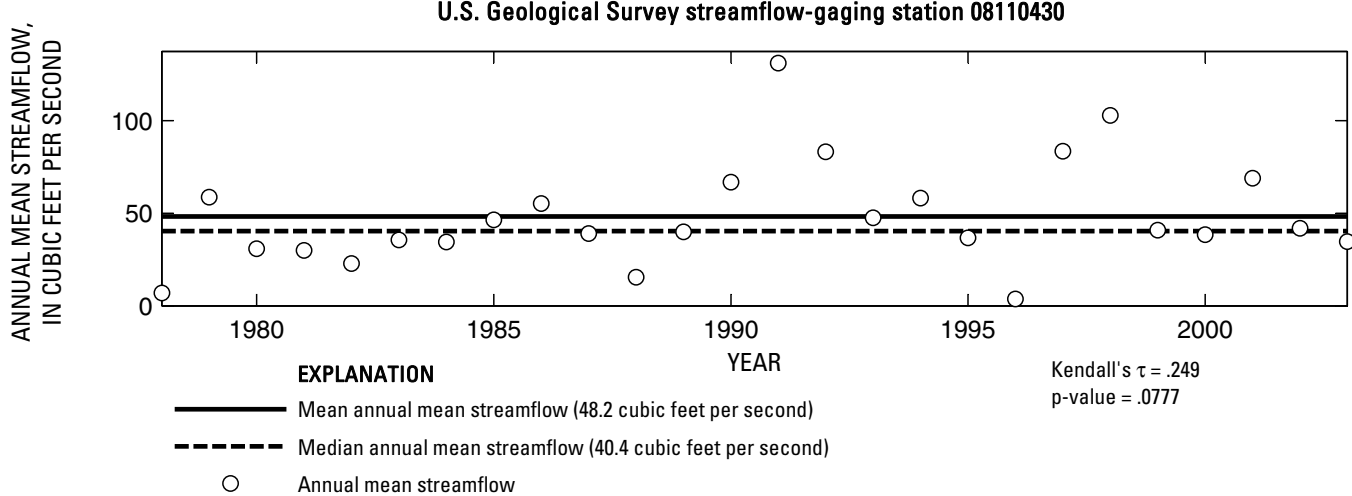

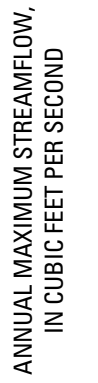

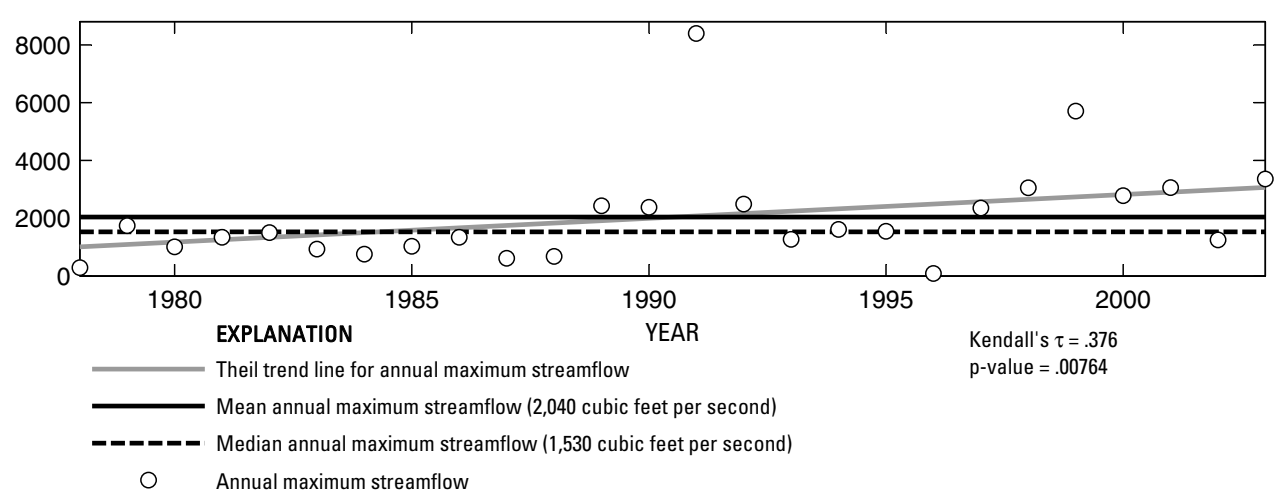

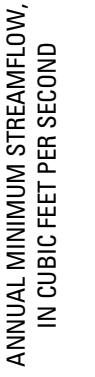

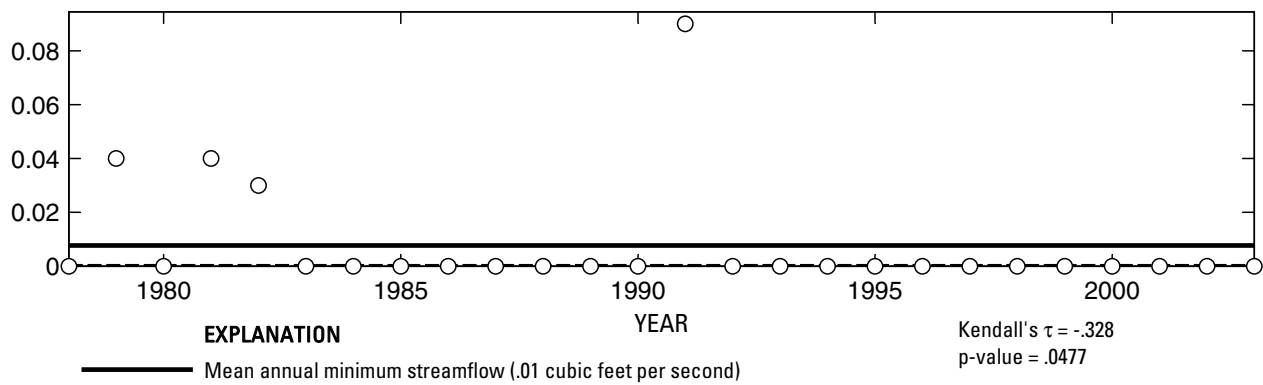

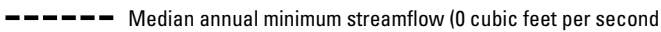

O Annual minimum streamflow

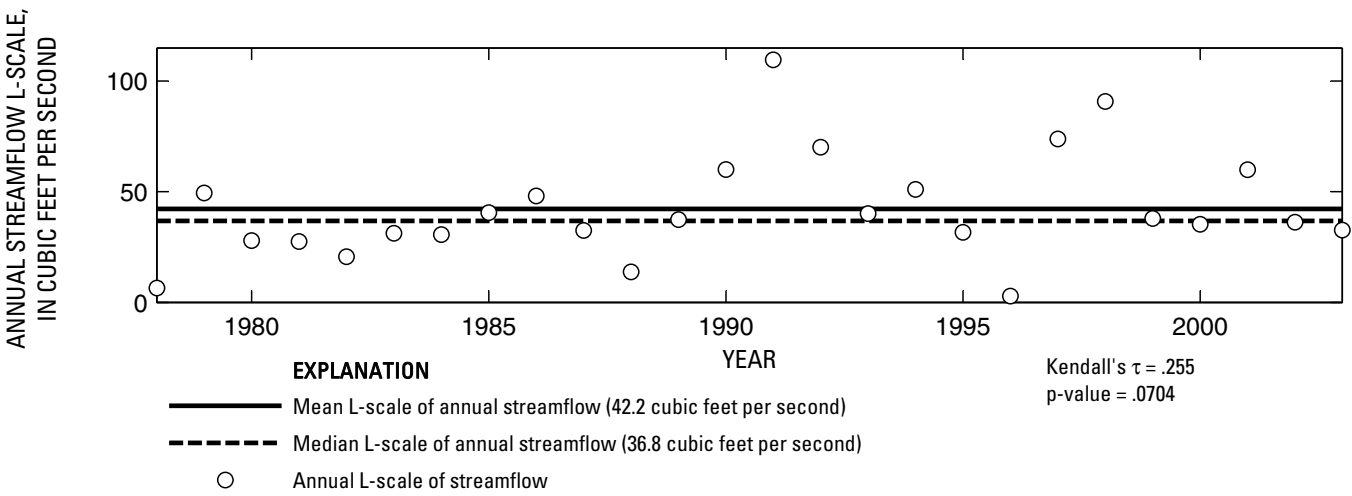

Figure 431. Analysis of annual mean, maximum, minimum, and L-scale statistics of daily mean streamflow for U.S. Geological Survey streamflow-gaging station 08110430 Big Creek near Freestone, Texas. 


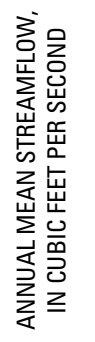

U.S. Geological Survey streamflow-gaging station 08110500

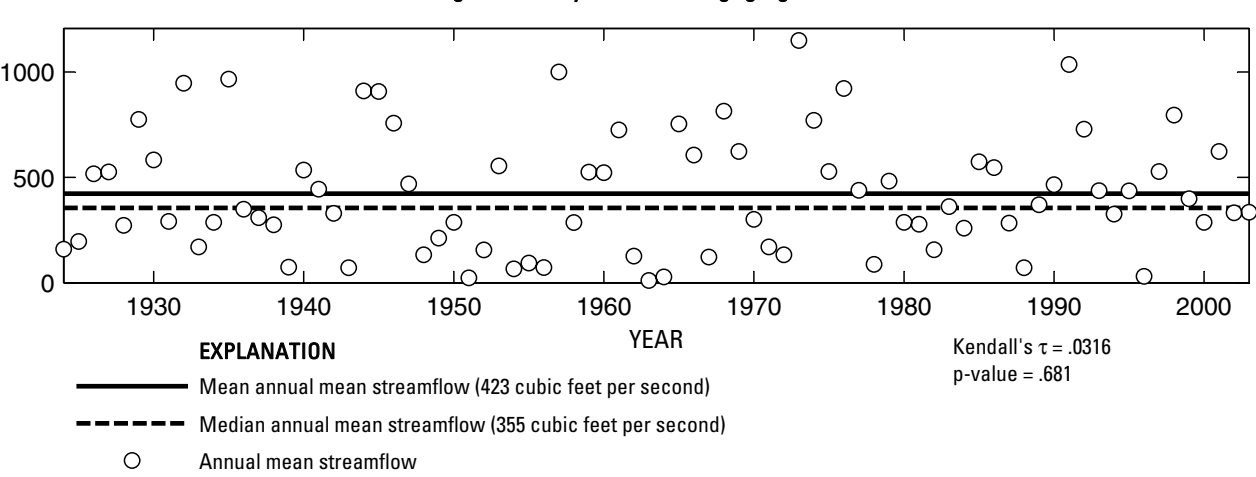

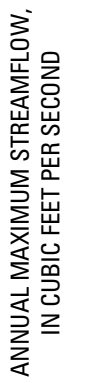

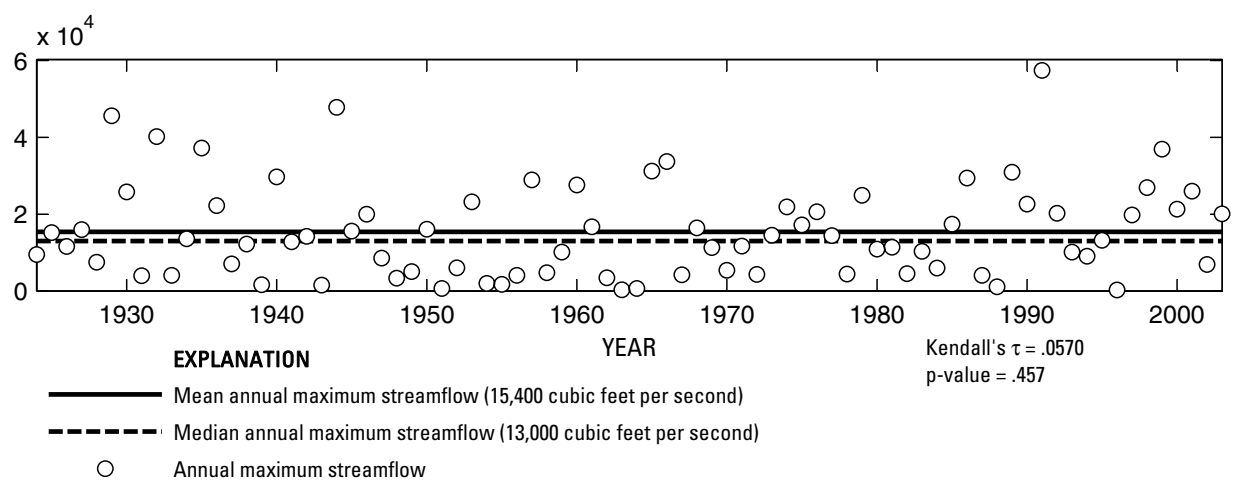

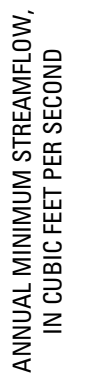

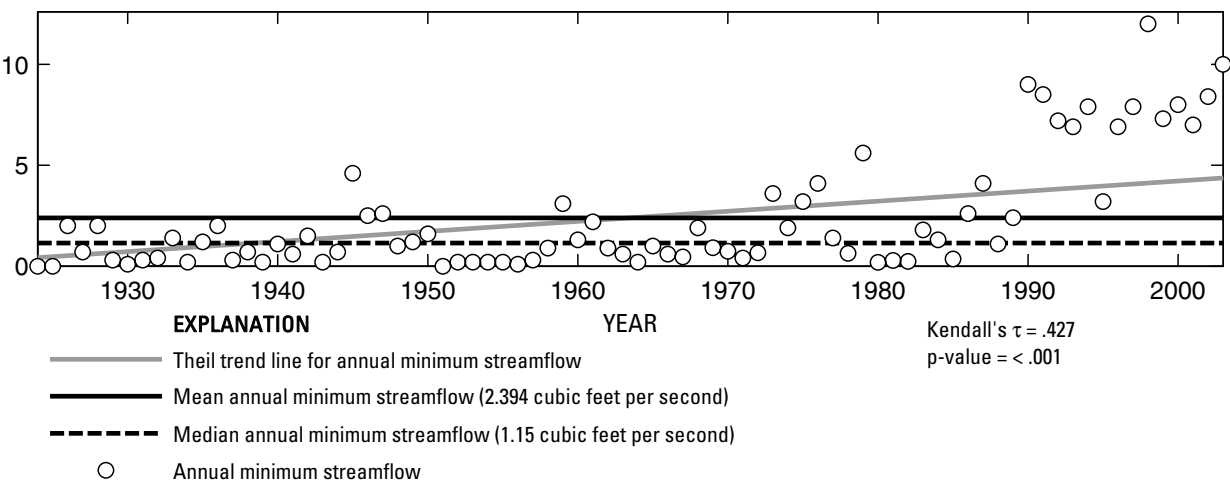

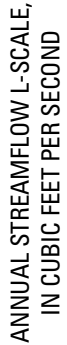

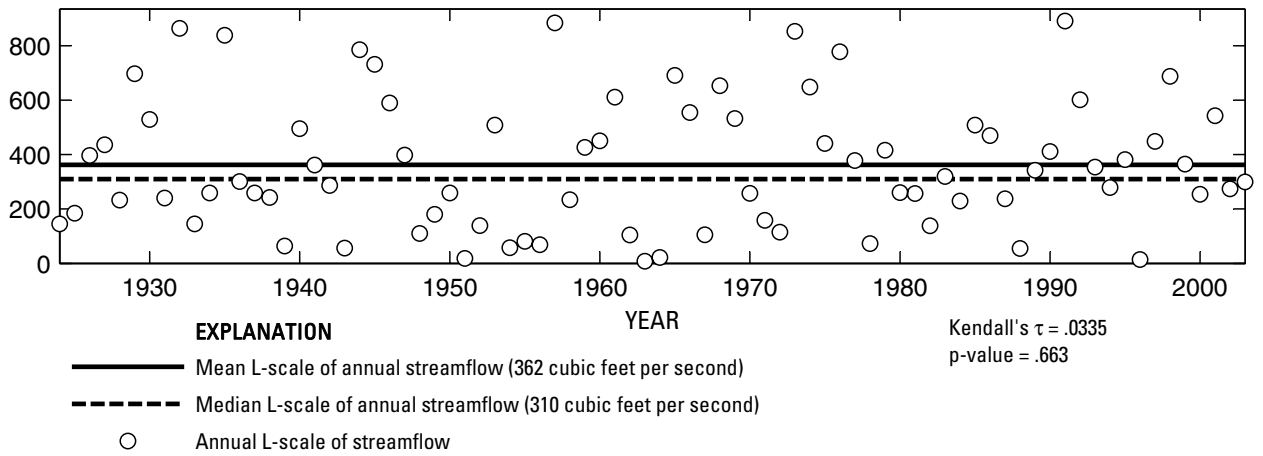

Figure 432. Analysis of annual mean, maximum, minimum, and L-scale statistics of daily mean streamflow for U.S. Geological Survey streamflow-gaging station 08110500 Navasota River near Easterly, Texas.

Index of Station Numbers 719 


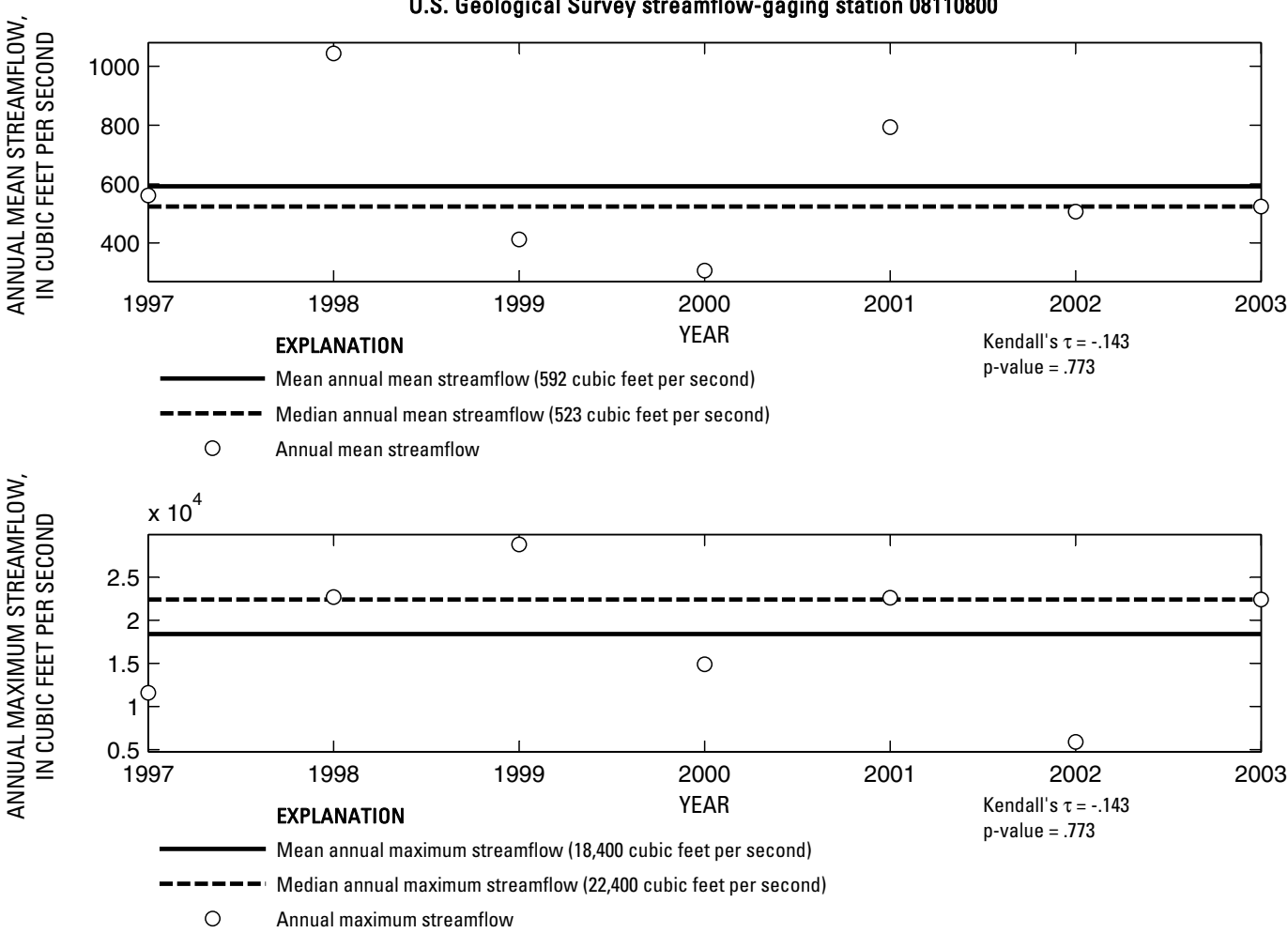

U.S. Geological Survey streamflow-gaging station 08110800

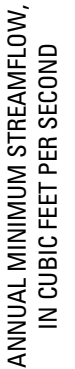

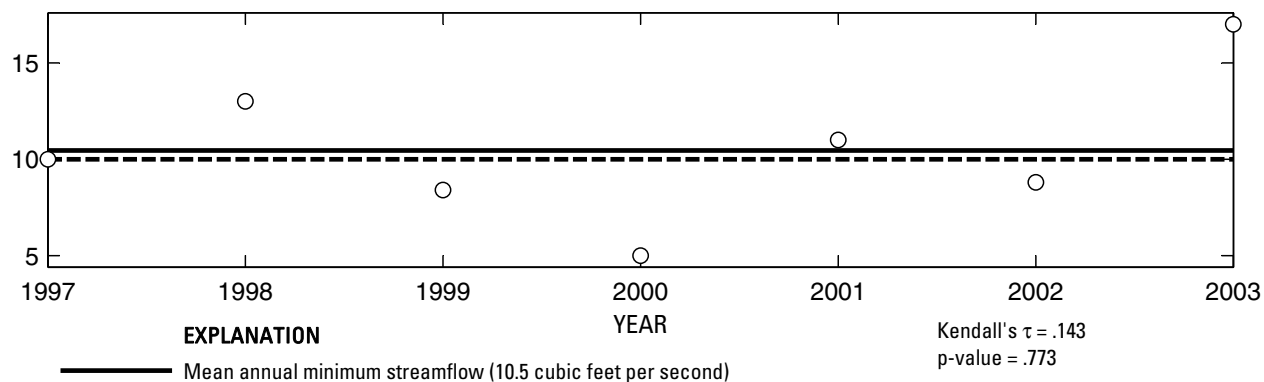

- - Median annual minimum streamflow (10 cubic feet per second)

○ Annual minimum streamflow

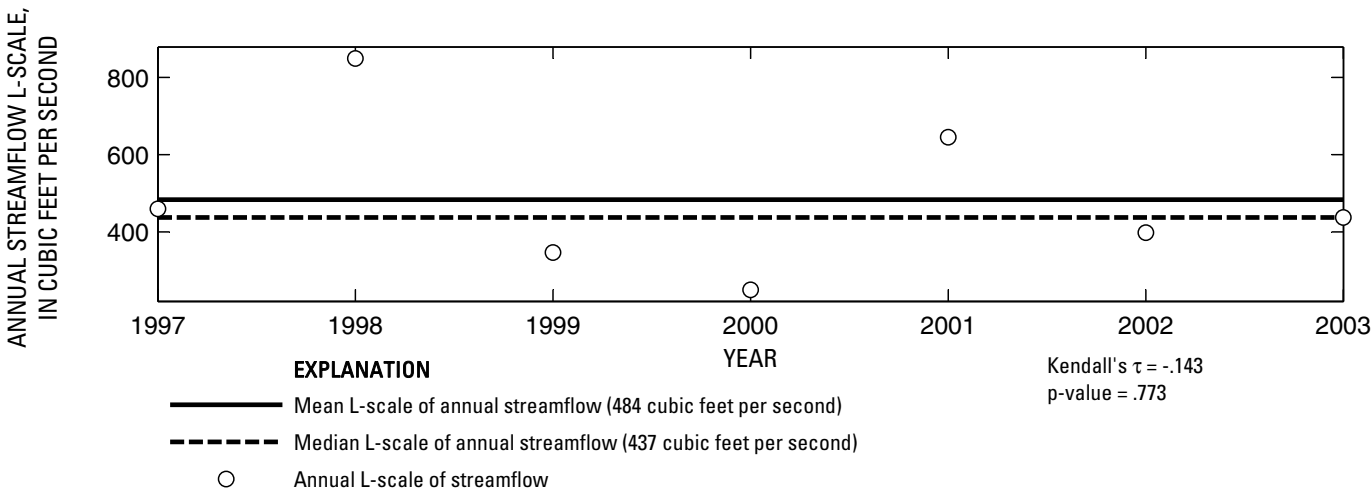

Figure 433. Analysis of annual mean, maximum, minimum, and L-scale statistics of daily mean streamflow for U.S. Geological Survey streamflow-gaging station 08110800 Navasota River at Old Spanish Road near Bryan, Texas. 


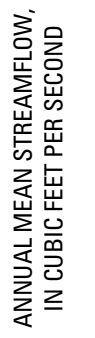

U.S. Geological Survey streamflow-gaging station 08111000

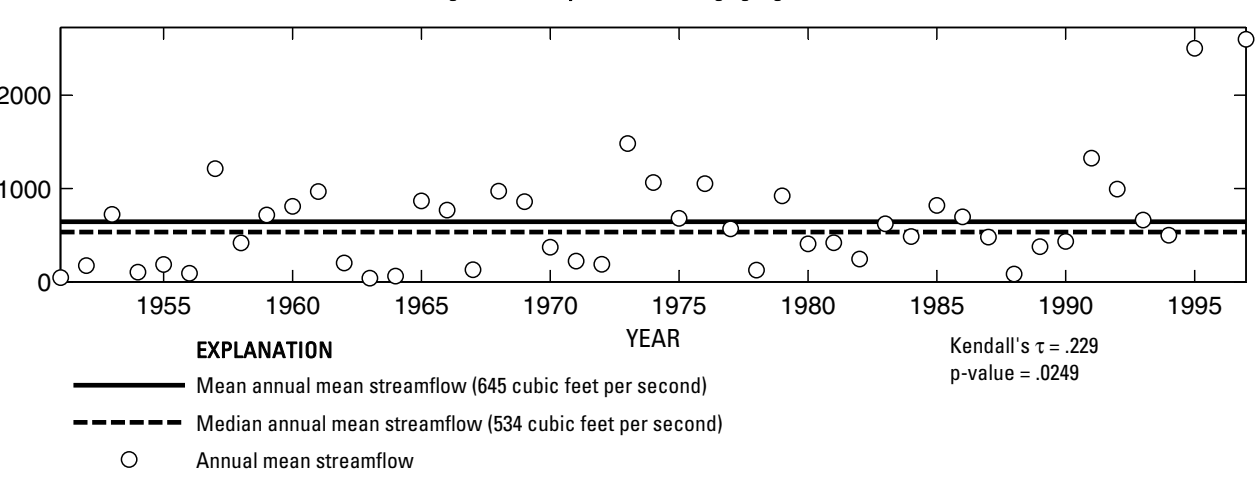

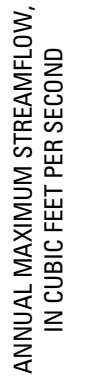

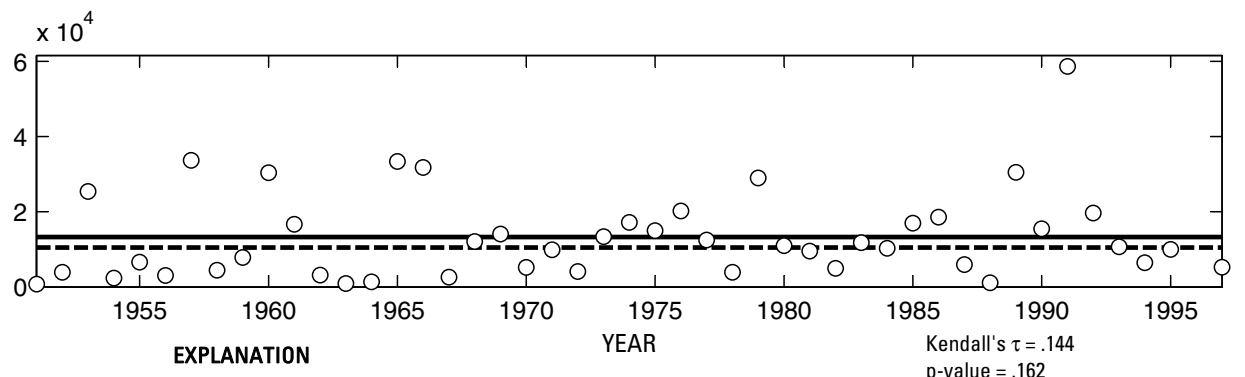

Mean annual maximum streamflow (13,300 cubic feet per second)

- Median annual maximum streamflow (10,500 cubic feet per second)

O Annual maximum streamflow

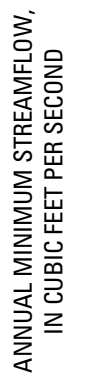

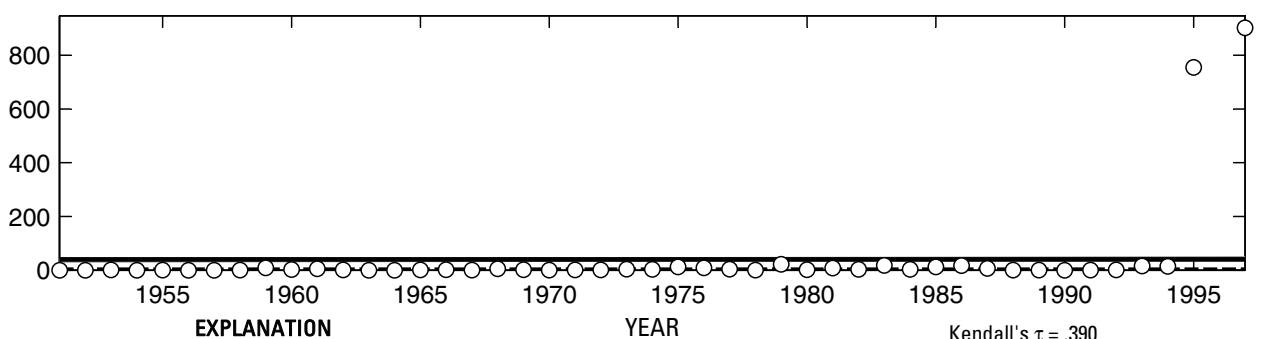

\section{EXPLANATION YEAR Kendall's $\tau=.390$}

Theil trend line for annual minimum streamflow

$\mathrm{p}$-value $=<.001$

Mean annual minimum streamflow (40.1 cubic feet per second)

- Median annual minimum streamflow (1.7 cubic feet per second)

O Annual minimum streamflow
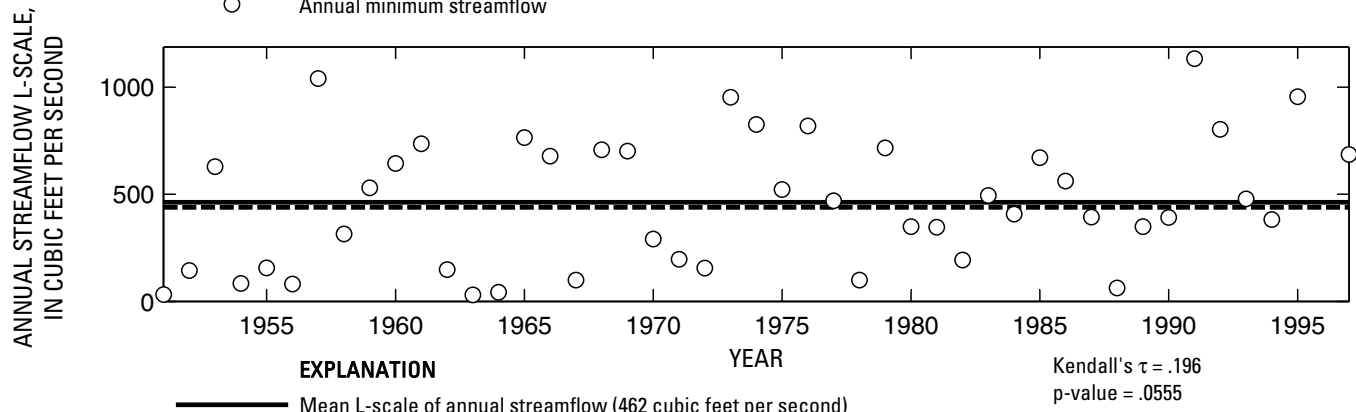

- - - - Median L-scale of annual streamflow (439 cubic feet per second)

Annual L-scale of streamflow

Figure 434. Analysis of annual mean, maximum, minimum, and L-scale statistics of daily mean streamflow for U.S. Geological Survey streamflow-gaging station 08111000 Navasota River near Bryan, Texas.

Index of Station Numbers 719 


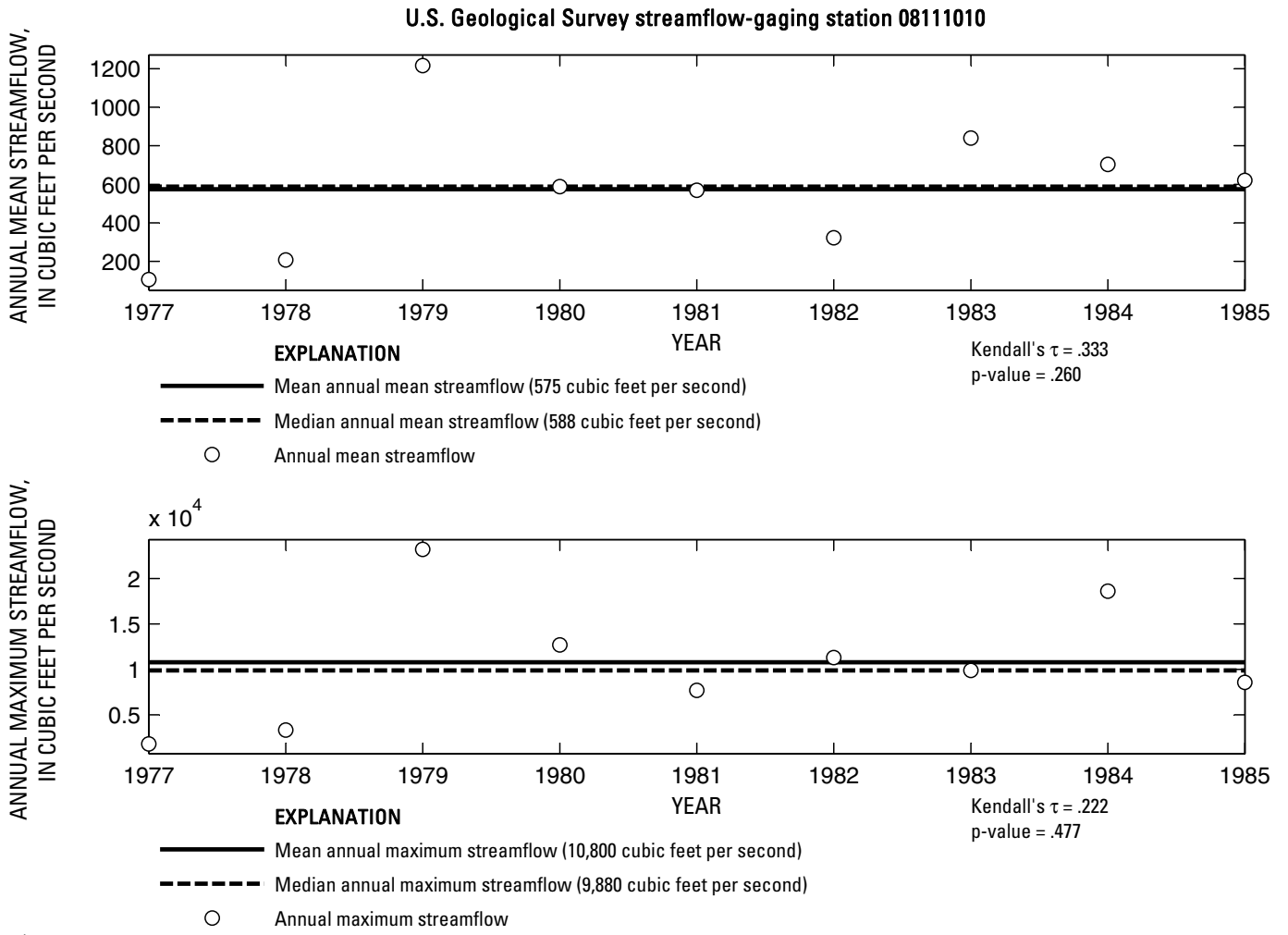

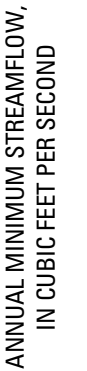

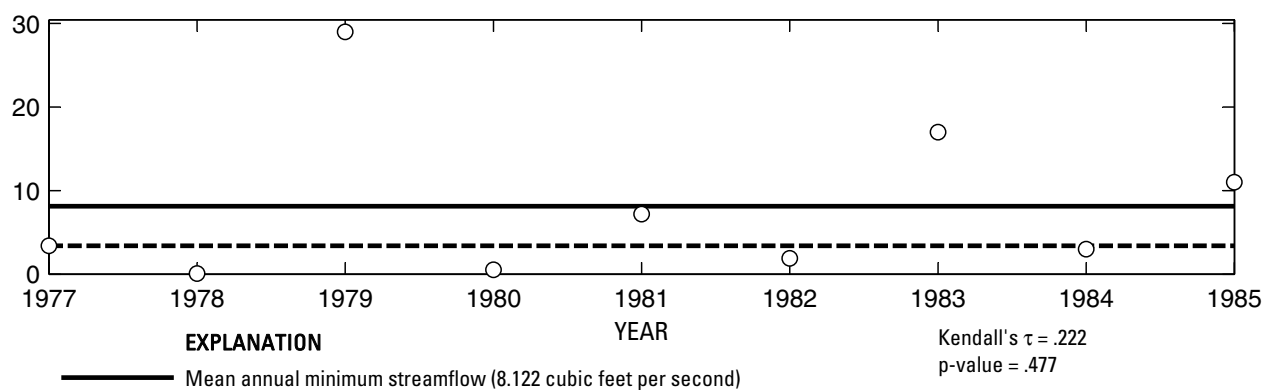

- - - - Median annual minimum streamflow (3.4 cubic feet per second)

O Annual minimum streamflow

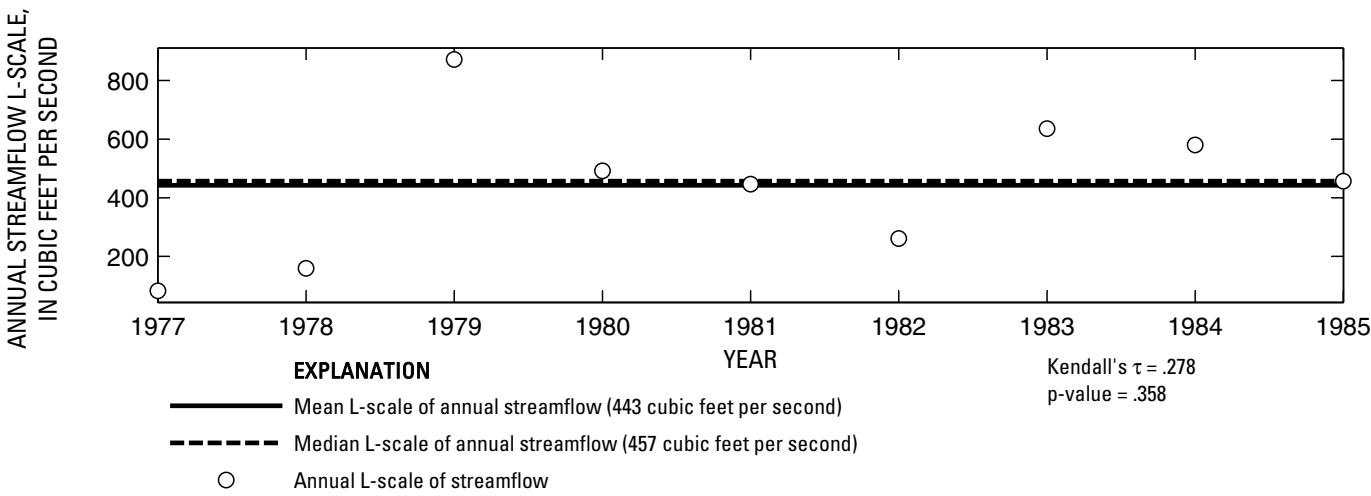

Figure 435. Analysis of annual mean, maximum, minimum, and L-scale statistics of daily mean streamflow for U.S. Geological Survey streamflow-gaging station 08111010 Navasota River near College Station, Texas. 

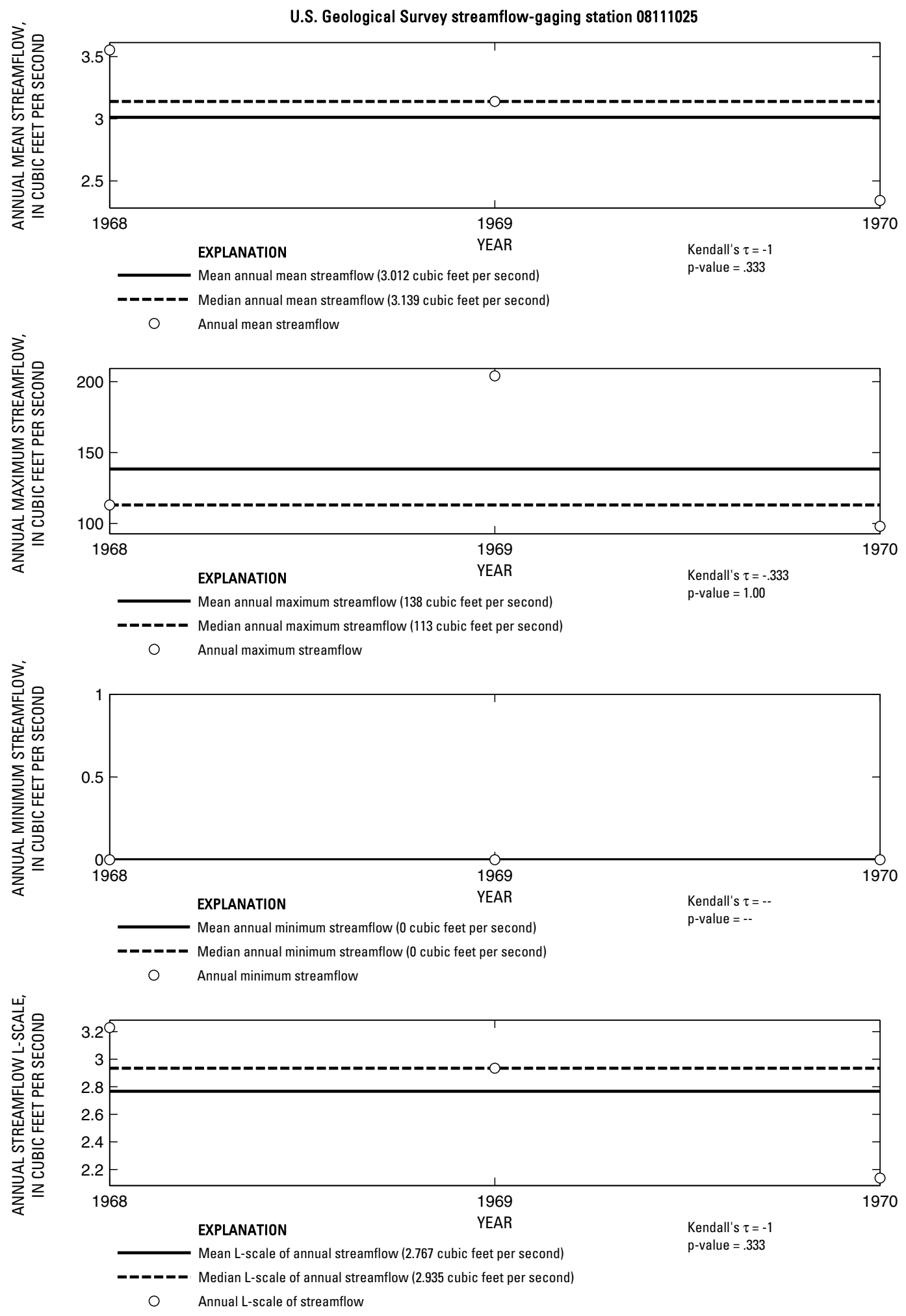

Figure 436. Analysis of annual mean, maximum, minimum, and L-scale statistics of daily mean streamflow for U.S. Geological Survey streamflow-gaging station 08111025 Burton Creek at Villa Maria Road, Bryan, Texas. 


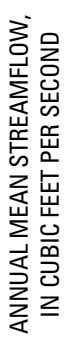

U.S. Geological Survey streamflow-gaging station 08111050

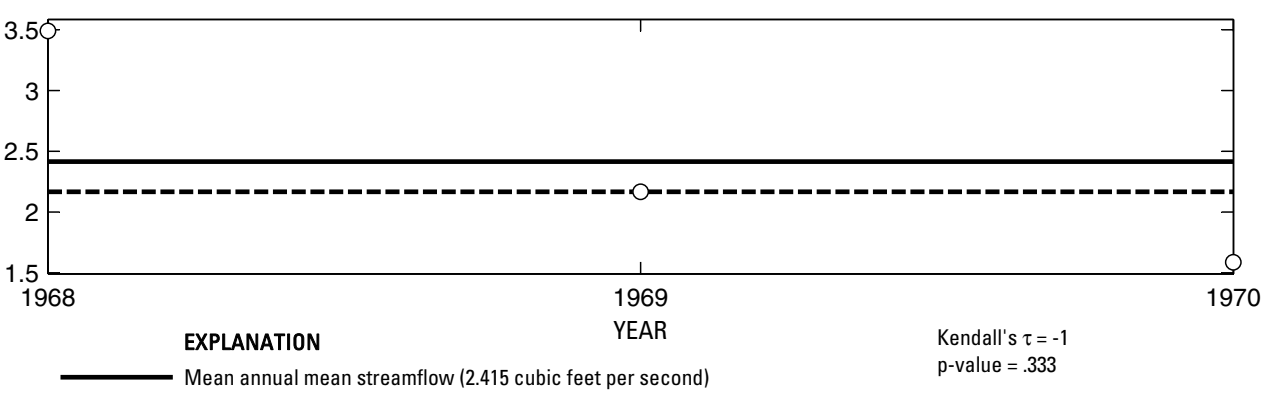

-__-_ Median annual mean streamflow (2.168 cubic feet per second)

- Annual mean streamflow
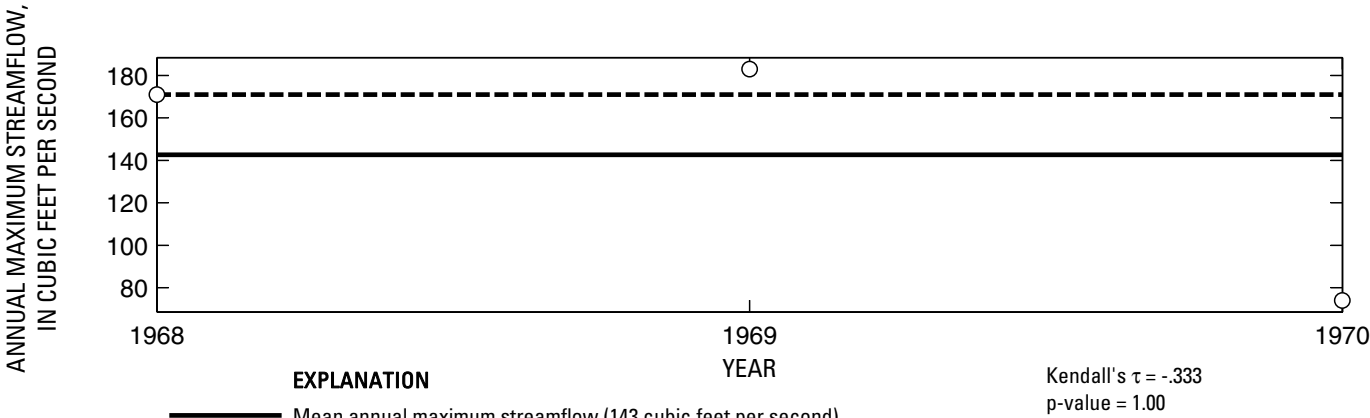

--0.- Median annual maximum streamflow (171 cubic feet per second)

Annual maximum streamflow

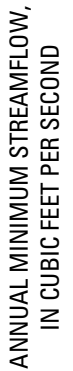

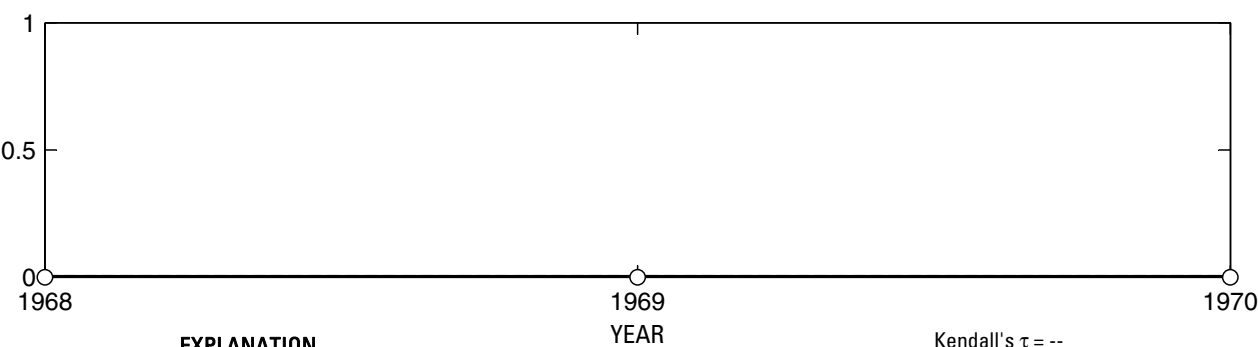

EXPLANATION KEAR $\quad$ Kendall's $\tau=$

Mean annual minimum streamflow (0 cubic feet per second)

p-value $=--$

- - Median annual minimum streamflow (0 cubic feet per second)

O Annual minimum streamflow
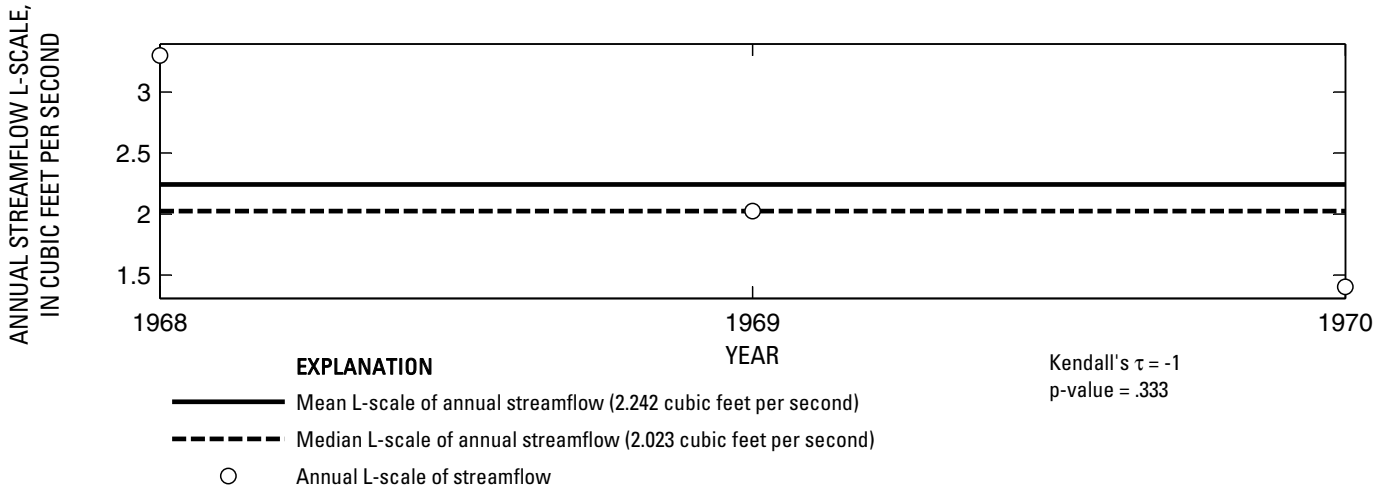

Figure 437. Analysis of annual mean, maximum, minimum, and L-scale statistics of daily mean streamflow for U.S. Geological Survey streamflow-gaging station 08111050 Hudson Creek near Bryan, Texas. 


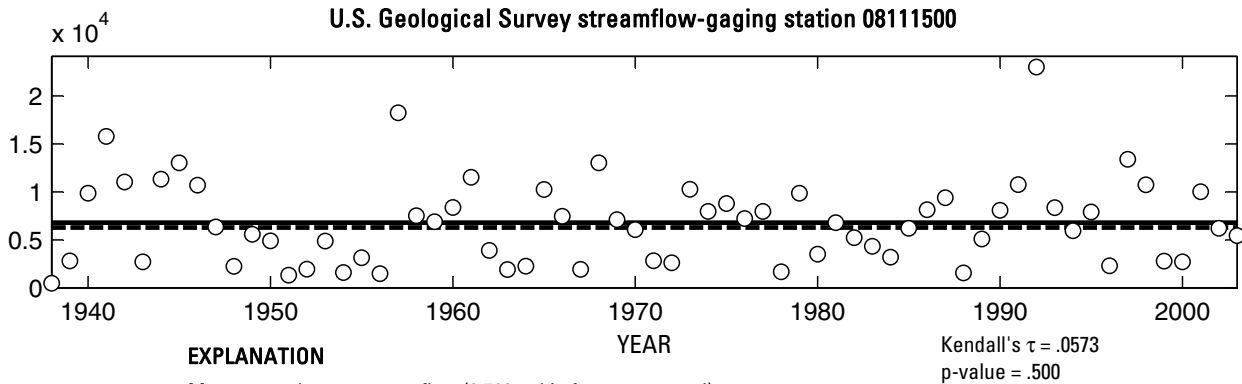

\footnotetext{
Mean annual mean streamflow (6,790 cubic feet per second)

O Annual mean streamflow
}
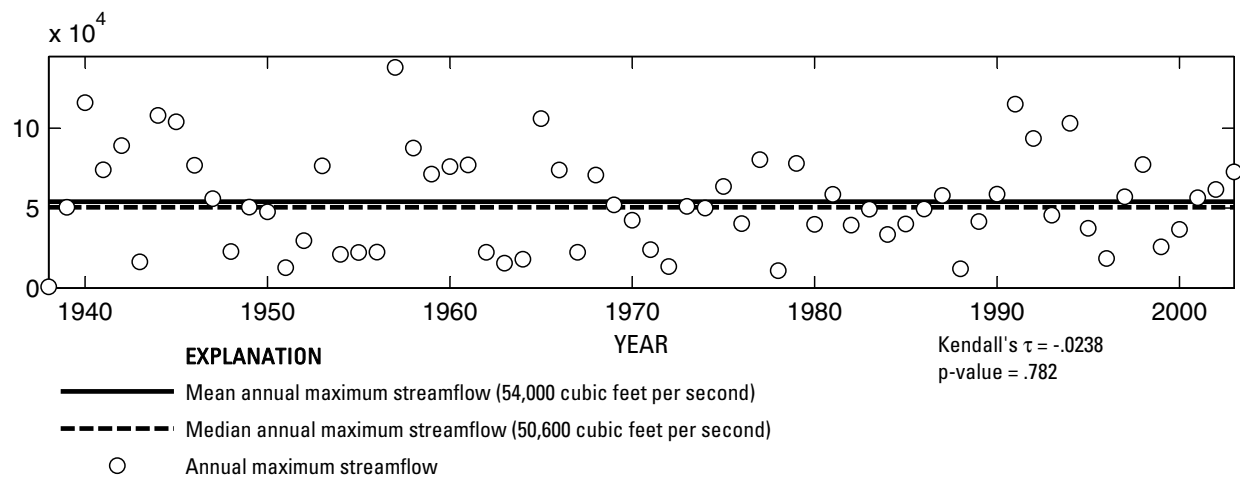

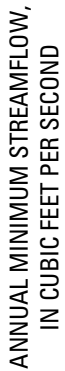

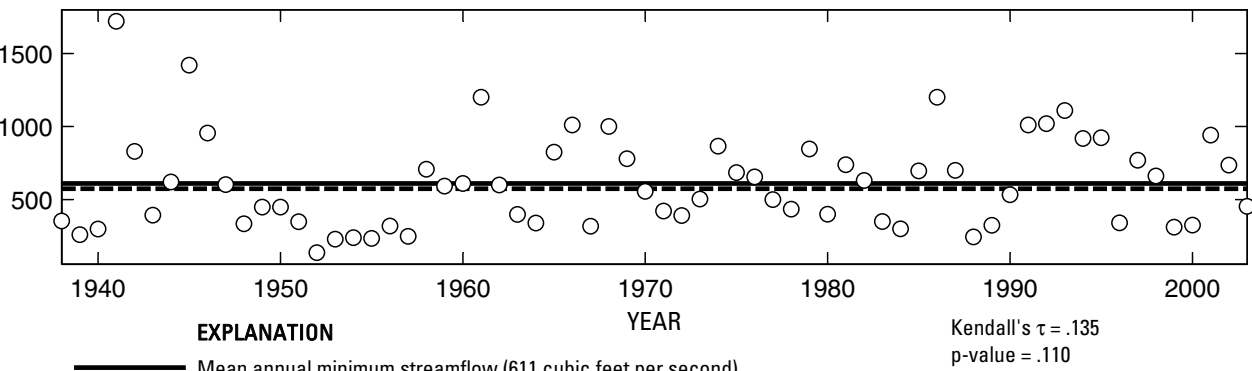

- Median annual minimum streamflow (574 cubic feet per second)

O Annual minimum streamflow

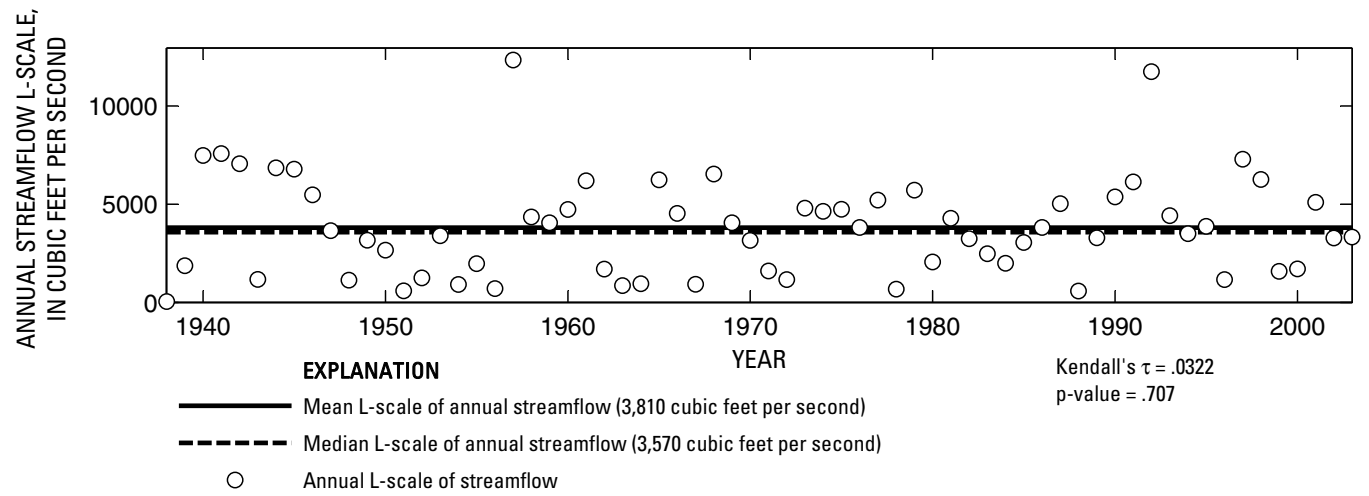

Figure 438. Analysis of annual mean, maximum, minimum, and L-scale statistics of daily mean streamflow for U.S. Geological Survey streamflow-gaging station 08111500 Brazos River near Hempstead, Texas. 


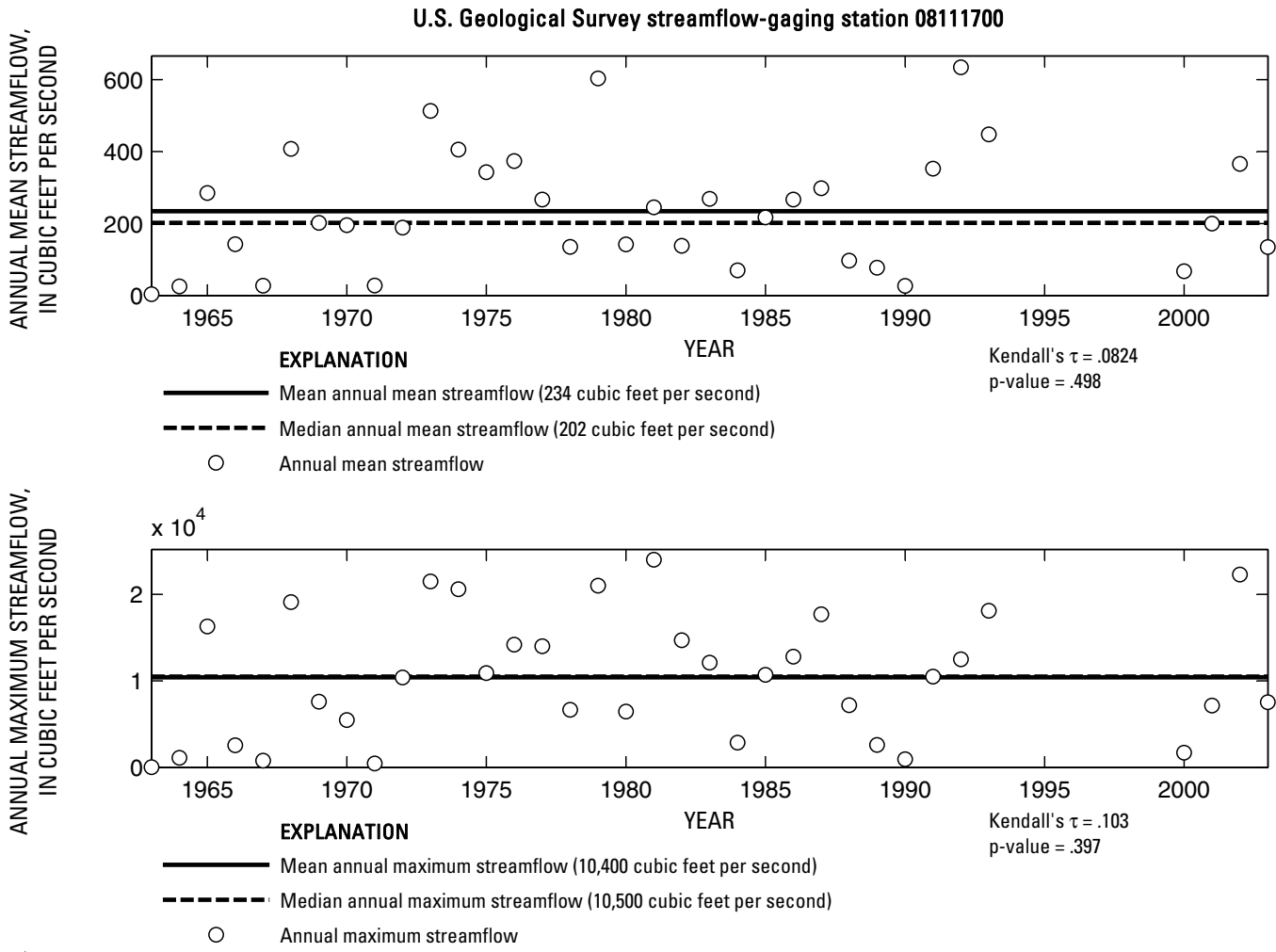

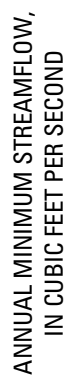

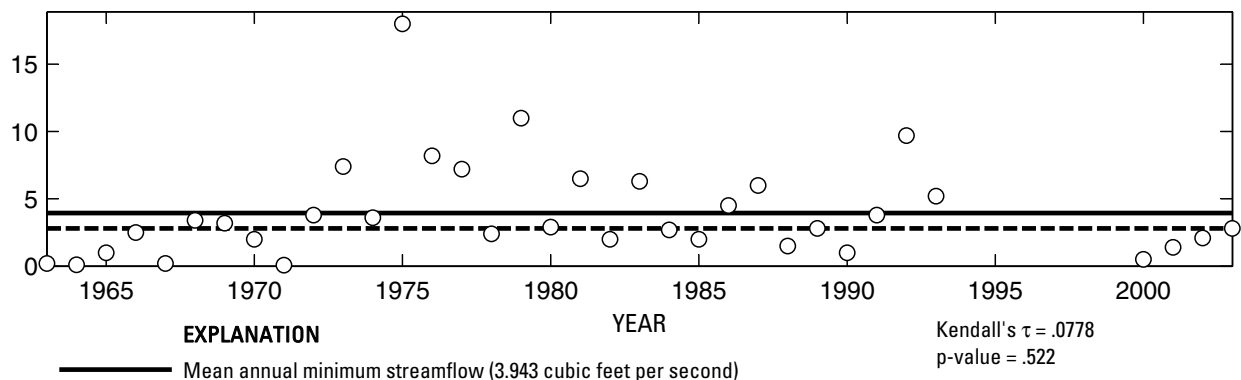

- - - - Median annual minimum streamflow (2.8 cubic feet per second)

O Annual minimum streamflow

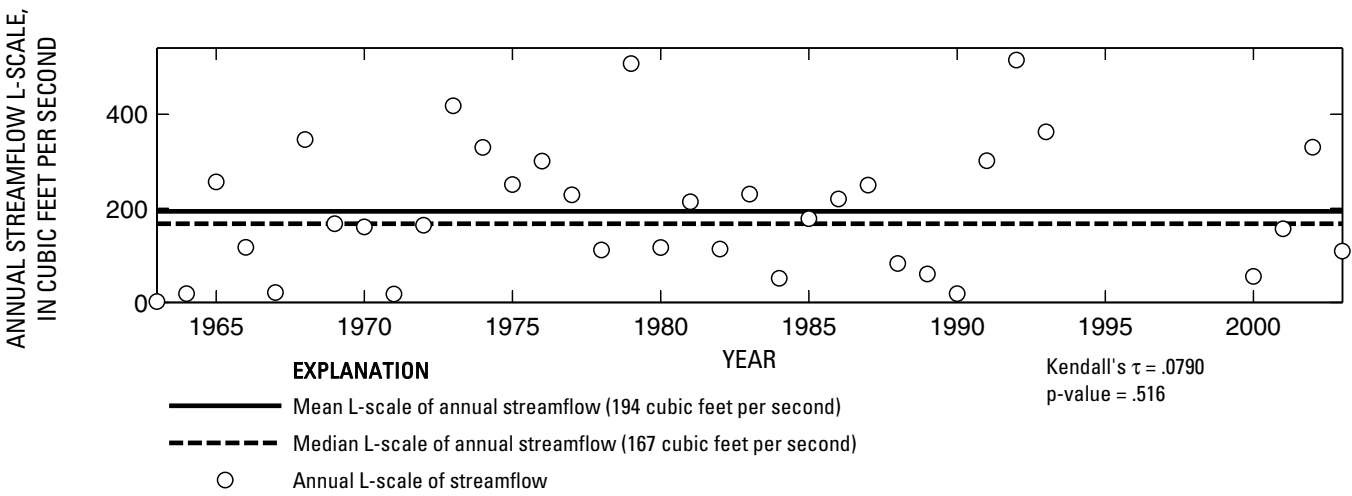

Figure 439. Analysis of annual mean, maximum, minimum, and L-scale statistics of daily mean streamflow for U.S. Geological Survey streamflow-gaging station 08111700 Mill Creek near Bellville, Texas. 
U.S. Geological Survey streamflow-gaging station 08114000

0.5

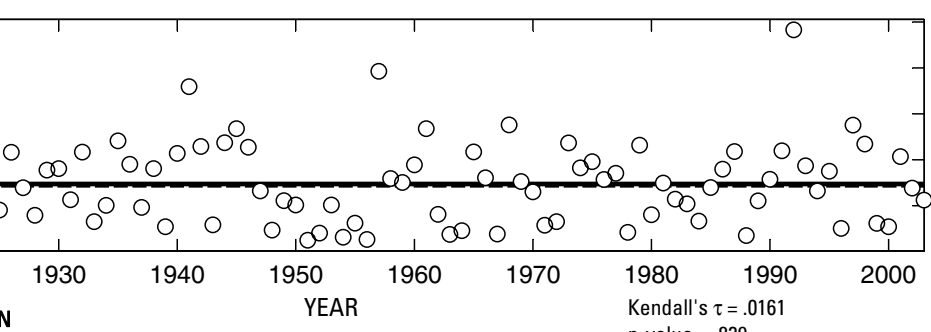

EXPLANATION

per second

$\mathrm{p}$-value $=.829$

- Median annual mean streamflow $(7,220$ cubic feet per second)

O Annual mean streamflow

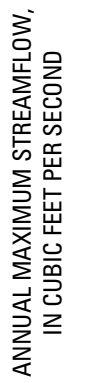
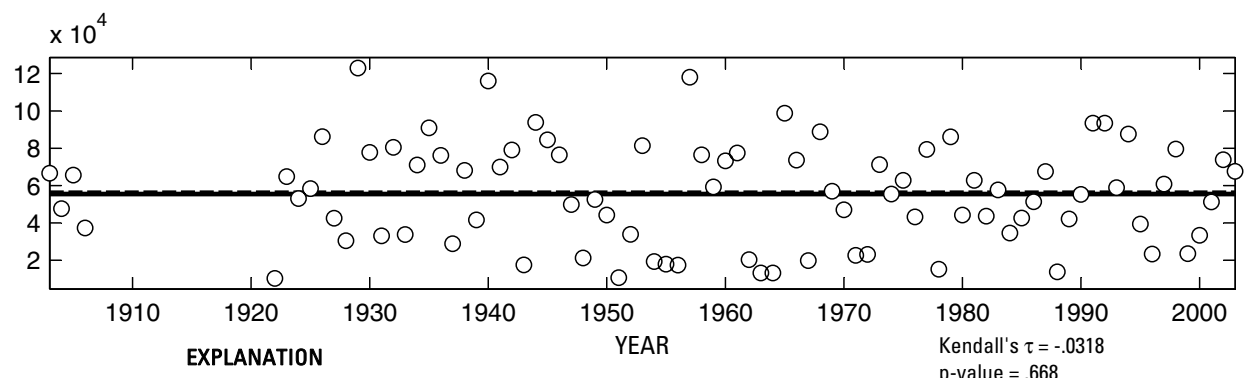

EXPLANATION

$\mathrm{p}$-value $=.668$

_ Median annual maximum streamflow (56,200 cubic feet per second)

O Annual maximum streamflow

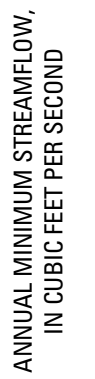

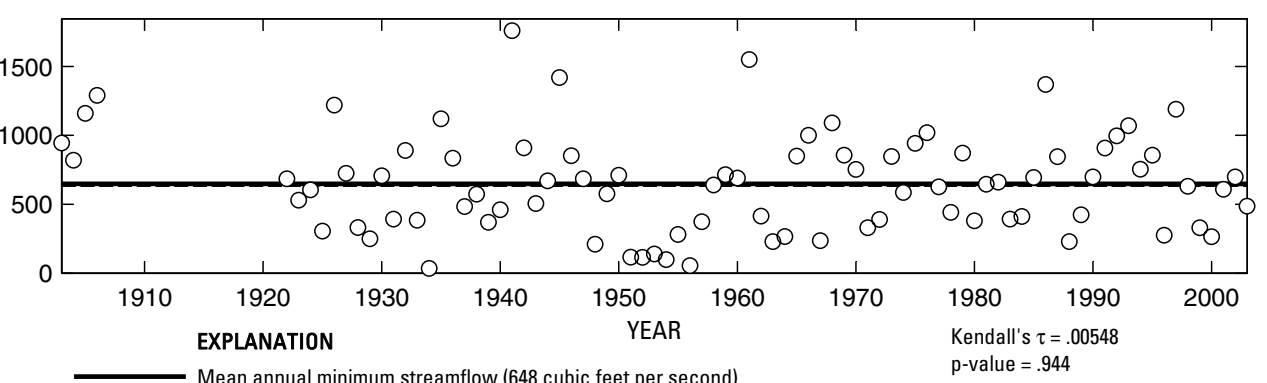

- Median annual minimum streamflow ( 643 cubic feet per second)

O Annual minimum streamflow

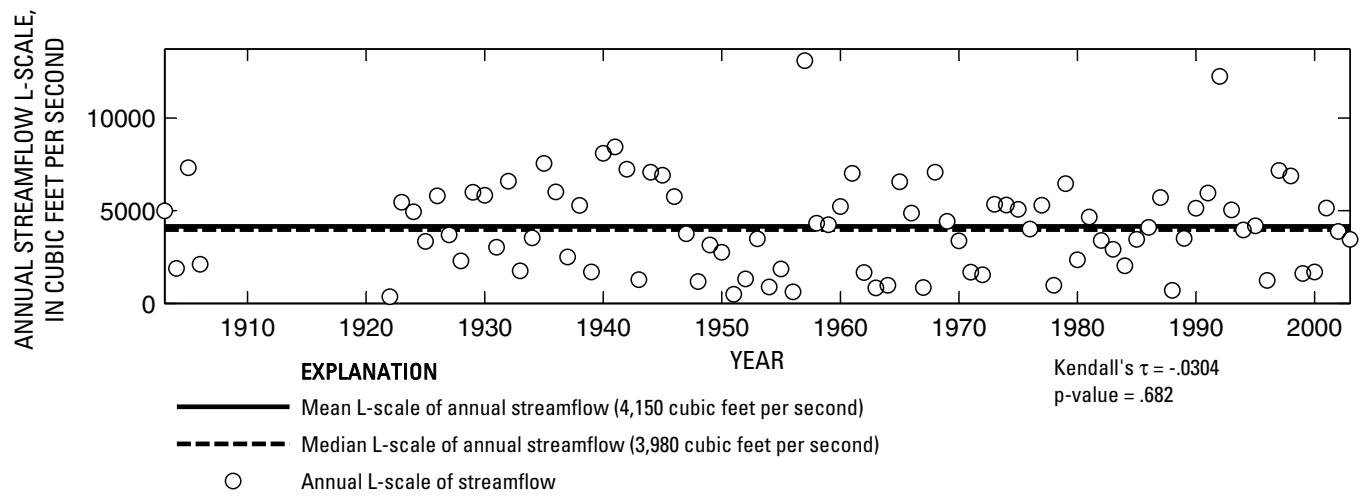

Figure 440. Analysis of annual mean, maximum, minimum, and L-scale statistics of daily mean streamflow for U.S. Geological Survey streamflow-gaging station 08114000 Brazos River at Richmond, Texas. 

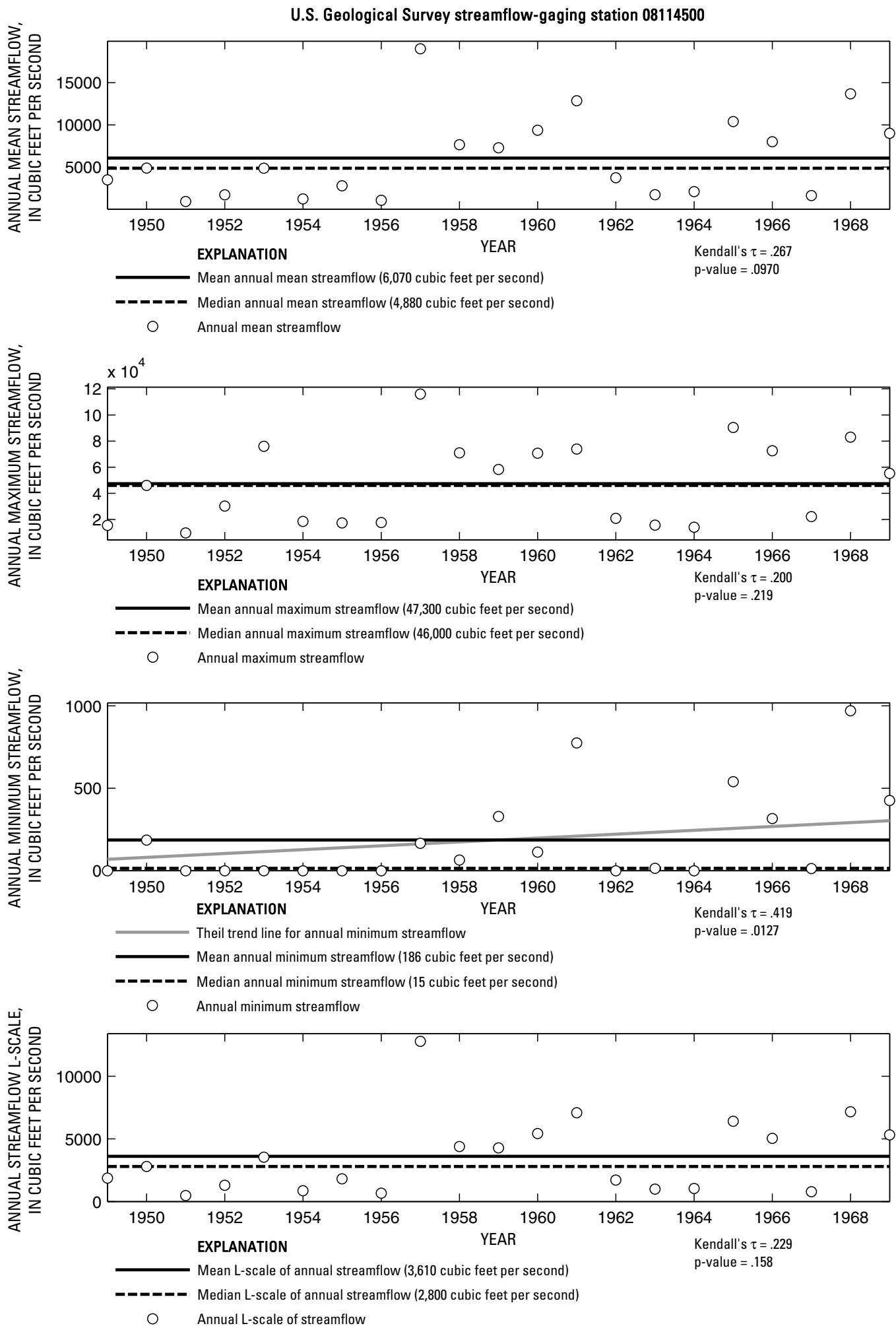

Figure 441. Analysis of annual mean, maximum, minimum, and L-scale statistics of daily mean streamflow for U.S. Geological Survey streamflow-gaging station 08114500 Brazos River near Juliff, Texas. 


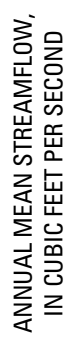

U.S. Geological Survey streamflow-gaging station 08115000
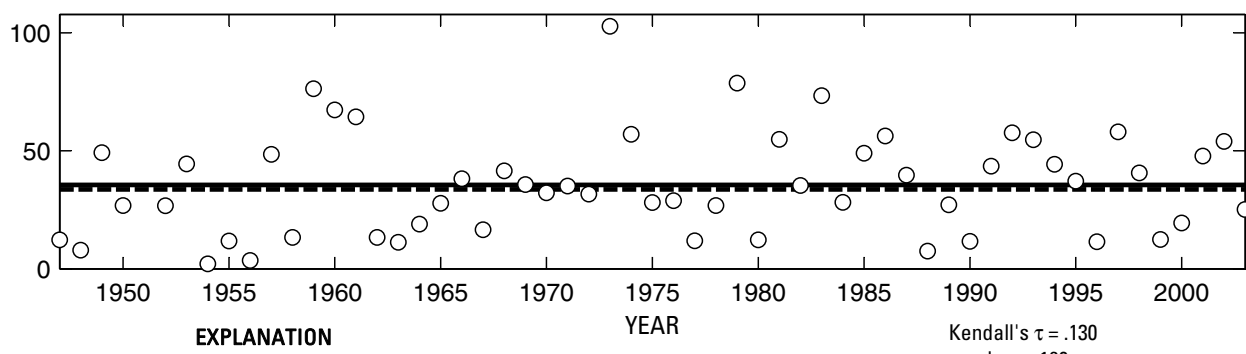

- Mean annual mean streamflow (35.6 cubic feet per second)

-ンー-ーー Median annual mean streamflow (33.6 cubic feet per second)

Annual mean streamflow

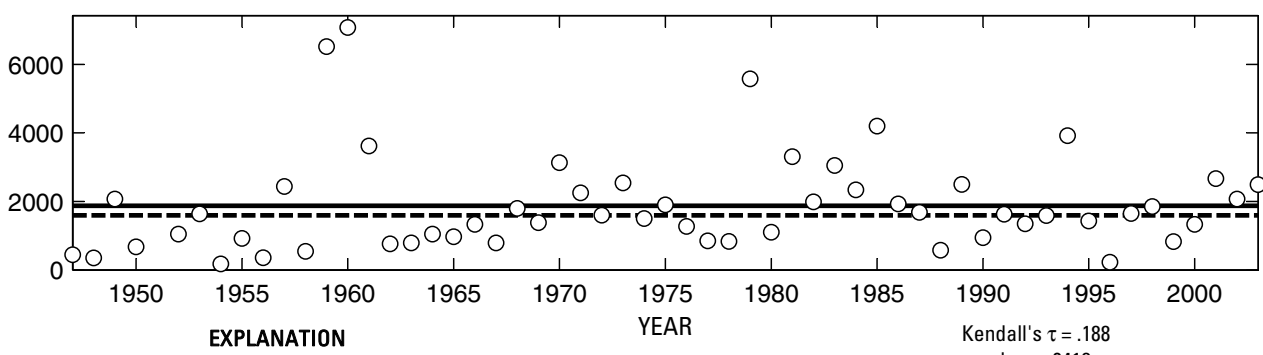

EXPLANATION

p-value $=.04$

- - - Median annual maximum streamflow (1,600 cubic feet per second)

O Annual maximum streamflow

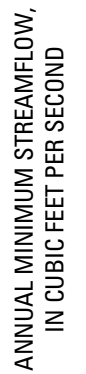

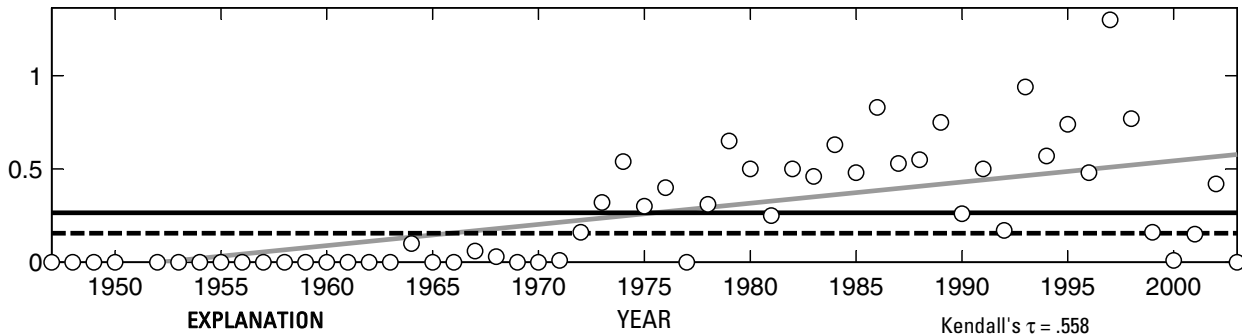

Theil trend line for annual minimum streamflow
Mean annual minimum streamflow (.2648 cubic feet per second)

-ーーーー Median annual minimum streamflow (.155 cubic feet per second)

O Annual minimum streamflow

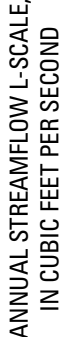

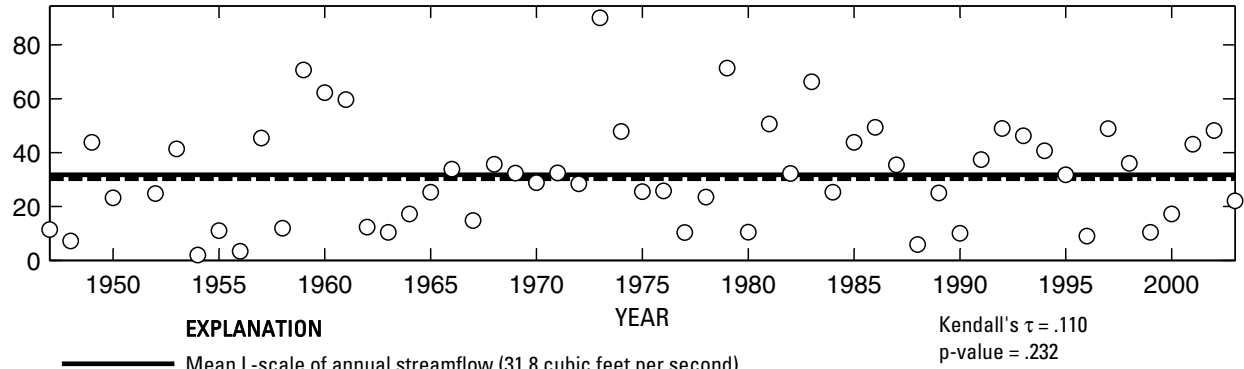

Mean L-scale of annual streamflow (31.8 cubic feet per second)

$\mathrm{p}$-value $=.232$

- - - - Median L-scale of annual streamflow (30.3 cubic feet per second)

Annual L-scale of streamflow

Figure 442. Analysis of annual mean, maximum, minimum, and L-scale statistics of daily mean streamflow for U.S. Geological Survey streamflow-gaging station 08115000 Big Creek near Needville, Texas.

Index of Station Numbers 719 


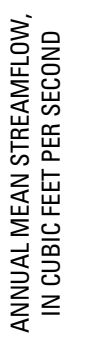

U.S. Geological Survey streamflow-gaging station 08115500

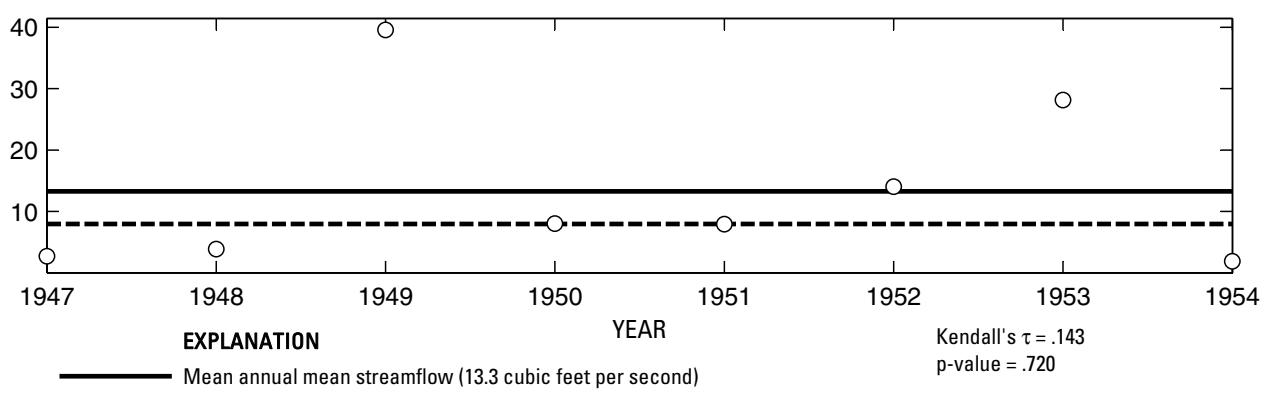

-_ーーー- Median annual mean streamflow (7.964 cubic feet per second)

Annual mean streamflow
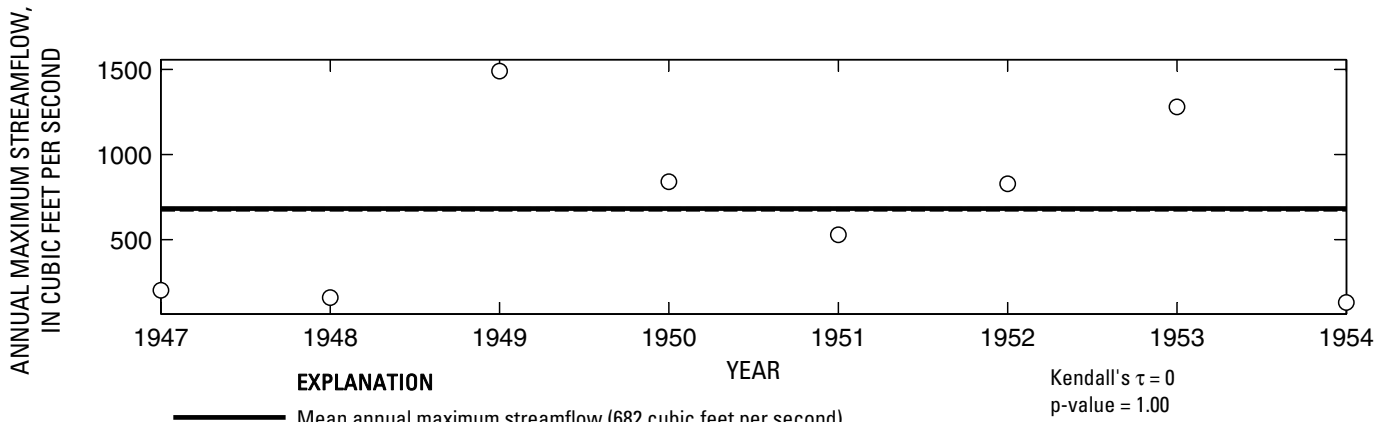

O Annual maximum streamflow
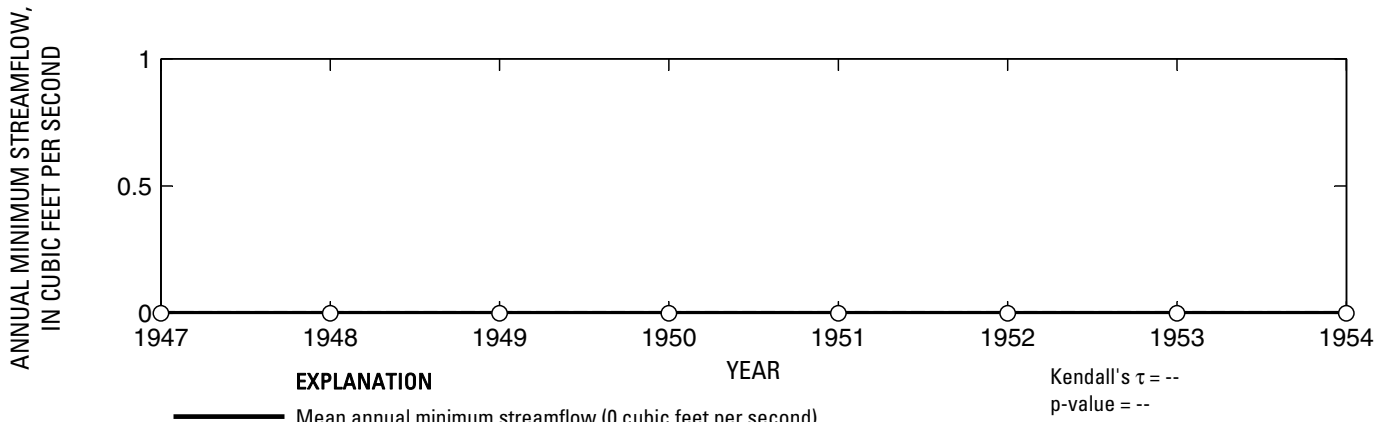

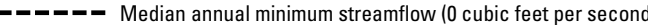

O Annual minimum streamflow

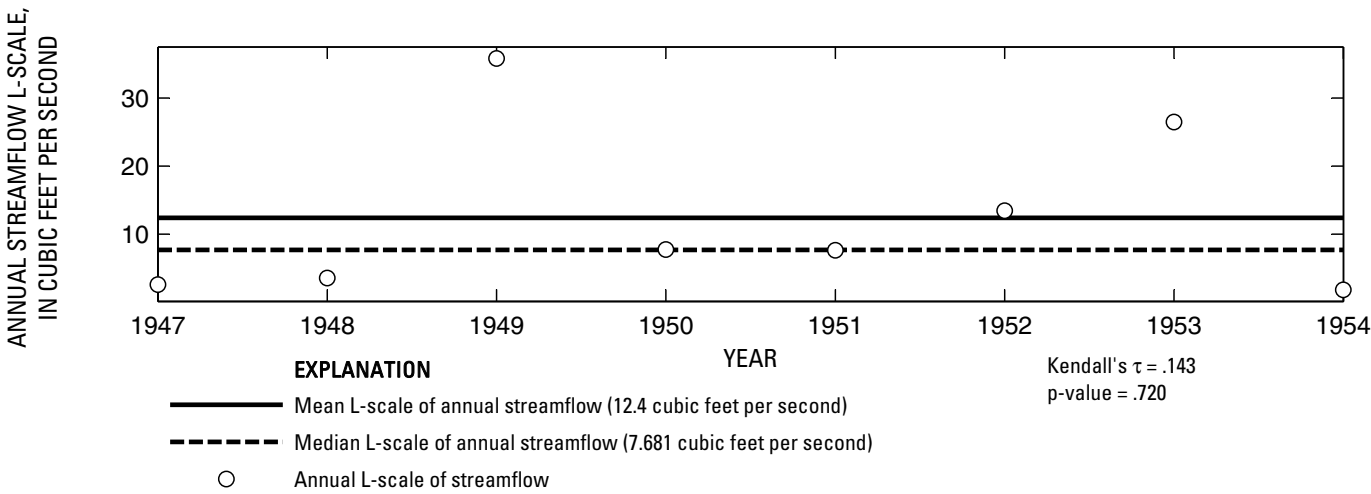

Figure 443. Analysis of annual mean, maximum, minimum, and L-scale statistics of daily mean streamflow for U.S. Geological Survey streamflow-gaging station 08115500 Fairchild Creek near Needville, Texas. 
U.S. Geological Survey streamflow-gaging station 08116000

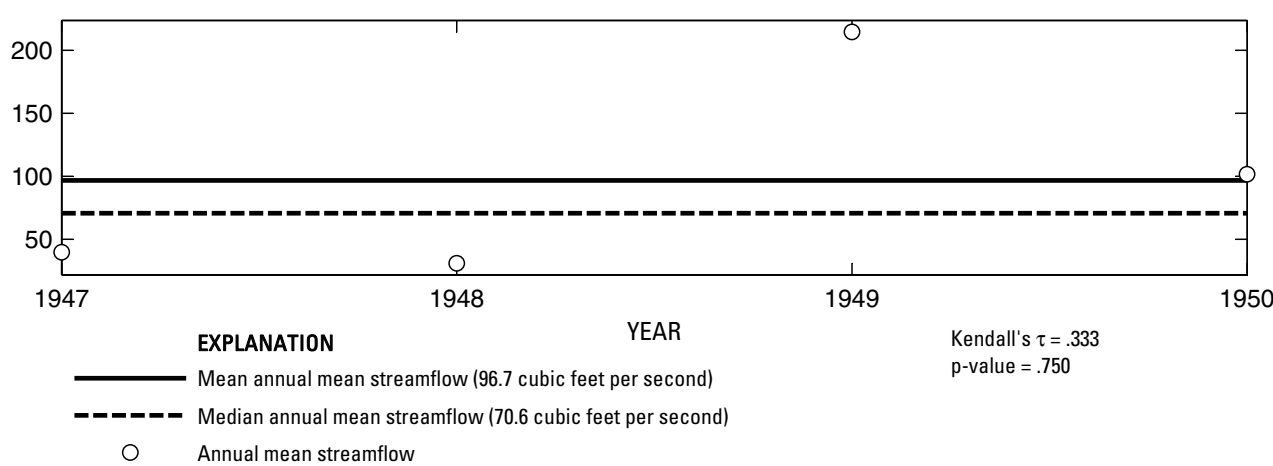

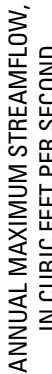

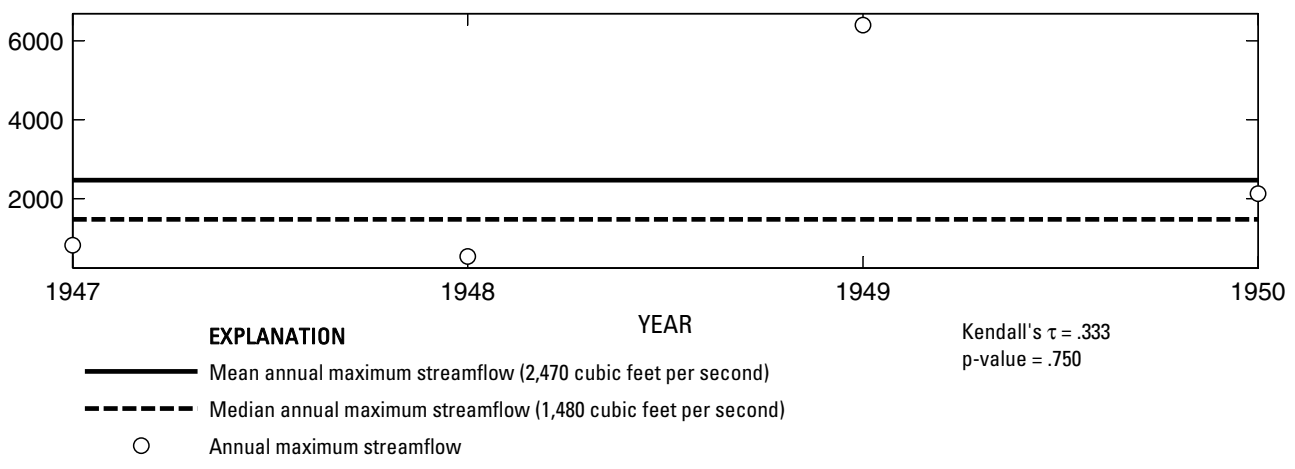

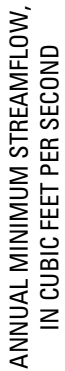

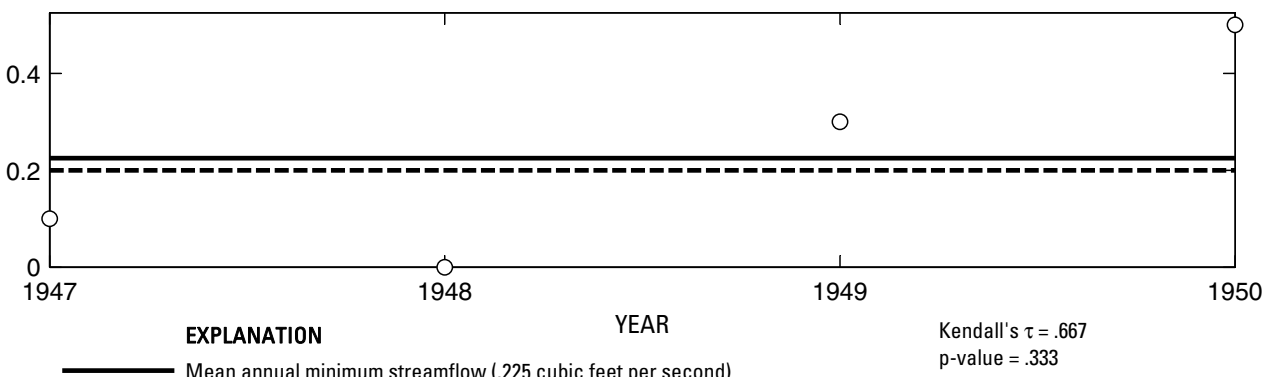

- - Median annual minimum streamflow (.2 cubic feet per second)

O Annual minimum streamflow

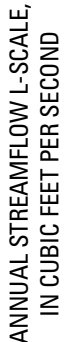

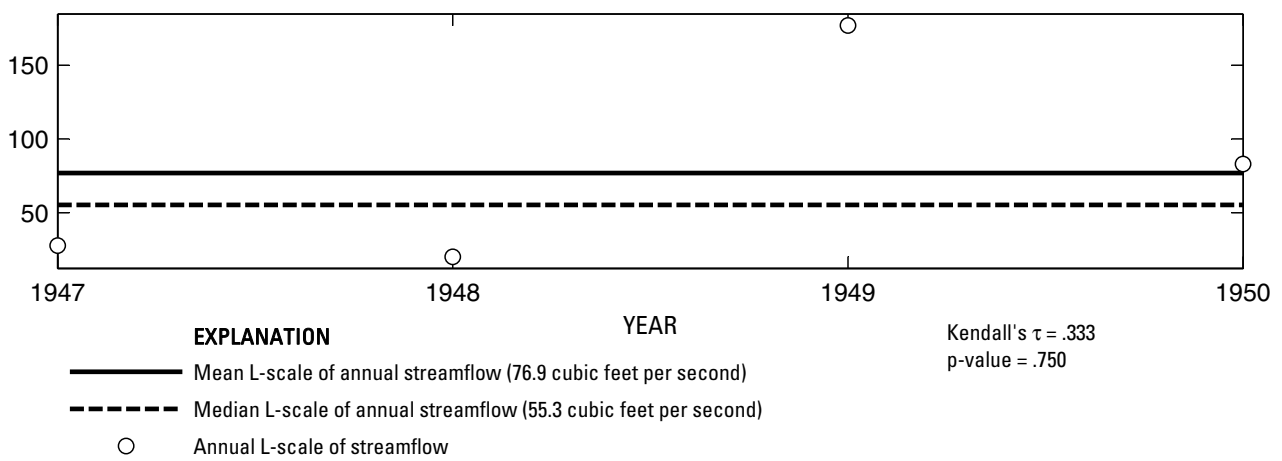

Figure 444. Analysis of annual mean, maximum, minimum, and L-scale statistics of daily mean streamflow for U.S. Geological Survey streamflow-gaging station 08116000 Big Creek near Guy, Texas.

Index of Station Numbers 719 


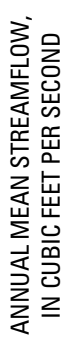

U.S. Geological Survey streamflow-gaging station 08116400

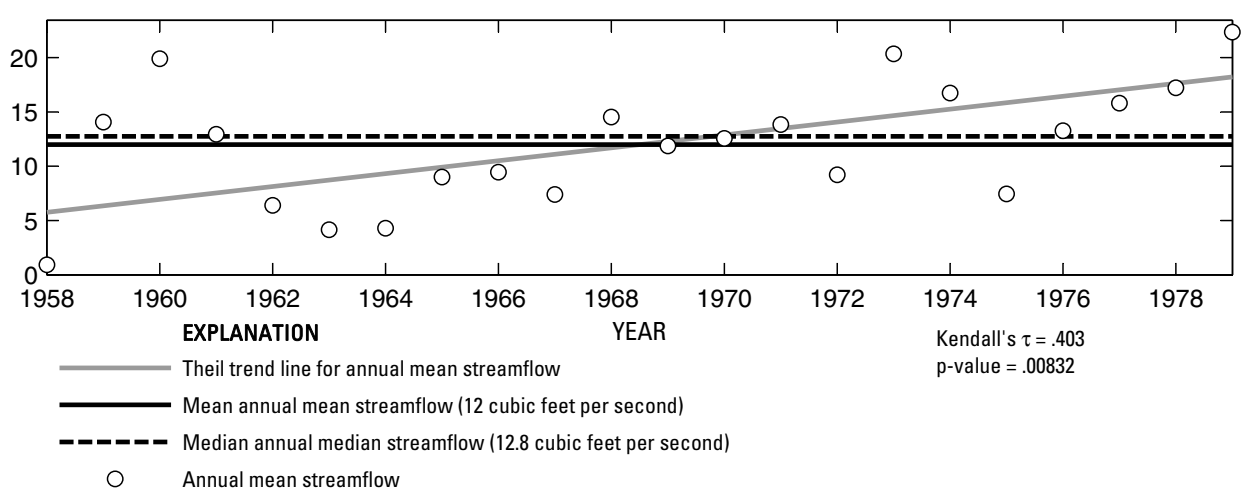

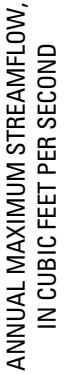

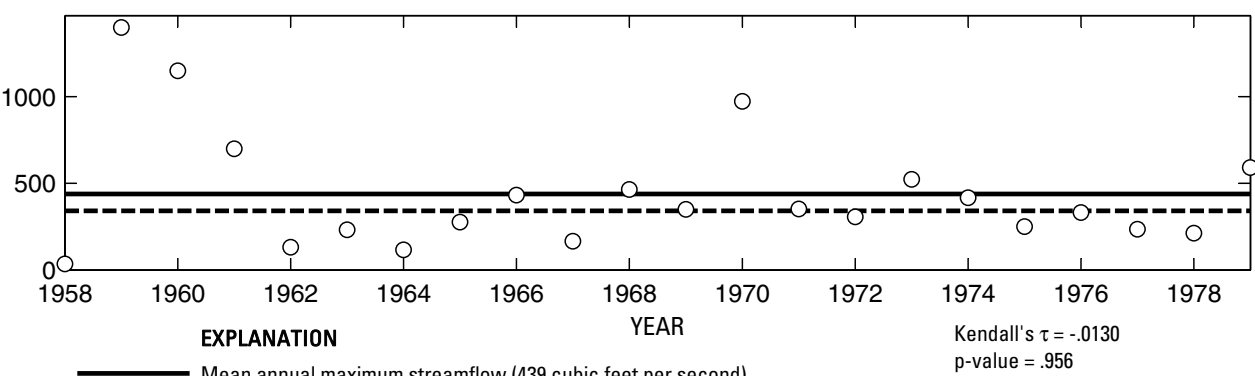

O Annual maximum streamflow

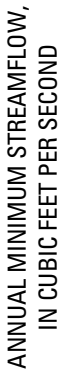

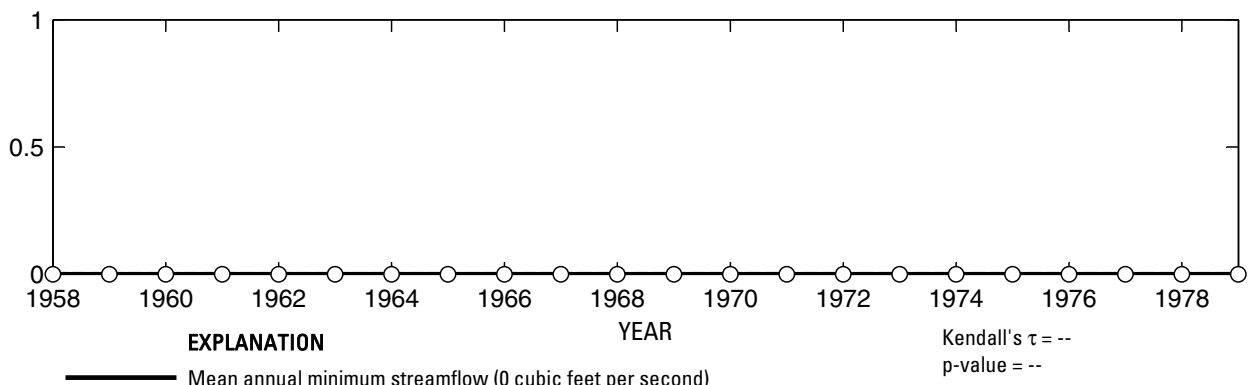

○ Annual minimum streamflow
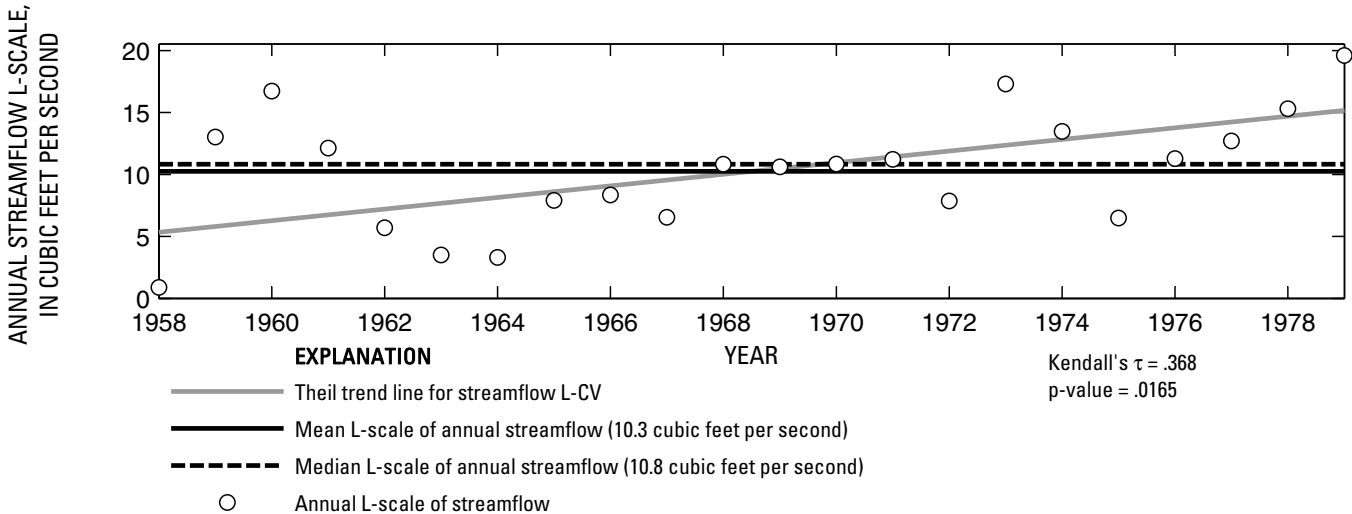

Figure 445. Analysis of annual mean, maximum, minimum, and L-scale statistics of daily mean streamflow for U.S. Geological Survey streamflow-gaging station 08116400 Dry Creek near Rosenberg, Texas. 
U.S. Geological Survey streamflow-gaging station 08116500

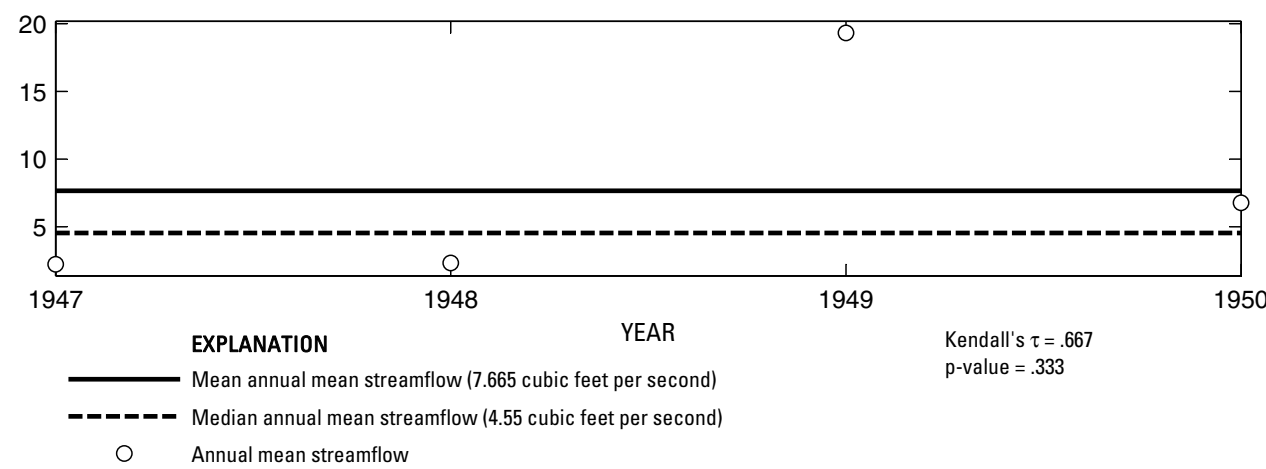

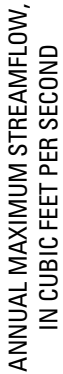

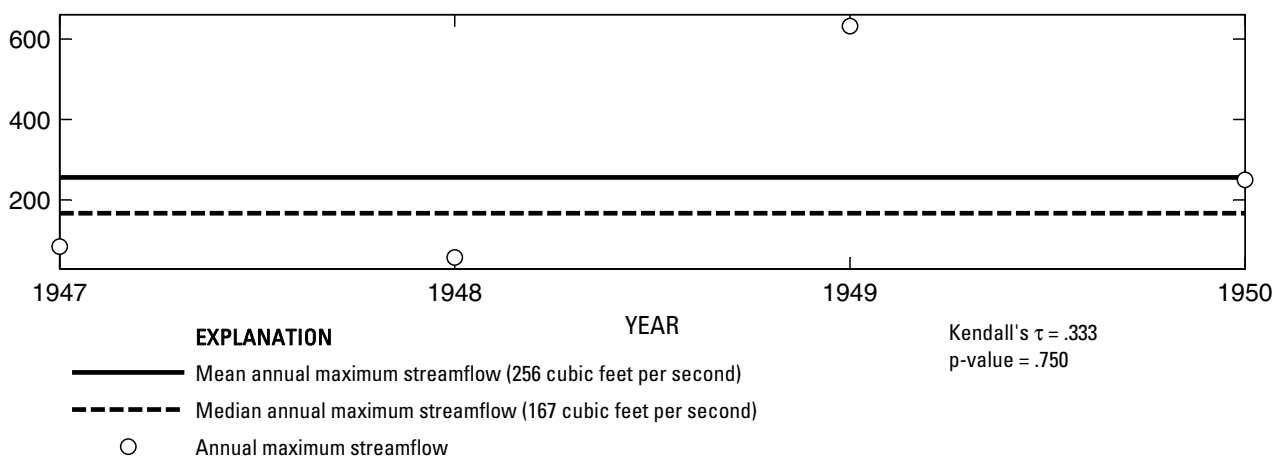

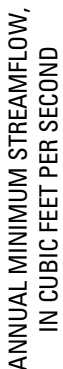

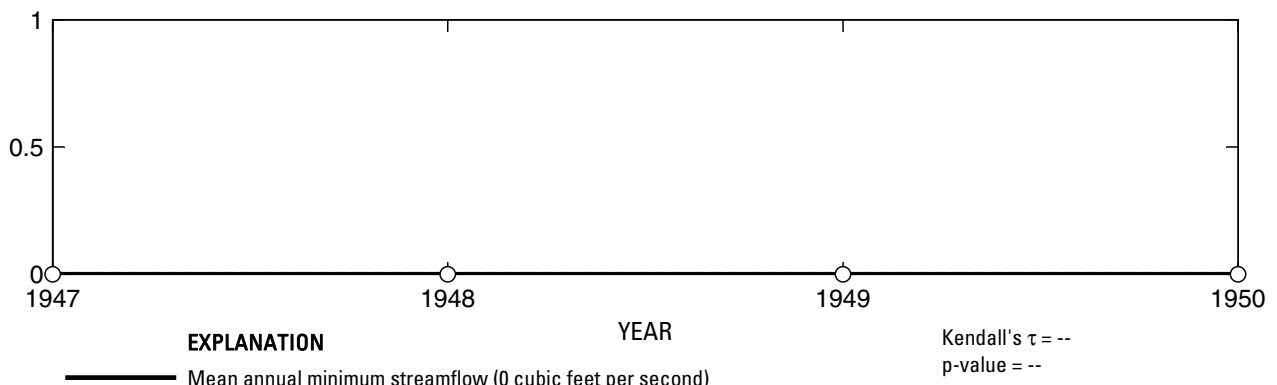

- Median annual minimum streamflow (0 cubic feet per second)

O Annual minimum streamflow

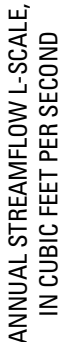

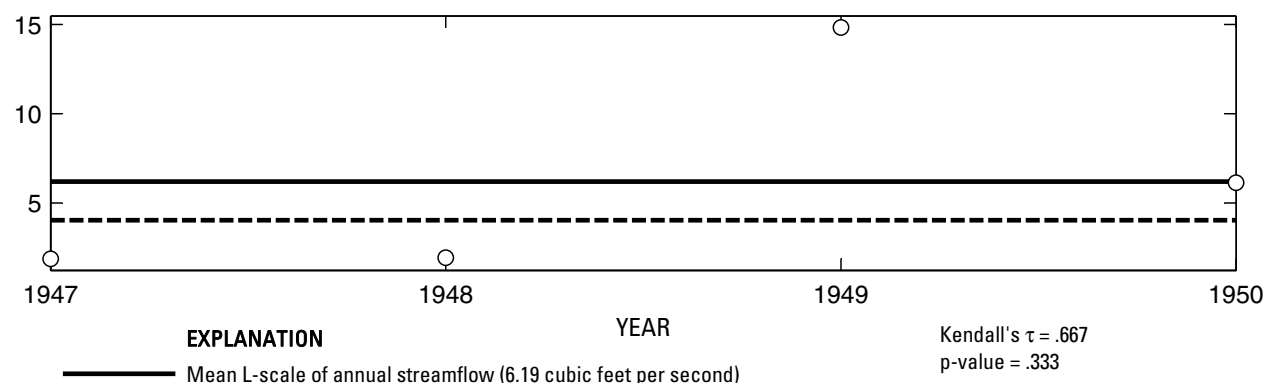

Mean L-scale of annual streamflow (6.19 cubic feet per second)

endall's $\tau=.667$

- -ーー-ー Median L-scale of annual streamflow (4.03 cubic feet per second)

Annual L-scale of streamflow

Figure 446. Analysis of annual mean, maximum, minimum, and L-scale statistics of daily mean streamflow for U.S. Geological Survey streamflow-gaging station 08116500 Dry Creek near Richmond, Texas. 


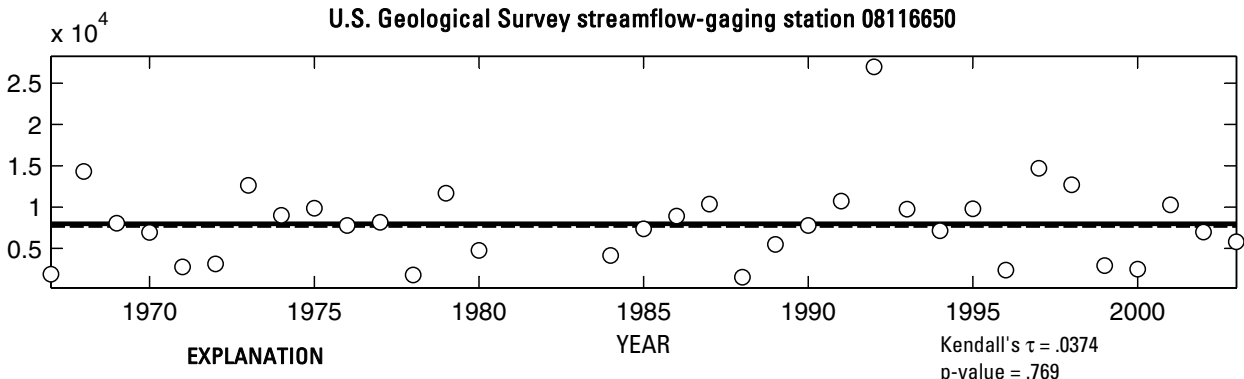

- Median annual mean streamflow (7,780 cubic feet per second)

O Annual mean streamflow

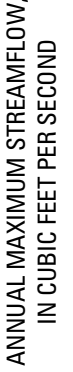

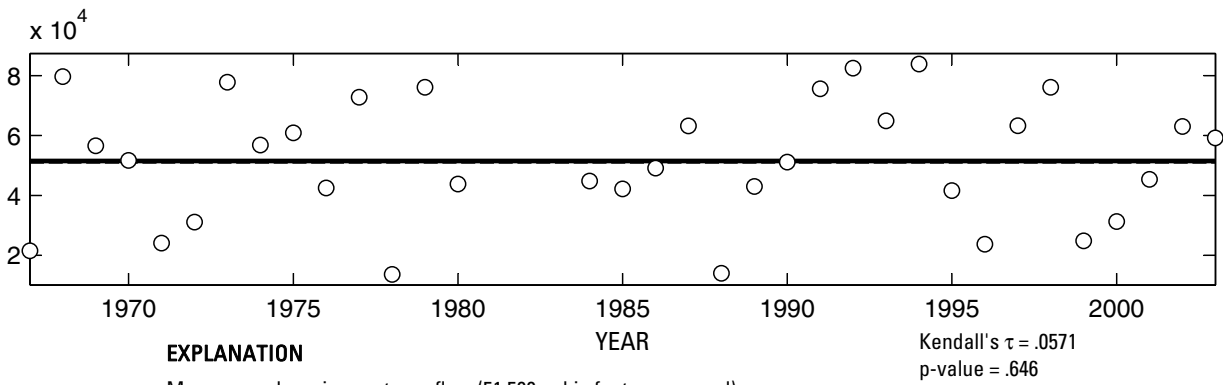

Mean annual maximum streamflow (51,500 cubic feet per second)

O Annual maximum streamflow

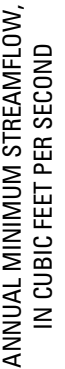

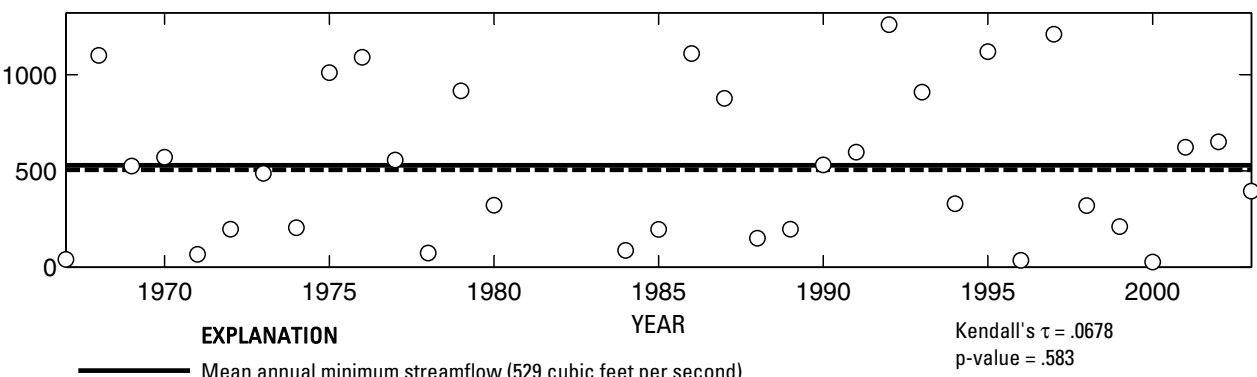

- Median annual minimum streamflow (506 cubic feet per second)

O Annual minimum streamflow

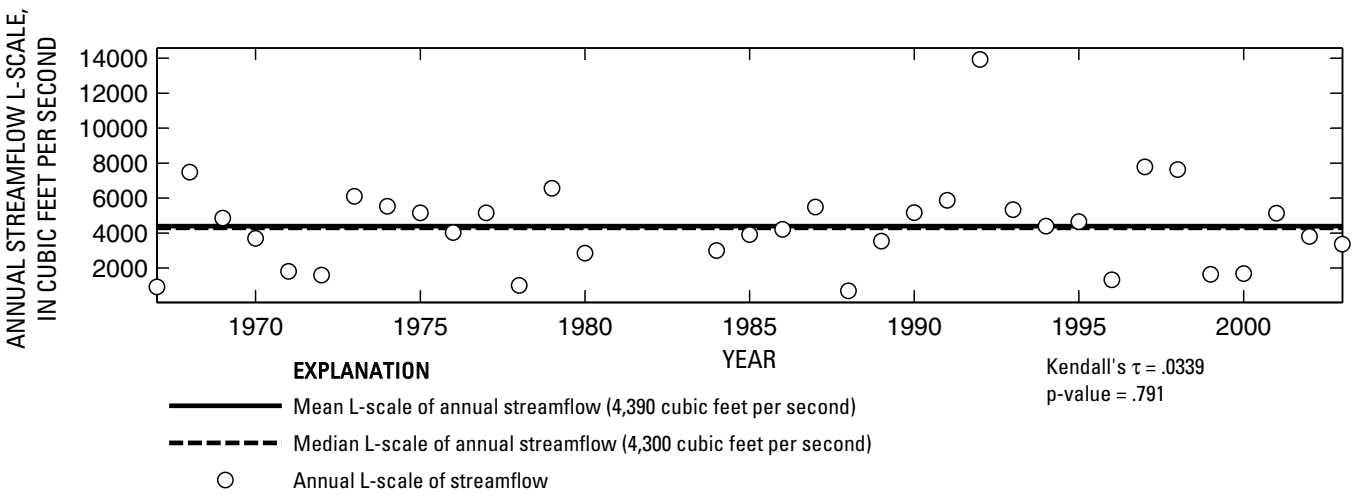

Figure 447. Analysis of annual mean, maximum, minimum, and L-scale statistics of daily mean streamflow for U.S. Geological Survey streamflow-gaging station 08116650 Brazos River near Rosharon, Texas. 


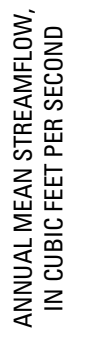

U.S. Geological Survey streamflow-gaging station 08117500

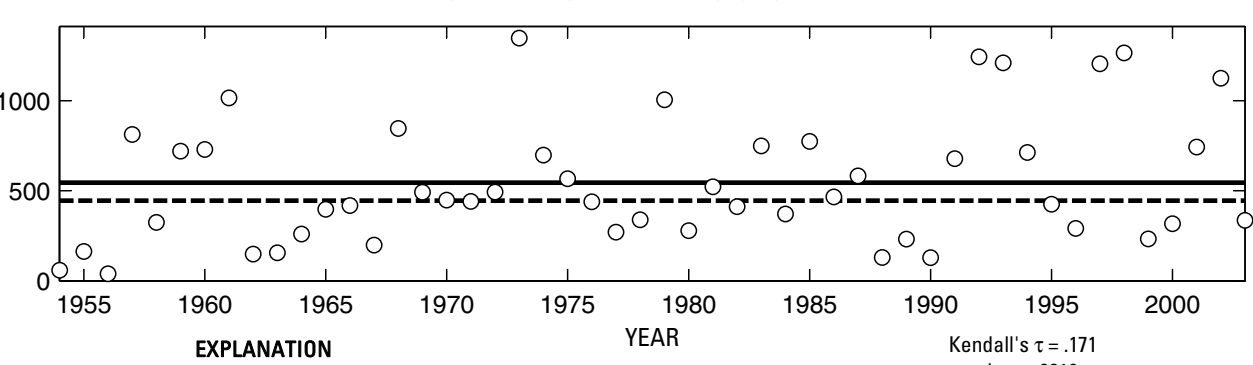

EXPLANATION

$\mathrm{p}$-value $=.0819$

- Median annual mean streamflow ( 445 cubic feet per second)

O Annual mean streamflow
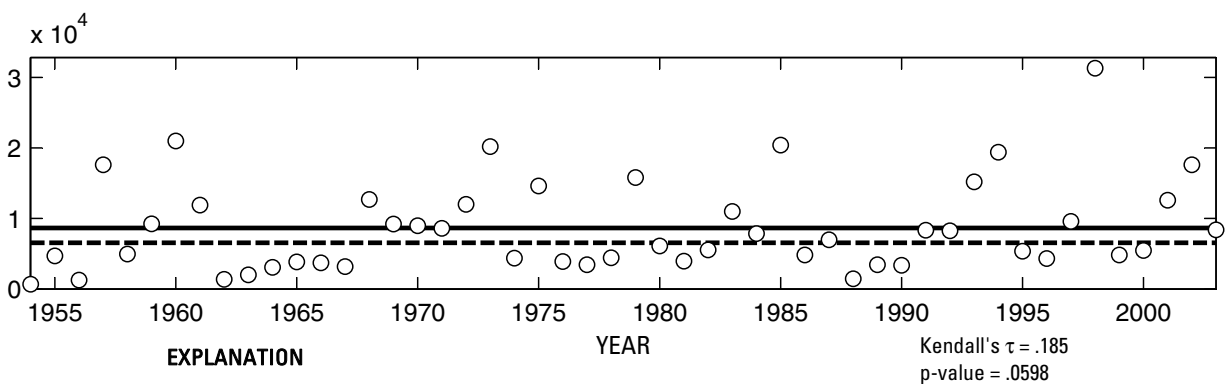

EXPLANATION

$\mathrm{p}$-value $=.0598$

- Median annual maximum streamflow (6,550 cubic feet per second)

O Annual maximum streamflow

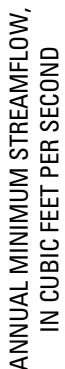

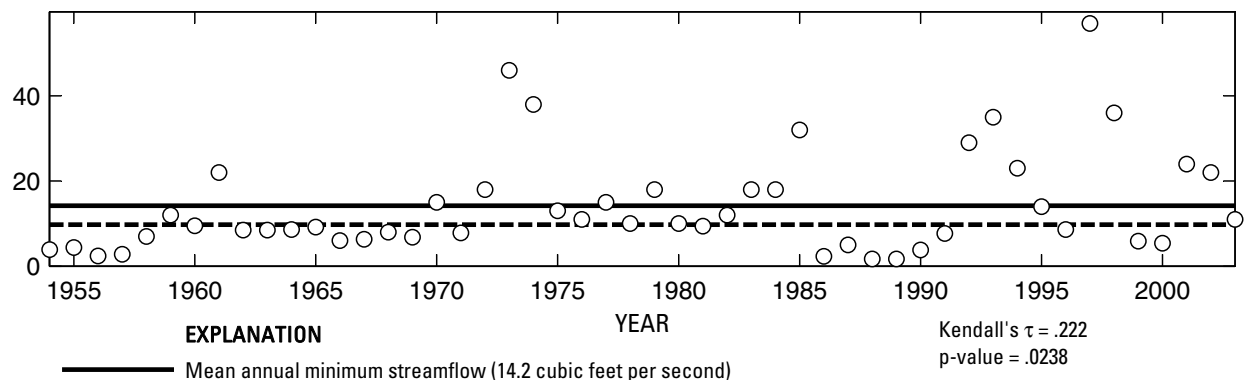

•ーーーー Median annual minimum streamflow ( 9.75 cubic feet per second)

O Annual minimum streamflow

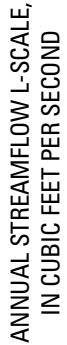

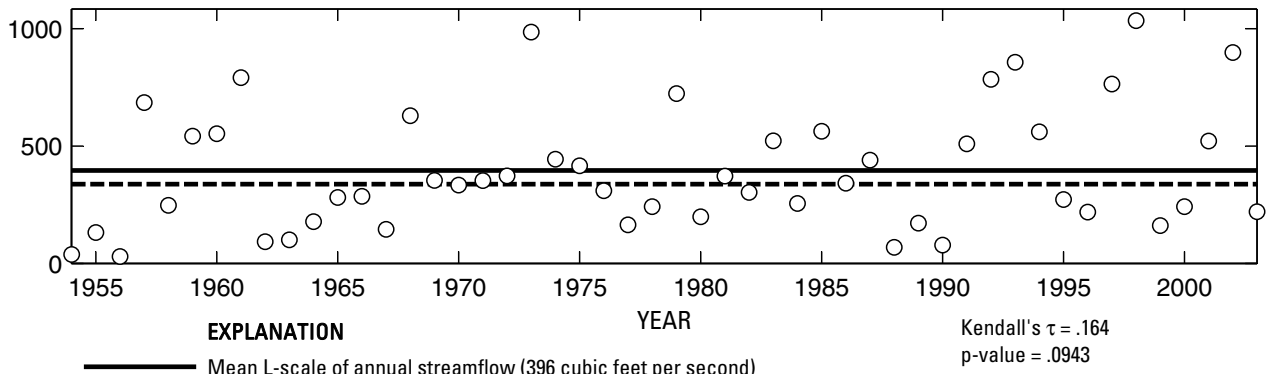

Mean L-scale of annual streamflow (396 cubic feet per second)

- --ー- Median L-scale of annual streamflow (338 cubic feet per second)

Annual L-scale of streamflow

Figure 448. Analysis of annual mean, maximum, minimum, and L-scale statistics of daily mean streamflow for U.S. Geological Survey streamflow-gaging station 08117500 San Bernard River near Boling, Texas.

Index of Station Numbers 719 


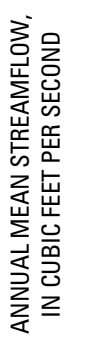

U.S. Geological Survey streamflow-gaging station 08117900

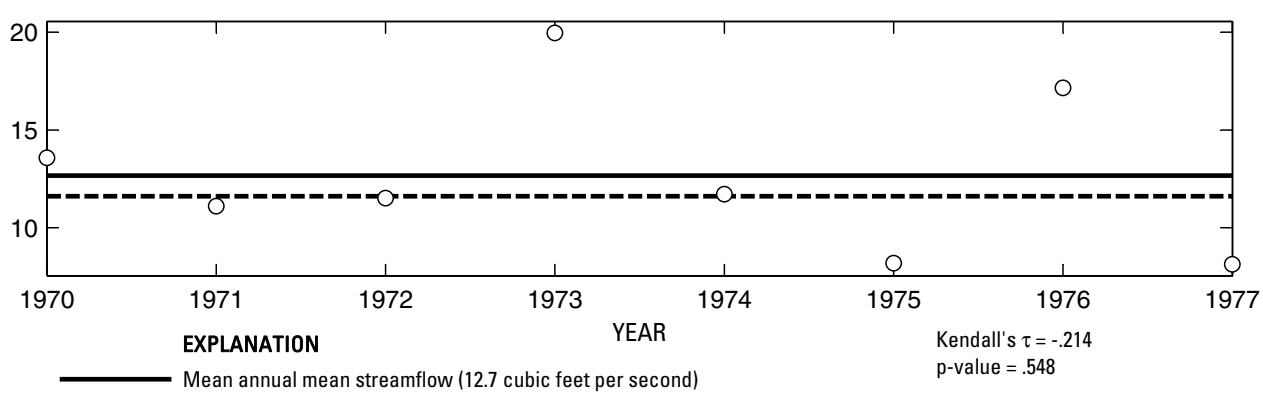

-_-_- Median annual mean streamflow (11.6 cubic feet per second)

O Annual mean streamflow
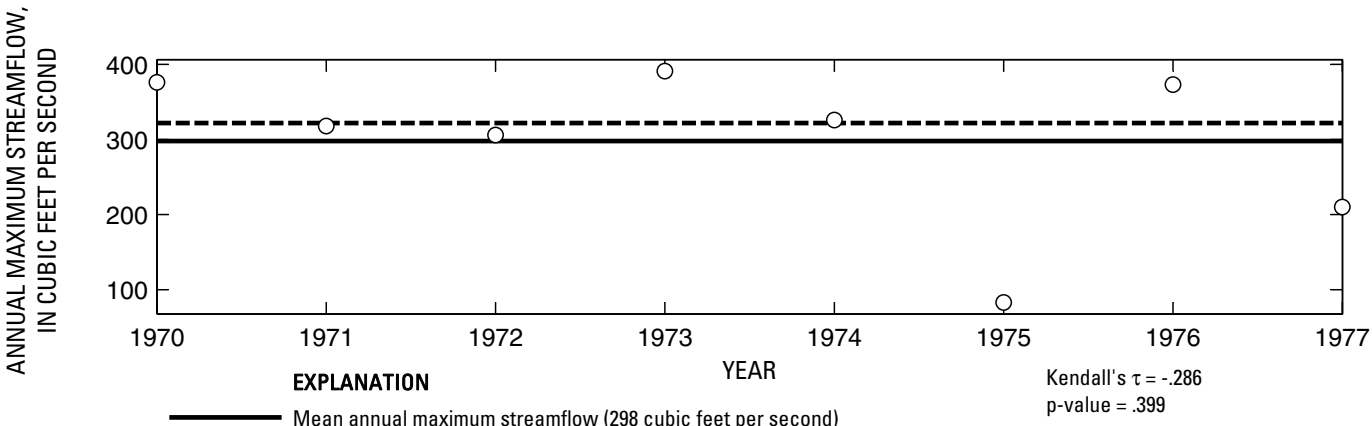

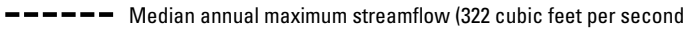

Annual maximum streamflow
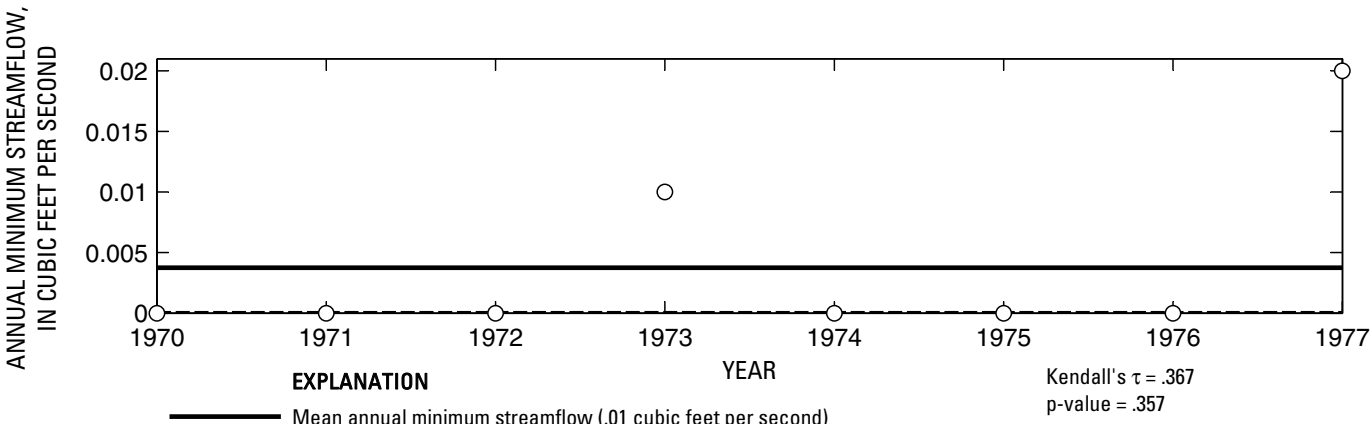

- ב-ב Median annual minimum streamflow (0 cubic feet per second)

O Annual minimum streamflow
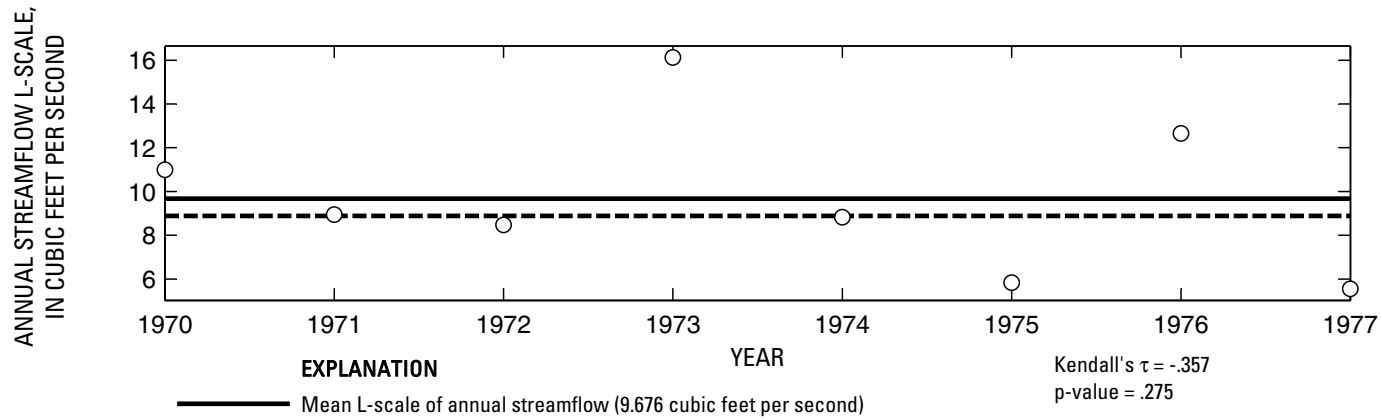

- - - - Median L-scale of annual streamflow (8.885 cubic feet per second)

Annual L-scale of streamflow

Figure 449. Analysis of annual mean, maximum, minimum, and L-scale statistics of daily mean streamflow for U.S. Geological Survey streamflow-gaging station 08117900 Big Boggy Creek near Wadsworth, Texas. 
U.S. Geological Survey streamflow-gaging station 08117995
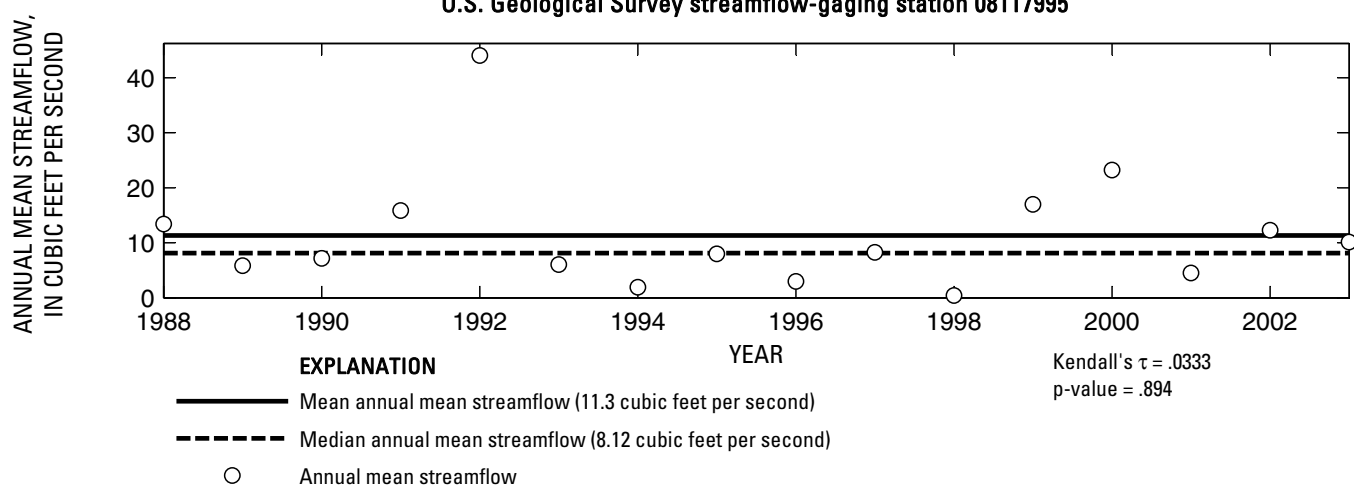

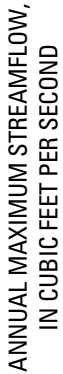

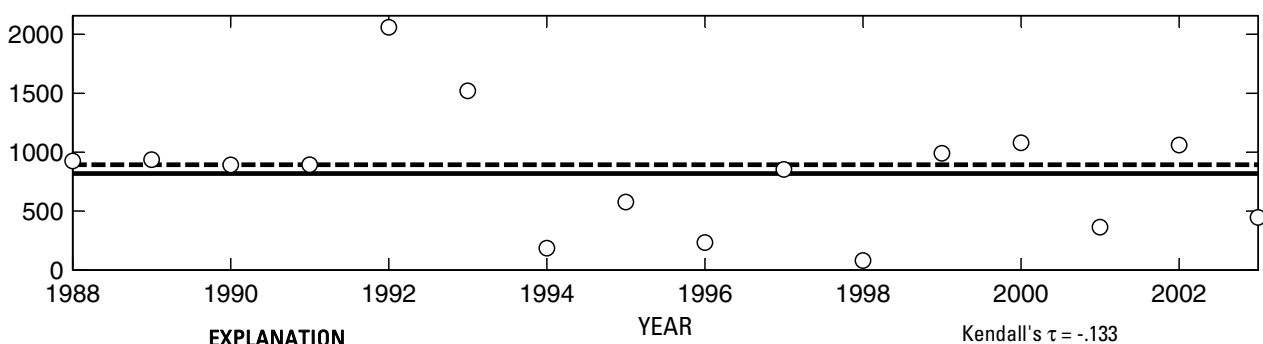

EXPLANATION KEAR Kendall's $\tau=-.133$

Mean annual maximum streamflow (819 cubic feet per second)

p-value $=.506$

--_-- Median annual maximum streamflow (893 cubic feet per second)

O Annual maximum streamflow

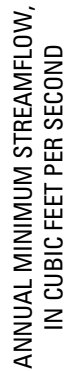

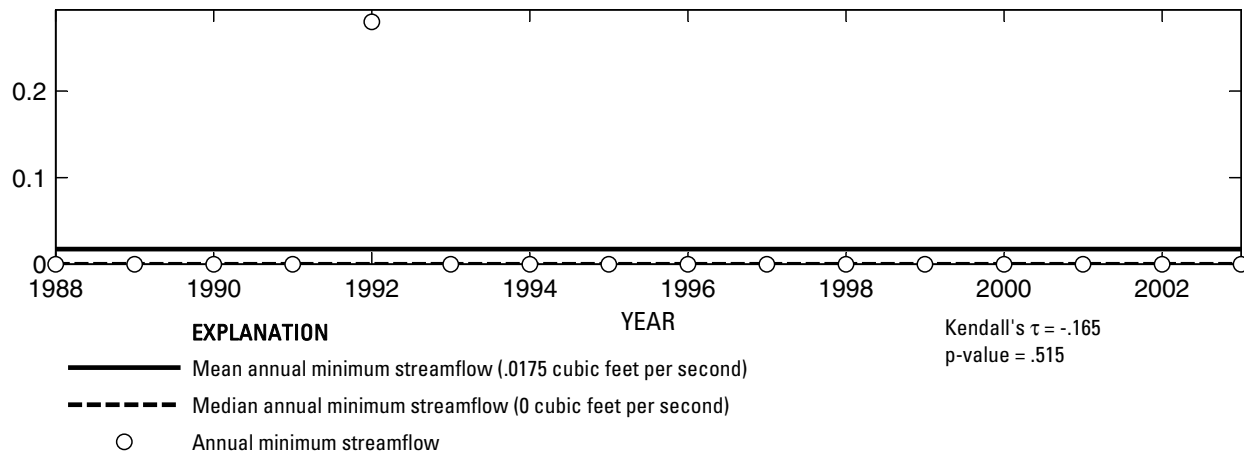

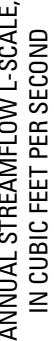

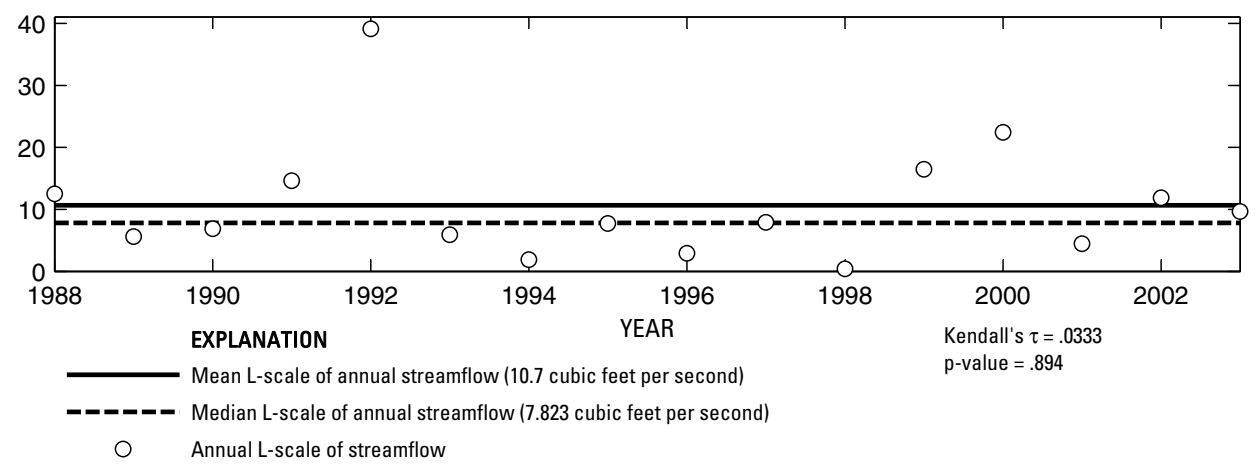

Figure 450. Analysis of annual mean, maximum, minimum, and L-scale statistics of daily mean streamflow for U.S. Geological Survey streamflow-gaging station 08117995 Colorado River near Gail, Texas.

Index of Station Numbers 719 


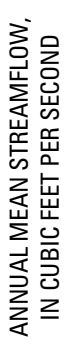

U.S. Geological Survey streamflow-gaging station 08118500

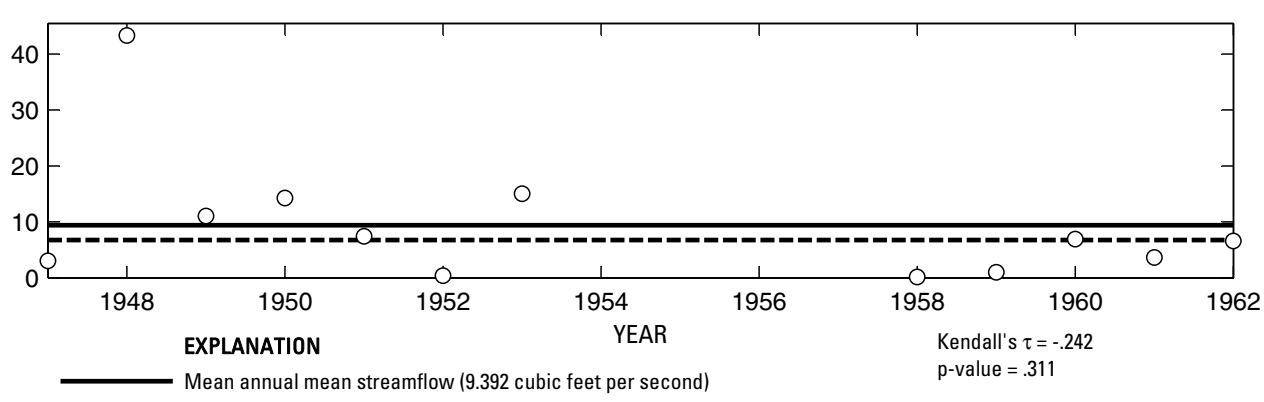

-_o_-_ Median annual mean streamflow (6.743 cubic feet per second)

- Annual mean streamflow
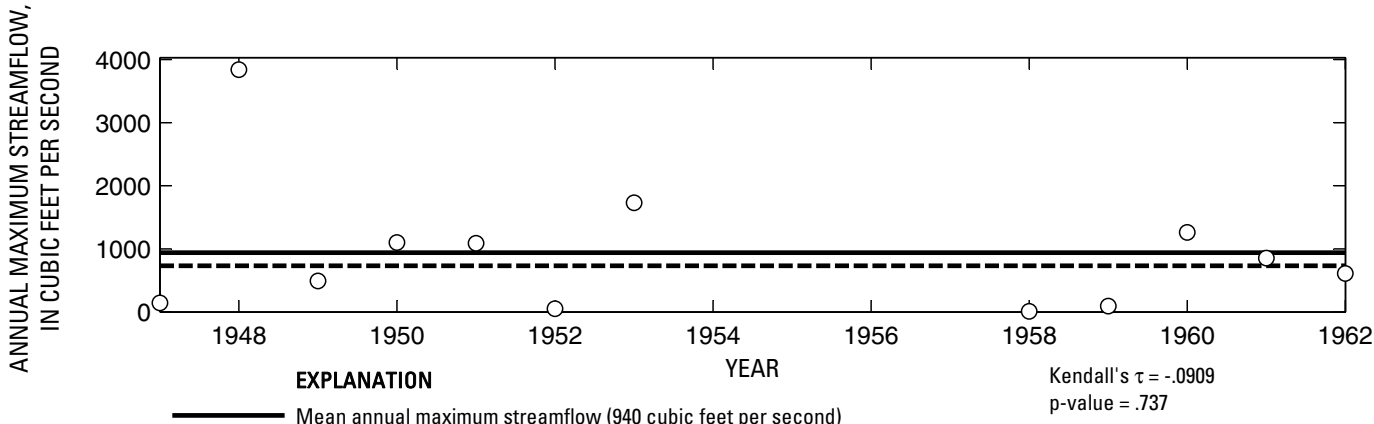

- - ב Median annual maximum streamflow (734 cubic feet per second)

Annual maximum streamflow

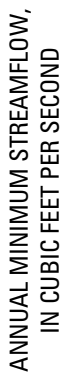

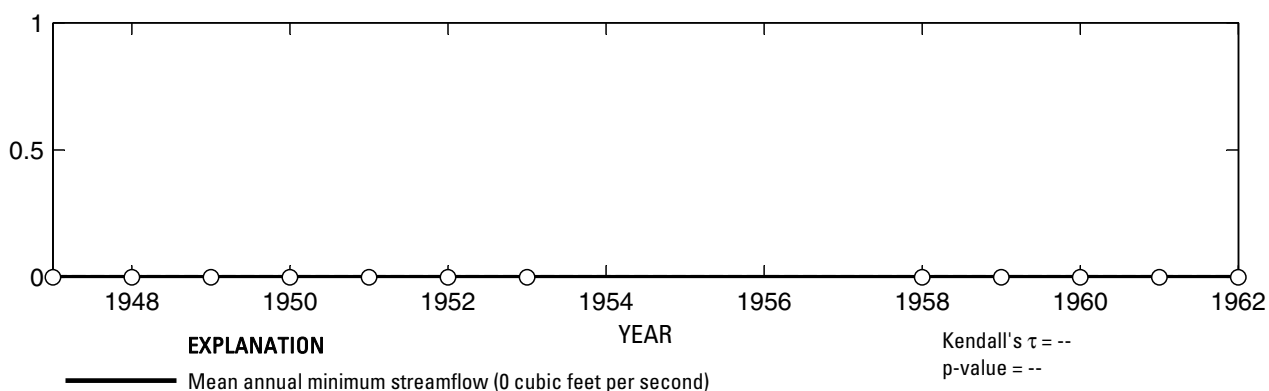

- Median annual minimum streamflow (0 cubic feet per second)

O Annual minimum streamflow

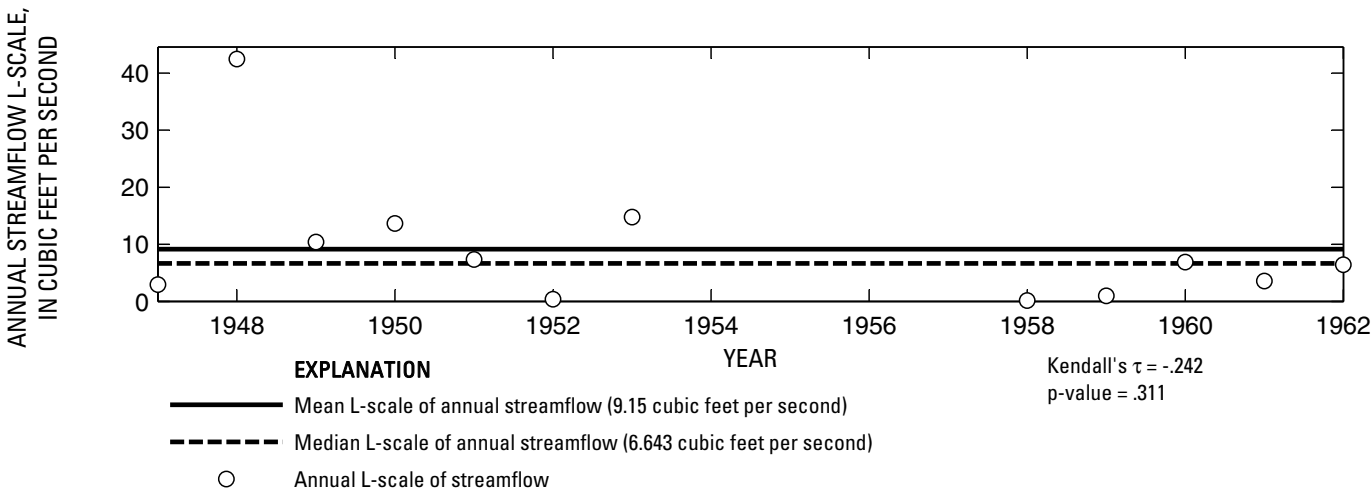

Figure 451. Analysis of annual mean, maximum, minimum, and L-scale statistics of daily mean streamflow for U.S. Geological Survey streamflow-gaging station 08118500 Bull Creek near Ira, Texas. 
U.S. Geological Survey streamflow-gaging station 08119000

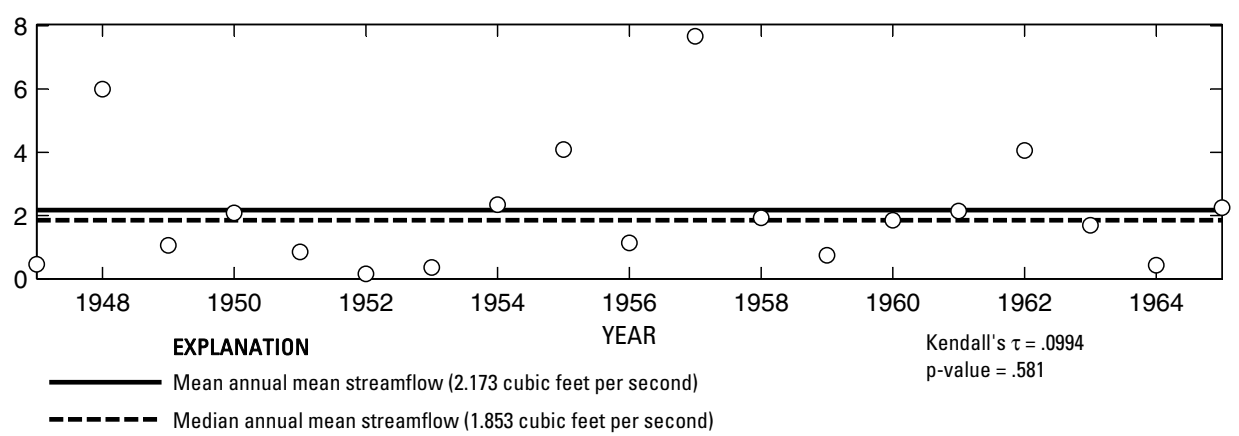

O Annual mean streamflow

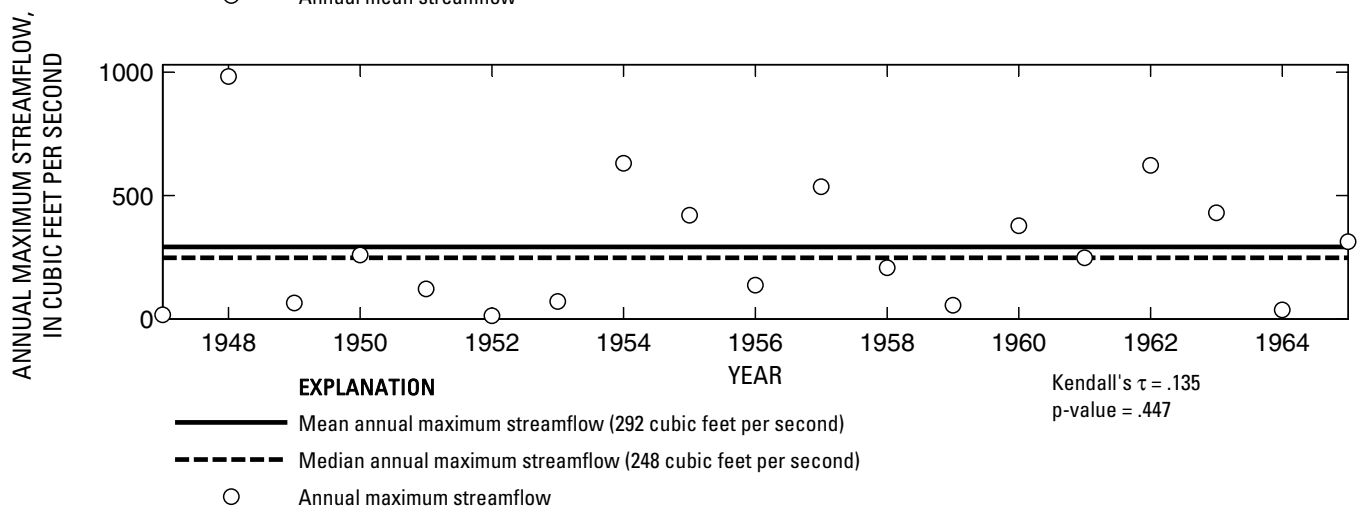

焉

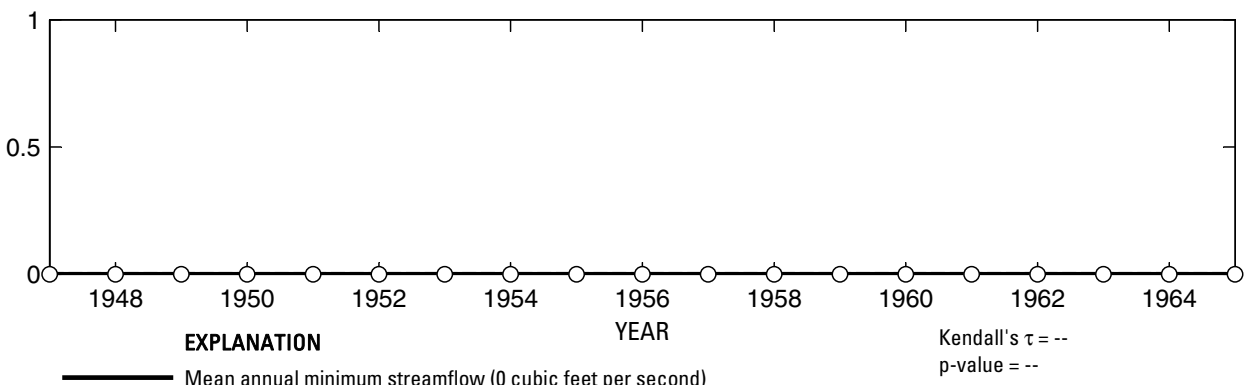

- Median annual minimum streamflow (0 cubic feet per second)

O Annual minimum streamflow

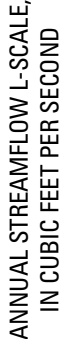

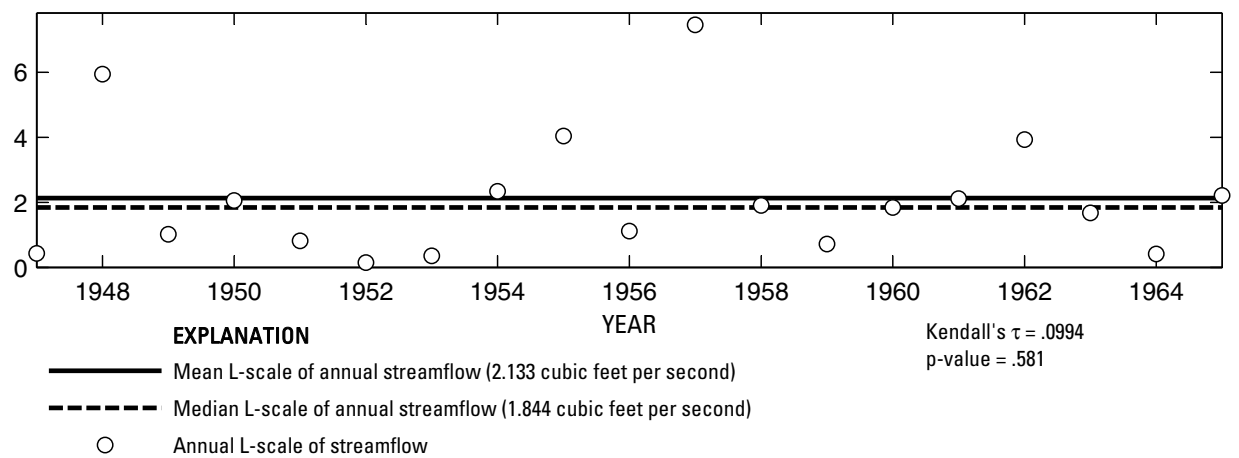

Figure 452. Analysis of annual mean, maximum, minimum, and L-scale statistics of daily mean streamflow for U.S. Geological Survey streamflow-gaging station 08119000 Bluff Creek near Ira, Texas.

Index of Station Numbers 719 

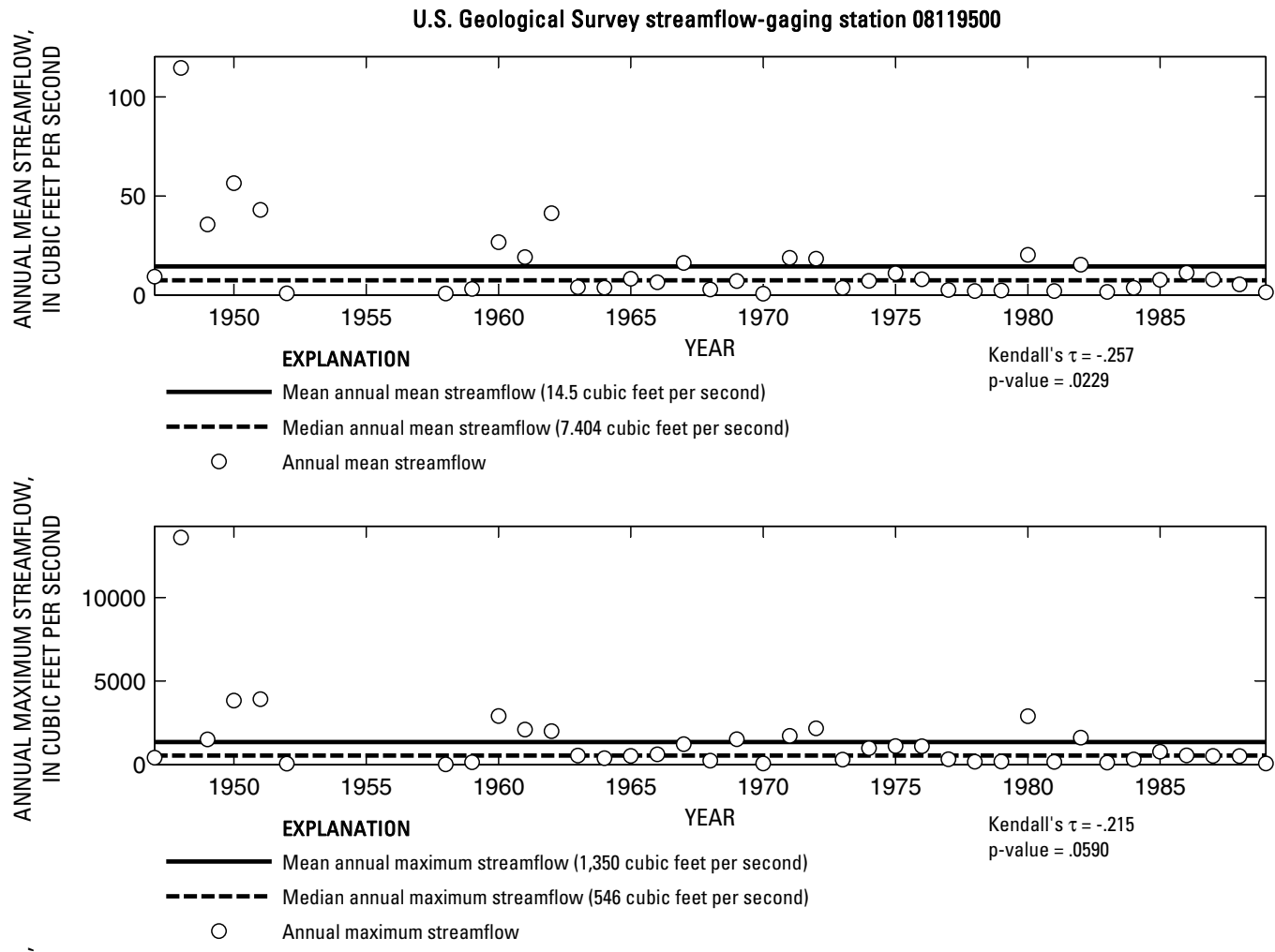

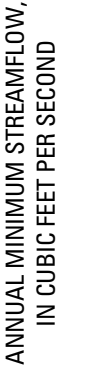

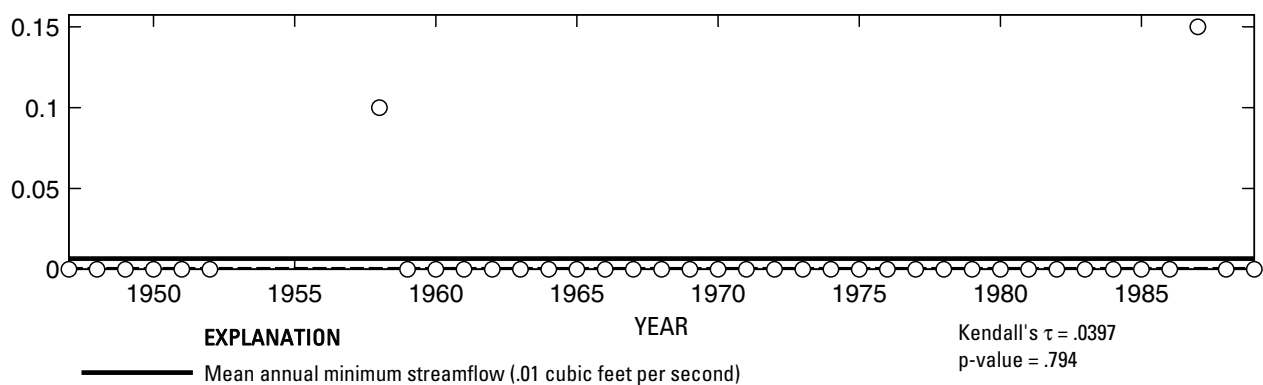

- ב- Median annual minimum streamflow (0 cubic feet per second)

O Annual minimum streamflow

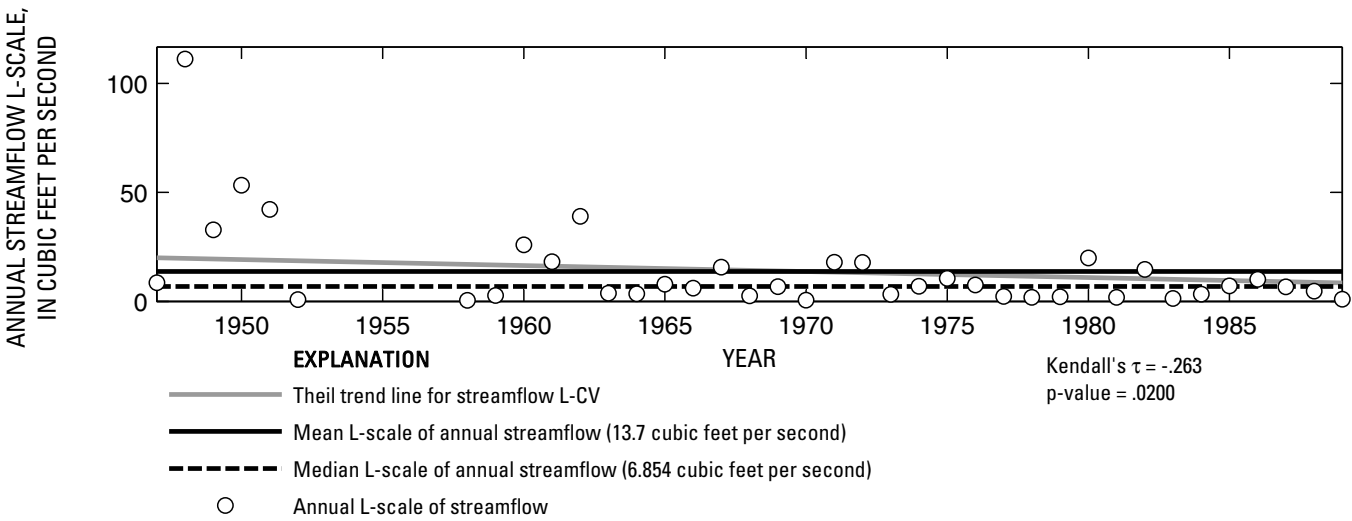

Figure 453. Analysis of annual mean, maximum, minimum, and L-scale statistics of daily mean streamflow for U.S. Geological Survey streamflow-gaging station 08119500 Colorado River near Ira, Texas. 
U.S. Geological Survey streamflow-gaging station 08120500
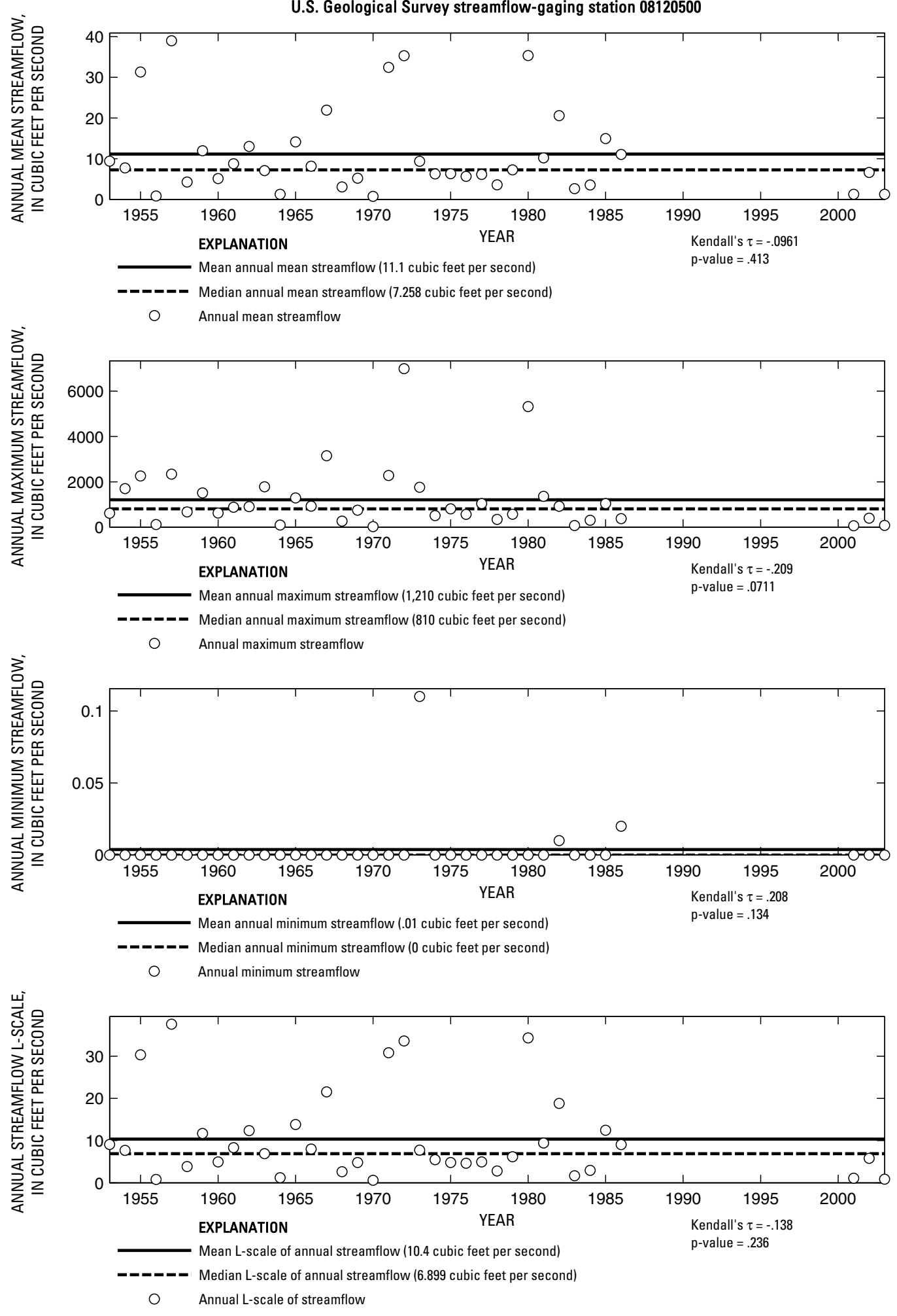

Figure 454. Analysis of annual mean, maximum, minimum, and L-scale statistics of daily mean streamflow for U.S. Geological Survey streamflow-gaging station 08120500 Deep Creek near Dunn, Texas.

Index of Station Numbers 719 


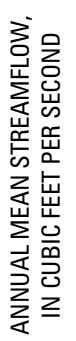

U.S. Geological Survey streamflow-gaging station 08120700

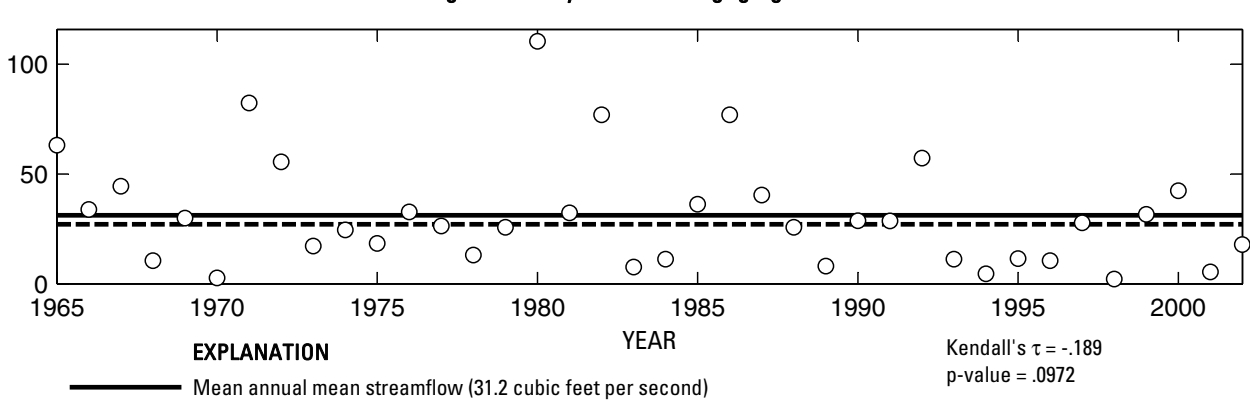

-_-_- Median annual mean streamflow (27.1 cubic feet per second)

O Annual mean streamflow
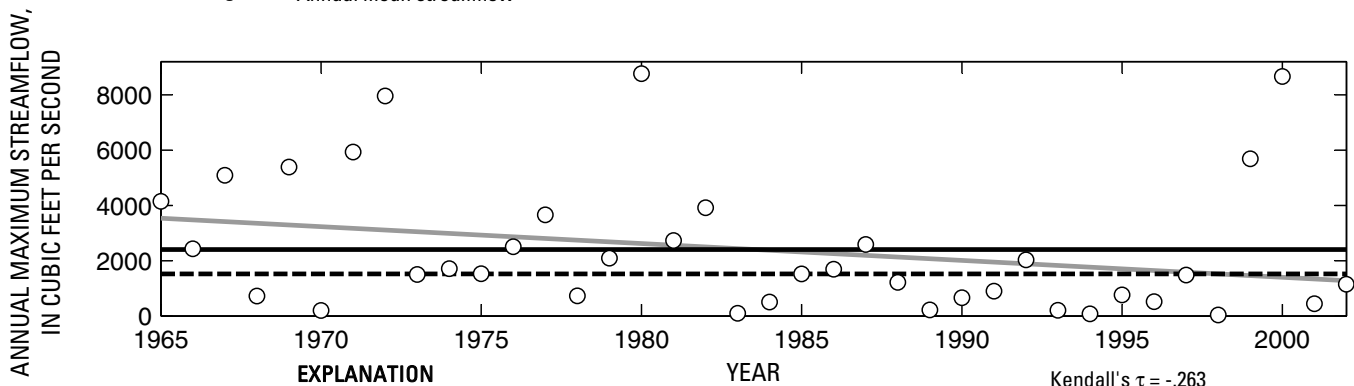

Theil trend line for annual maximum streamflow

Mean annual maximum streamflow (2,410 cubic feet per second)

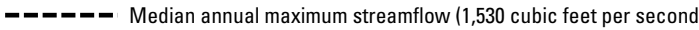

O Annual maximum streamflow

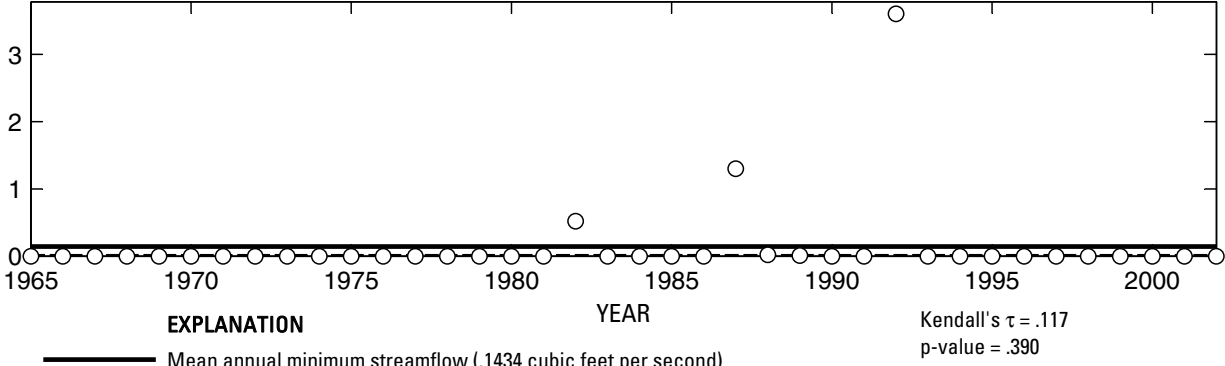

- Median annual minimum streamflow $(0$ cubic feet per second)

O Annual minimum streamflow

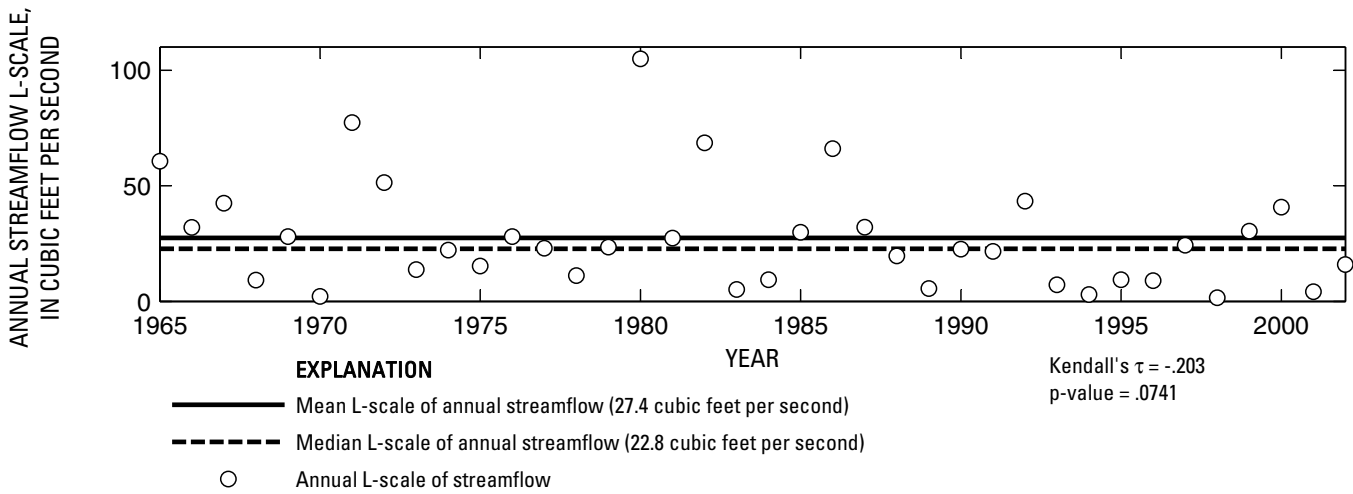

Figure 455. Analysis of annual mean, maximum, minimum, and L-scale statistics of daily mean streamflow for U.S. Geological Survey streamflow-gaging station 08120700 Colorado River near Cuthbert, Texas. 


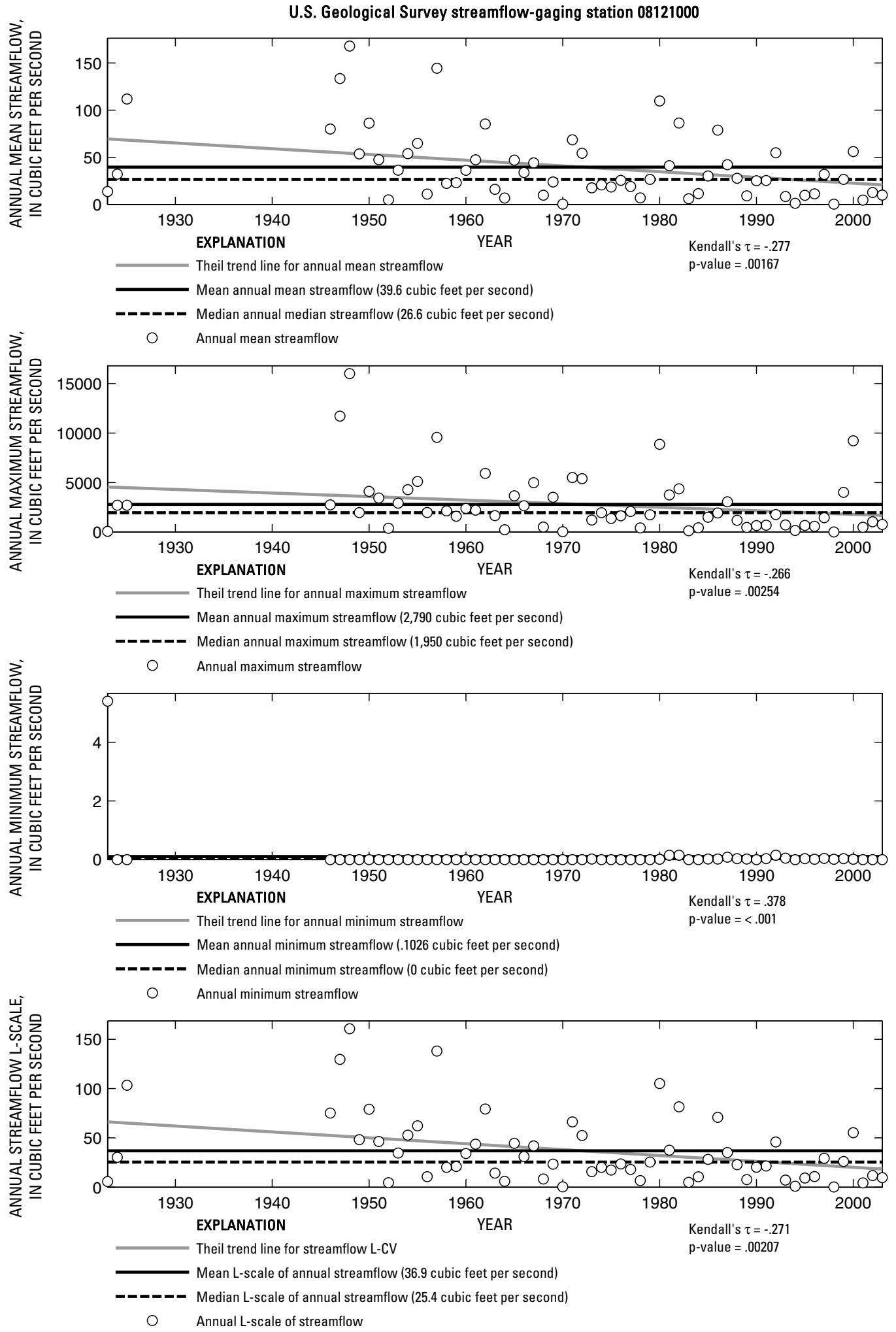

Figure 456. Analysis of annual mean, maximum, minimum, and L-scale statistics of daily mean streamflow for U.S. Geological Survey streamflow-gaging station 08121000 Colorado River at Colorado City, Texas.

Index of Station Numbers 719 


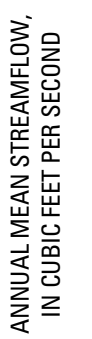

U.S. Geological Survey streamflow-gaging station 08121500

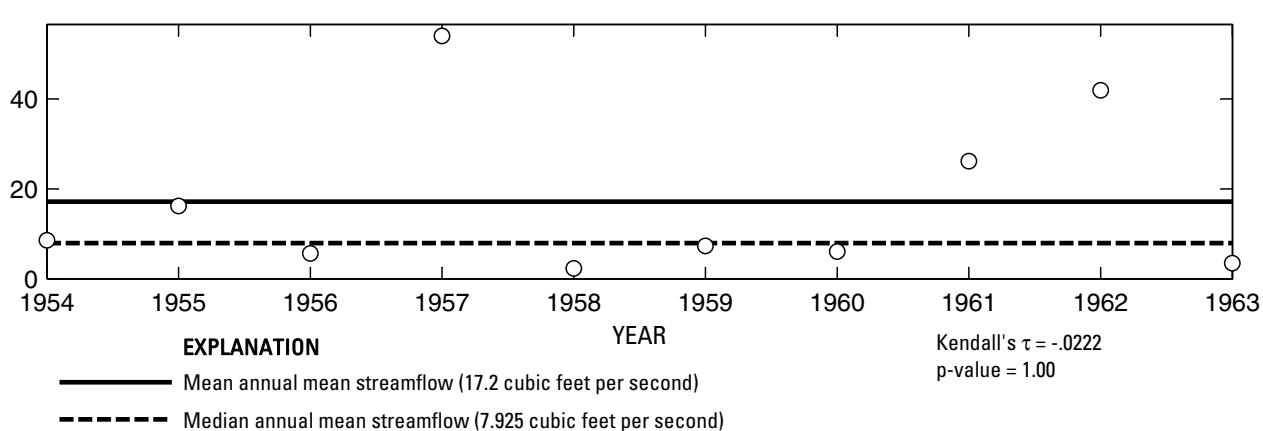

O Annual mean streamflow
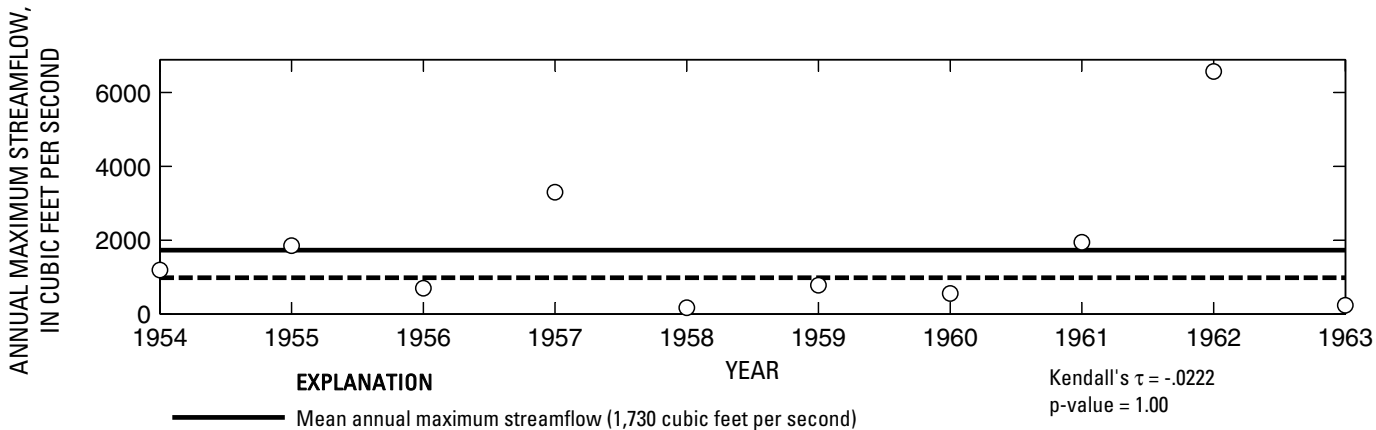

- - Median annual maximum streamflow (985 cubic feet per second)

Annual maximum streamflow
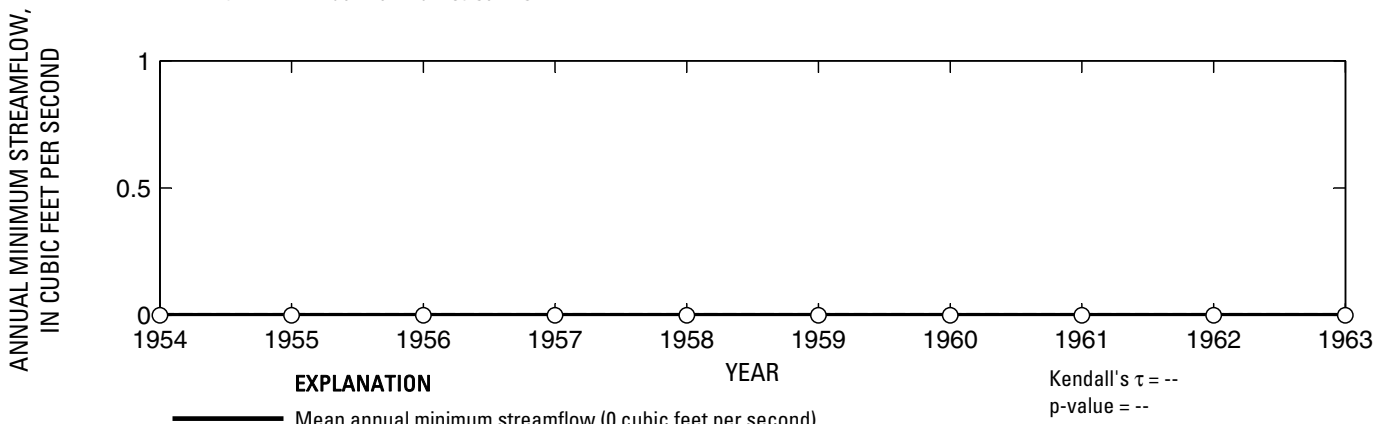

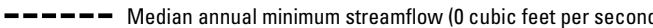

○ Annual minimum streamflow

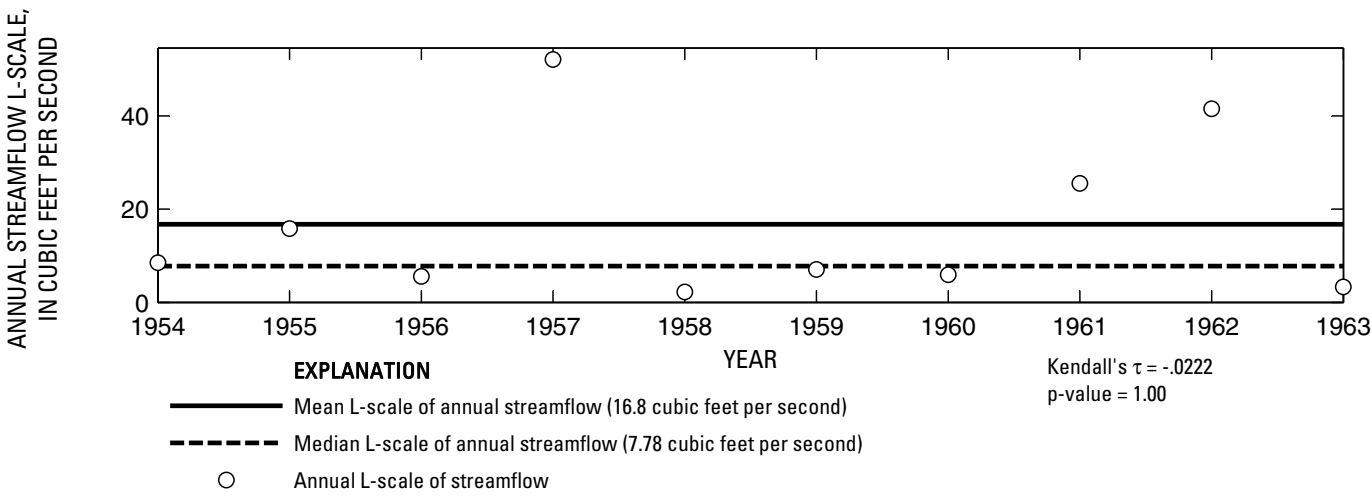

Figure 457. Analysis of annual mean, maximum, minimum, and L-scale statistics of daily mean streamflow for U.S. Geological Survey streamflow-gaging station 08121500 Morgan Creek near Westbrook, Texas. 


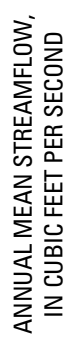

U.S. Geological Survey streamflow-gaging station 08122000

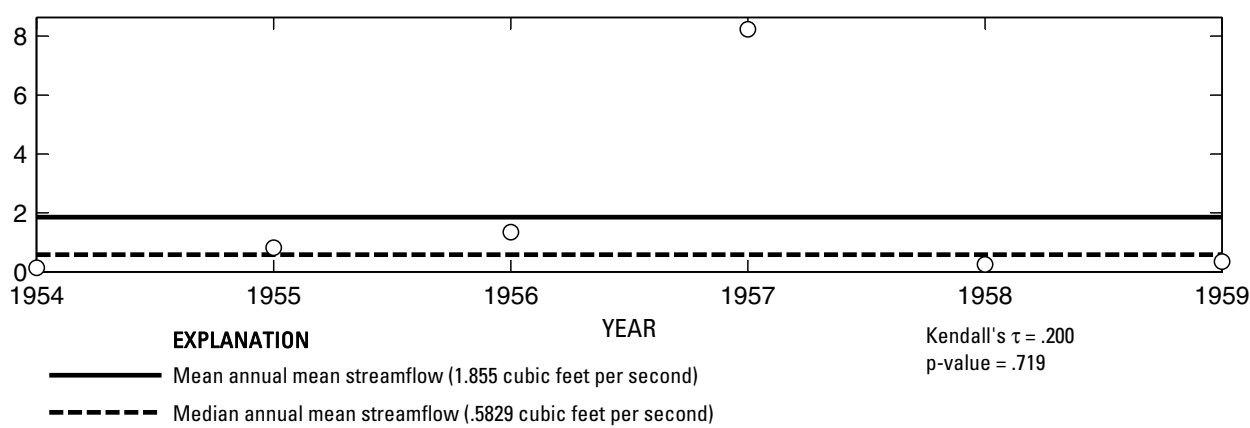

Annual mean streamflow

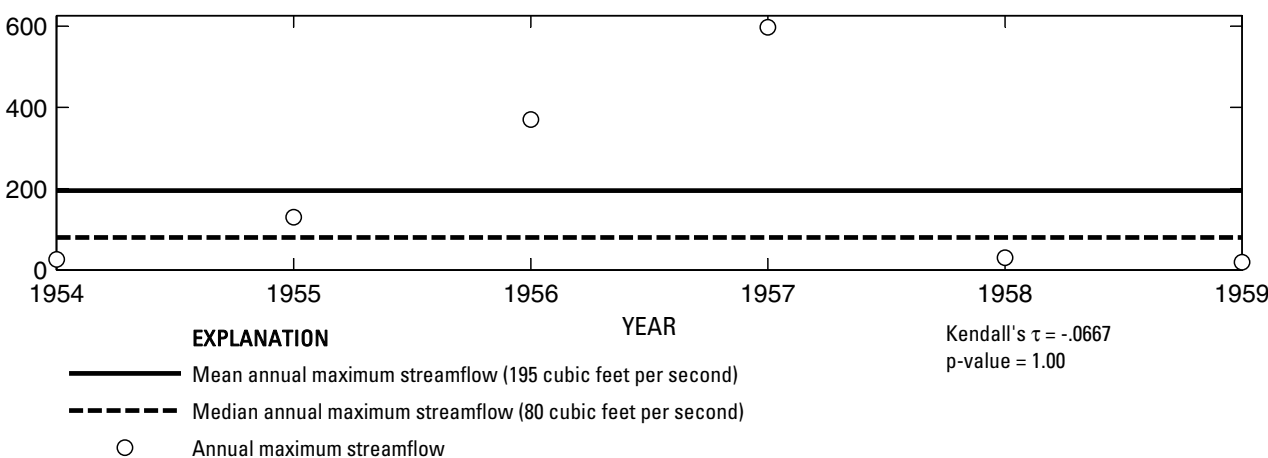

崔

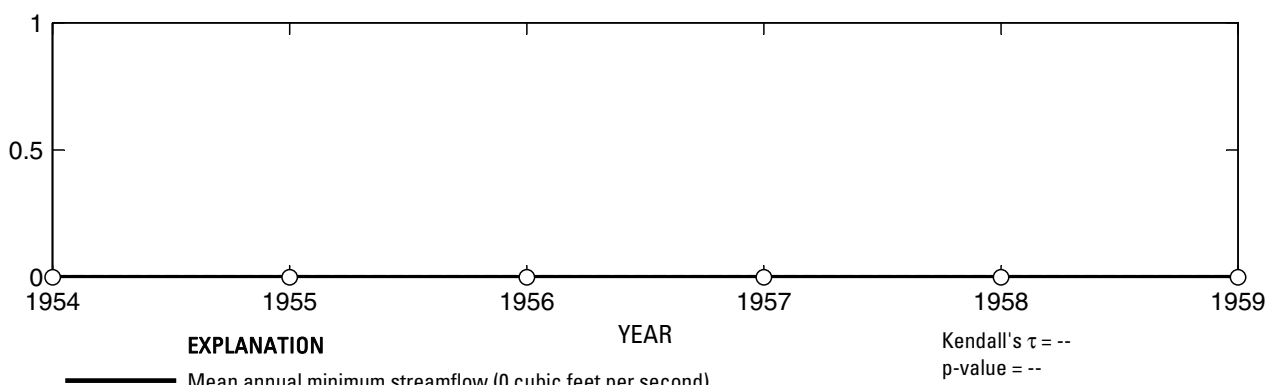

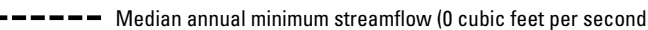

O Annual minimum streamflow

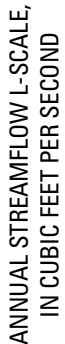

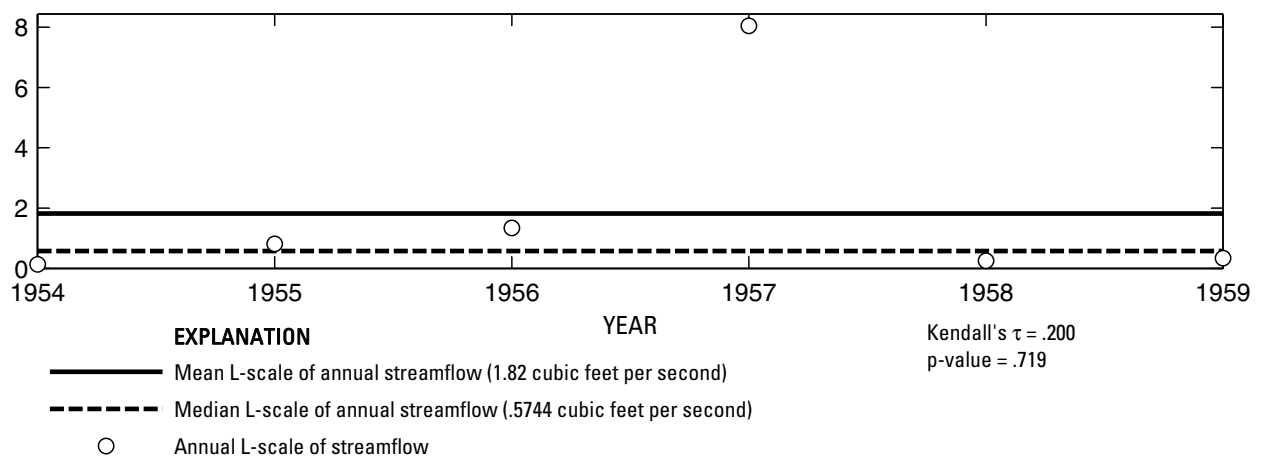

Figure 458. Analysis of annual mean, maximum, minimum, and L-scale statistics of daily mean streamflow for U.S. Geological Survey streamflow-gaging station 08122000 Graze Creek near Westbrook, Texas.

Index of Station Numbers 719 


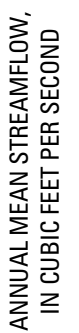

U.S. Geological Survey streamflow-gaging station 08122500

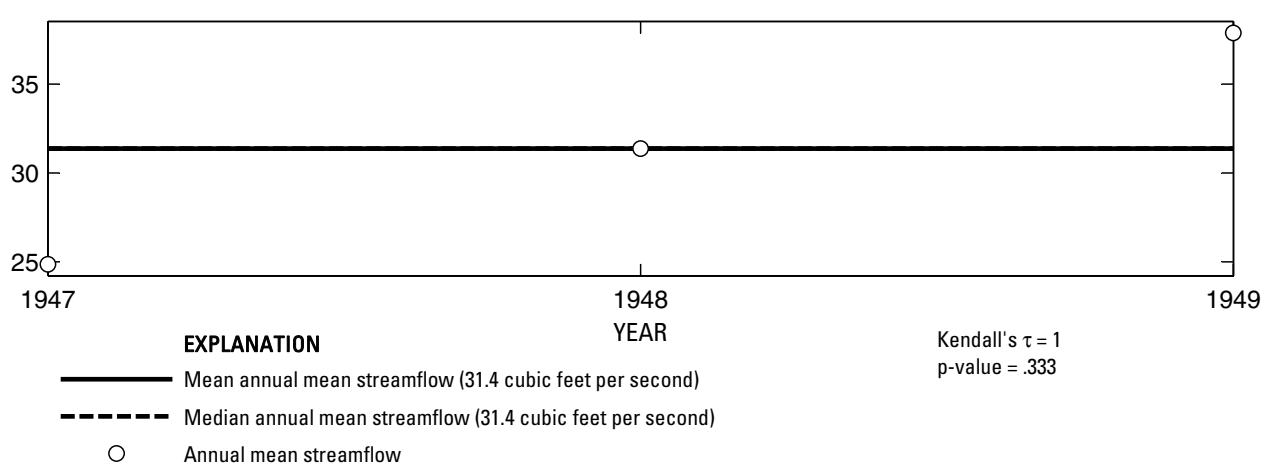

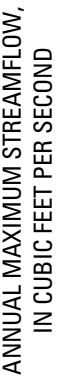

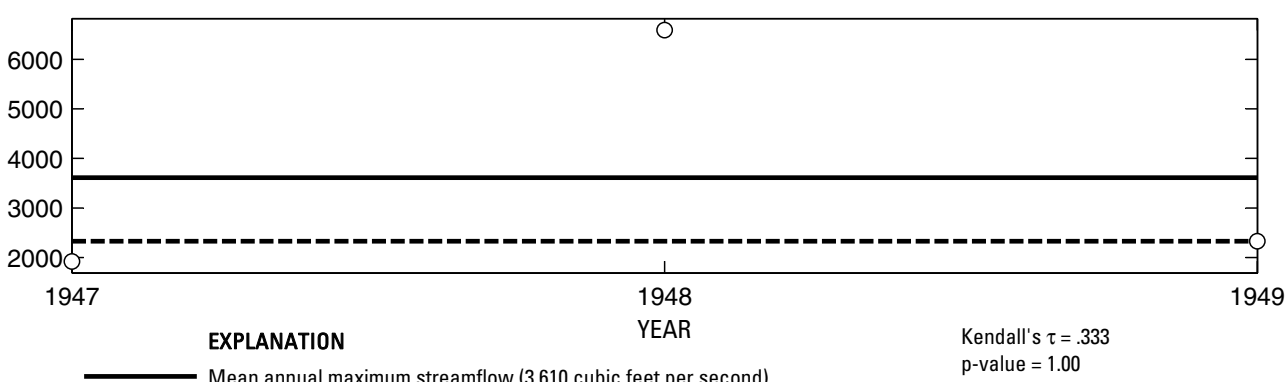

- _ _ - Median annual maximum streamflow (2,330 cubic feet per second)

Annual maximum streamflow
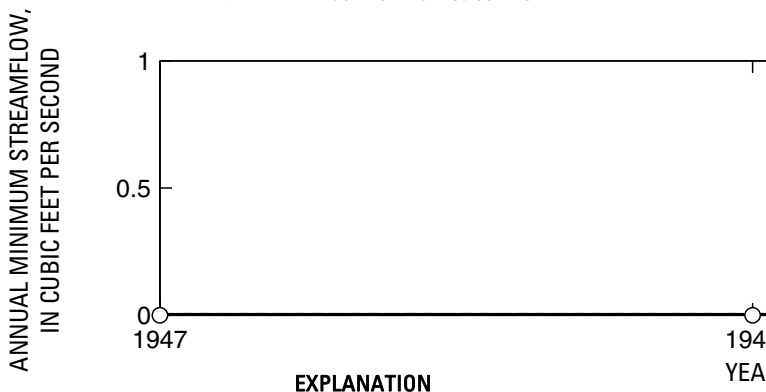

- Mean annual minimum streamflow (0 cubic feet per second)

p-value $=1.00$

O Annual minimum streamflow
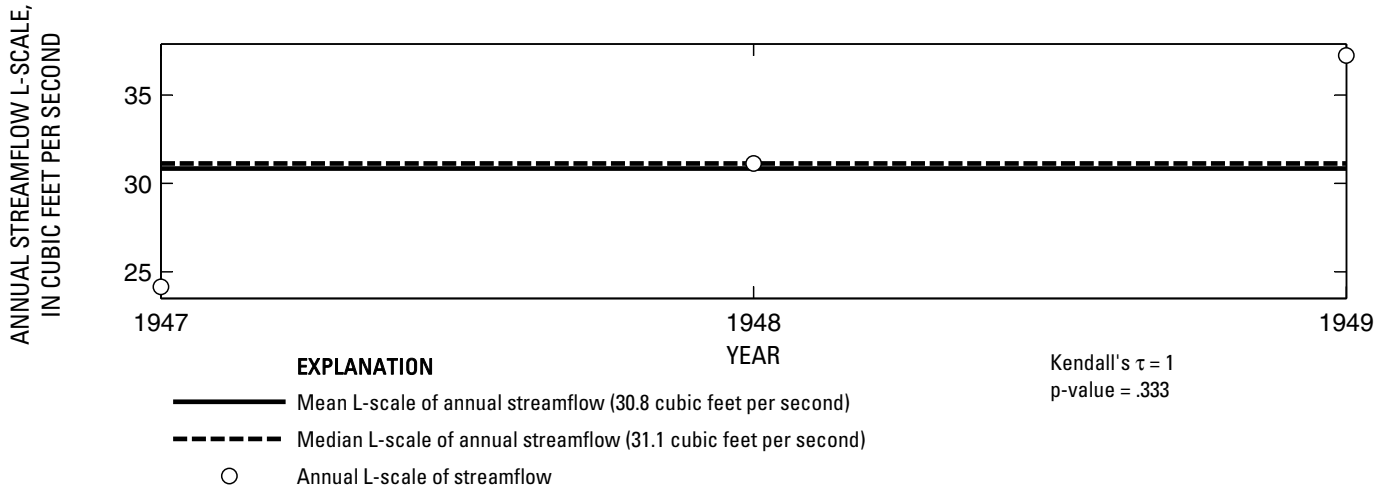

Figure 459. Analysis of annual mean, maximum, minimum, and L-scale statistics of daily mean streamflow for U.S. Geological Survey streamflow-gaging station 08122500 Morgan Creek near Colorado City, Texas. 
U.S. Geological Survey streamflow-gaging station 08123500

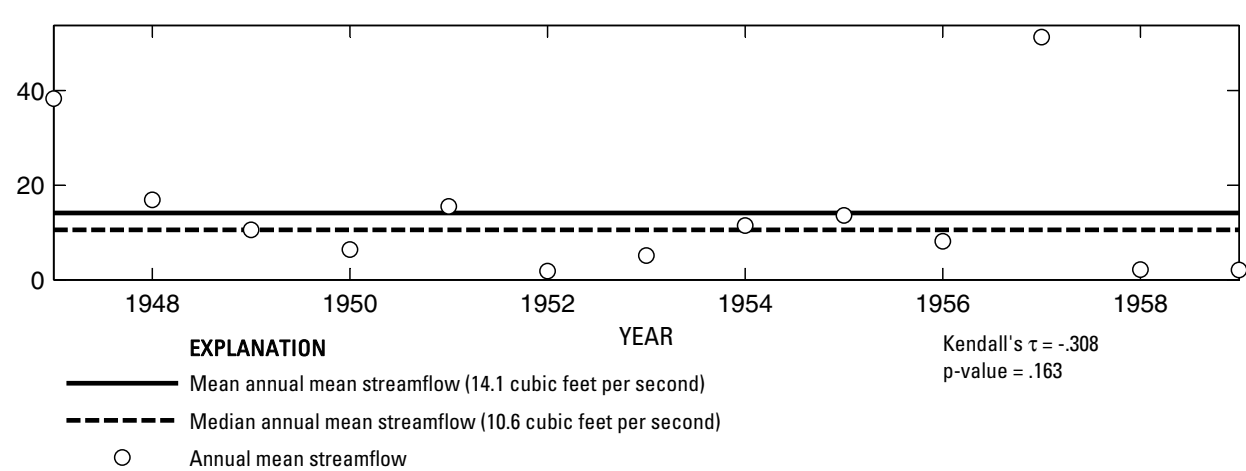

竞

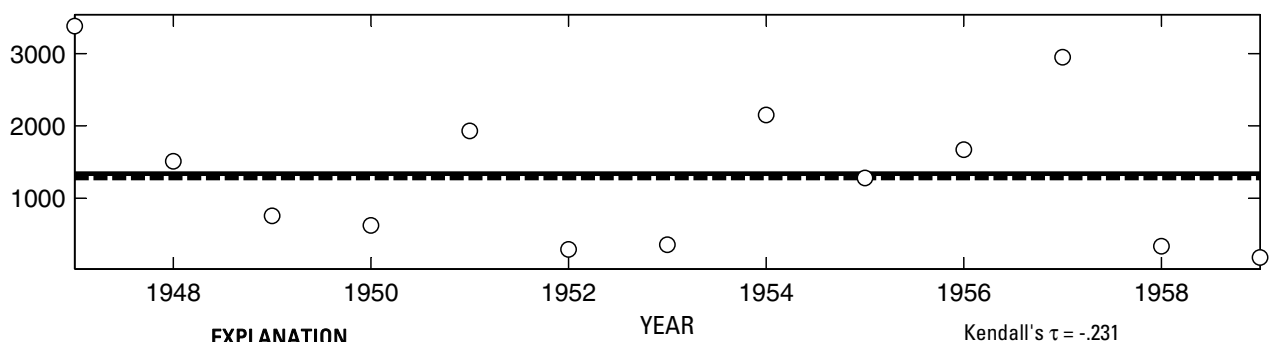

EXPLANATION

$\mathrm{p}$-value $=.306$

- _ - Median annual maximum streamflow $(1,280$ cubic feet per second

Annual maximum streamflow

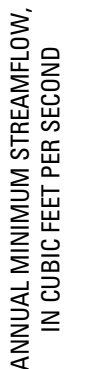

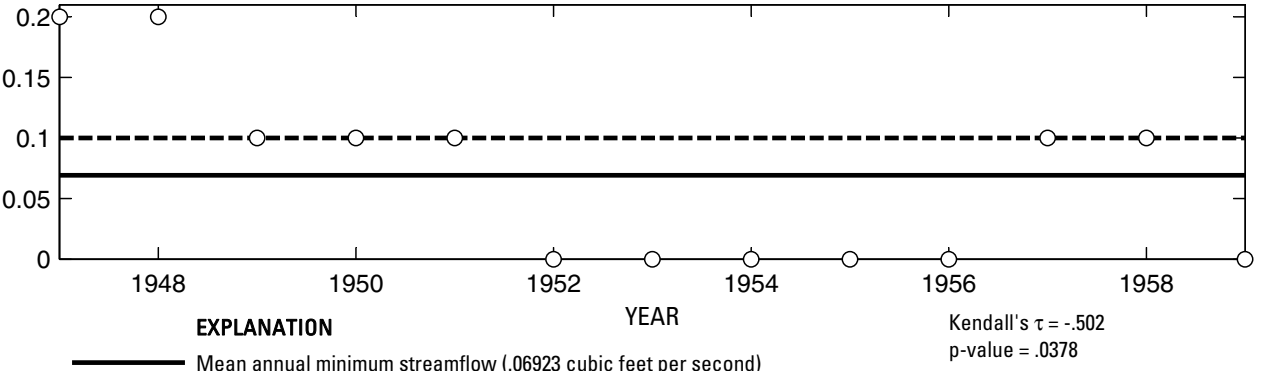

- Median annual minimum streamflow (.1 cubic feet per second)

O Annual minimum streamflow

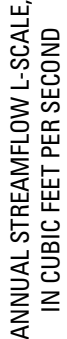

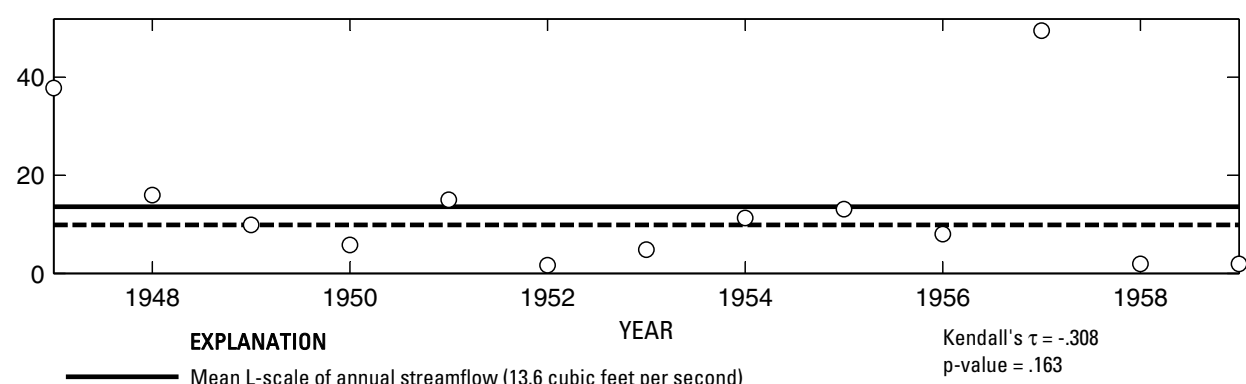

Mean L-scale of annual streamflow (13.6 cubic feet per second)

- - - - Median L-scale of annual streamflow (9.892 cubic feet per second)

Annual L-scale of streamflow

Figure 460. Analysis of annual mean, maximum, minimum, and L-scale statistics of daily mean streamflow for U.S. Geological Survey streamflow-gaging station 08123500 Champion Creek near Colorado City, Texas.

Index of Station Numbers 719 


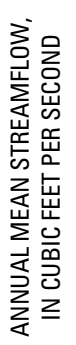

U.S. Geological Survey streamflow-gaging station 08123650

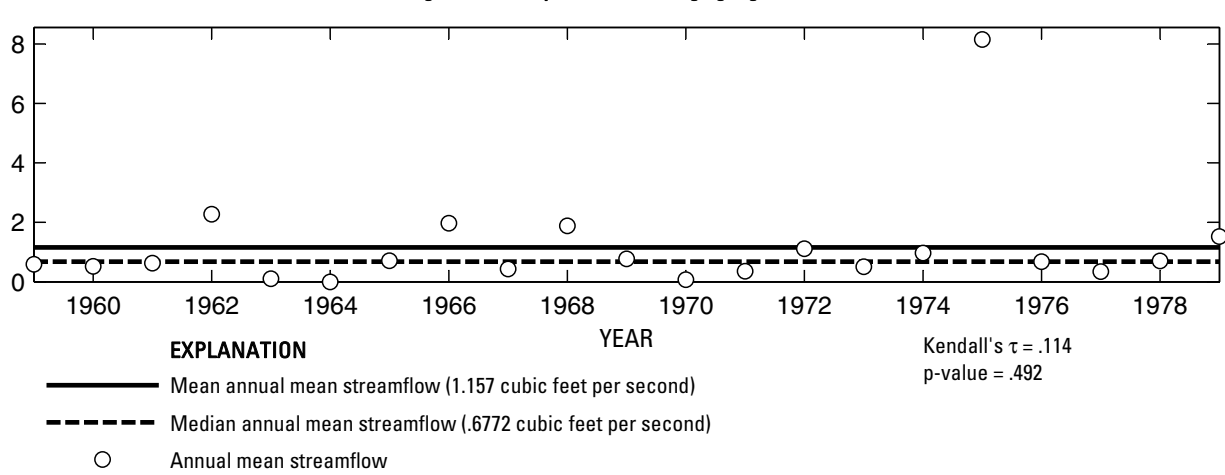

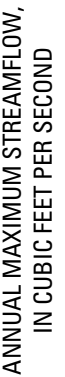

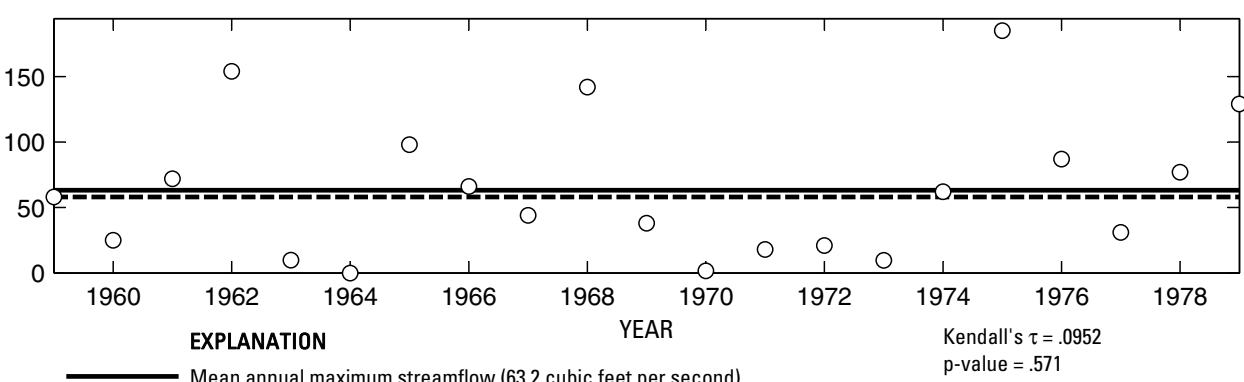

-

Annual maximum streamflow

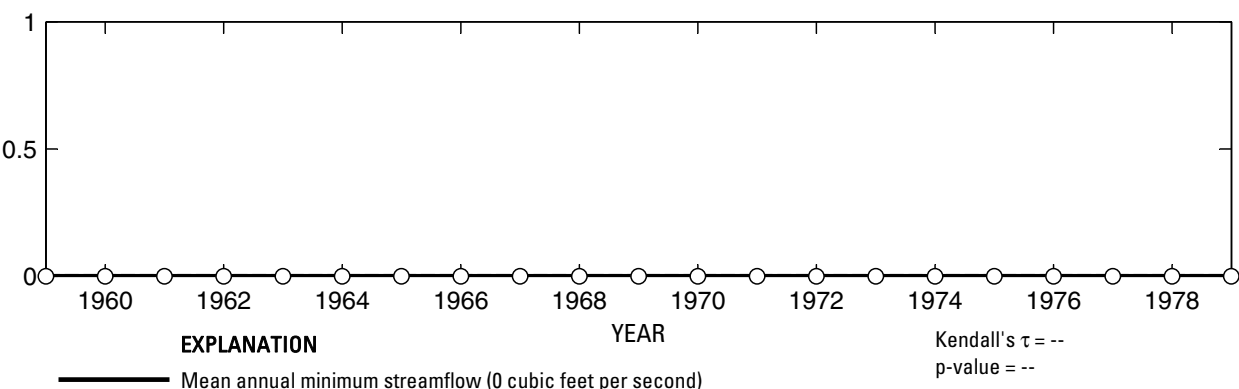

○ Annual minimum streamflow

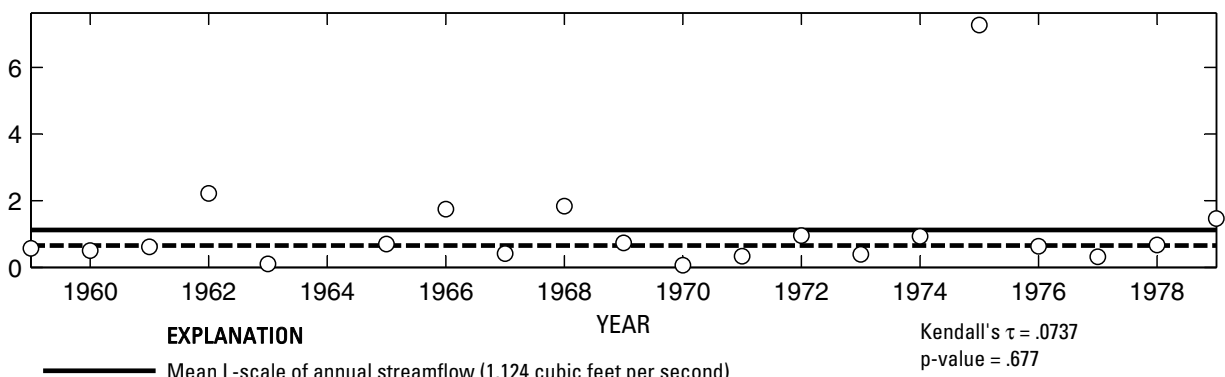

Mean L-scale of annual streamflow (1.124 cubic feet per second)

- - - - Median L-scale of annual streamflow (.654 cubic feet per second)

O Annual L-scale of streamflow

Figure 461. Analysis of annual mean, maximum, minimum, and L-scale statistics of daily mean streamflow for U.S. Geological Survey streamflow-gaging station 08123650 Beals Creek above Big Spring, Texas. 


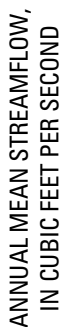

U.S. Geological Survey streamflow-gaging station 08123700

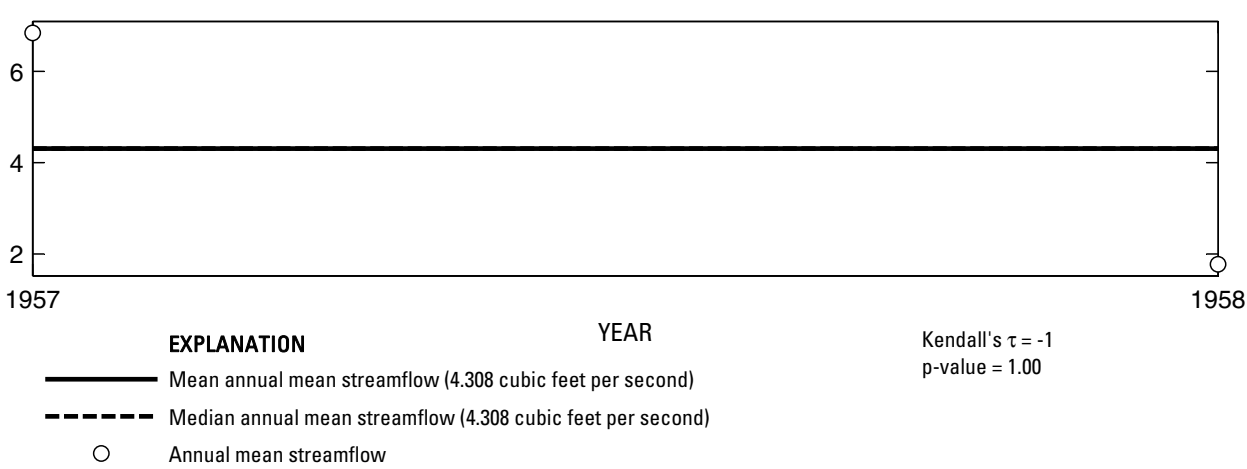

焉

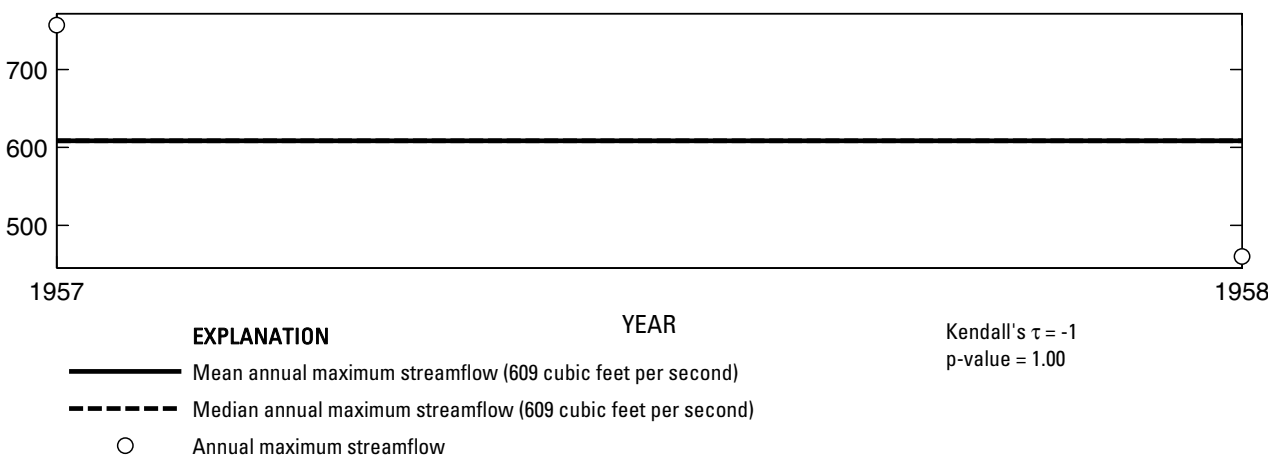

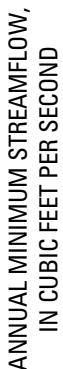

$$
\begin{aligned}
& 1 \\
& 0.5 \\
& 00 \\
& 1957
\end{aligned}
$$

Annual maximum streamflow

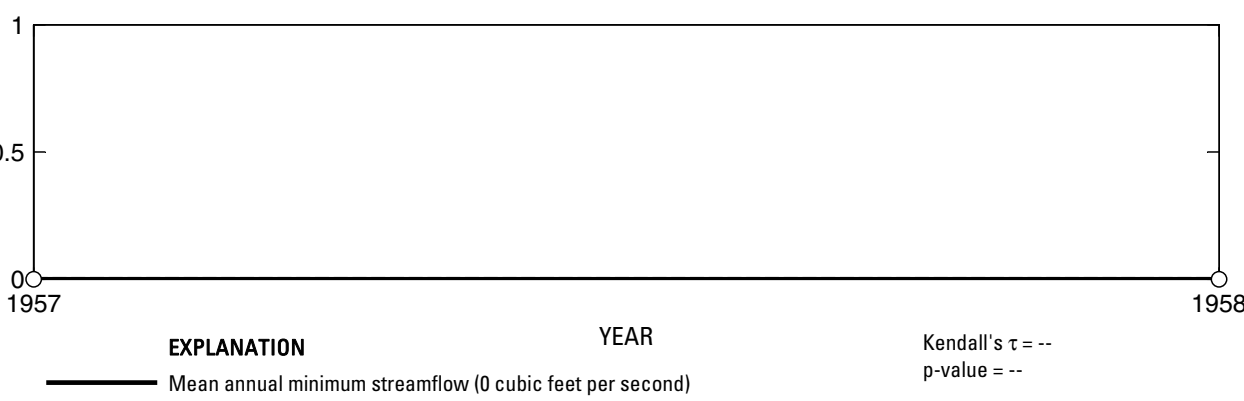

- - Median annual minimum streamflow (0 cubic feet per second)

O Annual minimum streamflow

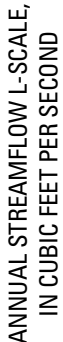

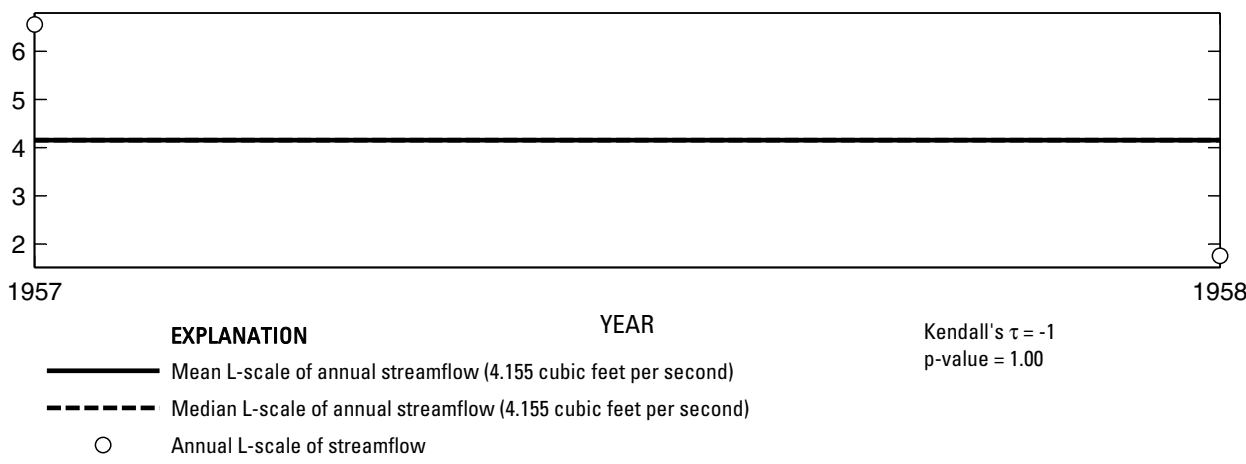

Figure 462. Analysis of annual mean, maximum, minimum, and L-scale statistics of daily mean streamflow for U.S. Geological Survey streamflow-gaging station 08123700 Beals Creek at Big Spring, Texas. 

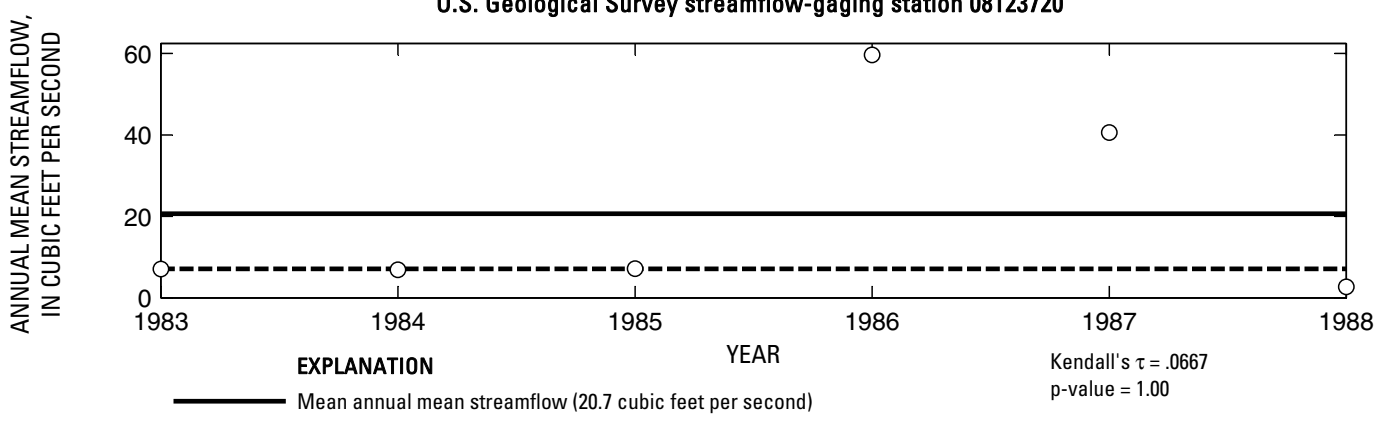

-_-_-_ Median annual mean streamflow (7.109 cubic feet per second)

O Annual mean streamflow
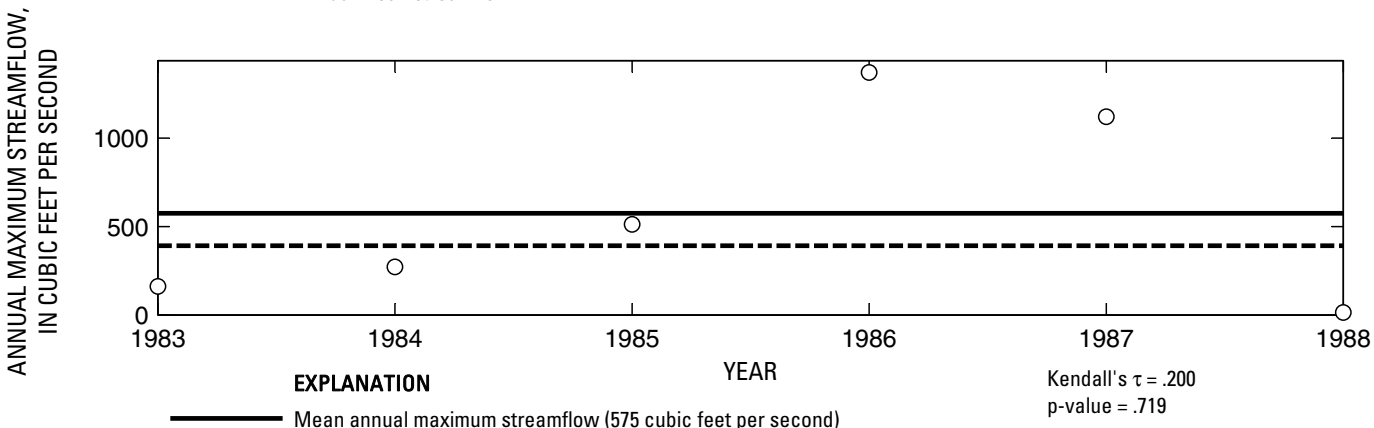

O Annual maximum streamflow
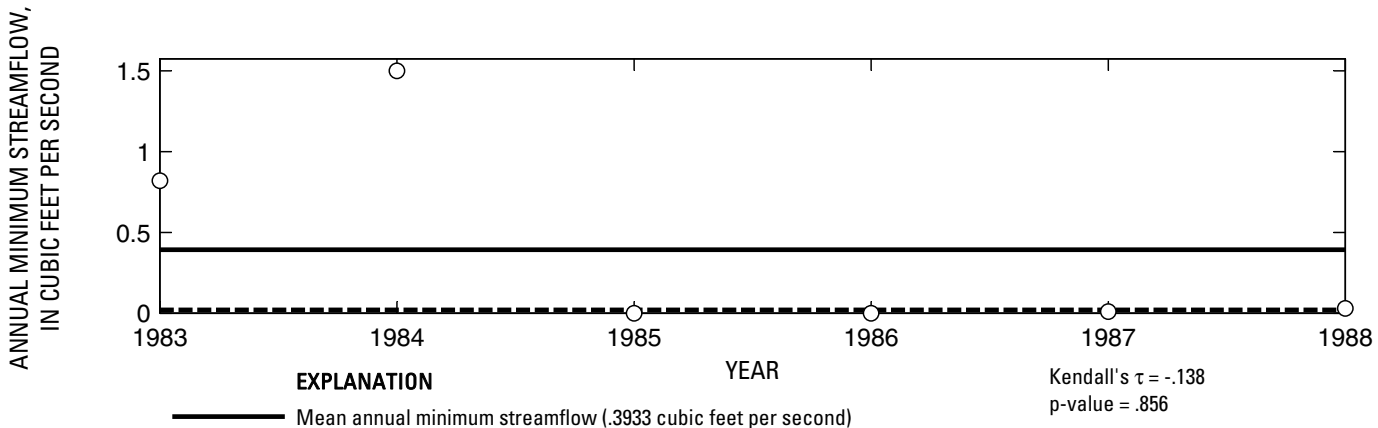

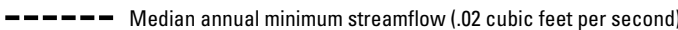

O Annual minimum streamflow
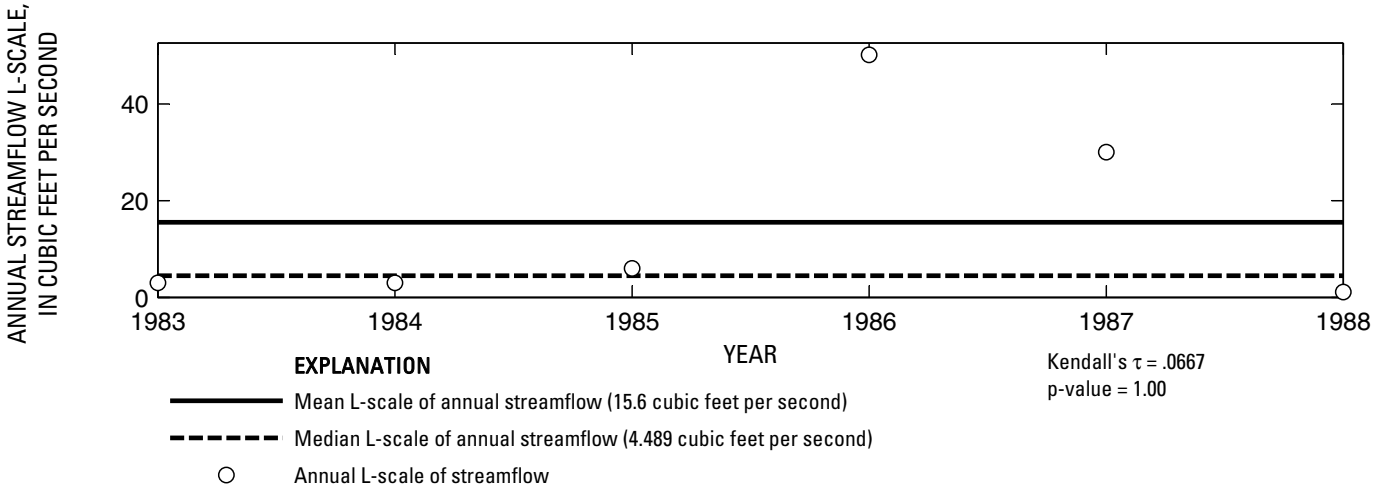

Figure 463. Analysis of annual mean, maximum, minimum, and L-scale statistics of daily mean streamflow for U.S. Geological Survey streamflow-gaging station 08123720 Beals Creek near Coahoma, Texas. 

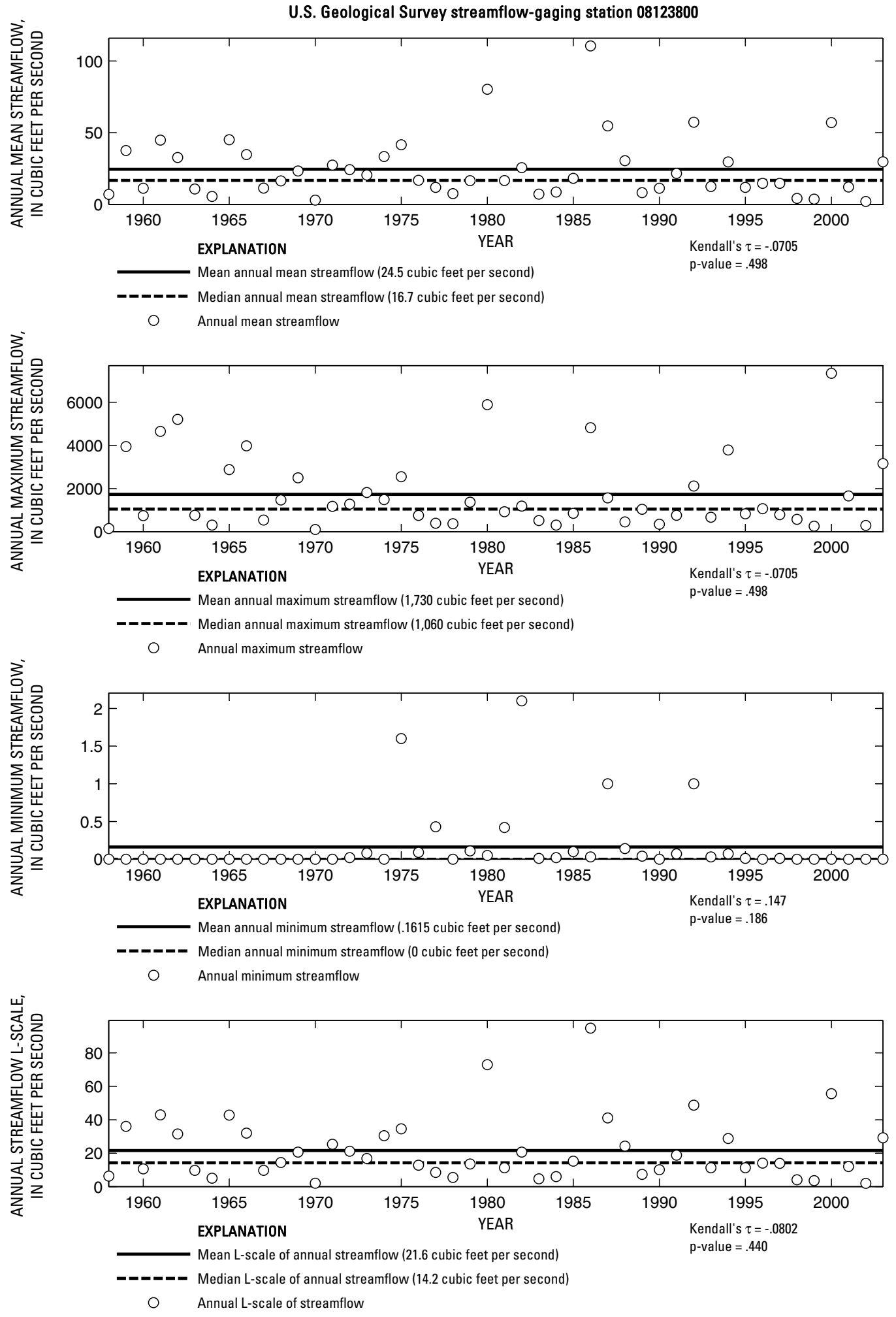

Figure 464. Analysis of annual mean, maximum, minimum, and L-scale statistics of daily mean streamflow for U.S. Geological Survey streamflow-gaging station 08123800 Beals Creek near Westbrook, Texas.

Index of Station Numbers 719 

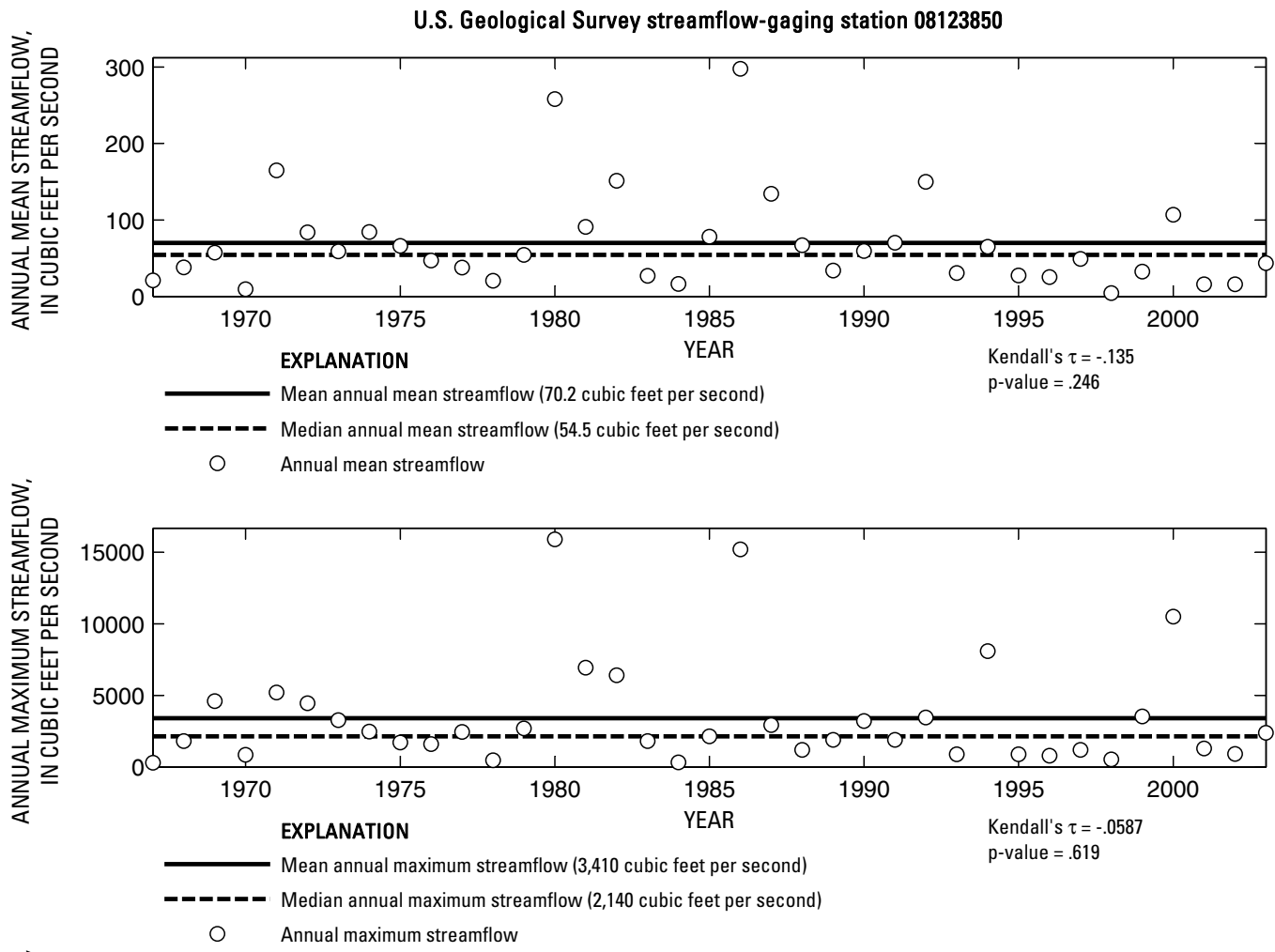

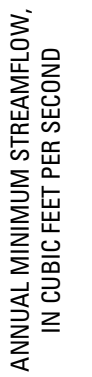

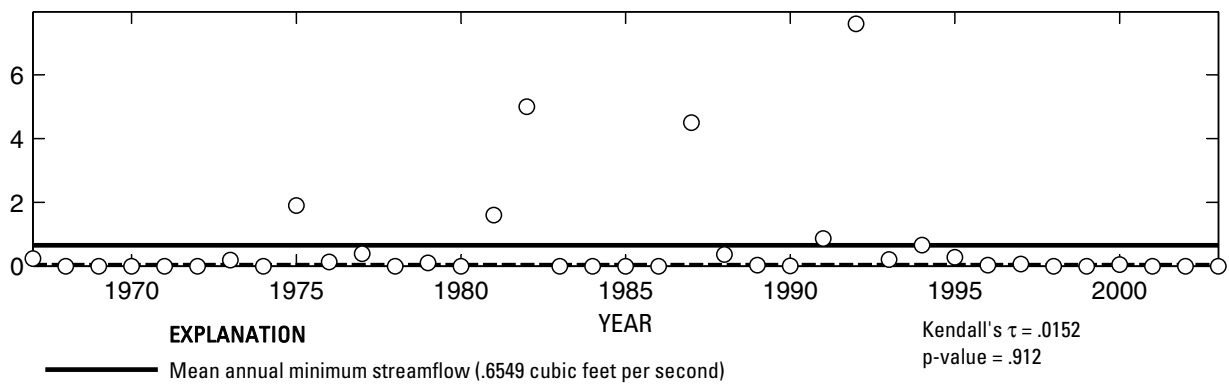

- - - - Median annual minimum streamflow (.03 cubic feet per second)

O Annual minimum streamflow

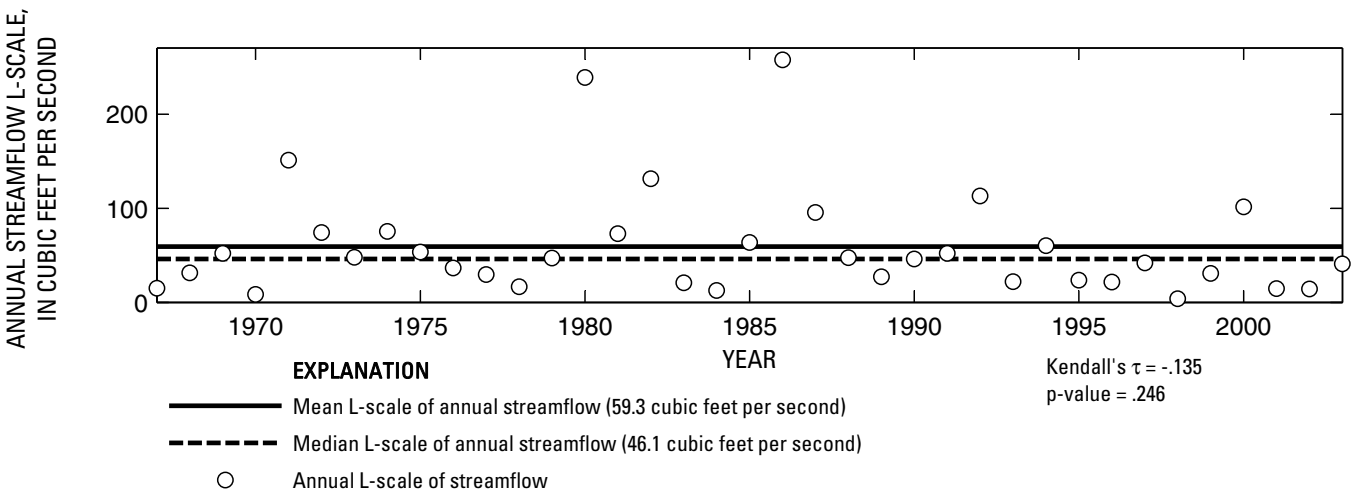

Figure 465. Analysis of annual mean, maximum, minimum, and L-scale statistics of daily mean streamflow for U.S. Geological Survey streamflow-gaging station 08123850 Colorado River above Silver, Texas. 

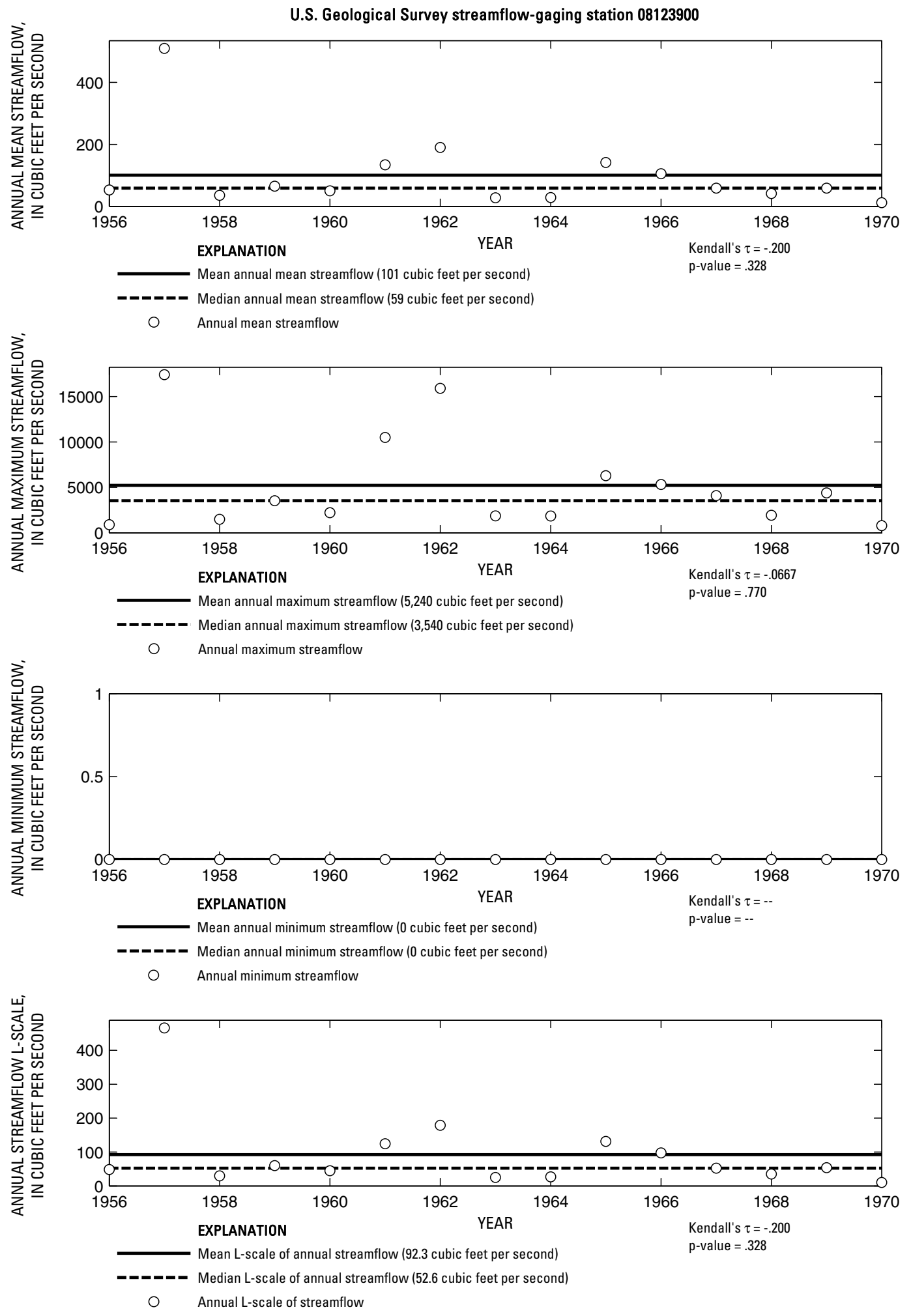

Figure 466. Analysis of annual mean, maximum, minimum, and L-scale statistics of daily mean streamflow for U.S. Geological Survey streamflow-gaging station 08123900 Colorado River near Silver, Texas. 


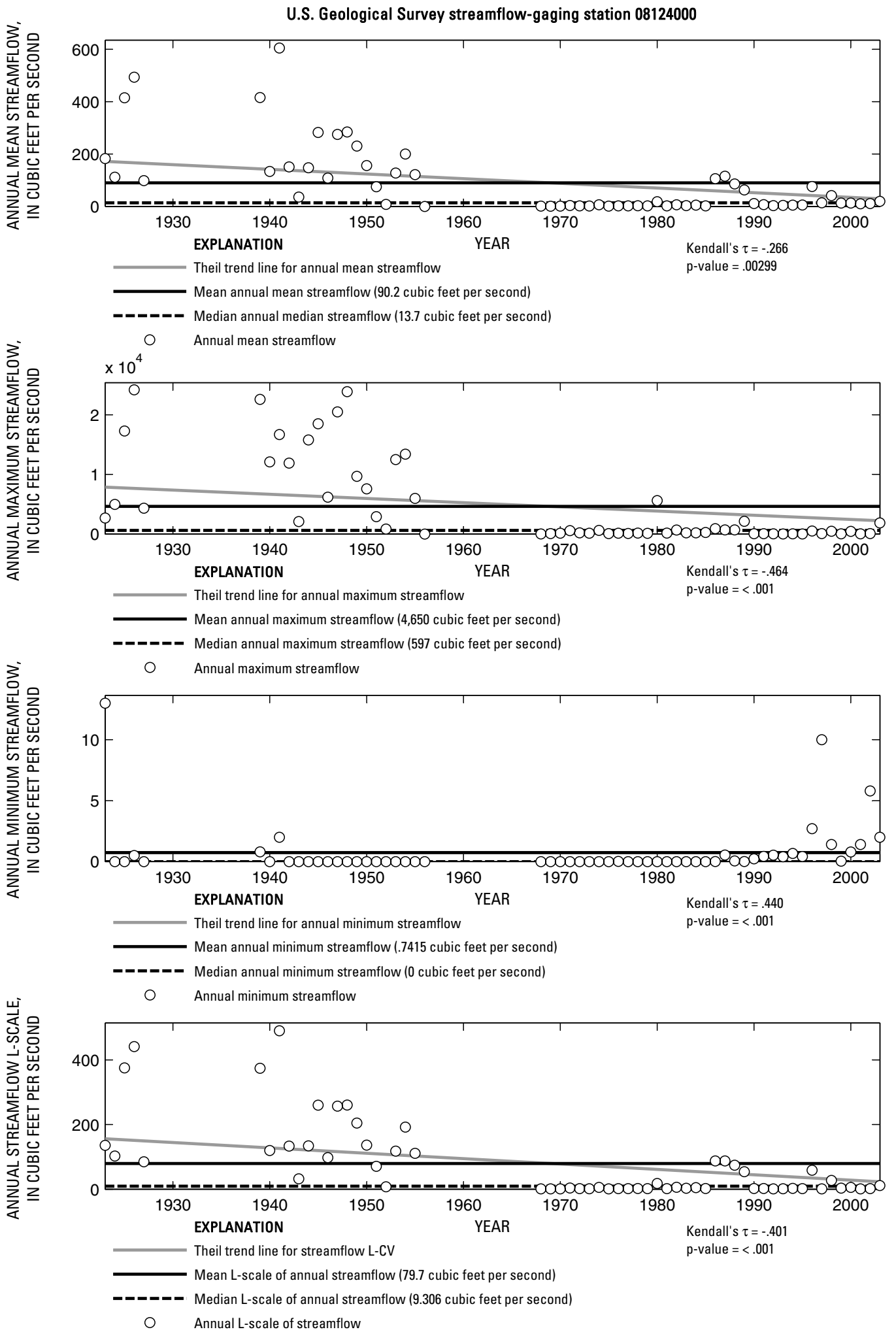

Figure 467. Analysis of annual mean, maximum, minimum, and L-scale statistics of daily mean streamflow for U.S. Geological Survey streamflow-gaging station 08124000 Colorado River at Robert Lee, Texas. 

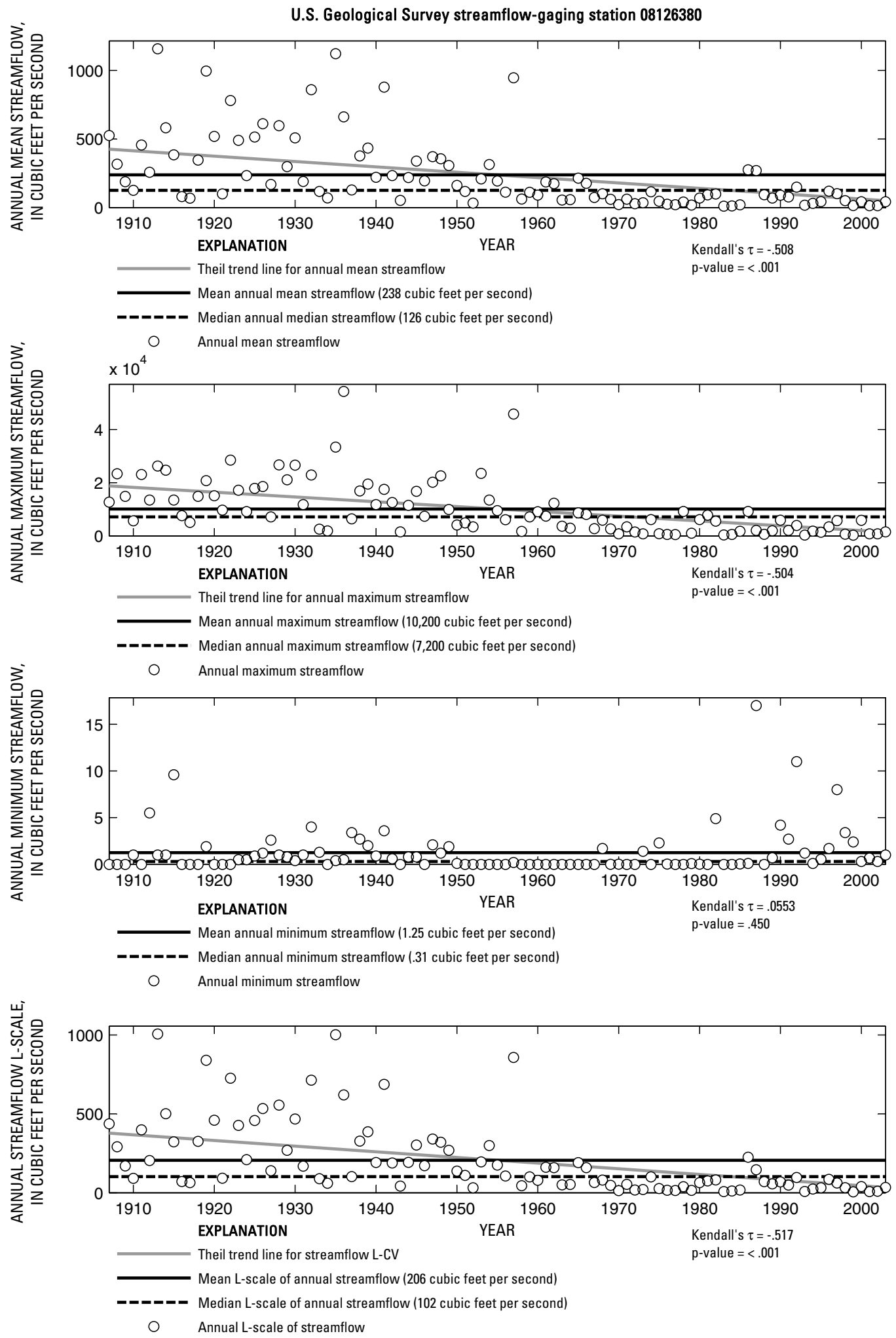

Figure 468. Analysis of annual mean, maximum, minimum, and L-scale statistics of daily mean streamflow for U.S. Geological Survey streamflow-gaging station 08126380 Colorado River near Ballinger, Texas.

|ndex of Station Numbers 719 

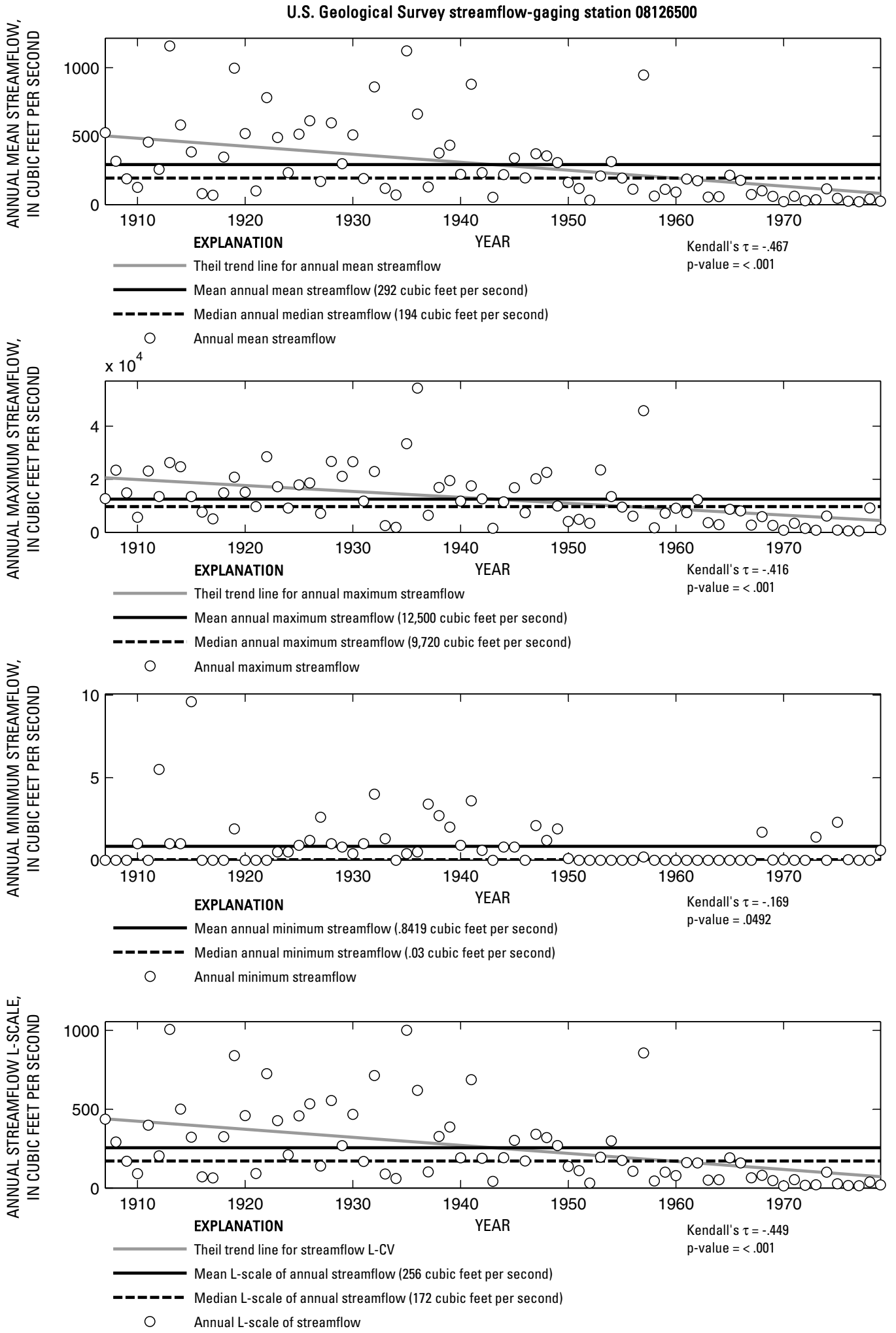

Figure 469. Analysis of annual mean, maximum, minimum, and L-scale statistics of daily mean streamflow for U.S. Geological Survey streamflow-gaging station 08126500 Colorado River at Ballinger, Texas. 

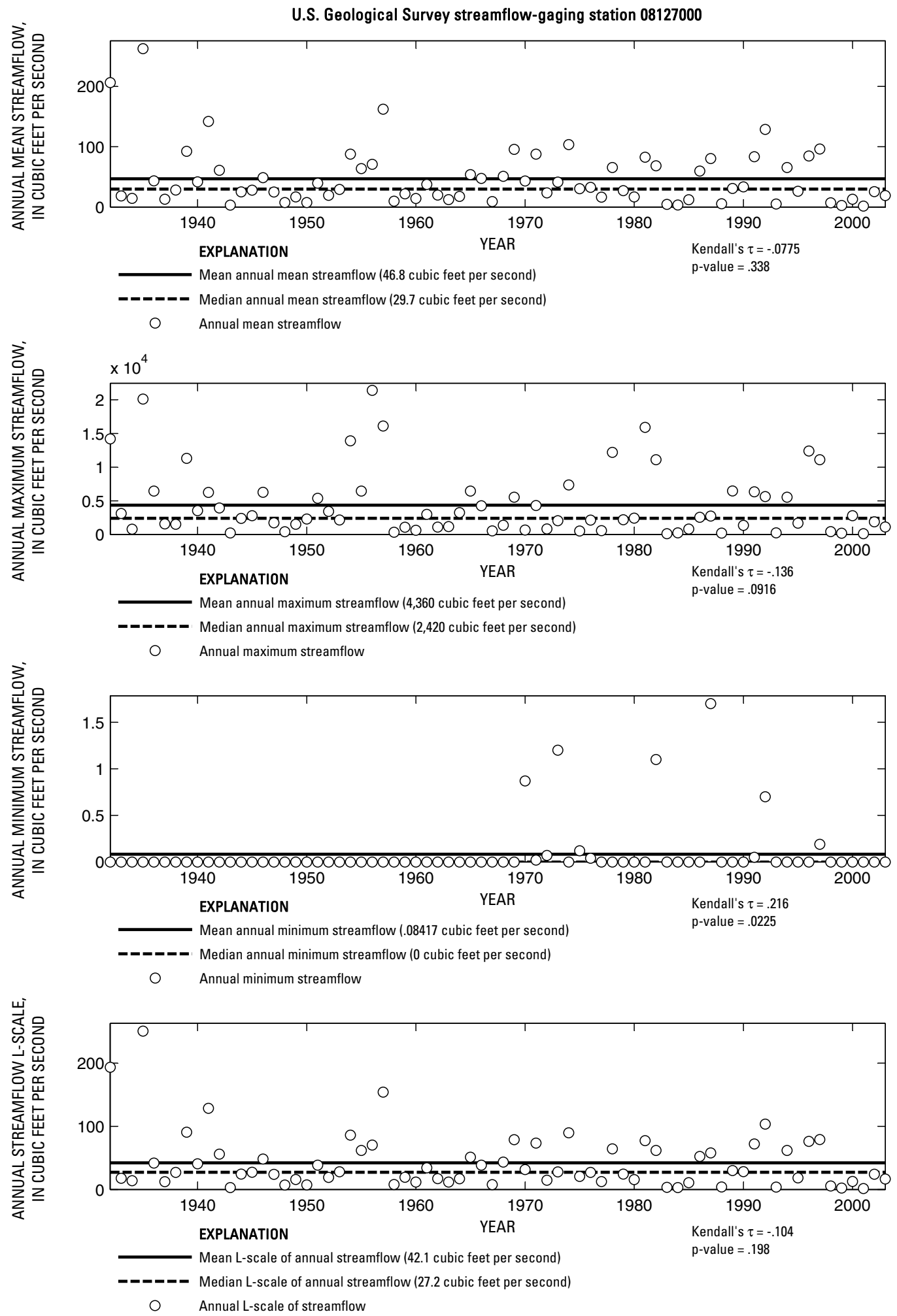

Figure 470. Analysis of annual mean, maximum, minimum, and L-scale statistics of daily mean streamflow for U.S. Geological Survey streamflow-gaging station 08127000 Elm Creek at Ballinger, Texas.

Index of Station Numbers 719 


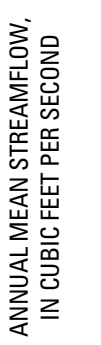

U.S. Geological Survey streamflow-gaging station 08128000

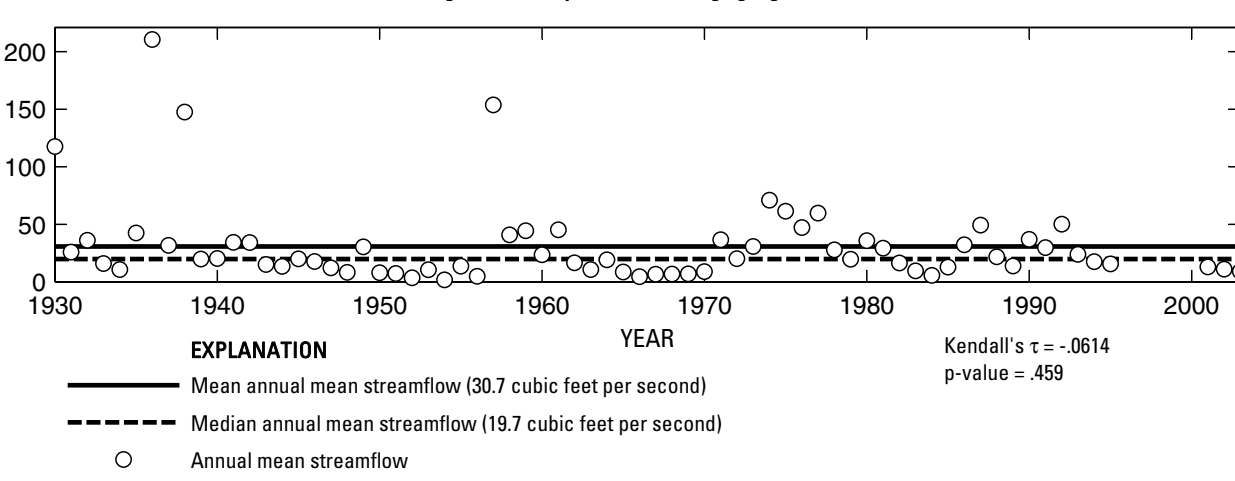

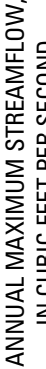
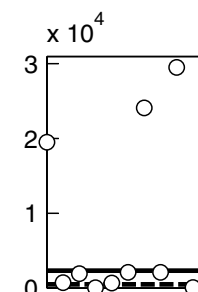

○

○

1930

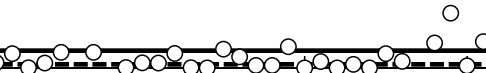

$1940 \quad 1950$

1960

EXPLANATION

YEAR

R

Mean annual maximum streamflow $(2,310$ cubic feet per second $)$

- -ーーーー Median annual maximum streamflow (487 cubic feet per second)

O Annual maximum streamflow

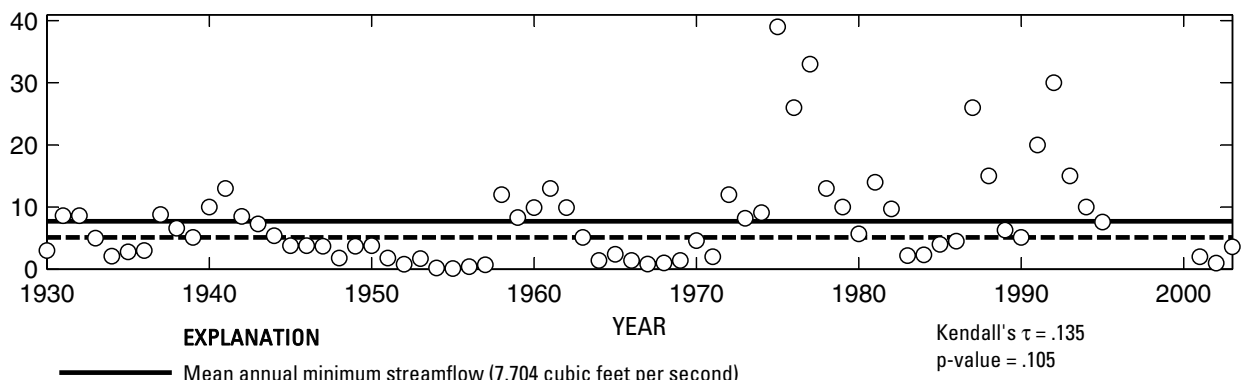

•ーーーーー Median annual minimum streamflow (5.1 cubic feet per second)

O Annual minimum streamflow

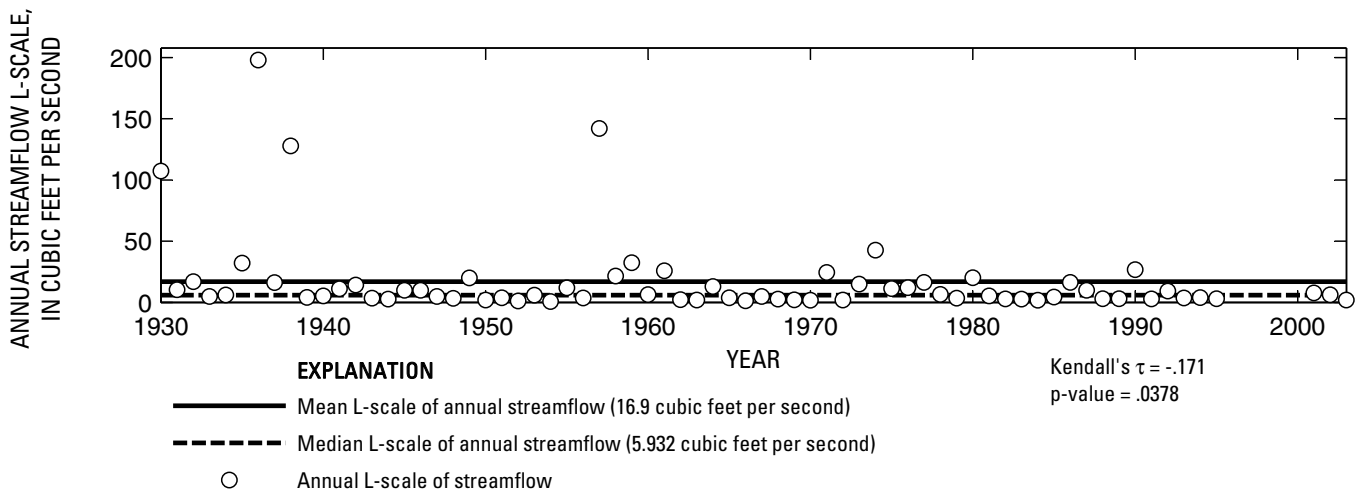

Figure 471. Analysis of annual mean, maximum, minimum, and L-scale statistics of daily mean streamflow for U.S. Geological Survey streamflow-gaging station 08128000 South Concho River at Christoval, Texas. 

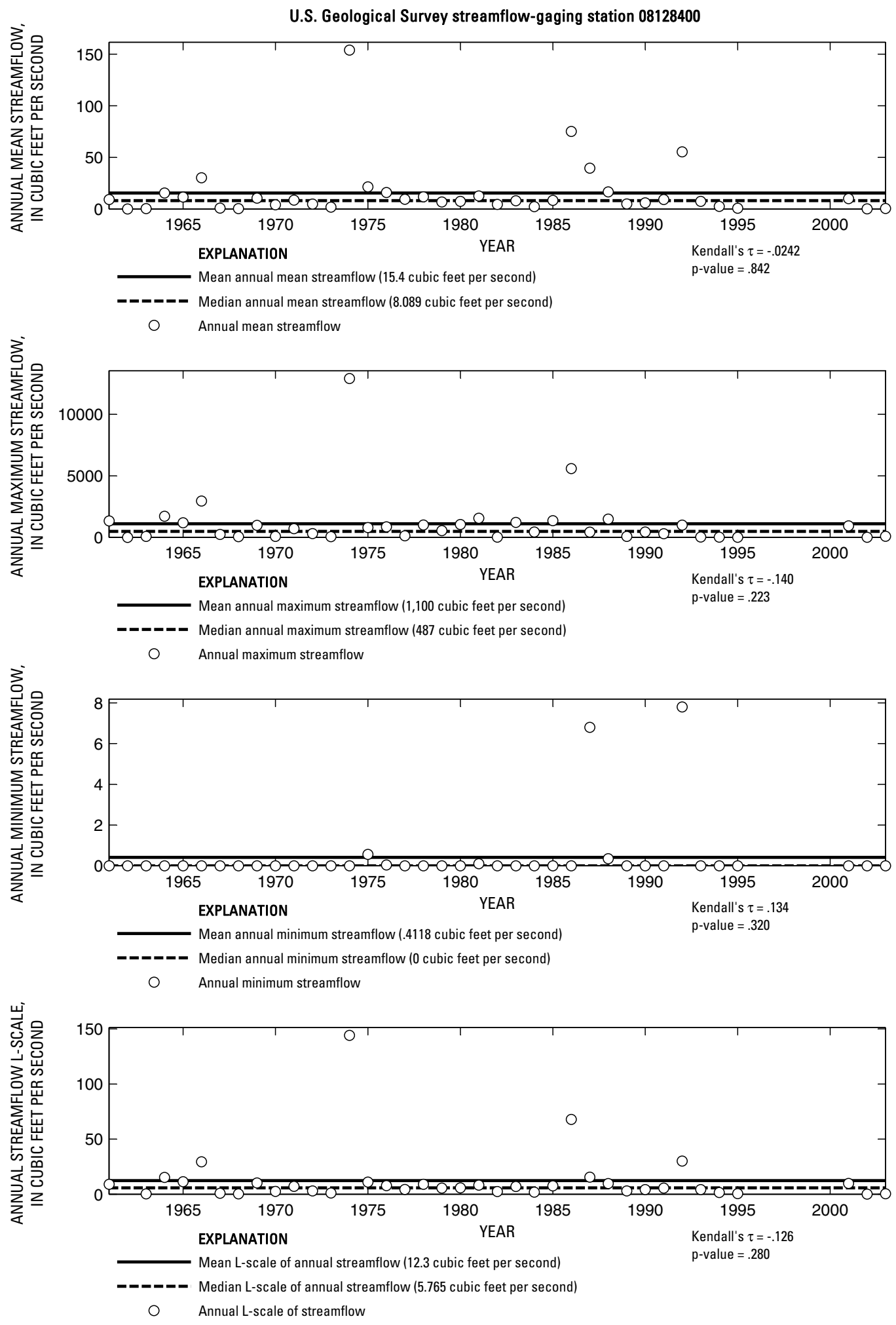

Figure 472. Analysis of annual mean, maximum, minimum, and L-scale statistics of daily mean streamflow for U.S. Geological Survey streamflow-gaging station 08128400 Middle Concho River above Tankersley, Texas.

Index of Station Numbers 719 

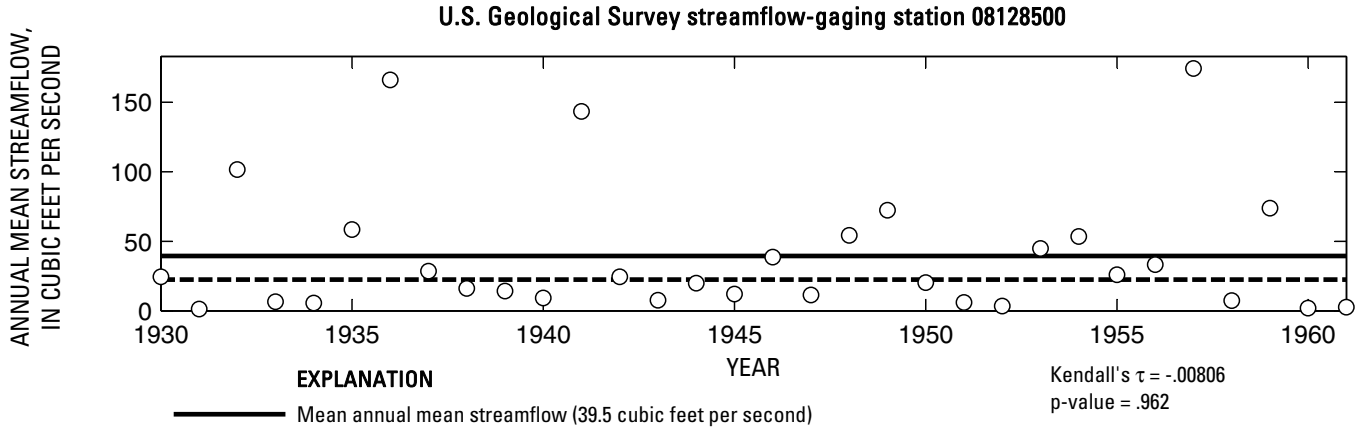

-_-_- Median annual mean streamflow (22.4 cubic feet per second)

O Annual mean streamflow

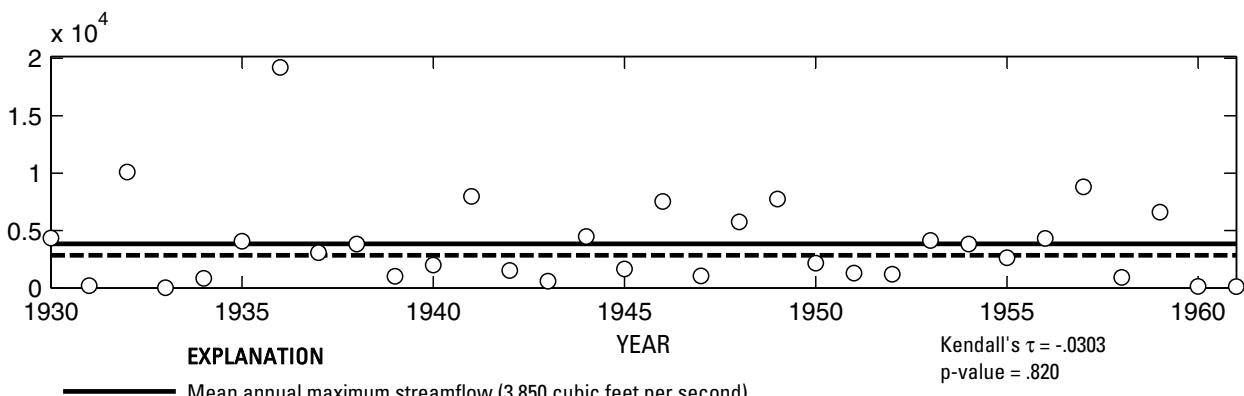

- ב - Median annual maximum streamflow (2,860 cubic feet per second)

Annual maximum streamflow

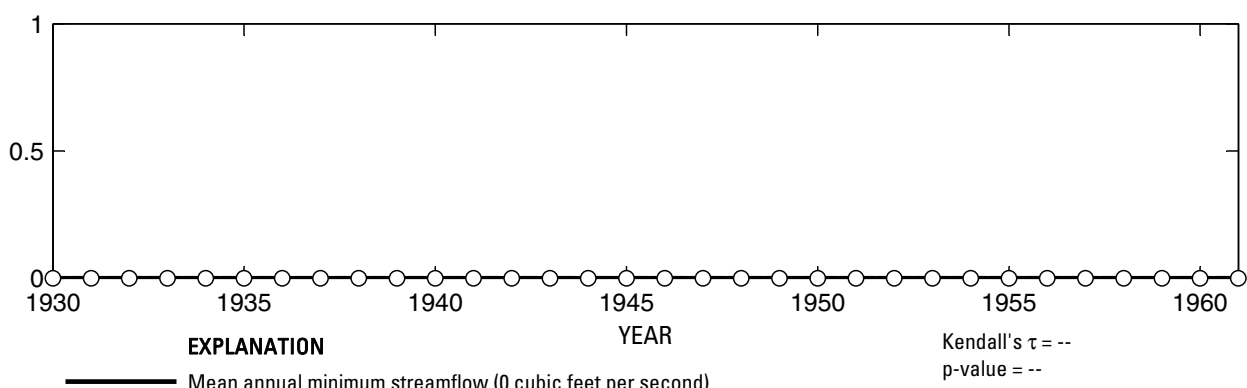

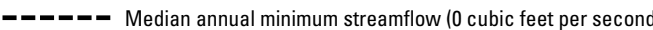

O Annual minimum streamflow

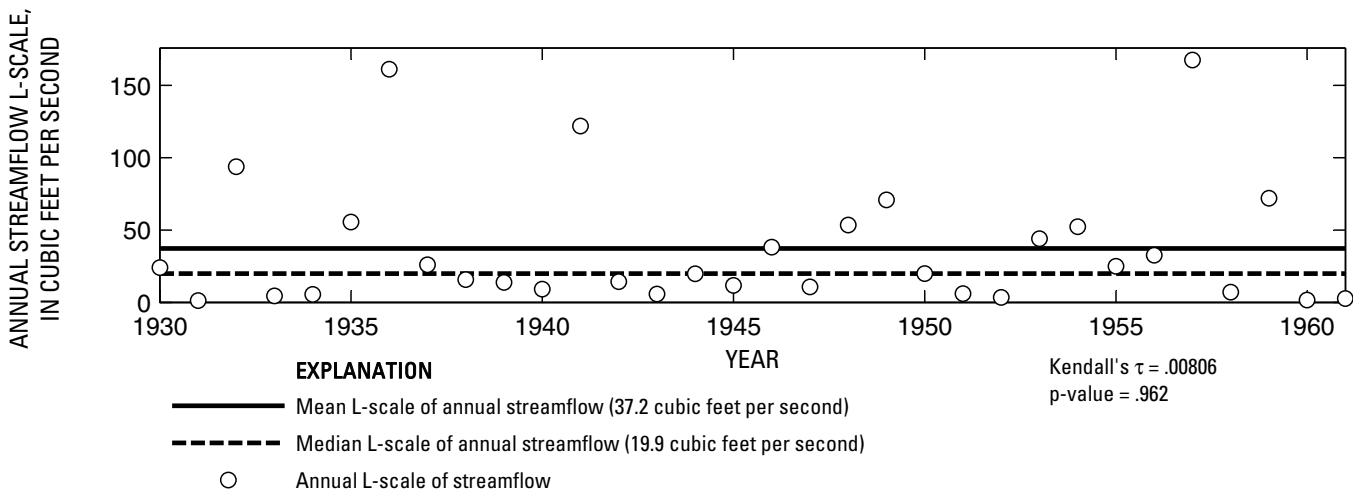

Figure 473. Analysis of annual mean, maximum, minimum, and L-scale statistics of daily mean streamflow for U.S. Geological Survey streamflow-gaging station 08128500 Middle Concho River near Tankersley, Texas. 

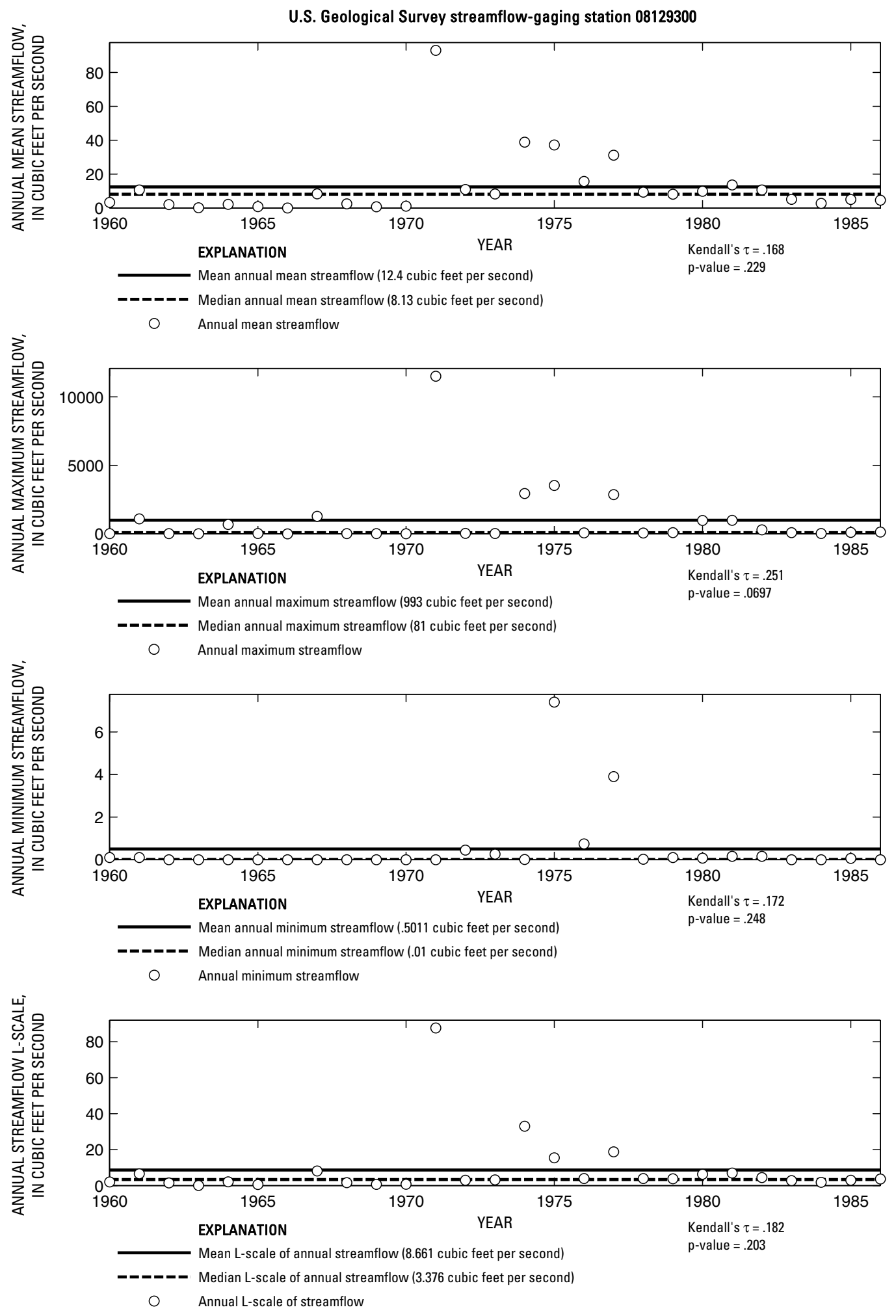

Figure 474. Analysis of annual mean, maximum, minimum, and L-scale statistics of daily mean streamflow for U.S. Geological Survey streamflow-gaging station 08129300 Spring Creek above Tankersley, Texas. 


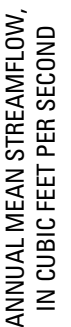

U.S. Geological Survey streamflow-gaging station 08130500

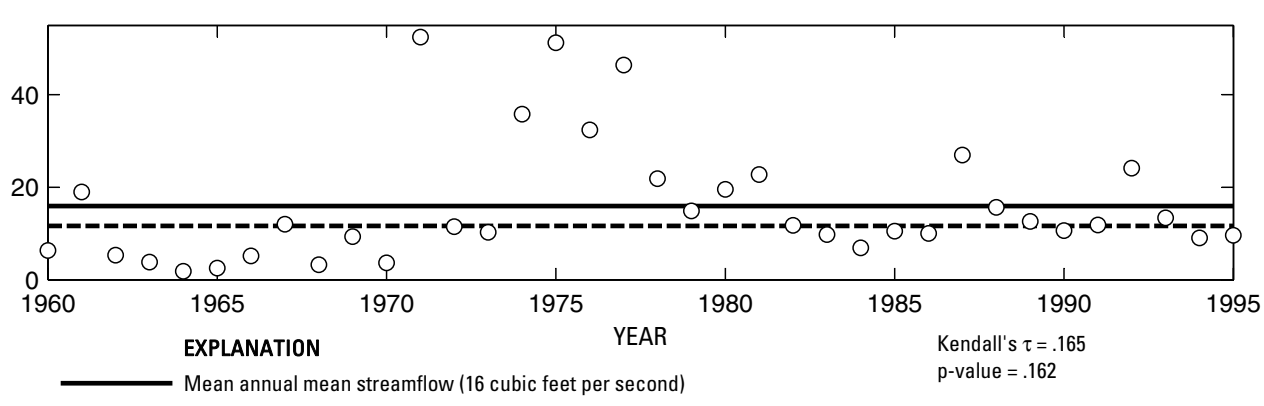

-_-_- Median annual mean streamflow (11.6 cubic feet per second)

O Annual mean streamflow

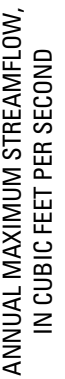

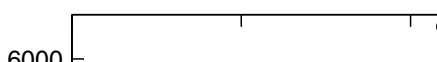

$6000-$

$4000-$

$2000-$

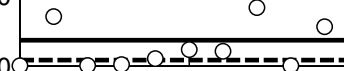

1960

1965

1970

EXPLANATION

Mean annual maximum streamflow (735 cubic feet per second)

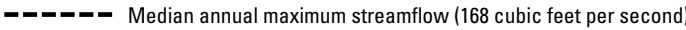

O Annual maximum streamflow

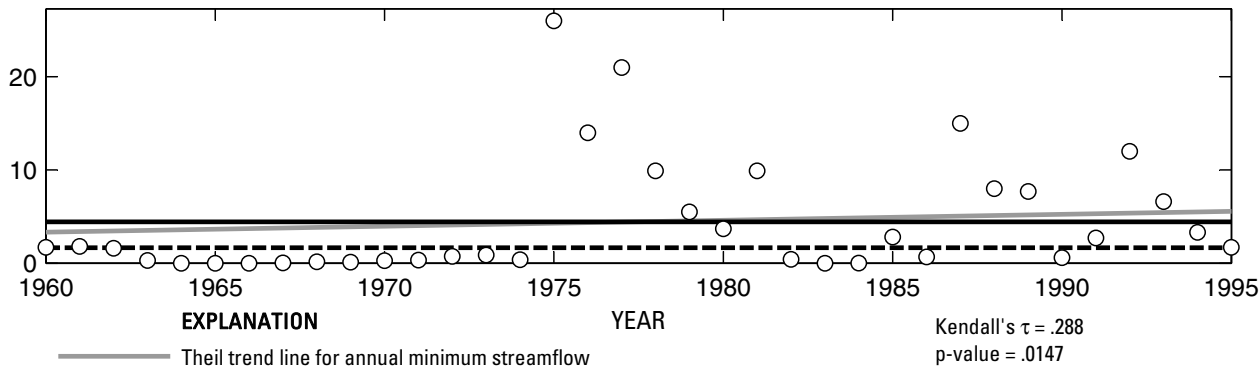

Mean annual minimum streamflow (4.438 cubic feet per second)

-ーーーーー Median annual minimum streamflow (1.65 cubic feet per second)

O Annual minimum streamflow
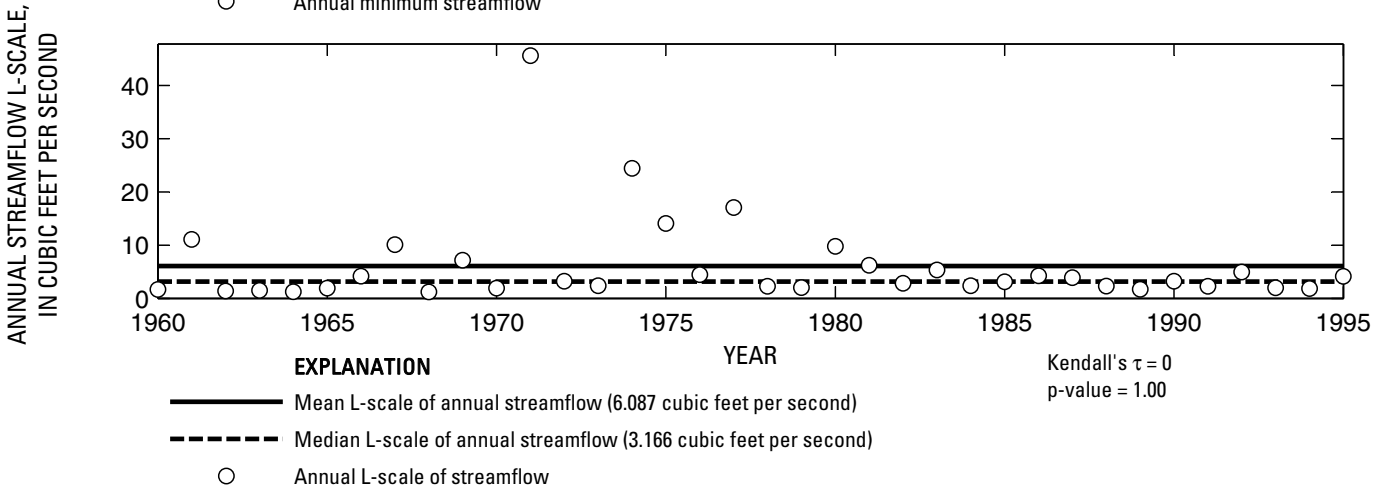

Figure 475. Analysis of annual mean, maximum, minimum, and L-scale statistics of daily mean streamflow for U.S. Geological Survey streamflow-gaging station 08130500 Dove Creek at Knickerbocker, Texas. 


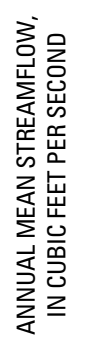

U.S. Geological Survey streamflow-gaging station 08130700

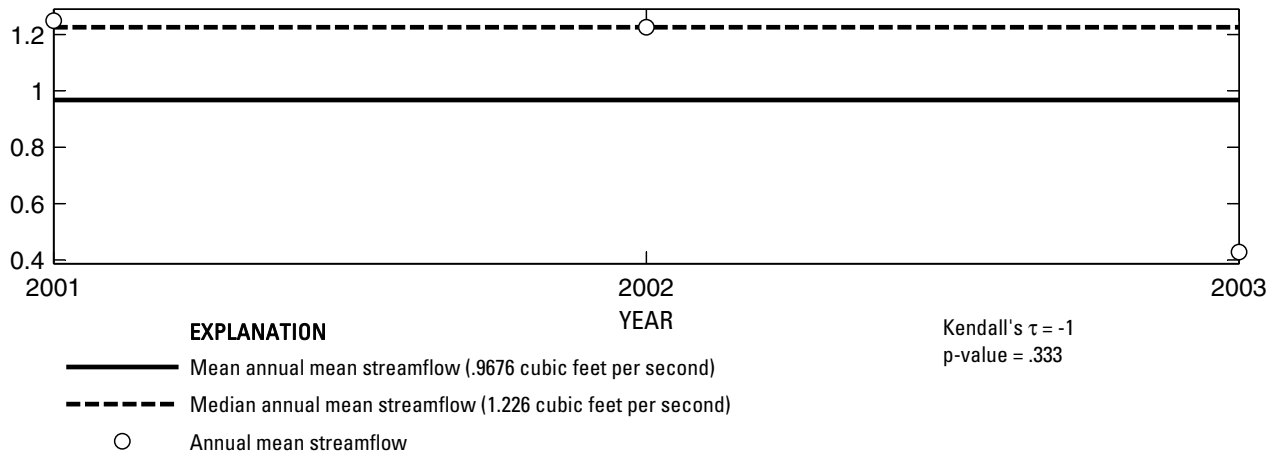

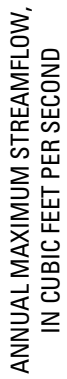

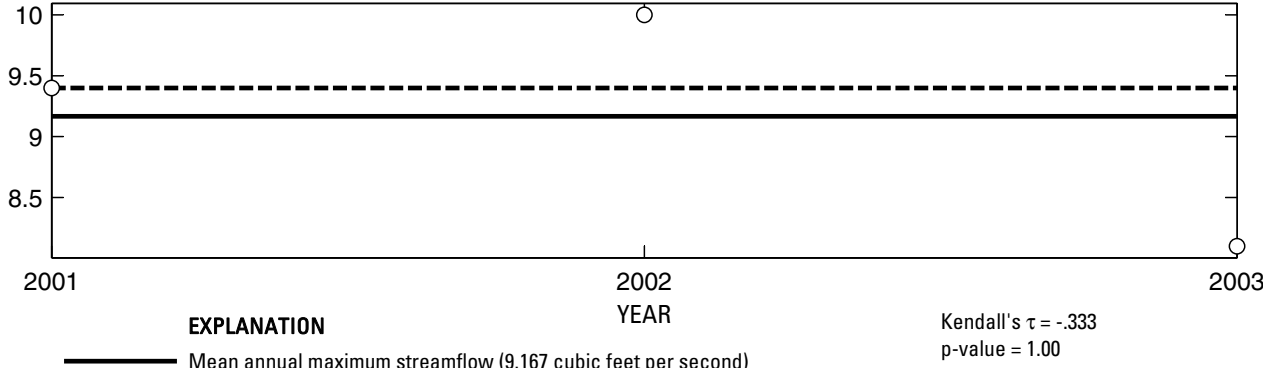

- Median annual maximum streamflow (9.4 cubic feet per second)

$\bigcirc \quad$ Annual maximum streamflow

崔

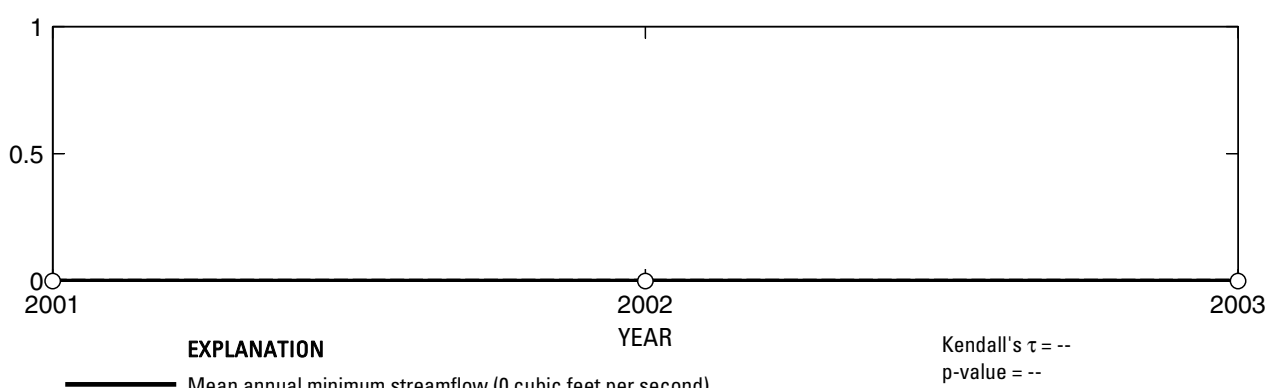

Mean annual minimum streamflow (0 cubic feet per second)

p-value $=--$

- - - Median annual minimum streamflow (0 cubic feet per second)

O Annual minimum streamflow

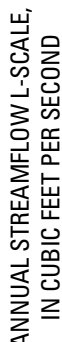

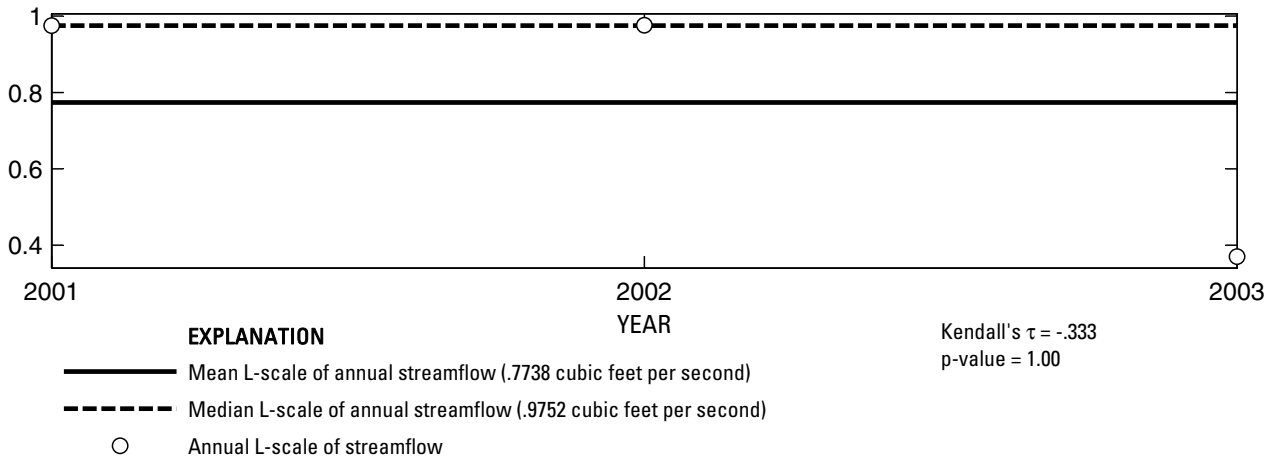

Figure 476. Analysis of annual mean, maximum, minimum, and L-scale statistics of daily mean streamflow for U.S. Geological Survey streamflow-gaging station 08130700 Spring Creek above Twin Buttes Reservoir near San Angelo, Texas. 


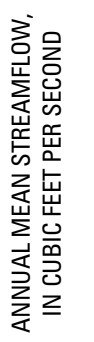

U.S. Geological Survey streamflow-gaging station 08131000

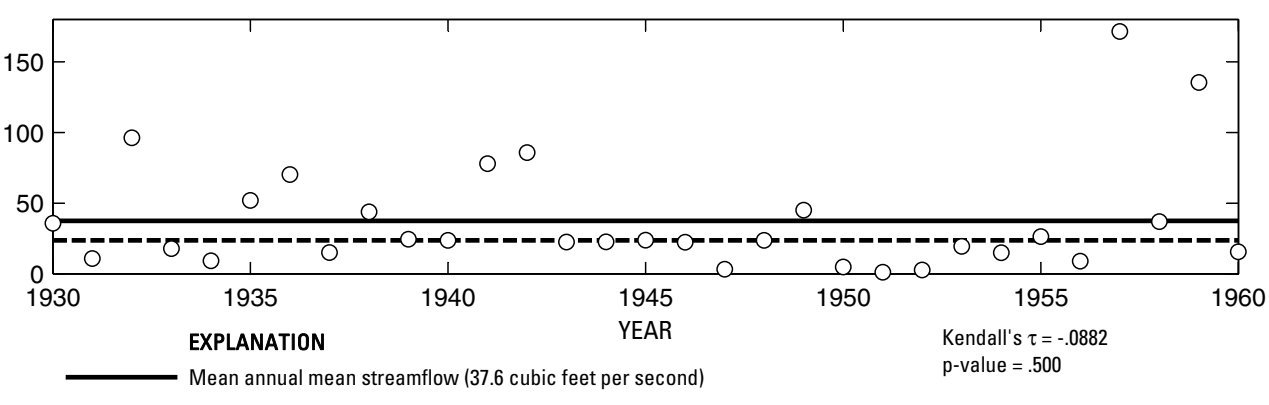

-_-_- Median annual mean streamflow (23.7 cubic feet per second)

O Annual mean streamflow

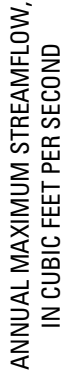

$\times 10^{4}$

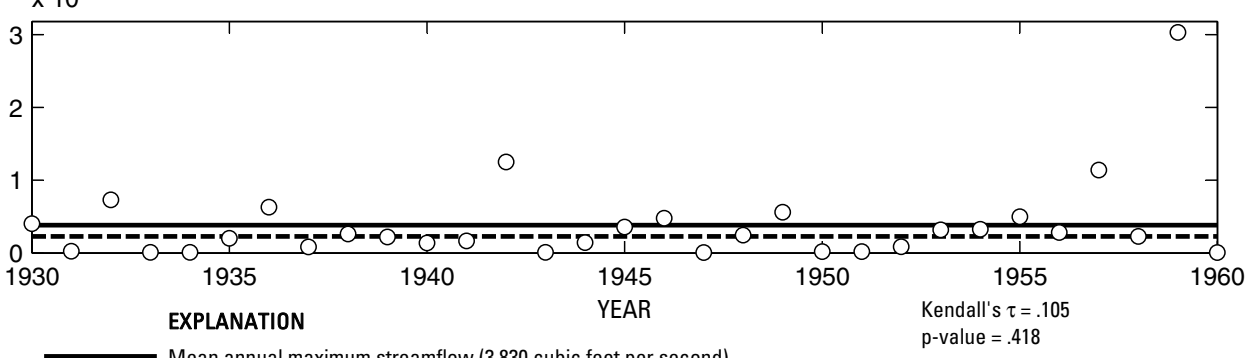

Mean annual maximum streamflow (3,830 cubic feet per second)

- - - Median annual maximum streamflow (2,280 cubic feet per second)

Annual maximum streamflow

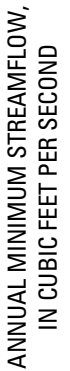

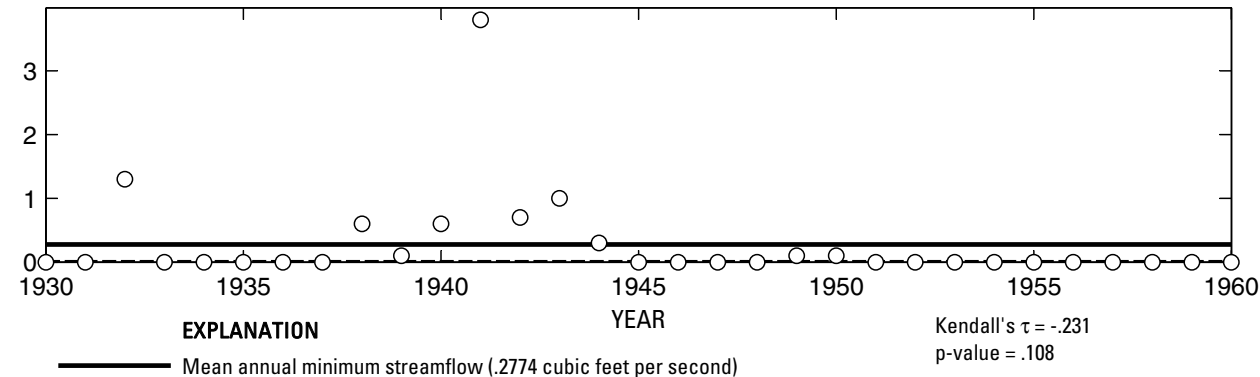

- - Median annual minimum streamflow (0 cubic feet per second)

O Annual minimum streamflow

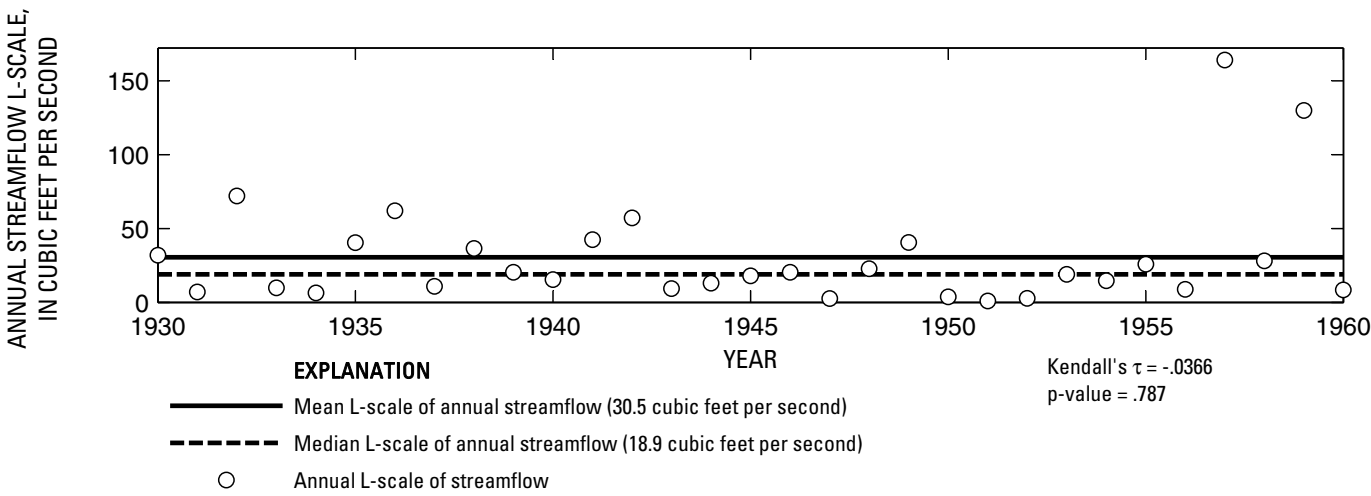

Figure 477. Analysis of annual mean, maximum, minimum, and L-scale statistics of daily mean streamflow for U.S. Geological Survey streamflow-gaging station 08131000 Spring Creek near Tankersley, Texas. 
U.S. Geological Survey streamflow-gaging station 08131400

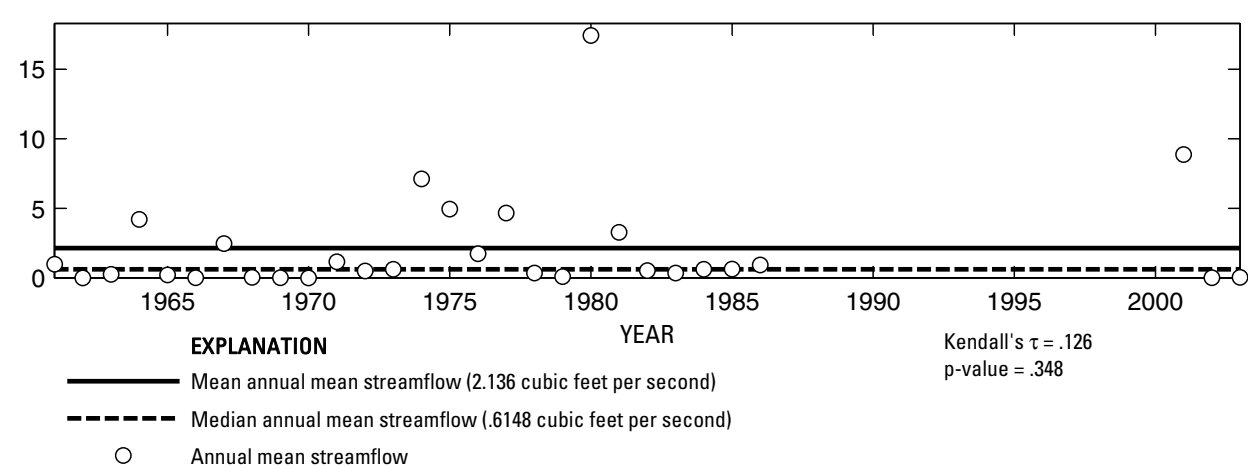

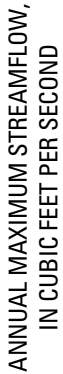

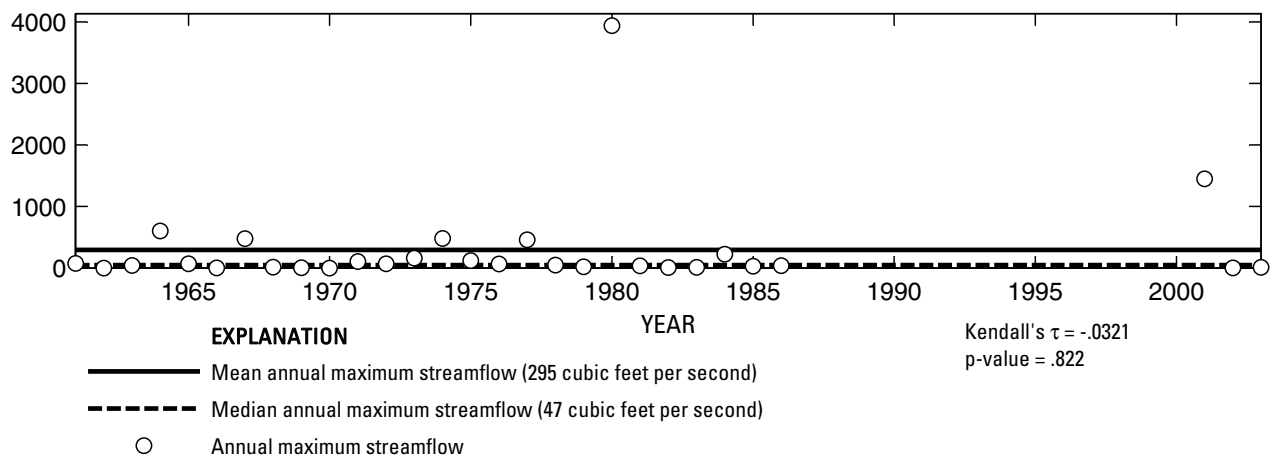

崔

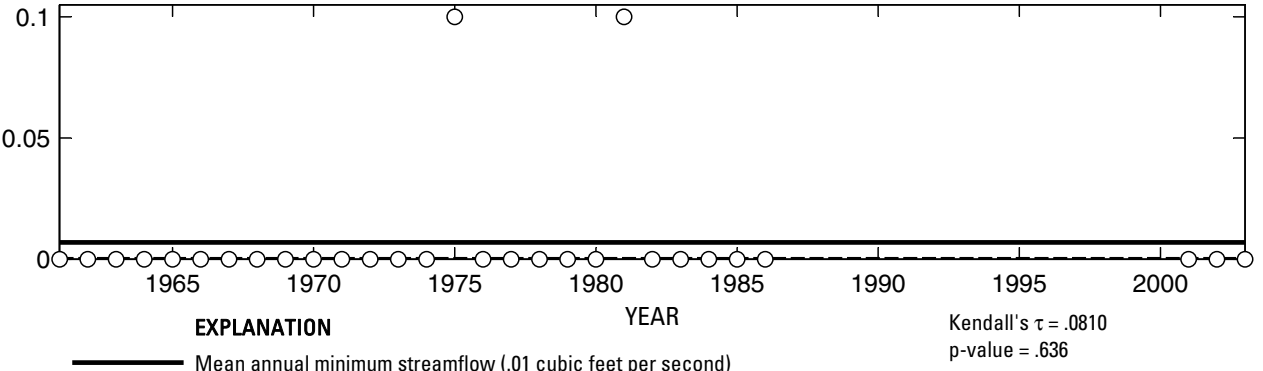

- Median annual minimum streamflow (0 cubic feet per second)

○ Annual minimum streamflow

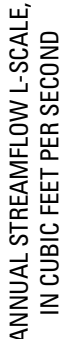

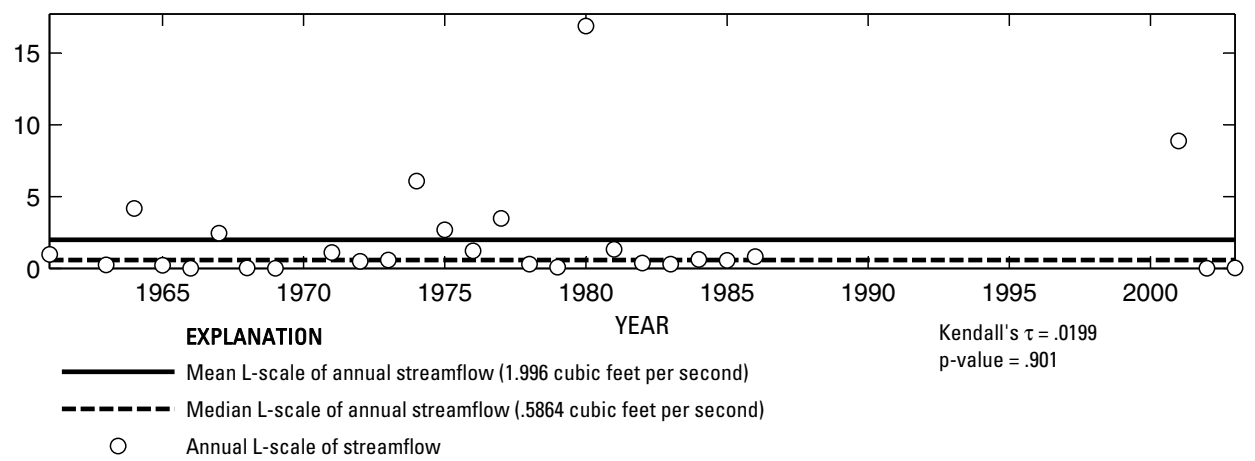

Figure 478. Analysis of annual mean, maximum, minimum, and L-scale statistics of daily mean streamflow for U.S. Geological Survey streamflow-gaging station 08131400 Pecan Creek near San Angelo, Texas.

Index of Station Numbers 719 


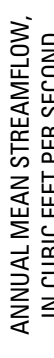

U.S. Geological Survey streamflow-gaging station 08132500

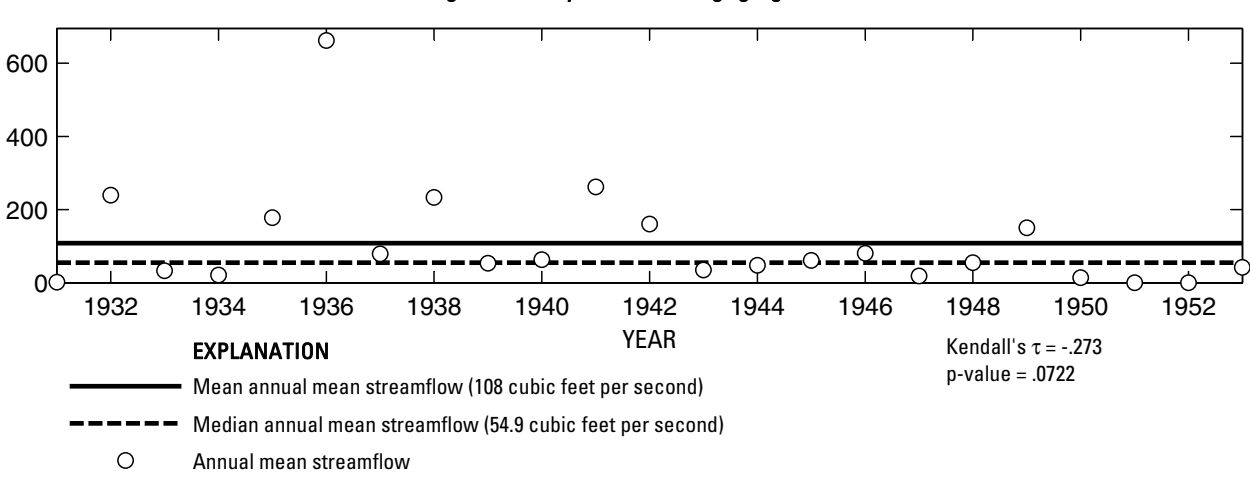

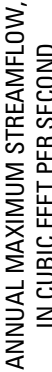

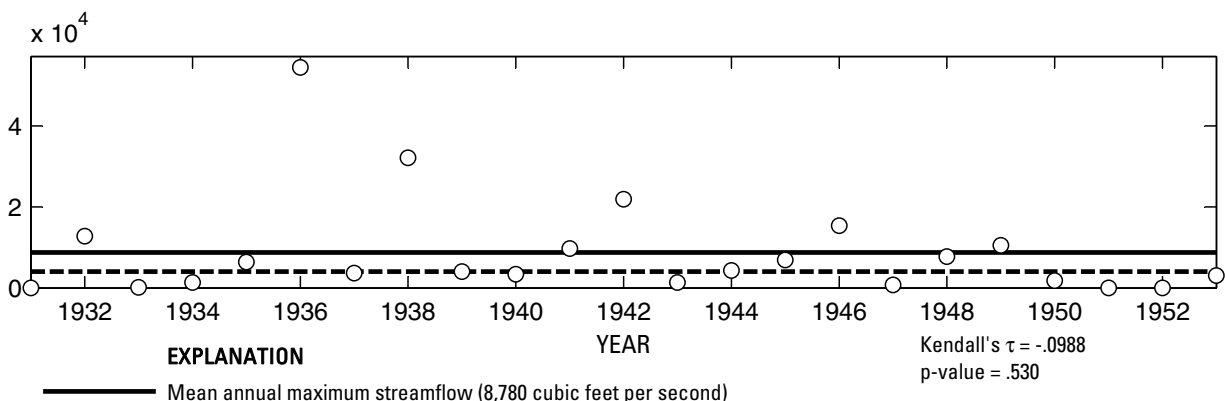

- _ - Median annual maximum streamflow (4,070 cubic feet per second)

Annual maximum streamflow

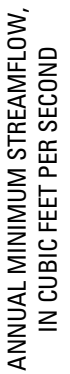

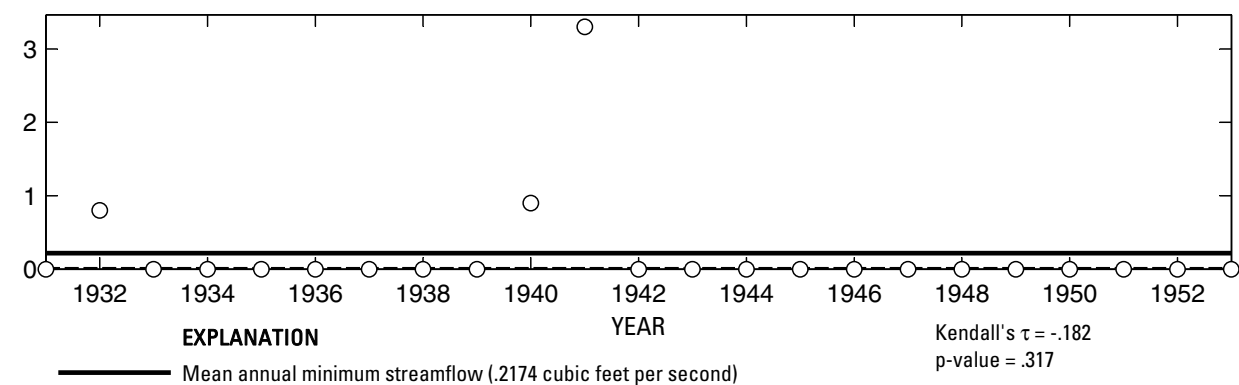

- Median annual minimum streamflow (0 cubic feet per second)

O Annual minimum streamflow

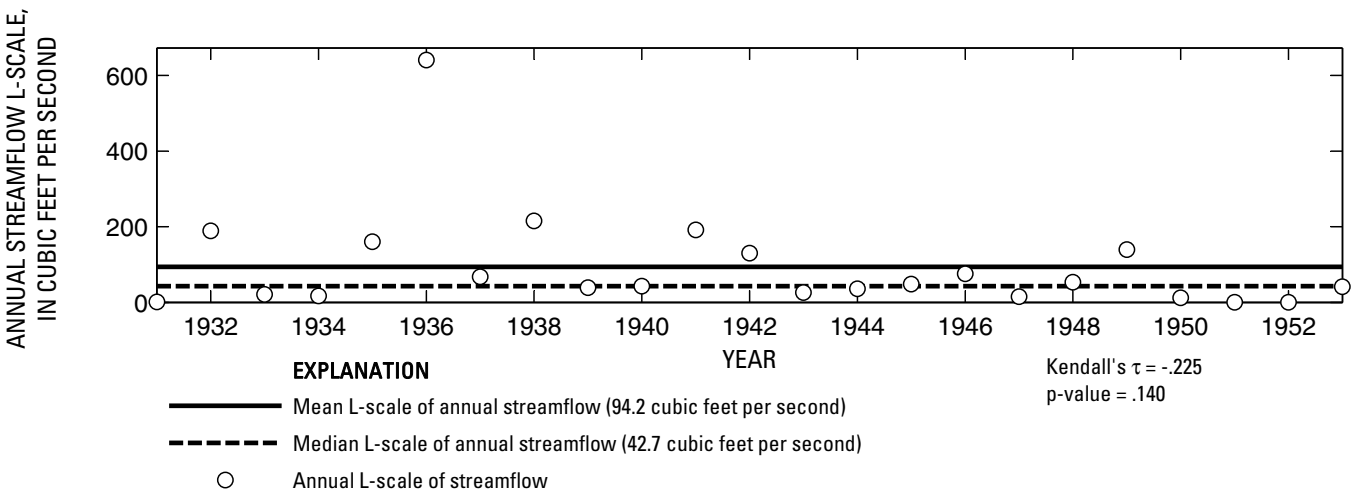

Figure 479. Analysis of annual mean, maximum, minimum, and L-scale statistics of daily mean streamflow for U.S. Geological Survey streamflow-gaging station 08132500 South Concho River at San Angelo, Texas. 


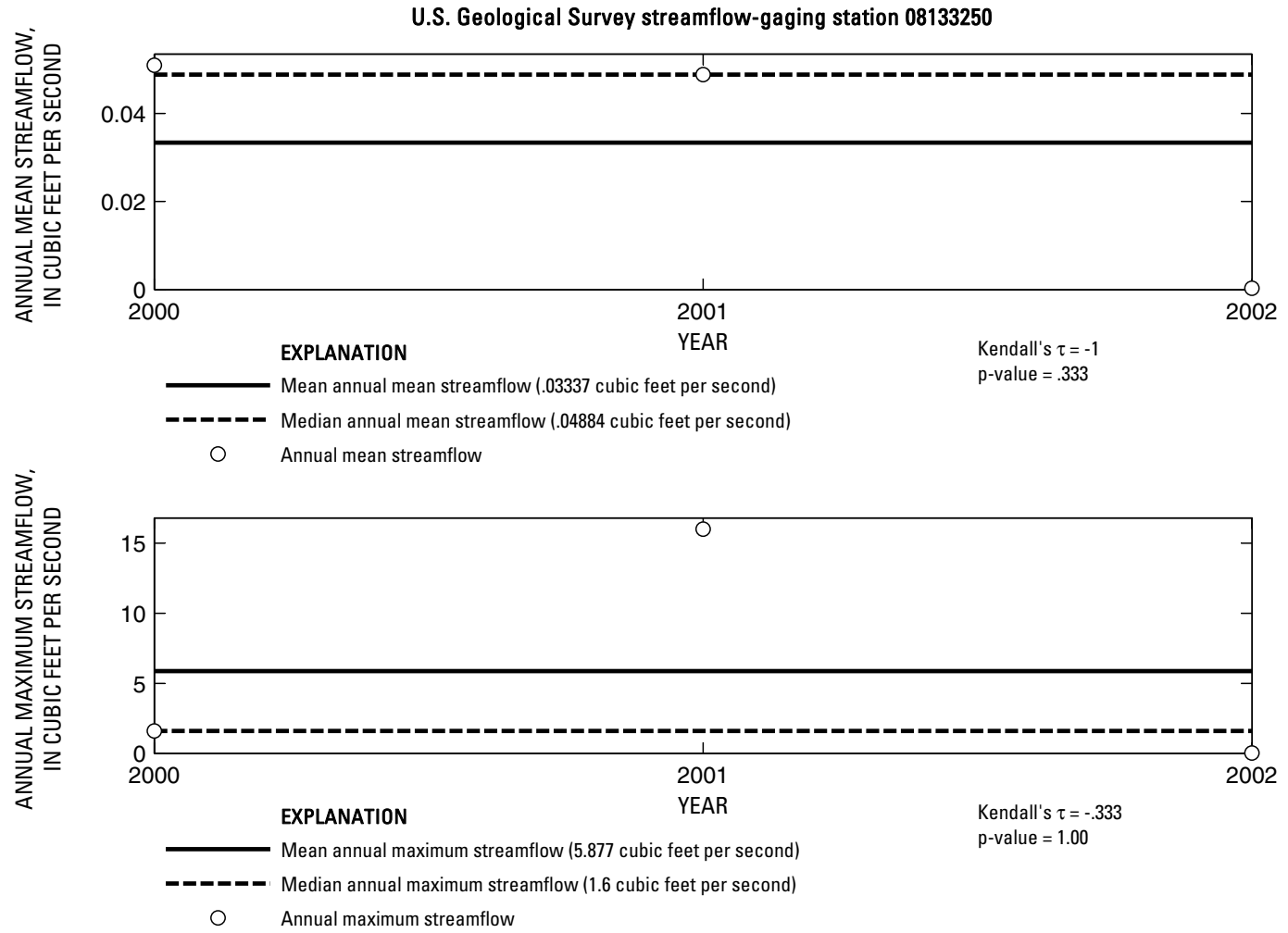

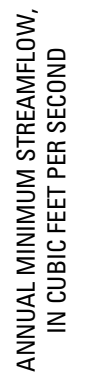

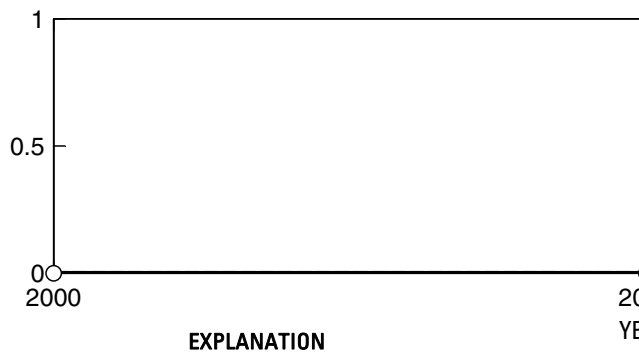

Mean annual minimum streamflow (0 cubic feet per second)

- ב-ב Median annual minimum streamflow (0 cubic feet per second)

O Annual minimum streamflow

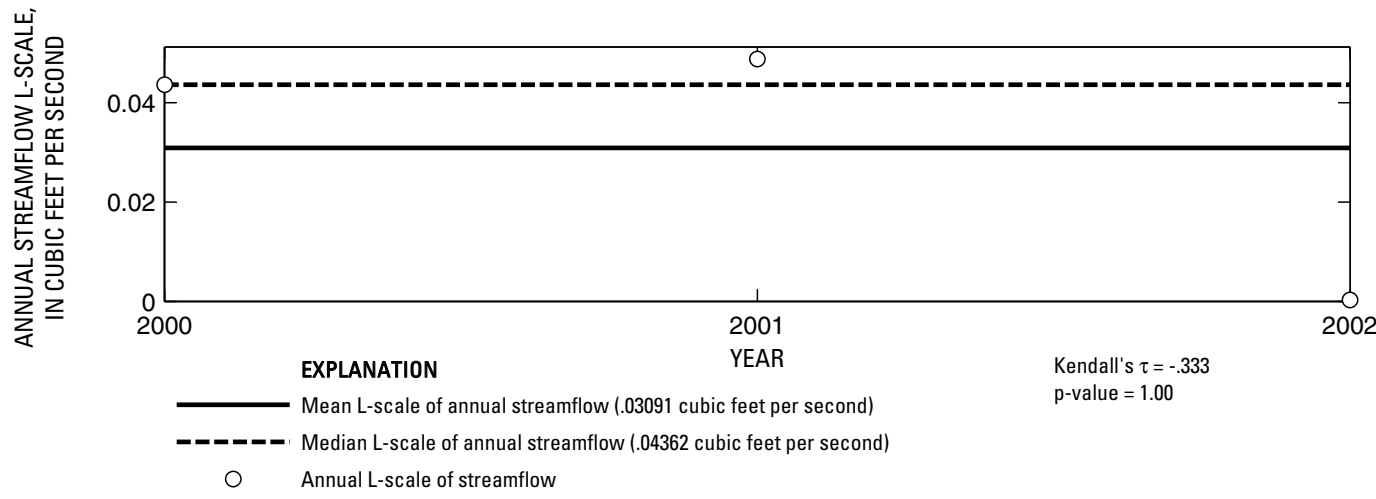

Figure 480. Analysis of annual mean, maximum, minimum, and L-scale statistics of daily mean streamflow for U.S. Geological Survey streamflow-gaging station 08133250 North Concho River above Sterling City, Texas.

Index of Station Numbers 719 


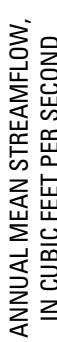

U.S. Geological Survey streamflow-gaging station 08133500

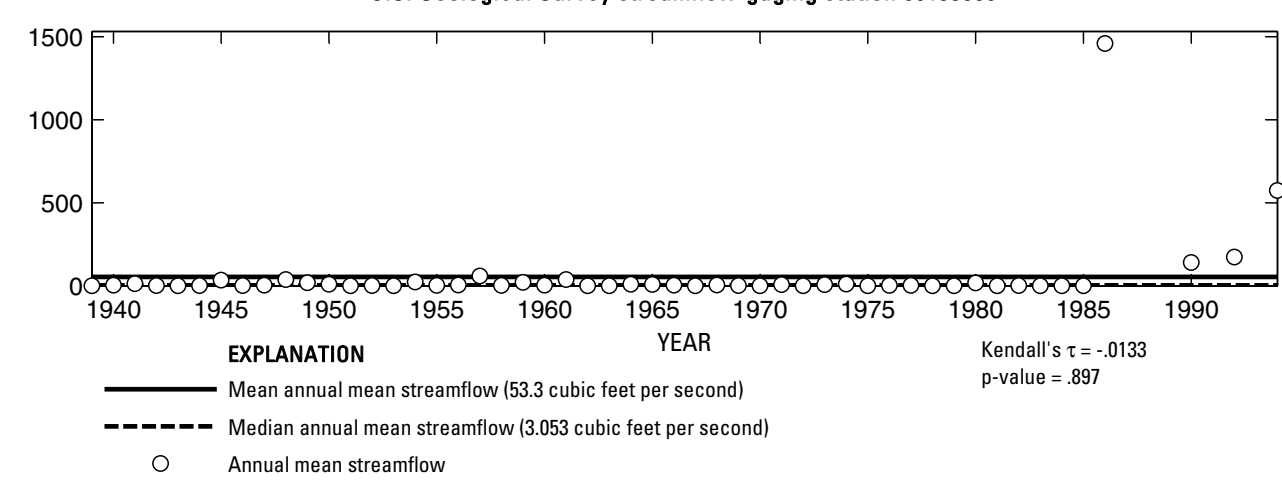

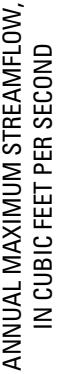

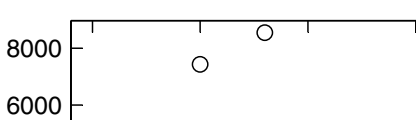

6000

2000

0

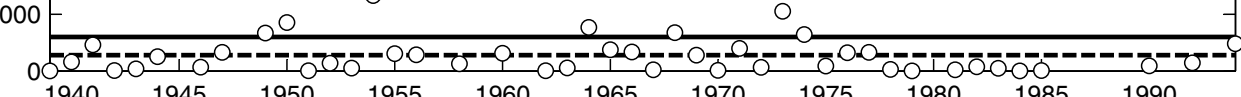

\begin{tabular}{rrrrrrrrrrr}
1940 & 1945 & 1950 & 1955 & 1960 & 1965 & 1970 & 1975 & 1980 & 1985 & 1990 \\
EXPLANATION & & & & YEAR & & \multicolumn{3}{c}{ Kendall's $\tau=-.0604$} &
\end{tabular}

Mean annual maximum streamflow (1,200 cubic feet per second)

$\mathrm{p}$-value $=.537$

- - - - Median annual maximum streamflow (558 cubic feet per second)

O Annual maximum streamflow

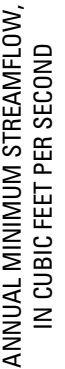

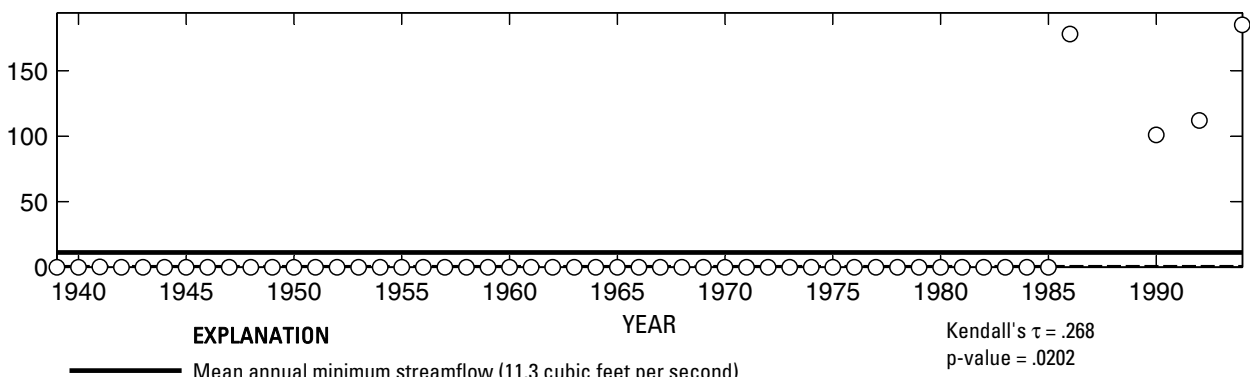

- - - - Median annual minimum streamflow $(0$ cubic feet per second)

O Annual minimum streamflow

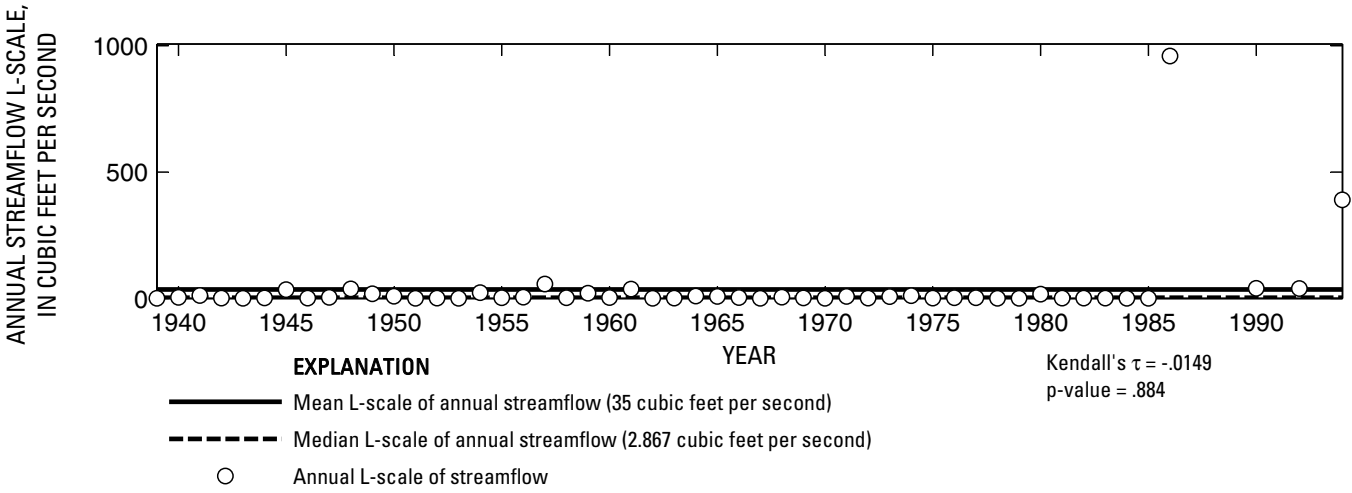

Figure 481. Analysis of annual mean, maximum, minimum, and L-scale statistics of daily mean streamflow for U.S. Geological Survey streamflow-gaging station 08133500 North Concho River at Sterling City, Texas. 
U.S. Geological Survey streamflow-gaging station 08133900

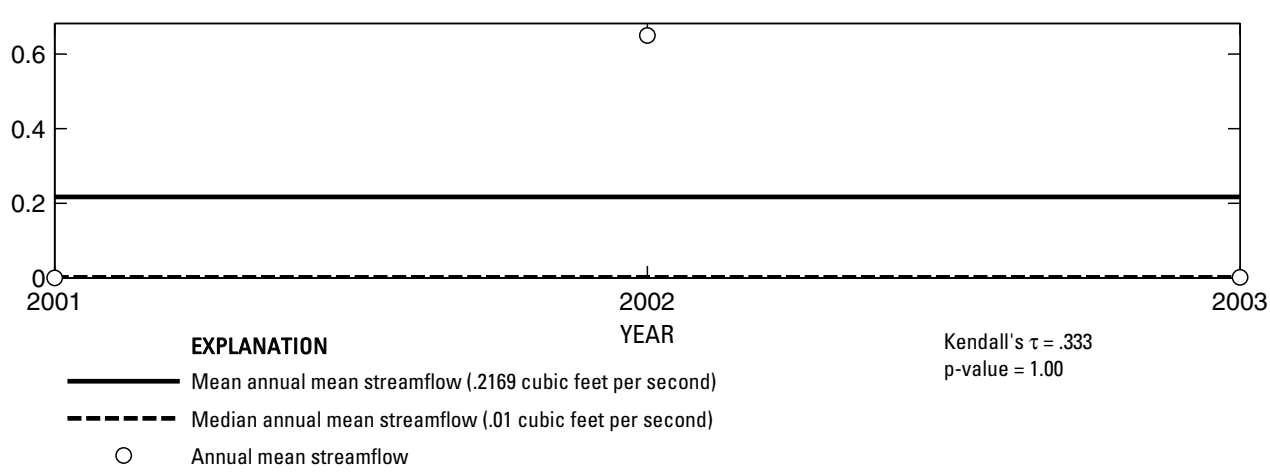

学

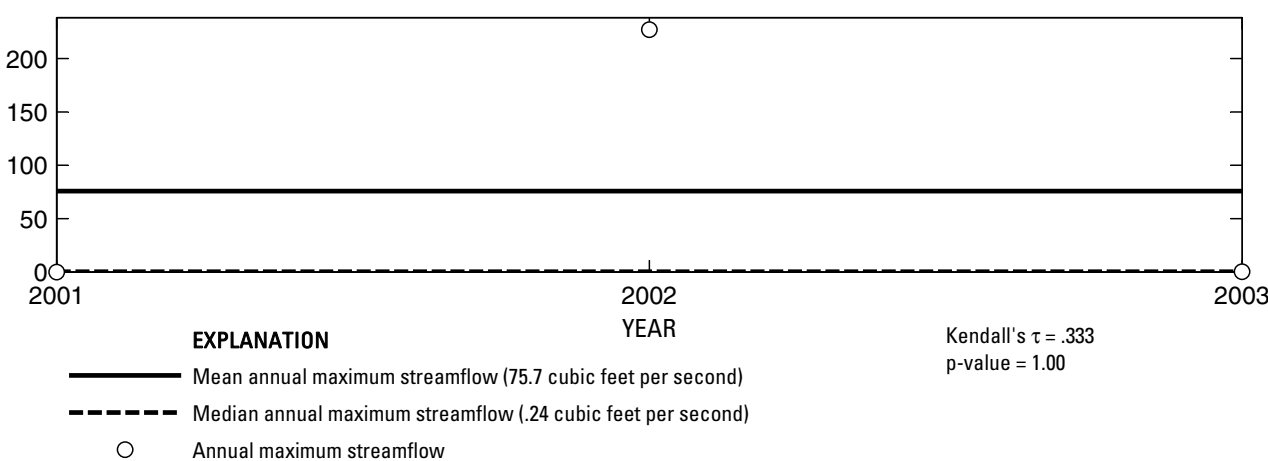

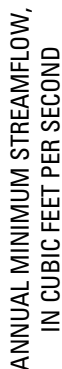

$$
\begin{array}{r}
1 \\
0.5 \\
0 \\
2001
\end{array}
$$

Annual maximum streamflow

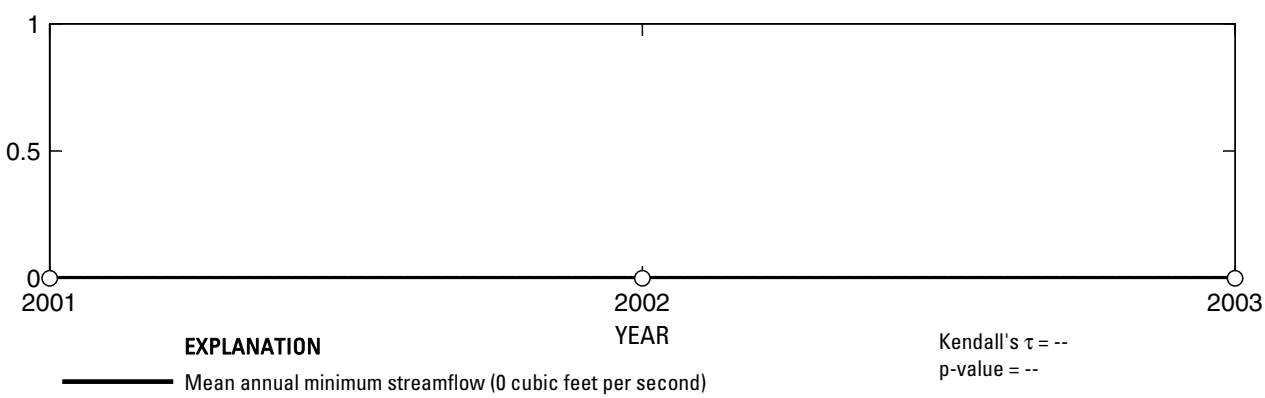

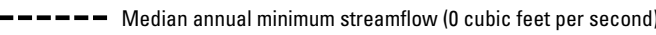

O Annual minimum streamflow

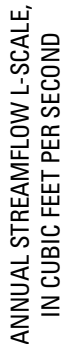

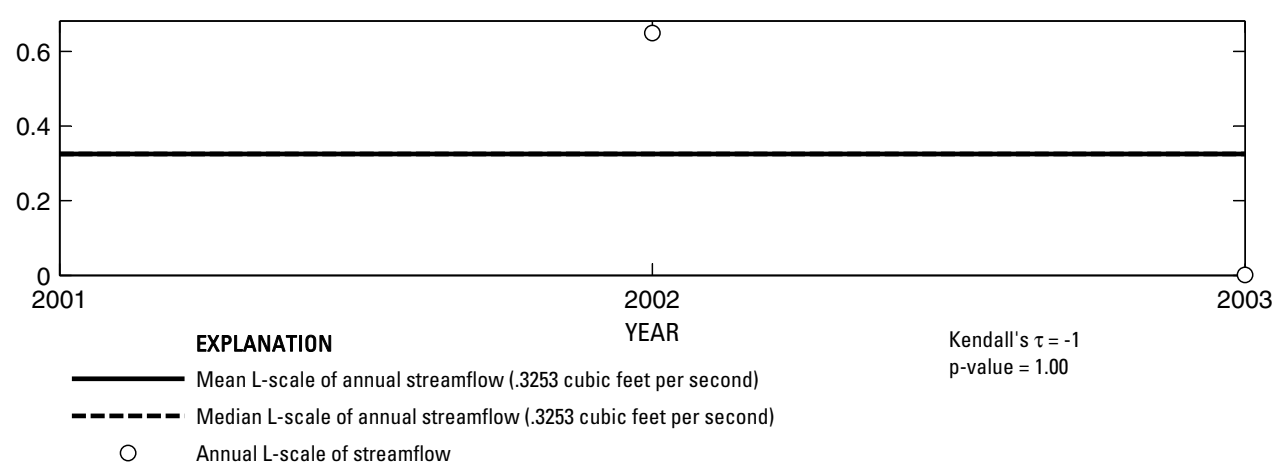

Figure 482. Analysis of annual mean, maximum, minimum, and L-scale statistics of daily mean streamflow for U.S. Geological Survey streamflow-gaging station 08133900 Chalk Creek near Water Valley, Texas.

Index of Station Numbers 719 

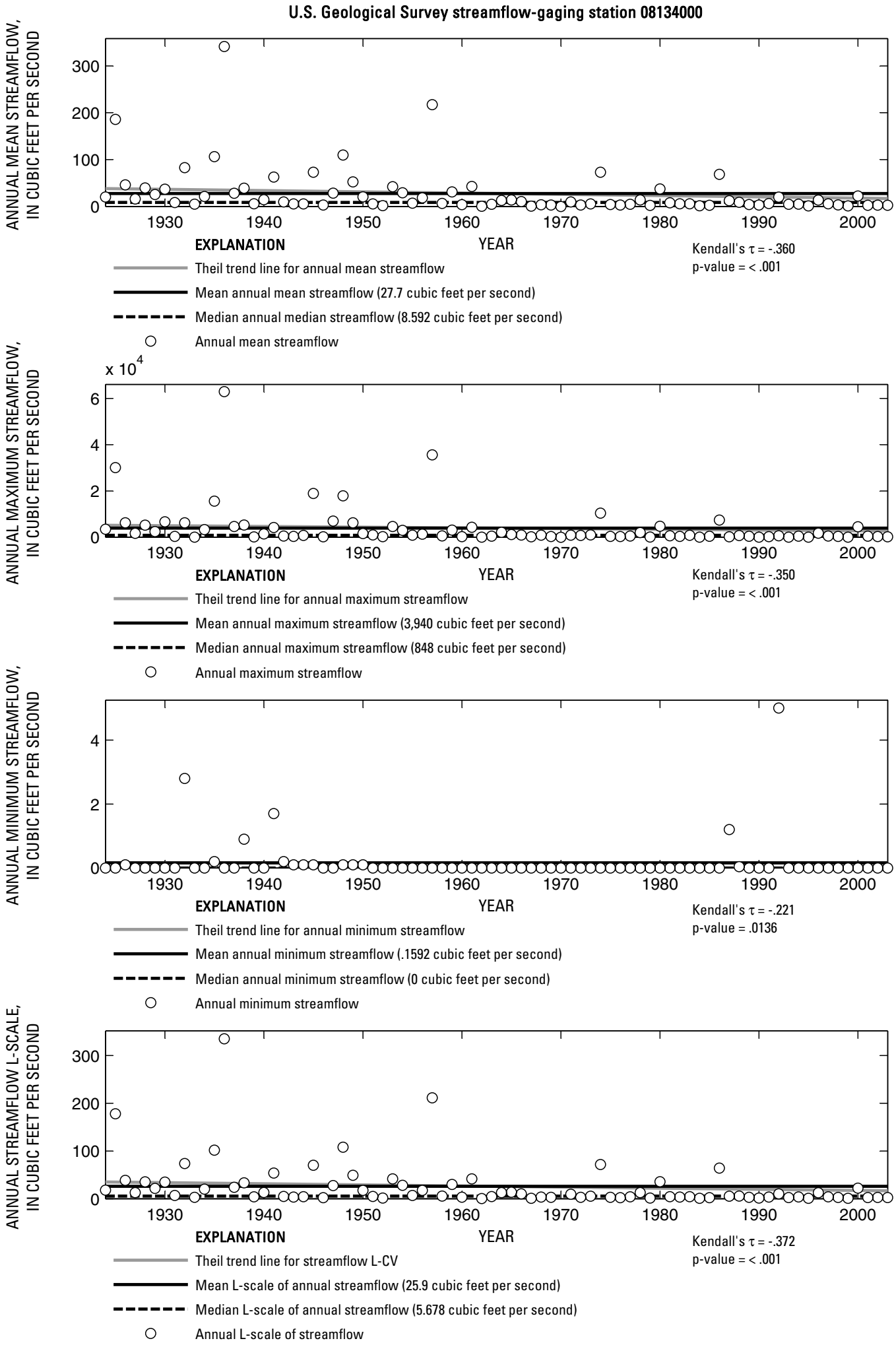

Figure 483. Analysis of annual mean, maximum, minimum, and L-scale statistics of daily mean streamflow for U.S. Geological Survey streamflow-gaging station 08134000 North Concho River near Carlsbad, Texas. 


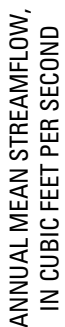

U.S. Geological Survey streamflow-gaging station 08134230

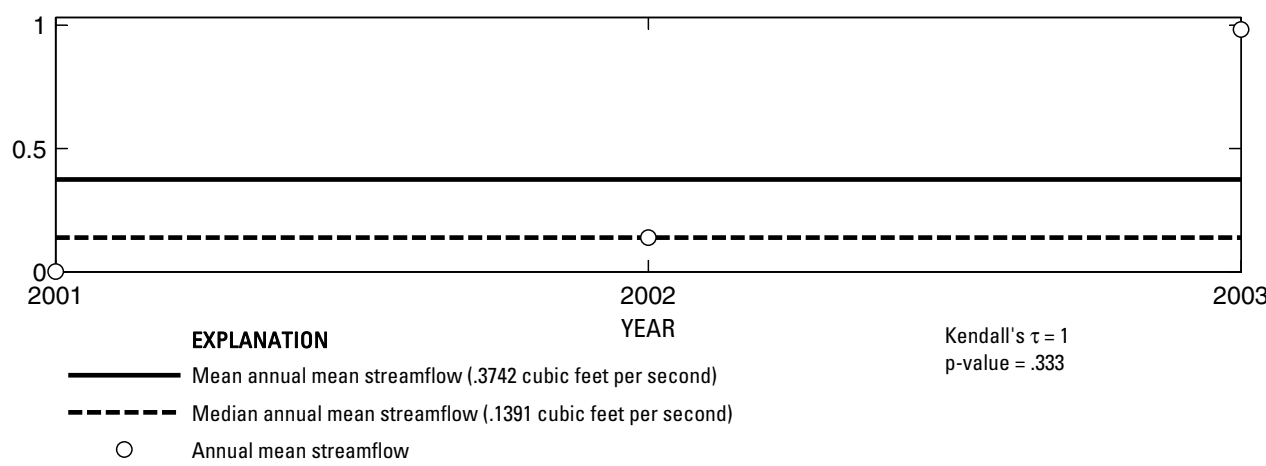

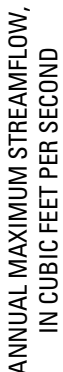

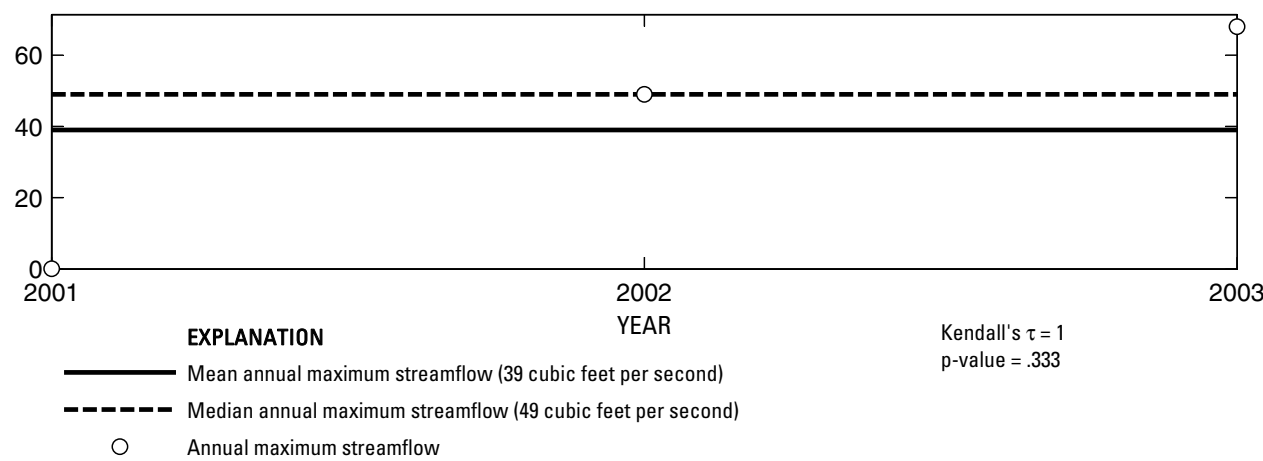

崔

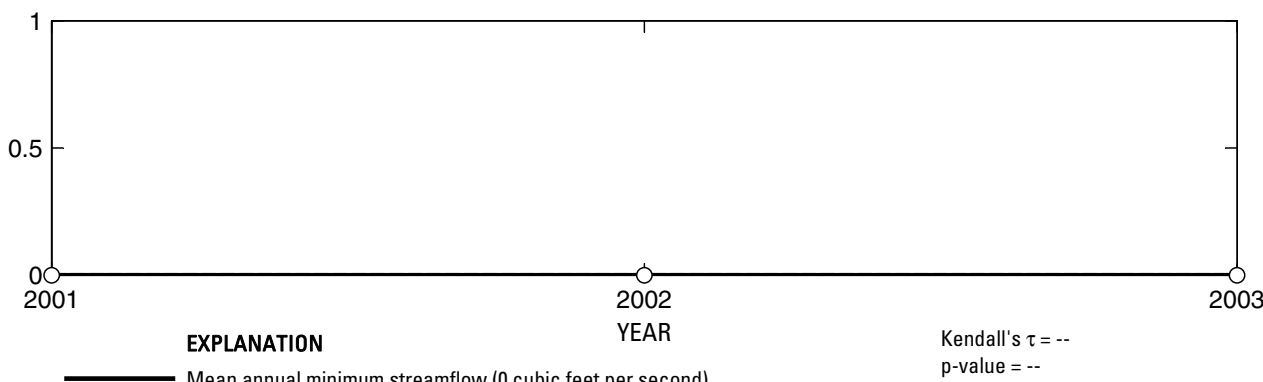

- Median annual minimum streamflow (0 cubic feet per second)

O Annual minimum streamflow

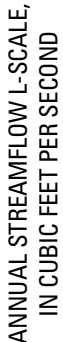

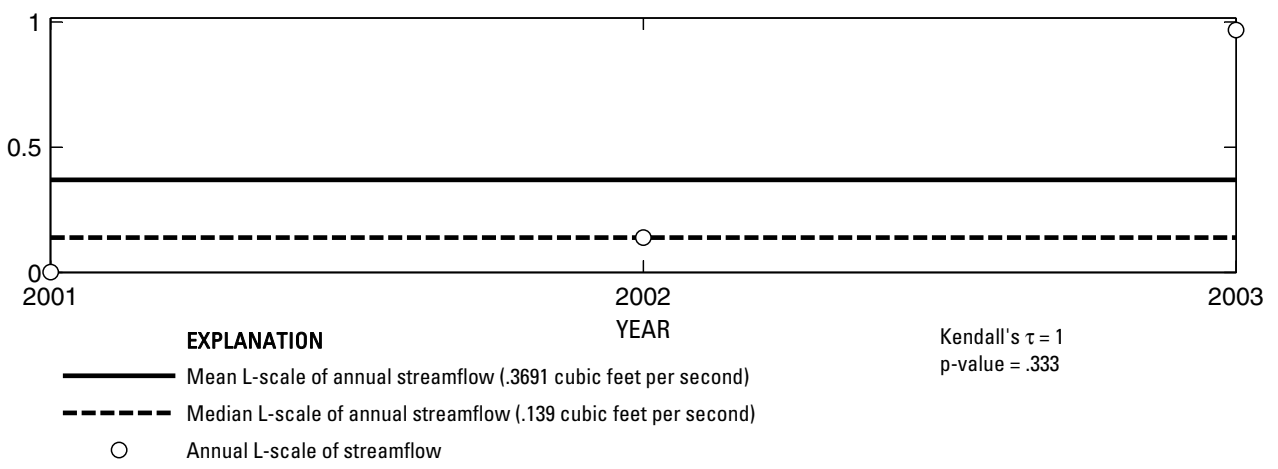

Figure 484. Analysis of annual mean, maximum, minimum, and L-scale statistics of daily mean streamflow for U.S. Geological Survey streamflow-gaging station 08134230 Grape Creek near Grape Creek, Texas.

Index of Station Numbers 719 

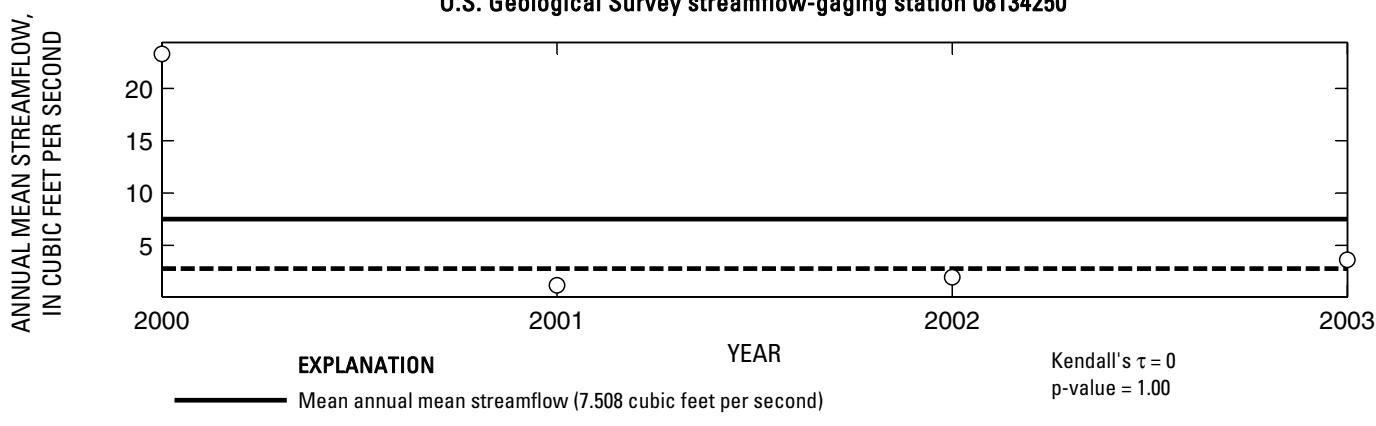

-_-_-_ Median annual mean streamflow (2.778 cubic feet per second)

O Annual mean streamflow
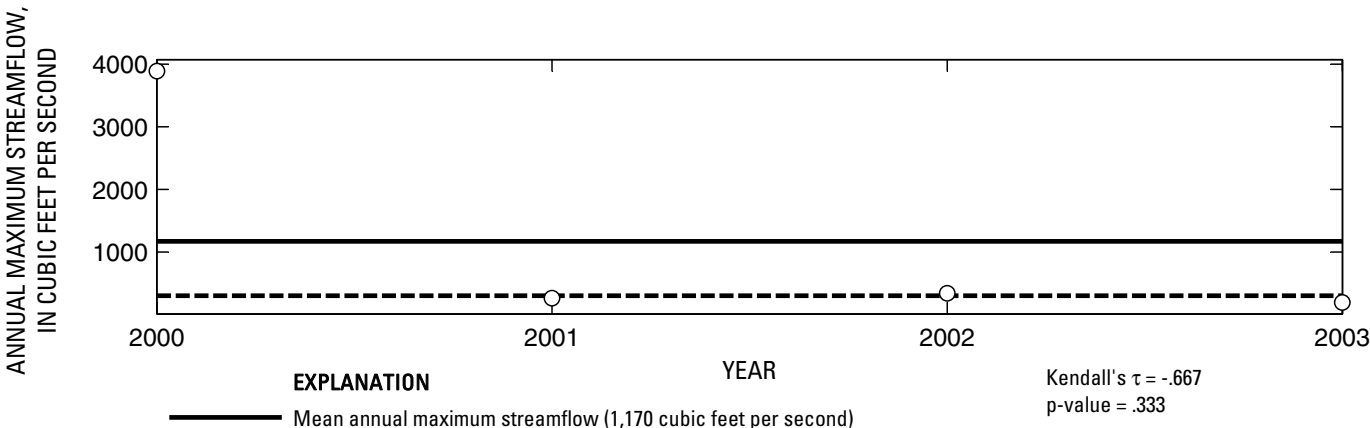

- _-_o- Median annual maximum streamflow ( 300 cubic feet per second)

Annual maximum streamflow
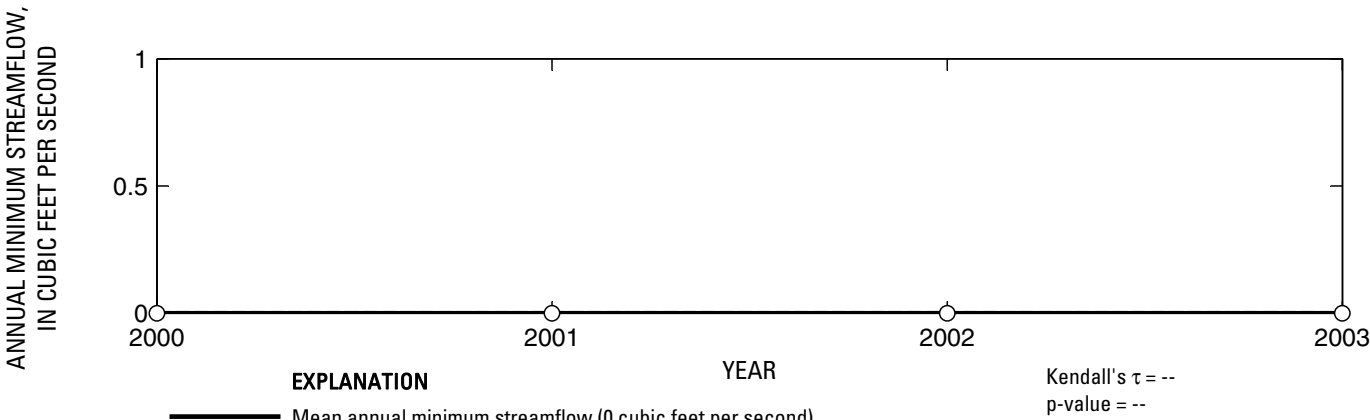

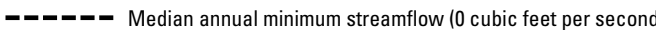

O Annual minimum streamflow
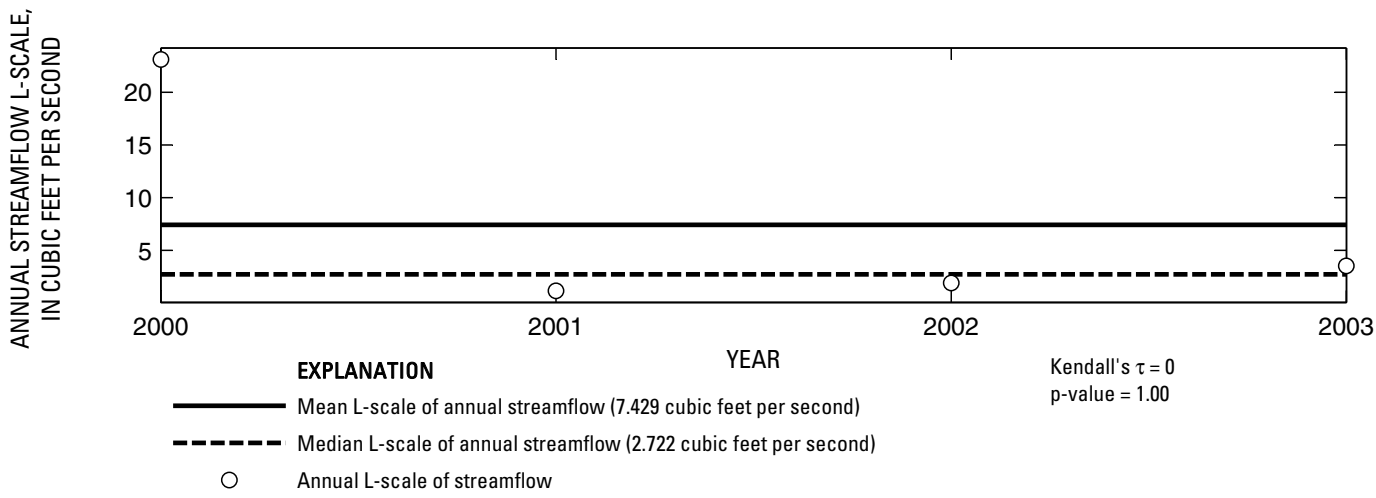

Figure 485. Analysis of annual mean, maximum, minimum, and L-scale statistics of daily mean streamflow for U.S. Geological Survey streamflow-gaging station 08134250 North Concho River near Grape Creek, Texas. 
U.S. Geological Survey streamflow-gaging station 08135000

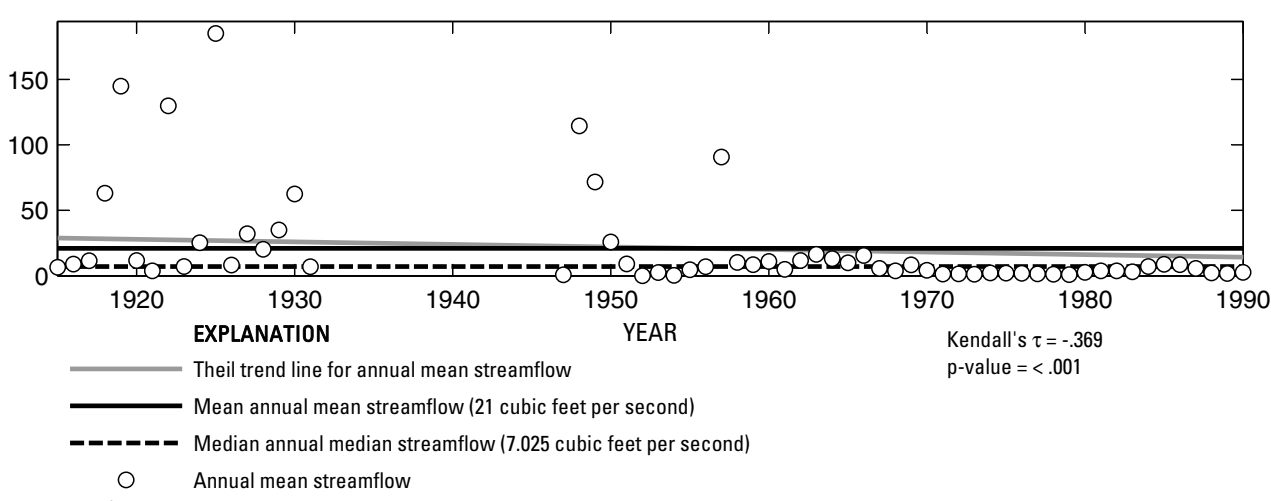

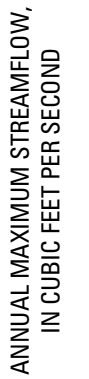

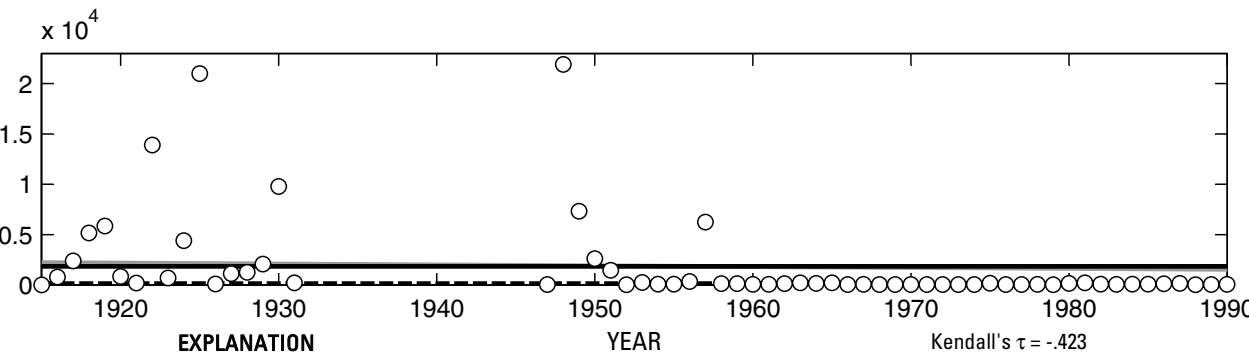

Theil trend line for annual maximum streamflow

- Median annual maximum streamflow (140 cubic feet per second)

O Annual maximum streamflow
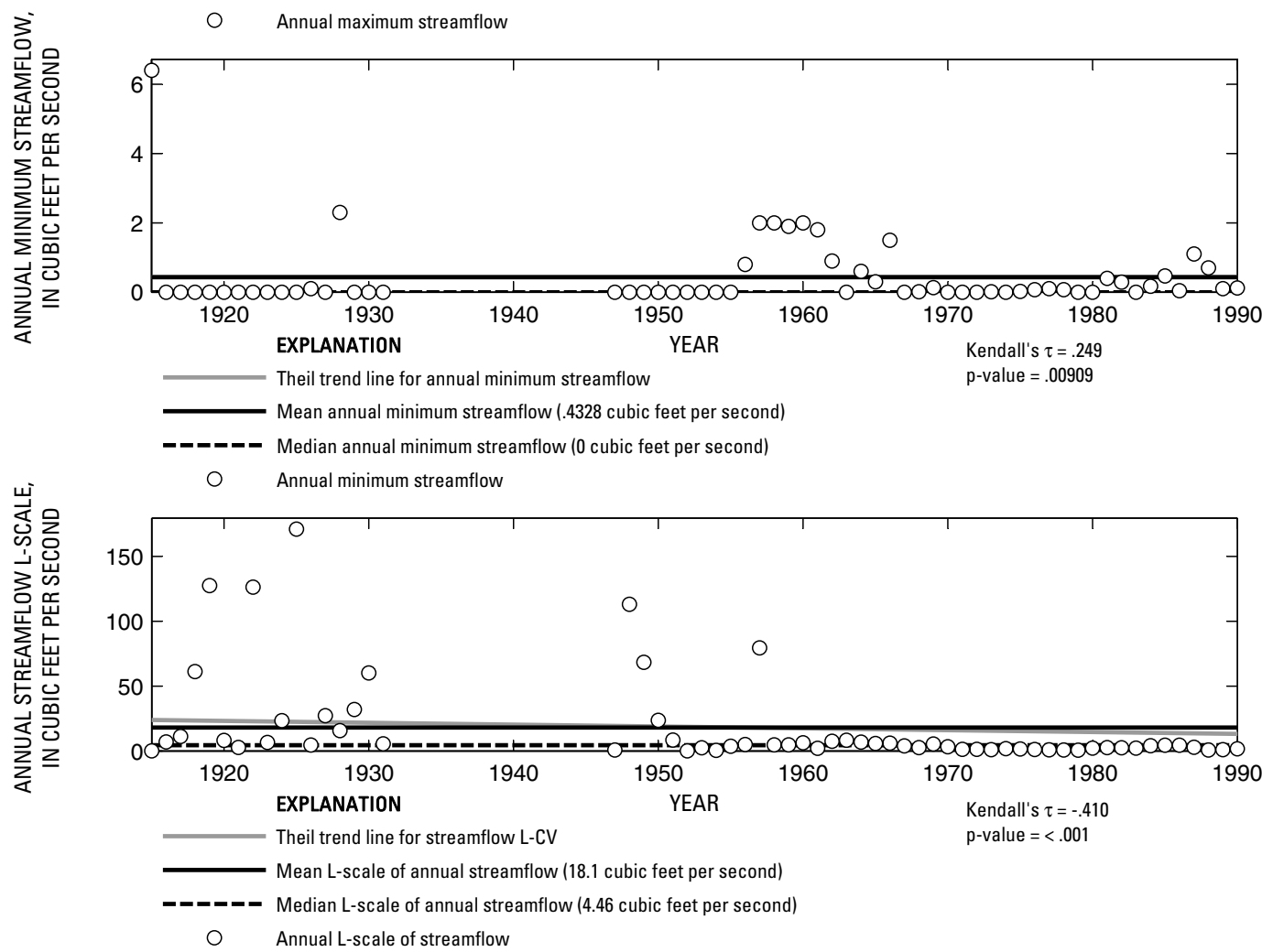

Figure 486. Analysis of annual mean, maximum, minimum, and L-scale statistics of daily mean streamflow for U.S. Geological Survey streamflow-gaging station 08135000 North Concho River at San Angelo, Texas.

Index of Station Numbers 719 


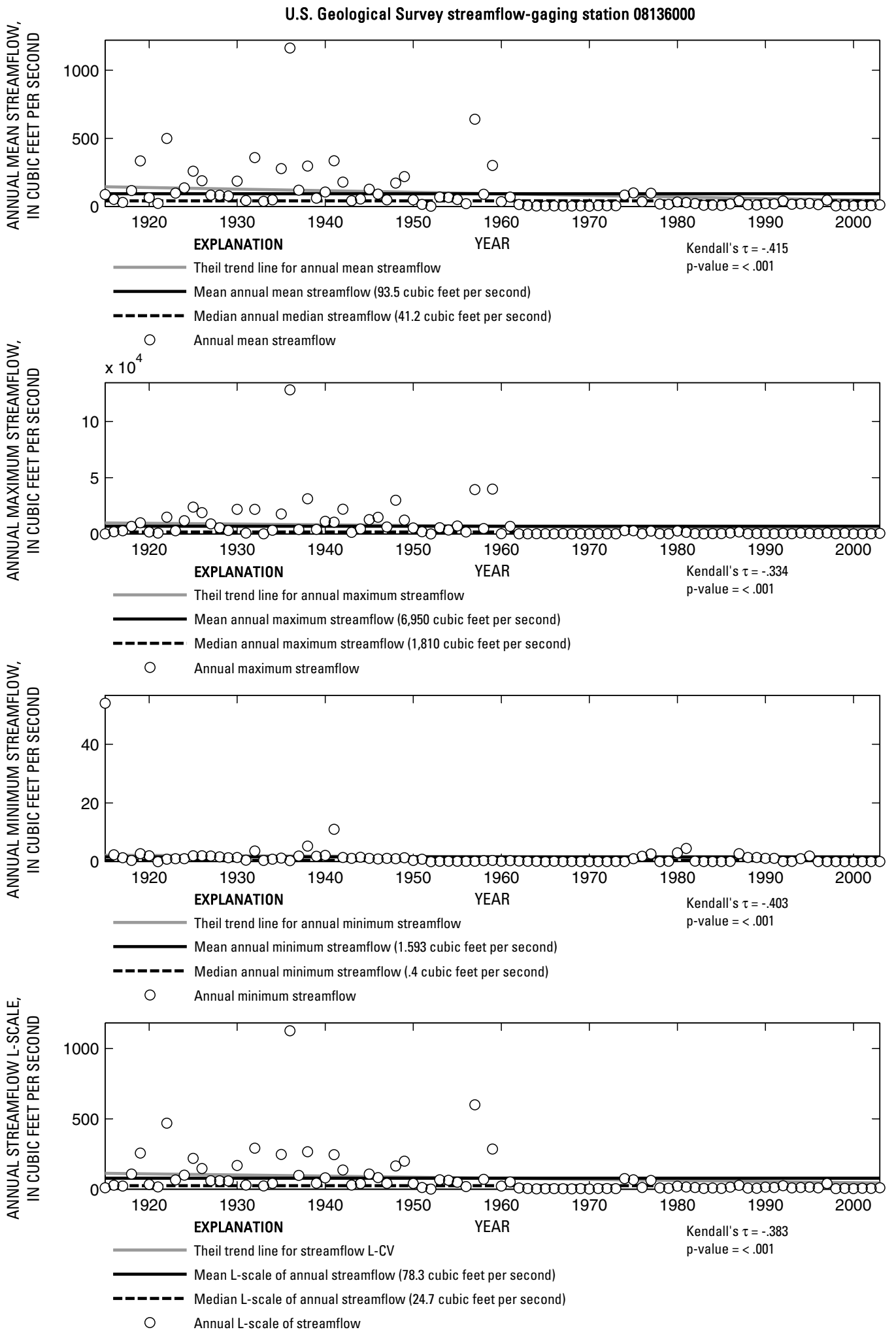

Figure 487. Analysis of annual mean, maximum, minimum, and L-scale statistics of daily mean streamflow for U.S. Geological Survey streamflow-gaging station 08136000 Concho River at San Angelo, Texas. 
U.S. Geological Survey streamflow-gaging station 08136500
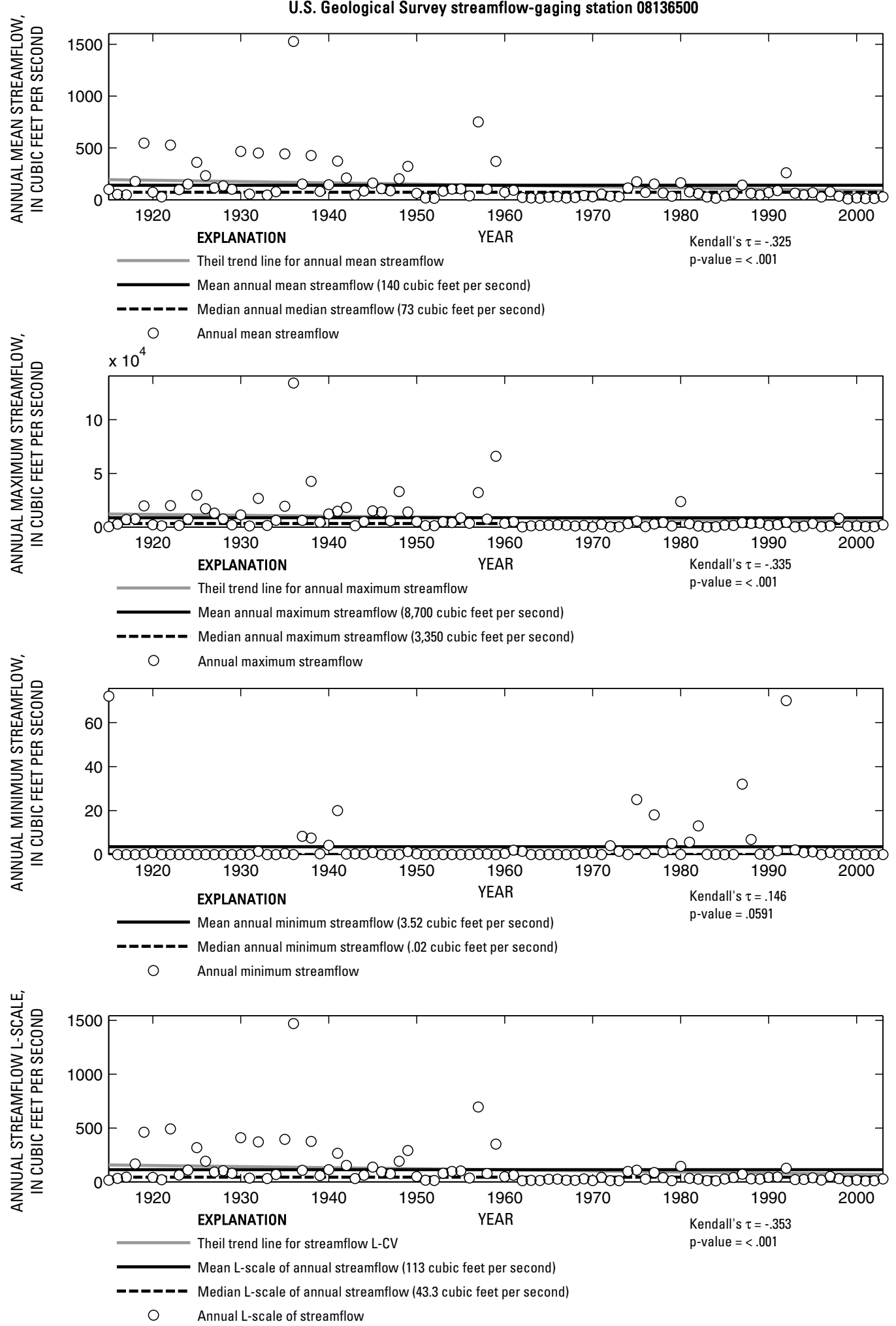

Figure 488. Analysis of annual mean, maximum, minimum, and L-scale statistics of daily mean streamflow for U.S. Geological Survey streamflow-gaging station 08136500 Concho River at Paint Rock, Texas.

Index of Station Numbers 719 

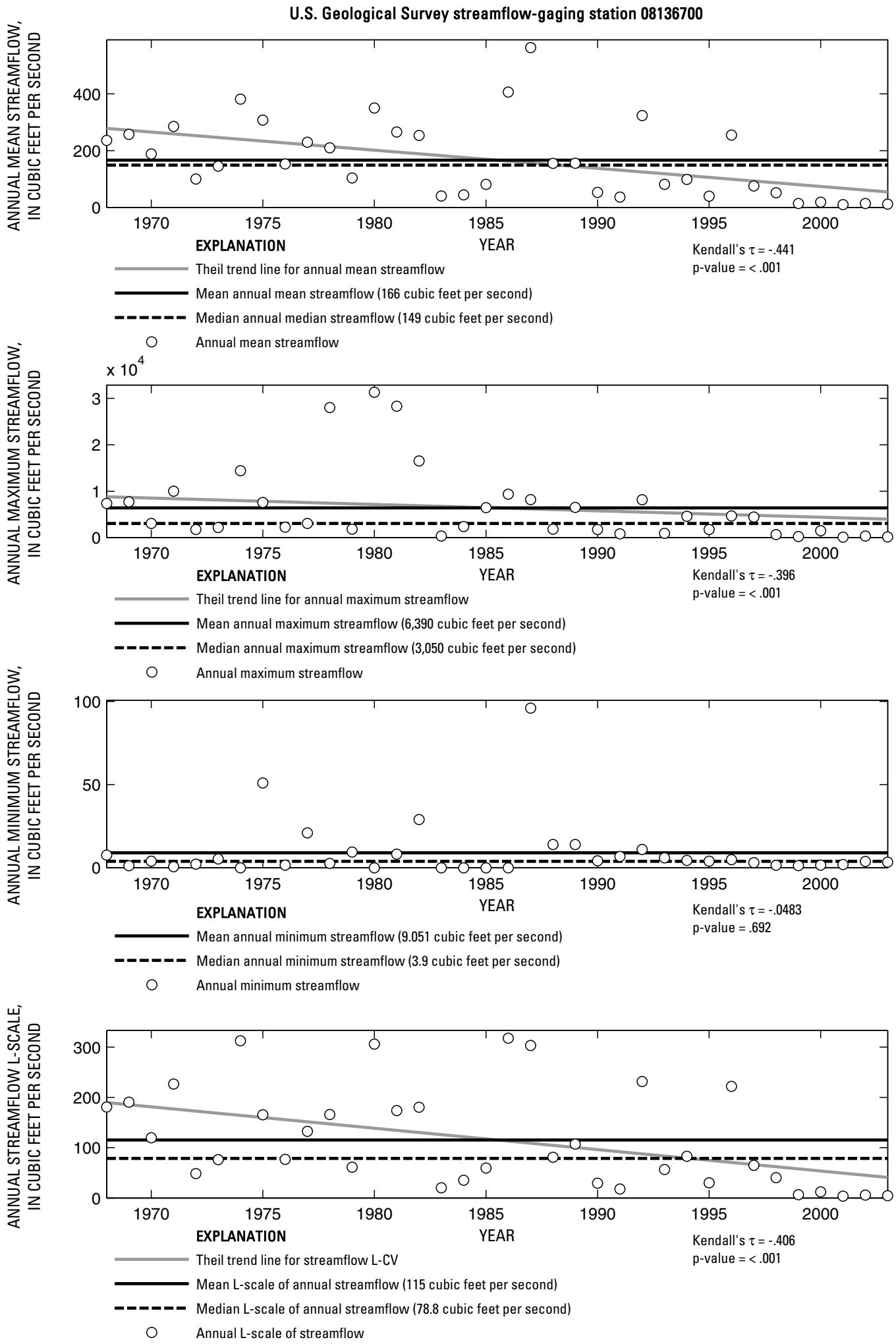

Figure 489. Analysis of annual mean, maximum, minimum, and L-scale statistics of daily mean streamflow for U.S. Geological Survey streamflow-gaging station 08136700 Colorado River near Stacy, Texas. 

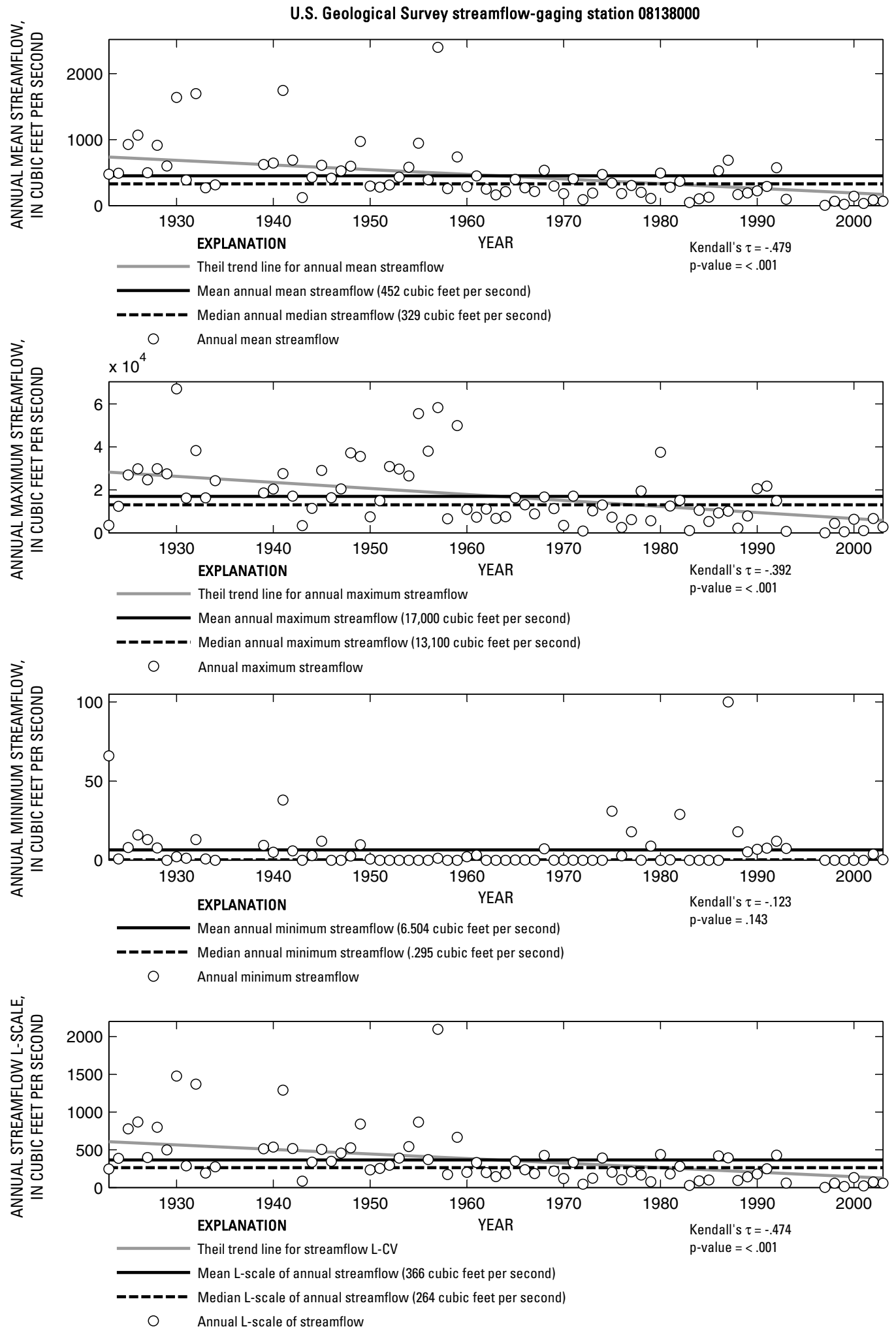

Figure 490. Analysis of annual mean, maximum, minimum, and L-scale statistics of daily mean streamflow for U.S. Geological Survey streamflow-gaging station 08138000 Colorado River at Winchell, Texas.

Index of Station Numbers 719 


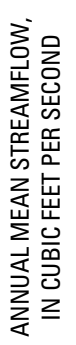

U.S. Geological Survey streamflow-gaging station 08139500

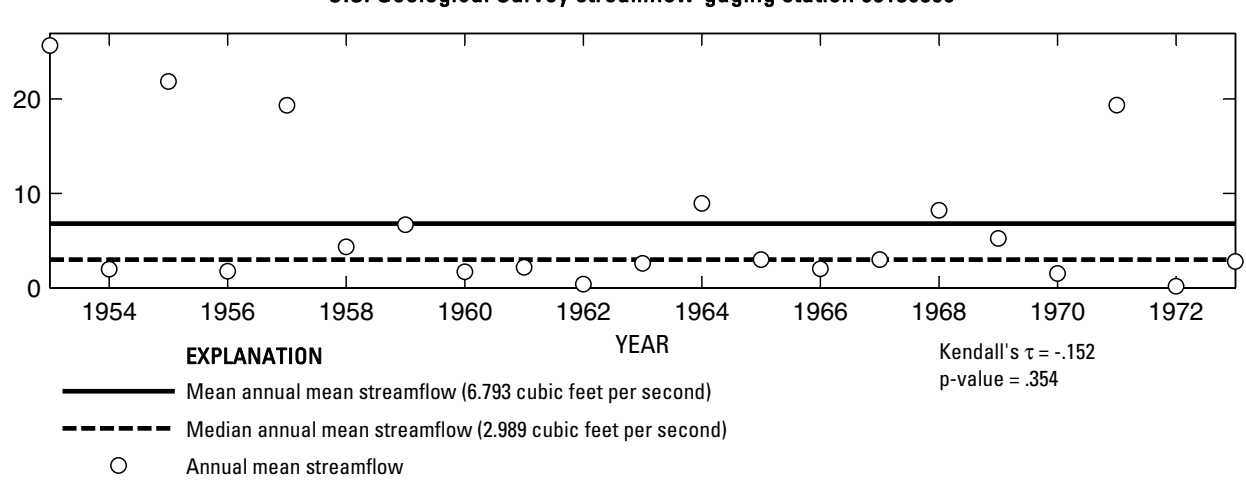

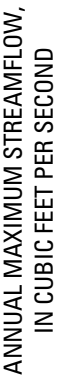

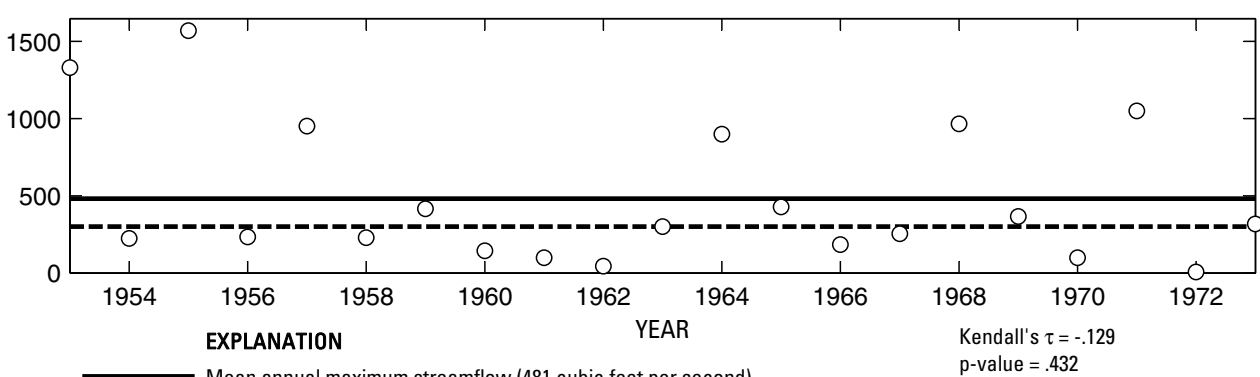

O Annual maximum streamflow

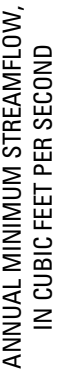

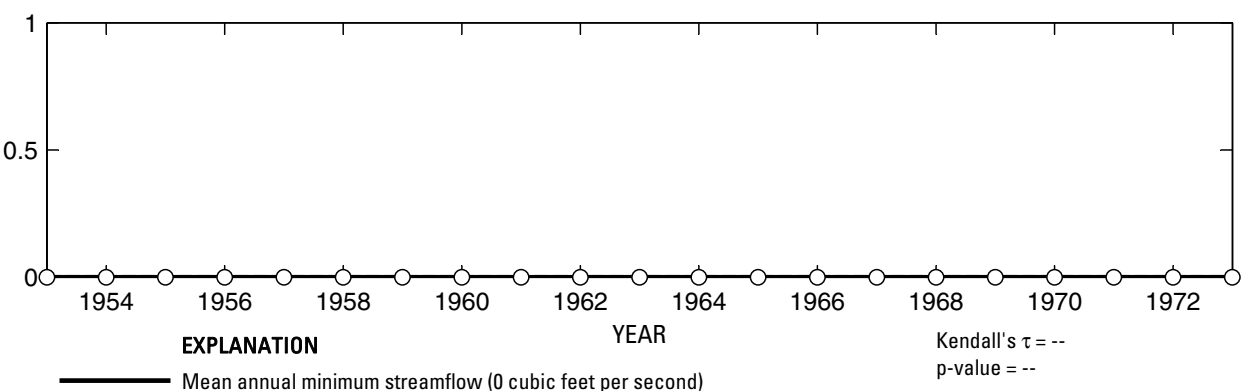

- Median annual minimum streamflow (0 cubic feet per second)

O Annual minimum streamflow
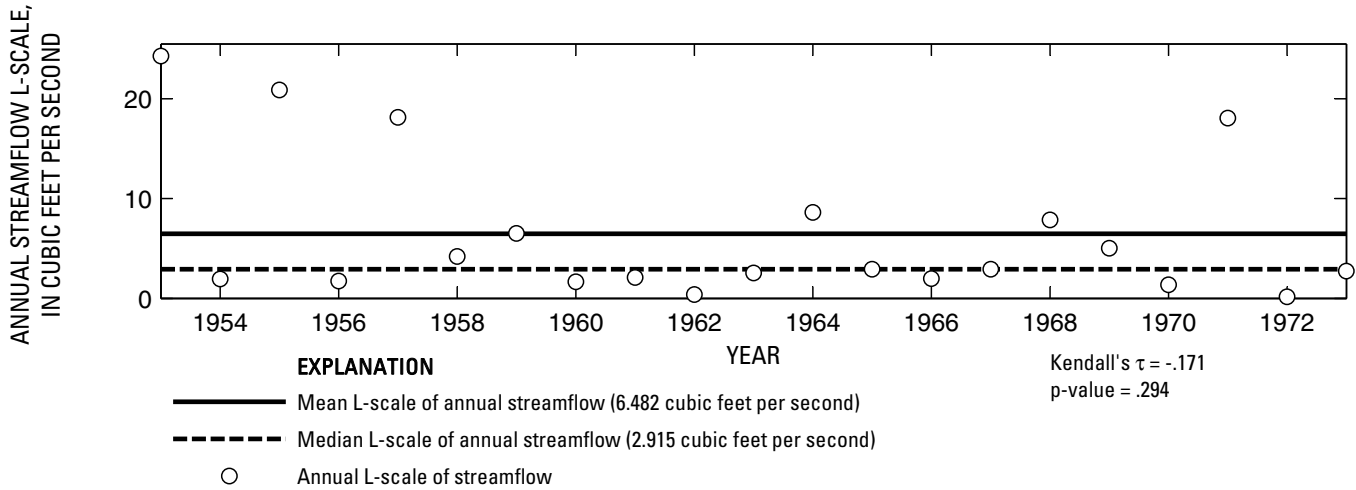

Figure 491. Analysis of annual mean, maximum, minimum, and L-scale statistics of daily mean streamflow for U.S. Geological Survey streamflow-gaging station 08139500 Deep Creek near Mercury, Texas. 


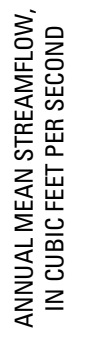

U.S. Geological Survey streamflow-gaging station 08140500

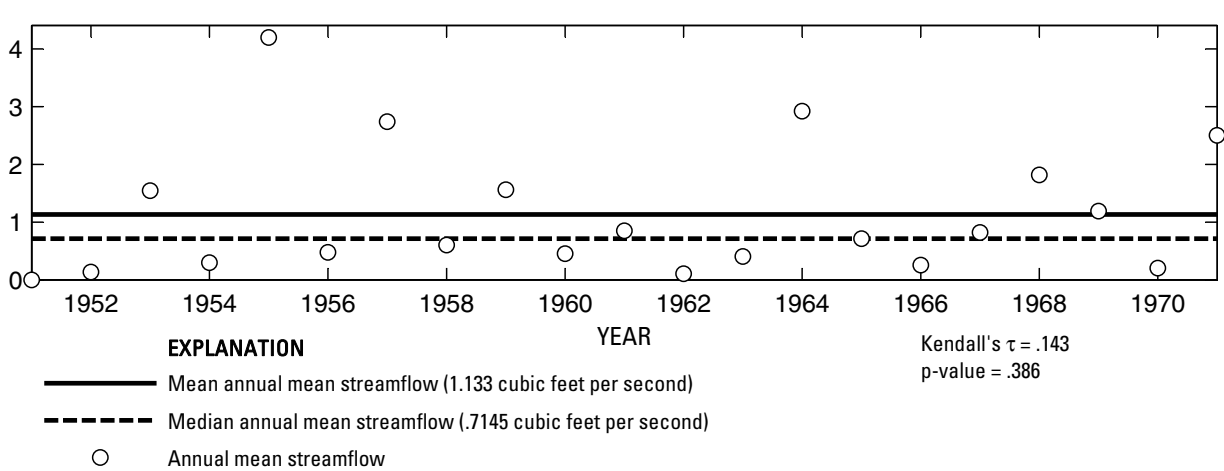

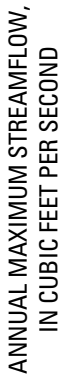

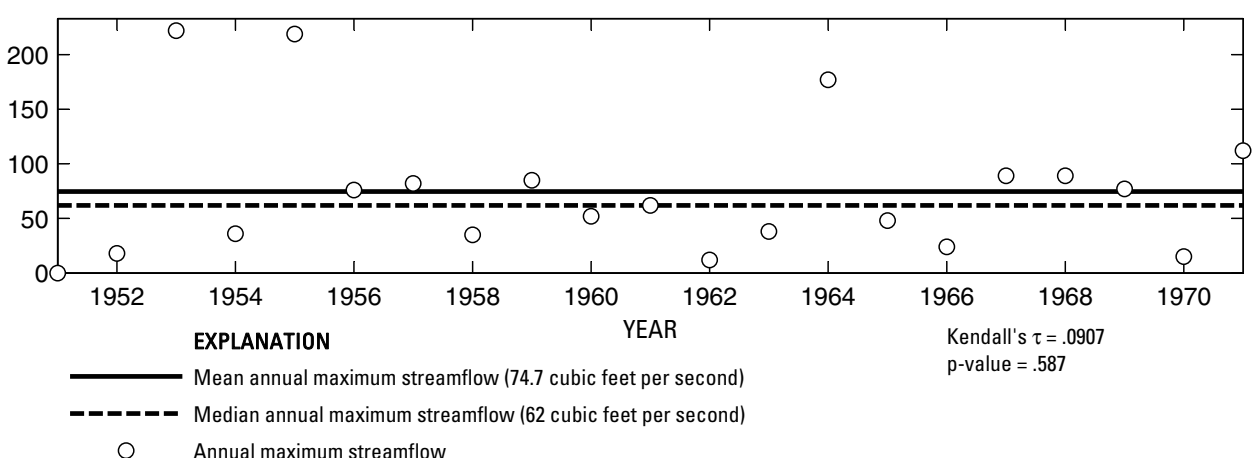

焉

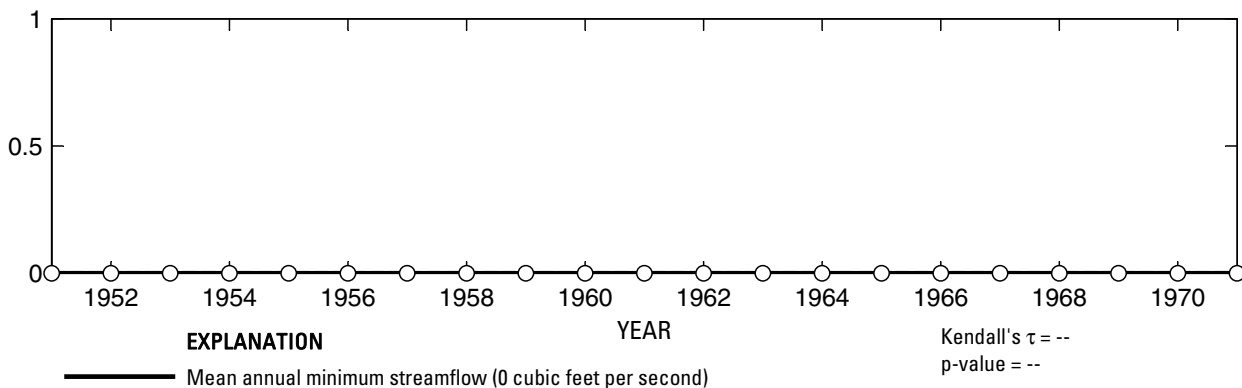

- Median annual minimum streamflow (0 cubic feet per second)

Annual minimum streamflow

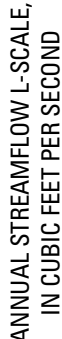

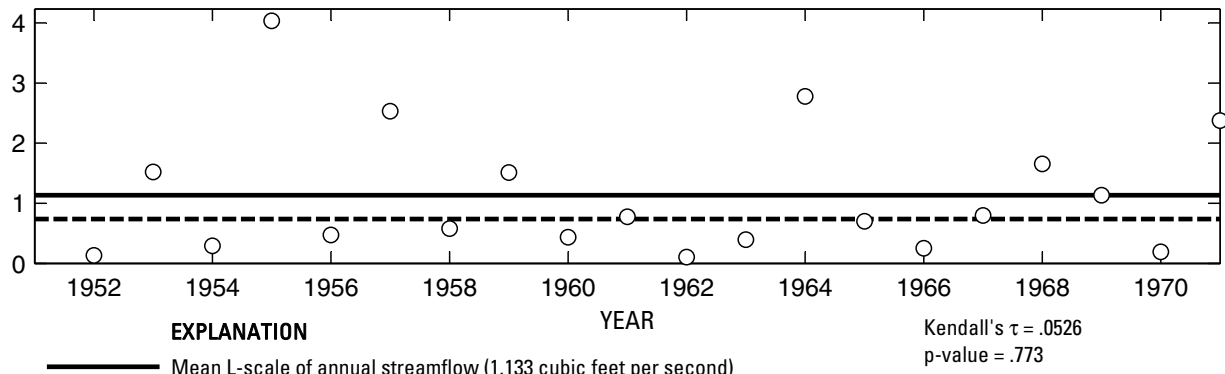

Mean L-scale of annual streamflow (1.133 cubic feet per second)

$\mathrm{p}$-value $=.773$

- - - - Median L-scale of annual streamflow (.7373 cubic feet per second)

Annual L-scale of streamflow

Figure 492. Analysis of annual mean, maximum, minimum, and L-scale statistics of daily mean streamflow for U.S. Geological Survey streamflow-gaging station 08140500 Dry Prong Deep Creek near Mercury, Texas.

Index of Station Numbers 719 


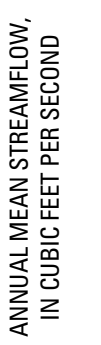

U.S. Geological Survey streamflow-gaging station 08140700

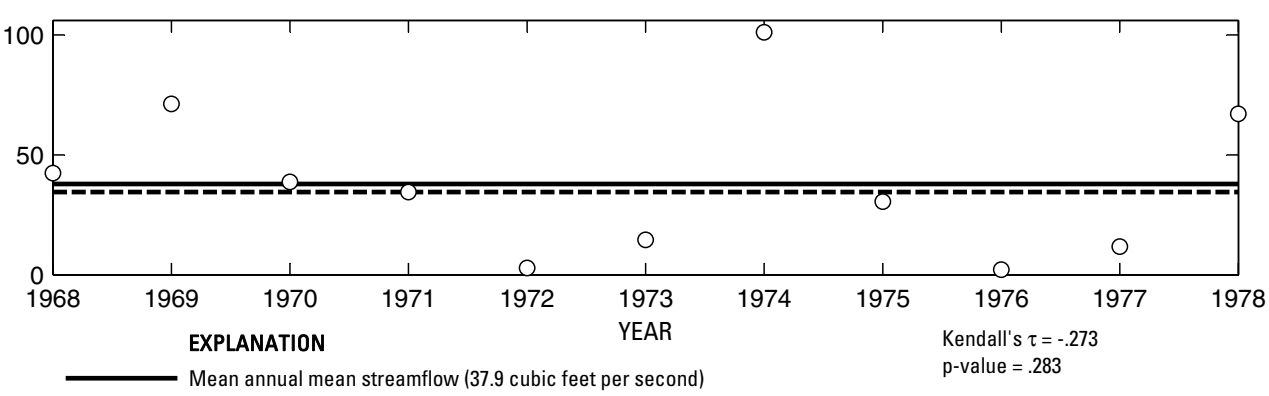

-_-_- Median annual mean streamflow (34.5 cubic feet per second)

O Annual mean streamflow
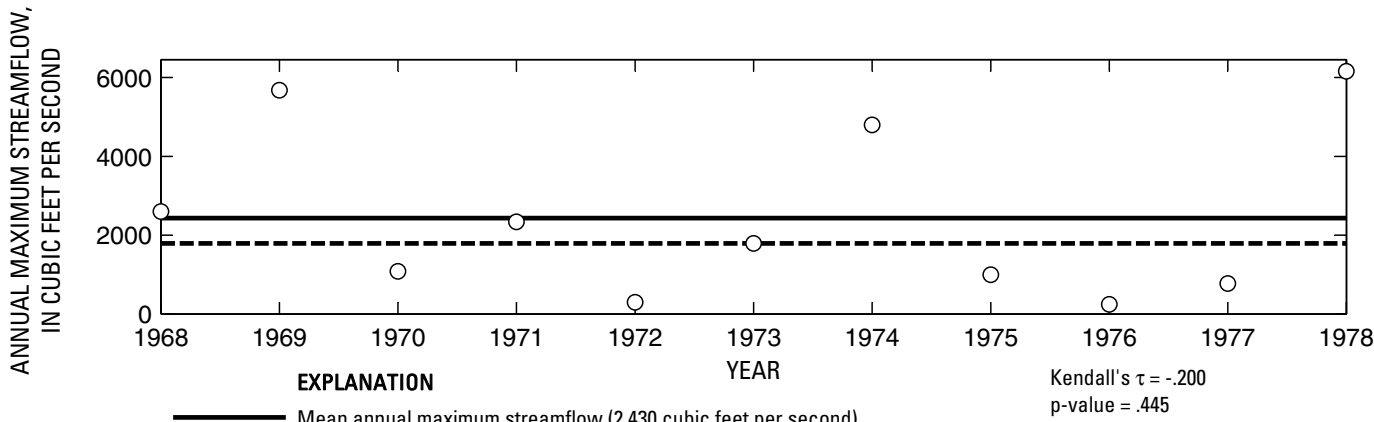

O Annual maximum streamflow
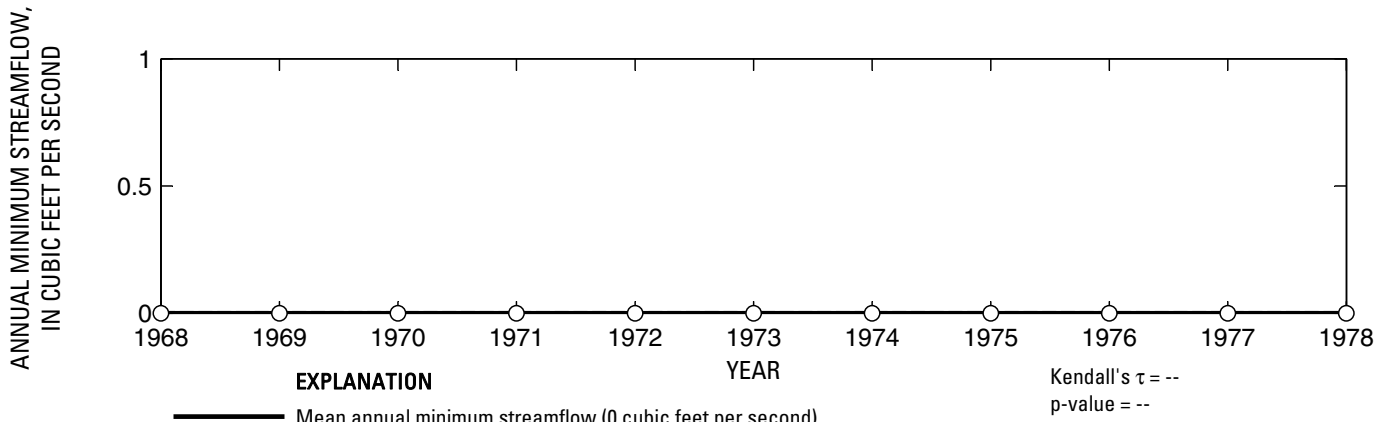

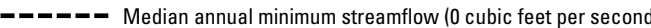

O Annual minimum streamflow

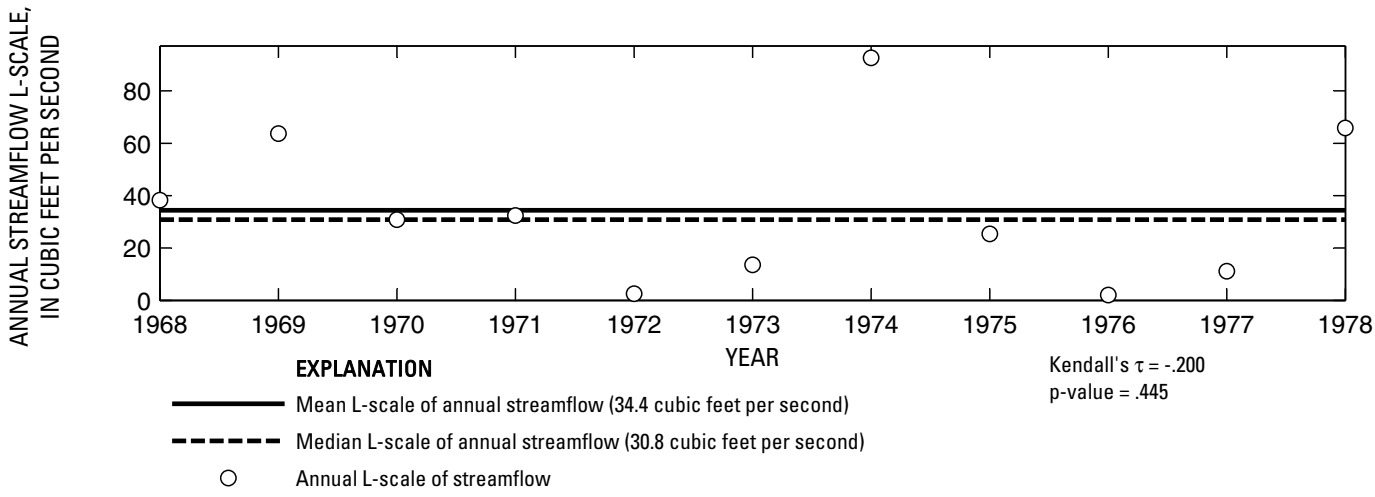

Figure 493. Analysis of annual mean, maximum, minimum, and L-scale statistics of daily mean streamflow for U.S. Geological Survey streamflow-gaging station 08140700 Pecan Bayou near Cross Cut, Texas. 
U.S. Geological Survey streamflow-gaging station 08140800

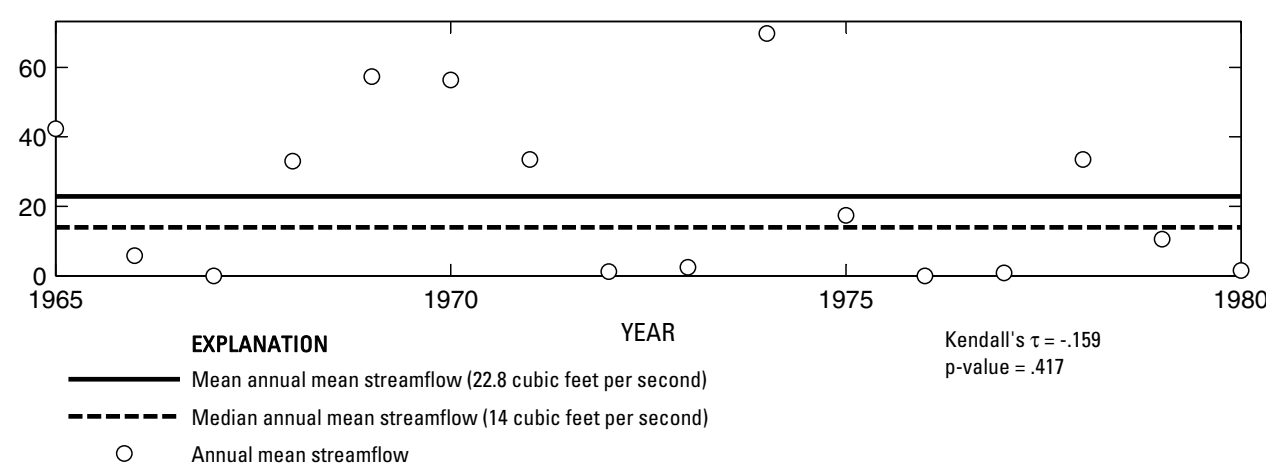

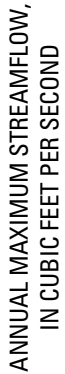

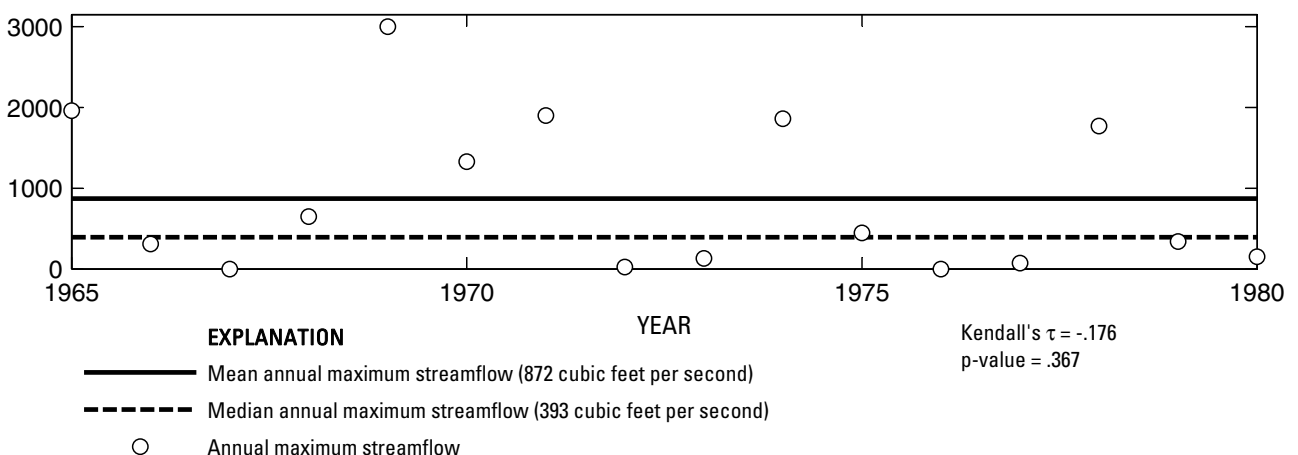

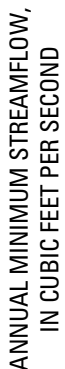

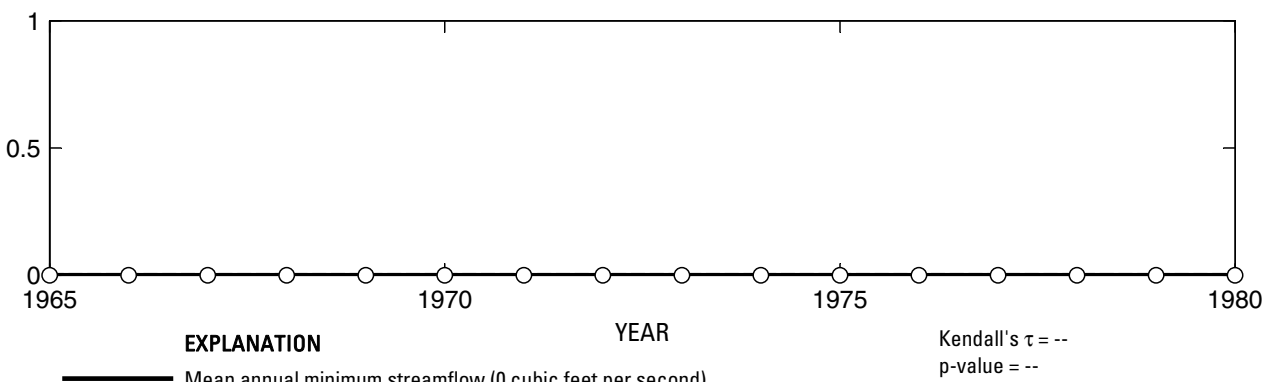

- Median annual minimum streamflow (0 cubic feet per second)

O Annual minimum streamflow

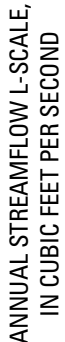

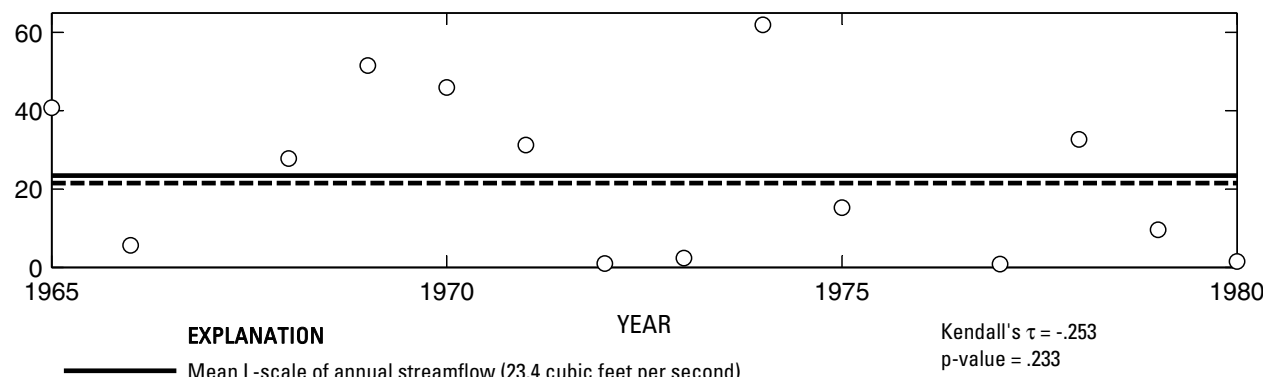

Mean L-scale of annual streamflow (23.4 cubic feet per second)

$\mathrm{p}$-value $=.233$

- - - - Median L-scale of annual streamflow (21.5 cubic feet per second)

Annual L-scale of streamflow

Figure 494. Analysis of annual mean, maximum, minimum, and L-scale statistics of daily mean streamflow for U.S. Geological Survey streamflow-gaging station 08140800 Jim Ned Creek near Coleman, Texas.

Index of Station Numbers 719 


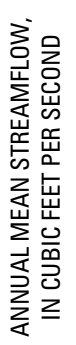

U.S. Geological Survey streamflow-gaging station 08141500

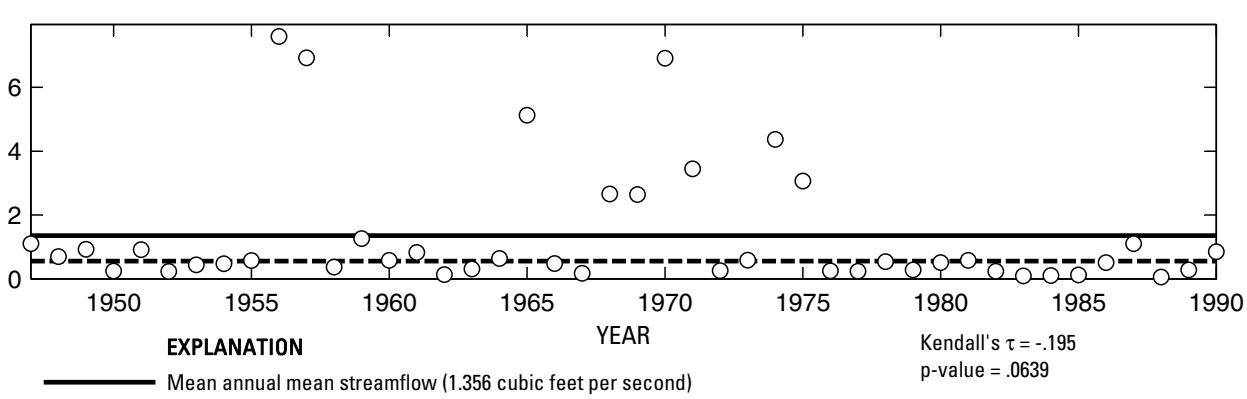

-_-_- Median annual mean streamflow (.557 cubic feet per second)

O Annual mean streamflow
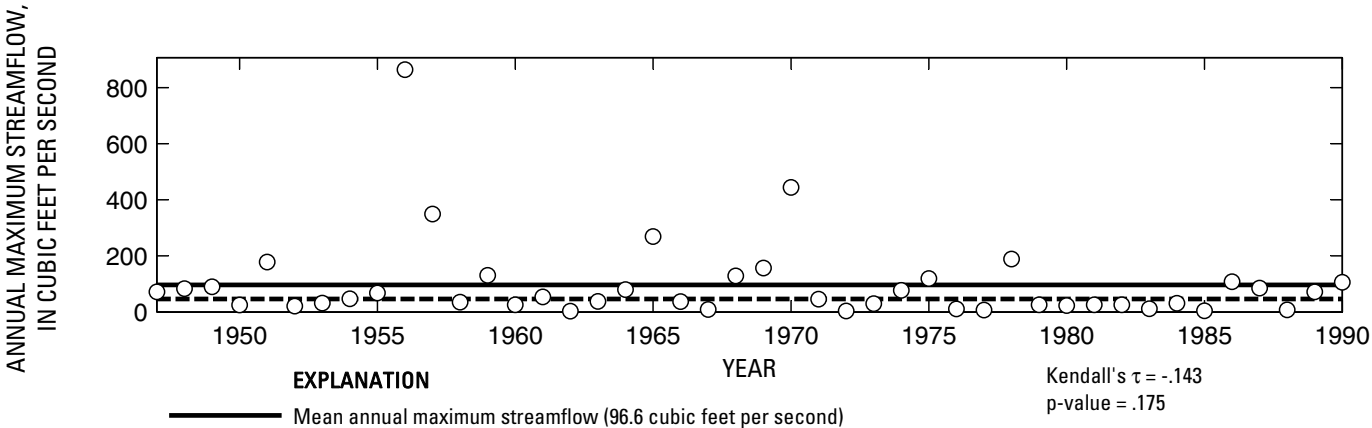

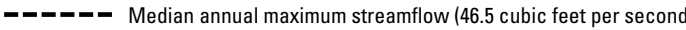

O Annual maximum streamflow
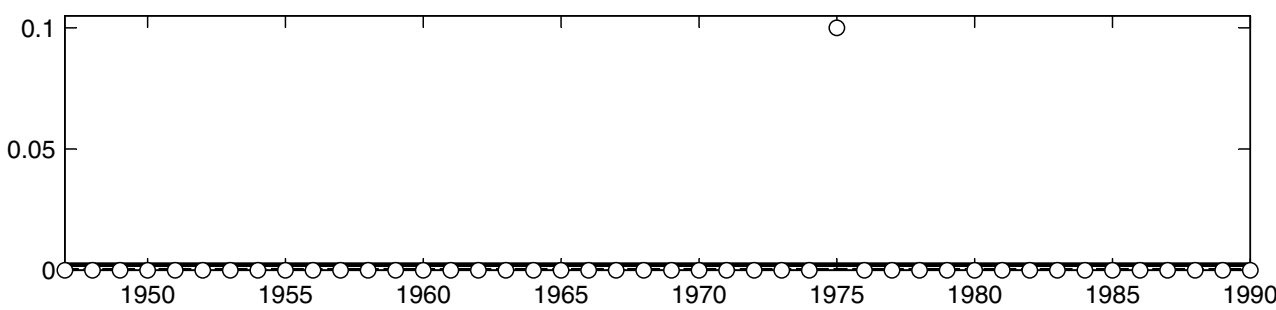

EXPLANATION YEAR Kendall's $\tau=.0645$

Mean annual minimum streamflow (.01 cubic feet per second)

$\mathrm{p}$-value $=.637$

- Median annual minimum streamflow (0 cubic feet per second)

O Annual minimum streamflow

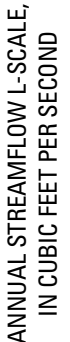

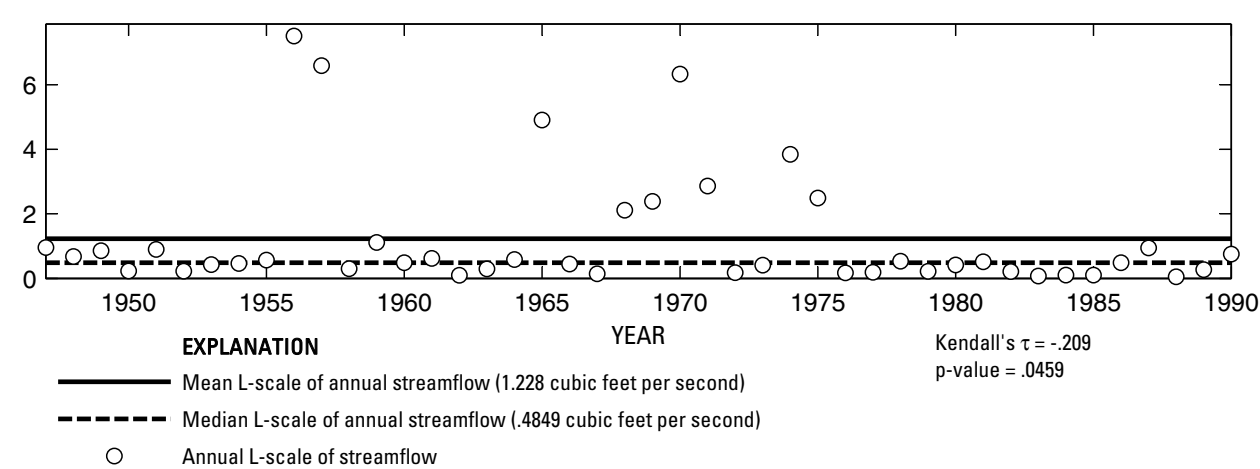

Figure 495. Analysis of annual mean, maximum, minimum, and L-scale statistics of daily mean streamflow for U.S. Geological Survey streamflow-gaging station 08141500 Hords Creek near Valera, Texas. 
U.S. Geological Survey streamflow-gaging station 08142000

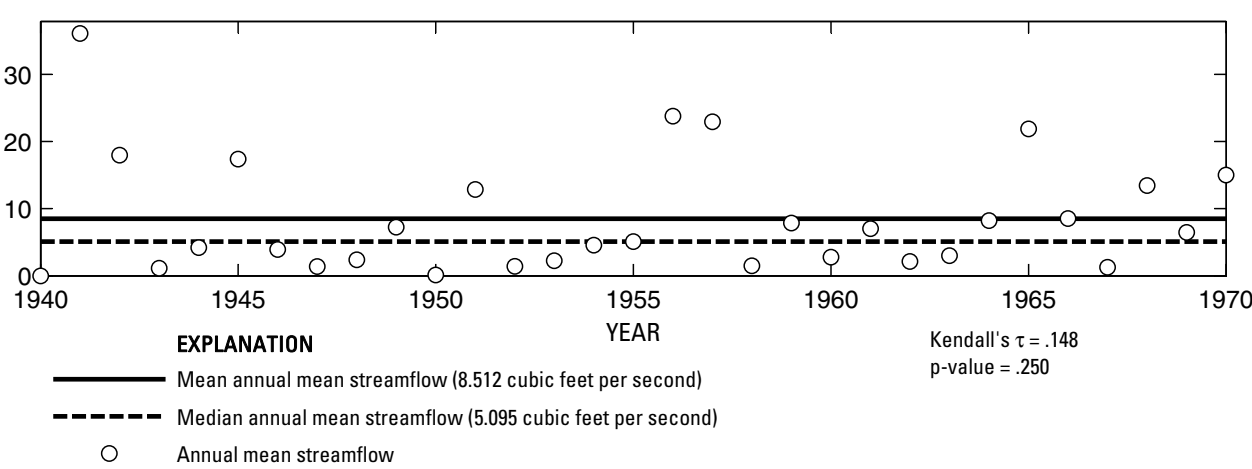

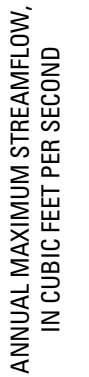

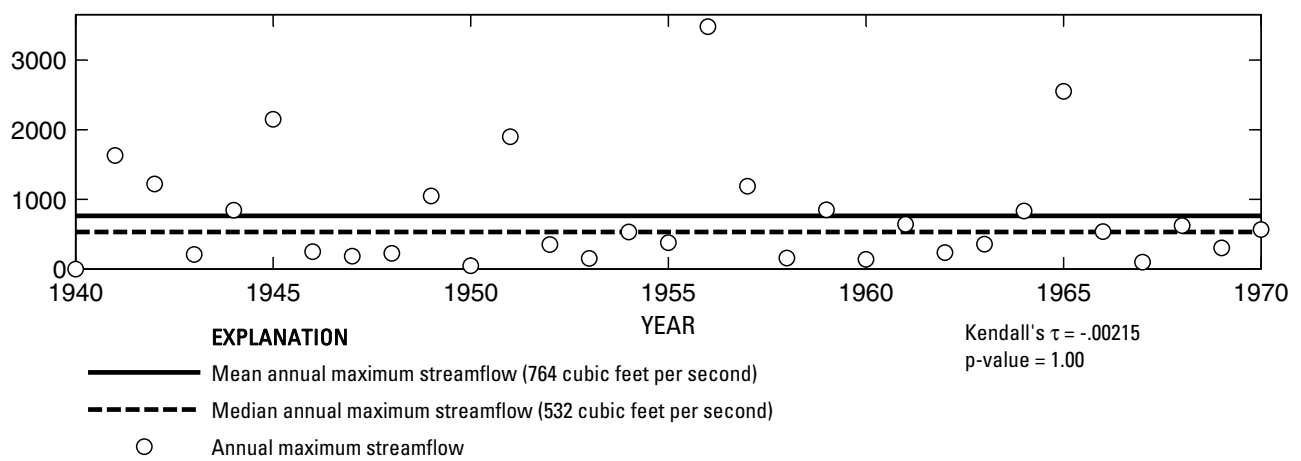

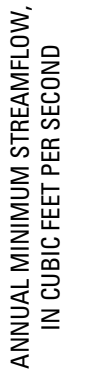

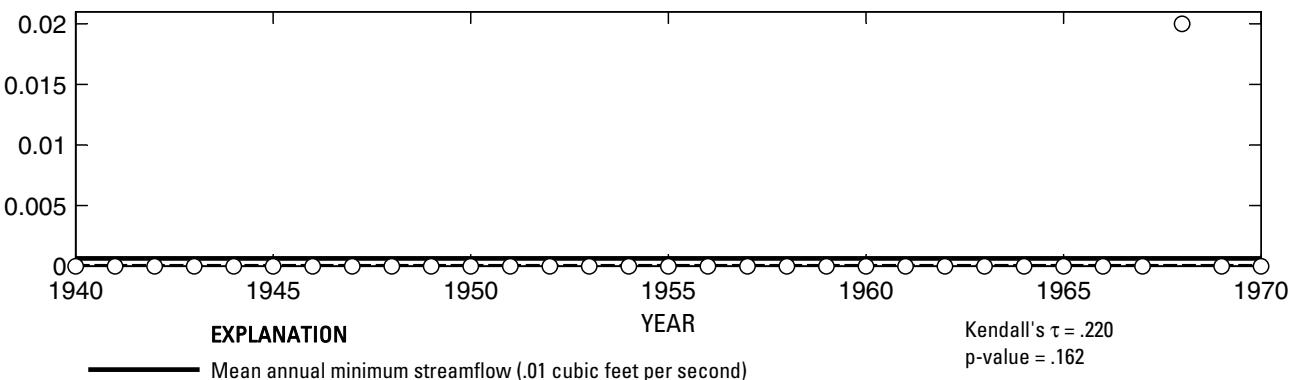

- Median annual minimum streamflow (0 cubic feet per second)

$\bigcirc \quad$ Annual minimum streamflow

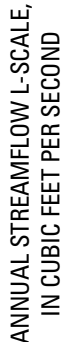

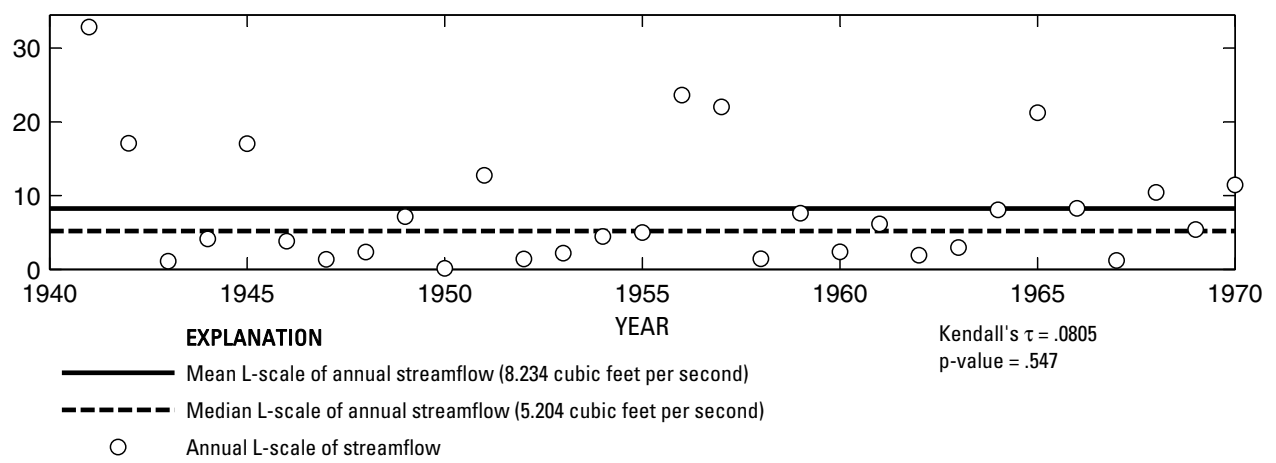

Figure 496. Analysis of annual mean, maximum, minimum, and L-scale statistics of daily mean streamflow for U.S. Geological Survey streamflow-gaging station 08142000 Hords Creek near Coleman, Texas.

Index of Station Numbers 719 

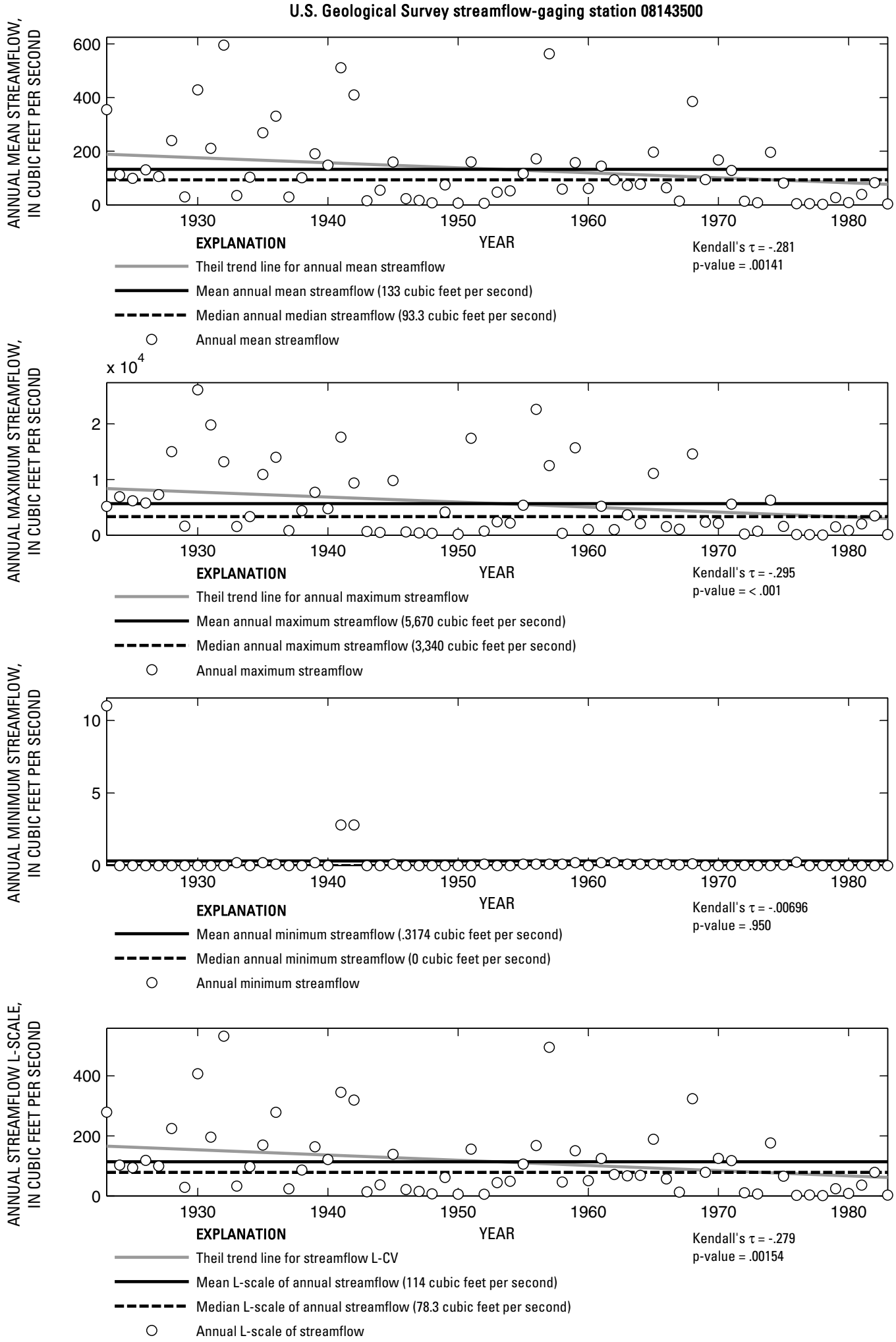

Figure 497. Analysis of annual mean, maximum, minimum, and L-scale statistics of daily mean streamflow for U.S. Geological Survey streamflow-gaging station 08143500 Pecan Bayou at Brownwood, Texas. 


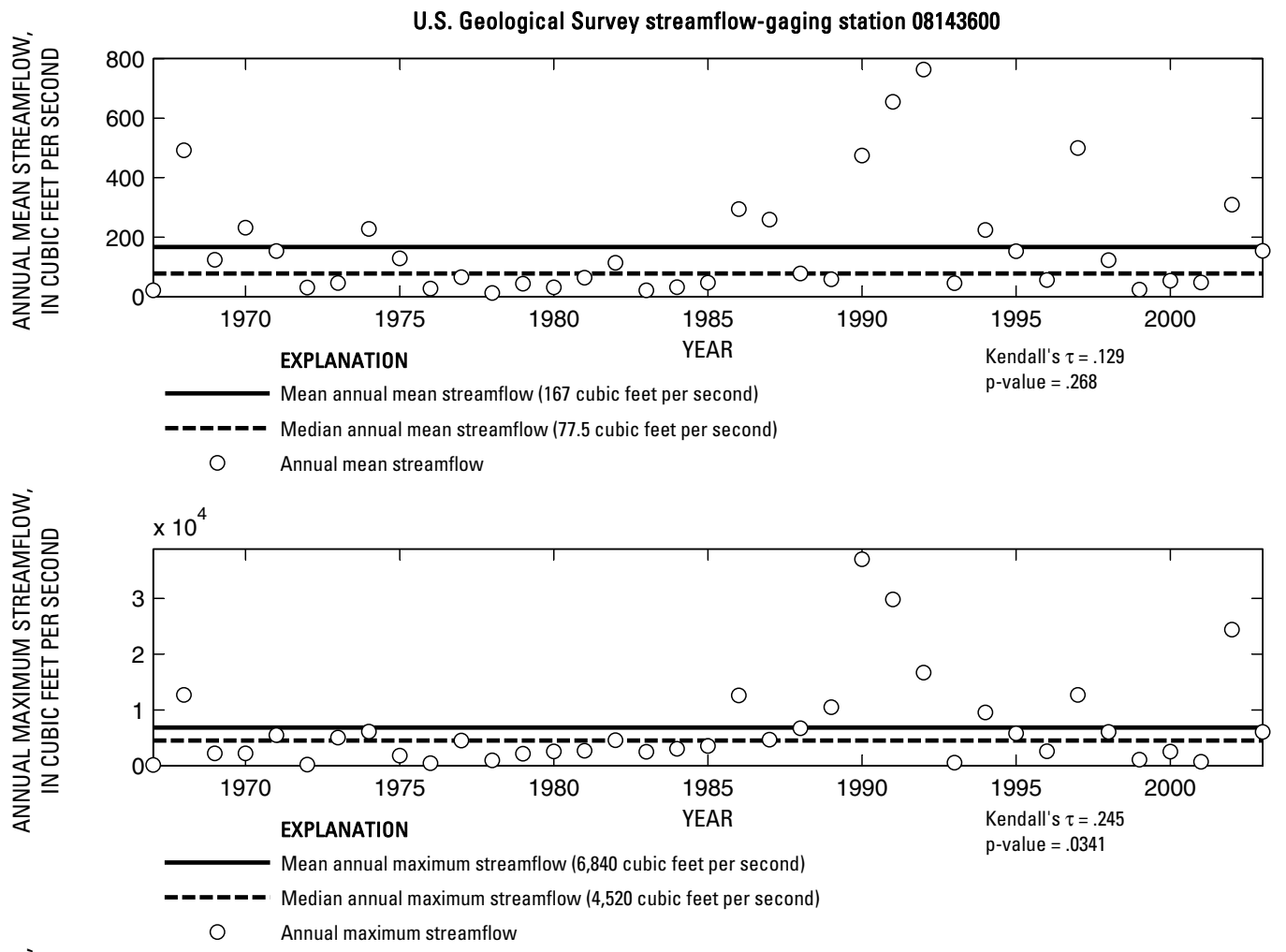

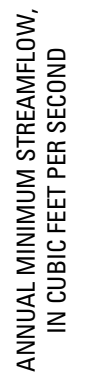

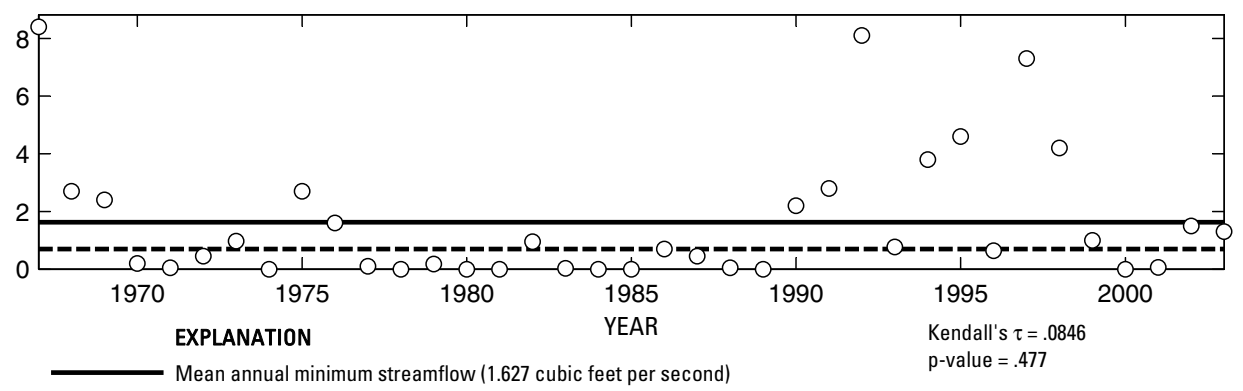

-_o-_ Median annual minimum streamflow (.7 cubic feet per second)

O Annual minimum streamflow

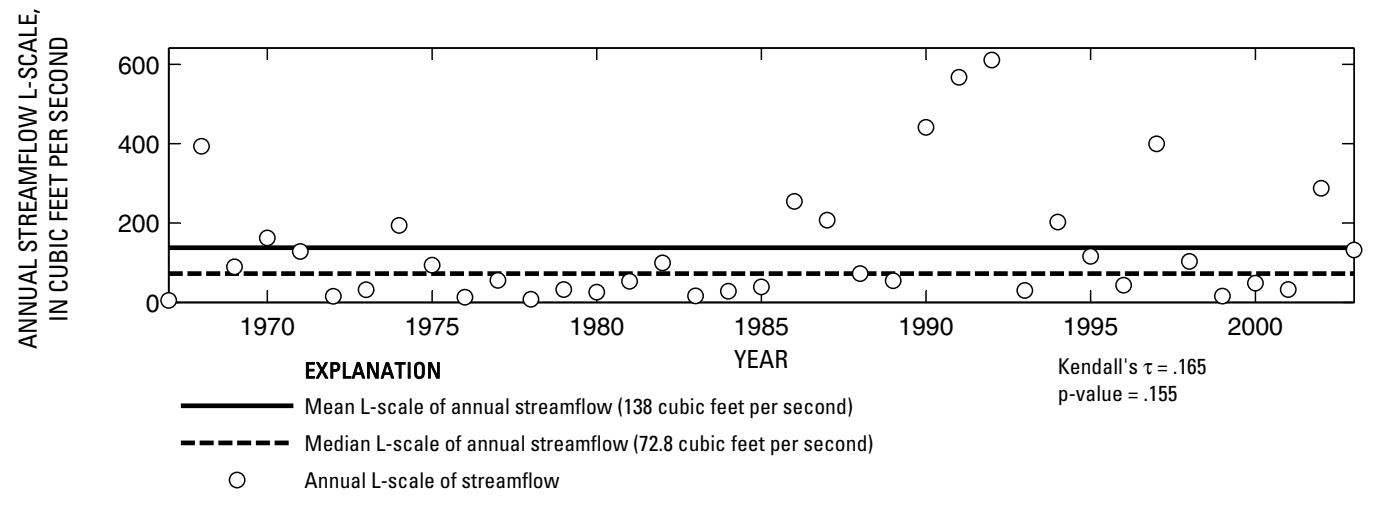

Figure 498. Analysis of annual mean, maximum, minimum, and L-scale statistics of daily mean streamflow for U.S. Geological Survey streamflow-gaging station 08143600 Pecan Bayou near Mullin, Texas. 


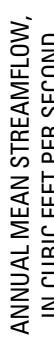

U.S. Geological Survey streamflow-gaging station 08144500

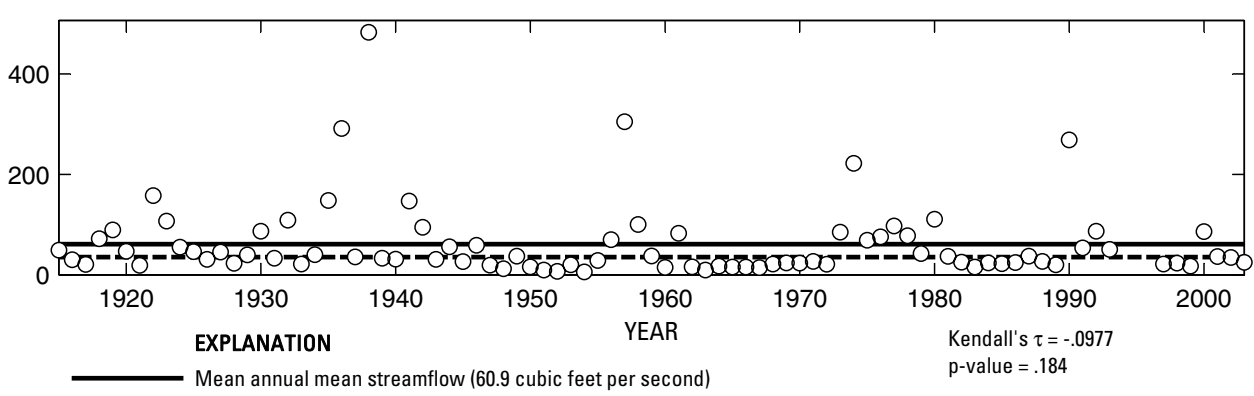

-_-_- Median annual mean streamflow (35.1 cubic feet per second)

O Annual mean streamflow

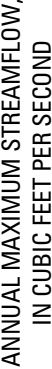

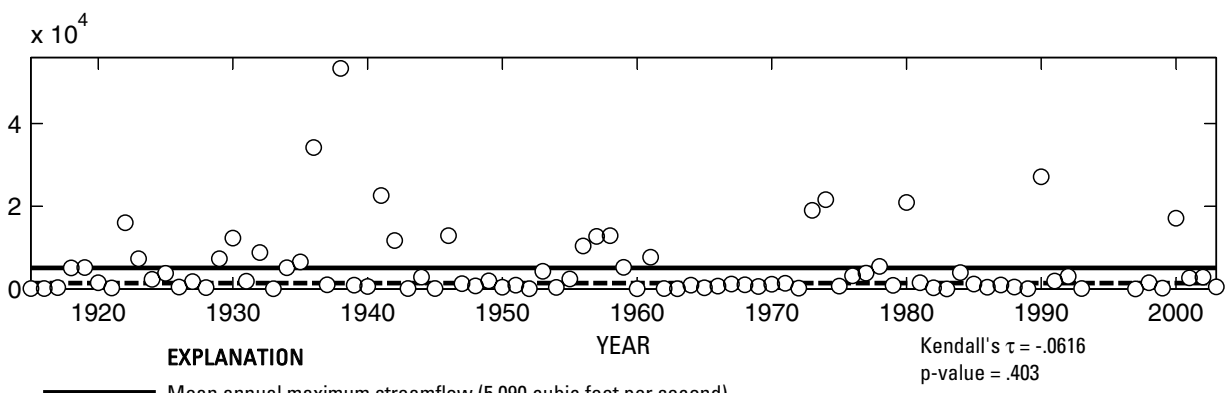

O Annual maximum streamflow

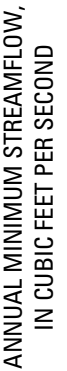

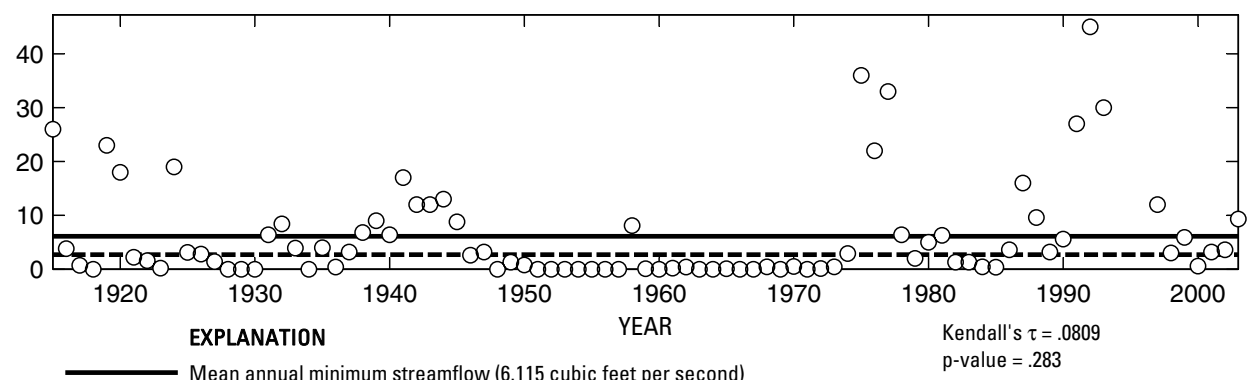

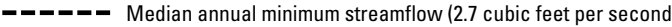

O Annual minimum streamflow

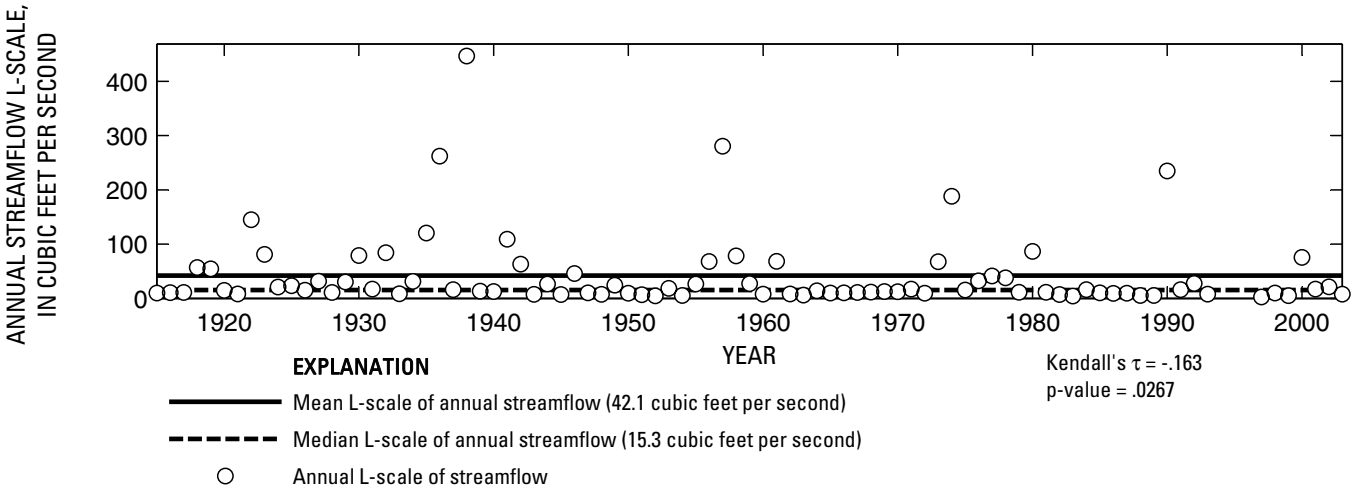

Figure 499. Analysis of annual mean, maximum, minimum, and L-scale statistics of daily mean streamflow for U.S. Geological Survey streamflow-gaging station 08144500 San Saba River at Menard, Texas. 
U.S. Geological Survey streamflow-gaging station 08144600

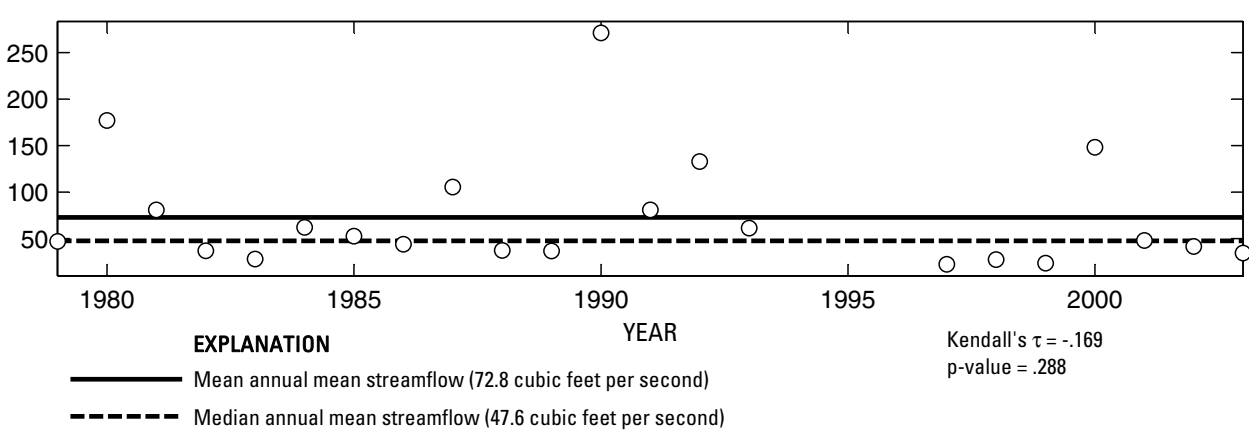

O Annual mean streamflow
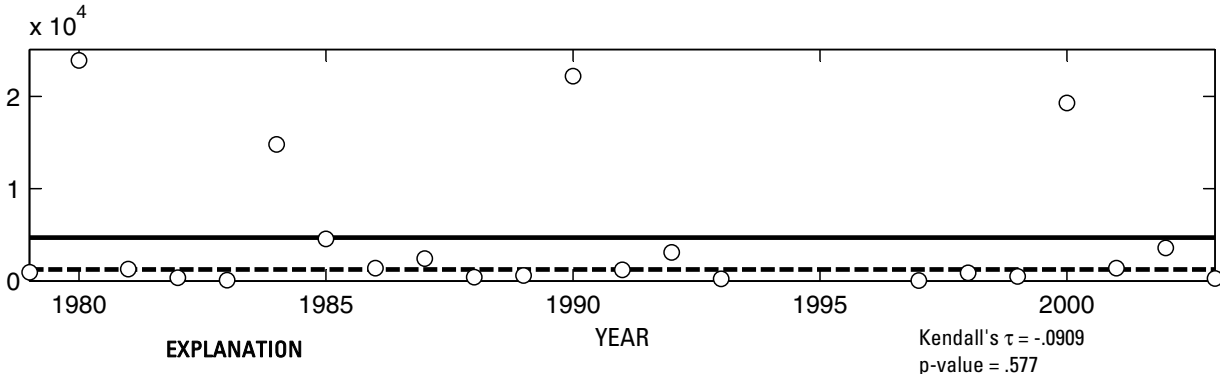

Mean annual maximum streamflow (4,700 cubic feet per second)

$\mathrm{p}$-value $=.577$

- - - - Median annual maximum streamflow (1,250 cubic feet per second

O Annual maximum streamflow

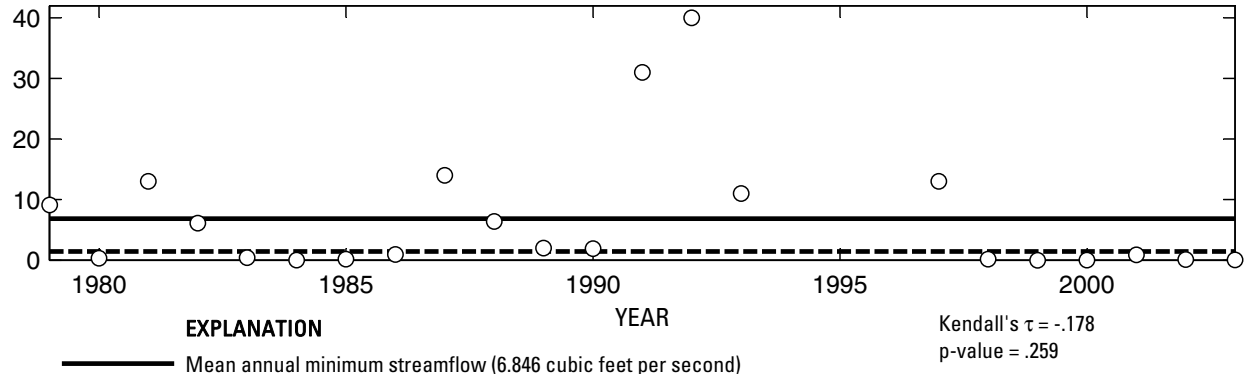

- Median annual minimum streamflow (1.425 cubic feet per second)

O Annual minimum streamflow

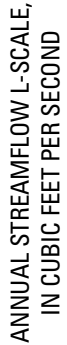

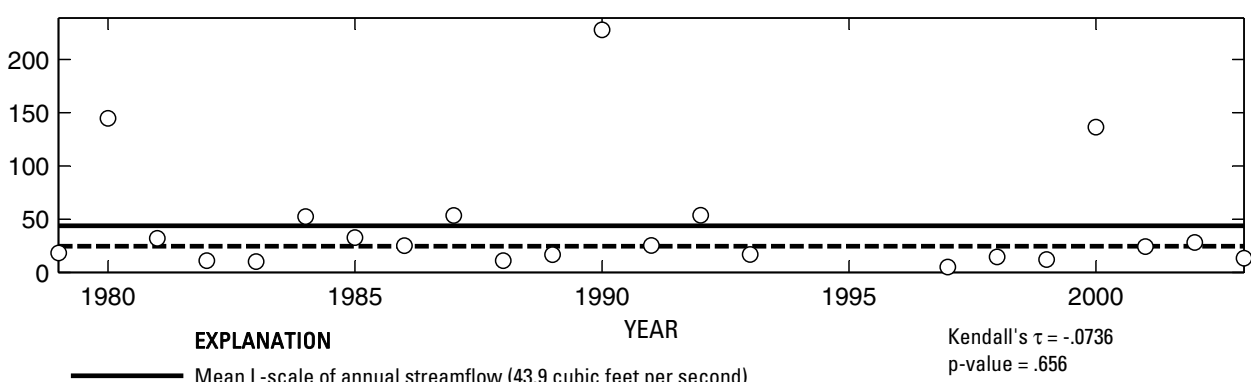

Mean L-scale of annual streamflow (43.9 cubic feet per second)

$\mathrm{p}$-value $=.656$

- - - - Median L-scale of annual streamflow (24.6 cubic feet per second)

Annual L-scale of streamflow

Figure 500. Analysis of annual mean, maximum, minimum, and L-scale statistics of daily mean streamflow for U.S. Geological Survey streamflow-gaging station 08144600 San Saba River near Brady, Texas. 


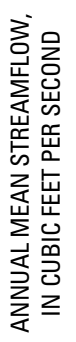

U.S. Geological Survey streamflow-gaging station 08144800

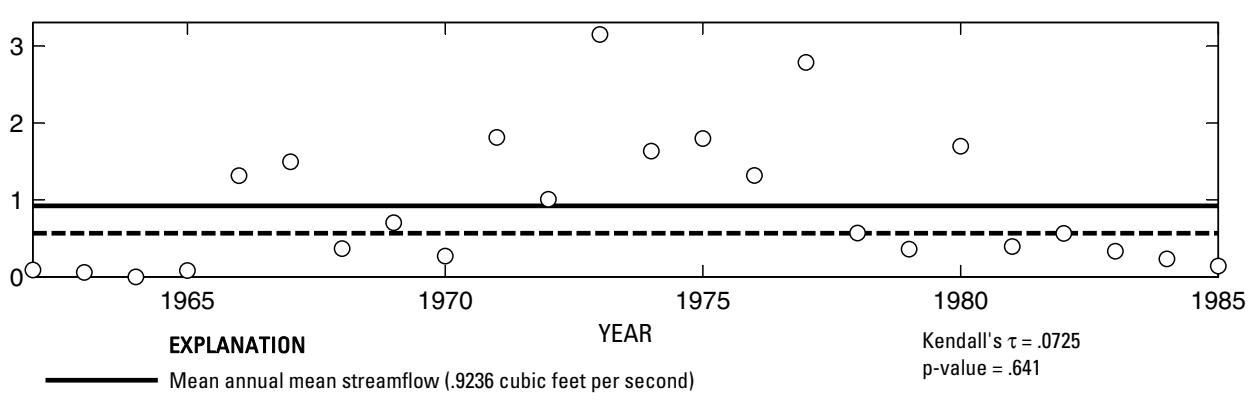

-ーーーーー Median annual mean streamflow (.5667 cubic feet per second)

O Annual mean streamflow

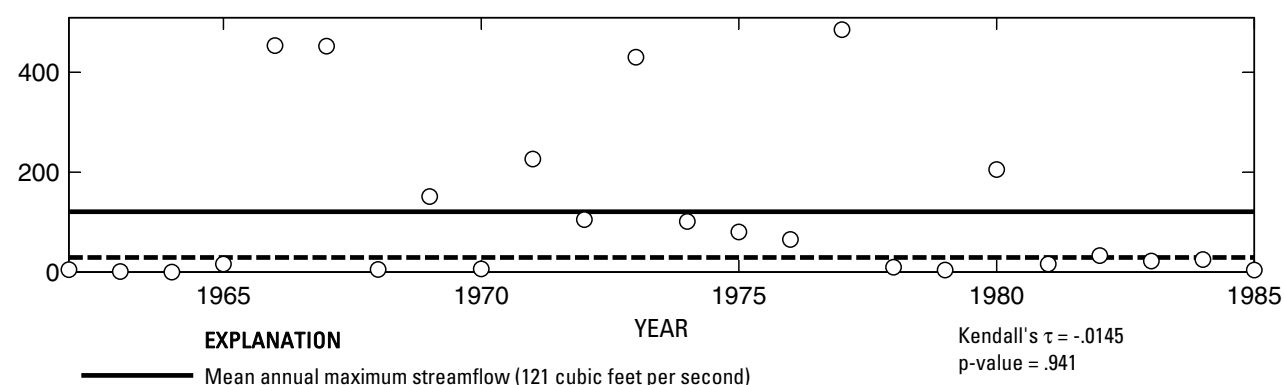

- - - Median annual maximum streamflow (29 cubic feet per second)

O Annual maximum streamflow

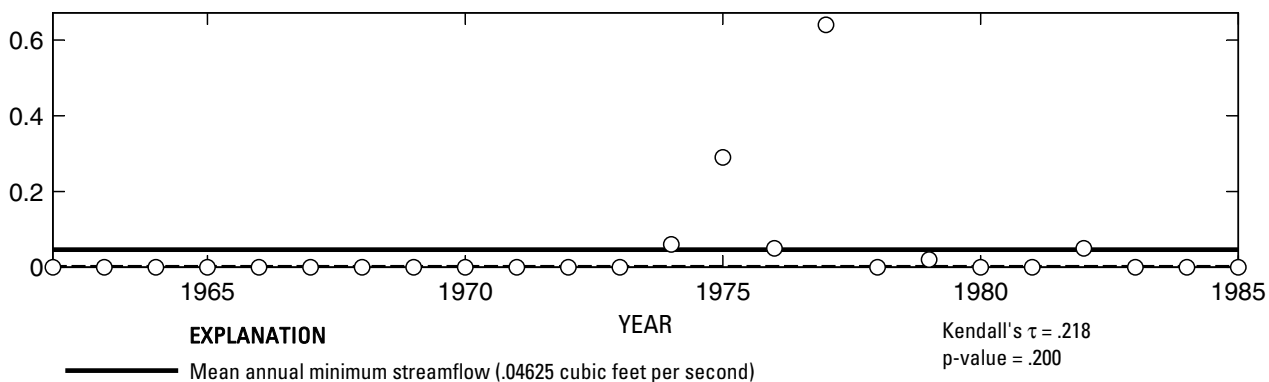

- ב-ב. Median annual minimum streamflow (0 cubic feet per second)

O Annual minimum streamflow
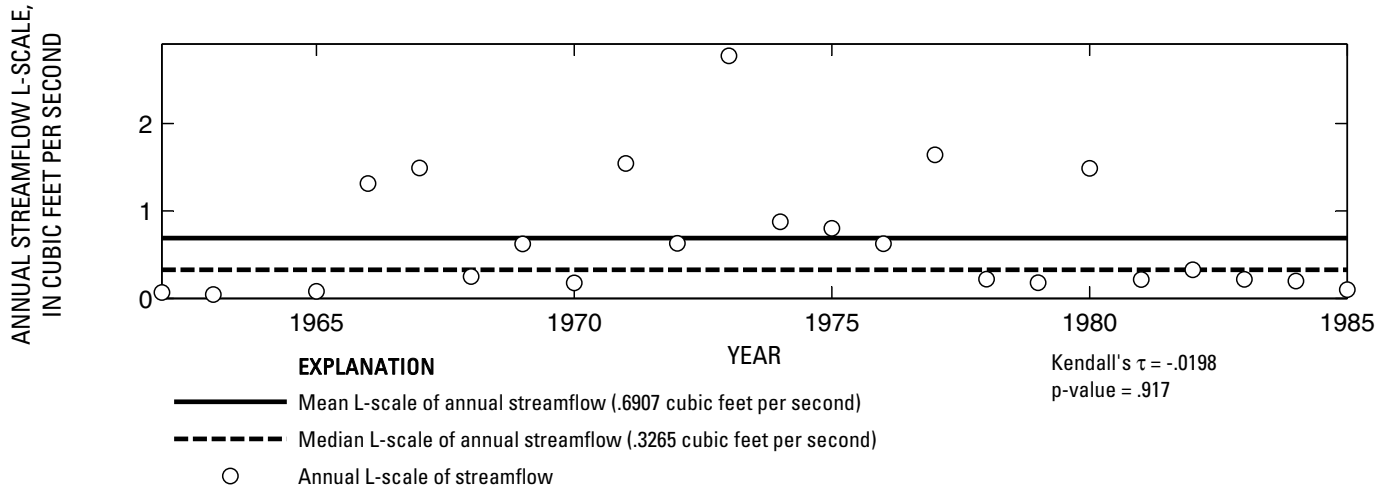

Figure 501. Analysis of annual mean, maximum, minimum, and L-scale statistics of daily mean streamflow for U.S. Geological Survey streamflow-gaging station 08144800 Brady Creek near Eden, Texas. 
U.S. Geological Survey streamflow-gaging station 08145000
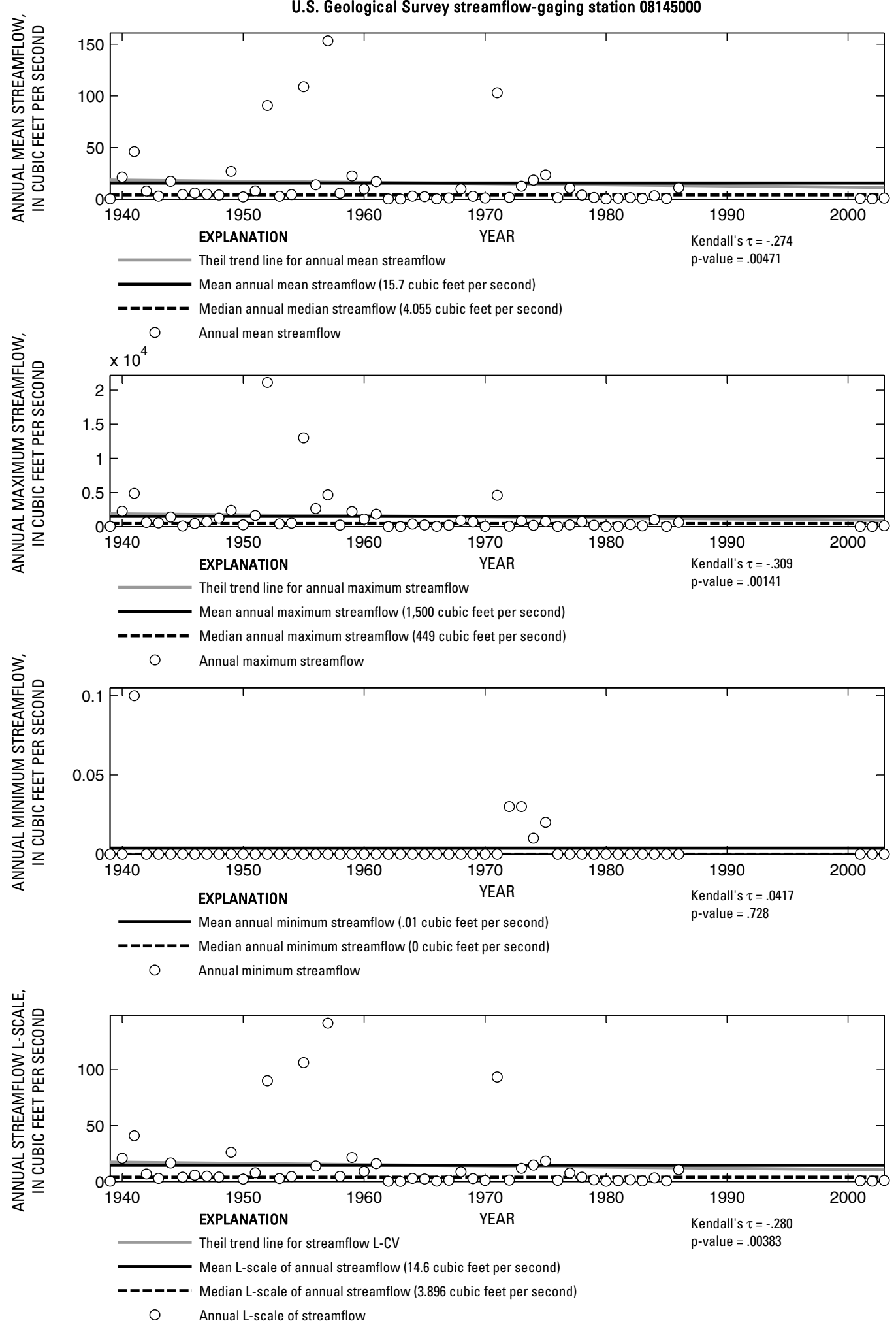

Figure 502. Analysis of annual mean, maximum, minimum, and L-scale statistics of daily mean streamflow for U.S. Geological Survey streamflow-gaging station 08145000 Brady Creek at Brady, Texas.

Index of Station Numbers 719 

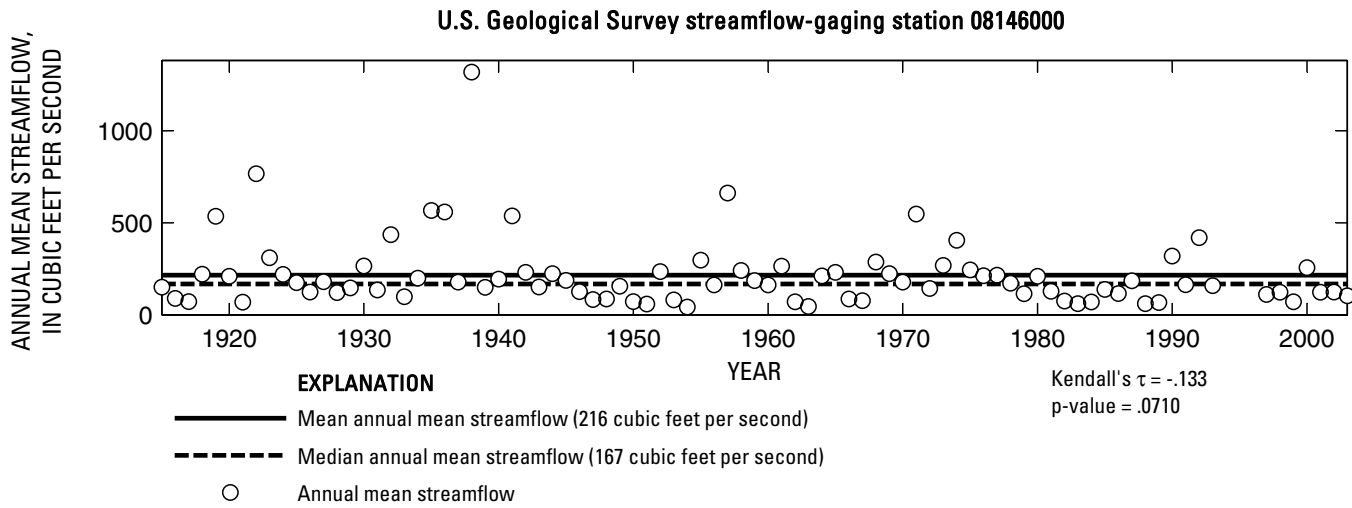

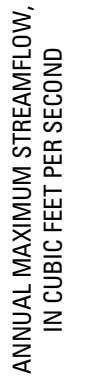

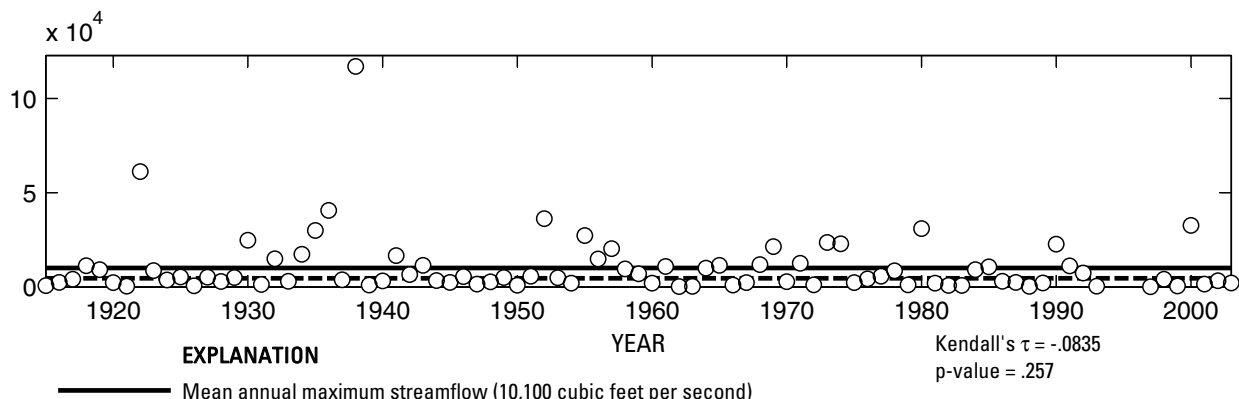

- _ _ - Median annual maximum streamflow (4,600 cubic feet per second)

O Annual maximum streamflow
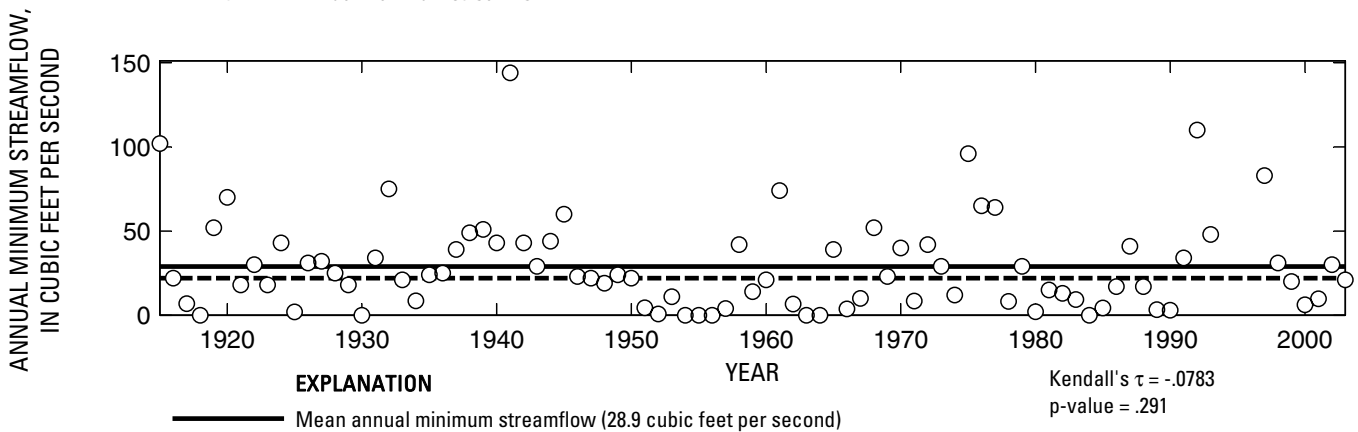

- ב-ב Median annual minimum streamflow (22 cubic feet per second)

○ Annual minimum streamflow

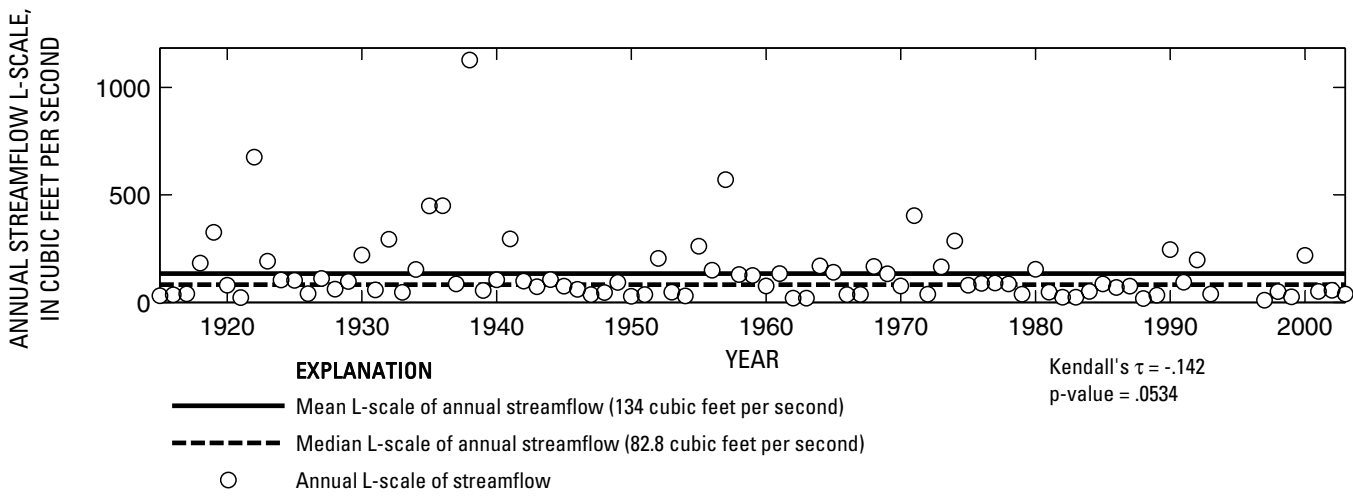

Figure 503. Analysis of annual mean, maximum, minimum, and L-scale statistics of daily mean streamflow for U.S. Geological Survey streamflow-gaging station 08146000 San Saba River at San Saba, Texas. 


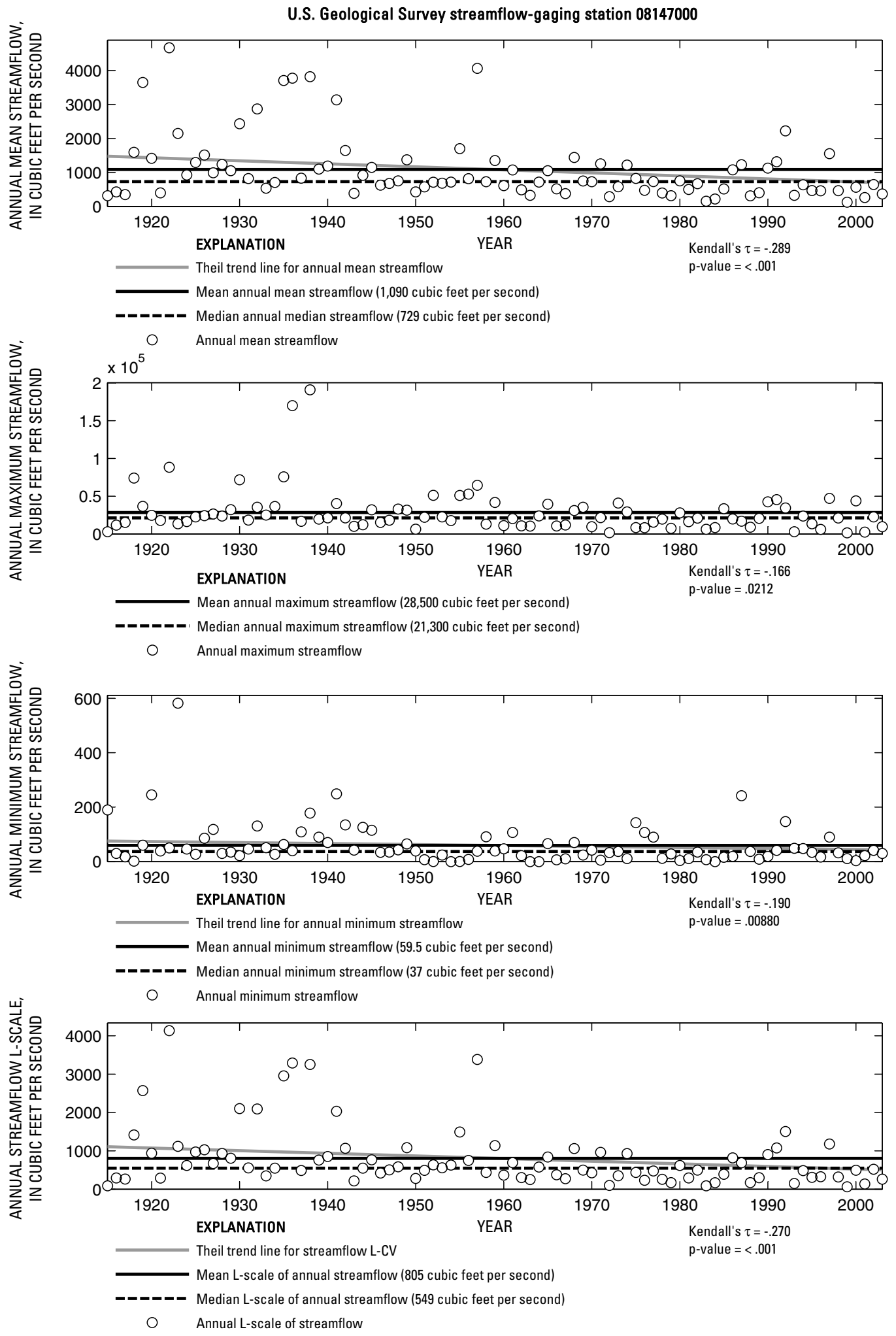

Figure 504. Analysis of annual mean, maximum, minimum, and L-scale statistics of daily mean streamflow for U.S. Geological Survey streamflow-gaging station 08147000 Colorado River near San Saba, Texas.

Index of Station Numbers 719 


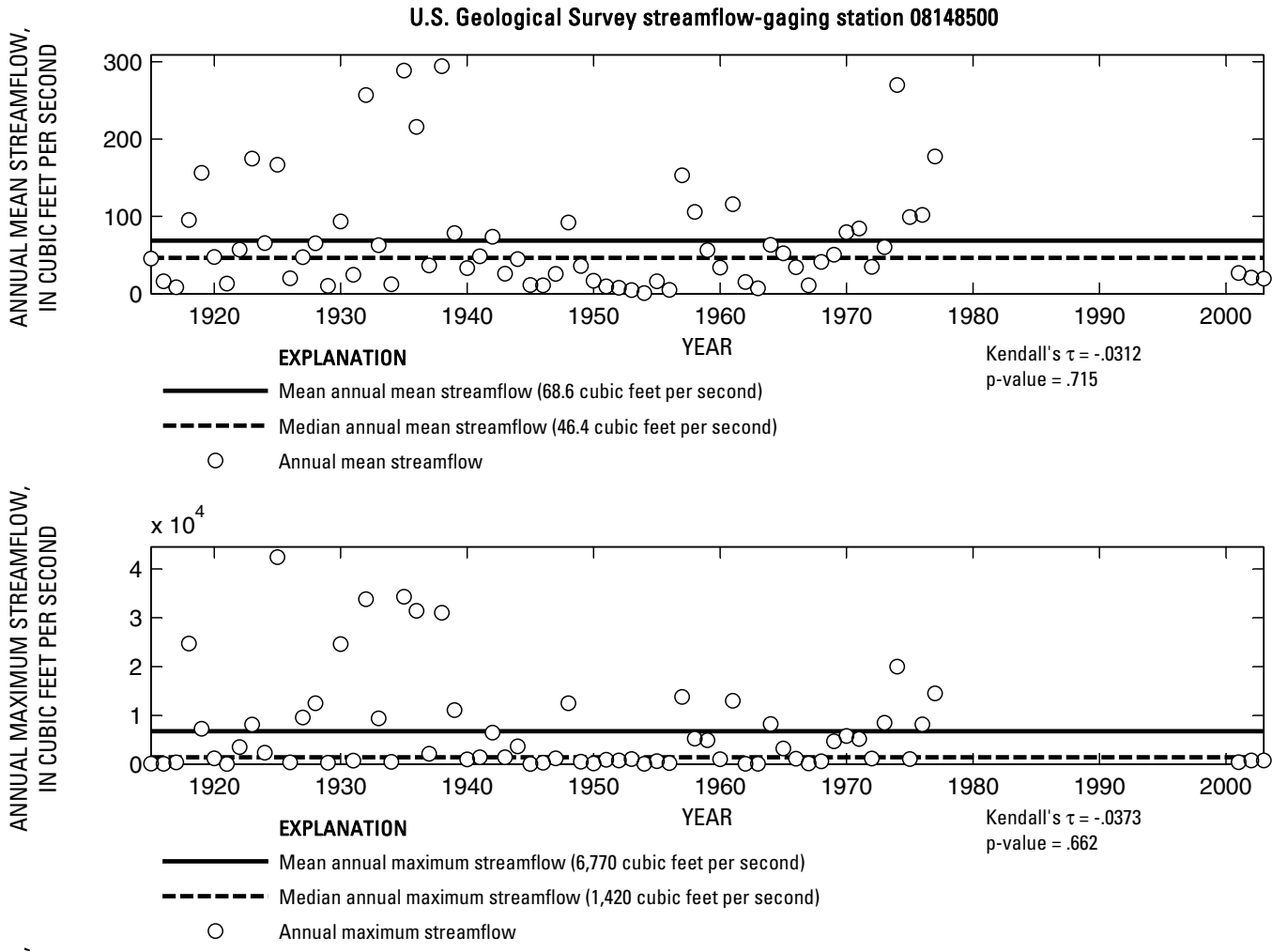

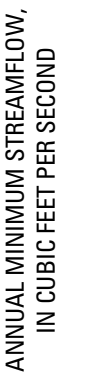

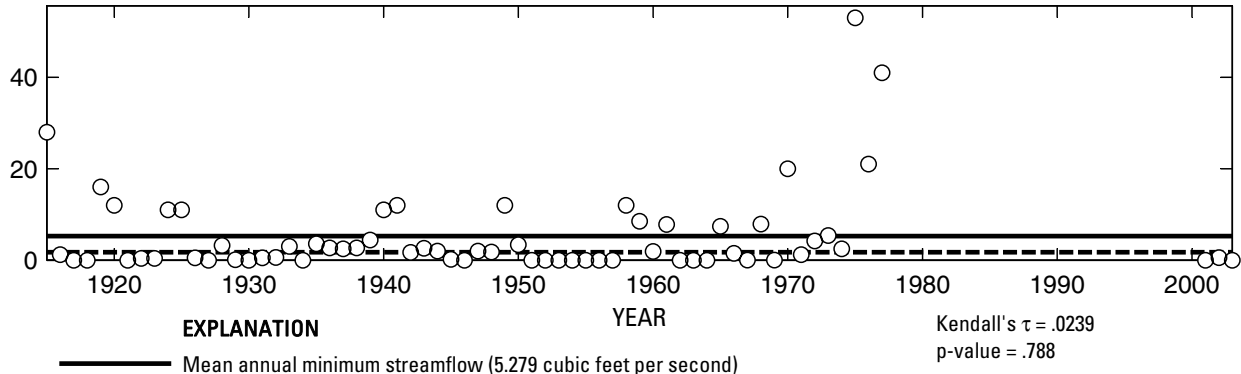

- ב-_ Median annual minimum streamflow (1.75 cubic feet per second)

○ Annual minimum streamflow

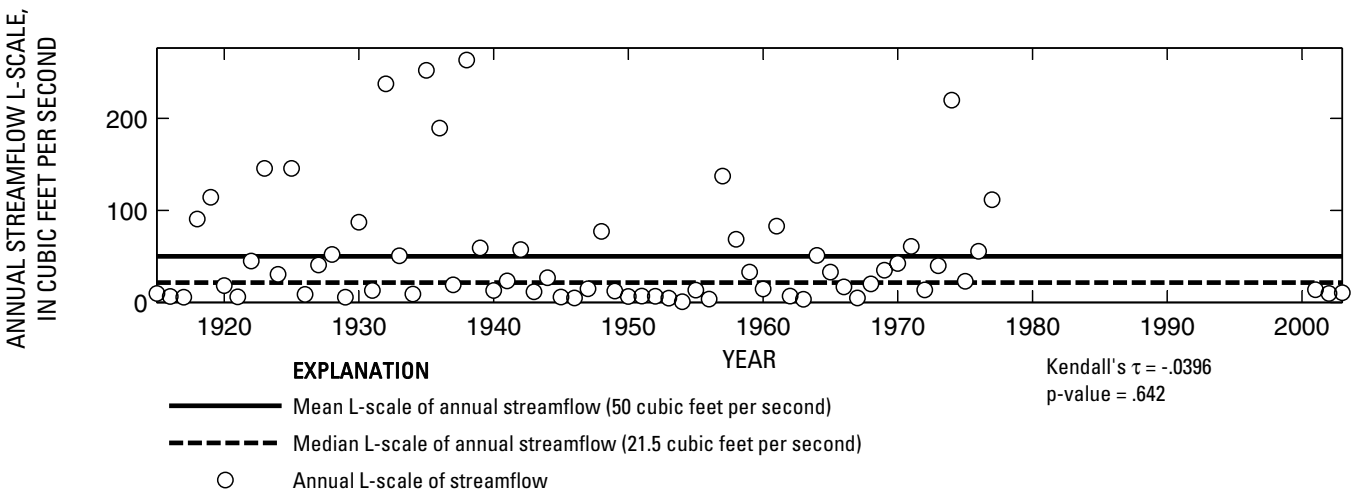

Figure 505. Analysis of annual mean, maximum, minimum, and L-scale statistics of daily mean streamflow for U.S. Geological Survey streamflow-gaging station 08148500 North Llano River near Junction, Texas. 


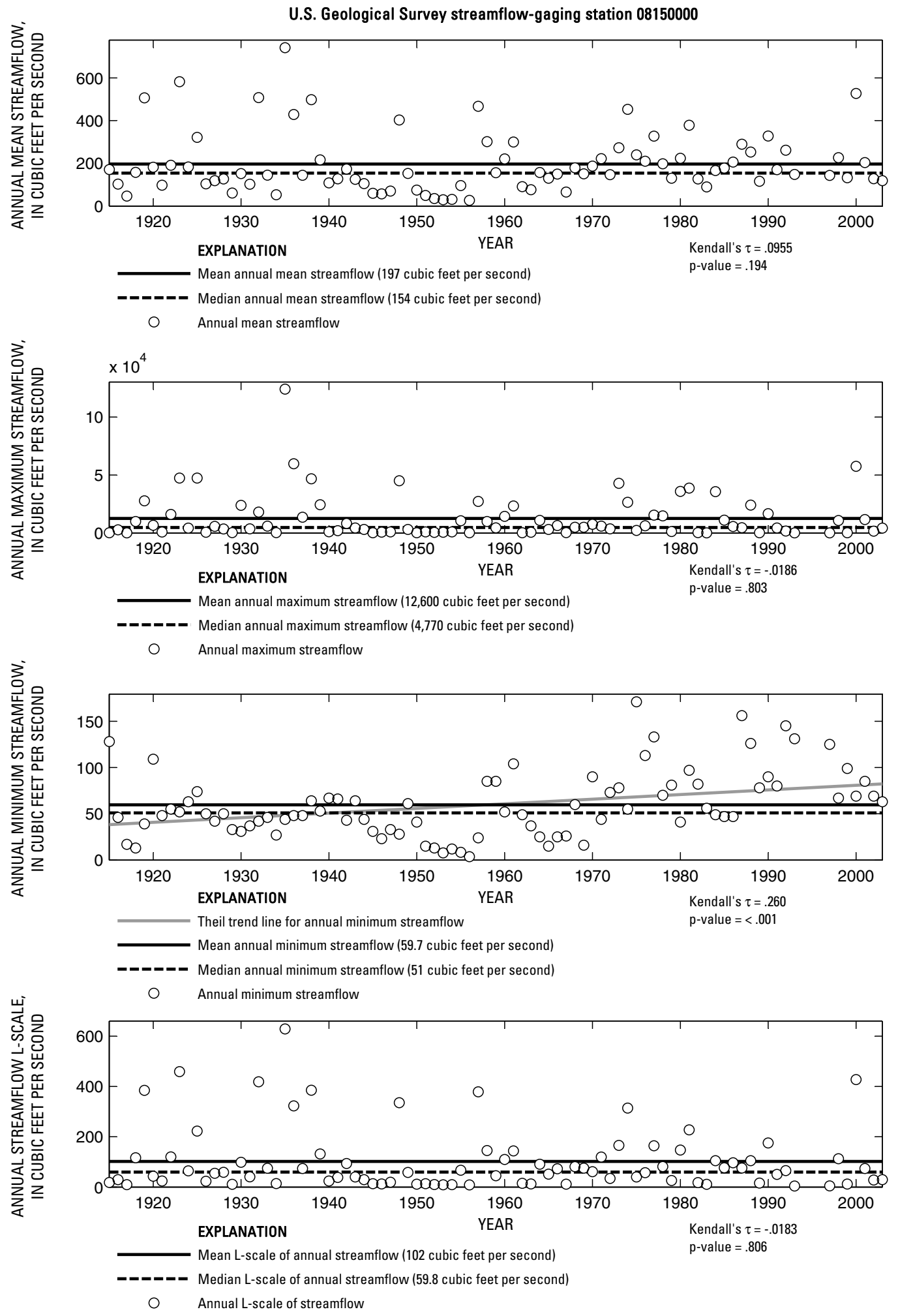

Figure 506. Analysis of annual mean, maximum, minimum, and L-scale statistics of daily mean streamflow for U.S. Geological Survey streamflow-gaging station 08150000 Llano River near Junction, Texas.

Index of Station Numbers 719 

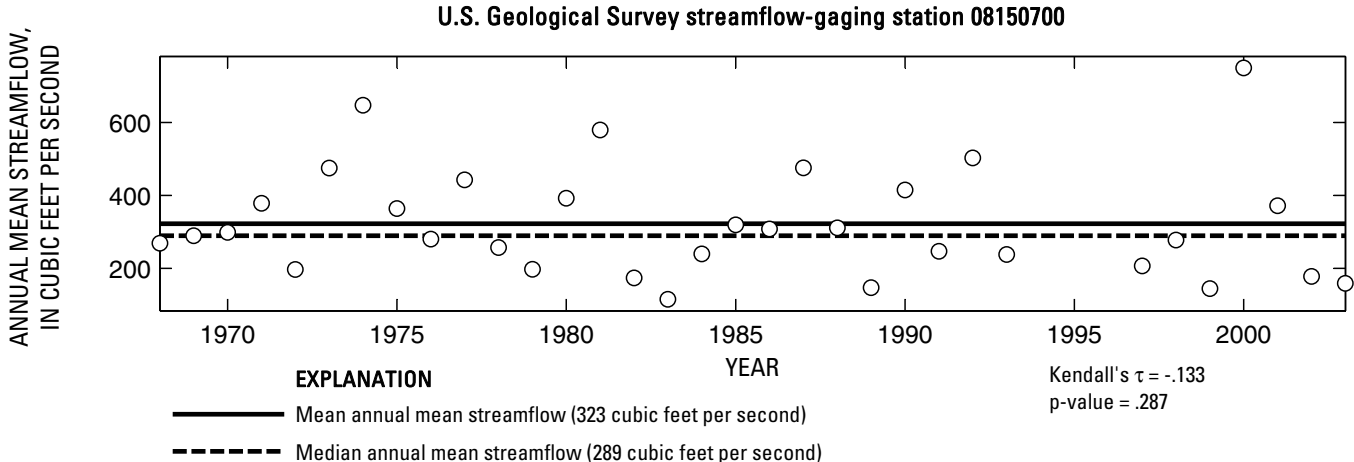

O Annual mean streamflow

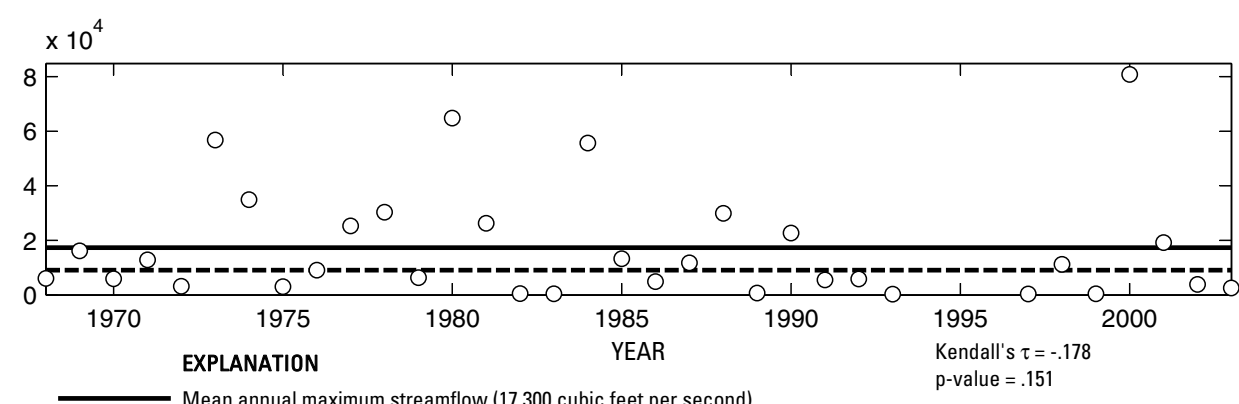

- _ _ - Median annual maximum streamflow (9,070 cubic feet per second

O Annual maximum streamflow

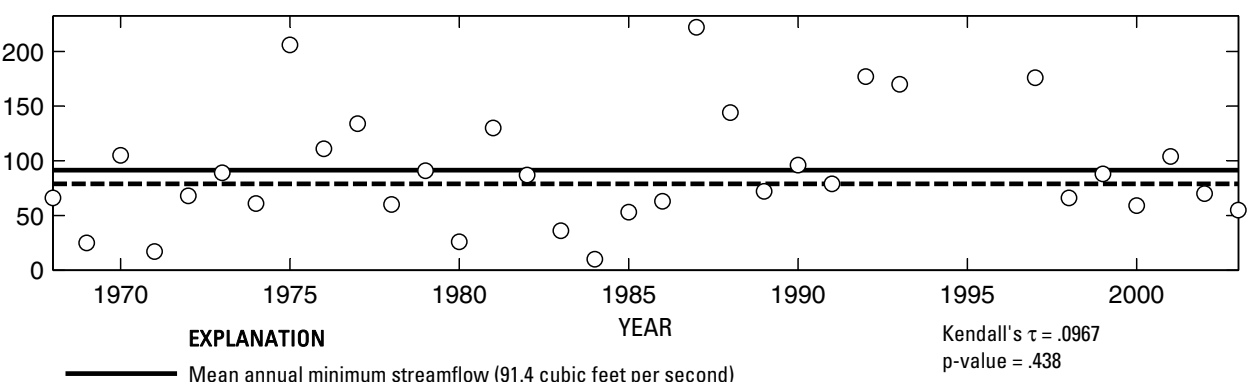

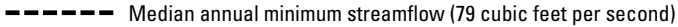

O Annual minimum streamflow

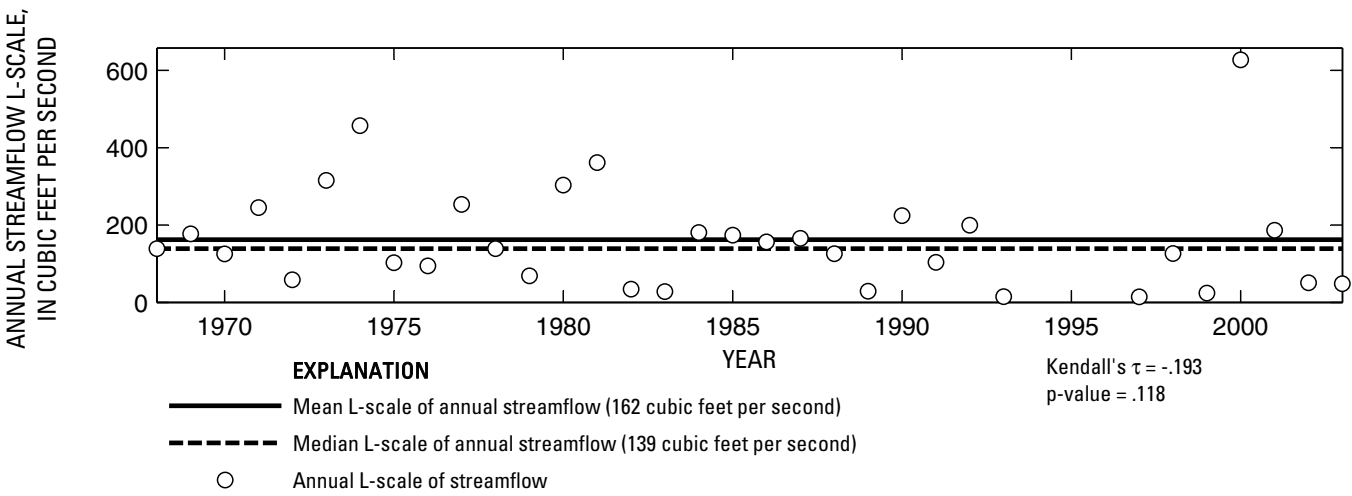

Figure 507. Analysis of annual mean, maximum, minimum, and L-scale statistics of daily mean streamflow for U.S. Geological Survey streamflow-gaging station 08150700 Llano River near Mason, Texas. 

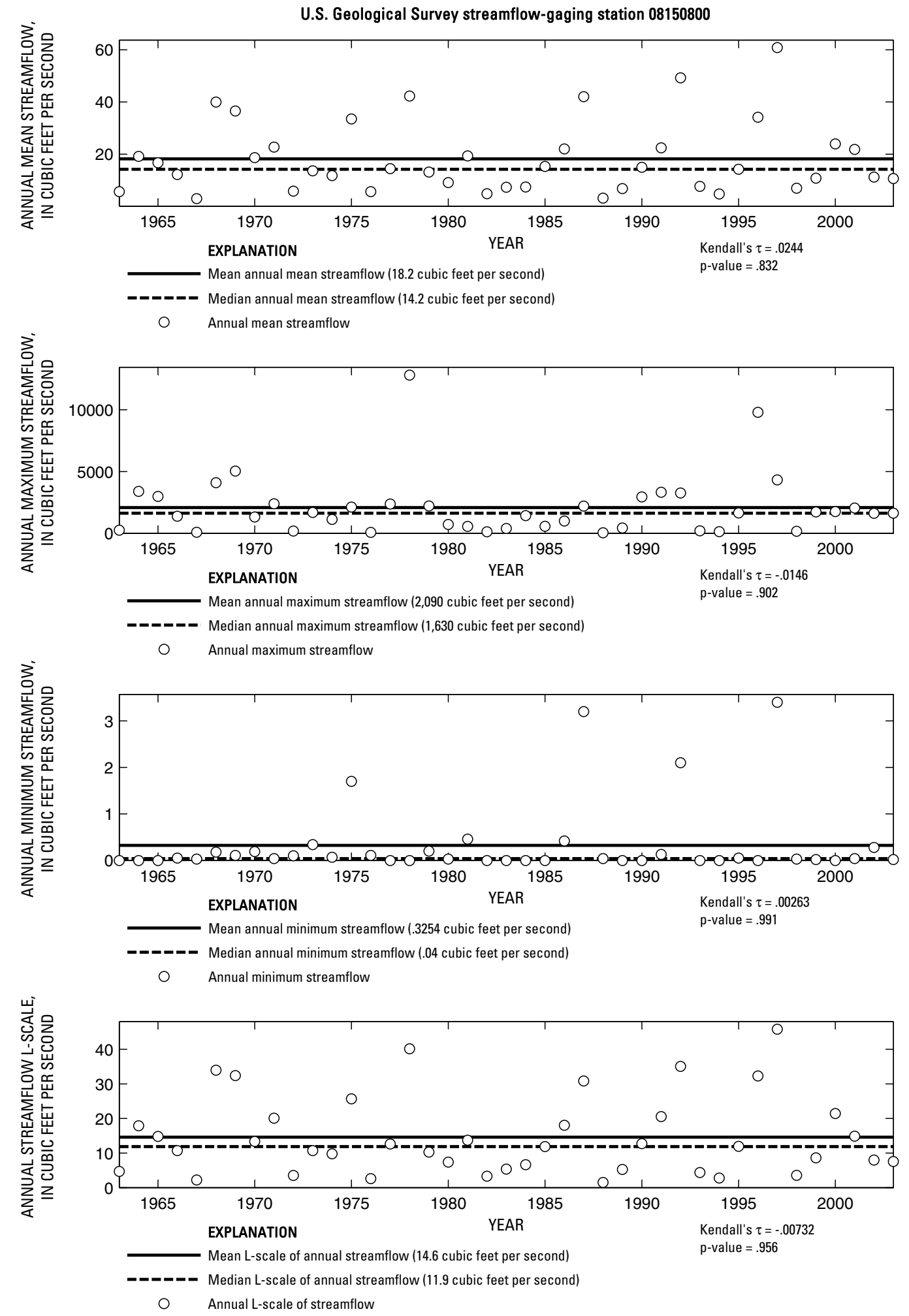

Figure 508. Analysis of annual mean, maximum, minimum, and L-scale statistics of daily mean streamflow for U.S. Geological Survey streamflow-gaging station 08150800 Beaver Creek near Mason, Texas. 


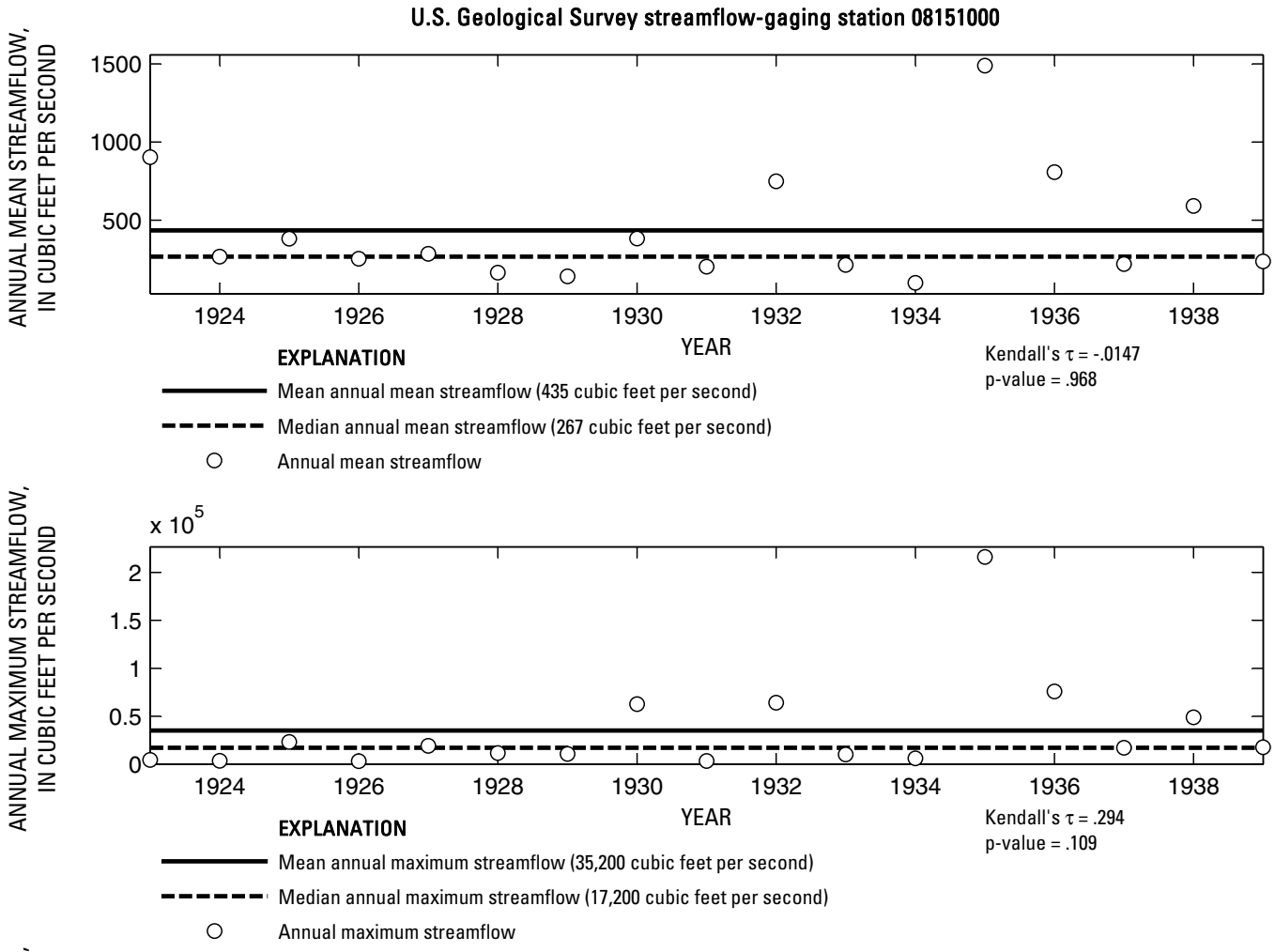

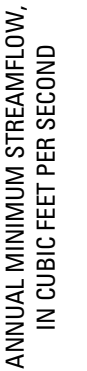

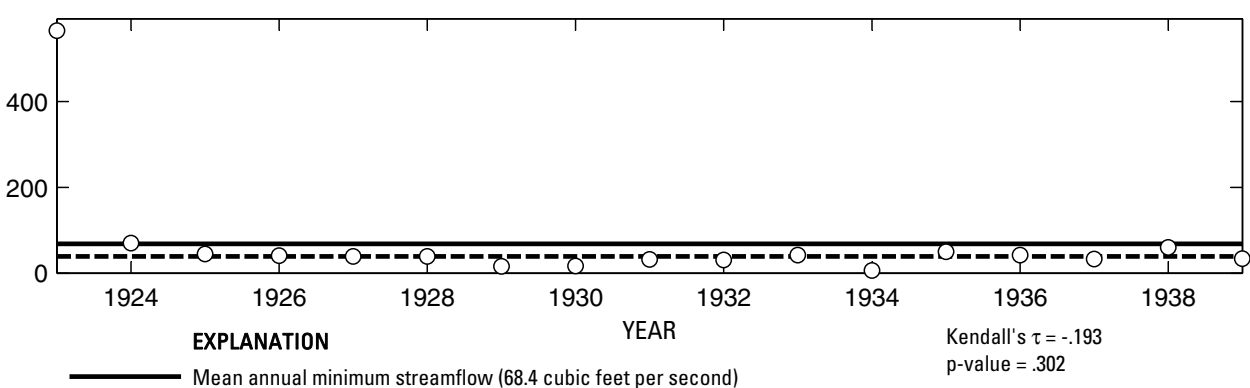

- - Median annual minimum streamflow (39 cubic feet per second)

○ Annual minimum streamflow

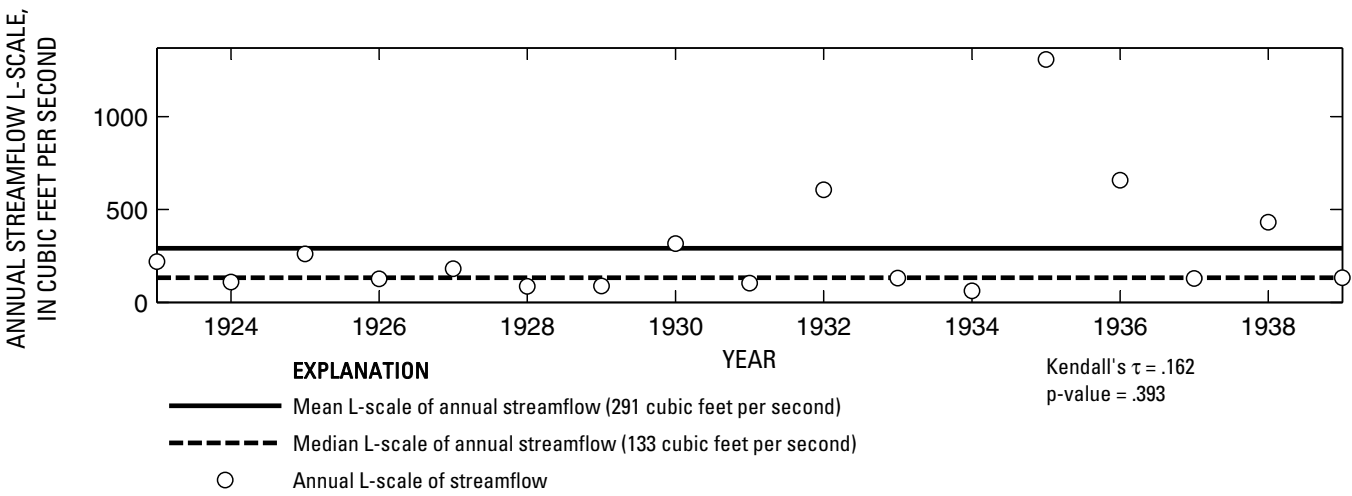

Figure 509. Analysis of annual mean, maximum, minimum, and L-scale statistics of daily mean streamflow for U.S. Geological Survey streamflow-gaging station 08151000 Llano River near Castell, Texas. 

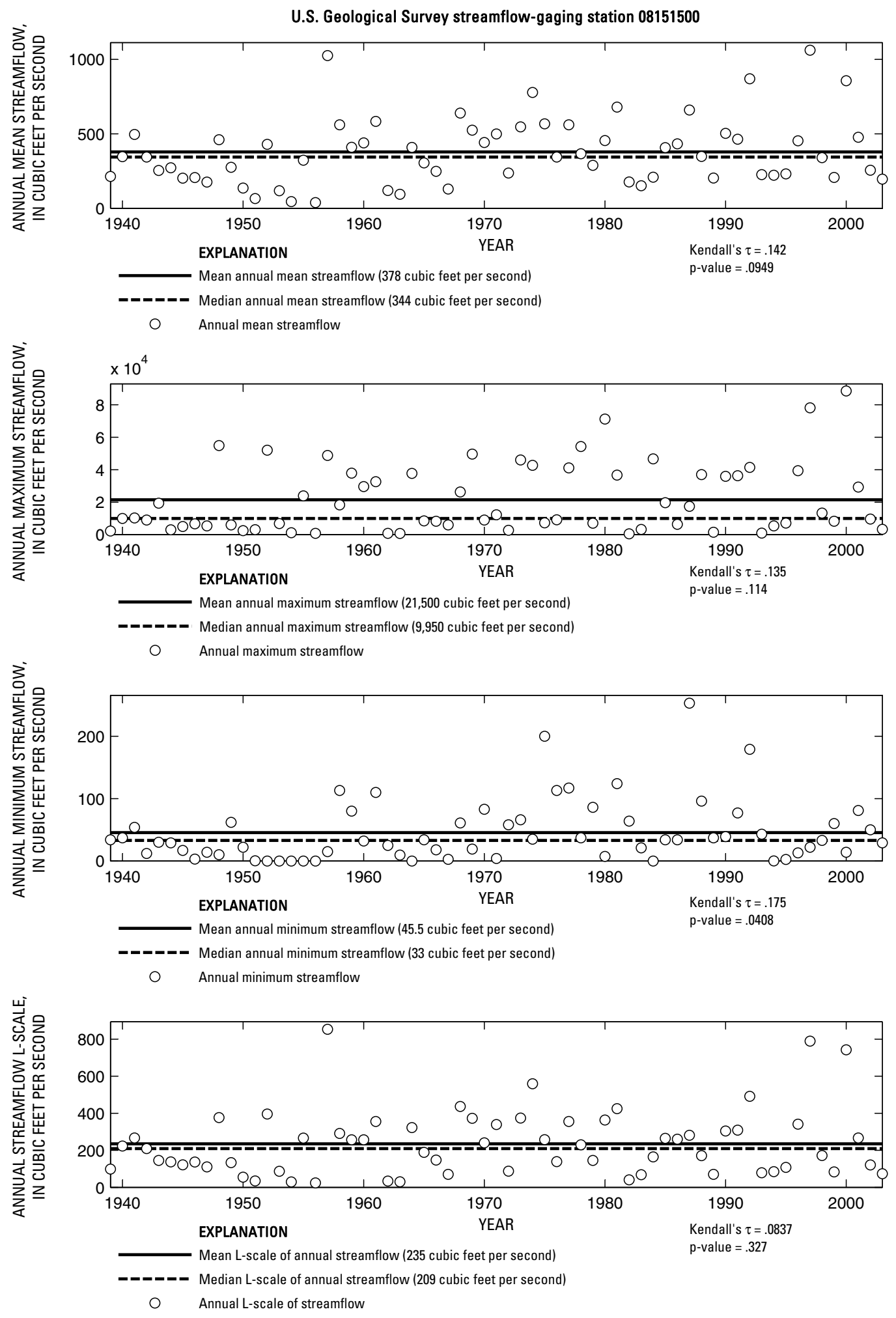

Figure 510. Analysis of annual mean, maximum, minimum, and L-scale statistics of daily mean streamflow for U.S. Geological Survey streamflow-gaging station 08151500 Llano River at Llano, Texas.

Index of Station Numbers 719 

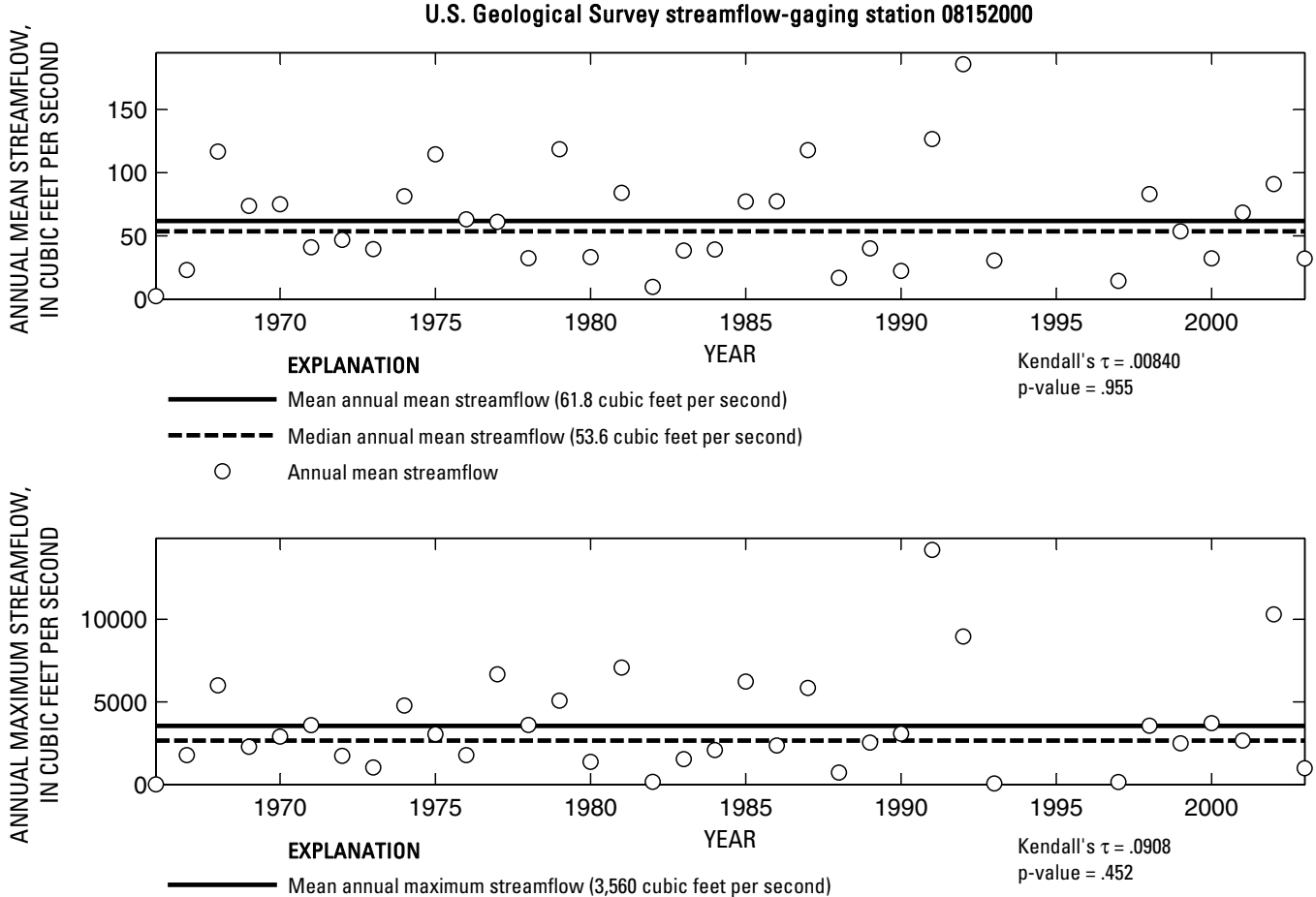

O Annual maximum streamflow
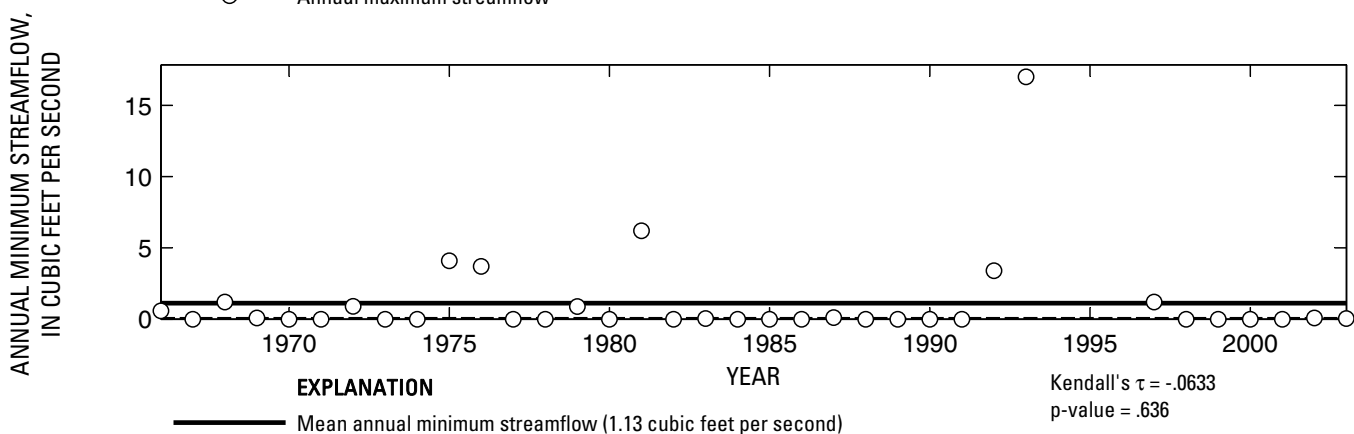

- $\mathbf{- 0}$ Median annual minimum streamflow (0 cubic feet per second)

O Annual minimum streamflow

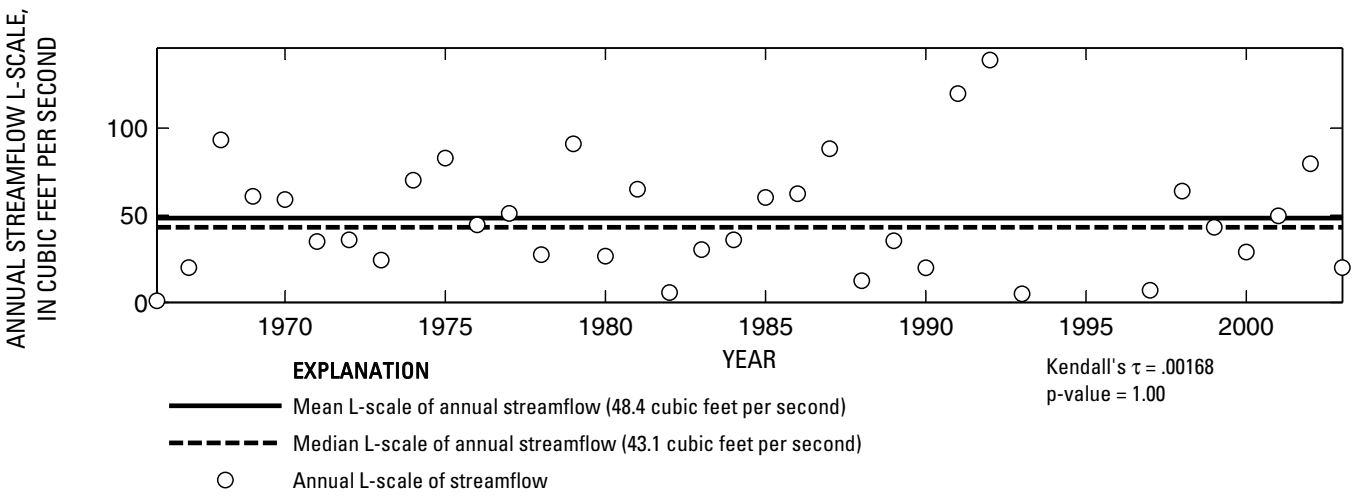

Figure 511. Analysis of annual mean, maximum, minimum, and L-scale statistics of daily mean streamflow for U.S. Geological Survey streamflow-gaging station 08152000 Sandy Creek near Kingsland, Texas. 

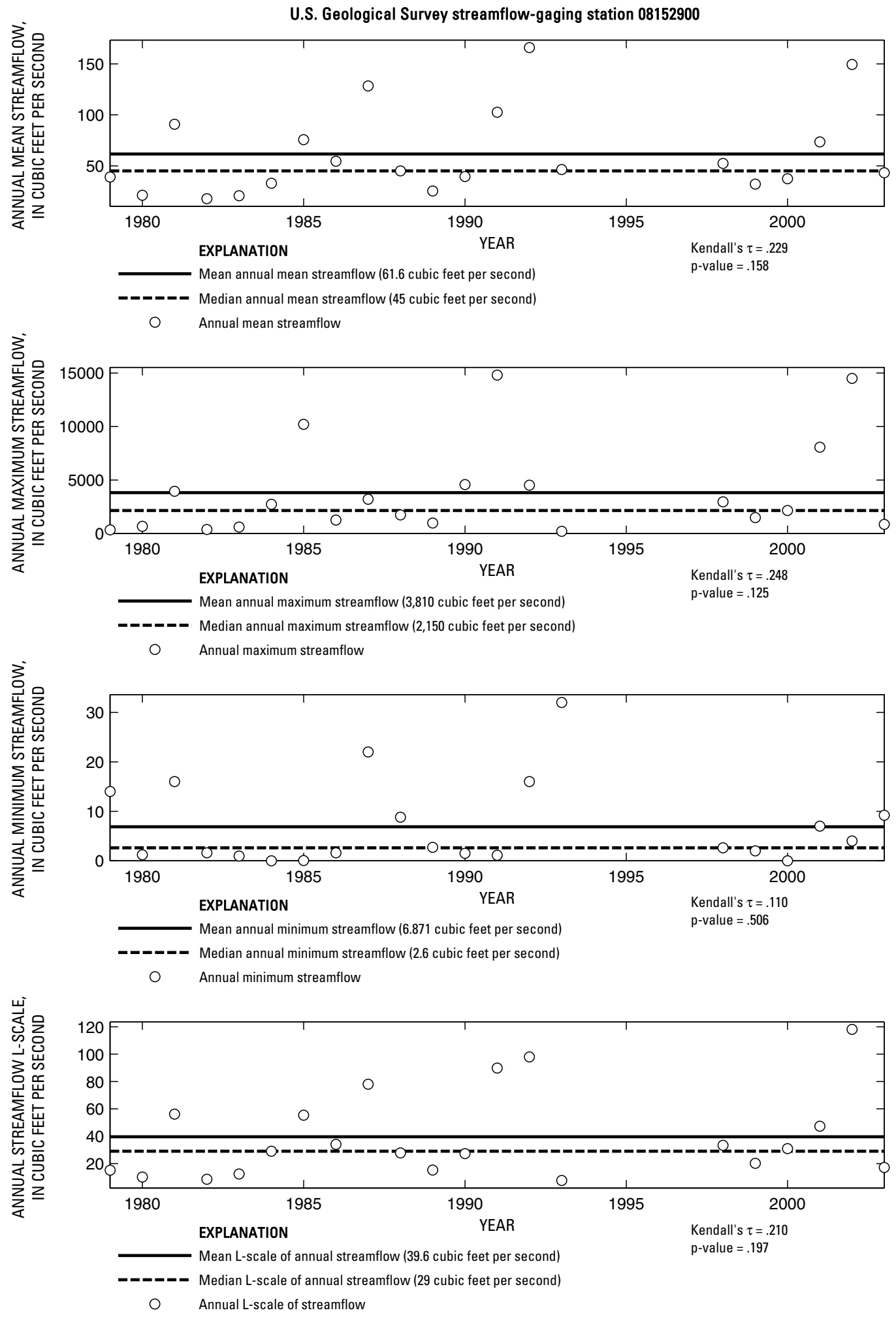

Figure 512. Analysis of annual mean, maximum, minimum, and L-scale statistics of daily mean streamflow for U.S. Geological Survey streamflow-gaging station 08152900 Pedernales River near Fredericksburg, Texas. 


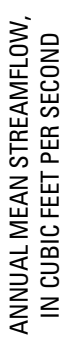

U.S. Geological Survey streamflow-gaging station 08153000

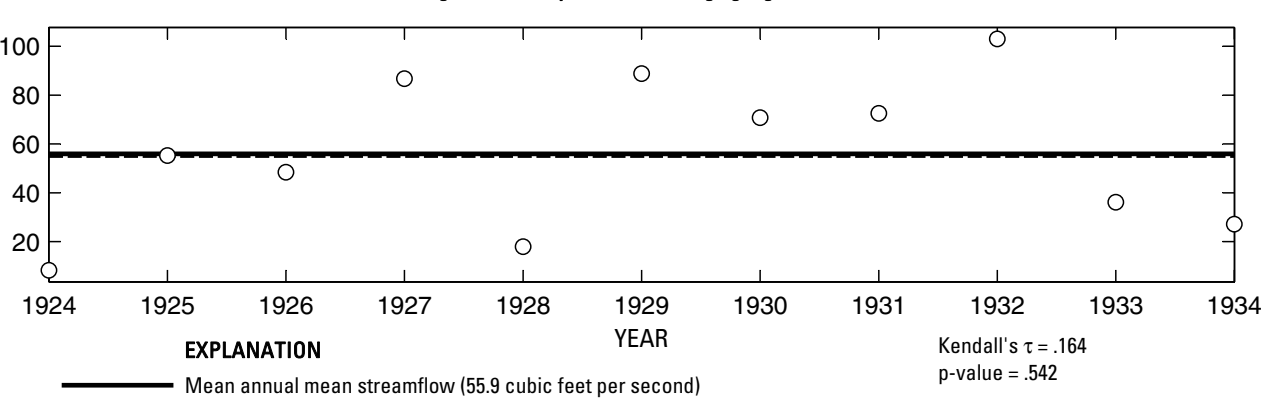

-_-_- Median annual mean streamflow ( 55.3 cubic feet per second)

O Annual mean streamflow
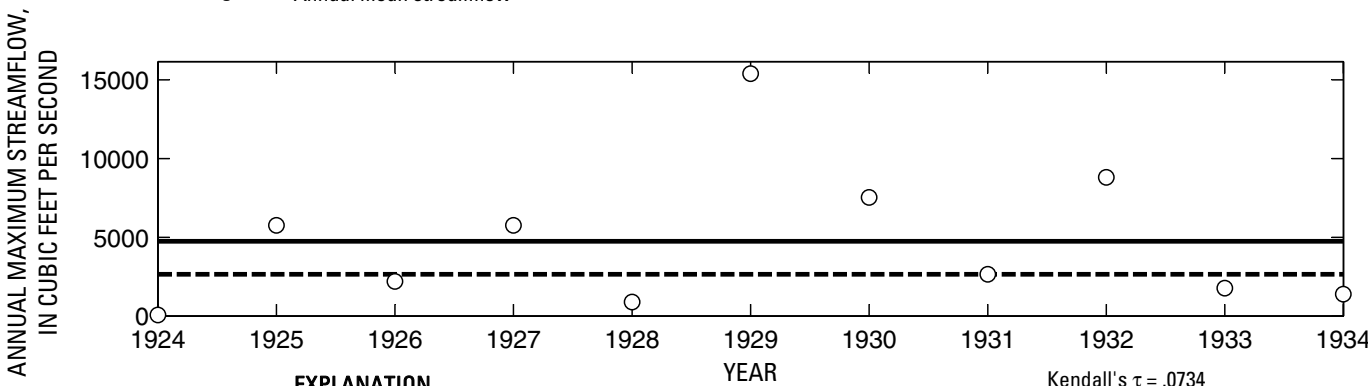

EXPLANATION

$\mathrm{p}$-value $=.815$

- Median annual maximum streamflow (2,650 cubic feet per second)

Annual maximum streamflow
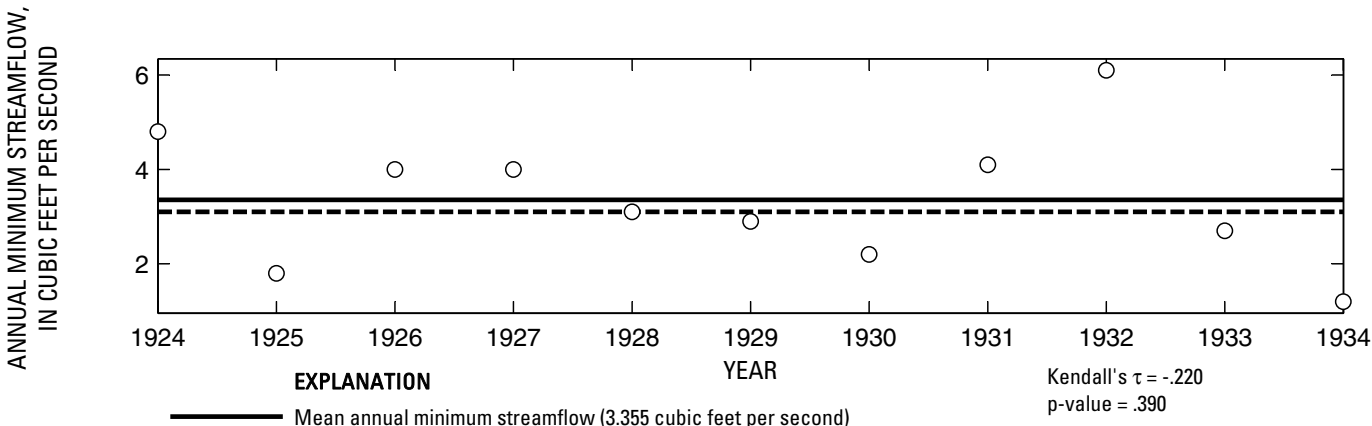

- - - Median annual minimum streamflow (3.1 cubic feet per second)

O Annual minimum streamflow

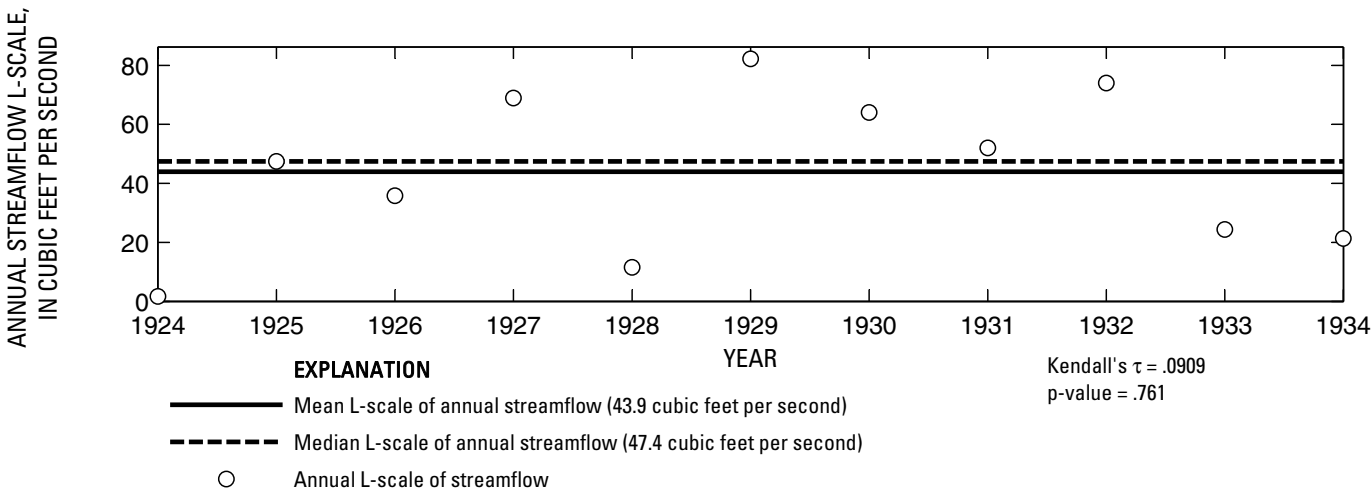

Figure 513. Analysis of annual mean, maximum, minimum, and L-scale statistics of daily mean streamflow for U.S. Geological Survey streamflow-gaging station 08153000 Pedernales River at Stonewall, Texas. 
U.S. Geological Survey streamflow-gaging station 08153500
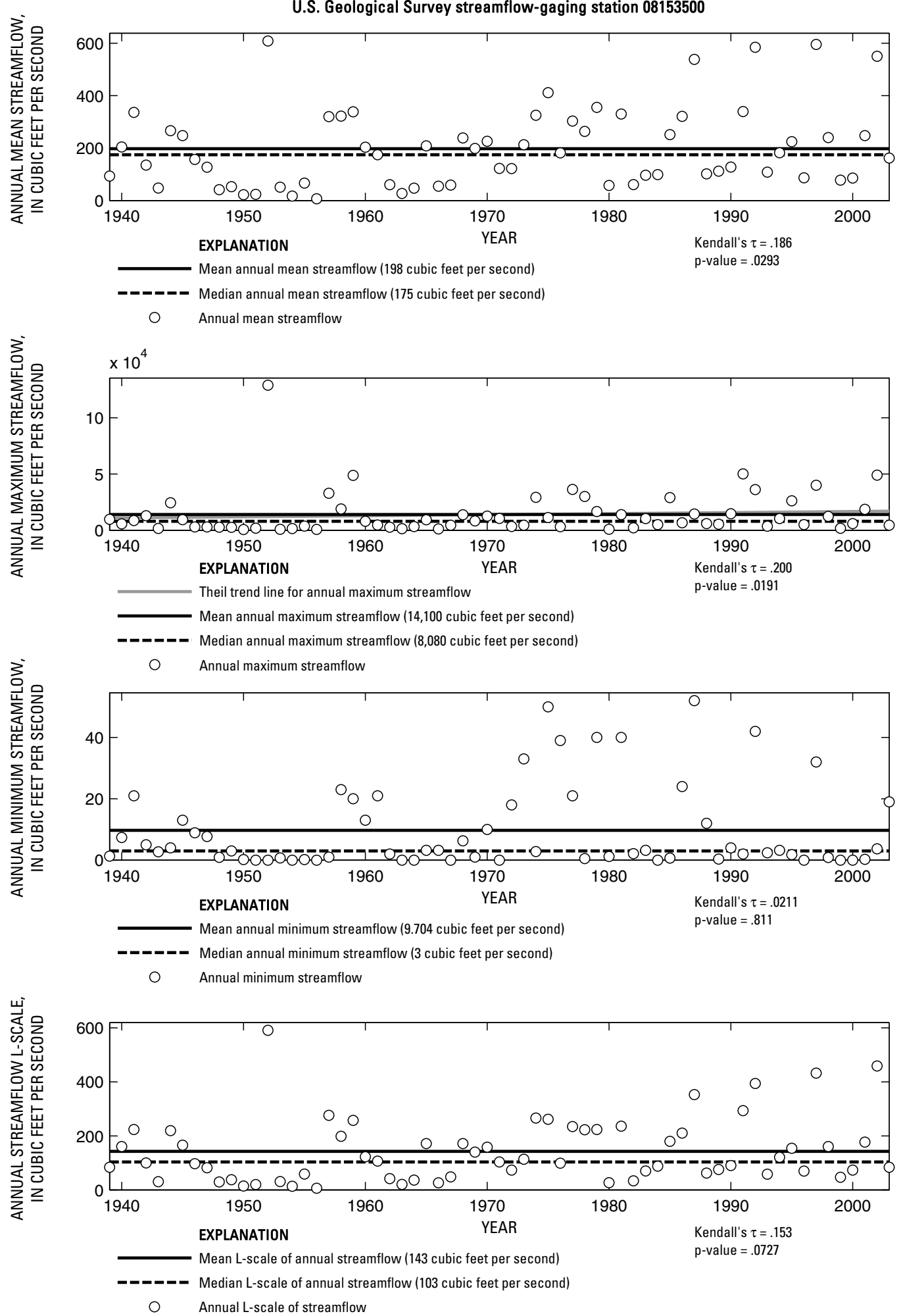

Figure 514. Analysis of annual mean, maximum, minimum, and L-scale statistics of daily mean streamflow for U.S. Geological Survey streamflow-gaging station 08153500 Pedernales River near Johnson City, Texas.

Index of Station Numbers 719 

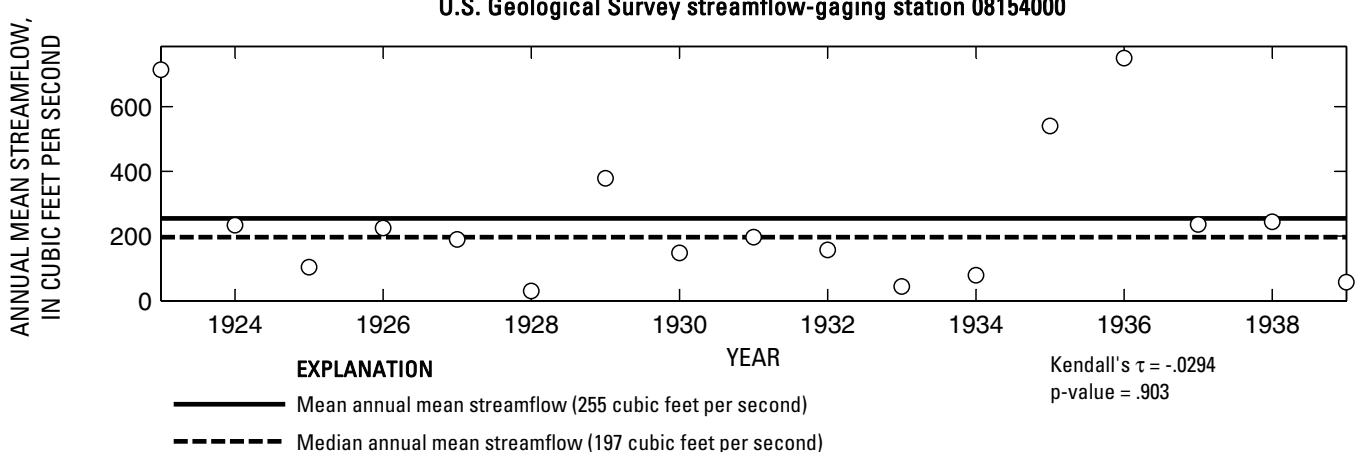

O Annual mean streamflow

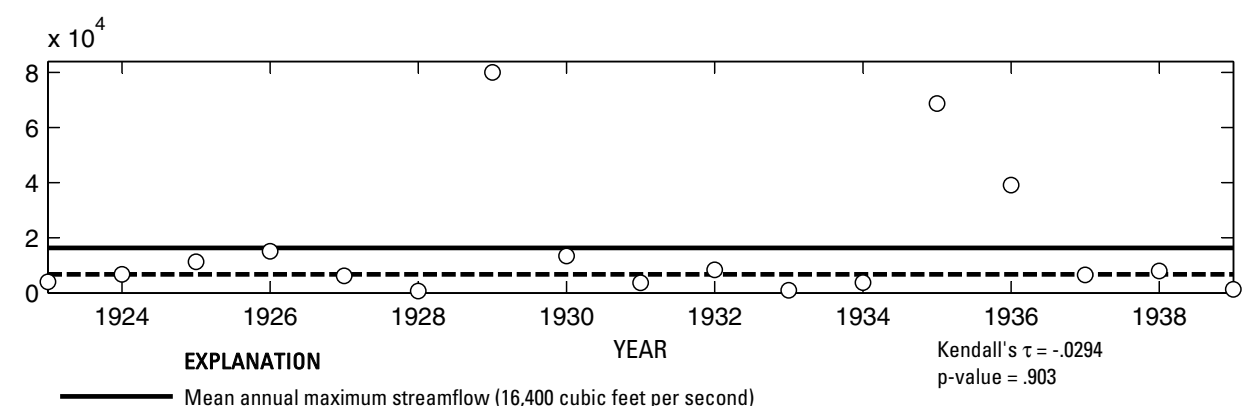

- _ _ - Median annual maximum streamflow (6,770 cubic feet per second

O Annual maximum streamflow

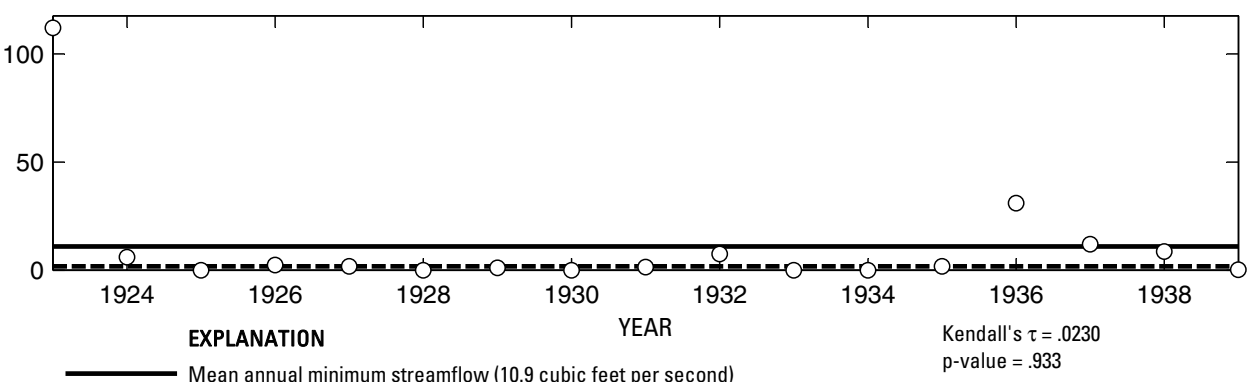

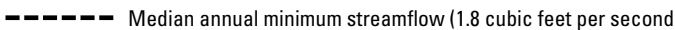

O Annual minimum streamflow

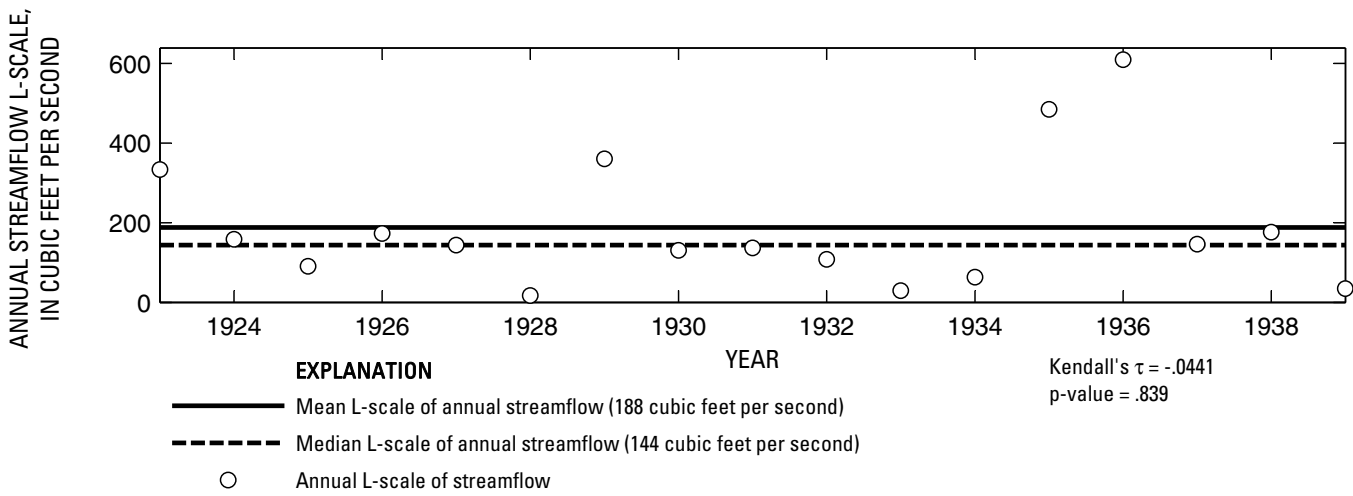

Figure 515. Analysis of annual mean, maximum, minimum, and L-scale statistics of daily mean streamflow for U.S. Geological Survey streamflow-gaging station 08154000 Pedernales River near Spicewood, Texas. 


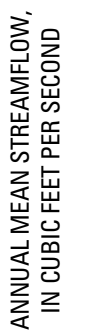

U.S. Geological Survey streamflow-gaging station 08154510

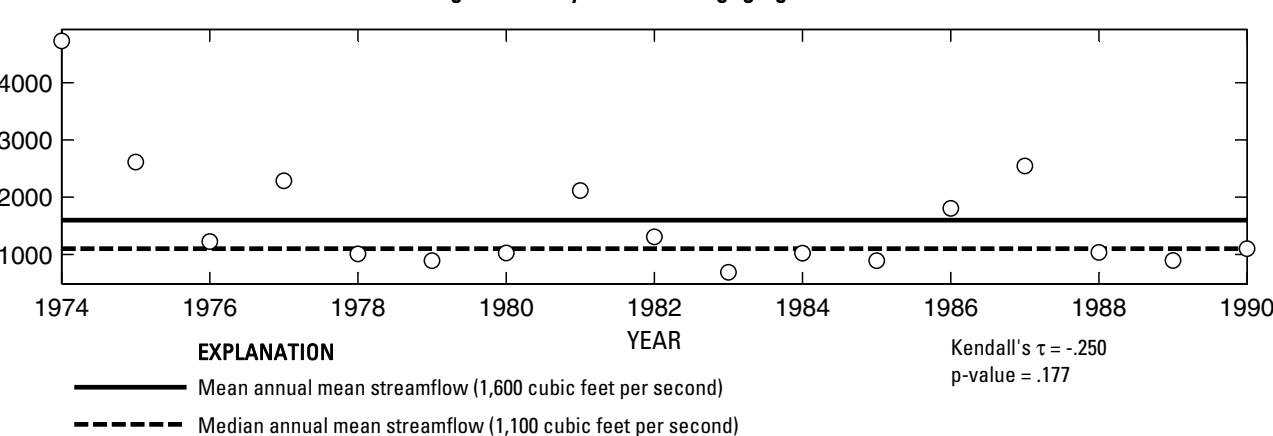

O Annual mean streamflow

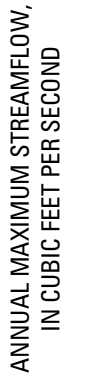

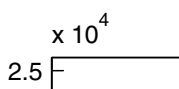

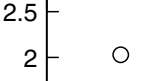

1.50

1
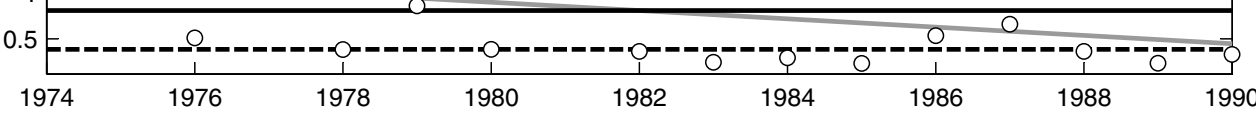

EXPLANATION YEAR Kendall's $\tau=-.456$

Theil trend line for annual maximum streamflow

$\mathrm{p}$-value $=.0103$

Mean annual maximum streamflow (8,080 cubic feet per second)

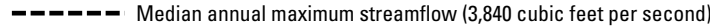

$\bigcirc \quad$ Annual maximum streamflow

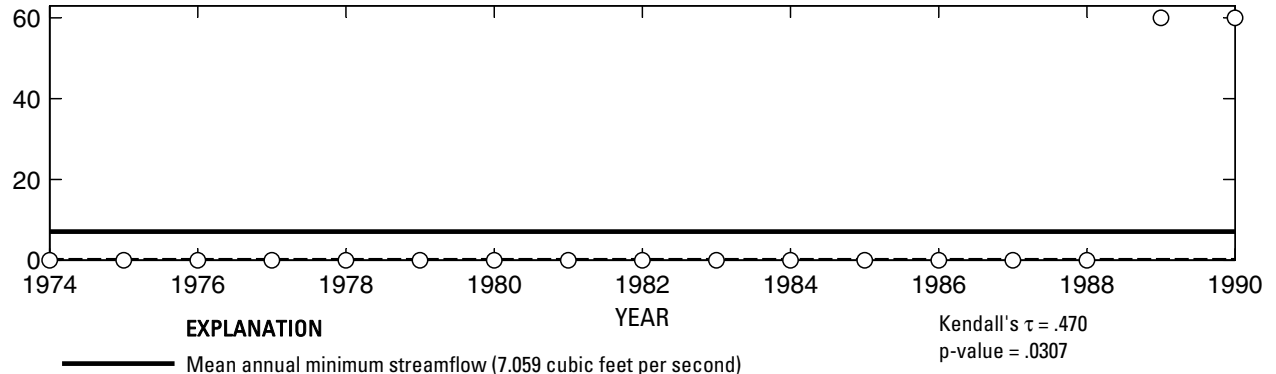

- Median annual minimum streamflow (0 cubic feet per second)

O Annual minimum streamflow

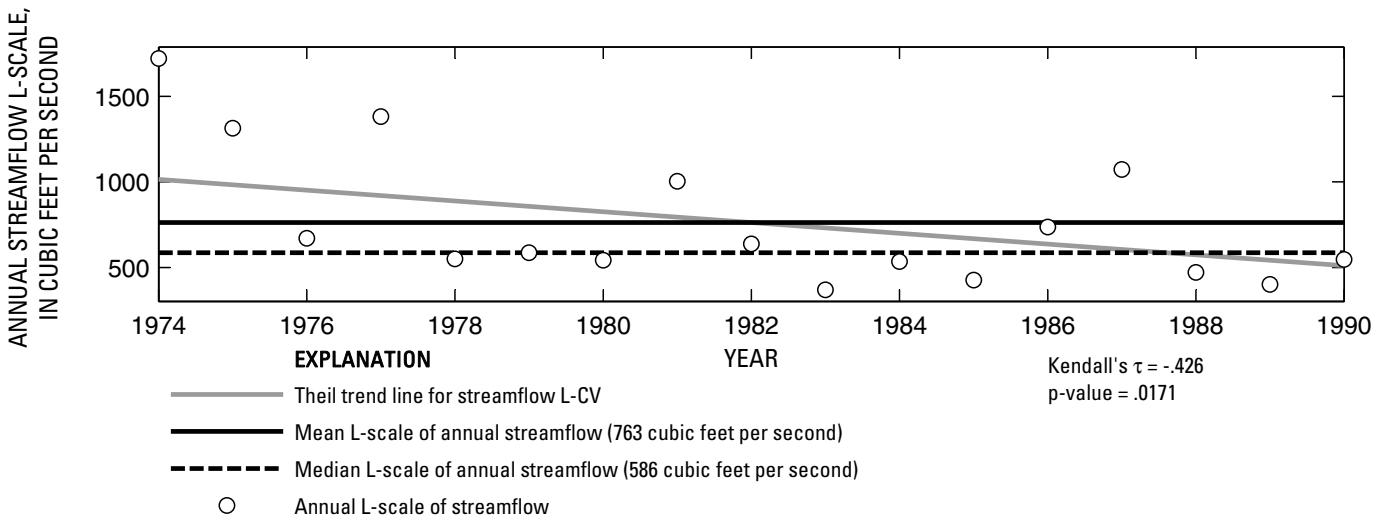

Figure 516. Analysis of annual mean, maximum, minimum, and L-scale statistics of daily mean streamflow for U.S. Geological Survey streamflow-gaging station 08154510 Colorado River below Mansfield Dam, Austin, Texas. 


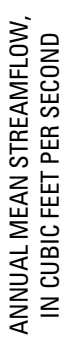

U.S. Geological Survey streamflow-gaging station 08154700

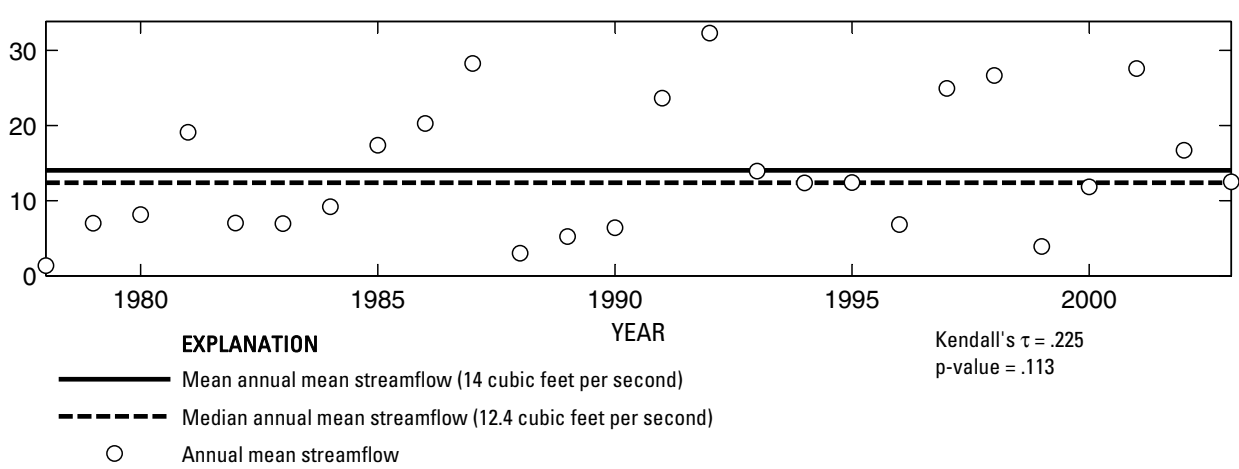

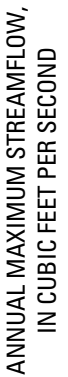

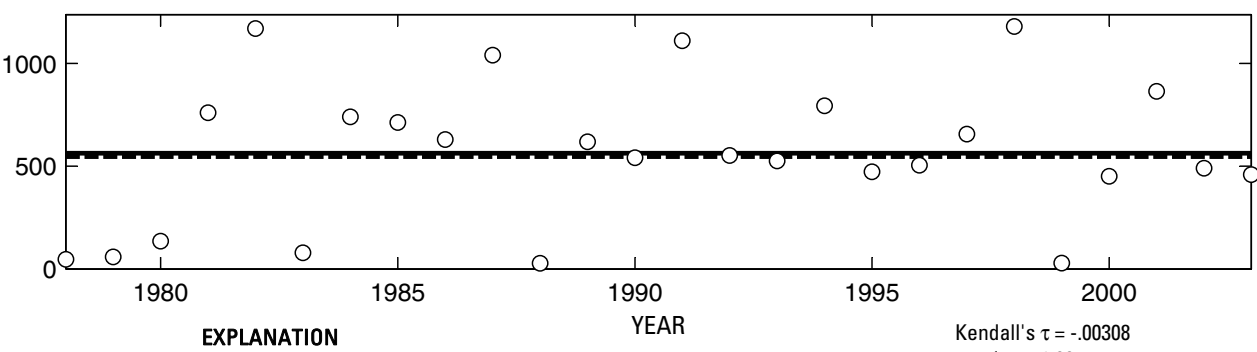

Mean annual maximum streamflow (563 cubic feet per second)

p-value $=1.00$

-____- Median annual maximum streamflow (547 cubic feet per second)

O Annual maximum streamflow

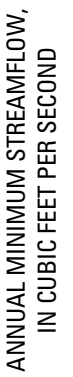

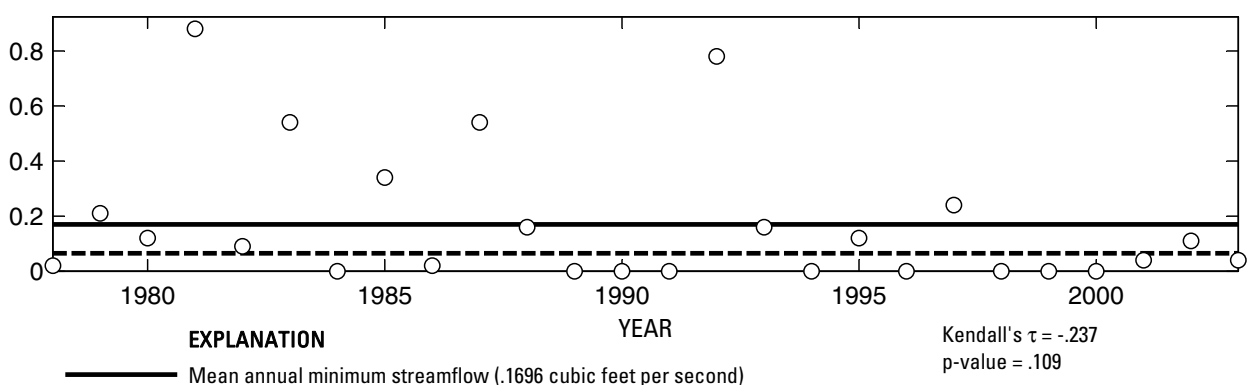

- - - Median annual minimum streamflow (.065 cubic feet per second)

○ Annual minimum streamflow
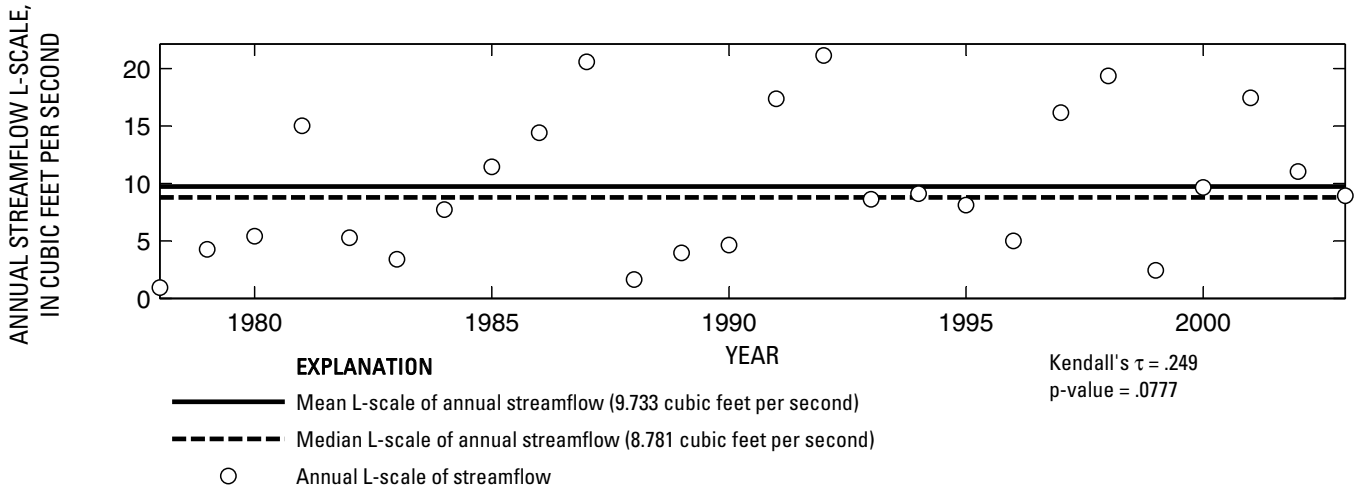

Figure 517. Analysis of annual mean, maximum, minimum, and L-scale statistics of daily mean streamflow for U.S. Geological Survey streamflow-gaging station 08154700 Bull Creek at Loop 360 near Austin, Texas. 


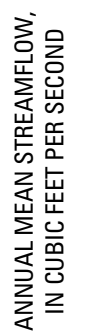

U.S. Geological Survey streamflow-gaging station 08155200

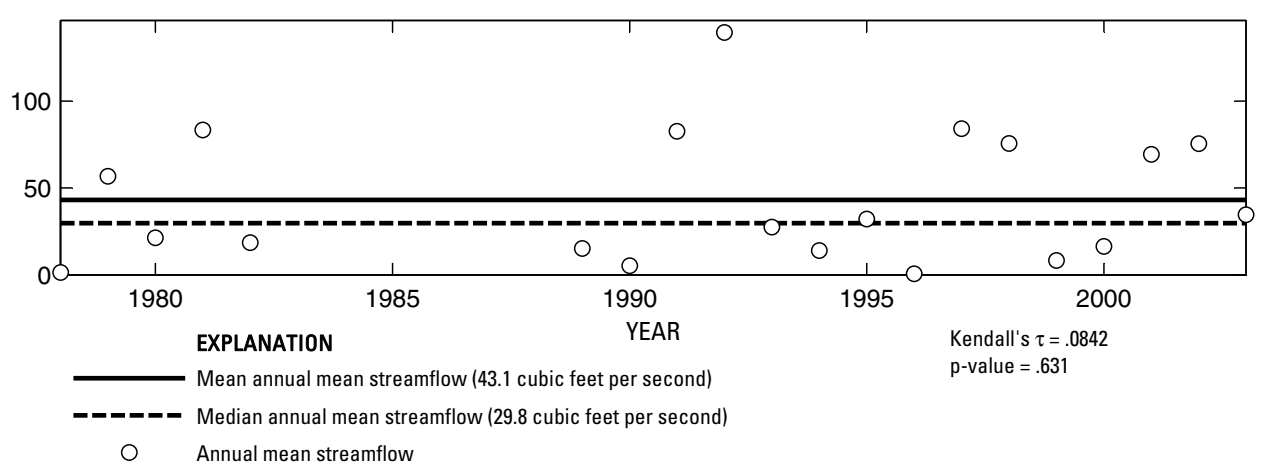

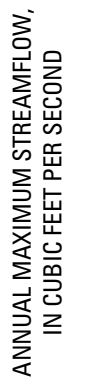

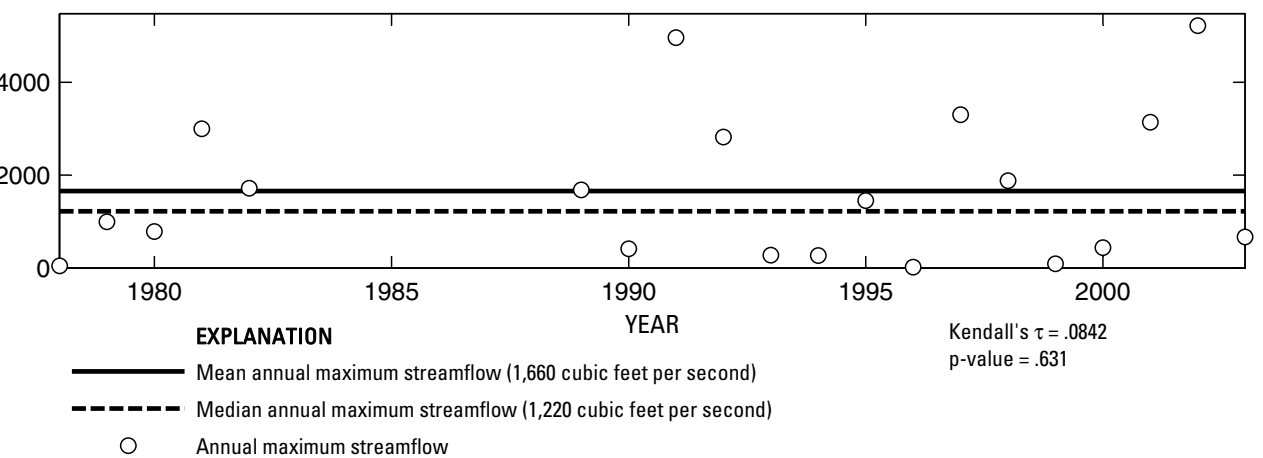

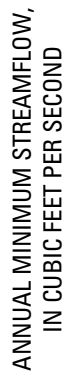

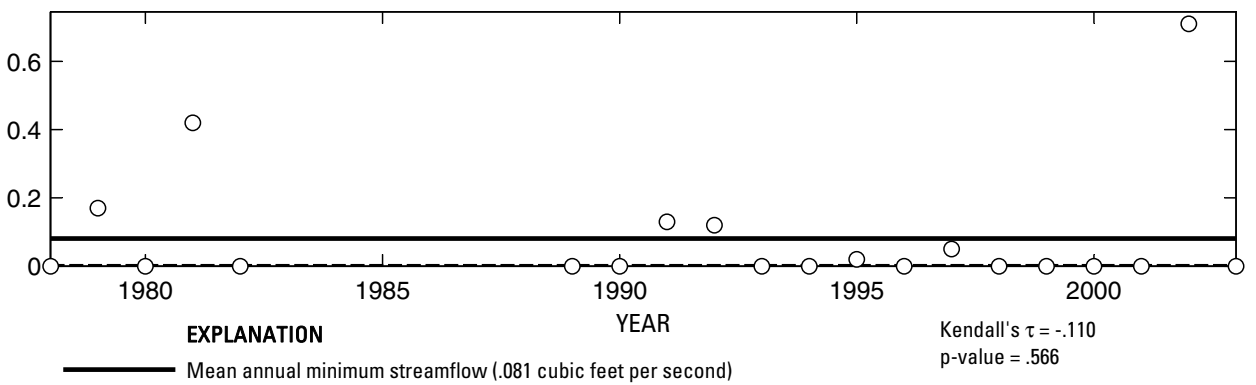

- Median annual minimum streamflow (0 cubic feet per second)

O Annual minimum streamflow

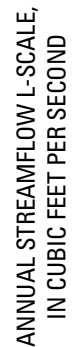

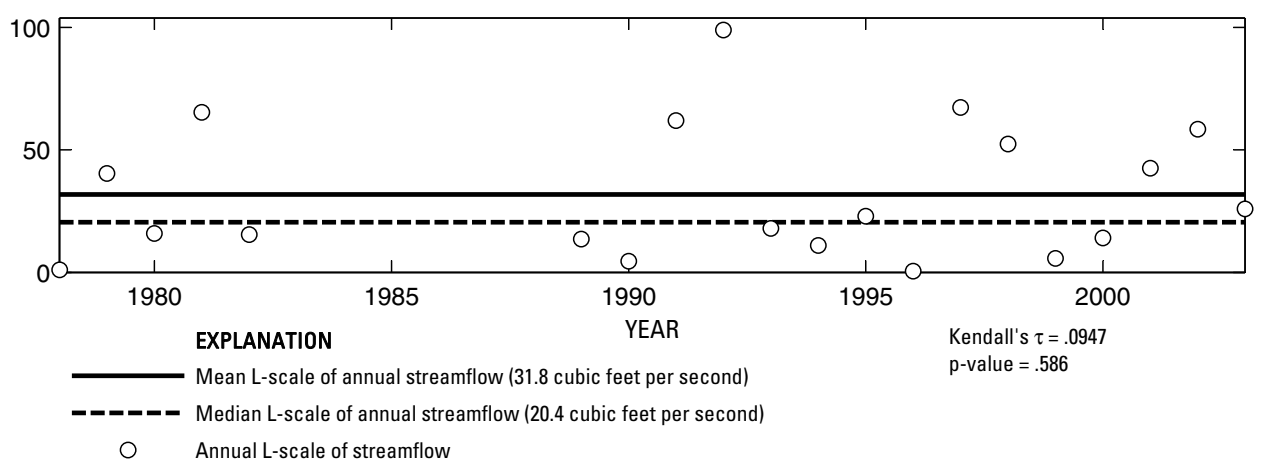

Figure 518. Analysis of annual mean, maximum, minimum, and L-scale statistics of daily mean streamflow for U.S. Geological Survey streamflow-gaging station 08155200 Barton Creek at State Highway 71 near Oak Hill, Texas.

Index of Station Numbers 719 


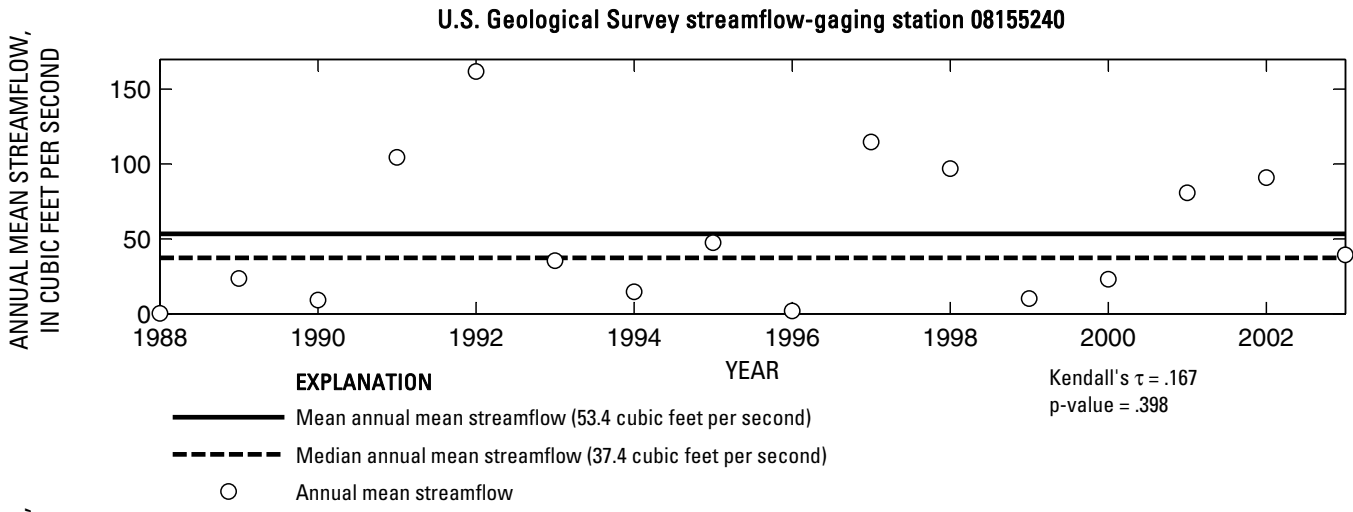

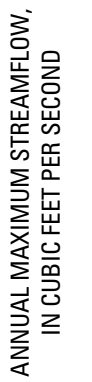

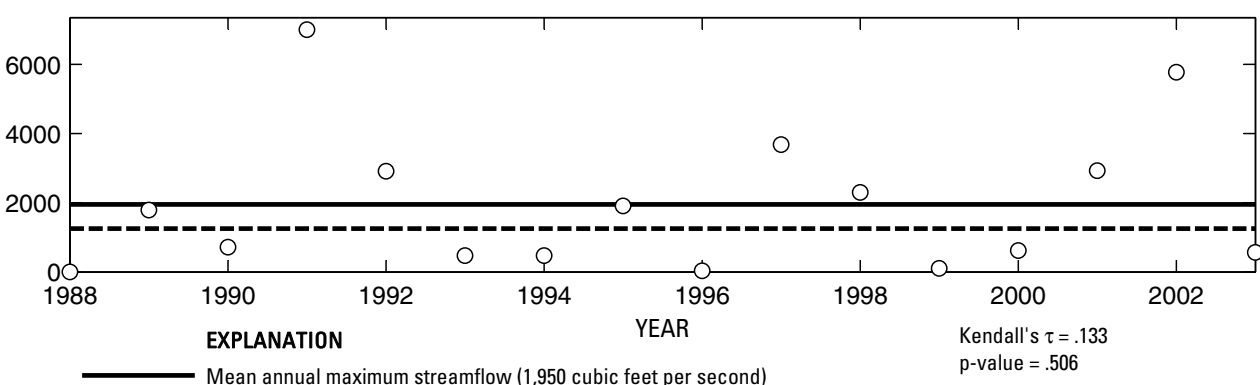

- ב - Median annual maximum streamflow (1,250 cubic feet per second

O Annual maximum streamflow

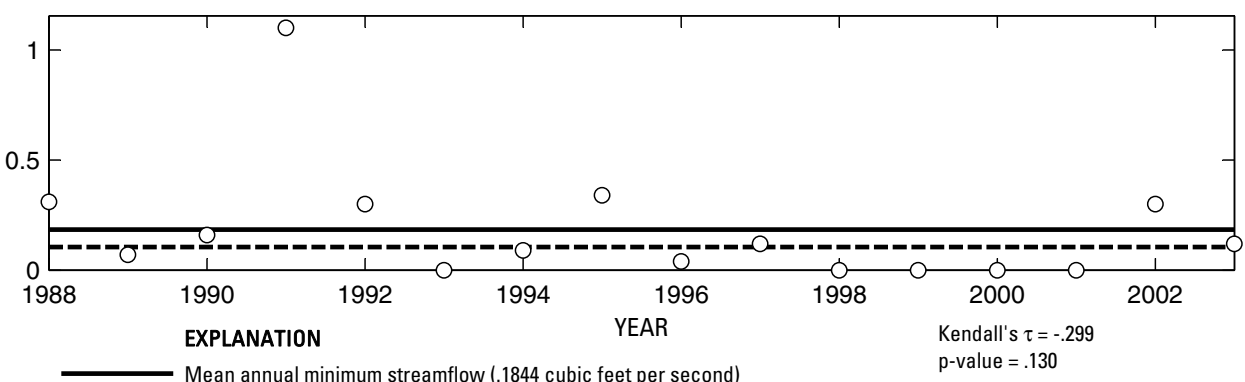

- - - Median annual minimum streamflow (.105 cubic feet per second)

○ Annual minimum streamflow

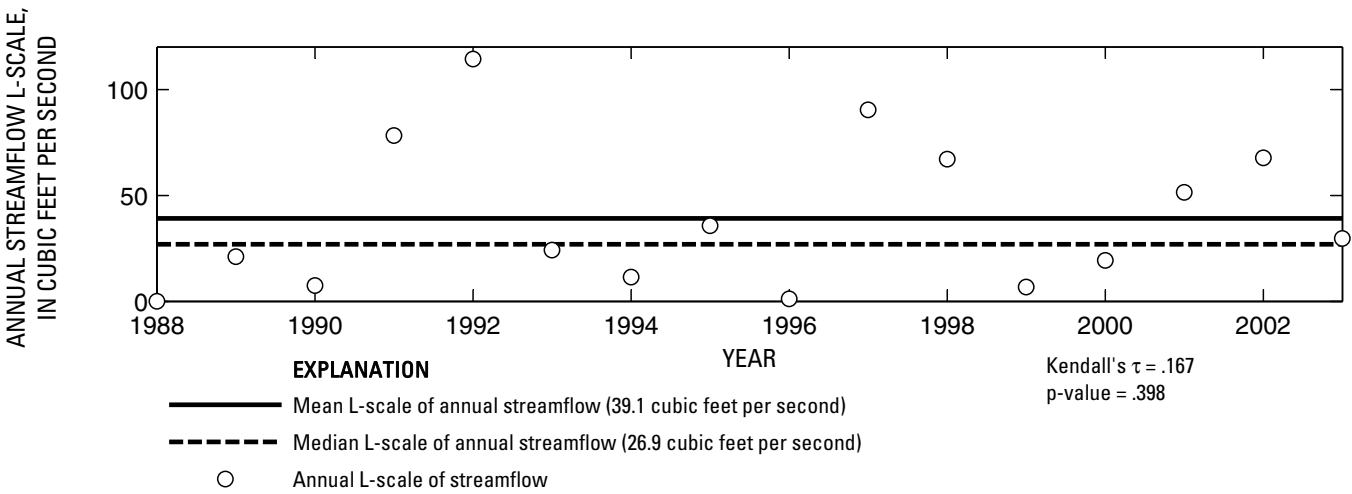

Figure 519. Analysis of annual mean, maximum, minimum, and L-scale statistics of daily mean streamflow for U.S. Geological Survey streamflow-gaging station 08155240 Barton Creek at Lost Creek Boulevard near Austin, Texas. 
U.S. Geological Survey streamflow-gaging station 08155260

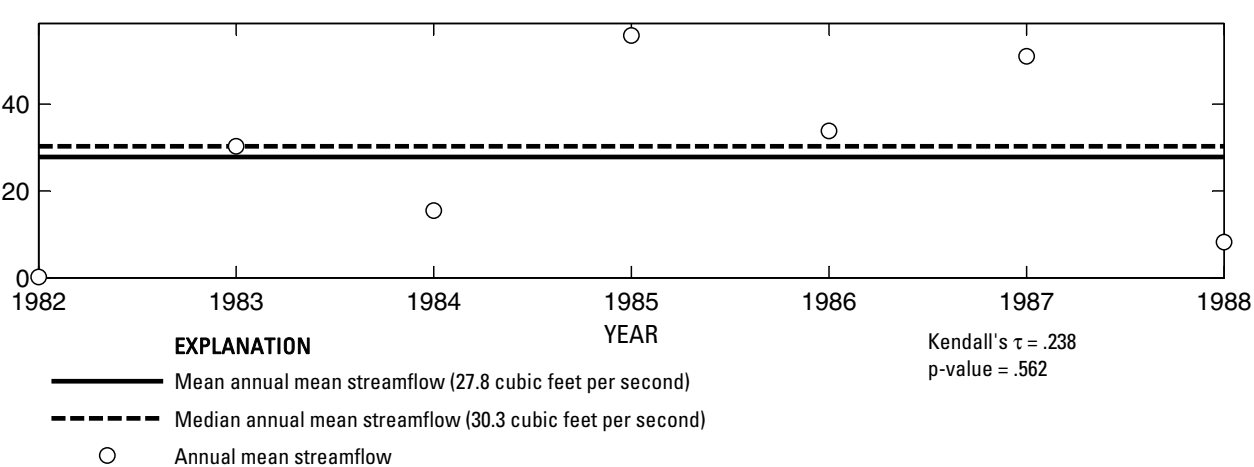

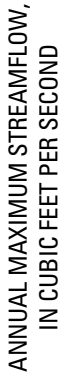

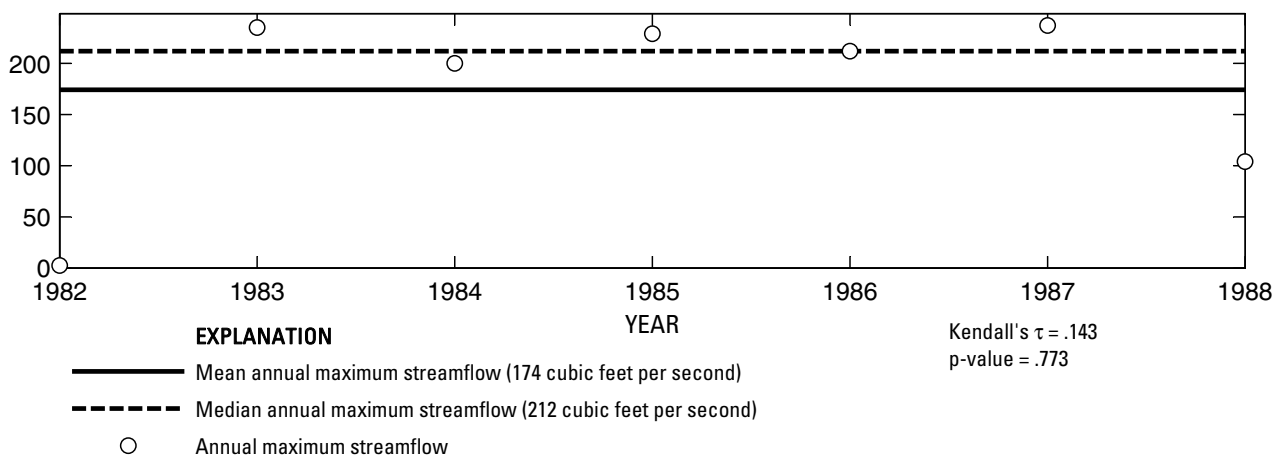

崔

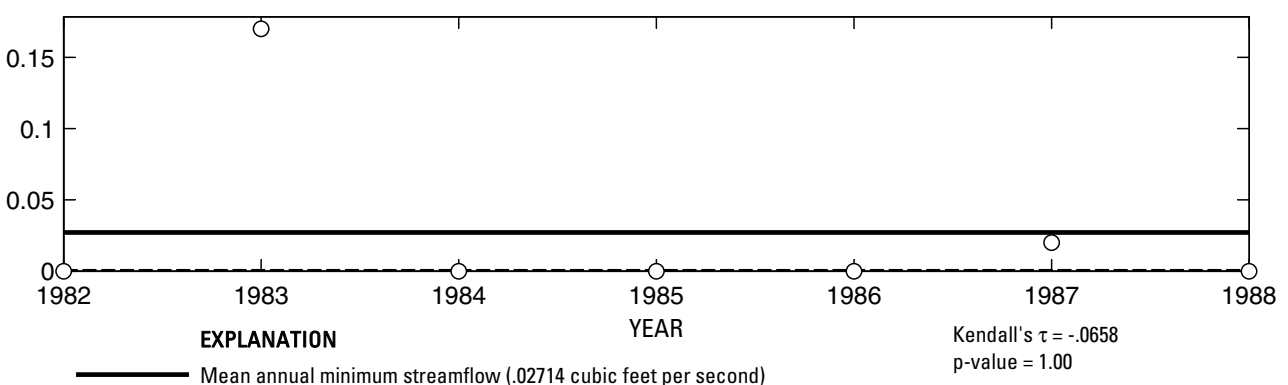

- Median annual minimum streamflow (0 cubic feet per second)

O Annual minimum streamflow

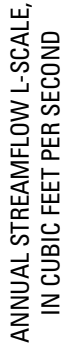

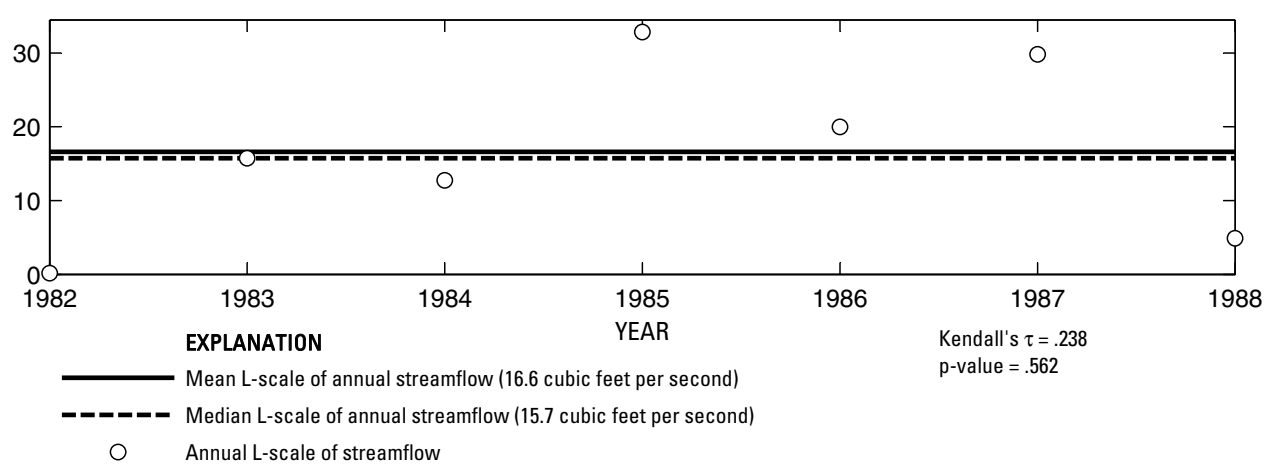

Figure 520. Analysis of annual mean, maximum, minimum, and L-scale statistics of daily mean streamflow for U.S. Geological Survey streamflow-gaging station 08155260 Barton Creek near Camp Craft Road near Austin, Texas.

Index of Station Numbers 719 


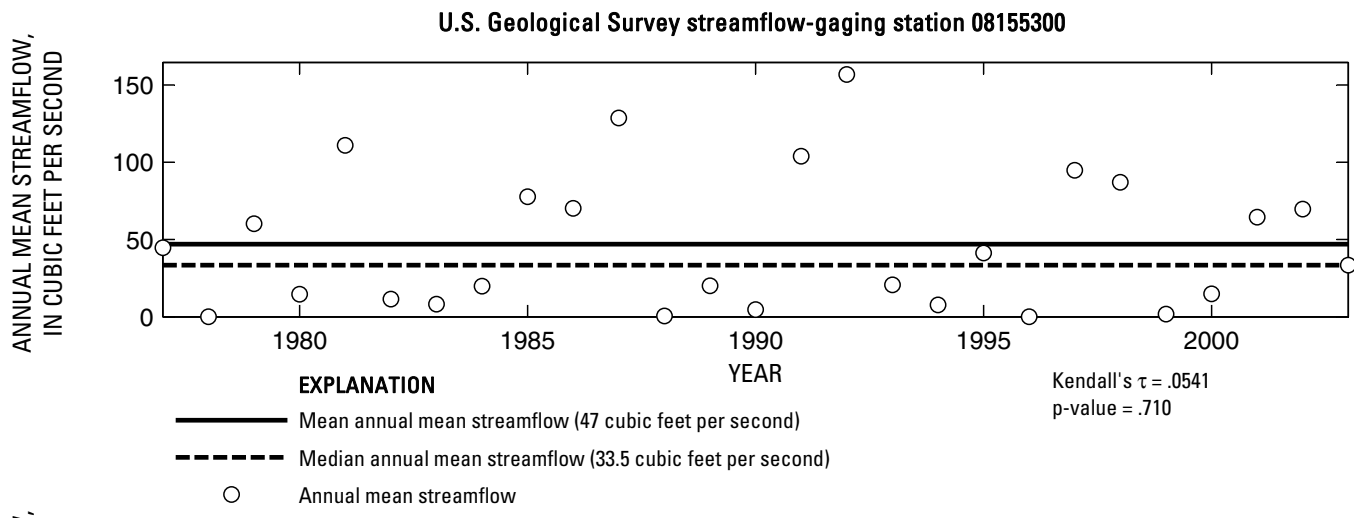

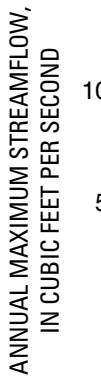

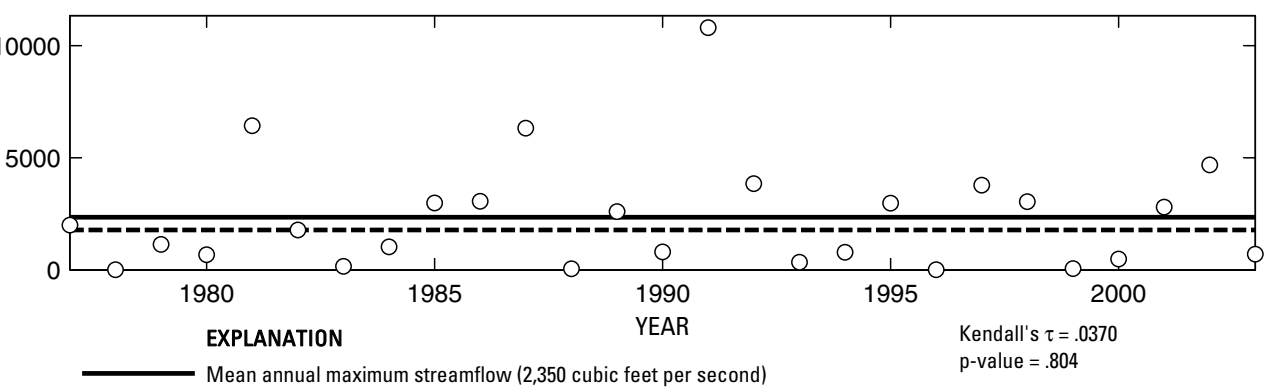

- _ _ - Median annual maximum streamflow (1,780 cubic feet per second

O Annual maximum streamflow

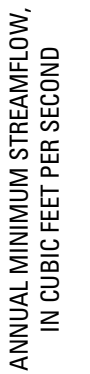

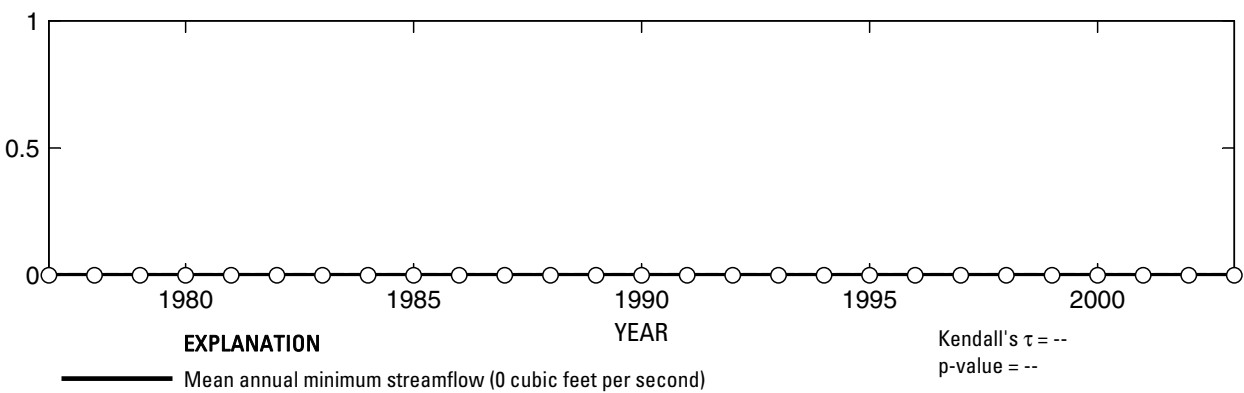

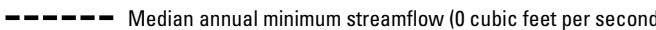

O Annual minimum streamflow

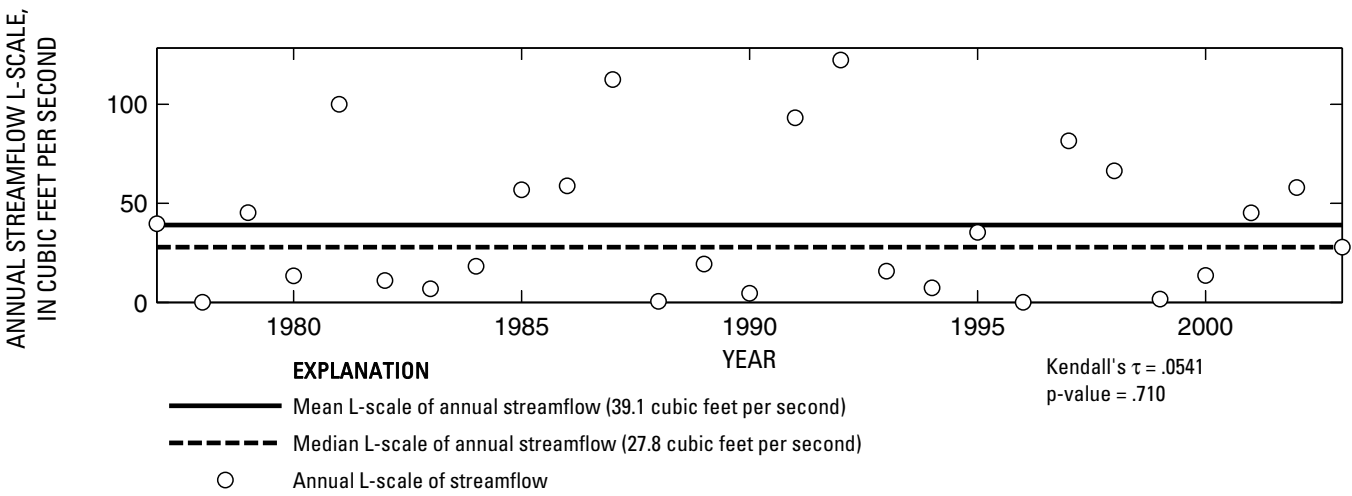

Figure 521. Analysis of annual mean, maximum, minimum, and L-scale statistics of daily mean streamflow for U.S. Geological Survey streamflow-gaging station 08155300 Barton Creek at Loop 360, Austin, Texas. 
U.S. Geological Survey streamflow-gaging station 08155400

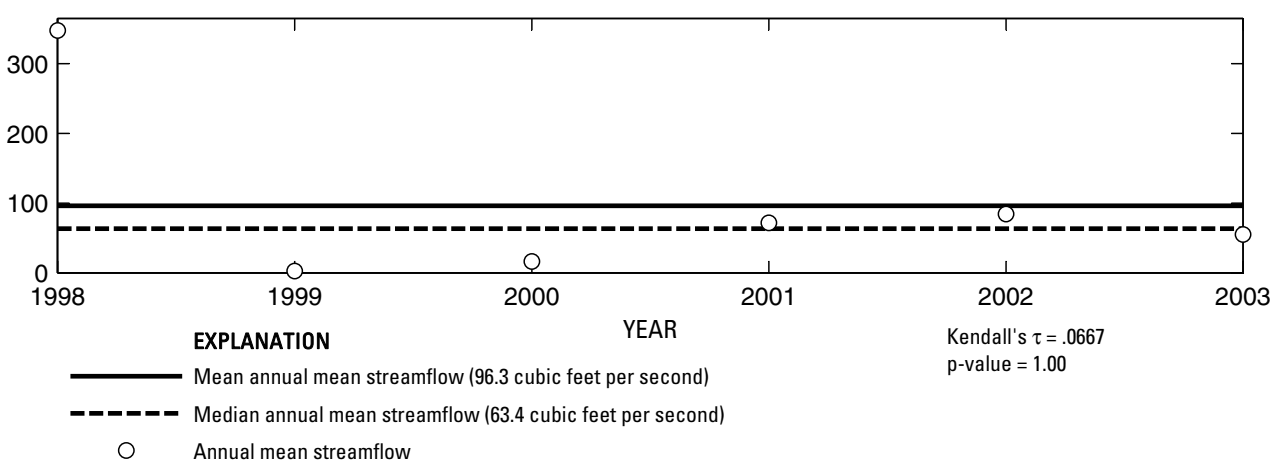

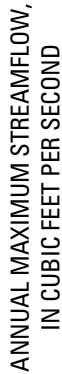

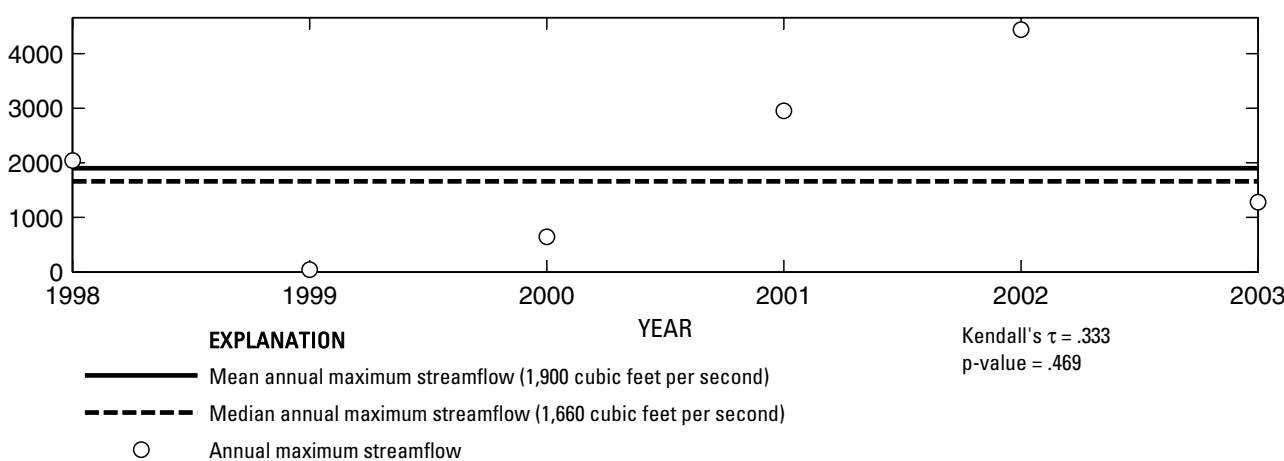

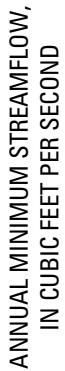

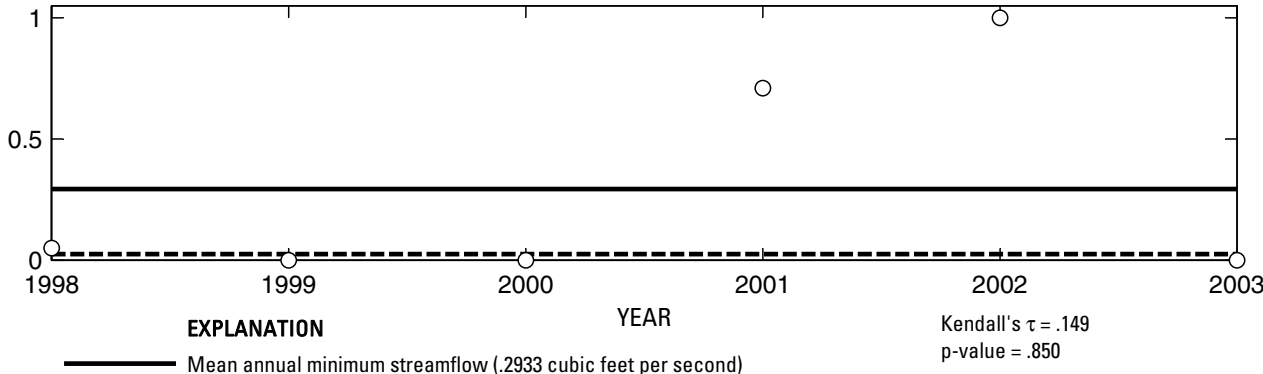

- - - Median annual minimum streamflow (.025 cubic feet per second)

O Annual minimum streamflow

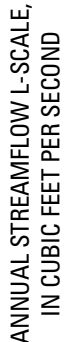

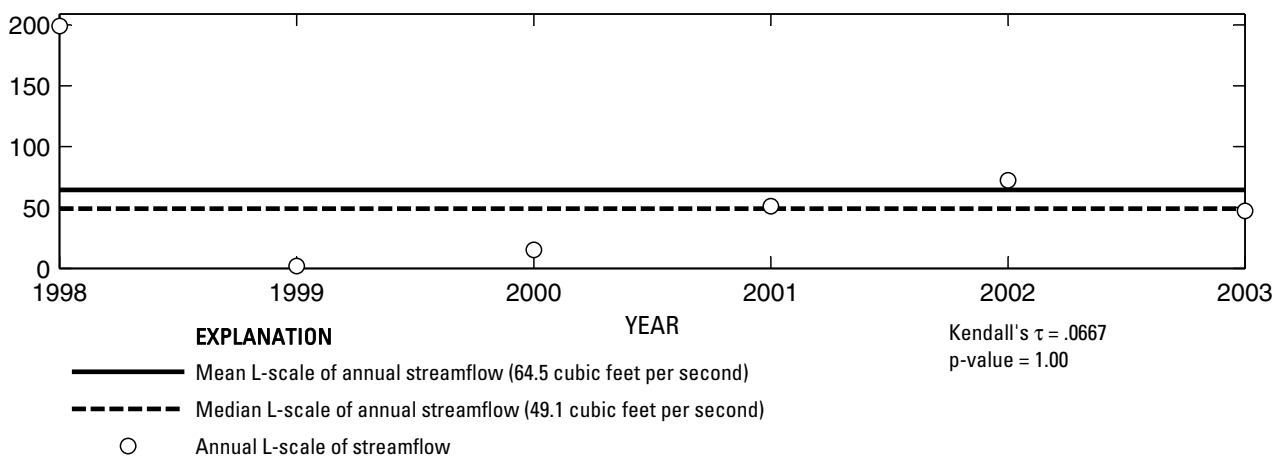

Figure 522. Analysis of annual mean, maximum, minimum, and L-scale statistics of daily mean streamflow for U.S. Geological Survey streamflow-gaging station 08155400 Barton Creek above Barton Springs at Austin, Texas.

Index of Station Numbers 719 


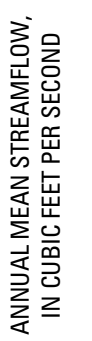

U.S. Geological Survey streamflow-gaging station 08156700

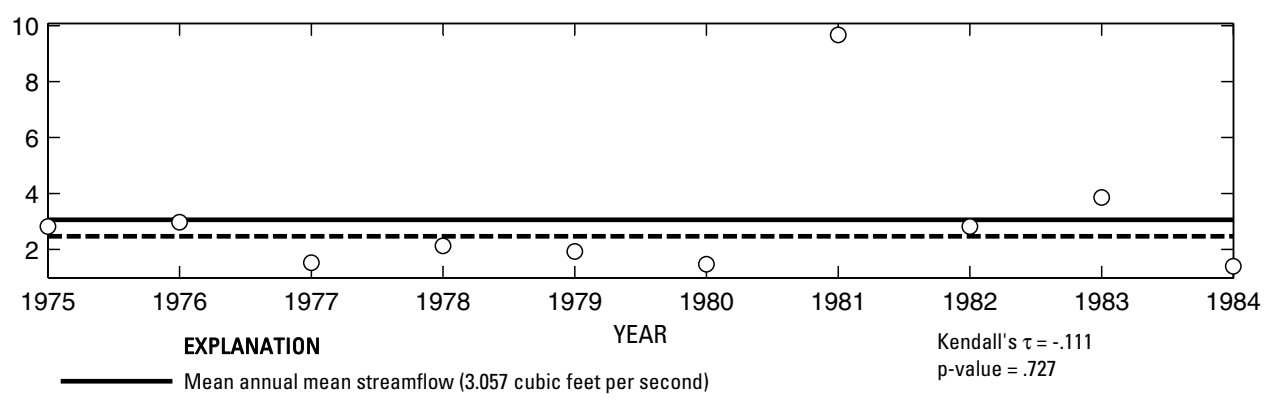

-_-_- Median annual mean streamflow (2.47 cubic feet per second)

- Annual mean streamflow

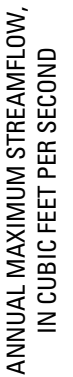

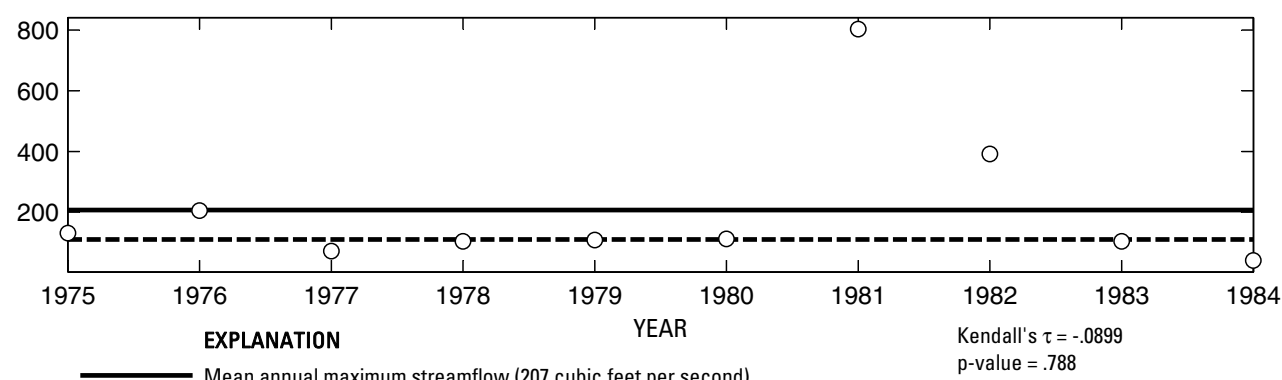

O Annual maximum streamflow
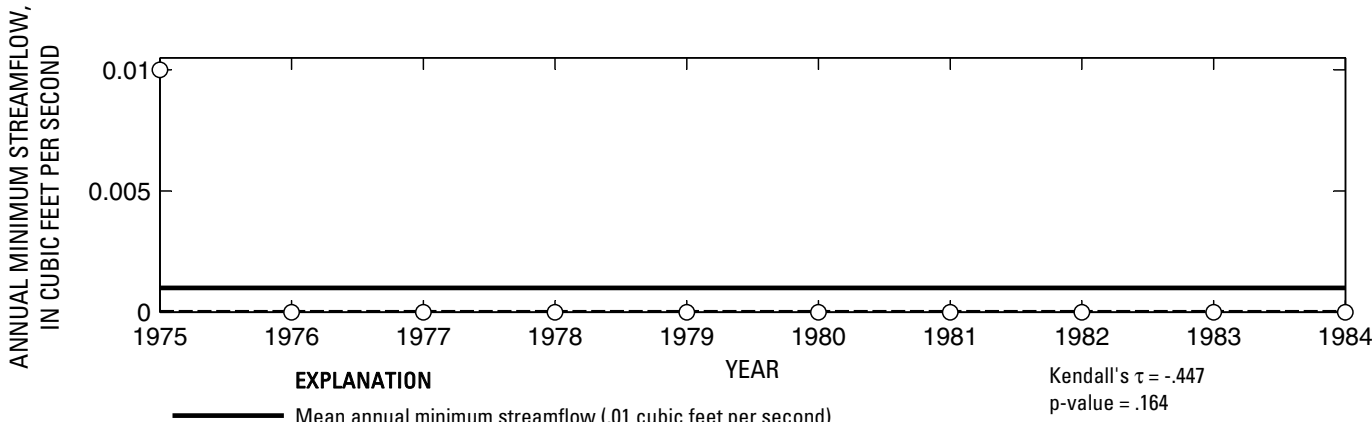

Mean annual minimum streamflow (.01 cubic feet per second)

- Median annual minimum streamflow (0 cubic feet per second)

O Annual minimum streamflow

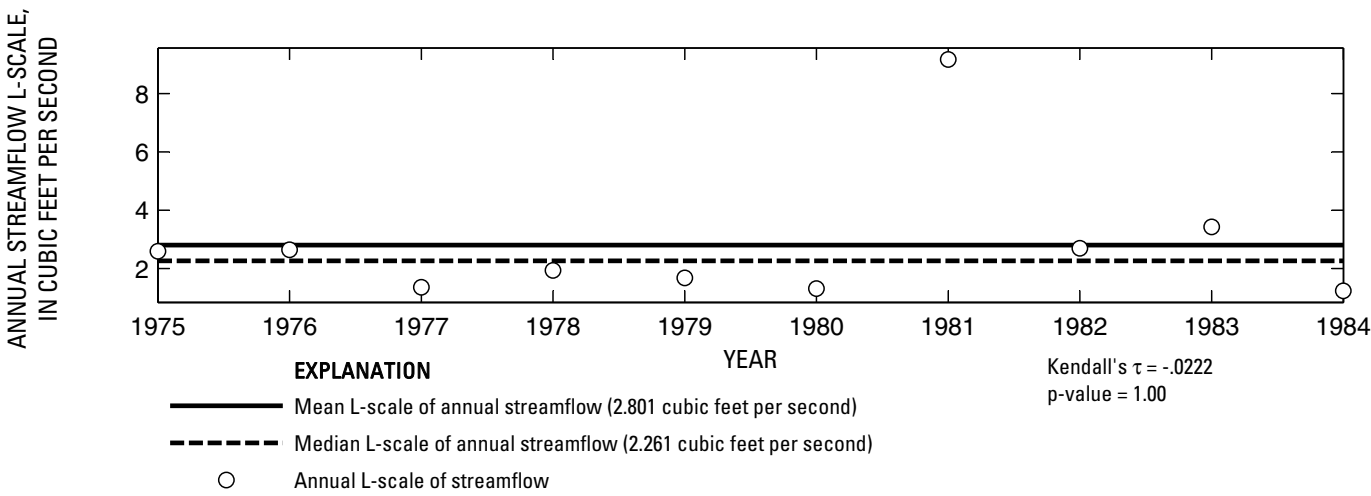

Figure 523. Analysis of annual mean, maximum, minimum, and L-scale statistics of daily mean streamflow for U.S. Geological Survey streamflow-gaging station 08156700 Shoal Creek at Northwest Park at Austin, Texas. 
U.S. Geological Survey streamflow-gaging station 08156800

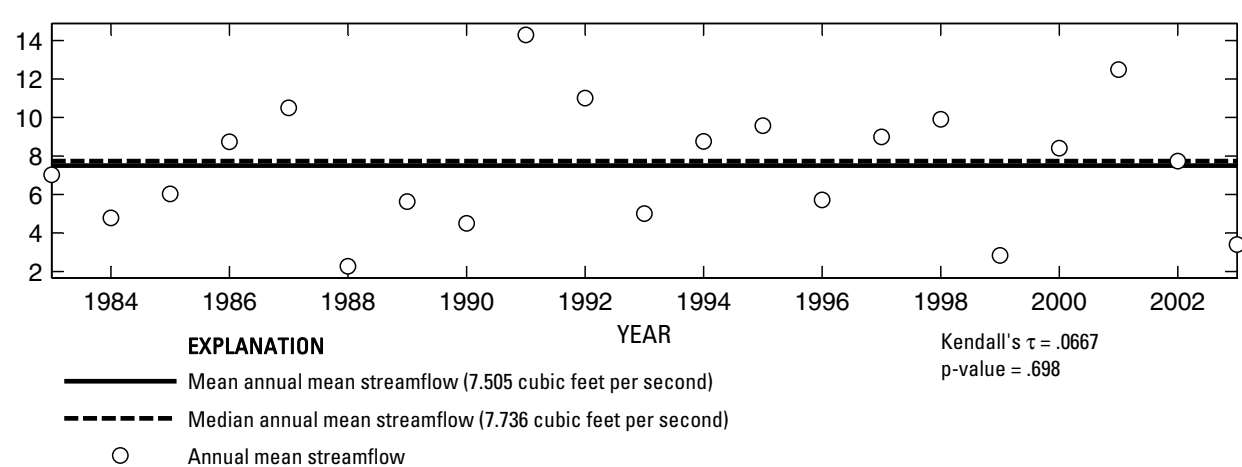

家

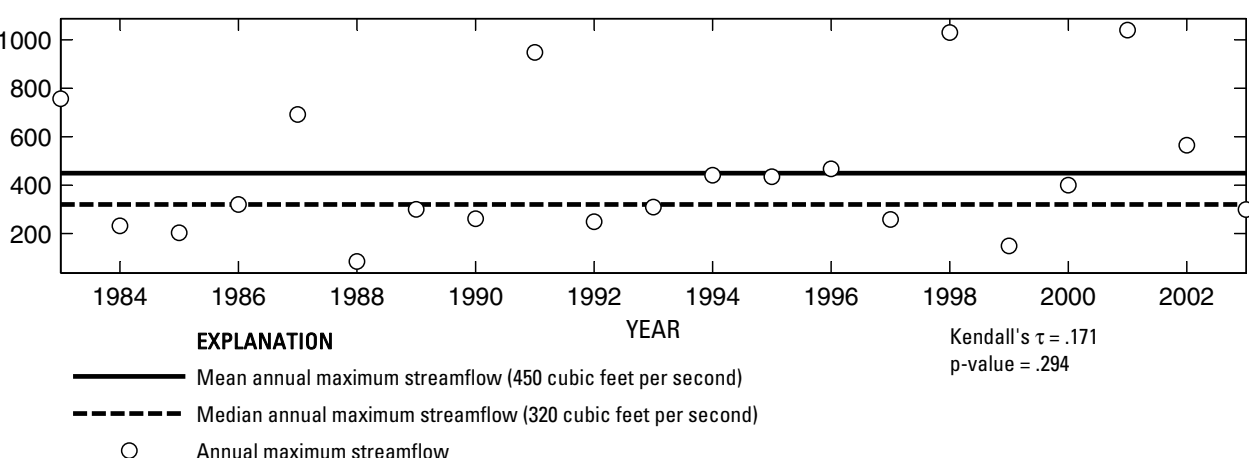

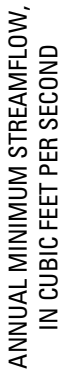

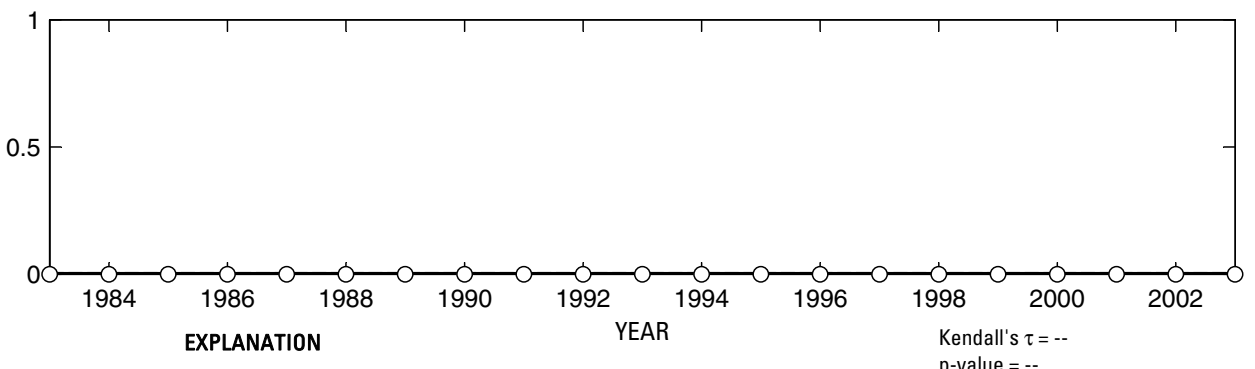

Mean annual minimum streamflow ( 0 cubic feet per second)

$\mathrm{p}$-value $=-\cdot$

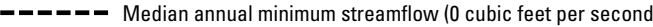

O Annual minimum streamflow

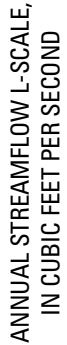

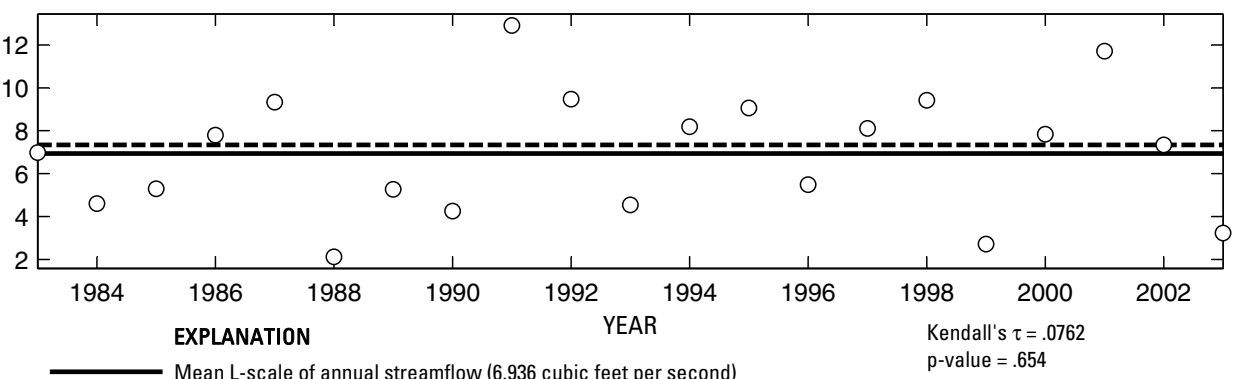

- - - Median L-scale of annual streamflow (7.342 cubic feet per second)

Annual L-scale of streamflow

Figure 524. Analysis of annual mean, maximum, minimum, and L-scale statistics of daily mean streamflow for U.S. Geological Survey streamflow-gaging station 08156800 Shoal Creek at West 12th Street, Austin, Texas.

Index of Station Numbers 719 


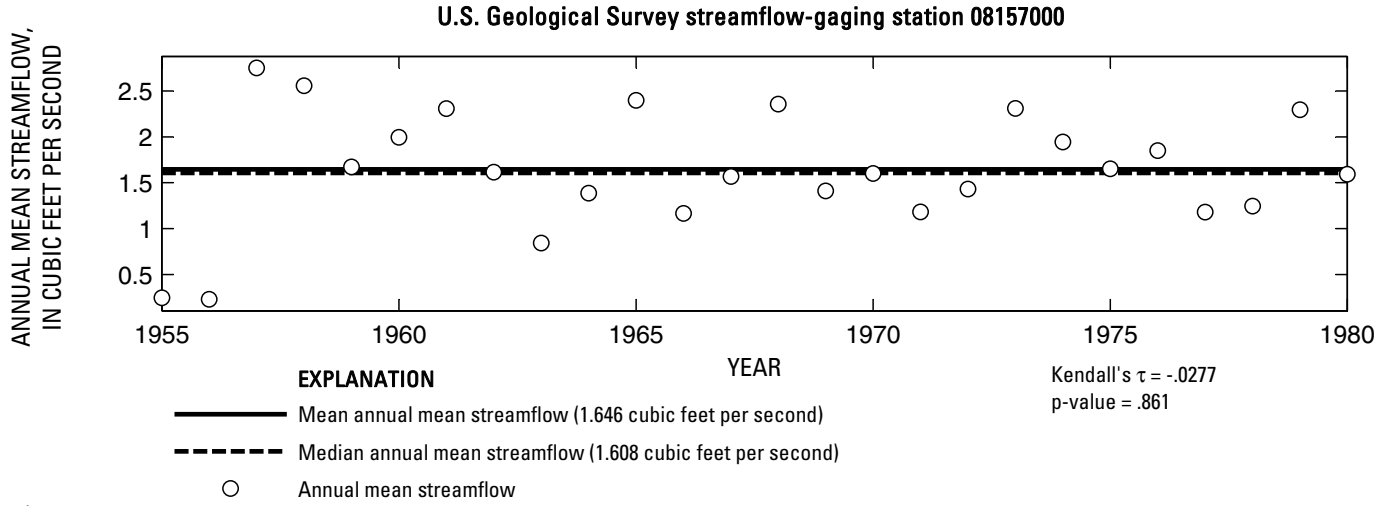

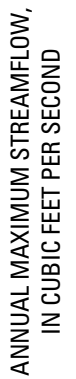

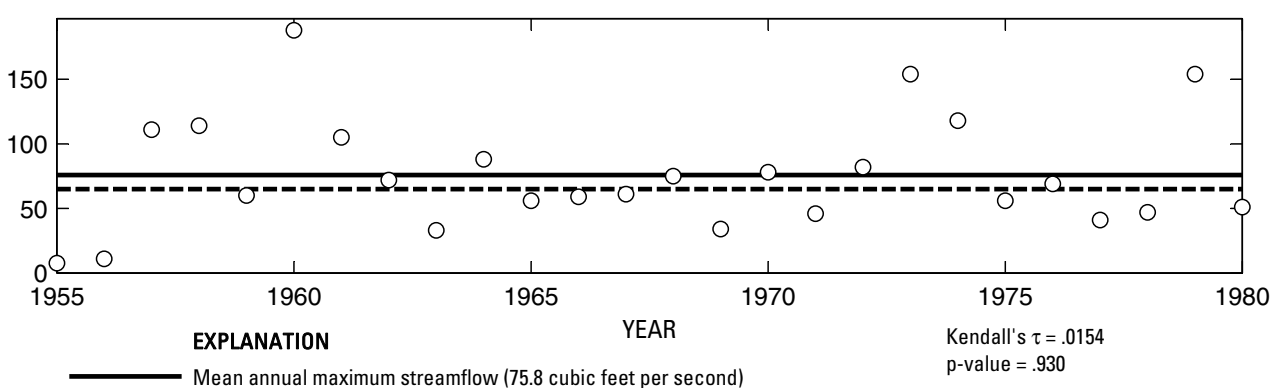

- - - Median annual maximum streamflow ( 65 cubic feet per second)

O Annual maximum streamflow

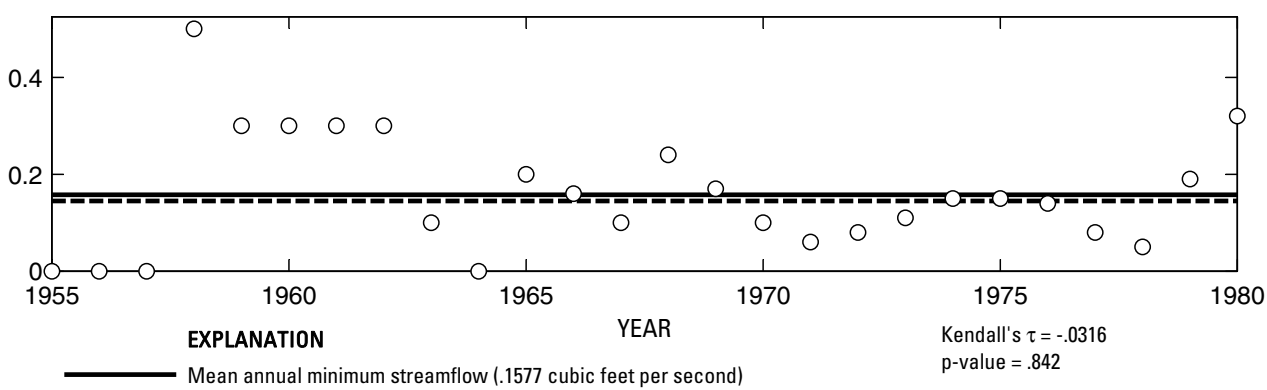

- ב-ב Median annual minimum streamflow (.145 cubic feet per second)

○ Annual minimum streamflow

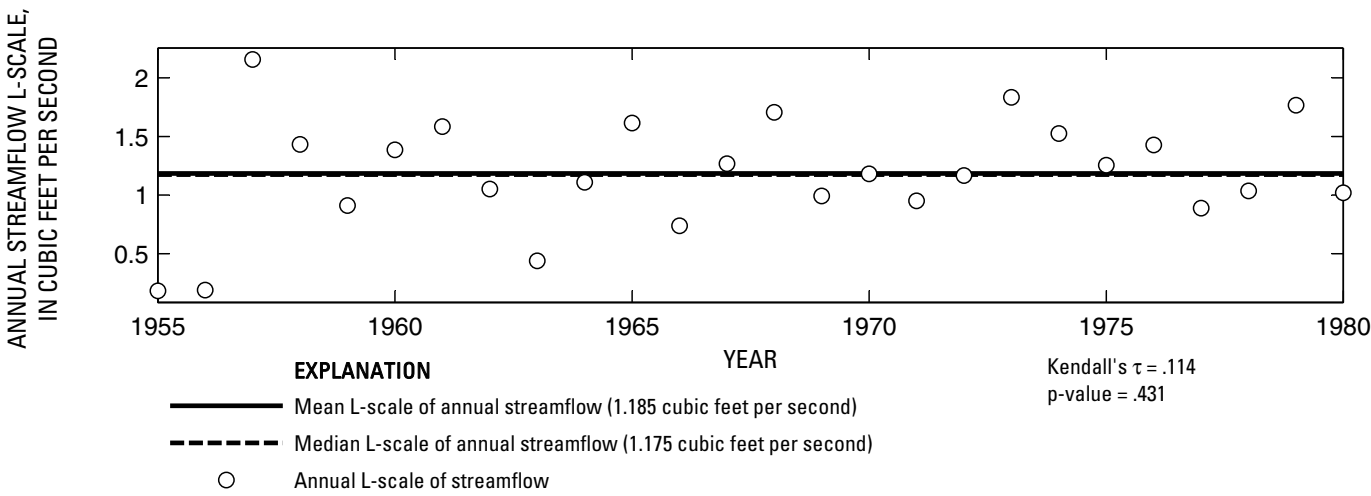

Figure 525. Analysis of annual mean, maximum, minimum, and L-scale statistics of daily mean streamflow for U.S. Geological Survey streamflow-gaging station 08157000 Waller Creek at 38th Street, Austin, Texas. 


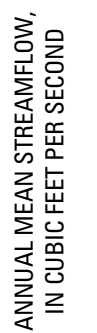

U.S. Geological Survey streamflow-gaging station 08157500

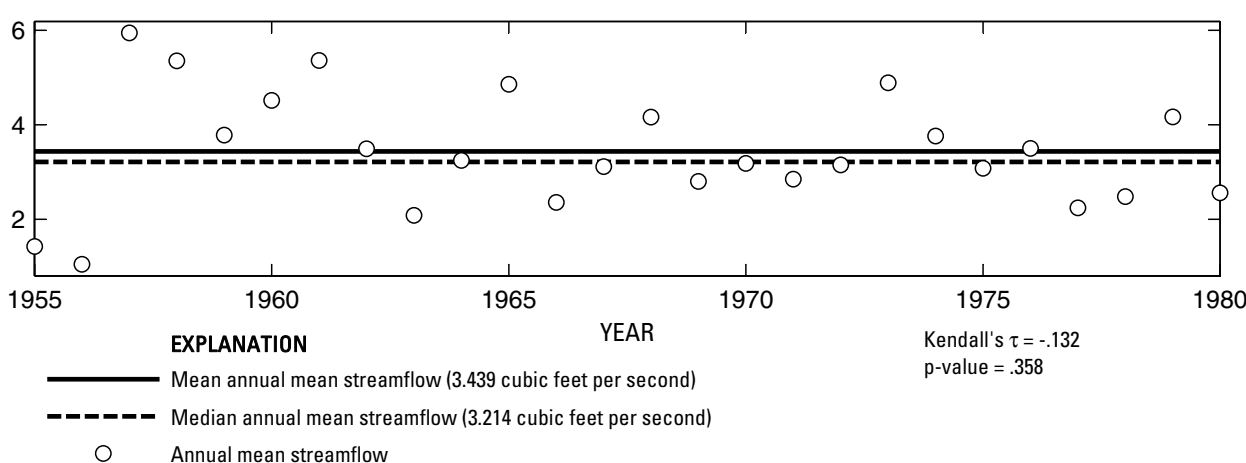

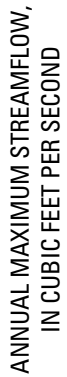

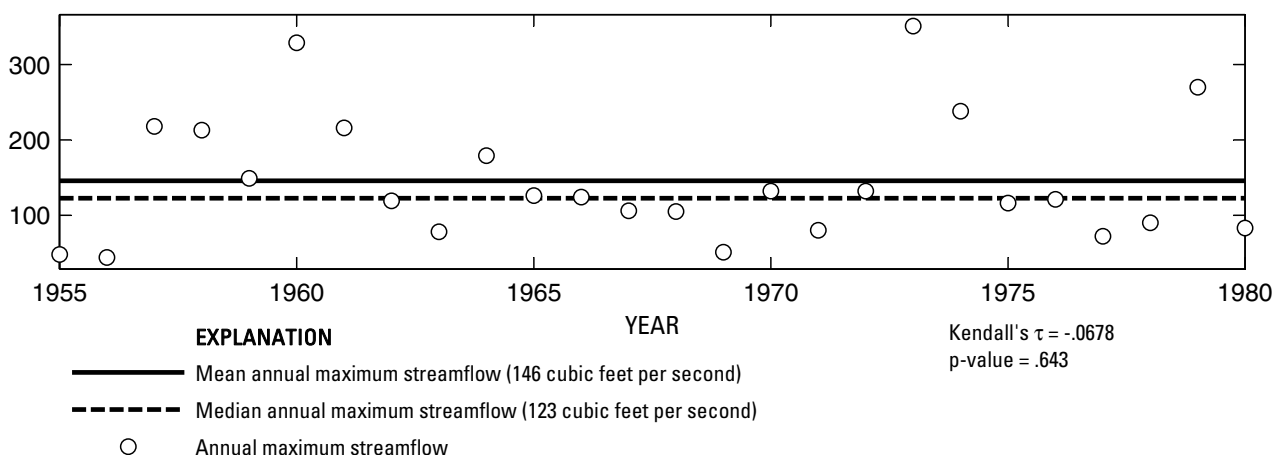

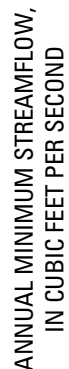

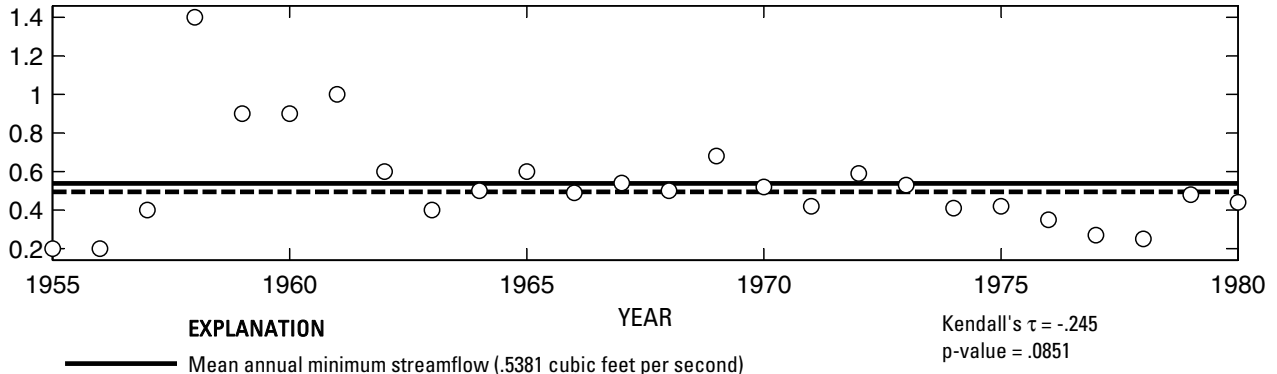

- ב- Median annual minimum streamflow (.495 cubic feet per second)

O Annual minimum streamflow

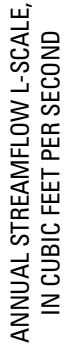

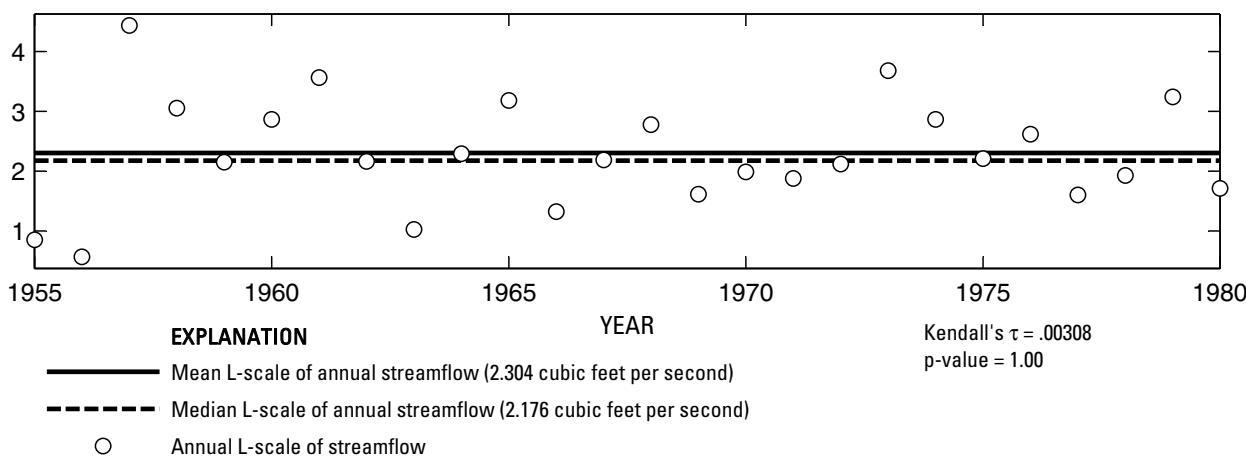

Figure 526. Analysis of annual mean, maximum, minimum, and L-scale statistics of daily mean streamflow for U.S. Geological Survey streamflow-gaging station 08157500 Waller Creek at 23rd Street, Austin, Texas.

Index of Station Numbers 719 


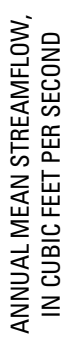

U.S. Geological Survey streamflow-gaging station 08157600

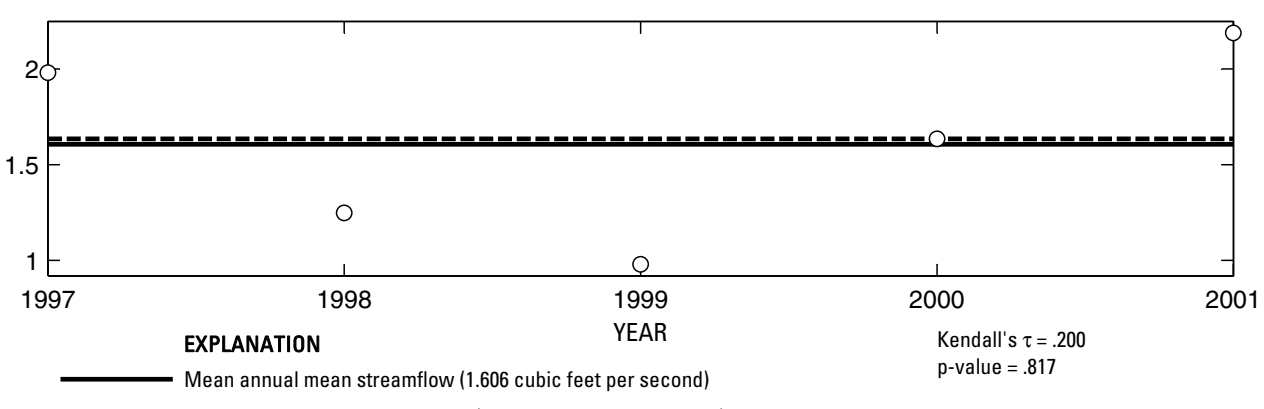

-__-_ Median annual mean streamflow (1.634 cubic feet per second)

O Annual mean streamflow

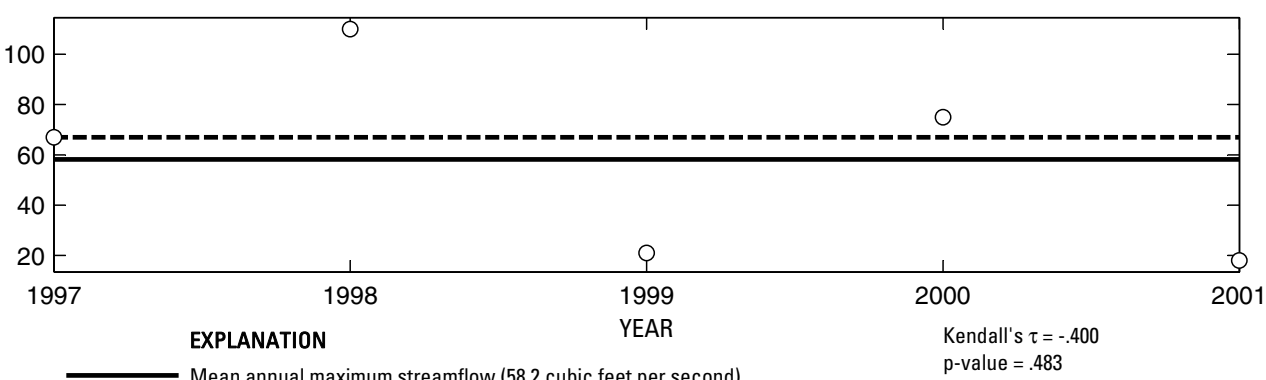

- - Median annual maximum streamflow (67 cubic feet per second)

Annual maximum streamflow

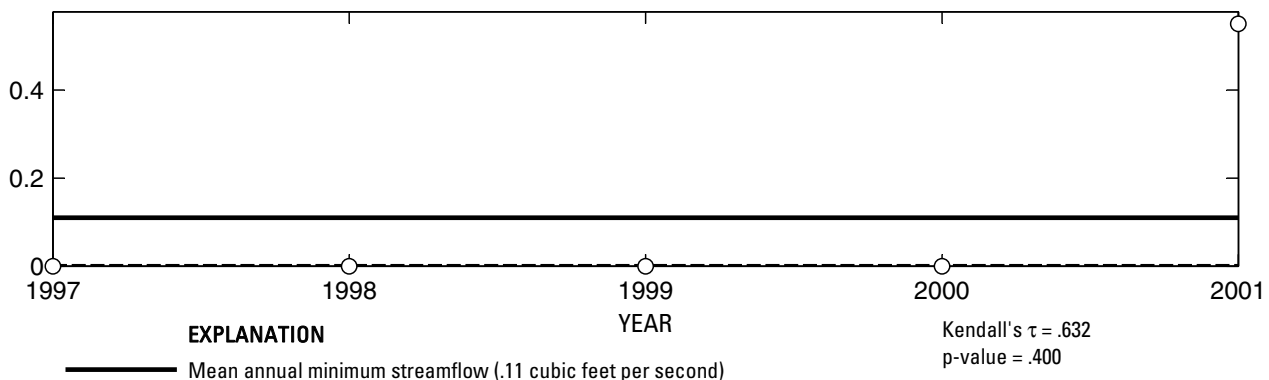

- ב-ב Median annual minimum streamflow (0 cubic feet per second)

O Annual minimum streamflow

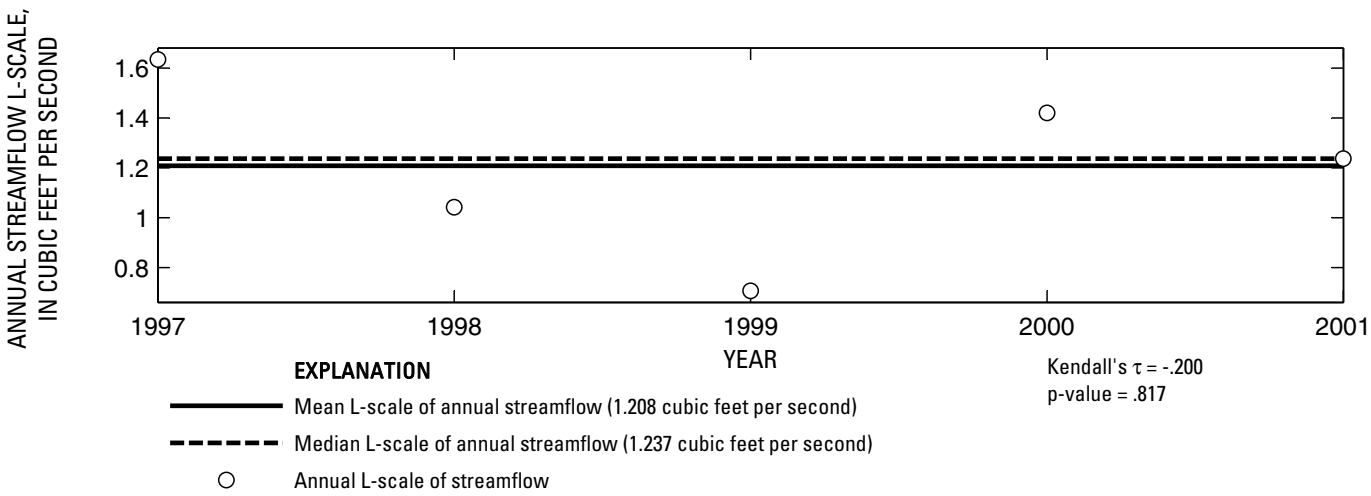

Figure 527. Analysis of annual mean, maximum, minimum, and L-scale statistics of daily mean streamflow for U.S. Geological Survey streamflow-gaging station 08157600 East Bouldin Creek at South 1st Street, Austin, Texas. 

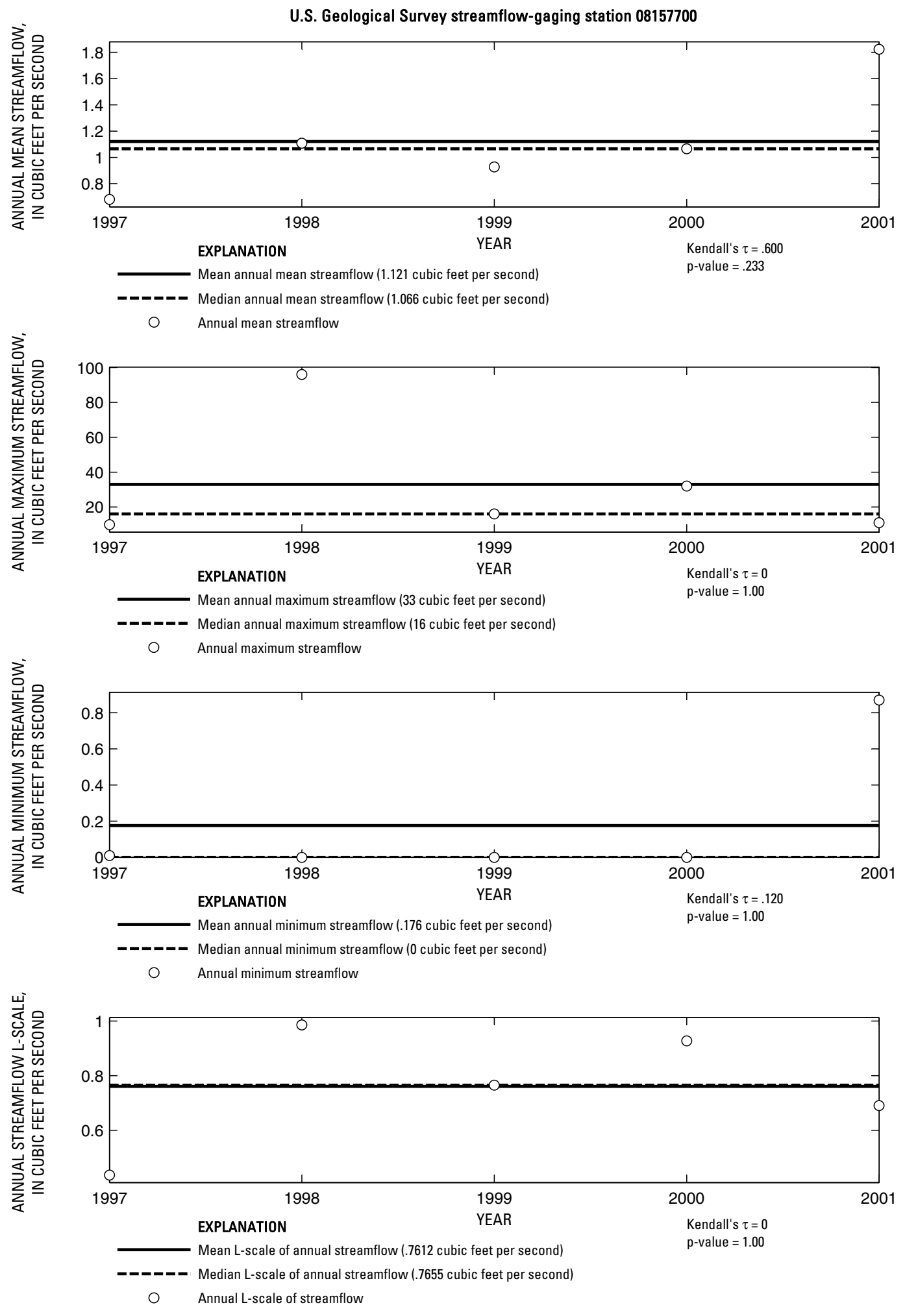

Figure 528. Analysis of annual mean, maximum, minimum, and L-scale statistics of daily mean streamflow for U.S. Geological Survey streamflow-gaging station 08157700 Blunn Creek near Little Stacy Park, Austin, Texas.

Index of Station Numbers 719 

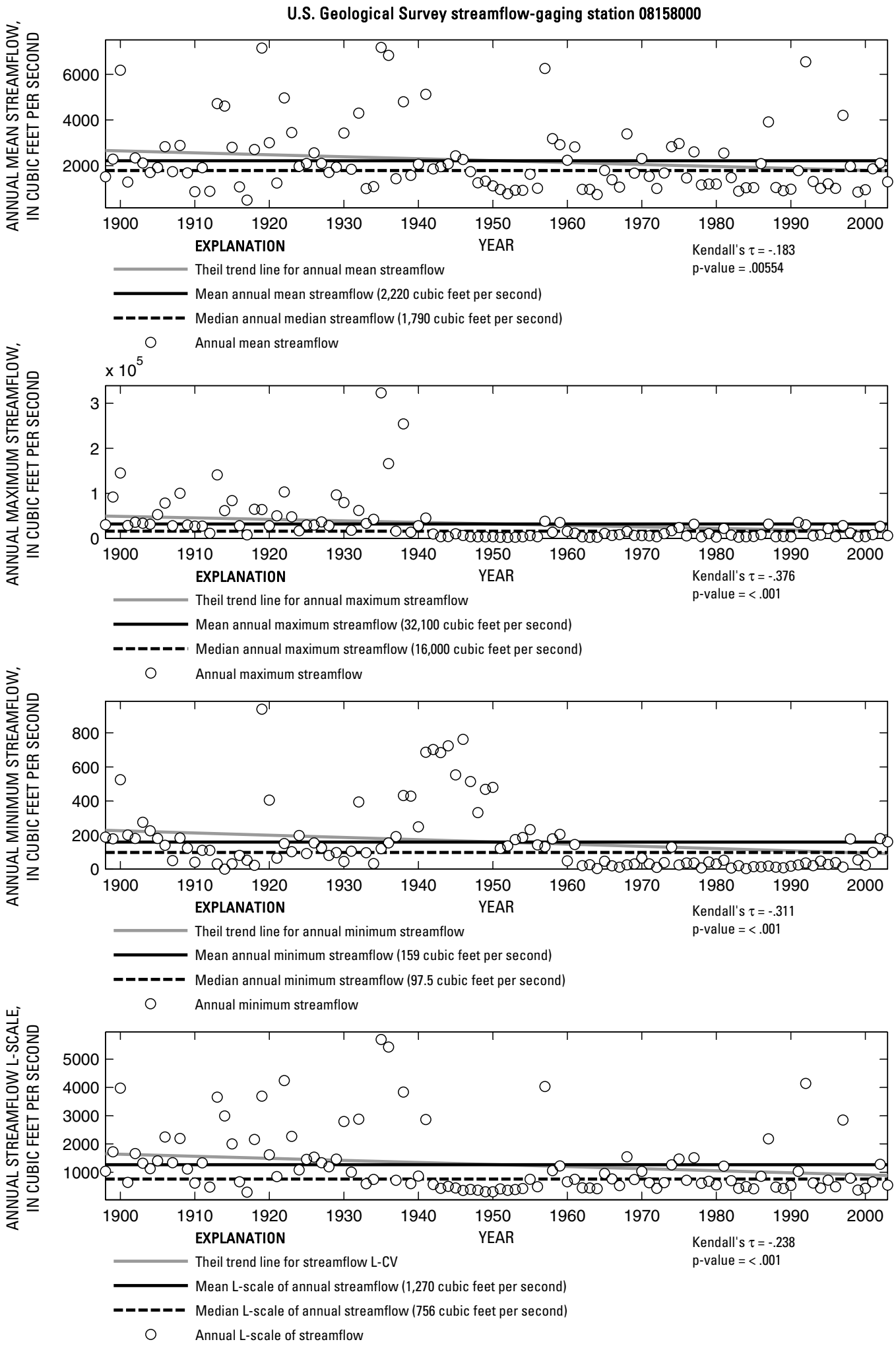

Figure 529. Analysis of annual mean, maximum, minimum, and L-scale statistics of daily mean streamflow for U.S. Geological Survey streamflow-gaging station 08158000 Colorado River at Austin, Texas. 


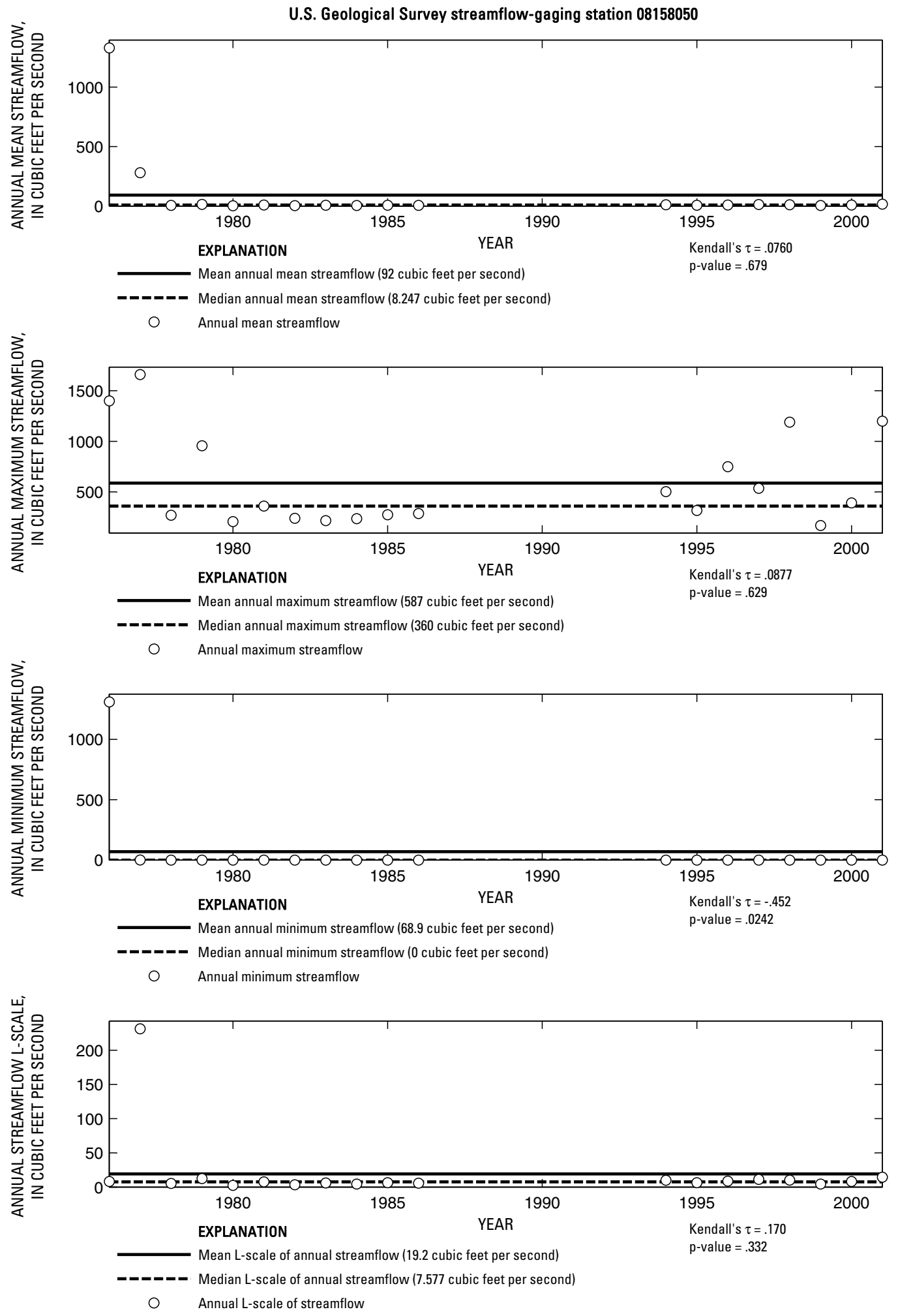

Figure 530. Analysis of annual mean, maximum, minimum, and L-scale statistics of daily mean streamflow for U.S. Geological Survey streamflow-gaging station 08158050 Boggy Creek at U. S. Highway 183, Austin, Texas.

Index of Station Numbers 719 

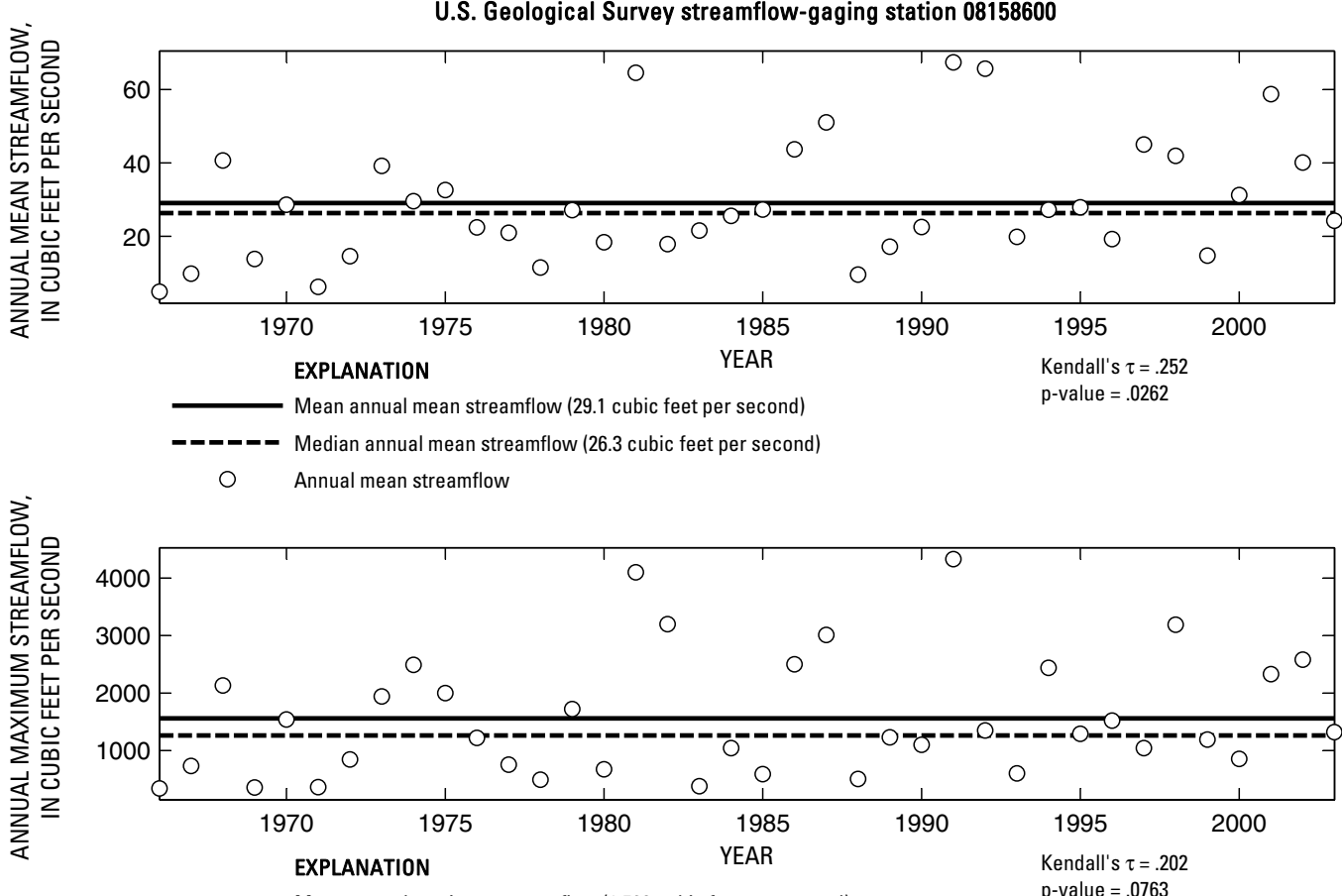

- Median annual maximum streamflow (1,260 cubic feet per second)

- Annual maximum streamflow
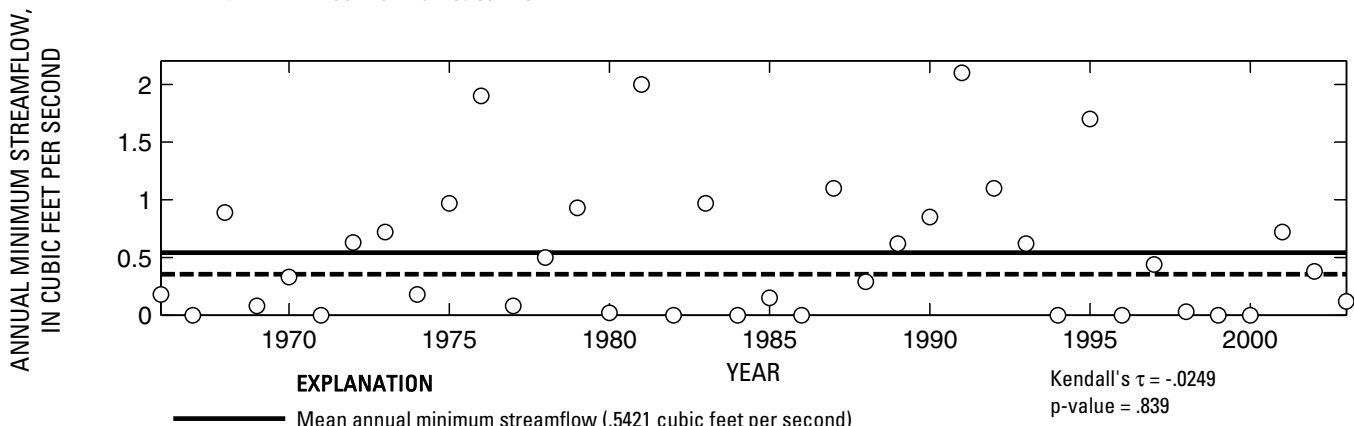

- - Median annual minimum streamflow (.355 cubic feet per second)

○ Annual minimum streamflow
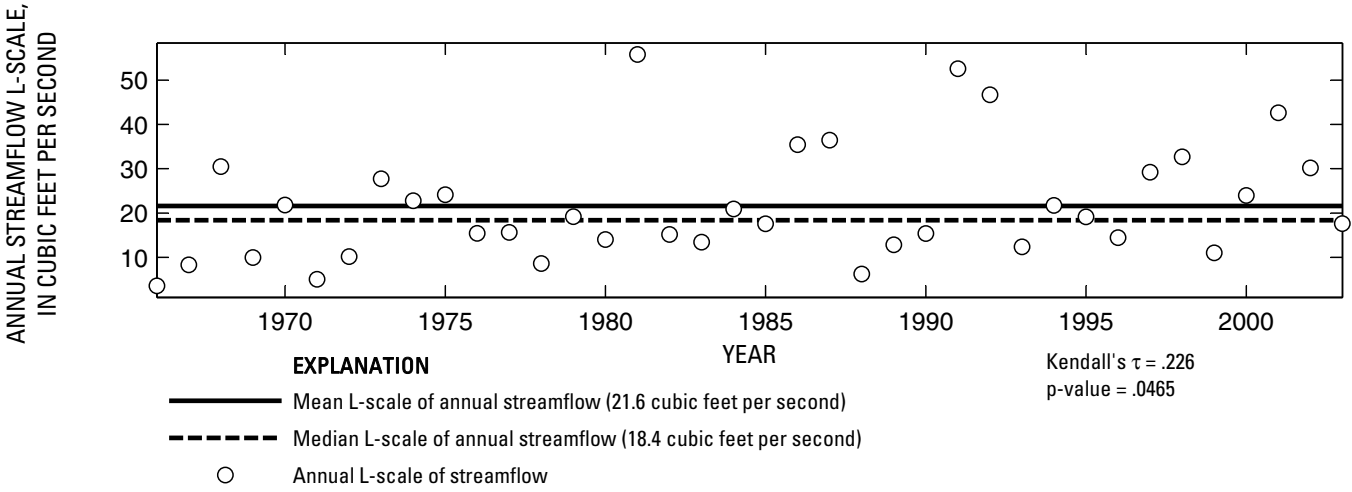

Figure 531. Analysis of annual mean, maximum, minimum, and L-scale statistics of daily mean streamflow for U.S. Geological Survey streamflow-gaging station 08158600 Walnut Creek at Webberville Road, Austin, Texas. 
U.S. Geological Survey streamflow-gaging station 08158700
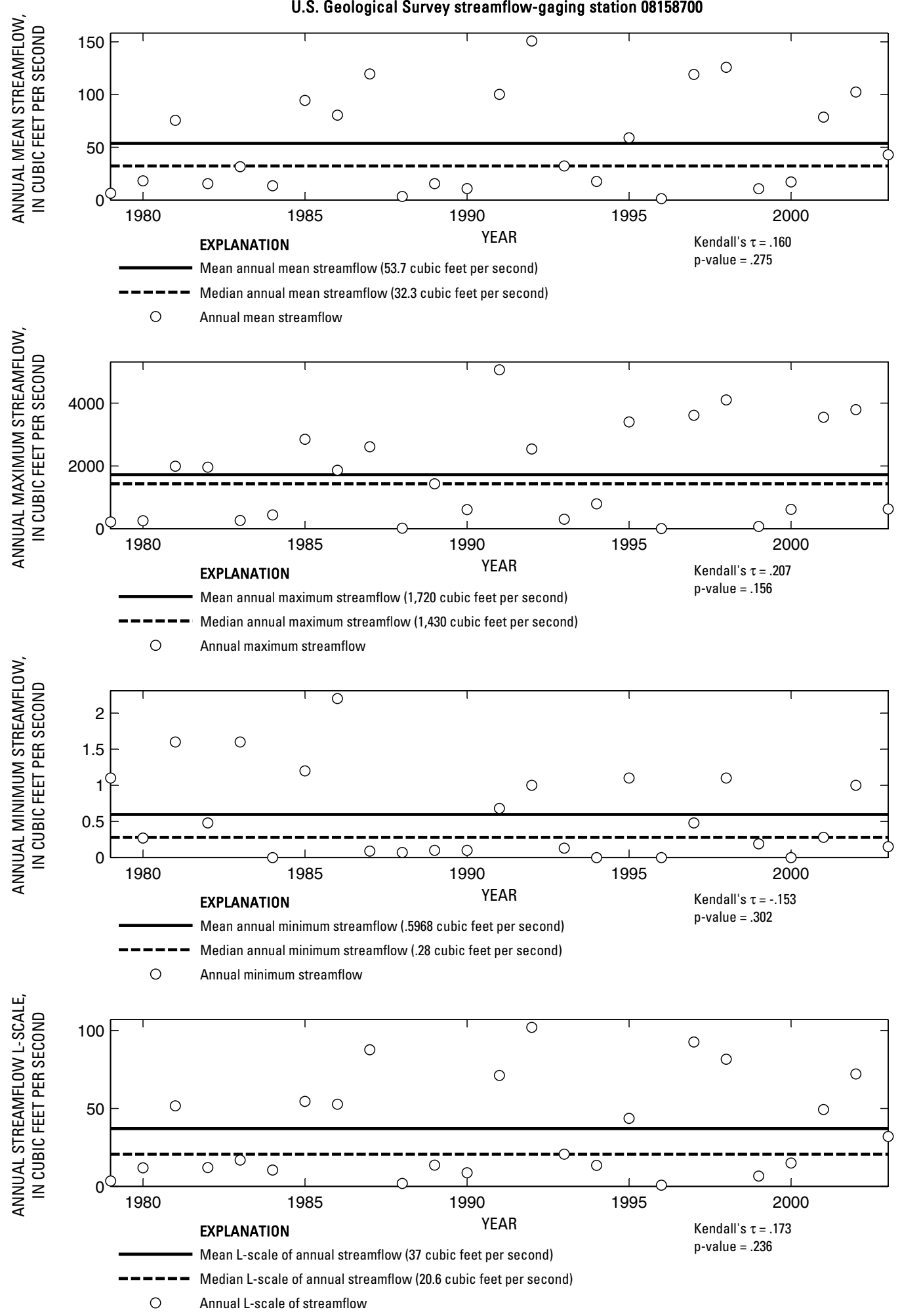

Figure 532. Analysis of annual mean, maximum, minimum, and L-scale statistics of daily mean streamflow for U.S. Geological Survey streamflow-gaging station 08158700 Onion Creek near Driftwood, Texas.

Index of Station Numbers 719 


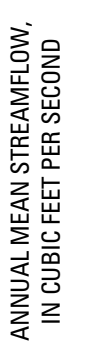

U.S. Geological Survey streamflow-gaging station 08158800

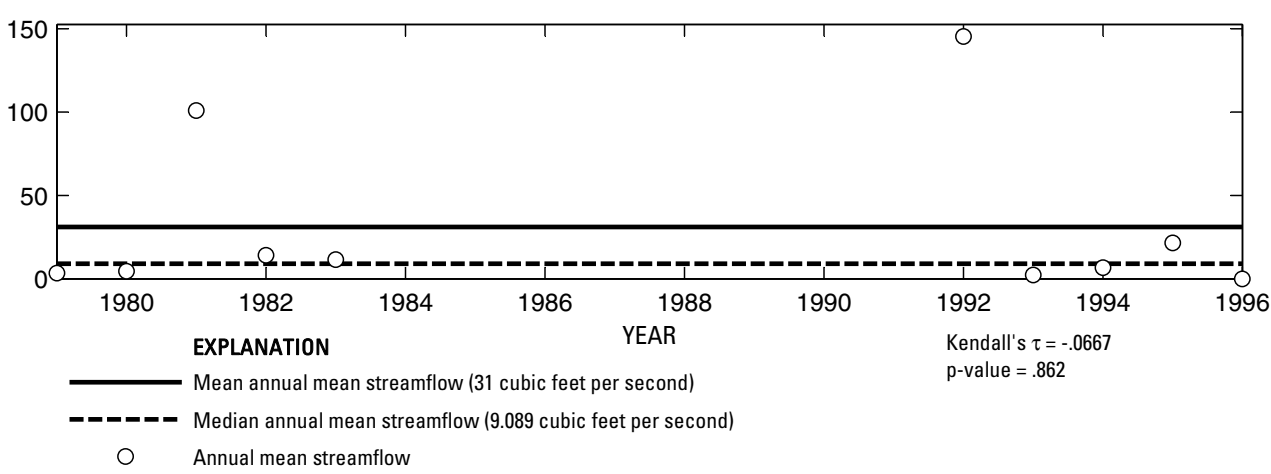

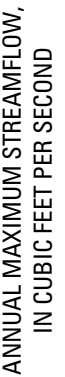

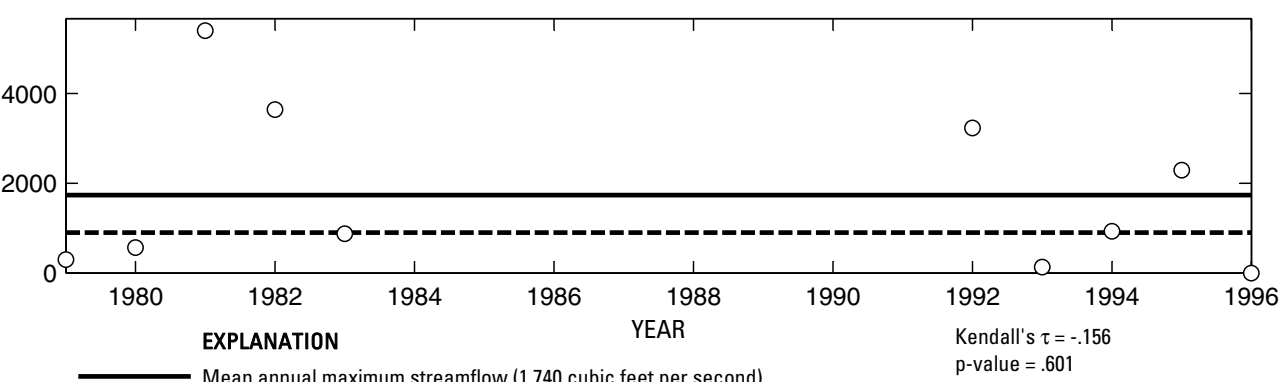

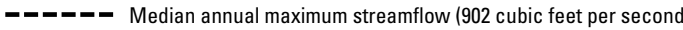

O Annual maximum streamflow
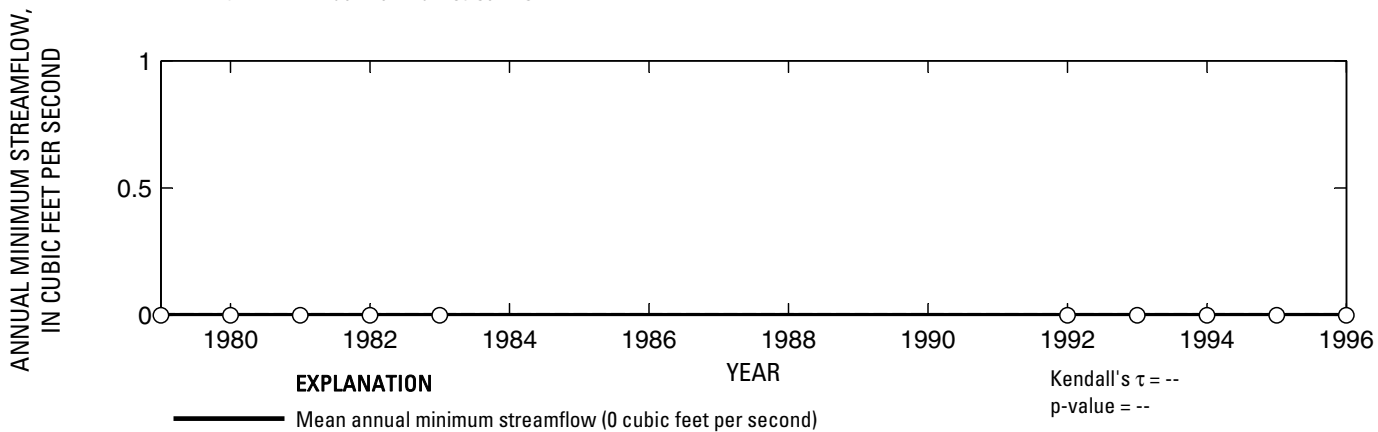

- ב- Median annual minimum streamflow (0 cubic feet per second)

○ Annual minimum streamflow

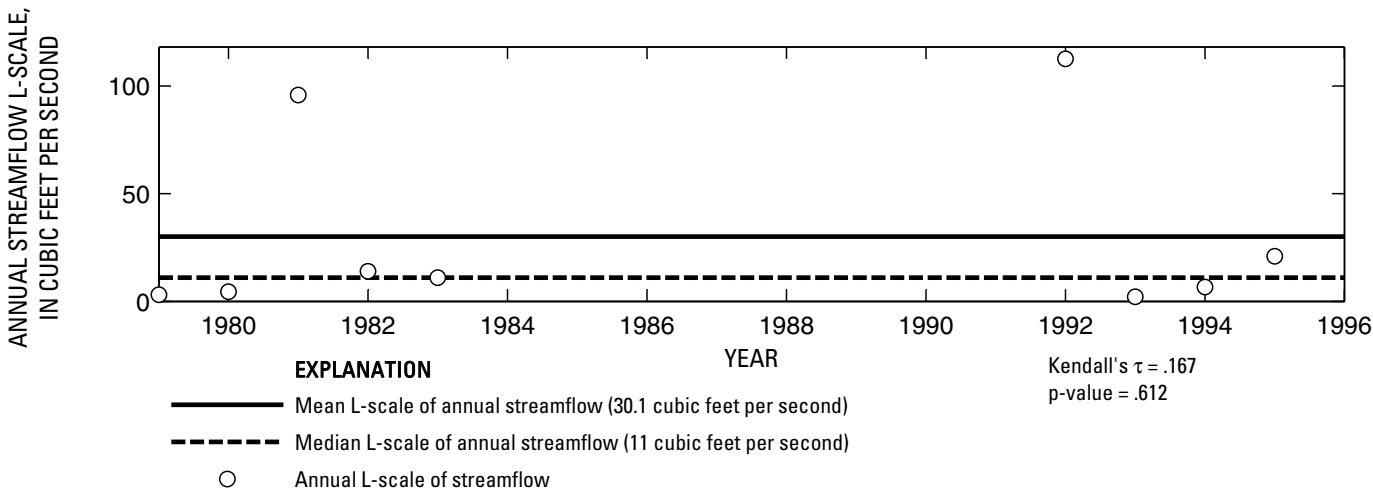

Figure 533. Analysis of annual mean, maximum, minimum, and L-scale statistics of daily mean streamflow for U.S. Geological Survey streamflow-gaging station 08158800 Onion Creek at Buda, Texas. 
U.S. Geological Survey streamflow-gaging station 08158810

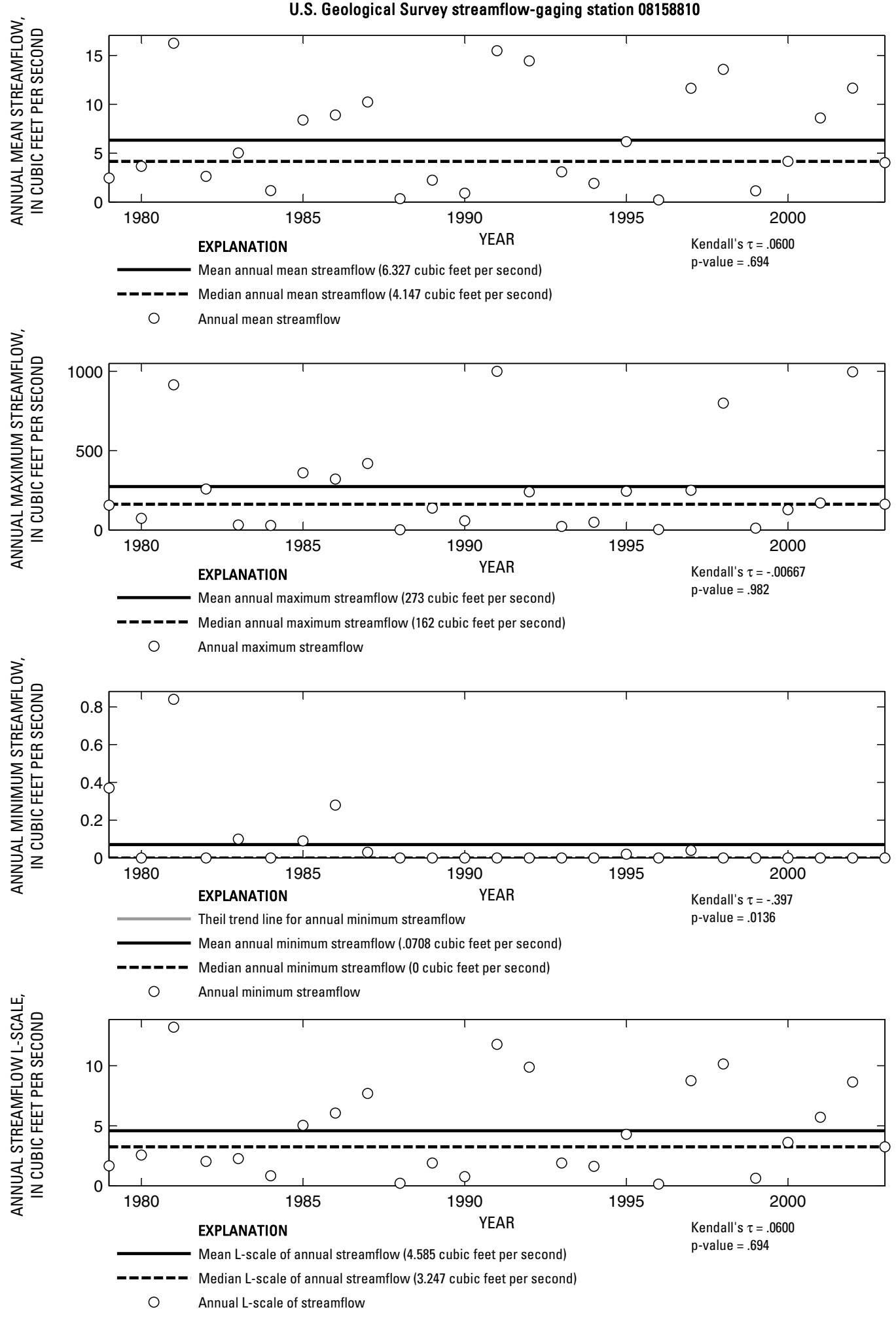

Figure 534. Analysis of annual mean, maximum, minimum, and L-scale statistics of daily mean streamflow for U.S. Geological Survey streamflow-gaging station 08158810 Bear Creek below Farm to Market Road 1826 near Driftwood, Texas. 


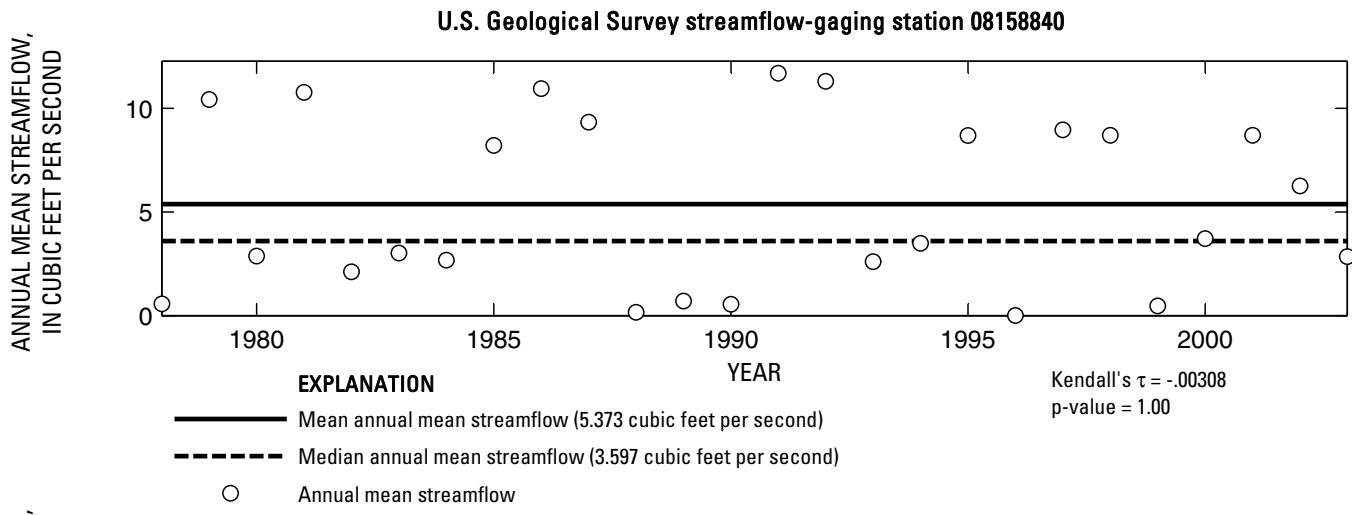

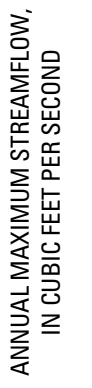

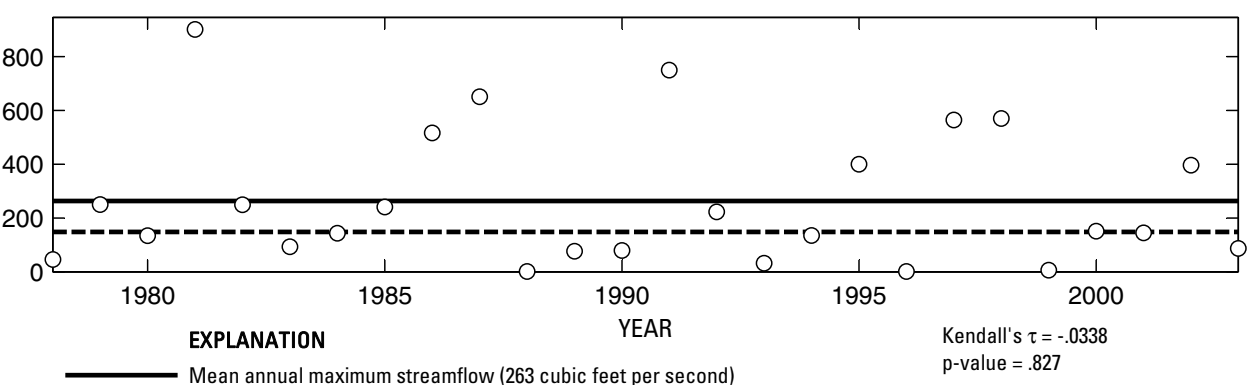

-_-_-_ Median annual maximum streamflow (148 cubic feet per second)

O Annual maximum streamflow

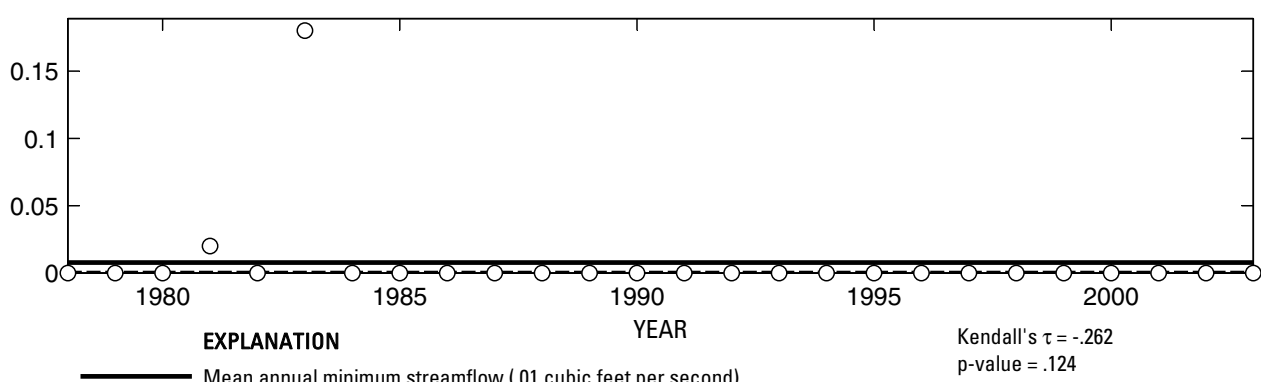

- - Median annual minimum streamflow $(0$ cubic feet per second

O Annual minimum streamflow

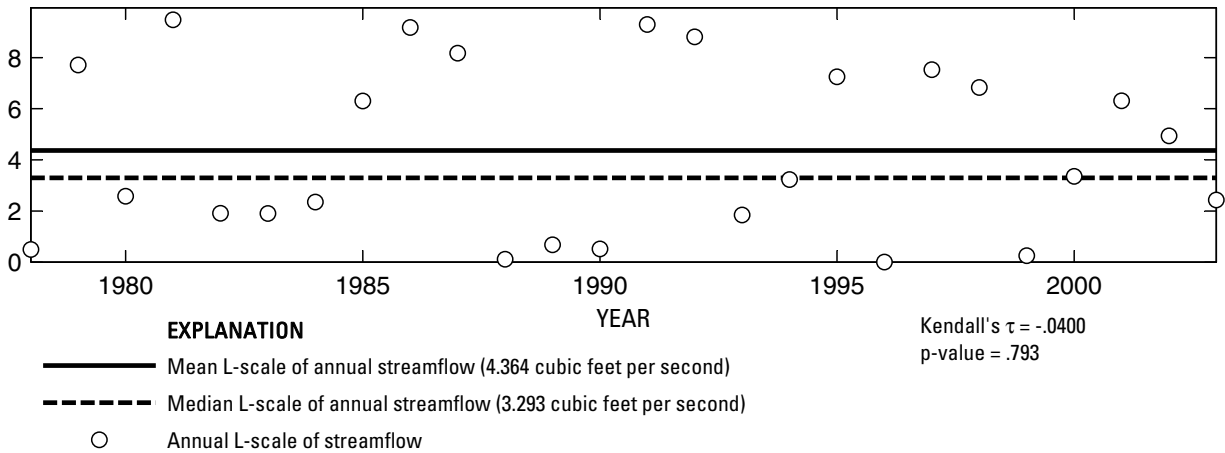

Figure 535. Analysis of annual mean, maximum, minimum, and L-scale statistics of daily mean streamflow for U.S. Geological Survey streamflow-gaging station 08158840 Slaughter Creek at Farm to Market Road 1826 near Austin, Texas. 

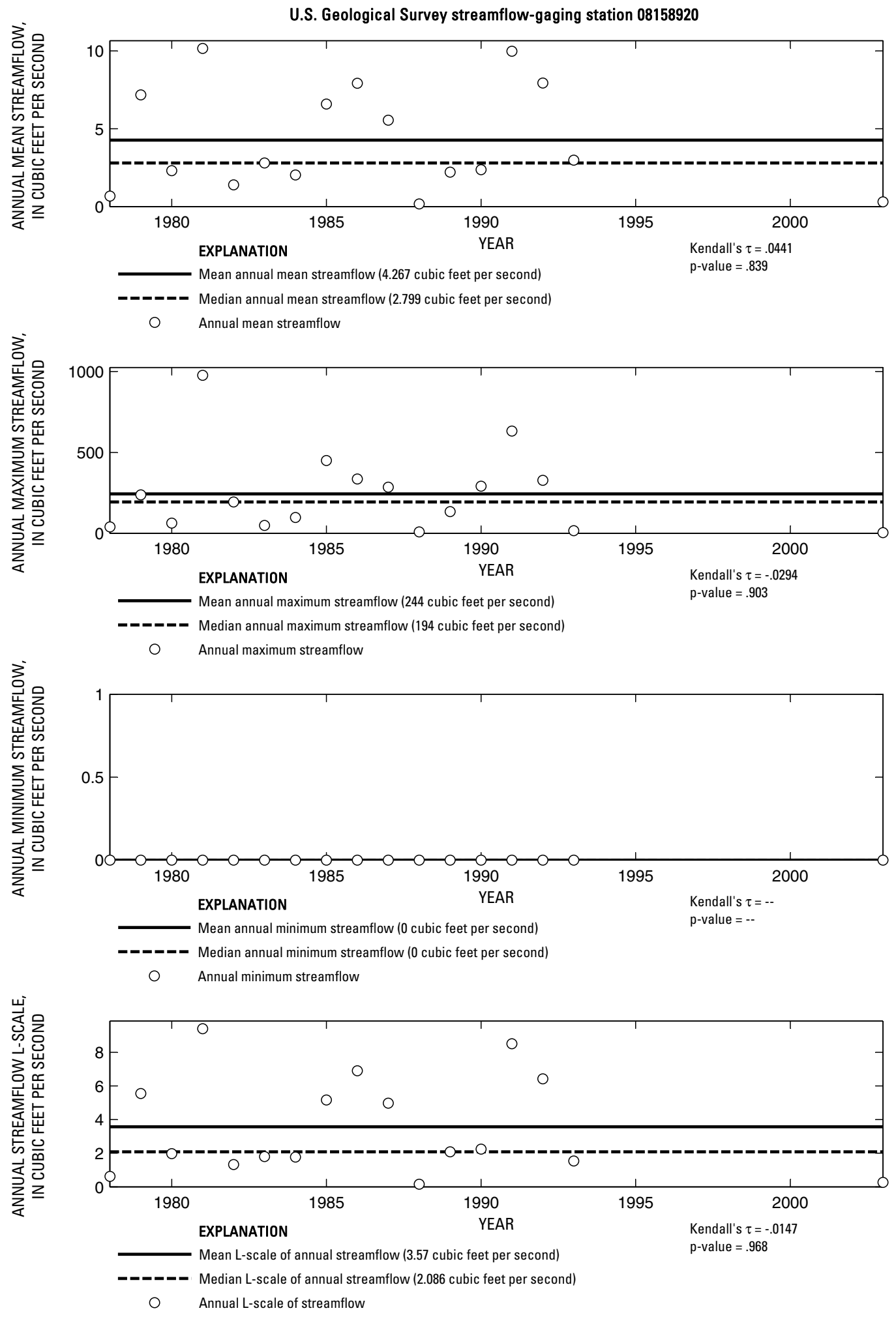

Figure 536. Analysis of annual mean, maximum, minimum, and L-scale statistics of daily mean streamflow for U.S. Geological Survey streamflow-gaging station 08158920 Williamson Creek at Oak Hill, Texas.

Index of Station Numbers 719 


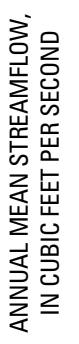

U.S. Geological Survey streamflow-gaging station 08158922

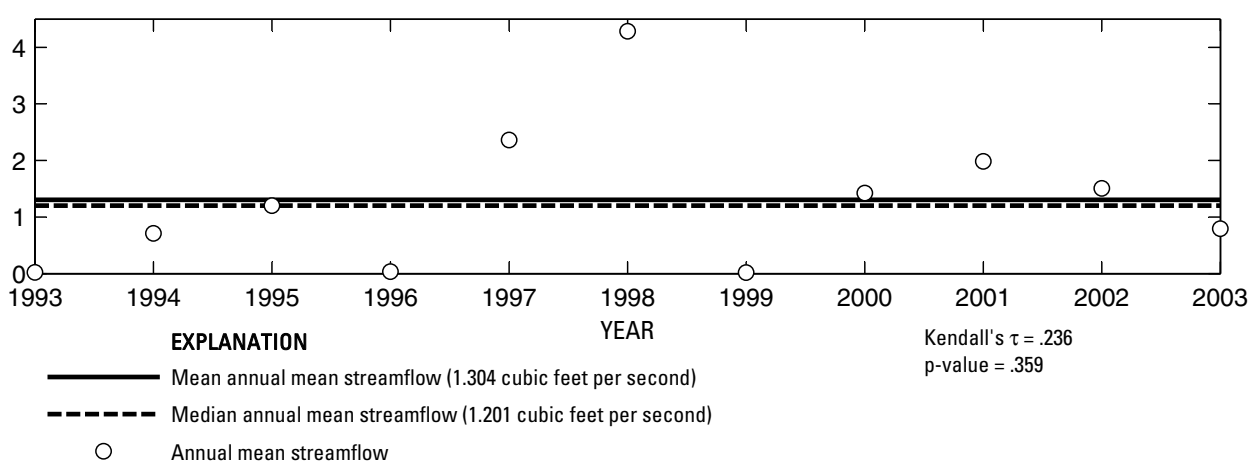

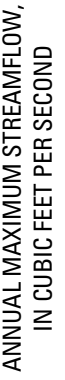

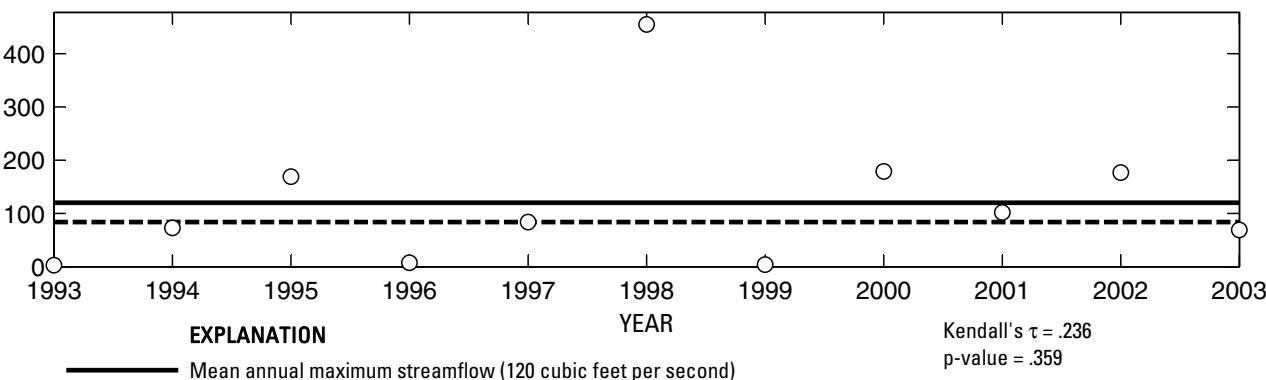

- - Median annual maximum streamflow (84 cubic feet per second)

○ Annual maximum streamflow

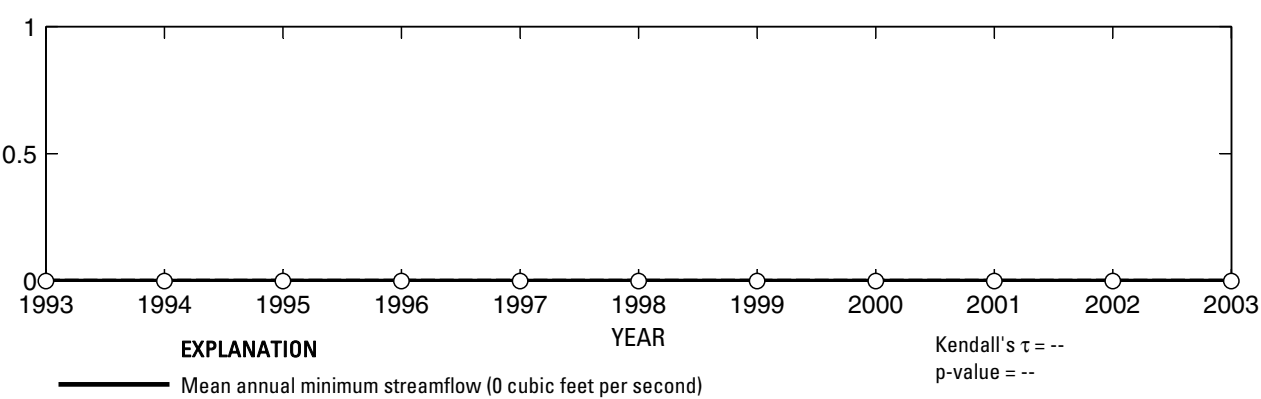

-ーーー- Median annual minimum streamflow (0 cubic feet per second)

○ Annual minimum streamflow

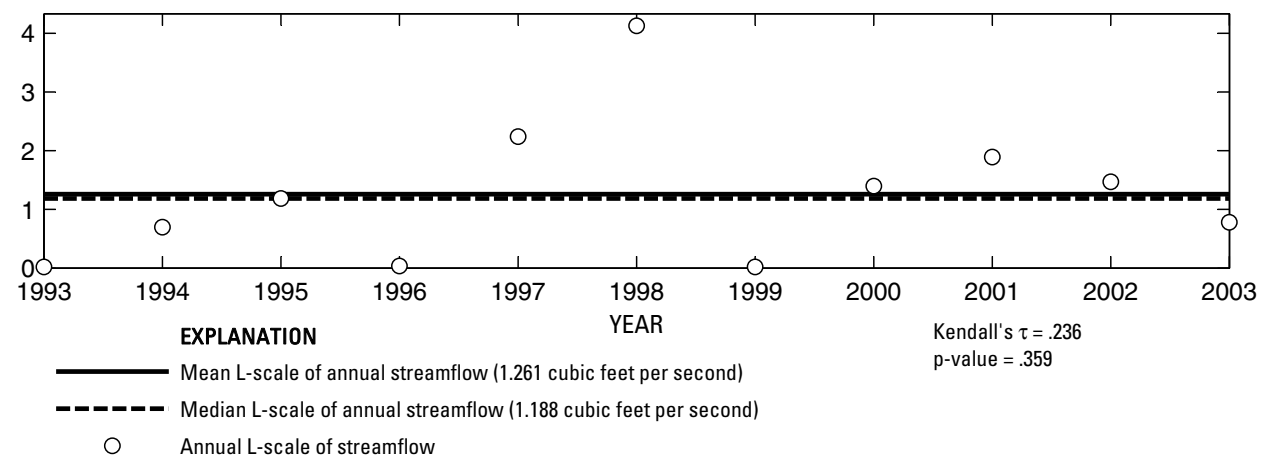

Figure 537. Analysis of annual mean, maximum, minimum, and L-scale statistics of daily mean streamflow for U.S. Geological Survey streamflow-gaging station 08158922 Williamson Creek at Brush Country Boulevard, Oak Hill, Texas. 


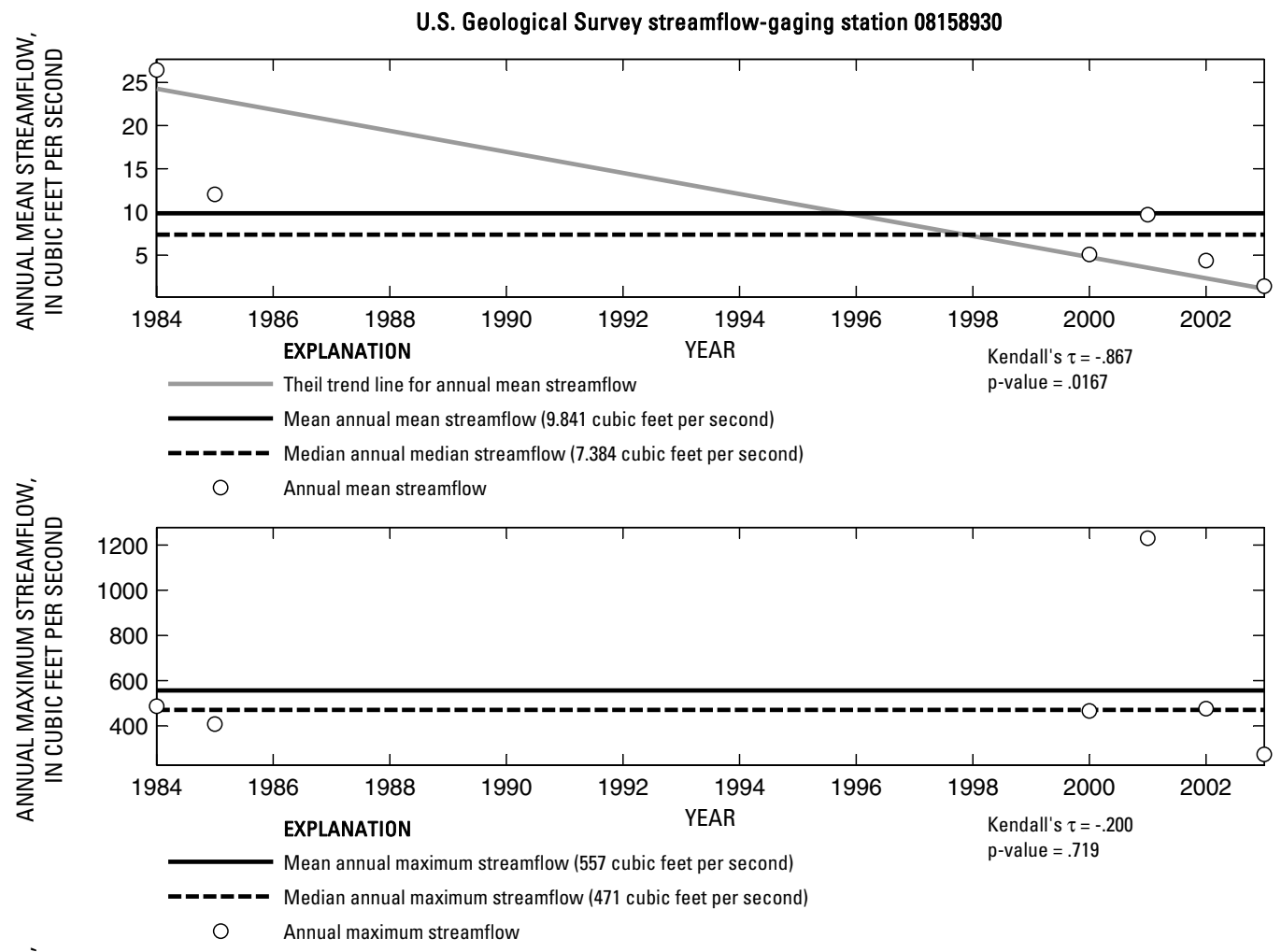

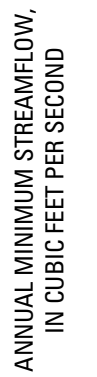

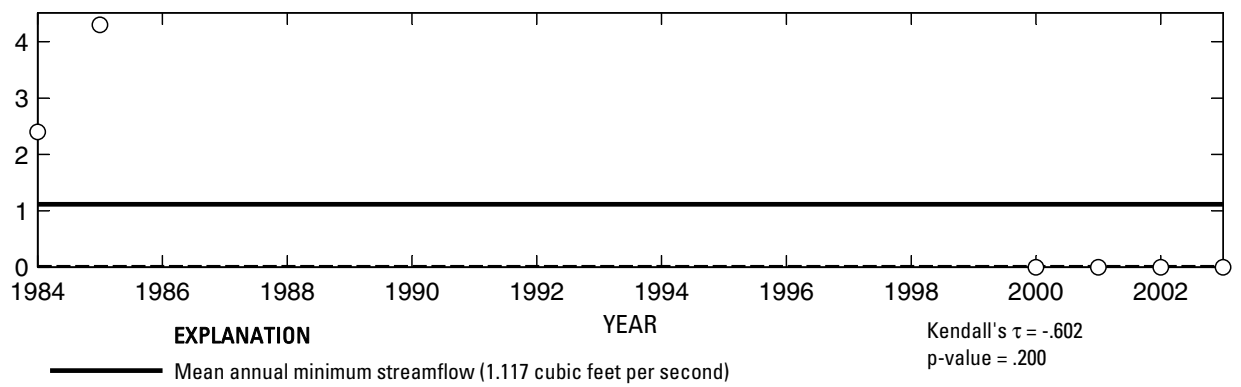

- ב-ב Median annual minimum streamflow (0 cubic feet per second)

O Annual minimum streamflow

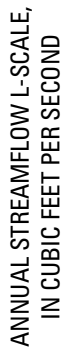

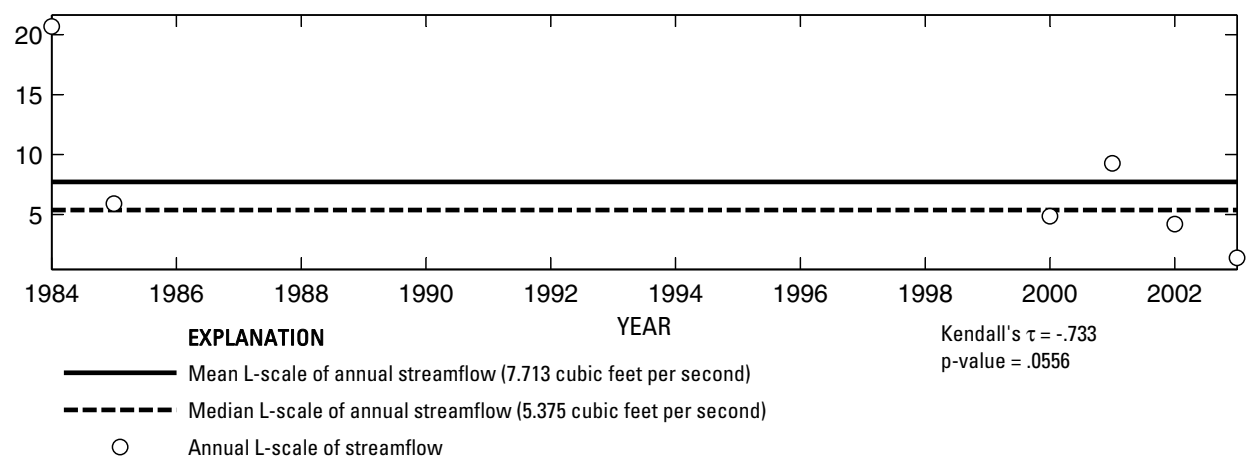

Figure 538. Analysis of annual mean, maximum, minimum, and L-scale statistics of daily mean streamflow for U.S. Geological Survey streamflow-gaging station 08158930 Williamson Creek at Manchaca Road, Austin, Texas.

Index of Station Numbers 719 


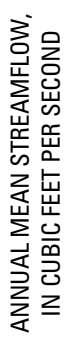

U.S. Geological Survey streamflow-gaging station 08158970

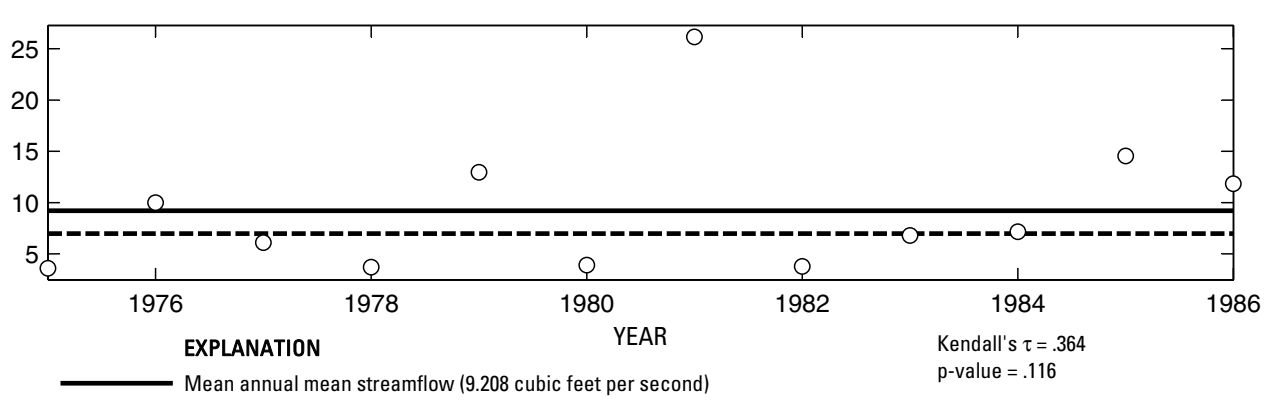

-_o_-_ Median annual mean streamflow (6.972 cubic feet per second)

O Annual mean streamflow
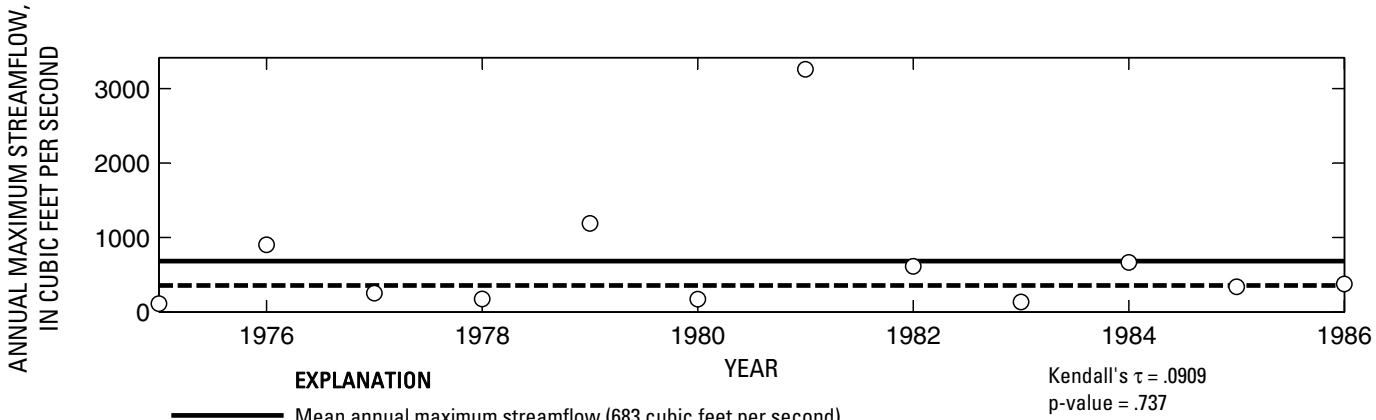

O Annual maximum streamflow

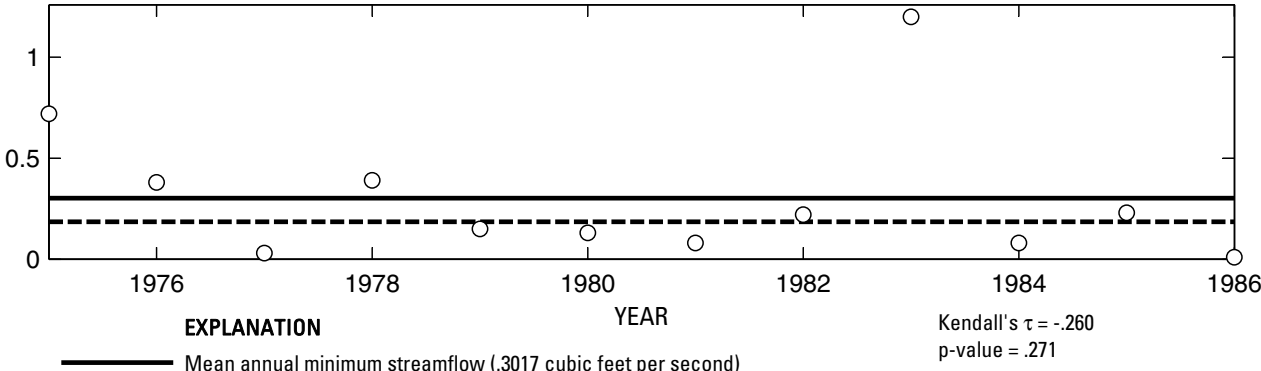

- - Median annual minimum streamflow (.185 cubic feet per second)

○ Annual minimum streamflow

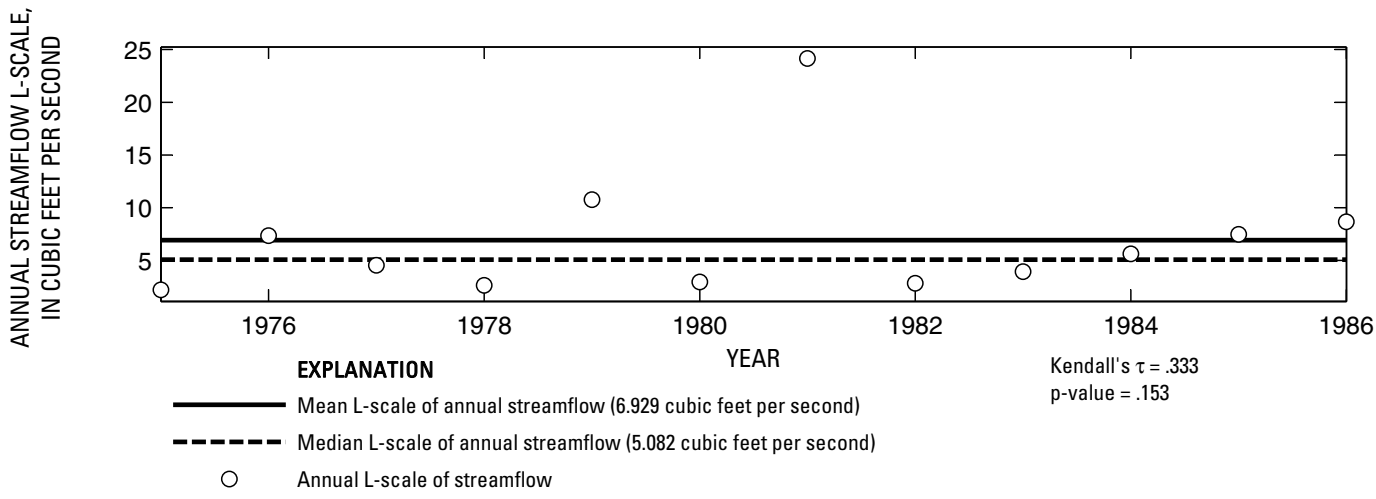

Figure 539. Analysis of annual mean, maximum, minimum, and L-scale statistics of daily mean streamflow for U.S. Geological Survey streamflow-gaging station 08158970 Williamson Creek at Jimmy Clay Road, Austin, Texas. 

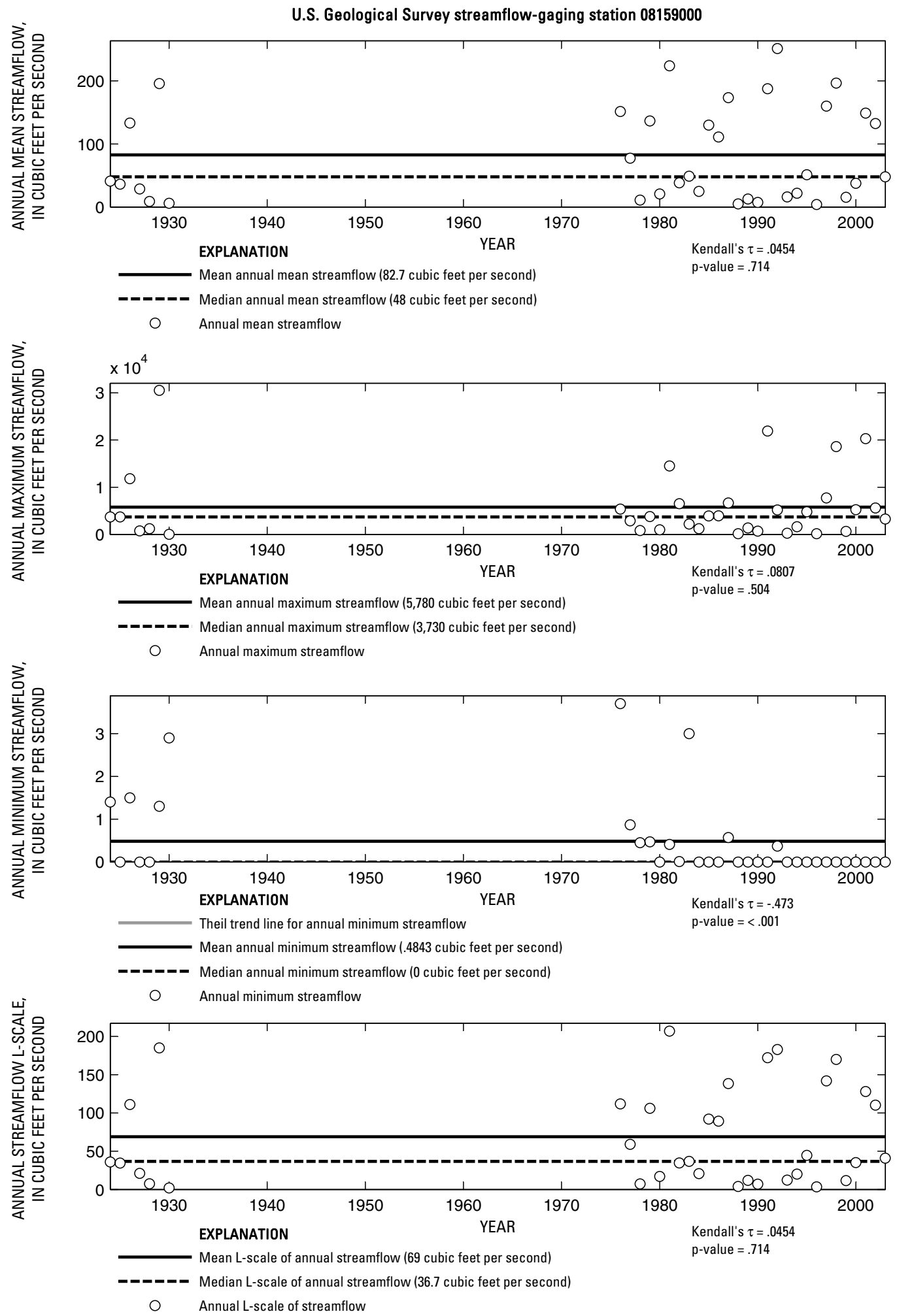

Figure 540. Analysis of annual mean, maximum, minimum, and L-scale statistics of daily mean streamflow for U.S. Geological Survey streamflow-gaging station 08159000 Onion Creek at U. S. Highway 183, Austin, Texas.

Index of Station Numbers 719 


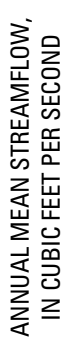

U.S. Geological Survey streamflow-gaging station 08159150

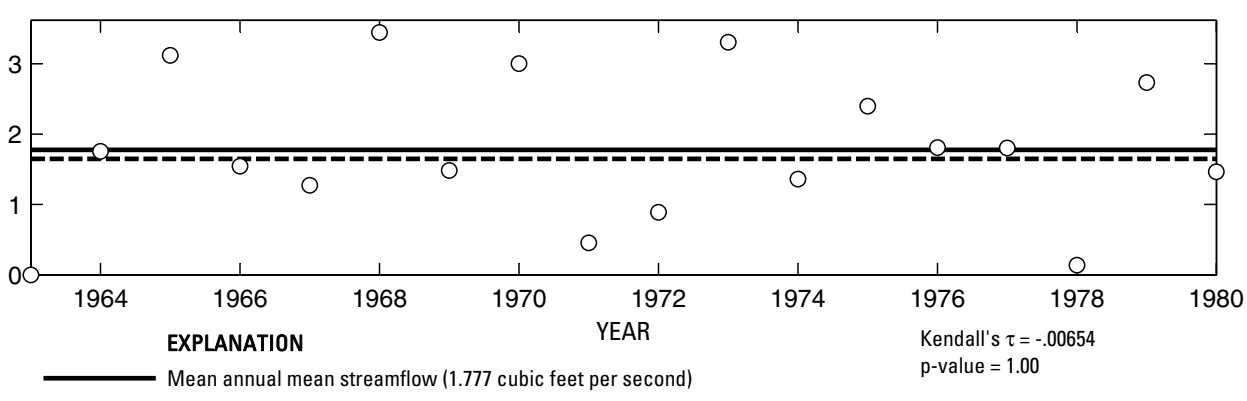

-_-_-_ Median annual mean streamflow (1.649 cubic feet per second)

- Annual mean streamflow
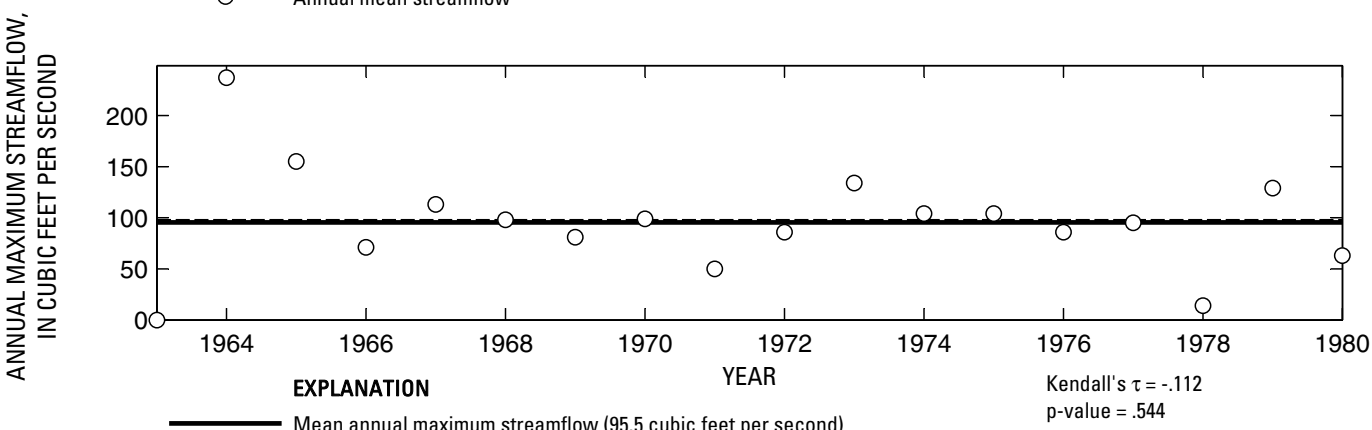

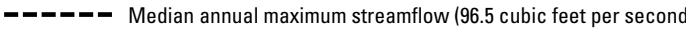

- Annual maximum streamflow
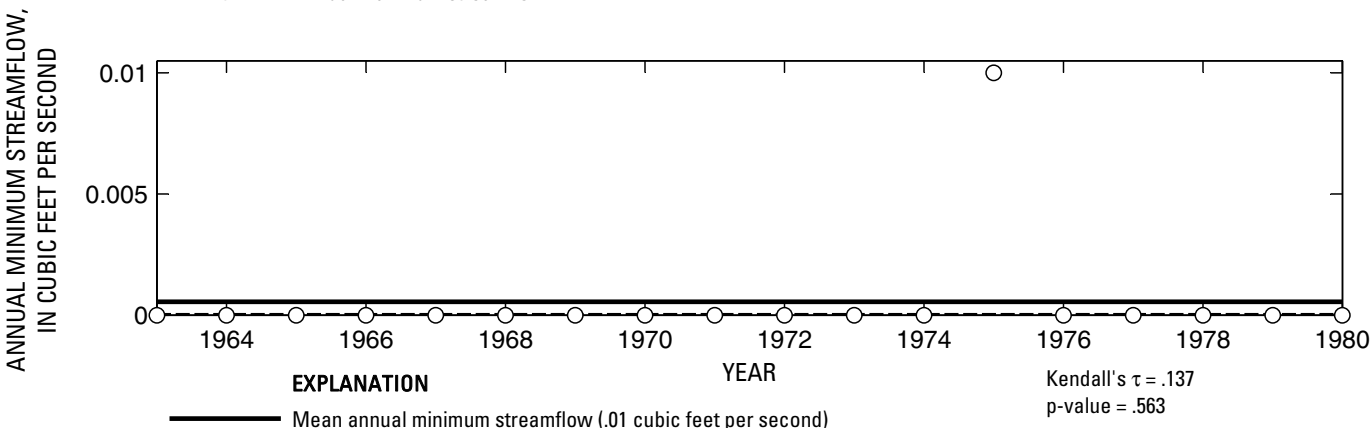

- - Median annual minimum streamflow (0 cubic feet per second)

O Annual minimum streamflow
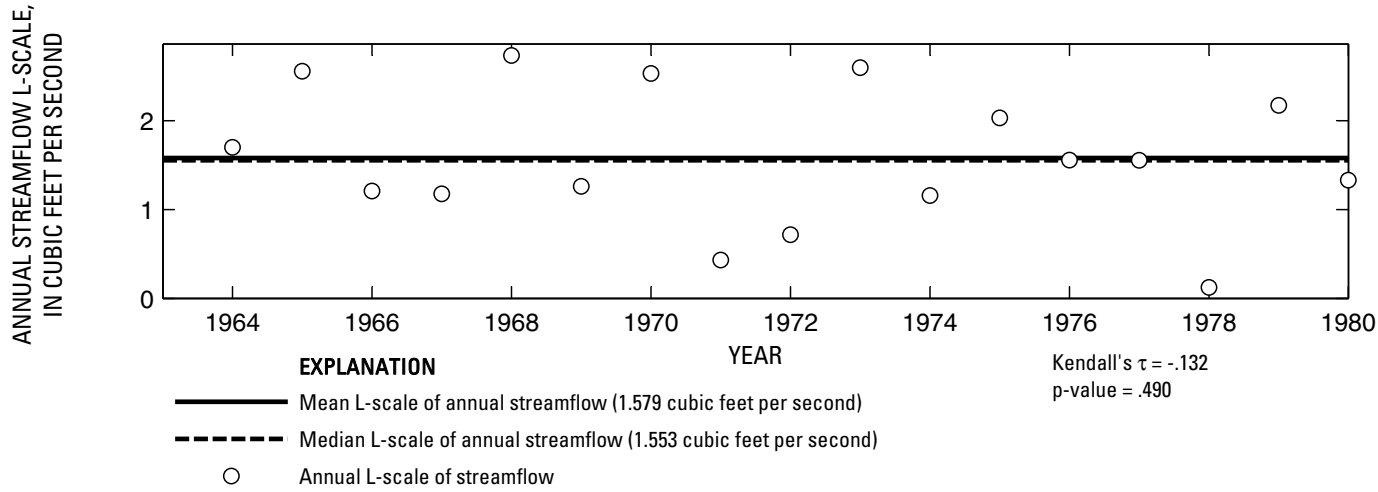

Figure 541. Analysis of annual mean, maximum, minimum, and L-scale statistics of daily mean streamflow for U.S. Geological Survey streamflow-gaging station 08159150 Wilbarger Creek near Pflugerville, Texas. 

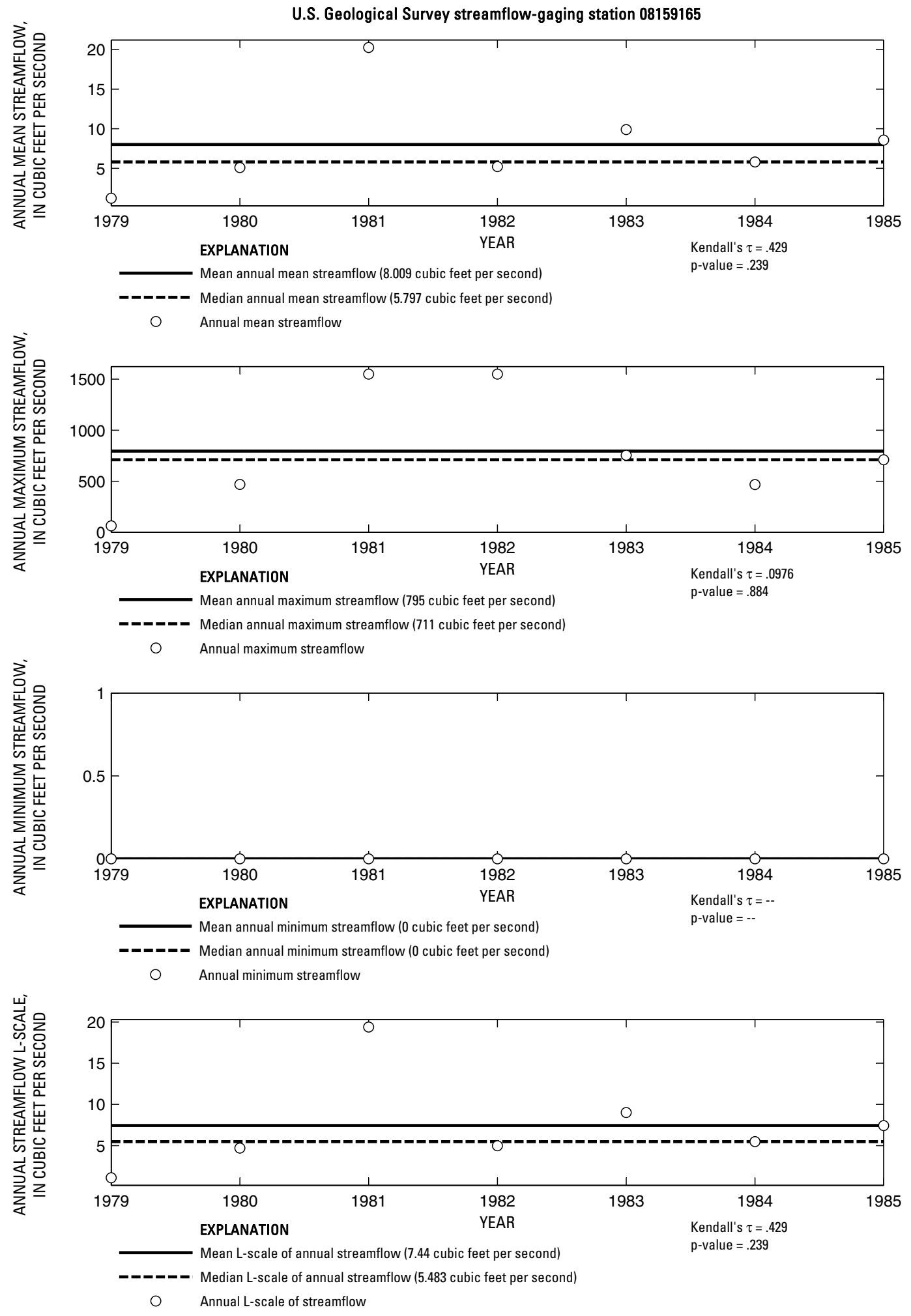

Figure 542. Analysis of annual mean, maximum, minimum, and L-scale statistics of daily mean streamflow for U.S. Geological Survey streamflow-gaging station 08159165 Big Sandy Creek near McDade, Texas. 

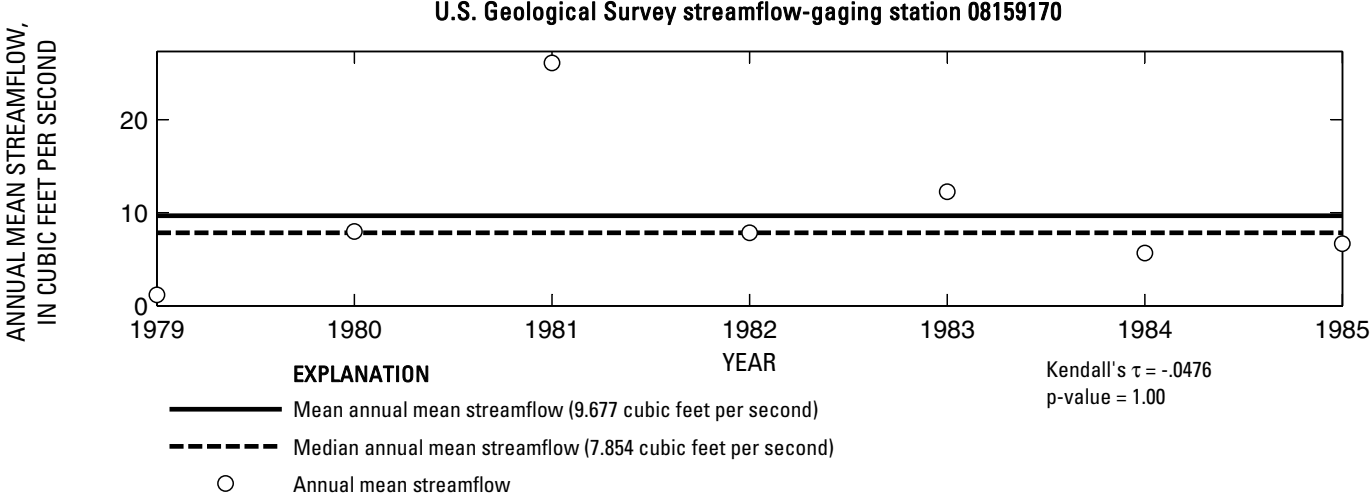

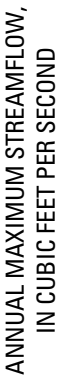

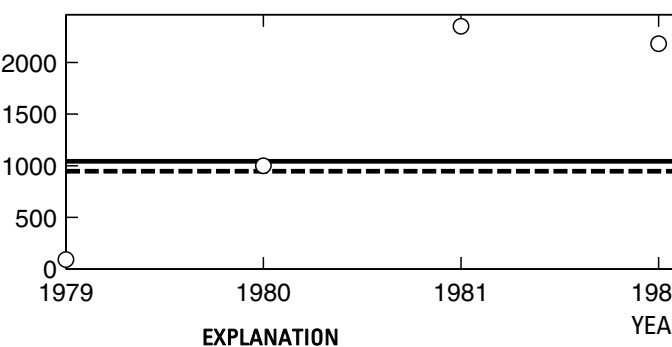

$\mathrm{O}$

Mean annual maximum streamflow (1,040 cubic feet per second)

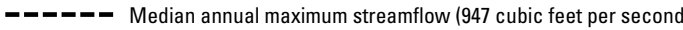

O Annual maximum streamflow
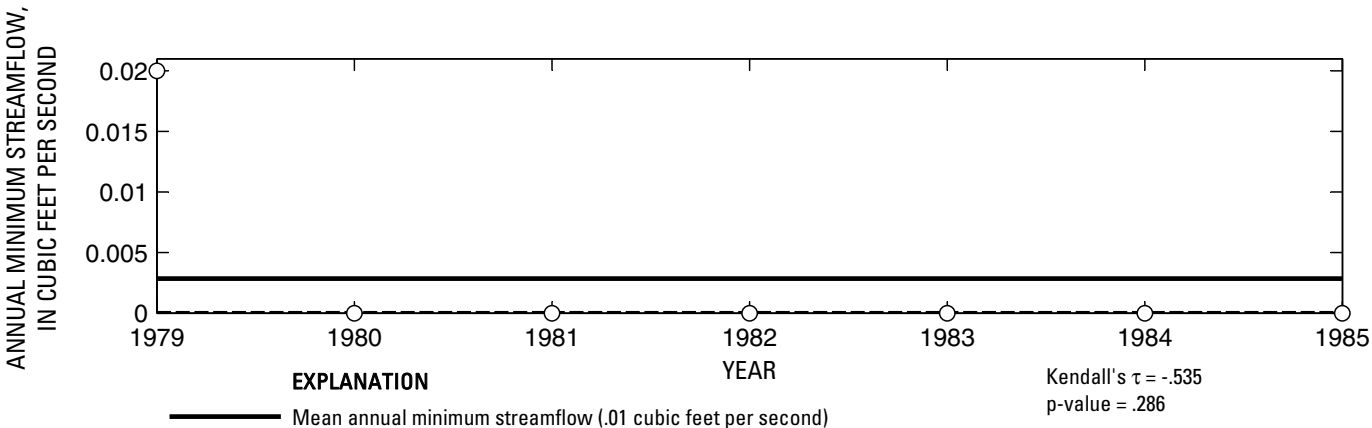

- ב-ב Median annual minimum streamflow (0 cubic feet per second)

O Annual minimum streamflow
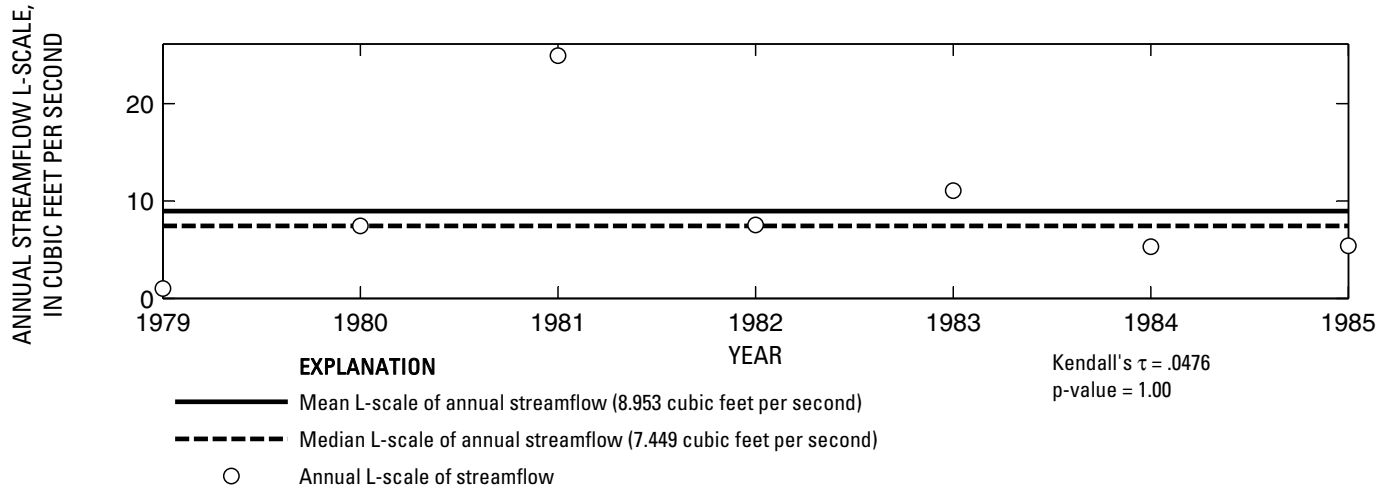

Figure 543. Analysis of annual mean, maximum, minimum, and L-scale statistics of daily mean streamflow for U.S. Geological Survey streamflow-gaging station 08159170 Big Sandy Creek near Elgin, Texas. 


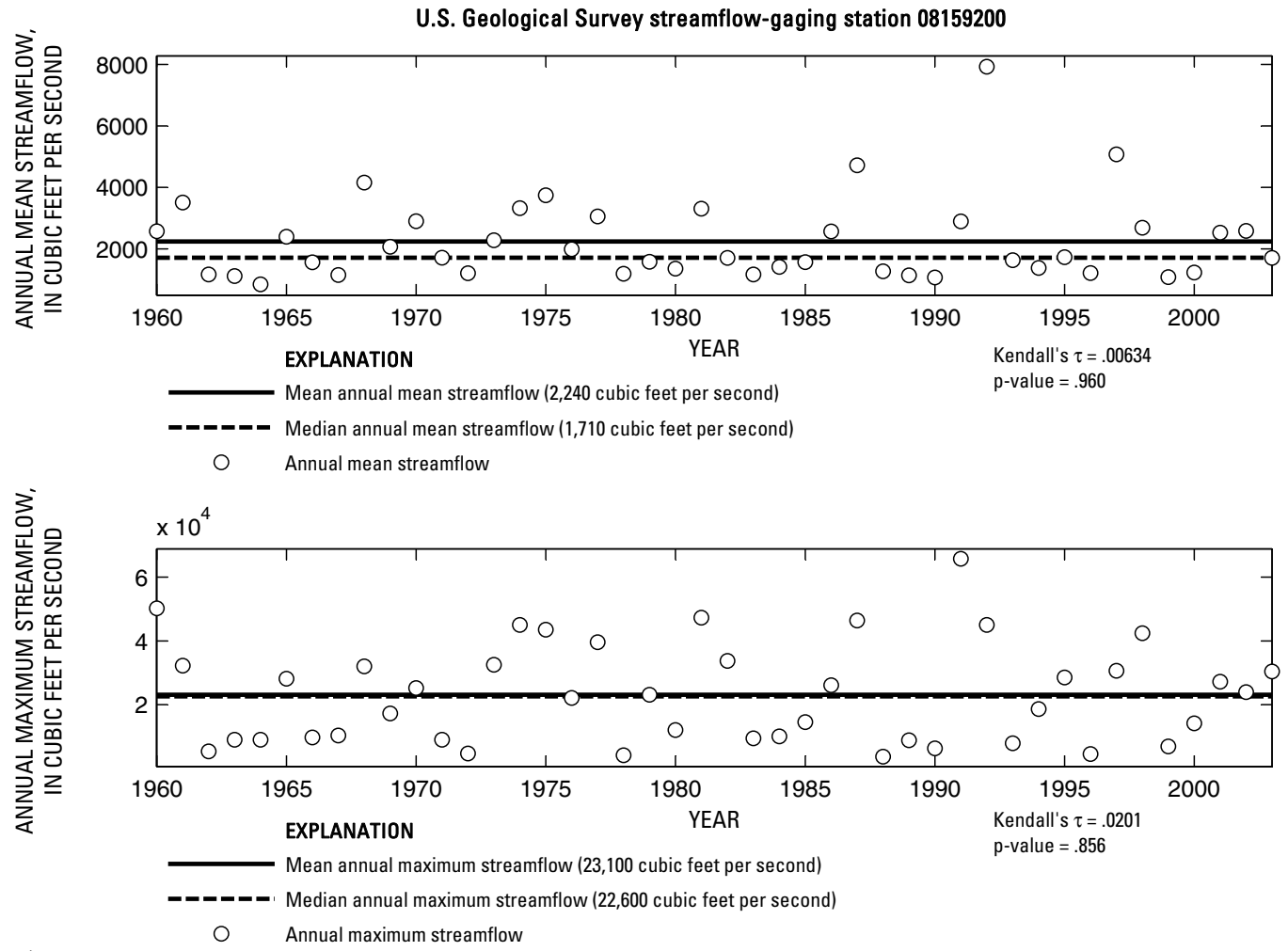

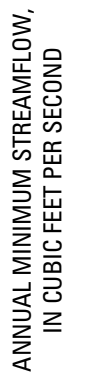

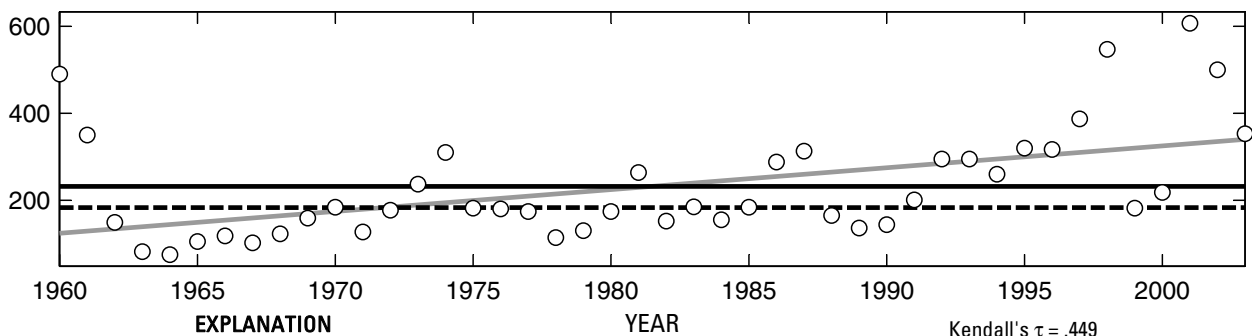

Theil trend line for annual minimum streamflow
Mean annual minimum streamflow (232 cubic feet per second)

- - - - Median annual minimum streamflow (183 cubic feet per second)

Annual minimum streamflow

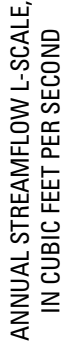

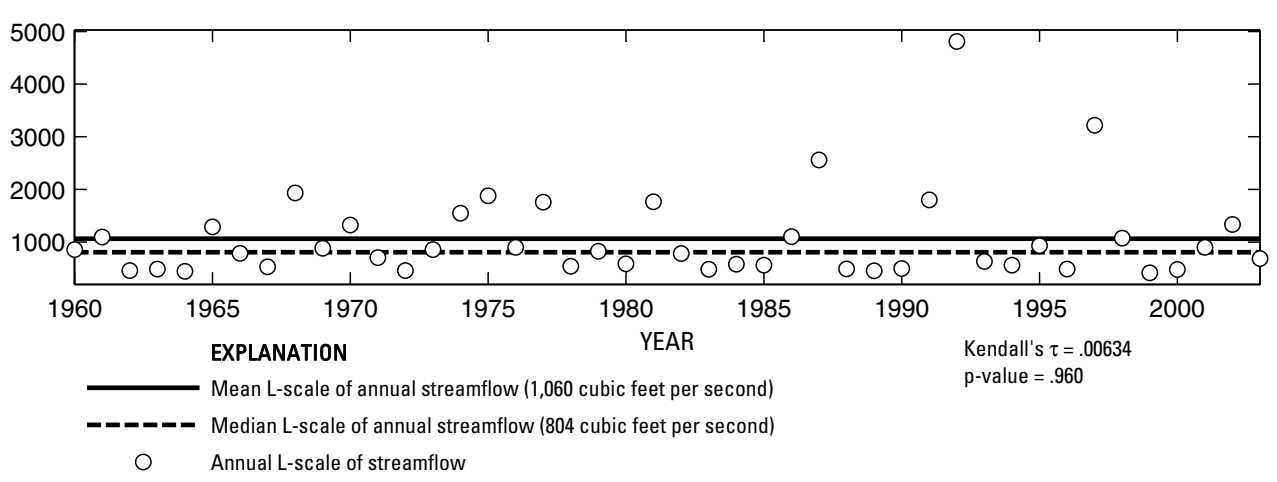

Figure 544. Analysis of annual mean, maximum, minimum, and L-scale statistics of daily mean streamflow for U.S. Geological Survey streamflow-gaging station 08159200 Colorado River at Bastrop, Texas.

|ndex of Station Numbers 719 


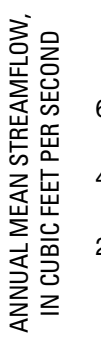

U.S. Geological Survey streamflow-gaging station 08159500

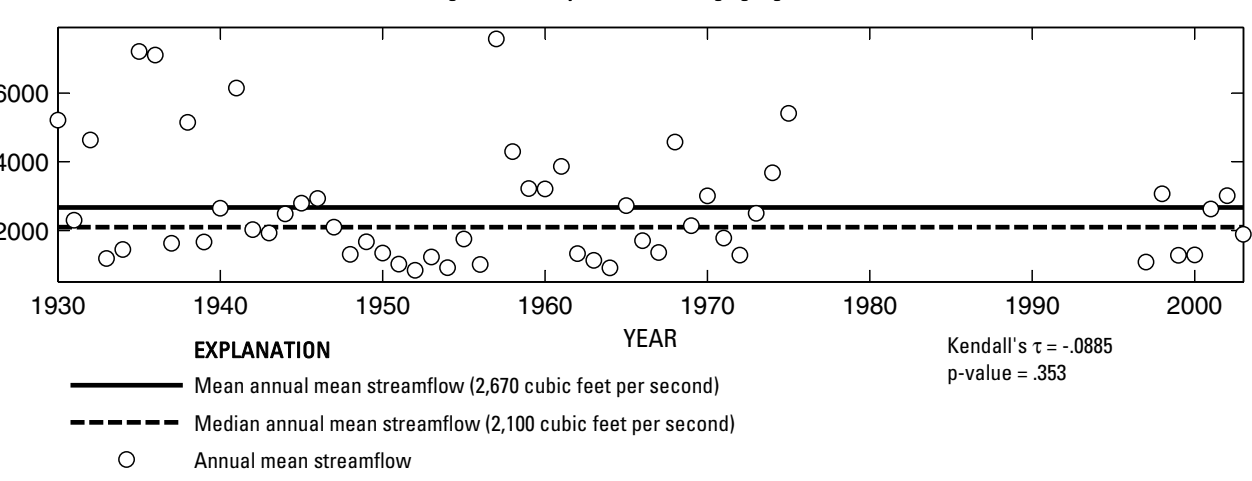

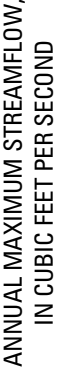

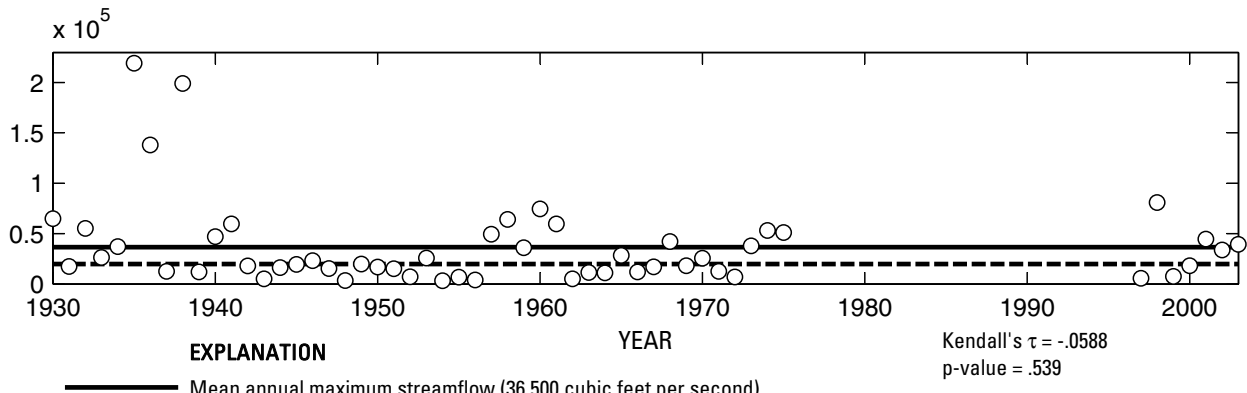

- _- Median annual maximum streamflow (19,900 cubic feet per second)

Annual maximum streamflow

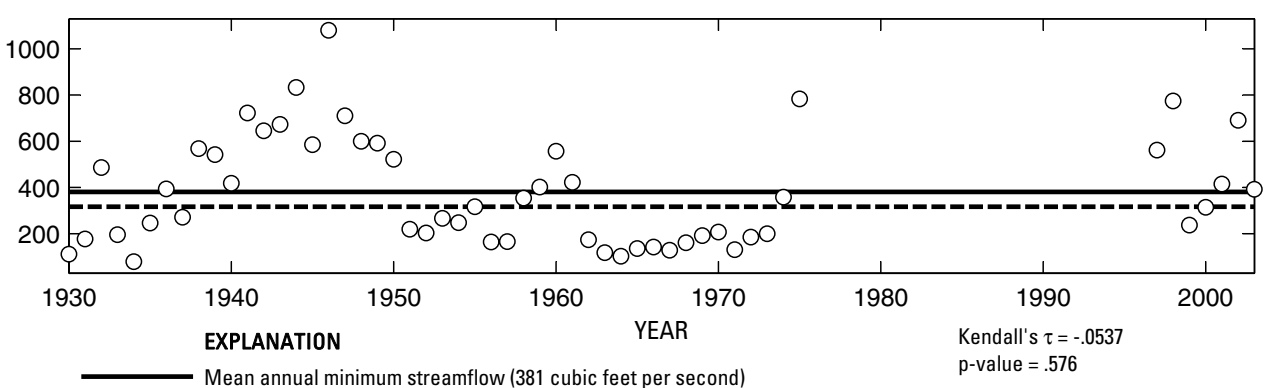

- - Median annual minimum streamflow (317 cubic feet per second)

O Annual minimum streamflow

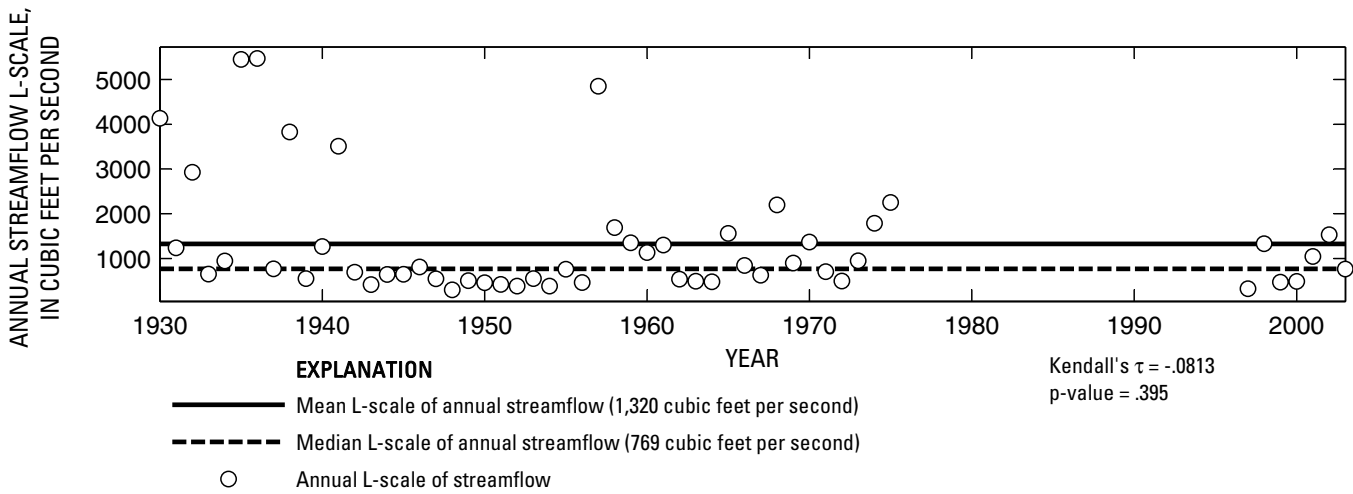

Figure 545. Analysis of annual mean, maximum, minimum, and L-scale statistics of daily mean streamflow for U.S. Geological Survey streamflow-gaging station 08159500 Colorado River at Smithville, Texas. 


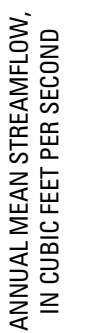

U.S. Geological Survey streamflow-gaging station 08160400

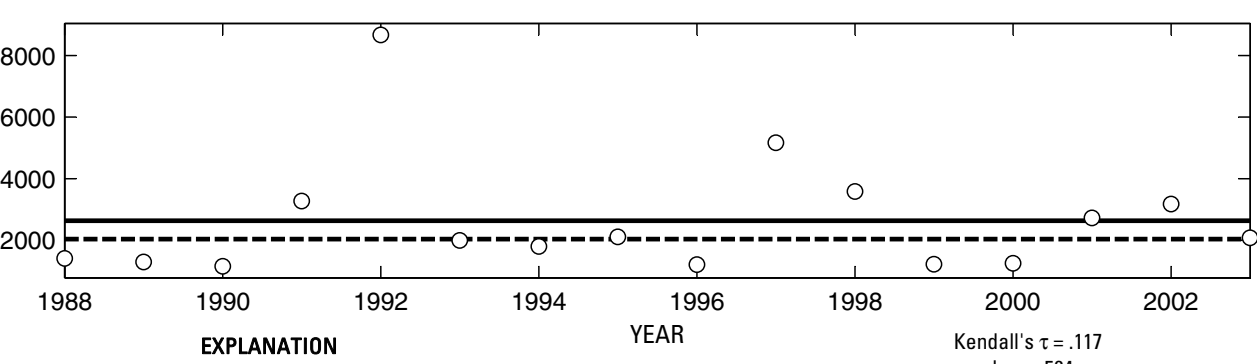

$\mathrm{p}$-value $=.564$

_ Median annual mean streamflow (2,040 cubic feet per second)

Annual mean streamflow

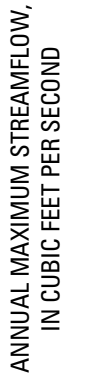

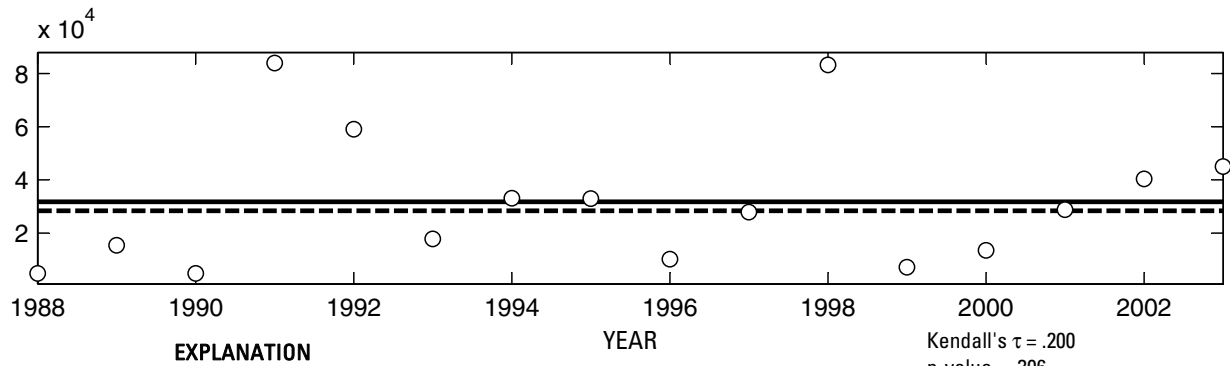

EXPLANATION

$\mathrm{p}$-value $=.306$

-_-_- Median annual maximum streamflow (28,400 cubic feet per second)

O Annual maximum streamflow

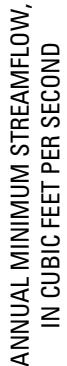

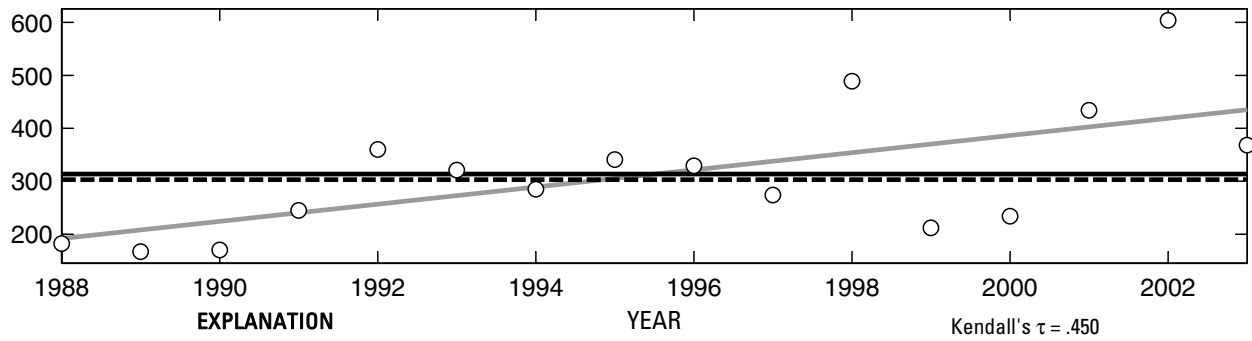

Theil trend line for annual minimum streamflow

- - - Median annual minimum streamflow (303 cubic feet per second)

O Annual minimum streamflow

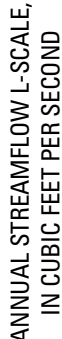

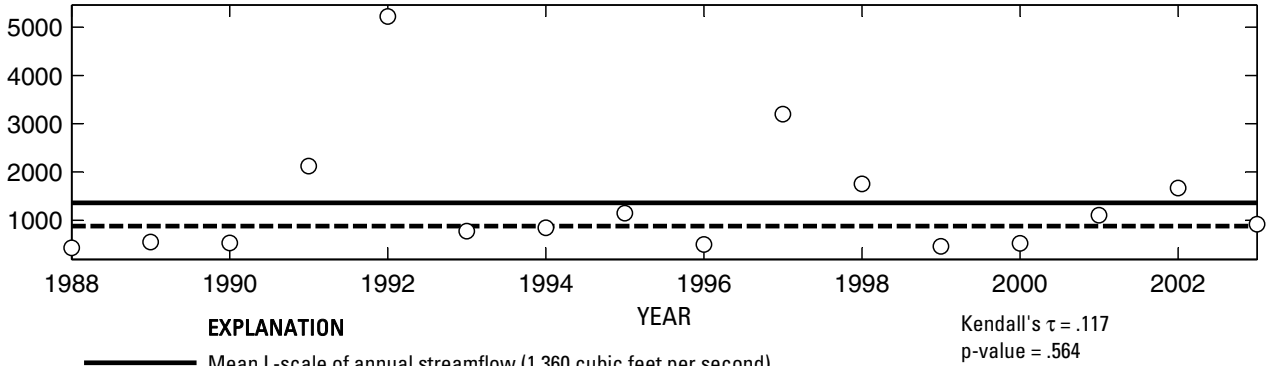

Mean L-scale of annual streamflow (1,360 cubic feet per second)

-ーーーー- Median L-scale of annual streamflow (880 cubic feet per second)

Annual L-scale of streamflow

Figure 546. Analysis of annual mean, maximum, minimum, and L-scale statistics of daily mean streamflow for U.S. Geological Survey streamflow-gaging station 08160400 Colorado River above La Grange, Texas.

Index of Station Numbers 719 

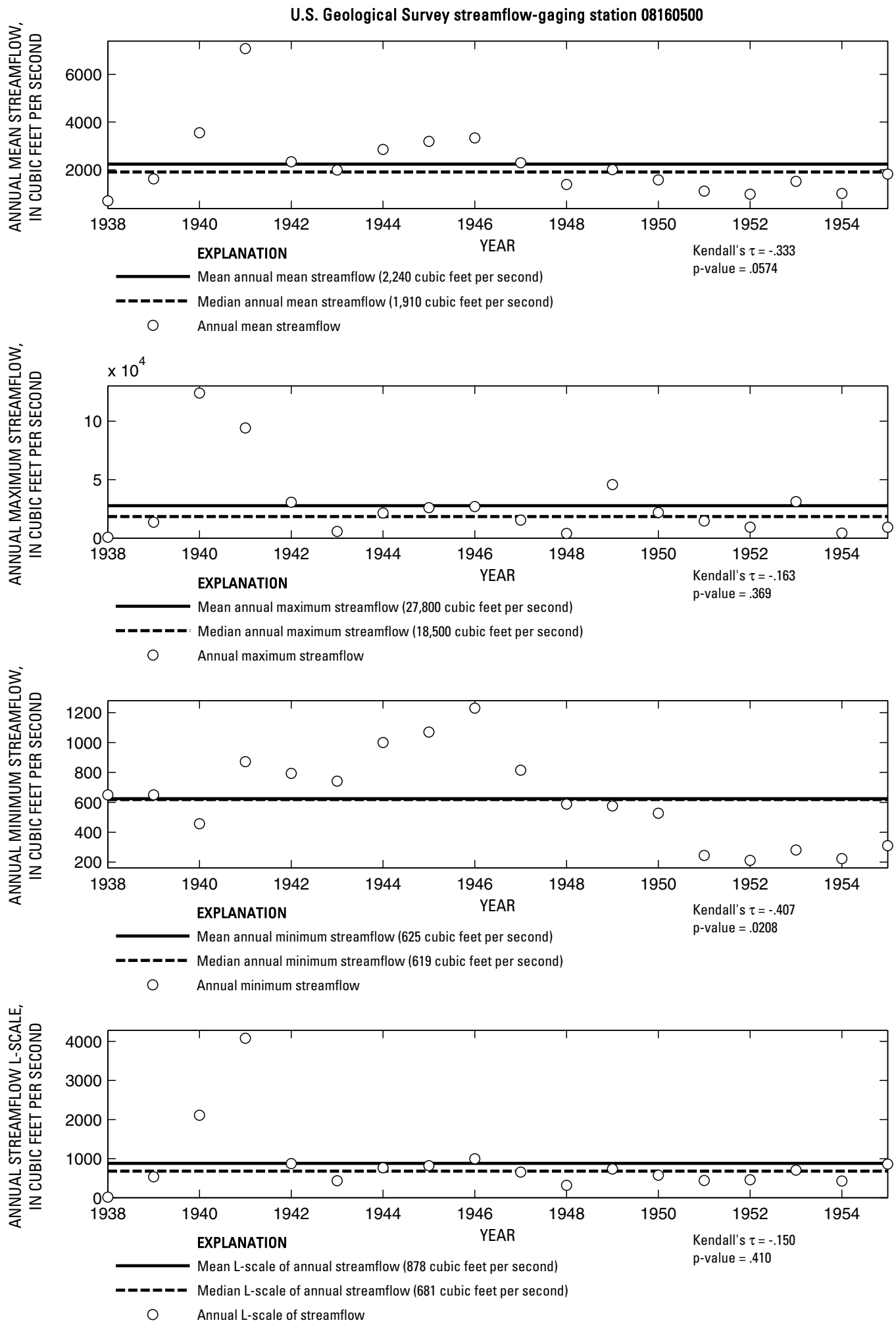

Figure 547. Analysis of annual mean, maximum, minimum, and L-scale statistics of daily mean streamflow for U.S. Geological Survey streamflow-gaging station 08160500 Colorado River at La Grange, Texas. 

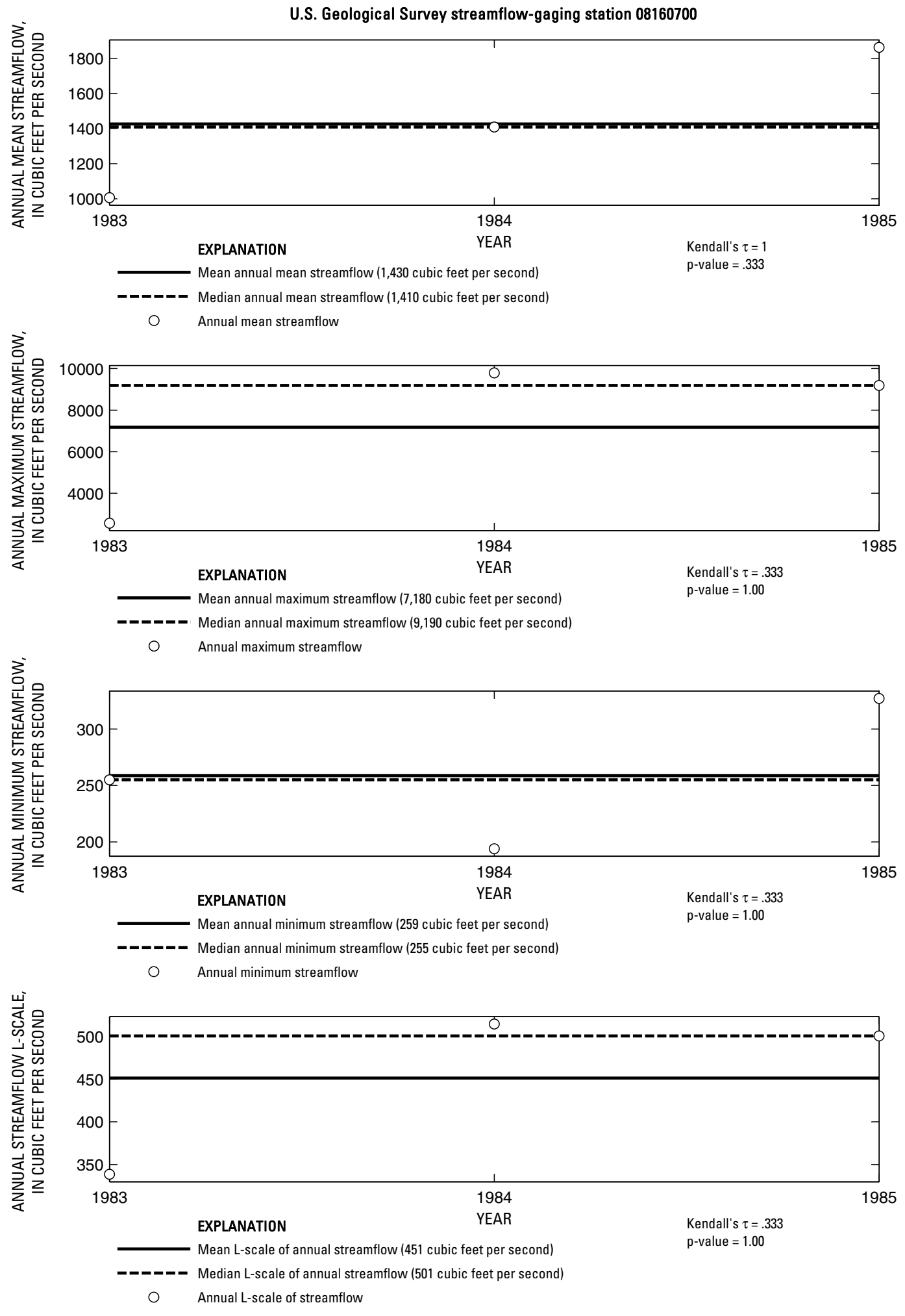

Figure 548. Analysis of annual mean, maximum, minimum, and L-scale statistics of daily mean streamflow for U.S. Geological Survey streamflow-gaging station 08160700 Colorado River above Columbus, Texas.

Index of Station Numbers 719 


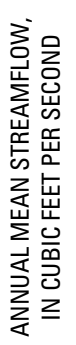

U.S. Geological Survey streamflow-gaging station 08160800

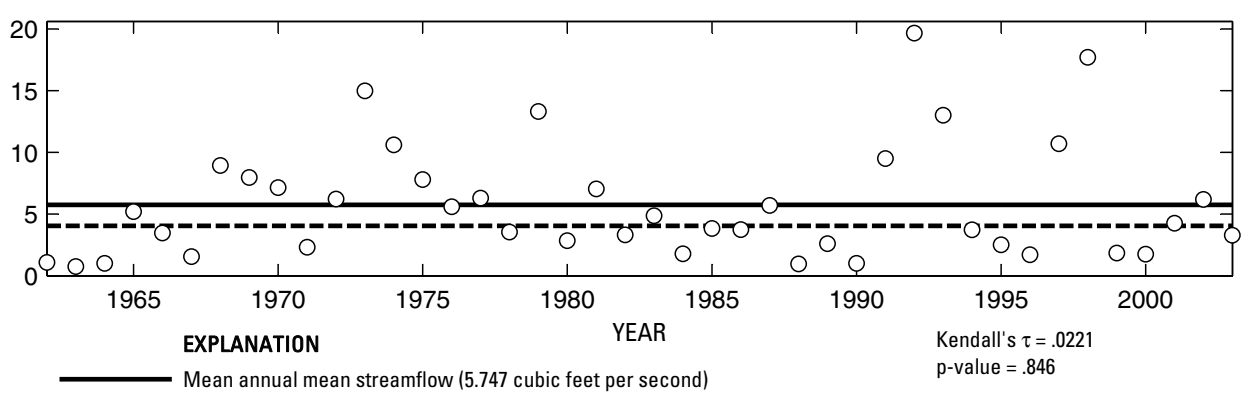

-__-_ Median annual mean streamflow (4.043 cubic feet per second)

- Annual mean streamflow

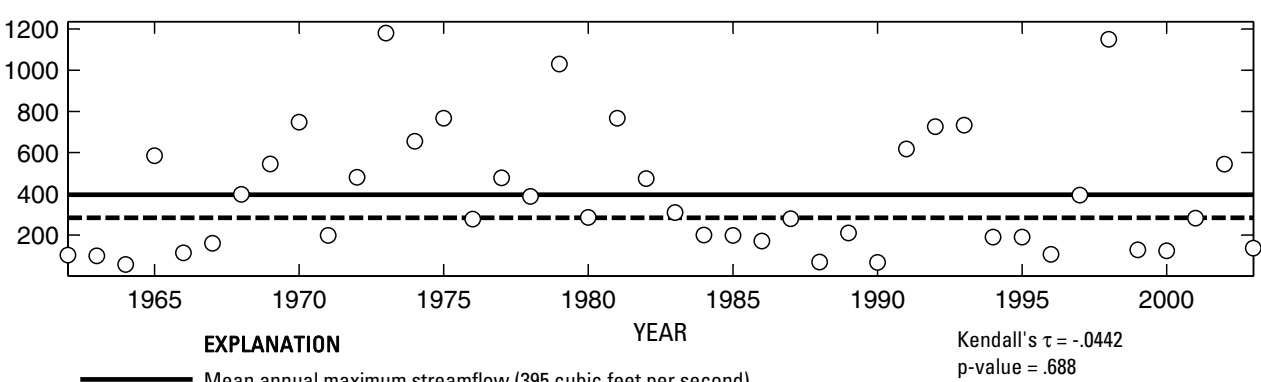

- - ב Median annual maximum streamflow (284 cubic feet per second)

Annual maximum streamflow

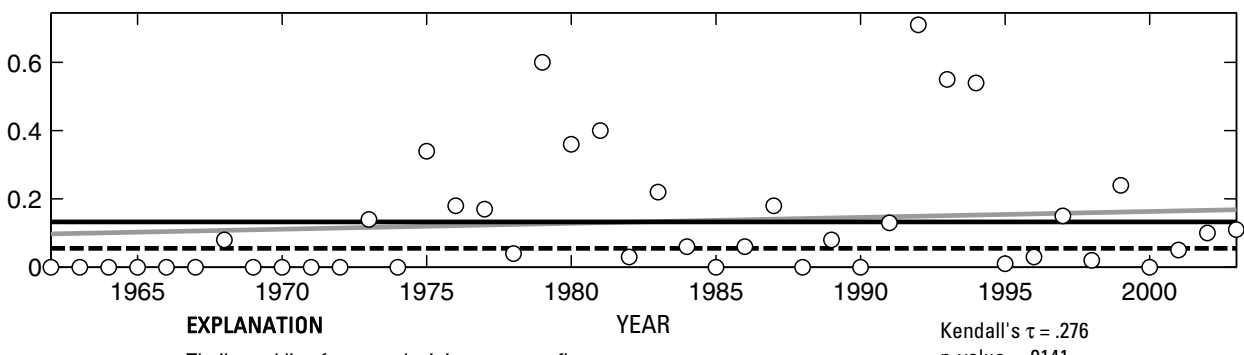

Theil trend line for annual minimum streamflow
Mean annual minimum streamflow (.1329 cubic feet per second)

- - - - Median annual minimum streamflow (.055 cubic feet per second)

O Annual minimum streamflow

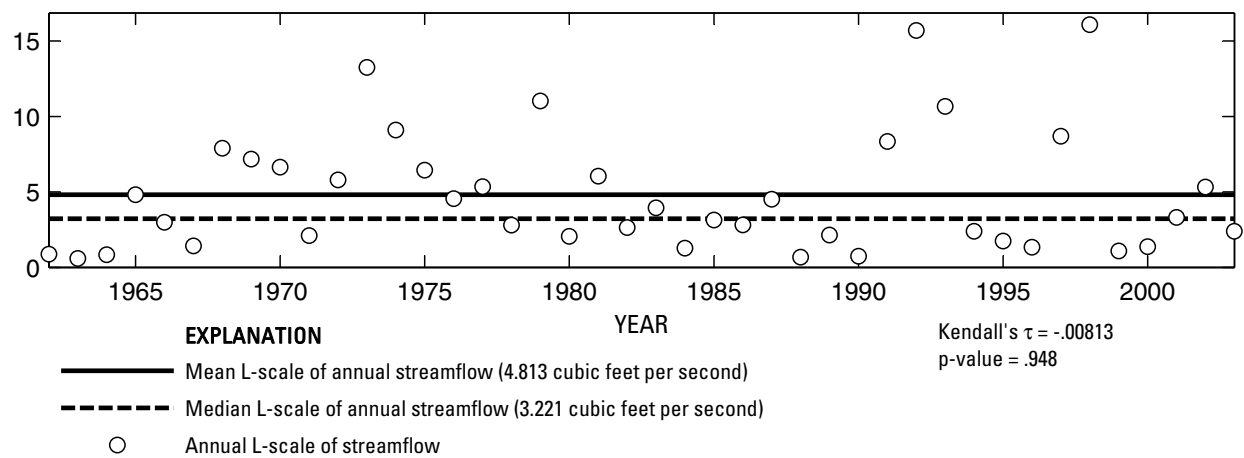

Figure 549. Analysis of annual mean, maximum, minimum, and L-scale statistics of daily mean streamflow for U.S. Geological Survey streamflow-gaging station 08160800 Redgate Creek near Columbus, Texas. 


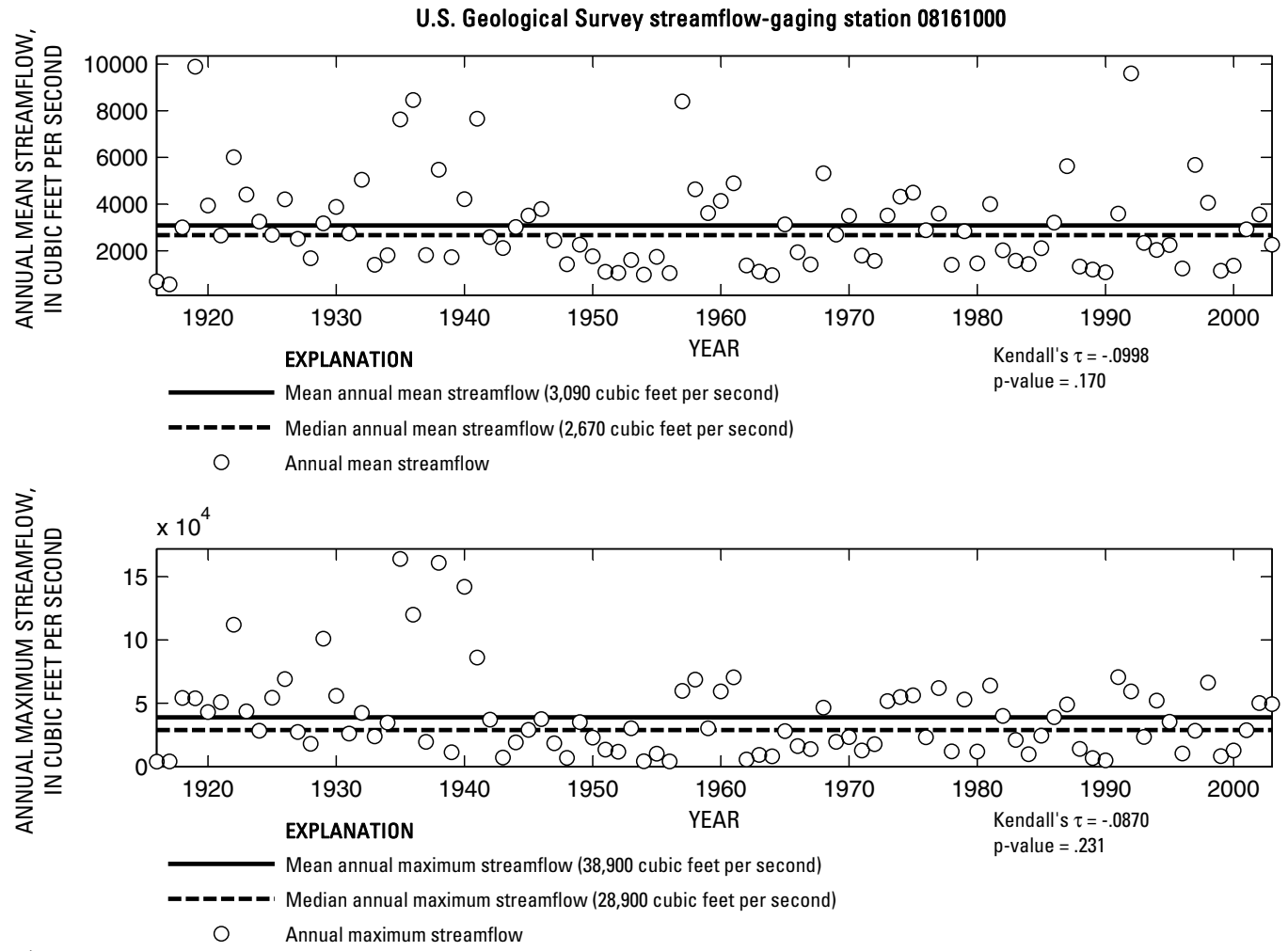

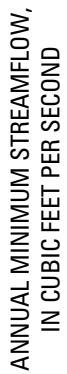

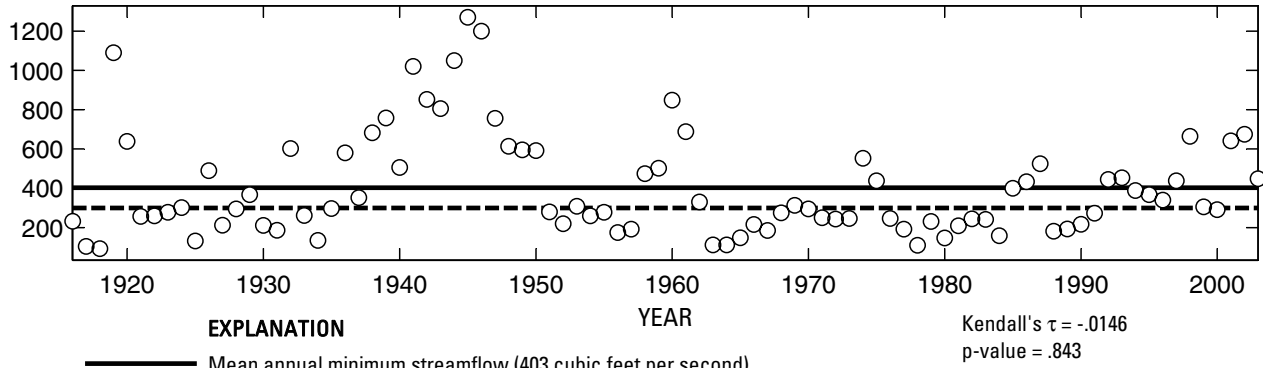

- Median annual minimum streamflow (300 cubic feet per second)

O Annual minimum streamflow

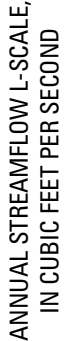

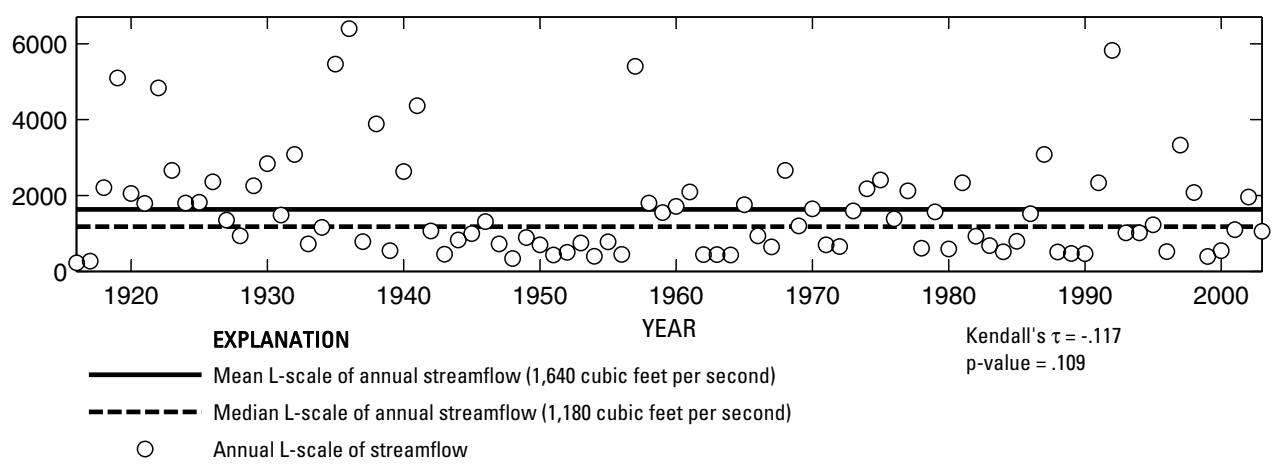

Figure 550. Analysis of annual mean, maximum, minimum, and L-scale statistics of daily mean streamflow for U.S. Geological Survey streamflow-gaging station 08161000 Colorado River at Columbus, Texas.

Index of Station Numbers 719 


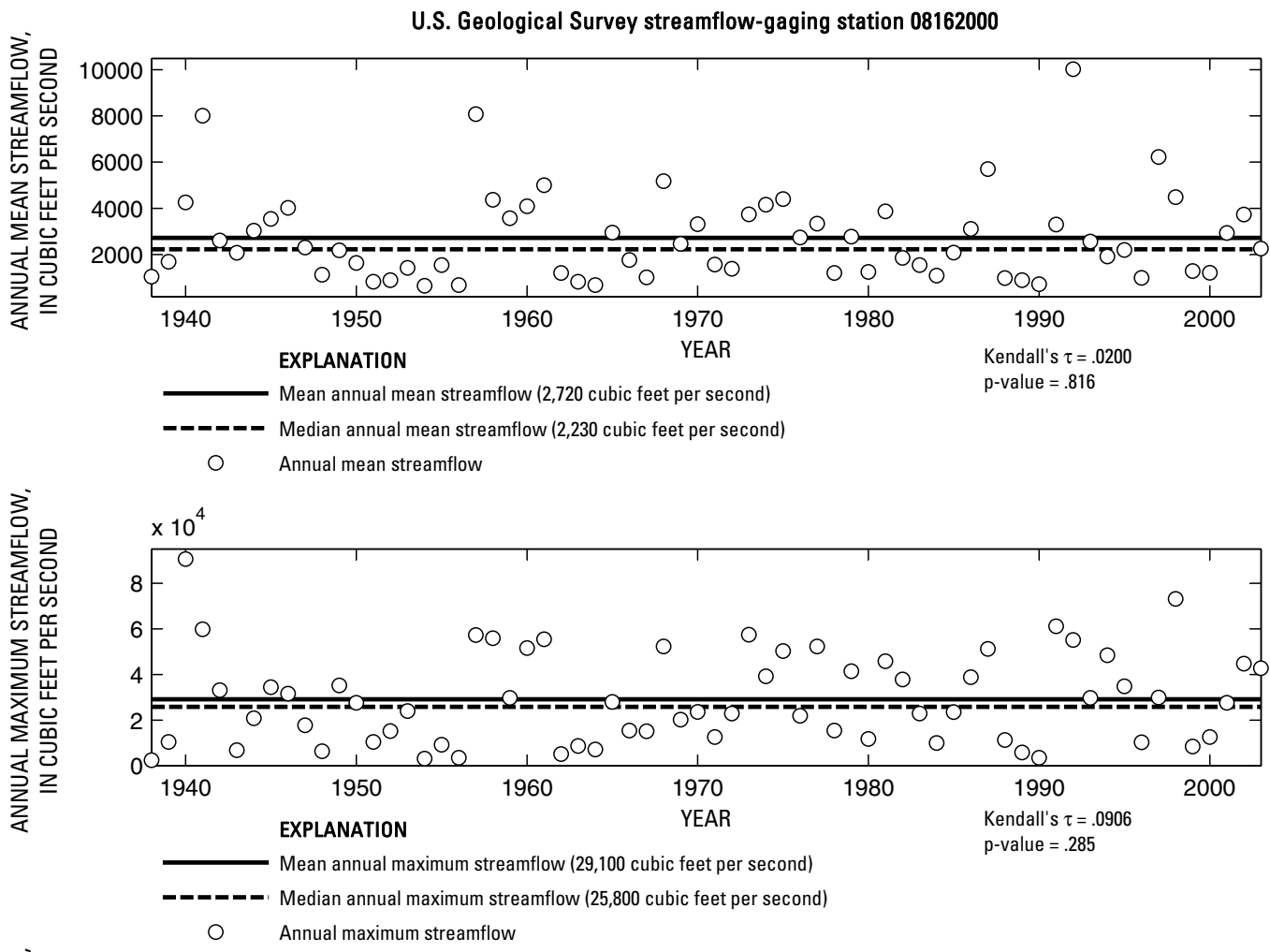

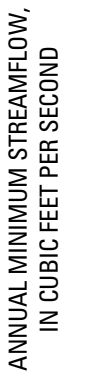

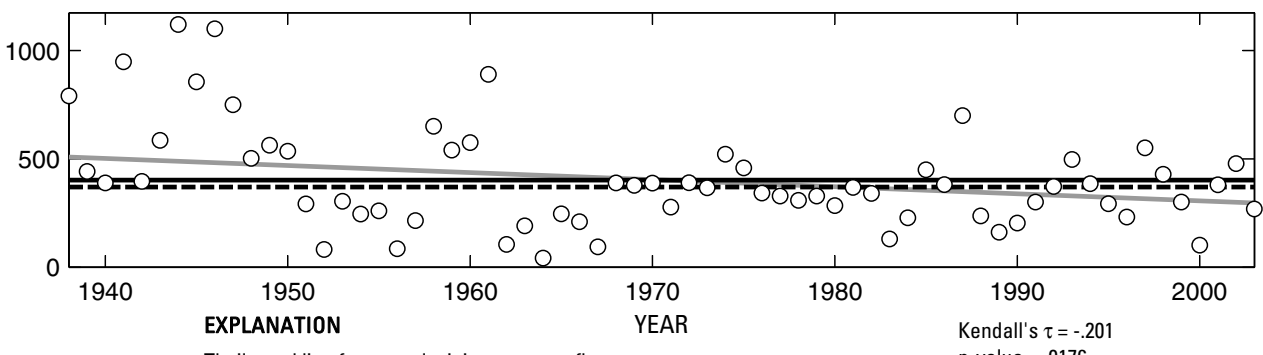

Theil trend line for annual minimum streamflow

p-value $=.0176$

O Annual minimum streamflow

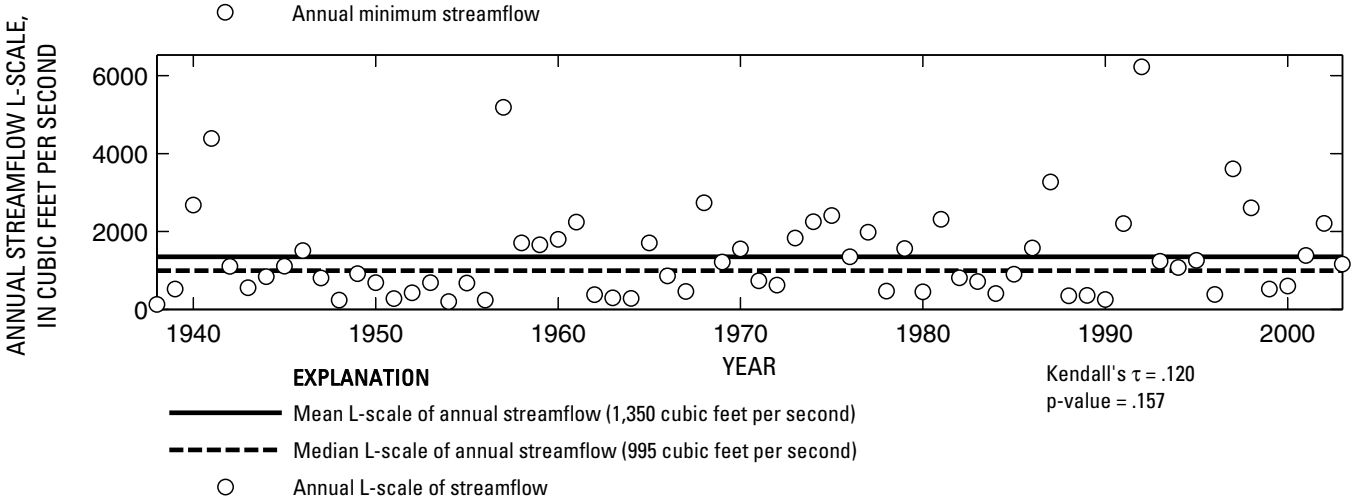

Figure 551. Analysis of annual mean, maximum, minimum, and L-scale statistics of daily mean streamflow for U.S. Geological Survey streamflow-gaging station 08162000 Colorado River at Wharton, Texas. 


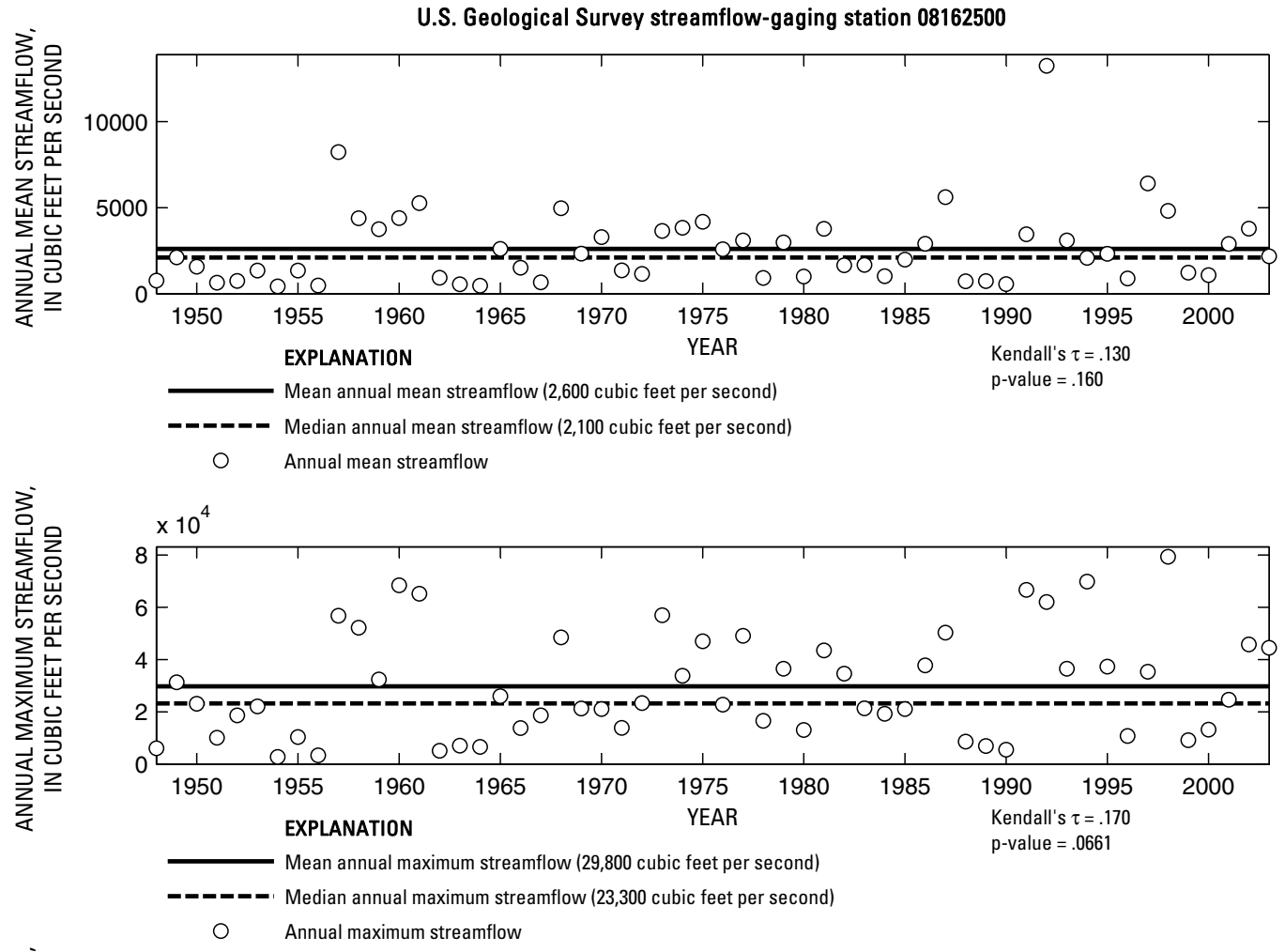

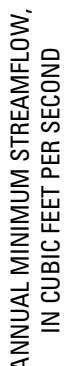

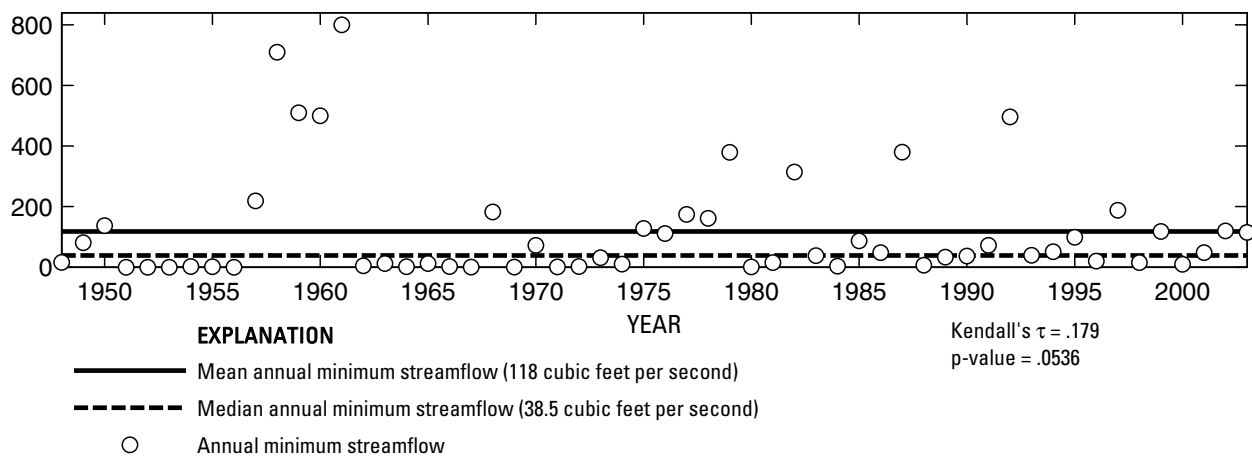

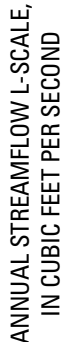

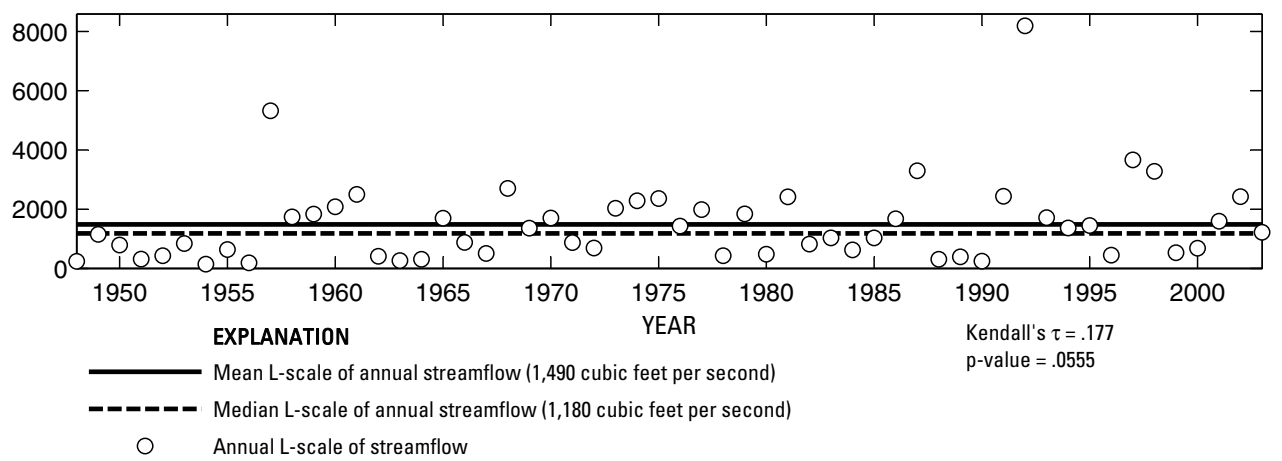

Figure 552. Analysis of annual mean, maximum, minimum, and L-scale statistics of daily mean streamflow for U.S. Geological Survey streamflow-gaging station 08162500 Colorado River near Bay City, Texas.

Index of Station Numbers 719 

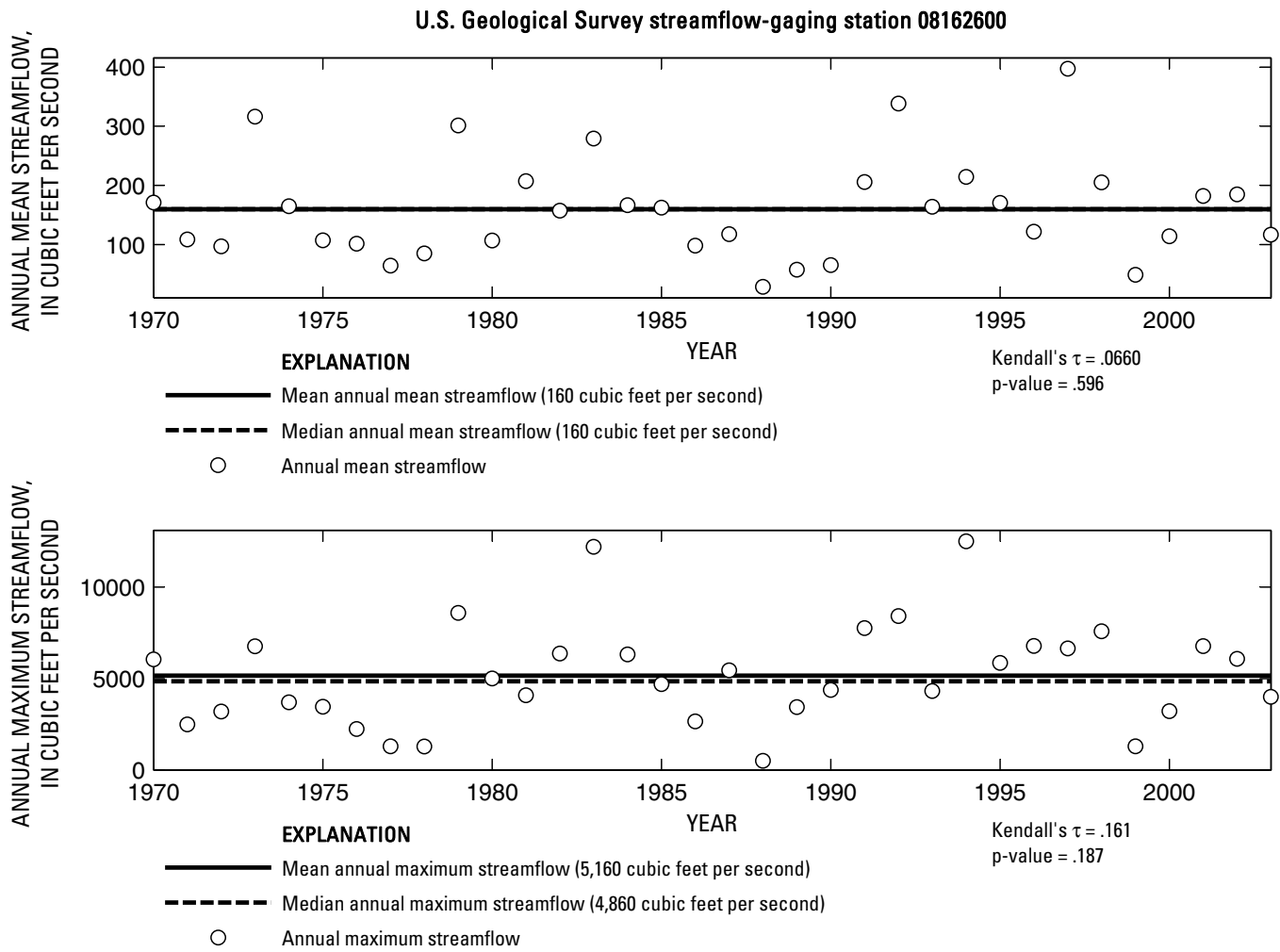

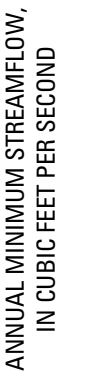

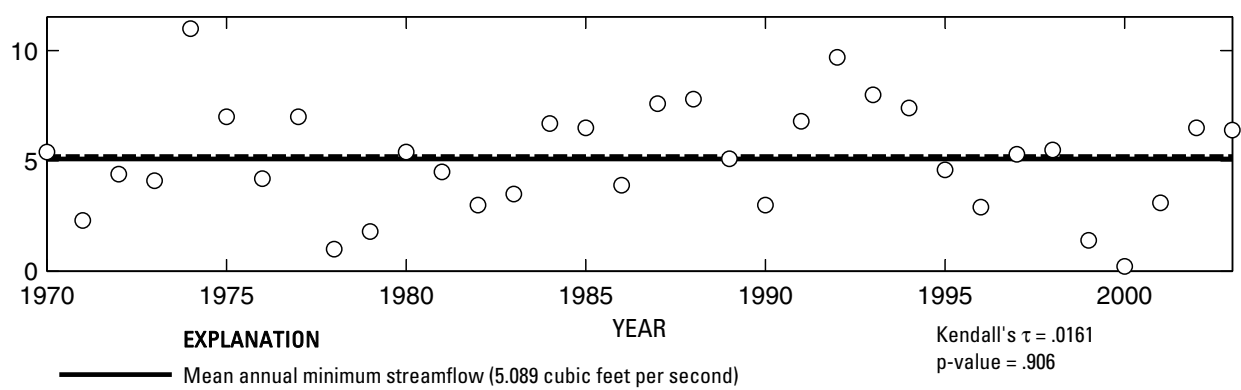

- ב-_- Median annual minimum streamflow (5.2 cubic feet per second)

O Annual minimum streamflow

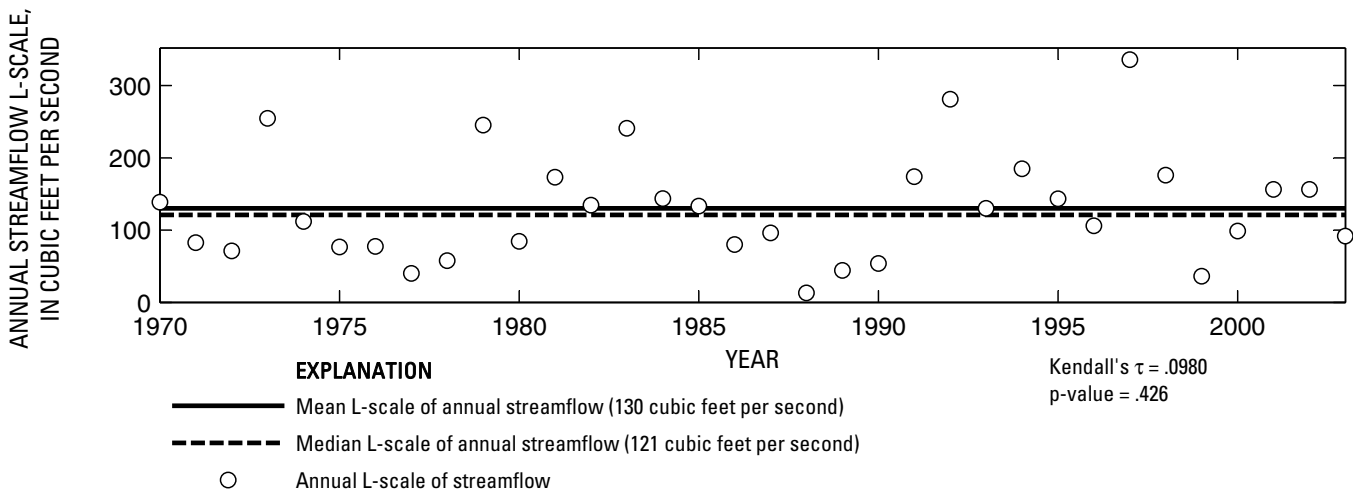

Figure 553. Analysis of annual mean, maximum, minimum, and L-scale statistics of daily mean streamflow for U.S. Geological Survey streamflow-gaging station 08162600 Tres Palacios River near Midfield, Texas.

Index of Station Numbers 779 


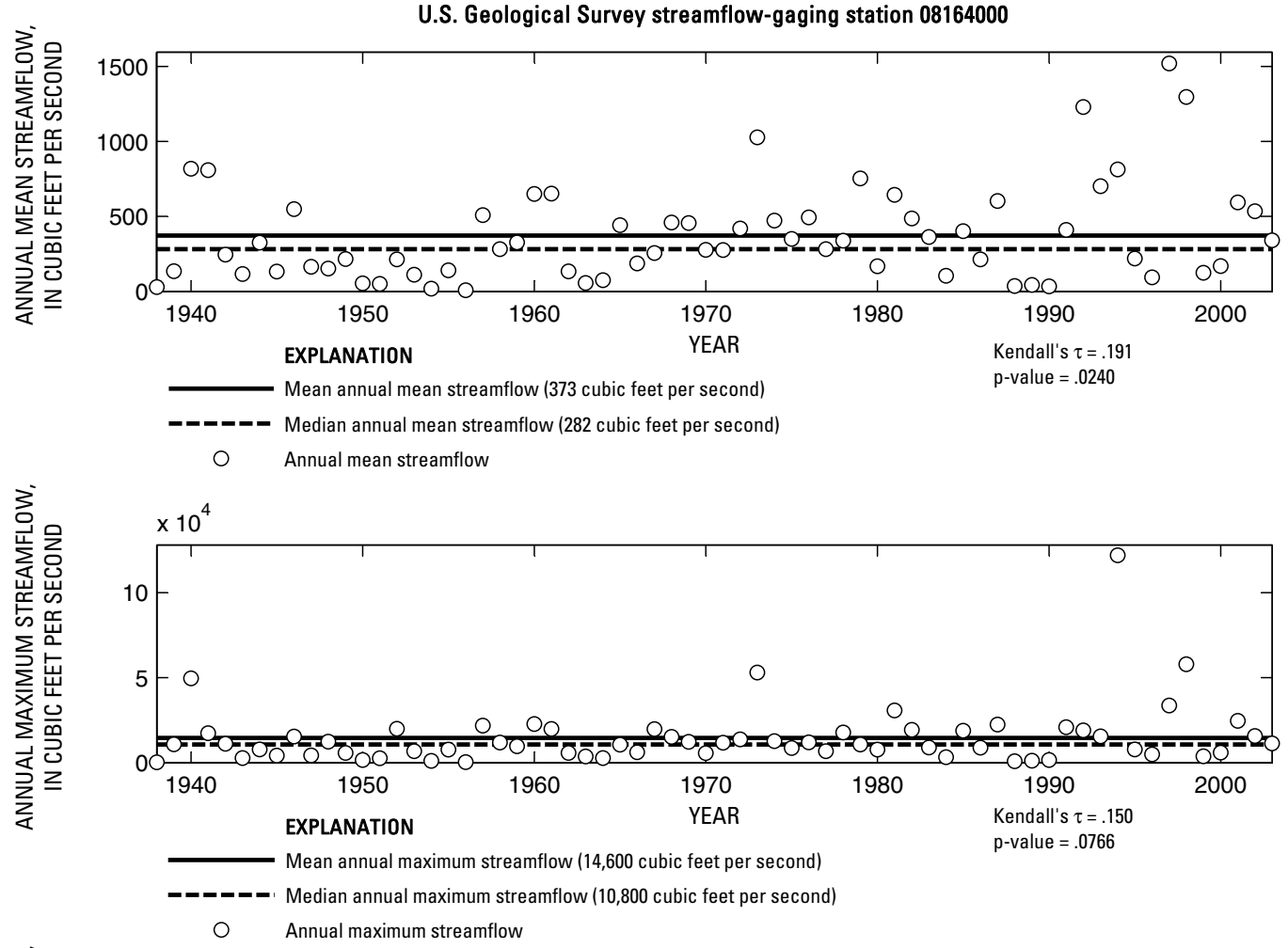

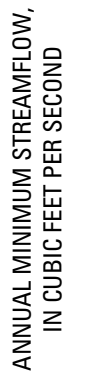

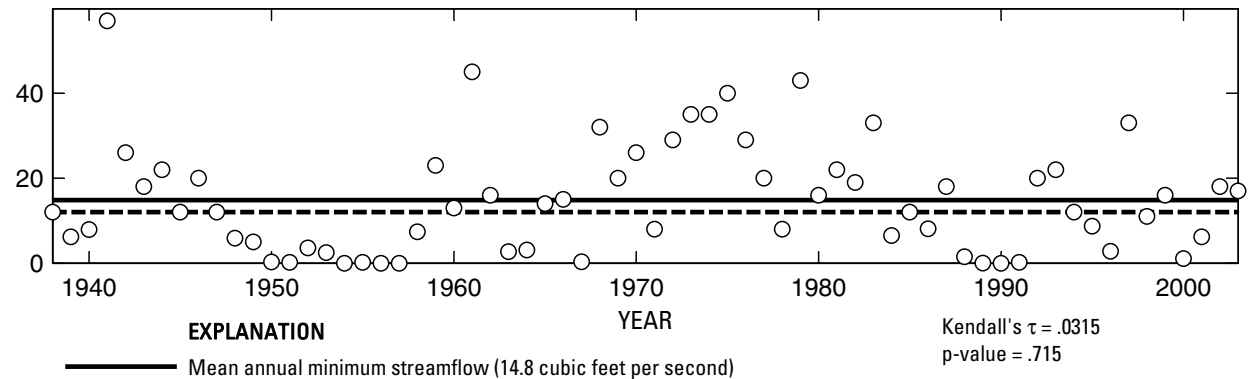

- ב-ב Median annual minimum streamflow (12 cubic feet per second)

O Annual minimum streamflow

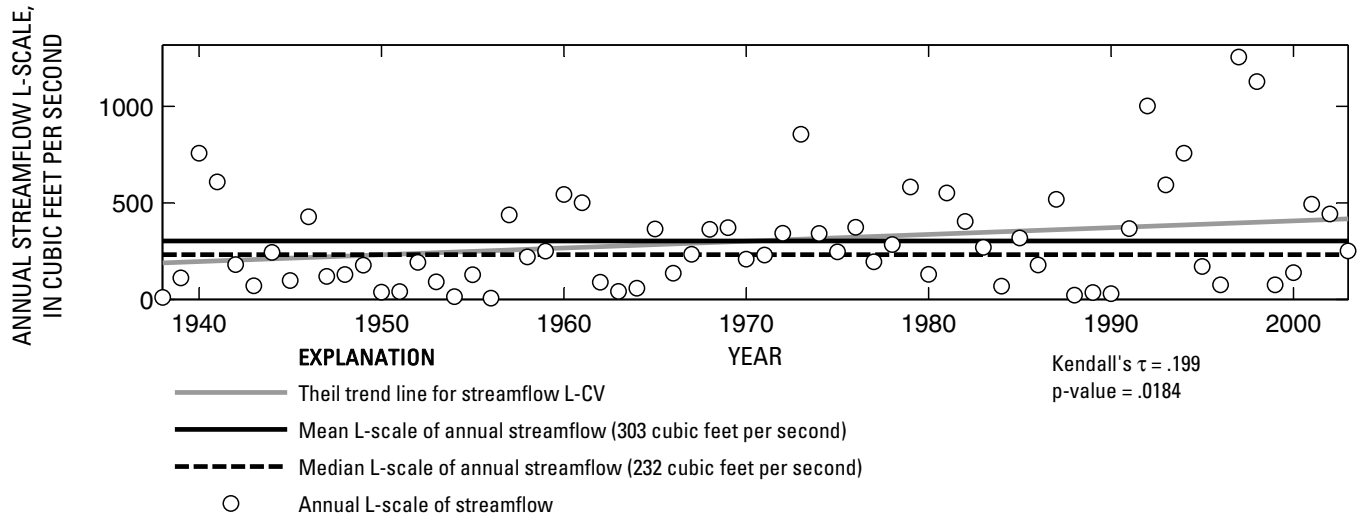

Figure 554. Analysis of annual mean, maximum, minimum, and L-scale statistics of daily mean streamflow for U.S. Geological Survey streamflow-gaging station 08164000 Lavaca River near Edna, Texas.

Index of Station Numbers 719 


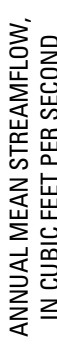

U.S. Geological Survey streamflow-gaging station 08164300

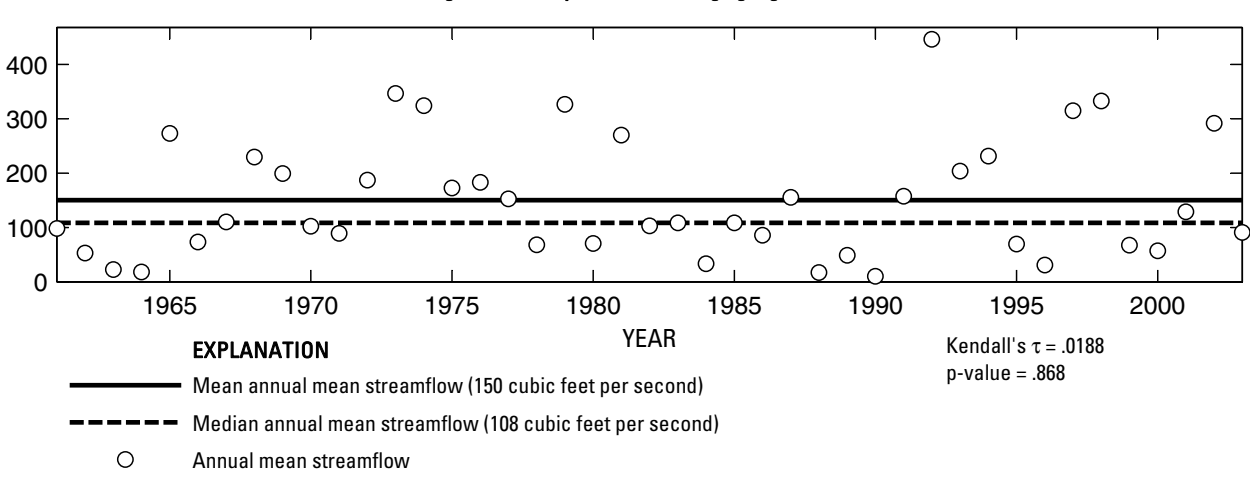

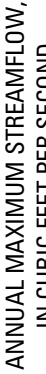

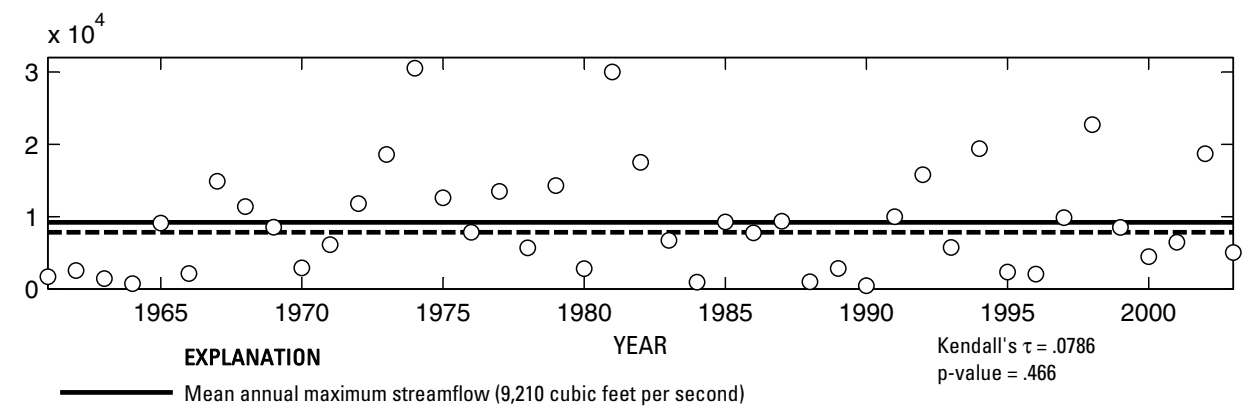

- _ _ _ - Median annual maximum streamflow (7,850 cubic feet per second)

O Annual maximum streamflow

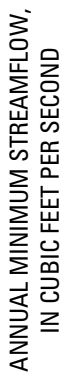

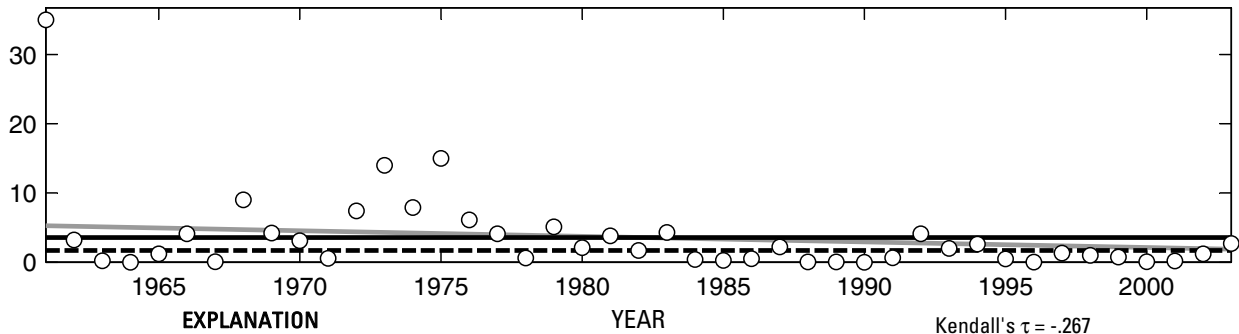

Theil trend line for annual minimum streamflow

Mean annual minimum streamflow (3.562 cubic feet per second)

-_-_- Median annual minimum streamflow (1.7 cubic feet per second)

O Annual minimum streamflow

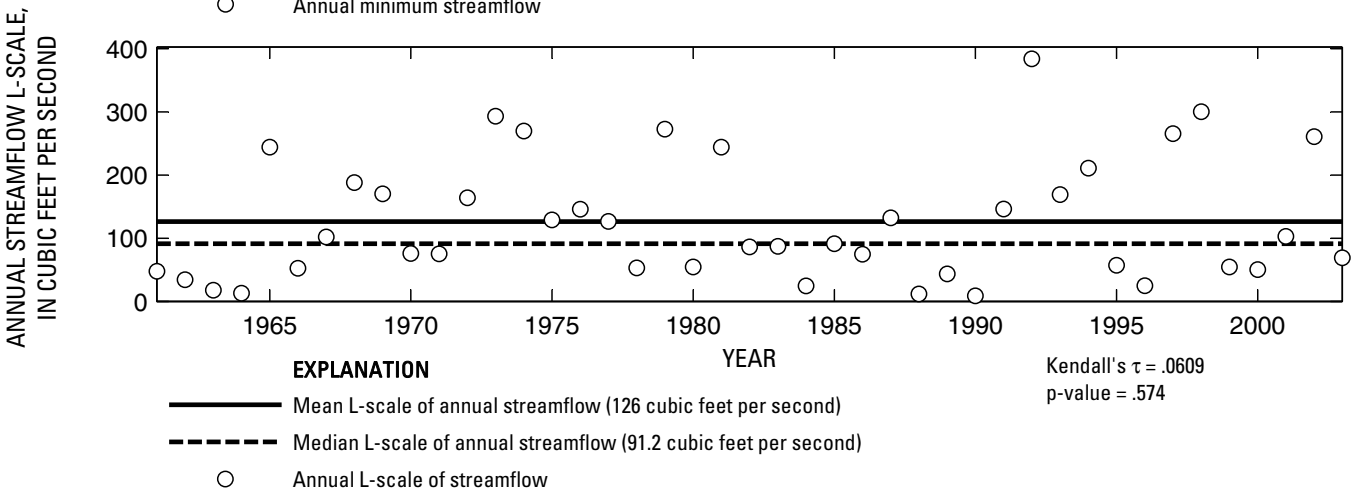

Figure 555. Analysis of annual mean, maximum, minimum, and L-scale statistics of daily mean streamflow for U.S. Geological Survey streamflow-gaging station 08164300 Navidad River near Hallettsville, Texas.

Index of Station Numbers 719 
U.S. Geological Survey streamflow-gaging station 08164350

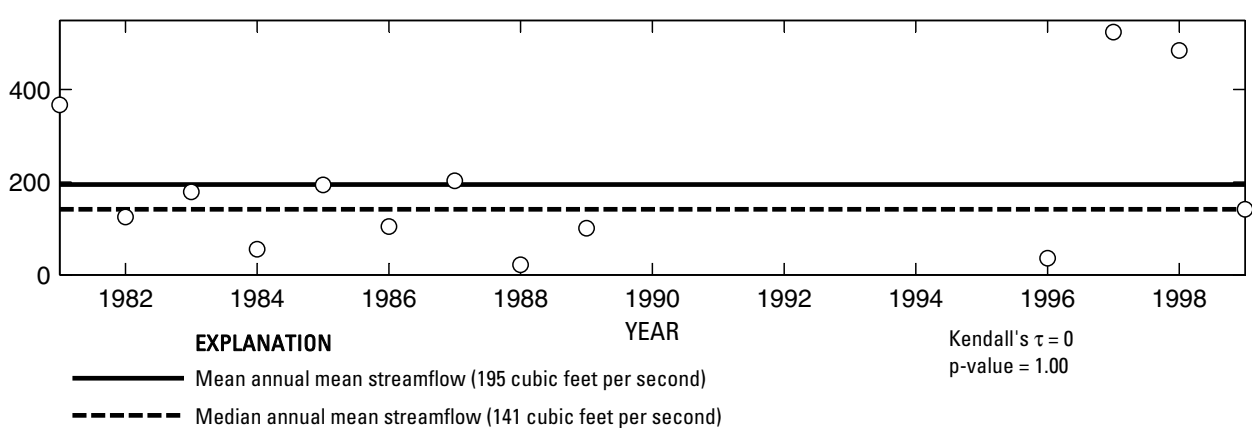

O Annual mean streamflow

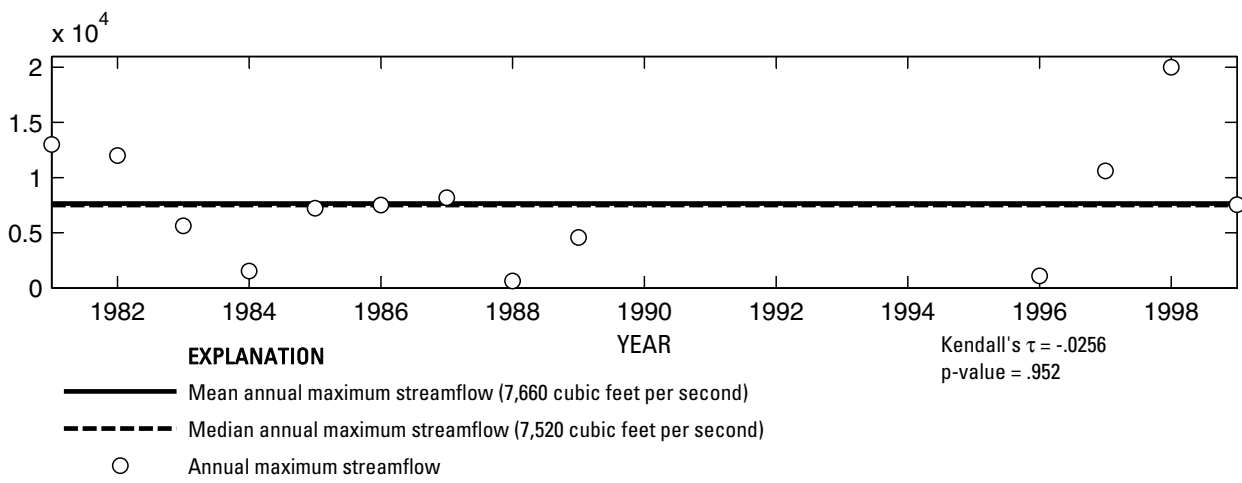

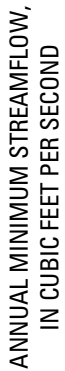

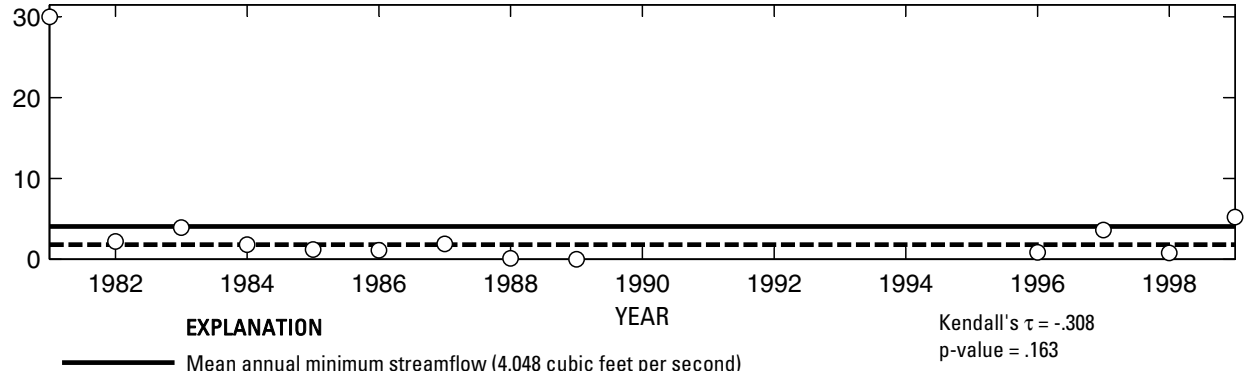

- Median annual minimum streamflow (1.8 cubic feet per second)

O Annual minimum streamflow

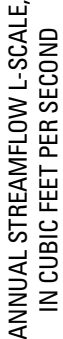

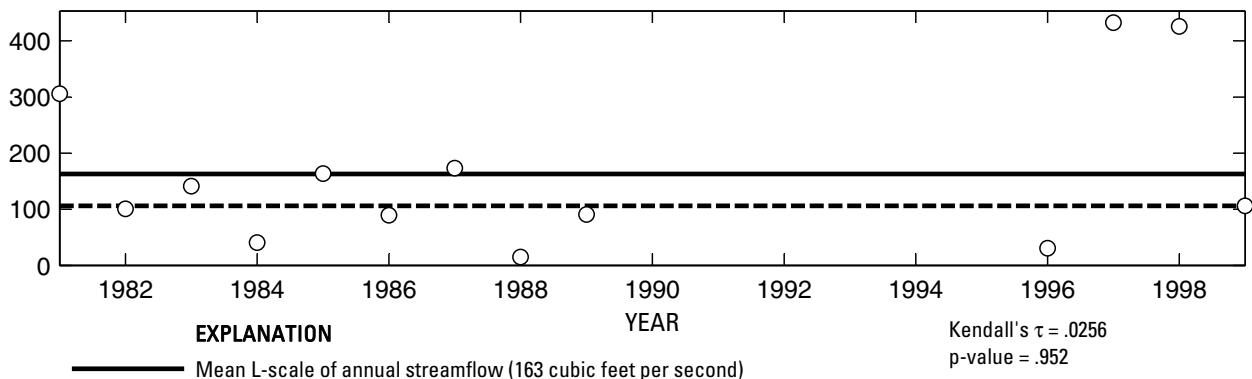

- - Median L-scale of annual streamflow (106 cubic feet per second)

Annual L-scale of streamflow

Figure 556. Analysis of annual mean, maximum, minimum, and L-scale statistics of daily mean streamflow for U.S. Geological Survey streamflow-gaging station 08164350 Navidad River near Speaks, Texas.

Index of Station Numbers 719 


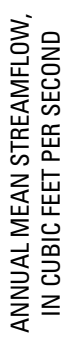

U.S. Geological Survey streamflow-gaging station 08164370

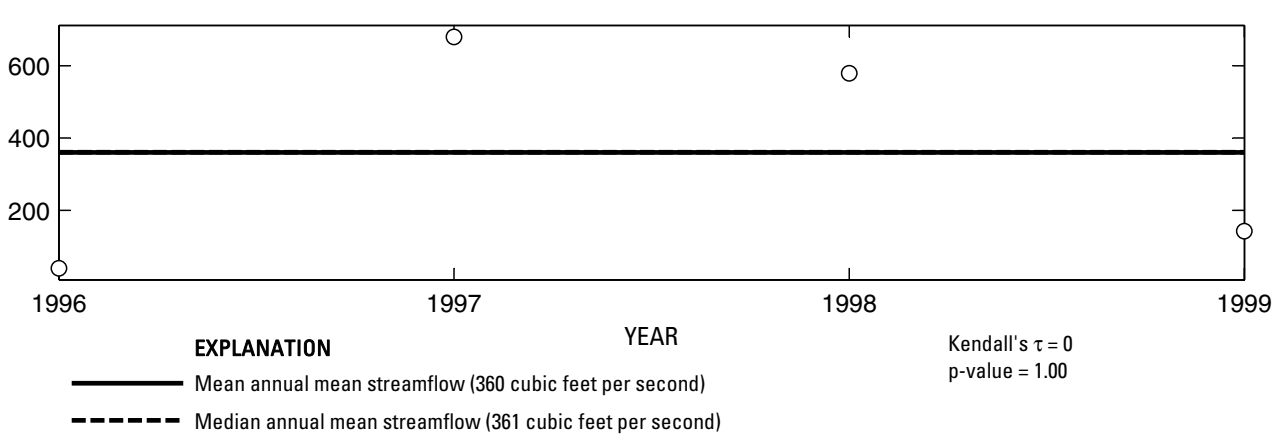

O Annual mean streamflow
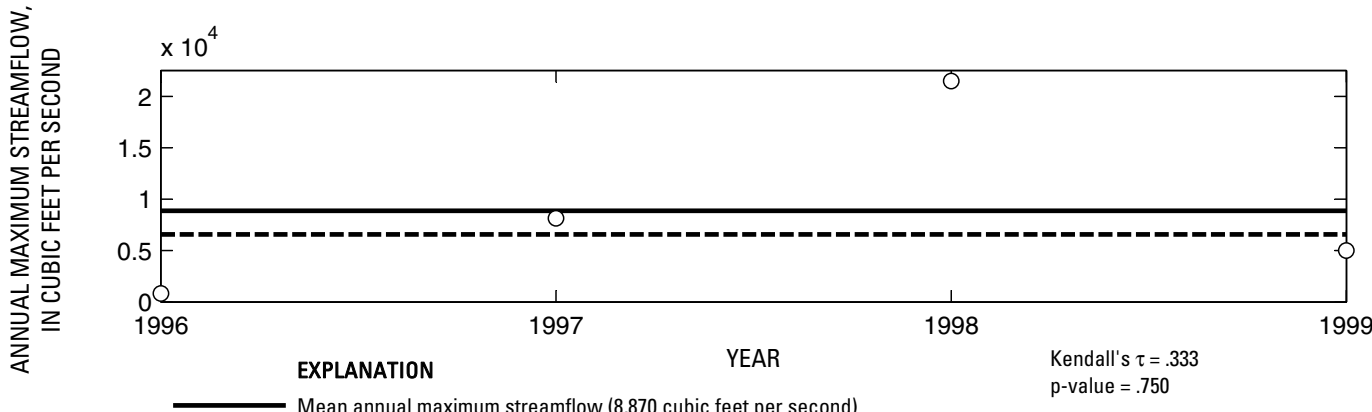

- ב - Median annual maximum streamflow (6,570 cubic feet per second

O Annual maximum streamflow
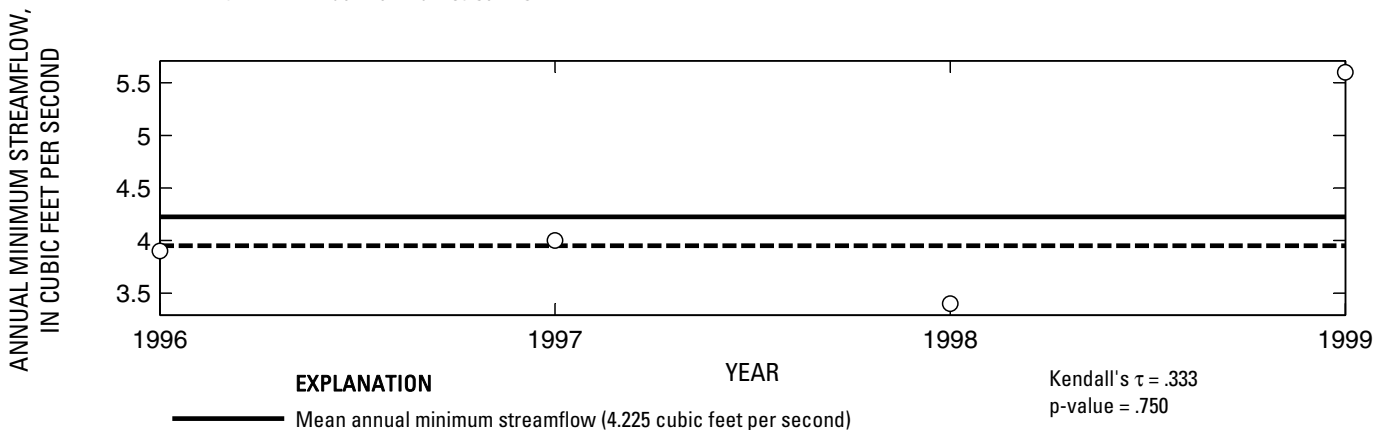

- ב- Median annual minimum streamflow (3.95 cubic feet per second)

O Annual minimum streamflow
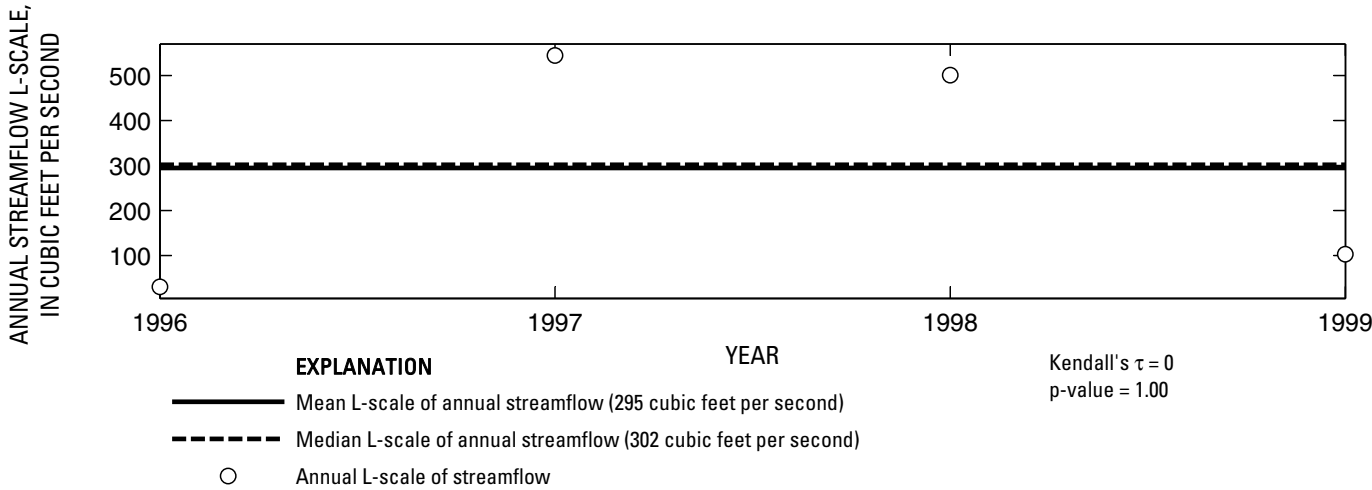

Figure 557. Analysis of annual mean, maximum, minimum, and L-scale statistics of daily mean streamflow for U.S. Geological Survey streamflow-gaging station 08164370 Navidad River at Morales, Texas. 
U.S. Geological Survey streamflow-gaging station 08164390
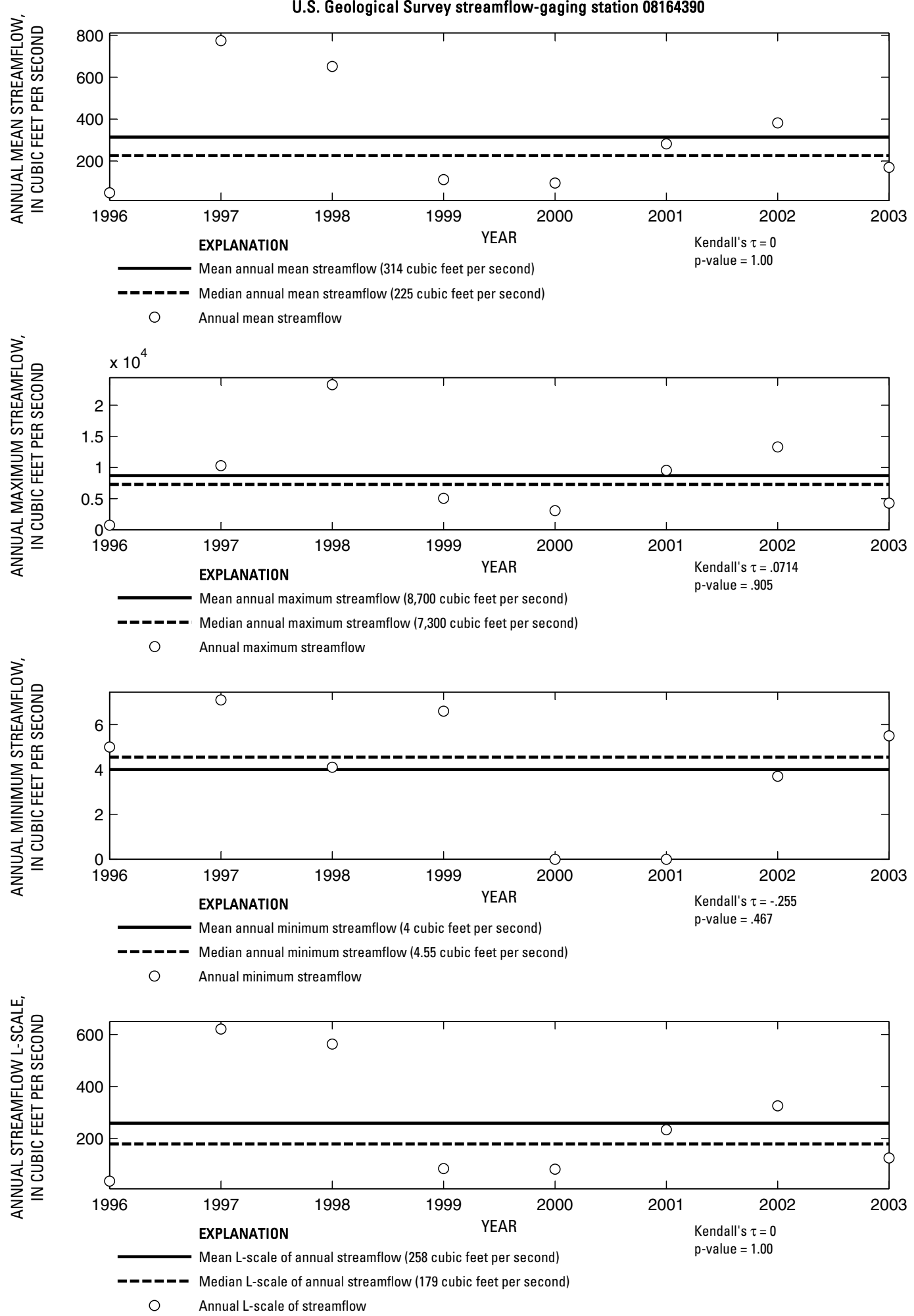

Figure 558. Analysis of annual mean, maximum, minimum, and L-scale statistics of daily mean streamflow for U.S. Geological Survey streamflow-gaging station 08164390 Navidad River at Strane Park near Edna, Texas. 


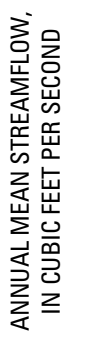

U.S. Geological Survey streamflow-gaging station 08164450

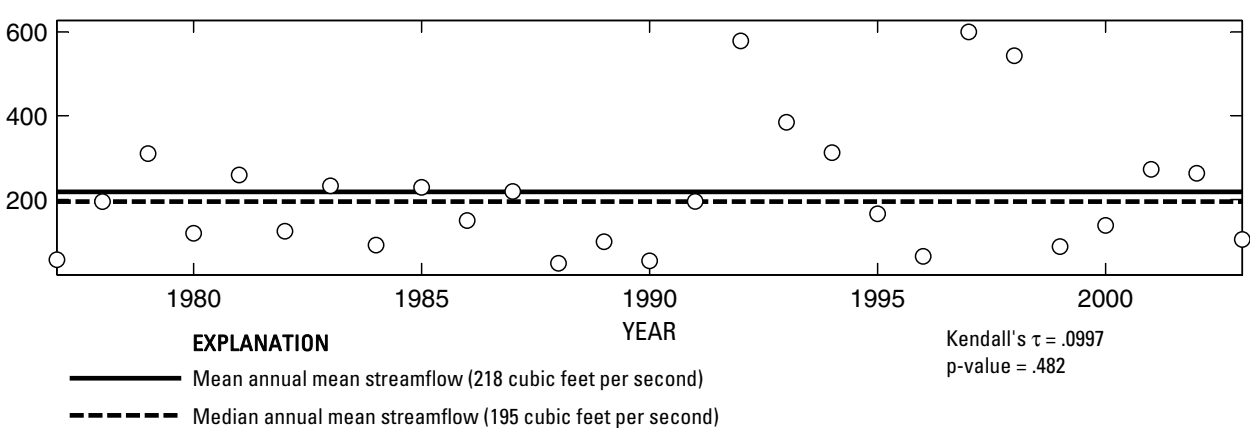

Annual mean streamflow

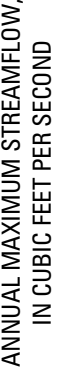
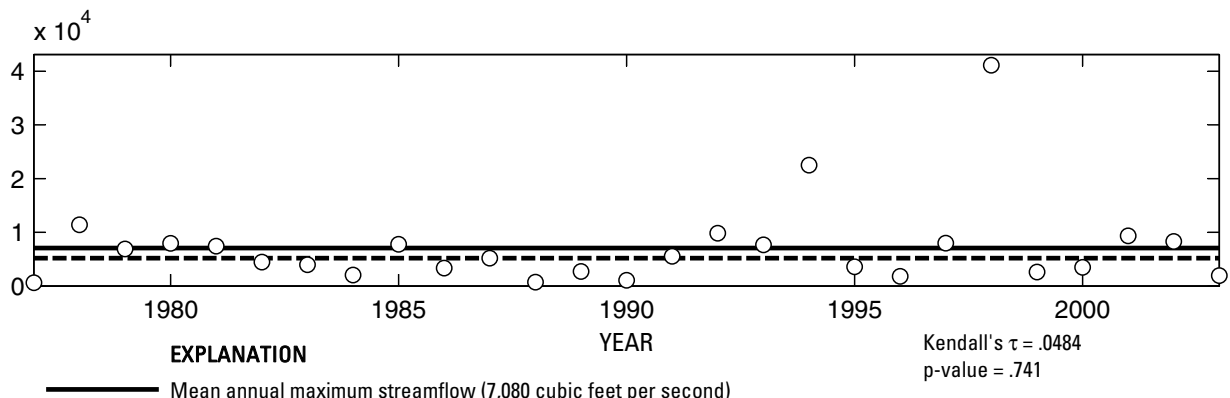

- Median annual maximum streamflow (5,190 cubic feet per second)

Annual maximum streamflow

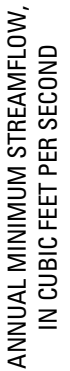

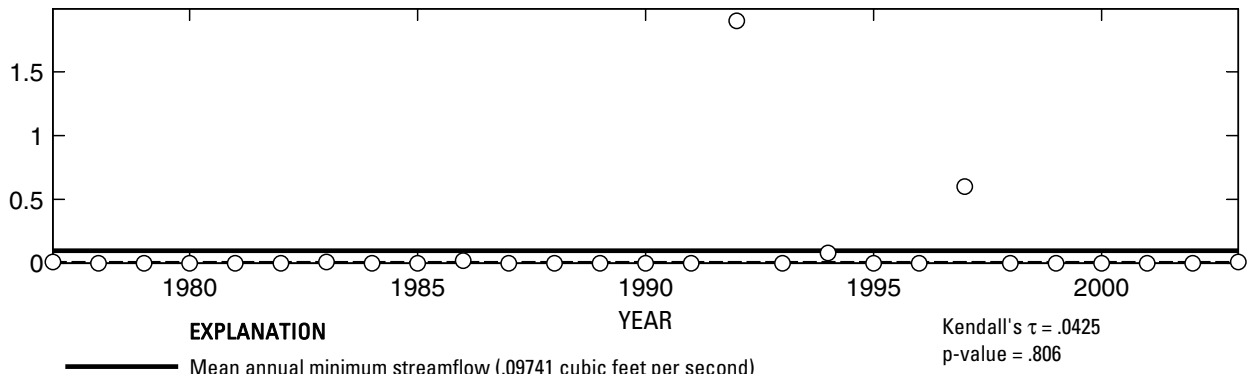

- Median annual minimum streamflow (0 cubic feet per second)

O Annual minimum streamflow

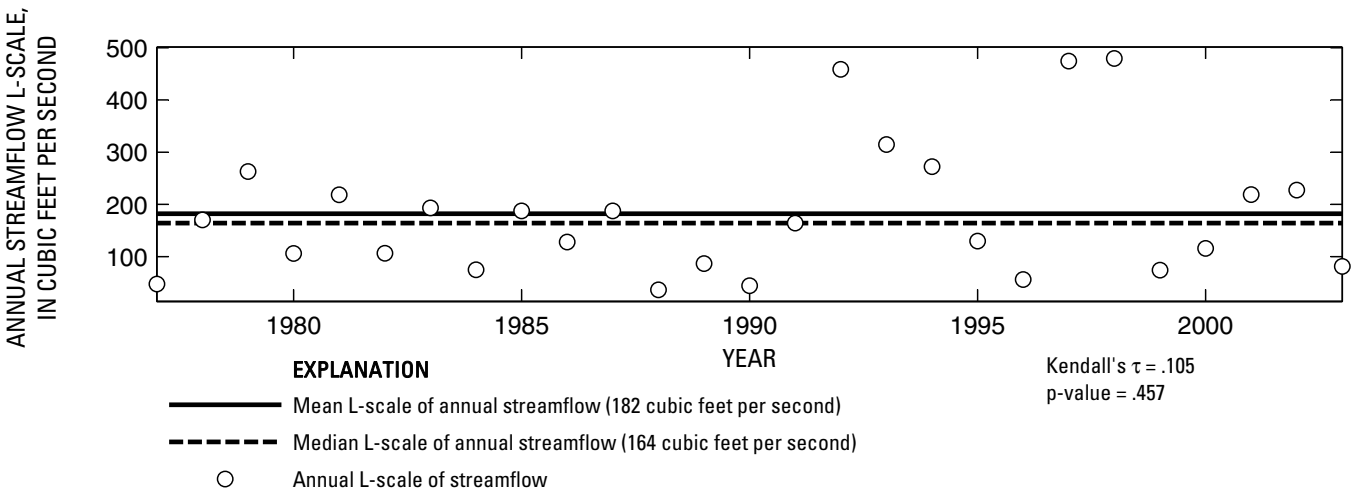

Figure 559. Analysis of annual mean, maximum, minimum, and L-scale statistics of daily mean streamflow for U.S. Geological Survey streamflow-gaging station 08164450 Sandy Creek near Ganado, Texas. 
U.S. Geological Survey streamflow-gaging station 08164500

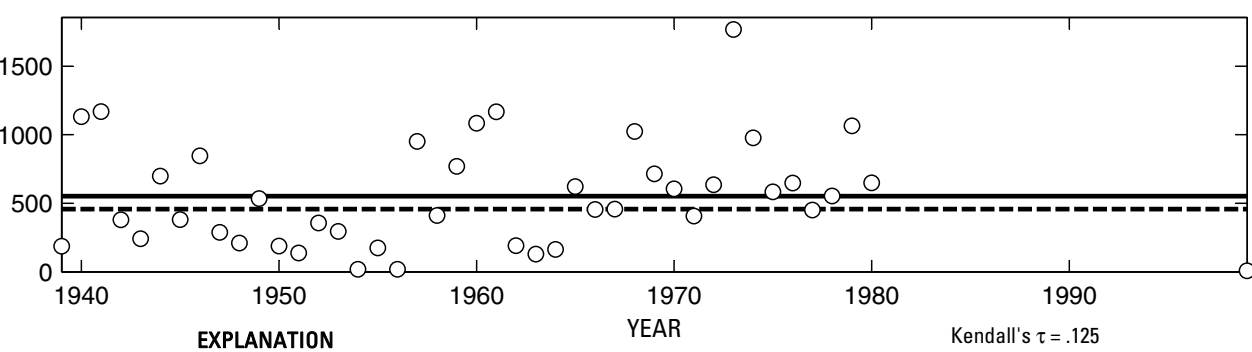

-ンーーー Median annual mean streamflow (457 cubic feet per second)

$\mathrm{p}$-value $=.243$

O Annual mean streamflow

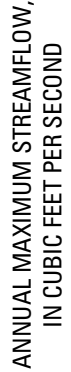

$\times 10^{4}$

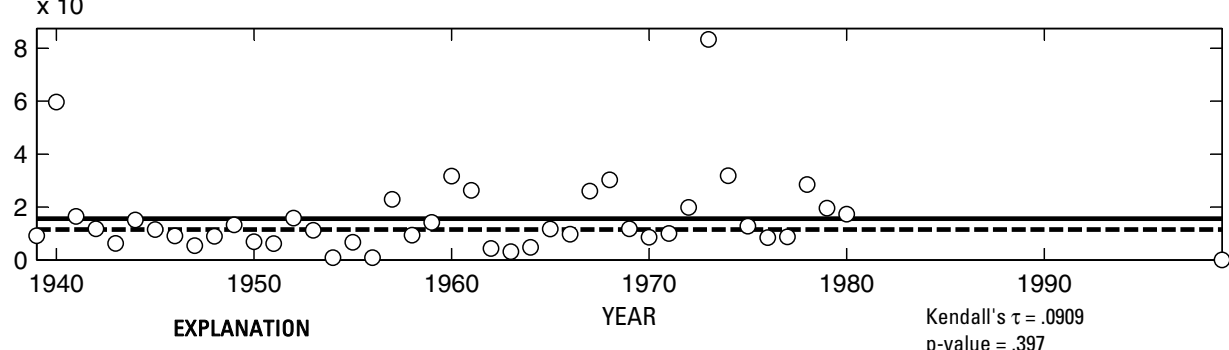

Mean annual maximum streamflow $(15,600$ cubic feet per second $)$

$\mathrm{p}$-value $=.397$

- Median annual maximum streamflow (11,500 cubic feet per second)

O Annual maximum streamflow

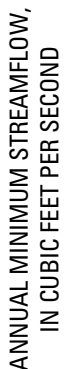

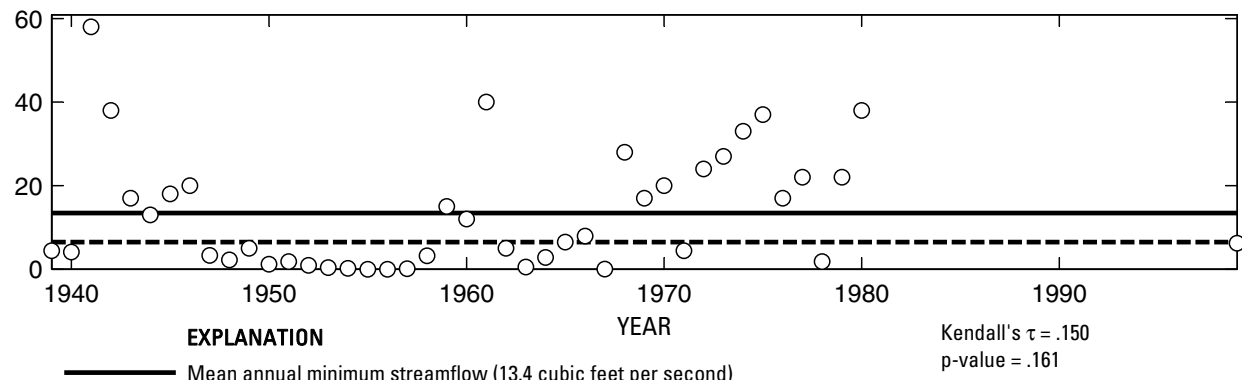

- Median annual minimum streamflow (6.5 cubic feet per second)

O Annual minimum streamflow

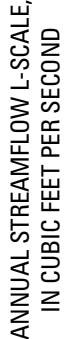

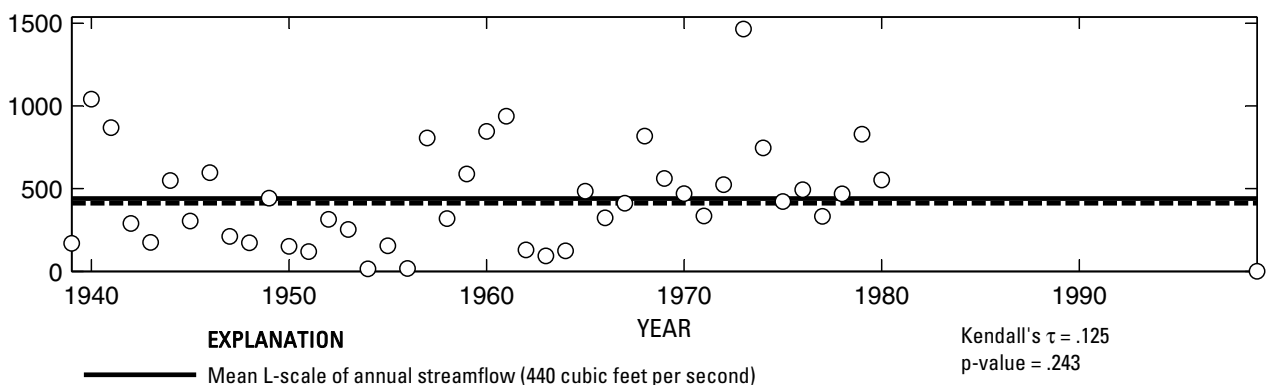

-ーーーーー Median L-scale of annual streamflow (412 cubic feet per second)

Annual L-scale of streamflow

Figure 560. Analysis of annual mean, maximum, minimum, and L-scale statistics of daily mean streamflow for U.S. Geological Survey streamflow-gaging station 08164500 Navidad River near Ganado, Texas.

Index of Station Numbers 719 

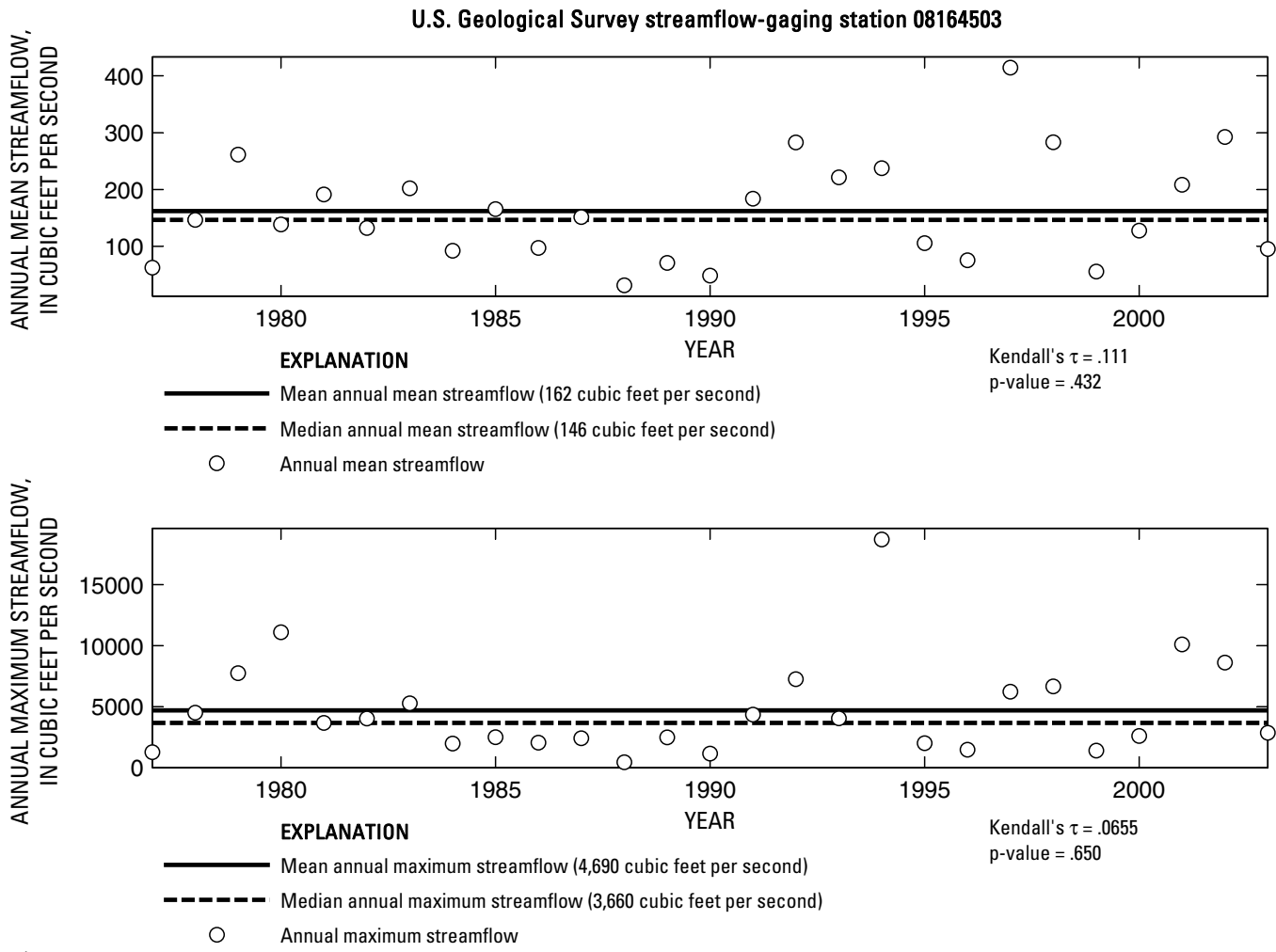

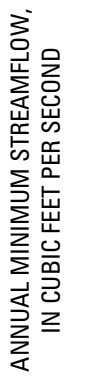

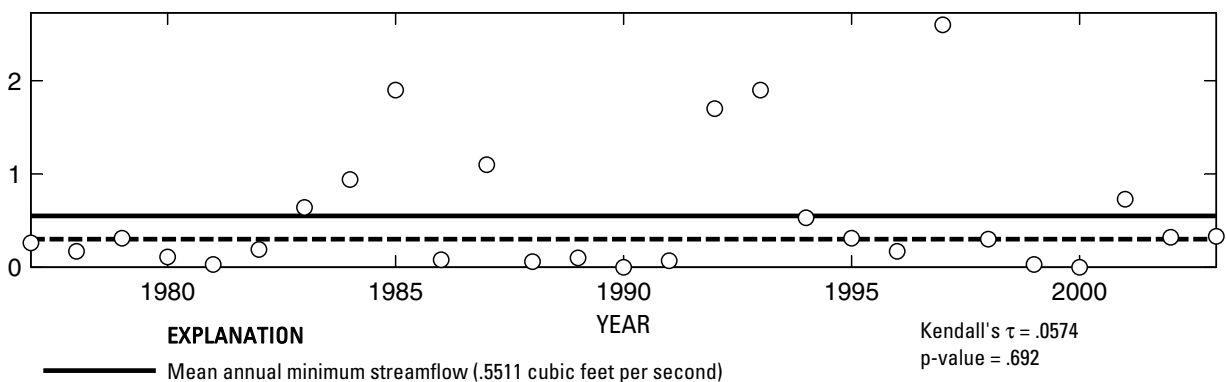

- ב-ב Median annual minimum streamflow (.3 cubic feet per second)

O Annual minimum streamflow

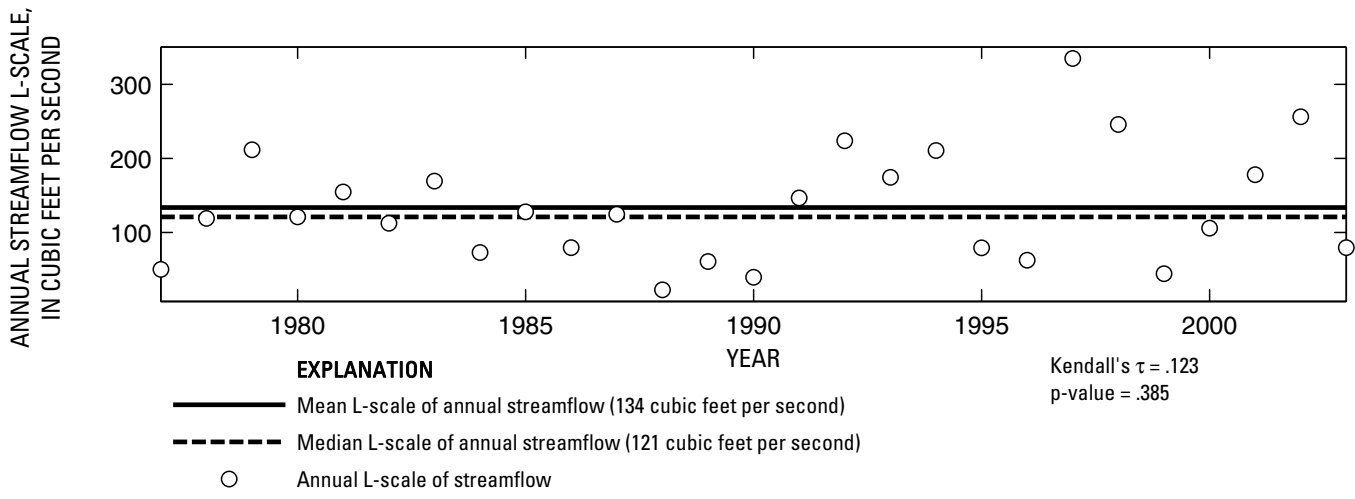

Figure 561. Analysis of annual mean, maximum, minimum, and L-scale statistics of daily mean streamflow for U.S. Geological Survey streamflow-gaging station 08164503 West Mustang Creek near Ganado, Texas. 
U.S. Geological Survey streamflow-gaging station 08164504

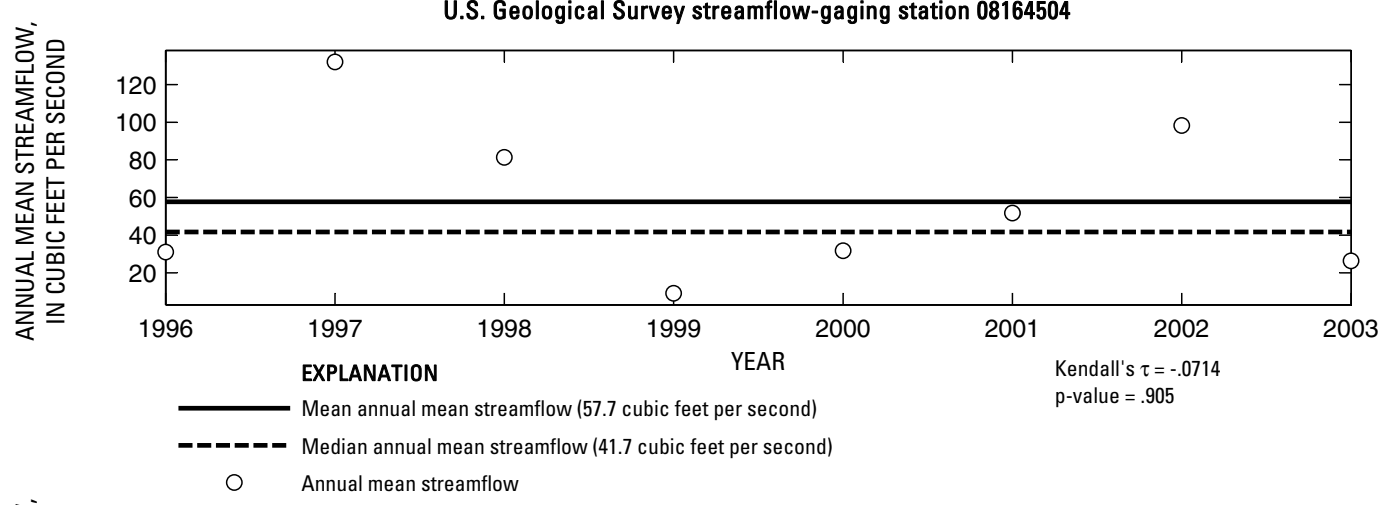

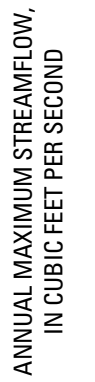

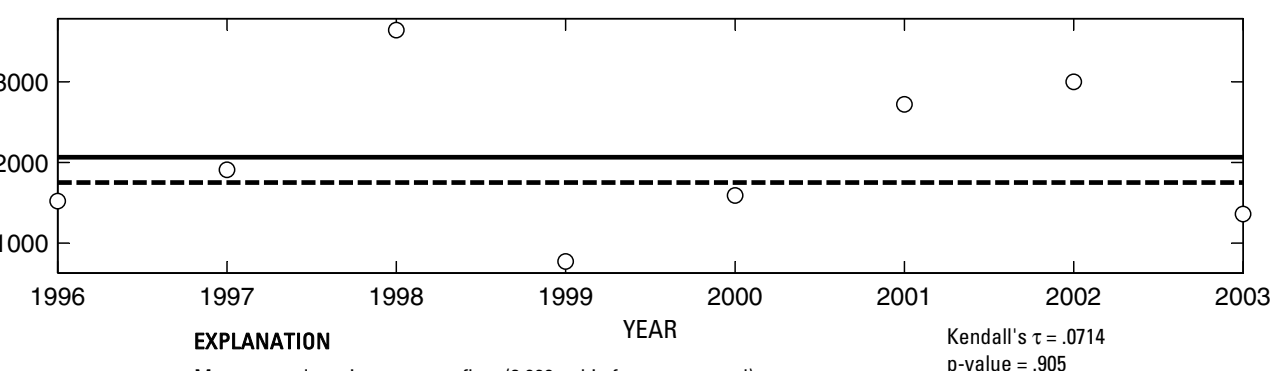

Mean annual maximum streamflow (2,060 cubic feet per second)

-ーーーーー Median annual maximum streamflow (1,750 cubic feet per second)

O Annual maximum streamflow
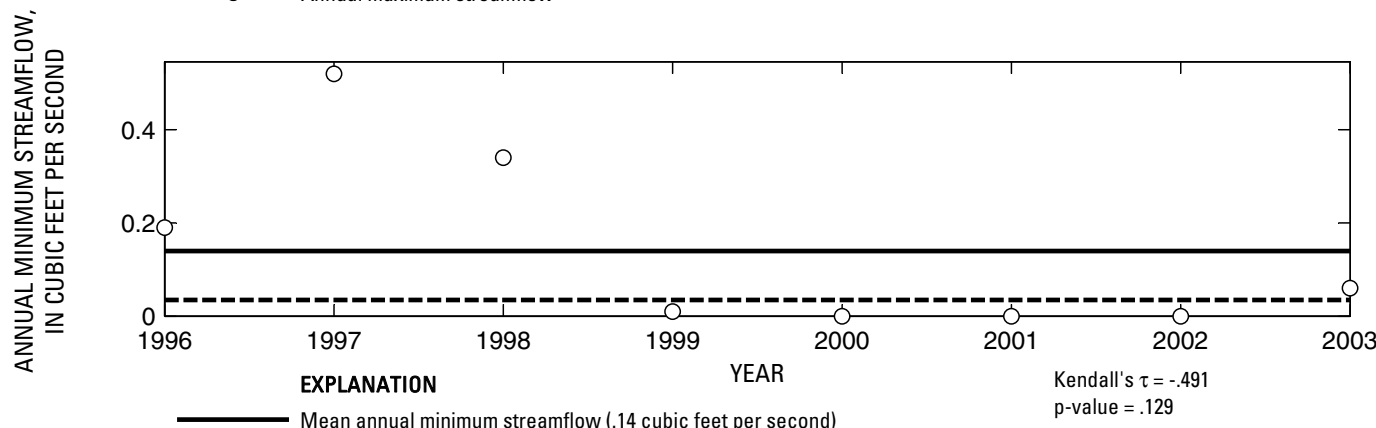

- Median annual minimum streamflow (.035 cubic feet per second)

O Annual minimum streamflow

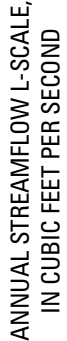

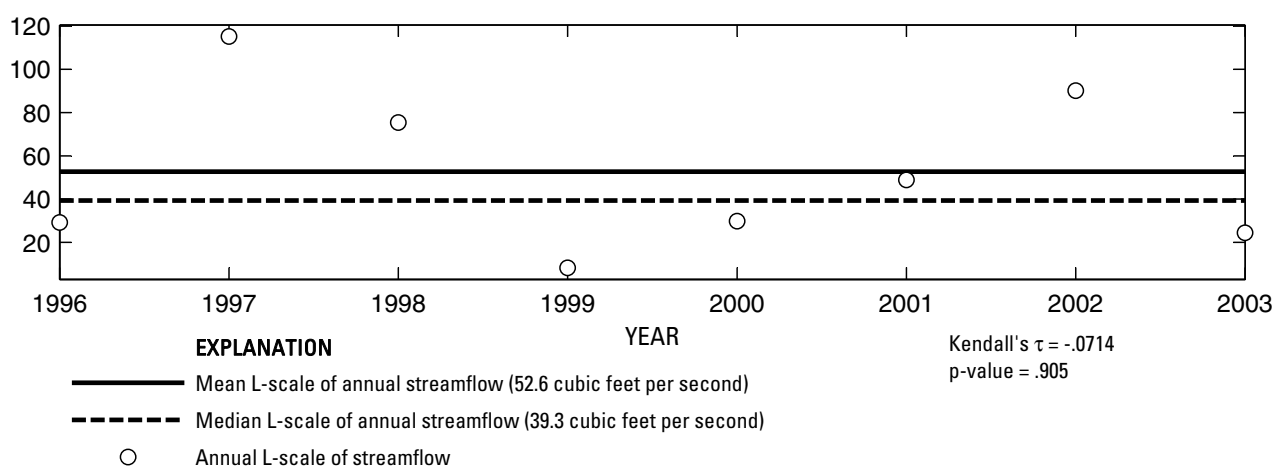

Figure 562. Analysis of annual mean, maximum, minimum, and L-scale statistics of daily mean streamflow for U.S. Geological Survey streamflow-gaging station 08164504 East Mustang Creek near Louise, Texas.

Index of Station Numbers 719 

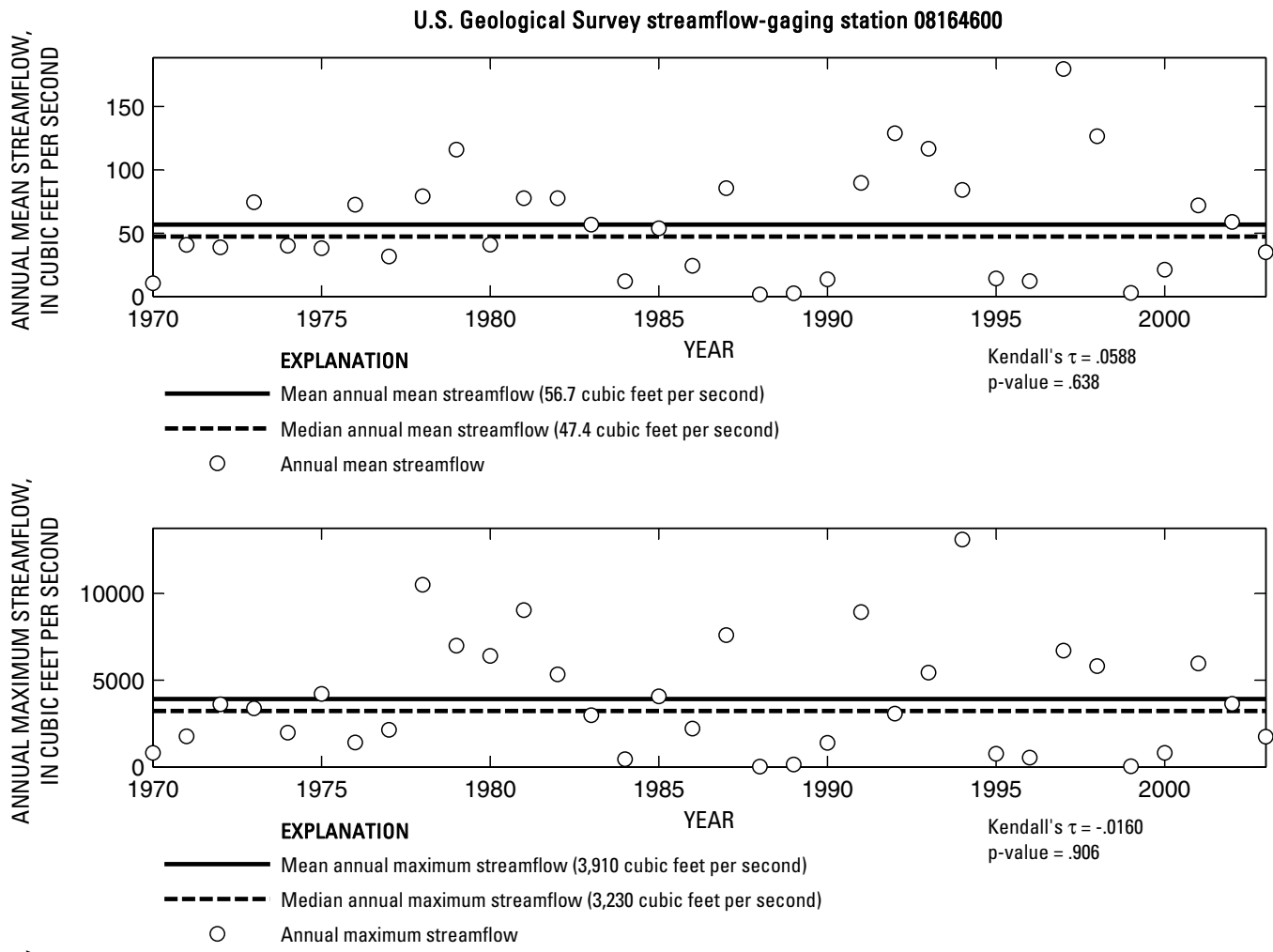

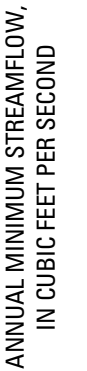

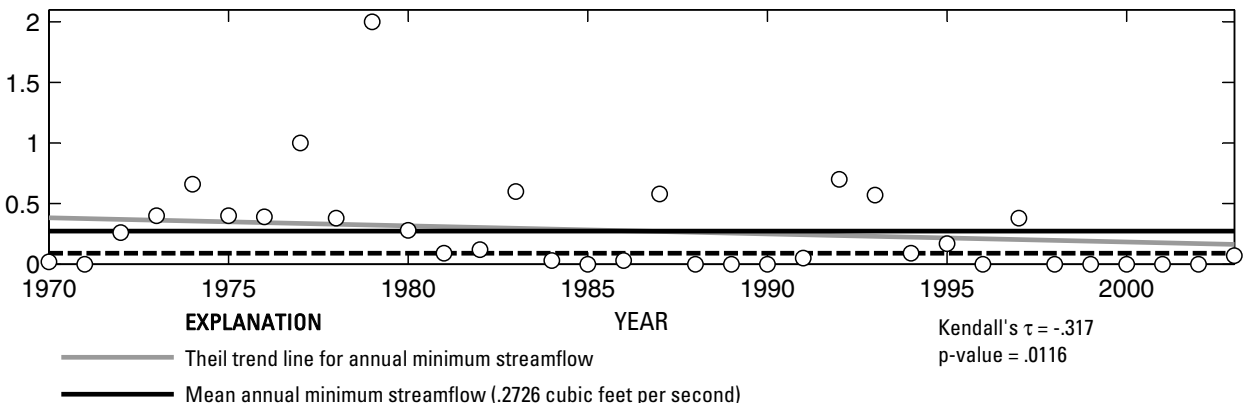

- ב-ב Median annual minimum streamflow (.09 cubic feet per second)

O Annual minimum streamflow

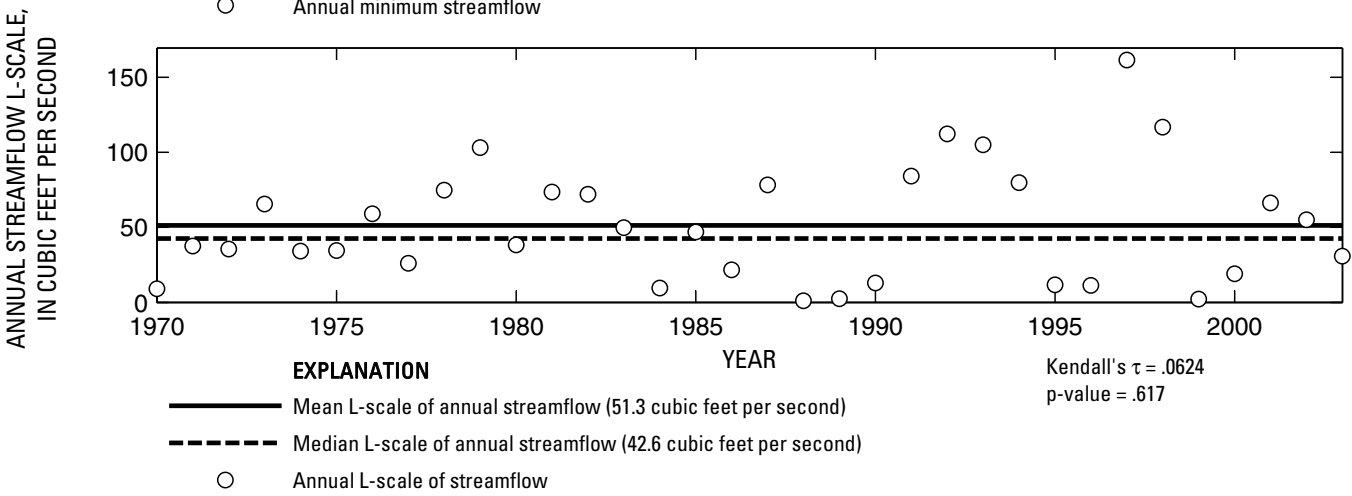

Figure 563. Analysis of annual mean, maximum, minimum, and L-scale statistics of daily mean streamflow for U.S. Geological Survey streamflow-gaging station 08164600 Garcitas Creek near Inez, Texas. 
U.S. Geological Survey streamflow-gaging station 08164800
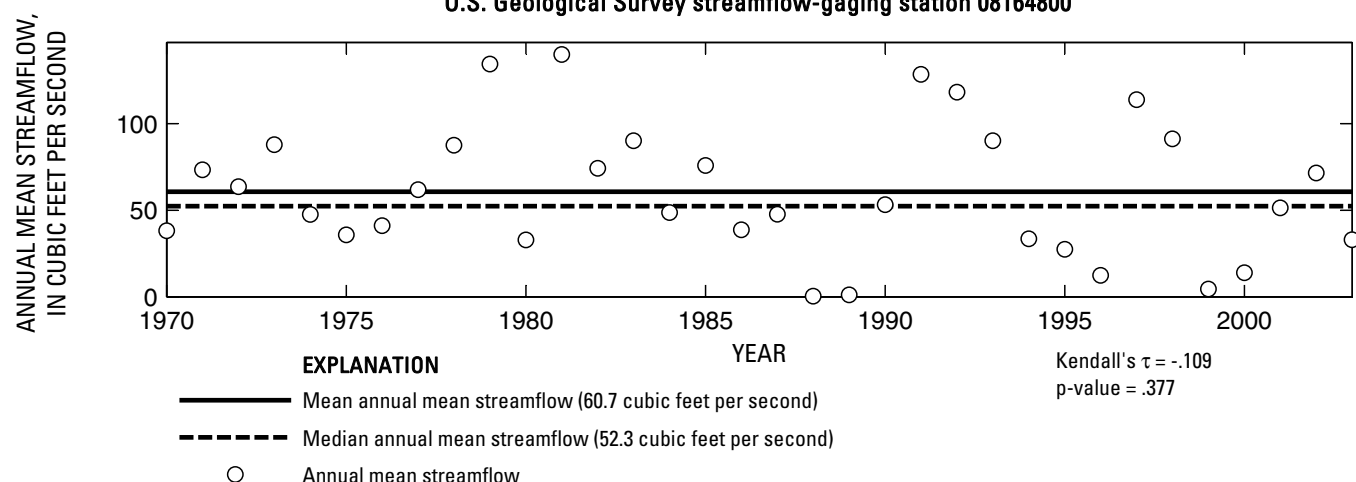

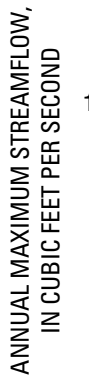

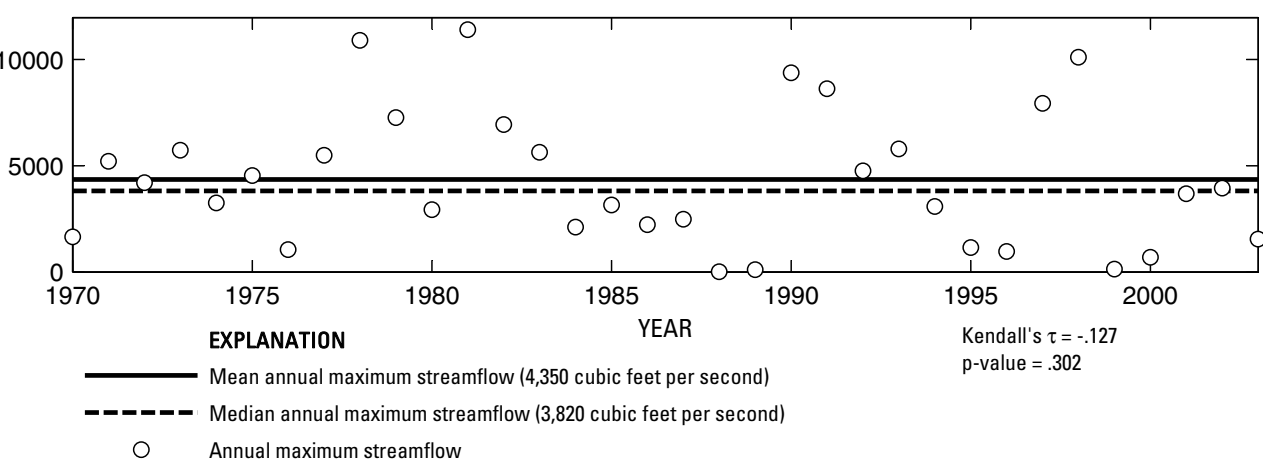

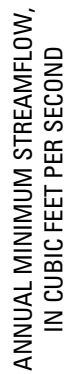

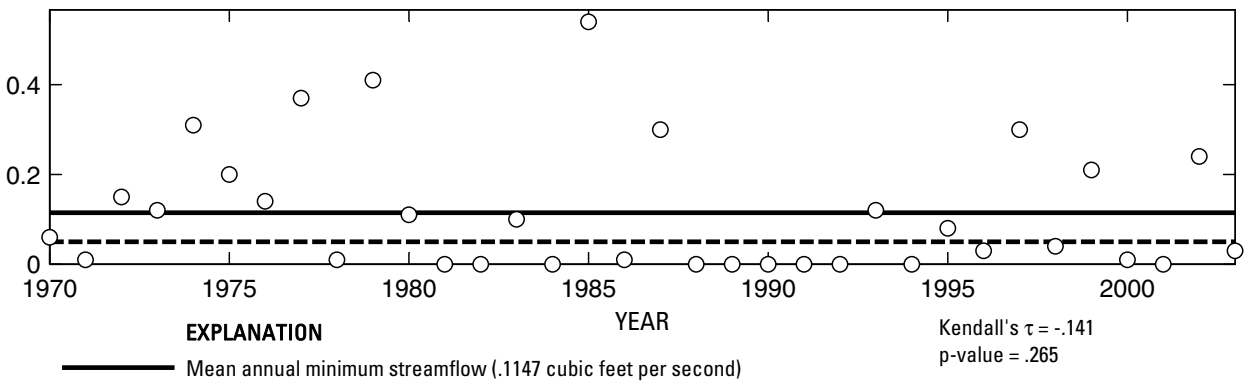

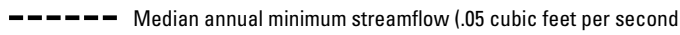

O Annual minimum streamflow

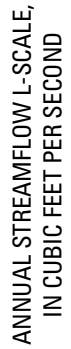

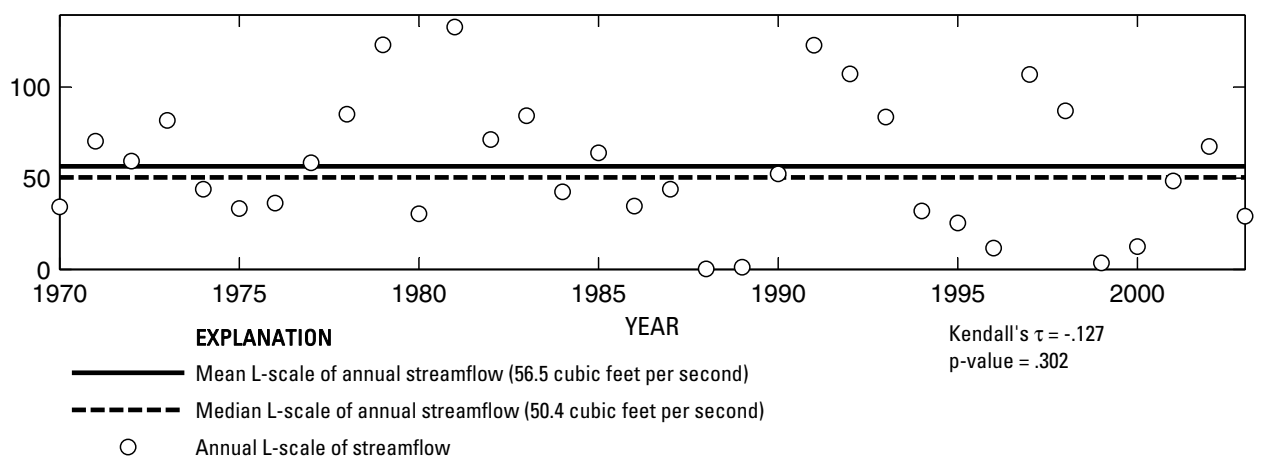

Figure 564. Analysis of annual mean, maximum, minimum, and L-scale statistics of daily mean streamflow for U.S. Geological Survey streamflow-gaging station 08164800 Placedo Creek near Placedo, Texas.

Index of Station Numbers 719 

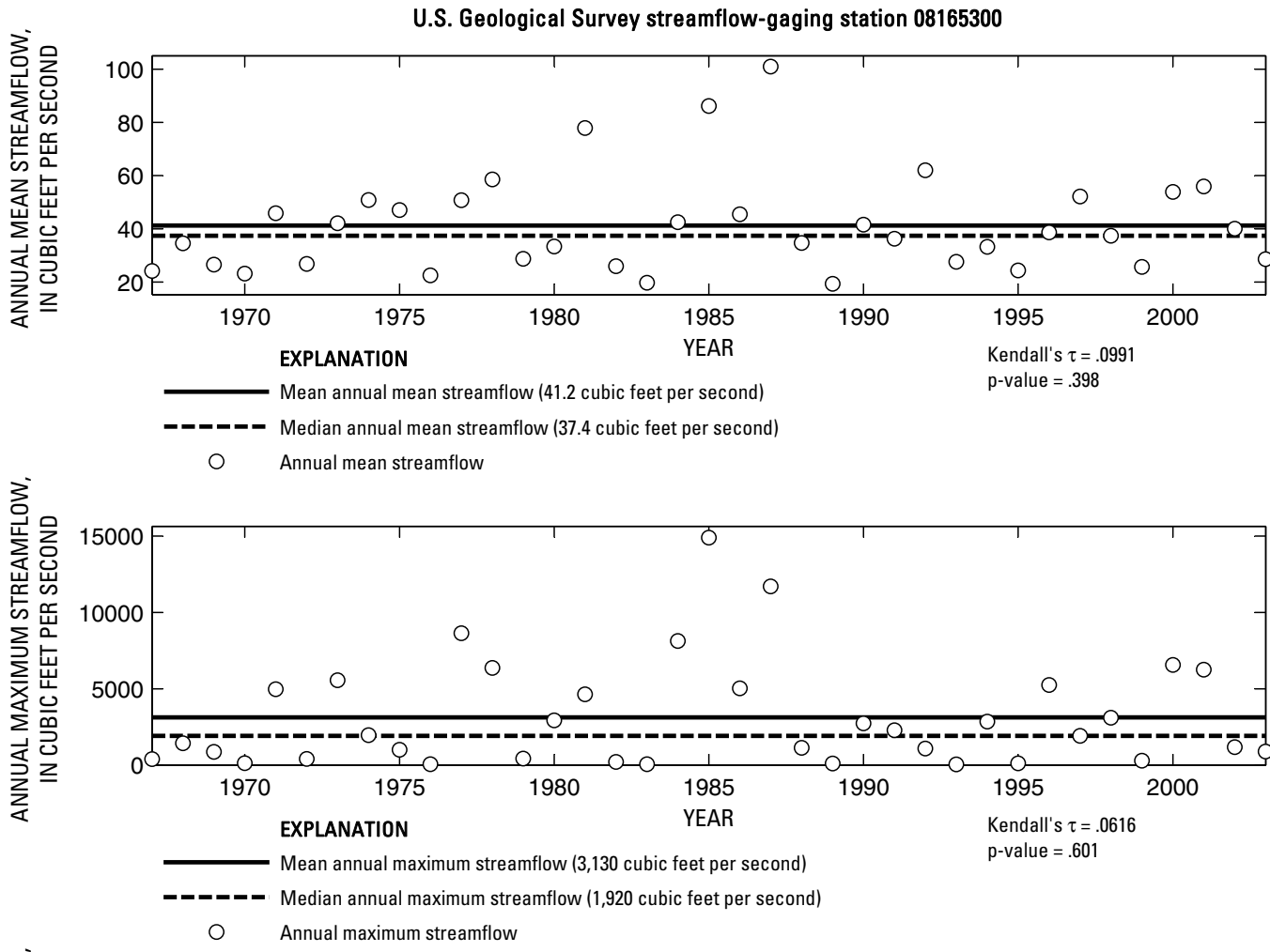

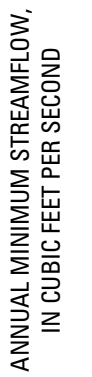

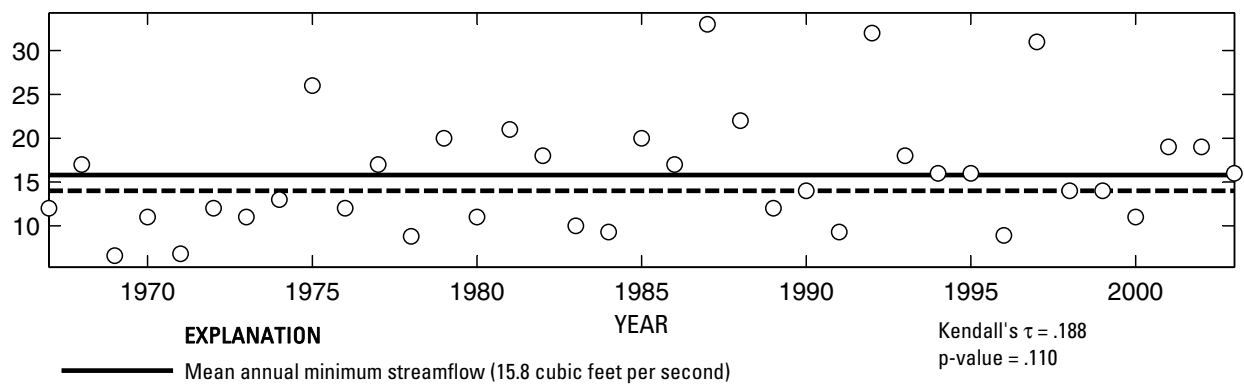

-_-_- Median annual minimum streamflow (14 cubic feet per second)

O Annual minimum streamflow

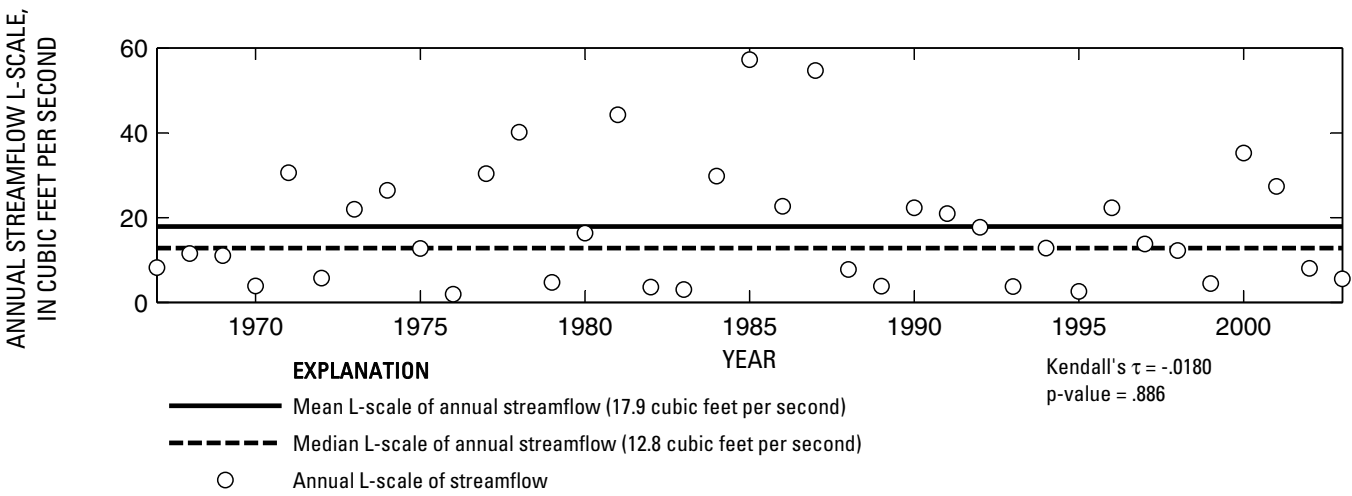

Figure 565. Analysis of annual mean, maximum, minimum, and L-scale statistics of daily mean streamflow for U.S. Geological Survey streamflow-gaging station 08165300 North Fork Guadalupe River near Hunt, Texas. 

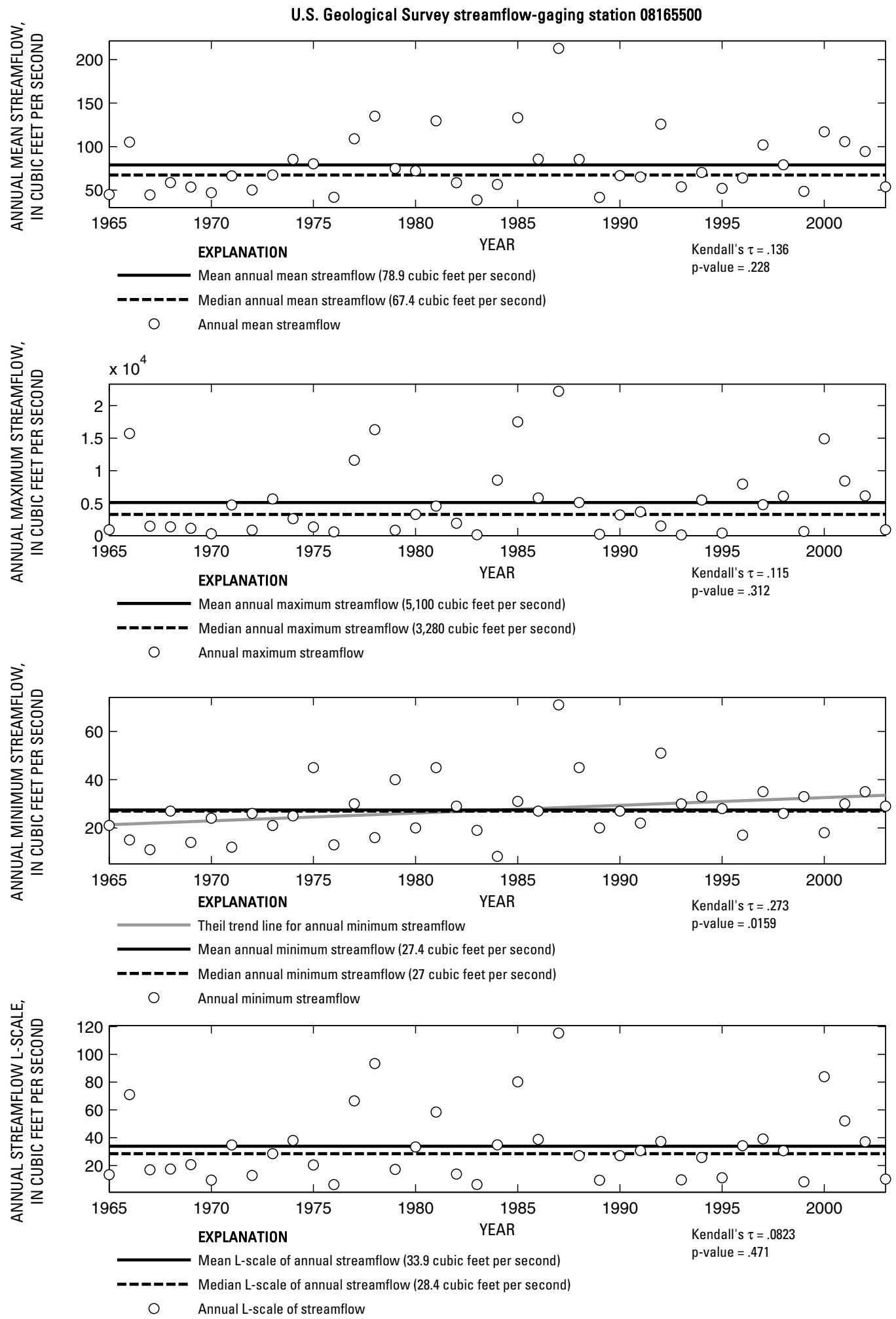

Figure 566. Analysis of annual mean, maximum, minimum, and L-scale statistics of daily mean streamflow for U.S. Geological Survey streamflow-gaging station 08165500 Guadalupe River at Hunt, Texas.

Index of Station Numbers 719 


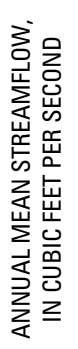

U.S. Geological Survey streamflow-gaging station 08166000

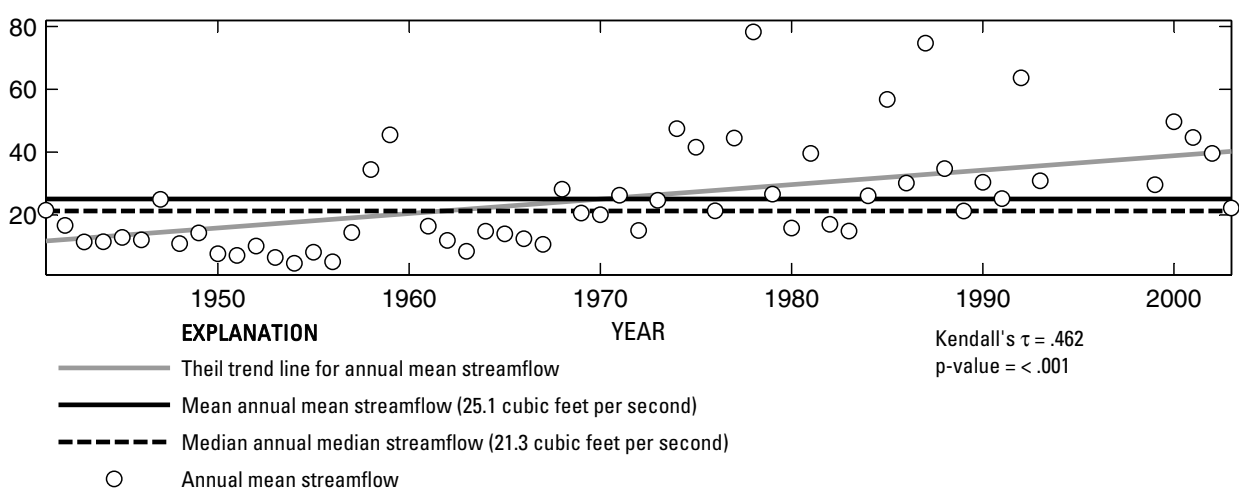

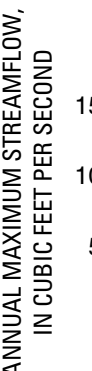

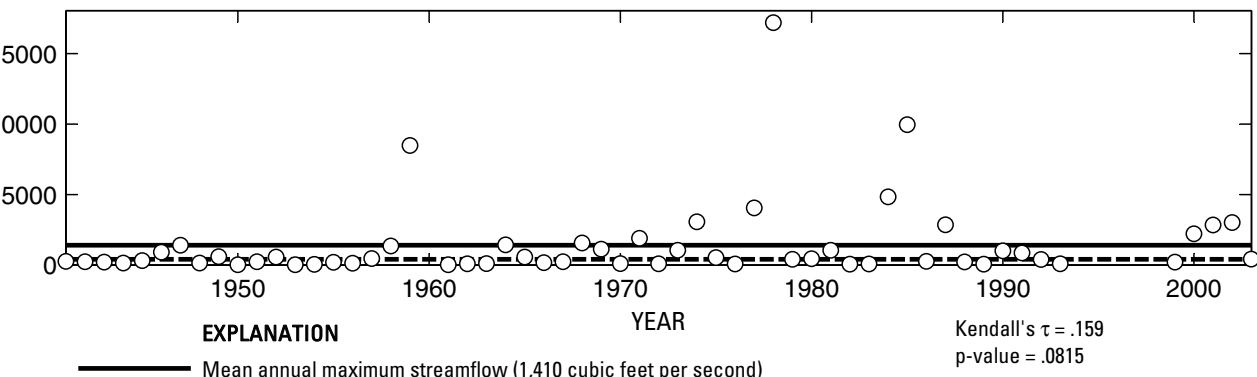

O Annual maximum streamflow
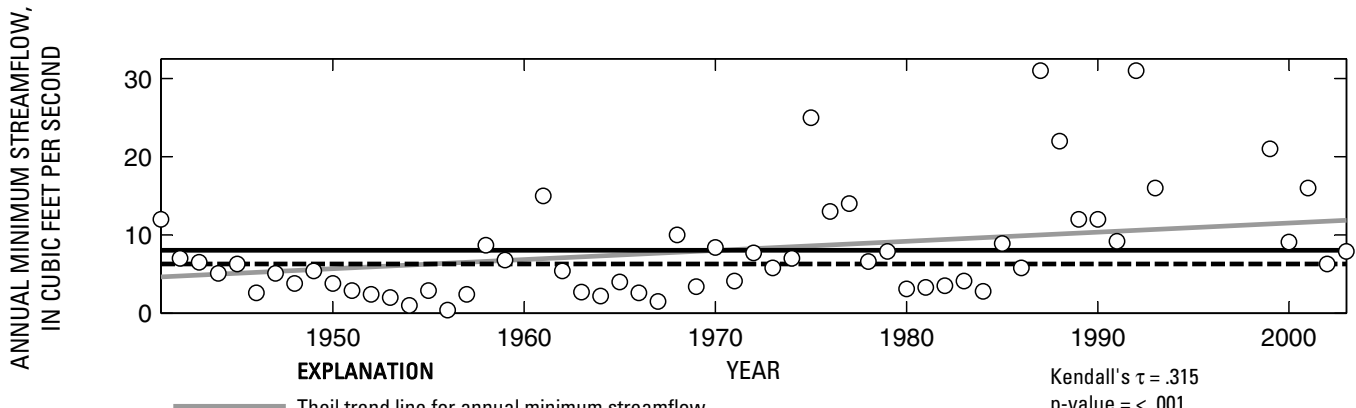

Theil trend line for annual minimum streamflow
Mean annual minimum streamflow (8.042 cubic feet per second)

- Median annual minimum streamflow (6.3 cubic feet per second)

O Annual minimum streamflow

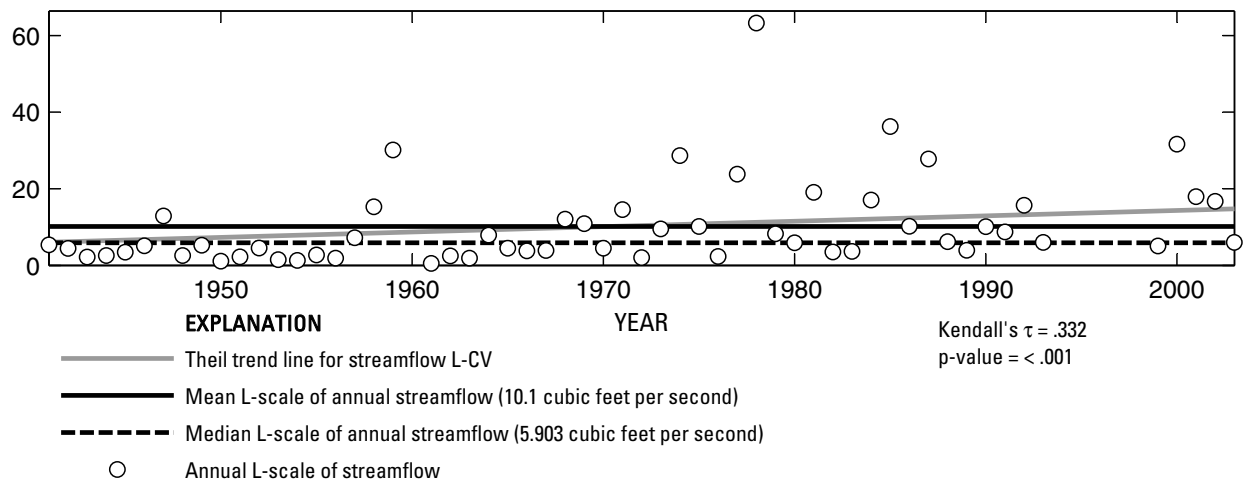

Figure 567. Analysis of annual mean, maximum, minimum, and L-scale statistics of daily mean streamflow for U.S. Geological Survey streamflow-gaging station 08166000 Johnson Creek near Ingram, Texas. 


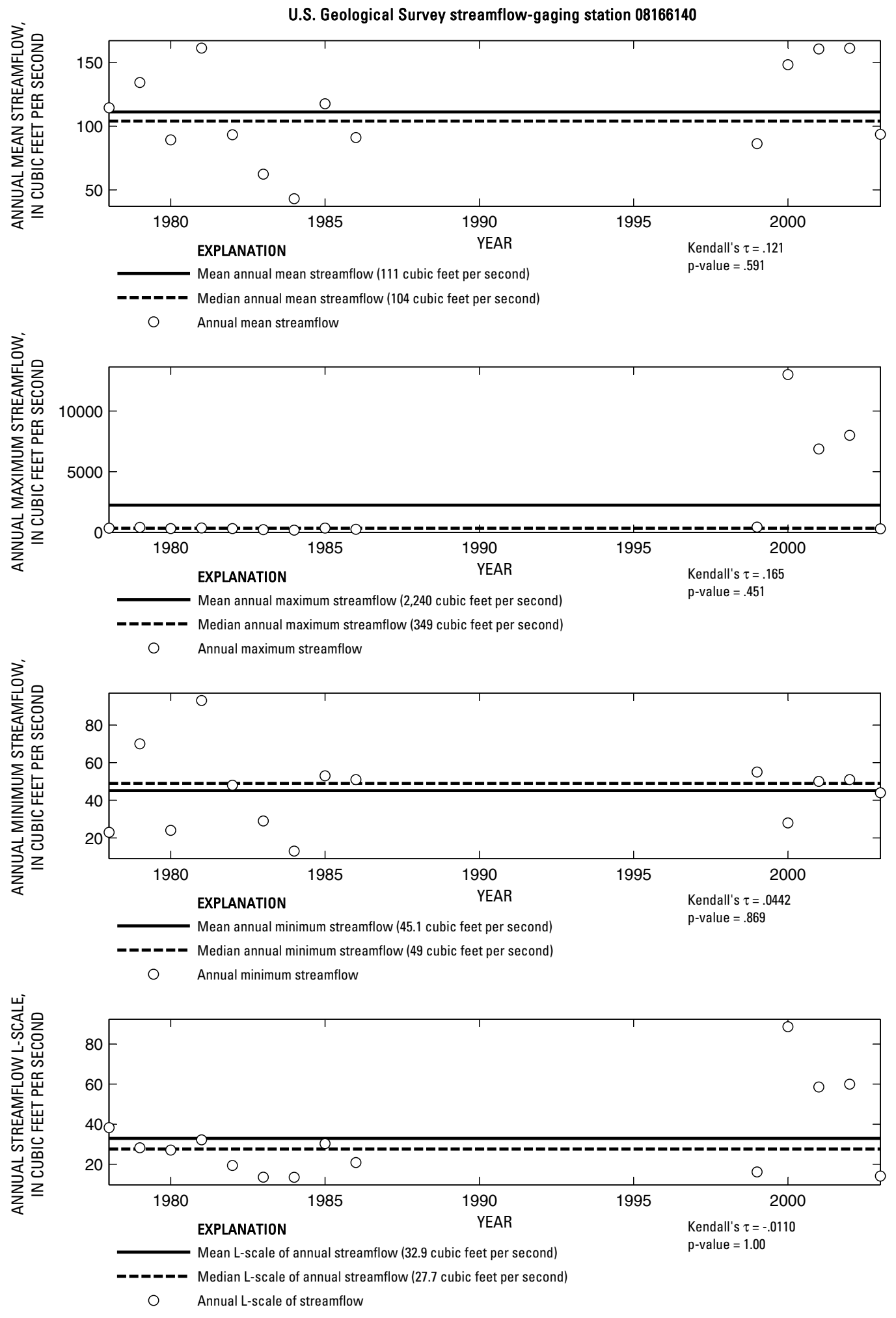

Figure 568. Analysis of annual mean, maximum, minimum, and L-scale statistics of daily mean streamflow for U.S. Geological Survey streamflow-gaging station 08166140 Guadalupe River above Bear Creek at Kerrville, Texas.

Index of Station Numbers 719 


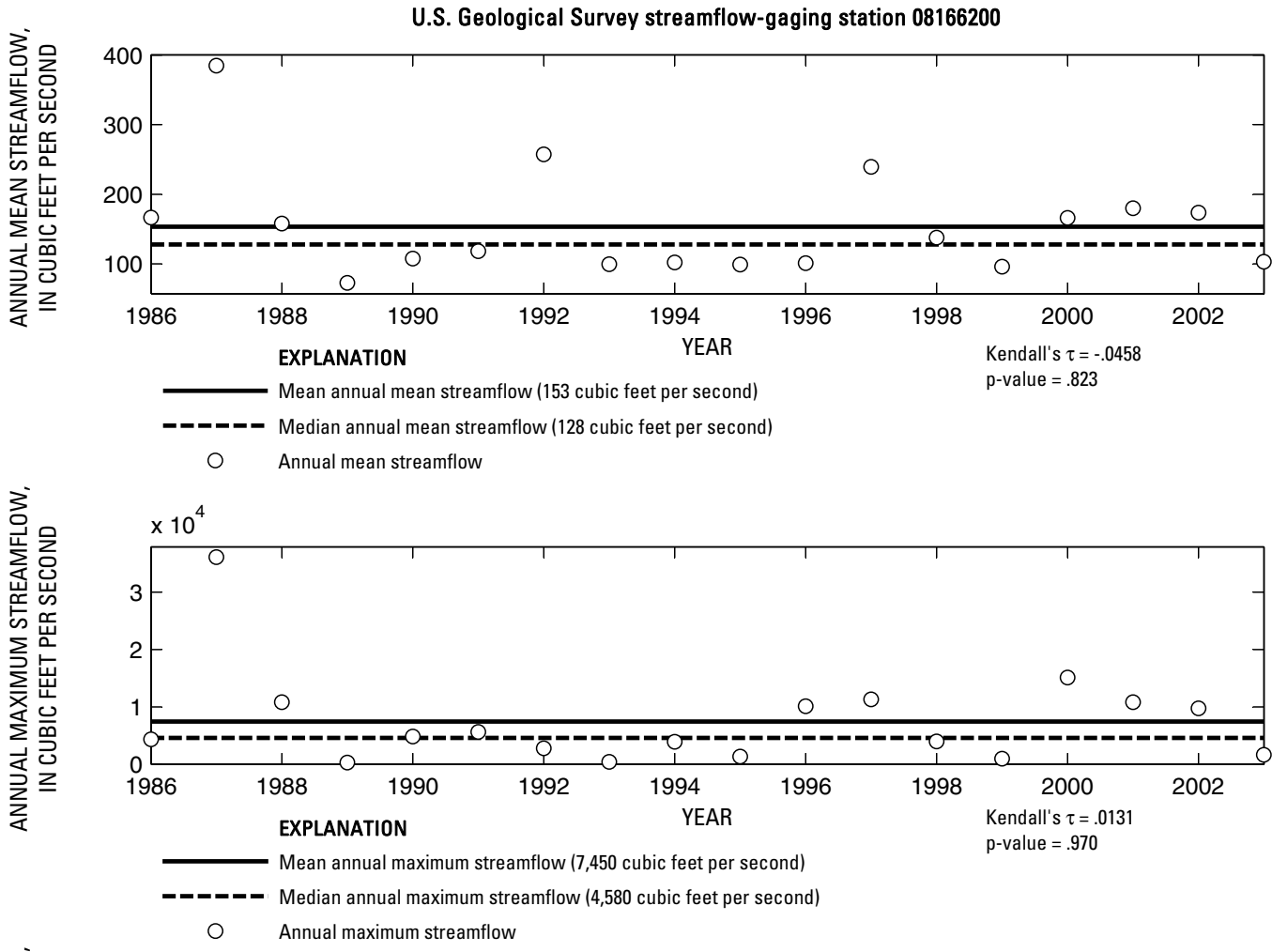

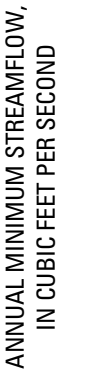

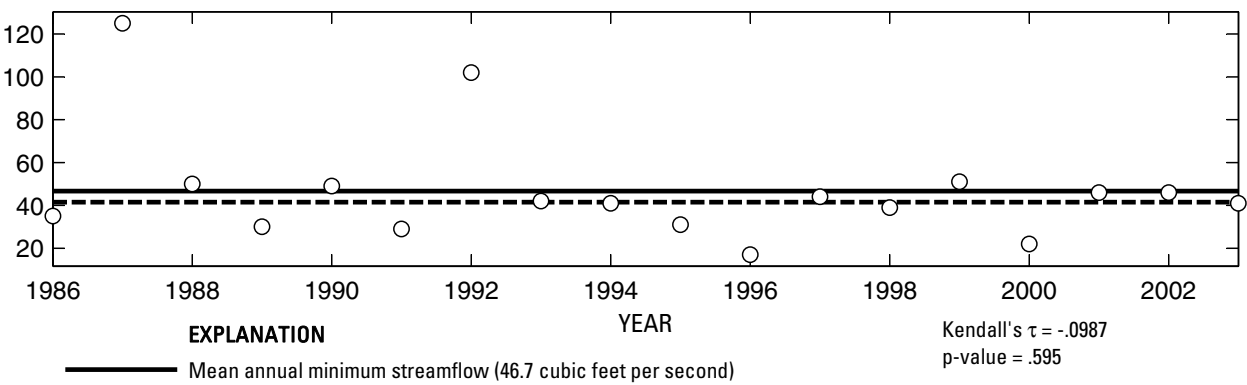

- ב-ב Median annual minimum streamflow (41.5 cubic feet per second)

○ Annual minimum streamflow

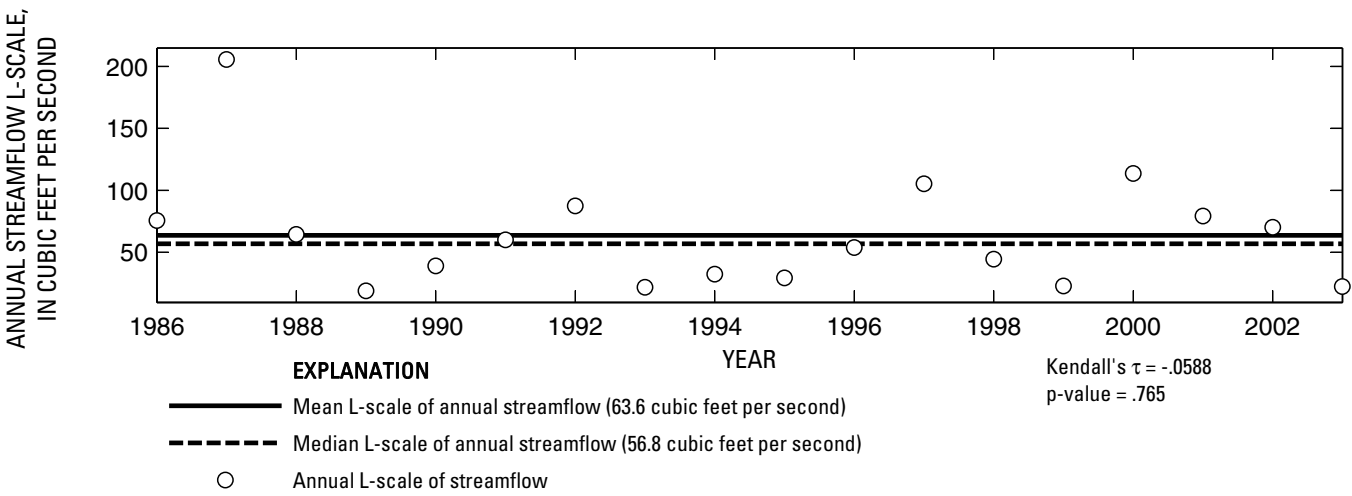

Figure 569. Analysis of annual mean, maximum, minimum, and L-scale statistics of daily mean streamflow for U.S. Geological Survey streamflow-gaging station 08166200 Guadalupe River at Kerrville, Texas. 

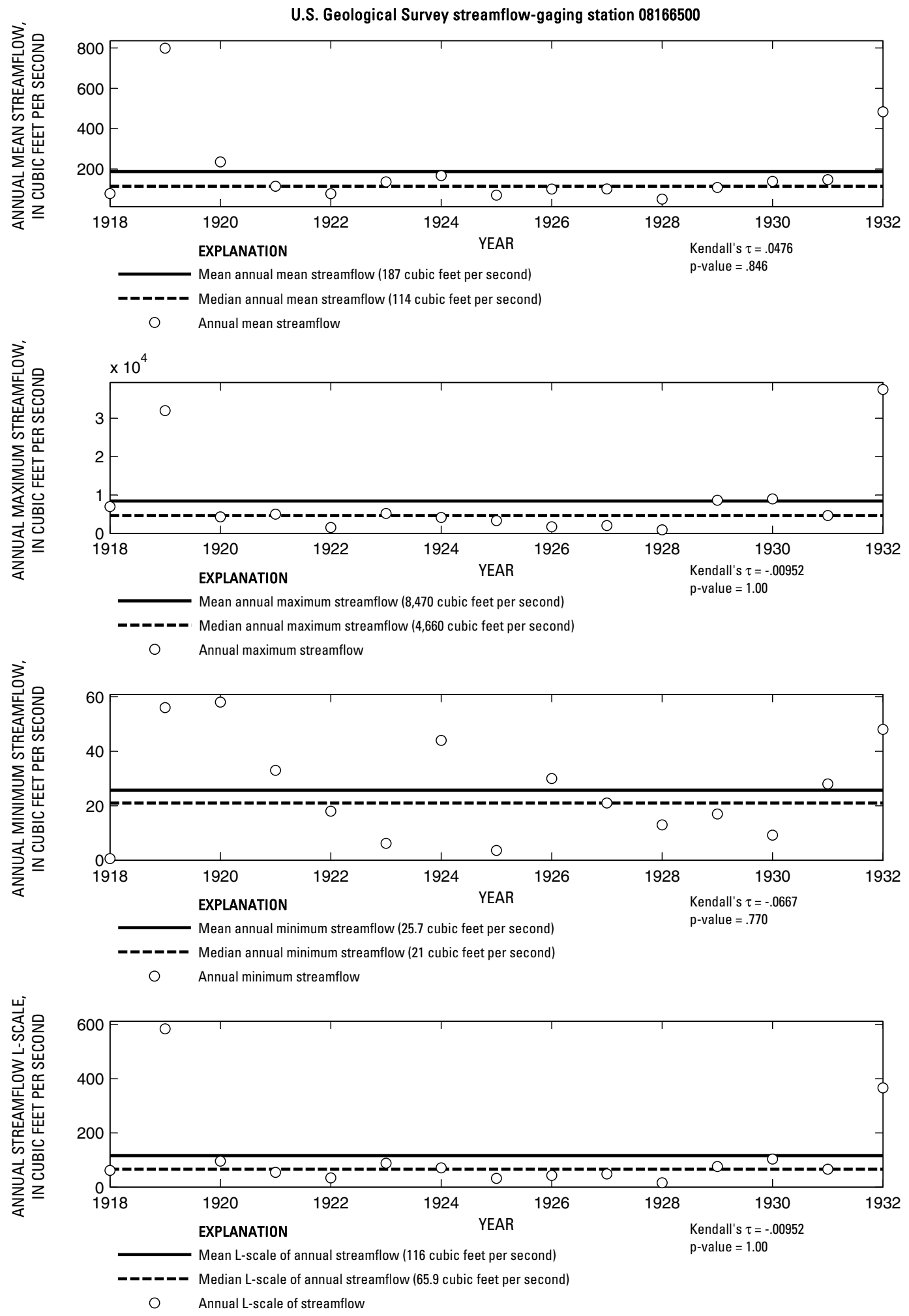

Figure 570. Analysis of annual mean, maximum, minimum, and L-scale statistics of daily mean streamflow for U.S. Geological Survey streamflow-gaging station 08166500 Guadalupe River near Comfort, Texas.

Index of Station Numbers 719 


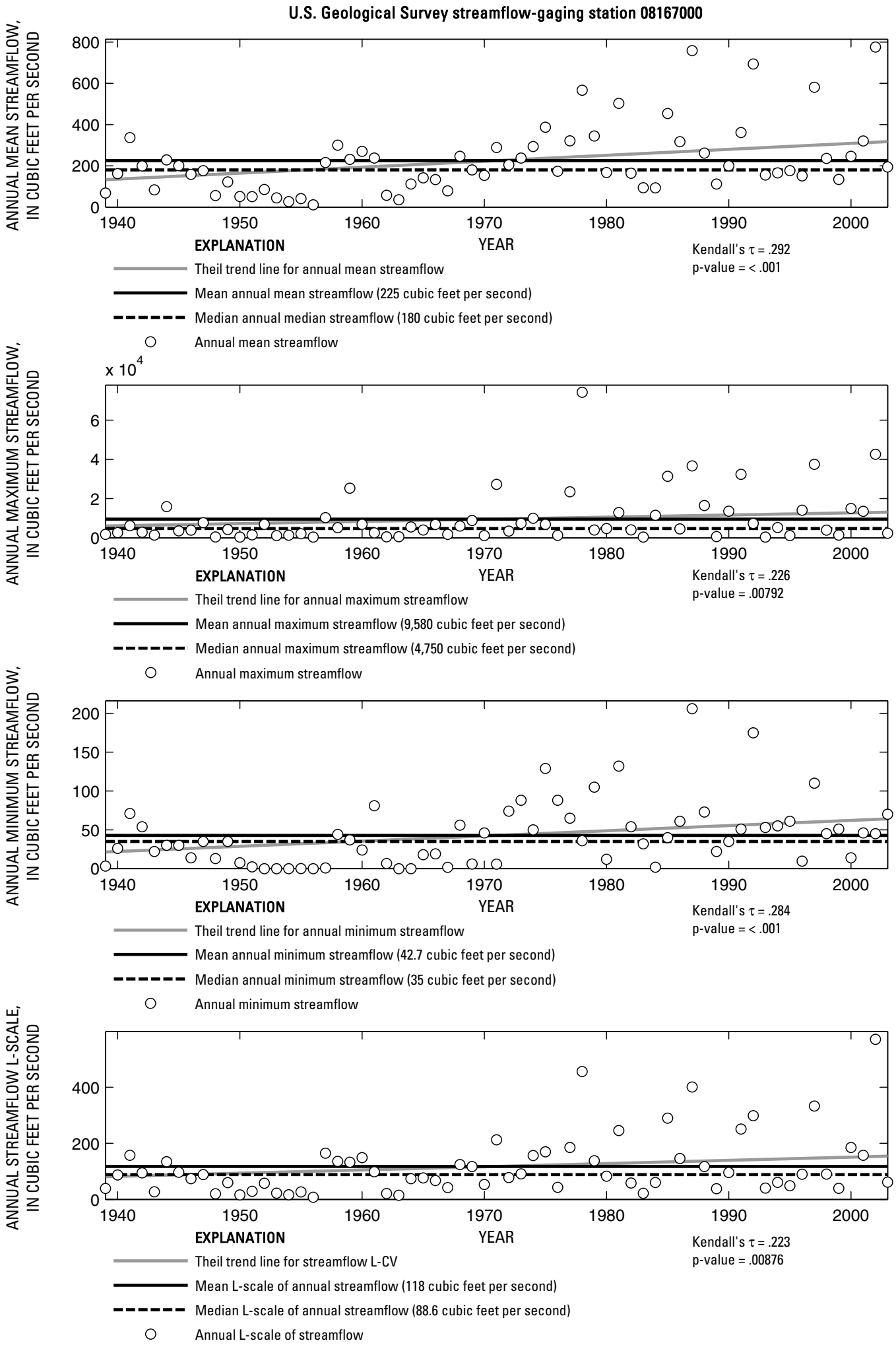

Figure 571. Analysis of annual mean, maximum, minimum, and L-scale statistics of daily mean streamflow for U.S. Geological Survey streamflow-gaging station 08167000 Guadalupe River at Comfort, Texas. 

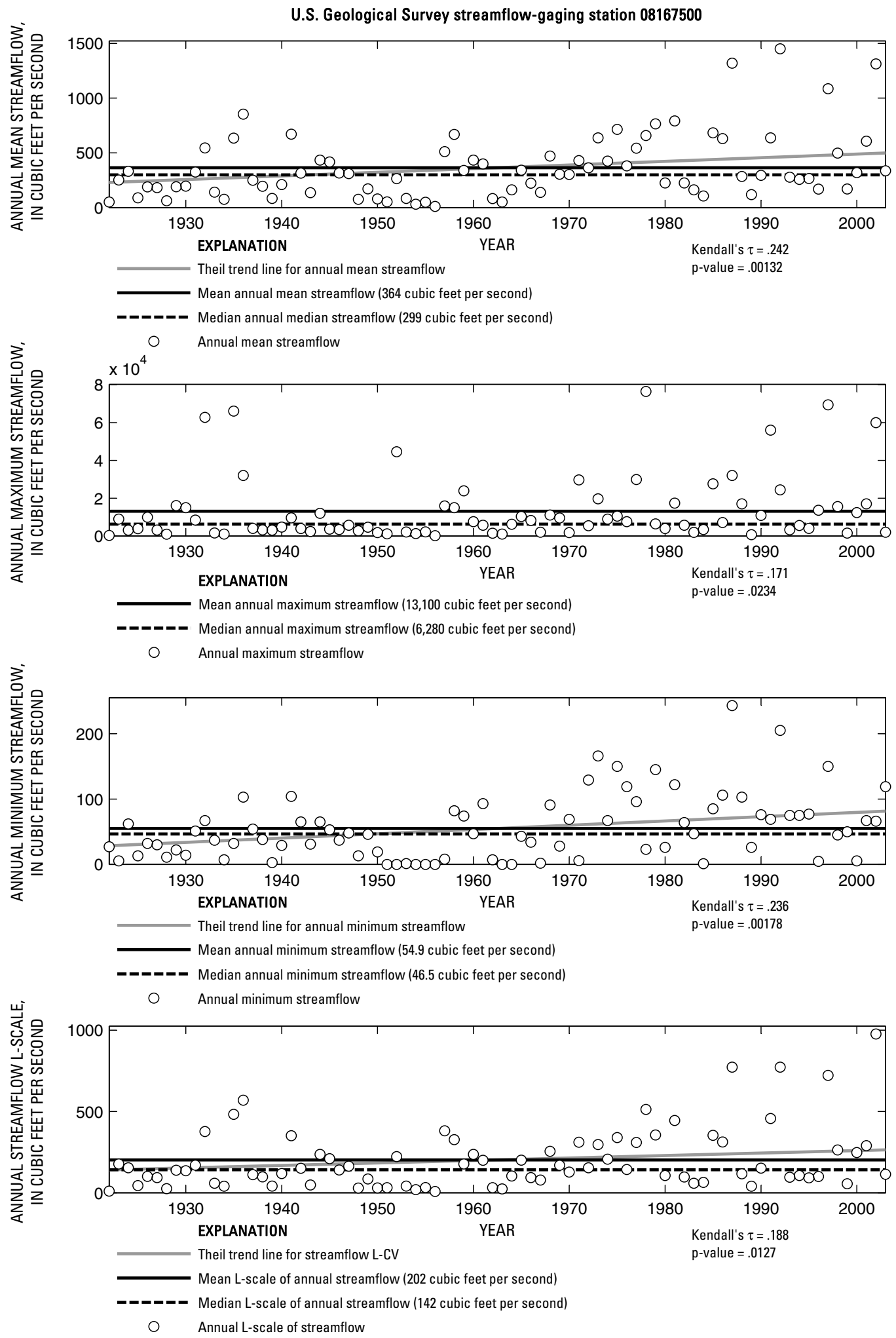

Figure 572. Analysis of annual mean, maximum, minimum, and L-scale statistics of daily mean streamflow for U.S. Geological Survey streamflow-gaging station 08167500 Guadalupe River near Spring Branch, Texas.

|ndex of Station Numbers 719 


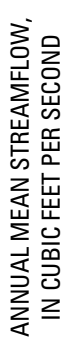

U.S. Geological Survey streamflow-gaging station 08167600

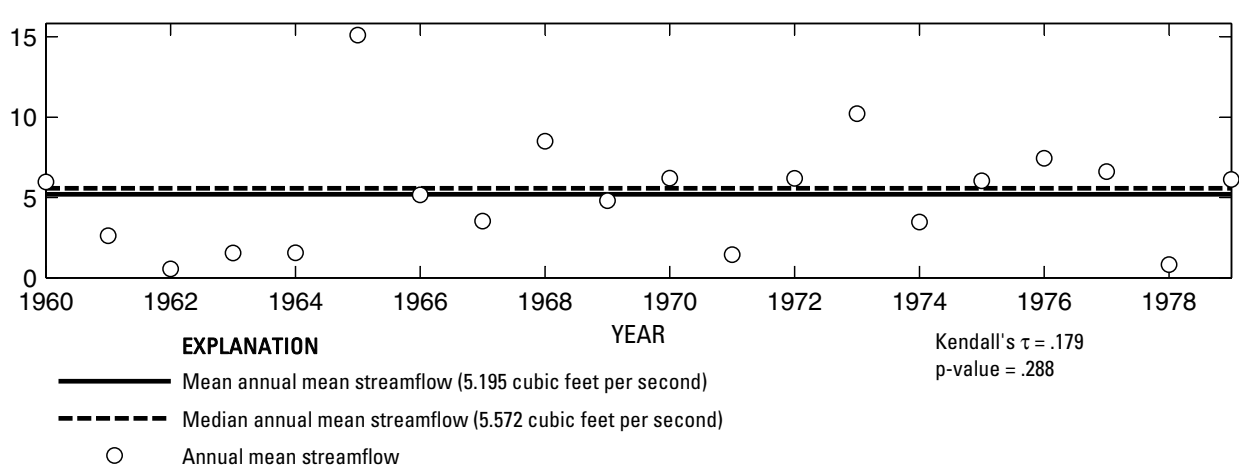

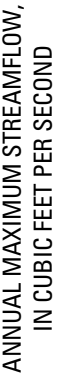

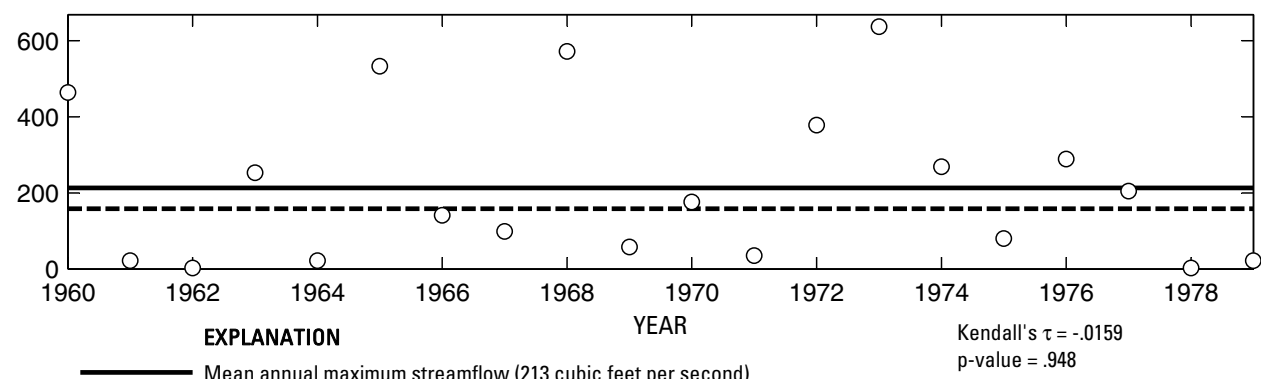

- - - Median annual maximum streamflow (159 cubic feet per second)

O Annual maximum streamflow

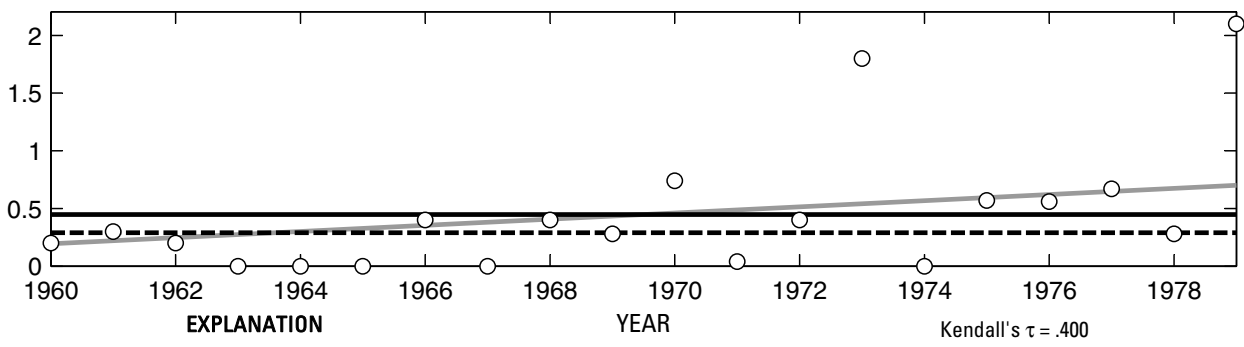

Theil trend line for annual minimum streamflow

Mean annual minimum streamflow (.447 cubic feet per second)

- - - Median annual minimum streamflow (.29 cubic feet per second)

○ Annual minimum streamflow

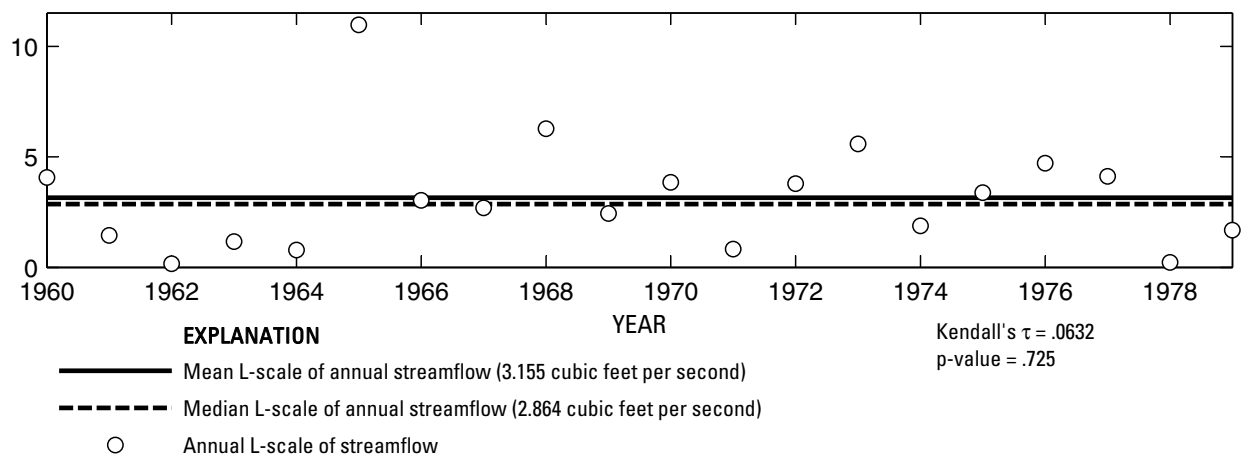

Figure 573. Analysis of annual mean, maximum, minimum, and L-scale statistics of daily mean streamflow for U.S. Geological Survey streamflow-gaging station 08167600 Rebecca Creek near Spring Branch, Texas. 

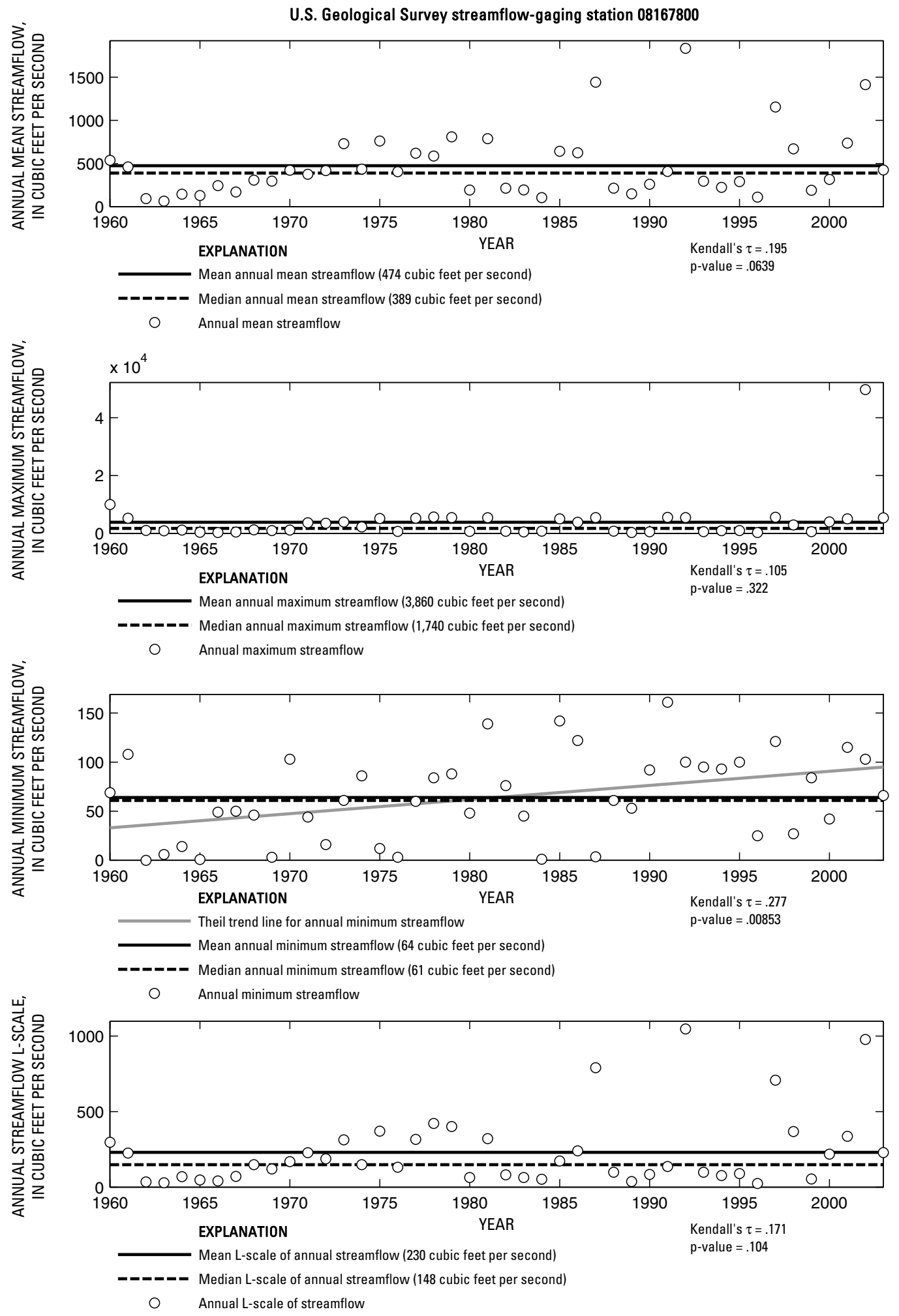

Figure 574. Analysis of annual mean, maximum, minimum, and L-scale statistics of daily mean streamflow for U.S. Geological Survey streamflow-gaging station 08167800 Guadalupe River at Sattler, Texas.

Index of Station Numbers 719 


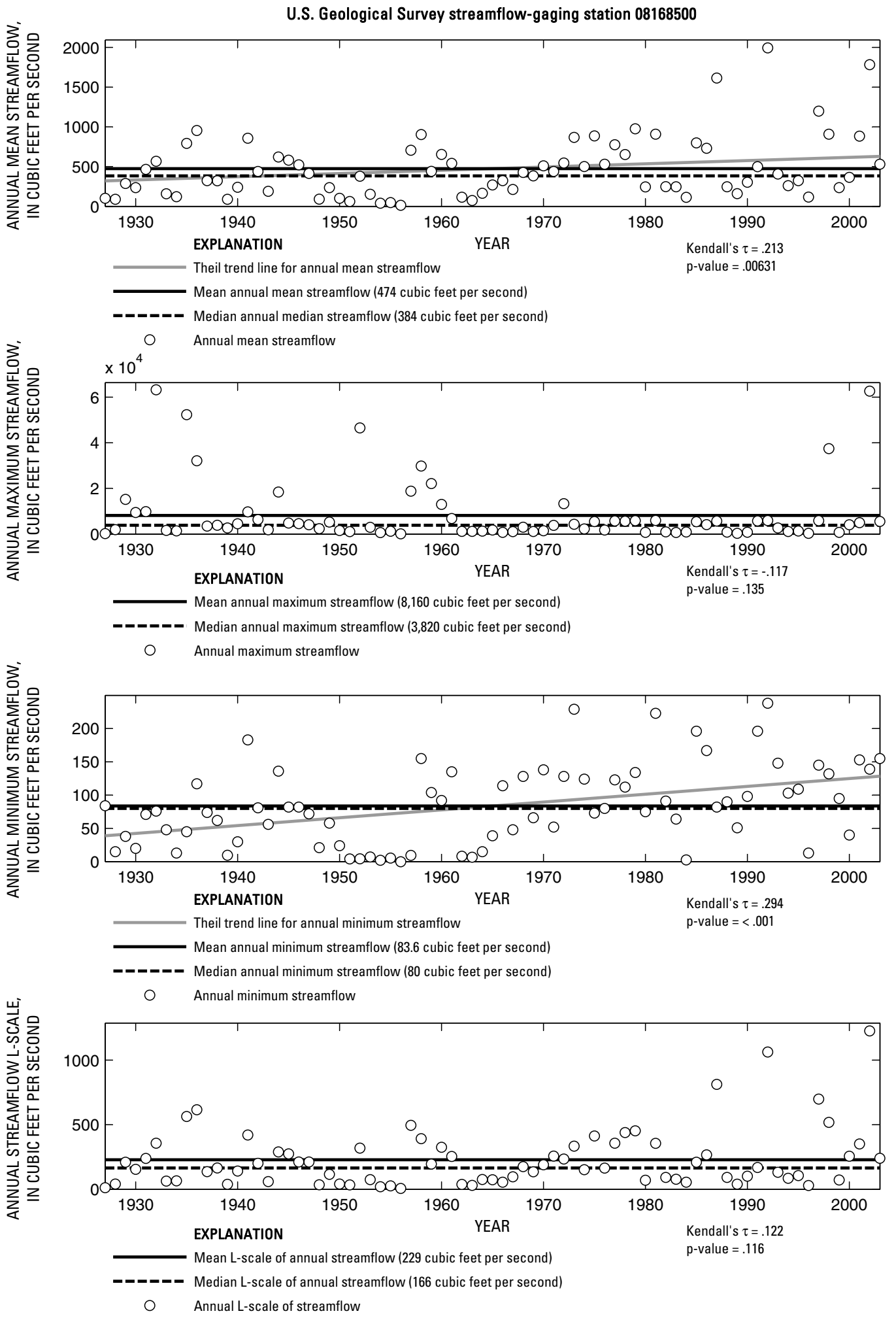

Figure 575. Analysis of annual mean, maximum, minimum, and L-scale statistics of daily mean streamflow for U.S. Geological Survey streamflow-gaging station 08168500 Guadalupe River above Comal River at New Braunfels, Texas. 
U.S. Geological Survey streamflow-gaging station 08169000

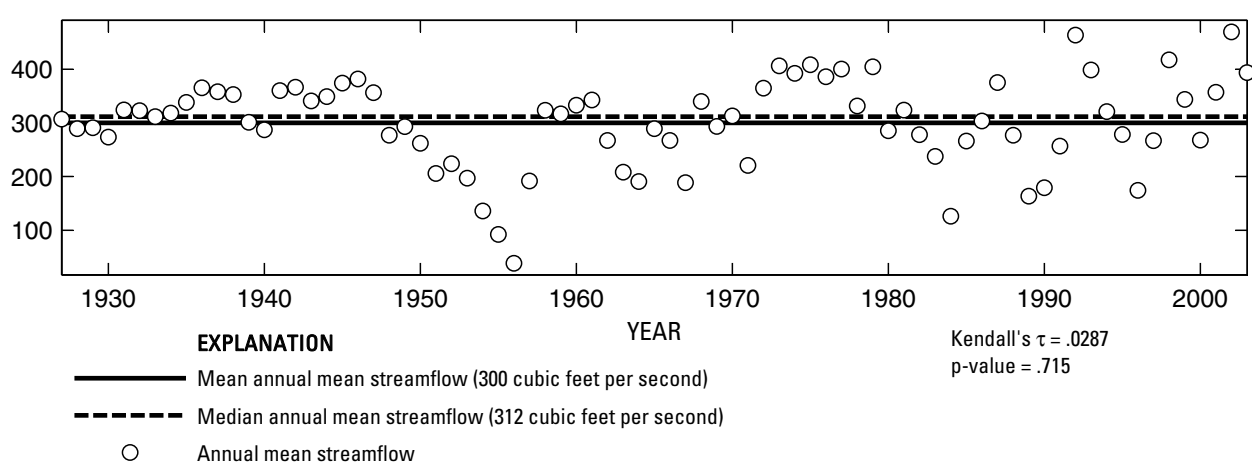

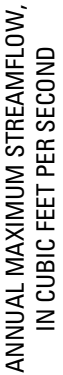
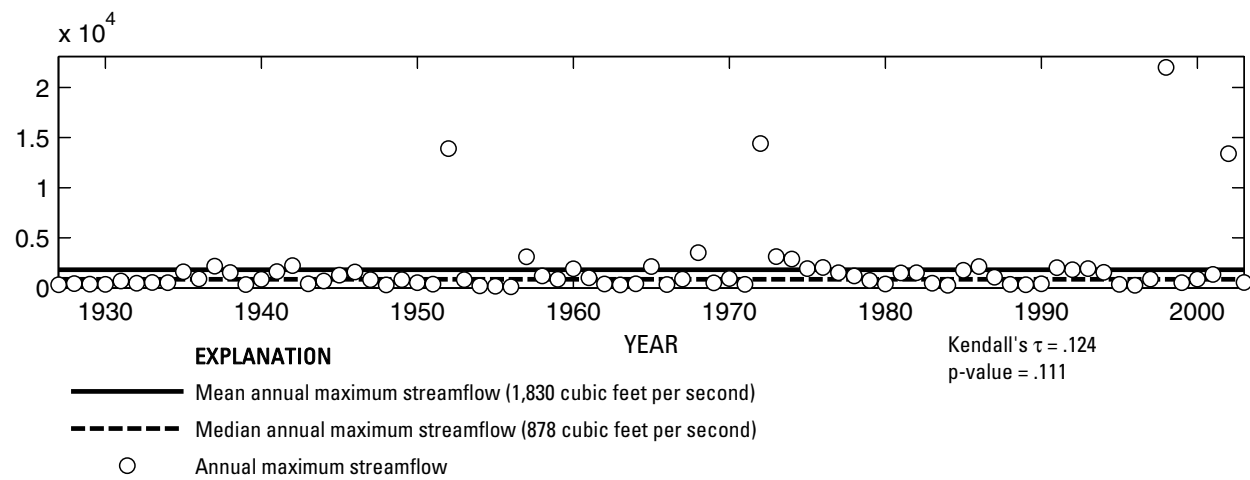

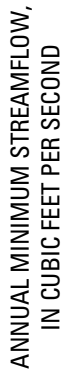

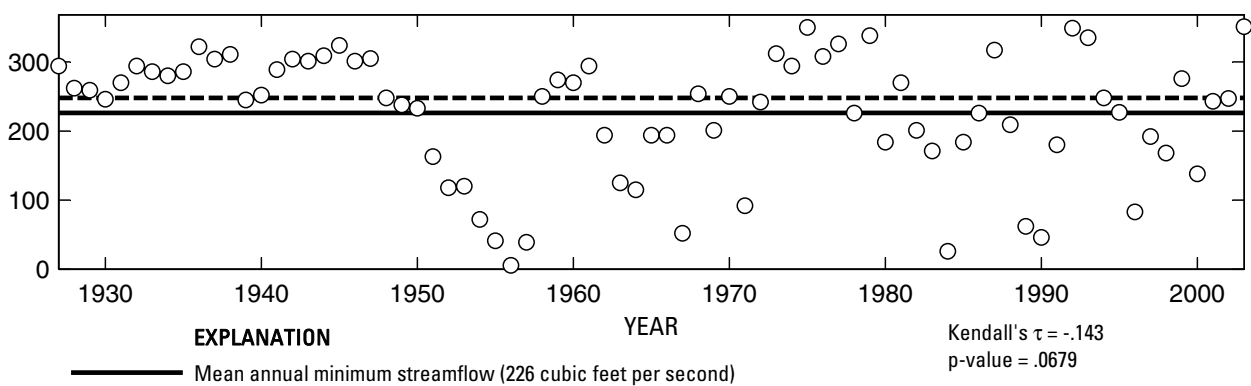

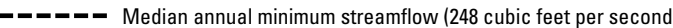

O Annual minimum streamflow

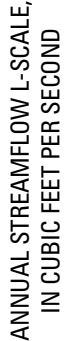

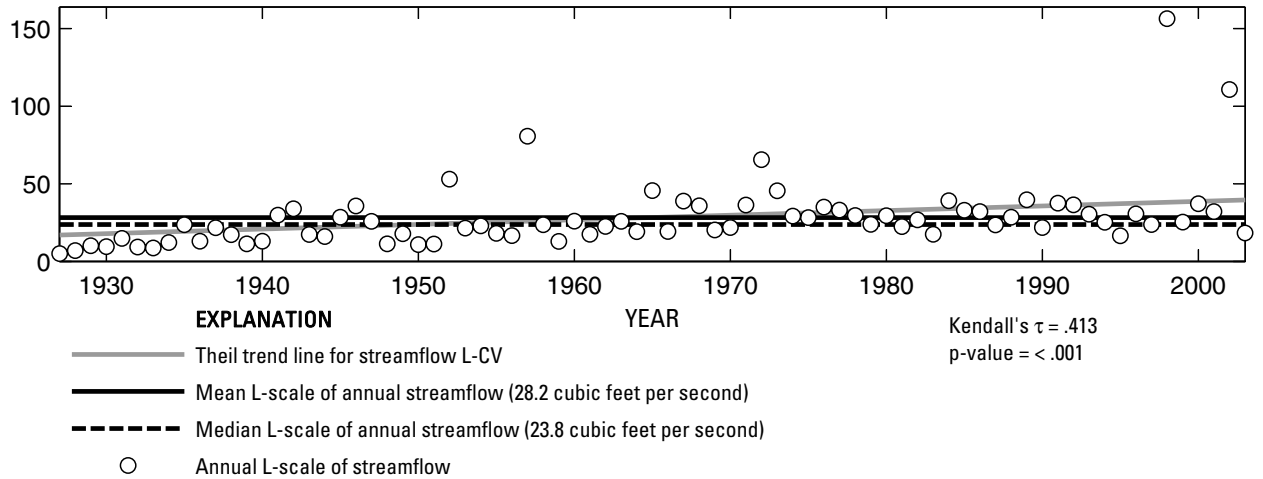

Figure 576. Analysis of annual mean, maximum, minimum, and L-scale statistics of daily mean streamflow for U.S. Geological Survey streamflow-gaging station 08169000 Comal River at New Braunfels, Texas.

Index of Station Numbers 719 

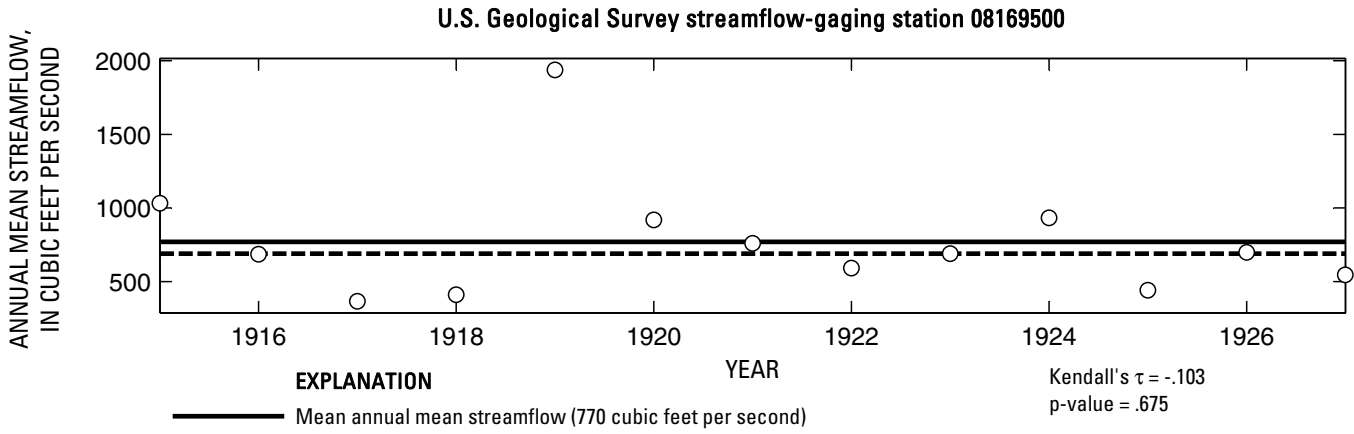

-_-_- Median annual mean streamflow (690 cubic feet per second)

O Annual mean streamflow
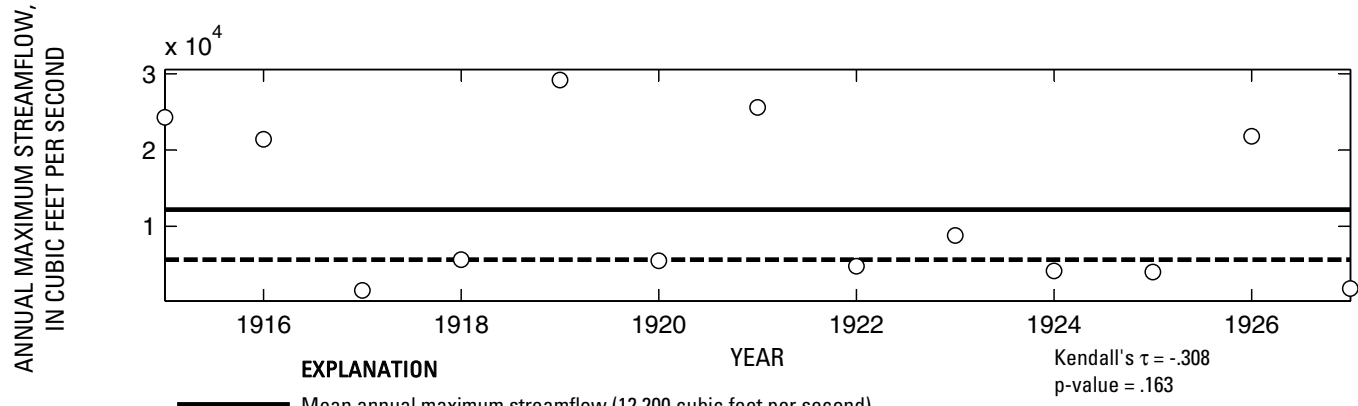

Mean annual maximum streamflow (12,200 cubic feet per second)

- - - - Median annual maximum streamflow (5,600 cubic feet per second)

O Annual maximum streamflow
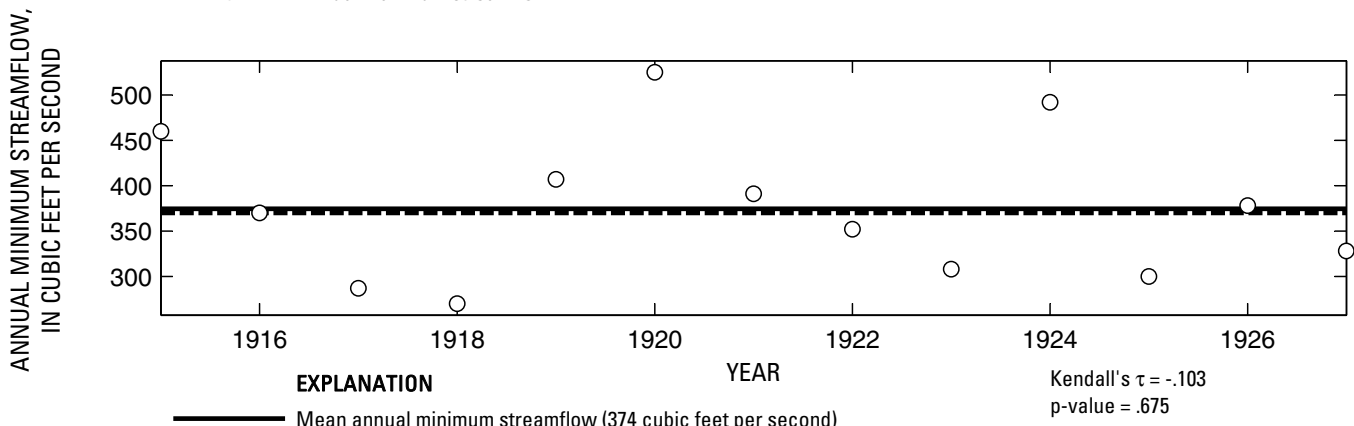

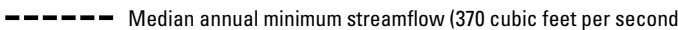

O Annual minimum streamflow

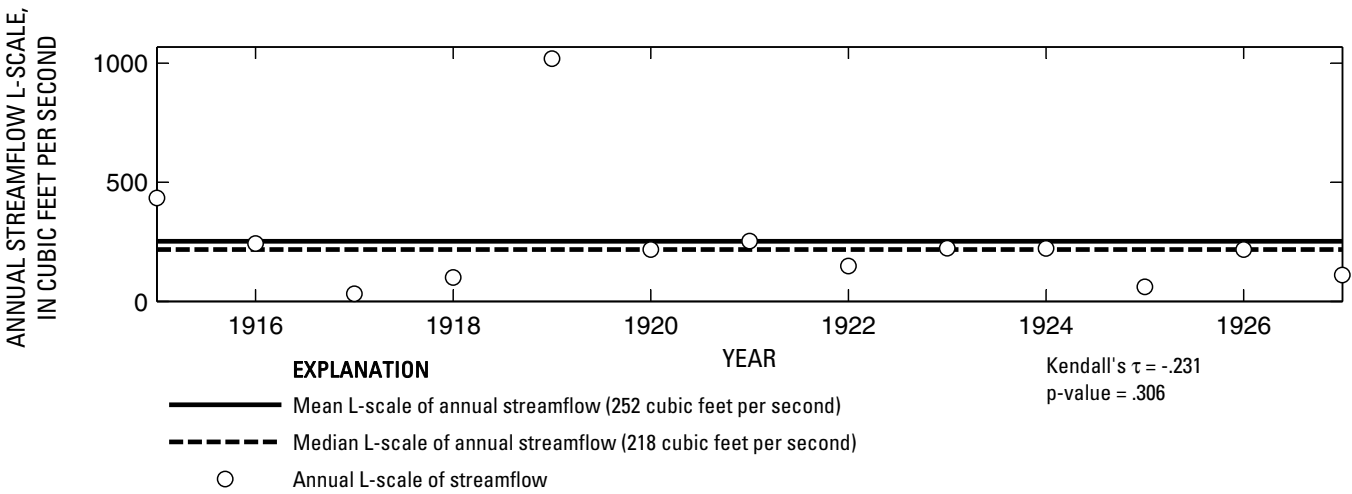

Figure 577. Analysis of annual mean, maximum, minimum, and L-scale statistics of daily mean streamflow for U.S. Geological Survey streamflow-gaging station 08169500 Guadalupe River at New Braunfels, Texas. 


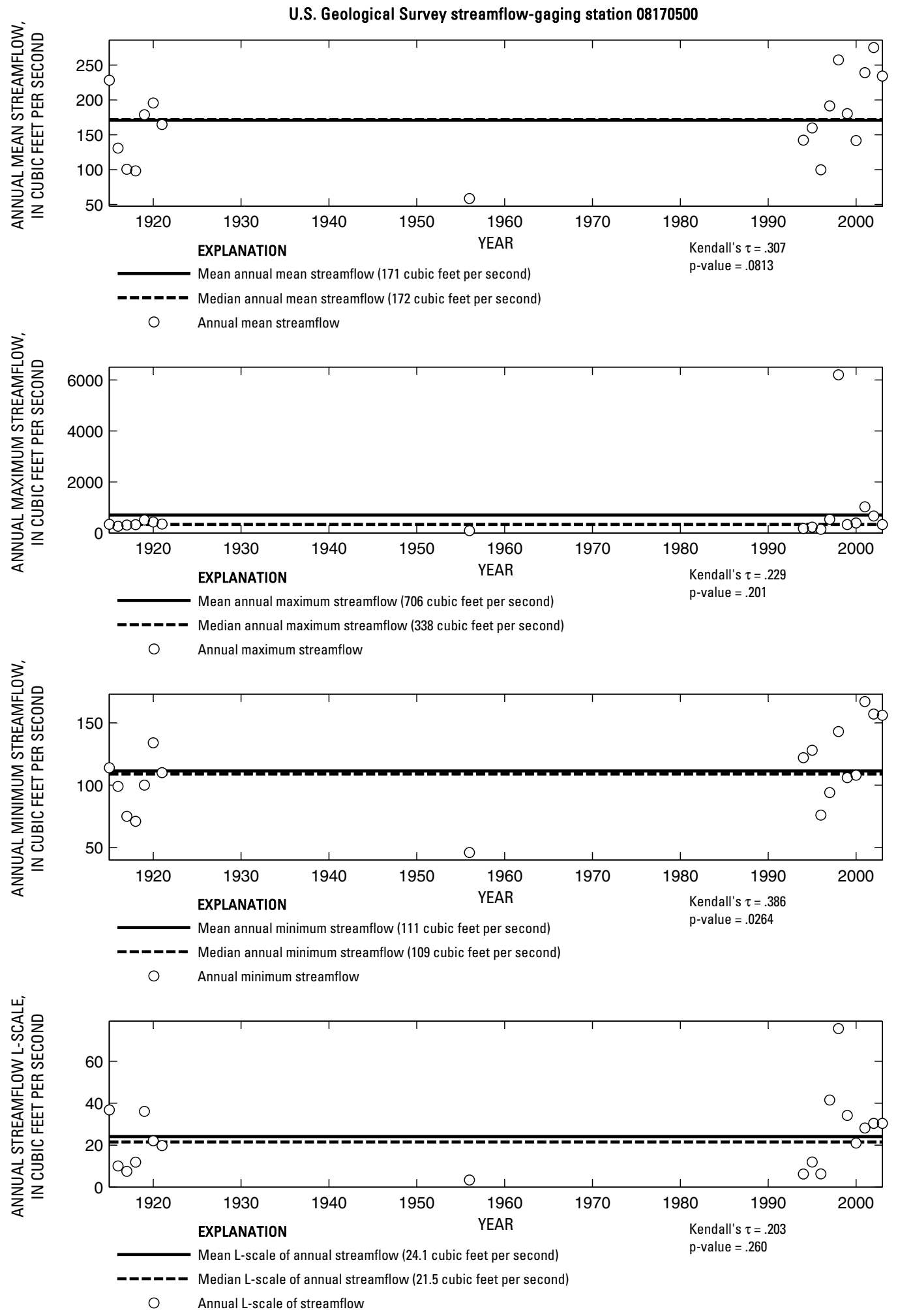

Figure 578. Analysis of annual mean, maximum, minimum, and L-scale statistics of daily mean streamflow for U.S. Geological Survey streamflow-gaging station 08170500 San Marcos River at San Marcos, Texas.

Index of Station Numbers 719 

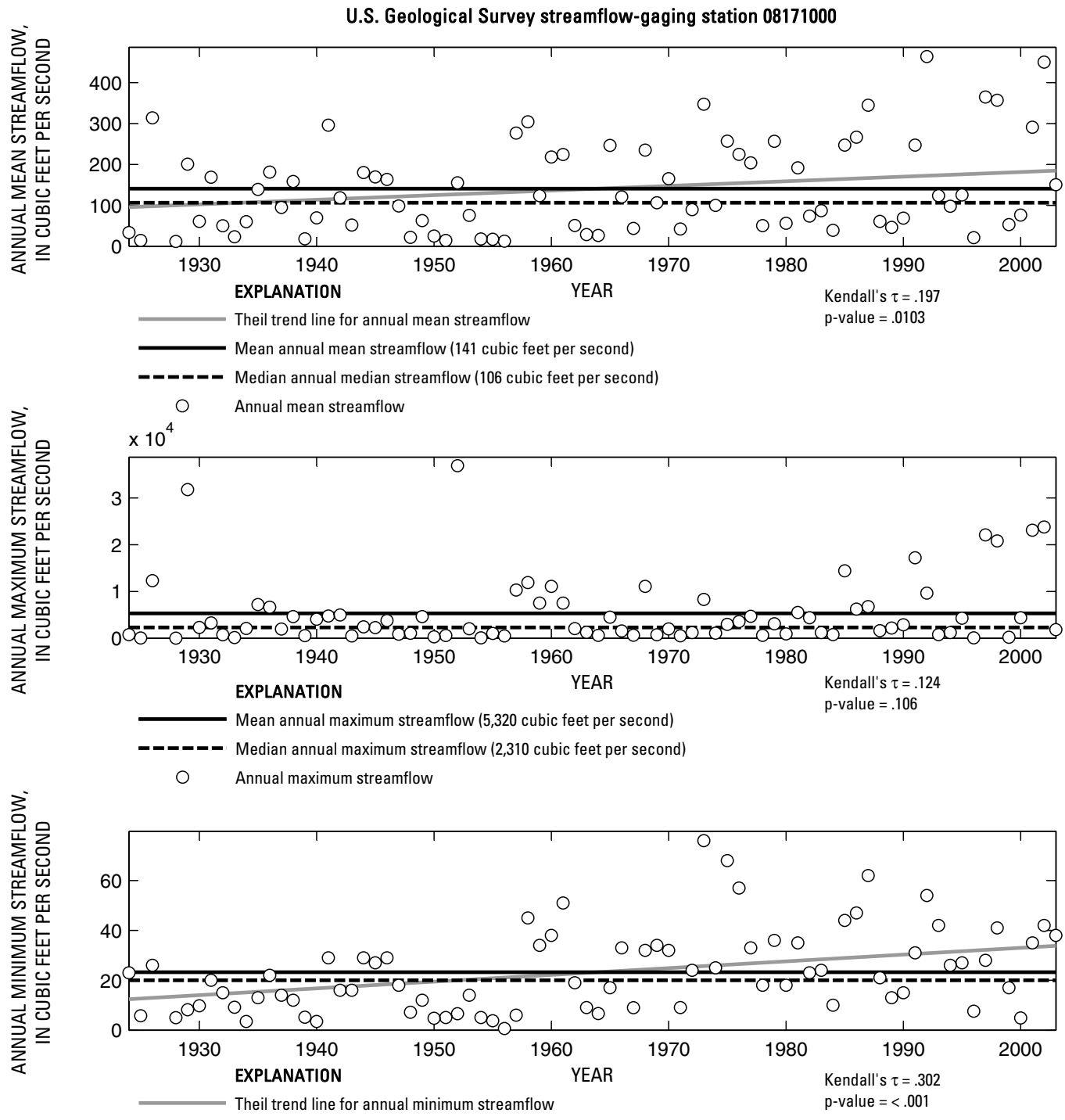

- Mean annual minimum streamflow (23.2 cubic feet per second)

Median annual minimum streamflow (20 cubic feet per second)

$\bigcirc \quad$ Annual minimum streamflow

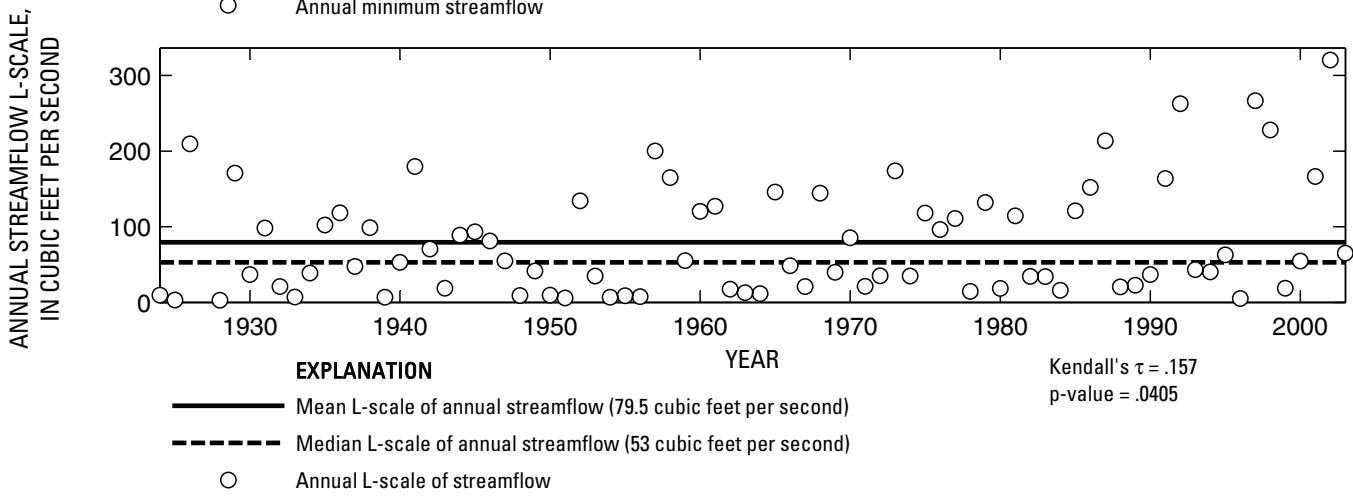

Figure 579. Analysis of annual mean, maximum, minimum, and L-scale statistics of daily mean streamflow for U.S. Geological Survey streamflow-gaging station 08171000 Blanco River at Wimberley, Texas. 


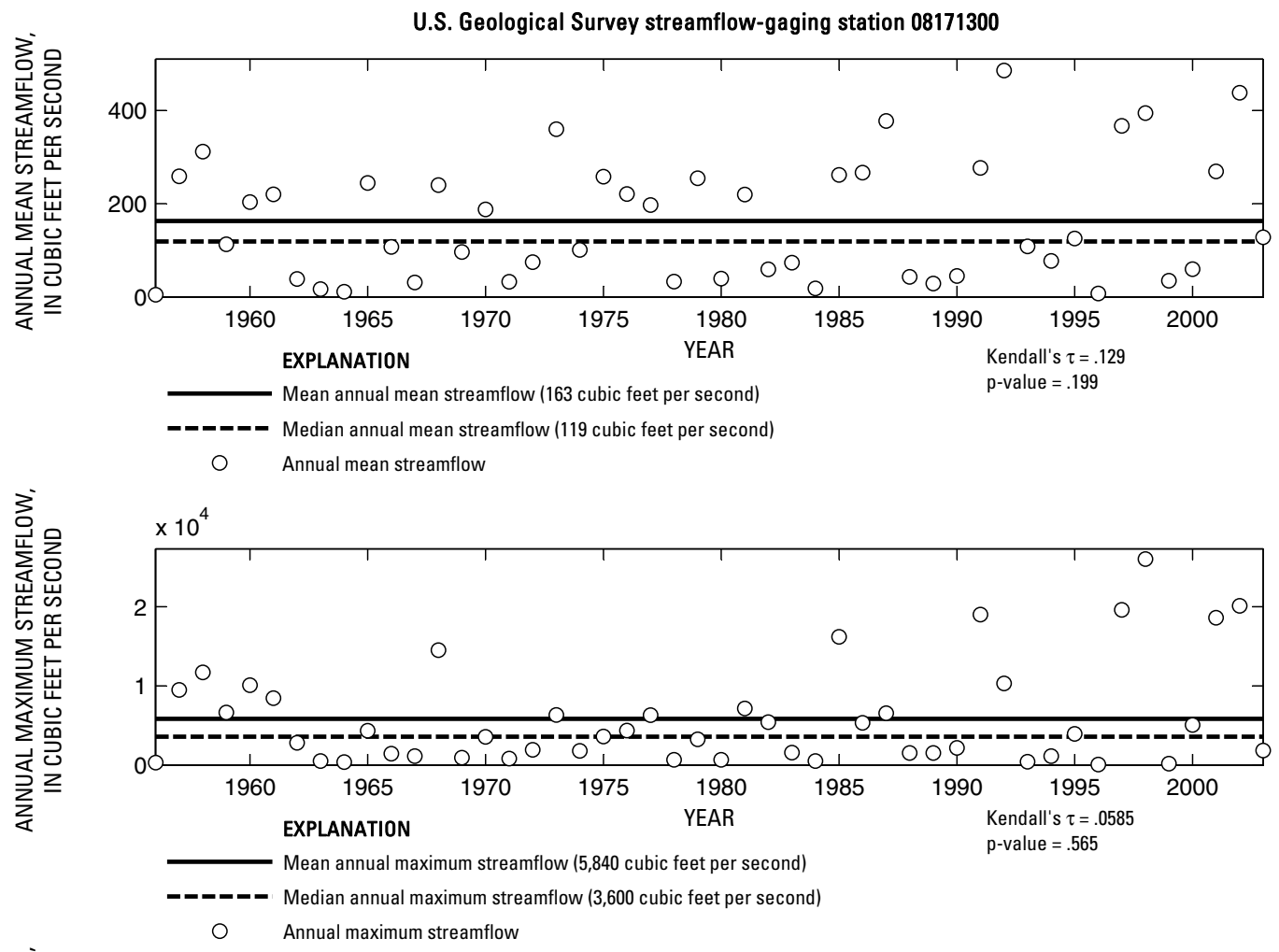

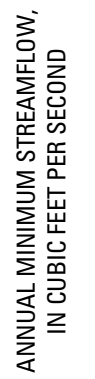

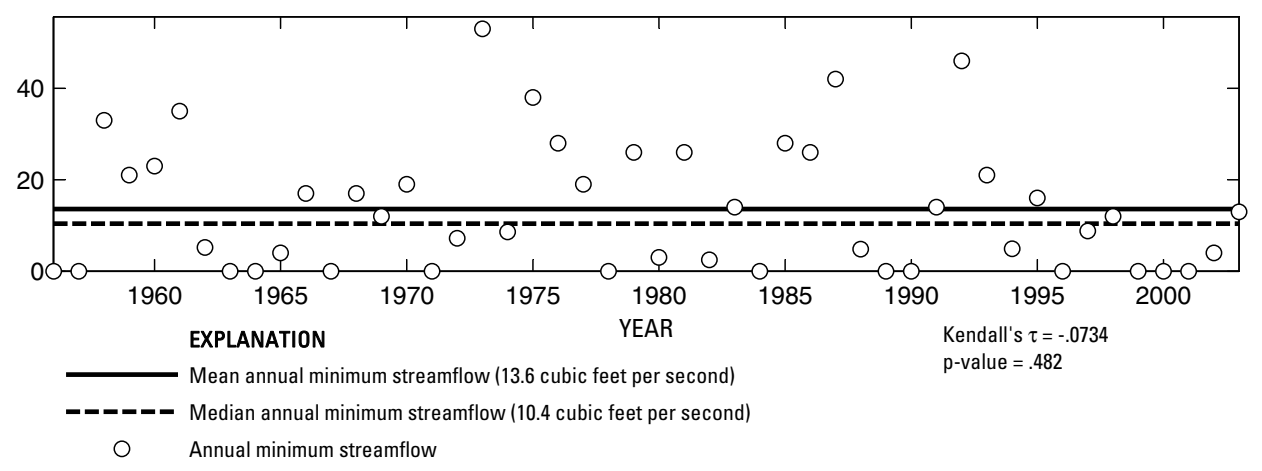

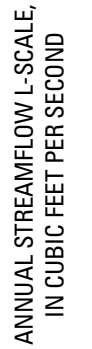

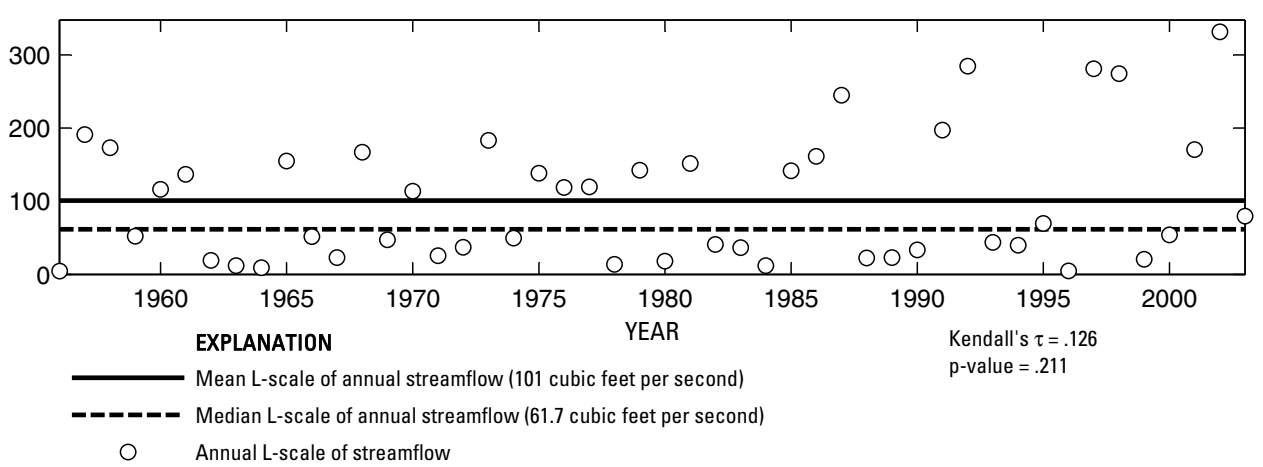

Figure 580. Analysis of annual mean, maximum, minimum, and L-scale statistics of daily mean streamflow for U.S. Geological Survey streamflow-gaging station 08171300 Blanco River near Kyle, Texas.

Index of Station Numbers 719 

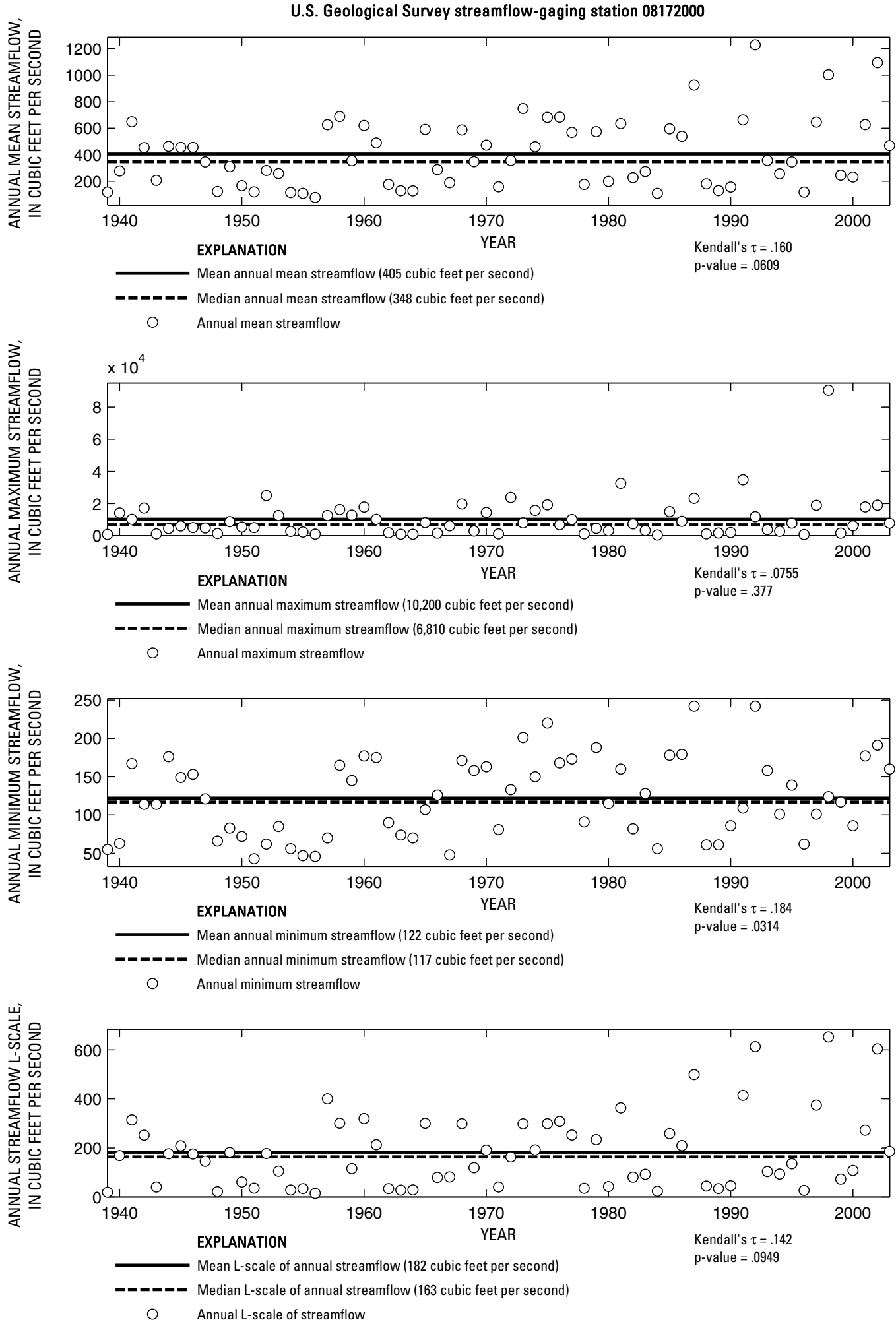

Figure 581. Analysis of annual mean, maximum, minimum, and L-scale statistics of daily mean streamflow for U.S. Geological Survey streamflow-gaging station 08172000 San Marcos River at Luling, Texas. 
U.S. Geological Survey streamflow-gaging station 08172400
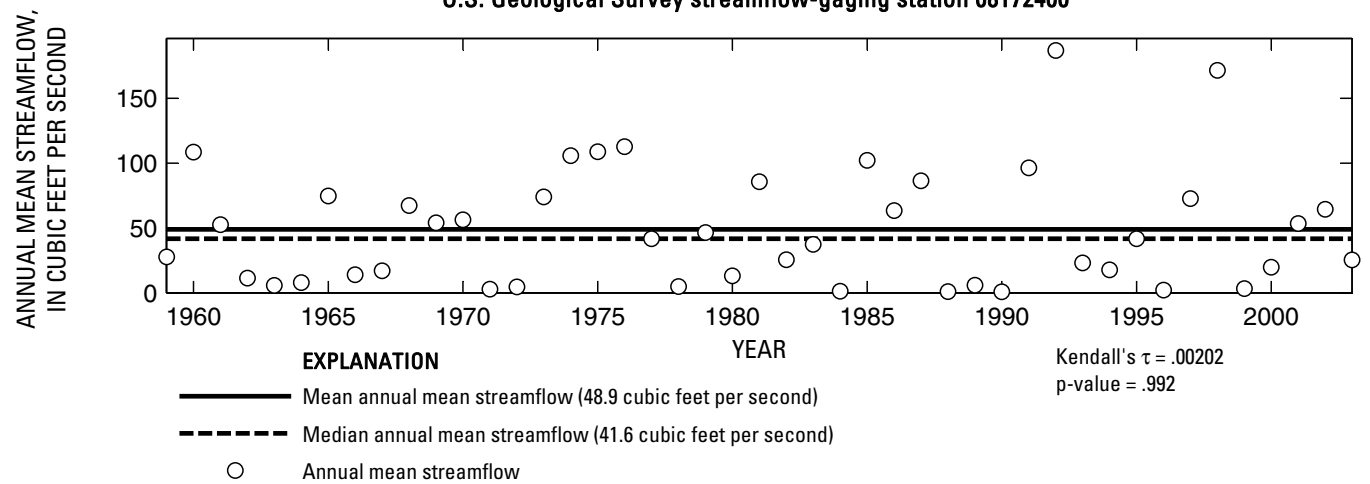

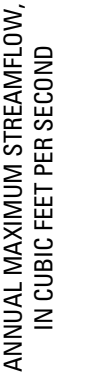

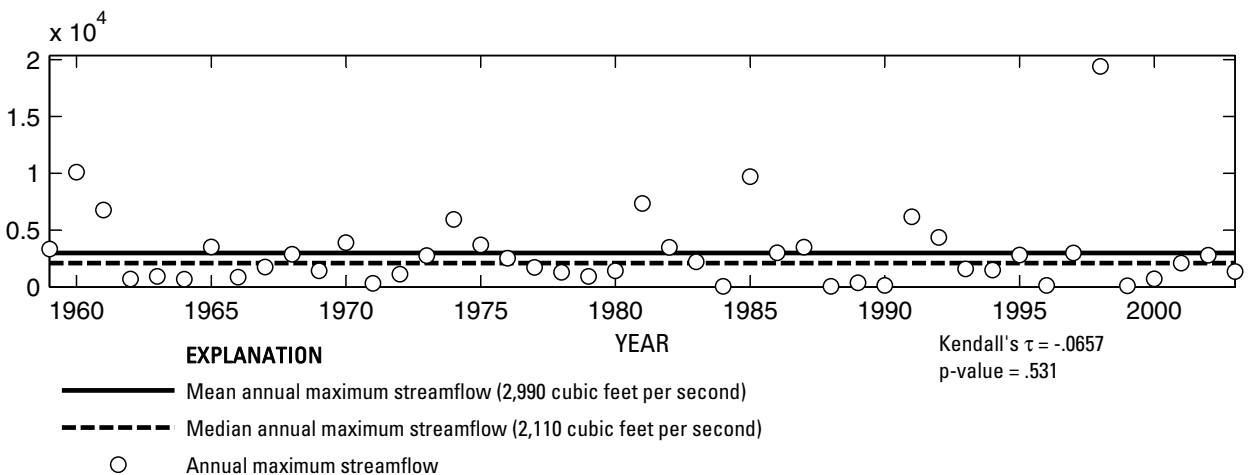

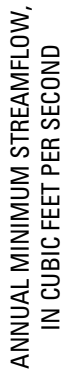

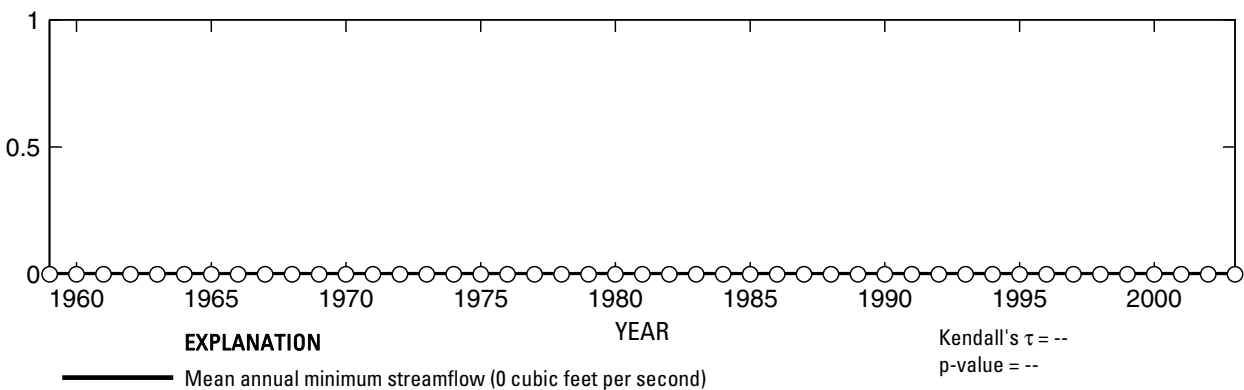

- Median annual minimum streamflow (0 cubic feet per second)

Annual minimum streamflow

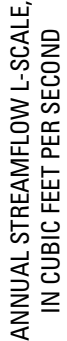

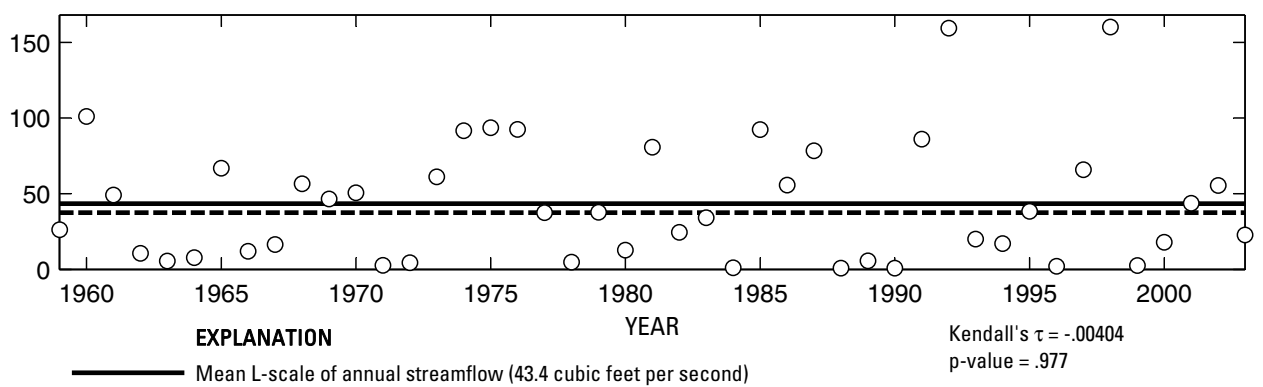

- - - - Median L-scale of annual streamflow (37.4 cubic feet per second)

Annual L-scale of streamflow

Figure 582. Analysis of annual mean, maximum, minimum, and L-scale statistics of daily mean streamflow for U.S. Geological Survey streamflow-gaging station 08172400 Plum Creek at Lockhart, Texas.

Index of Station Numbers 719 


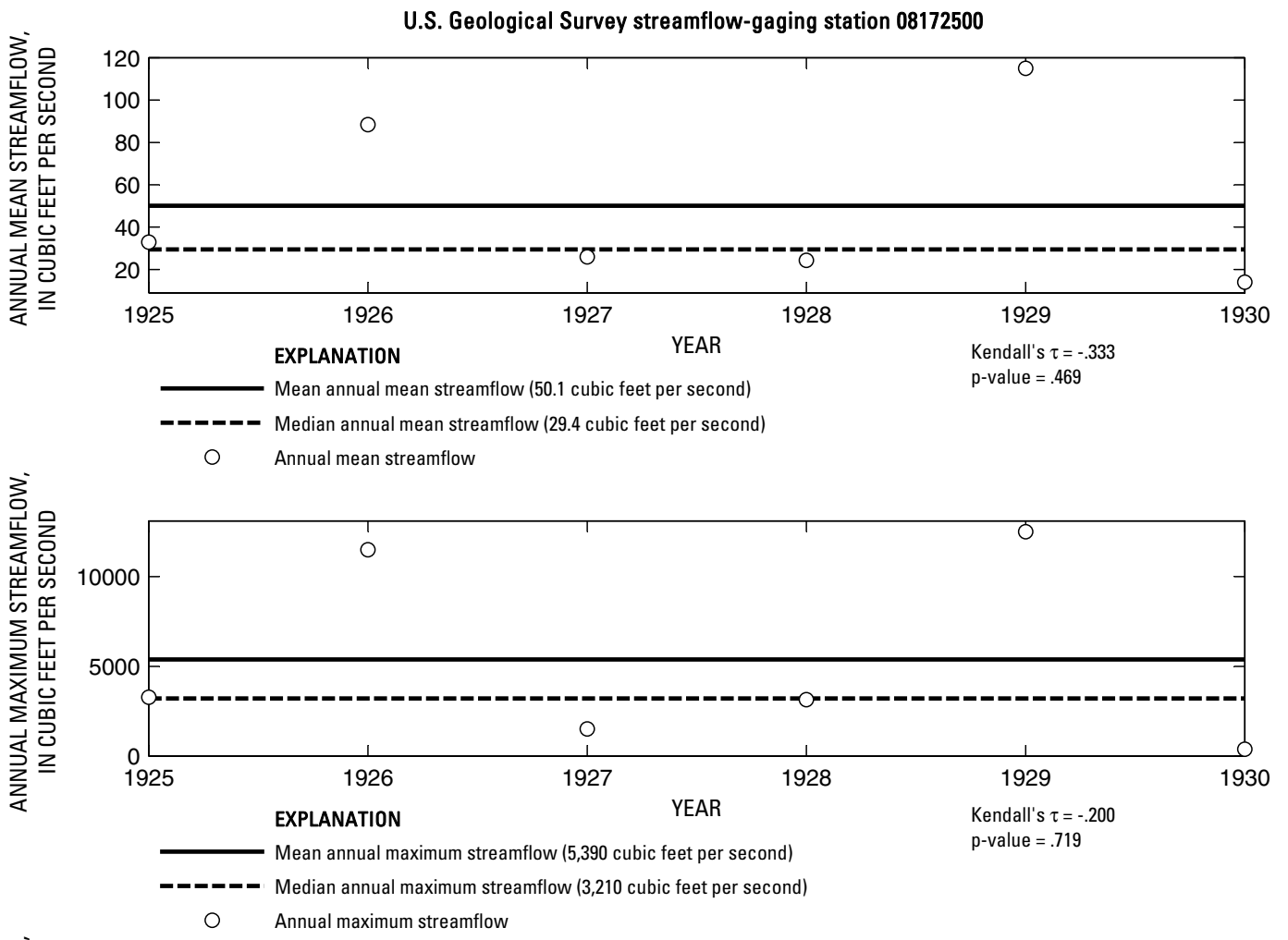

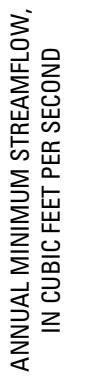

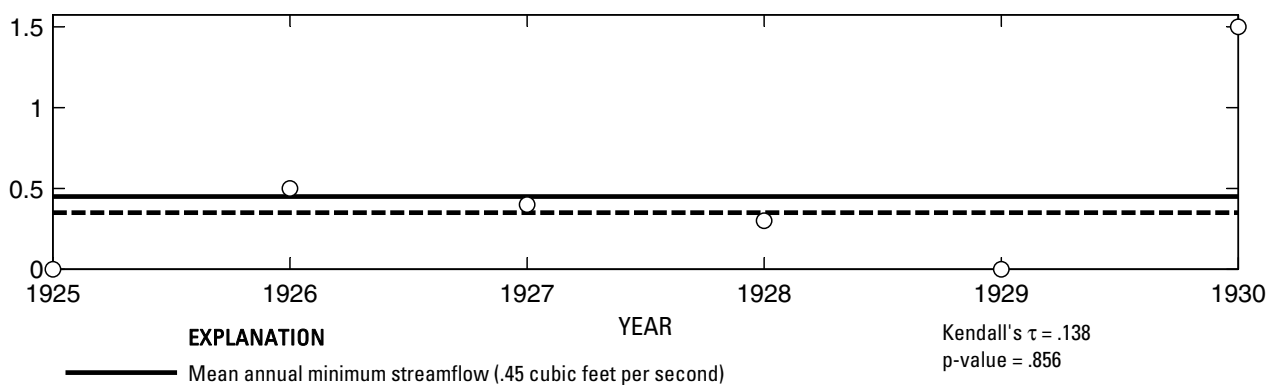

- - - Median annual minimum streamflow (.35 cubic feet per second)

○ Annual minimum streamflow

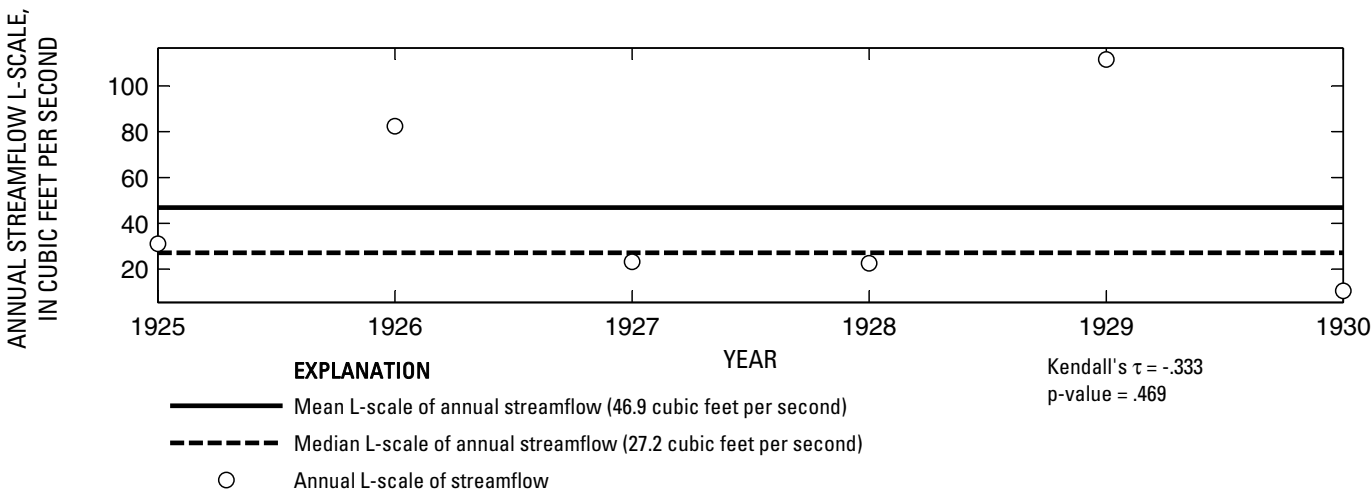

Figure 583. Analysis of annual mean, maximum, minimum, and L-scale statistics of daily mean streamflow for U.S. Geological Survey streamflow-gaging station 08172500 Plum Creek near Lockhart, Texas. 


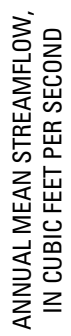

U.S. Geological Survey streamflow-gaging station 08173000

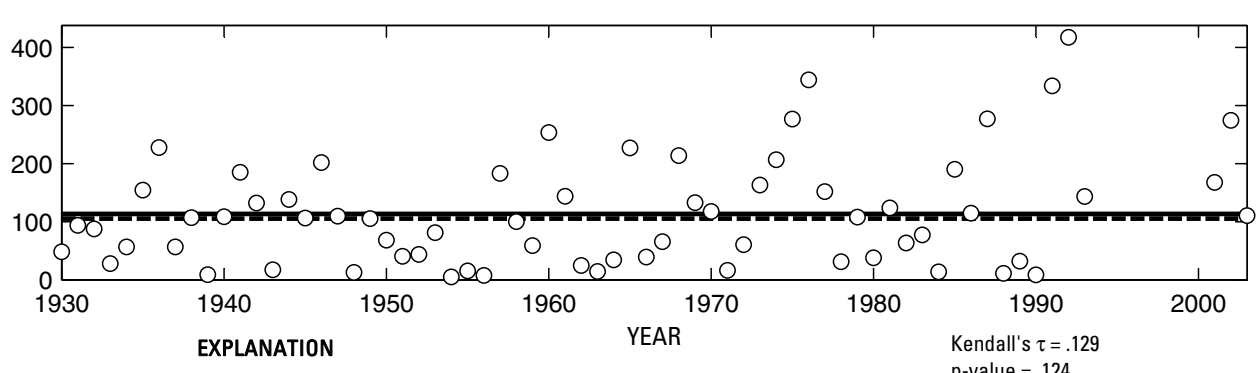

Mean annual mean streamflow (114 cubic feet per second)

- Median annual mean streamflow (105 cubic feet per second)

O Annual mean streamflow
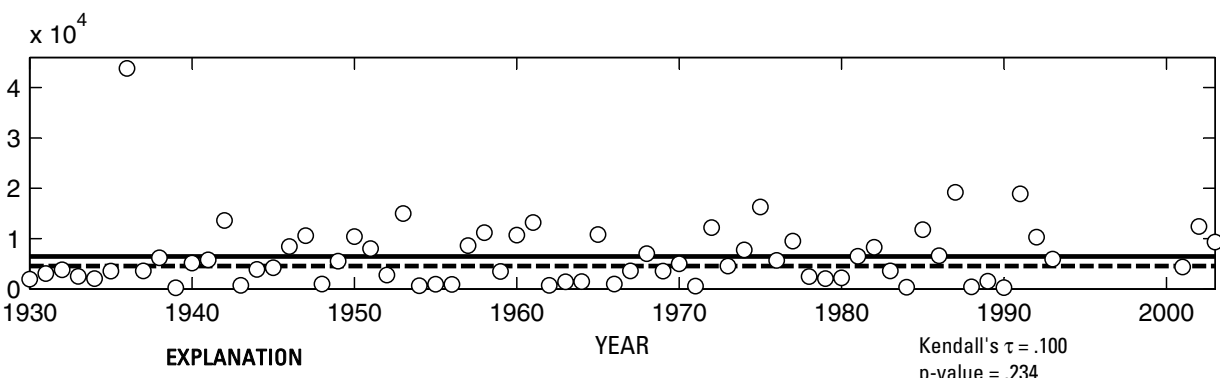

EXPLANATION

- Mean annual maximum streamflow (6,470 cubic feet per second)

- - Median annual maximum streamflow $(4,550$ cubic feet per second

O Annual maximum streamflow

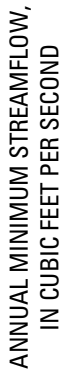

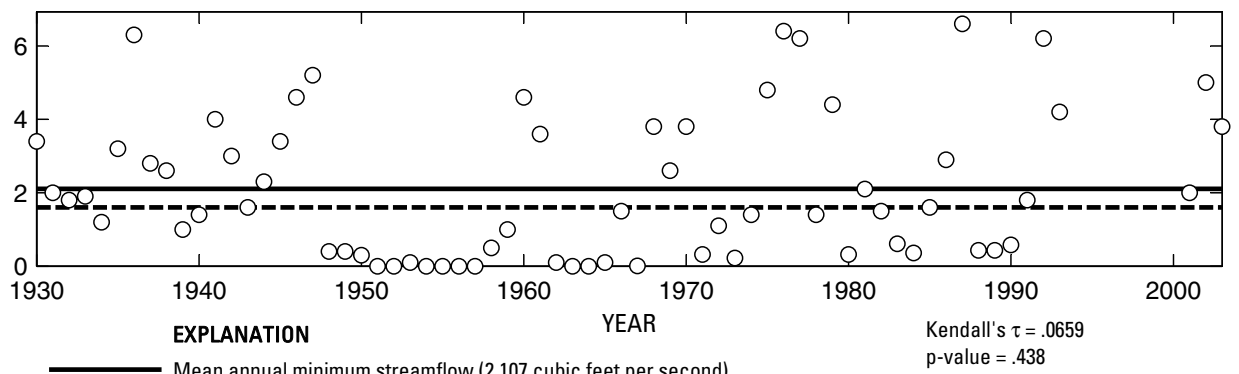

- Median annual minimum streamflow (1.6 cubic feet per second)

O Annual minimum streamflow

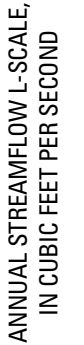

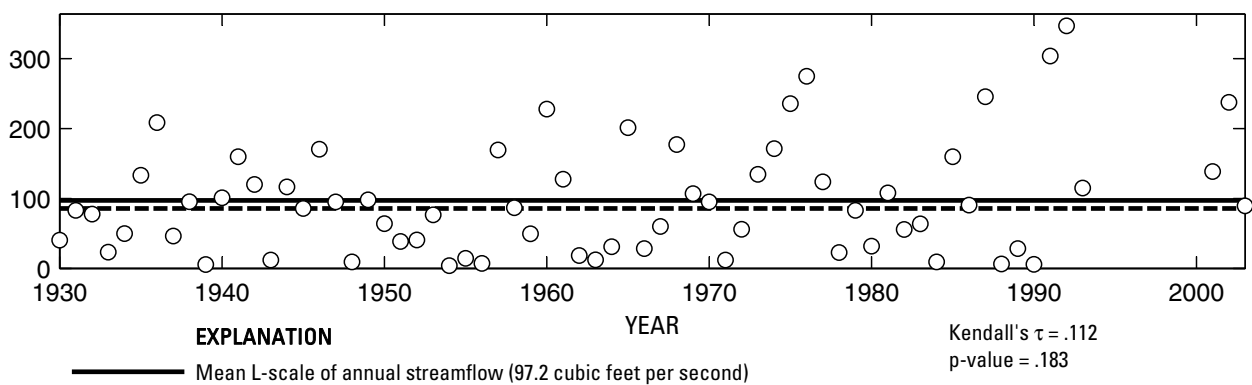

- - - Median L-scale of annual streamflow (85.7 cubic feet per second)

Annual L-scale of streamflow

Figure 584. Analysis of annual mean, maximum, minimum, and L-scale statistics of daily mean streamflow for U.S. Geological Survey streamflow-gaging station 08173000 Plum Creek near Luling, Texas.

Index of Station Numbers 719 


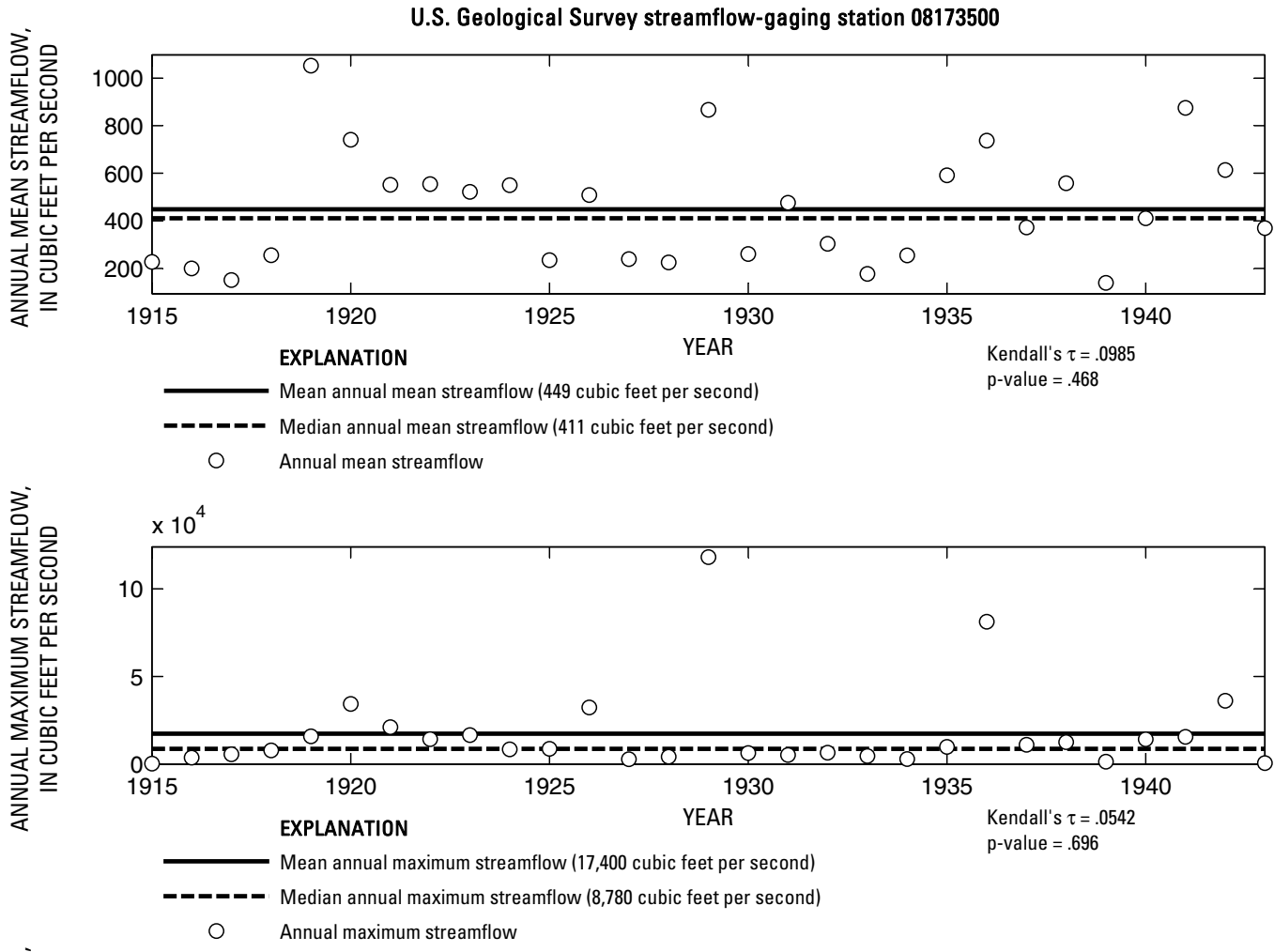

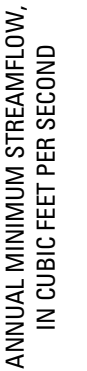

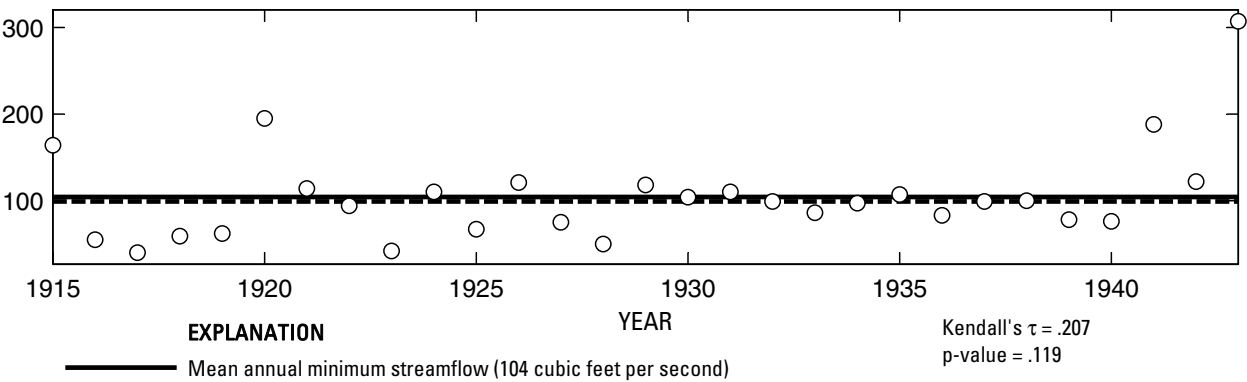

- - Median annual minimum streamflow (99 cubic feet per second)

O Annual minimum streamflow

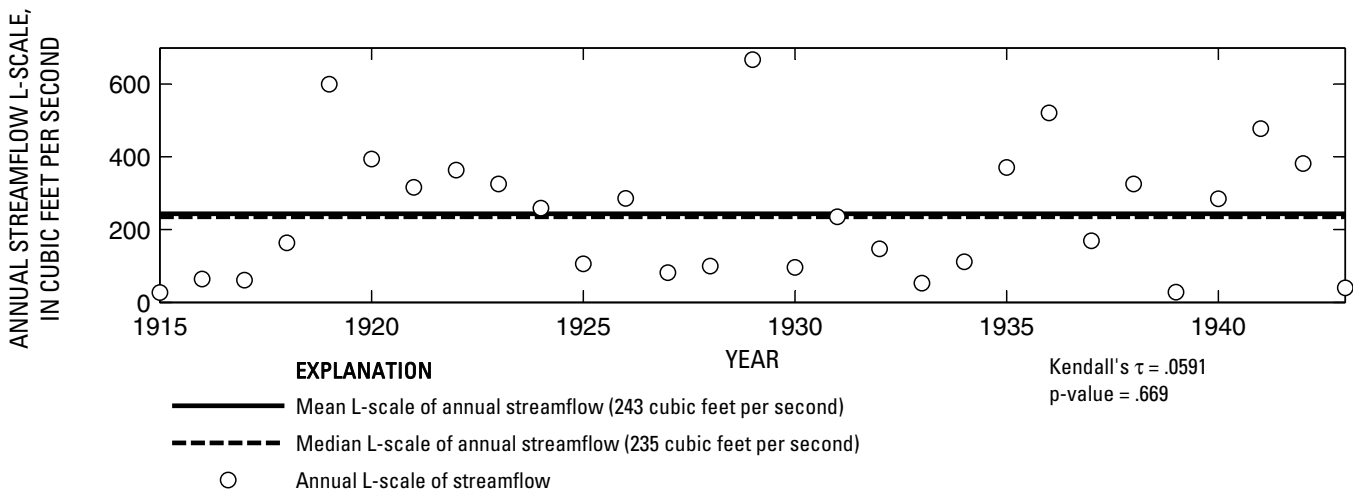

Figure 585. Analysis of annual mean, maximum, minimum, and L-scale statistics of daily mean streamflow for U.S. Geological Survey streamflow-gaging station 08173500 San Marcos River at Ottine, Texas. 


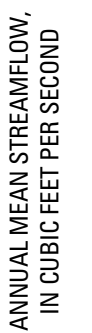

U.S. Geological Survey streamflow-gaging station 08173900

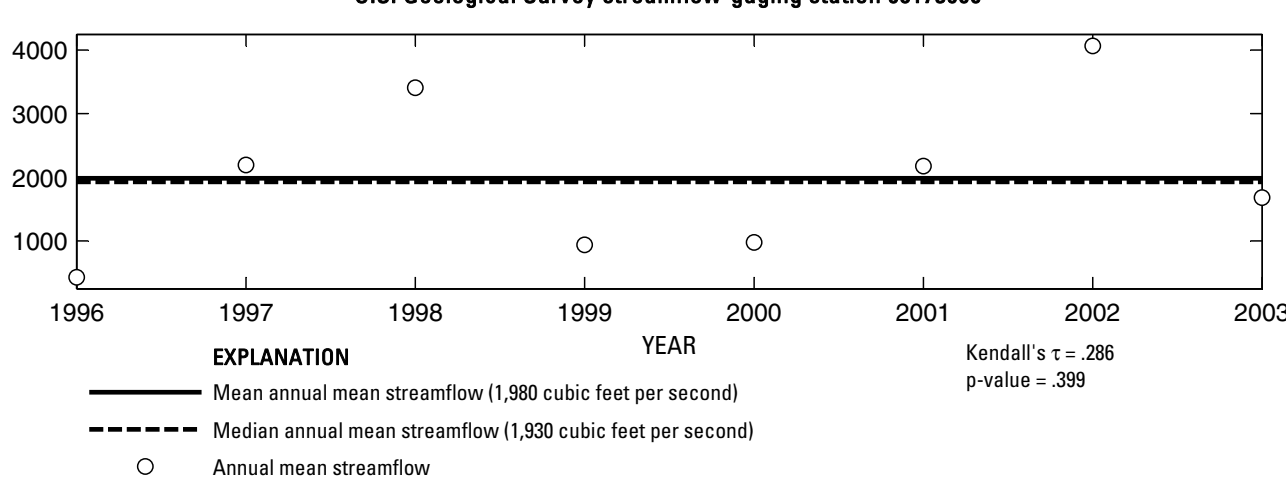

Annual mean streamflow

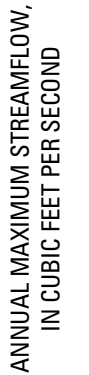

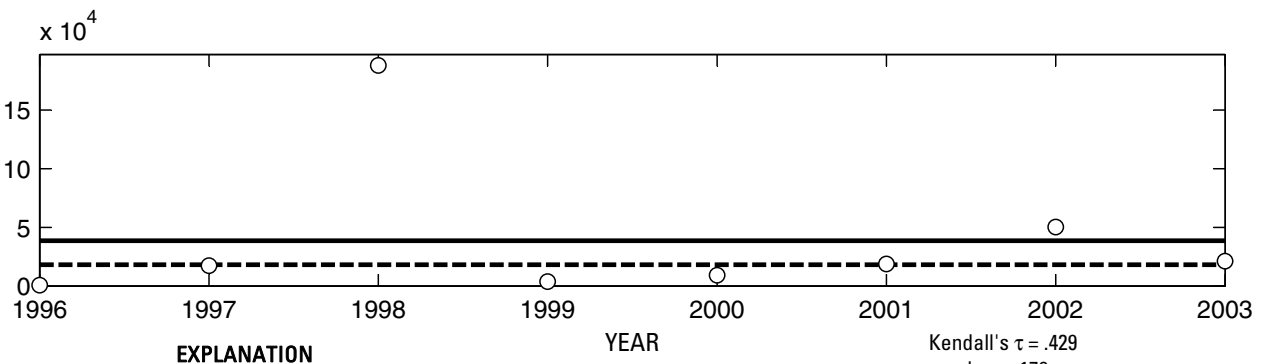

-ーーーーー Median annual maximum streamflow (18,100 cubic feet per second)

O Annual maximum streamflow

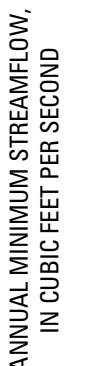

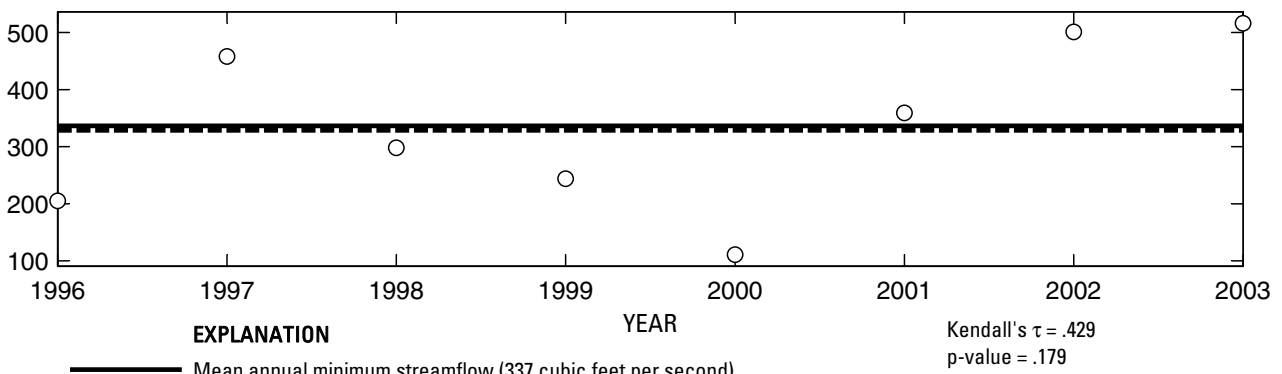

- Median annual minimum streamflow (329 cubic feet per second)

O Annual minimum streamflow

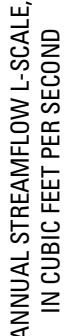

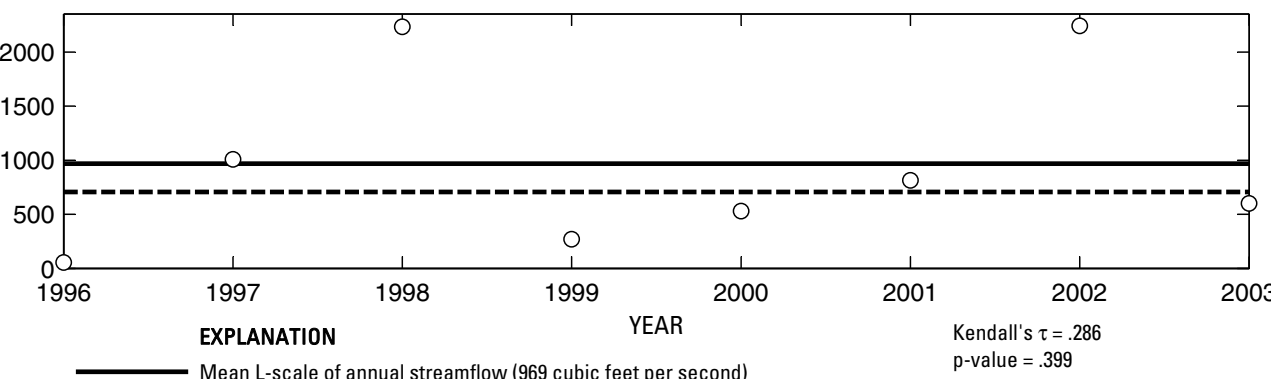

- - - Median L-scale of annual streamflow (707 cubic feet per second)

Annual L-scale of streamflow

Figure 586. Analysis of annual mean, maximum, minimum, and L-scale statistics of daily mean streamflow for U.S. Geological Survey streamflow-gaging station 08173900 Guadalupe River at Gonzales, Texas.

Index of Station Numbers 719 


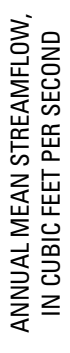

U.S. Geological Survey streamflow-gaging station 08174600

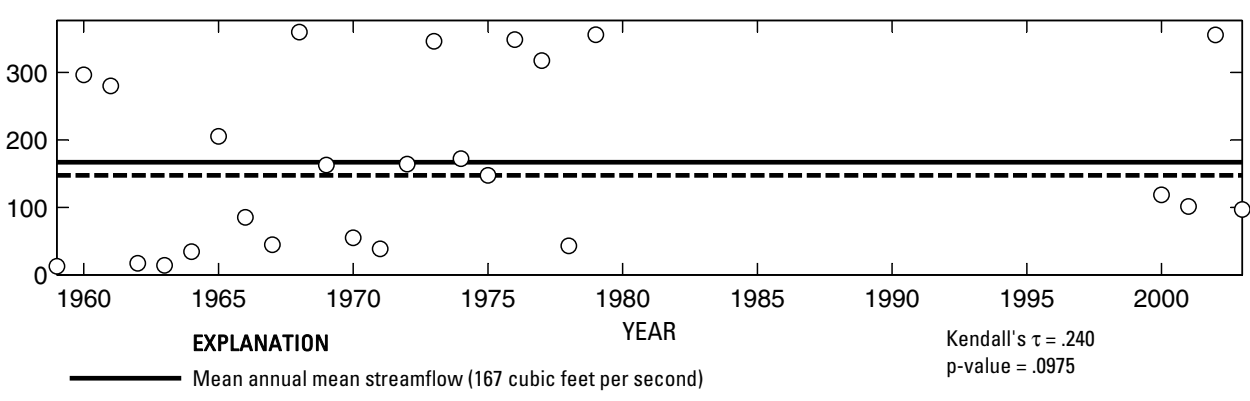

-_-_- Median annual mean streamflow (148 cubic feet per second)

O Annual mean streamflow

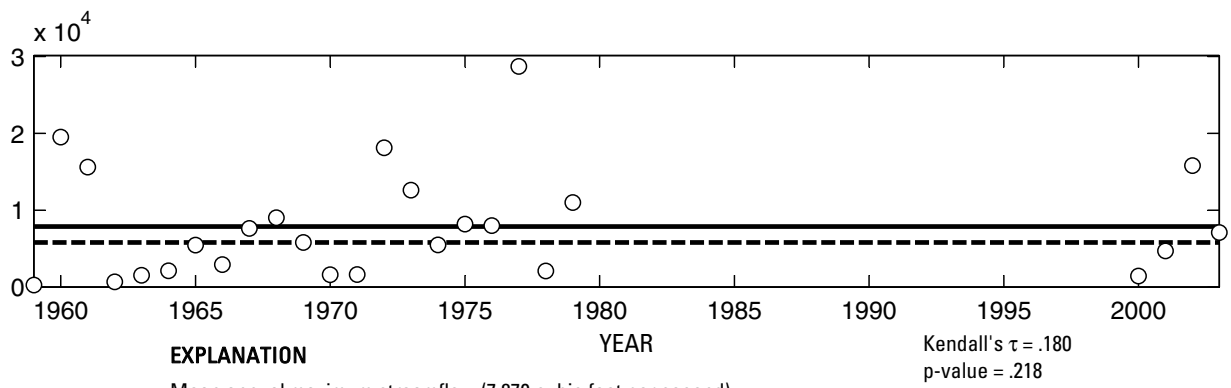

- Mean annual maximum streamflow (7,870 cubic feet per second)

Annual maximum streamflow

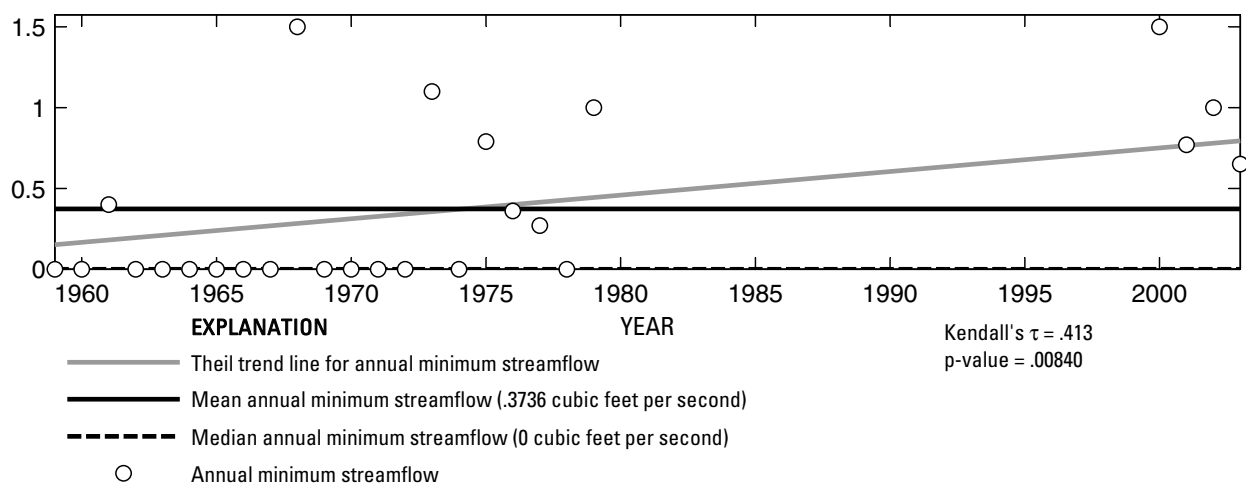

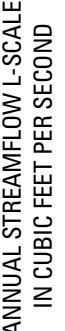

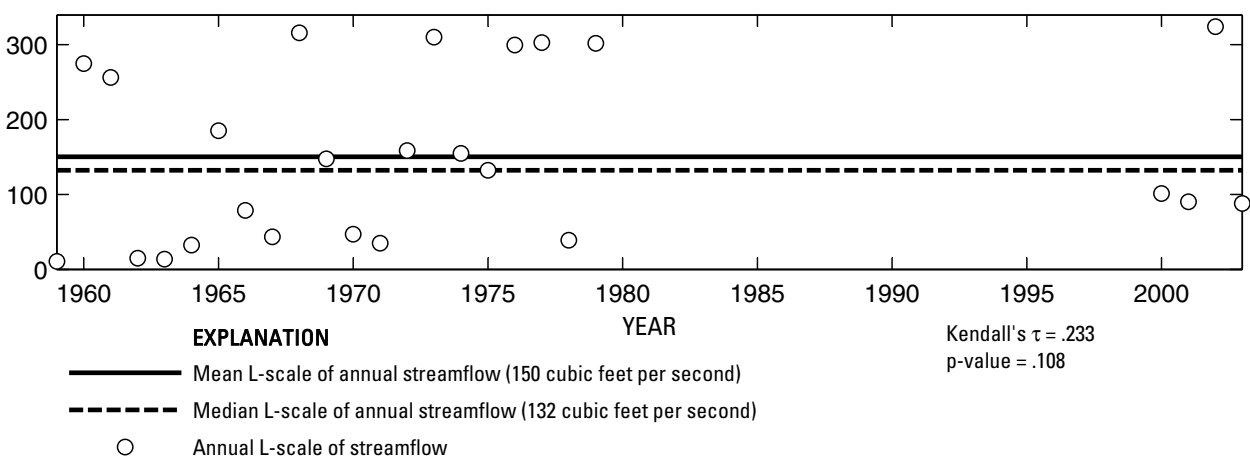

Figure 587. Analysis of annual mean, maximum, minimum, and L-scale statistics of daily mean streamflow for U.S. Geological Survey streamflow-gaging station 08174600 Peach Creek below Dilworth, Texas. 


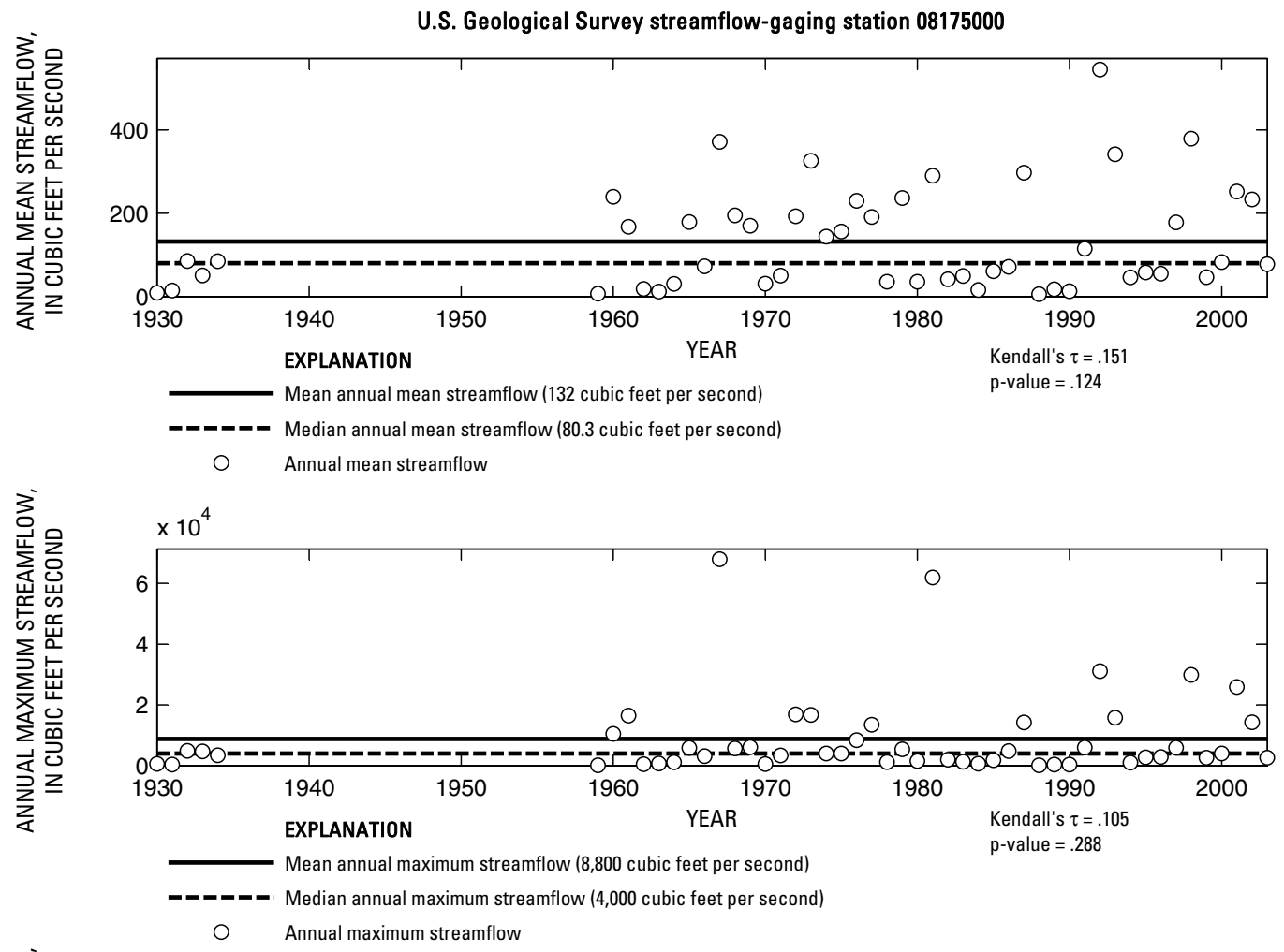

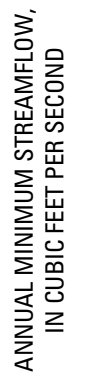
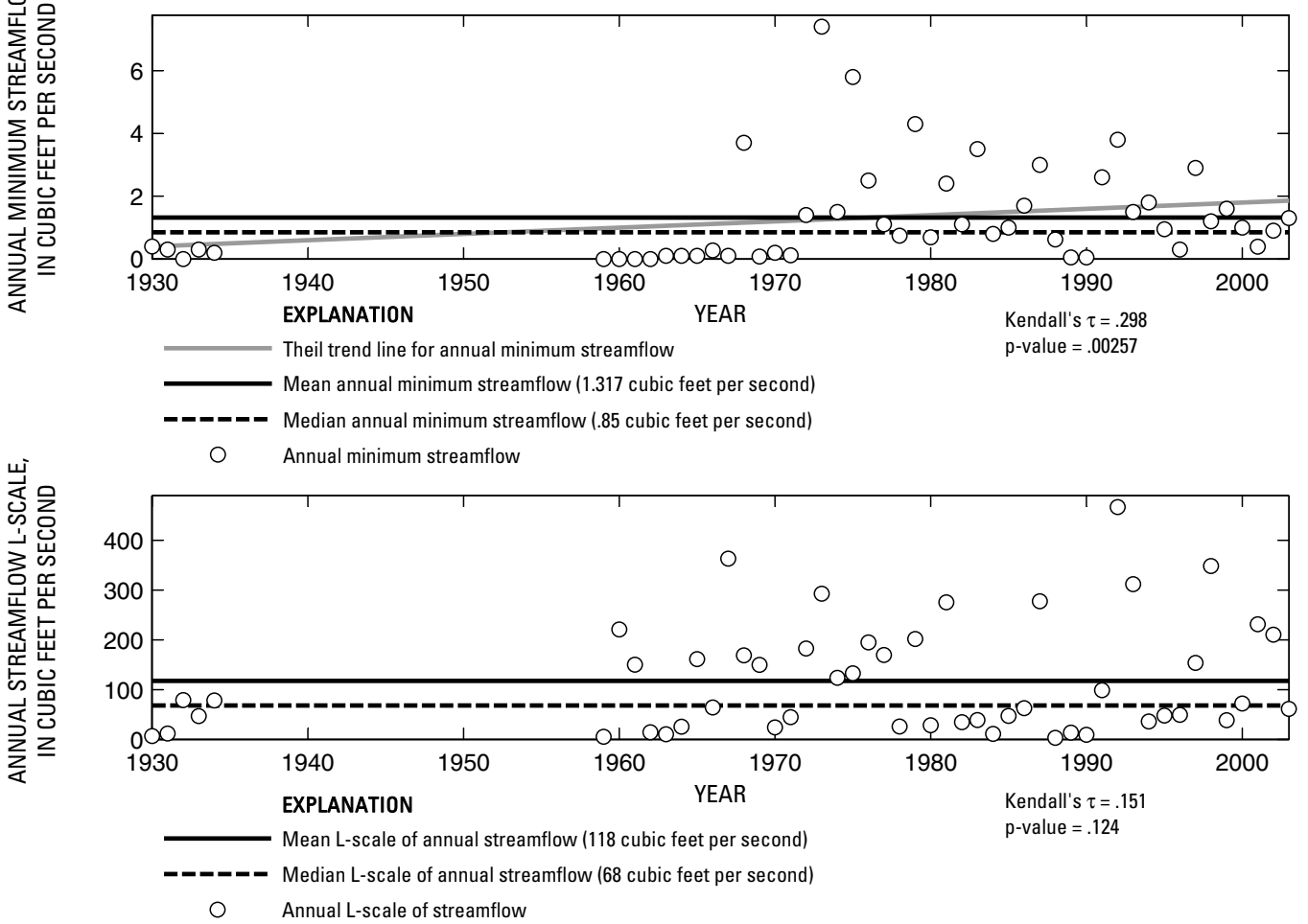

Figure 588. Analysis of annual mean, maximum, minimum, and L-scale statistics of daily mean streamflow for U.S. Geological Survey streamflow-gaging station 08175000 Sandies Creek near Westhoff, Texas.

Index of Station Numbers 719 

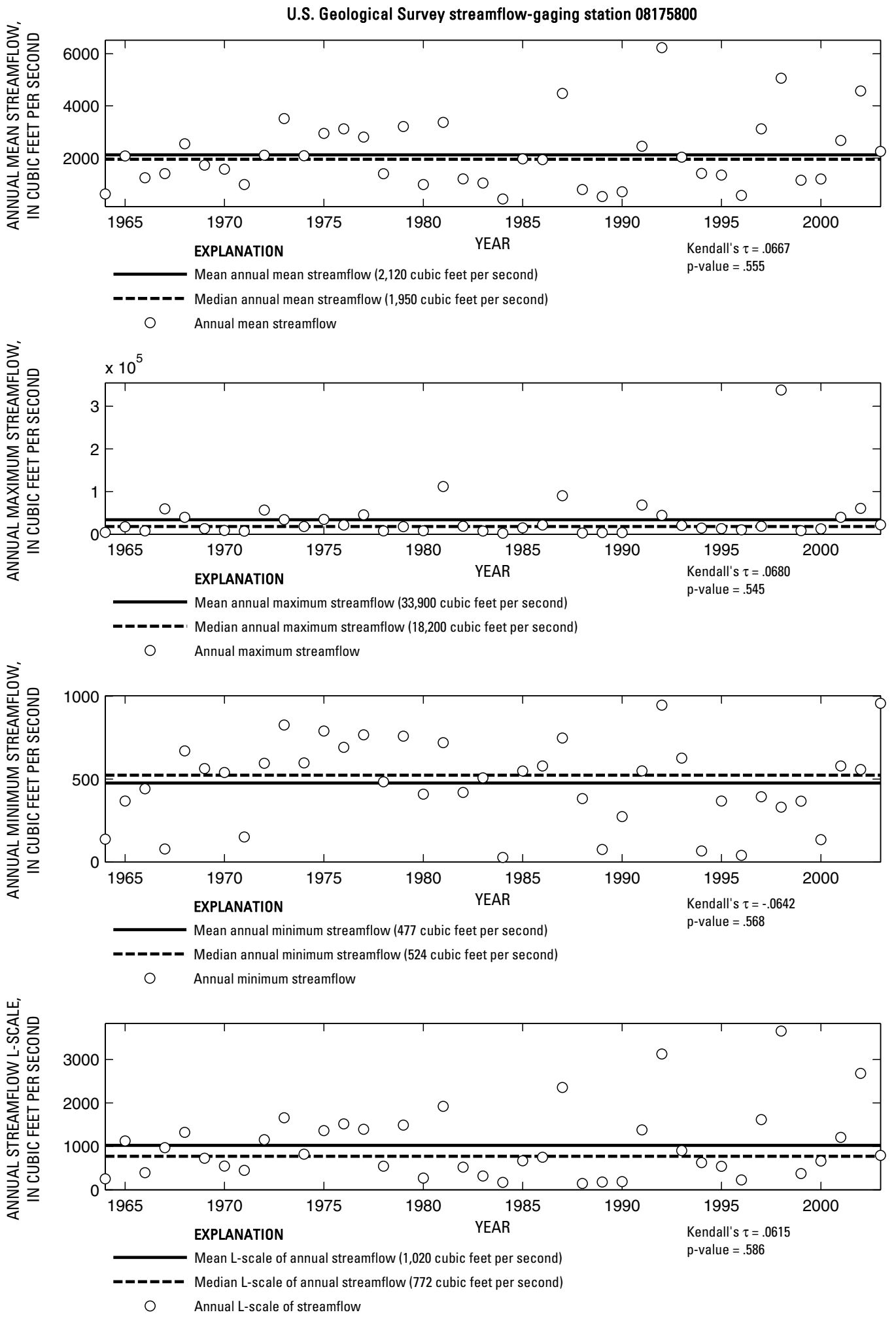

Figure 589. Analysis of annual mean, maximum, minimum, and L-scale statistics of daily mean streamflow for U.S. Geological Survey streamflow-gaging station 08175800 Guadalupe River at Cuero, Texas. 

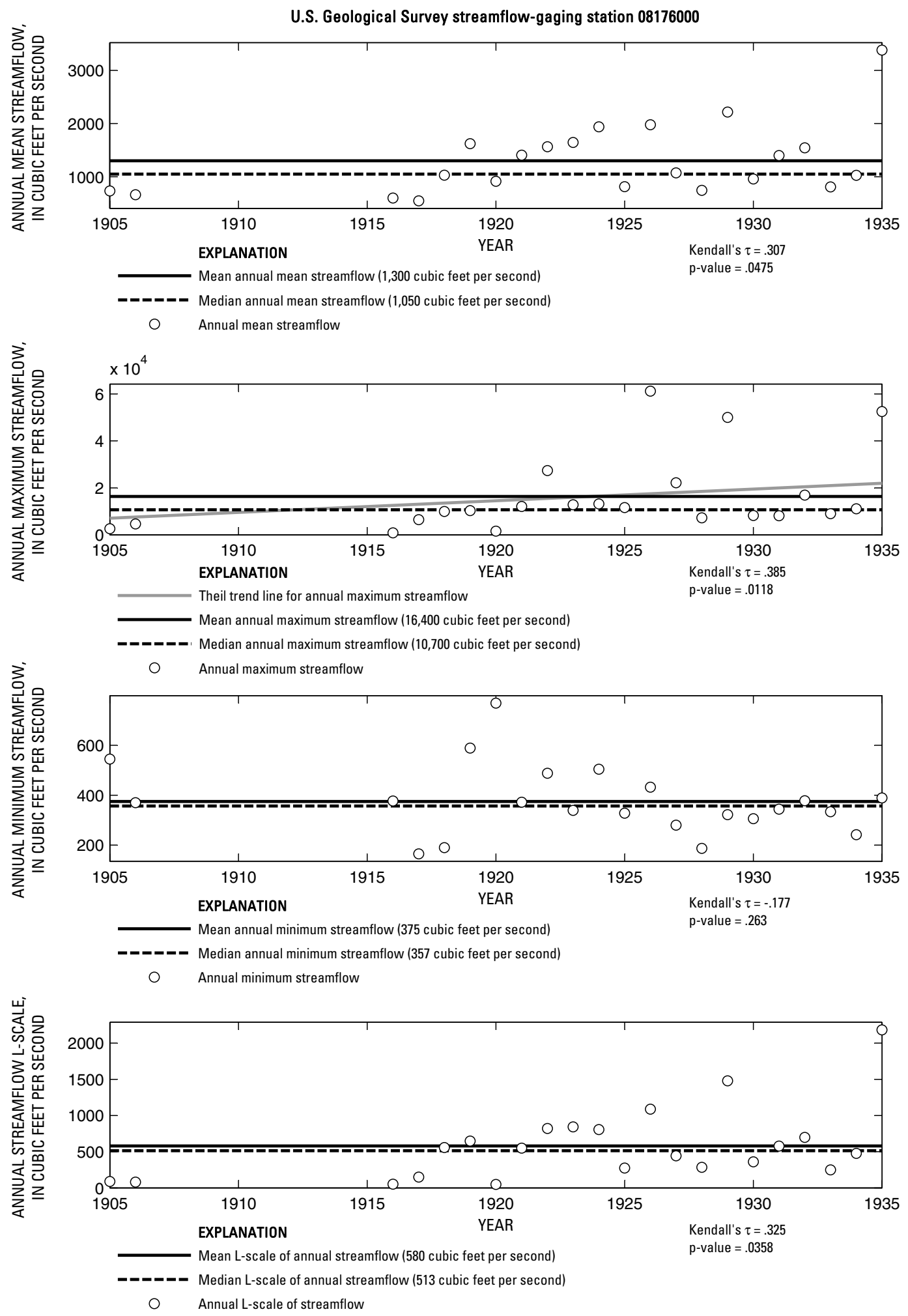

Figure 590. Analysis of annual mean, maximum, minimum, and L-scale statistics of daily mean streamflow for U.S. Geological Survey streamflow-gaging station 08176000 Guadalupe River below Cuero, Texas.

|ndex of Station Numbers 719 

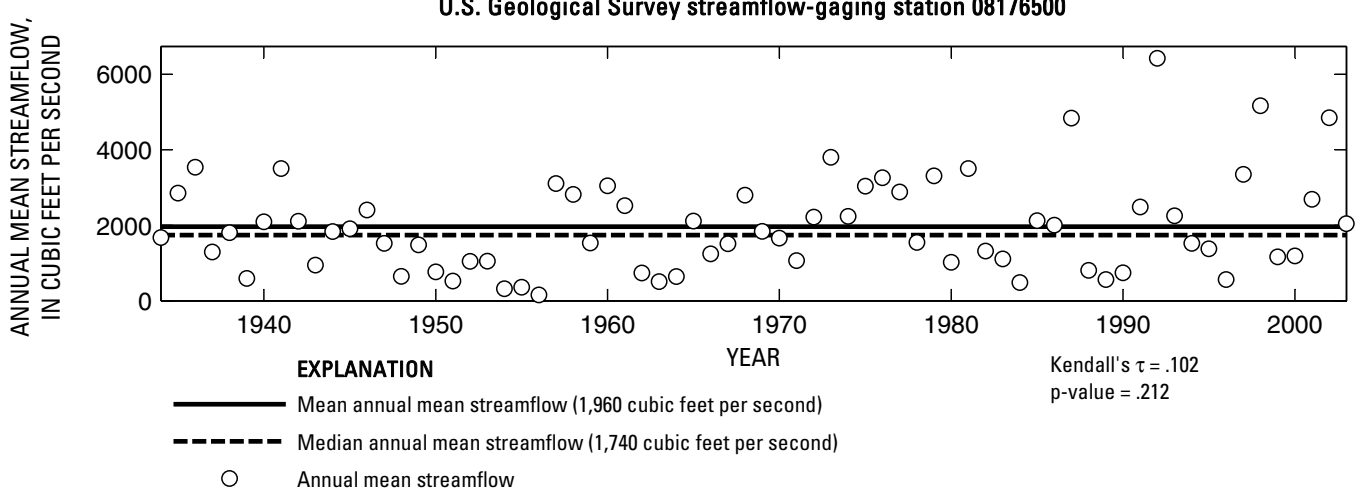

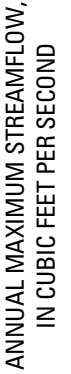
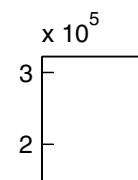

$1-$
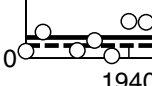

1940

EXPLANATION

Mean annual maximum streamflow $(28,400$ cubic feet per second)

- - Median annual maximum streamflow (17,400 cubic feet per second)

O Annual maximum streamflow

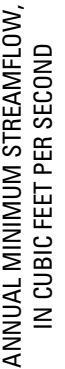

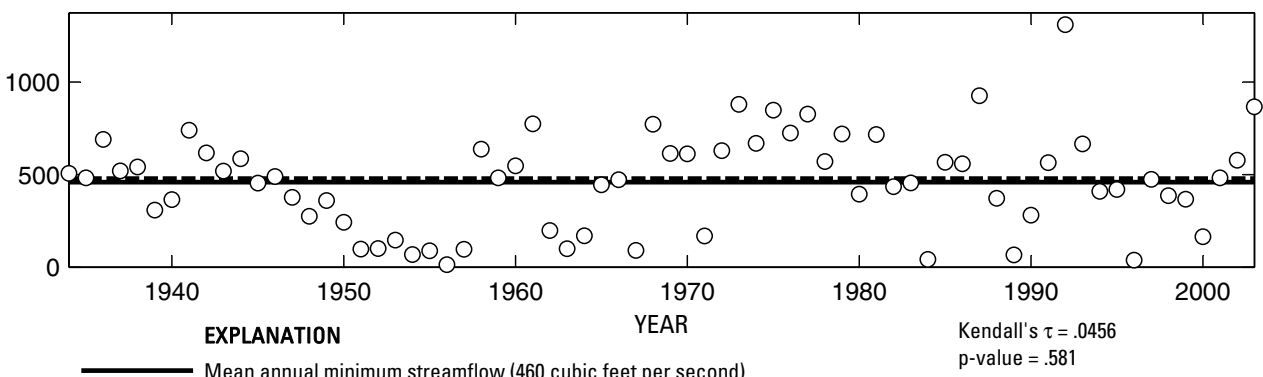

- Median annual minimum streamflow (479 cubic feet per second)

O Annual minimum streamflow

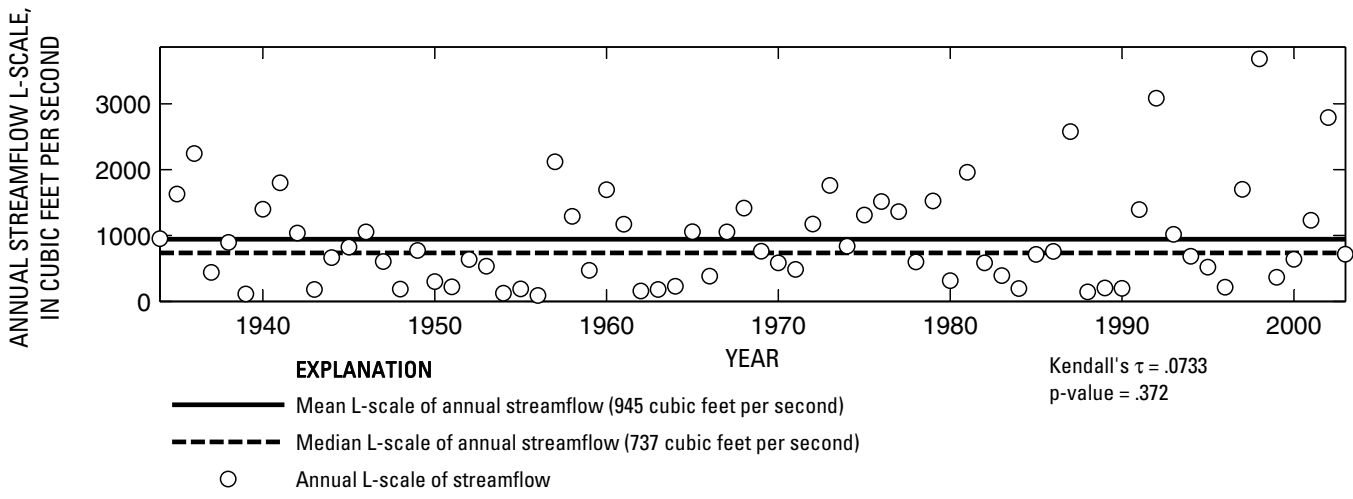

Figure 591. Analysis of annual mean, maximum, minimum, and L-scale statistics of daily mean streamflow for U.S. Geological Survey streamflow-gaging station 08176500 Guadalupe River at Victoria, Texas. 


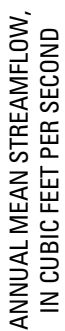

U.S. Geological Survey streamflow-gaging station 08176550

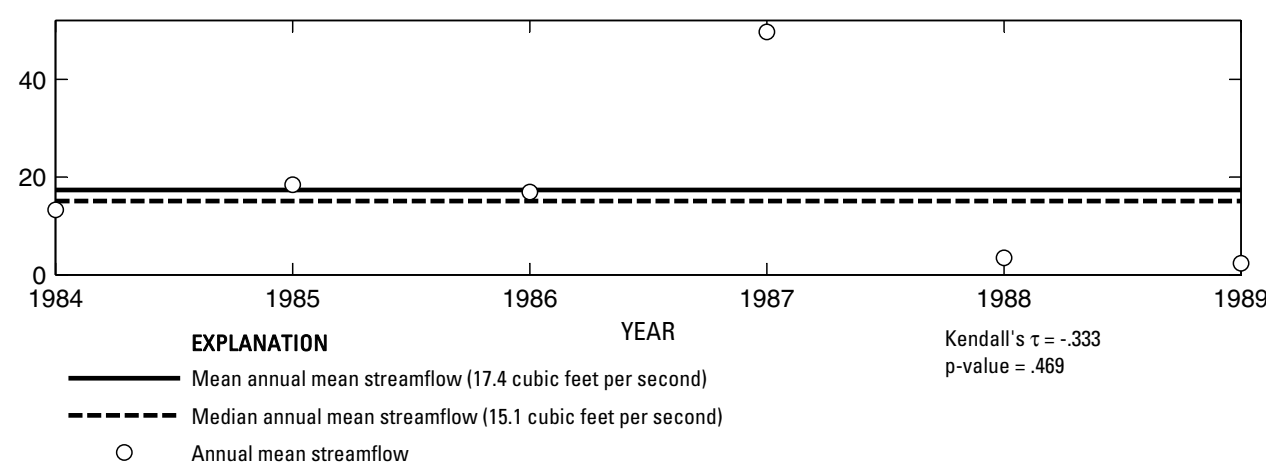

要

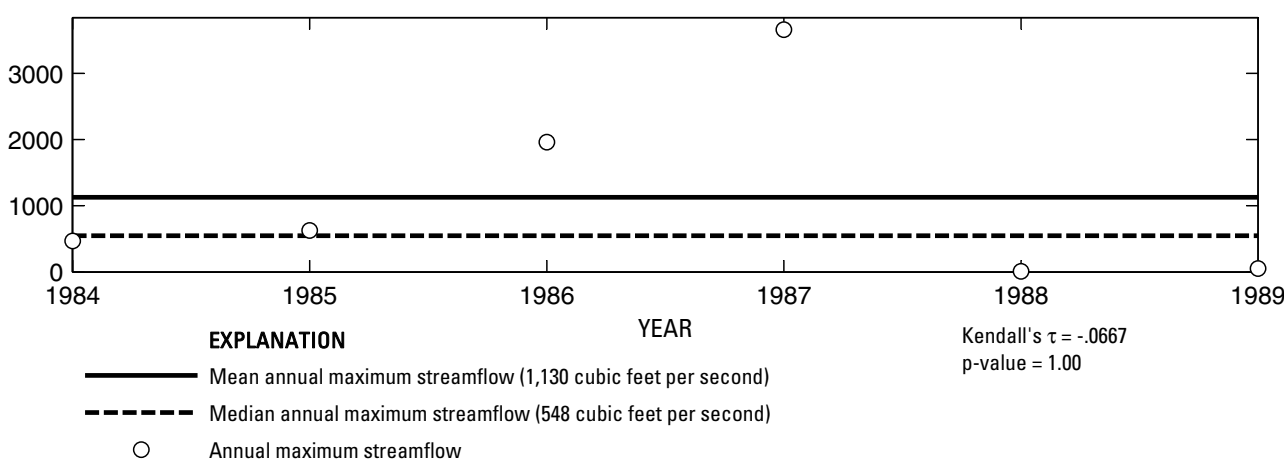

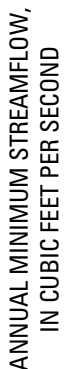

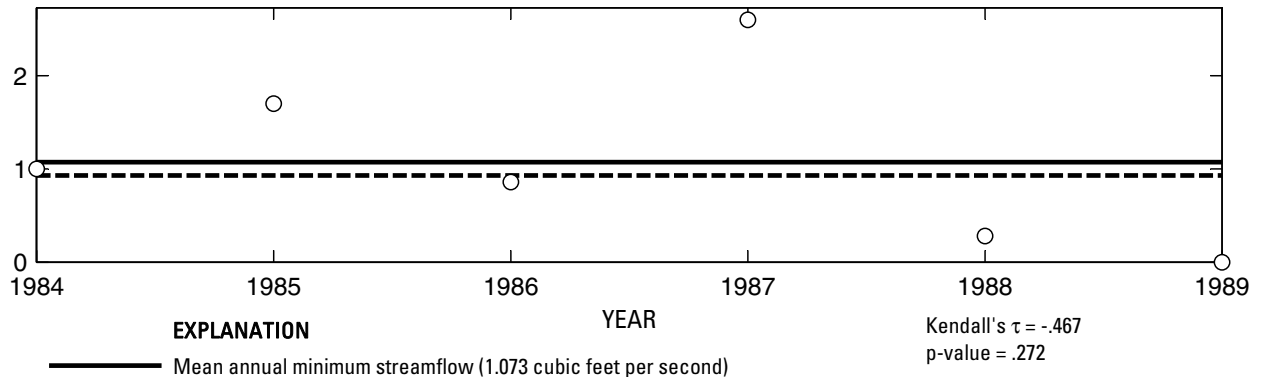

- Median annual minimum streamflow (.93 cubic feet per second)

O Annual minimum streamflow

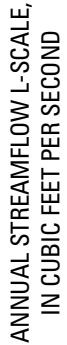

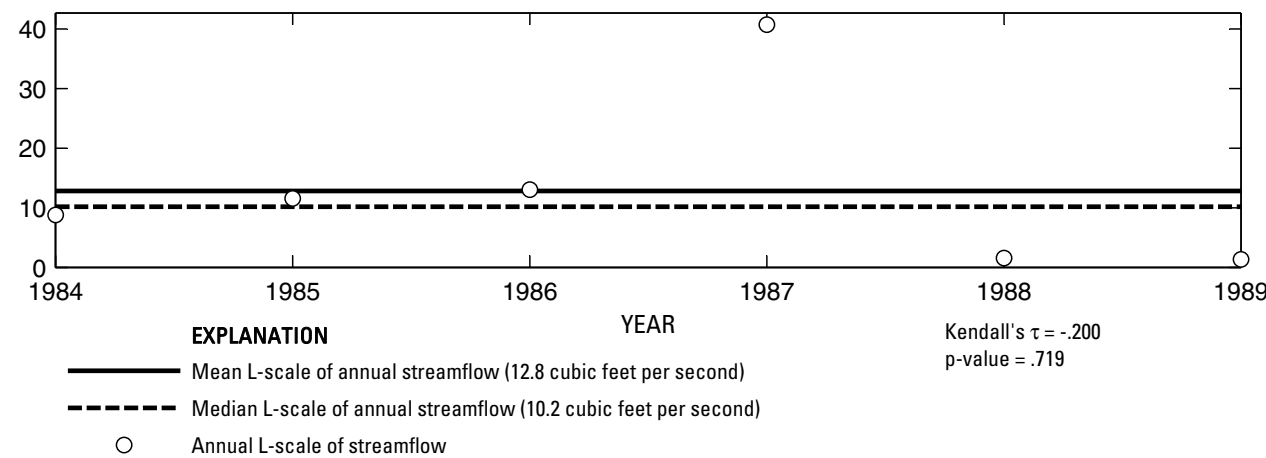

Figure 592. Analysis of annual mean, maximum, minimum, and L-scale statistics of daily mean streamflow for U.S. Geological Survey streamflow-gaging station 08176550 Fifteenmile Creek near Weser, Texas.

Index of Station Numbers 719 

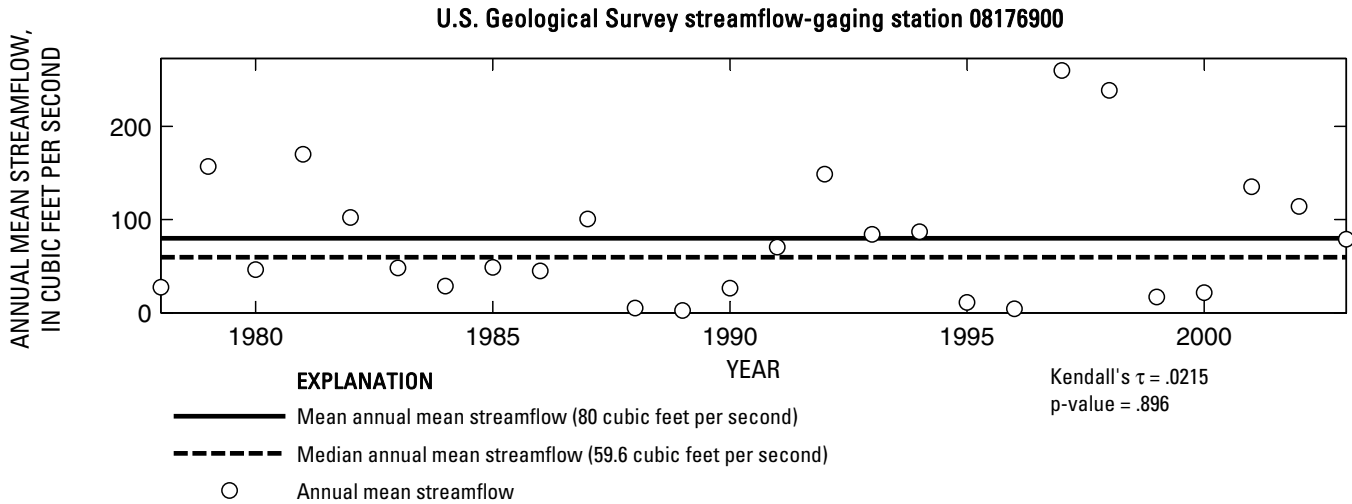

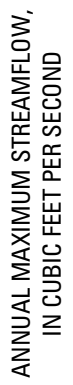

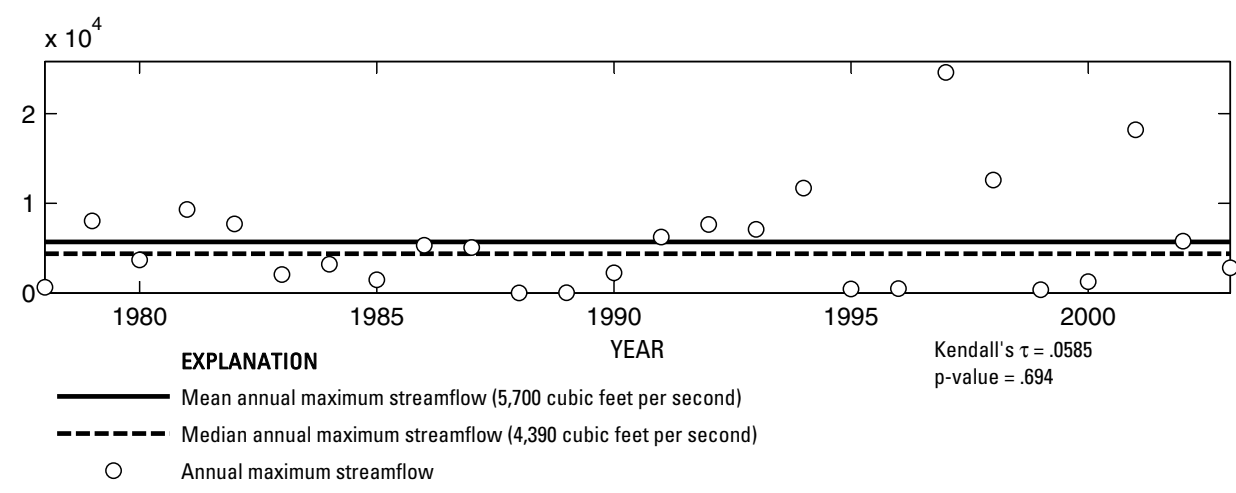

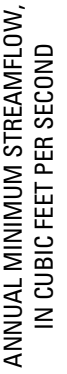

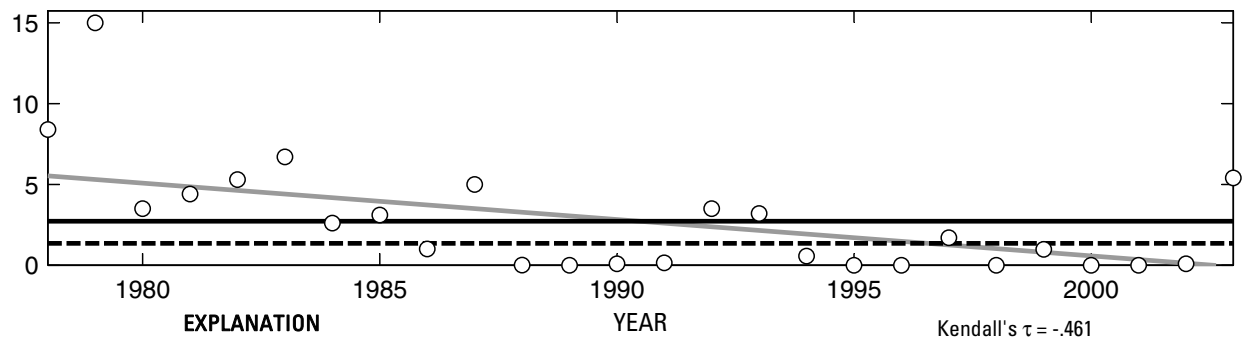

- Theil trend line for annual minimum streamflow

Theil trend line for annual minimum streamflow
Mean annual minimum streamflow ( 2.718 cubic feet per second)

- - Median annual minimum streamflow (1.35 cubic feet per second)

O Annual minimum streamflow

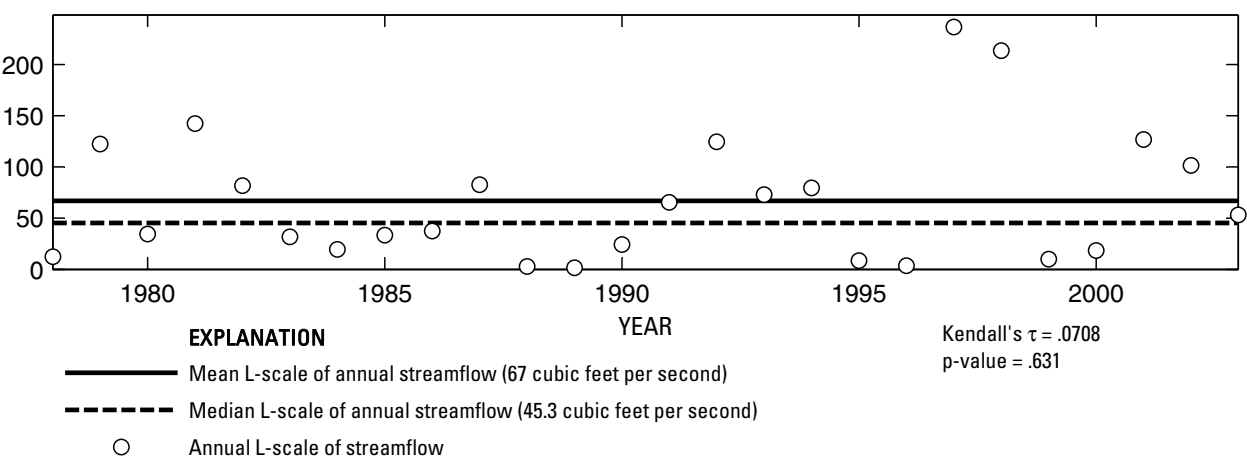

Figure 593. Analysis of annual mean, maximum, minimum, and L-scale statistics of daily mean streamflow for U.S. Geological Survey streamflow-gaging station 08176900 Coleto Creek at Arnold Road near Schroeder, Texas. 


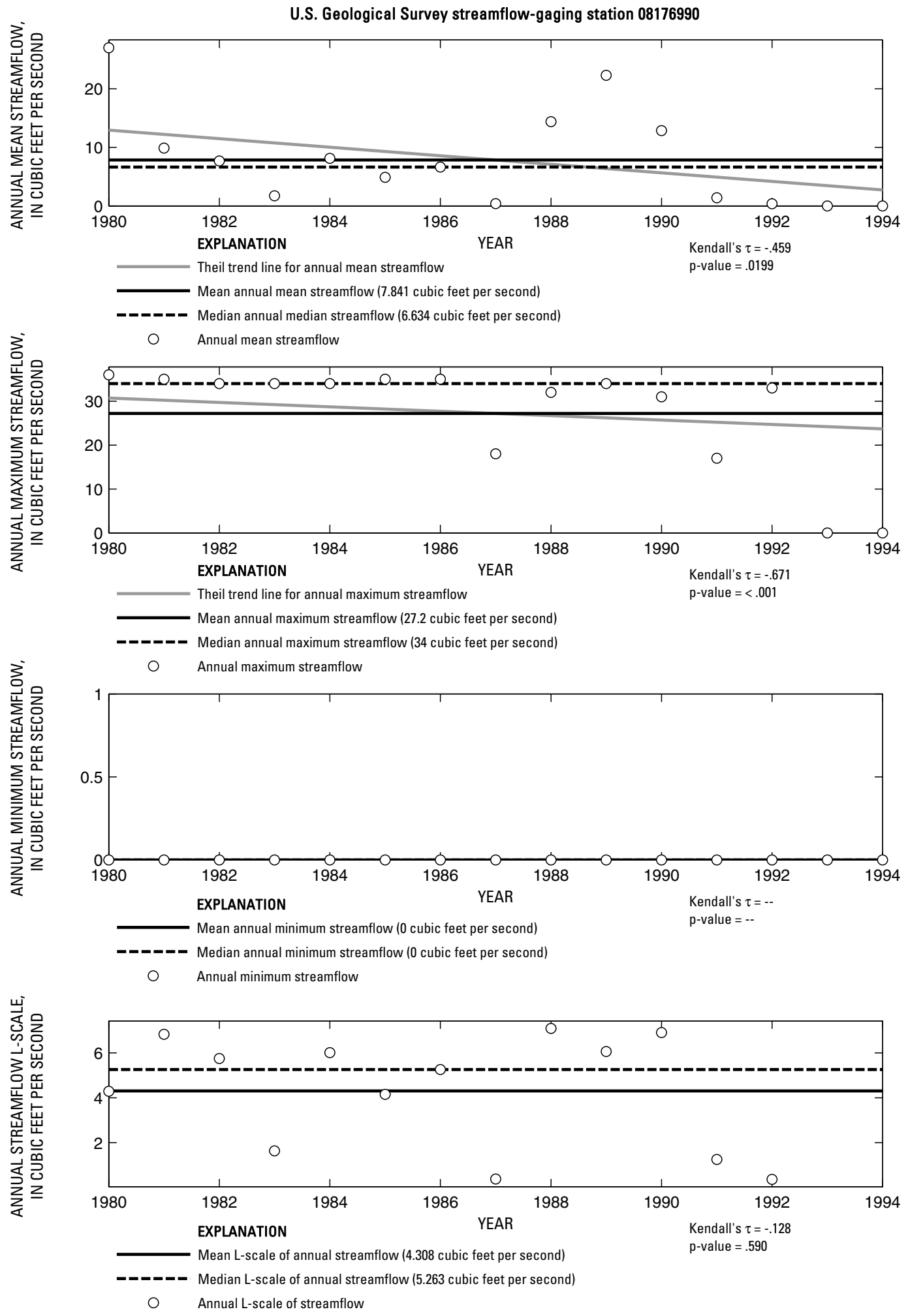

Figure 594. Analysis of annual mean, maximum, minimum, and L-scale statistics of daily mean streamflow for U.S. Geological Survey streamflow-gaging station 08176990 Coleto Creek Reservoir Inflow (Guadalupe Diversion) near Schroeder, Texas. 

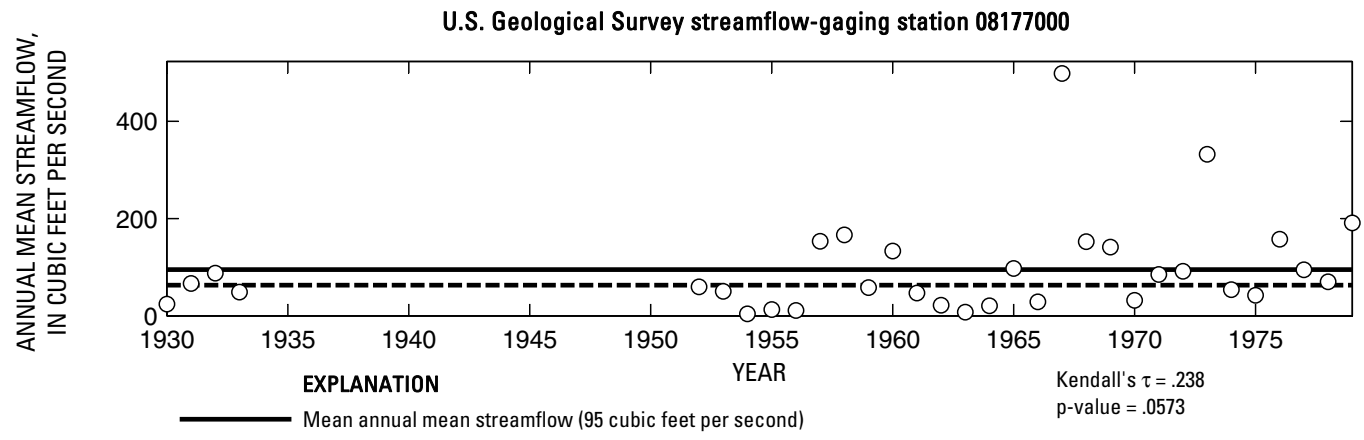

-_-_- Median annual mean streamflow (62.9 cubic feet per second)

O Annual mean streamflow

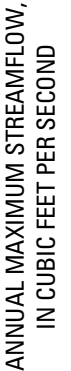

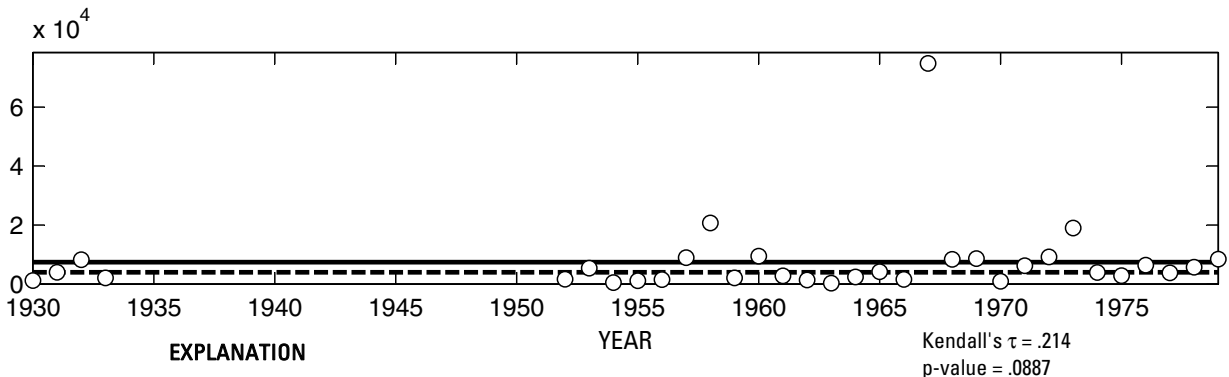

Mean annual maximum streamflow (7,420 cubic feet per second)

- - - Median annual maximum streamflow (3,960 cubic feet per second)

O Annual maximum streamflow

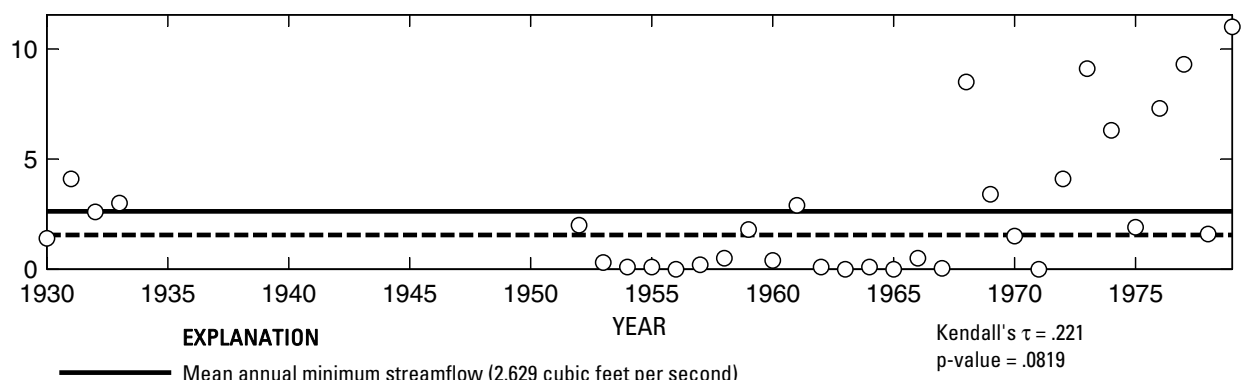

- Median annual minimum streamflow (1.55 cubic feet per second)

O Annual minimum streamflow

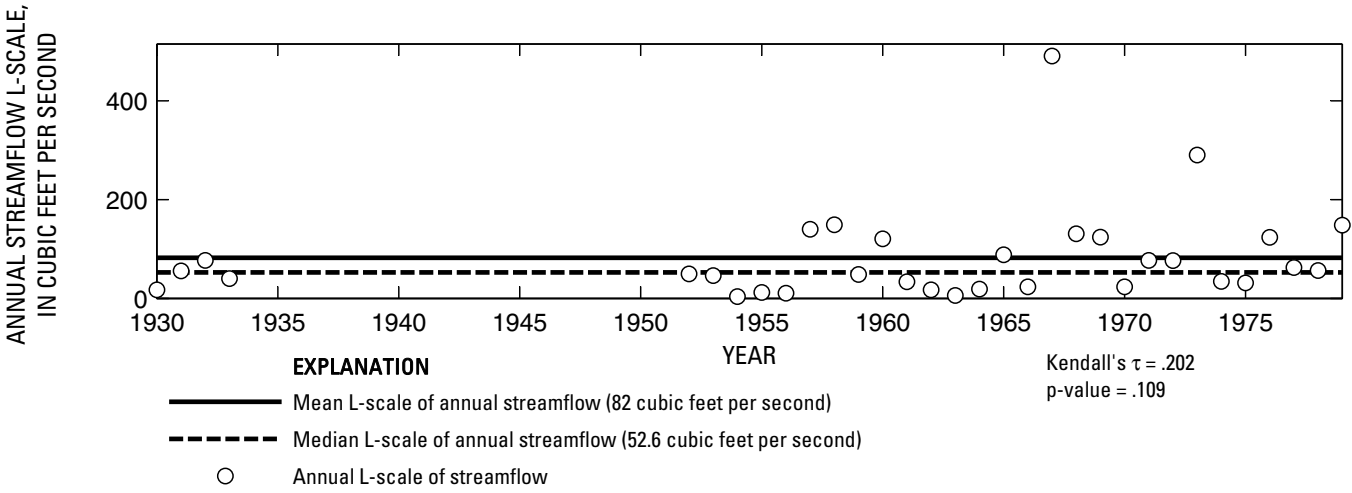

Figure 595. Analysis of annual mean, maximum, minimum, and L-scale statistics of daily mean streamflow for U.S. Geological Survey streamflow-gaging station 08177000 Coleto Creek near Schroeder, Texas. 


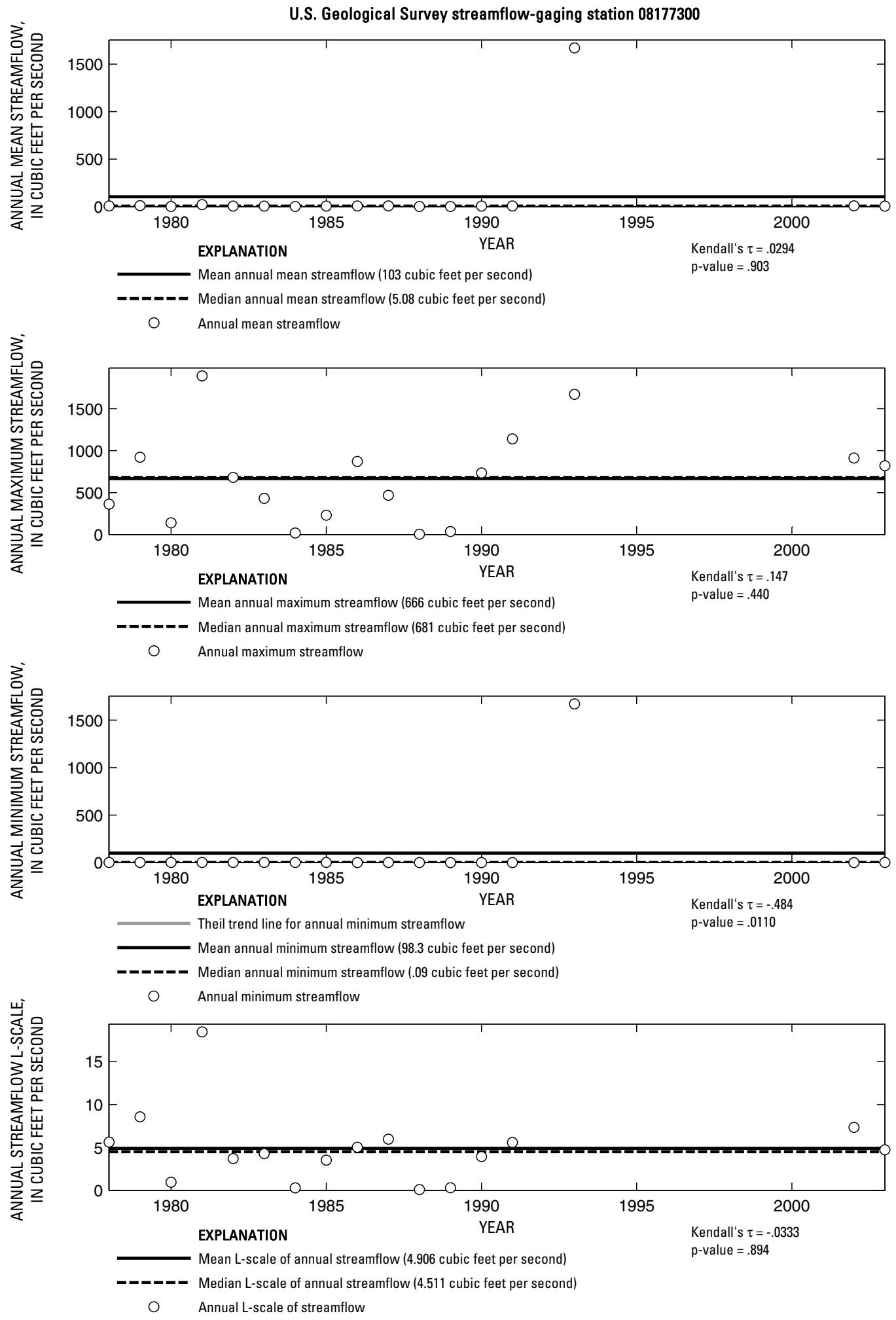

Figure 596. Analysis of annual mean, maximum, minimum, and L-scale statistics of daily mean streamflow for U.S. Geological Survey streamflow-gaging station 08177300 Perdido Creek at Farm to Market Road 622 near Fannin, Texas. 

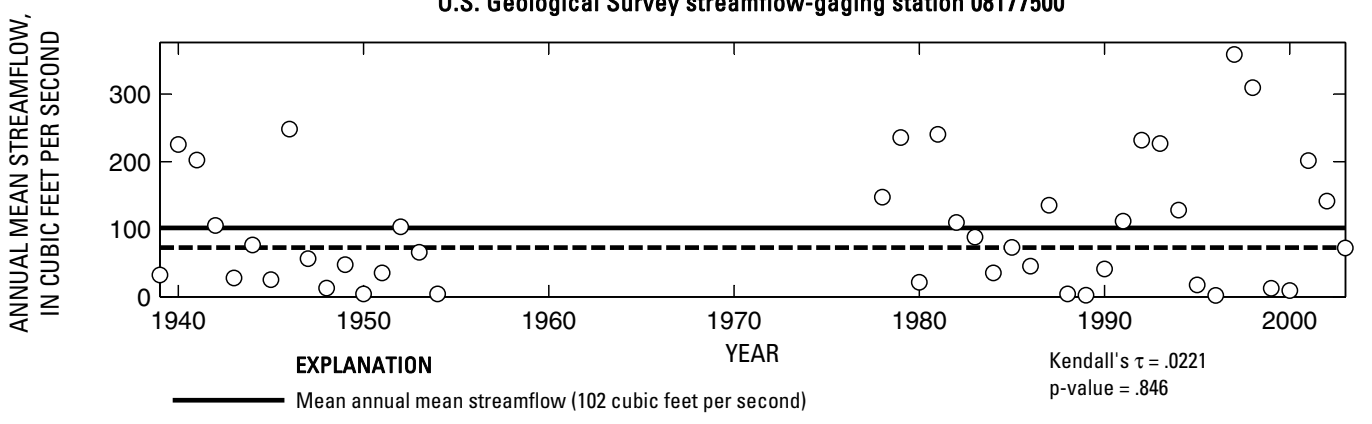

-_-_- Median annual mean streamflow (72.7 cubic feet per second)

O Annual mean streamflow

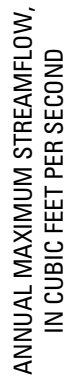
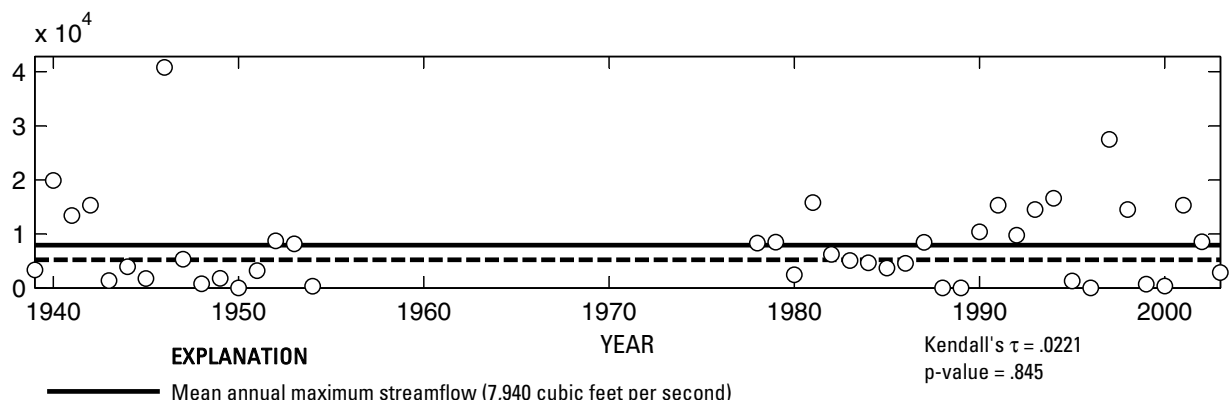

- ב-_ Median annual maximum streamflow (5,220 cubic feet per second)

O Annual maximum streamflow

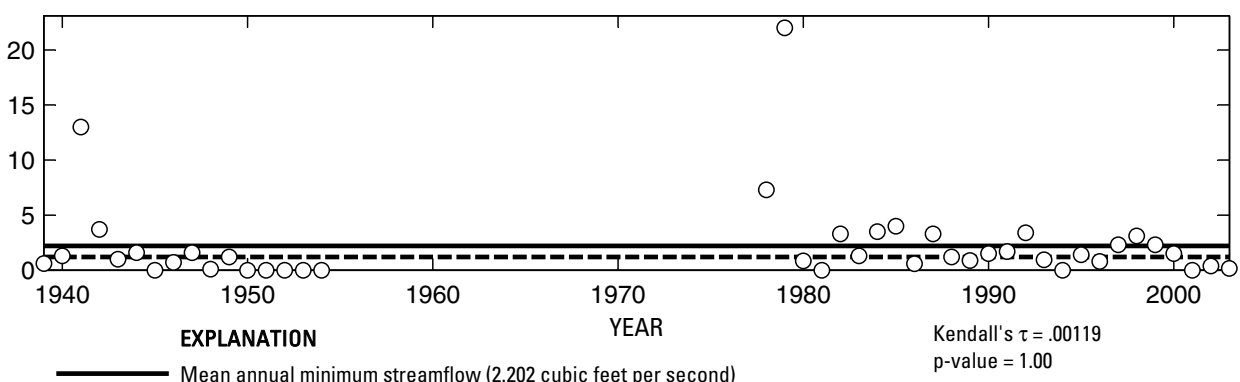

- Median annual minimum streamflow (1.2 cubic feet per second)

O Annual minimum streamflow

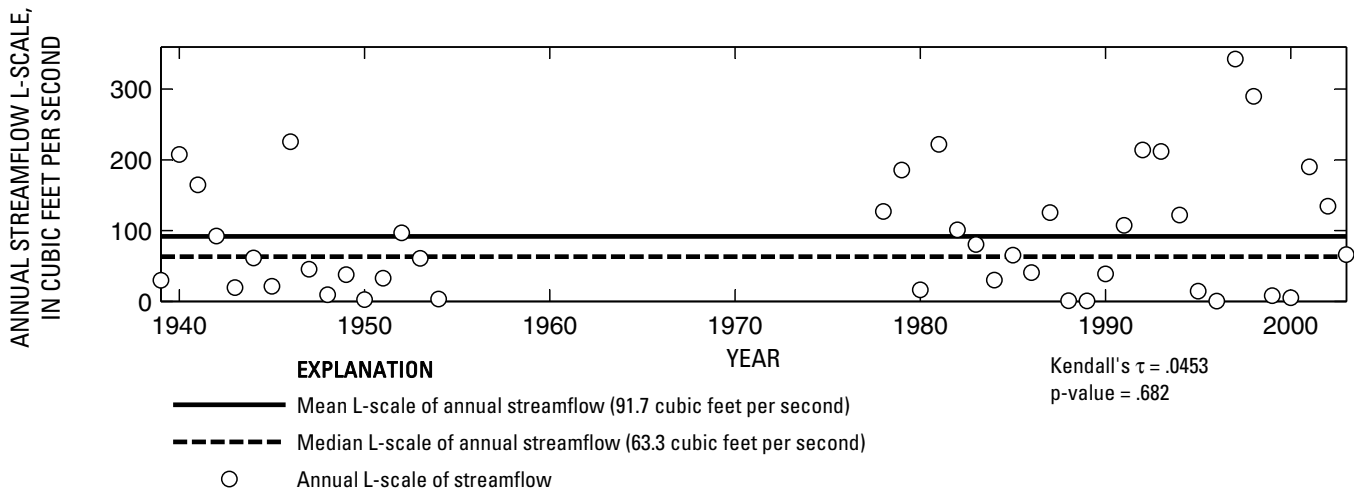

Figure 597. Analysis of annual mean, maximum, minimum, and L-scale statistics of daily mean streamflow for U.S. Geological Survey streamflow-gaging station 08177500 Coleto Creek near Victoria, Texas. 

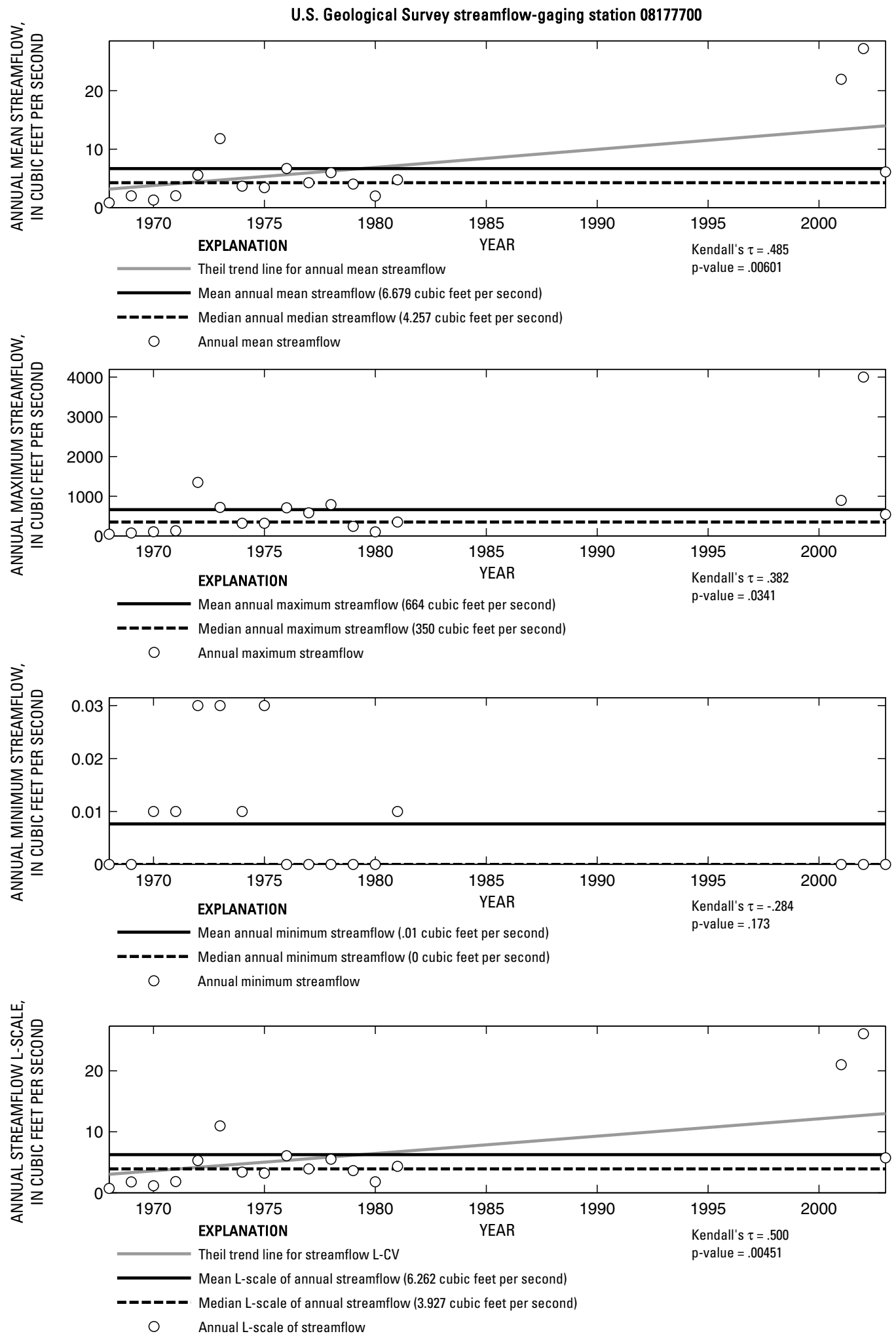

Figure 598. Analysis of annual mean, maximum, minimum, and L-scale statistics of daily mean streamflow for U.S. Geological Survey streamflow-gaging station 08177700 Olmos Creek at Dresden Drive, San Antonio, Texas.

Index of Station Numbers 719 


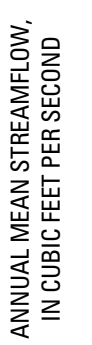

U.S. Geological Survey streamflow-gaging station 08177860

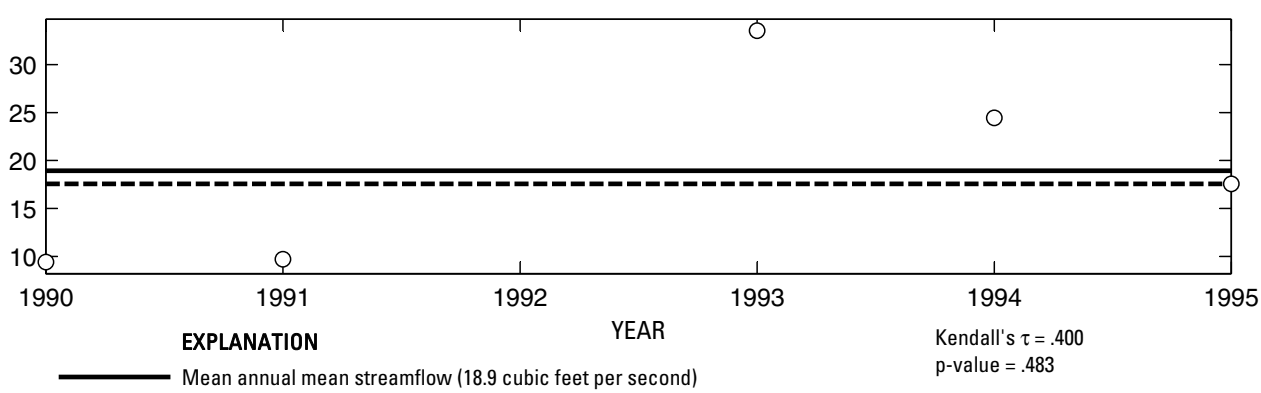

- - - - Median annual mean streamflow (17.6 cubic feet per second)

Annual mean streamflow
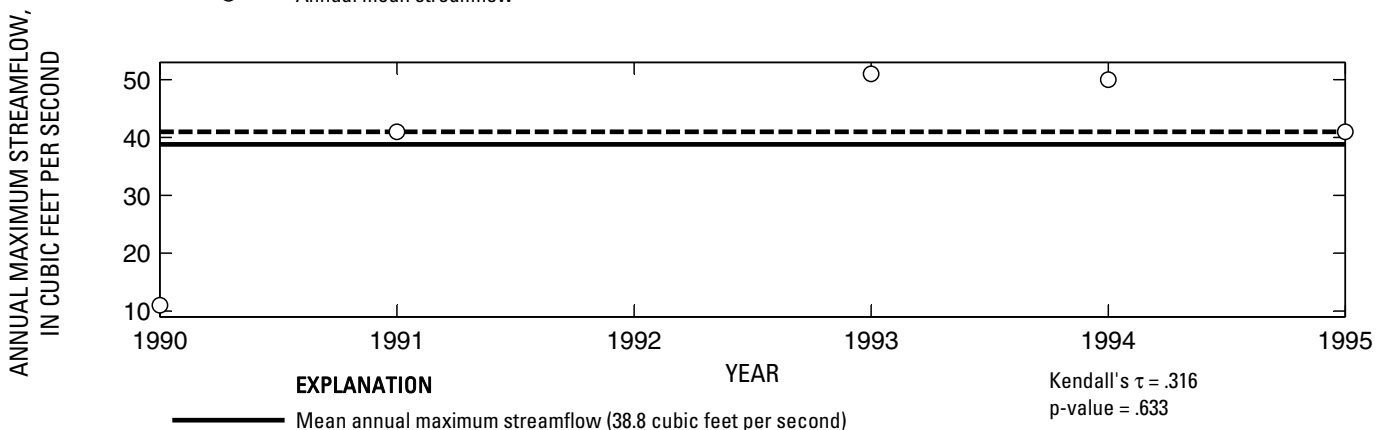

- - Median annual maximum streamflow (41 cubic feet per second)

O Annual maximum streamflow

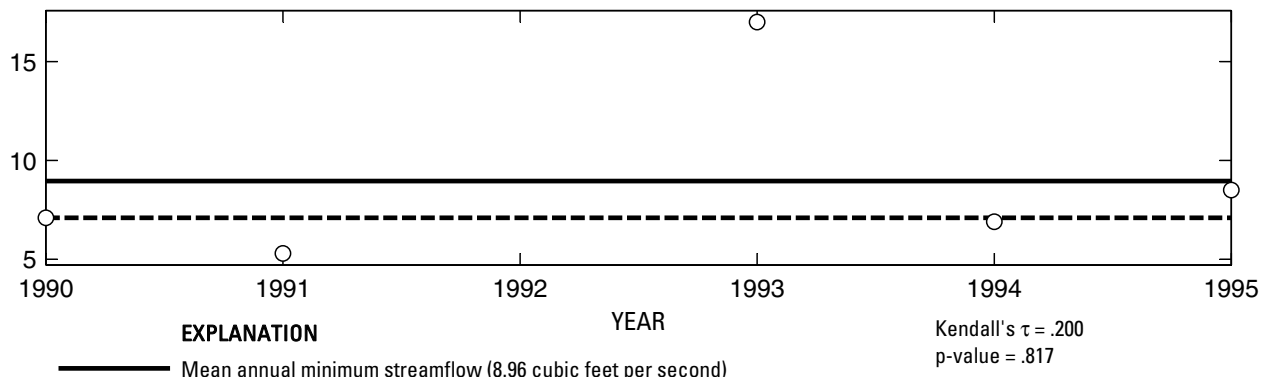

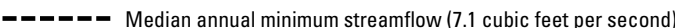

○ Annual minimum streamflow
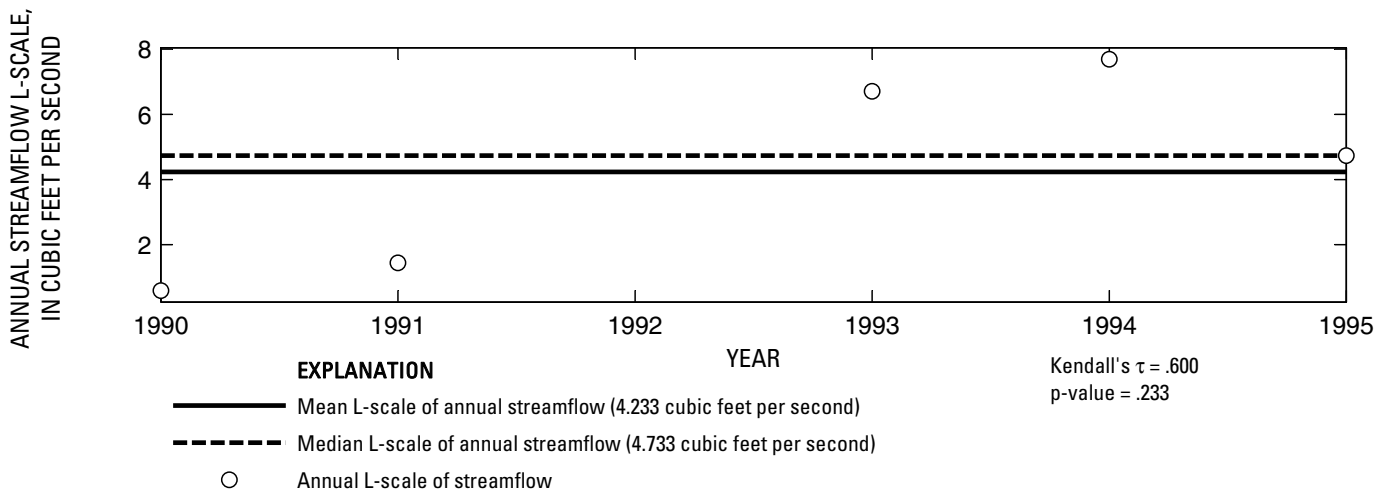

Figure 599. Analysis of annual mean, maximum, minimum, and L-scale statistics of daily mean streamflow for U.S. Geological Survey streamflow-gaging station 08177860 San Antonio River at Woodlawn Avenue, San Antonio, Texas. 


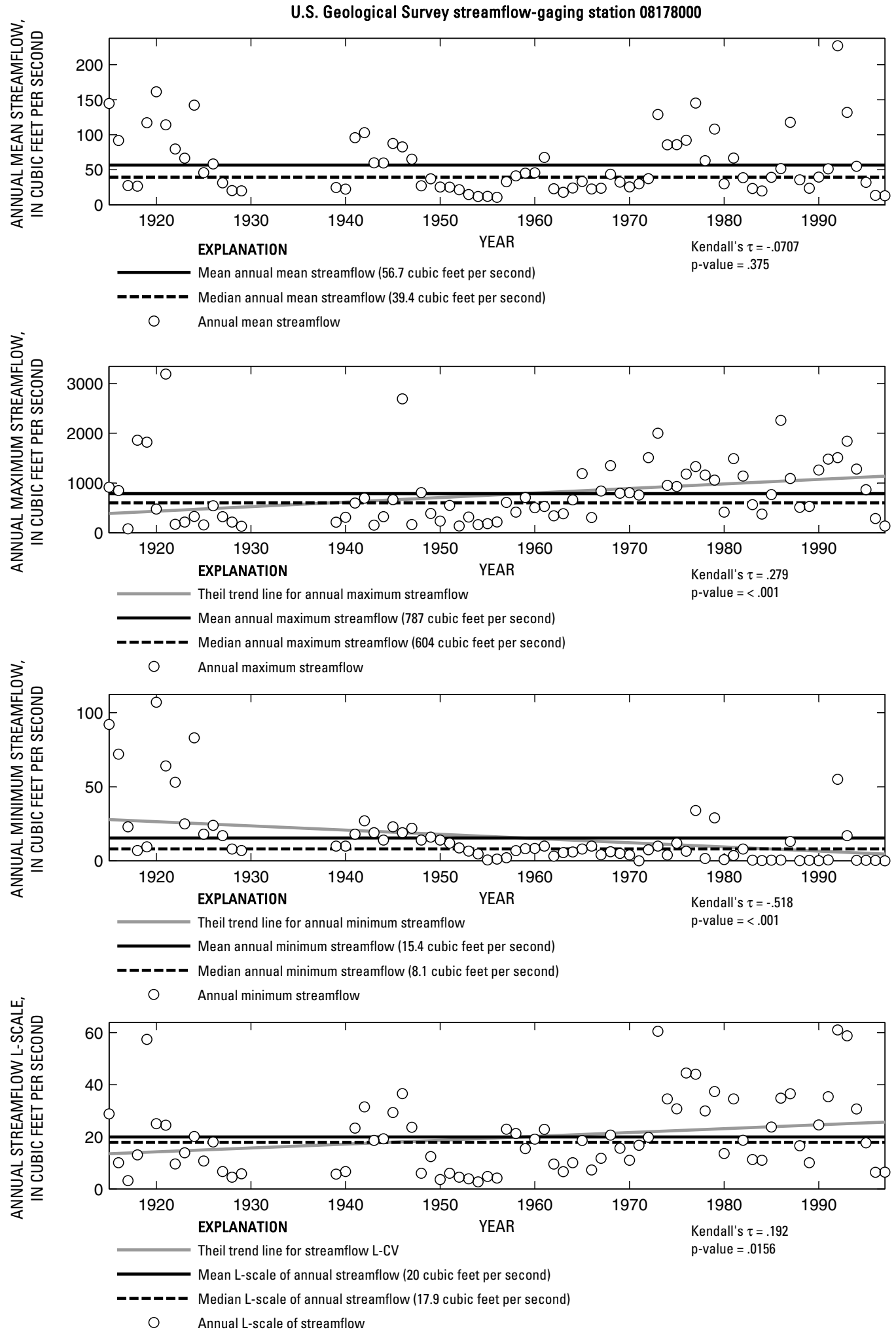

Figure 600. Analysis of annual mean, maximum, minimum, and L-scale statistics of daily mean streamflow for U.S. Geological Survey streamflow-gaging station 08178000 San Antonio River at San Antonio, Texas.

Index of Station Numbers 719 


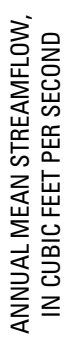

U.S. Geological Survey streamflow-gaging station 08178050

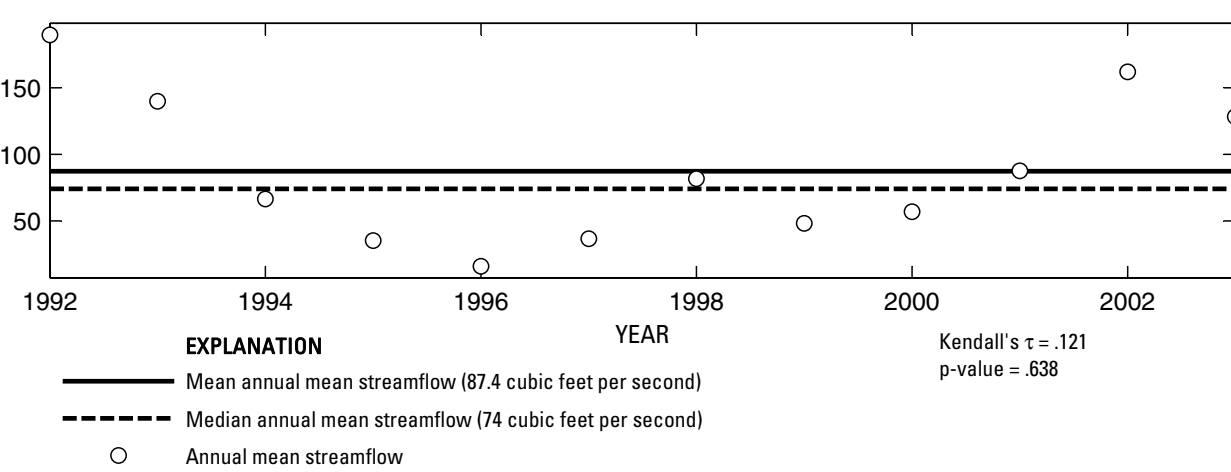

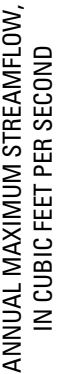

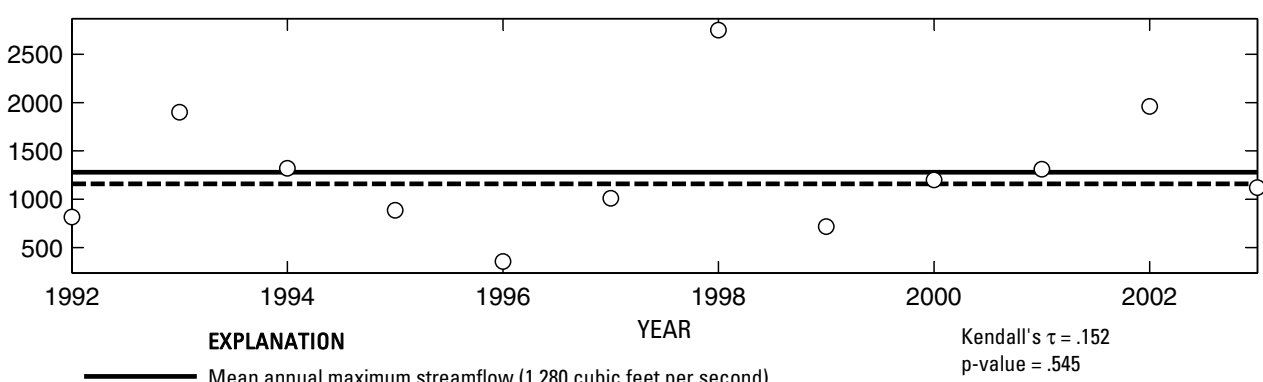

- _ - Median annual maximum streamflow (1,160 cubic feet per second

Annual maximum streamflow

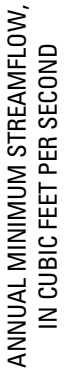

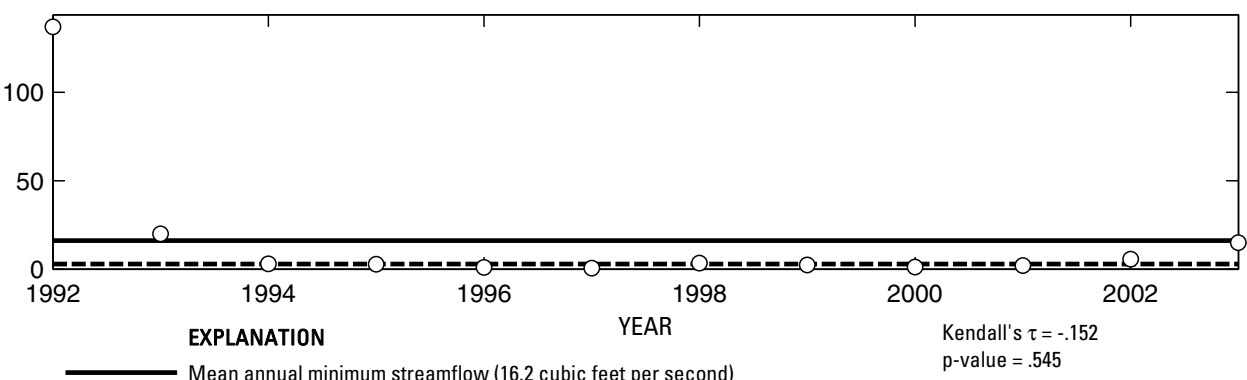

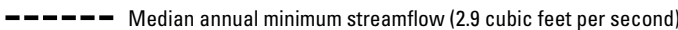

O Annual minimum streamflow

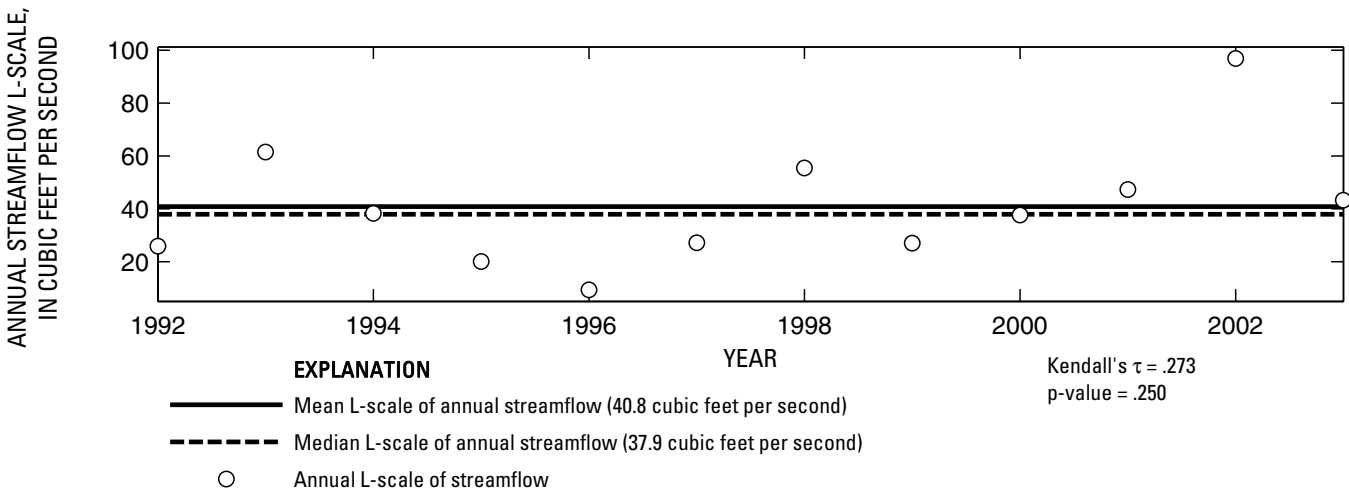

Figure 601. Analysis of annual mean, maximum, minimum, and L-scale statistics of daily mean streamflow for U.S. Geological Survey streamflow-gaging station 08178050 San Antonio River at Mitchell Street, San Antonio, Texas.

Index of Station Numbers 719 
U.S. Geological Survey streamflow-gaging station 08178500
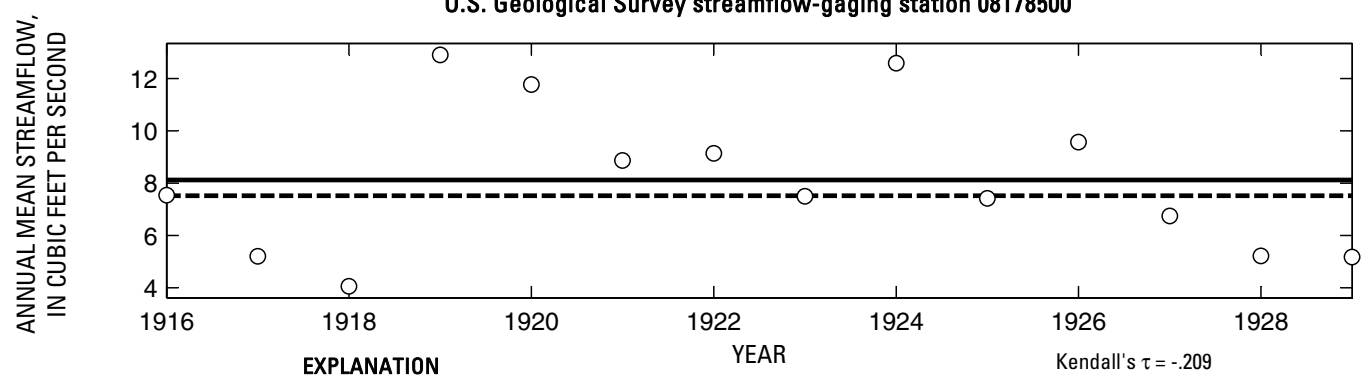

$\mathrm{p}$-value $=.331$

- - - - Median annual mean streamflow (7.524 cubic feet per second)

O Annual mean streamflow

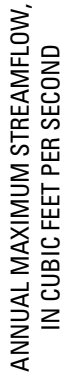

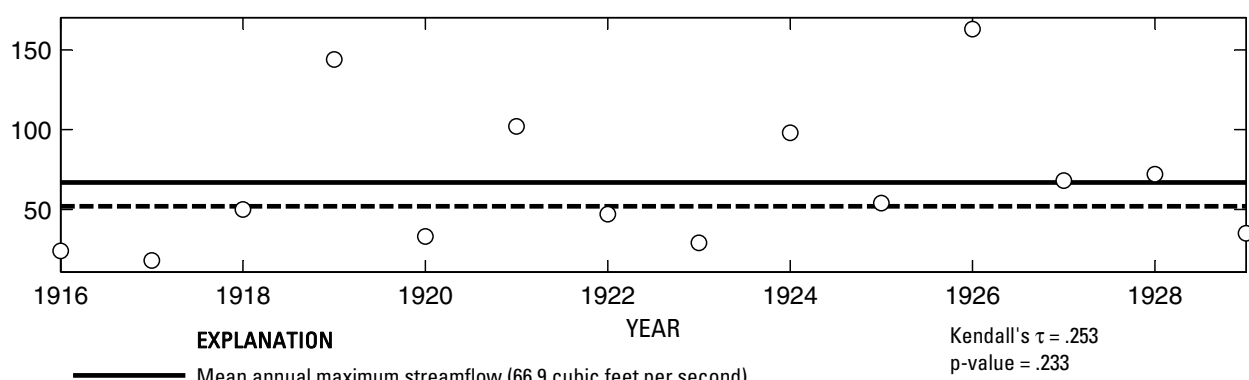

O Annual maximum streamflow

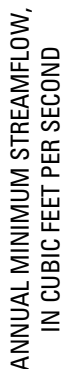

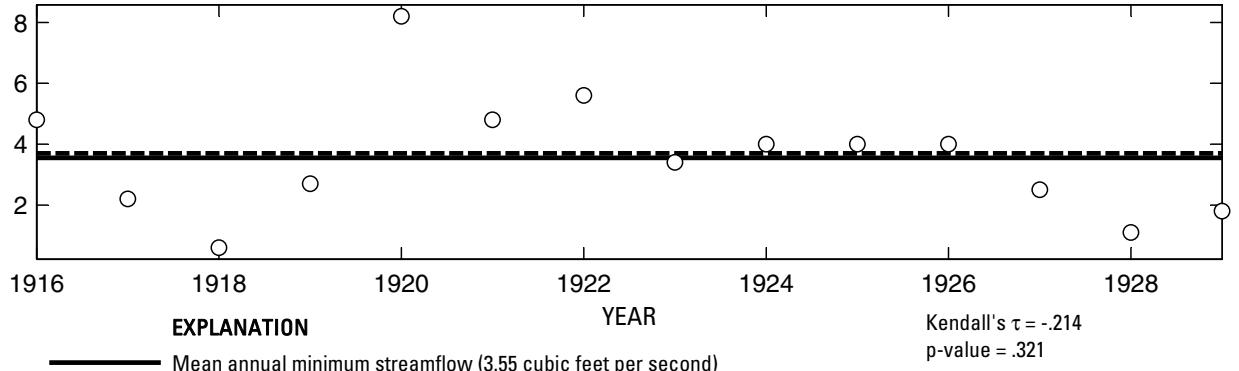

- Median annual minimum streamflow (3.7 cubic feet per second)

O Annual minimum streamflow

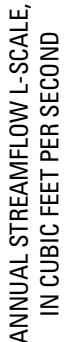

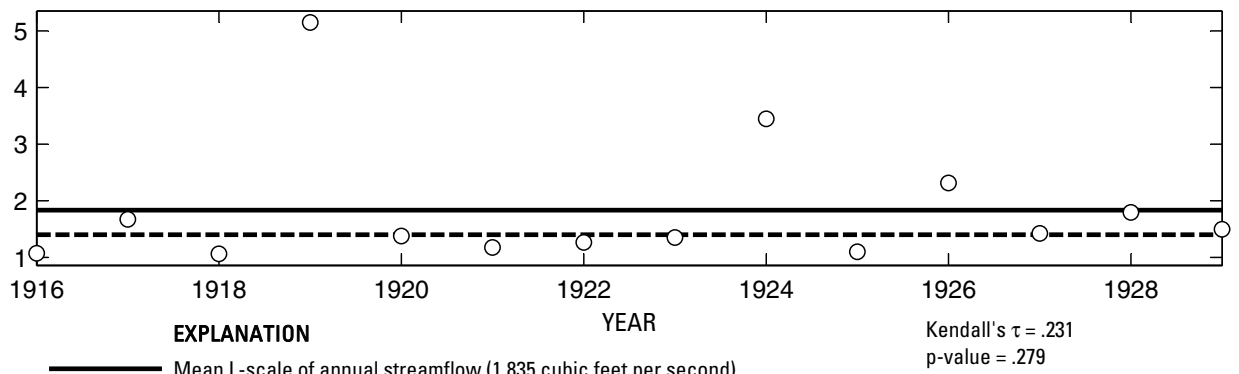

- - - - Median L-scale of annual streamflow (1.4 cubic feet per second)

O Annual L-scale of streamflow

Figure 602. Analysis of annual mean, maximum, minimum, and L-scale statistics of daily mean streamflow for U.S. Geological Survey streamflow-gaging station 08178500 San Pedro Creek at Furnish Street, San Antonio, Texas.

Index of Station Numbers 719 

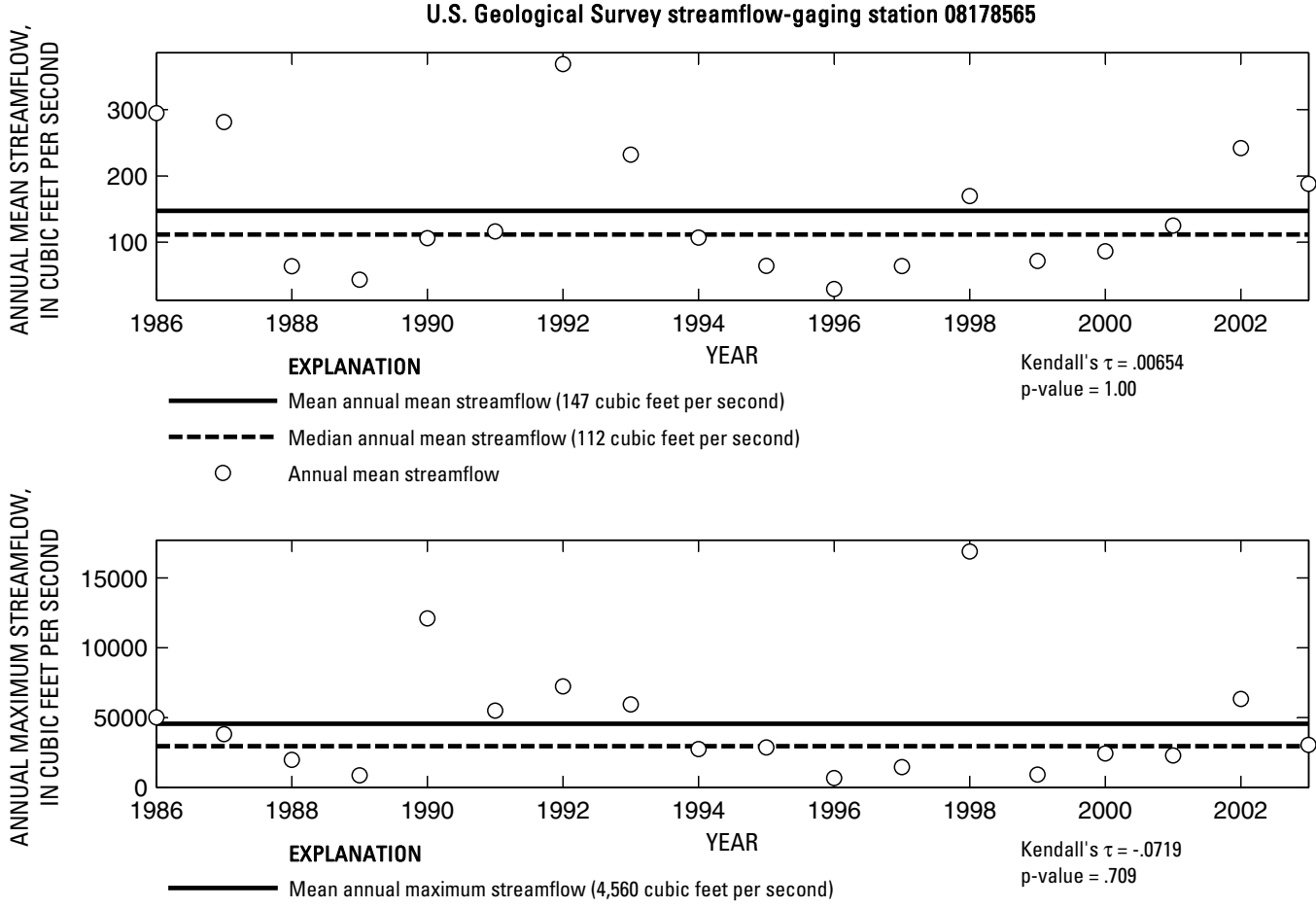

- _-_- Median annual maximum streamflow (2,960 cubic feet per second)

Annual maximum streamflow

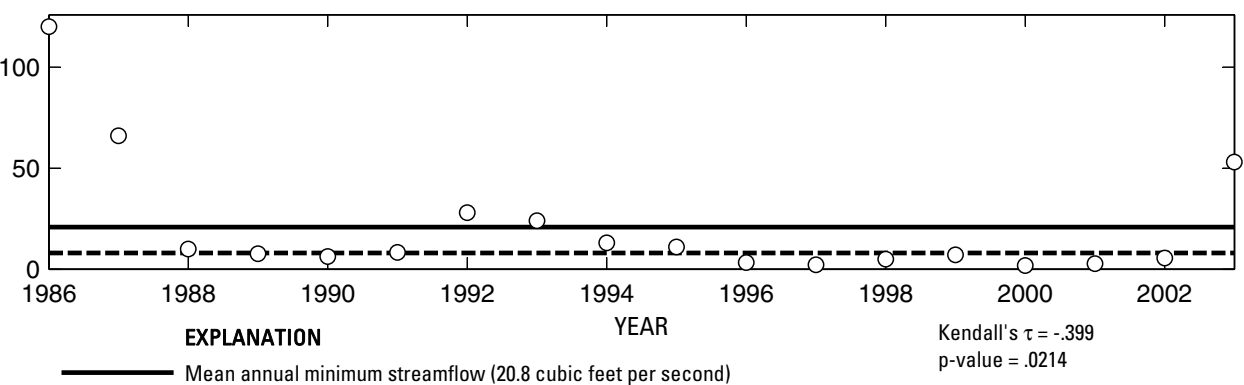

- ב-ב Median annual minimum streamflow (8 cubic feet per second)

O Annual minimum streamflow

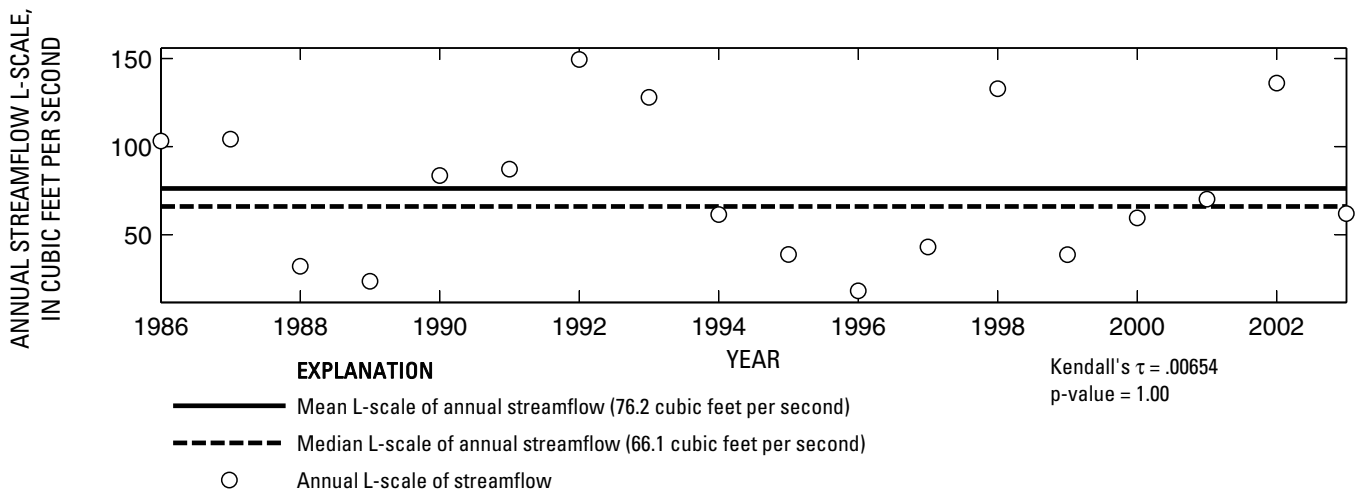

Figure 603. Analysis of annual mean, maximum, minimum, and L-scale statistics of daily mean streamflow for U.S. Geological Survey streamflow-gaging station 08178565 San Antonio River at Loop 410, San Antonio, Texas.

Index of Station Numbers 719 
U.S. Geological Survey streamflow-gaging station 08178585

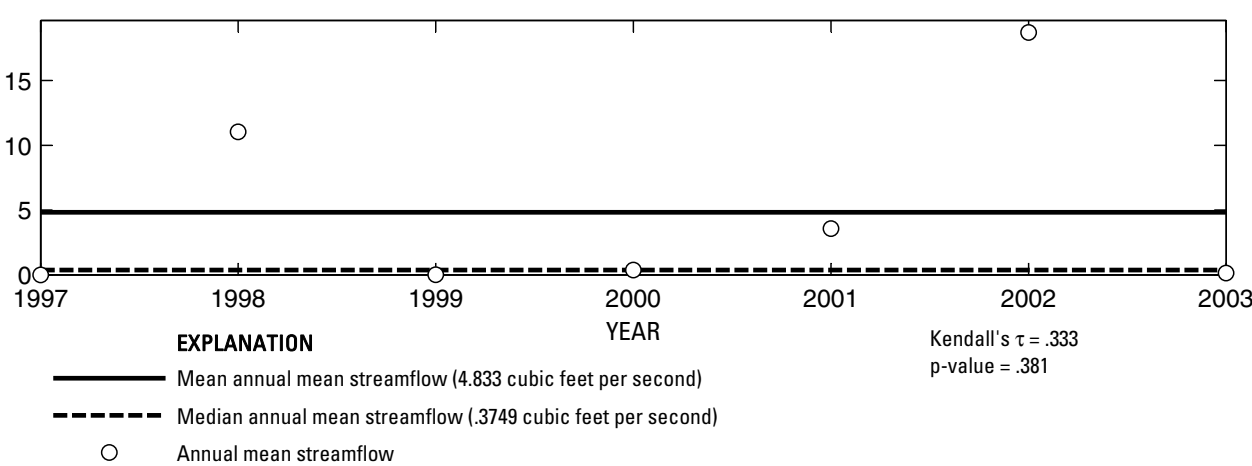

焉

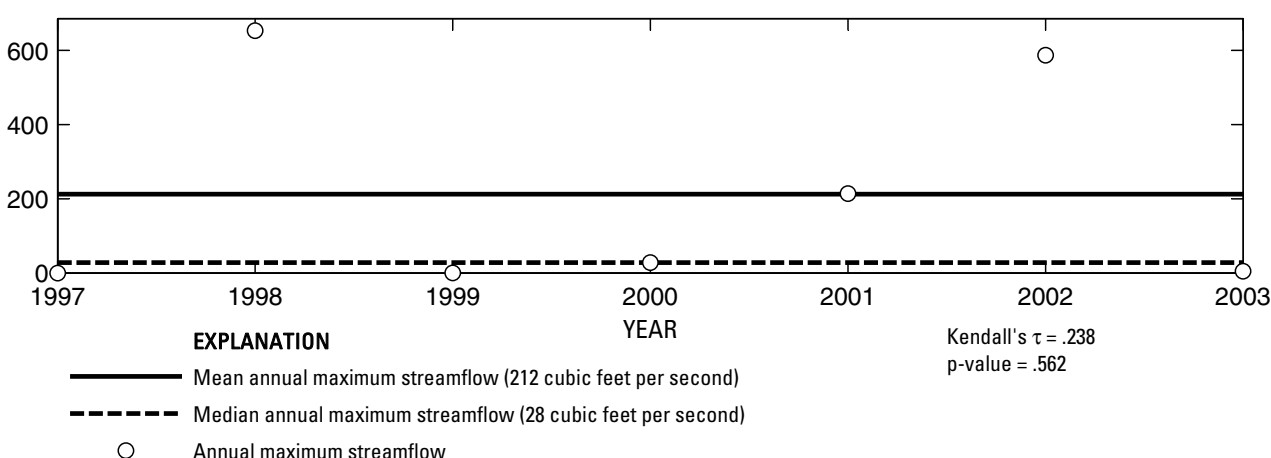

崔

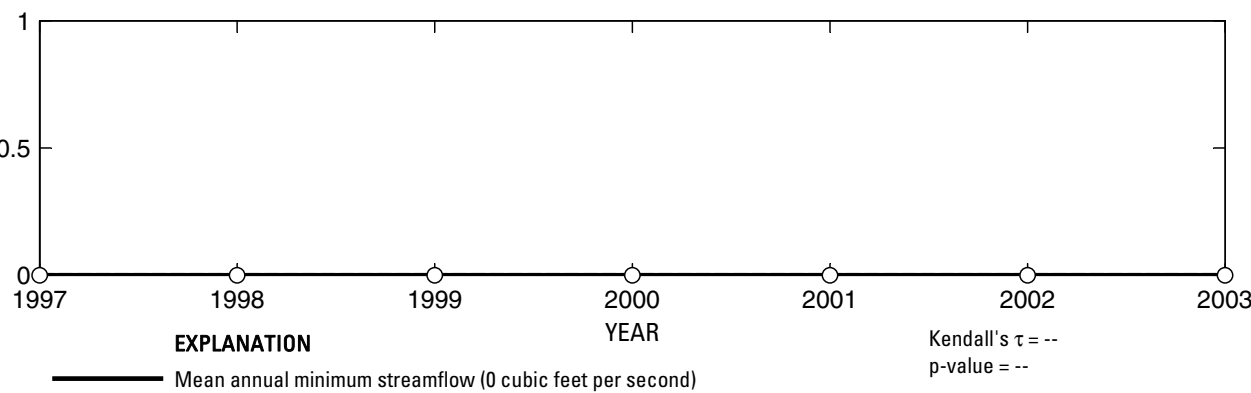

- Median annual minimum streamflow (0 cubic feet per second)

O Annual minimum streamflow

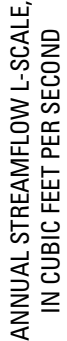

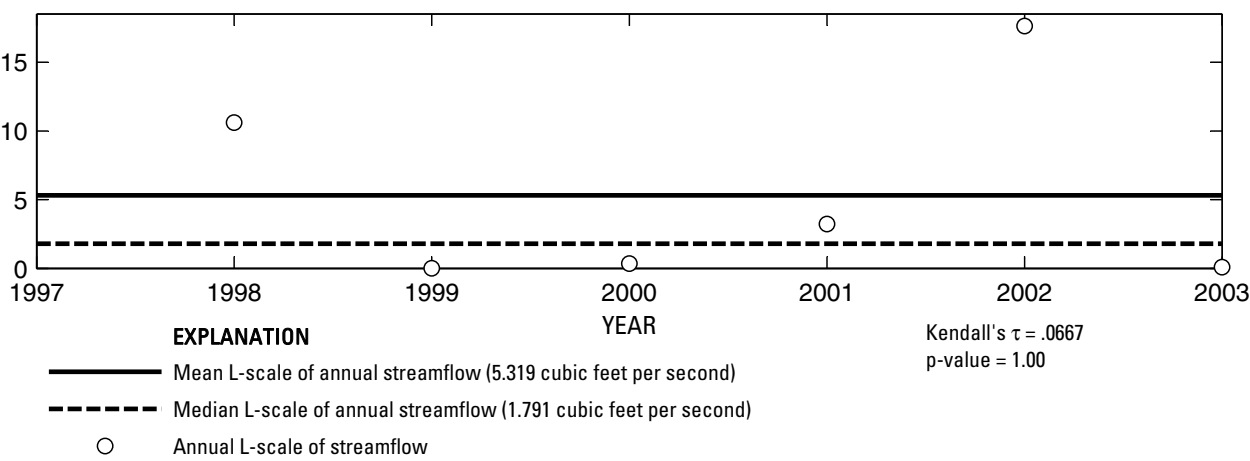

Figure 604. Analysis of annual mean, maximum, minimum, and L-scale statistics of daily mean streamflow for U.S. Geological Survey streamflow-gaging station 08178585 Salado Creek at Wilderness Road, San Antonio, Texas.

Index of Station Numbers 719 

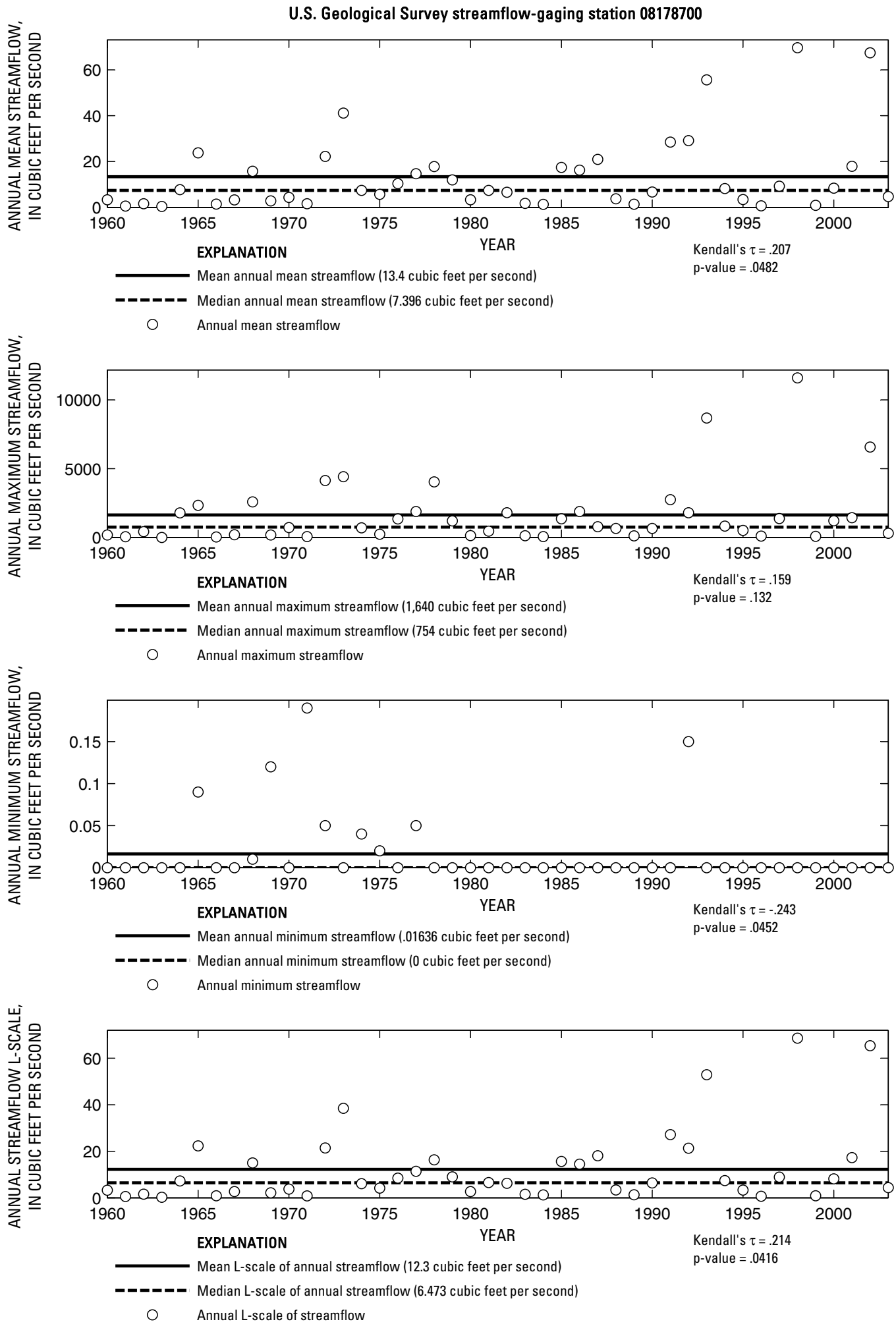

Figure 605. Analysis of annual mean, maximum, minimum, and L-scale statistics of daily mean streamflow for U.S. Geological Survey streamflow-gaging station 08178700 Salado Creek at Loop 410, San Antonio, Texas.

Index of Station Numbers 719 

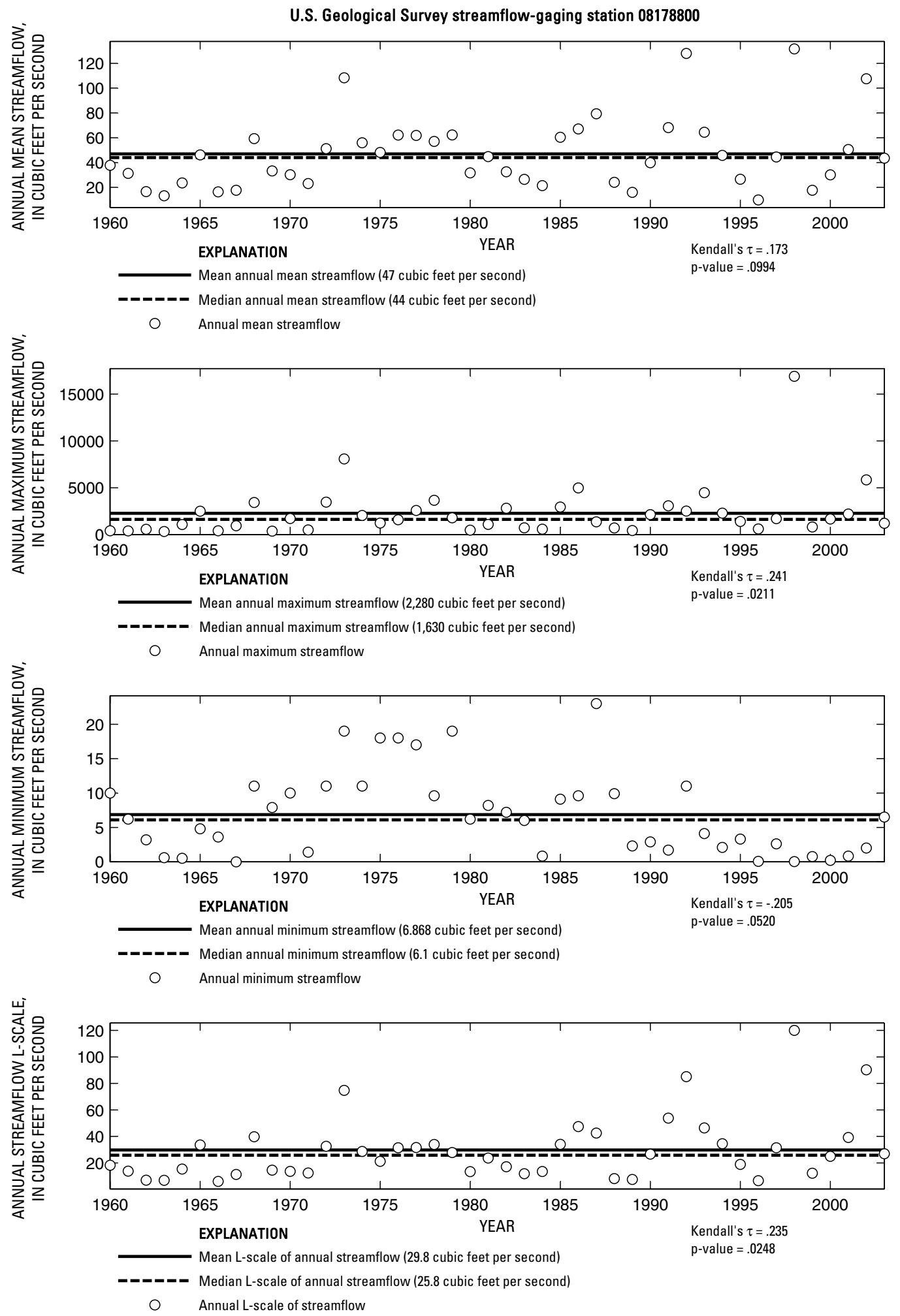

Figure 606. Analysis of annual mean, maximum, minimum, and L-scale statistics of daily mean streamflow for U.S. Geological Survey streamflow-gaging station 08178800 Salado Creek at Loop 13, San Antonio, Texas.

Index of Station Numbers 719 


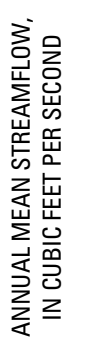

U.S. Geological Survey streamflow-gaging station 08178880

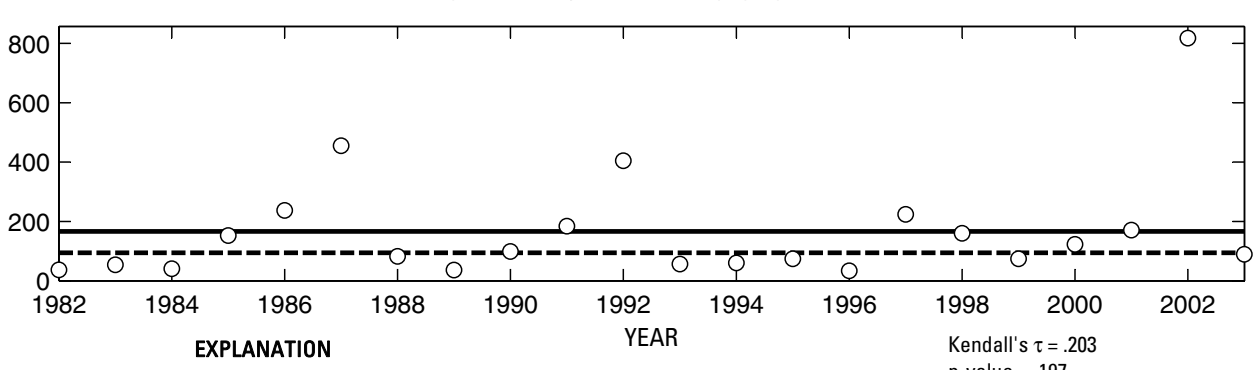

Mean annual mean streamflow (167 cubic feet per second) p-value $=197$

-_-_- Median annual mean streamflow (94.2 cubic feet per second)

O Annual mean streamflow

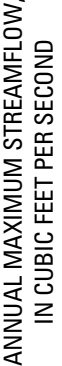

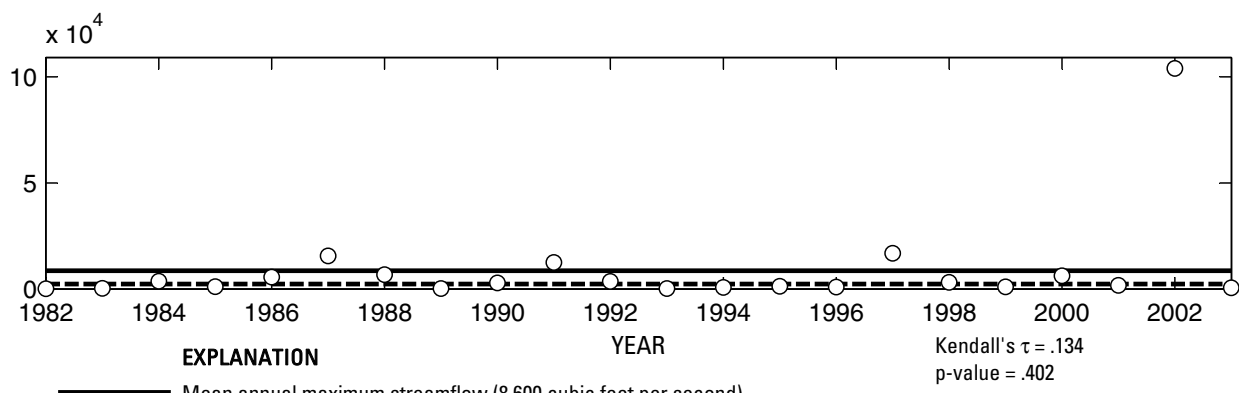

O Annual maximum streamflow

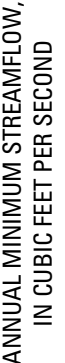

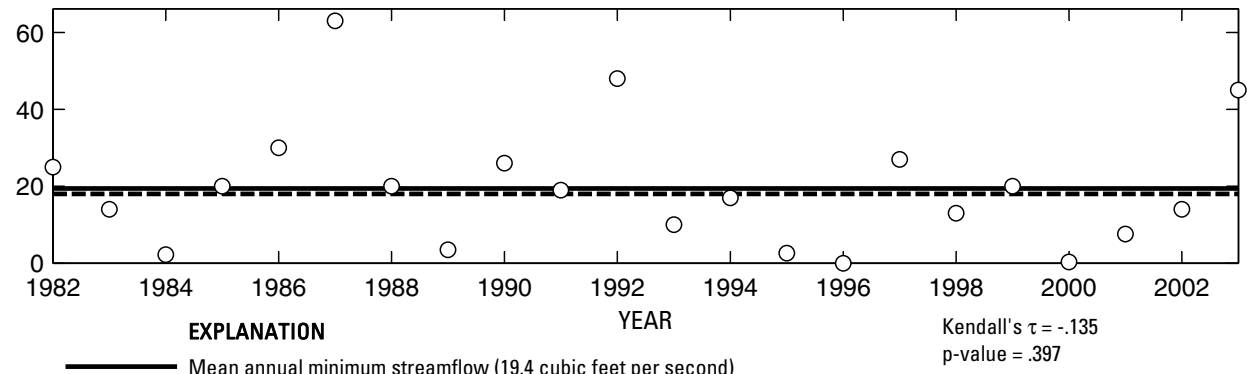

-חיט- Median annual minimum streamflow (18 cubic feet per second)

O Annual minimum streamflow

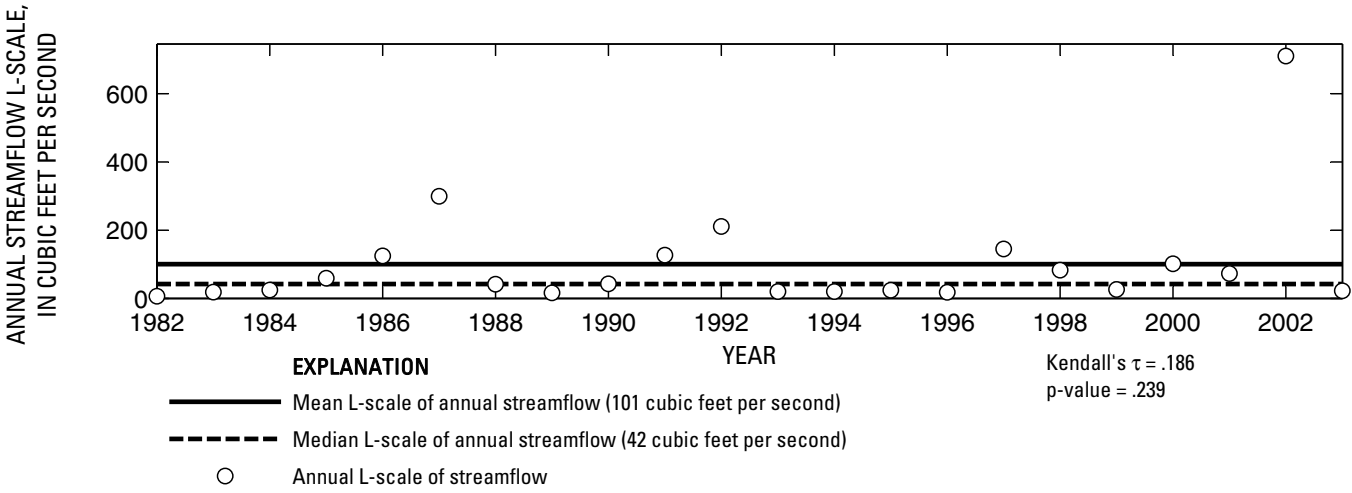

Figure 607. Analysis of annual mean, maximum, minimum, and L-scale statistics of daily mean streamflow for U.S. Geological Survey streamflow-gaging station 08178880 Medina River at Bandera, Texas.

Index of Station Numbers 719 

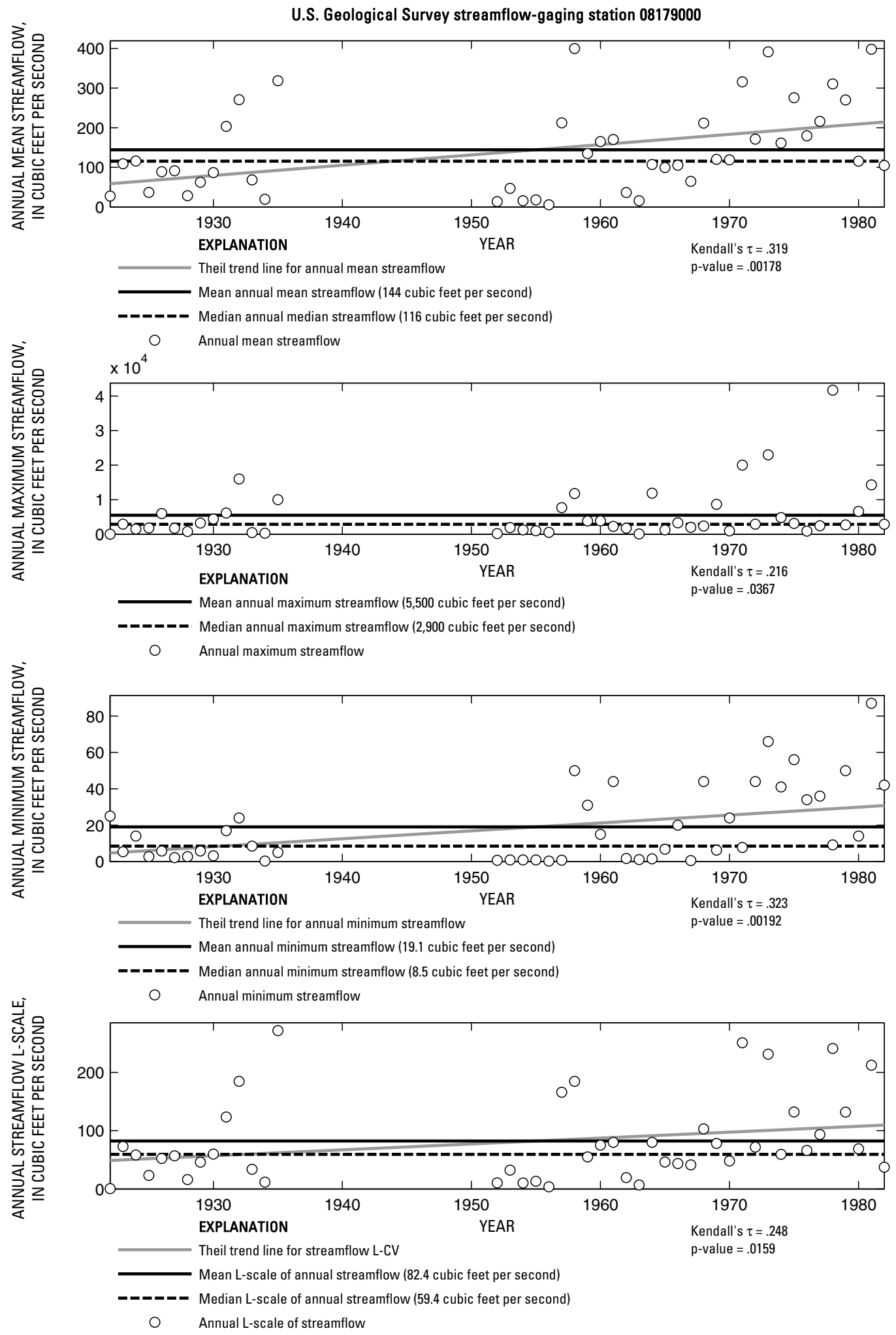

Figure 608. Analysis of annual mean, maximum, minimum, and L-scale statistics of daily mean streamflow for U.S. Geological Survey streamflow-gaging station 08179000 Medina River near Pipe Creek, Texas.

Index of Station Numbers 719 


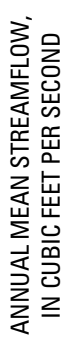

U.S. Geological Survey streamflow-gaging station 08179100

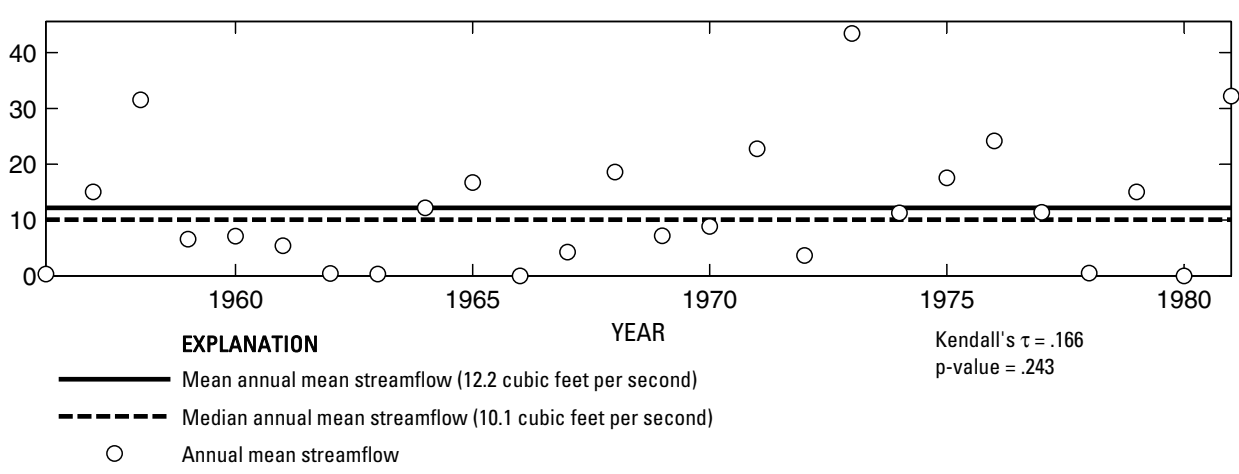

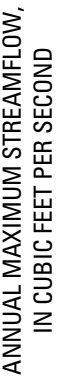

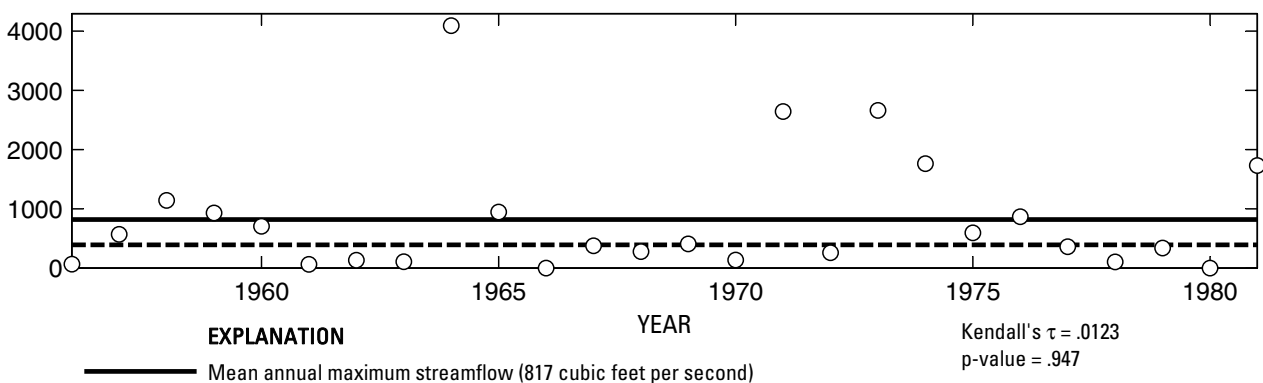

O Annual maximum streamflow

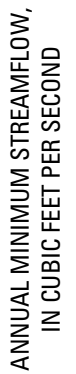

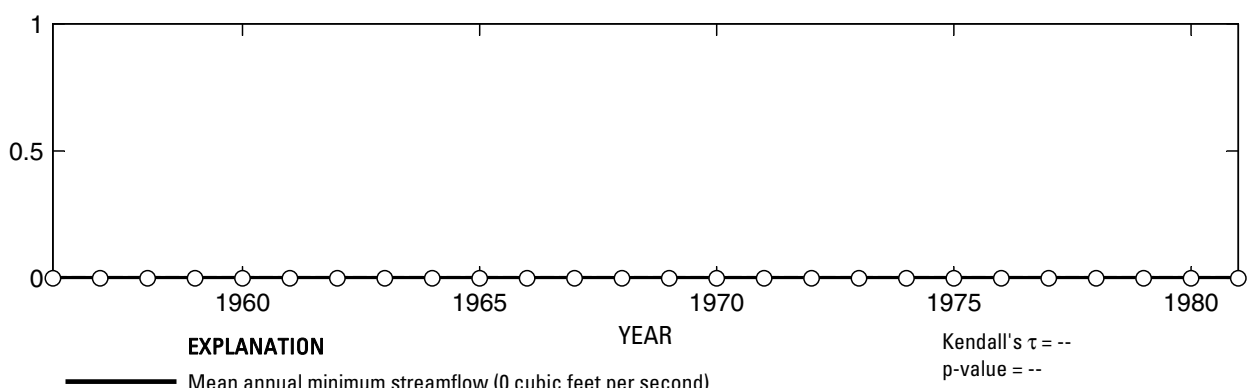

- Median annual minimum streamflow (0 cubic feet per second)

○ Annual minimum streamflow

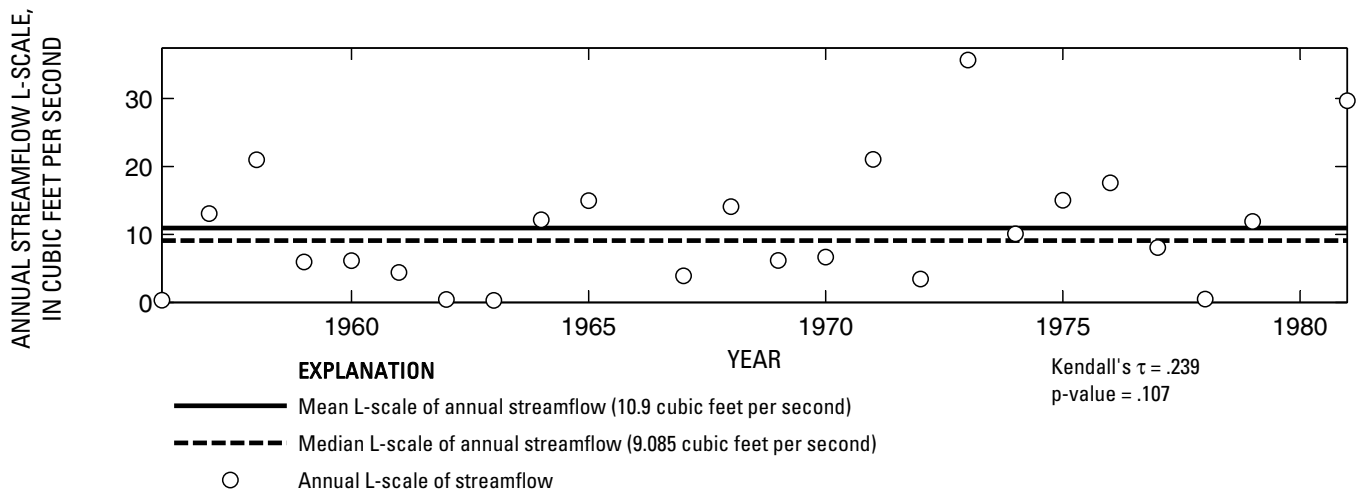

Figure 609. Analysis of annual mean, maximum, minimum, and L-scale statistics of daily mean streamflow for U.S. Geological Survey streamflow-gaging station 08179100 Red Bluff Creek near Pipe Creek, Texas.

Index of Station Numbers 719 


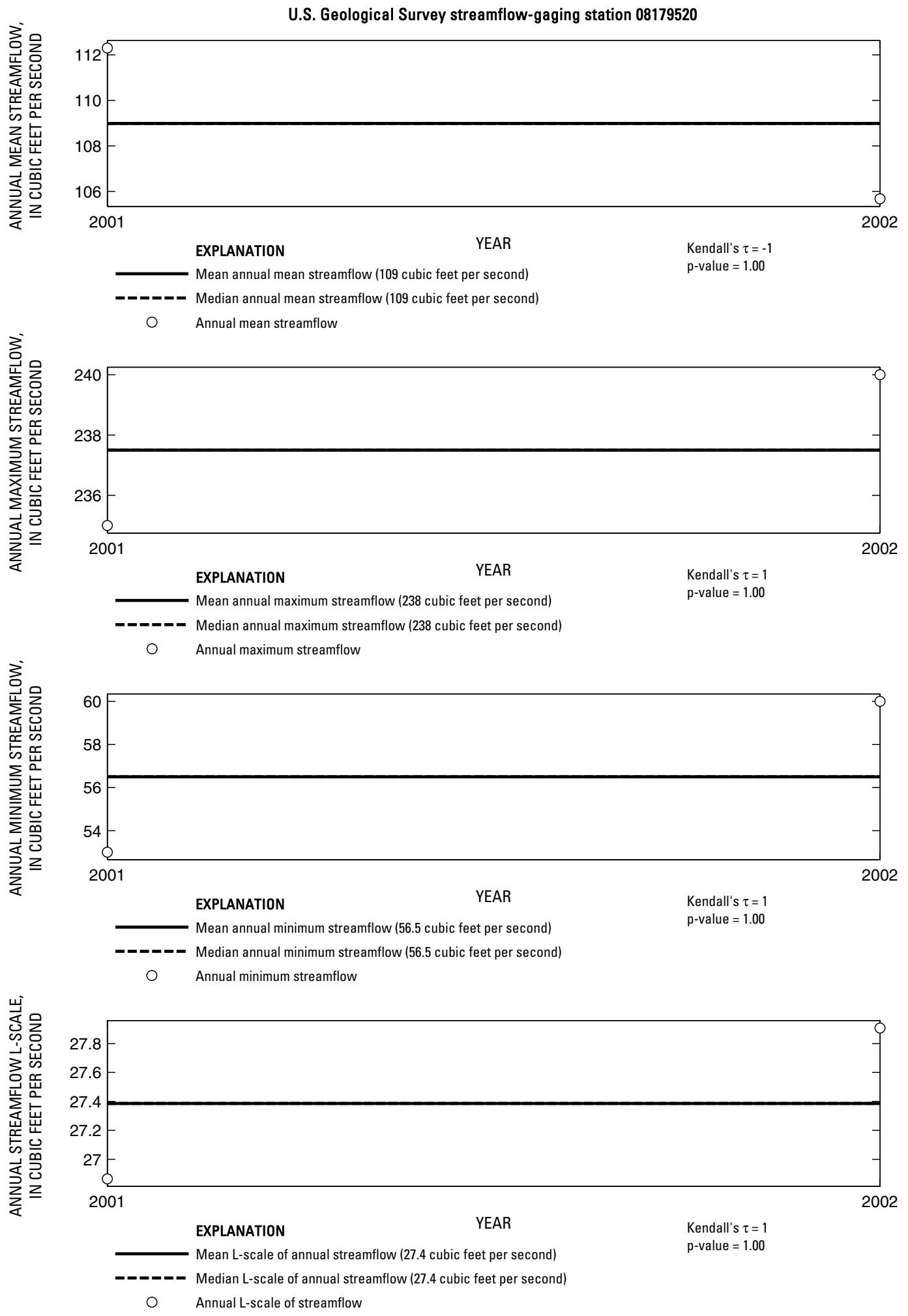

Figure 610. Analysis of annual mean, maximum, minimum, and L-scale statistics of daily mean streamflow for U.S. Geological Survey streamflow-gaging station 08179520 Medina River below Medina Lake near San Antonio, Texas. 


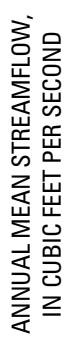

U.S. Geological Survey streamflow-gaging station 08180500

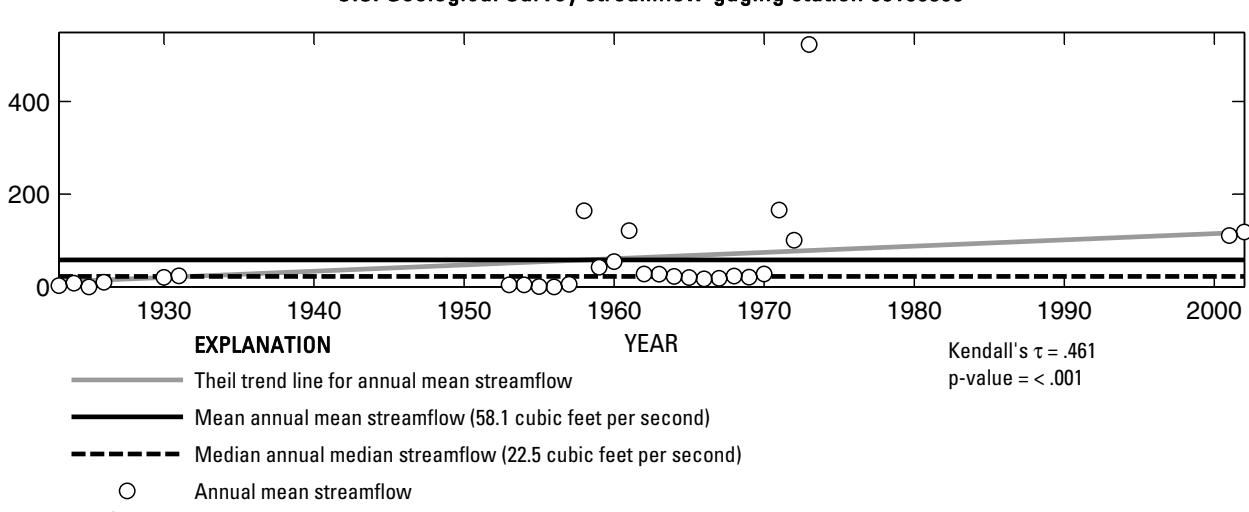

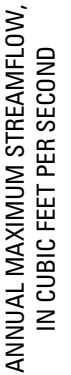
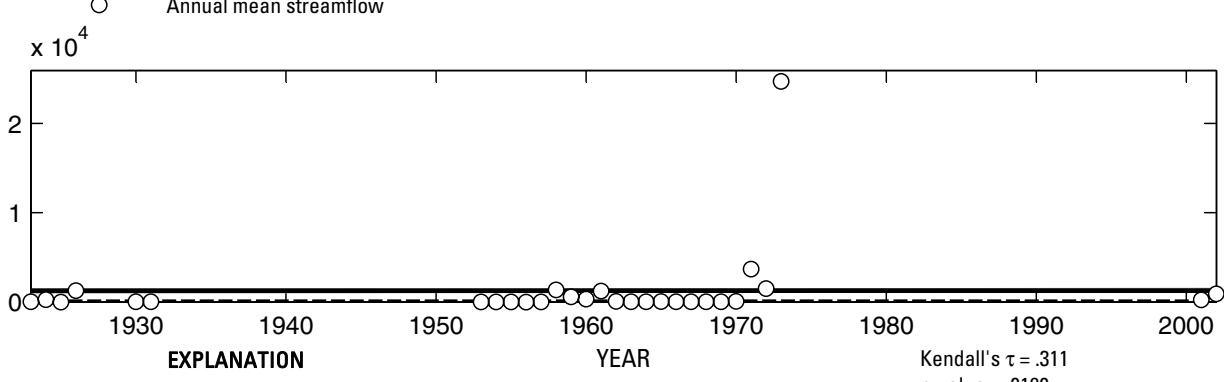
EXPLANATION YEAR

Kendall's $\tau=.31$

- Theil trend line for annual maximum streamflow

Mean annual maximum streamflow (1,260 cubic feet per second)

- - - Median annual maximum streamflow (42 cubic feet per second)

$\bigcirc \quad$ Annual maximum streamflow

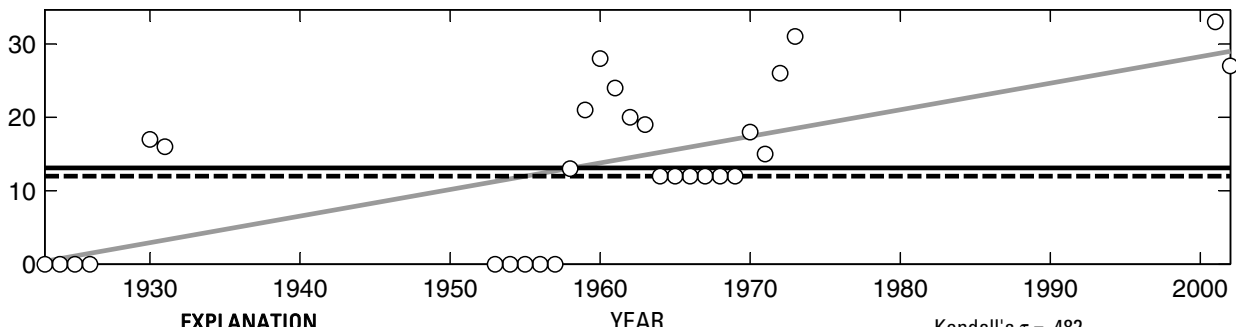

EXPLANATION

Theil trend line for annual minimum streamflow
Mean annual minimum streamflow (13.1 cubic feet per second)

Kendall's $\tau=.482$

-_-_- Median annual minimum streamflow (12 cubic feet per second)

O Annual minimum streamflow

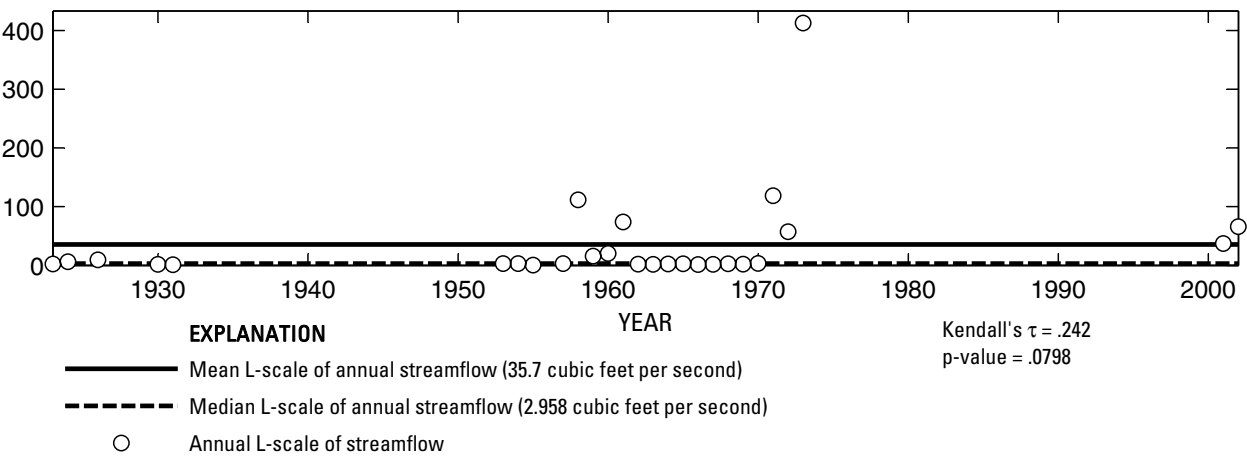

Figure 611. Analysis of annual mean, maximum, minimum, and L-scale statistics of daily mean streamflow for U.S. Geological Survey streamflow-gaging station 08180500 Medina River near Riomedina, Texas.

Index of Station Numbers 719 


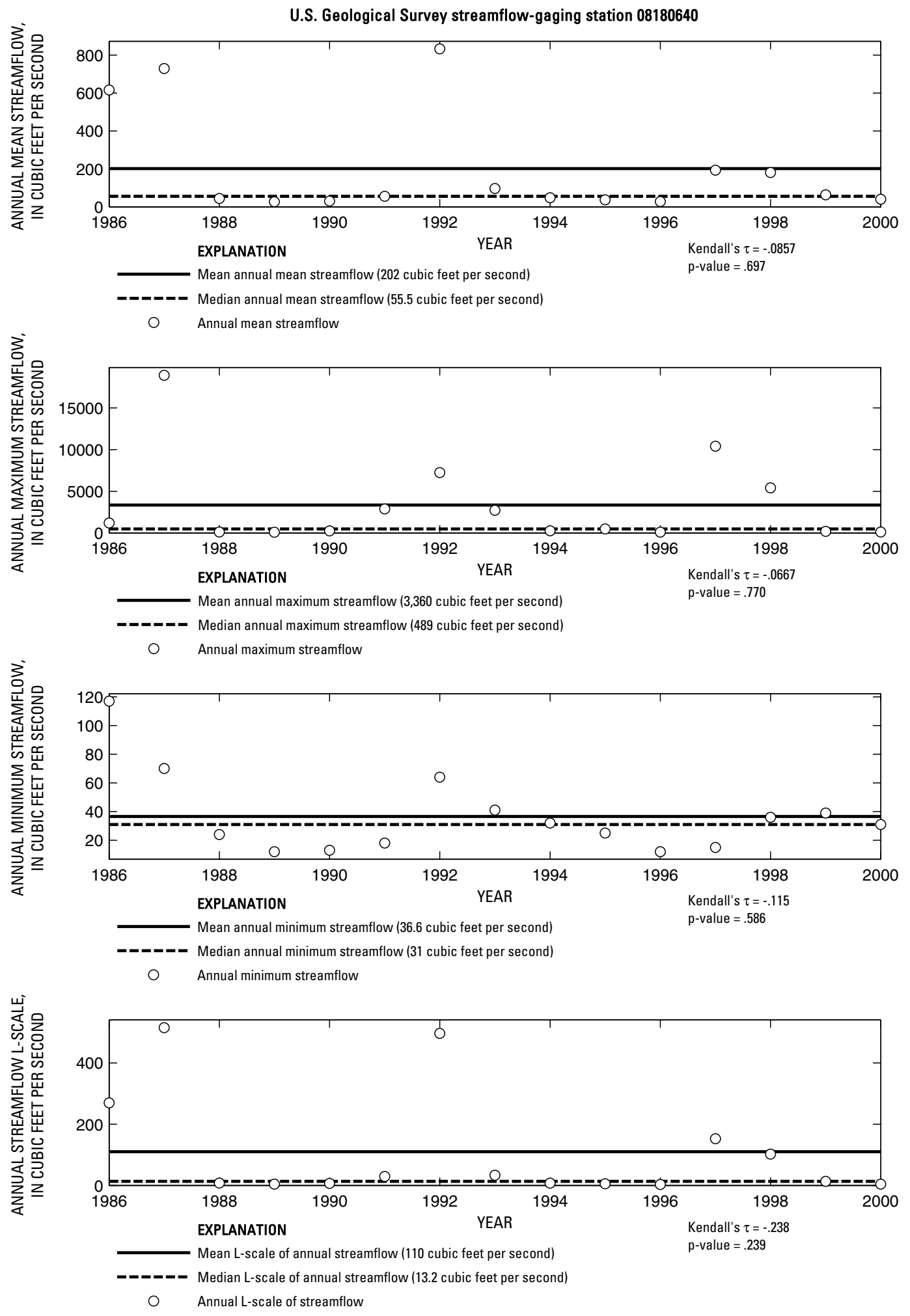

Figure 612. Analysis of annual mean, maximum, minimum, and L-scale statistics of daily mean streamflow for U.S. Geological Survey streamflow-gaging station 08180640 Medina River at La Coste, Texas.

Index of Station Numbers 719 


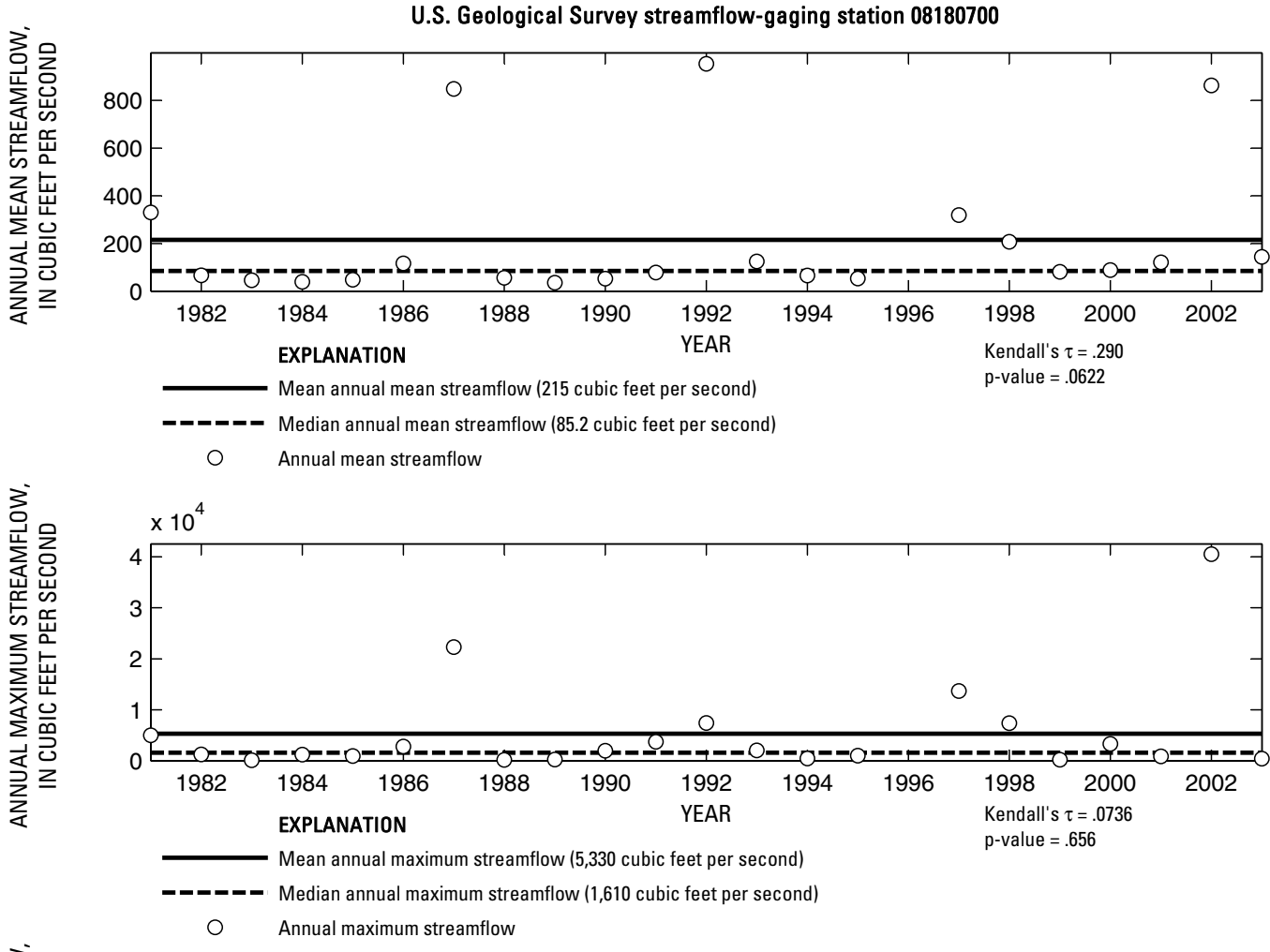

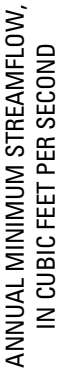

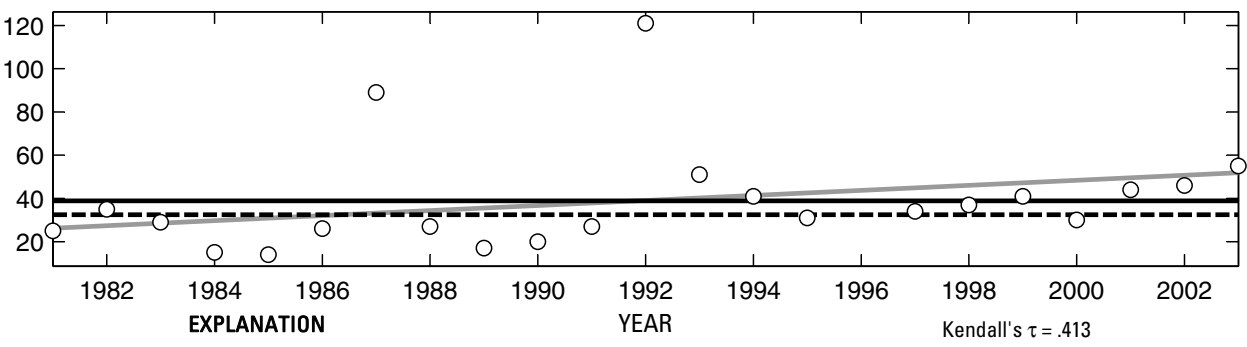

- Theil trend line for annual minimum streamflow

Mean annual minimum streamflow (38.9 cubic feet per second)

- - - Median annual minimum streamflow (32.5 cubic feet per second)

O Annual minimum streamflow

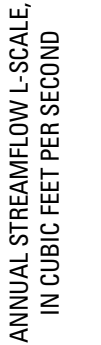

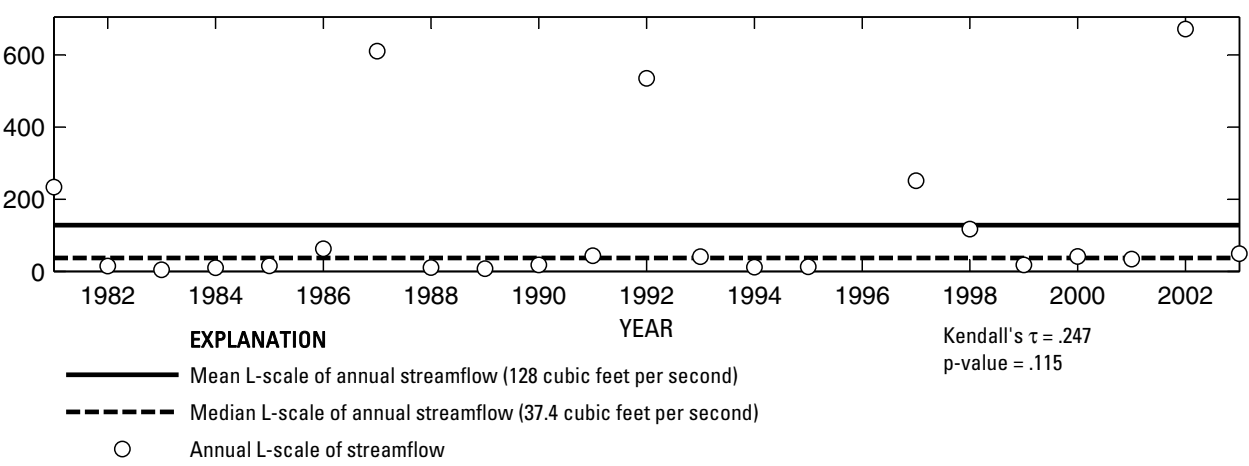

Figure 613. Analysis of annual mean, maximum, minimum, and L-scale statistics of daily mean streamflow for U.S. Geological Survey streamflow-gaging station 08180700 Medina River near Macdona, Texas.

Index of Station Numbers 719 

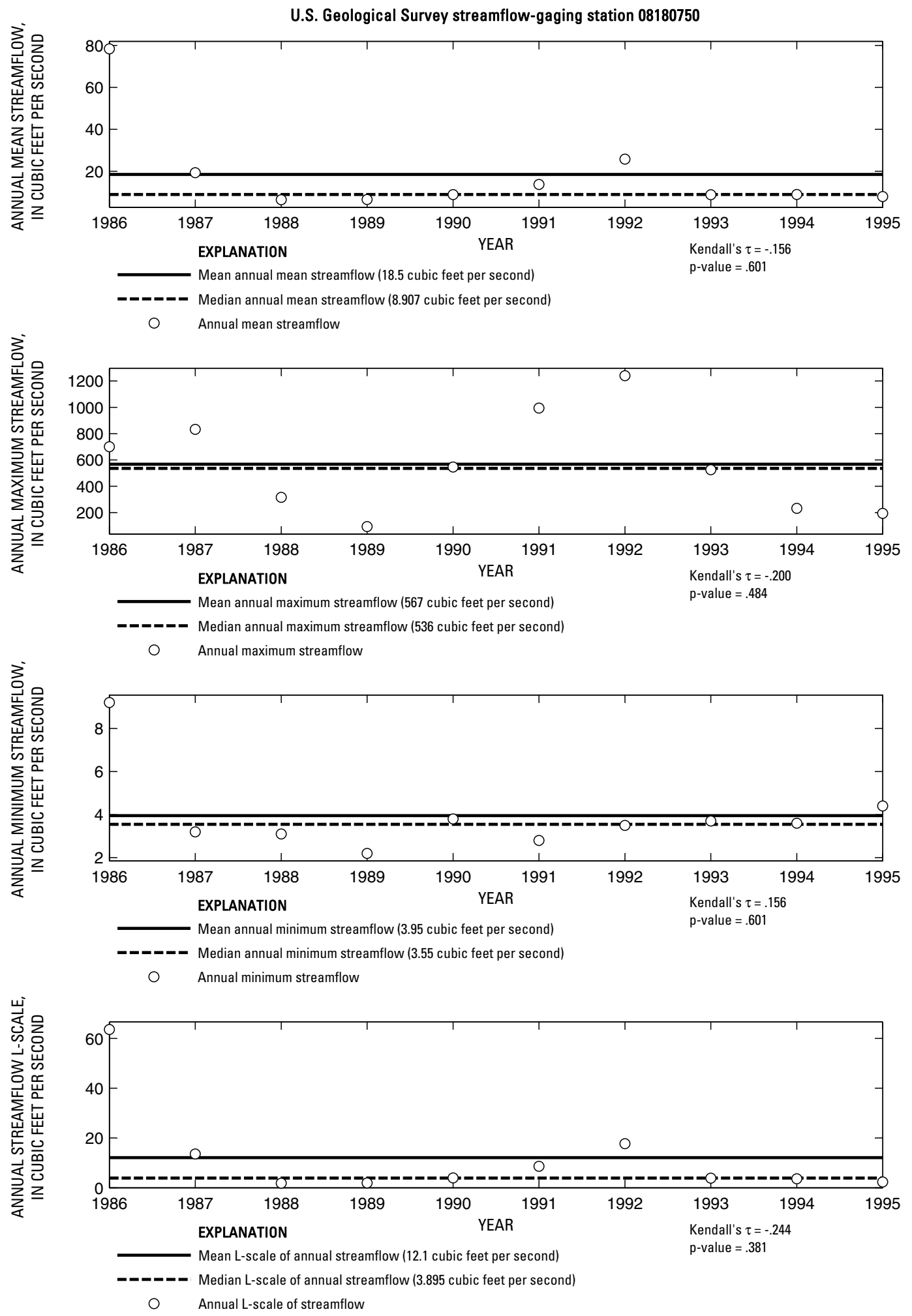

Figure 614. Analysis of annual mean, maximum, minimum, and L-scale statistics of daily mean streamflow for U.S. Geological Survey streamflow-gaging station 08180750 Medio Creek at Pearsall Road, San Antonio, Texas.

Index of Station Numbers 719 

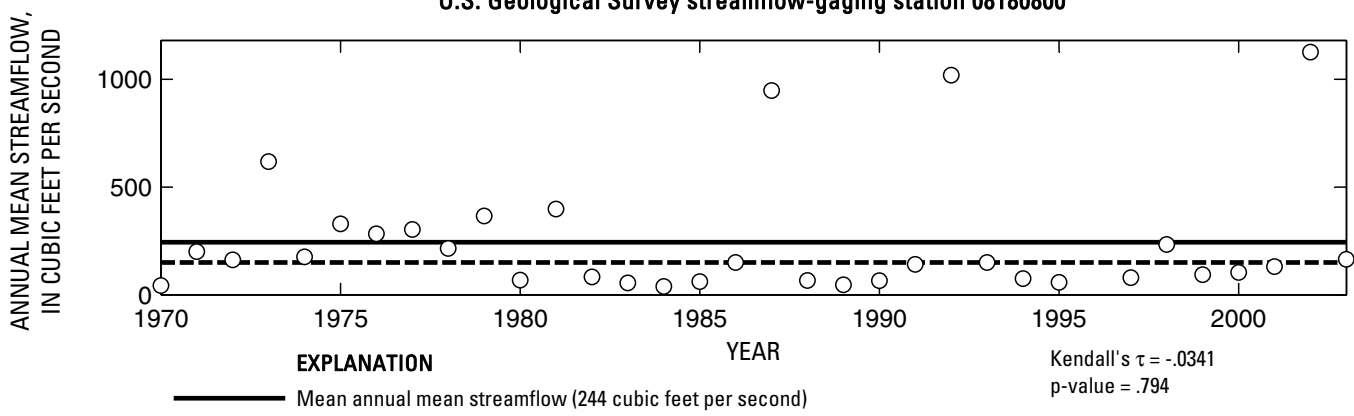

-_-_- Median annual mean streamflow (150 cubic feet per second)

O Annual mean streamflow

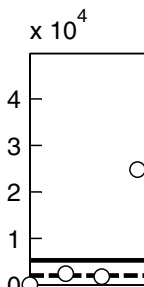

1970

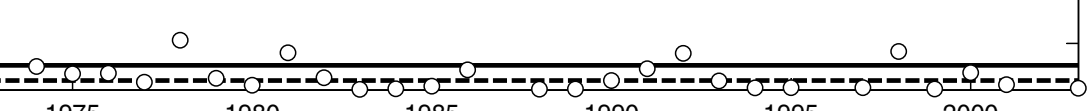

$\begin{array}{llllll}1975 & 1980 & 1985 & 1990 & 1995 & 2000\end{array}$

EXPLANATION

YEAR

Kendall's $\tau=-.0644$

p-value $=.612$

Median annual maximum streamflow $(2,020$ cubic feet per second)

O Annual maximum streamflow

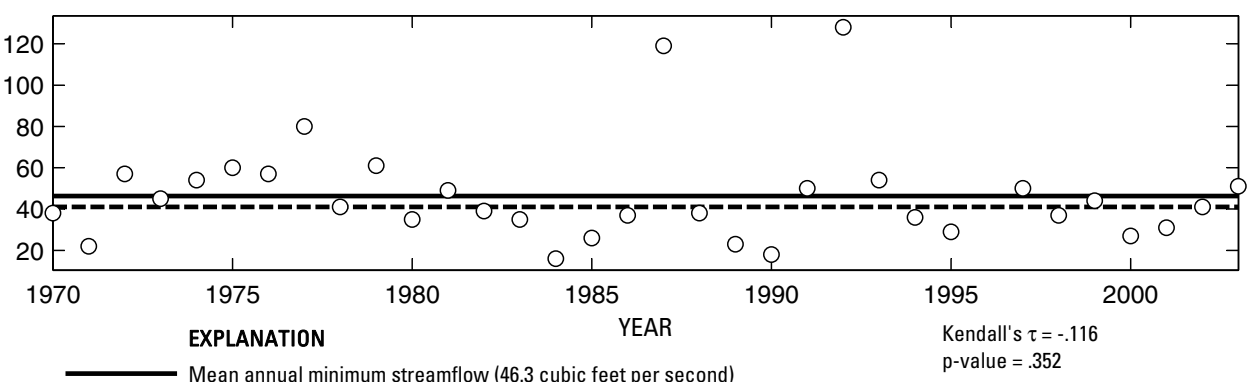

- ב-ב Median annual minimum streamflow (41 cubic feet per second)

O Annual minimum streamflow

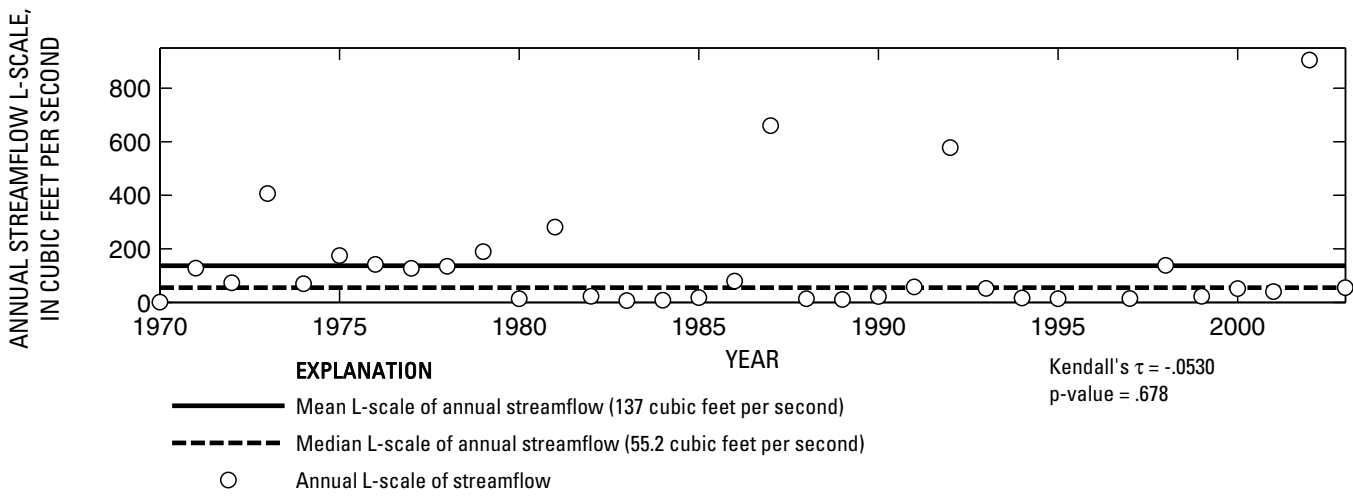

Figure 615. Analysis of annual mean, maximum, minimum, and L-scale statistics of daily mean streamflow for U.S. Geological Survey streamflow-gaging station 08180800 Medina River near Somerset, Texas.

Index of Station Numbers 719 
U.S. Geological Survey streamflow-gaging station 08181400

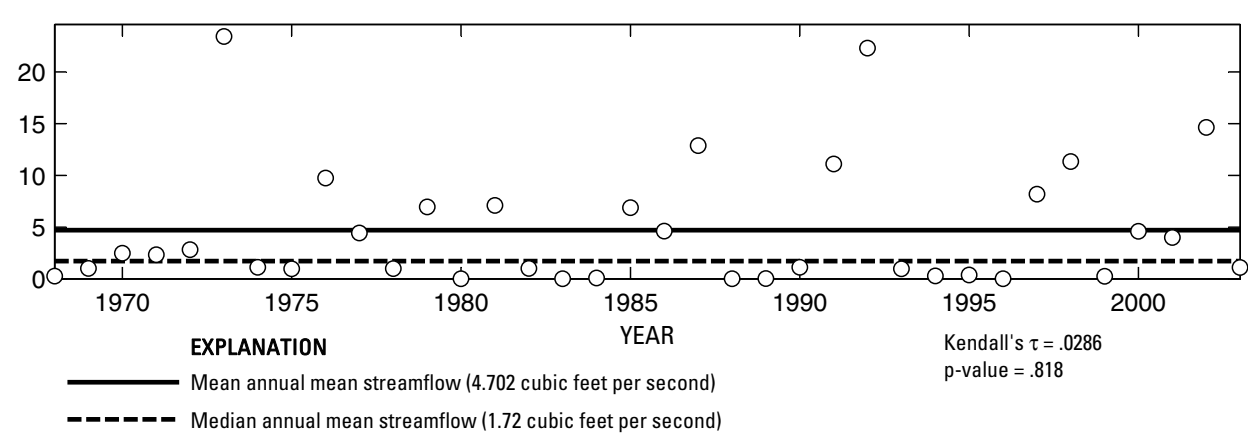

O Annual mean streamflow

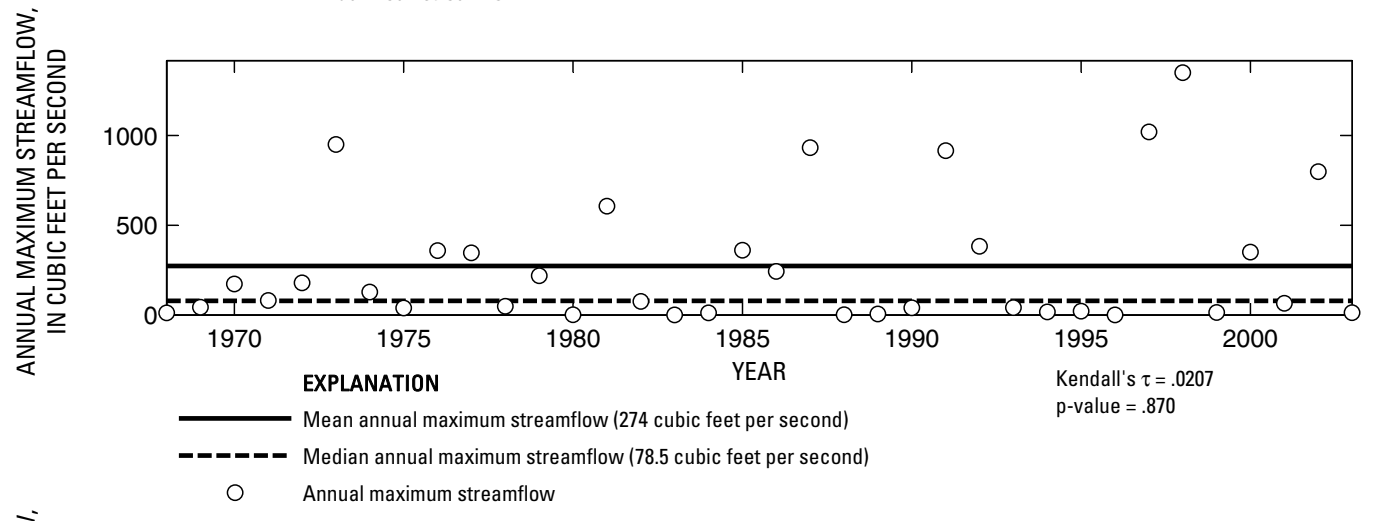

焉

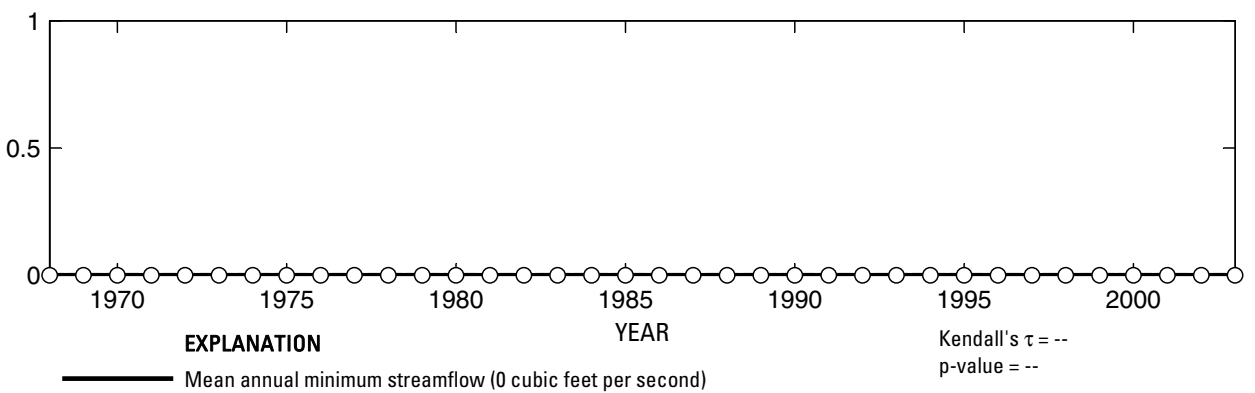

- Median annual minimum streamflow (0 cubic feet per second)

O Annual minimum streamflow

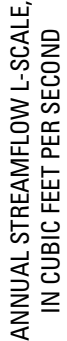

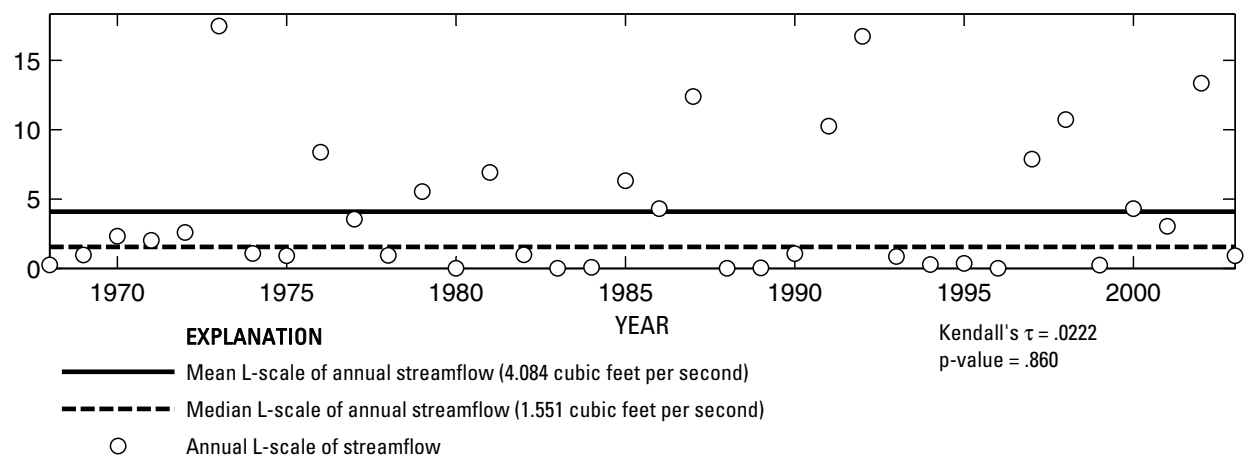

Figure 616. Analysis of annual mean, maximum, minimum, and L-scale statistics of daily mean streamflow for U.S. Geological Survey streamflow-gaging station 08181400 Helotes Creek at Helotes, Texas.

Index of Station Numbers 719 


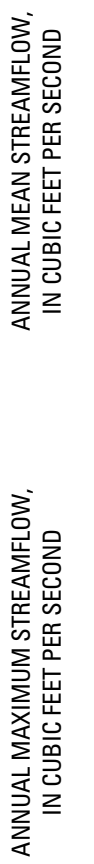

U.S. Geological Survey streamflow-gaging station 08181410
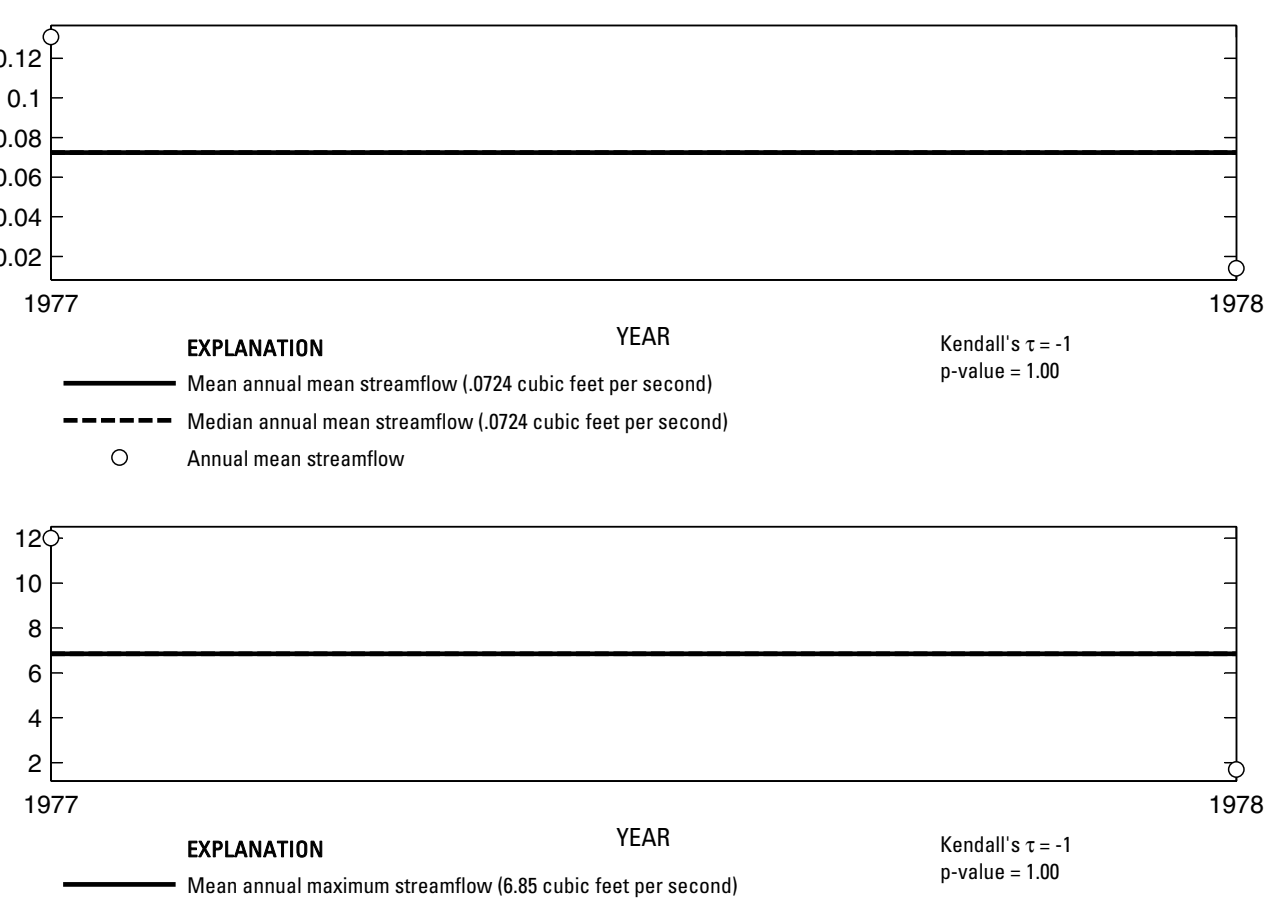

- - - Median annual maximum streamflow ( 6.85 cubic feet per second)

- Annual maximum streamflow
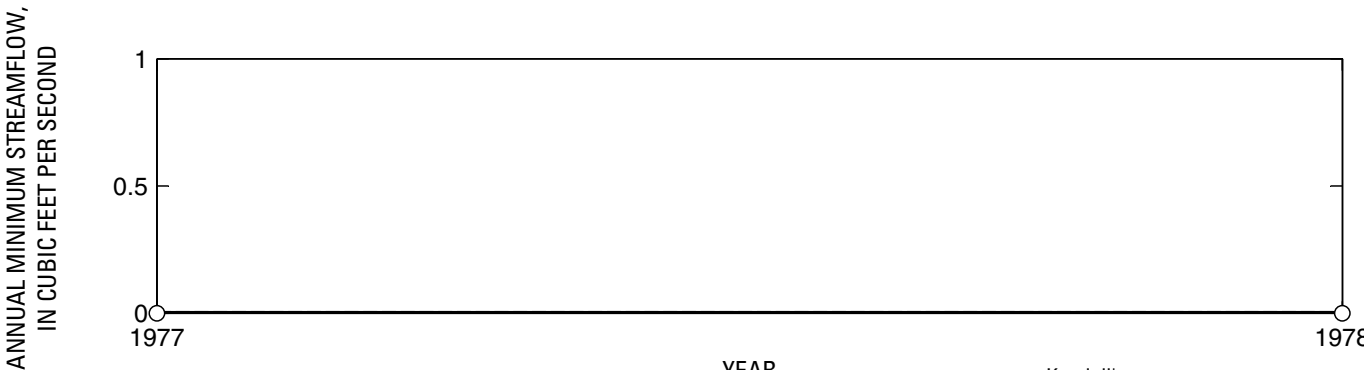

EXPLANATION

YEAR

Kendall's $\tau=-$

Mean annual minimum streamflow (0 cubic feet per second)

p-value $=--$

-_on Median annual minimum streamflow (0 cubic feet per second)

Annual minimum streamflow

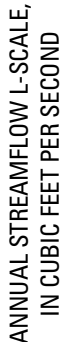

0.12
0.1
0.08
0.06
0.04
0.02
19

1977-

EXPLANATION

YEAR

1978

Mean L-scale of annual streamflow (.07232 cubic feet per second)

-ーーーーー Median L-scale of annual streamflow (.07232 cubic feet per second)

Annual L-scale of streamflow

Figure 617. Analysis of annual mean, maximum, minimum, and L-scale statistics of daily mean streamflow for U.S. Geological Survey streamflow-gaging station 08181410 Ranch Creek near Helotes, Texas.

Index of Station Numbers 719 


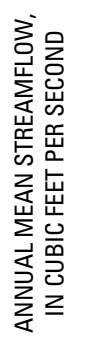

U.S. Geological Survey streamflow-gaging station 08181450

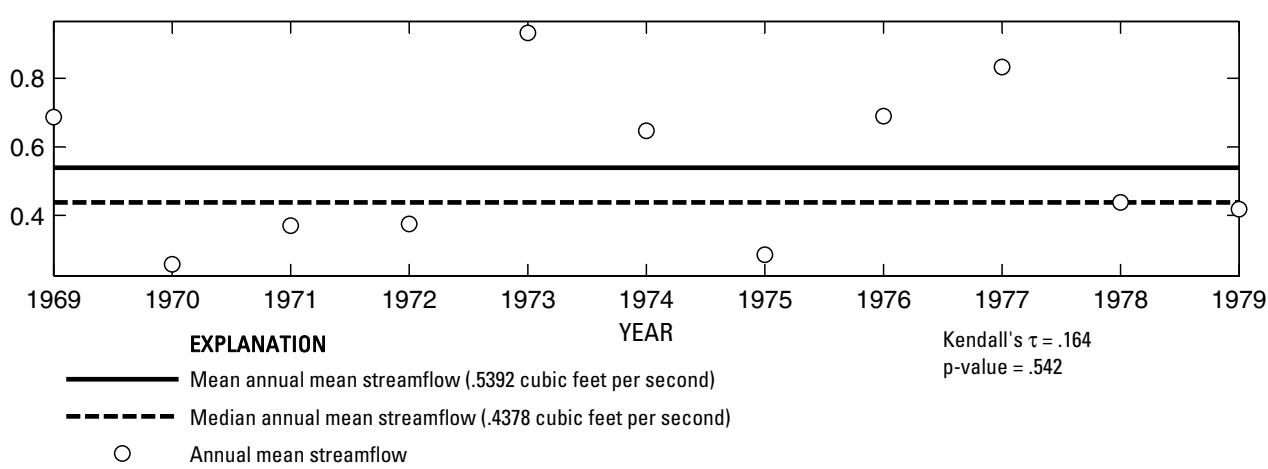

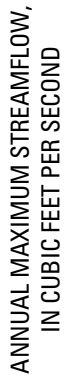

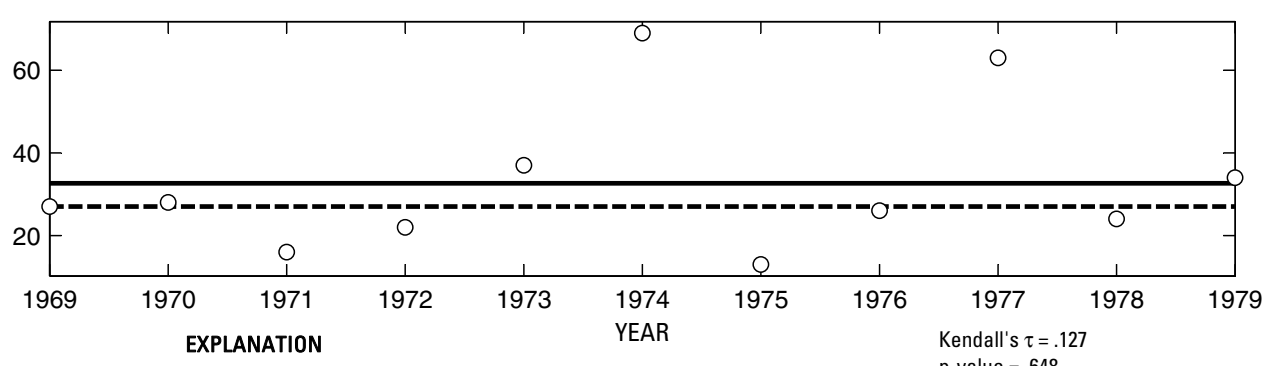

Mean annual maximum streamflow (32.6 cubic feet per second)

$\mathrm{p}$-value $=.648$

--ーー- Median annual maximum streamflow (27 cubic feet per second)

O Annual maximum streamflow

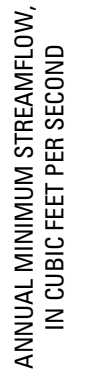

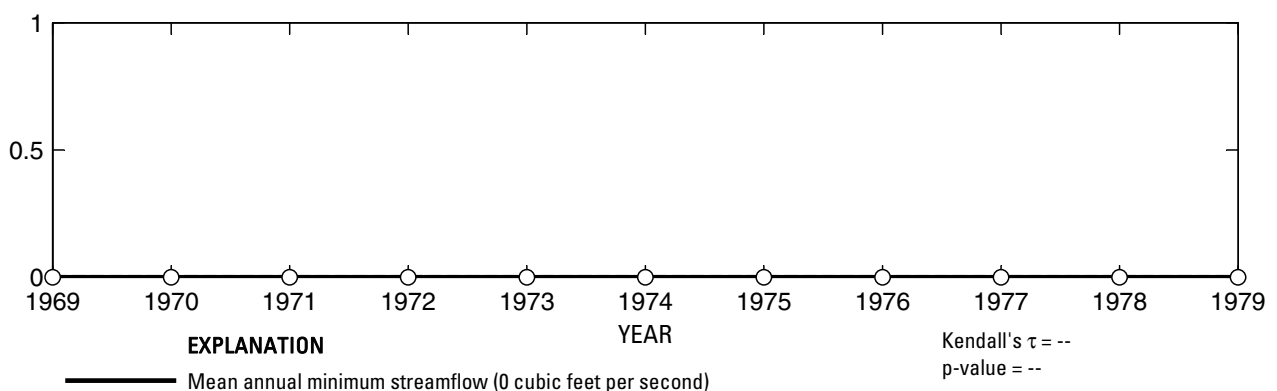

- Median annual minimum streamflow (0 cubic feet per second)

O Annual minimum streamflow

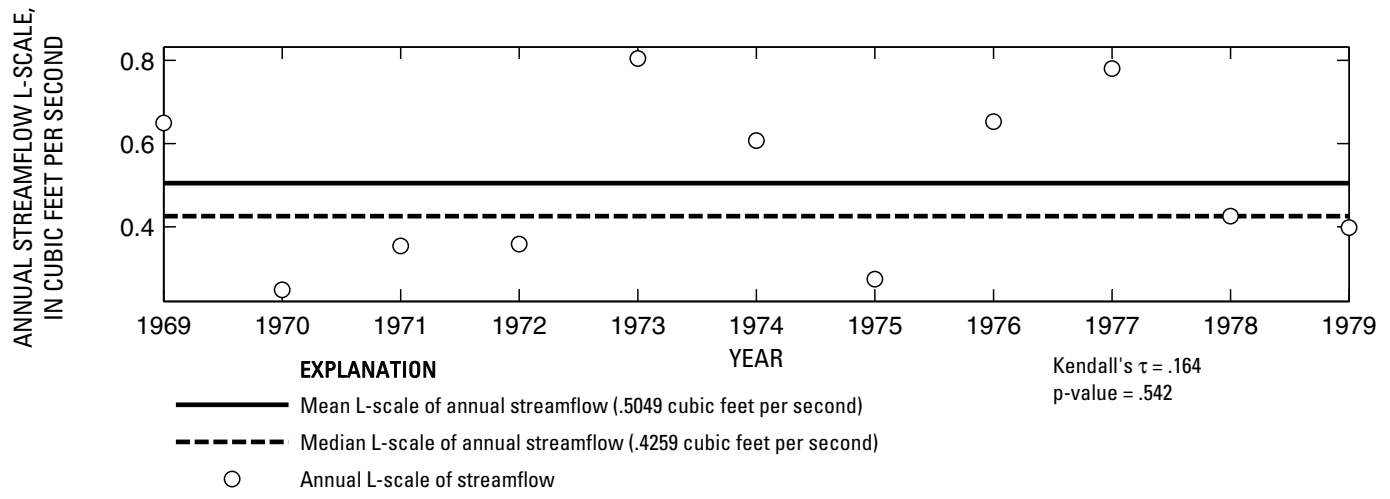

Figure 618. Analysis of annual mean, maximum, minimum, and L-scale statistics of daily mean streamflow for U.S. Geological Survey streamflow-gaging station 08181450 Leon Creek Tributary at Kelly Air Force Base, Texas.

Index of Station Numbers 719 


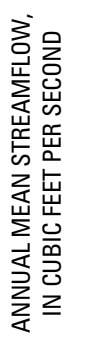

U.S. Geological Survey streamflow-gaging station 08181480

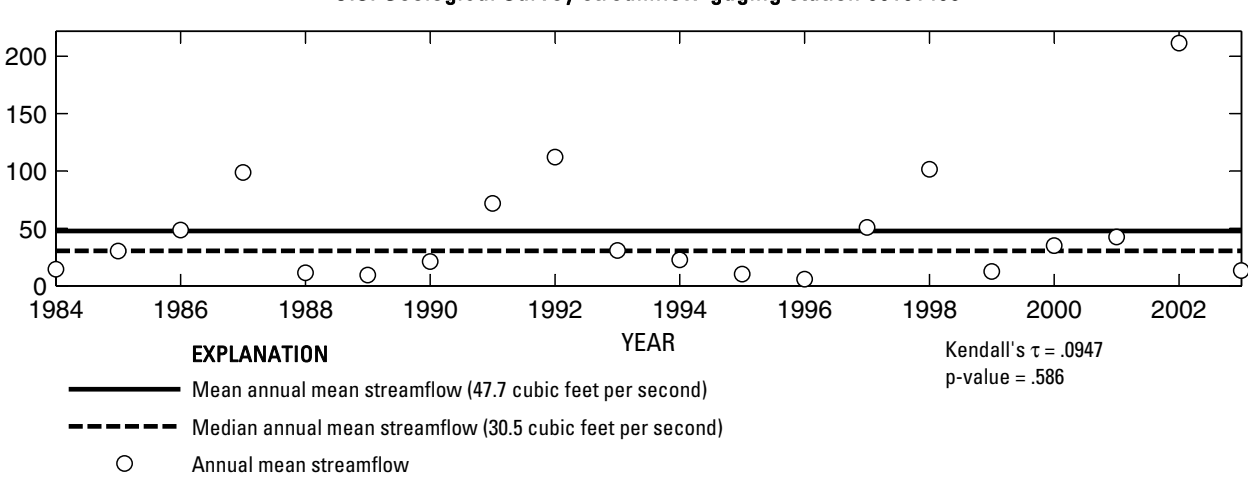

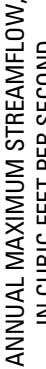

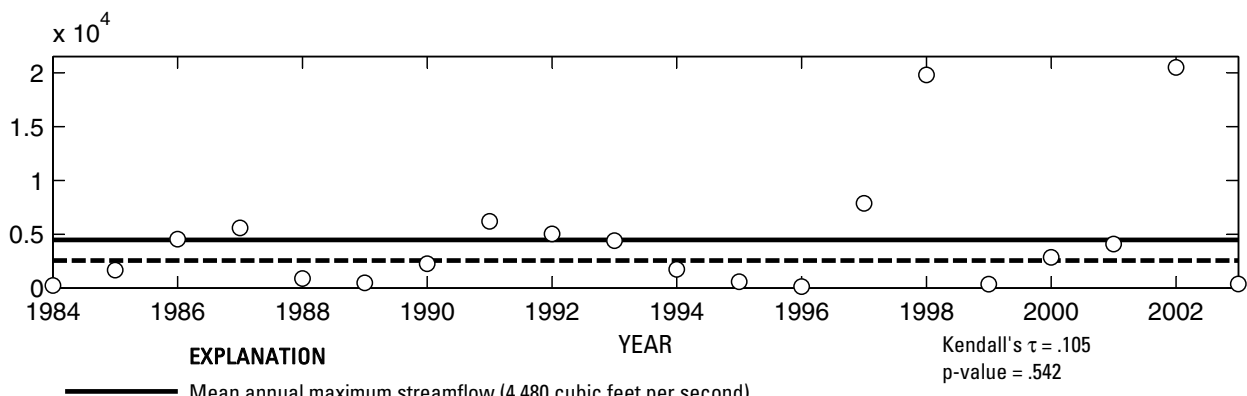

- ב - Median annual maximum streamflow (2,560 cubic feet per second)

○ Annual maximum streamflow

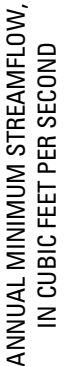

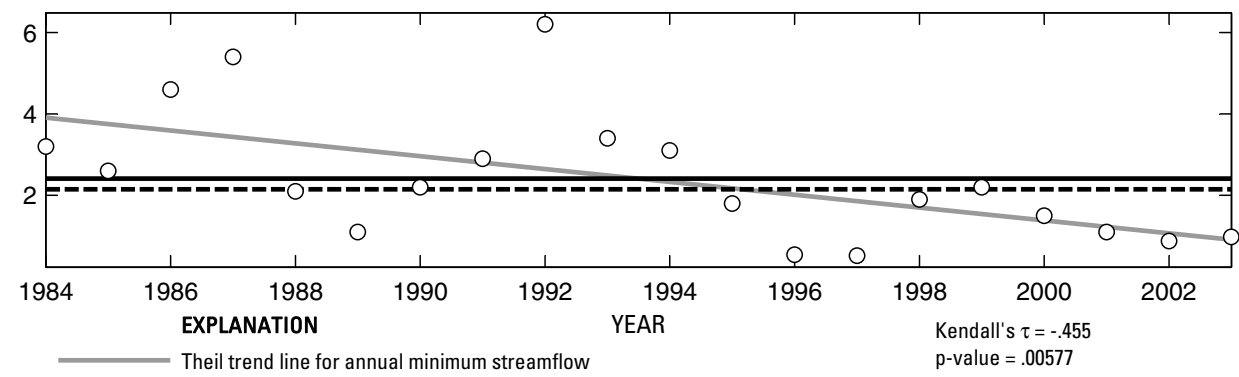

- Mean annual minimum streamflow (2.411 cubic feet per second)

- - Median annual minimum streamflow (2.15 cubic feet per second)

O Annual minimum streamflow
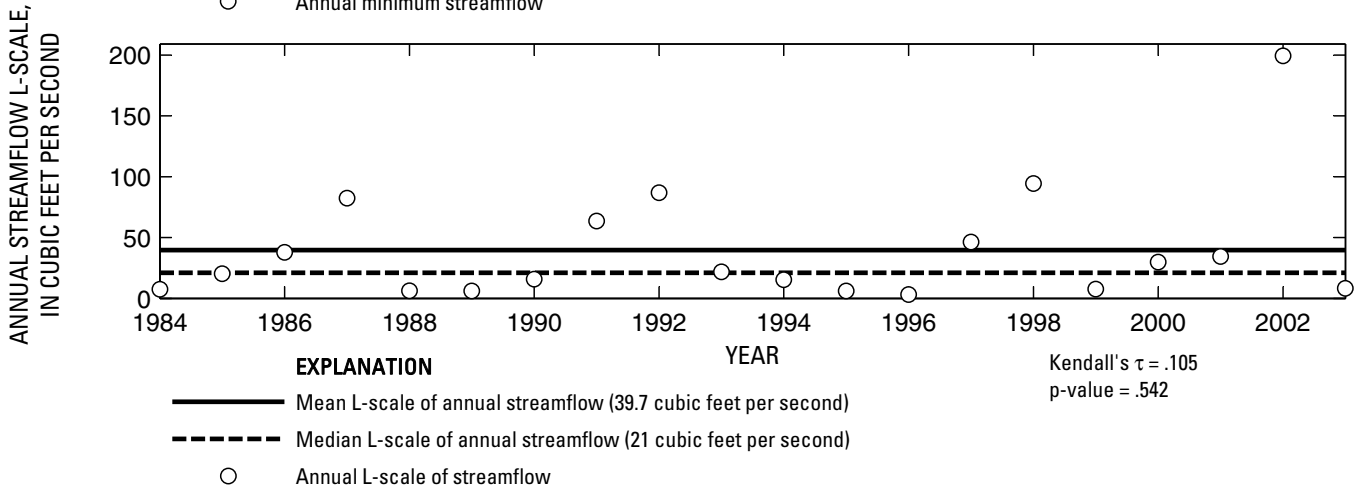

Figure 619. Analysis of annual mean, maximum, minimum, and L-scale statistics of daily mean streamflow for U.S. Geological Survey streamflow-gaging station 08181480 Leon Creek at Interstate Highway 35, San Antonio, Texas.

Index of Station Numbers 719 


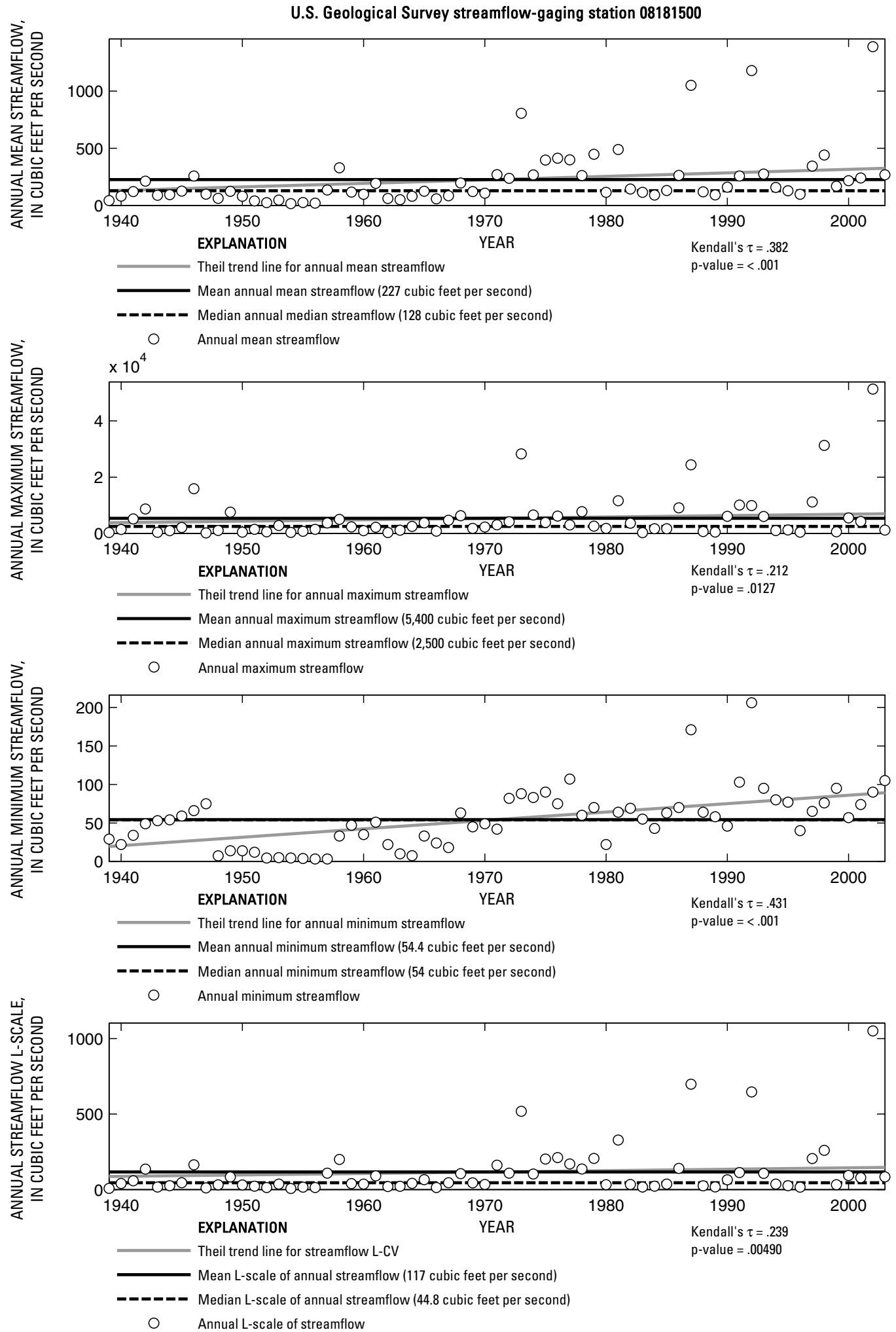

Figure 620. Analysis of annual mean, maximum, minimum, and L-scale statistics of daily mean streamflow for U.S. Geological Survey streamflow-gaging station 08181500 Medina River at San Antonio, Texas.

Index of Station Numbers 719 


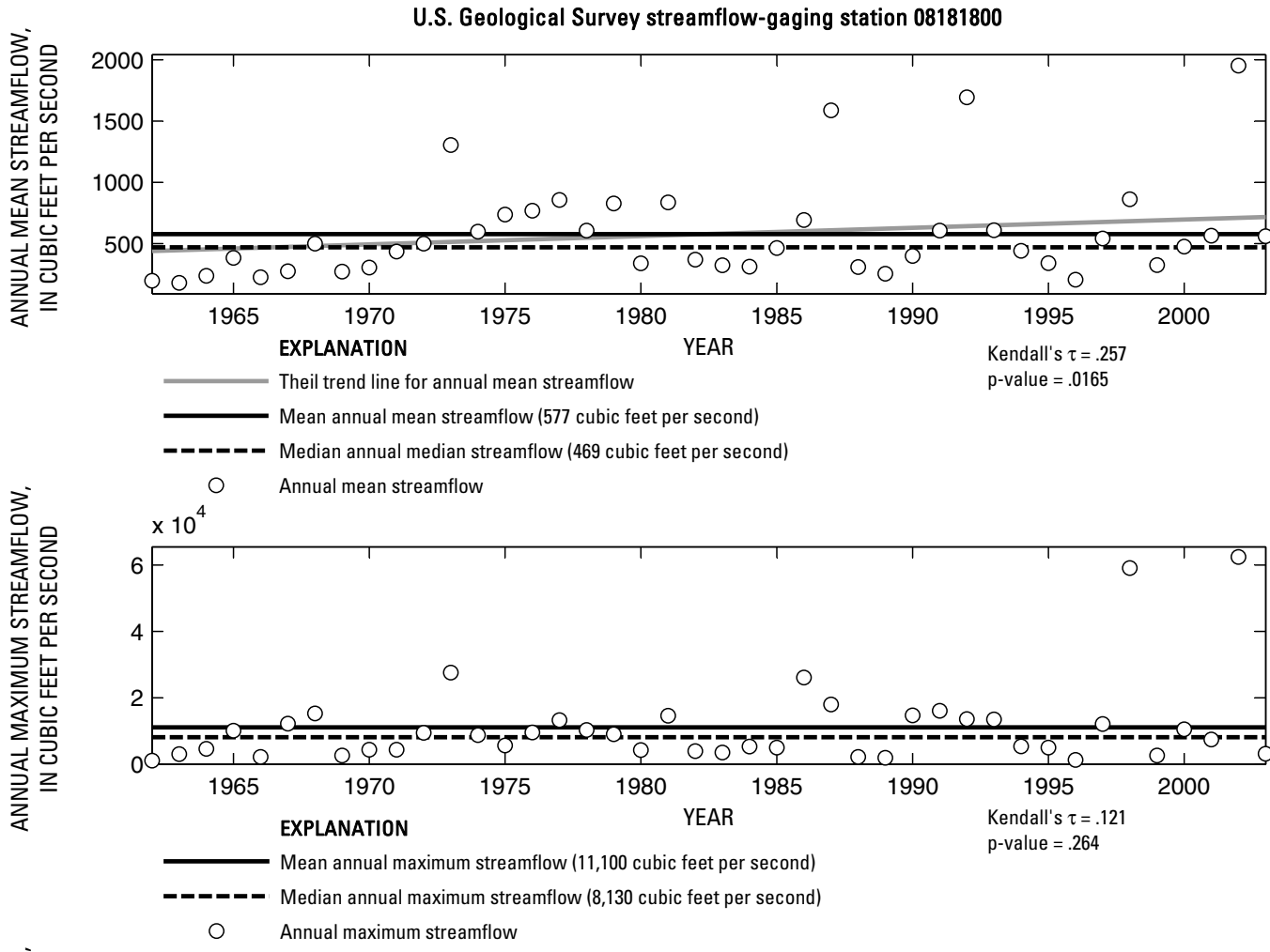

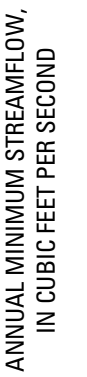

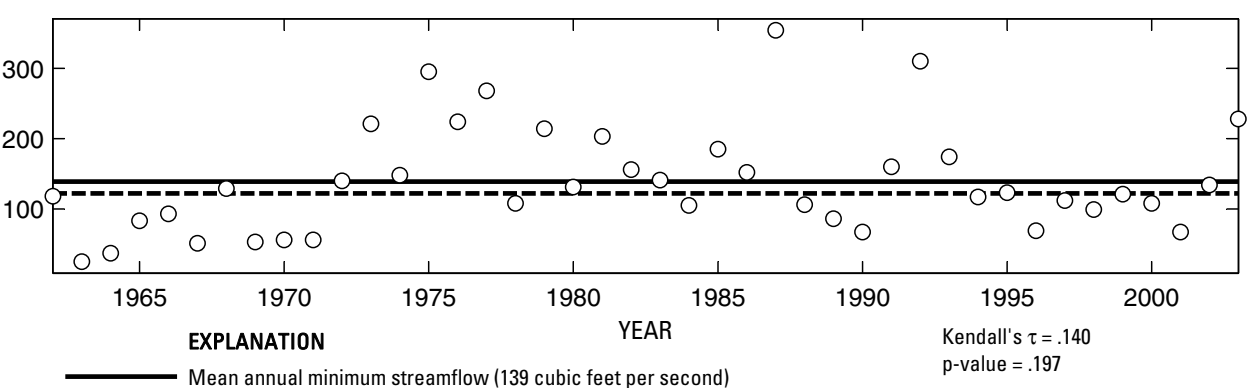

- - - Median annual minimum streamflow (122 cubic feet per second)

○ Annual minimum streamflow

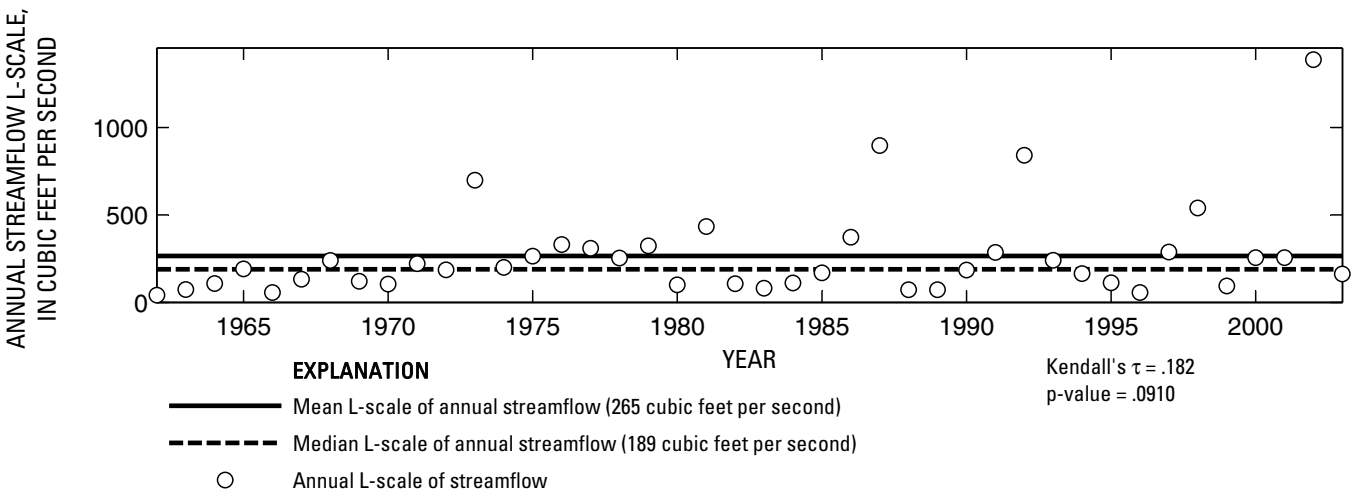

Figure 621. Analysis of annual mean, maximum, minimum, and L-scale statistics of daily mean streamflow for U.S. Geological Survey streamflow-gaging station 08181800 San Antonio River near Elmendorf, Texas.

Index of Station Numbers 719 


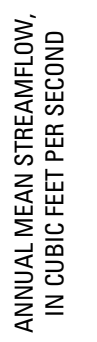

U.S. Geological Survey streamflow-gaging station 08182500

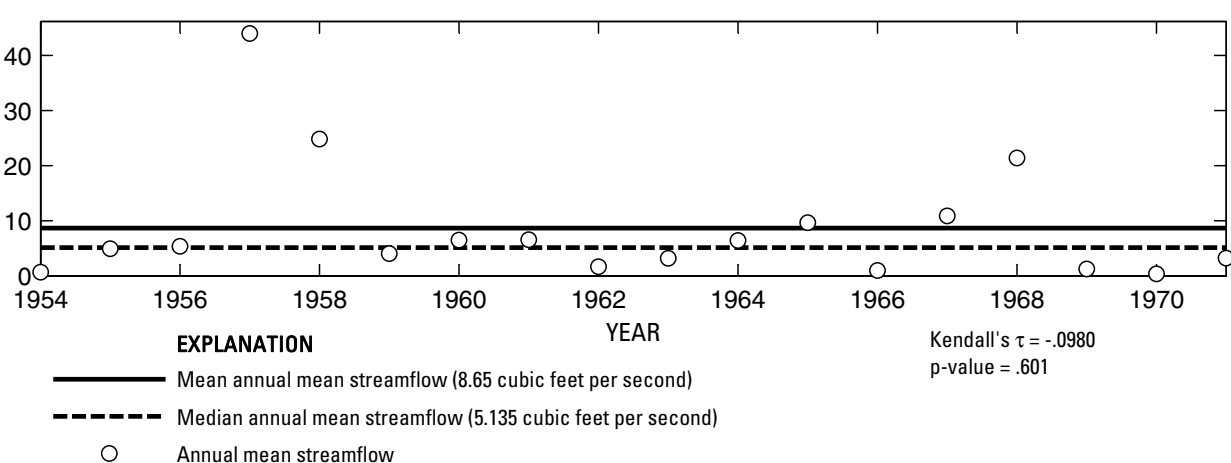

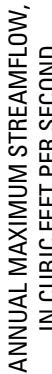

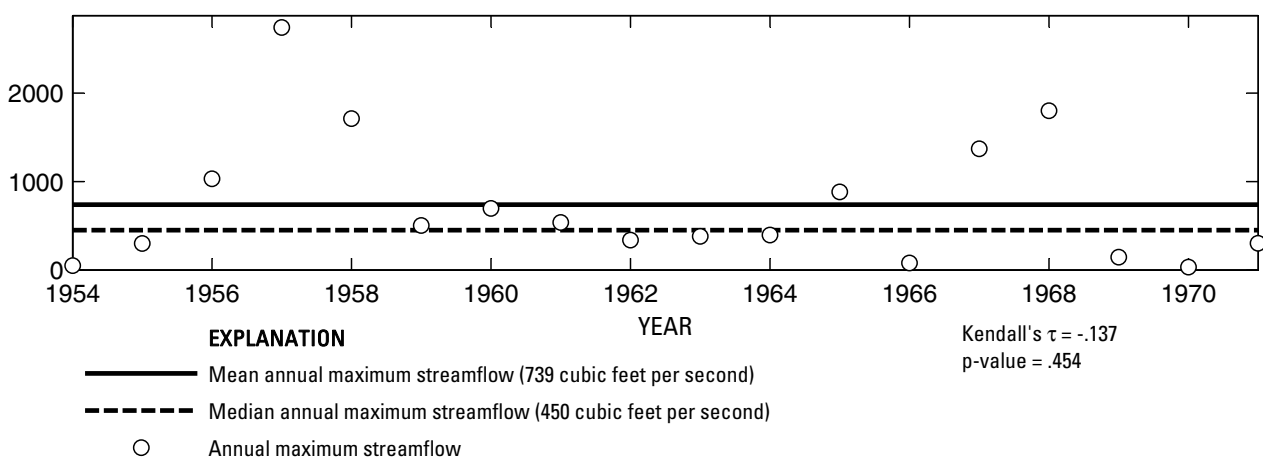

崔

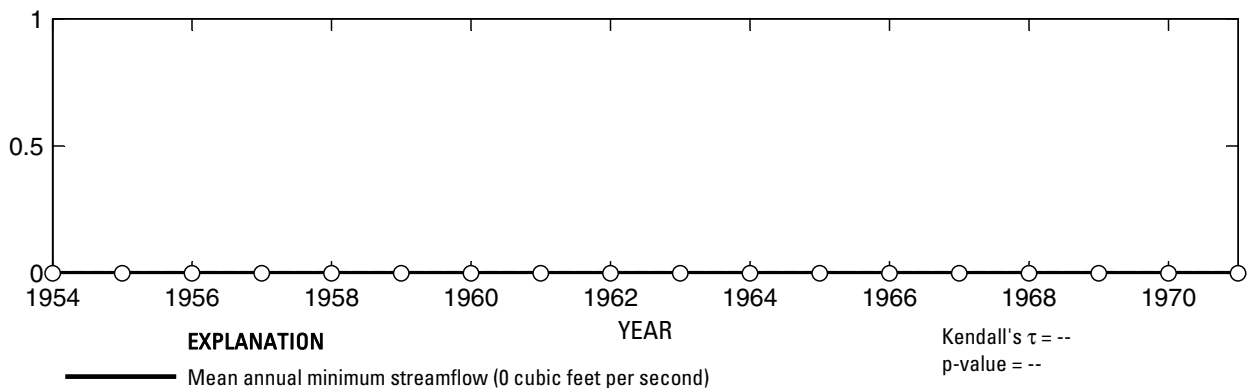

- Median annual minimum streamflow (0 cubic feet per second)

O Annual minimum streamflow

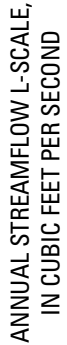

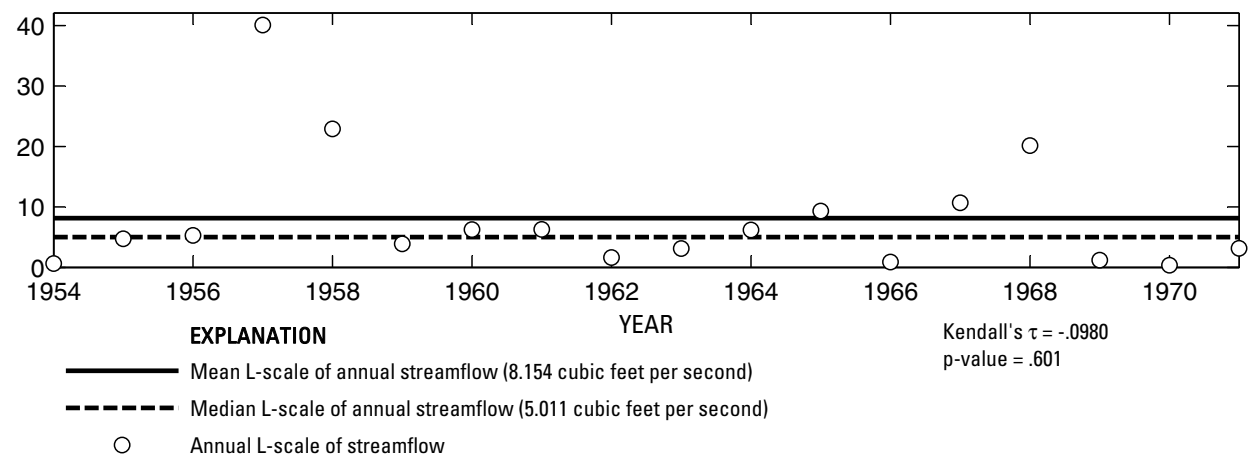

Figure 622. Analysis of annual mean, maximum, minimum, and L-scale statistics of daily mean streamflow for U.S. Geological Survey streamflow-gaging station 08182500 Calaveras Creek near Elemendorf, Texas.

Index of Station Numbers 719 


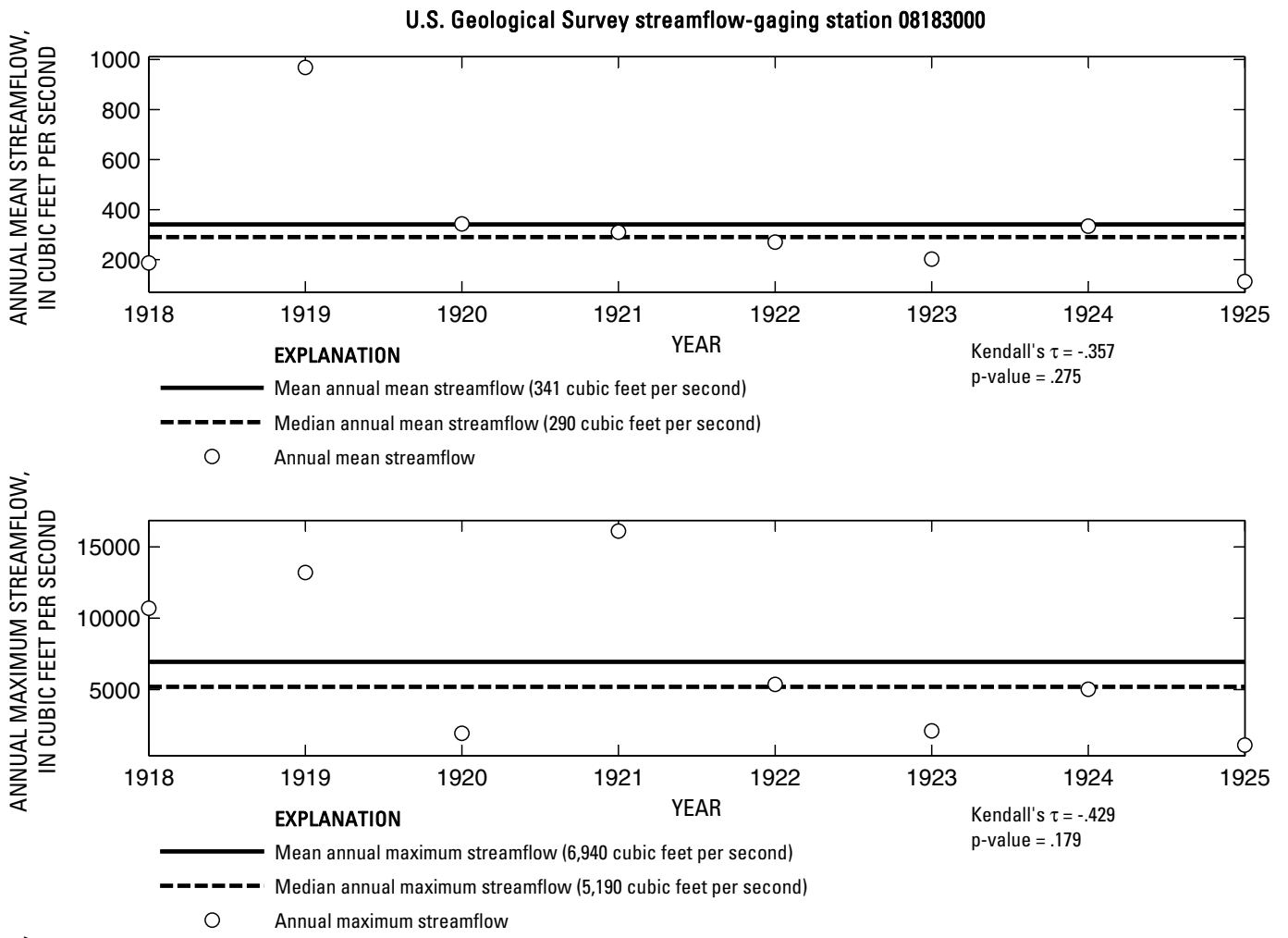

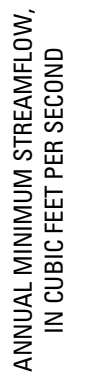

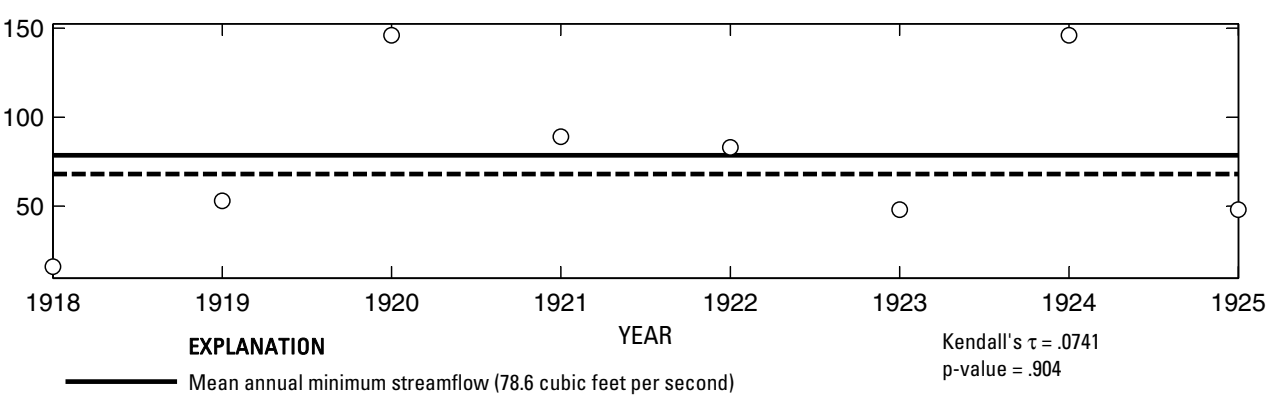

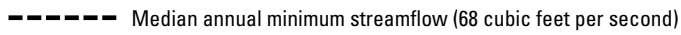

O Annual minimum streamflow

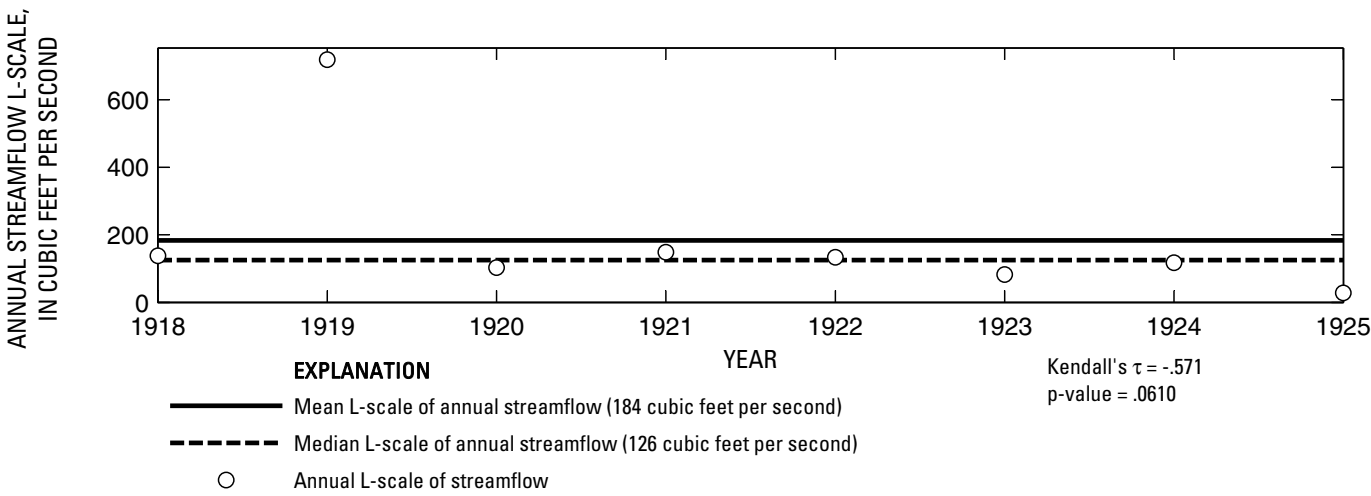

Figure 623. Analysis of annual mean, maximum, minimum, and L-scale statistics of daily mean streamflow for U.S. Geological Survey streamflow-gaging station 08183000 San Antonio River at Calaveras, Texas.

Index of Station Numbers 719 


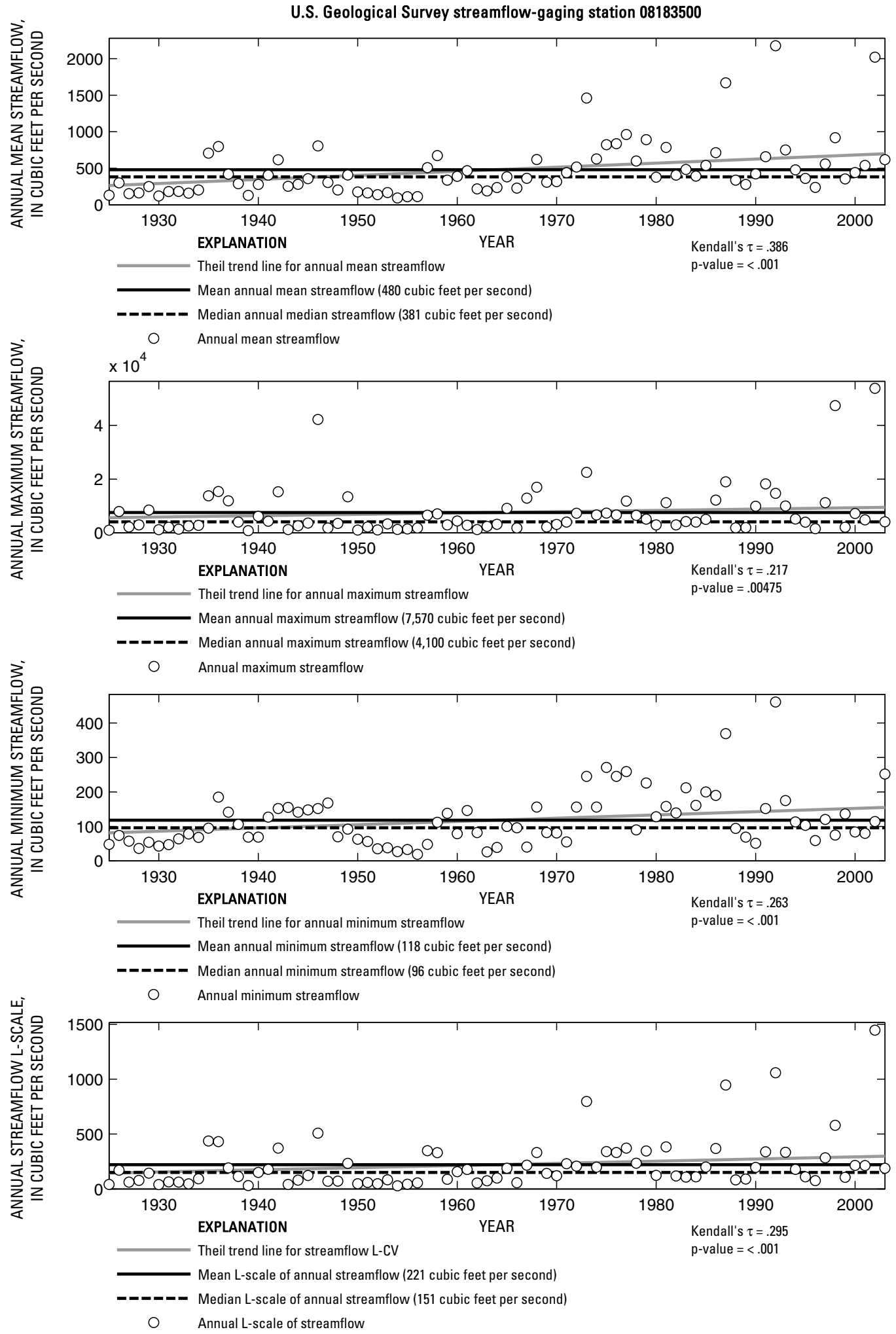

Figure 624. Analysis of annual mean, maximum, minimum, and L-scale statistics of daily mean streamflow for U.S. Geological Survey streamflow-gaging station 08183500 San Antonio River near Falls City, Texas.

Index of Station Numbers 719 


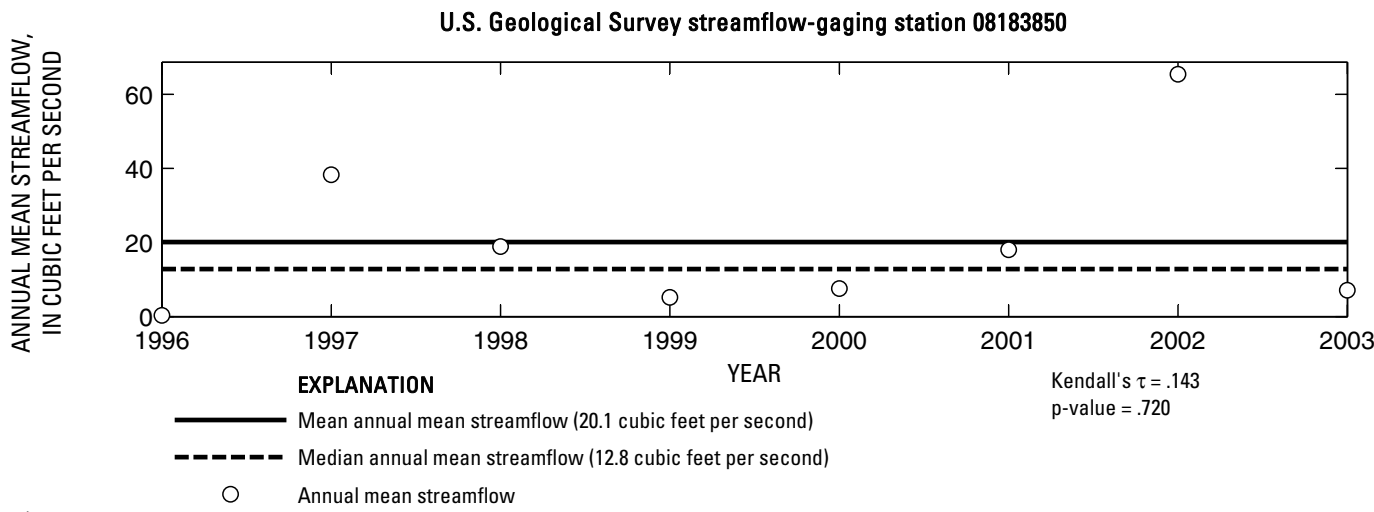

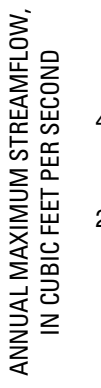

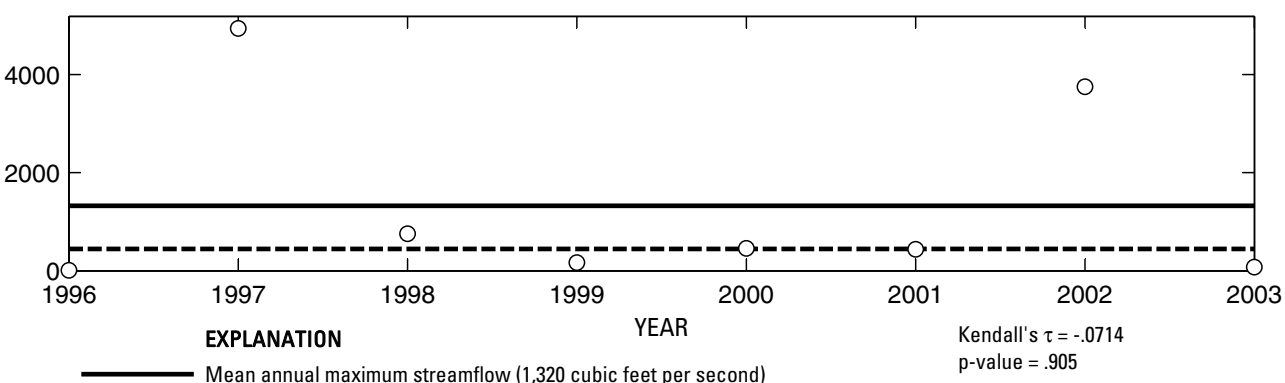

- - _- Median annual maximum streamflow (446 cubic feet per second)

O Annual maximum streamflow
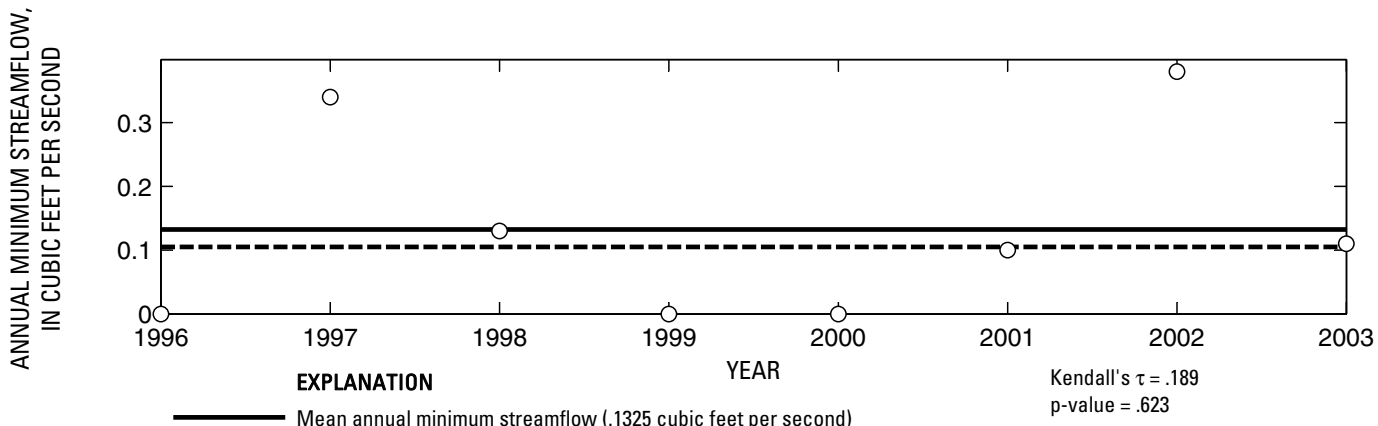

-ーーーーー Median annual minimum streamflow (.105 cubic feet per second)

O Annual minimum streamflow

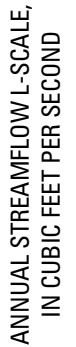

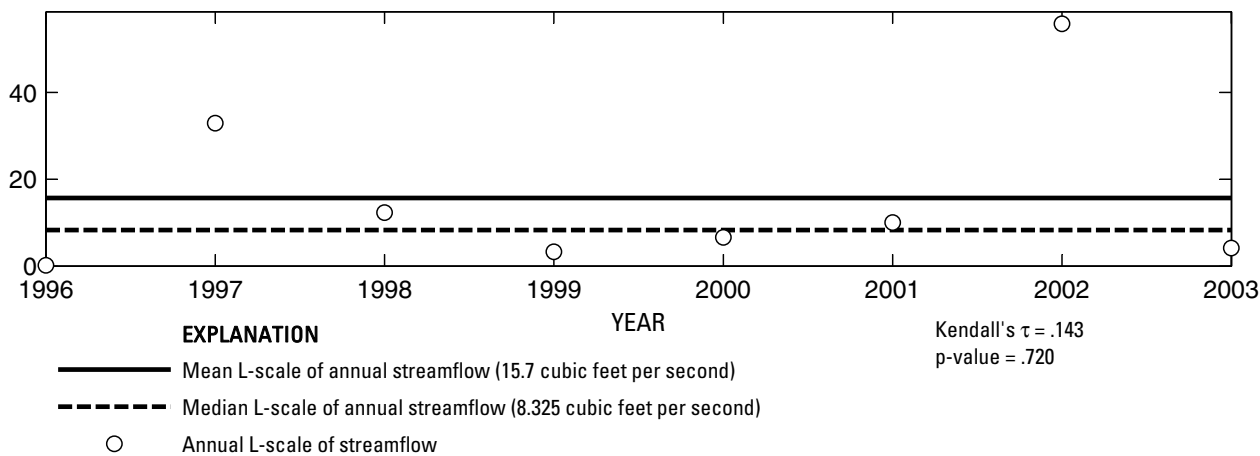

Figure 625. Analysis of annual mean, maximum, minimum, and L-scale statistics of daily mean streamflow for U.S. Geological Survey streamflow-gaging station 08183850 Cibolo Creek at Interstate Highway 10 above Boerne, Texas. 


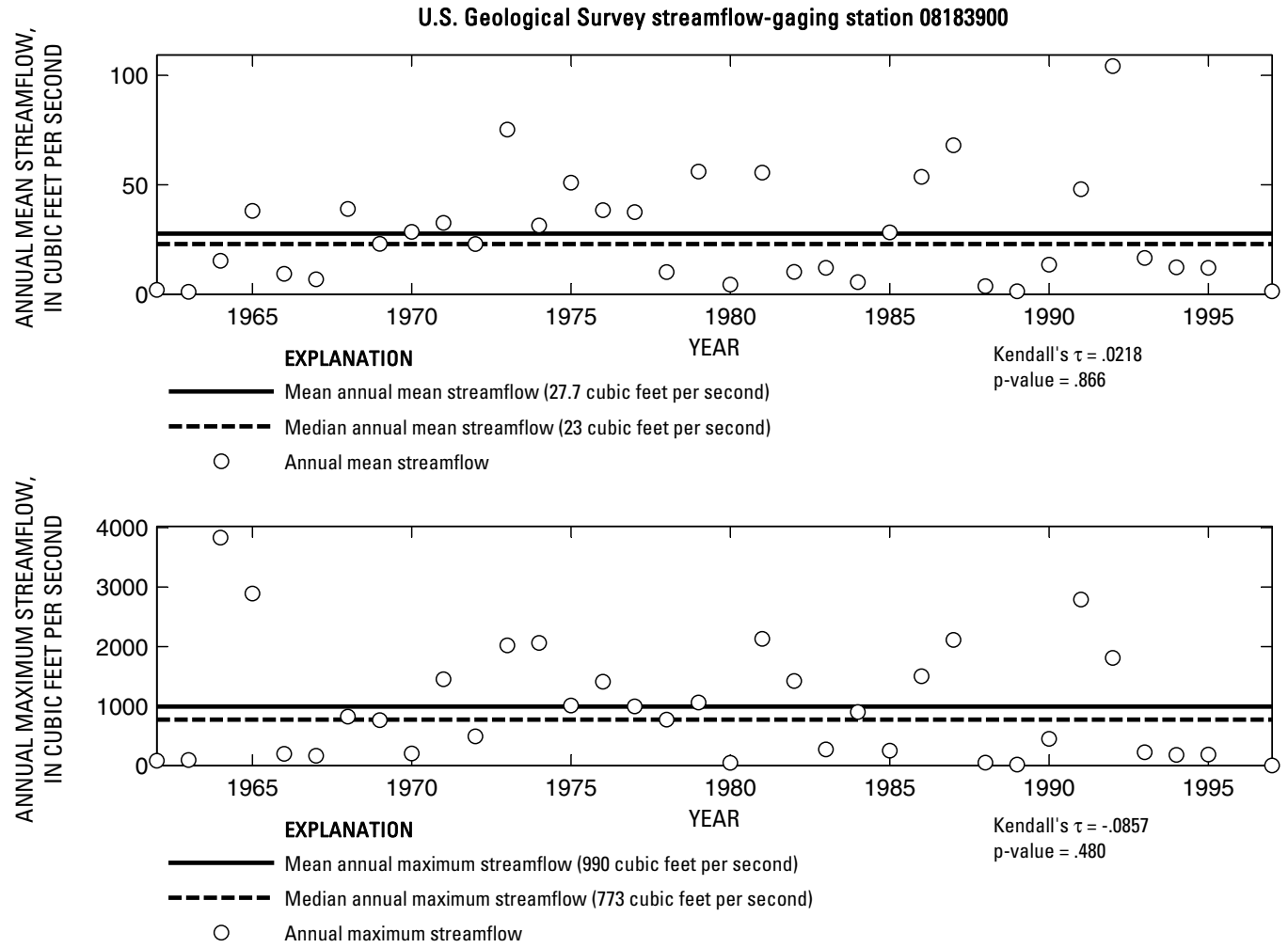

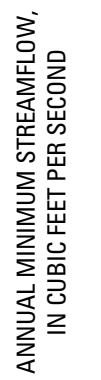

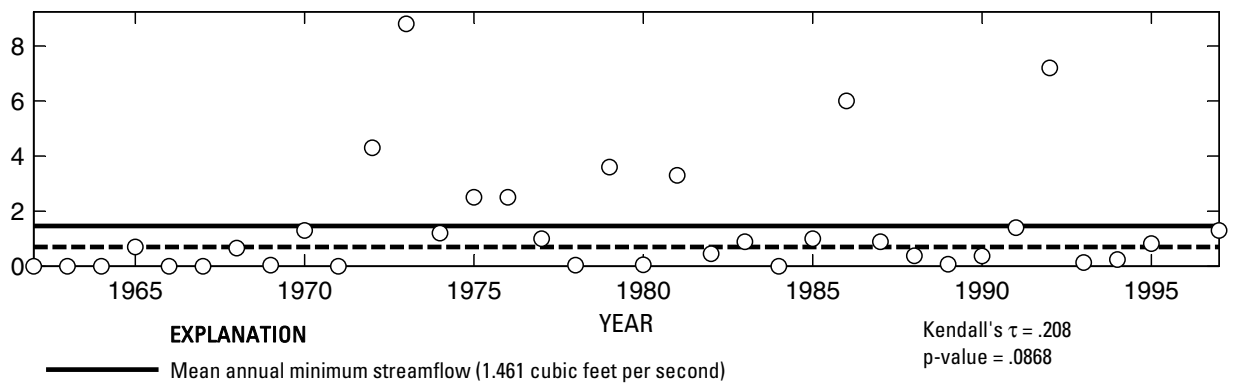

- Median annual minimum streamflow (.7 cubic feet per second)

O Annual minimum streamflow

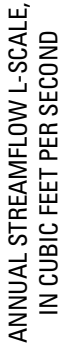

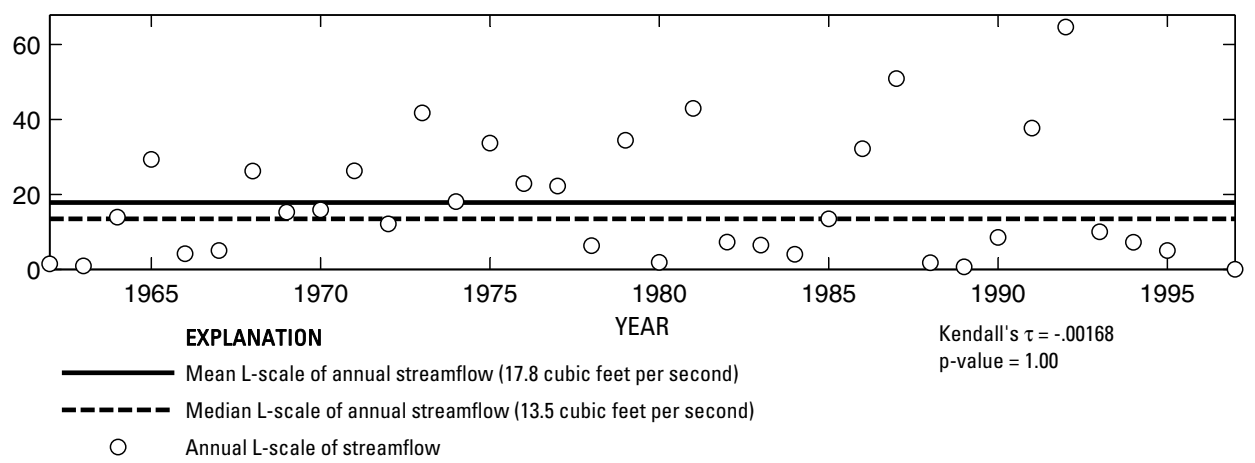

Figure 626. Analysis of annual mean, maximum, minimum, and L-scale statistics of daily mean streamflow for U.S. Geological Survey streamflow-gaging station 08183900 Cibolo Creek near Boerne, Texas.

Index of Station Numbers 719 


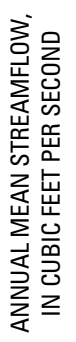

U.S. Geological Survey streamflow-gaging station 08184000

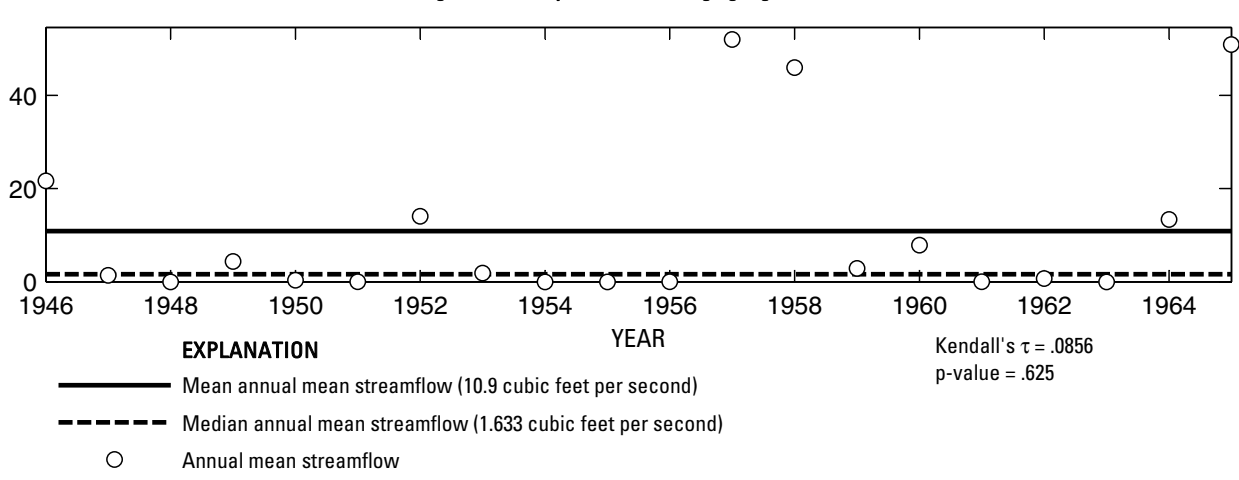

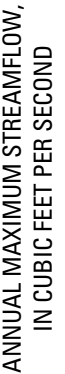

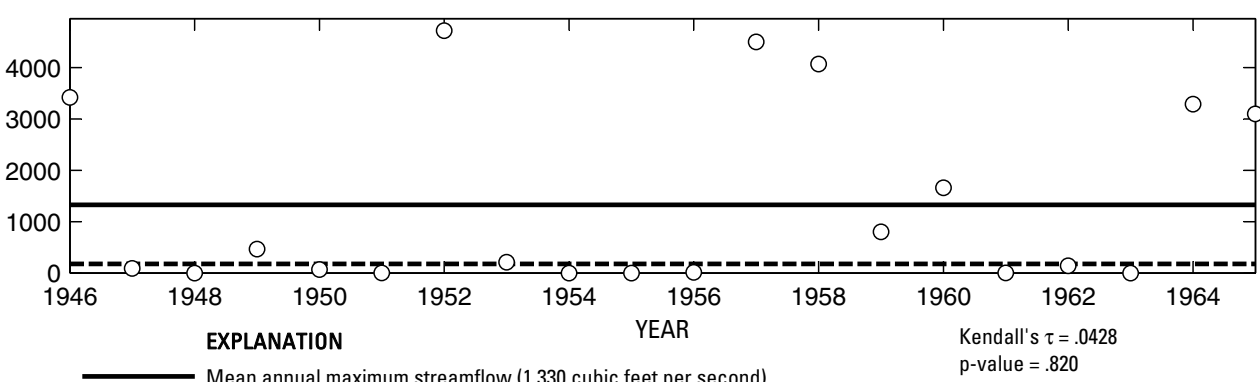

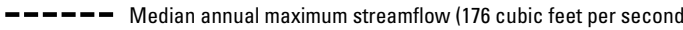

Annual maximum streamflow

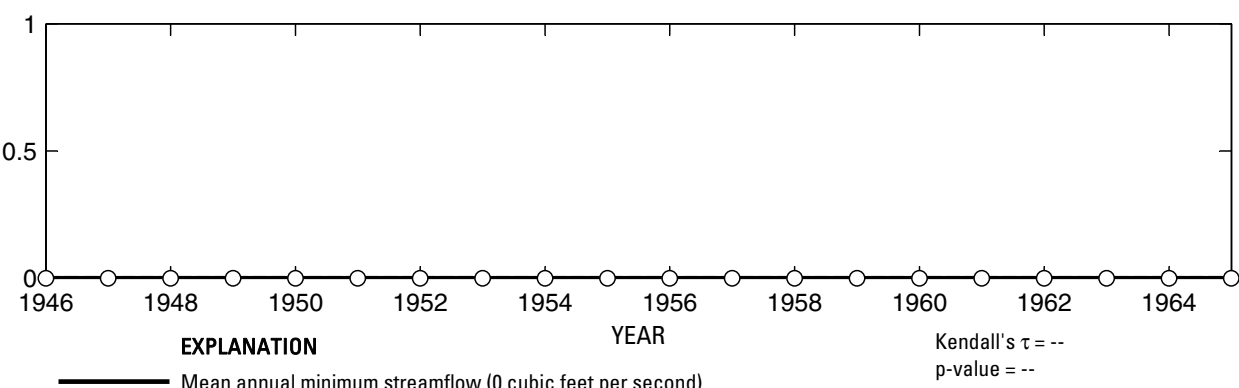

- Median annual minimum streamflow (0 cubic feet per second)

○ Annual minimum streamflow

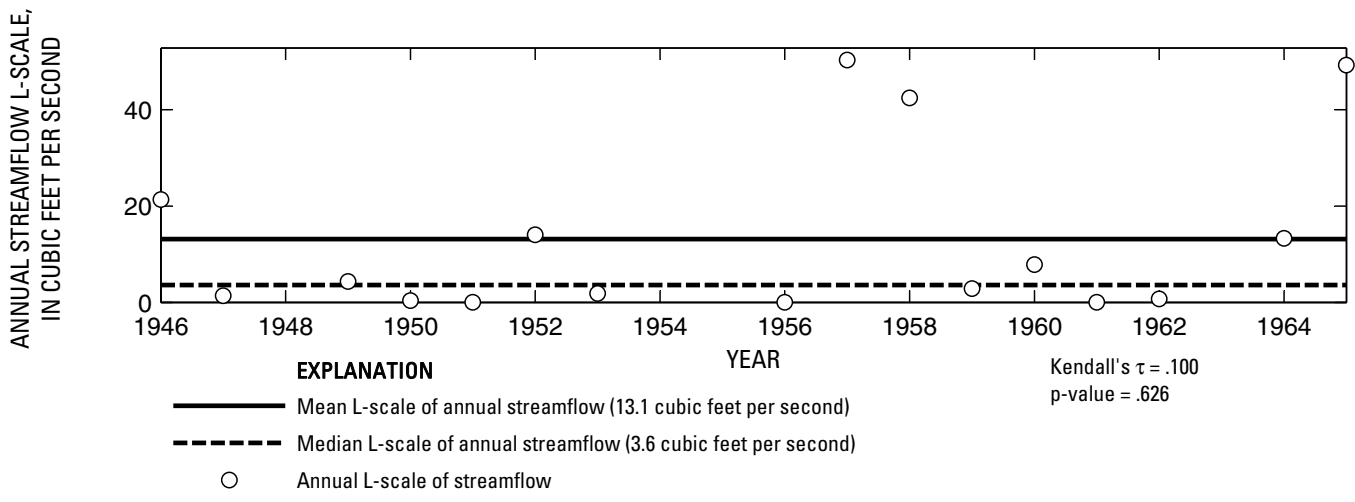

Figure 627. Analysis of annual mean, maximum, minimum, and L-scale statistics of daily mean streamflow for U.S. Geological Survey streamflow-gaging station 08184000 Cibolo Creek near Bulverde, Texas.

Index of Station Numbers 719 

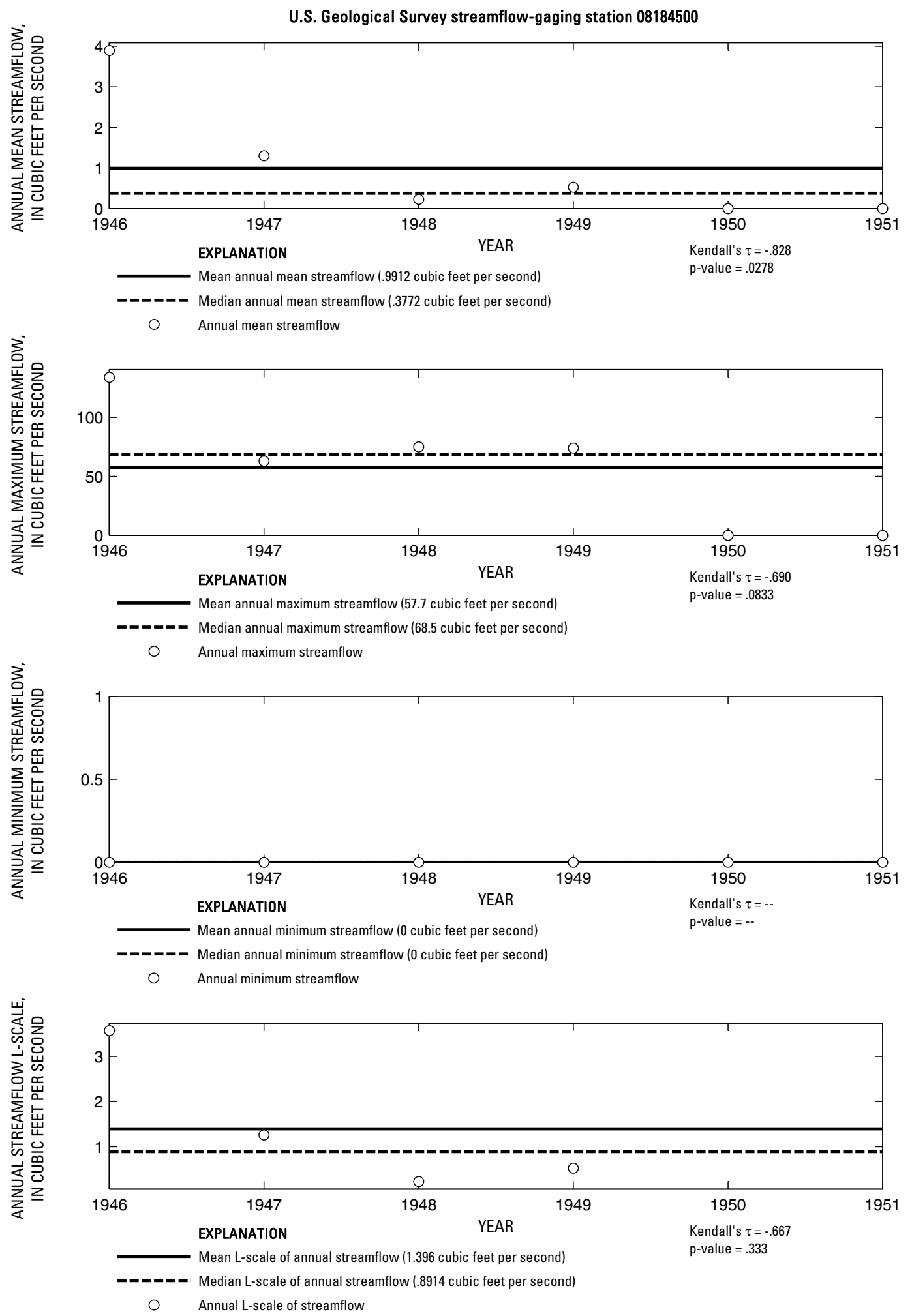

Figure 628. Analysis of annual mean, maximum, minimum, and L-scale statistics of daily mean streamflow for U.S. Geological Survey streamflow-gaging station 08184500 Cibolo Creek above Bracken, Texas.

|ndex of Station Numbers 719 


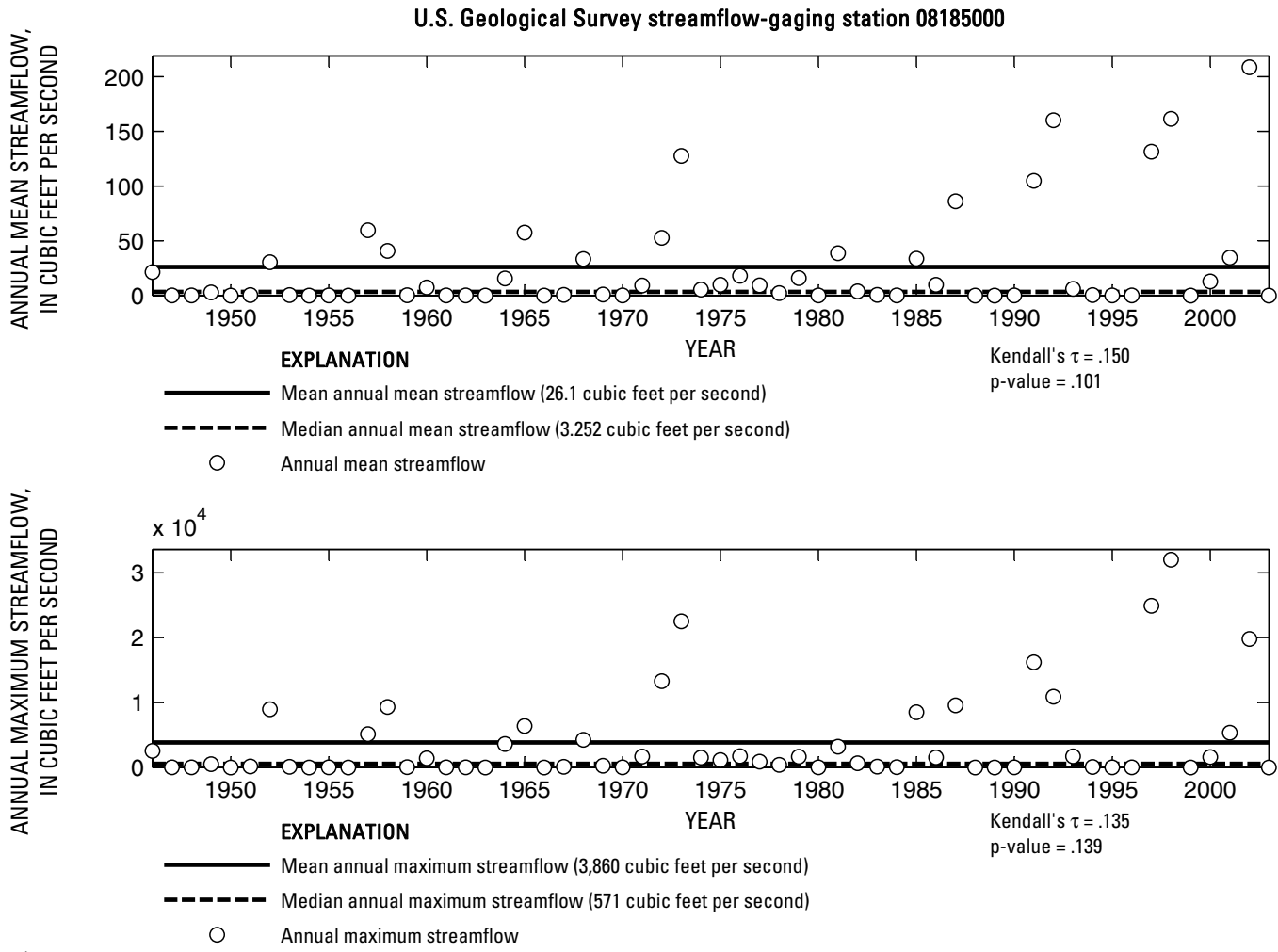

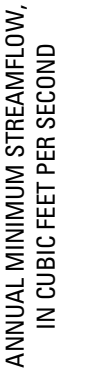

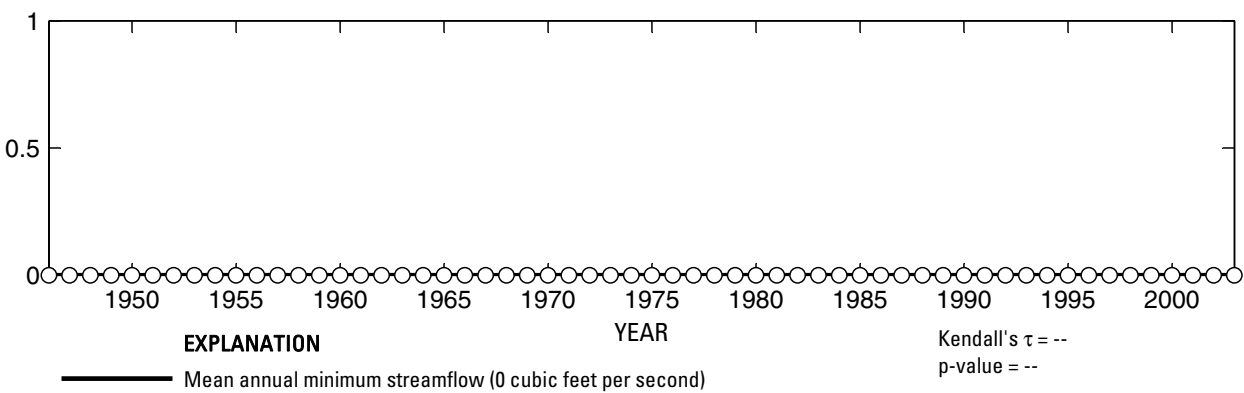

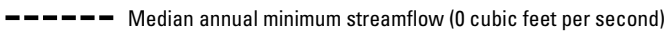

○ Annual minimum streamflow

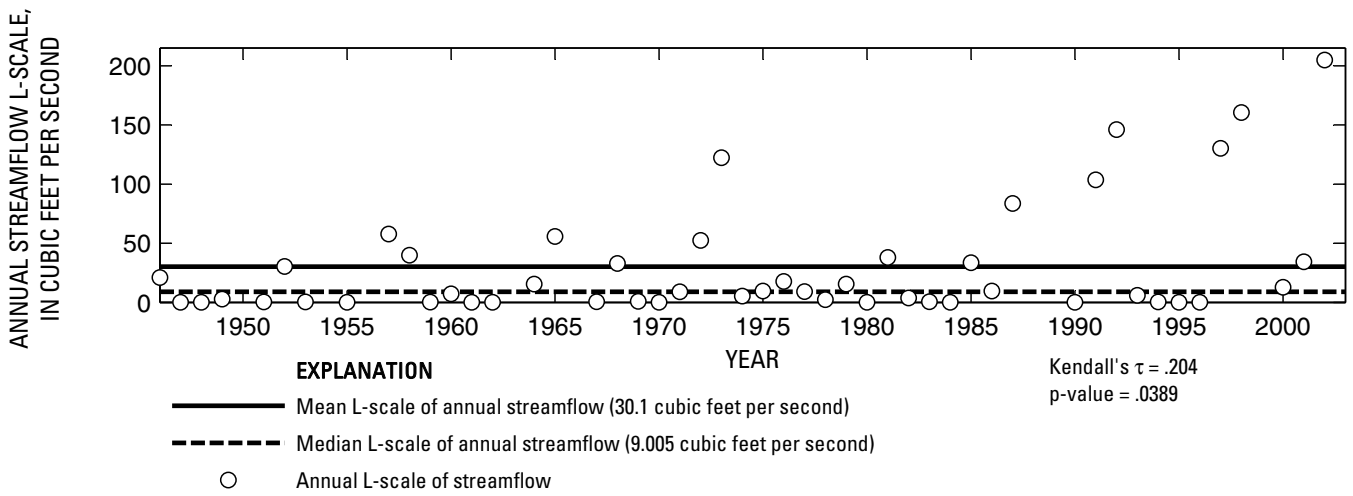

Figure 629. Analysis of annual mean, maximum, minimum, and L-scale statistics of daily mean streamflow for U.S. Geological Survey streamflow-gaging station 08185000 Cibolo Creek at Selma, Texas.

Index of Station Numbers 719 


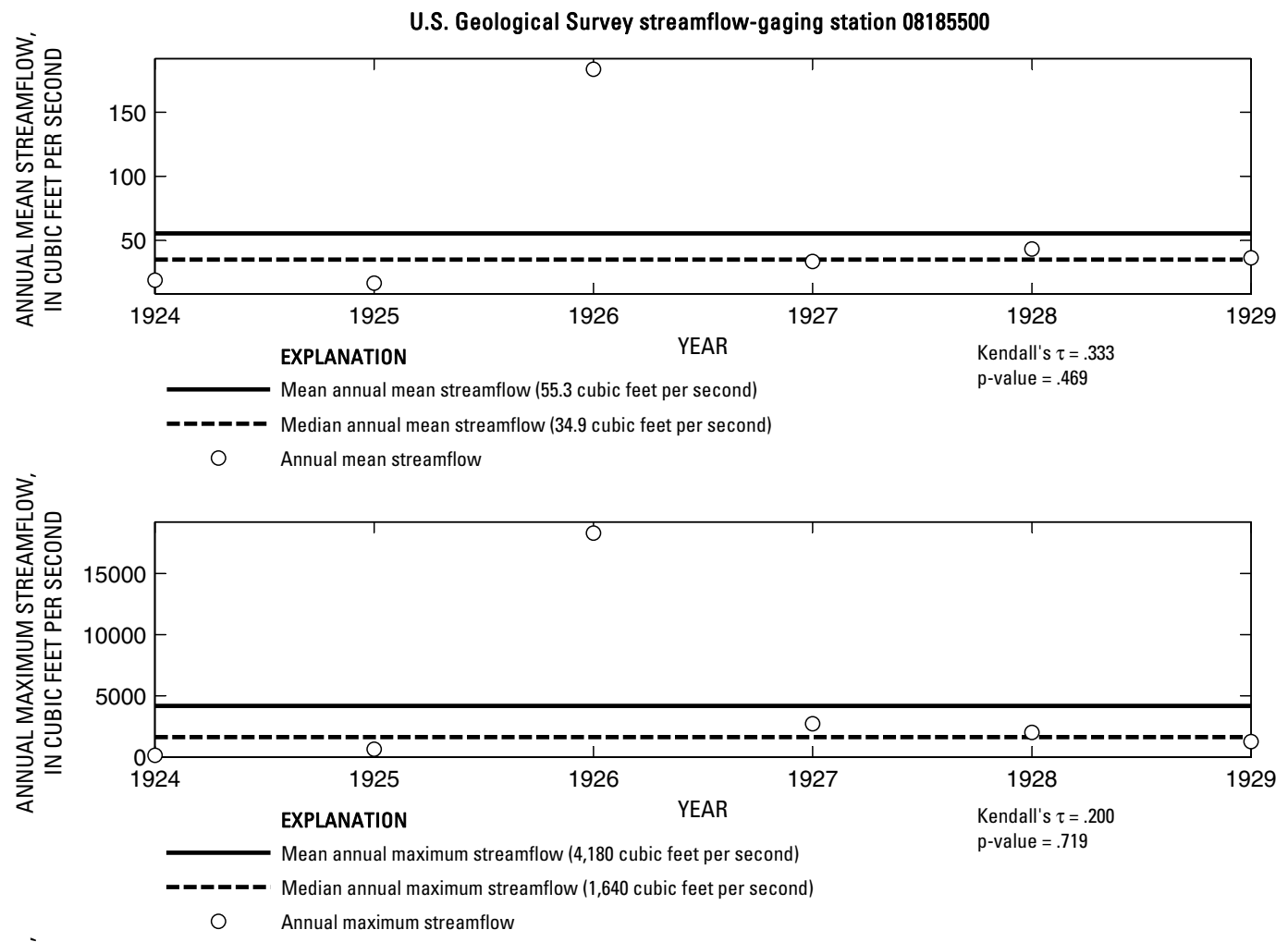

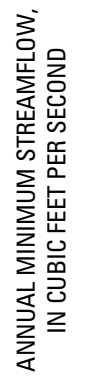

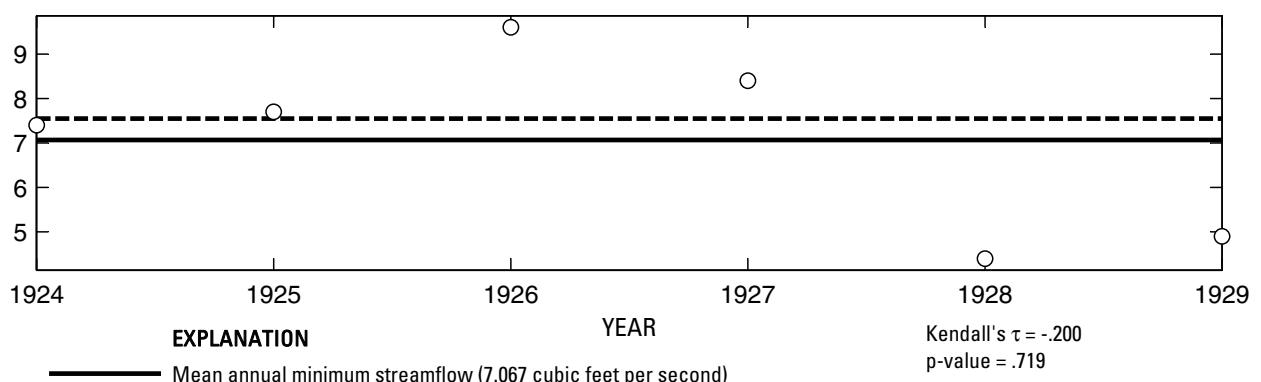

- ב-ב Median annual minimum streamflow (7.55 cubic feet per second)

O Annual minimum streamflow

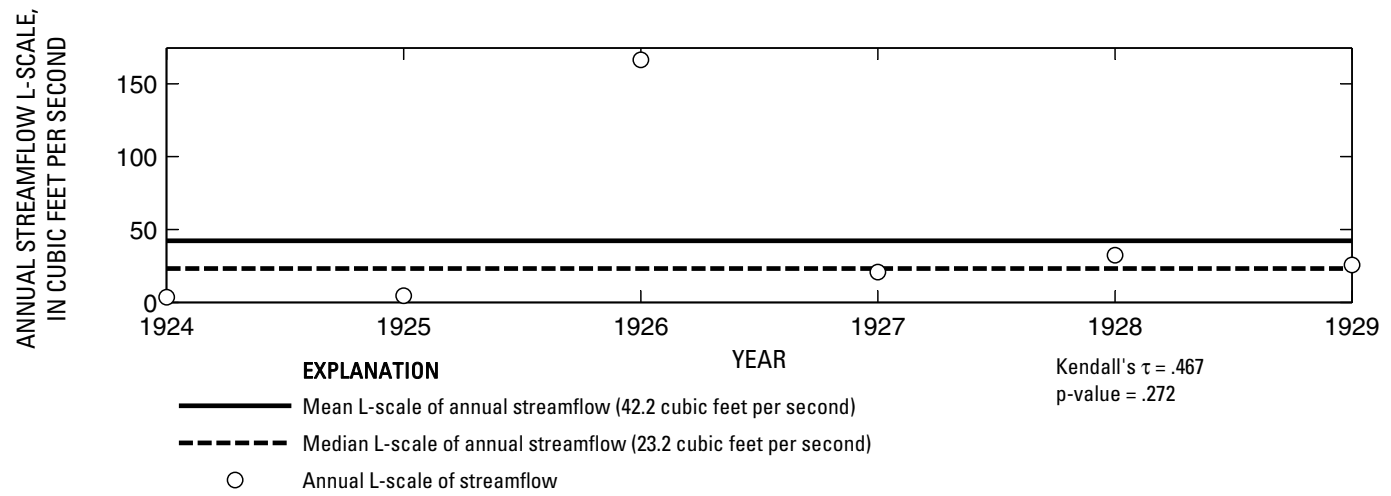

Figure 630. Analysis of annual mean, maximum, minimum, and L-scale statistics of daily mean streamflow for U.S. Geological Survey streamflow-gaging station 08185500 Cibolo Creek at Sutherland Springs, Texas.

Index of Station Numbers 719 

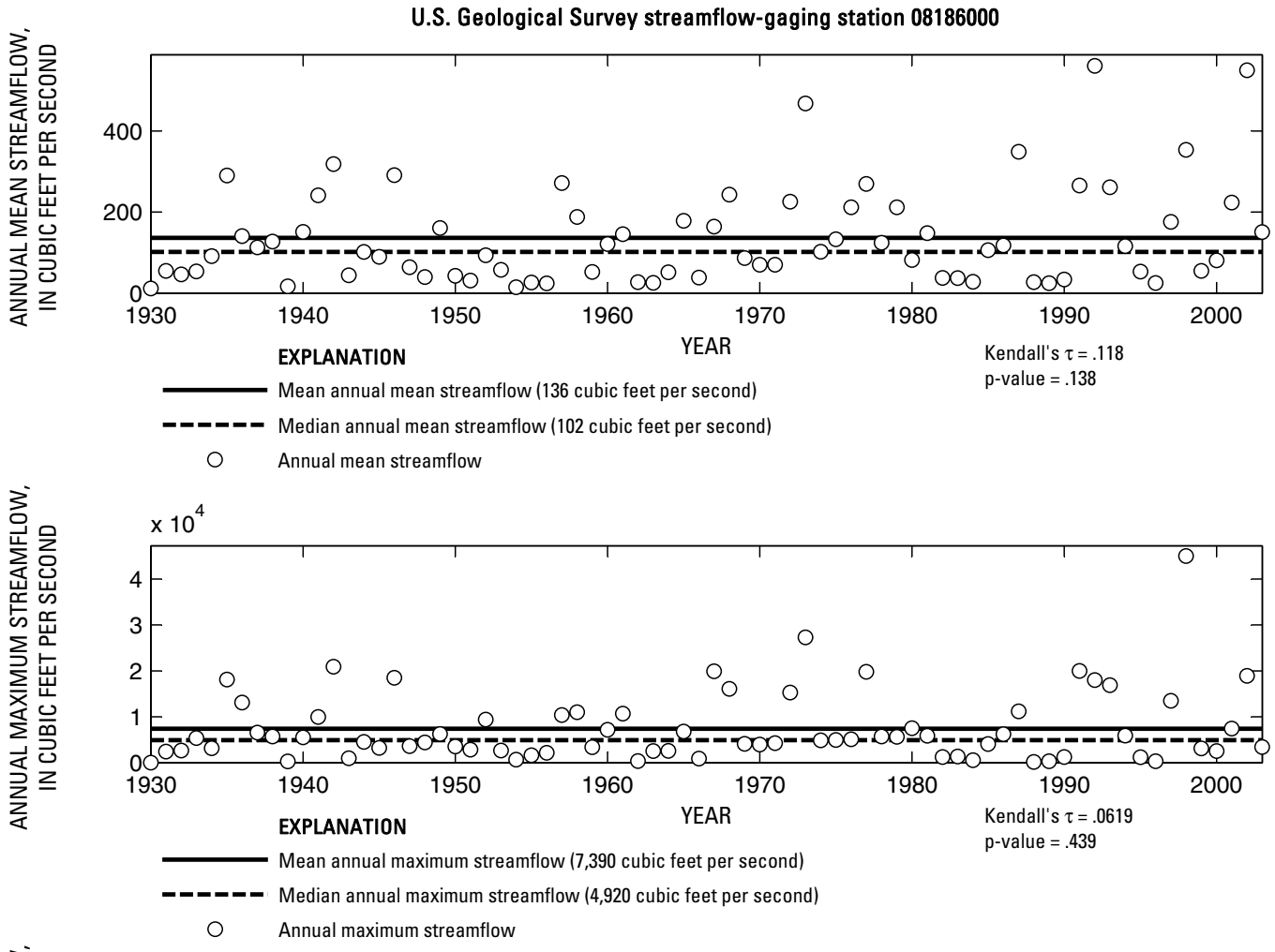

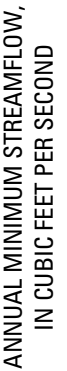

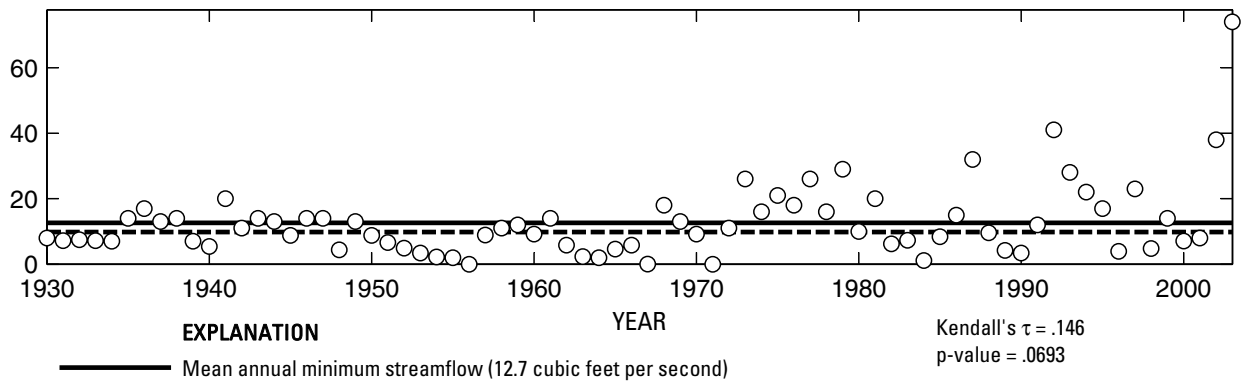

- - - Median annual minimum streamflow ( 9.8 cubic feet per second)

O Annual minimum streamflow

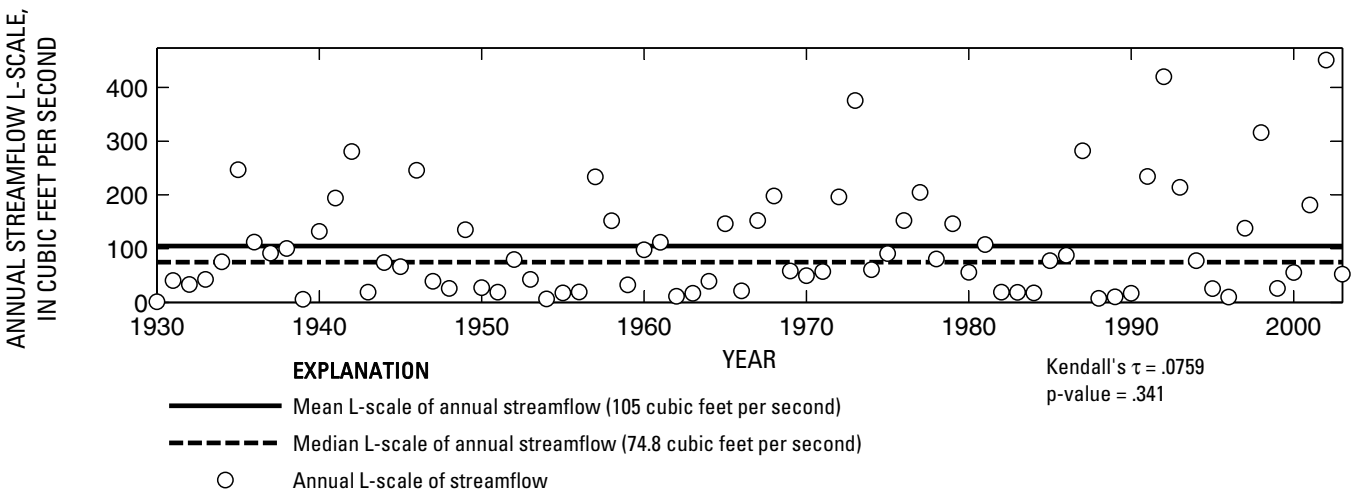

Figure 631. Analysis of annual mean, maximum, minimum, and L-scale statistics of daily mean streamflow for U.S. Geological Survey streamflow-gaging station 08186000 Cibolo Creek near Falls City, Texas.

Index of Station Numbers 719 
U.S. Geological Survey streamflow-gaging station 08186500

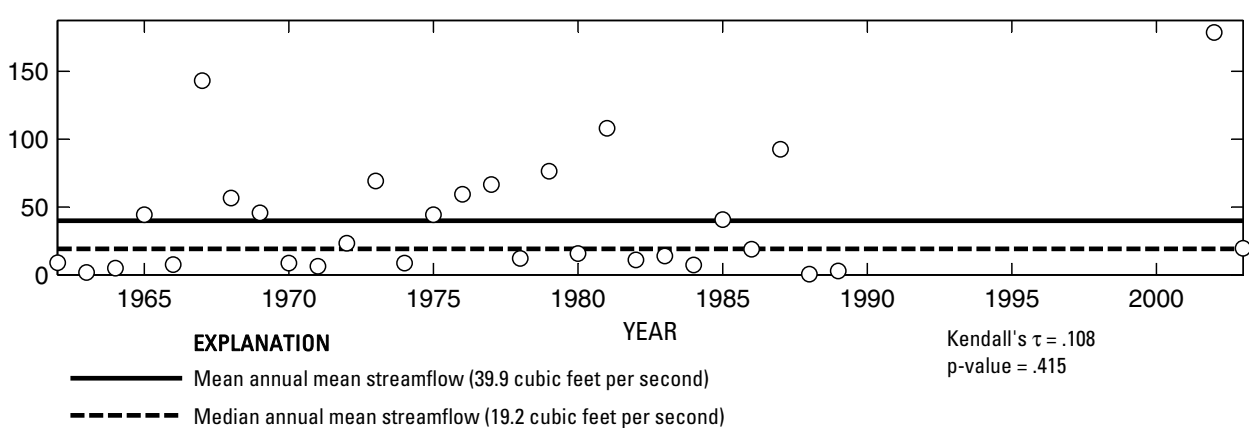

O Annual mean streamflow

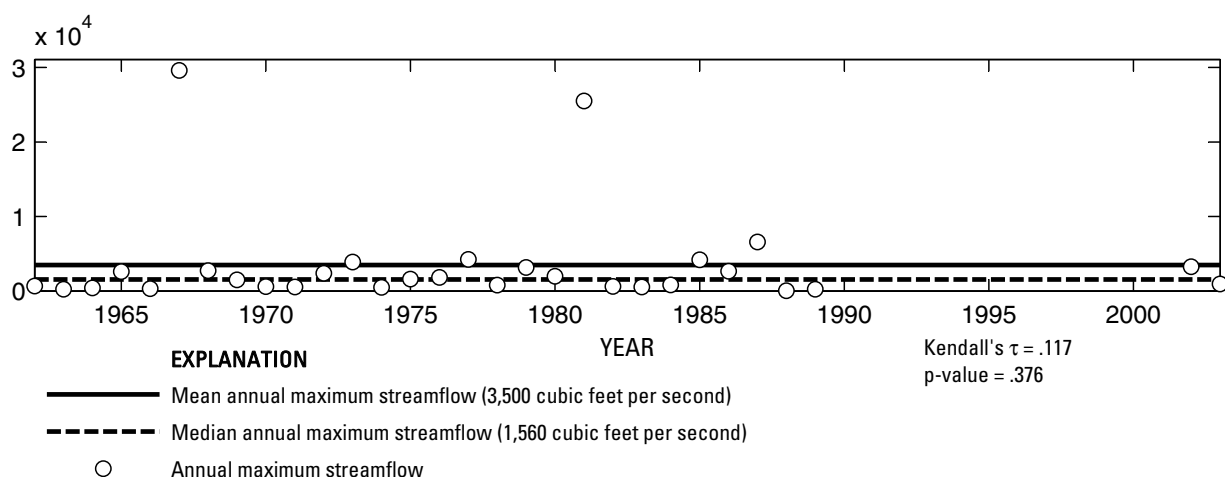

吾

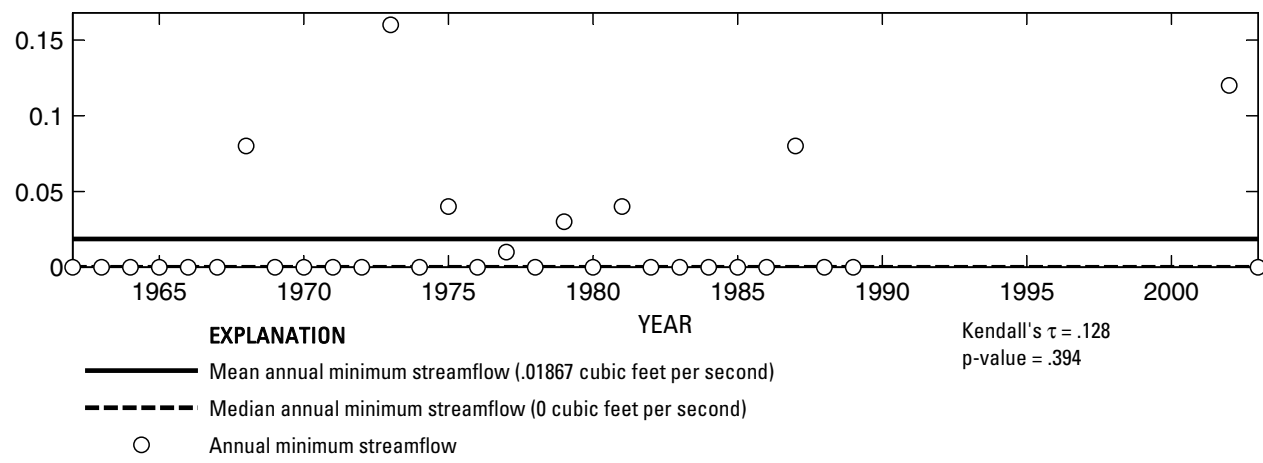

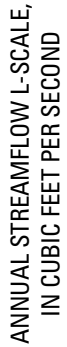

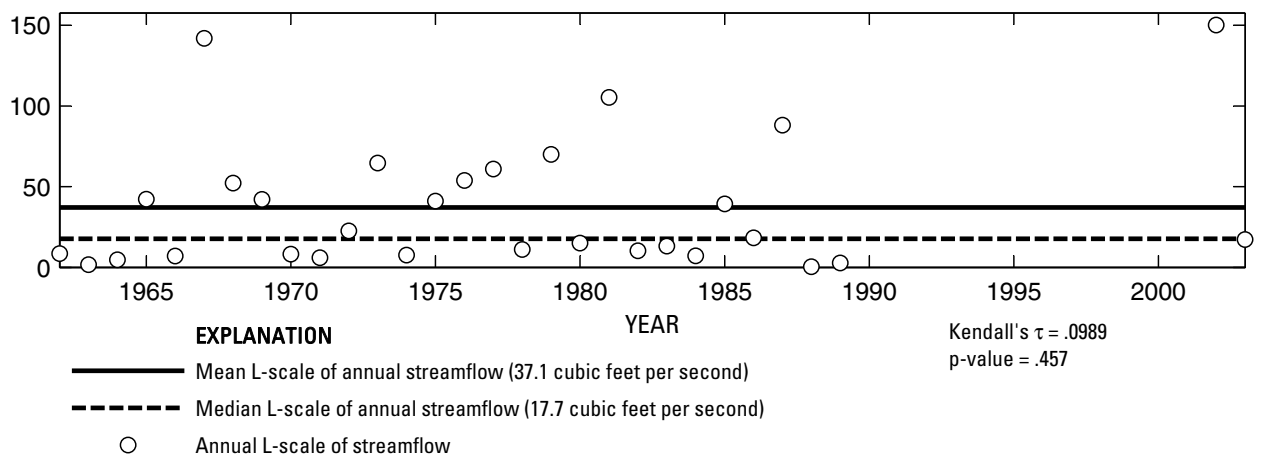

Figure 632. Analysis of annual mean, maximum, minimum, and L-scale statistics of daily mean streamflow for U.S. Geological Survey streamflow-gaging station 08186500 Ecleto Creek near Runge, Texas.

Index of Station Numbers 719 


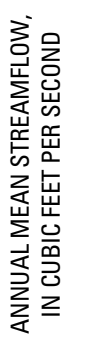

U.S. Geological Survey streamflow-gaging station 08187500

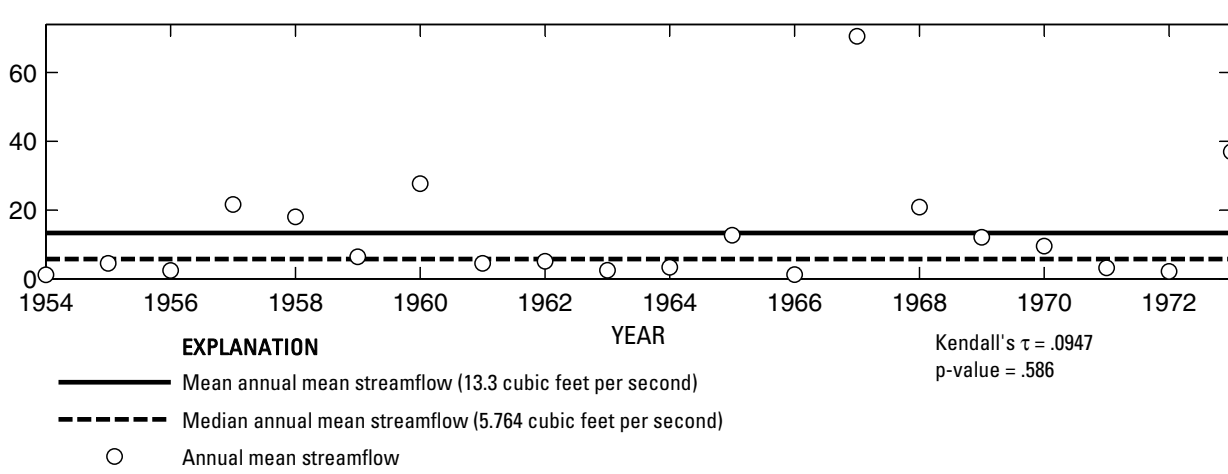

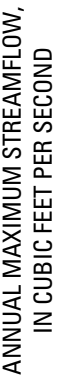

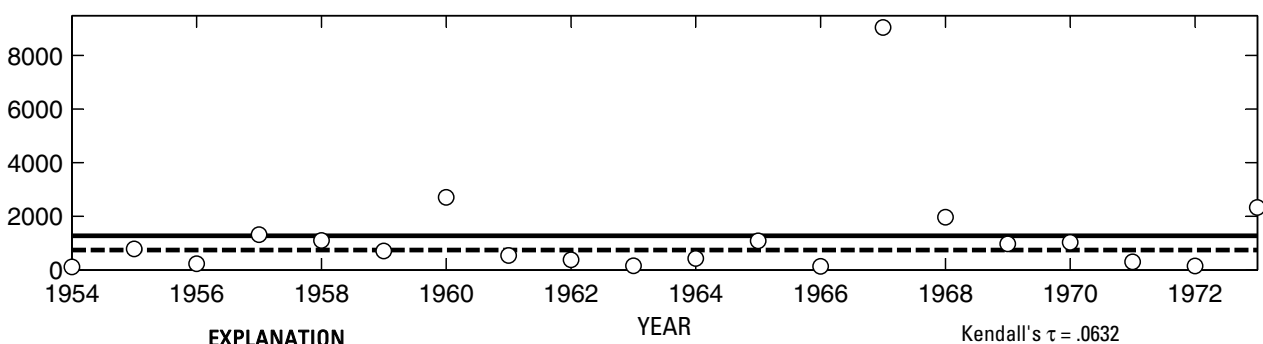

EXPLANATION

p-value $=.725$

-_-_- Median annual maximum streamflow (748 cubic feet per second)

Annual maximum streamflow
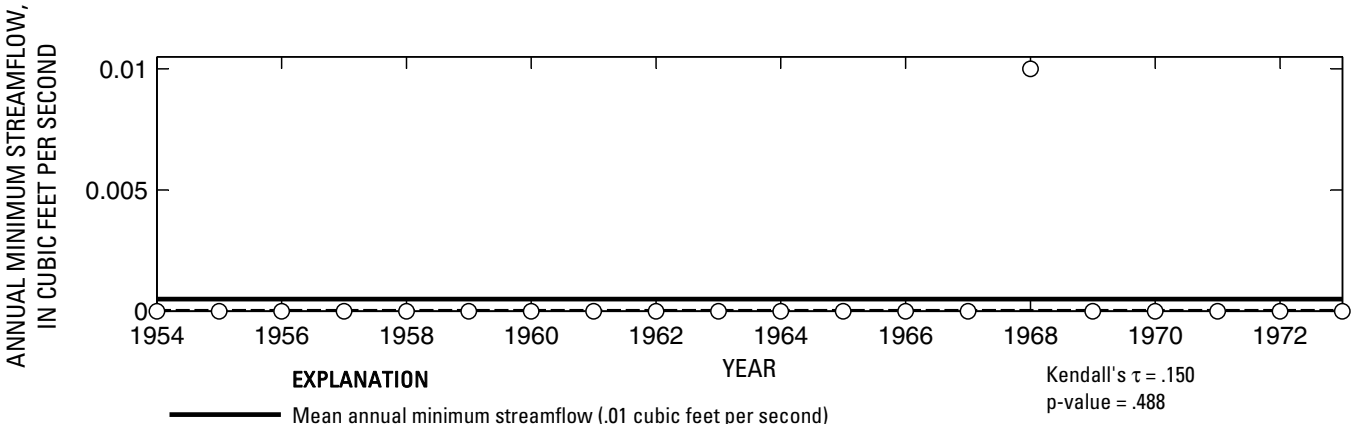

-_-_-_- Median annual minimum streamflow ( 0 cubic feet per second)

○ Annual minimum streamflow

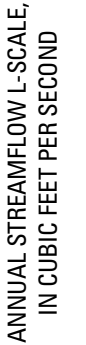

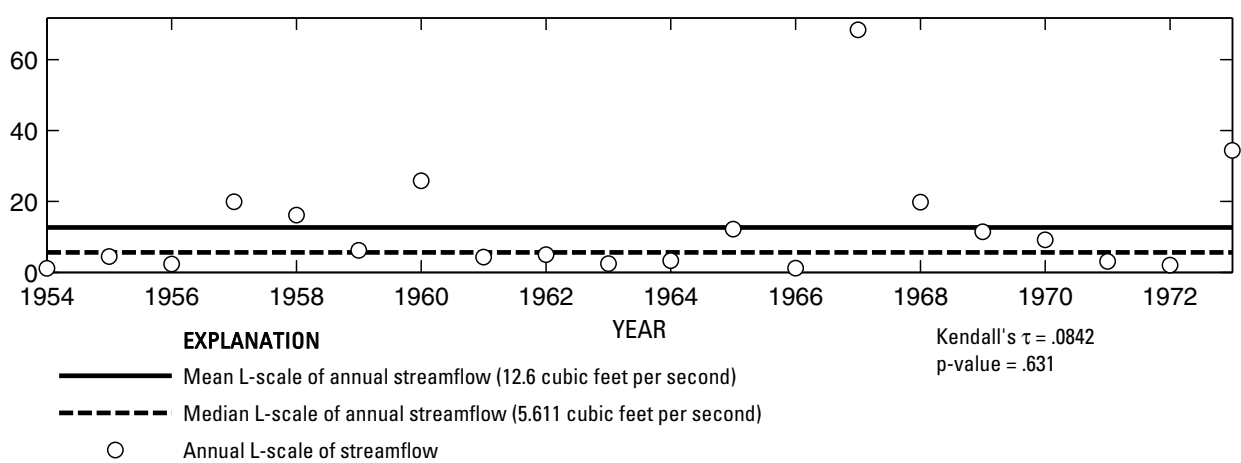

Figure 633. Analysis of annual mean, maximum, minimum, and L-scale statistics of daily mean streamflow for U.S. Geological Survey streamflow-gaging station 08187500 Escondido Creek at Kenedy, Texas.

Index of Station Numbers 719 


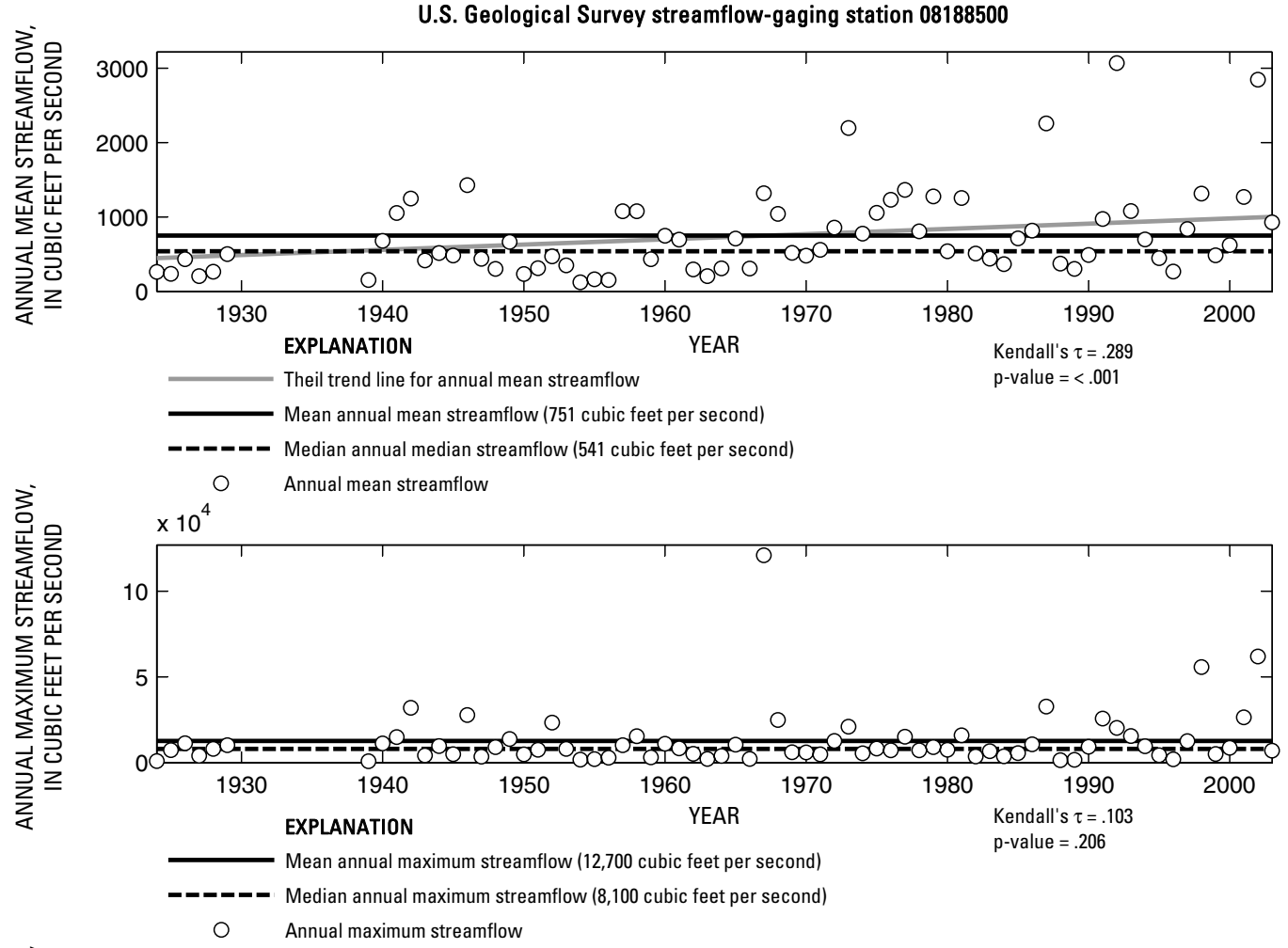

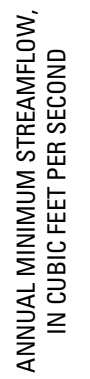

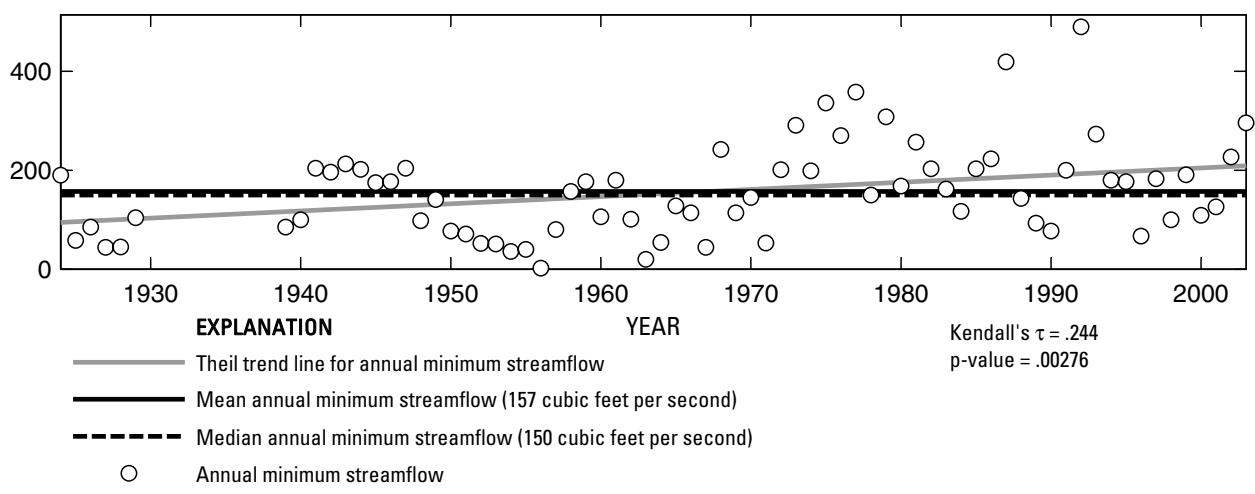

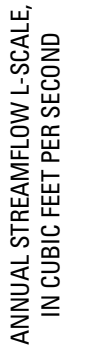

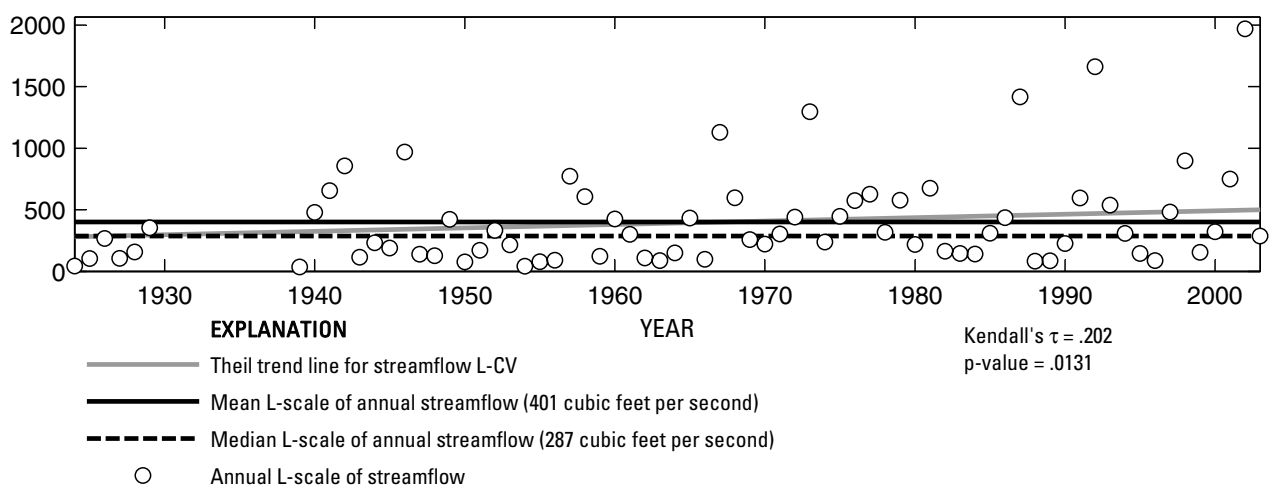

Figure 634. Analysis of annual mean, maximum, minimum, and L-scale statistics of daily mean streamflow for U.S. Geological Survey streamflow-gaging station 08188500 San Antonio River at Goliad, Texas.

Index of Station Numbers 719 

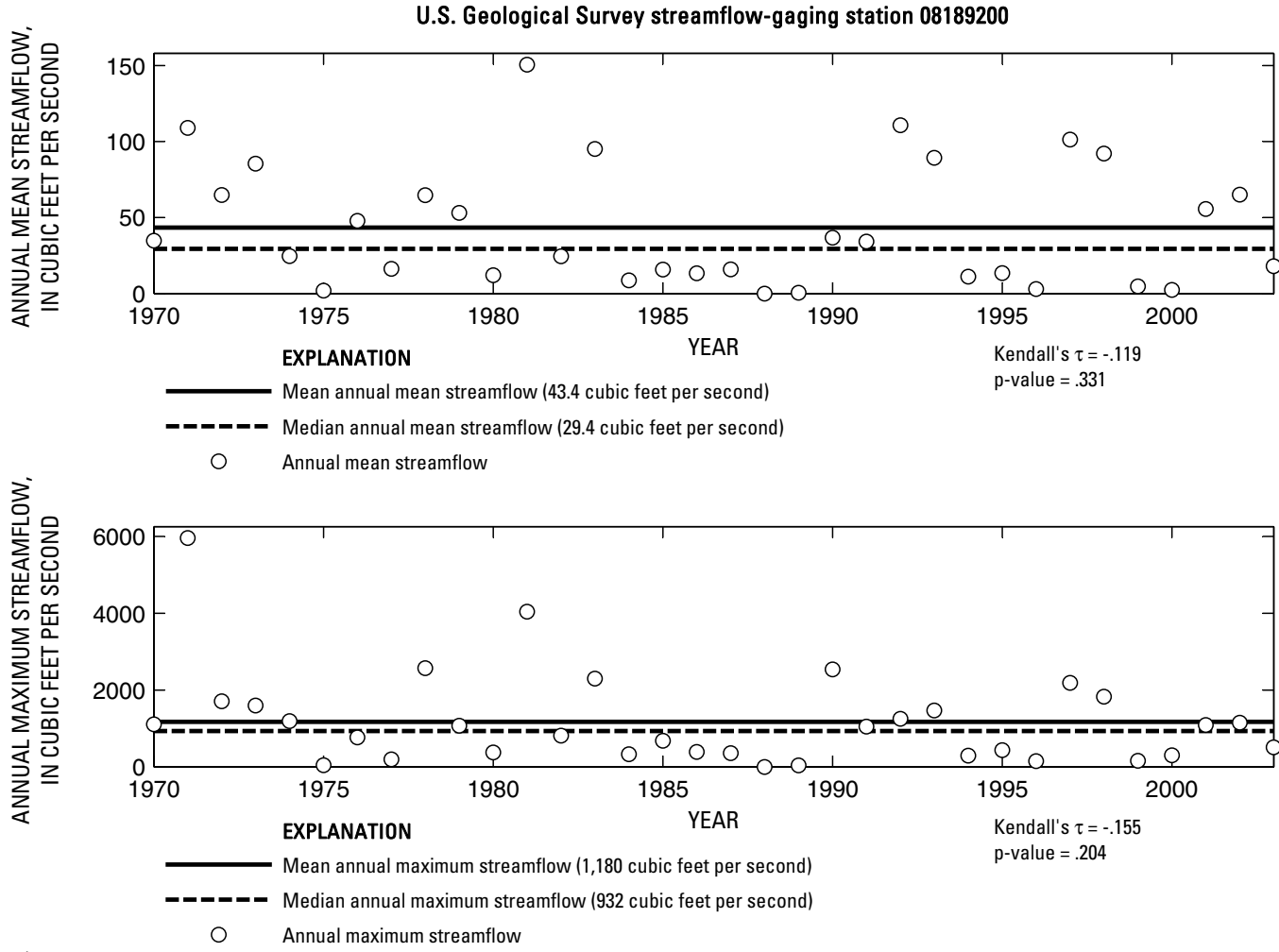

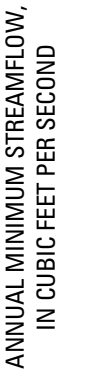

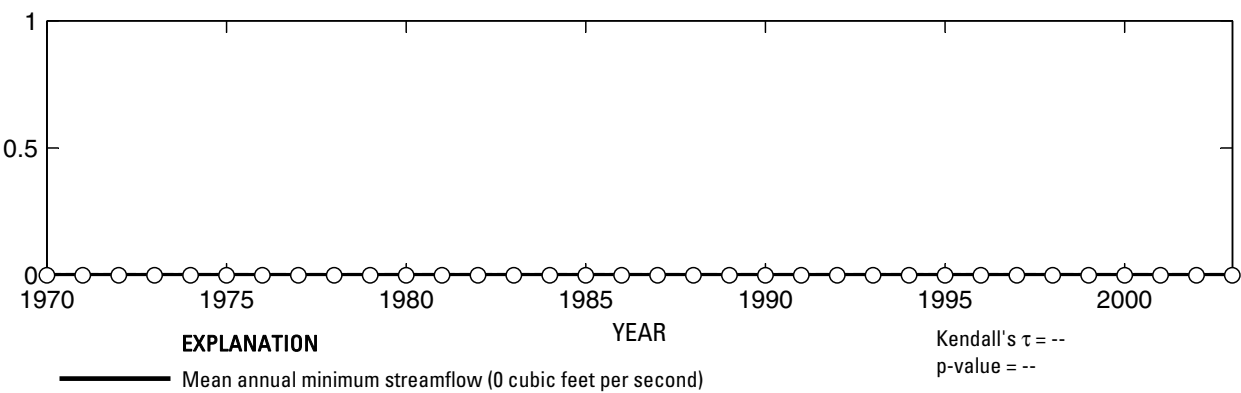

- Median annual minimum streamflow (0 cubic feet per second)

○ Annual minimum streamflow

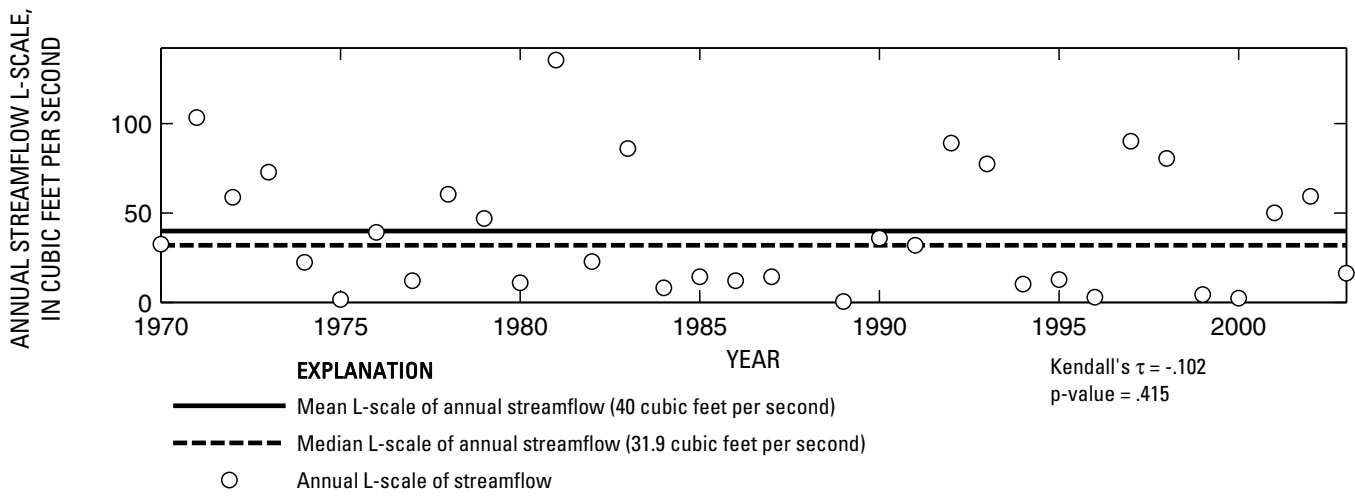

Figure 635. Analysis of annual mean, maximum, minimum, and L-scale statistics of daily mean streamflow for U.S. Geological Survey streamflow-gaging station 08189200 Copano Creek near Refugio, Texas. 

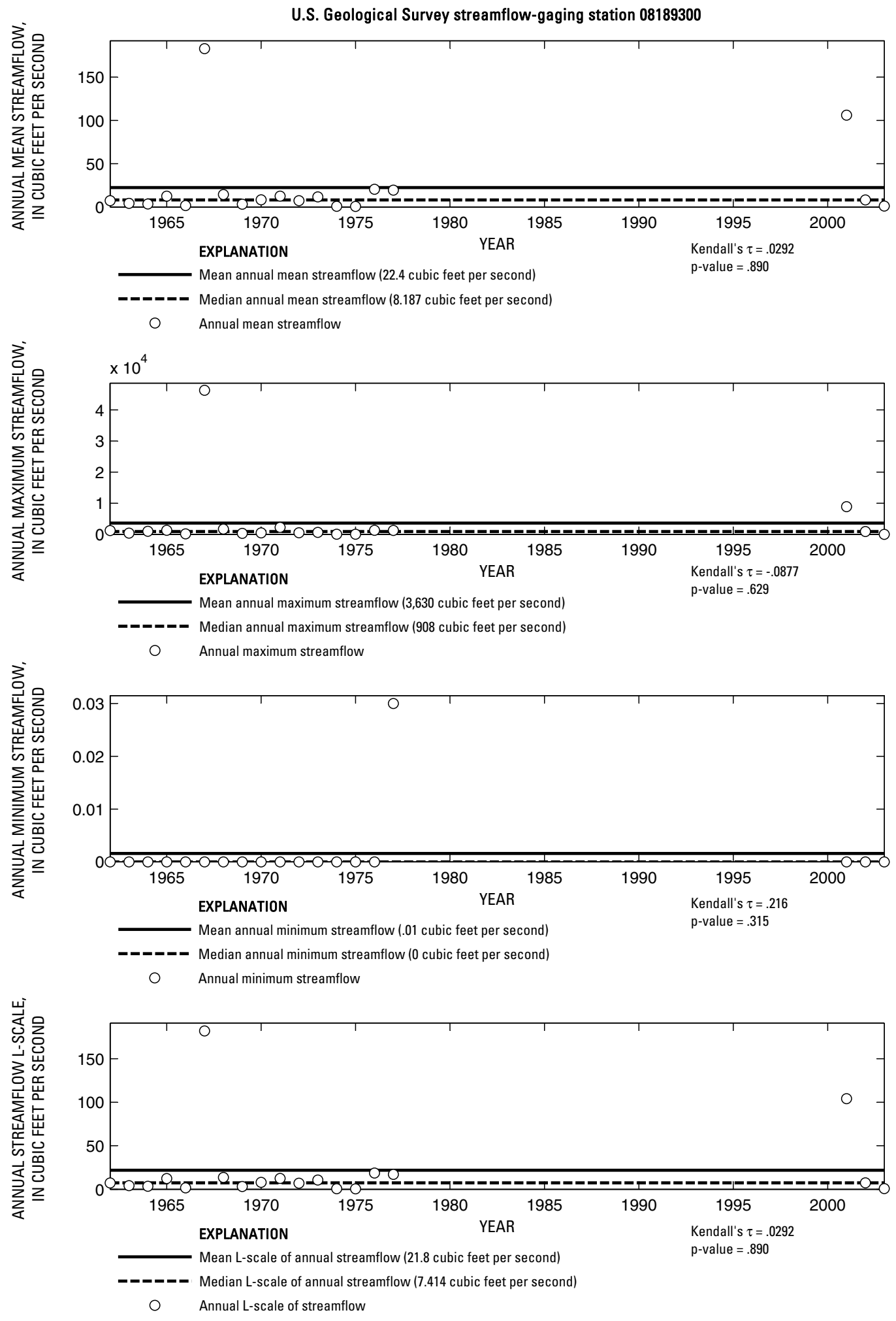

Figure 636. Analysis of annual mean, maximum, minimum, and L-scale statistics of daily mean streamflow for U.S. Geological Survey streamflow-gaging station 08189300 Medio Creek near Beeville, Texas. 

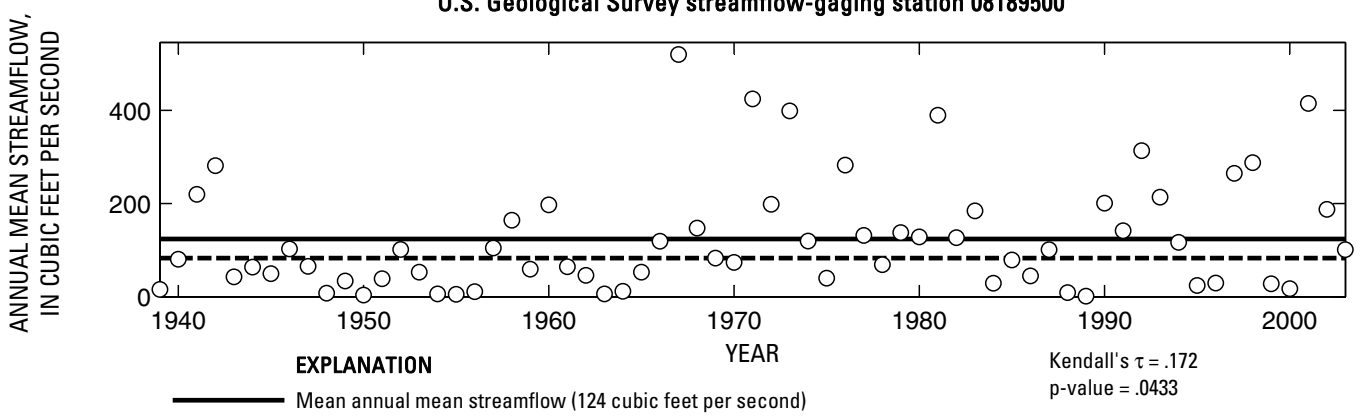

-_-_- Median annual mean streamflow (83.2 cubic feet per second)

- Annual mean streamflow

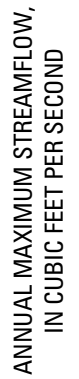

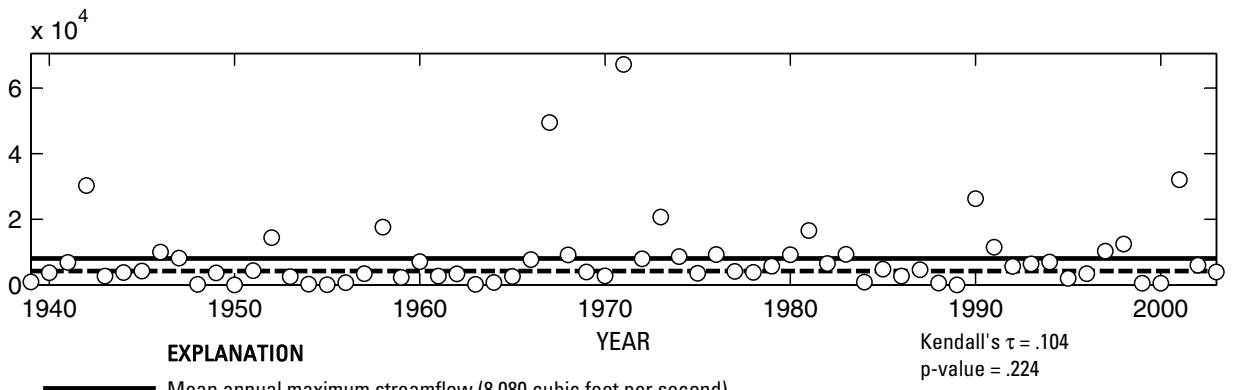

O Annual maximum streamflow

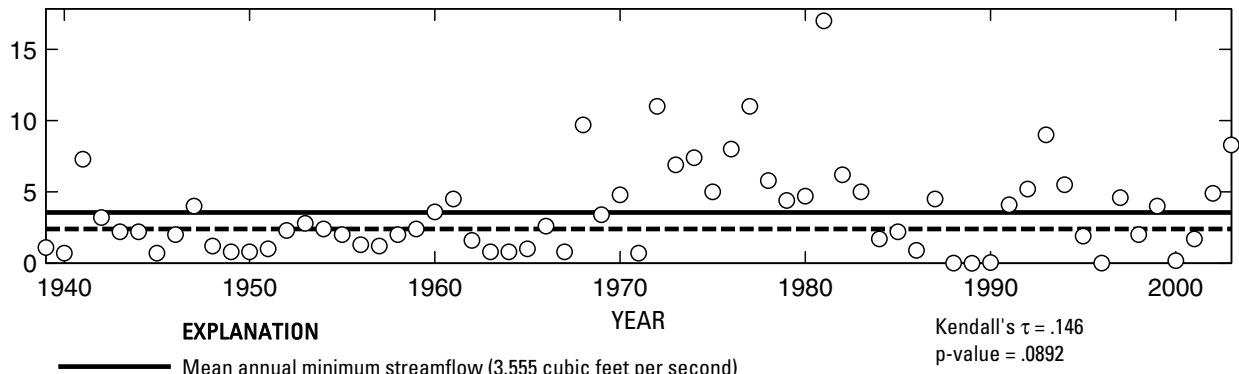

- - ב Median annual minimum streamflow (2.4 cubic feet per second)

O Annual minimum streamflow

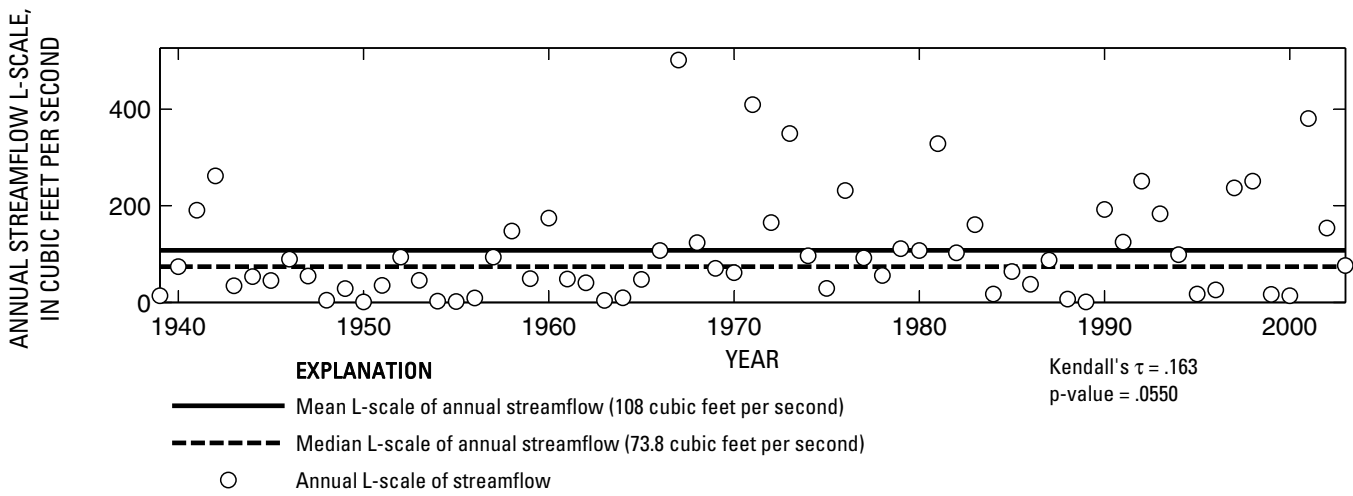

Figure 637. Analysis of annual mean, maximum, minimum, and L-scale statistics of daily mean streamflow for U.S. Geological Survey streamflow-gaging station 08189500 Mission River at Refugio, Texas. 

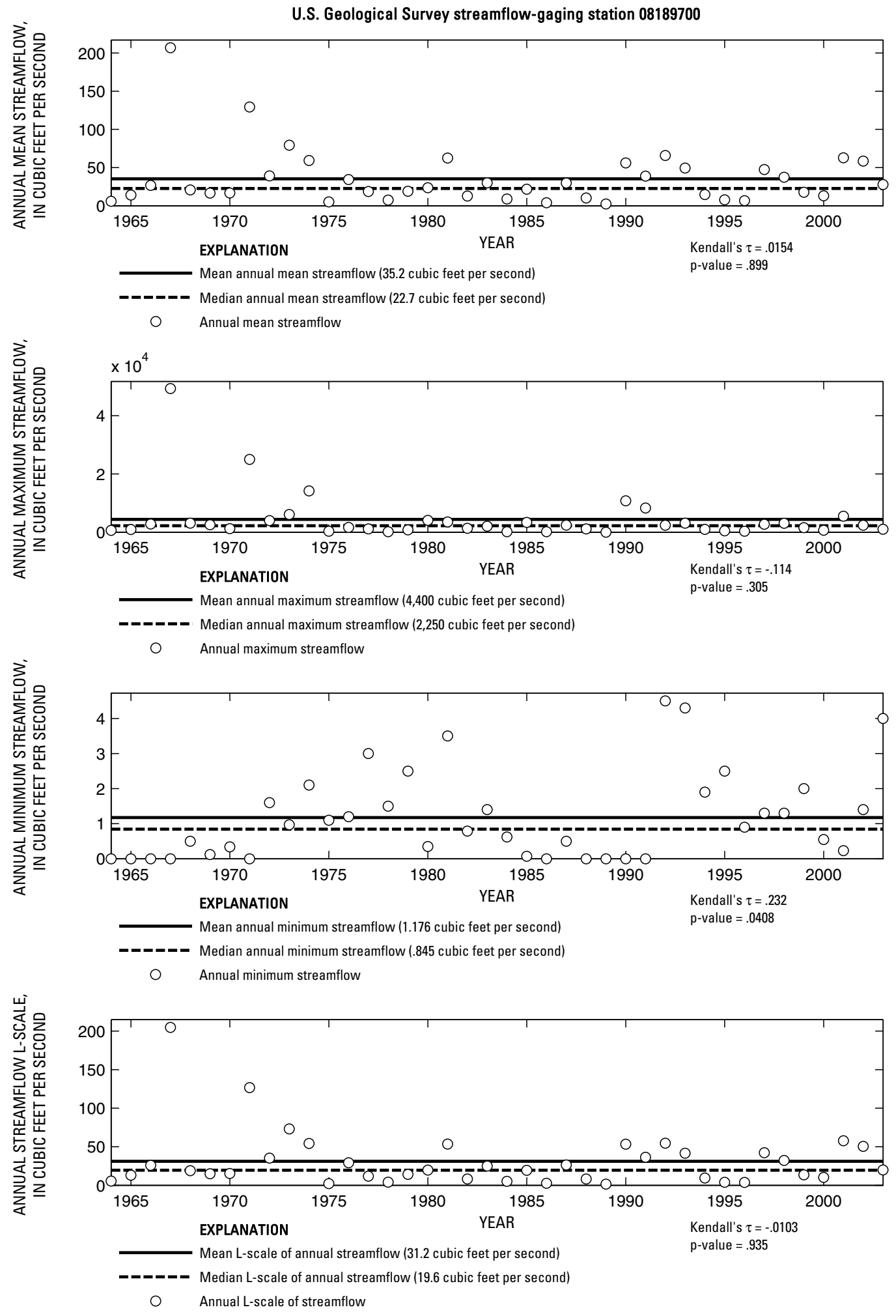

Figure 638. Analysis of annual mean, maximum, minimum, and L-scale statistics of daily mean streamflow for U.S. Geological Survey streamflow-gaging station 08189700 Aransas River near Skidmore, Texas.

Index of Station Numbers 719 


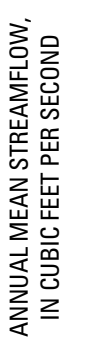

U.S. Geological Survey streamflow-gaging station 08189800

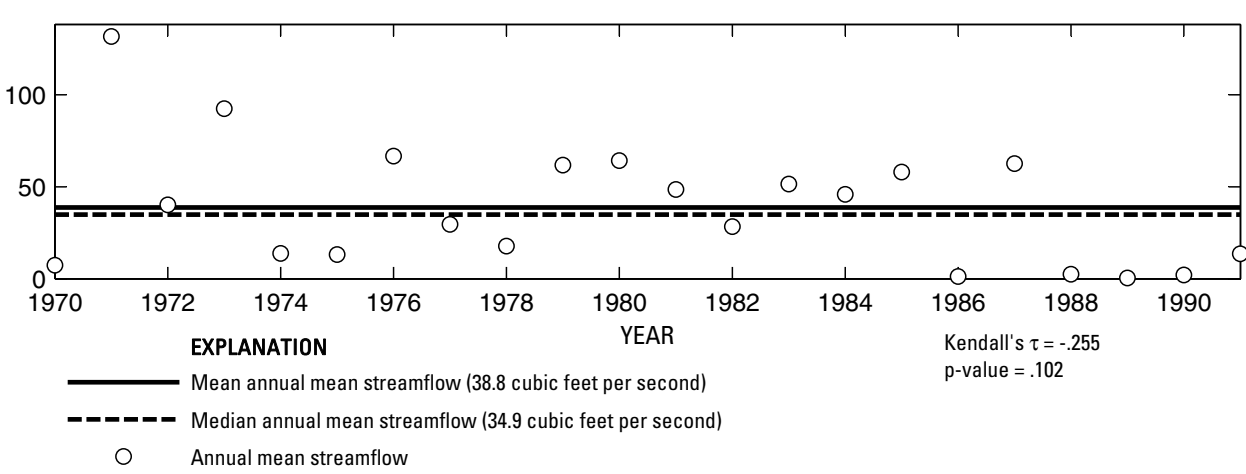

岕

Annual mean streamflow

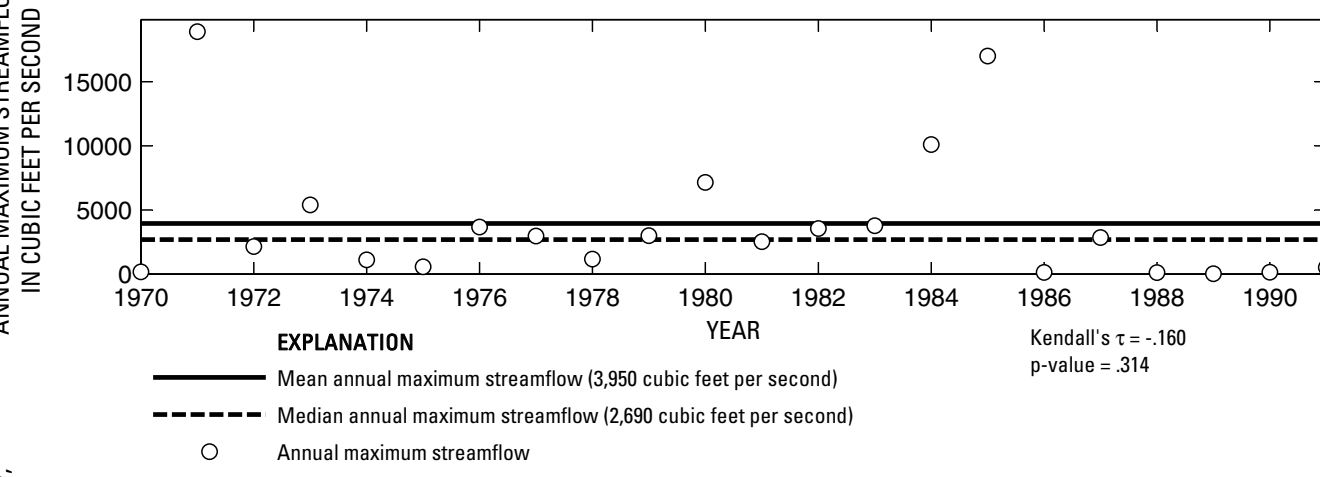

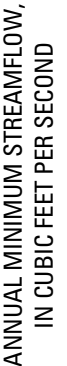

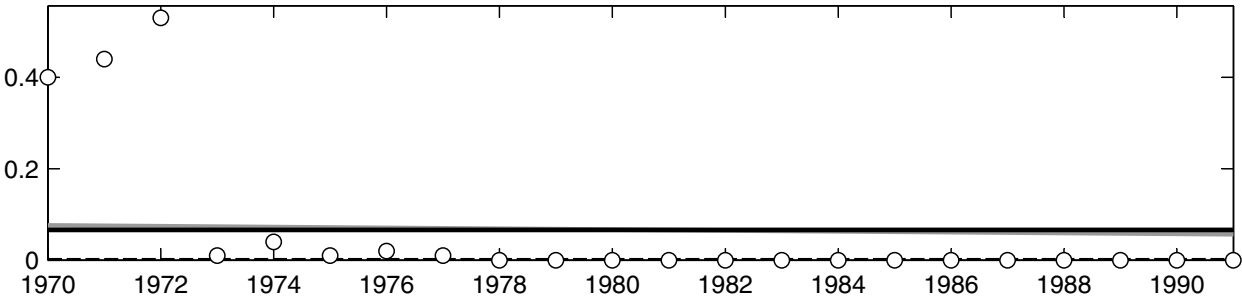

\section{EXPLANATION}

Theil trend line for annual minimum streamflow

Kendall's $\tau=-.703$

$\mathrm{p}$-value $=<.001$

- Mean annual minimum streamflow (.06636 cubic feet per second)

ーーーーーー・ Median annual minimum streamflow (0 cubic feet per second)

O Annual minimum streamflow
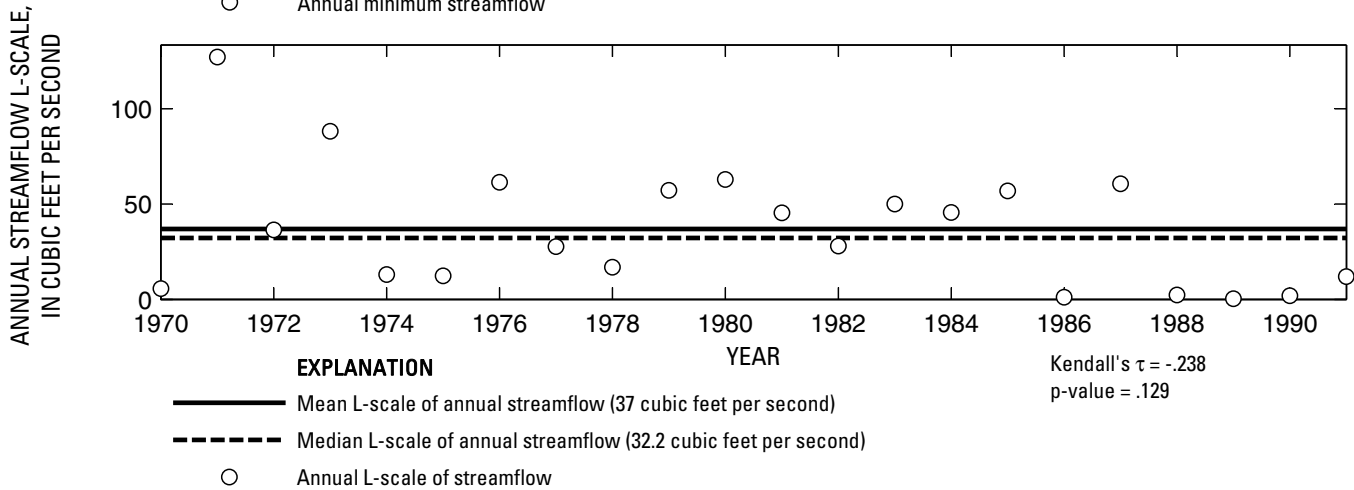

Figure 639. Analysis of annual mean, maximum, minimum, and L-scale statistics of daily mean streamflow for U.S. Geological Survey streamflow-gaging station 08189800 Chiltipin Creek at Sinton, Texas. 


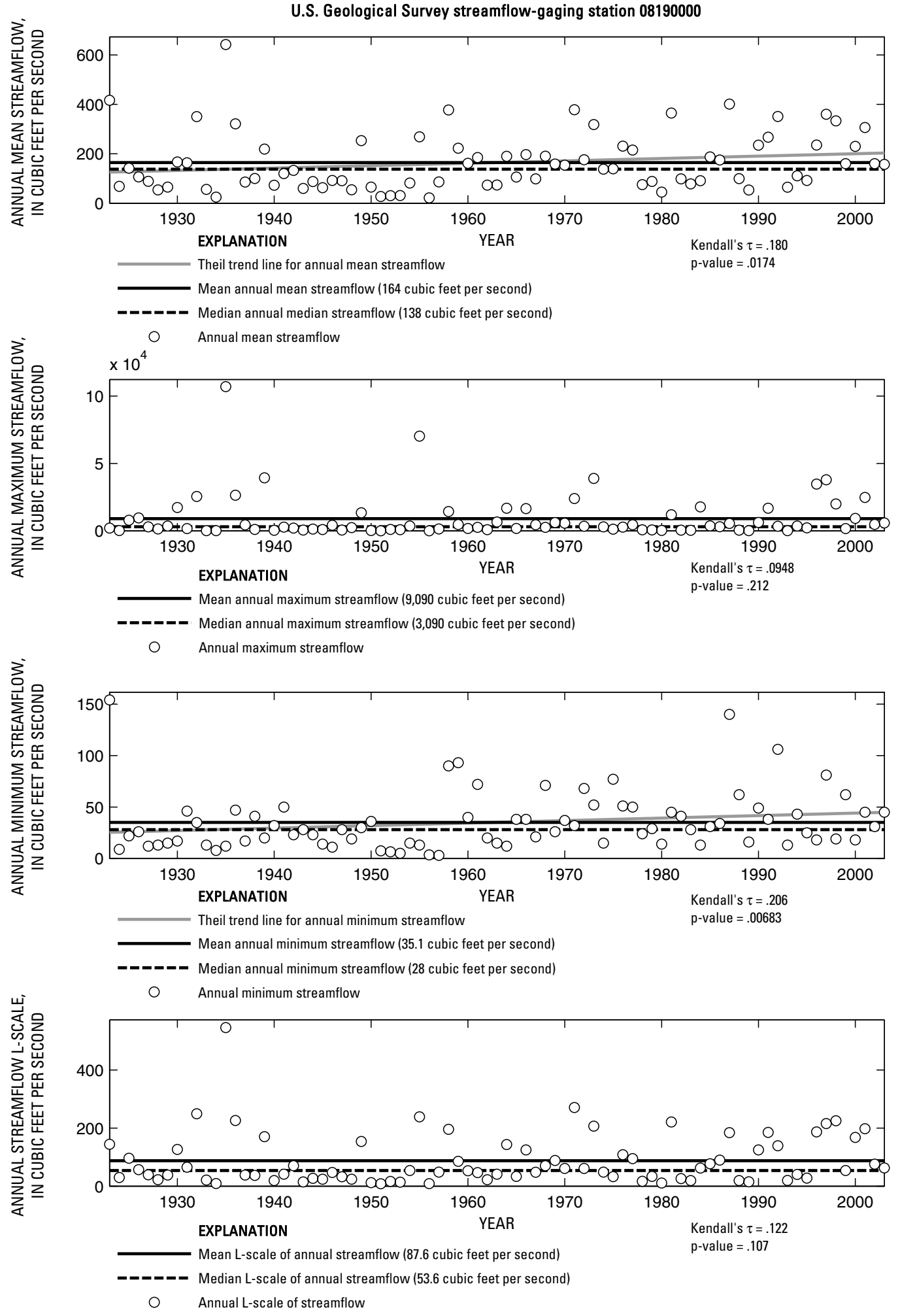

Figure 640. Analysis of annual mean, maximum, minimum, and L-scale statistics of daily mean streamflow for U.S. Geological Survey streamflow-gaging station 08190000 Nueces River at Laguna, Texas.

Index of Station Numbers 719 


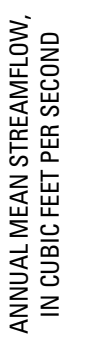

U.S. Geological Survey streamflow-gaging station 08190500

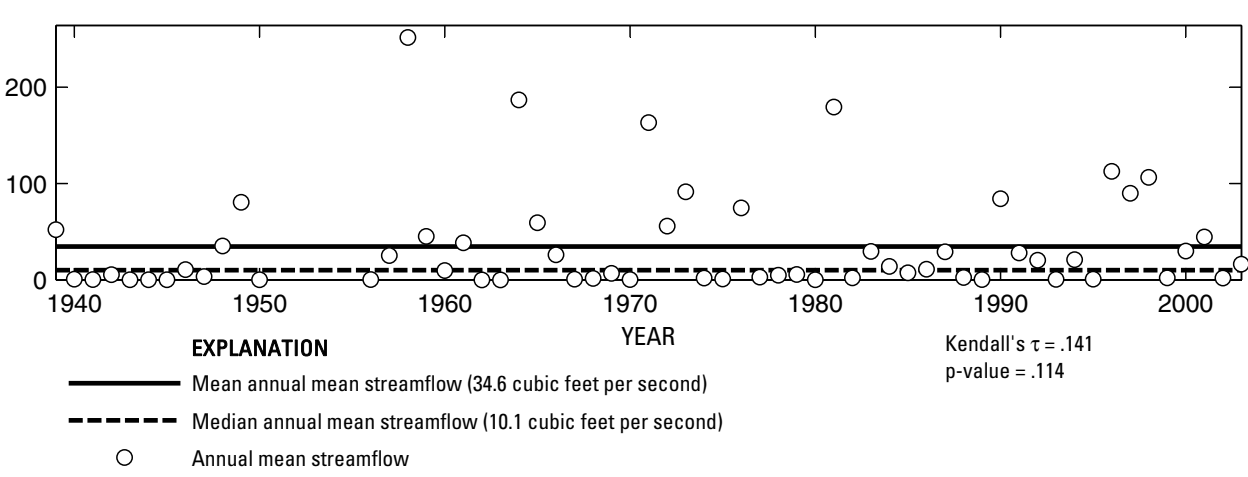

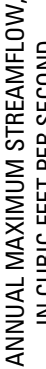

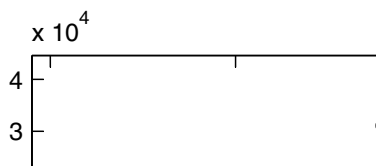

O

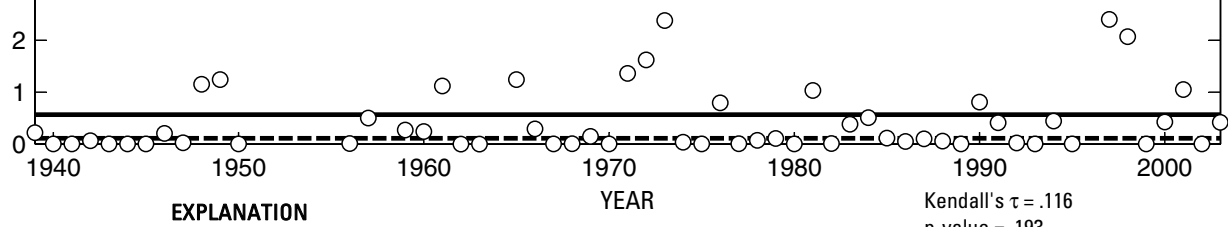

EXPLANATION

feet per second)

p-value $=193$

- _- Median annual maximum streamflow $(1,120$ cubic feet per second)

O Annual maximum streamflow

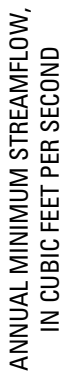

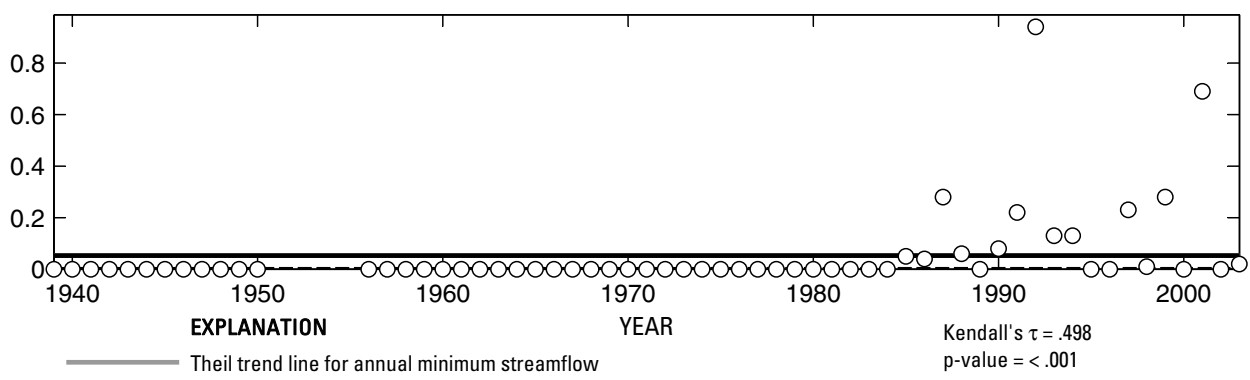

Theil trend line for annual minimum annual minimum streamflow (.05267 cubic feet per second)

- - - Median annual minimum streamflow (0 cubic feet per second)

O Annual minimum streamflow
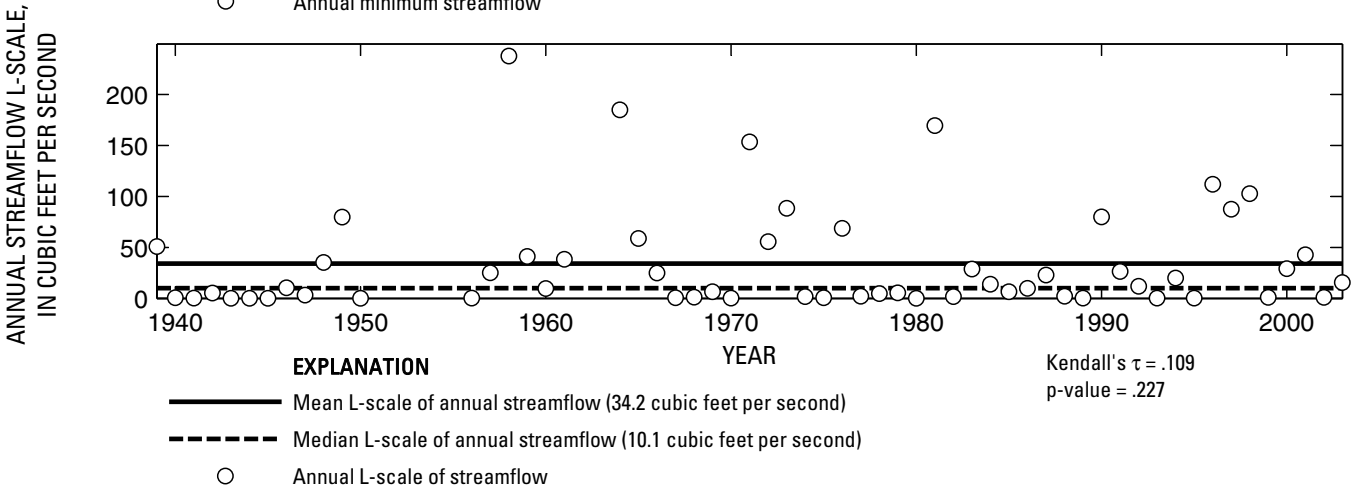

Figure 641. Analysis of annual mean, maximum, minimum, and L-scale statistics of daily mean streamflow for U.S. Geological Survey streamflow-gaging station 08190500 West Nueces River near Brackettville, Texas. 

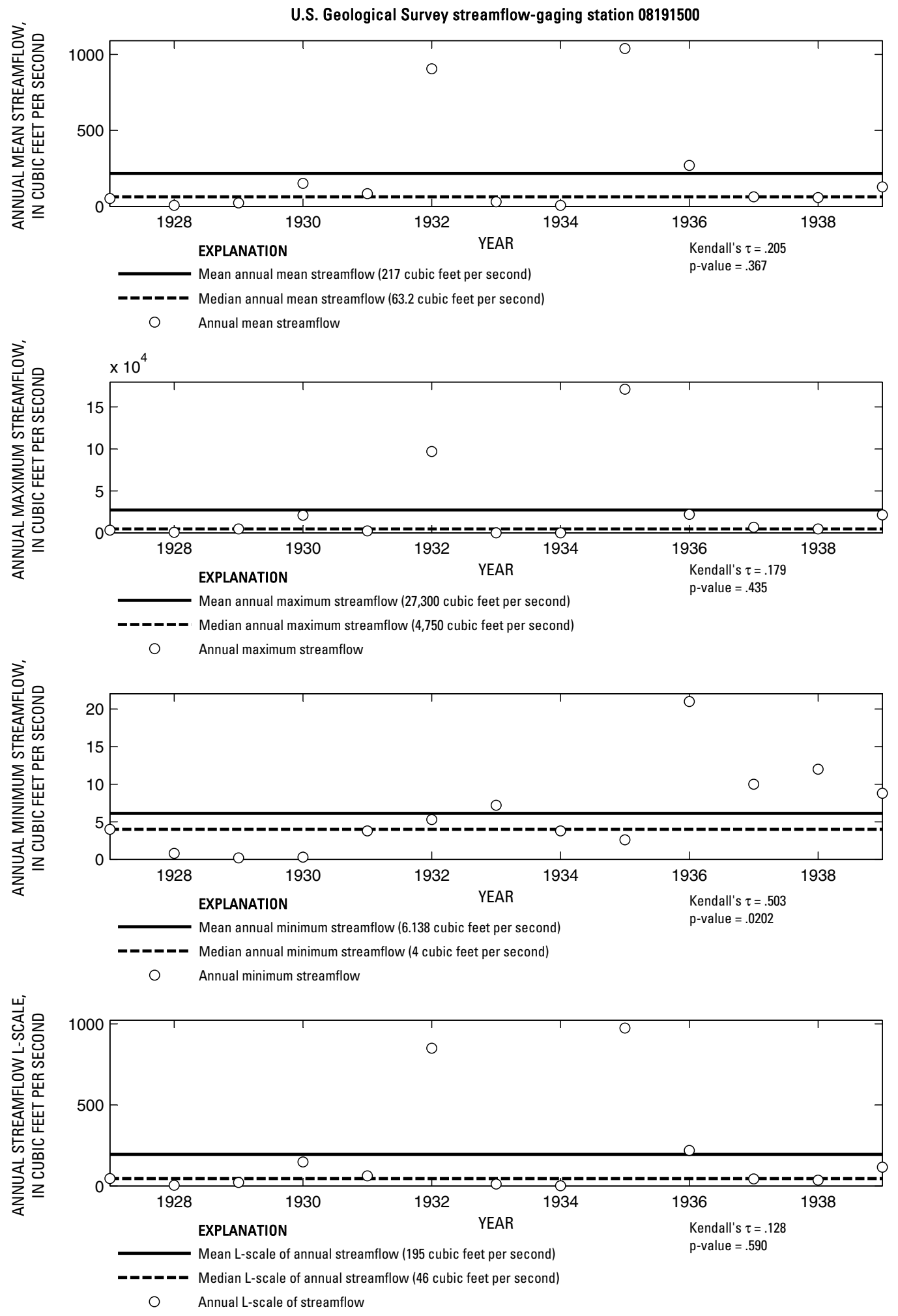

Figure 642. Analysis of annual mean, maximum, minimum, and L-scale statistics of daily mean streamflow for U.S. Geological Survey streamflow-gaging station 08191500 Nueces River near Uvalde, Texas. 


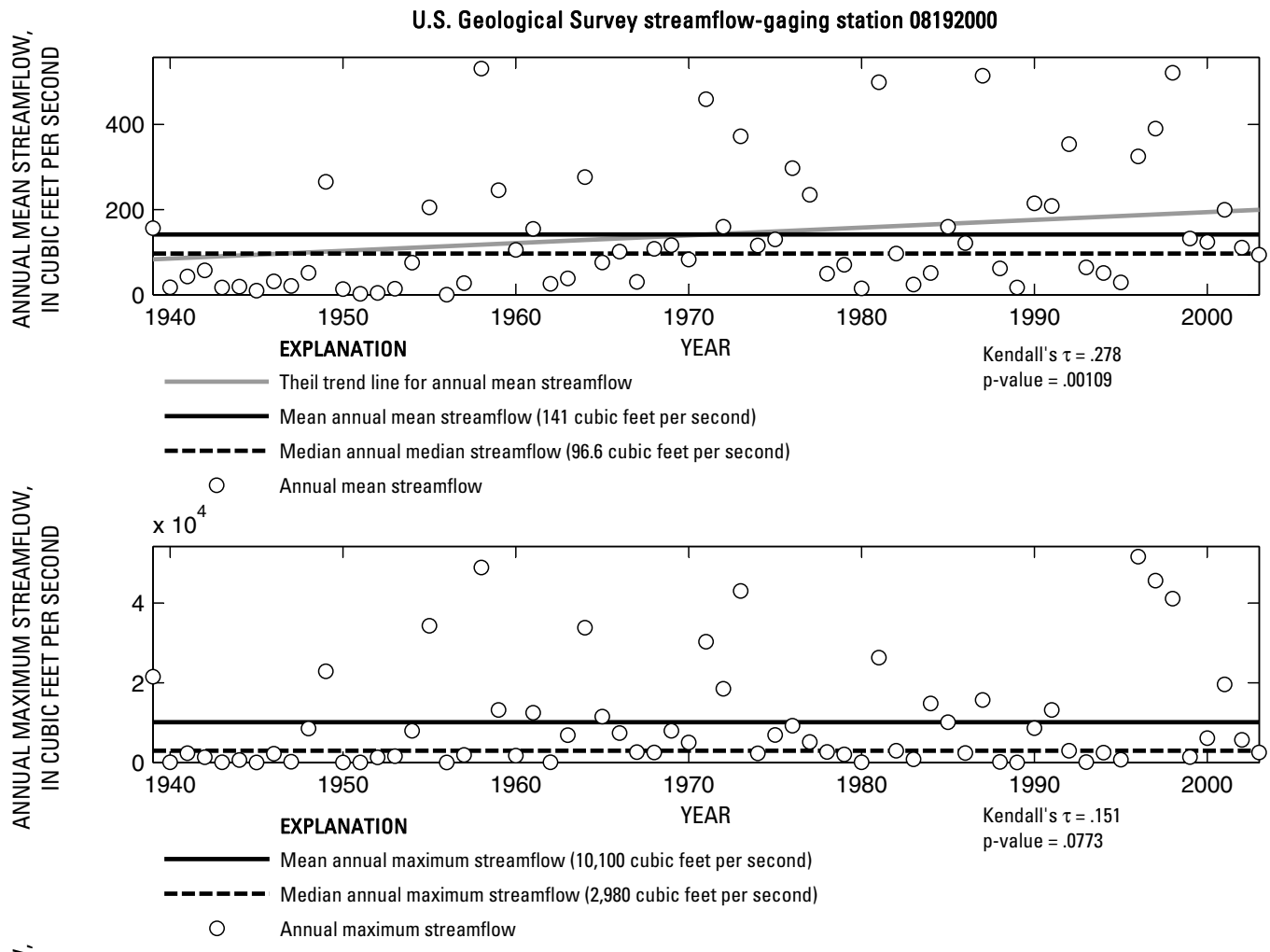

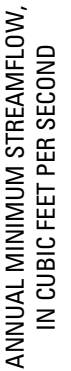

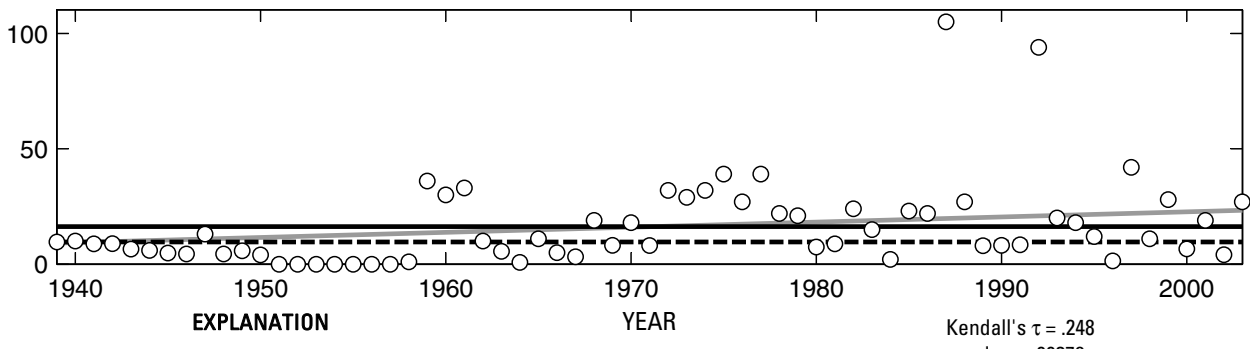

- Theil trend line for annual minimum streamflow p-value $=.00378$

O Annual minimum streamflow
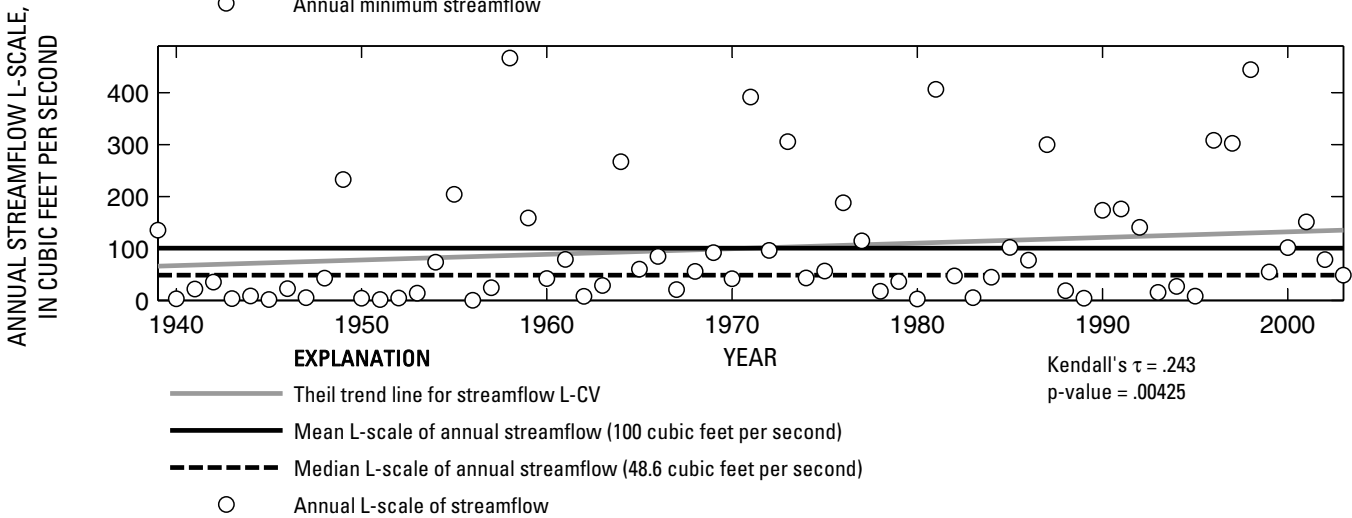

Figure 643. Analysis of annual mean, maximum, minimum, and L-scale statistics of daily mean streamflow for U.S. Geological Survey streamflow-gaging station 08192000 Nueces River below Uvalde, Texas. 

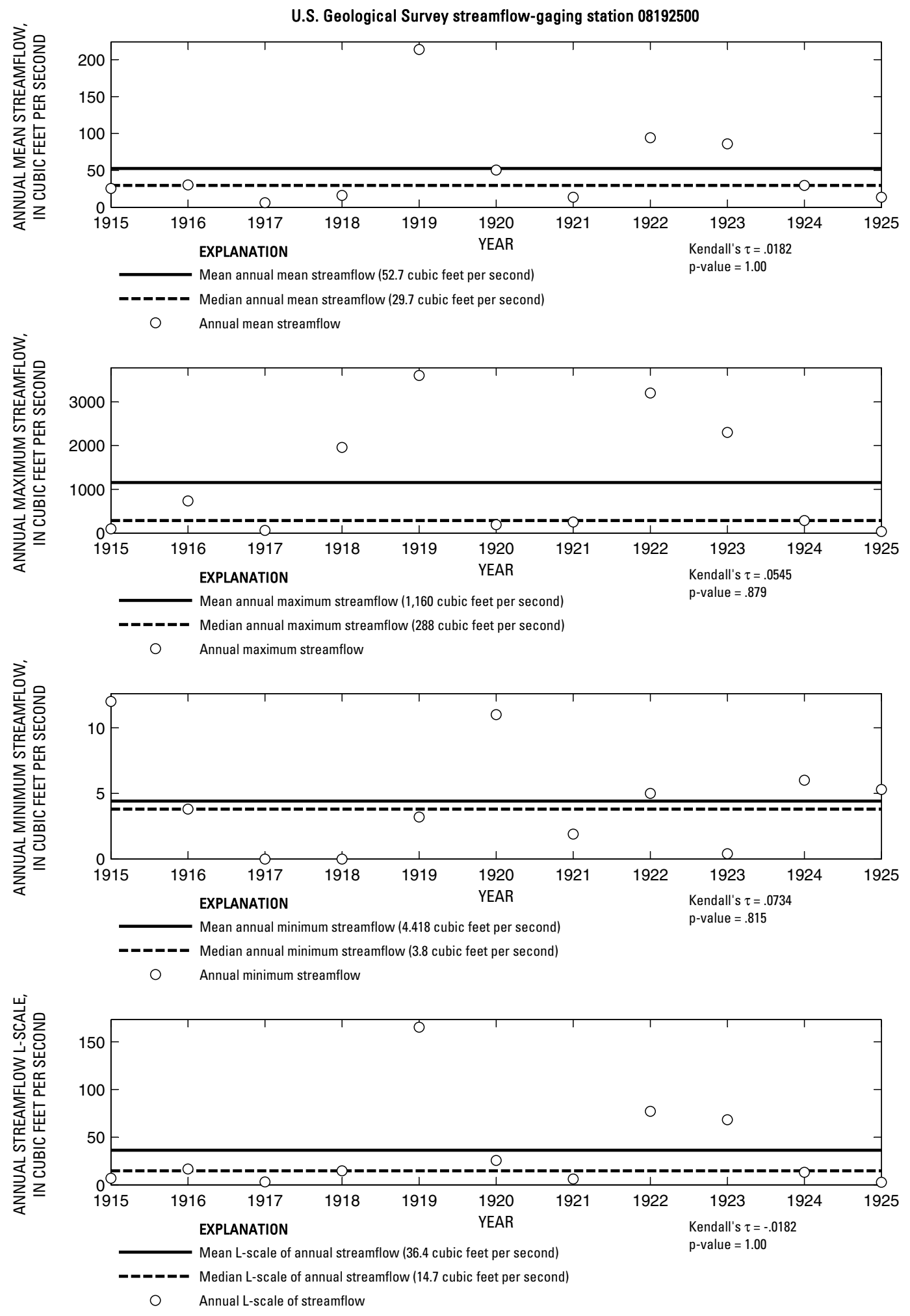

Figure 644. Analysis of annual mean, maximum, minimum, and L-scale statistics of daily mean streamflow for U.S. Geological Survey streamflow-gaging station 08192500 Nueces River near Cinonia, Texas.

Index of Station Numbers 719 


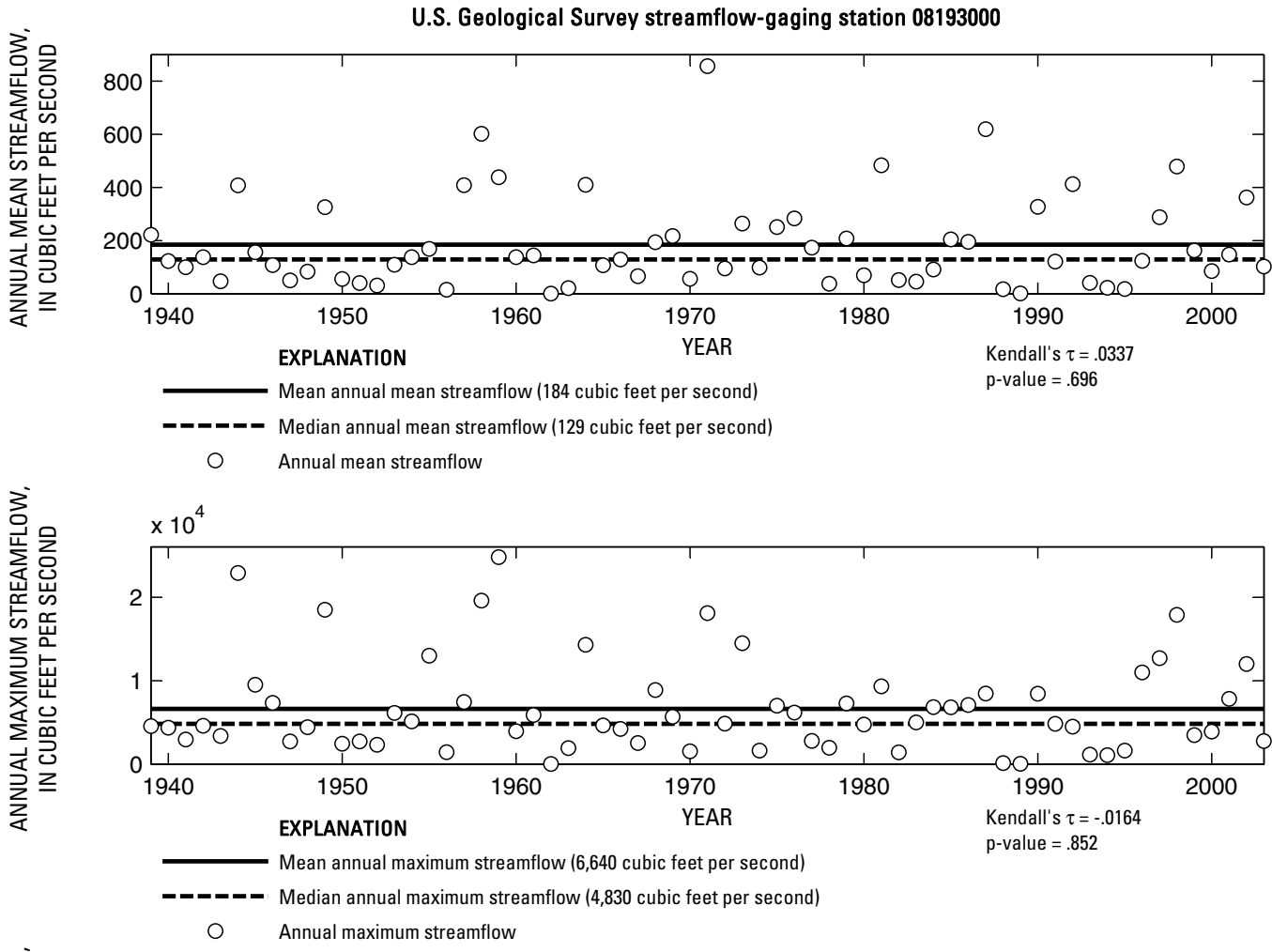

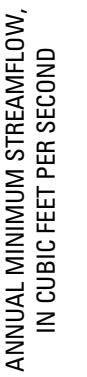
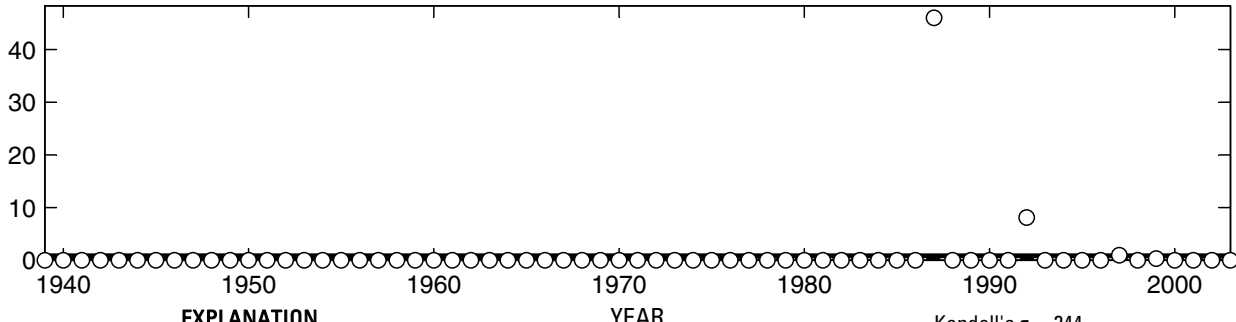

EXPLANATION

Kendall's $\tau=244$

Theil trend line for annual minimum streamflow

- - - Median annual minimum streamflow (0 cubic feet per second)

O Annual minimum streamflow

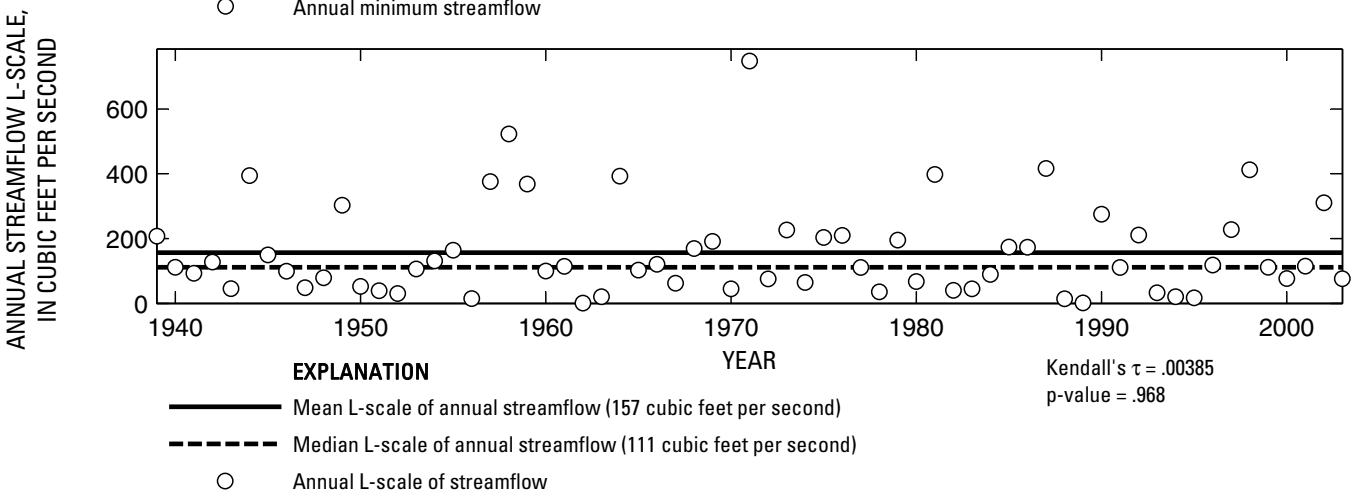

Figure 645. Analysis of annual mean, maximum, minimum, and L-scale statistics of daily mean streamflow for U.S. Geological Survey streamflow-gaging station 08193000 Nueces River near Asherton, Texas. 


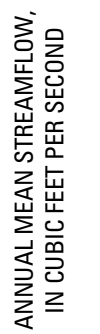

U.S. Geological Survey streamflow-gaging station 08194000

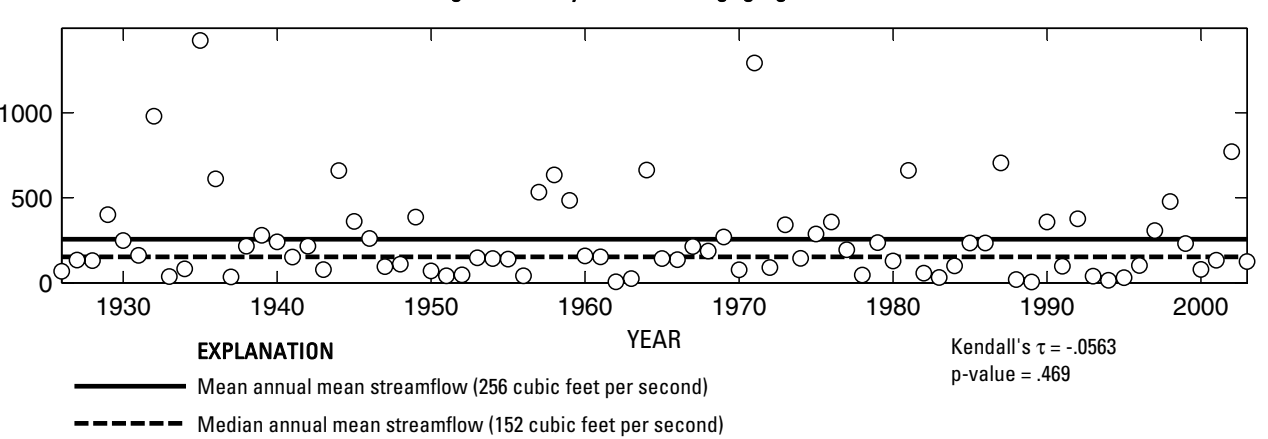

O Annual mean streamflow
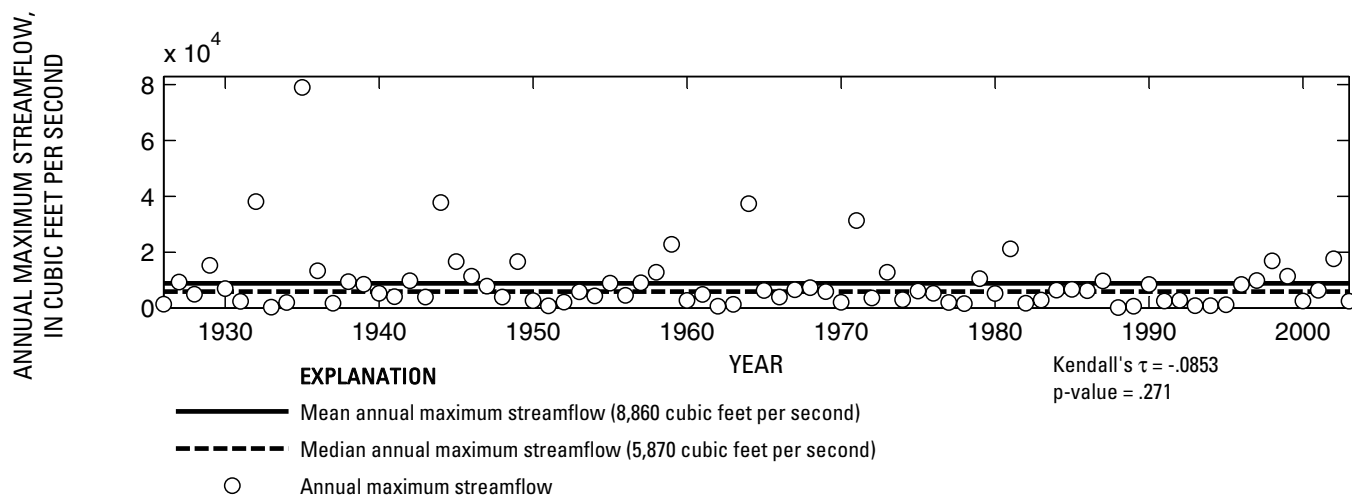

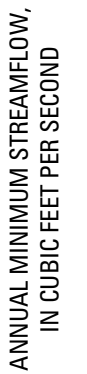

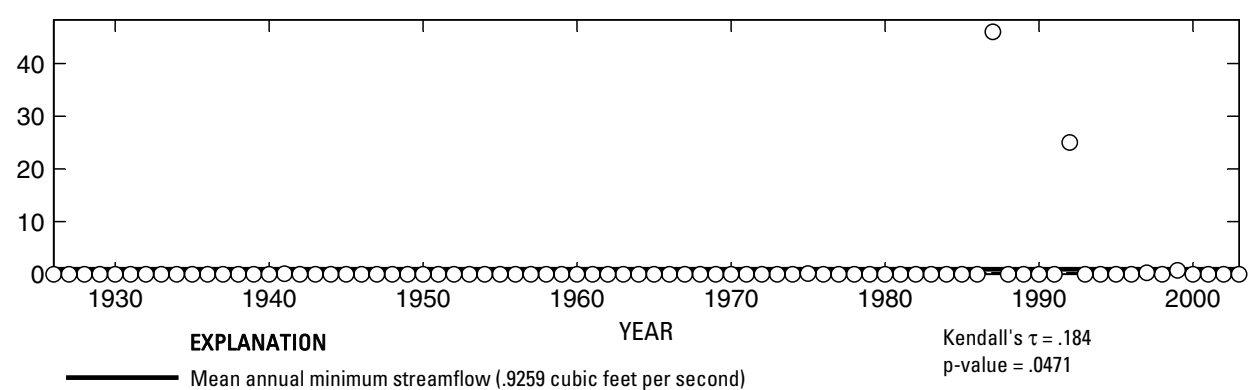

- Median annual minimum streamflow (0 cubic feet per second)

O Annual minimum streamflow

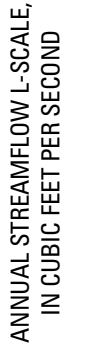

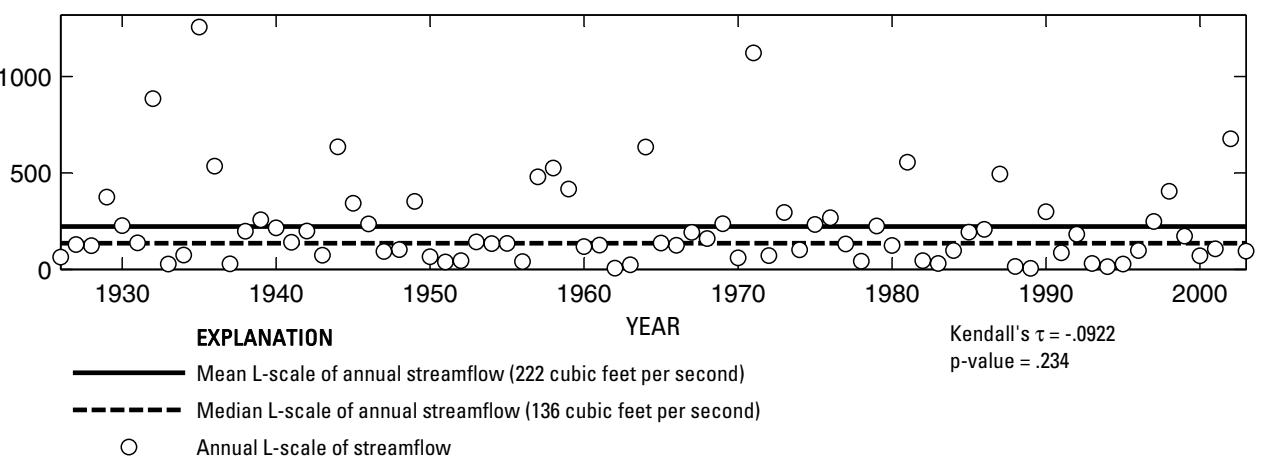

Figure 646. Analysis of annual mean, maximum, minimum, and L-scale statistics of daily mean streamflow for U.S. Geological Survey streamflow-gaging station 08194000 Nueces River at Cotulla, Texas.

Index of Station Numbers 719 

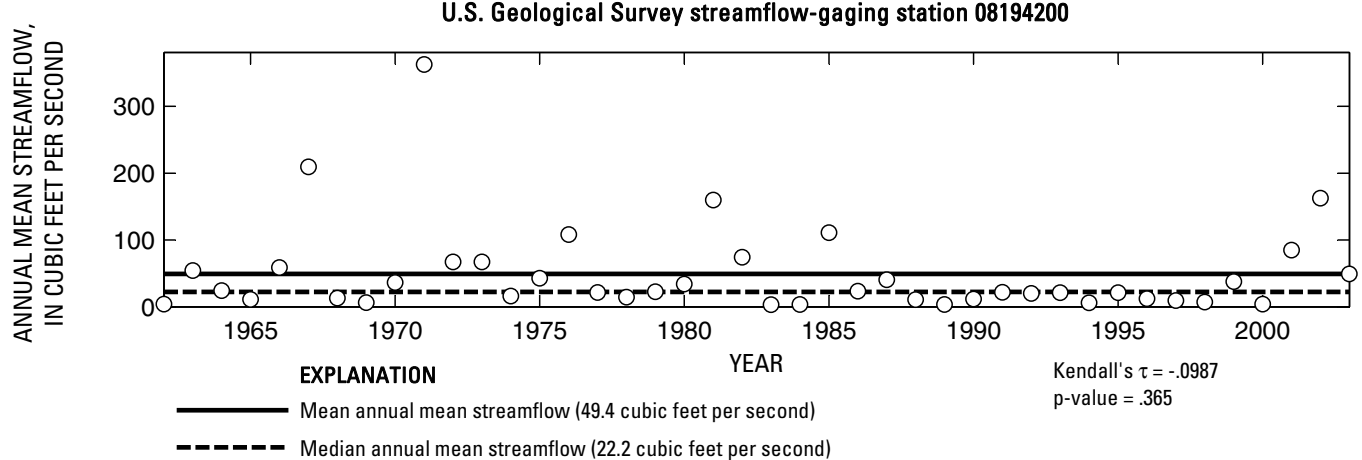

O Annual mean streamflow

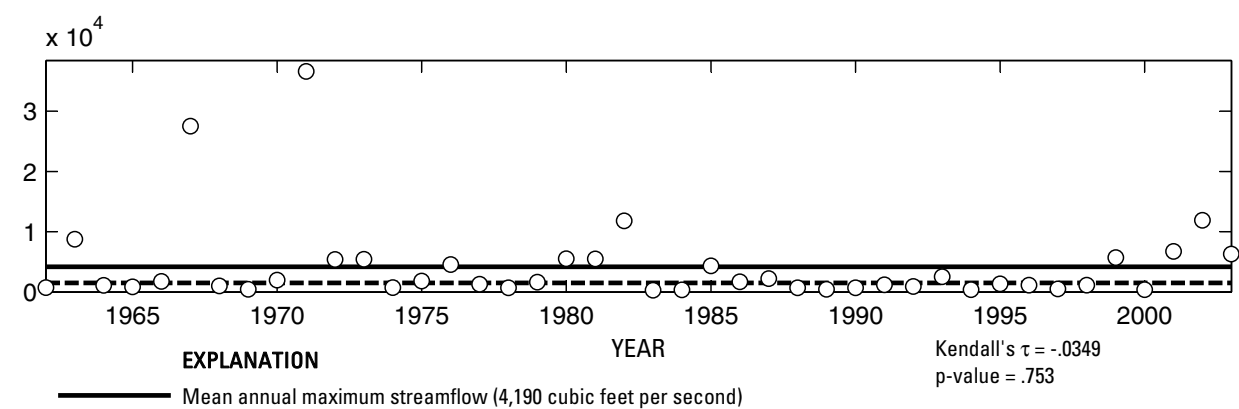

- ב - Median annual maximum streamflow (1,500 cubic feet per second)

O Annual maximum streamflow

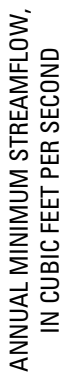

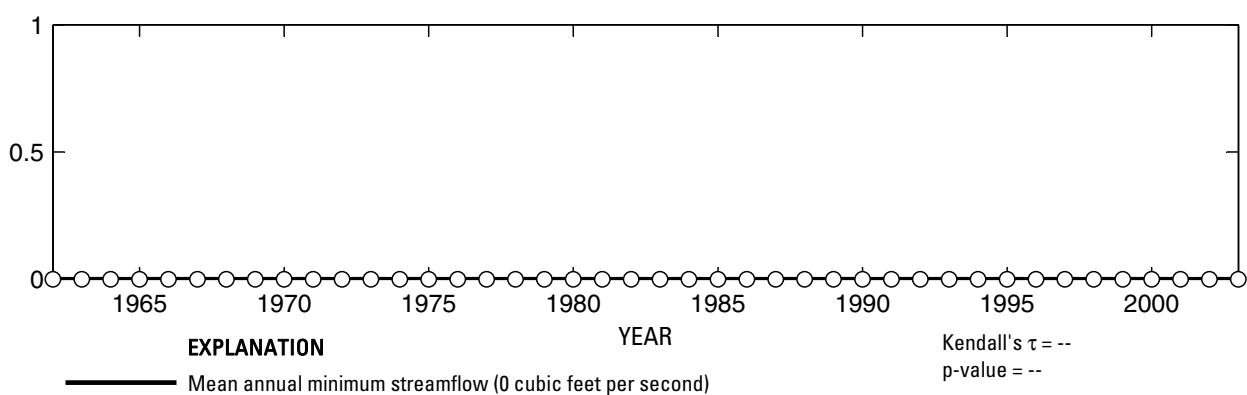

- ב-ב Median annual minimum streamflow (0 cubic feet per second)

O Annual minimum streamflow

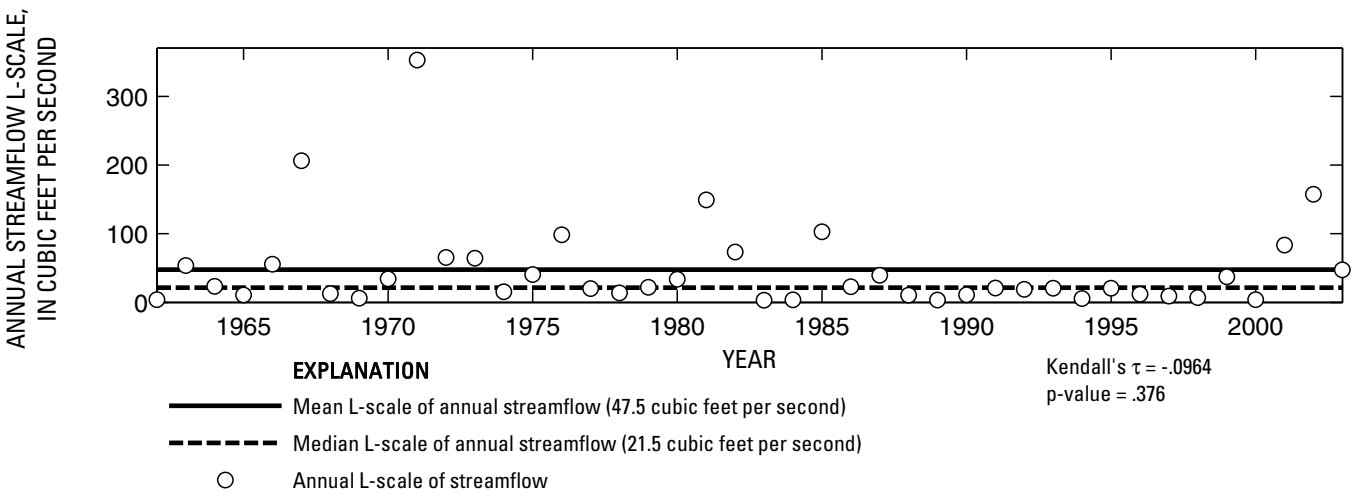

Figure 647. Analysis of annual mean, maximum, minimum, and L-scale statistics of daily mean streamflow for U.S. Geological Survey streamflow-gaging station 08194200 San Casimiro Creek near Freer, Texas. 

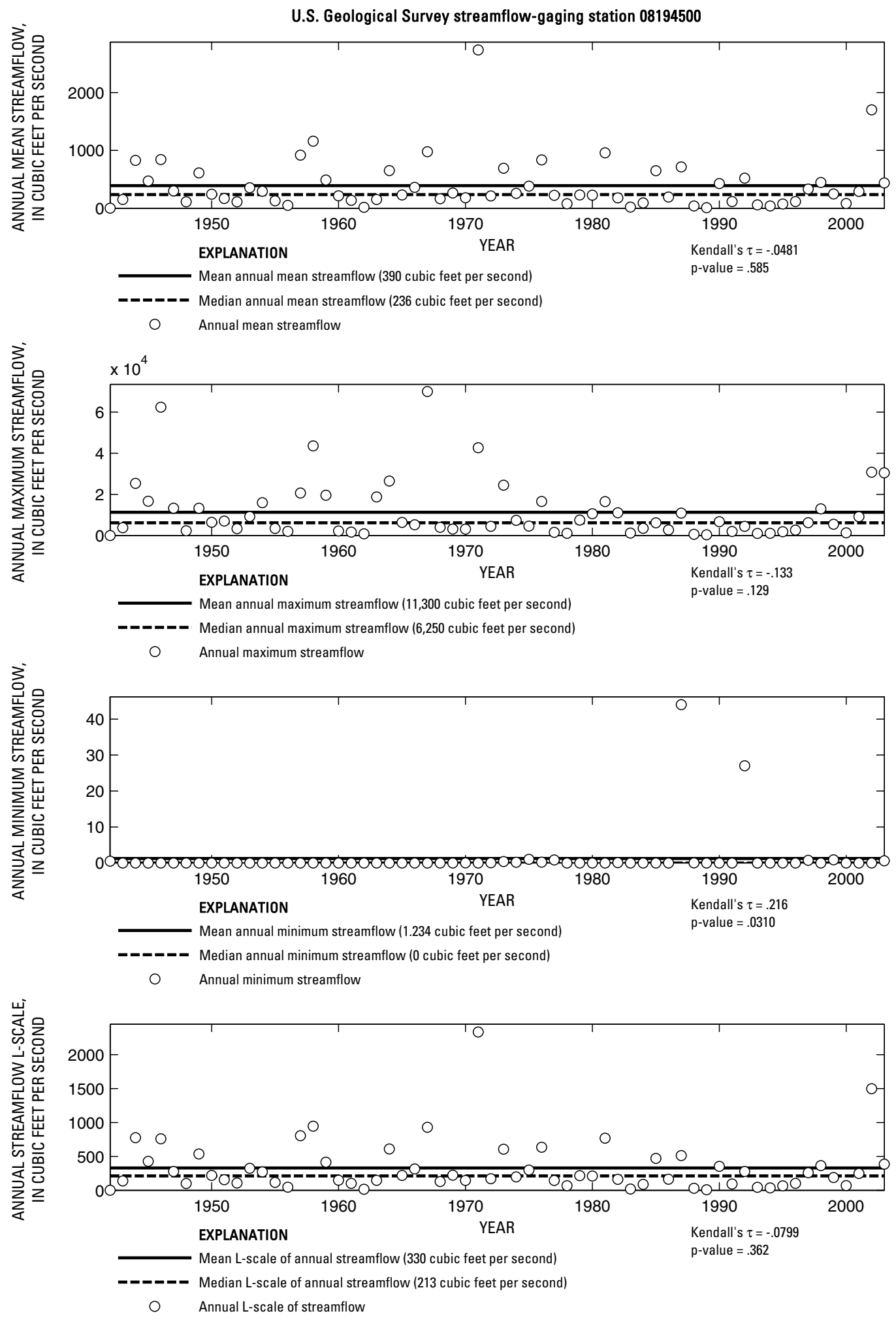

Figure 648. Analysis of annual mean, maximum, minimum, and L-scale statistics of daily mean streamflow for U.S. Geological Survey streamflow-gaging station 08194500 Nueces River near Tilden, Texas.

Index of Station Numbers 719 


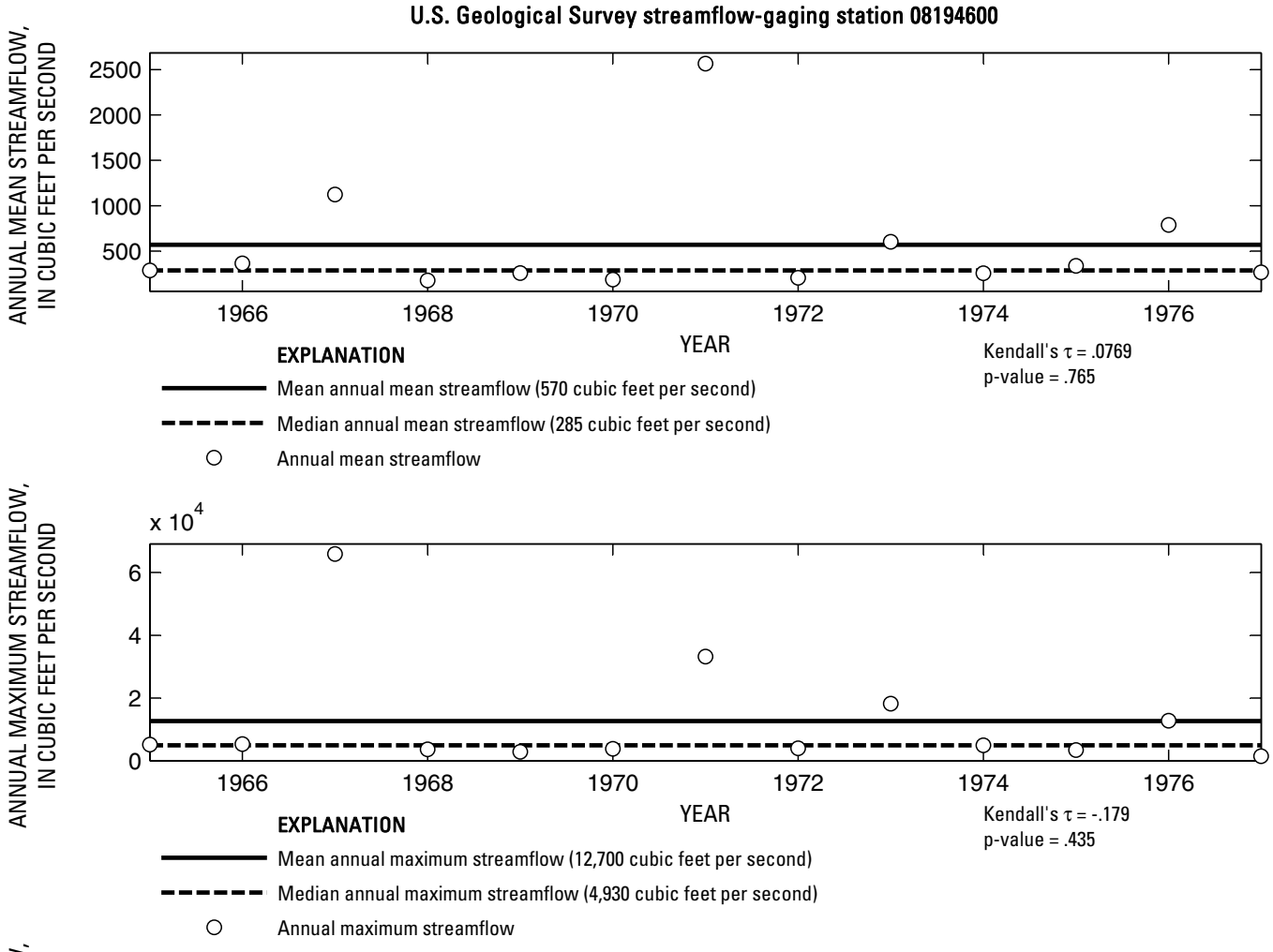

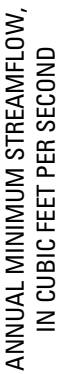

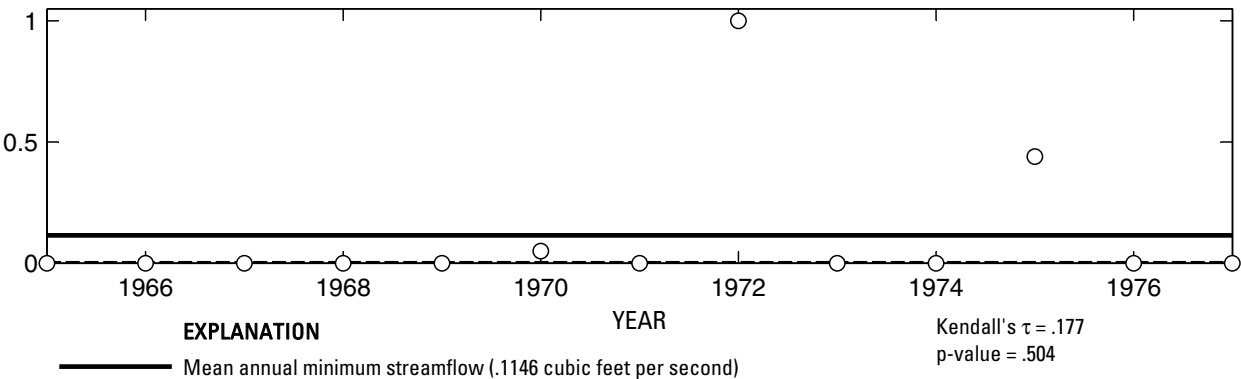

- ב-_ Median annual minimum streamflow (0 cubic feet per second)

O Annual minimum streamflow

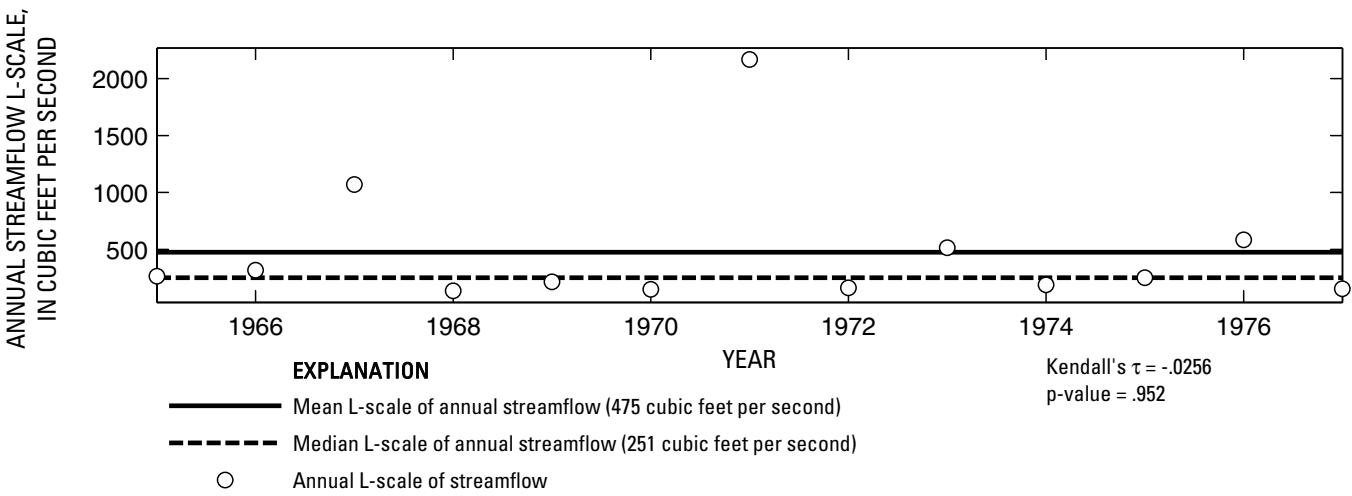

Figure 649. Analysis of annual mean, maximum, minimum, and L-scale statistics of daily mean streamflow for U.S. Geological Survey streamflow-gaging station 08194600 Nueces River at Simmons, Texas. 


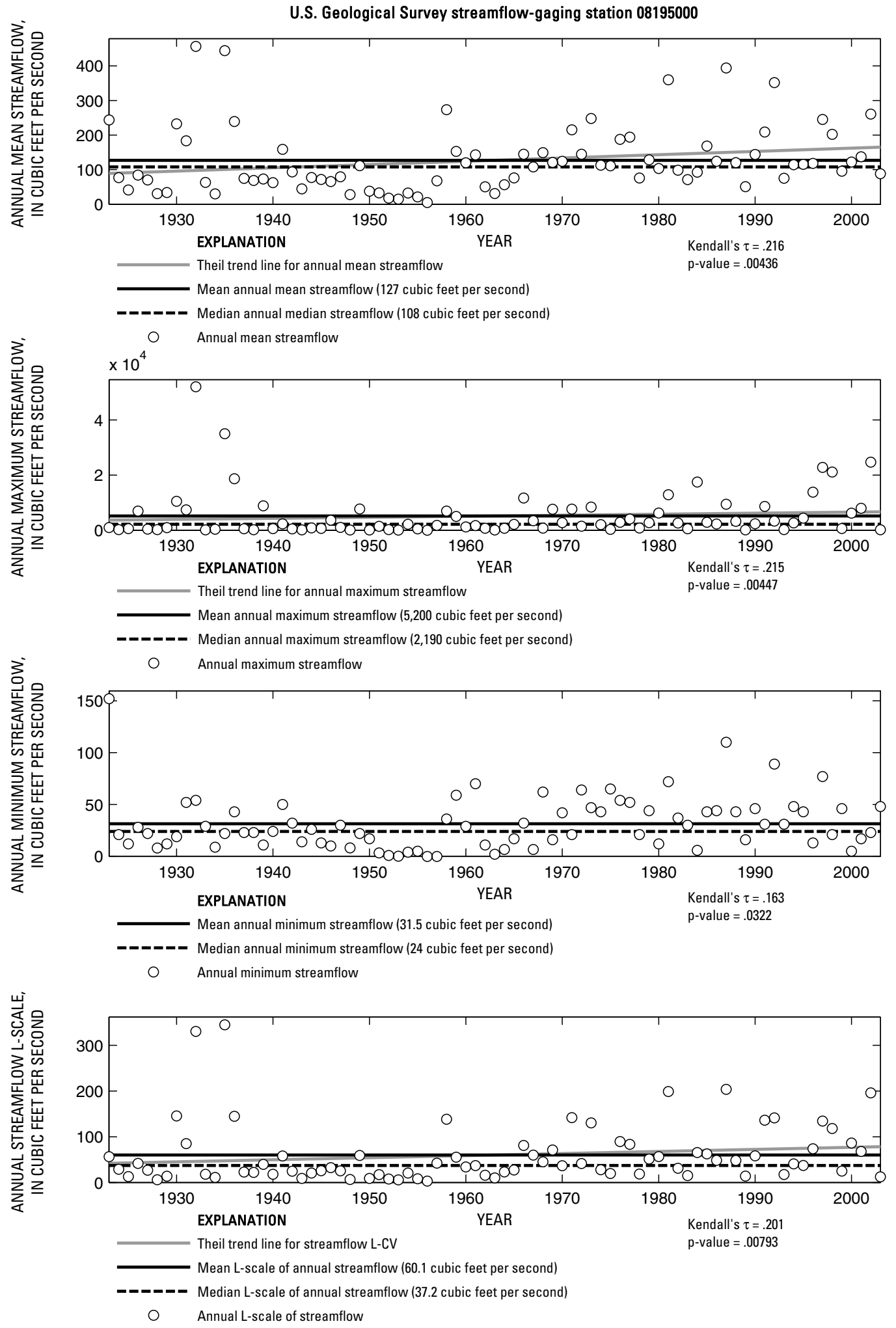

Figure 650. Analysis of annual mean, maximum, minimum, and L-scale statistics of daily mean streamflow for U.S. Geological Survey streamflow-gaging station 08195000 Frio River at Concan, Texas.

Index of Station Numbers 719 

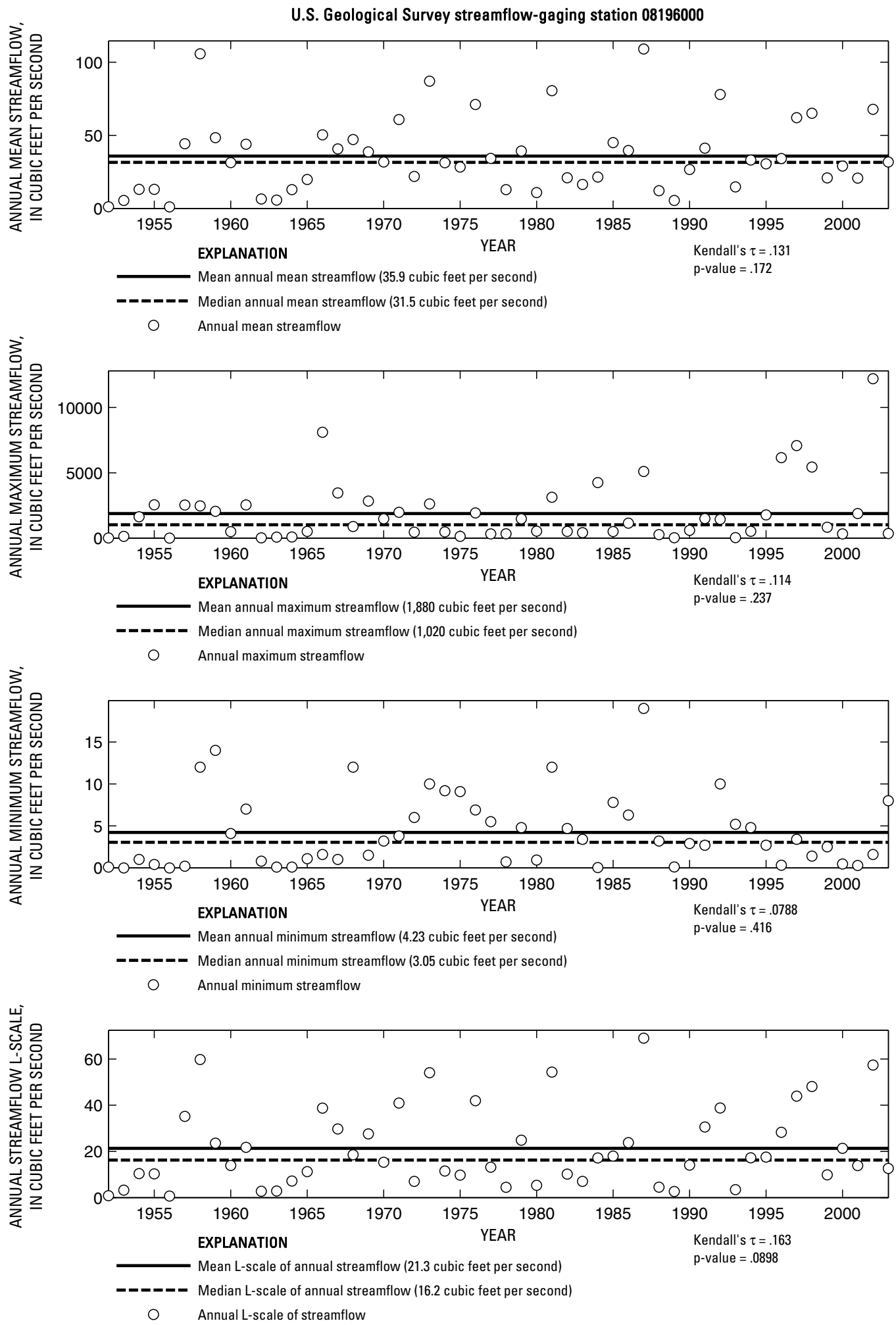

Figure 651. Analysis of annual mean, maximum, minimum, and L-scale statistics of daily mean streamflow for U.S. Geological Survey streamflow-gaging station 08196000 Dry Frio River near Reagan Wells, Texas. 


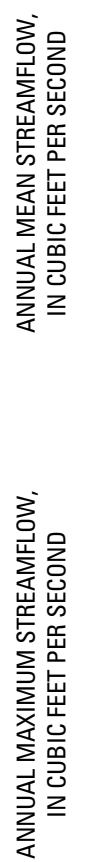

U.S. Geological Survey streamflow-gaging station 08196500

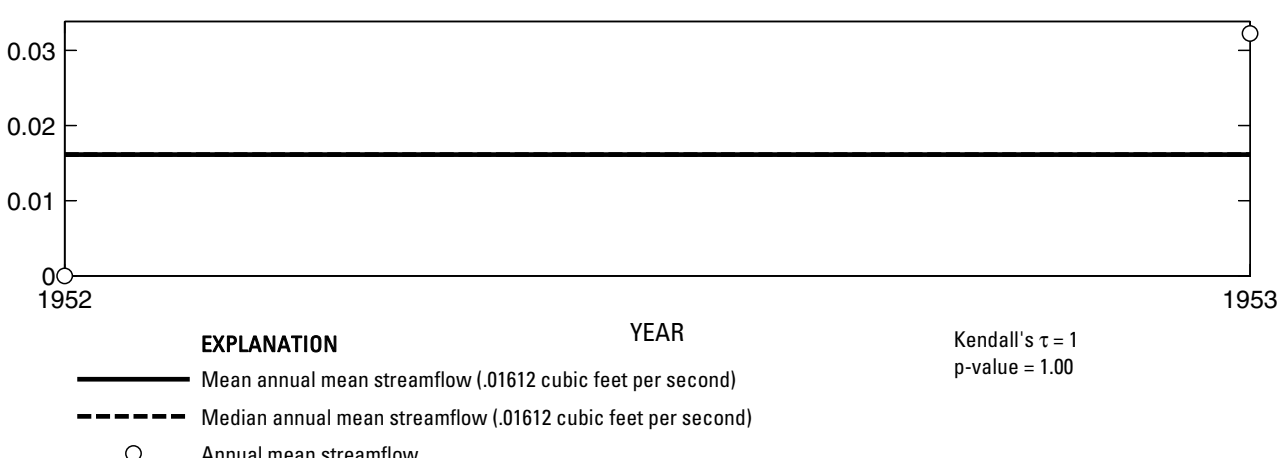

Annual mean streamflow

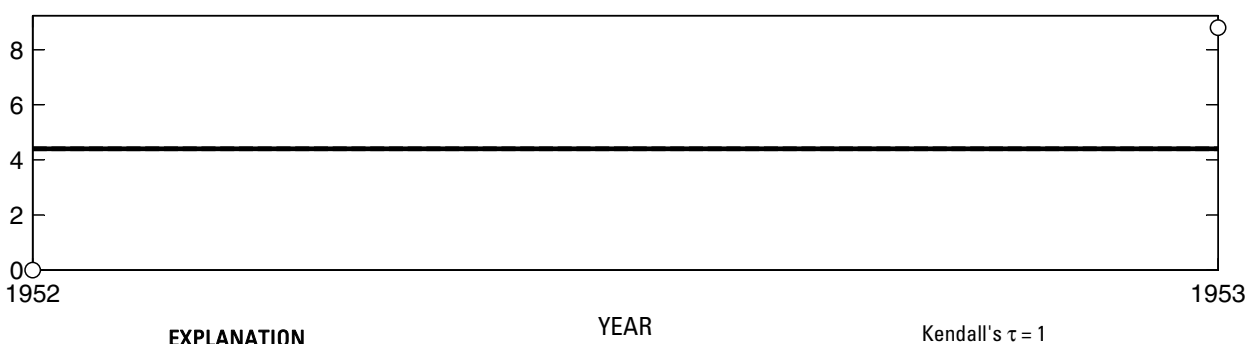

Mean annual maximum streamflow (4.4 cubic feet per second)

$\mathrm{p}$-value $=1.00$

-ーーーーー Median annual maximum streamflow (4.4 cubic feet per second)

Annual maximum streamflow

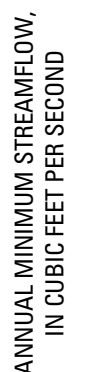
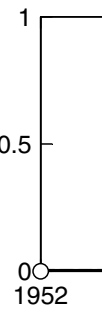


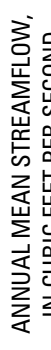

U.S. Geological Survey streamflow-gaging station 08197500

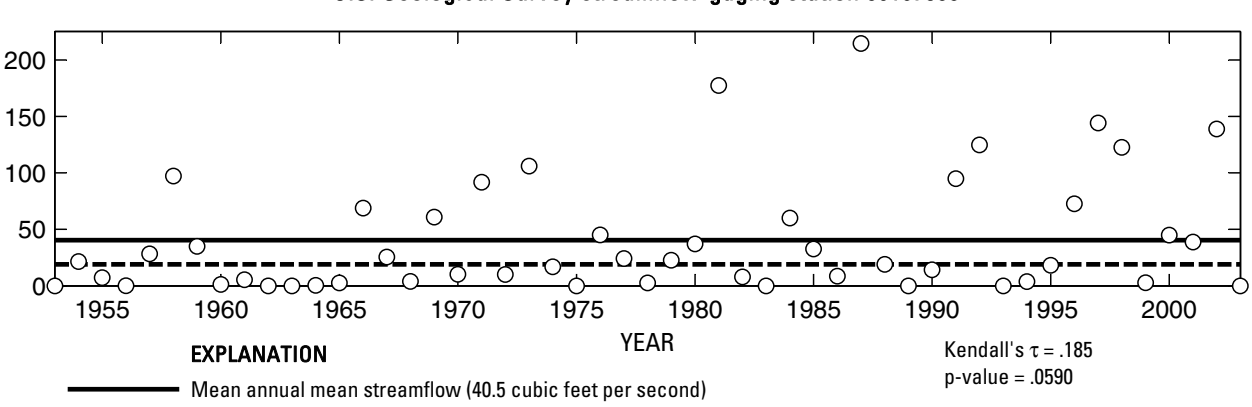

-_-_- Median annual mean streamflow (19 cubic feet per second)

O Annual mean streamflow

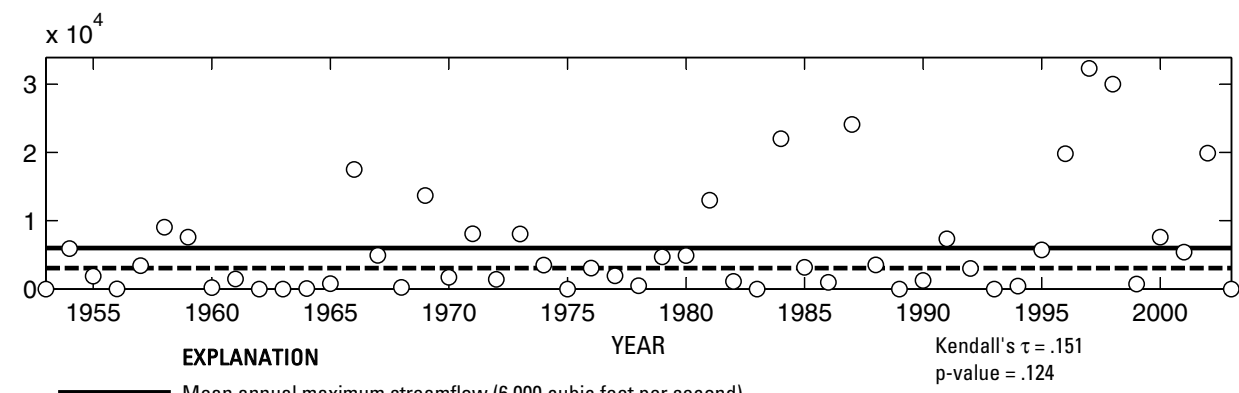

O Annual maximum streamflow

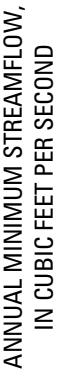

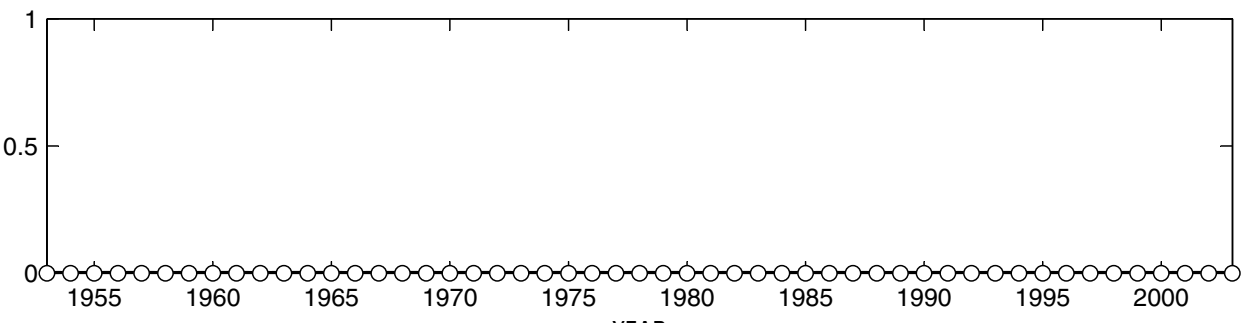
EXPLANATION

YEAR

Kendall's $\tau=-$.

Mean annual minimum streamflow (0 cubic feet per second)

p-value $=--$

-_-_- Median annual minimum streamflow (0 cubic feet per second)

O Annual minimum streamflow

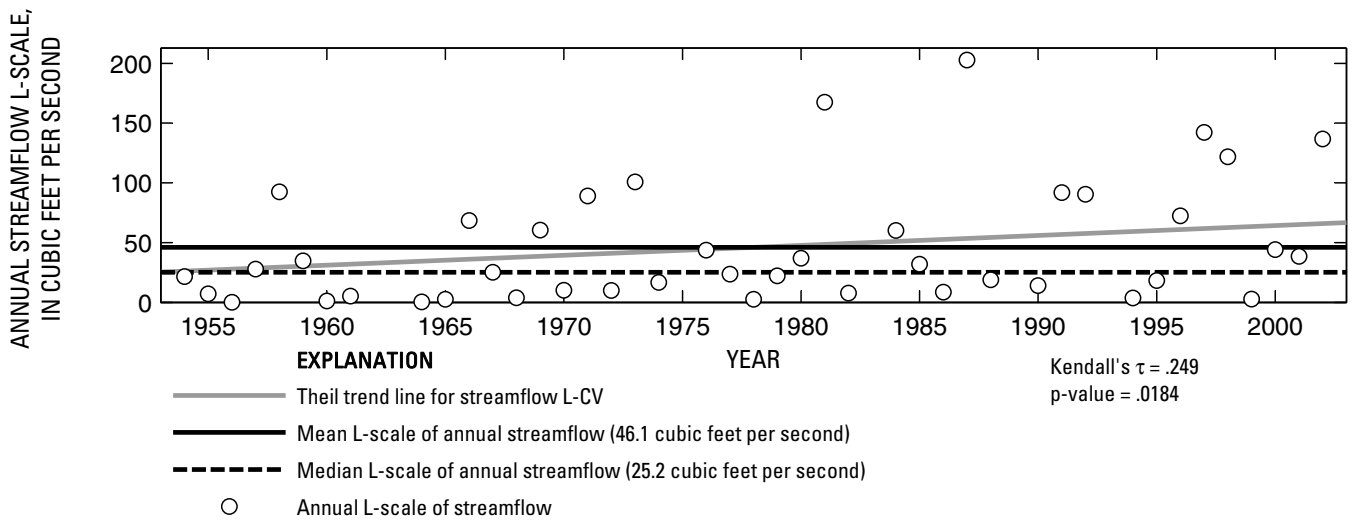

Figure 653. Analysis of annual mean, maximum, minimum, and L-scale statistics of daily mean streamflow for U.S. Geological Survey streamflow-gaging station 08197500 Frio River below Dry Frio River near Uvalde, Texas. 


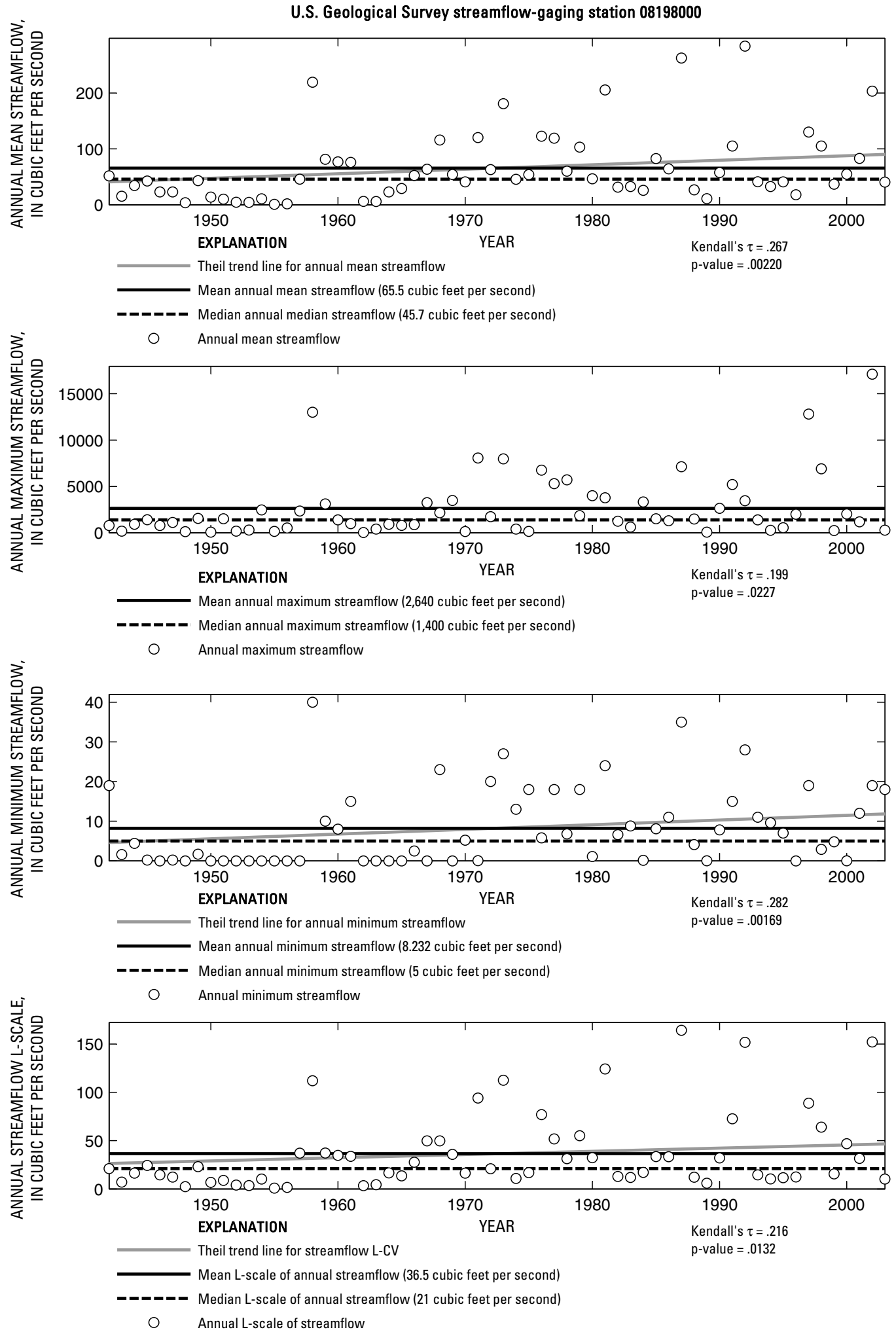

Figure 654. Analysis of annual mean, maximum, minimum, and L-scale statistics of daily mean streamflow for U.S. Geological Survey streamflow-gaging station 08198000 Sabinal River near Sabinal, Texas.

Index of Station Numbers 719 


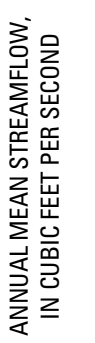

U.S. Geological Survey streamflow-gaging station 08198500

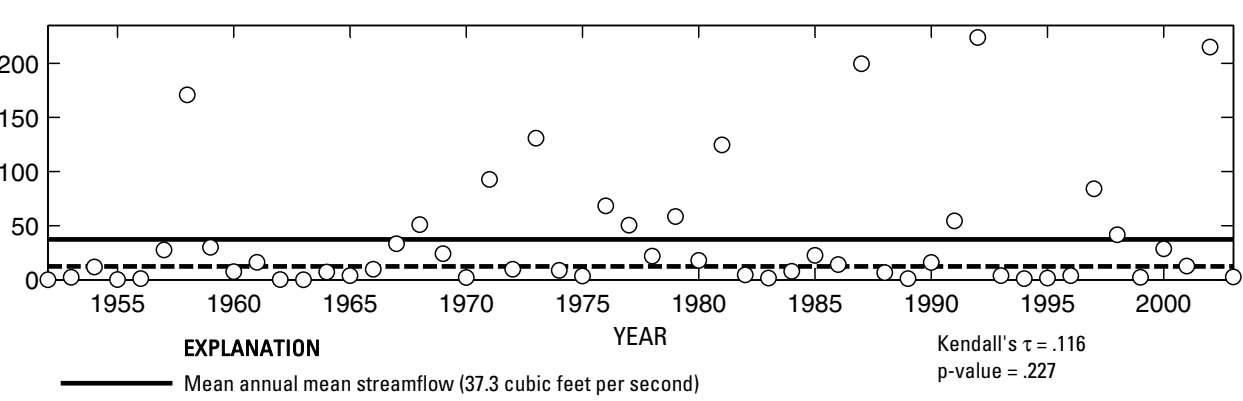

-_-_- Median annual mean streamflow (12.3 cubic feet per second)

O Annual mean streamflow

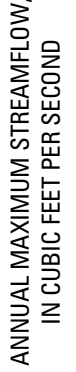

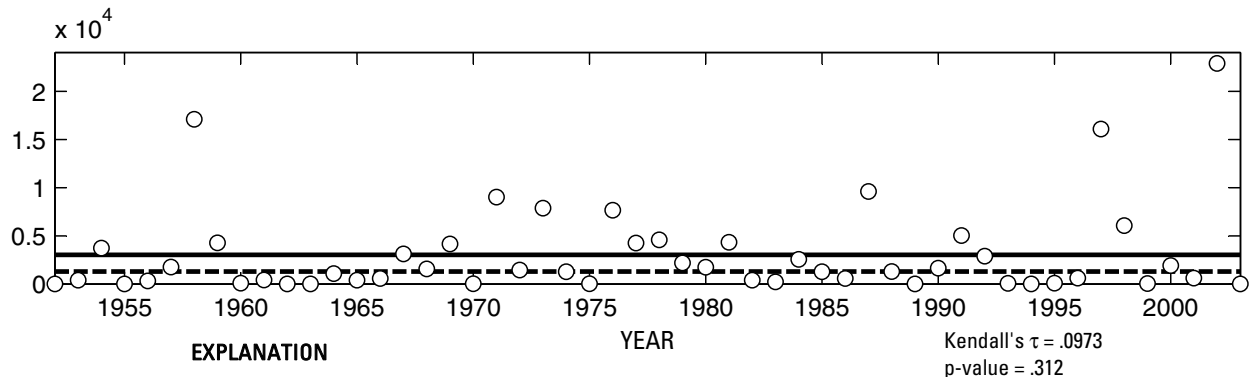

Mean annual maximum stram streamflow (1,290 cubic feet per second)

O Annual maximum streamflow

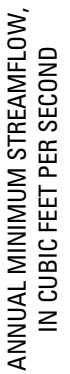

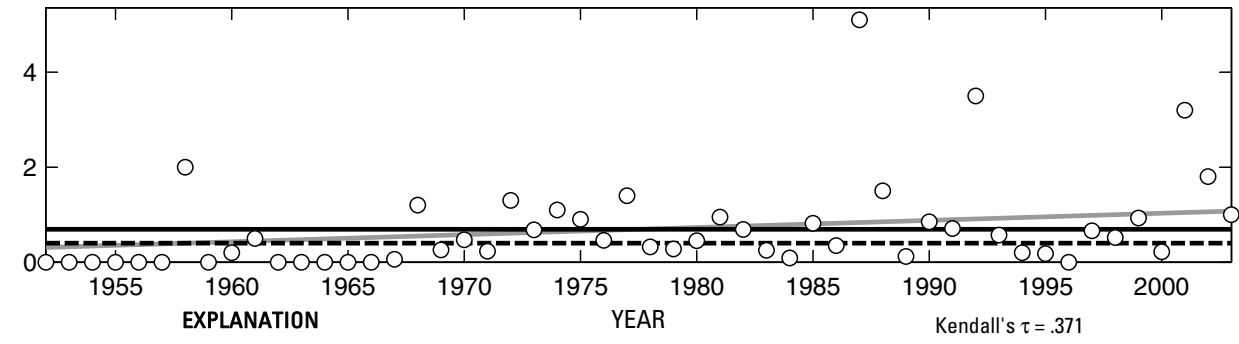

Theil trend line for annual minimum streamflow

$\mathrm{p}$-value $=<.00$

- Mean annual minimum streamflow (.6927 cubic feet per second)

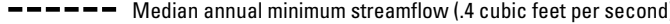

O Annual minimum streamflow

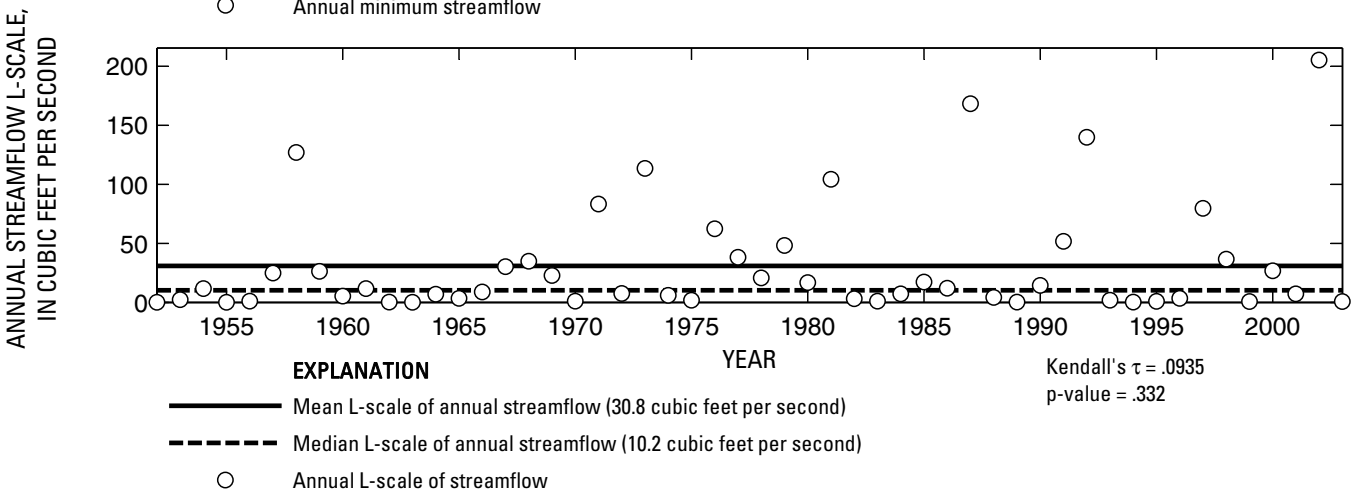

Figure 655. Analysis of annual mean, maximum, minimum, and L-scale statistics of daily mean streamflow for U.S. Geological Survey streamflow-gaging station 08198500 Sabinal River at Sabinal, Texas. 

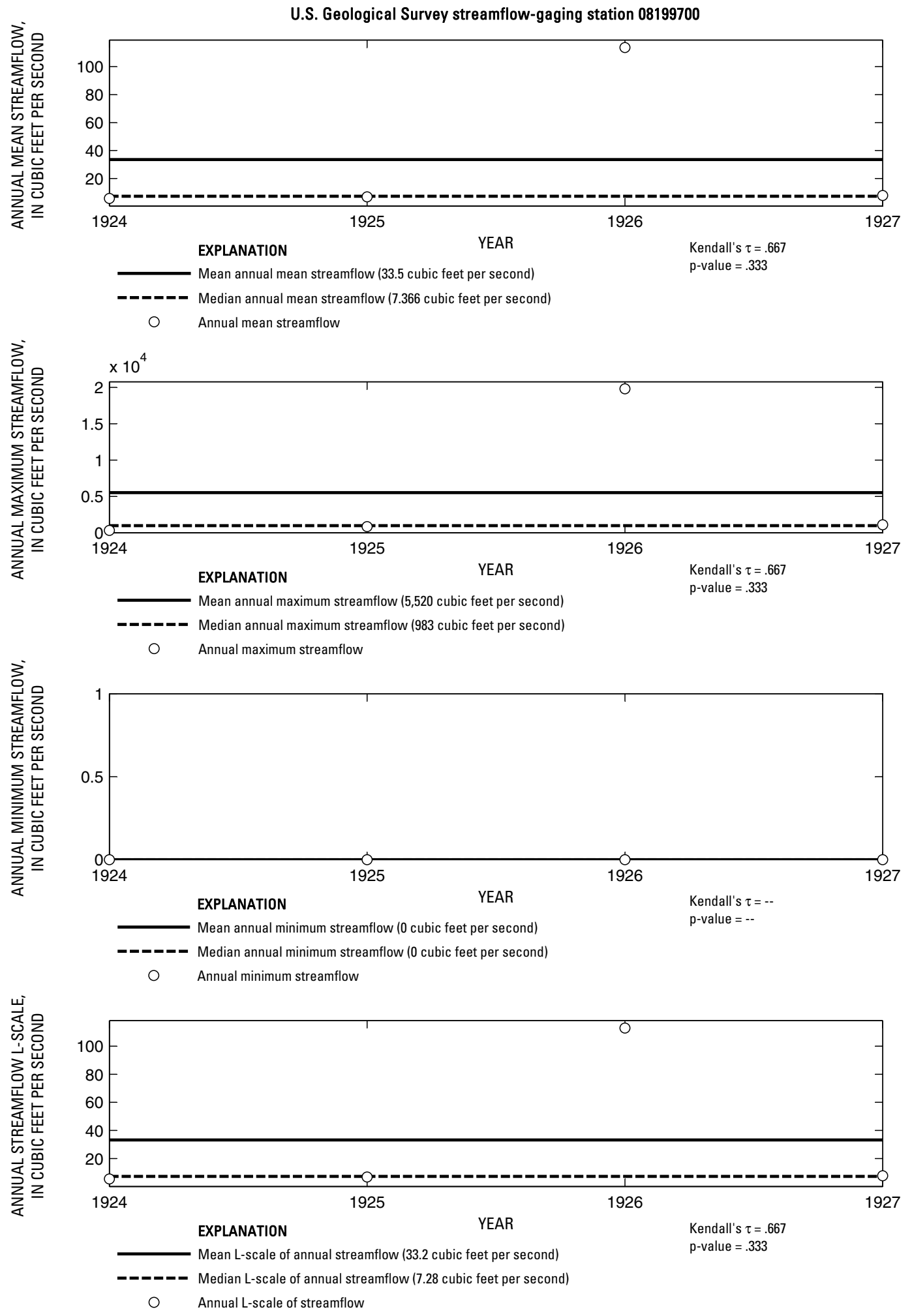

Figure 656. Analysis of annual mean, maximum, minimum, and L-scale statistics of daily mean streamflow for U.S. Geological Survey streamflow-gaging station 08199700 Frio River near Frio Town, Texas. 


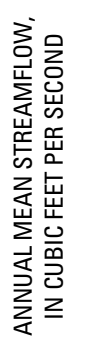

U.S. Geological Survey streamflow-gaging station 08200000

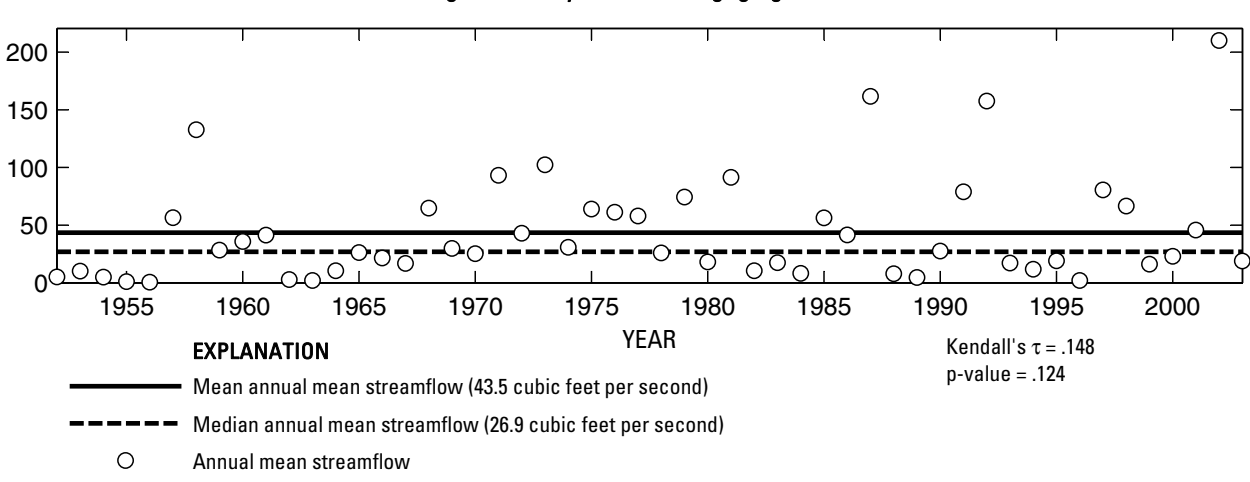

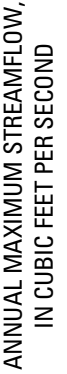

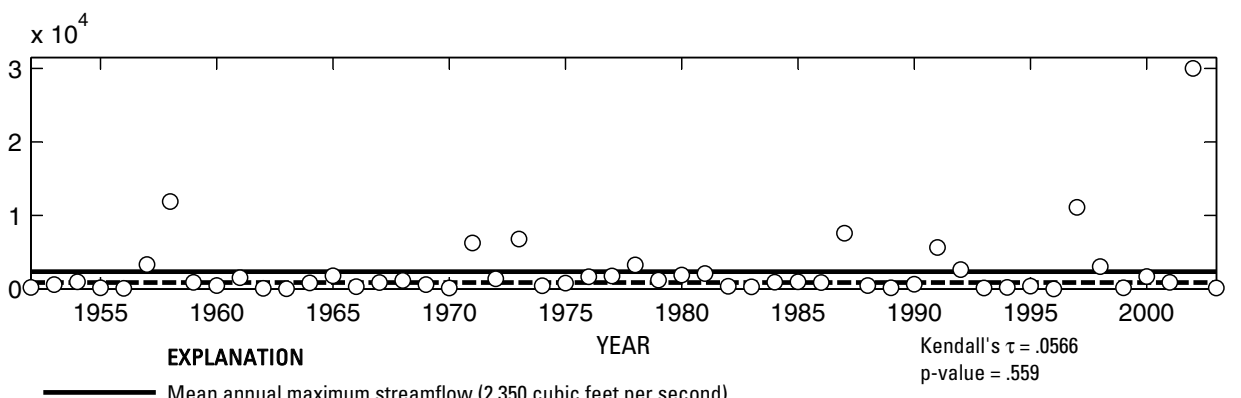

- - - Median annual maximum streamflow (891 cubic feet per second)

Annual maximum streamflow

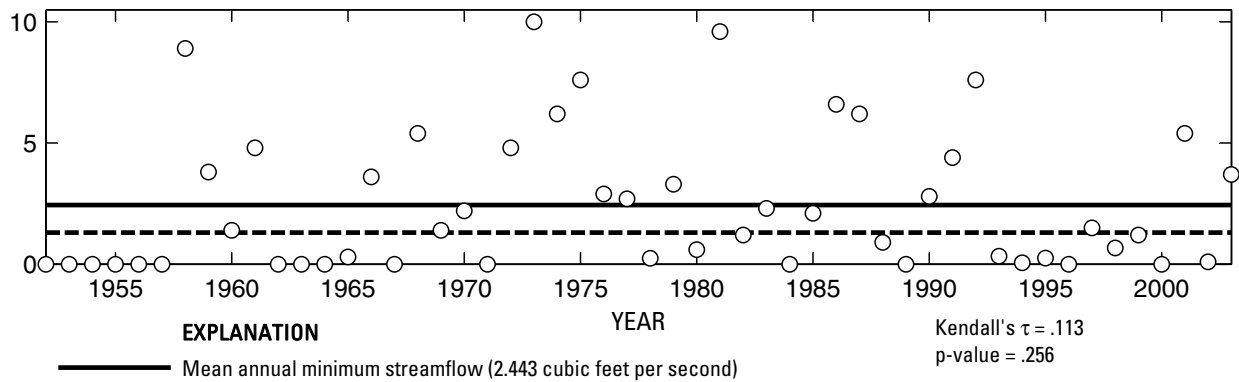

- ב-_ Median annual minimum streamflow (1.3 cubic feet per second)

O Annual minimum streamflow

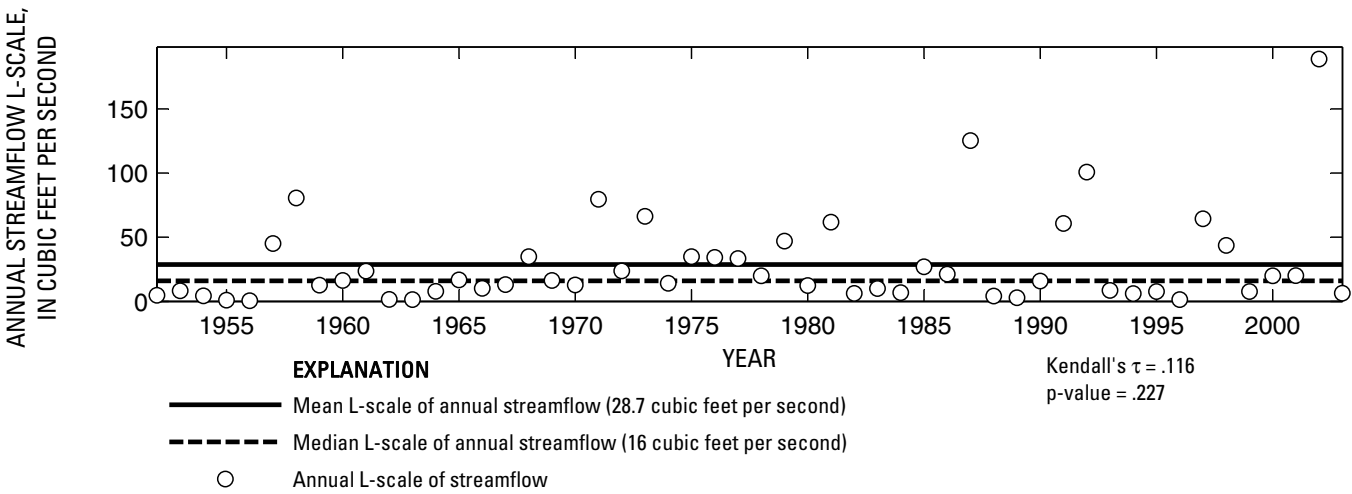

Figure 657. Analysis of annual mean, maximum, minimum, and L-scale statistics of daily mean streamflow for U.S. Geological Survey streamflow-gaging station 08200000 Hondo Creek near Tarpley, Texas. 

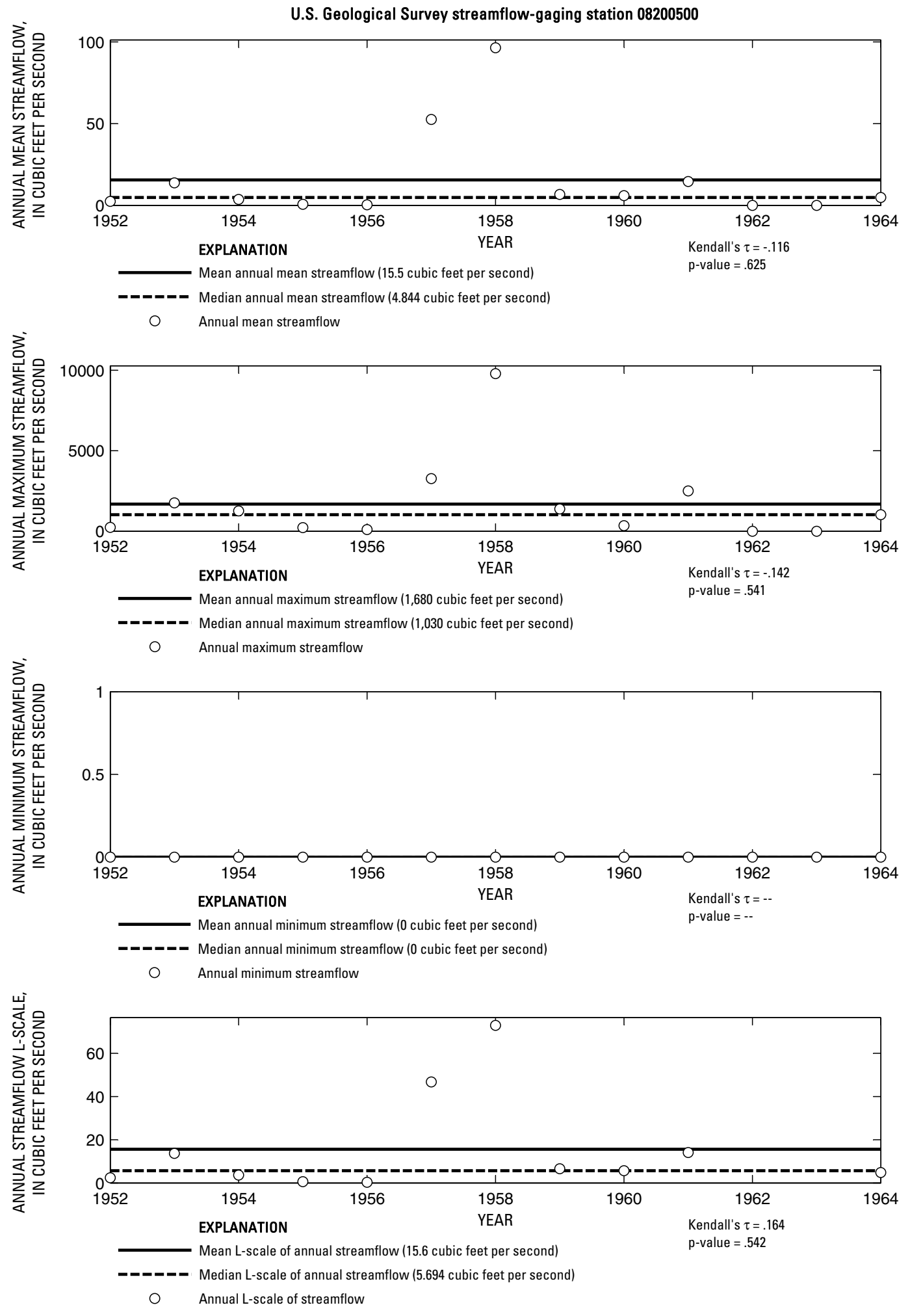

Figure 658. Analysis of annual mean, maximum, minimum, and L-scale statistics of daily mean streamflow for U.S. Geological Survey streamflow-gaging station 08200500 Hondo Creek near Hondo, Texas. 


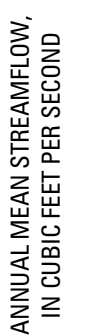

U.S. Geological Survey streamflow-gaging station 08200700

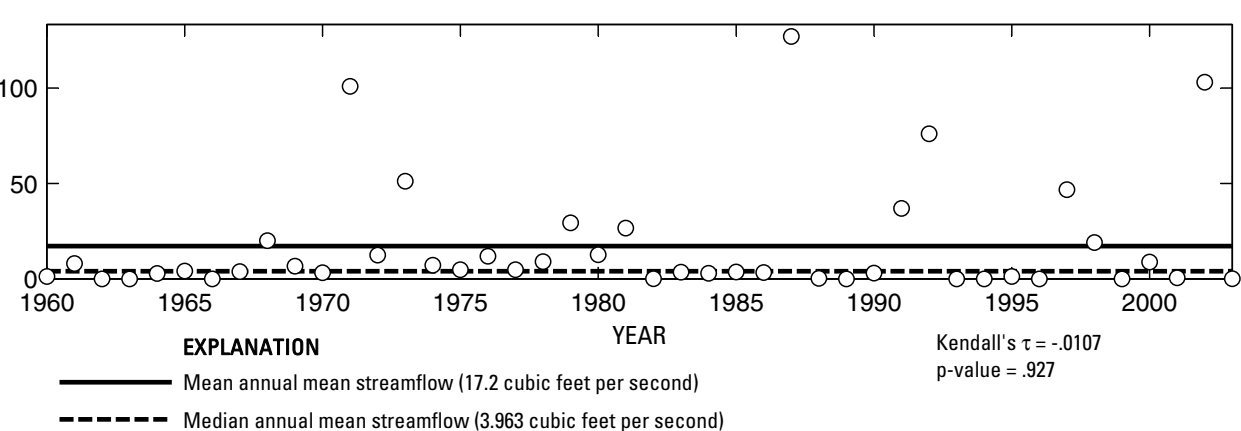

O Annual mean streamflow

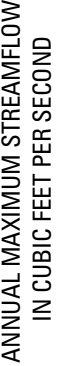

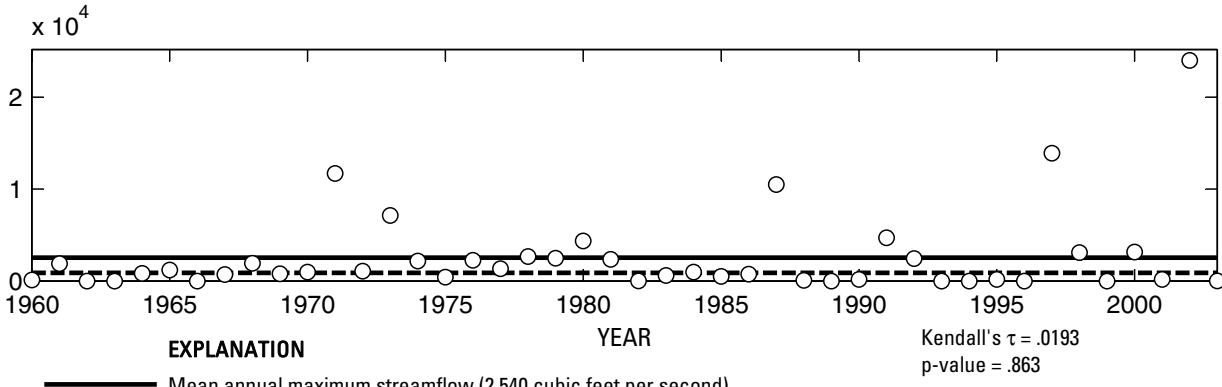

O Annual maximum streamflow
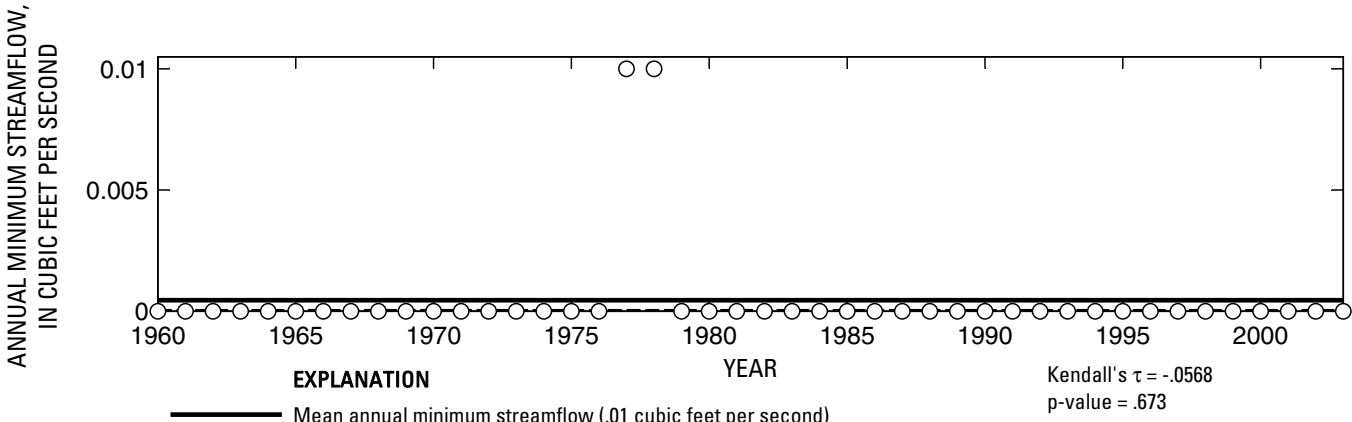

- Median annual minimum streamflow (0 cubic feet per second)

O Annual minimum streamflow

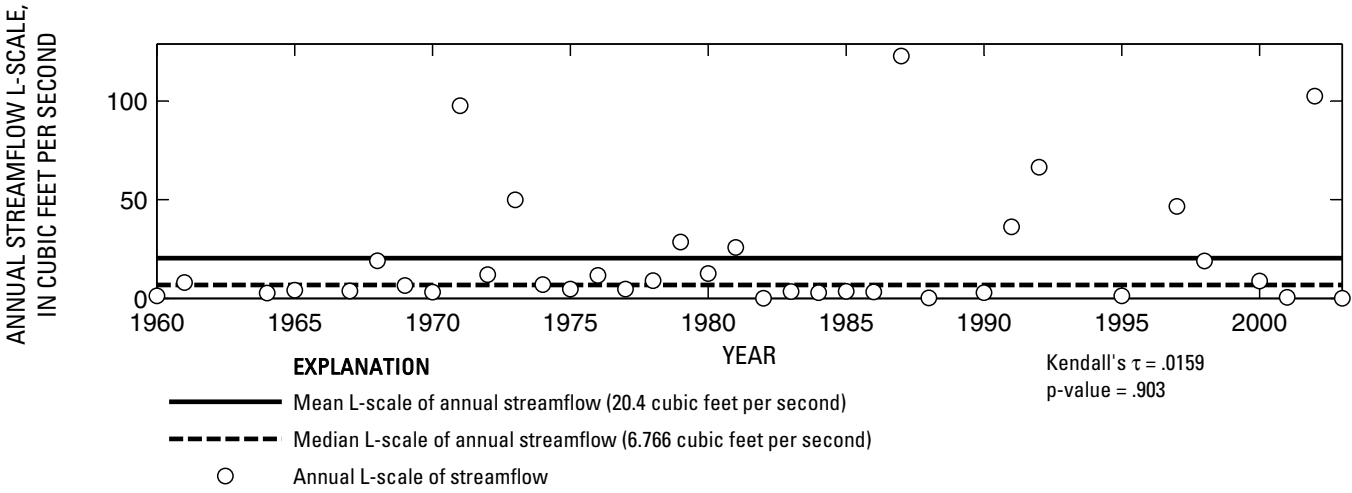

Figure 659. Analysis of annual mean, maximum, minimum, and L-scale statistics of daily mean streamflow for U.S. Geological Survey streamflow-gaging station 08200700 Hondo Creek at King Waterhole near Hondo, Texas. 


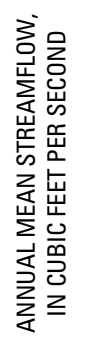

U.S. Geological Survey streamflow-gaging station 08201500

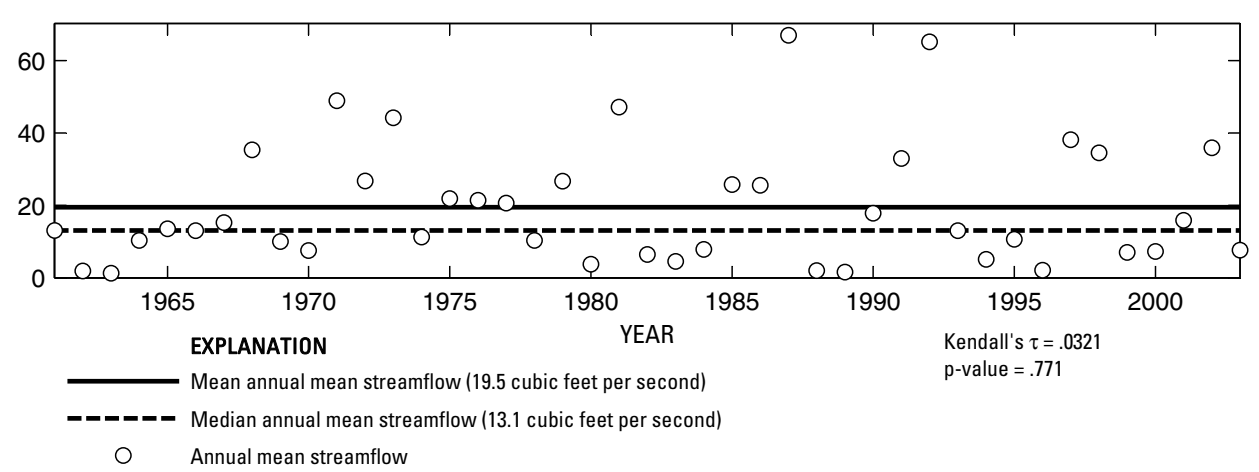

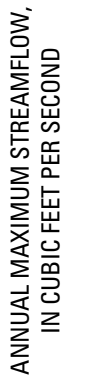

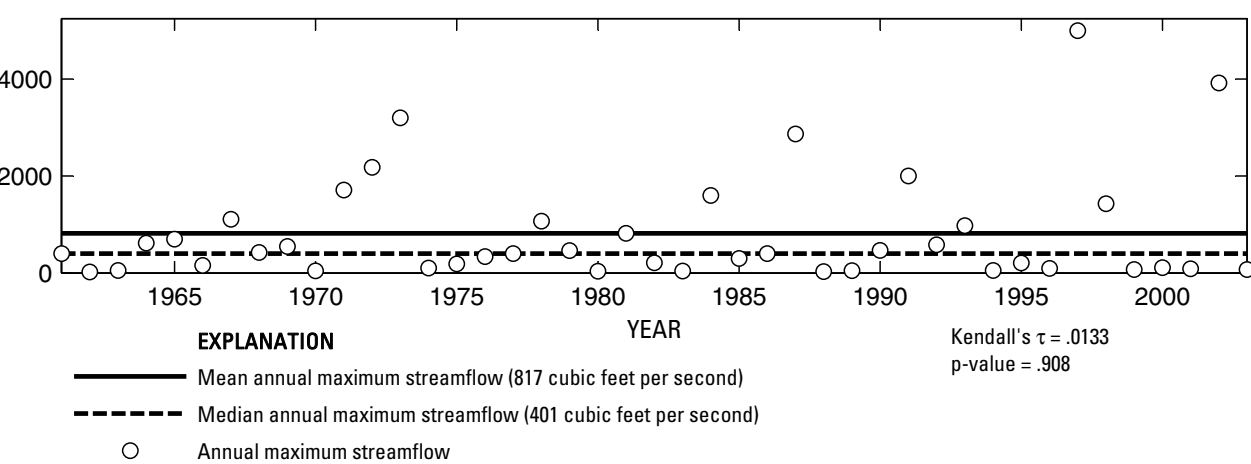

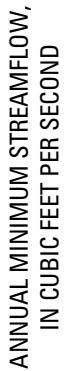

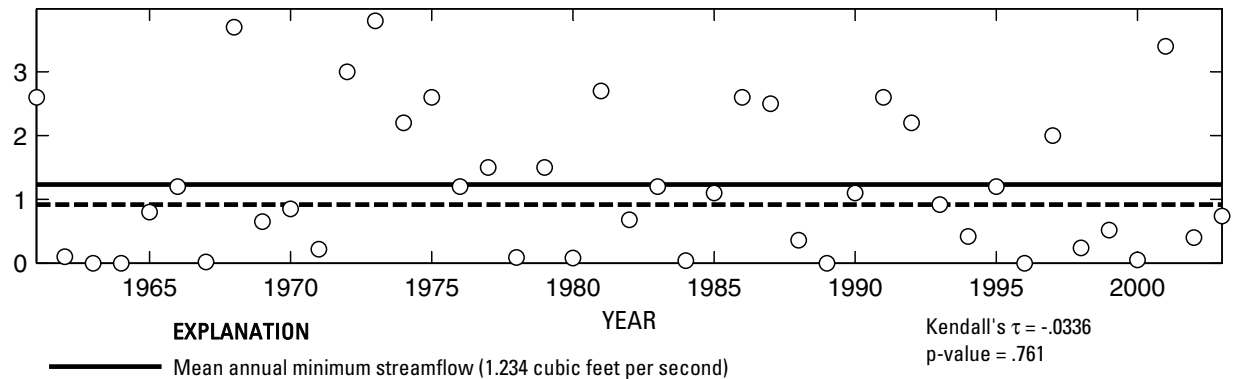

- Median annual minimum streamflow (.92 cubic feet per second)

O Annual minimum streamflow

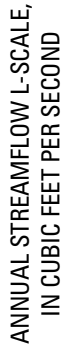

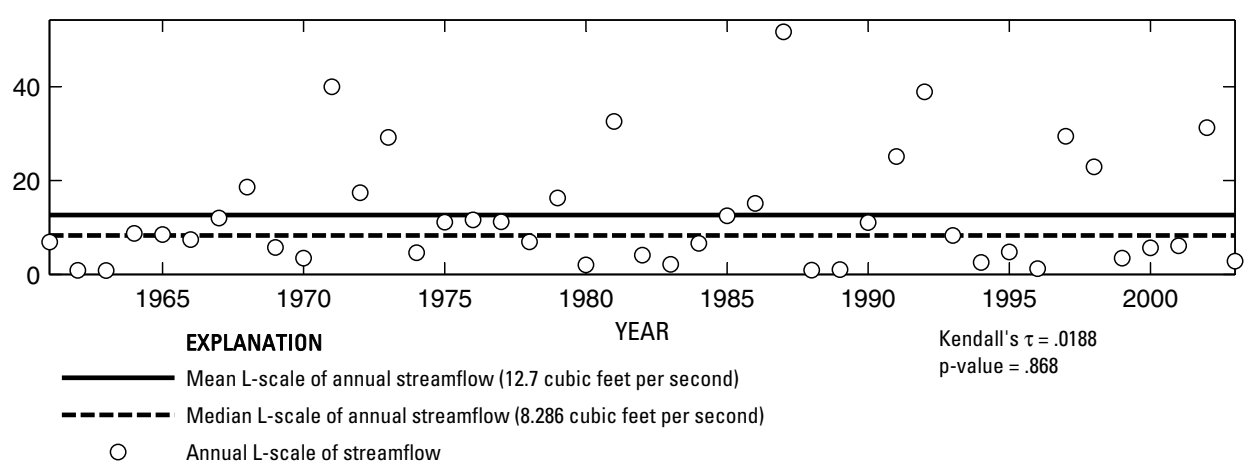

Figure 660. Analysis of annual mean, maximum, minimum, and L-scale statistics of daily mean streamflow for U.S. Geological Survey streamflow-gaging station 08201500 Seco Creek at Miller Ranch near Utopia, Texas.

Index of Station Numbers 719 

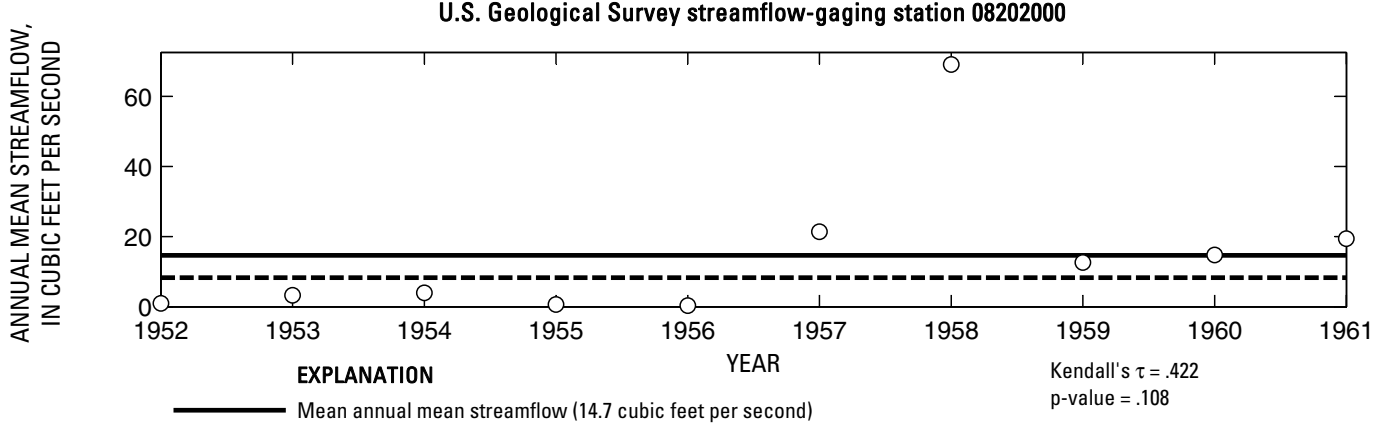

-ーーーー- Median annual mean streamflow (8.315 cubic feet per second)

O Annual mean streamflow

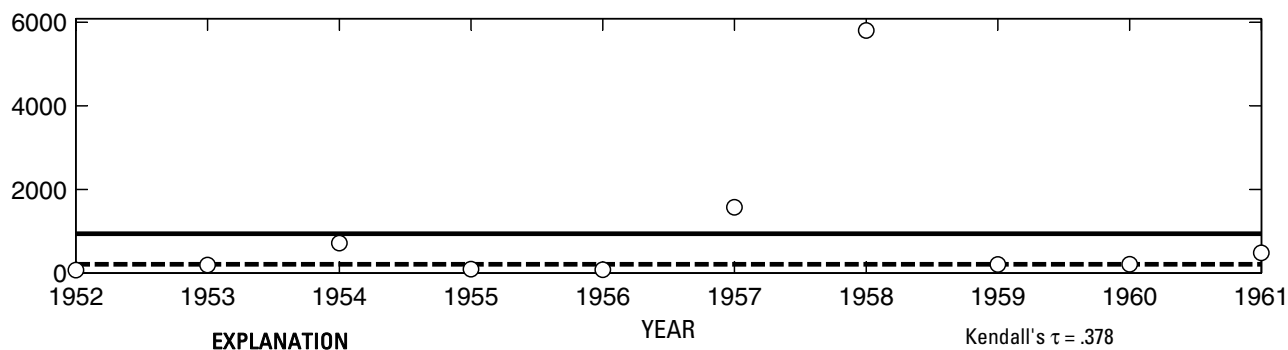

EXPLANATION

$\mathrm{p}$-value $=.156$

-_-_- Median annual maximum streamflow (207 cubic feet per second)

O Annual maximum streamflow

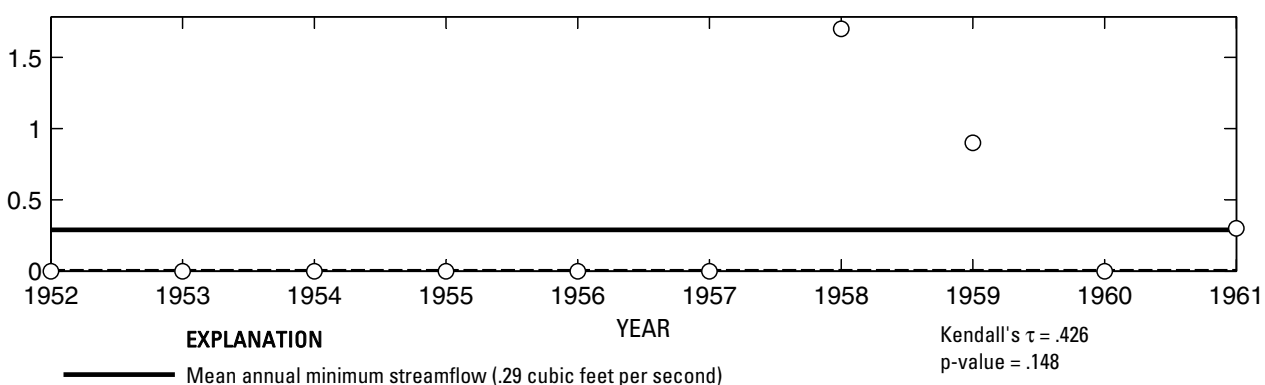

- - ב Median annual minimum streamflow (0 cubic feet per second)

O Annual minimum streamflow

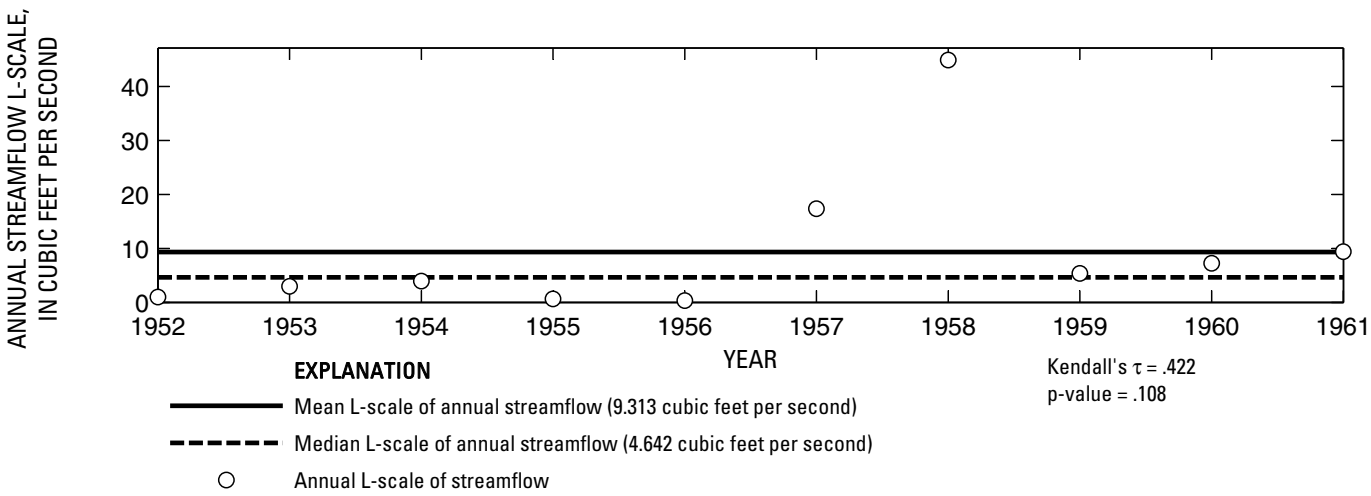

Figure 661. Analysis of annual mean, maximum, minimum, and L-scale statistics of daily mean streamflow for U.S. Geological Survey streamflow-gaging station 08202000 Seco Creek near Utopia, Texas. 

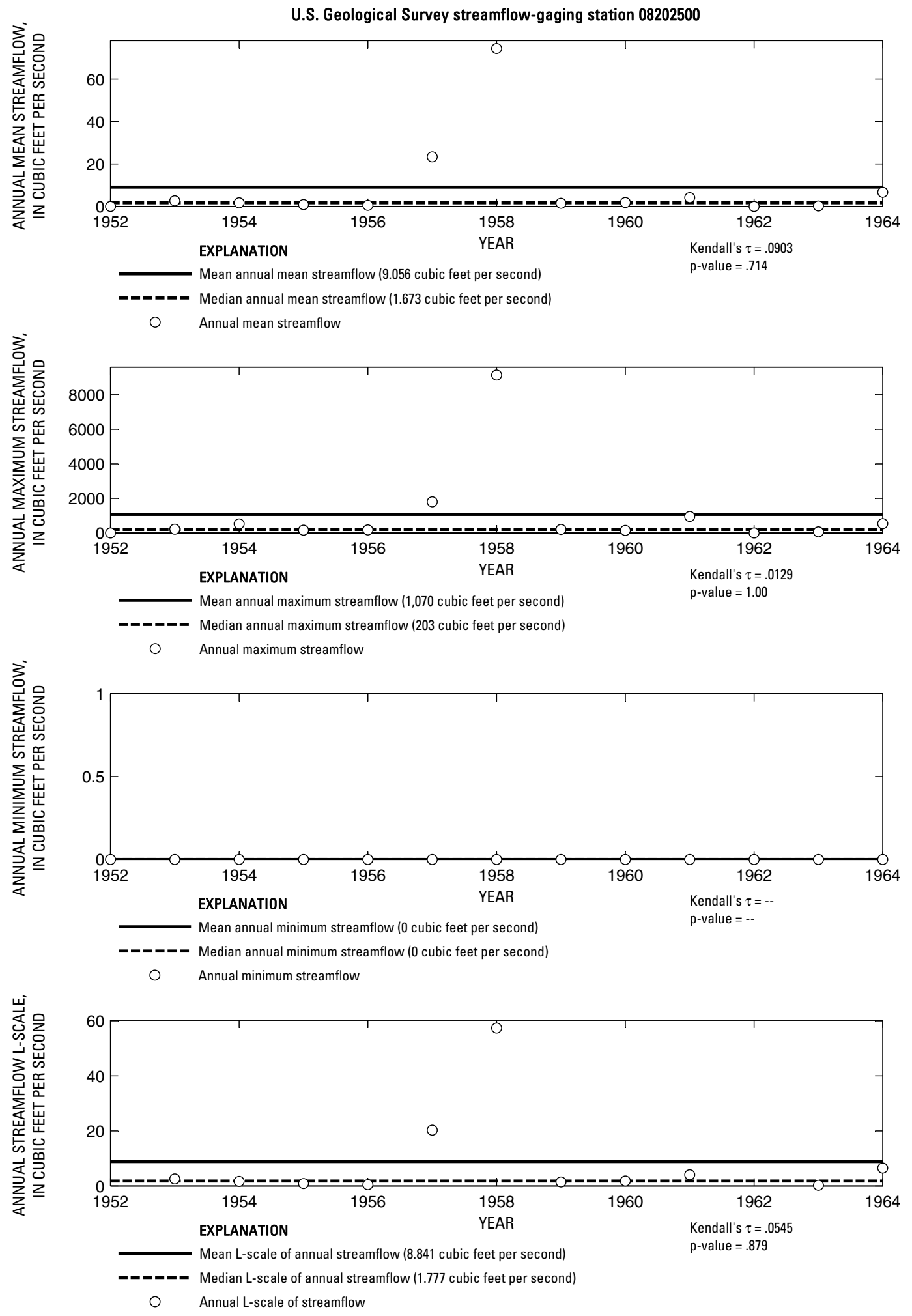

Figure 662. Analysis of annual mean, maximum, minimum, and L-scale statistics of daily mean streamflow for U.S. Geological Survey streamflow-gaging station 08202500 Seco Creek near D'Hanis, Texas.

Index of Station Numbers 719 

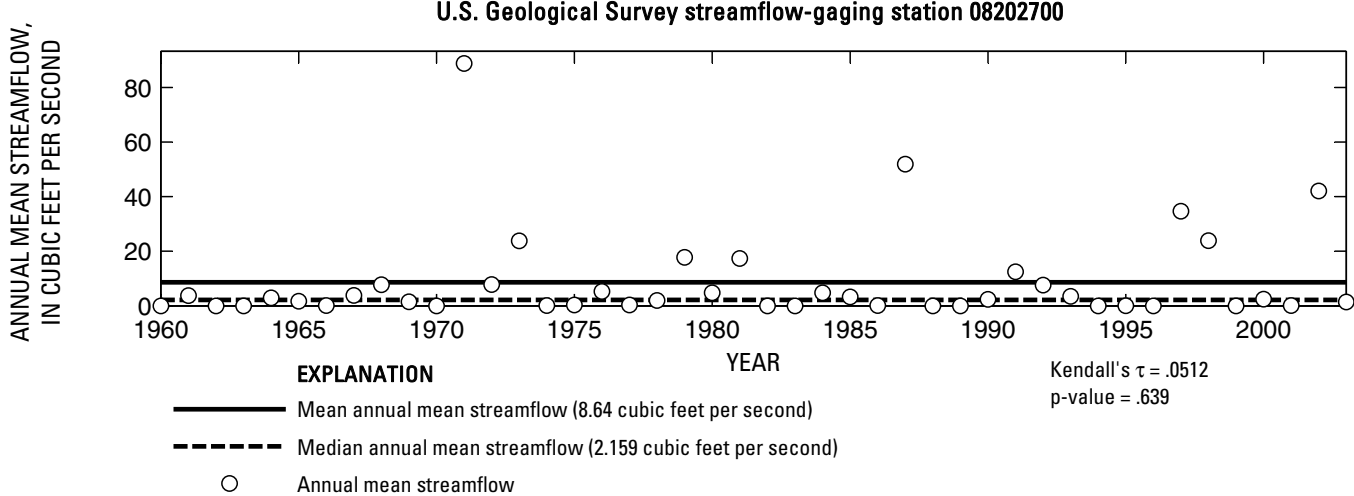

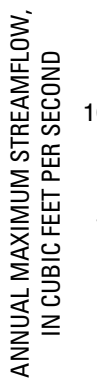

Annual mean streamflow

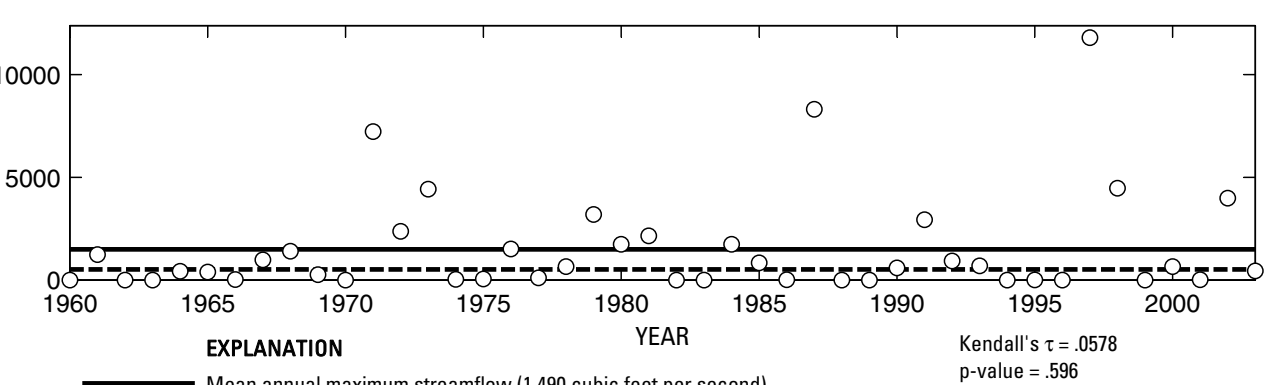

Mean annual maximum streamflow (1,490 cubic feet per second)

$\mathrm{p}$-value $=.596$

- - - Median annual maximum streamflow (517 cubic feet per second)

O Annual maximum streamflow

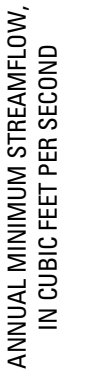

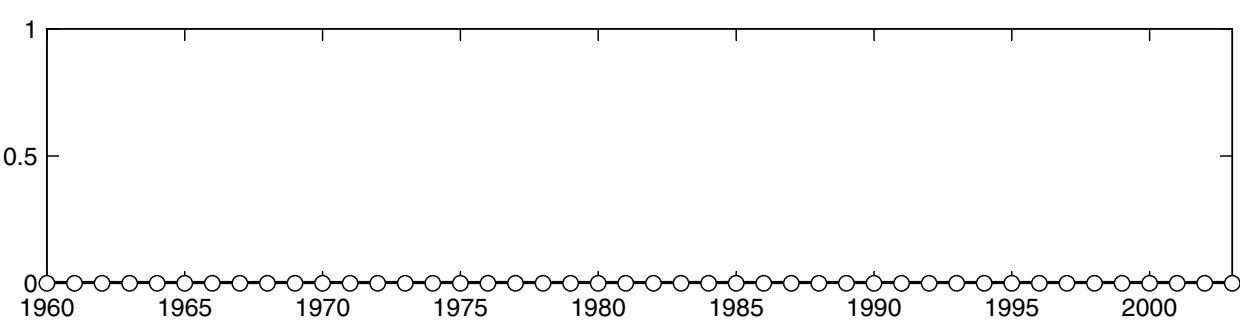

EXPLANATION YEAR Kendall's $\tau=-$

Mean annual minimum streamflow (0 cubic feet per second)

$\mathrm{p}$-value $=--$

- Median annual minimum streamflow (0 cubic feet per second)

O Annual minimum streamflow

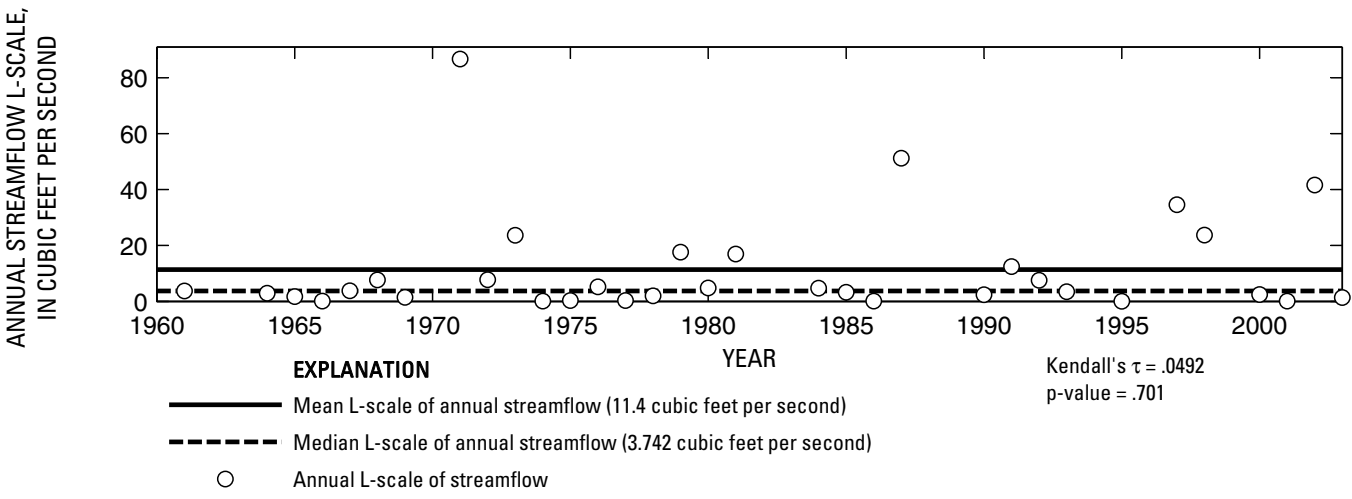

Figure 663. Analysis of annual mean, maximum, minimum, and L-scale statistics of daily mean streamflow for U.S. Geological Survey streamflow-gaging station 08202700 Seco Creek at Rowe Ranch near D'Hanis, Texas. 
U.S. Geological Survey streamflow-gaging station 08204005

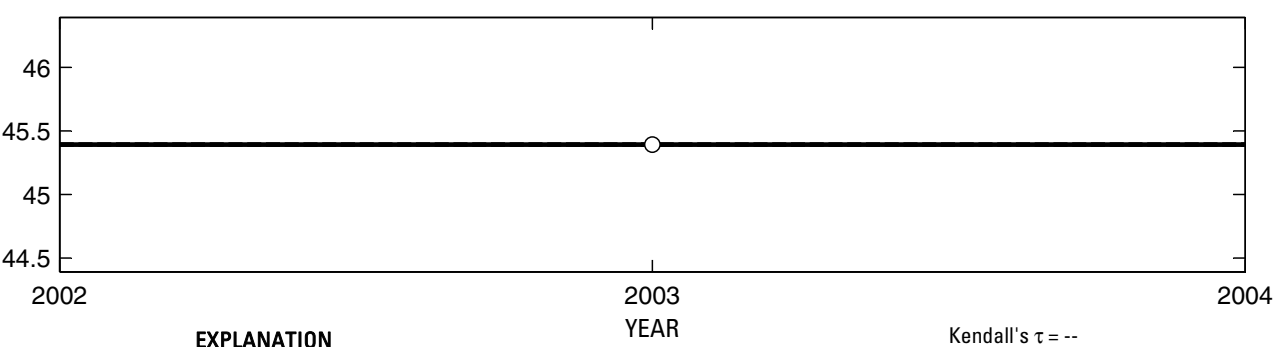

p-value $=-$

-ーーーーー Median annual mean streamflow (45.4 cubic feet per second)

Annual mean streamflow

辛
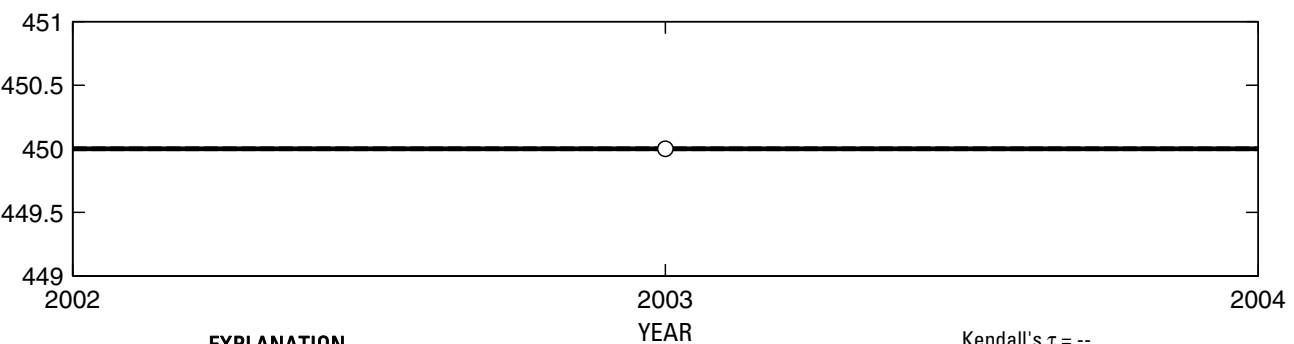

- - - Median annual maximum streamflow (450 cubic feet per second)

O Annual maximum streamflow

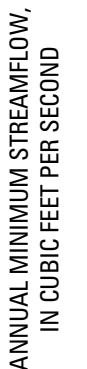

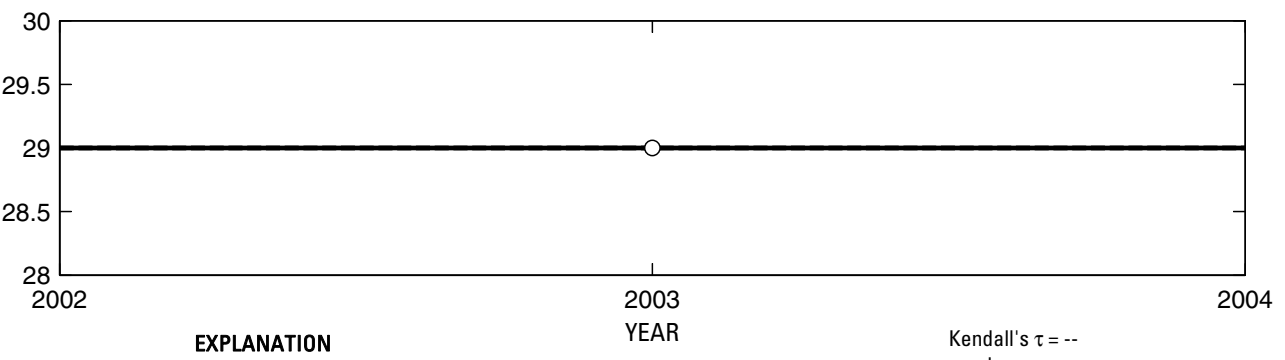

Mean annual minimum streamflow (29 cubic feet per second)

$\mathrm{p}$-value $=-$

- - Median annual minimum streamflow (29 cubic feet per second)

O Annual minimum streamflow

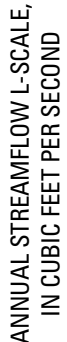

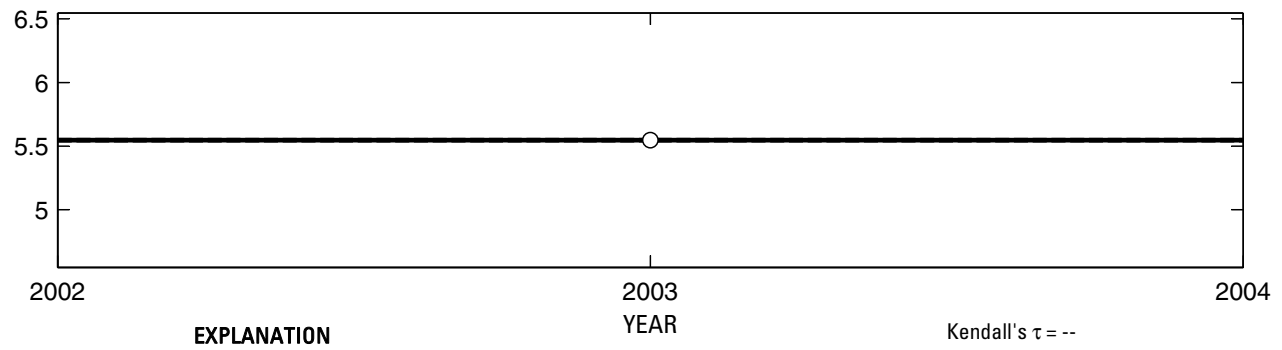

Mean L-scale of annual streamflow (5.547 cubic feet per second)

$\mathrm{p}$-value $=-$ -

- -ーーーー Median L-scale of annual streamflow (5.547 cubic feet per second)

Annual L-scale of streamflow

Figure 664. Analysis of annual mean, maximum, minimum, and L-scale statistics of daily mean streamflow for U.S. Geological Survey streamflow-gaging station 08204005 Leona River near Uvalde, Texas. 

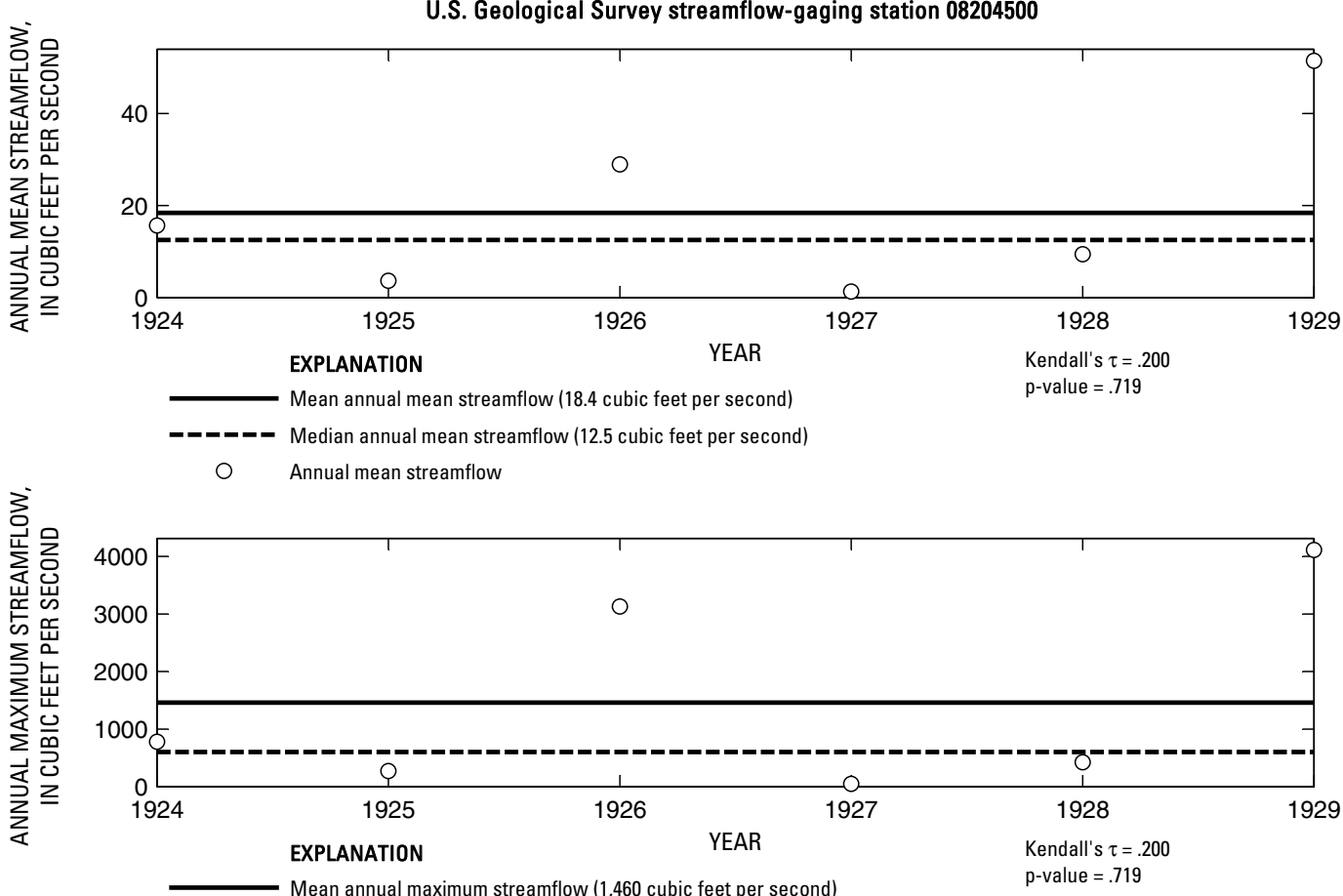

-_-_- Median annual maximum streamflow (603 cubic feet per second)

O Annual maximum streamflow
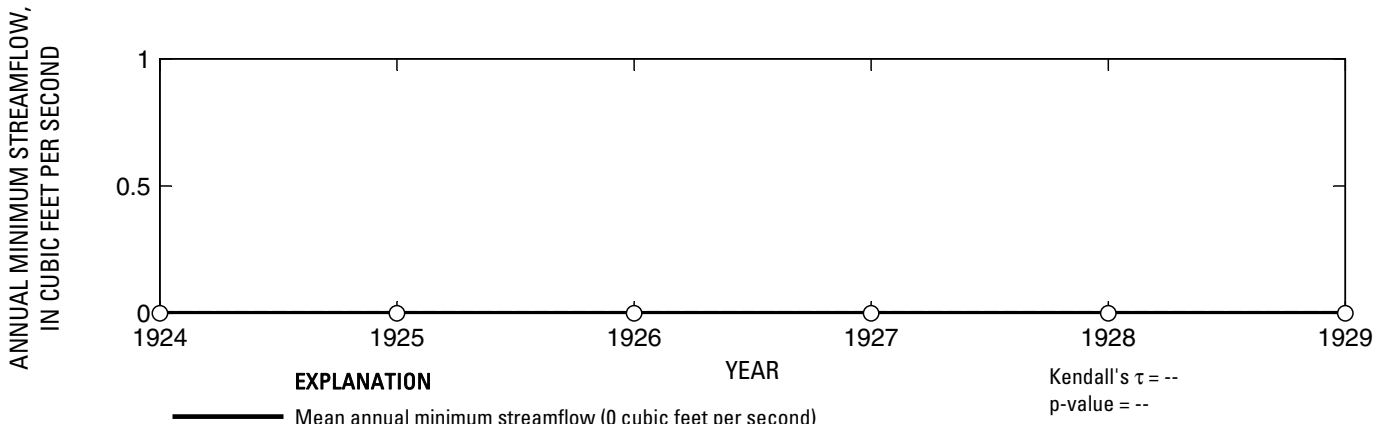

- ב-ב Median annual minimum streamflow (0 cubic feet per second)

○ Annual minimum streamflow
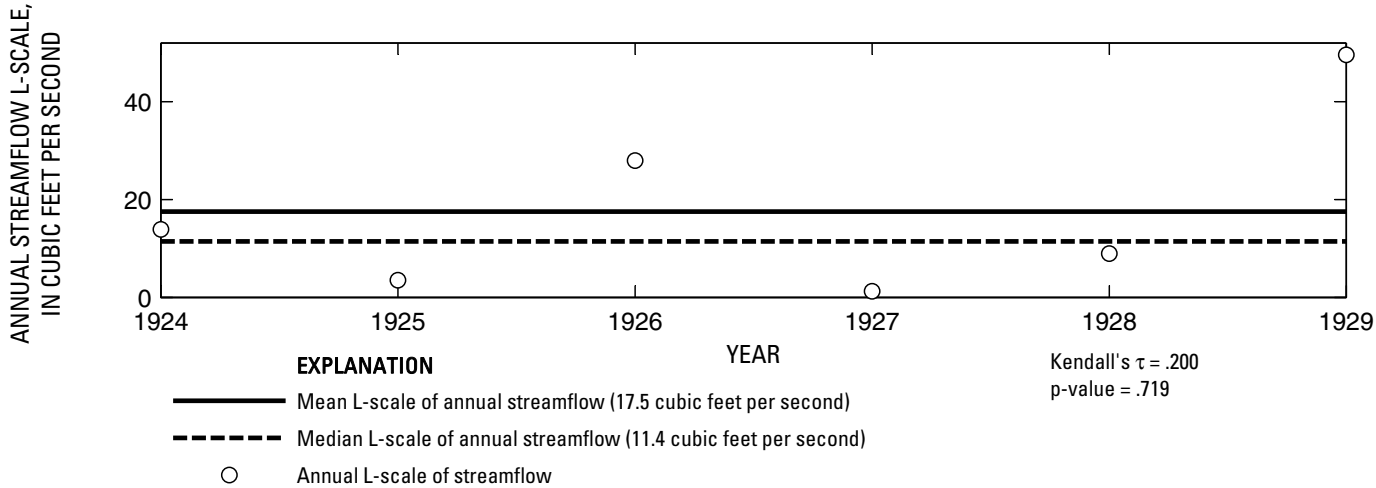

Figure 665. Analysis of annual mean, maximum, minimum, and L-scale statistics of daily mean streamflow for U.S. Geological Survey streamflow-gaging station 08204500 Leona River near Divot, Texas. 
U.S. Geological Survey streamflow-gaging station 08205500

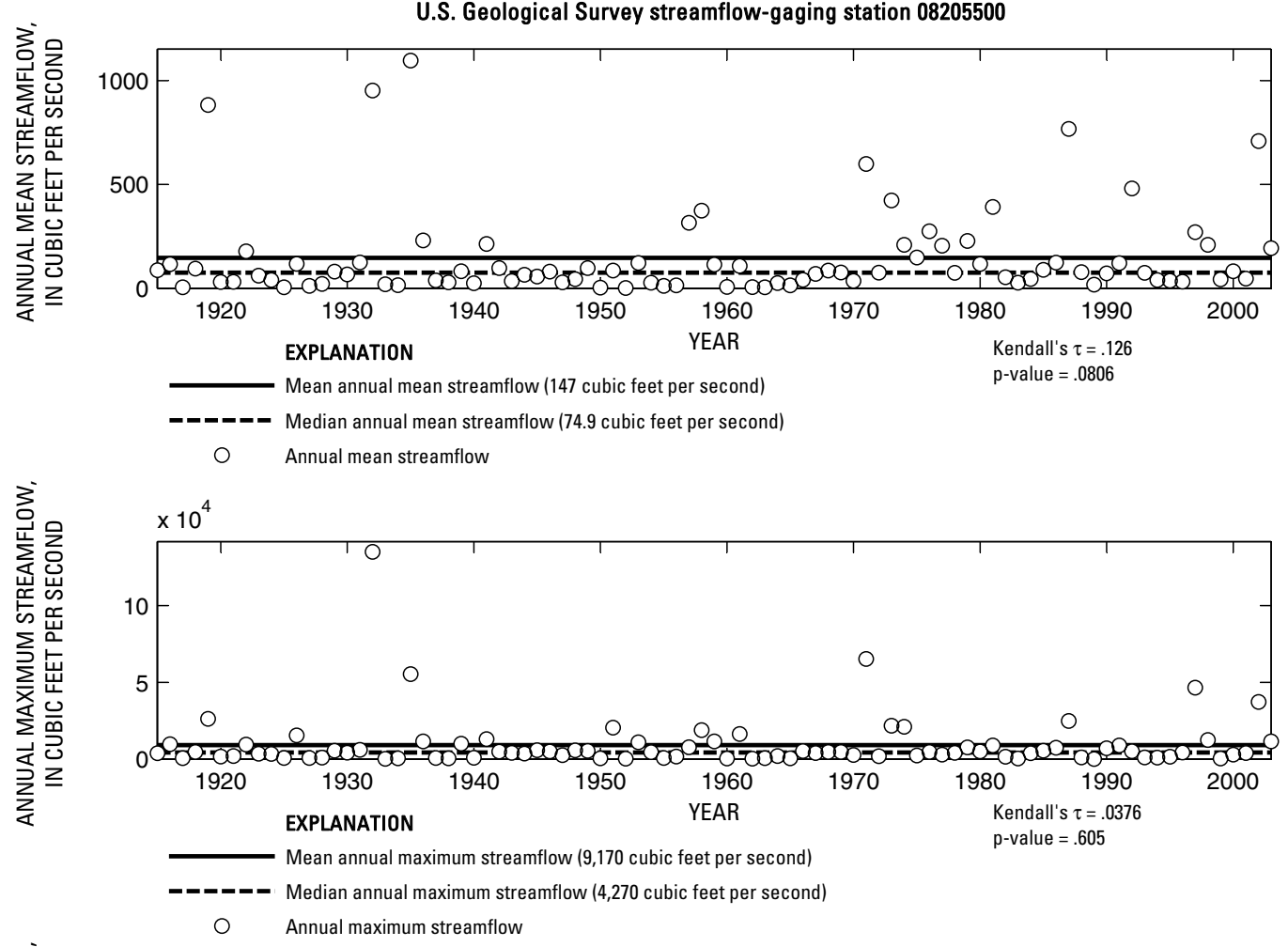

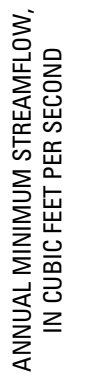

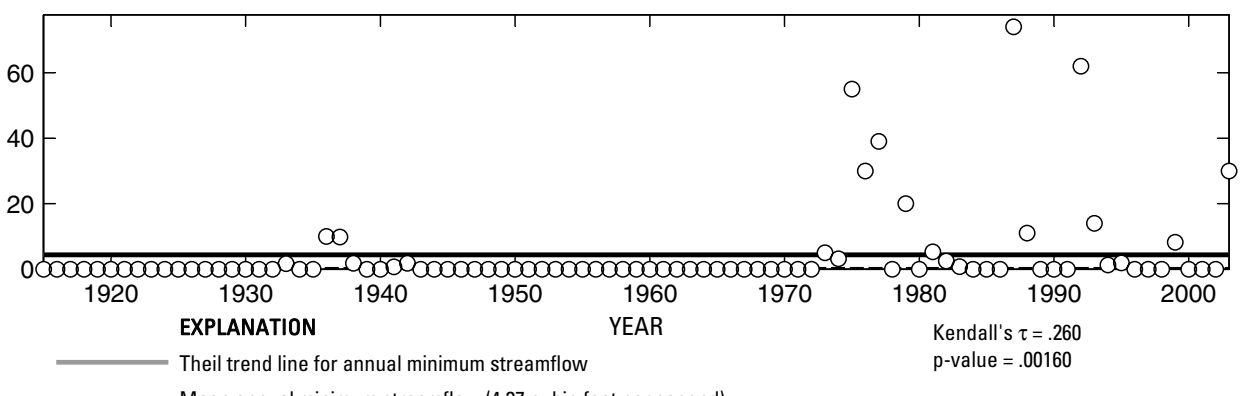

O Annual minimum streamflow

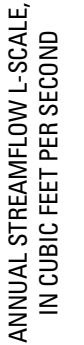

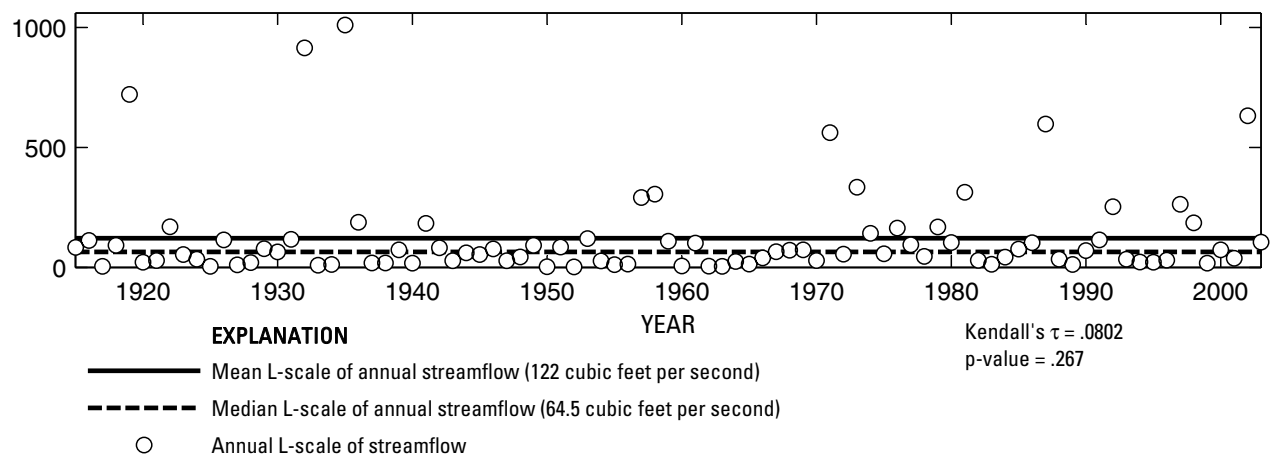

Figure 666. Analysis of annual mean, maximum, minimum, and L-scale statistics of daily mean streamflow for U.S. Geological Survey streamflow-gaging station 08205500 Frio River near Derby, Texas.

Index of Station Numbers 719 


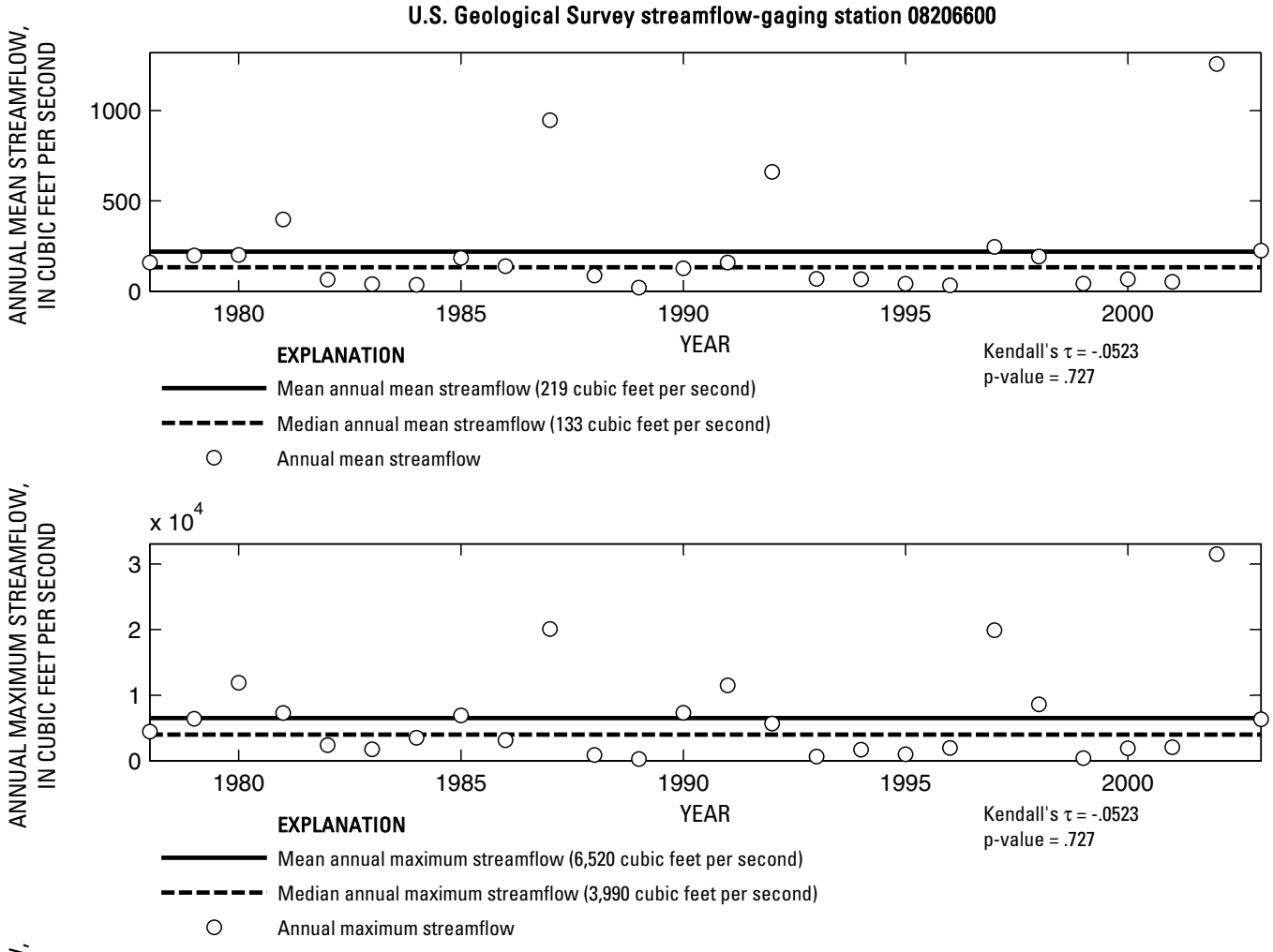

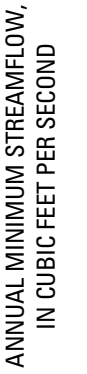

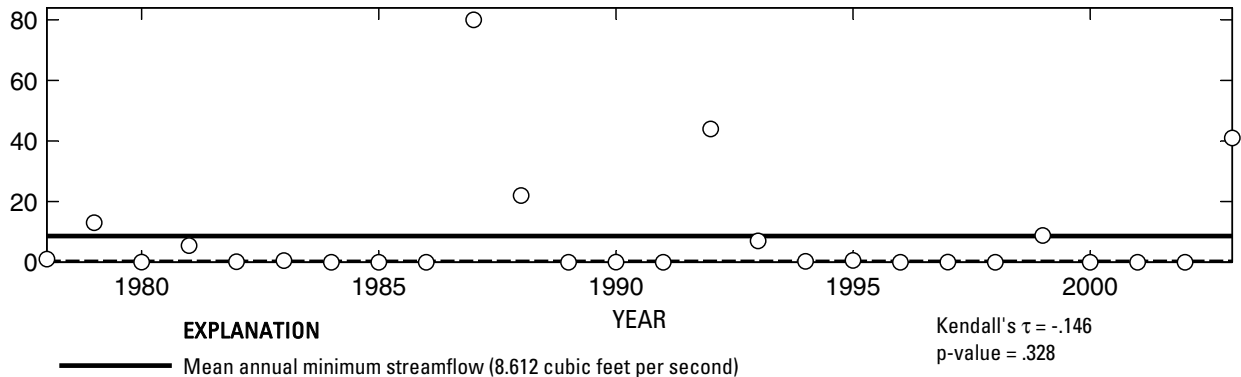

- $\mathbf{c o n}$ Median annual minimum streamflow (.1 cubic feet per second)

O Annual minimum streamflow

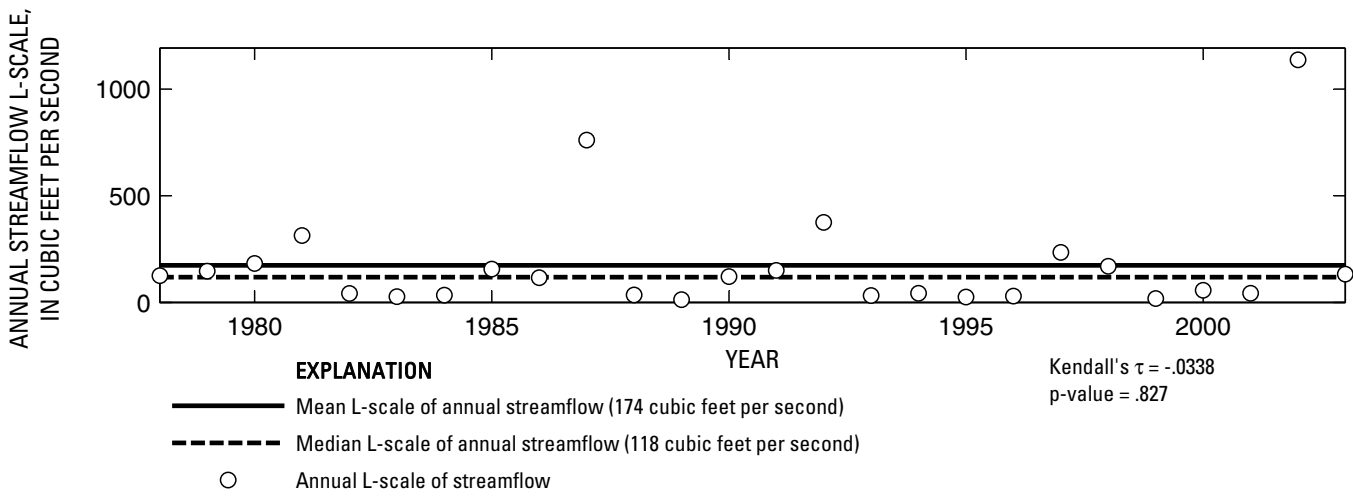

Figure 667. Analysis of annual mean, maximum, minimum, and L-scale statistics of daily mean streamflow for U.S. Geological Survey streamflow-gaging station 08206600 Frio River at Tilden, Texas. 

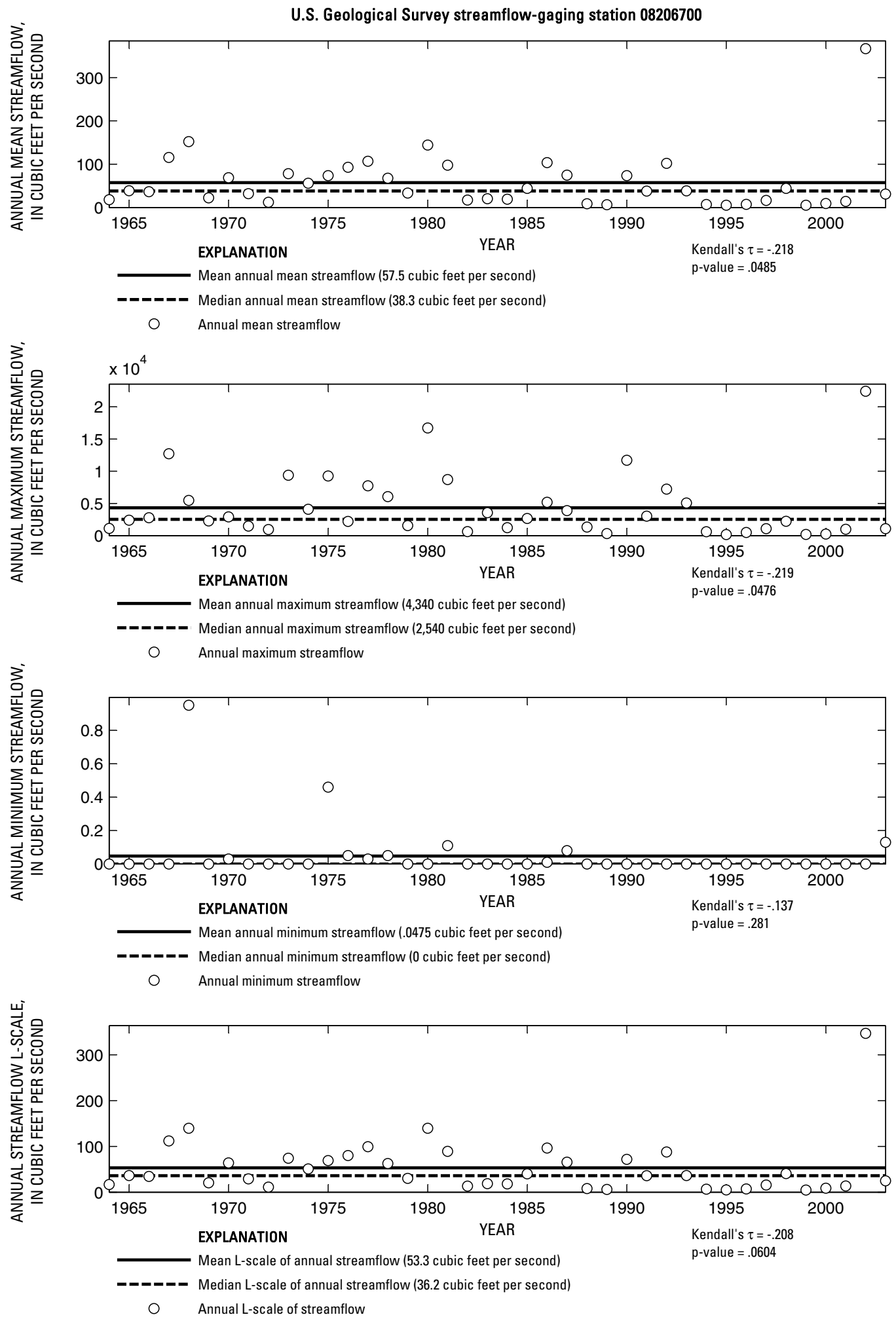

Figure 668. Analysis of annual mean, maximum, minimum, and L-scale statistics of daily mean streamflow for U.S. Geological Survey streamflow-gaging station 08206700 San Miguel Creek near Tilden, Texas.

Index of Station Numbers 719 


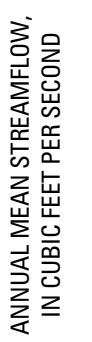

U.S. Geological Survey streamflow-gaging station 08206910

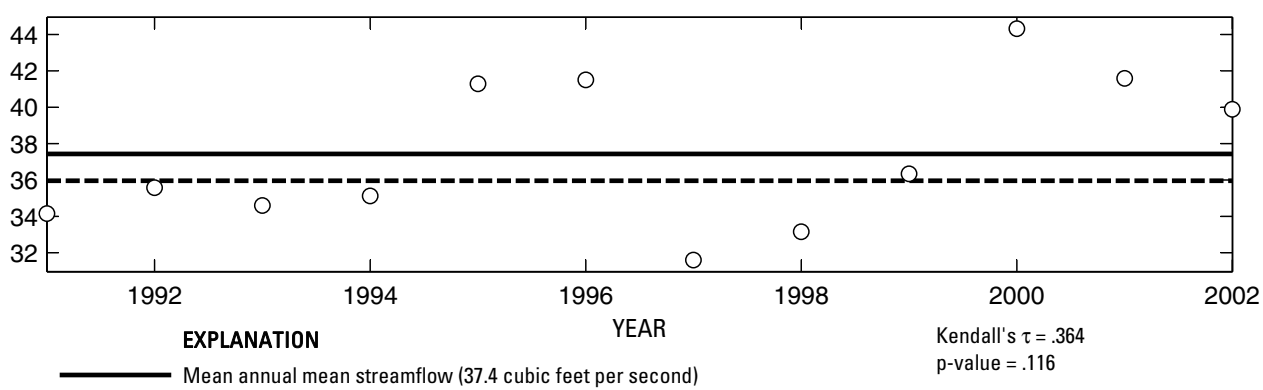

- - - - Median annual mean streamflow ( 36 cubic feet per second)

Annual mean streamflow
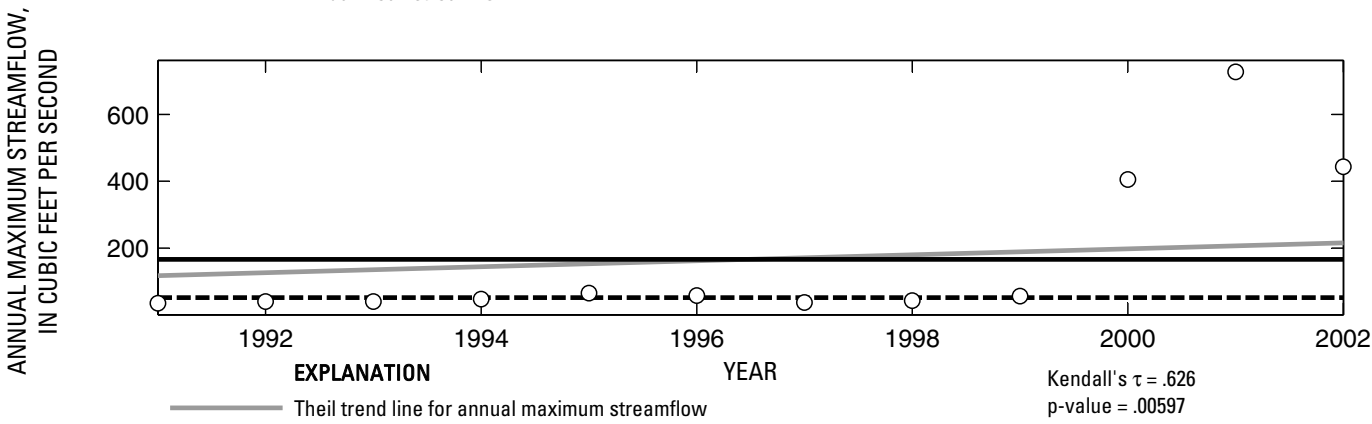

Mean annual maximum streamflow (166 cubic feet per second)

ーーーーーー Median annual maximum streamflow (51.5 cubic feet per second)

O Annual maximum streamflow

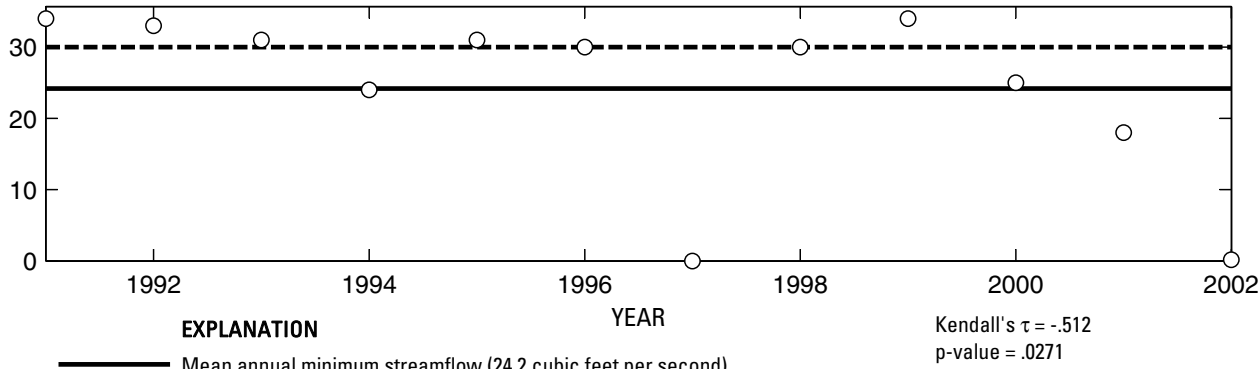

○ Annual minimum streamflow

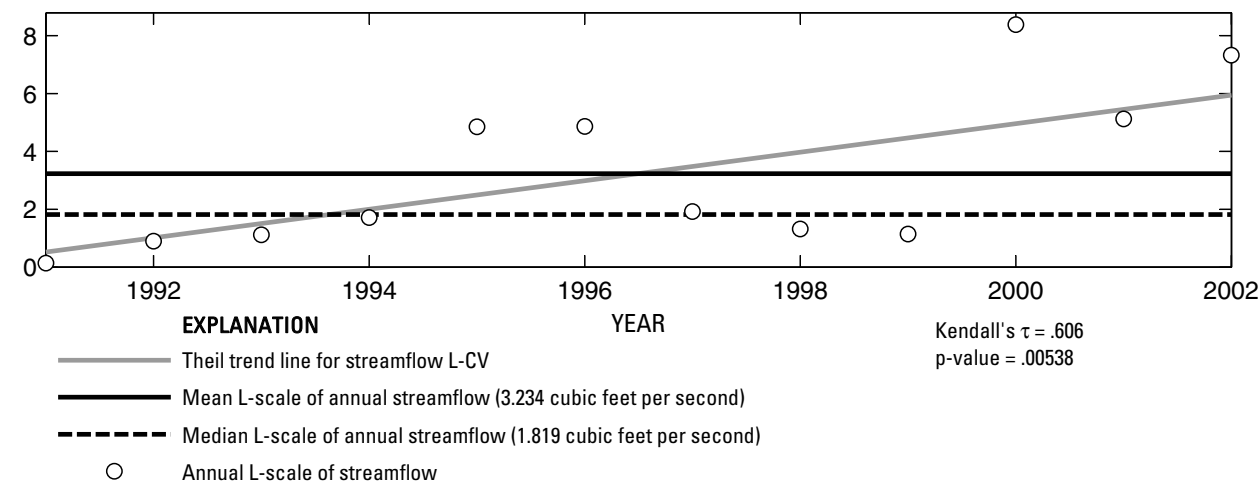

Figure 669. Analysis of annual mean, maximum, minimum, and L-scale statistics of daily mean streamflow for U.S. Geological Survey streamflow-gaging station 08206910 Choke Canyon Reservoir (Outlet Works Control) near Three Rivers, Texas. 

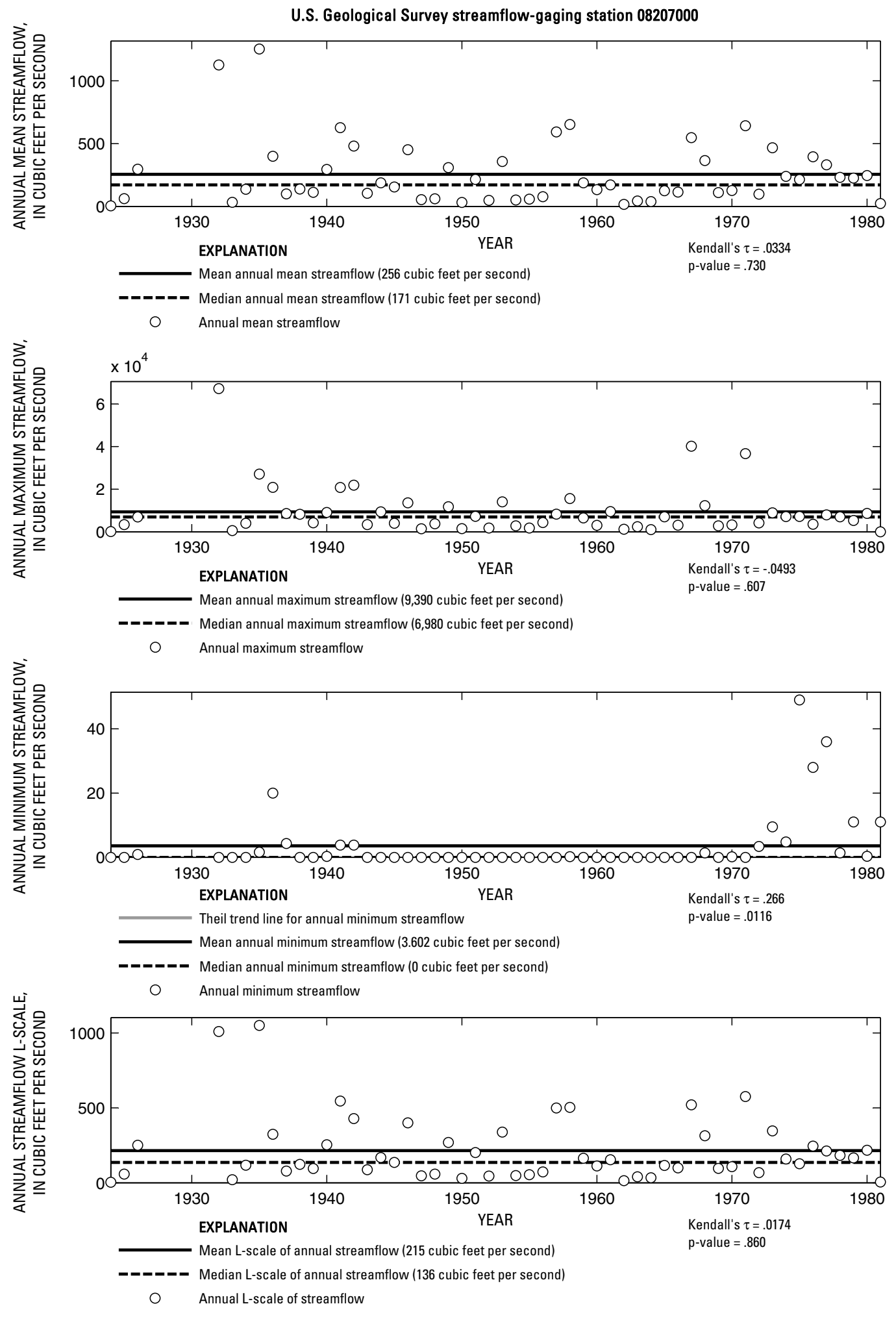

Figure 670. Analysis of annual mean, maximum, minimum, and L-scale statistics of daily mean streamflow for U.S. Geological Survey streamflow-gaging station 08207000 Frio River at Calliham, Texas.

Index of Station Numbers 719 


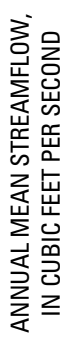

U.S. Geological Survey streamflow-gaging station 08207500

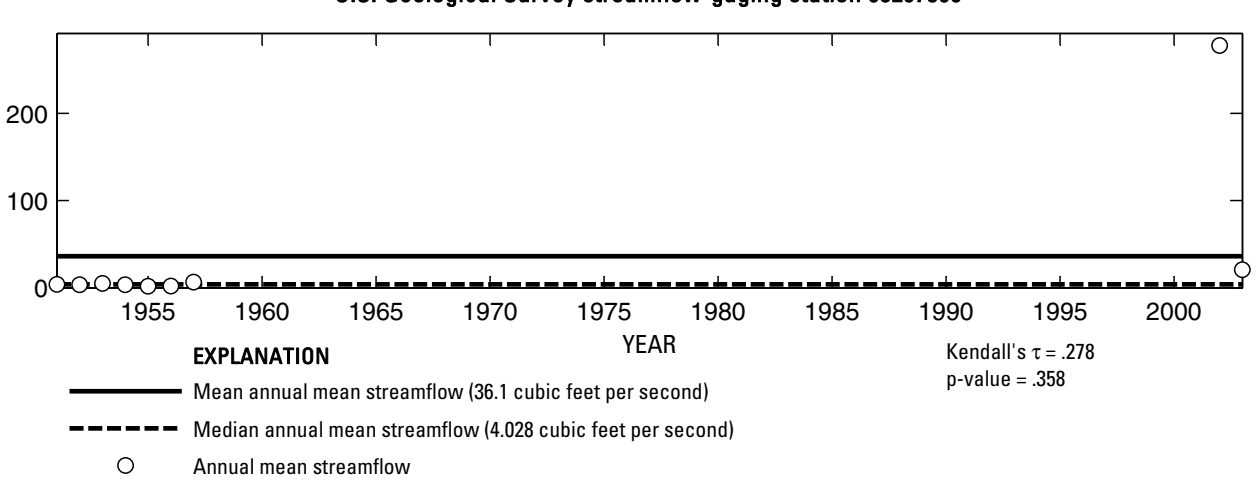

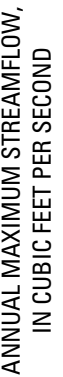

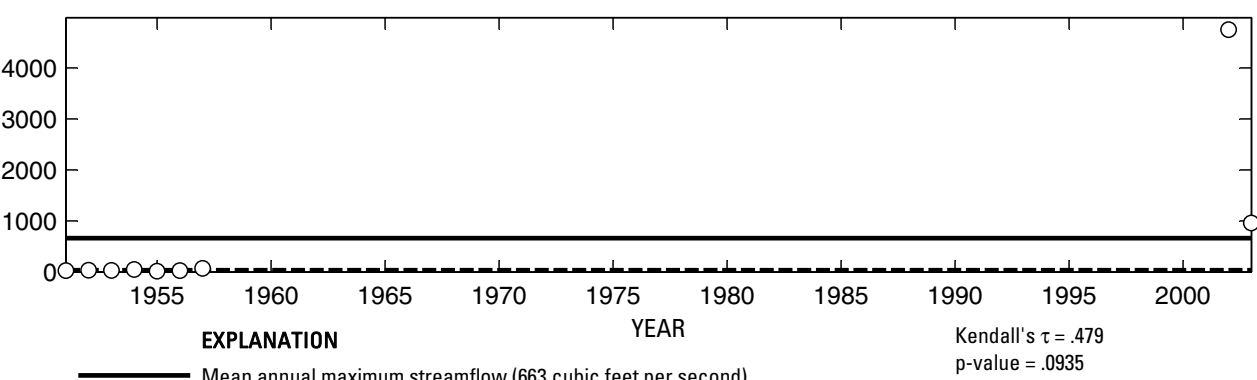

- - - Median annual maximum streamflow (34 cubic feet per second)

○ Annual maximum streamflow
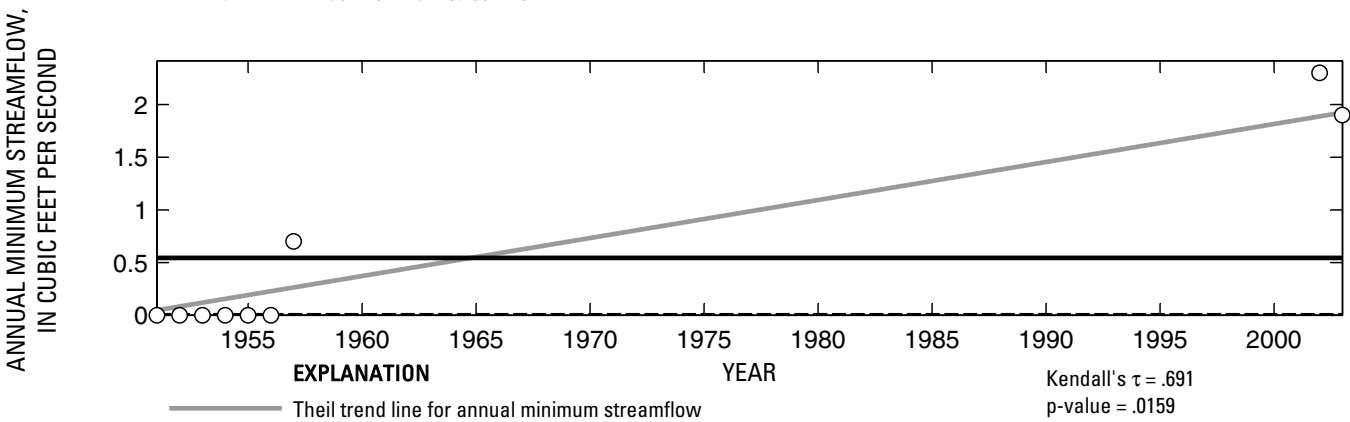

Mean annual minimum streamflow (.5444 cubic feet per second)

ーーーーーー Median annual minimum streamflow (0 cubic feet per second)

O Annual minimum streamflow

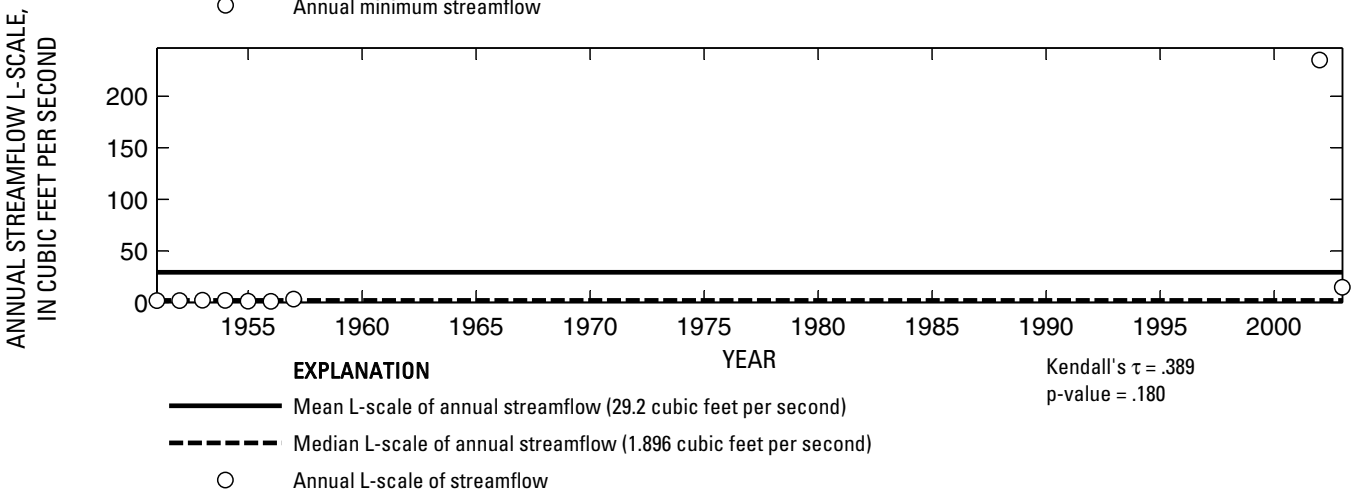

Figure 671. Analysis of annual mean, maximum, minimum, and L-scale statistics of daily mean streamflow for U.S. Geological Survey streamflow-gaging station 08207500 Atascosa River near McCoy, Texas. 

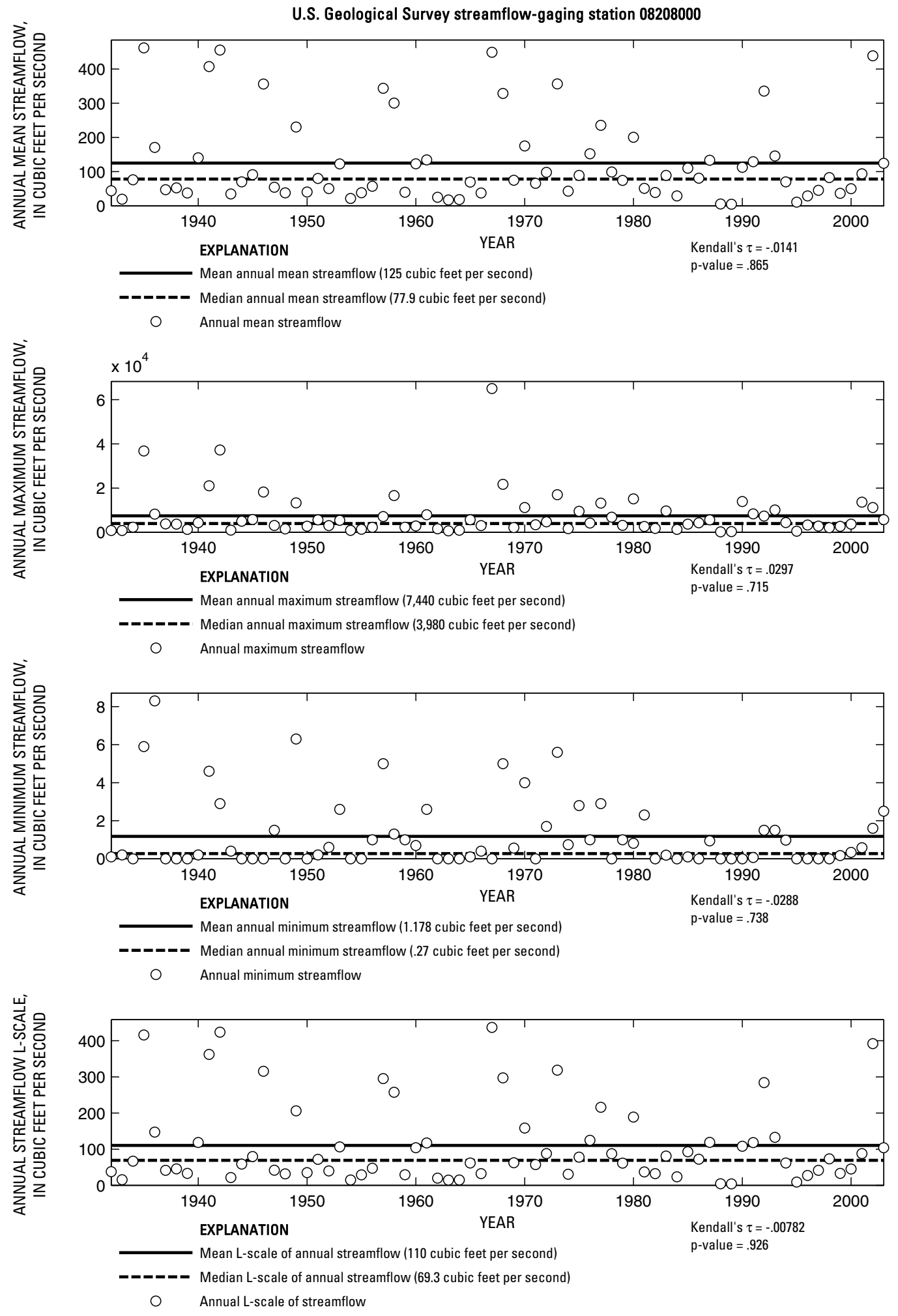

Figure 672. Analysis of annual mean, maximum, minimum, and L-scale statistics of daily mean streamflow for U.S. Geological Survey streamflow-gaging station 08208000 Atascosa River at Whitsett, Texas.

Index of Station Numbers 719 


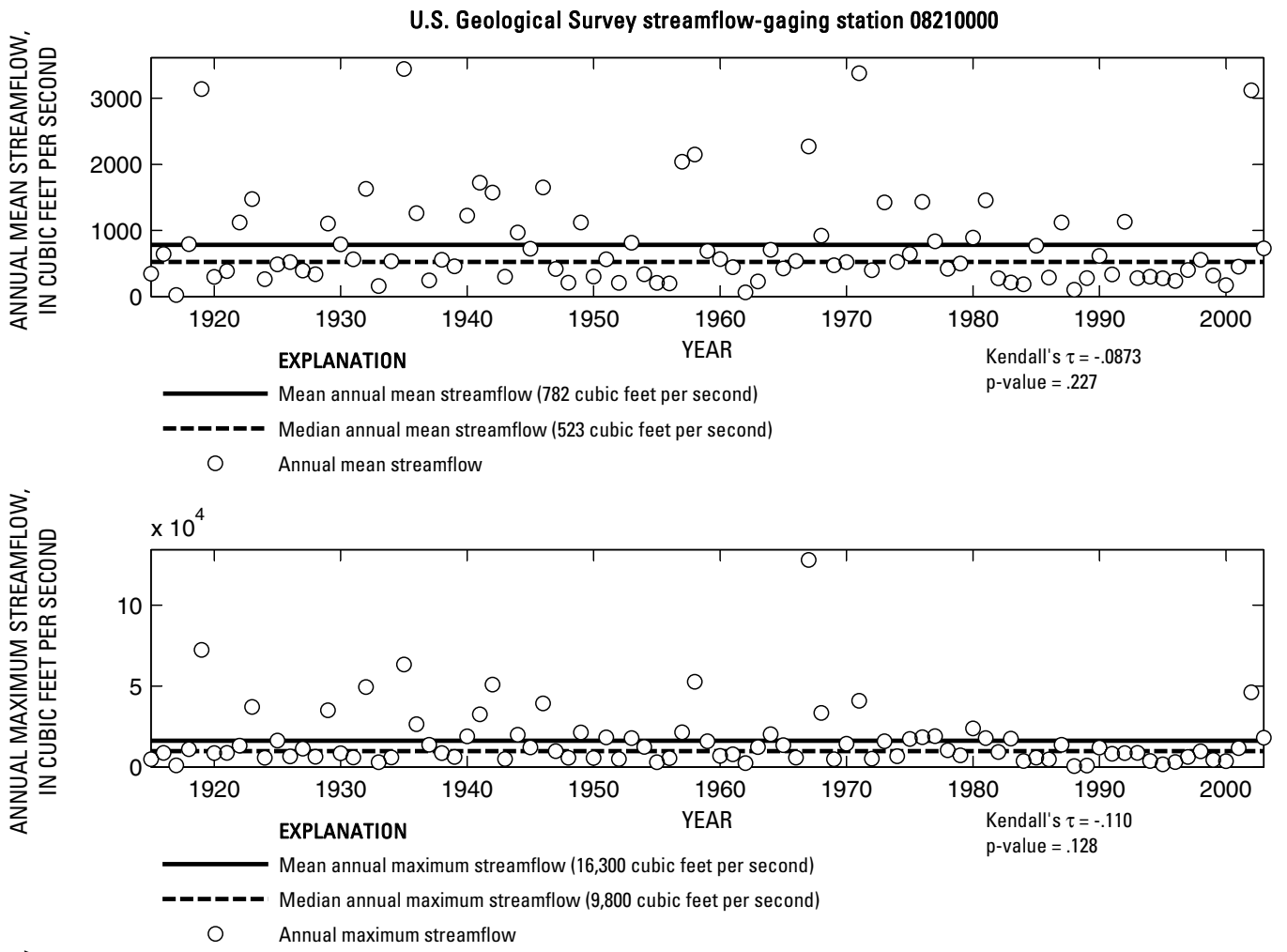

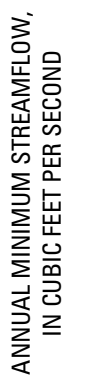

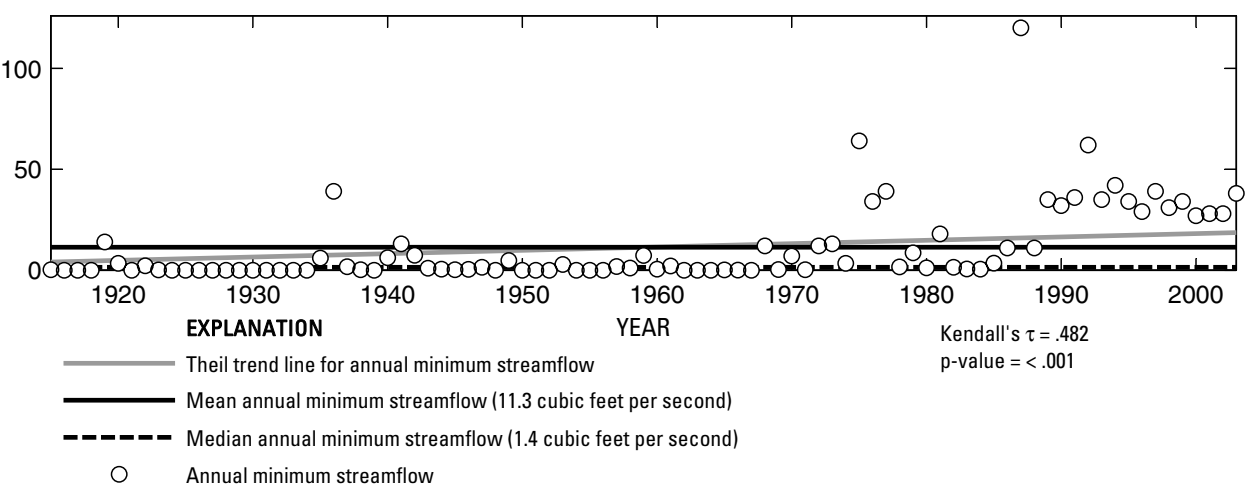

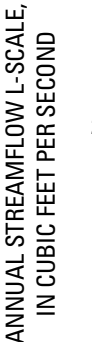

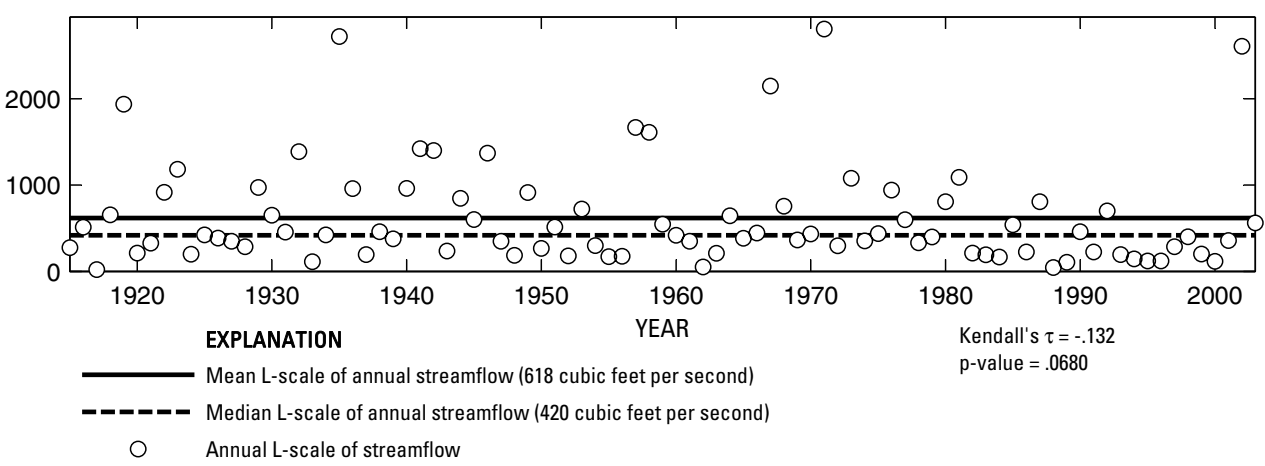

Figure 673. Analysis of annual mean, maximum, minimum, and L-scale statistics of daily mean streamflow for U.S. Geological Survey streamflow-gaging station 08210000 Nueces River near Three Rivers, Texas. 

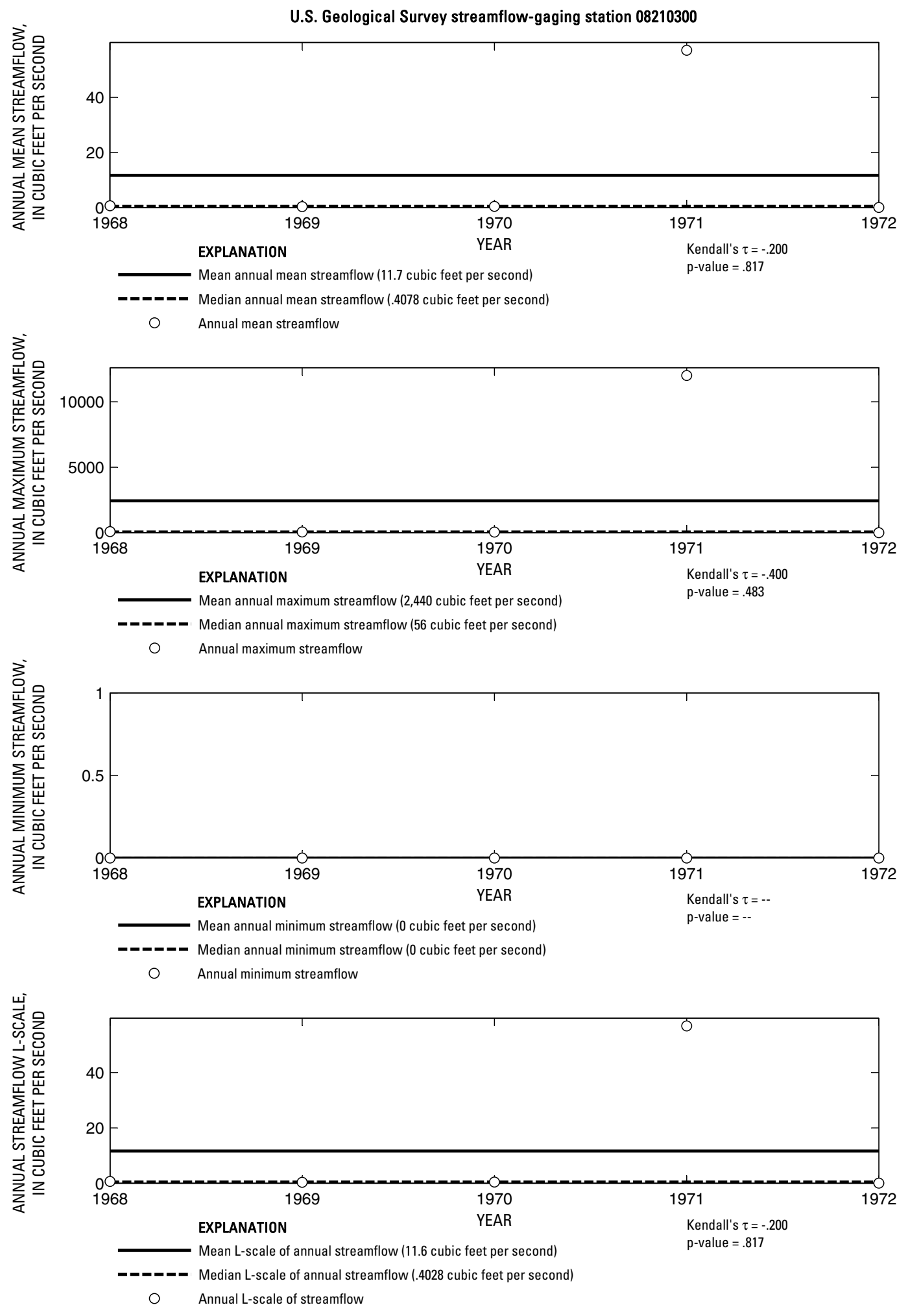

Figure 674. Analysis of annual mean, maximum, minimum, and L-scale statistics of daily mean streamflow for U.S. Geological Survey streamflow-gaging station 08210300 Ramirena Creek near George West, Texas.

Index of Station Numbers 719 


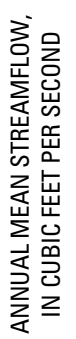

U.S. Geological Survey streamflow-gaging station 08210400

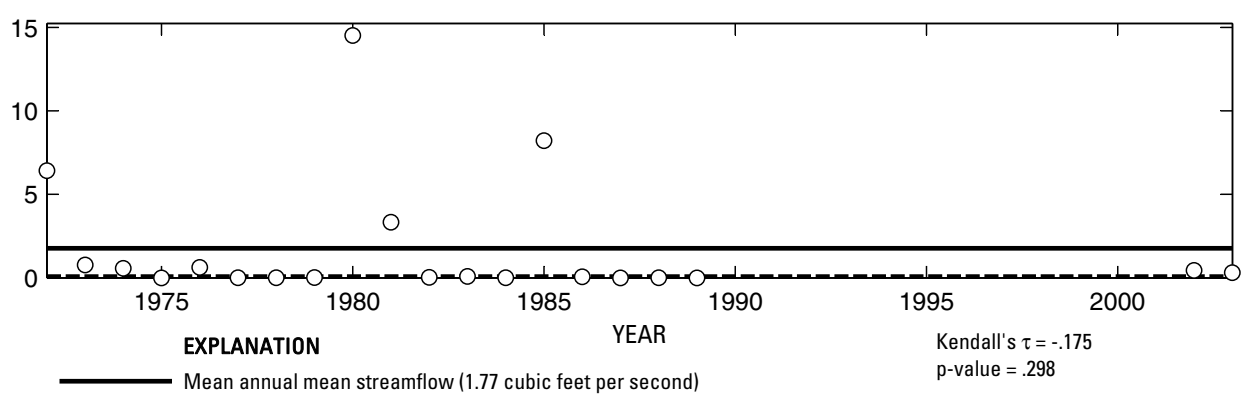

-_-_-_ Median annual mean streamflow (.07125 cubic feet per second)

O Annual mean streamflow
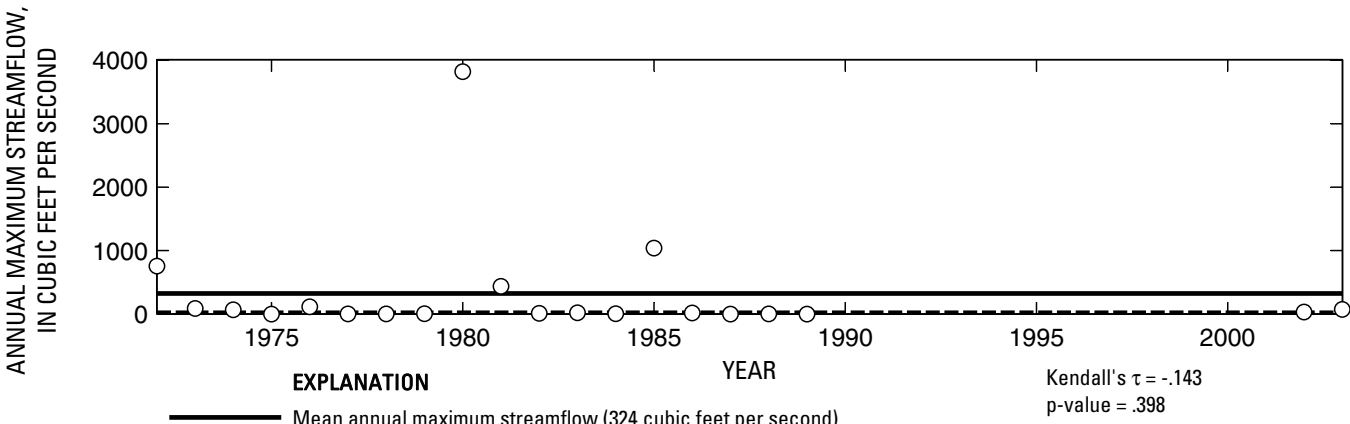

O Annual maximum streamflow

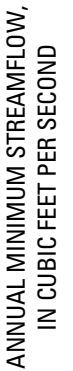

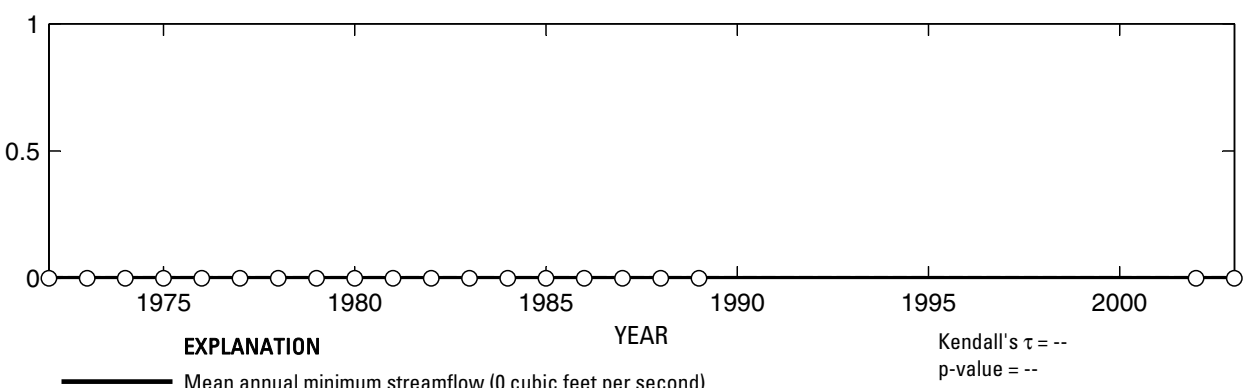

- ב-ב Median annual minimum streamflow (0 cubic feet per second)

O Annual minimum streamflow

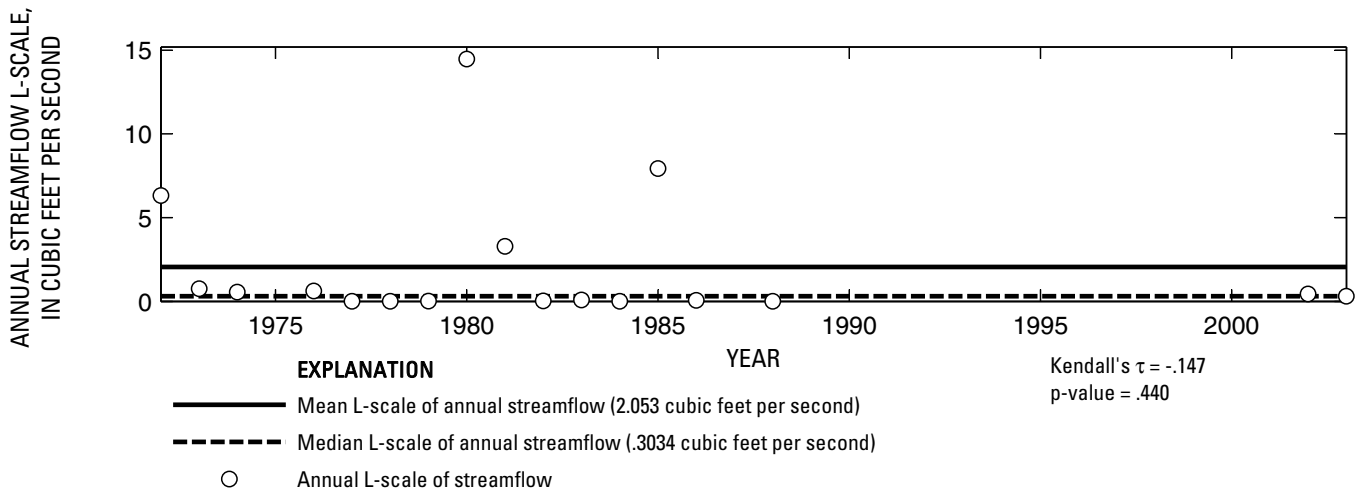

Figure 675. Analysis of annual mean, maximum, minimum, and L-scale statistics of daily mean streamflow for U.S. Geological Survey streamflow-gaging station 08210400 Lagarto Creek near George West, Texas. 


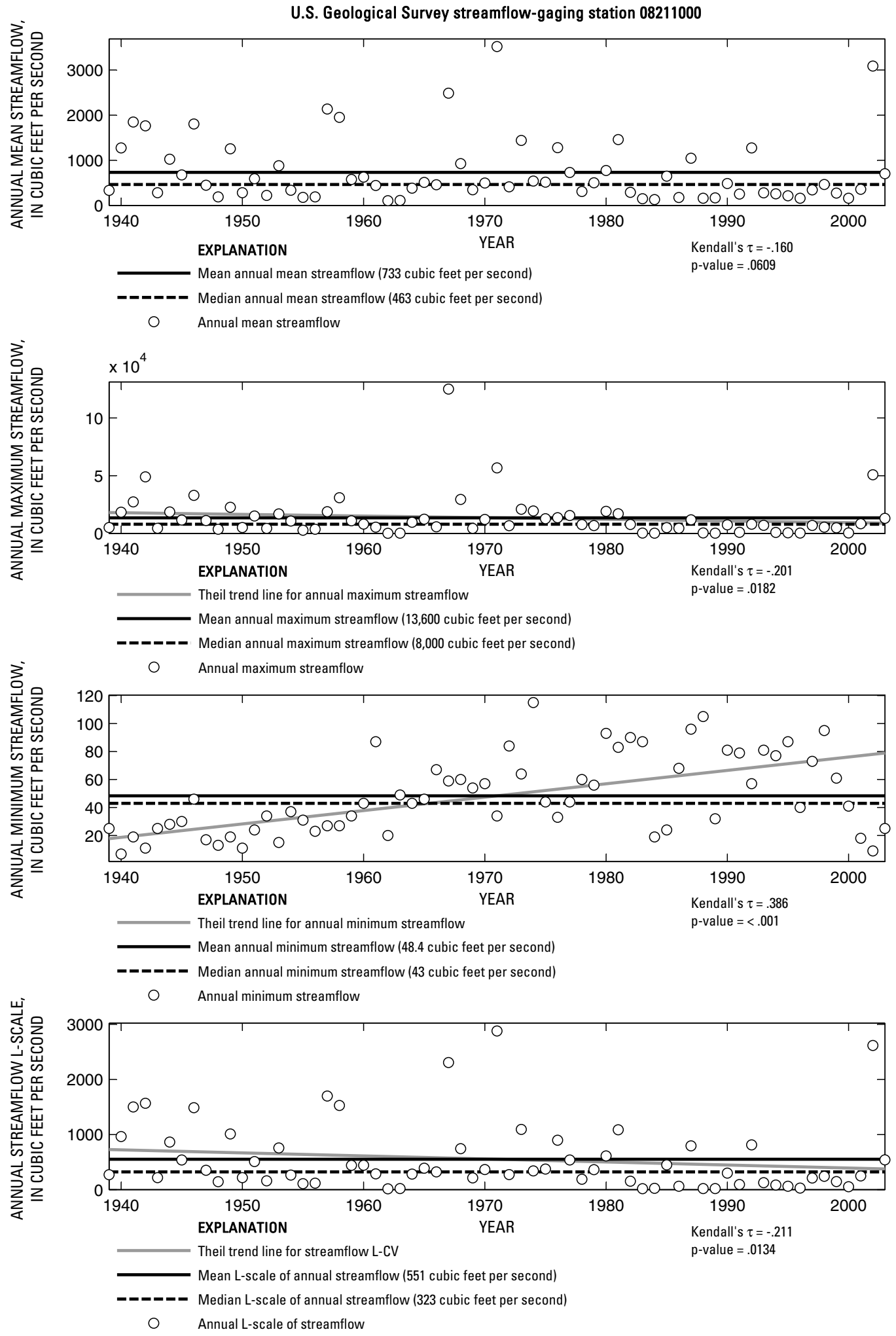

Figure 676. Analysis of annual mean, maximum, minimum, and L-scale statistics of daily mean streamflow for U.S. Geological Survey streamflow-gaging station 08211000 Nueces River near Mathis, Texas.

|ndex of Station Numbers 719 

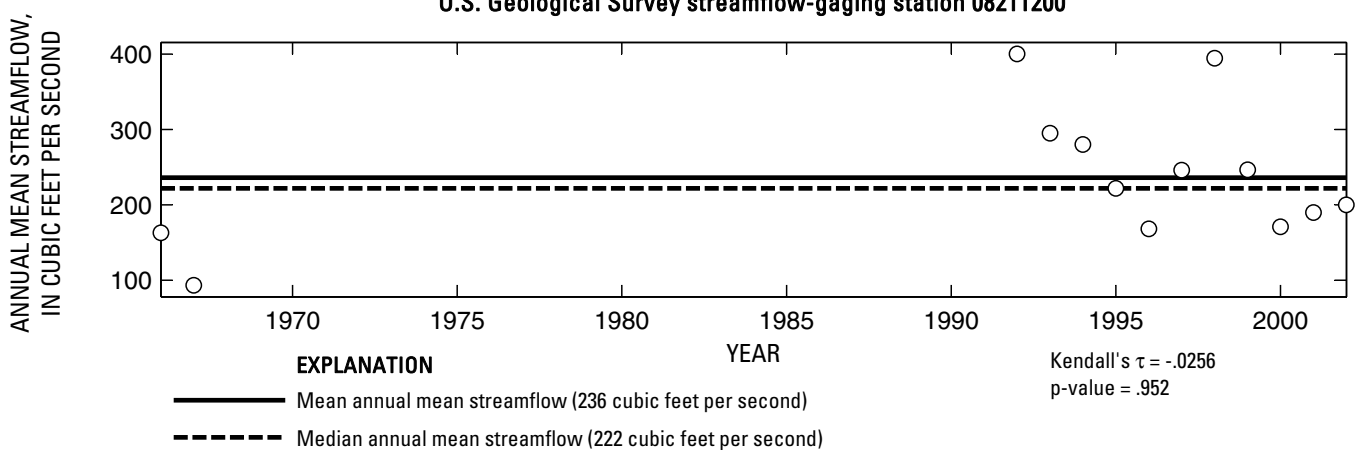

O Annual mean streamflow
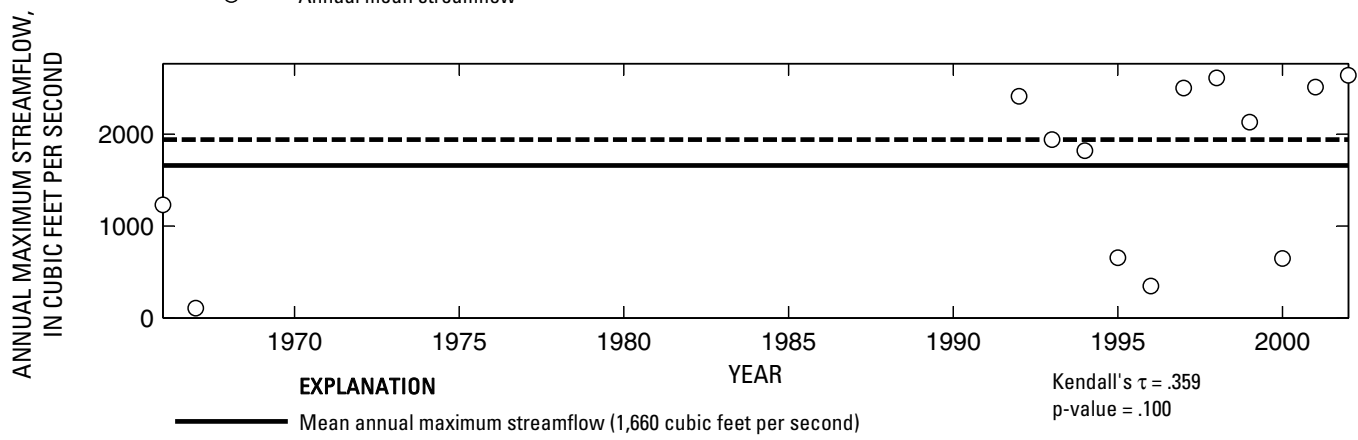

- _ _ - Median annual maximum streamflow (1,940 cubic feet per second)

- Annual maximum streamflow
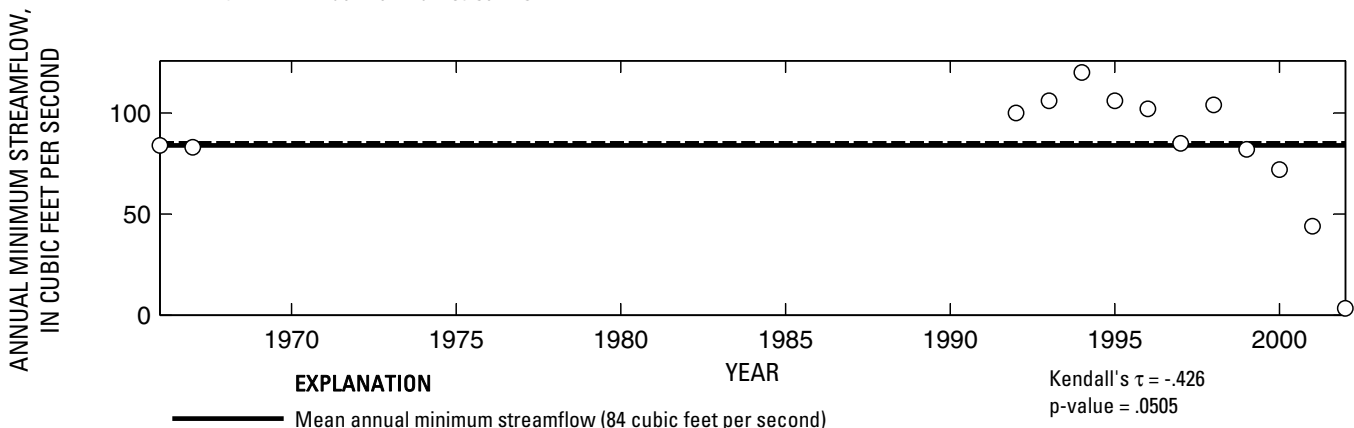

- ב- Median annual minimum streamflow (85 cubic feet per second)

O Annual minimum streamflow

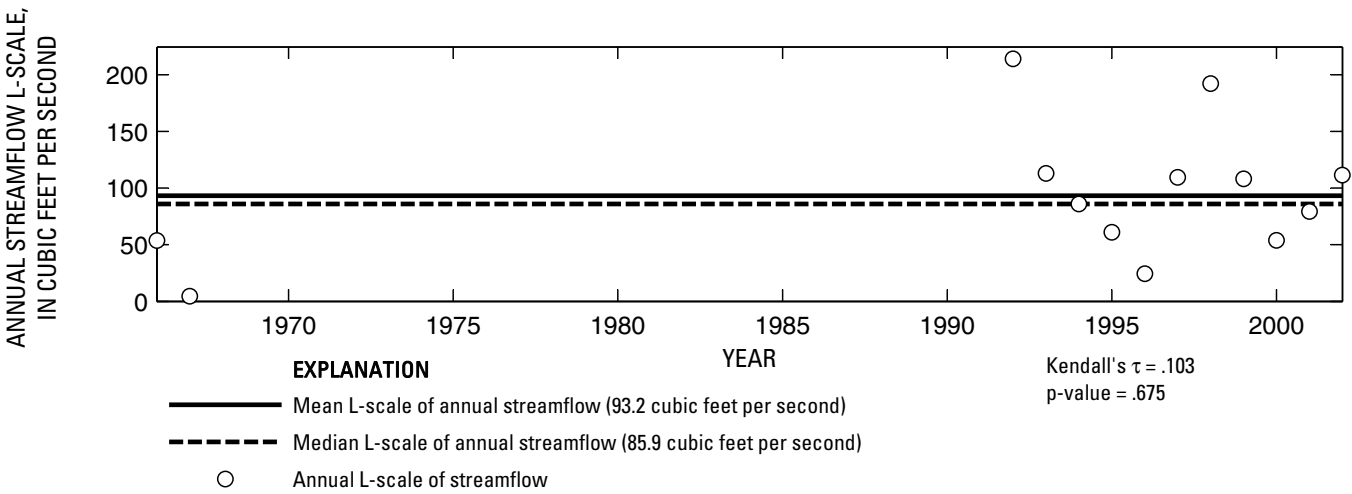

Figure 677. Analysis of annual mean, maximum, minimum, and L-scale statistics of daily mean streamflow for U.S. Geological Survey streamflow-gaging station 08211200 Nueces River at Bluntzer, Texas. 

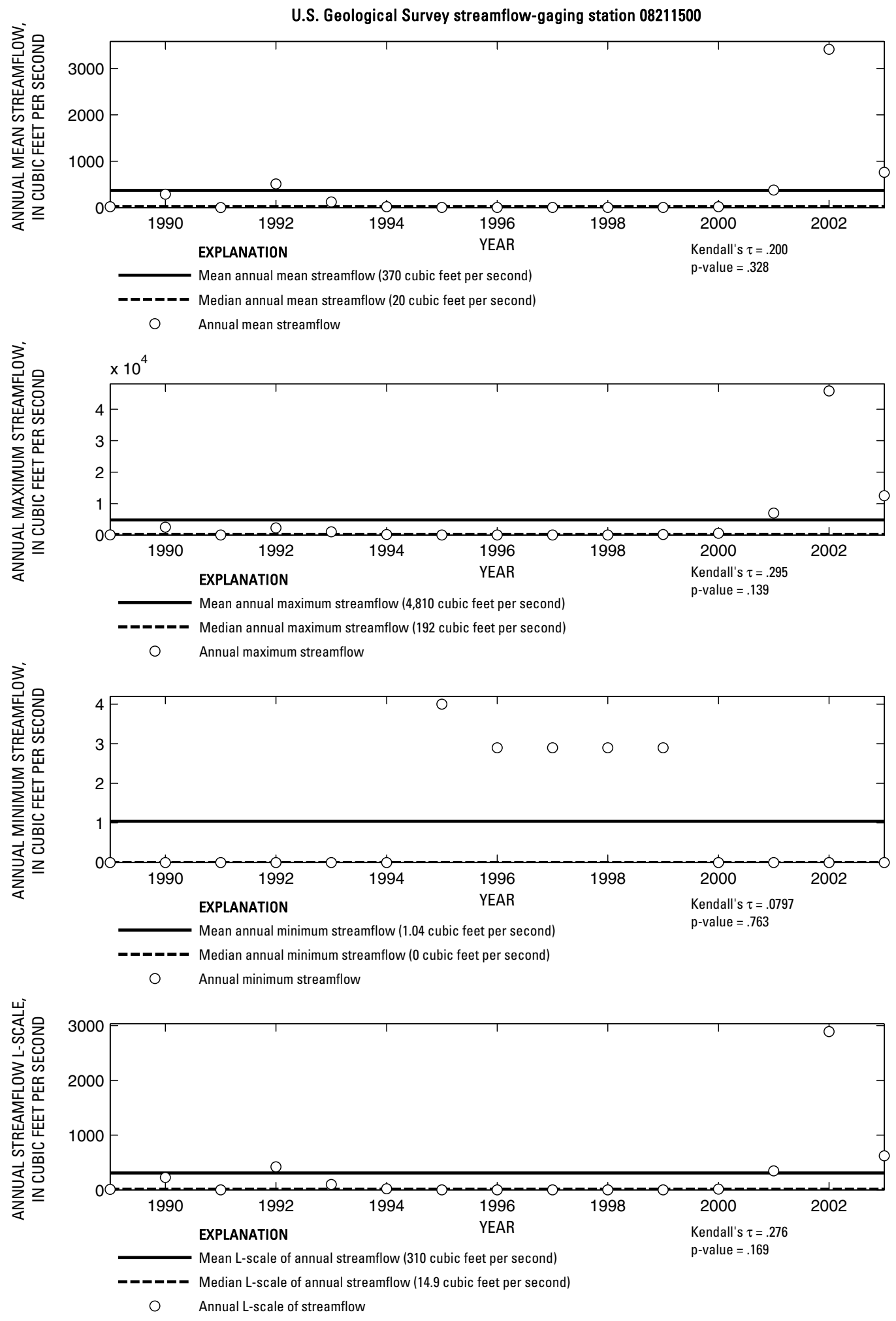

Figure 678. Analysis of annual mean, maximum, minimum, and L-scale statistics of daily mean streamflow for U.S. Geological Survey streamflow-gaging station 08211500 Nueces River at Calallen, Texas.

Index of Station Numbers 719 


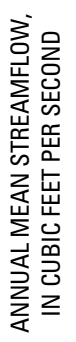

U.S. Geological Survey streamflow-gaging station 08211520

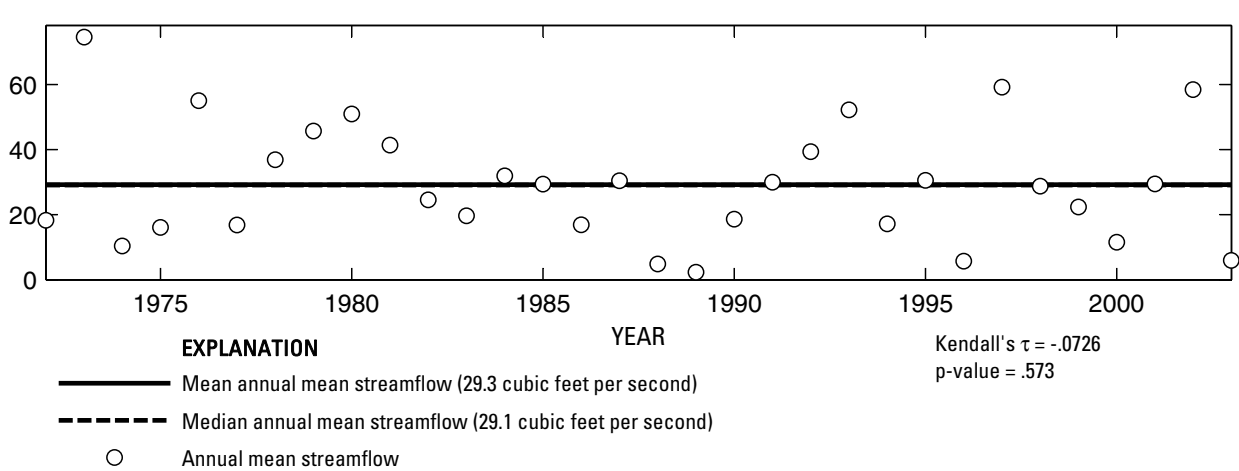

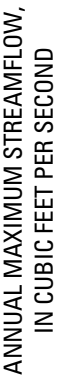

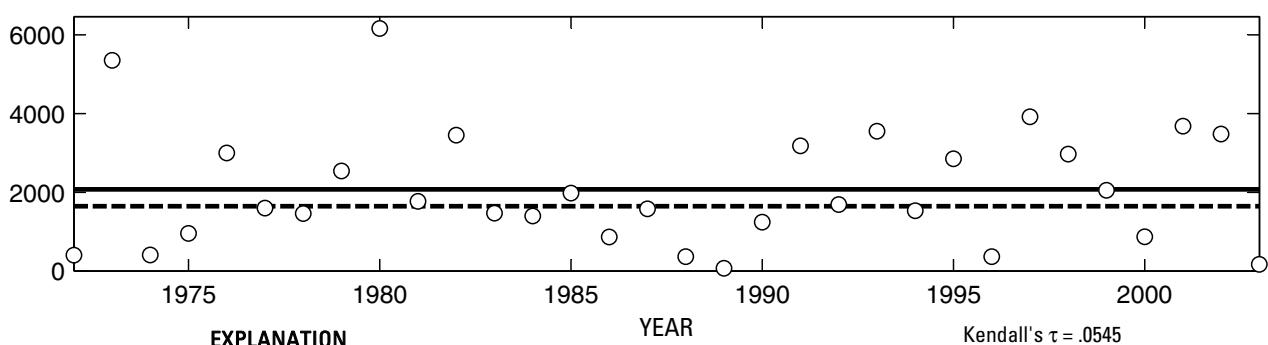

EXPLANATION

Mean annual maximum streamflow (2,070 cubic feet per second)

$\mathrm{p}$-value $=673$

- Median annual maximum streamflow (1,650 cubic feet per second)

O Annual maximum streamflow
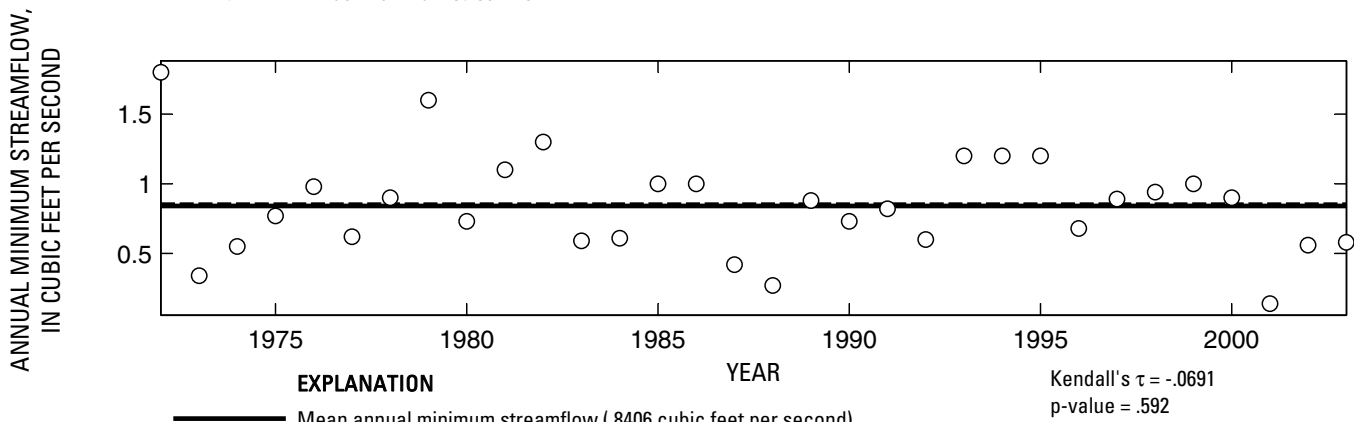

Mean annual minimum streamflow (.8406 cubic feet per second)

ーーーーーー Median annual minimum streamflow (.85 cubic feet per second)

O Annual minimum streamflow
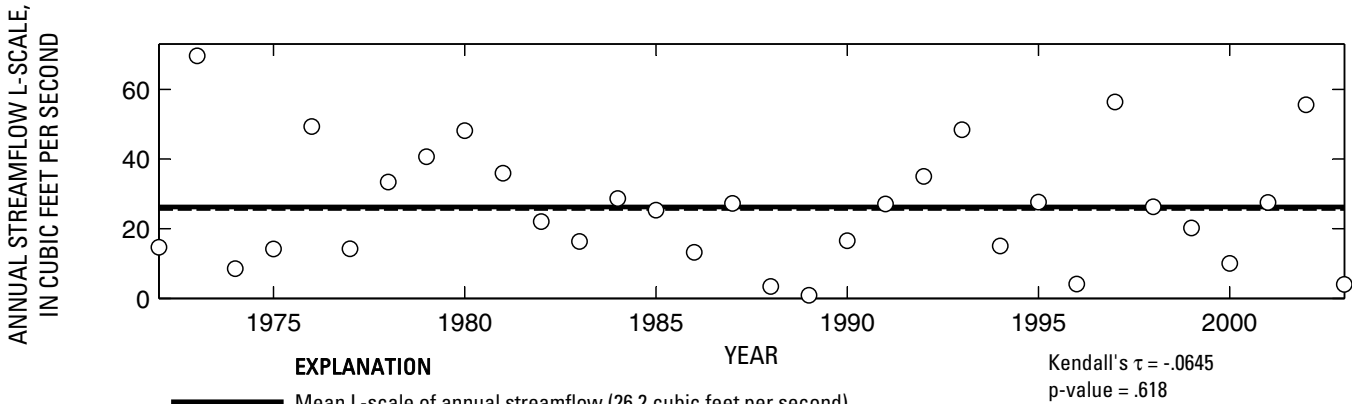

Mean L-scale of annual streamflow (26.2 cubic feet per second)

-ーーーーー Median L-scale of annual streamflow (25.8 cubic feet per second)

Annual L-scale of streamflow

Figure 679. Analysis of annual mean, maximum, minimum, and L-scale statistics of daily mean streamflow for U.S. Geological Survey streamflow-gaging station 08211520 Oso Creek at Corpus Christi, Texas.

Index of Station Numbers 719 

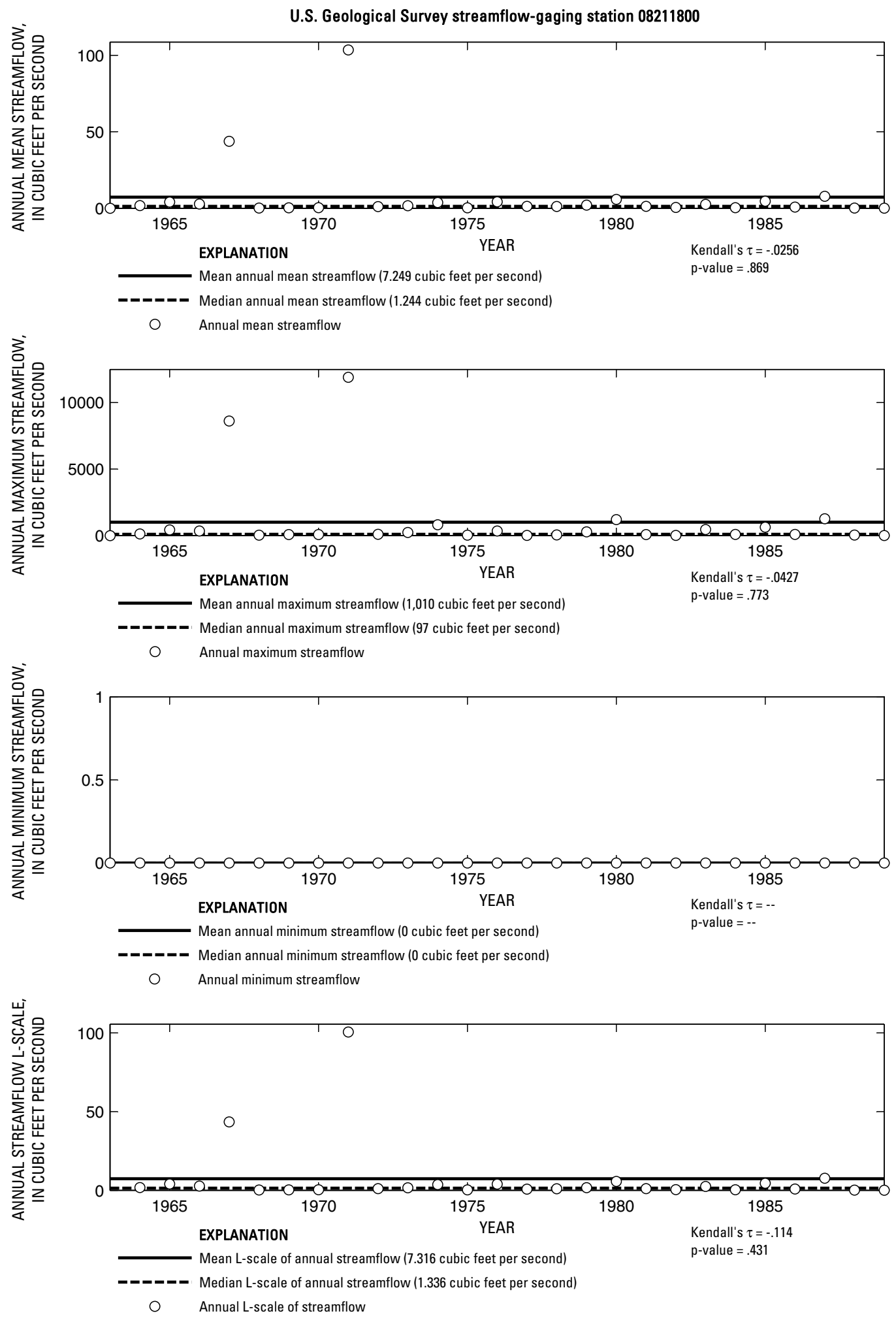

Figure 680. Analysis of annual mean, maximum, minimum, and L-scale statistics of daily mean streamflow for U.S. Geological Survey streamflow-gaging station 08211800 San Diego Creek at Alice, Texas.

Index of Station Numbers 719 


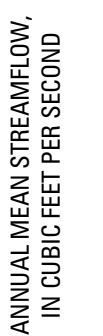

U.S. Geological Survey streamflow-gaging station 08211900

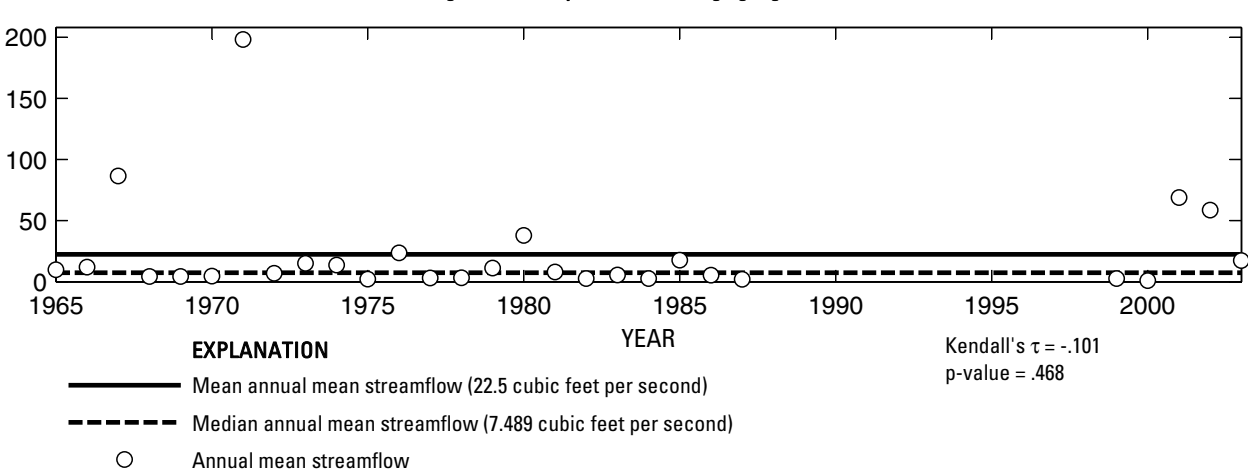

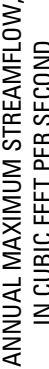

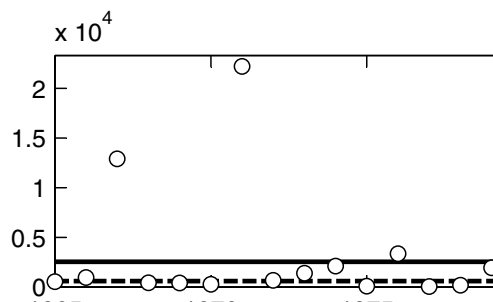

1965

1975

1980

EXPLANATION

YEAR

per second

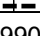

Mean annual maximum streamflow (2,540 cubic feet per second)

- - - - Median annual maximum streamflow (589 cubic feet per second)

O Annual maximum streamflow

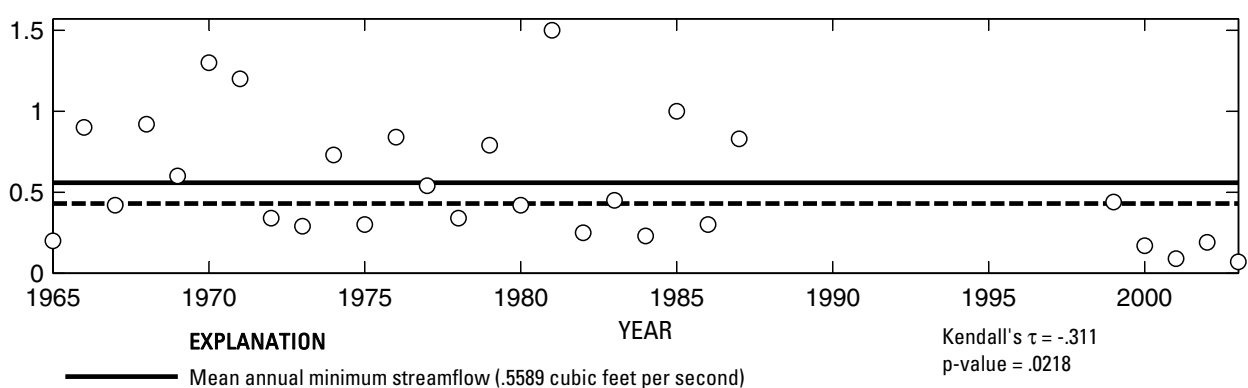

- - - Median annual minimum streamflow (.43 cubic feet per second)

O Annual minimum streamflow

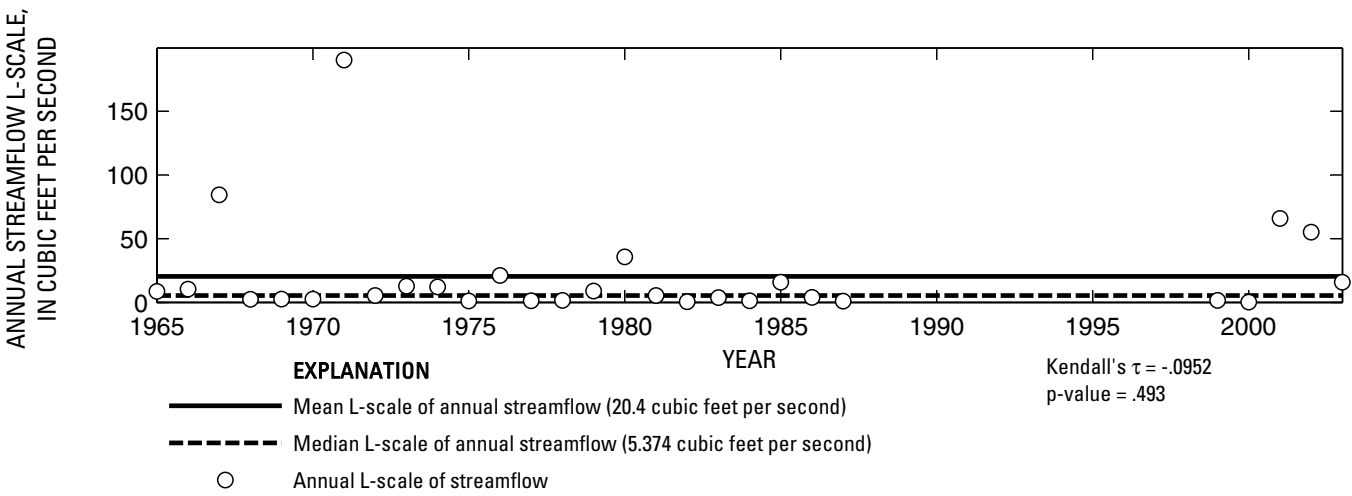

Figure 681. Analysis of annual mean, maximum, minimum, and L-scale statistics of daily mean streamflow for U.S. Geological Survey streamflow-gaging station 08211900 San Fernando Creek at Alice, Texas. 


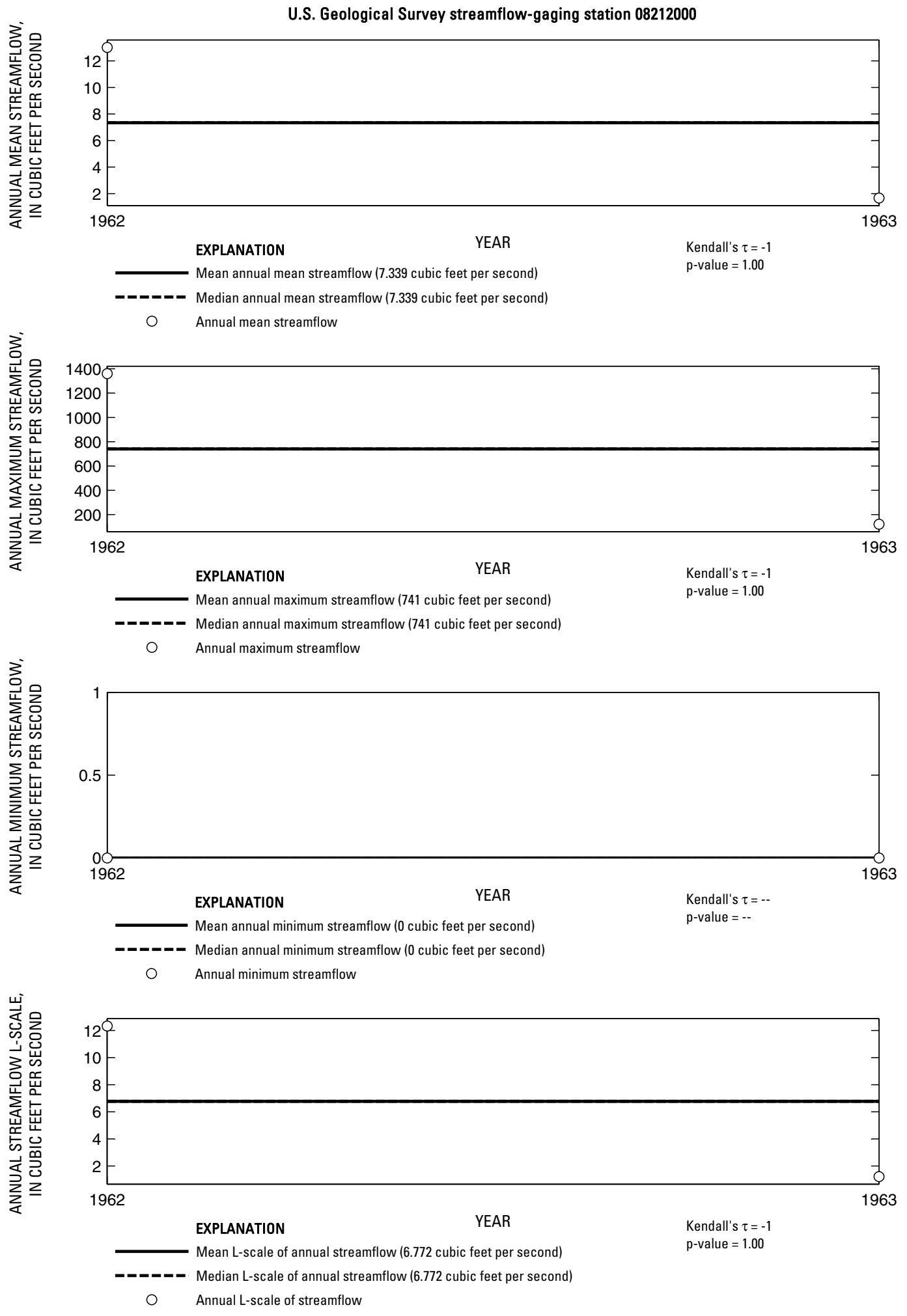

Figure 682. Analysis of annual mean, maximum, minimum, and L-scale statistics of daily mean streamflow for U.S. Geological Survey streamflow-gaging station 08212000 San Fernando Creek near Alice, Texas.

Index of Station Numbers 719 


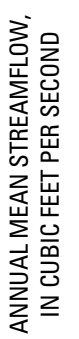

U.S. Geological Survey streamflow-gaging station 08212400

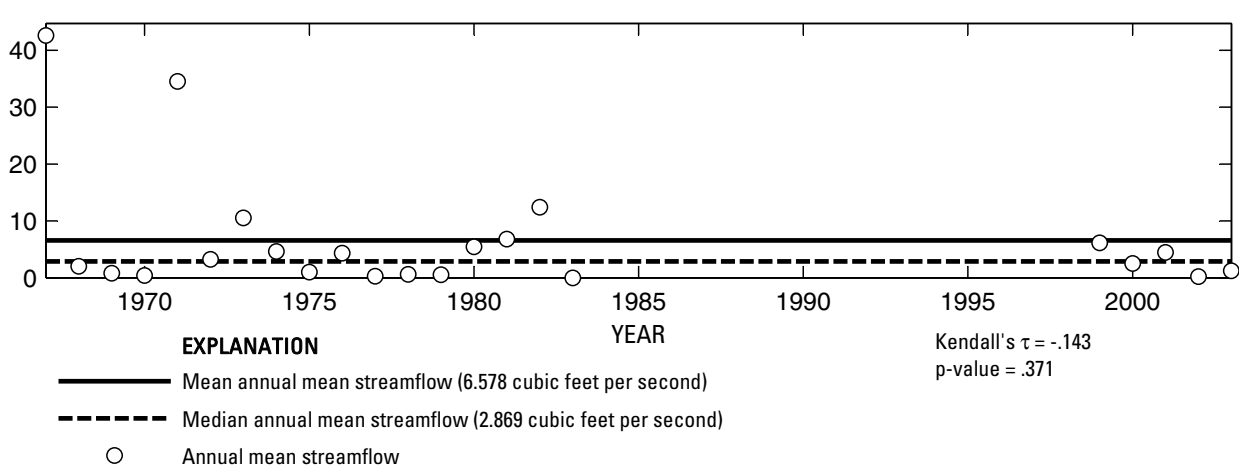

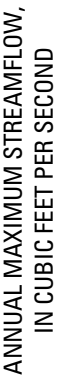

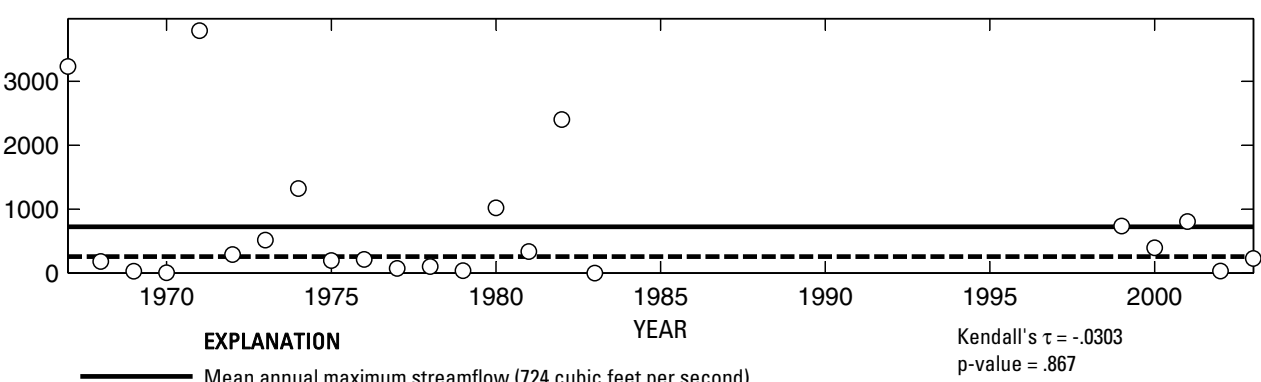

- - - Median annual maximum streamflow (258 cubic feet per second)

Annual maximum streamflow

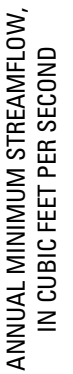

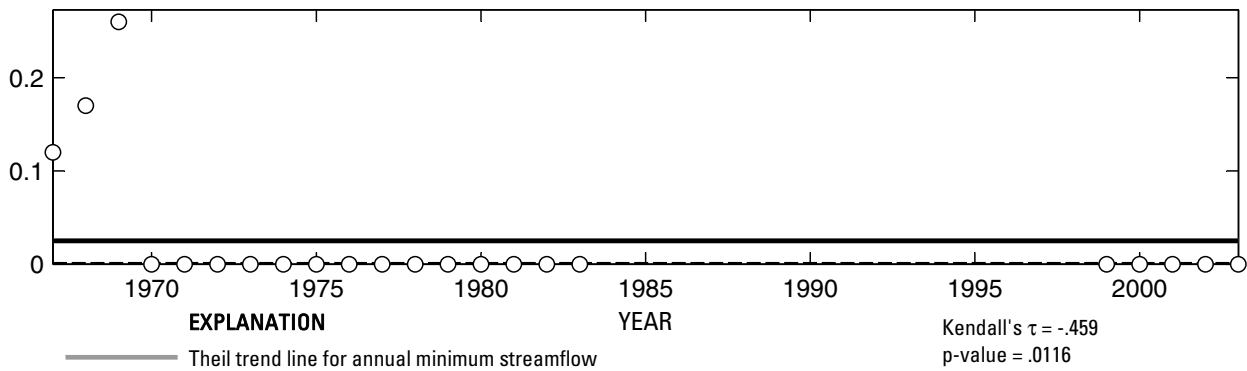

Median annual minimum streamflow ( 0 cubic feet per second)

$\bigcirc \quad$ Annual minimum streamflow
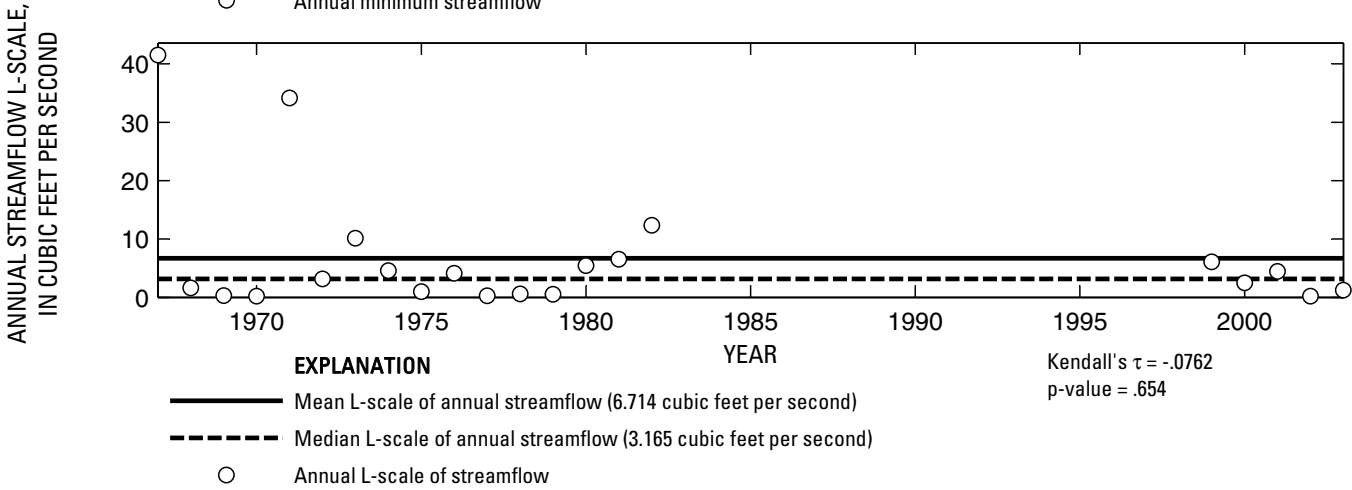

Figure 683. Analysis of annual mean, maximum, minimum, and L-scale statistics of daily mean streamflow for U.S. Geological Survey streamflow-gaging station 08212400 Los Olmos Creek near Falfurrias, Texas.

Index of Station Numbers 719 


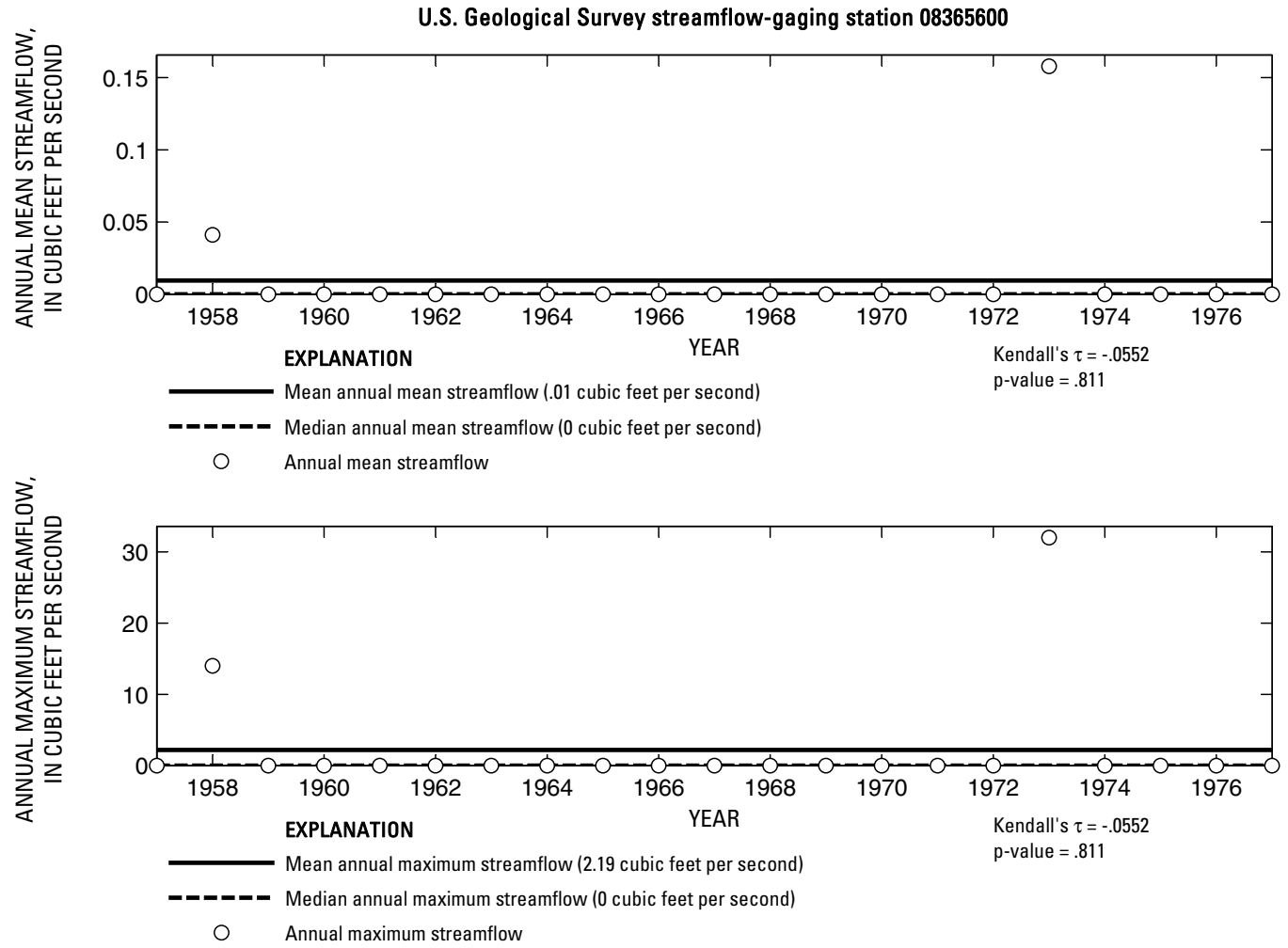

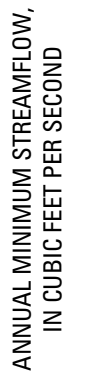

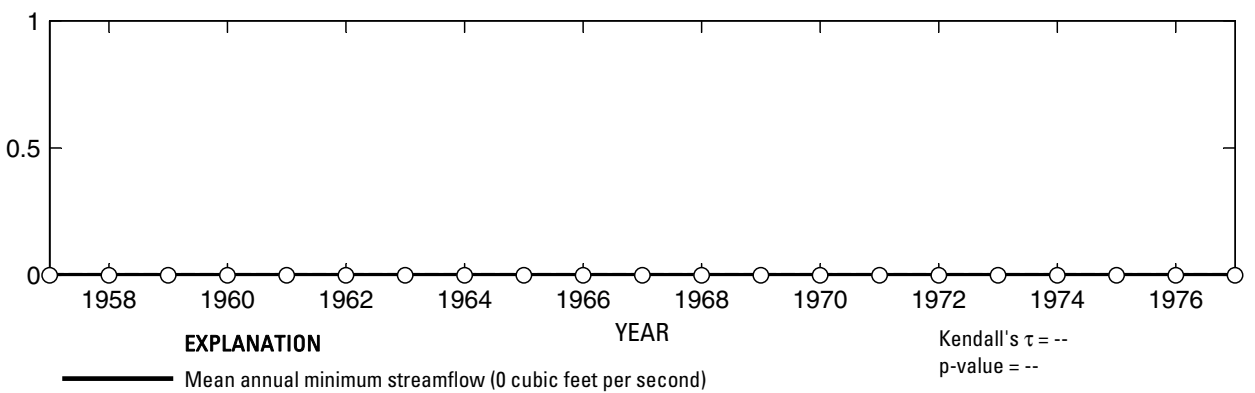

- Median annual minimum streamflow (0 cubic feet per second)

O Annual minimum streamflow

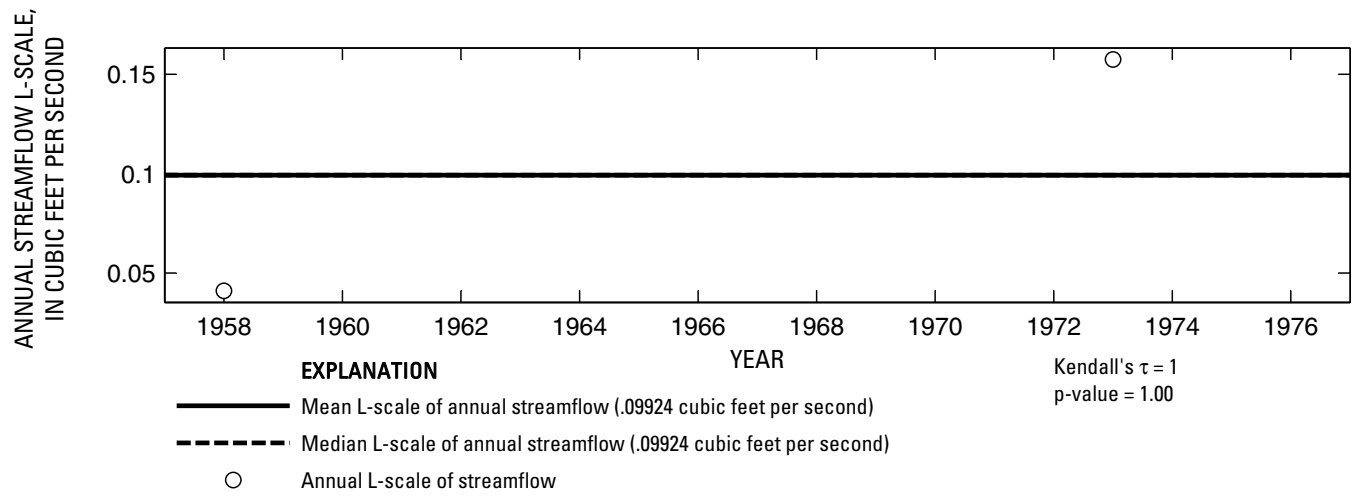

Figure 684. Analysis of annual mean, maximum, minimum, and L-scale statistics of daily mean streamflow for U.S. Geological Survey streamflow-gaging station 08365600 McKelligon Canyon at El Paso, Texas.

Index of Station Numbers 719 


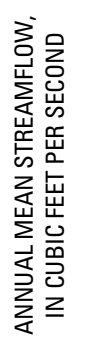

U.S. Geological Survey streamflow-gaging station 08365800

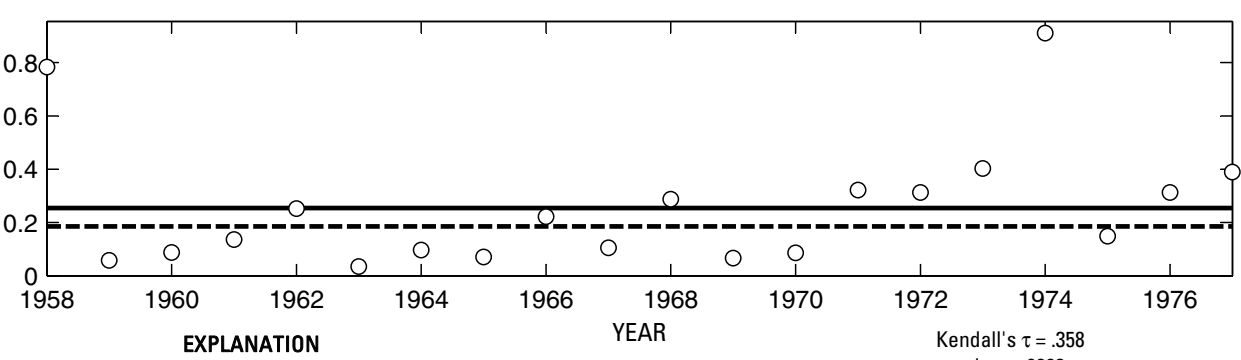

Mean annual mean streamflow (.2543 cubic feet per second)

$\mathrm{p}$-value $=.0283$

-ーーーー- Median annual mean streamflow (.1857 cubic feet per second)

O Annual mean streamflow

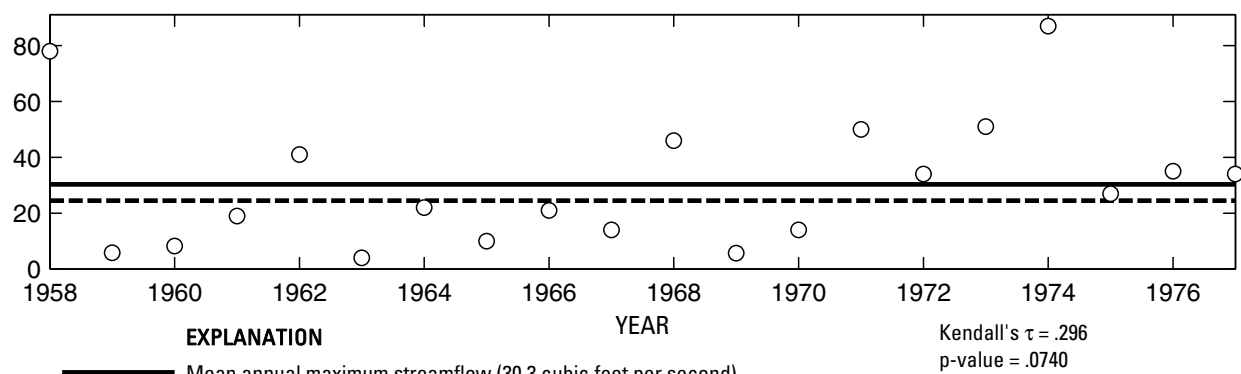

- - _- Median annual maximum streamflow (24.5 cubic feet per second)

Annual maximum streamflow

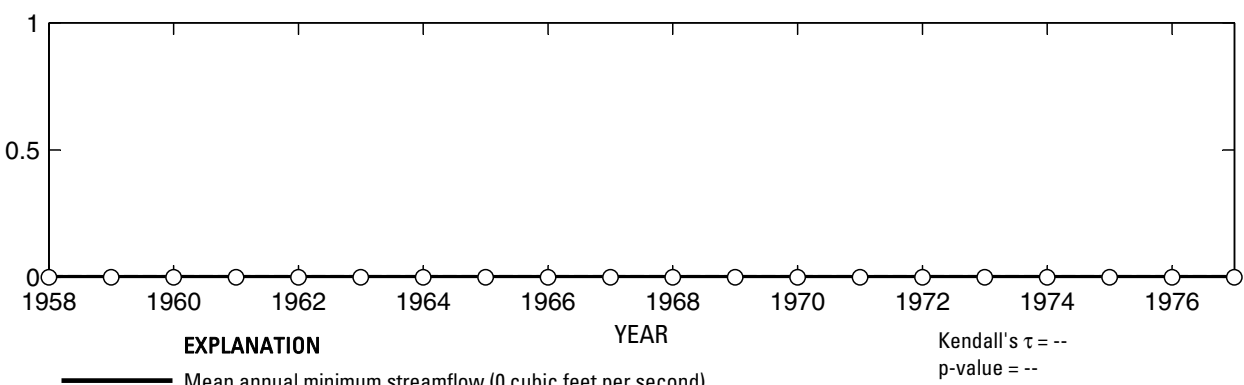

- ב-ב Median annual minimum streamflow (0 cubic feet per second)

○ Annual minimum streamflow

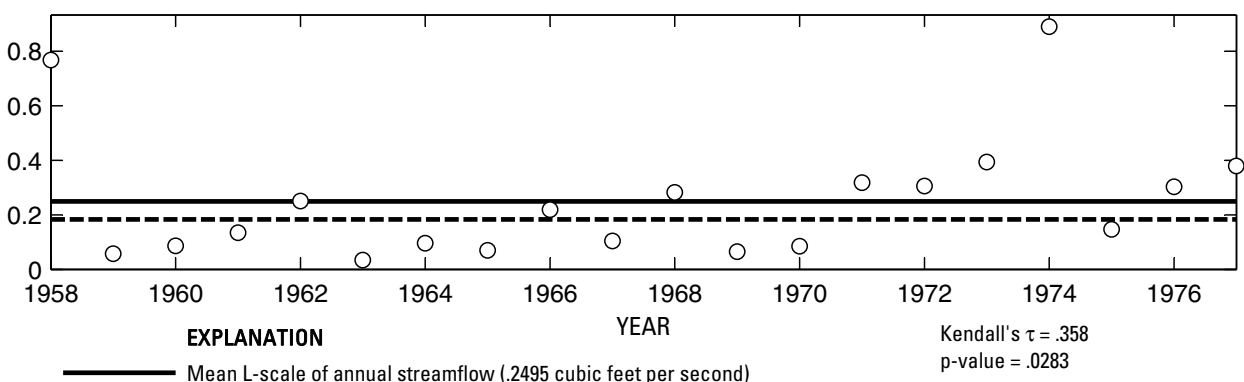

Mean L-scale of annual streamflow (.2495 cubic feet per second)

- - - - Median L-scale of annual streamflow (.183 cubic feet per second)

O Annual L-scale of streamflow

Figure 685. Analysis of annual mean, maximum, minimum, and L-scale statistics of daily mean streamflow for U.S. Geological Survey streamflow-gaging station 08365800 Government Ditch at El Paso, Texas. 

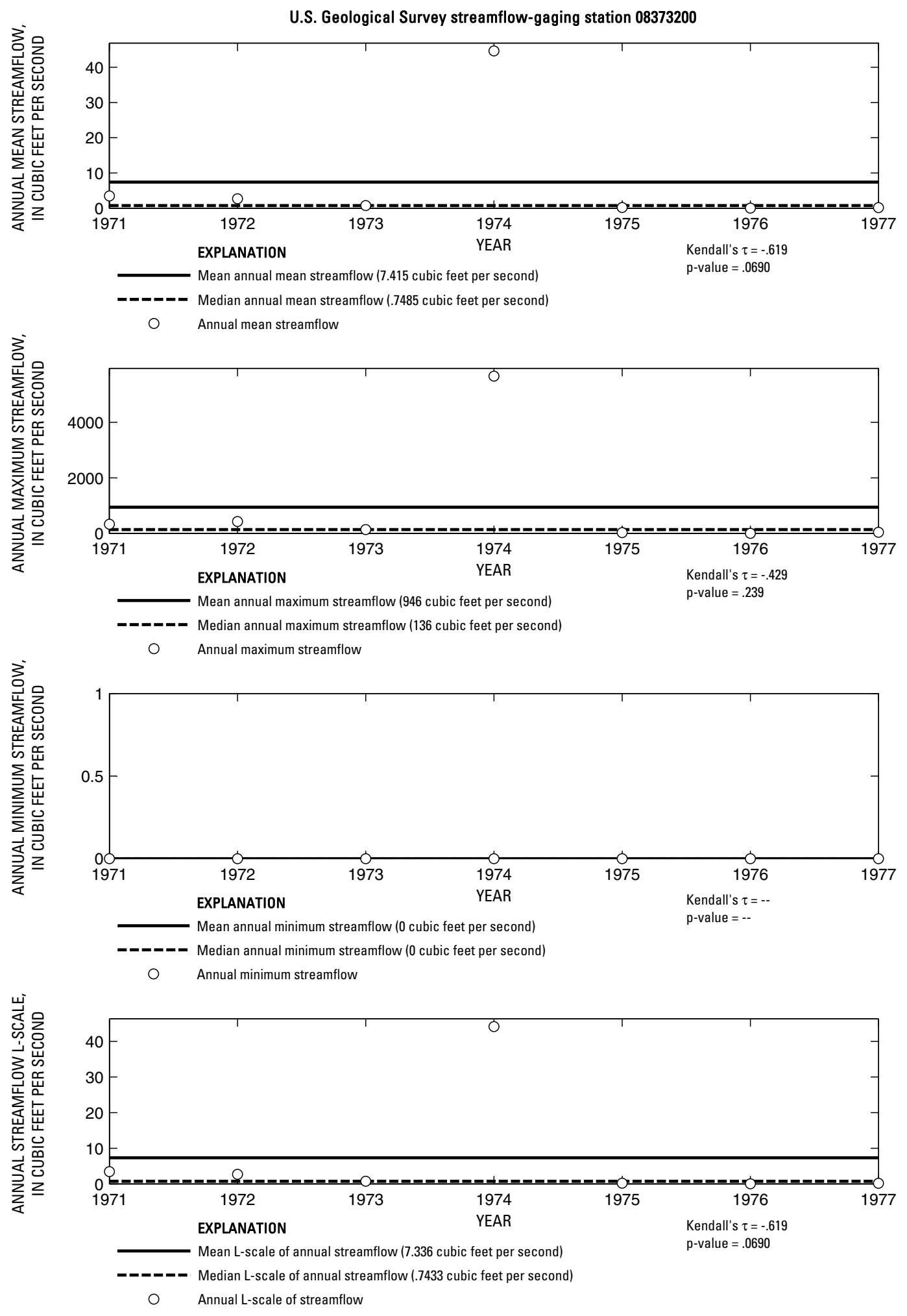

Figure 686. Analysis of annual mean, maximum, minimum, and L-scale statistics of daily mean streamflow for U.S. Geological Survey streamflow-gaging station 08373200 Cibolo Creek near Presidio, Texas. 

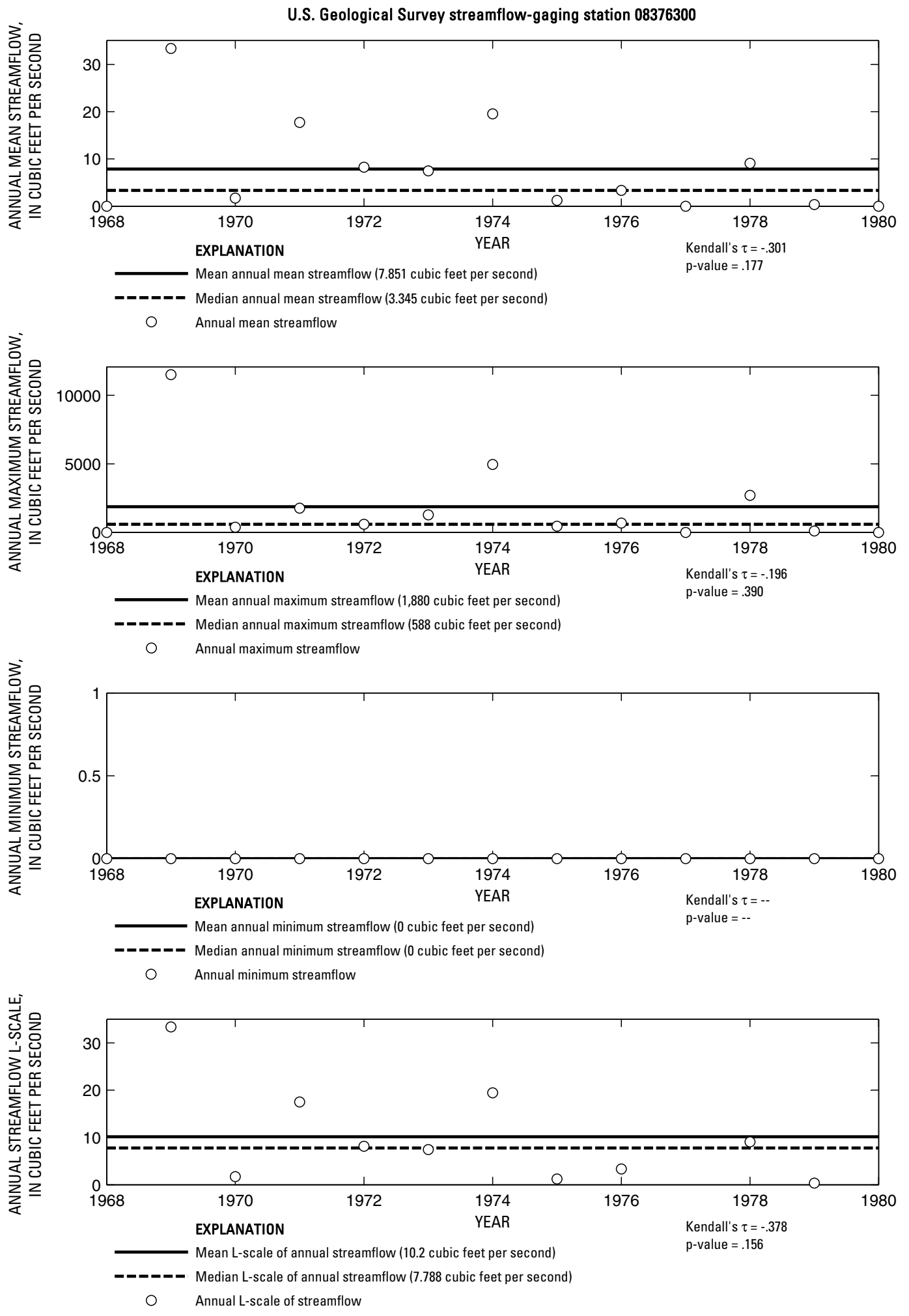

Figure 687. Analysis of annual mean, maximum, minimum, and L-scale statistics of daily mean streamflow for U.S. Geological Survey streamflow-gaging station 08376300 Sanderson Creek at Sanderson, Texas. 

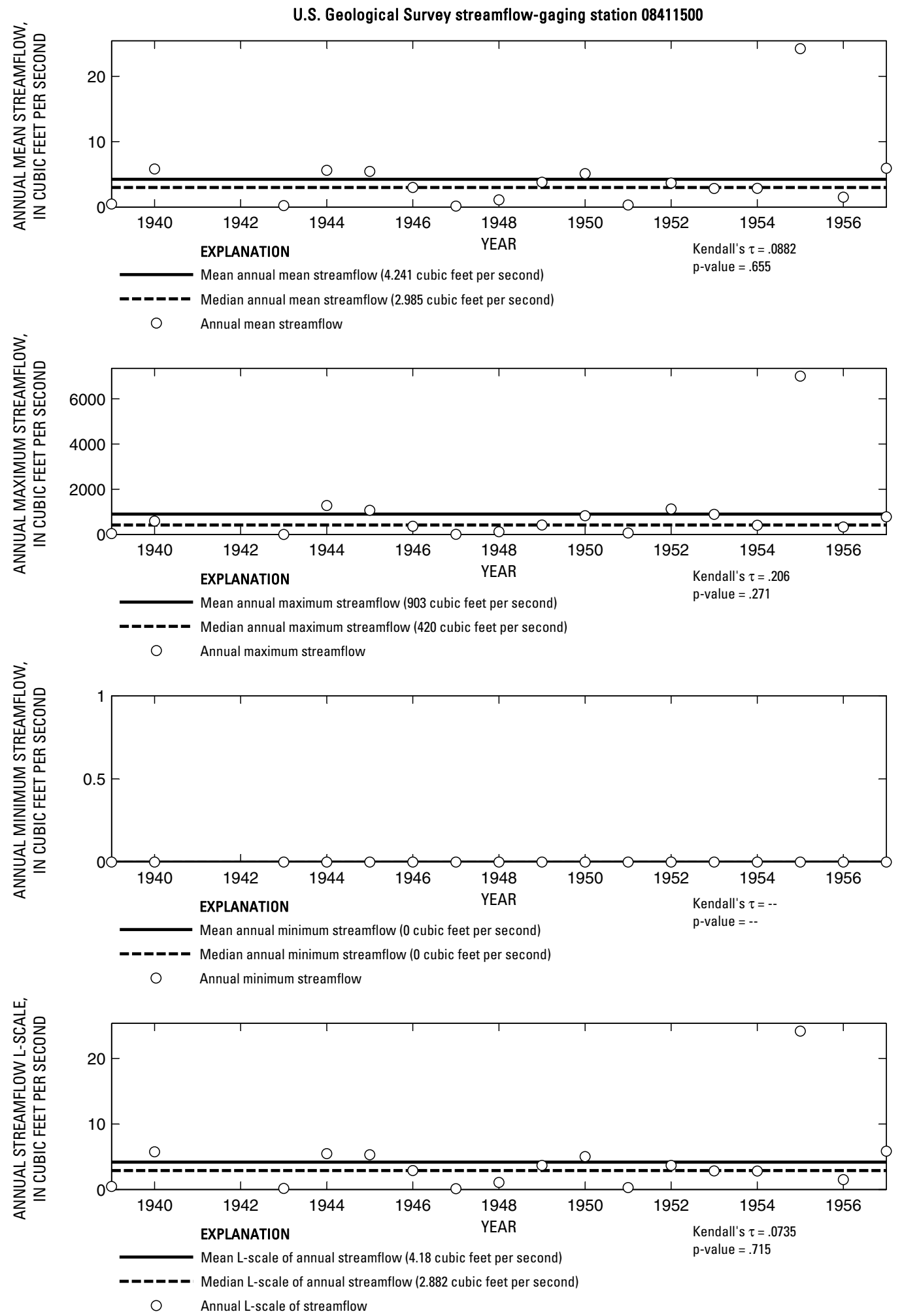

Figure 688. Analysis of annual mean, maximum, minimum, and L-scale statistics of daily mean streamflow for U.S. Geological Survey streamflow-gaging station 08411500 Salt Screwbean Draw near Orla, Texas.

Index of Station Numbers 719 


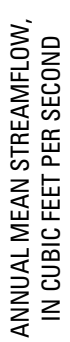

U.S. Geological Survey streamflow-gaging station 08412500

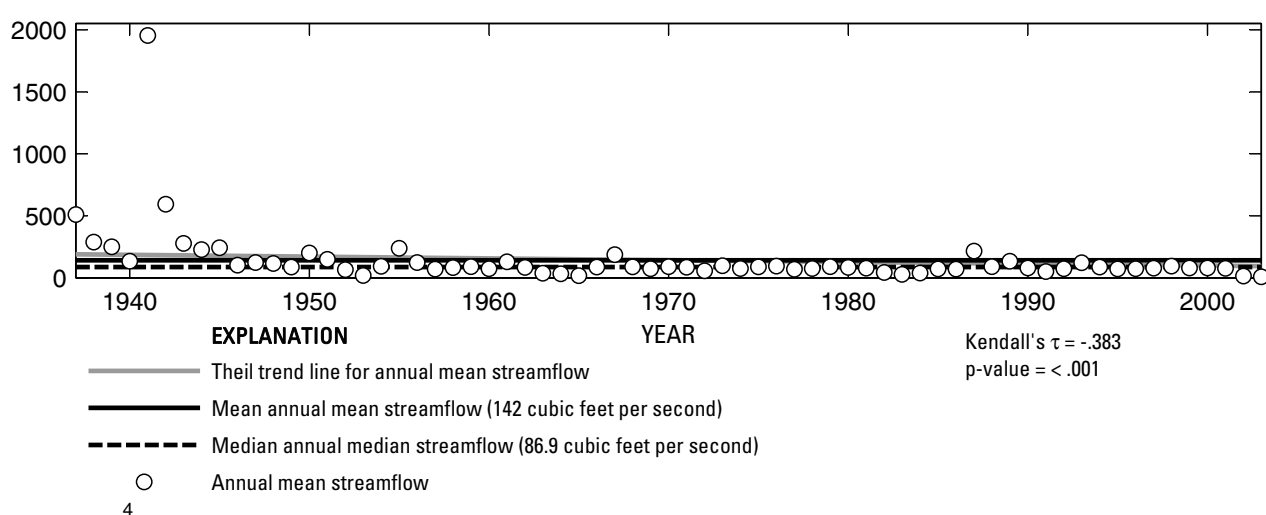

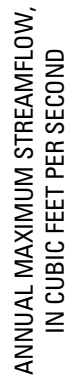

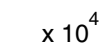

4

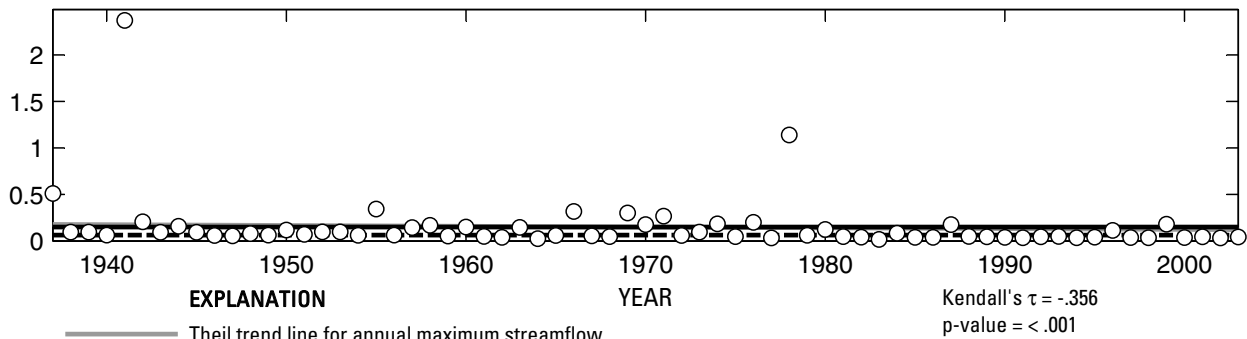

Mean annual maximum streamflow (1,500 cubic feet per second)

-ンーーーー Median annual maximum streamflow ( 625 cubic feet per second)

O Annual maximum streamflow

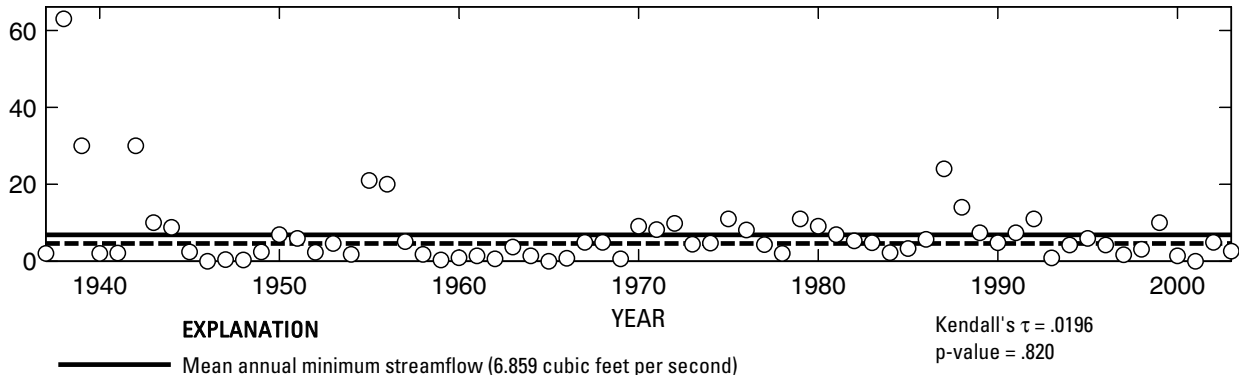

- Median annual minimum streamflow (4.6 cubic feet per second)

O Annual minimum streamflow

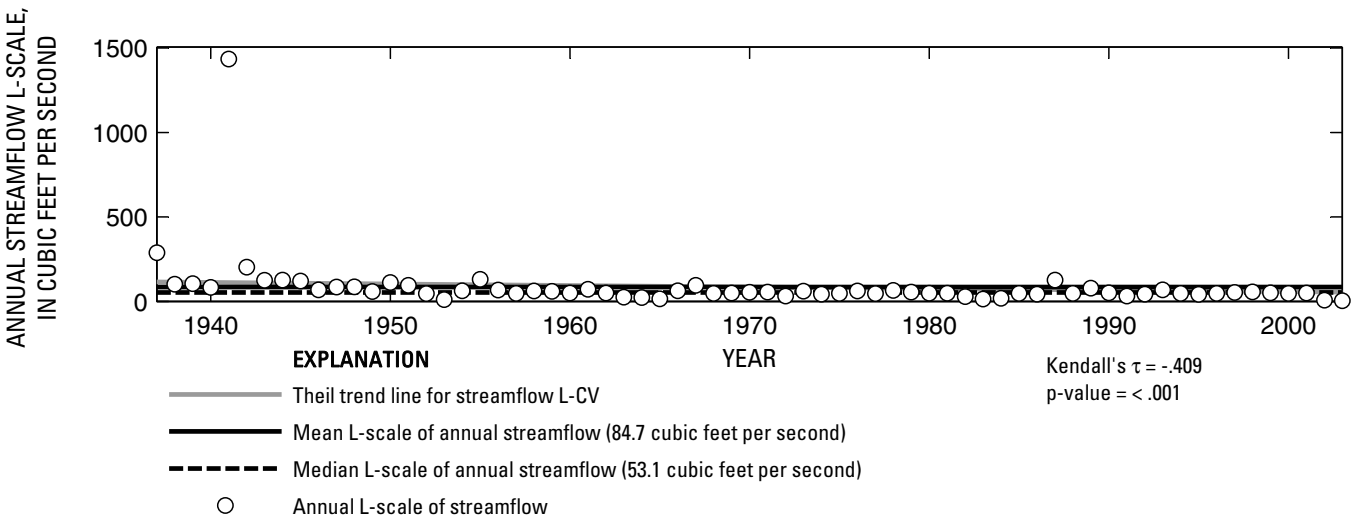

Figure 689. Analysis of annual mean, maximum, minimum, and L-scale statistics of daily mean streamflow for U.S. Geological Survey streamflow-gaging station 08412500 Pecos River near Orla, Texas. 

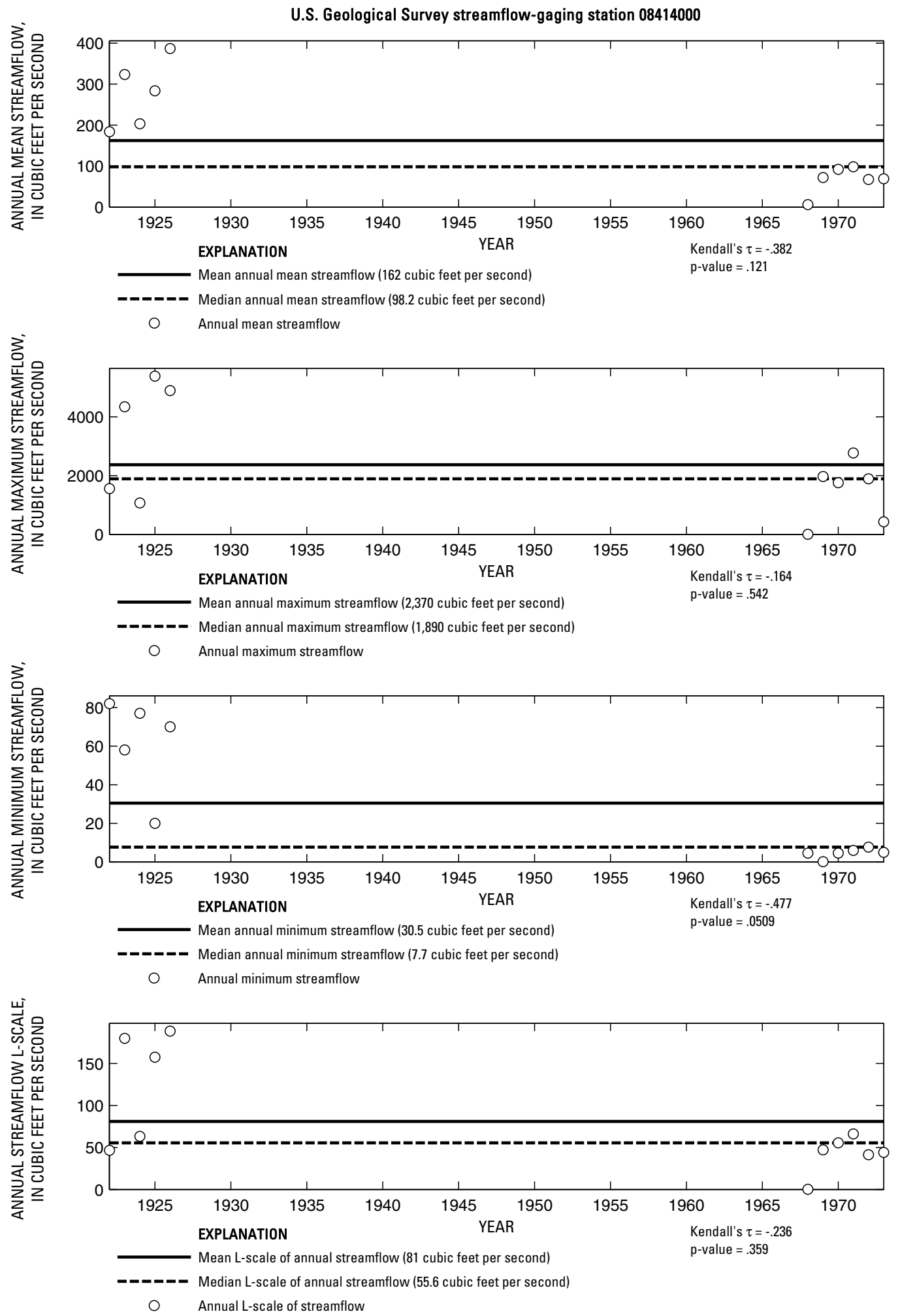

Figure 690. Analysis of annual mean, maximum, minimum, and L-scale statistics of daily mean streamflow for U.S. Geological Survey streamflow-gaging station 08414000 Pecos River near Mentone, Texas.

Index of Station Numbers 719 


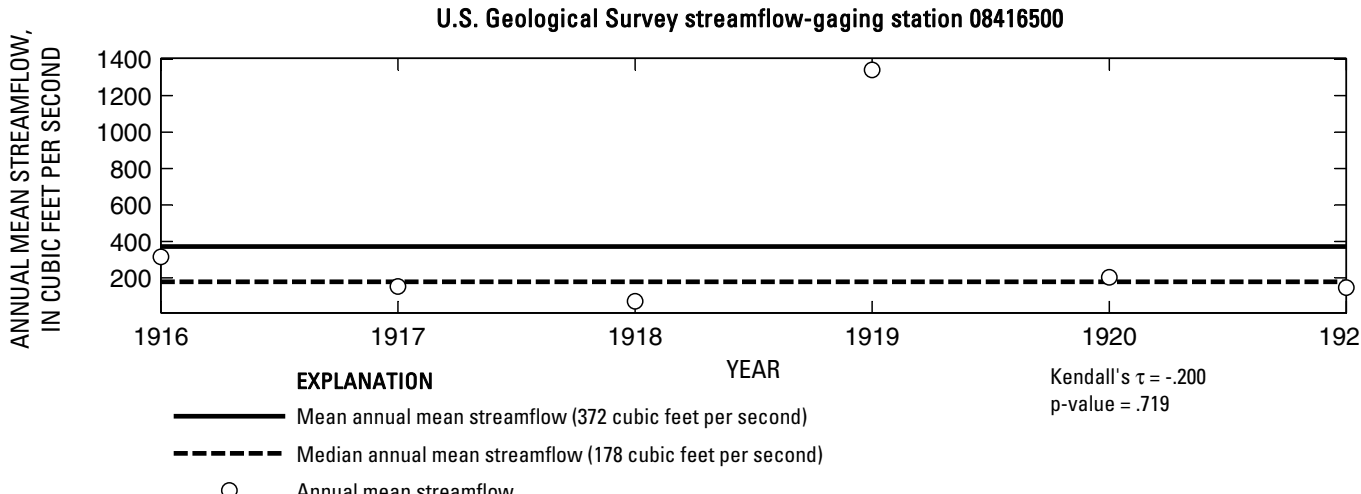

Annual mean streamflow
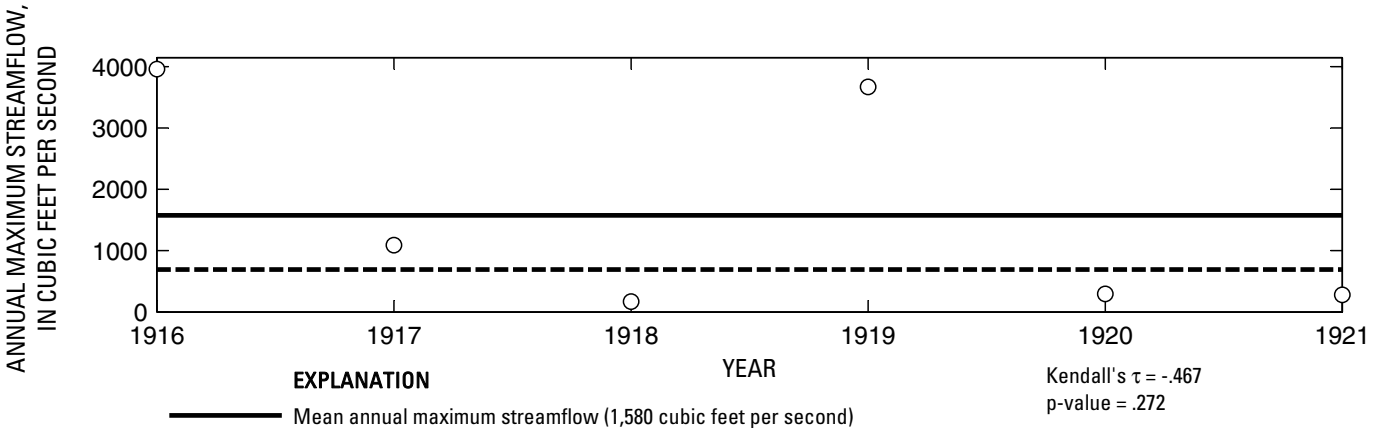

- - - Median annual maximum streamflow (693 cubic feet per second)

O Annual maximum streamflow
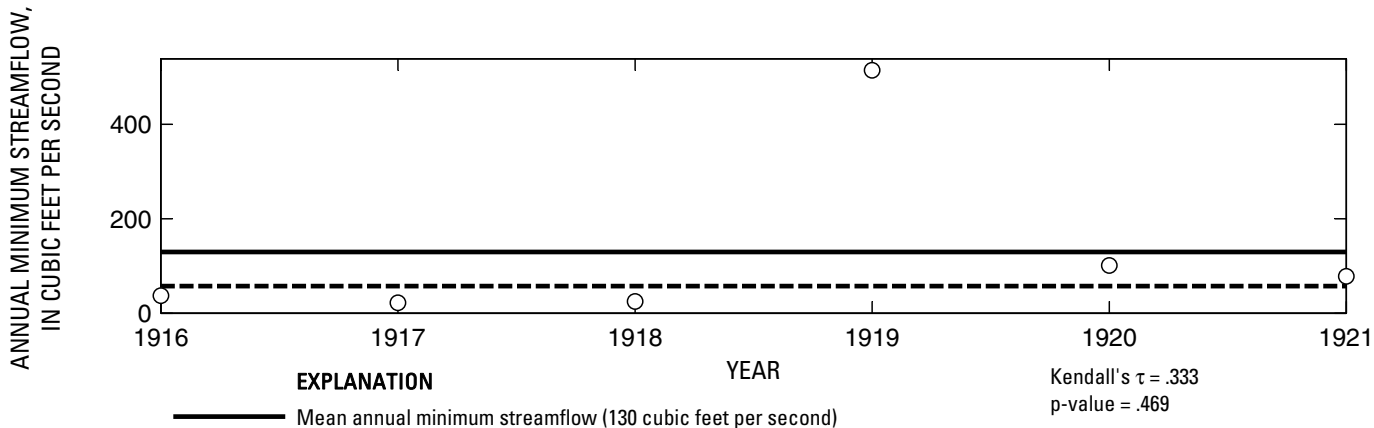

- ב-ב Median annual minimum streamflow ( 57.5 cubic feet per second)

O Annual minimum streamflow

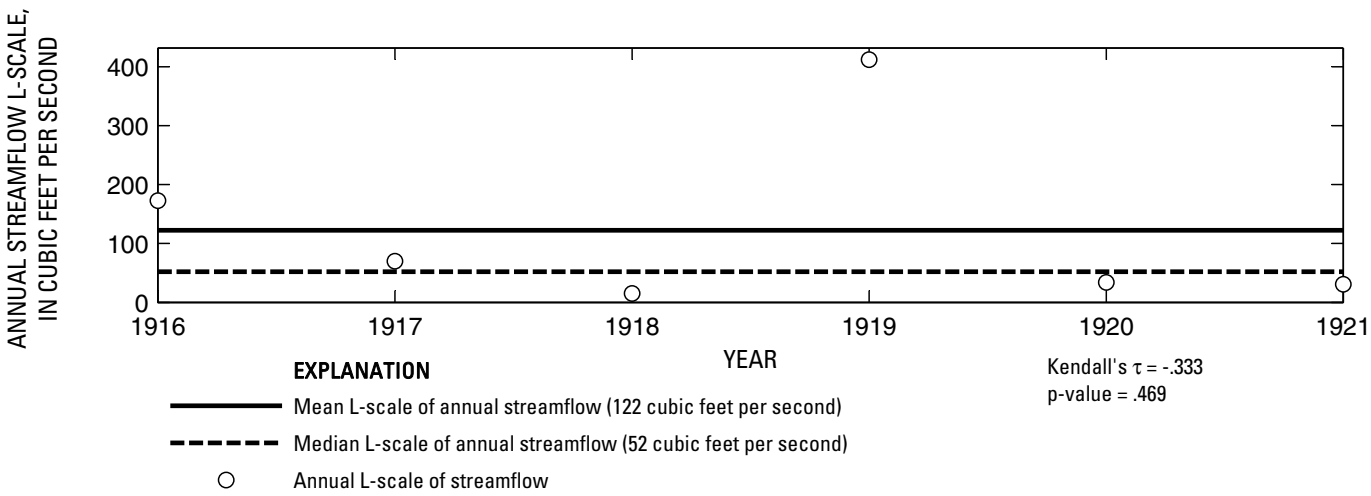

Figure 691. Analysis of annual mean, maximum, minimum, and L-scale statistics of daily mean streamflow for U.S. Geological Survey streamflow-gaging station 08416500 Pecos River above Barstow (Barstow Canal), Texas. 


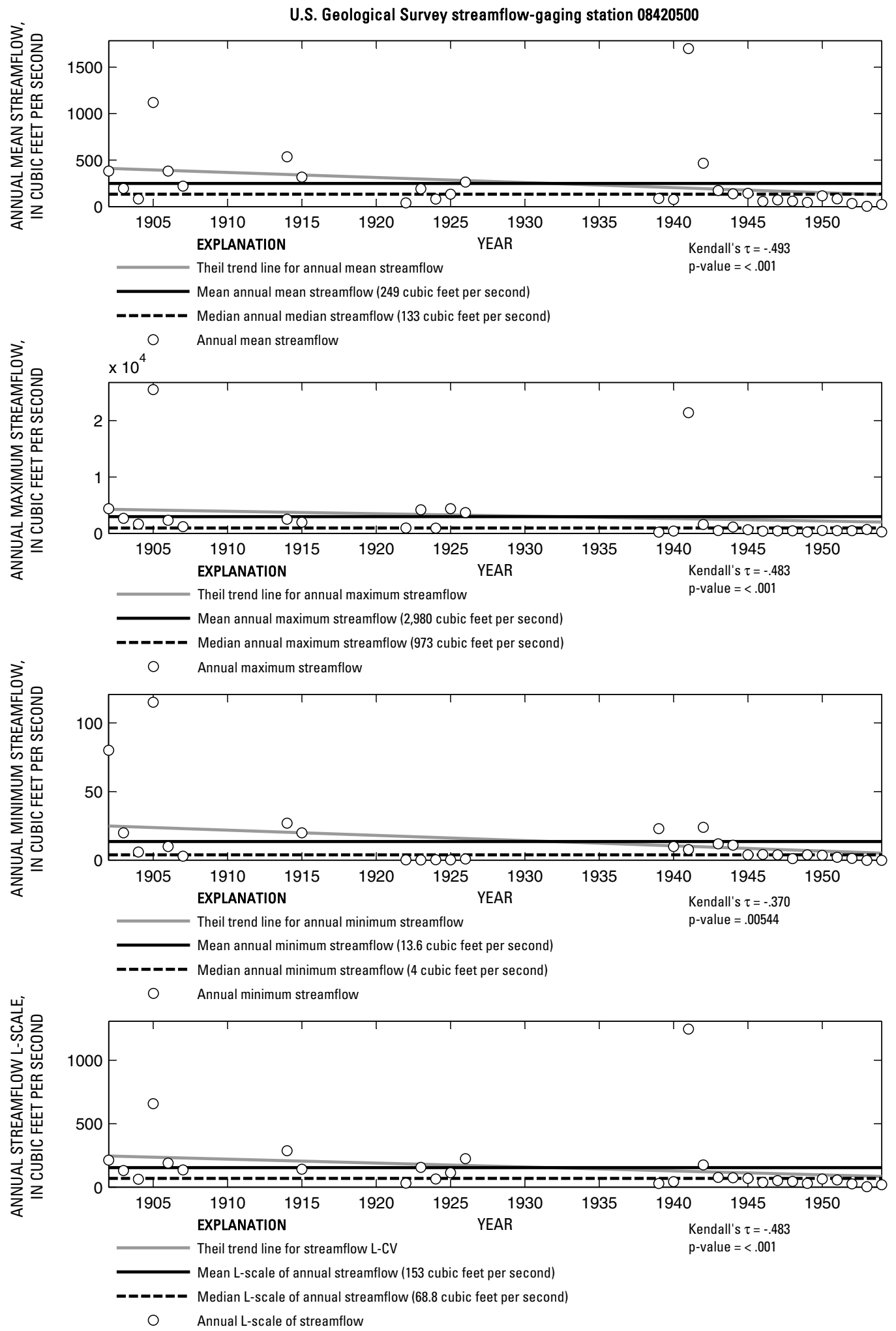

Figure 692. Analysis of annual mean, maximum, minimum, and L-scale statistics of daily mean streamflow for U.S. Geological Survey streamflow-gaging station 08420500 Pecos River at Pecos, Texas.

Index of Station Numbers 719 


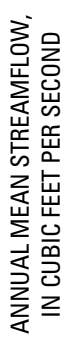

U.S. Geological Survey streamflow-gaging station 08424500

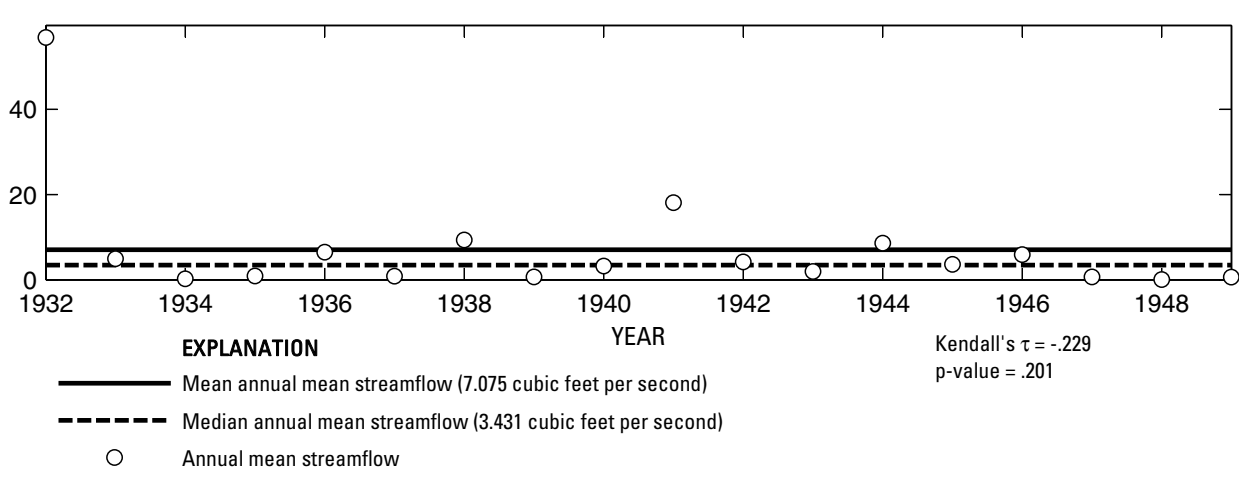

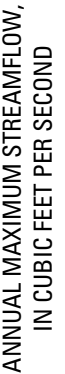
2000
1500
1000
500
0
1932

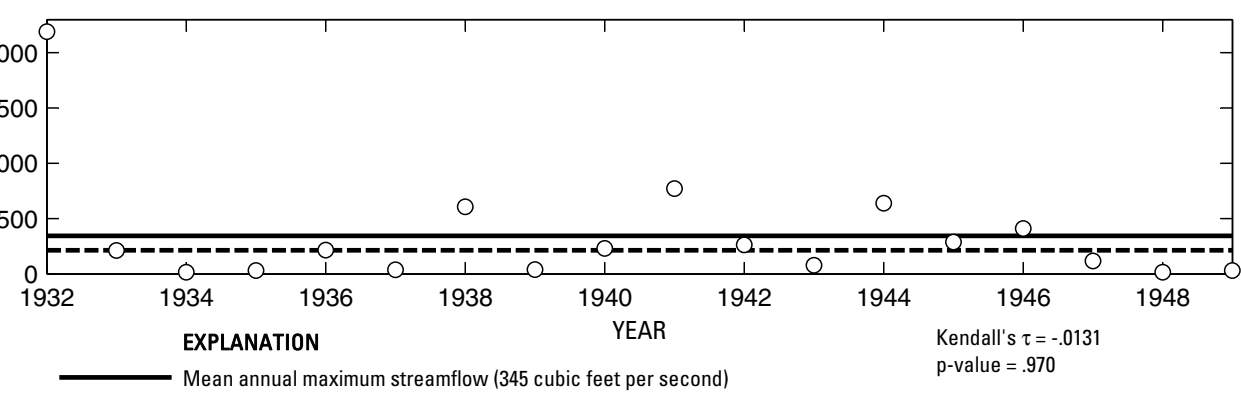

- - - Median annual maximum streamflow (215 cubic feet per second)

Annual maximum streamflow
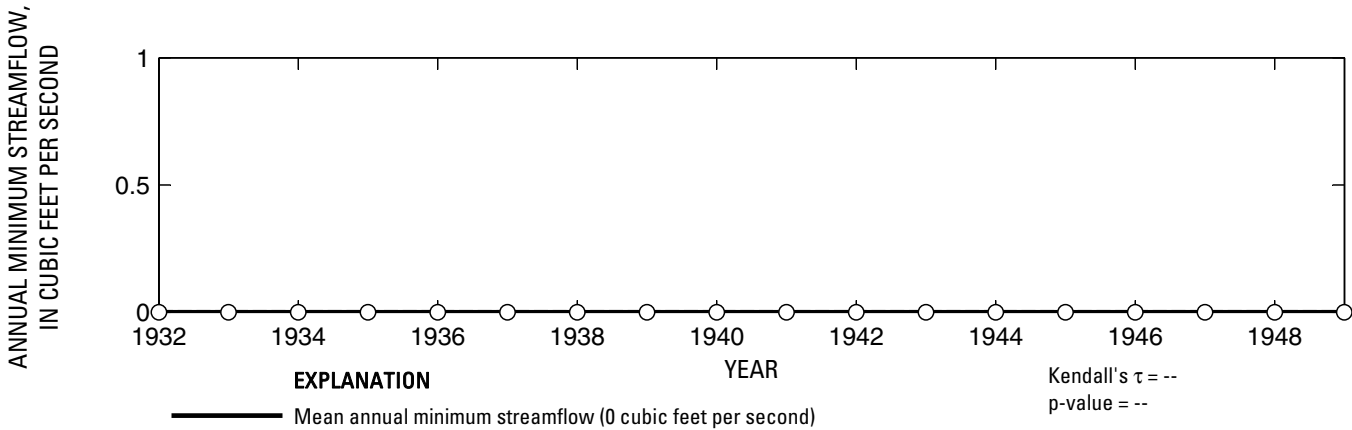

- ב- Median annual minimum streamflow (0 cubic feet per second)

○ Annual minimum streamflow

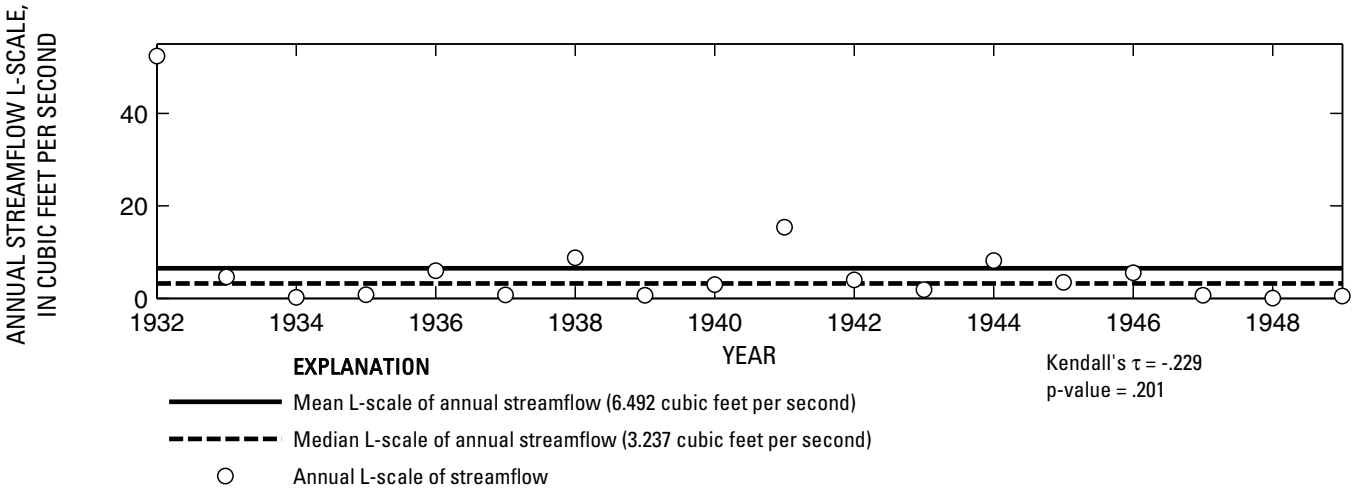

Figure 693. Analysis of annual mean, maximum, minimum, and L-scale statistics of daily mean streamflow for U.S. Geological Survey streamflow-gaging station 08424500 Madera Canyon near Toyahvale, Texas.

|ndex of Station Numbers 719 
U.S. Geological Survey streamflow-gaging station 08431000

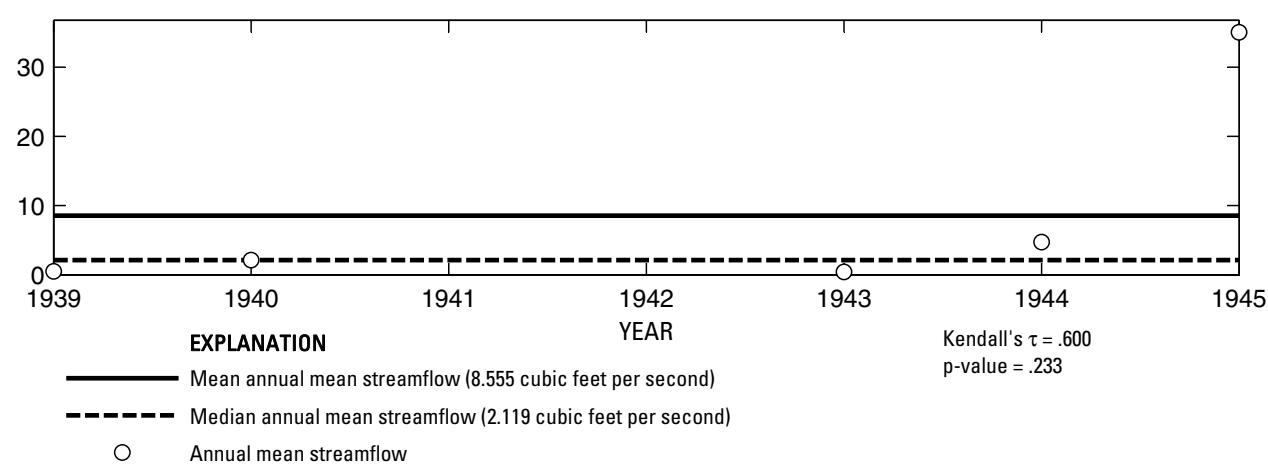

焉

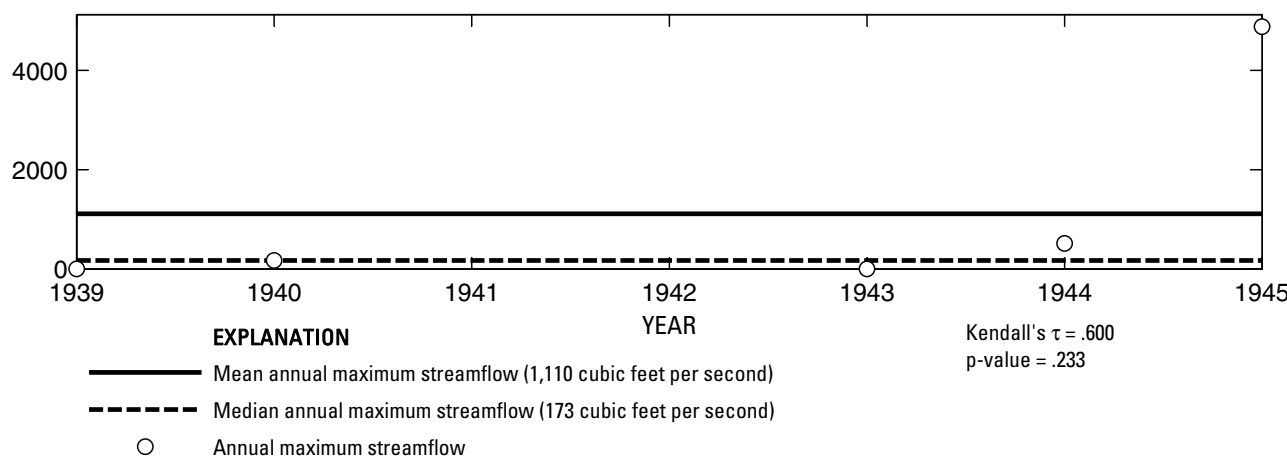

崔

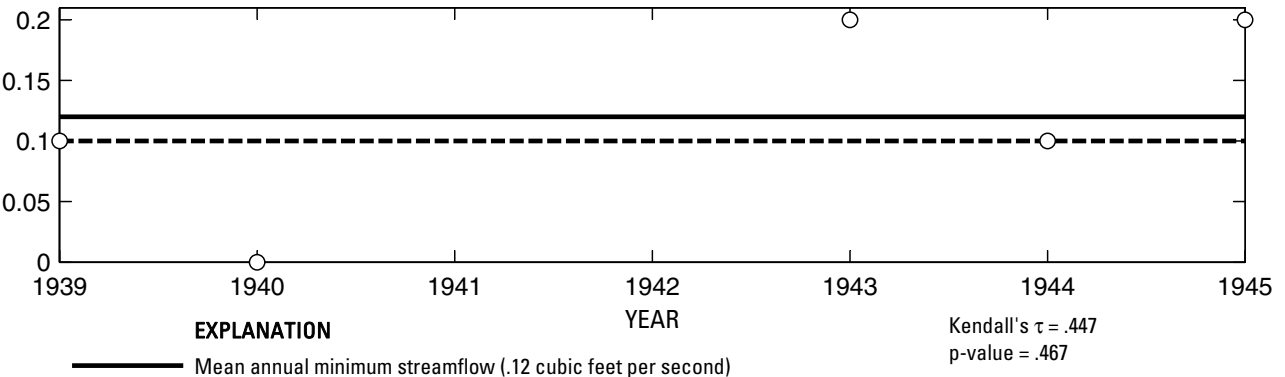

- Median annual minimum streamflow (.1 cubic feet per second)

O Annual minimum streamflow

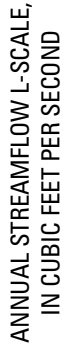

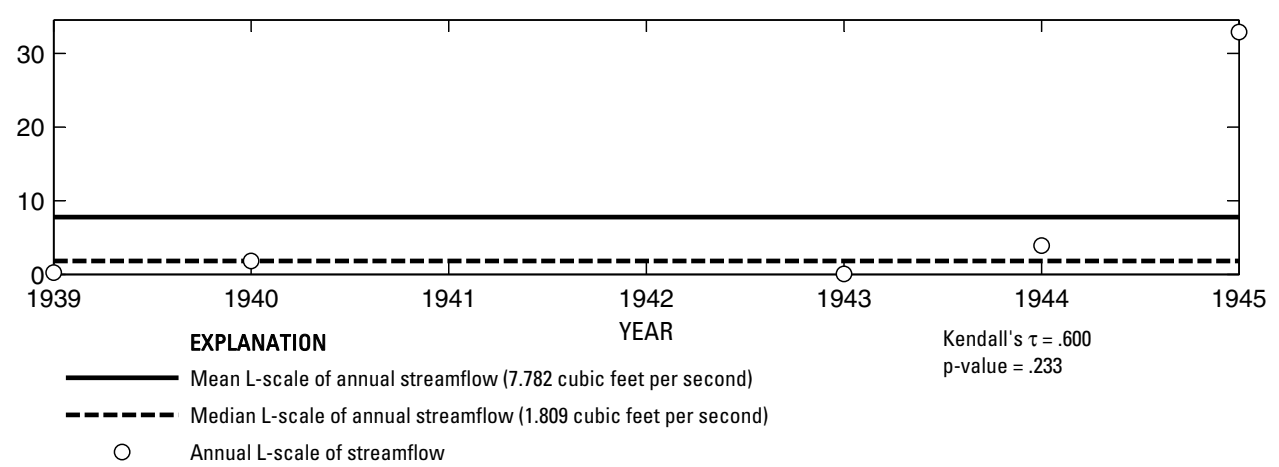

Figure 694. Analysis of annual mean, maximum, minimum, and L-scale statistics of daily mean streamflow for U.S. Geological Survey streamflow-gaging station 08431000 Toyah Creek near Pecos, Texas.

Index of Station Numbers 719 

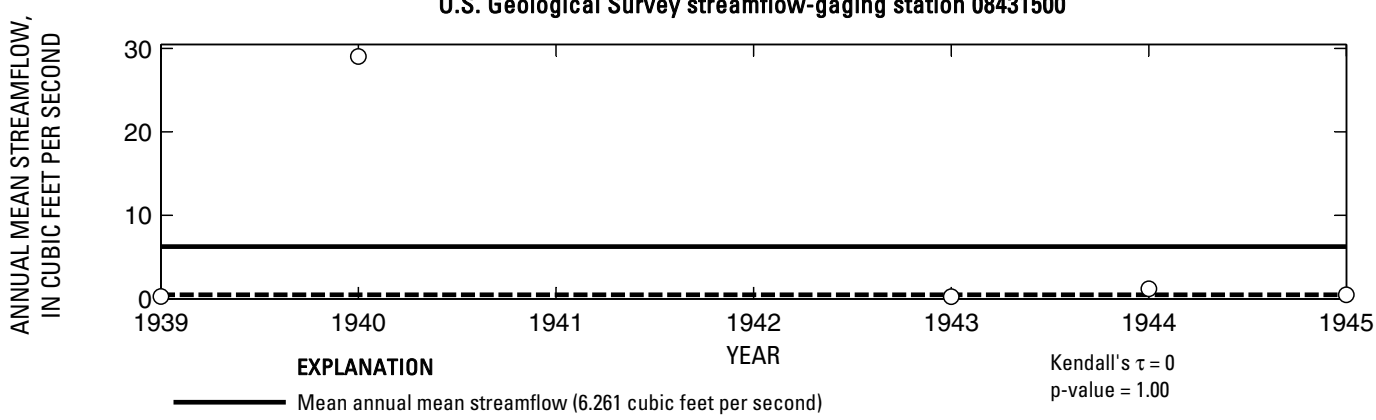

-_-_-_ Median annual mean streamflow (.4901 cubic feet per second)

O Annual mean streamflow
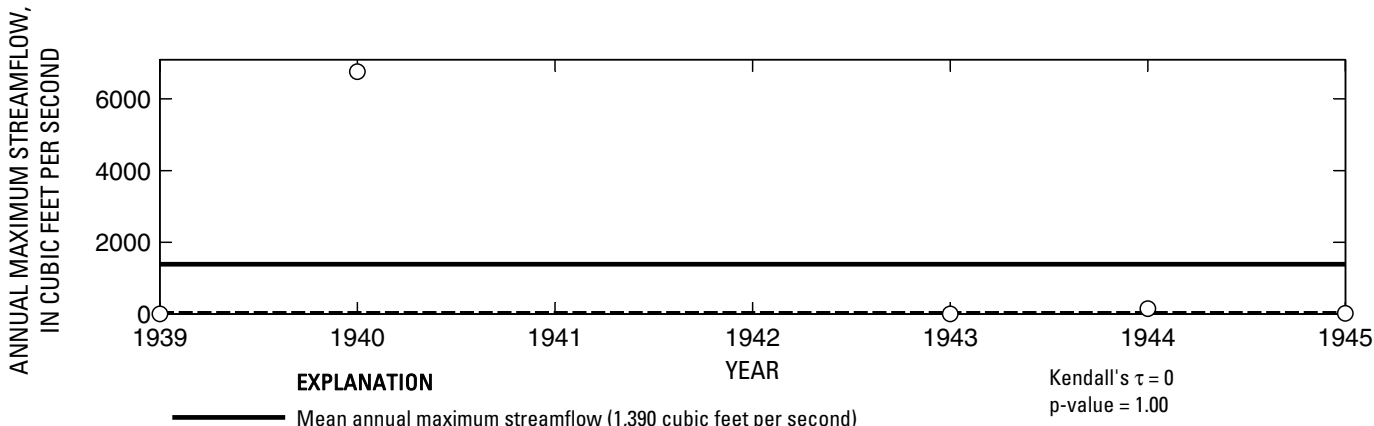

- - - - Median annual maximum streamflow (19 cubic feet per second)

Annual maximum streamflow
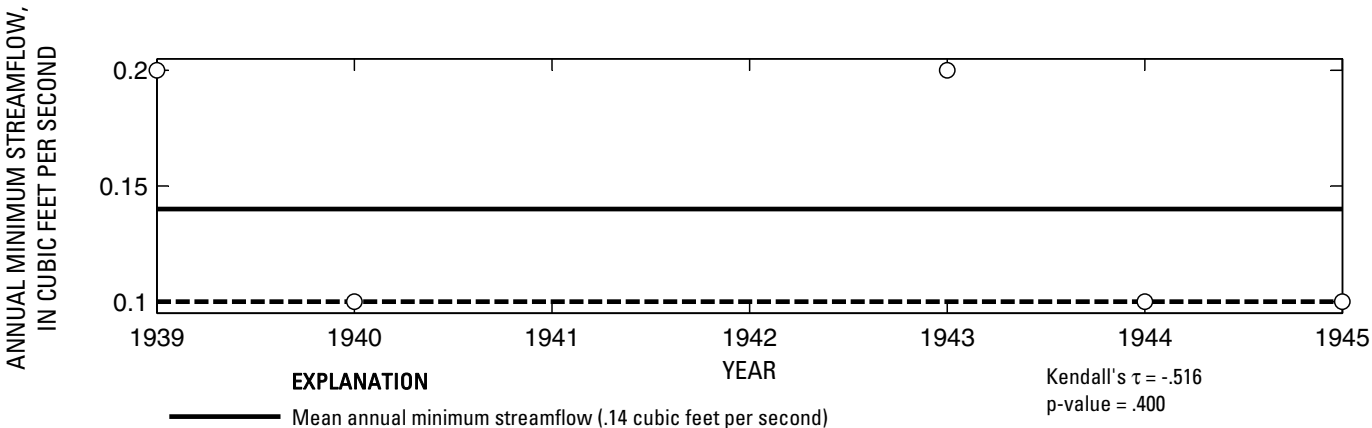

- _- Median annual minimum streamflow (.1 cubic feet per second)

O Annual minimum streamflow

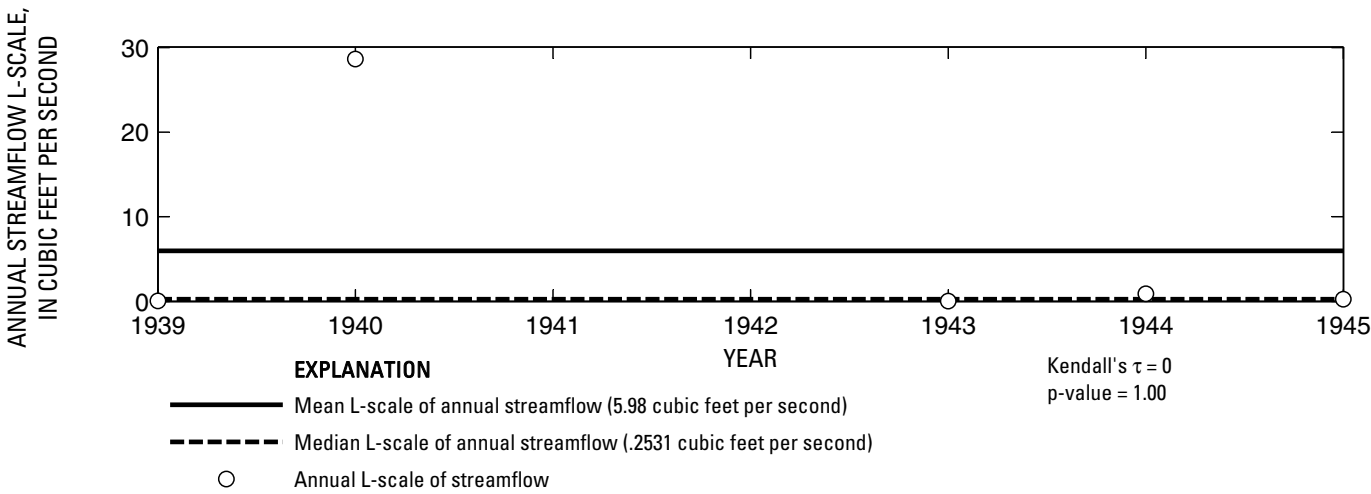

Figure 695. Analysis of annual mean, maximum, minimum, and L-scale statistics of daily mean streamflow for U.S. Geological Survey streamflow-gaging station 08431500 Salt Draw near Pecos, Texas. 

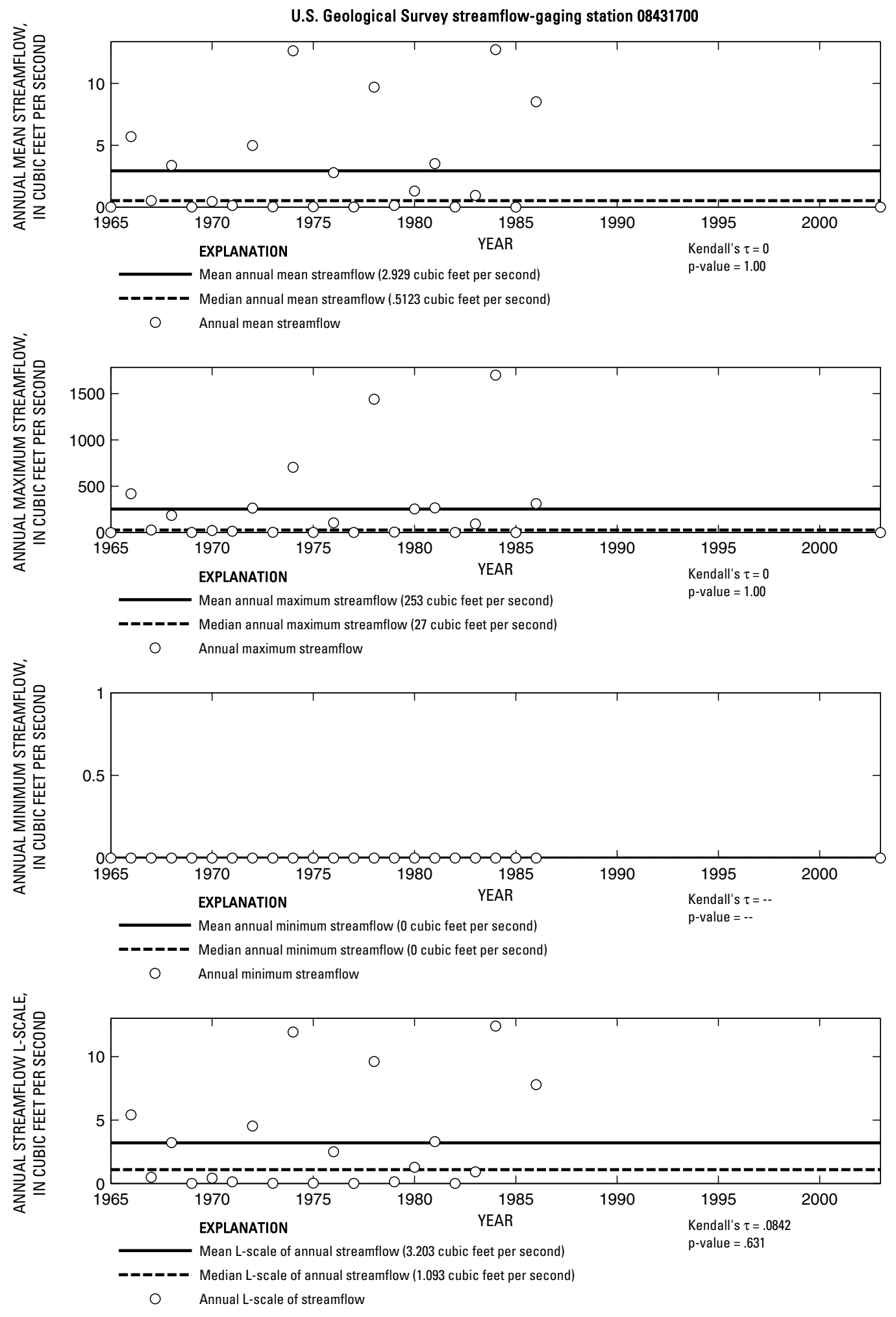

Figure 696. Analysis of annual mean, maximum, minimum, and L-scale statistics of daily mean streamflow for U.S. Geological Survey streamflow-gaging station 08431700 Limpia Creek above Fort Davis, Texas.

Index of Station Numbers 719 


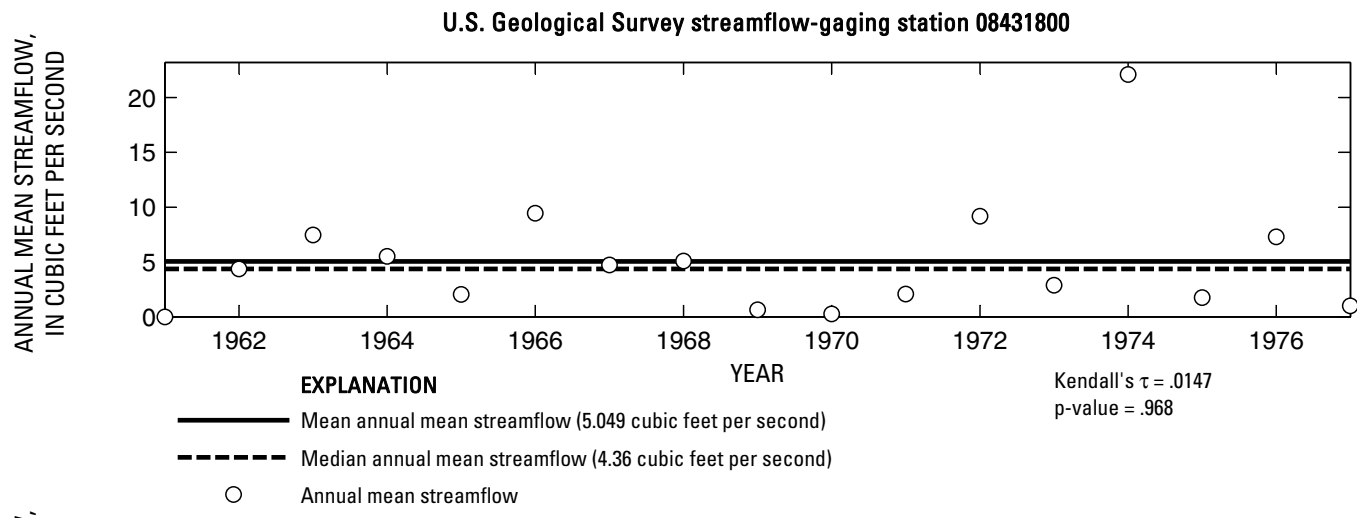

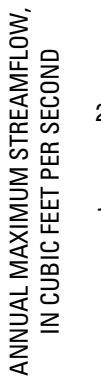

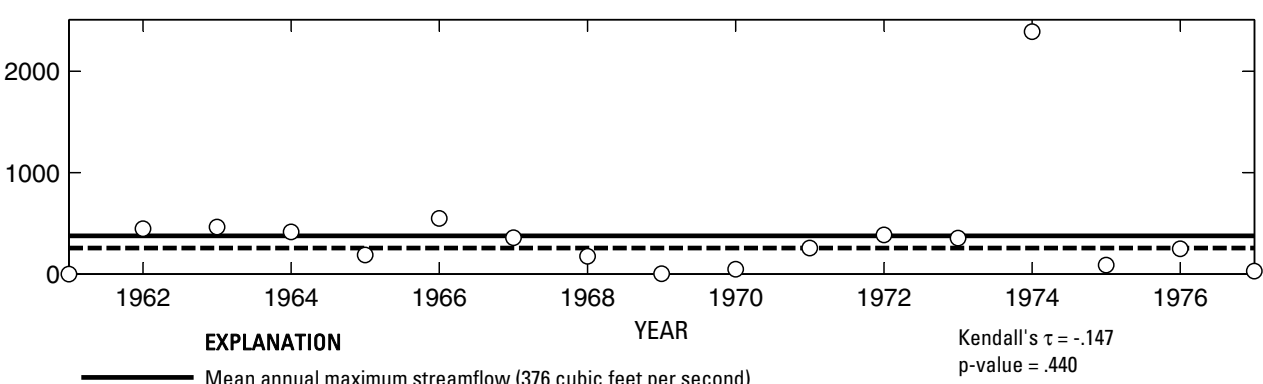

- - _- Median annual maximum streamflow (256 cubic feet per second)

- Annual maximum streamflow
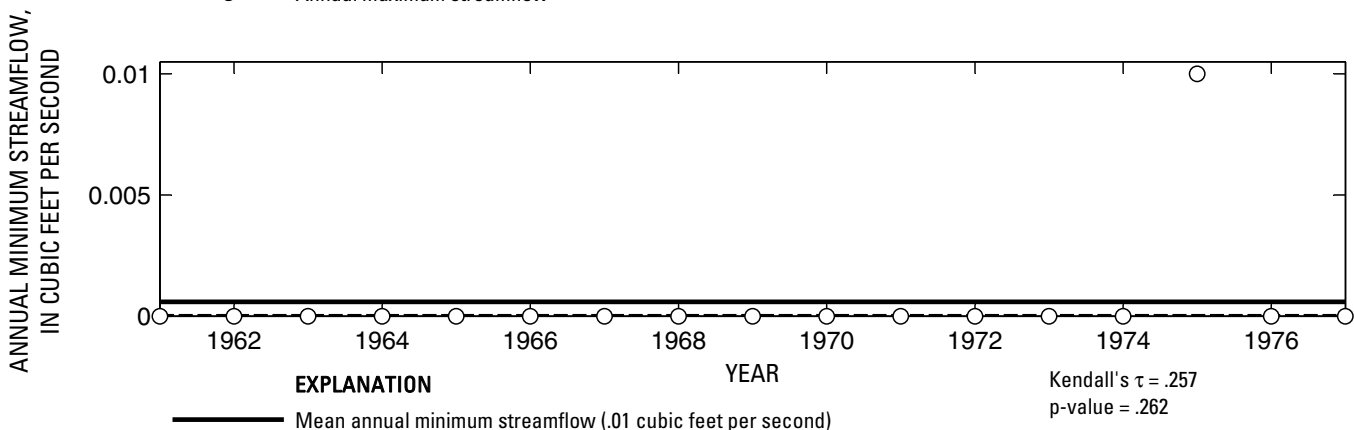

-_-_- Median annual minimum streamflow (0 cubic feet per second)

O Annual minimum streamflow

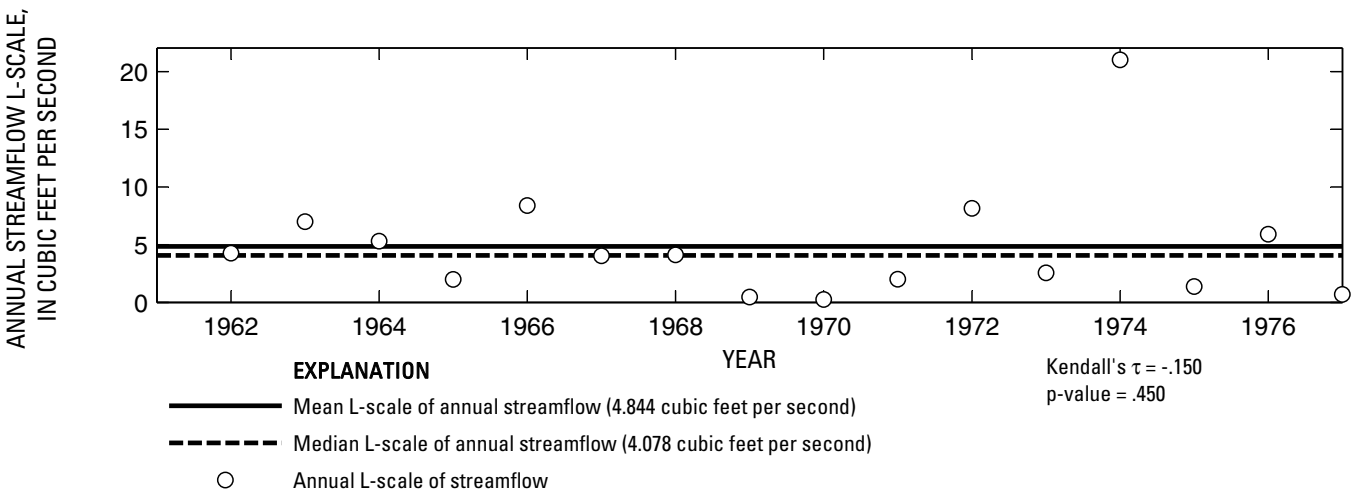

Figure 697. Analysis of annual mean, maximum, minimum, and L-scale statistics of daily mean streamflow for U.S. Geological Survey streamflow-gaging station 08431800 Limpia Creek below Fort Davis, Texas. 

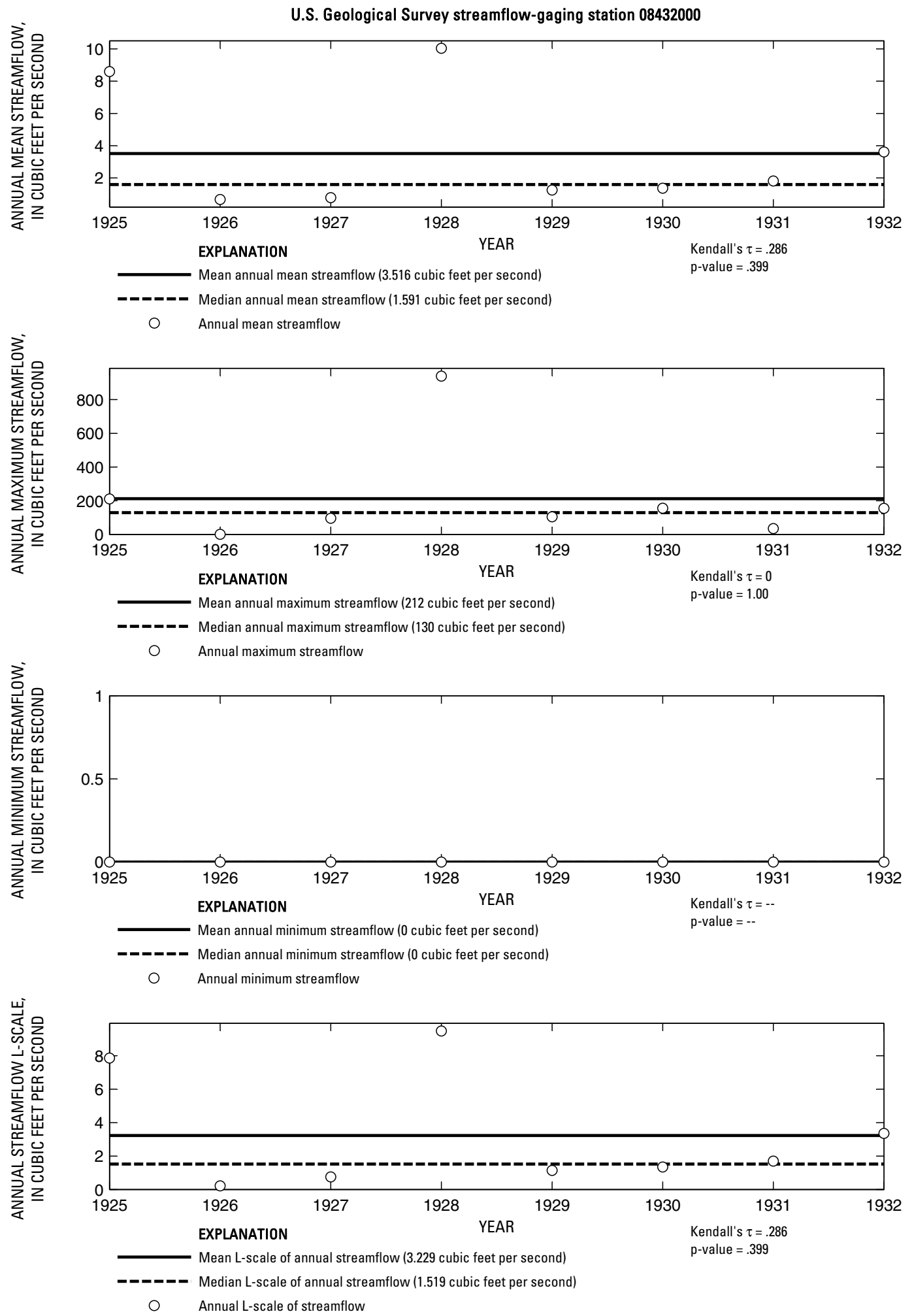

Figure 698. Analysis of annual mean, maximum, minimum, and L-scale statistics of daily mean streamflow for U.S. Geological Survey streamflow-gaging station 08432000 Limpia Creek near Fort Davis, Texas.

|ndex of Station Numbers 719 


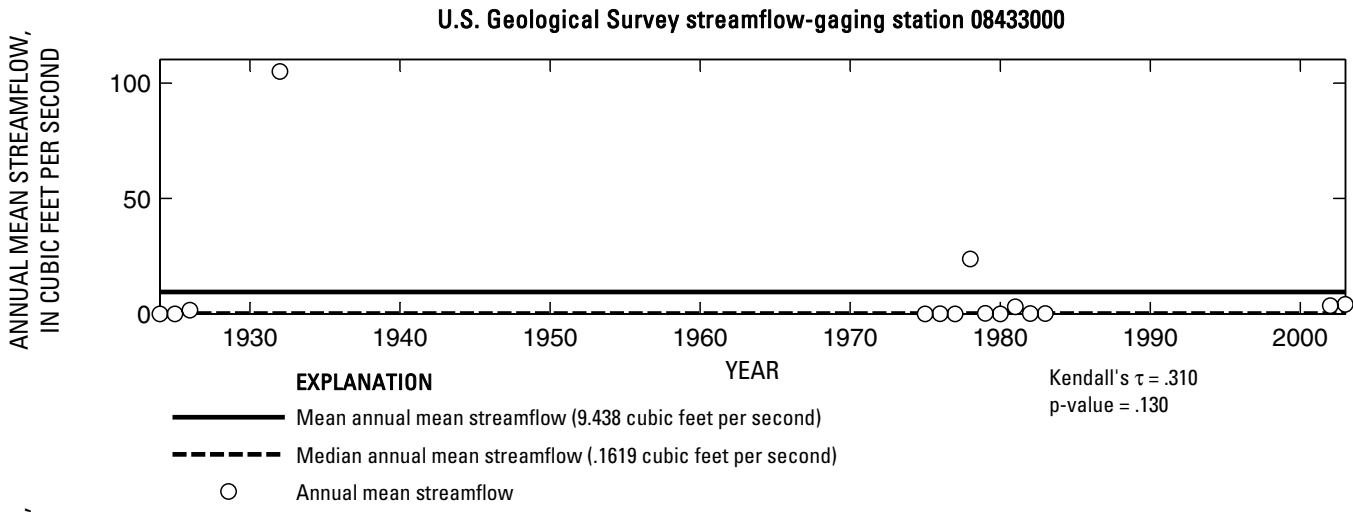

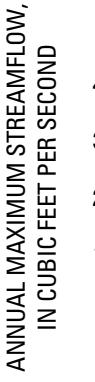

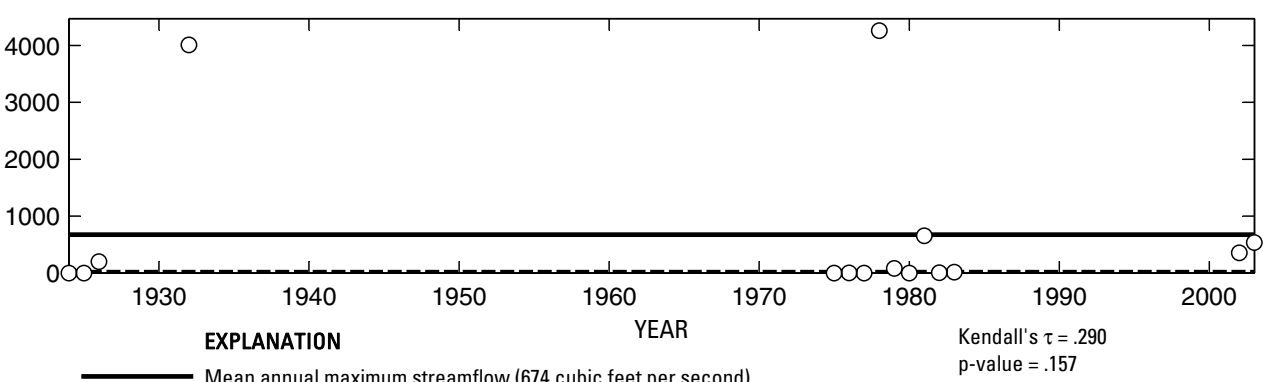

- - - Median annual maximum streamflow (14 cubic feet per second)

- Annual maximum streamflow

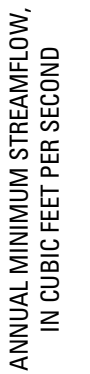

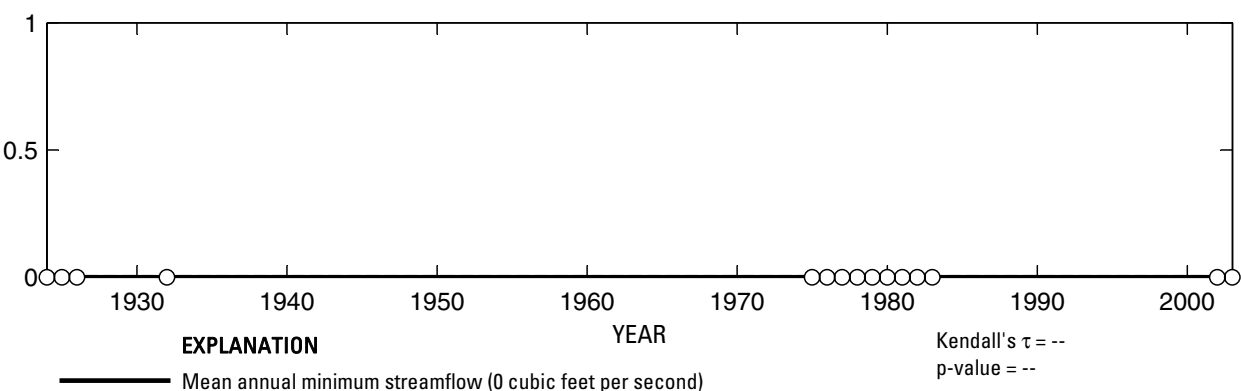

- Median annual minimum streamflow (0 cubic feet per second)

○ Annual minimum streamflow

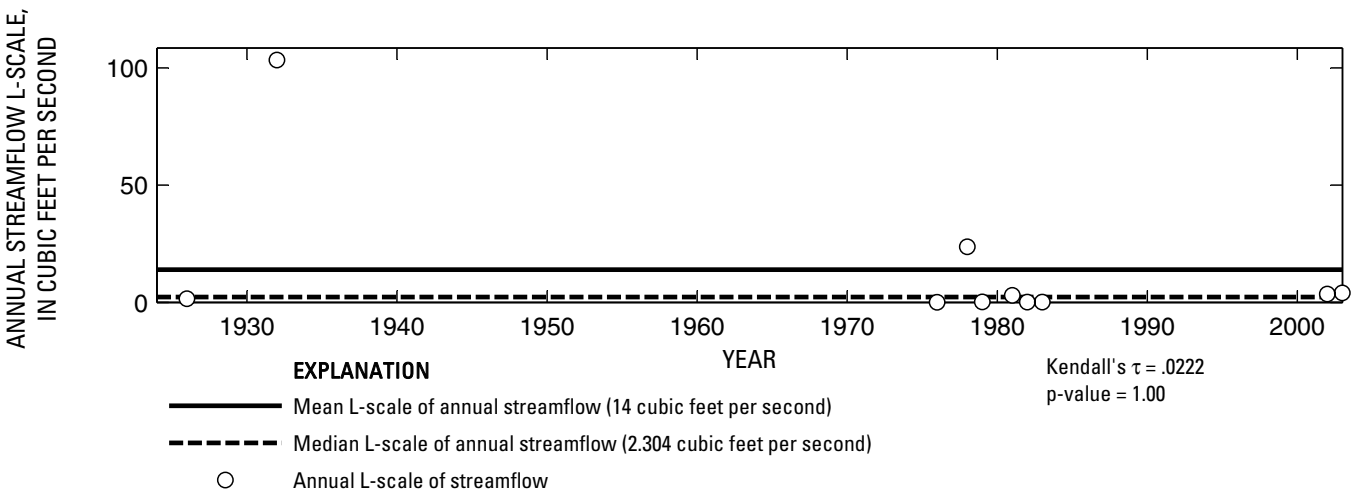

Figure 699. Analysis of annual mean, maximum, minimum, and L-scale statistics of daily mean streamflow for U.S. Geological Survey streamflow-gaging station 08433000 Barrilla Draw near Saragosa, Texas. 

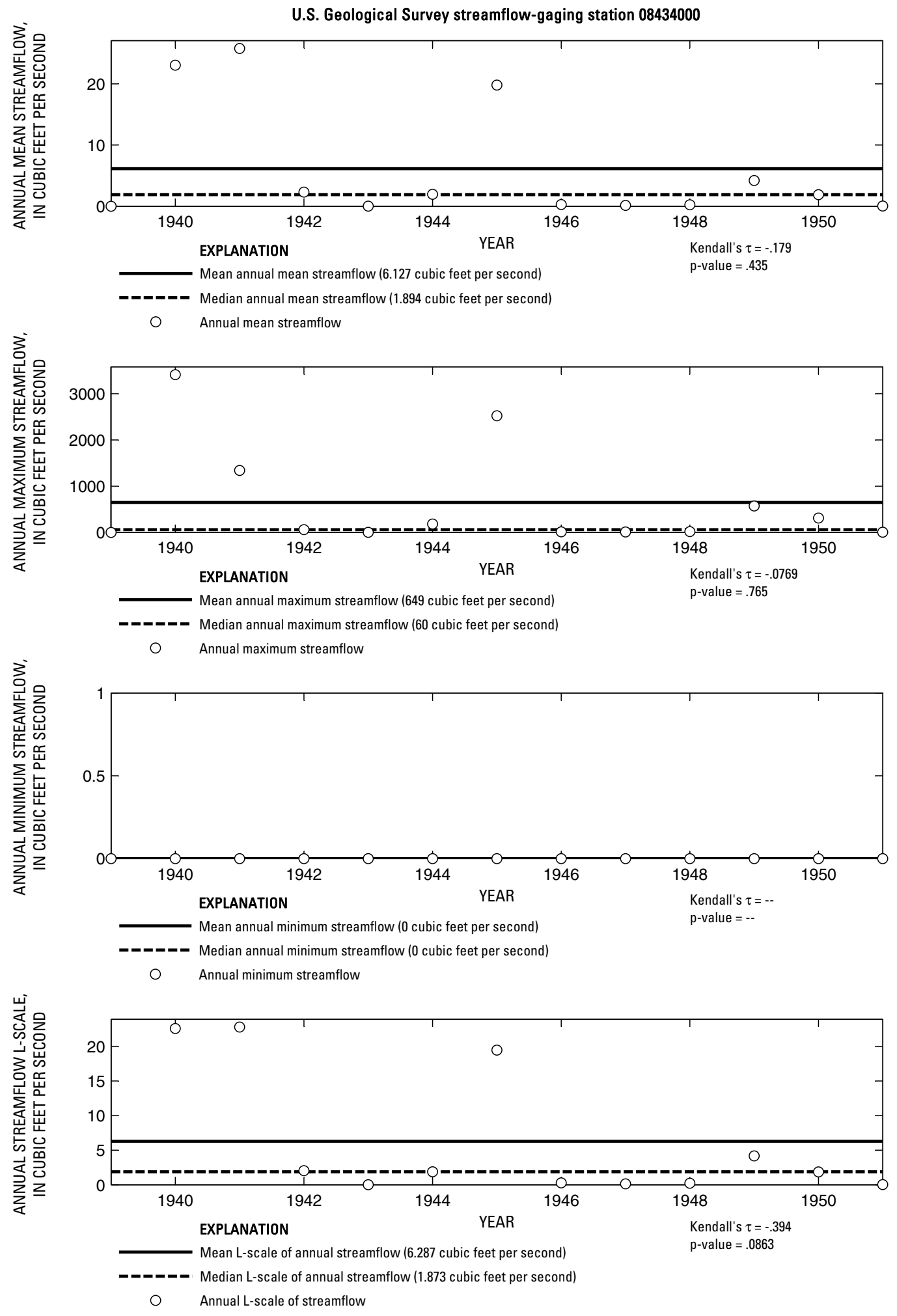

Figure 700. Analysis of annual mean, maximum, minimum, and L-scale statistics of daily mean streamflow for U.S. Geological Survey streamflow-gaging station 08434000 Toyah Creek below Toyah Lake near Pecos, Texas.

Index of Station Numbers 719 


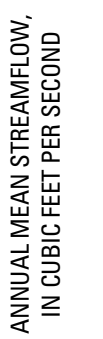

U.S. Geological Survey streamflow-gaging station 08435500

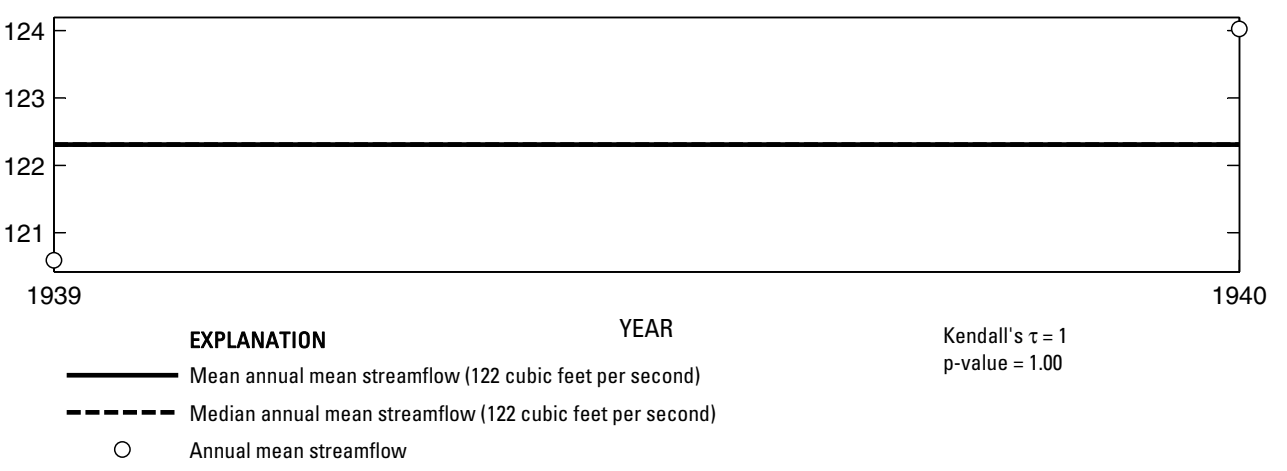

方

$$
1000
$$

1939

EXPLANATION

YEAR

940

Mean annual maximum streamflow (689 cubic feet per second)

-ーーー- Median annual maximum streamflow (689 cubic feet per second)

O Annual maximum streamflow

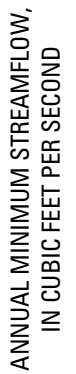

50
40
30
20
1939

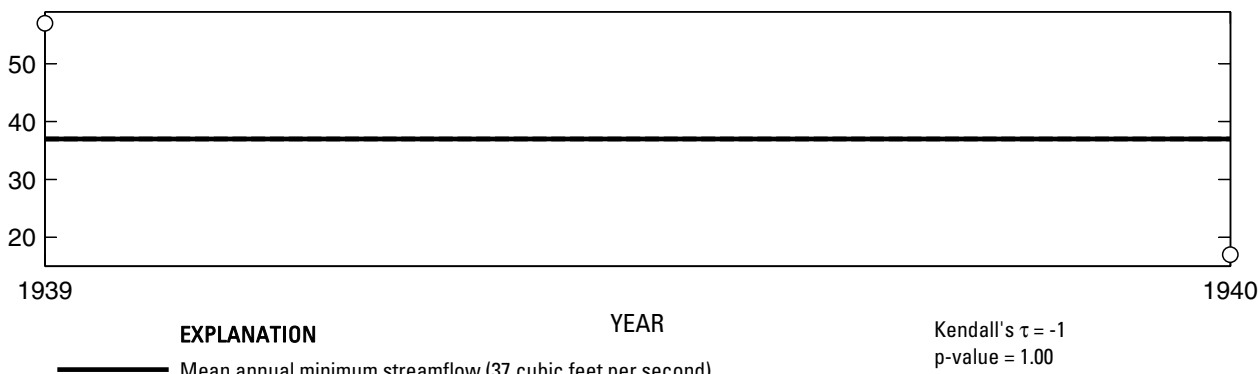

- - - ב Median annual minimum streamflow (37 cubic feet per second)

O Annual minimum streamflow
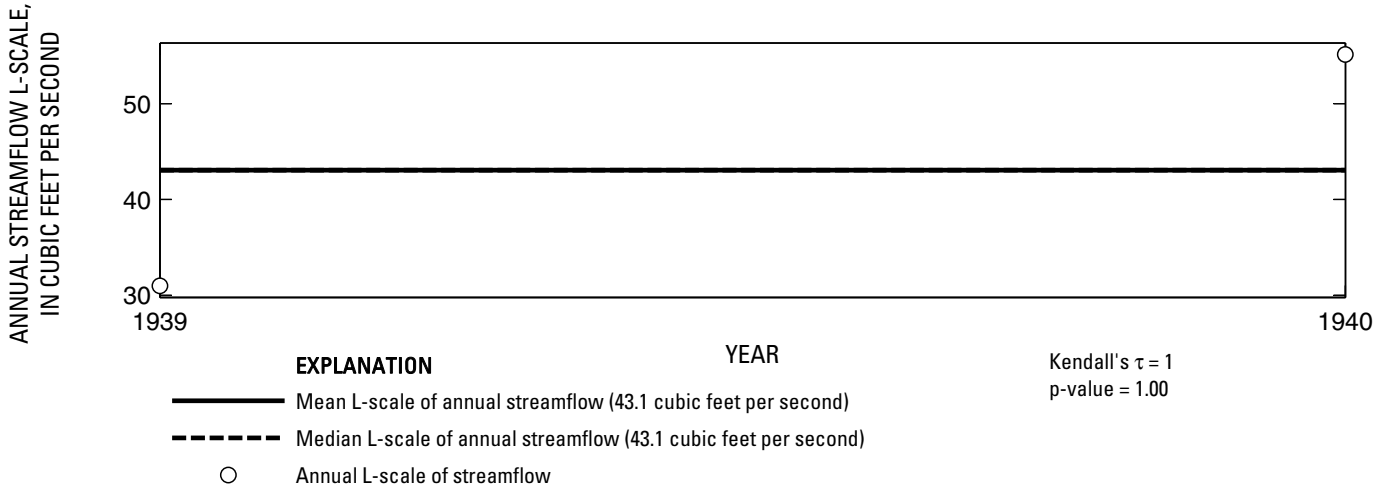

Figure 701. Analysis of annual mean, maximum, minimum, and L-scale statistics of daily mean streamflow for U.S. Geological Survey streamflow-gaging station 08435500 Pecos River below Barstow, Texas. 

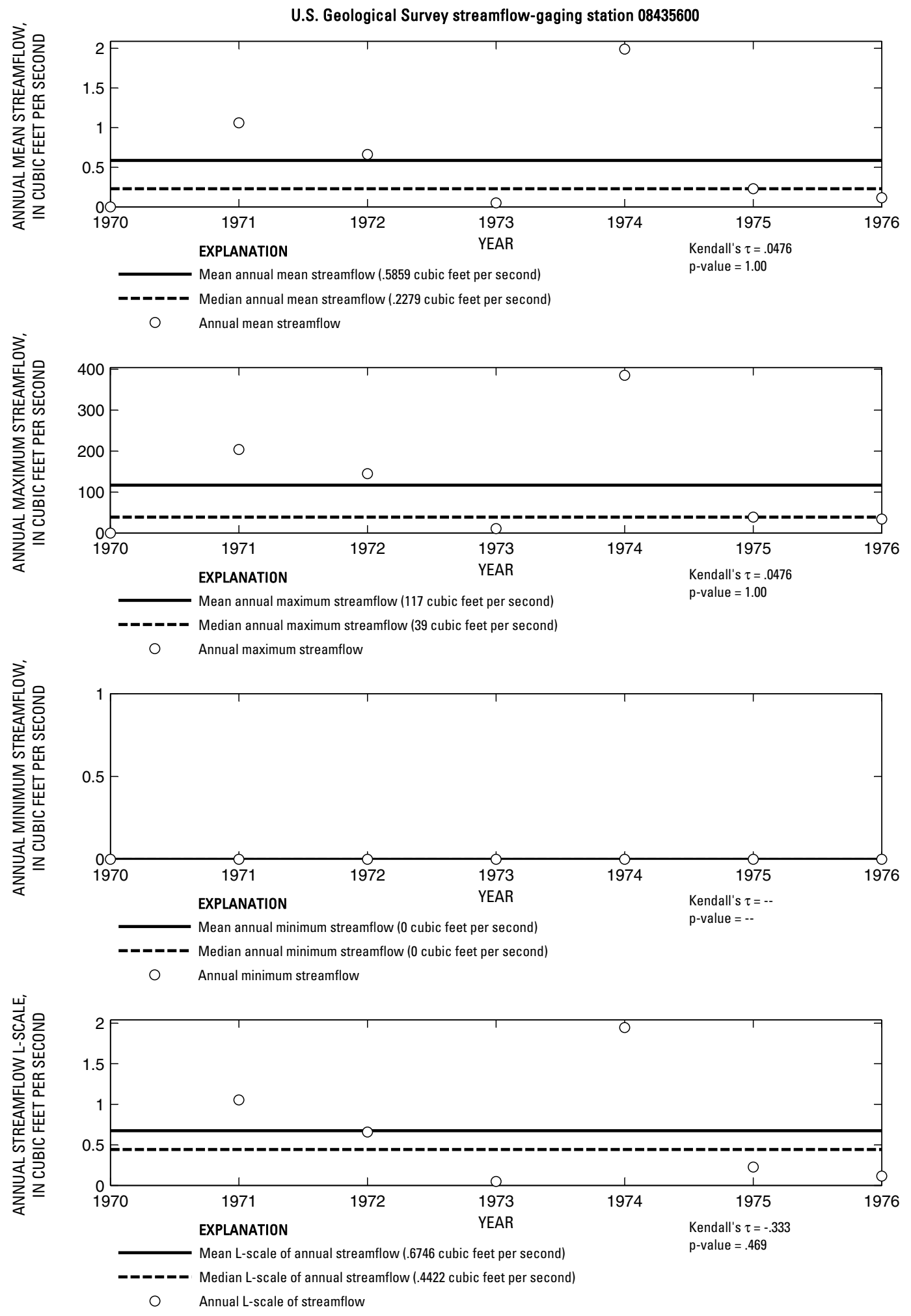

Figure 702. Analysis of annual mean, maximum, minimum, and L-scale statistics of daily mean streamflow for U.S. Geological Survey streamflow-gaging station 08435600 Toronto Creek near Alpine, Texas.

Index of Station Numbers 719 


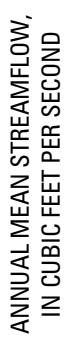

U.S. Geological Survey streamflow-gaging station 08435620

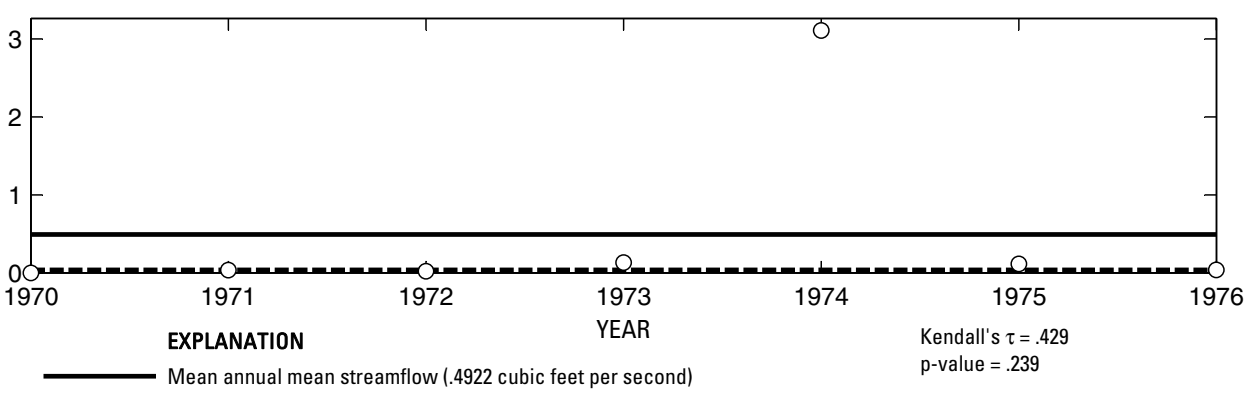

-_-_-_ Median annual mean streamflow (.03653 cubic feet per second)

O Annual mean streamflow

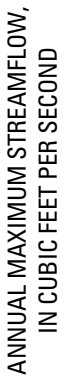

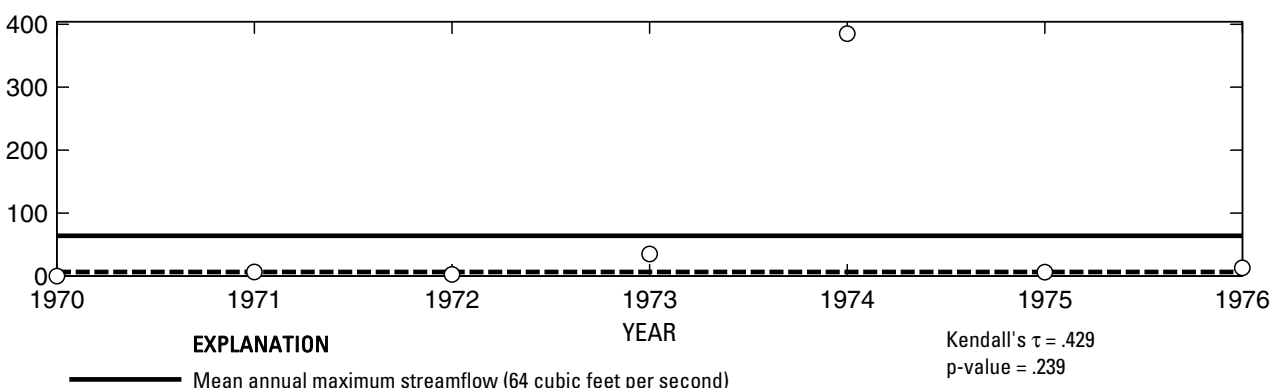

- - ב-_ Median annual maximum streamflow (6.5 cubic feet per second)

Annual maximum streamflow

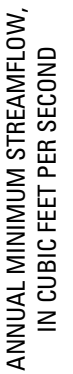

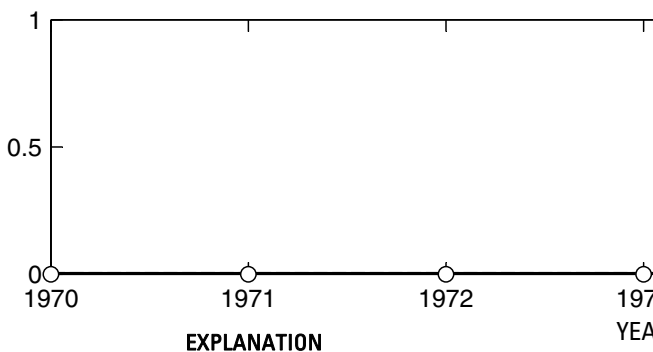

EXPLANATION

1973
YEAR
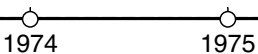

Kendall's $\tau=-$

Mean annual minimum streamflow (0 cubic feet per second)

$\mathrm{p}$-value $=--$

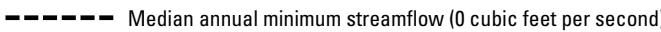

O Annual minimum streamflow

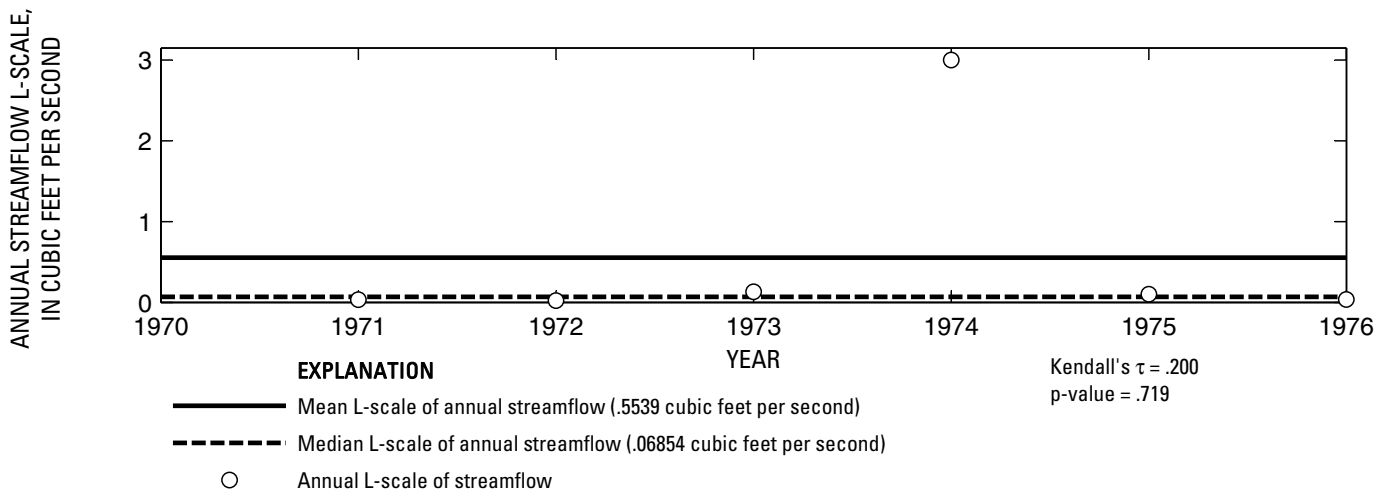

Figure 703. Analysis of annual mean, maximum, minimum, and L-scale statistics of daily mean streamflow for U.S. Geological Survey streamflow-gaging station 08435620 Alpine Creek at Alpine, Texas. 

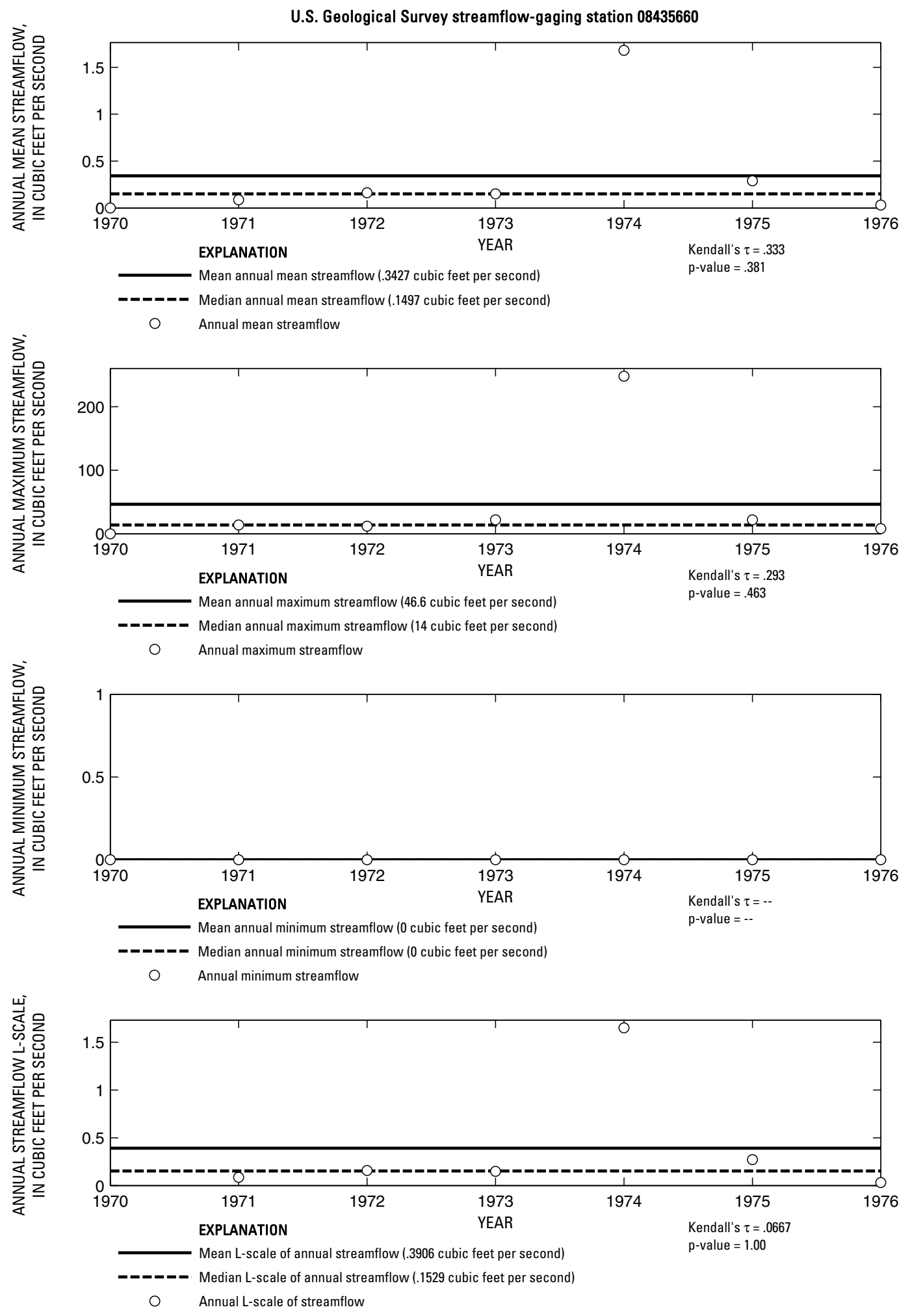

Figure 704. Analysis of annual mean, maximum, minimum, and L-scale statistics of daily mean streamflow for U.S. Geological Survey streamflow-gaging station 08435660 Moss Creek near Alpine, Texas.

Index of Station Numbers 719 

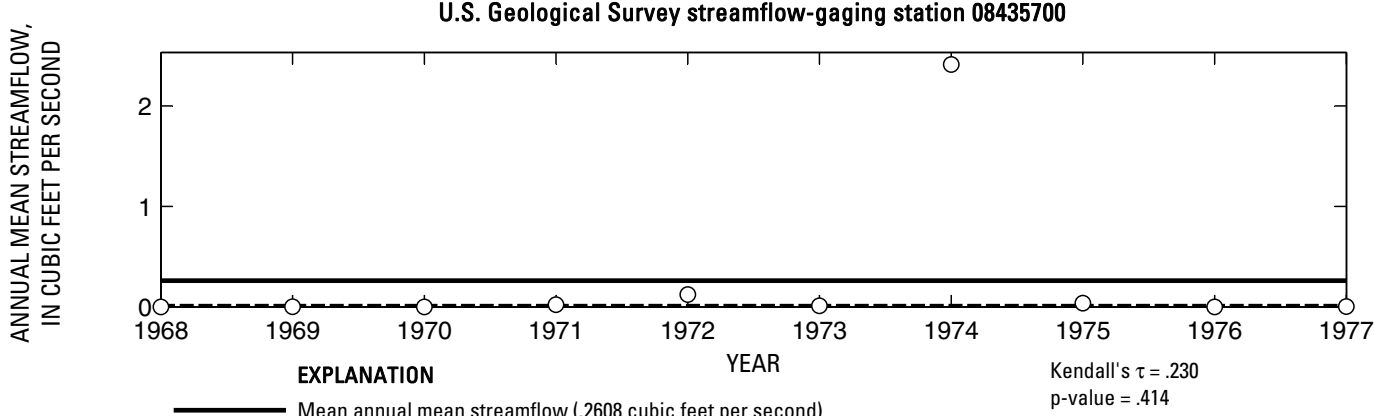

-_o-_- Median annual mean streamflow (.01 cubic feet per second)

O Annual mean streamflow
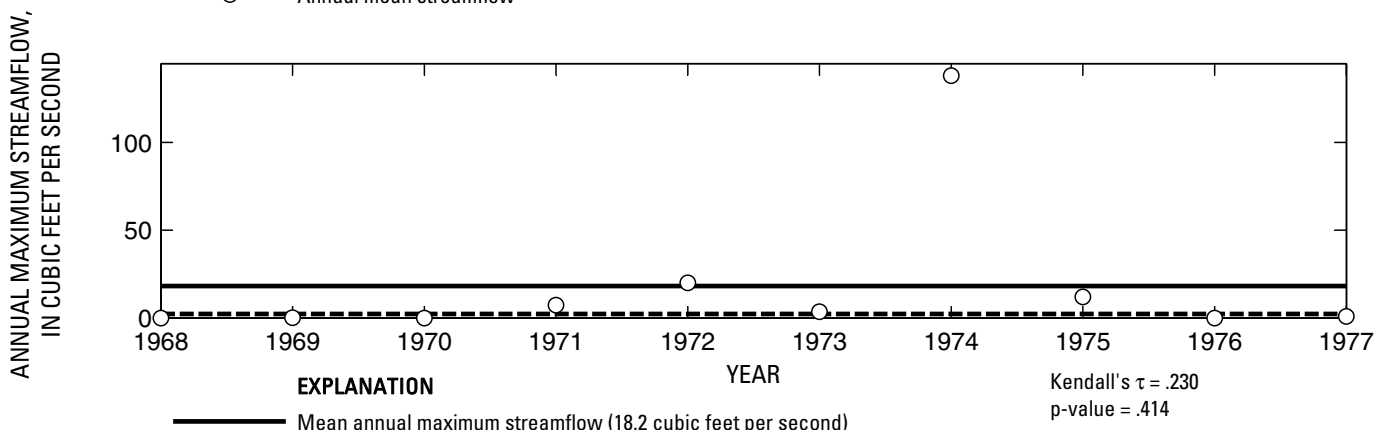

- _ _ - Median annual maximum streamflow (2.275 cubic feet per second)

O Annual maximum streamflow

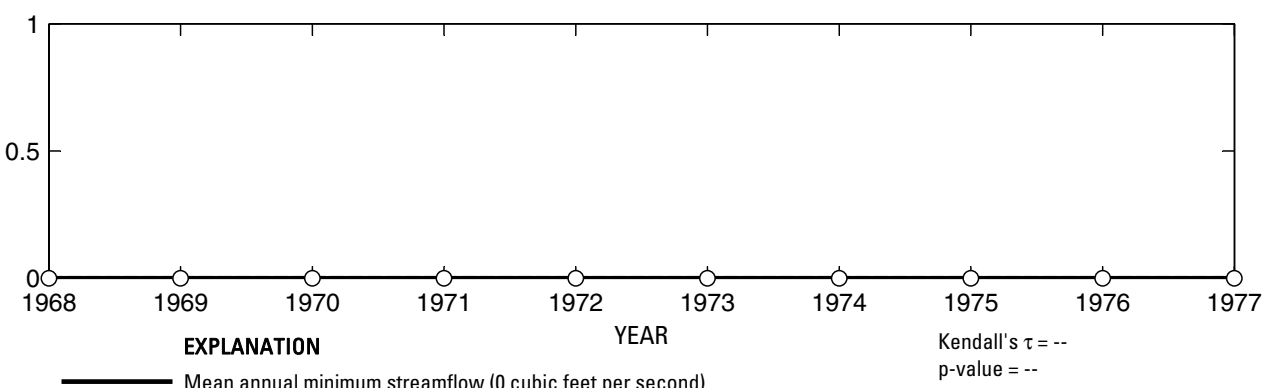

- Median annual minimum streamflow (0 cubic feet per second)

○ Annual minimum streamflow

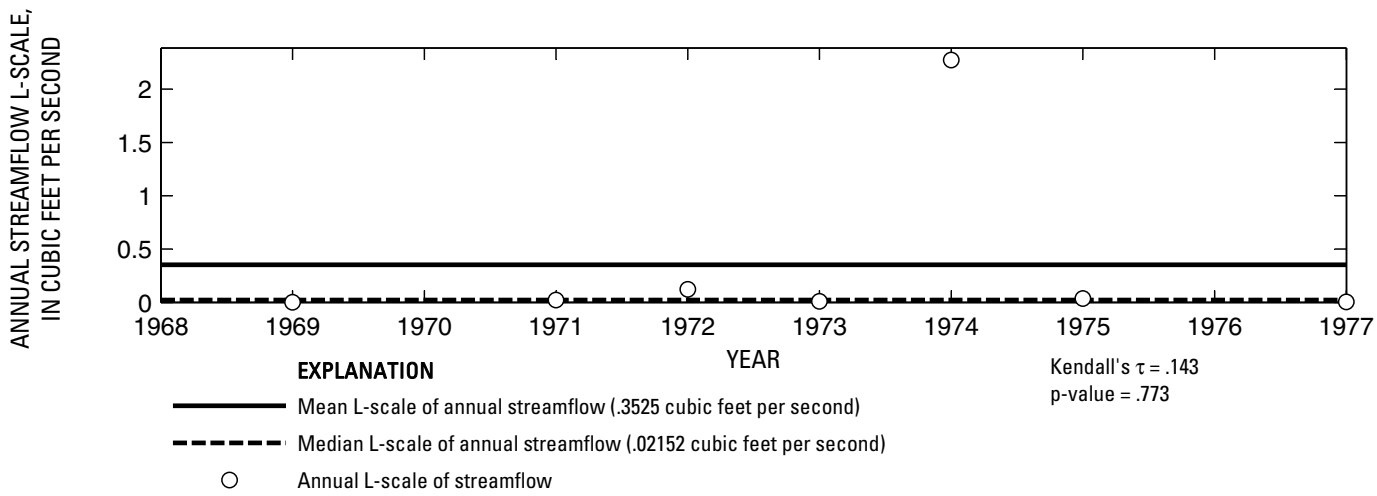

Figure 705. Analysis of annual mean, maximum, minimum, and L-scale statistics of daily mean streamflow for U.S. Geological Survey streamflow-gaging station 08435700 Sunny Glen Canyon near Alpine, Texas. 

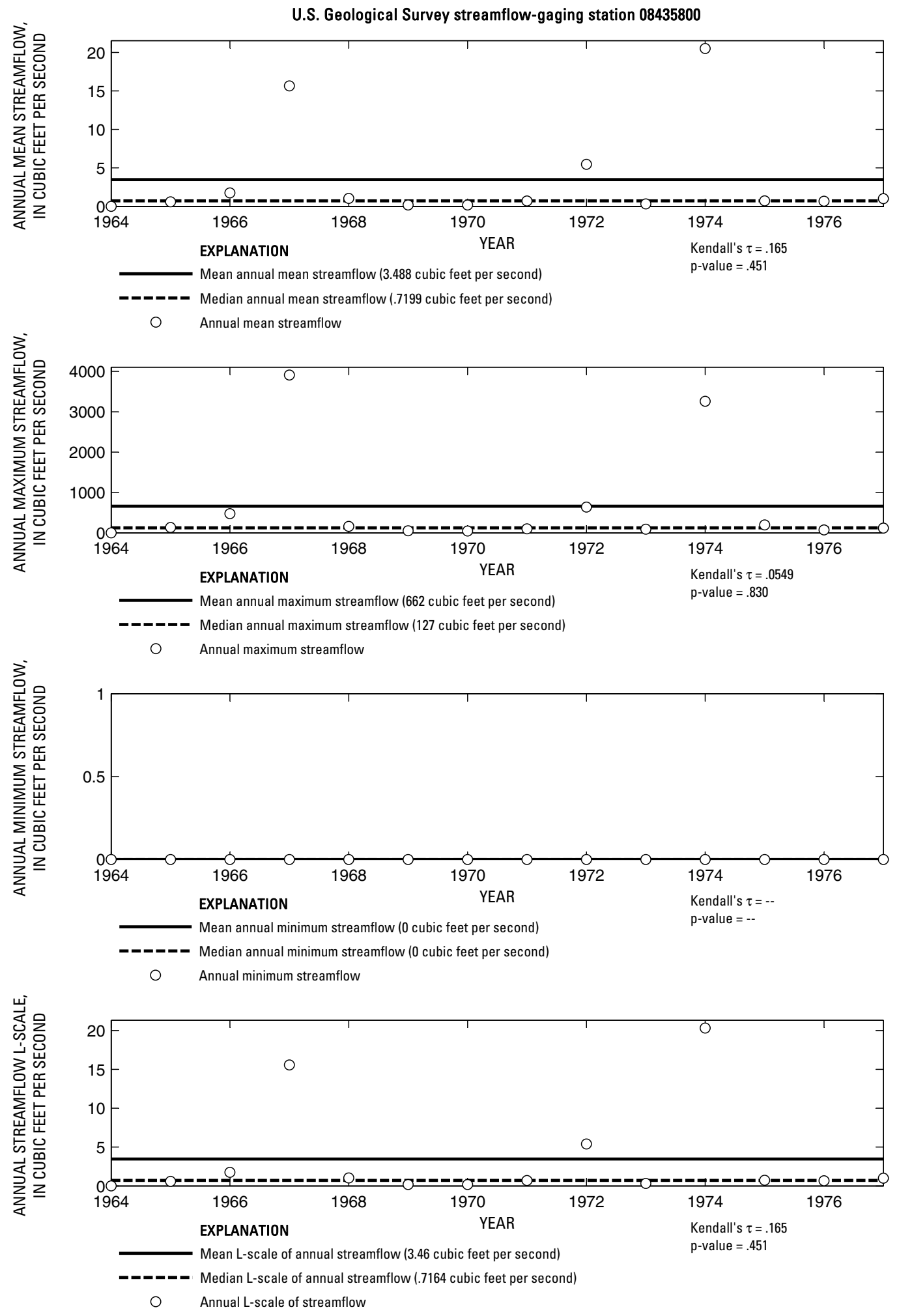

Figure 706. Analysis of annual mean, maximum, minimum, and L-scale statistics of daily mean streamflow for U.S. Geological Survey streamflow-gaging station 08435800 Coyanosa Draw near Fort Stockton, Texas.

Index of Station Numbers 719 


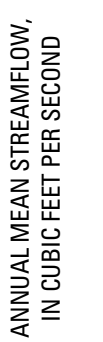

U.S. Geological Survey streamflow-gaging station 08438100

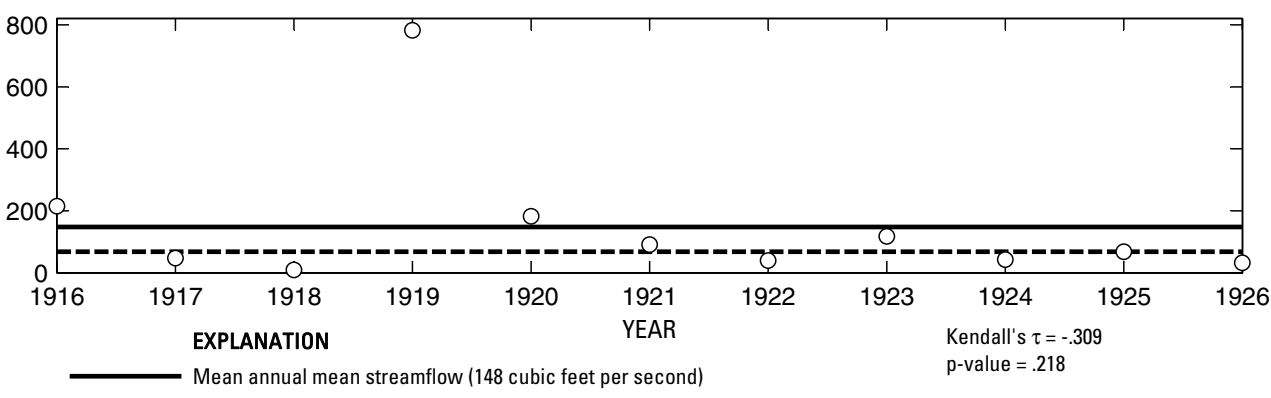

-_-_- Median annual mean streamflow (67.8 cubic feet per second)

O Annual mean streamflow
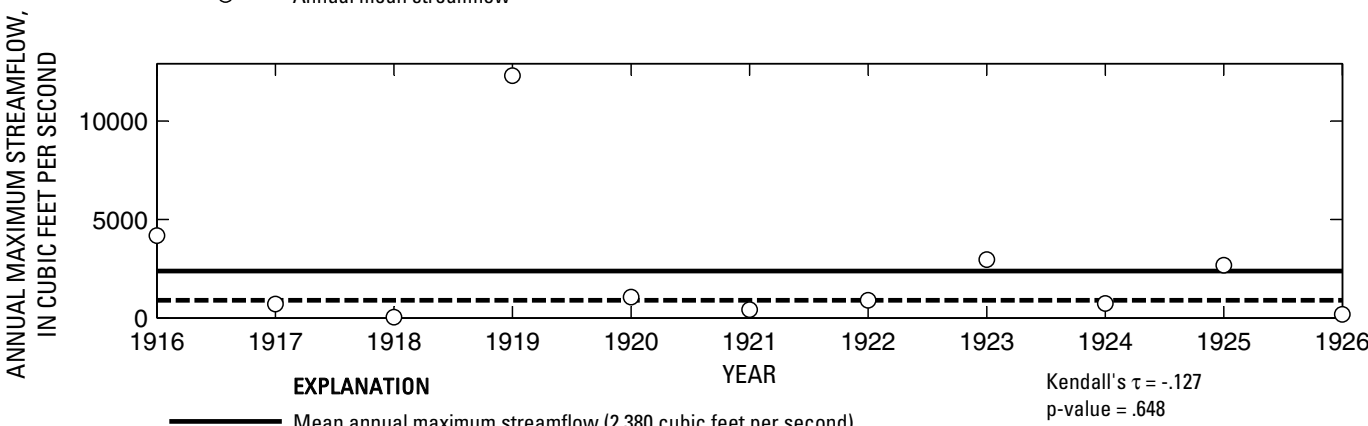

O Annual maximum streamflow

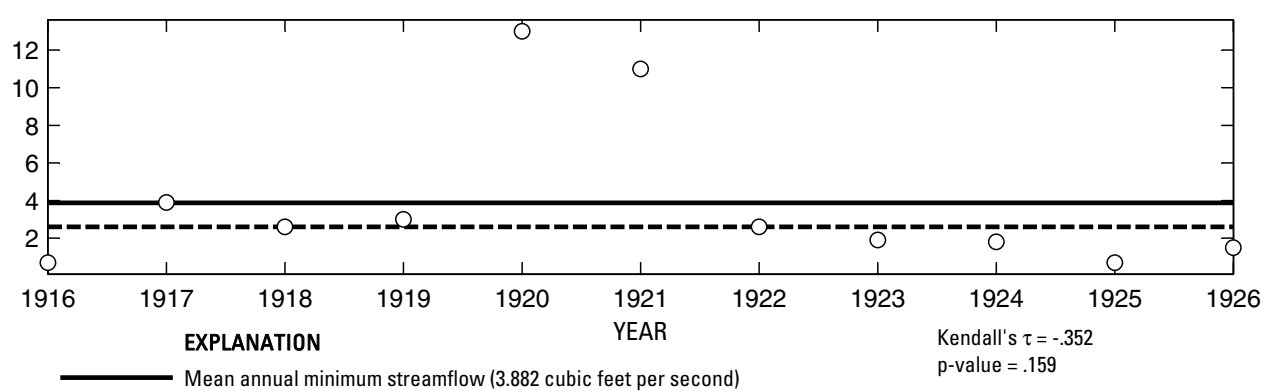

- - ב Median annual minimum streamflow (2.6 cubic feet per second)

O Annual minimum streamflow

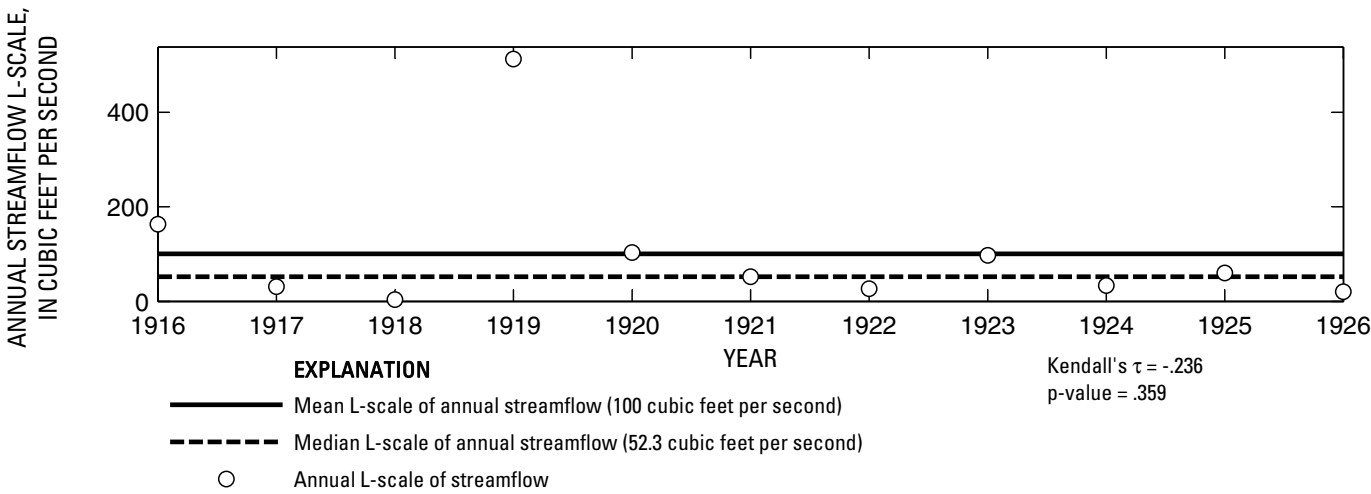

Figure 707. Analysis of annual mean, maximum, minimum, and L-scale statistics of daily mean streamflow for U.S. Geological Survey streamflow-gaging station 08438100 Pecos River near Grandfalls, Texas. 


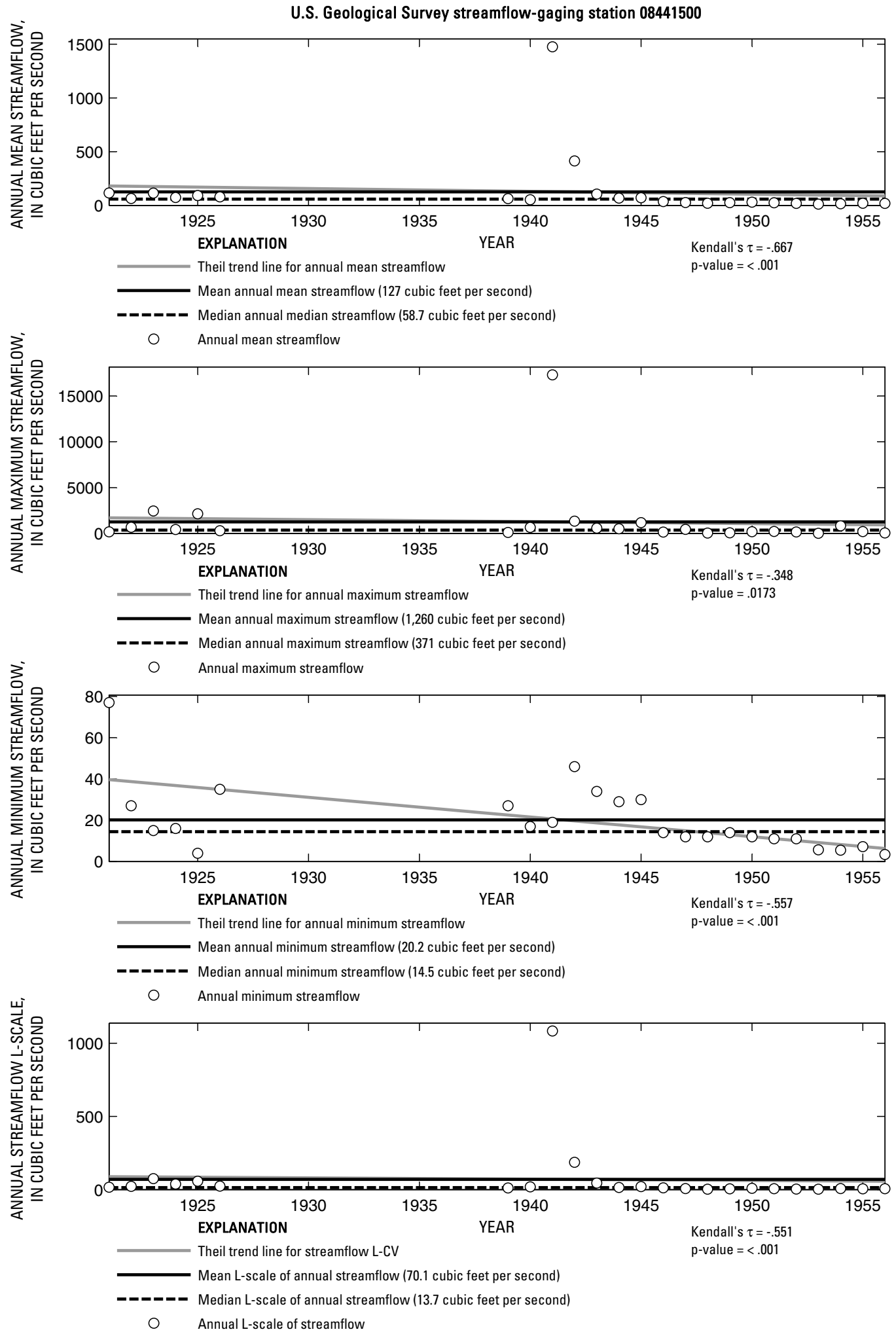

Figure 708. Analysis of annual mean, maximum, minimum, and L-scale statistics of daily mean streamflow for U.S. Geological Survey streamflow-gaging station 08441500 Pecos River below Grandfalls, Texas.

Index of Station Numbers 719 


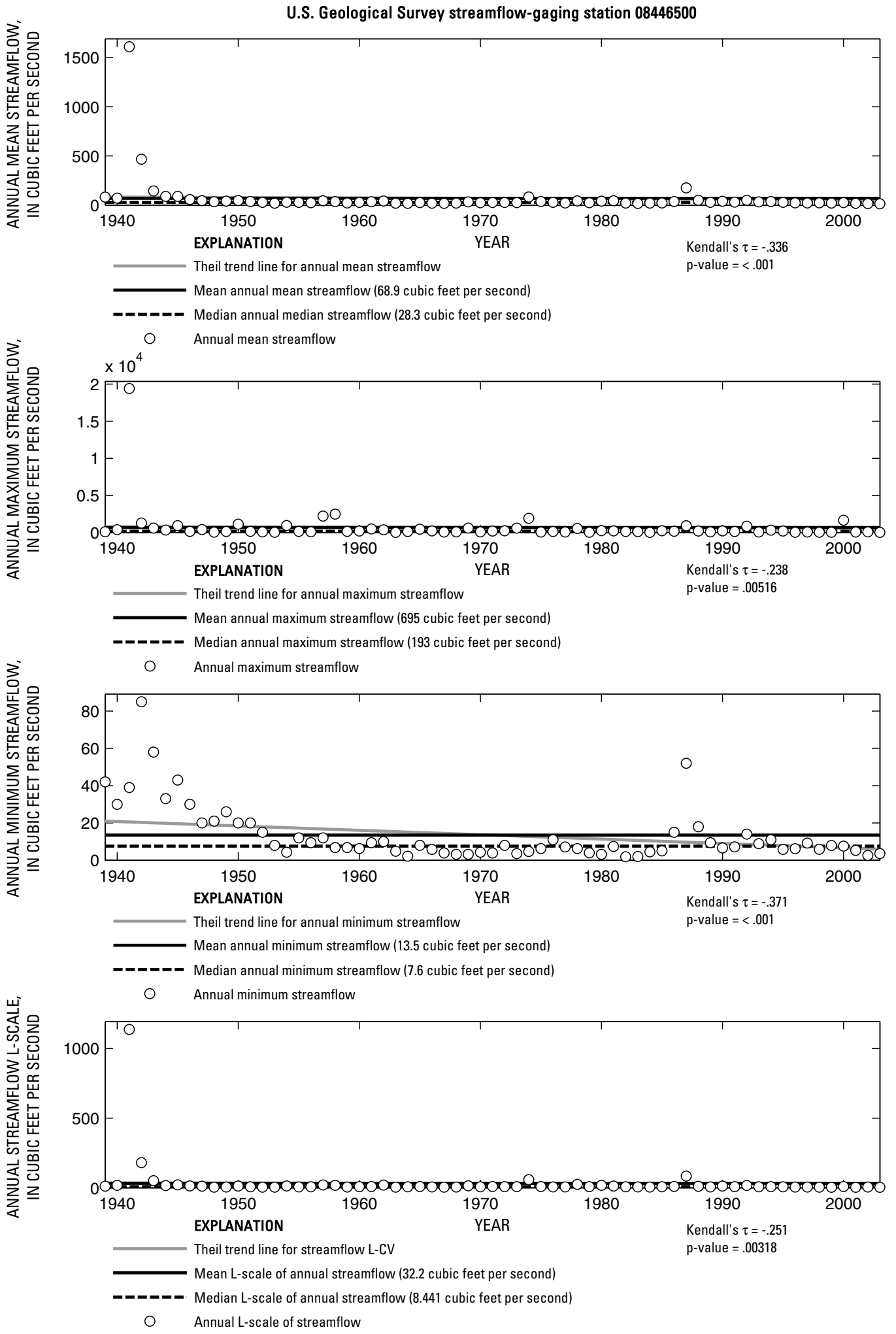

Figure 709. Analysis of annual mean, maximum, minimum, and L-scale statistics of daily mean streamflow for U.S. Geological Survey streamflow-gaging station 08446500 Pecos River near Girvin, Texas. 

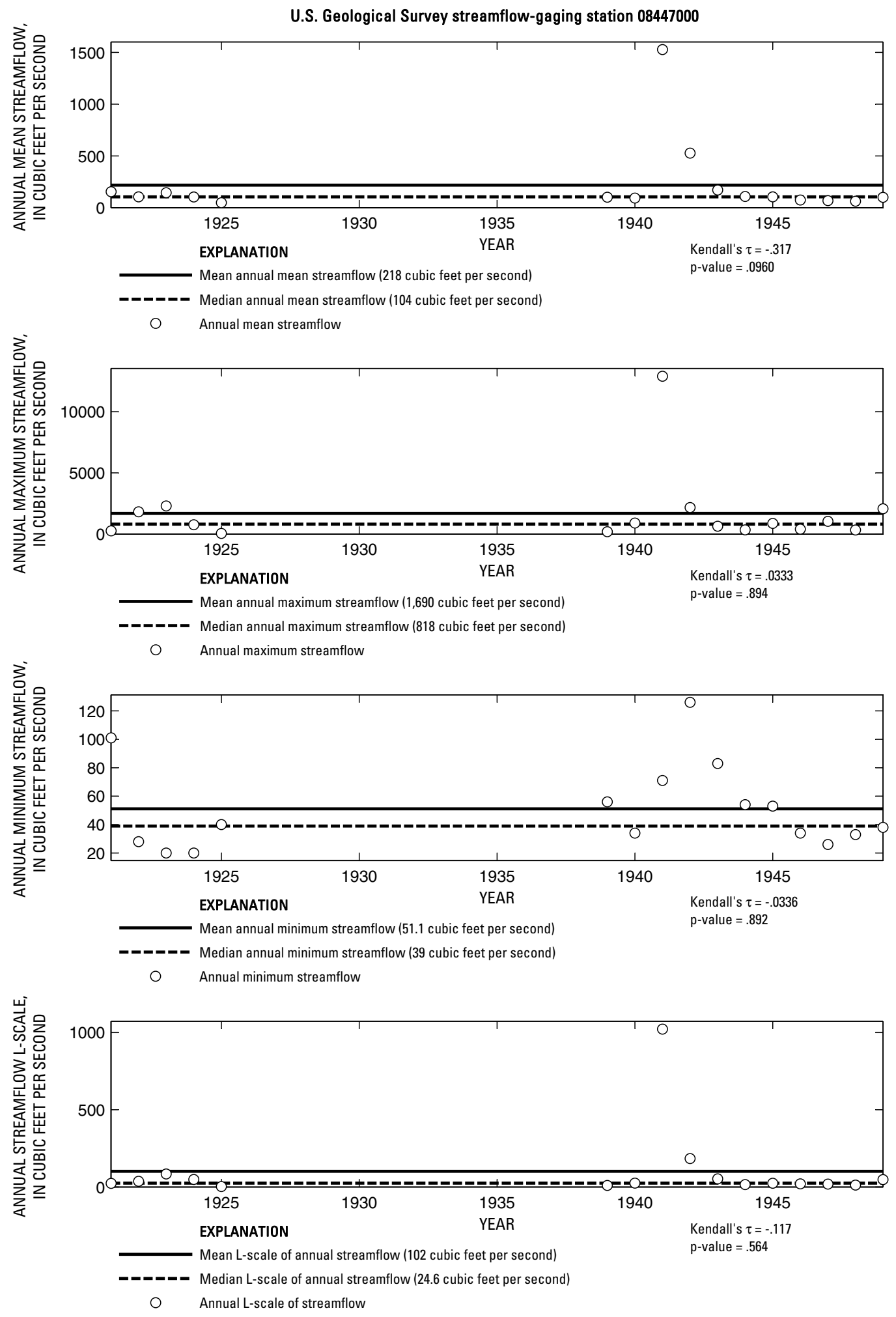

Figure 710. Analysis of annual mean, maximum, minimum, and L-scale statistics of daily mean streamflow for U.S. Geological Survey streamflow-gaging station 08447000 Pecos River near Sheffield, Texas. 


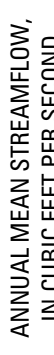

U.S. Geological Survey streamflow-gaging station 08447020

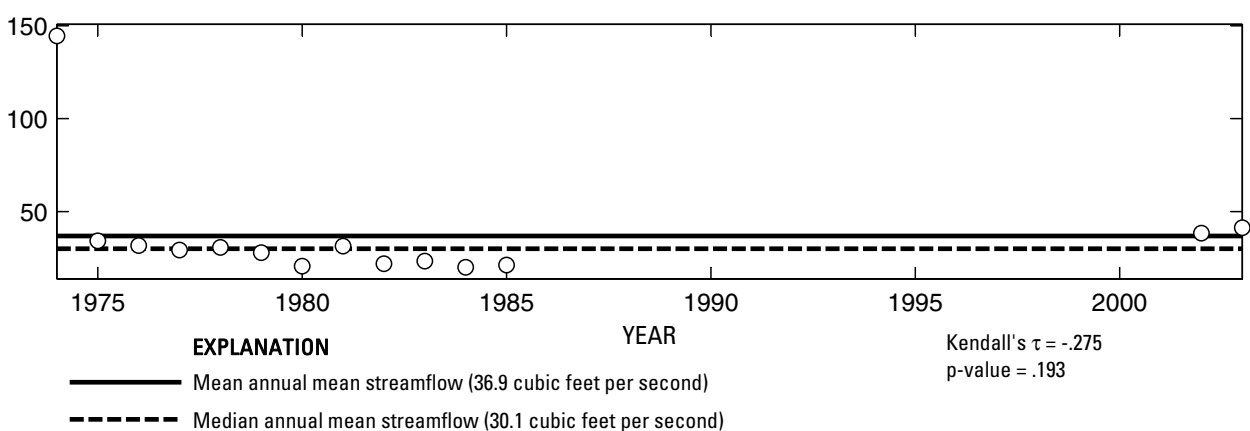

O Annual mean streamflow

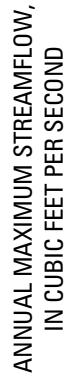

$\times 10^{4}$

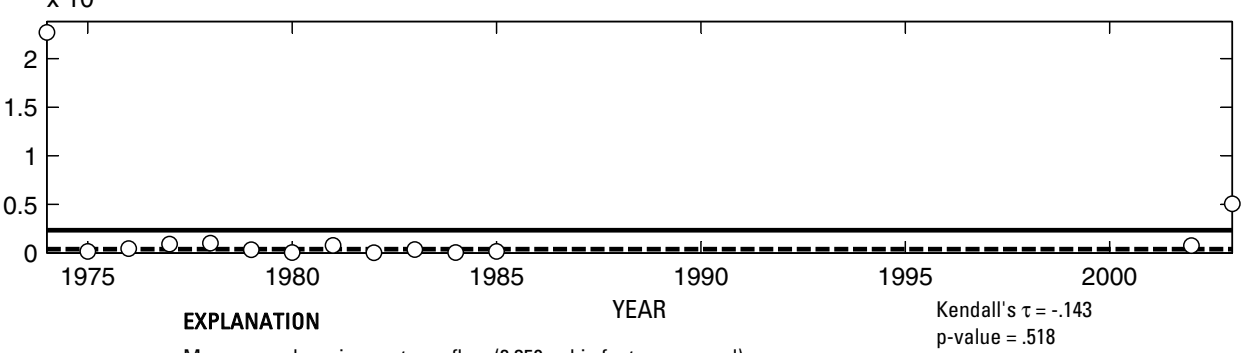

Annual maximum streamflow

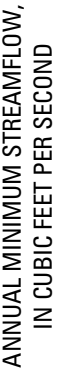

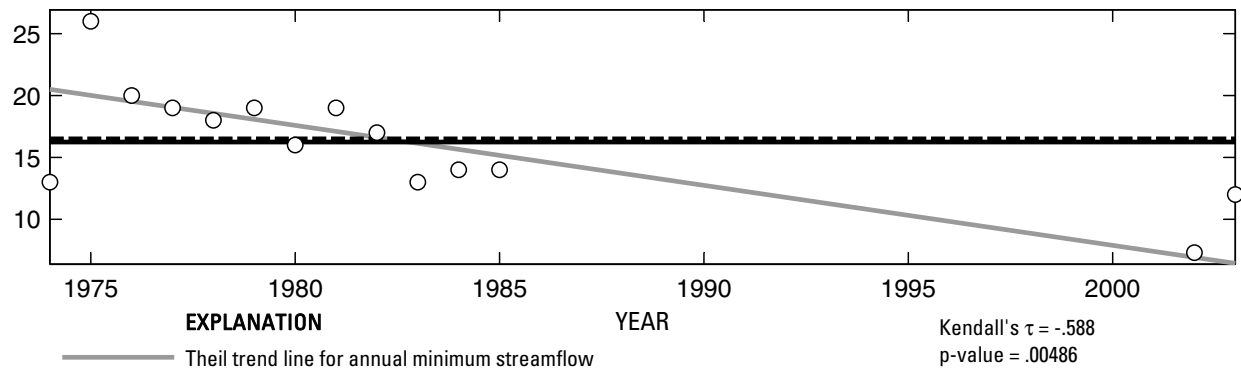

Median annual minimum streamflow (16.5 cubic feet per second)

O Annual minimum streamflow
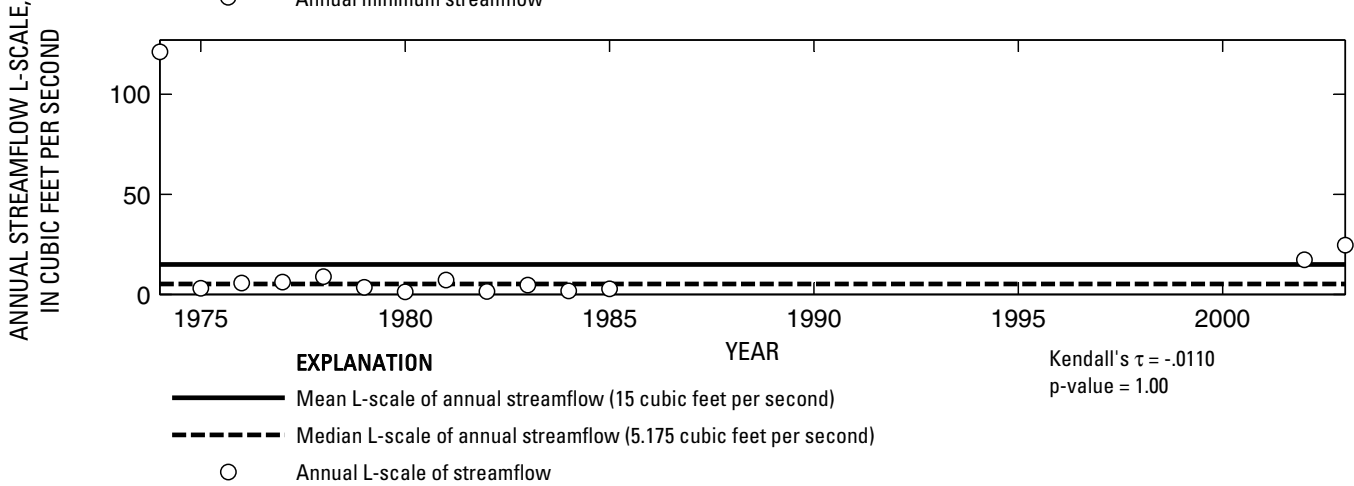

Figure 711. Analysis of annual mean, maximum, minimum, and L-scale statistics of daily mean streamflow for U.S. Geological Survey streamflow-gaging station 08447020 Independence Creek near Sheffield, Texas.

Index of Station Numbers 719 
U.S. Geological Survey streamflow-gaging station 08449000

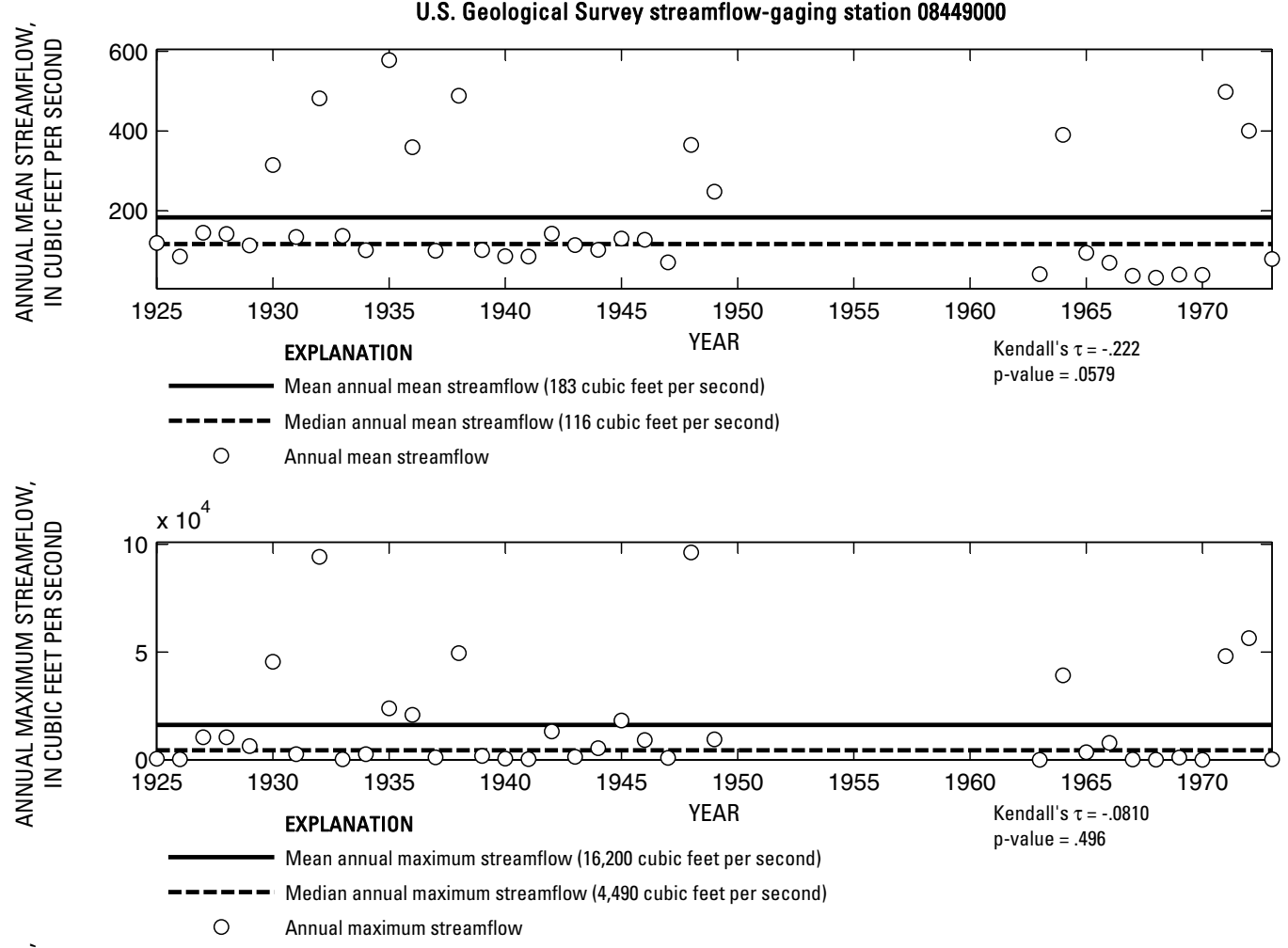

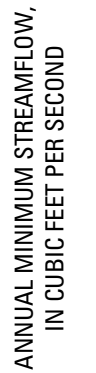

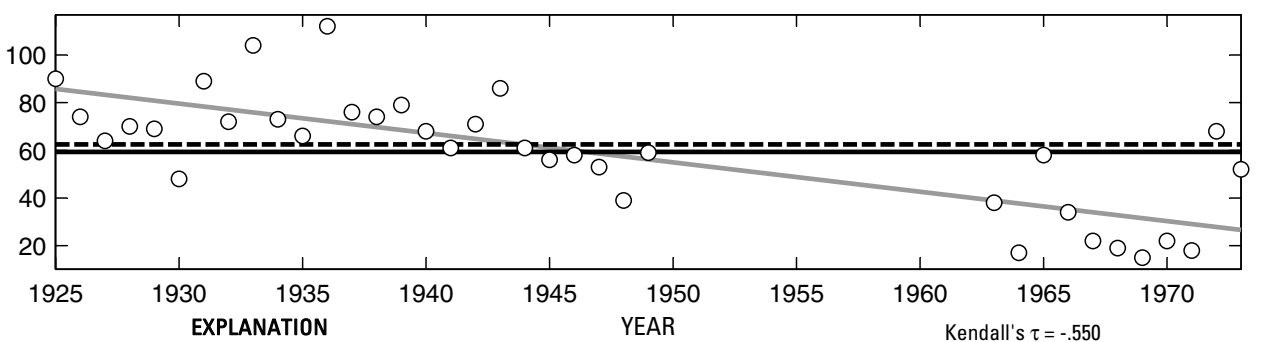

YEAR Kendall's $\tau=-.550$

- Theil trend line for annual minimum streamflow

$\mathrm{p}$-value $=<.001$

- Mean annual minimum streamflow ( 59.3 cubic feet per second)

ーーーー Median annual minimum streamflow (62.5 cubic feet per second)

O Annual minimum streamflow

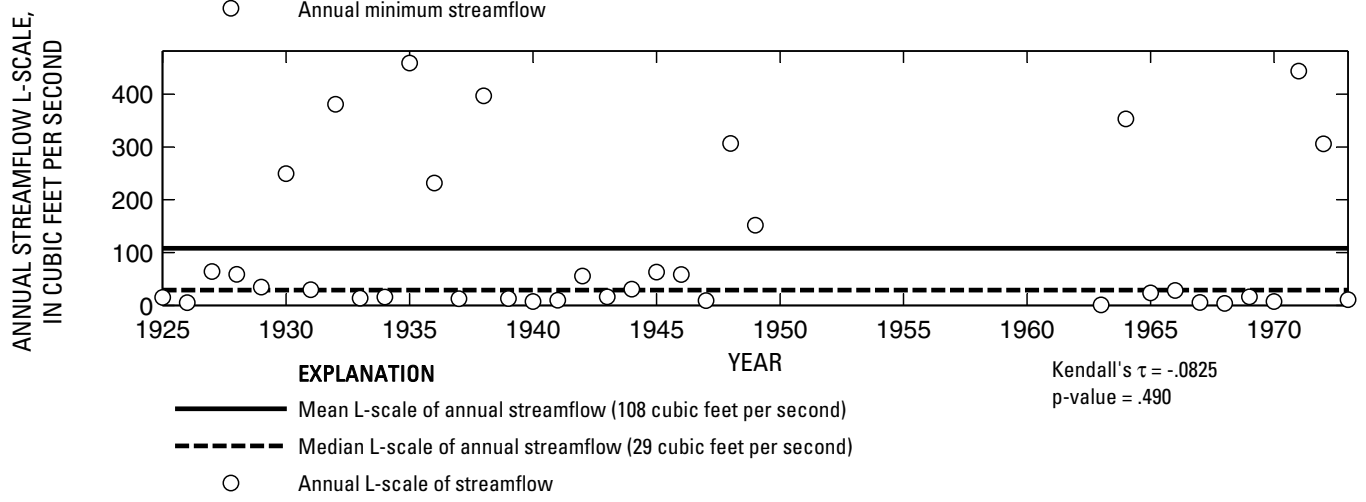

Figure 712. Analysis of annual mean, maximum, minimum, and L-scale statistics of daily mean streamflow for U.S. Geological Survey streamflow-gaging station 08449000 Devils River near Juno, Texas.

Index of Station Numbers 719 
U.S. Geological Survey streamflow-gaging station 08455000
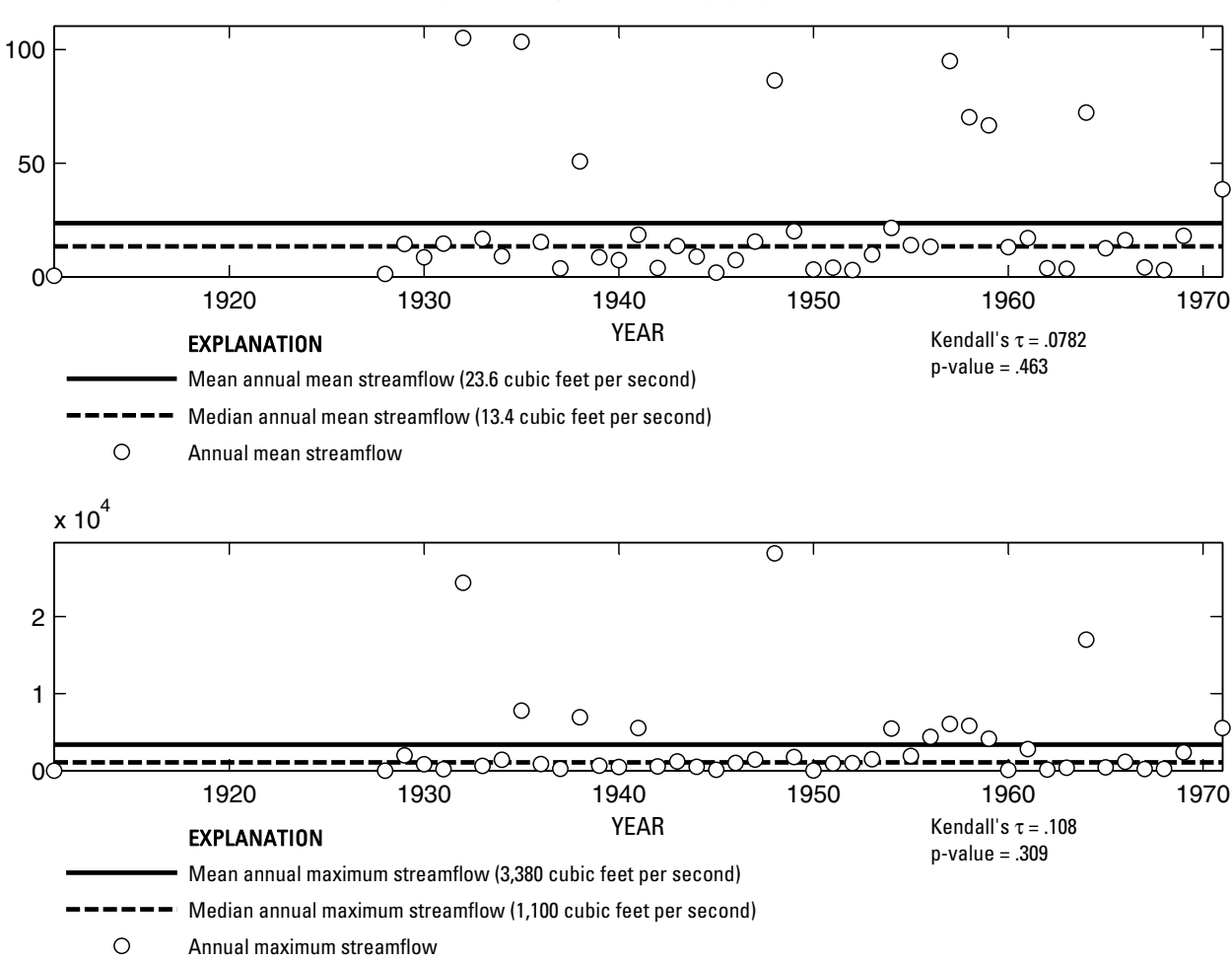

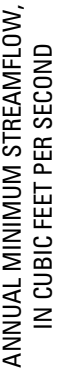

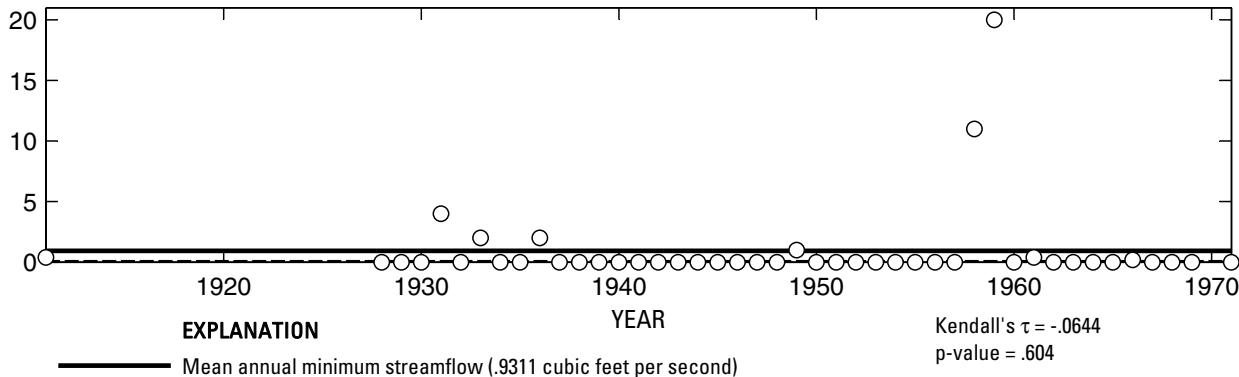

- ב-ב Median annual minimum streamflow (0 cubic feet per second)

O Annual minimum streamflow

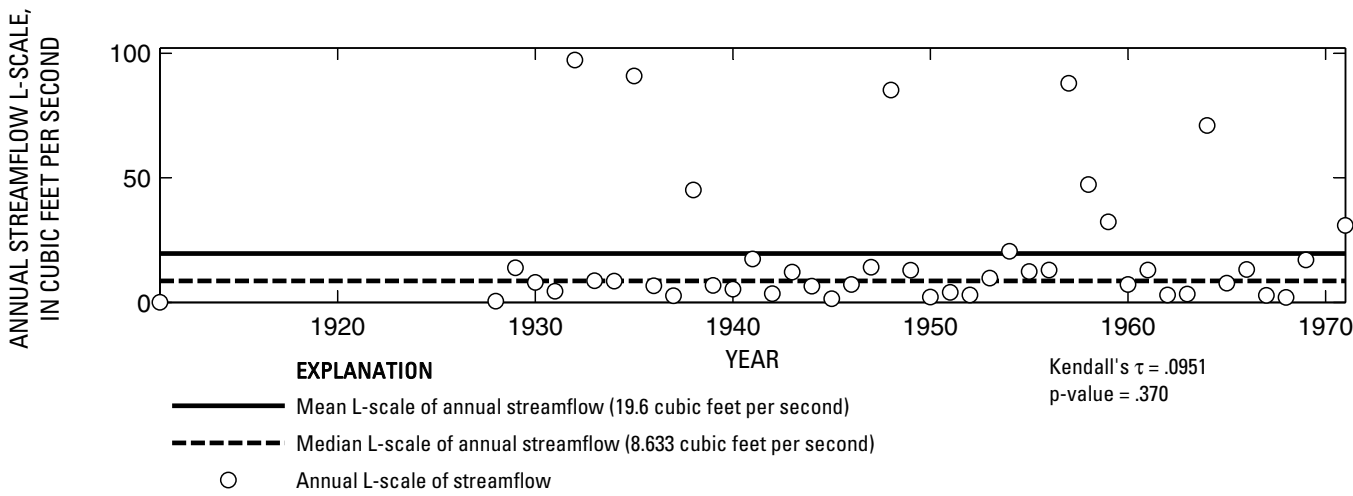

Figure 713. Analysis of annual mean, maximum, minimum, and L-scale statistics of daily mean streamflow for U.S. Geological Survey streamflow-gaging station 08455000 Pinto Creek near Del Rio, Texas.

|ndex of Station Numbers 719 
This page intentionally left blank. 


\section{Index of Station Numbers (hyperlinked)}

The page numbers of this index are hyperlinked to provide navigational convenience to the portable document format version of this report. A return link is provided at the bottom right of the linked page.

\begin{tabular}{|c|c|}
\hline $07227470 \ldots$. . 6 & 07311782 \\
\hline $07227500 \ldots$ & 07311783 \\
\hline $07227920 \ldots$ & 07311790 . \\
\hline $07228000 \ldots$ & 07311800 . \\
\hline $07233500 \ldots 10$ & 07311900 . \\
\hline $07235000 \ldots$ & 07312100 . \\
\hline $07295500 \ldots$ & 07312130 . \\
\hline 07296100 . & 07312200 . \\
\hline 07297500 . & 07312500 . \\
\hline 07297910 . & 07312700 . \\
\hline 07298000 . & 07314500 \\
\hline $07298200 \ldots$ & 07314900 . \\
\hline $07298500 \ldots$ & 07315200 . \\
\hline $07299000 \ldots$ & $07315400 \ldots 66$ \\
\hline $07299200 \ldots$ & $07316200 \ldots 63$ \\
\hline $07299300 \ldots$ & 07332600 . \\
\hline $07299500 \ldots$ & 07335400 . \\
\hline $07299512 \ldots$ & $07336750 \ldots 66$ \\
\hline $07299514 \ldots$ & $07336800 \ldots .67$ \\
\hline $07299530 \ldots$ & 07336820 . \\
\hline $07299540 \ldots$ & 07342465 . \\
\hline $07299570 \ldots$ & $07342470 \ldots$ \\
\hline $07299670 \ldots 28$ & $07342480 \ldots 71$ \\
\hline $07299850 \ldots . \overline{29}$ & $07342500 \ldots . \overline{72}$ \\
\hline $07299890 \ldots$ & 07343000 . \\
\hline $07300000 \ldots$ & 07343200 . \\
\hline $07301200 \ldots 32$ & $07343300 \ldots$ \\
\hline $07301300 \ldots$ & $07343500 \ldots$ \\
\hline $07301410 \ldots$ & 07344000 . \\
\hline $07307500 \ldots$ & 07344482 . \\
\hline $07307600 \ldots$ & 07344486 . \\
\hline $07307750 \ldots$ & 07344500 . \\
\hline $07307760 \ldots$ & 07345000 . \\
\hline $07307800 \ldots$ & 07346000 \\
\hline $07308000 \ldots 40$ & 07346045 . \\
\hline $07308200 \ldots$ & 07346050 . \\
\hline $07308500 \ldots 42$ & $07346070 \ldots$ \\
\hline $07311600 \ldots$ & $07346140 \ldots$ \\
\hline $07311622 \ldots 44$ & 08017200 . \\
\hline $07311630 \ldots 45$ & $08017300 \ldots$ \\
\hline $07311648 \ldots$ & $08017410 \ldots$ \\
\hline $07311700 \ldots \overline{47}$ & $08017500 \ldots$ \\
\hline $07311780 \ldots .48$ & $08018500 \ldots 91$ \\
\hline
\end{tabular}

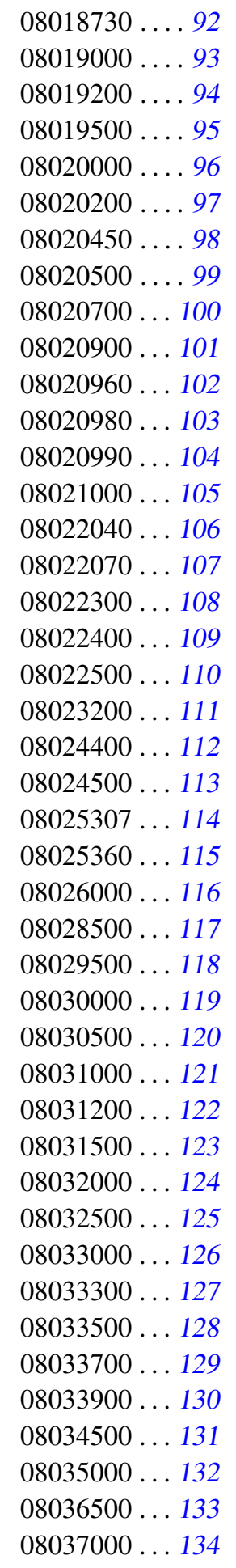

\begin{tabular}{|c|c|}
\hline $08037050 \ldots 135$ & $08049565 \ldots 178$ \\
\hline $08037500 \ldots 136$ & $08049569 \ldots 179$ \\
\hline $08038000 \ldots 137$ & $08049580 \ldots 180$ \\
\hline $08038500 \ldots 138$ & 08049600 . \\
\hline $08039100 \ldots 139$ & 08049700 . \\
\hline $08039500 \ldots 140$ & 08050000 . \\
\hline $08040600 \ldots 141$ & 08050100 . \\
\hline $08041000 \ldots 142$ & 08050300 . \\
\hline $08041500 \ldots 143$ & 08050400 . \\
\hline $08041700 \ldots 144$ & 08050500 . \\
\hline $08042000 \ldots 145$ & 08050800 . \\
\hline $08042500 \ldots 146$ & 08050840 . \\
\hline $08042700 \ldots 147$ & 08051000 . \\
\hline $08042800 \ldots 148$ & 08051130 . \\
\hline $08042900 \ldots 149$ & 08051500 . \\
\hline $08043500 \ldots 150$ & 08052000 . \\
\hline $08043950 \ldots 151$ & 08052650 . \\
\hline $08044000 \ldots 152$ & $08052700 \ldots$ \\
\hline $08044135 \ldots 153$ & $08052780 \ldots$ \\
\hline $08044140 \ldots 154$ & 08053000 . \\
\hline $08044500 \ldots 155$ & 08053500 . \\
\hline $08044800 \ldots 156$ & $08054000 \ldots$ \\
\hline $08045500 \ldots 157$ & $08055000 \ldots$ \\
\hline $08045850 \ldots 158$ & 08055500 . \\
\hline $08046000 \ldots 159$ & 08055700 . \\
\hline $08047000 \ldots 160$ & 08056500 . \\
\hline $08047050 \ldots 161$ & 08057000 . \\
\hline $08047500 \ldots 162$ & 08057100 . \\
\hline $08048000 \ldots 163$ & 08057200 . \\
\hline $08048520 \ldots 164$ & 08057300 . \\
\hline $08048530 \ldots 165$ & 08057410 . \\
\hline $08048540 \ldots 166$ & 08057445 . \\
\hline $08048543 \ldots 167$ & 08057448 . \\
\hline $08048600 \ldots 168$ & 08057450 . \\
\hline $08048800 \ldots 169$ & 08058500 . \\
\hline $08048850 \ldots 170$ & 08058900 . \\
\hline $08048970 \ldots 171$ & 08059000 . \\
\hline $08048980 \ldots 172$ & 08059400 . \\
\hline $08049000 \ldots 17$ & 08059500 . \\
\hline $08049500 \ldots 174$ & 08060000 . \\
\hline $08049550 \ldots 175$ & 08061000 . \\
\hline $08049553 \ldots 17$ & 08061500 . \\
\hline $08049556 \ldots$. 11 & $08061540 \ldots 2$ \\
\hline
\end{tabular}




\begin{tabular}{|c|c|}
\hline $08061700 \ldots 221$ & $08068520 \ldots 271$ \\
\hline $08061750 \ldots 222$ & 08068720 . \\
\hline $08061950 \ldots 223$ & 08068740 . \\
\hline $08062000 \ldots .224$ & 08068780 . \\
\hline $08062500 \ldots 225$ & 08068800 . \\
\hline $08062650 \ldots 226$ & 08068900 . \\
\hline $08062700 \ldots 227$ & 08069000 . \\
\hline $08062800 \ldots 228$ & 08069500 . \\
\hline $08062900 \ldots .229$ & 08070000 . \\
\hline $08062980 \ldots . \overline{230}$ & 08070200 . \\
\hline $08063000 \ldots 231$ & 08070500 \\
\hline $08063003 \ldots 232$ & 08071000 . \\
\hline $08063020 \ldots 233$ & 08071280 . \\
\hline $08063100 \ldots 234$ & 08071500 . \\
\hline $08063200 \ldots 235$ & 08072300 . \\
\hline $08063500 \ldots 236$ & 08072730 . \\
\hline $08063800 \ldots 237$ & 08072760 . \\
\hline $08064100 \ldots .238$ & 08073500 . \\
\hline $08064500 \ldots .239$ & 08073600 . \\
\hline $08064700 \ldots 240$ & 08073700 . \\
\hline $08064800 \ldots .241$ & 08074000 . \\
\hline $08065000 \ldots 242$ & 08074020 . \\
\hline $08065200 \ldots 243$ & 08074150 . \\
\hline $08065350 \ldots 244$ & 08074250 . \\
\hline $08065500 \ldots 245$ & 08074500 . \\
\hline $08065700 \ldots \overline{246}$ & 08074760 . \\
\hline $08065800 \ldots \overline{247}$ & 08074780 . \\
\hline $08066000 \ldots 248$ & 08074800 . \\
\hline $08066100 \ldots 249$ & 08074810 . \\
\hline $08066170 \ldots 250$ & 08075000 . \\
\hline $08066191 \ldots 251$ & 08075400 . \\
\hline $08066200 \ldots 252$ & 08075500 . \\
\hline $08066250 \ldots 253$ & 08075650 . \\
\hline $08066300 \ldots 254$ & 08075730 . \\
\hline $08066500 \ldots .255$ & 08075770 . \\
\hline $08067000 \ldots .256$ & 08075780 . \\
\hline $08067500 \ldots .257$ & 08075900 . \\
\hline $08067525 \ldots 258$ & 08076000 . \\
\hline $08067610 \ldots 259$ & 08076180 . \\
\hline $08067650 \ldots 260$ & $08076500 \ldots$ \\
\hline $08067700 \ldots 261$ & 08076700 . \\
\hline $08067900 \ldots 262$ & 08077000 . \\
\hline $08068000 \ldots 263$ & 08077540 . \\
\hline $08068090 \ldots 264$ & 08078000 . \\
\hline $08068275 \ldots .265$ & 08079000 . \\
\hline $08068325 \ldots 266$ & 08079500 . \\
\hline $08068390 \ldots 267$ & $08079575 \ldots$ \\
\hline $08068400 \ldots 268$ & $08079600 \ldots$ \\
\hline $08068450 \ldots 269$ & $08080000 \ldots$ \\
\hline $08068500 \ldots \overline{270}$ & $08080500 \ldots$ \\
\hline
\end{tabular}

$08080540 \ldots 321$

$08080700 \ldots 322$

$08080950 \ldots 323$

$08081000 \ldots 324$

$08081200 \ldots 325$

$08081500 \ldots 326$

$08082000 \ldots 327$

$08082100 \ldots 328$

$08082180 \ldots 329$

$08082500 \ldots 330$

$08082700 \ldots 331$

$08083000 \ldots 332$

$08083100 \ldots 333$

$08083230 \ldots 334$

$08083240 \ldots 335$

$08083245 \ldots 336$

$08083300 \ldots 337$

$08083400 \ldots 338$

$08083420 \ldots 339$

$08083430 \ldots 340$

$08083470 \ldots 341$

$08083480 \ldots 342$

$08084000 \ldots 343$

$08084800 \ldots 344$

$08085000 \ldots 345$

$08085500 \ldots 346$

$08086000 \ldots 347$

$08086015 \ldots 348$

$08086050 \ldots 349$

$08086100 \ldots 350$

$08086120 \ldots 351$

$08086150 \ldots 352$

$08086200 \ldots 353$

$08086210 \ldots 354$

$08086212 \ldots 355$

$08086235 \ldots 356$

$08086260 \ldots 357$

$08086290 \ldots 358$

$08086500 \ldots 359$

$08087300 \ldots 360$

$08088000 \ldots 361$

$08088100 \ldots 362$

$08088200 \ldots 363$

$08088300 \ldots 364$

$08088450 \ldots 365$

$08088600 \ldots 366$

$08088610 \ldots 367$

$08089000 \ldots 368$

$08090500 \ldots 369$

$08090800 \ldots 370$
$08091000 \ldots 371$

$08091500 \ldots 372$

$08091750 \ldots 373$

$08092000 \ldots 374$

$08092600 \ldots 375$

$08093100 \ldots 376$

$08093250 \ldots 377$

$08093360 \ldots 378$

$08093400 \ldots 379$

$08093500 \ldots 380$

$08093700 \ldots 381$

$08094800 \ldots 382$

$08095000 \ldots 383$

$08095200 \ldots 384$

$08095300 \ldots 385$

$08095400 \ldots 386$

$08095500 \ldots 387$

$08095600 \ldots 388$

$08096500 \ldots 389$

$08097500 \ldots 390$

$08098000 \ldots 391$

$08098290 \ldots 392$

$08098300 \ldots 393$

$08099100 \ldots 394$

$08099300 \ldots 395$

$08099500 \ldots 396$

$08100000 \ldots 397$

$08100500 \ldots 398$

$08101000 \ldots 399$

$08101500 \ldots 400$

$08102500 \ldots 401$

$08102600 \ldots 402$

$08103800 \ldots 403$

$08103900 \ldots 404$

$08104000 \ldots 405$

$08104100 \ldots 406$

$08104310 \ldots 407$

$08104500 \ldots 408$

$08104700 \ldots 409$

$08104900 \ldots 410$

$08105000 \ldots 411$

$08105095 \ldots 412$

$08105100 \ldots 413$

$08105200 \ldots 414$

$08105300 \ldots 415$

$08105400 \ldots 416$

$08105700 \ldots 417$

$08106300 \ldots 418$

$08106310 \ldots 419$

$08106350 \ldots 420$
$08106500 \ldots 421$

$08107000 \ldots 422$

$08107500 \ldots 423$

$08108000 \ldots 424$

$08108200 \ldots 425$

$08108700 \ldots 426$

$08109000 \ldots 427$

$08109700 \ldots 428$

$08109800 \ldots 429$

$08110000 \ldots 430$

$08110100 \ldots 431$

$08110200 \ldots 432$

$08110325 \ldots 433$

$08110400 \ldots 434$

$08110430 \ldots 435$

$08110500 \ldots 436$

$08110800 \ldots 437$

$08111000 \ldots 438$

$08111010 \ldots 439$

$08111025 \ldots 440$

$08111050 \ldots 441$

$08111500 \ldots 442$

$08111700 \ldots 443$

$08114000 \ldots 444$

$08114500 \ldots 445$

$08115000 \ldots 446$

$08115500 \ldots 447$

$08116000 \ldots 448$

$08116400 \ldots 449$

$08116500 \ldots 450$

$08116650 \ldots 451$

$08117500 \ldots 452$

$08117900 \ldots 453$

$08117995 \ldots 454$

$08118500 \ldots 455$

$08119000 \ldots 456$

$08119500 \ldots 457$

$08120500 \ldots 458$

$08120700 \ldots 459$

$08121000 \ldots 460$

$08121500 \ldots 461$

$08122000 \ldots 462$

$08122500 \ldots 463$

$08123500 \ldots 464$

$08123650 \ldots 465$

$08123700 \ldots 466$

$08123720 \ldots 467$

$08123800 \ldots 468$

$08123850 \ldots 469$

$08123900 \ldots 470$ 


\begin{tabular}{|c|c|c|c|}
\hline $08124000 \ldots 471$ & $08154700 \ldots 521$ & $08166000 \ldots 571$ & $08181410 \ldots 621$ \\
\hline $08126380 \ldots 472$ & $08155200 \ldots 522$ & $08166140 \ldots 572$ & $08181450 \ldots .622$ \\
\hline $08126500 \ldots 473$ & $08155240 \ldots 523$ & $08166200 \ldots 573$ & $08181480 \ldots 62$ \\
\hline $08127000 \ldots 474$ & $08155260 \ldots 524$ & $08166500 \ldots 574$ & $08181500 \ldots 624$ \\
\hline $08128000 \ldots 475$ & $08155300 \ldots 525$ & $08167000 \ldots 575$ & $08181800 \ldots 625$ \\
\hline $08128400 \ldots 476$ & $08155400 \ldots 526$ & $08167500 \ldots 576$ & $08182500 \ldots 62$ \\
\hline $08128500 \ldots 477$ & $08156700 \ldots 527$ & $08167600 \ldots 577$ & $08183000 \ldots 62$ \\
\hline $08129300 \ldots 478$ & $08156800 \ldots 528$ & $08167800 \ldots 578$ & $08183500 \ldots 628$ \\
\hline $08130500 \ldots 479$ & $08157000 \ldots 529$ & $08168500 \ldots 579$ & $08183850 \ldots 629$ \\
\hline $08130700 \ldots 480$ & $08157500 \ldots 530$ & $08169000 \ldots 580$ & $08183900 \ldots 630$ \\
\hline $08131000 \ldots .481$ & $08157600 \ldots 551$ & $08169500 \ldots 5$ & $08184000 \ldots 631$ \\
\hline $08131400 \ldots 482$ & $08157700 \ldots 532$ & $08170500 \ldots 582$ & $08184500 \ldots 6$ \\
\hline $08132500 \ldots .483$ & $08158000 \ldots 5$ & $08171000 \ldots 5$ & $08185000 \ldots 633$ \\
\hline $08133250 \ldots 484$ & $08158050 \ldots 534$ & $08171300 \ldots 584$ & $08185500 \ldots 634$ \\
\hline $08133500 \ldots 485$ & $08158600 \ldots 535$ & $08172000 \ldots 585$ & $08186000 \ldots 635$ \\
\hline $08133900 \ldots 486$ & $08158700 \ldots \overline{536}$ & $08172400 \ldots \overline{586}$ & $08186500 \ldots 6$ \\
\hline $08134000 \ldots 487$ & $08158800 \ldots 537$ & $08172500 \ldots 587$ & $08187500 \ldots$ \\
\hline $08134230 \ldots 488$ & $08158810 \ldots 538$ & $08173000 \ldots 588$ & $08188500 \ldots 638$ \\
\hline $08134250 \ldots \overline{489}$ & $08158840 \ldots \overline{539}$ & $08173500 \ldots 5$ & $08189200 \ldots \overline{639}$ \\
\hline $08135000 \ldots .4$ & $08158920 \ldots 540$ & $08173900 \ldots 5$ & $08189300 \ldots$ \\
\hline $08136000 \ldots 491$ & $08158922 \ldots 541$ & $08174600 \ldots 591$ & 08189500 . \\
\hline $08136500 \ldots .4992$ & $08158930 \ldots 542$ & $08175000 \ldots \overline{592}$ & 08189700 . \\
\hline $08136700 \ldots 493$ & $08158970 \ldots 543$ & $08175800 \ldots 593$ & $08189800 \ldots 6$ \\
\hline $08138000 \ldots 494$ & $08159000 \ldots 544$ & $08176000 \ldots 594$ & 08190000 . \\
\hline $08139500 \ldots 495$ & $08159150 \ldots 545$ & $08176500 \ldots 595$ & 08190500 . \\
\hline $08140500 \ldots 496$ & $08159165 \ldots 546$ & $08176550 \ldots 596$ & $08191500 \ldots$ \\
\hline $08140700 \ldots . \overline{497}$ & $08159170 \ldots \overline{547}$ & $08176900 \ldots \overline{597}$ & $08192000 \ldots 6$ \\
\hline $08140800 \ldots \overline{498}$ & $08159200 \ldots \overline{548}$ & $08176990 \ldots \overline{598}$ & $08192500 \ldots 6$ \\
\hline $08141500 \ldots .499$ & $08159500 \ldots 549$ & $08177000 \ldots 5$ & $08193000 \ldots$ \\
\hline $08142000 \ldots 500$ & $08160400 \ldots 550$ & $08177300 \ldots 600$ & 08194000 . \\
\hline $08143500 \ldots 501$ & $08160500 \ldots 551$ & $08177500 \ldots 601$ & 08194200 . \\
\hline $08143600 \ldots 502$ & $08160700 \ldots 552$ & $08177700 \ldots 602$ & $08194500 \ldots$ \\
\hline $08144500 \ldots 503$ & $08160800 \ldots 553$ & $08177860 \ldots 603$ & 08194600 . \\
\hline $08144600 \ldots 504$ & $08161000 \ldots 554$ & $08178000 \ldots 604$ & 08195000 . \\
\hline $08144800 \ldots 505$ & $08162000 \ldots 555$ & $08178050 \ldots 605$ & 08196000 . \\
\hline $08145000 \ldots . \overline{506}$ & $08162500 \ldots \overline{556}$ & $08178500 \ldots \overline{606}$ & $08196500 \ldots$ \\
\hline $08146000 \ldots . \overline{507}$ & $08162600 \ldots 5$ & $08178565 \ldots \overline{607}$ & 08197500 . \\
\hline $08147000 \ldots \overline{508}$ & $08164000 \ldots 5$ & 08178585 . & 08198000 . \\
\hline $08148500 \ldots 5$ & $08164300 \ldots$ & $08178700 \ldots$ & 08198500 . \\
\hline $08150000 \ldots 510$ & $08164350 \ldots 560$ & 08178800. & 08199700 . \\
\hline $08150700 \ldots 511$ & $08164370 \ldots 561$ & $08178880 \ldots 611$ & 08200000 . \\
\hline $08150800 \ldots 512$ & $08164390 \ldots 562$ & $08179000 \ldots 612$ & 08200500 . \\
\hline $08151000 \ldots \overline{513}$ & $08164450 \ldots \overline{563}$ & $08179100 \ldots \overline{613}$ & 08200700 . \\
\hline $08151500 \ldots 514$ & $08164500 \ldots 564$ & $08179520 \ldots 614$ & $08201500 \ldots$ \\
\hline $08152000 \ldots \overline{515}$ & $08164503 \ldots \overline{565}$ & $08180500 \ldots \overline{615}$ & $08202000 \ldots$ \\
\hline 08152900 . & $08164504 \ldots 566$ & $08180640 \ldots 616$ & 08202500 . \\
\hline $08153000 \ldots 517$ & $08164600 \ldots 567$ & $08180700 \ldots 617$ & 08202700 . \\
\hline $08153500 \ldots 518$ & $08164800 \ldots \overline{568}$ & $08180750 \ldots . \overline{618}$ & 08204005 . \\
\hline $08154000 \ldots 519$ & $08165300 \ldots 569$ & $08180800 \ldots 619$ & 08204500 . \\
\hline $08154510 \ldots \overline{520}$ & $08165500 \ldots \overline{570}$ & $08181400 \ldots \overline{620}$ & $08205500 \ldots \overline{6}$ \\
\hline
\end{tabular}

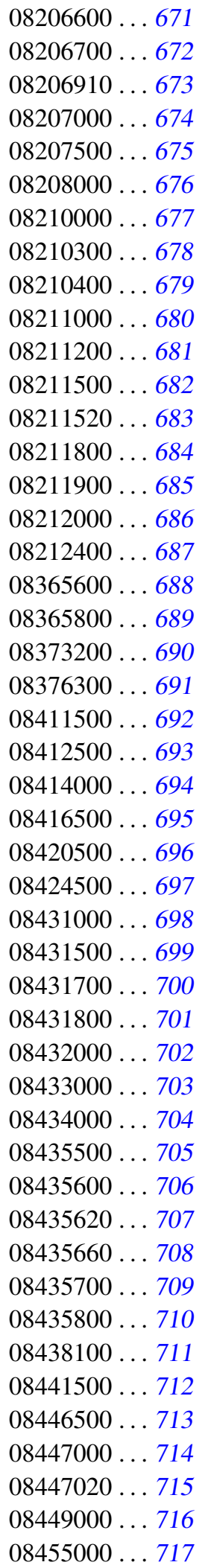

$08206600 \ldots 671$

$08206700 \ldots 672$

$08207000 \ldots 674$

$08207500 \ldots 675$

$08208000 \ldots 676$

$08210000 \ldots 677$

$08210300 \ldots 678$

$08210400 \ldots 679$

$08211000 \ldots 680$

$08211200 \ldots 681$

$08211500 \ldots 682$

$08211800 \ldots 684$

$08211900 \ldots 685$

$08212000 \ldots 686$

$08212400 \ldots 687$

$08365600 \ldots 688$

$08365800 \ldots 689$

$08373200 \ldots 690$

$08376300 \ldots 691$

$08411500 \ldots 692$

$08412500 \ldots 693$

$08414000 \ldots 694$

$08416500 \ldots 695$

$08420500 \ldots 696$

$08424500 \ldots 697$

$08431500 \ldots 699$

$08431700 \ldots 700$

$08431800 \ldots 701$

$08432000 \ldots 702$

$08433000 \ldots 703$

$08434000 \ldots 704$

$08435500 \ldots 705$

$08435600 \ldots 706$

$08435620 \ldots 707$

$08435660 \ldots 708$

$08435700 \ldots 709$

$08435800 \ldots 710$

$08438100 \ldots 711$

$08441500 \ldots 712$

$08447000 \ldots 714$

$08447020 \ldots 715$

$08455000 \ldots 717$ 
Prepared by William H. Asquith and the USGS Publishing Service Center 9 Edited by Gail J. Sladek

Illustrations by Laura S. Coplin (fig.11 and Joseph Vrabel (the rest)

Layout and typesetting by William $\mathrm{H}$. Asquith using $\mathrm{LTT}_{\mathrm{E}} \mathrm{X}$

Final portable document format preparation by Gloria J. Smith

For information regarding this report or water resources in Texas, contact:

U.S. Geological Survey

8027 Exchange Drive

Austin, Texas 78754-4733

(512) $927-3500$

http://tx.usgs.gov 


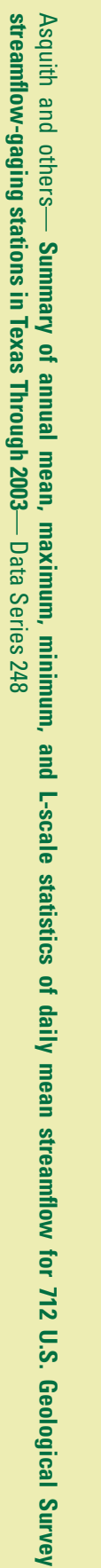

